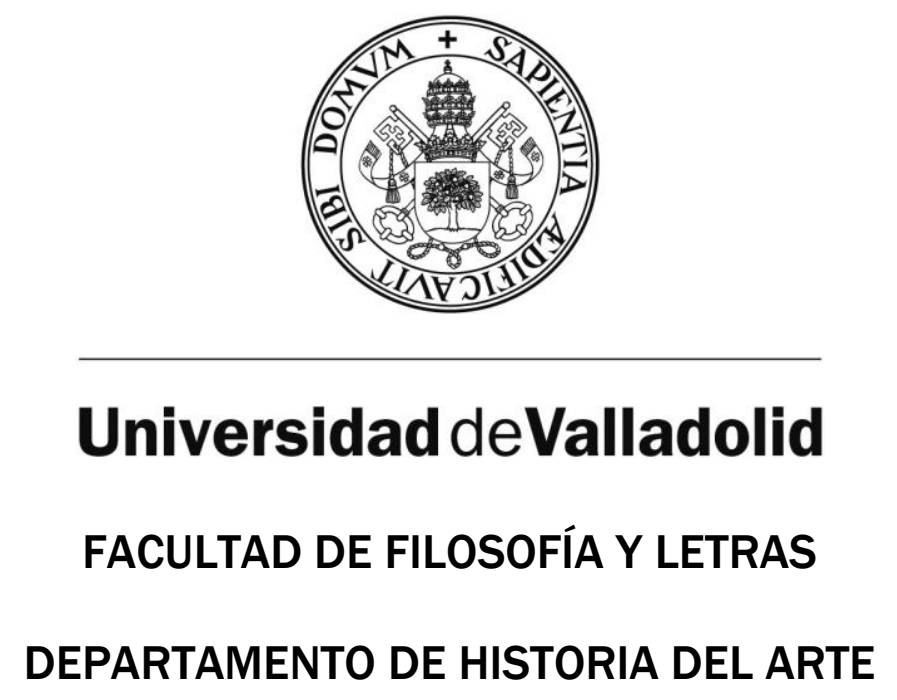

TESIS DOCTORAL:

\title{
LOS ÁVILA: UNA FAMILIA DE ESCULTORES BARROCOS VALLISOLETANOS
}

Presentada por Javier Baladrón Alonso para optar al grado de doctor por la Universidad de Valladolid

Dirigida por:

D. Jesús María Parrado del Olmo 





\section{ÍNDICE GENERAL}

\section{0.- INTRODUCCIÓN A LA TESIS DOCTORAL......................1}

$0-1$. Objetivos de la tesis.................................................

$0-2$. Metodología ....................................................... 5

A- Recopilación documental...........................................5

B- Labor de archivo................................................... 5

C- Trabajo de campo.............................................6

D- Redacción de la tesis.............................................6

$0-3$. Historiografía y estado de la cuestión..................................

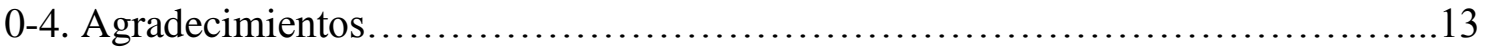

\section{1.- INTRODUCCIÓN HISTÓRICA.....................................15}

1-1. España (1650-1755): Entre Austrias y Borbones...................................... 17

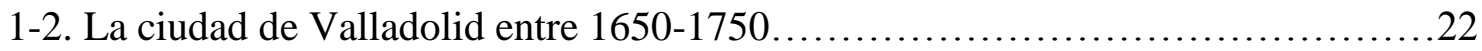

A- Población.......................................................23

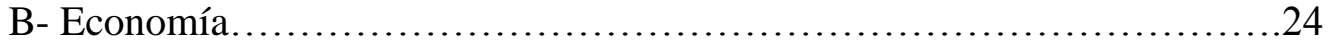

C- Sociedad.....................................................25

D- Religión.......................................................26

E- Cultura....................................................28

1-3. Principales acontecimientos sucedidos en Valladolid (1650-1750)............29

A- Acontecimientos religiosos.......................................29

B- Acontecimientos relacionados con la monarquía........................33

C- Otros acontecimientos........................................... 35

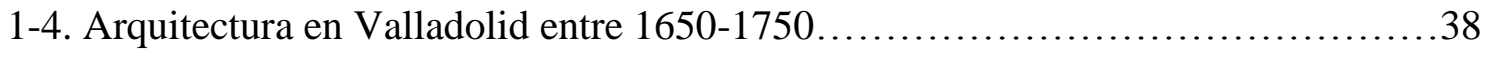

A- El cambio de estilo.............................................. 38

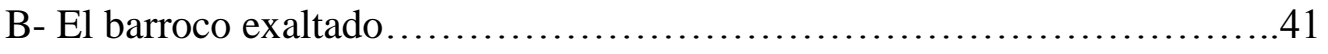

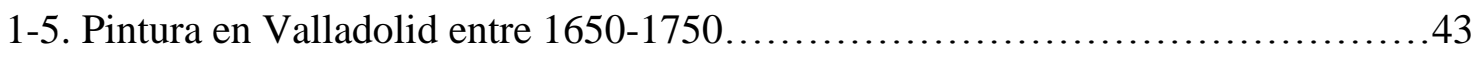

A- Segunda mitad del siglo XVII.....................................43

Panorama general de artistas......................................43

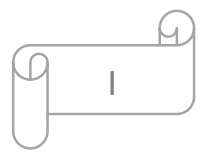


Amaro Alonso de Llanos (1640-1699)............................46

Agustín Bara (1650-1678).....................................49

Diego Díez Ferras (1640-d.1701)...............................51

Andrés Amaya (h.1645-1704).....................................54

B- Primera mitad del siglo XVIII.....................................56

Manuel Peti Bander (1662-1736)....................................56

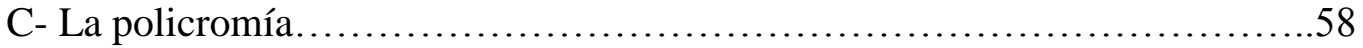

Joseph Martínez de Estrada (h.1638-1687).............................61

Alonso Gutiérrez (a.1652-d.1693)...............................62

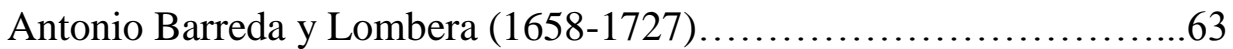

Manuel Martínez de Estrada (1659-1716)..........................66

Leonardo Martínez de Estrada (h.1670-1705)........................69

Santiago Montes (h.1674-1742)................................70

Manuel Barreda (1681-1757)...................................72

Bonifacio Núñez (1706-1746)..................................75

Relación de los Ávila con los policromadores..........................76

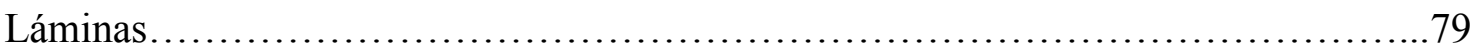

2.- LA ESCULTURA EN VALLADOLID (1650-1750)...............105

2-1. Escultura barroca: características generales.............................. 107

A- Generalidades.................................................... 108

B- Materiales.............................................................. 113

C- Postizos......................................................... 114

D- Indumentaria..................................................... 115

E- Iconografías ..................................................... 116

- Cristo............................................................. 117

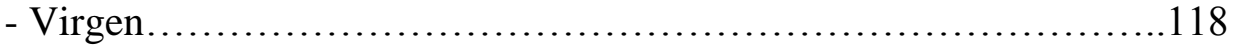

- San José.............................................................119

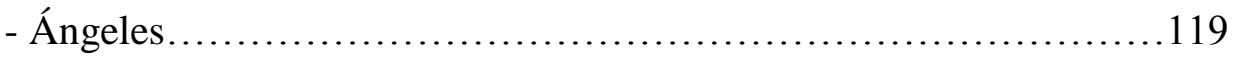

- Santos.......................................................... 120 
2-2. Panorámica de la escultura barroca en España.

A- Castilla.......................................................... 123

- Toro........................................................ 123

- Salamanca................................................... 124

- Otros focos castellanos.....................................124

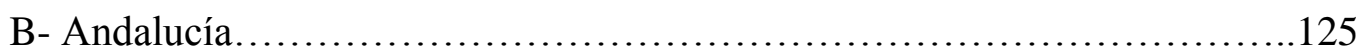

- Sevilla.................................................... 126

- Granada......................................................... 126

C- Madrid / La Corte..............................................127

2-3. La escultura vallisoletana contemporánea a los “Ávila"........................129

Alonso de Rozas (h.1625-1681) ....................................137

Pedro Salvador "el joven" (1635-1684) ..................................141

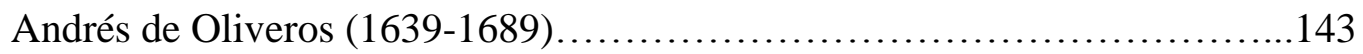

José Mayo (1642-1679/1680)........................................145

Antonio Vázquez (1650-1700)........................................147

Juan Antonio de la Peña (h.1650-1708)..................................149

Vicente Díez (1649-d.1708)..........................................153

Andrés de Pereda (h.1655-1733........................................ 155

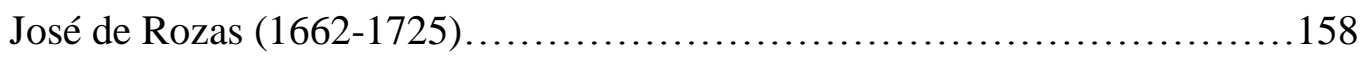

Joseph Pascual Robledo (1677-1714)..................................163

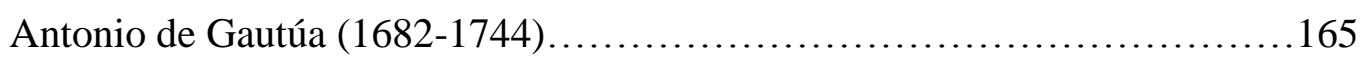

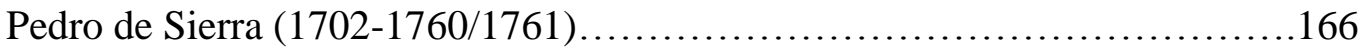

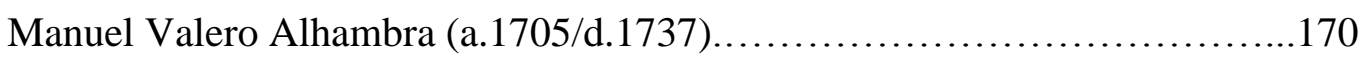

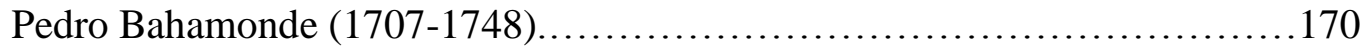

Juan Antonio Argüelles (a.1715-h.1766/1777)...........................174

José Fernández (a.1719-d.1776)......................................175

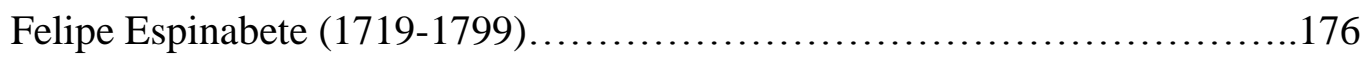

2-4. Evolución del retablo y ensambladores en Valladolid entre 1650-1750............177

A- El retablo "pre-churrigueresco" ................................... 177

Cristóbal Ruiz de Andino (h.1625-d.1689).........................179 
Antonio Billota (h.1630-1687)...................................181

Pedro de Cea (1633-d.1684)....................................183

Juan Guerrero de Horna (1639-d.1702)..........................186

B- El retablo "churrigueresco" .........................................187

Gregorio Díaz de Mata (h.1645-¿1720?)..........................190

Blas Martínez de Obregón (h.1650-1716)..............................193

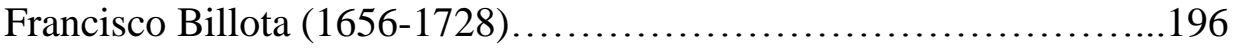

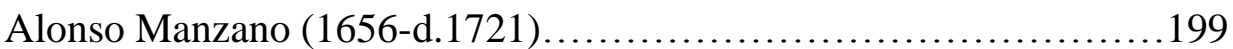

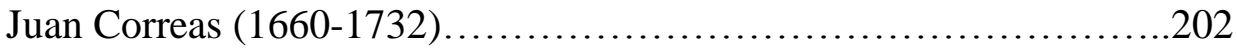

Pedro de Ribas (1666-1738).....................................205

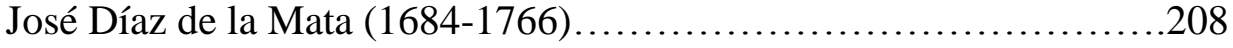

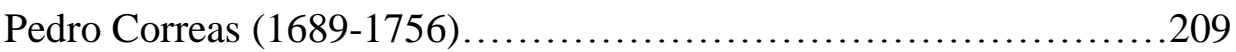

Pedro Roldán (h.1705-d.1744).................................214

Manuel Rodríguez (h.1705-d.1758)..............................214

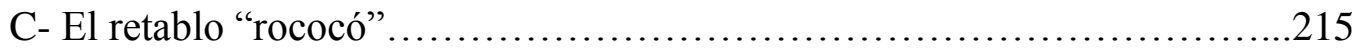

Bentura Ramos (h.1710-1756).................................217

Agustín Martín (h.1705-d.1762)...............................218

D- Relación de los Ávila con los ensambladores......................... 219

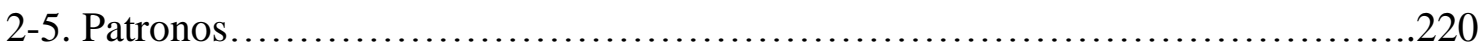

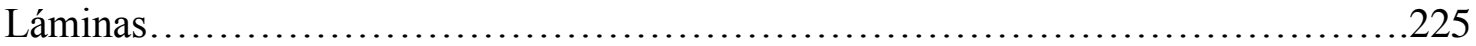

3.- JUAN DE ÁVILA. PERSONALIDAD...............................257

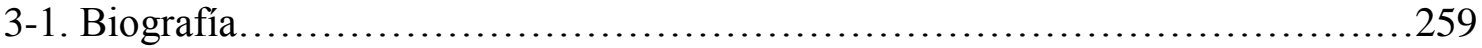

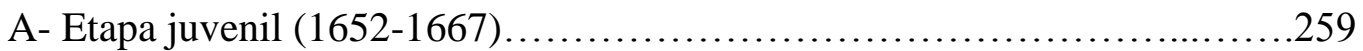

B- Formación en el taller de Tudanca $(1667-1672) \ldots \ldots \ldots \ldots \ldots \ldots \ldots \ldots \ldots . \ldots 262$

C- Apertura de taller propio y primer matrimonio $(1672-1686) \ldots \ldots \ldots \ldots \ldots . .267$

D- Etapa de prestigio y segundo matrimonio (1686-1702) .................286

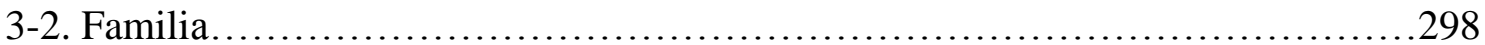

A- Abuelos paternos.................................................298

B- Padre: Hernando de Ávila...............................................299 
C- Abuelos maternos.................................................. 301

D- Madre: Juana Martínez................................................301

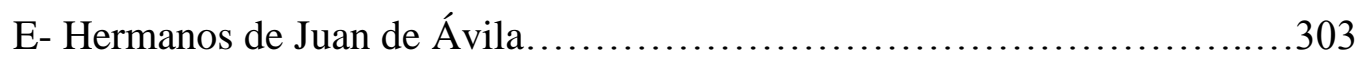

- Hernando de Ávila..................................................303

- Manuel de Ávila...................................................304

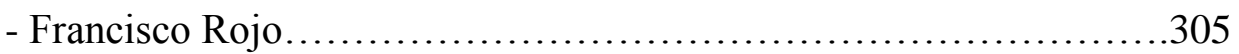

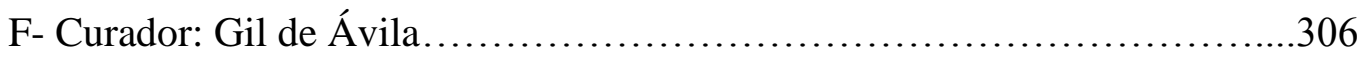

G- Primera mujer de Juan de Ávila: Francisca Ezquerra........................307

H- Hijos de Juan de Ávila y Francisca Ezquerra..............................309

- Josepha Antonia de Ávila...........................................309

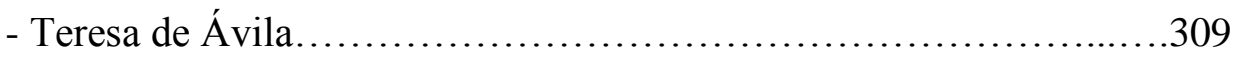

- Pedro de Ávila I...................................................311

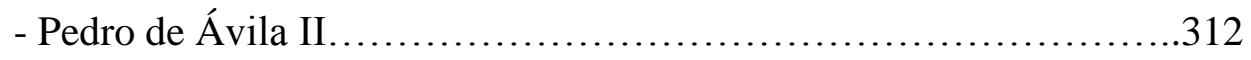

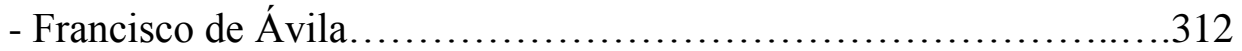

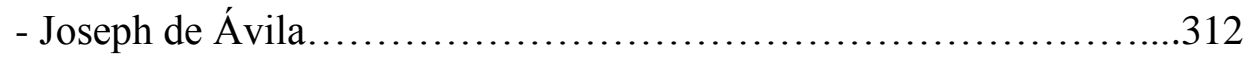

- Ana de Ávila.....................................................313

I- Segunda mujer de Juan de Ávila: Bentura Sedano.........................314

J- Hijos de Juan de Ávila y Bentura Sedano.................................315

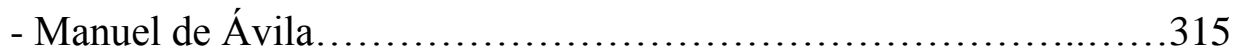

- Manuela de Ávila.................................................... 315

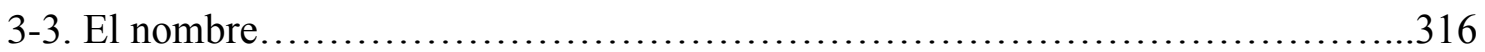

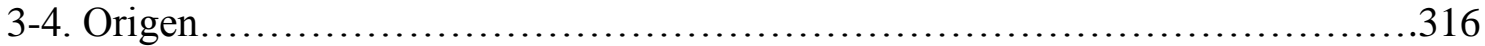

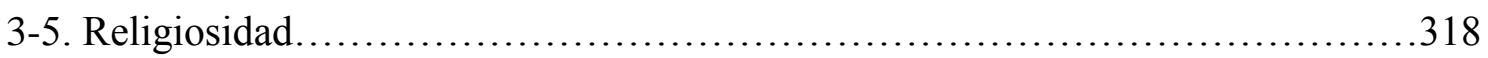

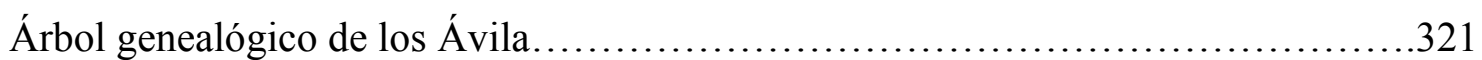

4.- EL ARTE DE JUAN DE ÁVILA..................................323

4-1. Marco de trabajo..................................................... 325

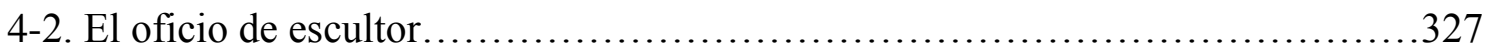

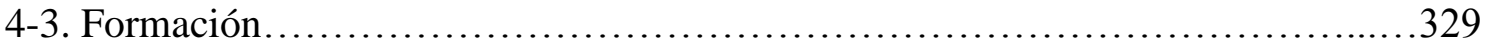

A- Francisco Díez de Tudanca............................................331 


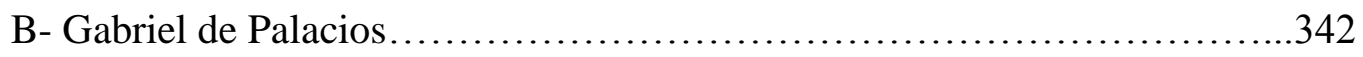

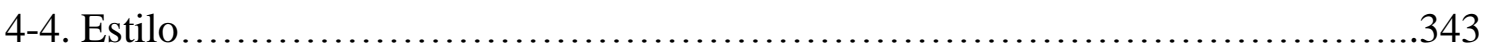

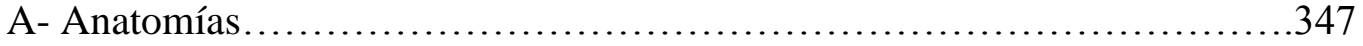

B- Ropajes/Indumentaria...........................................350

C- Iconografías.......................................................

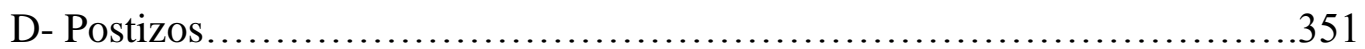

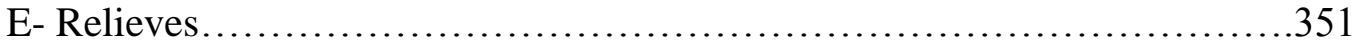

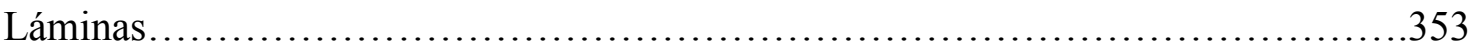

5.- JUAN dE ÁVILA. CATÁlOGO....................................361

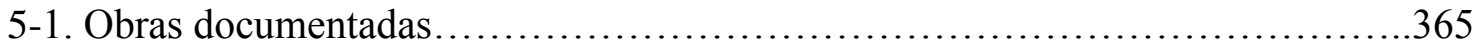

Marcos para cuadros. Iglesia de San Juan Bautista. Valladolid.................367

Peñasco. Iglesia parroquial de San Juan Bautista. Pesquera de Duero..........369

Paso "Preparativos para la Crucifixión". Museo Nacional de Escultura. Valladolid................................................................. 373

Santiago Matamoros y Arco-Hornacina. Iglesia de Santiago. Valladolid......388

Perspectiva para la fiesta de Santiago. Iglesia de Santiago. Valladolid..........391

Escultura para el retablo de don Francisco Pinacho. Iglesia parroquial de Santiago Apóstol. Cigales..................................................................393

Esculturas del retablo mayor. Hospital de San Juan de Dios. Valladolid.......395

Adornos para la cruz del cementerio. Iglesia de Santiago. Valladolid..........403

Intervenciones en los gigantes del Corpus. Ayuntamiento. Valladolid........405

Esculturas del retablo mayor. Iglesia colegial de San Pedro. Lerma...........408

Retablo mayor. Iglesia parroquial de San Martín. Traspinedo.................430

San Isidro y Santa María de la Cabeza. Ermita de San Isidro. Valladolid......433

Nuestra Señora de Gracia. Iglesia parroquial de San Esteban Protomártir. Torrecilla de la Abadesa.....................................................440

Esculturas del retablo mayor. Iglesia de Santiago. Valladolid................442

Esculturas y relieves para retablos colaterales. Oratorio de San Felipe Neri. Valladolid.

Esculturas del retablo de la Resurrección. Iglesia de San Andrés. Villasilos..467

5-2. Obras atribuidas. 
Santo Ángel de la Guarda. Iglesia de Santiago. Valladolid....................479

Santa Rosa de Viterbo. Iglesia de Santiago. Valladolid.......................483

San Miguel. Iglesia parroquial de San Miguel. Cevico de la Torre..............487

Santo Ángel de la Guarda. Iglesia de San Martín. Valladolid..................489

Santa Catalina de Bolonia. Convento de Santa Clara. Valladolid.............493

San Pedro Regalado. Palacio Real. Valladolid...............................495

La Virgen del Carmen Niña con el Niño Jesús. Santuario de Nuestra Señora del Carmen Extramuros. Valladolid...............................................497

San Pedro Regalado resucitando para dar de comer a un pobre. Iglesia parroquial de la Asunción. Laguna de Duero...............................................498

Santa Teresa. Iglesia parroquial de los Santos Juanes. Nava del Rey............502

Santa Rosa de Viterbo. Real Monasterio de Santa Clara. Tordesillas...........505

San Pedro Regalado. Iglesia de N. P. Jesús Nazareno. Valladolid...............507

Calvario. Real Colegio de San Albano. Valladolid............................513

Sagrada Familia. Real Colegio de San Albano. Valladolid.....................518

Sagrada Familia de la Virgen. Real Colegio de San Albano. Valladolid........ 521

Santa Catalina de Alejandría. Convento de Santa Catalina. Valladolid.........524

San Joaquín, Santa Ana y la Virgen. Colegiata. Covarrubias...................527

San Joaquín con la Virgen Niña. Museo Catedralicio. Salamanca..............528

San Juan Bautista. Iglesia de Santiago. Valladolid..........................530

San Joaquín. Capilla de la Congregación de la Inmaculada. Valladolid.........532

Santa Ana. Capilla de la Congregación de la Inmaculada. Valladolid............535

Inmaculada. Capilla de la Congregación de la Inmaculada. Valladolid.........536

San Felipe Neri. Oratorio de San Felipe Neri. Valladolid.......................538

Inmaculada. Ermita de la Concepción. Fuentecén...........................539

Esculturas del retablo mayor. Monasterio de San Quirce. Valladolid...........540

Cristo Resucitado. Monasterio de San Quirce. Valladolid.....................551

San José con el Niño. Convento de la Concepción. Valladolid.................553

San Joaquín y la Virgen Niña. Monasterio de San Benito. Valladolid..........555

San Pablo. Convento de Santa Catalina. Valladolid..........................561

Esculturas del antiguo retablo mayor de las Lauras. Convento de Porta Coeli. 
Esculturas del retablo mayor. Iglesia de Santa Marina. León...................568

Santa Rosa de Viterbo. Iglesia museo de San Francisco. Ampudia.............571

San Diego de Alcalá. Iglesia museo de San Francisco. Ampudia...............572

Traslación de San Pedro Regalado. Convento del Domus Dei. La Aguilera...575

San José con el Niño. Convento del Domus Dei. La Aguilera..................586

San Antonio de Padua. Convento del Domus Dei. La Aguilera..................588

Esculturas y relieves de los retablos colaterales. Monasterio de San Quirce. Valladolid. .590

Nuestro Padre Jesús con la cruz a cuestas. Monasterio de San Quirce. Valladolid .594

Virgen de la Soledad. Convento de Porta Coeli. Valladolid. 601

¿San Felipe Benizzi? Convento de Porta Coeli. Valladolid 604

Esculturas del retablo mayor. Monasterio de Santa Brígida. Valladolid ... .606

San Roque. Colegiata de San Miguel. Ampudia. 616

Santa Juliana. Colegiata de Santa Juliana. Santillana del Mar. .620

Santa María Magdalena. Convento de las Descalzas Reales. Valladolid....

Santa María Magdalena. Igreja de Santa María da Assunçao. Bragança.......626

Busto de Ecce Homo. Museo Nacional de Escultura. Valladolid...............628

Santa Rita de Casia. Museo Nacional de Escultura. Valladolid................630

Esculturas del retablo mayor. Iglesia de San Juan Bautista. Ataquines........633

Relieve de la Anunciación. Iglesia de San Juan Bautista. Ataquines............640

Virgen del Carmen. Iglesia parroquial de la Asunción. Bercero. 644

Esculturas del retablo mayor. Iglesia parroquial de San Esteban Protomártir. Torrecilla de la Abadesa... 648

Busto de Ecce Homo. Oratorio de San Felipe Neri. Valladolid. 656

5-3. Obras relacionadas.

San José. Centro Diocesano de Espiritualidad. Valladolid 661

San José con el Niño. Iglesia de San Nicolás. Valladolid. .662

San Roque. Iglesia parroquial de la Asunción. Cabezón de Pisuerga...........663

San José con el Niño. Convento de San José. Valladolid.........................664

Tránsito de San José. Hospital de la Piedad. Benavente........................664

“Preparativos para la Crucifixión”. Igreja de Sao Dámaso. Guimarães.......666 
San Roque. Iglesia parroquial de Santa Ana. Herrera de Pisuerga.............666

San Joaquín, Santa Ana y la Virgen. Catedral. Orense........................666

Ángel de la Oración del Huerto. Iglesia museo de San Antolín. Tordesillas...668

Addenda.................................................................

5-4. Obras descatalogadas...............................................673

San Francisco Javier. Centro Diocesano de Espiritualidad. Valladolid.........675

Crucificado. Convento de la Concepción. Valladolid.........................676

Esculturas del retablo mayor. Iglesia del Rosarillo. Valladolid.................676

Grupo de Santiago Matamoros. Iglesia de Santiago. Valladolid...............677

El Profeta San Elías. Monasterio de San Benito. Valladolid...................679

Inmaculada. Museo Nacional de Escultura. Valladolid.......................681

Esculturas del retablo mayor. Oratorio de San Felipe Neri. Valladolid.........681

San Felipe Neri. Oratorio de San Felipe Neri. Valladolid.....................682

San José con el Niño. Santuario Nacional. Valladolid.........................683

San Joaquín, Santa Ana y la Virgen. Colegiata. Aguilar de Campoo............684

San José. Monasterio de Santa Clara. Carrión de los Condes..................685

Esculturas del retablo mayor. Iglesia de Santa María del Camino. Carrión de los

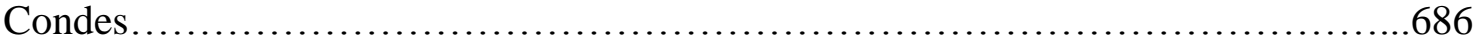

San Juan Bautista. Iglesia parroquial de San Martín. Cevico de la Torre......687

Cristo atado a la columna. Iglesia parroquial de San Miguel. Hornillos........688

Busto de Ecce Homo. Museo Catedralicio-Diocesano. León......................689

Cristo atado a la columna. Museo de Semana Santa. Medina de Rioseco......689

Virgen de la Alegría. Museo de Semana Santa. Medina Rioseco...............691

Relieve del Sueño de San José. Iglesia parroquial de los Santos Juanes. Nava del Rey. .691

Esculturas del retablo mayor. Convento de Santa Clara. Peñafiel.............692

Esculturas del retablo mayor. Iglesia de la Concepción. Toro................693

San Juan de Mata y San Félix de Valois. Iglesia de San Torcuato. Zamora....694 Láminas .695 
6.- DISCÍPULOS DE JUAN DE ÁVILA...............................755

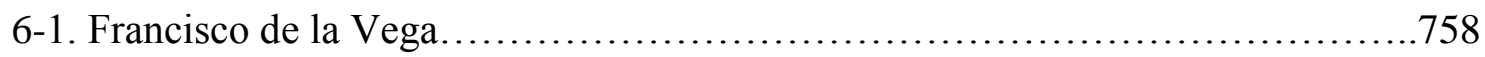

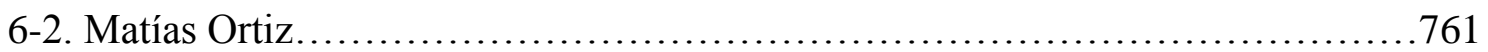

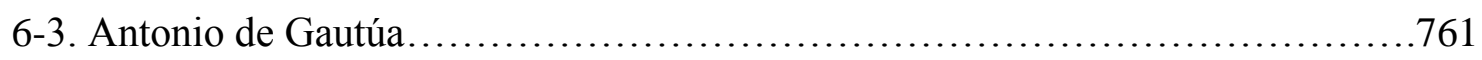

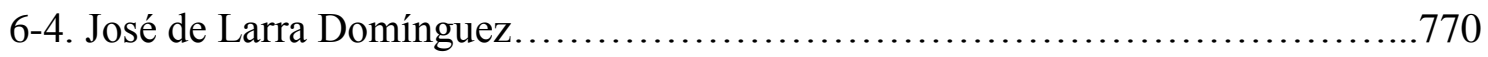

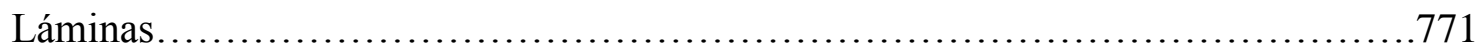

7.- PEDRO DE ÁVILA. PERSONALIDAD.............................777

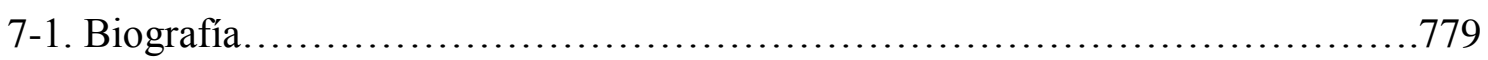

A- Etapa juvenil y aprendizaje en el taller paterno (1678-1700).................779

B- Primeras obras y cambio en el taller (1700-1708)..........................782

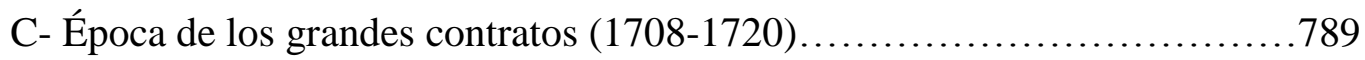

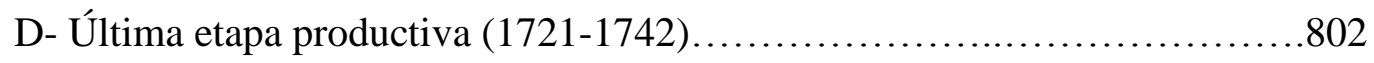

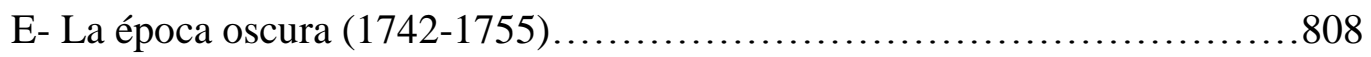

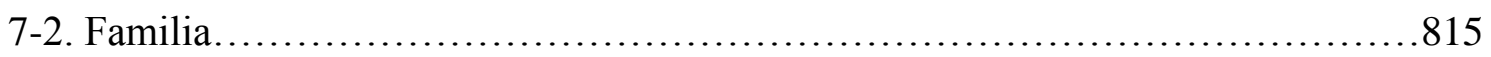

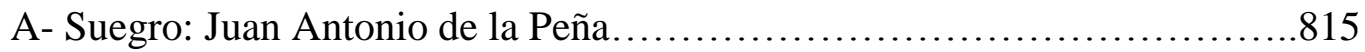

B- Primera mujer: María Lorenza de la Peña.................................815

C- Sobrina: María Barba............................................................

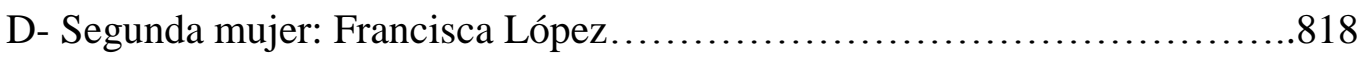

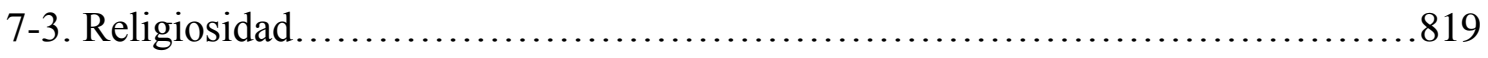

8.- EL ARTE DE PEDRO DE ÁVILA..................................821

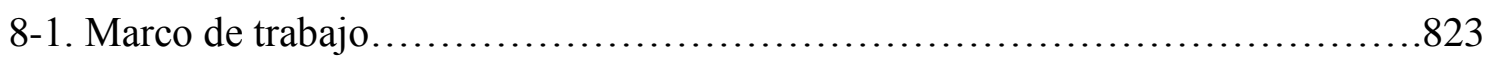

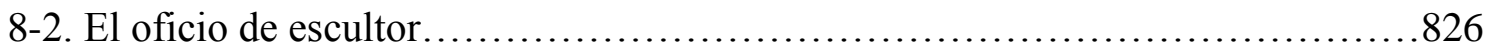

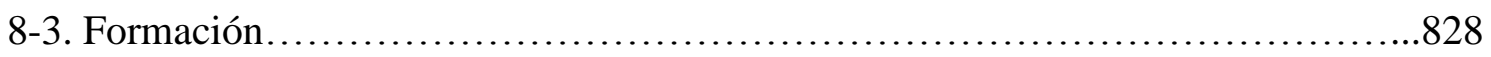

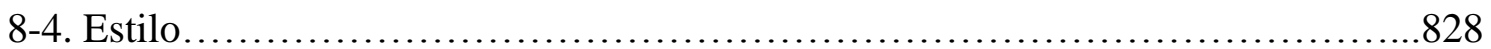

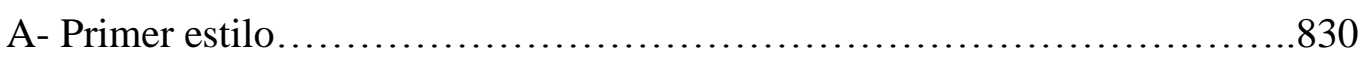

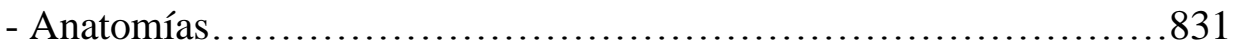

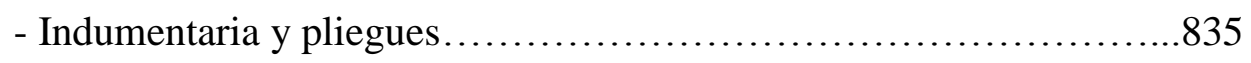

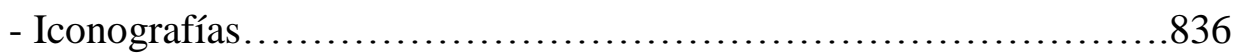


- Postizos...................................................... 836

B- Primer estilo........................................................ 837

- Anatomías.................................................. 846

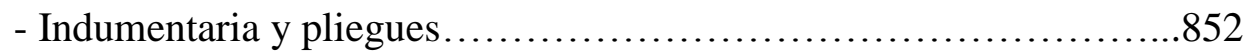

- Iconografías................................................. 853

- Postizos.......................................................... 855

Láminas................................................................. 857

9.- PEDRO dE ÁVILA. CATÁlogo...................................865

9-1. Obras documentadas................................................. 869

Dos "Niños". Iglesia de San Martín. Valladolid..............................871

Virgen de la Piedad. Real Colegio de San Albano. Valladolid.................873

Niño Jesús. Paradero desconocido......................................879

San Ildefonso. Iglesia del Salvador. Morales de Toro........................880

San José. Iglesia del Salvador. Morales de Toro............................882

Cristo Crucificado. Iglesia parroquial de San Esteban Protomártir. Torrecilla de la Abadesa. ... . .884

San Miguel. Iglesia parroquial de San Miguel Arcángel. Castil de Vela........890

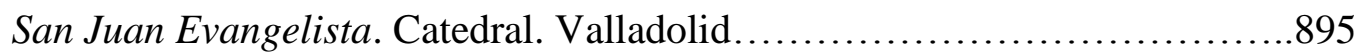

Santa María Magdalena. Catedral. Valladolid................................902

San José con el Niño. Catedral. Valladolid.................................906

San Pedro Apóstol. Catedral. Valladolid......................................908

San Miguel Arcángel. Catedral. Valladolid.................................911

Esculturas para retablos. Oratorio de San Felipe Neri. Valladolid.............913

San Pedro y San Pablo............................................ 921

Magdalena penitente............................................924

Cristo Crucificado.......................................... 927

Inmaculada Concepción...........................................931

Virgen de las Angustias. Iglesia de San Miguel. Íscar.........................937

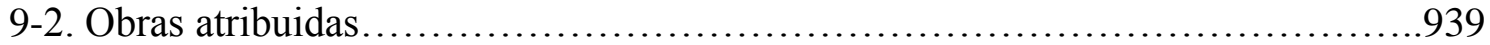

Busto de Dolorosa. Fundación Caja Cantabria. Santillana del Mar..............941 
Busto de Dolorosa. Monasterio de San Quirce. Valladolid

San Isidro. Iglesia parroquial de San Pedro. Aguasal.

Santa María Magdalena. Iglesia de Santa María Magdalena. Valladolid

Crucificado. Monasterio de Santa Brígida. Valladolid.

San Isidro. Iglesia parroquial de la Asunción. Puras

Cristo Resucitado. Iglesia parroquial de la Asunción. Puras.... .954

San Juan Bautista. Iglesia de San Juan Bautista. Almenara de Adaja.... 956

San Isidro. Iglesia parroquial de la Asunción. Muriel de Zapardiel. . . .959

San Joaquín, Santa Ana y la Virgen. Monasterio de Santa Brígida. Valladolid .962

San Joaquín, Santa Ana y la Virgen. Iglesia parroquial de Santa María del Castillo. Flores de Ávila. .965

San José y Santa Teresa. Iglesia de San Juan Evangelista. Fuente-Olmedo.....966

San Isidro. Iglesia parroquial de la Asunción. Villabáñez....................969

Inmaculada. Monasterio de Santa Brígida. Valladolid.........................970

Traslación de San Pedro Reglado. Iglesia del Salvador. Valladolid............972

Las lágrimas de San Pedro. Iglesia del Salvador. Valladolid. 981

Cristo atado a la columna. Iglesia penitencial de Nuestra Señora de las Angustias. Valladolid .988

Ecce Homo. Iglesia penitencial de Nuestra Señora de las Angustias. Valladolid..................................................................995

Santa Catalina de Alejandría. Iglesia parroquial de la Asunción. Geria........996

Santa Bárbara. Iglesia de Santa María. Alaejos.

Nuestra Señora de las Nieves. Iglesia parroquial de los Santos Juanes. Nava del Rey.... 1003

San Pío V. Convento de San Pablo. Valladolid..............................1008

Cristo Resucitado. Iglesia museo de San Francisco. Ampudia.................1012

Cristo Crucificado. Iglesia de San Vicente Mártir. Bernuy de Coca...........1016

Busto de Ecce Homo. Monasterio de Santa Brígida. Valladolid...............1018

Busto de Dolorosa. Monasterio de Santa Brígida. Valladolid.................1022

Santa Escolástica. Monasterio de Santa Brígida. Valladolid...................1023

Busto de Dolorosa. Museo Nacional de Escultura. Valladolid.................1025 
Inmaculada Concepción. Seminario Diocesano. Valladolid.

San Nicolás de Bari. Iglesia de Santa María del Castillo. Olmedo............1030

San Francisco Javier. Iglesia parroquial de la Asunción. Villabáñez.........1034

Virgen del Carmen con el Niño. Convento de San José. Pamplona............1036

Virgen del Refugio. Iglesia del Salvador. Valladolid.........................1037

San Lorenzo. Iglesia de San Lorenzo. Valladolid.......................... 1042

Anunciación. Iglesia parroquial de la Inmaculada Concepción. Renedo......1045

Ecce Homo. Iglesia parroquial de la Inmaculada Concepción. Renedo........1051

Jesús Nazareno. Iglesia parroquial de la Asunción. Tudela de Duero.........1055

Yacente. Iglesia penitencial de N. P. Jesús Nazareno. Valladolid..............1057

Inmaculada Concepción. Convento de la Inmaculada Concepción. Alfaro...1066

San Bernardo. Monasterio de San Quirce. Valladolid........................1068

San Francisco de Asís estigmatizado. Iglesia de la Asunción. La Seca........1070

Santa María Magdalena. Iglesia parroquial de Santa María Magdalena. Matapozuelos 1076

Ecce Homo. Monasterio de la Santísima Trinidad de Santa Clara de Bidaurreta. Oñate. 1079

San Francisco de Borja y San Estanislao de Kostka. Real Colegio de San Albano. Valladolid 1082

San José con el Niño. Santuario de Nuestra Señora del Henar. Cuéllar... 1085

Esculturas para el antiguo retablo mayor. Convento de Nuestra Señora de la Victoria. Valladolid. 1089

San Francisco de Paula y Santo Mínimo. Catedral. Valladolid........1091

San José. Iglesia de Ntra. Sra. de la Victoria. Valladolid..............1094

San Joaquín y Santa Ana. Santuario Nacional. Valladolid.............1094

San Antonio de Padua. Iglesia de la Asunción. La Seca......................1098

Inmaculada Concepción. Iglesia de San Francisco. Orense..................1100

Esculturas de la portada. Iglesia del Ex-convento de Santa Cruz de las Comendadoras de Santa Cruz................................................... 1102

Inmaculada Concepción........................................1104

San Agustín y Santa Mónica ..........................................1105

Esculturas del antiguo retablo mayor. Iglesia del Ex-convento de Santa Cruz de las Comendadoras de Santa Cruz. 1106 
Santiago Matamoros..............................................1109

San Francisco de Borja.............................................1112

San Ramón Nonato. Iglesia de Santa María de los Mártires. Íscar.............1116

San Antonio de Padua. Iglesia de San Miguel. Íscar...........................1119

9-3. Obras relacionadas.

San José con el Niño. Iglesia de San Martín de Tours. Aldeamayor de San Martin.

San Isidro. Iglesia de San Juan Bautista. Almenara de Adaja.................1124

San José con el Niño. Iglesia de Santa María. Curiel de Duero................1124

Inmaculada Concepción. Iglesia de San Ildefonso. La Cistérniga.............1125

San Antonio de Padua. Iglesia parroquial de Santa María Magdalena. Matapozuelos 1126

San Francisco Javier. Iglesia parroquial del Salvador. Simancas .1127

San José con el Niño. Iglesia parroquial de Nuestra Señora de la Visitación. Villanueva de Duero. 1128

San Francisco Javier. Iglesia parroquial de Santa María. Wamba............1130

Inmaculada Concepción. Iglesia de la Asunción. Gumiel de Izán.............1130

Inmaculada Concepción. Iglesia de la Asunción. Villaviudas.................1131

9-4. Obras descatalogadas

San Francisco Javier. Centro Diocesano de Espiritualidad. Valladolid.......1135

Santa María Magdalena. Iglesia de San Miguel. Valladolid..................1135

Quinta Angustia. Iglesia de San Pedro Apóstol. Valladolid...................1136

Santa Ana y Santa Apolonia. Iglesia del Salvador. Valladolid.................1136

San Benito. Monasterio de San Benito el Real. Valladolid.....................1137

San Antonio de Padua. Oratorio de San Felipe Neri. Valladolid..............1138

Cristo Yacente. Oratorio de San Felipe Neri. Valladolid.......................1139

Niño Jesús. Oratorio de San Felipe Neri. Valladolid.......................1140

San José con el Niño. Iglesia de San Cipriano. San Cebrián de Mazote.......1142

Jesús Nazareno. Ermita de la Santa Vera Cruz. Carrión de los Condes........1143

Virgen con el Niño. Iglesia de Ntra. Sra. de la Paz. Castrillo de Onielo.......1143

Jesús Nazareno en una de sus caídas. Convento de San Francisco el Real. León..........................................................................1144 
San Francisco Javier. Iglesia de Santa Marina la Real. León. 1145

Busto de Dolorosa. Catedral. Orense......................................1146

San José con el Niño. Seminario Mayor. Palencia...........................1147

Láminas

\section{1.- MANUEL DE ÁVILA. PERSONALIDAD}

11-1. Biografía 1231

A- Etapa juvenil y aprendizaje en el taller de su hermano (1690-1706)......1231

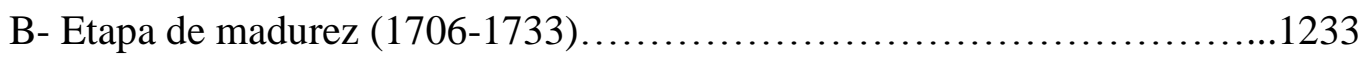

11-2. Familia

A- Abuelo materno: Mateo Sedano Enríquez.............................1242

B- Tía: María Sedano Osorno...........................................1248

C- Suegro: Joseph Martínez............................................1250

D- Tío político: Damián Cortés.........................................1252

E- Mujer: María Martínez........................................... 1255

F- Hijos de Manuel de Ávila y María Martínez................................1256

- María Teresa de Ávila...........................................1256

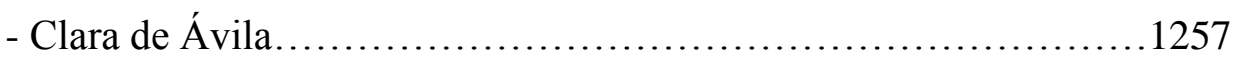

- Alfonsa María de la Paz de Ávila..................................1257

- Feliciana de Ávila.............................................1258

- Manuel Pedro de Ávila...........................................1258

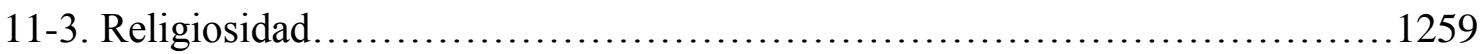

Árbol genealógico de Manuel de Ávila.............................................1261

\section{2.- EL ARTE DE MANUEL DE ÁVILA............................1263}

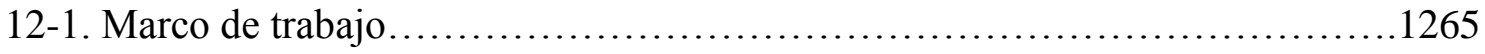

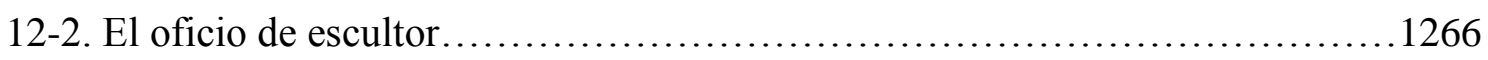

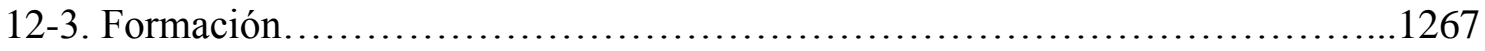


12-4. Estilo

- Anatomías............................................................ 1268

- Indumentaria y pliegues........................................... 1271

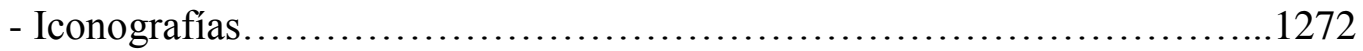

- Postizos............................................................

- Relieves..............................................................1272

\section{3.- MANUEL DE ÁVILA. CATÁLOGO..........................1275}

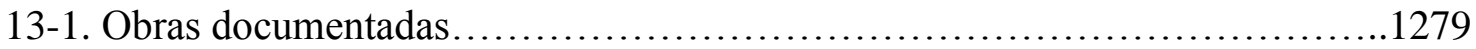

Esculturas del retablo mayor. Iglesia de Ntra. Sra. de la Antigua. Fuentes de Valdepero. 1281

Ángeles para dos retablos. Oratorio de San Felipe Neri. Valladolid...........1294

San José con el Niño. Iglesia de N. P. Jesús Nazareno. Valladolid.............1295

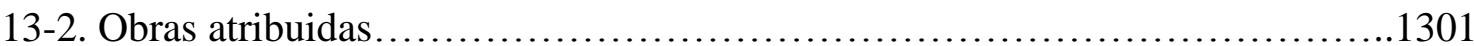

Ángeles del órgano. Iglesia de San Pedro. Tordesillas......................1303

San Gabriel y San Rafael. Iglesia de San Pedro. Tordesillas...................1304

Santa Bárbara. Iglesia de Ntra. Sra. de la Antigua. Fuentes de Valdepero...1307

Esculturas del retablo mayor. Iglesia de Santa María. Castromocho..........1310

Láminas. 


\section{O-INTRODUCCIÓN A \\ LA TESIS DOCTORAL}




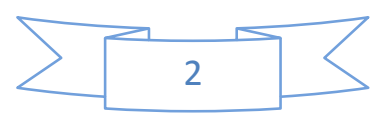




\section{0-1 OBJETIVOS DE LA TESIS}

La escultura barroca castellana, y principalmente la escuela vallisoletana, ha sido ampliamente estudiada por grandes eruditos, historiadores e historiadores del arte, siendo los mayores exponentes en este campo Juan José Martín González, Jesús Urrea y María Antonia Fernández del Hoyo; y desde el punto de vista documental José Martí y Monsó y Esteban García Chico.

La mayoría de los trabajos (libros, artículos, comunicaciones e incluso catálogos de exposiciones) que se han realizado hasta hace muy poco tiempo tenían como protagonista único a Gregorio Fernández que si bien fue uno de los escultores españoles más importantes de la historia de España, el interés por su figura ha llevado al ostracismo a gran cantidad de maestros castellanos, y sobre todo vallisoletanos, que trabajaron desde comienzos del siglo XVII hasta finales del siglo XVIII; es decir, durante todo el periodo barroco. Por suerte, en los últimos años este panorama ha cambiado y estudiosos como los citados Martín González y Jesús Urrea, a los que habría que sumar a la profesora Fernández del Hoyo, entre otros, han publicado una serie de artículos que han servido para rescatar la vida y obra de escultores tan interesantes como Francisco del Rincón, Manuel del Rincón, Bernardo del Rincón, Andrés de Solanes, Juan Rodríguez, Francisco Alonso de los Ríos, Francisco Díez de Tudanca, Alonso de Rozas, Felipe Espinabete, etc.... Pero no solo eso, sino que se ha ido clarificando y separando las diferentes personalidades que conformaron el taller de Gregorio Fernández.

A pesar de estos avances, la escultura vallisoletana de la segunda mitad del siglo XVII y de todo el siglo XVIII nos es todavía bastante desconocida, especialmente en lo que toca a la decimoctava centuria. Bien es cierto que conocemos bastantes nombres, pero muchos de ellos se nos muestran vacíos de contenido, ya sea porque no poseemos ninguna nota biográfica o bien porque no les podemos asignar ninguna obra, y en los mejores casos tan solo se les ha documentado un puñado de ellas. Tan solo escapan a ese total desconocimiento unas pocas gubias: las de Alonso de Rozas, Juan de Ávila, José de Rozas, Pedro de Ávila, Pedro de Sierra, Felipe Espinabete, etc...

El principal objetivo de esta tesis es desentrañar y clarificar la vida y obra de parte de estos interesantísimos escultores, concretamente los que conformaron la familia Ávila (Juan y sus hijos Pedro y Manuel), la familia artística más extensa y de mayor calidad de cuantas laboraron en Valladolid durante el periodo barroco. Hay otras familias, pero no son ni tan extensas ni poseen una calidad tan alta y sostenida: los Rozas, los Correas, etc... En este caso no incluiríamos a los Sierra, que es la gran familia de escultores castellanos junto a los Tomé, por cuanto tan solo mantuvo abierto obrador en Valladolid Pedro, manteniéndose el resto de miembros trabajando en Medina de Rioseco.

Hablando ya de los objetivos más puntuales de esta tesis, había varios que concernían a las biografías de nuestros escultores. Así, el primero de ellos era intentar clarificar si Juan de Ávila era descendiente de Juan da Vila (o Dávila), escultor manierista gallego 
que trabajó abundantemente en Valladolid y en otros puntos de su actual provincia (caso del Hospital Simón Ruiz de Medina del Campo). Este problema, como ya veremos, ha quedado resuelto en la presente tesis. También es objetivo de esta tesis la elaboración de las biografías y catálogos de los tres artistas, pero no solo eso, sino que también se abordan las relaciones que mantuvieron con otros artistas con los que trabajaron o tan solo mantuvieron una amistad. Éstos principalmente fueron pintores, ensambladores y policromadores, puesto que no podemos olvidar que todas estas profesiones, además de la de escultor eran las que estaban relacionadas con la construcción de retablos, una de las principales tareas artísticas que se llevaron a cabo durante esta época.

Otros grandes objetivos de la tesis son los que conciernen a la clarificación del aprendizaje de los tres escultores; especial relevancia tendrá en este aspecto el posible viaje que realizó a Madrid Pedro de Ávila, pues solo así podríamos explicar la misteriosa mutación que tuvo su arte, rompiendo con todo lo hasta entonces aprendido, ya que en un breve lapso de tiempo pasó de ser un mero continuador de la estética vallisoletana aprendida de su padre y de su suegro (Juan de Ávila y Juan Antonio de la Peña) al gran innovador de la escuela vallisoletana, puesto que introducirá en ella influencias berninescas y cortesanas, las cuales sin duda debió de aprender en Madrid. Aunque este punto es bastante negro, intentaremos dar una respuesta lógica basada en influencias y datos concretos.

En lo que respecta a sus catálogos, el objetivo es analizar no solo sus obras documentadas sino especialmente las atribuidas, de tal manera que mediante un estudio estilístico y tipológico podamos mantener esa atribución o bien desecharla, siendo en ese caso englobada en el apartado de obras relacionadas con el estilo de nuestros escultores o bien descatalogadas por completo por no poseer ningún punto de contacto con ellos.

Finamente, he querido reconstruir de una manera más o menos global el panorama artístico que acaeció en el Valladolid en que vivieron y trabajaron los Ávila, es decir, entre 1650-1755. Especial relevancia he concedido en la tesis al estudio de los escultores y ensambladores de este periodo, de tal manera que he querido subsanar la falta de un estudio global sobre la escultura barroca vallisoletana. Bien es cierto que un estudio de estas características ya lo realizó Martín González en su fundamental Escultura barroca castellana; sin embargo, el hecho de que ya haya pasado más de medio siglo desde su publicación y hayan aparecido numerosos datos nuevos, hacía precisa una urgente actualización de ese estudio. Mi objetivo en este aspecto no es el de elaborar ese nuevo estudio, pues por su extensión sería imposible tratarlo en una tesis, sino recopilar las noticias biográficas que se tienen sobre estos artistas, así como conformar el catálogo de todas las obras que se le tienen documentadas, puesto que estas se hallan dispersas en multitud de artículos, libros, etc... De esta manera, se puede conocer mejor el mundo artístico en el que trabajaron los miembros de la familia Ávila. 


\section{0-2. METODOLOGÍA}

\section{A- RECOPILACIÓN DOCUMENTAL}

La primera fase para la elaboración de la tesis fue la de recopilar cuanto se había escrito sobre los Ávila, que no era mucho, así como los diferentes artistas (escultores, ensambladores, pintores, doradores) que trabajaron contemporáneamente en Valladolid. Para ello se consultaron obras fundamentales para este tema como son los dos tomos de Escultura barroca castellana y el de Escultura barroca en España 1600-1770, todos ellos escritos por Martín González; también podemos destacar los diferentes tomos de Documentos para el estudio del arte en Castilla elaborados por García Chico, al cual también recurrimos al consultar otros libros suyos como Valladolid: Papeletas de Historia y Arte. Especial relevancia ha tenido en esta fase la consulta de Inventarios y Catálogos Monumentales, en especial el Inventario Artístico de Valladolid y su provincia dirigido por Martín González, y los veintiún tomos del Catálogo Monumental de la provincia de Valladolid, realizados por diferentes eruditos y miembros del Departamento de Historia del Arte de la Universidad de Valladolid. Finalmente, también se han consultado numerosísimos artículos que han ido aportando datos puntuales tanto sobre los Ávila como sobre otros artífices sobre los que hablaremos en los diferentes contextos artísticos.

\section{B- LABOR DE ARCHIVO}

La labor de archivo se comenzó a realizar una vez recopilada la información necesaria de la etapa anterior. Las visitas a los diferentes archivos han sido prolongadas a lo largo de la elaboración de toda la tesis, y no se han limitado a un momento determinado, ya que nuevos hallazgos obligaban a nuevas consultas. Los dos archivos fundamentales a los que he accedido y que me han proporcionado numerosa documentación han sido el Archivo Histórico Provincial de Valladolid (A.H.P.V.) y el Archivo General Diocesano de Valladolid (A.G.D.V.). En el A.H.P.V., cuyos fondos los integran en su mayoría protocolos notariales y legajos de escribanos, hemos hallado numerosos asientos de aprendiz, contratos de obras, demandas jurídicas, capitulaciones matrimoniales, testamentos, etc...; mientras tanto, en el A.G.D.V. hemos localizado gran cantidad de datos que hacen referencia a momentos vitales de todos los artistas de los que se hablará en la tesis: bautizos, confirmaciones, actas matrimoniales, actas de defunción, pero además, también hemos hallado algunas obras nuevas gracias a la consulta de los libros de cuentas y de fábrica de diferentes cofradías y parroquias de la diócesis.

También hemos investigado en otros archivos, si bien de una manera bastante más puntual. Son los casos del Archivo Municipal de Valladolid (A.M.V.), en el que hemos encontrado algún dato interesante, como es el de la participación de Juan de Ávila en la restauración de diferentes figuras que desfilaban durante las fiestas del Corpus Christi organizadas por la Corporación Municipal, y del Archivo Histórico Nacional (A.H.N.), radicado en Madrid, en el cual hemos consultado datos sobre los diferentes conventos y

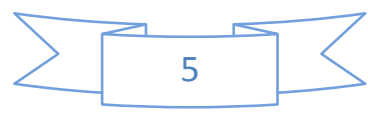


monasterios vallisoletanos que fueron desamortizados. Finalmente, también hay que señalar otra serie de archivos en los cuales hemos encontrado algún dato concreto, aunque en la mayoría de ocasiones las búsquedas en ellos han resultado infructuosas: Archivo de la Universidad de Valladolid (A.U.), Archivo de la Diputación Provincial de Valladolid, Archivo de la Real Chancillería de Valladolid (A.R.Ch.V.), Archivo General de Simancas (A.G.S.), Archivo Diocesano de Palencia (A.D.P.), Archivo Histórico Provincial de Palencia (A.H.P.P.), Archivo Histórico Provincial de Segovia (A.H.P.S.), Archivo Diocesano de Segovia, Archivo parroquial de Cuéllar, Archivo Histórico Provincial de Zamora (A.H.P.Za.), Archivo General de la Administración de Alcalá de Henares (A.G.A.) y Archivo del Instituto del Patrimonio Cultural de España (I.P.C.E.).

Especial relevancia ha tenido, por la escasez de fototecas, la consulta al Archivo Fotográfico del Departamento de Historia del Arte de la Universidad de Valladolid. Aquí se han conseguido fotografías de ciertos monumentos u obras de arte que en la actualidad no se conservan o han sufrido ciertos cambios desde el momento en que fueron tomadas.

\section{C- TRABAJO DE CAMPO}

Durante esta etapa se realizaron los viajes a las distintas poblaciones cuyas iglesias, monasterios o museos conservaban alguna obra de nuestros escultores. Allí se estudiaron las piezas in situ y se tomaron fotografías detalladas de todas ellas con el objetivo de un posterior estudio y análisis mucho más profundo. La mayor parte de los lugares a los que nos hemos trasladado para ello pertenecen a la provincia de Valladolid, muy especialmente a la propia capital, dentro de la cual hemos visitado la catedral, iglesias, conventos, museos, salas de exposiciones (antiguo Monasterio de las Comendadoras de Santa Cruz), etc... También hemos tenido que trasladarnos a otras provincias, ya que hemos localizado obras bastante dispersas: así, hemos visitado las provincias de Ávila, Burgos, León, Palencia, Salamanca, Segovia, Zamora, Orense, y la comunidad uniprovincial de Cantabria.

\section{D- REDACCIÓN DE LA TESIS}

Lo primero dentro de esta última etapa fue la elaboración de un esquema, el cual con el tiempo se ha ido ampliando y complicando, de tal manera que en su última fase ha constituido el índice de la tesis. El estudio partió de lo más general (estudio histórico y artístico de aquella época en Valladolid) para desembocar en el estudio de la vida y obra de nuestros tres artistas. Para ello se ha tratado todo lo que a ellos concierne: sus biografías, sus familias, sus creencias, sus aprendizajes, sus estilos artísticos, sus catálogos e, incluso, en algunos casos, sus discípulos. 
En cuanto a la constitución de sus catálogos, las obras se han analizado desde todas las vertientes posibles: estilísticamente, para en el caso de las obras atribuidas poder discernir si esa atribución podía confirmarse o bien desecharse; tipológicamente; e iconográficamente, estudiando al personaje representado en esa imagen.

\section{0-3 HISTORIOGRAFÍA Y ESTADO DE LA CUESTIÓN}

Por desgracia, los miembros de la familia Ávila no han suscitado el interés de los investigadores, tan solo Inés Durruty Romay dedicó un artículo monográfico sobre nuestros artistas, concretamente acerca del Cristo del Olvido que Pedro de Ávila tallara en el año 1720 para la Congregación de San Felipe Neri. Pienso que este hecho es una consecuencia del excesivo protagonismo de Fernández, lo cual ha ido en detrimento del resto de escultores que trabajaron en Valladolid durante los siglos XVII y XVIII. Este olvido no solo ha afectado a los Ávila sino a la mayoría de escultores castellanos, en particular, y del norte peninsular, en general. Todo lo contrario es lo que acaeció en Andalucía, en la que numerosas personalidades compartieron ese protagonismo; allí se dio una mayor variedad y riqueza.

Como acabamos de comentar, a lo largo de los años el interés se centró casi por completo en el imaginero y escultor más destacado del barroco castellano, Gregorio Fernández, dejando de lado a una numerosa serie de escultores; ya fueran discípulos, oficiales, meros copistas de sus modelos o escultores influenciados en mayor o menor medida por él (no hay que olvidar que podemos encontrar huellas de su estilo hasta bien entrado el siglo XVIII). Este desconocimiento llevó, y sigue llevando, a atribuir cualquiera buena escultura barroca castellana a Gregorio Fernández o a su taller. Así, se fueron clasificando multitud de tallas, algunas de las cuales ni siquiera eran contemporáneas del gallego, como obras suyas. Un claro ejemplo que, además, enlaza con Juan de Ávila es el retablo mayor de la iglesia parroquial de Santiago de Valladolid, el cual fue descrito por el erudito local Casimiro González GarcíaValladolid como "de tres cuerpos, dorado y de columnas con emparrados, ofrece de notable la efigie del Santo titular, obra del escultor Gregorio Hernández". Pero no quedan ahí las citas a la referida escultura. Otro escritor que la alababa fue Matías Sangrador, el cual en su Historia de Valladolid comenta que "es muy notable la efigie de Santiago que ocupa el centro del retablo"2. Al que ya no le gustó tanto el retablo y la escultura de Santiago fue a Francisco de Cossío que dijo que "en él [se refiere al retablo] se advierte el lamentable barroquismo de la época. La efigie de Santiago se ha

1 GONZÁLEZ GARCÍA-VALLADOLID, Casimiro: Valladolid, sus recuerdos y sus grandezas: religión, historia, ciencias, literatura, industria, comercio y política, Tomo I, Imprenta de Juan Rodríguez Hernando, Valladolid, 1900-1902, p. 769.

2 SANGRADOR Y VÍTORES, Matías: Historia de la Muy Noble y Leal Ciudad de Valladolid..., op. cit., Tomo II, p. 316 
atribuido, generalmente, a Gregorio Fernández. Quizá sea una pieza salida del taller del gran escultor, pero en ella no se advierten huellas indubitables del maestro"3.

En otras ocasiones algunas obras se describían simplemente como "taller de Gregorio Fernández", "seguidor de Gregorio Fernández" o incluso "discípulo de Gregorio Fernández". Algunas veces la atribución es todavía más general llegando a tacharse como salida de "Taller Vallisoletano". En numerosas ocasiones nos encontramos con que para referirse a Juan de Ávila se le tacha como seguidor de Gregorio Fernández, afirmación del todo incorrecta ya que a la muerte de Fernández habrían de pasar más de 25 años para que naciera el escultor en la calle de Santiago.

Por suerte, en los últimos años han empezado a tomar cuerpo ciertas personalidades de la época gracias, entre otros, a los artículos publicados en el Boletín del Seminario de Arte y Arqueología sobre Andrés Solanes, Francisco Alonso de los Ríos, Francisco Díez de Tudanca, Bernardo del Rincón, Luis Fernández de la Vega, José Mayo, Andrés de Oliveros, los Rozas (Alonso y José) y otros muchos competidores, discípulos e imitadores del gran maestro gallego. Hay que destacar, llegados a este extremo, la ardua labor investigadora llevada a cabo, entre otros, por María Antonia Fernández del Hoyo y Jesús Urrea Fernández.

Ninguno de los tres Ávila figura en los grandes repertorios históricos que recogían noticias y biografías de artistas españoles, pues si bien no siempre trataban a los más importantes sino de los que se tenían certezas documentales. A saber: el tercer tomo del Museo pictórico y escala óptica (1715-1724) de Acisclo Antonio Palomino, titulado El parnaso español pintoresco laureado, con las vidas de los pintores y estatuarios eminentes españoles...; el Diccionario histórico de los más ilustres profesores de las Bellas Artes en España (1800) de Juan Agustín Ceán Bermúdez; y los cuatro tomos que Cipriano Muñoz y Manzano "el Conde de la Viñaza" tituló Adiciones al diccionario histórico de los más ilustres profesores de las Bellas Artes en España de Don Juan Agustín Ceán Bermúdez (1889-1894). Hay que ser justos y señalar que ninguno de ellos cita a escultores vallisoletanos de la época de los Ávila, a excepción de una breve reseña que dedica Ceán Bermúdez a Alonso de Rozas ${ }^{4}$. Si en cambio podemos ver los nombres de algunos pintores vallisoletanos ilustres: Diego Valentín Díaz, Felipe Gil de Mena, etc...

No es hasta los albores del año 1900 cuando José Martí y Monsó en sus Estudios histórico-artísticos relativos principalmente a Valladolid: basados en la investigación de diversos archivos aporta las primeras noticias acerca del escultor; las cuales, por cierto, han pasado del todo desapercibidas, si bien solo hacen referencia a obras secundarias del artista. Se trata de los marcos para las pinturas de la Cofradía de la Pasión. Posteriormente se alude a la supervisión que ejerció, junto al escultor Juan

\footnotetext{
3 COSSÍO, Francisco de: Guía de Valladolid y su provincia (1922), Grupo Pinciano, Valladolid, 1922 , p. 68.

4 CEÁN BERMÚDEZ, Juan Agustín: Diccionario histórico de los más ilustres profesores de las Bellas Artes en España, tomo I, Imprenta de la viuda de Ibarra, Madrid, 1800, p. 255.
} 
Antonio de la Peña y al pintor Amaro Alonso, de las reparaciones hechas por Valentín Gómez de Salazar en los pasos de la citada cofradía ${ }^{5}$.

Hubo que esperar hasta 1925 para que Agapito y Revilla volviera a tratar sobre Juan de Ávila. En su maravilloso libro Las cofradías, las procesiones y los pasos de Semana Santa en Valladolid aporta una detallada relación de los sucesos que acaecieron en la Cofradía de Jesús Nazareno entre la propuesta de Ávila para realizar el paso del Despojo y su adjudicación al propio escultor ${ }^{6}$. Asimismo, duda si atribuir a Ávila o a Juan Antonio de la Peña el boceto del Cristo del Despojo que se conservaba en la sacristía de la penitencial (Agapito se confunde al aludir a la Cofradía de la Pasión), craso error ya que es más de un siglo posterior a estos artífices, siendo su autor Pedro León Sedano. Finaliza su repaso a Juan de Ávila tratando dos temas en los que ya habían entrado otros eruditos: su formación y su genealogía. En cuanto a su formación establece la hipótesis de que pudiera haber sido oficial o aprendiz de Gregorio Fernández, "pero lo que no admite duda es que el estilo, la escultura del maestro, seguía"7. Como vemos, no existía ningún progreso en el conocimiento de su biografía, estilo ni producción. De este último tan solo se conocía este paso y los marcos para los cuadros de la Penitencial de la Pasión. Finalmente, en lo referente a su ascendencia, sigue las hipótesis establecidas por Filemón Arribas Arranz, las cuales hacían a nuestro escultor hijo de otro artífice homónimo, el gallego Juan Dávila e, incluso, el último producto de una larga serie de artistas, tales como el pintor Alonso de Ávila ${ }^{8}$. Como veremos, ninguna de estas propuestas tiene el más mínimo viso de realidad, pues nuestro escultor provenía de una humilde familia de zapateros emigrados desde Alaejos.

El mismo Agapito y Revilla vuelve a reiterar años después en sus Catálogos del Museo de Bellas Artes de Valladolid. I que a Juan de Ávila le pertenecía el paso del Despojo de la Penitencial de Jesús Nazareno. Además, continúa intentando averiguar la filiación artística del escultor. Par entonces había cambiado de opinión, ya no le veía como aprendiz u oficial de Gregorio Fernández, sino que pensaba que "no pudo ya ser discípulo u oficial de Gregorio Fernández, pues que vivía sesenta años después de fallecido el maestro, y pocas enseñanzas pudo recibir de él en edad tierna, aun suponiendo que alcanzara longeva vida". En lo referente a su biografía nos aporta un nuevo dato, así como una hipótesis. Un dato verosímil es que "en 5 de abril de 1667 entró cofrade de la de Jesús Nazareno"; por su parte, la hipótesis hace referencia a su posible genealogía, conjetura que, como veremos, no ha prosperado: "Yo considero a Juan de Ávila, nieto de otro escultor de los mismos nombre y apellido, que en 1598 contrató, acompañado de Pedro de la Cuadra y Francisco del Rincón, el retablo y estatuas orantes de alabastro de la capilla del Hospital de Simón Ruiz, de Medina del

5 MARTÍ Y MONSÓ, José: Estudios histórico-artísticos relativos principalmente a Valladolid: basados en la investigación de diversos archivos, Imprenta de Leonardo Miñón, Valladolid, 1898-1901, p. 502 .

6 AGAPITO Y REVILLA, Juan: Las cofradías, las procesiones y los pasos de Semana Santa en Valladolid, Editorial Maxtor, Valladolid, 2007, p. 14.

7 Ídem, pp. 14-15.

$8 \quad$ Ídem, pp. 15-16. 
Campo. Lo que parece cierto es que Juan de Ávila venía de familia de artistas que trabajaron ya a principios del siglo XVI, en Valladolid. En ella hubo plateros, pintores algunos muy íntimos de los famosos Berruguete y Rabuyate, y otro titulado pintor de su majestad en 1606". Es decir, no había cambiado un ápice su parecer desde la publicación del anterior libro. Agapito finaliza su reseña a Juan de Ávila confesando que "no conozco más trabajo que el paso del Cristo del Despojo, y es probable que laborase mucho en Valladolid, donde tenía prestigios de gran artista".

Los años 40 del siglo XX trajeron consigo dos publicaciones fundamentales para el conocimiento de la familia ya que aportan numerosos documentos inéditos. Se trata de los Documentos para el estudio del arte en Castilla. 2, Escultores de Esteban García Chico y la monografía sobre la Cofradía Penitencial de N.P. Jesús Nazareno de Valladolid. Los Documentos de García Chico son la única gran aportación documental a la escultura vallisoletana, y por ende al conocimiento de los Ávila ${ }^{10}$. En ellos, además de los referidos a Juan de Ávila, vemos por primera vez citados a los dos hijos que siguieron el oficio paterno: Pedro y Manuel. Del primero nos presenta sus capitulaciones matrimoniales, así como el trabajo realizado en el Oratorio de San Felipe Neri, tarea en la que también participó Manuel de Ávila. A Juan de Ávila le documenta los dos relieves y el San Francisco de Sales también del Oratorio de San Felipe Neri.

La otra publicación, la Cofradía Penitencial de N.P. Jesús Nazareno de Valladolid de Filemón Arribas Arranz ${ }^{11}$, aporta importantes novedades en lo referido al catálogo de nuestros escultores. En cuanto a Juan de Ávila amplía los datos conocidos sobre el paso del Despojo, así como establece hipótesis acerca del paso, la relación de las figuras que lo componían y la génesis del mismo. Es el primer intento de estudio serio de un paso de nuestra Semana Santa. Asimismo, Arribas aporta otras noticias sobre Juan como son las que hacen referencia a los cargos que ostentó en la cofradía. En lo que falla flagrantemente es en la genealogía del escultor ya que le hacía hijo de un alguacil ordinario de la ciudad. Lo más importante es que nos incrementa notablemente su catálogo: las esculturas del retablo mayor del Hospital de San Juan de Dios y las tallas de San Isidro y Santa María de la Cabeza para la Cofradía de San Isidro. Asimismo, reseña que Agapito le había documentado las esculturas del retablo mayor de la parroquia de Santiago Apóstol. No menos interesante es su aportación al estudio de Manuel de Ávila ya que consigue documentarle el San José con el Niño que posee la cofradía en su iglesia, así como su intervención-restauración llevada a cabo en el paso "Sed Tengo" en el año 1731.

En 1758 García Chico vuelve a hacer una brillante aportación ya que publica diversos documentos sobre Juan de Ávila: los documentos y partidas presupuestarias relativas al

\footnotetext{
9 AGAPITO Y REVILLA, Juan: Catálogos del Museo de Bellas Artes de Valladolid. I, Escultura, Casa Santarén, Valladolid, 1930, p. 87.

10 GARCÍA CHICO, Esteban: Documentos para el estudio del arte en Castilla. 2, Escultores, Universidad de Valladolid, Valladolid, 1941.

11 ARRIBAS ARRANZ, Filemón: La Cofradía Penitencial de N.P. Jesús Nazareno de Valladolid, Imprenta y librería Casa Martín, Valladolid, 1946, pp. 76-82.
} 
paso del Despojo, retablo de Santiago Apóstol, las esculturas de San Isidro y Santa María de la Cabeza $a^{12}$. No aportaba nada nuevo, pero ayudaba a profundizar en el conocimiento de las referidas obras.

Ese mismo año Martín González en su legendaria Escultura barroca castellana se convierte en el primer investigador que realiza un acopio de toda la información conocida sobre estos autores y la transforma en un texto coherente en el que aborda tanto sus biografías como sus obras documentadas; además, aporta dos hechos fundamentales: intenta una aproximación al estilo de ambos y realiza una serie de atribuciones que aún hoy en día siguen totalmente vigentes ${ }^{13}$. Por entonces no se conocía el parentesco entre Manuel de Ávila y Pedro de Ávila; de hecho, el propio Martín González duda de si Manuel era hijo o hermano de Pedro ${ }^{14}$.

Años después el mismo autor en su libro Escultura barroca en España 1600-1770, publicado en 1993, a través de los dos capítulos en que aborda la escultura del foco vallisoletano, hace un resumen de lo dicho años antes en el otro libro y además aporta nuevas atribuciones ${ }^{15}$. Me resulta especialmente interesante, por lo breve y concisa, la descripción que hace del estilo de Juan de Ávila: “Juan de Ávila encarna perfectamente el momento de transición de la escultura. Por un lado mantiene vigente el ya decantado estilo de Fernández en las esculturas del paso del Despojo; pero ya se pronuncia con gran barroquismo en las esculturas del retablo mayor de Santiago de Valladolid"16.

La mejor aportación al catálogo de Juan y Pedro de Ávila, tanto en obras documentadas como atribuidas, ha sido la realizada por los diferentes tomos que conforman el Catálogo Monumental de la provincia de Valladolid. En ellos se documentaron obras tanto de Juan (el peñasco del retablo de Pesquera de Duero y la efigie de Nuestra Señora de Gracia para Torrecilla de la Abadesa) como de Pedro (Virgen de las Angustias de Íscar). Importantísima fue también la labor desarrollada con anterioridad por el Inventario artístico de Valladolid y su provincia, cuya dirección recayó en Martín González. El mismo es, por ejemplo, el único lugar en el que se atribuye a Pedro de Ávila la escultura de San José sita en la iglesia de la Victoria ${ }^{17}$. Asimismo, realiza otras atribuciones a Pedro de Ávila, las cuales, como veremos, no comparto en absoluto. Asimismo, habla de una Dolorosa en la iglesia de San Miguel Arcángel de Íscar (Valladolid), la cual por entonces no se tenía constancia que fuera de Pedro de Ávila. La

12 GARCÍA CHICO, Esteban: Valladolid: Papeletas de Historia y Arte, Gráficas Andrés Martín, Valladolid, 1958, pp. 61-63 y 101-108.

13 MARTÍN GONZÁLEZ, Juan José: Escultura barroca castellana, Fundación Lázaro Galdiano, Madrid, 1959, pp. 320-325.

$14 \quad$ Ídem, p. 325.

15 MARTÍN GONZÁLEZ, Juan José: Escultura barroca en España, 1600-1770, Cátedra, Madrid, 1991, pp. 79-81 y 447-449.

16 MARTÍN GONZÁLEZ, Juan José: Escultura barroca castellana..., op. cit., p. 136.

17 MARTÍN GONZÁLEZ, Juan José (dir.): Inventario artístico de Valladolid y su provincia, Ministerio de Educación, Valladolid, 1970, p. 62. 
importancia de esta reseña reside en que es la única ocasión en que se la cita ya que posteriormente desapareción ${ }^{18}$.

En los últimos años se han sucedido diversas publicaciones que han aportado más datos acerca de los tres escultores. En 1981 Luis Cervera Vera consiguió documentar a favor de Juan de Ávila las esculturas del retablo mayor de la Colegiata de Lerma ${ }^{19}$; en 1991 Parrado del Olmo confirmó la autoría de Pedro de Ávila de un Crucificado sito en la iglesia parroquial de Torrecilla de la Abadesa, localidad para la que nuestros artistas debieron de trabajar bastante ${ }^{20}$. Por su parte, Urrea ha conseguido documentar a favor de Pedro de Ávila las cinco esculturas (San Juan Evangelista, la Magdalena, San José, San Pedro y San Miguel Arcángel) que la catedral contrata en 1714 con destino a otras tantas capillas de la seo $^{21}$, así como dar a conocer numerosos aspectos biográficos de los primeros años de matrimonio entre Pedro de Ávila y su primera mujer, María Lorenza de la Peña, hija del escultor Juan Antonio de la Peña ${ }^{22}$.

Pero sin duda la aportación más importante de estos años fue la llevada a cabo por María Antonia Fernández del Hoyo ${ }^{23}$. En su artículo relativo al escultor Francisco Díez de Tudanca desvela que este fue el maestro de Juan de Ávila, aportando para ello la carta de aprendizaje. Además, desvela la fecha del primer matrimonio del escultor y las partidas de bautismo de algunos de sus hijos, ente ellos la de Pedro.

Dentro de los grandes estudios generales sobre la escultura del siglo XVII han de tenerse especialmente en cuenta los respectivos volúmenes de las colecciones Summa Artis $^{24}$ y Ars Hispaniae ${ }^{25}$, si bien a nuestros escultores tan solo se les cita de pasada, y en la mayoría de ocasiones Manuel ni siquiera es mencionado.

Una de las últimas publicaciones que cita a nuestros tres escultores es el libro $\mathrm{La}$ escultura. Del renacimiento a la actualidad, realizado por Pedro García Gutiérrez y José Landa Bravo, el cual contiene numerosos fallos de datos que ya eran sobradamente conocidos. Por ejemplo, la fecha del fallecimiento de Juan de Ávila la sitúa en 1707,

18 Ídem, p. 141.

19 CERVERA VERA, Luis: La iglesia colegial de San Pedro de Lerma, Caja de Ahorros Municipal de Burgos, Burgos, 1981, p. 205.

20 PARRADO DEL OLMO, Jesús María: Datos histórico artísticos inéditos de la provincia de Valladolid, Diputación Provincial de Valladolid, Valladolid, 1991, pp. 104-106.

21 URREA FERNÁNDEZ, Jesús: "Capillas y patronos de la catedral de Valladolid", B.R.A.C., Tomo XL, 2005, p. 123.

22 URREA FERNÁNDEZ, Jesús: “La biografía al servicio del conocimiento...”, op. cit., p. 56.

23 FERNÁNDEZ DEL HOYO, María Antonia: "El escultor vallisoletano Francisco Díez de Tudanca (1616-?)", B.S.A.A., Tomo. L, 1984, pp. 383-386.

24 HERNÁNDEZ DÍAZ, José, MARTÍN GONZÁLEZ, Juan José y PITA ANDRADE, Manuel: Summa Artis. Tomo XXVI. La escultura y la arquitectura españolas del siglo XVII, Espasa-Calpe, Madrid, 1991, p. 317; CAMÓN AZNAR, José: Summa Artis: historia general del arte; 27. Arte español del siglo XVIII, Espasa Calpe, Madrid, 1984.

25 GÓMEZ-MORENO, María Elena: Ars Hispaniae: historia universal del arte hispánico; 16. Escultura del siglo XVII, Plus Ultra, Madrid, 1963; SÁNCHEZ CANTÓN, Francisco Javier: Ars Hispaniae: historia universal del arte hispánico; 17. Escultura y pintura del siglo XVIII, Plus Ultra, Madrid, 1965. 
cuando ya estaba documentado que aconteció en el año $1702^{26}$. Pero no quedan ahí todos los errores, quizás el más grave sea el adjudicar la autoría del San José de la iglesia de Jesús Nazareno a Pedro de Ávila, la cual ya fue descubierta por Filemón Arribas Arranz hace más de 70 años ${ }^{27}$.

\section{0-4. AGRADECIMIENTOS}

La elaboración de la presente tesis ha contado con la participación de numerosas personas, sin las cuales su ejecución habría sido prácticamente imposible. En primer lugar, quiero dar las gracias a don José Luis Velasco Martínez, delegado de patrimonio del Arzobispado de Valladolid, el cual me proporcionó toda su ayuda, y más, para poder acceder a las iglesias que le solicité tanto de Valladolid capital como de su provincia, así como a diferentes clausuras de la provincia. Estas gracias se hacen extensivas a los delegados diocesanos de patrimonio de Burgos (don Juan Álvarez Quevedo), Segovia (don Miguel Ángel Barbado Esteban) y Zamora (don José Ángel Rivera de las Heras). También dentro de este ámbito quisiera agradecer la ayuda a todos los curas, párrocos, monjas y encargados de las diferentes iglesias que he visitado; todos los cuales, salvo alguna rara excepción, me han proporcionado toda la ayuda que les he solicitado, e incluso me han abierto las iglesias a horas bastante inoportunas. Gracias a todos ellos.

Relacionado con las visitas a los pueblos quisiera dar las gracias a mi tío José María Huerga y a mi amigo Sergio Núñez por haberme llevado en sus coches a la mayor parte de estos pueblos dado que yo no poseía carnet de conducir, y sin los cuales me hubiera sido imposible estudiar muchas de las esculturas de esos pueblos, así como realizar gran parte del corpus fotográfico de la tesis.

También quiero dar las gracias al Museo Nacional de Escultura, a su subdirector don Manuel Arias Martínez, y, especialmente, a doña Ana María Pérez, técnico del museo en el Departamento de Documentación del mismo, quien me ha proporcionado todas las fotografías de esculturas que le he solicitado. Especial importancia ha tenido su participación ya que se trataba de imágenes que no se suelen exponer, sino que se guardan en el almacén de la institución. Además, he de darle las gracias por darme a

\footnotetext{
26 "Juan de Ávila (1678-1707). Castellano, miembro de una importante familia de artistas, seguidor de la estética de Gregorio Fernández. Su estilo se basa en paños suavemente curvados, figuras delicadas, aunque es un poco torpe en los relieves como los del retablo de Ataquines (Valladolid). Obras suyas son el Paso del Despojo (Museo de Valladolid) y el retablo mayor de la Oratorio de San Felipe Neri, el del Monasterio de San Quirce y el de la ermita de San Isidro, todos de Valladolid”. GARCÍA GUTIÉRREZ, Pedro F. y LANDA BRAVO, José: La escultura. Del renacimiento a la actualidad, Ediciones Antiqvaria S.A., Madrid, 1994, p. 134.

27 "Pedro de Ávila (trabaja hacia 1702-1720). Castellano de la primera mitad del XVIII. Hijo del escultor Juan de Ávila. Muy relacionado con el estilo de los Rozas. Realizó algunas esculturas para la Oratorio de San Felipe Neri en Valladolid. Su estilo es de gran perfección, a base de algunos cortes, su policromía es mate. Realiza con gran maestría el desnudo de sus crucificados. También hizo un San José para la iglesia de Jesús en Valladolid”. Ídem, p. 212.
} 
conocer obras inéditas de las que no tenía ni el más mínimo conocimiento sobre su existencia.

Tampoco me quiero olvidar de mi amigo don Alberto San José Mendo, autor de las reconstrucciones virtuales de diferentes retablos, los cuales actualmente han perdido sus advocaciones titulares (retablos del Oratorio de San Felipe Neri, Renedo, Íscar, etc...) y gracias a él las han recuperado, aunque sea de manera virtual, como ya hemos dicho. Y por supuesto, quiero dar las gracias a mi director de tesis, don Jesús María Parrado del Olmo, el cual me ha ido guiando, corrigiendo errores y dando consejos sobre la estructura y capítulos de las tesis, así como sobre la conveniencia o no de incluir ciertas obras y escultores. También al Departamento de Historia del Arte de la Universidad de Valladolid que ha puesto sus medios a mi disposición.

Finalmente quiero dar las gracias a las siguientes personas, si bien sé que alguna de las que me han ayudado se me está olvidando:

A Don Andrés Álvarez Vicente y Don Juan Carlos Álvarez Sánchez, restauradores de la Escuela de Arte y Superior de Conservación y Restauración de Bienes Culturales de Valladolid, el primero profesor y el segundo alumno; gracias a los cuales he podido estudiar de cerca, en el momento en que estaban siendo intervenidas, el San Juan Evangelista que Pedro de Ávila talló para la catedral, y el Cristo del Olvido que el mismo artista talló para el Oratorio de San Felipe Neri.

A Don Jesús del Río, responsable del Museo del Monasterio de San Joaquín y Santa Ana, por comentarme los avatares del San Joaquín que, procedente del Oratorio de San Felipe Neri, se conserva en dicho museo.

A Don José Carlos Brasas Egido, ex catedrático de Historia del Arte de la Universidad de Salamanca, por darme a conocer ciertas piezas en la ciudad de Ávila que, aunque podrían ser atribuidas a Juan de Ávila, he preferido no incluirlas en este estudio por ser su autoría bastante dudosa, aunque vallisoletana.

A Don Rubén Fernández Mateos, doctorando en Historia del Arte y prestigioso guía en diferentes exposiciones de las Edades del Hombre y actualmente de la Catedral de Palencia, por facilitarme fotografías generales y detalles de diferentes obras de los Ávila, las cuales, de no haber sido por él, no podría haberlas obtenido.

A Doña Lorena García García, doctora en Historia del Arte, por haberme proporcionado fotografías del San José conservado en la clausura del Convento de Santa Clara de Carrión de los Condes (Palencia).

Y por supuesto a mis padres y a mi abuela, por todo y más. 


\section{I-INTRODUCCIÓN IISTORICA}




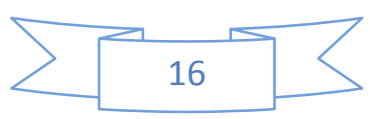




\section{1-1 ESPAÑA (1650-1755): ENTRE AUSTRIAS Y BORBONES}

El marco cronológico al que debemos ceñirnos abarca el reinado de cinco monarcas: dos de la Casa Austria y tres de los Borbones. Juan de Ávila nace en pleno reinado de Felipe IV (1621-1665), al que sucedería su hijo Carlos II (1665-1700). Tras el fallecimiento de este sin descendencia se desataría en la Monarquía Hispánica la Guerra de Sucesión (1701-1713). Una vez se alzó con la victoria el bando Borbónico ascendió al trono Felipe V (1700-1724 y 1724-1746), el cual reinó durante dos periodos, separados por el breve interregno de su hijo Luis I (1724). Tras el fallecimiento de Felipe V sería Fernando VI (1746-1759) el encargado de dirigir los designios de España. Sería en este último reinado en el que se produce el óbito de Pedro de Ávila.

El año 1652, en que nace Juan de Ávila, no fue fácil para España: en el plano político habían tenido lugar las sublevaciones de Portugal y Cataluña, si bien ese mismo año Felipe IV logra conquistar Barcelona; por otro lado, en lo referente al mundo del arte, fallecía en Nápoles uno de los mejores pintores que dio nuestro país: José de Ribera "il Spagnoletto".

Los siguientes años tampoco fueron positivos

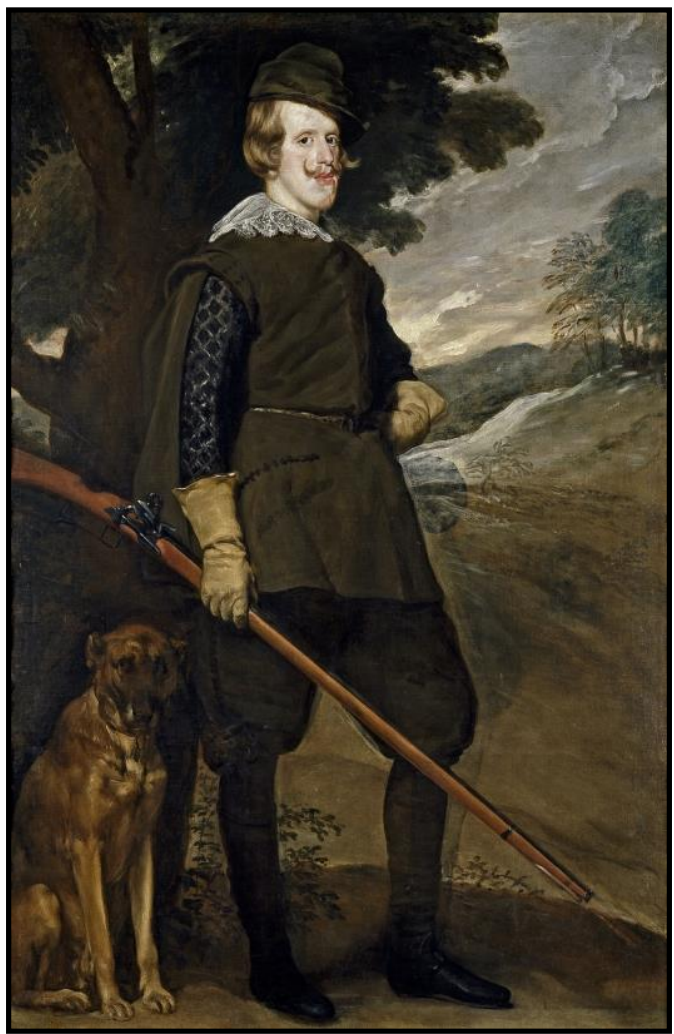

Il. 1- Diego Velázquez. Felipe IV, cazador. Museo del Prado. Madrid. para la Monarquía Hispánica, la cual se encontraba en franca decadencia: en 1657 Inglaterra y Francia pactan el reparto del Flandes español, a esto se sumó la derrota en la Batalla de Dunquerque que obligó al rey y a su valido, don Luis Méndez de Haro y Guzmán (1598-1661), a firmar el 7 de noviembre de 1659, en la Isla de los Faisanes, en la frontera entre Francia y España, el Tratado de los Pirineos, que ponía fin a la Guerra de los Treinta Años iniciada en 1635. En el aspecto territorial, el tratado supuso la entrega a Francia del Condado de Artois, así como de una serie de ciudades y fortificaciones en Flandes y Luxemburgo; para los ingleses quedó Dunquerque. Se puede decir que este tratado puso fin a la hegemonía española.

Meses antes del fallecimiento de Felipe IV se produjo una nueva estocada a la Monarquía Hispánica: la derrota en la Batalla de Villaviciosa (también conocida como de Montes Claros), la cual supuso el fin de las aspiraciones a una unión entre las monarquías española y portuguesa. 
Tras el fallecimiento de "El Grande" y ante la minoría de edad de su hijo Carlos II, asume la regencia Mariana de Austria, si bien la reina viuda estaría apoyada por su valido, Juan Everardo Nithard, y seis miembros de la Junta de Regencia: el Presidente

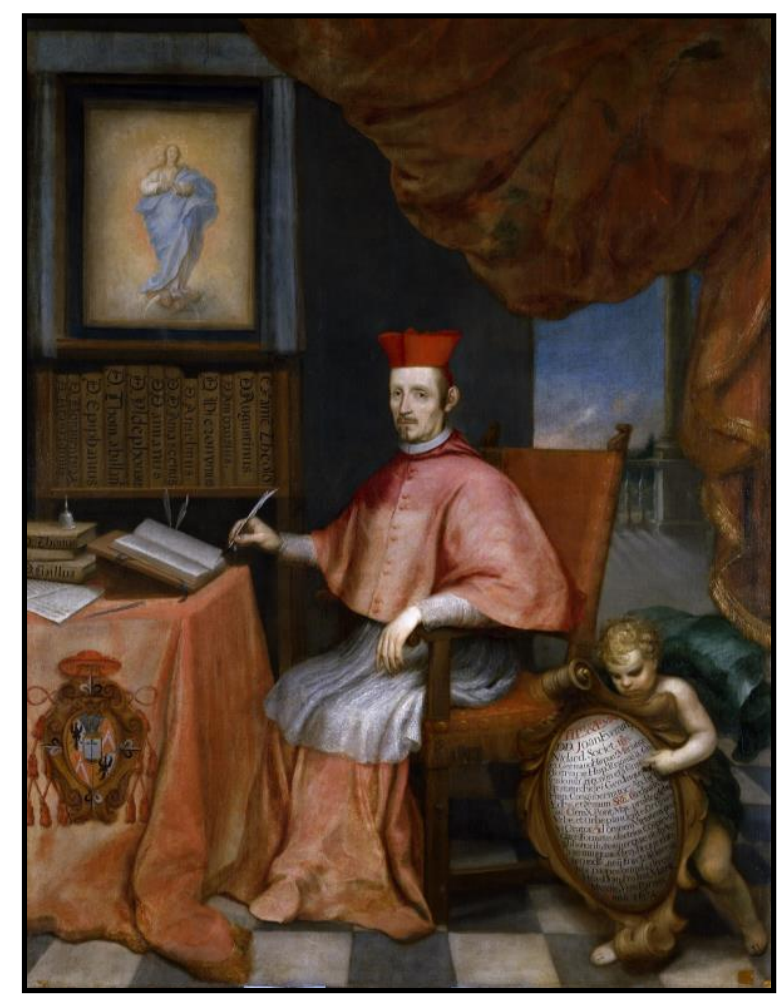

Il. 2- Alonso del Arco. El cardenal Juan

Everardo Nithard. Museo del Prado. Madrid. del Consejo de Castilla, el Vicecanciller del Consejo de Aragón, un representante del Consejo de Estado, un Grande de España, el Inquisidor General y el Arzobispo de Toledo como máxima autoridad religiosa de la Monarquía. El hecho más destacado de este periodo, que se extenderá hasta 1675 , será la firma del tratado de Lisboa en 1668, por el cual se reconocía la intendencia de Portugal. Fue un periodo de gobierno de gran dificultad para la reina puesto que, a los graves problemas económicos de la hacienda real, las numerosas pérdidas territoriales en la política exterior y la gran impopularidad de su valido Nithard, se sumaba la exclusión del núcleo del poder político de don Juan José de Austria, lo que provocó una gran inestabilidad e incluso una guerra abierta entre este último y Nithard. Quizás debido a estos motivos la reina decidió sustituir al jesuita por Fernando de Valenzuela, conocido como "el duende de Palacio".

Llegado el año 1675 Carlos II asume el poder, y tras una serie de acontecimientos que supusieron el enfrentamiento entre Valenzuela y don Juan José de Austria, el rey decidió sustituir al primero de ellos como valido, nombrando en su puesto a su hermanastro don Juan José de Austria. El gobierno del valido comenzó con el alejamiento de la Corte de sus enemigos: Mariana de Austria fue "encarcelada" en el Alcázar de Toledo, mientras que, a Valenzuela, además de desterrársele a Filipinas, se le quitaron todas sus posesiones y títulos. El breve gobierno de don Juan José (16771679) representó un intento por luchar contra la corrupción administrativa heredada de anteriores gobiernos, así como por la implantación de unos aires reformistas y renovadores. También realizó intentos para revitalizar la economía y frenar la despoblación. A pesar de todas estas buenas intenciones, su gobierno se vio ensombrecido por una serie de hechos acaecidos tanto en el interior como en el exterior.

La crisis económica y política continuará. Así, en 1679 España firma con Francia la Paz de Nimega, por la cual se cede el Franco Condado al país vecino. Ese mismo año el rey sufre un nuevo revés cuando fallece su hermanastro, quedando el puesto de valido vacante, puesto que ya no se volverá a recuperar, y que incluso algunos historiadores 
piensan que el último fue Valenzuela, siendo don Juan José de Austria un "breve experimento de caudillismo español"1.

El año 1680 fue un año lleno de novedades, puesto que, al matrimonio del rey con María Luisa de Orleans, sobrina de Luis XIV de Francia, hubo que añadir la elección del Duque de Medinaceli como "Primer Ministro", al cual sucedió el Conde de Oropesa, siendo ambos aristócratas aupados a este puesto por las intrigas de la Corte más que por la elección del propio rey. El primero de estos hombres fue de gran importancia puesto que a él se le deben importantes reformas monetarias, ya esbozadas por don Juan José de Austria, una de estas reformas fue la devaluación de la moneda castellana debido a "la revolución del cobre", pasando la moneda de vellón a valer una cuarta parte de su antiguo valor. Estas medidas tuvieron beneficios a largo plazo pues supuso la estabilización monetaria.

Las pérdidas territoriales de la Monarquía continuaron en 1684 con la entrega de Luxemburgo tras la Tregua de Ratisbona, y en 1697 con la ocupación del Palatinado por parte de Francia tras la Paz de Ryswick, tratado importante por cuanto dejaría a Francia la posibilidad de acceder en un futuro al trono español. Mientras tanto en estos años el rey perdería a su mujer y volvería a contraer matrimonio; en este caso la afortunada fue Mariana de Neoburgo, con la cual se casó en el Convento de San Diego de Valladolid, acontecimiento que quizá presenciara nuestro escultor.

El reinado finalizaría de la peor manera posible: la muerte del rey sin descendencia. Ya durante los años anteriores a su óbito la cuestión sucesoria se convirtió en asunto internacional. Tanto Luis XIV de Francia, representante de la Casa Borbón, como Leopoldo I, emperador del Sacro Imperio Romano Germánico, de la Casa Habsburgo, alegaron derechos a la sucesión del rey español debido a que las madres de ambos eran hijas de Felipe III y además sus esposas eran hijas de Felipe IV. Finalmente prevaleció el testamento

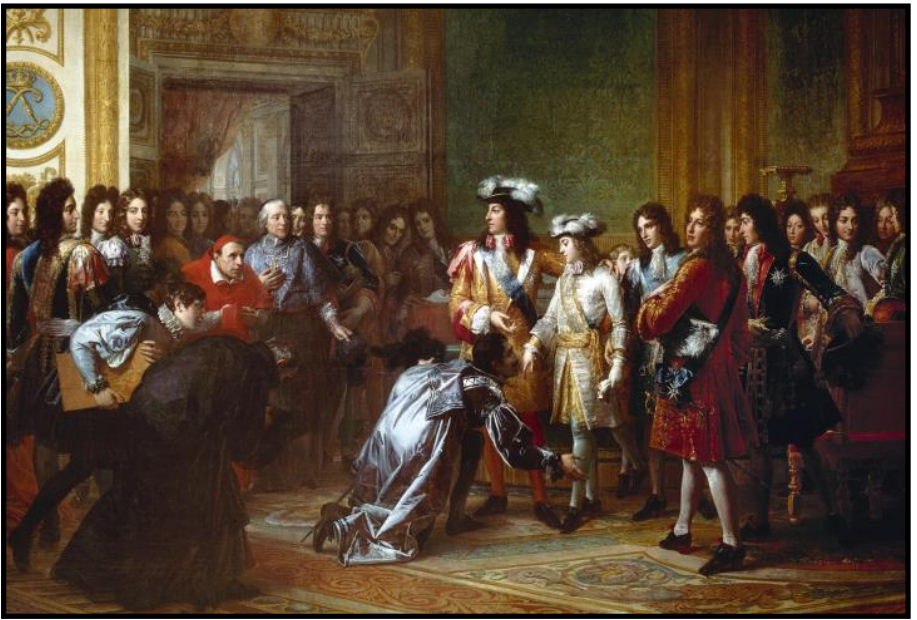

Il. 3- François Gérard. Proclamación de Felipe V como Rey otorgado por Carlos II el 2 de de España en el Palacio de Versales. Château de Chambord.
octubre de 1700 en el cual nombraba como su sucesor a Felipe de Anjou, nieto de Luis XIV. Al año siguiente entra en Madrid el futuro Felipe V, donde es proclamado rey. Al poco tiempo algunas de las potencias extranjeras recelosas de una posible alianza entre Francia y España decidieron inmiscuirse en la cuestión sucesoria. En realidad, lo que vieron fue una oportunidad para sacar tajada. Así Inglaterra y Holanda deseaban hacerse

1 MARTÍNEZ RUIZ, Enrique, GIMÉNEZ, Enrique, ANTONIO ARMILLAS, José Antonio y MAQUEDA, Consuelo: La España Moderna, Istmo, Madrid, 1995, p. 339. 
con el monopolio del comercio con América, y Portugal atacar a sus vecinos castellanos que tanto les habían hostigado. Así Austria, Holanda e Inglaterra, conocidos como la Gran Alianza de la Haya, se alinearon con Carlos de Habsburgo, hijo del Emperador, con lo cual quedaría inaugurada la Guerra de Sucesión Española, que tras numerosos avatares se daría por concluida en 1713 con la firma del Tratado de Utrecht, tratado que significaría el certificado de defunción de las posesiones europeas de España, así como la cesión de ciertos territorios interiores a Inglaterra (Gibraltar, Menorca, etc...).

La pérdida de los territorios europeos, especialmente de los italianos, causó gran conmoción en la corona, y fue ese el motivo para que la reina, Isabel de Farnesio, apoyada por los consejeros de la corte decidiera lanzarse a la "reconquista" de los reinos de Parma, Toscana y Nápoles. El primer paso para la recuperación de estos territorios fue la toma de Cerdeña (1717) y la invasión de Sicilia (1718). Estos hechos trajeron dos consecuencias: el descuido de las posesiones americanas y el "casus belli" para que Gran Bretaña, Francia, Holanda y Austria se unieran bajo el nombre de la Cuádruple Alianza, la cual atacó y destrozó a la armada española, suceso que causó graves pérdidas para el país.

En 1724 Felipe V renunciará al trono en favor de su Luis I, el cual fallecerá a los 229 días de asumir la jefatura del estado, por lo que su padre volverá a tomar las riendas del país. A partir de entonces las tensas relaciones con las potencias europeas se irán suavizando: así, en 1725 se firman tratados de paz y alianza con Carlos VI de Austria; en 1729 la boda entre el Príncipe de Asturias, Fernando VI, y Bárbara de Braganza servirá para limar las tensiones con el país vecino; y, finalmente, en ese mismo año, el Pacto de Sevilla con Francia y Gran Bretaña permitirá a nuestro país recuperar Parma y Toscana a cambio de privilegios comerciales.

Los pactos durarán poco, puesto que una vez desatada la Guerra de Sucesión Polaca España une sus fuerzas a Francia en el conocido como Primer Pacto de Familia, llegando a ocupar Nápoles y Sicilia, el visto bueno del Emperador costó a España la cesión de Parma. Mientras tanto los ingleses atacaron las posesiones españolas en América, en lo que habrían de suponer una guerra por la supremacía del transporte marítimo entre Europa y el viejo continente. Esta guerra se prolongaría casi una década (1739-1748), llegando a tener batallas tan destacadas como la Guerra del Asiento, más conocida como la "Guerra de la oreja de Jenkins".

La ascensión al poder de Fernando VI, y con él la llegada a los cargos de responsabilidad de personalidades como José de Carvajal, el Marqués de la Ensenada y Ricardo Wall, provocó un cambio en la diplomacia española, olvidando el carácter belicista del reinado de su padre y la toma de cierta neutralidad hacia los demás países, lo que favoreció una centralización de las fuerzas en las reformas internas. Así, al final de su reinado, que coincide con el fallecimiento de Pedro de Ávila, se puede afirmar que Fernando VI había conseguido normalizar las relaciones con las potencias europeas, además de alejarse de la "tutela" de Francia, llegando incluso a provocarse un acercamiento a Gran Bretaña. 
En el aspecto interior del país, la primera mitad del siglo XVIII supuso una leve mejora respecto a cómo se encontraba España a la muerte del último Austria. Así, la población experimentó, poco a un poco, un aumento considerable. Uno de los hechos más importantes del nuevo sigo fueron los Decretos de Nueva Planta promulgados por Felipe V, por los cuales quedaban abolidas las leyes e instituciones propias de la Corona de Aragón, con lo cual quedaba suprimida la estructura compuesta de la Monarquía Hispánica de los Austrias y con ello se logró la centralización administrativa que trajo consigo la creación de un Estado moderno. Durante su largo reinado se consiguió una reconstrucción de la Hacienda, el ejército y la armada. Tampoco se puede desdeñar la mejora económica que supuso este reinado, puesto que a la ruinosa situación que se encontró legó un país con una economía, y hacienda, muy saneadas. Para ello luchó contra la corrupción, creó nuevos impuestos e impulsó una intervención del Estado en la economía, favoreciendo la agricultura y creando las manufacturas reales.

El último reinado que comprende la cronología de nuestros escultores es el de Fernando VI, conocido como "el Prudente" o "el Justo". Este periodo se puede dividir en dos épocas: una primera, que engloba las luchas entre dos modos de ver la política: por un lado, el Marqués de la Ensenada (francófilo), y, por otro, José de Carvajal y Lancaster, partidario de una alianza con Gran Bretaña; y una segunda en la que el hombre fuerte del rey será Ricardo Wall. Los proyectos más importantes para la renovación del país vinieron de mano del Marqués de la Ensenada: así, diseño la supresión de los antiguos impuestos por uno único, el catastro, que significaba que cada uno pagaba a la hacienda en función de sus ingresos; modernizó la marina; impulsó la creación en 1752 de la

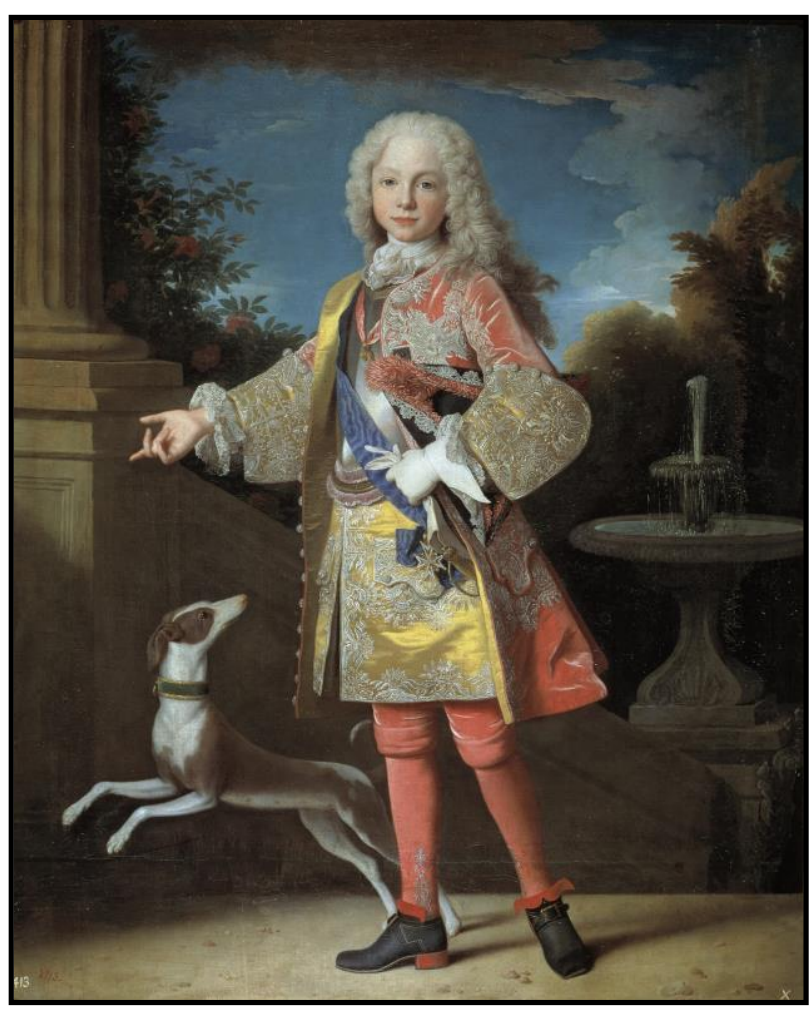

Il. 4- Jean Ranc. Fernando VI, niño. Museo del Prado. Madrid.

Real Academia de Bellas Artes de San Fernando; e incluso impulsó el maltrecho comercio con las Indias.

A modo de anécdota, y para finalizar este repaso a la historia de España durante esta centuria, me gustaría señalar que en el año en que falleció Pedro de Ávila, 1755, sucedió uno de los episodios más recordados en nuestra ciudad: el 1 de noviembre, a eso de las 9:30 horas se desata el Terremoto de Lisboa que, además de sentirse en medio mundo, trajo consigo graves daños en la torre de la catedral de Valladolid. 


\section{1-2 LA CIUDAD DE VALLADOLID ENTRE 1650 - 1750}

La situación en la que se encuentra la ciudad de Valladolid a comienzos de la segunda mitad del siglo XVII es un calco a la que por entonces sufría el país. Sin embargo, el panorama en la ciudad del Pisuerga era aún más desolador, puesto que tenía el plus de seguir sufriendo las desastrosas consecuencias que dejó la marcha de la corte a Madrid en el año 1606. La ciudad era un caos en casi todos sus ámbitos: se produjo un dramático descenso de población, un hundimiento de la economía, un empeoramiento de las condiciones de salubridad, etc... En definitiva, Juan de Ávila vio la luz en una ciudad, y en un país, en crisis.

El vertiginoso descenso de población provocó, además de una decadencia económica, el abandono de muchas casas, lo que llevó a que muchas de ellas se fueran paulatinamente hundiendo. La consecuencia inmediata fue la reducción del caserío urbano y el aumento de los espacios vacíos dentro de la propia urbe. Según Adriano Gutiérrez, la ciudad "se fue pareciendo cada vez más a un viejo barco semiderruido y semivacío"2. Otra consecuencia de la falta de población fue la escasa demanda de viviendas, y por lo tanto la caída en los arrendamientos, lo que llevó a la pérdida de la rentabilidad de la propiedad urbana, y por lo tanto el abandono y degradación de las casas. Muchas de las casas que se caían ya no se volvían a levantar. Desde el punto de vista del plano urbano se puede hablar que Valladolid era una ciudad convento ${ }^{3}$.

A todo esto, hay que sumar un empeoramiento de la salubridad pública. A lo largo del siglo XVII el habitante de Valladolid se abastecía de agua de tres maneras: a través de pozos caseros, a través de aguadores o por medio de fuentes públicas, sobresaliendo entre ellas últimas las llamadas "fuentes de Argales". La escasa preparación de los encargados de mantener las fuentes llevó al mal estado de las mismas a mediados del siglo XVII. Por ejemplo, en 1663 el regidor comisario de fuentes informaba al ayuntamiento que "las fuentes estaban perdidas y a riesgo de acabarse".

Más importancia, de cara a la salud pública, tenía la evacuación de aguas residuales. La falta de infraestructura era total, no existía una red de alcantarillado. Los pozos negros no abundaban. El drenaje urbano se realizaba básicamente a través del río Esgueva, cuyas aguas limpias y claras en el Prado de la Magdalena se iban volviendo oscuras y malolientes a su paso por la ciudad. De ahí la constante preocupación del Consejo por evitar que sus aguas se estancaran, ordenando limpiarle a menudo e impidiendo la construcción de presas río arriba. Debido al deficiente sistema de desagüe, el estado de las calles era peligro para la salud de los vallisoletanos, a ellas iba a parar de todo: residuos fecales, restos de comidas, las basuras, los animales domésticos muertos, etc. Los estercoleros en el interior de la ciudad eran algo muy común.

2 GUTIÉRREZ ALONSO, Adriano: "Valladolid en el siglo XVII". En GUTIÉRREZ ALONSO, Adriano (et. al.): Valladolid en el siglo XVII, Ateneo de Valladolid, Valladolid, 1982, p. 33.

$3 \quad$ Ver CHUECA GOITIA, Fernando: Breve historia del urbanismo, Alianza, Madrid, 1995. 


\section{A- POBLACIÓN}

El descenso de población no fue algo propio de esta época, sino que ya se sufría desde la marcha de la Corte; sin embargo, fue durante el periodo 1666-1670 el momento en el que Valladolid alcanzó su nivel más bajo de población, registrándose durante dichos años la media mínima de bautismos anuales. Las causas de esta pérdida de población fueron múltiples: gran parte de culpa hay que achacarla a las emigraciones, ya fuera por motivos económicos (pagar menos impuestos), de trabajo o de leva de soldados ${ }^{4}$. La pérdida de habitantes también se dio dentro de los muros de la ciudad, así las hambres, las pestes, las epidemias, la climatología adversa (fundamentalmente las grandes lluvias) o las plagas tuvieron mucha culpa de esta pérdida de población. Todo ello provocó un crecimiento vegetativo negativo.

Según el profesor Valdeón Baruque "la crisis demográfica y económica no modificó sustancialmente los comportamientos demográficos de los vallisoletanos". Los pucelanos siguieron casándose muy jóvenes, si bien los matrimonios no eran muy duraderos debido al fallecimiento prematuro de uno de los integrantes de la pareja. Muchos de los artistas de este periodo contrajeron dos, o incluso tres matrimonios, teniendo en cada uno de ellos numerosa descendencia. Este hecho parece apuntar a un fallecimiento de las mujeres durante, o después, del parto debido a las nulas condiciones higiénicas disponibles en la ciudad. Los hombres tan solo guardaban el luto unas pocas semanas, o a lo sumo unos meses. El motivo fundamental para tal rapidez era "la necesidad de encontrar una nueva ama de casa que cuidara del hijo o de los hijos habidos en el anterior matrimonio". Otros dos factores que explican la crisis demográfica es el temprano fallecimiento de los recién nacidos (pocos lograron llegar a la vida adulta) y, finalmente, el celibato, ya fuera por el auge del estado eclesiástico o por la imposibilidad de muchos jóvenes de acceder al matrimonio dado su escaso patrimonio. Este último hecho trajo como consecuencia el aumento de hijos ilegítimos ${ }^{6}$.

El cambio de rumbo de la población vallisoletana llega en el año 1670. A partir de entonces el número de habitantes crecerá moderadamente llegando a finales de siglo a unos 3.607 vecinos (alrededor de 14.500 habitantes). A comienzos del siglo XVIII la velocidad de recuperación de población se fue acentuando, si bien el verdadero aumento de población aconteció bien entrado ya el siglo. Así, según diversas estimaciones, a mediados del siglo XVIII Valladolid contaría con una población estimada entre 20.000 - 24.000 habitantes. José María Palomares contabiliza 6.000 vecinos (unos 24.000 habitantes) en el año 1744, mientras que Elena Maza, basándose en el Catastro de Ensenada rebaja la cantidad hasta los 4.906 vecinos (unos 20.000 habitantes) ${ }^{7}$.

\footnotetext{
$4 \quad$ Durante el periodo 1640-1660 las levas de soldados en Valladolid fueron muy frecuentes debido a las múltiples contiendas que mantenía España tanto en el exterior (Francia y Portugal) como en el interior (Cataluña). GUTIÉRREZ ALONSO, Adriano: op. cit., p. 48.

VALDEÓN BARUQUE, Julio (dir.): Historia de Valladolid, Ámbito, Valladolid, 1997, p. 140.

Ídem, p. 141.

ENCISO RECIO, Luis Miguel: "La Valladolid ilustrada”. En ENCISO RECIO, Luis Miguel (et. al.): Valladolid en el siglo XVIII, Ateneo de Valladolid, Valladolid, 1984, p. 26.
} 


\section{B- ECONOMÍA}

La economía vallisoletana durante este periodo se basó fundamentalmente en cuatro pilares: el comercio, la industria, la producción agrícola y vinícola, y en menor medida la ganadería. Asimismo, la artesanía observaba un marcado carácter medieval ${ }^{8}$.

El comercio, que empleaba un $11 \%$ de la población vallisoletana, fue uno de los sectores que en menor medida sufrieron la crisis. La causa fundamental a la que hemos de achacar esta circunstancia es a la ventajosa situación geográfica de la ciudad para ser centro de intercambio a nivel tanto regional como nacional. El abastecimiento de los hogares se hacía de tres maneras: el mercado de los "obligados", el comercio libre y el de los Cinco Gremios. El de mayor importancia era el de los "obligados", modelo en el que empresario y Ayuntamiento firmaban un contrato por el cual el empresario se ganaba un contrato de exclusividad de ese producto en la ciudad durante un año. Con ello se lograba unificar precios, aunque también creó un comercio clandestino. Los productos vendidos en este sistema eran todos ellos de primera necesidad: carne, pescado, vino y aceite, entre otros. ${ }^{\text {. }}$

La industria durante este periodo, a pesar de contar con numerosos oficios, tan solo representaba el $31 \%$ de la actividad, siendo el sector más destacado el textil, y dentro de éste el de la lana. Tampoco se puede desdeñar la producción de pasamanería, mantas, sombreros $\mathrm{y}$, sobre todo, de paños y estameñas, productos, estos últimos, muy apreciados en su época ${ }^{10}$. Un capítulo importante de la industria vallisoletana de estos momentos es la llegada de empresarios foráneos, como Miguel de Ravellart o Gil de Angot, que se empeñaron en impulsar la calidad y cantidad de la lana mediante la introducción de novedosas técnicas e iniciativas ${ }^{11}$.

La producción agrícola, fundamentalmente de secano, estaba basada en su mayor medida en el cultivo del trigo, la cebada, el centeno y la vena. Especial relevancia dentro de la agricultura vallisoletana tenía la producción de rubia, planta de la cual se obtenían unos tintes muy apreciados y se llegaron a producir 70.000 arrobas en polvo durante un quinquenio, siendo posteriormente exportadas a Cataluña, Francia, Gran Bretaña u Holanda ${ }^{12}$.

El viñedo, por su parte, poseía una mayor importancia que los cereales, puesto que su producción y precio era superior. En Valladolid la mayoría de los viticultores eran propietarios, todo lo contrario que acontecía con el resto de trabajadores del campo. Los productores de vino llegaron a constituir una de las instituciones más importantes, poderosas, influyentes y ricas de la ciudad: el gremio de los herederos de viñas. Tenemos casos en el que importantes artistas de la urbe, como los ensambladores y tallistas Gregorio Díaz de la Mata, Francisco de Billota o Pedro Correas, tuvieron una

GUTIÉRREZ ALONSO, Adriano: op. cit., p. 53.

ENCISO RECIO, Luis Miguel: op. cit., p. 48.

Ibídem.

VALDEÓN BARUQUE, Julio (dir.): op. cit., p. 167.

ENCISO RECIO, Luis Miguel: op. cit., p. 46. 
vertiente comercial, comprando y vendiendo viñas. Este hecho quizás tenga que ver con puntuales apuros económicos en el que la falta de trabajo en sus profesiones les llevó a tener que buscarse la vida en otros campos.

La crisis acaecida hasta, aproximadamente, finales del siglo XVII se sintió con mayor fuerza en los cereales que en el vino dado, que estos dependían del tiempo, y de si había buenas o malas cosechas, lo que implicaba en los mercados una ostensible variación de precios que condicionaba mucho la vida de los vallisoletanos más humildes ${ }^{13}$. También hubo un escenario de crisis en la industria. Los factores fueron varios: el descenso del consumo, el aumento de los impuestos, la importación de manufacturas extranjeras, o, incluso, el declive de las ferias. Además de estos factores, de carácter más general, también influyeron otros específicamente vallisoletanos, como fueron los impuestos municipales sobre el consumo, denominados "sisas" y "arbitrios"14.

\section{C- SOCIEDAD}

En el Valladolid de estos años permanecían en Valladolid muy pocos nobles. Casi todos marcharon a Madrid siguiendo a la Corte, la burguesía tampoco era una bolsa de población muy importante, todo lo contrario que el clero (alrededor del 10\%) y el tercer estado. Como en la actualidad, a lo largo de la crisis acontecida durante el siglo XVII se produjo una polarización de la sociedad: la población humilde fue perdido recursos, muchos de los "medianos" caían en la pobreza, mientras tanto la minoría más rica cada vez lo era más, es decir, estos últimos se aprovecharon de la crisis en su propio beneficio $^{15}$. A pesar de esta acusada estamentalización, los grupos sociales se encontraban mezclados en los mismos barrios e incluso, en algunos casos, en los mismos inmuebles. Sin embargo hubo zonas, que por tradición, siguieron manteniendo preferencias: los nobles abundaban en las parroquias de Santa María de la Antigua, San Martín y San Pedro; los comerciantes en Fuente Dorada, mientras que los agricultores se focalizaban en las parroquias de San Andrés y San Nicolás ${ }^{16}$.

En la cúspide de la pirámide social se encontraban los nobles, el Concejo municipal y la iglesia. El estamento nobiliario ya no era el que fue tras la marcha de la Corte a Madrid. Muchos nobles dejaron la ciudad, lo que a la larga supuso el abandono de sus palacios y el deterioro de los mismos, si bien de alguno de ellos se sirvieron los conventos para su expansión, así, por ejemplo, tenemos el Palacio del Licenciado Butrón fusionado al Convento de Santa Brígida.

El Concejo municipal, también conocido como Regimiento, era el encargado de gobernar la ciudad. A la cabeza estaban el Corregidor y los regidores (en número indeterminado), dos procuradores del Común y dos escribanos. En el Concejo se

GUTIÉRREZ ALONSO, Adriano: op. cit., p. 50.

Ídem, p. 54.

VALDEÓN BARUQUE, Julio (dir.): op. cit., p. 148.

ENCISO RECIO, Luis Miguel: op. cit., p. 31.

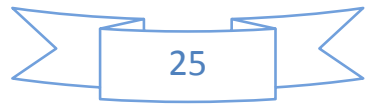


discutían y aprobaban las cuestiones referentes a la ciudad y además era el receptor de las órdenes reales, desde donde se mandaban cumplir. En teoría, las decisiones se tomaban por mayoría simple. El voto del Corregidor sólo tenía valor cuando se empataba, pues él era el que decía la balanza a un lado y otro; pero en la práctica el corregidor solía presionar para conseguir que se cumpliera lo que él quisiera.

La importancia de la iglesia, cuyo poder en el siglo XVII fue mayor que en anteriores épocas, no solo se demostrará en sus influencias, sino también en sus riquezas, muy desigualmente repartidas. Como ya hemos dicho, en este periodo aumentó de forma espectacular el número de "vocaciones". Numerosos serían los motivos para ingresar en este estado, muchos de ellos nada vocacionales. Así, por ejemplo, existía un deseo en los padres de que alguno de sus hijos tomara el hábito para así no fraccionar demasiado la herencia entre su numerosa descendencia. Por otro lado, los religiosos contaban en Valladolid con gran prestigio e influencia social. Esto último queda patente en el monopolio que tenían del mundo de la cultura y de la enseñanza. Finalmente, la riqueza de la iglesia se demostraba en muchos aspectos; quizás fueran los más importantes la asistencia social y sobre todo la labor de muchos eclesiásticos, iglesias, cofradías, etc... como patronos de obras de arte, lo que trajo consigo el que Valladolid continuara un importante foco artístico ${ }^{17}$.

Entre lo que podemos denominar las clases medias se incluirían los mercaderes y artesanos, los cuales se verían golpeados por la crisis con gran fuerza debido al aumento de los impuestos, lo que primeramente conllevó el cierre de sus tiendas y a continuación la disminución del grupo y la pérdida de potencia económica. Los dos gremios de mayor importante en este periodo fueron los de paños y joyas y los del gremio del vino. En una posición totalmente opuesta se encontraban los esparteros y zapateros, gremio éste último al que pertenecieron numerosos componentes de la familia de Juan de Ávila.

En el punto más bajo de la escala social encontramos a los pobres, pobres de solemnidad. Las malas condiciones económicas de estos momentos trajeron consigo un aumento del número de pobres, vagabundos, ladrones y de niños abandonados. Fuera de estos parámetros están los esclavos, los cuales seguían existiendo en Valladolid durante el siglo XVII, así, en el año 1700 se bautizaba a uno en la iglesia parroquial de San Julián ${ }^{18}$.

\section{D- RELIGIÓN}

El vallisoletano de estos momentos era un hombre profundamente religioso. Para nada es gratuita la afirmación que tachaba a Valladolid de ciudad levítica. Según palabras de Adriano Gutiérrez "la religión no sólo no era discutida, sino que era la guía que daba

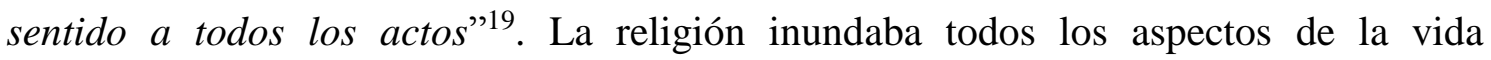

17 VALDEÓN BARUQUE, Julio (dir.): op. cit., pp. 150-151.

18 GUTIÉRREZ ALONSO, Adriano: op. cit., p. 64.

19 Ídem, p. 101 
cotidiana: desde un plano más personal en el que se afirma que todos los hombres oían misa diaria hasta el plano más general en el que la muchedumbre afirmaba su religiosidad por permio de las plegarias, procesiones de Semana Santa, etc...

Las procesiones son un magnífico termómetro que nos muestra hasta qué punto lo religioso formaba parte de la vida de los vallisoletanos. La gente llevaba a imbuirse tanto en los "pasos" que veía que llegaron incluso a lanzar piedras a los sayones.

La religión tenía una vertiente artística, que es la que más nos importa en esta tesis. El fervor de muchos fieles, cofradías y clérigos particulares llevó a la construcción de nuevos templos, retablos, capillas, esculturas, pinturas, etc... En la mayoría de los casos el motivo que les llevaba a ello era el puro fervor a una iglesia o a un santo, pero en otros casos el motivo era la canonización de un santo de la ciudad o relacionado con ella. Un momento de especial importancia era la bendición de la obra, para ello se organizaba una gran procesión que recorría diversos templos; y en las calles se preparaban altares, verdaderos retablos efímeros, realizados con los más variados materiales. Gracias a las descripciones del diarista Ventura Pérez conocemos muchos de los altares que inundaron muchas de las procesiones acaecidas durante el siglo XVIII: no se limita a narrarnos donde se puso y quien lo levantó, sino que en ocasiones explica muy pormenorizadamente las imágenes que lo componían y los materiales con que se construyeron.

Relacionado con la Semana Santa hay que señalar el gran desarrollo de la Cofradías Penitenciales durante el siglo XVII, aunque posteriormente en el XVIII se inicia su larga decadencia, que culminará a mediados de siglo. Durante el periodo tratado se realizaron algunos de los últimos pasos procesionales históricos. Como por ejemplo el Despojo, tallado por Juan de Ávila, o incluso reparos a los ya existentes, como veremos más adelante Juan de Ávila supervisará los reparos a los pasos de la Cofradía de la Sagrada Pasión de Cristo, mientras que años después su hijo Manuel restaurará los de la Cofradía de N. P. Jesús Nazareno. Asimismo, alguna de las cinco cofradías históricas construirá su iglesia penitencial, otras las reformarán, ampliarán o incluso levantarán nuevas capillas dedicadas a su imagen titular: véase la Cofradía de las Angustias con su Virgen, obra de Juan de Juni. También se encargarán del amueblamiento interior de las iglesias: algunas cofradías encargarán retablos, cuadros y esculturas con que embellecer sus interiores, mientras que otras tan solo harán encargos puntuales para sustituir antiguos retablos. Gran importancia en esta renovación tendrá la construcción de los retablos mayores. Durante este periodo cuatro de las penitenciales, a excepción de la Cofradía de Nuestra Señora de las Angustias, levantarán sus retablos mayores: la Piedad se lo encargará a Pedro de Cea, la de la Vera Cruz a Antonio de Billota y Juan Guerrero, la de la Pasión a Alonso y Antonio Billota, mientras que la de Jesús Nazareno hará lo propio con Blas Martínez de Obregón. 


\section{E- CULTURA}

En el Valladolid en el que vivieron nuestros escultores tener estudios era todo un lujo. El analfabetismo imperaba en una ciudad en la que la mayoría de familias tan solo contaba con el dinero justo para sobrevivir, y en algunos casos ni eso. A pesar de todo, Valladolid contaba con una variada infraestructura educativa, más si lo comparamos con otras ciudades del reino.

La primera enseñanza que recibían los niños, la básica, comenzaba a los 6 o 7 años. Consistía en aprender a leer y escribir en castellano, realizar sencillas operaciones matemáticas, y recitar partes del catecismo y algunas oraciones. Esta educación básica la podían obtener los vallisoletanos por tres medios: los más ricos acudían al "ayo", mientas que los niños de familias más humildes debían de recalar en las "escuelas públicas" o en las privadas, siendo estas últimas dependientes de ciertas órdenes religiosas. Existía una cuarta posibilidad, aunque esta solamente era válida para los niños abandonados o huérfanos. Se trataba de las escuelas especiales de las instituciones de beneficencia como el Colegio de Niñas Huérfanas o el Colegio de los Niños del Amor de Dios, más conocido por el de "Niños de la Doctrina".

Finalizados los estudios primarios los que se lo podían permitir accedían a una especie de "escuela secundaria" que se impartía en las Escuelas de Gramática. Allí los muchachos recibían lecciones de gramática latina, la asignatura más importante si después querían acceder a la universidad, geografía, historia, filosofía, etc... Existían varios centros donde podían seguirse estos estudios,

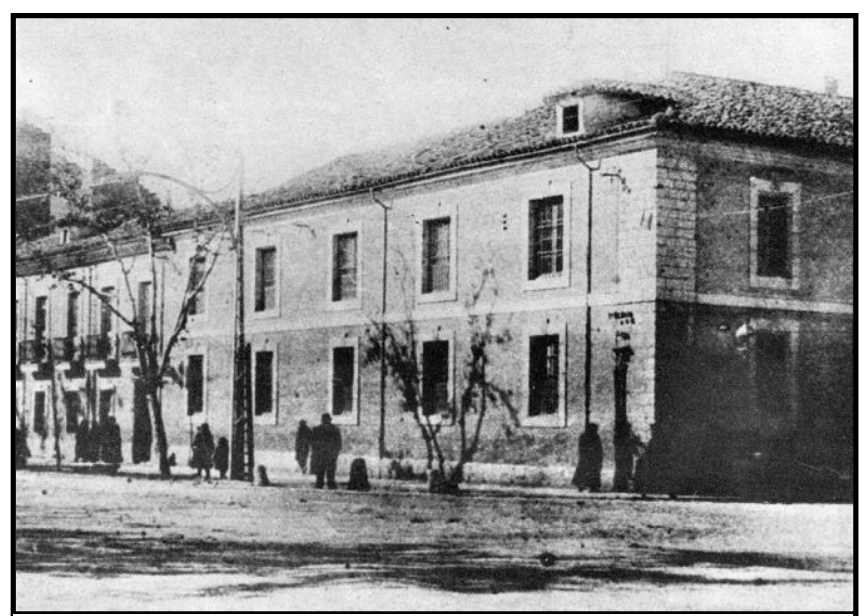

Il. 5- Colegio de Niñas Huérfanas. Valladolid. siendo los más descollantes la Cátedra de Gramática de la Universidad y el Colegio de los jesuitas.

$\mathrm{Si}$, como hemos visto, los alumnos aprendían gramática latina llegarían al cenit de la educación vallisoletana: la Universidad, la tercera más importante de Castilla tras las de Salamanca y Alcalá de Henares. Allí los jóvenes obtendrían los títulos de bachiller, licenciado y doctor, los cuales les servirían para encontrar un empleo en la administración, la Chancillería o en la propia universidad. Vinculados a esta institución se encontraban los Colegios universitarios. Estos se hallaban vinculados con la Universidad, pero tenían personalidad propia. El más prestigioso era el Colegio Mayor de Santa Cruz, "el cual surgió para dar una oportunidad a los estudiantes pobres y a la vez formar una élite académica"20. 


\section{1-3 PRINCIPALES ACONTECIMIENTOS SUCEDIDOS EN VALLADOLID (1650-1750)}

Durante el periodo estudiado los acontecimientos más importantes que sucedieron en la ciudad tuvieron como grandes protagonistas a la iglesia y a la monarquía, aunque también acaecieron otros... Como tampoco es nuestra intención señalar todos ni analizar en profundidad cada uno de ellos haremos una breve reseña para enmarcar mejor el Valladolid en el que vivieron nuestros escultores, pudiendo haber asistido ellos a alguno de ellos.

\section{$\underline{\text { A- ACONTECIMIENTOS RELIGIOSOS }}$}

Este grupo está compuesto por eventos muy heterogéneos: rogativas, procesiones, celebraciones por la consagración de algún santo o incluso la fundación o inauguración de alguna iglesia, retablo, capilla, etc...

\section{$>$ 1667. Auto de Fe en la Plaza Mayor}

El 30 de octubre se celebró en la Plaza Mayor "uno de los sucesos más notables" del reinado de Carlos II: un auto general de Fe presidido por el Inquisidor Presidente don José Paniagua. El auto debió de ser importante puesto que Sangrador Vítores refiere que "el lúgubre aparato que se desplegó por el tribunal [era] superior en un todo al de los celebrados anteriormente" ${ }^{21}$. La gente respondió al acto acudiendo masivamente, tanto que "muchas personas por la noche en los soportales de la plaza"22. El número de condenados ascendió a 85, aunque tan solo fueron ejecutados dos " $y$ cinco fueron relajados en estatua, entre estos, tres mujeres, siendo los restantes reconciliados. Duró la ceremonia desde las ocho de la mañana hasta las cinco de la tarde, pronunciando el sermón de costumbre el P. Maestro Fr. Miguel de Olmedo, calificador del Santo Oficio" ${ }^{23}$.

$>\underline{\text { 1681. Grandes fiestas con motivo de la inauguración de la iglesia de la Vera }}$ $\underline{\text { Cruz }}$

En este año se finalizaron las obras de ampliación de la iglesia penitencial. Asimismo, aconteció el traslado de "la milagrosísima antigua hechura de Cristo, socorro universal de los pecadores" que la cofradía tenía en su humilladero "fuera de la puerta del campo" al recientemente estrenado

21 SANGRADOR Y VÍTORES, Matías: Historia de la Muy Noble y Leal Ciudad de Valladolid, desde su más remota antigüedad hasta la muerte de Fernando VII, Tomo I, Imprenta de D. M. Aparicio, Valladolid, 1854, p. 485.

22 ALCALDE PRIETO, Domingo: Manual histórico de Valladolid, Grupo Pinciano, Valladolid, 1992, p. 82.

23 Ibídem. 
retablo mayor del remozado templo. Los dos acontecimientos se celebraron con "magníficas fiestas de Iglesia no siendo menos las profanas, desafiando en un certamen poético a todos los ingenios". Una pormenorizada descripción de estos fastos se recoge en un librito editado con motivo de aquellos hechos, uno de cuyos ejemplares se puede consultar en el Archivo Municipal de Valladolid ${ }^{24}$.

\section{Inauguración del templo de San Felipe Neri}

Iniciada su construcción el 14 de junio de 1675 por el maestro de obras Antonio de la Iglesia, las obras se prolongaron debido a la escasez de fondos de la Congregación ${ }^{25}$. La apertura de un templo de estas características trajo consigo la contratación de numerosos artistas que se debieron de encargar de la realización de retablos, esculturas, pinturas, etc... entre ellos se encontraban nuestros tres escultores: Juan, Pedro y Manuel de Ávila.

\section{Inauguración de la Capilla de Nuestra Señora de las Angustias}

La creciente popularidad y devoción de los vallisoletanos hacia la Virgen de las Angustias determinó a la cofradía a construirle un espacio propio en el que sus devotos pudieran orarla con mayor recogimiento. El encargado de su edificación fue el arquitecto Francisco Pérez, el cual tardó seis años en concluirlas (1704-1710) ${ }^{26}$.

1727. Canonización de San Juan de la Cruz, San Luis Gonzaga y San Estanislao de Kostka.

El 9 de septiembre tuvo lugar la canonización por parte de Benedicto XIII de ocho santos, entre los cuales se encontraban San Juan de la Cruz, San Luis Gonzaga y San Estanislao de Kostka. La ciudad lo celebró con una gran procesión que partió desde la catedral, y en la que además de las imágenes de estos santos participaron las de Santo Toribio de Mogrovejo, San Peregrino, San Francisco Solano, San Jacobo y Santa Inés de Monte Policiano. Según relata Ventura Pérez: "Asistieron las comunidades todas y cada una llevaba su patriarca: hubo cuatro altares; el uno le pusieron los padres trinitarios descalzos a la puerta de las Angustias; los padres franciscanos pusieron otro a la puerta de la Cruz; estos religiosos ni los dominicos no fueron en la procesión; los clérigos menores pusieron otro altar en la calle de la Cárcava, a

24 Archivo Municipal de Valladolid (en adelante A.M.V.) CH. 14-11.

25 MARTÍN GONZÁLEZ, Juan José y URREA FERNÁNDEZ, Jesús: Catálogo Monumental de la provincia de Valladolid. Tomo XIV. Monumentos religiosos de la ciudad de Valladolid ( ${ }^{a}$ parte), Institución Cultural Simancas, Valladolid, 1985, p. 292.

26 Ídem, p. 232. 
la entrada; otro pusieron a la puerta del hospital de Esgueva; otro pusieron en la casa detrás de la carnicería de los curas que tiene muchas rejas, que vivía en ella el señor provisor D. Cayetano Landa"27.

\section{Capítulo General de la Orden Seráfica}

El Capítulo general tuvo lugar en el Convento de San Francisco. Comenzó el día 26 de mayo, fiesta de la Asunción, prolongándose hasta el 4 de junio, fecha en que se eligió como general a fray Cayetano Labrino, napolitano, de la provincia de Nápoles y comisario general de la curia romana. Al día siguiente, festividad de la Pascua del Espíritu Santo, "a las ocho de la mañana, se celebró la procesión de toda la orden seráfica, que anduvo las calles de la procesión del Corpus (...). Llevaban en el cuerpo de la procesión muchos santos, como fueron San Luis, mártir, donado, que llevaban los donados, San Pedro Regalado, San Antonio de Padua, San Bernardino de Siena, San Pedro Alcántara, San Luis, obispo, San Luis, rey de Francia, Santa Rosa de Viterbo, Santa Isabel, reina de Hungría, Santa Clara, San Buenaventura y San Francisco, con su bandera, y detrás de cada santo iba un religioso vestido con capa pluvial, y la última iba la Purísima Concepción, la que tienen en el coro" 28 . La procesión se dirigió a la catedral, donde celebró misa el nuevo general, tras los actos "volvieron en la misma forma por la calle de los Orates". Ese mismo día por la tarde quedó electo como comisario general el Padre fray José Losada.

\section{Fundación del Colegio de Agustinos Filipinos}

Se trata de una de las pocas fundaciones conventuales acaecidas en Valladolid en el siglo XVIII ${ }^{29}$.

\section{$\underline{\text { 1746. Beatificación de San Pedro Regalado }}$}

El 25 de julio la ciudad recibe la noticia de que el papa Benedicto XIV acababa de canonizar a un paisano, Pedro de la Costanilla, que ya gozaba desde hacía mucho tiempo de un aura de santidad. Las fiestas por la canonización del santo Regalado hubieron de esperar unos días puesto que acababa de fallecer el rey Felipe V y se estaban realizando las exequias del monarca, de hecho ni se 
pudieron "disparar cohetes" 30 . Sin que hubiera acabado el luto se anunciaron "por medio de impresos las funciones que se habian de celebrar en 20 de mayo de 1747, y fue tal la afluencia de forasteros, que por falta de local tuvieron muchos que albergarse en los pueblos inmediatos" 31 .

\section{$\underline{\text { 1747. Primera piedra de la nueva iglesia de San Norberto }}$}

El 19 de febrero se colocó la primera iglesia "que se iba a hacer nueva de planta en el convento de padres premostratenses de esta ciudad". La localización de la misma era en el pie del machón toral del lado del evangelio, junto al presbiterio. Presidió el acto el obispo de Valladolid, Ilmo. Sr. D. Martin Delgado $^{32}$.

\section{$\underline{\text { 1747. Traslación de la reliquia de San Pedro Regalado }}$}

En la noche del 4 de marzo llegó a Valladolid "en un coche por la puerta de Tudela, con grandes acompañamientos de calesas y gente de a caballo" una reliquia, un hueso de la cadera, de San Pedro Regalado procedente del convento del Domus Dei de La Aguilera. Al día siguiente las calles se encontraban "adornadas de tapices; la calle de Santiago y la Platería toda de abanicos y cenefas en las primeras ventanas, y entre ventana y ventana un rey o reina de la casa de Austria". Tampoco faltaron los característicos altares efímeros por el recorrido que realizó la reliquia ${ }^{33}$.

\section{Fiestas principales de San Pedro Regalado}

El martes 20 de junio por la tarde, la comunidad de San Francisco, acompañada por la de San Domingo "Santo Domingo, padres descalzos de San Diego, la comunidad del Abrojo, caballeros de esta ciudad y particulares" llevaron a la catedral la imagen de San Pedro Regalado que el convento de San Francisco tenía en la capilla de Copacabana, con este traslado dieron comienzo las fiestas principales celebradas en honor del santo vallisoletano. Las celebraciones fueron importantísimas, quizás las de mayor relumbre que vivió

30 PÉREZ, Ventura: op. cit., pp. 228-229; Ver: EGIDO LÓPEZ, Teófanes: "La religiosidad colectiva de los vallisoletanos". En ENCISO RECIO, Luis Miguel (et. al.): Valladolid en el siglo XVIII, Ateneo de Valladolid, Valladolid, 1984, pp. 157-260; Actas Municipales del año 1746.

31 ALCALDE PRIETO, Domingo: op. cit., pp. 88-89.

32 PÉREZ, Ventura: op. cit., pp. 240-241.

33 Ídem, pp. 241-243. 
Valladolid durante el siglo XVIII, mezclándose tanto actos religiosos como $\operatorname{profanos}^{34}$.

\section{$\underline{1753 .}$ Incendio del retablo mayor del Convento de San Norberto.}

El 31 de mayo, a eso de la una de la tarde, se quemó el retablo mayor de la iglesia conventual, "se quemaron dos santos que tenían a los lados, vestidos de canónigos, y de Nuestra Señora de los Afligidos se quemó parte del vestido se deshizo la corona, se ahumó y maltrató el rostro; el órgano que estaba detrás se derritió mucha parte" ${ }^{\text {35 }}$.

\section{B- ACONTECIMIENTOS RELACIONADOS CON LA MONARQUÍA}

En relación con otras épocas la presencia de los reyes o miembros de la familia real en Valladolid fue muy escasa. Tan sólo se pueden reseñar breves apariciones de Felipe IV y Felipe V por la ciudad, un hecho especialmente destacado es la celebración en el Convento de San Diego del segundo matrimonio de Carlos II.

\section{Fiestas con motivo del paso por la ciudad del rey Felipe IV}

Se celebraron grandes fastos en honor de Felipe IV a su paso de vuelta a la Corte tras haber celebrado en Fuenterrabía (Isla de los Faisanes), el 9 de junio, las ceremonias nupciales entre su hija la infanta María Teresa de Austria y Luis XIV de Francia. La presencia del Rey, nacido en Valladolid, llenaría de gozo y alegría a sus vallisoletanos, que darían todo de sí para que el viejo Austria se encontrara a gusto en su ciudad natal. En la preparación de los numerosos festejos que agasajaron al rey participaron gran parte de los mejores artistas de la ciudad $^{36}$. Entre estos destacaban las corridas de toros, las mascaradas, los juegos de cañas y los fuegos artificiales en el Pisuerga, que el rey observaría desde el Palacio de la Ribera. Estos últimos fueron descritos con gran precisión por Alcalde Prieto: "Llegado la noche se dio principio a los fuegos de artificio, para lo cual se había levantado en el rio una alta torre, a la cual bombardeaban con cohetes desde los barcos, hasta que prendiéndole fuego, se iluminó de brillantes luces el espacio en medio de los entusiastas vítores al Monarca"37.

Ídem, pp. 245-252.

Ídem, p. 292.

FERNÁNDEZ DEL HOYO, María Antonia: "Fiestas en Valladolid a la venida de Felipe IV en 1660", Boletín del Seminario de Arte y Arquitectura (en adelante B.S.A.A.), Tomo LIX, 1993, pp. 379392.

37 ALCALDE PRIETO, Domingo: op. cit., p. 81. 
El 4 de mayo son desposados por el Arzobispo de Santiago de Compostela en la iglesia conventual de San Diego el Rey Carlos II y Mariana de Neoburgo. Al enlace asistió "el Patriarca de las Indias y toda la Grandeza"38. Así lo relata Domingo Alcalde Prieto: "Iguales funciones poco más o menos se repitieron en 4 de mayo de 1690 con motivo de haber venido a esta ciudad el Rey a esperar a su nueva esposa $D^{a}$ Mariana de Neoburgo, con la cual se habían ya desposado por poder, y en esta población se velaron en la Iglesia de San Diego". De aquel excepcional suceso quedó recuerdo en una inscripción, hoy desaparecida, que se situaba sobre el arco de la reja de la capilla de la Virgen de la Portería: "Año de 1690, a 4 de mayo, día de la Ascensión, se casó en esta iglesia de San Diego el católico rey de las Españas Carlos II con la Serma. Señora Da Mariana de Neoburgo"39.

\section{Guerra de Sucesión}

Tras el fallecimiento de Carlos II, el 30 de noviembre, "en cumplimiento de la disposición testamentaria de dicho Monarca que instituía por heredero de la corona a D. Felipe de Borbón, Duque de Anjou, y nieto de Luis XIV de Francia" la ciudad le proclamó, y reconoció, como su legítimo Rey, siendo "una de las ciudades, que durante la guerra de sucesión, más fidelidad y simpatías mostraron al nuevo Monarca pues cuando el Archiduque Carlos, su competidor al torno, envió a pedir las llaves a esta ciudad en testimonio de su reconocimiento, se le contestó sin titubear, que en esta ciudad no se reconocía otro Soberano que a $D$. Felipe $V$ de Borbón, y que no entregaría a otro las llaves sino a la fuerza" ${ }^{\text {"40. }}$

\section{$\underline{\text { 1710. Estancia de Felipe V en el Palacio Real }}$}

Después de perder la batalla de Zaragoza (20 de agosto) Felipe V decide abandonar Madrid y refugiarse en Valladolid junto a su familia y los tribunales, residiendo durante unos días en el Palacio Real"1. Con posterioridad "vino la reina doña María Luisa Gabriela de Saboya, y traía al príncipe D. Luis, el cual la misma reina en persona lo enseñó donde el mirador del peinador; hubo mucho regocijo y fuegos en la plazuela de San Pablo" ${ }^{\prime 2}$. Felipe V llegó a la ciudad en un momento en el que ésta se hallaba ocupada preparando las fiestas

\footnotetext{
38 SANGRADOR Y VÍTORES, Matías: Historia de la Muy Noble y Leal Ciudad de Valladolid..., op. cit., Tomo I, p. 492.

39 ALCALDE PRIETO, Domingo: op. cit., p. 84.

40 Ídem, pp. 85-86.

41 http://es.wikipedia.org/wiki/Batalla_de_Zaragoza.

42 PÉREZ, Ventura: op. cit., pp. 29-30.
}

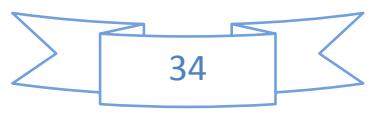


para la traslación de la Virgen de las Angustias a su nueva capilla dentro de la iglesia penitencial del mismo nombre. Desde esta misma ciudad Felipe V suplicó ayuda a su abuelo Luis XIV, el cual le envió " 14.000 hombres al mando del Duque de Vendôme y del Mariscal de Noailles; los que llegados a Valladolid, se ocuparon de reorganizar el ejército del Rey, reclutando y disciplinando gente sin descanso y al cabo de dos meses lograron contar con un cuerpo de ejército suficiente para competir con el del Archiduque y sus aliados"43.

\section{C- OTROS ACONTECIMIENTOS}

\section{$\underline{1684 . \text { Una gran peste asola la ciudad }}$}

Durante este año una peligrosa epidemia se extendió por toda España, cebándose especialmente con Valladolid. El hecho quedó reflejado en una inscripción que se conservaba en una casa contigua a la iglesia de San Andrés: "Año de 1684 fue el eclipse grande de sol, hubo peste general de gusanos largos y peludos por todas partes, y en Valladolid cerraron las puertas de la Ciudad, murió mucha gente en toda España"44. Fue durante esta peste cuando, según la tradición, se puso el apodo de "Puerta de la Pestilencia"45 a uno de los accesos a la ciudad, puesto que se creía que fue por esa puerta por la que accedieron los insectos que infectaron a la población ${ }^{46}$.

\section{$>\underline{\text { 1700. Construcción del paso del Espolón Nuevo }}$}

Desde hacía tiempo corría paralela a la margen derecha del Pisuerga una zona de paseo muy transitada. Se trataba del Paseo del Espolón Viejo, también conocido como Espolón del Campo, que conectaba las proximidades de la iglesia de San Lorenzo hasta la Plaza de las Tenerías, con zonas de acceso al río para los aguadores y para las caballerías que van allí a abrevar. Con la intención de ampliar este magnífico lugar de esparcimiento se decidió hacer el Espolón Nuevo (Fig. 1), del mismo estilo que éste, que abarcaría desde el puentecillo de la Cárcel hasta el Puente Mayor. La obra comenzó en 1691 sufriendo algunas interrupciones. De nuevo se reanudó en enero de 1701 quedando acabada en

43 ALCALDE PRIETO, Domingo: op. cit., p. 86.

44 SANGRADOR Y VÍTORES, Matías: Historia de la Muy Noble y Leal Ciudad de Valladolid..., op. cit., Tomo I, p. 491.

45 La puerta se halaba situada en el lado sur del Campo Grande. Daba comienzo al Camino de la Pestilencia, que tenía un trazado similar a la actual carretera de Madrid. FERNÁNDEZ DEL HOYO, María Antonia: Desarrollo urbano y proceso histórico del Campo Grande de Valladolid, Ayuntamiento de Valladolid, Valladolid, 1981, p. 170.

$46 \quad$ La tradición no es siempre la realidad. En este caso el nombre de "Puerta de la Pestilencia es bastante anterior, puesto que ya se refleja este apodo en los libros de acuerdos del ayuntamiento de los años 1602 y 1611. SANGRADOR Y VÍTORES, Matías: Historia de la Muy Noble y Leal Ciudad de Valladolid..., op. cit., Tomo I, p. 491. 
septiembre de 1702. Según Merino Beato "llevaba un pretil de piedra adornado con balaustre de rica rejería, rematado todo él con la misma decoración, de bolas sobre pedestales, que lleva el Espolón Viejo" ${ }^{47}$.

1707. Muerte del Padre Benete

El 7 de enero falleció el pintor y religioso jesuita Jerónimo Benete, siendo enterrado en el Colegio de San Ambrosio. Según Ventura Pérez "fue varón virtuoso; se ejercitaba en andar por las calles enseñando la doctrina cristiana a los niños; tocando una campanilla por las calles; mantenía de limosna un hospicio de estudiantes junto a la puerta principal del Salvador" 48 . Su labor como pintor, bastante mediocre, le permitiría entablar amistad con otros artistas de la ciudad. Así, por ejemplo, sabemos de su estrecha amistad con el escultor Juan Antonio de la Peña, llegando incluso a apadrinar a alguno de sus hijos $^{49}$.

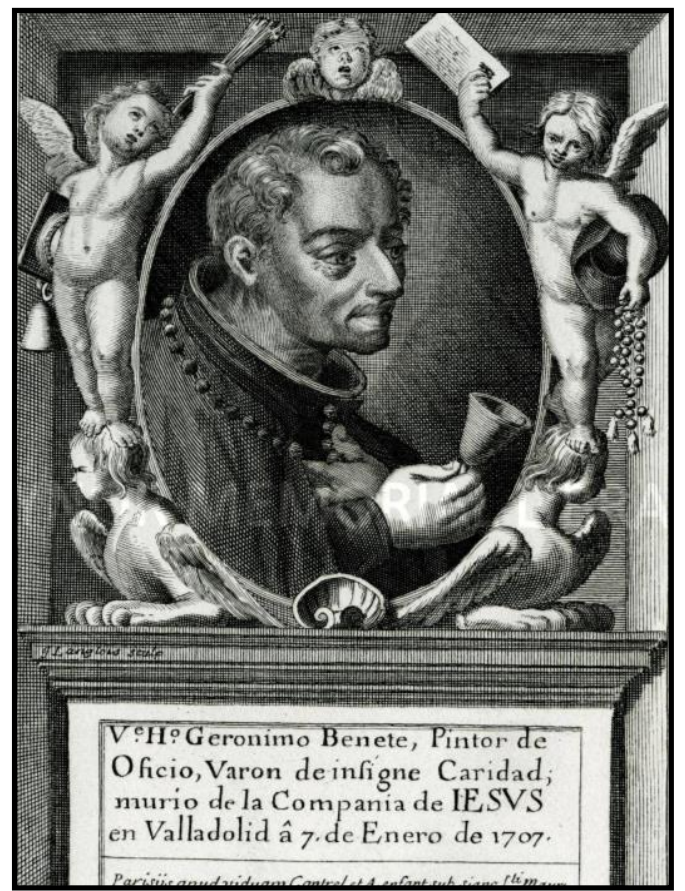

Il. 6- Jean Langlois. El Venerable Hermano Jerónimo Benete. Biblioteca Nacional de España. Madrid.

\section{$\underline{\text { 1715. Ampliación de la Universidad y construcción de la fachada monumental }}$}

Con el tiempo la vieja universidad gótica se había quedado pequeña y vetusta por lo cual en 1715 deciden ampliarla mediante la construcción de unos Nuevos Generales, con un patio de mayores dimensiones ${ }^{50}$. Sin embargo, la empresa estrella de esta remodelación era la apertura de una gran fachada monumental a la plaza de Santa María desde la que realizar los actos públicos. Ventura Pérez fecha el comienzo de todas estas obras en el mes de octubre, señalando asimismo que cuando se iniciaron las obras en la plazuela de Santa María se abrieron "unos hoyos grandes (...) en donde se encontraron muchos

47 MERINO BEATO, María Dolores: Urbanismo y arquitectura de Valladolid en los siglos XVII y XVIII, Tomo II, Ayuntamiento de Valladolid, Valladolid, 1990, p. 98.

48 PÉREZ, Ventura: op. cit., pp. 25-26.

49 URREA FERNÁNDEZ, Jesús: "La biografía al servicio del conocimiento artístico. El escultor Juan Antonio de la Peña", Boletín de la Real Academia de Bellas Artes de la Purísima Concepción (en adelante B.R.A.C.), Tomo XLII, Valladolid, 2007, p. 46.

50 MARTÍN GONZÁLEZ, Juan José: Catálogo Monumental de la provincia de Valladolid. Tomo XIII. Monumentos civiles de la ciudad de Valladolid, Diputación de Valladolid, Valladolid, 1983, p. 117.

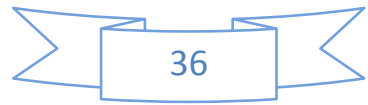


sepulcros antiguos de romanos, hechos unos cajones con cuatro piedras y dos testeros" ${ }^{51}$. La fachada, finalizada en 1718, resulto ser todo un hito de la arquitectura española, llegando a considerase como una de las más significativas del barroco civil.

\section{Fenómeno astrológico}

El 19 de octubre, hacia las 8 de la tarde, se pudo observar "un globo de luz, que llaman los astrólogos fenómeno, que causó mucha admiración y permaneció hasta las 10; se dijo que había sucedido lo mismo en diversas partes de Europa"52. Este mismo hecho fue recogido por el polifacético escritor salmantino Diego de Torres Villarroel en su "Discurso del globo de luz que se vio en la esfera celeste, así en esta ciudad de Salamanca como en la corte de Madrid, la noche del día 19 de octubre próximo pasado de 1726"53.

\section{$>\underline{1729 . \text { Frío invierno }}$}

El invierno de 1728 a 1729 fue extremadamente crudo en la ciudad. Las heladas duraron desde el 24 de diciembre de ese año hasta el 17 de enero siguiente, prolongándose el temporal hasta el 1 de febrero. Durante este tiempo se congeló el río, llegado a rodar por él los carros ${ }^{54}$.

\section{$>$ 1739. Crecida del Pisuerga y de las Esguevas}

Entre los días 5 y 6 de diciembre la ciudad sufrió una nueva tragedia: la crecida de los dos ríos que surcaban la ciudad, "tomando sus aguas casi la misma altura que en 1636, si bien no llegó Pisuerga hasta Santa Teresa, pero invadió mucha parte de la plazuela de San Nicolás, cubriendo el pretil de puente mayor; al propio tiempo que el Esgueva se enseñoreaba de las calles de Francos, Esgueva, plazuela d las Angustias, Cantarranas y Platería, hasta llegar a la plaza mayor como media vara de altura, siendo esta en la Platería de dos varas y media, entrando en la Iglesia de la Cruz hasta tocar los pies de la Virgen de los Dolores" ${ }^{\prime 5}$.

51 PÉREZ, Ventura: op. cit., pp. 44-45.

52 CANESI ACEVEDO, Manuel: Historia de Valladolid (1750), Tomo III, Grupo Pinciano, Valladolid, 1996, p. 649.

53 http://www.cervantesvirtual.com/portales/diego_de_torres_villarroel/su_obra_bibliografia/

$54 \quad$ SANGRADOR Y VÍTORES, Matías: Historia de la Muy Noble y Leal Ciudad de Valladolid..., op. cit., Tomo I, p. 498.

55 ALCALDE PRIETO, Domingo: op. cit., p. 87. 
1740. Importante nevada

El 26 de enero cayó una nevada tan copiosa que "en muchas años no se había visto cosa mayor, según declararon muchas personas ancianas"

\section{1-4 ARQUITECTURA EN VALLADOLID ENTRE 1650 - 1750}

\section{$\underline{\text { A- EL CAMBIO DE "ESTILO” }}$}

Hacia mediados del siglo XVII se produce en Valladolid un cambio en el mundo de la arquitectura. Si durante la primera mitad del siglo el "clasicismo" había dominado el panorama arquitectónico vallisoletano, en esta segunda mitad, si bien se siguieron manteniendo ciertos aspectos del dicho estilo, la diferencia radicará en el progresivo apoderamiento de las superficies por parte de la decoración, que poco a poco se irá haciendo más abultada.

Por estas mismas fechas se produce en España una reacción en la arquitectura española, por cual se irá abandonando la sobriedad: Así, Alonso Cano en Granada además de idear la tarjeta abultada de hojarasca inaugura la moda de decorar a base de placas recortadas. Mientras tanto, en Castilla la "chispa" de esta nueva etapa, más decorativa, prende en la capilla de San Isidro de la madrileña iglesia de San Andrés. En ella se decora la cúpula mediante estucos policromados, figuras de ángeles y $\operatorname{roleos}^{57}$.

En Valladolid, la transición hacia este nuevo "estilo" fue lenta debido a que en la ciudad radicaba uno de los bastiones del clasicismo derivado de Juan de Herrera: la escuela clasicista vallisoletana ${ }^{58}$. En esta ciudad vivieron y trabajaron algunos de los grandes arquitectos que profesaron este estilo: Francisco de Mora, Juan de Nates, Diego y Francisco de Praves...

Durante esta primera mitad de siglo se construyó mucho, si bien la mayoría fueron edificios religiosos, y más concretamente conventos. Esto nos conduce a esa afirmación que definía a Valladolid como una "ciudad levítica". Apenas se levantaron palacios y casas nobles. El motivo no era otro que el que la nobleza que durante los años de la Corte estuvo asentada en Valladolid había emigrado a Madrid. El resultado fue el abandono y progresivo deterioro de los palacios ${ }^{59}$. En comparación, la actividad constructiva en la segunda mitad del siglo XVII sería más pobre puesto que apenas se levantan edificios de nueva planta.

56 CANESI ACEVEDO, Manuel: Historia de Valladolid (1750), Tomo III..., op. cit., p. 652.

57 MARTÍN GONZÁLEZ, Juan José: Arquitectura barroca vallisoletana, Diputación Provincial de Valladolid, Valladolid, 1967, p. 91.

58 BUSTAMANTE GARCÍA, Agustín: La arquitectura clasicista del foco vallisoletano (15611640), Institución Cultural Simancas, Valladolid, 1983.

59 MARTÍN GONZÁLEZ, Juan José: “Arquitectura, urbanismo y escultura del siglo XVII”. En Valladolid en el siglo XVII. Historia de Valladolid, IV, Ateneo de Valladolid, Valladolid, 1982, p. 111. 
Ya en la década de 1660 el barroquismo comienza a penetrar en los edificios, fundamentalmente en sus interiores. Así, veremos cómo estos interiores se pueblan de abovedamientos y yeserías. En cambio, las fachadas, las plantas y los exteriores de las iglesias seguirán siguiendo, más o menos fielmente, los dictados clasicistas. Dos de los hitos que marcan este primer momento son los abovedamientos de la Catedral $(1655)^{60}$ y de la iglesia penitencial de Nuestra Señora de la Pasión (1661) (Figs. 2-3). Las bóvedas de la nave central de la catedral están ya concebidas con una intención más decorativa, dejando atrás la característica desornamentación herreriana: así, veremos los adornos de puntas de diamante y tableros quebrados, diseño este último que corresponde ya a una evolución decorativa perceptible desde mediados del siglo XVII ${ }^{61}$.

Según palabras de Martín González, la iglesia de Nuestra Señora de la Pasión es la "que mejor señala el giro hacia el barroquismo en Valladolid"62. El gran impulsor de este cambio fue el arquitecto paredeño Felipe Berrojo de Isla ${ }^{63}$, al cual se le encargó la realización de las bóvedas de la iglesia. En ellas veremos por primera vez un cambio en el tipo de la decoración. Realizadas en yeso policromado, las ornamentaciones se basaban en motivos lineales con dibujos vegetales: hojas crespas, tarjetas, roleos, grandes rameados avolutados, de formas espinosas, etc... ${ }^{64}$. También utiliza para las bóvedas grandes tarjetas de formas hinchadas como hojas de cactus. La bóveda de la nave, que servía para ocultar el techo de madera del siglo XVI, era de cañón con lunetos. Los arcos fajones se apeaban en ménsulas, decoradas con veneras y hojarasca.

En el año 1666 ya se había finalizado la decoración de la nave, precisándose que "era necesario se tratase de hacer en la media naranja de la capilla mayor otra obra que correspondiese de la dicha iglesia, diferenciando las labores, florones y rosones". Cómo podemos comprobar la reforma no afectó a ningún elemento estructural, tan sólo se tocaron los abovedamientos del templo.

La otra gran intervención llevada a cabo en la iglesia, y que a su vez pregona la llegada de un nuevo estilo mucho más decorativo, tiene por protagonista a la fachada (Fig. 4). En 1671 el arquitecto Pedro Ezquerra traza el segundo cuerpo de la fachada, encargándose de su ejecución, de manera conjunta, con Antonio de la Iglesia. La fachada se distribuye en dos cuerpos, remate y espadaña. Los elementos, posiblemente procedentes de Felipe Berrojo, que la integran son típicamente barrocos: "los vanos se orlan con gruesos baquetones, a veces con orejas. Las columnas del cuerpo inferior van decoradas con acanaladuras helicoidales, cuya ilusión de movimiento es mayor a causa de que en los fustes se disponen cinco tambores, cuya acanaladuras van en sentido

\footnotetext{
$60 \quad$ Ídem, p. 123.

Ibídem.

Ídem, p. 125.

Del prestigio que gozaba por entonces Felipe Berrojo habla bien la afirmación que se expone en el contrato que se hizo para encargarle la obra de las bóvedas: se habla de él como "el más insigne que se conoce de su profesión e que no hay otro en esta ciudad de que se pueda fiar". Ibídem.

64 MARTÍN GONZÁLEZ, Juan José: Arquitectura barroca..., op. cit., p. 95.
} 
alternante (...) Dentro de tarjetas de formas carnosas se disponen emblemas de la Pasión" "65. En definitiva, "toda esta ornamentación es muy abultada y claroscurista"66.

Una fase más avanzada la representa el Real Colegio de los Ingleses (1672-1679), que si bien no exhibe mucha decoración nos muestra su barroquismo en la adopción de una planta de plan central, concretamente octogonal alargado ${ }^{67}$, modelo tomado de la iglesia de San Antonio de los Portugueses de Madrid, y de la iglesia conventual de las Bernardas de Alcalá de Henares ${ }^{68}$. La gran virtud de las iglesias de plan octogonal alargado es la total visibilidad de la misma, así como la buena acústica derivada del uso de yeserías. Desde el punto de vista religioso existía la posibilidad de celebrar numerosas misas simultáneamente debido a la multiplicación de las capillas (Figs. 5-7).

Otro elemento que nos muestra una tendencia claramente barroca es el embutido de lienzos en las cúpulas o en las bóvedas (tenemos otro ejemplo en la iglesia de San Felipe Neri). Las del Colegio son obra de Diego Díez Ferreras mientras que las de San Felipe Neri se atribuyen a Amaro Alonso.

Entre los escasos edificios civiles las dos obras de mayor empeño fueron el Archivo y Cárcel de la Real Chancillería (1675) y la Hospedería del Colegio Mayor de Santa Cruz (1675). El Archivo y Cárcel de la Real Chancillería (Fig. 8) fue construido de manera conjunta por Felipe Berrojo, Juan Tejedor Lozano y Juan de Medina Arguelles, los cuales debían de seguir los planos elaborados en 1675 por el arquitecto Nicolás Bueno $^{69}$. Las obras del Archivo fueron a buen ritmo, de manera que en 1682 el edificio estaba concluido, en cambio las de la cárcel se alargaron. En 1698 se realizó un nuevo pregón para su construcción, quedándose con la obra José Gómez y el maestro de obras Pedro del Biermo, el cual la terminó a principios de la siguiente centuria. La fachada es toda de piedra y las rejas son de gruesos barrotes. No hay espacio apenas para la decoración.

La Hospedería del Colegio Mayor de Santa Cruz (Fig. 9) fue trazada por Antonio del Solar, mientras que de su construcción se encargó el maestro de obras Francisco de la Torre $^{70}$. El edificio posee un plan muy sencillo: se trata de un edificio de planta cuadrada con las fachadas de ladrillo y mampostería. El patio, que asemeja un claustro, también cuadrado, cuenta con dos pisos de arquerías de medio punto. La fachada principal está orientada hacia las traseras del Colegio de Santa Cruz.

Finalmente, no podemos dejar de reseñar un modelo de la iglesia (fundamentalmente de tipo conventual) que consiguió gran fortuna en Valladolid: se trataba de iglesias con

\footnotetext{
65 Ídem, p. 96.

Ídem, p. 97.

La planta de tipo octogonal alargado tendrá un gran desarrollo en España, puesto que se halla más acorde con los principios del barroquismo. Además de la iglesia del Colegio de los Ingleses, en la zona vallisoletana también se levantará con este modelo la iglesia del convento de Santa Clara de Tordesillas. Ídem, p. 106.

68 Ídem, p. 99.

69 MARTÍN GONZÁLEZ, Juan José: “Arquitectura, urbanismo...”, op. cit., p. 127.

$70 \quad$ Ídem, p. 128.
} 
planta de cruz latina, cubierta con bóvedas de medio cañón y cúpula no trasdosada sobre el crucero, que presenta una fachada íntegramente realizada en ladrillo, salvo el basamento. Dentro de esta tipología encontraremos numerosos ejemplos, entre los que destacan la iglesia de la Congregación de San Felipe Neri y la conventual de Santa Brígida $^{71}$ (Figs. 10-11).

Podemos convenir que durante la segunda mitad del siglo XVII se produjo un claro estancamiento de la actividad arquitectónica en la ciudad. Tan solo las remodelaciones $\mathrm{o}$ decoraciones de algunos edificios (iglesias penitenciales de la Pasión y de la Vera Cruz, catedral, etc...), que supusieron una actualización de los mismos, además de algún empeño personal como el del Padre Calatayud en su deseo de dotar de un santuario a la Virgen Vulnerata (colegio de los Ingleses) dinamizaron el pobre panorama arquitectónico vallisoletano. Esta pobreza constructiva no hemos de confundirla con una decadencia en cuanto a la capacidad de nuestros arquitectos puesto que, al igual que los escultores y pintores, estuvieron muy solicitados en las provincias limítrofes, y aún más allá.

\section{$\underline{\text { B- EL BARROCO EXALTADO }}$}

El desarrollo decorativo de los edificios comenzado con Felipe Berrojo en los años de 1660, y que apenas tuvieron incidencia, se vio culminado en la primera mitad del siglo XVIII, periodo que fue tildado por el profesor Martín González como de "barroco exaltado"72. Durante esta etapa no solo la decoración irá en aumento (habrá una mayor exuberancia ornamental), sino que el barroquismo se irá vislumbrando también en otros elementos: en las líneas movidas de las fachadas y las plantas, en los elementos de apoyo, etc... A pesar del fuerte influjo del barroco, la llama del clasicismo no terminará de extinguirse ${ }^{73}$.

En los interiores de las iglesias existirá una dicotomía: mientras que las plantas siguen siendo, por lo general, bastante simples, las yeserías y decoraciones de sus interiores se irán complicando cada vez más. Las bóvedas y los vanos se cubrirán con formas vegetales, grandes rameados, líneas quebradas y mixtilíneas, etc. Se llegará en algunos extremos a un verdadero horror vacui.

La aparición y progresiva consolidación del barroco exaltado en Valladolid llegará de fuera puesto que los arquitectos locales, más bien maestros de obras, seguirán en gran medida fórmulas clasicistas, si bien ya no con tanta pureza. Las influencias de este barroco exaltado proceden fundamentalmente de Salamanca y de Madrid. De Salamanca llegarán fray Pedro de la Visitación y Alberto Churriguera, los cuales legarán a la ciudad dos obras emblemáticas: la nueva fachada principal de la

\footnotetext{
71 Otros ejemplos, aunque ya desaparecidos, son la iglesia penitencial de Nuestra Señora de la Piedad y la del Convento del Carmen Calzado.

72 MARTÍN GONZÁLEZ, Juan José: Arquitectura barroca ..., op. cit., p. 123.

73 Ibídem.
} 
Universidad (Figs. 12), y el segundo cuerpo de la fachada principal de la Catedral (Figs. 13). Desde Madrid no se recibirán arquitectos sino influencias, concretamente comparecerán las del gran arquitecto castizo Pedro Ribera de manos del vallisoletano Manuel Serrano, el artífice local más importante de la primera mitad del siglo XVIII. Nacido en Valladolid hacia 1700, residió durante algunos años en Madrid, momento en el cual recibiría las influencias del gran arquitecto cortesano Pedro de Ribera ${ }^{74}$. Su arquitectura denota claramente la influencia del madrileño: así, muestra una gran afición por las plantas curvas, fachadas movidas y molduras flexuosas.

El regreso a Valladolid fue motivado por la obra de la iglesia parroquial de Renedo (1736) (Figs. 14-15), iglesia que junto a la parroquial de Rueda (1738-1742) (Fig. 16) son sus obras más descollantes. En la iglesia parroquial de Renedo aunque utiliza el viejo sistema de una sola nave con capillas laterales entre contrafuertes, introduce como novedades, además del movimiento de la fachada, el hecho de que las capillas, con plantas curvas, no se comuniquen entre ellas ${ }^{75}$.

En Valladolid capital su obra más emblemática fue la desaparecida iglesia del monasterio premostratense de San Norberto (1747-1753) (Fig. 17). Canesi refiere que los cimientos del templo los realizó "el maestro de tan suntuosa fábrica Manuel Serrano, hijo de esta ciudad, en este sitio, que fueron casas de los Maldonado" "76. La fachada era semicircular, con formas en avance y en retroceso, se encontraba enmarcada por un baquetón mixtilíneo envolvente, a la manera que había utilizado en las iglesias de Renedo y Rueda. También las capillas de los laterales debían ser similares a las de estas dos iglesias, puesto que Casimiro González García-Valladolid llega a afirmar que eran "de arcos", es decir, con planta curva".

Otro representante autóctono del barroco exaltado es Matías Machuca. Si bien desconocemos casi por completo su vida y formación, Martín González lo ha puesto en relación con Alberto de Churriguera ${ }^{78}$. Este arquitecto tendrá el gran honor de levantar en 1732 la fachada más barroca de la ciudad: la de la iglesia del hospital de San Juan de Letrán (Fig. 18-22). Que la nueva fachada gustó a Manuel Canesi da buena prueba el comentario que la dedicó: " $Y$ es tan superior la idea que ha formado Matías Machuca para la fachada, que es toda de piedra, con el adorno de varias columnas y estatuas, que bien examinadas, han declarado los peritos en la arquitectura que es de lo mejor que hay en Castilla y lo mismo el pulimento de la iglesia"79. La fachada se estructura a través de un gran cuerpo central dividido en dos pisos, dos alas laterales poligonales y un pequeño ático. La planta es muy movida con sus curvas y sus contracurvas. No sería muy aventurado decir que fue la fachada más barroca de la ciudad junto a la del convento de Premostratenses. La decoración se concentra en la calle central. Las columnas son plenamente barrocas debidas a ese aspecto bulboso y esponjoso. En el

Ídem, p. 146.

Ídem, p. 147

Ídem, p. 156.

Ibídem.

Ídem, p. 132.

CANESI ACEVEDO, Manuel: Historia de Valladolid (1750), Tomo III..., op. cit., p. 281. 
ático se desarrollan sendas torrecillas en los laterales y una central más amplia que alberga en su interior una imagen del titular del templo: San Juan Bautista. A ambos lados de esta torrecilla encontramos las esculturas de la Fe y la Caridad.

Conservamos noticias de un buen puñado de obras realizadas por Matías Machuca: así, por ejemplo, en 1722 levanta parte del Convento de Nuestra Señora de la Victoria (Fig. 23) que se había arruinado en 1717; en 1725 trabaja para la iglesia de la Merced Descalza, donde se encargó de levantar la fachada, capilla mayor y decoraciones barrocas del interior (yeserías) en forma de "pompas y morteros y otros adornos de este género"80; y en 1734 erige, de manera conjunta con Manuel Morante, la iglesia del Convento de las Comendadoras de Santa Cruz, la cual contiene también unas suntuosas yeserías (Fig. 24).

En contraposición a la arquitectura comentada, netamente barroca, en Valladolid se siguieron desarrollando los modelos clasicistas que habían triunfado en la primera mitad del siglo XVII, y que desde entonces continuaban, aunque cada vez en menor proporción. Según palabras del profesor Martín González, "hay que reconocer que existió frente a una arquitectura netamente barroca, otra que frenó la fantasía y mostró singular interés por los arcaicos planos" $"$. Uno de los factores que favoreció la prolongación de este modelo fue el hecho de que resultaban ser unos planes mucho más económicos ${ }^{82}$. Los maestros que desarrollaron este tipo de arquitectura eran por lo general locales. Dicha arquitectura se caracterizaba por mantener la línea recta tanto en fachadas, exteriores, plantas y alzados. Uno de los edificios más emblemáticos de esta tipología es la actual iglesia de San Nicolás (Figs. 25-27), antigua conventual de los Trinitarios Descalzos. La iglesia se comenzó a edificar en 1715, estando ya en 1740 concluida $^{83}$. La fachada, aunque clasicista, posee ciertos elementos barrocos como es el almohadillado que favorece la creación de volumen a través del claroscurismo.

\section{1-5 PINTURA EN VALLADOLID ENTRE 1650 - 1750}

\section{A- SEGUNDA MITAD DEL SIGLO XVII}

\section{$\underline{\text { Panorama general de artistas }}$}

Durante la segunda mitad del siglo, la actividad pictórica en Valladolid sufre un fuerte descenso tanto en cantidad como en calidad. Para Enrique Valdivieso las dos causas más importantes de esta crisis fueron "la falta de talento de los jóvenes pintores" y el

80 BRASAS EGIDO: José Carlos: “Arquitectura y urbanismo del siglo XVIII”. En Valladolid en el siglo XVIII. Historia de Valladolid, V, Ateneo de Valladolid, Valladolid, 1984, p. 301.

$81 \quad$ Ídem, p. 293.

82 MARTÍN GONZÁLEZ, Juan José: Arquitectura barroca..., op. cit., p. 162.

83 Ídem, p. 163 
"éxodo de los más hábiles a la Villa y Corte de Madrid"84. También supone que influiría la "decadencia padecida por la ciudad del Pisuerga en todos los órdenes" $\$$. El mismo autor nos pinta un panorama desolador: "pésimos pintores, carentes de talento, que ejecuta toscamente sus obras y las concluyen de manera imperfecta y apresurada. Sus ideas artísticas son mediocres, sus composiciones aparecen torpemente amañadas, de aspecto vulgar, con una colectiva falta de gusto y de delicadeza pictórica. Son en suma pintores insignificantes, más modestos artesanos que artistas, con la única pretensión de sobrevivir a toda costa en el ejercicio de su profesión" $"$.

Si bien Valladolid nunca se había caracterizado por poseer una importante escuela pictórica, debido en gran parte al éxito que alcanzó la escultura en Valladolid y en los territorios limítrofes, sí que durante la primera mitad del siglo la ciudad había disfrutado de algunos pintores de ciertos vuelos. Así, Diego Valentín Díaz (1586-1660) (Fig. 28) fue el pintor vallisoletano más importante, así como el artista más poderoso de la ciudad tras la desaparición de Gregorio Fernández. Otro magnífico exponente fue Francisco Martínez (1574-1626) (Fig. 29), hijo del gran pintor manierista Gregorio Martínez, del cual conservamos una serie de obras de muy desigual calidad. También hay que destacar al portugués Bartolomé de Cárdenas (c.1575-1628) (Fig. 30). En un escalón inferior a estos se situaban Jerónimo de Calabria (a.1584-1661), Blas de Cervera (a.1585-h.1663), Matías Velasco o Tomás Peñasco (h.1600-1677) (Fig. 31). Estos pintores tienen en común, según el parecer de Jesús Urrea, su falta de creatividad, lo que les llevaba a utilizar en multitud de ocasiones estampas de origen toscano, lombardo y flamenco $^{87}$.

Aunque Valentín Díaz no fallece hasta 1660 su obra pertenece a la primera mitad del siglo. El pintor que sirve de nexo de unión con la segunda mitad del mismo, y que es el encargado de salvaguardar el "prestigio" de la escuela vallisoletana, es un discípulo de éste, Felipe Gil de Mena (Fig. 32), el cual puede ser ya considerado, según la opinión de Valdivieso González, "como un verdadero pintor barroco por su decidido interés hacia la pintura naturalista" 88 . Del prestigio de Gil de Mena bien nos habla la afirmación de Palomino de que "fue también muy excelente en los retratos y muy naturalistas" $"$. Una de sus principales características fue la de la inclusión en sus composiciones, sean de la temática que sean, de bodegones.

A pesar de la referida decadencia, la escuela vallisoletana seguirá siendo la más importante del noroeste peninsular. Cuando un particular, una iglesia u otra institución de este territorio requerían de una pintura de cierta calidad, y no podía permitirse una

\footnotetext{
84 VALDIVIESO GONZÁLEZ, Enrique: La pintura en Valladolid en el siglo XVII, Diputación Provincial de Valladolid, Valladolid, 1971, p. 42.

85 Ibídem.

$86 \quad$ Ídem, p. 43.

87 URREA, Jesús: "La pintura en Valladolid en el siglo XVII". En GUTIÉRREZ ALONSO, Adriano (et. al.): Valladolid en el siglo XVII, Ateneo de Valladolid, Valladolid, 1982, p. 158.

$88 \quad$ Ídem, p. 161.

89 URREA FERNÁNDEZ, Jesús: El retrato en la pintura vallisoletana del siglo XVII, Caja de Ahorros Popular de Valladolid, Valladolid, 1983.
} 
obra del foco madrileño, acudían a la ciudad del Pisuerga, motivo por el cual veremos cuadros vallisoletanos diseminados por diferentes puntos de Castilla, Galicia, Asturias o incluso Navarra.

Este mismo fenómeno se vivió en Valladolid a la inversa: la recepción de obras de autores madrileños. Así, entre los pintores cortesanos representados en nuestras iglesias, conventos, etc... encontramos a Francisco Solís, Ignacio Ruiz de la Iglesia, Alonso del Arco o Acisclo Antonio Palomino ${ }^{90}$. Un caso excepcional fue Mateo Cerezo el cual vivió cierto tiempo en la ciudad dejando en ella alguna de sus mejores obras. Así por ejemplo pinta los lienzos del retablo mayor del Convento de Jesús y María (Figs. 3334), y algunos otros cuadros para diversas parroquias e incluso para la catedral. Entre todos ellos destaca el Cristo yacente acompañado de ángeles (Fig. 35) conservado en la iglesia de San Lorenzo.

Metiéndonos ya de fondo en la escuela vallisoletana lo primero que llama la atención es el hecho de que de la amplia nómina de pintores documentados tan sólo conservamos obras de unos pocos. Partiendo de la mediocridad general de los pintores activos en este momento quizás el más interesante sea Andrés Amaya "por su talante abierto a principios renovadores" ", autor del que conservamos un escaso catálogo de obras. Tan sólo la obra de otros cuatro pintores será verdaderamente reseñable: Agustín Bara, Amaro Alonso, Bartolomé Santos y el prolífico pintor sevillano Diego Díez Ferreras, autor con una obra muy dispersa, buena prueba de su prestigio, prestigio que no siempre era sinónimo de calidad ${ }^{92}$. En un escalón ya claramente inferior se encuentran otros maestros que en algunas ocasiones demuestran ser casi unos artesanos: los hijos de Felipe Gil de Mena (Felipe y Manuel Gil de Mena y Muga), Antonio y Lucas Caniego, Antonio Novoa Osorio, Jerónimo Benete, etc... ${ }^{93}$.

Del resto de pintores documentados tan solo conservamos datos biográficos o profesionales (contratos de obras desaparecidas, asientos de aprendices...). Según se desprende de la documentación obtenida en diferentes archivos, algunos otros pintores pudieron llegar a tener alguna trascendencia en el panorama pictórico vallisoletano de la época; sin embargo, la pérdida de su memoria y de sus obras nos les muestran en la actualidad como fantasmas. Este grupo lo conformarían: Francisco Cocho, José Martínez de Ollora, Manuel y Lucas de Ocio, Manuel Juárez o Pedro de Calabria (no confundir con su hijo Pedro de Calabria Escudero, pintor y grabador vallisoletano emigrado a la Corte.

Como hemos repetido bastantes veces, en este momento la pintura vallisoletana no aspira a realizar lienzos de gran calidad sino a satisfacer el gusto popular y la piedad privada y colectiva. Un caso curioso de esta piedad es el del padre Jerónimo Benete,

\footnotetext{
90 URREA, Jesús: "La pintura en Valladolid en el siglo XVII”, op. cit., p. 161.

$91 \quad$ Ídem, p. 158.

92 Un caso similar en el terreno escultórico lo tenemos en Francisco Díez de Tudanca, activo por estas mismas fechas.

93 URREA, Jesús: “La pintura en Valladolid en el siglo XVII”, op. cit., p. 158.
} 
pintor de nula calidad aunque afamado por sus pinturas de la Virgen y de la Pasión de Cristo $^{94}$.

Un apartado especial dentro de la pintura de este periodo lo conforma la Cofradía de San Lucas, institución que agrupó a los pintores en un primer momento, pero que posteriormente admitió en su seno a escultores, ensambladores y tallistas. El principal objetivo de dicha cofradía era el defender "los derechos generalmente fiscales, adquiridos con anterioridad, haciendo hincapié en la liberalidad de su arte, preocupándose por vigilar la calidad de las pintura que se vendían en el comercio, festejando a su santo patrón, el evangelista pintor, o participando en las numerosas ceremonias religiosas que se celebraban en la ciudad" 95.

Como no es el objetivo de esta tesis abordar la pintura barroca vallisoletana en profundidad, aunque sí formarnos una idea de los pintores más significativos que vivieron en aquella época y que compartieron ciudad, y en algunas ocasiones amistad, con los miembros de la familia Ávila, se realizará una escueta biografía de ellos, así como una lista de sus obras documentadas para así formarnos una idea de sus personalidades y producciones:

\section{AMARO ALONSO DE LLANOS $(1640$ - 1699)}

Amaro Alonso de Llanos Valdés, en realidad Amaro Alonso Méndez, vio la luz en Valladolid. Bautizado en la parroquia de la Santa Iglesia Catedral el 23 de enero de $1640^{96}$, sus padres fueron Amaro Alonso de Llanos, tendero de aceite y vinagre, e Isabel Méndez Redondo, ambos naturales "del lugar de San Simón cerca de la ciudad de Lugo"97.

La primera noticia sobre el pintor se fecha en el 21 de octubre de 1662, día en el que otorga testamento tras haber sufrido una puñalada, de la cual culpaba la justicia al pintor Diego Díez Ferreras. Sin embargo, Amaro Alonso le exculpó puesto que vio perfectamente a las dos personas que perpetraron el ataque: el emballenador Juan González y el sastre Manuel Vázquez. No pudo precisar quién de los dos fue el que le agredió "porque con la oscuridad de la noche no puedo conocer cuál era"98. Las cláusulas del testamento nos aportan valiosa información sobre su personalidad y parte de su producción artística perdida. Finalmente nombraba como testamentarios a su hermana, Teresa Alonso, y al bodegonero Felipe Viana. Entre los testigos que lo

94 GONZÁLEZ GARCÍA VALLADOLID, Casimiro: Datos para la historia biográfica de la M. N. M. N. H. y Excma. ciudad de Valladolid, Tomo I, Maxtor, Valladolid, 2003, pp. 178-180.

95 CASASECA CASASECA, Antonio (et. al.): Historia del arte de Castilla y León. 6: Arte barroco, Editorial Ámbito, Valladolid, 1997, p. 354.

96 Amaro Alonso hijo de padres solteros, ella vive a la Caraba. "En 23 de enero de 1640 el licenciado Carrizo cura de esta dicha iglesia según forma de ella bauticé a Amaro hijo de Amaro Alonso y de Isabel Méndez personas solteras sin haberse desposado fueron sus padrinos Bartolomé López y María González vecinos de ella y lo firmo fecho ut supra". A.G.D.V., Catedral, 1618B, f. 173.

97 Archivo Histórico Provincial de Valladolid (en adelante A.H.P.V.), Leg. 2.615, ff. 430-431.

98 MARTÍ Y MONSÓ, José: Estudios histórico-artísticos ..., op. cit., p. 502. 
firmaron figura el pintor Diego Díez Ferreras, señal de que la acusación era falsa y de que ambos gozaban de una buena amistad.

El 31 de marzo de 1665 ingresa en la Cofradía Penitencial de Nuestro Padre Jesús Nazareno $^{99}$. Un año después, el 4 de marzo de 1666, contrae matrimonio con Bernarda de Andrade en la iglesia parroquial de San Julián ${ }^{100}$, templo en el que fueron bautizadas sus dos hijas: Josefa Gabriel, el 2 de abril de $1668^{101}$, y María Benita, el 6 de abril de $1673^{102}$. Su otro hijo, Simón Amaro, fue bautizado en la iglesia de San Miguel el día 10 de noviembre de $1678^{103}$.

En el año 1681 vemos trabajar codo a codo a Amaro Alonso con nuestro Juan de Ávila. Mientras que el escultor realizaba una nueva imagen procesional de Santiago Matamoros ${ }^{104}$ y "unas perspectivas" -seguramente arquitecturas efímeras-con las que adornar dicho estreno ${ }^{105}$, Amaro Alonso se ocuparía de policromar la "perspectiva", tarea por la que percibió 180 reales ${ }^{106}$. A partir de entonces, si no antes, surgiría una buena amistad cómo podemos volver a comprobar en el bautizo de José de Ávila, hijo de Juan, y donde Amaro Alonso actuó como padrino.

Durante el año 1687 ostenta el cargo de mayordomo de fábrica secular de la antigua iglesia de San Miguel $^{107}$. Siete años después contrae matrimonio en segundas nupcias en la iglesia parroquial de Santiago Apóstol con Damiana Jalón y Gallo, viuda del también pintor Juan Sanz. Entre los testigos del enlace figura el pintor Andrés de Amaya ${ }^{108}$.

\begin{tabular}{ll}
\hline 99 & Ídem, p. 495. \\
100 & A.G.D.V., San Julián, 1664M, f. 4. \\
101 & A.G.D.V., San Julián, 1624B, f. 144. \\
102 & A.G.D.V., San Julián, 1671B, f. 8. \\
103 & "En diez días del mes de noviembre de mil seiscientos y setenta y ocho yo don Sebastián Ramos
\end{tabular} Nieto cura propio de la iglesia parroquial de señor San Miguel de esta ciudad de Valladolid bauticé e impuse los santos óleos según forma de la santa iglesia romana a Simón Amaro hijo legítimo de Amaro Alonso de Llanos y de Bernarda de Andrade su mujer fueron padrinos don Antonio de Tapia Valcárcel y Josepha Gabriela de Llanos dieronle por abogados a Nuestra Señora de la Esperanza y San José siendo testigos los licenciados Manuel Gimeno, Andrés Merino y Francisco del Corral presbíteros beneficiados de esta dicha iglesia y en fe de ello lo firmé ut supra”. A.G.D.V., San Miguel, 1669B, ff. 102-103.

104 "1682-1683. Más pagué a Juan de Ávila del Santiago que hizo de talla con un peñasco sobre que se pone para la fiesta de Santiago = y de hechura de un arco grande que hizo para dicho santo todo tallado con sus remates seiscientos y cincuenta reales en que se concertó todo". Archivo General Diocesano de Valladolid (en adelante A.G.D.V.), Santiago. Libro de fábrica 1673-1707, f. 147. MARTÍN GONZÁLEZ, Juan José y URREA FERNÁNDEZ, Jesús: Catálogo Monumental de la provincia de Valladolid. Tomo XIV..., op. cit., p. 202.

105 "1682-1683.- Gastos menudos y extraordinarios. Más pagaron a Juan de Ávila de una perspectiva que hizo de tres arcos con su grada en medio de tres gradas para dicha fiesta cien reales". A.G.D.V., Santiago, Libro de fábrica 1673-1707, s/f.

106 "Más pagaron a Amaro Alonso de pintar los tres arcos de la perspectiva y el respaldo de ella y la tramoya para encerrar a su majestad ciento y ochenta reales". A.G.D.V., Santiago, Libro de fábrica 16731707, s/f.

107 A.G.D.V., San Miguel, 1653D, f. 233.

108 En ocho de septiembre de mil seiscientos y noventa y cuatro años yo don Juan Fernández Salazar cura propio de la parroquial de Santiago de ésta ciudad de Valladolid, habiendo precedido las tres municiones que el santo concilio manda y licencia del señor don Jerónimo Ibáñez provisor general de dicha ciudad y su obispado, refrendada de Marcos de Porras notario de asiento de la audiencia episcopal de ella su fecha de siete de dicho mes: desposé por palabras de presente según ordena la santa madre iglesia a Amaro Alonso de Llanos y Valdés viudo de doña Bernarda de Andrade, con doña Damiana Jalón 
El 6 de noviembre de 1695 accede a su taller el único aprendiz que hemos podido documentar: Leonardo Vázquez de Codesal. El padre del muchacho le asentó en el taller para que aprendiera el "arte de pintor como es a dibujar todo género de figuras y el más tocante y perteneciente del dicho arte" $" 109$.

El 29 de abril de 1696 las vidas profesionales de Amaro Alonso y Juan de Ávila vuelven a cruzarse: se encargan de inspeccionar, junto con el también escultor Juan Antonio de la Peña, las labores de retoque de las figuras de los pasos de la cofradía de la Pasión que corrían a cargo del pintor Valentín Gómez de Salazar ${ }^{110}$.

Amaro Alonso de Llanos y Valdés fallece el 12 de julio de $1699^{111}$, siendo enterrado en la desaparecida iglesia de San Miguel de Valladolid. Su cuerpo debía ser colocado en una sepultura propia (le fue obsequiada por dicha iglesia en agradecimiento a la donación que hizo de un busto de Ecce Homo) dentro de la capilla mayor. El Ecce Homo, que fue regalado "el año de 1698 (...) con otras alhajas", era una imagen de "medio cuerpo de escultura admirable, con su peana de media talla dorada", que se guardaba "en el archivo de los privilegios de Valladolid que está sobre la puerta de la torre". El referido busto aparece en sucesivos inventarios del "Libro de Alhajas" de la iglesia de San Miguel. Sirvan de ejemplos los de los años $1702^{112}$ y $1711^{113}$. Atribuido a Manuel Pereira, en la actualidad forma parte del pequeño museo parroquial $^{114}$.

\section{$\underline{\text { Catálogo }}$}

1662. Seis pasajes con ermitaños, seis pasajes con historias y doce lienzos. Diversos comitentes $^{115}$. Paradero desconocido.

y Gallo viuda de Juan Sanz vecinos de ésta dicha ciudad fueron testigos Andrés de Amaya y Valdés, Manuel Gómez y don Francisco de Medina y lo firmé. A.G.D.V., Santiago, 1673M, f. 202.

109 A.H.P.V., Leg. 2.788, f. 305.

110 MARTÍ Y MONSÓ, José: Estudios histórico-artísticos..., op. cit., p. 495.

111 "En doce de julio de mil y seiscientos y noventa y nueve murió habiendo recibido los santos sacramentos Amaro Alonso de Llanos y Valdés pintor, otorgó su testamento ante Juan Salmón Rasilla escribano real en diez de éste presente mes y año, mándose enterrar en esta parroquia de San Miguel donde era parroquiano en sepultura propia dentro de la capilla mayor, que se la dio la fábrica por una hechura de un Santo Ecce Homo de escultura y un cuadro de las Ánimas que dio a la iglesia por dicha sepultura, nombró por testamentarios a don Francisco González su yerno relator de ésta Real Chancillería, y a don Miguel de Landa y a mí don Antonio Sangáriz y por sus herederos a sus hijas, señaló por su alma trescientas misas la cuarta en la parroquia y lo firmé”. A.G.D.V., San Miguel, 1653D, f. 283.

112 "Imagen del Santo Ecce Homo. Más tiene dicha iglesia un Santo Ecce Homo de medio cuerpo de escultura admirable, con su peana de media talla dorada (ilegible) ¿izquierda? en el archivo de los privilegios de Valladolid que está sobre la puerta de la torre que la dio en el año pasado de 1698 Amaro Alonso pintor con otras alhajas, por una sepultura con su losa que le dio la fábrica, al entrar en la capilla mayor, frontero del dicho archivo". A.G.D.V., San Miguel y San Julián, Caja 5, Libro de Alhajas, 17021768, f. 2.

113 "Imagen del Ecce Homo. Ítem una imagen del Ecce Homo, muy rica, que dio a la fábrica Amaro Alonso Fernández pintor con otras alhajas, con su peana, de media talla, que se guarda en el archivo de los privilegios de ésta ciudad". A.G.D.V., San Miguel y San Julián, Caja 5, Libro de Alhajas, 1702-1768, f. 3-4 (1711).

114 MARTÍN GONZÁLEZ, Juan José y URREA FERNÁNDEZ, Jesús: Catálogo Monumental de la provincia de Valladolid. Tomo XIV..., op. cit., p. 127.

115 MARTÍ Y MONSÓ, José: Estudios histórico-artísticos..., op. cit., p. 502. 
1675. Lienzos de la Santa Cena, la Degollación del Bautista (Fig. 36), Salomé presentando la cabeza del Bautista a Herodes y Herodías (Fig. 37). Cofradía de Nuestra Señora de la Pasión. Valladolid ${ }^{116}$. Los dos últimos se conservan en la iglesia de San Juan Bautista.

1685-1686. "Retocar y hacer de nuevo los cuadros que están puestos en el altar mayor". Iglesia de San Juan Bautista. Valladolid ${ }^{117}$.

1687. Pinturas encastradas de los cuatro Evangelistas, el Padre Eterno, la Asunción, San Felipe Neri con la Inmaculada, la Anunciación y el Arrepentimiento de San Pedro (Figs. 38-39). Oratorio de San Felipe Neri. Valladolid ${ }^{118}$.

1690. Pintar "la capilla mayor y mejoras de pintar pilastras, cornisas y celosías de dicha obra". Ermita de Nuestra Señora de la Peña. Tordesillas (Valladolid) ${ }^{119}$.

1691. Cuadros de San Pedro, San Antonio y San Fernando. Iglesia parroquial de San Pedro. Zaratán (Valladolid) ${ }^{120}$. Desaparecidos.

1696. Pinturas de la cúpula y de las pechinas. Ermita de Nuestra Señora de la Peña. Tordesillas (Valladolid) ${ }^{121}$.

1698. Cuadro de la Asunción. Iglesia parroquial de La Overuela (Valladolid) ${ }^{122}$. Desaparecido.

\section{$\underline{\text { AGUSTÍN BARA }}(1650$ - 1678)}

Agustín Bara Portillo encarna perfectamente el caso paradigmático de pintor prometedor cuya carrera su trunca a una edad muy temprana ${ }^{123}$. Vio la luz en la localidad vallisoletana de Olivares de Duero, en cuya iglesia parroquial de San Pelayo fue bautizado el día 19 de septiembre de 1650. Sus padres fueron el escribano "de su

\footnotetext{
116 Ibídem.

117 A.G.D.V., San Juan, Caja 3, Libro de fábrica 1651-1690. Años 1685-1686.

118 URREA FERNÁNDEZ, Jesús: "El oratorio de San Felipe Neri de Valladolid", B.R.A.C., Tomo
} XXXIII, 1998, pp. 18-19.

119 ARA GIL, Clementina Julia y PARRADO DEL OLMO, Jesús María: Catálogo Monumental de la provincia de Valladolid. Tomo XI. Antiguo partido judicial de Tordesillas, Diputación de Valladolid, Valladolid, 1980, p. 311.

120 MARTÍN GONZÁLEZ, Juan José: Catálogo Monumental de la provincia de Valladolid. Tomo VI. Antiguo partido judicial de Valladolid, Diputación de Valladolid, Valladolid, 1973, p. 171.

$121 \quad$ Ídem, p. 313.

122 Ídem, pp. 57-58

123 "En la villa de Olivares a diez y nueve días del mes de septiembre de mil y seiscientos y cincuenta años yo el bachiller Pedro Rodríguez cura y beneficiado de preste de la parroquial del señor San Pelayo de dicha villa puse los santos óleos y crisma por estar bautizado en casa de necesidad a Agustín Bara hijo de Juan Bara Gutiérrez y de Isabel Portillo su legítima mujer mis parroquianos fueron sus padrinos Baltasar Toribio mozo e Isabel de Sancho los cuales con el bautizado y su padre y madre contrasien parentesco espiritual que impide el matrimonio testigos Francisco Casbe y Marcos de la Fuete y Juan Núñez de Tovar, diosele por abogado a la degollación de San Juan Bautista y lo firmé fecho ut supra". A.G.D.V., Olivares de Duero, San Pelayo, f. 65. 
majestad" Juan Bara Gutiérrez e Isabel Portillo, ambos vecinos y naturales de Tudela de Duero. Seguramente la estancia de sus padres en Olivares de Duero tenga que ver con las obligaciones laborales del cabeza de familia.

Desconocemos tanto el momento en que llega a Valladolid como en el que entra al taller en el que se forma como pintor. Su escasa obra tampoco nos ayuda a averiguar la identidad de su mentor.

El 2 de julio de 1674 se desposa en la iglesia de San Martín, de Valladolid, con María Antonia Gavilán, nieta del gran genio de la escultura Gregorio Fernández ${ }^{124}$. Un año después, el 19 de agosto de 1675, el matrimonio fue velado en la iglesia de San Lorenzo $^{125}$. Por entonces el matrimonio vivía en la plaza de la Santísima Trinidad.

El 29 de marzo de 1677 recibe como aprendiz en su taller a un tal Juan Fernández, al cual debería enseñar "el dicho arte de pintura y todo lo al tocante". El tiempo de aprendizaje sería de seis años, cobrando a cambio Bara 800 reales ${ }^{126}$.

El 2 de septiembre de 1678 muere su mujer, siendo enterrada según su deseo en el Convento del Carmen Calzado ${ }^{127}$. El día 18 de ese mismo mes Agustín Bara "estando enfermo en cama" y, por lo tanto, no pudiendo disponer "mi testamento, mandas y legados", decide comunicar sus disposiciones a su cuñado el pintor José Martínez de Ollora y a fray Francisco Fernández de Llano, religioso en el convento de Nuestra Señora de la Merced ${ }^{128}$. También los instituyó como albaceas y testamentarios, y como heredera universal dejaba nombrada a su hermana Beatriz, esposa de Martínez de Ollora. Bara fallece cinco días después, el 23 de septiembre, siendo enterrado en la iglesia de San Lorenzo, a la cual estuvo tan vinculado durante su corta estancia en Valladolid $^{129}$.

\section{$\underline{\text { Catálogo }}$}

1675. Pinturas de El nacimiento de San Juan Bautista (Fig. 40), La predicación de San Juan en el desierto (Fig. 41) y El bautismo de Cristo (Fig. 42). Cofradía de Nuestra Señora de la Pasión. Valladolid ${ }^{130}$. Las tres obras se conservan en la actual iglesia de San Juan Bautista.

Fecha indeterminada. Atribuidas. Pinturas del Nacimiento, la Adoración de los Magos y la Circuncisión $^{131}$.

\footnotetext{
124 A.G.D.V., San Martín, 1659M, ff. 77-78.

125 A.G.D.V., San Lorenzo, 1671M, f. 12.

126 A.H.P.V., Leg. 2.792, f. 371.

127 MARTÍ Y MONSÓ, José: Estudios histórico-artísticos..., op. cit., p. 403.

128 A.H.P.V., Leg. 2.772/1, ff. 704-705.

129 A.G.D.V., San Lorenzo, 1671D, f. 18; MARTÍ Y MONSÓ, José: Estudios histórico-artísticos..., op. cit., p. 403.

$130 \quad$ Ídem, p. 502.

131 BRASAS EGIDO, José Carlos: Catálogo Monumental de la provincia de Valladolid. Tomo X. Antiguo partido judicial de Olmedo, Diputación de Valladolid, Valladolid, 1977, p. 191.
} 
Diego Díez Ferreras fue el pintor más prolífico de la escuela vallisoletana de la segunda mitad del siglo XVII. Se puede afirmar que sucedió a Diego Valentín Díaz y a Felipe Gil de Mena en el papel de pintor más prestigioso de la capital castellana. Aunque nacido en Carmona (Sevilla), vivió durante casi toda su vida en Valladolid, ciudad en la que habitó en la acera de la Plaza Mayor entonces conocida como la de los "escribanos o del Caballo de Troya".

Dispersó su obra por toda Castilla de la mano de los encargos que recibía de la orden Carmelita y de la Compañía de Jesús. Para los carmelitas trabajó en Medina de Rioseco, Soria o Peñaranda de Bracamonte. Asimismo, para los jesuitas lo hizo en Valladolid o Segovia. Cofradías (de la Pasión y Angustias), parroquias (Portillo, San Cebrián de Campos, etc.) e incluso varias catedrales (El Burgo de Osma o Palencia) solicitaron frecuentemente sus servicios ${ }^{132}$.

Desde su primera obra documentada, las pinturas del retablo mayor de la iglesia de Santa Cruz de Medina de Rioseco (Fig. 43-44), aparece ya configurado plenamente su estilo sin que en sus pinturas posteriores se aprecien cambios. Aficionado a composiciones repletas de figuras, con las que intenta crear sensación de movimiento, el pintor vallisoletano recurre a grises, azules y rosas, que denotan su preferencia por las tonalidades frías que aplica con pinceladas sueltas. Respecto a esto último, el profesor Pérez Sánchez le define como "hijo de su tiempo en el color alegre y en la factura más suelta que las de sus predecesores locales" ${ }^{133}$. Su estilo ingenuo y popular le debió de proporcionar fama y crédito artístico dado que son abundantes las obras documentadas como las que fácilmente se le atribuyen. Los fondos de paisaje, estereotipados y repetitivos, aparecen como telones sin que consiga integrar en ellos a los personajes ${ }^{134}$.

Diego Díez Ferreras nace en Carmona (Sevilla) el 23 de enero de 1640. Sus padres fueron Diego Díez Ferreras (oriundo de Puebla de Lillo) y Catalina Fernández ${ }^{135}$. El primer documento que nos indica su presencia en Valladolid son las capitulaciones matrimoniales con su primera esposa, efectuadas el 22 de diciembre de $1661^{136}$. Tan solo dos años después, el 20 de agosto de 1663, fallece su esposa, siendo enterrada en la iglesia de Santiago ${ }^{137}$. El luto no duraría mucho puesto que ese mismo año contrae matrimonio con Inés de Osorio en la iglesia parroquial de San Lorenzo ${ }^{138}$.

\footnotetext{
132 CASASECA CASASECA, Antonio (et. al.): op. cit., pp. 374-378.

133 PÉREZ SÁNCHEZ, Alfonso Emilio: Pintura barroca en España (1600-1750), Cátedra, Madrid, 2010 , p. 346.

134 MONTANER LÓPEZ, Emilia: La pintura barroca en Salamanca, Universidad de Salamanca, Salamanca, 1987, pp. 194-198.

135 CADENAS Y VICENT, Vicente de: Pleitos de Hidalguía que se conservan en el Archivo de la Real Chancillería de Valladolid. Extracto de sus expedientes. Siglo XIX, Tomo IX - Letras T-Z, Instituto Salazar y Castro, Madrid, 1980, p. 152.

136 A.H.P.V., Leg. 2.511, ff. 530-531.

137 MARTÍ Y MONSÓ, José. En VV.AA.: Boletín de la Sociedad Castellana de Excursiones III (1907-1908), Grupo Pinciano, Valladolid, 1984, p. 344.

138 A.G.D.V., San Lorenzo, 1602M, f. 295.
} 
En el año 1662, como ya hemos visto, fue acusado de haber apuñalado al pintor Amaro Alonso, extremo que el propio Alonso negó en su testamento otorgado el día 21 de octubre de ese año. Posteriores documentos nos los sitúan como buenos amigos ${ }^{139}$. Tres años después figura como testigo en el contrato que firmaron los ensambladores Cristóbal Ruiz de Andino y Juan Fernández para realizar el retablo de Nuestra Señora del Rosario para la iglesia de San Cebrián de Campos ${ }^{140}$.

El 16 de noviembre de 1679 el mayordomo de la ciudad, don Juan Francisco de Rivera, paga a Díez Ferreras 300 reales de vellón "por retocar y componer la pintura de Nuestra Señora del consistorio"141. Las últimas noticias datan del año 1701. Aunque no hemos logrado localizar su partida de defunción, es comprensible que falleciera por aquellas fechas.

\section{Catálogo}

1665. Pinturas del retablo mayor. Iglesia de Santa Cruz. Medina de Rioseco (Valladolid) $)^{142}$.

1668. La muerte de San José (Fig. 45) y El Hogar de Nazaret. Iglesia penitencial de Nuestra Señora de las Angustias. Valladolid ${ }^{143}$.

1672. La transverberación de Santa Teresa y San José con el Niño. Convento de Carmelitas Descalzos. Pamplona ${ }^{144}$.

1674. San Juan Bautista y San José con el Niño. Iglesia parroquial de Santa María. Portillo (Valladolid) ${ }^{145}$.

1675. El Anuncio del ángel a Zacarías (Fig. 46). Iglesia de San Juan Bautista. Valladolid.

1675. Apoteosis de San Ignacio (Fig. 47). Iglesia de San Miguel. Valladolid ${ }^{146}$.

139 MARTÍ Y MONSÓ, José: Estudios histórico-artísticos..., op. cit., p. 502. A.H.P.V., Leg. 1.392, ff. 34-35.

140 A.H.P.V., Leg. 2.792, f. 373-374.

$141 \quad$ Al pintor por el retocar el cuadro de Nuestra Señora de la Escalera.

"Pagará vuestra majestad D. Juan Francisco de Rivera mayordomo de la ciudad al Sr. Diego Díez trescientos reales de vellón que son por retocar y componer la pintura de Nuestra Señora del consistorio y de esto se ha de tomar la razón en la contaduría Valladolid y noviembre 16 de 1679.

Son 300 reales de vellón. Sírvase vuestra majestad Sr. D. Juan Francisco de Rivera de mandar dar al pintor". A.M.V., CH. 107-3, f. 2.

142 VALDIVIESO GONZÁLEZ, Enrique: op. cit., p. 172.

143 GARCÍA CHICO, Esteban: Valladolid: Papeletas..., op. cit., p. 69. MARTÍN GONZÁLEZ, Juan José y URREA FERNÁNDEZ, Jesús: Catálogo Monumental de la provincia de Valladolid. Tomo $X I V \ldots$, op. cit., p. 234.

144 ORBE SIVATTE, Mercedes [et. al.]: Catálogo monumental de Navarra. 5. III, Merindad de Pamplona. Índices generales de la obra, Institución Príncipe de Viana, Pamplona, 1997, pp. 285 y 289.

145 BRASAS EGIDO, José Carlos: Catálogo Monumental de la provincia de Valladolid. Tomo X..., op. cit., p. 191.

146 MARTÍN GONZÁLEZ, Juan José y URREA FERNÁNDEZ, Jesús: Catálogo Monumental de la provincia de Valladolid. Tomo XIV..., op. cit., p. 123

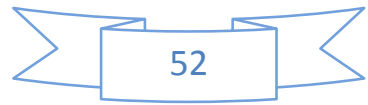


1678. Pinturas de la Anunciación, la Visitación y la Inmaculada. Iglesia de San Cornelio y San Cipriano. San Cebrián de Campos (Palencia) ${ }^{147}$.

1679. Pinturas del retablo mayor. Iglesia del Seminario Conciliar. Segovia ${ }^{148}$.

1679. Pinturas encastradas de la cúpula (Fig. 48). Colegio de los Ingleses. Valladolid $^{149}$.

1682. La Asunción. Colegiata de San Antolín. Medina del Campo (Valladolid) ${ }^{150}$.

1682. Bautismo de Jesús. Museo Diocesano. Zamora ${ }^{151}$.

1685. La Asunción y la Coronación de la Virgen del retablo mayor. Iglesia de la Asunción. Laguna de Duero (Valladolid) ${ }^{152}$.

h. 1686-1690. Pinturas del antiguo retablo mayor. Iglesia de Santa Marina la Real. León ${ }^{153}$.

1686. Escudos de armas. Iglesia de San Miguel Arcángel. Valladolid ${ }^{154}$.

1689. Retrato de una beata fundadora. Convento de San Antonio el Real. Segovia ${ }^{155}$.

1695. Pinturas de los ángeles de las enjutas de la bóveda. Convento de Santa Brígida. Valladolid $^{156}$.

Sin datar. San Elías arrebatado por los aires en un carro de fuego. Museo de Almería. Almería ${ }^{157}$.

Sin datar. San Elías arrebatado por los aires en un carro de fuego. Museo Nacional de Escultura. Valladolid ${ }^{158}$.

147 URREA FERNÁNDEZ, Jesús y MARTÍN GONZÁLEZ, Juan José: Inventario artístico de Palencia y su provincia II, Antiguos partidos judiciales de Carrión de los Condes, Saldaña y Aguilar de Campoó, Ministerio de Cultura, Madrid, 1980, p. 181.

148 VALDIVIESO GONZÁLEZ, Enrique: op. cit., p. 271. VERA, Juan: “José Vallejo, autor del retablo de la Compañía”, Estudios Segovianos, 1966, p. 83.

149 MARTÍN GONZÁLEZ, Juan José y PLAZA SANTIAGO, Francisco Javier de la: Catálogo Monumental de la provincia de Valladolid. Tomo XV. Monumentos religiosos de la ciudad de Valladolid ( $2^{a}$ parte), Institución Cultural Simancas, Valladolid, 2001, p. 299.

150 URREA FERNÁNDEZ, Jesús (coord.): Patrimonio restaurado de la provincia de Valladolid 1997-2003. Del olvido a la memoria (vol. 1). Pintura y Escultura, Diputación de Valladolid, Valladolid, 2008, p. 168.

151 http://meditacionesartecristiano.blogspot.com.es/2013/05/cerca-de-mi.html.

152 MARTÍN GONZÁLEZ, Juan José: Catálogo Monumental de la provincia de Valladolid. Tomo VI..., op. cit., p. 67.

153 LLAMAZARES RODRÍGUEZ, Fernando: Fuentes documentales para el arte barroco en la provincia de León: ensambladores, escultores y pintores, Universidad de León, León, 2008, p. 60.

154 GARCÍA CHICO, Esteban: Documentos para el estudio del arte en Castilla. 3, Pintores II, Universidad de Valladolid, Valladolid, 1946, p. 237.

155 CASASECA CASASECA, Antonio (et. al.): op. cit., pp. 374-378.

156 MARTÍN GONZÁLEZ, Juan José y PLAZA SANTIAGO, Francisco Javier de la: Catálogo Monumental de la provincia de Valladolid. Tomo XV..., op. cit., pp. 37 y 46.

157 http://www.museodelprado.es/enciclopedia/enciclopedia-on-line/voz/diez-ferreras-diego/. 
Sin datar. San Elías confortado por el ángel. Museo Nacional de Escultura. Valladolid $^{159}$.

\section{ANDRÉS AMAYA (h.1645 - 1704)}

La figura del pintor Andrés Amaya está cubierta por una enorme bruma. Desconocemos sus principales datos biográficos, aunque se piensa que pudo nacer en Burgos, Palencia o Valladolid. Su estilo no puede relacionarse con el de ningún artista vallisoletano. Ceán Bermúdez, primer escritor en dedicarle una biografía - por cierto, bastante breve -, comenta que fue discípulo de Vicente Carducho, extremo imposible si tenemos en cuenta las cronologías de ambos pintores. A Ceán debemos la documentación de "los lienzos del retablo mayor de la parroquia de San Martín de Segovia, y otros dos que están en el presbiterio, cuyos asuntos son de la vida del santo titular. Tienen mejor gusto de color que corrección en el dibujo" $"$.

En sus primeros cuadros conocidos, conservados en la iglesia segoviana de San Martín (1682), presentan una concepción pictórica mucho más avanzada que impide relacionar su formación con cualquier pintor vallisoletano. Su estilo formado en aquella fecha, podría vincularse al de Francisco Solís o al del burgalés José Moreno y por supuesto con los pintores cortesanos de la segunda mitad del $\operatorname{siglo}^{161}$.

Sus cuadros casi nunca se hallan fechados lo que nos impide establecer una cronología en su obra conocida, la cual, por otro lado, se encuentra sumamente dispersa: tenemos cuadros suyos en Valladolid (iglesias de San Pedro, San Miguel y de la Vera Cruz, convento de Agustinos y Catedral) hay que añadir otros conservados, en Toro, Palencia (iglesia de San Miguel), San Millán de la Cogolla, Villafranca del Bierzo o León (San Isidoro) ${ }^{162}$. Tal vez, el número de obras suyas conservadas en Valladolid permiten confirmar una estancia larga en esta ciudad.

Fue artista bien preparado para la composición, sabiamente estudiada, como en el color rico y vibrante. Muestra una gran habilidad en la agrupación y relación de las figuras. Sus obras conocidas son todas de asunto religioso, pero en ellas puede apreciarse un gusto por los detalles de naturaleza muerta y se sabe que también pintó retratos. Se esforzó en buscar una tipología para sus personajes y sus obras son fácilmente

\footnotetext{
158 MARTÍ Y MONSÓ, José: Catálogo Provisional del Museo de Pintura y Escultura de Valladolid, a cargo de la Academia de Bellas Artes de la misma, Imprenta y Librería Nacional y Extranjera de Hijos de Rodríguez, Valladolid, 1874, p. 32.

159 "DIEGO DÍEZ FERRERAS. Inscripción posterior. San Elías profeta consolado en el desierto por un Ángel. 1,50 x 1,40 m". Ibídem.

160 CEÁN BERMÚDEZ, Juan Agustín: op. cit., p. 26.

161 CASASECA CASASECA, Antonio (et. al.): op. cit., p. 378.

162 VV.AA.: Pintura del Museo Nacional de Escultura. Siglos XV al XVIII. II., Museo Nacional de Escultura, Valladolid, 2002, p. 85.
} 
reconocibles por el modelo de cabezas de ángeles, de caras gordas y narices respingonas y por los perfiles de sus modelos femeninos ${ }^{163}$.

Estuvo casado con doña Isabel Lozano, y vivía "fuera de la Puerta del Campo", es decir aproximadamente en la actual plaza de Zorrilla. Sabemos que tuvo por discípulo al pintor vallisoletano Ignacio de Prado, al cual su viuda le nombró como su heredero por ser "persona de mi cariño y de que tengo entera satisfacción"164. Falleció el 29 de octubre de $1704^{165}$.

\section{$\underline{\text { Catálogo }}$}

1682. Pinturas del retablo mayor. Iglesia de San Martín. Segovia ${ }^{166}$.

1693. San Francisco y Santa Teresa. Iglesia Penitencial de la Vera Cruz. Valladolid ${ }^{167}$.

Hacia 1693. Sagrada Familia. Iglesia Penitencial de la Vera Cruz. Valladolid ${ }^{168}$.

Hacia 1700. San Joaquín. Iglesia de San Pedro. Valladolid ${ }^{169}$.

Fecha indeterminada. San José con el Niño. Catedral. Valladolid ${ }^{170}$.

Fecha indeterminada. La Virgen apareciéndose a Fernando III el Santo (Fig. 49). Museo Nacional de Escultura. Valladolid ${ }^{171}$.

Fecha indeterminada. San José con el Niño (Fig. 50). Museo Nacional de Escultura. Valladolid $^{172}$.

Fecha indeterminada. Serie de lienzos sobre la vida de San Juan Bautista. Real Colegiata Basílica de San Isidoro. León ${ }^{173}$.

\footnotetext{
163 CASASECA CASASECA, Antonio (et. al.): op. cit., p. 378.

164 COLLAR DE CÁCERES, Fernando: "Una serie de Ignacio de Prado en Esquivias (Toledo)", B.S.A.A., tomo LXI, 1995, pp. 425-432.

165 CASASECA CASASECA, Antonio (et. al.): op. cit., p. 378.

166 CEÁN BERMÚDEZ, Juan Agustín: op. cit., p. 26.

167 MARTÍN GONZÁLEZ, Juan José y URREA FERNÁNDEZ, Jesús: Catálogo Monumental de la provincia de Valladolid. Tomo XIV..., op. cit., p. 211.

$168 \quad$ Ídem, p. 212.

169 MARTÍN GONZÁLEZ, Juan José y URREA FERNÁNDEZ, Jesús: Catálogo Monumental de la provincia de Valladolid. Tomo XIV..., op. cit., p. 167.

170 URREA, Jesús (dir.): La navidad en el arte vallisoletano, Caja de Ahorros Popular, Valladolid, 1985.

171 GONZÁLEZ MARTÍNEZ, Pedro: Compendio histórico y descriptivo de Valladolid: seguido del catálogo de pinturas y esculturas que ecsisten [sic] en el museo de esta ciudad, Imprenta de don Julián Pastor, Valladolid, 1843, p. 63. MARTÍ Y MONSÓ, José: Catálogo Provisional..., op. cit., p. 55. VV.AA.: Pintura del Museo Nacional de Escultura..., op. cit., p. 83.

172 GONZÁLEZ MARTÍNEZ, Pedro: op. cit., p. 54.

173 LLAMAZARES RODRÍGUEZ, Fernando: Fuentes documentales..., op. cit., p. 139.
}

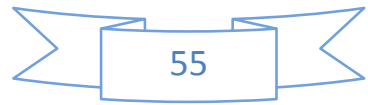




\section{B- PRIMERA MITAD DEL SIGLO XVIII}

El siglo XVIII comenzó de la peor manera posible para la ya de por sí mermada pintura vallisoletana puesto que en 1704 fallece su mejor artífice: Andrés Amaya ${ }^{174}$. El encargado de ocupar el puesto como pintor vallisoletano más destacado durante el primer tercio de siglo Manuel Peti Bander (1662-1736), hijo del pintor Simón Peti "el Viejo", artista que se caracteriza por la utilización de los "métodos más avanzados y el que permitió entrever en la escena pictórica local el arte novedoso del napolitano Luca Giordano"175. Otros dos pintores destacan en el mediocre panorama pictórico vallisoletano: Fray Diego de Frutos, del cual conservamos una abundantísima producción a raíz de sus extensas series de cuadros de temática franciscana, e Ignacio de Prado, pintor amigo de Juan de Ávila que fue nombrado por éste como uno de sus testamentarios.

Tras la muerte de todos estos maestros se creó un enorme vacío que nadie fue capaz de llenar. Por primera vez desde hacía mucho tiempo no existía una figura descollante. Hasta bien entrada la segunda mitad del siglo, es decir en los albores del Neoclasicismo, no volveremos a ver pintores de cierta categoría: Francisco de Prado (hijo de Ignacio de Prado), Diego Pérez Martínez, José y Leonardo de Araujo (padre e hijo respectivamente), José Pastrana, y Ramón y Joaquín Canedo (padre e hijo). Sin ningún género de dudas Diego Pérez y los Canedo serán los que piloten con mayor dignidad la escuela vallisoletana durante la segunda mitad del siglo XVIII.

\section{MANUEL PETI BANDER (1662-1736)}

Fue sin duda el pintor más destacado del primer tercio del siglo XVIII, el de métodos más avanzados y el que permitió entrever en la escena pictórica local el arte novedoso del napolitano Luca Giordano, como puede ser en las composiciones y en su abocetada forma de pintar una clara influencia del italiano Luca Giordano. En alguna ocasión se ha sugerido un posible viaje de Peti a la Corte, lugar en el que entraría en contacto con el pintor italiano, y, es más, algunos han supuesto que llegaría a ser discípulo suyo. Hoy en día, la idea más extendida es la de que el conocimiento de la obra de Giordano le venga a Peti a través de algunas pinturas que llegaron a Valladolid. Tanto en el dibujo como en el colorido, demuestra soltura y dominio de los matices. Movimiento y composición son estudiados con capacidad y acierto ${ }^{176}$. Sus pinturas siempre se caracterizan por una entonación vibrante a base de manchas de color y por no prestar atención alguna al dibujo $^{177}$.

$174 \quad$ URREA, Jesús: "La pintura, la rejería y la platería en Valladolid en el siglo XVIII”. En ENCISO RECIO, Luis Miguel (et. al.): Valladolid en el siglo XVIII, Ateneo de Valladolid, Valladolid, 1984, p. 353.

175 Ibídem.

176 VALDIVIESO GONZÁLEZ, Enrique: op. cit., p. 192.

177 CASASECA CASASECA, Antonio (et. al.): op. cit., pp. 378-380.

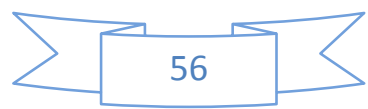


Manuel Simón Peti (Manuel Peti Bander) fue bautizado el 25 de junio de 1662 en la iglesia de la Antigua ${ }^{178}$. Sus padres fueron el pintor Simón Peti "el viejo" y Ana Rodríguez. Otros miembros de la familia siguieron el oficio paterno: Simón Peti "el joven", hijo de Simón Peti "el viejo" y Bonifacio Quevedo Peti, nieto de Simón Peti "el viejo", y, por lo tanto, sobrino de Manuel y Simón Peti “el joven”.

El 31 de marzo de 1676 ingresa como cofrade en la Cofradía Penitencial de Nuestro Padre Jesús Nazareno ${ }^{179}$. A esta cofradía ya pertenecía su padre, el cual había ostentado diferentes cargos en ella.

El 11 de noviembre de 1683 recibe en su taller al, cronológicamente hablando, primer aprendiz. Se trata de Manuel Polanco, hijo del sangrador José Polanco ${ }^{180}$. Peti, que debía enseñar los rudimentos de la pintura al joven durante tres años, enseñanza por la que cobraría 300 reales. Dos días después recibe como aprendiz a Manuel Álvarez ${ }^{181}$, a quien debería formar en el arte de la pintura a lo largo de seis años.

En 1702 realiza el trabajo de reconocimiento de las pinturas murales que se realizaron en las pechinas y cúpula de la Ermita de Nuestra Señora de la Peña de Tordesillas ${ }^{182}$. Las pinturas fueron hechas, en su mayor parte, por el pintor vallisoletano Amaro Alonso. Asimismo, Peti pintó, entre otras cosas, el coro de dicha iglesia, percibiendo por ello 34 reales $^{183}$.

El 15 de octubre de 1710 encontrándose preso en la cárcel otorga poder a los procuradores Andrés de Arce, Cosme de Arellano y Pedro de Velasco para que le defiendan en el "pleito y causa fulminada contra mí por el caballero corregidor de esta dicha ciudad" sobre "suponer ser infidente en las cosas del gobierno y estado de esta monarquía". Según Peti dichas acusaciones eran inciertas, para lo cual argumentaba que era " quien he conocido y conozco por tal mi rey y señor natural y no a otro alguno sino a ver cosa al contrario" "184. Por estas fechas debió de regentar una casa en la Plaza Mayor,

178 "En Valladolid hoy domingo veinte y cinco días del mes de junio de mil seiscientos y sesenta y dos años yo el doctor don Juan Capillas y Balboa cura propio de Nuestra Señora la Antigua de dicha ciudad habiendo precedido los exorcismo de la santa madre iglesia de Roma según orden y forma de la misma santa iglesia de Roma bauticé e impuse los santos óleo y crisma a Manuel Simón hijo legítimo de Simón Peti y Ana Rodríguez que viven a la calle de Cantarranas límites de esta dicha parroquia fueron sus padrinos Juan Pardo y Antonia Mateo su mujer vecinos de esta dicha ciudad a los cuales avisé del parentesco espiritual dile por abogados a Nuestra Señora y a San Juan Bautista fueron testigos Manuel Juárez y Joseph del Canto y Francisco García estudiante estante en esta ciudad y lo firmé juntamente con el padrino y los testigos infrascritos fecho ut supra”. A.G.D.V., La Antigua, 1652B, f. 110.

179 MARTÍ Y MONSÓ, José: Estudios histórico-artísticos..., op. cit., p. 495.

180 A.H.P.V., Leg. 20.803/2, f. 153.

181 A.H.P.V., Leg. 2.786, f. 146 (1683). GARCÍA CHICO, Esteban: Documentos para el estudio del arte en Castilla. 3..., op. cit., p. 260.

182 ARA GIL, Clementina Julia y PARRADO DEL OLMO, Jesús María: Catálogo Monumental de la provincia de Valladolid. Tomo XI..., op. cit., p. 309.

183 "34 reales... a un maestro pintor llamado Pitti, vecino de la ciudad de Valladolid en que se ajustó en pintar el coro de la iglesia de Nuestra Señora y otras cosas”. Ídem, p. 314.

184 CASASECA CASASECA, Antonio (et. al.): op. cit., pp. 378-380. 
concretamente en una casa situada en la acera del Caballo de Troya (también conocida como la de "los escribanos") 185 .

Manuel Peti Bander falleció "a causa de un accidente que no dio lugar" el 4 de agosto de $1736^{186}$. Por entonces vivía en la plazuela del Almirante, siendo un soltero "de crecida edad". Unos días antes de fallecer, el día 27 de julio había testado ante el escribano Manuel de Mier y Terán. Ordenaba que su cuerpo se enterrase en la iglesia penitencial de Nuestra Señora de las Angustias, donde se rezarían doscientas misas por su alma; mientras que dejaba instituido como heredero universal a su sobrino Bonifacio de Quevedo Peti.

\section{$\underline{\text { Catálogo }}$}

Hacia 1700. Caída de San Pablo (Fig. 51). Catedral. Valladolid ${ }^{187}$.

Hacia 1700. San Fernando entrando en Sevilla (Fig. 52). Catedral. Valladolid ${ }^{188}$.

1710. Serie de lienzos sobre los Siete Dolores de la Virgen. Iglesia Penitencial de Nuestra Señora de las Angustias. Valladolid ${ }^{189}$.

Fecha indeterminada. El taller de Nazaret. Catedral. Valladolid ${ }^{190}$.

Fecha indeterminada. Santiago en la Batalla de Clavijo. Museo Diocesano y Catedralicio. Valladolid ${ }^{191}$.

\section{C- LA POLICROMÍA}

Un capítulo especialmente importante dentro de la pintura, y más para una tesis como ésta dedicada a la escultura, es el de la policromía de las imágenes y el dorado de los retablos. El oficio de policromador solía ser desarrollado, por lo general, por los mismos pintores “de caballete”. Según señala Álvarez Vicente, "el examen, según se conoce por documentos, exigía el conocimiento de las distintas técnicas de preparación de una escultura para la policromía, así como entender del dorado y de los adornos del esgrafiado y carnaciones, aunque esto también dependía de las ordenanzas específicas de cada lugar. Y además de sus labores propias también se encargaban de tareas tales como la eliminación de focos resinosos, quema de nudos, asegurar grietas con lienzos...".

185 Es un arrendamiento hecho el 21 de agosto de 1713 se dice que el cuarto principal que se quería arrendar era el mismo “que vivió Manuel Peti pintor”. A.H.P.V., Leg. 3.028/1, f. 96.

186 A.G.D.V., Catedral, 1684D, f. 254.

187 MARTÍN GONZÁLEZ, Juan José y URREA FERNÁNDEZ, Jesús: Catálogo Monumental de la provincia de Valladolid. Tomo XIV..., op. cit., p. 13.

$188 \quad$ Ibídem.

189 VALDIVIESO GONZÁLEZ, Enrique: op. cit., p. 192.

190 REDONDO CANTERA, María José: "El taller de Nazaret". En VV.AA.: Las Edades del Hombre. El contrapunto y su morada [Exposición. Salamanca, 1993-1994], Las Edades del Hombre, Valladolid, 1993, pp. 246-247.

191 URREA FERNÁNDEZ, Jesús (coord.): Patrimonio restaurado..., op. cit., p. 170. 
Sin embargo, en Valladolid son escasos los ejemplos de pintores "de caballete" que también se aplicaron al dorado y policromado: el caso más conocido es el de Diego Valentín Díaz, pero también podemos esgrimir el del mediocre Antonio Novoa Osorio. Tampoco tenemos noticias de que algún escultor vallisoletano hubiera policromado sus propias obras si bien tengo serias dudas en el caso de Juan de Ávila, como veremos más adelante.

Por lo general, cuando el escultor terminaba de tallar la imagen la dejaba "en blanco", es decir, dejar la madera en su color natural. Si la pieza era muy voluminosa se esperaba un tiempo prudencial a la hora de comenzar con la preparación del policromado, esto se hacía con la intención de estabilizar el material ${ }^{192}$. El policromado, utilizado para acentuar la sensación de realismo de las esculturas, constaba de tres o cuatro pasos, dependiendo la escultura: aparejo, dorado (no siempre), estofado y encarnado o carnación.

$1^{\circ}$ Aparejo. El pintor se encarga de dar varias capas de yeso grueso y yeso mate (normalmente 5 capas de cada una), pulimentándolas, para a continuación echar bol amarillo, rojo o negro, todo ello con el objetivo de dejar una superficie apta para que pueda recibir el dorado ${ }^{193}$.

$2^{\circ}$ Dorado. En la época que tratamos no se suele utilizar esta técnica, salvo en muy contadas ocasiones.

$3^{\text {o }}$ Estofado. Se trata de la imitación de suntuosas telas en la realización de ropajes y vestiduras. Existen dos modalidades: el esgrafiado, "que consiste en raspar el color aplicado a la superficie, haciendo los dibujos con el punzón y apareciendo el oro por debajo"; y el de punta de pincel, en que hay que "raspar el color en determinadas zonas $y$ pintar con un pincel sobre el oro bruñido" ${ }^{\text {194 }}$. Con esta última técnica se imitaban tejidos usuales, "ya de oro, de lana o de otra fibra"195.

En Valladolid durante el siglo XVII se utilizaron dos tipos de estofados: el de colores planos con o sin labores y el de adornos imitando telas, grabadas o pintadas ${ }^{196}$. En las cenefas se representan grutescos, niños, pájaros, motivos vegetales o animales, posteriormente todo ello fue sustituido por las orlas. Gran importancia tendrá la suntuosa representación de los hábitos de las distintas órdenes: jesuitas, agustinos, franciscanos..., según Martín González aquí también es "donde se explaya libremente el genio barroquizante" 197 . Durante este mismo siglo se comienza a utilizar el puntillado o

\footnotetext{
192 ÁlVAREZ VICENTE, Andrés y GARCÍA RODRÍGUEZ, Julio César: Dolor y Gloria, Ayuntamiento de Valladolid, Valladolid, 2006, p. 146.

193 GONZÁLEZ-MARTÍNEZ ALONSO, Enriqueta: Patrimonio y Restauración: Tecnología Tradicional y Tecnología Actual, Universidad Politécnica de Valencia, Valencia, 2006, p. 116.

$194 \quad$ Ibídem, p. 116.

195 MARTÍN GONZÁLEZ, Juan José: "La policromía en la escultura castellana”, A.E.A., Madrid, 1953, p. 302.

196 Ídem, p. 307.

197 MARTÍN GONZÁLEZ, Juan José: Escultura barroca castellana ..., op. cit., p. 40.
} 
"picado de lustre". Para conseguirlo "se golpea con un punzón sobre la parte dorada, variando el efecto según el grosor de la punta de dicho instrumento"198.

Ya en el siglo XVIII los motivos se harán más naturales, así, las decoraciones suelen dejan de estar encerradas en las orlas "para inundar toda la superficie del vestido"199.

El gusto del barroco hispano por lo sangriento hará que las cabezas, espaldas, costados y rodillas se vean recorridas por grandes regueros de sangre. La imitación de las heridas de Cristo llega en algunos casos a lo más extremo.

$4^{\circ}$ Encarnado. Es la policromía de las partes del cuerpo que permanecen descubiertas. Las hay de tres tipos: mate, mixto y a pulimento. En Valladolid la mayoritaria será la mate o de "paletilla", que "restringía el excesivo lustre y permitía matizar suavemente la piel" 200 , si bien en la segunda mitad de siglo "se acostumbró a encarnar primero a pulimento, que daba una gran consistencia a la encarnación, y encima a mate, que limitaba el excesivo destellar y permitía señalar las calidades de la piel"201.

Según explica Álvarez Vicente, "la carnación se comenzaba a ejecutar por la frente y los ojos, y en las figuras con cabellos tallados la unión entre los distintos tonos de pelo y las carnaciones se suavizaban con sombreados que se difuminaban con la carnación. En la mayoría de los casos se imitan cabellos con pinceladas a punta de pincel sobre la carnación, continuando así desde donde se terminó el trabajo con la gubia"202. Para resaltar los cabellos se utilizaba el peleteado: en las esculturas que representaban personajes jóvenes se usaba el oro, pero cuando estas personificaban santos de avanzada edad se utilizaba la plata para similar las canas.

Muy relacionado con los cuatro pasos comentados estaba la utilización de los postizos: así, el cristal se usaba para representar lágrimas o la sangre que brotaba del pecho de Cristo tras la lanzada; los dientes solían realizarse de pasta, mientras que para las llagas se utilizaba el corcho ${ }^{203}$. Otros postizos serán los cuchillos para representar los dolores de la Virgen, la soga en el cuello de Cristo, las vestiduras, las coronas de espino, etc...

Gran importancia tenía la ejecución de los ojos, puesto que era lo que dotaba a la escultura de una mayor o menor expresividad. Si estos no estaban tallados y policromados existían los postizos: para ello se abría un hueco en el ojo y se colocaba una pieza de vidrio pintada simulando la pupila y el iris, con ello se conseguía un efecto muy naturalista. Con el tiempo la técnica mejoró y se consiguieron unos ojos todavía más realistas.

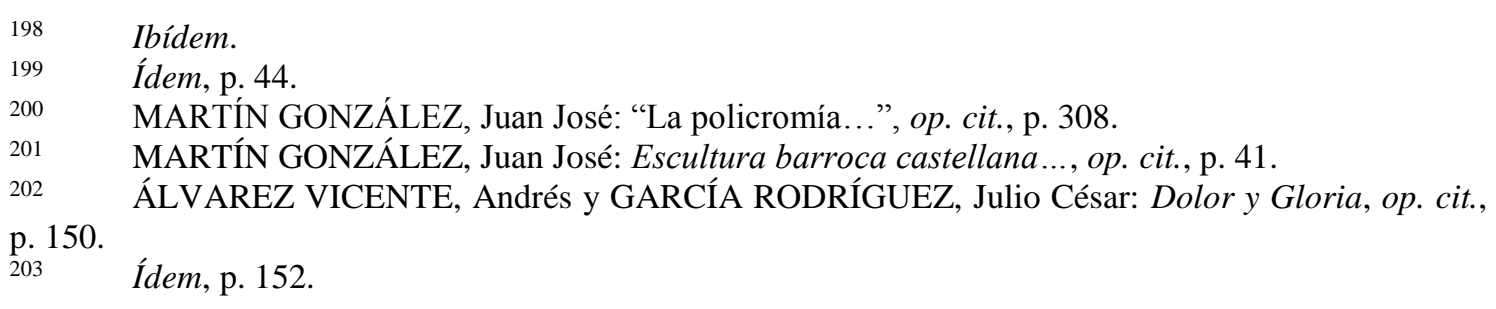


A continuación, vamos a referirnos a una serie de policromadores y doradores que vivieron y trabajaron en Valladolid al mismo tiempo que los Ávila. Como la lista sería interminable tan solo se seleccionan aquellos que tenemos documentado que "compartieron" obras con nuestros tres escultores.

\section{JOSEPH MARTÍNEZ DE ESTRADA (h.1638-1687)}

Desconocemos el lugar de nacimiento de Joseph Martínez de Estrada, si bien este debió de acontecer hacia los años 1630-1635. La primera noticia que nos consta sobre el dorador es su enlace con Isabel Díez de Aragón el 16 de septiembre de 1658 en la iglesia de San Lorenzo ${ }^{204}$. Con toda probabilidad esta Isabel sería familiar de los doradores Joseph y Manuel Díez de Aragón, artífices con los que ya previamente habría tenido contacto, o amistad, nuestro Joseph Martínez de Estrada. La pareja tendría una numerosa descendencia, dándose la paradoja de que todos sus hijos varones ejercieron la profesión paterna: Manuel, Agustín, Cristóbal, Claudio y Leonardo.

Entre los años 1675-1676 se encarga de dorar unos hacheros de la iglesia de Santiago que el escultor Francisco Díez de Tudanca había aderezado por estar "hechos pedazos" "205. Años después volverá a trabajar para la referida parroquia: entre 1682-1683 dora y estofa la imagen de Santiago Apóstol, el peñasco sobre el que asentaba la imagen y un arco para dicha imagen que había tallado el escultor Juan de Ávila ${ }^{206}$.

El 14 de julio de 1677 la Cofradía de Nuestra Señora de la Piedad comisiona a ciertos cofrades para que "se puedan convenir y ajustar con José de Estrada estofador y dorador de esta dicha ciudad o con otra cualquiera persona de dicho arte" para dorar el retablo mayor de la iglesia y el del Santísimo Cristo de la Humildad "para que estén con el mayor ornato y reverencia" 207 . El dorado lo debieron de llevar a cabo tanto él como Bartolomé Duque Gómez puesto que el nombre del primero figura en los libros de la cofradía como el autor del referido dorado ${ }^{208}$, mientras que fue Duque Gómez, el 20 de mayo de 1678, quien firma la escritura para el dorado del dicho retablo ${ }^{209}$.

El 26 de mayo de 1682, viviendo con su familia en la plazuela de la Trinidad, fallece uno de sus hijos ${ }^{210}$. Aquel mismo año se encontraba trabajando en el dorado del retablo mayor de la iglesia parroquial de Cevico de la Torre (Palencia) ${ }^{211}$.

\footnotetext{
204 A.G.D.V., San Lorenzo, 1602M, f. 281.

205 A.G.D.V., Santiago, Libro de fábrica 1673-1707, Años 1675-1676.

206 A.G.D.V., Santiago, Libro de fábrica 1673-1707, Años 1682-1683.

207 A.H.P.V., Leg. 2.849, ff. 118-119.

208 ALARCOS LLORACH, Emilio: "Obras y artistas que se citan en los libros de la Cofradía de Nuestra Señora de la Piedad, de Valladolid”, B.S.A.A., tomo VII, 1940-1941, pp. 197-204.

209 A.H.P.V., Leg. 2.849, ff. 24-27.

210 A.G.D.V., San Lorenzo, 1671D, f. 30.

211 Archivo Diocesano de Palencia (en adelante A.D.P.), Cevico de la Torre, Tomo 46.
} 
En 1683 se ocupa de dorar el majestuoso retablo mayor de la iglesia de San Martín de Valladolid tallado por Cristóbal Ruiz de Andino, ensamblador con el cual mantuvo, al menos, unas relaciones laborales fluidas ${ }^{212}$.

Joseph Martínez de Estrada fallece el 8 de septiembre de 1687 siendo enterrado en la iglesia de San Lorenzo, en una de las sepulturas de la Cofradía de las Ánimas de la cual era cofrade ${ }^{213}$. No redactó testamento "por ser pobre".

\section{ALONSO GUTIÉRREZ (a.1652-d.1693)}

Pocos datos conservamos de este artífice que parece bastante relacionado con el escultor Juan Antonio de la Peña y con el ensamblador Francisco de Billota.

El grueso de su obra documentada se encuentra en la Colegiata de San Luis de Villagarcía de Campos (Valladolid). Allí, en 1678 se encargó de dorar y estofar los retablos de San Francisco de Borja ${ }^{214}$, San Juan Bautista ${ }^{215}$, del Santo Cristo ${ }^{216}$, también se le podía atribuir el dorado de los otros tres retablos de las capillas del cuerpo de la iglesia puesto que en los seis retablos trabajaron los mismos artistas. Años después, en 1682, policroma las esculturas de San Pedro, San Lucas y San Marcos, realizadas por Juan Antonio de la Peña para el retablo mayor de la capilla del Relicario $^{217}$; y la de Santa Lucía del colateral de la Epístola de esta misma capilla. Finalmente, en 1692, para esa misma capilla policroma las esculturas de San Marcos, San Vicente y San Eutimio realizadas por Tomás de Sierra; y dora el retablo relicario tallado por el referido escultor riosecano y la reja de la capilla ${ }^{218}$.

En 1680 percibe, junto con el escultor Juan Antonio de la Peña, una importante suma de dinero por parte de Ataquines, quizás en relación con el retablo mayor de la iglesia parroquial $^{219}$.

El 28 de febrero de 1688 recibe en su taller como aprendiz a Bernardo Izquierdo, natural de Meneses de Campos ${ }^{220}$. Unas semanas después, el 11 de abril, se concierta, junto con el también dorador Antonio Barreda, para dorar el retablo mayor de la iglesia del convento y hospital de San Juan de Dios (DOCUMENTO 39).

212 MARTÍN GONZÁLEZ, Juan José y URREA FERNÁNDEZ, Jesús: Catálogo Monumental de la provincia de Valladolid. Tomo XIV..., op. cit., p. 104.

213 "En ocho de septiembre de mil seiscientos y ochenta y siete murió Joseph Estrada recibió los sacramentos de la penitencia eucaristía y extremaunción no hizo testamento por ser pobre enterrose en esta iglesia en la sepultura de la Cofradía de las Ánimas de donde era cofrade y lo firmé”. A.G.D.V., San Lorenzo, 1671D, f. 43.

214 PÉREZ PICÓN, Conrado: Villagarcía de Campos: estudio histórico-artístico, Institución Cultural Simancas, Valladolid, 1982, p. 119.

215 Ídem, p. 121.

216 Ídem, p. 123.

217 Ídem, p. 154

218 Ídem, pp. 158-159.

219 BRASAS EGIDO, José Carlos: Catálogo Monumental de la provincia de Valladolid. Tomo X..., op. cit., p. 56.

220 A.H.P.V., Leg. 2.809, ff. 175-176. 
El 29 de junio de 1691 se obliga a dorar y estofar "un retablo colateral intitulado San José que está en la iglesia parroquial de la villa de Castrillo de Duero a mano derecha como se entra en dicha parroquia",221.

El 3 de abril de 1693 se concierta con el Convento de Nuestra Señora de la Laura para "dorar y estofar el retablo, custodia y otras cosas de la iglesia del dicho Convento de Nuestra Señora de la Laura y el monumento de ella" por un precio de 9.500 reales (DOCUMENTO 53). También estofaría las imágenes del retablo, que serían dos: Santa María Magdalena y Santa Rosa. Una de las condiciones redactadas por el dorador nos descifra el nombre del autor del retablo: Francisco Billota: "Es condición que tengo de componer el pedestal de la manera que dijere Francisco Billota con florones de oro".

\section{ANTONIO BARREDA Y LOMBERA (1658-1727)}

Antonio Barreda Lombera, nacido como Antonio Barreda y Baler, vio la luz en Valladolid en el mes de junio de 1658, siendo bautizado por sus padres, Tomás de Barreda y María de Baler Blanquez, en la santa iglesia catedral el día 23 del referido mes $^{222}$. El dorador contrajo matrimonio en dos ocasiones: el 18 de agosto de 1680 con Isabel Serrano y Ramos en la santa iglesia catedral ${ }^{223}$; y, nuevamente en este templo, el 13 de mayo de 1696 con María Álvarez Briz ${ }^{224}$.

La primera noticia que poseemos de Antonio Barreda relacionado con su oficio es el asiento de aprendiz realizado el 16 de mayo de 1680 por el cual nuestro dorador se concierta con Juan Rodríguez de la Cancela para que se enseñe dicho oficio a su hijo Antonio Rodríguez ${ }^{225}$. No es el único aprendiz que le tenemos documentado: el 21 de diciembre de 1700 llega a su taller Fernando Fernández de Navia, vecino de La Bañeza $(\text { León })^{226}$.

Del año 1682 datan las únicas pinturas que conocemos de su autoría pues el resto de su obra no es más que dorados, policromados y estofados. Se trata de las cuatro pinturas de la predela el retablo de Nuestra Señora de la Encarnación de la iglesia penitencial de Nuestra Señora de las Angustias ${ }^{227}$. Quizás sea también suyo el cuadro del Arcángel

\footnotetext{
221 A.H.P.V., Leg. 3.006/1, ff. 15-16.

222 "En veinte y tres de junio de mil y seiscientos y cincuenta y ocho años yo el licenciado Quiroga cura de la catedral de esta ciudad habiendo precedido los santos exorcismos bauticé y puse los santos óleo y crisma según forma de la santa madre iglesia de Roma a Antonio hijo de Tomás Barreda y María de Balas su mujer mis parroquianos fueron sus padrinos Jacinto Gil Negrete e Isabel María de la Peña su mujer testigos Andrés López, Francisco Alonso dieronle por abogados a San José y San Juan en fe de lo cual lo firmé dicho día”. A.G.D.V., Catedral, 1656B, f. 14.

223 A.G.D.V., Catedral, 1673M, f. 60.

224 A.G.D.V., Catedral, 1695M, f. 6

225 A.H.P.V., Leg. 2.700/3, f. 809.

226 A.H.P.V., Leg. 2.952, ff. 547-550.

227 VALDIVIESO GONZÁLEZ, Enrique: op. cit., pp. 194-195; MARTÍN GONZÁLEZ, Juan José y URREA FERNÁNDEZ, Jesús: Catálogo Monumental de la provincia de Valladolid. Tomo XIV..., op. cit., p. 251.
} 
San Gabriel que remata el retablo (Fig. 53) ${ }^{228}$. Cuatro años después volverá trabajar para la misma cofradía dorando el retablo de Cristo Crucificado de, así como los dos ángeles del paso del "Santo Sepulcro". Por todo ello percibió 3.500 reales $^{229}$. Aún actuará otra vez más en la iglesia penitencia será en 1710 dando unas manos de yeso " $a$ las columnas y diferentes piezas para dorar el tabernáculo" ${ }^{230}$.

El 25 de enero de 1684 ingresa en la Cofradía Penitencial de Nuestra Señora de la Piedad, cofradía para la que trabajaría asiduamente: dora la reja de la capilla de Nuestra Señora de la Piedad, dora las andas y pinta la encarnadura del Cristo de la Humildad, ejerce el cargo de escribano durante cierto tiempo... ${ }^{231}$.

El 11 de abril de 1688 asume la tarea de dorar, de manera conjunta con Alonso Gutiérrez, el retablo mayor de la iglesia y hospital de San Juan de Dios de Valladolid (DOCUMENTO 39).

El 9 de julio de 1689 sale por fiador, junto al escultor Antonio Vázquez, del ensamblador Blas Martínez de Obregón cuando este se obliga a realizar el retablo mayor de la iglesia de Nuestra Señora del Rosario ${ }^{232}$. Si tenemos en cuenta que la escultura del retablo corrió a cargo de Vázquez, es plausible creer que Barreda fue el encargado de dorarlo y de policromar las tallas. Esta es la primera ocasión en la que aparecen asociados Martínez de Obregón y Barreda, binomio que se repetiría posteriormente en otras ocasiones: así, el 20 de julio de 1690 sale por fiador del ensamblador Blas Martínez de Obregón en el concierto que realiza este para realizar el retablo de la capilla de don Pedro de Arce en la catedral vallisoletana ${ }^{233}$. Con toda probabilidad se ocupó del dorado del mismo; el 19 de diciembre de 1695 se comprometía con la priora del Convento de Porta Coeli a "dorar y estofar el monumento que se está haciendo por los dichos Antonio Álvarez y Blas Martínez de Obregón para la iglesia del dicho Convento de Porta Coeli guardando y cumpliendo en su ejecución todas las calidades y condiciones y circunstancias puestas en las condiciones hechas" por él mismo ${ }^{234}$; y, en 1702, se encarga de dorar y estofar el retablo mayor de la iglesia parroquial de Villalba de los Alcores (Valladolid). Por dicho trabajo le abonaron 9.000 reales $^{235}$.

\footnotetext{
$228 \quad$ Ibídem.

229 AGAPITO Y REVILLA, Juan: Las cofradias..., op. cit., p. 106; MARTÍN GONZÁLEZ, Juan José y URREA FERNÁNDEZ, Jesús: Catálogo Monumental de la provincia de Valladolid. Tomo XIV..., op. cit., p. 251.

$230 \quad$ Ibídem

231 ALARCOS LLORACH, Emilio: op. cit., p. 199.

232 BALADRÓN ALONSO, Javier: "Nuevas obras de Francisco Díez de Tudanca y otros datos de escultores barrocos vallisoletanos", B.S.A.A., Tomo LXXVIII, 2012, p. 161.

233 URREA FERNÁNDEZ, Jesús: "Don Pedro de Arce y su capilla en la Catedral de Valladolid", B.R.A.C., Tomo XXXIX, 2004, pp. 90-91.

$234 \quad$ A.H.P.V., Leg. 2.858, ff. 870-873.

235 PARRADO DEL OLMO, Jesús María: Catálogo Monumental de la provincia de Valladolid. Tomo XVI. Antiguo partido judicial de Medina de Rioseco, Diputación de Valladolid, Valladolid, 2002, p. 361.
} 
El 15 de mayo de 1693 hace puja en la subasta de la obra del dorado de los dos retablos de la capilla de Nuestra Señora del Rosario de la iglesia parroquial de San Cebrián de Campos. A esa subasta también se sumaron Alonso Gómez (vecino de Mazuecos de Valdeginate), Manuel Martínez de Estrada y Sebastián Puerta Albarado ${ }^{236}$.

Entre los años 1696-1698 se encarga de pintar y dorar el monumento del retablo mayor del Real Hospital de Santa María de Esgueva, así como los marcos de las dos pinturas que llevaría dicho retablo ${ }^{237}$.

En 1703 redacta, de manera conjunta con Leonardo Martínez de Estrada, las condiciones para el dorado del retablo mayor de la iglesia de Santa María de Pozaldez (Valladolid) $^{238}$. A la subasta acudió, además de estos dos, el vallisoletano Santiago Montes y el burgalés Bernardo López de Sagredo. La obra recayó finalmente en Leonardo Martínez de Estrada.

Entre 1703-1705 asume la tarea de policromar el retablo de la capilla de don Gaspar Vallejo en la iglesia de San Martín de Valladolid ${ }^{239}$, así como jaspear el pedestal de la reja de la capilla y pintar los dos escudos de armas que están a los lados de ella.

El año 1709 es el primero en que nos consta que Barreda trabaja para la Universidad vallisoletana. Este año realiza diferentes composiciones y pinturas en los Generales pero las cuentas no especifican exactamente en qué constaron ${ }^{240}$. En 1733 pinta quince rótulos en los Generales de Leyes, Cánones y Teología ${ }^{241}$.

En julio de 1715 Antonio y su hijo Manuel Barreda realizan las condiciones para "dorar y estofar los tres retablos, el uno mayor y los otros dos colaterales, que están en la capilla de dicha Orden Tercera" del Convento de San Francisco de Valladolid. Finalmente la obra la realizaron los hermanos Claudio y Cristóbal Martínez de Estrada $^{242}$.

Antonio Barreda fallece el día 5 de agosto de 1727, siendo sepultado en la iglesia penitencial de Nuestra Señora de las Angustias, de donde era diputado ${ }^{243}$. Los derechos del entierro los pagó "un hijo suyo por ser el dicho Antonio Barreda muy pobre".

\footnotetext{
236 A.H.P.V., Leg. 2.857, ff. 683-686.

237 A.M.V., HE. 381-5, f. 69.

238 VILLÁN. Miguel Ángel y FRAILE GÓMEZ, Ana María: Catálogo Monumental de la provincia de Valladolid. Tomo XVIII. Antiguo partido judicial de Medina del Campo, Diputación de Valladolid, Valladolid, 2003, pp. 219-220.

239 MARTÍN GONZÁLEZ, Juan José y URREA FERNÁNDEZ, Jesús: Catálogo Monumental de la provincia de Valladolid. Tomo XIV..., op. cit., p. 107.

$240 \quad$ Archivo Universitario (en adelante A.U.), Libro de cuentas no 437 (1708-1758).

$241 \quad$ A.U., Libro de cuentas $n^{\circ} 437$ (1708-1758).

242 GARCÍA CHICO, Esteban: Documentos para el estudio del arte en Castilla. 3..., op. cit., p. 279.

243 "En cinco días del mes de agosto de este año de mil setecientos y veinte y siete murió en esta parroquia de la catedral junto a la Antigua Antonio Barreda viudo de Isabel Serrano y casado al presente con María Álvarez; el cual recibió todos los santos sacramentos con el de la extremaunción enterrose en las Angustias de donde era diputado pagó los derechos un hijo suyo por ser el dicho Antonio Barreda muy pobre y para que conste lo firmé como cura que soy de dicha santa iglesia fecho ut supra. A.G.D.V., Catedral, 1684D, f. 220.
} 
Manuel Martínez de Estrada fue sin lugar a dudas el dorador vallisoletano más prolífico de su época; buena prueba de ello son los numerosos encargos que le llegan de provincias limítrofes: Zamora, León, Palencia, Burgos y Soria. Sus padres, el dorador Joseph Martínez de Estrada e Isabel Díez de Aragón, le bautizaron el 30 de junio de 1659 en la iglesia de San Lorenzo ${ }^{244}$. En el mes de mayo de 1680 contrae matrimonio con Ángela Basurto en la iglesia parroquial de San Lorenzo ${ }^{245}$, si bien fueron desposados por el cura de San Miguel dado que la contrayente era parroquiana de dicha iglesia. La pareja no logró tener descendencia.

Su primera obra documentada es el dorado del retablo mayor y colaterales de la capilla de don Gabriel López de León en la iglesia de San Pedro y San Ildefonso de Zamora ${ }^{246}$. Las esculturas de estos retablos habían sido realizadas por el vallisoletano Alonso de Rozas.

El 26 de abril de 1684 se obliga, fiado por su padre Joseph Martínez de Estrada, con Diego Muñoz, mayordomo de la Cofradía del Santísimo Cristo de la parroquial de San Pedro, de "dorar y estofar y poner en toda forma el retablo de madera que al presente está en la capilla del Santo Cristo según y con las condiciones que el dicho Manuel Martínez tienen hechas"247.

El 4 de mayo de 1686 se compromete a "renovar, pintar y dorar y limpiar la capilla del Santo Sepulcro que está en dicho Convento de San Francisco". Se trataba de la capilla presidida por el magnífico grupo del Santo Entierro tallado por Juan de Juni ${ }^{248}$.

En 1689 Juan de las Puertas y Manuel Martínez de Estrada presentan condiciones para pintar y dorar el retablo de la ermita de Nuestra Señora del Carrascal de Castilfrío de la Sierra, comprometiéndose, al año siguiente, a llevar a cabo este retablo. El 29 de mayo de 1690 ambos doradores acuden juntos a una obra, en este caso a pintar y dorar el retablo de Nuestra Señora de la Paz de la iglesia de Cabrejas del Pinar ${ }^{249}$.

\footnotetext{
244 "En la ciudad de Valladolid a treinta de junio de 1659 yo el licenciado Francisco Ruiz de Obeso teniente de cura de la iglesia parroquial de Nuestra Señora de San Lorenzo bauticé e impuse los santos óleos según forma de la santa madre iglesia romana a un niño que se llamó Manuel hijo legítimo de Joseph de Estrada y de Isabel Díaz de Aragón su legítima mujer fueron sus padrinos Lucas de Bartolomé y Francisca Ezquerra siendo testigos Juan de Arbayza escribano de su majestad, Francisco de Tudanca (...) por abogado a San Juan y San José y por verdad lo firmé fecho ut supra”. A.G.D.V., San Lorenzo, 1601B, f. 384.

245 A.G.D.V., San Lorenzo, 1671M, f. 24.

246 VASALLO TORANZO, Luis, ALMARAZ VÁZQUEZ, María de las Mercedes y BLANCO SÁNCHEZ, José: “Antonio Tomé en el retablo de los Trinitarios de Zamora”, B.S.A.A., Tomo LXXI-2, 2005, p. 222.

247 FERNÁNDEZ DEL HOYO, María Antonia: "El convento de San Francisco de Valladolid. Nuevos datos para su historia”. B.S.A.A., Tomo LI, 1985, p. 433.

248 FERNÁNDEZ DEL HOYO, María Antonia: Patrimonio perdido: Conventos desaparecidos de Valladolid, Ayuntamiento de Valladolid, Valladolid, 1998, p. 97.

249 GUTIÉRREZ PEÑA, Joaquina y HERRERO GÓMEZ, Javier: El retablo barroco en la ciudad de Soria, Caja Duero, Soria, 2008, p. 108.
} 
El 9 de octubre de 1690 la Congregación de San Felipe Neri se ajusta con Manuel de Estrada para que dorara el retablo mayor "para mayor adorno y culto de la dicha iglesia" (DOCUMENTO 47). El dorador cobró por tan magna empresa la importante cantidad de 19.000 reales de vellón pagados en tres plazos. En el año 1701 vuelve a trabajar para la Congregación de San Felipe Neri, en este caso ejecutando el dorado de los retablos colaterales. El dorado se finalizaba en el mes de octubre de ese mismo año, aunque el abono de los emolumentos del artista no se liquidó hasta el 17 de julio de $1702^{250}$.

Ese mismo año de 1690 diseña la traza y redacta las condiciones con las cuales se habría de ejecutar el nuevo retablo mayor de la Colegiata de Lerma ${ }^{251}$. El coste de la obra proyectada por Martínez de Estrada, sin incluir en este precio el dorado, ascendía a 25.000 reales $^{252}$. Entre las condiciones dadas por el vallisoletano tenemos algunas muy típicas en este tipo de contratos como que "toda la madera que hubiere de gastar sea seca y limpia de tea, y, si acaso no se pudiese remediar, que se saque los nudos (...) y se metan piezas muy bien ajustadas". Una condición específica para este retablo dictaba que " $y$, si acaso se hubiere de poner la custodia que dicha iglesia tiene, por ser rica se pueden poner tres gradas, si acaso con las dos no alcanzare" 253 . El retablo finalmente fue realizado por el ensamblador burgalés, aunque de procedencia cántabra, Diego Alonso de Suano ${ }^{254}$.

En 1693 redacta las condiciones que se habrían de seguir para dorar los dos retablos que "están en la capilla de Nuestra Señora del Rosario de la iglesia parroquial de la villa de San Cebrián [de Campos]"255. Tras una serie de pujas la obra quedó en manos del dorador de Mazuecos de Valdeginate Alonso Gómez.

Entre los años 1698-1702 se encarga de dorar las esculturas del retablo mayor de la iglesia parroquial de Santiago Apóstol de Valladolid, obras documentadas del escultor Juan de Ávila ${ }^{256}$.

En el año 1703 se encontraba dorando el retablo, sagrario y monumento del altar mayor de la iglesia conventual de Santa Brígida, así como los retablos colaterales y el púlpito. Las religiosas quedaron tan conformes con el trabajo del dorador que le dieron "de guantes" 500 reales $^{257}$.

\footnotetext{
250 MARTÍN GONZÁLEZ, Juan José y URREA FERNÁNDEZ, Jesús: Catálogo Monumental de la provincia de Valladolid. Tomo XIV..., op. cit., p. 303.

251 CERVERA VERA, Luis: La iglesia colegial..., op. cit., p. 115.

252 PAYO HERNANZ, René Jesús: El retablo en Burgos y su comarca durante los siglos XVII y XVIII, tomo II, Diputación Provincial de Burgos, Burgos, 1997, p. 146.

253 CERVERA VERA, Luis: op. cit., p. 206.

254 Para profundizar el conocimiento de este interesante ensamblador: PAYO HERNANZ, René Jesús: El retablo..., op. cit., Tomo II, pp. 141-161.

255 A.H.P.V., Leg. 2.857, ff. 683-686.

256 GARCÍA CHICO, Esteban: Valladolid: Papeletas..., op. cit., pp. 101-103.

257 MARTÍN GONZÁLEZ, Juan José y PLAZA SANTIAGO, Francisco Javier de la: Catálogo Monumental de la provincia de Valladolid. Tomo XV..., op. cit., p. 47.
} 
El 7 de julio de 1704 el dorador, fiado por su hermano Agustín, presenta su pliego de condiciones para dorar el retablo mayor de la iglesia de San Bartolomé de Astorga. Una vez sacada la obra al pregón no concurrió ningún interesado por lo que el vallisoletano se quedó con la obra por la suma de 12.000 reales. Martínez de Estrada se obligó a dorar el retablo y estofarlo en un tiempo de cinco meses. Se daría oro limpio en todo el conjunto y después se bruñiría. En el fondo de la caja del Santo Cristo se pintaría la ciudad de Jerusalén y se encarnaría el Crucifijo y los dos ángeles de los cubos extremos que se habrían de colocar ${ }^{258}$.

En 1705 se encarga del dorado del retablo mayor de la iglesia parroquial de Villerías, realizado en 1702 por el ensamblador montañés Lucas Ortiz de Boar ${ }^{259}$.

En 1706 policromó y doró el retablo mayor de la iglesia de Santiago de los Caballeros de Medina de Rioseco. La arquitectura del retablo corrió a cargo de Santiago Carnicero, si bien la traza fue dada por Joaquín de Churriguera, mientras que la escultura recayó en Tomás de Sierra ${ }^{260}$.

En 1708 se encarga de dorar dos retablos de la iglesia de San Esteban de Fuentesecas (Zamora) bajo las condiciones que él mismo había redactado tres años antes ${ }^{261}$.

En 1709, en compañía de su hermano Agustín, dora el retablo mayor del Hospital de los Convalecientes de la localidad zamorana de Toro $^{262}$, el cual se piensa que pudo haberlo fabricado dos años antes el vallisoletano Pedro de Ribas. A cargo de los hermanos corrió también la policromía de las esculturas de Antonio Tomé, así como la de las puertas que accedían a la sacristía y al antiguo $\operatorname{archivo}^{263}$.

En 1712 redacta las condiciones para dorar el retablo mayor de la iglesia penitencial de N. P. Jesús Nazareno. El 30 de mayo de ese año la cofradía, viendo que "de algunos años a esta parte con un retablo puesto en el altar mayor de dicha iglesia pieza muy exquisita y para su lucimiento y adorno hemos tratado y conferido se dore", da poder a José de Rozas, junto a Joseph de Navia, Blas Martínez de Obregón, Pedro de Ribas, Juan Correas e Ignacio de Prado "todos diputados de ella", para que "en nuestro nombre y de esta santa cofradía" se ajusten con los doradores Manuel Martínez de Estrada, Santiago Montes y Antonio Barreda Lombera "o con otros cualesquier de dicha ciudad" para dorar el dicho retablo ${ }^{264}$.

\footnotetext{
258 LLAMAZARES RODRÍGUEZ, Fernando: El retablo barroco en la provincia de León, Universidad de León, León, 1991, p. 346.

259 URREA FERNÁNDEZ, Jesús y MARTÍN GONZÁLEZ, Juan José: Inventario artístico de Palencia y su provincia II..., op. cit., p. 315.

260 WATTENBERG GARCÍA, Eloísa: Catálogo Monumental de la provincia de Valladolid. Tomo XVII. Medina de Rioseco, ciudad, Diputación de Valladolid, Valladolid, 2003, p. 112.

261 NAVARRO TALEGÓN, José; Catálogo Monumental de Toro y su alfoz, Publicaciones de la Caja de Ahorros Provincial de Zamora, Zamora, 1980, p. 313.

262 Ídem, p. 86.

263 NAVARRO TALEGÓN, José: Inventario y catálogo de bienes muebles de interés cultural propios del Excmo. Ayuntamiento de Toro, pp. 41-42

264 A.H.P.V., Leg. 3.014/4, ff. 5-6.
} 
$\mathrm{Su}$ última labor documentada es el "estofar encarnar y dorar y poner los ojos de cristal" a la escultura de San Miguel que Pedro de Ávila había tallado para la iglesia parroquial de Castil de Vela ${ }^{265}$. Manuel Martínez de Estrada fallece el 17 de septiembre de 1716 en Santo Toribio de Liébana (Cantabria) "yendo de devoción a visitar aquel Santuario donde se sepultó"266.

\section{LEONARDO MARTÍNEZ DE ESTRADA (h.1670-1705)}

El dorador Leonardo Martínez de Estrada es hermano de Manuel e hijo de José Martínez de Estrada y de Isabel Díez de Aragón. Desconocemos la fecha de su nacimiento, aunque diversos documentos permiten fecharlo hacia el año 1670. Contrajo matrimonio en dos ocasiones: el 12 de julio de 1690 con Manuela Fau Villalobos ${ }^{267}$, y el 22 de enero de 1698 con Josefa Sánchez de Aranzamendi ${ }^{268}$. Un último dato biográfico nos lo proporciona el listado de vecinos llevado a cabo en las parroquias de Valladolid el 24 de julio de 1691 por el que sabemos que vivía en la de San Lorenzo, que tenía 21 años y se encontraba ya casado ${ }^{269}$.

El 9 de mayo de 1700 presenta las condiciones para dorar el retablo mayor de la colegiata de Lerma (Burgos) ${ }^{270}$, retablo que años antes había diseñado su hermano Manuel, el cual quizás influyó a la hora de su contratación. Unos días después, el 21 de junio de 1700, el escultor vallisoletano José de Rozas, Manuel Martínez de Estrada (su hermano), José Garzón y Manuel Hernández firman un documento en Valladolid por el cual salen como fiadores de Leonardo Martínez de Estrada en la obra del "dorar un retablo que está en la santa iglesia colegial de señor San Pedro de la villa de Lerma en precio de veinte y ocho mil reales de vellón"271.

En 1703 redacta, de manera conjunta con Antonio Barreda Lombera, las condiciones para el dorado del retablo mayor de la iglesia de Santa María de Pozaldez. (Valladolid) $^{272}$. A la subasta acudió, además de estos dos, el vallisoletano Santiago Montes y el burgalés Bernardo López de Sagredo. La obra recayó finalmente en Leonardo Martínez de Estrada, el cual lo realizó entre los años 1703-1705 ${ }^{273}$, los últimos pagos se le abonaron a su viuda entre $1705-1706^{274}$.

\footnotetext{
265 A.D.P., Castil de Vela, San Miguel, Caja 32, f. 93.

266 FERNÁNDEZ DEL HOYO, María Antonia: "El convento...", op. cit., p. 436.

267 A.G.D.V., San Lorenzo, 1671M, f. 47.

268 A.G.D.V., San Lorenzo, 1671M, f. 67.

269 A.H.P.V., Leg. 2.638, ff. 274-278.

270 CERVERA VERA, Luis: op. cit., p. 115.

271 A.H.P.V., Leg. 3.012, ff. 316-317.

272 MARCOS VILLÁN. Miguel Ángel y FRAILE GÓMEZ, Ana María: Catálogo Monumental de la provincia de Valladolid. Tomo XVIII..., op. cit., pp. 219-220.

273 Ídem, pp. 191 y 202.

274 Ibídem.
} 
Desconocemos sus principales datos biográficos. La primera noticia data del año 1703 en que acude a la subasta para el dorado del retablo mayor de la iglesia de Santa María de Pozaldez (Valladolid), que se había de ejecutar según las condiciones dictadas por Leonardo Martínez de Estrada y Antonio Barreda Lombera ${ }^{275}$. A la subasta acudió, además de estos tres, el burgalés Bernardo López de Sagredo. La obra recayó en Leonardo Martínez de Estrada.

El 8 de julio de 1709 sale por fiador, junto con el escultor José de Rozas, del ensamblador Juan Correas en la escritura de obligación que hace éste para fabricar un retablo mayor de la iglesia parroquial de Hérmedes de Cerrato (Palencia) ${ }^{276}$. Ese mismo año realiza el dorado de los retablos colaterales de la Concepción ${ }^{277}$ y de San Sebastián $^{278}$ sitos en la parroquial de Villabáñez (Valladolid). Aún en 1709, el 15 de diciembre, se obliga a dorar, fiado por el batidor de oro Dionisio García, el tabernáculo de talla que presidiría la nueva capilla que se había "fabricado en la iglesia de Nuestra Señora de las Angustias para colocar hace majestad de ella"279. Debía seguir puntualmente las calidades y condiciones hechas por Antonio Barreda. Entre los testigos de la escritura figura Francisco Billota, posible autor del desaparecido tabernáculo.

En el verano de 1710 se encontraba atareado dorando diversos elementos de la recién construida capilla de Nuestra Señora de las Angustias sita en la iglesia del mismo nombre. Así, se le abonaron 6.150 reales por dorar retablos, marcos de frontales, cartelas, los balcones de los tribunales, antepechos, etc... ${ }^{280}$.

El 25 de julio de 1711 se concierta con "los señores licenciados D. Manuel Navarro de Isla comisario del Santo Oficio y abad de la cofradía de Nuestra Señora de Fuentes y Felipe Vallecillo procurador de ella" para dorar el retablo de la ermita de Nuestra Señora de Fuentes sita en Villalón de Campos $^{281}$. Debía seguir las condiciones impuestas por Alonso Gómez.

El 30 de mayo de 1712 la Cofradía Penitencial de Nuestro Padre Jesús Nazareno, viendo que "de algunos años a esta parte con un retablo puesto en el altar mayor de dicha iglesia pieza muy exquisita y para su lucimiento y adorno hemos tratado y conferido se dore", da poder a José de Rozas, junto a Joseph de Navia, Blas Martínez de Obregón, Pedro de Ribas, Juan Correas e Ignacio de Prado "todos diputados de ella",

\footnotetext{
$275 \quad$ Ídem, pp. 163 y 220.

276 GARCÍA CHICO, Esteban: Documentos para el estudio del arte en Castilla. 2..., op. cit., pp. 363-365.

277 MARTÍN GONZÁLEZ, Juan José: Catálogo Monumental de la provincia de Valladolid. Tomo VI..., op. cit., pp. 154-155.

$278 \quad$ Ídem, pp. 155-156.

279 A.H.P.V., Leg. 2.763, ff. 132-133.

280 MARTÍN GONZÁLEZ, Juan José y URREA FERNÁNDEZ, Jesús: Catálogo Monumental de la provincia de Valladolid. Tomo XIV..., op. cit., pp. 253-254.

281 ZALAMA RODRÍGUEZ, Miguel Ángel: Ermitas y Santuarios de la Provincia de Valladolid, Diputación de Valladolid, Valladolid, 1987, p. 163.
}

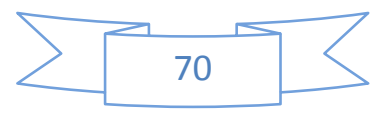


para que "en nuestro nombre y de esta santa cofradía" se ajusten con los doradores Manuel Martínez de Estrada, Santiago Montes y Antonio Barreda Lombera "o con otros cualesquier de dicha ciudad" para dorar el retablo mayor de la iglesia penitencial, "no subiendo de veinte y dos mil reales de vellón y se ha de hacer y ejecutar conforme las condiciones hechas y entregadas por el dicho Manuel de Estrada"282.

En 1714 se encarga, junto con Claudio Martínez de Estrada, de dorar y estofar el retablo mayor de la iglesia de San Juan de Tamariz de Campos (Valladolid), actualmente en la catedral de Santander. Montes se ocupó del estofado de la escultura de San Juan y del dorado del sagrario ${ }^{283}$.

La empresa más importante acometida por Santiago Montes fue la del dorado de los retablos de las capillas del cuerpo de la iglesia de la catedral. Aquella empresa tuvo tres artífices: Pedro de Ribas se encargó de construir los retablos, Pedro de Ávila de dotarles de la imagen principal y Santiago Montes del dorado de los retablos. Tan solo tenemos documentada su participación en los de la Magdalena y San José. Por el dorado de estos dos últimos, efectuado en el año 1716, se le abonaron 13.427, cantidad en la que entraban "otras cosas"284. El nombre de este dorador también nos lo proporciona Manuel Canesi en su Historia de Valladolid al referirse al retablo de la capilla de San Juan Evangelista: "Es la $1^{a}$ de mano izquierda la que sirve de parroquia y está dedicada a S. Juan Evangelista, adornada con nuevo retablo desde el año 1716 en que este y otros doró al uso de ahora Santiago Montes y se concluyeron otras obras de menos entidad; pero todas primorosas y de mucha labor"285. Desconocemos si fue Santiago Montes el que también se encargó del dorado de los otros tres retablos: en 1721 se ejecutaron los de San Juan Bautista y San Pedro ${ }^{286}$, y en 1723 el de la capilla de San Miguel $^{287}$. Es previsible que todos ellos se encomendaran al mismo artífice.

El 1 de junio de 1725 contrata el dorado del retablo de Nuestra Señora la Emparedada en Boadilla de Rioseco. En esta ocasión también debía de realizar el dorado según las condiciones establecidas por Alonso Gómez, dorador vecino de Mazuecos ${ }^{288}$.

Según indica Canesi, el 28 de abril de 1726 Montes finaliza de dorar el retablo de la Sagrada Familia de la iglesia parroquial de San Lorenzo ${ }^{289}$. Ese mismo año se ocupa de tasar el dorado de los marcos que poseía Antonio Canesi cuando éste decide inventariar sus bienes antes de casarse con Isabel de Mata ${ }^{290}$. Ambas noticias nos hablan de la cercanía existente entre el dorador y la familia Canesi, uno de cuyos miembros, el

\footnotetext{
282 A.H.P.V., Leg. 3.014/4, ff. 5-6.

283 PARRADO DEL OLMO, Jesús María: Catálogo Monumental de la provincia de Valladolid. Tomo XVI..., op., cit., p. 211.

284 MARTÍN GONZÁLEZ, Juan José: "Noticias documentales sobre la Catedral de Valladolid", B.S.A.A., Tomo XXVI, 1960, p. 194.

285 CANESI ACEVEDO, Manuel: Historia de Valladolid (1750), Tomo III..., op. cit., p. 335.

286 MARTÍN GONZÁLEZ, Juan José: "Noticias documentales...”, op. cit., p. 194.

287 Ibídem.

288 PÉREZ DE CASTRO, Ramón: "Un retablo en Boadilla de Rioseco (Palencia) de Santiago Carnicero y Tomás de Sierra”, B.S.A.A., tomo LXXI, 2005, p. 248.

289 CANESI ACEVEDO, Manuel: Historia de Valladolid (1750), Tomo I..., op. cit., pp. 327-328.

290 A.H.P.V., Leg. 3.160, f. 420 (1726).
}

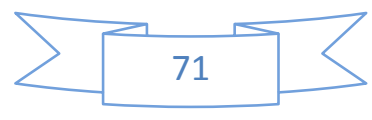


referido Antonio, pudo haberle suministrado el oro necesario para su oficio dado que era batidor de oro.

En 1732 se encarga del dorado de las piezas metálicas que portarían los cuatro padres de la iglesia que los escultores Pedro Bahamonde y Antonio de Gautúa esculpirían para la fachada de la catedral vallisoletana ${ }^{291}$.

Santiago Montes falleció el 9 de abril de 1742, siendo sepultado en la iglesia parroquial de Santiago Apóstol ${ }^{292}$. Por entonces, se encontraba viudo de su esposa Isabel Gil, viviendo en la calle de Zúñiga.

\section{MANUEL BARREDA $(1681-1757)$}

Manuel Barreda y Lombera, nacido Manuel Isidro Barreda Serrano, vio la luz en Valladolid en el mes de mayo de 1681. Sus padres, Antonio Barreda e Isabel Serrano, le bautizaron en la santa iglesia catedral el día 26 del referido mes ${ }^{293}$.

El 26 de diciembre de 1708 se desposa en la iglesia parroquial de San Esteban con María Ruiz "vecina de la villa de Támara diócesis de Palencia"294. Unos días después, el 30 de enero de 1709 el matrimonio es velado en la misma iglesia ${ }^{295}$. Barreda contraerá matrimonio en otras dos ocasiones: el 15 de octubre de 1725 con doña Antonia de Palencia en la iglesia de Santa María la Antigua ${ }^{296}$; y el 5 de noviembre de 1732 con Beatriz González ${ }^{297}$, un día antes el matrimonio había recibido las velaciones ${ }^{298}$. Entre sus hijos hemos de destacar a Urban Barreda y Lombera que seguirá el oficio familiar.

La primera referencia artística data del año 1710 que es cuando dora y estofa la escultura de Santa Juliana que el maestro José Pascual talla para la iglesia parroquial de Villarmentero de Esgueva ${ }^{299}$.

\footnotetext{
291 MARTÍN GONZÁLEZ, Juan José: Escultura barroca castellana ..., op. cit., p. 347.

A.G.D.V., Santiago, 1728D, f. 125. 293 "En veinte y seis de mayo de este presente año de mil y seiscientos y ochenta y uno yo el
licenciado Francisco Izquierdo sacristán mayor de la santa iglesia catedral de esta ciudad de Valladolid de licencia del licenciado Manuel Garrote y Prado cura propio de la parroquial de ella bauticé solemnemente y puse el santo óleo y Crisma según forma de la santa madre iglesia a Manuel Isidro hijo legítimo de Antonio Barreda y de Isabel Serrano sus padres mis parroquianos que al presente viven junto al cementerio de la Antigua fueron sus padrinos el licenciado don Juan Ramos y doña Josepha Ramos dieronle por abogados a Nuestra Señora del agrario y a San Isidro y a Santo Tomás fueron testigos Joseph Muñiz y el licenciado Andrés Escudero y Francisco González todos vecinos y estantes en esta dicha ciudad y por verdad lo firmé con dicho cura”. A.G.D.V., Catedral, 1656B, f. 234.

294 A.G.D.V., San Esteban, 1693M, f. 93.

295 A.G.D.V., San Esteban, 1693M, f. 93.

296 A.G.D.V., La Antigua, 1692M, f. 210.

297 A.G.D.V., La Antigua, 1692M, ff. 253-254.

298 A.G.D.V., Salvador, 1732M, f. 1.

299 "URREA FERNÁNDEZ, Jesús: Catálogo Monumental de la provincia de Valladolid. Tomo XX. Antiguo partido judicial de Valoria la Buena, Diputación de Valladolid, Valladolid, 2004, p. 139.
} 
Entre 1711-1712 le vemos trabajando en la iglesia de Santa Cruz de Pedrosa del Rey (Valladolid): en 1711 doraba el desaparecido retablo mayor ${ }^{300}$ y en 1712 la custodia del altar de las Angustias ${ }^{301}$. Posiblemente también sea obra suya el dorado del retablo del Santo Cristo del Consuelo ${ }^{302}$.

Otra de las parroquias del antiguo partido judicial de Tordesillas para la que trabaja con asiduidad es la de San Esteban de Torrecilla de la Abadesa (Valladolid): la primera obra que realizará, que será la más importante, es el dorado del retablo mayor en el año $1712^{303}$. Por esas mismas fechas la Cofradía de Nuestra Señora del Rosario sita en dicha iglesia le encarga el dorado de las andas de su imagen titular ${ }^{304}$. Gracias a una carta escrita por el propio dorador el 6 de noviembre de 1714 sabemos que corrió a su cargo la tarea de policromar y encarnar el Cristo Crucificado que ese mismo año había tallado el escultor Pedro de Ávila ${ }^{305}$. En 1723 se le abonan 40 reales por retocar una escultura de San Blas ${ }^{306}$. Finalmente, en 1729 corre a su cargo el dorar el retablo colateral, dedicado al Cristo de la Esperanza, pintar la capilla mayor y encarnar y estofar la escultura de San Roque ${ }^{307}$.

Dos ocasiones son las que trabajó Barreda para la parroquial de Serrada: en 1716 pintando unos hacheros y tres pinturas con los temas de la Oración en el Huerto, la Flagelación y el Ecce Homo para el monumento tallado ese mismo año por el ensamblador Francisco Billota ${ }^{308}$; y en 1720 dorando el retablo mayor de la iglesia y estofando los santos del mismo (San Pedro, San Andrés, relieve de San Francisco de Asís y un San Antonio de Padua desaparecido) ${ }^{309}$.

En 1725 la Congregación de San Felipe Neri le encomienda la tarea de dorar los seis retablos de las capillas laterales que se acababan de fabricar así como otras tantas rejas de las dichas capillas ${ }^{310}$. Según relata Ventura Pérez el dorador concluyó su trabajo el 15 de junio de $1725^{311}$. Cuatro días después la Congregación aún le abonaba salarios atrasados ${ }^{312}$.

\footnotetext{
300 ARA GIL, Clementina Julia y PARRADO DEL OLMO, Jesús María: Catálogo Monumental de la provincia de Valladolid. Tomo XI..., op. cit., p. 107.

$301 \quad$ Ídem, p. 108.

$302 \quad$ Ibídem.

303 Ídem, pp. 343-346.

$304 \quad$ Ídem, p. 347

305 PARRADO DEL OLMO, Jesús María: Datos histórico artísticos..., op. cit., p. 106.

306 ARA GIL, Clementina Julia y PARRADO DEL OLMO, Jesús María: Catálogo Monumental de la provincia de Valladolid. Tomo XI..., op. cit., p. 334.

$307 \quad$ Ibídem.

308 MARCOS VILLÁN. Miguel Ángel y FRAILE GÓMEZ, Ana María: Catálogo Monumental de la provincia de Valladolid. Tomo XVIII..., op. cit., p. 415.

$309 \quad$ Ídem, p. 416.

310 MARTÍN GONZÁLEZ, Juan José y URREA FERNÁNDEZ, Jesús: Catálogo Monumental de la provincia de Valladolid. Tomo XIV..., op. cit., p. 294.

311 PÉREZ, Ventura: op. cit., p. 75.

312 Archivo de la Congregación de San Felipe Neri (en adelante A.S.F.N.), Congregación en 19 de junio de 1725, Caja 14. $2^{\circ}$ Libro de acuerdos (1690-1740), f. 194.
} 
Todavía en este mismo año se encargaba de jaspear varios retablos y de policromar una escultura de Santa Bárbara que ese mismo año había tallado el maestro Antonio Gautúa para la iglesia de San Benito el Viejo ${ }^{313}$, y de dorar los marcos de los retratos de Felipe $V$ y Luis I que había pintado el renombrado Antonio Palomino un año antes para la Universidad $^{314}$. Los retratos se instalaron en el salón de claustros, aunque en la actualidad desconocemos su paradero.

El 26 de julio de 1727 la Cofradía de Nuestra Señora de la Piedad le da honores de diputado de la misma "por su equidad en el dorado de las gradas del altar mayor", así "como los arcos, compostura de retablos y otras cosas que ha hecho" "315.

En los años 1730-1731 le vemos trabajando en la localidad de Bercero (Valladolid). En 1731 pinta una serie de lienzos para una de las sacristías (Figs. 54-55) de las iglesias que tenía la población ${ }^{316}$, Ara Gil y Parrado piensan que puedan ser las conservadas en la iglesia parroquial: representan a la Asunción, San Juan Evangelista, San Lucas, San Marcos y la Virgen con San Juan y Ángeles, que son el fondo de un Crucifijo de talla, de la misma época ${ }^{317}$. Un año antes un tal Manuel Barreda, titulado "tallista y entallador" se comprometía a tallar dos Crucifijos y un San Francisco Javier ${ }^{318}$.

En 1735 la iglesia parroquial de Simancas le encarga dorar el nuevo tabernáculo del retablo mayor que acababa de renovar Pedro Bahamonde ${ }^{319}$. Años después, en 1744, volverá a trabajar para la iglesia pintando el púlpito y su sombrero ${ }^{320}$.

En 1738 dora y estofa el retablo mayor de la parroquial de la localidad de San Pelayo $(\text { Valladolid) })^{321}$. Un año después hará lo propio con el de Nuestra Señora del Rosario ${ }^{322}$.

En una fecha indeterminada entre los años 1738-1741 se encarga de dorar la caja del órgano de la iglesia del Convento de Santa Cruz de las Comendadoras de Santiago ${ }^{323}$. El órgano había corrido a cargo de don Pedro Chavarría, mientras que la hechura de la caja la había fabricado el ensamblador Pedro de Ribas.

\footnotetext{
313 MARTÍN GONZÁLEZ, Juan José y URREA FERNÁNDEZ, Jesús: Catálogo Monumental de la provincia de Valladolid. Tomo XIV..., op. cit., p. 289.

314 MARTÍN GONZÁLEZ, Juan José: Catálogo Monumental de la provincia de Valladolid. Tomo XIII, op. cit., p. 129.

315 ALARCOS LLORACH, Emilio: op. cit., pp. 197-204.

316 ARA GIL, Clementina Julia y PARRADO DEL OLMO, Jesús María: Catálogo Monumental de la provincia de Valladolid. Tomo XI..., op. cit., p. 25.

$317 \quad$ Ídem, p. 20.

$318 \quad$ Ídem, p. 25.

319 MARTÍN GONZÁLEZ, Juan José: Catálogo Monumental de la provincia de Valladolid. Tomo VI..., op. cit., p. 109.

320 Ídem, p. 110.

321 PARRADO DEL OLMO, Jesús María: Catálogo Monumental de la provincia de Valladolid. Tomo IX. Antiguo partido judicial de Mota del Marqués, Diputación de Valladolid, Valladolid, 1976, p. 178.

322 Ídem, p. 182.

323 A.H.P.V., Leg. 3.283, f. 615.
} 
En 1741 policroma las imágenes de San Juan Evangelista, San Nicolás y Santa Catalina que había tallado el escultor José Fernández para la capilla universitaria ${ }^{324}$.

En 1746 dora la custodia del retablo mayor de la iglesia de Piña de Esgueva que por entonces acababa de realizar el vallisoletano Pedro Bahamonde ${ }^{325}$.

Manuel Barreda y Lombera falleció el 21 de abril de 1757, siendo su cuerpo sepultado en la iglesia de San Juan Bautista, de la cual era cura párroco su hijo Pedro ${ }^{326}$.

\section{BONIFACIO NÚÑEZ (1706-1746)}

Bonifacio Núñez González nace el 6 de abril de 1706 en Aldea de San Miguel. Sus padres, Simón Núñez e Isabel González, lo bautizaron el día 28 de ese mismo mes en la iglesia parroquial de San Miguel de la dicha villa ${ }^{327}$. Hacia el año 1730 contraería matrimonio con Manuela de Castro, seguramente en la iglesia de San Lorenzo de Valladolid.

En septiembre de 1730 la Cofradía Penitencia de N. P. Jesús Nazareno le comisiona para que dore y estofe la escultura de San José que acababa de realizar Manuel de Ávila ${ }^{328}$. Por dicha labor percibió 150 reales, acabados de pagar el 12 de agosto de $1731^{329}$.

El 13 de septiembre de 1735 entra en su taller como aprendiz Manuel de Urosa, uno de los doradores y estofadores más importantes de Valladolid en los años centrales del siglo XVIII ${ }^{330}$.

\footnotetext{
$324 \quad$ A.U., Libro de cuentas no 437 (1708-1758).

325 URREA FERNÁNDEZ, Jesús: Catálogo Monumental de la provincia de Valladolid. Tomo XX..., op. cit., p. 185.

326 "En veinte y uno de abril de mil setecientos y cincuenta y siete habiendo recibido los sacramentos de eucaristía, penitencia y extremaunción murió en esta parroquia de San Juan Bautista Manuel Barreda y Lombera padre del infrascrito cura de ella y viudo de segundas nupcias de doña Antonia Palencia y de primeras de doña María Ruiz de quien tuvo y dejó a don Pedro, Manuel y Urban. No hizo testamento por no tener de qué dejando al dicho su hijo la disposición funeral a su voluntad Enterrose en sepultura propia de la sacramental y por los derechos de hacheros, tumba, rescate de cera y paño dio a la fábrica de dicha iglesia su hijo don Pedro cincuenta reales y lo firmé fecha ut supra". A.G.D.V., San Juan Bautista, 1649D, ff. 414-415.

327 "[28 de abril] Año de mil setecientos y seis bauticé solemnemente e impuse los santos óleos y crisma según orden y disposición de nuestra madre la iglesia romana a Bonifacio hijo legítimo y de legítimo matrimonio de Simón Núñez vecino y natural de este dicho lugar y de Isabel González vecina de él y natural de la Villaconancio obispado de la ciudad de Palencia (a quienes velé dicho día constará del libro de desposados velados a folio setenta y uno) el cual nació en seis días de dicho mes de abril; fueron sus padrinos Manuel González y Manuela Núñez, a quienes advertí la cognación y parentesco espiritual que habían contraído con dicho bautizado su padre y madre y la obligación de su oficio; dieronle por abogados a Nuestra Señora, San Miguel y San José esposo de la Virgen Santísima fueron testigos el licenciado Jerónimo de Ovilo, Joseph Núñez y Pedro de Vargas sacristán y para que conste lo firmé ut supra”. A.G.D.V., Aldea de San Miguel, San Miguel, 1693B, f. 50.

328 ARRIBAS ARRANZ, Filemón: La Cofradía Penitencial..., op. cit., p. 93.

329 Ídem, p. 134.

330 BRASAS EGIDO, José Carlos: "Noticias documentales de artistas vallisoletanos de los siglos XVII y XVIII"; B.S.A.A., Tomo L, 1984, p. 474.
}

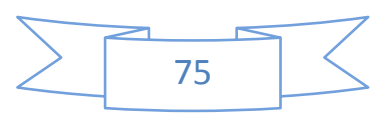


En 1742 contrata la que será su obra más importante: el policromado y dorado de las esculturas que Pedro de Sierra había hecho para el retablo mayor de la iglesia de San Andrés de Valladolid ${ }^{331}$.

Bonifacio Núñez fallece el 20 de diciembre de 1746 siendo enterrado en la iglesia de San Lorenzo. Días antes había dictado testamento, en el cual instituyó como sus herederos universales a sus hijos Manuela, Josefa, Juliana, Remigio y Crisanto ${ }^{332}$.

\section{RELACIÓN DE LOS ÁVILA CON LOS POLICROMADORES}

El policromador con el que coincide en un mayor número de ocasiones Juan de Ávila es Manuel Martínez de Estrada, miembro de una extensa familia de doradores. Ambos trabajan juntos en el retablo mayor de la colegiata de Lerma, en el retablo mayor y colaterales del oratorio de San Felipe Neri, en el retablo mayor de la parroquial de Santiago Apóstol. A estas obras podríamos añadir el retablo mayor y uno de los colaterales de Santa Brígida, y el retablo mayor de San Francisco de Toro (Zamora), todos ellos dorados por Martínez de Estrada, cuyas esculturas, sin documentar, están atribuidas con bastante fundamento a nuestro escultor.

Tenemos documentada la labor de otros doradores: cuando Juan de Ávila talla la escultura de Santiago Matamoros para la sacristía de la parroquial del mismo nombre el encargado de su policromado es José de Estrada (José Martínez de Estrada), cabeza de familia de la saga de doradores Martínez de Estrada. Con Alonso Gutiérrez coincidió en el retablo mayor de San Juan de Dios y, quizás, en el retablo mayor del convento de Las Lauras. Finalmente, también tendría relaciones laborales con los Barreda: con Antonio, el padre, trabajaría en el citado retablo de San Juan de Dios, y con Manuel, el hijo, en el retablo mayor de la parroquial de Torrecilla de la Abadesa (Valladolid), cuyas esculturas se le atribuyen.

Por su parte, Pedro de Ávila coincidió con alguno de los doradores que trabajaron con su padre. Así, Manuel Barreda policromó el Crucificado que talló para la parroquial de Torrecilla de la Abadesa, y posiblemente también policromó las esculturas que ejecutó, unas documentadas y otras no, para el oratorio de San Felipe Neri. Asimismo, Barreda doró los retablos de las capillas que contendrían parte de estas esculturas. El otro dorador con el que coincidió fue Santiago Montes, concretamente en las esculturas que Ávila talló para diferentes capillas de la catedral, y en los dos retablos colaterales de la capilla de Nuestra Señora de las Angustias, en la penitencial del mismo nombre. En

331 ARMENDÁRIZ UBIOLA, Fermín: "El retablo de la iglesia de San Andrés, de Valladolid", B.S.A.A., tomo VII, 1940-1941, pp. 187-195.

332 "En veinte días del mes de diciembre de mil setecientos y cuarenta y seis años murió en ésta parroquia Bonifacio Núñez quien otorgó su testamento ante Francisco de Rojas receptor de la Real Chancillería de ésta ciudad en catorce de diciembre de éste mismo año, por el que mandó enterrarse en ésta iglesia en sepultura de la fábrica mandó se dijesen por su alma cien misas rezadas la cuarta en ésta iglesia, dejó por sus testamentarios a Juan Antonio Otero su cuñado y a su mujer Manuela de Castro y por herederos a su mujer Manuela de Castro y sus hijos Manuela, Josepha, Juliana, Remigio y Crisanto Núñez de Castro y lo firmo dicho día, mes y año”. A.G.D.V., San Lorenzo, 1671D, f. 197. 
este último caso las esculturas que presiden sendos altares están solamente atribuidas, aunque con bastante fundamento.

Finalmente, solamente tenemos documentada una coincidencia entre Manuel de Ávila y los doradores o policromadores: Bonifacio Núñez fue el encargado de dar vida y color al San José que el pequeño de los Ávila talló magistralmente para la Cofradía Penitencial de N. P. Jesús Nazareno.

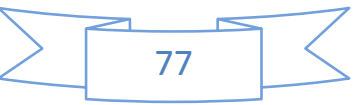




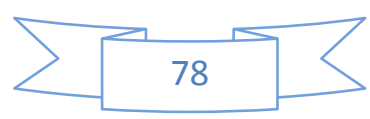




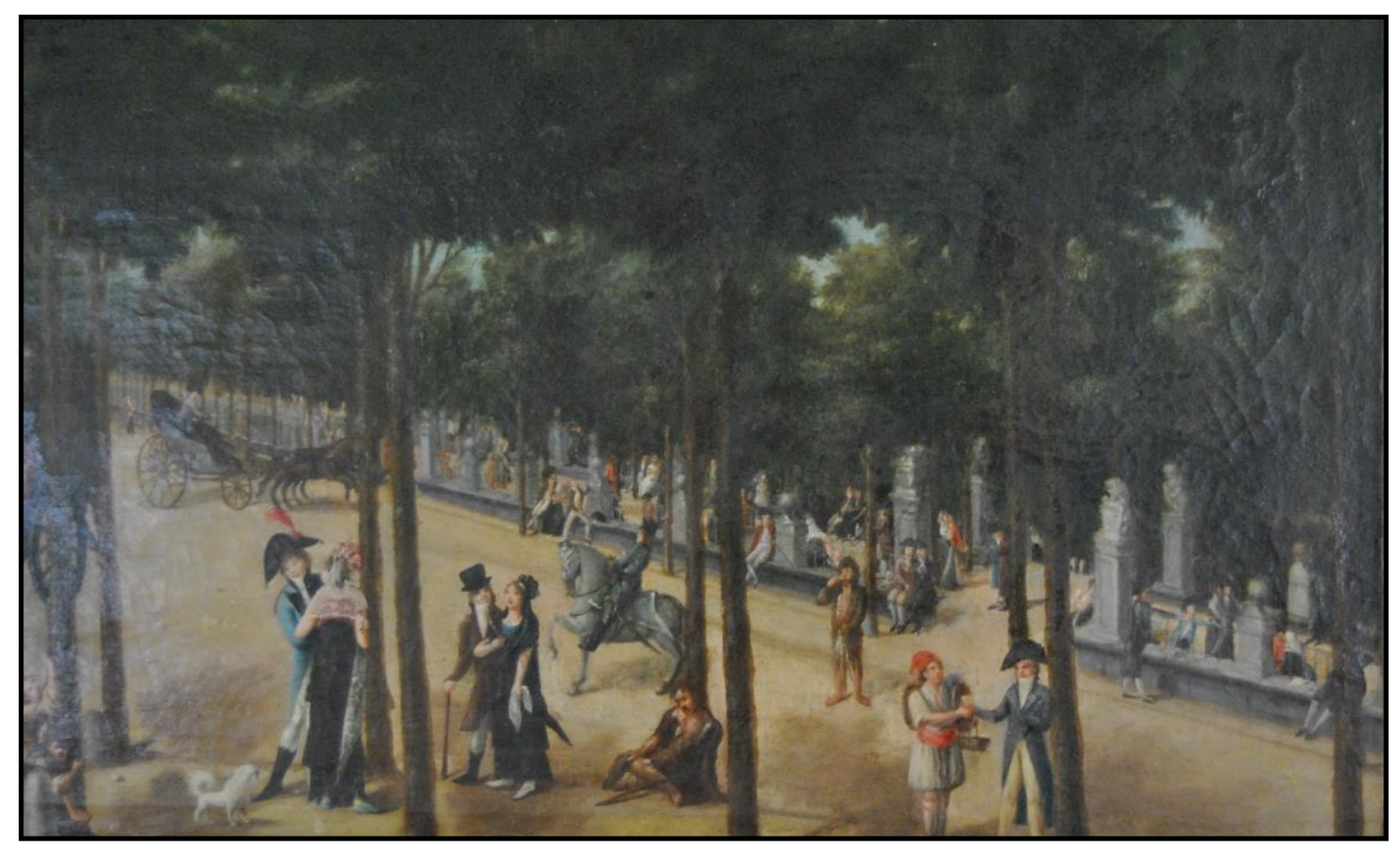

Fig. 1- Leonardo Araujo. El Espolón nuevo. Casa-Museo Zorrilla. Valladolid.

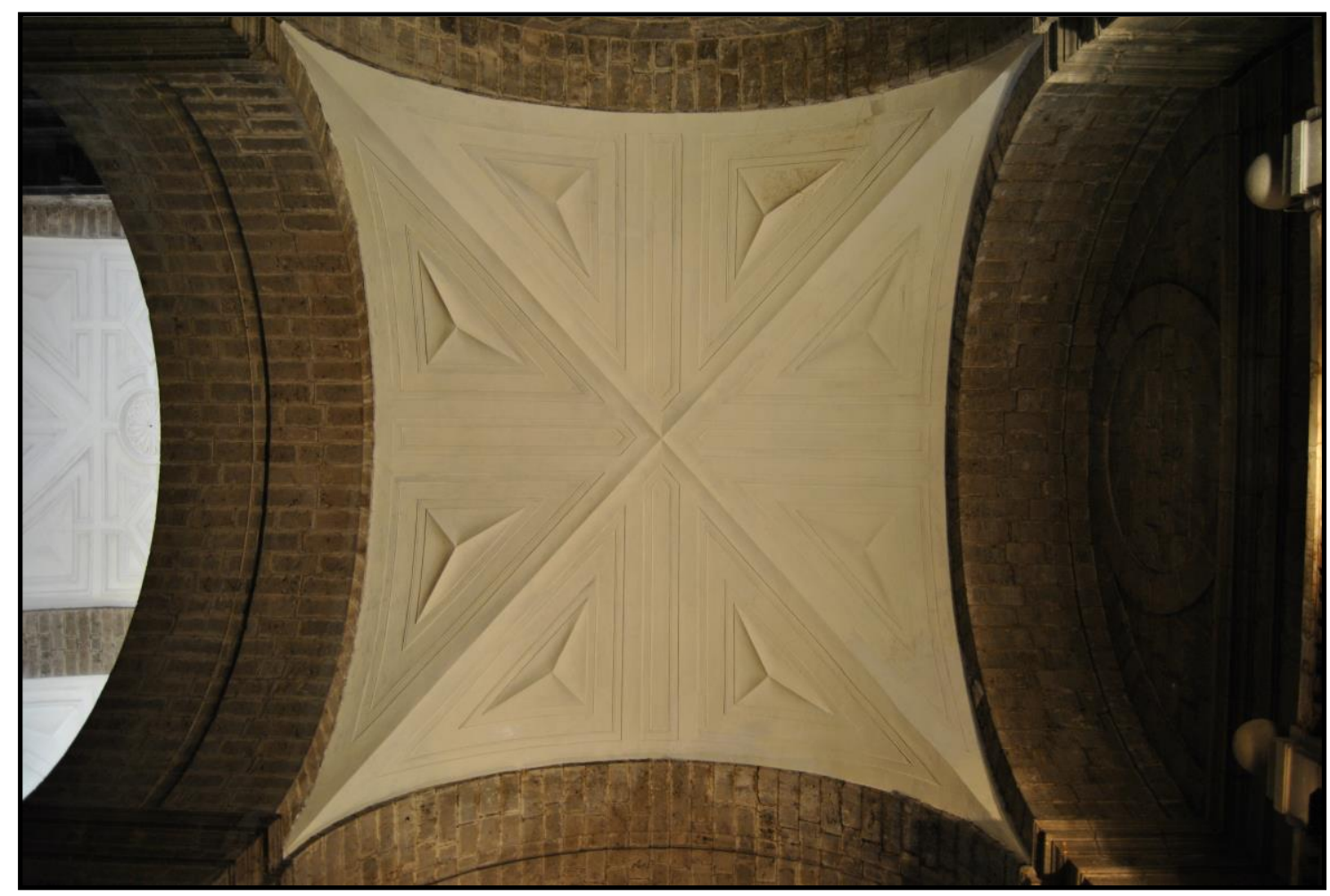

Fig. 2- Abovedamiento de la nave de la Epístola. Catedral. Valladolid.

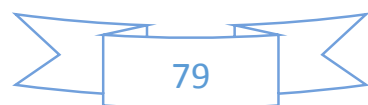




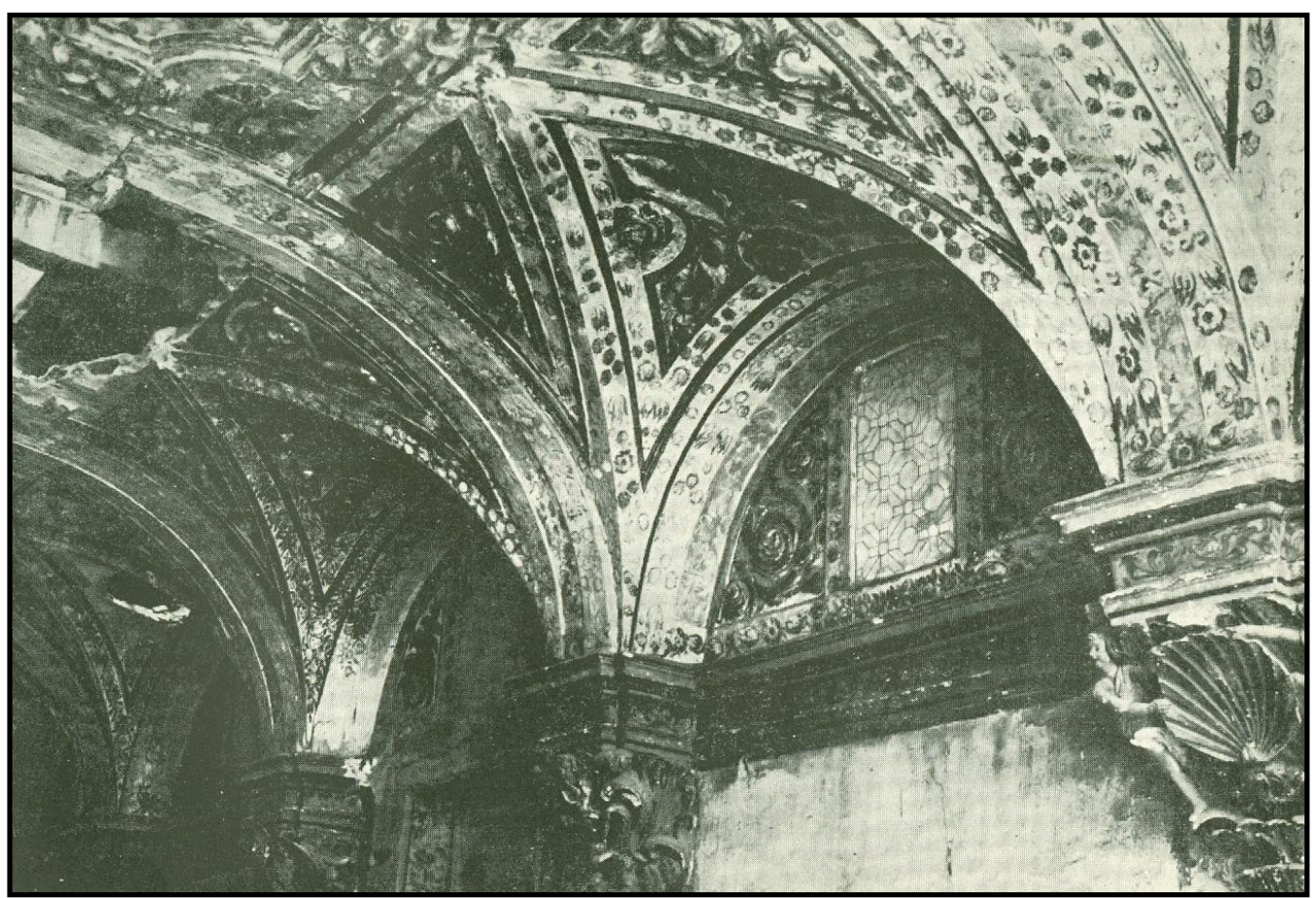

Fig. 3- Felipe Berrojo. Abovedamiento de la nave. Iglesia penitencial de Nuestra Señora de la Pasión. Valladolid.

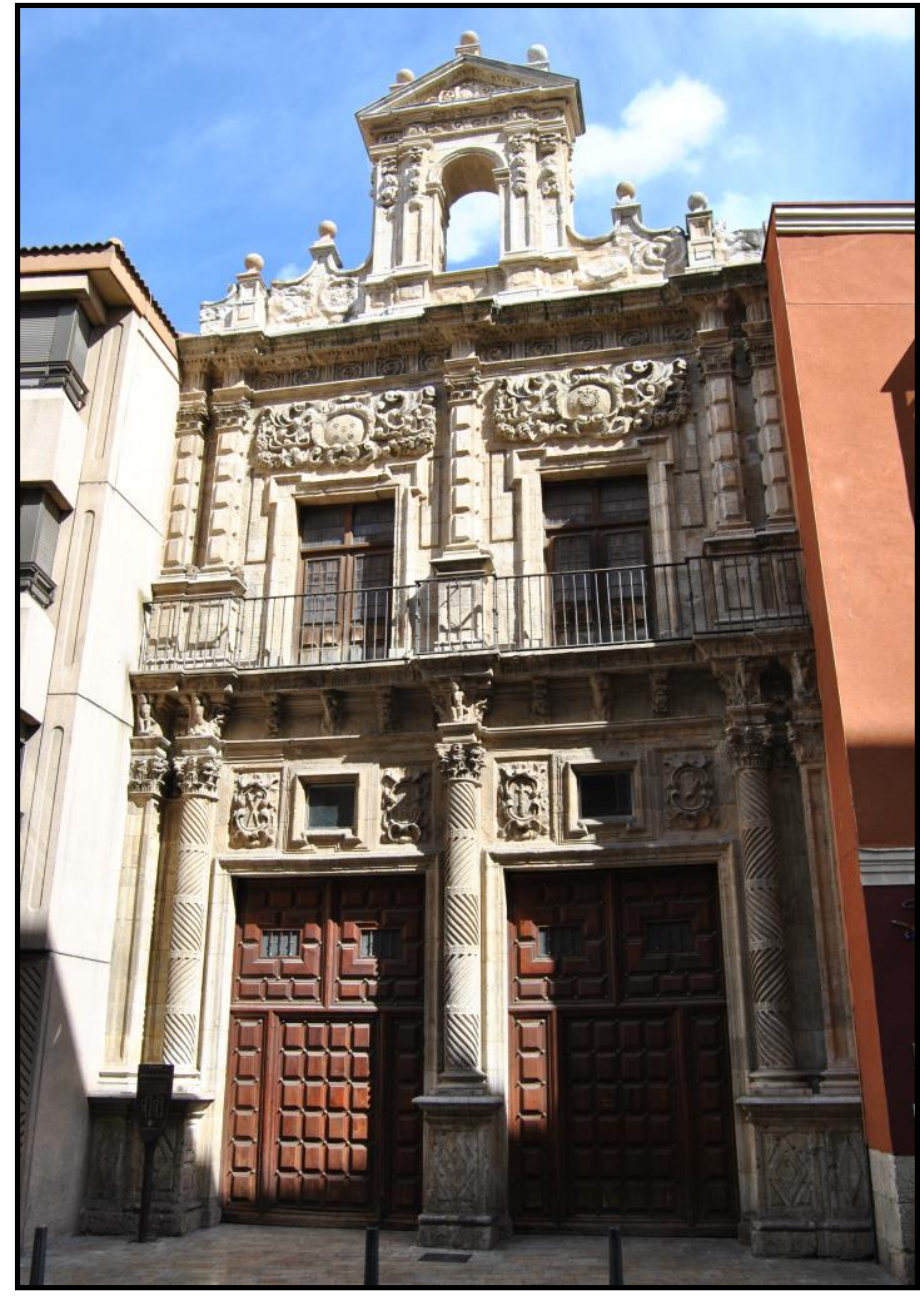

Fig. 4- Pedro Ezquerra. Fachada de la Iglesia penitencial de Nuestra Señora de la Pasión. Valladolid.

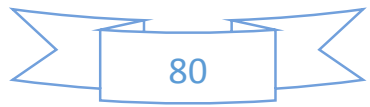




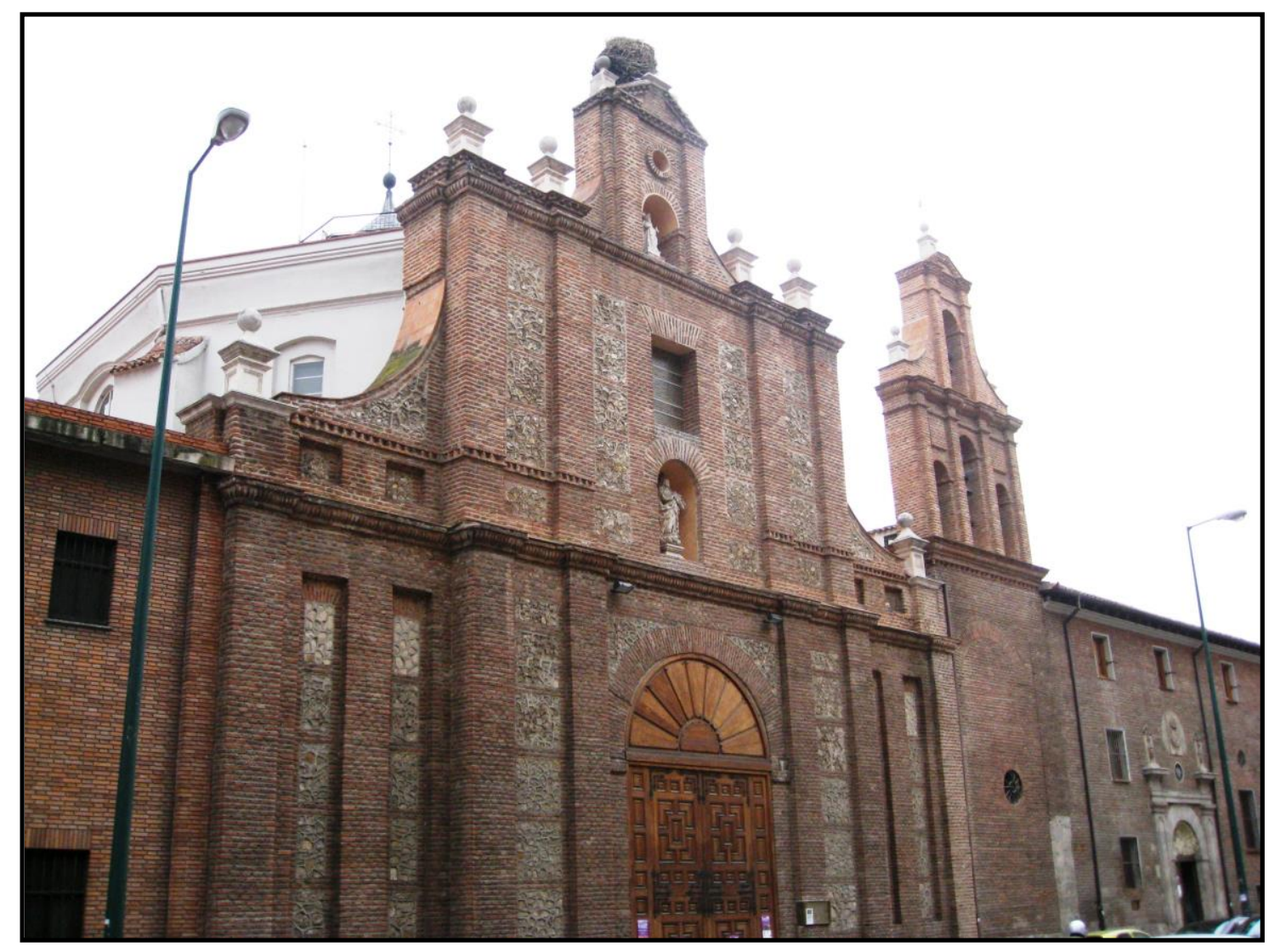

Fig. 5- Pedro Bibanco. Real Colegio de los Ingleses. Valladolid.

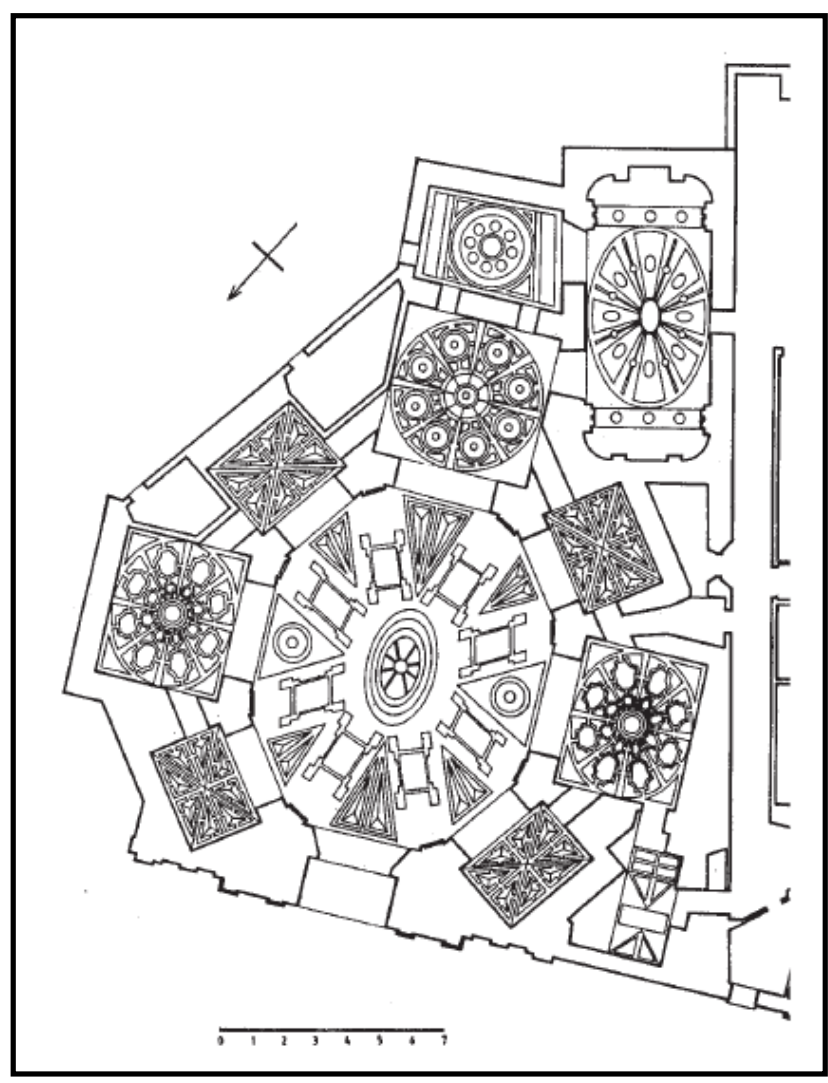

Fig. 6- Planta. Real Colegio de los Ingleses.

Valladolid.

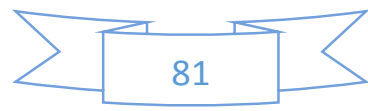




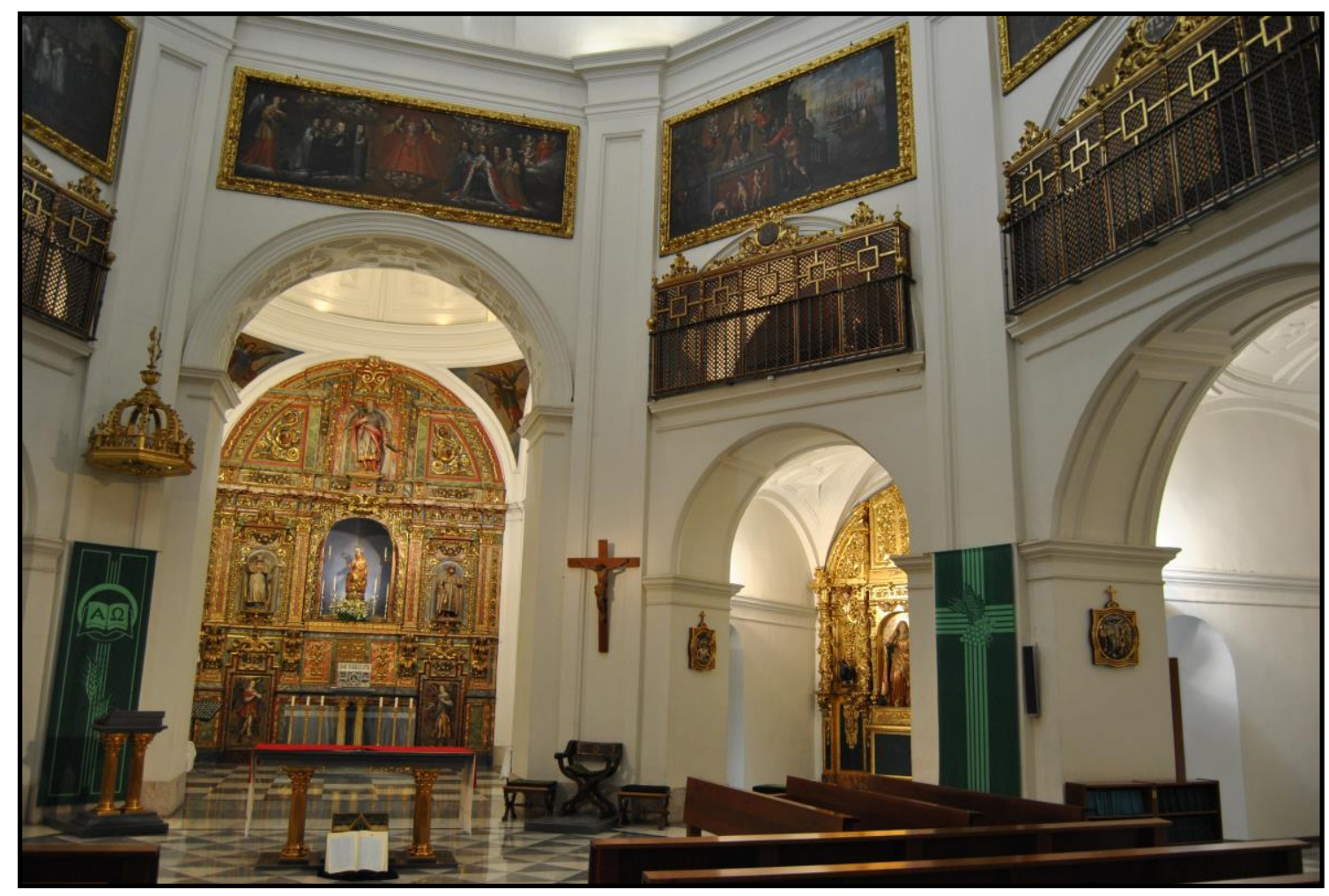

Fig. 7- Pedro Bibanco. Real Colegio de los Ingleses. Valladolid.

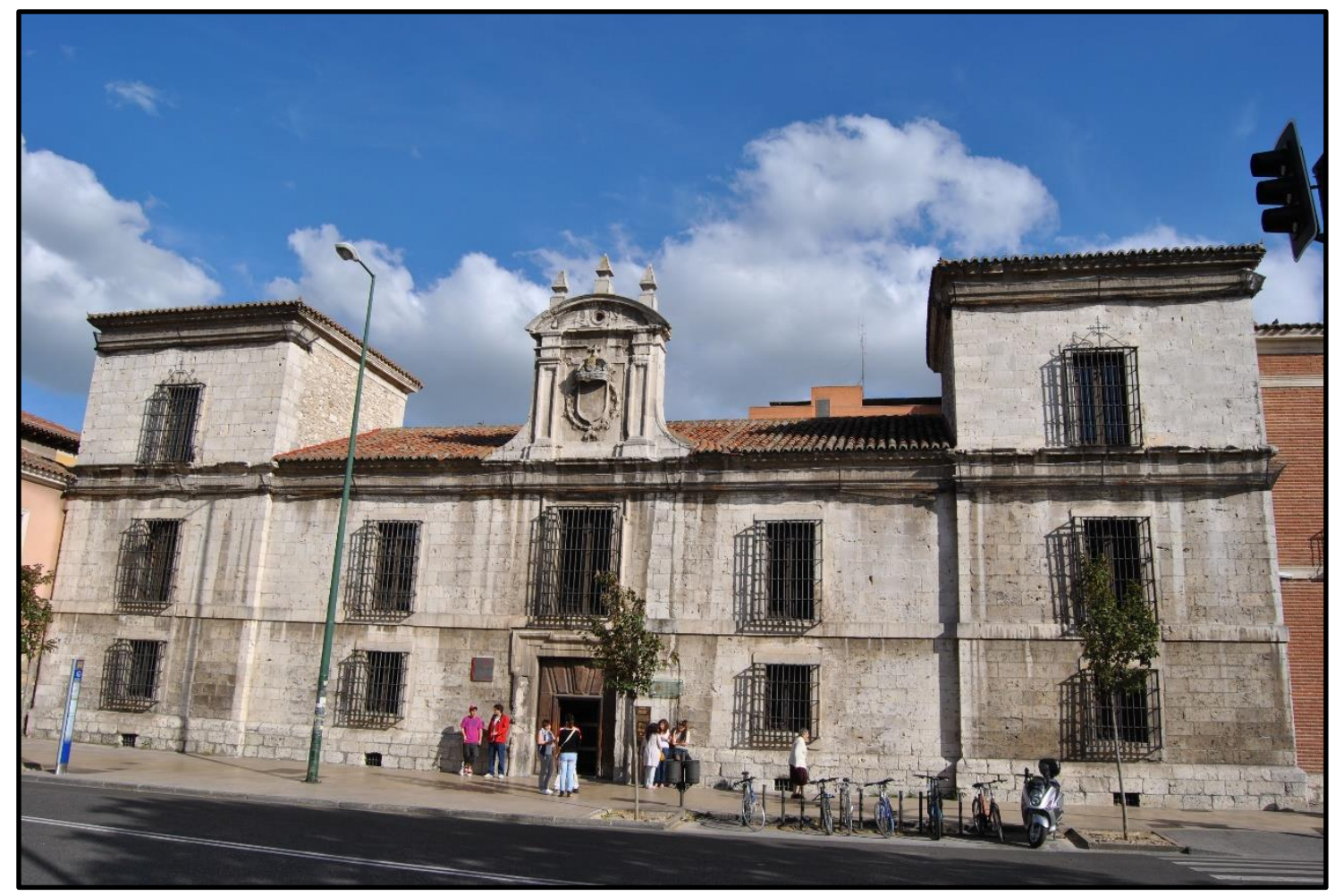

Fig. 8- Felipe Berrojo, Juan Tejedor Lozano y Juan de Medina Argüelles. Archivo y Cárcel de la Real Chancillería. Valladolid.

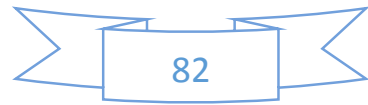




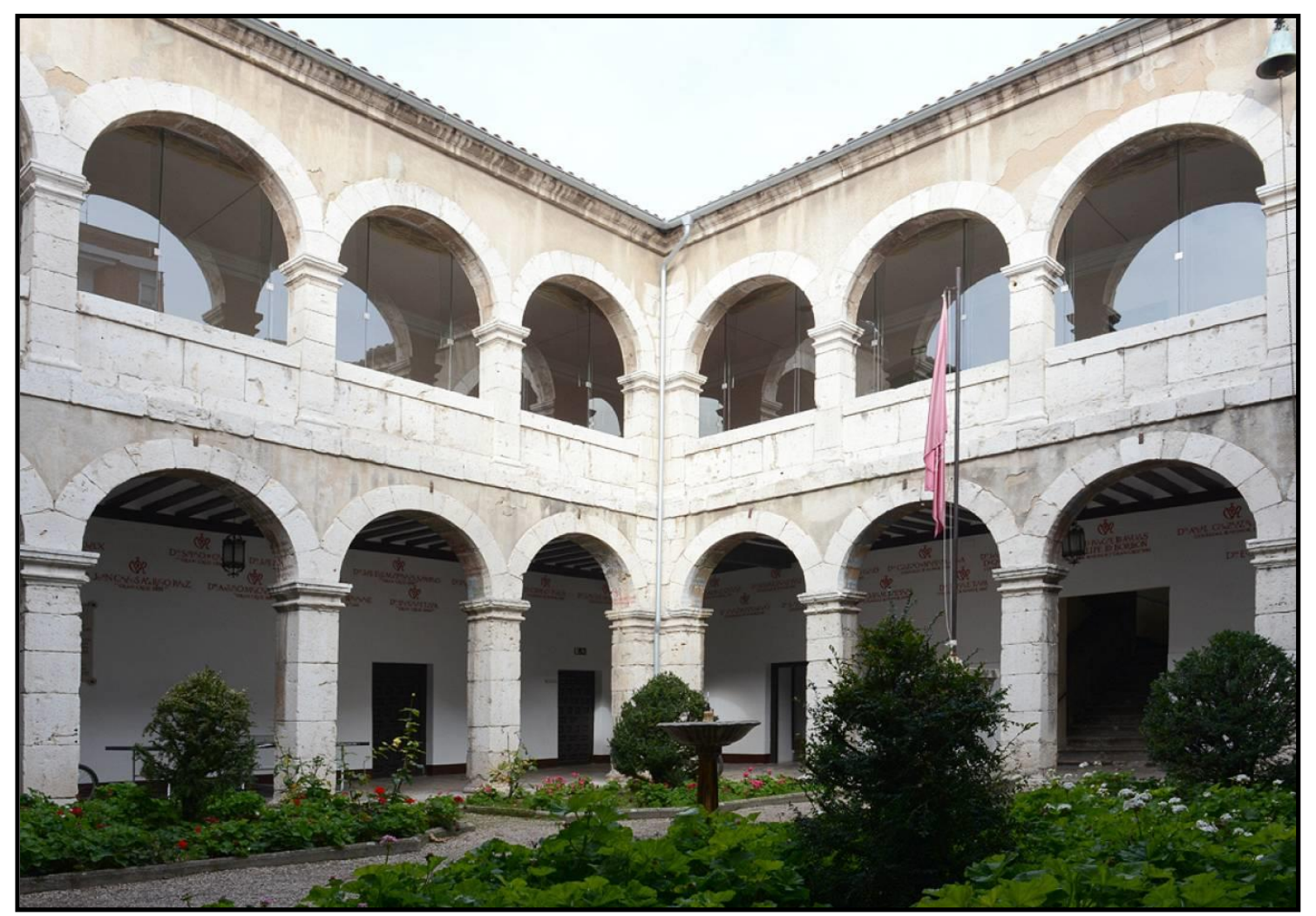

Fig. 9- Antonio del Solar (traza) y Francisco de la Torre. Hospedería del Colegio Mayor de Santa Cruz. Valladolid.

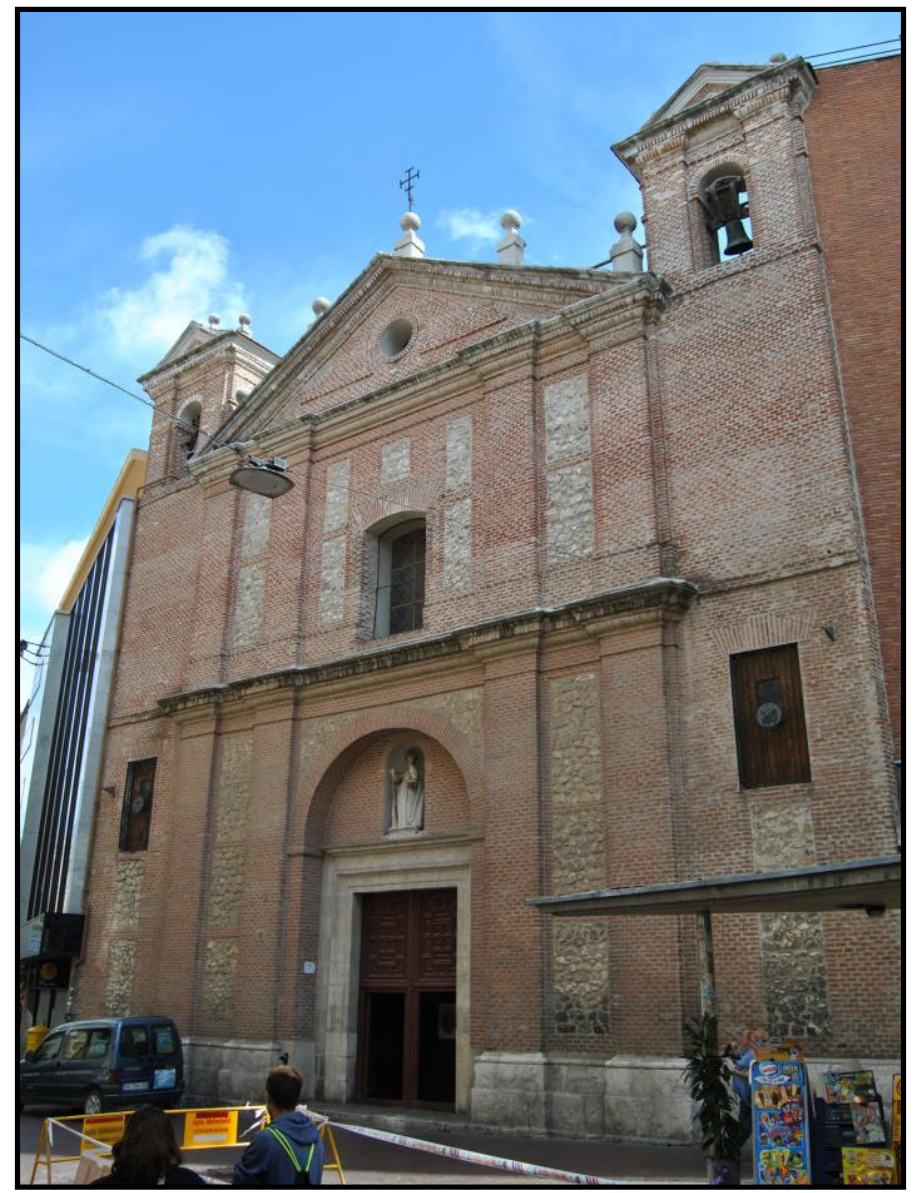

Fig. 10- Fachada del Oratorio de San Felipe Neri. Valladolid.

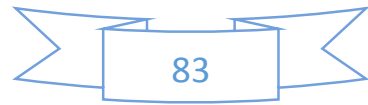




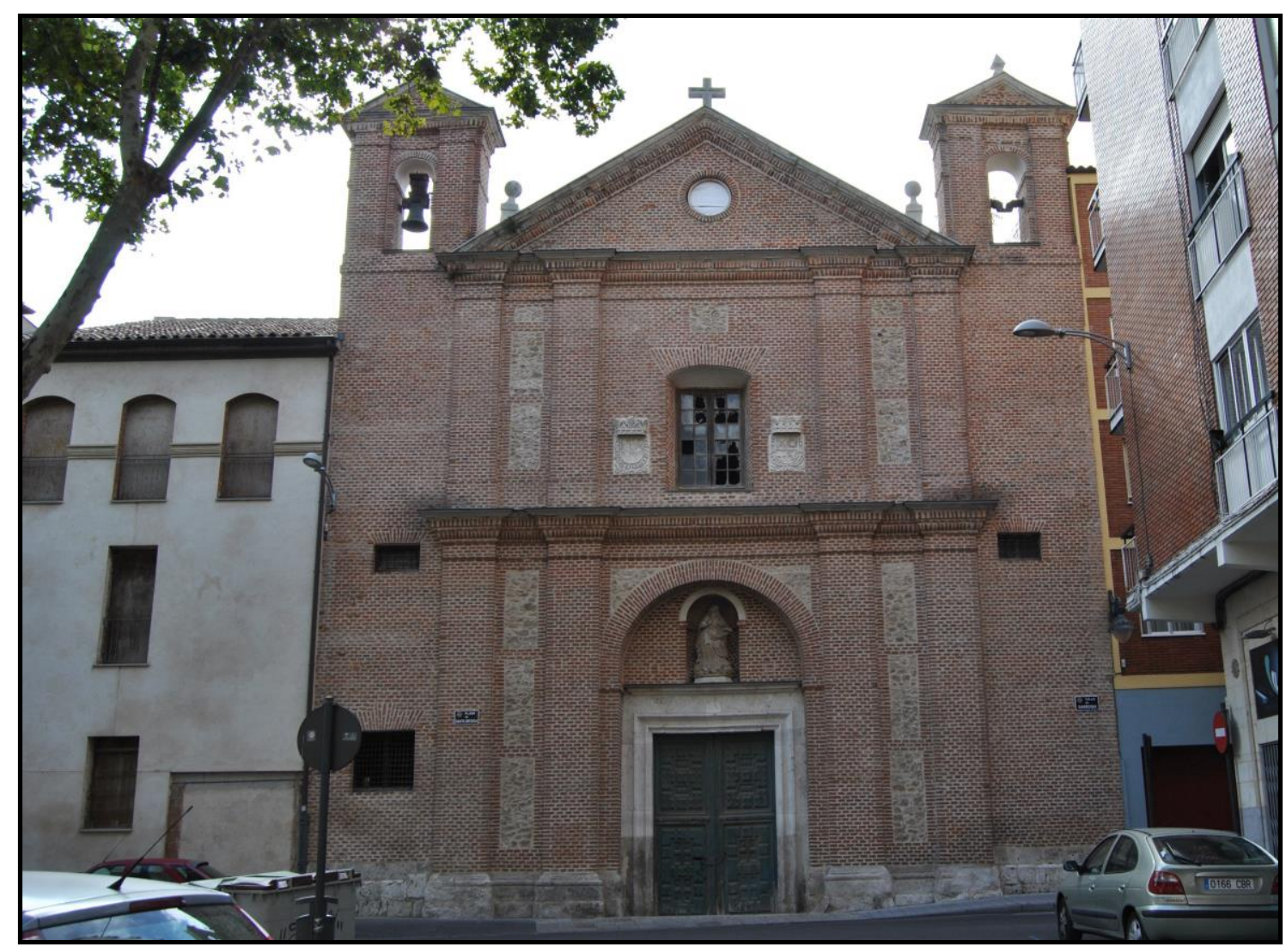

Fig. 11- Fachada del Monasterio de Santa Brígida. Valladolid.

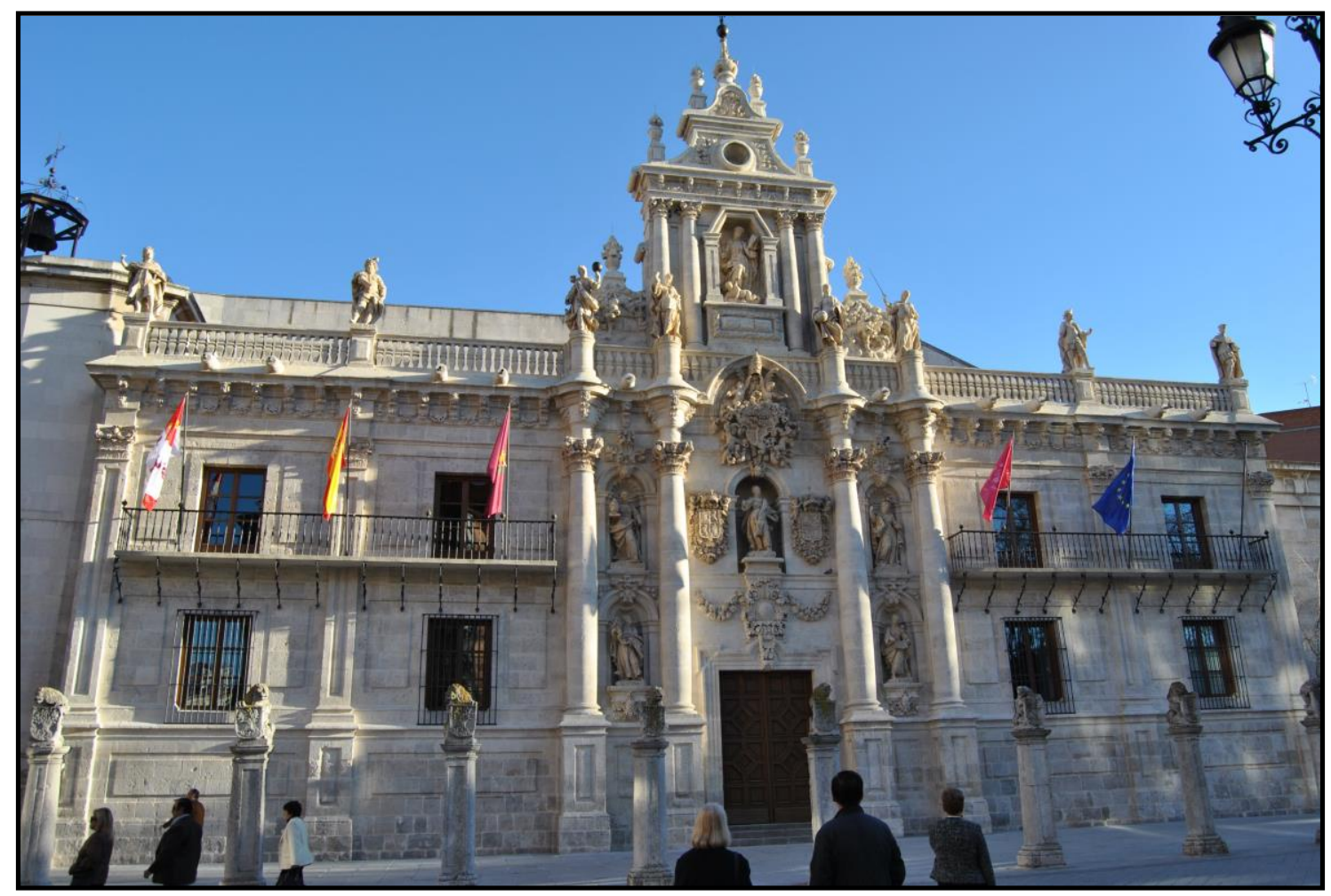

Fig. 12- Fray Pedro de la Visitación. Nueva fachada de la Universidad. Valladolid.

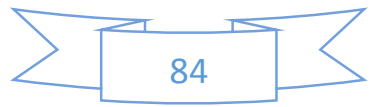




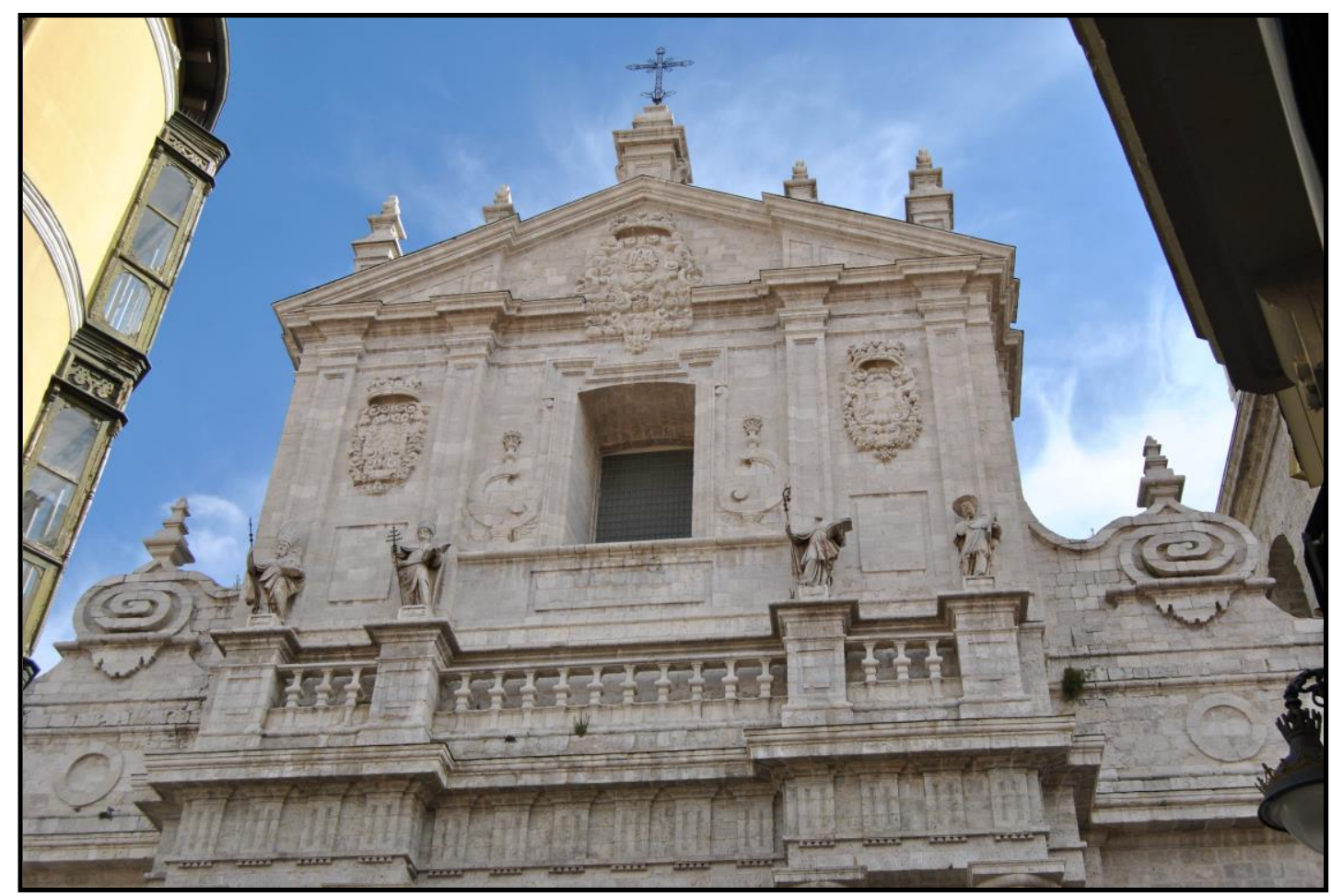

Fig. 13- Alberto Churriguera. Segundo cuerpo de la fachada principal de la Catedral. Valladolid.

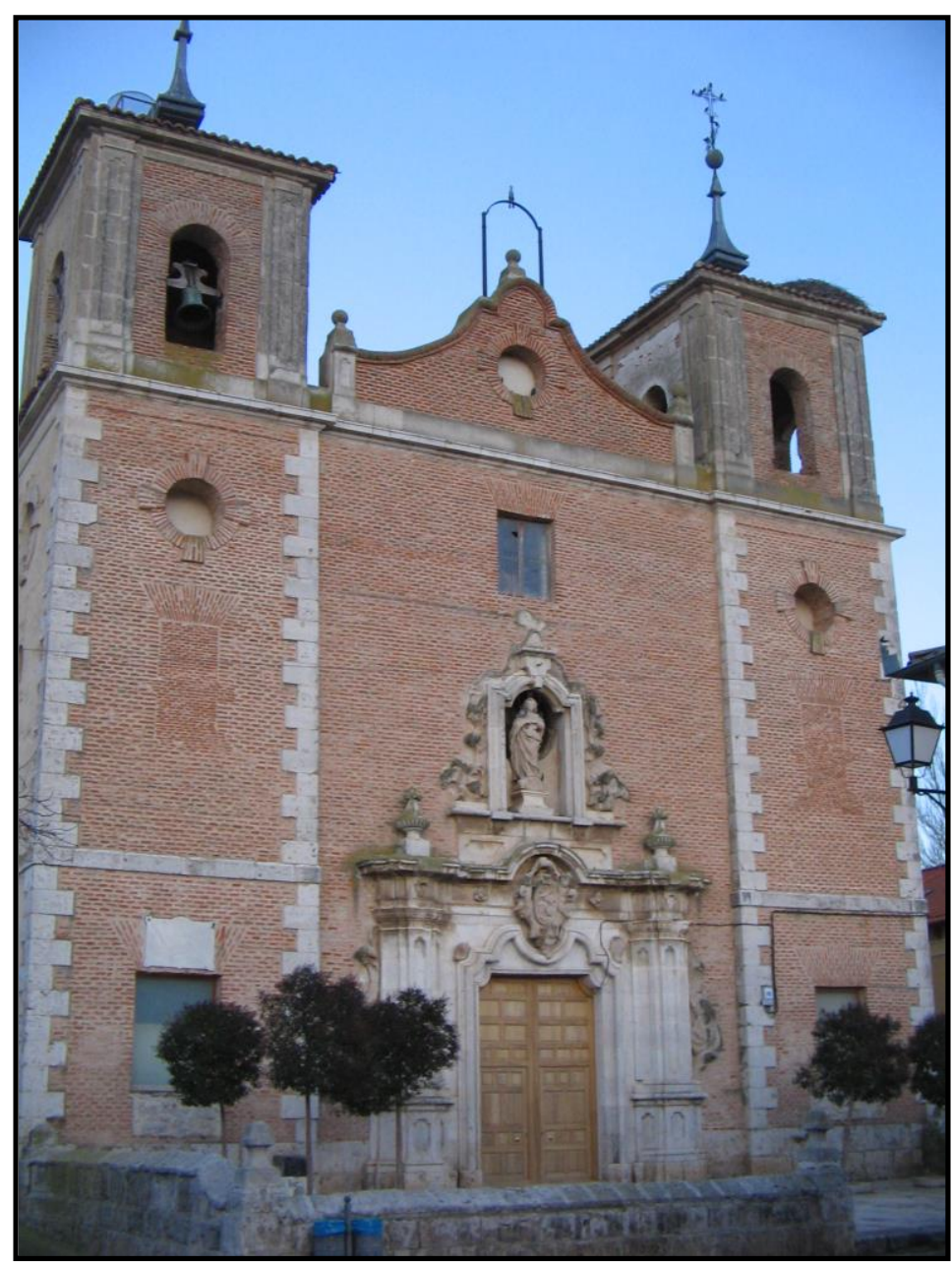

Fig. 14- Manuel Serrano. Iglesia parroquial. Renedo (Valladolid).

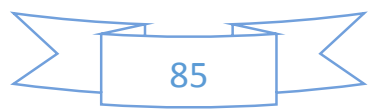




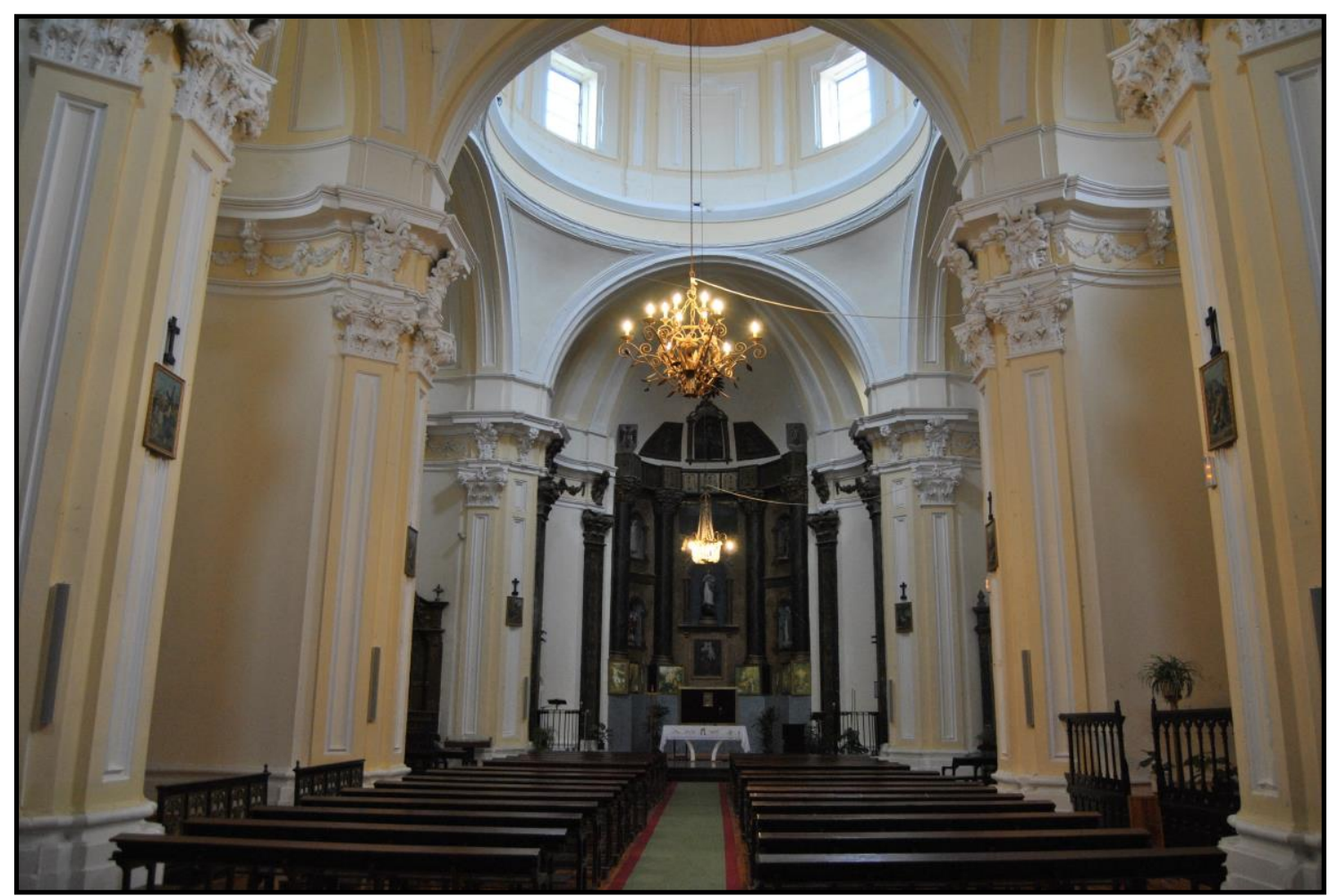

Fig. 15- Manuel Serrano. Iglesia parroquial. Renedo (Valladolid).

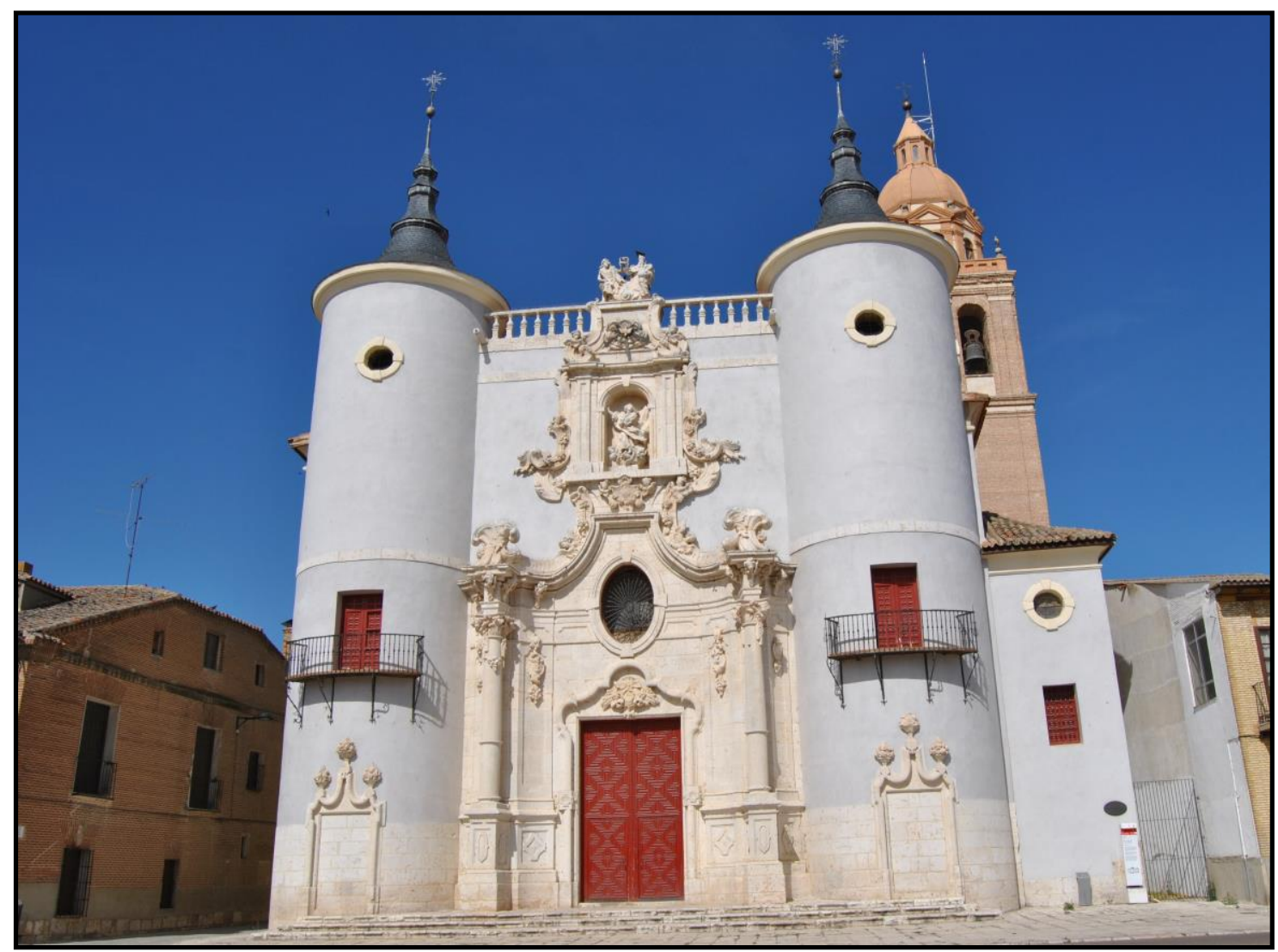

Fig. 16- Manuel Serrano. Iglesia parroquial. Rueda (Valladolid).

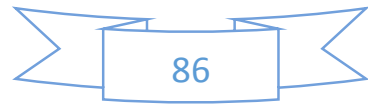




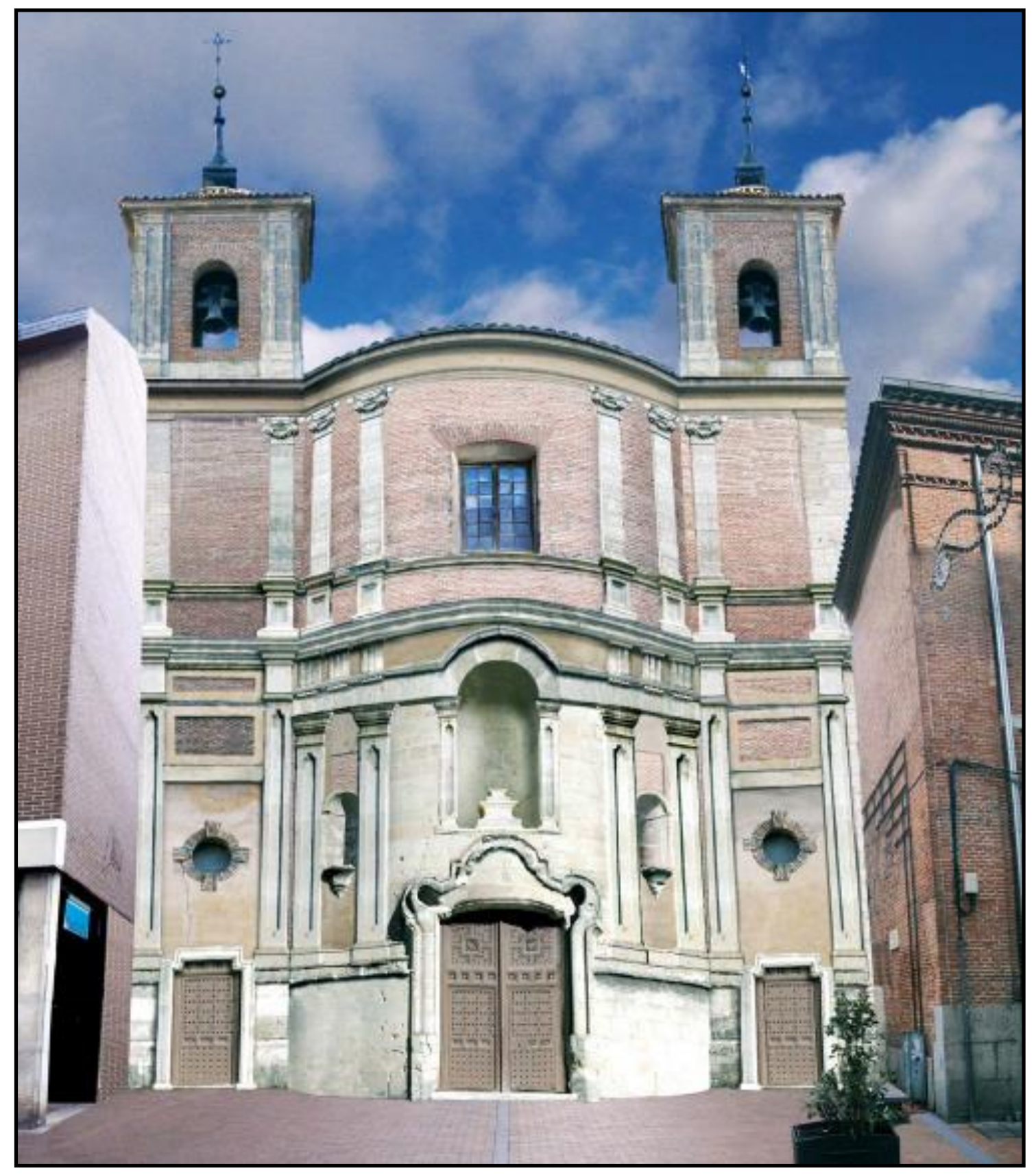

Fig. 17- Manuel Serrano. Monasterio Premostratense de San Norberto. Valladolid. (C) Reconstrucción informática de Juan Carlos Urueña Paredes.

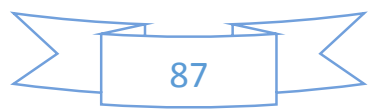




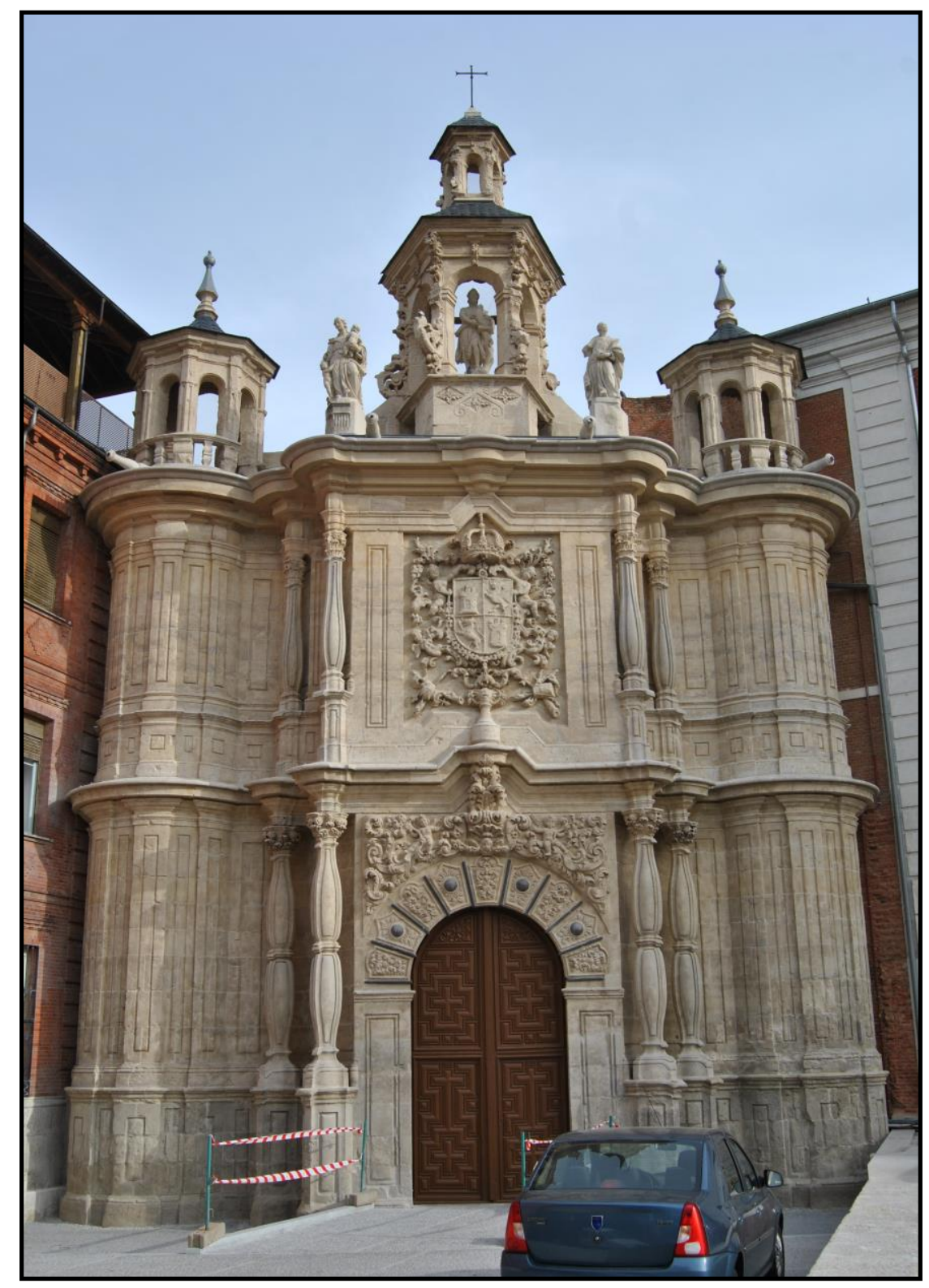

Fig. 18- Matías Machuca. Iglesia de San Juan de Letrán. Valladolid.

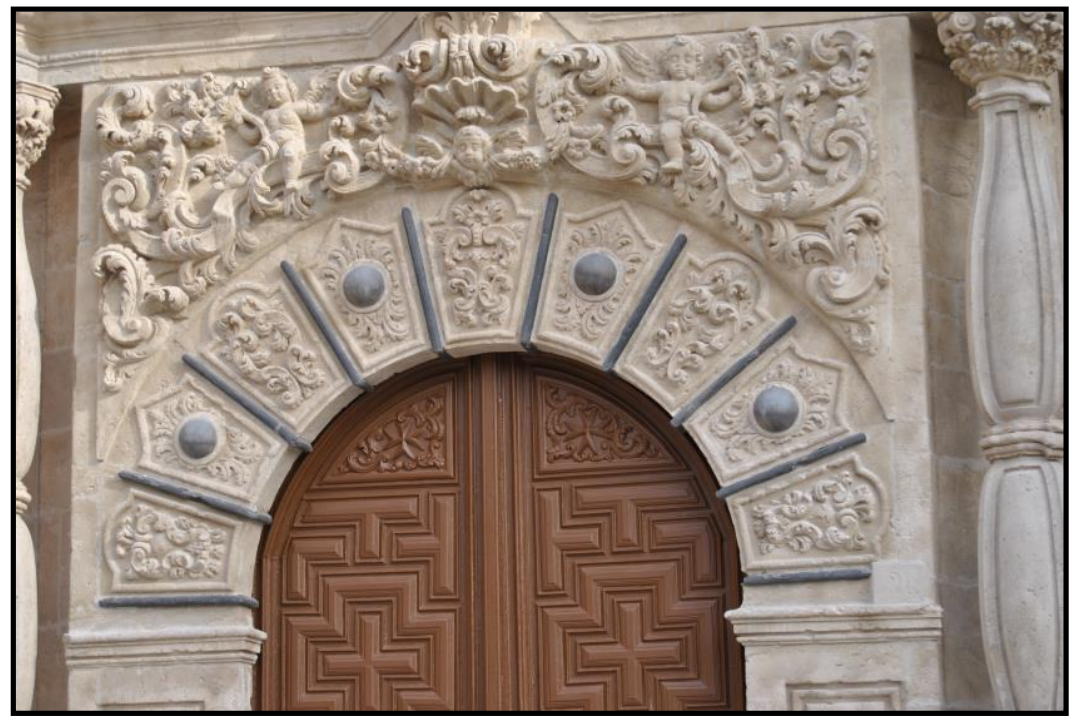

Fig. 19- Matías Machuca. Detalle Iglesia de San Juan de Letrán.

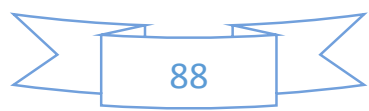



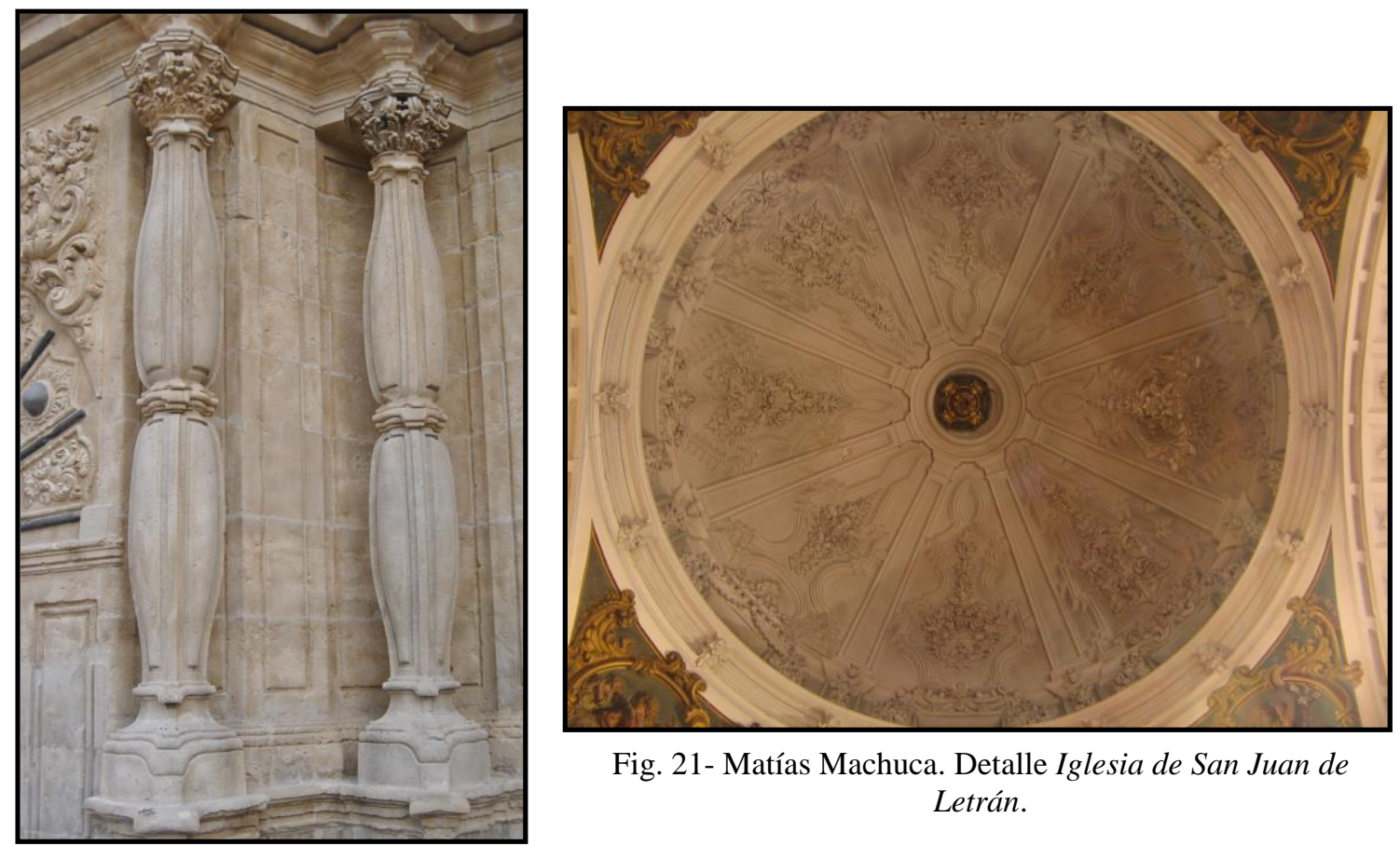

Fig. 21- Matías Machuca. Detalle Iglesia de San Juan de Letrán.

Fig. 20- Matías Machuca. Detalle Iglesia de San Juan de Letrán.

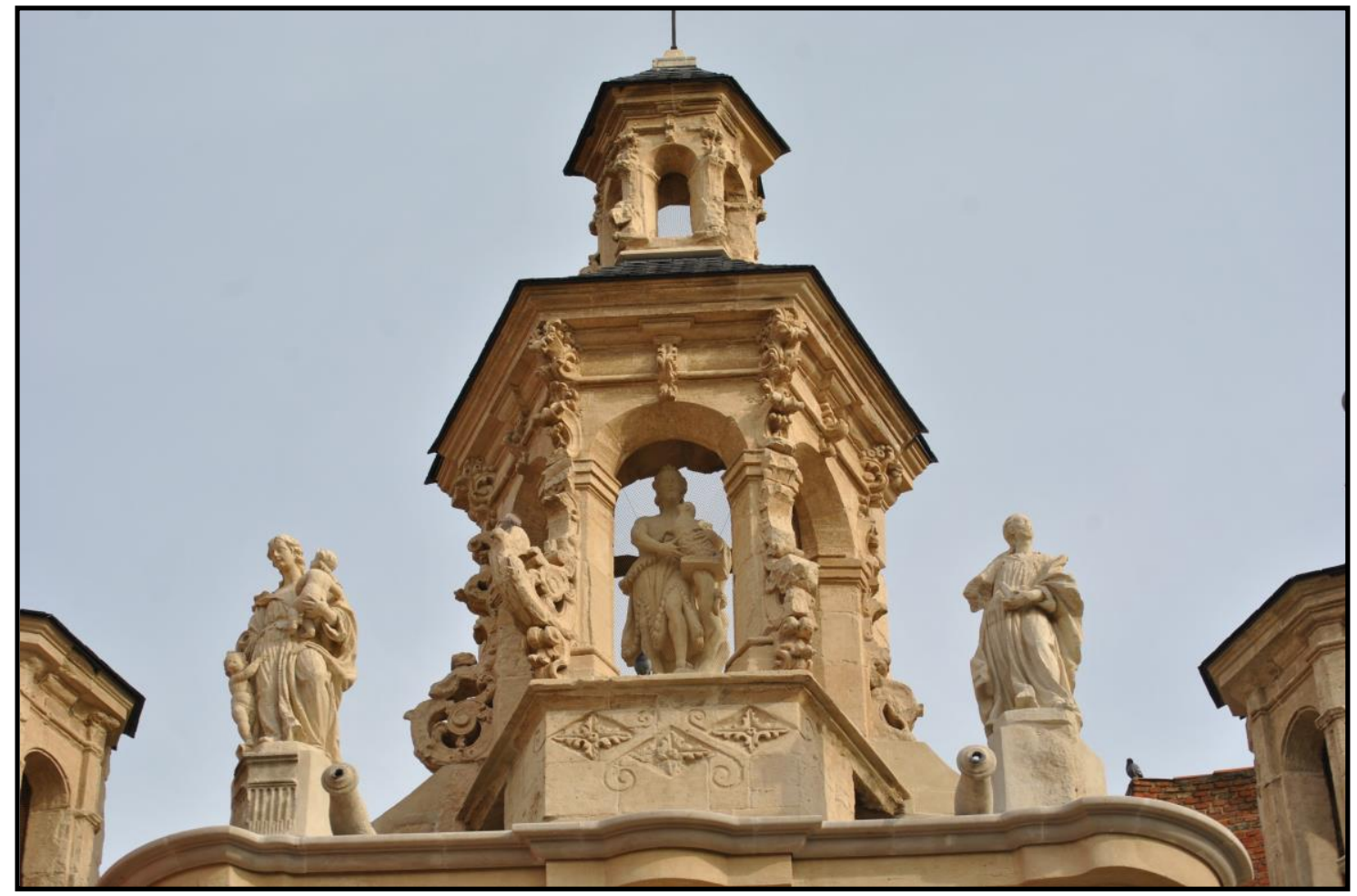

Fig. 22- Matías Machuca. Detalle Iglesia de San Juan de Letrán.

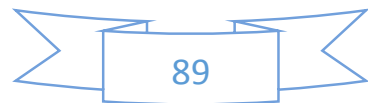




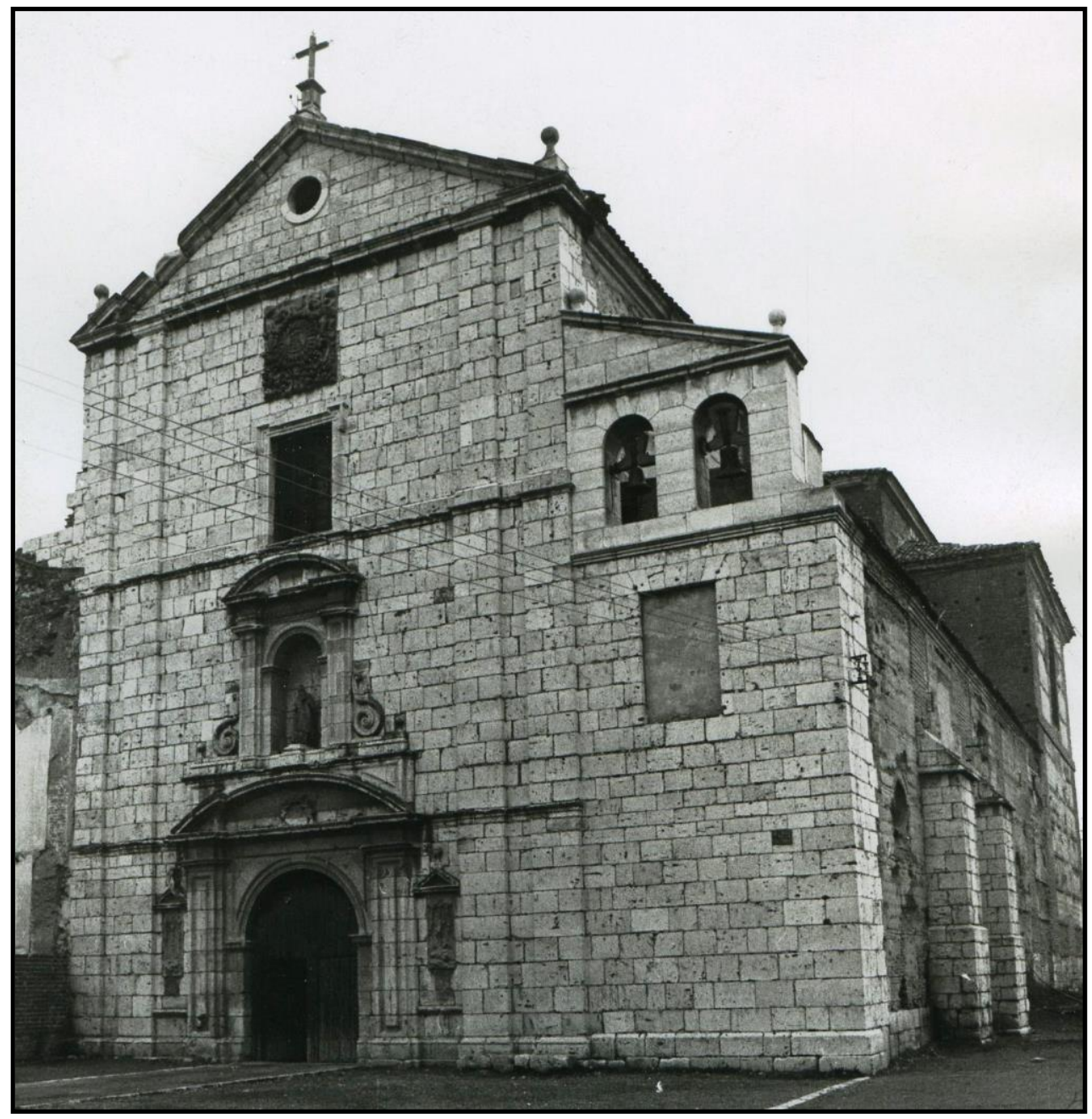

Fig. 23- Matías Machuca. Iglesia del Convento de Nuestra Señora de la Victoria. Valladolid. ( ) Departamento de Historia del Arte de la Universidad de Valladolid.

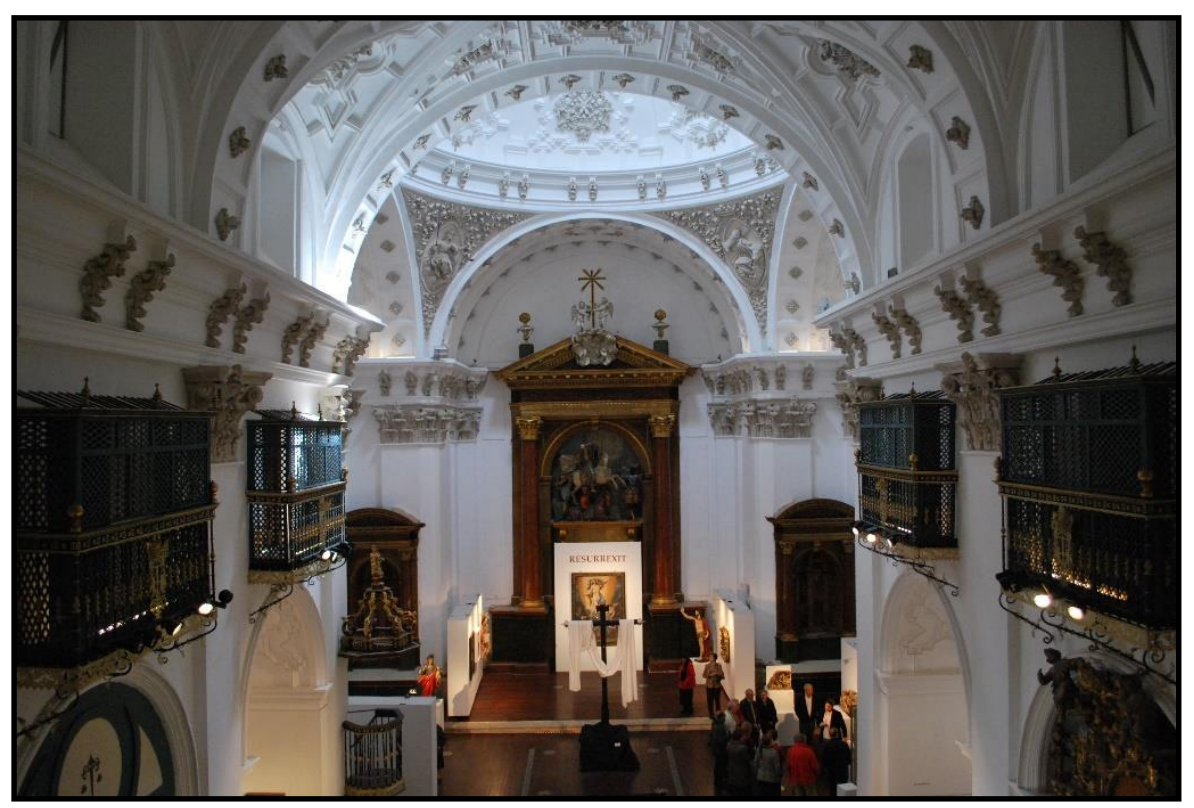

Fig. 24- Matías Machuca. Convento de las Comendadoras de Santa Cruz. Valladolid.

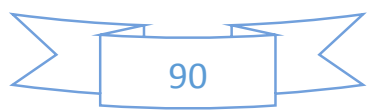



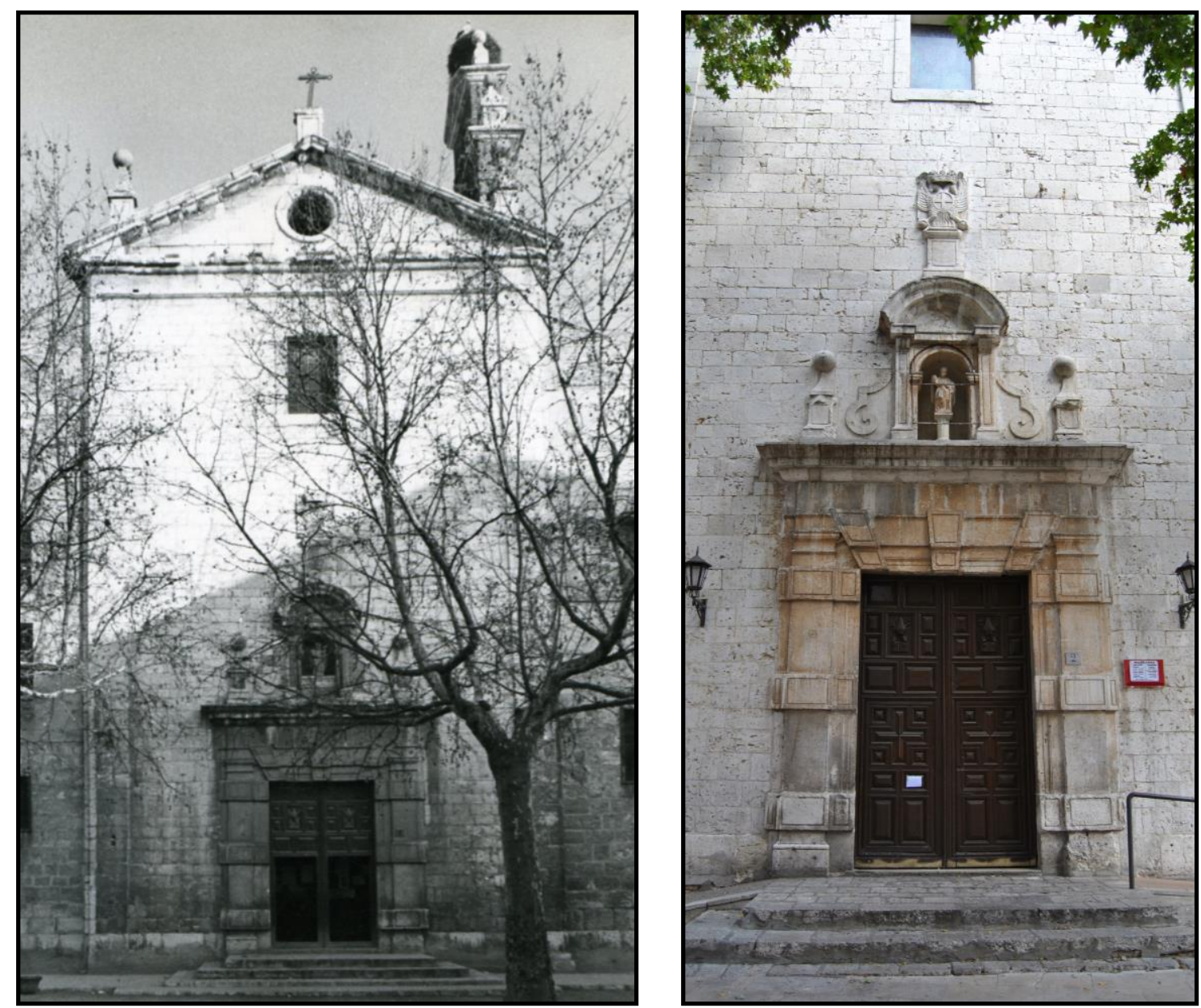

Figs. 25-26- Antigua iglesia del Convento de Trinitarios Descalzos (actual iglesia de San Nicolás). Valladolid. Fig. 25 (C) Departamento de Historia del Arte de la Universidad de Valladolid.

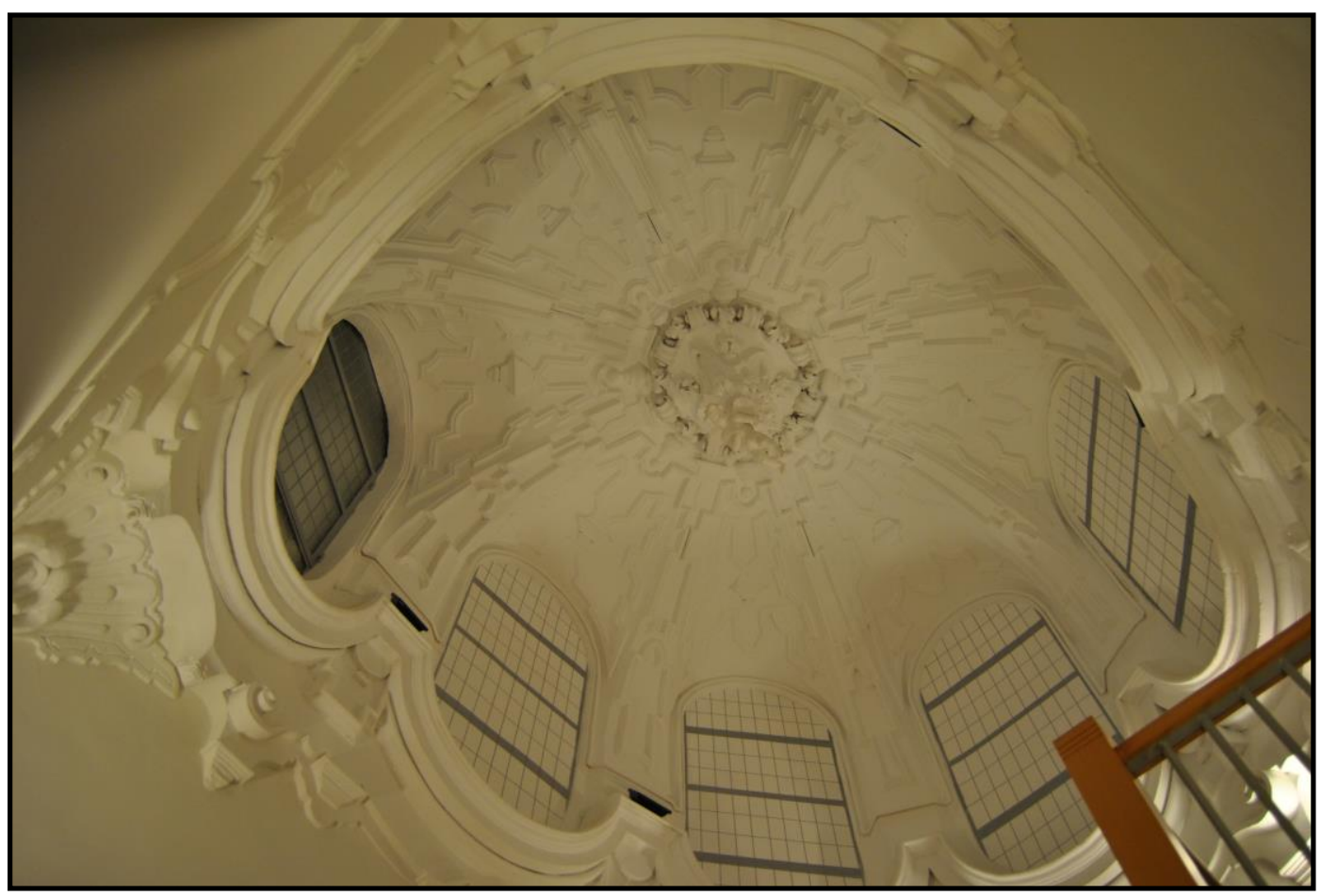

Fig. 27- Escalera del Convento de Trinitarios Descalzos (actual iglesia de San Nicolás). Valladolid.

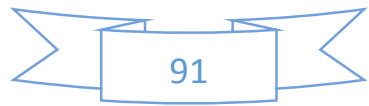




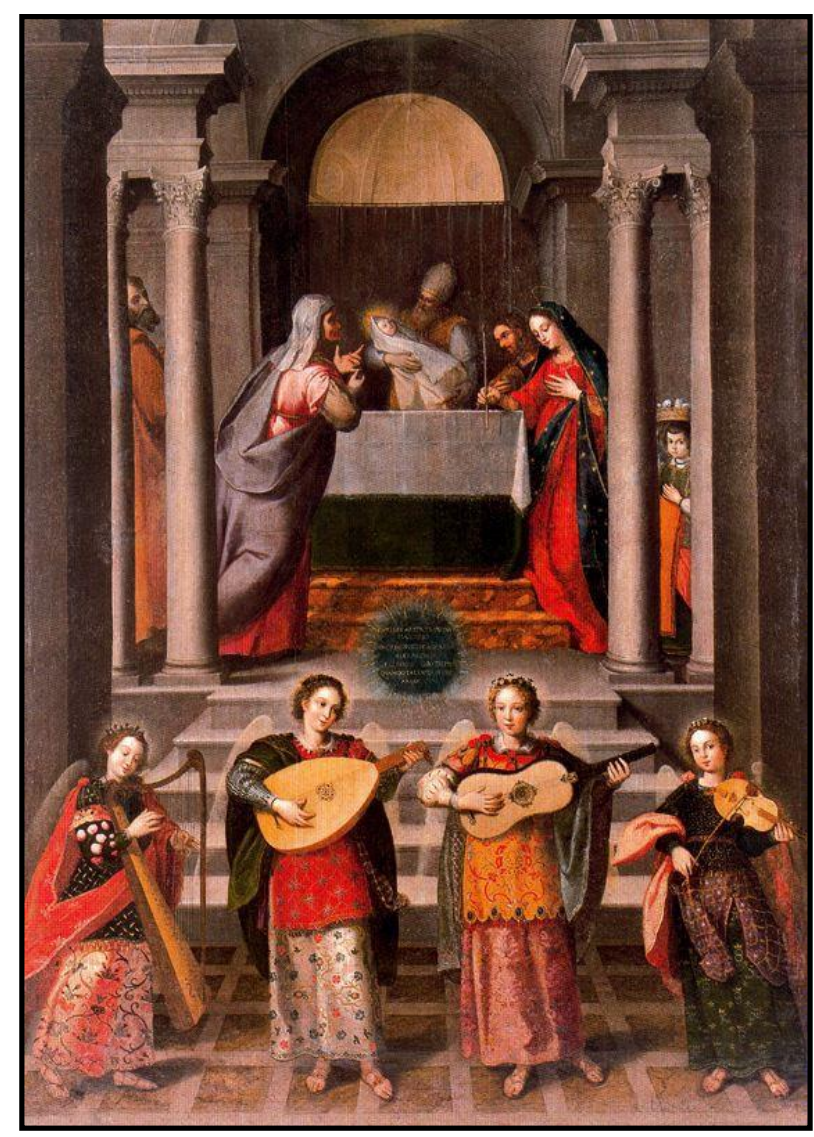

Fig. 28- Diego Valentín Díaz. Presentación de Jesús en el templo. Museo Nacional de Escultura. Valladolid.

Fig. 29- Francisco Martínez. Retrato orante de Don Antonio de Aguilar. Museo Diocesano y Catedralicio. Valladolid.
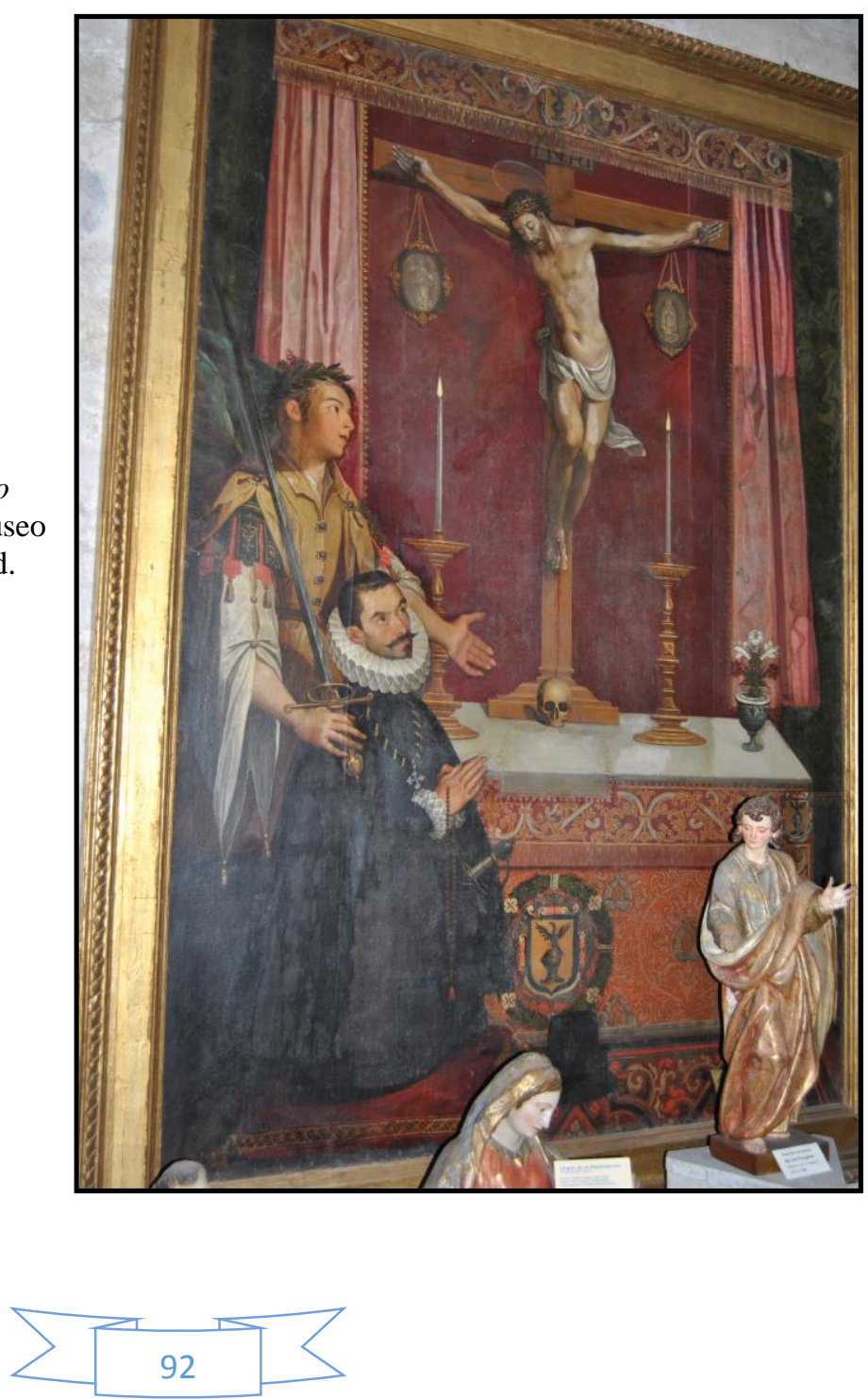


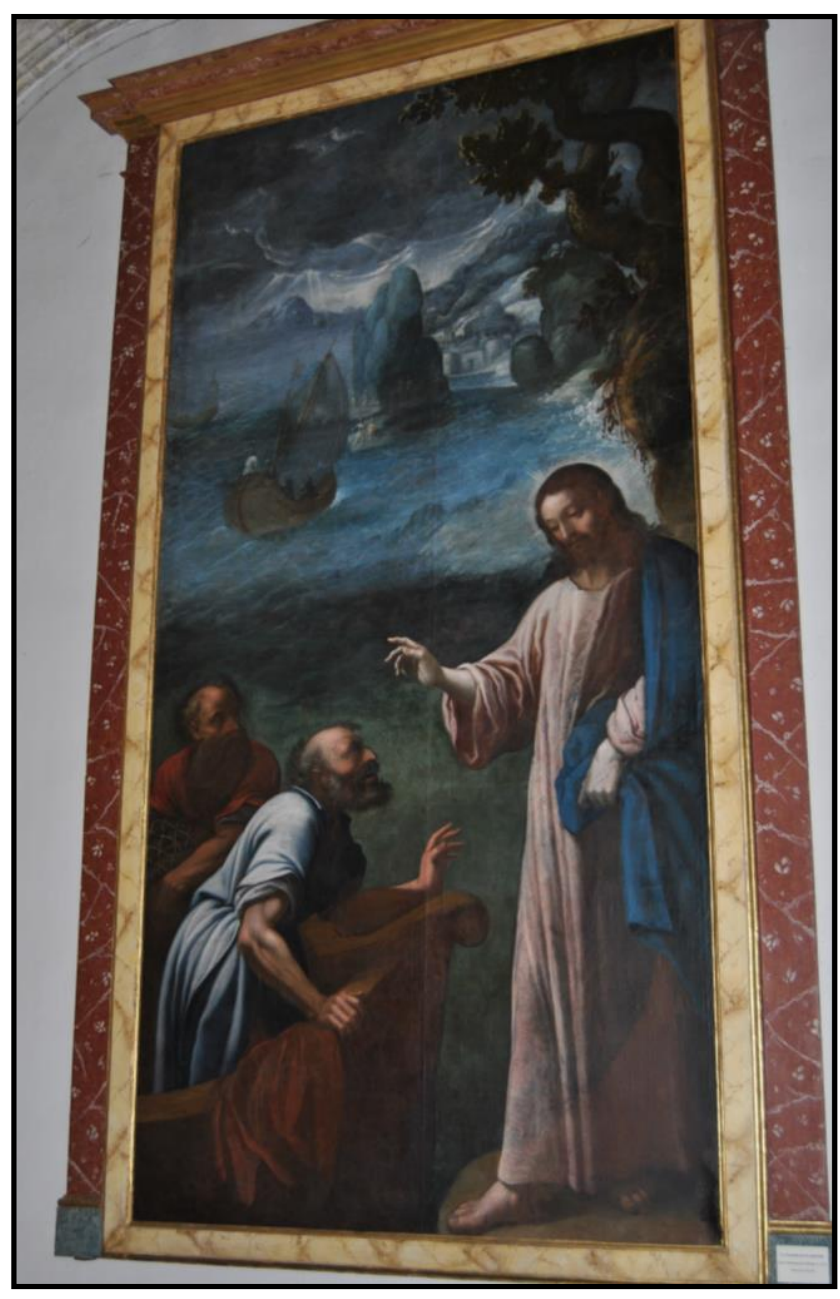

Fig. 30- Bartolomé de Cárdenas.

Vocación de San Pedro y San Pablo.

Convento de San Pablo. Valladolid.

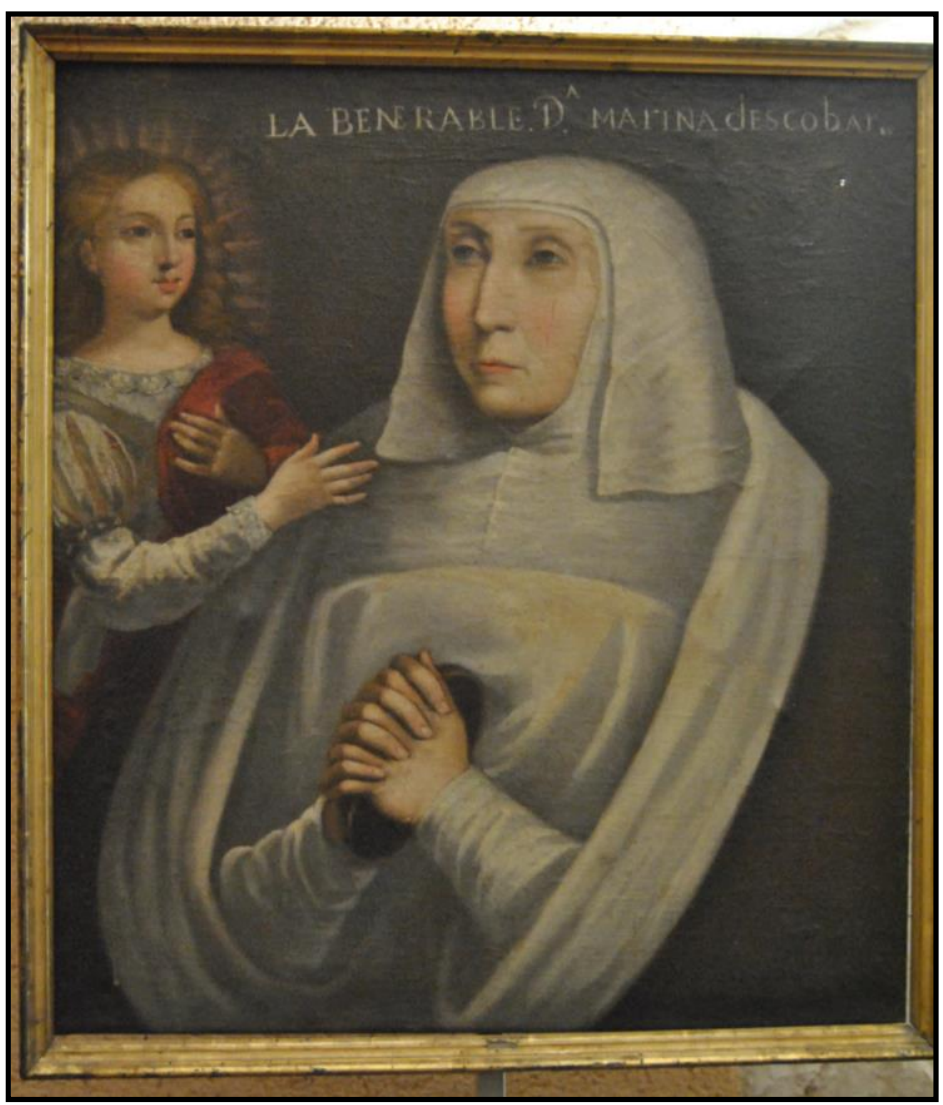

Fig. 31- Tomás Peñasco. La

Venerable Doña Marina Escobar.

Centro de Espiritualidad. Valladolid.

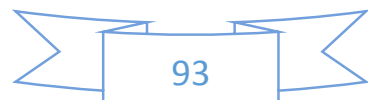




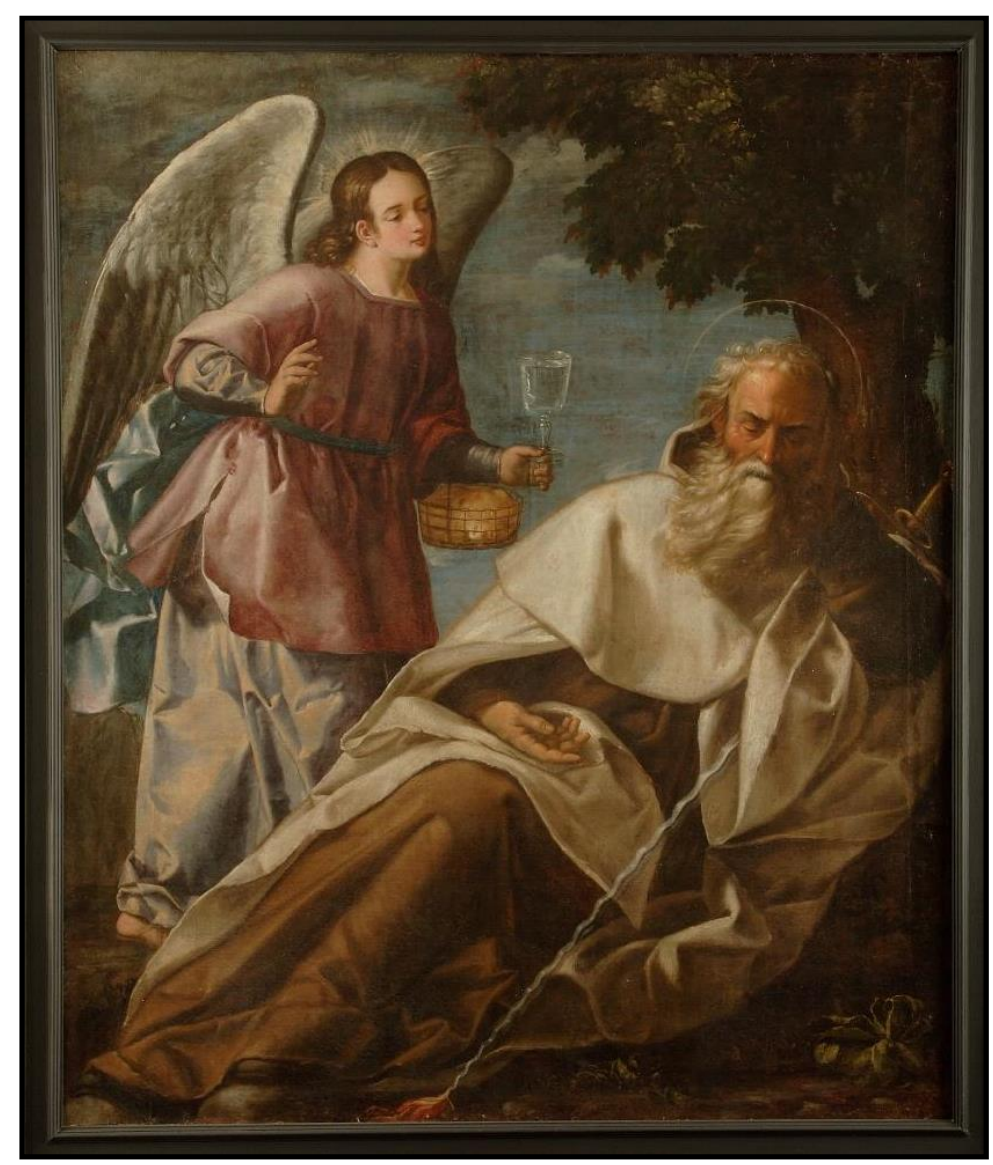

Fig. 32- Felipe Gil de Mena. El profeta Elías en el desierto reconfortado por un ángel. Museo Nacional de Escultura. Valladolid. @ Museo Nacional de Escultura.

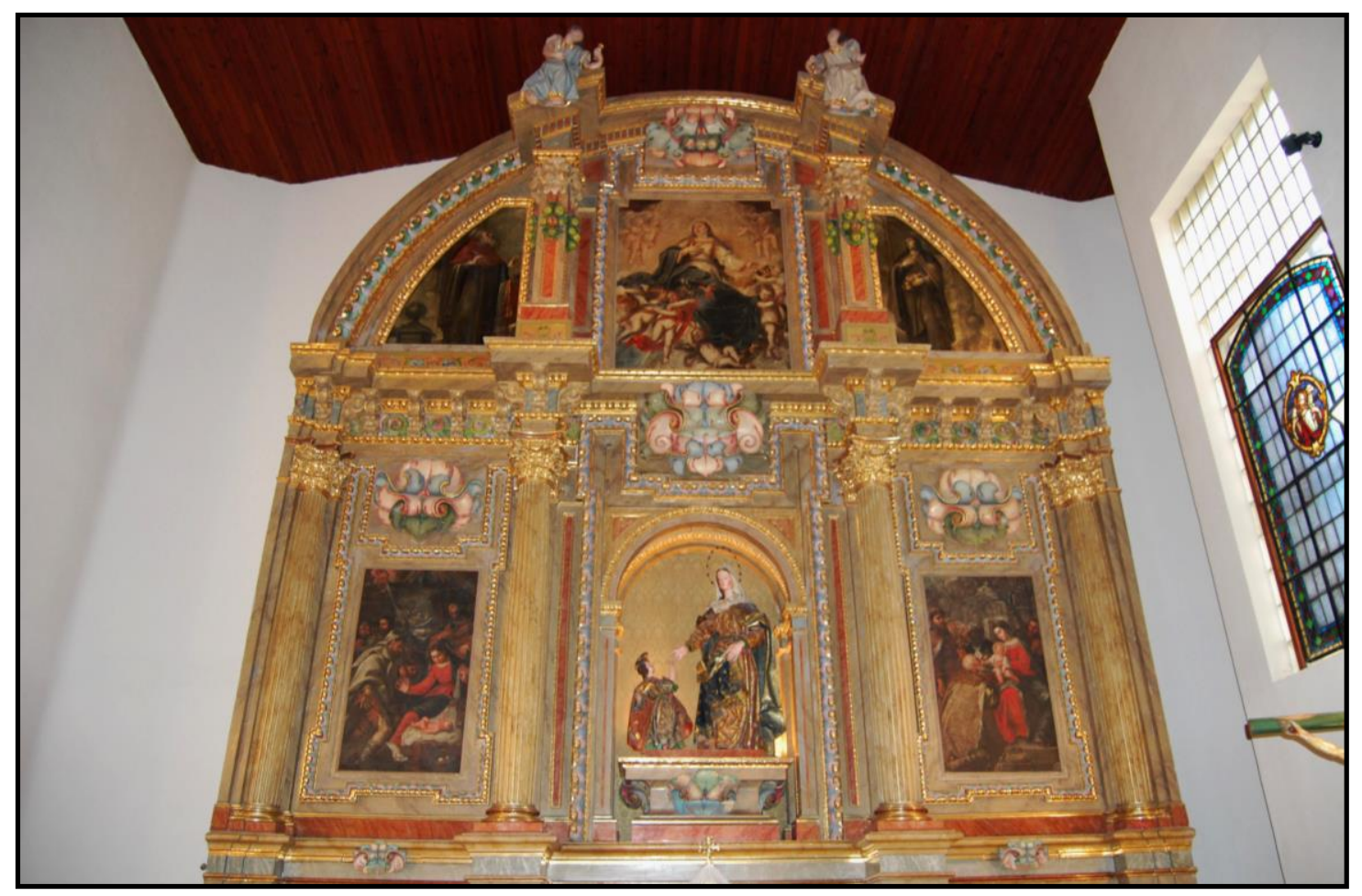

Fig. 33- Mateo Cerezo. Pinturas del retablo mayor. Convento de Jesús y María. Valladolid.

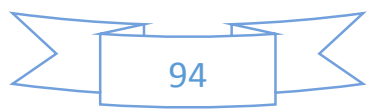




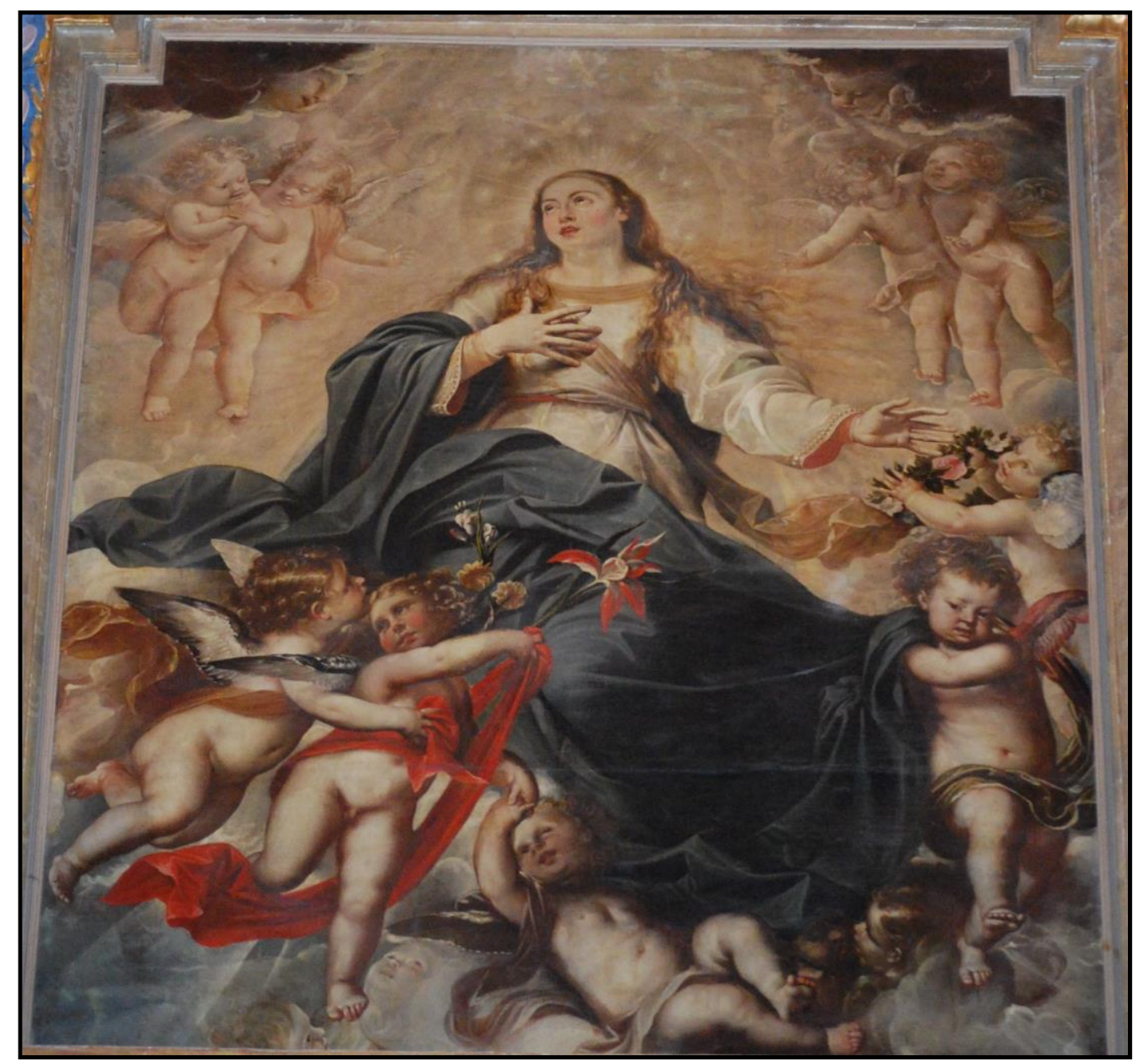

Fig. 34- Mateo Cerezo. Inmaculada del retablo mayor. Convento de Jesús y María.

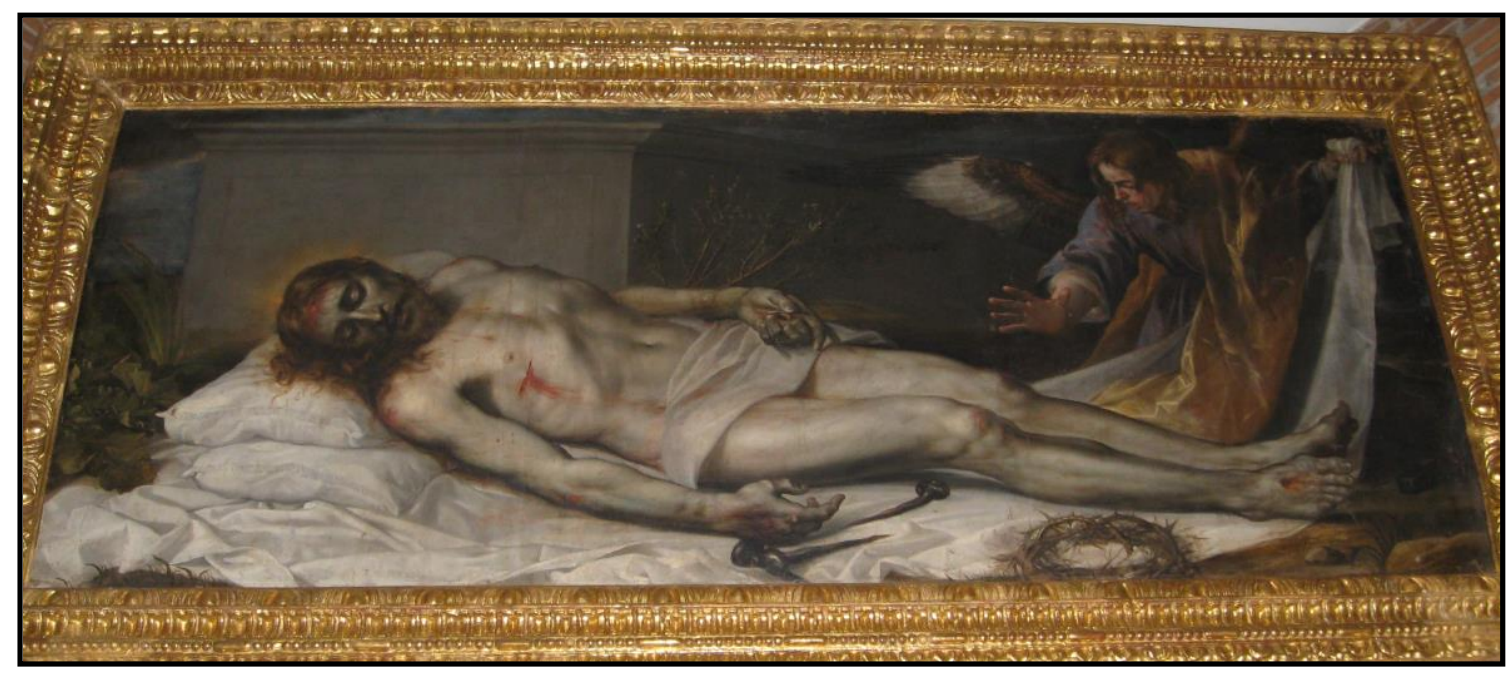

Fig. 35- Mateo Cerezo. Cristo yacente acompañado de un ángel. Iglesia de San Lorenzo. Valladolid.

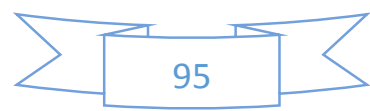




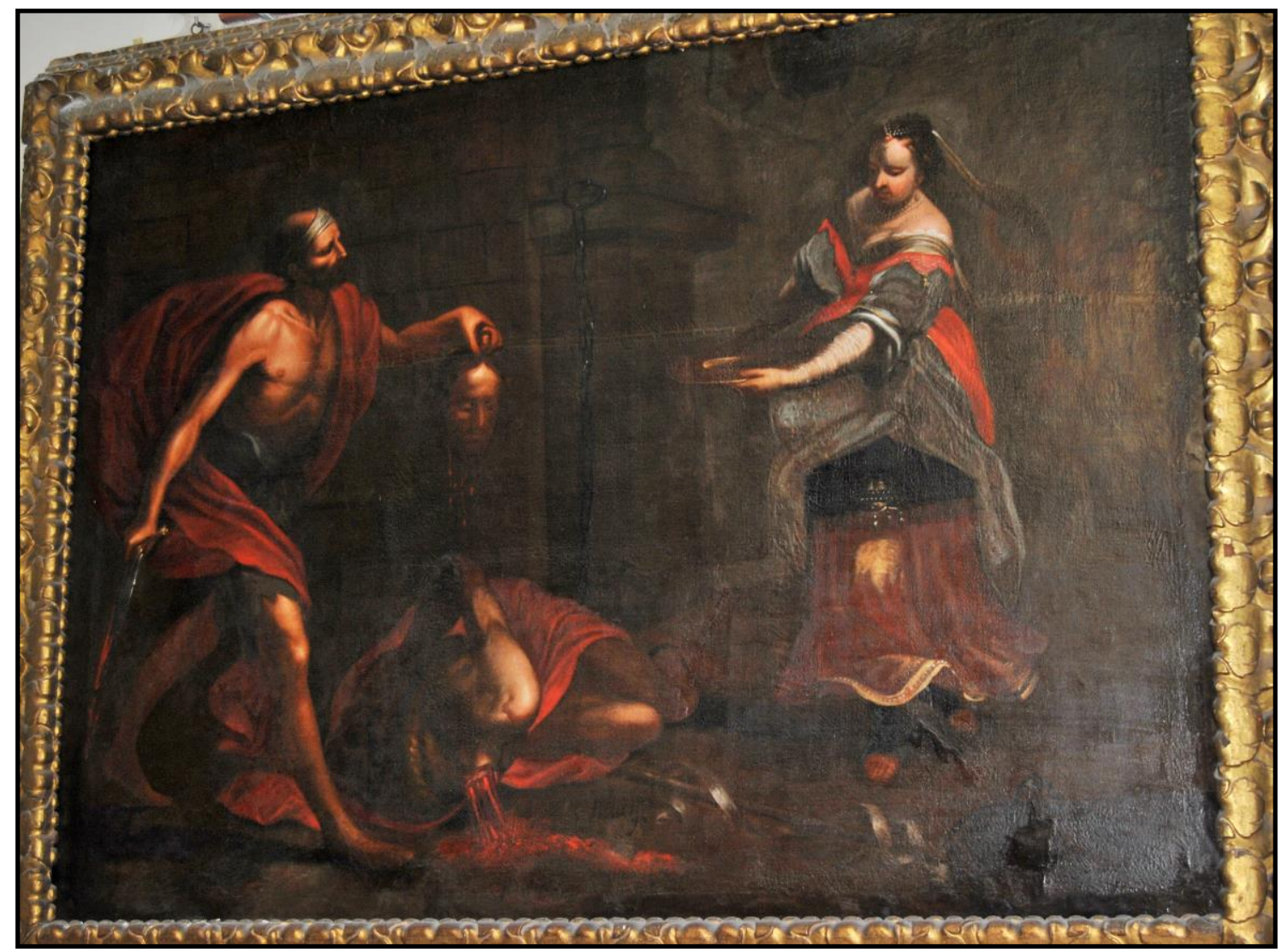

Fig. 36- Amaro Alonso. Degollación del Bautista. Iglesia de San Juan Bautista. Valladolid.

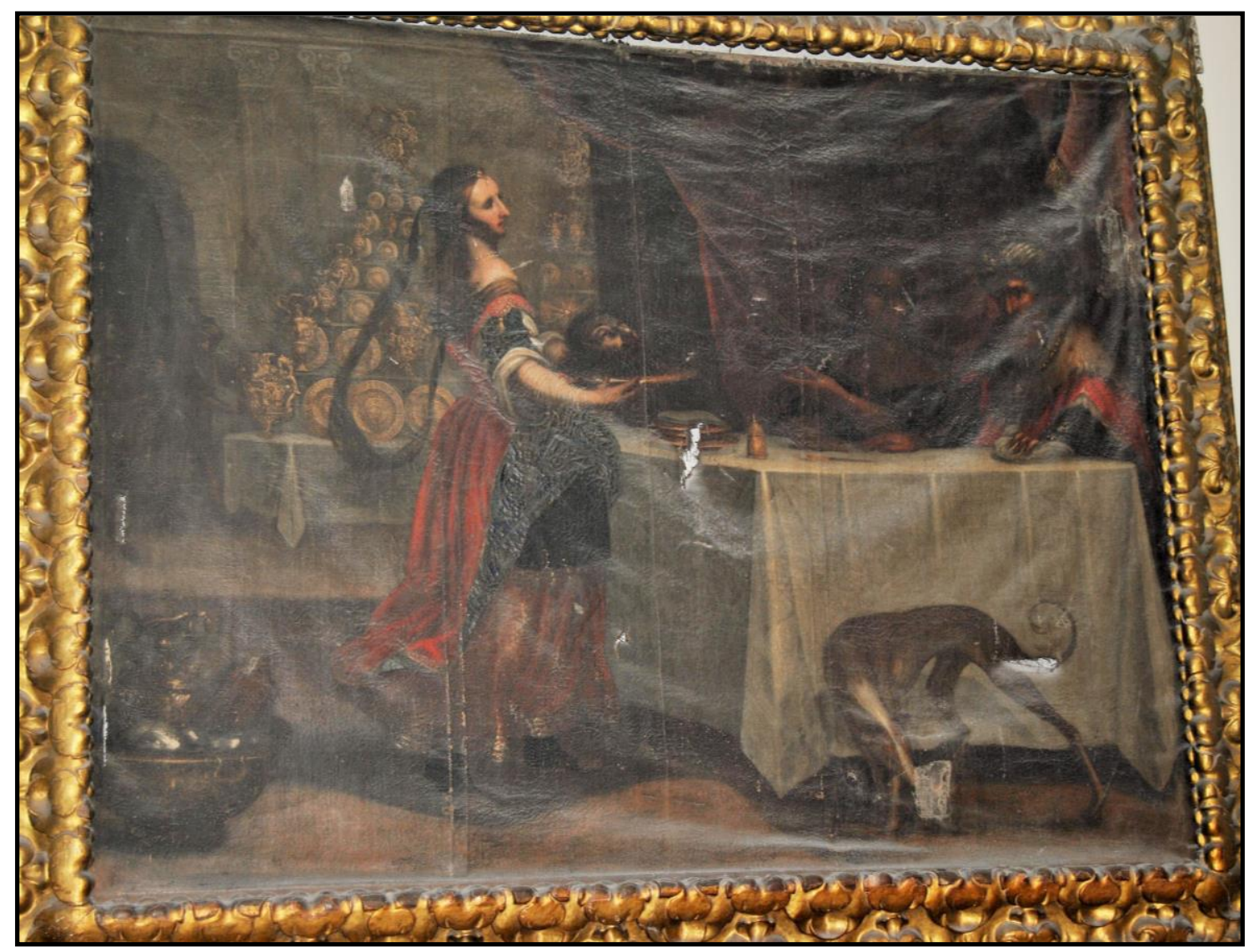

Fig. 37- Amaro Alonso. Salomé presentando la cabeza del Bautista a Herodes y Herodías. Iglesia de San Juan Bautista. Valladolid.

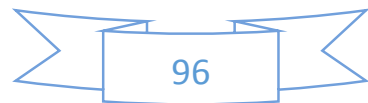



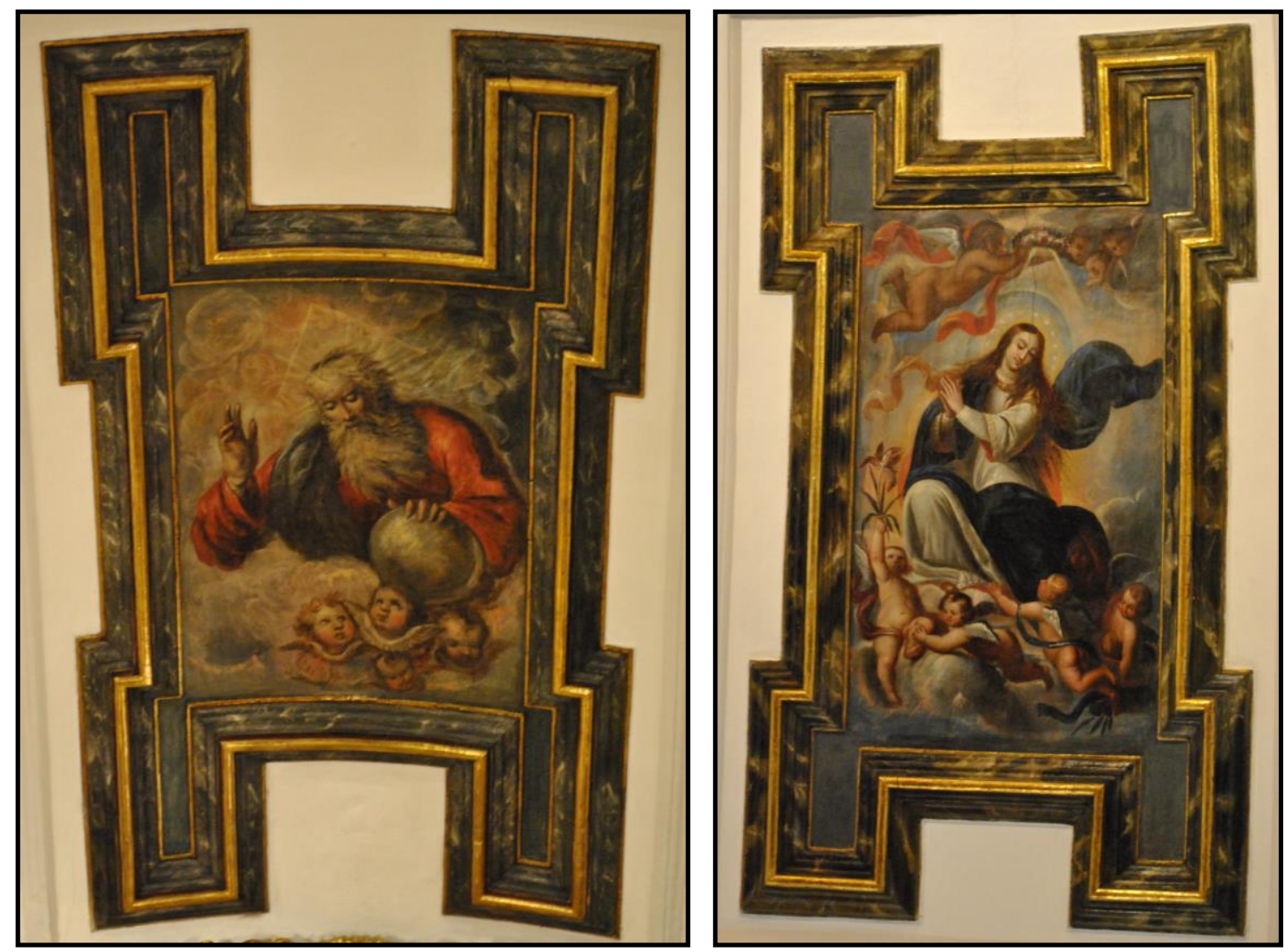

Figs. 38-39- Amaro Alonso. El Padre Eterno y la Asunción. Oratorio de San Felipe Neri. Valladolid.

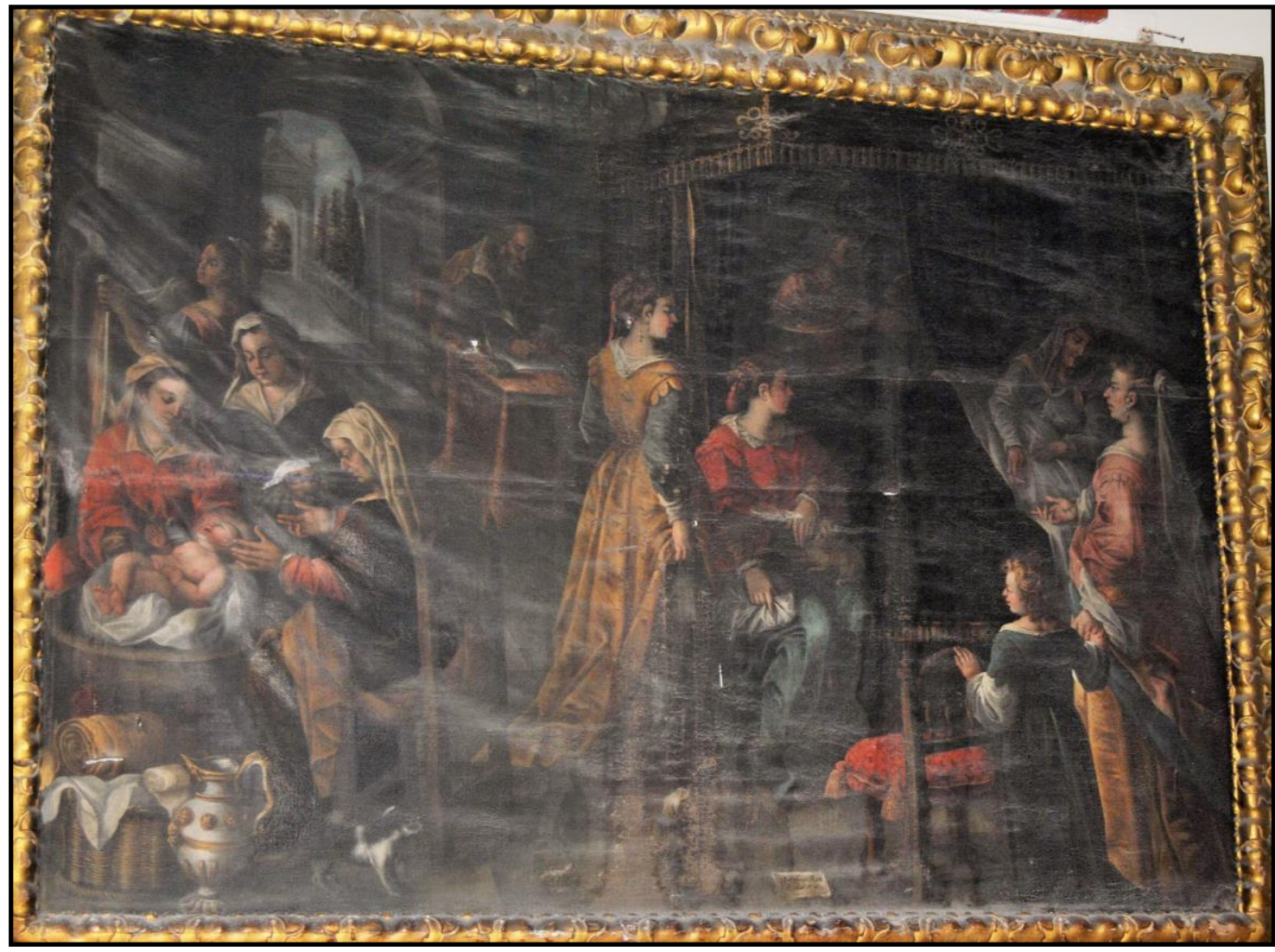

Fig. 40- Agustín Bara. El nacimiento de San Juan Bautista. Iglesia de San Juan Bautista. Valladolid.

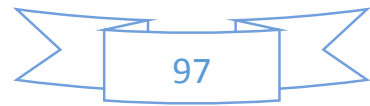




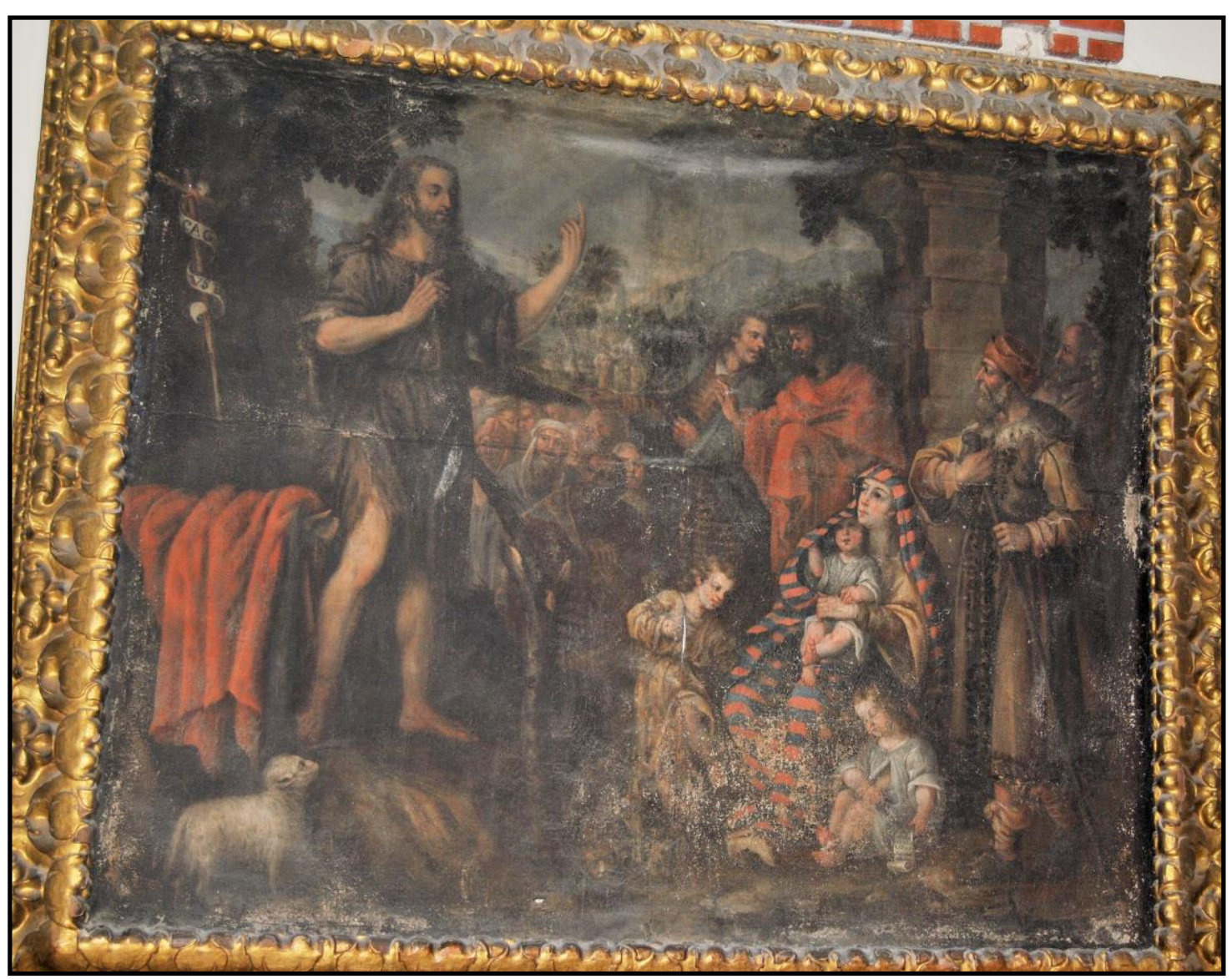

Fig. 41- Agustín Bara. La predicación de San Juan en el desierto. Iglesia de San Juan Bautista. Valladolid.

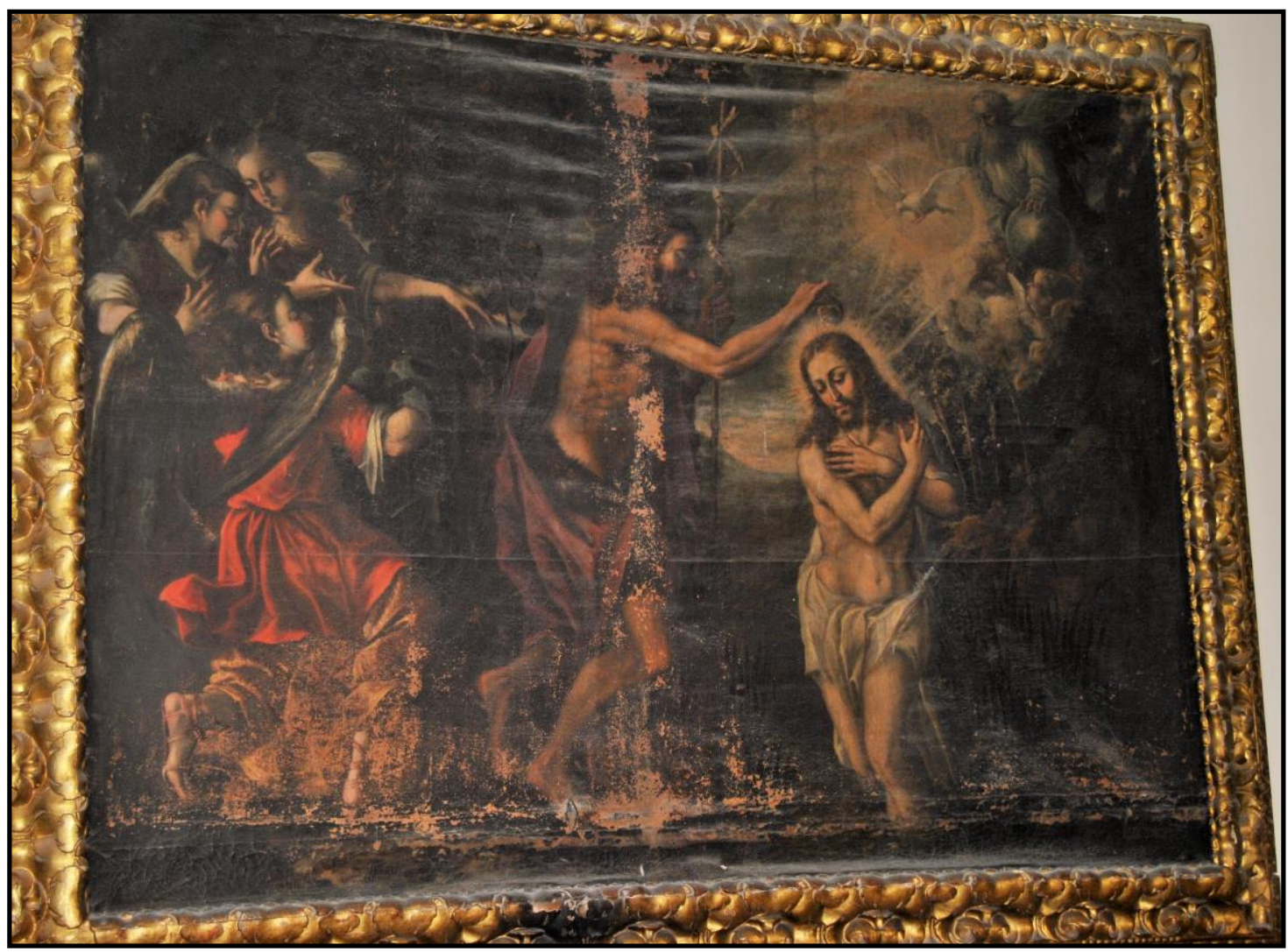

Fig. 42- Agustín Bara. El bautismo de Cristo. Iglesia de San Juan Bautista. Valladolid.

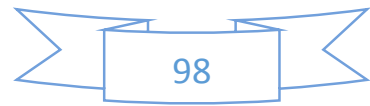



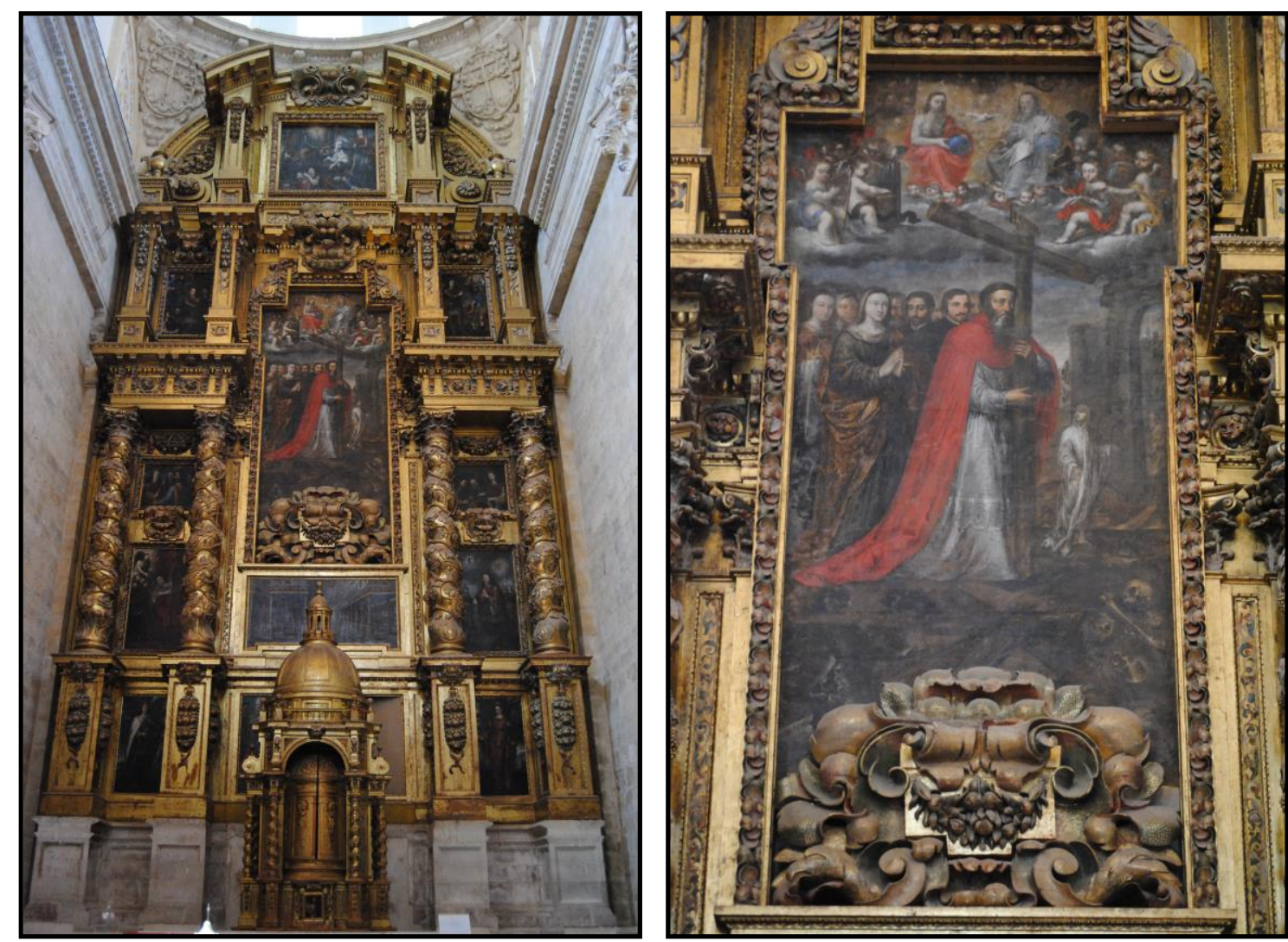

Figs. 43-44- Diego Díez Ferreras. Pinturas del retablo mayor. Iglesia de Santa Cruz. Medina de Rioseco (Valladolid).

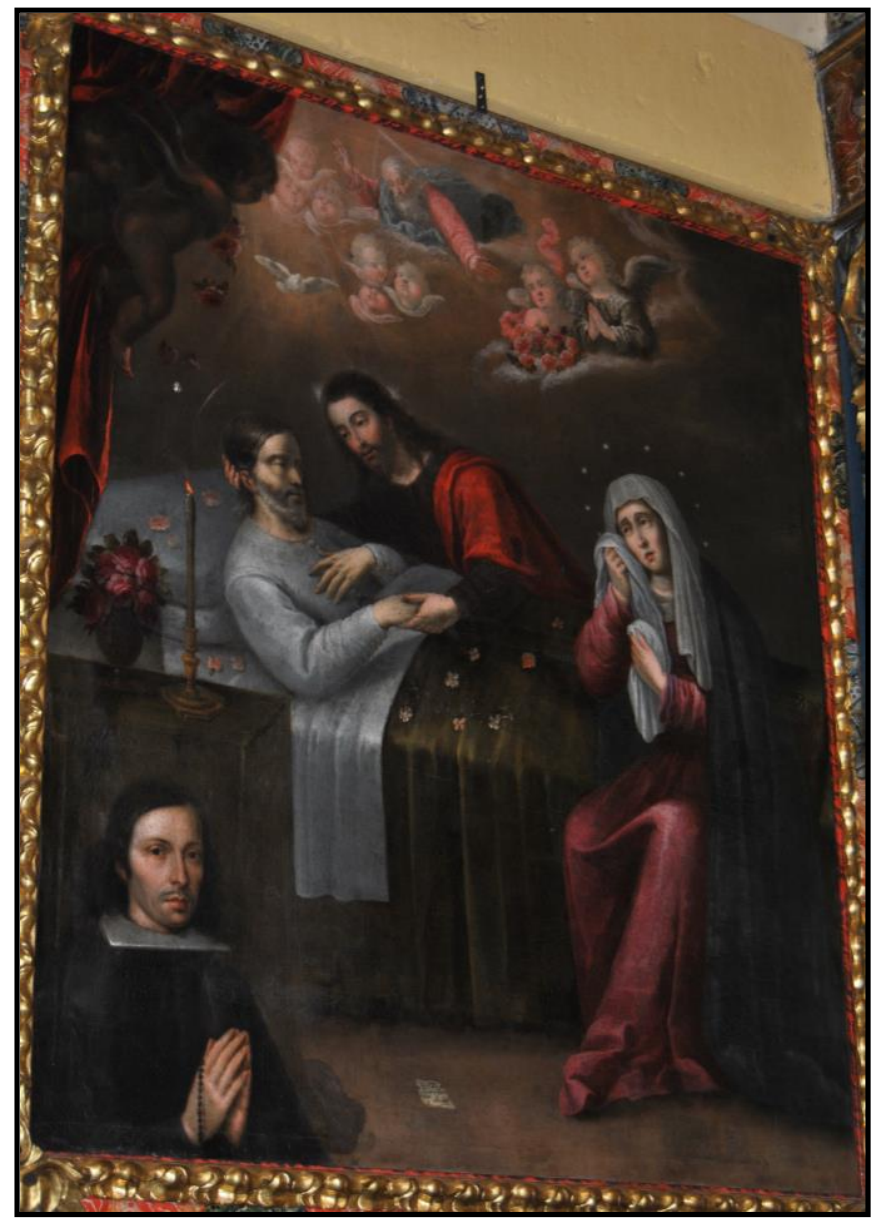

Fig. 45- Diego Díez Ferreras. La muerte de San José. Iglesia Penitencial de Nuestra Señora de las Angustias. Valladolid.

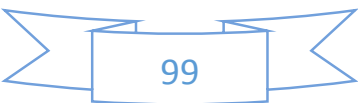




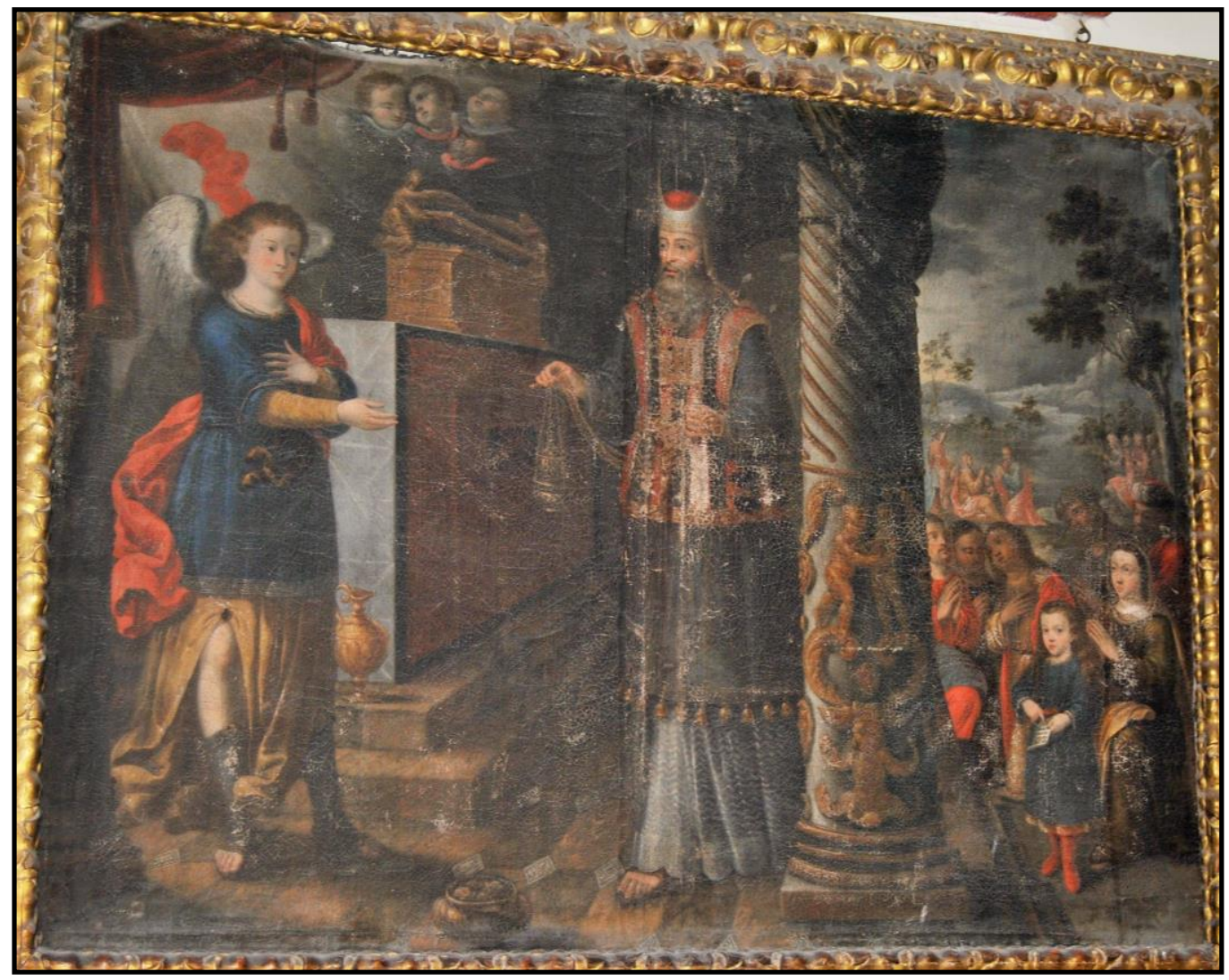

Fig. 46- Diego Díez Ferreras. El Anuncio del ángel a Zacarías. Iglesia de San Juan Bautista. Valladolid.

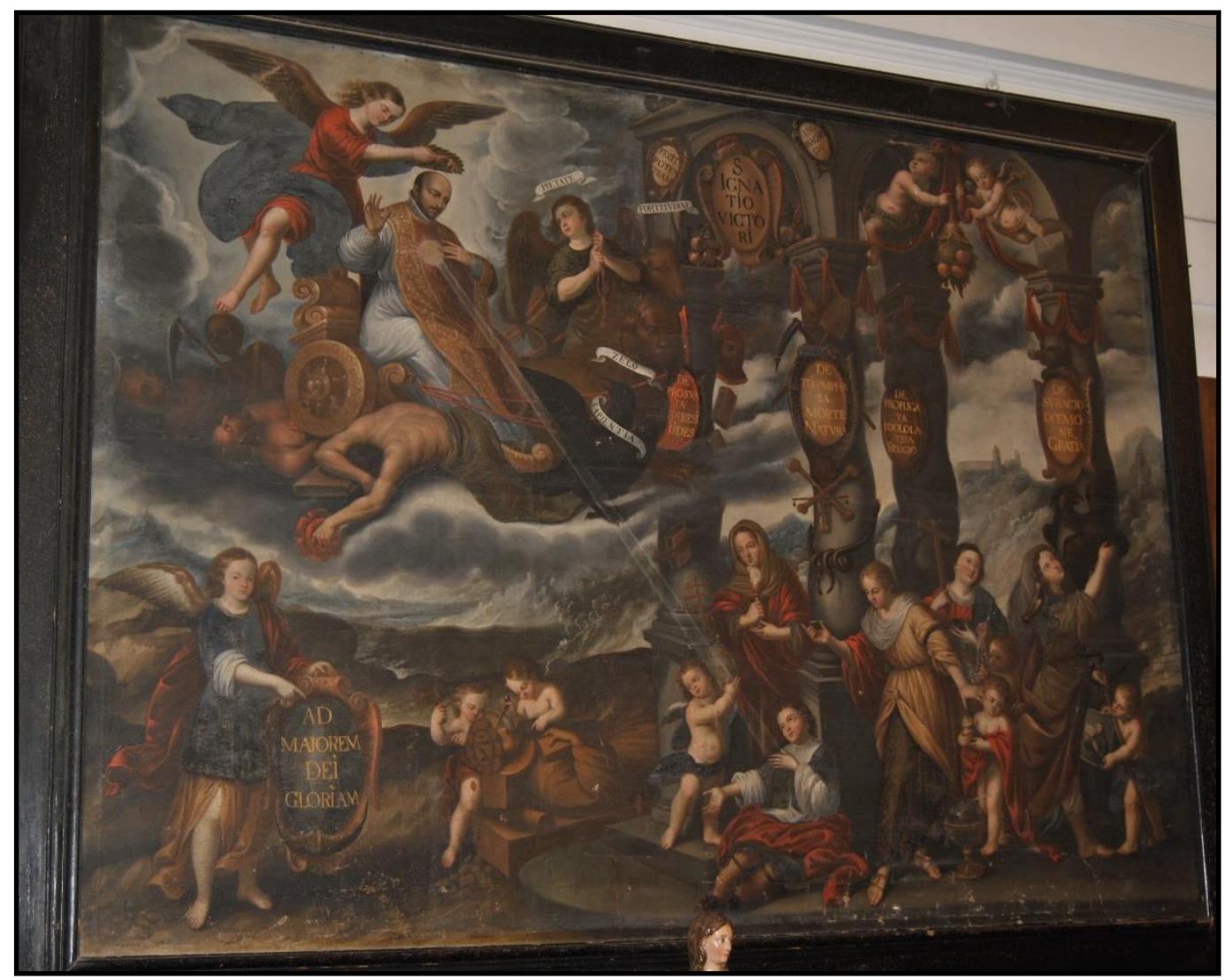

Fig. 47- Diego Díez Ferreras. Apoteosis de San Ignacio. Iglesia de San Miguel. Valladolid.

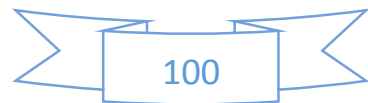




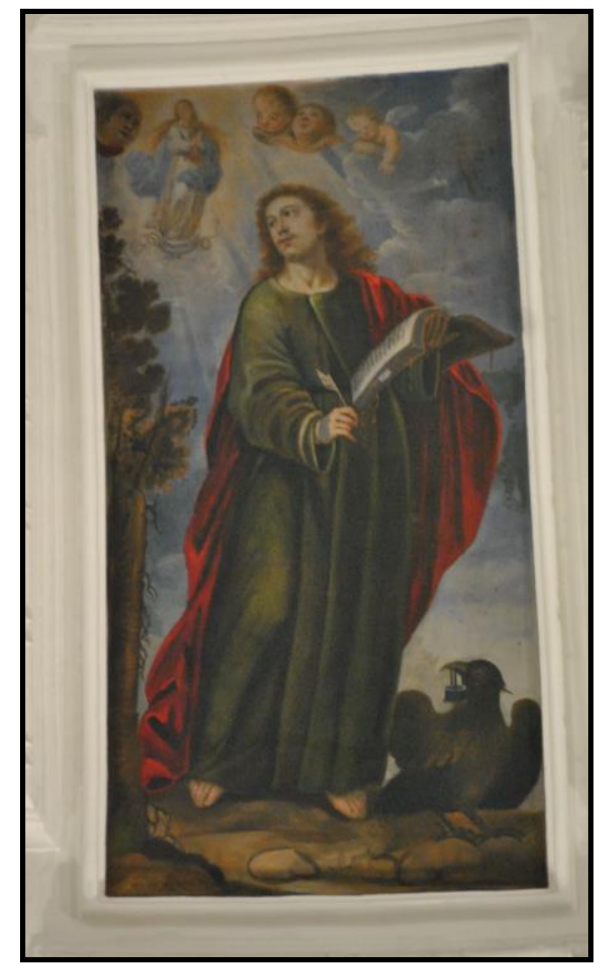

Fig. 48- Diego Díez Ferreras. Pinturas de la cúpula. San Juan Evangelista. Colegio de los Ingleses. Valladolid.

Fig. 49- Andrés Amaya. La Virgen apareciéndose a Fernando III el Santo. Museo Nacional de Escultura. Valladolid.
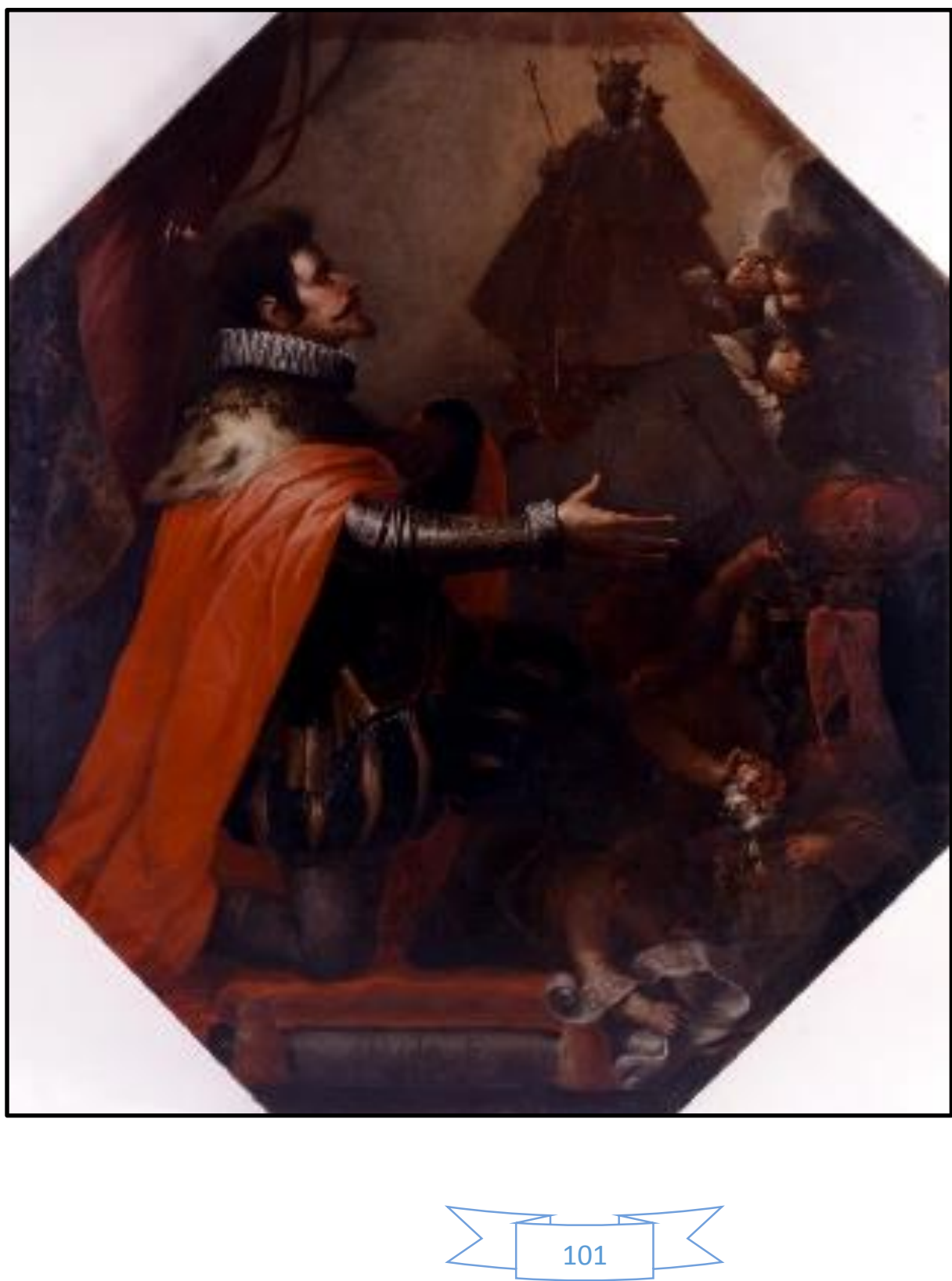


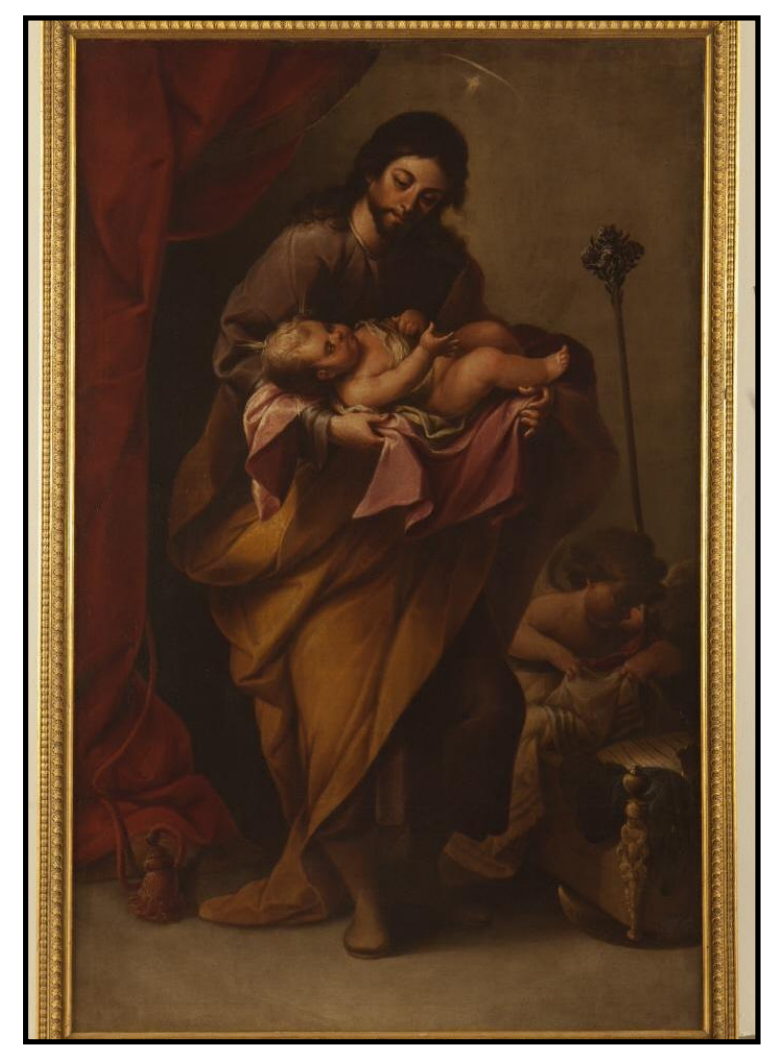

Fig. 50- Andrés Amaya. San José con el Niño.

Museo Nacional de Escultura. Valladolid. () Museo Nacional de Escultura.

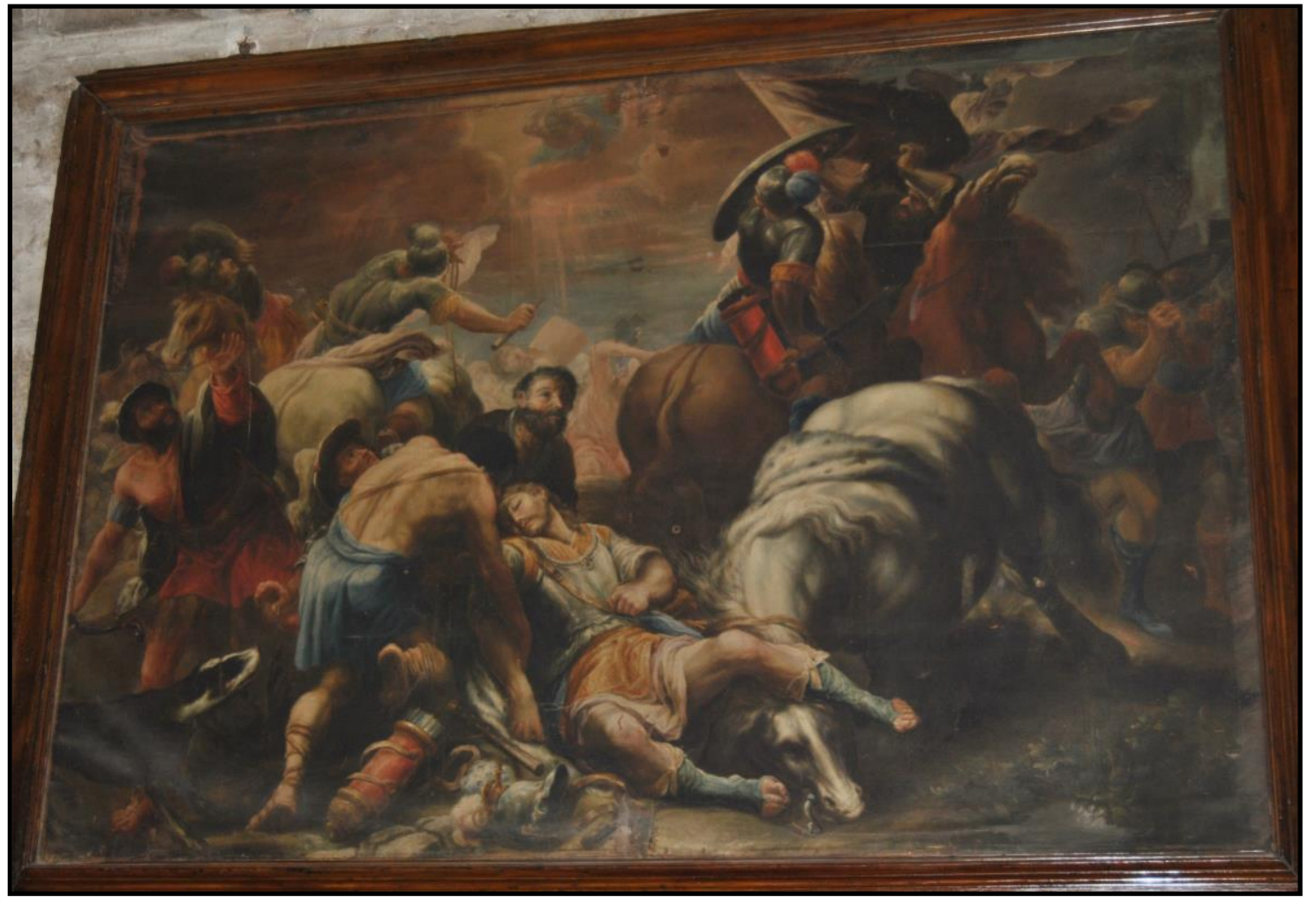

Fig. 51- Manuel Peti Bander. Caída de San Pablo. Catedral. Valladolid.

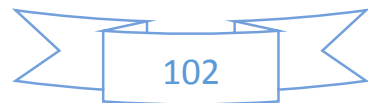




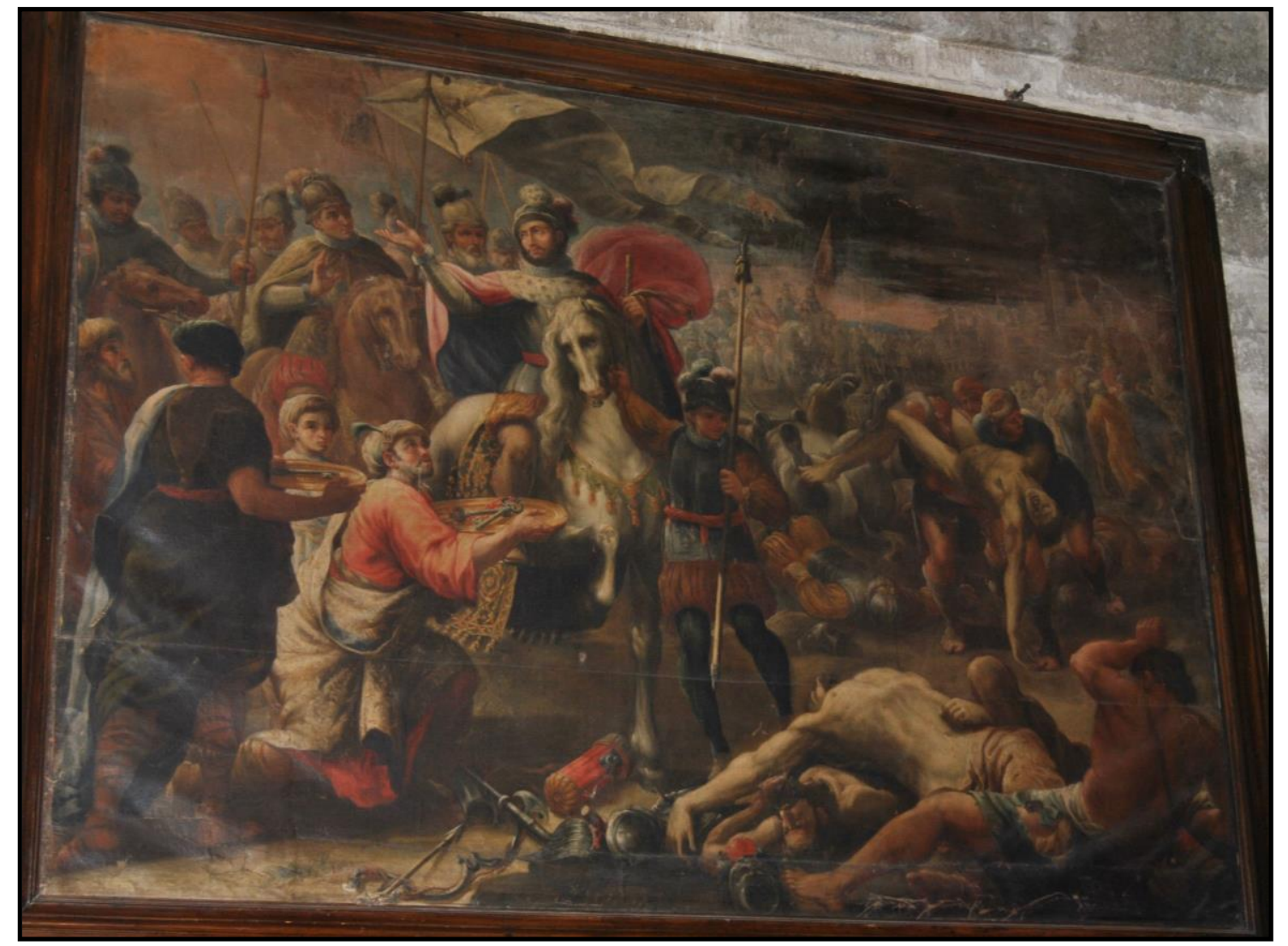

Fig. 52- Manuel Peti Bander. San Fernando entrando en Sevilla. Catedral. Valladolid.

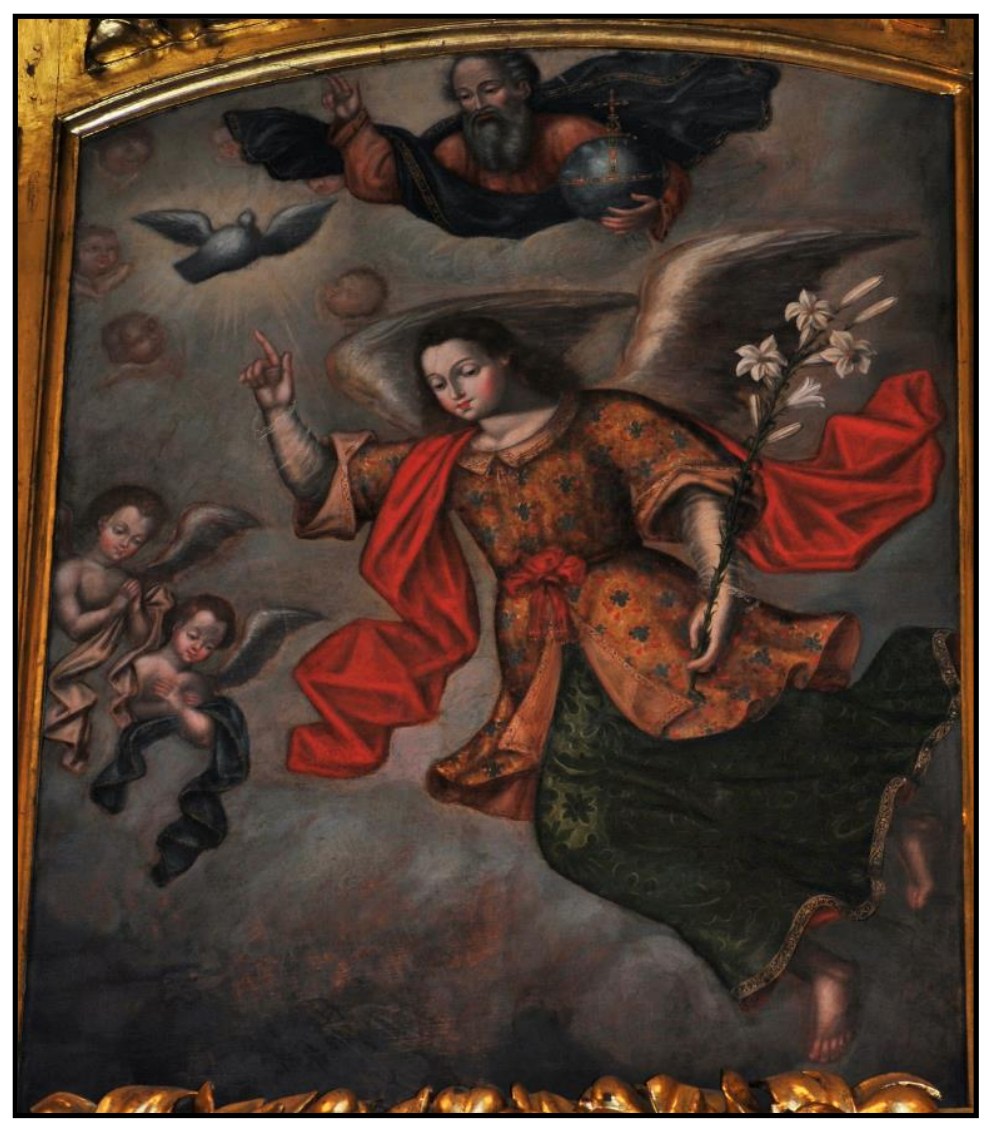

Fig. 53- Antonio Barreda y Lombera. El Arcángel San Gabriel. Iglesia Penitencial de Nuestra Señora de las Angustias. Valladolid.

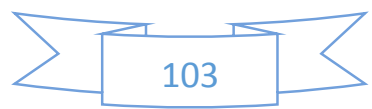




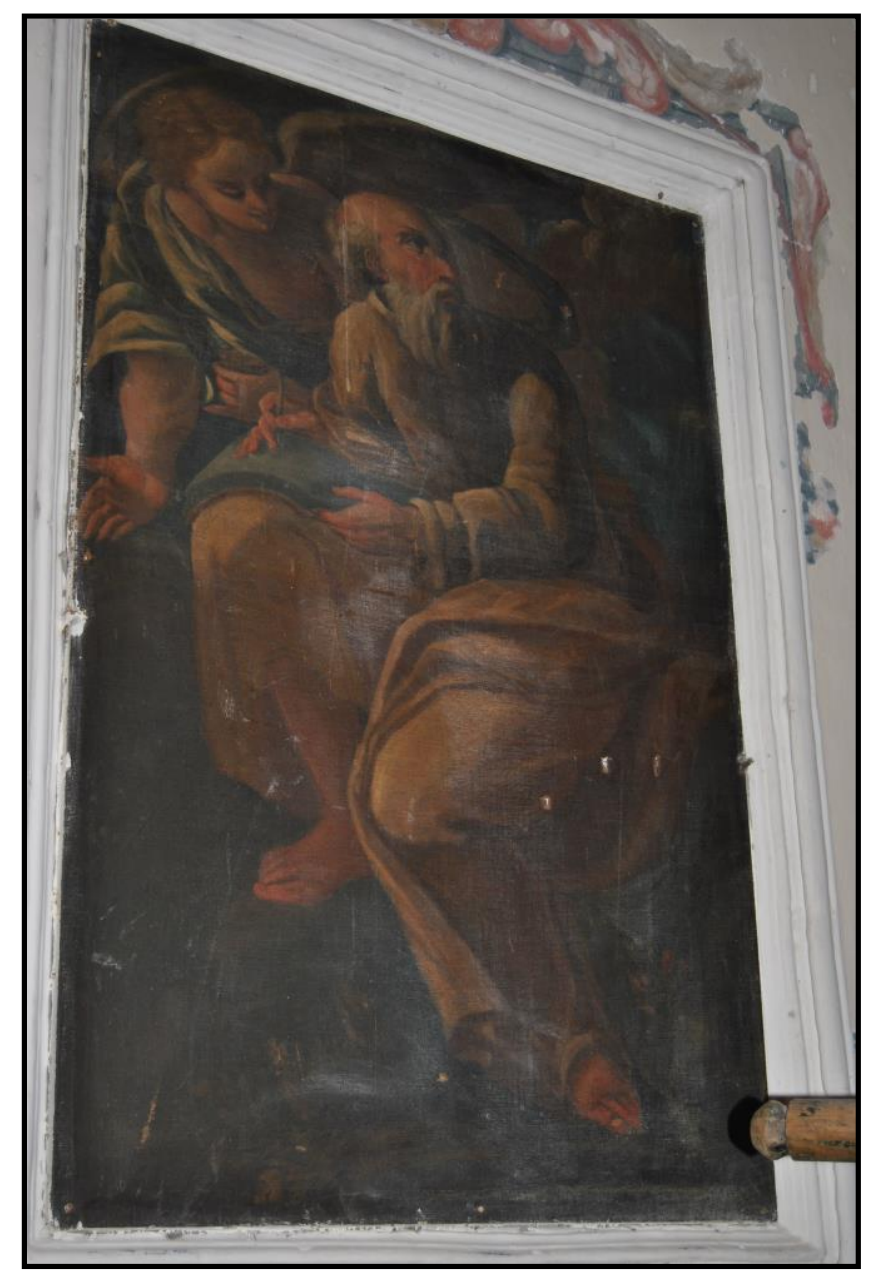

Figs. 54-55- Manuel Barreda. San Mateo y La Asunción. Iglesia parroquial de la Asunción. Bercero (Valladolid).
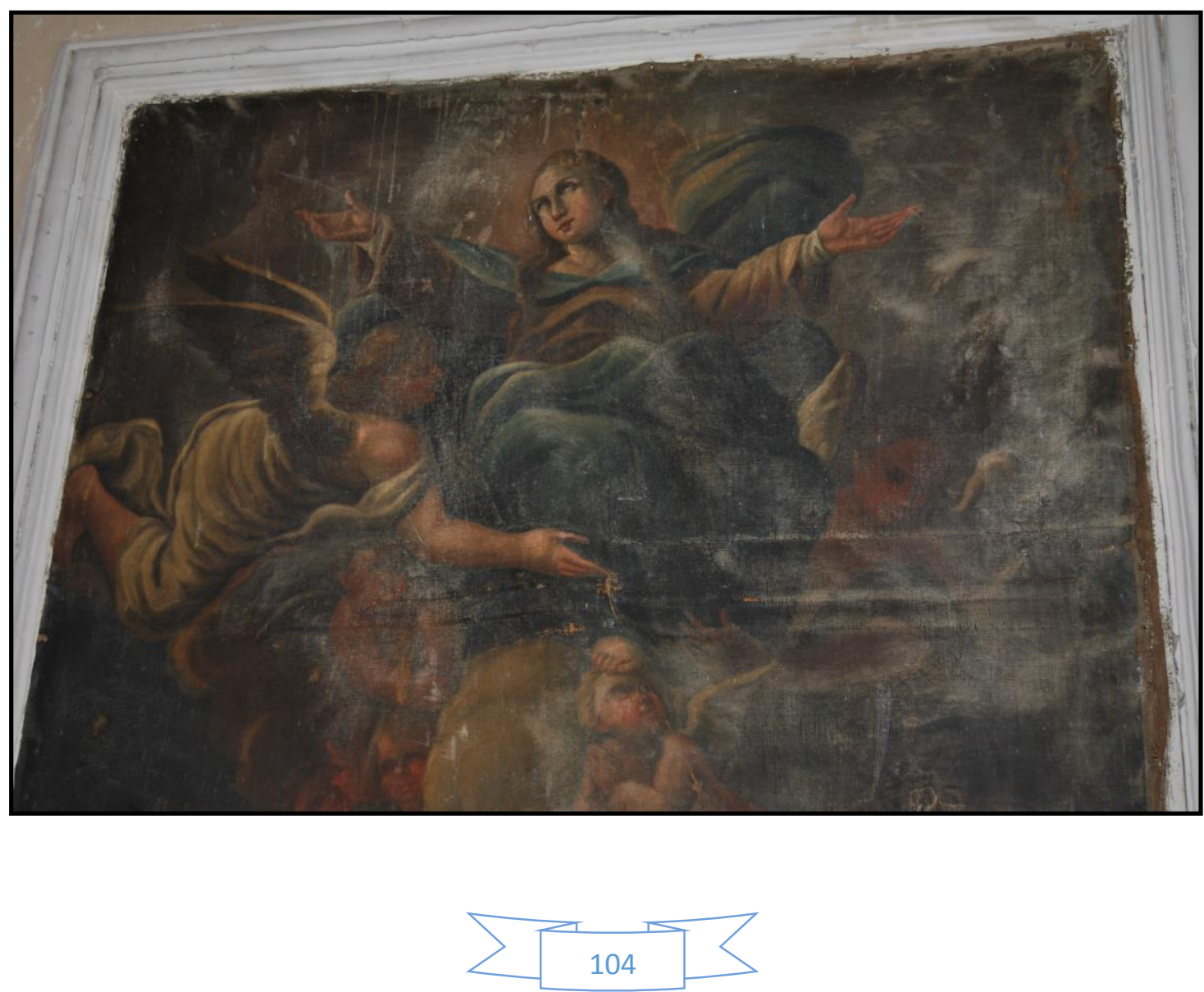


\section{Z- LA ESCULTURA EN VALLADOLID (1650-1750)}




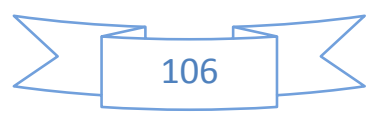




\section{2-1 ESCULTURA BARROCA: CARACTERÍSTICAS GENERALES}

El arte barroco no es sino aquel que fue promocionado y propugnado por la contrarreforma para combatir el protestantismo, cuyo punto de partida fue el Concilio de Trento (1545-1563), y más concretamente el decreto del día 3 de diciembre de $1563^{1}$. En él además de regularse todos los aspectos de la vida religiosa se reglamentaron las artes de manera que se pudiera dar respuesta a la reforma luterana.

En el concilio se decretó el deber de instruir a los fieles acerca de la invocación a los Santos, el culto a sus reliquias y el fomento del uso de imágenes, esta última característica entraba plenamente en confrontación con la iconoclastia protestante. El hecho de promover el uso masivo de imágenes puede llevar a pensar en idolatría pero se dejó bien claro que “... el honor que se les tributa, se refiere a los originales que ellas representan; de manera que por medio de las imágenes que besamos y ante las cuales descubrimos nuestra cabeza y nos prosternamos, adoramos a Cristo y veneramos a los Santos, cuya semejanza ostentan aquéllas..."2. De esta forma los fieles se acercan a Cristo, a la Virgen y a los Santos a través de imágenes que los representan, por tanto, cualquier manifestación artística es un puente entre el fiel y ese personaje sagrado. Tenemos de ejemplo del Cristo atado a la columna (Gregorio Fernández, 1619) de la Cofradía Penitencial de la Santa Vera Cruz de Valladolid, la cual solicitó al Papa Pablo V indulgencias especiales y jubileo justificando que la escultura era venerada por la representación de las llagas de la espalda ${ }^{3}$.

Una de las conclusiones más importantes del

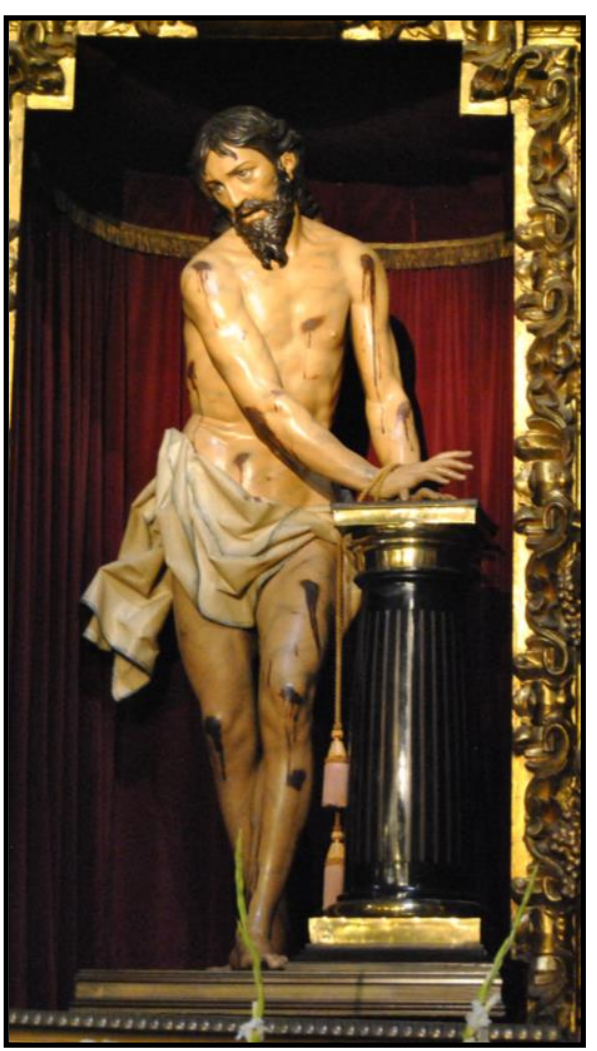

Il. 1- Gregorio Fernández. Cristo atado a la columna. Iglesia penitencial de la

Santa Vera Cruz. Valladolid.

Concilio fue la que exhortaba a los obispos para que se apoyaran en las representaciones artísticas para catequizar al pueblo. Por medio de estas se intentaba persuadir, catequizar y conmover a los fieles y en algunos casos lograr su conversión: "Enseñen también diligentemente los obispos por medio de las historias de los ministerios de nuestra redención, representadas en pinturas u otras reproducciones, se instruye y confirma el pueblo en el recuerdo y culto constante de los artículos de la fe; aparte de que de todas las sagradas imágenes se percibe grande fruto, no solo porque recuerdan al pueblo los

MARTÍN GONZÁLEZ, Juan José: Escultura barroca en España ..., op. cit., p. 20.

ÁLVAREZ ALLER, Eduardo: "La estética procesional barroca". En ALONSO PONGA, José Luis y PANERO GARCÍA, Pilar: Gregorio Fernández: Antropología, historia y estética del Barroco, Ayuntamiento de Valladolid, Valladolid, 2008, p. 440.

3 Ibídem. 
beneficios y dones que le han sido concedidos por Cristo, sino también porque se ponen ante los ojos de los fieles los milagros que obra Dios por los Santos y sus saludables ejemplos, a fin de que den gracias a Dios por ellos, compongan su vida y costumbres a imitación de los santos y se exciten a adorar y amar a Dios y a cultivar la piedad"4.

Señala Orozco Díaz que el Concilio de Trento más que dictar normas para limitar y prohibir "desnudeces o impropiedades en la escena religiosa o el puro alarde de la complicación artística, lo que de carácter positivo se marca en los acuerdos de la sesión XXV es una orientación de sentido expresivo devocional cuya realización había de llevar, en sus últimas consecuencias a una concepción barroca. Porque unen a lo dicho una intención didáctica para que las imágenes y pinturas instruyan y confirmen al pueblo en la fe y, sobre todo, el propósito de excitar en el fiel la gratitud ante el milagro y beneficios recibidos, ofreciéndole el ejemplo a seguir y excitándole a adorar y a amar a Dios. Para cumplir esa aspiración había que romper con la estética renacentista movida por la búsqueda de la perfección y la belleza en sí y lanzarse a una sobrevaloración de la expresión comunicativa rompiendo no sólo módulos y tipos ideales, sino aun alterando las formas de la realidad para exaltar de ella lo que podía mover el alma del creyente y despertar en él esos sentimientos apasionados y sobrenaturales. Esa tendencia de la obra barroca a la expresión desbordante y comunicativa que busca el enlace con el espectador la va a extremar precisamente la imaginería española y especialmente la imaginería de Pasión"5.

La contrarreforma no solamente promocionaba la religiosidad dentro de los muros, sino que también impulsó la devoción pública, lo que condujo a su momento de máximo esplendor a las procesiones, particularmente las de Semana Santa. En ellas se "combinan el sentido de la penitencia pública con un deseo de lujo y grandiosidad que debe darse a la divinidad en su culto". Una de las consecuencias más importantes para el arte de esta piedad pública fue la realización de nuevas imágenes procesionales que pudieran ser contempladas desde diferentes puntos de vista, de manera que la acción desarrollada en los pasos tuviera la mayor verosimilitud posible, era una forma de catequizar al pueblo y a la vez de conmoverle. Estamos hablando de un verdadero teatro religioso al servicio de la piedad popular.

\section{$\underline{\text { A- GENERALIDADES }}$}

Antes de enumerar las características que pueden definir a la escultura barroca castellana hay que traer al recuerdo las sabias palabras que don Juan José Martín González refirió al respecto de querer delimitar un periodo artístico en unas pocas características o particularidades: "todo intento por someter a una generalización los

Ídem., p. 441.

OROZCO DÍAZ, Emilio: Introducción al Barroco: ensayos inéditos, Universidad de Granada, Granada, 2009, p. 211.

6 GARCÍA GUTIÉRREZ, Pedro F. y LANDA BRAVO, José: La escultura. Del renacimiento a la actualidad, Ediciones Antiqvaria S.A., Madrid, 1994, p. 115. 
caracteres artísticos de un periodo, de cualquier clase que sean, tropieza con el inconveniente de las numerosas excepciones que se presentan"7. Pero, ¿de dónde procede la palabra "Barroco"? A lo largo de la historia el origen del concepto "barroco" ha suscitado dos teorías: por una parte la que propone que proceda de portugués "barrôco" (perla irregular), mientras que otros, suponiéndole una origen más culto, piensan que está relacionado con el término silogístico "baroco", cuarto modo de la segunda figura de la lógica formal ${ }^{8}$. Para Orozco Díaz el barroco "constituyó la espiritualidad contrarreformista y el no menos importante influjo del ambiente creado por la literatura ascética y mística española. Hay que reconocer que este estilo suponía, aun considerándolo desde un punto de vista formalista, una tendencia a la exaltación expresiva y en consecuencia era por su sentido y recursos el más capacitado e inclinado a la representación del tema del dolor así como de lo alegre, y en su visión más extrema y contrastada"9.

$\mathrm{El}$ arte barroco español es mayoritariamente religioso, ahora bien, la temática religiosa en lo referente a la escultura es casi absoluta. Ambos hechos son pruebas fehacientes de que aquella España seguía creyéndose la guardiana de la ortodoxia religiosa. Las representaciones mitológicas no fueron tan comunes como en el resto de países europeos, los únicos lugares en los que tuvieron cabida fueron la Corona y cierta nobleza. Según van saliendo a la luz nuevos inventarios realizados con motivo de los fallecimientos de los artistas de la época vemos que, aunque de forma muy minoritaria, la mitología siguió presente en la vida de los españoles. Otra de las diferencias que tiene en esta época la escultura española, y por ende la castellana, y la realizada en Italia, Francia u otros países es el material predominante. Mientras que en España el uso de la madera policromada es abrumador respecto a otros materiales, en los otros países el mármol será el más utilizado, este último en España tan sólo había tenido predicamento en los monumentos funerarios y conmemorativos, al desaparecer estos el uso del mármol quedó reducido a la mínima expresión.

El siglo XVII fue muy fructífero en canonizaciones y beatificaciones, especialmente de muchos religiosos españoles: San Ignacio de Loyola (1609), Santa Teresa de Jesús (1614), San Francisco Javier y San Isidro Labrador (1619), San Francisco de Borja (1624) y San Fernando (1671), etc... Este hecho supone la fijación de sus respectivas iconografías y por consiguiente un elevado número de encargos por parte de diversas instituciones religiosas a los escultores, pintores y otros artistas, los cuales debían de crear imágenes devocionales que incitaran a la compasión y a la piedad de los fieles. Muchos de estos santos ya contaban con representaciones tiempo antes de su canonización, la cual en ocasiones se demoraba en demasía. No es extraño ver esculturas o pinturas encarnando a "beatos" o a "venerables".

\footnotetext{
7 MARTÍN GONZÁLEZ, Juan José: Escultura barroca castellana..., op. cit., p. 11.

8 RODRÍGUEZ-SAN PEDRO BEZARES, Luis Enrique: Lo Barroco: la cultura de un conflicto, Plaza Universitaria, Salamanca, 1988, p. 9.
}

$9 \quad$ OROZCO DÍAZ, Emilio: op. cit., p. 209. 
Además, la contrarreforma impulsa la representación de los martirios de los santos, tema mucho más cultivado en la pintura pero que también cuenta con ejemplares dentro de la escultura, son famosos los grupos de San Tirso, San Esteban, San Bartolomé... Pero no solo los martirios, también la exhibición de santos ascetas: San Siro, Santa María Magdalena, Santa María Egipciaca, San Jerónimo en el desierto... El sufrimiento y el dolor exacerbado debían de estremecer a sus posibles contempladores.

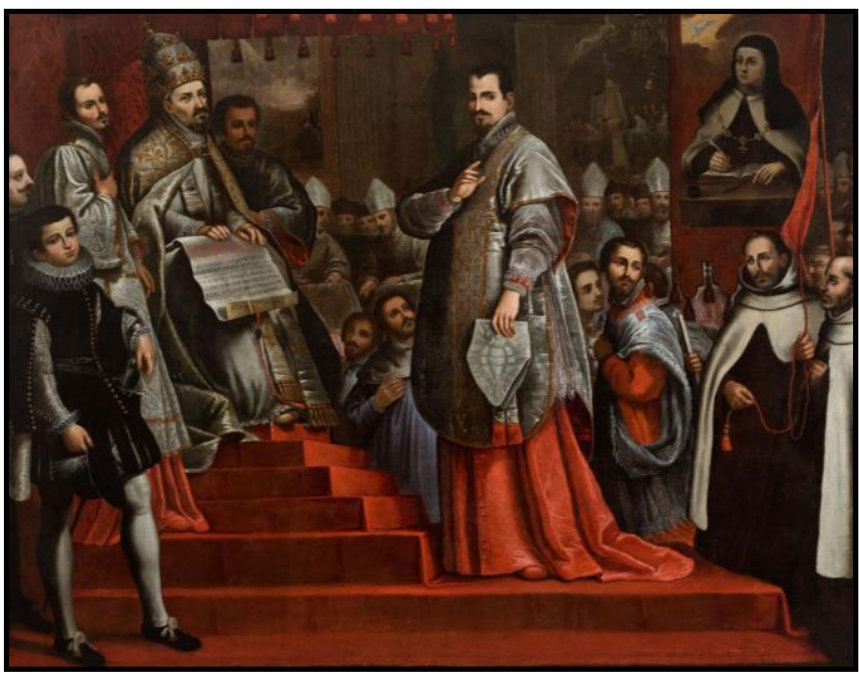

Il. 2- Anónimo. Ceremonia de canonización de Santa Teresa Monasterio de la Anunciación de Nuestra Señora de MM. Carmelitas Descalzas. Alba de Tormes (Salamanca).

Una característica muy personal de la escultura española es el desarrollo de la temática pasionista, hecho que se vio favorecido por el esplendor de las cofradías penitenciales, y por lo tanto de las procesiones de Semana Santa. Un nuevo arte se comienza a desarrollar a raíz de las procesiones, se trata de los pasos procesionales, que se conciben para ser contemplados en la calle, no en las iglesias. Esta circunstancia conlleva que las esculturas fueran de bulto redondo para poder ser observadas desde múltiples puntos de vista, lo que exigía a los escultores gran creatividad y destreza compositiva. Las tallas principales de los conjuntos se mantenían expuestas al culto durante todo el año en las iglesias y capillas correspondientes.

El arte buscó una descripción realista y a la vez expresiva para poder captar la atención del público, como si esa escena fuera real. Habrá una tendencia a la exageración para alcanzar esos propósitos. Cuando los imagineros se disponen a crear determinadas escenas intentarán conmover a los fieles, de ahí que se utilicen imágenes más vivaces que las reales. El cuerpo de las imágenes se convierte en uno de los componentes más expresivos. Habrá un verdadero lenguaje a través de las manos, del mismo modo que la boca entreabierta será muy utilizada para expresar cansancio, sorpresa, muerte o resignación ${ }^{10}$.

El realismo/naturalismo se traduce en composiciones asimétricas, la línea recta no tiene apenas cabida, mientras tanto el contraposto gana mucho peso. Se busca las posiciones inestables, las composiciones en diagonal, la línea abierta. A pesar de todo, los movimientos violentos no tienen cabida en la escultura castellana. Muchas veces se ha dicho que no hay escultura en Valladolid más movida que el Santo Domingo que Gregorio Fernández talla para el Convento de San Pablo. Los seguidores del gallego no hicieron sino "templar más las actitudes, de manera que, en general, puede decirse que

10 ÁlVAREZ ALLER, Eduardo: "La estética procesional barroca". En ALONSO PONGA, José Luis y PANERO GARCÍA, Pilar: op. cit., p. 447. 
la escultura del siglo XVII se significa por la calma. El mismo paño anguloso contribuye a aquietar el ritmo; es como un lastre que llevan las esculturas, del que no saben desembarazarse" ${ }^{11}$. El movimiento y las contorsiones hacen su aparición en Castilla ya en el siglo XVIII. La forma más habitual de remarcarlos es mediante el uso "frecuente del paño ondeante hacia uno de los lados, terminando en punta, que semeja el tremolar de una bandera" 12 . Como ejemplos tenemos las esculturas que los Tomé fabrican para la fachada de la Universidad de Valladolid, la sillería que Pedro de Sierra talla para el Convento de San Francisco, las esculturas de Pedro de Ávila con sus pliegues "a cuchillo", etc... Hay una tendencia, sobre todo en el siglo XVIII, a concebir las imágenes con poses oratorias o declamatorias, todo muy grandilocuente. Gustan las actitudes afectadas. Es el teatralismo barroco llevado a sus últimas consecuencias. En ciertas ocasiones estos personajes figuran desprovistos "de una resonancia espiritual que justifique y valorice tales posturas"13.

Uno de los pocos elementos que acusan el movimiento, y además nos pueden llegar a revelar la identidad de un artista y de la época en que fue tallada, son los pliegues del ropaje. Señala Martín González que "si durante el Renacimiento los pliegues nos muestran un sentido epocal propio, y dentro de él cada maestro añade el sello de individualidad. En el Barroco encontramos más vigente el plegado epocal que el individual, por causa de la escasa diferenciación y valía personal de los artistas. En periodo tan dilatado se observan diferentes tipos de pliegues, de en valor general"14.

El paño barroco vallisoletano, y por ende castellano, tiene su origen en el utilizado por Gregorio Fernández en sus inicios. Este es claramente deudor del manierista, "es un paño sumamente curvado, algodonoso"15. Martín González lo define como un pliegue "escultórico, alatonado, que imita papeles doblados o telas encoladas, persigue un fin claroscurista, pictórico diremos. Este paño presta una gran pesadez a las figuras y hasta las inmoviliza dentro de semejantes corazas" ". Durante su última etapa practica un pliegue pictórico, muy poco profundo, que aporta a la talla de un efecto de claroscuro. Es mucho más anguloso y quebrado que el anterior, parece "obtenerse como golpeando una superficie metálica con instrumento cortante" ${ }^{17}$. El pliegue sobrevivirá a Fernández llegando a ser utilizado hasta finales del siglo XVII, si bien tendrá ciertas modificaciones, como la multiplicación de dobladuras, siendo estas mucho más sencillas y bastas. Martín González considera este hecho "un amaneramiento del estilo de Fernández". En ciertas ocasiones esta multiplicación es tan exagerada que los escultores llegan utilizar tela encolada en los bordes. A finales del siglo XVII desaparece este pliegue heredado de Fernández, imponiéndose uno basado en amplias líneas que caen verticalmente, con las angulosidades encapsuladas en la parte baja de

\footnotetext{
11 MARTÍN GONZÁLEZ, Juan José: Escultura barroca castellana..., op. cit., pp. 9-10.

12 Ibídem.

13 Ídem., p. 12.

14 Ídem, p. 18.

15 Ibídem.

16 Ibídem.

17 Ibídem.
} 
los vestidos. Estos pliegues cambian el quebramiento por la dulzura, son suaves y redondeados ${ }^{18}$.

Este último pliegue se mantiene hasta comienzos de la década de 1710 en que Pedro de Ávila introduce en Castilla el denominado "de pliegues de cuchillo". Este pliegue conlleva la introducción de las influencias exteriores, las cuales no habían tenido cabida en el siglo XVII. El paño utilizado por Ávila, y posteriormente por otros escultores

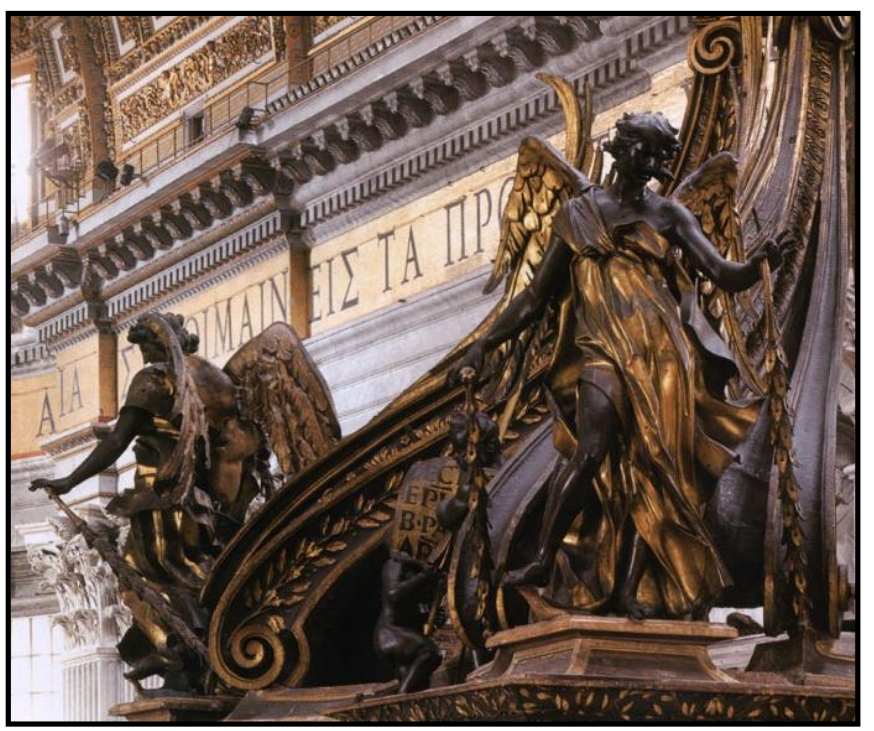

Il. 3- Gian Lorenzo Bernini. Baldaquino. Basílica de San Pedro del Vaticano. Roma.

como Pedro de Sierra, Felipe Espinabete y, en menor medida, Pedro Bahamonde, no es sino la penetración en Castilla del paño creado por Bernini casi medio siglo antes en Roma. Uno de los ejemplos berninescos en que mejor se observa este pliegue es en los ángeles del baldaquino que "Il Cavaliere" construye en el transepto de la Basílica de San Pedro de El Vaticano. Apunta Martín González que a pesar de esa imitación "el pliegue castellano se distingue por ser menos profundo, y menos claroscurista, por tanto; forma artistas fuertemente biseladas, como cortadas por rápidos golpes de gubia. Entre nosotros solemos decir que son paños cortados a cuchillo. Con esto adquiere la escultura un aire trepidante, muy barroco; es decir, entramos en un periodo barroco por antonomasia de nuestra escultura" ${ }^{19}$. Con este plegado "romano" convivirá otro "más blando, pero igualmente movido".

Las imágenes se conciben con multiplicidad de puntos de vista, especialmente las destinadas a los pasos procesionales, esto no quiere decir que se destierre por completo la vista frontal, la cual se seguirá utilizando para muchas esculturas de retablo. A la hora de componer escenas suelen aparecer gran número de figuras, frecuentemente desordenadas. El "desorden ordenado" es un elemento muy barroco. Esta propensión a formar grandes conjuntos "supone el acercamiento de la escultura al teatro, los pasos de Semana Santa serán un buen ejemplo de ello. Se busca un equilibrio dinámico, de la máxima inestabilidad, consecuencia a su vez del afán de instantaneizar la vida"20.

El patetismo será una de las singularidades de la escultura barroca española, en general, y de la castellana, en particular. Este dramatismo se expresa mediante las actitudes, los

Ibídem.

Ídem, p. 19.

Ídem, p. 24. 
rostros, pero sobre todo mediante las heridas de Cristo, testimonios vivos de su Pasión. Para conseguirlo los escultores utilizaron toda una gama de postizos ${ }^{21}$.

\section{B- MATERIALES}

El material más utilizado en el Valladolid de la época, pero no solamente aquí sino también en Castilla, y, por lo general, en España, fue la madera. Esto ya supone un elemento diferenciador con la mayoría de países europeos en que el material predilecto era el mármol: Italia, Gran Bretaña, Francia, etc... Pienso que la utilización del mármol quizás tenga relación con la preeminencia de la escultura mitológica clásica, es decir Grecia y Roma, culturas en las que el material predilecto fue, efectivamente, el mármol. En la España barroca la mitología no tuvo demasiada incidencia en las capas sociales bajas, siendo la religiosa la mayoritaria. El mármol, o más bien el alabastro, se utilizó fundamentalmente para bustos, monumentos funerarios y escultura mitológica, la cual tuvo su mayor desarrollo en los ambientes reales. La conclusión es clara: la madera se adaptaba mejor al sentimiento religioso español.

Dentro de la rica y variada gama de maderas la predominante en Valladolid y en Castilla fue la de pino. Cada población utiliza lo que tiene más a mano y Valladolid si por algo destaca es por tener relativamente cerca multitud de pinares, si bien los más demandados por escultores y comitentes eran los de Hontalbilla o los de Soria. También se traía madera de otros pinares más o menos próximos: Cuéllar, Traspinedo, Portillo, Valsaín, Navas del Marqués, Quintanar de la Sierra, etc... ${ }^{22}$. Además, esta madera tenía otras ventajas: bajo coste, ligereza, fácil talla, etc... Se utilizaron otros tipos de madera, como por ejemplo la de nogal, que posee tal calidad que es innecesario policromarla, lo que la hacía ideal para construir sillerías, las del convento de San Francisco y San Benito de Valladolid elaboradas durante esta época son buenas muestras de ello.

La utilización de otras materias fue muy minoritaria, ya fuera por la escasez puesto que su traída era muy costosa, o bien porque con el carácter castellano casaba mejor la madera. Así, por ejemplo, la piedra solo se utiliza para la escultura monumental, ejemplificada en las imágenes destinadas a las fachadas de las iglesias o de la misma catedral.

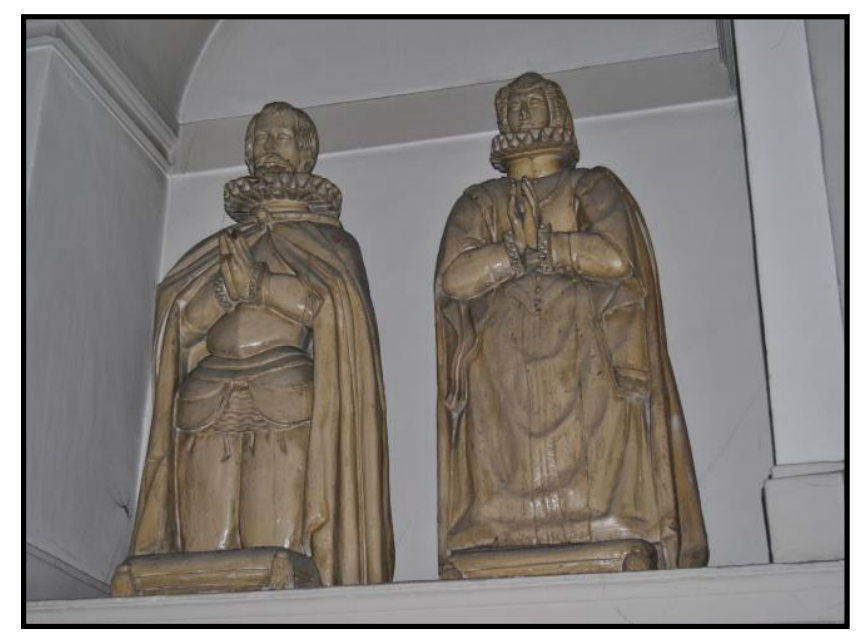

Il. 4- Francisco Alonso de los Ríos. Esculturas funerarias de los Maldonado. Iglesia de San Andrés. Valladolid.

21 ÁLVAREZ ALLER, Eduardo: "La estética procesional barroca". En ALONSO PONGA, José Luis y PANERO GARCÍA, Pilar: op. cit., p. 447.

22 MARTÍN GONZÁLEZ, Juan José: Escultura barroca castellana ..., op. cit., pp. 9-10. 
También en ocasiones se destina para la escultura funeraria, de la cual no existen muchos ejemplos. A pesar de todo, el material más utilizado para la escultura funeraria es el alabastro, ya que su coste no era tan prohibitivo como el del mármol. Uno de los mayores exponentes de la plástica funeraria en alabastro en Valladolid fue Pedro de la Cuadra, tan solo contamos con otro ejemplo durante el baroco en la ciudad: los bultos funerarios que Gregorio Fernández talla en la iglesia jesuítica de San Ignacio, actual parroquia de San Miguel, para los Condes de Fuensaldaña ${ }^{23}$. Tampoco hay que desdeñar la posibilidad de que no existieran en la ciudad artífices capacitados para trabajar la piedra. Es curioso que Francisco Alonso de los Ríos tallara cuatro bultos funerarios para la capilla de las Maldonado en la iglesia de San Andrés en madera pintada de blanco, queriendo de esta manera simular alabastro o mármol, material que quizás los comitentes no se pudieron permitir.

En contadas ocasiones veremos el uso de la cera para componer una especie de cuadros que efigian guirlandas de flores y frutas, escenas de santos o de vida cotidiana, pasajes de la biblia, etc... ${ }^{24}$. Por lo general estas pequeñas obras, muy delicadas, proceden de Madrid. El mejor ejemplo de escultura en cera que poseemos en Valladolid es el escaparate que representa La Fundación de la Orden

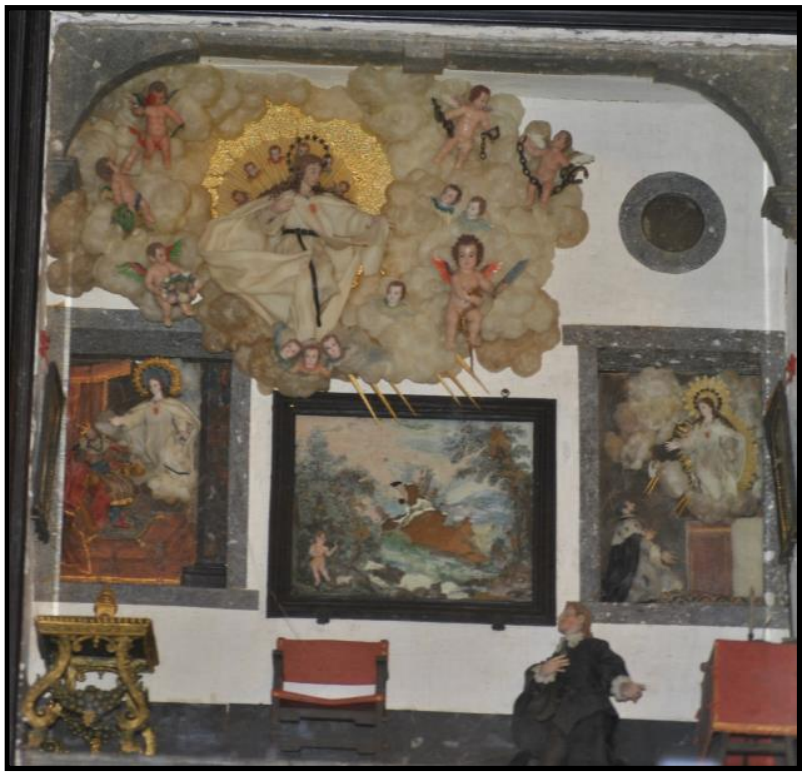

Il. 5- Fray Eugenio de Torices. La Fundación de la Orden de la Merced. Convento de las Descalzas Reales. Valladolid.

de la Merced, conservado en el antecoro del Convento de las Descalzas Reales. Aparece firmado y fechado. Fue realizado por fray Eugenio de Torices en $1698^{25}$.

\section{$\underline{\text { C- POSTIZOS }}$}

Durante el barroco se comienzan a usar con asiduidad los postizos, con los cuales se buscaba dar mayor realce y realismo a las tallas. Podemos asociar los postizos en dos grandes grupos: por un lado, los que van unidos de manera indivisible a la escultura, y, por otro, los externos. Mientras que la función de los primeros es dar mayor verismo a las imágenes, la de los segundos es aportar lujo y suntuosidad, aura divina. Este último grupo lo forman elementos como los vestidos, coronas, espadas, colgantes, anillos,

23 FERNÁNDEZ DEL HOYO, María Antonia: "La compañía, Gregorio Fernández y los Condes de Fuensaldaña”, B.S.A.A., Tomo XLVIII, 1982, pp. 420-429.

24 URREA FERNÁNDEZ, Jesús: "Apuntes para el estudio de la escultura en cera en España", B.S.A.A, Tomo XLV, 1979, pp. 488-495.

${ }_{25}$ MARTÍN GONZÁLEZ, Juan José y DE LA PLAZA SANTIAGO, Francisco Javier: Catálogo Monumental de la provincia de Valladolid. Tomo XV..., op. cit., p. 99. 
nimbos, etc... Hay que referir que los vestidos en algunas ocasiones si son parte indivisible de la talla se trata de imágenes de bastidor, en otras oportunidades las hechuras estaban completamente talladas, por lo que el vestido no era más que un complemento, con lo cual estaríamos dentro de los postizos del segundo grupo. Gracias a Gregorio Fernández se generaliza la fabricación de coronas de espino natural ${ }^{26}$.

Los postizos del primer grupo lo aglutinan elementos realizados con materiales muy heterogéneos. Todo en aras del mayor grado de naturalidad, lo que traería consigo la piedad del observador. Así, por ejemplo, el cristal se utiliza para los ojos, las lágrimas o para las gotas de sangre que emergen del costado de Cristo tras la lanzada. El caso de los ojos es especialmente importante dado que es uno de los postizos que otorgan mayor expresividad a la imagen, aunque muchas veces se hacen de cristal en otras ocasiones pueden llevar una tapilla de pasta vítrea o policromados directamente sobre la madera. Estos de tapilla "se elaboraban con dos técnicas: con vidrio embutido y pintado por la parte cóncava como hacían ya los egipcios, o bien como se hará en el siglo XVIII con vidrio por la técnica del soplado, que es un resultado más realista pero que necesita a abrir la cabeza para introducirlos" ${ }^{27}$. Con la pasta se elaboraban los dientes, con el asta de toro las uñas de manos y pies, y además si esta se calentaba se podían modelar, lo que conllevaba un acentuado realismo ${ }^{28}$. Finalmente, hay que reseñar el empleo de corcho para las llagas, los ejemplos más sobresalientes de la utilización de este material lo tenemos en las espaldas llagadas del Cristo atado a la Columna y del Cristo del Descendimiento que Gregorio Fernández elabora para la Cofradía Penitencial de la Santa Vera Cruz, o en el actualmente conocido como Cristo de la Luz, conservado en la capilla universitaria, sita en el vallisoletano Colegio de Santa Cruz.

\section{D- INDUMENTARIA}

En lo referente a la indumentaria que visten las esculturas la podemos encontrar de dos tipos: los personajes sagrados figuran con una vestimenta intemporal (túnicas, sayas, hábitos, etc...), mientras que los que forman el historiado de las escenas o pasos procesionales, como pueden ser los soldados y sayones, visten a la moda de la época en que trabaja el escultor ${ }^{29}$.

Los monjes de las diferentes órdenes religiosas visten con el hábito correspondiente a su respectiva orden. Unas veces podremos diferenciar la orden por el tipo de hábito o por el tipo de manga, en otras ocasiones será el policromador el que mediante el color nos proporcione las pistas necesarias para saber la orden a la que pertenece, suele ocurrir así con la franciscana. Por lo general, el resto de santos se incluye dentro de la corriente de

\footnotetext{
26 ÁlVAREZ VICENTE, Andrés y GARCÍA RODRÍGUEZ, Julio César: Dolor y Gloria..., op. cit., p. 150. 
personajes sagrados: ropa intemporal a base de túnica y manto que les cubre la totalidad del cuerpo. Hay algunos santos que rompen con esta normativa: por ejemplo, San Isidro que suele aparecer tocado con su gorguera y vestido a la usanza de los labriegos de aquel momento.

Los sayones de los pasos procesionales, y de algún que otro relieve, nos dejan entrever la moda utilizada en aquella época. Es allí donde los artistas se permiten la licencia de mostrarnos a sus contemporáneos. El propósito que buscaban los escultores era el de proporcionar a la escena mayor total veracidad al adaptarla a su tiempo, y quizás cierta pedagogía pues así el pueblo llano podría comprender mejor el suceso representado. En muchas ocasiones esa veracidad y comprensión derivaba en una clara repulsa hacia los sayones, los cuales eran apedreados por el vulgo. Los sayones vallisoletanos están caracterizados de dos formas: la mayoría visten ropa militar, mientras que hay otros, precisamente los tallados por Juan de Ávila para el paso del Despojo, que aparecen efigiados como judíos, con sus rasgos faciales perfectamente señalados. Puntualiza Martín González que "estos trajes derivan de los que durante el siglo XVI habían divulgado los lansquenetes alemanes, por eso suelen usar gorras muy flexibles; mangas y calzones con los típicos acuchillados, que en esta época ya solo se usaba en la indumentaria militar. Para señalar la baja moral de estos soldados, se les presentan con mangas remangadas y las piernas descubiertas" 30 .

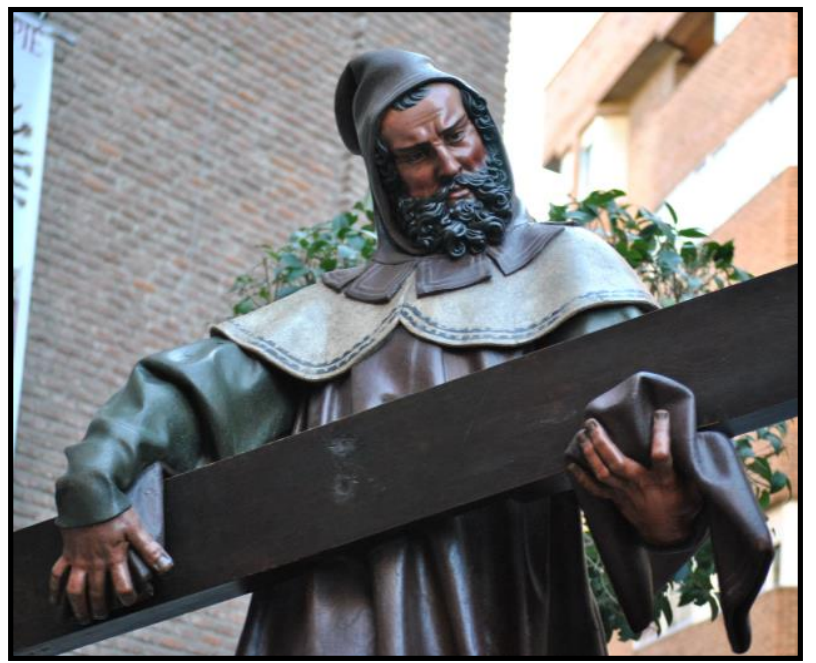

En los pasos también encontramos otra seria de personajes que no son santos ni tampoco sayones o soldados: Nicodemo, José de Arimatea, la Verónica, el Cirineo. Estos suelen vestir a la manera de la época, especial interés revela este último al cual Gregorio Fernández le viste cual labriego castellano de la época: gorra, jubón, coleto, calzas, calcetas y zapatos o botas altas ${ }^{31}$.

Il. 6- Gregorio Fernández. "Cirineo" de Camino del Calvario. Museo Nacional de Escultura. Valladolid.

\section{E- ICONOGRAFÍAS}

Como ya se ha dicho muchas veces la inmensa mayoría de la producción escultórica española es de carácter religioso. Los temas utilizados en la escultura castellana no difieren mucho de los utilizados en otros territorios del país, si bien cada uno de ellos contaba con ciertas excepciones, las cuales se materializaban en la devoción a santos locales o regionales.

$\begin{array}{ll}30 & \text { Ídem, p. } 53 . \\ 31 & \text { Ibídem. }\end{array}$


La variedad iconográfica es tremenda, por lo que nos vamos a centrar en las más demandadas. Podríamos agruparlas en cuatro grandes grupos: las referidas a Cristo, a la Virgen, a los Ángeles y a los Santos. En cuanto a historia sagrada, las representaciones del antiguo testamento desaparecerán casi por completo, los retablos e iglesias no se verán enriquecidos con nuevas esculturas de los profetas, Abraham, Noé, etc...

En las postrimeras del barroco comienza a despuntar una nueva iconografía: los Sagrados Corazones. Si bien en las iglesias de Castilla no menudean mucho las esculturas de ambos corazones sí que suelen servir para decorar retablos. La devoción al Corazón de Jesús la inició Santa Margarita María de Alacoque, si bien su gran impulsor fue el jesuita vallisoletano Bernardo de Hoyos, al cual se le apreció el Sagrado Corazón "abrasado en llamas, traspasado por la lanza, rodeado de espinas y coronado por la cruz" ${ }^{32}$. En 1735 tuvo lugar la primera novena. Poco después su desarrollo comenzó a correr paralelo al de la devoción al Corazón de María.

\section{- Cristo}

La exaltación religiosa del pueblo favoreció el desarrollo de la iconografía pasionista, por lo que las iconografías fundamentales de Cristo tienen que ver con su Pasión, muerte y resurrección. En ello influyó mucho el auge de las procesiones de Semana Santa. Si bien en ciudades como en Valladolid se contó con escenas de la Pasión comprendidas desde la Sagrada Cena a la Resurrección, los temas más recurrentes son los episodios centrales del tormento: Cristo atado a la Columna, el Ecce Homo, el Cristo del Perdón, Cristo camino del Calvario, la Crucifixión, Cristo Yacente... Sin ninguna duda el más representado es la Crucifixión, momento cumbre de la redención. La pauta a seguir la dio el Concilio de Trento, el cual "dejó en libertad a los artistas en lo referente a emplear uno o dos clavos para sujetar los pies. Gregorio Fernández labró sus cristos con corona de espinas natural, postiza, costumbre que se siguió observando en los tiempos siguientes" ${ }^{\text {"3. }}$.

A Gregorio Fernández se le debe la fijación de los modelos que durante muchos años se tomaron como ejemplo, no solo en Valladolid sino en buena parte de los territorios situados en la mitad norte de España. Veremos Yacentes suyos, o de imitadores, desde Galicia hasta Madrid.

En las clausuras femeninas se desarrolla una iconografía mucho más dulce, la de los Niños Jesús. Esto no significa que haya algunos radicados en iglesias, por ejemplo, el conservado en la hornacina inferior del retablo de la Inmaculada de la iglesia de San Felipe Neri de Valladolid. Suelen aparecer desnudos, las ropitas las tejían las propias religiosas. Hay multitud de variantes, siendo las más difundidas las que nos muestra a los niños recostados en sus cunas, de pie bendiciendo o bien portando los "Arma Christi", este último grupo se denomina de los "Niño Jesús de la Pasión". Hay

MARTÍN GONZÁLEZ, Juan José: Escultura barroca castellana ..., op. cit., p. 17.

Ídem., p. 29. 
ocasiones en las que Cristo aparece jugueteando con su primo, San Juan Bautista, creando una composición muy dulce, ciertamente relamida.

Relacionado con Cristo se encuentra el tema de la Sagrada Familia, iconografía que goza de gran popularidad durante este periodo. Viene a ser una alegoría de la familia cristiana. En ella vemos representados tres de los grandes pilares de la temática barroca: Cristo, como figura central del mensaje redentor, San José, cuya iconografía sufre una fuerte expansión en esta época, y la Virgen, cuya figura gozará, en la mayoría de ocasiones, de tanta importancia artística, como la de su Hijo. En ciertas ocasiones esta Sagrada Familia, la "terrestre" (San José, la Virgen y Jesús), estará contrapuesta con la Sagrada Familia "celeste" (Dios Padre, Dios Hijo, Espíritu Santo). Otra variante es la de la Sagrada Familia de la Virgen (San Joaquín, Santa Ana y la Virgen). Si bien la representación conjunta de las Sagradas Familias "terrestre y celeste" es más frecuente en la pintura, la de las familias de Jesús y la Virgen la podemos ver materializada también en esculturas. Un ejemplo lo tenemos en la iglesia del Colegio de San Albano, de los Ingleses, en el que una y otra aparecen afrontadas en sendos retablos.

\section{- $\quad \underline{\text { Virgen }}$}

El desarrollo de la iconografía mariana no tiene parangón con ninguna otra, Martín González habla de un siglo XVII "esencialmente mariológico" "34. La propagación de la devoción de la Virgen corre paralela a la proclamación del voto inmaculista, la cual motivó una "disputa" entre las ciudades por ver cuáles eran las que primeramente lo emitían. Con este motivo se encargaron imágenes que presidieran dicho acto en las diversas ciudades, fundamentalmente fueron esculturas: en Segovia la realizó Antonio de Herrera Barnuevo, en Palencia Mateo Sedano Enríquez o en Granada Alonso de Mena.

Gregorio Fernández fija el modelo de Inmaculada que se seguiría en Castilla hasta comienzos del siglo XVIII. Fernández ideó dos variantes: la que asienta sobre un trono de ángeles y la que se apoya sobre un horrible dragón. El éxito del modelo llevó a que los comitentes siguieran solicitando hasta muchas décadas después de la muerte del maestro copias de este fecundo modelo. Tanto el modelo

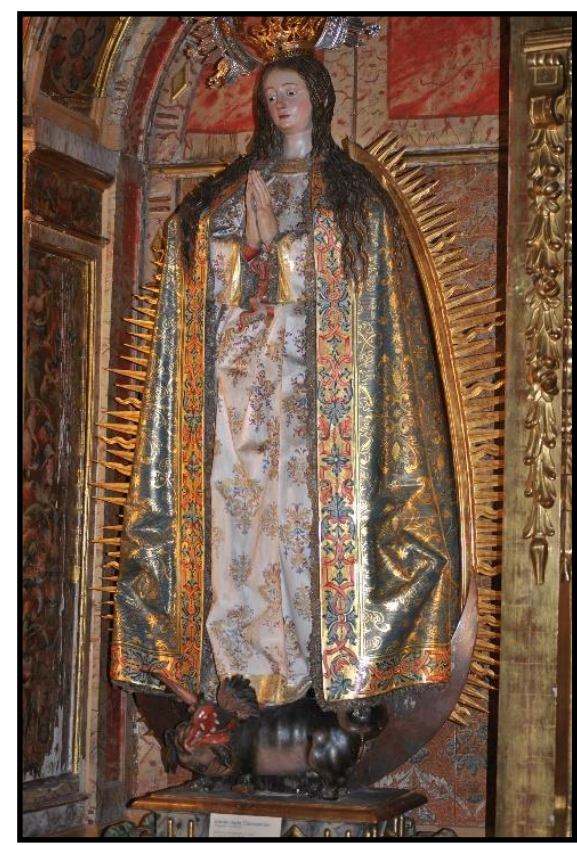

Il. 7- Gregorio Fernández. Inmaculada Concepción. Convento de Santa Clara. fernandesco como otros, por ejemplo, los de Herrera Barnuevo para la catedral de

34 MARTÍN GONZÁLEZ, Juan José: Escultura barroca en España ..., op. cit., p. 21. 
Segovia y José de Rozas para el Monasterio de las Descalzas Reales de Valladolid, aparecen rodeadas de una aureola de rayos alternativamente rectos y ondulados.

La otra gran iconografía mariana es la de la Asunción, la cual preside gran parte de los retablos que por entonces se construyen. Tampoco es despreciable el número de iglesias que se encuentran bajo su advocación. Se la suele representar completamente rodeada de ángeles, incluso la base sobre la que asienta suele estar formada por cabezas de angelillos. Ella levanta los brazos y los ojos, mirando directamente al cielo.

A estas dos iconografías preponderantes se suman una infinidad de advocaciones, siendo las más importantes las del Rosario, que viene a ser la puesta al día de la Virgen con el Niño medieval, o la Virgen del Carmen. Esta última, la carmelitana, al igual que la Inmaculada, tuvo gran repercusión en Valladolid gracias al modelo creado por Gregorio Fernández, el cual se mantiene vigente hasta bien entrado el siglo XVIII ${ }^{35}$.

\section{- $\underline{\text { San José }}$}

$\mathrm{Su}$ tratamiento siempre fue secundario dentro de las representaciones artísticas, se puede afirmar que era una figura secundaria dentro de las Epifanías. En este momento, su iconografía sufre un fuerte impulso que lleva a que su devoción se extienda hasta límites inimaginables. Se quiere mostrar fundamentalmente sus facetas de "padre amantísimo, o como educador" "36. le veremos llevar a su hijo en brazos o paseando agarrados por la mano, a estas temáticas se las suele contraponer la de San Joaquín con la Virgen Niña. En ocasiones puede figurar él solo asiendo ciertas herramientas de su oficio. Muy escasa es la representación de la muerte de San José.

\section{- $\underline{\text { Ángeles }}$}

La representación de los ángeles logra, gracias a los teólogos del Concilio de Trento, su momento de mayor expansión. No solo se trata de los más conocidos (San Miguel, San Rafael, San Gabriel), sino que también menudean serafines, querubines, angelillos por doquier. Sus cuerpos o cabezas llegan a inundar retablos y sillerías, incluso llegan a acompañar pasajes (la Anunciación) o formar los tronos de ciertas imágenes, como pueden ser la Inmaculada, la Asunción o algún santo, por ejemplo, el San Francisco de Paula de la vallisoletana iglesia del Salvador.

Los angelotes aparecen en las más diversas actitudes: rezando, tocando instrumentos musicales, jugueteando, etc... De Gregorio Fernández parte la propuesta de colmar los áticos de los retablos de ángeles turiferarios, portaestandartes o portadores de las Arma Christi. También se ornan con ángeles, preferiblemente arcángeles, la entrada a las capillas mayores de los templos. En Valladolid tenemos numerosos ejemplos: la actual 
iglesia de San Miguel, el Santuario del Carmen Extramuros, la iglesia conventual de Santa Isabel de Hungría o la iglesia de San Andrés. Este último es el caso más desconocido de todos y del que solo tenemos constancia de ello gracias a las fotografías antiguas. Señala Martín González que la idea proviene de los dos ángeles que Bernini esculpió en mármol para la iglesia de Sant 'Andrea delle Fratte (Roma) ${ }^{37}$.

Sin duda los seres celestiales que más fortuna alcanzaron durante el barroco fueron los Arcángeles San Rafael, San Gabriel y San Miguel, a los cuales se une en este momento el Santo Ángel de la Guarda, cuya devoción sufre un fuerte incremento gracias a la creación de diversas cofradías dedicadas a su figura. En Valladolid, por ejemplo, existen dos imágenes del Santo Ángel, ambas atribuidas a Juan de Ávila. Entre todos ellos sobresale la devoción a San Miguel, sobre todo en el siglo XVIII. Su representación tuvo gran éxito en el barroco debido a que poseía unas iconografías, como por ejemplo el abatimiento de Lucifer, que se prestaban a la teatralidad y al movimiento violento.

\section{- $\underline{\text { Santos }}$}

Las representaciones de los santos será otro de los grandes pilares de la plástica barroca. Mucha culpa de ello tiene el Concilio de Trento, el cual fomentó su

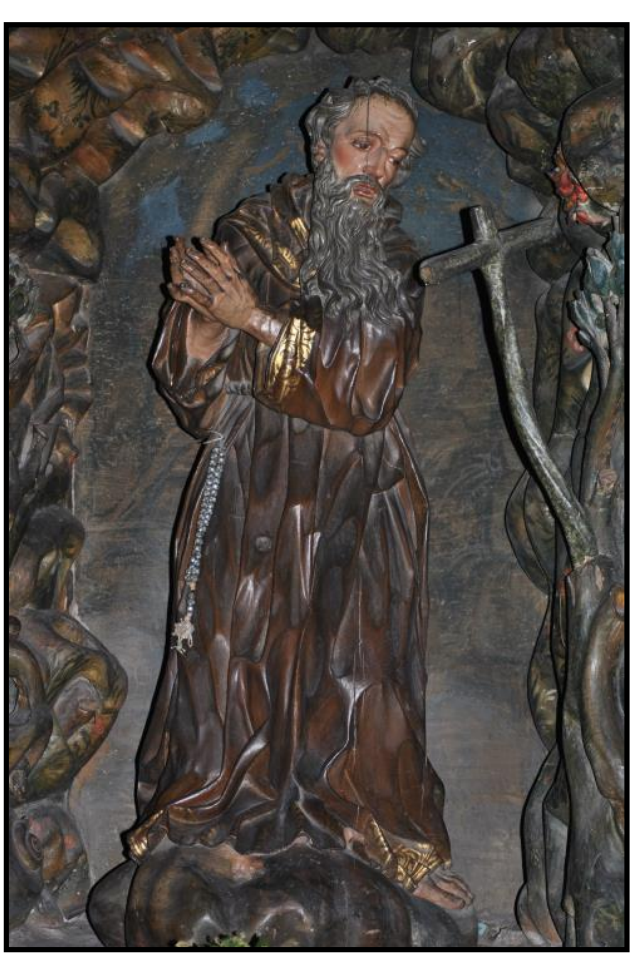

Il. 8- Pedro de Sierra (atrib.). San Siro. Iglesia de San Miguel. Valladolid. culto por considerarlos mediadores entre el ser humano y la divinidad, "era el reconocimiento de que Dios actúa a través de los hombres y de que la santidad se puede adquirir" ${ }^{38}$. A los santos ya tratados en épocas anteriores se suman gran cantidad de novedades, la mayoría de ellos personas del siglo XVI que se distinguieron por su recta conducta cristiana y que se ven recompensados con la beatificación un siglo después.

Por el tipo de representación los podemos dividir en dos grupos, si bien hay muchos que no pueden ser encasillados en ninguno de ellos. Se trata de las representaciones místicas y de las martiriales. Dentro de este último grupo alcanzaron gran fortuna las cabezas de santos degollados, principalmente las de San Pablo y San Juan Bautista. Uno de los primeros ejemplos, casi se puede hablar de un precedente, es el grupo procesional de San Juan Bautista degollado que Juan de Rada esculpe en 
1579 para la Cofradía de la Sagrada Pasión de Cristo de Valladolid ${ }^{39}$.

Entre los santos místicos destacan las representaciones de San Siro, San Jerónimo en el desierto, Santa María Magdalena, Santa María Egipciaca. Estas dos últimas santas ofrecían al escultor la posibilidad de recrearse en la obtención del vestido de espadaña, el cual fue elaborado de manera magistral por Pedro de Mena en la Magdalena que talló para el Colegio Imperial de Madrid. Pueden aparecer tumbados, de rodillas ante el crucifijo o incluso sentadas asiéndole fuertemente. En ocasiones se les puede representar alojados en cuevas, como así sucede con el San Siro y la Santa María Magdalena conservados en la actual iglesia de San Miguel y San Julián, antiguo colegio jesuita de San Ignacio.

Cobran gran protagonismo las órdenes religiosas, las cuales quieren copar los altares de sus iglesias con representaciones de sus propios santos.

Los franciscanos, como no podía ser de otra forma tuvieron como tema predilecto a San Francisco de Asís. Se le representa de las más diversas formas, si bien cobra gran relevancia la representación de su momia con los brazos cruzados a la altura del pecho y con la vista perdida mirando al cielo. El tema procede de la pintura, uno de los primeros ejemplos fue el óleo del francés Laurent de la Hire custodiado en el Museo del Louvre $^{40}$. Otros franciscanos que gozarán de gran popularidad fueron San Antonio de Padua, San Buenaventura, San Pedro de Alcántara y San Pedro Regalado. Este último goza de especial relevancia en Valladolid, su ciudad natal y de la que fue nombrado patrón años después, desbancando al que hasta entonces lo era, San Miguel Arcángel.

Una de las ordenes más pujantes en este momento fue la de los Carmelitas, cuya fundadora, la española Santa Teresa de Jesús, fue una de las "santas barrocas" por antonomasia. Suele representársela como Doctora de la Iglesia: portando el libro de reglas de la Orden en una de sus manos, mientras que en la otra sostiene una pluma. En ciertas ocasiones puede sobrevolarla una paloma, la cual es observada por la santa con gran fijación. Se trata de la paloma inspiradora del Espíritu Santo. La importancia de Santa Teresa en España fue triple puesto que no solamente era española, sino que también fue la fundadora de las Carmelitas y fue nombrada compatrona de España junto a Santiago Apóstol. Otros santos de la orden representados con bastante frecuencia son San Juan de la Cruz, Santa María Magdalena de Pazzi e incluso el Profeta Elías, tan relacionado con el Monte Carmelo.

Quizás la orden que tuvo más importancia en esta época fue la Compañía de Jesús, no en vano sus tres cabezas más visibles (San Ignacio, fueron San Francisco Javier y San Francisco de Borja) fueron beatificadas con escasa diferencia temporal. Pero no solamente los retablos y altares se copan de imágenes de estos tres, también veremos representaciones de San Luis Gonzaga, los mártires de Nagasaki (San Diego Kisai, San Pablo Miki y San Juan Gotó). Algo posterior es la devoción a San Estanislao de Kostka.

39 MARTÍ Y MONSÓ, José: Estudios histórico-artísticos..., op. cit., p. 498.

40 MARTÍN GONZÁLEZ, Juan José: Escultura barroca castellana ..., op. cit., p. 33. 
Otras órdenes que tuvieron gran significación artística fueron la de los Cartujos de San Bruno y la Congregación del Oratorio de San Felipe Neri. La Cartuja se distinguió por las representaciones de su fundador. Casi todas las grandes figuras del momento trabajaron su figura: Gregorio Fernández para El Abrojo, Manuel Pereira para la Cartuja de Miraflores y para la Hospedería de la Cartuja del Paular en Madrid, José de Mora para la cartuja de Granada o Martínez Montañés para la sevillana de Santa María de las Cuevas.

También se fomentó la piedad hacia los santos guerreros, encabezados por Santiago Matamoros, cuya iconografía se ve enriquecida y fomentada en esta época. Hasta entonces las representaciones se fijaron más en su faceta de peregrino. Otros santos guerreros son San Millán y San Jorge. No se puede pasar por alto a los santos más populares, cuyo fervor no disminuyó: San Antonio Abad (vulgo San Antón), San Sebastián, San Blas, etc...

Los dos últimos grupos que podemos mencionar son los de los santos agricultores, cuyos miembros más conocidos son el matrimonio formado San Isidro Labrador y Santa María de la Cabeza, y los santos comarcales. Esta última familia es muy extensa pues cada territorio tenía sus propias devociones. Podemos nombrar a San Pedro Regalado, cuyo culto se fomentó en Valladolid y en la Ribera burgalesa; San Fernando en toda Castilla y en Sevilla. En

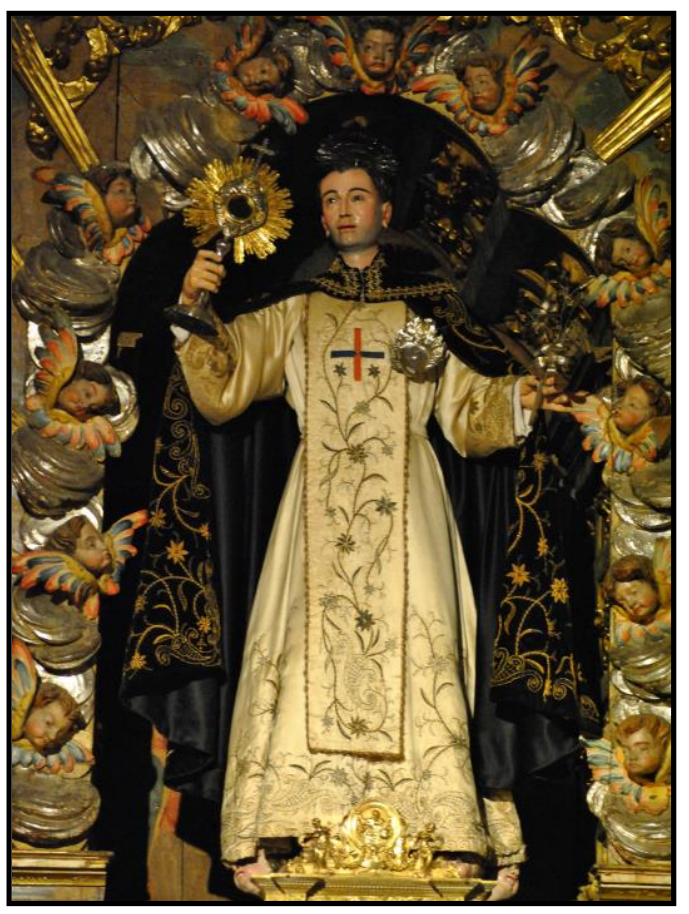

Il. 9- Anónimo. San Miguel de los Santos. Iglesia de San Nicolás. Valladolid.

Valladolid también contamos con otros ejemplos, algo más tardíos que los citados: San Miguel de los Santos, Santo Toribio de Mogrovejo y San Simón de Rojas.

\section{2-2 PANORÁMICA DE LA ESCULTURA BARROCA EN ESPAÑA}

La escultura barroca en España la podemos dividir en dos grandes bloques: la que aborda el siglo XVII y la englobada entre los años 1700-1750. Tres fueron los grandes focos: Castilla, con Valladolid a la cabeza, Madrid, gracias a la implantación de la Corte, y Andalucía, con los florecientes focos sevillano y granadino. Aún con sus momentos de luces y sombras estos tres núcleos se mantuvieron casi inmutables a lo largo de todo el barroco, tan solo cambió la jerarquía entre ellos: si en un primer momento Castilla y Andalucía monopolizaron el negocio gracias a genios como Gregorio Fernández, Martínez Montañés, Alonso Cano o Pedro de Mena, la absorción 
de los grandes artistas provenientes de todo el territorio español ya a finales del siglo XVII derivó en el fortalecimiento de la escuela madrileña y el bajón de las otras dos. A lo largo del siglo XVIII la diferencia entre Madrid y el resto de escuelas no hizo sino aumentar $^{41}$.

\section{$\underline{\text { A- CASTILLA }}$}

Durante gran parte del siglo XVII la escuela castellana tiene casi como el único referente a Valladolid. La escultura vallisoletana tiene su máximo, y casi exclusivo, exponente en Gregorio Fernández (1576-1636), el cual extiende su influencia a lo largo de todo el noroeste español, desde Galicia hasta Navarra. También envió obra a Madrid, Extremadura, Valencia, Portugal e incluso América. Además de Valladolid, los otros focos escultóricos pujantes fueron Toro y Salamanca, los cuales mantienen su importancia tanto en el siglo XVII como en el XVIII. A comienzos de esta decimoctava centuria cobra especial relevancia Medina de Rioseco, con los Sierra como protagonistas.

\section{- $\underline{\text { Toro }}$}

Durante el siglo XVII trabajan allí dos maestros muy particulares que a lo largo de un amplio periodo de tiempo trabajaron codo a codo, formando una de las escasas compañías de escultores conocidas. Son los denominados "Maestros de Toro": Esteban de Rueda (h.1585-1626/1627) y Sebastián Ducete (1568-1620) (Fig. 1). Ambos artífices basculan entre el Manierismo y el primer barroco. En ellos se perciben influjos de dos de los grandes maestros castellanos: en Rueda el de Juan de Juni y en Ducete el primer estilo de Gregorio Fernández ${ }^{42}$. Cuando ambos escultores unen su talento crean obas que muestran una perfecta síntesis del estilo de ambas leyendas y de ellos mismos. Ya en el siglo XVIII germina uno de los clanes más importantes del país: los Tomé. El fundador fue Antonio Tomé, el cual engendró a los escultores Narciso (1690-1742) y Diego y al pintor Andrés Tomé. Otro miembro de la familia es Simón Gavilán Tomé (1708-h.1791), sobrino de Antonio y primo de Narciso, Diego y Andrés, que trabaja fundamentalmente para Salamanca. Los tres hermanos suelen trabajar de manera conjunta. Así, entre sus obras más destacadas se encuentra las esculturas de la fachada de la Universidad de Valladolid y, por supuesto, el Transparente de la Catedral de Toledo. Ambas obras son el cénit de la escultura civil y religiosa, respectivamente, de su momento.

\footnotetext{
41 Para esta sección se recomienda fervientemente: MARTíN GONZÁLEZ, Juan José: Escultura barroca en España ..., op. cit. Para completar se pueden consultar las diferentes monografías que con el tiempo se han ido elaborando de muchos de ellos. La bibliografía se puede consultar en el propio libro de don Juan José Martín González.

$42 \quad$ Ídem, p. 84.
} 


\section{- $\underline{\text { Salamanca }}$}

Tampoco hay que menospreciar la labor del foco salmantino. En él florecieron un buen número de escultores y ensambladores. Hay que destacar la relación de ida y vuelta existente entre Valladolid y Salamanca durante este período: en un primer momento fue muy importante la influencia de Gregorio Fernández, sobretodo en el escultor salmantino Antonio de Paz (h.1585-1647), cuyos modelos continua de manera brillante; posteriormente llegan desde Valladolid el escultor Juan Rodríguez (h.1616-h.1676), que deja una buena cantidad de obras en la capital charra, y el ensamblador Juan Fernández (h.1630-h-1695), el cual lleva a cabo uno de los retablos españoles más importantes de este periodo: el retablo mayor de la Clerecía. Entre los escultores locales sobresale Bernardo Pérez de Robles (h.1621-1683) (Fig. 2). Será uno de los escasos ejemplos de artista castellano que marcha a trabajar a América, dejando allí buenas muestras de su arte. Desde la vuelva de América observa Martín González en su estilo "el recuerdo de Martínez Montañés"43. Otros escultores más secundarios, aunque también interesantes, son Pedro Hernández (h.1580-d.1655) y Jerónimo Pérez (h.1570-d.1643).

En el siglo XVIII la escultura salmantina se ve reforzada gracias a uno de los mejores escultores españoles del momento: el vallisoletano Alejandro Carnicero (1693-1756) (Fig. 3). El iscariense llegó a trabajar en la obra de decoración del nuevo Palacio Real, lo que nos da buena muestra de su valorado que era su arte. Maestro de este, y seguramente también vallisoletano, fue José de Larra Domínguez (h.1665-1739). A él se deben gran parte de las esculturas que pueblan los retablos salmantinos de ese momento. En el haber de Carnicero también figura el adiestramiento de uno de los maestros neoclásicos más importantes del país: el salmantino Manuel Álvarez de la Peña, alias “El Griego" (1727-1797).

\section{- Otros focos castellanos}

Burgos sobresale en la retablística, aunque cuenta con un déficit de escultores que le obliga a nutrirse de escultores foráneos, en su mayoría provenientes de la Merindad de Trasmiera (Santander). Hay una dispersión de talleres, por lo que la ciudad de Burgos no tendrá especial importancia. En la retablística destacan Policarpo de la Nestosa y Fernando de la Peña. Un caso similar ocurre en Segovia en que sobresale su retablística gracias, en parte, a artífices madrileños, pero también a los notables arquitectos y ensambladores locales como José Vallejo Vivanco y Juan de Ferreras. Tiene gran importación la aparición de José de Churriguera trabajando en el retablo mayor de la capilla del Sagrario, o de los Ayala, de la catedral. El panorama no será tan rico en lo referente a escultura. Las mejores tallas proceden del foco vallisoletano (Gregorio Fernández, Juan Imberto) y del madrileño (José Ratés y Antonio de Herrera Barnuevo).

43 Ídem, p. 98. 
El foco santanderino/cántabro, si bien no destaca especialmente por su calidad, presenta unas particularidades que le hacen digno de ser reseñado. A diferencia de lo que ocurre en la mayoría de territorios españoles durante el siglo XVII, en Cantabria tiene un papel primordial el patronazgo de la nobleza. También es característico de esta zona el amplio desarrollo que gozó la escultura funeraria en piedra. Suelen representar al finado de rodillas, sobre un cojín, con las manos juntas en actitud de plegaria. Es decir, son de "tipo orante". El foco cántabro ha sido siempre muy generoso ya que sus mejores artífices, dedicados a todas las artes, marcharon a trabajar a otros puntos. Es reseñable la gran cantidad de arquitectos trasmeranos que militaron dentro del foco clasicista vallisoletano.

Durante el siglo XVIII la actividad de los tres territorios decae de forma notable, tan solo se salva la retablística burgalesa, lo que sin duda favoreció a la escultura. En cambio, en este momento surgen otros dos focos pujantes: Medina de Rioseco y Palencia. Si bien Rioseco ya había gozado de buenos artífices durante el siglo XVII no fue hasta la llegada del berciano Tomás de Sierra (h.1654-1726) cuando la escuela cobra gran vigor (Fig. 4). El legado de Sierra a Rioseco no solo fue el de cuantiosas creaciones sino el de una amplia saga familiar que se prolongaría hasta finales del siglo XVIII. La generación siguiente fue la de sus hijos: los escultores Pedro (17021760/1761), José (1694-1751) y Francisco (1681-1760), el pintor Tomás de Sierra "el joven" (1687-1753) y el ensamblador y religioso Fray Jacinto (1698- ¿?). A estos les sucedieron los hijos, sobrinos y algún nieto de José. Rioseco durante el barroco y parte del neoclasicismo aparece indisolublemente unido a esta gran familia. Palencia, por su parte, cuenta en el siglo XVII con la familia de escultores Sedano, cuyo artífice más destacado, Mateo Sedano (h.1612-1686) (Fig. 5), emparenta con nuestro Juan de Ávila, siendo, asimismo, abuelo de Manuel de Ávila. En el siglo XVIII Palencia destaca en el campo de la retablística con Gregorio Portilla (a.1691-d.1752), Pablo Villazán (1680d.1731) y Juan Manuel Becerril (h.1730-d.1781). La escultura de este momento llega desde los territorios limítrofes: Valladolid, Medina de Rioseco, Cantabria y Burgos.

\section{B- ANDALUCÍA}

Andalucía fue junto con Castilla los centros de producción escultórica más importantes del siglo XVII, si bien el primero se beneficia de una mayor variedad de artífices. En Castilla la personalidad de Fernández lo acaparó todo. Existen dos grandes escuelas: la sevillana y la granadina, cada una de las cuales ejerció influencia sobre otras provincias andaluces. A pesar de su "disputa artística" ambas urbes mantienen intercambios (Montañés se forma en Granada, mientras que Alonso Cano reside durante cierto tiempo en Sevilla) y características similares. Ambos fabrican junto a Gregorio Fernández las obras maestras de la escultura española de siglo XVII. La escultura andaluza tiene la particularidad, entre otras muchas, de haber desarrollado la escultura de barro cocido, en Castilla apenas la había practicado Juan de Juni. Muchas de las grandes personalidades de la escultura andaluza marcharon a Madrid con la intención de conseguir el 
prestigioso título de "escultor del Rey", por ejemplo, José de Mora y Luisa Roldán "Roldana". No hay que obviar que la escultura andaluza tuvo mucho tirón en la capital, casi más que la castellana, la cual apenas cuenta con lo realizado por Gregorio Fernández. Autores andaluces representados en la corte son Alonso Cano, Juan Martínez Montañés, Andrés de Ocampo, José de Mora, Pedro Roldán, Alonso de Mena, Pedro de Mena, la "Roldana"...

- $\underline{\text { Sevilla }}$

Los grandes maestros del barroco sevillano fueron Juan Martínez Montañés (1568-1649) (Fig. 6), en el siglo XVII, y Pedro Duque Cornejo, en el XVIII. El "Lisipo andaluz" nos ha legado una gran cantidad de obras maestras, lo cual hizo que Martín González le calificara como "una de las cúspides de la estatuaria española"44: el Cristo de la Clemencia y la Inmaculada de la catedral sevillana, el San Jerónimo penitente del Monasterio de Santiponce, el San Ignacio de Loyola de la catedral de Sevilla... Montañés es sin duda el contrapeso andaluz al castellano Fernández.

Continuador de la estética montañesina, aunque con caracteres propios, es Juan de Mesa (1583-1627), a quien se le debe alguna de las más bellas imágenes procesionales de la ciudad: el Jesús del Gran Poder (Fig. 7). Tras un tercio central de siglo bastante anodino, en el que tan solo destaca la familia Ribas, especialmente Felipe de Ribas (1609-1648), a finales de la centuria surgen tres grandes figuras: Pedro Roldán (16241699), la hija de este, Luisa Roldan "la Roldana" (1652-1706, escultora de cámara de Carlos II) y Francisco Ruiz Gijón (1653-1720). Ya en el siglo XVIII el artífice más cualificado es Pedro Duque Cornejo (1677-1757), también miembro de la familia Roldán ya que era hijo de José Duque Cornejo y Francisca Roldan, esta última hija del fundador de la estirpe, Pedro Roldán.

\section{- $\underline{\text { Granada }}$}

El foco granadino de la decimoséptima centuria se asienta sobre tres grandes pilares, quizás de los más acreditados de su época: Alonso Cano (1601-1667) (Fig. 8), Pedro de Mena (1628-1688) y José de Mora (1642-1724). El primero es un artista polifacético ya que además de su faceta escultórica cultiva de manera sobresaliente la pintura e incluso diseña trazas arquitectónicas para edificios y para retablos. Las llamadas de la Corte le vinieron en su calidad de pintor, no de escultor. Sus imágenes se caracterizan por ser de pequeño tamaño, pero con un acabado muy perfecto. Uno de sus mayores logros fue la creación de un modelo de Inmaculada, de forma ahusada, que goza de gran repercusión e influencia en épocas posteriores tanto en Andalucía como en Madrid. Uno de los escultores que trabajó el modelo canesco de Inmaculada fue Pedro de Mena. No le siguió servilmente, sino que tomándola como ejemplo la personalizó, de

$44 \quad$ Ídem, p. 131. 
manera que consiguió una Inmaculada completamente nueva y característica de su autor. A Mena le debemos la fijación de una gran cantidad de iconografías, especial relevancia tienen los diversos tipos de busto de Ecce Homo y Dolorosa, los cuales fueron ampliamente distribuidos. Encontramos ejemplos por todos los lados: Madrid, Valladolid, América, Zamora, Aragón, etc... No podemos olvidar otras dos iconografías que ayudó a popularizar, aunque durante algún tiempo se creyó que podía haberlas creado él: el San Francisco de Asís muerto y la Magdalena penitente (Fig. 9). Desde entonces, y sobre todo en Castilla y en Madrid, el número de copias es francamente abrumador. La fama de Mena fue tan sobresaliente que llegó a ser llamado desde la Corte madrileña por don Juan José de Austria. Además, llegó a ostentar el título de escultor de la catedral primada de Toledo.

El tercer artífice en discordia es José de Mora (Fig. 10), miembro de un taller familiar a la manera de los Ávila, Tomé, Churriguera, Mena, Roldán, Sierra, etc... El patriarca fue Bernardo de Mora, nacido en Palma de Mallorca, aunque posteriormente se traslada a Granada. Engendró a otros dos escultores: José y Diego de Mora, el primero de ellos el más importante de todos. José llegó a realizar para Carlos II "diferentes efigies de su devoción" 45 , lo cual le llevaría a ostentar el título de "escultor del rey". A pesar de su fama se le conocen muy pocas obras documentadas, lo que no ayuda a establecer una evolución.

Granada ve todavía en el siglo XVIII la actividad de importantes escultores. Son los casos de José Risueño (1655-1721) (Fig. 11) y Torcuato Ruiz del Peral (1708-1773) (Fig. 12). El primero se distinguió por la escultura en pequeño formato y por haberse aplicado tanto a la escultura en barro, en donde sin duda se muestra como uno de los mejores artífices, como a la madera. Por su parte, Ruiz del Peral fue discípulo de José de Mora. Al igual que Risueño practicó tanto la escultura como la pintura. Su obra más conocida es una Cabeza de San Juan Bautista que viene a ser un eslabón más dentro de la colección de santos degollados que se desarrolla en España a lo largo de los siglos XVII y XVIII, aunque con antecedentes en el XVI ${ }^{46}$.

\section{C- MADRID / LA CORTE}

La ciudad de Madrid nunca había destacado en la práctica de la escultura. Hasta este momento no contaba con artífices locales cualificados, tan solo fue residencia temporal de algunos artistas importantes como Francisco Giralte o Pompeo Leoni, a quienes puede considerarse como semillas en las que habría de germinar la escuela barroca madrileña, la cual iría "in crescendo" durante todo el siglo XVII. Al "olvido" de la escultura contribuyó de manera decisiva la preferencia en la Corte por la pintura.

\footnotetext{
$45 \quad$ Ídem, p. 228.

46 MARTÍN GONZÁLEZ, Juan José: “Cabezas de santos degollados en la escultura barroca española”, Goya: revista de arte, $\mathrm{n}^{\circ} 16,1957$, pp. 210-213.
} 
Los encargos más importantes, realizados fundamentalmente por el Rey y la nobleza, se hacían tanto a Castilla como a Andalucía. Del bando castellano las obras llegaban del taller de Gregorio Fernández, "el escultor de mayor primor que hay en mis Reinos", según palabras de Felipe IV, y Juan Rodríguez. Pero no solo llegaron obras de estos dos puntos. En Madrid se dieron cita algunos de los mejores escultores españoles, y europeos del momento. Son los casos del portugués Manuel Pereira (1588-1683) (Fig. 13); los castellanos Pedro Alonso de los Ríos (1641-1702), Alonso Grana (1690-1768), Juan Sánchez Barba (1602-1673) (Fig. 14), Manuel Gutiérrez; los catalanes Antonio Riera y José Ratés; los andaluces Martínez Montañés, Alonso de Mena, Pedro de Mena, Alonso Cano, José de Mora, la Roldana, Pedro Duque Cornejo etc...

Todos estos se unieron a los escasos escultores madrileños de renombre que por entonces ejercían su oficio. Gente como Antonio de Herrera Barnuevo (h.1585-1646), Sebastián de Herrera Barnuevo (1619-1671), Domingo de la Rioja o Miguel de Rubiales (1647-1713), del cual se conservan fotos de un espléndido paso procesional del Descendimiento, que contrasta bastante con el paso homónimo que Gregorio Fernández talló para la Cofradía Penitencial de la Santa Vera de Valladolid. Una personalidad muy definida es la de Fray Eugenio Gutiérrez de Torices, uno de los escasos cultivadores de la escultura en cera.

La importación de esculturas italianas tuvo gran trascendencia, especialmente de la napolitana. Son obras de firmas tan destacadas como Pietro Tacca, Gian Lorenzo Bernini o Domenico Guidi. Ejemplares napolitanos llegaron en número crecido, siendo las de mayor calidad las realizadas por el prolífico Nicola Fumo. También cuentan las iglesias y clausuras madrileñas con hechuras de Michele Perrone, Giacomo Colombo o

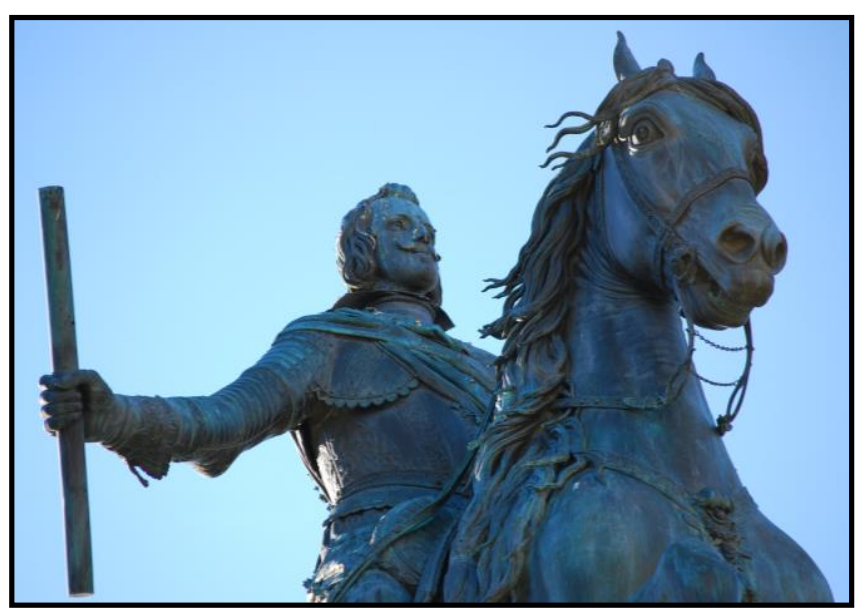

Il. 10- Pietro Tacca. Felipe IV a caballo. Plaza de Oriente. Madrid. Michelangelo Naccherino.

Llegado el siglo XVIII la escultura madrileña sobrepasa en importancia a otras escuelas, quedándose poco a poco, a lo largo del siglo, como el foco de mayor importancia. En esta centuria encontraremos dos tipos de escultura: la tradicional y la cortesana. Entre los participantes del barroco castizo figuran artífices tan acreditados como los asturianos Juan Alonso Villabrille y Ron (h.1663-h.1732) (Fig. 15) y Juan de Villanueva y Barbarles (1681-1765), el jienense Pablo González Velázquez, los vallisoletanos Luis Salvador Carmona (1708-1767) (Fig. 16) y Alejandro Carnicero (1693-1756), el toledano Juan Pascual de Mena (1707-1784) o el valenciano Felipe del Corral. La pujanza de la Corte derivó en la orfandad de diferentes territorios dado que sus hijos más celebrados emigraron a trabajar a Madrid conscientes de su valía. 


\section{2-3 LA ESCULTURA VALLISOLETANA CONTEMPORÁNEA A LOS "ÁVILA"}

Desde el siglo XVI Valladolid venía siendo centro de producción y consumo de escultura. En la ciudad se ubicaban diversos talleres que absorbían a maestros de otras procedencias, no hace falta recordar al palentino Alonso Berruguete o al francés Juan de Juni. En el siglo XVII llegan maestros procedentes de Galicia, entre ellos Juan Antonio de la Peña, Alonso de Rozas, o el mismísimo Gregorio Fernández. Valladolid en su momento de mayor esplendor llegó a exportar obras, además de a la totalidad de la actual provincia de Valladolid, al resto de las actuales provincias que conforman Castilla y León y a otros puntos más alejados como Madrid, Extremadura, Valencia, Galicia, Asturias, Cantabria e incluso, aunque de manera puntual, al País Vasco, Navarra, Portugal y a las colonias americanas.

Ya en el siglo XVIII el taller vallisoletano se nutre de maestros locales y otros procedentes de las cercanías. El foco pucelano aún gozaba de prestigio, el cual irá disminuyendo según nos aproximemos al fin de la centuria. Los maestros seguirán trabajando para diversos puntos de la actual comunidad de Castilla y León, lo que hace que la difusión de la estatuaria vallisoletana sea todavía un hecho, sobre todo por las tierras palentinas meridionales. Queda aún mucho por investigar en numerosas parroquias rurales de Ávila, Burgos, Palencia, Segovia y Zamora.

La historia de la escultura barroca en Valladolid se ha dividido habitualmente en dos grandes etapas: la primera, encarnada Gregorio Fernández, que ocupa el primer tercio del siglo XVII, y la otra, la verdaderamente barroca, abarca el último tercio del siglo XVII y la primera mitad del XVIII. Pienso que esta clasificación se puede matizar bastante más, como veremos a continuación. Solamente se tratará en profundidad las épocas coincidentes con la actividad de los Ávila.

$1^{\text {a) }}$ Primera etapa (1605-1636)

Esta primera época es la englobada por Gregorio Fernández, sus oficiales y discípulos directos. Las fechas corresponden al año en que tenemos documentada su primera obra en Valladolid y la del año de su óbito ${ }^{47}$.

47 Ver: MARTÍN GONZÁLEZ, Juan José: Escultura barroca castellana..., op. cit.; MARTÍN GONZÁLEZ, Juan José: Escultura barroca castellana. Segunda parte, Fundación Lázaro Galdiano, Madrid, 1971; MARTÍN GONZÁLEZ, Juan José: El escultor Gregorio Fernández, Ministerio de Cultura, Madrid, 1980; URREA FERNÁNDEZ, Jesús: “Acotaciones a Gregorio Fernández y su entorno artístico”, B.S.A.A., Tomo XLVI, 1980, pp. 375-396; FERNÁNDEZ DEL HOYO, María Antonia: "Oficiales del taller de Gregorio Fernández y ensambladores que trabajaron con él", B.S.A.A., Tomo IL, 1983, pp. 347-374; URREA FERNÁNDEZ, Jesús: "Escultores coetáneos y discípulos de Gregorio Fernández en Valladolid”, B.S.A.A., Tomo L, 1984, pp. 349-370; MARTÍN GONZÁLEZ, Juan José: Escultura barroca en España..., op. cit.; URREA FERNÁNDEZ, Jesús: "Escultores coetáneos y discípulos de Gregorio Fernández en Valladolid II”, Tomo LVIII, 1992, pp. 393-402; FERNÁNDEZ DEL 
Es la protagonizada por los imitadores y discípulos más inmediatos de Gregorio Fernández. Eso sí, al haber carecido este de un alumno aventajado "el panorama de la escuela en lo que restaba de siglo se integra por seguidores adocenados y meros copistas. Estos últimos forman legión" 48 . Apunta acertadamente Orueta a este respecto que "aunque no se formara en su taller ningún gran artista, quizás no haya un solo escultor en España hasta la invasión del arte francés que nos trajo Felipe V, que no tenga algo de él, que no reciba inspiración de sus obras y que no deba llamarse discípulo, o, por lo menos, seguidor suyo. No hay ningún maestro español que haya impreso tan profundamente la huella de su alma como Gregorio Fernández"49.

En estos momentos apenas existen obras que acusen una personalidad independiente, los comitentes demandaban modelos fernandescos y los artífices se doblegaban a ello. Efectivamente, utilizaban los modos de Fernández... pero no era Fernández. Todo ello conduce a una monotonía y similitud de estilos que hace que sea muy complicada la clasificación y atribución de multitud de obras anónimas que pueblan las iglesias, conventos y museos de gran parte de Castilla.

Si bien "son caracteres generales la falta de contacto con el extranjero y la escasa originalidad de los artistas, no pierde Valladolid la condición de centro de la escultura barroca castellana, en la región del Duero" ${ }^{50}$. La existencia de un buen maestro que rompiera con la tradición hubiera provocado una diversificación que habría enriquecido la escultura vallisoletana. La tradición fernandesca provocó cosas buenas (prestigio, encargos, mantenimiento de una escuela centenaria), pero también malas (repetición de modelos, ausencia de evolución, adocenamiento). A pesar de todo Valladolid seguirá siendo el taller de referencia en Castilla, tanto como punto de encargo de obras de cierta calidad como por ser polo de atracción de maestros foráneos. En opinión de Martín González esto se debía a "la existencia de buenos talleres, de ambiente artístico y de trabajo, pues, aun contando con la decadencia de la ciudad, precisa saber que las poblaciones de la periferia vivían una vida más lánguida"51. En épocas futuras sucederá justo lo contrario: Valladolid será la que envíe fuera a parte de sus mejores artífices, especialmente a la Corte. Son los casos, entre otros, de Pedro Alonso de los Ríos (1641$1702)^{52}$, Alonso de Grana (1690-1768) $)^{53}$, Alejandro Carnicero (1693-1756) ${ }^{54}$ y Luis Salvador Carmona $(1708-1767)^{55}$.

HOYO, María Antonia: "Ensambladores del círculo de Gregorio Fernández: los Velázquez y Beya", B.R.A.C., Tomo XLIV, 2009, pp. 47-60.

$48 \quad$ MARTÍN GONZÁLEZ, Juan José: Escultura barroca castellana..., op. cit., p. 135.

49 ORUETA, Ricardo de: Gregorio Fernández / La expresión de dolor en la escultura castellana, Museo Nacional de Escultura, Valladolid, 2013, p. 26.

50 MARTÍN GONZÁLEZ, Juan José: Escultura barroca castellana..., op. cit., p. 135.

51 Ídem, p. 279.

52 Ver: BARRIO MOYA, José Luis: "El arquitecto Manuel García y el escultor Pedro Alonso de los Ríos en el convento de Nuestra Señora de la Cruz en Cubas de la Sagra", B.S.A.A., Tomo XLVIII, 1982, pp. 438-441; BARRIO MOYA, José Luis: "El escultor vallisoletano Pedro Alonso de los Ríos: aportación documental", B.S.A.A., Tomo LXIII, 1997, pp. 411-425; BARRIO MOYA, José Luis: "Los relieves del Trasaltar de la Catedral de Burgos, obra de Pedro Alonso de los Ríos y otras noticias sobre el 
Pienso que la fecha límite de este etapa podría ser el año 1660 por cuanto en él confluyen diversos hechos importantes: los fallecimientos de Francisco Alonso de los Ríos $^{56}$ y Bernardo del Rincón ${ }^{57}$, últimos discípulos y competidores directos del gran maestro, y la datación de la primera obra de Alonso de Rozas, el cual ya se encontraba establecido en la ciudad, al menos, desde mediados del año $1654^{58}$.

\section{$3^{\text {a) }}$ Tercera etapa (1660-h.1685)}

Cuando en 1667 Juan de Ávila comienza su aprendizaje la escultura vallisoletana no pasaba por su mejor momento: acababan de fallecer los últimos discípulos directos (Bernardo del Rincón, 1621-1660) y “competidores” de Fernández (Francisco Alonso de los Ríos, h.1595-1660), y no había otros escultores que sostuvieran la escuela.

Aparte de la inexistencia de una gran figura que hiciera olvidar a Fernández había otro problema que aún seguía vigente: a los nuevos escultores de mediados de siglo les estaba "vetado" el tener estilo propio, tampoco sabemos si hubieran querido o sido capaces de ello. El obstáculo infranqueable era el hecho de que los propios comitentes que les solicitaban obra seguían demandando los modelos popularizados por Fernández, y cuánto más se pareciera a ellos mejor. Si esta clientela no podía conseguir un original suyo al menos aspiraban a tener "algo" que se le pareciera.

Como vemos, aún existe "una verdadera fiebre por copiar a Fernández”. Sin embargo, "algunas copias son tan hábiles, sin embargo, que han pasado frecuentemente por originales de aquél" ${ }^{59}$. Véase, por ejemplo, el Nazareno de la parroquial de San Cebrián

artista", B.S.A.A., Tomo LVXII, 2001, pp. 247-248; AGULLÓ COBO, Mercedes: "El escultor Pedro Alonso de los Ríos (1641-1702)”, Boletín del Museo Nacional de Escultura, n 5, 2001, pp. 15-22.

$53 \quad$ El único estudio sobre su vida y obra lo encontramos en: TÁRRAGA BALDÓ, María Luisa: "El escultor vallisoletano Alonso de Grana”, Homenaje al profesor Martín González, Valladolid, 1995, pp. 447-452. Para su obra en la galería de reyes del Palacio Real de Madrid: PLAZA SANTIAGO, Francisco Javier de: Investigaciones sobre el Palacio Real Nuevo de Madrid, Universidad de Valladolid, Valladolid, 1975.

$54 \quad$ Existen multitud de artículos acerca de su persona y sobre alguna de sus obras en particular. La recopilación de toda la bibliografía y el estudio monográfico más completo es: ALBARRÁN MARTÍN, Virginia: El escultor Alejandro Carnicero entre Valladolid y la Corte (1693-1756), Diputación de Valladolid, Valladolid, 2012, p. 56.

55 Dos son las grandes monografías sobre el artista: GARCÍA GAINZA, María Concepción: El escultor Luis Salvador Carmina, Universidad de Navarra, Navarra, 1990; MARTÍN GONZÁLEZ, Juan José: "Luis Salvador Carmona: escultor y académico", Alpuerto, Madrid, 1990. A esto hemos de añadir el catálogo de una reciente exposición: URREA FERNÁNDEZ, Jesús: Luis Salvador Carmona: 1708-1767 [exposición], Diputación de Valladolid, Valladolid, 2009. Además, existen multitud de artículos que completan su vida y obra, muchos de ellos recogidos en las publicaciones comentadas.

56 Ver URREA FERNÁNDEZ, Jesús: "El escultor Francisco Alonso de los Ríos ¿-1660), B.S.A.A., Tomo XXXVIII, 1972, pp. 355-369. URREA FERNÁNDEZ, Jesús: “Escultores coetáneos y discípulos de Gregorio Fernández en Valladolid II”, op. cit., pp. 397-398.

57 Ver FERNÁNDEZ DEL HOYO, María Antonia: "El Cristo del Perdón, obra de Bernardo del Rincón”, B.S.A.A., Tomo IL, 1983, pp. 476-480.

$58 \quad$ A.H.P.V., Leg. 2.352, f. 254.

59 MARTÍN GONZÁLEZ, Juan José: Escultura barroca castellana..., op. cit., p. 136. 
de Campos, considerada en un primer momento de Fernández, en la actualidad no hay dudas de que su factura se debe a Alonso de Rozas.

Uno de los motivos por los cuales la escuela vallisoletana de estos momentos mantuvo el prestigio y una nutrida clientela fue, además de por la demanda de copias de Gregorio Fernández, por la fabricación de pasos procesionales, a imitación de los vallisoletanos, para diferentes puntos de las actuales provincia de Valladolid y comunidad de Castilla y León ${ }^{60}$. Los más generalizados fueron el Oración del Huerto, Atado a la Columna, Ecce Homo, Camino del Calvario, Despojo, Descendimiento y Santo Entierro. Podemos encontrar por ambos territorios multitud de pasos a imagen y semejanza de los pucelanos, algunos anónimos, pero otros con el sello de alguno de los escultores que se citarán a continuación.

La ciudad de Valladolid contaba por entonces con muy pocos artífices, siendo sus mayores figuras Francisco Díez de Tudanca (1616-1689) y Alonso de Rozas (h.16251681), este último llegado providencialmente de tierras gallegas para elevar el nivel de la escuela vallisoletana y dar los primeros pasos para crear una verdadera escultura "barroca", es decir, movida. Otros escultores a destacar son el salmantino Juan Rodríguez (a.1616-d.1674), que dejó en la ciudad muestras de su buen hacer hasta que marchó a Salamanca en 1661, fue un artista fecundo y con una clientela bastante distinguida, como por ejemplo la Marquesa de Astorga ${ }^{61}$; y los vallisoletanos José Mayo (1642-1679/1680), discípulo de Díez de Tudanca; Pedro Salvador "el joven" (16351684), hijo y sobrino de oficiales de Gregorio Fernández; y Andrés de Oliveros (16391689). En todos ellos se aprecia un incremento de las quebraduras, lo que aumenta el "carácter pictórico del paño barroco y del movimiento"62. Siempre nos quedará la duda de cómo habría evolucionado la escuela vallisoletana si Bernardo del Rincón y José Mayo no hubieran fallecido en plena madurez artística, es un caso similar al ocurrido años antes con el abuelo del primero, Francisco del Rincón.

Francisco Díez de Tudanca es el gran dominador, le llovían los encargos. Los motivos para esta supremacía en el mercado escultórico vallisoletano no les hemos de buscar en su calidad sino en lo económico de sus precios. Ya comentó Martín González respecto a sus aptitudes que aunque "se perciben influjos de Fernández, Díez de Tudanca acredita ser un escultor poco inspirado"63. La popularidad de su taller llevó a que muchos padres cuyos hijos sintieron un deseo de practicar dicho arte les asentaran allí para que Tudanca les enseñara los rudimentos de la escultura y así poder labrarse un futuro.

\footnotetext{
60 Para ahondar en este aspecto y consultar bibliografía específica: BALADRÓN ALONSO, Javier: "Nuevas obras de Francisco Díez de Tudanca y otros datos de escultores barrocos vallisoletanos", B.S.A.A., Tomo LXXVIII, 2012, pp. 153-170.

61 Sobre Juan Rodríguez: URREA FERNÁNDEZ, Jesús: “Escultores coetáneos y discípulos de Gregorio Fernández en Valladolid”, Tomo L, 1984, pp. 349-370; RODRÍGUEZ DE CEBALLOS, Alfonso y CASASECA CASASECA, Antonio: "Escultores y ensambladores salmantinos de la segunda mitad del siglo XVII", B.S.A.A. Tomo LII, 1986, pp. 321-342.

62 MARTÍN GONZÁLEZ, Juan José: Escultura barroca castellana..., op. cit., p. 135.

63 MARTÍN GONZÁLEZ, Juan José: Escultura barroca en España..., op. cit., p. 74.
} 
La otra gran personalidad del momento, Alonso de Rozas, es mucha más creativa, llegó incluso a codificar nuevas iconografías, algo extraordinario ya que desde Fernández nadie lo había logrado. Rozas vendría a Valladolid con la esperanza de seguir los pasos de su compatriota Gregorio Fernández. A pesar de que no se les puede comparar, llegó a ser el escultor de mayor importancia que residió en la ciudad durante este periodo. Su importancia radica en que fue el encargado de evolucionar los modos y tipos de Fernández. A lo largo de su obra veremos "que es sensible a los nuevos tiempos, que reclaman mayor dinamismo"64. La Asunción que talla para el retablo mayor de la iglesia de Santa María, de Tordesillas, da buena muestra de ello: otorga un mayor movimiento y barroquismo a esculturas que en el fondo seguían siendo deudoras del genio de Sarria.

Al contrario de Tudanca, su taller parece que no fue tan demandando, pero por su obra documentada sí que le podemos calificar como un buen escultor. Tudanca tenía la fama, pero Rozas las aptitudes. Si comparamos el catálogo de ambos observamos que pertenecen a dos "mundos diferentes": la obra documentada de Tudanca es muy amplia, por lo general bastante mediocre, si bien la mayoría ha desaparecido o ignoramos su paradero; en cambio, la de Rozas es bastante más reducida, aunque de una calidad más sostenida. En cuanto a los comitentes: a Tudanca acudieron muchos particulares, parroquias rurales pertenecientes a diferentes provincias de la actual Castilla y León, llegando incluso a tierras extremeñas (Hervás y Montehermoso de Coria), y varias instituciones vallisoletanas: la Cofradía Penitencial de la Pasión, el Convento de San Francisco y el de los Trinitarios Calzados; en cambio, la clientela de Rozas se nos muestra más distinguida: parroquias y conventos rurales importantes (iglesia de Santa María de Tordesillas, conventos de Santa Clara de Medina de Rioseco y de San Zoilo de Carrión de los Condes), colegiatas (Villagarcía de Campos), catedrales (Palencia, Zamora, y, posiblemente, Valladolid), instituciones religiosas de otras ciudades cercanas (iglesia de San Pedro de Zamora, Monasterio de San Pelayo de Oviedo), e, incluso, cofradías vallisoletanas (la de las Angustias). Por lo tanto, podemos concluir que mientras que Tudanca hacía una escultura bastante popular para instituciones más modestas salvo honrosas excepciones, caso del vallisoletano Convento de San Francisco.

\section{$\left.4^{a}\right)$ Cuarta etapa (h.1685-1714)}

A finales del siglo XVII y primeros años del XVIII "los recuerdos de Fernández van paulatinamente desvaneciéndose. Es verdaderamente un momento de transición. Los pliegues se suavizan poco a poco, acabando por desaparecer las quebraduras a lo Fernández" ${ }^{65}$. A pesar de todo algunos modelos iconográficos creados por el gallego siguen utilizándose más o menos fielmente. Véase las Inmaculadas, imágenes de Santa Teresa, Crucificados, etc... 
Si en la etapa anterior veíamos que la producción escultórica estaba destinada fundamentalmente a los pasos procesionales y a imágenes de devoción, en estos momentos la mayoría de la producción se utilizó para rellenar los múltiples retablos que por entonces se hicieron en la ciudad: Convento de las Brígidas, Real Monasterio de San Quirce, iglesia-oratorio del Rosarillo, oratorio de San Felipe Neri, iglesia de Santiago Apóstol, etc... A estas alturas la escultura de los retablos se concentraba en la hornacina principal, las laterales, el Calvario de la portada del ático y a los lados de este otros santos o bien los típicos ángeles. Martín González define perfectamente este hecho: "Un buen plantel de escultores se aplica a la tarea de dotar de iconografía a los retablos. La escultura procesional se encuentra ya en su ocaso"66. A pesar del barroquismo de los retablos este no se ve correspondido por el de las tallas que los adornan. Se ha llegado a afirmar en múltiples ocasiones que en el Valladolid del siglo XVII "ningún escultor fue más barroco que Gregorio Fernández en el Santo Domingo, de la iglesia de San Pablo"67. Si bien los pliegues se elaborarían con las mismas quebraduras, estas poco a poco se fueron suavizando y relegándose a la parte baja de las tallas.

Como acabamos de decir, la fabricación de escultura procesional había decaído bastante. A pesar de todo se llegaron a realizar una serie de piezas que podemos clasificar en dos grupos: por un lado las cofradías vallisoletanas encargaron a los escultores que volvieran a tallar ciertos pasos, o imágenes sueltas, para sustituir a otros anteriores (paso del Despojo, el Crucifijo del "Paso Grande" de los Nazarenos y los ángeles del Santo Sepulcro de la Cofradía de las Angustias), mientras que por otro se tiene constancia tan solo de dos encargos foráneos, los pasos del Camino del Calvario y de Longinos para la cofradía de Jesús Nazareno de Palencia ${ }^{68}$.

Llegados a estos años finales del siglo XVII, en el que todavía trabajaban algunos de los escultores anteriormente mencionados, los talleres vallisoletanos comienzan a vivir una segunda juventud: en la ciudad surgen grandes maestros como Juan de Ávila (16521702) y José de Rozas (1662-1725), a los que hay que añadir la llegada de otros artífices de primera categoría, caso del gallego Juan Antonio de la Peña (h.1650-1708). A estos se sumaron otros escultores foráneos, como los burgaleses Andrés de Pereda (h.16551733) y Ventura Fernández (h.1654-1699), y locales, Antonio Vázquez (1650-1700) y Vicente Díez (1649-d.1708). Un poco posterior, y quizás el último escultor que fue ajeno al influjo foráneo, fue el hijastro de José de Rozas, Joseph Pascual (1677-1714). Maestro bastante prometedor pero que falleció en plena madurez artística. Un nuevo caso de esperanza truncada que tanto se dio en el arte barroco español.

Salvando a los tres grandes maestros de este periodo el resto aún son bastante mal conocidos, si bien no cabe duda de que pusieron su granito de arena para que el taller vallisoletano volviera a ser el más importante de todo el norte español. Los encargos

\footnotetext{
66 MARTÍN GONZÁLEZ, Juan José: “Arquitectura, urbanismo...”, op. cit., p. 154.

67 MARTÍN GONZÁLEZ, Juan José: Escultura barroca en España ..., op. cit., p. 77

68 GARCÍA CUESTA, Timoteo: "La Cofradía de Jesús Nazareno en Palencia”, B.S.A.A., Tomo XXXVI, 1970, pp. 111-120.
} 
volvieron a llegar desde los lugares más dispares: Galicia, Asturias, Cantabria, País Vasco, Navarra, Extremadura, etc..., por no hablar de las innumerables peticiones realizadas desde las provincias castellanas.

\section{$\left.5^{a}\right)$ Quinta etapa (1714- ¿1780?)}

En esta última etapa las lecciones de Gregorio Fernández han sido ya plenamente superadas, si bien algunas veces encontraremos tallas que sigan los modelos del maestro, aunque su estilo ya nada tendrá que ver con él. Es un periodo en el que entran de lleno las corrientes europeas, aunque muchos escultores no participarán de ellas. Dos son los artífices que nos muestran estos nuevos aires foráneos: Pedro de Ávila y Pedro de Sierra. Ávila será el primero que haga uso de los pliegues a cuchillos creados y popularizados por Gian Lorenzo Bernini más de medio siglo atrás. Es por tanto una influencia italiana. La otra, la francesa, tiene por embajador a Pedro de Sierra, el cual recibe influjos galos en las obras del Palacio Real de La Granja de San Ildefonso de manos de los escultores René Frémin y Jean Thierry. Esta influencia se hará notar en la delicadeza y dulzura de las tallas, con unas formas más bellas y agradables a la vista.

El influjo francés en Sierra se manifiesta por vez primera en las esculturas de la fachada de la iglesia de Santa Cruz, de Medina de Rioseco (1726), mientras que el berninesco lo había hecho en 1712 cuando Pedro de Ávila talla las imágenes de San Ildefonso y San José para la localidad zamorana de Morales de Toro. Conocemos de dónde le viene la influencia a Sierra, aún es una incógnita como Pedro de Ávila llegó a conocer aquél tipo de paño.

La fecha final de este periodo no está clara, algunos piensan que el barroco comenzó a declinar en 1750, Martín González en su libro Escultura barroca en España da el de 1770. Pienso que la fecha más aproximada al fin de la escultura barroca en nuestra ciudad es la de 1780, puesto que es a finales de la década anterior cuando nuestro último gran escultor barroco, Felipe de Espinabete, hace sus últimas obras de manera continuada. Es una fecha muy tardía pero no hemos de olvidar que desde hacía tiempo las novedades artísticas llegaban a la ciudad con gran retraso. Alguna vez se ha querido retrasar aún más este final, esgrimiendo que el barroco desaparece cuando fallece Claudio Cortijo (1813). Bien pudo existir hasta entonces una rama barroca, pero el neoclasicismo ya se había impuesto con escultores con Eustaquio Bahamonde, Pedro León Sedano y otros.

Una característica que diferenciará a algunos escultores de este periodo de otros anteriores es que no se dedicaran en exclusiva a la talla de imágenes, sino que también se ocuparán del diseño y fábrica de retablos. Es decir, además de escultores serán ensambladores, lo que da lugar a la denominación de tallista, muy popular en esta época. Respecto a esto recordar la cita de Martín González, que dice así: "El retablo constituye el mejor exponente de la evolución escultórica. En él coinciden el ensamblador y el escultor. Ciertamente ambas profesiones son diferentes, pero pueden 
coincidir. Lo normal es que un retablo se concierte con un ensamblador; puede él mismo hacer la escultura o subcontratarla con otro maestro de tal especialidad"69. Entre estos tallistas destacan nombres como los de Pedro Correas (1689-1752), Pedro de Sierra (1702-1760/1761) y Pedro Bahamonde (1707-1748).

Además de estos tres escultores, el otro gran protagonista es Felipe Espinabete (17191799), "digno broche de la escuela vallisoletana" ", cuya producción se extiende a lo largo de la segunda mitad de la centuria. A estos hemos de añadir al semidesconocido José Fernández (a.1719-d.1776) y las aportaciones puntuales de dos maestros establecidos durante cierto tiempo en nuestra ciudad, de los cuales ignoramos dónde se produjo su nacimiento y su formación: Manuel Valero Alhambra (a.1705-d.1737) y Juan Antonio Argüelles (a.1718-d.1766).

En los momentos previos al fallecimiento de Pedro de Ávila (1755) se empezaron a formar los escultores que dominarían la escuela vallisoletana de la segunda mitad del siglo, otros acababan de abrir taller propio. Este grupo lo conforman nombres Andrés Carballo (h.1720-1792) ${ }^{71}$, Juan Macías (1721-1802) $)^{72}$, Fernando González (17241806) ${ }^{73}$, Antonio Bahamonde (1731-1783) ${ }^{74}$, Pedro León Sedano (1736-1809) y Juan López (h.1730-d.1798) ${ }^{75}$. El más joven de todos, Claudio Cortijo (1748-1813), será el último representante de la plástica barroca en la ciudad, con él se extingue la afamada escuela. Muchas de las esculturas dieciochescas que pueblan las iglesias y retablos de la ciudad de Valladolid y su provincia probablemente se deban a estos semidesconocidos artífices que se debatieron entre el último barroquismo y los albores neoclásicos, el cual solamente se pudo imponer tras la creación de la Real Academia de Bellas Artes de la Purísima Concepción en el año $1779^{76}$.

A continuación, se tratará de forma pormenorizada las personalidades más destacadas que trabajaron en Valladolid durante los años que vivieron los Ávila, es decir entre 1652-1757 (aprox.). Las fichas contienen los datos biográficos básicos y una relación de sus obras documentadas. En esta lista no figuran Francisco Díez de Tudanca, Antonio de Gautúa ni Felipe Espinabete por cuanto he creído más conveniente tratar sobre ellos al hablar de los maestros y los discípulos de Juan y Pedro de Ávila.

\footnotetext{
69 MARTÍN GONZÁLEZ, Juan José: Escultura barroca en España..., op. cit., p. 447.

70 MARTÍN GONZÁLEZ, Juan José: Escultura barroca castellana..., op. cit., p. 137.

71 Ver: ARRIBAS, Filemón: "Dos censos vallisoletanos de artistas", B.S.A.A., XIV, 1947-1948, pp. 232-237; BALADRÓN ALONSO, Javier: op. cit., pp. 153-170.

72 Ver: ARRIBAS, Filemón: "Dos censos...", op. cit., pp. 232-237; BALADRÓN ALONSO, Javier: op. cit., pp. 153-170.

73 Ver: URREA FERNÁNDEZ, Jesús: “El escultor Fernando González (1725-?), B.S.A.A., Tomo LIX, 1993, pp. 465-470; PAYO HERNANZ, René Jesús: El retablo..., op. cit., pp. 379-393.

74 Ver: PARRADO DEL OLMO, Jesús María: "Precisiones sobre los Bahamonde", B.S.A.A., Tomo LV, 1989, pp. 343-356; REDONDO CANTERA, María José: Los Bahamonde, una familia de artistas dedicados al retablo en Valladolid y Palencia: desde el barroco tardio hasta su disolución, Xunta de Galicia, 2002, pp. 288-312.

75 Ver: ARRIBAS, Filemón: "Dos censos...”, op. cit., pp. 232-237; BALADRÓN ALONSO, Javier: op. cit., pp. 153-170.

76 PRIETO CANTERO, Amalia: Historia de la Real Academia de Nobles y Bellas Artes de la Purísima Concepción de Valladolid, Institución Cultural Simancas, Valladolid, 1983.
} 
El conocimiento de buena parte de los escultores sobre los que se hablará a continuación es muy precario, lo que conlleva a que algunos dispongan de un catálogo muy reducido, problema que, a buen seguro, se solucionará con un profundo rastreo archivístico. En otras ocasiones los datos se hayan dispersos en multitud de artículos o libros, por lo que convendría una publicación que realizara una puesta al día de la escultura barroca vallisoletana. El orden de aparición de los escultores está basado en la fecha de nacimiento de los mismos.

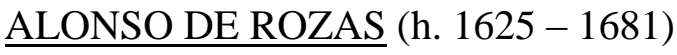

Alonso de Rozas ${ }^{77}$ el gran maestro del tercer cuarto de siglo de la escuela vallisoletana. Llega a Valladolid, como otros muchos escultores gallegos, para aprender, o perfeccionar, el oficio de escultor esperanzado en poder seguir los pasos de su compatriota Gregorio Fernández. Al llegar a la ciudad encuentra un ambiente totalmente impregnado por el recuerdo del maestro de Sarriá, y eso que ya habían pasado muchos años desde su fallecimiento. Este es el punto de partida desde donde Rozas desarrolla su propio estilo, a él ira incorporando un progresivo barroquismo localizado en las actitudes y en la multiplicación de pliegues, que poco a poco irán alejándose de esa rigidez y envaramiento tan característico de Fernández.

García Chico define el estilo de Rozas, al igual que el del resto de epígonos de Fernández de la segunda mitad del siglo XVII, como un arte "vulgar, casero, sin horizontes, pobre de matices y sin alma"78. Por su parte Martín González asevera que "fue otro firme reducto del arte de Fernández en el tercer cuarto del siglo XVIII. Sin embargo, que es sensible a los nuevos tiempos, que reclaman mayor dinamismo, lo apreciamos en su Asunción de las Claras de Medina de Rioseco, posiblemente su mejor obra"79. Una opinión más actual, y a la vez positiva, de la figura de Rozas nos la ofrece Pérez de Castro: “Alonso Fernández de Rozas fue uno de los escultores más importantes del segundo tercio del siglo XVII. Su importancia viene dada además por ser uno de los maestros que evolucionaron partiendo de las formas Fernández hacia una concepción diferente de la escultura" 80 . Lorena García nos proporciona la frase que mejor define, en mi opinión, el arte de Alonso de Rozas: "Entre los seguidores de Gregorio

77 CEÁN BERMÚdEZ, Juan Agustín: op. cit., Tomo IV, p. 255; GARCÍA CHICO, Esteban: Documentos para el estudio del arte en Castilla. 2..., op. cit., pp. 328-331; MARTÍN GONZÁLEZ, Juan José: "Documentación de las obras de escultura de la capilla del Relicario de la Colegiata de Villagarcía de Campos", B.S.A.A., tomo XX, 1953-1954, p. 207; MARTÍN GONZÁLEZ, Juan José: Escultura barroca castellana..., op. cit., pp. 298-302; URREA FERNÁNDEZ, Jesús: "La capilla de D. Gabriel López de León en la iglesia de San Pedro de Zamora”, B.S.A.A., Tomo LI, 1985, pp. 500-506; MARTÍN GONZÁLEZ, Juan José: Escultura barroca en España ..., op. cit., p. 76.

78 GARCÍA CHICO, Esteban: Documentos para el estudio del arte en Castilla. 2 ..., op. cit., p. 331. MARTÍN GONZÁLEZ, Juan José: Escultura barroca castellana..., op. cit., p. 136. PÉREZ DE CASTRO, Ramón: "La huella de Gregorio Fernández y la escultura del siglo XVII
en Medina de Rioseco". En PÉREZ DE CASTRO, Ramón y GARCÍA MARBÁN, Miguel (coord.): Cultura y arte en Tierra de Campos. I Jornadas Medina de Rioseco en su historia, Diputación Provincial de Valladolid, Valladolid, 2001, p. 166. 
Fernández figura el escultor de la escuela vallisoletana Alonso de Rozas, cuya gubia sigue la estela del gallego, sin llegar a proporcionar obras creativas" $"$.

De lo que no cabe ninguna duda es que la dispersión y la importancia de algunos de esos encargos pregonan la fama que alcanzó. Existe un foco importante que se benefició de la impronta de Rozas: Oviedo. Cuando Rozas acude a tallar las esculturas para el Convento de San Pelayo de la capital del Principado lo hace con su discípulo Antonio Borja, el cual se convertirá en el gran protagonista de la escuela asturiana del último cuarto del siglo XVII y primeros años de la siguiente centuria. Para Ramallo Asensio, la huella de Rozas "no se perdió y tuvo fundamental importancia para la evolución de la escultura asturiana, por haber tenido como oficial a Antonio Borja", el cual elevó "el nivel de calidad y difundiendo el cambio de estilo propugnado por Rozas" $"$. Otro de los logros de Alonso de Rozas fue el de haber creado un modelo iconográfico para representar a San Fernando, para lo cual siguió un grabado de Claude Audran ${ }^{83}$.

Alonso Fernández de Rozas nace en Santa María de Germán o Termar "obispado de Mondoñedo en el reino de Galicia" hacia el año $1625^{84}$, siendo sus padres Amaro de Rozas e Inés Fernández. El documento más antiguo que le sitúa en Valladolid es un arrendamiento realizado por el escultor Juan Rodríguez el 4 de julio de 1654 de una casa "en la plazuela del Almirante junto a la iglesia de las Angustias". Rozas firma como testigo ${ }^{85}$, ¿puede significar esto, unido a la proximidad estilística entre ambos, el que Rozas haya sido discípulo de Rodríguez?

El 17 de julio de 1656 firma las capitulaciones matrimoniales junto a su futura mujer, Isabel Fernández, y los padres de ésta, el cerrajero Gregorio Fernández e Isabel de Montoya $^{86}$. El matrimonio tuvo muchos hijos, entre los cuales figura el futuro escultor José de Rozas: Felipe (1657), después llegarían Isabel (1658), María Damiana (1659), José Antonio (1662), Isabel María (1664), Teresa “primera” (1666), Juan (1670), Teresa "segunda" (1672), y Manuel (1676) ${ }^{87}$. La familia residió toda su vida en el barrio de San Miguel, desde antes de junio de 1668 moraba en unas casas en la plazuela del Conde de Nieva "que lindan con casas de la Cofradía de Ánimas y Sacramento de dicha iglesia y casa del señor don Juan de Arce y Otalora"88.

Rozas fue un hombre comprometido tanto con su oficio como con la iglesia parroquial a la que acudía a orar. Así, le veremos en el año 1661 interviniendo en la defensa de los

81 GARCÍA GARCÍA, Lorena: Evolución del patrimonio religioso en Carrión de los Condes, Palencia, desde la Baja Edad Media hasta nuestros días (tesis doctoral inédita), Universidad de Valladolid, Valladolid, 2012, p. 203.

82 RAMALLO ASENSIO, Germán: Escultura barroca en Asturias, Instituto de Estudios Asturianos, Oviedo, 1985, p. 292

83 URREA FERNÁNDEZ, Jesús: “San Fernando en Castilla y León”, B.S.A.A., Tomo LII, 1986, pp. 484-487.

84 GARCÍA CHICO, Esteban: Documentos para el estudio del arte en Castilla. 2..., op. cit., p. 331.

85 A.H.P.V., Leg. 2.352, f. 254.

86 GARCÍA CHICO, Esteban: Documentos para el estudio del arte en Castilla. 2..., op. cit., p. 331.

87 A.G.D.V., San Miguel, 1644B, ff. 243, 258, 275, 402, 434, 455, 477. A.G.D.V., San Miguel, 1669B, ff. 35, 81.

88 URREA FERNÁNDEZ, Jesús: “La capilla...”, op. cit., p. 506. 
intereses de su gremio, ganando, junto con otros compañeros, el pleito denominado " $d e l$ soldado"89; y en 1679 siendo nombrado mayordomo de fábrica por el periodo de un año de la desaparecida iglesia parroquial de San Miguel $^{90}$.

El 31 de julio de 1670 renuncia y traspasa a su hermano Juan de Rozas, "vecino de la feligresía de Santa María de Termar, obispado de Mondoñedo, reino de Galicia (...) el derecho y acción y otro cualquier asunto que en cualquier manera me pertenezca o pueda pertenecer de todos los bienes muebles y raíces" que le tocaban por el fallecimiento de sus padres ${ }^{91}$. A cambio de esta renuncia su hermano le habría de abonar 1.110 reales de vellón.

El 29 de enero de 1680 tenemos noticia de que Alonso de Rozas se había encargado de tasar "toda la herramienta del oficio de escultor" que dejó José Mayo tras su fallecimiento ${ }^{92}$.

El 4 de marzo siguiente le encontramos en la ciudad de Oviedo concertándose con el Convento de religiosas de San Pelayo el Real para realizar unas esculturas para el retablo mayor que por entonces acabada de construir el ensamblador leonés José de Margotedo $^{93}$. Se trataba de Nuestra Señora de la Asunción, San Pelayo, San Juan Bautista, San Juan Evangelista, "y asimismo los bultos de los ángeles y serafines". Apenas un mes después, el 7 de abril, Rozas y el convento vuelven a firmar un nuevo contrato en el que se realizaban adiciones y cambios ${ }^{94}$. El escultor debió de fallecer en Oviedo poco después de finiquitar este trabajo. Ignoramos las circunstancias sobre su fallecimiento. Lo único claro es que el 27 de septiembre de 1681 encontramos en Oviedo a su viuda, Isabel de Montoya, otorgando carta de pago en favor del citado convento con motivo de haber percibido toda la cantidad que se adeudaba a su marido ${ }^{95}$.

La estela de Rozas la seguirían, además de su hijo José, los dos únicos aprendices que hemos logrado documentar: el 15 de junio de 1674 recibe en su taller a Juan Marcos, el cual debería aprender "el arte de escultor" durante cinco años que empezarían a contarse desde ese mismo día ${ }^{96}$, mientras que el 2 de febrero de 1680 se comprometía a enseñar el oficio a Baltasar Gómez a lo largo de los siete años que duraría el aprendizaje $^{97}$.

89 "RÓXAS (Alonso de) escultor y vecino de Valladolid, donde disputó con otros profesores acreditados el año de 1661 el pleito del soldado contra el corregidor de aquella ciudad, logrando ejecutoria de la chancillería a favor de las tres nobles artes. Véase Juárez (Manuel) pintor". CEÁN BERMÚDEZ, Juan Agustín: op. cit., Tomo IV, p. 255.

$90 \quad$ "Año nuevo de 1679 mayordomo de fábrica Alonso de Rozas". A.G.D.V., San Miguel, 1653D, f. 178.

91 URREA FERNÁNDEZ, Jesús: “La capilla...”, op. cit., p. 506.

92 A.H.P.V., Leg. 19.530, f. 89.

93 RAMALLO ASENSIO, Germán: Documentos para el estudio de la escultura barroca en Asturias, Instituto de Estudios Asturianos, Oviedo, 1991, pp. 129-132.

$94 \quad$ Ídem, pp. 133-134.

95 Ídem, pp. 134-135.

96 URREA FERNÁNDEZ, Jesús: “La capilla...”, op. cit., p. 506.

97 A.H.P.V., Leg. 2.786, f. 18 (1680). 
No poseemos ningún documento que lo confirme, pero creo que también se pudo formar en su taller el escultor de origen burgalés Andrés de Pereda, para ello me baso en la amistad que se entrevé entre Pereda, Alonso y José de Rozas en diversos documentos, camaradería que llega a su cenit en las capitulaciones matrimoniales de Pereda, en las cuáles Rozas figura como testigo. Además, sus nombres aparecen asociados en diversas obras. Quizás esta amistad pudiera proceder de los años de aprendizaje que ambos compartieron en el taller de Alonso de Rozas. No podemos olvidar que en la escasa obra documentada de Pereda se rastrea cierto influjo de Rozas.

\section{$\underline{\text { Catálogo }}$}

1660. Asunción para el retablo mayor. Iglesia de Santa María. Tordesillas

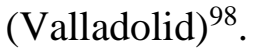

1661. Esculturas para el retablo mayor (la Asunción, San Juan, San Bartolomé, San Benito, San Félix y San Zoilo). Monasterio de San Zoilo. Carrión de los Condes $(\text { Palencia })^{99}$. Desaparecidas.

1663. Esculturas para el retablo mayor. Convento de Santa Clara. Medina de Rioseco (Valladolid) ${ }^{100}$. Aunque el retablo y algunas imágenes han desaparecido, todavía se conservan las imágenes del Crucificado, la Asunción, San Francisco de Asís con el Crucifijo y San Antonio de Padua.

1665. Cristo Crucificado (Fig. 17). Iglesia parroquial de la Asunción. Bercero $(\text { Valladolid })^{101}$.

1666. Inmaculada y relieve del tabernáculo del retablo mayor de la Capilla del Relicario. Colegiata de San Luis. Villagarcía de Campos (Valladolid) ${ }^{102}$.

1667. Cristo Crucificado. Convento de Nuestra Señora del Consuelo de Carmelitas Descalzos. Valladolid ${ }^{103}$.

1667. Virgen del Rosario y Jesús Nazareno para sendos retablos. Iglesia de los Santos Cornelio y Cipriano. San Cebrián de Campos (Palencia) ${ }^{104}$.

1669. San Marcos y unos ángeles. Colegiata de San Luis. Villagarcía de Campos $(\text { Valladolid })^{105}$.

1671. San Fernando. Catedral. Palencia ${ }^{106}$.

98 PARRADO DEL OLMO, Jesús María: "Nuevos datos sobre el retablo mayor de Santa María de Tordesillas", B.S.A.A., Tomo XLVIII, 1982, p. 436.

99 GARCÍA GARCÍA, Lorena: op. cit., pp. 203-204.

100 GARCÍA CHICO, Esteban: Documentos para el estudio del arte en Castilla. 2..., op. cit., pp. 328-333; PÉREZ DE CASTRO, Ramón: “La huella de Gregorio Fernández...”, op. cit., pp. 166-168.

101 URREA FERNÁNDEZ, Jesús: “La capilla...”, op. cit., p. 506.

102 MARTÍN GONZÁLEZ, Juan José: "Documentación...”, op. cit., p. 207; PÉREZ PICÓN, Conrado: op. cit., p. 150.

103 URREA FERNÁNDEZ, Jesús: “La capilla...”, op. cit., p. 506.

104 Ibídem.

105 MARTÍN GONZÁLEZ, Juan José: “Documentación...”, op. cit., p. 207. 
1671. San Fernando (Fig. 18). Catedral. Zamora ${ }^{107}$.

1673. Santa Inés para la hornacina central de uno de los retablos laterales de la capilla del Relicario. Colegiata de San Luis. Villagarcía de Campos (Valladolid) ${ }^{108 .}$

1674. Paso procesional del Santo Sepulcro o "de los Durmientes" (Fig. 19) para la Cofradía Penitencial de Nuestra Señora de las Angustias. Museo Nacional de Escultura. Valladolid $^{109}$. Se comprometió a realizar cuatro soldados y dos ángeles.

1675. Bultos funerarios de don Bentura de Onís y de $D^{a}$ Isabel de Onís para la iglesia del Convento de Jesús y María ${ }^{110}$. Desaparecidos.

1678. Esculturas para el retablo mayor de la Capilla de Gabriel López de León (Crucifijo, dos ángeles, dos virtudes y la Inmaculada Concepción) (Fig. 20). Iglesia de San Pedro. Zamora ${ }^{111}$.

1679. Se encuentra en Madrid realizando esculturas para los arcos de triunfo que se levantaron con motivo de la solemne entrada de la Reina María Luis de Orleans ${ }^{112}$.

1680. Esculturas del retablo mayor (seis santos, seis ángeles y una gloria de nubes y serafines). Monasterio de San Pelayo el Real ${ }^{113}$. Oviedo. Colaboró con él su discípulo Antonio Borja. Conjunto desaparecido.

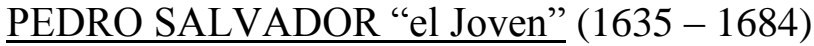

Pedro Salvador "el Joven" ${ }^{114}$, hijo y sobrino de dos oficiales de Gregorio Fernández ${ }^{115}$, nace en Valladolid el 8 de marzo de 1635, siendo bautizado el 1 de abril de ese mismo año en la iglesia de San Andrés ${ }^{116}$. Fueron sus padres Pedro Salvador y Ana de Castro, los cuales habían contraído matrimonio en la referida iglesia el 19 de marzo de $1633^{117}$.

El 22 de enero de 1667 recibe como aprendiz a Francisco Sanz, el cual debía permanecer en su taller cinco años, empezados a contar el 16 de enero de ese mismo

\footnotetext{
106 URREA FERNÁNDEZ, Jesús: “San Fernando...”, op. cit., p. 484.

107 Ídem, p. 487.

108 PÉREZ PICÓN, Conrado: op. cit., p. 152.

109 GARCÍA CHICO, Esteban: Documentos para el estudio del arte en Castilla. 2..., op. cit., pp. 333-335.

110 BRASAS EGIDO, José Carlos: "Noticias documentales...”, op. cit., p. 468.

111 URREA FERNÁNDEZ, Jesús: “La capilla...”, op. cit., p. 505.

112 CONDE DE POLENTINOS, "La Plaza Mayor y la Real Casa Panadería”, B.S.C.E., 1913, p. 37. ZAPATA, Teresa: La entrada en la Corte de María Luisa de Orleans: arte y fiesta en el Madrid de Carlos II, Madrid Fusión, Madrid, 2000, pp. 56, 113, 114, 133.

113 RAMALLO ASENSIO, Germán: Escultura..., op. cit., pp. 292-294.

114 Para consultar la bibliografía actualizada del escultor: BALADRÓN ALONSO, Javier: op. cit., pp. 156-158. Además: VERA, Juan de: "Una industria, una capilla y un linaje", Estudios Segovianos, Tomo LV, 1967, pp. 103-104

115 FERNÁNDEZ DEL HOYO, María Antonia, “Oficiales del taller...”, op. cit., pp. 347-374.

116 BALADRÓN ALONSO, Javier: op. cit., p. 157.

117 A.G.D.V., San Andrés, 1630M, f. 13.
} 
año ${ }^{118}$. En dicho tiempo le había de dar "hábil y suficiente para poderle usar y ejercer por oficial", cobrando por dicha tarea 400 reales. Además, se especifica que el aprendiz "debía asistir al dicho Pedro Salvador sólo a lo tocante al dicho oficio y no a otro ministerio". Años después, en 1679, tenemos documentada la llegada de otro aprendiz a su obrador: Manuel Díez ${ }^{119}$.

Vivió durante una temporada en una casa, arrendada a finales del año 1674, propiedad de " $D^{a}$ Beatriz de Astete y Monroy viuda del señor D. Juan de Arce y Otalora caballero de la dicha orden que fue del Consejo Supremo de Castilla", que linda "con la principal (del mayorazgo de los Astete) y hace esquina a la calle nueva a San Miguel de esta ciudad toda de arriba"120. Pedro Salvador "el joven" fallece el 30 de agosto de 1684, siendo su cuerpo sepultado en la iglesia de San Miguel $^{121}$.

Su obra nos le revela como un escultor de no muy altos vuelos, de hecho, Pérez de Castro le define como "un escultor de escasos recursos estéticos que sin embargo se suma a la moda imperante de la utilización de los pliegues múltiples y nerviosamente quebrados, de fuerte sentido decorativo y que vienen a ser un manierismo del estilo de Fernández. Los tipos son secos e inexpresivos y pueden enlazarse con las realizaciones de Tudanca o, sobre todo, Juan Rodríguez (Virgen del retablo mayor del convento de Jesús y María de Valladolid)" ${ }^{\prime 22}$.

Catálogo

1666. Cristo Resucitado. Iglesia de Santa María. Fuentepelayo (Segovia) ${ }^{123}$.

1668. La Asunción. Catedral. Valladolid ${ }^{124}$ ¿ ¿Desaparecida?

1669. Esculturas para el retablo de la capilla de José Fernández Isidro (Sagrada Familia, San Antonio, Santa Isabel y Santa Ana $)^{125}$ (Figs. 21-22). Iglesia de Santa Cruz. Medina de Rioseco (Valladolid).

1672. Relicario, puerta y custodia para el tabernáculo del altar mayor. Catedral. Valladolid $^{126}$. Desaparecidos.

1674. Peñasco para el trono de la Virgen de la Peña de Francia. Iglesia de San Martín. Valladolid $^{127}$.

\footnotetext{
118 A.H.P.V., Leg. 2.699/1, ff. 109-110.

119 BALADRÓN ALONSO, Javier: op. cit., p. 158.

120 A.H.P.V., Leg. 2.315, f. 1.113.

121 "En treinta de agosto de mil seiscientos y ochenta y cuatro murió y se enterró en mi parroquia Pedro Salvador hizo testamento ante Santiago Centeno escribano del rey nuestro señor y comisario del Santo Oficio, no dejó fundación ni declaró misa alguna más de la de cuerpo presente por no tener con que decirlas, testamentarios a mí el dicho cura y su mujer y por herederos a la dicha su mujer y sus hijas y lo firmé”. A.G.D.V., San Miguel, 1653D, f. 209.

122 PÉREZ DE CASTRO, Ramón: “La huella de Gregorio Fernández...”, op. cit., pp. 166-168.

GARCÍA CHICO, Esteban: Documentos para el estudio del arte en Castilla 2..., op. cit., p. 289.

MARTÍN GONZÁLEZ, Juan José: "Noticias documentales...”, op. cit., p. 189.

PÉREZ DE CASTRO, Ramón: "La huella de Gregorio Fernández...”, op. cit., pp. 177-180.

URREA FERNÁNDEZ, Jesús: "Noticias documentales...”, op. cit., pp. 531.
} 
1676. Cuatro esculturas para tres pasos procesionales: Oración en el Huerto (Cristo y Ángel), Cristo atado a la columna, Cristo de la Coronación de Espinas. Ermita de la Santa Vera Cruz. Ampudia (Palencia) ${ }^{128}$. Desaparecidos.

1677. San Bartolomé para el retablo mayor. Iglesia parroquial de San Bartolomé. Palazuelos de Eresma (Segovia) ${ }^{129}$.

Antes de 1680. Crucifijo y Santo Sepulcro para la Cofradía del Sepulcro. Tordesillas (Valladolid). Se desconoce con exactitud si se conservan ${ }^{130}$.

\section{ANDRÉS DE OLIVEROS $(1639$ - 1689)}

Andrés de Oliveros Pesquera ${ }^{131}$ nace en Valladolid a finales del año 1639. Sus padres, Alonso de Oliveros e Inés de Pesquera lo bautizaron en la iglesia de San Andrés el día 4 de diciembre de ese mismo año ${ }^{132}$. Toda su vida se encuentra ligada a esta parroquia: allí contraería matrimonio, bautizaría a sus hijos y hasta mandaría enterrarse en una de sus sepulturas. Nuestro escultor debía de tener algún parentesco con el canónigo Pesquera, patrón de la capilla de la Inmaculada de la referida iglesia ${ }^{133}$.

Se sabe que vivía "en la calle ancha del dicho barrio de Villanubla pasada la puentecilla como se va de la calle de Teresa Gil y al Convento de los Mercedarios Descalzos y al camino de la villa de Laguna a mano derecha"134. El 8 de noviembre de 1689 otorga testamento ${ }^{135}$, falleciendo al día siguiendo. Su cuerpo fue sepultado en la iglesia de San Andrés ${ }^{136}$.

$\mathrm{Su}$ obra por lo general apenas tiene interés. La mayoría no son más que mediocres copias de modelos creados por Gregorio Fernández. Uno de los ejemplos más flagrantes lo tenemos en las esculturas subsistentes de los pasos de Semana Santa que talló para

\footnotetext{
127 MARTÍN GONZÁLEZ, Juan José: Escultura barroca castellana ..., op. cit., p. 292.

128 BALADRÓN ALONSO, Javier: op. cit., pp. 157-158.

129 VERA, Juan de: op. cit., p. 104.

130 BALADRÓN ALONSO, Javier: op. cit., p. 157.

131 Para consultar la bibliografía actualizada del escultor: Ídem, pp. 158-159.

132 "Yo el licenciado Antonio Muñoz teniente de cura de ésta iglesia parroquial del señor San Andrés de ésta ciudad de Valladolid bauticé y puse los santos óleos según orden de nuestra santa madre iglesia a Andrés hijo legítimo de Alonso de Oliveros y Canosa e Inés de Pesquera, fueron sus padrinos el licenciado Bernardino de Pesquera Isabel de Quevedo, siendo testigos Sebastián de Benavente y el licenciado Andrés de Pesquera y Andrés de Muesinde y lo firmé en Valladolid a cuatro de diciembre de mil y seiscientos y treinta y nueve años”. A.G.D.V., San Andrés, 1620B, f. 251.

133 MARTÍN GONZÁLEZ, Juan José y URREA FERNÁNDEZ, Jesús: Catálogo Monumental de la provincia de Valladolid. Tomo XIV..., op. cit., p. 52.

$134 \quad$ A.H.P.V., Leg. 2.792, ff. 443-446.

135 A.H.P.V., Leg. 2.741, ff. 462-467.

136 "En la ciudad de Valladolid a nueve días del mes de noviembre de mil seiscientos y ochenta y nueve años murió Andrés de Oliveros mi parroquiano que vivía en la calle de los Labradores recibió todos los santos sacramentos dejó poder para testar a su yerno Andrés Salgado enterrose junto a la capilla del canónigo Pesquera por no haber referido instrumentos bastantes valió a la fábrica cuatro reales del rescate del paño y lo firmé ut supra”. A.G.D.V., San Andrés, 1653D, f. 218.
} 
Medina del Campo, actualmente conservadas en la capilla de las Angustias de la Colegiata de San Antolín ${ }^{137}$.

Catálogo

1663. Esculturas de la Fe y de la Esperanza. Iglesia de Santa María. Tordesillas $(\text { Valladolid })^{138}$.

1664. Esculturas para el retablo de la capilla del obispo de Málaga. Iglesia parroquial de San Pedro. Itero de la Vega (Palencia) ${ }^{139}$.

1668. Esculturas y relieves del retablo mayor. Iglesia de Santiago Apóstol. Cigales (Valladolid) ${ }^{140}$.

1672. Esculturas del retablo mayor (Calvario y San Martín partiendo la capa con el mendigo), Iglesia de San Martín, Cevico de la Torre (Palencia) ${ }^{141}$.

1673. Paso procesional de "La Crucifixión" (Figs. 23-24) o "La lanzada de Longinos". Capilla de los Pasos Grandes. Medina de Rioseco (Valladolid) ${ }^{142}$.

1674. Retablo de San Ildefonso (Fig. 25). Iglesia de Santiago de los Caballeros. Medina de Rioseco (Valladolid) ${ }^{143}$.

1674. Pasos procesionales "Camino del Calvario" y "El Descendimiento". Medina del Campo $^{144}$. Ambos conjuntos han desaparecido a excepción de las esculturas de San Juan (Fig. 26) y la Magdalena que se conservan en la Colegiata de San Antolín ${ }^{145}$.

1676. Cuatro relieves para un retablo. Iglesia parroquial de San Lorenzo. Oteruelo de Campos (Valladolid) ${ }^{146}$. Desaparecidos.

1679. Doce columnas para el ensamblador Juan de Medina Argüelles ${ }^{147}$.

137 En 1674 se forma contrato con el escultor para realizar, además de este Paso del Camino del Calvario, otro dedicado al Descendimiento, del que nada se ha conservado. ROJO VEGA, Anastasio: Fiesta y Comedias en Valladolid: siglos XVI-XVII, Ayuntamiento de Valladolid, Valladolid, 1999, pp. 173-174.

138 URREA, Jesús: "Los autores del retablo de Santa María de Tordesillas: nuevos datos", B.S.A.A., tomo LIV, 1988, pp. 438-439.

139 A.H.P.V., Leg. 2.361, ff. 417-418.

140 URREA FERNÁNDEZ, Jesús: Catálogo Monumental de la provincia de Valladolid. Tomo $X X \ldots$, op. cit., p. 161.

141 URREA FERNÁNDEZ, Jesús y MARTÍN GONZÁLEZ, Juan José: Inventario artístico de Palencia y su provincia I..., op. cit., p. 136.

142 GARCÍA CHICO, Esteban: Catálogo Monumental de la provincia de Valladolid. Tomo I. Medina de Rioseco, Diputación de Valladolid, Valladolid, 1956, pp. 201-202, 204-211.

143 PÉREZ DE CASTRO, Ramón: “La huella de Gregorio Fernández...”, op. cit., pp. 181-182.

144 ROJO VEGA, Anastasio: op. cit., pp. 173-174.

145 ARIAS MARTÍNEZ, Manuel, HERNÁNDEZ REDONDO, José Ignacio y SÁNCHEZ DEL BARRIO, Antonio: Catálogo Monumental de la provincia de Valladolid. Tomo XIX. Medina del Campo, Diputación de Valladolid, Valladolid, 2004, p 109.

146 BALADRÓN ALONSO, Javier: op. cit., p. 159.

147 GARCÍA CHICO, Esteban: Documentos para el estudio del arte en Castilla. 2..., op. cit., pp. 324-325. 
José Mayo nace en Valladolid a mediados del mes de marzo del año $1642^{148}$. Sus padres, el pintor Alonso Mayo ${ }^{149}$ y Antonia Fernández, moradores en el Val, deciden bautizarle en la iglesia de Santiago Apóstol el día 24 de ese mismo mes ${ }^{150}$. Debió de ser hermano del pintor Jacinto Mayo.

El 3 de octubre de 1656 sus padres le meten a estudiar el noble arte de la escultura en el taller de Díez de Tudanca ${ }^{151}$. El muchacho debía de asistir "por tiempo de cuatro años en casa del dicho Francisco de Tudanca a todo aquello que es costumbre asistir tales aprendices excepto fregar y barrer otra cosa que el taller donde se trabaje y traer niños en brazos ni a andar que estas cosas no se le han de mandar ni él ha de tener obligación a hacerlas". Mayo asistiría al taller de Tudanca "todos los días de trabajo a las horas que es costumbre comenzar a trabajar (...) así en verano, como en invierno, volviéndose a las horas que levantaren de obra". Mucho antes del hallazgo del asiento de aprendiz, Martín González ya había señalado la similitud entre el arte entre Mayo y el de Tudanca: "El arte de José Mayo se relaciona con el de Díez de Tudanca. Con ello ya queda indicado que sus figuras pregonan todavía la resonancia del arte de Fernández" ${ }^{\prime 152}$. Asimismo, refiriéndose a su trabajo en la Colegiata de Villagarcía de Campos, asevera que "a juzgar por ello entra también en la categoría de los imitadores sin talento de Fernández" "153. Estando de acuerdo en que su arte se basa en Fernández, Llamazares Rodríguez aprecia en el arte de Mayo "rasgos de auténtica originalidad"154.

\footnotetext{
148 El escultor José Mayo es un artista que aún hoy en día se nos presenta en la bruma. Apenas conocemos obras salidas de sus gubias, y todavía tenemos menos certezas sobre su vida. El conocimiento de este escultor nos viene dado por García Chico a través de su obra en la Colegiata de San Luis de Villagarcía de Campos (Valladolid), pues hasta entonces su figura nos era desconocida. Posteriores descubrimientos realizados por Martín González, Fernández del Hoyo, Pérez de Castro y Llamazares Rodríguez nos ha permitido poder saber quién fue su maestro, así como conocer nuevas obras de este modesto, aunque interesante, escultor. GARCÍA CHICO, Esteban: "Los artistas de la Colegiata de Villagarcía de Campos", B.S.A.A., Tomo XX, 1953-1954, pp. 43-80; MARTÍN GONZÁLEZ, Juan José: Escultura barroca castellana..., op. cit.; LLAMAZARES RODRÍGUEZ, Fernando: “José Mayo. Las esculturas del Monasterio de Santa María de Carrizo", Tierras de León, 1975, Tomo XXII, pp. 17-22; FERNÁNDEZ DEL HOYO, María Antonia: "El escultor vallisoletano Francisco Díez de Tudanca...", op. cit., pp. 371-388; PÉREZ DE CASTRO, Ramón y GARCÍA MARBÁN, Miguel (coord.): op. cit.

149 Alonso Mayo (h. 1600-1681) era uno más de los mediocres pintores que por aquel entonces vivían en los alrededores de la iglesia de Santiago. Se conoce su participación en alguna de las más importantes empresas llevadas a cabo en aquellos años por el Ayuntamiento, como pudieran ser los arcos para los recibimientos de los reyes o algún que otro trabajo para celebrar diferentes festividades relacionadas con la monarquía o con el Corpus Christi. FERNÁNDEZ DEL HOYO, María Antonia: "Fiestas en Valladolid a la venida de Felipe IV en 1660", B.S.A.A., Tomo LIX, 1993, pp. 379-392.

$150 \quad$ "En veinte y cuatro de marzo de mil y seiscientos y cuarenta y dos años bauticé e impuse los óleos santos conforme el santo concilio manda a Joseph hijo de Alonso Mayo y de Antonia Fernández fueron padrinos Juan Mayo vecino de la ciudad de León y Ângela Ruiz testigos Alonso Díez y Domingo Fernández dieronle por abogada a Nuestra Señora y Santiago y lo firmé ut supra”. A.G.D.V., Santiago, 1606B, f. 980. Fernández el Hoyo indica que nació en marzo de 1642, sin ninguna duda es un error tipográfico. FERNÁNDEZ DEL HOYO, María Antonia: op. cit., p. 379.

${ }_{151}$ FERNÁNDEZ DEL HOYO, María Antonia: "El escultor vallisoletano Francisco Díez de Tudanca...", op. cit., p. 379.

152 MARTÍN GONZÁLEZ, Juan José: Escultura barroca castellana..., op. cit., p. 287.

153 Ídem, p. 136.

154 LLAMAZARES, Fernando: “José Mayo..., op. cit., p. 22.
}

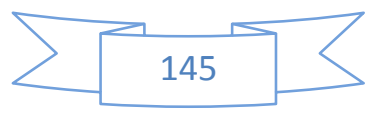


La amistad entre las familias Mayo y Tudanca la vemos refrendada en multitud de ocasiones, tal vez este fue uno de los motivos por los cuales Alonso mandó a su hijo José al obrador de Tudanca. Años después, durante las fiestas del Corpus Christi del año 1660 vemos trabajando codo a codo a Alonso Mayo y a Francisco Díez de Tudanca. Mientras que Tudanca se encargaba de "los reparos de los gigantes y otras cosas para la fiesta del Corpus" 155 , además de hacer otros nuevos "los gigantes y tramoya de pasta"156, Alonso Mayo se concentraba en "aderezar los gigantes" "enlenzar los carros", y en "poner lienzo, clavarlo y aparejarlo para los cuatro medios carros nuevos y las tramoyas" $" 157$. No sería descabellado pensar que en alguna ocasión Tudanca pudo haber solicitado a su amigo Alonso Mayo que policromara alguna de sus esculturas.

La primera noticia que poseemos de José Mayo relacionada con su oficio data del 5 de mayo de 1665, ese día se encarga de tasar las esculturas que dejó al fallecer don Martín de Bárcena $^{158}$.

El 22 de julio de 1668 se desposa con Francisca Martínez de Mendoza en la iglesia de Santiago Apóstol. Entre los testigos del enlace figura Manuel de Tudanca, hermano de su maestro, con lo cual volvemos a comprobar la buena relación entre ambas familias ${ }^{159}$. Unos meses después, el 2 de febrero de 1669, el matrimonio fue velado "in facie ecclesiae" en la misma iglesia ${ }^{160}$. El 11 de junio de 1669 nace el primer hijo de la pareja, Manuel ${ }^{161}$. Gracias al testamento de Francisca Martínez sabemos que el matrimonio tuvo, al menos, otro hijo llamado Juan ${ }^{162}$.

José Mayo debió de fallecer a finales del año 1679, o comienzos de 1680, siendo enterrado en una sepultura propia que poseía en el Convento de la Santísima Trinidad, como más adelante veremos. Su partida de defunción no figura en ninguna de las parroquias de la ciudad lo que hace suponer que marchó a trabajar a otra localidad, quizás en la Tierra de Campos.

José Mayo había ordenado en su testamento que se tasase "toda la herramienta del oficio de escultor" que dejara tras su fallecimiento, dándose a "Tomás de Sierra oficial que a la sazón era y que se le bajase la cuarta parte". El encargado de la tasación fue Alonso de Rozas, el cual valuó todo en 400 reales "que bajada la cuarta parte importó trescientos reales y con lo demás que el dicho Tomás de Sierra tomó de otros géneros de los bienes de los que dejó dicho José Mayo importó en todo quinientos reales de vellón así de lo comprado como de las herramientas bajadas dicha cuarta parte de los que dichos quinientos reales la dicha $D^{a}$ Francisca de Mendoza como curadora de sus hijos se dio por satisfecha y pagada y confesó haber entregado dichas herramientas y bienes comprados". El 29 de enero de 1680 su viuda Francisca Martínez, como tutora y

$\begin{array}{ll}155 & \text { A.M.V., CH. 65-7, p. } 19 . \\ 156 & \text { A.M.V., CH. 65-7, p. 20. } \\ 157 & \text { A.M.V., CH. 65-7, pp. 19-20. } \\ 158 & \text { A.H.P.V., Leg. 253/3, f. 702. } \\ 159 & \text { A.G.D.V., Santiago, 1609M, f. } 299 . \\ 160 & \text { A.G.D.V., Santiago, 1644V. } \\ 161 & \text { A.G.D.V., Santiago, 1668B, f. 31. } \\ 162 & \text { A.H.P.V., Leg. 252, f. 21 (1681) }\end{array}$


curadora de sus hijos, otorga carta de pago y finiquito en favor de Tomás de Sierra en razón "de dicha cantidad procedida de dicha tasación y de lo que dicho Tomás de Sierra compra"163. ¿La referencia de "Tomas de Sierra oficial" quiere decir que fue oficial de José Mayo?, y, es más, ¿José Mayo fue el maestro de Tomás de Sierra?

Unos meses después del fallecimiento de José, el 5 de junio de 1681, su viuda, encontrándose "enferma en la cama de la enfermedad que Dios nuestro señor ha sido servido de me dar aunque en mi juicio y entendimiento natural", otorga testamento ${ }^{164}$. Gracias a las últimas voluntades de Francisca sabemos que Mayo fue enterrado en una sepultura propia que poseía en el Convento de la Santísima Trinidad Calzada.

\section{$\underline{\text { Catálogo }}$}

1666-1667. Seis ángeles niños para la custodia. Iglesia de Santa Cruz. Medina de Rioseco (Valladolid) ${ }^{165}$. Desaparecidos.

1669. Esculturas del retablo mayor (San Bernardo, San Benito, Asunción, Santa Umbelina, San Alberico y el Calvario). Monasterio de Santa María. Carrizo de Ribera (León) ${ }^{166}$.

1670. Sepulcros de don Isidro y don Pedro Morán Pereira. Hospital de la Encarnación. Zamora $^{167}$.

1671. Busto de San Ignacio. Colegiata de San Luis. Villagarcía de Campos $(\text { Valladolid })^{168}$.

1672. Esculturas de San Luis Gonzaga (Fig. 27) y San Estanislao de Kostka (Fig. 28); relieves de los Mártires del Japón, de la Aparición de Cristo a San Ignacio. Colegiata de San Luis. Villagarcía de Campos (Valladolid) ${ }^{169}$.

1675. Esculturas de la Fe y de dos Ángeles para el antiguo retablo mayor (Fig. 29). Catedral. Valladolid ${ }^{170}$.

\section{$\underline{\text { ANTONIO VÁZQUEZ }}(1650$ - 1700)}

Antonio Vázquez Rodríguez ${ }^{171}$ nace el 7 de enero de 1650, siendo bautizado el 27 de dicho mes en la iglesia de San Lorenzo de Valladolid ${ }^{172}$. Sus padres fueron Antonio

\footnotetext{
163 A.H.P.V., Leg. 19.530, f. 89.

164 A.H.P.V., Leg. 252, f. 21 (1681).

165 PÉREZ DE CASTRO, Ramón: “La huella de Gregorio Fernández...”, op. cit., p. 180.

166 LLAMAZARES RODRÍGUEZ, Fernando: “José Mayo...”; op. cit., pp. 17-22.

167 RAMOS DE CASTRO, Guadalupe: El hospital de la Encarnación, Fundación Ramos de Castro, Zamora, 1986, pp. 82-83.

168 MARTÍN GONZÁLEZ, Juan José: “Documentación...”, op. cit., p. 207.

169 GARCÍA CHICO, Esteban: "Los artistas de la Colegiata...", op. cit., p. 43.

170 MARTÍN GONZÁLEZ, Juan José: "Noticias documentales...”, op. cit., p. 192.

171 Para consultar la bibliografía actualizada del escultor: BALADRÓN ALONSO, Javier: op. cit., pp. 159-162.
} 
Vázquez e Isabel Rodríguez, los cuales vivían junto a la portería del Convento de la Santísima Trinidad. El 7 de noviembre de 1663 testa su madre, la cual expresa el deseo de ser enterrada en la iglesia de San Ildefonso. Nombró como testamentario a su marido, Antonio Vázquez, y por herederos "a los dichos Antonio y Santiago Vázquez mis hijos" $" 173$.

El 23 de junio de 1673 firma como testigo, junto al también escultor Andrés de Pereda, en el testamento que otorga el ensamblador Pablo de Freiría ${ }^{174}$. Artistas con los cuales debió de mantener relaciones vitales y laborales.

El 15 de agosto de 1680 casa en primeras nupcias en la iglesia de San Martín y San Benito el Viejo con María Francisca de los Ríos ${ }^{175}$. La pareja tuvo seis hijos: Antonio (1684), Manuel I (1685), Ventura (1687), Manuel II (1690), Isabel (1691), y Sabina $(1693)^{176}$. Algunos de ellos tuvieron por padrino al pintor Jerónimo Benete, lo que es indicativo de la amistad existente entre ambos artífices. Como veremos, Benete también apadrinó a varios hijos del escultor Juan Antonio de la Peña. Podemos concluir que el pintor mantuvo muy buenas relaciones con sus compañeros artistas. El 29 de agosto de 1694 vuelve a contraer matrimonio, en este caso con María del Cabo, en la iglesia de San Miguel ${ }^{177}$. Con ella tendrá otros dos hijos: María (1695) y Micaela $(1696)^{178}$.

La familia vivió en un primer momento en una casa de la Plazuela Vieja ${ }^{179}$, si bien poco tiempo después se mudarían a un domicilio sito en la calle Platerías, morada en la que aún aparece establecido en el año $1691^{180}$. Ya casado con su segunda esposa, en el año 1699, toma en arrendamiento del deán y cabildo catedralicio una casa que "dicho cabildo tiene en la Platería de dicha ciudad que llaman del racionero Agustín González parroquia de San Miguel"181.

El 26 de octubre de 1699 otorga testamento conjuntamente con su esposa. Declaraban encontrarse "sanos y sin enfermedad ninguna y en nuestro juicio y entendimiento natural y por si acaso de la enfermedad que Dios nuestro señor fuere servido de nos dar". El matrimonio suplicaba que al fallecer sus cuerpos fueran sepultados en la iglesia de San Miguel "o en la iglesia donde lo fuéremos al tiempo de nuestro fallecimiento". Al carecer de descendencia se nombraron por herederos el uno al otro para que el

\footnotetext{
$172 \quad$ Ídem, p. 159.

173 A.H.P.V., Leg. 2.398/11, ff. 16-17.

174 GARCÍA CHICO, Esteban: Documentos para el estudio del arte en Castilla. 2..., op. cit., p. 350.

175 A.G.D.V., San Martín, 1659M, ff. 116-117.

176 A.G.D.V., San Miguel, 1669B, ff. 159, 168, 189, 222, 233, 252.

177 A.G.D.V., San Miguel, 1681M, f. 61.

178 A.G.D.V., San Miguel, 1669B, ff. 281, 299.

179 BALADRÓN ALONSO, Javier: op. cit., p. 160.

180 "Calle Platería. Casa de Antonio Vázquez: En la casa de Antonio Vázquez. Al mismo oficio escultor. Casado tiene de edad treinta y seis años. Tiene tres hijos menores y éste tiene un criado soltero de veinte años sin impedimentos". Ibídem.

181 A.H.P.V., Leg. 3.023, f. 105.
} 
superviviente heredara los bienes del otro ${ }^{182}$. Antonio Vázquez fallece el 5 de julio de 1700, siendo enterrado en la iglesia de San Miguel $^{183}$.

\section{$\underline{\text { Catálogo }}$}

1689. Esculturas de San Francisco y Santo Domingo (Figs. 30-31). Iglesia de Nuestra Señora del Rosario. Valladolid ${ }^{184}$. Realizadas de manera conjunta con José de Rozas.

1691-1693. Esculturas de San Pablo y cuatro ángeles (Fig. 32) para el ático del retablo mayor. Iglesia parroquial de Santiago. Villalba de los Alcores (Valladolid) ${ }^{185}$. La parte escultórica del retablo la comparte con Manuel Ordóñez y Tomás de Sierra.

1692. Paso de "Longinos" para la Cofradía de Jesús Nazareno. Capilla de Jesús Nazareno. Palencia ${ }^{186}$. Realizado de manera conjunta con José de Rozas.

1693. Paso de "Camino del Calvario” para la Cofradía de Jesús Nazareno. Capilla de Jesús Nazareno. Palencia ${ }^{187}$. Realizado de manera conjunta con José de Rozas.

\section{JUAN ANTONIO DE LA PEÑA (h. 1650 - 1708)}

Juan Antonio de la Peña nace hacia el año 1650 en la feligresía de Santa María de Galdo $^{188}$, perteneciente al obispado de Mondoñedo en el reino de Galicia ${ }^{189}$, siendo sus padres Jacinto Fernández de la Peña y María López Sanjurjo ${ }^{190}$. Seguramente se trasladó a Valladolid como otros jóvenes gallegos para aprender el oficio de escultor, anhelando obtener al prestigio al que accedió su paisano Gregorio Fernández, y en menor medida Alonso de Rozas.

Residiendo ya en Valladolid se desposa con Francisca de Santiago en la iglesia de Santa María la Antigua el 5 de abril de $1673^{191}$, el matrimonio fue velado en la misma iglesia $^{192}$. La familia materna de su esposa mantenía una posición acomodada, en ella

\footnotetext{
182 BALADRÓN ALONSO, Javier: op. cit., p. 160.

183 "En cinco de julio de 1700 murió Antonio Vázquez escultor habiendo recibido los santos sacramentos enterrose en ésta parroquia de San Miguel tenía otorgado testamento ante Jerónimo López Ceballos escribano del número de ésta ciudad en veinte y seis de octubre del año pasado de noventa y nueve, señala en él cien misas, la cuarta en la parroquia nombra por testamentarios a Francisco del Cabo y a Gregorio Ebrea platero y por heredera a María del Cabo su mujer por no quedar hijos". A.G.D.V., San Miguel, 1653D, f. 293.

184 BALADRÓN ALONSO, Javier: op. cit., pp. 160-162.

185 PARRADO DEL OLMO, Jesús María: Catálogo Monumental de la provincia de Valladolid. Tomo XVI..., op. cit., p. 351.

186 GARCÍA CUESTA, Timoteo: “La Cofradía...”, op. cit., p. 76.

187 Ídem, pp. 111-112.

188 MARTÍN GONZÁLEZ, Juan José: Escultura barroca castellana..., op. cit., pp. 288-290. M

MARTÍN GONZÁLEZ, Juan José: Escultura barroca en España..,, op. cit., p. 77; URREA FERNÁNDEZ, Jesús: "La biografía al servicio del conocimiento...”, op. cit., pp. 43-56.

189 Santa María de Galdo es una parroquia del municipio de Viveiro, en la provincia de Lugo.

190 URREA FERNÁNDEZ, Jesús: "La biografía al servicio del conocimiento...", op. cit., p. 45.

191 Ibídem.

192 A.G.D.V., La Antigua, 1650M, f. 170.
}

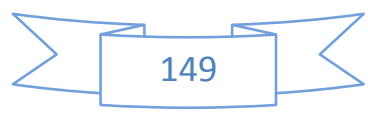


había un Comisario del Santo Oficio ${ }^{193}$. La pareja tuvo diez hijos: José (1672), Roque Manuel (1674), José (1676), José (1677), Antonio (1678), María Lorenza (1682), Juana (1686), Baltasar (1689), Luisa María (1690) y Teresa $(1692)^{194}$, de los cuales solo sobrevivieron tres: José, el primogénito, que estudió pintura en Madrid y en 1696 marchaba a vivir a Miranda do Douro (Portugal); María Lorenza y Juana Rosa, tras el fallecimiento del escultor esta última ingresó como monja agustina en el convento de San Nicolás de Valladolid ${ }^{195}$.

El escultor estuvo primeramente asentado en la calle de Cantarranas, en una casa intitulada "la del pozo", pegada a la de don Juan de Larrumbe (hoy $\mathrm{n}^{\mathrm{o}} 7$ de la calle Macías Picavea), posteriormente se trasladó a otra muy cercana en la calle que "sube a San Miguel" o "calle de San Miguel", que hacía "esquina a la que sube por detrás de la ermita del Santo Cristo de la Cruz a la calle de las Damas" (se trataría de la actual calle de San Antonio de Padua esquina plaza de los Arces) ${ }^{196}$.

Su obra conocida está realizada íntegramente en madera, sin embargo, sabemos que también esculpió la piedra. Efectivamente, en 1675 la catedral vallisoletana le encomienda la apertura de "dos escudos de las armas reales y de la ciudad que están en el segundo cuerpo de la torre", empresa por la que cobró 100 reales ${ }^{197}$. Como la mayoría de artífices de la época también realizó tasaciones: así, el 1 de diciembre de 1683 valúa las esculturas de José Gutiérrez del Mazo, abogado de la Real Chancillería ${ }^{198}$. Al año siguiente hará dos nuevas tasaciones: el 7 de abril de 1684 de las esculturas que dejó a su muerte el presbítero Gregorio Francisco de Tordesillas ${ }^{199}$; y el 20 de octubre de las esculturas de Domingo Rojo Salgado, escribano que fue de lo civil de la Real Audiencia y Chancillería de Valladolid ${ }^{200}$. Realizará una última tasación el 17 de abril de 1691, en esta ocasión de las hechuras que dejó el boticario Fernando Vela ${ }^{201}$.

El 26 de diciembre de 1684 se reúnen los parroquianos de la iglesia de San Miguel de Valladolid para nombrar "mayordomos de fábrica así eclesiásticos como seglar de ella para el dicho que viene de mil seiscientos y ochenta y cinco". Entre los propuestos figuraron el presbítero Juan Antonio González y nuestro escultor, los cuales "salieron por tales mayordomos eclesiástico y seglar" ${ }^{202}$.

\footnotetext{
193 URREA FERNÁNDEZ, Jesús: “La biografía al servicio del conocimiento...”, op. cit., p. 45.

194 Ídem, p. 55

$195 \quad$ Ídem, pp. 45 y 55.

196 URREA FERNÁNDEZ, Jesús: "La biografía al servicio del conocimiento...”, op. cit., p. 46.

197 1675.- "100 reales a Juan Antonio, maestro escultor, por abrir los dos escudos de las armas reales y de la ciudad que están en el segundo cuerpo de la torre”. MARTÍN GONZÁLEZ, Juan José: "Noticias documentales...", op. cit., p. 192.

198 URREA FERNÁNDEZ, Jesús: “La biografía al servicio del conocimiento...,, op. cit., p. 56.

199 A.H.P.V., Leg. 2.325, f. 446.

200 A.H.P.V., Leg. 2.738, f. 190 (1684).

201 A.H.P.V., Leg. 2.638, f. 212.

202 A.H.P.V., Leg. 19.530, f. 288.
} 
Gracias al censo realizado en las parroquias vallisoletanas en el año 1691, ya comentado anteriormente, sabemos que Juan Antonio tenía 30 años y que vivía por entonces en el Corralillo de San Miguel con su mujer y cuatro hijos menores de edad ${ }^{203}$.

El 29 de abril de 1696 se encarga de inspeccionar, junto al también escultor Juan de Ávila y al pintor Amaro Alonso de Llanos, la restauración, llevada a cabo por el pintor Valentín Gómez de Salazar, de unas esculturas que conformaban los pasos de la Cofradía Penitencial de la Sagrada Pasión de Cristo ${ }^{204}$.

El 16 de julio de 1699 otorga testamento su mujer, Francisca de Santiago, previa licencia que había pedido a su padre. En él ordenaba ser sepultada en la iglesia de San Miguel con el hábito de San Francisco. Como testamentarios instituía a su padre, Francisco de Santiago, y a su marido, a quien suplicaba se sirviera "mirar por el dicho Francisco de Santiago y Juana de Llanos mis padres y asistirles mientras vivieren respecto de hallarme con mucha edad y pocos medios". Finalmente nombraba por herederos universales a sus hijos Joseph, María y Juana ${ }^{205}$.

El 10 de agosto de 1700 tienen lugar las capitulaciones matrimoniales entre su hija María Lorenza y el escultor Pedro de Ávila ${ }^{206}$. En ella comparecieron de una parte Juan Antonio de la Peña, su mujer y su hija, mientras que de la otra lo hacen Juan de Ávila y su hijo Pedro. Juan Antonio y su mujer se obligaban a pagar de dote a su hija "para ayuda de sus alimentos cargas y obligaciones de dicho matrimonio y por capitales y caudales suyos propios y por cuenta de la herencia paterna y materna" 500 ducados de vellón (5.500 reales) en dinero, alhajas de por casa, ropa blanca y alhajas de oro y plata. El enlace tuvo lugar al día siguiente en la desaparecida iglesia de San Miguel $^{207}$.

El 24 de mayo de 1701 el ensamblador Santiago Carnicero proyecta la realización de un nuevo retablo mayor para la iglesia parroquial de Amusco. El propio ensamblador comenta que la parte escultórica del mismo era "condición que la ha de hacer Thomas de Sierra escultor vecino de Rioseco o Juan Antonio de la Peña vecino de Valladolido Joseph de Rozas vecino de dicha ciudad" ${ }^{208}$.

El 27 de mayo de 1706 el escultor trasmerano Pedro del Mazo Vélez se obliga a realizar la parte escultórica del retablo mayor, y de los dos colaterales, de la iglesia de San Julián de Carrión de los Condes (Palencia). En dicho contrato se apunta a que una vez acabadas las tallas estas debían de pasar por "vista y aprobación de Juan Antonio de la

\footnotetext{
203 "Corralillo de San Miguel. Casa de Juan Antonio de la Peña: En la casa de Juan Antonio de la Peña oficio escultor. Casado de treinta años. Cuatro hijos menores sin impedimento". A.H.P.V., Leg. 19.530, f. 10 (1691).

$204 \quad$ MARTÍ Y MONSÓ, José: Estudios histórico-artísticos..., op. cit., p. 499.

205 A.H.P.V., Leg. 2.894/2, ff. 18-19.

206 GARCÍA CHICO, Esteban: Documentos para el estudio del arte en Castilla. 2..., op. cit., pp. 368-369.

207 A.G.D.V., San Miguel, 1681M, f. 88.

208 PÉREZ DE CASTRO, Ramón: "Un retablo en Boadilla de Rioseco (Palencia) de Santiago Carnicero y Tomás de Sierra”, B.S.A.A., tomo LXXI, 2005, p. 249.
} 
Peña maestro de escultor vecino de la ciudad de Valladolid o de Tomás de Sierra vecino de Rioseco cualquiera de los dos el que eligiere dicho señor D. Manuel"209.

El 17 de agosto de 1707 es nombrado por el escultor José de Rozas como uno de sus testamentarios $^{210}$. Tres meses después, el 17 de noviembre, su esposa le entrega un poder para que en su nombre redactara testamento ya que se encontraba "afligida de la enfermedad que Dios nuestro señor ha sido servido de darla entiende no tendrá tiempo para hacer su testamento y última voluntad y disponer de sus cosas como conviene y que las tiene comunicadas y su voluntad muchas veces con Juan Antonio de la Peña su marido de quien siempre ha tenido mucha satisfacción y tiene por su cristiandad y buen celo" ${ }^{211}$. Francisca fallece poco tiempo después ya que el día 9 de diciembre De la Peña otorga el testamento que le había encargado su mujer ${ }^{212}$. Por entonces el escultor enferma de gravedad, teniendo que redactar testamento el día 29 de ese mismo mes. Actuaron como testigos del mismo, entre otros, los escultores José de Rozas y Andrés de Pereda, el ensamblador José de Zamora. La muerte le alcanzó el 2 de enero de 1708, su cuerpo fue sepultado según su deseo en la iglesia de San Miguel ${ }^{213}$.

\section{$\underline{\text { Catálogo }}$}

1674. Relieve de San Martín partiendo la capa para dársela a un pobre del retablo mayor (Fig. 33). Iglesia de San Martín. Valladolid ${ }^{214}$.

1675. Cristo Crucificado (Fig. 34). Iglesia de San Pedro. Montealegre de Campos $(\text { Valladolid })^{215}$.

1680. Esculturas para el retablo mayor. Iglesia de la Degollación del Bautista. Ataquines (Valladolid) ${ }^{216}$. Desconocemos si se llegaron a realizar tanto el retablo como las imágenes.

1682. Nuestra Señora de la Soledad (Fig. 35) para la Cofradía de Nuestra Señora de la Soledad. Iglesia de San Martín. León ${ }^{217}$.

1682. Esculturas de San Pedro, San Lucas y San Marcos (Fig. 36) para el retablo mayor de la Capilla del Relicario. Colegiata de San Luis. Villagarcía de Campos $(\text { Valladolid })^{218}$.

\footnotetext{
209 A.H.P.P., Leg. 5.021.

210 GARCÍA CHICO, Esteban: Documentos para el estudio del arte en Castilla. 2..., op. cit., pp. 337-339.

$211 \quad$ A.H.P.V., Leg. 2.763, f. 233.

212 A.H.P.V., Leg. 2.763/2, ff. 244-245

213 URREA FERNÁNDEZ, Jesús: “La biografía al servicio del conocimiento..., op. cit., p. 48.

214 MARTÍ Y MONSÓ, José: Estudios histórico..., op. cit., p. 642.

215 URREA FERNÁNDEZ, Jesús: “Los bienes artísticos del Monasterio. El Prado disperso". En WATTENBERG, Eloísa y GARCÍA SIMÓN, Agustín: El Monasterio de Nuestra Señora de Prado, Junta de Castilla y León: Consejería de Cultura y Turismo, Valladolid, 1997, p. 261.

216 BRASAS EGIDO, José Carlos: Catálogo Monumental de la provincia de Valladolid. Tomo X..., op. cit., p. 56.

217 URREA FERNÁNDEZ, Jesús: “La biografía al servicio del conocimiento...”, op. cit., p. 53.

218 MARTÍN GONZÁLEZ, Juan José: “Documentación...”, op. cit., p. 208.
} 
1682. Santa Lucía para un retablo lateral de la Capilla del Relicario. Colegiata de San Luis. Villagarcía de Campos (Valladolid) ${ }^{219}$.

1684. Santísimo Cristo de la Agonía (Fig. 37). Iglesia Penitencial de Nuestro Padre Jesús Nazareno. Valladolid ${ }^{220}$.

1694. Esculturas para el retablo mayor (San Pedro, San Pablo, San Juan Bautista, San Jerónimo). Iglesia de San Sebastián de Soreasu. Azpeitia (Guipúzcoa) ${ }^{221}$.

1699. Esculturas del retablo mayor de la capilla de don Gaspar Vallejo (Santo Toribio de Mogrovejo, San Juan de Sahagún, Santo Tomás de Villanueva y relieve del martirio de San Bartolomé). Iglesia de San Martín (Valladolid). Sólo se conservan el relieve y la imagen de San Juan de Sahagún ${ }^{222}$.

\section{VICENTE DÍEZ (1649 - d. 1708)}

Vicente Díez es uno de los escultores barrocos vallisoletanos más desconocidos, si bien hemos podido conseguir alguna información sobre él. Nació en Valladolid a comienzos del mes de febrero de 1649, siendo bautizado el día 14 de ese mismo mes en la iglesia de San Pedro Apóstol ${ }^{223}$. Sus padres fueron Damián Díez y Catalina de Padilla, ambos difuntos ya en el año 1671. Uno de sus hermanos fue un tal Damián Díez, el cual en algunos documentos se le cita como escultor ${ }^{224}$, ensamblador ${ }^{225}$ y entallador ${ }^{226}$.

Entre 1683 y 1688 debió de residir permanentemente en Tordesillas puesto que en 1685 se refieren a él como "vecino de esta villa". Durante esta época no le faltaría actividad en la localidad puesto que se encargaría de realizar las esculturas titulares de algunas de las iglesias parroquiales: San Pedro $(1683)^{227}$, San Antolín $(1685)^{228}$ y San Juan Bautista $(1688)^{229}$.

\footnotetext{
219 PÉREZ PICÓN, Conrado: op. cit., p. 152.

220 ARRIBAS ARRANZ, Filemón: La Cofradía Penitencial..., op. cit., pp. 122-123.

221 ASTIAZARIN ACHABLA, María Isabel: "La construcción del retablo de la parroquia de San Sebastián de Soreasu en Azpeitia: una obra de Juan de Apaeztegui, Martín de Olaizola y José de Echeverría", Boletín de la Real Sociedad Bascongada de Amigos del País, 46, 1-2, 1990, pp. 11-40; URREA FERNÁNDEZ, Jesús: "La biografía al servicio del conocimiento...”, op. cit., p. 47.

222 MARTÍN GONZÁLEZ, Juan José y URREA FERNÁNDEZ, Jesús: Catálogo Monumental de la provincia de Valladolid. Tomo XIV..., op. cit., p. 106.

223 "En catorce de febrero de mil y seiscientos y cuarenta y nueve años yo el licenciado Juan Hidalgo teniente de cura de la iglesia parroquial de señor San Pedro de esta ciudad de Valladolid impuse los santos óleos según orden de la santa madre iglesia romana a Vicente hijo de Damián Díez y de Catalina Padilla su legítima mujer fueron sus padrinos Juan Álvarez de Trasmiera y Ana Vázquez de Rebera diosele por abogados al Ángel de la Guarda y a Nuestra Señora y lo firmé por verdad fecha ut supra”. A.G.D.V., San Pedro, 1606B, f. 335.

$224 \quad$ A.H.P.V., Leg. 2.328, f. 299.

225 A.H.P.V., Leg. 2.791, ff. 361-362.

226 A.H.P.V., Leg. 3.013/7, f. 10.

227 ARA GIL, Clementina Julia y PARRADO DEL OLMO, Jesús María: Catálogo Monumental de la provincia de Valladolid. Tomo XI..., op. cit., p. 227.

228 Ídem, p. 175.

229 Ídem, p. 262
} 
El 22 de agosto de 1699 toma en arrendamiento del cabildo catedralicio una casa "que llaman de Manuel Ruiz" en la plazuela de las Carnicerías, por un espacio de cuatro años. Sale por su fiador el ensamblador y escultor Juan Correas ${ }^{230}$. Una vez finalizado el contrato lo prorrogaría por otros cuatro años ${ }^{231}$.

El 17 de julio de 1701 contrae matrimonio con María Tabares en la iglesia de Santa María de la Antigua ${ }^{232}$. Unos meses después, el 22 de febrero de 1702 se velaron en la misma iglesia ${ }^{233}$.

El 17 de agosto de 1707 José de Rozas dicta testamento. En él declaraba haber contratado "hará como cosa de seis a siete años" con el cura de La Dehesa, "jurisdicción de la villa de Cuéllar", ciertas esculturas para "poner en la iglesia de dicho lugar". Por cuenta de aquella obra había recibido 600 reales en dinero y otros 200 reales "en un papel que me dieron contra Vicente Díez escultor vecino de esta ciudad quien estaba obligado a hacer cierta escultura y no ha ejecutado por cuya razón le puse pleito para que pagase dichos doscientos reales que si está pendiente"234.

La última noticia que poseemos sobre el artista es una tasación que realiza el 11 de noviembre de 1708 de las esculturas que dejó al fallecer María Guillén ${ }^{235}$ : Desconocemos la fecha de su fallecimiento. Sabemos de un ensamblador llamado Vicente Díez que se conviene con el escultor Pedro Bahamonde en el año 1737 para ejecutar entre ambos un retablo para la Cofradía de Nuestra Señora de la Salve y el Niño Jesús de la iglesia de Santa María Magdalena de Valladolid ${ }^{236}$. Es muy improbable que este Vicente Díez sea el mismo puesto que tendría una edad muy avanzada: 88 años. Lo más lógico es pensar que fuera un hijo que siguió el oficio paterno.

\section{$\underline{\text { Catálogo }}$}

1673. San Pedro. Iglesia de San Pedro. Tordesillas (Valladolid) ${ }^{237} \cdot$ ¿Desaparecido ${ }^{238}$.

1685. Dos ángeles para la custodia del retablo mayor. Iglesia parroquial de la Asunción. Rueda (Valladolid) ${ }^{239}$. Desaparecidos

\footnotetext{
$230 \quad$ A.H.P.V., Leg. 3.023/1, f. 122.

231 A.H.P.V., Leg. 3.023, f. 150 (1703).

232 A.G.D.V., La Antigua, 1692M, f. 45

233 A.G.D.V., La Antigua, 1692M, f. 49.

234 GARCÍA CHICO, Esteban: Documentos para el estudio del arte en Castilla. 2..., op. cit., pp. 337-339.

235 A.H.P.V., Leg. 2.922, f. 225.

236 AGULLÓ Y COBO, Mercedes: Documentos sobre escultores, entalladores y ensambladores de los siglos XVI al XVIII, Universidad de Valladolid, Valladolid, 1978.

237 ARA GIL, Clementina Julia y PARRADO DEL OLMO, Jesús María: Catálogo Monumental de la provincia de Valladolid. Tomo XI..., op. cit., p. 227.

238 Existe la posibilidad de que esta imagen sea la que preside la hornacina superior de una puerta de acceso a la iglesia, actualmente inutilizada. La imagen, realizada en madera, presenta al santo "in cátedra". El estado de conservación es pésimo, habiendo perdido parte del rostro y de las piernas debido a la exposición a los efectos atmosféricos.

239 MARCOS VILLÁN. Miguel Ángel y FRAILE GÓMEZ, Ana María: Catálogo Monumental de
} la provincia de Valladolid. Tomo XVIII..., op. cit., p. 288. 
1685. San Antolín (Fig. 38). Iglesia de San Antolín. Tordesillas (Valladolid) ${ }^{240}$.

1688. San Juan Bautista. Iglesia de San Juan Bautista. Tordesillas (Valladolid) ${ }^{241}$.

1695. San Isidro Labrador. Iglesia parroquial de San Miguel. Pozal de Gallinas (Valladolid) $^{242}$.

\section{ANDRÉS DE PEREDA (h. 1655 - 1733)}

Andrés Martínez de Pereda ${ }^{243}$ nace en Medina de Pomar (Burgos) hacia el año 1655, siendo sus padres Juan de Pereda y María Ruiz de Tachuelo. Llegado a Valladolid, quién sabe si gracias a la intervención del ensamblador Cristóbal Ruiz de Andino (como más adelante se referirá), entraría en el taller de un escultor, quizás en el de Alonso de Rozas, con quién debió de mantener una buena amistad. Compadreo que también mantuvo con el hijo de éste, José de Rozas.

El 23 de junio de 1673 firma como testigo, junto al también escultor Antonio Vázquez, en el testamento otorgado por el ensamblador Pablo de Freiría ${ }^{244}$.

El 12 de agosto de 1680 contrae matrimonio en la iglesia de San Pedro de Valladolid con Luisa de Billota, hermana del ensamblador Francisco de Billota, y asimismo hija y nieta de ensambladores: Antonio de Billota y Alonso de Billota ${ }^{245}$. De esta manera emparentaba con el linaje de ensambladores más importante de Valladolid durante la segunda mitad del siglo XVII y principios del XVIII, con los que quizá colaborara en alguna ocasión. Unos días antes de la boda, el 28 de julio, firma las capitulaciones matrimoniales, en las cuales figura como testigo el escultor Alonso de Rozas ${ }^{246}$.

La descendencia de la pareja fue numerosa, si bien casi ninguno de ellos llegó a la mayoría de edad. El primer hijo fue Antonio, nacido en 1681, posteriormente llegarían Melchor (1684), Manuela Juana de Pereda (1687), Francisco Ignacio (1689), Francisca Pereda (1691), María (1693), Teresa María (1695) y Águeda María (1698) ${ }^{247}$. Muchos de ellos tuvieron por padrino al pintor y clérigo Jerónimo Benete.

El 14 de enero de 1685 da poder a su tío Francisco Ruiz Tachuelo, cura y beneficiado del lugar de La Aldea, para que representando su persona "parezca ante la justicia ordinaria de dicha villa de Medina de Pomar y pida posesión (...) de una fanega de

240 ARA GIL, Clementina Julia y PARRADO DEL OLMO, Jesús María: Catálogo Monumental de la provincia de Valladolid. Tomo XI..., op. cit., p. 175.

$241 \quad$ Ídem, p. 262.

242 MARCOS VILLÁN. Miguel Ángel y FRAILE GÓMEZ, Ana María: Catálogo Monumental de la provincia de Valladolid. Tomo XVIII..., op. cit., p. 156

243 Para consultar la bibliografía actualizada del escultor: BALADRÓN ALONSO, Javier: op. cit., pp. 162-165.

244 GARCÍA CHICO, Esteban: Documentos para el estudio del arte en Castilla. 2..., op. cit., p. 350.

245 A.G.D.V., San Pedro, 1655M, f. 497.

246 BALADRÓN ALONSO, Javier: op. cit., p. 162.

247 A.G.D.V., San Miguel, 1669B, ff. 128, 156, 187, 218, 228, 255, 286 y 317. 
sembradura que está sita en término del lugar de Barruelo jurisdicción de dicha villa", y asimismo para que le defienda en "todos mis pleitos civiles y criminales movidos y por mover así ante la justicia de dicha villa de Medina de Pomar como ante los demás jueces y justicias de su majestad que Dios padre de todos estos reinos y señoríos de España"248.

El 3 de enero de 1689 toma por aprendiz, el único conocido hasta la fecha, a Andrés Hernández, el cual debía de permanecer a su lado cinco años ${ }^{249}$. El escultor le daría "de comer, cama y ropa limpia" y le curaría de "las enfermedades ocho días", a cambio de esto el escultor recibiría 300 reales.

Gracias a un censo realizado en 1691 en las parroquias de la ciudad, sabemos que Pereda vivía al Corralillo de San Miguel, que tenía 32 años, y que poseía un criado llamado Andrés Pérez ${ }^{250}$.

En 1691 tasa junto con el ensamblador Alonso de Manzano y José del Amo el retablo mayor de la parroquial de Támara, obra de Fernando de la Peña ${ }^{251}$. El 29 de junio de ese mismo año sale por fiador del dorador vallisoletano Alonso Gutiérrez en la obligación que tenía éste de dorar "un retablo colateral intitulado de San José" sito en la iglesia parroquial de Castrillo de Duero. Este hecho, unido a la similitud estilística de la imagen San José con el Niño de dicho retablo con la obra conocida de Pereda me hizo llevar a atribuirle esta pieza ${ }^{252}$.

El 30 de junio de 1692 otorga, junto a los escultores Juan Antonio de la Peña y José de Rozas y otros parroquianos de la iglesia de San Miguel, un poder a los mayordomos de la fábrica ${ }^{253}$.

En 1694 supervisa, según mandato de la Cofradía de Jesús Nazareno de Palencia, las imágenes de Jesús Nazareno (tallada por José de Rozas), la Verónica y el sayón (obras de Antonio Vázquez) que se realizaron para el paso de Jesús Nazareno camino del Calvario para comprobar "si estaban según las condiciones con que dichos maestros las dieron por buenas" 254 .

El 5 de mayo de 1700 muere Luisa de Billota, la cual es enterrada en la iglesia de San Miguel $^{255}$. Apenas transcurrido un año, el 23 de mayo de 1701, vuelve a contraer

\footnotetext{
248 A.H.P.V., Leg. 2.777, f. 529.

249 BALADRÓN ALONSO, Javier: op. cit., p. 163.

250 "Corralillo de San Miguel. Casa de Andrés de Pereda: En la casa de Andrés de Pereda al dicho oficio escultor. Casado de treinta y dos años. Tiene cuatro hijos menores. Y éste tiene un criado de diez y ocho años llamase Andrés Pérez es soltero sin impedimento". A.H.P.V., Leg. 19.530, f. 11.

251 MARTÍN GONZÁLEZ, Juan José: Escultura barroca castellana..., op. cit., p. 403.

252 A.H.P.V., Leg. 3.006/1, ff. 15-16.

253 URREA FERNÁNDEZ, Jesús: “La biografía al servicio del conocimiento...”, op. cit., p. 56.

$254 \quad$ Visita del paso. "Más se le hacen buenos ochenta reales que pagó a Andrés de Pereda y compañero, maestros escultores y vecinos de Valladolid, por el coste que tuvieron de visitar las tres figuras referidas y dijesen si estaban según las condiciones con que dichos maestros las dieron por buenas, por estar según arte". GARCÍA CUESTA, Timoteo: “La Cofradía...", op. cit., p. 123.

255 "En cinco de mayo de mil y setecientos murió habiendo recibido los santos sacramentos Luisa de Billota mujer de Andrés Pereda escultor recibió los santos sacramentos no testó por no tener de qué,
} 
matrimonio. En este caso lo hace María de Bustillo en la iglesia de San Miguel; en dicho enlace firman como testigos los escultores José de Rozas y su hijastro Joseph Pascual $^{256}$. De éste segundo matrimonio también nació un gran número de hijos: Águeda Dorotea (1702), Josepha Ángela (1703), María (1704), Isabel (1705), Manuel (1707), Gertrudis Francisca (1709), Manuela (1710), Miguel Antonio (1712), Francisca Benita (1715) y Gertrudis (1716) $)^{257}$. Muchos de ellos tampoco llegaron a la edad adulta.

El 23 de julio de 1705 Pereda da poder a Andrés de Arce, procurador del número, y a Juan Ortiz de Zárate, procurador de la Real Audiencia y Chancillería, para que le defiendan en un pleito que tenía puesto ante el teniente de corregidor y Pedro de Valdenebro escribano del número de ella contra Gregorio Díez de Mata "ensamblador y tallista, sobre haberme mandado hacer dos ángeles de escultura y pedirle me dé satisfacción de ellos y negar él habérmelos mandado hacer y otras cosas contenidas en el dicho pleito" $" 258$.

El 2 de enero de 1708 actúa como testigo, junto con el también José de Rozas, el ensamblador José de Zamora, el maestro de primeras letras Francisco Alonso de Ordás y el tejedor de lienzos José García, en el testamento otorgado por su amigo el escultor José Antonio de la Peña ${ }^{259}$. Otro de sus camaradas debió de ser el también escultor Joseph Pascual, en cuyo testamento también firma como testigo ${ }^{260}$.

Tenemos noticia de dos tasaciones realizadas por Pereda: el 13 de noviembre de 1710 valúa las "hechuras de escultura" que quedaron tras el fallecimiento de Bernardo Gil de la Torre ${ }^{261}$, declarando al final de la tasación tener unos 60 años más o menos; mientras que el 9 de marzo de 1717 hace lo propio con las que dejó el mercader Tomás Andrés Guerra $^{262}$. Aquí declara tener unos 64 años más o menos. Como vemos tenían una noción del tiempo bastante más laxa que nosotros.

Andrés de Pereda fallece de forma inesperada, recibiendo sepultura en la parroquia de San Miguel el 6 de febrero de $1733^{263}$. Años después lo haría su mujer, concretamente el 28 de marzo de 1748, no habiendo redactado testamento debido a "un letargo que la sobrevino" 264 . Al tiempo de morir era criada de la condesa de Ribadavia.

enterrose en San Miguel en sepultura propia que dijo ser y lo firmé”. A.G.D.V., Valladolid, San Miguel, $1653 \mathrm{D}$, f. 289.

256 A.G.D.V., San Miguel, 1681M, f. 94.

257 A.G.D.V., San Miguel, 1669B, ff. 358, 368, 380 y 400. A.G.D.V., San Miguel, 1705B, ff. 17, 34, 44, 64, 94 y 112 .

258 BALADRÓN ALONSO, Javier: op. cit., p. 164.

259 URREA FERNÁNDEZ, Jesús: “La biografía al servicio del conocimiento..., op. cit., p. 48.

260 A.H.P.V., Leg. 2.764, f. 156; A.H.P.V., Leg. 2.764, ff. 157-158.

261 BALADRÓN ALONSO, Javier: op. cit., p. 164.

262 Ibídem.

263 "En seis de febrero, año de mil setecientos y treinta y tres, murió de repente Andrés de Pereda, morador que fue a la calle de San Miguel y marido de María Bustillo. Enterróse en ésta parroquia de dicho Santo Arcángel, y como cura propio de ella lo firmé en Valladolid". A.G.D.V., Valladolid, San Miguel, 1711D, ff. 102-103.

264 A.G.D.V., San Benito el Viejo, 1685D, f. 53.

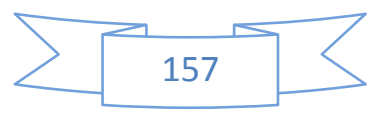


Ya apunté con anterioridad la posible relación familiar entre Andrés de Pereda y el ensamblador Cristóbal Ruiz de Andino, conclusión a la que se llega al confrontar dos documentos: por un lado uno en el que solicita que "se pida posesión lo tome y aprenda (...) una fanega de sembradura que está sita en término del lugar de Barruelo jurisdicción de dicha villa"265. Mientras que en otro Cristóbal Ruiz de Andino declara que el total de sus bienes quiere "cederlo renunciarlo y donarlo al Venerable don Andrés de Pereda mi sobrino cura y beneficiado del lugar de Barruelo jurisdicción de la villa de Medina de Pomar diócesis de Burgos"266. La coincidencia de lugar entre el escultor y el sobrino del ensamblador, y la del apellido puedan indicar una posible relación familiar entre ambos Peredas, y quizás también entre el escultor y el ensamblador.

\section{$\underline{\text { Catálogo }}$}

1689-1690. Esculturas para el retablo mayor del Oratorio de San Felipe Neri (San Felipe Neri, Joaquín con la Virgen Niña, San José con el Niño Jesús, Calvario, cuatro relieves y dos ángeles) (Fig. 39). Oratorio de San Felipe Neri. Valladolid ${ }^{267}$. Realizados de manera conjunta con José de Rozas.

1693. Arreglo de los brazos de un ángel. Iglesia de San Pedro. Mucientes (Valladolid) $^{268}$.

1696. Esculturas para el retablo mayor (San Pedro, San Pablo y dos ángeles portaestandartes) (Figs. 40-41). Iglesia de Santa María. Pozaldez (Valladolid) ${ }^{269}$.

Antes de 1705. Dos ángeles. Paradero y destino desconocidos ${ }^{270}$.

\section{JOSÉ DE ROZAS $(1662-1725)$}

José de Rozas nació hacia mediados de abril de 1662 en Valladolid ${ }^{271}$, siendo bautizado en la iglesia de San Miguel el día 25 de ese mismo mes con el nombre de José

\footnotetext{
265 BALADRÓN ALONSO, Javier: op. cit., p. 163.

266 En dicho documento, fechado el 22 de agosto de 1687, Ruiz de Andino enumera diferentes cantidades de dinero que le estaban debiendo algunas personas de obras que había realizado. En primer lugar, comenta que la Cofradía de la Vera Cruz de Valladolid le debía 600 reales "de resto de la obra que hice en el retablo y puertas de dicha iglesia y otras cosas". Seguramente la obra en el retablo haga referencia a algún arreglo o retoque en el retablo mayor, puesto que el estilo del mismo nada tiene que ver con el de Ruiz de Andino. Asimismo, le debía cierta cantidad de maravedíes la "ciudad de Valladolid (...) por razón del altar que hice cuando las fiestas de la traslación del Santísimo y del castillo de fuego que se hizo en la plaza mayor para dichas fiestas". También le adeudaba dinero la iglesia parroquial de Olmos de Peñafiel por razón por razón "del retablo que hice". Posiblemente se trate de un retablo situado en el lado del Evangelio, en cuya hornacina se sitúa un Crucificado del siglo XVII. BALADRÓN ALONSO, Javier: op. cit., p. 163.

267 URREA FERNÁNDEZ, Jesús: "El oratorio...”, op. cit., p. 18.

268 URREA FERNÁNDEZ, Jesús: Catálogo Monumental de la provincia de Valladolid. Tomo XX..., op. cit., p. 88.

269 MARCOS VILLÁN. Miguel Ángel y FRAILE GÓMEZ, Ana María: Catálogo Monumental de la provincia de Valladolid. Tomo XVIII..., op. cit., p. 163.

$270 \quad$ BALADRÓN ALONSO, Javier: op. cit., pp. 164-165.
} 
Antonio $^{272}$. Sus padres fueron el escultor gallego Alonso de Rozas e Isabel Fernández de Montoya, los cuales se habían casado en la iglesia de San Julián de Valladolid el 19 de julio de 1656 .

Como no puede ser de otra manera aprendería el oficio en el taller paterno. Su estilo, de formas más dulces, continúa en un primer momento las directrices marcadas por su padre que derivaban, a su vez, de las impuestas por Gregorio Fernández; aumenta el número de pliegues y los quiebra más, según apreciación de Martín González quien también detecta a lo largo de su obra una progresiva tendencia hacia formas más calmadas.

El estilo de José de Rozas ha ocasionado en multitud de ocasiones confusión con el de Juan de Ávila, lo que ha conllevado que muchas veces algunas esculturas hayan sido atribuidas a ambos, por ejemplo, los dos grupos de San José con el Niño y San Joaquín con la Virgen de la iglesia de San Felipe Neri de Valladolid. Primeramente se atribuyeron a Juan de Ávila ${ }^{273}$.Tras numerosas investigaciones, Urrea los ha documentado como obras de Rozas y Pereda ${ }^{274}$. Otro ejemplo es el de las esculturas del retablo mayor de la iglesia de San Quirce y Santa Julita, las cuales se han asignado indistintamente a ambos artífices.

El prestigio que con el tiempo va adquiriendo le lleva a ser solicitado en numerosas ocasiones como tasador, en algunas de las valuaciones llega a figurar como "maestro entallador": así, el 2 de enero de 1691 tasa los bienes de madera que dejó al fallecer don Francisco Maldonado Labanza ${ }^{275}$; posteriormente, el 17 de febrero de 1695 valúa las esculturas que dejó al fallecer el entallador Antonio López ${ }^{276}$; en 1697 las esculturas del doctor don Lorenzo González ${ }^{277}$; y, en 1700, las de Ana María de la Paz ${ }^{278}$. Ese renombre y prestigió le condujo a trabajar para otras ciudades de la península: Segovia, León, Zamora, Monforte de Lemos o Bilbao.

271 GARCÍA CHICO, Esteban: Documentos para el estudio del arte en Castilla. 2..., op. cit., pp. 337-339; ARRIBAS ARRANZ, Filemón: La Cofradía Penitencial..., op. cit., p. 46; MARTÍN GONZÁLEZ, Juan José: Escultura barroca castellana..., op. cit., pp. 302-304; RODICIO, Cristina: "Fray Pedro Martínez y la fachada del Monasterio de San Pedro de Eslonza", Tierras de León, Vol. 19, № 34-35, 1979, pp. 49-53; MARTÍN GONZÁLEZ, Juan José: Escultura barroca en España..., op. cit., pp. 78-79; BALADRÓN ALONSO, Javier: op. cit., pp. 160-162.

$272 \quad$ "En veinte y cinco días del mes de abril de éste año de mil seiscientos y sesenta y dos años yo el licenciado Pedro Álvarez Zorrilla cura propio de ésta iglesia de señor San Miguel de ésta ciudad de Valladolid bauticé y puse los santos óleos según orden y forma de la santa iglesia de Roma a Joseph Antonio hijo legítimo de Alonso de Rozas y de Isabel Fernández fueron sus padrinos el licenciado Pedro Barruso y Juliana Hernández dieronle por abogados a San Antonio y a Nuestra Señora de la Esperanza siendo testigos el licenciado D. Andrés Merino Alonso del Cura Nicolás Jacinto vecinos de ésta dicha ciudad y en fe de ello lo firmé". A.G.D.V., San Miguel, 1644B, f. 402.

273 MARTÍN GONZÁLEZ, Juan José y URREA FERNÁNDEZ, Jesús: Catálogo Monumental de la provincia de Valladolid. Tomo XIV..., op. cit., pp. 295-296.

274 URREA FERNÁNDEZ, Jesús: "El oratorio...", op. cit., p. 18.

275 A.H.P.V., Leg. 2.382/4, f. 3.

276 A.H.P.V., Leg. 2.641, f. 66.

277 A.H.P.V., Leg. 2.388, f. 536

278 A.H.P.V., Leg. 2.936, f. 80. 
Como la mayoría de los artistas de su época fue miembro de diversas cofradías, en especial de las penitenciales. Así, le vemos el 22 de marzo de 1682 ingresando en la Cofradía Penitencial de Nuestro Padre Jesús Nazareno, en cuya junta de oficiales desempeñó diferentes $\operatorname{cargos}^{279}$; ya en 1703 lograría acceder a la alcaldía de la $\operatorname{misma}^{280}$.

El 17 de abril de 1692 José de Rozas toma en arrendamiento de "don Fermín de Charola (...) poderhabiente del Ilustrísimo señor D. Manuel de Arce y Astete caballero del orden del Santiago del Consejo de su Majestad y su presidente en la Real Chancillería de Granada" una casa que está en la calle de San Miguel "en que vivió María de Losada y Juan Alonso su yerno" por espacio de cuatro años, durante cada uno de los cuales el escultor abonaría 12 ducados $^{281}$.

El 11 de mayo de 1692 contrae matrimonio con Dorotea Francisca de Herguedas ${ }^{282}$, madre del también escultor Joseph Pascual, en la iglesia de Santiago Apóstol. Como testigo del enlace figura Andrés Amaya, el pintor más destacado de la ciudad en el tránsito del siglo XVII al XVIII. A pesar de las escasas obras conocidas de Pascual no cabe duda de que se formó con Rozas, cuyo estilo sigue puntualmente. Quizás el matrimonio se conociera a raíz del aprendizaje de Pascual en el taller de Rozas.

Un día después el ensamblador Santiago Carnicero proyecta la realización de un nuevo retablo mayor para la iglesia parroquial de Amusco. El propio ensamblador comenta que la parte escultórica del mismo era "condición que la ha de hacer Thomas de Sierra escultor vecino de Rioseco o Juan Antonio de la Peña vecino de Valladolid o Joseph de Rozas vecino de dicha ciudad, esta condición se pone porque somos mortales"283. El proyecto no llegó a materializarse.

El 17 de agosto de 1707 José de Rozas dicta testamento al encontrarse "enfermo y en cama de la enfermedad que Dios nuestro señor ha sido servido de me dar pero sano de mi juicio y entendimiento natural" 284 . En él ordenaba ser sepultado en la desaparecida iglesia parroquial de San Miguel, "en la capilla de Nuestra Señora de la Esperanza". Lo más destacable de este testamento, al igual que del segundo que redacta, es la cantidad de obras inéditas de que nos da noticia, muchas de las cuales aún se conservan in situ. Nombró por testamentarios a su mujer Dorotea Francisca Herguedas y a su buen amigo el escultor Juan Antonio de la Peña. Por fortuna superó la enfermedad con éxito.

Años después, el 6 de enero de 1725 otorga un segundo testamento ${ }^{285}$. En él repite la mayoría de las cláusulas del anterior. También en esta escritura tenemos la fortuna de que enumera una serie de obras que hasta el momento del hallazgo del testamento eran

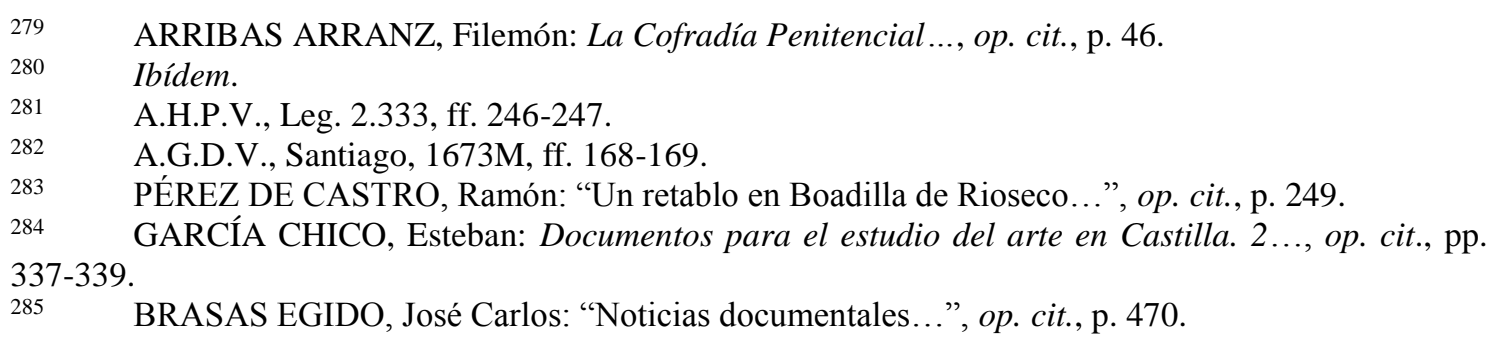


desconocidas y que han ayudado a ampliar sensiblemente su catálogo. Tres días después fallecía, siendo sepultado en la iglesia de San Miguel $^{286}$. Su viuda moriría poco después, el 14 de febrero de $1727^{287}$.

\section{$\underline{\text { Catálogo }}$}

1689. Esculturas de San Francisco y Santo Domingo. Iglesia de Nuestra Señora del Rosario. Valladolid ${ }^{288}$. Las realiza de manera conjunta con Antonio Vázquez.

1689-1690. Esculturas para el retablo mayor del Oratorio de San Felipe Neri (San Felipe Neri, Joaquín con la Virgen Niña, San José con el Niño Jesús, Calvario, cuatro relieves y dos ángeles). Oratorio de San Felipe Neri. Valladolid ${ }^{289}$. Realizados de manera conjunta con José de Rozas.

1690. Asunción rodeada de seis ángeles para el retablo mayor. Iglesia de Santa María. Pozaldez (Valladolid) ${ }^{290}$.

1691. Santo Cristo de la Humildad para la Cofradía de la Piedad (Fig. 42). Santuario Nacional de la Gran Promesa. Valladolid ${ }^{291}$.

1691. "Una concha [para el retablo del Santo Sepulcro] para que con facilidad pudiese entrar y salir la efigie". Iglesia Penitencial de Nuestra Señora de las Angustias. Valladolid $^{292}$.

1691-1692 Paso de "Longinos" para la Cofradía de Jesús Nazareno. Capilla de Jesús Nazareno. Palencia ${ }^{293}$. Realizado de manera conjunta con Antonio Vázquez.

1693-1694. Paso de "Camino del Calvario" para la Cofradía de Jesús Nazareno. Capilla de Jesús Nazareno. Palencia ${ }^{294}$. Realizado de manera conjunta con Antonio Vázquez, ampliado posteriormente por Bernardo López de Frías.

\footnotetext{
286 "En nueve de enero, año de mil setecientos y veinte y cinco habiendo recibido los santos sacramentos de la Penitencia, eucaristía y extremaunción murió Joseph de Rozas morador que fue a la calle de San Miguel y marido de Dorotea Herguedas. Otorgó su testamento ante Joseph de Valladares (...) a seis de dicho mes y año. Mando por su alma doscientas misas. Instituyó por su heredera a la referida su mujer, a quien nombró por testamentaria (...) mándose enterrar, y se enterró en esta parroquial de San Miguel y por verdad lo firmé en Valladolid como cura propio de dicha iglesia". A.G.D.V., San Miguel, 1711D, f. 60.

287 A.G.D.V., Santiago, 1673D, f. 749.

288 GARCÍA CHICO, Esteban: Documentos para el estudio del arte en Castilla. 2..., op. cit., p. 338; BALADRÓN ALONSO, Javier: op. cit., pp. 160-162.

289 URREA FERNÁNDEZ, Jesús: “El oratorio...”, op. cit., p. 18.

290 GARCÍA CHICO, Esteban: Documentos para el estudio del arte en Castilla. 2..., op. cit., p. 337; MARCOS VILLÁN. Miguel Ángel y FRAILE GÓMEZ, Ana María: Catálogo Monumental de la provincia de Valladolid. Tomo XVIII..., op. cit., p. 163.

291 ALARCOS LLORACH, Emilio: op. cit., p. 203.

292 GARCÍA MARTÍN, Enrique: Las cofradías y arte de Valladolid (siglos XVI-XVIII) (Tesis Doctoral inédita), Universidad de Valladolid, Valladolid.

293 GARCÍA CUESTA, Timoteo: “La Cofradía...”, op. cit., p. 76.

294 Ídem, pp. 111-112.
} 
1694. Virgen del Carmen (Fig. 43) para un convento de Valladolid, siendo comprada al año siguiente por la Cofradía de la Virgen del Carmen de San Isidoro de Zamora. Iglesia de San Isidoro. Zamora ${ }^{295}$.

1696. Dos Ángeles (Fig. 44) para el paso del Santo Sepulcro o "de los Durmientes" de la Cofradía de Nuestra Señora de las Angustias. Museo Nacional de Escultura. Valladolid ${ }^{296}$.

1702. Esculturas del antiguo retablo mayor de la iglesia Penitencial de Nuestro Padre Jesús Nazareno (Inmaculada, San Pedro, San Pablo, historia de la Oración del Huerto y dos ángeles con los atributos de la Pasión). Iglesia Penitencial de Nuestro Padre Jesús Nazareno. Valladolid. En la actualidad tan solo se conservan las imágenes de San Pedro y San Pablo ${ }^{297}$.

1701-1707 Esculturas del retablo mayor (San Pedro, San Sebastián, San Roque, la Asunción y cuatro ángeles). Iglesia de San Pedro. Dehesa de Cuéllar (Segovia) ${ }^{298}$.

1703. Parte de la decoración escultórica del retablo mayor (la Oración del Huerto, otras dos historias, dos ángeles, relieve del Salvador y relieve de la Virgen). Iglesia penitencial de Nuestro Padre Jesús Nazareno. Valladolid ${ }^{299}$.

1704. Dos ángeles para el retablo de San Cayetano. Desaparecida iglesia de San Miguel. Valladolid ${ }^{300}$.

1705. San Bartolomé, San Juan Bautista, San Fernando, Crucificado y Virgen de las Angustias (Fig. 45). Iglesia de San Bartolomé. Astorga (León) ${ }^{301}$.

1706. Historia de San Jerónimo para la sillería. Monasterio de Nuestra Señora de Prado. Valladolid $^{302}$.

Antes de 1707. Santa Águeda. Iglesia de San Boal. Pozaldez (Valladolid) ${ }^{303}$.

Hacia 1707. San Juan para Manuel Hernández. Paradero Desconocido ${ }^{304}$.

Hacia 1707. Cuatro angelotes para el órgano. Monasterio de San Benito el Real. Valladolid $^{305}$. Desaparecidos.

\footnotetext{
295 http://jesusario.blogspot.com.es/2013/01/virgen-del-carmen-de-san-isidoro.html.

296 GARCÍA CHICO, Esteban: Documentos para el estudio del arte en Castilla. 2..., op. cit., pp. 336-337.

297 ARRIBAS ARRANZ, Filemón: La Cofradía Penitencial ..., op. cit., pp. 41-44.

298 GARCÍA CHICO, Esteban: Documentos para el estudio del arte en Castilla. 2..., op. cit., pp. 337-339.

299 ARRIBAS ARRANZ, Filemón: La Cofradía Penitencial..., op. cit., pp. 41-44.

300 A.H.P.V., Leg. 2.762, p. 79. GARCÍA CHICO, Esteban: Documentos para el estudio del arte en Castilla. 2..., op. cit., pp. 337-339.

301 MARTÍN GONZÁLEZ, Juan José: Escultura barroca castellana..., op. cit., pp. 156-157.

302 GARCÍA CHICO, Esteban: Documentos para el estudio del arte en Castilla. 2..., op. cit., p.

337.

$303 \quad$ Ídem, p. 339.

$304 \quad$ Ídem, pp. 337-339.
} 
Hacia 1707. Crucifijo. Iglesia parroquial de San Nicolás de Bari. Pollos. Valladolid ${ }^{306}$. ¿Desaparecido?

1712. Esculturas para la fachada (San Adriano, Santa Natalia, San Bernardo, San Benito y San Pedro) $)^{307}$.

1714. Santa Eulalia para el retablo mayor. Matilla de los Caños (Valladolid) ${ }^{308}$.

1719. Inmaculada Concepción. Convento de San Nicolás de Tolentino. Valladolid ${ }^{309}$. Desaparecida

Antes de 1725. Tres esculturas para una iglesia indeterminada. Bilbao ${ }^{310}$.

Antes de 1725. San Nicolás de Bari. Iglesia de Santa María Magdalena. Gomezserracín $(\text { Segovia })^{311}$.

Antes de 1725. Santiago Apóstol. Iglesia de San Pedro. Guaza de Campos (Palencia) ${ }^{312}$.

1725 o antes. San Miguel y dos ángeles niños. Iglesia parroquial de la Asunción. Villabáñez (Valladolid) ${ }^{313}$.

1725. Virgen del Carmen. ¿Monforte de Lemos? (Lugo) ${ }^{314}$. La dejó sin acabar.

Sin fechar. San Juanito. Iglesia de San Pedro. Villanueva de la Condesa (Valladolid) ${ }^{315}$.

\section{JOSEPH PASCUAL ROBLEDO $(1677$ - 1714)}

Joseph Pascual Robledo encarna a la perfección el prototipo de joven artista prometedor que muere sin haber llegado a los 40 años. Nace en Valladolid el 21 de marzo de $1677^{316}$, siendo bautizado el 8 de abril de ese mismo año en la iglesia de Santiago. Sus de cura de esta iglesia parroquial del Señor Santiago de Valladolid exorcice e impuse los santos óleos como el santo concilio manda a un niño bautizado extra ecclesiam por mí el dicho Juan de Carrión ob uninimen periculum mortis hijo legítimo de Joseph Pascual y Dorotea Francisca Herguedas parroquianos de dicha iglesia a la calle de Santa María pusieronle por nombre Joseph el cual nació a veinte y uno de marzo próximo pasado de este año según me lo aseguraron sus padrinos que lo fueron Alejandro de la Espada y Antonia de Salcedo y Gamboa su mujer dieronle por abogados a Nuestra Señora y a San Benito
} 
padres fueron Joseph Pascual y Dorotea Francisco Herguedas, los cuales se habían casado el 12 de julio de 1673 en la iglesia de Santiago ${ }^{317}$. Apenas cumplidos los 7 años, el 8 de mayo de 1684, recibe la confirmación en la iglesia de Santiago ${ }^{318}$. Poco tiempo después, el 15 de octubre de 1685, quedaba huérfano de padre ${ }^{319}$.

El 11 de mayo de 1692 su madre vuelve a contraer matrimonio. Este hecho marca decisivamente la vida del joven Joseph Pascual puesto que su padrastro será el escultor José de Rozas. El enlace se celebró en la iglesia de Santiago, siendo uno de los testigos del feliz acontecimiento el pintor Andrés Amaya. Desconocemos si ya por entonces Pascual estaba aprendiendo el oficio de escultor en el taller de Rozas o si bien fue el conocimiento de este hombre la razón por la cual Pascual se decantó por el mundillo artístico.

Ignoramos la fecha en que contrajo matrimonio con María Martínez, si bien este debió acontecer hacia el año 1700. El 23 de mayo de 1701 figura como testigo, al igual que José de Rozas, en la boda de su común amigo el escultor Andrés de Pereda ${ }^{320}$.

El 15 de enero de 1704 toma en arrendamiento del Convento de Santa Isabel una casa sita en la calle Guadamacileros por un espacio de seis años que debían de comenzar a contarse desde el día de Navidad pasado del año 1703, pagando en cada uno de los dichos años 100 reales $^{321}$.

El 28 de julio de 1712 toma por aprendiz al riosecano Alonso Mozo, único discípulo conocido hasta la fecha ${ }^{322}$. Pascual se comprometía a que a lo largo de seis años le daría "enseñado hábil y capaz al dicho Alonso Mozo en el arte de escultor así en el dibujo como en la ejecución de hechuras y demás tocante al dicho arte de escultor dejándole muy suficiente y hábil a vista de maestros peritos". No tendría tiempo de consumar el aprendizaje puesto que Pascual fallecería dos años después de contraer el compromiso. El muchacho seguiría el aprendizaje en otro taller vallisoletano.

Joseph Pascual enferma gravemente, lo que le mueve a disponer su testamento el 28 de mayo de $1713^{323}$ previa licencia que pidió a su madre y su padrastro ${ }^{324}$. En estas postrimeras voluntades declaraba encontrarse casado con María Martínez, aunque sin descendencia alguna. Deseaba ser sepultado con el hábito de San Francisco en la iglesia de San Miguel, como así se hizo, concretamente "dentro de la capilla mayor como

fueron testigos Juan de Rozas y Andrés Niño todos vecinos de esta dicha ciudad y lo firmé”. A.G.D.V., Santiago, 1668B, f. 218.

317 A.G.D.V., Santiago, 1609M, f. 351.

318 "En ocho de marzo de dicho año confirmó dicho señor obispo por la tarde a las personas siguientes siendo padrinos D. Joseph Sorribas y Da María García. Joseph. Natural de esta ciudad hijo legítimo de Joseph Pascual y Dorotea Francisca a la calle de los moriscos". A.G.D.V., Santiago, Libro de confirmados, f. 28.

319 A.G.D.V., Catedral, 1684D, ff. 7-8.

320 A.G.D.V., San Miguel, 1681M, f. 94.

$321 \quad$ A.H.P.V., Leg. 3.135, f. 272.

322 A.H.P.V., Leg. 2.958 , ff. 834-837.

323 GARCÍA CHICO, Esteban: Documentos para el estudio del arte en Castilla. 2..., op. cit., pp. 362-363. A.H.P.V., Leg. 2.764, ff. 157-158.

$324 \quad$ Entre los testigos de la escritura figura el escultor Andrés de Pereda. 
cofrade que soy de la cofradía del Santísimo Sacramento y Ánimas de dicha parroquia", aunque en caso de no haber sitio se hiciera en la capilla de Nuestra Señora de la Esperanza. Hombre religioso, como la inmensa mayoría de la gente de la época, pertenecía a varias cofradías: a la del Santísimo Sacramento y Ánimas de la iglesia de San Migue, a la de San Lucas "de los pintores sita en el Convento de niñas huérfanas", y a la Penitencial de la Santa Vera Cruz, de la cual era diputado. Lo que más nos interesa del testamento son las deudas que diferentes personas tenían contraídas con él, puesto que se trata de diferentes esculturas que había talló, o se encontraba tallando en esos momentos, con destino a diversos lugares, estando la mayoría de ellas, por desgracia, en paradero desconocido. Su maltrecha salud le duró hasta el 17 de marzo de 1714, día en que fallece y se le entierra en la iglesia de San Miguel $^{325}$.

\section{$\underline{\text { Catálogo }}$}

1710. Santa Juliana (Fig. 46). Iglesia parroquial de Santa Juliana. Villarmentero de Esgueva (Valladolid) ${ }^{326}$.

Antes de 1713. Varias esculturas sin especificar para Gregorio Díaz de la Mata ${ }^{327}$.

Antes de 1713. San José y San Joaquín para el dorador Manuel de Santiesteban ${ }^{328}$.

Antes de 1713. Santo Cristo. Convento de San Diego. ¿Peñaranda de Bracamonte (Salamanca)? ${ }^{329}$

Hacia 1713. San Pedro. Iglesia parroquial de San Pedro. Zaratán (Valladolid) ${ }^{330}$.

Sin fechar. Esculturas del retablo de la capilla de Nuestra Señora de los Dolores. Catedral. Valladolid ${ }^{331}$.

\section{ANTONIO DE GAUTÚA $(1682-1744)$}

He preferido situar la vida y obra del escultor Antonio de Gautúa en la sección de discípulos de Juan de Ávila pues, aunque no tengo ninguna prueba documental, pienso que se formó en su taller.

\footnotetext{
325 A.G.D.V., San Miguel, 1711D, f. 14.

326 URREA FERNÁNDEZ, Jesús: Catálogo Monumental de la provincia de Valladolid. Tomo XX..., op. cit., p. 138.

327 GARCÍA CHICO, Esteban: Documentos para el estudio del arte en Castilla. 2..., op. cit., p. 362.

328 Ídem, pp. 362-363.

$329 \quad$ Ídem, p. 363.

$330 \quad$ Ídem, p. 362.

331 URREA FERNÁNDEZ, Jesús: "Reflexiones sobre la Catedral de Valladolid y noticia de algunas de sus pinturas", II Curso de patrimonio cultural (2008-2009), Ayuntamiento de Valladolid, Valladolid, 2009 , p. 126
} 
Pedro de Sierra y Oviedo ${ }^{332}$ nace en Medina de Rioseco el 12 de mayo de 1702, siendo bautizado en la iglesia de Santa María de Mediavilla el día 20 de dicho mes ${ }^{333}$. Sus padres fueron el escultor Tomás de Sierra e Inés de Oviedo. Según Martín González, Pedro vino a dar una "espléndida continuidad al taller de su padre"334.

Desenvolvió su actividad en el campo de la arquitectura y de la escultura, si bien esta última fue su verdadera especialidad. En diversos documentos se intitula "maestro de las artes de escultura y arquitectura". En realidad, tan sólo le conocemos una obra arquitectónica: el remate de la torre de la iglesia de Santa María, de Medina de Rioseco (1739). También dio modelos para obras de platería: custodia procesional y las andas de plata de la iglesia de Santiago, de Medina de Rioseco ${ }^{335}$.

Sus primeras lecciones las aprendería en el taller paterno, "posteriormente Tomás de Sierra, persuadido del talento de su hijo, procuraría alistarle en los trabajos reales, no sabemos por qué medio" ${ }^{336}$. Desconocemos la fecha de su marcha a La Granja de San Ildefonso. Sea como fuere, el caso es que el 24 de enero de 1725 al hacerse el inventario de los bienes que había dejado su padre al fallecer Pedro no pudo acudir por encontrarse allí trabajando. En el citado palacio real experimentó el influjo de los escultores franceses Frémin y Thierry "introduciéndose de esta suerte en su arte la corriente rococó europea. Al mismo tiempo, hubo de beneficiarle el contacto con los Tomé, en Toledo, de cuyo arte adoptó ciertas peculiaridades" 337 . Por entonces los citados escultores franceses se encontraban enfrascados en la elaboración de la primera gran serie escultórica para los jardines del palacio ${ }^{338}$. Martín González comenta al respecto que "la nueva fuente de alimentación de su arte -La Granja y Toledo-hace que lo que conocemos documentado del maestro no guarde la menor relación con el sedimento familiar de procedencia. El estilo de Pedro de Sierra es netamente barroco, en el sentido de un agitado dinamismo. Los pliegues están cortados con aristas vivas, como acuchilladas; pero estos pliegues estaban en la escuela vallisoletana desde que los introduce Pedro de Ávila. Puede apreciarse un recuerdo de Juan de Juni, sobre todo en las esculturas del retablo de Rueda, pero por lo común su arte acredita un sentido

332 GARCÍA CHICO, Esteban: Documentos para el estudio del arte en Castilla. 2..., op. cit.; MARTÍN GONZÁLEZ, Juan José: Escultura barroca castellana..., op. cit., pp. 383-399; MARTÍN GONZÁLEZ, Juan José: "Los Sierra. Escultores del barroco castellano", Goya: revista de arte, no 107, 1972, pp. 282-289; NICOLAU CASTRO, Juan: "Nuevos datos documentales sobre Pedro de Sierra", B.S.A.A., tomo IL, 1983, pp. 509-512; ASTIAZARAIN ACHABAL, María Isabel: "La obra de los Sierra en el Convento de Bidaurreta en Oñate. Un nuevo ensayo estructuras para la retablística guipuzcoana", B.S.A.A., Tomo LVII, 1991, pp. 453-470; MARTÍN GONZÁLEZ, Juan José: Escultura barroca en España ..., op. cit., pp. 460-467; CENDOYA ECHÁNIZ, Ignacio: "La aportación del taller de los Sierra a la escultura barroca en Guipúzcoa", Ondare: cuadernos de artes plásticas y monumentales, $\mathrm{n}^{\circ}$ 19, 2000, pp. 521-531.

333 GARCÍA CHICO, Esteban: Documentos para el estudio del arte en Castilla. 2..., op. cit., p.

426.

334 MARTÍN GONZÁLEZ, Juan José: Escultura barroca castellana..., op. cit., p. 383.

335 MARTÍN GONZÁLEZ, Juan José: Escultura barroca en España..., op. cit., p. 461.

336 Ídem, p. 460.

337 MARTÍN GONZÁLEZ, Juan José: Escultura barroca castellana..., op. cit., p. 383.

338 MARTÍN GONZÁLEZ, Juan José: Escultura barroca en España..., op. cit., p. 460. 
personal. Una peculiaridad de su estilo es el canon esbelto de las figuras y el reducido tamaño de las cabezas" 339 .

Poco tiempo después se trasladaría a Toledo, durante su estancia en esta ciudad es cuando el toresano Narciso Tomé realiza el Transparente de la catedral primada, "la obra más expresiva del barroquismo español". Si Pedro no llegó a participar directamente en ella seguro que tomó buena lecciones de él ya que en su arte se da cita tanto la influencia francesa como la de los Tomé ${ }^{340}$. Además, durante esta estancia en Toledo contrajo matrimonio con Josefa Sevilla, natural de Los Yébenes (Toledo). No conocemos la fecha exacta, si bien debió celebrase con anterioridad al 22 de marzo de $1726^{341}$. Este último año pasó un breve lapso de tiempo en su ciudad natal, lo necesario para percibir los 400 ducados que le había dejado su tía doña María de Paz y 1.117 reales que le correspondían en la división de los bienes que quedaran de su padre. Asimismo se concertó para realizar la labor escultórica de la fachada de la iglesia de Santa Cruz ${ }^{342}$.

Aún en Toledo, el 15 de enero de 1732 Sierra y su esposa "reciben del Hospital de Santa Cruz niños expósitos de esta ciudad (...) de que son patronos y perpetuos administradores los Ilustrísimos Señores Deán y Cabildo de esta Santa Primada Iglesia (...) la persona de Josefa María ¿Sacir? expósita para que les sirva y a su casa y familia en lo que la mandasen lícito de hacer por tiempo de diez años (...) en cuyo tiempo se obligan de educarla alimentarla curarla sus enfermedades y vestirla de todo lo necesario y al fin dar la porción de salario por todo el dicho tiempo de doscientos reales de vellón" 343 .

Un año después, el 9 de marzo de 1733, un documento nos lo sitúa trabajando en el Palacio Real de Aranjuez, si bien desconocemos las tareas de las que se ocupó. Sierra acude a Bernardo López, escribano público de Alameda de la Sagrada, villa cercana a Aranjuez, para redactar un poder para su hermano Francisco con el fin de que pudiera comparecer ante los tribunales que hicieran falta para solicitar "la partición de los bienes y hacienda que quedaron por la fin y muerte de Tomás de Sierra e Inés de Oviedo mis padres, y de la parte o partes que me tocaren como a uno de sus herederos percibiendo lo que así fuese así otorgado a favor de los demás coherederos la escritura o escrituras de transacción y concordia cartas de pago y demás instrumentos que sean necesarios" 344 .

El establecimiento en Valladolid debió producirse hacia 1736, ya que en este año contrata una hechura de la Virgen con el Niño para la cofradía de la Piedad ${ }^{345}$. A lo largo de su prolongada estancia vallisoletana puja en diferentes subastas de retablo, no

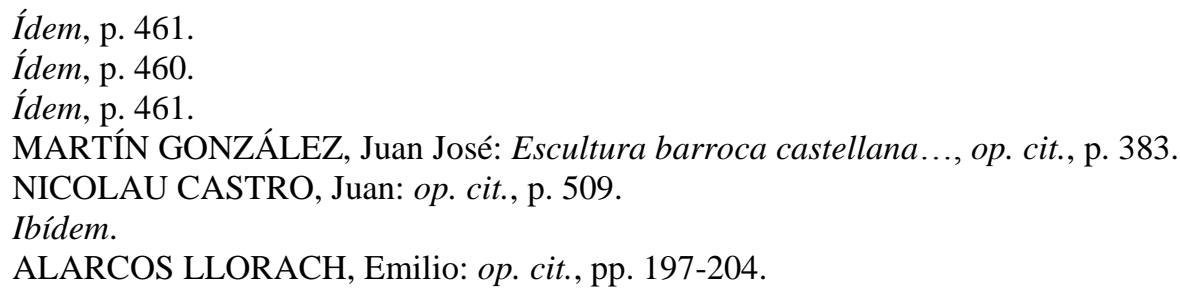


consiguiendo alzarse con la victoria en ninguna: en 1737 acude a la del retablo de la Cofradía de Nuestra Señora de la Salve y el Niño Jesús, sita en la parroquia de la Magdalena de esta ciudad ${ }^{346}$, el 3 de julio de 1740 presenta una postura en la obra del retablo mayor de la parroquial de Torrecilla de la Torre (Valladolid) ${ }^{347}$, en 1745 presenta traza y condiciones para realizar el retablo mayor de la catedral de Coria ${ }^{348}$, y el 9 de noviembre de 1755 concurre a la subasta del retablo de la Congregación del Amante Corazón de Jesús, cofradía radicada en la vallisoletana iglesia de San Julián y Santa Basilisa ${ }^{349}$.

También tuvo tiempo para salir por fiador de algunos de sus más allegados: así, el 25 de enero de 1747 sale por fiador de su hermano Tomás en el contrato que hace este último para dorar, estofar y encarnar el retablo mayor del Convento de Nuestra Señora de la Victoria $^{350}$, y el 17 de mayo de 1752 hace lo propio con el dorador Manuel de Urosa en el compromiso contraído por este para dorar el retablo mayor de la iglesia parroquial de Valdestillas (Valladolid) ${ }^{351}$.

Debió de hacer continuos viajes entre Valladolid y Toledo puesto que en 1739 la toledana iglesia de los Santos Justo y Pastor solicita de sus servicios para fabricar las esculturas en plomo vaciado de los dos santos titulares del templo ${ }^{352}$.

El 7 de agosto de 1742 recibe a uno de sus pocos discípulos conocidos: el vallisoletano Juan López. Sierra se obligaba a enseñar "el citado oficio de Escultura al expresado Juan López menor en el discurso de cuatro años que han de empezar a correr y contarse desde hoy día de la fecha" "353. El contrato contiene las cláusulas típicas en este tipo de documentos. Firman como testigos de la escritura dos oficiales de Sierra: Manuel Gómez y Manuel de Ribas. El 24 de noviembre de ese mismo año se encarga de supervisar el retablo mayor que Pedro Correas había fabricado para la iglesia de San Andrés Apóstol de Valladolid. Sierra declaró favorablemente sentenciando que "dicho otorgante tenía cumplido en todo con mucho exceso con lo que se obligó en dicha escritura y que en dicho retablo había hecho ciertas mejoras dicho otorgante que importaban tres mil seiscientos y cincuenta y dos reales" 354 . Este hecho habla bien del prestigio que ya por entonces poseía Sierra.

El 10 de noviembre de 1748 recibe como aprendiz al vallisoletano Santiago Infanzón “el joven”, el cual es asentado en el taller de Sierra por su padre Santiago Infanzón "el

\footnotetext{
346 AGULLÓ Y COBO, Mercedes: Documentos sobre escultores..., op. cit.

347 PARRADO DEL OLMO, Jesús María: Catálogo Monumental de la provincia de Valladolid. Tomo IX..., op. cit., pp. 207-212.

348 MARTÍN GONZÁLEZ, Juan José: Escultura barroca castellana..., op. cit., p. 391; MARTÍN GONZÁLEZ, Juan José: Escultura barroca en España..., op. cit., p. 466.

349 BRASAS EGIDO, José Carlos: "Noticias documentales...", op. cit., p. 472.

350 A.H.P.V., Leg. 3.353, ff. 13-17 (1747).

351 GARCÍA CHICO, Esteban: Documentos para el estudio del arte en Castilla. 3..., op. cit.

352 NICOLAU CASTRO, Juan: op. cit., p. 511.

353 BALADRÓN ALONSO, Javier: op. cit., p. 169.

354 MARTÍN GONZÁLEZ, Juan José y URREA FERNÁNDEZ, Jesús: Catálogo Monumental de la provincia de Valladolid. Tomo XIV..., op. cit., p. 53.
} 
viejo" "355. El artista se comprometía a "enseñar el oficio de escultor al dicho Santiago Infanzón en el discurso de cuatro años que han de empezar a contarse desde hoy día de la fecha (...) sin que por razón de su enseñanza hay de llevar ni lleve maravedies algunos". Como en los otros dos asientos de aprendiz Sierra no cobraría nada al padre o tutor de su aprendiz, sino que abonaría 500 reales "para ayuda de alimentos vestir cama y ropa limpia". También acordaron que si el joven Santiago caía enfermo "luego que este se halle bueno para poder trabajar le volverá a recibir a la dicha su casa y taller y acabado el tiempo de dichos cuatro años cumplirá el que hubiese estado malo".

El aprendizaje no llegaría a completarse puesto que tan solo un año y medio después, el 1 junio de 1750, Santiago Infanzón "el viejo" acude a ciertos procuradores y peritos de la Real Chancillería para demandar a Sierra con el propósito de que le pagara "quinientos reales que se halla no satisfacerme por razón de alimentos y vestido que debía dar así propuesto mi hijo por no haberle acabado de enseñar en el ministerio de escultor y demás del correspondiente (...) soliciten su confirmación y devolución con condenación de costes por temerario litigante" 356 .

El último documento que poseemos de Sierra es el contrato que firma el 15 de marzo de 1760 con la Cofradía de Nuestra Señora de Castilviejo de Medina de Rioseco para fabricar "un coro en dicha ermita para colocar en él un órgano o realejo que un devoto dio para dicho culto" 357 . Desconocemos si llegó a acabar esta obra. El caso es que Sierra falleció en el periodo comprendido entre esta escritura y el día 2 de junio de 1761. Su esposa, Josefa Sevilla, al enviudar y encontrarse sin ningún hijo vuelve a su tierra. Una vez allí el referido día 2 de junio otorgada todo su poder a Manuel López de Rojas para que en su nombre pudiera vender una casa que había heredado de su marido en Medina de Rioseco. Asimismo se lo daba al procurador vallisoletano Joseph Coiz, que había administrado aquella casa y otra que el matrimonio poseía en la calle Platerías de Valladolid ${ }^{358}$.

\section{$\underline{\text { Catálogo }}$}

1726. Esculturas de la fachada (Fig. 47). Iglesia de Santa Cruz. Medina de Rioseco $(\text { Valladolid })^{359}$.

1736. Virgen con el Niño para la Cofradía Penitencial de Nuestra Señora de la Piedad. Valladolid $^{360} \cdot$ ¿Desaparecida?

1736. Dos retablos. Iglesia parroquial de Nuestra Señora la Antigua. Palacios de Campos (Valladolid) ${ }^{361}$.

\footnotetext{
355 BRASAS EGIDO, José Carlos: "Noticias documentales...”, op. cit., p. 472.

356 A.H.P.V., Leg. 3.662, f. 117.

357 ZALAMA, Miguel Ángel: Ermitas y santuarios de la provincia de Valladolid, Diputación Provincial de Valladolid, Valladolid, 1987, p. 90.

$358 \quad$ NICOLAU CASTRO, Juan: op. cit., p. 512.

359 GARCÍA CHICO, Esteban: Documentos para el estudio del arte en Castilla. 3..., op. cit., pp. 346-347.

360 ALARCOS LLORACH, Emilio: op. cit., p. 203. Pudiera tratarse de una imagen que se conserva en la iglesia parroquial de la Asunción de Renedo (Valladolid).
} 
1737-1739. Coronación de la torre. Iglesia de Santa María de Mediavilla. Medina de Rioseco (Valladolid) ${ }^{362}$.

1739. Santos Justo y Pastor (Fig. 48). Iglesia de los Santos Justo y Pastor. Toledo ${ }^{363}$.

1741. Retablo mayor y traza para los retablos colaterales (Figs. 49-51). Iglesia parroquial de la Asunción. Rueda (Valladolid) ${ }^{364}$.

1760. Coro y escalera. Ermita de Nuestra Señora de Castilviejo. Medina de Rioseco $(\text { Valladolid })^{365}$.

\section{MANUEL VALERO ALHAMBRA $(\mathrm{a} .1705$ - d.1737)}

Manuel Valero Alhambra es hoy por hoy un completo desconocido. Ignoramos los datos fundamentales sobre su figura: lugar de nacimiento, taller en el que se formó, fecha en que llega a Valladolid... Tan solo sabemos que residió en la ciudad entre 17351736, un año después estaba afincado en Ávila. Durante su estancia en Valladolid, concretamente en 1735, figura como "maestro escultor, arquitecto y adornista", obligándose a enseñar los referidos tres oficios a un tal Pedro Clemente "natural y originario del Reino de Valencia y de la villa de Almidóbar (sic) del Pinar de la Sierra" ${ }^{366}$.

\section{$\underline{\text { Catálogo }}$}

1735. Cristo del Descendimiento y Virgen de la Soledad. Valmaseda (Vizcaya) ${ }^{367}$.

1737. Retablo mayor. Iglesia de Santo Tomás. Mediana de Voltoya (Ávila) ${ }^{368}$.

\section{PEDRO BAHAMONDE $(1707$ - 1748)}

La importancia de Pedro Bahamonde ${ }^{369}$ para la escultura y retablística vallisoletana es capital puesto que, según señala Redondo Cantera, de él "proceden varias generaciones

\footnotetext{
361 PARRADO DEL OLMO, Jesús María: Catálogo Monumental de la provincia de Valladolid. Tomo XVI..., op. cit., p. 144

362 GARCÍA CHICO, Esteban: Documentos para el estudio en Castilla. 1, Arquitectos, Universidad de Valladolid, Valladolid, 1940, pp. 228-235.

363 NICOLAU CASTRO, Juan: op. cit., p. 511.

364 MARTÍN GONZÁLEZ, Juan José: Escultura barroca castellana..., op. cit., pp. 386-388.

365 ZALAMA, Miguel Ángel: op. cit., p. 90.

366 AGULLÓ Y COBO, Mercedes: Documentos sobre escultores..., op. cit., p. 13.

367 BRASAS EGIDO, José Carlos: “Noticias documentales...”, op. cit., p. 471.

368 VÁZQUEZ GARCÍA, Francisco: El retablo barroco en las iglesias parroquiales de la zona norte de la provincia de Ávila, Tomo II, Universidad Complutense de Madrid, Madrid, 1991, p. 1.228.

369 MARTÍN GONZÁLEZ, Juan José: Escultura barroca castellana..., op. cit., pp. 343-349; MARTÍN GONZÁLEZ, Juan José: "Una atribución a Pedro de Bahamonde", B.S.A.A., Tomo XXIX, 1963, p. 263; PARRADO DEL OLMO, Jesús María: "Precisiones...”, op. cit., pp. 343-361; MARTÍN GONZÁLEZ, Juan José: Escultura barroca en España ..., op. cit., p. 451; REDONDO CANTERA, María José: Los Bahamonde..., op. cit., pp. 287-316.
}

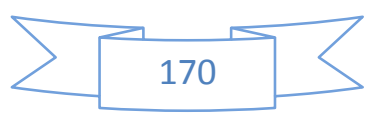


de escultores y tallistas, que prolongan la actividad hasta comienzos del siglo XIX"370. Es indudable la calidad de sus producciones, si bien Parrado del Olmo piensa que su obra no pueda comprarse "con la personalidad de Pedro de Sierra, contemporáneo suyo, el más importante escultor del momento" ${ }^{371}$.

Bahamonde fue escultor en el pleno sentido de la palabra, pues labró la piedra y la madera, trazó y realizó retablos, esculpió esculturas para ellos y talló otras piezas lígneas de mobiliario religioso. Por eso aparece citado en los documentos como "maestro escultor", "maestro tallista", "maestro arquitecto", "maestro de hacer retablos" o "retablero". Puntualiza Redondo Cantera que "en el ambiente profesional vallisoletano de mediados del siglo XVIII, escultores y tallistas eran diferentes entre sí, y a su vez, se distinguían de los "ensambladores" y "entalladores", al menos a efectos fiscales, aunque no había ningún problema para que un mismo artista ejerciera al mismo tiempo en varias de estas actividades. Los entalladores se ocupaban de realizar labores de talla de tipo decorativo, mientras que los tallistas podían esculpir también esculturas en madera. Por su parte, los escultores estarían capacitados además para labrar materiales duros, como la piedra, pero sobre todo para esculpir en bulto redondo" $" 372$.

Pedro Antonio Bahamonde nació en Muros (A Coruña) en $1707^{373}$, siendo bautizado por sus padres Domingo Bahamonde y Francisca García ${ }^{374}$, el 13 de febrero de dicho año. Desconocemos donde se formaría, Redondo Cantera piensa que "tendría lugar previsiblemente en tierras gallegas, quizá en el foco compostelano, o bien en el orensano, se trasladaría posteriormente a Valladolid, atraído por la pujanza artística y

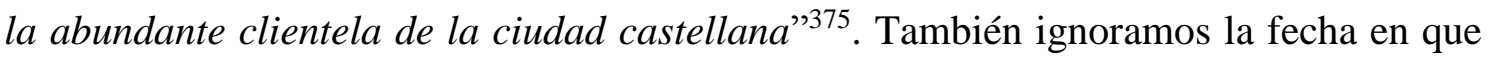
llegó a Valladolid. Sea como fuere, la primera noticia que poseemos del escultor data del 21 de febrero de 1729. Este día firma las capitulaciones matrimoniales con Antonia Romero, la cual al acabar el día ya se habían convertido en matrimonio en la iglesia de Santa María la Antigua ${ }^{376}$. Su padrino de boda fue el ensamblador José Díaz de Mata, con quien mantendrá a lo largo de su vida una óptima amistad. La pareja tuvo una numerosa descendencia: trece hijos, de los cuales ocho sobrevivieron al escultor.

Además de José Díaz de Mata, entre sus amistades contaba con la del ensamblador Agustín Martín. Así, en 1733 Bahamonde ejerce de padrino de la pequeña Fausta Celestina Martín ${ }^{377}$. También formó parte de este grupo el ensamblador Juan Saco.

Su primera actividad profesional documentada en Valladolid data de 1731 y es bastante modesta. Se trataba de la "compostura" del grupo procesional de San Martín con el

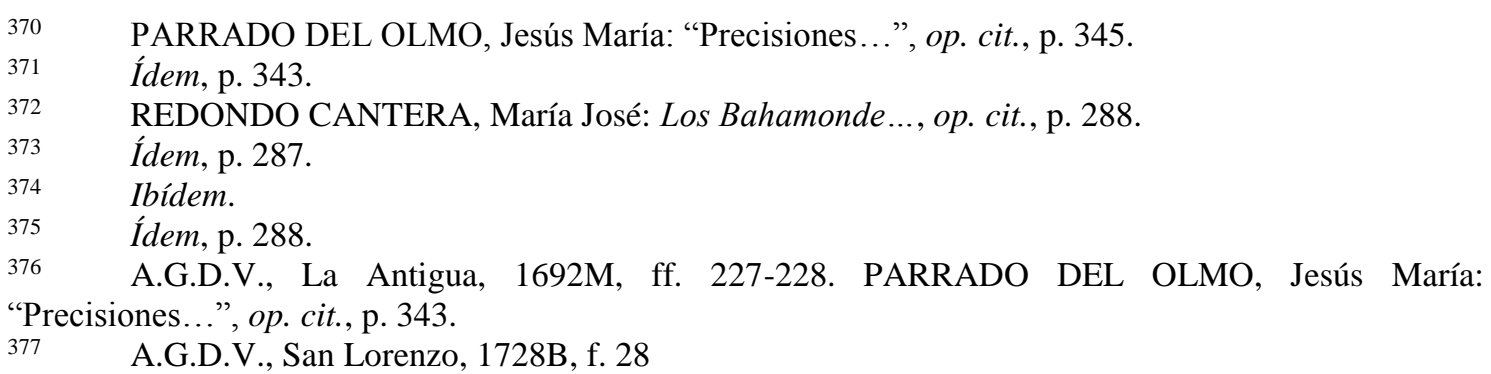


pobre que había tallado Gregorio Fernández en el año $1606^{378}$ para la iglesia parroquial homónima ${ }^{379}$. Un año antes figura elaborando "un adorno y graderías para el altar mayor" de la iglesia de San Miguel de la villa de Arévalo (Ávila) ${ }^{380}$.

Desconocemos qué obras de interés habría realizado hasta ese momento. Debía de haber dado buenas muestras de su valía pues en 1732 recibió dos encargados que capital importancia que nos muestra el prestigio que tenía en la capital vallisoletana y en tierras palentinas. Precisa Redondo Cantera que "en ambos casos empezó siguiendo trazas ajenas, pero con el avance del trabajo fue afirmando su personalidad y en la prolongación del encargo acabó proporcionándolas él mismo" ${ }^{381}$.

La primera de estas dos obras eran las esculturas de San Ambrosio y San Agustín, realizadas en piedra de Castrojimeno, para la fachada principal de la Catedral vallisoletana. Para su ejecución debía atenerse a los modelados enviados desde Salamanca por José de Larra Churriguera ${ }^{382}$. El trabajo de Bahamonde dejó tan satisfecho al cabildo catedralicio vallisoletano que a continuación le encargó las otras tres figuras de la fachada (la Asunción, San Pedro y San Pablo), para las que ya empleó sus propios modelos ${ }^{383}$.

La otra obra realizada en 1732, que además le abrirá las puertas del obispado palentino, será el completo amueblamiento de la iglesia parroquial de Santa Eufemia de Autillo de Campos (Palencia): el retablo mayor, los retablos colaterales, los púlpitos y el diseño de la sillería del coro de la iglesia parroquial de Santa Eufemia de Autillo de Campos (Palencia). Todo ello formaba parte de un proceso de renovación de la iglesia, que se llevó a cabo durante los quince años siguientes ${ }^{384}$. Para el retablo debía de seguir la traza dada por su compadre el tallista José Díaz de Mata.

El 23 de julio de 1748 se encontraba tan gravemente enfermo que no pudo dictar testamento, debido a lo cual dio poder a su mujer para que lo hiciera en su nombre ${ }^{385}$. Entre sus últimas voluntades figuraba la de ser sepultado con el hábito franciscano en la capilla de la Soledad de la parroquia de la Antigua, pues le pertenecía una sepultura, por ser cofrade de las Benditas Ánimas. Instituía por herederos a sus hijos Antonio, Pedro, Manuel, Santiago, Margarita, Agustina, Antonia y Juliana, todos menores de edad. Bahamonde falleció tres días después, siendo su cuerpo sepultado, según su deseo, en la

\footnotetext{
378 MARTÍN GONZÁLEZ, Juan José: El escultor..., op. cit., p. 206.

379 MARTÍN GONZÁLEZ, Juan José y URREA FERNÁNDEZ, Jesús: Catálogo Monumental de la provincia de Valladolid. Tomo XIV..., op. cit., p. 104. Actualmente la pieza se custodia en el Museo Diocesano y Catedralicio de Valladolid.

380 VÁZQUEZ GARCÍA, Francisco: El retablo barroco..., op. cit., Tomo I, p. 1.144.

381 REDONDO CANTERA, María José: Los Bahamonde..., op. cit., p. 289.

382 GARCÍA CHICO, Esteban: Documentos para el estudio del arte en Castilla. 2..., op. cit., pp. 386-387; MARTÍN GONZÁLEZ, Juan José: Escultura barroca castellana..., op. cit., pp. 347-348; MARTÍN GONZÁLEZ, Juan José: "Noticias documentales...”, op. cit., p. 194.

383 GARCÍA CHICO, Esteban: Documentos para el estudio del arte en Castilla. 2..., op. cit., pp. 387-388.

384 Ídem, pp. 384-385; MARTÍN GONZÁLEZ, Juan José: Escultura barroca castellana..., op. cit., pp. 343-347; REDONDO CANTERA, María José: Los Bahamonde ..., op. cit., p. 290.

385 PARRADO DEL OLMO, Jesús María: “Precisiones...”, op. cit., p. 344.
} 
iglesia de Santa María la Antigua ${ }^{386}$. Su viuda no otorgó el testamento del escultor hasta el año 1752 justificando la demora por las ocupaciones que había tenido en sacar adelante a su crecida prole ${ }^{387}$.

\section{$\underline{\text { Catálogo }}$}

1730. Adorno y graderías para el altar mayor. Iglesia de San Miguel. Arévalo $(\text { Ávila) })^{388}$.

1731. El Salvador. Iglesia del Santísimo Salvador. Simancas (Valladolid) ${ }^{389}$.

1732. Retablo mayor, retablos colaterales y púlpitos. Iglesia parroquial de Santa Eufemia. Autillo de Campos (Palencia) ${ }^{390}$.

1732. San Ambrosio y San Agustín para la fachada principal (Fig. 52). Catedral. Valladolid ${ }^{391}$.

1733. Asunción, San Pedro y San Pablo para la fachada principal (Fig. 53). Catedral. Valladolid ${ }^{392}$.

1734-1737. Retablo mayor. Iglesia parroquial. Cubillas de Santa Marta (Valladolid) ${ }^{393}$.

1734. Retablos colaterales. Iglesia de San Ginés. Ciguñuela (Valladolid) ${ }^{394}$.

1735. Retablo mayor. Iglesia de Montesión. Herrín de Campos (Valladolid) ${ }^{395}$.

1735. Custodia para el retablo mayor. Iglesia del Salvador. Simancas (Valladolid) ${ }^{396}$.

1736. Retablo de la capilla de la Cofradía de la Soledad (Fig. 54). Iglesia de San Andrés. Valladolid ${ }^{397}$.

1735. Retablo para la Archicofradía de Nuestra Señora de la Consolación. Convento de San Agustín. Valladolid ${ }^{398}$.

\footnotetext{
386 A.G.D.V., La Antigua, 1699D, f. 392; PARRADO DEL OLMO, Jesús María: "Precisiones...", op. cit., p. 344.

$387 \quad$ Ídem, p. 345.

388 VÁZQUEZ GARCÍA, Francisco: El retablo barroco..., op. cit., Tomo I, p. 1144.

389 PLAZA SANTIAGO, Francisco de la: "El retablo de Nuestra Señora del Rosario, en Simancas", B.S.A.A., Tomo XXXVII, 1971, pp. 297-298.

390 GARCÍA CHICO, Esteban: Documentos para el estudio del arte en Castilla. 2..., op. cit., p. 385.

391 Ídem, pp. 386-387; MARTÍN GONZÁLEZ, Juan José: "Noticias documentales...”, op. cit., p. 194.

392 MARTÍN GONZÁLEZ, Juan José: Escultura barroca castellana ..., op. cit., p. 347.

393 URREA FERNÁNDEZ, Jesús: Catálogo Monumental de la provincia de Valladolid. Tomo XX..., op. cit., pp. 61 y 63.

394 REDONDO CANTERA, María José: Los Bahamonde..., op. cit., p. 293.

395 Ibídem.

396 MARTÍN GONZÁLEZ, Juan José: Catálogo Monumental de la provincia de Valladolid. Tomo VI..., op. cit., pp. 99 y 109.

397 URREA FERNÁNDEZ, Jesús: La iglesia parroquial de San Andrés de Valladolid, Valladolid, 1974 , p. 7.
} 
1737. Retablos colaterales y arreglos del retablo mayor. Iglesia parroquial de San Miguel. San Miguel del Pino (Valladolid) ${ }^{399}$.

1739. Santa María Magdalena. Iglesia de la Magdalena. Arévalo (Ávila) ${ }^{400}$.

Hacia 1740. Esculturas de San Ambrosio y San Luis Gonzaga para la fachada del Colegio de San Ambrosio. Hospedería del Colegio de Santa Cruz. Valladolid ${ }^{401}$.

1740. Retablo mayor. Convento de la Merced Descalza. Valladolid ${ }^{402}$.

1741. Retablo mayor. Convento de San Agustín. Valladolid ${ }^{403}$.

1743. Retablos colaterales. Convento de la Merced Descalza. Valladolid ${ }^{404}$.

1744. Retablo mayor. Iglesia de Santa María. Piña de Esgueva (Valladolid) ${ }^{405}$.

1747. Retablo mayor (Fig. 55). Colegio Jesuita de San Lorenzo (actual Santuario de Nuestra Señora de la Calle), Palencia ${ }^{406}$.

1747. Retablo mayor y retablos colaterales. Convento de Santa Brígida. Paredes de Nava (Palencia) ${ }^{407}$.

\section{JUAN ANTONIO ARGÜELLES (a.1715 - h.1766/1777)}

Pocas noticias conservamos sobre Juan Antonio Arguielles. Debió de nacer en Asturias hacia el año 1715. Sus padres fueron Juan Antonio Argüelles y Leonor Antonia de Mata, naturales de Oviedo y Pola de Siero, respectivamente ${ }^{408}$. Estuvo casada con María Martínez Villamar, hermana de los ensambladores y tallistas Francisco y Tomás Martínez Villamar, con los que quizás colaborara en algún proyecto.

\footnotetext{
398 GARCÍA CHICO, Esteban: Documentos para el estudio del arte en Castilla. 2..., op. cit., 1941, pp. 390-391.

399 ARA GIL, Clementina Julia y PARRADO DEL OLMO, Jesús María: Catálogo Monumental de la provincia de Valladolid. Tomo XI..., op. cit., p. 115.

400 VÁZQUEZ GARCÍA, Francisco: El retablo barroco..., op. cit., Tomo I, p. 1144.

401 MARTÍN GONZÁLEZ, Juan José: "Una atribución a Pedro de Bahamonde", B.S.A.A., Tomo XXIX, 1963, p. 263; MARTÍN GONZÁLEZ, Juan José: Catálogo Monumental de la provincia de Valladolid. Tomo XIII..., op. cit., p. 38; MARTÍN GONZÁLEZ, Juan José y URREA FERNÁNDEZ, Jesús: Catálogo Monumental de la provincia de Valladolid. Tomo XIV..., op. cit., p. 320; MARTÍN GONZÁLEZ, Juan José y DE LA PLAZA SANTIAGO, Francisco Javier: Catálogo Monumental de la provincia de Valladolid. Tomo XV..., op. cit., p. 254.

402 FERNÁNDEZ DEL HOYO, María Antonia: Patrimonio perdido..., op. cit., pp. 572-574.

403 Ídem, p. 256.

404 BRASAS EGIDO, José Carlos: "Noticias documentales...", op. cit., p. 471; FERNÁNDEZ DEL HOYO, María Antonia: Patrimonio perdido..., op. cit., pp. 574-575.

405 URREA FERNÁNDEZ, Jesús: Catálogo Monumental de la provincia de Valladolid. Tomo XX..., op. cit., pp. 182-184.

406 BRASAS EGIDO, José Carlos: “Noticias documentales...”, op. cit., p. 472.

$407 \quad$ Ibídem.

$408 \quad$ A.H.P.V., Leg. 3.519, f. 85.
} 
En 1751 ostentaba el cargo de hermano mayor de la Hermandad de Nuestra Señora del Rosario de la iglesia de San Miguel. Como tal hermano mayor, el 31 de julio se concierta con el dorador Mateo Prieto para dorar el retablo de Nuestra Señora del Rosario según las condiciones redactadas por el también dorador Joseph Mayo ${ }^{409}$. Perteneció a otras cofradías, por ejemplo a la de San José de maestros entalladores, sita en la iglesia penitencial de Nuestra Señora de las Angustias ${ }^{410}$.

Debía de haber fallecido ya en 1777 puesto que en el testamento otorgado por Francisco Martínez Villamar, hermano de María Martínez Villamar, esposa de Argüelles, este declaraba que dejaba por su "única y universal heredera a María Martínez Villamar mi hermana viuda que quedó de Juan Antonio de Argüelles ya difunto"411.

\section{$\underline{\text { Catálogo }}$}

1749. Retablo y tabernáculo del altar mayor (Fig. 56). Convento de Nuestra Señora de la Piedad. Palencia ${ }^{412}$.

1751. Dos relicarios. Iglesia de San Miguel. Vega de Valdetronco (Valladolid) ${ }^{413}$

1761-1762. Retablos de San Blas y del Santo Cristo. Iglesia de San Pedro. Villabuena del Puente (Zamora) ${ }^{414}$

1761-1762. Retablo mayor. Iglesia de la Asunción. Villasexmir (Valladolid) ${ }^{415}$.

1766. Santísimo Cristo de la Salud (Fig. 57). Ermita del Santo Cristo de la Salud. La Puebla de Almoradiel (Toledo) ${ }^{416}$.

\section{JOSÉ FERNÁNDEZ (a.1719 - d.1776)}

Ignoramos cualquier dato biográfico sobre este interesante escultor que quizás proceda de Cuenca de Campos. Durante cierto tiempo residió en la calle de Cantarranas ${ }^{417}$.

Urrea al documentar las esculturas que realizó para la parroquial de Valoria la Buena, las primeras que se le documentaron, señalaba que eran "de gran interés (...) a juzgar

\footnotetext{
409 A.H.P.V., Leg. 3.519, ff. 80-82.

410 A.H.P.V., Leg. 3.521, ff. 9-10.

411 A.H.P.V., Leg. 3.999, ff. 413-414.

412 BRASAS EGIDO, José Carlos: "Noticias documentales...”, op. cit., p. 472.

413 Ibídem.

$414 \quad$ NAVARRO TALEGÓN, José: Catálogo monumental de Toro..., op. cit., p. 412.

415 PARRADO DEL OLMO, Jesús María: Catálogo Monumental de la provincia de Valladolid. Tomo IX..., op. cit., p. 299.

416 En una reciente restauración se encontró en un hueco del costado un pergamino con la siguiente inscripción: "Juan Antonio Argüelles me hizo en el año 1766, rogad a Dios por él". http://es.wikipedia.org/wiki/La_Puebla_de_Almoradiel.

417 A.H.P.V., Leg. 3.475, f. 274. El 11 de agosto de 1783 fallece en esa misma calle un tal "Josef Fernández natural que fue de Cuenca de Campos obispado de León y vecino de esta referida ciudad", ignoro si se trata de nuestro escultor. A.G.D.V., La Antigua, 1752D, f. 252.
} 
por la calidad de las mismas mantenía viva en Valladolid y con cierta dignidad, nuestra tradicional escuela" ${ }^{418}$.

Mantuvo relaciones profesionales con el pintor Nicolás Rico, como así se desprende del testamento otorgado por este último el 25 de junio de 1762 en el cual declaraba que Fernández le adeudaba 90 reales $^{419}$. Los mismos reales le seguía debiendo el 8 de agosto de $1773^{420}$. El platero Sebastián de la Fuente debió ser uno de sus más allegados puesto que cuando este dicta testamento, el 25 de septiembre de 1776, le nombra como uno de sus testamentarios y albaceas ${ }^{421}$.

\section{$\underline{\text { Catálogo }}$}

1741. San Juan Evangelista, San Nicolás y Santa Catalina. Universidad. Valladolid ${ }^{422}$. Desaparecidos.

1749. María Santísima de los Dolores. Iglesia de San Pedro. Valladolid ${ }^{423}$.

1752. Nuestra Señora (sin especificar). Iglesia de San Pedro. Valladolid ${ }^{424}$.

1764. Nuestra Señora del Rosario (Fig. 58). Iglesia parroquial de Santa María la Mayor. Corcos del Valle (Valladolid) ${ }^{425}$.

1775. Inmaculada, San Simón y San Judas (Figs. 59-61). Iglesia parroquial de San Pedro Apóstol. Valoria la Buena (Valladolid) ${ }^{426}$.

\section{FELIPE ESPINABETE $(1719$ - 1799)}

Hablaremos brevemente sobre Felipe Espinabete en la sección de discípulos de Pedro de Ávila pues, aunque no tengo ninguna prueba documental, pienso que es factible que se formara en su taller.

\footnotetext{
418 URREA FERNÁNDEZ, Jesús: Catálogo Monumental de la provincia de Valladolid. Tomo $X X \ldots$, op. cit., p. 128.

419 "Joseph Fernández de ejercicio escultor vecino de esta ciudad noventa reales". A.H.P.V., Leg. 3.523/1, ff. 126-129.

$420 \quad$ "Y Joseph Fernández de ejercicio escultor vecino de esta ciudad me debe noventa reales es mi voluntad se cobre". A.H.P.V., Leg. 3.525/7, ff. 47-49.

421 A.H.P.V., Leg. 3.881, ff. 96-98.

422 REDONDO CANTERA, María José: "El edificio de la Universidad durante los siglos XVII y XVIII" en Historia de la Universidad de Valladolid, tomo II, Universidad de Valladolid, Valladolid, 1989, p. 657.

423 MARTÍN GONZÁLEZ, Juan José y URREA FERNÁNDEZ, Jesús: Catálogo Monumental de la provincia de Valladolid. Tomo XIV..., op. cit., p. 167.

$424 \quad$ Ibídem.

425 URREA FERNÁNDEZ, Jesús: Catálogo Monumental de la provincia de Valladolid. Tomo $X X \ldots$, op. cit., p. 58.

$426 \quad$ Ídem, p. 128.
} 


\section{2-4 EVOLUCIÓN DEL RETABLO Y ENSAMBLADORES EN VALLADOLID ENTRE 1650-1750}

A lo largo del proceso creativo de los tres escultores Ávila (Juan, Pedro y Manuel) se desarrollan en Valladolid tres tipologías de retablos, siempre siguiendo el criterio expuesto por Martín González en su indispensable libro Escultura barroca castellana $^{427}$ : prechurrigueresco (1650-1690 aprox.), churrigueresco (1690-1740 aprox.) y rococó (1740-1780 aprox.). Hay que tener presente que la mayoría de ensambladores o tallistas no participan solamente de uno de estos movimientos, sino que evolucionan e intervienen en sucesivos estadios. También es cierto que existen ciertos maestros más conservadores que no presentan cambios significativos a lo largo de su trayectoria.

A la hora de abordar la retablística vallisoletana de la forma más breve y concisa, pero que a la vez sirva de recapitulación de todo lo hasta ahora conocido, he creído que la mejor manera es la siguiente: primeramente, explicar cada uno de los periodos con sus características, ejemplos más importantes y artífices más destacados y finalizar hablando de la relación de los Ávila con los ensambladores. En las fichas de cada ensamblador se hará un pequeño bosquejo biográfico y posteriormente un listado de su producción documentada, a la manera que hemos hecho con los escultores.

\section{A- EL RETABLO "PRE-CHURRIGUERESCO" (aprox. 1650-1690)}

El tipo de retablo que se lleva a cabo en este periodo es el denominado "prechurrigueresco", que se caracteriza por ser el primero con singularidades netamente barrocas: resurrección de la ornamentación, la cual se labra en mayor cantidad y abultamiento $^{428}$. Tiene lugar la aparición de las tarjetas cactiformes, los marcos de tarjetillas y los cogollos de los frisos. Todo ello aporta al retablo juegos de claroscuros que potencian sus volúmenes escultóricos.

El soporte más utilizado es la columna, fundamentalmente la salomónica, aunque en algún caso todavía se usa la de fuste estriado, aunque los ensambladores también se sirven del machón. Los retablos más descollantes de este periodo son los del convento de Jesús y María, el de la iglesia parroquial de San Martín, el de la iglesia de Santa María, de Tordesillas, y el de la iglesia penitencial de Nuestra Señora de la Pasión. Por desgracia este último no se conserva, si bien conocemos el modelo que se utilizó para realizar su traza. La utilización de la columna salomónica en este periodo todavía no está generalizada, así en dos de estos retablos se usa la de fuste estriado con machones en el ático y en los otros dos la referida columna salomónica.

El hecho más destacable durante esta etapa es la aparición de la columna salomónica en Valladolid. Tiene lugar en 1657 en el retablo mayor de la iglesia penitencial de Nuestra

427 MARTÍN GONZÁLEZ, Juan José: Escultura barroca castellana..., op. cit; MARTÍN GONZÁLEZ, Juan José: El retablo barroco en España, Alpuerto, Madrid, 1993.

428 MARTÍN GONZÁLEZ, Juan José: Escultura barroca castellana ..., op. cit., p. 68. 
Señora de la Pasión. Se trata de una aparición tardía dado que, según Otero Túñez, las primeras columnas salomónicas en España son las realizadas por Bernardo Cabrera para el retablo de las Reliquias de la catedral de Santiago de Compostela $(1625)^{429}$. El retablo de la penitencial vallisoletana fue contratado por los ensambladores Alonso y Antonio de Billota y el escultor Francisco Díez de Tudanca ${ }^{430}$. Tendría seis columnas salomónicas gigantes siguiendo las trazas del retablo mayor de la madrileña iglesia del Buen Suceso. En estos momentos Madrid era el principal distribuidor peninsular de modelos para retablos, sus tracistas gozaban de gran prestigio, y de hecho dos de sus grandes exponentes trabajaran en Valladolid: Pedro de la Torre y Sebastián de Benavente $^{431}$.

El madrileño Pedro de la Torre, arquitecto y ensamblador, es uno de los grandes renovadores de la retablística barroca. En abril de 1655 diseña la traza para el retablo mayor de la iglesia de Santa María, de Tordesillas; en el contrato figura como "maestro de obras de Su Majestad"432. Tan solo aporta la traza pues de su realización se ocupa el segoviano José de Arroyo. La obra se ejecuta según el modelo imperante en la escuela madrileña: monumentalización del cuerpo principal, que se alza sobre un gran banco; ornamentación prolífica; marcos adornados con tarjetillas; tarjetas cactiformes, etc... ${ }^{433}$. También es característicamente madrileño la utilización mayoritaria de pinturas, quedando relegada la escultura a la hornacina principal y al ático.

El influjo madrileño también está presente en el retablo mayor del convento de Jesús y María, de Valladolid. Lo concertó en 1658 Juan Velázquez, hijo de Francisco Velázquez, pero había de seguir la traza del ensamblador madrileño Sebastián de Benavente. El retablo se articula con columnas corintias de fuste estriado en su cuerpo principal y dos machones decorados con múltiples festones en su ático. Estos últimos sostienen un entablamento partido. El cierre culmina en semicírculo, en cuyo punto más alto encontramos una jugosa tarjeta cactiforme. Sobre los dos trozos de entablamento cabalgan sendas virtudes. Las mismas voluminosas tarjetas las podemos observar sobre la hornacina principal y las pinturas de las calles laterales. Tanto las tres hornacinas y cajas del cuerpo principal como las del ático, en total seis, se hallan metidas dentro de marcos de tarjetillas. Nuevamente vemos una característica puramente madrileña: proliferación de pinturas en detrimento de la escultura: tan solo encontramos tallas en la hornacina que preside el retablo, con los titulares del Convento, y las dos virtudes del ático. Las pinturas, realizadas por Mateo Cerezo, añaden mayor valor al retablo.

El último retablo que vamos a destacar es el de la iglesia de San Martín de Valladolid, realizado en 1672 por Pedro de Cea, si bien no fue finalizado hasta 1681 por Cristóbal

429 OTERO TÚÑEZ, Ramón; Las primeras columnas salomónicas de España, Boletín de la Universidad Compostelana, № 63, 1955

$430 \quad$ GARCÍA CHICO, Esteban: Documentos para el estudio del arte en Castilla. 2..., op. cit., pp. 300-301.

431 MARTÍN GONZÁLEZ, Juan José: Escultura barroca castellana..., op. cit., p. 73.

432 Ibídem,

433 Ídem, p. 68. 
Ruiz de Andino en $1681^{434}$. Está formado de un potente banco en el que sobresalen las ménsulas pobladas de vegetación muy jugosa, un único cuerpo recorrido por seis columnas salomónicas de orden gigante y un ático semicircular. La profundidad, y por ende los efectos claroscuristas, se ve garantizada por la disposición escalonada de las columnas, las cuales sostienen unos entablamentos recurvados. Al referido juego de luces y sombres contribuye de manera decisiva el gran recargamiento y la hinchazón de decoración que lleva el retablo. El ático se cierra en semicírculo, para lo cual se curvan los machones. La raigambre vallisoletana la constatamos en que tan solo se utiliza la escultura. En la hornacina principal se sitúa Nuestra Señora de la Peña de Francia, imagen de vestir, tras la cual se abre un transparente. A los lados de esta, en sendos intercolumnios encontramos a San Pedro y San Pablo. Finalmente, en el ático, un relieve de San Martín partiendo la capa para dársela al pobre ocupa el espacio cuadrangular entre los dos machones. Este retablo representa un primer estadio hacia la configuración del retablo-camarín, aunque aquí es solamente un transparente en un camarín sin profundidad. Este retablo será cabeza de serie de una larga lista de retablos: un solo cuerpo, articulado por columnas salomónicas gigantes, y ático rematado en forma semicircular ${ }^{435}$.

Los principales artífices de este periodo son: Cristóbal Ruiz de Andino (h.1625 d.1687), Antonio Billota (h.1630 - 1687), Pedro de Cea (1633 - d.1684) y Juan Guerrero de Horna (1639 - d.1702). Cabría incluir otros nombres como el del ensamblador Pablo de Freiría, cuya última etapa participa del prechurriguerismo, si bien prefiero no incorporarle dado que la mayoría de su obra conservada pertenece a la etapa anterior: el retablo contrarreformista.

\section{CRISTÓBAL RUIZ DE ANDINO (h.1625 - d.1689)}

Cristóbal Ruiz de Andino ${ }^{436}$ nació en la localidad burgalesa de Barruelo en una fecha indeterminada en torno al año 1625, siendo sus padres Sebastián Ruiz y María de Andino. Muy joven debió de venir a Valladolid, ciudad en la que se formaría como ensamblador. La primera noticia que nos le sitúa en la ciudad de Pisuerga proviene de una escritura relativa a un pleito sostenido en el año 1650 entre el ensamblador José Castilla y la Cofradía de Mancebos Sastres del Convento de San Francisco ${ }^{437}$.

Pocos años después contrae matrimonio con Beatriz Corona. Los desposorios tuvieron lugar el 3 de mayo de 1655 en la iglesia parroquial del Salvador de Simancas, mientras que las velaciones se celebraron el 2 de febrero de 1656 en la antigua iglesia de San Miguel de Valladolid ${ }^{438}$. Desconocemos la fecha de su fallecimiento, si bien este

\footnotetext{
434 MARTÍN GONZÁLEZ, Juan José y URREA FERNÁNDEZ, Jesús: Catálogo Monumental de la provincia de Valladolid. Tomo XIV..., op. cit., p. 101.

435 MARTÍN GONZÁLEZ, Juan José: Escultura barroca castellana ..., op. cit., p. 69.

436 Ver: Ídem, pp. 294-298. MARTÍN GONZÁLEZ, Juan José: Escultura barroca en España..., op. cit., p. 74.

437 FERNÁNDEZ DEL HOYO, María Antonia: "El convento de San Francisco...”, op. cit., p. 423.

438 A.G.D.V., San Miguel, 1651M, f. 47.
} 
aconteció con posterioridad a los años 1689-1690, periodo en el que se estaba dirimiendo un pleito que le había planteado la ermita de Nuestra Señora de la Peña de Tordesillas (Valladolid) ${ }^{439}$.

Además de ensamblador pudo practicar la escultura. Martín González piensa que pudo modelar los relieves de los bultos funerarios de don Luis Méndez de Quijada y doña Magdalena de Ulloa para las paredes laterales de la capilla mayor de la Colegiata de San Luis, de Villagarcía de Campos ${ }^{440}$. Creo que tendríamos que poner esta atribución con las máximas reservas dado que no encontramos ningún documento en el que figure como escultor ni hay otras obras escultóricas con las que pueda ser relacionado.

\section{$\underline{\text { Catálogo }}$}

1660. Reparos en la Casa Consistorial. Ayuntamiento. Valladolid ${ }^{441}$.

1660. Retablo mayor. Iglesia de San Torcuato. Esguevillas de Esgueva (Valladolid) ${ }^{442}$. Realizado conjuntamente con el ensamblador Juan de Medina Argüelles.

1664. Sillería del coro. Convento de San Agustín. Valladolid ${ }^{443}$.

1665. Retablo mayor de la Capilla del Relicario (Fig. 62). Colegiata de San Luis. Villagarcía de Campos (Valladolid) ${ }^{444}$.

1666-1670. Retablo mayor (Fig. 63). Iglesia de San Martín. Cevico de la Torre (Palencia). Realizado conjuntamente con Antonio de Billota ${ }^{445}$.

1667. Retablo de Nuestra Señora del Rosario y Retablo del Santo Cristo de la Vera Cruz. Iglesia parroquial de San Cornelio y San Cipriano. San Cebrián de Campos $(\text { Palencia })^{446}$.

1669. Retablos colaterales de Santa Inés y Santa Lucía de la Capilla del Relicario (Fig. 64). Colegiata de San Luis. Villagarcía de Campos (Valladolid) ${ }^{447}$.

1672. Bultos funerarios de don Luis Quijada y doña Magdalena de Ulloa, Cancel y retablos colaterales. Colegiata de San Luis. Villagarcía de Campos (Valladolid) ${ }^{448}$.

\footnotetext{
439 ARA GIL, Clementina Julia y PARRADO DEL OLMO, Jesús María: Catálogo Monumental de la provincia de Valladolid. Tomo XI..., op. cit., p. 308.

$440 \quad$ MARTÍN GONZÁLEZ, Juan José: Escultura barroca castellana..., op. cit., p. 298.

441 FERNÁNDEZ DEL HOYO, María Antonia: "Fiestas en Valladolid..., op. cit., p. 387.

442 URREA FERNÁNDEZ, Jesús: Catálogo Monumental de la provincia de Valladolid. Tomo $X X \ldots$, op. cit., p. 174.

443 FERNÁNDEZ DEL HOYO, María Antonia: Patrimonio perdido..., op. cit., p. 278.

444 MARTÍN GONZÁLEZ, Juan José: “Documentación...”, op. cit., p. 207.

445 URREA FERNÁNDEZ, Jesús y MARTÍN GONZÁLEZ, Juan José: Inventario artístico de Palencia y su provincia II..., op. cit., p. 135.

446 GARCÍA CHICO, Esteban: Documentos para el estudio del arte en Castilla. 2..., op. cit., pp. 339-340; CABALlERO, Arturo: San Cebrián de Campos: iglesia de los Santos Cornelio y Cipriano, Diputación Provincial de Palencia, Palencia, 1994, pp. 21-23 y 41.

447 MARTÍN GONZÁLEZ, Juan José: “Documentación...”, op. cit., p. 207.
} 
1673. Dos balcones y celosías para los testeros del crucero de la iglesia. Colegiata de San Luis. Villagarcía de Campos (Valladolid) ${ }^{449}$.

1677. Retablo para la capilla de Santa Rosa. Convento de San Pablo. Valladolid ${ }^{450}$.

1679. Arco para el recibimiento de la reina Mariana de Neoburgo. Calle de la Lonja. Valladolid. Realizado de manera conjunta con el pintor Pedro de Calabria ${ }^{451}$.

Antes de 1687. Retablo. Iglesia de Santa Engracia. Olmos de Peñafiel (Valladolid) ${ }^{452}$.

Antes de 1687. Obra en el retablo mayor, puertas de la iglesia y otras cosas. Iglesia Penitencial de la Santa Vera Cruz. Valladolid ${ }^{453}$.

Hacia 1689. Pórtico. Ermita de Nuestra Señora de la Peña. Tordesillas (Valladolid) ${ }^{454}$.

\section{$\underline{\text { ANTONIO BILLOTA }}$ (h.1630 - 1687)}

El ensamblador Antonio Billota ${ }^{455}$ pertenece a una de las sagas de ensambladores más importantes de Valladolid. Iniciada por su padre Alonso sería continuada por el propio Antonio y posteriormente por su hijo Francisco y nieto Joaquín. Antonio debió de nacer en nuestra ciudad hacia el año 1630. Sus padres fueron el referido Alonso Billota, natural de Saldaña (Palencia) ${ }^{456}$, y una mujer llamada Marina, de la cual ignoramos los apellidos. Aprendería el oficio junto a su padre, heredando el taller tras su fallecimiento.

El 22 de agosto de 1655 contrae nupcias con Manuela de la Fuente en la iglesia del Santísimo Salvador de Valladolid ${ }^{457}$. El matrimonio tuvo cuatro hijos. El mayor, que

448 GARCÍA CHICO, Esteban: Catálogo Monumental de la provincia de Valladolid. Tomo II. Partido judicial de Medina de Rioseco, Diputación de Valladolid, Valladolid, 1959, p. 161.

$449 \quad$ Ídem, p. 162.

450 URREA FERNÁNDEZ, Jesús: “La biografía al servicio del conocimiento...”, op. cit., p. 56.

451 A.H.P.V., Leg. 2.320, ff. 180-182.

452 BALADRÓN ALONSO, Javier: op. cit., p. 163.

453 Ibídem.

454 ARA GIL, Clementina Julia y PARRADO DEL OLMO, Jesús María: Catálogo Monumental de la provincia de Valladolid. Tomo XI..., op. cit., p. 308.

455 Ver: MARTÍN GONZÁLEZ, Juan José: Escultura barroca castellana..., op. cit., p. 305; FERNÁNDEZ DEL HOYO, María Antonia: "El convento de San Francisco...”, op. cit., pp. 411-439; PARRADO DEL OLMO, Jesús María: "Patronos y obras de arte en Santa María de Tordesillas", B.S.A.A., Tomo LVI, 1990, pp. 518-541.

456 GARCÍA CHICO, Esteban: Documentos para el estudio del arte en Castilla. 2..., op. cit., p. 307.

457 "En veinte y dos días del mes de agosto de mil y seiscientos y cincuenta y cinco años habiéndose hecho las tres canónicas municiones que el Santo Concilio de Trento manda y no resultado impedimento alguno de licencia del señor licenciado don Diego Sarmiento provisor general en esta ciudad de Valladolid y todo su obispado por ante Domingo de Blas notario de asiento en veinte y un días de dicho mes yo el licenciado Juan de la Cueva teniente de cura de la iglesia parroquial del Salvador de esta dicha ciudad de Valladolid desposé por palabras de presente que hicieron verdadero matrimonio y juntamente velé in facie ecclesiae según forma de la santa madre iglesia a Antonio de Billota hijo de Alonso Billota y Marina de Répide sus padres vecinos de esta ciudad con Manuela de la Fuente hija de Francisco de la Fuente y Anna de Santander vecinos de dicha ciudad, siendo testigos el licenciado Alonso Billota, 
heredaría el taller y oficio paterno, fue Francisco $(1656)^{458}$, a la cual siguieron Bernarda $(1659)^{459}$, Luisa Gregoria $(1660)^{460}$ y Clara María $(1671)^{461}$.

Antonio fallece el 24 de marzo de $1687^{462}$ sin poder haber comenzado la construcción del retablo mayor de la iglesia de San Felipe Neri para el cual había redactado condiciones junto a su hijo ${ }^{463}$. Un mes después sus hijos Francisco, Luisa y Bernarda, "herederos que quedaron por fin y muerte de Antonio de Billota y Manuela de la Fuente sus padres", dirimían asuntos sobre la herencia ${ }^{464}$.

El conocimiento del físico y las circunstancias personales de los artistas vallisoletanos de esta época nos es completamente desconocida. Es por tanto un dato de gran importancia el que nos presenta a Antonio Billota como una persona con deficiencias auditivas. En varias ocasiones se hará referencia a su sordera cuando se señala que no se le leen las escrituras de contratos por este motivo, debiendo él mismo leerlas para conocer el contenido de las mismas ${ }^{465}$.

Por desgracia, la casi totalidad de su obra ha desaparecido o se encuentra en paradero desconocido, lo que nos impide conocer en profundidad su estilo. Si bien, a juzgar por lo poco conservado no se debió apartar demasiado de las líneas generales desarrolladas en el retablo de esta época, y no parece ser un innovador. A pesar de todo debió ser un ensamblador reputado y prestigioso a la luz de los comitentes que le encargaron obra: la catedral vallisoletana, el Convento de San Francisco, el Monasterio de Nuestra Señora de Prado, el colegio jesuítico de San Ambrosio, cofradías penitenciales... Le encontramos asociado en diversas ocasiones con Juan Guerrero de Horna, con quien debió formar compañía.

Antonio Martínez y Felipe Alonso, padrinos de las velaciones dicho Antonio Martínez y María Alonso de que doy fe". A.G.D.V., El Salvador, 1612M, f. 436.

458 "En diez del mes de diciembre de mil y seiscientos y cincuenta y seis años yo el licenciado Quiroga cura de la catedral de esta ciudad de Valladolid bauticé e impuse óleo y crisma según forma de la santa madre iglesia habiendo precedido los santos exorcismos a Francisco hijo de Antonio de Billota y Manuela de la Fuente su mujer mis parroquianos, fueron sus padrinos el licenciado Alonso de Billota y María Alonso vecinos de esta ciudad, testigos el licenciado Andrés Escudero y Joseph García de Valdivieso, dieronle por abogados a Nuestra Señora y a San Andrés en fe de lo cual lo firmé en dicho día". A.G.D.V., Catedral, 1656B, f. 2.

$459 \quad$ A.G.D.V., Catedral, 1656B, f. 18.

$460 \quad$ A.G.D.V., Catedral, 1656B, f. 28.

461 A.G.D.V., San Pedro, 1655B, f. 168.

462 FERNÁNDEZ DEL HOYO, María Antonia: "El convento de San Francisco...”, op. cit., p. 436.

463 Ibídem.

$464 \quad$ Ibídem.

$465 \quad$ "Y por causa de ser sordo el dicho Antonio Billota yo el escribano le entregué esta escritura para que la leyese y después de haberla leído dijo en presencia de los dichos testigos que así lo otorgaba". A.H.P.V., Leg. 2.676, ff. 114-115. En la escritura para fabricar el retablo de la capilla de Nuestra Señora de Prado del monasterio homónimo también se vuelve a citar dicha discapacidad: "Doy fe que el dicho Antonio Billota leyó esta escritura antes de firmarla por ser sordo". BRASAS EGIDO, José Carlos: "Notas sobre la iglesia del monasterio de Nuestra Señora de Prado de Valladolid", B.S.A.A., Tomo XLIV, 1978, pp. 466-467. 


\section{$\underline{\text { Catálogo }}$}

1657. Retablo mayor. Iglesia Penitencial de Nuestra Señora de la Pasión. Valladolid. Realizado conjuntamente con su padre Alonso Billota y el escultor Francisco Díez de Tudanca ${ }^{466}$.

1663. Custodia del retablo mayor. Iglesia de San Pedro Apóstol. Valladolid ${ }^{467}$.

1665. Retablos de la capilla de la Anunciación y retablo de la capilla del Salvador. Colegio de San Ambrosio. Valladolid ${ }^{468}$.

1666-1670. Retablo mayor. Iglesia de San Martín. Cevico de la Torre (Palencia). Realizado conjuntamente con Cristóbal Ruiz de Andino ${ }^{469}$.

1669. Retablo colateral del Evangelio o del "Santo Cristo del Consuelo". Catedral. Valladolid $^{470}$.

1674. Retablo de la capilla de Nuestra Señora de Prado. Monasterio de Nuestra Señora de Prado. Valladolid ${ }^{471}$. Realizado conjuntamente con Juan Guerrero.

1675. Retablo mayor de la Capilla de la V.O.T., Convento de San Francisco. Valladolid $^{472}$.

1678. Finalización de un retablo contratado por Pedro de Cea. Iglesia parroquial de San Pedro. Mucientes (Valladolid) ${ }^{473}$.

1679. Retablo mayor y retablos colaterales. Monasterio de Nuestra Señora de Prado. Valladolid ${ }^{474}$. Realizado conjuntamente con Juan Guerrero.

\section{PEDRO DE CEA $(1633-\mathrm{d} .1684)$}

Aunque alguna vez se le ha supuesto oriundo de Galicia ${ }^{475}$, ahora podemos aclarar este extremo. Pedro de Cea Gutiérrez ${ }^{476}$ vio la luz en la pequeña localidad palentina de

\footnotetext{
466 GARCÍA CHICO, Esteban: Documentos para el estudio del arte en Castilla. 2..., op. cit., pp. 300-301.

467 A.H.P.V., Leg. 2.676, ff. 114-115. Agradezco el conocimiento de esta obra a doña Guadalupe Ramos de Castro.

468 FERNÁNDEZ DEL HOYO, María Antonia: "El convento de San Francisco...", op. cit., p. 435.

469 URREA FERNÁNDEZ, Jesús y MARTÍN GONZÁLEZ, Juan José: Inventario artístico de Palencia y su provincia II..., op. cit., p. 135.

$470 \quad$ URREA FERNÁNDEZ, Jesús:" El retablo mayor y los colaterales de la Catedral de Valladolid", B.R.A.C., Tomo XXXVI, 2001, p. 127.

471 BRASAS EGIDO, José Carlos: "Notas sobre la iglesia...", op. cit., pp. 466-467.

472 GARCÍA CHICO, Esteban: Documentos para el estudio del arte en Castilla. 2..., op. cit., pp. 309-310.

473 FERNÁNDEZ DEL HOYO, María Antonia: "El convento de San Francisco...”, op. cit., p. 436.

474 BRASAS EGIDO, José Carlos: "Notas sobre la iglesia...," op. cit., p. 466.

475 "Seguramente es también oriundo de Galicia, pues en las provincias de Orense y Pontevedra hay varias localidades de esta denominación”. MARTÍN GONZÁLEZ, Juan José: Escultura barroca castellana..., op. cit., p. 290.
} 
Torremormojón a mediados del mes de marzo de 1633. Sus padres, Pedro de Cea y María Gutiérrez, lo bautizaron en la iglesia parroquial de la villa, intitulada de Nuestra Señora del Castillo, el día 19 de ese mismo mes. Se le adjudicó como abogado a San José, patrón de los carpinteros, toda una premonición ${ }^{477}$.

Una vez establecido en tierras vallisoletanas, a donde vendría a aprender el oficio, contrae matrimonio el 15 de agosto de 1663 con Manuela de Medina Argüelles, hermana del ensamblador riosecano Juan de Medina Argüelles ${ }^{478}$, en la iglesia de Santa María de la Antigua ${ }^{479}$. La pareja tuvo cinco hijos: Pedro $(1664)^{480}$, Cristóbal $(1666)^{481}$, Manuel $(1667)^{482}$, Francisco $(1669)^{483}$ y Teresa $(1672)^{484}$. Realizó asiduos cambios de vivienda y de parroquia hasta que finalmente se estableció en la de Santiago Apóstol, uno de los barrios más ligados a los artistas, en especial a pintores y escultores.

Colaboró en diversas ocasiones con su cuñado Juan de Medina Argüelles, quien asimismo le proporcionaría algún comitente en sus comienzos. La obra más destacada realizada entre ambos fue el suntuoso retablo mayor de la iglesia parroquial de Santiago Apóstol, de Cigales (Valladolid) ${ }^{485}$. Martín González define a Cea como "entregado a un barroquismo más acentuado, tanto por lo que se refiere al ensamblaje, de violento claroscuro, como al movimiento de las imágenes, de pliegues muy duros y agitados". Sus retablos, según el historiador del arte "constituyen magníficos ejemplares de estilo prechurrigueresco" 486 .

Desconocemos el lugar y fecha de su fallecimiento. Cabe la posibilidad de que en el último periodo de su vida se estableciera en Tordesillas, villa para la que trabajó bastante, así como para ciertas poblaciones de sus inmediaciones. La última noticia que poseemos sobre él se fecha en 1684 cuando figura diseñando la traza y condiciones para realizar el retablo mayor de la iglesia parroquial de Villavieja del Cerro ${ }^{487}$.

\footnotetext{
476 Ver: Ídem, pp. 290-293. MARTÍN GONZÁLEZ, Juan José: Escultura barroca en España..., op. cit., p. 73.

477 "En diez y nueve de marzo de este año de mil y seiscientos y treinta y tres años yo el cura Juan Cantoro beneficiado mayor en la iglesia de Santa María del Castillo de esta villa de la torre bauticé a Pedro hijo de Pedro de Cea y de María Gutiérrez fueron sus padrinos Antonio Gutiérrez y Catalina Martín dile por abogado a San Joseph y advertí a los padrinos del parentesco espiritual que con el bautizado y sus padres habían contraído testigos Baltasar González de la Cuesta y Cristóbal Díez todos vecinos de esta dicha villa y lo firmé con el padrino y un testigo". A.D.P., Torremormojón, Iglesia parroquial de Nuestra Señora del Castillo, Bautizados, Tomo 5, f. 67.

478 Se puede pensar en una posible formación de Pedro de Cea en Medina de Rioseco en el taller de su cuñado Medina Argüelles, lugar donde conocería a la hermana del ensamblador. A la vista del estilo de ambos artistas no habría problemas a la hora de aceptar esta teoría.

479 A.G.D.V., La Antigua, 1650M, f. 104.

480 A.G.D.V., San Andrés, 1661B, f. 35.

481 A.G.D.V., San Lorenzo, 1601B, f. 409.

482 A.G.D.V., Santiago, 1643B, f. 519.

483 A.G.D.V., Santiago, 1668B, f. 39.

484 A.G.D.V., Santiago, 1668B, f. 98.

485 MARTÍN GONZÁLEZ, Juan José: Escultura barroca castellana..., op. cit., p. 290.

486 Ídem, p. 136

487 ARA GIL, Clementina Julia y PARRADO DEL OLMO, Jesús María: Catálogo Monumental de la provincia de Valladolid. Tomo XI..., op. cit., p. 460.
} 
$\underline{\text { Catálogo }}$

1666. Retablo mayor (Fig. 65). Iglesia de Santiago Apóstol. Cigales (Valladolid) ${ }^{488}$.

1670-1672. Retablo-baldaquino para el altar mayor. Catedral. Valladolid ${ }^{489}$.

1672. Retablo mayor (Fig. 66). Iglesia de San Martín. Valladolid ${ }^{490}$.

1672. Retablo de la capilla de Nuestra Señora de la Cabeza. Iglesia de Santiago Apóstol. Valladolid ${ }^{491}$.

1675. Reparos en el retablo mayor. Iglesia parroquial de la Asunción. Laguna de Duero (Valladolid) $)^{492}$.

Antes de 1676. Retablo. Iglesia parroquial de San Pedro. Amusco (Palencia) ${ }^{493}$.

1677. Cancel. Iglesia de San Antolín. Tordesillas (Valladolid) ${ }^{494}$.

1677. Retablo de la capilla de los Gaitán. Iglesia de San Pedro. Tordesillas

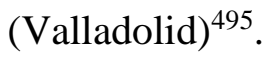

Antes de 1678. Retablo. Iglesia parroquial de San Pedro. Mucientes (Valladolid) ${ }^{496}$. Contrata el retablo, pero no sabemos porque motivos lo finaliza Antonio Billota.

1678. Marco para el frontal del altar mayor. Iglesia de San Miguel. Tordesillas (Valladolid $)^{497}$.

1678. Cinco hacheros. Iglesia de San Pedro. Tordesillas (Valladolid) ${ }^{498}$.

1678. Retablo. Iglesia parroquial de San Pedro. Mucientes (Valladolid) ${ }^{499}$. Fue finalizado por Antonio de Billota.

488 GARCÍA CHICO, Esteban: Documentos para el estudio del arte en Castilla. 2..., op. cit., pp. 320-321; URREA FERNÁNDEZ, Jesús: Catálogo Monumental de la provincia de Valladolid. Tomo $X X \ldots$, op. cit., p. 161.

489 MARTÍN GONZÁLEZ, Juan José: "Noticias documentales...”, op. cit., p. 191; URREA FERNÁNDEZ, Jesús: "Noticias documentales...”, op. cit., p. 531; URREA FERNÁNDEZ, Jesús:” El retablo mayor y los colaterales de la Catedral de Valladolid", B.S.A.A., Tomo XXXVI, 2001, pp. 126-128. $490 \quad$ MARTÍ Y MONSÓ, José: Estudios histórico-artísticos..., op. cit., p. 642.

491 MARTÍN GONZÁLEZ, Juan José y URREA FERNÁNDEZ, Jesús: Catálogo Monumental de la provincia de Valladolid. Tomo XIV..., op. cit., p. 200.

492 MARTÍN GONZÁLEZ, Juan José: Catálogo Monumental de la provincia de Valladolid. Tomo VI..., op. cit., p. 62.

493 URREA FERNÁNDEZ, Jesús y MARTÍN GONZÁLEZ, Juan José: Inventario artístico de Palencia y su provincia I..., op. cit., p. 68.

$494 \quad$ PARRADO DEL OLMO, Jesús María: Datos histórico artísticos..., op. cit., p. 90.

495 MARTÍN GONZÁLEZ, Juan José: “La capilla de los Gaitán, de Tordesillas”, B.S.A.A., Tomo XXXIX, 1973, p. 231.

496 FERNÁNDEZ DEL HOYO, María Antonia: “El convento de San Francisco...”, op. cit., p. 436.

497 ARA GIL, Clementina Julia y PARRADO DEL OLMO, Jesús María: Catálogo Monumental de la provincia de Valladolid. Tomo XI..., op. cit., p. 270.

$498 \quad$ Ídem, pp. 220 y 240.

499 FERNÁNDEZ DEL HOYO, María Antonia: “El convento de San Francisco...”, op. cit., p. 436. 
1680. Retablo para la capilla de San Fernando (Fig. 67). Catedral. Valladolid ${ }^{500}$.

1680. Retablo para la capilla de Nuestra Señora del Sagrario. Catedral. Valladolid ${ }^{501}$.

1682. Andas procesionales. Iglesia de San Pedro. Tordesillas (Valladolid) ${ }^{502}$.

\section{JUAN GUERRERO DE HORNA $(1639-\mathrm{d} .1702)$}

Según se va indagando en los archivos van apareciendo nuevos datos sobre este interesante ensamblador que debió de gozar de cierta importancia que actualmente no podemos calibrar. Juan Guerrero de Horna nace en Valladolid a comienzos del año 1639. Sus padres, Diego Guerrero y María de Villanueva, lo llevan a bautizar el día 9 de enero en la primitiva iglesia de San Miguel $^{503}$.

El 25 de junio de 1662 se desposa con Ana Gutiérrez en la iglesia de Santa María de la Antigua $^{504}$, teniendo lugar las velaciones del matrimonio en el referido templo el 14 de mayo de $1663^{505}$. En 1669 le encontramos viviendo en la calle de la Puente ${ }^{506}$, aunque no por mucho tiempo puesto que mantiene pleitos con su arrendatario, el Monasterio de Nuestra Señora de Prado ${ }^{507}$. Posteriormente, en el año 1688 figura como vecino del Barrio Nuevo (actual parroquia de San Nicolás) ${ }^{508}$.

Sobre su faceta profesional hay que subrayar el hecho de que en algunas de sus obras trabaja en compañía del también ensamblador Antonio Billota. Entre sus amistades dentro del gremio se debía de encontrar Blas Martínez de Obregón, del cual saldrá por fiador cuando contrate el retablo mayor de la capilla de la Virgen de Copacabana del desaparecido Monasterio de San Francisco de Valladolid ${ }^{509}$.

A su escaso catálogo podemos añadir una nueva obra, que por suerte se conserva. Se trata del retablo de Nuestra Señora del Amparo de la iglesia parroquial de Santa Colomba de Castropodame (León). El 19 de enero de 1681 Guerrero se concierta con el bachiller don Antonio de Quiroga y Losada "cura propio de la parroquial de señor San Juan extramuros de esta dicha ciudad" para realizar un retablo con destino "a tierra del

\footnotetext{
500 URREA FERNÁNDEZ, Jesús: “Capillas y patronos...”, op. cit., p. 112.

501 URREA FERNÁNDEZ, Jesús: "La capilla de Nuestra Señora del Sagrario en la Catedral de Valladolid”, B.R.A.C., Tomo XLI, 2006, pp. 70-71.

502 ARA GIL, Clementina Julia y PARRADO DEL OLMO, Jesús María: Catálogo Monumental de la provincia de Valladolid. Tomo XI..., op. cit., p. 240.

503 "Certifico yo el licenciado Juan Pérez teniente de cura en esta iglesia parroquial de señor San Miguel de esta ciudad de Valladolid que en ella bauticé y puse los santos óleos según orden de nuestra madre la iglesia a Juan hijo legítimo de Diego Guerrero y de María de Villanueva, moradores al Azoguejo fueron sus padrinos Felipe Guerrero e Isabel de Villanueva dieronle por abogados a Nuestra Señora y a señor San Juan Evangelista y en fe de ello lo firmé en Valladolid a nueve de enero de mil y seiscientos y treinta y nueve años". A.G.D.V., San Miguel, 1616B, p. 323.

$504 \quad$ A.G.D.V., La Antigua, 1650M, f. 91.

505 A.G.D.V., La Antigua, 1650M, f. 103

506 A.H.P.V., Leg. 2.621, f. 584

$507 \quad$ A.H.P.V., Leg. 2.622, f. 541

508 A.H.P.V., Leg. 2.385 (2), f. 72

509 A.H.P.V., Leg. 2.423, f. 149 y ff. 675-676
} 
Bierzo y lugar de Castropodame" $" 510$. Además del retablo construiría una custodia "con sus cartelas en la conformidad que está diseñado en dicha traza", que habría "de ser retráctil para encajarla en los días de Jueves Santo en el cuerpo y medio del dicho retablo en donde se ha de poner Nuestra Señora que es en el hueco del camarín". A los lados del ático tendría que poner "dos ángeles", los cuales "los haya de dar el dicho Juan Guerrero aparejados de tabla para que el dicho D. Antonio de Quiroga los haga dibujar a su gusto y elección y después se le han de volver". Como vemos, los áticos poblados de ángeles, derivados de Gregorio Fernández, todavía se mantienen, y además amplían su "territorio de influencia".

\section{$\underline{\text { Catálogo }}$}

1668. Retablo de la Capilla de Nuestra Señora del Sagrario. Catedral. Valladolid ${ }^{511}$.

1669. Pie para el Órgano. Catedral. Valladolid ${ }^{512}$.

1674. Retablo de la capilla de Nuestra Señora de Prado. Monasterio de Nuestra Señora de Prado. Valladolid ${ }^{513}$. Realizado conjuntamente con Antonio de Billota.

1679. Retablo mayor y retablos colaterales. Monasterio de Nuestra Señora de Prado. Valladolid ${ }^{514}$. Realizado conjuntamente con Antonio de Billota.

1681. Retablo de Nuestra Señora del Amparo. Iglesia parroquial de Santa Colomba. Castropodame (León) ${ }^{515}$.

1682. Retablo de la capilla de la Encarnación (Fig. 68). Iglesia Penitencial de Nuestra Señora de las Angustias. Valladolid ${ }^{516}$.

Antes de 1700. Retablo del Santo Sepulcro. Iglesia Penitencial de Nuestra Señora de la Piedad. Valladolid ${ }^{517}$. Desaparecido.

\section{B- EL RETABLO “CHURRIGUERESCO” (aprox. 1690-1740)}

En este periodo se ven culminados los cambios que se habían iniciado en la etapa anterior. Como bien indica el nombre asignado a esta etapa, buena culpa de las transformaciones acaecidas en el campo de la retablística durante este momento la tuvieron los Churriguera. También debió de tener especial relevancia en esta evolución

\footnotetext{
$510 \quad$ A.H.P.V., Leg. 2.782, ff. 125-126.

511 URREA FERNÁNDEZ, Jesús: “La capilla de Nuestra Señora del Sagrario...”, op. cit., p. 70.

512 MARTÍN GONZÁLEZ, Juan José: "Noticias documentales...”, op. cit., p. 191.

513 BRASAS EGIDO, José Carlos: "Notas sobre la iglesia...", op. cit., pp. 466-467.

$514 \quad$ Ídem, p. 466.

515 A.H.P.V., Leg. 2.782, ff. 125-126.

516 GARCÍA CHICO, Esteban: Documentos para el estudio del arte en Castilla. 2..., op. cit., p. 343; MARTÍN GONZÁLEZ, Juan José y URREA FERNÁNDEZ, Jesús: Catálogo Monumental de la provincia de Valladolid. Tomo XIV..., op. cit., pp. 236 y 251.

517 ALARCOS LLORACH, Emilio: op. cit., pp. 197-204.
} 
la actividad del salmantino Cristóbal de Honorato "el Joven"518. En este momento la decoración llega a cubrir todo el retablo, "haciéndose, en cambio, muy menuda y nerviosa de factura" ${ }^{\text {519 }}$. La decoración le gana la batalla espacial a la escultura, la cual se limita a la imagen titular de la hornacina central y en algunos casos a las de las hornacinas laterales, además del Calvario y los ángeles del cierre. La columna salomónica continúa gozando de gran salud, sin embargo, su utilización se combina en ocasiones con el estípite, cuyo uso impera en estos momentos. Según Martín González el empleo de la columna salomónica decae a partir de 1710, siendo sustituida por otra columna "recubierta de colgantes y cabezas pequeñas de serafines" retablo de un solo cuerpo, con cuatro o seis columnas salomónicas y con el ático semicircular.

Este tipo de retablo es uno de los más abundantes de Valladolid, especialmente en su capital. Los ejemplos que mejor ilustran el churriguerismo son los retablos mayores de la iglesia de Santa María, de Pozaldez (Valladolid), el de la parroquial de Villanubla (Valladolid), el de la iglesia de Santa María, de Fuentes de Valdepero, el de la parroquia de Santiago de los Caballeros, de Medina de Rioseco y el de Santiago Apóstol en la capital vallisoletana. El periodo culmina con el retablo mayor de la iglesia de San Miguel de Reoyo, de Peñafiel (Valladolid), y el de la Buena Muerte de la iglesia de San Miguel, de Valladolid.

El retablo mayor de la iglesia de Santa María, de Pozaldez, realizado en 1689 por Francisco Billota y Gregorio Díez de Mata, supuso un paso más a la hora de un mayor incremento en la ornamentación del retablo poco a poco nos acercamos a un "horror vacui". La talla es tan incisiva que ha provocado la desaparición de las formas carnosas del retablo prechurrigueresco, la tarjeta cactiforme ha dado paso a una tarjeta crespa donde la línea recta no tiene cabida. En la portada del ático han desaparecido los machones, los cuales se han visto sustituidos por columnas salomónicas. Es el retablo barroco en su total esplendor. Los netos del banco van decorados con elementos vegetales. La escultura sigue desterrada a la hornacina principal, las laterales y el ático. En este último siguen campeando los típicos ángeles fernandescos, en esta ocasión portaestandartes. La portada del ático la ocupa un relieve, el cual se ve rematado con una gran tarjeta decorativa de formas muy crespas.

Un nuevo hito dentro de este periodo lo representa el retablo mayor de la parroquial de Villanubla (1694), labrado también por Francisco Billota y Gregorio Díez de Mata. Será el primer retablo en el que se utilice el estípite del nuevo tipo "constituido por un tronco de pirámide invertida y dos fragmentos de entablamento superpuestos, con numerosos adornos" ${ }^{21}$. El estípite alcanza su mayor monumentalidad en el gigantesco retablo mayor de la iglesia parroquial de Fuentes de Valdepero (Valladolid), realizado en 1711

518 PARRADO DEL OLMO, Jesús María: "La colaboración entre ensambladores en los proyectos de retablos de finales del siglo XVII y unas obras inéditas de Tomás de Sierra". B.S.A.A., Tomo LXII, 1996, pp. 401-420.

519 MARTÍN GONZÁLEZ, Juan José: Escultura barroca castellana ..., op. cit., p. 70.

$520 \quad$ Ibídem.

$521 \quad$ Ídem, p. 71. 
por Alonso Manzano siguiendo las trazas dadas por Lucas Ortiz de Boar ${ }^{522}$. La columna salomónica en esta ocasión ha sido relegada a los laterales de la hornacina principal y de las calles laterales. En este retablo, que ha quedado en "blanco" y nos permite ver mejor la labra de la madera, las columnas solamente tienen una función decorativa. La decoración cubre la totalidad de la superficie arquitectónica.

El retablo más gigantesco del churrigueresco vallisoletano es el proyectado en 1703 por Joaquín de Churriguera para el ábside mayor de la iglesia de Santiago de los Caballeros, de Medina de Rioseco. Llevado a cabo por los ensambladores Diego de Suano y Francisco Pérez la escultura corrió a cargo del prolífico artífice riosecano, aunque berciano de origen, Tomás de Sierra Vidal. El retablo debía adaptarse a un ábside tan sumamente alto que no había posibilidad de utilizar el orden gigante, por lo que el tracista recurre a dos cuerpos articulados mediante columnas corintias de tercio tallado y con los otros dos tercios decorados con colgantes. Este tipo de columna tendrá gran predicamento en las últimas décadas del churrigueresco. El retablo trajo muchas más novedades: las cartelas decoradas con niños atlantes, los estípites y la utilización de marcos ovalados "forma tan unida al rococó" "523. Finalmente, en el ático se sitúan a plomo de las columnas cuatro santos sentados "con las piernas colgando hacia afuera, en actitud muy naturalista.", si bien no es el primer retablo en que se utilizan sí que es el ejemplo más importante.

La apoteosis de la columna salomónica en Valladolid capital tiene lugar en el retablo mayor de la iglesia de Santiago Apóstol, de Valladolid, realizado en su parte arquitectónica por Alonso Manzano y la escultórica por Juan de Ávila ${ }^{524}$. La planta es semicircular para adaptarse al ábside gótico. Sobre grandes ménsulas con decoración vegetal se levantan cuatro columnas salomónicas de orden gigante, las cuales están rematadas por entablamentos, sobre los cuales van sentados unos ángeles, la parte superior se completa con un cascarón semicircular que termina de forrar el ábside. Según Martín González "debe considerarse este retablo como uno de los más espléndidos del Barroco" 525 .

Los dos retablos que culminan este periodo son los de San Miguel, de Peñafiel y el de la Buena Muerte de la iglesia de San Miguel, de Valladolid. El primero de ellos, tallado por Tomás Ruiz en 1729 "constituye la más deslumbrante gruta que se pueda imaginar" ${ }^{\$ 26}$. A pesar de la gran altura que debía salvar utilizó columnas de tercio inferior tallado y estípites de orden gigante, estos últimos en los extremos. Todo ello conlleva un ático extremadamente amplio pero que no rompe la armonía general. La planta "resulta articulada en profundidad, semejando una portada de iglesia medieval" ${ }^{527}$. El otro retablo, fechado ya en 1738, se le considera como el punto 
culminante de la exaltación del estípite ${ }^{528}$. El uso de la columna salomónica quedó ya atrás. Este retablo pertenece ya, según Martín González, a un "fase de ornato apretadísimo, ofuscante, donde el efecto de conjunto lo es todo, si bien el detalle está soberbiamente tratado. Los retablos se hacen para ser contemplados de lejos. No atraen en rigor por la imaginería, como en las obras del Gótico y el Renacimiento, sino por la caligrafía y el arabesco" ${ }^{529}$. Su autor sigue siendo un misterio. El retablo lo componen multitud de cuerpos prismáticos decorados con placas recortadas $\mathrm{y}$ superpuestas. El dorado y el nicho central completamente decorado con espejos contribuyen a darle aire de magnificencia.

Los ensambladores más destacados de este periodo, uno de los más importantes y de mayor expansión de la retablística vallisoletana fueron: Gregorio Díaz de Mata (h.1645¿1720?), Blas Martínez de Obregón (h.1650 - 1716), Francisco Billota (1656 - 1728), Alonso Manzano (1656 - 1720), Juan Correas (1660-1732), Pedro de Ribas (1666 1738), y José Díaz de Mata (1684-1766). A estos se suma Joaquín Billota (h.1690 1763), del que tan solo tenemos constancia que ayudó a su padre en la fabricación de los retablos de las capillas laterales de la iglesia de San Felipe Neri, de Valladolid, y otros ensambladores menores, hoy por hoy semidesconocidos, que pudieron gozar de cierta relevancia en la época y ser autores de parte de la gran cantidad de retablos que actualmente permanecen anónimos y con unas características que no permiten relacionarlos con los ensambladores arriba citados. Este grupo lo conforman, entre otros, Pedro Roldán y Manuel Rodríguez.

\section{GREGORIO DÍAZ DE MATA (h.1645 - ¿1720?)}

Gregorio Díez de Mata ${ }^{530}$ nació en Valladolid hacia el año 1645. Sus padres fueron Pedro Díez de Mata y Ana Sánchez. Aunque no hemos podido encontrar su partida de bautismo creemos que esto se puede deber a que tenía un nombre compuesto. Entre los hijos del matrimonio nacidos en estos años encontramos dos varones: Pedro $(1643)^{531}$ y Antolín (1645) ${ }^{532}$. Quizás, Gregorio pudiera ser uno de estos.

El 12 de noviembre de 1681 contrae matrimonio con la vallisoletana María Teresa Valcárcel en la desaparecida iglesia de San Miguel ${ }^{533}$. La pareja tuvo tres hijos: José (1684), el futuro ensamblador, Francisco Xavier (1691) y María Manuela (1693) ${ }^{534}$, los cuales fallecerían siendo aún niños.

\footnotetext{
528 URREA FERNÁNDEZ, Jesús: "Villabrille y Ron y la capilla de la Buena Muerte, de San Ignacio de Valladolid", Boletín del Museo Nacional de Escultura, No 11, 2007, pp. 22-29.

529 MARTÍN GONZÁLEZ, Juan José: Escultura barroca castellana..., op. cit., p. 73.

530 Ver: Ídem, pp. 319-320. MARTÍN GONZÁLEZ, Juan José: Escultura barroca en España ..., op.

cit., p. 77; PARRADO DEL OLMO, Jesús María: Datos histórico artísticos ..., op. cit.

531 A.G.D.V., San Pedro, 1606B, f. 296.

532 A.G.D.V., San Pedro, 1606B, f. 311.

533 A.G.D.V., Santiago, 1651M, f. 204.

534 A.G.D.V., San Miguel, 1669B, ff. 157, 241, 252.
} 
El 9 de abril de 1708 contrae matrimonio en segundas nupcias con Águeda García de Robledo en la iglesia de San Miguel ${ }^{535}$. Las velaciones y "bendiciones nupciales según el ritual romano" tuvieron lugar el 16 de enero de 1709 en la iglesia de Santiago ${ }^{536}$. Aún vuelve a contraer matrimonio en una tercera ocasión, y la afortunada será Juana Gómez. La ceremonia se desarrolla el 18 de octubre de 1713 en la iglesia de San Nicolás ${ }^{537}$. Previamente, el día anterior, el provisor del obispado don Andrés de Orbe y Larreátegui les había concedido la licencia y las "tres canónicas municiones". Entre los testigos del enlace figura su hijo José Díaz de Mata.

El 25 de marzo de 1720 Gregorio Díaz de Mata, "estando en pie aunque con algunos achaques que Dios nuestro señor se ha servido darme y en mi sano juicio y entendimiento natural", decide otorgar testamento. Como es normal en este tipo de testamentos, lo primero que refiere es el lugar en el que deseaba que reposara su cuerpo. Este fue en una sepultura propia que poseía en la iglesia de San Miguel "junto a la pila de agua bendita que enfrenta al altar de San Cayetano". Para cumplir el testamento dejaba nombrados como albaceas a su hijo José y a José Alonso, cura de La Overuela. Como era de esperar, instituyó por heredero universal a su único hijo José Díaz de Mata, aunque le pedía que entregara a su "nieto hijo del referido quinientos reales de vellón para su socorro en los estudios u otra facultad o parte por una vez" "538. No debió de quedar Gregorio Díaz de Mata muy contento con lo expresado en el testamento, o bien quería puntualizarlo, puesto que cinco días después, el 30 de marzo, otorga un codicilo $^{539}$. Consta que el 30 de julio de 1720 ya había fallecido, por cuanto su hijo se proclama "heredero único que soy de Gregorio Díaz de Mata mi padre ya difunto" 540.

Desconocemos en que taller se formó. Sus retablos no poseen ningún elemento distintivo que nos permita identificar su mano, si bien por lo general adolecen de cierta planitud en la labor de la talla, la cual no es tan exuberante como la demostrada por otros artífices de la época como Martínez de Obregón o Manzano.

Además de las labores propias de su arte también tuvo una faceta de agricultor, seguramente para sacar un dinero extra ante las pocas obras que lograba contratar. Por ejemplo, el 20 de julio de 1705 toma en renta y arrendamiento del Monasterio de San Quirce por un periodo de nueve años "una tierra de panllevar que antes fue viña que está en término de esta ciudad, a las arcas del sol que hace seis iguadas poco más o menos cercada con diferentes tapias y otras caídas que linda por una parte al cierzo con tierra de D. Gabriel de Saavedra y por otra parte con tierra de una viuda de la ciudad de Salamanca que administra Francisco Ruiz Caballero procurador del número de la Real Chancillería de esta ciudad" ${ }^{\prime 54}$.

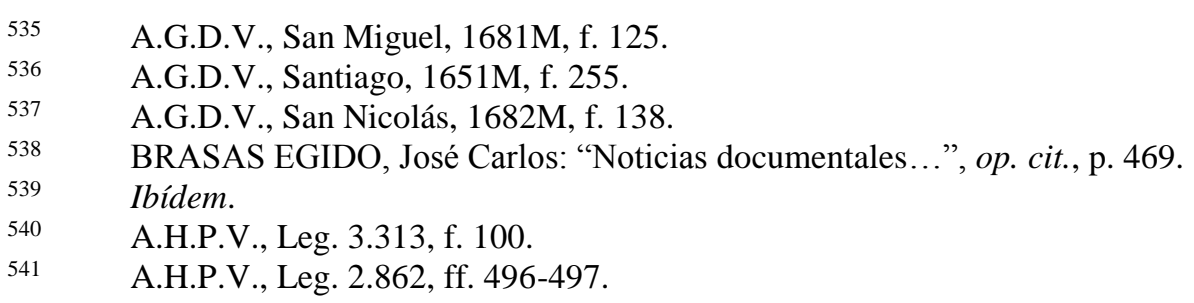


Sabemos que trabajó junto al escultor Joseph Pascual ya que cuando este último otorga testamento declara que Díez de Mata le debía 110 reales "de todas cuentas y hechuras que hecho de su orden de diferentes efigies para retablos que el susodicho ha hecho para fuera y otras partes" ${ }^{\prime 42}$.

\section{$\underline{\text { Catálogo }}$}

1685-1688. Retablo mayor (Fig. 69). Iglesia de Santa María. Pozaldez (Valladolid) ${ }^{543}$. Realizado conjuntamente con Blas Martínez de Obregón y Francisco Billota.

1696. Custodia del altar mayor. Iglesia de Santa María. Pozaldez (Valladolid) ${ }^{544}$. Realizado conjuntamente con Blas Martínez de Obregón y Francisco Billota.

1696-1702. Retablo mayor. Iglesia parroquial de la Asunción. Villanubla (Valladolid). Realizado conjuntamente con Francisco Billota.

1710. Retablos colaterales y tres marcos para la Capilla de la Virgen de las Angustias. Iglesia Penitencial de Nuestra Señora de las Angustias. Valladolid ${ }^{545}$.

1710. Siete retablos del camarín de la Virgen de las Angustias. Iglesia Penitencial de Nuestra Señora de las Angustias. Valladolid ${ }^{546}$.

1710-1711. Retablo del Santo Cristo del Consuelo. Iglesia de la Santa Cruz. Pedrosa del Rey (Valladolid) ${ }^{547}$.

1712. Retablo mayor (Fig. 70). Iglesia de la Asunción. Casasola de Arión

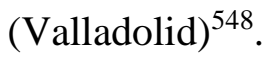

1713. Retablos colaterales y sombrero para el púlpito. Iglesia parroquial de la Asunción. Casasola de Arión (Valladolid) ${ }^{549}$. Realizados conjuntamente con su hijo José Díaz de Mata.

1714. Retablos colaterales. Iglesia parroquial de San Esteban Protomártir. Torrecilla de la Abadesa (Valladolid). Realizados junto con su hijo José Díaz de Mata ${ }^{550}$.

542 GARCÍA CHICO, Esteban: Documentos para el estudio del arte en Castilla. 2..., op. cit., pp. 362-363.

543 MARCOS VILLÁN. Miguel Ángel y FRAILE GÓMEZ, Ana María: Catálogo Monumental de la provincia de Valladolid. Tomo XVIII..., op. cit., pp. 162-163.

$544 \quad$ Ibídem.

545 MARTÍN GONZÁLEZ, Juan José y URREA FERNÁNDEZ, Jesús: Catálogo Monumental de la provincia de Valladolid. Tomo XIV..., op. cit., p. 237.

$546 \quad$ Ibídem.

547 ARA GIL, Clementina Julia y PARRADO DEL OLMO, Jesús María: Catálogo Monumental de la provincia de Valladolid. Tomo XI..., op. cit., pp. 104 y 107.

548 PARRADO DEL OLMO, Jesús María: Catálogo Monumental de la provincia de Valladolid. Tomo IX..., op. cit., pp. 40-41.

549 Ídem, pp. 40-41 y 44.

550 ARA GIL, Clementina Julia y PARRADO DEL OLMO, Jesús María: Catálogo Monumental de la provincia de Valladolid. Tomo XI..., op. cit., p. 526. 


\section{BLAS MARTÍNEZ DE OBREGÓN (h.1650 - 1716)}

Blas Martínez de Obregón ${ }^{551}$ debió de nacer hacia el año 1650 en algún pueblo de la Trasmiera. Martín González piensa que pueda tener una ascendencia montañesa debido a que "este nombre aparece vinculado a la provincia de Santander" que se formaría allí, pasando posteriormente a Valladolid, ciudad en la que se existía un pujante negocio retablístico. Es uno de los artífices de este momento cuya obra se encuentra más dispersa, traspasando los límites de la actual provincia vallisoletana: Cuéllar, Meneses de Campos, Sahagún... ${ }^{553}$. Además de ensamblador se le denomina maestro arquitecto, como así figura en las condiciones que establece para el retablo de la capilla mayor de la iglesia de San Pedro de Villalón de Campos (1693) o cuando se presenta al concurso para realizar la fachada de la Universidad vallisoletana $(1716)^{554}$.

Estuvo casado con María Román, con la cual contrajo matrimonio con anterioridad a 1678. El 9 de septiembre de ese mismo año Obregón junto con su mujer, María Román, se obligaban a pagar al pintor Diego Díez Ferreras 212 reales que le adeudaban de un préstamo que éste les había hecho el 20 de enero ${ }^{555}$. Desconocemos cualquier otro dato biográfico, salvo el de que su fallecimiento, que se produjo el 31 de marzo de 1716, siendo sepultado en la iglesia de San Miguel ${ }^{556}$. No otorgó testamento por ser pobre.

A su amplia producción, que por fortuna se conserva en su mayoría, podemos añadir una curiosa intervención que tuvo lugar durante las fiestas que se celebraron en Valladolid en 1689 con motivo del casamiento del rey Carlos II en la ciudad. Durante aquellas fiestas concierta junto al también ensamblador Antonio Álvarez "las cuatro galeras y castillo que se ha de hacer en el río para las dichas fiestas" por 13.000 reales $^{557}$, los cuales se les fueron pagando en varios plazos ${ }^{558}$. También se les abonan otras cantidades por "dos castillos y barcas del río para estas fiestas", que no sabemos

551 Ver: MARTÍN GONZÁLEZ, Juan José: Escultura barroca castellana..., op. cit., pp. 318-319. MARTÍN GONZÁLEZ, Juan José: Escultura barroca en España..., op. cit., pp. 77 y 79 ; FERRERO MAESO, Concepción: "El mecenazgo de la familia Berrio en la iglesia de San Julián (Carrión de los Condes). En CALlEJA GONZÁLEZ, María Valentina: Actas del III Congreso de Historia de Palencia, Vol. IV, Diputación Provincial de Palencia, Palencia, 1995, pp. 585-600; GARCÍA GARCÍA, Lorena: op. cit.

552 MARTÍN GONZÁLEZ, Juan José: Escultura barroca castellana..., op. cit., p. 318.

553 GARCÍA GARCÍA, Lorena: op. cit., p. 208.

554 Concurren junto a él el maestro de obras Pablo Mínguez y Fray Pedro de la Visitación que fue quien se quedó con la obra.

555 A.H.P.V., Leg. 2.876, ff. 146-147.

556 A.G.D.V., San Miguel, 1711D, f. 22; FERNÁNDEZ DEL HOYO, María Antonia: "El convento de San Francisco...", op. cit., p. 419.

557 Antonio Álvarez y Blas Martínez de Obregón. Castillo del río. "En 29 del dicho mes por libranza de los dichos señores comisarios se libraron en el señor don Antonio de Tapia 500 reales a Antonio Álvarez y Blas Martínez de Obregón por cuenta de los 13.000 reales en que se les remató a toda costa las cuatro galeras y castillo que se ha de hacer en el río para las dichas fiestas”. A.M., CH. 105-7, f. 1.

$558 \quad$ Antonio Álvarez y Blas de Obregón. "En 31 de marzo de 1690 por libranza de los dichos señores se libraron a Antonio Álvarez y Blas de Obregón 4.000 reales en cuenta de los 13.000 en que se les remató las cuatro galeras y castillo del fuego del río y se libran en dicho señor Tapia por cuenta de la facultad”. A.M., CH. 105-7, f. 1. 
si se refiere a las sobredichas cuatro galeras y castillo, o son otras obras diferentes ${ }^{559}$. Asimismo ambos se encargaron de construir "el tablado para el fuego de la plaza de palacio", cobrando por dicha obra 40.000 reales $^{560}$.

\section{$\underline{\text { Catálogo }}$}

1677. Retablo mayor (Fig. 71). Real Colegio de los Ingleses. Valladolid ${ }^{561}$.

1678. Retablo de Nuestra Señora de la Consolación. Iglesia de San Juan Bautista (desaparecida). Valladolid ${ }^{562}$. Desaparecido.

1678. Retablo mayor, cuatro retablos colaterales y otras cosas para la Capilla de Nuestra Señora de Copacabana. Convento de San Francisco. Valladolid ${ }^{563}$.

1685. Retablo para el licenciado don Francisco Pinacho y Pareja. Iglesia de Santiago Apóstol. Cigales (Valladolid) ${ }^{564}$.

1685-1688. Retablo mayor. Iglesia de Santa María. Pozaldez (Valladolid) ${ }^{565}$. Realizado conjuntamente con Francisco Billota y Gregorio Díez de Mata.

1689. Túmulo de la reina María Luisa de Orleans promovido por el Ayuntamiento. Valladolid $^{566}$. Realizado conjuntamente con el ensamblador Antonio Álvarez.

1689. Retablo mayor (Fig. 72). Iglesia de Nuestra Señora del Rosario. Valladolid ${ }^{567}$. 1690. Retablo para la capilla del doctor Juan de Arce. Catedral. Valladolid ${ }^{568}$.

\footnotetext{
559 Castillo y barcas del río Antonio Álvarez y Blas Martínez de Obregón. "En 3 de noviembre de 1689 por libranza de los dichos señores se libraron a Antonio Álvarez y Blas Martínez de Obregón 3.000 reales por cuenta de lo que han de haber por los dos castillos y barcas del río para estas fiestas y dicha cantidad se libra en dicho señor por cuenta de la facultad que está concedida". A.M., CH. 105-7, f. 3.

$560 \quad$ Antonio Álvarez y Blas Martínez de Obregón tablado de palacio. "En 29 de septiembre por libranza de los dichos señores se libraron a Antonio Álvarez y las Martínez de Obregón 3.000 reales en cuenta de 40.000 en que ha ajustado el tablado para el fuego de la plaza de palacio y dicha cantidad se libra en el señor don Antonio de Tapia”. A.M., CH. 105-7, f. 1.

561 MARTíN GONZÁLEZ, Juan José y DE LA PLAZA SANTIAGO, Francisco Javier: Catálogo Monumental de la provincia de Valladolid. Tomo XV..., op. cit., pp. 272 y 282-283.

562 MARTÍN GONZÁLEZ, Juan José y URREA FERNÁNDEZ, Jesús: Catálogo Monumental de la provincia de Valladolid. Tomo XIV..., op. cit., pp. 74 y 78.

563 FERNÁNDEZ DEL HOYO, María Antonia: "El convento de San Francisco...”, op. cit., pp. $418-419$.

564 URREA FERNÁNDEZ, Jesús: Catálogo Monumental de la provincia de Valladolid. Tomo XX..., op. cit., pp. 50 y 162.

565 MARCOS VILLÁN. Miguel Ángel y FRAILE GÓMEZ, Ana María: Catálogo Monumental de la provincia de Valladolid. Tomo XVIII..., op. cit., pp. 162-163.

566 MARTÍ Y MONSÓ, José: Estudios histórico-artísticos..., op. cit., p. 498; FERNÁNDEZ DEL HOYO, María Antonia: "El convento de San Francisco...", op. cit., p. 419; AMIGO VÁZQUEZ, Lourdes: "El espectáculo de las postrimerías. Exequias reales en Valladolid durante los siglos XVII y XVIII", B.R.A.C., Tomo XLV, 2010, p. 54.

567 BALADRÓN ALONSO, Javier: op. cit., p. 161.

568 URREA FERNÁNDEZ, Jesús: "Don Pedro de Arce y su capilla en la Catedral de Valladolid", B.R.A.C., Tomo XXXIX, 2004, pp. 90-91.
} 
1690. Custodia del altar mayor. Iglesia parroquial de Nuestra Señora de Tovar. Meneses de Campos (Palencia) ${ }^{569}$.

1691. Retablo mayor (Fig. 73). Iglesia parroquial de Santiago. Villalba de los Alcores $(\text { Valladolid })^{570}$.

1692-1693. Custodia del altar mayor. Iglesia de Santa María. Peñaflor de Hornija $(\text { Valladolid })^{571}$.

1693-1694. Retablos colaterales. Convento de San Quirce. Valladolid ${ }^{572}$.

1695. Monumento de Semana Santa. Convento de Porta Coeli. Valladolid ${ }^{573}$. Realizado conjuntamente con el ensamblador Antonio Álvarez.

1696. Custodia del altar mayor. Iglesia de Santa María. Pozaldez (Valladolid) ${ }^{574}$. Realizado conjuntamente con Francisco Billota y Gregorio Díez de Mata.

1696. Reforma del retablo mayor. Convento de las Agustinas Recoletas. Valladolid ${ }^{575}$.

1696. Retablo de Nuestra Señora de la Piedad. Iglesia parroquial de San Esteban. Villamayor de Campos (Zamora) ${ }^{576}$.

1697. Retablo mayor. Iglesia de Santa María. Villanueva de Duero (Valladolid) ${ }^{577}$.

1697. Retablo mayor. Ermita de Nuestra Señora del Villar. Laguna de Duero $(\text { Valladolid })^{578}$.

1699. Sillería del coro alto. Monasterio de San Benito el Real. Sahagún (León) ${ }^{579}$.

569 SALCEDO TAPIA, Modesto: "Vida de don Tello Téllez de Meneses, Obispo de Palencia", Publicaciones de la Institución Tello Téllez de Meneses, Tomo LIII, 1985, p. 151.

$570 \quad$ 1691.- "1.400 reales que dicho mayordomo dio a Blas Martínez de Obregón, primera paga del retablo que está haciendo para el altar mayor". PARRADO DEL OLMO, Jesús María: Catálogo Monumental de la provincia de Valladolid. Tomo XVI..., op. cit., pp. 360-361; PARRADO DEL OLMO, Jesús María: "La colaboración...”, op. cit., pp. 401-420.

571 PARRADO DEL OLMO, Jesús María: Catálogo Monumental de la provincia de Valladolid. Tomo IX..., op. cit., p. 135.

572 MARTÍN GONZÁLEZ, Juan José: Escultura barroca castellana..., op. cit., p. 318; A.H.P.V., Leg. 2.898, ff. 173-174.

573 GARCÍA CHICO, Esteban: Documentos para el estudio del arte en Castilla. 2..., op. cit., p. 360.

574 MARCOS VILLÁN. Miguel Ángel y FRAILE GÓMEZ, Ana María: Catálogo Monumental de la provincia de Valladolid. Tomo XVIII..., op. cit., pp. 162-163.

575 GARCÍA CHICO, Esteban: Documentos para el estudio del arte en Castilla. 2..., op. cit., pp. 360-362.

576 FERNÁNDEZ DEL HOYO, María Antonia: “El convento de San Francisco...”, op. cit., p. 419.

577 GARCÍA CHICO, Esteban: Documentos para el estudio del arte en Castilla. 2..., op. cit., p.

360.

578 CASTELLANOS CUESTA, Margarita: Ermita de Nuestra Señora del Villar. Laguna de Duero, Colección Tierras de Valladolid, Valladolid, 2012, pp. 98-99.

579 LLAMAZARES RODRÍGUEZ, Fernando: Fuentes documentales para el arte barroco en la provincia de León: ensambladores, escultores y pintores, Universidad de León, León, 2008, p. 139. 
1699. Retablo mayor y retablos colaterales. Iglesia de San Julián. Carrión de los Condes (Palencia) ${ }^{580}$.

1702. Retablo mayor. Iglesia Penitencial de Nuestro Padre Jesús Nazareno. Valladolid ${ }^{581}$.

1704. Sillería y puertas de entrada al coro. Real Monasterio de Nuestra Señora de Prado. Valladolid ${ }^{582}$.

1706. Retablos colaterales. Iglesia Penitencial de Nuestro Padre Jesús Nazareno. Valladolid $^{583}$.

1711. Retablo mayor. Iglesia de Santa María de la Cuesta. Cuéllar (Segovia) ${ }^{584}$. Realizado conjuntamente con Juan Correas.

\section{FRANCISCO BILLOTA $(1656-1728)$}

El ensamblador Francisco Billota ${ }^{585}$ de la Fuente nació en Valladolid a comienzos del mes de diciembre de 1656. Sus padres, Antonio de Billota y Manuela de la Fuente, lo bautizaron en la Santa Iglesia Catedral el día 10 de diciembre de ese mismo año ${ }^{586}$.

Billota contrajo matrimonio en cuatro ocasiones. Su primera esposa fue María de Iglesias; a la que siguieron Bentura de Arana (1693-1702) ${ }^{587}$, Micaela Cebrián de la Cuadra $(1702-1708)^{588}$ y Ángela Santos del Álamo $(1708-1728)^{589}$. Tan sólo logró concebir un hijo: Joaquín (1696) ${ }^{590}$, fruto del matrimonio con Bentura de Arana.

Fue cofrade de la Penitencial de las Angustias, iglesia para la cual realizó el tabernáculo para la capilla de la Virgen. En sus últimos años, llevado de sus fervores religiosos, solicita el ingreso como bienhechor en la venerable Congregación de San Felipe Neri,

\footnotetext{
580 FERRERO MAESO, Concepción: "El mecenazgo de la familia Berrio”, op. cit., pp. 593-598.

581 ARRIBAS ARRANZ, Filemón: La Cofradía Penitencial..., op. cit., pp. 41-44.

582 GARCÍA CHICO, Esteban: Documentos para el estudio del arte en Castilla. 2..., op. cit., p. 337.

583 ARRIBAS ARRANZ, Filemón: La Cofradía Penitencial..., op. cit., pp. 45-46.

584 ARRIBAS, Miguel María: "Retablo de Juan Correas y Blas Martínez de Obregón en Cuéllar", Estudios Segovianos, Tomo XXV, no 74-75, 1973, pp. 556-560; VELASCO BAYÓN, Balbino: Historia de Cuéllar, Diputación Provincial de Segovia, Segovia, 1988, pp. 422-423.

585 Ver: MARTÍN GONZÁLEZ, Juan José: Escultura barroca castellana..., op. cit., pp. 305-313. MARTÍN GONZÁLEZ, Juan José: Escultura barroca en España..., op. cit., p. 76.

586 "En diez del mes de diciembre de mil y seiscientos y cincuenta y seis años yo el licenciado Quiroga cura de la catedral de esta ciudad de Valladolid bauticé e impuse óleo y crisma según forma de la santa madre iglesia habiendo precedido los santos exorcismos a Francisco hijo de Antonio de Billota y Manuela de la Fuente su mujer mis parroquianos, fueron sus padrinos el licenciado Alonso de Billota y María Alonso vecinos de esta ciudad, testigos el licenciado Andrés Escudero y Joseph García de Valdivieso, dieronle por abogados a Nuestra Señora y a San Andrés en fe de lo cual lo firmé en dicho día”. A.G.D.V., Catedral, 1656B, f. 2.

587 A.G.D.V., Catedral, 1673M, f. 164

588 A.G.D.V., La Antigua, 1692M, f. 53

589 A.G.D.V., La Antigua, 1692M, f. 92.

590 A.G.D.V., La Antigua, 1652B, f. 408.
}

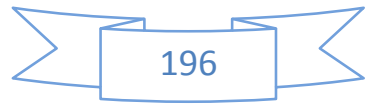


donde funda una capellanía y además entrega como muestra de profundo agradecimiento por tan singular favor una fuente de plata labrada ${ }^{591}$.

Según las sabias palabras de Martín González Francisco Billota, "miembro de una esclarecida familia de ensambladores", es "quien mejor contribuye a la implantación del churriguerismo". Según el mismo autor, Billota "crea un tipo de retablo que tiene una gran difusión por la comarca vallisoletana, y cuyo prototipo es el mayor de la parroquial de Pozaldez. También fue él quien utilizara por vez primera el estípite barroco constituido por varios cuerpos superpuestos". Hay que tener en cuenta que su padre, Antonio de Billota, fue el autor del primer retablo vallisoletano que incluyó columnas salomónicas, elemento característico del retablo prechurrigueresco. Finalmente, el historiador del arte concluye precisando que "similares en estilo a Francisco Billota son Blas Martínez de Obregón y Gregorio Díaz de Mata"592.

El 11 de abril de 1724 el viejo ensamblador dicta su primer testamento ${ }^{593}$ y un año después, el 14 de febrero de 1725 , el segundo, y a la postre el último ${ }^{594}$. Francisco Billota fallece el 2 de agosto de 1728, siendo sepultado en la iglesia de San Felipe Neri, tal y como él deseaba ${ }^{595}$. Extraña que en el libro de difuntos de la parroquia del Salvador aparezca como fenecido el 5 de septiembre de este mismo año ${ }^{596}$.

A su amplio y variado catálogo añadimos ahora una nueva obra. Se trata de un "arco tallado y dorado para Nuestra Señora de la Asunción". Dicha escultura sería la que presidiera el tabernáculo del retablo mayor de la catedral. La obra comenzó antes de noviembre de 1718 y se concluiría en marzo de $1719^{597}$.

\section{$\underline{\text { Catálogo }}$}

1685-1688. Retablo mayor. Iglesia de Santa María. Pozaldez (Valladolid) ${ }^{598}$. Realizado conjuntamente con Blas Martínez de Obregón y Gregorio Díez de Mata.

1688. Cancel. Iglesia de San Felipe Neri. Valladolid ${ }^{599}$.

1689. Cancel. Iglesia de San Martín. Valladolid ${ }^{600}$.

\footnotetext{
591 GARCÍA CHICO, Esteban: Documentos para el estudio del arte en Castilla. 2..., op. cit., p. 279.

592 MARTÍN GONZÁLEZ, Juan José: Escultura barroca castellana..., op. cit., p. 136.

593 BRASAS EGIDO, José Carlos: "Noticias documentales...", op. cit., pp. 469-470.

594 A.H.P.V. Leg. 3.187/2, ff. 8-9.

595 A.G.D.V., La Antigua, 1699D, f. 215.

596 A.G.D.V., Salvador, 1708 D, f. 153.

597 "Más recibí del señor doctoral D. Joseph Flores Osorio como heredero único del señor D. Pedro Moreno por mano del escribano Ochoa quinientos reales con los cuales quedó pagado enteramente de los tres mil y ciento en que se ajustó la obra del arco de Nuestra Señora de la Asunción tallado y dorado Valladolid y marzo 15 de mil setecientos y diez y nueve". A.H.P.V., Leg. 3.158, ff. 222-223.

598 MARCOS VILLÁN. Miguel Ángel y FRAILE GÓMEZ, Ana María: Catálogo Monumental de la provincia de Valladolid. Tomo XVIII..., op. cit., pp. 162-163.

599 MARTÍN GONZÁLEZ, Juan José y URREA FERNÁNDEZ, Jesús: Catálogo Monumental de la provincia de Valladolid. Tomo XIV..., op. cit., pp. 300-301.

$600 \quad$ Ídem, p. 100.
} 
1689-1691. Retablo mayor (Fig. 74). Iglesia de San Felipe Neri. Valladolid ${ }^{601}$.

1693. Retablo mayor. Convento de Nuestra Señora de la Laura. Valladolid (DOCUMENTO 53).

1693-1694. Seis hacheros y tres puertas. Iglesia de Santiago Apóstol. Valladolid ${ }^{602}$.

1696. Custodia del altar mayor. Iglesia de Santa María. Pozaldez (Valladolid) ${ }^{603}$. Realizado conjuntamente con Blas Martínez de Obregón y Gregorio Díez de Mata.

1696-1702. Retablo mayor. Iglesia parroquial de la Asunción. Villanubla (Valladolid) $^{604}$. Realizado conjuntamente con Gregorio Díaz de la Mata.

1697-1698. Dieciséis sillas para el coro. Catedral. Valladolid ${ }^{605}$.

1698. Retablo mayor y retablos colaterales. Convento de Santa Brígida. Valladolid ${ }^{606}$.

1698-1699. Retablos colaterales. Iglesia de San Felipe Neri. Valladolid ${ }^{607}$.

Hacia 1710. Tabernáculo para Nuestra Señora de las Angustias. Iglesia Penitencial de Nuestra Señora de las Angustias. Valladolid ${ }^{608}$.

1711-1712. Retablo de Nuestra Señora de los Remedios. Iglesia de Santa Cruz. Pedrosa del Rey (Valladolid) ${ }^{609}$.

1712. Retablo mayor (Fig. 75). Iglesia parroquial de San Pedro Apóstol. Serrada (Valladolid) $^{610}$.

\footnotetext{
601 URREA FERNÁNDEZ, Jesús: “El oratorio...”, op. cit., p. 18.

602 MARTÍN GONZÁLEZ, Juan José y URREA FERNÁNDEZ, Jesús: Catálogo Monumental de la provincia de Valladolid. Tomo XIV..., op. cit., pp. 192-193.

603 MARCOS VILLÁN. Miguel Ángel y FRAILE GÓMEZ, Ana María: Catálogo Monumental de la provincia de Valladolid. Tomo XVIII..., op. cit., pp. 162-163.

604 MARTÍN GONZÁLEZ, Juan José: Catálogo Monumental de la provincia de Valladolid. Tomo VI..., op. cit., p. 164.

605 MARTÍN GONZÁLEZ, Juan José: "Noticias documentales...”, op. cit., p. 193.

606 MARTÍN GONZÁLEZ, Juan José y DE LA PLAZA SANTIAGO, Francisco Javier: Catálogo Monumental de la provincia de Valladolid. Tomo XV..., op. cit., p. 47.

607 "Decretose que para efecto de reconocer la obra de los dos colaterales ejecutados por Francisco Billota se diese comisión a los señores don Felipe Sánchez de Paz y Juan de Salazar y don Pedro de Rozas para que buscasen maestros viesen las condiciones y planta si estaban conforme a ellas y se diese cuenta a dicha Congregación que en esta forma se acabó dicha junta y lo firmó dicho señor Ministro y el presente secretario de que doy fe". A.S.F.N., Caja 14, 2º Libro de acuerdos (1690-1740), f. 42; MARTÍN GONZÁLEZ, Juan José y MARTÍN GONZÁLEZ, Juan José y URREA FERNÁNDEZ, Jesús: Catálogo Monumental de la provincia de Valladolid. Tomo XIV ..., op. cit., p. 293; URREA FERNÁNDEZ, Jesús: "El oratorio...", op. cit., p. 18.

608 GARCÍA CHICO, Esteban: Documentos para el estudio del arte en Castilla. 2..., op. cit., p. 279; MARTÍN GONZÁLEZ, Juan José y URREA FERNÁNDEZ, Jesús: Catálogo Monumental de la provincia de Valladolid. Tomo XIV..., op. cit., p. 238.

609 ARA GIL, Clementina Julia y PARRADO DEL OLMO, Jesús María: Catálogo Monumental de la provincia de Valladolid. Tomo XI..., op. cit., p. 108.

610 MARCOS VILLÁN. Miguel Ángel y FRAILE GÓMEZ, Ana María: Catálogo Monumental de la provincia de Valladolid. Tomo XVIII..., op. cit., p. 407.
} 
1712-1713. Retablo de Nuestra Señora de las Angustias. Iglesia de Santa Cruz. Pedrosa del Rey (Valladolid) ${ }^{611}$.

1716. Custodia para el retablo mayor, seis hacheros y cornucopias y monumento de talla. Iglesia parroquial de San Pedro Apóstol. Serrada (Valladolid) ${ }^{612}$.

1718-1719. Arco para Nuestra Señora de la Asunción. Catedral. Valladolid ${ }^{613}$.

1719-1722. Retablos de las seis capillas (Fig. 76). Iglesia de San Felipe Neri. Valladolid $^{614}$.

\section{$\underline{\text { ALONSO MANZANO }}(1656-\mathrm{d} .1721)$}

"Alonso Manzano es, a no dudarlo, el mejor representante del retablo churrigueresco, en su aspecto florido. Hermosea gallardamente la columna salomónica, que alcanza límites de primor inigualable en el retablo mayor de Santiago, de Valladolid" ${ }^{\prime 215}$. Con estas palabras nos presentaba Martín González al brillante ensamblador vallisoletano que vivió parte de su existencia "en las casas que llaman de don Galván, sitas en la plazuela del convento de la Santísima Trinidad" ${ }^{\prime 616}$. Estas mismas casas son en las que años después fallecería Pedro Correas.

Alonso Manzanillo Granado (Alonso Manzano) ${ }^{617}$ nació en la localidad vallisoletana de Padilla de Duero en los primeros días del mes de febrero de 1656. Sus padres fueron Alonso Manzano y María Granado, los cuales le bautizaron en la iglesia parroquial del pueblo el día 12 de ese mismo mes ${ }^{618}$.

Aún sin haber contraído matrimonio, el 9 de abril de 1707 nace su hijo Alonso, fruto de la relación que mantenía con Bárbara González. El recién nacido fue bautizado en la

\footnotetext{
611 ARA GIL, Clementina Julia y PARRADO DEL OLMO, Jesús María: Catálogo Monumental de la provincia de Valladolid. Tomo XI..., op. cit., p. 108.

612 MARCOS VILLÁN. Miguel Ángel y FRAILE GÓMEZ, Ana María: Catálogo Monumental de la provincia de Valladolid. Tomo XVIII..., op. cit., p. 410.

$613 \quad$ A.H.P.V., Leg. 3.158, ff. 222-223.

614 GARCÍA CHICO, Esteban: Documentos para el estudio del arte en Castilla. 2..., op. cit., pp. 381-382.

615 MARTÍN GONZÁLEZ, Juan José: Escultura barroca castellana..., op. cit., p. 319.

616 "Era vecino de Valladolid y vivió en la placetuela del convento de la Santísima Trinidad. Le cita Martí y Monsó, con motivo del retablo mayor de la penitencial de Jesús. Trabajó mucho y bien, siguiendo las normas del estilo barroco, suntuoso y exuberante. Debió de ser uno de sus adalides más exaltados". GARCÍA CHICO, Esteban: Documentos para el estudio del arte en Castilla. 2..., op. cit., p. 352.

617 Ver: MARTÍN GONZÁLEZ, Juan José: Escultura barroca castellana..., op. cit., pp. 313-318. MARTÍN GONZÁLEZ, Juan José: Escultura barroca en España..., op. cit., p. 77.

618 "En doce de febrero del año de mil y seiscientos y cincuenta y seis años yo el cura Domingo Lucas bauticé puse óleo y crisma e hice los demás exorcismos que dispone el santo concilio de Trento a Alonso hijo de Alonso Manzano y de María Granado fueron sus padrinos Francisco Ortega e Isabel García a los cuales amoneste el parentesco espiritual y lo demás de su obligación diose por abogado al santo de su nombre siendo testigos el licenciado Juan Millán y el licenciado Matías Martínez fírmelo dicho día y mes con uno de los dichos testigos ut supra”. A.G.D.V., Padilla de Duero, Iglesia de la Asunción, 1652BCM, f. 7.
} 
iglesia de Santiago el día 25 de dicho mes ${ }^{619}$. La pareja formalizaría su relación tiempo después contrayendo matrimonio el 10 de agosto de 1711 en la catedral vallisoletana ${ }^{620}$. Este feliz acontecimiento se vería ensombrecido meses después ya que Bárbara fallecería, siendo sepultada en la referida catedral el 9 de noviembre de ese mismo año ${ }^{621}$. Por entonces la familia moraba en una casa "a la calle de Ruiz Hernández", propiedad del cabildo catedralicio ${ }^{622}$. Desconocemos la fecha de su fallecimiento. Las últimas noticias que poseemos sobre el ensamblador nos las proporcionan el testamento que otorgó el 23 de abril de $1720^{623}$ y el diseño de las rejas de las seis capillas del cuerpo de la iglesia de San Felipe Neri ${ }^{624}$.

Además de ensamblador de retablos y de tracista debió de practicar la escultura. Efectivamente, en 1717 se ajusta con la parroquial de Villavieja del Cerro (Valladolid) para realizar las esculturas de San Miguel y San Rafael ${ }^{625}$. Podría pensarse en que Manzano subarrendó a un escultor esta tarea, si bien la rudeza de las mismas me hace pensar que sean suyas. Ningún escultor vallisoletano de la época era tan tosco como para perpetrar ambas tallas.

A su extenso e importante catálogo podemos añadir una nueva obra de juventud: el 26 de mayo de 1690 se ajusta para realizar el retablo mayor de la iglesia del colegio jesuítico de San Miguel de los Ángeles de la ciudad de León ${ }^{626}$. A pesar de su desaparición debió de marcar un hito importantísimo en la ciudad ya que en el confluyeron tres de los artistas vallisoletanos más importantes de la época: junto a Manzano trabajaron el prolífico pintor Diego Díez Ferreras y, quizás, Juan de Ávila.

\section{$\underline{\text { Catálogo }}$}

1685-1696. Retablo mayor. Iglesia de Santa María. Villavieja del Cerro (Valladolid) ${ }^{627}$.

1687. Retablo mayor. Hospital de San Juan de Dios. Valladolid ${ }^{628}$. Desaparecido. Realizado de manera conjunta con Juan Correas.

1688. Retablo mayor. Iglesia de San Pedro Mártir. Medina de Rioseco (Valladolid) ${ }^{629}$.

\footnotetext{
619 A.G.D.V., Santiago, 1703B, f. 80.

620 A.G.D.V., Catedral, 1695M, f. 108.

621 A.G.D.V., Catedral, 1684D, f. 184.

622 A.H.P.V., Leg. 2.925, f. 25.

623 A.H.P.V., Leg. 3.158, f. 698.

624 MARTÍN GONZÁLEZ, Juan José y URREA FERNÁNDEZ, Jesús: Catálogo Monumental de la provincia de Valladolid. Tomo XIV..., op. cit., p. 295.

625 ARA GIL, Clementina Julia y PARRADO DEL OLMO, Jesús María: Catálogo Monumental de la provincia de Valladolid. Tomo XI..., op. cit., p. 463.

626 A.H.P.V., Leg. 2.384, ff. 345-348.

627 ARA GIL, Clementina Julia y PARRADO DEL OLMO, Jesús María: Catálogo Monumental de la provincia de Valladolid. Tomo XI..., op. cit., p. 437.

628 GARCÍA CHICO, Esteban: Documentos para el estudio del arte en Castilla. 2..., op. cit., pp. 352-354.

629 ALONSO PONGA, José Luis (coordinador): La semana santa en la tierra de campos vallisoletana, Grupo Página, Valladolid, 2003, p. 152.
} 
1690. Retablo mayor. Iglesia del Colegio de San Miguel de los Ángeles de la Compañía de Jesús. León ${ }^{630}$.

1693-1699. Retablo mayor. Iglesia de San Pedro. Villalón de Campos (Valladolid) ${ }^{631}$.

1693. Retablos colaterales (Fig. 77). Iglesia Penitencial de la Santa Vera Cruz. Valladolid ${ }^{632}$.

1695. Retablos colaterales. Iglesia de San Pedro Mártir. Medina de Rioseco $(\text { Valladolid })^{633}$.

1695. Retablo de Nuestra Señora de la Soledad. Capilla de la Cofradía de la Quinta Angustia y Soledad de Nuestra Señora. Medina de Rioseco (Valladolid) ${ }^{634}$.

1696. Trono y caja para Nuestra Señora de la Soledad. Capilla de la Cofradía de la Quinta Angustia y Soledad de Nuestra Señora. Medina de Rioseco (Valladolid) ${ }^{635}$.

1696. Retablo mayor, retablos colaterales y retablo de la Virgen de la Calzada. Iglesia parroquial de la Asunción. Brías (Soria) ${ }^{636}$.

1699. Retablo de la capilla de don Gaspar Vallejo. Iglesia de San Martín. Valladolid ${ }^{637}$.

1700-1702. Retablo mayor. Iglesia de Santiago Apóstol. Valladolid ${ }^{638}$.

1702. Retablos colaterales. Iglesia de San Pedro. Villalón de Campos (Valladolid) ${ }^{639}$.

1702. Retablo mayor. Iglesia de Nuestra Señora de la Calle. Palencia ${ }^{640}$.

1703. Retablo mayor y cuatro retablos colaterales (Fig. 78). Convento de Santa Clara. Peñafiel (Valladolid) ${ }^{641}$.

1705. Estantería de la Biblioteca (Fig. 79). Colegio de Santa Cruz. Valladolid ${ }^{642}$.

\footnotetext{
$630 \quad$ A.H.P.V., Leg. 2.384, ff. 345-348.

631 PARRADO DEL OLMO, Jesús María: “La colaboración...”, op. cit., pp. 406-407.

632 GARCÍA CHICO, Esteban: Documentos para el estudio del arte en Castilla. 2..., op. cit., pp. 354-355.

633 ALONSO PONGA, José Luis (coord.): La semana santa en la tierra de campos vallisoletana, Grupo Página, Valladolid, 2003, p. 152.

634 GARCÍA CHICO, Esteban: Documentos para el estudio del arte en Castilla. 2..., op. cit., pp. 355-357.

635 ALONSO PONGA, José Luis (coord..): op. cit., p. 153.

636 LLAMAZARES RODRÍGUEZ, Fernando: "Alonso de Manzano y Tomás de Sierra en tierras sorianas", Liño: Revista anual de historia del arte, no 15, 2009, ff. 39-55.

637 MARTÍN GONZÁLEZ, Juan José y URREA FERNÁNDEZ, Jesús: Catálogo Monumental de la provincia de Valladolid. Tomo XIV..., op. cit., pp. 101 y 106.

638 GARCÍA CHICO, Esteban: Documentos para el estudio del arte en Castilla. 2..., op. cit., p. 373; MARTÍN GONZÁLEZ, Juan José y URREA FERNÁNDEZ, Jesús: Catálogo Monumental de la provincia de Valladolid. Tomo XIV..., op. cit., p. 198.

639 DUQUE HERRERO, Carlos: Villalón de Campos: historia y patrimonio artístico: del siglo XVII hasta nuestros días, Valladolid, 2005, p. 113.

640 GARCÍA CHICO, Esteban: Documentos para el estudio del arte en Castilla. 2..., op. cit., pp. 358-359.

641 URREA FERNÁNDEZ, Jesús: “La biografía al servicio del conocimiento...”, op. cit., p. 56.
} 
1708-1709. Cancel para la puerta principal. Iglesia de San Miguel. Valladolid ${ }^{643}$.

1709. Retablo de la capilla de San Pedro Regalado. Iglesia del Salvador. Valladolid ${ }^{644}$.

1711. Retablo mayor. Iglesia de Nuestra Señora de la Antigua. Fuentes de Valdepero (Palencia) ${ }^{645}$.

1712. Cancel para la puerta principal y copetes para tres rejas de las capillas. Catedral. Valladolid ${ }^{646}$.

1714. Retablo mayor. Iglesia de Santa María. Valverde de Campos (Valladolid) ${ }^{647}$.

1715. Retablo mayor de la iglesia de San Juan de Tamariz de Campos (Valladolid) ${ }^{648}$. Actualmente en el presbiterio de la catedral de Santander.

1716-1717. Retablos colaterales (Figs. 80-81). Iglesia parroquial de Santa María. Villavieja del Cerro (Valladolid) ${ }^{649}$.

\section{JUAN CORREAS $(1660-1732)$}

Juan Correas ${ }^{650}$ nació en la población vallisoletana de Peñafiel, por entonces obispado de Palencia. Sus padres, Pedro Correas y Luisa Carbonero, lo bautizaron el 26 de agosto de 1660 en la iglesia de Santa María de Mediavilla de dicha villa ${ }^{651}$. Es probable que sus padres se trasladaran siendo él muy niño a Valladolid en busca de mayor prosperidad, adquiriendo unas casas en el barrio de San Andrés. El aprendizaje de Correas tendría lugar en uno de los numerosos talleres de ensambladores. Por aquellos momentos (década de 1670) los más prestigiosos eran los de Cristóbal Ruiz de Andino, Antonio Billota y Pedro de Cea.

El 25 de septiembre de 1686 contrae matrimonio con Ana Teresa Calderón de la Barca en la iglesia del Salvador, parroquia en la que viviría la novia. Posteriormente las

\footnotetext{
642 GARCÍA CHICO, Esteban: Valladolid: Papeletas..., op. cit., pp. 109-110.

643 URREA FERNÁNDEZ, Jesús: "La biografía al servicio del conocimiento...”, op. cit., p. 56.

644 A.H.P.V., Leg. 2.923, f. 460.

645 MARTÍN GONZÁLEZ, Juan José: Escultura barroca castellana ..., op. cit., p. 315.

646 URREA, Jesús; "Ilustraciones a una postal. El coro de la catedral de Valladolid", B.R.A.C., Tomo XXX, 1995, p. 87; MARTÍN GONZÁLEZ, Juan José: “Noticias documentales...”, op. cit., p. 193. 647 GARCÍA CHICO, Esteban: Documentos para el estudio del arte en Castilla. 2..., op. cit., pp. 357-358.

648 PARRADO DEL OLMO, Jesús María: Catálogo Monumental de la provincia de Valladolid. Tomo XVI..., op. cit., p. 199

649 ARA GIL, Clementina Julia y PARRADO DEL OLMO, Jesús María: Catálogo Monumental de la provincia de Valladolid. Tomo XI..., op. cit., p. 463.

650 Ver: MARTÍN GONZÁLEZ, Juan José: Escultura barroca castellana..., op. cit., p. 326. MARTÍN GONZÁLEZ, Juan José: Escultura barroca en España ..., op. cit., p. 449.

651 "En veinte y seis de agosto mil y seiscientos y sesenta años yo el licenciado D. Diego Alonso con permiso del cura Rodrigo Vaca Alavete bauticé a Juan hijo de Pedro Correas y de Luisa del Carbonero sus padres legítimos fueron sus padrinos Marcos González y Catalina Huertas y lo firmé siendo testigos Manuel Labrador y Pedro Juan”. A.G.D.V., Peñafiel, Santa María de Mediavilla, 1652B, f. 48 .
} 
velaciones tuvieron lugar en el Convento de la Merced Calzada ${ }^{652}$. Sin embargo, la pareja marchó a vivir a las casas que Juan poseía en el barrio de San Andrés, heredadas de sus padres. Allí nació su primera hija llamada Manuela $(1687)^{653}$. La vivienda se les quedaría pequeña, motivo que, junto con otros, les movería a trasladarse a la Plazuela de la Trinidad, cerca de la iglesia de San Lorenzo, parroquia en la que bautizarían al resto de sus hijos: Pedro (1689), Joseph (1691), Juan Antonio (1693), Teresa (1699) ${ }^{654}$. El matrimonio tuvo otro hijo llamado Gaspar, del que desconocemos su partida de nacimiento o si bien cambió su nombre secular al profesar en el Convento de San Norberto, en este último caso podría tratarse de Juan Antonio.

El 18 de mayo de 1725 Juan Correas y su esposa Teresa Calderón de la Barca dictan testamento en conformidad. Si bien el ensamblador se encontraba bien de salud su cónyuge estaba "enferma en cama de la enfermedad que Dios nuestro señor ha sido servido de me dar y ambos en nuestro sano juicio y entendimiento natural"655. El matrimonio ordenaba ser enterrado en la iglesia de San Lorenzo, concretamente en una "de las sepulturas de la Cofradía Sacramental de ella que nos corresponde por cofrades de dicha cofradía". Declaraban tener por hijos legítimos a Pedro, José, Manuela y Gaspar Correas, este último "religioso del orden de San Bernardo", a quienes dejaban por herederos universales. Por albaceas nombraban a sus dos hijos varones y a Antonio Solera, esposo de su hija Manuela.

Teresa fallecería poco después, el 3 de julio de 1725, siendo sepultada en la iglesia de San Lorenzo ${ }^{656}$. Pasadas unas semanas Juan conocería a Paula Díez de Perales, una mujer viuda con un hijo a su cargo, Melchor García. Casaría en segundas nupcias con ella el 9 de agosto de 1725 en la iglesia de San Lorenzo ${ }^{657}$. Dos meses después, el 21 de octubre de dicho año se hizo una misa secundis nuptis a los referidos Juan Correas y Paula Díez de Perales ${ }^{658}$. El matrimonio no tuvo descendencia.

El 13 de diciembre de 1727 "estando en pie y en sana salud y en mi buen juicio y entendimiento natural" decide otorgar un nuevo testamento. La razón no será otra que su avanzada edad ${ }^{659}$. En el disponía ser enterrado en la iglesia de San Lorenzo “de donde soy parroquiano". Juan Correas fallece el 27 de marzo de 1732, siendo sepultado en la iglesia de San Lorenzo ${ }^{660}$. Dejó por herederos a sus hijos José y Pedro. Ese mismo día tuvo lugar el inventario y tasación de los bienes que había dejado ${ }^{661}$.

\footnotetext{
652 A.G.D.V., Salvador, $1685 \mathrm{M}$, f. 18.

653 A.G.D.V., San Andrés, 1680B, ff. 74-75.

654 A.G.D.V., San Lorenzo, 1671B, f. 103, 118, 126-127, 151.

655 A.H.P.V., Leg. 3.223, ff. 428-429.

656 A.G.D.V., San Lorenzo, 1671D, f. 141.

657 A.G.D.V., San Lorenzo, 1671M, f. 138.

658 A.G.D.V., San Lorenzo, 1671M, f. 139.

659 GARCÍA CHICO, Esteban: Documentos para el estudio del arte en Castilla. 2..., op. cit., p. 367.

660 A.G.D.V., San Lorenzo, 1671D, ff. 160-161. GARCÍA CHICO, Esteban: Documentos para el estudio del arte en Castilla. 2..., op. cit., p. 367.

661 BRASAS EGIDO, José Carlos: "Noticias documentales...”, op. cit., pp. 470-471.
} 


\section{$\underline{\text { Catálogo }}$}

1687. Retablo mayor. Hospital de San Juan de Dios. Valladolid ${ }^{662}$. Desaparecido. Realizado de manera conjunta con Alonso Manzano.

1698. Custodia del retablo mayor. Convento de San Bartolomé. Valladolid ${ }^{663}$. Desaparecida.

1709. Retablo mayor. Iglesia de San Juan Bautista. Hérmedes (Palencia) ${ }^{664}$. La traza fue diseñada conjuntamente por él y su hijo Pedro

1711. Retablo mayor (Fig. 82). Iglesia de Santa María de la Cuesta. Cuéllar (Segovia) $^{665}$. Realizado conjuntamente con Blas Martínez de Obregón.

1713. Retablo mayor. Iglesia de la Vera Cruz. Nava del Rey (Valladolid) ${ }^{666}$.

1713. Facistol. Iglesia de San Pedro. Tordesillas (Valladolid) ${ }^{667}$.

1715. Retablo ¿mayor? Iglesia de Santa María. Palazuelo de Vedija (Valladolid) ${ }^{668}$.

1717. Retablo de San José. Iglesia de los Santos Juanes. Nava del Rey (Valladolid) ${ }^{669}$.

1719. Retablo del Santo Sepulcro para el Hospital de la Resurrección (Fig. 83). Iglesia de Santa María Magdalena. Valladolid ${ }^{670}$. Realizado conjuntamente con su hijo Pedro.

1719. Retablo y andas para la Virgen del Rosario. Iglesia parroquial. Castrodeza $(\text { Valladolid })^{671}$.

1722. Sombrero para un púlpito. Iglesia de Nuestra Señora de la Asunción. Rueda

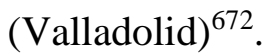

662 GARCÍA CHICO, Esteban: Documentos para el estudio del arte en Castilla. 2..., op. cit., pp. $352-354$

663 BRASAS EGIDO, José Carlos: "Noticias documentales...”, op. cit., p. 469.

664 GARCÍA CHICO, Esteban: Documentos para el estudio del arte en Castilla. 2..., op. cit., pp. 363-365.

665 ARRIBAS, Miguel María: op. cit., pp. 556-560; VELASCO BAYÓN, Balbino: op. cit., pp. 422423.

666 GARCÍA CHICO, Esteban y BUSTAMANTE GARCÍA, Agustín: Catálogo Monumental de la provincia de Valladolid. Tomo V... op. cit., p. 104.

667 ARA GIL, Clementina Julia y PARRADO DEL OLMO, Jesús María: Catálogo Monumental de la provincia de Valladolid. Tomo XI..., op. cit., pp. 219 y 233.

668 GARCÍA CHICO, Esteban: Documentos para el estudio del arte en Castilla. 2..., op. cit., pp. 365-367; PARRADO DEL OLMO, Jesús María: Catálogo Monumental de la provincia de Valladolid. Tomo XVI..., op. cit., p. 155.

669 GARCÍA CHICO, Esteban y BUSTAMANTE GARCÍA, Agustín: Catálogo Monumental de la provincia de Valladolid. Tomo V..., op. cit., pp. 83-84; CASTÁN LANASPA, Javier: Catálogo Monumental de la provincia de Valladolid. Tomo XXI. Antiguo partido judicial de Nava del Rey, Diputación de Valladolid, Valladolid, 2006, p. 90.

670 BENITO ARRANZ, Juan: "Un retablo desaparecido: el de la capilla del Santo Sepulcro del Hospital de la Resurrección de Valladolid”, B.S.A.A., Tomo IX, 1942-1943, pp. 173-178.

671 ARA GIL, Clementina Julia y PARRADO DEL OLMO, Jesús María: Catálogo Monumental de la provincia de Valladolid. Tomo XI..., op. cit., pp. 44, 45 y 51. 
1723. Retablo para la capilla de Nuestra Señora de las Doncellas. Iglesia de Santiago Apóstol. Valladolid ${ }^{673}$.

Hacia 1728. Cajonería para la sacristía. Iglesia de San Miguel. Íscar (Valladolid) ${ }^{674}$.

1728. Retablo de la Dolorosa. Iglesia Penitencial de Nuestro Padre Jesús Nazareno. Valladolid ${ }^{675}$.

\section{$\underline{\text { PEDRO DE RIBAS }}(1666$ - 1738)}

Pedro de Ribas Fernández ${ }^{676}$ nació en Valladolid el 16 de octubre de 1666. Sus padres, el maestro de obras Pedro de Ribas e Inés Fernández, le llevaron a bautizar a la iglesia de Santiago Apóstol el día 7 de noviembre de ese mismo año ${ }^{677}$.

La educación del pequeño preocupó mucho a su padre. Así, procuró darle una amplia formación artística lo más completa posible para que se pudiera ganar bien la vida en el futuro. Efectivamente, el 29 de junio de 1679 lo asentó en el taller de Francisco Prieto, maestro de hacer "marcos, bastidores, mesas, camas, armas y cofres" 678 . Posteriormente, el 6 de julio de 1681 le manda al taller del entallador Andrés de Estrada para que aprenda el oficio, con quien debía de permanecer cinco años ${ }^{679}$. La marcha de Estrada a Peñafiel provocó el cambio de taller, pasando Ribas a culminar su aprendizaje al de Pedro Rodríguez de Vega ${ }^{680}$.

El 6 de noviembre de 1689 contrae matrimonio con María Vázquez en la iglesia de Santiago $^{681}$. Poco después el matrimonio toma en arrendamiento del pintor Juan Bautista de San José una casa que hacía "esquina al cementerio de Santiago"682. Es decir, sería casi vecino de Juan de Ávila. Su mujer fallecería al poco tiempo ya que en

672 MARCOS VILLÁN. Miguel Ángel y FRAILE GÓMEZ, Ana María: Catálogo Monumental de la provincia de Valladolid. Tomo XVIII..., op. cit., pp. 269 y 291.

673 MARTÍN GONZÁLEZ, Juan José y URREA FERNÁNDEZ, Jesús: Catálogo Monumental de la provincia de Valladolid. Tomo XIV..., op. cit., p. 195.

674 BRASAS EGIDO, José Carlos: Catálogo Monumental de la provincia de Valladolid. Tomo X..., op. cit., p. 92.

$675 \quad$ ARRIBAS ARRANZ, Filemón: La Cofradía Penitencial..., op. cit., pp. 53 y 131.

676 Ver: MARTÍN GONZÁLEZ, Juan José: Escultura barroca castellana..., op. cit., pp. 349-350; NAVARRO TALEGÓN, José: Catálogo monumental de Toro..., op. cit.

677 "En siete de noviembre de mil seiscientos y sesenta y seis años bauticé e impuse los santos óleos como el santo concilio manda a Pedro hijo legítimo de Pedro de Ribas y de Inés Fernández nació en diez y seis de octubre de este año fueron padrinos Gregorio de Salinas y Da Manuela Vela dieronle por abogados a Nuestra Señora y San José testigos Fernando Vela y Juan de Silvosa y lo firmé’. A.G.D.V., Santiago, 1643B, f. 493.

$678 \quad$ A.H.P.V., Leg. 2.768, f. 87.

679 A.H.P.V., Leg. 2.759/7.

680 A.H.P.V., Leg. 2.380/3, f. 450.

681 A.G.D.V., Santiago, 1673M, f. 136.

682 A.H.P.V., Leg. 2.953. 
1693 nacería su hijo Pedro, fruto de matrimonio en segundas nupcias con Isabel de las Puertas $^{683}$. A este le seguirían Joseph (1696) y Francisca $(1701)^{684}$.

Pedro de Ribas fallece el 25 de febrero de 1738, siendo enterrado al día siguiente en la capilla de San Pedro Regalado en la Catedral de Valladolid ${ }^{655}$; por entonces el viejo ensamblador moraba en calle de los Roperos de Viejo. Así nos lo narra su amigo y discípulo Ventura Pérez: "Muerte de mi hermano Pedro de Ribas. Año de 1738, día 25 de febrero, murió mi maestro Pedro de Ribas, que santa gloria haya. Se enterró en la capilla de San Pedro Regalado, al pie de la grada del altar" ${ }^{\prime 68}$.

Debió de ser uno de los artistas más completos y cualificados de aquel Valladolid ya que además de ser ensamblador (diseñar y realizar retablos y otros muebles litúrgicos) también fue entallador, arquitecto ${ }^{687}$, altarero ${ }^{688}$ y repostero ${ }^{689}$. Su obra retablística se centra fundamente en Valladolid y en los alrededores de Toro (Zamora), lugares para los cuales talla retablos para sus altares y canceles para sus puertas. Asimismo, para la catedral efectuó otra serie de tareas como fueron el realizar los andamios para la obra de la fachada principal o el subir y colocar la campana grande de la torre ${ }^{690}$. El 18 de febrero de 1697 realiza un asiento de compañía con Juan Fernández “altarero" ${ }^{691}$. En él se conviene "por todos los días de su vida de hacer todos los altares, monumentos, túmulos, tablados de fuegos y colgados de colgaduras y tapices en todas las festividades y fiestas que se ofrezcan hacer así en esta ciudad como en todas las demás ciudades, villas y lugares de estos reinos y señoríos donde les llamaren".

Como anécdota hay que señalar que el 21 de marzo de 1727 recibió por aprendiz al famoso cronista Ventura Pérez, el cual con anterioridad se había instruido como organista $^{692}$.

\section{$\underline{\text { Catálogo }}$}

1705. Cancel de la puerta principal. Iglesia de San Juan Bautista. Tagarabuena (Zamora) ${ }^{693}$.

\footnotetext{
683 A.G.D.V., Santiago, 1683B, f. 249.

684 A.G.D.V., Santiago, 1683B, ff. 354, 441.

685 A.G.D.V., Catedral, 1684D, f. 255.

686 PÉREZ, Ventura: op. cit., p. 151.

687 Fue el tracista y director de la obra de la sacristía de la iglesia del Salvador, uno de los mejores ejemplos de barroquismo de la ciudad. MARTíN GONZÁLEZ, Juan José y URREA FERNÁNDEZ, Jesús: Catálogo Monumental de la provincia de Valladolid. Tomo XIV ..., op. cit., p. 40. También aparece citado como arquitecto en su reconocimiento de las iglesias vieja y nueva del Convento de las Comendadoras de Santa Cruz. FERNÁNDEZ DEL HOYO, María Antonia: "El Convento de Comendadoras de Santa Cruz, de Valladolid. Nuevos datos para su historia", Valladolid, historia de una ciudad, Vol. 1: La ciudad y el arte; Valladolid villa (época medieval), Ayuntamiento de Valladolid, Valladolid, 1999, pp. 105-114.

688 PÉREZ, Ventura: op. cit., pp. 91 y 126.

689 URREA FERNÁNDEZ, Jesús: “Noticias documentales...”, op. cit., p. 533.

690 PÉREZ, Ventura: op. cit., pp. 104 y 111.

691 A.H.P.V., Leg. 2.856, ff. 97-98.

692 PÉREZ, Ventura: op. cit., p. 89.

693 NAVARRO TALEGÓN, José: Catálogo monumental de Toro..., op. cit., pp. 380-381.
} 
1707. Cancel septentrional y confesionarios. Iglesia de San Juan Bautista. Tagarabuena (Zamora $)^{694}$.

Hacia 1707. Caja del órgano. Monasterio de San Benito el Real. Valladolid ${ }^{695}$.

1709. Cancel. Iglesia del Santísimo Salvador. Valladolid ${ }^{696}$.

1709. Pabellón de talla para el lienzo de la Inmaculada. Ayuntamiento. Toro (Zamora) ${ }^{697}$.

1711. Retablo del Cristo de la Vera Cruz y Puertas para las sacristías (Fig. 84). Iglesia de San Juan Bautista. Tagarabuena (Zamora) ${ }^{698}$.

1712. Dos Canceles. Iglesia de la Trinidad. Toro (Zamora) ${ }^{699}$.

1712. Dos Canceles. Catedral. Zamora ${ }^{700}$.

1713-1715. Cancel para la puerta del Evangelio. Iglesia de Santiago Apóstol. Valladolid $^{701}$.

1714-1715. Retablos para las capillas de Santa María Magdalena, San Pedro, San José, San Miguel y San Juan Evangelista (Fig. 85). Catedral. Valladolid ${ }^{702}$.

1717 Cancel para la puerta "que está al lado del pozo". Iglesia de Santiago Apóstol. Valladolid ${ }^{703}$.

1717. Retablo de San Sebastián. Iglesia parroquial de San Miguel Arcángel. Fuentelcésped (Burgos) $)^{704}$.

1723. Canceles. Colegiata de Santa María la Mayor. Toro (Zamora) ${ }^{705}$.

695 Ídem, pp. 380-381. 339.

696 MARTÍN GONZÁLEZ, Juan José y URREA FERNÁNDEZ, Jesús: Catálogo Monumental de la provincia de Valladolid. Tomo XIV..., op. cit., p. 40.

697 NAVARRO TALEGÓN, José: Inventario y catálogo..., op. cit., pp. 5-6.

698 NAVARRO TALEGÓN, José: Catálogo monumental de Toro..., op. cit., pp. 380-381.

699 Ídem, p. 206.

700 RIVERA DE LAS HERAS, José Ángel: Por la catedral, iglesias y ermitas de la ciudad de Zamora, Edilesa, León, 2001, p. 31.

$701 \quad$ Cancel nuevo. "Ítem son data dos mil reales que valen sesenta y ocho mil maravedíes los mismos que dio Miguel Fernández mayordomo que fue el año pasado de mil setecientos y quince de limosna y tuvo de costa el cancel que se puso en dicha iglesia al lado de la capilla de la Concepción y de dicha cantidad va hecho cargo al n 100 de éstas cuentas". A.G.D.V., Santiago, Libro de fábrica 1708-1730. Años 1713-1715.

702 MARTÍN GONZÁLEZ, Juan José: “Noticias documentales...”, op. cit., pp. 193 y 194.

703 Cancel. "Ítem son data mil ochocientos y ochenta reales que valen sesenta y tres mil novecientos y veinte maravedíes pagados a Pedro de Ribas por el cancel que puso en la puerta que está al lado del pozo y en dicha cantidad entra el herraje y las dos puertas que se hicieron para la entrada del coro y de la torre como parece de recibo que se entrega". A.G.D.V., Santiago, Libro de fábrica 1708-1730, Años 1716-1717.

704 ZAPARAÍN YÁÑEZ, María José: Fuentelcésped: la villa y su patrimonio, siglos XVII y XVIII, EMAN, San Sebastián, 1998, p. 186. 


\section{JOSÉ DÍAZ DE MATA (1684-1766)}

José Díaz de Mata ${ }^{706}$ nació, según dijeron sus padres y los testigos, el 18 de marzo de 1684, siendo bautizado el 28 de ese mismo mes en la iglesia de San Miguel ${ }^{707}$. Contrae matrimonio con Josepha Fernández del Río el 25 de marzo de $1708^{708}$ en la iglesia del Salvador, siendo posteriormente velados en la de San Miguel el 17 de mayo de ese mismo año ${ }^{709}$. La pareja, que por entonces pasó a vivir a la plaza de San Miguel, tuvo una numerosa descendencia: Joseph Martín (1714), Joseph (1718), Manuel Joseph (1725), Josepha Petrona (1726), María Brígida (1729) y Manuel Bentura (1731) ${ }^{710}$.

El 11 de junio de 1762 José Díaz de Mata, ya viudo de su esposa y "estando enfermo de la que Dios nuestro señor ha sido servido darme, y en mi sano juicio y entendimiento natural", decide otorgar el que será su testamento definitivo ${ }^{711}$. Su primer deseo era ser enterrado en la iglesia de San Miguel, con el hábito de San Diego, "en la sepultura mía propia que está en la capilla mayor junto a la de los capellanes no obstante tenerla en la misma capilla como mayordomo de fábrica que he sido". Para cumplir todos sus mandatos dejaba nombrados como albaceas al cura de San Miguel, don Joseph Román de Aguilar, al presbítero teniente de la misma iglesia, don Francisco Gil de Reinoso, y a su propia hija Josefa Díaz de Mata, a quien también instituyó como heredera universal y sobre quien recayó el referido vínculo.

José Díaz de Mata muere el 6 de diciembre de $1766^{712}$. En esos momentos aún era vecino de la plazuela de San Miguel. Fue enterrado en sepultura propia en la iglesia parroquial del mismo nombre. Dejó por heredera, al igual que su mujer, a la única hija superviviente, Josepha.

705 NAVARRO TALEGÓN, José: Catálogo monumental de Toro..., op. cit., p. 117.
706 Ver: MARTÍN GONZÁLEZ, Juan José: Escultura barroca castellana..., op. cit., pp. 319-320;
PARRADO DEL OLMO, Jesús María: Datos histórico artísticos..., op. cit.
$707 \quad$ "En veinte y ocho de marzo de mil seiscientos y ochenta y cuatro yo don Antonio Sangáriz cura
propio de la parroquial del señor San Miguel de ésta ciudad de Valladolid bauticé e impuse los santos
óleos según forma de la santa madre iglesia a José hijo legítimo de Gregorio de Mata y María Valcárcel
fueron sus padrinos Juan de Vergario e Isabel de Blas testigos el licenciado don Miguel de Landa y
Andrés González dieronle por abogados a Nuestra Señora de la Esperanza y San José, dicen nació en diez
y ocho de dicho mes y lo firmé”. A.G.D.V., San Miguel, 1669B, f. 157.
$708 \quad$ A.G.D.V., Salvador, 1685M, f. 196.
$709 \quad$ A.G.D.V., San Miguel, 1651M, f. 255 .
$710 \quad$ A.G.D.V., San Miguel, 1705B, ff. 89 y 138. A.G.D.V., San Miguel, 1722B, ff. 31, 45-46, 83, 115-116.

$711 \quad$ A.H.P.V., Leg. 3.838, ff. 76-77.

712 "En seis de diciembre de mil setecientos sesenta y seis habiendo recibido los santos sacramentos murió en ésta parroquial de San Miguel Joseph Díaz de Mata de estado viudo morador a la plazuela que llaman de San Miguel, enterrose en dicha iglesia en sepultura propia como lo mandó en su testamento que otorgó en testimonio de Lucas de Carcedo escribano del número de ésta ciudad su fecha en ella. Mandó se dijesen por su alma treinta misas rezadas a dos reales cada una la cuarta en dicha iglesia, nombró por sus testamentarios a D. Joseph Román Aguilar cura propio de la expresada parroquia, D. Francisco Gil de Reinoso teniente de cura de ella y a $\mathrm{D}^{\mathrm{a}}$ Josepha Díaz de Mata su hija, a quien instituyó por su única y universal heredera de todos sus bienes y como teniente de cura de dicha iglesia lo firmé en Valladolid fecha ut supra". A.G.D.V., San Miguel, 1711D, f. 241. 
En las diferentes escrituras en las que se le cita se refieren a él como "ensamblador y arquitecto"713 o "maestro de tallista" "114. Sabemos que realizó numerosas trazas de retablos, los cuales fueron llevados a cabo por otros artífices. También participó en numerosas subastas no alzándose con la victoria en la mayoría de las ocasiones.

\section{$\underline{\text { Catálogo }}$}

1710-1711. Retablo mayor. Iglesia de Santa Cruz. Pedrosa del Rey (Valladolid). Desaparecido $^{715}$.

1713. Retablos colaterales y sombrero para el púlpito (Fig. 86). Iglesia parroquial de la Asunción. Casasola de Arión (Valladolid) ${ }^{716}$. Realizados conjuntamente con su padre Gregorio Díaz de Mata.

1713. Custodia del altar mayor. Iglesia penitencial de Nuestro Padre Jesús Nazareno. Valladolid $^{717}$. Desaparecida.

1714. Retablos colaterales. Iglesia de San Esteban Protomártir. Torrecilla de la Abadesa (Valladolid) $)^{718}$. Realizados conjuntamente con su padre Gregorio Díaz de Mata.

1722. Retablo mayor. Iglesia de la Compañía de Jesús. Pontevedra ${ }^{719}$.

1731. Dos canceles. Iglesia parroquial de San Esteban Protomártir. Torrecilla de la Abadesa (Valladolid) ${ }^{720}$.

1741. Retablo mayor. Iglesia del Salvador. Cuéllar (Segovia) ${ }^{721}$.

1741. Retablo mayor. Convento de San Pablo. Coca (Segovia) ${ }^{722}$. Desaparecido

\section{PEDRO CORREAS $(1689-1756)$}

Pedro Correas ${ }^{723}$ fue uno de los ensambladores más brillantes del segundo cuarto del siglo XVIII; de hecho Martín González a la vista de su obra documentada y atribuida

\footnotetext{
$713 \quad$ A.H.P.V., Leg. 3.313, f. 100.

714 A.H.P.V., Leg. 5.456, ff. 1-3 (1729).

715 ARA GIL, Clementina Julia y PARRADO DEL OLMO, Jesús María: Catálogo Monumental de la provincia de Valladolid. Tomo XI..., op. cit., pp. 104-107.

716 PARRADO DEL OLMO, Jesús María: Catálogo Monumental de la provincia de Valladolid. Tomo IX..., op. cit., pp. 40-41 y 44.

717 MARTÍN GONZÁLEZ, Juan José y URREA FERNÁNDEZ, Jesús: Catálogo Monumental de la provincia de Valladolid. Tomo XIV..., op. cit., p. 219.

718 ARA GIL, Clementina Julia y PARRADO DEL OLMO, Jesús María: Catálogo Monumental de la provincia de Valladolid. Tomo XI..., op. cit., p. 526.

719 BRASAS EGIDO, José Carlos: "Noticias documentales...”, op. cit., p. 469.

720 ARA GIL, Clementina Julia y PARRADO DEL OLMO, Jesús María: Catálogo Monumental de la provincia de Valladolid. Tomo XI..., op. cit., p. 324.

$721 \quad$ VELASCO BAYÓN, Balbino: op. cit., p. 424.

722 RODRÍGUEZ MARTÍNEZ, Felipe: Corpus documental de Coca, Visión Libros, Madrid, 2010, pp. 564-568.
} 
llegó a comentar que "nos le permiten imaginar como el más importante del foco de Valladolid" de este momento ${ }^{724}$. De su importancia nos hablan bien las referencias que hace sobre su persona y producción el diarista Ventura Pérez, contemporáneo suyo y a quien debió de conocer bien ya que también practicaba el ensamblaje. Muchos años después Casimiro González García-Valladolid incluye una biografía suya en sus Datos para la historia biográfica de la M. N. M. N. H. y Excma. ciudad de Valladolid $(1893)^{725}$.

$\mathrm{Su}$ actividad se centra fundamentalmente en la provincia de Valladolid y en la mitad sur de la de Palencia. Debió de mantener fuertes lazos con la Orden Franciscana ya que trabajó para numerosos comitentes, conventos y parroquias relacionadas con ésta. Piensa Martín González que buena parte de las esculturas que pueblan sus retablos pudieran haber sido hechas por él mismo ${ }^{726}$. Conocemos con seguridad este extremo puesto que además de aparecer citado en los documentos como arquitecto, ensamblador, entallador o tallista también lo hace como escultor, práctica en la que también llegó a destacar dentro del denso panorama escultórico vallisoletano de la época. El estilo que demuestra en sus esculturas le acerca bastante a los Sierra, si bien en alguna ocasión Martín González ha vislumbrado ciertos rasgos de estirpe juniana, algo que no sería muy extraño puesto que ésta también aparece en los Sierra.

Nació en Valladolid el 18 de enero de 1689. Sus padres, el ensamblador Juan Correas y Teresa Calderón de la Barca, le bautizaron en la iglesia de San Lorenzo el día 30 de ese mismo mes ${ }^{727}$. Desconocemos cuando se independizó del hogar familiar, el caso es que cuando lo hizo marchó a vivir cerca de esté, a la casa que poseía el duque de Béjar en la calle de la Boariza (actual c/ María de Molina) ${ }^{728}$.

El primer trabajo del que tenemos constancia es una traza que diseña en el año 1706 para el retablo mayor de la iglesia parroquial de La Seca (Valladolid) ${ }^{729}$. Finalmente se eligió la elaborada por el salmantino Joaquín de Churriguera en 1711.

El 28 de julio de 1720 contrae matrimonio con María Ana Penco en la iglesia del Salvador el 28 de julio de ese mismo año ${ }^{730}$. Unos meses después, el 15 de octubre, los

723 Ver: MARTÍN GONZÁLEZ, Juan José: Escultura barroca castellana..., op. cit., pp. 326-343. MARTÍN GONZÁLEZ, Juan José: Escultura barroca en España..., op. cit., pp. 449-451; ZAPARAÍN YÁÑEZ, María José: “Dos obras vallisoletanas...”, op. cit., pp. 463-468.

$724 \quad$ MARTÍN GONZÁLEZ, Juan José: Escultura barroca castellana..., op. cit., p. 331.

725 GONZÁLEZ GARCÍA VALLADOLID, Casimiro: Datos para la historia biográfica..., op. cit., Tomo I, p. 334.

726 MARTÍN GONZÁLEZ, Juan José: Escultura barroca en España ..., op. cit., p. 449.

727 "En la ciudad de Valladolid a treinta de enero de mil seiscientos y ochenta y nueve yo el licenciado Juan Antonio González teniente de cura de la iglesia parroquial de Ntra. Sra. de San Lorenzo de esta ciudad bauticé y puse los santos óleos según el orden de la santa madre iglesia de Roma a Pedro hijo legítimo de Juan Correas y Teresa Calderón parroquianos de esta parroquia moradores en la plazuela de la Trinidad nació a diez y ocho de dicho mes y año fue su padrino Juan Pérez vecino de esta ciudad al cual advertí el parentesco espiritual y su obligación diosele por abogados a Nuestra Señora y San José y lo firmé". A.G.D.V., San Lorenzo, 1671, f. 103.

728 MARTÍN GONZÁLEZ, Juan José: Escultura barroca castellana..., op. cit., p. 326.

729 MARCOS VILLÁN. Miguel Ángel y FRAILE GÓMEZ, Ana María: Catálogo Monumental de la provincia de Valladolid. Tomo XVIII..., op. cit., p. 366. 
consortes son velados en la iglesia de San Lorenzo ${ }^{731}$. Esta mujer pudo ser de nacionalidad italiana ya que años después un documento nos descubre que el padre de esta era natural del "lugar de Santo Laio seis o siete millas de la ciudad de Génova". La pareja no lograría tener descendencia ${ }^{732}$.

El 7 de febrero de 1725 vuelve a contraer matrimonio. En esta ocasión lo hará con Ana María de Mendiguren en la iglesia de San Lorenzo, parroquia en la que fue bautizado. $\mathrm{Su}$ padre Juan Correas ejerció de testigo ${ }^{733}$. Un día después la pareja celebraría las velaciones en la iglesia del Salvador, parroquia en la que residiría Ana María ${ }^{734}$. También en esta ocasión Juan Correas actuó de testigo. La pareja tuvo cuatro hijos, todos ellos bautizados en la iglesia de San Lorenzo: Antonia (1727), Antonia (1731), Antonio (1737) y Manuel (1740) ${ }^{735}$.

En la madrugada del día 25 al 25 de septiembre de 1736 se desata un espantoso "grande incendio y fuego en la casa del mayorazgo de velón intitulada del padre Galván", viviendas en las que Correas moraba y tenía instalado su taller ${ }^{736}$. El obrador sufriría graves desperfectos, perdiéndose buena parte de las obras que en ellas momentos se encontraba preparando. Según ciertos documentos, Correas tenía allí "herramienta mucha madera de Soria y Hontalbilla así de vigas como de tabla y porción de bienes muebles", parte de los cuales los tenía en depósito, siendo pertenecientes al "inventario hecho de los que quedaron por muerte de doña Manuela de Santisteban viuda que fue de Luis Antonio Canedo escribano que fue de provincia de esta Corte". Por desgracia estos últimos se quemaron "y abrasó lo más y sólo ha quedado cortísima porción de dicha herramienta madera y bienes que se halla en los corrales de la expresada casa" 737 .

El 7 de marzo de 1749 Correas, Pedro Roldán, Bentura Ramos y Manuel de Ribas, todos ellos ensambladores, consiguen una ejecutoria a favor de los profesores en dicho arte "sobre el repartimiento de camas para los alojamientos de soldados"738.

Hallándose gravemente enfermó, el 18 de enero de 1752 dio poder a su mujer para que en su nombre hiciera testamento ${ }^{739}$; y ella le otorgó a 9 de febrero de $1752^{740}$. Entre otros asuntos, declaraba que su cuerpo debía de ser "sepultado en la iglesia parroquial de Nuestra Señora de San Lorenzo de esta ciudad, donde soy parroquiano, y en la sepultura que tengo mía propia, y con el hábito de Nuestro Padre San Francisco". Declaraba tener por sus hijos a Antonio y Antonia, a los cuales instituía por sus únicos y

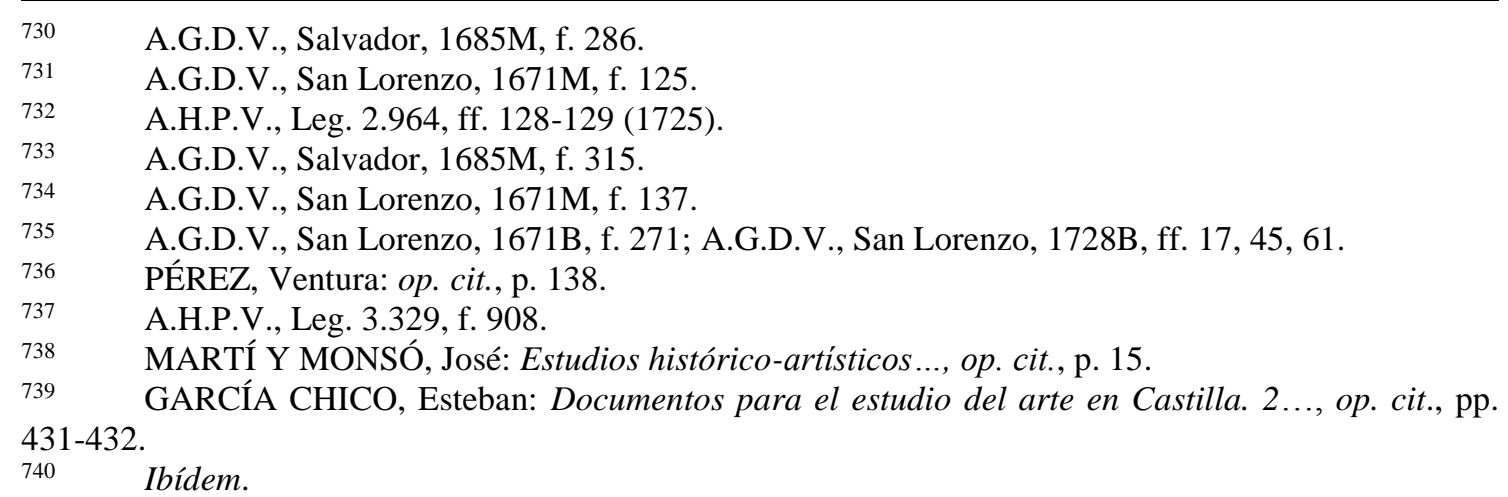


universales herederos. Al ser menores de edad nombraba a su esposa, y asimismo madre de sus hijos, como "tutora y curadora de las personas y bienes de los referidos don Antonio y doña Antonia Correas Mendiguren". El testamento definitivo no difiere mucho de los extremos contenidos en el poder anterior. A todo lo anterior añade una lista de las cofradías a la que perteneció su marido: la Cofradía Sacramental de San Lucas, la de Ánimas y San Antonio Abad de la parroquial de Santiago, la de San Antonio de Padua del Convento de San Francisco y las cofradías penitenciales de la Santa Vera Cruz, Nuestra Señora de la Pasión y Jesús Nazareno ${ }^{741}$.

Pedro Correas fallece el 6 de febrero de 1752, siendo enterrado, como era su deseo, en la parroquia de San Lorenzo ${ }^{742}$.

\section{$\underline{\text { Catálogo }}$}

1709. Traza para el retablo mayor. Iglesia de San Juan Bautista. Hérmedes

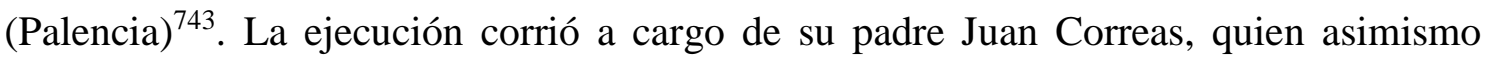
tuvo parte en la elaboración de la traza.

1719. Retablo del Santo Sepulcro para el Hospital de la Resurrección. Iglesia de Santa María Magdalena. Valladolid ${ }^{744}$. Realizado conjuntamente con su padre.

1720. Traza para el retablo de la Purísima Concepción de la capilla de don Diego de Carrascal. Iglesia de Santiago de los Caballeros. Medina de Rioseco (Valladolid) ${ }^{745}$. Su ejecución corrió a cargo del riosecano Carlos Carnicero.

1720-1721. Retablo de la capilla de Nuestra Señora de las Doncellas. Iglesia de Santiago Apóstol. Valladolid ${ }^{746}$.

1722. Sombrero para un púlpito. Iglesia de Nuestra Señora de la Asunción. Rueda

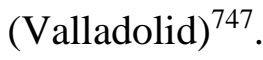

1723. Sagrario para el altar mayor. Iglesia parroquial. Castrodeza (Valladolid) ${ }^{748}$.

1728. Retablo de San Antonio. Iglesia de San Juan Bautista. Tordesillas (Valladolid) ${ }^{749}$.

\footnotetext{
741 MARTÍN GONZÁLEZ, Juan José: Escultura barroca castellana..., op. cit., p. 326.

742 GARCÍA CHICO, Esteban: Documentos para el estudio del arte en Castilla. 2..., op. cit., p. 432.

743 Ídem, pp. 363-365.

744 BENITO ARRANZ, Juan: op. cit., pp. 173-178.

745 WATTENBERG GARCÍA, Eloísa: Catálogo Monumental de la provincia de Valladolid. Tomo XVII..., op. cit., p. 110.

746 Retablo que se puso en la capilla de Nuestra Señora de las Doncellas. "Ítem son data doscientos reales que valen seis mil y ochocientos maravedíes los mismos pagó a Correa entallador por el retablo y adorno que se puso en la capilla de Nuestra Señora de las Doncellas porque aunque costó más el exceso y adornos de la imagen salieron de algunas limosnas que dieron algunos devotos". A.G.D.V., Santiago, Libro de fábrica 1708-1730, Años 1720-1721.

747 MARCOS VILLÁN. Miguel Ángel y FRAILE GÓMEZ, Ana María: Catálogo Monumental de la provincia de Valladolid. Tomo XVIII..., op. cit., pp. 269 y 291.

748 ARA GIL, Clementina Julia y PARRADO DEL OLMO, Jesús María: Catálogo Monumental de la provincia de Valladolid. Tomo XI..., op. cit., p. 45.
} 
1728-1729. Reforma del cascarón del retablo mayor. Iglesia de Santiago Apóstol. Valladolid $^{750}$.

1729. Retablo mayor. Convento de San Francisco. Aranda de Duero (Burgos) ${ }^{751}$. Desaparecido.

1730. Retablo mayor (Fig. 87). Convento de Santa Clara. Valladolid ${ }^{752}$.

1730. Coronación de la reja del baptisterio. Iglesia de San Pedro. Tordesillas $(\text { Valladolid })^{753}$.

1730. Traza para el retablo mayor. Ermita de la Santísima Trinidad. Fuentespina (Burgos) $)^{754}$.

1736. Nuestra Señora de la Paz (Fig. 88). Ermita de Nuestra Señora de la Paz. Cáceres $^{755}$.

1740. Retablo mayor. Iglesia parroquial de San Pedro. Mucientes (Valladolid) ${ }^{756}$.

1741. Retablo mayor (Fig. 89). Iglesia de San Andrés. Valladolid ${ }^{757}$.

1743. Retablo mayor. Iglesia Santa María. Villabrágima (Valladolid) ${ }^{758}$. Desaparecido

1748. Retablo mayor. Ermita de Nuestra Señora de las Viñas. Adalia (Valladolid) ${ }^{759}$. Desaparecido.

1749. Dos retablos y esculturas de San Antonio Abad, Ecce Homo y la Verónica. Iglesia de Santa Eulalia. Adalia (Valladolid) ${ }^{760}$. Desaparecidos.

\footnotetext{
$749 \quad$ Ídem, p. 247.

750 A.G.D.V., Santiago, Libro de fábrica 1708-1730, f. 361.

751 ZAPARAIIN YÁÑ̃E, María José: “Dos obras vallisoletanas...”, op. cit., pp. 463-468.

752 GARCÍA CHICO, Esteban: "Valladolid. Iglesia conventual de Santa Clara. Retablo mayor". B.S.A.A., Tomo XXI-XXII, 1954-1956, pp. 159-162; MARTÍN GONZÁLEZ, Juan José y DE LA PLAZA SANTIAGO, Francisco Javier: Catálogo Monumental de la provincia de Valladolid. Tomo $X V \ldots$, op. cit., pp. 65,66 y 68.

753 ARA GIL, Clementina Julia y PARRADO DEL OLMO, Jesús María: Catálogo Monumental de la provincia de Valladolid. Tomo XI..., op. cit., pp. 217 y 235.

754 ZAPARAÍN YÁÑEZ, María José: “Dos obras vallisoletanas...”, op. cit., pp. 463-468.

755 http://www.aedesars.com/kits-construccion/kits-monumentos-historicos/conjunto-monumentalcaceres.

756 GARCÍA CHICO, Esteban: Documentos para el estudio del arte en Castilla. 2..., op. cit., p. 431; MARTÍN GONZÁLEZ, Juan José: Escultura barroca castellana..., op. cit., p. 329; URREA FERNÁNDEZ, Jesús: Catálogo Monumental de la provincia de Valladolid. Tomo XX..., op. cit., p. 87.

757 ARMENDÁRIZ UBIOLA, Fermín: "El retablo de la iglesia de San Andrés, de Valladolid", B.S.A.A., Tomo VII, 1940-1941, pp. 187-195; MARTÍN GONZÁLEZ, Juan José y URREA FERNÁNDEZ, Jesús: Catálogo Monumental de la provincia de Valladolid. Tomo XIV ..., op. cit., p. 53.

758 PARRADO DEL OLMO, Jesús María: Catálogo Monumental de la provincia de Valladolid. Tomo XVI..., op. cit., p. 281.

759 PARRADO DEL OLMO, Jesús María: Catálogo Monumental de la provincia de Valladolid. Tomo IX..., op. cit., p. 17.

760 Ídem, p. 16.
} 
1750. Retablo mayor y dos retablos colaterales. Iglesia de Santa Eulalia. Adalia $(\text { Valladolid })^{761}$. Desaparecidos.

\section{PEDRO ROLDÁN (h.1705 - d.1744)}

Las escasas noticias que poseemos sobre el ensamblador Pedro Roldán son sobre su oficio, pues nada sabemos de su biografía. Casualidad, o no, la totalidad de su obra documentada se encuentra concentrada en las tierras zamoranas más cercanas al límite con la provincia de Valladolid, es decir, en el antiguo partido judicial de Toro. Vista tal cantidad de obra concentrada en unos pocos kilómetros alrededor de Toro lleva a pensar si Roldán entabló amistad con los Tomé, toresanos de pro, cuando estos vinieron a Valladolid para trabajar en la escultura de la fachada de la Universidad.

\section{$\underline{\text { Catálogo }}$}

1731. Retablo mayor. Iglesia de San Miguel. Villavendimio (Zamora) ${ }^{762}$.

1732. Cancel principal. Iglesia de la Asunción. Bustillo de Oro (Zamora) ${ }^{763}$.

1737. Retablos del Santo Cristo de las Batallas (Fig. 90). Iglesia del Salvador. Morales de Toro $(1737)^{764}$.

1737-1738. Dos canceles. Iglesia de la Asunción. Villavieja del Cerro (Valladolid) ${ }^{765}$.

1738-1739. Retablo de Nuestra Señora de Roncesvalles. Iglesia del Salvador. Morales de Toro (Zamora) ${ }^{766}$.

1741. Retablo mayor. Iglesia de San Juan Bautista. Bóveda de Toro (Zamora) ${ }^{767}$.

1744. Tabernáculo. Iglesia de Santo Tomás. Morales de Toro (Zamora) ${ }^{768}$.

\section{MANUEL RODRÍGUEZ (h.1705 - d.1758)}

Al igual que ocurre con Pedro Roldán no tenemos ningún conocimiento acerca de su biografía, y sobre su oficio las noticias son contadas.

\footnotetext{
$761 \quad$ Ibídem.

762 NAVARRO TALEGÓN, José: Catálogo monumental de Toro..., op. cit., p. 433.

763 Ídem, p. 308.

764 Ídem, p. 340.

765 ARA GIL, Clementina Julia y PARRADO DEL OLMO, Jesús María: Catálogo Monumental de la provincia de Valladolid. Tomo XI..., op. cit., pp. 435 y 439.

766 NAVARRO TALEGÓN, José: Catálogo monumental de Toro..., op. cit., p. 341.

767 Ídem, p. 298.

768 Ídem, p. 335
} 
$\underline{\text { Catálogo }}$

1731. Retablo mayor. Iglesia de San Nicolás de Bari. Valladolid ${ }^{769}$. Desaparecido.

1731-1733. Retablos colaterales. Iglesia de San Millán. Velliza (Valladolid) ${ }^{770}$.

1732. Retablos colaterales. Colegiata de Santa Ana. Peñaranda de Duero (Burgos) ${ }^{771}$. Desaparecidos.

1737. Caja del órgano. Iglesia de la Asunción. Villabáñez (Valladolid). Realizado conjuntamente con el ensamblador Antonio Vélez ${ }^{772}$.

1758. Retablo de Santa Marina (Fig. 91). Iglesia de Santiago Apóstol. Cigales (Valladolid) $)^{773}$.

\section{C- EL RETABLO “ROCOCÓ” (aprox. 1740-1780)}

A partir del año 1740 la decoración comienza a desaparecer de todos los miembros del retablo. El movimiento no lo veremos en sus elementos sustentantes sino en las plantas y alzados, que "se mueven agitadamente, imperando una ágil articulación borrominesca". Las influencias en estos momentos llegarán desde la familia Tomé y también desde la Corte. La columna salomónica y el estípite no tendrán cabida en este nuevo momento, y su lugar será ocupado por la columna clásica acanalada, sin apenas decoración. En un primer momento la decoración característica serán las "cabezas de serafines dispuestas sobre placa adventicia, motivo que ya había aparecido unos años antes", si bien con el tiempo hará aparición la rocalla ${ }^{774}$. La escultura, que había sido relegada a un par de lugares del retablo, vuelve a retomar importancia. Es característico de este momento que en el remate de los retablos figure un rompimiento de gloria presidido por el Padre Eterno, el Espíritu Santo o por ambos.

Podemos destacar tres retablos de esta época, con la condición de que su fecha de ejecución no exceda de 1755, año en que presumiblemente falleció Pedro de Ávila: el retablo mayor de la Monasterio de Santa María de Valbuena de Duero (Valladolid), el retablo mayor de la parroquial de Rueda (Valladolid) y el retablo mayor de la parroquial de Cabezón de Pisuerga (Valladolid).

\footnotetext{
769 BRASAS EGIDO, José Carlos: "Noticias documentales...”, op. cit., p. 470.

770 1731.- "1.000 reales que pagó a Manuel Rodríguez, ensamblador vecino de la ciudad de Valladolid, en cuenta de los 1.800 reales en que está ajustado hacer un retablo de un colateral...". ARA GIL, Clementina Julia y PARRADO DEL OLMO, Jesús María: Catálogo Monumental de la provincia de Valladolid. Tomo XI..., op. cit., p. 388.

771 BRASAS EGIDO, José Carlos: "Noticias documentales...”, op. cit., p. 471.

772 MARTÍN GONZÁLEZ, Juan José: Catálogo Monumental de la provincia de Valladolid. Tomo VI..., op. cit., p. 141.

773 SAN JOSÉ DÍEZ, Mariano: La parroquia de Cigales, Ayuntamiento de Cigales, Cigales (Valladolid), 1992, pp. 104-105.

774 MARTÍN GONZÁLEZ, Juan José: Escultura barroca castellana..., op. cit., p. 74.
} 
El retablo del Monasterio de Valbuena inaugura la tipología de retablo-tabernáculo, que en años posteriores contaría con un ejemplar en Valladolid: el retablo de la Congregación del Amante Corazón de Jesús de la iglesia de San Julián ${ }^{775}$. El retablo en sí es la ampliación de la custodia, sobre la cual acontece la coronación de la Virgen por un teatral ángel que la sobrevuela. Se puede deambular alrededor de la custodia viendo a numerosos santos y entre ellos diversas alabanzas que elogian a la Virgen María. Las columnas están decoradas con numerosas cabezas de ángeles y elementos pegajosos. Todavía no hace acto de aparición la rocalla. Desconocemos al autor de tan soberbia máquina, si bien se cree con bastante fundamento que pudo encargarse de su elaboración Pedro Correas.

Uno de los retablos más importantes y novedosos de todo el territorio peninsular de estos momentos es el realizado por Pedro de Sierra en 1741 para la iglesia parroquial de Rueda (Valladolid). La planta es mixtilínea, las tres calles se curvan y contra curvan creando una sensación de movimiento a la manera de la fachada de la iglesia de San Carlo alle Quattro Fontane (Roma) de Borromini. En el banco tiene cabida uno de los elementos más extraordinarios de la monumental máquina: entre las repisas de las columnas se sitúan los cuatro padres de la iglesia, los cuales mantienen una total independencia con respecto al retablo, especialmente los de los extremos. El retablo se articula a través de un único cuerpo surcado por cuatro grandes columnas acanaladas de orden gigante que sostienen gruesos trozos de entablamento decorados con cabezas aladas de serafines. A plomo, sobre estos trozos de entablamento, se sitúan los cuatro evangelistas. El fuste de las mismas se halla recorrido también por cabezas aladas "sobre placas recortadas de blanda consistencia"776. El ático lo preside un majestuoso relieve, o casi bulto redondo, de la Trinidad coronando a la Virgen, la cual ocupa la hornacina central del retablo. La Trinidad asienta sobre una gran nube poblada de cabezas aladas de ángeles. A los lados de ésta, dos medallones con santos mártires. Es un mundo irreal y fantasioso.

El último de los ejemplos elegidos es el retablo mayor de Cabezón de Pisuerga (Valladolid), realizado en 1751 por Bentura Ramos ${ }^{777}$. En él vemos ya la totalidad de las características de este periodo: utilización de columnas acanaladas de orden gigante con el fuste decorado con angelotes, aparición de la rocalla, que también es perceptible en las columnas, aparición del Padre Eterno en el punto más alto del ático, decoración menuda, etc... Se puede decir que es uno de los retablos que presagian la llegada del Neoclasicismo.

Los ensambladores y tallistas más destacados de este periodo son, además de Pedro de Sierra, ya estudiado en el apartado de escultores, los semidesconocidos Bentura Ramos y Agustín Martín. Hay otros artífices si bien su obra conocida se limita a una o dos obras. Todavía queda mucho por investigar en este periodo, quizás el peor conocido de la retablística vallisoletana.

\footnotetext{
775 BRASAS EGIDO, José Carlos: "Noticias documentales...”, op. cit., p. 472.

776 MARTÍN GONZÁLEZ, Juan José: Escultura barroca castellana..., op. cit., p. 75.

777 Ibídem.
} 
Desconocemos cualquier dato referente a la vida y circunstancias de Bentura Ramos ${ }^{778}$ salvo su testamento, descubierto por Brasas Egido. El 6 de septiembre de 1756 "estando enfermo en cama de enfermedad que Dios nuestro señor ha sido servido darme pero en mi sano juicio y entendimiento natural" decide dictar testamento ${ }^{779}$. En él suplicaba que su cuerpo fuera sepultado en la iglesia de San Lorenzo "en la sepultura que les pareciere a mis testamentarios con el hábito de Nuestro Padre San Francisco y se me tome una bula de difuntos". Bentura declaraba que varias personas le eran deudoras de diferentes cantidades, entre ellos don Joseph Obago y Buisto "colegial de Santa Cruz (...) de resto de un retablo que de su orden hice en el Convento de Santa Clara de la villa de Cuellar" y la Cofradía de la Consolación de Valladolid "de resto del retablo que tengo concluido". Instituía por herederos a todos los hijos que tenía en aquel momento: Manuel, Ángela, María, Petra y Bentura Ramos "mis cinco hijos legítimos y de Antonia Miguelez de la Serna mi legítima mujer".

Bentura Ramos fallece el 11 de septiembre de 1756 siendo enterrado, como era su deseo, en la parroquia de San Lorenzo ${ }^{780}$.

\section{Catálogo}

1738. Tabernáculo. Iglesia de la Asunción. Villasarracino (Palencia) ${ }^{781}$.

1739. Retablo de Nuestra Señora del Carmen. Iglesia de la Asunción. Melgar de Fernamental (Burgos) ${ }^{782}$.

1740. Púlpito. Iglesia de Santiago Apóstol. Valladolid ${ }^{783}$.

1749. Retablo mayor (Fig. 92). Iglesia de la Asunción. Cabezón de Pisuerga (Valladolid) $^{784}$.

1753. Retablos colaterales. Iglesia de la Asunción. Cabezón de Pisuerga (Valladolid) ${ }^{785}$.

1753. Retablo de la Santísima Trinidad. Convento de la Santísima Trinidad (Valladolid) ${ }^{786}$. Desaparecido.

\footnotetext{
$778 \quad$ Ver: Ídem, p. 350.

779 BRASAS EGIDO, José Carlos: "Noticias documentales...”, op. cit., p. 473.

780 A.G.D.V., San Lorenzo, 1671D, f. 219

781 URREA FERNÁNDEZ, Jesús y MARTÍN GONZÁLEZ, Juan José: Inventario artístico de Palencia y su provincia II..., op. cit., p. 277.

782 PAYO HERNANZ, René Jesús: El retablo..., op. cit., Tomo II, pp. 157-158

$783 \quad$ Púlpito. "Son data cuatrocientos y seis reales de vellón que valen trece mil ochocientos y cuatro maravedíes pagados a Manuel de Rojas y Bentura Ramos ensambladores, de un púlpito de madera nuevo y herraje y trabajo de los mozos que lo llevaron a la iglesia consta de recibo". A.G.D.V., Santiago, Libro de fábrica 1731-1753, Año 1740.

784 URREA FERNÁNDEZ, Jesús: Catálogo Monumental de la provincia de Valladolid. Tomo XX..., op. cit., p. 17.

785 Ídem, p. 18.

786 FERNÁNDEZ DEL HOYO, María Antonia: Patrimonio perdido..., op. cit., p. 132.
} 
1754. Armazón del carro triunfal del Corpus. Catedral. Palencia ${ }^{787}$.

1755. Retablo mayor. Convento de Agustinas Canónigas. Palencia ${ }^{788}$.

Antes de 1756. Retablo. Cofradía de la Consolación. Valladolid ${ }^{789}$. ¿Desaparecido?

Antes de 1756. Retablo. Convento de Santa Clara. Cuéllar (Segovia) ${ }^{790}$.

\section{AGUSTÍN MARTÍN (h.1705 - d.1762)}

Apenas sabemos algún dato biográfico sobre este artista, circunstancia común a la mayoría de escultores, ensambladores y tallistas vallisoletanos del siglo XVIII. Tan solo que tuvo dos hijos (Joseph y Fernando) que siguieron el oficio paterno y le auxiliaron en algunas de sus obras.

\section{$\underline{\text { Catálogo }}$}

1733-1734. Yeserías-marcos para cuadros. Iglesia de la Asunción. La Seca $(\text { Valladolid })^{791}$.

1749-1750. Retablo del Santo Sepulcro, sombrero para púlpito y grupo escultórico de la Traslación de San Pedro Regalado. Iglesia de San Benito el Viejo. Valladolid ${ }^{792}$. Desaparecidos y el San Pedro Regalado en paradero desconocido ${ }^{793}$.

1753. Custodia. Iglesia de San Miguel. Aldea de San Miguel (Valladolid) ${ }^{794}$.

1755-1756. Retablo de la Congregación del Amante Corazón de Jesús. Iglesia de San Julián y Santa Basilisa. Valladolid ${ }^{795}$. Desaparecido.

1761-1762. Retablo mayor. Iglesia de San Antonio Abad. Valladolid ${ }^{796}$.

1762. Retablo mayor (Fig. 93). Iglesia parroquial de la Asunción. La Pedraja de Portillo $(\text { Valladolid })^{797}$.

\footnotetext{
787 GARCÍA CHICO, Esteban: Documentos para el estudio del arte en Castilla: plateros de los siglos XVI, XVII y XVIII, Universidad de Valladolid, Valladolid, 1963, p. 166.

$788 \quad$ La muerte le sorprende antes de acabarlo. De su finalización se ocupan en 1759 Domingo de Ondátegui, Juan Manuel Becerril y Manuel Ramos, hijo de Bentura. BRASAS EGIDO, José Carlos: "Noticias documentales...", op. cit., p. 473.

789 Ibídem.

$790 \quad$ Ibídem.

791 MARCOS VILLÁN. Miguel Ángel y FRAILE GÓMEZ, Ana María: Catálogo Monumental de la provincia de Valladolid. Tomo XVIII..., op. cit., f. 370.

792 MARTÍN GONZÁLEZ, Juan José y URREA FERNÁNDEZ, Jesús: Catálogo Monumental de la provincia de Valladolid. Tomo XIV..., op. cit., p. 288.

793 Existen numerosos grupos escultóricos efigiando este episodio por toda la ciudad.

794 BRASAS EGIDO, José Carlos: Catálogo Monumental de la provincia de Valladolid. Tomo X..., op. cit., p. 30.

795 BRASAS EGIDO, José Carlos: "Noticias documentales...”, op. cit., p. 472.

796 BALADRÓN ALONSO, Javier: op. cit., p. 169.
} 


\section{D- RELACIÓN DE LOS ÁVILA CON LOS ENSAMBLADORES}

\section{$\underline{\text { Juan de Ávila }}$}

Antes de comenzar el desarrollo del tema hay que señalar que Juan, a diferencia de sus hijos Pedro y Manuel, pudo haber ejercido labores de ensamblaje, dado que además de referirse a él así en un documento sabemos que talló un arco hornacina para la sacristía de la vallisoletana iglesia de Santiago Apóstol, labor más relacionada con los ensambladores que con los escultores.

Una importante amistad debió de unirle a Blas Martínez de Obregón ya que además de fiarle en el contrato para la realización de un retablo para la parroquial de Cigales (1685), es probable que el propio Ávila hiciera las tallas que lo ornaran. En 1702 ambos artífices se encargan de dar el visto bueno al retablo que Francisco Billota y Gregorio Díaz de Mata habían tallado para el altar mayor de la parroquia de Villanubla (Valladolid). Quizás, ambos artistas pudieron haber trabajado juntos, uno haciendo arquitecturas y el otro esculturas, en 1679 en los retablos de la capilla de Copacabana del Convento de San Francisco de Valladolid, y entre 1689-1694 en el retablo mayor y colaterales del Real Monasterio de San Quirce y San Julita.

También debió de pertenecer al círculo próximo a Ávila el ensamblador Alonso Manzano, con el cual colaboró en diversas ocasiones. La primera documentada es en el retablo mayor del Hospital de San Juan de Dios (1687), trabajo en el cual les ayudaron los también ensambladores Juan Correas y Bernardo de Carvajal. Sin duda el gran trabajo en el que compartieron horas de brega fue el retablo mayor de la iglesia de Santiago Apóstol de Valladolid, retablo para el cual había presentado también traza Martínez de Obregón. La maestría con que llevaron a cabo sus respectivos menesteres me hace pensar que ambos artífices habrían tenido numerosos encargos de no haber sido por el temprano fallecimiento del escultor. Finalmente, en 1701 Ávila y Francisco Billota se encargan de dar el visto bueno al retablo fabricado por Manzano y el escultor Juan Antonio de la Peña para la capilla de San Juan de Sahagún en la vallisoletana iglesia de San Martín. A partir de aquí entramos en el terreno de las hipótesis, de las atribuciones. Entre 1690-1691 Manzano lleva a cabo el retablo mayor del Colegio de la Compañía de Jesús de León, cuyas esculturas, como veremos, se le atribuye. Hacia 1700 se atribuye a ambos la ejecución de la arquitectura y esculturas del actual retablo mayor de la parroquial de Ataquines, procedente del Convento de la Encarnación de Arévalo.

El tercero de los ensambladores con los que debió de trabajar abundantemente fue Francisco Billota, si bien tan solo tenemos documentada la actuación de ambos en los retablos colaterales de la iglesia de San Felipe Neri, para los cuales el escultor talló las imágenes centrales y los relieves de los áticos. Obras de Billota para las cuales Ávila pudo aportar esculturas fueron el retablo mayor y colaterales del Domus Dei de La

797 BRASAS EGIDO, José Carlos: Catálogo Monumental de la provincia de Valladolid. Tomo X..., op. cit., pp. 107-108. 
Aguilera (1690), el retablo mayor del Convento de la Laura (1690) y el retablo mayor y colaterales del Monasterio de Santa Brígida. Además, en 1701, como ya hemos visto, ambos artífices dieron el visto bueno al retablo realizado por Manzano y De la Peña para la iglesia de San Martín.

Otros ensambladores con los que compartió trabajo, pero nada más ya que Juan de Ávila enviaba las piezas desde su taller vallisoletano y los ensambladores pertenecían a otros focos artísticos, fueron el burgalés, aunque de procedencia cántabra, Diego Alonso de Suano (retablo mayor de la Colegiata de Lerma) y el vallisoletano Gregorio Díaz de Mata (retablo del Hospital de San Juan de Dios y probablemente en el retablo mayor de la iglesia parroquial de Torrecilla de la Abadesa).

\section{$\underline{\text { Pedro de Ávila }}$}

De Pedro de Ávila sabemos que mantuvo relaciones laborales con el ensamblador y polifacético artista Pedro de Ribas (los cinco retablos de otras tantas capillas de la Catedral para los que Ávila talló su imagen titular) y con Francisco Billota (retablos del cuerpo de la nave de la iglesia de San Felipe Neri). Entre sus amistades debía encontrarse el ensamblador simanquino Juan Llorente, ya que le fió cuando éste se obligó con el Convento de San Pablo a realizarles un cancel. Otros ensambladores y tallistas con los que mantuvo contacto fueron el medinense Felipe Sánchez y, hacia el final de su vida, con un tal Francisco Xavier Pérez. La escasez de obra documentada, así como el hecho de que hiciera imágenes de culto debió mermar bastante sus relaciones labores con profesionales de las artes aplicadas al retablo.

\section{$\underline{\text { Manuel de Ávila }}$}

La escasa documentación manejada de este escultor tanto referente a biografía como a su oficio hace que tan solo tengamos noticia de que trabajó con Alonso Manzano (retablo mayor de la parroquial de Fuentes de Valdepero), al igual que su padre, y con Francisco Billota en los retablos de la iglesia de San Felipe Neri.

\section{2-5 PATRONOS}

A grandes rasgos dos son las características principales que presenta el patronazgo durante este largo siglo y medio que dura el barroco: la decadencia del patrocinio ejercido por la nobleza y el aumento del porcentaje de obras de arte auspiciadas por la Iglesia. La importancia de la Iglesia dentro del arte no es una novedad. Durante siglos los escultores habían trabajado para todo tipo de instituciones y edificios religiosos: ermitas, iglesias, colegiatas, conventos, monasterios, catedrales, basílicas, cofradías 
sacramentales, etc... pero son otras diferentes las que durante el barroco cobran gran vigor y se convierten en las grandes dinamizadoras del mercado escultórico, sobre todo en Castilla y en Andalucía: las cofradías penitenciales, las cuales encargan a los imagineros diferentes tallas aisladas o grupos procesionales para desfilar durante la Semana Santa, provocando todo tipo de sentimientos en el espectador. Las cofradías "rivalizaban en conseguir las mejores esculturas de los santos de su devoción, y procuraban que sus altares, festejos y procesiones fueran los más celebrados. Esta competencia era altamente beneficiosa para los intereses artísticos. La cuota ordinaria y la limosna especial salían al paso de gastos de toda índole en pro del boato de la cofradía"798.

Las otras impulsoras de los talleres escultóricos fueron las iglesias parroquiales, ya urbanas ya rurales, las cuales se encargaron, en ocasiones ayudadas por ciertas cofradías sacramentales, de "forrar" los muros de sus templos con grandes y lujosos retablos, especialmente en la capilla mayor. Aunque ya no ocurría como en el Renacimiento en que los retablos se encontraban cuajados de imágenes, los escultores encontraron en estas máquinas grandes oportunidades laborales.

Durante el barroco escasea en Valladolid tanto el patronazgo real como el efectuado por la nobleza, los cuales, en su mayoría, habían abandonado la ciudad en 1606 siguiendo los pasos de la familia real. Explica Martín González que esta nobleza "desde mediados del siglo XVII, arruinada y decaída, deja al cuidado de otras manos la tarea de proteger el arte-. A partir de ahora será excepcional el ver escudos en capillas y retablos. Y tampoco es la realeza, con su beneficioso patronato, la encargada de velar por los intereses del arte religioso. El quebranto de la economía se acusaba en los tres poderosos resortes que tanto impulsaron el arte del Renacimiento: el Estado, la nobleza y el alto clero; y ello influyó considerablemente en la penuria del arte ${ }^{\$ 799}$.

El estamento civil de vez en cuando participa en la ejecución de una obra de capital importancia, sobre todo en los pueblos. Así, por ejemplo, tenemos a los ayuntamientos de Nava del Rey y de Rueda costeando los retablos mayores de sus respectivas parroquiales. No escatimaron en gastos ya que en uno participó Gregorio Fernández y en el otro Pedro de Sierra. En la capital el consistorio realizó encargos a los artistas exclusivamente cuando había que celebrar alguna fiesta, como el Corpus Christi, o cuando se veía en la necesidad de levantar algún altar en la calle con motivo de la beatificación de algún santo o de la conmemoración de alguna cofradía penitencial, e incluso para levantar arcos para agasajar a los reyes en su paso por la urbe. Aunque menor, también es importante, y más en nuestra ciudad, el papel de la Universidad, ya que durante este momento costeó la apertura y decoración de una nueva fachada monumental. A continuación, vamos a examinar brevemente quienes fueron las personas o instituciones que confiaron en el saber hacer de los Ávila: 798 MARTÍN GONZÁLEZ, Juan José: Escultura barroca castellana..., op. cit., p. 11.
799 Ídem, p. 10. 


\section{$\underline{\text { Juan de Ávila }}$}

Dos son los dos tipos de comitentes que requieren los servicios de Juan de Ávila: la iglesia, de forma mayoritaria, y el consistorio vallisoletano, para el cual trabaja, al menos, durante dos años consecutivos realizando reparos y nuevas figuras para la fastuosa celebración del Corpus Christi que organizaba el propio ayuntamiento. El grupo religioso es muy heterogéneo. Dentro de él tienen cabida tanto personas particulares (clérigos y obispos) como instituciones: iglesias parroquiales, cofradías sacramentales, cofradías penitenciales, colegiatas y conventos. No podemos descartar que también trabajara para algún particular, el cual solicitaría a Ávila alguna pequeña escultura que presidiera un hipotético oratorio particular.

El grupo documentado más numeroso es el de parroquias, tanto urbanas como rurales: la de San Juan Bautista de Pesquera de Duero (Valladolid), la de Santiago Apóstol de Valladolid, la de Santiago de Cigales (Valladolid) y la de San Andrés de Villasilos (Burgos). Entre las colegiatas tenemos documentada su participación en la escultura del retablo mayor de la de San Pedro de Lerma (Burgos). Finalmente, y en este ámbito, trabajaría para la iglesia de San Felipe Neri de Valladolid.

Dentro de las órdenes religiosas tenemos el caso de la Orden de San Juan de Dios, la cual le encarga las hechuras de su nuevo retablo mayor. Aunque no tenemos documentada su colaboración con otras órdenes parece claro que trabajó para la franciscana. Es posible que el vallisoletano Convento de San Francisco acudiera a él cuando necesitó una imagen de San Pedro Regalado para la capilla de Copacabana. Este encargo pudo ser la carta de presentación para otros cenobios franciscanos. Así, años después pudo concertarse con El Abrojo para tallar un retablo-relieve del San Pedro Regalado resucitando para dar de comer a un pobre, y con el Domus Dei de La Aguilera para realizar el grupo de la Traslación de San Pedro Regalado y las esculturas de San José con el Niño y San Antonio de Padua. Quizás esta supuesta y continuada relación de Ávila con los franciscanos, así como su presencia en La Aguilera la podamos explicar gracias a la figura del padre fray Hernando de la Rúa, hijo del convento de San Francisco de Valladolid. Él fue quien costeó la construcción de la capilla de Copacabana y, quizás, de los cinco retablos de la misma; pero, además, fue quien trajo a la Virgen de Copacabana desde las Indias ${ }^{800}$. Pero no queda todo ahí, relata Canesi que la generosidad de fray Hernando de la Rúa fue todavía mayor, al igual que

800 Canesi nos aporta más datos sobre este generoso bienhechor: era "hijo del convento de Palencia, lector jubilado en Teología, vicario provincial de esta provincia de la Concepción por los años de 1676 sobre que tuvo muchas contradicciones por defender las inmunidades y privilegios reales y pontificios de los conventos de las Indias y ganó los pleitos con mucha gloria por ser persona de singular destreza en el majeo de los papeles, y llevó allá religiosos de la Santa Recolección de esta provincia y puso formal recolección con las mismas constituciones de la Aguilera y Abrojo en las provinciales del Santo Evangelio de Méjico, Guatemala y Michoacán (según escribe el P. F. Matías Alonso tomo 1 libro 2 folio 347), y fue compasión general de aquel dilatado reino occidental; volvió a España y a su provincia en la que es y será su memoria muy gloriosa por haber empleado en obras pías algunos caudales que para este efecto trajo de bienhechores devotos, reedificó la capilla de nuestra Señora de Copacabana en este, obra muy suntuosa y mucha parte de ella está pintada y concluida, colocó en ella con grandes fiestas el año de 1679 tan soberana Señora en un retablo precioso matizado de varios colores y en la capacidad". CANESI ACEVEDO, Manuel: Historia de Valladolid (1750), Tomo I..., op. cit., p. 461. 
su devoción hacia San Pedro Regalado, puesto que "en la Aguilera también hizo el P. Rúa a San Pedro Regalado una maravillosa capilla para colocar sus reliquias de las celebradas de estos tiempos (...)"801. Es decir, debió ser fray Hernando de la Rúa el que sugirió el nombre de Juan de Ávila a los religiosos del Domus Dei para que ejecutara las esculturas del retablo mayor y de los colaterales dado que ya conocía sus facultades dado que habría trabajado "a sus órdenes" para la capilla de Copacabana del Convento de San Francisco de Valladolid.

De confirmarse estos extremos estaríamos hablando de que la relación entre el escultor y los franciscanos fue muy fructífera, llegando a convertirse en su comitente más fiel y abriendo la posibilidad de que trabajara para otros establecimientos de la orden. Tampoco podemos olvidar que Ávila se vería obligado a visitar El Abrojo para ver de cerca el San Pedro in Cátedra de Gregorio Fernández y así tomar nota para realizar su propia versión/copia del mismo para el retablo de la Colegiata de Lerma.

El otro gran grupo de instituciones religiosas lo forman las cofradías. Dentro de las sacramentales laboró para la de Nuestra Señora del Rosario y del Nombre de Jesús, sita en la iglesia parroquial de San Esteban protomártir de Torrecilla de la Abadesa (Valladolid), mientras que entre las penitenciales mantuvo relaciones laborales, y espirituales, con las de Jesús Nazareno y Pasión de Cristo de la capital vallisoletana.

Finalmente tenemos el caso de personajes particulares pertenecientes al estamento religioso. Son los casos simultáneos, ya que encargaron dos obras que se habrían de complementar (San Isidro y Santa María de la Cabeza para la Cofradía de San Isidro de Valladolid), del obispo vallisoletano don Diego de la Cueva y Aldana y don Luis de la Vega.

\section{$\underline{\text { Pedro de Ávila }}$}

Dadas las esculturas documentadas y las atribuidas con total seguridad estamos ante el escultor más solicitado de la familia, y quizás el que logró mayor prestigio en su época. Las tempranas muertes de su padre y su hermano favorecieron este hecho.

Su obra documentada nos indica que trabajó para iglesias parroquiales (la del Salvador de Morales Toro, la de San Esteban de Torrecilla de la Abadesa, la de San Miguel de Íscar y la de San Miguel de Castil de Vela), para la catedral vallisoletana, lo que conllevó el posterior reconocimiento del artista como maestro mayor del obispado, y para la Congregación de San Felipe Neri, la cual requirió también los servicios de su padre y de su hermano Manuel. Para la iglesia de San Miguel de Íscar también realizó un San Antonio de Padua. Todavía le salió otra oferta de trabajo en la localidad por aquellas fechas: los fieles iscarienses de San Ramón Nonato le encargaron una imagen suya para la iglesia de Santa María.

801

Ibídem. 
Además, estamos seguros de que trabajó para otros muchos particulares, parroquias, cofradías y órdenes monásticas. Entre las órdenes monásticas parece que fue la franciscana la que más le solicitó obra, al igual que a su padre, puesto que fueron dos establecimientos de esta orden los que le requirieron: el convento de San Francisco de Orense y el de las concepcionistas de Fuensaldaña. Para los dominicos de San Pablo de Valladolid ejecutó un formidable San Pío $V$ con motivo de la canonización del santo. Las otras órdenes que le rogaron esculturas fueron las de las Brígidas del Santísimo Salvador y las de San Quirce de la capital, las cuales habían tenido ya contacto con su padre. Tampoco quisieron perder la oportunidad de tener obras del mejor escultor de la ciudad las Comendadoras de la Santa Cruz.

Tres fueron, al menos, los particulares que le solicitaron obra: la Traslación de San Pedro Regalado para la capilla del santo en la iglesia del Salvador corrió a cargo de un personaje anónimo (quizás el marqués de Aguilafuente); las tallas de la Virgen del Refugio y de las Lágrimas de San Pedro las sufragó el cura de la parroquial de Santiago don Pedro Rábago; y finalmente las de San Antonio de Padua, el Niño Jesús y Cristo Yacente para la iglesia de San Felipe Neri fueron abonadas por el canónigo Santiago Manzano.

Finalmente, fueron tres las cofradías penitenciales que se concertaron con él: las vallisoletanas de las Angustias y Jesús Nazareno y, posiblemente, la de la Vera Cruz de la localidad de Ampudia (Palencia).

El resto de supuestos comitentes fueron parroquias rurales, excepto un San Nicolás de Barí que ejecutó para el hospital del mismo nombre en Olmedo. La lista la conformarían las iglesias parroquiales de Almenara, Puras, Matapozuelos, Nava del Rey, Geria, Bernuy de Coca y la de Santa María de Alaejos.

\section{$\underline{\text { Manuel de Ávila }}$}

Los comitentes documentados que solicitaron obra al pequeño de la saga fueron tan solo tres. Por una parte, tenemos una iglesia parroquial, la de Nuestra Señora de la Antigua de Fuentes de Valdepero (Palencia), la cual requirió sus servicios para las esculturas y relieves del retablo mayor y para ejecutar una imagen de Santa Bárbara que habría de presidir un retablo reaprovechado. Pudiera darse la circunstancia de que la iglesia no le encomendara la obra del retablo mayor, sino que se la subcontratara el ensamblador del mismo, Alonso Manzano, con el cual su padre y hermano ya había tenido ocasión de trabajar. Los otros dos patronos fueron la Congregación de San Felipe Neri de Valladolid y la Cofradía Penitencial de Nuestro Padre Jesús Nazareno. Se da la casualidad de que para ambas instituciones ya habían trabajado su padre Juan y su hermano Pedro, por lo que el conocimiento entre ellas y la familia de escultores era pleno, sabían a quién se lo encargaban y que el resultado sería óptimo. 


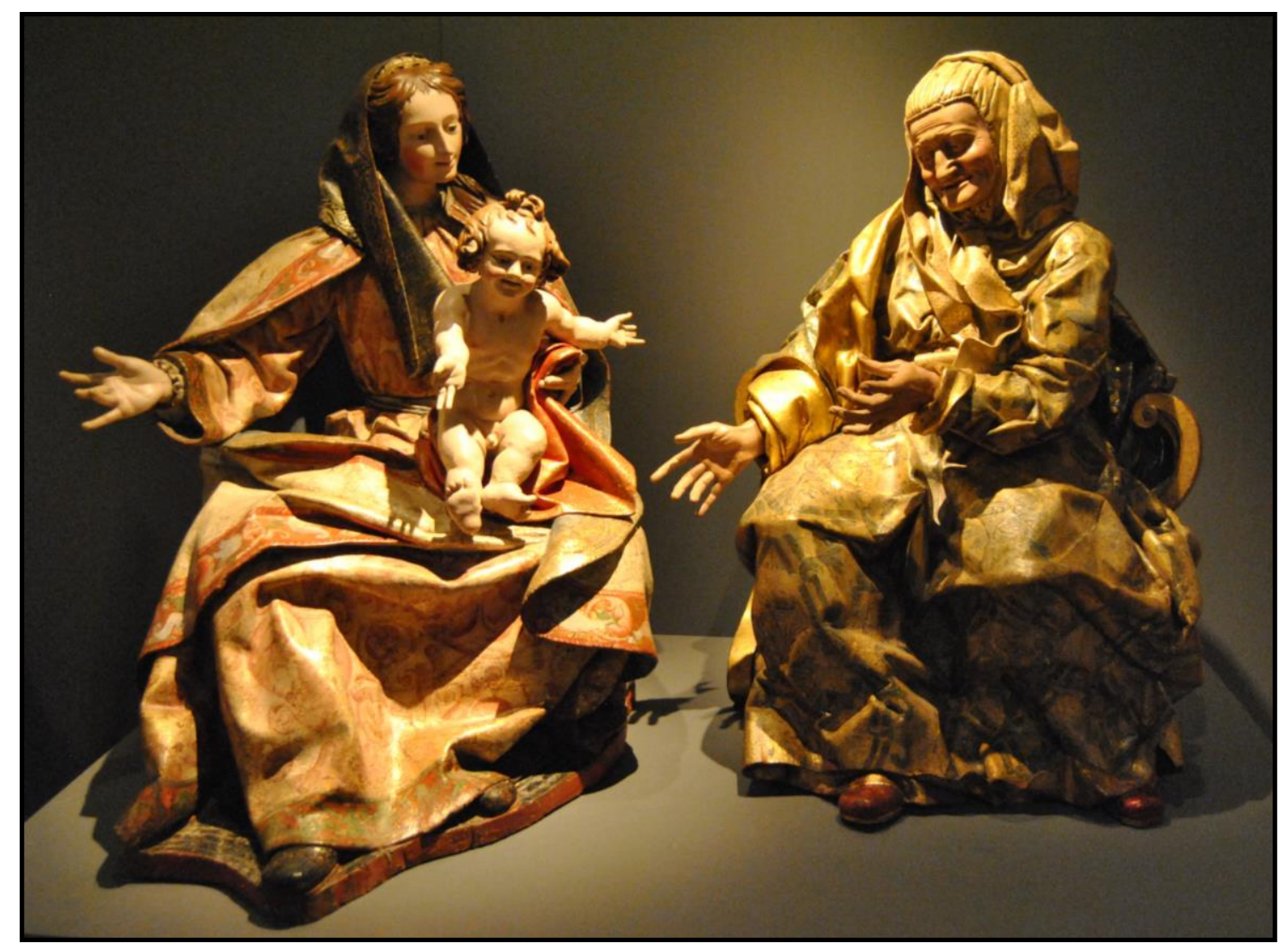

Fig. 1- Esteban de Rueda. Santa Ana, la Virgen y el Niño. Iglesia de Santa María. Villavellid (Valladolid).

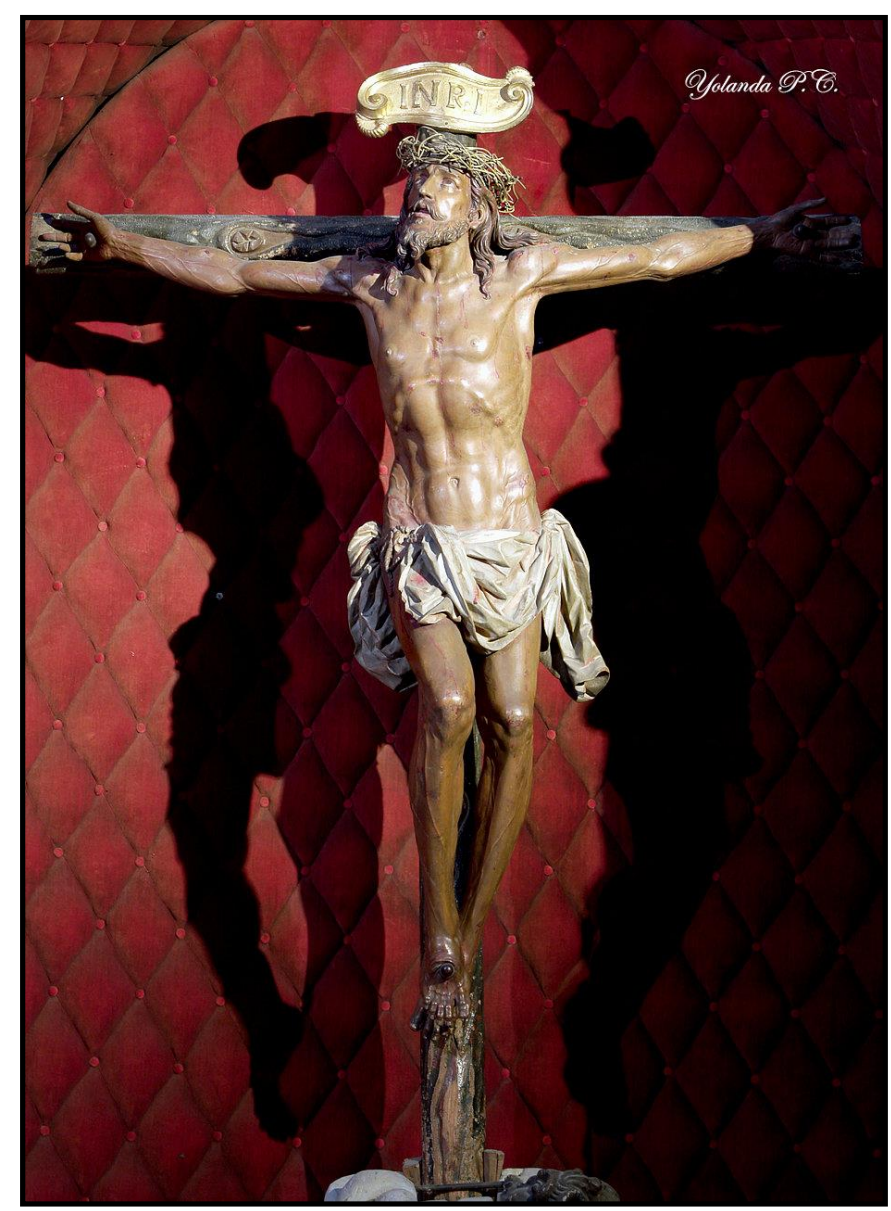

Fig. 2- Bernardo Pérez de Robles.

Cristo de la Agonía. Convento de los

PP. Capuchinos. Salamanca.

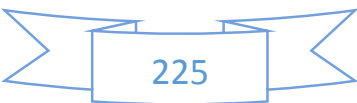




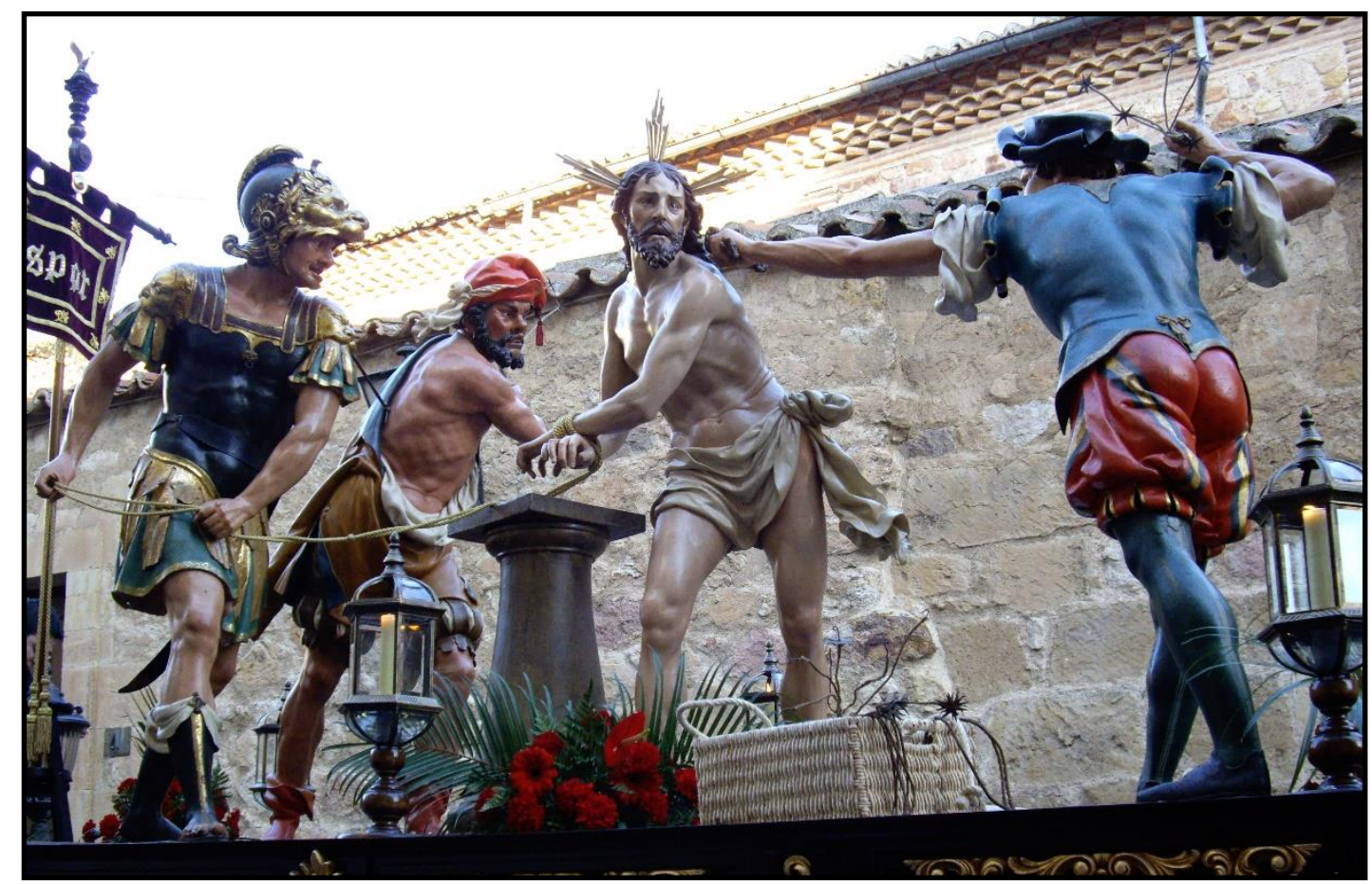

Fig. 3- Alejandro Carnicero. Paso de la "Flagelación". Capilla de la Vera Cruz. Salamanca

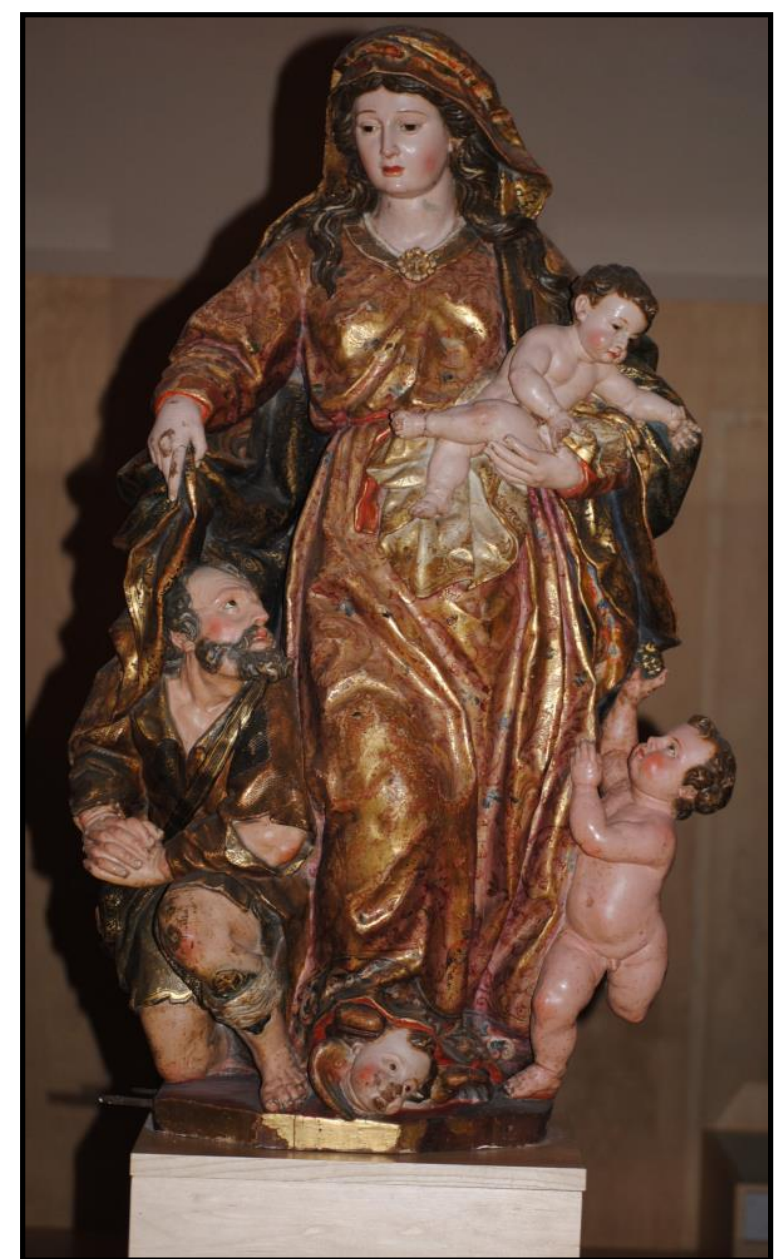

Fig. 4- Tomás de Sierra. Virgen de los Pobres. Museo de San Francisco. Medina de Rioseco (Valladolid)

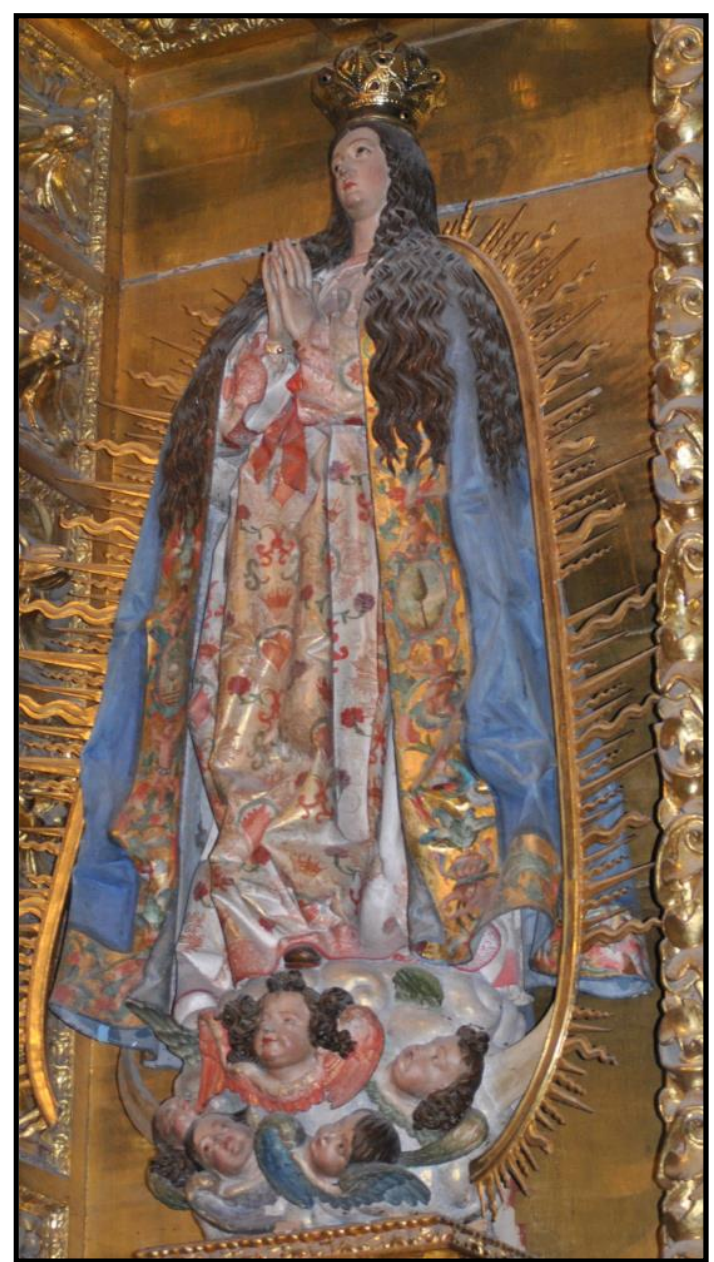

Fig. 5- Mateo Sedano. Inmaculada. Catedral. Palencia. 


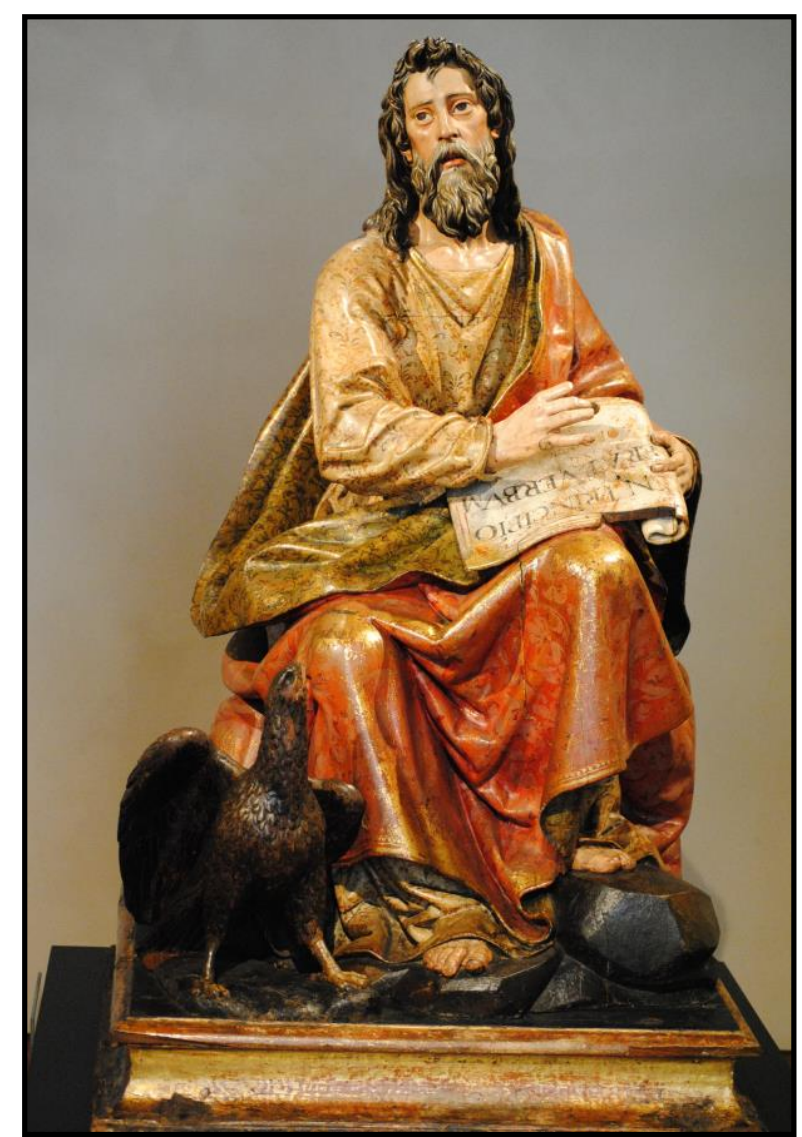

Fig. 6- Juan Martínez Montañés. San Juan Evangelista. Museo Nacional de Escultura. Valladolid.

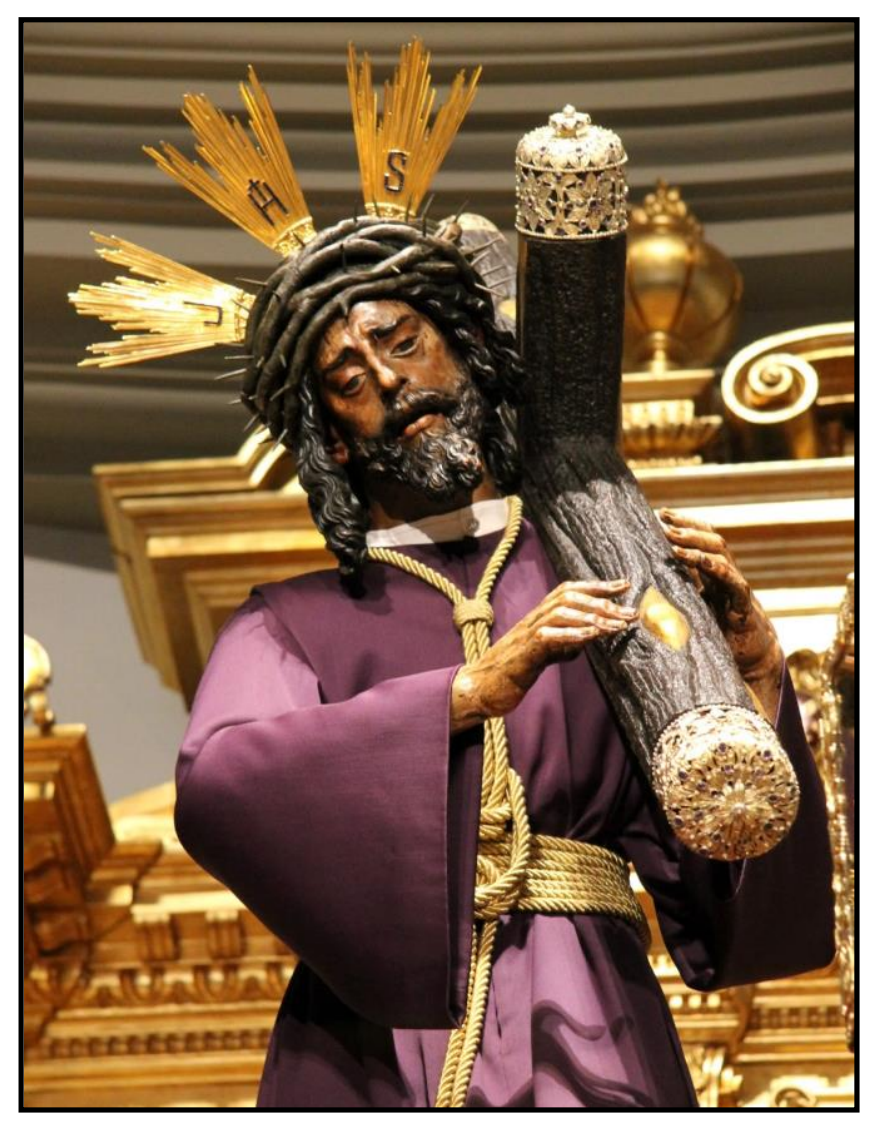

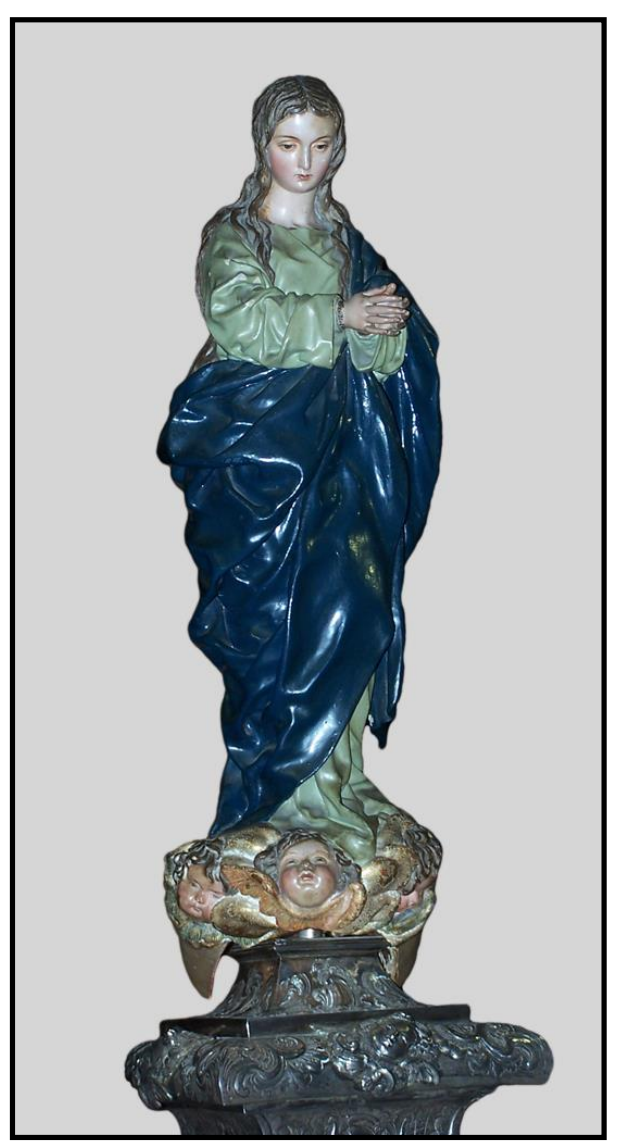

Fig. 7- Alonso Cano. Inmaculada. Catedral. Granada.
Fig. 8- Juan de Mesa. Jesús del Gran Poder. Basílica del Gran Poder. Sevilla.

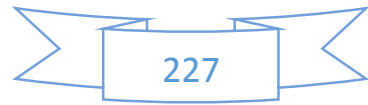




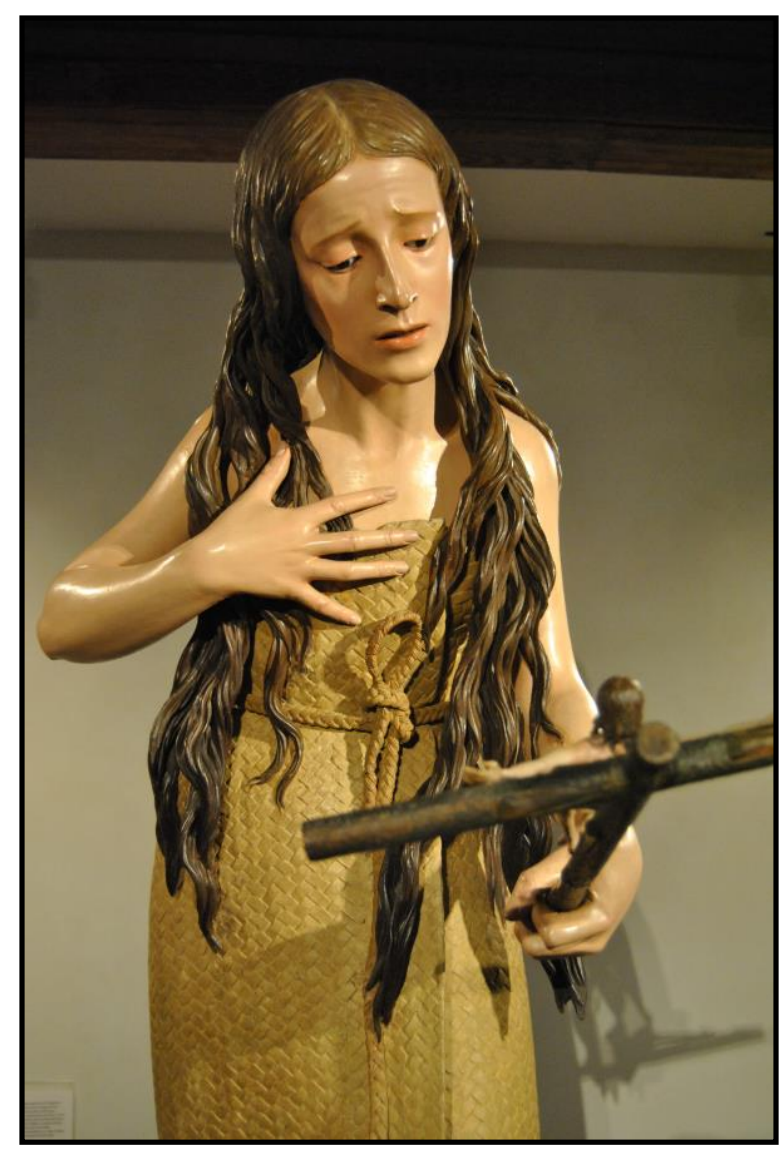

Fig. 9- Pedro de Mena. Magdalena Penitente. Museo Nacional de Escultura. Valladolid.

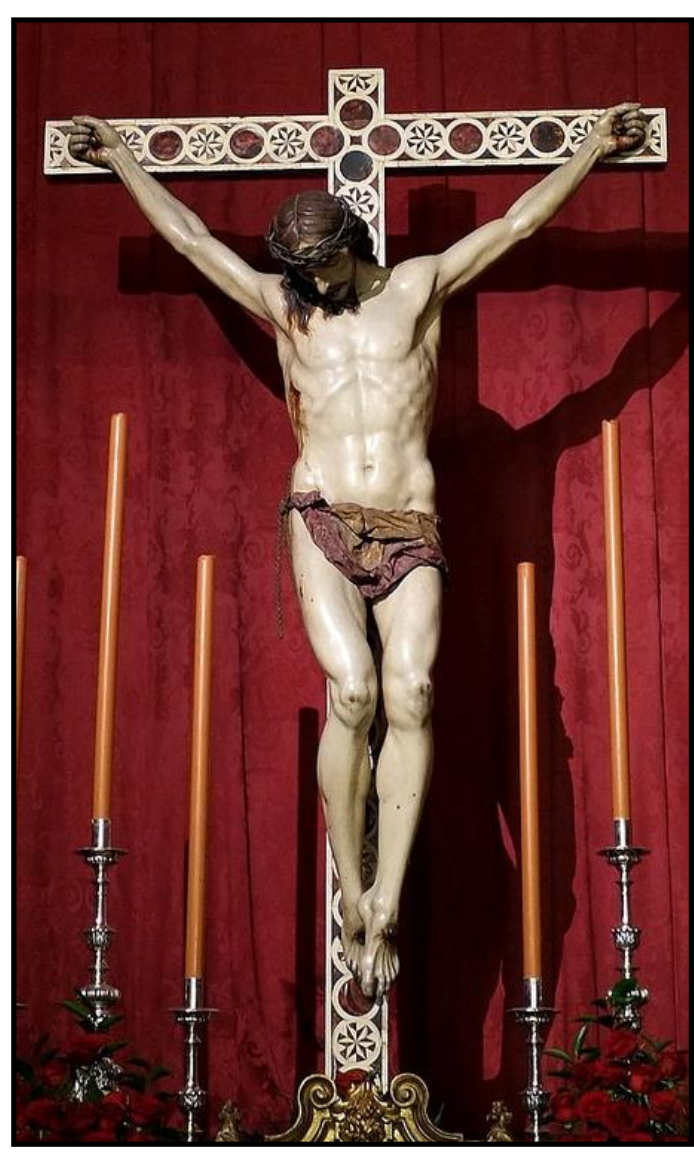

Fig. 10- José de Mora. Cristo de la Misericordia. Iglesia de San José. Granada.

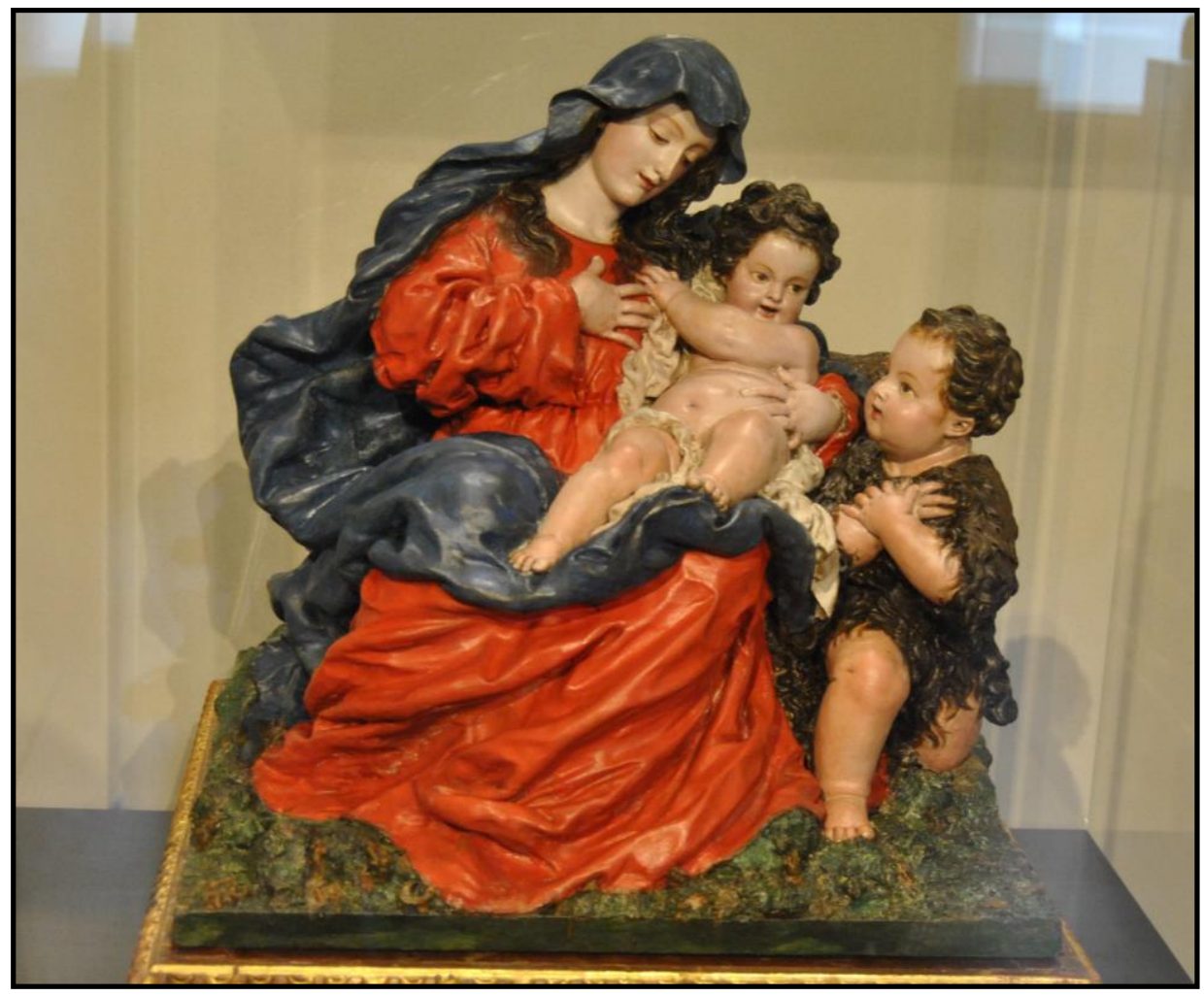

Fig. 11- José Risueño. La Virgen con el Niño y San Juanito. Museo Nacional de Escultura. Valladolid.

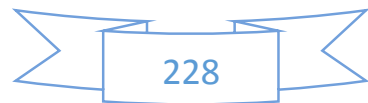




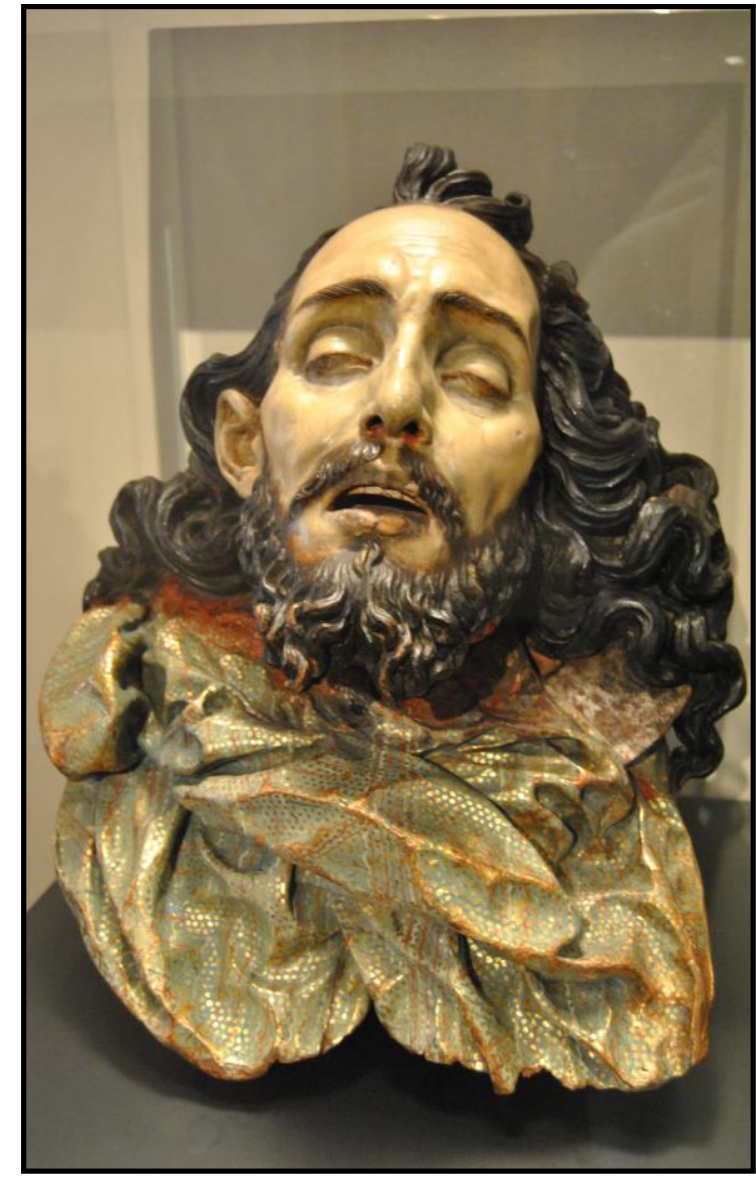

Fig. 12- Torcuato Ruiz del Peral. Cabeza de San Juan Bautista degollado. Museo Nacional de Escultura. Valladolid.

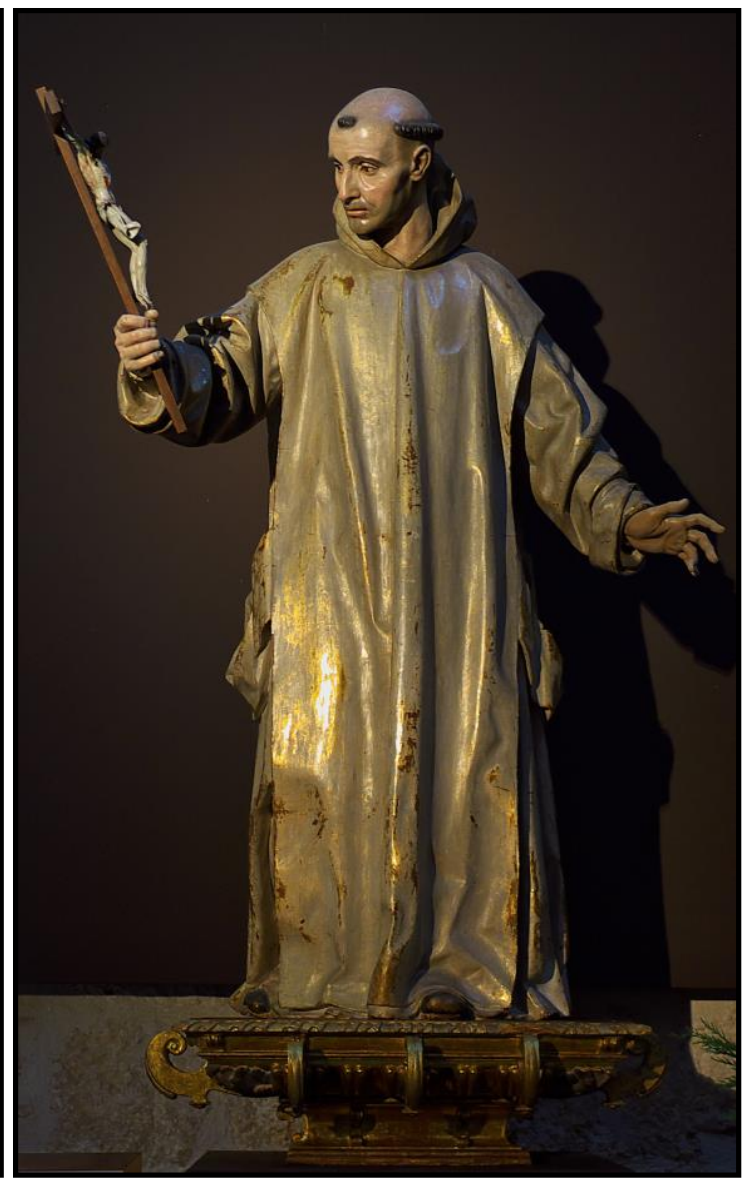

Fig. 13- Manuel Pereira. San Bruno. Cartuja de Miraflores. Burgos.

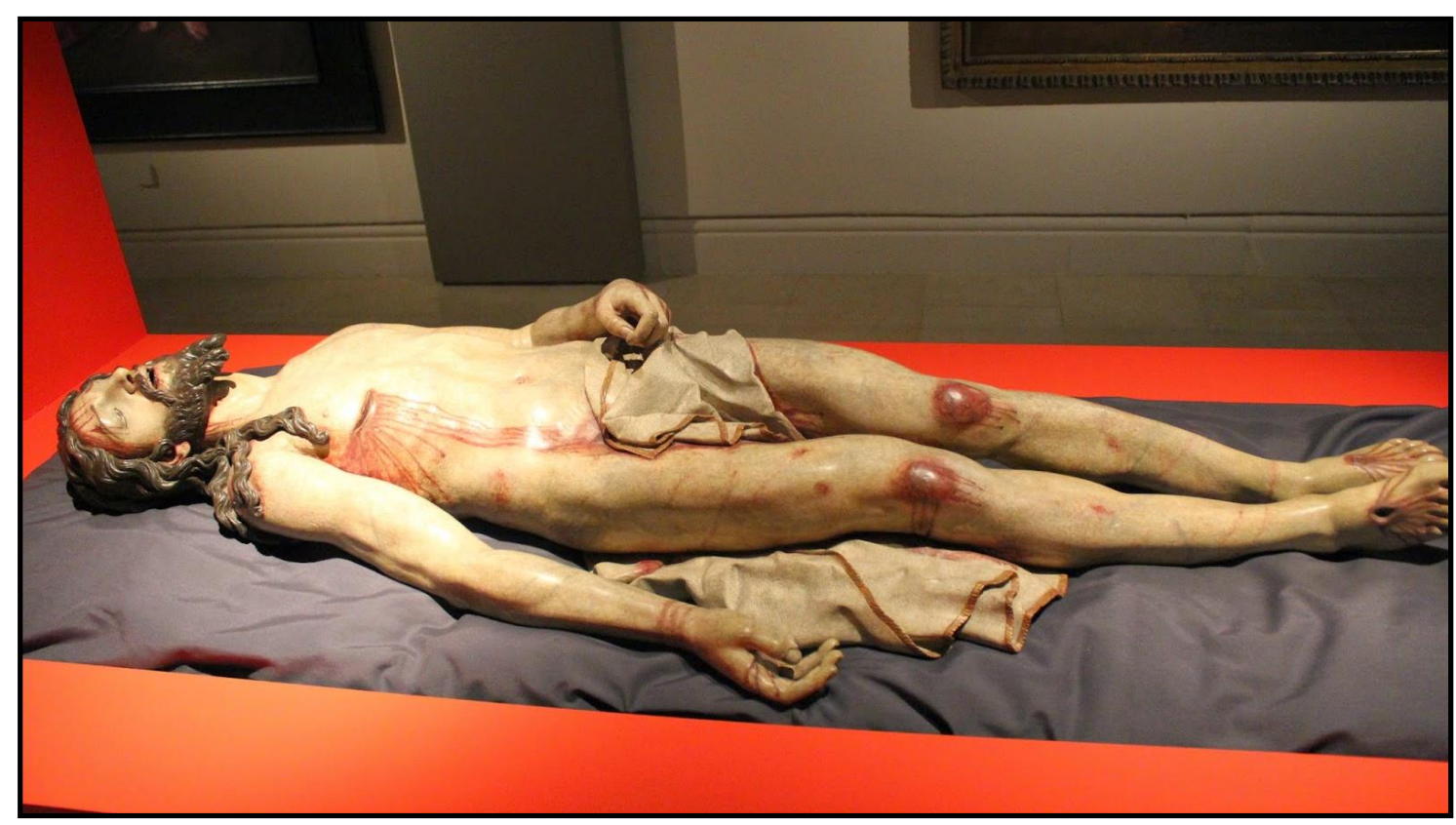

Fig. 14- Juan Sánchez Barba. Cristo Yacente. Iglesia de Nuestra Señora del Carmen. Madrid.

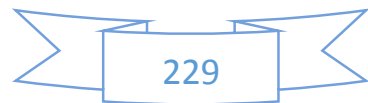




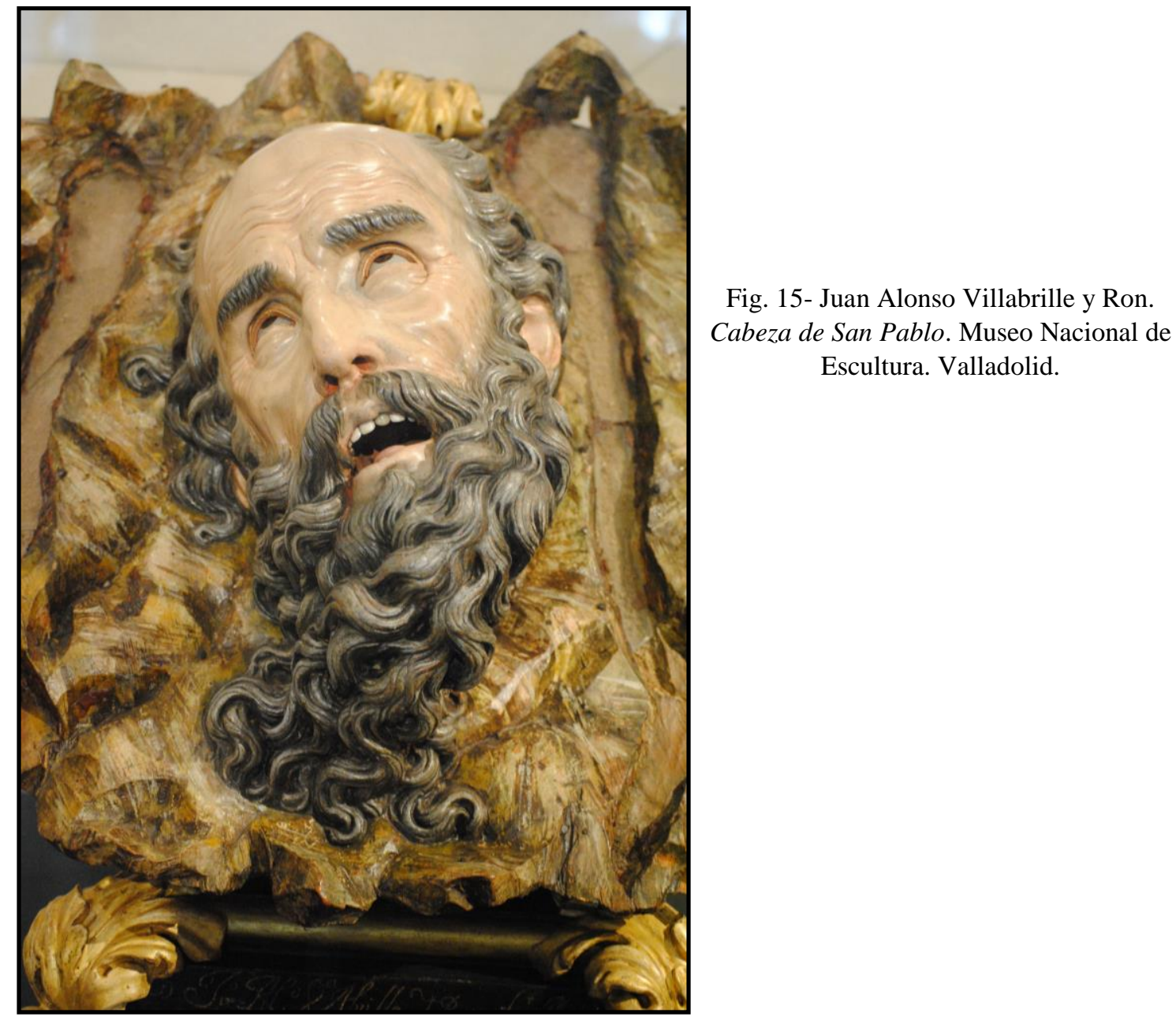

Fig. 16- Luis Salvador Carmona. Cristo Crucificado. Museo Nacional de Escultura. Valladolid.
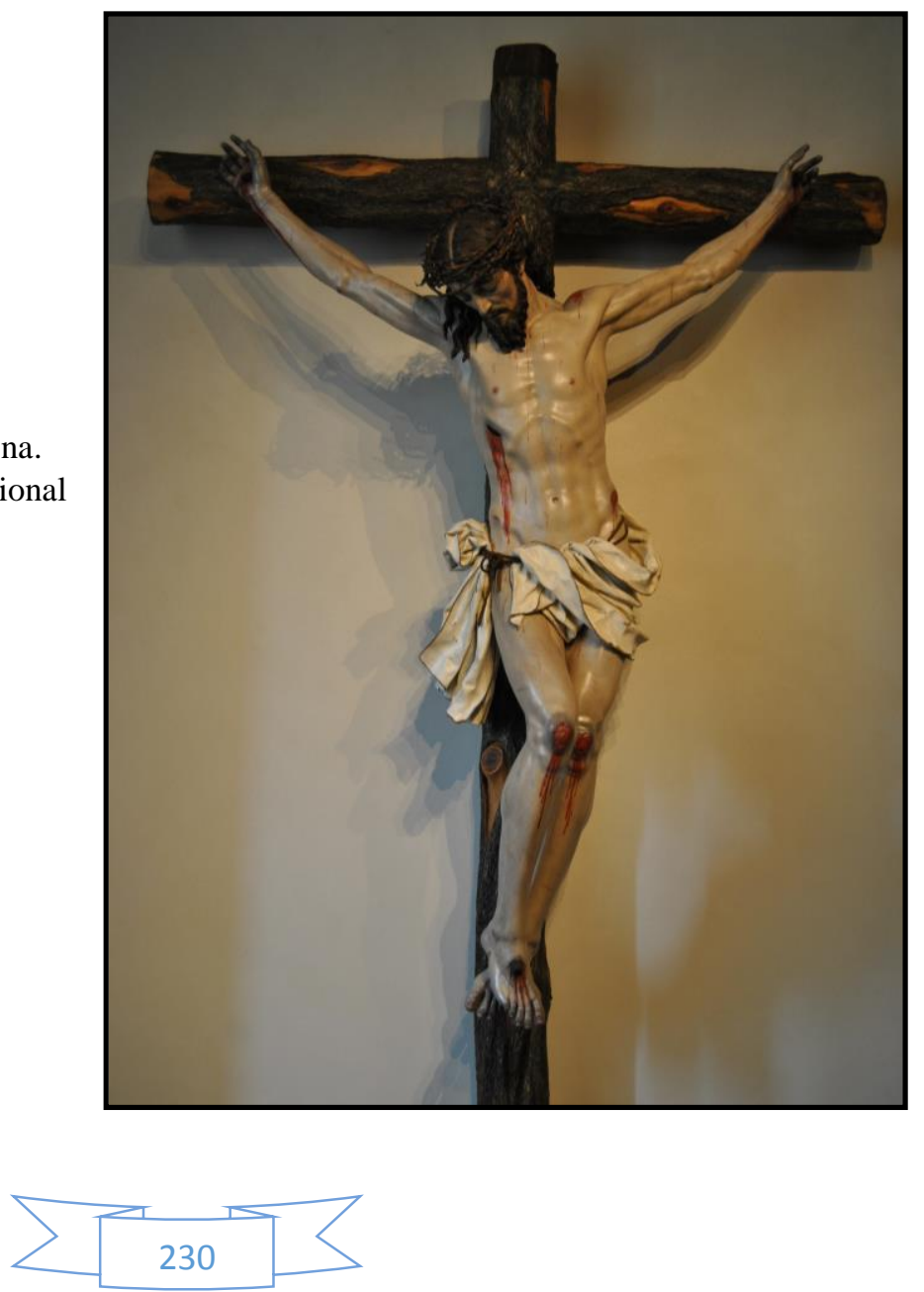


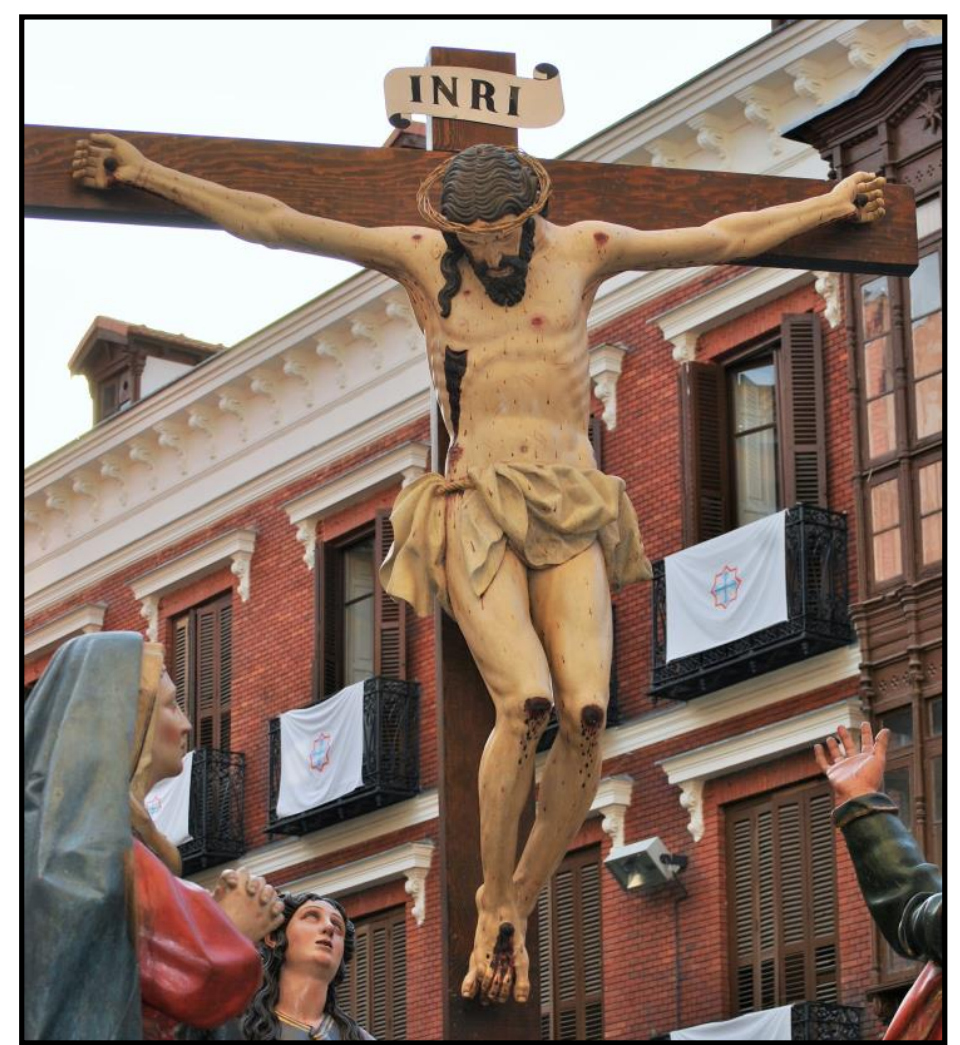

Fig. 17- Alonso de Rozas. Cristo Crucificado. Iglesia parroquial. Bercero (Valladolid).

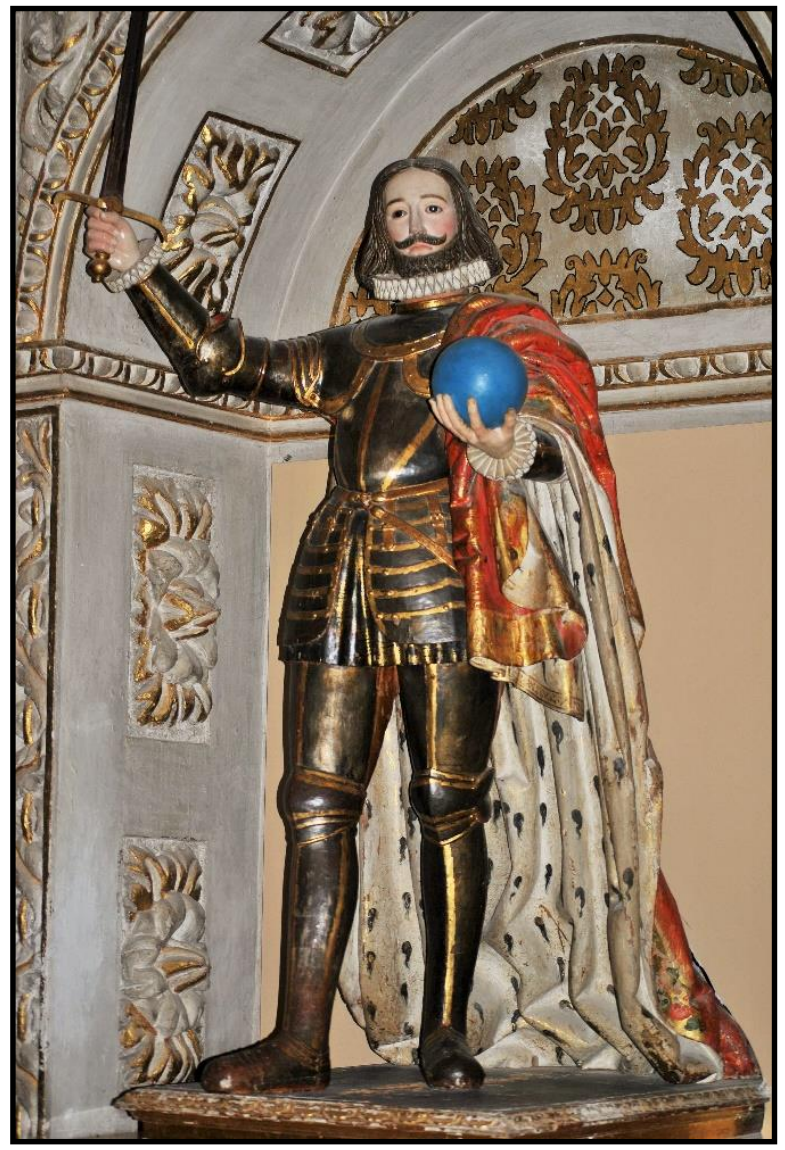

Fig. 18- Alonso de Rozas. San Fernando. Catedral. Zamora.

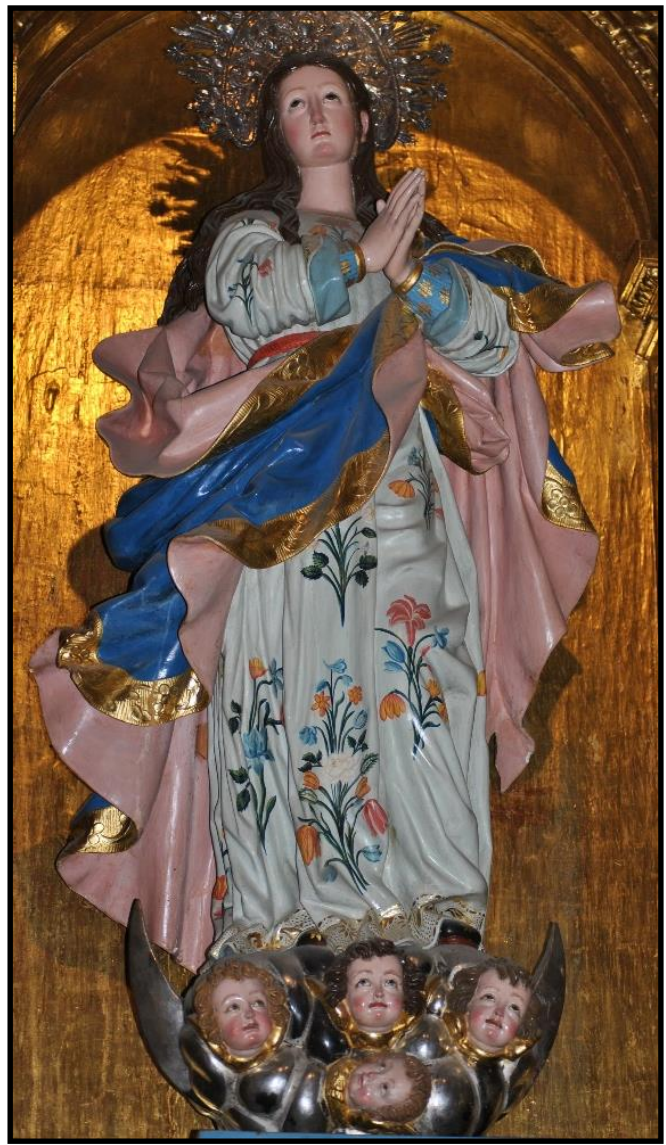

Fig. 20- Alonso de Rozas. Inmaculada. Iglesia de San Pedro. Zamora. 


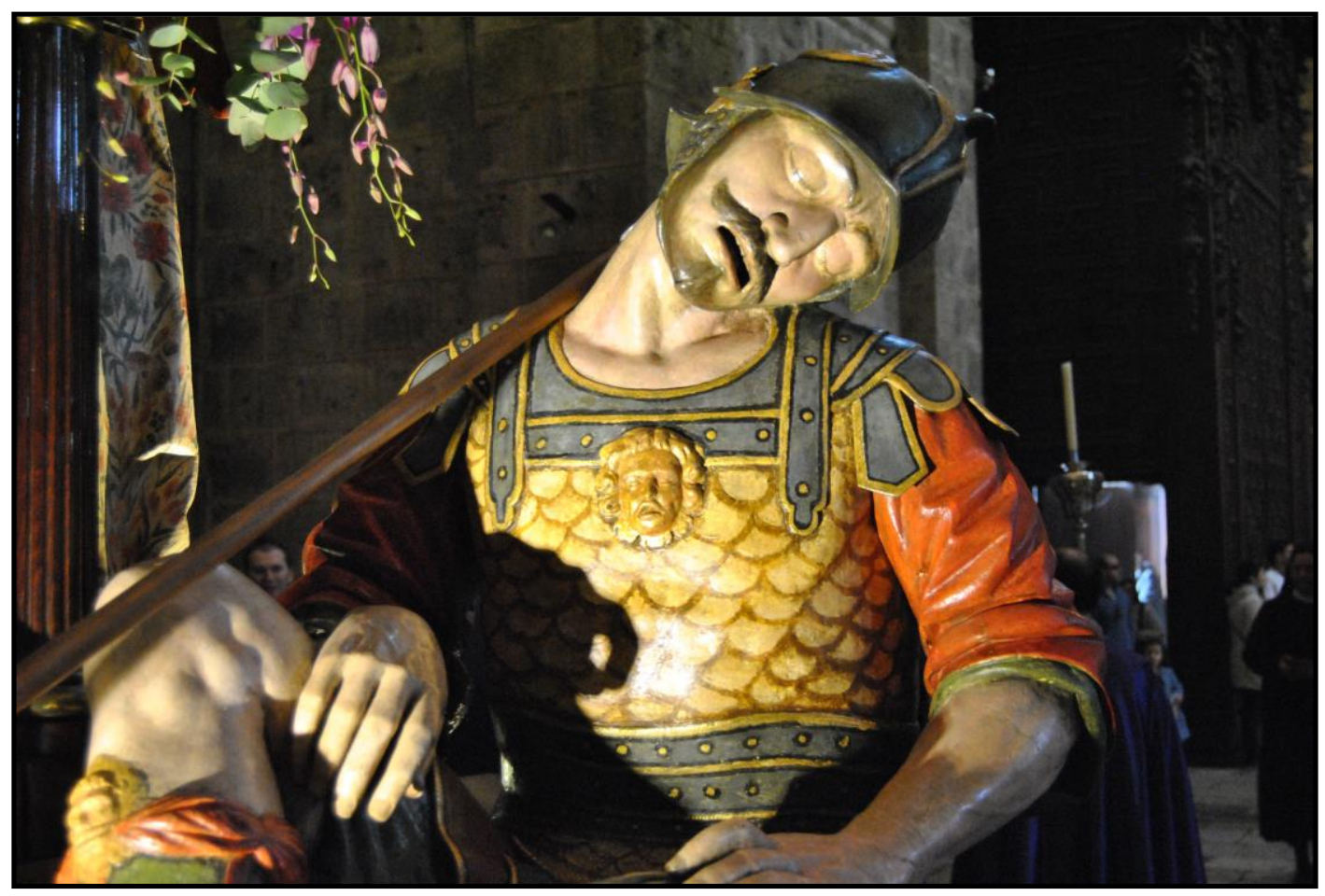

Fig. 19- Alonso de Rozas. Durmiente del Santo Sepulcro. Museo Nacional de Escultura. Valladolid.

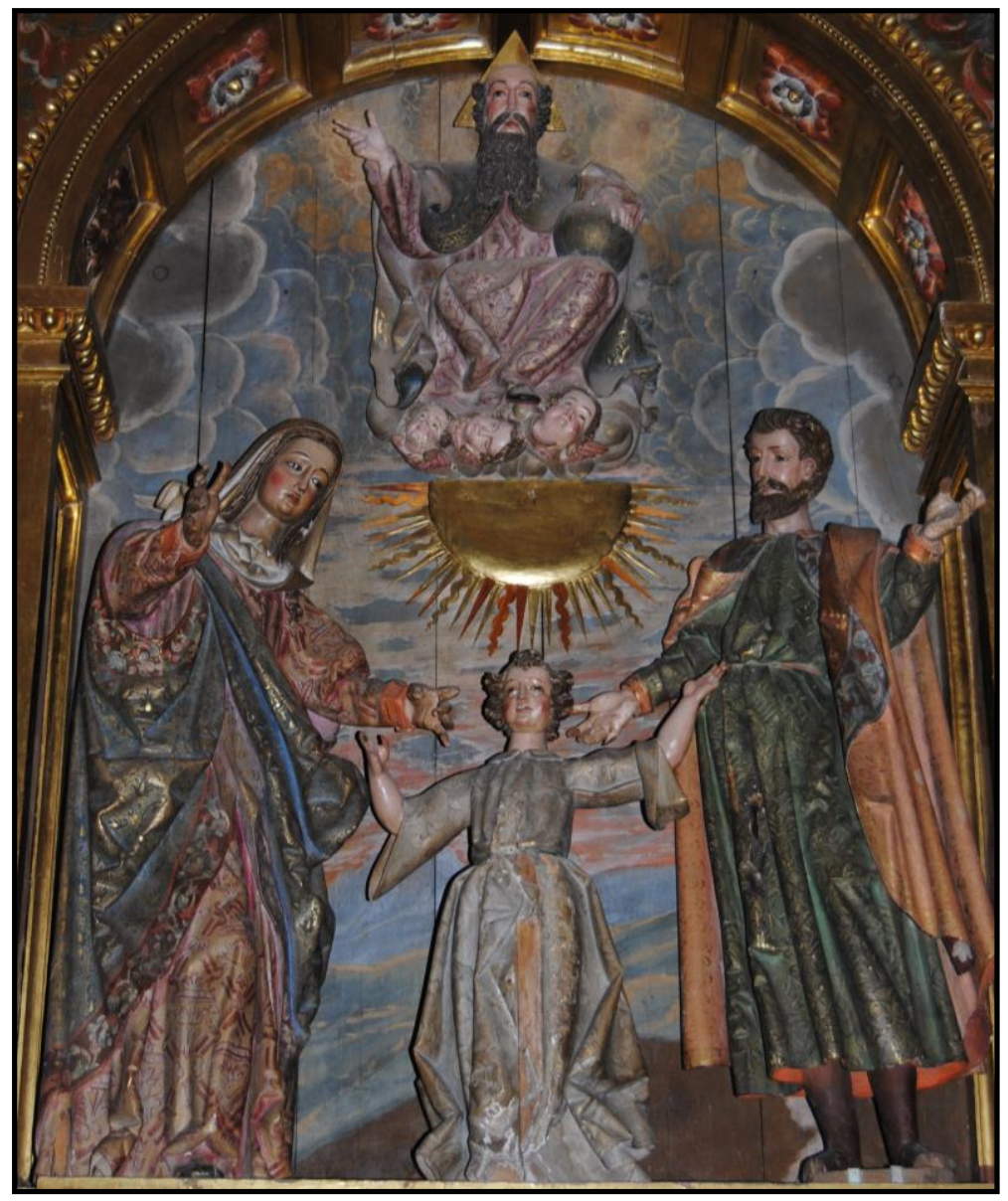

Fig. 21 - Pedro Salvador "el joven”. Sagrada Familia del retablo de la capilla de José Fernández Isidro. Iglesia de Santa Cruz. Medina de Rioseco (Valladolid).

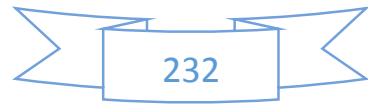




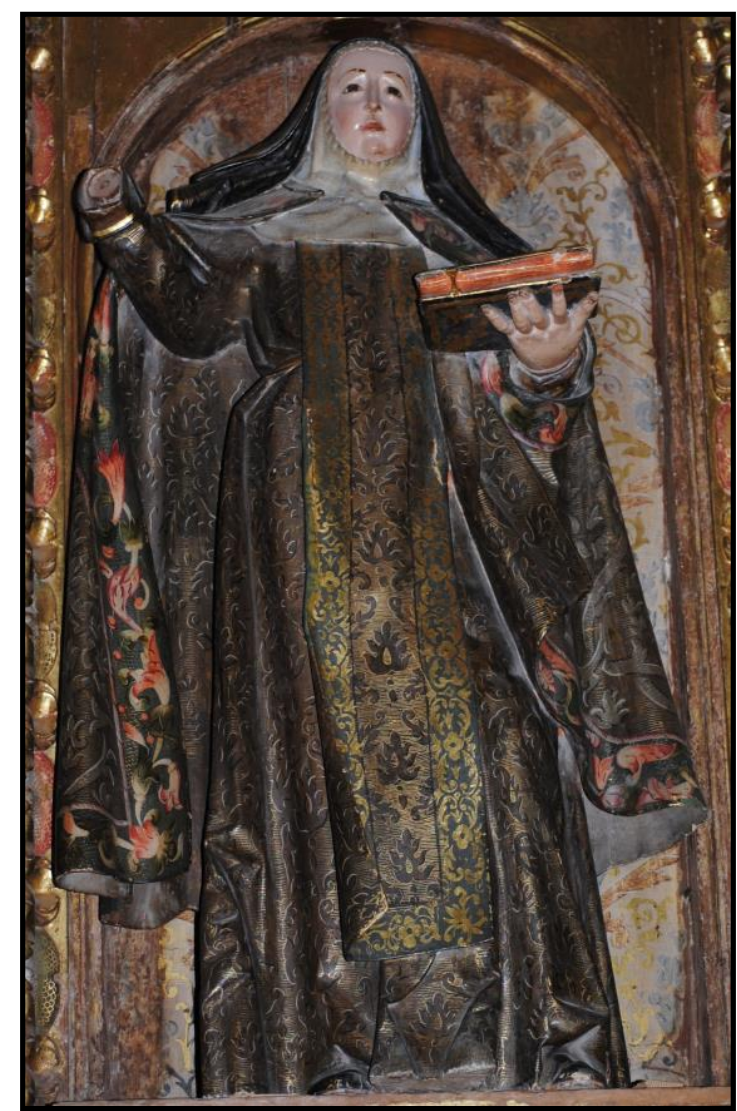

Fig. 22- Pedro Salvador “el joven”. Santa Teresa del retablo de la capilla de José Fernández Isidro. Iglesia de Santa Cruz. Medina de Rioseco (Valladolid).

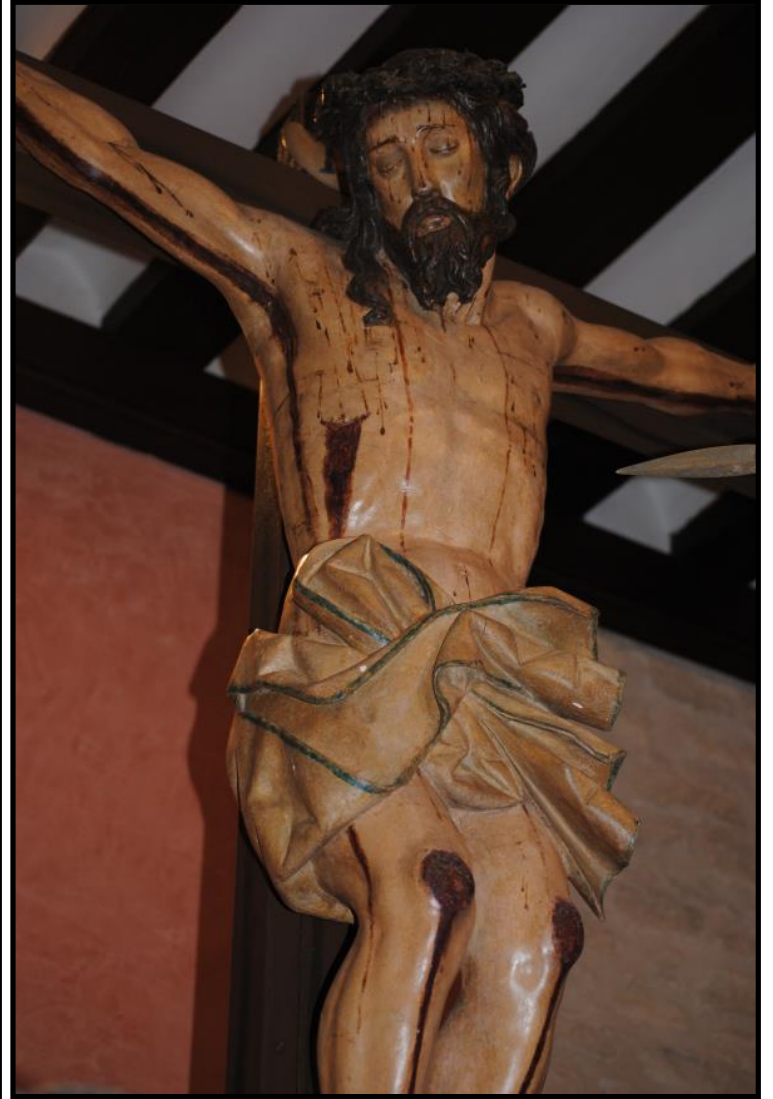

Fig. 23- Andrés de Oliveros. La lanzada de Longinos. Capilla de los Pasos Grandes. Medina de Rioseco (Valladolid).

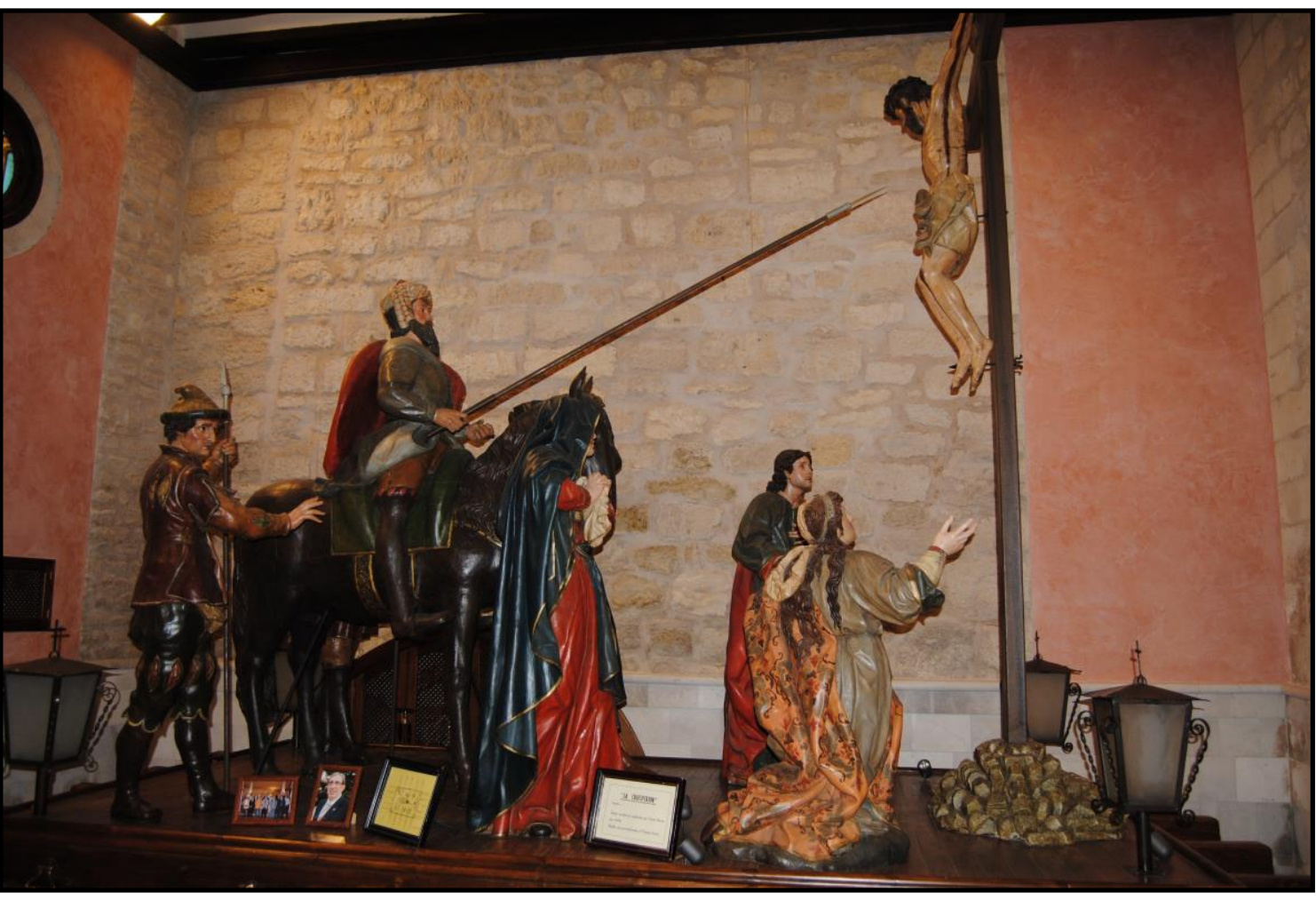

Fig. 24- Andrés de Oliveros. La lanzada de Longinos. Capilla de los Pasos Grandes. Medina de Rioseco (Valladolid).

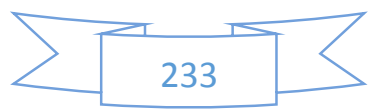




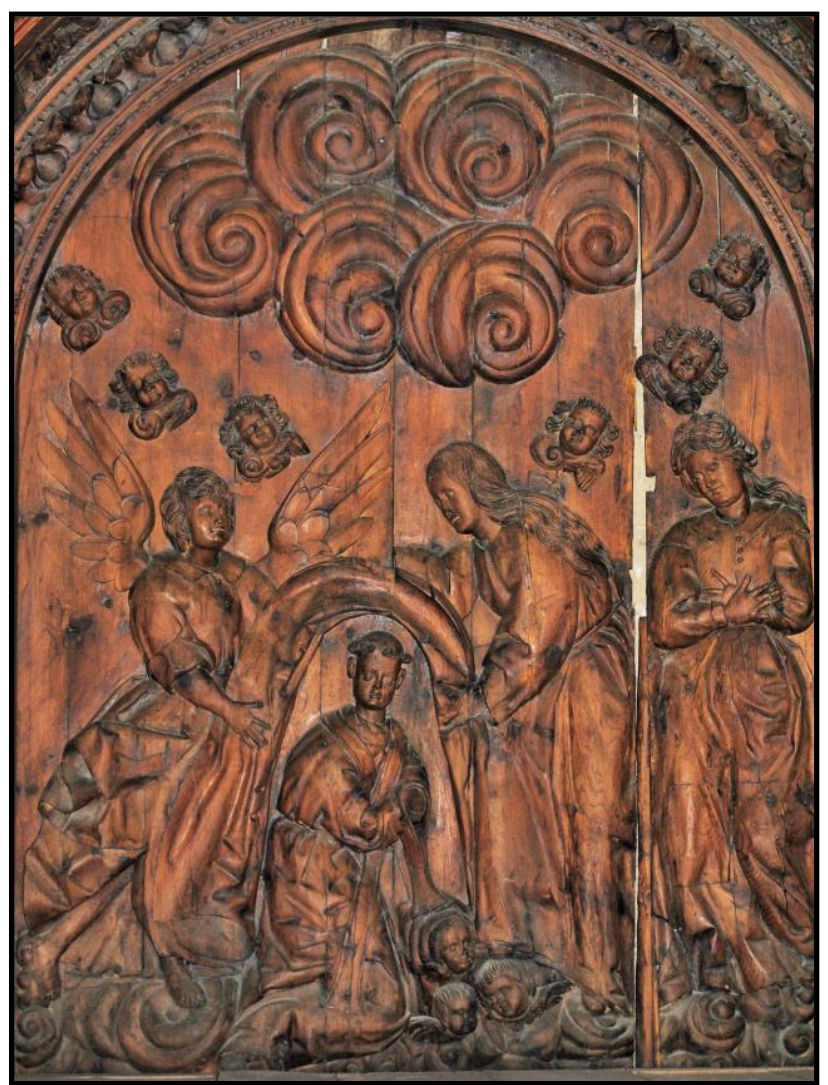

Fig. 25- Andrés de Oliveros. Retablo de San

Ildefonso. Iglesia de Santiago de los Caballeros. Medina de Rioseco (Valladolid).

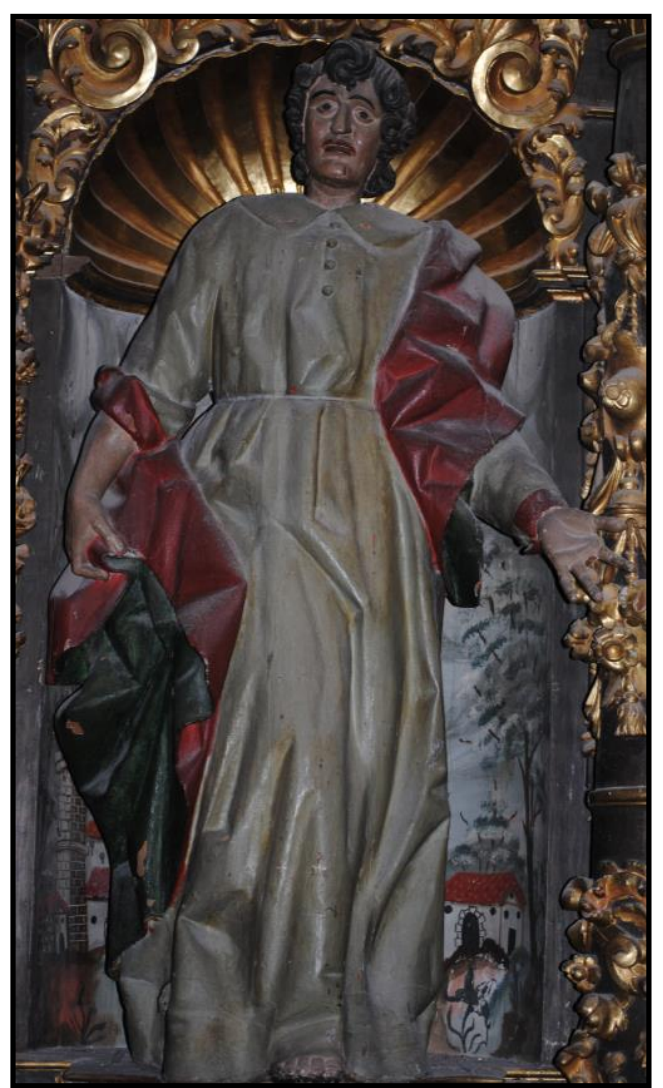

Fig. 26- Andrés de Oliveros. San Juan del Descendimiento. Colegiata de San Antolín. Medina del Campo (Valladolid).

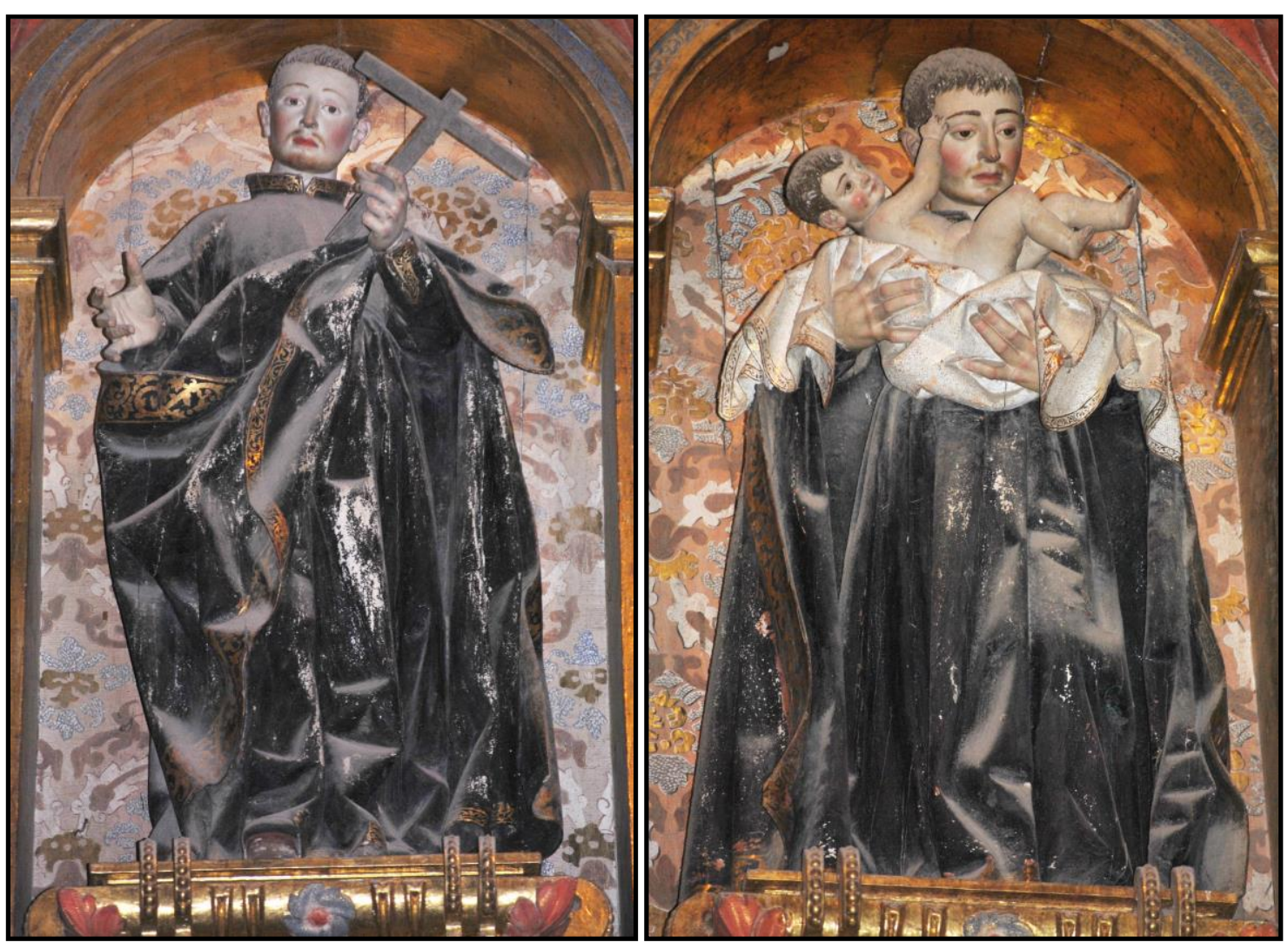

Figs. 27-28- José Mayo. San Luis Gonzaga y San Estanislao de Kostka. Colegiata de San Luis. Villagarcía de Campos (Valladolid).

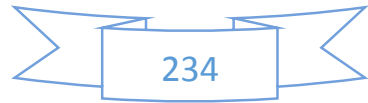




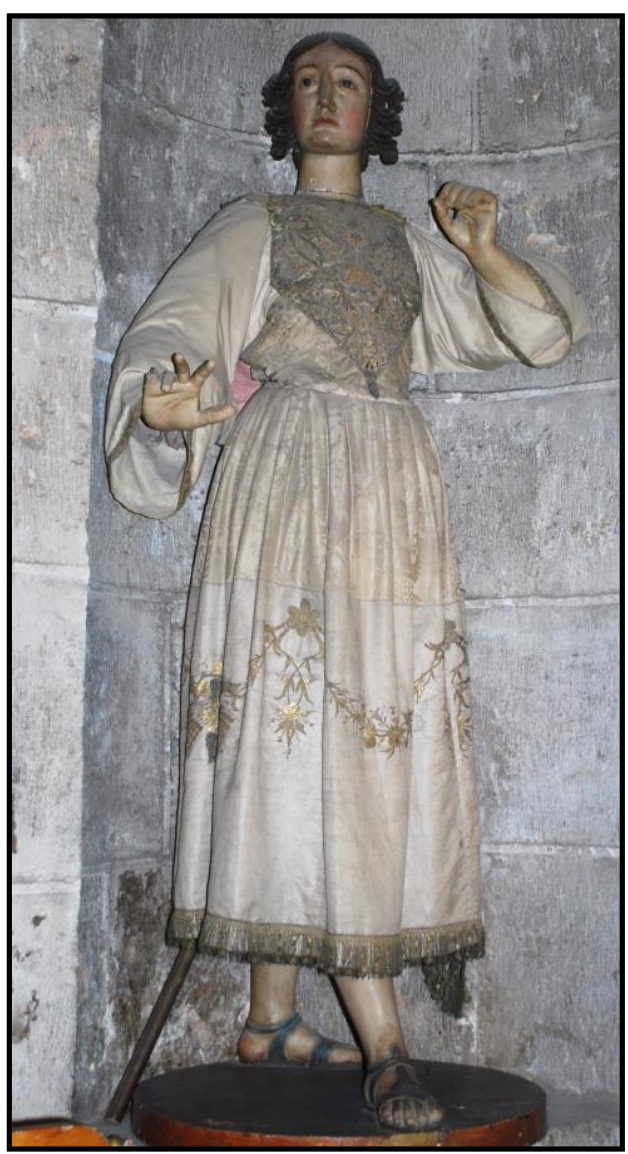

Fig. 29- José Mayo. Ángel. Catedral. Valladolid.

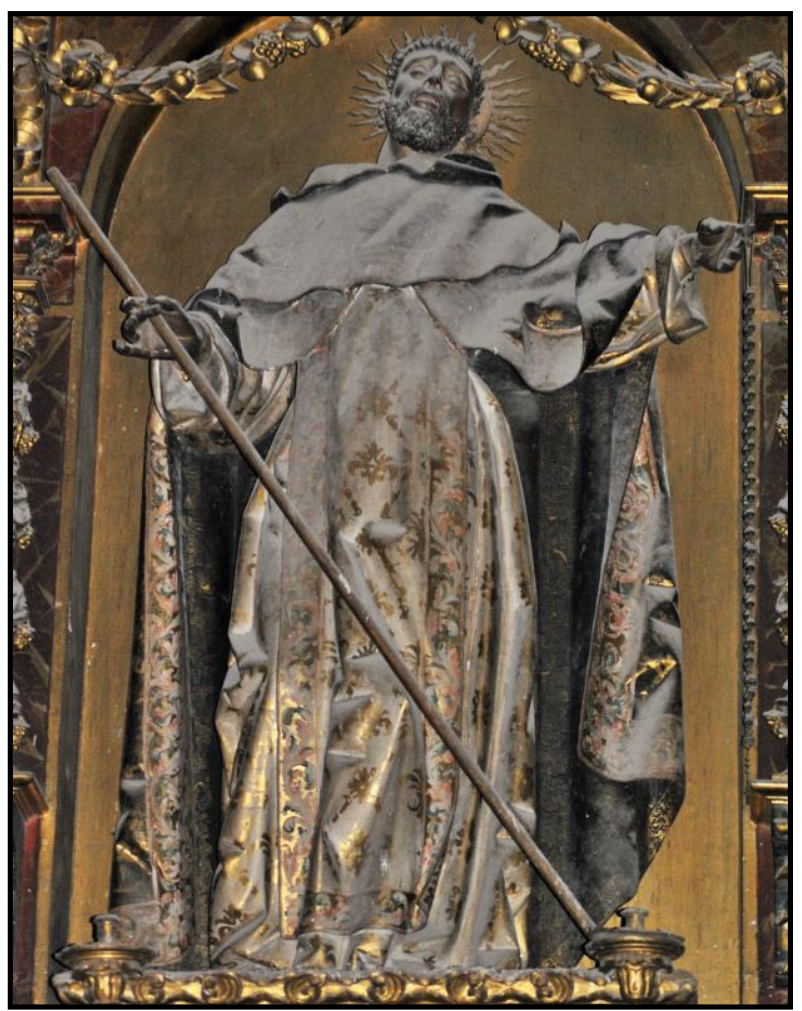

Fig. 31- Antonio Vázquez. Santo Domingo de Asís. Iglesia de Ntra. Sra. Del Rosario. Valladolid.

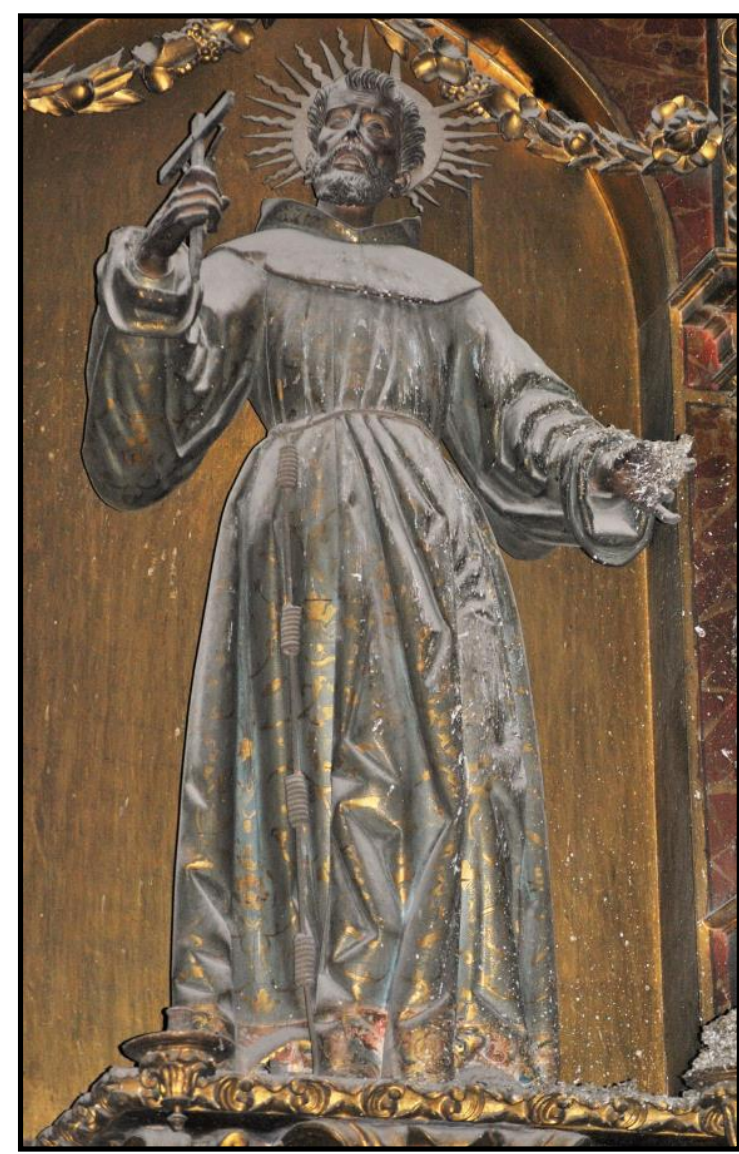

Fig. 30- Antonio Vázquez. San Francisco de Asís. Iglesia de Ntra. Sra. Del Rosario. Valladolid.

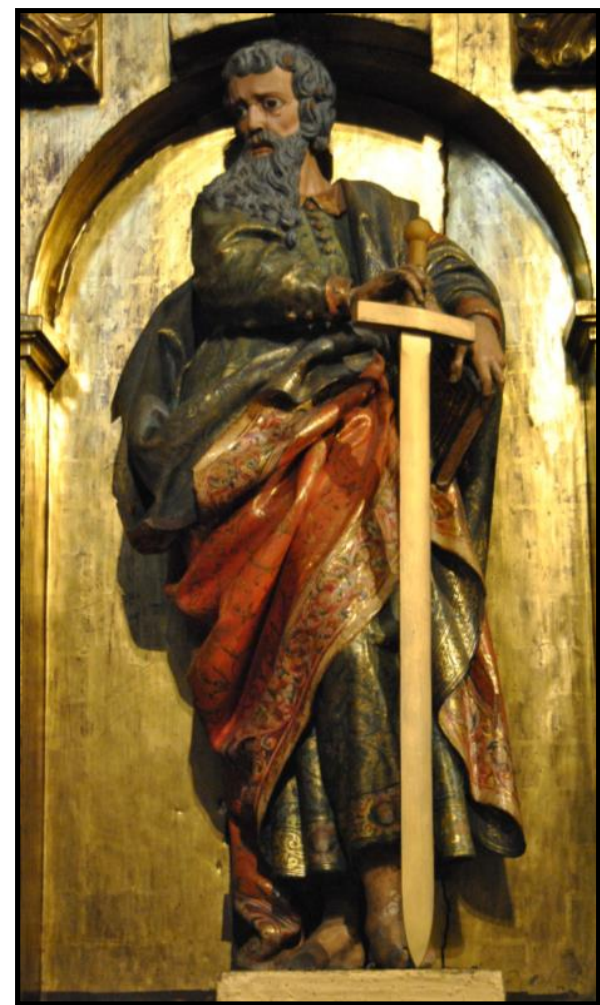

Fig. 32- Antonio Vázquez. San Pablo. Iglesia parroquial de Santiago.

Villalba de los Alcores (Valladolid). 


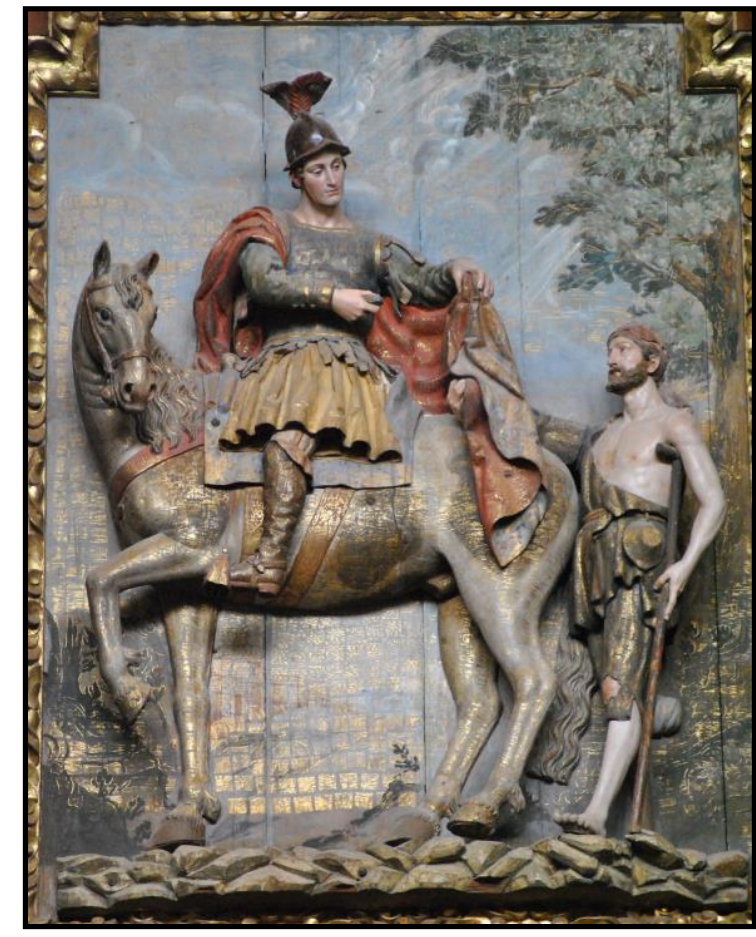

Fig. 33- Juan Antonio de la Peña. San Martín y el pobre. Iglesia de San Martín. Valladolid.

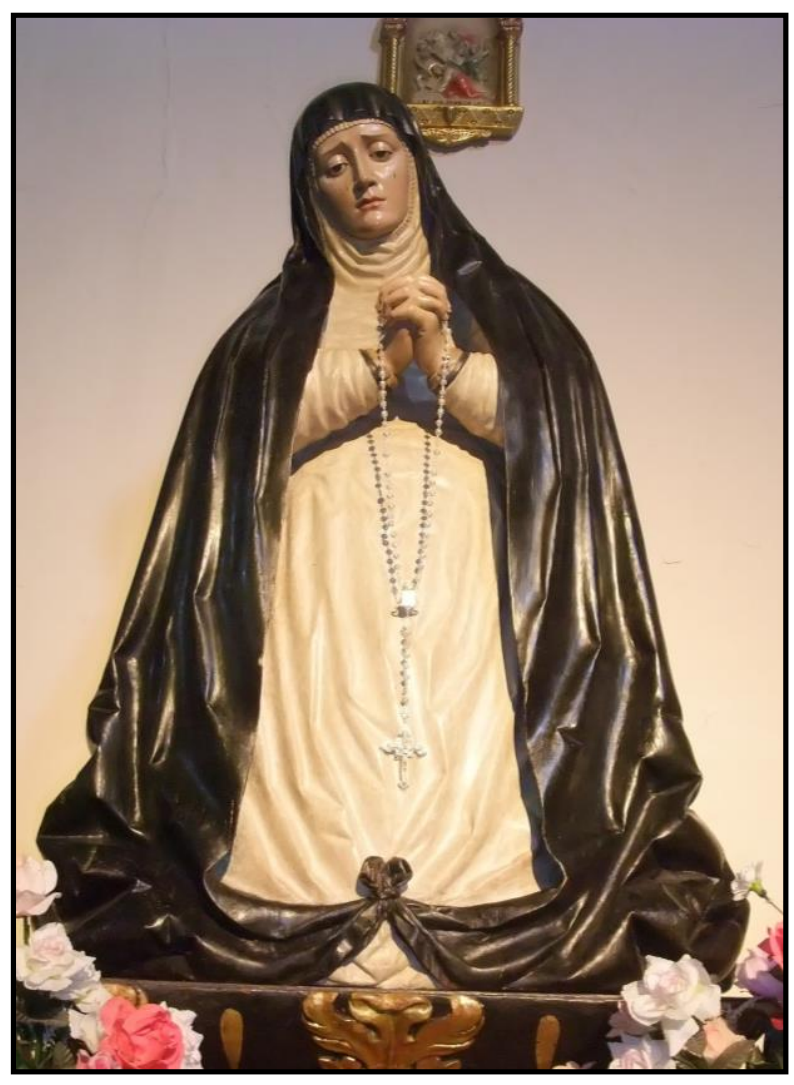

Fig. 35- Juan Antonio de la Peña. Nuestra Señora de la Soledad. Iglesia de San Martín. León.

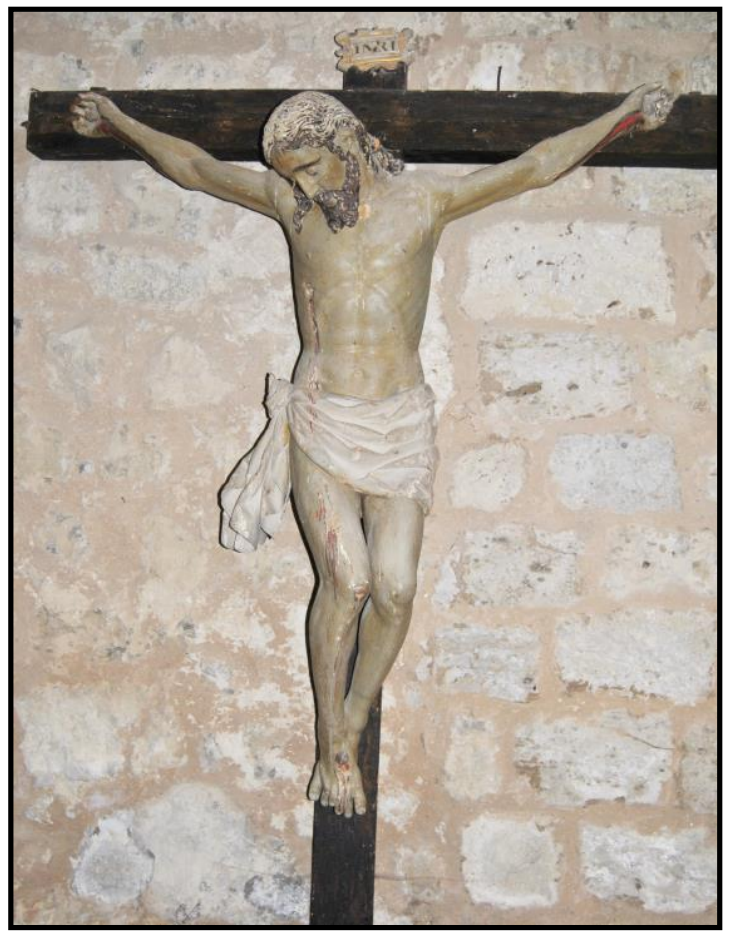

Fig. 34- Juan Antonio de la Peña. Cristo Crucificado. Iglesia de San Pedro.

Montealegre de Campos (Valladolid).

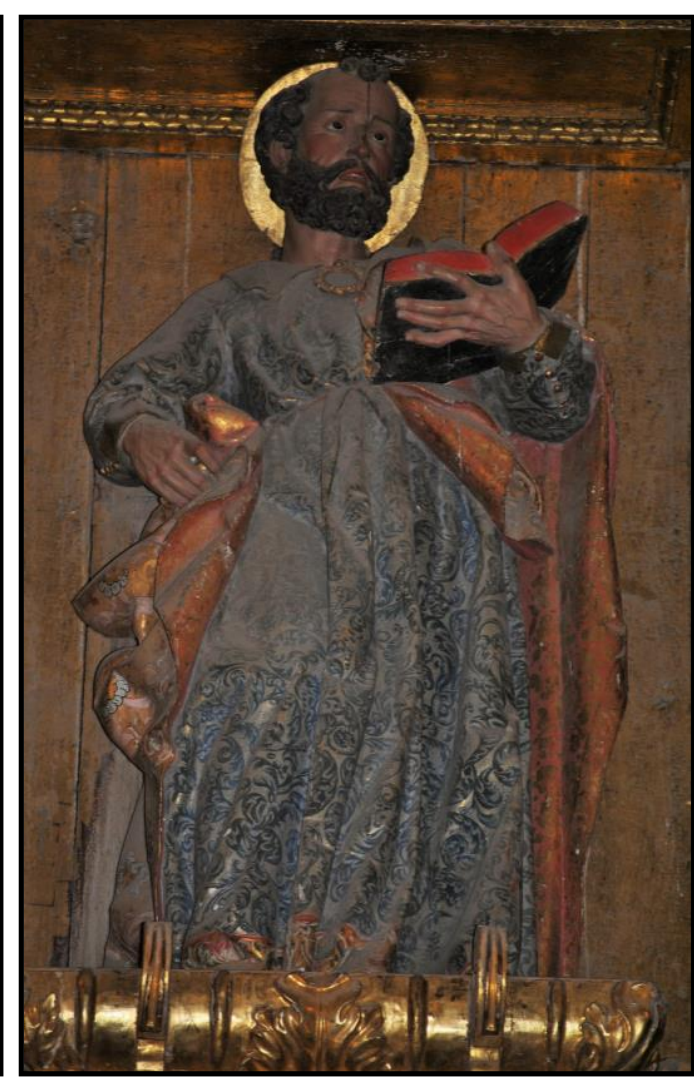

Fig. 36- Juan Antonio de la Peña. San

Pedro. Colegiata de San Luis. Villagarcía de Campos (Valladolid)

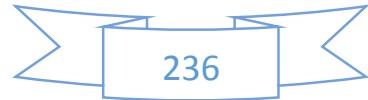




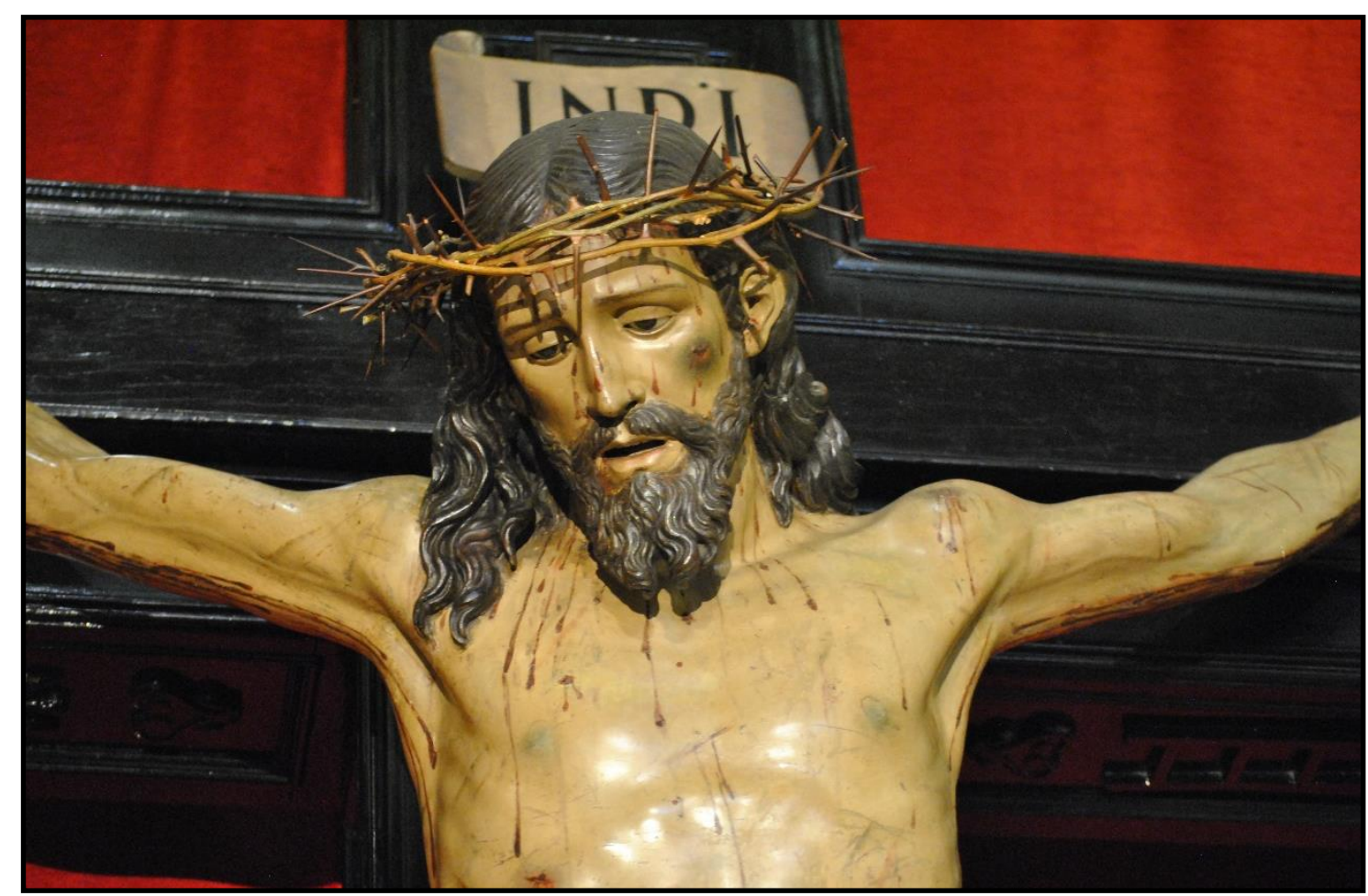

Fig. 37- Juan Antonio de la Peña. Santísimo Cristo de la Agonía. Iglesia penitencial de Nuestro Padre Jesús Nazareno. Valladolid.

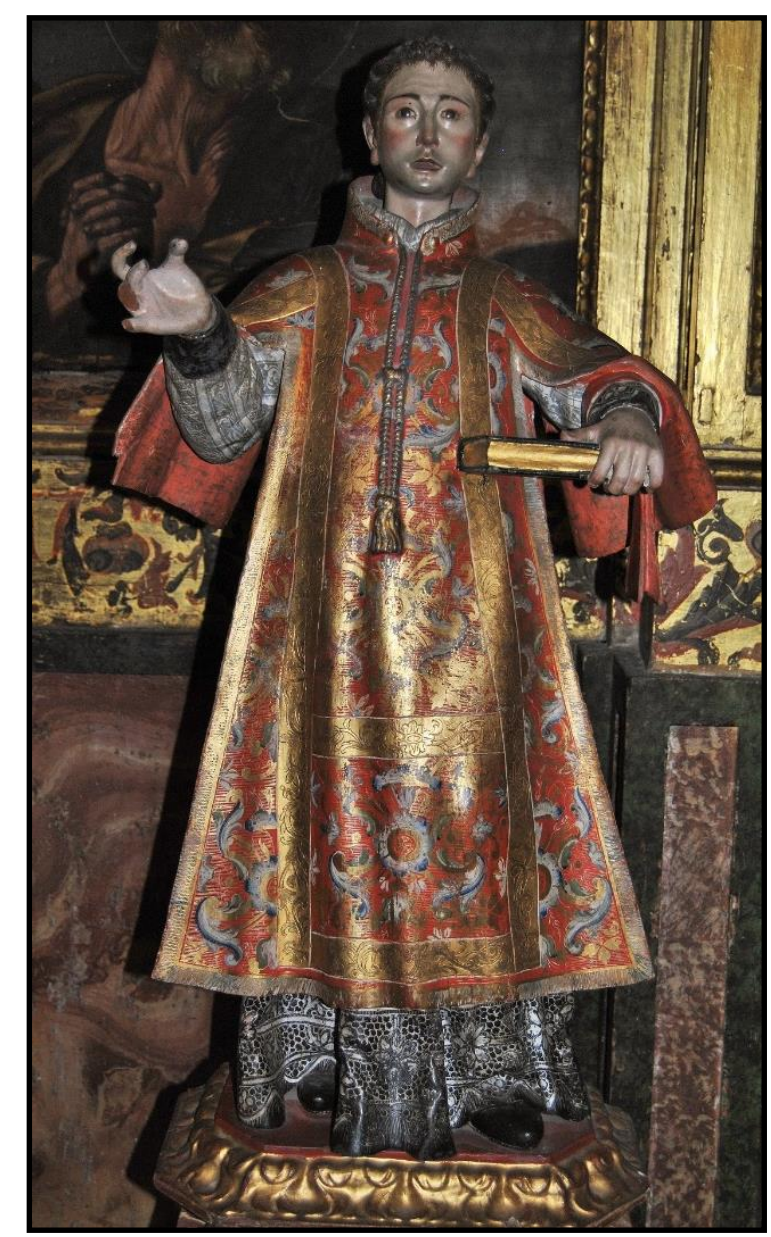

Fig. 38- Vicente Díez. San Antolín. Museo de San Antolín. Tordesillas (Valladolid).

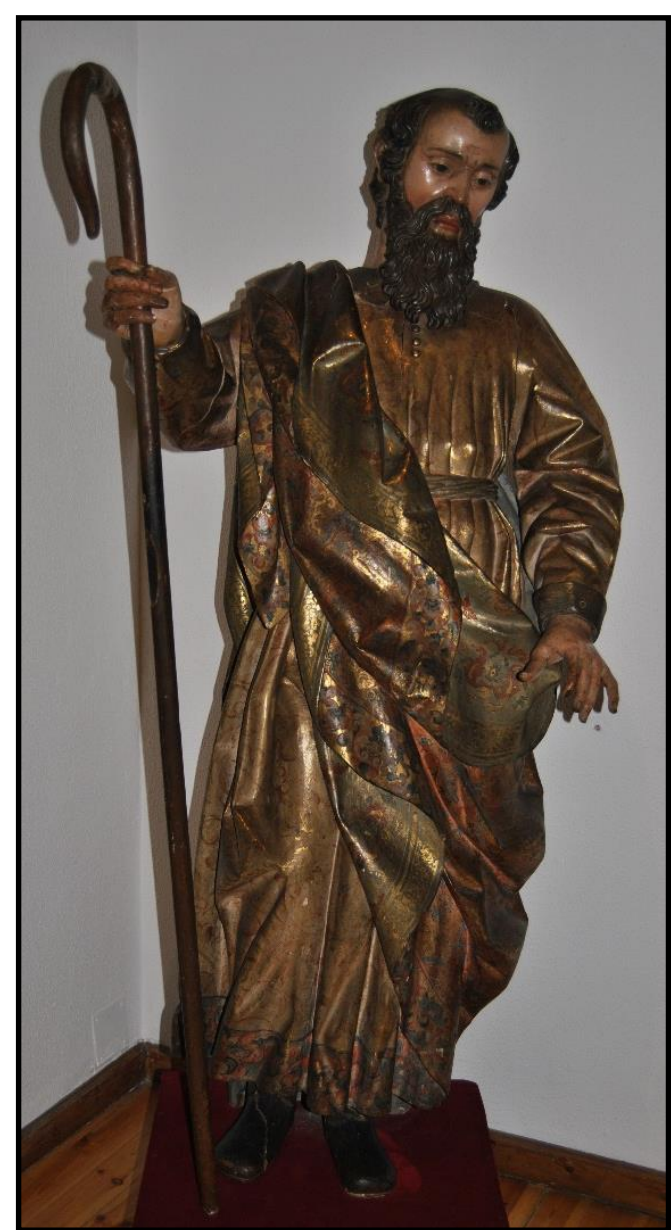

Fig. 39- Andrés de Pereda. San Joaquín. Museo de San Joaquín y Santa Ana. Valladolid.

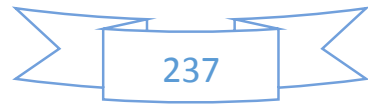




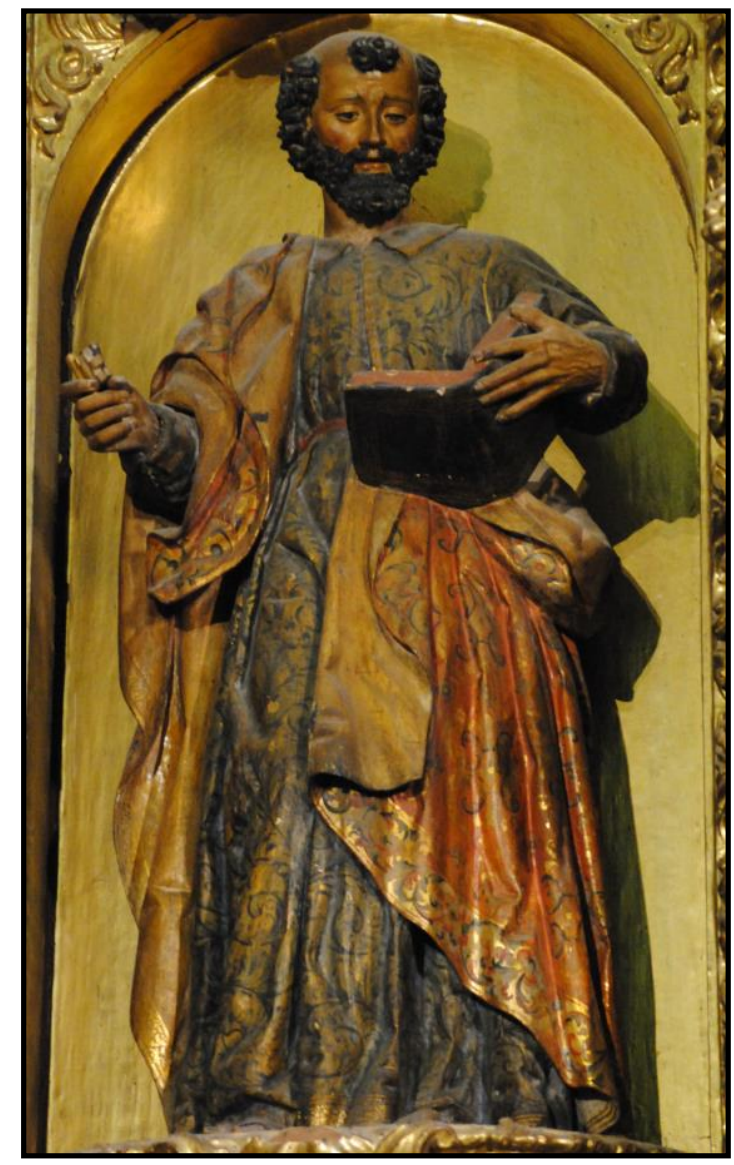

Fig. 40- Andrés de Pereda. San Pedro. Iglesia de Santa María. Pozaldez (Valladolid).

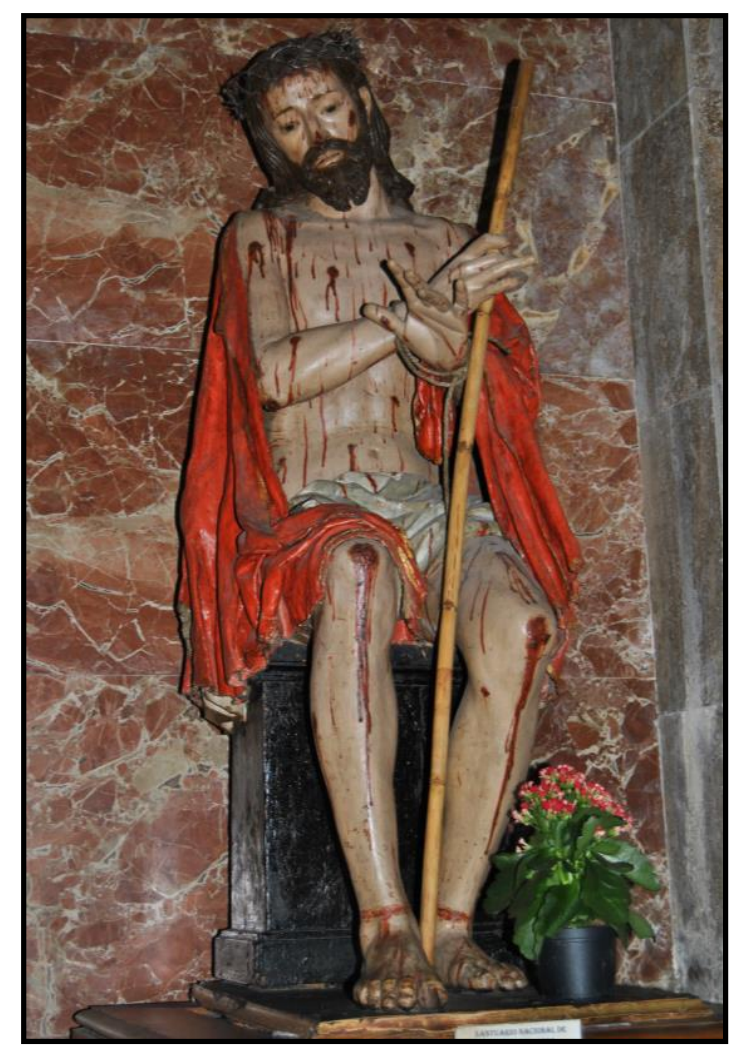

Fig. 42- José de Rozas. Cristo de la Humildad. Santuario Nacional. Valladolid.

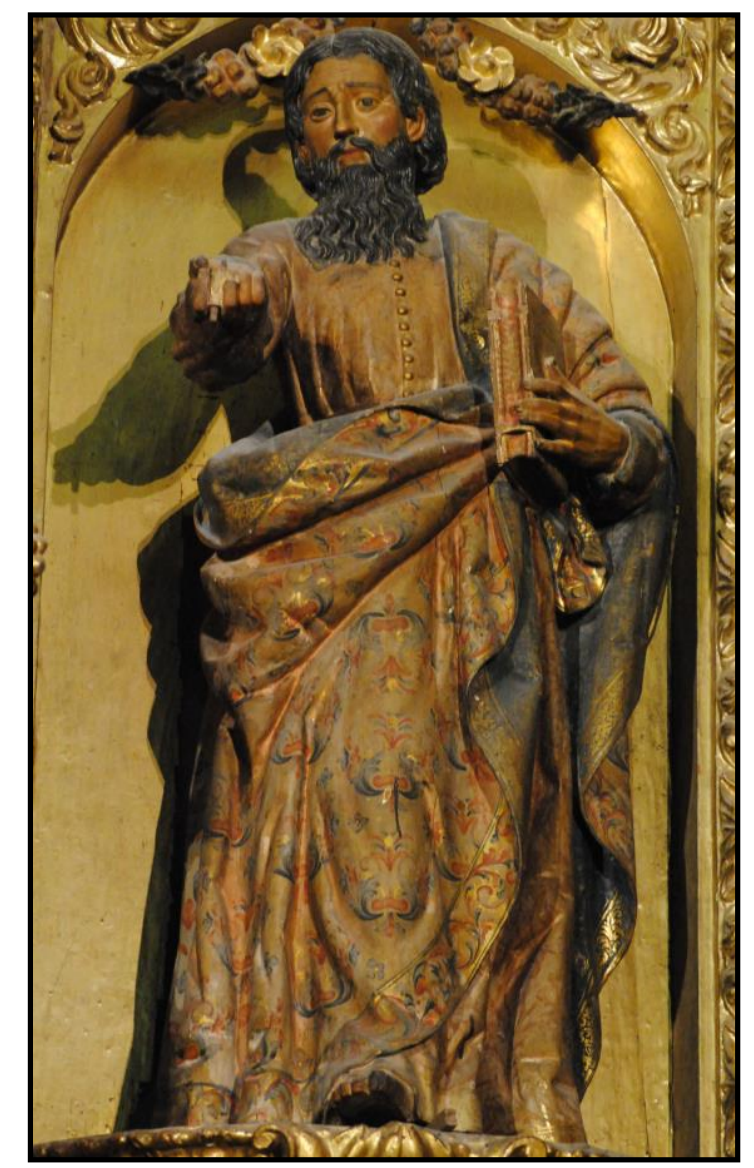

Fig. 41- Andrés de Pereda. San Pablo. Iglesia de Santa María. Pozaldez (Valladolid).

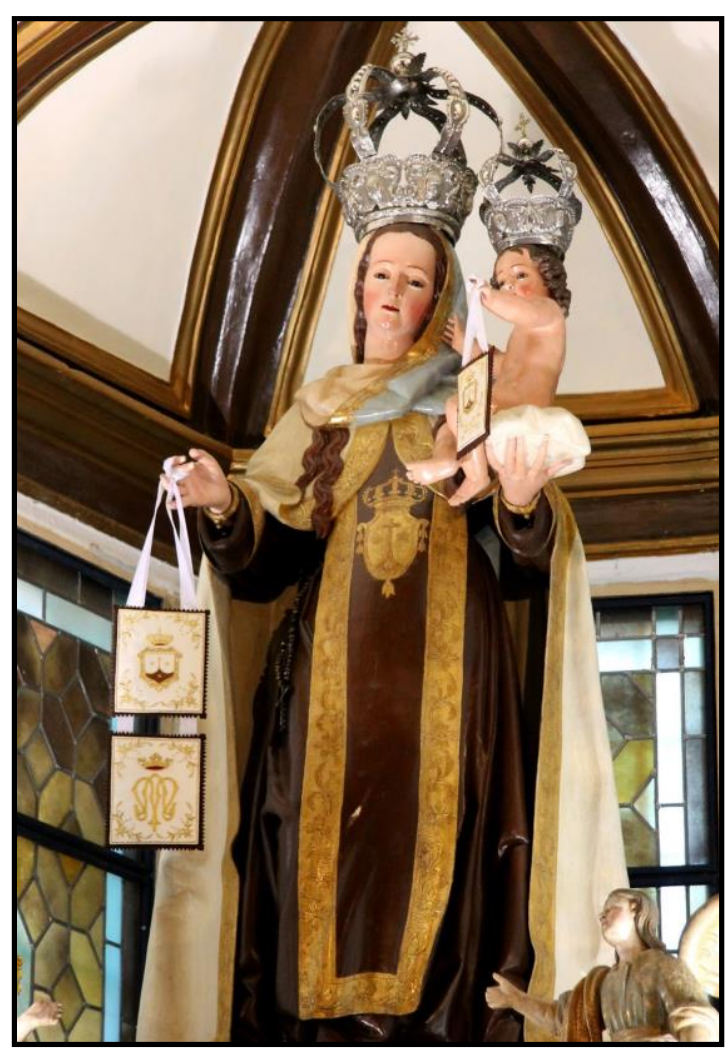

Fig. 43- José de Rozas. Virgen del Carmen. Iglesia de San Isidoro. Zamora. 


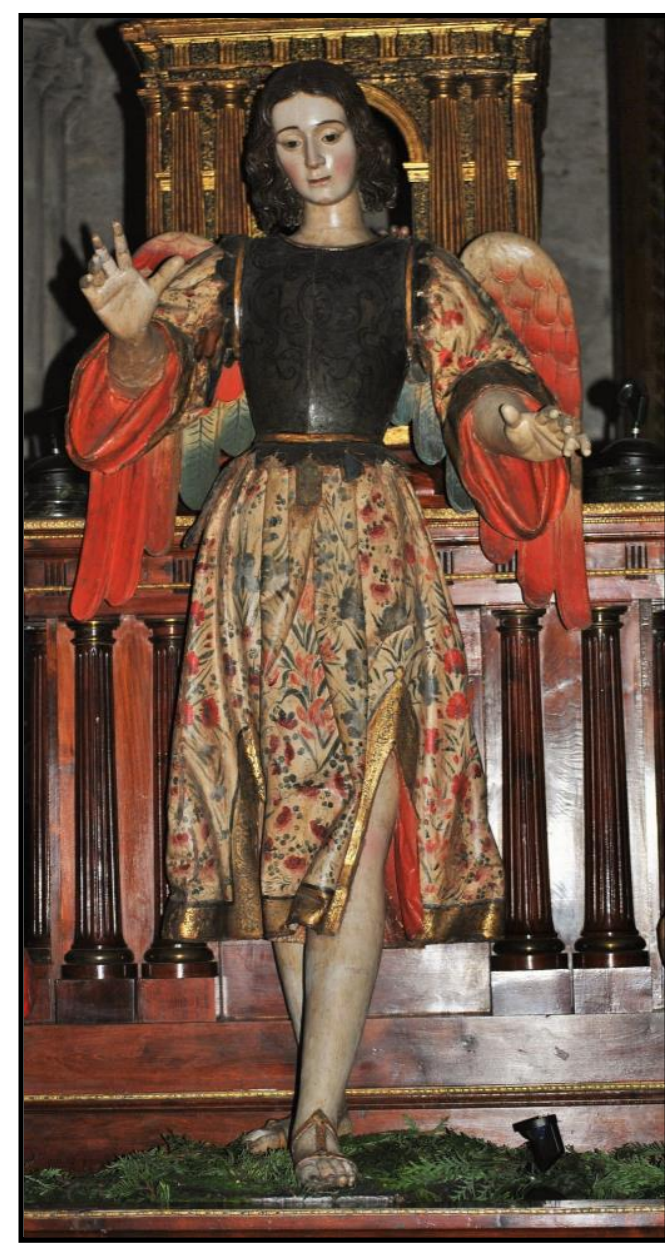

Fig. 44- José de Rozas. Ángel del Santo Sepulcro. Museo Nacional de Escultura. Valladolid.

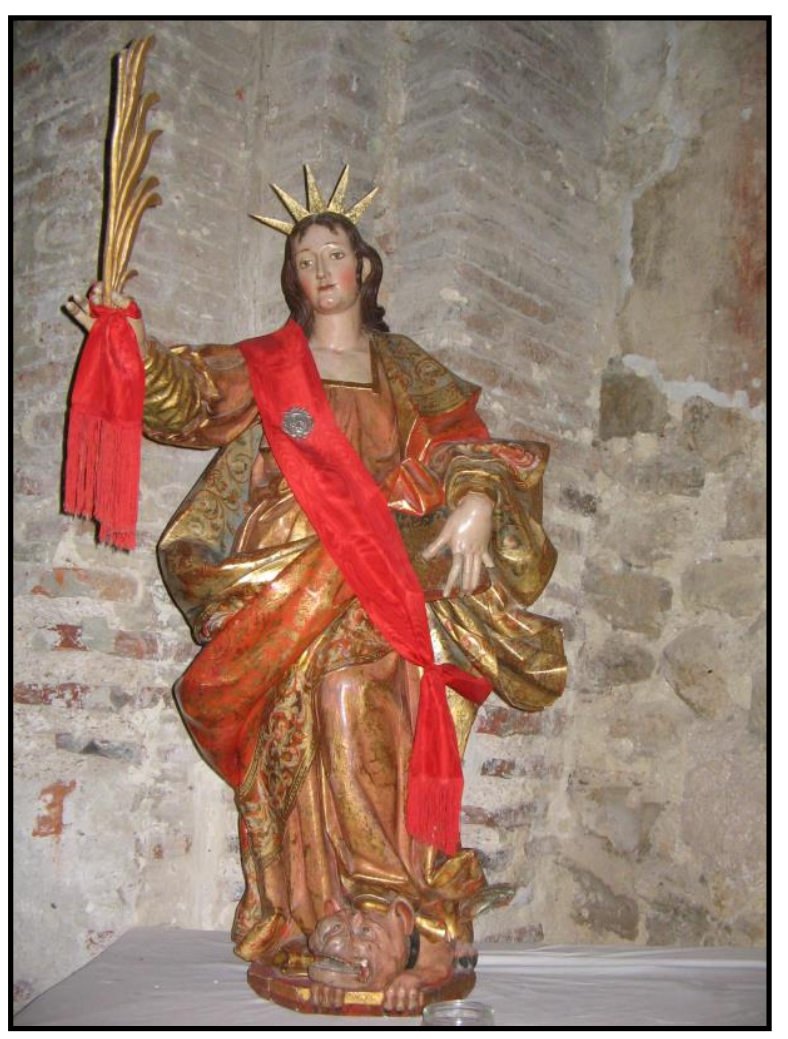

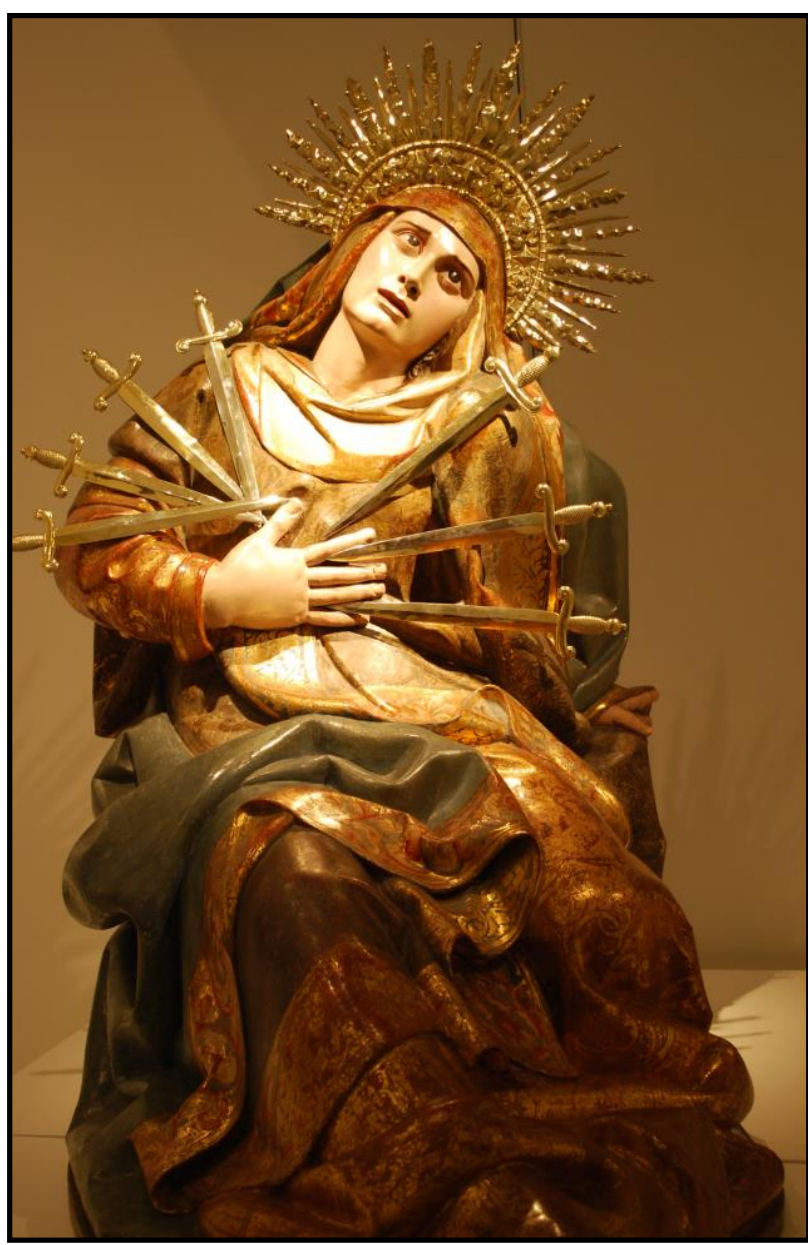

Fig. 45- José de Rozas. Virgen de las Angustias. Iglesia de San Bartolomé. Astorga (León).

Fig. 46- Joseph Pascual. Santa Juliana. Iglesia parroquial de Santa Juliana. Villarmentero de Esgueva (Valladolid).

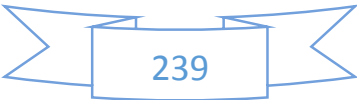




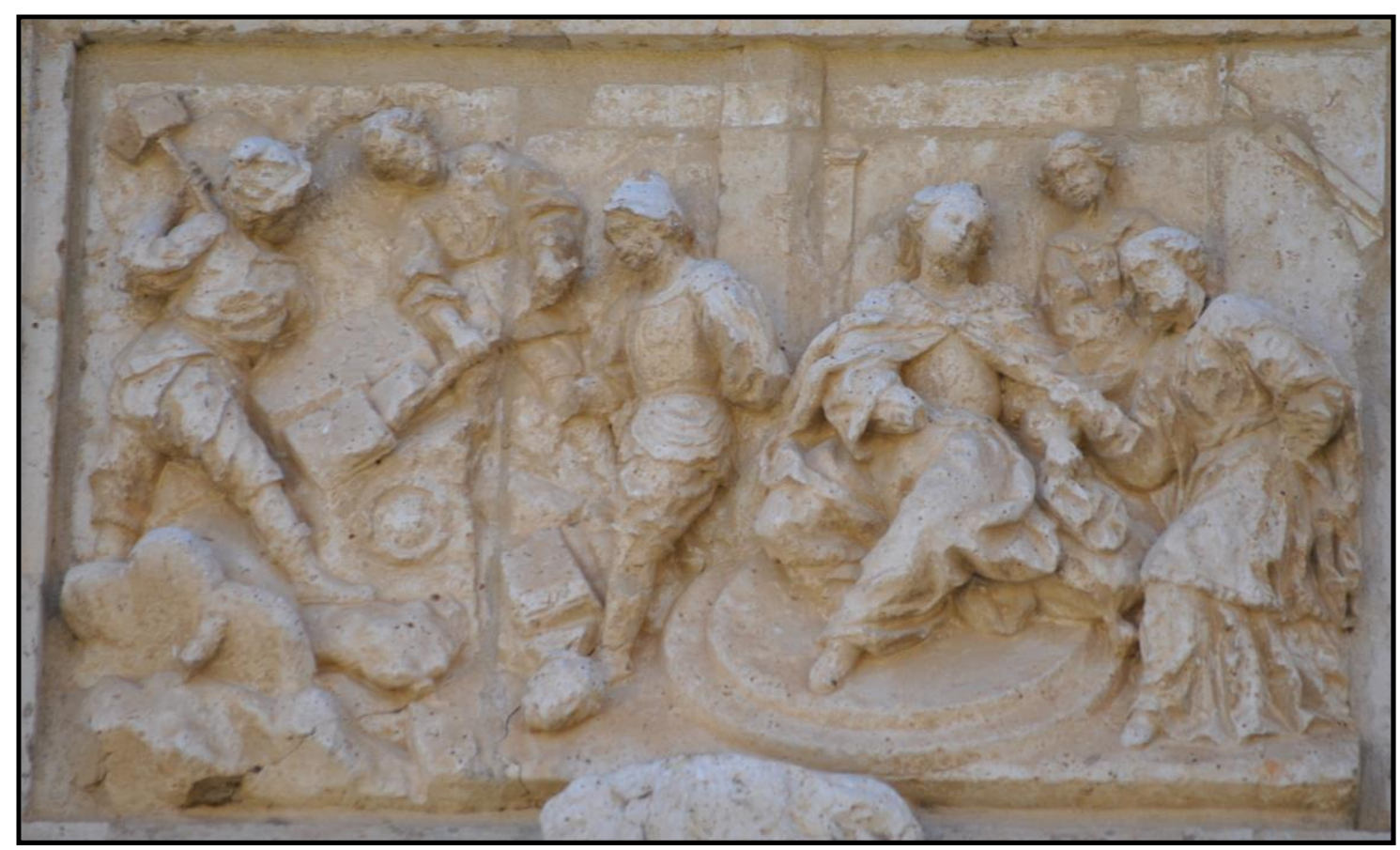

Fig. 47- Pedro de Sierra. Santa Elena hallando la Santa Cruz en el Gólgota. Iglesia de Santa Cruz. Medina de Rioseco (Valladolid).

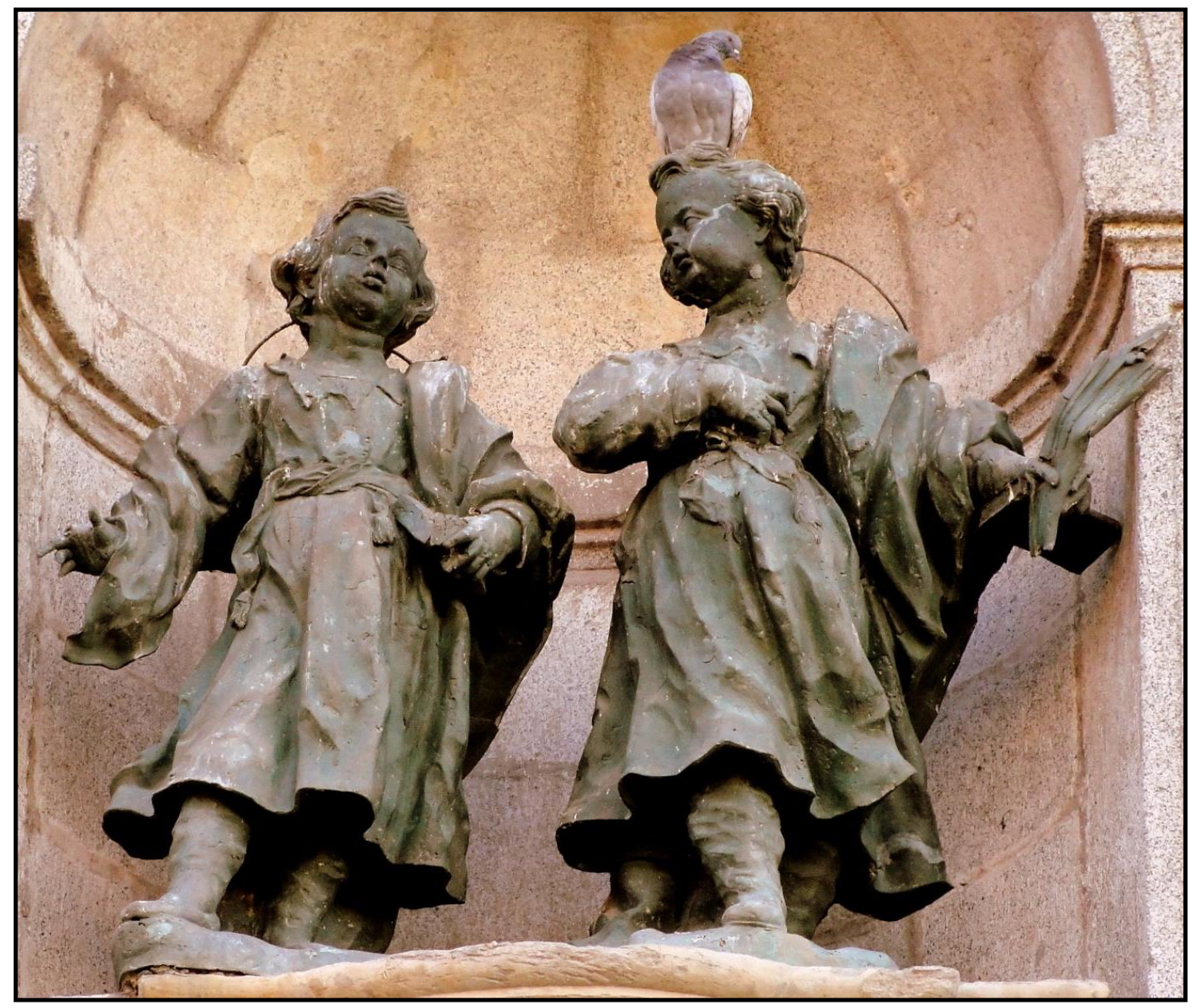

Fig. 48- Pedro de Sierra. Santos Justo y Pastor. Iglesia de los Santos Justo y Pastor. Toledo.

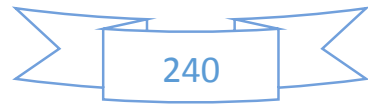




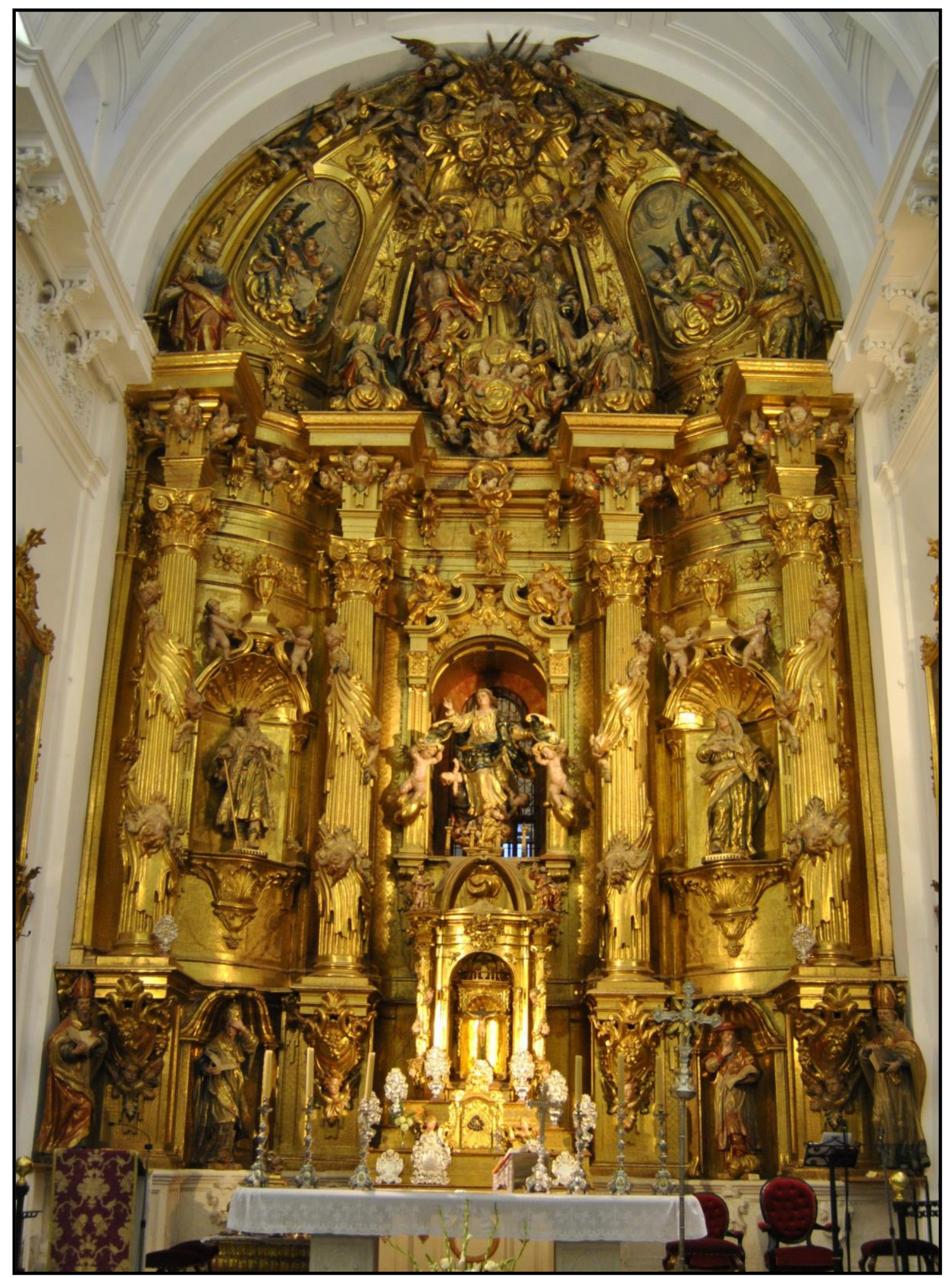

Fig. 49- Pedro de Sierra. Retablo mayor. Iglesia parroquial de la Asunción. Rueda (Valladolid).

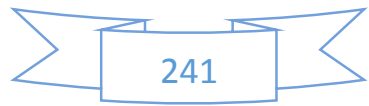




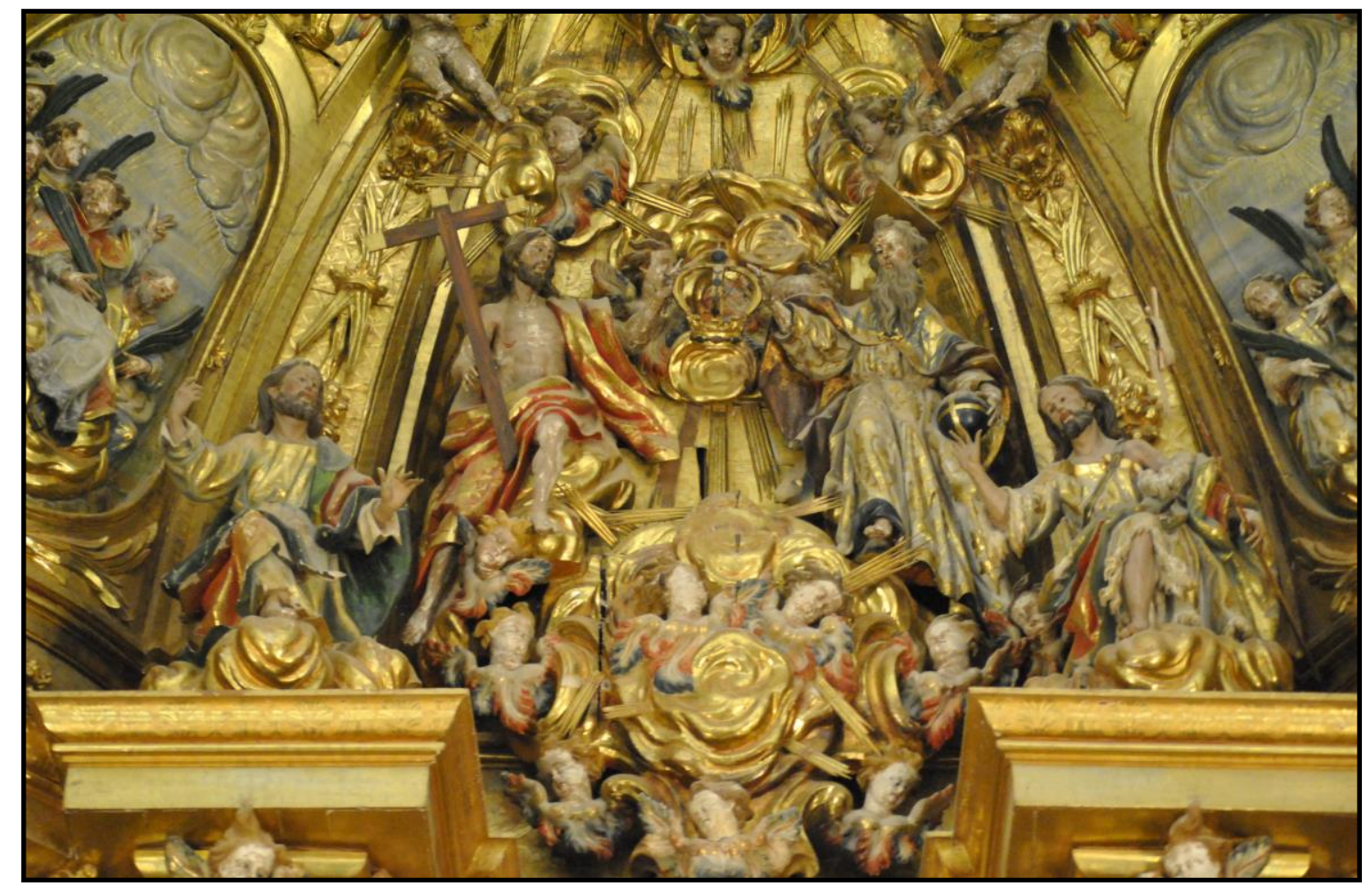

Fig. 50- Pedro de Sierra. Retablo mayor. Iglesia parroquial de la Asunción. Rueda (Valladolid).

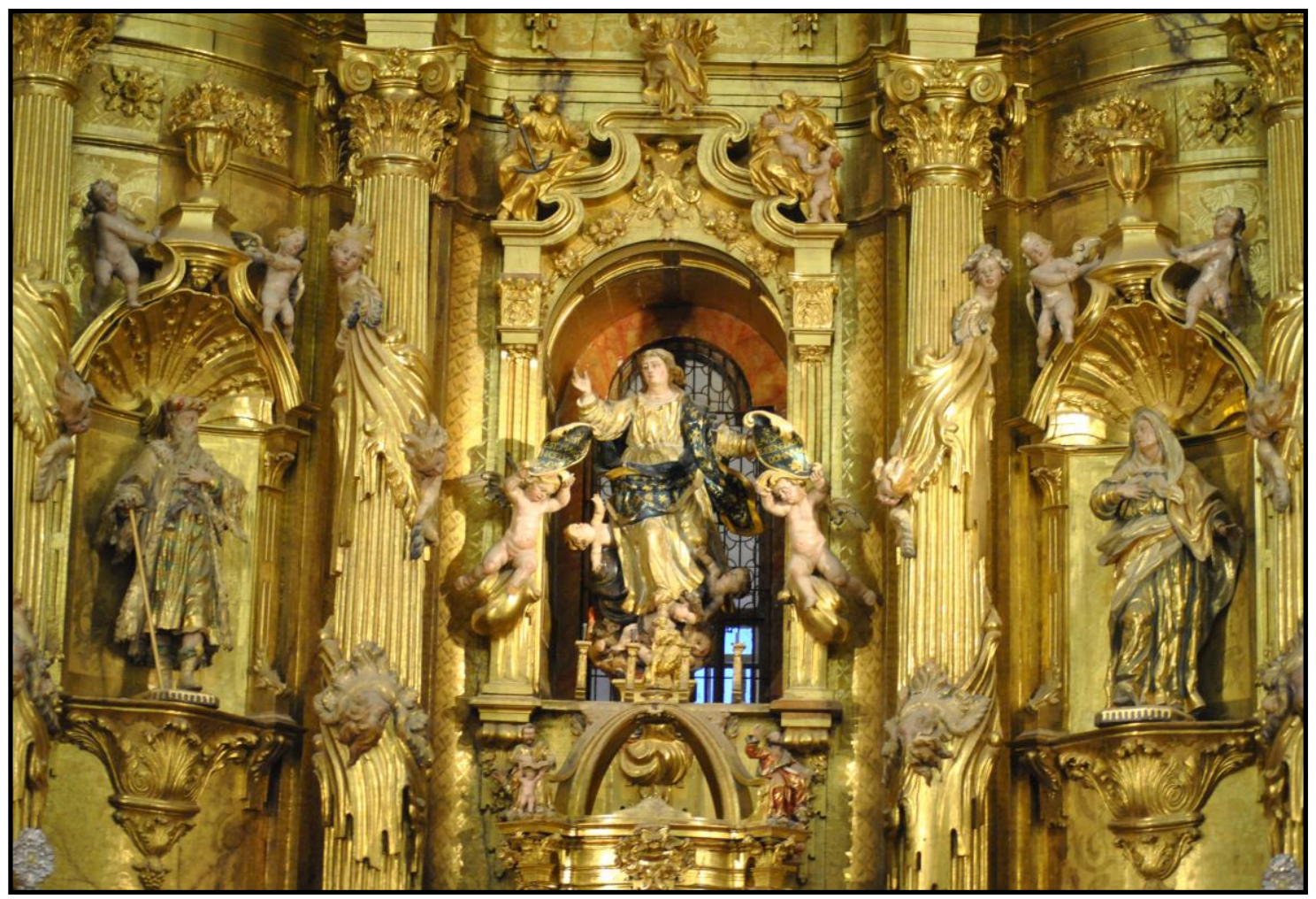

Fig. 51- Pedro de Sierra. Retablo mayor. Iglesia parroquial de la Asunción. Rueda (Valladolid).

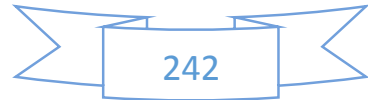




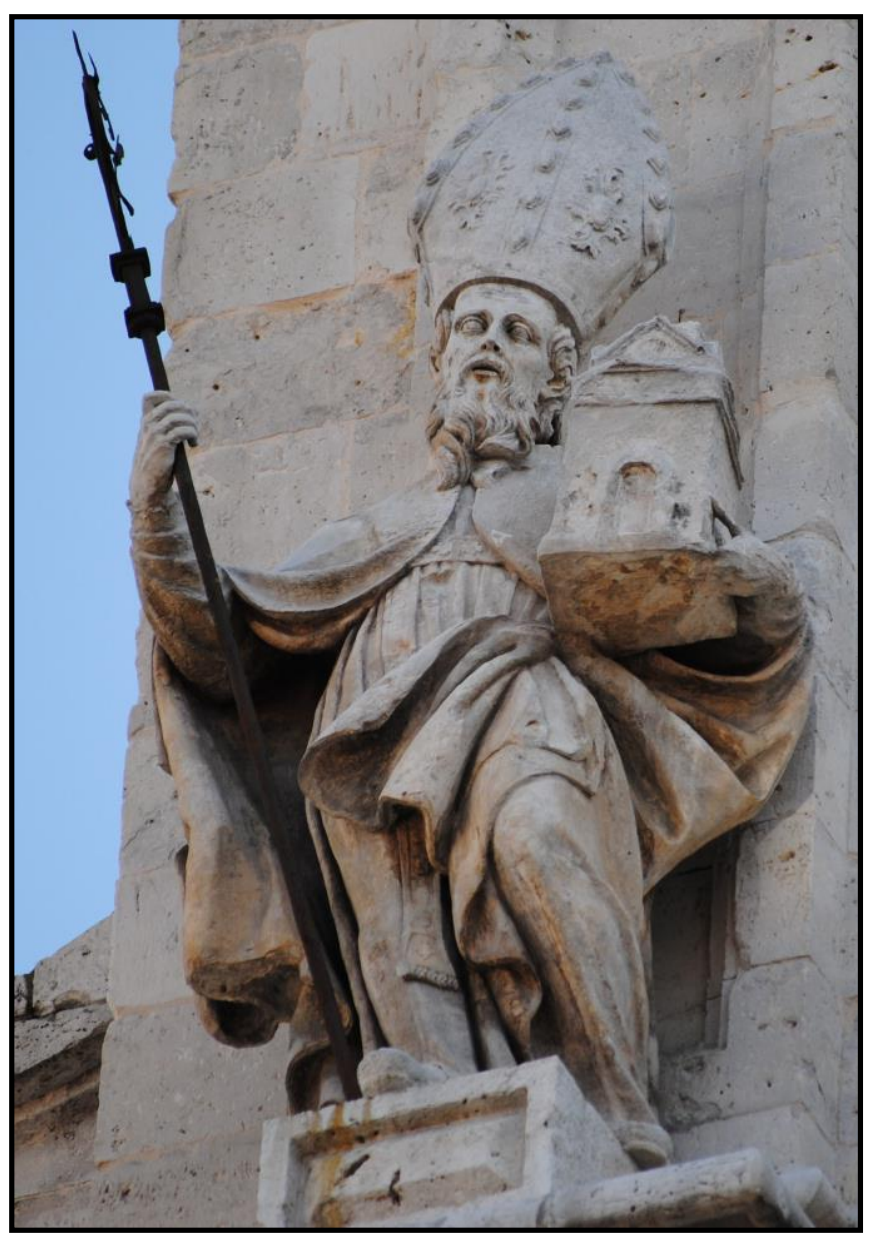

Fig. 52- Pedro Bahamonde. San Agustín. Catedral. Valladolid.

Fig. 53- Pedro Bahamonde. Inmaculada. Catedral. Valladolid.
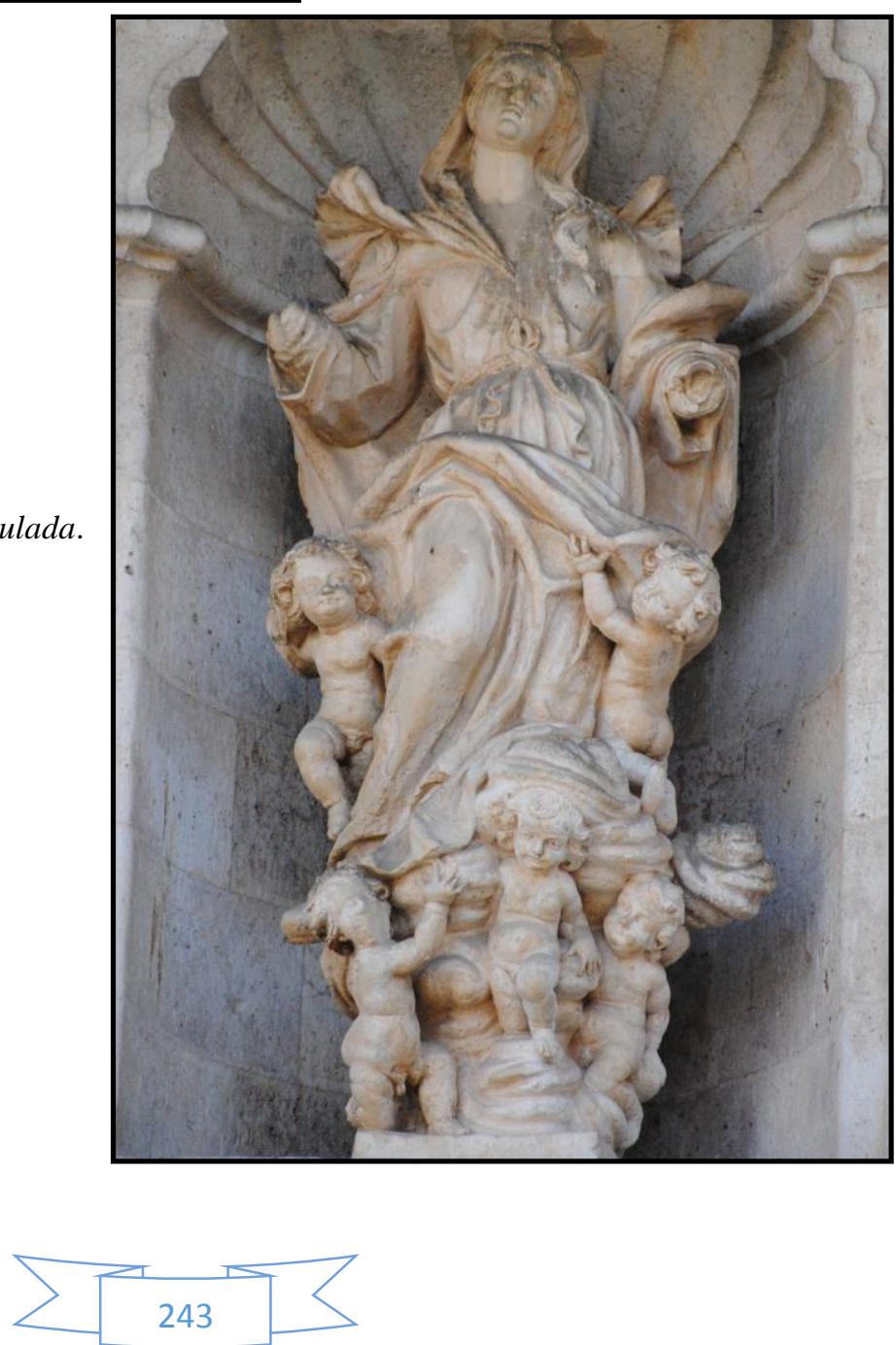


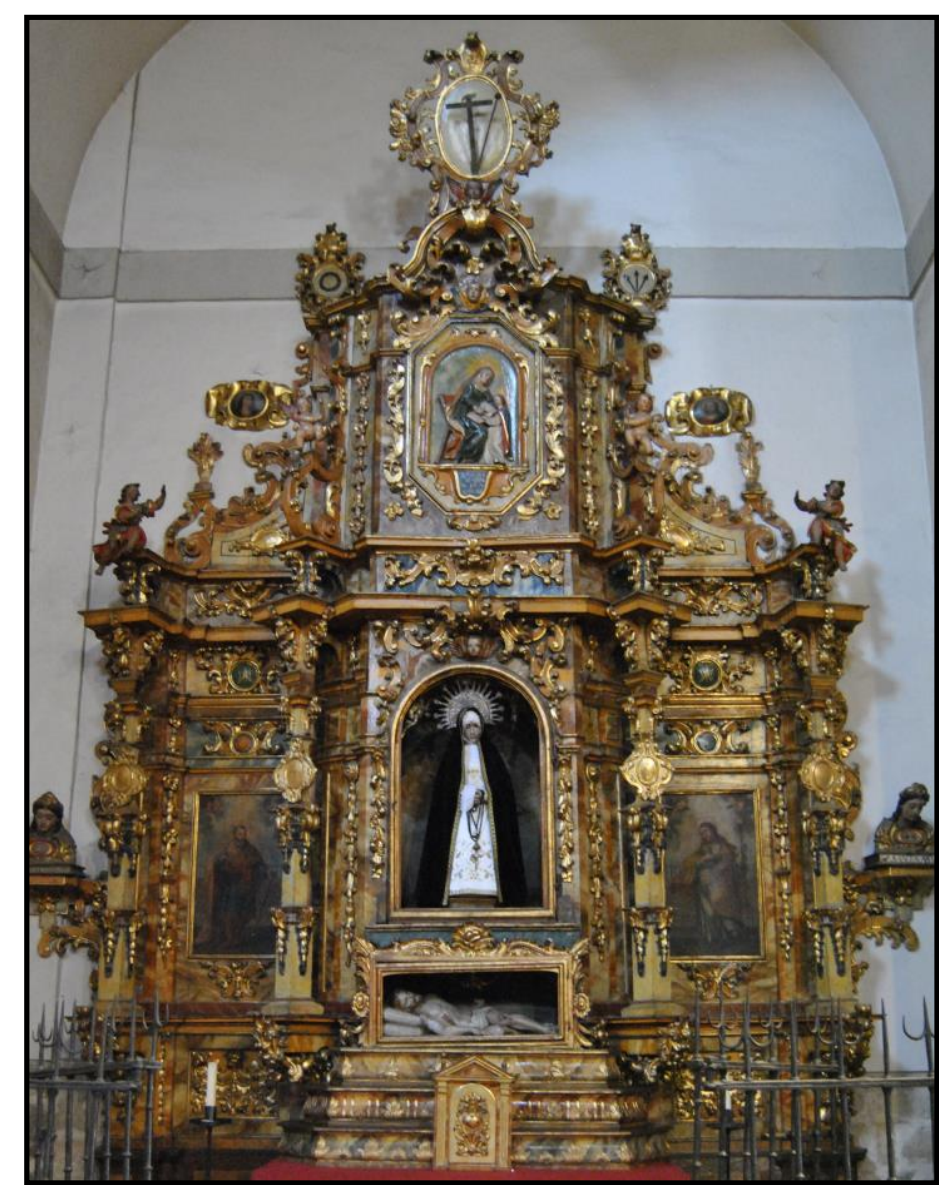

Fig. 54- Pedro Bahamonde. Retablo de la Cofradía de la Soledad. Iglesia de San Andrés. Valladolid.

Fig. 55- Pedro Bahamonde. Retablo mayor. Santuario de Nuestra Señora de la Calle. Palencia.
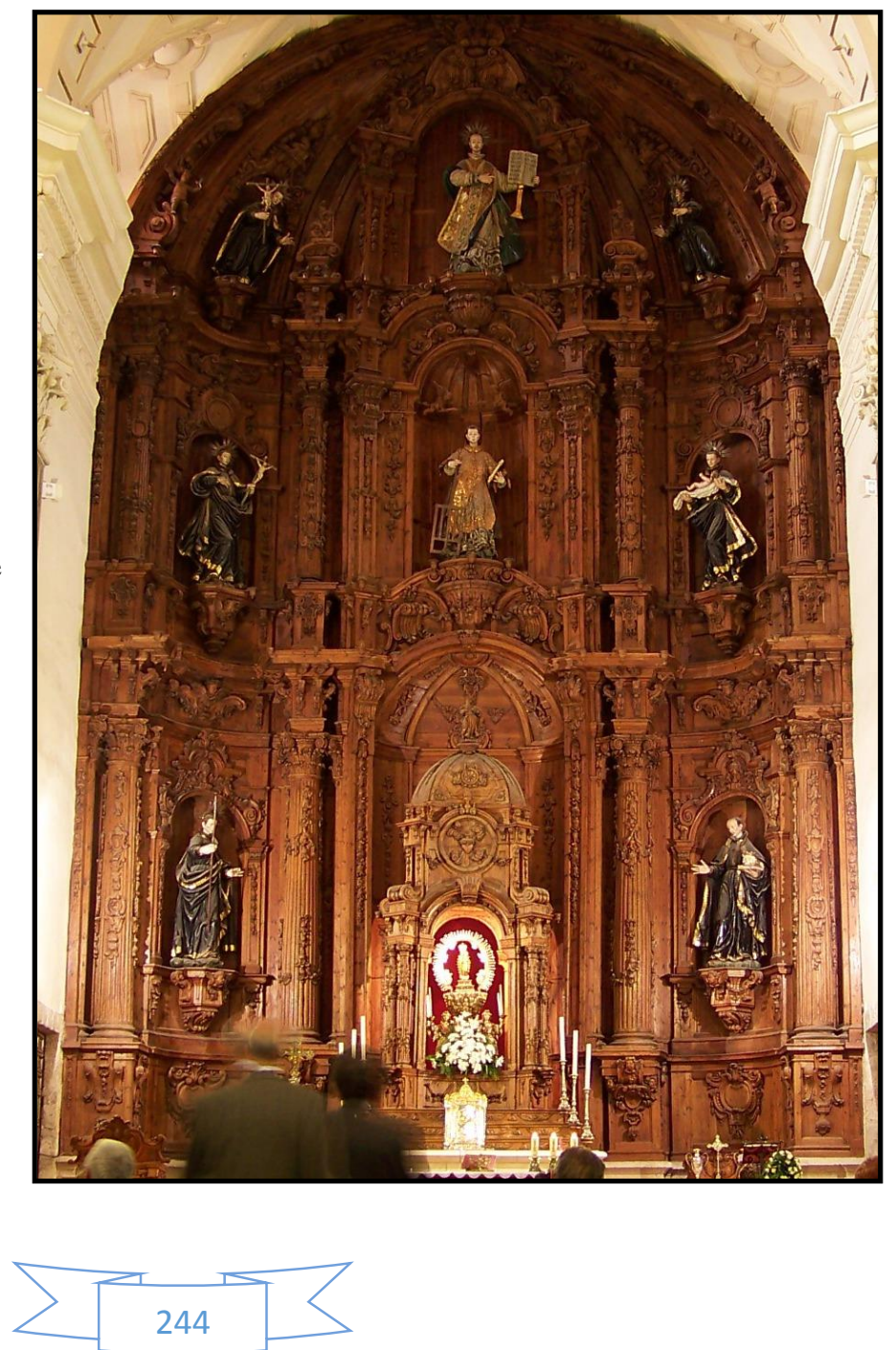


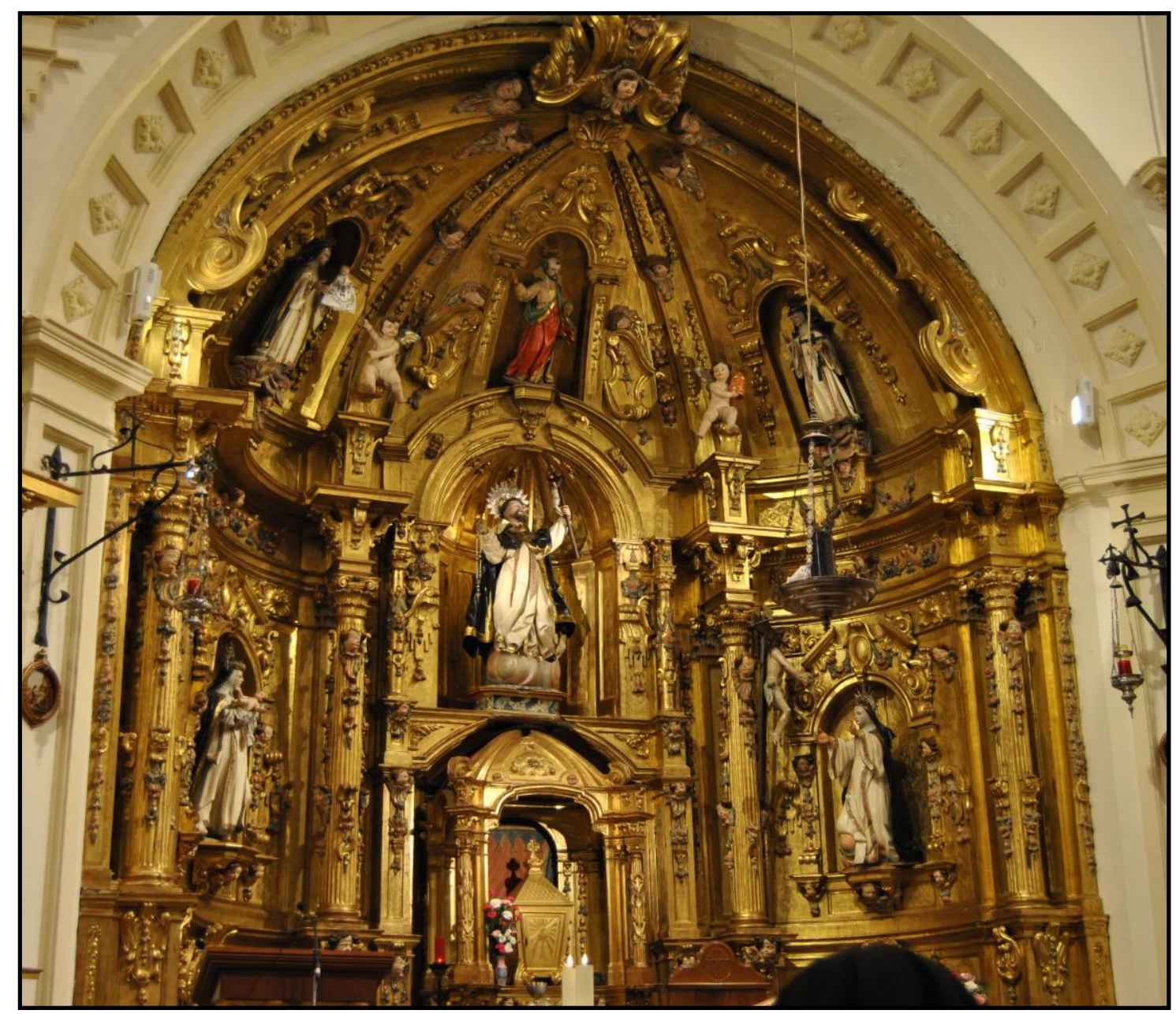

Fig. 56- Juan Antonio Argüelles Mata. Retablo mayor y tabernáculo. Convento de Nuestra Señora de la Piedad. Palencia.

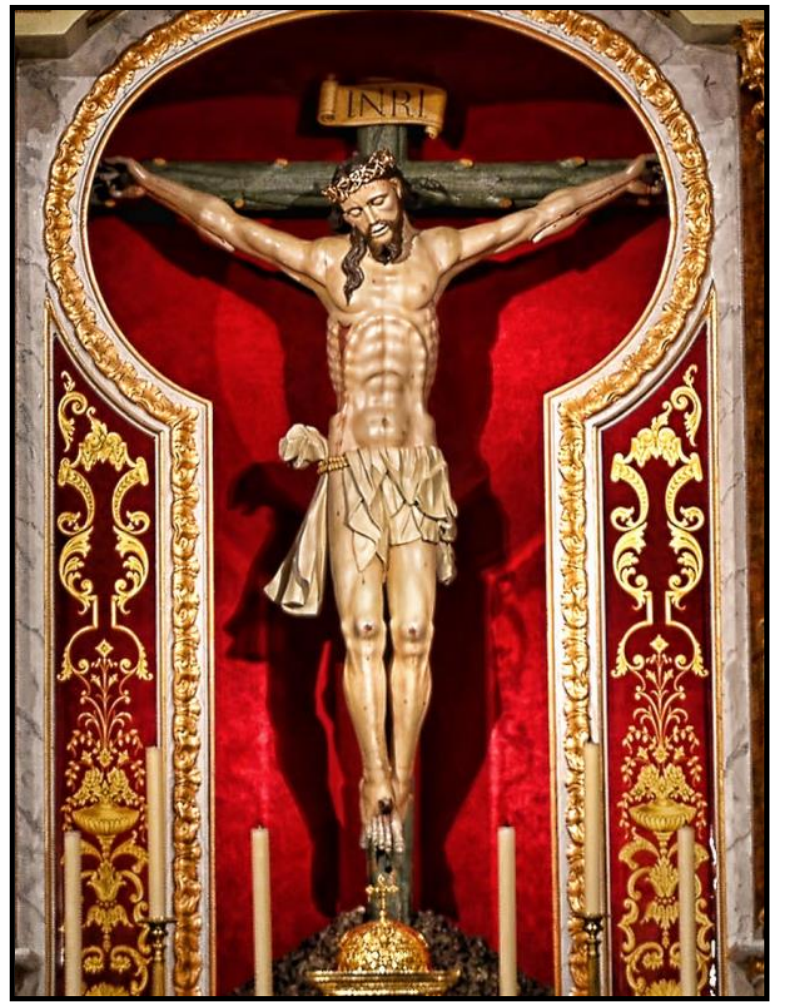

Fig. 57- Juan Antonio Argüelles Mata. Santísimo Cristo de la Salud. Ermita del Santo Cristo de la Salud. Puebla de Almoradiel (Toledo). 


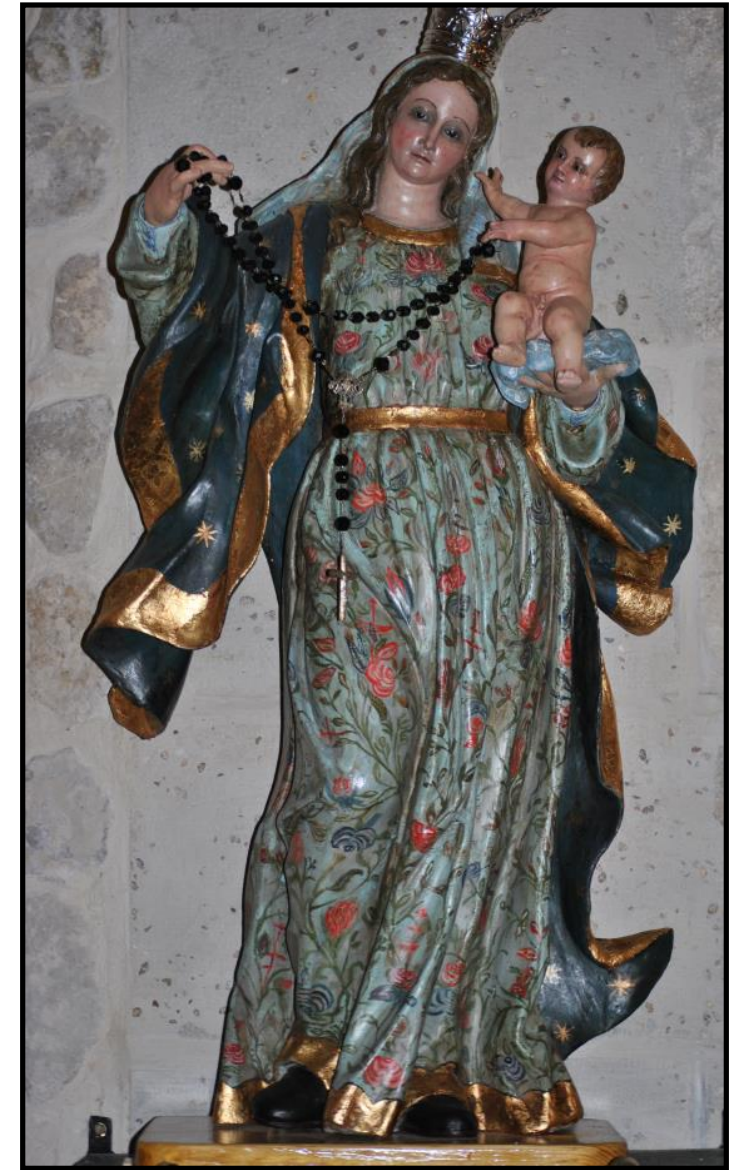

Fig. 58- José Fernández. Nuestra Señora del Rosario. Iglesia parroquial. Corcos del Valle (Valladolid).

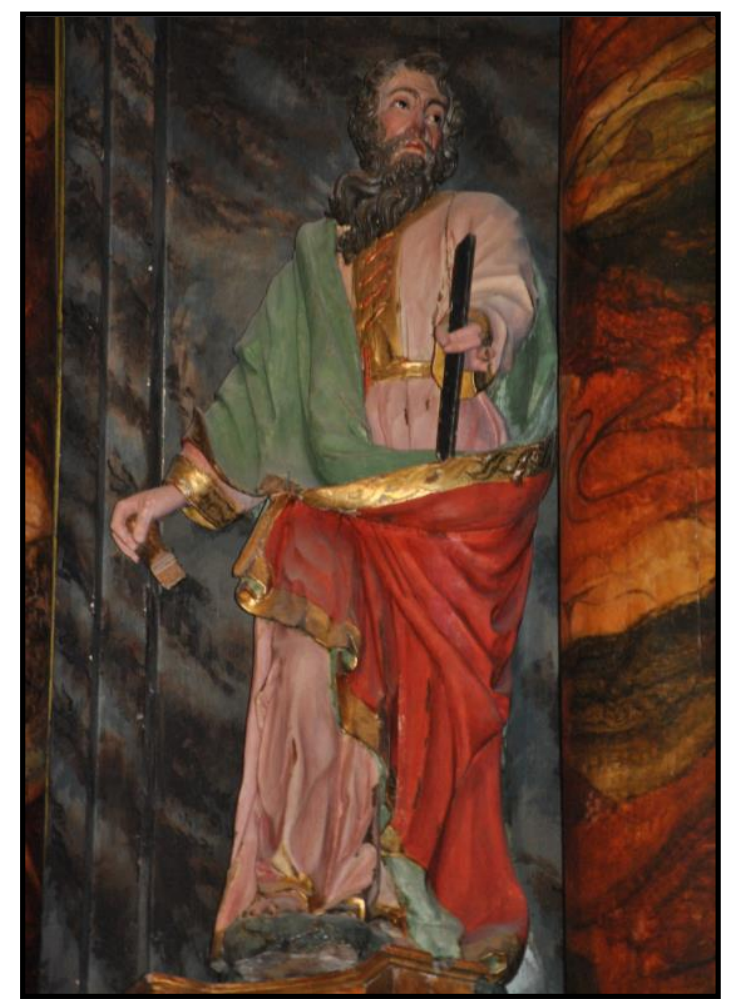

Fig. 60- José Fernández. San Simón. Iglesia de San Pedro. Valoria la Buena (Valladolid).

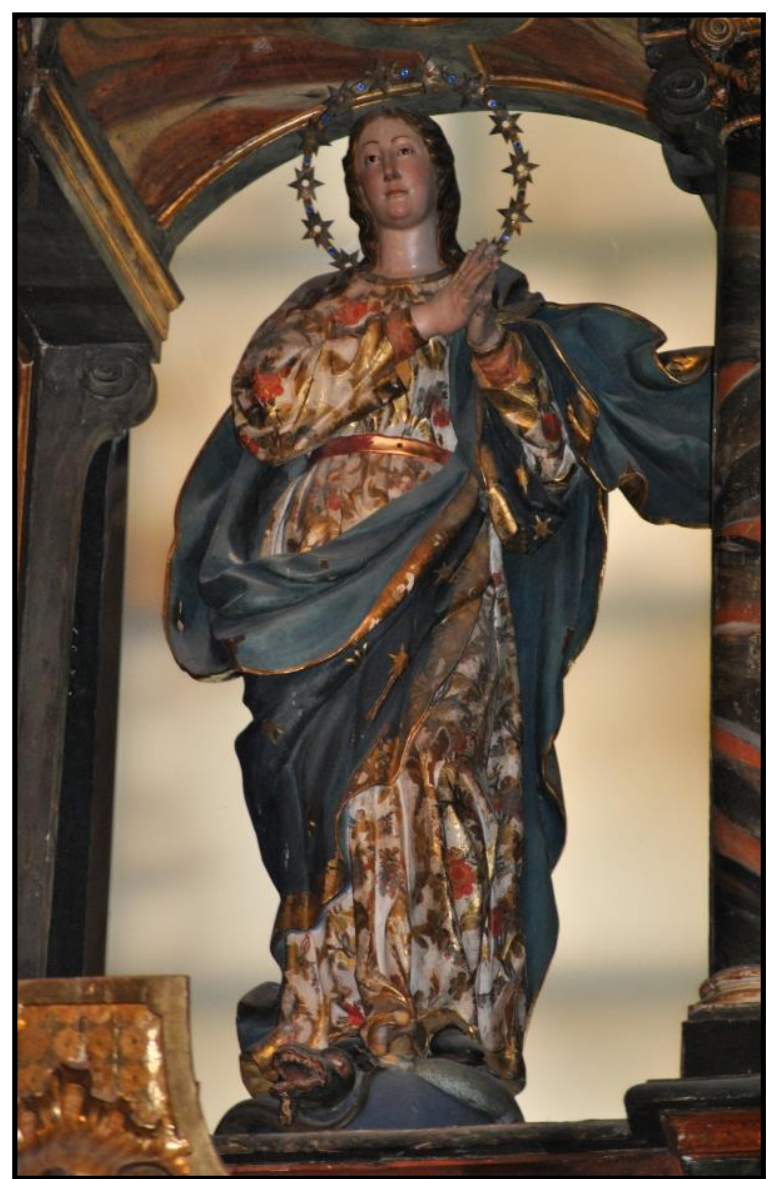

Fig. 59- José Fernández. Inmaculada. Iglesia de San Pedro. Valoria la Buena (Valladolid).

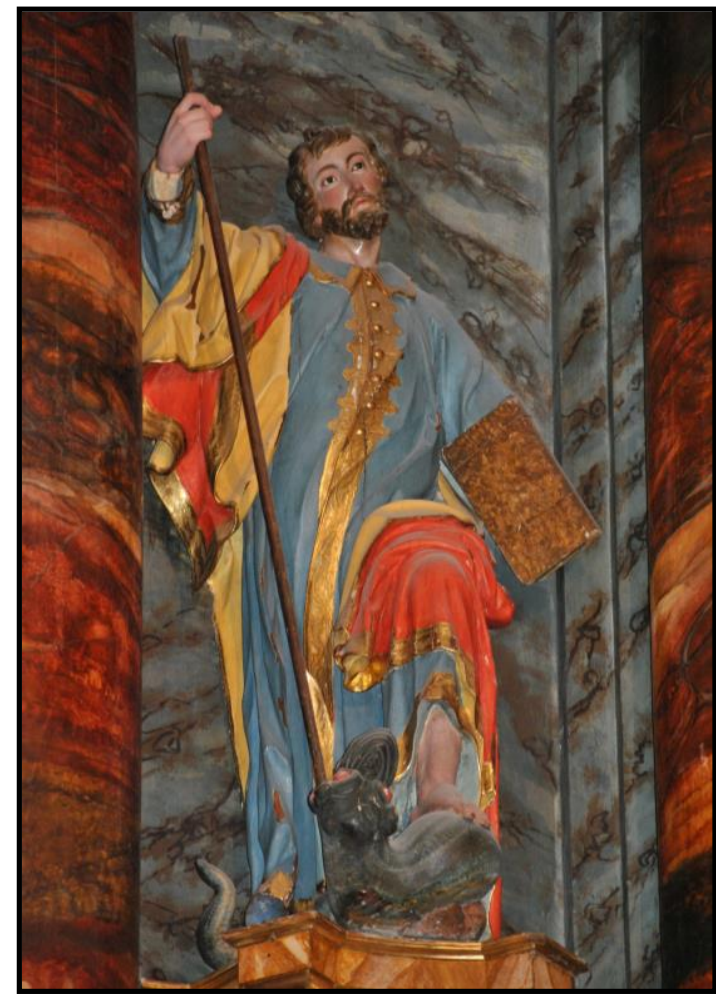

Fig. 61- José Fernández. San Judas. Iglesia de San Pedro. Valoria la Buena (Valladolid).

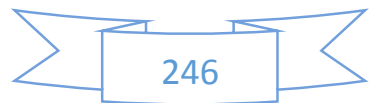




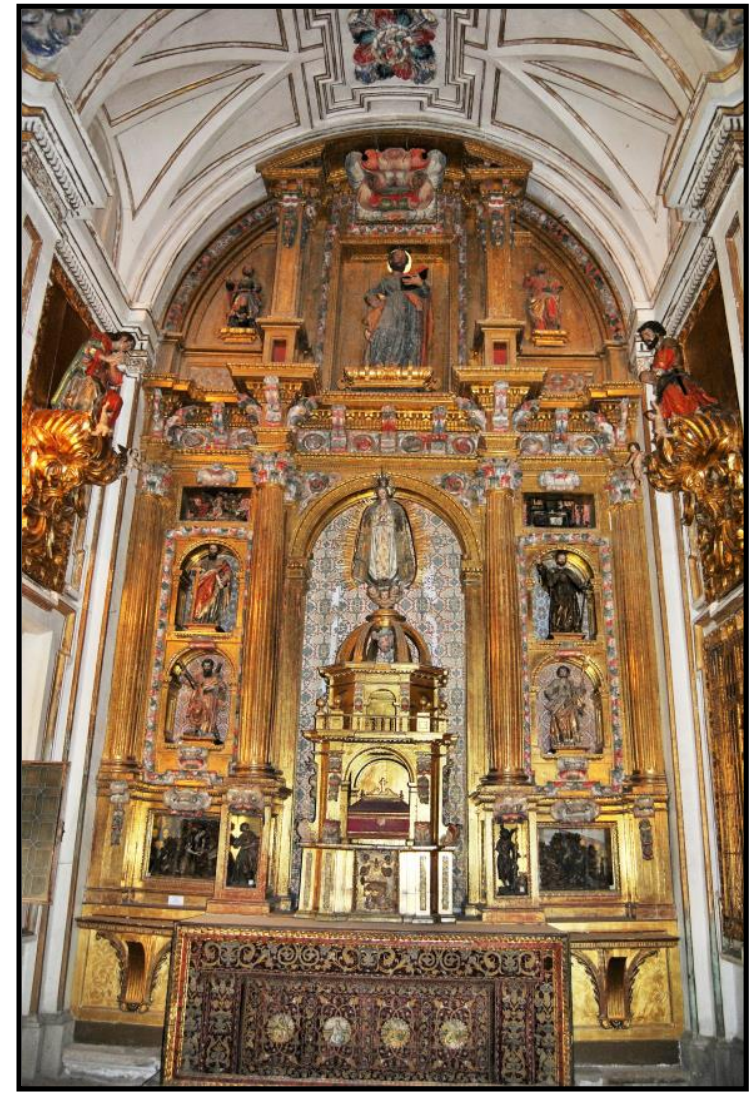

Fig. 62- Cristóbal Ruiz de Andino. Retablo mayor. Colegiata de San Luis. Villagarcía de Campos (Valladolid).

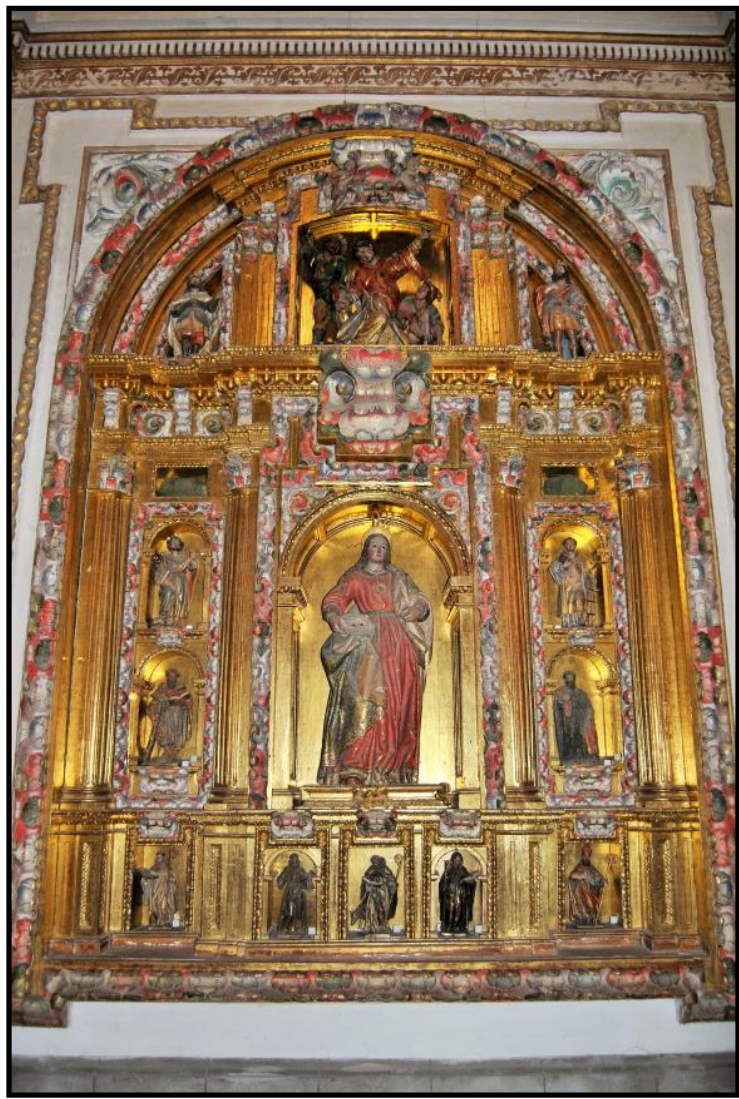

Fig. 64- Cristóbal Ruiz de Andino. Retablo de Santa Lucía. Colegiata de San Luis. Villagarcía de Campos (Valladolid).

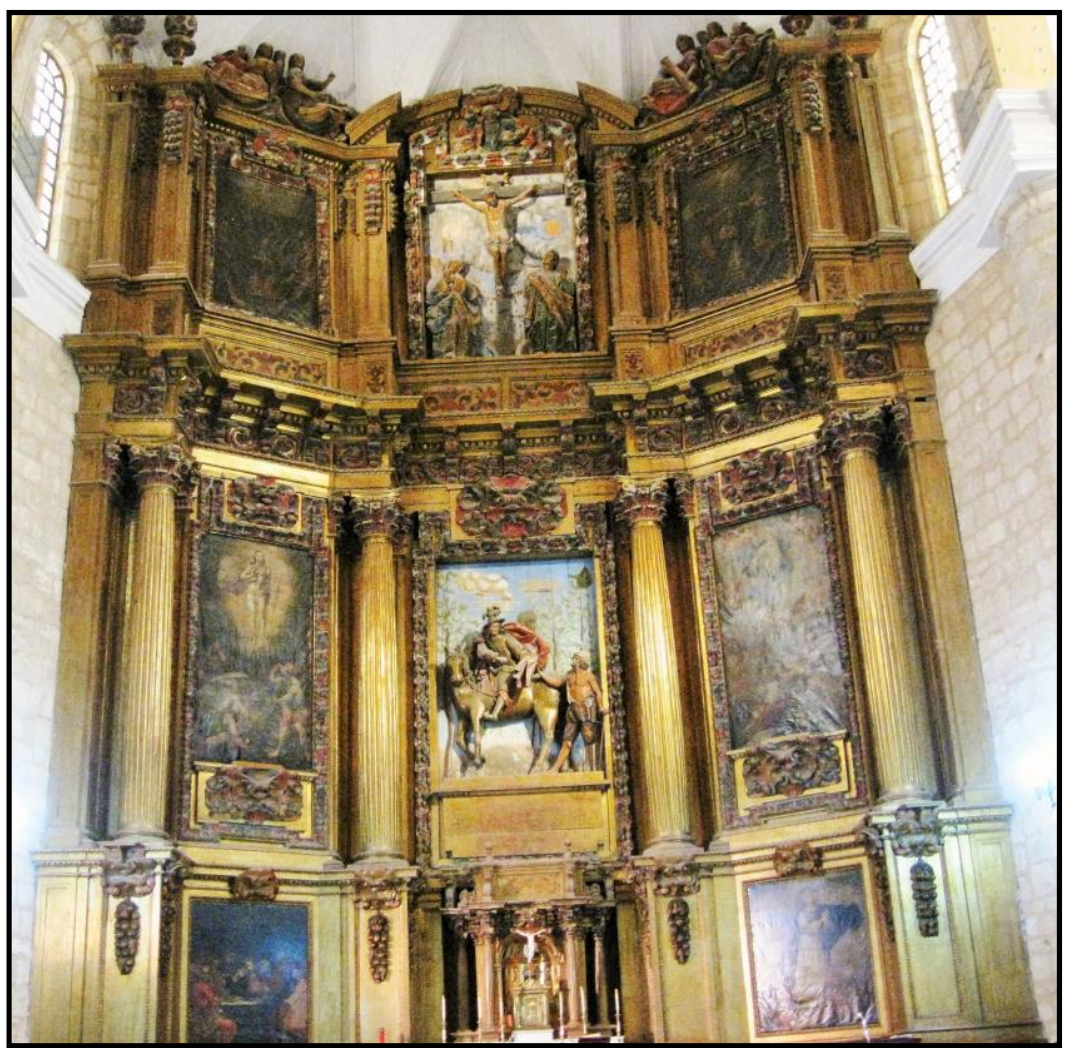

Fig. 63- Cristóbal Ruiz de Andino. Retablo mayor. Iglesia parroquial de San Martín. Cevico de la Torre (Palencia).

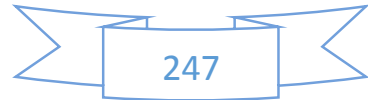




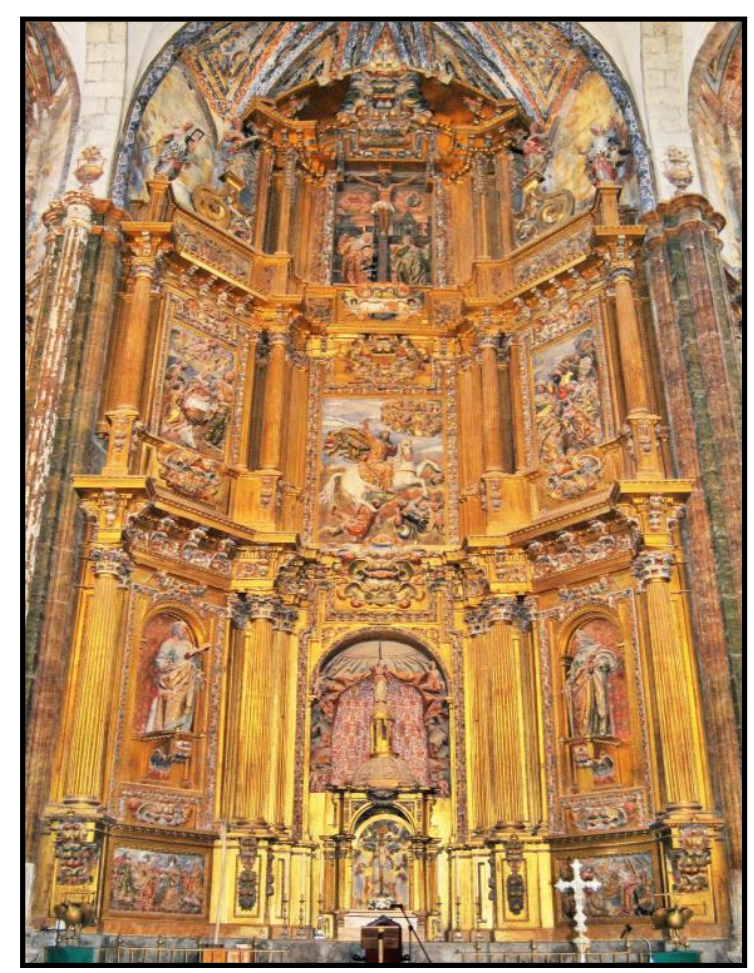

Fig. 65- Pedro de Cea. Retablo mayor. Iglesia de Santiago Apóstol. Cigales (Valladolid).

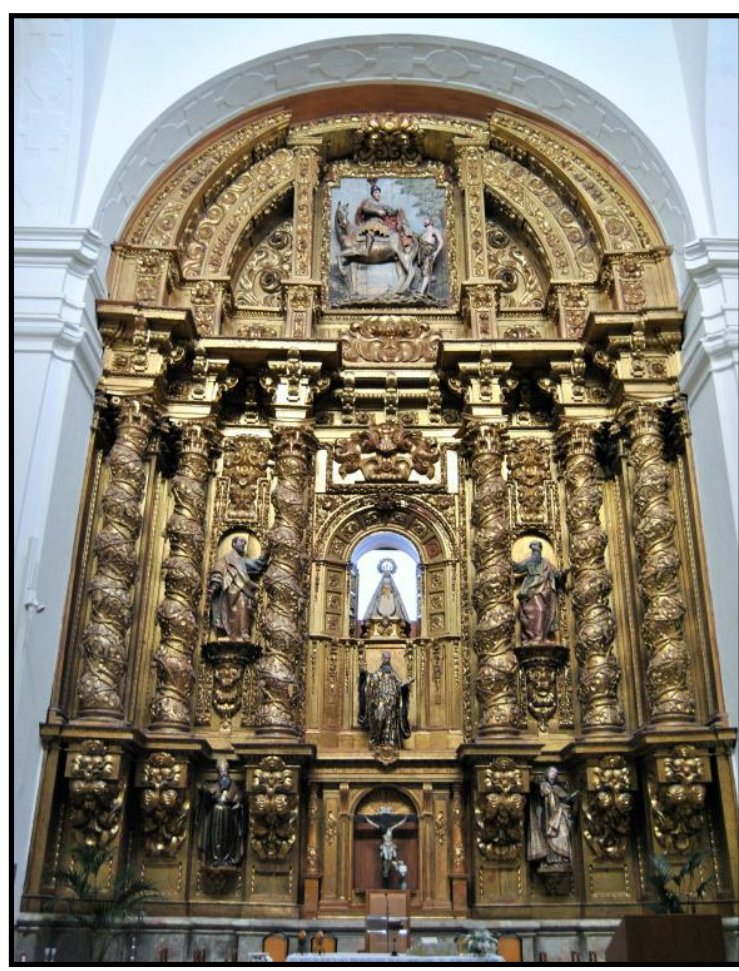

Fig. 66- Pedro de Cea. Retablo mayor. Iglesia de San Martín. Valladolid.

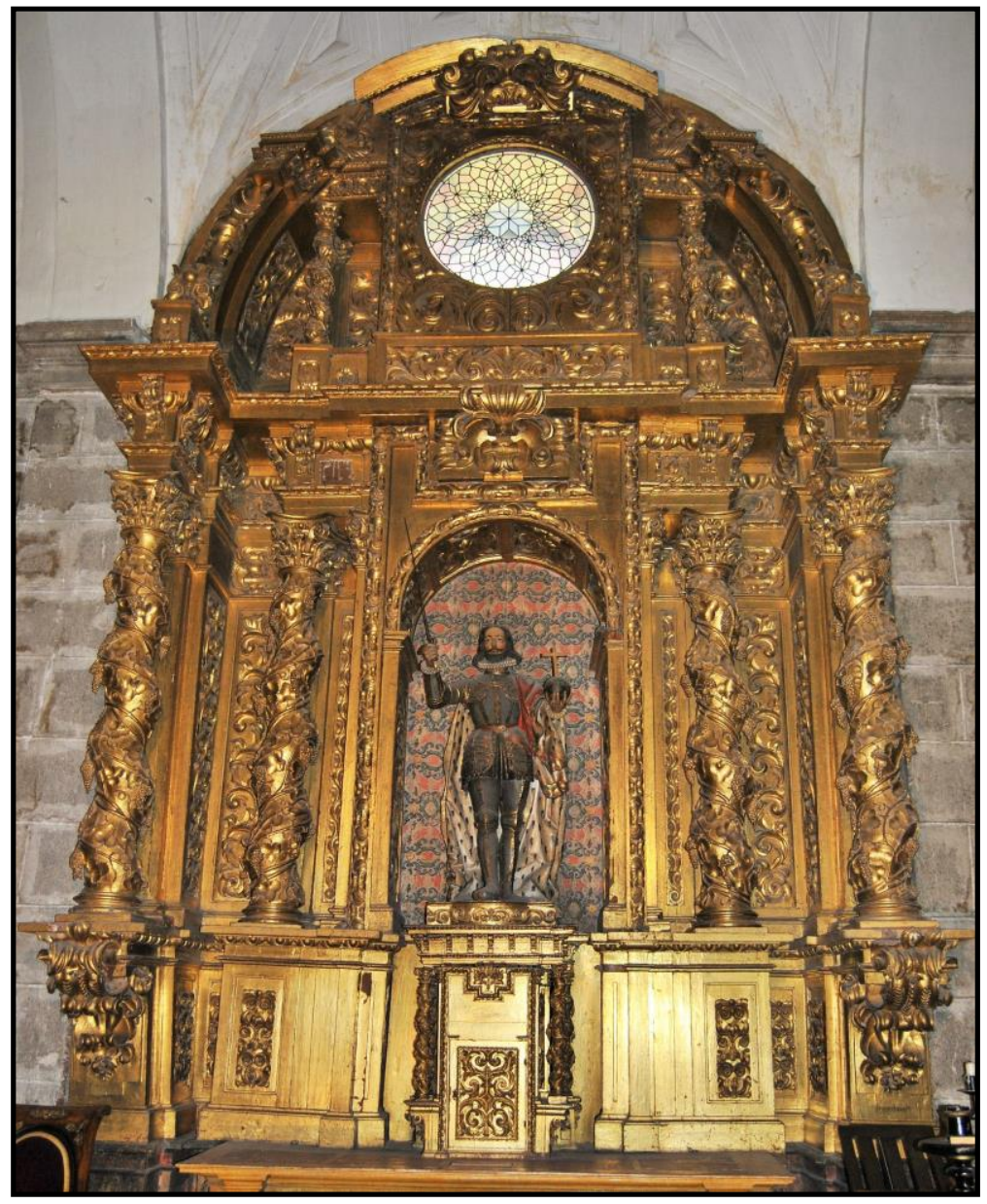

Fig. 67- Pedro de Cea. Retablo de San Fernando. Catedral. Valladolid.

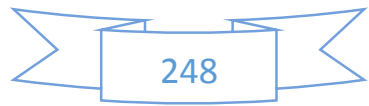




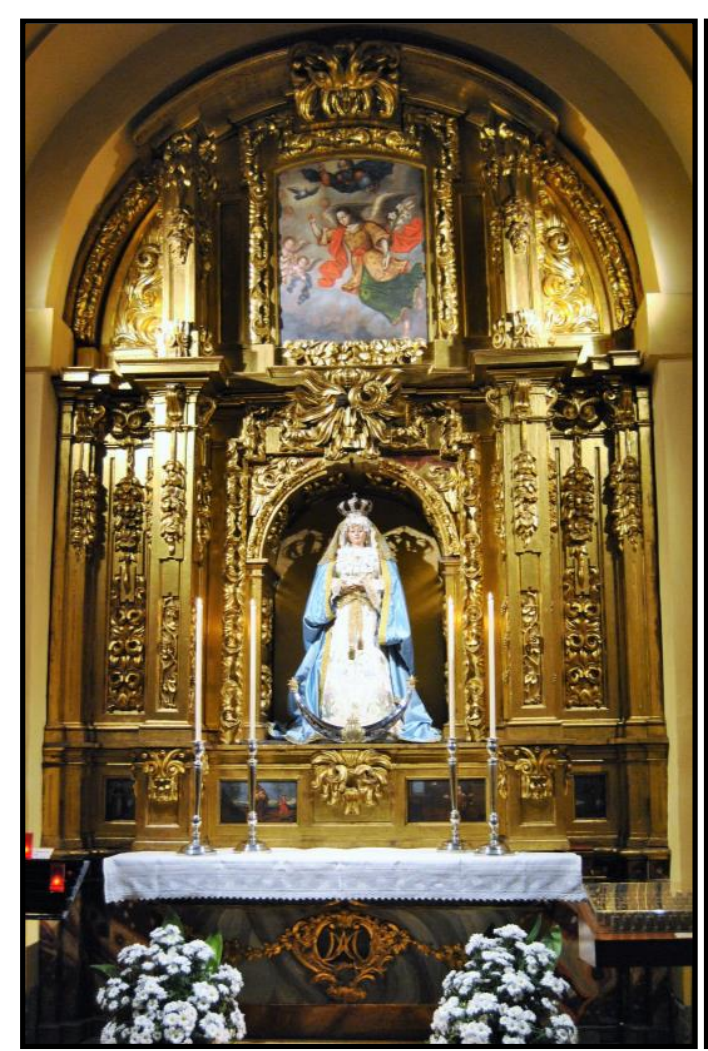

Fig. 68- Juan Guerrero. Retablo de la Encarnación. Iglesia penitencial de Nuestra Señora de las Angustias. Valladolid.

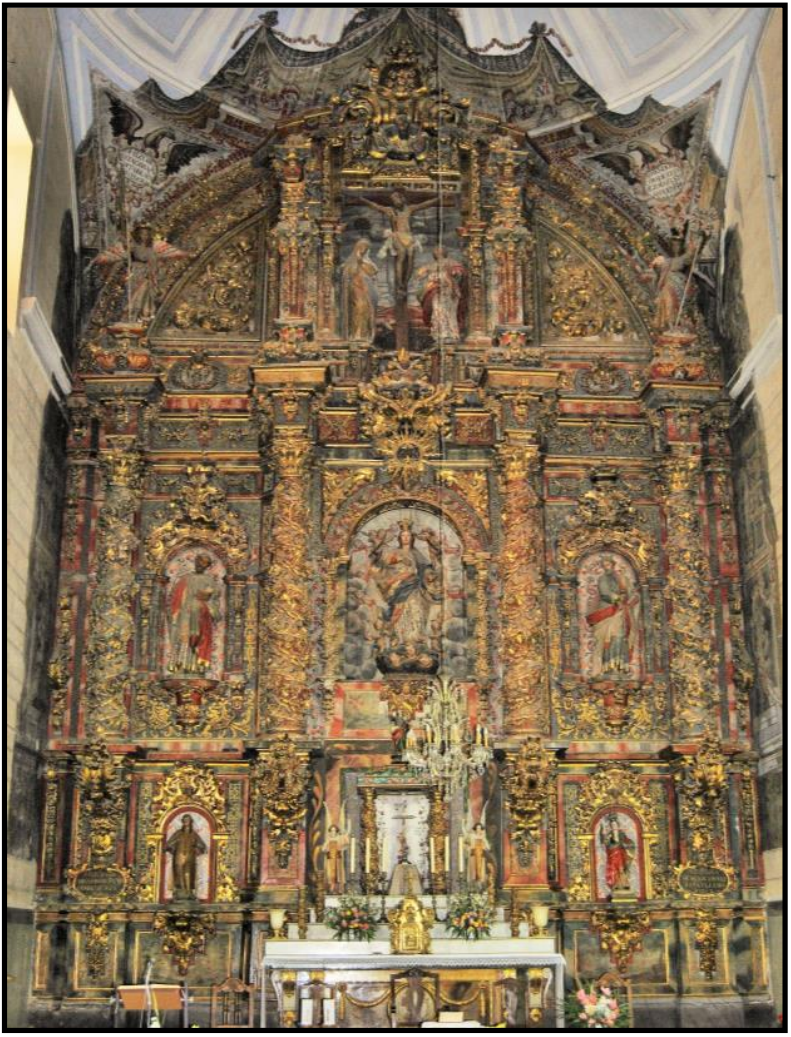

Fig. 70- Gregorio Díaz de Mata. Retablo mayor. Iglesia de la Asunción. Casasola de Arión (Valladolid).

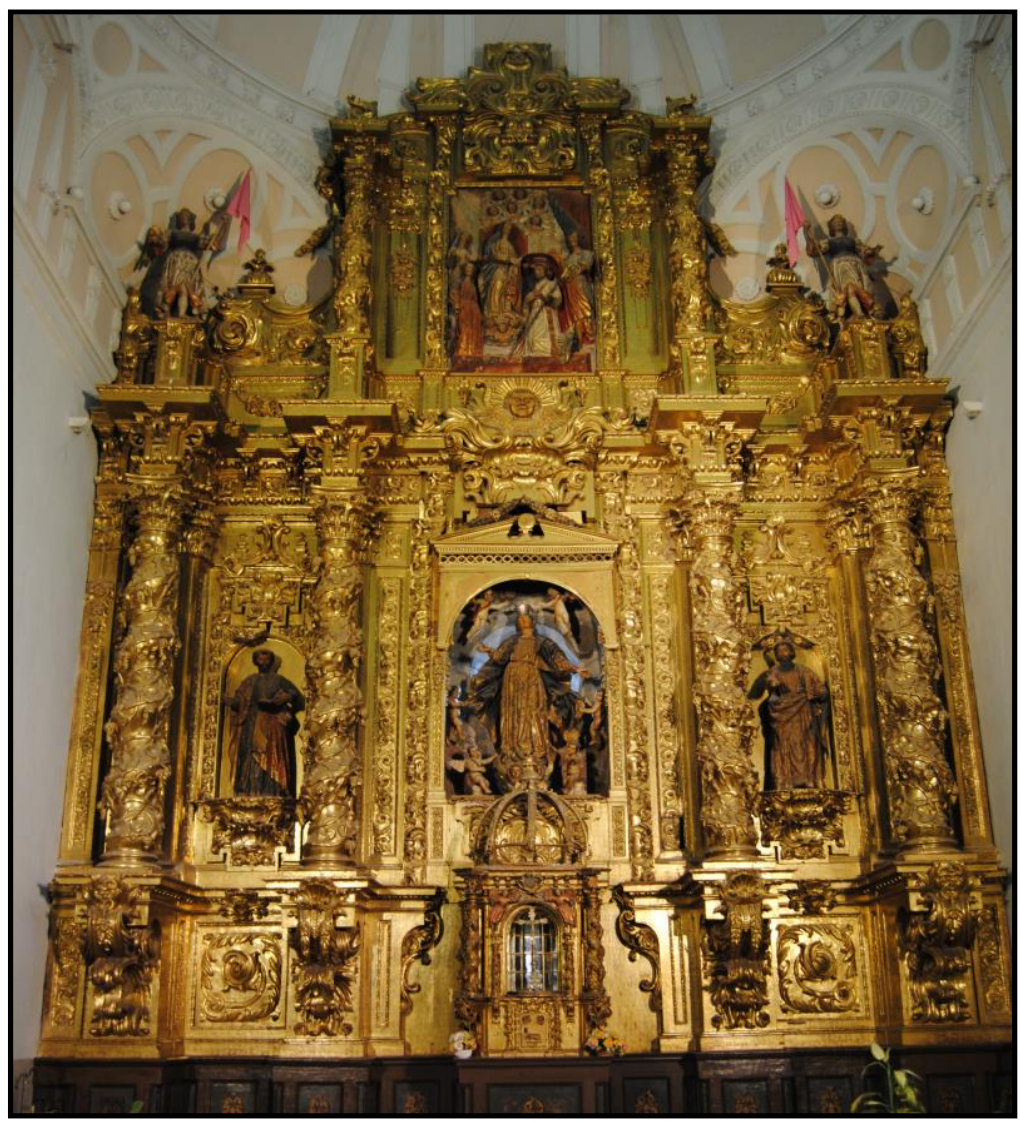

Fig. 69- Gregorio Díaz de Mata, Blas Martínez de Obregón y Francisco Billota. Retablo mayor. Iglesia de Santa María. Pozaldez (Valladolid).

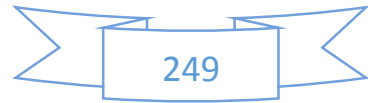




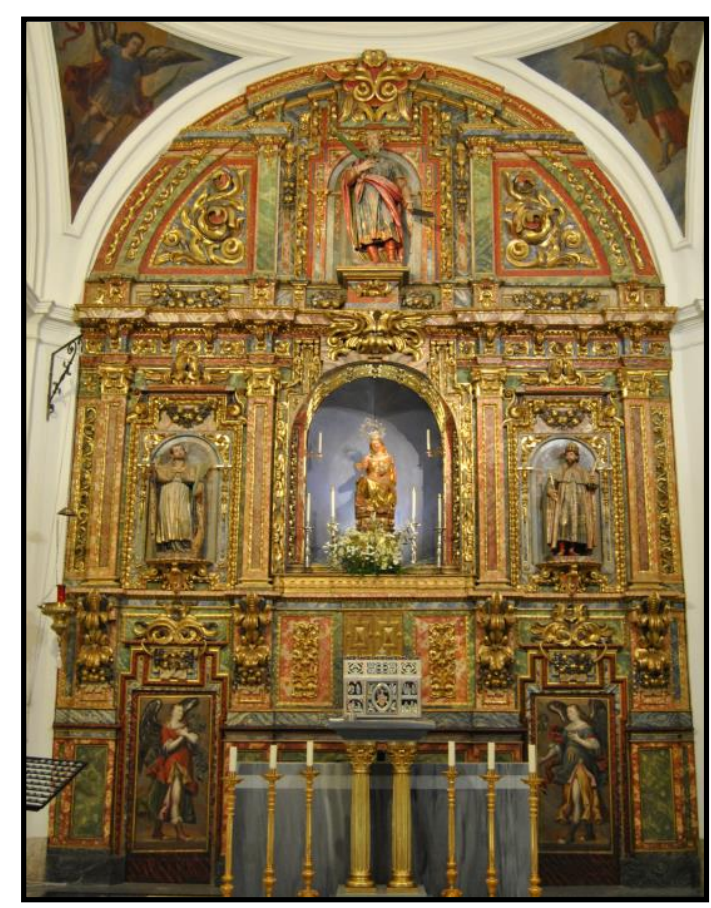

Fig. 71- Blas Martínez de Obregón. Retablo mayor. Colegio de los Ingleses. Valladolid.

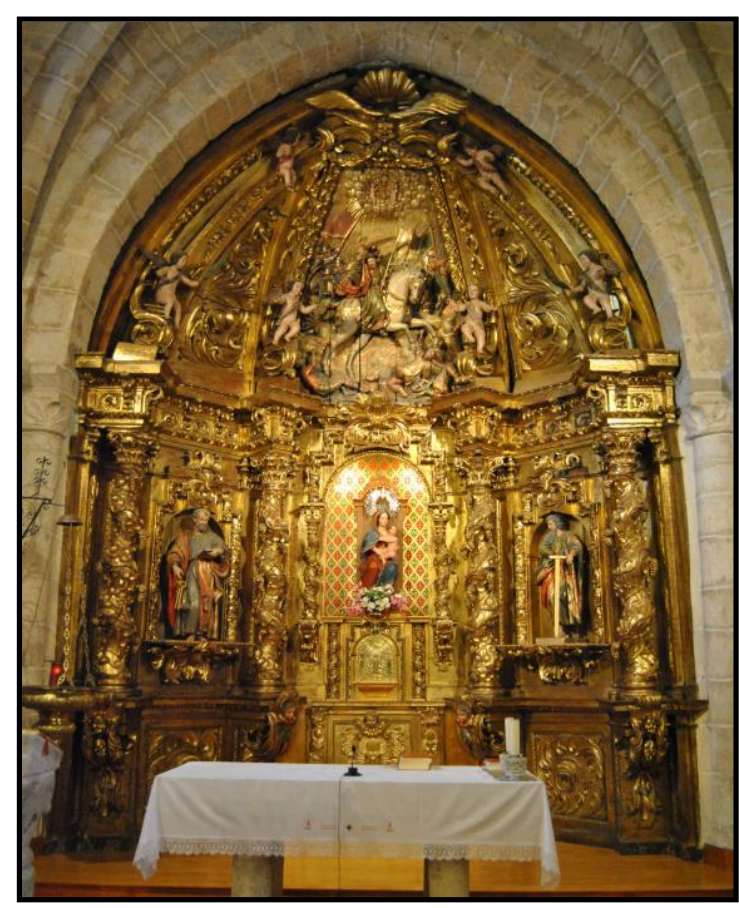

Fig. 73- Blas Martínez de Obregón. Retablo mayor. Iglesia parroquial de Santiago. Villalba de los Alores (Valladolid).

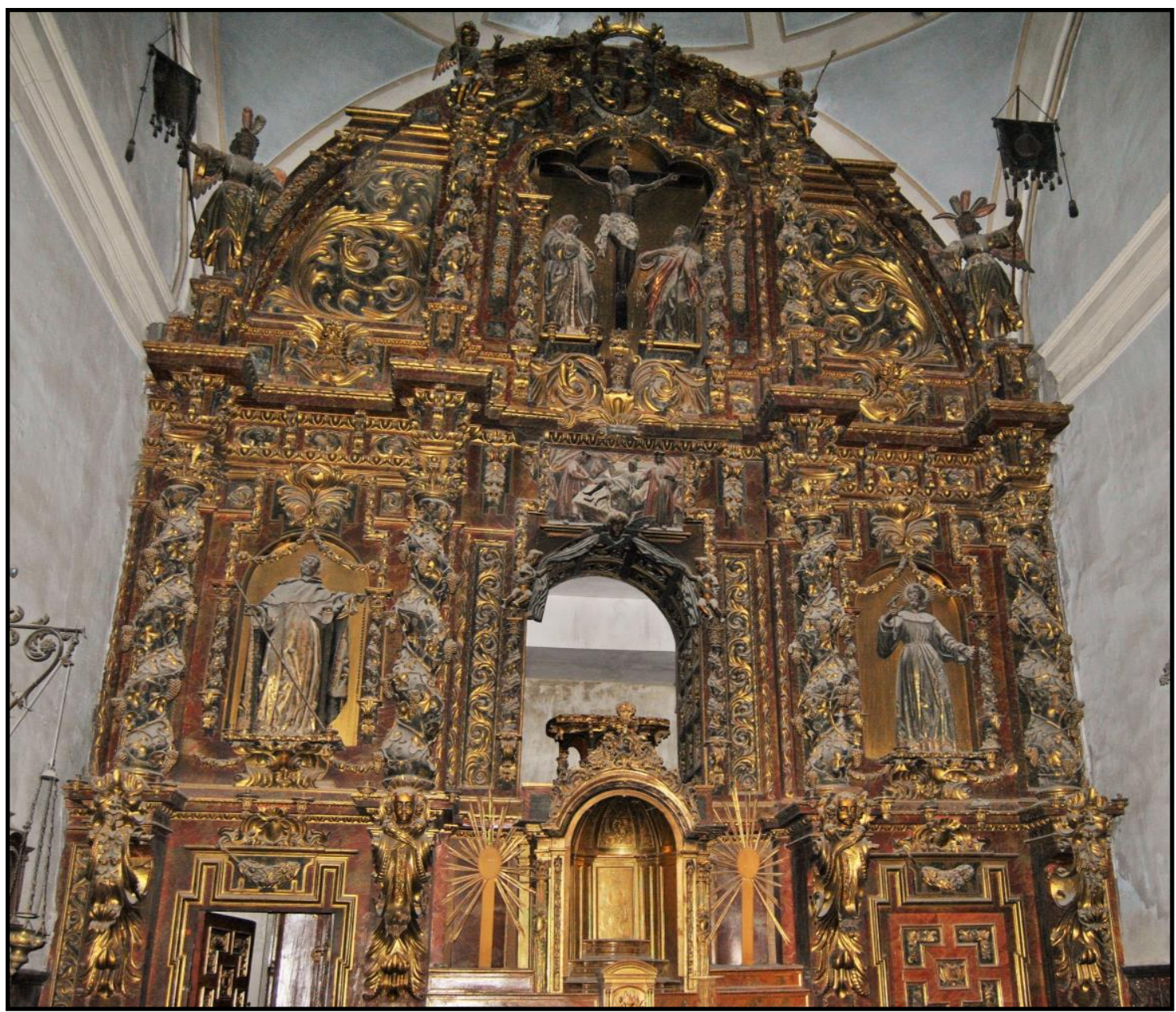

Fig. 72- Blas Martínez de Obregón. Retablo mayor. Iglesia de Nuestra Señora del Rosario. Valladolid.

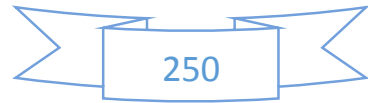




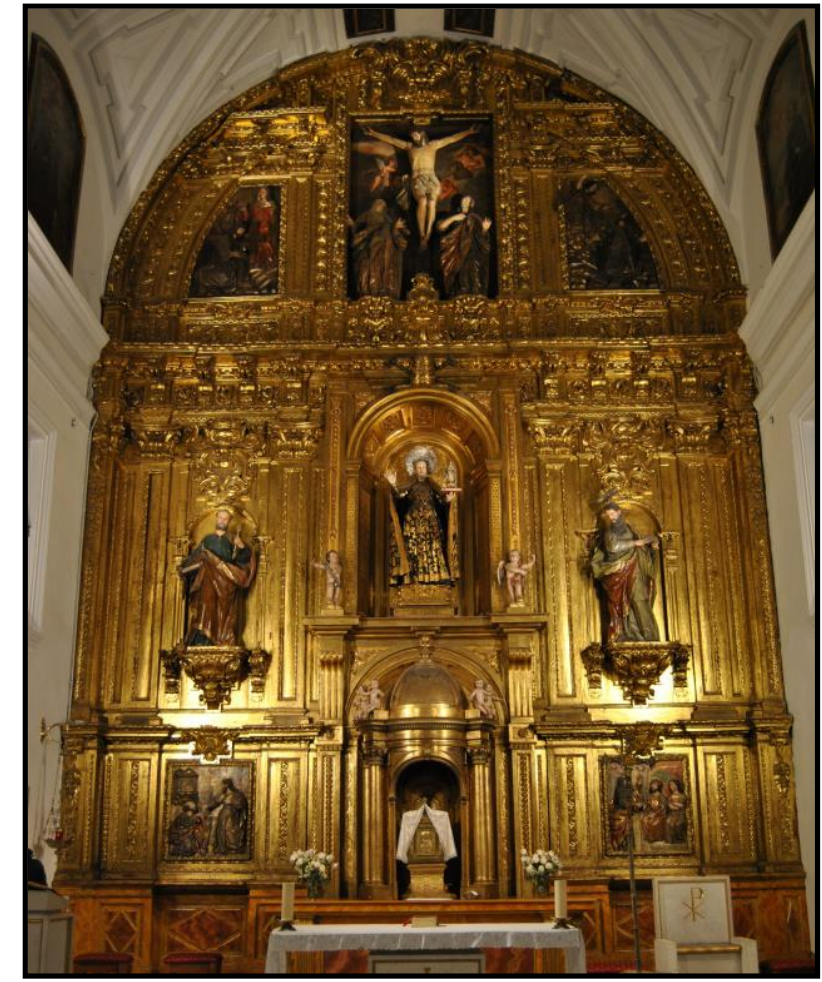

Fig. 74- Francisco Billota. Retablo mayor. Oratorio de San Felipe Neri. Valladolid.

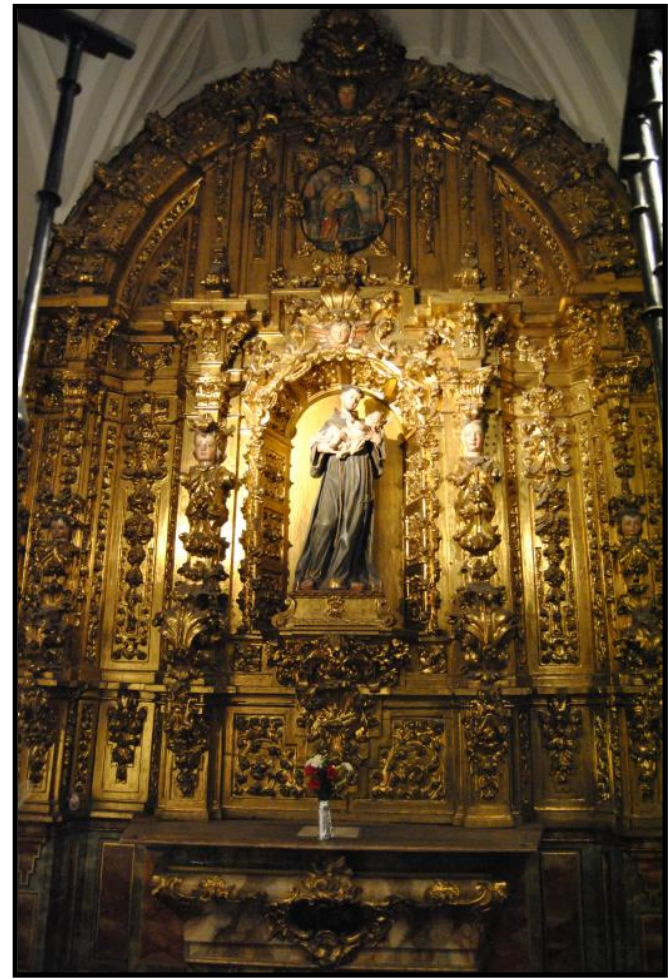

Fig. 76- Francisco Billota. Retablo del cuerpo de la iglesia. Oratorio de San Felipe Neri. Valladolid.

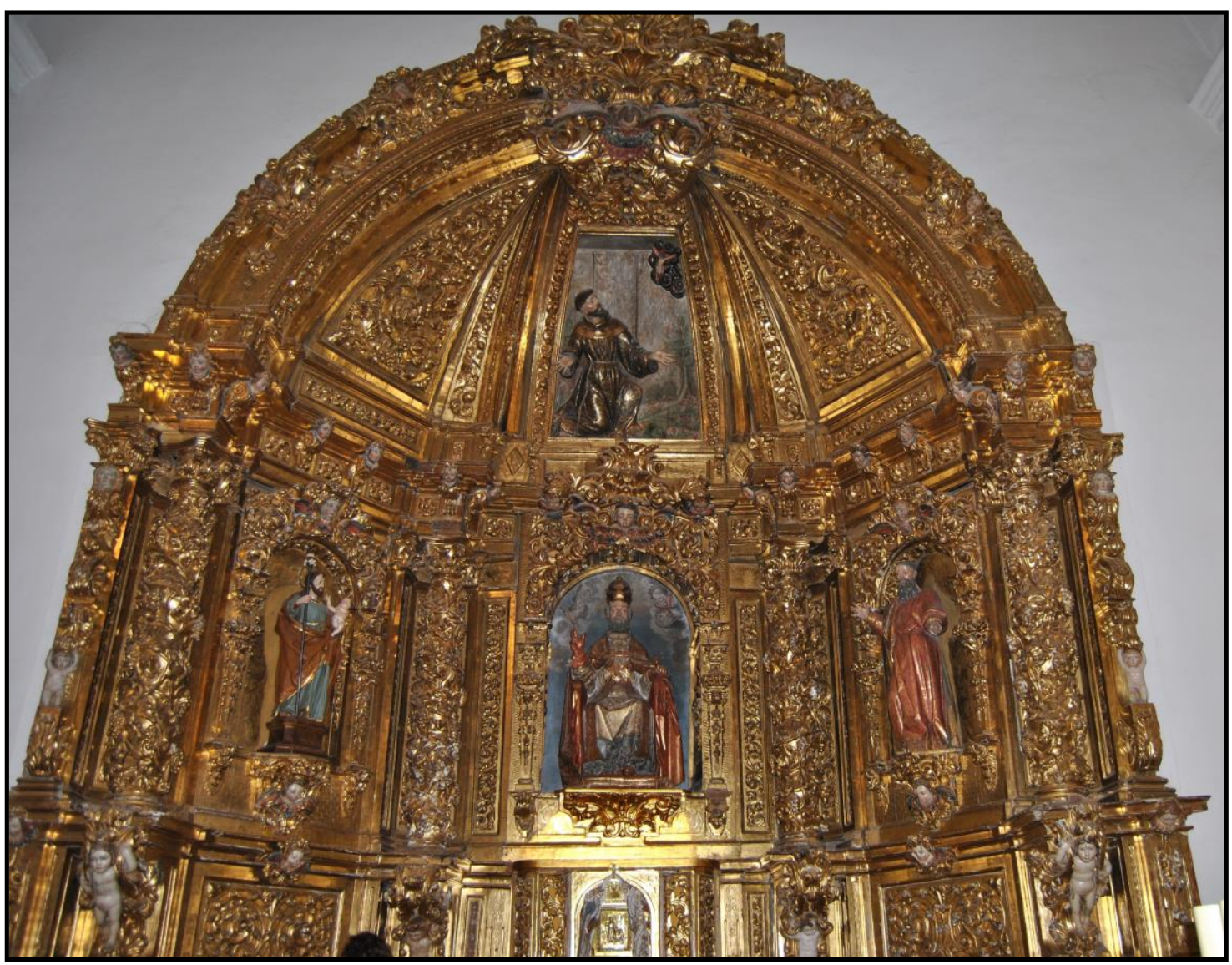

Fig. 75- Francisco Billota. Retablo mayor. Iglesia parroquial de San Pedro Apóstol. Serrada (Valladolid).

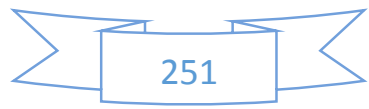




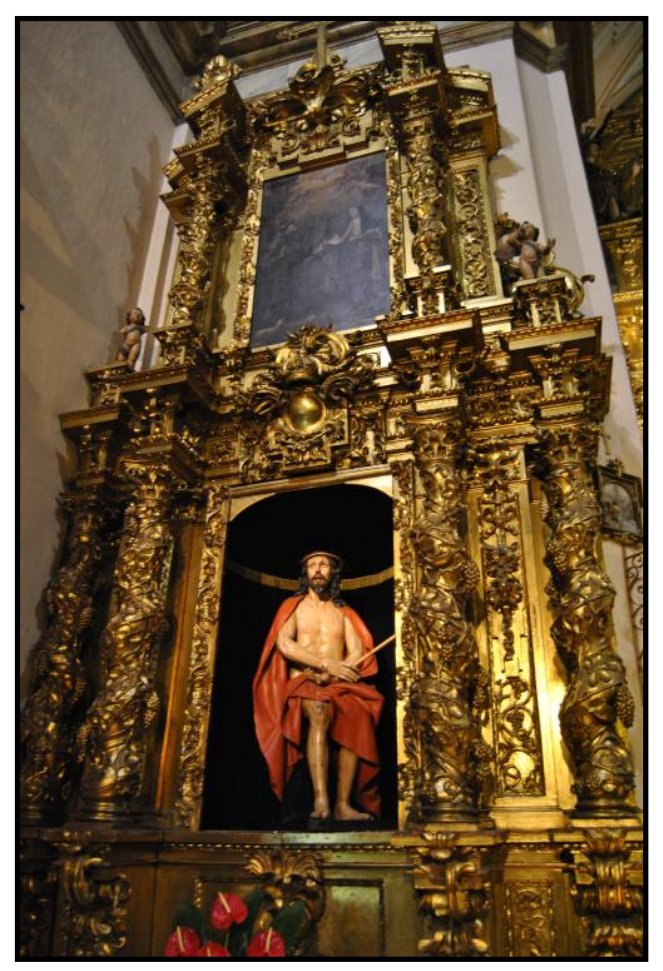

Fig. 77- Alonso Manzano. Retablo colateral del Evangelio. Iglesia penitencial de la Santa Vera Cruz.

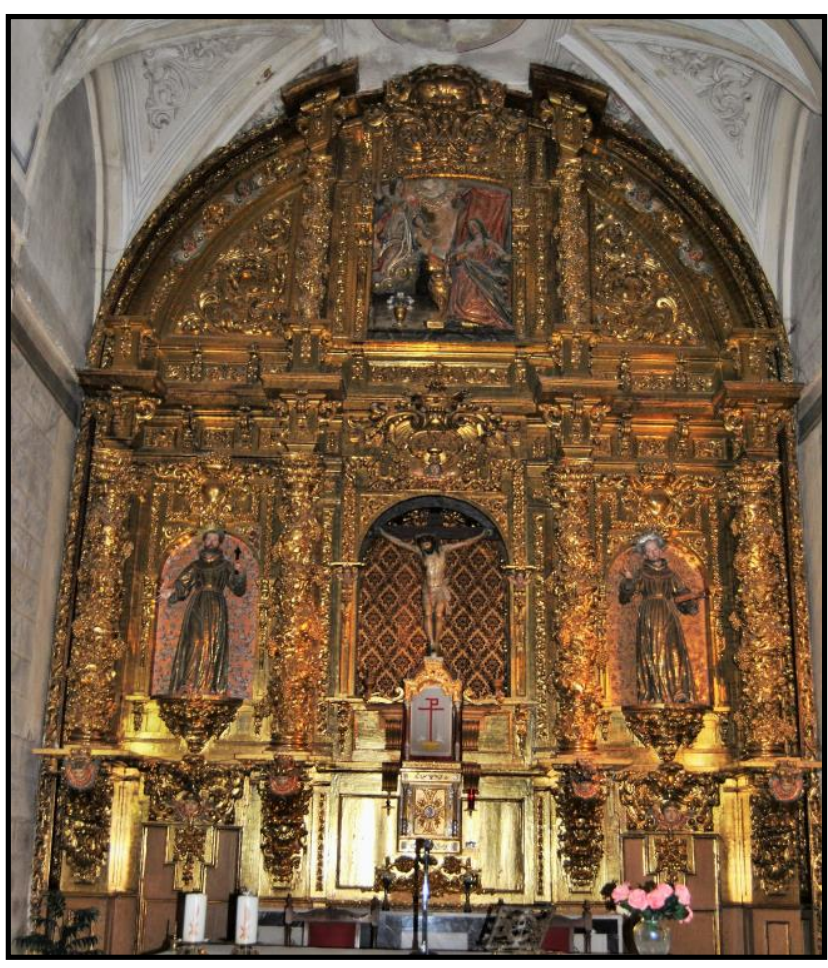

Fig. 78- Alonso Manzano. Retablo mayor. Convento de Santa Clara. Peñafiel (Valladolid).

Valladolid.

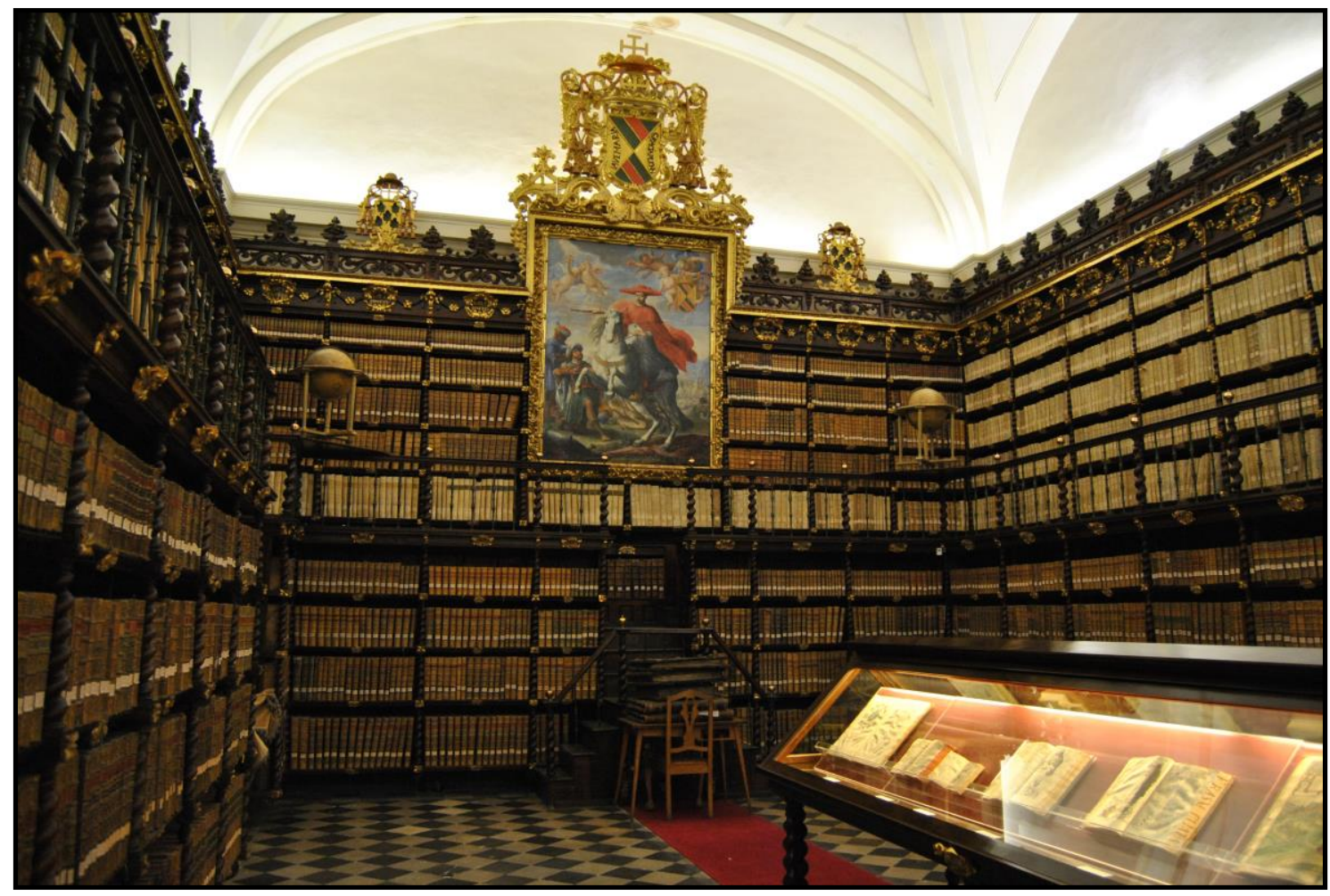

Fig. 79- Alonso Manzano. Estantería de la Biblioteca. Colegio de Santa Cruz. Valladolid.

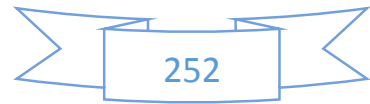



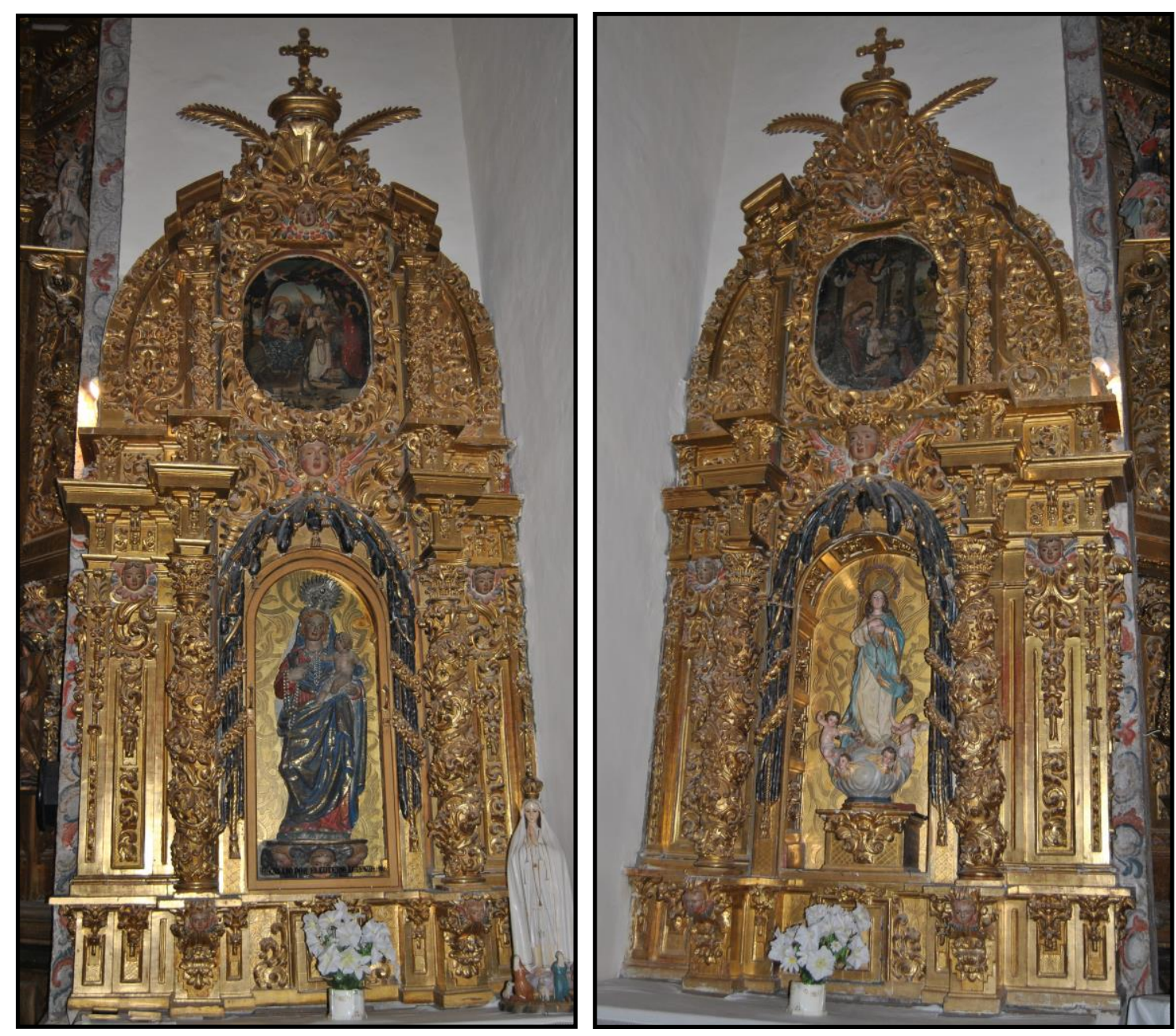

Figs. 80-81- Alonso Manzano. Retablos colaterales. Iglesia parroquial. Villavieja del Cerro (Valladolid).

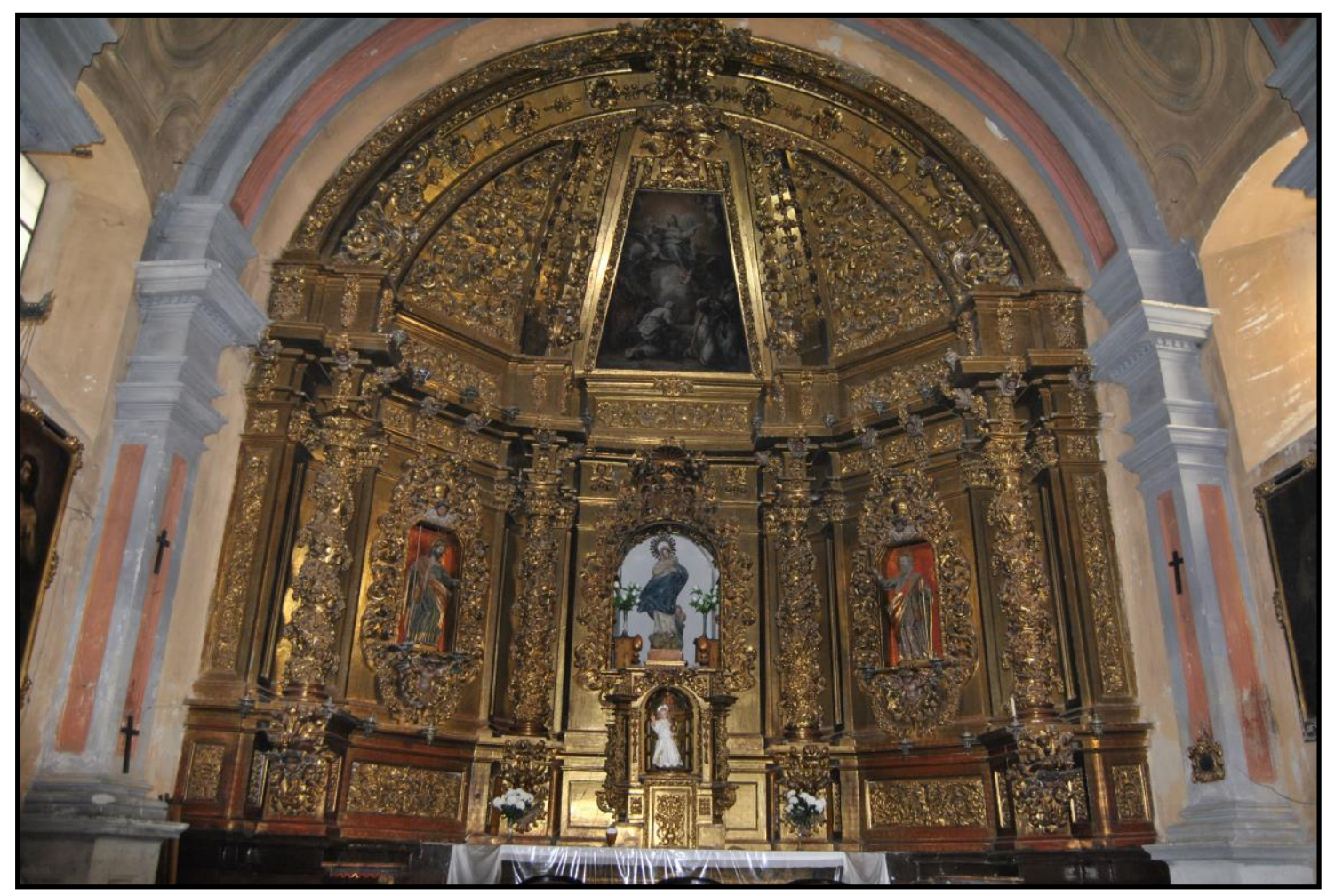

Fig. 82- Juan Correas. Retablo mayor. Iglesia de Santa María de la Cuesta. Cuéllar (Segovia).

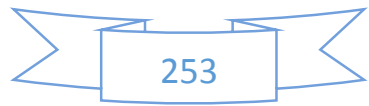




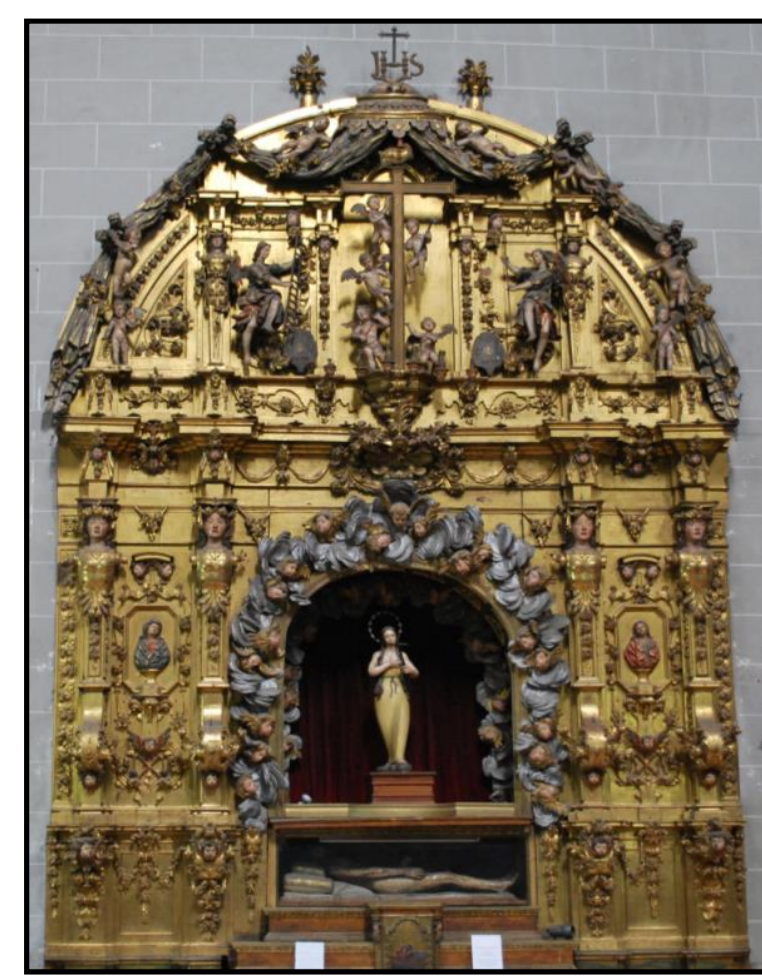

Fig. 83- Juan Correas. Retablo del Santo Sepulcro. Iglesia de Santa María Magdalena. Valladolid.

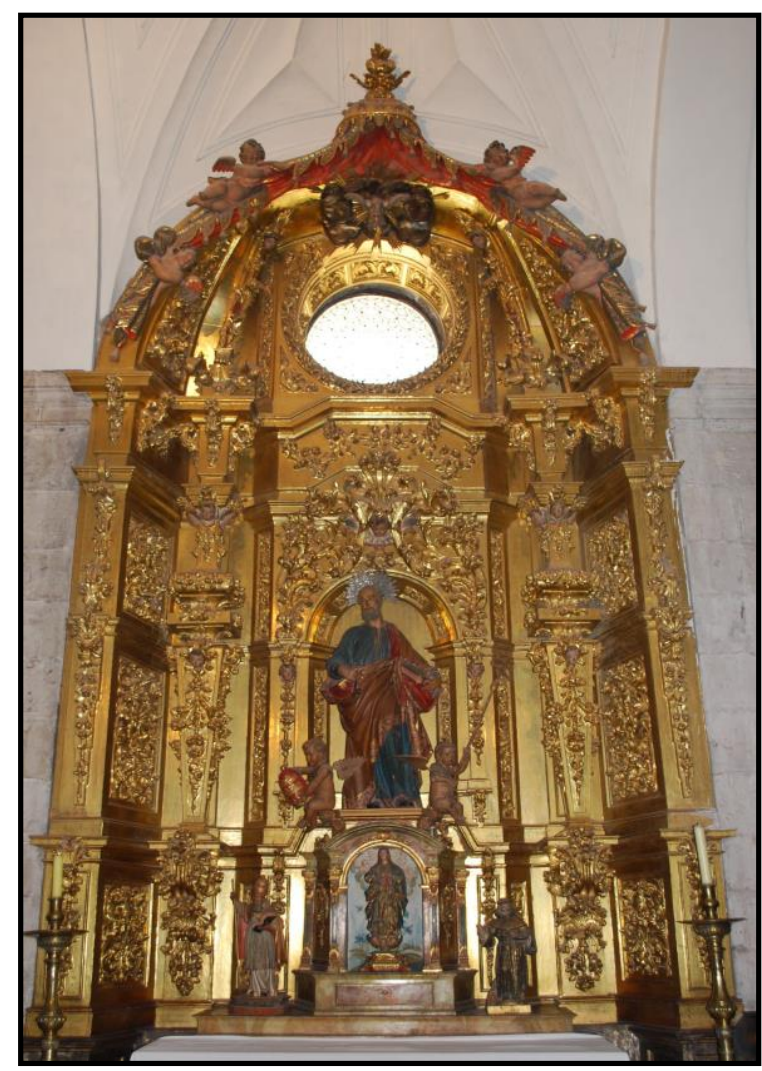

Fig. 85- Pedro de Ribas. Retablo de San Pedro. Catedral. Valladolid.

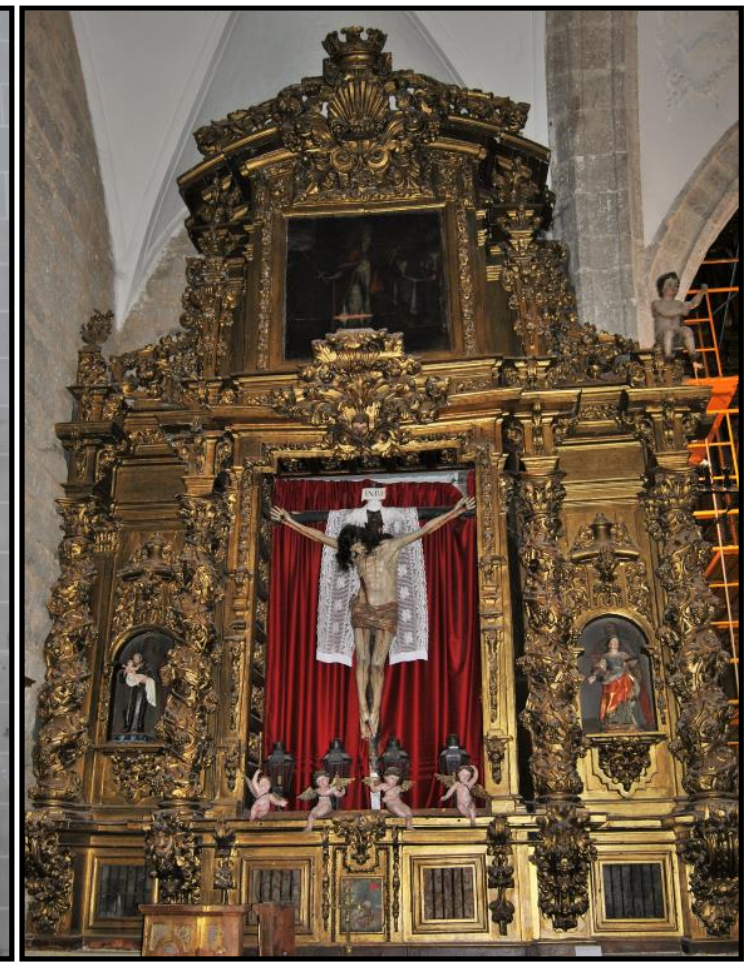

Fig. 84- Pedro de Ribas. Retablo del Cristo de la Vera Cruz. Iglesia de San Juan Bautista. Tagarabuena (Zamora).

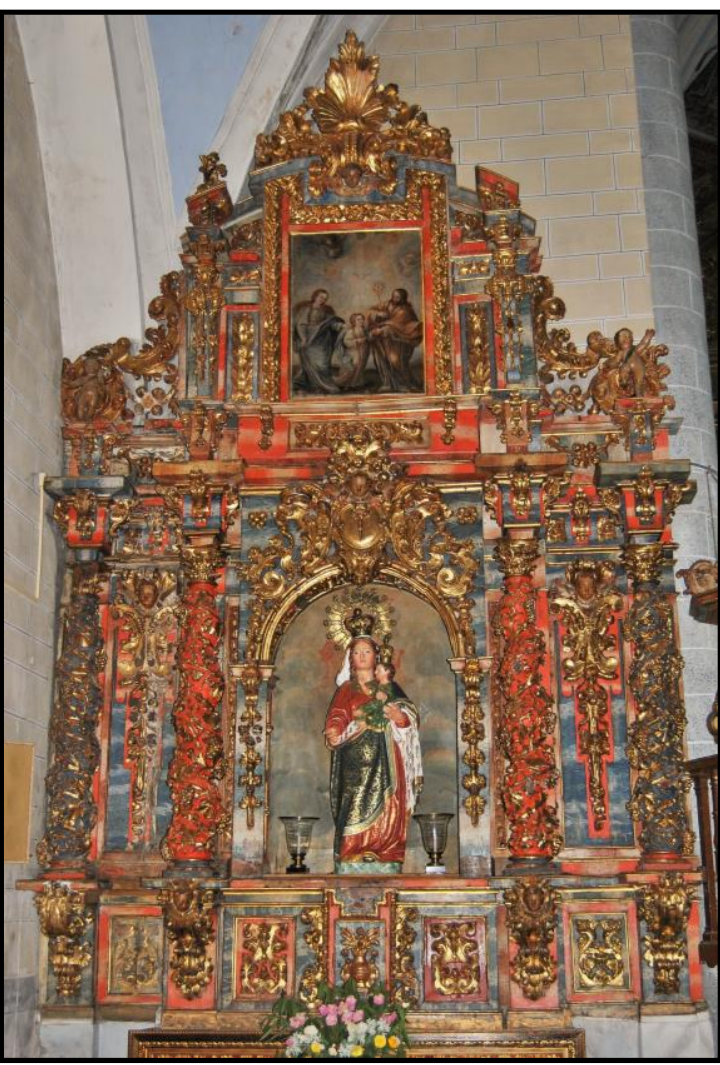

Fig. 86- José Díaz de Mata. Retablo colateral del Evangelio. Iglesia de la Asunción.

Casasola de Arión (Valladolid). 


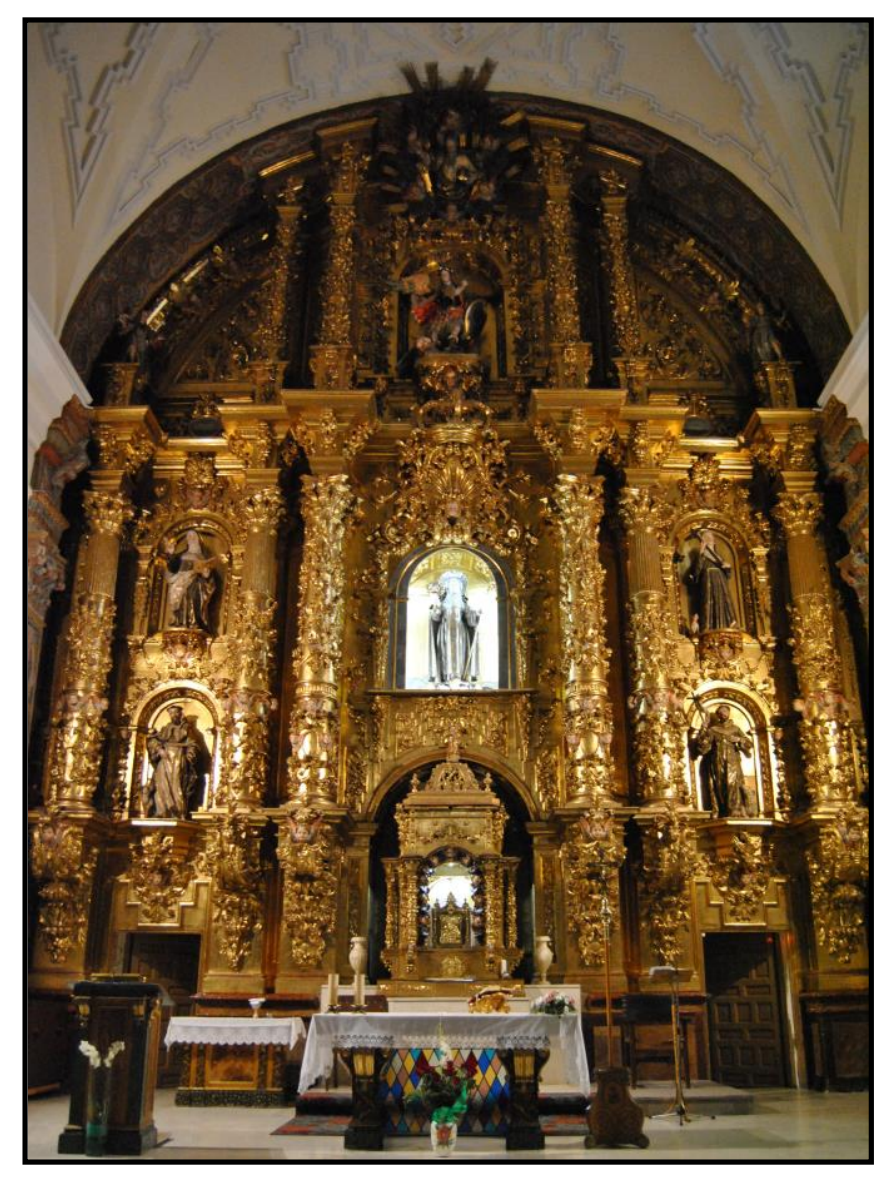

Fig. 87- Pedro Correas. Retablo mayor. Convento de Santa Clara. Valladolid.

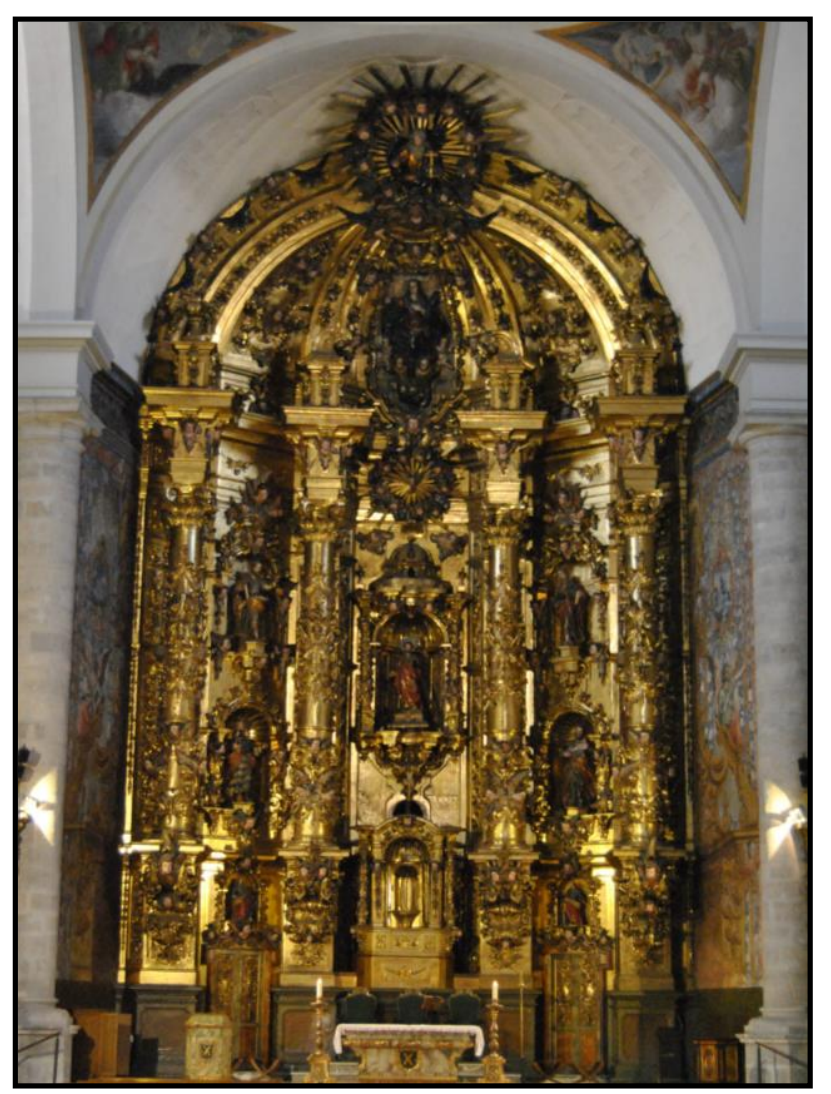

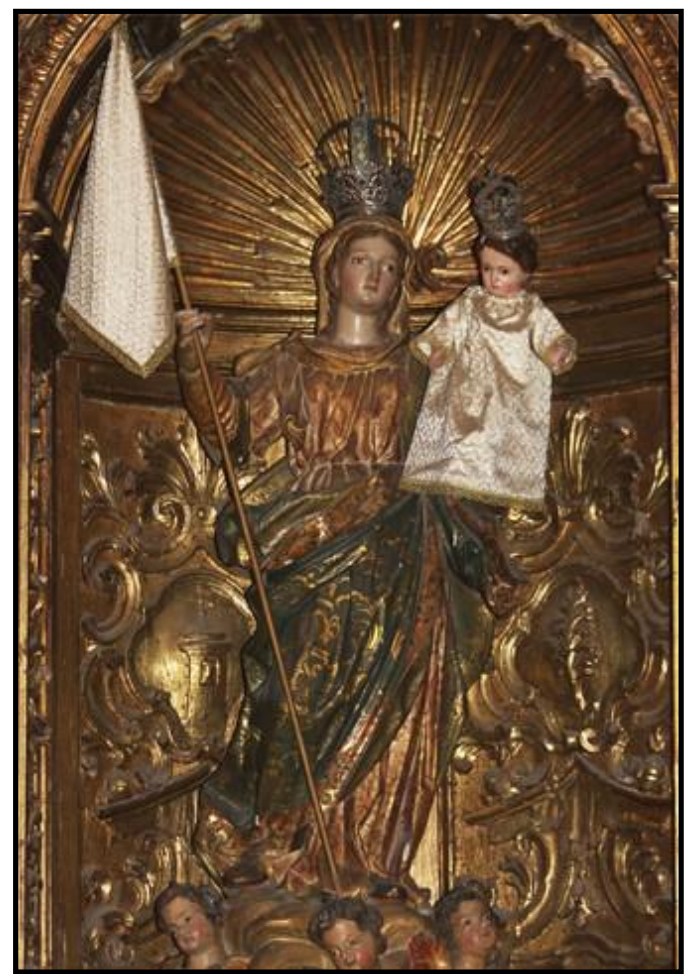

Fig. 88- Pedro Correas. Nuestra Señora de la Paz. Ermita de Nuestra Señora de la Paz. Cáceres.

Fig. 89- Pedro Correas. Retablo mayor.

Iglesia de San Andrés. Valladolid.

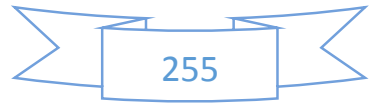




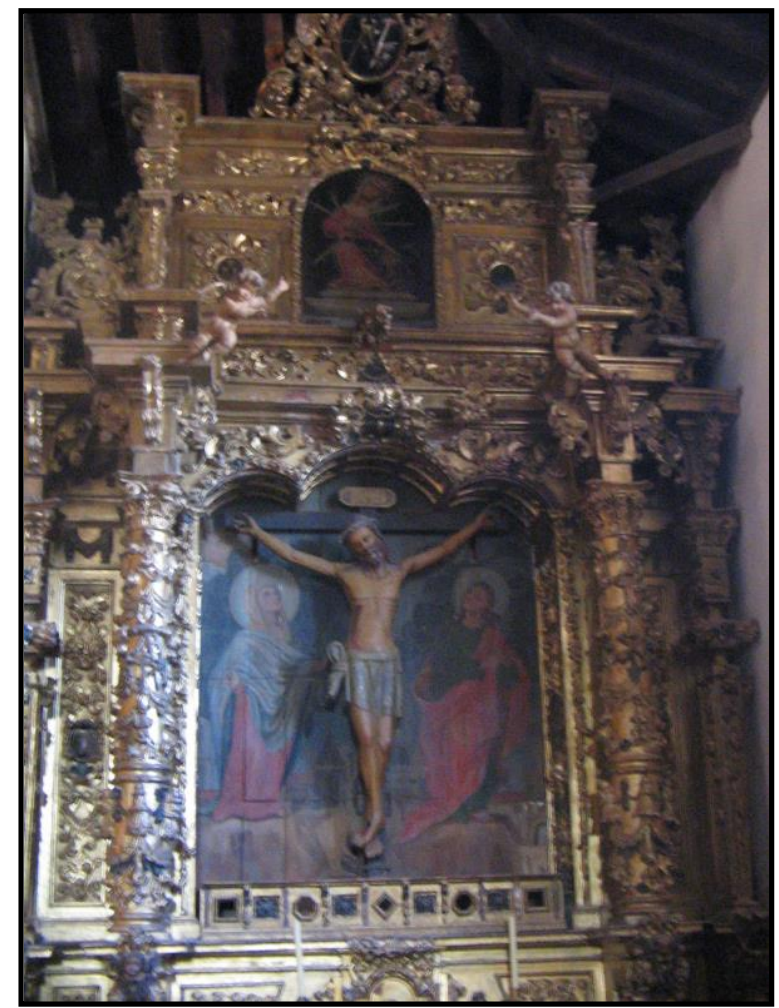

Fig. 90- Pedro Roldán. Retablo del Santo Cristo de las Batallas. Iglesia del Salvador. Morales de Toro (Zamora).

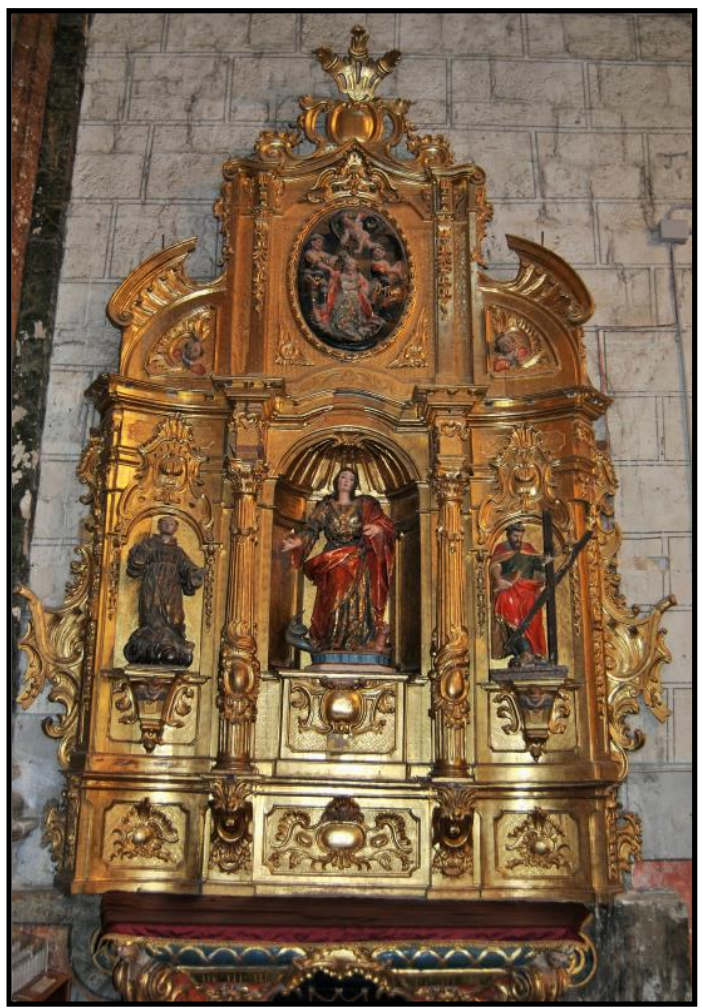

Fig. 91- Manuel Rodríguez. Retablo de Santa Marina. Iglesia parroquial de Santiago. Cigales (Valladolid).

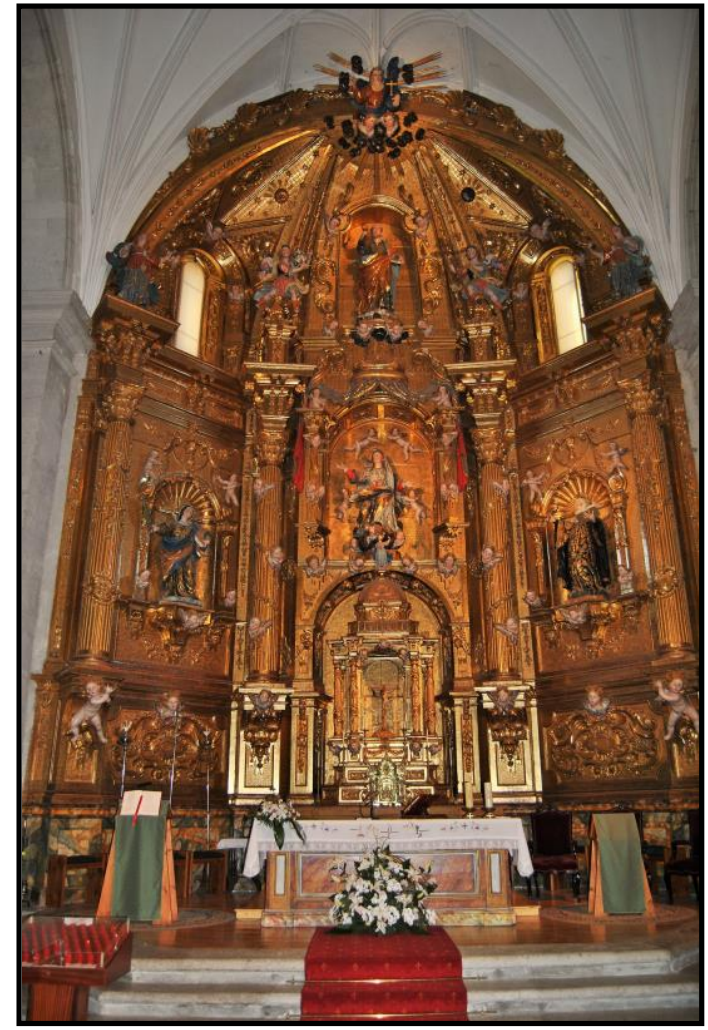

Fig. 92- Bentura Ramos. Retablo mayor. Iglesia parroquial de la Asunción. Cabezón de Pisuerga (Valladolid).

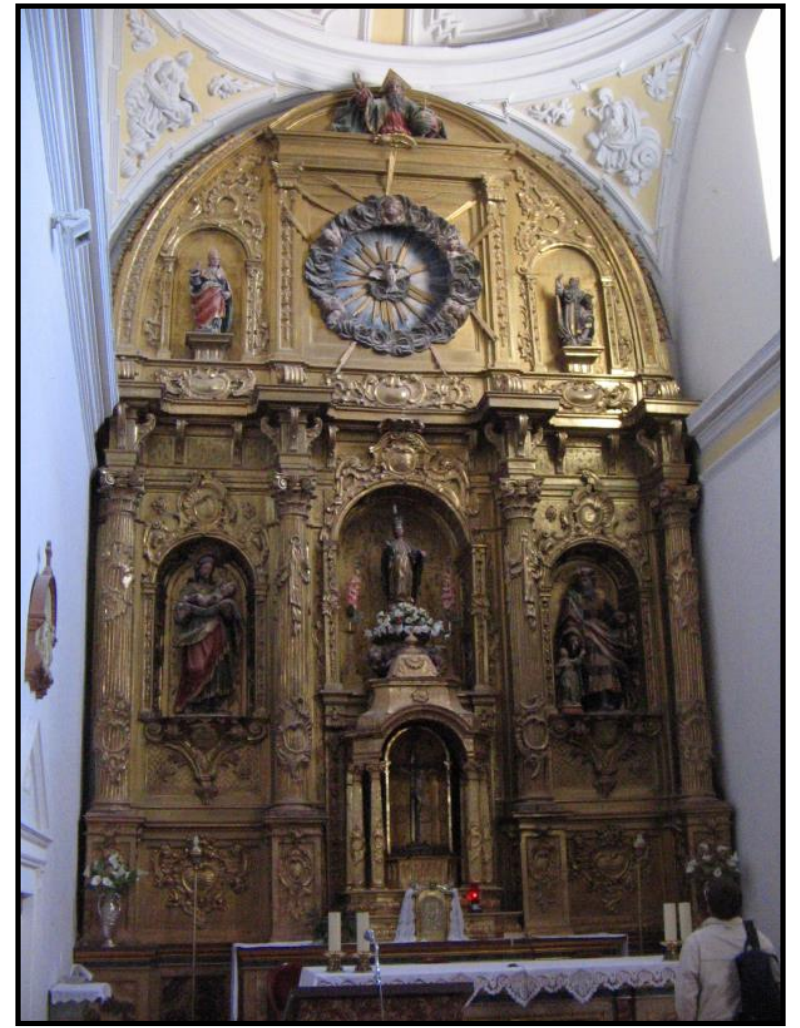

Fig. 93- Agustín Martín. Retablo mayor. Iglesia parroquial de la Asunción. La Pedraja de Portillo (Valladolid). 


\section{3- JUAN DE ÁVILA. PERSONAIIDAD}


$\sum[258 \leq$ 


\section{3-1 BIOGRAFÍA}

\section{A- ETAPA JUVENIL $(1652-1667)$}

Juan de Ávila viene al mundo en el seno de una modesta familia de zapateros residentes en la vallisoletana calle del Campo (o de Santiago), si bien la ascendencia paterna procedía de la villa de Alaejos (Valladolid). Tanto el barrio que presidía la parroquia de Santiago Apóstol como la calle del mismo nombre destacaban desde hacía tiempo, y siguieron destacando, por contar entre sus habitantes con multitudes de artistas y maestros de obra prima (zapateros). En un principio la mayoría de estos artistas fueron pintores, con el paso del tiempo veremos nacer y vivir allí a escultores, arquitectos, ensambladores e incluso plateros.

Del esplendor que gozó la ciudad a principios de siglo tan sólo queda el recuerdo en los más adultos. Abandono y pobreza son las características de la vida local en estos años. La ciudad se va despoblando a marchas forzadas y, al mismo tiempo, el caserío queda abandonado por los que emigran, lo que conlleva la ruina de los edificios ${ }^{1}$. Era una ciudad sucia y en la que por algunas calles la pestilencia era la norma. A pesar de todo, la labor artística en la ciudad no se interrumpió y sus talleres siguieron gozando de un crédito y prestigio merecidos. Es en este ámbito en el que nace uno de los vallisoletanos que alcanzó unas cotas más altas dentro del mundo de la escultura.

Juan de Ávila Martínez nace el día 7 de febrero de 1652 en la casa que sus padres poseían en la populosa y céntrica calle de Santiago, la cual dicha casa lindaba "con casas del Colegio de San Gregorio". Sus progenitores Hernando de Ávila y Juana Martínez le llevaron a recibir las aguas bautismales el día 21 de ese mismo mes a la iglesia de Santiago Apóstol. El encargado de sacramentar al pequeño fue el cura Francisco García $^{2}$. Ejercieron de padrinos de la

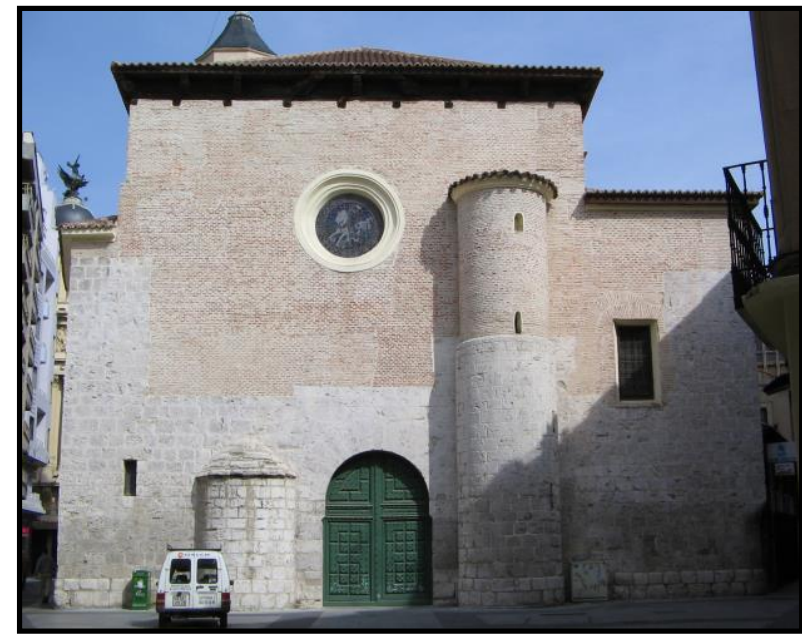

Il. 1- Iglesia de Santiago Apóstol. Valladolid. criatura el mercader Francisco Díez Moreno e Isabel de Ballerna, mientras que asistieron al feliz acontecimiento en calidad de testigos Diego de Pesquera y Manuel Gallegos. Como abogado se le dio a San Victoriano $^{3}$, patrón de la villa de Arévalo

GUTIÉRREZ ALONSO, Adriano: op. cit., p. 33.

"En veinte y uno de febrero de mil seiscientos y cincuenta y dos bauticé e impuse los santos oleos conforme el Santo Concilio manda a Juan hijo de Hernando de Ávila y de Juana Martínez fueron padrinos Francisco Díez Moreno y Isabel de Ballerna fueron testigos Diego de Pesquera y Manuel Gallegos nació en siete del dicho mes dieronle por abogado a San Victoriano". A.G.D.V., Santiago, 1643B, f. 160. FERNÁNDEZ DEL HOYO, María Antonia: "El escultor vallisoletano Francisco Díez de Tudanca...”, op. cit., p. 384.

3 San Victoriano, Bitorino, Vitorino o Victorino fue un mártir romano, hermano de San Claudio y tío de San Sinforiano, que ejerció el cargo de Alcaide de los presos. Se convirtió al cristianismo al igual 
(Ávila). Pudiera ser que los orígenes de la familia paterna se remontaran a Arévalo dada la devoción que tenían por el santo arevalense. Además, dicha localidad, la cual no se halla muy distante de Alaejos, casaría muy bien con el apellido Ávila.

Contando con apenas cinco años, el 6 de agosto de 1657, su padre fallece, dejándole a él como a su hermano Manuel huérfanos ${ }^{4}$. En el testamento realizado por Hernando (DOCUMENTO 1), otorgado ese mismo día, les dejaba nombrados a ambos, "hijos legítimos de la dicha mi mujer", como herederos universales, si bien sería su esposa, y madre de ambos, la que se encargaría de administrar los bienes de los niños hasta que estos alcanzaran la mayoría de edad, cifrada por entonces en 25 años.

El 6 febrero de 1659 su madre rehízo su vida y contrajo matrimonio por tercera vez ${ }^{5}$, en este caso junto al maestro de obra prima Gabriel Rodríguez del Pozo. El padrastro de Juan de Ávila debió de tratarle tanto a él como a su hermano Manuel como si en realidad fueran hijos suyos, de hecho Juana confiesa en su testamento que a los "hijos del dicho Hernando de Ávila los ha alimentado y sustentado, vestido y calzado hasta hoy (...) y enseñándoles a leer y escribir" (DOCUMENTO 2).

La escasez de noticias de su infancia, lógica por otra parte, hace que hasta el 28 de julio de 1665 no sepamos nada de él. Ese día recibe la confirmación en la iglesia de Santa María Magdalena, a los pies del grandioso retablo mayor, obra del romanista Esteban Jordán. El padrino de la celebración fue el cura de San Benito el Viejo, Juan de Navas ${ }^{6}$. Confirmada su fe no faltaría ni los domingos ni las fiestas de guardar a oír misa a la iglesia de Santiago donde el joven quedaría marcado al ver obras tan importantes como el Cristo de la Luz o de las Mercedes atribuido a Pompeo Leoni, y el retablo de la Epifanía de Alonso Berruguete. No cabe duda de que si Ávila tuvo desde pequeño inclinaciones artísticas

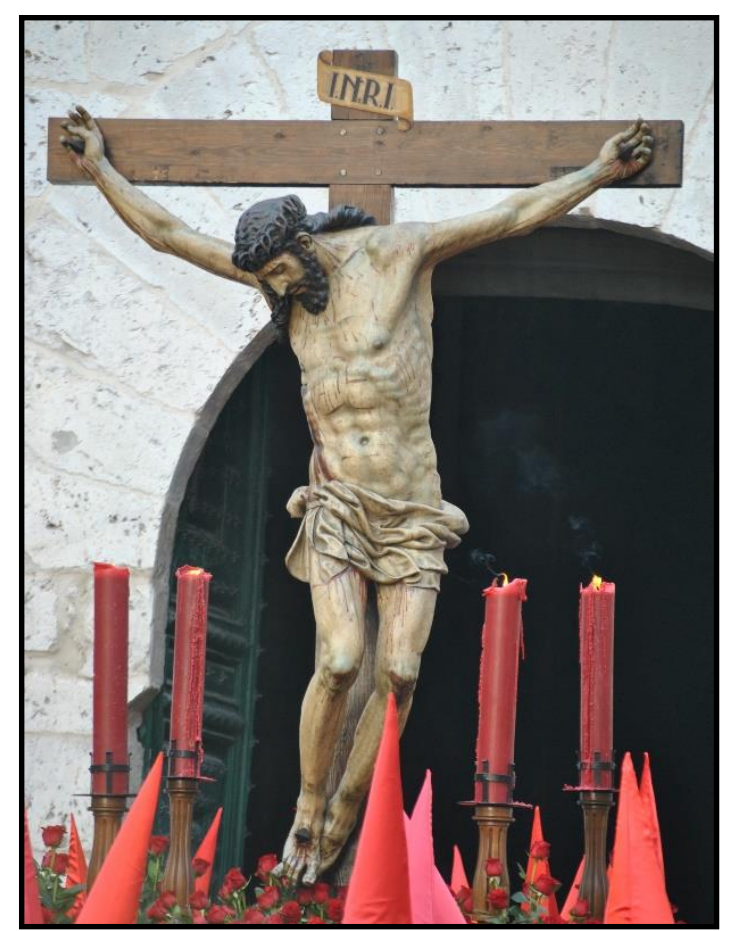

Il. 2- ¿Pompeyo Leoni? Cristo de las Mercedes. Iglesia de Santiago Apóstol. Valladolid.

que sus dos parientes gracias a las predicaciones y milagros de San Sebastián. Se le condenó a morir lanzado al mar atado con grandes pesas.

Como ya se dijo anteriormente había un tercer hermano, Hernando, pero no sabemos en qué fecha moriría, aunque lo hizo antes de la muerte de su padre en 1657 , pues no aparece citado en su testamento.

5 A.G.D.V., Valladolid, Santiago, 1609M, f. 215

6 "En veinte y siete de julio de mil y seiscientos y sesenta y cinco años su señoría Ilma. El Señor don Francisco de Seijas y Losada obispo de esta ciudad de Valladolid confirmó en la iglesia de Santa María Magdalena y fue padrino el licenciado Juan de Navas cura de San Benito el Viejo (...) Segundo día de confirmación veinte y ocho de julio su padrino el dicho licenciado Juan de Navas cura de San Benito el Viejo (...) Juan. Hijo de Hernando de Ávila y de Juana Martínez”. A.G.D.V., Santiago, 1643B, s/f. 
la visión de obras de artistas tan relevantes terminaron por inclinar la balanza.

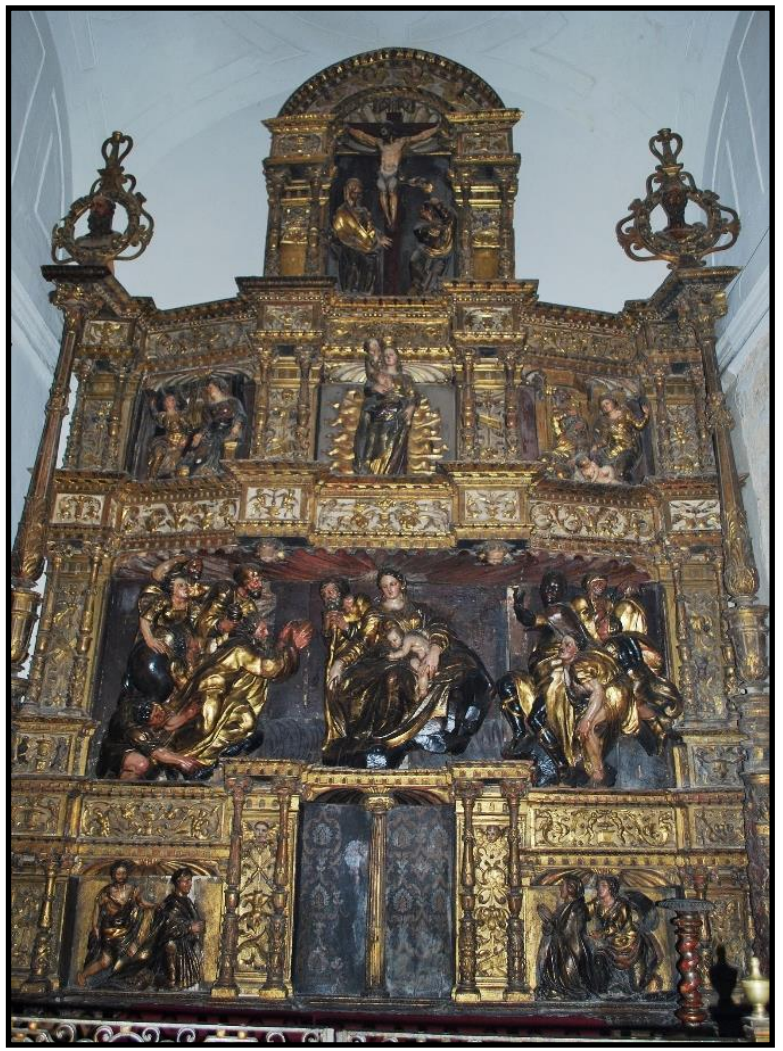

Il. 3- Alonso Berruguete. Retablo de la Epifanía. Iglesia de Santiago Apóstol. Valladolid.

Un año después, el 14 de mayo de 1666, los pequeños quedarían en la orfandad más absoluta dado que fallece su madre, a la cual se la entierra, según su deseo, en la iglesia de Santiago Apóstol ${ }^{7}$. Unos días antes había dictado testamento ante el escribano Miguel Casero, y no ante Matías Pérez como figura en la partida de defunción (DOCUMENTO 2). Juana dispuso en sus postrimeras voluntades nombrar al procurador Marco Antonio de Anaya como curador ad litem de sus dos hijos, si bien también desempeñaron ese cargo Gil de Ávila, tío de los muchachos, y el propio Gabriel Rodríguez del Pozo, padrastro de ambos $^{8}$. Asimismo, determinó que con el dinero que se obtuviera de la venta de sus bienes Juan ingresara en el taller del escultor Francisco Díez de Tudanca.

Como acabamos de decir Gil de Ávila se ocupó de los pequeños tras el fallecimiento de Juana. Efectivamente, el 30 de septiembre de 1667, Gil de Ávila como "curador que soy de las personas y bienes de Manuel y Juan de Ávila mis sobrinos hijos de Hernando de Ávila y Juana Martín su mujer difuntos vecinos que fueron de esta ciudad", otorga todo su poder a su hermana Isabel, residente en Alaejos, para que recibiera "toda la renta caída y que cayere de las dos tierras que tenemos en la dicha villa de Alaejos y sus términos la una a do llaman la Sola y la otra do llaman el Peñón" (DOCUMENTO 5). Pudiera ser que hasta que ambos hermanos alcanzaran la mayoría de edad tuvieron como curador de sus personas a Gil de Ávila, el cual se ocuparía de la educación y vida cotidiana, mientras que Marco Antonio de Anaya, curador ad litem, se centraría en los asuntos legales de los muchachos: herencia de los padres, asiento de aprendiz de Juan de Ávila con Tudanca.

A.G.D.V., Valladolid, Santiago, 1650D, f. 255. 8 "Marco Antonio de Anaya en mi responsabilidad como curador al litem de Manuel y Juan de
Ávila mis menores igual digo que se ha hecho inventario de los bienes y haciendas que dejo la madre de mis partes. Y para efecto de vestirlos y poner a el uno a oficio de escultor por tiempo de cinco años es necesario se vendan los dichos bienes inventariados para el dicho efecto y dar y pagar a Francisco de Tudanca doscientos reales y comprar un jergón una sábana y una manta para efecto de dormir el dicho menor para cuyo efecto el dicho depositario entregué los dichos bienes. A su majestad suplico así lo provea y mande por ser justicia que pido y costase". A.H.P.V., Leg. 2.276. 
Pocos meses después del fallecimiento de su madre Juan de Ávila es ingresado en el taller de Gabriel de Palacios "pintor vecino de esta ciudad" por su padrastro Gabriel Rodríguez del Pozo. La escritura de asiento de aprendiz tiene lugar el 3 de noviembre de 1666 (DOCUMENTO 9). Entre las condiciones dispuestas se estipulaba que el aprendizaje tendría una duración de "cuatro años que corren desde todos los santos de este año de sesenta y seis". A lo largo de ellos Palacios se comprometía a tenerle en su casa y "darle de comer y cama y enseñarle el dicho arte de pintor de forma que esté hábil para trabajar como oficial del dicho arte". Por su parte Gabriel Rodríguez entregaría una manta colorada "para que utilice el dicho mi andado" y abonaría al maestro pintor por la enseñanza del joven Ávila 300 reales pagados en dos plazos: 150 reales de contado y otra tanta cantidad "para la Pascua de Flores" del año 1667. Se trata de un característico contrato de aprendizaje.

Extraña el hecho de que tan solo unos meses antes de entrar como aprendiz al taller del escultor Francisco Díez de Tudanca su padrastro le metiera en el de un pintor. Dos son las grandes hipótesis que se nos plantean: lo más lógico es pensar que pasados esos meses se rompería el contrato y Ávila tan solo acudiría al taller de Tudanca, seguramente porque una vez dentro del mundo artístico el propio Ávila se diera cuenta de que se manejaría mejor como escultor que como pintor; menos factible, aunque más sugestiva, es la posibilidad de que compaginara el aprendizaje de ambas artes, completando así una formación integral en ambas artes que le hubiera permitido policromar alguna de sus esculturas. La realidad nos desmiente esta hipótesis ya que las pocas esculturas que le tenemos documentadas fueron policromadas por maestros especializados y reconocidos dentro del ámbito vallisoletano.

Otro asunto a dirimir es si la entrada al taller del pintor partió de los deseos del propio Ávila o bien fue propuesta por su padrastro Gabriel Rodríguez del Pozo. No hemos de olvidar que todos estos actores (Juan de Ávila, Gabriel Rodríguez, Gabriel Palacios y Francisco Díez de Tudanca) residían en la calle de Santiago muy cerca los unos de los otros. Mi opinión es que Ávila se sintió atraído desde pequeño por las artes plásticas, motivo por el cual decidió probar suerte en el taller de un pintor, y viendo que no era lo suyo decidió cambiar de disciplina y encaminar sus pasos hacia el de la escultura, y si fue así no se equivocó.

\section{B- FORMACIÓN EN EL TALLER DE TUDANCA (1667-1672)}

El 8 de marzo de 1667 Juan de Ávila entra al taller de Francisco Díez de Tudanca con el ánimo de aprender el oficio de escultor. Seguro que en la mentalidad de muchos escultores vallisoletanos de estos momentos seguía presente la idea de poder seguir los pasos del maestro, cuya presencia artística en la ciudad seguía siendo abrumadora. Por entonces el joven aún no había cumplido los quince años, edad que incluso puede considerarse tardía dado que la mayoría de aprendices entraba a los obradores con 12 o 14 años, aproximadamente, si bien existen excepciones. Es indudable que Ávila fue su alumno más destacado, juntamente con José Mayo, aunque este último en un plano algo 
más modesto que nuestro escultor. Pero no solo eso sino que Tudanca formó al maestro más destacado de la escuela vallisoletana del último cuarto del siglo XVII, posición que ocupa junto a Juan Antonio de la Peña y José de Rozas.

Ese mismo día tuvo lugar la protocolaria firma del "asiento de aprendiz al arte de escultor" por parte de Marco Antonio de Anaya "curador ad litem de Manuel y Juan de Ávila mi menor" y Francisco Díez de Tudanca. El compromiso realizado por ambas partes estipulaba que la duración del aprendizaje sería de cinco años "que han de comenzar a correr y contarse desde hoy día de la fecha de esta escritura en adelante y se cumplirán a ocho días del mes de marzo del año que viene de mil seiscientos y setenta y dos años". Durante este periodo Tudanca se obligaba a dar enseñado al joven aspirante "dicho oficio y arte a vista y satisfacción de maestros peritos en él", además le proporcionaría "ropa limpia y le ha de curar sus enfermedades como no pase de quince días". Si durante los cinco años Ávila no hubiera conseguido dominar el oficio, Tudanca, que debía de tratarle "bien de obra y palabra", se obligaba a tenerle en su "casa trabajando hasta que lo este y le ha de dar por cada día lo mismo que ganare un oficial hasta tanto que este capaz y suficiente" (DOCUMENTO 10). Es decir, se penalizaba más la falta de capacidad del maestro para enseñar el oficio que el talento del alumno para aprenderlo. Por la enseñanza del muchacho Tudanca percibiría 200 reales de vellón, una cifra dentro de los estándares de la época. El aprendizaje de Ávila lo podemos calificar de "interno" ya que debería de residir en casa de su maestro. Efectivamente, su curador debía de proporcionarle "para que duerma el dicho mi menor un jergón y una sábana y una manta y el vestir y calzar ha de ser por cuenta del dicho mi menor". En otras ocasiones al alumno se le impone un horario pero por la noche vuelve a dormir a su hogar familiar. Fernández del Hoyo piensa que el taller se localizaría en la Plaza Mayor'.

Díez de Tudanca fue un escultor bastante limitado que gozó de gran renombre en su época, Fernández del Hoyo define su caso perfectamente: "El caso de Tudanca puede ser representativo de un fenómeno sociológico hoy frecuente pero que rebasa la consideración temporal: la supervaloración de un determinado artista por encima de sus merecimientos" ${ }^{\prime \prime}$. Nacido en Valladolid en 1616, desconocemos con quién se formó, si bien lo más probable es que fuera en el taller de algún discípulo de Gregorio Fernández. Acabado su aprendizaje abre taller en la Plaza Mayor, estudio en el que recibe a multitud de discípulos, la mayoría de ellos completamente desconocidos en la actualidad. Su producción escultórica fue numerosa, si bien en la actualidad ha desaparecido en gran parte. Destacó por las copias que hizo de modelos creados por Gregorio Fernández: Inmaculadas, Yacentes, Pasos procesionales, etc. Sus obras conservadas más significativas son el Paso del Descendimiento, encargado por la Cofradía de la Soledad de Medina de Rioseco (para la cual ejecutó también el Paso del Santo Entierro) y la parte escultórica del retablo de la iglesia de la Asunción de Bercero

9 FERNÁNDEZ DEL HOYO, María Antonia: "El escultor vallisoletano Francisco Díez de Tudanca...", op. cit., p. 374.

$10 \quad$ Ídem, p. 371 
(trabajó conjuntamente con Juan Rodríguez). Sus últimas actuaciones, fechadas en 1678, fueron la renovación de una escultura de San Pedro in cátedra para la iglesia de San Pedro de Tiedra (Valladolid) ${ }^{11}$, y la parte escultórica del retablo mayor de la iglesia parroquial de Traspinedo ${ }^{12}$, la cual pasó posteriormente a su discípulo Juan de Ávila como más adelante veremos.

Desconocemos el por qué eligió Marco Antonio de Anaya el taller de Tudanca para que su "andado" aprendiera el oficio de escultor, si bien hemos de tener presente que era el más famoso y concurrido de la ciudad. Además del hecho de que fuera el taller más solicitado existen otras hipótesis bastantes factibles: una es la cercanía entre la casa de Juan de Ávila y la de Tudanca; la otra es el conocimiento por parte de Marco Antonio de Anaya de Francisco Díez de Tudanca, hecho más que probable dado que debió de trabajar en más de una ocasión con un hermano de este, Manuel de Tudanca, escribano y procurador.

Ningún otro taller tuvo, ni de lejos, la avalancha de aprendices que tuvo éste. Es todo un misterio por qué el estudio de Tudanca era tan solicitado cuando él no era más que un mediocre escultor y sus alumnos tampoco destacaron, ni siquiera en el panorama local, a excepción de José Mayo y Juan de Ávila. Algunos de estos fueron: Antonio Brizuela $(1645-1651)^{13}$, Pedro Baños (1655-1657) ${ }^{14}$, José Mayo (1656-1660) ${ }^{15}$, Martín Gutiérrez de Perusillo (1660-1663) ${ }^{16}$, Juan González (1661-1667) ${ }^{17}$, Bernardo del Rincón "el joven" (1661-1665) ${ }^{18}$, José de Paz (1674-1679) ${ }^{19}$, Manuel González (1678-1683) ${ }^{20}$. Además sabemos que entre los oficiales que asistieron a Tudanca estuvieron: Felipe del Rincón (1647-1655) ${ }^{21}$, Juan Martínez, Manuel Gómez Otero o Pedro Herrero ${ }^{22}$.

Parece ser que una vez que Marco Antonio de Anaya resolvió el futuro de Juan de Ávila abandonó su puesto de curador ya que el 30 de septiembre de ese mismo año de 1667 el que figura en tal puesto es el tío de Juan y Manuel, Gil de Ávila. Un documento fechado el referido día nos explica que Gil, en el citado papel de curador de Juan y Manuel de Ávila, da poder a su hermana Isabel, residente en Alaejos, para que "pueda recibir haber y cobrar toda la renta caída y que cayere de las dos tierras que tenemos en la dicha villa de Alaejos y sus términos". (DOCUMENTO 5). Desconocemos las tierras

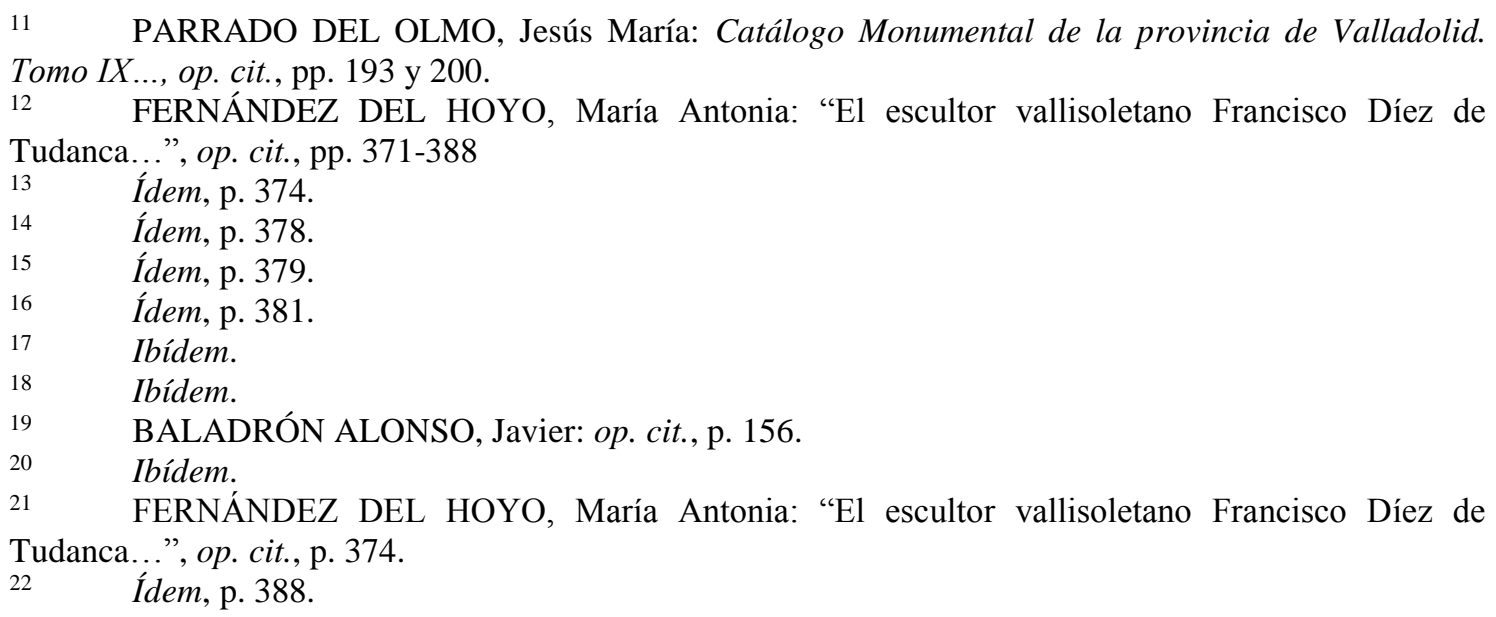


que pudieran poseer ambos hermanos, seguramente heredadas de su padre, puesto que no conservamos ningún documento relativo a ellas.

Durante los años que Ávila permaneció en el taller de Tudanca debió de conocer a multitud de aprendices y oficiales del maestro, aunque por el momento solo tenemos constancia documental de que coincidió con el palentino Juan González, el cual se mantuvo allí entre los meses de mayo de 1661-166723. También debió de coincidir con Manuel Gómez Otero, el cual accedió al obrador de Tudanca por las mismas fechas en que Ávila se disponía a abandonarlo ${ }^{24}$. La relación entre Tudanca y Gómez Otero se prolongó más allá del aprendizaje de éste ya que continuó en el taller del maestro como oficial. Que Gómez Otero y Ávila se conocieron allí y mantuvieron desde entonces una amistad óptima lo indica la presencia del nombre del primero en los bautizos de varios de los hijos de Ávila, entre ellos, casualidades de la vida, de los de los futuros escultores Pedro y Manuel de Ávila.

Tudanca enseñaría el oficio a sus alumnos según el método tradicional. No parece que fuera un maestro revolucionario dados los frutos surgidos de su taller. Siguiendo de cerca los testimonios que poseemos sobre la faceta como profesor del escultor vallisoletano Alejandro Carnicero podemos hacernos una idea aproximada de cómo se desarrollaron los aprendizajes de este arte antes de que las reales academias acabaran con este sistema gremial. Cabe señalar que cada maestro pondría el énfasis en determinados aspectos, pero el tronco común no variaría demasiado.

Las primeras lecciones que recibiría Ávila de su maestro tendrían relación con el dibujo puesto que esta disciplina es la madre de todas las artes. Puede que ya hubiera tomado alguna en el taller del pintor Gabriel de Palacios, si bien desconocemos si esta enseñanza se llegó a producir. De la importancia capital del dibujo nos hablan unas palabras muy clarividentes del escultor vallisoletano Alejandro Carnicero, el cual pensaba que "sin este principio de dibujar y figurar en barro, ningún aprendiz puede salir perfecto oficial" ${ }^{25}$. Las lecciones de dibujo irían complicándose progresivamente según el alumno iba adquiriendo la destreza necesaria. Así se comenzaría por la copia de dibujos sencillos, tales como partes aisladas del cuerpo humano (cabezas, manos, pies), posteriormente se pasaría a composiciones más complejas "de estampas y diseños de maestros conocidos, pasando por la de figuras tridimensionales y, finalmente, del natural"26. Al mismo tiempo que los muchachos aprendían a delinear también se les adiestraría en el mundo del modelado, proceso indispensable a la hora de realizar bocetos, y en el de corte y talla de la madera. Señala Albarrán Martín que según

23 Nos es desconocida su trayectoria posterior, de la cual no hemos hallado ninguna noticia por lo que lo más lógico sería pensar que se enroló como oficial al taller de algún maestro, quizás el de Tudanca. Juan González, natural de Palencia, ingresó en el obrador de Tudanca el 13 de mayo de 1661. Debía de permanecer bajo sus órdenes seis años durante los cuales le enseñaría "el dicho arte de escultor y todo lo contante a él de forma que esté hábil para usarle". Por el trabajo de su enseñanza Tudanca percibiría 300 reales "la mitad de ellos para dicho día de la fecha de ésta y la otra mitad de la fecha en seis años". Ídem, p. 381 .

24 A.H.P.V., Leg. 2.819/2, ff. 51-52.

25 ALBARRÁN MARTÍN, Virginia: El escultor Alejandro Carnicero ..., op. cit., p. 144.

26 Ibídem. 
Leonardo da Vinci "todos los autores habían reiterado la necesidad de ir superando progresivamente cada uno de los estadios del aprendizaje, alentado a los alumnos a proseguir en el estudio como único modo de alcanzar la perfección como artista"27.

El papel de Juan de Ávila en el taller de Tudanca iría "in crescendo" poco a poco, Fernández del Hoyo presume que "sus destacadas dotes fueron inmediatamente apreciadas por el maestro y es presumible su intervención en la preparación del crecido número de encargos que se recibirían en el taller, muchos procedentes de fuera de Valladolid" 28 .

Durante los años que duró el aprendizaje de Ávila, Tudanca mantuvo una actividad bastante importante en su obrador. Así, le veremos trabajando tanto de escultor como ensamblador. Encargo propio de un ensamblador es el que tomó en 1671 de la iglesia de Santa María de Peñaflor de Hornija, para la cual realizó “dos hacheros grandes para esta iglesia con hachas fingidas de madera, pintados, con encarnación y los remates de tres hacheros dorados y con sus cornucopias" ${ }^{29}$. Tenemos documentadas durante estos cinco años diversas esculturas contratadas de Tudanca en las que, a no dudarlo, Ávila colaboraría en su confección. Además de la teoría y la práctica, el joven aprendiz compaginaría todo ello con la visita a las numerosas iglesias y templos de la ciudad con el fin de ver y tomar apuntes de la obra de Gregorio Fernández, aquél al que todos añoraban, pero no solamente de la suya sino también de la que legaron los Juan de Juni, Esteban Jordán, Alonso Berruguete, Francisco del Rincón, Francisco Alonso de los Ríos, Pompeo Leoni... La sola contemplación de las múltiples imágenes del maestro gallego le aportaría lecciones que jamás podría haber aprendido del mediocre Tudanca. También tendría la oportunidad de estudiar la perspectiva y la composición al observar los renombrados pasos vallisoletanos.

Los encargos recibidos por Tudanca durante este lapso de tiempo fueron las siguientes: en 1667 realiza un San Miguel con destino a la iglesia de Santiago, de Ávila ${ }^{30}$, que por fortuna se conserva allí mismo. Según Fernández del Hoyo se trata de una "pieza de aceptable calidad, pese a su rigidez; en su rostro mantiene la expresión de ceño fruncido, dolorosa, rasgo muy habitual en otras obras del artista" ${ }^{\text {"1 }}$. Ese mismo año le veremos en una de las facetas por la que fue más demandando: la de copista de pasos vallisoletanos. Efectivamente, en octubre de ese año tenemos noticia de que se encontraba enfrascado en la realización de una réplica del Descendimiento para la localidad zamorana de Benavente ${ }^{32}$. Es de creer que la fama de la copia que hizo para Rioseco llego hasta allí. En 1668 talla una imagen procesional de Santa Águeda para la

\footnotetext{
$27 \quad$ Ídem, p. 148.

28 FERNÁNDEZ DEL HOYO, María Antonia: "El escultor vallisoletano Francisco Díez de Tudanca...", op. cit., p. 384.

29 PARRADO DEL OLMO, Jesús María: Catálogo Monumental de la provincia de Valladolid. Tomo IX..., op. cit., p. 141.

30 FERNÁNDEZ DEL HOYO, María Antonia: "El escultor vallisoletano Francisco Díez de Tudanca...", op. cit., p. 384.

31 Ibídem.

32 Ibídem.
} 
iglesia parroquial de San Martín de Bernuy de Zapardiel (Ávila) ${ }^{33}$. Los dos siguientes encargos los podemos tachar de menores dado que se trata de la ejecución de ÁguilasAtriles para las iglesias de Santiago de los Caballeros de Medina de Rioseco (1668) ${ }^{34}$ y de Santa María de Torrelobatón $(1671)^{35}$. La última obra que llegaría a ver preparar Ávila a Tudanca en esta época, si bien habían pasado tres meses desde que expirara su periodo de formación, fue el Cristo atado a la columna (1672) que le encargaron los mayordomos de la Cofradía del Santísimo Sacramento de la villa de Mojados (Valladolid) ${ }^{36}$. La imagen "figura redonda y del natural y dibujo conforme el que está en la Sagrada Pasión de la ciudad de Valladolid", cofradía a la que pertenecieron, y con la que trabajaron, tanto Tudanca como Ávila. Como vemos la demanda de obras le llegaban a Tudanca desde los más diversos puntos de la geografía de la actual comunidad de Castilla y León.

Tenemos constancia de una obra en la que confluyen ambos artistas. Se trata del retablo mayor de la iglesia de la Degollación de San Juan Bautista de Pesquera de Duero (Valladolid) ${ }^{37}$. Como veremos más adelante, Juan de Ávila se encarga de realizar el peñasco sobre el que asienta la imagen del Bautista, la cual supuestamente se debe a Tudanca.

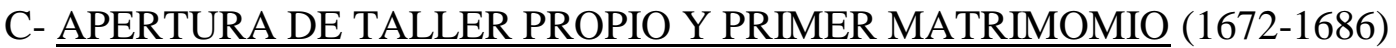

A punto de expirar el periodo de aprendizaje, Ávila habría completo ya su formación, momento a partir del cual se iría desligando poco a poco del estilo de Tudanca, de tal manera que si no se hubiera hallado la carta de asiento de aprendiz hubiera sido bastante difícil relacionar a ambos artistas. Ni siquiera las obras más tempranas se encuentran en relación con Tudanca.

Durante los cinco años en que Ávila permanece bajo la tutela artística de Tudanca el aprendiz tuvo la oportunidad de conocer a las sobrinas del maestro: Juana (1660), Jacinta (1661) y Francisca Ezquerra (1650), esta última llamada de forma homónima a su tía, la mujer de Tudanca, y, asimismo, todas hijas de Romualdo Ezquerra. Que el alumno residiera en la casa del maestro no era un hecho extraordinario, más bien al contrario. Tampoco podemos olvidar que el contacto sería frecuente puesto que Ávila vivía en casa de Tudanca y el taller se hallaba en el propio patio de la vivienda.

La joven, que apenas superaba los veinte años se encontraba viviendo en casa de sus tíos desde hacía cerca de un década (h. 1664) debido al expreso deseo de su padre, Romualdo Ezquerra, el cual antes de fallecer, encontrándose ya viudo, realizó una

\footnotetext{
33 Ídem, p. 385.

34 PÉREZ DE CASTRO, Ramón: “La huella de Gregorio Fernández...”, op. cit., p. 172.

35 PARRADO DEL OLMO, Jesús María: Catálogo Monumental de la provincia de Valladolid.

Tomo IX..., op. cit., p. 230.

36 ZALAMA, Miguel Ángel: op. cit., p. 132

37 VALDIVIESO, Enrique: Catálogo Monumental de la provincia de Valladolid. Tomo VIII. Antiguo partido judicial de Peñafiel, Diputación de Valladolid, Valladolid, 1975, pp. 177-178.
} 
escritura de compromiso con su cuñado Francisco de Tudanca por la cual el escultor quedaba encargado "de tener en su casa y compañía a la dicha Francisca Ezquerra y Juana Ezquerra su hermana y sustentarlas y alimentarlas hasta que tomasen estado" (DOCUMENTO 11). Para ayuda del sustento de ambas, Romualdo ofrecía a Tudanca "lo que podían redituar cada año así los dichos cien ducados como el dicho oficio de portero", si bien con las cantidades procedidas de ambos elementos "no era posible haber bastante para el dicho alimento y crianza".

Juan se iría haciendo poco a poco imprescindible para su maestro tanto en el plano artístico como en el personal puesto que a falta de descendencia y dado que estaba a cargo de tres sobrinas el joven aprendiz sería lo más parecido a un hijo que tendría, y al revés también, puesto que Ávila se encontraba huérfano desde hacía muchos años, y tan solo le quedaba su hermanastro Francisco Rojo. Como iremos comprobando la relación entre ambos artífices sobrepasaría lo meramente familiar. Al mismo tiempo la relación con Francisca se iría fortaleciendo de tal manera que a comienzos del año 1672 los jóvenes anunciarían a sus tíos el deseo de contraer matrimonio. La convivencia en la misma casa pudo originar con facilidad el contacto sexual entre ambos. El enlace debió de precipitarse dado que Francisca debía de encontrarse ya embarazada puesto que el día 6 de agosto de ese mismo año la pareja tuvo a su primera hija, Josepha Antonia.

La boda tuvo lugar en la cercana iglesia de Santiago Apóstol el día 7 de febrero, es decir, un mes antes de que se cumpliera el lustro dispuesto para la instrucción de Ávila en el oficio de escultor ${ }^{38}$. El feliz acontecimiento tuvo por testigos al orgulloso tío y preceptor de ambos jóvenes, Francisco Díez de Tudanca, a Tomás Martínez y al torero Joseph Ferrel, este último hermano de Custodio Ferrel, discípulo del pintor Simón Peti "el viejo". El enlace sería visto con sumo gusto por parte del anciano escultor ante la circunstancia de no haber podido tener descendencia, de esta manera vería asegurada la continuidad de su taller, y una vez jubilado, sus herramientas, y quizá sus contactos, pasarían a Ávila.

El día precedente había tenido lugar la firma de las capitulaciones matrimoniales por parte de los contrayentes. Ambos eran muy jóvenes, hecho que se hace constar en la escritura: "por ser menores de veinte y cinco años aunque mayores de veinte juraron a Dios y a una cruz en forma no ir contra esta escritura ni pedir restitución por la menor edad en ningún tiempo" (DOCUMENTO 11). Francisca Ezquerra, tres años mayor que su marido, era una mujer que podemos definir como de clase acomodada, así lo indican los bienes y prebendas que aportaba al matrimonio. Como bienes dotales contribuía con 300 ducados derivados de diferentes prebendas otorgadas por cofradías y personas particulares: así, 50 ducados procedentes de una prebenda "en que fue elegida por los testamentarios del licenciado Francisco García Álvarez cura que fue del lugar de Santovenia", otros 50 ducados de "la prebenda de la cofradía de Nuestra Señora del Pilar sita en el Convento de Santa Ana", otros 50 ducados "de la prebenda de la Cofradía de las Ánimas de la parroquial de Santiago de esta ciudad", y otra tanta

38 FERNÁNDEZ DEL HOYO, María Antonia: "El escultor vallisoletano Francisco Díez de Tudanca...", op. cit., p. 385. 
cantidad "por los mismos que por cláusula del testamento que otorgó Ana Gómez del Real vecina que fue de esta ciudad (...) la mandó para ayuda de su remedio"; completaba la suma otros 100 ducados "por los mismos que entraron en poder de Francisco de Tudanca escultor vecino de esta ciudad que los cobró de Santiago Muñoz vecino de Villanubla los cuales se los mandó Francisco Ezquerra su abuelo por cláusula de su testamento para ayuda de su remedio que todas las dichas partidas hacen los dichos trecientos ducados". Tudanca se comprometía a abonar todas estas partidas a su discípulo una vez que hubiera tenido efecto el matrimonio con su sobrina, la paga sería en dinero y en "ropa blanca, vestidos y ajuares de por casa tasados y valuados por personas nombradas por ambas partes sin que se le pueda pedir lo entregue en otros efectos".

Además de todo ello Francisca aportaba un "oficio de portero del número de esta ciudad que propio suyo durante su vida por gracia que hizo la Casa de Linajes ${ }^{39}$ al dicho Francisco Ezquerra su abuelo" que comenzaría a "gozar desde el día de Navidad fin del año pasado de setenta y uno en adelante" 40 . Por entonces el dicho oficio de portero se encontraba arrendado en Joseph Cenzano, el cual abonaba por su tenencia la módica cantidad de 10 ducados anuales ${ }^{41}$.

La contribución de Francisca al matrimonio no acababa ahí puesto que adicionaba la mitad de una viña "de diez y siete alanzadas camino de Fuensaldaña a huerta de Moro" que había heredado, juntamente con sus hermanas Juana y Jacinta, de sus abuelos Francisco Ezquerra y Juana Fernández de Geria. Y digo la mitad y no la posesión completa dado que sus abuelos repartieron el terreno entre sus dos hijos Francisca y Romualdo, una vez fallecido Romualdo éste partió la posesión entre sus tres hijas. Por lo tanto, a las hermanas pertenecían "ocho alcanzadas y media que es la mitad de dicha viña a la dicha Francisca Ezquerra y Juana y Jacinta Ezquerra sus hermanas entre quien se ha de partir y lo que tocare a la dicha Francisca Ezquerra ha de ser y quedar por bienes dotales suyos". Además de todas estas partidas, Francisco de Tudanca, por el mucho amor que tenía a su sobrina, la prometía 50 ducados en "ropa y ajuares y herramientas del oficio de escultor para que la susodicha los tenga por más aumento de

\footnotetext{
39 La Casa de Linajes estaba situada en la Calle de Expósitos. Según palabras de Agapito y Revilla, dicha casa era en la que "se reunían en los primeros días de cada año y otras ocasiones, las diez casas de los linajes para hacer el nombramiento de alcaldes, regidores, procuradores de cortes, fieles, veedores, aposentadores y demás oficiales de la villa, dividiéndose las diez casas y agrupándose en dos grandes linajes, que llamaban de Tovar y Reoyo; y desde la "casa de los linajes" acudían todos los vecinos a la Iglesia Mayor donde conjuntamente se hacían las juntas”. La Casa de los Linajes cayó en declive y fue suprimida debido a los alborotos y trastornos que formaron los bandos de los Tovar y de los Reoyo a causa de los nombramientos del año 1332. AGAPITO Y REVILLA, Juan: Las calles de Valladolid: Nomenclátor histórico, Tipografías Casa Martín, Valladolid, 1937, pp. 166-167.

40 Aunque la vara fue un regalo de su abuelo Francisco Ezquerra "para ayuda de su remedio" sería su padre Romualdo el que la administrara hasta su mayoría de edad. Por uno de esos arriendos de la vara, concretamente el realizado a comienzos de 1668, sabemos que se trataba de la vara de "portero de la casa de don Gonzalo Díez del Linaje de Tobar". Entre los testigos de la citada escritura figura su tío Francisco de Tudanca. A.H.P.V., Leg. 1.975, f. 456.

$41 \quad$ Los Porteros de Vara eran la mano derecha de los Alcaldes de Barrio. Se encargaban de montar guardia en sus cuarteles y acompañarles en las rondas que por la ciudad éstos efectuasen.
} 
dote y los entregará al dicho Juan de Ávila luego que tenga efecto el matrimonio y no lo haciendo se le ha de ejecutar por ello".

Por su parte Juan de Ávila dada "la honra y linaje de la dicha Francisca Ezquerra" la prometía en arras y dotación proternúpcias "para más aumento de su dote" 200 ducados de vellón que confesaba le cabían en la décima parte de los bienes que "al presente tiene y en caso que no quepan se los sitúa y señala en lo mejor y más bien parado de los bienes que tuviere y adquiriere de aquí adelante a donde la susodicha los quisiere escoger a su elección y voluntad". Una vez que Ávila recibiera todos los referidos bienes de su esposa el escultor prometía otorgar carta de pago en favor de ella "juntamente con los dichos doscientos ducados de arras en favor de la dicha Francisca Ezquerra para que todo ello lo tenga como bienes dotales sin que el dicho Juan de Ávila los pueda obligar ni enajenar".

Los testigos de la escritura fueron el portero Ignacio González del Portal, familiar de la abuela de Francisca, Ana González del Portal, el torero Joseph Ferrel y el pintor Diego de Fuertes, quizás pariente de Pedro de Fuertes, ensamblador con el cual coincidiría Ávila en la obra del retablo mayor de Pesquera de Duero.

Una vez que se hicieron efectivos tanto el matrimonio como la entrega de bienes expresados en las capitulaciones matrimoniales el escultor y su flamante esposa comenzaron a otorgar las respectivas cartas de pago a las instituciones que habían dotado con prebendas a Francisca. Así, el 15 de febrero de 1672 dieron carta de pago en favor de las "Memorias que para casar huérfanas fundaron María del Milagro y Mateo Tristán de Abellaneda sitas en la Cofradía de la Virgen del Pilar que está en el Convento de Santa Ana de esta dicha ciudad", que como hemos visto ya aparecía reseñada en las capitulaciones matrimoniales. Francisca Ezquerra había resultado premiada en el concurso celebrado en el año 1668 en razón de ser "huérfana y bautizada en la pila de la iglesia de Santiago de esta dicha ciudad". La dotación era de 440 reales, si bien en las capitulaciones se señalan 50 ducados (= 550 reales) que se harían efectivos una vez hubiera "mudado estado y respecto de haberse casado con el dicho Juan de Ávila recibe los dichos cuatrocientos y cuarenta reales y de ellos los otorgantes se dieron por contentos". Entre los testigos de la escritura figura Francisco de Tudanca (DOCUMENTO 12).

Otra carta de pago fue la expedida un día después (16 de febrero), por parte de la Cofradía del Santísimo Sacramento radicada en la iglesia parroquial de Santiago Apóstol (DOCUMENTO 13). En la escritura confesaban "haber recibido realmente y con efecto del señor don Simón de Contreras y Rojas regidor de esta ciudad como depositario de las Memorias del doctor Montemayor y doña Ana Núñez sita en la Cofradía del Santísimo Sacramento de señor Santiago" 50 ducados de vellón "por razón de la prebenda que se adjudicó a la dicha Francisca Ezquerra por los electores de la dicha cofradía de que para su cobranza entrega fe de velaciones y nombramiento de la dicha prebenda". 
A la feliz noticia de la boda acompañaría la llegada casi consecutiva del primer retoño de la pareja. El 6 de agosto sacaron de la pila de la iglesia de Santiago a su primera hija: Josepha Antonia. La buena sintonía entre la pareja y Tudanca llevó a este último y a su mujer a ejercer de padrinos del bautizo. Desconocemos por qué le impusieron sus padres este nombre, no existe ninguna razón de santoral o de dedicación familiar, razones que sí veremos en los nombres del resto de hijos del escultor. Tras el nacimiento del primer bebé la familia marcharía a vivir a la casa que Juan había heredado de sus padres, la cual estaba repartida a medias con su hermano Manuel. Asimismo, allí instalaría su taller independizándose de esta manera de Tudanca, independencia que no significa que no pudieran haber colaborado en épocas posteriores.

El 21 de julio de 1673 Ávila, Tudanca y sus respectivas mujeres vendían "una heredad de viña que está descepada y hecha erial al presente en término de esta ciudad al pago que llaman Huerta del Moro que hacía ocho alanzadas poco más o menos", la cual dicha viña había sido heredada por las Ezquerra de Francisco Ezquerra, padre de una y abuelo de otra: Francisca (mujer de Tudanca), hija de Francisco Ezquerra, y Francisca (mujer de Juan de Ávila), Juana y Jacinta, todas tres hijas de Romualdo Ezquerra, su padre difunto y a su vez hijo de Francisco Ezquerra. Al no haber trabajado y cuidado de las viñas desde hacía mucho tiempo éstas se hicieron "erial y no tiene cepas ni otros plantios de manera que no ha sido ni es de ningún provecho", por lo cual se tomó el acuerdo de darlas "en venta real por juro de heredad" al mercader Matías Martínez por 450 reales (DOCUMENTO 14).

La felicidad de nuestro escultor quedó truncada a finales del año 1673, pues el día 7 de octubre tiene lugar el fallecimiento de su hermano Manuel ${ }^{42}$. Dos días antes éste había otorgado testamento ante el escribano Cristóbal Redondo. En él dejaba nombrados por albaceas y testamentarios a sus hermanos Juan de Ávila y Francisco Rojo (DOCUMENTO 3). Gracias a estas sus últimas voluntades sabemos que nuestro escultor era deudor a su hermano de 100 reales, cantidad procedida de algún préstamo que este la había hecho. Podríamos pensar que el adelanto pedido por Juan tenía como objetivo la apertura de taller propio, para lo cual necesitaría comprar herramientas, maderas, modelos, grabados, adecuar el patio de su casa, etc...

Tan solo una semana después del fallecimiento de su hermano, el 14 de octubre, su mujer Francisca daba a luz a la segunda hija de la pareja "según aseguró el dicho su padre". Le dieron por nombre Teresa, en alusión a la Santa Teresa de Jesús, cuyas festividades se celebraban los días 15 y el 26 de octubre, día, este último, en el que la recién nacida recibió las aguas bautismales en la iglesia de Santiago Apóstol. El hecho de que se le dieran por abogados al Santo Ángel de la Guarda y a San Lucas puede ser indicativo de que ya por entonces Ávila fuera miembro de ambas cofradías, la primera radicada en la iglesia de Santiago y la segunda en el Colegio de Niñas Huérfanas. La

42 "En siete de octubre de mil seiscientos y setenta y tres años se enterró en ésta iglesia Manuel de Ávila vivía en la calle de Santiago recibió los sacramentos hizo testamento ante Cristóbal Redondo escribano real en cinco de este presente mes testamentarios Francisco Rojo y Juan de Ávila manda por todas sesenta misas y lo firmé". A.G.D.V., Valladolid. Santiago, 1650D, f. 366. 
pertenencia a la primera cofradía la tenemos documentada, sin embargo su vinculación a esta segunda congregación está pendiente de confirmación.

Es probable que una de sus primeras obras, si no la primera, fuera el Santo Ángel de la Guarda que se custodia en la iglesia de Santiago Apóstol. Fue realizado con anterioridad al año 1673, aunque no mucho antes ${ }^{43}$. El rostro y la concepción de los mechones hacen pensar que Ávila la tallara aún bajo las órdenes de Francisco Díez de Tudanca, a quien se deberá el diseño de la misma. También pudiera ser que la contratara por sí mismo, no podemos olvidar que el Santo Ángel de la Guarda era el patrón de una cofradía homónima radicada en la iglesia de Santiago y de la cual Ávila fue cofrade. Podemos pensar que al igual que ocurrirá años después cuando talle las imágenes de San Isidro y Santa María de la Cabeza y la cofradía del santo agricultor le nombre cofrade, aquí también una vez esculpida la cofradía le hiciera miembro honorario de la misma. Como ya dijimos anteriormente, en ella desempeñó, entre otros, los cargos de depositario y alcalde en años sucesivos.

Dadas las escasas noticias relacionadas con su oficio que poseemos de los años inmediatamente posteriores a la adquisición del título de maestro escultor cabe pensar si la gente no requirió sus servicios o bien que se encontraba enfrascado en otras tareas. Con esto último me refiero a que no hemos de descartar una posible participación de Ávila en los encargos recibidos por Tudanca entre 1674-1675, años de escasa actividad para el discípulo pero frenética para el maestro ya que le encomendaron desde la Cofradía de Jesús Nazareno de León la realización de los pasos del Expolio (1674) y la Coronación de Espinas, además de la fabricación de la imagen del Cirineo para el paso de Jesús Nazareno ${ }^{44}$. Ante la gran cantidad de trabajo y dado que se trataba de un comitente importante Tudanca se vería obligado a contar a su lado con un escultor solvente que le ayudara a completar los dos pasos de la manera más rápida y eficaz. Que mejor artífice para dichas tareas que Juan de Ávila, su discípulo predilecto y familia política desde hacía poco tiempo. Quizás esta posible participación de Ávila en el paso del Expolio leonés fue el germen del encargo que años después recibiría para tallar el mismo paso para la Cofradía de Nuestro Padre Jesús Nazareno de Valladolid.

La sequía de noticias artísticas de estos primeros años, en los cuales viviría a la sombra de Tudanca, finalizan el 4 de julio de 1674. Ese día recibe en el obrador a su primer aprendiz. Tan solo hemos podido documentar a dos aprendices, amén de su hijo Pedro de Ávila, aunque seguramente fueran muchos más los que desfilaron por su taller. No podemos olvidar que se trataba de uno los talleres más prestigiosos de la ciudad, en particular, y en Castilla, en general. El primer aprendiz documentado es Francisco de la Vega, cuyo padre, Pedro de la Vega, le asienta en el estudio de Juan de Ávila el referido día 4 de julio de 1674, fecha en la que se redacta la consabida "escritura de aprendiz al oficio y arte de escultor" (DOCUMENTO 15). Ambas partes se convinieron en que el periodo de aprendizaje duraría cinco años "que comienzan desde hoy día de la fecha", al

43 A.G.D.V., Santiago, Libro de fábrica 1673-1707, Visita de 1673.

44 LLAMAZARES RODRÍGUEZ, Fernando: "El escultor Francisco Díez de Tudanca en la ciudad de León”, Tierras de León, 1979, Tomo XXXIV-XXV, pp. 55-57. 
final de los cuales el aspirante debía estar "hábil a vista y declaración de dos oficiales del dicho oficio nombrados por cada parte el suyo". Ávila debía de tener al aprendiz en su casa, es decir un aprendizaje interno (como le ocurrió al propio Ávila con Tudanca), durante los cuales le daría "de comer y cama a su costa". Francisco no podría ausentarse "de la casa y servicio del dicho Juan de Ávila su maestro y si lo hiciere se le haya de volver el dicho Pedro de la Vega dentro de ocho días de cómo hiciere dicha ausencia". Por el trabajo de enseñar el oficio Ávila percibiría 200 reales de vellón: 100 reales abonados ese mismo día y otra tanta cantidad "para el día del señor San Juan de junio del año que viene".

El 24 de septiembre de ese mismo año da "en venta y por arrendamiento a Manuel Fernández vecino de esta dicha ciudad la vara de portero" que había heredado su mujer de Romualdo Ezquerra, su padre, "portero del número que fue de esta ciudad", con sus "emolumentos y demás que le toca y pertenece según y de la forma que la uso y ejecutó Joseph de Cencano ya difunto que la tuvo en arrendamiento" (DOCUMENTO 16). El arrendamiento duraría dos años, los cuales comenzaban a contarse desde el día "que el susodicho fuere recibido al uso y ejercicio del ficho oficio de portero", pagando en "cada año diez ducados y un año de adelantando y el año adelantado que son diez ducados estoy satisfecho de ellos cuanto me los ha de pagar Andrés Carro que siendo necesario me doy por entregados de ellos".

Entre los vecinos y, quizás, amistades que frecuentaría nuestro escultor se encontraban gran número de pintores, la mayoría de ellos formaban parte de los denominados "pintores de la calle Santiago", se trataba de un grupo de pintores de bajos vuelos que se encontraban más cerca de la artesanía que del Arte. Estos eran Francisco de la Cruz Ribadeneira $^{45}$, Alejandro López, Joseph Ruiz, Joseph Iglesias, Joseph Martínez de Ollora, Manuel Juárez, Jacinto Mayo, Lucas Caniego o Diego Díez Ferreras. Tan solo se conservan obras de estos dos últimos. Algunos vivieron en la calle de Santiago, o del Campo, de manera puntual, sin embargo otros desarrollaron toda su trayectoria vital allí, siendo bautizados, casados y sepultados en la iglesia de Santiago Apóstol, al igual que Juan de Ávila. Este grupo lo forman Lucas Caniego, Jacinto Mayo o Joseph Martínez de Ollora.

El 29 de junio de 1675 nace el tercer hijo de nuestro escultor y su esposa Francisca, que es el primer varón. Le pusieron por nombre Pedro en alusión a la festividad que se conmemoraba ese día: el de los Santos Pedro y Pablo, apóstoles y mártires. Su bautizo aconteció el 15 de julio siguiente en la iglesia de Santiago Apóstol, tuvo por padrino a Francisco de Tudanca. Le dieron por abogados a Nuestra Señora y a San Antonio. El niño debió de fallecer al poco tiempo ya que como comentamos no figura en las confirmaciones celebradas por la parroquia en el año 1684, fecha en que sí que aparecen sus hermanos Teresa y Pedro, el futuro escultor.

De este año de 1675 datan sus primeras obras documentadas. Se trata de obras menores, de un carácter casi artesanal. Juan de Ávila debía de fabricar una serie de marcos para

$45 \quad$ A.H.P.V., Leg. 2.857, f. 126. 
los cuadros que por entonces se encontraban creando una serie de pintores para colgar en la nave de la iglesia penitencial de Nuestra Señora de la Pasión, iglesia que por entonces se estaba terminando de adecentar para reabrirla ${ }^{46}$. En un principio se le contrató para tallar los marcos para los cuadros grandes de la capilla mayor y otro para la nave, pero cabe esperar que sean todos suyos por cuanto son similares. También existiría la opción de que hubiera un modelo común y se hicieran por otros escultores o ensambladores. Es la primera ocasión en que Juan colabora con la Cofradía Penitencial de Nuestra Señora de la Pasión, hermandad de la cual fue cofrade.

Un año después, el 26 de abril de 1676 Ávila adquiere a Francisca de Argüello, viuda y heredera de su hermano Manuel, la mitad que le correspondía de una casa que les había dejado a ambos hermanos sus padres. Ya se ha dicho que ésta casa estaba situada en la calle de Santiago, lindando "por una parte con casas del Colegio de San Gregorio de esta ciudad y por la otra casas de Isabel de Navas vecina de ella, que dicha casa y linderos son notorios" (DOCUMENTO 17). Así pues, Juan de Ávila se aprestaba a retomar el control total de la vivienda familiar, y para ello abonó a la referida Francisca de Argüello 1.250 reales, cantidad en que fue tasada la mitad de la casa. Además tendría que encargarse "de un censo perpetuo que sobre ella tiene la Cofradía de Nuestra Señora de la Espina de veinte y dos reales y dos maravedíes". Firman como testigos de la escritura su hermano Francisco Rojo y el carpintero Manuel de Solera. Ese mismo día el escultor abonaba a su cuñada y al nuevo marido de ésta una parte de la cantidad, comprometiéndose, asimismo, a reembolsarla los 832 reales de vellón restantes en dos plazos iguales: el primero para el último día de agosto de ese año y el otro para el las Carnestolendas de 1677 "con más diez ducados de la renta de ella" (DOCUMENTO 18).

A comienzos del año 1677 recibe al segundo, y último, de los aprendices que hemos logrado documentar, si exceptuamos a su hijo Pedro de Ávila: Matías Ortiz. Habla muy bien del prestigio del que gozaba por entonces Ávila el que siendo tan joven, y habiendo pasado tan poco tiempo desde su independencia artística, tuviera ya dos aprendices, hecho que contrasta con la casi total ausencia de obras documentadas. El día 22 de febrero Ávila se concierta con Gregorio Partearroyo, quizás familiar o curador del muchacho, el cual por entonces tenía "doce años, poco más o menos", para enseñar a Matías Ortiz el oficio de escultor "por tiempo y espacio de siete años que han de comenzar a correr y contarse desde hoy día de la fecha” (DOCUMENTO 19) ${ }^{47}$. En esta ocasión parece que también el aprendiz residiría en casa de Ávila puesto que la

46 MARTÍ Y MONSÓ, José: Estudios histórico-artísticos..., op. cit., p. 502.

47 Con toda probabilidad Partearroyo era familiar de Matías Ortiz. Partearroyo, hijo de Julián de Partearroyo y María Ortiz de Velasco, nació en Santa Cruz de Mena, en el burgalés Valle de Mena. Gracias a su testamento, otorgado el 7 de enero de 1676, sabemos que era beneficiado de la iglesia parroquial de Santa Cruz del Valle de Mena y también de la iglesia del Salvador de Valladolid, el beneficio de esta última lo tenía arrendado de don Juan Antonio Bernardo de Quirós. En la familia había otros miembros dentro del estamento religioso, así, tenía una sobrina en el Convento de Santa Catalina, aunque todavía no había profesado. Terminaba su testamento ordenando ser sepultado en la sacristía de la iglesia del Salvador, parroquia en la que era capellán de la capellanía fundada por el doctor Rodríguez. A.H.P.V., Leg. 2.371/6, ff. 41-42. También se encontraba relacionado con la Venerable Congregación de San Felipe Neri. A.H.P.V., Leg. 2.748, f. 16. 
escritura puntualiza que Ortiz "ha de asistir en casa y servicio del dicho Juan de Ávila y le ha de dar de comer y ropa limpia y curarle las enfermedades que en el discurso del dicho tiempo tuviere", además se especifica que Partearroyo debería de proporcionar al joven un colchón y una manta. De la ropa necesaria para vestir y calzar se ocuparían las dos partes: los cuatro primeros años correría a cargo de Partearroyo y los tres últimos de Juan de Ávila. Nuestro escultor percibiría por la instrucción del adolescente 400 reales de vellón, los cuales se le abonarían el día de Nuestra Señora del mes de marzo de ese mismo año. Por una pequeña anotación en la parte baja del folio sabemos que el pago tuvo lugar el día 2 de mayo.

El 12 junio de ese mismo año -1677- Ávila sale por "fiador y principal pagador $y$ obligado" de su hermanastro Francisco Rojo en un documento por el cual él y su mujer se obligaban a usar "de la tutela y curaduría de los dichos Francisco y Juana González bien y fielmente en todo lo que a dichos menores tocare, educándolos rigiendo y administrando todos sus bienes y hacienda que les tocase y fuere adjudicado en las cuentas y particiones que se han de hacer de los bienes que quedaron de los dichos sus padres" (DOCUMENTO 4). En otras palabras, el matrimonio decidía adoptar a sus dos sobrinos, hijos de un hermano de Juana, que habían quedado huérfanos.

El año 1678 fue muy positivo para el escultor ya que además de llegarle su cuarto hijo, Pedro de Ávila, el cual vino para engrandecer el taller paterno, tuvo lugar el contrato para efectuar una de sus obras más importantes y conocidas: el 5 de marzo se concierta con la Cofradía Penitencial de Nuestro Padre Jesús Nazareno para tallar el paso del Despojo, también llamado Preparativos para la Crucifixión, que vendría a sustituir uno anterior que la cofradía había sido condenada por la Chancillería a devolver al Convento de San Agustín ${ }^{48}$. Puede resultar bastante extraño el hecho de que la cofradía se conviniera con un escultor tan novel para ejecutar una obra tan importante. Pienso que no sería un escultor tan novato. El problema con el que nos encontramos es el de no haber podido documentar todavía ninguna obra de estos primeros años de magisterio. Ávila debía ya de haber mostrado suficientemente su valía como para que la cofradía decidiera, primeramente, aceptarle la oferta, y, a continuación, encargarle la ejecución del paso. La otra persona que pujó por la obra fue "Juan Antonio, maestro escultor", que no es otro que Juan Antonio de la Peña, miembro, al igual que Ávila, de la cofradía y el cual años después trabajará para la penitencial tallando el Crucifijo del Paso Grande, actualmente conocido como Cristo de la Agonía ${ }^{49}$. Ese mismo año se ocupó de confeccionar una obra menor: el peñasco sobre el que asienta la imagen de San Juan Bautista que preside la hornacina central del retablo mayor de la iglesia parroquial de Pesquera de Duero.

El otro hecho fundamental acaecido este año fue el nacimiento de su hijo Pedro, el futuro escultor, el día 30 de junio ${ }^{50}$. Dos hechos no excluyentes llevarían a Juan y

\footnotetext{
$48 \quad$ ARRIBAS ARRANZ, Filemón; La Cofradía Penitencial..., op. cit., p. 77.

49 AGAPITO Y REVILLA, Juan: Catálogos del Museo de Bellas Artes..., op. cit., p. 93

50 FERNÁNDEZ DEL HOYO, María Antonia: "El escultor vallisoletano Francisco Díez de Tudanca...”, op. cit., p. 385.
} 
Francisca a llamar Pedro a este nuevo vástago: el fallecimiento de su anterior hijo, también llamado Pedro, lo que vendría a suponer un "recuerdo" del finado, y por otro lado que el día precedente, 29 de junio, se celebra la fiesta de los Santos Pedro y Pablo, motivo suficiente en una sociedad tan sacralizada para llamar así a la criatura. De haber seguido al pie de la letra la tradición de dar al recién nacido el nombre del santo que se conmemora ese día habrían tenido dos opciones: Adolfo, por el monje y obispo San Adolfo de Osnabrück (1185-1224), y Marcial, por el santo francés San Marcial de Limoges. El futuro escultor recibió las aguas del bautismo en la pila de la iglesia de Santiago Apóstol el día 10 de julio del referido año. Ejercieron de padrinos Francisco Díez de Tudanca y su mujer Francisca Ezquerra. Jamás pudo imaginar el viejo Tudanca que el niño al que apadrinaba llegaría a ser una de las cumbres de la escultura española de la primera mitad del siglo XVIII. Otro aspecto a destacar es el de que las relaciones entre los antiguos maestro y aprendiz, ahora convertidos en sobrino y tío políticos, seguían gozando de una buenísima salud. Una vez más queda claro que Juan fue el hijo que Tudanca jamás tuvo.

Parece presumible que a finales de 1678 o comienzos de 1679 el vecino Convento de San Francisco, una de las instituciones más importantes de la ciudad, requirió de sus servicios. Por entonces, el 3 de diciembre de 1678, el establecimiento franciscano había contratado con el ensamblador Blas Martínez de Obregón la realización de cuatro retablos colaterales para la capilla de Copacabana, los cuales irían ocupados por San Buenaventura, San Joseph, Santa Teresa de Jesús y San Pedro Regalado ${ }^{51}$. Que sepamos tan solo se ha conservado esta última imagen en la iglesia penitencial de Jesús Nazareno, un simple análisis basta para que engrose las obras atribuidas a Ávila. Es probable que nuestro escultor se ocupara de las otras tres imágenes.

Por estas fechas la actividad en el taller debía ser incesante, con lo que el obrador que tenía en su casa se quedó pequeño ante tanta demanda. Seguramente debido a ello, el 7 de enero de 1679 el escultor toma en renta de las Memorias que había dejado el pintor Andrés de Carreño ${ }^{52}$ una casa que por entonces se hallaba regentada por Manuel Delfín (DOCUMENTO 20). El escultor entraría a vivir en junio de ese mismo año y la habitaría durante nueve años, en cada uno de los cuales habría de pagar la nada desdeñable cantidad de 38 ducados (= 418 reales). El presente arrendamiento tendría su ser, como acabamos de decir, en la búsqueda de un inmueble más espacioso dado el incremento de su actividad, pero tampoco podemos obviar que por entonces también creció su familia. Ambos hechos llevaron al escultor a alquilar una casa cercana de mayores dimensiones, Ávila no tuvo intención de desligarse de su barrio ni de su calle. El contrato no se terminó de cumplir por cuanto el 20 de julio de 1684, cuatro años antes de finiquitarse el convenio, vuelve a arrendarla por otros dos años. Gracias a esta

51 FERNÁNDEZ DEL HOYO, María Antonia: "El convento de San Francisco de Valladolid. Nuevos datos para su historia”. B.S.A.A., Tomo LI, 1985, p. 419.

52 Andrés Carreño (1591-1660) fue un pintor de origen asturiano. Trabajo en Valladolid durante la primera mitad del siglo XVII, llegando a gozar de bastante popularidad. No se conserva ninguna obra de su mano. Su mayor logro fue ser tío del gran pintor asturiano, aunque de la escuela madrileña Juan Carreño de Miranda (1614-1685). VALDIVIESO GONZÁLEZ, Enrique: op. cit., pp. 249-250. 
última escritura sabemos que la casa se encontraba "en la calle de Santiago en la acera de los pintores" (DOCUMENTO 22). Finalizados los dos años prorroga el arriendo por otros dos, si bien el alquiler había bajado hasta los 28 ducados (= 308 reales) (DOCUMENTO 23). Aún viviría allí otro año, hasta poco después de contraer segundas nupcias, puesto que en junio de 1689 entró a vivir allí su amigo el pintor Jacinto Mayo, el cual había suscrito la escritura de arriendo el 20 de junio de 1689, puntualizando que la vivienda se encontraba "en la calle de Santiago de esta ciudad frontero de las tapias del Convento de San Francisco en que al presente vive Juan de Ávila escultor vecino de esta ciudad" (DOCUMENTO 24). Años después Ávila debió de volver a habitar esta vivienda hasta su muerte ya que cuando el pintor Isidro Fernández de la Cabeza la alquila en diciembre de 1702 se comenta en la escritura que dicha vivienda "que la vivió Juan de Ávila maestro escultor hasta que murió" (DOCUMENTO 25).

Una vez desocupada su vivienda familiar decidió darla en arrendamiento, de esta manera la sacaría un rendimiento económico y la casa estaría cuidada, con lo cual no se le estropearía, como así ocurrió con infinidad de viviendas durante gran parte del siglo XVII. Seguramente la casa fue arrendada nada más mudarse a la vivienda alquilada, si bien no tenemos un alquiler documentado hasta el día 27 de enero de 1684. Ese día daba en alquiler al espartero Isidro Francos "una casa que tengo mía propia en la calle Santiago linda casas del Colegio de San Gregorio y de Alonso Martínez" (DOCUMENTO 21). Francos entraría a vivir allí el día de San Juan de junio, la duración del contrato era de seis años, en cada uno de los cuales debería abonar al escultor 20 ducados (= 220 reales). Este precio, casi la mitad de lo que le costaba a Ávila el alquiler de la nueva casa, nos vuelve a confirmar que el cambio de hogar se vio propiciado por la necesidad de una vivienda de mayores dimensiones.

Juan debió de tener varias casas en propiedad, todas ellas radicadas en la calle Santiago/Campo. De una de ellas conocemos su localización exacta, es concretamente la que legó a su hijo Pedro, y que éste a su vez vendería en 1717 (DOCUMENTO 73). La casa, en dicho año de 1717, se ubicaba "en la calle de Santiago de esta dicha ciudad que al presente linda por una parte con casas del Colegio de San Gregorio y por otra casas de Francisco Sáenz boticario vecino de ella sobre que la Cofradía de la Santa Espina sita en la Santa Iglesia Catedral de esta dicha ciudad tiene un censo perpetuo" ${ }^{\circ 3}$.

No poseemos ninguna otra noticia del escultor durante este año hasta que, a finales del mismo, o principios del de 1680, marcha junto a Francisco Diez de Tudanca, Pedro Salvador "el joven" y el desconocido Alonso Pérez a Madrid. Es la primera y única ocasión que nos consta que Juan de Ávila viaja fuera de Valladolid, si bien no sería nada extraño que hubiera acudido a contratar obra a algún pueblo. La marcha de los cuatro escultores a Madrid estaba relacionada con la preparación de los fastos para conmemorar la entrada en la Villa y Corte de la reina María Luisa de Orleans, esposa de

53 A.H.P.V., Leg. 3.126, ff. 934-935. 
Carlos II, tras la boda con el Rey. La entrada real constituía la ceremonia con la que el concejo y, a veces, algunos gremios agasajaban públicamente a un rey, a una reina consorte o a un alto personaje de la realeza, y posteriormente se le hacía entrega de las llaves de la ciudad ${ }^{54}$. Desde el punto de vista artístico estas entradas suponían, según Teresa Zapata, "uno de los espectáculos más ricos, sorprendentes y complejos, para el que se levantaban monumentales arcos de triunfo y otras arquitecturas efimeras jalonadas de pinturas, esculturas, poesías y elementos alegóricos y emblemáticos" $"$.

El trayecto solía ser siempre el mismo, por lo que podríamos hablar de una "carrera oficial". La comitiva pasaba por las calles más importantes de la Villa y Corte: carrera de San Jerónimo, Puerta del Sol, calle Mayor, Puerta de Guadalajara, Platería, plaza de la Villa, calle de Santa María de la Almudena, hasta la plaza de Palacio, en donde el rey recibiría a su esposa ${ }^{56}$. Para decorar las calles y plazas por las que se desarrollaría la "procesión" se levantaron numerosas arquitecturas efímeras, entre las cuales destacaban cuatro arcos triunfales: "el primero, al principio de la carrera de San Jerónimo; el segundo, también en la carrera, a la altura del Hospital de los Italianos; el tercero, en la Puerta del Sol, y el cuarto, junto a la parroquia de Santa María de la Almudena, a los que sumó otro el levantado en la Puerta de Guadalajara por el gremio de los mercaderes de seda"57. Los arcos del triunfo se realizan a la manera romana ya que también venían a honrar al soberano, si bien tenían una gran diferencia: se trataba de arcos que se apoyaban en los edificios de uno y otro lado de la calle, no eran exentos ${ }^{58}$. Otras arquitecturas efímeras completaban el espectáculo: carros, tarascas, templetes, montes parnasos, altares, túmulos, etc... ${ }^{59}$. Además de estas arquitecturas, también se decoraban las fachadas de las iglesias, de los conventos, las casas de los nobles y edificios oficiales con tapices y reposteros ${ }^{60}$.

La construcción de estos arcos triunfales juntaba a una gran cantidad de profesiones: los arquitectos se encargaban de las trazas y de los programas iconográficos, los ensambladores daban forma a esas trazas, los escultores tallaban las imágenes y los adornos. Los pintores se ocupaban de policromar el arco, las estatuas y los adornos, pero también de confeccionar óleos para ornar las arquitecturas. Finalmente, por cuenta de los bordadores corrían determinadas decoraciones y los vestidos de algunas esculturas, ya que estas iban hechas en materiales ligeros, y la madera solo se utilizaba para las cabezas, manos y pies. Según relata Teresa Zapata: "Las estatuas pertenecen a la categoría de escultura de vestir o de "bastidor", en las que el cuerpo, no visible, se fabricaba con recortes de madera, aros de cedazo, tablas..., mientras que las partes visibles -cabezas, brazos, manos, piernas y pies-se moldeaban con pasta de papel que se encarnaba al óleo. Los ropajes que las cubrían eran de lienzo encolado, policromado al temple. Con frecuencia, el escultor, que solamente estaba obligado a

$\begin{array}{ll}54 & \text { ZAPATA, Teresa: op. cit., p. } 21 . \\ 55 & \text { Ídem, p. } 17 . \\ 56 & \text { Ídem, p. } 22 . \\ 57 & \text { Ídem, p. } 25 . \\ 58 & \text { Ídem, p. } 23 . \\ 59 & \text { Ídem, p. } 21 . \\ 60 & \text { Ídem, p. } 22 .\end{array}$


entregarlas en blanco, contaba con la ayuda de un sastre para vestirlas. En ocasiones, estas estatuas iban doradas. A diferencia de los arquitectos y pintores, en los contratos con los escultores no se establece la cantidad total que debían percibir, sino que se deja al resultado de una tasación, una vez concluido el trabajo"61.

Ante tal avalancha de trabajo los responsables de las obras se vieron en la necesidad de pedir ayuda a artistas de otras ciudades importantes que vinieran a apoyar a los artífices madrileños. En este sentido nos interesa la participación del escultor vallisoletano, aunque radicado en la Corte desde hacía ya muchos años, Pedro Alonso de los Ríos ${ }^{62}$, hijo del también escultor vallisoletano Francisco Alonso de los Ríos. A él se le encomendó la decoración escultórica de los arcos del Hospital de los Italianos y de la Puerta del Sol. Con él colaboraron los escultores del foco madrileño Manuel Gutiérrez, Enrique Cardona o Mateo Rodríguez. Como acabamos de decir, estos se vieron sobrepasados por el ingente número de esculturas y el escaso tiempo con que contaban para realizarlas. Ante la falta de otros prestigiosos escultores en Madrid, la Junta encargada decide llamar a escultores de otros focos cercanos, como fue el caso del "vallisoletano" Alonso de Rozas. A este le acompañaron posteriormente Francisco Díez de Tudanca, Pedro Salvador "el joven, Alonso Pérez y Juan de Ávila ${ }^{63}$. No cabe duda de que la iniciativa de traer a los vallisoletanos corrió por cuenta de su paisano Pedro Alonso, a cuyo cargo estuvieron los arcos en los que trabajó Rozas (Arco de los Italianos y Arco de la Puerta del Sol). Cuando quisieron llegar a Madrid como refuerzos Ávila y sus otros tres compañeros se vieron en la tesitura de que ya no necesitaban su ayuda. La Junta decidió compensarles con 1.200 reales en concepto de gastos de desplazamiento. Una vez recibida dicha cantidad se volvieron para Valladolid ${ }^{64}$.

Poco antes de marchar a Madrid debió de acabar de tallar el paso del Despojo dado que la cofradía que se lo encargó tenía la intención de procesionarlo ya el Viernes Santo del año 1680. A la conclusión de este paso, habrían de pasar algo más de tres siglos para que un escultor volviera a tallar nuevos sayones para la Semana Santa vallisoletana ${ }^{65}$.

Desconocemos el tiempo exacto que nuestro escultor permaneció en Madrid, no muchos días si hacemos caso a los documentos aportados por Teresa Zapata. Es probable que

$61 \quad$ Ídem, p. 26.

62 Pedro Alonso de los Ríos (1641-1702) fue un importante y reconocido escultor vallisoletano que desarrolló la mayor parte de su actividad en Madrid. Por desgracia no es mucha su obra documentada, y la mayor parte de ella ha desaparecido. Entre sus discípulos se encuentran los magníficos escultores asturianos Juan de Villanueva, y, sobre todo, Juan Alonso Villabrille y Ron. AGULLÓ COBO, Mercedes: "El escultor Pedro Alonso de los Ríos...", op. cit., pp. 15-22; BARRIO MOYA, José Luis: "El escultor vallisoletano Pedro Alonso de los Ríos...", op. cit., pp. 411-425; BARRIO MOYA, José Luis: "El arquitecto Manuel García...", op. cit., pp. 438-441; BARRIO MOYA, José Luis: "Los relieves del Trasaltar...”, op. cit., pp. 247-248; GONZÁLEZ GARCÍA VALLADOLID, Casimiro: Datos para la historia biográfica..., op. cit., Tomo I, p. 51; CRUZ YABAR, Juan María: "El escultor Pedro Alonso de los Ríos. I. Biografía y obra", Anales del Instituto de Estudios Madrileños, Tomo 47, 2007, pp. 133-154; CRUZ YABAR, Juan María: "El escultor Pedro Alonso de los Ríos. II. Inventario de sus bienes y otros aspectos", Anales del Instituto de Estudios Madrileños, Tomo 49, 2009 pp. 97-116.

63 ZAPATA, Teresa: op. cit., p. 56.

$64 \quad$ Ibídem.

65 Este honor lo tienen los sayones (el de la lanza, el de la linterna y Malco) del paso del Prendimiento, realizado por el escultor vallisoletano Miguel Ángel Tapia entre 1995-2011. 
durante este corto intervalo tuviera la oportunidad de conocer a algunos de los muchos escultores cortesanos y de otras latitudes que se dieron cita en la capital de España, entre ellos destacaba un nutrido grupo de imagineros andaluces. Queda por resolver la incógnita de si Alonso de los Ríos y Ávila ya se conocían de cuando el primero vivía en Valladolid o bien entablaron relación en Madrid. Otra duda que nos plantea el viaje de Ávila a Madrid es si en tan corto espacio de tiempo tuvo la oportunidad de ver y asimilar la obra de los artistas madrileños y andaluces y que estas pudieran influir algo en su estilo a partir de entonces.

Unos meses después de su regreso a Valladolid, el 23 de septiembre de 1680 le veremos aplicado a uno de los diversos trabajos que podía desarrollar un escultor: la de tasador de esculturas y retablos. En otras ocasiones encontramos escultores valuando pintores e incluso bienes elaborados en madera (puertas, armarios, escritorios...). Pues bien, ese día tasa las "hechuras de bulto" que había dejado tras su óbito Paula del Hierro ${ }^{66}$. Entre las piezas inventariadas figuran "dos hechuras de Nápoles", una muestra más de la popularidad con la que entonces gozaba la escultura partenopea en España. Todavía está por estudiar la incidencia que tuvo la escuela napolitana en la evolución de la imaginería castellana desde los últimos modelos "fernandescos" a finales del siglo XVII y el desarrollo de una verdadera escultura dieciochesca a partir del segundo decenio del siglo XVIII.

El 30 de octubre de ese mismo año nuestro escultor firma como testigo en el enlace entre Antonio Fieles y María Saavedra en la iglesia de Santiago ${ }^{67}$. Ambos hombres no solo debieron de mantener una relación de amistad y vecindad sino que podríamos

66 "En la ciudad de Valladolid el dicho mes y año en prosecución del dicho inventario y tasación y para efecto de hacerla de lo tocante a hechuras de bulto se recibió juramento de Juan de Ávila maestro de escultor vecino de esta ciudad el cual habiendo jurado se inventarió y tasó lo siguiente:

- Dos hechuras de Nápoles de bulto la una de un Niño Jesús y la otra de San Juan con sus peanas doradas a treinta ducados cada una.

- Una hechura de San Diego de bulto de una tercia de alto con su peana dorada en ciento y cincuenta reales.

- Una hechura de un Santo Cristo de bulto de cosa de una sexma con la cruz y peana de peral con un doselillo de estameña encarnado con guarnición de plata falsa que está en la cabecera de la cama en cincuenta reales todo,

- Cuatro jarras de madera doradas con dos jaspes cada una a Diez y seis reales cada una.

- Cuatro pirámides pequeñas de madera con sus bolas de jaspe a ocho reales cada una.

- Una hechura de Nuestra Señora del Rosario de pasta y manos de madera la tunicela blanca y el manto azul de media vara de alto en doce reales.

La cual dicha tasación dijo estar bien y fielmente hecha sin agravio para el juramento que hizo y lo firmó y que es de edad de treinta años poco más o menos”. A.H.P.V., Leg. 2.425, f. 420.

67 "En treinta de octubre de mil y seiscientos y ochenta yo Francisco García cura propio de la iglesia de señor Santiago de ésta ciudad de Valladolid habiendo precedido las tres municiones que el santo concilio manda desposé por palabras de presente según orden de la santa madre iglesia a Antonio Fieles natural de la ciudad de Ávila hijo de Antonio Fieles y de Ana Reimon con María de Saavedra vecina de ésta ciudad viuda de Juan de Rueda fueron testigos Damián del Río Tomás de Castro y Juan de Ávila y lo firmé". A.G.D.V., Santiago, 1673B, f. 61. 
hablar incluso de hermandad puesto que un año después, el 9 de diciembre de 1681, el escultor será padrino del primogénito del matrimonio Manuel Fieles Saavedra ${ }^{68}$.

El 29 de enero de 1681 Juan de Ávila y Francisca Ezquerra se vieron bendecidos con la llegada de un nuevo hijo, y ya iban cuatro. El bautizo tuvo lugar el 24 de febrero en la iglesia de Santiago Apóstol ${ }^{69}$. Le pusieron de nombre Francisco seguramente en alusión al recientemente canonizado San Francisco de Sales ${ }^{70}$, cuya festividad se celebraba el día del nacimiento del pequeño. La alegría inicial por la llegada de un nuevo retoño se vería pronto ensombrecida ya que, como en los casos de Josepha Antonia y del primer Pedro, el bebé fallecería muy pronto. Quizás viviera unos pocos años y sea a él a quien pertenece una partida de defunción fechada el 1 de agosto de 1689 en uno de los libros sacramentales de la parroquia de Santiago, en ella figura escrito: "criatura de Juan de Ávila"71.

Su militancia y relación laboral con la Cofradía de Jesús Nazareno no pasó desapercibida para los hermanos de la penitencial, los cuales resolvieron en marzo de 1681 proponerle para ocupar la alcaldía de la misma. Aunque no logró los votos necesarios para tal propósito tan solo tuvo que esperar un año más para desempeñar ese honroso cargo. En él se mantuvo hasta junio de 1683. Una vez finalizado el mandato, siguió copando otros puestos de responsabilidad en la cofradía: por ejemplo, fue mayordomo de $\operatorname{pasos}^{72}$, función que desempeñó hasta el año 1688.

Relación devocional y también laboral tuvo con la iglesia de Santiago. Esta última comenzaría, si nuevos documentos no lo desmienten, en este año de 1681. A lo largo de este año se conviene con la iglesia para tallar el grupo procesional de Santiago Matamoros, que vendría a sustituir a uno anterior ejecutado por Juan Imberto en 1622, el cual debía encontrarse en un estado bastante defectuoso. También debía de elaborar un Arco-hornacina en una de las paredes de la sacristía, lugar en el que se custodiaría al santo todo el año ${ }^{73}$. Por fortuna ambas obras se conservan, y además en el lugar para el que fueron hechas. La imagen tenía una función procesional, y es precisamente para ese

68 "En nueve días de diciembre de mil seiscientos y ochenta y un años yo Mateo González teniente de cura de la iglesia parroquial de Señor Santiago de esta ciudad de Valladolid bauticé e impuse los santos óleos como el Santo Concilio manda a un niño hijo legítimo de Antonio Fieles y María de Saavedra parroquianos de esta dicha parroquia en la calle de Santiago pusieronle por nombre Manuel que nació en veinte y ocho de noviembre de este presente año según me lo aseguraron sus padrinos que lo fueron Juan de Ávila y Juana de Ezquerra dieronle por abogados a San Gregorio y a Nuestra Señora fueron testigos Domingo Fernández y Pedro Cordón y lo firmé”. A.G.D.V., Valladolid, Santiago, 1668B. 69 A.G.D.V., Santiago, 1668B, f. 294.

70 El proceso de beatificación y canonización de San Francisco de Sales (1567-1622) transcurrió rápidamente: el 8 de enero de 1662 le beatificó Alejandro VII, y el mismo Papa fue el encargado de canonizarle el 19 de abril de 1665.

71 "En primero de agosto de seiscientos y ochenta y nueve se enterró en esta iglesia una criatura de Juan de Ávila y (vivía) a la calle de Santiago y lo firmé”. A.G.D.V., Santiago, 1673D, f. 307.

72 Su cometido era el de armar los pasos para las procesiones de Semana Santa, ya que durante el resto del año se encontraban desmontados. La imagen titular, la de devoción, solía presidir todo el año un altar o retablo en la iglesia mientras que el historiado (sayones y otras figuras) se guardaba de forma bastante descuidada en los almacenes.

73 MARTÍN GONZÁLEZ, Juan José y URREA FERNÁNDEZ, Jesús: Catálogo Monumental de la provincia de Valladolid. Tomo XIV..., op. cit., p. 202. 
primer desfile, celebrado el 25 de julio de 1681, cuando Ávila realizó una "perspectiva que hizo de tres arcos con su grada en medio de tres gradas"74. Esta perspectiva no sería otra cosa que una arquitectura efímera que serviría para realzar al santo. Es interesante el hecho de que le veamos realizando un arco-hornacina y una "perspectiva" puesto que nos le muestra como un maestro multidisciplinar ya que la primera obra es más propia de un ensamblador y la segunda de un arquitecto. No puede desecharse la idea de que Ávila ejerciese ambas artes ya que en algunos documentos le veremos nombrado como "maestro ensamblador" " o "maestro arquitecto"76. La iglesia vio en su parroquiano la persona a la que acudir cuando necesitara realizar cualquier obra de carácter artístico. Así en 1688 le encargan el embellecimiento de la cruz que por entonces se había tallado para que presidiera el cementerio parroquial. La intervención consistió en la fabricación de "por hacer tres remates de piedra para la cruz que se puso en dicho cementerio en dicho tiempo y abrir en la peana dos conchas y dos hábitos de Santiago"77. No podemos descartar que también corriera por su cuenta el cincelado de la propia cruz. Aunque se trata de una obra modesta es suficiente para saber que el escultor también se aplicó a la talla en piedra. Como veremos más adelante la relación laboral entre la iglesia y el artista culminaría de la mejor forma posible: con la participación de Ávila en la obra del nuevo retablo mayor.

La siguiente noticia sobre su vida data del día 1 de marzo de 1682, fecha en que tanto Juan como su esposa Francisca actúan de padrinos en el bautizo de una niña llamada María Araujo, hija de los portugueses Juan de Araujo y Faustina Martínez de Chozas, naturales de Braga y Miranda do Douro, respectivamente ${ }^{78}$. Desconocemos todo acerca de este portugués, excepto que vivía en la calle del Campo, siendo por lo tanto vecino y amigo del escultor puesto que no podemos explicar de otra manera que Ávila ejerza de padrino de su hija. El asiento de Araujo en la calle del Campo y su amistad con Juan de Ávila nos abre un abanico de especulaciones acerca de su profesión: pudo ejercer de zapatero de obra prima, de pintor o de escultor, las dos primeras eran las profesiones

74 A.G.D.V., Santiago, Libro de fábrica 1673-1707, s/f.

75 En la tasación de las esculturas de don Antonio Rogel se le cita como "Juan de Ávila maestro ensamblador vecino de esta dicha ciudad" A.H.P.V., Leg. 2.713, ff. 475-477.

$76 \quad$ Así se le vemos nombrado en un arrendamiento realizado en 1686: "Juan de Ávila maestro de arquitectura vecino de esta ciudad" (DOCUMENTO 23).

77 A.G.D.V., Santiago, Libro de fábrica 1673-1707, f. 286.

78 "En primero de marzo de mil seiscientos y ochenta y dos años yo Julián de Granda beneficiado de ésta iglesia de señor Santiago de Valladolid de licencia del licenciado Francisco García cura de ella bauticé e impuse los santos óleos como ordena el manual romano a una niña hija legítima de Juan de Araujo Coto vecino de ésta ciudad y natural de la ciudad de Braga en el reino de Portugal y de Faustina Martínez Chozas su mujer natural del lugar de Viñas arzobispado de Miranda de Duero, parroquianos de ésta iglesia a la calle del Campo pusieronla por nombre María de Araujo Coto, la cual nació en trece de febrero de dicho año según lo declararon y aseguraron sus padrinos Juan de Ávila y Juana María Izquierda, dieronla por abogados a San Antonio de Padua y al Ángel de nuestra Guarda, fueron testigos el licenciado Juan Gil capellán en dicha iglesia y Manuel de Rojas todos vecinos de dicha ciudad y lo firmé en ella con el dicho señor cura en dicho día mes y año, Adviertese que el dicho Juan de Araujo padre de dicha bautizada se llamó Pedro como consta de la fe que presentó de su bautismo sacada del licenciado Paulo Gómez vicario de la catedral de dicha ciudad, y por su declaración dijo se había mudado el nombre en la confirmación de Pedro en Juan dijo ser hijo legítimo de Antonio Francisco Coto y de María de Araujo vecinos de dicha ciudad de Braga y para la legitimación su persona pidió se asentase en la forma referid ut supra”. A.G.D.V., Santiago, 1668B, f. 314. 
más extendidas en esta calle mientras que la opción de que fuera escultor proviene de esa desconocida relación con Ávila. Bien pudo ser compañero de taller de Ávila en el obrador de Tudanca o aprendiz del propio Ávila.

Unos días después del bautizo de la pequeña portuguesa el escultor y su esposa vuelven a ser padres. Su nuevo vástago, al que llamaron Joseph, vio la luz el día 15 de marzo ${ }^{79}$, si bien el bautizo no tuvo lugar hasta el día 30 de ese mes. La elección de dicho nombre tendrá su ser por la cercanía con la celebración de la onomástica de San José el 19 de marzo. Cabe destacar que el pintor Amaro Alonso de Llanos ejerció de padrino en el bautizo del pequeño. Con este hecho comprobamos que la relación entre Ávila y Alonso iba más allá de la puramente laboral ya que habían coincidido en la obra de las "perspectivas" para las fiestas de Santiago Apóstol del año 1681: Juan de Ávila las diseñó y Amaro Alonso las policromó.

El 2 de septiembre de 1682 volvemos a ver al escultor arrendando la vara de portero que había heredado de su suegro. Hasta entonces había estado arrendada a Manuel Fernández, quien la tomó para si en 1674 , pero con motivo de su fallecimiento la vara regresó a Ávila y este decidió darla en arrendamiento a otra persona. El locatario fue Simón Bautista Camer y Castellanos, el cual tomó la posesión de la vara durante de tres años, abonando en cada uno de ellos 15 ducados (= 165 reales), cabe esperar, como sucedió con Manuel Fernández, que quisiera prorrogar el arrendamiento para años sucesivos (DOCUMENTO 26).

Por estas mismas fechas el Colegio de San Ambrosio debió de recurrir a sus servicios para dotar de esculturas a los retablos que por entonces se estaban construyendo para la recientemente edificada capilla de la Congregación, aneja a la propia iglesia ${ }^{80}$. Las cuatro imágenes crean un programa plenamente inmaculadista: la Inmaculada preside el retablo mayor; sobre ésta un altorrelieve de la Santísima Trinidad, la cual parece ser una alusión a la coronación de la Virgen; los retablos laterales están regentados por San Joaquín y Santa Ana, padres de María.

El 16 de diciembre de 1683 Juan de Ávila y su mujer, Francisca Ezquerra se conciertan con el escribano Mateo de Carballas y su esposa para comprarles "la tienda que tienen hecha y fabricada en la casa que viven en la calle del Campo que son propias de las Memorias que fundó Andrés Carreño y en que vive el presente escribano con todas las mercaderías de joyería y especería que en ella hay y en la trastienda de ella y con los pesos, ollas, mesas y demás que tienen sin reservar cosa ni género alguno salvo un peso grande de cobre que dijeron no ser suyo" (DOCUMENTO 27). El precio de la compra ascendió a 1.350 reales de vellón, los cuales serían abonados por el escultor en varios plazos. Entre los testigos de la escritura firman Damián Díez, quizás el semidesconocido escultor. La adquisición de la tienda y de la trastienda podemos entenderla de dos

79 A.G.D.V., Santiago, 1668B, f. 316. FERNÁNDEZ DEL HOYO, María Antonia: "El escultor vallisoletano Francisco Díez de Tudanca...”, op. cit., p. 385.

80 FERNÁNDEZ DEL HOYO, María Antonia: "Notas sobre el Colegio de San Ambrosio de Valladolid", B.R.A.C., Tomo XXXVII, 2002, p. 82. 
maneras: por un lado, puede que quisiera diversificar su dinero, de tal manera que si le faltaban encargos poder de esta forma subsistir con lo ganado en la tienda. No podemos olvidar que muchos escultores además de su profesión tenían otro negocio, mayoritariamente el de viñas, pero otros regentaban una tienda; la otra opción es que la adquiriera para convertirla en una prolongación de su taller, es posible que esta tienda estuviera pared con pared de la casa alquilada en la que vivía por entonces el escultor, al igual que aquella la tienda de joyería estaba radicada en casas que también pertenecían a las Memorias de Andrés Carreño. Es decir, un incremento de la actividad del escultor le llevó a comprar el local inmediato y mediante la rotura del tabique medianero poder tener un taller mucho más amplio con que poder satisfacer las demandas.

Con la treintena cumplida, el 9 de mayo de 1684 vuelve a tomar la confirmación en la iglesia de Santiago, siendo padrinos el licenciado Francisco García, cura de la dicha parroquia, y casualmente quien le bautizó, y Catalina Cepeda ${ }^{81}$. Extraña verle nuevamente recibir un sacramento que tan solo puede tomarse una vez. Tras comprobar repetidamente que es el mismo Juan de Ávila, y habiendo consultado a varios sacerdotes, no hemos logrado descifrar este enigma.

Ávila siguió ejerciendo las funciones de tasador. Así, el 20 mayo de 1685 se encarga de tasar las esculturas que dejó al fallecer el cirujano Luis de San Juan ${ }^{82}$, el cual poseía una

81 "En nueve de dicho mes y año prosiguió dicho señor obispo a dicha confirmación en esta dicha iglesia de señor Santiago y se confirmaron las personas siguientes siendo padrinos el licenciado Francisco García cura de esta parroquia y Catalina Cepeda: Juan de Ávila. Vecino de esta ciudad casado con Francisca Ezquerra hijo de Hernando de Ávila y Juana Martínez vecinos que fueron de esta ciudad". A.G.D.V., Santiago, Confirmados, f. 30

82 "Escultura. En Valladolid dicho día por ante mí el escribano Juan de Ávila escultor vecino de esta ciudad tasador para lo tocante a su arte y habiendo jurado a Dios y a una cruz prometió hacer bien y fielmente la dicha tasación y debajo de dicho juramento tasó lo siguiente:

- Un niño Jesús de Pasión de tres cuartas de alto con su peana cerrada tallada y dorada veinte ducados.

- Un remate de un Santo Cristo Crucificado con su peñasco y peana ochavada dorada y tallada la cruz con remates dorados con San Juan y Nuestra Señora a los lados de la cruz y la hechura del Santo Cristo tiene de alto una cuarta doscientos y cincuenta reales.

- $\quad$-Una hechura de Jesús Nazareno con los sayones doce reales.

- Una caja pequeña con dos puertas y en ella la Magdalena dorada la caja tres ducados.

- Una caja grande dorada con sus lajones y gradas y puertas con pinturas diferentes y dentro el Niño Jesús San Joseph y Nuestra Señora de bulto con dos ramilleteros y jarras verdes la caja en cinco ducados y las hechuras del Niño tres ducados, Nuestra Señora diez y ocho reales y el San José dos ducados.

- Un San Antonio pequeño diez reales.

- Un Niño Jesús pequeño con cabellera y peana diez reales.

- Una Nuestra Señora con el Niño Jesús y manto azul veinte y cuatro reales.

- Una cruz pintada un Santo Cristo con peana de jaspe doce reales.

- Dos pirámides de alabastro.

- Dos velas digo tres pirámides de pino con bolas de jaspe a seis reales cada una.

- Cuatro candelericos de pino plateados seis reales.

- Dos jarritas verdes con ramilletes dos reales.

- Las dos jarritas verdes con ramilletes que estaban en la caja grande dos reales.

- Cuatro cornucopias en blanco a tres reales.

- Las dos cornucopias doradas y talladas que están con la pintura del Niño Jesús, catorce reales.

- Un cetro de bronce de la Pasión con vara dorada, diez y ocho reales. 
buena colección de tallas, cornucopias y otros objetos artísticos. Por dicho trabajo el escultor percibió seis reales. Unos meses después llegaría el último hijo de la pareja: el 8 de agosto vio la luz Ana de Ávila, cuyo nombre sería un homenaje a su abuela paterna, Ana González del Portal ${ }^{83}$. El bautizo tuvo lugar el día 30 de ese mes en la iglesia de Santiago Apóstol. Al igual que otros de sus hermanos, falleció al poco tiempo ya que ni aparece en las listas de confirmados ni se la cita en documento alguno. El mismo día del bautizo de la pequeña, Ávila sale por fiador del ensamblador Blas Martínez de Obregón en la escritura por la que concierta la fabricación de un retablo para la iglesia parroquial de Santiago Apóstol de Cigales (Valladolid) (DOCUMENTO 28). Es probable que corriera por cuenta de Ávila la parte escultórica del retablo, de la cual tan solo sabemos que se fabricaría "el santo que eligiere el dicho señor Canónigo". El santo no sería otro que San Francisco, en honor del comitente: el licenciado don Francisco Pinacho y Pareja, canónigo de la catedral de Palencia.

Esta etapa que veíamos comenzar con la independencia de Ávila de su maestro y con su enlace con Francisca Ezquerra terminará abruptamente a finales del año 1686 con el prematuro fallecimiento de ésta. El feliz matrimonio había tenido siete hijos, de los cuales aún vivían tres (Teresa, Pedro y Joseph). Desconocemos que es lo que produjo el óbito de Francisca: puede que contrajera una enfermedad, que falleciera repentinamente, o bien que estuviera nuevamente encinta y que el embarazo se complicara, lo que tuvo como resultado el fallecimiento tanto del feto como de la madre. Sea como fuere, el 17 de noviembre de 1686 tuvo lugar uno de los momentos más dolorosos en la vida de nuestro escultor: el fallecimiento de su mujer. Contaba tan sólo con 36 años ${ }^{84}$. El escultor quedaba viudo muy joven, con todo lo que ello significaba: tener que compaginar su profesión con el cuidado de sus tres hijos, todos ellos menores de edad: Teresa, la mayor, tan solo tenía 14 años, pero debió ya desde entonces ayudar a su padre a cuidar de los pequeños Pedro y Joseph, convirtiéndose de esta manera en la segunda madre de estos.

Al entierro de Francisca acudirían como era costumbre delegaciones de las cofradías a las que pertenecían tanto ella como su marido, muy especialmente en las que Ávila había ocupado cargos de responsabilidad. Entre ellas se encontraría la Penitencial de Nuestra Señora de la Pasión y la del Santo Ángel de la Guarda de la iglesia de Santiago Apóstol, como así aparece reflejado en uno de los libros de mayordomía de la parroquia $^{85}$. Tampoco faltarían al sepelio sus queridos tíos Francisca Ezquerra y Francisco Díez de Tudanca, los cuales, ya muy mayores, se volcarían en la medida de sus posibilidades con el joven escultor viudo.

Y en la forma referida hizo la dicha tasación que declaro hizo bien y fielmente sin agravio de partes debajo de dicho juramento en que se afirmó y ratificó y lo firmó que es de edad de treinta y cuatro años. Y recibió de la ocupación de esta tasación seis reales”. A.H.P.V., Leg. 2.325, f. 927.

83 A.G.D.V., Santiago, 1683B, f. 63.

84 A.G.D.V., Santiago, 1673D, f. 576.

85 “Juan de Ávila como depositario de la Cofradía del Ángel me tiene pagados dos años hasta el marzo de 1686, y asimismo entierro y misas por su mujer”. A.G.D.V., Santiago, Libro de mayordomía, f. 32. 


\section{D- ETAPA DE PRESTIGIO Y SEGUNDO MATRIMONIO (1686-1702)}

Este último periodo se enmarca dentro de dos hechos luctuosos: los fallecimientos de su primera esposa y el suyo propio. Entre medias volverá a contraer matrimonio y cosechará numerosos éxitos en su oficio, recibiendo encargos que son buena prueba de su maestría, la cual se prolongó mucho más allá de la ciudad y su área de influencia. El nuevo matrimonio le brindaría la oportunidad de tener otros dos hijos, uno de los cuales, Manuel, heredaría con toda dignidad el oficio paterno.

Unos meses después del fallecimiento de Francisca Ezquerra, Ávila comienza una etapa repleta de importantes encargos. El primero llega el 7 de febrero de 1687; ese día se concierta junto a los ensambladores Alonso Manzano, Bernardo de Carvajal ${ }^{86}$ y Juan Correas, la realización del desaparecido retablo mayor del Hospital de San Juan de Dios (DOCUMENTO 29). Tanto por el número de esculturas a realizar, cinco imágenes (San José, Santo Domingo, la Fe con el Santísimo, el Arcángel San Rafael y San Carlos Borromeo), como por la institución para la que fueron hechas, el retablo mayor de una de las instituciones más reconocidas de la ciudad, se puede asegurar que fue el encargo que consagró al artista. Tanto la desaparición del retablo con todas sus imágenes como del edificio que lo albergaba a finales del siglo XIX nos han privado de conocer una de las obras más importantes del escultor. Cabría esperar, siendo muy optimistas, que si no el retablo, las esculturas hubieran ido a parar a alguna iglesia rural, al igual que pasó con otros bienes artísticos desamortizados a lo largo del penoso siglo XIX.

Por estas mismas fechas llegaría a la capital del Pisuerga Bentura Sedano, futura mujer de Juan de Ávila. Nos consta su presencia en la ciudad al menos desde el 7 de noviembre de 1687, fecha en que redacta un poder notarial a favor de sus tíos Martín García y Catalina Caballero, vecinos de Palencia, para que en su nombre "pidan y tomen cuentas judicial o extrajudicialmente a todas y cualesquier personas así eclesiásticas como seglares de cualquier estado y calidad que sean o de quien las deban dar de todos los bienes y hacienda que me tocaron por las cuentas y particiones que se hicieron de los bienes que quedaron por fin y muerte de los dichos mis padres" (DOCUMENTO 8). Años después, ya casada con Juan de Ávila, volveremos a ver que Bentura pedirá ayuda a sus tíos en diferentes asuntos legales que debía resolver en tierras palentinas.

El padre de Bentura Sedano no era otro que el afamado escultor palentino Mateo Sedano Enríquez, el cual había fallecido hacía poco tiempo: el 21 de septiembre de 1686 dictaba testamento, muriendo a las pocas horas. Por otra parte, su madre, Isabel Caballero, también había fallecido hacía muchísimos años, siendo la primera de las dos mujeres que tuvo el escultor palentino. Llama la atención el hecho de que en el

86 Tan solo se le conoce un retablo churrigueresco conservado en el Museo de Salamanca, aunque proveniente de la iglesia de Santiago de Alba de Tormes (Salamanca). Debió ser asimismo escultor dado que talló las hechuras de San Jacinto y Santo Domingo que presidían las hornacinas laterales. SÁNCHEZ MARCOS, Marta: "La Virgen de las Nieves. Transformaciones de una imagen vestidera". En Codex Aquilarensis: Cuadernos de investigación del Monasterio de Santa María la Real, no 9, 1993, p. 98. 
testamento de Mateo Sedano Bentura aparece citada como "Isabel mi hija legítima y de Isabel Caballero mi primera mujer" $" 87$.

Desconocemos el motivo que llevó a Bentura a cambiar su ciudad natal por Valladolid; el caso es que tras fallecer su padre se encamina hacia la ciudad del Pisuerga, quizás en compañía de su hermanastra María Sedano, fruto del segundo matrimonio del escultor palentino. Sospecho que quizás influyera en el ánimo de las hermanas el contar con un tío clérigo presbítero en Valladolid: Bernardo de Osorno y Torralba, hermano de Inés de Osorno, madre de María Sedano. No tenemos ningún dato acerca del religioso, tan solo que el 30 de octubre de 1686 es nombrado curador por parte de María Sedano ${ }^{88}$, y que unos años después, el 16 de junio de 1690, firma en las capitulaciones matrimoniales entre ella y el vendedor de libros Santiago Izquierdo. Es curioso, aunque nada extraño, el hecho de que aparezca citada en la escritura con los dos apellidos del padre "María Sedano Enríquez" y no como debería: "María Sedano Osorno" "89. Un año después, el 16 de octubre de 1691, Santiago Izquierdo otorgaba carta de pago en favor de su esposa en razón de haber recibido todos los bienes prometidos en las capitulaciones matrimoniales ${ }^{90}$.

Es toda una incógnita como se conocieron Bentura y Juan, si bien parece previsible que fuera durante alguna colaboración entre Ávila y Mateo Sedano ${ }^{91}$, la cual por el momento no tenemos documentada. Pudiera ser que este conocimiento llegara en un viaje de Juan de Ávila a Palencia para contratar alguna obra, o al revés, o quizás compartieran la labor de dotar a un retablo de esculturas. Habrá que esperar a nuevas averiguaciones. Lo que está claro es que a pesar de no contar con ninguna certeza documental Juan de Ávila trabajó para el obispado palentino. Esta sería una de las explicaciones por las cuales tenemos obras suyas y de sus hijos, tanto documentadas como atribuidas, en este territorio. Sea como fuere, Juan y Bentura contraen matrimonio el 6 de febrero de 1689 en la iglesia del Santísimo Salvador ${ }^{92}$. Allí se celebraron los desposorios, pasando posteriormente a ser velados en el Convento de Agustinos Recoletos $^{93}$.

87 A.H.P.P., Leg. 7.232. A.H.P.P., Leg. 7.232. GARCÍA CUESTA, Timoteo: "El retablo de la Inmaculada, de la Catedral de Palencia y noticia de los Sedano", B.S.A.A., Tomo XXVIII, 1962, pp. 183184

$88 \quad$ A.H.P.V., Leg. 2.381, f. 362.

$89 \quad$ A.H.P.V., Leg. 2.382/4, ff. 58-59.

$90 \quad$ A.H.P.V., Leg. 2.382/4, ff. 56-57.

91 Mateo Sedano (h.1612-1686) perteneció a una amplia familia de escultores, en el que destacaban sus hermanos Juan y Carlos y su padre Juan Sedano. Siguió de cerca el estilo y los modelos creados por Gregorio Fernández. Su trabajo, que comprende el segundo y tercer cuarto del siglo XVII, se localiza exclusivamente en el ámbito del obispado palentino. Su obra de mayor empeño es la Inmaculada Concepción que talla en 1653 para que el cabildo catedralicio palentino pudiera celebrar el juramento del misterio de la Inmaculada. MARTÍN GONZÁLEZ, Juan José: Escultura barroca castellana. Segunda parte..., op. cit., pp. 216-217.

$92 \quad$ A.G.D.V., El Salvador, $1685 \mathrm{M}$, f. 35.

93 Se trataba del antiguo Convento de San Nicolás de Tolentino o de Agustinos Descalzos. El convento se encontraba situado a la altura de la actual Casa del Príncipe, en la Acera de Recoletos, de quien toma su nombre. Para el mejor conocimiento de este convento agustino: FERNÁNDEZ DEL 
Ese mismo año, el 12 de junio de 1689 otorga una escritura de arrendamiento ante el escribano Matías Torrecilla por la cual tomaba en arrendamiento a partir del día de San Juan de ese año la " $3^{a}$ casa alrededor de la iglesia" de Santiago Apóstol" ${ }^{94}$. Por aquel entonces la " 4 a casa alrededor de la iglesia" tomaba en arrendamiento el pintor Jacinto Mayo, con lo cual ambos artistas trabajaron o vivieron pared con pared ${ }^{95}$. Esa misma casa que tomó Ávila estuvo anteriormente arrendada, al menos desde el año 1684, a un tal Francisco Díez ${ }^{96}$, que pudiera ser su maestro, Francisco Díez de Tudanca, lo que nos permitiría establecer dos hipótesis: la primera, que Tudanca falleció hacia finales del mes de junio de 1689, y, la segunda, que la casa alquilada era el taller del viejo profesor. Tras el óbito de éste su antiguo alumno quiso seguir arrendando ese taller para instalar allí parte del suyo ya que supuestamente el gran taller estaba localizado en la casa que tenía arrendada de las Memorias de Andrés Carreño y una tienda que había adquirido a un joyero.

El 5 de mayo de 1689 tasa las esculturas que dejó a su muerte don Antonio Rogel ${ }^{97}$. El día anterior Pedro de Calabria ${ }^{98}$ y Diego Díez Ferreras había hecho lo propio con las pinturas 99 . En dicha tasación nuestro escultor es nombrado como "maestro ensamblador", este hecho unido al de que en otra ocasión figura como arquitecto puede

HOYO, María Antonia: Desarrollo urbano..., op. cit.; FERNÁNDEZ DEL HOYO, María Antonia: Patrimonio perdido..., op. cit.

$94 \quad$ "Hoy en 30 de junio de 1689 me pagó Granda el susodicho 71 reales con que me acabó de pagar la venta de la casa en que vivió hasta el San Juan de (...) Dicho año Granda quedó por ésta casa desde San Juan de ochenta y nueve por un año Juan de Ávila en la misma cantidad arrendamiento ante Matías Torrecilla en 12 de junio de $1689 "$ ".

"En cinco de enero de noventa y uno arrendó esta casa Juan de Ávila (...) a razón de a nueve ducados en cada un año y por tiempo de... corre desde primero de enero de 91 en adelante". A.G.D.V., Santiago, Libro de mayordomía, f. 9.

95 A.G.D.V., Santiago, Libro de mayordomía, f. 10.

$96 \quad 3^{\mathrm{a}}$ Casa alrededor de la iglesia: Francisco Díez paga en cada un año... ocho ducados para el arrendamiento de la casa en que vive que es la tercera a espaldas de la capilla mayor.

En 27 de septiembre de 86 me puso Francisco Díez cuarenta y tres reales por cuenta de dicho arrendamiento del recibo.

En 16 de marzo de 1689 me pagó el señor Francisco Díez treinta y un reales por la cuenta de harina no llevó recibo". A.G.D.V., Santiago, Libro de mayordomía, f. 9.

$97 \quad$ Tasación de las hechuras de bulto y sillas y demás madera. "En la ciudad de Valladolid a cinco días del mes de mayo de mil y seiscientos y ochenta y nueve años yo el escribano estando en las casas donde vivía y murió el dicho D. Antonio Rogel y presente los dichos D. Francisco Rogel su hermano y Francisco Arias pareció Juan de Ávila maestro ensamblador vecino de esta dicha ciudad que está nombrado para tasar y valuar las hechuras de bulto (...):

- Primeramente, una Nuestra Señora de los Peligros con su Niño en los brazos de bulto con su corona de plata y un vestido de raso de flores con su peana que la tasó el dicho Juan de Ávila en cien reales.

- Una hechura de San Juan de piedra con su vestido de raso y su peana dorada que la tasó en cuarenta reales.

- Cuatro hechuras de alabastro de una cuarta de alto que las tasó todas en treinta reales.

- Dos cornucopias doradas las tasó en diez y ocho reales.

- Una hechura de un Santo Cristo crucificado con su cruz para la cabecera de la cama que la tasó en doscientos reales (...)". A.H.P.V., Leg. 2.713, ff. 475-477.

98 Pedro de Calabria (h.1650-1704) fue padre de Pedro de Calabria Escudero (1675-1738), pintor y grabador vallisoletano que desarrolló toda su actividad en la Villa y Corte de Madrid. Ceán Bermúdez lo hace discípulo de Luca Giordano. CEÁN BERMÚDEZ, Juan Agustín: op. cit., pp. 186-187.

$99 \quad$ A.H.P.V., Leg. 2.713, f. 472. 
indicarnos que Ávila pudo diseñar o incluso tallar retablos u otras piezas de mobiliario litúrgico: canceles, cornucopias, etc...

A principios de este año de 1689 o durante el anterior las monjas del Real Monasterio de San Quirce y Santa Julita solicitan los servicios del escultor para fabricar el programa escultórico de su retablo mayor, el cual lo estaban construyendo por entonces el ensamblador Blas Martínez de Obregón ${ }^{100}$. Las religiosas debieron de quedar tan satisfechas con el trabajo desarrollado por Ávila que años después, entre 1693-1694, le encargan las esculturas y relieves de los retablos colaterales, los cuales también llevan la firma de Martínez de Obregón (DOCUMENTO 51). No sería descabellado que también corriera a su cargo un Cristo Resucitado que preside el ático de un retablo situado a los pies del templo ${ }^{101}$. Este establecimiento religioso, al igual que otros como la iglesia de San Felipe Neri o de Santiago Apóstol, son buenos ejemplos de cómo Juan de Ávila abrió el camino para sus hijos y fidelizó comitentes para la familia de escultores. En este mismo monasterio encontramos dos imágenes, un busto de Dolorosa y San Bernardo, que son plenamente atribuibles a Pedro de Ávila ${ }^{102}$.

El 12 de enero de 1690 Juan y Bentura se ven bendecidos con la llegada de su primer hijo, al cual pusieron por nombre Manuel ${ }^{103}$. La elección de este nombre, que en hebreo significa "El Dios que está con nosotros" o "El Dios que está entre nosotros", tendría relación con la cercanía del día 1 de enero en que se celebraba la fiesta de "Emmanuel", que es el nombre con el que se cita a Jesucristo en la Biblia. También podríamos pensar en que Juan dio este nombre a su hijo en homenaje a su hermano fallecido. Diez días después el futuro escultor recibió las aguas bautismales en la parroquia de Santiago Apóstol.

El 28 de febrero de 1690 Juan de Ávila tasa las esculturas que dejó al fallecer Andrés de Morencia $^{104}$. De la valuación de las pinturas se encargó el pintor Manuel Juárez. Aún volveremos a ver una vez más a Juan de Ávila desarrollar esta tarea. Será el 6 de agosto de 1692 con las "piezas de escultura" que quedaron tras el óbito de Damián López del Águila ${ }^{105}$. Por su parte, el pintor Ignacio de Prado estimó las pinturas. Tenemos algunas

100 MARTÍN GONZÁLEZ, Juan José: Escultura barroca castellana ..., op. cit., p. 318.

101 MARTÍN GONZÁLEZ, Juan José y DE LA PLAZA SANTIAGO, Francisco Javier: Catálogo Monumental de la provincia de Valladolid. Tomo XV..., op. cit., p. 189.

$102 \quad$ Ibídem, pp. 191-192.

103 A.G.D.V., Santiago, 1683B, f. 171.

104 En la ciudad de Valladolid a 2 de dicho mes y año ante mí el escribano pareció Juan de Ávila tasador nombrado par lo tocante a escultura del cual yo recibí juramento por Dios y a una cruz en favor y habiéndole hecho como se requiere prometió hacerla (...):

- Un Niño Jesús de bulto con su peana de tres cuartas de alto con la peana tasado en diez ducados.

- Una imagen de bulto de la Concepción con su peana y sus rayos de vara y cuarta, tasado en treinta ducados de vellón.

- Una imagen pequeña de bulto de mala pintura con su caja, todo tasado en ocho reales.

- Un cetro de la cruz de Cristo tasado en tres ducados.

La cual dicha tasación el dicho Juan de Ávila lo tasó a su saber y entender sin agravio de ninguna de las partes y lo firmó el dicho alguacil y en fe de ello yo el escribano lo firmé. A.H.P.V., Leg. 2.855, f. 250.

105 "En Valladolid dicho día seis de agosto de mil seiscientos y noventa y dos años ante mí el escribano pareció Juan de Ávila maestro escultor vecino de ésta ciudad tasador nombrado para tasar las piezas de escultura que quedaron por fin y muerte de Damián López del Águila vecino que fue de ésta 
noticias acerca de este Damián López del Águila, el cual ejerció en 1686 el cargo de regidor del consistorio de Valladolid, y asimismo por aquellas fechas también ostentaba el cargo de depositario de la Cofradía de la Consolación ${ }^{106}$. En enero de ese mismo año de 1686 se encontraba pleiteando con el ensamblador Blas Martínez de Obregón en razón de 30 ducados que supuestamente le debía el artista en concepto del alquiler de una casa en la calle del Campo ${ }^{107}$.

El 30 de mayo de 1690 Juan y su esposa dan comienzo a los trámites legales para que esta pudiera percibir la herencia que le había tocado por el óbito de su tía Juana Caballero, esposa de Pedro de Soto, vecinos de Castrojeriz, la cual había fallecido "abintestato por cuya causa sus bienes y hacienda me tocan y pertenecen como su heredera por no haber dejado otro más legítimo". Es decir, la tía había fallecido sin haber dictado testamento ni nombrado herederos, debido a esto Bentura da poder a su tía Catalina Caballero, hermana de la finada y vecina de Palencia, para que en su nombre realizara los trámites necesarios para que "la den y entreguen en mi nombre todos los bienes muebles y raíces que por muerte me hubieren quedado y tocaren a dicha herencia aceptándole con beneficio de inventario y no de otra forma (...) y pida se me declare a mí la dicha Bentura Sedano Caballero por heredera única de la dicha Juana Caballero" (DOCUMENTO 30). No sé si es que la tía de Bentura falleció o no supo hacer los trámites necesarios pero el hecho es que unas semanas después, el 12 de julio, el matrimonio da poder también a don Francisco Artacho, vecino de Castrojeriz, para que en su nombre pareciera "ante la justicia de la dicha villa y los demás tribunales que convenga y pida se me declare a mí la dicha Bentura Sedano Caballero por heredera única de la dicha Juana Caballero y declarada pida se la den y entreguen en mi nombre todos los bienes muebles y raíces que por su muerte hubieren quedado y tocaren a dicha herencia" (DOCUMENTO 31).

Los años 1690-1691 pudieron ser de gran actividad para Juan de Ávila ya que su taller pudo recibir muchas e importantes peticiones. Creo que durante este bienio acudieron al obrador los dominicos (Convento de Nuestra Señora de la Laura de Valladolid), jesuitas (Colegio de la Compañía de Jesús de León) y franciscanos (Convento del Domus Dei de La Aguilera, Burgos). Para las Lauras ejecutó una serie de esculturas que tenían como destino el retablo mayor (Santa María Magdalena, Santa Rosa, dos ángeles) y, quizás,

ciudad y del dicho tasador yo el escribano recibí juramento por Dios y una cruz en forma de derecho y le hizo prometer de decir verdad y hacer la tasación bien y fielmente sin agravio de las partes y habiendo visto y reconocido los dichos bienes hizo la tasación en la manera siguiente:

- Primeramente, una hechura de Cristo en la cruz de media vara pintado y blanco con cruz y peana de perol pintada de negro tasado en ciento y diez reales.

- (...) la hechura de un Niño Jesús de escultura (...)

- $\quad(.$.$) de escultura de San Juan (...) con su peana dorada (...)$

- Ítem tasé una hechura de escultura pequeña de Cristo nuestro señor en la cruz en sesenta y seis reales.

Cuya tasación declaró el dicho Juan de Ávila haber hecho bien y fielmente según su arte y ejercicio a lo que Dios nuestro señor le ha dado a entender sin agravio a ninguna de las partes y dijo ser la verdad debajo del juramento que lleva hecho en que se afirmó y ratificó y lo firmó y declaró ser de treinta y seis años poco más o menos y lo firmé”. A.H.P.V., Leg. 2.740, ff. 900-901.

106 A.H.P.V., Leg. 2.738, f. 140 (1686).

107 FERNÁNDEZ DEL HOYO, María Antonia: "El convento de San Francisco...”, op. cit., p. 419. 
los colaterales: tan solo tenemos noticias de una Santa María Magdalena, la cual pudo haber ocupado uno de dichos colaterales. Los retablos fueron realizados por Francisco Billota en 1690, año en que, según Canesi, se inauguran: "Este convento es de los más estrechos que hay en Valladolid. Por los años de 1690 pusieron nuevo dorado, retablo y colaterales, de suerte que la iglesia es un aseado oratorio"108. Por estas mismas fechas el Colegio de la Compañía de Jesús de León le debió de comisionar la ejecución de la parte escultórica del retablo mayor de la iglesia. La arquitectura del mismo corrió a cargo de Alonso Manzano, con el cual había colabora a lo largo de su vida en diversas ocasiones. Ya en 1691 los franciscanos del Domus Dei de La Aguilera (Burgos), santuario en el que reposaban los restos del vallisoletano San Pedro Regalado, le ordenarían labrar la escultura de su santo patrón para que presidiera la magna iglesia que acababan de construir. La imagen en cuestión, La Traslación de San Pedro Regalado, tendría una gran repercusión y sirvió de modelo para esculturas posteriores, una de las cuales fue tallada por el hijo de Juan de Ávila, Pedro, para presidir la capilla que el santo contaba en la vallisoletana iglesia del Santísimo Salvador, parroquia en la que Pedro de la Costanilla fue bautizado. Asimismo, debieron correr a cargo de Ávila las esculturas de los retablos colaterales del referido convento burgalés: San José con el Niño y San Antonio de Padua.

El 11 de septiembre de 1691 nace el segundo, y, último, hijo de la pareja. El bebe fue niña, a la cual se la impuso el nombre de Manuela. Su bautizo tuvo lugar en la iglesia de Santiago el 23 de ese mismo mes ${ }^{109}$. No encuentro ningún motivo concreto para que le pusieran este nombre dado que su nacimiento no se produjo cerca del día 1 de enero, fecha en que, como ya hemos visto con su hermano, se celebraba la fiesta de "Emmanuel". El nacimiento de Manuela se produjo el día en que se festeja a San Orlando, o Rolando, mártir; San Proto y San Jacinto. Quizás se lo pusieron en contraposición a su hermano. Como ocurrió con otros hijos de Juan de Ávila, Manuela fallecería al poco de nacer dado que su nombre no figura en los libros de confirmados ni en documentos posteriores.

No deja de ser llamativo que los únicos dos hijos engendrados durante este segundo matrimonio se llamen Manuel y Manuela. Probablemente no sea más que una casualidad, pero quizás haya alguna otra motivación. Ya desde la Reconquista el nombre se había popularizado, más cuando los moros y judíos conversos les pusieron este nombre a sus hijos para manifestar de esta manera su sincera conversión de forma pública. Por lo tanto, el bautizar a sus hijos con los nombres de Manuel o Manuela era una especie de salvoconducto para evitar las sospechas de las autoridades y soportar la presión, de muy diferentes tipos, a la que estaban sometidos. ¿Tendría algo que ver con esto el que Juan de Ávila aparezca tomando el sacramento de la confirmación en dos ocasiones?

A medida que se van localizando documentos va desapareciendo la idea de que Juan de Ávila era, como la mayoría de los escultores españoles de la época, un escultor que tan

108 CANESI ACEVEDO, Manuel: Historia de Valladolid (1750), Tomo III, op. cit., p. 509.

109 A.G.D.V., Santiago, 1643B, f. 215. 
solo se aplicaba a la escultura religiosa en madera policromada. Ya hemos visto como practicó la escultura en piedra, realizó arquitecturas efímeras y pudo desarrollar labores de arquitecto y ensamblador. Pues bien, Juan de Ávila también trabajó la escultura profana. Efectivamente, el escultor labora en los años 1691 y 1692 para el consistorio vallisoletano realizando diferentes hechuras de manera conjunta con el pintor Jacinto Mayo, su vecino y amigo, para la Procesión del Corpus Christi de sendos años. En 1691 corre a su cargo la restauración de algunas de las figuras de los gigantes que desfilaban en la procesión y la realización de cabezas nuevas para otros gigantes dado que se encontraban especialmente maltratadas ${ }^{110}$. $\mathrm{Al}$ año siguiente, también en compañía del referido Mayo, realiza dos cabezas nuevas para los gigantes y otra para la gigantilla, y además talla nuevas manos y repara algunos de los referidos gigantes ${ }^{111}$. La endeblez y baja calidad de los materiales conllevaba continuas reparaciones.

El 7 de abril de 1692 le llega el encargo más importante y prestigioso de su carrera: la elaboración de la parte escultórica del retablo mayor de la iglesia colegial de San Pedro de Lerma (Burgos). En un principio, ambas partes se concertaron en "hacer seis hechuras de esculturas a vista de maestros"112, si bien posteriormente fueron siete: San Pedro in cátedra, San Pablo, San Andrés y cuatro Virtudes (Fortaleza, Justicia, Templanza y la Fe). La imposición al escultor por parte de la colegiata de realizar la imagen de San Pedro in cátedra siguiendo el modelo "que está en el Abrojo, de Padres Recoletos de San Francisco" parece indicar que en el cabildo había algún personaje relacionado con la orden francisana. También puede ser que los padres franciscanos del cercano convento ribereño de La Aguilera animasen al cabildo de la Colegiata de Lerma a que copiaran para su retablo mayor la escultura que poseían sus hermanos de religión del convento del Abrojo ${ }^{113}$. Este hecho no hace sino reforzar el prestigio que gozaban tanto la escultura de Fernández como el propio Ávila, al cual se le atribuyen varias piezas en el Domus Dei, muy especialmente el grupo que preside la iglesia: la Traslación de San Pedro Regalado. El encargo mantuvo ocupado a Ávila hasta mediado de 1694 , fechas en las que termina de percibir las últimas cantidades adeudadas.

Es probable que por las fechas en que contrata el retablo lermeño comenzara a frecuentar el taller su hijo Pedro, el cual por entonces contaba con 14 años, edad aproximada a la que los jóvenes comenzaban su aprendizaje.

El 25 de octubre de 1694 entrega completa la obra que había realizado en el retablo mayor de la parroquial de Traspinedo (Valladolid) (DOCUMENTO 32). En un principio la máquina fue contratada por Francisco Díez de Tudanca, saliendo Juan de Ávila únicamente como fiador. Es de creer que tras el fallecimiento del primero la parroquial se concertara con Ávila para que éste terminara lo que no pudo su amigo y maestro. Desconocemos el programa iconográfico que exhibía el retablo, tan solo

\footnotetext{
110 A.M.V., CH. 175-29, ff. 1-3.

111 A.M.V., CH. 175-29.

112 CERVERA VERA, Luis: La iglesia colegial..., op. cit., p. 205.

113 URREA, Jesús: "Gregorio Fernández en el Convento de Scala Coeli del Abrojo", Boletín del Museo Nacional de Escultura, nº 3, Valladolid, 1998-1999, p. 29.
} 
sabemos con certeza que Ávila debía de tallar la "hechura de un Santo Cristo y dos remates y dos festones que cuelgan a los lados de los arbotantes de dicho retablo y dos tarjetas que caen encima de las hechuras de Santa Teresa y Santa Catalina". Quizás se debieran a Ávila las imágenes de ambas santas, a las que habría que añadir la del patrón de la iglesia, San Martín de Tours, a no ser que se reaprovechara una escultura anterior.

Una noticia puramente anecdótica nos la proporciona el testamento de Julián Granda. El día 17 de marzo de 1695 el beneficiado de preste de la iglesia parroquial de Santiago Apóstol, y capellán del Convento de San Felipe de la Penitencia, dicta sus últimas voluntades, entre las cuales figura una deuda de 15 reales con Juan de Ávila: "Declaro debo a Juan de Ávila quince reales mando se le paguen" ${ }^{114}$. ¿Esta deuda tendría relación con alguna obra realizada por Juan de Ávila para el clérigo o para la iglesia de Santiago?

El 29 de abril de 1696 inspecciona junto a sus compadres, el escultor Juan Antonio de la Peña y el pintor Amaro Alonso de Llanos, la restauración que había llevado a cabo el también pintor Valentín Gómez de Salazar ${ }^{115}$ en las esculturas que conformaban los pasos de la Cofradía Penitencial de la Sagrada Pasión de Cristo ${ }^{116}$. En esta época las cofradías ya no encargan nuevos pasos procesionales ya que no los necesitaban, es por eso que los escultores y pintores se aplicarán a la recomposición y reparación de las figuras existentes. Las imágenes más deterioradas solían ser las que formaban el "historiado", es decir los sayones, soldados y demás figuras accesorias, puesto que eran las que se guardaban durante todo el año con menor cuidado, siendo sus lugares de recogimiento sótanos y trasteros. Las imágenes principales de los pasos (véase imágenes de Jesús, la Virgen, San Juan, etc...) se las exponía todo el año al culto en la iglesia ya fuera en altares o retablos.

Es probable que por estas fechas Ávila recibiera en su taller como aprendiz al vallisoletano Antonio de Gautúa. De confirmarse este extremo estaríamos hablando del único discípulo, junto al propio Pedro de Ávila, del que tenemos seguro que tuvo una

\footnotetext{
114 A.H.P.V., Leg. 3.010/3, ff. 10-11 (1695).

115 Valentín Gómez de Salazar debió de nacer hacia 1648-1652, muriendo poco después del año 1707. Su vida y su obra nos son casi completamente desconocidas, aunque con toda seguridad se trate de uno de los múltiples pintores de carácter artesanal que moraban por entonces en la ciudad. Sobre su faceta artística podemos apuntar que realiza tasaciones de pinturas en los años 1678 y 1681 (A.H.P.V., Leg. 2.376, f. 178; A.H.P.V., Leg. 2.849, f. 310). Asimismo, toma por aprendices a Manuel González, el 11 de julio de 1678, y a Juan de Morales, el 14 de marzo de 1680 (A.H.P.V., Leg. 2.711, f. 57; A.H.P.V., Leg. 2.790, f. 354). El 12 de octubre de 1705 D. Andrés González del Valle, prebendado de la santa iglesia de Valladolid, le nombra, junto a Doña Catalina de Carriedo y D. Manuel de Lagunilla como testamentario y albacea (A.H.P.V., Leg. 2.955, ff. 322-325). El 9 de abril de 1707 realiza un poder para testar para María González del Valle, su mujer. En él mandaba ser enterrado en la capilla de Nuestra Señora de la Guía, sita en la parroquia del Salvador, de la cual era parroquiano (A.H.P.V., Leg. 2.956, f. 197).

116 "29 de abril de 1696. Se propuso (...) que todas las figuras efigies de los Pasos (...) estaban muy maltratadas y que así por el señor Valentín Gómez de Salazar (...) se había dicho que a su obligación tomaría al retocar y dorar las figuras... que eran muchas y que cada una le había de tener de costa más de setenta reales se acordó que el dicho Valentín Gómez de Salazar repusiese una de las figuras para que con vista de ello y con la declaración que hiciesen los señores Amaro Alonso pintor Juan Antonio de la Peña y Juan de Ávila escultores de ir en perfección y conforme arte (...) proseguir". MARTÍ Y MONSÓ, José: Estudios histórico-artísticos..., op. cit., p. 499.
} 
exitosa carrera dado que ni de Matías Ortiz ni de Francisco de la Vega poseemos ninguna certeza; es más, de Ortiz no volveremos a tener noticia alguna.

Por un documentado fechado el 22 de diciembre de 1696 sabemos que ejerció el cargo de depositario de los bienes de su hermano mientras este tenía formado "pleito y concurso de acreedores a sus bienes ante la justicia ordinaria de esta ciudad y ante mí el escribano y en él dio Memorial de bienes y de acreedores". Una vez más volvemos a comprobar la relación de cordialidad existente entre los hermanos. Uno de los citados acreedores, el "de mejor derecho", era ni más ni menos que su propia esposa Antonia González, a la cual se le adeudaban los 300 ducados de la dote y otros 100 de las arras. Una vez se sentenció el litigio en los tribunales se decidió que se le entregasen a Antonia los bienes de su marido que custodiaba Ávila por el valor de la deuda. Para ello por "auto de siete de febrero del año pasado de mil y seiscientos y noventa y uno se mandó que tasados los bienes del dicho concurso por las tasaciones se entregare a la dicha Antonia González por vía de depósito". Así hizo Ávila, entregó los bienes y recibió la "carta de pago como a su derecho conviene al que desde luego dan por libre de los dichos depósitos sin que por razón de ellos ni en otra forma se le pueda pedir ni pedirán por los acreedores ni por otra ninguna persona los dichos bienes" (DOCUMENTO 33).

Hacia 1697-1698 el Monasterio del Santísimo Salvador de Santa Brígida debió de encargarle las esculturas del retablo mayor de su iglesia. Probablemente las monjas habían visto el gran trabajo que el escultor había hecho en el retablo mayor del cercano Monasterio de San Quirce. De confirmarse este extremo estaríamos hablando de que Juan de Ávila fue, tras Gregorio Fernández, el gran artífice de la escultura retablística barroca en la capital. Los encargos recibidos posteriormente debieron de impedirle la conclusión de estas tallas ya que el Crucificado del ático presenta unos rasgos plenamente concordantes con los de su hijo Pedro de Ávila, el cual debió de realizar otras muchas obras para el establecimiento, si bien ninguna de ellas está documentada.

El prestigio del que gozaba se había consolidado de tal manera que en 1698 el obispo de Valladolid, don Diego de la Cueva y Aldana, le encarga la realización de una imagen procesional de Santa María de la Cabeza. Casi de manera simultáneamente don Luis de Vega le encomienda la hechura de San Isidro labrador ${ }^{117}$. Ambas piezas fueron donadas por los benefactores a la Cofradía de San Isidro Labrador. Ávila, que debía de finalizar ambas hechuras al mismo de tiempo, no las tendría dispuestas para la procesión del santo de 1699 dado que la primera vez que la cofradía las sacó fue en 1700.

El taller a partir de entonces no pararía de recibir encargos. Es curioso que la mayor parte de su obra documentada se concentre en sus últimos cinco años de vida: en 1698 talla una "hechura que hizo nueva de Nuestra Señora de Gracia" para la Cofradía de Nuestra Señora del Rosario y del Nombre de Jesús sita en la iglesia parroquial de San

117 GARCÍA CHICO, Esteban: Documentos para el estudio del arte en Castilla. 2..., op. cit., pp. 371-372. 
Esteban Protomártir de Torrecilla de la Abadesa (Valladolid) ${ }^{118}$. Es probable que tras la entrega de la esta Virgen la propia iglesia le comisionara la realización de la parte escultórica del retablo mayor, el cual fue construido por entonces. Su autor pudiera haber sido el ensamblador vallisoletano Gregorio Díaz de Mata. Ese mismo año toma a su cargo la parte escultórica del retablo mayor de la iglesia Santiago Apóstol (grupos de Santiago Matamoros y de la Aparición de la Virgen del Pilar, San José, San Juan Bautista y Ángeles) ${ }^{119}$, encargo que le haría especial ilusión dado que es la iglesia de la que fue siempre parroquiano y en la que celebró todos y cada uno de los momentos más importantes de su vida: nacimientos, bodas, entierros... En 1699 la Congregación de San Felipe Neri se concierta con él para fabricar los relieves y esculturas de bulto redondo que presidirían los retablos colaterales de su iglesia. Es a saber: la escultura de San Francisco de Sales, los relieves de San Juan Bautista predicando en el desierto y San Francisco de Sales predicando ${ }^{120}$ y la hechura de San Juan Bautista. Bien es cierto que tan solo tenemos documentadas las tres primeras, la última es una atribución, pero segura. Por estas mismas fechas, sin poder concretar el año, acordó con la iglesia de San Andrés Apóstol de Villasilos (Burgos) la ejecución de la parte escultórica del retablo de la Resurrección ${ }^{121}$. El prestigio que nos hacen vislumbrar estos pedidos tiene que concretarse, a buen seguro, en el hallazgo de documentación de obras anteriores en las cuales se cimentara su crédito.

Estos últimos años también resultaron felices para el escultor. La alegría más importante se la dio su hijo Pedro, el cual mantuvo una relación con María Lorenza de la Peña, hija del escultor Juan Antonio de la Peña. Ambos padres, Juan Antonio de la Peña y Juan de Ávila, además de conocerse debían de mantener una buena amistad; ambos hombres figuran juntos, como hemos visto, supervisando la reparación de los pasos de la Cofradía de la Pasión unos años antes. El idilio entre ambos jóvenes tiene su punto culminante el 11 de agosto de 1700, fecha en que contraen matrimonio en la primitiva iglesia de San Miguel Arcángel, templo del que eran parroquianos los De la Peña ${ }^{122}$. La ceremonia fue oficiada por el presbítero Juan Antonio González "de licencia de don Antonio Sangáriz cura propio de la parroquia", mientras que los testigos de la misma fueron Francisco de Santiago, abuela de María Lorenza, el doctor don Juan Crisóstomo de la Comba y Santiago Izquierdo, tío político de Pedro de Ávila. De padrinos ejercieron el propio Juan de Ávila e Isabel Santos. La "fusión" de los dos talleres escultóricos vallisoletanos más importantes del momento es ya un hecho. Esta unión beneficiaría las relaciones entre ambos suegros, si bien el gran favorecido fue Pedro de Ávila, el cual sumaría al aprendizaje dado por su padre, que formaría la base de su arte, las enseñanzas de su suegro, con el cual trabajará en calidad de oficial una vez fallecido Juan de Ávila.

118 ARA GIL, Clementina Julia y PARRADO DEL OLMO, Jesús María: Catálogo Monumental de la provincia de Valladolid. Tomo XI..., op. cit., p. 347.

119 GARCÍA CHICO, Esteban: "El Barroco en Valladolid”, B.S.A.A., Tomo XI, 1944-1945, pp. $165-166$.

120 URREA FERNÁNDEZ, Jesús: “El oratorio...”, op. cit., p. 19.

121 PAYO HERNANZ, René Jesús: El retablo..., op. cit., Tomo II, p. 570.

122 A.G.D.V., San Miguel, 1681M, f. 88. 
Un día antes, el 10 de agosto, tanto Juan como su hijo Pedro habían firmado las capitulaciones matrimoniales con María Lorenza de la Peña y sus padres (DOCUMENTO 34). Entre los testigos firmantes de la escritura figura Joseph de Ávila, hermano de Pedro.

En 1701 se encarga junto con el ensamblador Francisco Billota de dar el visto bueno al retablo llevado a cabo por el también ensamblador Alonso Manzano y por el escultor Juan Antonio de la Peña para la capilla de San Juan de Sahagún, sita en la iglesia parroquial de San Martín de Valladolid ${ }^{123}$. El retablo ha desaparecido, aunque se conservan provenientes de dicho retablo la escultura de San Juan de Sahagún y un relieve del martirio de San Bartolomé, ambos incrustados actualmente en un retablo neoclásico en la misma capilla.

En 1702 revisa junto con el ensamblador Blas Martínez de Obregón el retablo mayor de la iglesia parroquial de la Asunción de Villanubla ${ }^{124}$, el cual había sido contratado en 1696 por los ensambladores Francisco Billota y Gregorio Díaz de Mata ${ }^{125}$. El retablo, que por entonces se encontraba en blanco, sería dorado en 1744 por Antonio Canesi (hermano del famoso cronista vallisoletano Manuel Canesi) y Antonio Barreda. El retablo consta de banco, un cuerpo, y acaba rematado por un cascarón en forma de media naranja que se adapta, perfectamente, a la cabecera de la iglesia. En el nicho central se sitúa la Asunción, y en las hornacinas laterales dos santos obispos. Las columnas, de orden salomónico, separan las calles, y unas salomónicas más pequeñas enmarcan las hornacinas laterales. En el cascarón figura un relieve de la Coronación de la Virgen, y se remata en una carnosa tarjeta ${ }^{126}$.

En este mismo año se fecha la última noticia, cronológicamente hablando, que poseemos sobre el escultor. El 2 de marzo Ávila y Agustín González, en calidad de diputados nombrados al efecto por la Cofradía de la Sagrada Pasión de Cristo, se ajustan con Santiago Galindo y Manuel de Araujo "hermanos del trabajo" para que sacaran "todos los pasos de que se compone el día Jueves Santo que vendrá de este presente año la procesión que celebra la Cofradía de la Sagrada Pasión de Cristo" (DOCUMENTO 35). Debían de portarlos "en la forma ordinaria que se llevan en la dicha procesión por todas las calles que es uso y costumbre y con la regla que siempre van", y en caso de ser necesaria más gente para transportarlos "tendremos prevenida toda la gente de que se necesitare". En el supuesto de que "los dichos pasos y sus

\footnotetext{
123 "8.360 reales que tuvo de costa el nuevo retablo y efigies de santos puesto en la capilla del señor San Juan de Sahagún. 5.250 reales a Alonso Manzano maestro de arquitectura por el coste del dicho retablo en blanco y su pedestal. 2.500 reales a Juan Antonio de la Peña maestro escultor por el coste de los santos en blanco puestos en él. 550 reales a dichos dos maestros por razón de mejoras y los 60 reales restantes a Francisco Villota y Juan de Ávila maestros de arquitectura y escultura por las declaraciones que hicieron del cumplimiento de la obra". MARTÍN GONZÁLEZ, Juan José y URREA FERNÁNDEZ, Jesús: Catálogo Monumental de la provincia de Valladolid. Tomo XIV..., op. cit., p. 106.

124 1702.- "29 reales que gastó en dar de comer a dos maestros de escultura y ensamblador, Blas Martínez de Obregón y Juan de Ávila, vecinos de la ciudad de Valladolid, el día que vinieron a ver dicho retablo y declarar si estaba conforme a la traza y condiciones". MARTÍN GONZÁLEZ, Juan José: Catálogo Monumental de Valladolid. Tomo VI..., op. cit., p. 166.

125 Ídem, pp. 166-167.

126 Ídem, pp. 164-165.
} 
hechuras" hubieran sufrido algún daño "porque se quiebren o por otro accidente alguno hasta dejarlos en el sitio que se acostumbra lo que costare componer el dicho daño nos obligamos en toda forma a lo pagar de nuestros bienes". En caso de realizar bien su trabajo, Ávila y González debían de abonarles 315 reales de vellón "en una vez y paga y sin dilación".

Desconocemos si ya se encontraba enfermo o fue algo súbito, el caso es que el 6 de noviembre de 1702 fallece en su casa de la calle del Campo. Fue enterrado, habiendo recibido previamente los sacramentos, en la iglesia de Santiago. Con anterioridad había testado ante el escribano Francisco de Colinas, habiendo dejado nombrados como sus testamentarios al pintor Ignacio Díez de Prado y a su cuñado, el librero Santiago Izquierdo. Por desgracia no conservamos dicho testamento y tampoco el inventario de sus bienes realizado tras el óbito, lo que nos impide conocer su hogar y su taller en profundidad. En una de las mandas ordenaba que se re rezaran por él cincuenta misas. Así concluía la vida de nuestro escultor, dejando tras de sí nueve hijos, de los cuales solamente le sobrevivieron cuatro, y una gran cantidad de obras de arte repartidas por las iglesias de la ciudad, y sobre todo para su querida parroquia de "señor Santiago"127. Nunca sabremos que derroteros habría tomado la escuela vallisoletana si Juan de Ávila no hubiera muerto tan pronto, a pesar de que era una edad bastante común en la época. Este asunto no es baladí puesto que, entre otras cosas, Pedro de Ávila no habría tenido que marchar como oficial al taller de su suegro Juan Antonio de la Peña. Sea como fuere éste y José de Rozas se beneficiaron del fallecimiento de Ávila, quedando como los dos artífices más acreditados de la ciudad, puesto que perdieron años después tras el ascenso vertiginoso de Pedro de Ávila.

Un mes después del fallecimiento de nuestro escultor, el 1 de diciembre de 1702 la casa en la que vivió y falleció, propiedad de las Memorias de Andrés de Carreño, fue dada en arrendamiento a otro artista: se trataba del desconocido pintor Isidro Fernández de la Cabeza (DOCUMENTO 25), que estaba fiado en la escritura de arriendo por el también pintor Francisco Escobedo ${ }^{128}$. Este arrendamiento nos proporciona algún dato más para fijar con mayor exactitud la situación de la casa: "en la calle del Campo de esta ciudad con un aposentillo que está en el portal de ella que corresponde a otra casa de dichas Memorias aunque sirve a la declarada que linda con casas del Convento de Prado y otra de dichas Memorias toda ella y dicho aposentillo de alto abajo con sus ventanas y salidas usos".

\footnotetext{
127 "En seis de noviembre de setecientos y dos se enterró en esta iglesia Juan de Ávila maestro escultor vivía en la calle del Campo recibió los sacramentos testó ante Francisco Colinas escribano real en veinte y siete de octubre pasado de este año testamentarios Ignacio Díez de Prado y Santiago de Izquierdo manda por todas cincuenta misas y lo firmo". A.G.D.V., Santiago, 1673D, f. 576.

128 Sobre el pintor Francisco Escobedo tenemos muy pocos datos. Debió de nacer hacia 1650-1653, muriendo en una fecha imprecisa después del año 1702. El 6 de noviembre de 1683 el entallador Joseph Sánchez deja declarado en su codicilo que Francisco Escobedo "pintor vecino de ésta ciudad es deudor de ciento y treinta y cinco reales de marcos y bastidores que ha llevado de su tienda". (A.H.P.V., Leg. 2.324, ff. 192-193). El 22 de abril de 1689 recibe en su taller, por aprendiz, a Manuel Andrés de Aguilar (A.H.P.V., Leg. 2.847, f. 130). Como la mayoría de los pintores de la época realizó numerosas tasaciones de pinturas: en los años 1685, 1688, 1699 (A.H.P.V., Leg. 2.851, f. 815; A.H.P.V., Leg. 2.853, f. 144; A.H.P.V., Leg. 2.853, f. 208; A.H.P.V., Leg. 2.952, f. 37).
} 


\section{3-2 LA FAMILIA}

A continuación vamos a desgranar la familia de nuestro escultor, desde sus abuelos hasta sus hijos. En ningún caso se va a hacer referencia a las familias que formaron sus hijos Pedro y Manuel puestos que estas serán abordadas en su respectivo momento.

\section{A- ABUELOS PATERNOS}

La abuela, Ana Monge, nace en Alaejos en 1594, siendo bautizada el día 13 de mayo de dicho año en la iglesia de Santa María de dicha villa ${ }^{129}$. Su muerte acaecería después de 1658, año en que su hijo Hernando la cita en su testamento. Sobre Juan de Ávila "el viejo" no se ha localizado ningún dato. Quizás pueda referirse a él una partida de defunción, con fecha de 5 de febrero de $1652^{130}$, anotada en uno de los libros de difuntos de la iglesia de Santa María de Alaejos. El enlace de los abuelos de nuestro escultor se celebró el 8 de enero de 1609 en la referida iglesia de Santa María ${ }^{131}$. El matrimonio tendría una numerosa descendencia: Juan $(1609)^{132}$, Beatriz $(1614)^{133}$, Ana $(1618)^{134}$, Isabel $(1621)^{135}$, Catalina $(1624)^{136}$, Hernando (1627) y Gil (1630) ${ }^{137}$.

\footnotetext{
129 "En trece días del mes de mayo de éste año de mil y quinientos y noventa y cuatro años yo el bachiller Clemente Sobremonte prebendado y prior en la iglesia de Santa María doy fe conforme bauticé una hija de Juan Monge marido y de su legítima mujer Cristina de Medina (...) y por verdad lo firmé (...)”. A.G.D.V., Alaejos, Santa María, 1591B, f. 20.

130 "En cinco de febrero murió Juan Ávila enterrose en el cuerpo de la iglesia (...)". A.G.D.V., Alaejos, Santa María, 1631D, f. 303.

131 "En ocho días del mes de enero de mil y seiscientos y nueve años yo el licenciado Alonso Segurado cura y beneficiado de la iglesia de Santa María de ésta villa de Alaejos velé con la solemnidad que la santa iglesia manda a Juan Dávila y a Ana Monge y fueron sus padrinos Gil Dávila e Isabel Calvos y por verdad lo firmé ut supra". A.G.D.V., Alaejos, Santa María, 1614M, f. 151.

132 "En veinte y uno de noviembre de mil seiscientos y nueve yo el licenciado Francisco Rodríguez beneficiado en esta iglesia de Santa María (...) bauticé a Juan hijo de Juan de Ávila y de Ana Monje (...)". A.G.D.V., Alaejos, Santa María, 1653B, f. 163.

133 "En quince de octubre de mil seiscientos y catorce años (...) bauticé e impuse los santos óleos según orden de la Santa Iglesia (...) a Beatriz hija de Juan de Ávila y de su legítima mujer Ana Monge fue su padrino el maestro Luis Campos (...)”. A.G.D.V., Alaejos, Santa María, 1614B, f. 17.

134 "En primero día del mes de junio de mil y seiscientos y diez y ocho años yo el licenciado Francisco Hernández cura beneficiado en esta Santa Iglesia de Santa María de ésta villa de Alaejos bauticé a Ana hija de Juan de Ávila y de Ana Monge su legítima mujer fueron sus padrinos Manuel Garabito y Nicolasa López y en fe y por verdad lo firmé ut supra". A.G.D.V., Alaejos, Santa María, 1614B, f. 67.

135 "En veinte y cuatro de febrero de mil y seiscientos y veinte un años yo el bachiller Lucas Cascajo beneficiado mayor de la iglesia de Santa María bauticé y puse los santos óleos a Isabel hija de Juan de Ávila y su legítima mujer Ana Monge fueron sus padrinos Juan Vadillo sacristán mayor y Nicolasa López (...)”. A.G.D.V., Alaejos, Santa María, 1614B, f. 107.

136 "En primero día del mes de marzo de seiscientos y veinte y cuatro años yo el licenciado Alonso Segurado beneficiado y cura de la iglesia de señora Santa María de la villa de Alaejos (...) bauticé a una hija de Juan de Ávila y su legítima mujer Ana Monge llamose la niña Catalina fueron sus padrinos Jerónimo de Ávila tío de la bautizada y María López y en fe por verdad lo firmé (...). A.G.D.V., Alaejos, Santa María, 1614B, f. 138.

137 "En diez de febrero de seiscientos y treinta años (...) bauticé a un hijo de Juan de Ávila y de su mujer Ana Monge llamose al niño Gil de Ávila fueron sus padrinos Simón Guetón y Nicolasa López por verdad lo firmé ut supra”. A.G.D.V. Alaejos, Santa María, 1614B, f. 191.
} 


\section{B- PADRE: HERNANDO DE ÁVILA}

Hernando de Ávila nace a finales de febrero del año 1627, siendo bautizado el día 1 de marzo en la iglesia de Santa María de Alaejos ${ }^{138}$. Como acabamos de comprobar tuvo muchos hermanos, si bien con el que mantuvo una relación más cercana a lo largo de toda su vida fue Gil, al cual llega incluso a citar en su testamento ${ }^{139}$. Es más, ambos hermanos debieron de venir juntos a Valladolid, ciudad en la que abrieron sendos talleres de zapatería y en la que contrajeron matrimonio con dos mujeres que poseían lazos familiares entre sí: Juana Martínez, esposa de Hernando, era madre de Damiana Rojo, cónyuge de Gil.

La profesión de Hernando de Ávila fue la de "maestro de obra prima", artesanos conocidos también como zapateros de nuevo, los cuales constituían el gremio menor de zapateros, pero a su vez era la actividad de zapatería más importante. Hernando no fue el único familiar de nuestro escultor que desarrolló dicho oficio ya que también lo profesaron su tío Gil ${ }^{140}$, su hermano Manuel o su hermanastro Francisco Rojo. Al llegar a Valladolid, Hernando abriría taller en la casa que había adquirido en la calle Santiago.

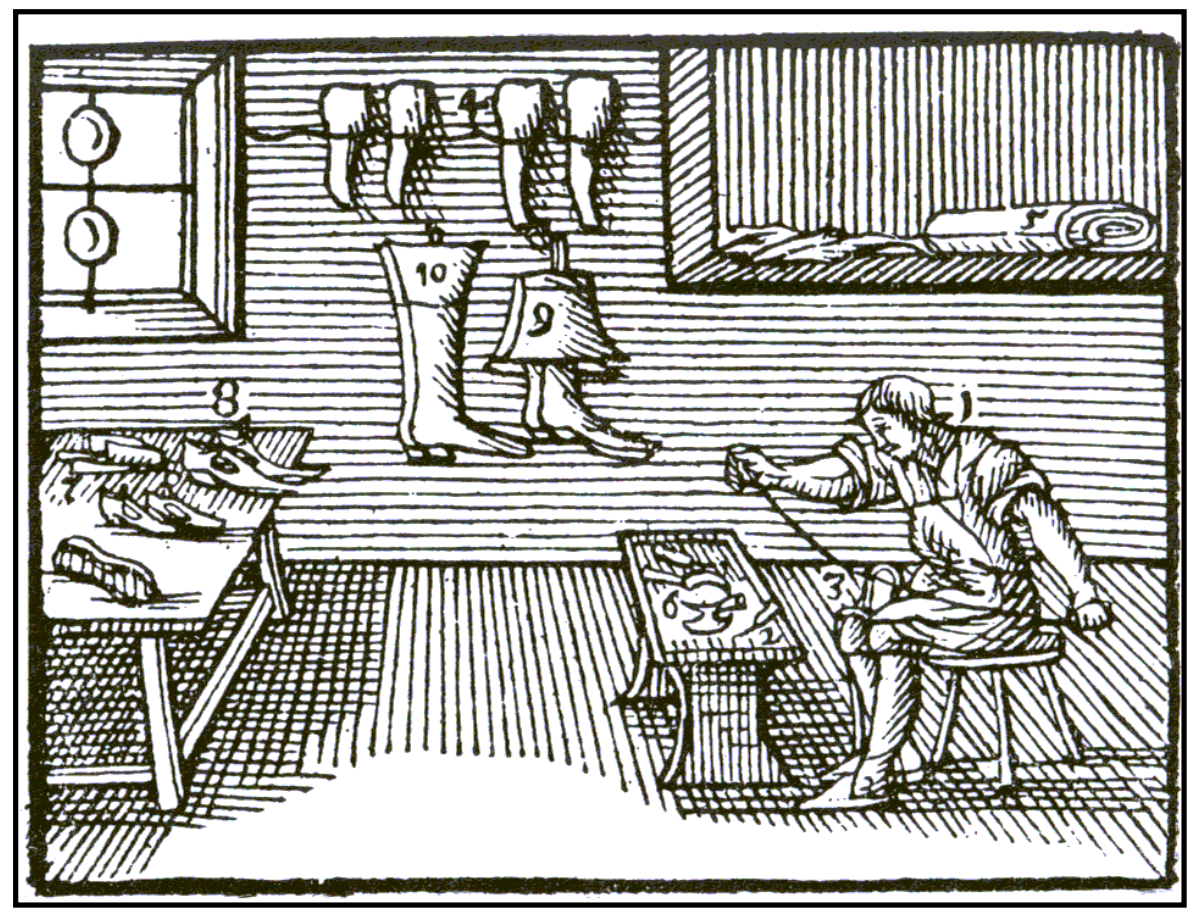

Il. 4- Jan Amos Komenský. Grabado de un zapatero del Orbis sensualium pictus.

\footnotetext{
$138 \quad$ "En primero de marzo de seiscientos y veinte y siete años yo el licenciado Cristóbal Marqués beneficiado y teniente de cura de ésta iglesia de Santa María de la villa de Alaejos doy fe que con la solemnidad y ceremonias que la Santa Madre Iglesia de Roma manda bauticé a un hijo de Juan de Ávila y de su legítima mujer Ana Monje llamose el niño Hernando fueron sus padrinos Jerónimo de Ávila y Juan de Ávila y testigos Juan Badillo y Simón Gil clérigos y lo firmé ut supra”. A.G.D.V., Santiago, 1614B, f. 163.

139 "Ítem declaro que al tiempo y cuando se casó Damiana Rojo con Gil de Ávila mi hermano yo la di en dote y casamiento cien ducados en una cama de ropa y vestir ambos a dos y paganle dos años de casa que fueron veinte y cuatro ducados a la iglesia mayor de esta ciudad y otros bienes que la di que montaron la dicha cantidad declaro lo así para que conste la verdad. (DOCUMENTO 1).
}

$140 \quad$ A.H.P.V., Leg. 2.735/1, f. 283.

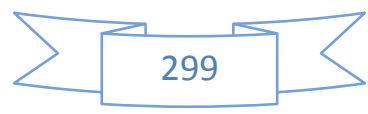


Tenemos numerosos testimonios y noticias relativas a su oficio. Así, el 7 de abril de 1653 Hernando y su esposa Juana Martínez adquieren “cordobán suela y otras $\operatorname{cosas"~}^{141}$; el 2 de julio de dicho año ambos se obligan a pagar al mercader Juan Marcos Padilla 633 reales y medio "por razón de once docenas de becerros que nos ha vendido para el gasto de nuestra tienda"142; el 2 de mayo de 1654 la pareja se apremia a abonar a Santiago Rodríguez y Pedro Gutiérrez, vecinos del lugar de Cortiguera, 660 reales "en moneda de vellón usual y corriente al tiempo de la paga que le debemos y son por razón de cinco docenas de becerros" ${ }^{\prime 143}$; el 7 de noviembre de 1654 Hernando confiesa que el referido Santiago Rodríguez le había vendido otras cinco docenas de becerros ${ }^{144}$; el 15 de mayo de 1655 el matrimonio abona 65 ducados de vellón (= 715 reales) a "Rodrigo del Morat vecino del lugar de Cortiguera jurisdicción del Valledonos montañas de Burgos y a Joseph de Cepos vecino de esta ciudad" por razón de la compra de seis docenas de becerros ${ }^{145}$; finalmente, el 1 de octubre de ese mismo año Hernando paga 880 reales "a Alonso Muñoz vecino de Peñaranda y mercader en ella (...) del valor de diez y seis lomos de suela" $"$.

Al igual que su hijo, Hernando militó en varias cofradías ${ }^{147}$. Así, en su testamento declara haber pertenecido a la de San Antonio de Padua de mancebos sastres, sita en la capilla de San Antonio el Rico del Convento de San Francisco ${ }^{148}$, en la penitencial de la Santa Vera Cruz y en la de Nuestra Señora de la Cabeza, radicada en la parroquia de Santiago Apóstol ${ }^{149}$. A pesar de no contar con noticias al respecto también debió de pertenecer a la Cofradía de San Crispín y San Crispiniano (cofradía gremial de los zapateros de obra prima), en cuya sala de cabildos se examinaban los aspirantes a maestros en dicho oficio. Una vez los candidatos habían aprobado el examen se procedía a anotar el nombre del nuevo maestro "en el libro de la dicha cofradía de San Crispín y San Crispiniano, donde se asientan todos los que se examinan y aprueban, como es público y notorio" ${ }^{\prime 150}$.

La llegada de Hernando a Valladolid debió de producirse antes del enlace con su primera mujer, Juana del Castillo, de la cual desconocemos todo, y a la cual no sabemos si conoció en Alaejos o ya en la ciudad del Pisuerga. El matrimonio, que se desposaría con anterioridad al año 1647, no tendría descendencia. Según palabras del propio

\footnotetext{
141 A.H.P.V., Leg. 2.268/1, f. 173.

142 A.H.P.V., Leg. 2.268/2, f. 33 .

143 A.H.P.V., Leg. 2.336/2, f. 133.

144 A.H.P.V., Leg. 2.336/2, f. 214.

145 A.H.P.V., Leg. 2.477 , f. 86.

146 A.H.P.V., Leg. 2.103/2, f. 150.

147 "Mando me entierre la cofradía de Nuestra Señora de la Cabeza de donde soy cofrade y tengo pagada la entrada igual, y también me acompañe la cofradía de la Cruz donde soy cofrade (...). Ítem mando me acompañe la cofradía de San Antonio de Padua de los mancebos sastres y se pague lo que se concertase". (DOCUMENTO 1).

148 http://www.diputaciondevalladolid.es/imprimir/modulo/archivo-provincial/informaciongeneral/119070/

149 http://www.diputaciondevalladolid.es/imprimir/modulo/archivo-provincial/informaciongeneral/119070/

150 GARCÍA FERNÁNDEZ, Máximo: Los viejos oficios castellanos, Neumáticos Michelin, Valladolid, 1996, p. 149.
} 
Hernando sabemos que durante su matrimonio con Juana del Castillo esta adquirió una casa en la calle de Santiago ${ }^{151}$, en la cual, como ya se ha dicho, Hernando establecería tanto su taller como su hogar.

Una vez fallecida Juana del Castillo, el 17 de noviembre de $1647^{152}$, Hernando contrae matrimonio en segundas nupcias con Juana Martínez en la iglesia de Santiago, siendo testigos Juan González "el Mozo", Gregorio Moreno y Juan de Ávila ¿el padre o el hermano de Hernando? Este segundo matrimonio sería más fructífero en lo relativo a la descendencia puesto que de él nacerían tres hijos: Hernando (1648), Manuel (1650) y Juan (1652).

El 6 de agosto de 1657, encontrándose gravemente enfermo, otorga testamento (DOCUMENTO 1), nombrando como testamentarios a su mujer Juana Martínez, al maestro de obra prima Francisco Flores ${ }^{153}$ y a Francisco Moreno. Un día después Hernando fallecía, siendo sepultado su cuerpo en la iglesia de Santiago ${ }^{154}$.

\section{C-ABUELOS MATERNOS}

Desconocemos cualquier dato sobre ellos salvo que se llamaban Simón Martínez e Inés González.

\section{D- MADRE: JUANA MARTÍNEZ}

Juana Martínez, hija de Simón Martínez e Inés González, fue bautizada en la iglesia de Santiago de Valladolid el 27 de julio de $1619^{155}$. A lo largo de su vida contrajo matrimonio en tres ocasiones: en un primer momento con Pedro Rojo, luego llegaría Hernando de Ávila y finalmente Gabriel Rodríguez del Pozo. Desconocemos el oficio

\footnotetext{
151 "Declaro que yo tengo una casa mía propia en la calle de Santiago que la compre durante el matrimonio con mi mujer doña Juana del Castillo". (DOCUMENTO 1).

152 "En diez y siete de noviembre de mil y seiscientos y cuarenta y siete años se desposaron Hernando de Ávila y Juana Martínez fueron testigos Juan González el Mozo Gregorio Moreno y Juan de Ávila como consta de mandamiento que tengo en mi poder y lo firmé". A.G.D.V., Santiago, 1609M, f. 145. "En diez y siete de noviembre de mil seiscientos y cuarenta y siete años vele in facie ecclesiae y di las condiciones nupciales que el Santo Concilio manda a Hernando de Ávila con Juana Martínez fueron padrinos Jorge Tejero y Gregoria de Nájera testigos Juan de Ávila Juan González el mozo y Gregorio Moreno y lo firmé ut supra". A.G.D.V., Santiago, 1644V, f. 16.

153 Seguramente sea el mismo Francisco Flores que se concierta en 1653 con el escultor Francisco Díez de Tudanca para que este le talle una imagen de la Inmaculada Concepción. FERNÁNDEZ DEL HOYO, María Antonia: “El escultor vallisoletano Francisco Díez de Tudanca...”, op. cit., p. 378.

154 "En siete de agosto de mil y seiscientos y cincuenta y siete años se enterró en esta iglesia Hernando de Ávila vivía en la calle de Santiago recibió los sacramentos hizo testamento ante Matías Pérez escribano real en seis de éste presente mes testamentarios Juana Martínez su mujer Francisco Flores y Francisco Moreno mando cincuenta misas y en esta iglesia mandaron se dijesen veinte y cinco". A.G.D.V., Santiago. 1650D, f. 97.

155 "En veinte y siete de julio de mil seiscientos y diez y nueve años bauticé a Juana hija de Simón Martínez y de Inés González padrinos Francisco Fernández y Ana Fernández y lo firmé”. A.G.D.V., Santiago, 1606B, f. 276.
} 
que desarrolló Pedro Rojo, sin embargo, casualidad o no, los otros dos fueron maestros de obra prima.

La boda con Pedro Rojo tuvo lugar el 28 de noviembre de 1631 en la iglesia de Santa María la Antigua ${ }^{156}$. El matrimonio tuvo siete hijos: Simón (1633) ${ }^{157}$, Josepha (h. 1637), María de la Concepción (1638) ${ }^{158}$, Antonia (1640) ${ }^{159}$, Antonia (1642) ${ }^{160}$ y Francisco $(1644)^{161}$, a los que habría que sumar Damiana, casada con Gil de Ávila, tío de escultor.

El enlace con Hernando de Ávila se celebró el 17 de noviembre de 1647 en la iglesia de Santiago. La pareja tuvo tres hijos: Hernando (1648), Manuel (1650) y nuestro escultor Juan (1652). Tras el fallecimiento de Hernando Juana se desposa una tercera vez, en esta ocasión será con Gabriel Rodríguez del Pozo ${ }^{162}$ el día 6 de febrero de 1659 en la referida iglesia de Santiago ${ }^{163}$. Siete años después, el 14 de mayo de 1666 , fallece y es

156 "Certifico yo el licenciado Juan de Arce beneficiado propio en la parroquial de Ntra. Sra. la Antigua de esta ciudad de Valladolid y teniente de cura de ella que habiendo hecho las tres municiones que el santo concilio manda en tres días festivos a la misa mayor al ofertorio de cada una de ellas, y de ellas no haber resultado impedimento canónico y habiendo precedido licencia del Sr. Dr. Lucas Vela de Sayoane provisor y vicario general en esta dicha ciudad y todo su obispado desposé por palabras de presente que hicieron verdadero matrimonio a Pedro Rojo con Juana Martínez mis parroquianos y moradores en la Plazuela Vieja siendo testigos Nicolás de Oliveros y Juan de Naxara y Cristóbal de Villamar, y asimismo certifico que los susodichos Pedro Rojo y Juana Martínez recibieron las bendiciones nupciales según orden y forma de la santa madre iglesia de Roma siendo testigos los arriba dichos. Pasó la licencia de este matrimonio ante Cristóbal de Madrigal notario de la Audiencia Episcopal en veinte y ocho de noviembre de mil y seiscientos y un años y lo firmé en Valladolid a veinte y nueve del dicho mes y del dicho año”. A.G.D.V., La Antigua, 1629M, f. 35.

157 "Certifico yo el licenciado Juan de Arce beneficiado propio en la parroquial de Nuestra Señora de la Antigua de esta ciudad y teniente de cura de ella que según orden y forma de la santa madre iglesia de Roma bauticé a Simón hijo de Pedro Rojo y de Juana Martínez su mujer, fueron sus padrinos Diego de Arteta y Jusepa de Simancas dieronle por abogado a San Josef y lo firmé en Valladolid a seis de noviembre de mil y seiscientos y treinta y tres años". A.G.D.V., La Antigua, 1603B, f. 408.

158 "En diez y ocho de diciembre de mil y seiscientos y treinta y ocho años bauticé e impuse los santos óleos conforme el Santo Concilio manda a María de la Concepción hija de Pedro Rojo y de Juana Martínez fueron sus padrinos Francisco Ruiz de Rozas y Juana García fueron testigos Antonio López y Alonso Gabriel y Diego de Pesquera dieronle por abogado a Nuestra Señora de la Concepción y lo firmé ut supra". A.G.D.V., Santiago Apóstol, 1606B, f. 968.

159 "En veinte y cuatro de abril de mil y seiscientos y cuarenta años bauticé e impuse los santos óleos como el santo concilio manda a Antonia hija de Pedro Rojo y de Juana Martínez padrinos Rodrigo Bueno y Magdalena Roja dieronle por abogados a San Marcos y Nuestra Señora testigos Isidro de Veresfa y Francisco García y lo firmé ut supra”. A.G.D.V., Santiago, 1606B, f. 1.002.

160 "En diez y seis de septiembre de mil y seiscientos y cuarenta y dos años bauticé e impuse los óleos santos conforme el santo concilio manda a Antonia hija de Pedro Rojo y de Juana Martínez padrinos Gonzalo Montero y Catalina García dieronle por abogado a San Francisco testigos Pedro Álvarez y Diego Centeno y lo firmé ut supra”. A.G.D.V., Santiago, 1606B, f. 988.

161 "En veinte y tres de noviembre de mil y seiscientos y cuarenta y cuatro años bauticé e impuse los santos óleos conforme el Santo Concilio manda a Francisco Rojo hijo de Pedro Rojo y de Juana Martínez fueron padrinos Bernabé Ruiz de Comona e Isabel de Arguello fueron testigos Diego de Pesquera y Pedro Álvarez dieronle por abogados a todos los santos y lo firmé ut supra”. A.G.D.V., Santiago, 1643B, f. 28.

162 El 20 de febrero de 1664 figura dando su poder a Juan Ruiz de Chaves para que este percibiera en su nombre "de Felipe de la Beya Ruiz maestro de cantería vecino de esta ciudad trescientos y ochenta y cinco reales que me debe". A.H.P.V., Leg. 1.974, f. 604.

163 "En seis de febrero de mil seiscientos y cincuenta y nueve años yo Francisco García teniente de cura de ésta iglesia de Señor Santiago de esta ciudad de Valladolid habiendo precedido las tres municiones que el Santo Concilio manda desposé por palabras de presente según orden de la Santa Madre Iglesia a Gabriel Rodríguez del Pozo hijo de Juan Rodríguez del Pozo y de María Álvarez con Juana 
enterrada en dicha iglesia ${ }^{164}$. A pesar de que en la partida de defunción consta que la finada había dictado testamento ante el escribano Matías Pérez la realidad no es así pues el testamento se encuentra en la escribanía de Miguel Casero (DOCUMENTO 2). Las últimas voluntades de Juana no aportan demasiados datos de interés más allá de las disposiciones para su entierro y la relación de las diferentes deudas que tenía contraídas con diferentes personas. Sí que tiene cierta relevancia el hecho de que al tratar sobre su segundo matrimonio, el contraído con Hernando de Ávila, relata que "durante el matrimonio el dicho Hernando de Ávila compró la casa en que vivo que está en la calle de Santiago de esta ciudad que linda con casas del Colegio de San Gregorio y casa de María Rodríguez con cargo de dos ducados que se pagan de renta perpetua a la Cofradía de la Espina y (...) otra carga la cual es propia del dicho Hernando de Ávila y mía por haberse comprado durante nuestro matrimonio". Esta casa tendrá su importancia puesto que será objeto de diferentes avatares a lo largo de las vidas de Juan y Pedro de Ávila. Juana ordenaba que la dicha casa "la habite y goce el dicho Gabriel del Pozo mi tercero marido". Tras el fallecimiento de este pasaría a poder de los hijos que tuvo durante su matrimonio con Hernando: Juan y Manuel de Ávila Martínez.

Dejaba nombrados como testamentarios y albaceas a su tercer marido Gabriel del Pozo y a Simón Escudero y Francisco Díez Moreno. Como herederos universales instituyó a sus cuatro hijos vivos: Francisco y Damiana, habidos en su matrimonio con Pedro Rojo; y a Manuel y Juan, concebidos durante su matrimonio con Hernando de Ávila. Asimismo, declaraba que "a la dicha Damiana Roja la di en dote y casamiento cuando se casó con Gil de Ávila su marido hasta dos mil reales en bienes y dinero en que entra lo que le dio el dicho Hernando de Ávila mi marido y su hermano". Juana refleja también que Gabriel del Pozo, su tercer marido, se había ocupado de los "hijos del dicho Hernando de Ávila los ha alimentado y sustentado, vestido y calzado hasta hoy (...) y enseñándoles a leer y escribir y así lo declaro por descargo de mi conciencia".

\section{E- HERMANOS DE JUAN DE ÁVILA}

\section{HERNANDO DE ÁVILA}

Hernando fue el primer vástago del matrimonio formado por Hernando de Ávila y Juana Martínez. Nació a primeros de septiembre de 1648, siendo bautizado el día 6 de dicho mes en la iglesia de Santiago ${ }^{165}$. Sus padrinos fueron Jorge Tejero y Gregoria de Nájera.

Martínez viuda de Hernando de Ávila fueron testigos Paulo del Río Francisco Moreno y Juan de Ávila y lo firmé”. A.G.D.V., Valladolid, Santiago, 1609M, f. 215.

164 "En catorce de mayo de mil y seiscientos y sesenta y seis años se enterró en esta iglesia del señor Santiago de ésta ciudad Juana Martínez mujer de Gabriel del Pozo recibió los santos sacramentos dijo testamento ante Matías Pérez escribano de su majestad en seis de dicho mes y año como de él consta testamentarios dicho Gabriel del Pozo su marido Simón de Escudero (...) dejó por herederos a sus hijos mando se digan pro su alma misa de cuerpo presente y cincuenta misas lo firmé". A.G.D.V., Valladolid, Santiago, 1650D, f. 255.

165 "En seis de septiembre de mil y seiscientos y cuarenta y ocho años bauticé e impuse los santos óleos como lo manda el Santo Concilio de Trento a Hernando hijo de Hernando de Ávila y de Juana Martínez fueron padrinos, Jorge Tejero y Gregoria de Nájera su mujer dieronle por abogados a Nuestra 
Asimismo, se le dieron por abogados a Nuestra Señora del Buen Suceso y a San Juan. No debió vivir mucho puesto que su padre no le nombra entre sus herederos en el testamento otorgado en 1657.

\section{MANUEL DE ÁVILA}

El mediano de los hermanos fue bautizado en la iglesia de Santiago el 9 de enero de $1650^{166}$, siendo sus padrinos Andrés Gago y Gregoria Nájera. Se le dio por abogado a San Silvestre ${ }^{167}$. Contrae matrimonio con Francisca Arguelles (n. 1647), natural de Simancas ${ }^{168}$, el día 2 de mayo de 1668 en la iglesia parroquial de Santiago de Valladolid $^{169}$. Como ya se ha dicho, su oficio fue el de zapatero. Siendo todavía menores de edad Manuel y su hermano Juan dan en arrendamiento la casa de sus padres, aunque cuando Manuel comenzó a trabajar la reclamó para instalar allí su taller de zapatero, al igual que lo tenía su padre.

Sintiéndose enfermo, el 5 de octubre de 1673 otorga testamento ante el escribano Cristóbal Redondo (DOCUMENTO 3). En él declaraba su deseo de ser sepultado en la iglesia parroquial de Santiago Apóstol por la Cofradía Penitencial de la Sagrada Pasión de Cristo, de la cual era miembro. Dejaba nombrados por testamentarios a sus hermanos Francisco Rojo y Juan de Ávila, mientras que por heredera instituía a su joven esposa. Manuel falleció dos días después, siendo enterrado en la iglesia que él mismo había elegido $^{170}$.

Señora del Buen Suceso y a San Juan, testigos Diego de Pesquera, Diego González de Pinilla y Diego de Soto Beltrán y lo firmé ut supra”. A.G.D.V. Valladolid, Santiago, 1643B, f. 89.

$166 \quad$ "En nueve de enero de mil y seiscientos y cincuenta años bauticé e impuse los santo óleos como el Santo Concilio manda a Manuel hijo de Fernando de Ávila y Juana Martínez fueron padrinos Andrés Gago y de Gregoria Nájera dieronle por abogado a San Silvestre fueron testigos Francisco González y Diego de Soto Beltrán y lo firmé ut supra”. A.G.D.V., Santiago, 1643B, fol. 116.

${ }_{167}$ "Declaro que yo tengo por mis hijos legítimos y de la dicha Juana Martín a Manuel y Juan de Ávila mis hijos legítimos de la dicha mi mujer". (DOCUMENTO 1).

168 "Yo el licenciado Juan de Nabas cura propio de Señor San Salvador de la villa de Simancas, bauticé, y puse los santos óleos (según la orden de la Santa Madre Iglesia Romana) a Francisca hija legítima de Toribio de Argüelles y de Juana del Valle sus padre, y mis feligreses, fueron sus padrinos Francisco Bautista Díez y María Delgado dieronle por abogados a San Joseph, y nuestra Señora la Virgen María, siendo testigos Jerónimo de Oviedo y Marcos García y por verdad lo firmé en Simancas a veinte y siete de octubre de mil y seiscientos y cuarenta y siete años". A.G.D.V. Simancas, San Salvador, 1628B, f. 141.

169 "En dos de mayo de mil seiscientos y sesenta y ocho yo el bachiller Andrés de Mata Varona teniente de cura de la iglesia de señor Santiago de esta ciudad de Valladolid desposé por palabras de presente a Manuel de Ávila natural de esta ciudad hijo de Hernando de Ávila y de Juana Martínez con Francisca de Arguello natural de la villa de Simancas hija de Toribio de Arguello y de Juana del Valle fueron testigos Nicolás de Vallejo y don Juan de Quirós y lo firmé”. A.G.D.V., Santiago, 1609M, f. 298.

$170 \quad$ "En siete de octubre de mil seiscientos y setenta y tres años se enterró en ésta iglesia Manuel de Ávila vivía en la calle de Santiago recibió los sacramentos hizo testamento ante Cristóbal Redondo escribano real en cinco de este presente mes testamentarios Francisco Rojo y Juan de Ávila manda por todas sesenta misas y lo firmé". A.G.D.V., Santiago, 1673D, f. 366. 


\section{FRANCISCO ROJO}

Francisco Rojo era hermanastro de Juan de Ávila por parte de madre. Fue concebido por Juana Martínez durante su matrimonio con Pedro Rojo. Recibió las aguas del bautismo en la iglesia de Santiago el día 23 de noviembre de $1644^{171}$. Francisco será una persona muy cercana a sus hermanastros pues su nombre aparece muy ligado a los suyos en numerosos documentos, incluso como testamentario. Tuvo una hermana, Damiana Rojo, la cual se desposó con Gil de Ávila, hermano de Hernando de Ávila, su futuro padrastro.

Sin llegar todavía a la veintena, el 21 de septiembre de 1664, firma las capitulaciones matrimoniales con Antonia González, su futura esposa ${ }^{172}$. Unas semanas después, el 12 de octubre, la pareja contrae matrimonio en la iglesia de Santiago ${ }^{173}$, y el día 19 de ese mismo mes Francisco otorga carta de pago y recibo de dote en favor de su suegro ${ }^{174}$. La pareja tuvo una numerosísima descendencia: Felipa (1666), Catalina (1669), Francisco (1671), Manuel (1672), Francisco (1674), Juan Antonio (1675), Francisco (1676), Antonio (1680), Francisco (1681), Josepha María (1682), Juan (1683) y Eugenia $(1685)^{175}$. Por si no fuera poco el matrimonio se hizo cargo en el año 1677 de dos sobrinos que acababan de quedar huérfanos: Francisco y Juana González, hijos de Ana Vilches y Manuel González. Juan de Ávila salió por fiador de su hermano y cuñada en el referido contrato de tutoría (DOCUMENTO 4).

Vivió casi toda su vida en el barrio de Santiago, concretamente en la calle del mismo nombre, muy cerca de las casas de sus hermanos ${ }^{176}$. Hacia el final de su vida cambió de barrio, puesto que el 10 de abril de 1690 toma en arrendamiento "de los acreedores a los bienes de Josepha Hidalgo viuda de Manuel Domínguez curtidor vecino que fue de esta ciudad la casa principal en que el susodicho vivía en las Tenerías", concretamente "la casa grande pasado los soportales con su tenería"177.

Desconocemos la fecha de su fallecimiento, el cual acaecería después del año 1700. La última noticia que poseemos es una obligación hecha en 1691 por la cual debía de abonar al mercader Diego Martínez "arrendatario de la alcabala de heredades de esta ciudad este año de noventa y uno o a quien su poder hubiere" 400 reales de vellón en

\footnotetext{
171 "En veinte y tres de noviembre de mil y seiscientos y cuarenta y cuatro años bauticé e impuse los santos óleos conforme el Santo Concilio manda a Francisco Rojo hijo de Pedro Rojo y de Juana Martínez fueron padrinos Bernabé Ruiz de Comona e Isabel de Arguello fueron testigos Diego de Pesquera y Pedro Álvarez dieronle por abogados a todos los santos y lo firmé ut supra”. A.G.D.V., Santiago, 1643B, f. 28.

172 A.H.P.V., Leg. 1.974, ff. 864-865.

173 "En doce de octubre de mil seiscientos y sesenta y cuatro años yo Diego de Soto Beltrán teniente de cura de la iglesia de señor Santiago de esta ciudad de Valladolid habiendo precedido las tres municiones que el Santo Concilio manda desposé por palabras de presente según orden de la Santa Madre Iglesia a Francisco Rojo hijo de Pedro Rojo y de Juana Martínez con Antonia González hija de Bartolomé González y de Bárbara de la Mata ambos naturales de ésta ciudad fueron testigos Bartolomé Hernández y Bartolomé González y Manuel González y lo firmé”. A.G.D.V., Santiago, 1609M, f. 269.

174 A.H.P.V., Leg. 1.974, ff. 898-899.

175 A.G.D.V., El Salvador, 1636B, f. 404; A.G.D.V., Santiago, 1668B, ff. 42, 73, 98, 147, 172, 212, 274, 293, 316; A.G.D.V., Santiago, 1683B, ff. 14, 61.

176 A.H.P.V., Leg. 2.735/4, f. 175.

177 A.H.P.V., Leg. 2.431, f. 117.
} 
que se convino "con el susodicho por razón de alcabala del censo que siendo en favor del licenciado Juan Gil capellán de la capellanía de Toribio Guerra y María de la Cuesta su mujer vecinos de esta ciudad de ocho mil reales de principal por la hipoteca y de una casa en las Tenerías que quedó de Josepha Hidalgo y Manuel Domínguez su marido de que me constituyo por llano deudor". En este documento figura como curtidor.

Un dato anecdótico, relacionado con el mundo de la escultura, nos lo proporciona el testamento del buratero Gabriel de Cenastu, el cual deja ordenado que se entregue a Francisco Rojo "maestro de obra prima una hechura de Cristo crucificado de bulto de boj que tiene en su poder y le pido me encomiende a Dios" $" 178$.

\section{F- CURADOR: GIL DE ÁVILA}

Incluyo una breve semblanza de Gil de Ávila, tío de Juan, por cuanto a la muerte de Hernando y Juana fue la persona que, en el papel de curador, se ocupó tanto de él como de su hermano Manuel. Gil de Ávila había nacido en la villa de Alaejos a principios del mes de febrero de 1630. Como ya dijimos, debió de venir a Valladolid en compañía de su hermano Hernando, ciudad en la que decide abrir un taller de zapatería.

En 1653 contrae matrimonio con Damiana Rojo, hijastra de su hermano Hernando. Tanto las velaciones ${ }^{179}$ como los desposorios ${ }^{180}$ tienen lugar el día 29 de junio en la iglesia de Santiago. Hernando de Ávila se encarga de abonarle la dote de Damiana Rojo, a la sazón su hijastra ${ }^{181}$. La pareja tuvo al menos tres hijos: Francisca (1656), que tuvo por testigo de su bautizo al pintor Lucas Caniego; Fernando (1663), cuyos padrinos fueron Juana Martínez, madre de Juan de Ávila, y Gabriel Rodríguez del Pozo, tercer y último marido de Juana, y Anastasia (1668) ${ }^{182}$.

El 29 de marzo de 1662 le vemos solicitar un traslado del examen que realizó para alcanzar el grado de "maestro del oficio de zapatería de obra prima" para así probar que lo había superado correctamente y por lo tanto poder abrir "tienda pública con oficiales y aprendices así en esta ciudad como en la dicha villa de Tordesillas y demás

\footnotetext{
$178 \quad$ A.H.P.V., Leg. 2.736, ff. 333-336.

179 "En veinte y nueve de junio de mil seiscientos y cincuenta y tres años vele in facie ecclesiae y di las bendiciones nupciales (...) a Gil de Ávila hijo de Juan de Ávila y Ana Monge natural de la villa de Alaejos con Damiana Rojo hija de Pedro Rojo y Juana Martínez fueron padrinos Alonso de León y Catalina de Leiva testigos el licenciado Francisco García y Santiago Fernández y lo firmé ut supra". A.G.D.V., Santiago, 1644V, f. 52.

180 "En veinte y nueve de junio de mil y seiscientos y cincuenta y tres años desposé (...) a Gil de Ávila hijo de Juan de Ávila y Ana Monge con Damiana Roja hija de Pedro Rojo y de Juana Martínez (...) testigos Alonso de León Francisco Pérez Santiago Fernández (...) y lo firmé ut supra”. A.G.D.V., Santiago, 1609M, f. 175.

181 "Ítem declaro que al tiempo y cuando se casó Damiana Rojo con Gil de Ávila mi hermano yo la di en dote y casamiento cien ducados en una cama de ropa y vestir ambos a dos y paganle dos años de casa que fueron veinte y cuatro ducados a la iglesia mayor de esta ciudad y otros bienes que la di que montaron la dicha cantidad declaro lo así para que conste la verdad". (DOCUMENTO 1).

182 A.G.D.V., Santiago, 1643B, ff. 253, 416; A.G.D.V., Santiago, 1668B, f. 3.
} 
partes de estos reinos". La prueba, realizada el 13 de diciembre de 1654, fue llevada a cargo por la Cofradía de San Crispín y San Crispiniano "advocación de la cofradía del dicho oficio" de la villa de Tordesillas, localidad en la que debió de vivir durante un tiempo ${ }^{183}$. También relacionado con su oficio tenemos la noticia de que el 29 de octubre de 1664 se obligaba a pagar 200 reales de vellón que le había prestado Pedro González Antolín, maestro de obra prima. En este documento se le cita como "oficial de zapatero" $" 184$.

El 30 de septiembre de 1667, actuando como "curador que soy de las personas y bienes de Manuel y Juan de Ávila mis sobrinos", otorga todo su poder a su hermana Isabel, residente en Alaejos, para que "pueda recibir haber y cobrar toda la renta caída y que cayere de las dos tierras que tenemos en la dicha villa de Alaejos y sus términos la una a do llaman la Sola y la otra do llaman el Peñón". (DOCUMENTO 5).

\section{G- PRIMERA MUJER DE JUAN DE ÁVILA: FRANCISCA EZQUERRA}

Francisca de Ezquerra fue la primogénita del matrimonio formado por Romualdo Ezquerra y de Ana González del Portal, los cuales contrajeron se desposaron el 30 de mayo de 1649 en la vallisoletana iglesia de San Miguel ${ }^{185}$. Su padre, Romualdo (hijo de Francisco Ezquerra y de Juana de Geria Hernández), fue bautizado en la iglesia de Santiago el 19 de marzo de $1625^{186}$. Su profesión fue la de mercader de especería. Casó con Ana González del Portal, con la que tendría, al menos, cuatro hijas: la dicha Francisca (1650), Juana (1660) ${ }^{187}$, Jacinta (nacida en $1661^{188}$ y fallecida en $1675^{189}$ ), y

183 A.H.P.V., Leg. 1.973, ff. 875-876.

184 A.H.P.V., Leg. 2.735/1, f. 283.

185 "Certifico yo el licenciado Sebastián Alonso cura propio de la iglesia de señor San Miguel de esta ciudad de Valladolid que habiéndose hecho en ella en tres días festivos continuos inter missarum solemnia las tres canónicas municiones seguidas, de las tres que el Santo Concilio de Trento manda en dos días festivos continuos, inter missarum solemnia y habiendo dispensado en la tercera su señoría el señor obispo de esta dicha ciudad y no habiendo resultado de ellas ni al tiempo del desposorio impedimento canónigo alguno con licencia de su señoría despachada por su secretario de cámara en treinta días del mes de mayo del año de mil y seiscientos y cuarenta y nueve los contenidos en dicha licencia Romualdo Ezquerra hijo legítimo de Francisco Ezquerra y de Juana Fernández y doña Ana González del Portal contrajeron matrimonio por palabras de presente dicho día conforme al derecho del dicho santo concilio en mi presencia siento testigos Juan Cortés y Fernando del Cura y Juan Zapata y otros muchos vecinos y estantes en esta dicha ciudad y en fe de ello lo firmé dicho día, mes y año". A.G.D.V., San Miguel, 1621M, ff. 411-412.

186 "En diez y nueve de marzo de mil y seiscientos y veinte y cinco bauticé e impuse los oleos santos conforme el Santo Concilio manda a Romualdo hijo de Francisco Ezquerra y Juana de Geria Hernández fueron padrinos Juan de Garral cura de San Lorenzo y Ana de la Fuente testigos Juan Martínez de Miranda y Luis Tejerina dieronle por abogado a San Joseph y por verdad lo firmé ut supra”. A.G.D.V., Santiago, 1606B, f. 388.

187 "En once días del mes de julio de mil y seiscientos y sesenta yo el licenciado Manuel Fernández teniente de cura de ésta iglesia de señor San Miguel de ésta ciudad de Valladolid bauticé y puse los santos óleos según orden y forma de la santa iglesia de Roma a Juana hija legítima de Romualdo Ezquerra y de Ana González del Portal, fueron sus padrinos Francisco de Tudanca y María de Villanueva, dieronla por abogados a Nuestra Señora de la Paz y a San Miguel siendo testigos Diego Gómez Osorio y Manuel de Tudanca y en fe de ello lo firmé”. A.G.D.V., San Miguel, 1644B, f. 285.

188 "En veinte y uno del mes de julio de éste año de mil y seiscientos y sesenta y uno yo el licenciado Manuel Fernández teniente de cura de ésta iglesia de señor San Miguel de ésta ciudad de 
Margarita (1662) ${ }^{190}$. Romualdo fallece el 18 de febrero de $1669^{191}$, actuando como su testamentario el escultor Francisco de Tudanca. Ana del Portal había fallecido cuatro años antes, el 2 de septiembre de 1665, siendo enterrada en la iglesia de Santiago ${ }^{192}$.

Francisca Ezquerra nace en Valladolid el 1 de noviembre de 1650. Recibe las aguas bautismales en la parroquia de Santiago el día 14 de ese mismo mes. Actuaron como padrinos sus abuelos paternos (Francisco Ezquerra y Juana Fernández de Geria) y como testigos su tío el escultor Francisco Díez de Tudanca, Matías Pérez y Alonso Gabriel ${ }^{193}$.

La siguiente noticia que poseemos de su escasa biografía es la de su enlace con Juan de Ávila, celebrado el 7 de febrero de 1672 en la iglesia de Santiago ${ }^{194}$. Los padrinos de la ceremonia fueron el escultor Francisco de Tudanca y María Buzón, mientras que como testigos firmaron el escribano Manuel de Tudanca y Tomás Martínez. Francisca se casaría ya embarazada de su primera hija Josepha Antonia (1672). Posteriormente llegarían Teresa (1673), Pedro (1675), Pedro (1678), Francisco (1681), Joseph (1682) y Ana (1685).

Valladolid bauticé y puse los santos óleos según orden y forma de la santa iglesia de Roma a Jacinta hija legítima de Romualdo Ezquerra y de Ana González del Portal fueron sus padrinos Francisco de la Montaña y Francisca Ezquerra dieronla por abogados a Nuestra Señora de la Paz y a San José siendo testigos Francisco Díez de Tudanca y Antonio Caniego vecinos de ésta dicha ciudad y en fe de ello lo firmé”. A.G.D.V., San Miguel, 1644B, f. 300.

189 "En diez y nueve de junio de mil y seiscientos y setenta y cinco años se enterró en esta iglesia en sepultura propia Jacinta de Ezquerra hija de Romualdo de Ezquerra y Ana González del Portal vivía al pasadizo de Don Alonso era de edad de catorce años recibió los sacramentos no hizo testamento por no tener de que y lo firme". A.G.D.V., Santiago, 1673D, f. 20.

$190 \quad$ "En treinta y un días del mes de julio de éste año de mil y seiscientos y sesenta y dos yo el licenciado Manuel Fernández teniente de cura de ésta iglesia de señor San Miguel de ésta ciudad de Valladolid bauticé y puse los santos óleos según orden forma de la santa iglesia de Roma a Margarita hija legítima de Romualdo Ezquerra y Ana González del Portal fueron sus padrinos Francisco Ezquerra y Francisca Ezquerra dieronle por abogados a Nuestra Señora de la Concepción y a San José siendo testigos Francisco de Obeso y el licenciado Pedro Reaños vecinos de ésta dicha ciudad y en fe de ello lo firmé". A.G.D.V., San Miguel, 1644B, f. 406.

191 "En diez y ocho de febrero de mil seiscientos y sesenta y nueve años se enterró en ésta iglesia en sepultura propia Romualdo de Ezquerra vivía al pasadizo de don Alonso recibió los sacramentos hizo testamento ante Andrés Casado escribano real en diez y siete de este presente mes testamentario Francisco de Tudanca manda por todas veinte misas y lo firmé". A.G.D.V., Santiago, 1673D, f. 299.

192 "En dos de septiembre de mil seiscientos y sesenta y cinco años se enterró en ésta iglesia en sepultura propia Ana del Portal mujer de Romualdo Ezquerra vivía en la calle empedrada no hizo testamento por ser pobre y lo firmé". A.G.D.V., Santiago, 1650D, f. 242.

193 "En catorce de noviembre de mil seiscientos y cincuenta años bauticé y puse los óleos santos conforme el Santo Concilio manda a Francisca hija de Romualdo Ezquerra mercader de especería y de Ana González del Portal fueron sus padrinos Francisco Ezquerra y Juana Fernández de Geria sus abuelos nació a primero de éste mes diose por su abogado a todos los santos testigos Francisco Díez de Tudanca y Matías Pérez y Alonso Gabriel lo firmé". A.G.D.V., Santiago, 1643B, f. 134. FERNÁNDEZ DEL HOYO, María Antonia: “El escultor vallisoletano Francisco Díez de Tudanca...”, op. cit., p. 385.

194 "En siete de febrero de mil seiscientos y setenta y dos años yo Francisco García cura propio de la iglesia del Señor Santiago de esta ciudad de Valladolid desposé por palabras de presente según orden de la Santa Madre Iglesia a Juan de Ávila natural de esta ciudad hijo de Hernando de Ávila y de Juana Martínez con Francisca Ezquerra natural de esta ciudad hija de Romualdo Ezquerra y de Ana González fueron testigos Tomás Martínez y Francisco de Tudanca y Joseph Ferrer y lo firmé". A.G.D.V., Santiago, 1609M, f. 341. FERNÁNDEZ DEL HOYO, María Antonia: "El escultor vallisoletano Francisco Díez de Tudanca...”, op. cit., p. 385. 
La muerte sorprendió a Francisca el 17 de noviembre de 1686 cuando la pareja vivía en la calle del Campo. Fue enterrada ese mismo día en la iglesia de Santiago, no otorgó testamento $^{195}$. No podemos descartar que el fallecimiento se debiera a complicaciones surgidas durante un nuevo embarazo que se malogró.

\section{H- HIJOS DE JUAN DE ÁVILA Y FRANCISCA EZQUERRA}

\section{JOSEPHA ANTONIA DE ÁVILA}

Josepha Antonia fue la primogénita de Juan de Ávila y Francisca Ezquerra. Su llegada a este mundo provocó que sus padres tuvieran que contraer matrimonio precipitadamente. Nació el 6 de agosto de 1672, procediéndose a su bautizo el día 18 de ese mismo mes en la iglesia de Santiago ${ }^{196}$. Sus padrinos fueron el escultor Francisco Díez de Tudanca y su esposa Francisca Ezquerra, tíos de Francisca. Por abogados se la dieron a la Virgen y a San José, mientras que como testigos firmaron Gabriel de Cenastu y Matías Serrano. Debió de morir al poco de nacer puesto que su nombre no figura en el libro de confirmaciones de la iglesia.

\section{TERESA DE ÁVILA}

Teresa fue la segunda hija de la pareja y, junto a sus hermanos Joseph, Pedro y Manuel, fueron los únicos hijos de Juan de Ávila que alcanzaron la vida adulta. Nacida el 14 de octubre de 1673 "según aseguró el dicho su padre"197, se celebró su bautismo el día 26 de ese mismo mes, siendo sus padrinos Tomás González y Beatriz de Ávila ${ }^{198}$. Los testigos de la ceremonia fueron Hernando de Bibas ${ }^{199}$ y Matías Serrano..

\footnotetext{
195 "En diez y siete de noviembre de mil y seiscientos y ochenta y seis años se enterró en ésta iglesia Francisca Ezquerra vivió en la calle del Campo recibió los sacramentos no testó la cual estaba casada con Juan de Ávila escultor y lo firme". A.G.D.V., Santiago, 1673D, f. 576.

196 "En diez y siete de agosto de mil y seiscientos y setenta y dos años yo Francisco García cura propio de la iglesia de Santiago de esta ciudad de Valladolid bauticé e impuse los santos óleos como el Santo Concilio manda a Josepha Antonia hija legítima de Juan de Ávila y de Francisca Ezquerra nació en seis de este presente mes y año fueron padrinos Francisco de Tudanca y Francisca Ezquerra dieronse por abogados a Nuestra Señora y San José fueron testigos Gabriel de Cenastu y Matías Serrano y lo firmé". A.G.D.V., Santiago, 1668B, f. 103. FERNÁNDEZ DEL HOYO, María Antonia: "El escultor vallisoletano Francisco Díez de Tudanca...”, op. cit., p. 385.

197 "En veinte y seis de octubre de mil y seiscientos y setenta y tres años yo el licenciado Julián de Granda beneficiado de preste de la iglesia de Señor Santiago de esta ciudad de Valladolid de licencia del licenciado Francisco García cura propio de dicha iglesia bauticé e impuse los santos óleos como dispone el Manual Romano a una niña hija legítima de Juan de Ávila y de Francisca Ezquerra mis parroquianos que viven en la calle de Santiago pusieronla por nombre Teresa que según aseguró el dicho su padre nació en catorce de este presente mes y año fueron padrinos Thomas González y Beatriz de Ávila dieronla por abogados al Ángel de la Guarda y San Lucas fueron testigos Hernando de Bibas y Matías Serrano y lo firme juntamente con el dicho cura". A.G.D.V., Santiago, 1668B, f. 136. FERNÁNDEZ DEL HOYO, María Antonia: "El escultor vallisoletano Francisco Díez de Tudanca...", op. cit., p. 385.

198 Beatriz de Ávila era tía de Juan de Ávila, es decir hermana de su padre; mientras que Tomás González era su esposa. Esto es indicativo de que el escultor mantenía una fluida relación con su familia
} 
La siguiente noticia que poseemos de la joven es la de su confirmación, que la realizó conjuntamente con su hermano Pedro el día 7 de mayo de 1684 en la iglesia de Santiago. La ceremonia fue oficiada por el obispo de Valladolid, don Diego de la Cueva y Aldana ${ }^{200}$. Este hecho nos corrobora que tanto Josepha Antonia como el primer Pedro de Ávila fallecieron al poco de nacer.

Teresa contrajo matrimonio con el maestro cubero Santiago Barba el 22 de julio de 1714 en la iglesia de Santiago $^{201}$. Ese mismo día se realizaron las capitulaciones matrimoniales (DOCUMENTO 6). Los padrinos del enlace fueron Alonso Meléndez, sobrino de Santiago Barba, y María de la Peña, que no es otra que María Lorenza de la Peña, mujer de Pedro de Ávila, y por lo tanto cuñada de Teresa. La velación del matrimonio tuvo lugar en la capilla de San Juan Evangelista de la catedral vallisoletana, la cual durante cierto tiempo funcionó como parroquia independiente ${ }^{202}$.

El 19 de diciembre de ese mismo año Teresa y su marido compran al Convento de San Francisco de Valladolid una sepultura sita en la iglesia, era la "tercera enfrente de la puerta principal de la capilla de Nuestra Señora de la Encarnación en el séptimo lecho como se baja desde la reja de la capilla mayor a la referida de Nuestra Señora de la Encarnación", la cual "hoy no tiene puesta piedra losa ni rótulo"203.

El matrimonio tuvo solamente una hija, María Barba, la cual nació el 15 de abril de 1717, siendo bautizada el día 22 de ese mismo mes en la parroquia de San Juan

paterna, pues no hemos de olvidar que otro tío suyo, Gil de Ávila, ejerció el cargo de curador de Juan de Ávila durante cierto tiempo tras el fallecimiento de Hernando.

199 Hernando de Bibas era primo político de Juan de Ávila puesto que estaba casado con María de Ávila, prima carnal de Juan. A.G.D.V., Santiago, 1609M, f. 175. María de Ávila era hija de Juan de Ávila Monge, hermano mayor de Hernando de Ávila, padre de nuestro escultor. A.G.D.V. Alaejos, Santa María, 1653B, f. 163.

200 "En Santiago. En la ciudad de Valladolid a seis días del mes de mayo de mil seiscientos y ochenta y cuatro años el Ilustrísimo señor don Diego de la Cueva y Aldana obispo de esta ciudad de Valladolid celebró el santo sacramento de la confirmación en esta iglesia de señor (...) siendo padrinos Doña María Antonia Pérez y el licenciado D. Juan Delfín 7 de mayo de 1684. Pedro y Teresa hermanos: naturales de esta ciudad, hijos legítimos de Juan de Ávila y Francisca Ibarra a la calle de Santiago". A.G.D.V., Santiago, Confirmados, f. 26. No cabe duda de que el apellido de Francisca estaba mal escrito, puesto que no era Ibarra sino Ezquerra.

201 "En veinte y dos de julio de mil setecientos y catorce yo D. Marcos Ibáñez presbiterio y canónigo de la Santa Iglesia Catedral de esta ciudad de Valladolid de licencia de D. Domingo de Libarona cura propio de la iglesia parroquial del Señor San Miguel de dicha ciudad (...) desposé por palabras de presente, que hacen verdadero matrimonio a Santiago Barba vecino de ésta referida ciudad y viudo de Juliana Meléndez con Doña Teresa de Ávila natural de ésta ciudad hija legítima de Juan de Ávila y de Doña Francisca Ezquerra. Fueron testigos Don Manuel Lagunilla y Don Domingo de Libarona presbíteros y otras muchas personas y padrinos Alonso Meléndez y Doña María de la Peña. Y en fe de ello lo firmé junto con dicho cura dicho día mes y año". A.G.D.V., San Miguel, 1681M, f. 88.

202 "En veinticuatro de septiembre de mil setecientos y catorce años yo D. Juan de Toro sacristán mayor de la Santa Iglesia Catedral de esta ciudad de Valladolid de licencia de Don Francisco del Álamo cura propio de la parroquial del Señor San Juan Evangelista inclusa en dicha Santa Iglesia velé in facie ecclesiae y di las bendiciones nupciales según forma de la Santa Madre Iglesia Romana en la de Nuestra Señora de la Caridad de esta susodicha ciudad, a Santiago Barba vecino de ella y viudo de Juliana Meléndez y a Doña Teresa de Ávila natural de esta dicha ciudad hija legítima de Juan de Ávila y de Doña Francisca Ezquerra fueron padrinos Alonso Meléndez y Doña María de la Peña, testigos D. Manuel de Lagunilla y Joseph Vázquez y lo firmé con dicho cura". A.G.D.V., Catedral, 1695M, f. 131.

203 A.G.D.V., Leg. 2.960, ff. 380-384. 
Evangelista $^{204}$. Como padrinos de la recién nacida actuaron su tía María Lorenza de la Peña y Alonso Meléndez, es decir, las mismas personas que actuaron de padrinos en la boda de sus padres. Por abogados se le dieron a Nuestra Señora del Sagrario, a San José y a Santa Basilisa. Es fácilmente explicable el hecho de que se le pusiera por abogada a Nuestra Señora del Sagrario puesto que su capilla, sita también en la catedral, se encontraba casi al lado del lugar en que fue bautizada.

El 12 de agosto de 1721, sintiéndose enferma, otorga un poder para testar a su marido para que cuando ella fallecería él pudiera dictar testamento en su nombre (DOCUMENTO 7). En él Teresa dejaba nombrada por heredera universal a su hija María, y como testamentarios a su marido Santiago Barba y a su hermano Pedro de Ávila. El óbito acaeció dos días después, siendo su cuerpo sepultado "en el Convento de San Francisco de esta ciudad", en la sepultura que el matrimonio había adquirido unos años antes ${ }^{205}$. Dos semanas después, el día 30, Santiago Barba cumplía el mandato de su mujer y otorgaba el testamento que esta le había comunicado ${ }^{206}$.

\section{$\underline{\text { PEDRO DE ÁVILA I }}$}

Con la llegada al mundo de Pedro Juan de Ávila lograría cumplir el sueño de tener un hijo varón, si bien la felicidad se truncaría al poco tiempo ya que debió de fallecer muy pronto. El nacimiento tuvo lugar el 29 de junio de 1675, recibiendo las aguas del bautismo el 15 de julio en la iglesia parroquial de Santiago ${ }^{207}$. Actuaran de padrinos Francisco de Tudanca y María de Guyón, se le dieron por abogados a Nuestra Señora y a San Antonio. Como testigos actuaron Pedro Cordón y, nuevamente, Matías Serrano.

\footnotetext{
204 "En veintidós de abril de mil setecientos y diez y siete años yo Don Francisco del Álamo cura propio de la parroquial del Señor San Juan Evangelista inclusa en Santa Iglesia Catedral de esta ciudad de Valladolid bauticé (...) a María hija legítima de Santiago Barba y de Doña Teresa de Ávila mis feligreses (...) dieronla por abogados a Nuestra Señora del Sagrario, San José y Santa Basilisa testigos D. Juan de Toro, Tomás Rodríguez y Jerónimo Vázquez y lo firmé.” A.G.D.V. Catedral, 1656B, f. 82.

205 "En catorce de agosto de mil setecientos y veinte y un años a la calle de los tintes habiendo recibido los santos sacramentos con el de la extremaunción murió Teresa de Ávila que al presente estaba casada con Santiago Barba feligresa de la Parroquial del Señor San Juan Evangelista inclusa en la Santa Iglesia Catedral de esta ciudad de Valladolid otorgó poder para testar en doce del dicho ante Tomás de San Juan escribano del número de esta dicha ciudad a favor de Santiago Barba su marido por el cual se mandó enterrar en el Convento de San Francisco de esta ciudad y nombró al dicho por heredero y a María Barba su hija de dicho Santiago Barba y la sepultura es propia; y la firmé". A.G.D.V. San Miguel, 1684D, f. 193.

206 A.H.P.V., Leg. 2.962, ff. 624-625.

207 "En quince de julio de mil y seiscientos y setenta y cinco años yo Francisco García cura propio de la iglesia de Señor Santiago de esta ciudad de Valladolid bauticé e impuse los santos óleos como el Santo Concilio manda a Pedro hijo legítimo de Juan de Ávila y de Francisca Ezquerra nació en veinte y nueve de junio de este año fueron padrinos Francisco de Tudanca y María de Guyón dieronle por abogados a Nuestra Señora y San Antonio fueron testigos Pedro Cordón y Matías Serrano y lo firmé”. A.G.D.V., Santiago, 1668B, f. 176. FERNÁNDEZ DEL HOYO, María Antonia: "El escultor vallisoletano Francisco Díez de Tudanca...”, op. cit., p. 385.
} 


\section{PEDRO DE ÁVILA II}

Se hablará en su capítulo correspondiente.

\section{FRANCISCO DE ÁVILA}

Francisco nació el 29 de enero de 1681, siendo bautizado el 24 de febrero del mismo año en la iglesia de Santiago Apóstol ${ }^{208}$. Se le dieron por abogados a la Virgen y a San José, dupla muy repetida a lo largo en los bautizos de los hijos del escultor. Como padrino ejerció el licenciado Julián de Granda, cura y beneficiado de la dicha iglesia, mientras que como testigos actuaron Andrés González ${ }^{209}$ y Bartolomé Sánchez, quien ya había realizado la misma función en el bautizo de Pedro de Ávila.

Nada más sabemos de su vida. Su nombre tampoco aparece en el libro de confirmados de la parroquia por lo que es previsible que muriera a los pocos días.

\section{JOSEPH DE ÁVILA}

Joseph nace el 15 de marzo de 1682. Sus padres le llevaron a bautizar a la parroquia de Santiago el día 30 de ese mismo mes ${ }^{210}$. Sus padrinos fueron Juana Ezquerra (hermana de su madre) y Amaro Alonso de Llanos, uno de los pintores más solicitados en la ciudad en aquella época. Como padrinos actuaron Josepha Martínez y, nuevamente, el licenciado Julián de Granda, hecho que nos prueba las buenas relaciones existentes entre el clérigo y el escultor. Por abogados se le adjudicaron a San Ildefonso y a San Antonio.

El 7 de septiembre de 1687 es confirmado por el obispo de la ciudad, don Diego de la Cueva y Aldana ${ }^{211}$ en una ceremonia oficiada en la iglesia de Santiago. Nada más

\footnotetext{
208 "En veinte y cuatro de febrero del año de mil y seiscientos y ochenta y un años yo Mateo González teniente de cura de la parroquia del señor Santiago de ésta ciudad de Valladolid bauticé e impuse los santos óleos como el santo concilio manda a un niño hijo legítimo de Juan de Ávila y de Francisca Ezquerra pusieronle por nombre Francisco el cual nació en veinte y nueve de enero de éste dicho año según me lo aseguraron sus padrinos que lo fue el licenciado Julián de Granda beneficiado de la dicha iglesia diole por abogados a Nuestra Señora y a San José fueron testigos el licenciado Andrés González y Bartolomé Sánchez y lo firmé”. A.G.D.V., Santiago, 1668B, f. 294.

209 Pudiera tratarse de un oficial de escultor que en 1683 estaba pleiteando con Francisco Díez de Tudanca "en razón de ciertas palabras que entre los dos hubo". F FERNÁNDEZ DEL HOYO, María Antonia: "El escultor vallisoletano Francisco Díez de Tudanca...”, op. cit., p. 388.

$210 \quad$ "En treinta de marzo de mil seiscientos y ochenta y dos años yo Mateo González teniente de cura de la iglesia parroquial de señor Santiago de esta ciudad de Valladolid bauticé e impuse los santos óleos como el Santo Concilio manda a un niño hijo legítimo de Juan de Ávila y de Francisca de Ezquerra parroquianos de esta dicha parroquia a la calle del Campo pusieronle por nombre Joseph que nació en quince días de presente mes de marzo según me lo aseguraron sus padrinos que lo fueron Amaro Alonso de Llanos Y Juana de Ezquerra dieronle por abogados a Nuestra Señora y San Ildefonso y San Antonio y San Lázaro fueron testigos el licenciado Julián Granda y Josepha Martínez firmé”. Ídem, p. 385.

211 "En la ciudad de Valladolid a siete días del mes de septiembre de mil y seiscientos y ochenta y siete años el Ilustrísimo señor D. Diego de la Cueva y Aldana obispo de dicha ciudad de Valladolid
} 
conocemos de su vida, quizás siguiera el oficio paterno, ayudando en el taller de su padre y a la muerte de este en el de su hermano Pedro. Hay un dato que puede llevar a confundirle con otro ¿escultor? homónimo: a comienzos del siglo XVIII debía de trabajar un escultor llamado José de Ávila, el cual esculpió en 1715 junto al vallisoletano Antonio de Gautúa unos ángeles para el órgano de la iglesia de San Pedro de Tordesillas ${ }^{212}$. El escultor en cuestión no puede ser el hijo de Juan de Ávila puesto este que fallece en 1708. Al no tener documentados ni más datos sobre él ni ninguna obra más es plausible pensar que pueda tratarse de un error del escribano, y que en realidad quisiera poner Pedro o Manuel puesto que los ángeles del citado órgano concuerdan plenamente con los postulados artísticos desarrollados por los dos hermanos, a este hemos de sumar que el escultor Antonio de Gautúa aparece casi siempre asociado a la familia Ávila, motivo que me ha llevado a pensar en un posible aprendizaje al lado de Juan de Ávila. Tampoco es menor el hecho de que Pedro trabajara para la cercana localidad de Torrecilla de la Abadesa y Manuel contratara obra para la propia Tordesillas.

Como acabamos de referir, Joseph de Ávila Ezquerra falleció en 1708 "habiendo recibido los santos sacramentos con el de la extremaunción". Recibió cristiana sepultura el 14 de agosto en la catedral vallisoletana ${ }^{213}$.

\section{$\underline{\text { ANA DE ÁVILA }}$}

En 1685 nace el último retoño del matrimonio. Ve la luz el día 8 de agosto de 1685 , siendo bautizada el día 20 de ese mismo mes ${ }^{214}$. Como padrinos ejercieron su tía Juana Ezquerra y el licenciado Julián de Granda, ambos expertos ya en estas lides. Los licenciados Pedro de Hordejos y Juan González fueron los testigos de bautizo. Al igual que ocurrió con sus hermanos Josepha Antonia, Pedro y Francisco debió de fallecer al

celebró el santo sacramento de la confirmación en ésta iglesia de señor Santiago a las personas siguientes siendo padrinos el licenciado D. Juan Fernández de Salazar cura de esta parroquia y Francisca Ezquerra. Joseph. Natural de esta dicha ciudad hijo de Juan de Ávila y Francisca Ezquerra ya difunta a la calle de Santiago". A.G.D.V., Santiago, Confirmados, f. 34.

212 "195 reales que pagó a Antonio de Gaute, vecino de Valladolid, maestro escultor, por la hechura de cuatro niños que se pusieron en los arbotantes del órgano nuevo. Consta de recibos de dicho maestro y de Joseph de Ávila, también maestro de dicho arte”. ARA GIL, Julia y PARRADO DEL OLMO, Jesús María; Catálogo Monumental de la provincia de Valladolid XI..., op. cit., p. 234.

213 "En 14 de agosto de 1708 habiendo recibido los santos sacramentos con el de la extremaunción murió en esta parroquia de la catedral Joseph de Ávila soltero mi parroquiano hijo de Juan de Ávila y de Manuela Ezquerra vecinos de esta ciudad difuntos no hizo testamento (...) enterrose en 15 de este dicho mes en Valladolid”. A.G.D.V., Catedral, 1684D, f. 160. El nombre de la madre es erróneo puesto que era Francisca y no Manuela.

214 "En veinte días del mes de agosto de mil y seiscientos y ochenta y cinco años yo Mateo González teniente de cura de la iglesia parroquial de señor Santiago de ésta ciudad de Valladolid bauticé e impuse los santos óleos como el santo concilio manda a una niña hija legítima de Juan de Ávila y de Francisca Ezquerra parroquianos de ésta iglesia a la calle del Campo pusieronla por nombre Ana la cual nació en ocho de agosto según me lo aseguraron sus padrinos que lo fueron el licenciado don Julián de Granda beneficiado de dicha iglesia y Juana Ezquerra dieronla por abogados a Nuestra Señora y a Santiago y a San Lorenzo fueron testigos el licenciado don Pedro de Hordejos y el licenciado Juan González y lo firmé”. A.G.D.V., Santiago, 1683B, f. 63. 
poco de nacer ya que su nombre tampoco figura en el libo de confirmaciones de la parroquia.

\section{I- SEGUNDA MUJER DE JUAN DE ÁVILA: BENTURA SEDANO}

Bentura Sedano era hija del afamado escultor palentino Mateo Sedano y de Isabel Caballero, su primera mujer. Desconocemos su fecha de nacimiento, si bien este debió de acontecer hacia mediados de siglo. A pesar de aparecer en todos los documentos referida como Bentura Sedano, en realidad debía de llamarse Isabel Bentura, puesto que en el testamento de su padre figura como "Isabel mi hija legítima y de Isabel Caballero mi primera mujer" 215 .

Cuando muere su padre el domingo 22 de septiembre de 1686 "a hora de las nueve de la noche poco más o menos", tanto Bentura como su hermana María se hallaban "ausentes de esta ciudad", tal y como nos lo desvela el inventario de bienes del escultor fallecido $^{216}$. Es probable que vivieran en Valladolid en casa de su tío el licenciado Bernardo de Osorno, a la sazón capellán de coro de la catedral vallisoletana. Desconocemos la razón por la cual estarían viviendo con su tío clérigo y no con su padre; puesto que, además, María era menor de edad (tenía menos de 25 años, pero más de 19).

Un día antes de fallecer, Mateo Sedano había dictado testamento, en él nombraba como herederas universales tanto a Bentura como a María, esta última habida en su segundo matrimonio $^{217}$. Sea como fuere, a finales del año 1687 ya figura como vecina de Valladolid, ya que el día 7 de noviembre de 1687, declarando "ser mayor de veinte y cinco años", daba poder a sus tíos Martín García y Catalina Caballero, vecinos de Palencia, para que en su nombre "pidan y tomen cuentas judicial o extrajudicialmente a todas y cualesquier personas así eclesiásticas como seglares de cualquier estado y calidad que sean o de quien así deban dar de todos los bienes y hacienda que me tocaron por las cuentas y particiones que se hicieron de los bienes que quedaron por fin y muerte de los dichos mis padres entre mí y demás herederos de los susodichos que constaran por mi abuela, y los dichos bienes y hacienda los perciban y cobren de las personas en cuyo poder pararen con todo lo que hubieren rentado desde el día que entraron en su poder hasta que se haga la entrega de los dichos bienes y de todo lo que recibieren y cobraren den y otorguen las cartas de pago, finiquitos, cesiones y lastos y los demás recado" (DOCUMENTO 8).

215 GARCÍA CUESTA, Timoteo: “El retablo de la Inmaculada...”, op. cit., pp. 183-184. Tras el cambio de signaturas de los legajos efectuado en el Archivo Histórico Provincial de Palencia, la referencia actual es: A.H.P.P., Leg. 7.232.

216 A.H.P.P., Leg. 7.232.

217 Ibídem. 
El 6 de febrero de 1689 contrae matrimonio con Juan de Ávila en la iglesia del Santísimo Salvador ${ }^{218}$. La pareja tuvo dos hijos: Manuel (1690) y Manuela (1691). No volvemos a tener noticias de ella, tal es el desconocimiento que tenemos desde entonces que no hay constancia de la fecha de su fallecimiento. Pienso, solo es una suposición, que falleciera antes que su marido, Juan de Ávila, ya que en la partida de defunción de éste no se hace alusión a ella. También pudiera haber ocurrido que viviera y quedara viuda. Un tercera posibilidad sería que Bentura abandonara el hogar conyugal y se escapara, aunque es una opción más arriesgada hay algunos casos similares, como los de los escultores Pedro Alonso de los Ríos ${ }^{219}$ y Pedro de Sierra.

\section{J- HIJOS DE JUAN DE ÁVILA Y BENTURA SEDANO}

\section{MANUEL DE ÁVILA}

Se hablará en su capítulo correspondiente.

\section{MANUELA DE ÁVILA}

Manuela de Ávila Sedano nació en Valladolid el 11 de septiembre de 1691, recibiendo las aguas bautismales el día 23 de ese mismo mes ${ }^{220}$. Ejercieron de padrinos sus tíos Santiago Izquierdo y María Sedano. Al igual que otros hijos del primer matrimonio de Juan de Ávila debió de fallecer en la más tierna infancia.

\footnotetext{
218 "En seis del mes de febrero de mil seiscientos y ochenta y nueve años habiendo precedido las tres canónicas municiones que el santo concilio de Trento manda y no resultado impedimento alguno y licencia del señor licenciado D. Francisco Antonio Zabala y Zolocha provisor general en esta ciudad y obispado, refrendada de Nicolás de Burgueño, notario de asiento de la audiencia episcopal de ella, habiendo precedido licencia del señor D. Joseph Díaz Bravo cura propio de dicha parroquia yo el licenciado Francisco Ortiz desposé por palabras de presente que hicieron verdadero matrimonio a Juan de Ávila viudo de Francisca Ezquerra, con Bentura Sedano natural de la ciudad de Palencia hija legítima de Mateo Sedano y de Isabel Caballero, fueron testigos Manuel Santos de Villegas y Antonio Merino. Y luego incontinenti velé in facie ecclesiae y di las bendiciones nupciales según forma de la santa madre iglesia a los susodichos Juan de Ávila y Bentura Sedano en el Convento de Recoletos Agustinos, fueron padrinos Miguel Santos y Magdalena de Villegas y lo firmé con dicho señor cura ut supra". A.G.D.V., El Salvador, $1685 \mathrm{M}, \mathrm{f} .35$.

219 CRUZ YABAR, Juan María: “El escultor Pedro Alonso de los Ríos. I...”, op. cit., p. 150.

$220 \quad$ "En veinte y tres días del mes de septiembre de mil seiscientos y noventa y un año de licencia del licenciado don Juan Fernández de Salazar cura propio de ésta iglesia de señor Santiago de ésta ciudad de Valladolid yo Julián de Granda beneficiado de presente de dicha iglesia bauticé e impuse los santos óleos como el santo concilio manda a una niña hija legítima de Juan de Ávila y Bentura Sedano moradores a la calle del Campo pusieronla por nombre Manuela que nació en once de dicho año fueron padrinos Santiago Izquierdo y María Sedano abogado a Nuestra Señora y San José fueron testigos Jacinto Pajares y Manuel Gómez y lo firmé con dicho cura". A.G.D.V., Santiago, 1643B, f. 215.
} 


\section{3-3 EL NOMBRE}

El apellido deriva de "Dávila", palabra de origen castellano que procede de los conquistadores y pobladores de Ávila, ciudad que fundaron a comienzos del siglo XIII dos grandes familias con el mismo apellido, pero distintas entre sí. El cabeza de familia de la primera fue D. Blasco Gimeno, gobernador de Ávila a finales del siglo XII, originario de Asturias. El segundo clan fue fundado por D. Esteban Domingo, alcalde mayor y alcalde de Ávila en 1216, hermano de Domingo Muñoz, conquistador de la ciudad de Córdoba, y ambos descendientes de D. Marín Muñoz, Ricohombre de Castilla, descendiente, a su vez de Nuno Rasura, Conde y Juez de Castilla. En sucesivas generaciones ambas familias entroncaron en numerosas ocasiones ${ }^{221}$.

En los documentos vemos nombrar a nuestro escultor de dos formas "Juan de Ávila" y "Juan de Abila"; si bien el artista siempre firma con la segunda forma. Una tercera opción, pero que más bien creo que fue un error por parte del escribano, es la de "Juan de Ablitas", denominación que figura en su partida de bautismo. Este apellido, Ablitas, se dio bastante en Valladolid en esta misma época, como así lo testimonian dos escribanos llamados Juan de Ablitas y Bernardo de Ablitas.

\section{3-4 ORIGEN}

Aunque nacido en la capital del Pisuerga Juan de Ávila tiene ascendencias foráneas, más concretamente alaejanas. La familia paterna, incluido el propio progenitor, procedía de Alaejos, habiendo sido todos sus miembros hijos de pila de la iglesia parroquial de Santa María. Este dato permite descartar una relación familiar directa entre nuestro escultor y el artífice gallego homónimo que laboró en las últimas décadas del siglo XVI y primeros años del XVII. Este último, llamado en ocasiones Juan da Vila, trabajó durante unos años en Valladolid y sus alrededores, motivo por el cual se llegó a pensar en un posible parentesco entre ambos artistas.

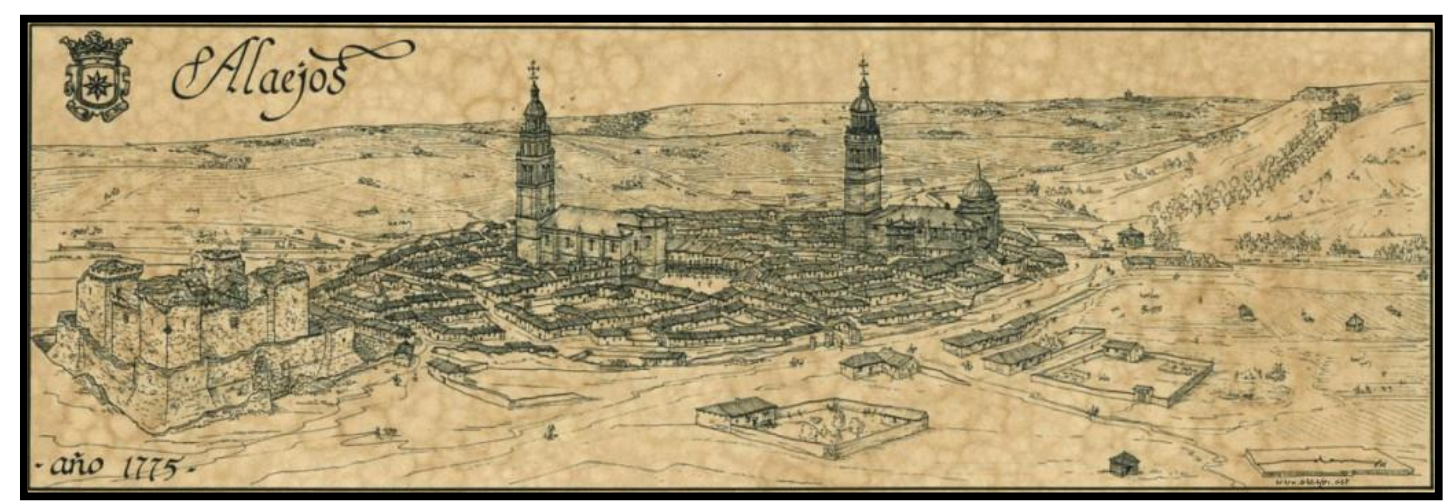

Il. 5- Anónimo. Vista de Alaejos en el año 1775.

221 GARCÍA CARRAFFA, Alberto: Diccionario heráldico y genealógico de los apellidos españoles y americanos, Imprenta Antonio Marzo, Madrid, 1920, pp. 129-130. 
Juan da Vila nació hacia el año 1560 en la diócesis de Tuy ${ }^{222}$. Contrajo matrimonio en dos ocasiones, durante los cuales engendró a tres hijos. Con su primera esposa, Jerónima Remesal (con la cual se desposó en Valladolid), tan solo tuvo un vástago; posteriormente contrajo segundas nupcias en Santiago de Compostela con Antonia Ruiz Durana, con la cual tuvo otros dos: Juan y Catalina.

El documento que descarta que ambos sean familia directa es el testamento otorgado por Juan da Vila en el año 1610. En él reconoce que su hijo se encontraba "aún por criar"223. Por otra parte, los abuelos del Juan de Ávila vallisoletano (Juan de Ávila y Ana Monge) se desposaron en la iglesia de Santa María de Alaejos en 1609. Como vemos ambas noticias nos dan un desfase cronológico que nos deja claro que ambos no eran familia directa. Con toda probabilidad tampoco tuvieran otro tipo de parentesco.

Existe otro error relativo a los antepasados de Juan de Ávila. Filemón Arribas explica en su libro sobe la Cofradía Penitencial de N. P. Jesús Nazareno de Valladolid que el escultor Juan de Ávila "era hijo de otro

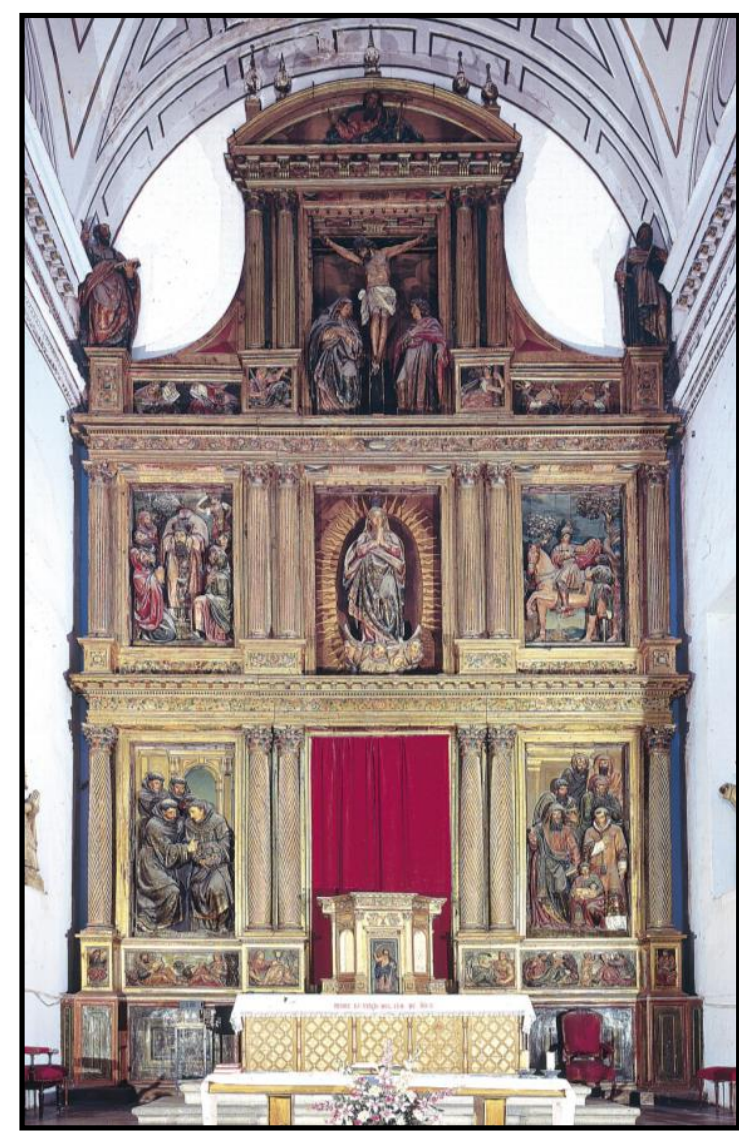

Il. 6- Juan da Vila, Francisco del Rincón y Pedro de la Cuadra. Retablo mayor. Hospital de Simón Ruiz. Medina del Campo (Valladolid). Juan de Ávila, alguacil ordinario de la ciudad, ambos cofrades de Jesús, ingresados en 15 de febrero de 1647 el padre y en 5 de abril de 1667 el hijo. Y posiblemente descendiente de Alonso de Ávila, que vivió en la calle de Cazalla, admitido cofrade en 16 de marzo de 1602, y de otro Juan de Ávila, también escultor, que en abril de 1587 tasaba la sillería del monasterio de Santa María de Palazuelos..."224. Ninguno de estos datos, salvo los ingresos en la Cofradía Penitencial, tiene la menor base documental. Como veremos más adelante, Juan de Ávila era hijo de Hernando de Ávila y nieto de otro Juan de Ávila, siendo estos dos últimos naturales de la localidad de Alaejos (Valladolid).

Otra "propuesta" claramente errónea fue la sugerida por Agapito y Revilla en su brillante libro titulado Las cofradías, las procesiones y los pasos de Semana Santa en Valladolid. Allí no solamente aceptaba los postulados expuestos por Arribas Arranz sino que además insinuaba que Juan de Ávila podía ser el último eslabón de una larga

222 PÉREZ CONSTANTI, Pablo: Diccionario de artistas que florecieron en Galicia durante los siglos XVI y XVII, Imprenta del Seminario C. Central, Santiago, 1930, p. 559.

223 Ídem, p. 566-567.

224 ARRIBAS ARRANZ, Filemón; La Cofradia Penitencial..., op. cit., p. 80. 
serie de artistas del siglo XVI apellidados Ávila. Así, comentaba que sería descendiente del platero Cristóbal de Ávila y de los pintores Alonso de Ávila (amigo de Alonso Berruguete), Antonio de Ávila y Francisco de Ávila. Para Agapito "todos estos Ávilas debían ser de la misma familia, como he dicho, del Juan de Ávila (nieto) -nuestro escultor-; pero fueron artistas modestos" ${ }^{225}$.

\section{3-5 RELIGIOSIDAD}

En el siglo XVII la sociedad no puede ser calificada de otra manera que "sacralizada", los artistas no fueron ajenos a este hecho. Martín González define a la perfección la acervada religiosidad de algunos de nuestros escultores, siendo el mayor ejemplo, o quizás el mejor conocido, Gregorio Fernández: "Los escultores viven el ambiente religioso de la época. Muchas imágenes han nacido a golpe de gubia y de oración a la vez"226.

Al igual que la mayoría de los artistas de su época, Juan de Ávila tuvo una acentuada religiosidad que derivó, entre otras cosas, en su compromiso con varias cofradías. Que sepamos, fue cofrade de la del Santo Ángel de la Guarda, sita en la iglesia de Santiago Apóstol, de la de San Isidro Labrador ${ }^{227}$ y de las penitenciales de Nuestra Señora de la Pasión y de Nuestro Padre Jesús Nazareno.

Múltiples documentos nos prueban que el escultor fue un activo miembro de la del Santo Ángel de la Guarda. Dicha cofradía, fundada en 1598 en la iglesia de Santiago, tenía como finalidad la fundación de misas de ánimas y sufragios. En un primer momento sus miembros eran tan solo maestros toqueros, más adelante se permitió el ingreso de otros miembros ${ }^{228}$. Dentro de la referida cofradía, a la cual debió unirse en torno al año $1677^{229}$, ostentó todo tipo de cargos, así entre 1682-1683 figura como alcalde junto al pintor José Martínez de Ollora ${ }^{230}$, y en los años 1686 y 1687 lo hace como depositario $^{231}$. Como veremos más adelante, la militancia de Juan de Ávila en dicha cofradía es un punto de apoyo más sobre el que sentar la creencia de que pudo tallar la imagen titular de la cofradía, actualmente conservada en su respectivos retablo y capilla, la cuarta del lado del evangelio de la iglesia de Santiago. Fueron muy frecuentes entonces los "cofrades-escultores", que fueron aquellos que militando en una cofradía hacían para ella las imágenes que esta necesitara. Este trabajo en ocasiones no

\footnotetext{
225 AGAPITO Y REVILLA, Juan: Las cofradias ..., op. cit., pp. 15-16.

226 MARTÍN GONZÁLEZ, Juan José: Escultura barroca en España ..., op. cit., p. 13.

227 La Cofradía de San Isidro decidió nombrarle cofrade al tiempo de realizar las imágenes de San Isidro y Santa María de la Cabeza, titulares de la cofradía.

228 http://www.diputaciondevalladolid.es/imprimir/modulo/archivo-provincial/informaciongeneral/119070/

229 A.H.P.V., Leg. 2.757/6, f. 26.

230 A.H.P.V., Leg. 2.466, ff. 217-218; A.H.P.V., Leg. 2.790, f. 428

231 A.H.P.V., Leg. 2.774, f. 395; 2.896, f. 278.
} 
era remunerado puesto que los artistas podían hacerlo gratuitamente, es decir por devoción, o bien con la promesa de ser eximidos de los oficios de alcalde o de otros que pudieran restarle horas de trabajo. Dentro de este último caso tenemos el ejemplo de Alonso de Rozas, el cual talló el paso procesional del Santo Sepulcro para que le excusaran "del oficio de alcalde de ella porque si llegase el caso de nombrarle en él no podría servir con la puntualidad y vigilancia que debiera por la razón de la ocupación de su oficio de escultor y la falta que haría no sólo en la dicha cofradía sino a la de su casa por tener muchos hijos y hallarse con pocas conveniencias para los sustentar y que menos lo podría hacer no asistiendo a su oficio a trabajar no teniendo otra hacienda de que se poder sustentar más que de su trabajo" ${ }^{232}$. Otros cofradesescultores, sin entrar el hecho por el que tallaron las imágenes, fueron el propio Juan de Ávila y Juan Antonio de la Peña para la penitencial de Jesús Nazareno, o José de Rozas para la de las Angustias.

También ostentó cargos de importancia dentro de las penitenciales de la Pasión y de Jesús Nazareno. Tenemos noticia de que en 1681 figura como diputado al igual que el escultor Juan Antonio de la Peña, su futuro consuegro ${ }^{233}$, en la cofradía de la Pasión, y en el periodo 1682-1683 como alcalde de la de Jesús Nazareno. Para esta última cofradía seguiría trabajando desde otros ámbitos, así años después será el mayordomo de pasos, cargo que ostenta hasta $1688^{234}$.

232 GARCÍA CHICO, Esteban: Documentos para el estudio del arte en Castilla. 2..., op. cit., pp. 333-335.

233 "Los alcaldes diputados y cofrades de la Cofradía de la Sagrada Pasión de Cristo de esta ciudad de Valladolid estando juntos y congregados en la sala de cabildos de la dicha cofradía sitio acostumbrado para tratar y conferir cosas tratantes al servicio de Dios nuestro señor bien y utilidad de la dicha cofradía llamados y convocados por son de campana y por Alejandro Mazo llamador de la dicha cofradía estando especial y señaladamente (...) Juan de Ávila (...) Juan Antonio de la Peña (...) todos diputados de la dicha Cofradía (...)". A.H.P.V., Leg. 2.737, ff. 296-297.

234 ARRIBAS ARRANZ, Filemón: La Cofradía..., op. cit., p. 80. 
$\sum[320]$ 


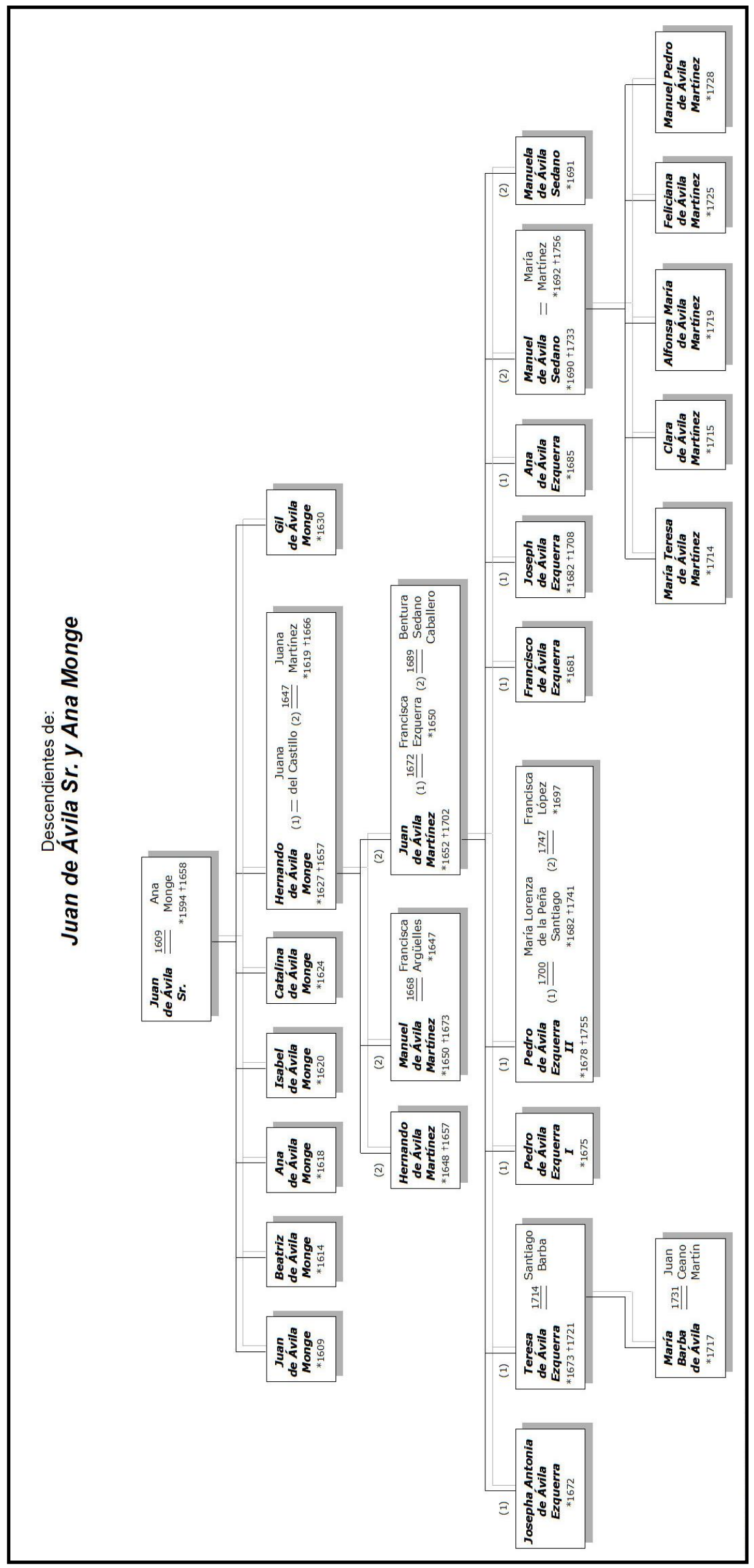

Fig. 1- Árbol genealógico general de la familia Ávila.

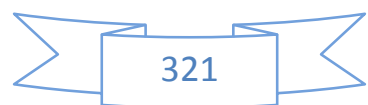


$\sum[322]$ 
4-ELARTE DE

JUAN DE AVILA 
$\sum 324 \leq$ 


\section{4-1 MARCO DE TRABAJO}

La calle de Santiago y la iglesia parroquial del mismo nombre fueron el epicentro de la vida de nuestro escultor puesto que allí nace, se casa, bautiza a sus hijos, abre y mantiene su taller y muere. En aquella época, y aún hoy, fue una de las calles más importantes de la ciudad. Su trascendencia como arteria urbana era primordial ya que comunicaba la Plaza Mayor y el Convento de San Francisco con la Puerta del Campo y la principal salida hacia Madrid, vía por la que llegarían y marcharían los reyes en sus visitas a la ciudad. La calle de Santiago/Campo daba cabida a edificios relevantes: el referido Convento de San Francisco, la ermita de Juan Hurtado de Mendoza, la iglesia parroquial de Santiago Apóstol, la casa del conde de Monterrey, el Convento de las Comendadoras de Santa Cruz, la casa del conde de Villamor, la ermita de Nuestra Señora de la Consolación y el Arco o Puerta del Campo, que vendría a ser el fondo arquitectónico de calle. No muy lejos del taller de Juan de Ávila se encontraban otras construcciones y establecimientos religiosos, para alguno de los cuales trabajó. Así, en la calle de la Guariza estaban los conventos de San Juan de Dios y de la Santísima Trinidad; en la Plaza de la Trinidad el Monasterio de San Joaquín y Santa Ana; en la calle de la Pasión, la iglesia penitencial de Nuestra Señora de la Pasión; en la Red la iglesia penitencial de Nuestro Padre Jesús Nazareno. Como vemos, era un territorio en el que florecían los establecimientos religiosos, fundamentalmente conventos y ermitas, pero en el que escaseaban las casas nobles. La más destacada, y casi la única, era la del Conde de Monterrey ${ }^{1}$.

La calle toma el nombre de una antigua ermita que había en la zona, advocada bajo la denominación de Santiago Apóstol ${ }^{2}$. Por aquel entonces se encontraba fuera de los

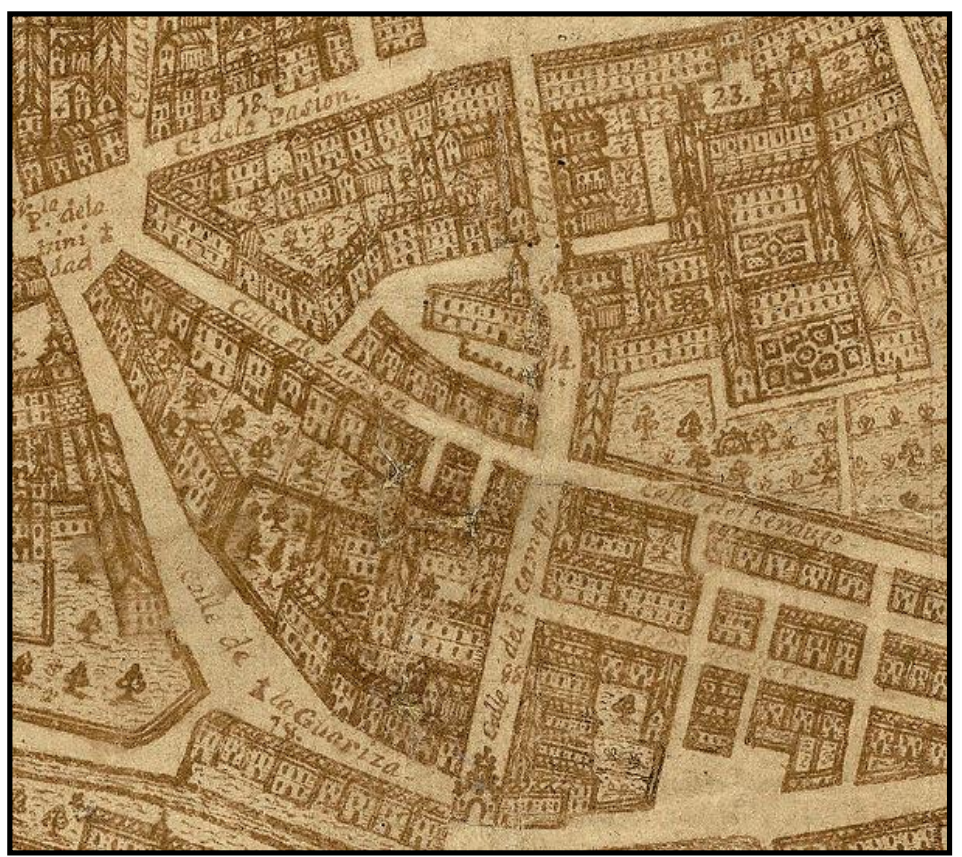

Il. 1- Inmediaciones de la calle de Santiago o del Campo en el mapa de Bentura Seco de 1738.

límites de la villa, pero al construirse la segunda muralla de la ciudad a finales del siglo XII, y parte del siguiente, la ermita quedó ya dentro de los límites de la misma. Posteriormente en dicha calle se construyó una puerta monumental, quizá la de mayor importancia junto a la de Madrid o "del Carmen": fue la llamada puerta "del Campo", nombre que durante algún tiempo dio nombre a uno de los tramos de la calle Santiago.

1 URREA, FERNÁNDEZ, Jesús: Arquitectura y nobleza: casas y palacios de Valladolid, IV Centenario Ciudad de Valladolid, Valladolid, 1996, pp. 302-303.

2 AGAPITO Y REVILLA, Juan: Las calles de Valladolid..., op, cit., p. 460.

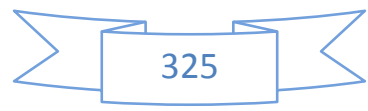


La primera vez que la calle aparece con la denominación de "Santiago" es el 8 de septiembre de 1470, fecha en la que se cita una lucha acaecida en dicha calle entre dos cofradías. Sin embargo, esta artería urbana tuvo otros nombres como el de "Calle Real"3, esto sucedió en la época en la que el rey Felipe III instaló la Corte en la ciudad (1601-1606). En otras ocasiones algún tramo de la calle tomó diferentes nombres, como "calle de cofrería" o "calle de carpintería", pero desde luego el que tuvo mayor repercusión fue el nombre de "Calle del Campo", nombre que se daba al tramo que iba desde la calle de Zúñiga hasta la Puerta del Campo.

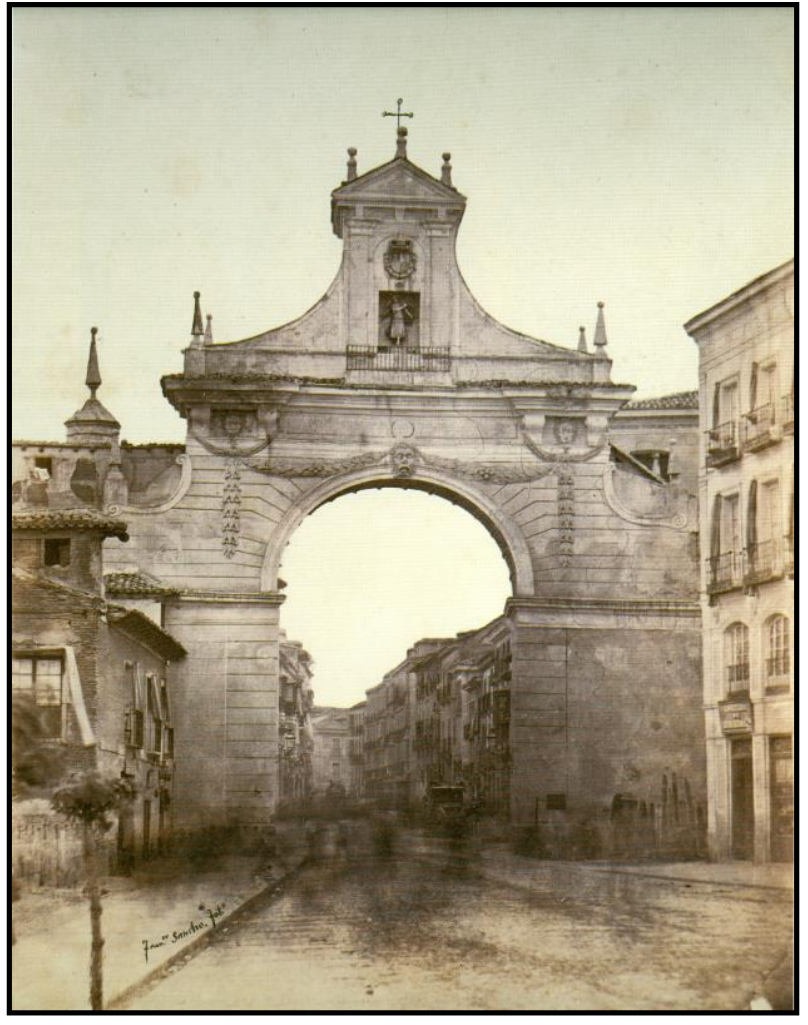

Il. 2- Arco de Santiago. Valladolid.

La calle no contaba apenas con talleres escultóricos; tan solo se pueden reseñar los de Francisco Díez de Tudanca y José Mayo, casualmente maestro y compañero de taller, respectivamente, de nuestro Ávila. Por aquel entonces el que podríamos considerar como "barrio de los escultores" era el de San Miguel. Allí tenían abierto su obrador Alonso y José de Rozas, Juan Antonio de la Peña, Andrés de Pereda y Antonio Vázquez.

Como ya hemos dicho los oficios mayoritarios en la calle eran el de zapateros y el de pintores, este último llegó a gozar de gran trascendencia, importancia que no corría paralela a la calidad de los pintores que allí moraban y trabajaban. Apunta

Fernández del Hoyo que "la actividad pictórica vallisoletana en el siglo XVII e incluso en el XVIII tiene como escenario la calle de Santiago, considerada el corazón viario de la ciudad, la "calle mayor" de la ciudad tradicional"4. Tampoco faltaban en la calle maestros de obras, carpinteros y mercaderes ${ }^{5}$.

La mayoría de los establecimientos de pintores, muchos de ellos dedicados únicamente a la venta de óleos de otros artífices, se situaban "en la actual acera de los impares, frente al ábside del templo". Tal aglomeración de talleres mereció la denominación de "Acera de los Pintores" ". Ese mismo hecho también debió de influir en el calificativo con el que se comenzó a conocer a estos artistas: "pintores de la calle de Santiago" o

Ídem, p. 462.

FERNÁNDEZ DEL HOYO, María Antonia: Pintura y sociedad en Valladolid durante los siglos XVI y XVII, Real Academia de Bellas Artes de la Purísima Concepción de Valladolid, Valladolid, 2000, p. 36.

5 Ibídem.

Ibídem. 
"pinturas de la calle de Santiago". Piensa Fernández del Hoyo que este último término "aludiría no solamente al lugar donde se vendían sino también a creaciones de una determinada categoría, si bien el formato y calidad no serían enteramente uniformes"7.

\section{4-2 EL OFICIO DE ESCULTOR}

Juan de Ávila fue fundamentalmente escultor, pues vive en una época, el barroco, en la que se destila el "especialismo", sobre todo en la Castilla del siglo XVII ${ }^{8}$. A pesar de que todas las noticias nos llevan a pensar que fue únicamente escultor hay sospechas de que pudo dedicarse al ensamblaje, a realizar trazas e incluso, aunque menos probable, a policromar alguna de las imágenes que previamente había tallado. Estas suposiciones se basan en varios datos. Así, la hipótesis de que pudiera diseñar trazas, fundamentalmente para arquitecturas efímeras, y quizás retablos, surge al comprobar como corrió a su cargo una "perspectiva" para las fiestas patronales de la iglesia de Santiago Apóstol del año 1681. Esta tesis se refuerza al ver que en una de las escrituras de arrendamiento que realiza Ávila se le define "Juan de Ávila maestro de arquitectura vecino de esta ciudad" (DOCUMENTO 23).

La presunción de que fuera ensamblador también está fundada. Quizás pudiera haber recibido ciertas nociones de ensamblaje por parte de Tudanca ya que éste en sus últimos años efectuó ciertos encargos que eran más labor de un ensamblador que de un escultor. Así, para la iglesia de Santiago Apóstol de Valladolid trabajó en diversas ocasiones realizando y reparando ciertos hacheros grandes ${ }^{9}$; para la parroquial de Villamayor de Campos (Zamora) contrata en 1661 la ejecución de "dos añadimientos de dos colaterales para el retablo de la iglesia de Santa María de la villa de Villamayor de Campos"10; para la de Santa María de Peñaflor de Hornija (Valladolid) también fabricó dos hacheros y unas cornucopias ${ }^{11}$, y, finalmente, para la de Santa Cruz de Medina de Rioseco deshizo el altar de la capilla mayor ${ }^{12}$.

Dos hechos nos terminan de demostrar que Juan de Ávila ejerció labores propias de un ensamblador: el que en una de las tasaciones que realiza el escribano se refiera a él como "maestro ensamblador"13 y el compromiso para la finalización del retablo mayor de la iglesia parroquial de Traspinedo (DOCUMENTO 32). Tampoco era nada nuevo

\footnotetext{
$7 \quad$ Ídem, p. 37

MARTÍN GONZÁLEZ, Juan José: El escultor Gregorio..., op. cit., p. 51.

"Más pagué a Francisco de Tudanca escultor veinte y siete reales y medio del aderezo que se hizo en los cuatro hacheros grandes dorados de que hay carta de pago". A.G.D.V., Santiago, Libro de fábrica 1651-1654.

10 FERNÁNDEZ DEL HOYO, María Antonia: "El escultor vallisoletano Francisco Díez de Tudanca...", op. cit., p. 382.

11 PARRADO DEL OLMO, Jesús María: Catálogo Monumental de la provincia de Valladolid. Tomo IX..., op. cit. p. 141.

12 PÉREZ DE CASTRO, Ramón: “La huella de Gregorio Fernández...”, op. cit., p. 172.

13 A.H.P.V., Leg. 2.713, ff. 475-477.
} 
que escultores diseñaran y/o ejecutaran retablos, en especial en el siglo XV. Además, en épocas posteriores fue muy frecuente que escultores levantaran retablos y tallaran las esculturas que debían ornarlos; este tipo de profesional se denominó como tallista. En este grupo cabría incluir a Pedro de Sierra, Pedro Correa y Pedro Bahamonde. Pues bien, el retablo de Traspinedo fue contratado por Díez de Tudanca, el cual fue fiado por Ávila. Probablemente tras el fallecimiento del primero, Ávila se hizo con la terminación de la obra; esto no quiere decir que no le hubiera ayudado ya con anterioridad. Entre los elementos que faltaban por tallar se encontraban dos remates, dos festones y dos tarjetas, componentes propios de la arquitectura del retablo, y por lo tanto dependientes de la mano de un ensamblador.

A pesar de conservar una carta de aprendizaje por la cual Ávila accedía como alumno al taller del pintor Gabriel de Palacios (maestro asimismo de Jerónimo Benete) justo antes de entrar en el obrador de Tudanca, pienso que este hecho no tuvo ninguna repercusión. Pudo llegar aprender lo más básico, o, quizás, ni eso.

Una de sus ocupaciones como escultor fue la de tasador de esculturas y otro tipo de objetos de madera, labor, esta última, que en otras ocasiones la vemos ejercida por carpinteros, ensambladores o entalladores. Por ejemplo, las "cuatro pirámides pequeñas de madera con sus bolas de jaspe" que poseía doña Paula del Hierro, o las pirámides, candeleros, jarras y cornucopias que pertenecieron al cirujano Luis de San Juan. Tenemos contabilizadas hasta cinco tasaciones, fechadas en el corto espacio comprendido entre los años 1680-1692, las cuales sin duda serán una pequeña parte de las que en realidad hizo. Cuatro de los individuos a los cuales Ávila valúa los bienes que habían dejado tras su fallecimiento parece que pertenecieron a una clase acomodada: efectivamente, tenemos a doña Paula del Hierro - la cual poseía incluso "dos hechuras de Nápoles" $-{ }^{14}$, al cirujano don Luis de San Juan ${ }^{15}$, a don Antonio Rogel ${ }^{16}$ y al corregidor vallisoletano don Damián López del Águila ${ }^{17}$. Del quinto, don Andrés de Morencia, no tenemos ningún dato que nos informe acerca de su posición social o económica $^{18}$. Es interesante la tasación de los bienes de don Antonio Rogel, por cuanto en ella nuestro escultor figura como "maestro ensamblador".

Su escaso catálogo nos le muestra aplicado a la elaboración de imágenes de devoción (Nuestra Señora de Gracia), escultura para retablos (Retablo de Santiago o el de San Juan de Dios), esculturas de carácter procesional (Santiago Apóstol y San Isidro y Santa María de la Cabeza), pasos procesionales (Paso del Despojo) y marcos para cuadros, además de como supervisor de las labores escultóricas de otros artistas (restauración de los pasos procesionales de la Cofradía de la Pasión por parte de Valentín Gómez de Salazar).

14 A.H.P.V., Leg. 2.425, f. 420.

A.H.P.V., Leg. 2.325, f. 927.

A.H.P.V., Leg. 2.713, ff. 475-477.

A.H.P.V., Leg. 2.740, ff. 900-901.

A.H.P.V., Leg. 2.855 , f. 250 . 
Se aplicó tanto a la escultura de bulto redondo como a la de relieve. No se dedicó en exclusiva a la talla de madera, puesto que también tenemos noticia de que labró la piedra (embellecimiento de la cruz del cementerio de la iglesia de Santiago Apóstol) e incluso pudo trabajar con la pasta $\mathrm{u}$ otros materiales débiles, elementos que quizá utilizara para fabricar y restaurar las figuras de los gigantes que desfilaban en la fiesta del Corpus Christi. Este último hecho nos muestra a Ávila como un escultor que no se dedicó únicamente a la escultura religiosa. También practicó, aunque de forma residual, la profana.

Sabiendo que trabajó la piedra, si bien de manera secundaria, podemos plantearnos si pudo haberse aplicado alguna vez más a la escultura monumental, concretamente a la labra de imágenes para las fachadas de las iglesias. De momento no tenemos base para sustentar dicha hipótesis, aunque la gran cantidad de esculturas anónimas de este tipo conservadas en las iglesias de las diócesis de Valladolid y sus alrededores nos permiten mantenerla. De la escultura en piedra o en mármol no podemos hablar mucho ya que en aquella época ni en los años inmediatamente anteriores o posteriores hubo en Valladolid escultores especializados en la talla de estos materiales. Tampoco es que existieran muchas oportunidades para aplicarse a ellas. A esto contribuyó de manera decisiva la nula demanda de escultura funeraria, la cual había tenido como su último gran artífice a Francisco del Rincón, si exceptuamos las estatuas orantes de los Condes de Fuensaldaña, conservadas en la iglesia de San Miguel, realizadas por Gregorio Fernández.

\section{4-3 FORMACIÓN}

El aprendizaje de la técnica escultórica por parte de Juan de Ávila tuvo lugar en el solicitado taller del mediocre Francisco Díez de Tudanca, establecimiento que debía estar situado en plena Plaza Mayor o quizás en la calle de Santiago ${ }^{19}$. La cercanía entre las viviendas del escultor y del padrastro de Ávila, Gabriel Rodríguez del Pozo, debió de ser uno de los factores determinantes para que el futuro artífice recalara en el taller de Tudanca.

El estilo de Tudanca entronca con el de Gregorio Fernández, si bien desconocemos la forma en que lo aprendió, es decir, si fue discípulo directo del gran maestro gallego, hipótesis bastante improbable, o bien lo fue de uno de los numerosos colaboradores de Fernández. En este caso deberíamos poner los focos en nombres como Andrés de Solanes (h.1595-1635), Antonio de Ribera (h.1606-h.1648), Francisco Fermín (h.1599d.1641), Juan Antonio de Estrada (h.1600-1647) y Pedro Salvador "el viejo" (16071654). Fernández del Hoyo apunta a estos dos últimos artífices dado que mantuvieron

19 FERNÁNDEZ DEL HOYO, María Antonia: "El escultor vallisoletano Francisco Díez de Tudanca...", op. cit., p. 374. 
taller cerca de la vivienda de Tudanca ${ }^{20}$. Tampoco podemos descartar a Manuel Rincón dadas las relaciones que mantenía Tudanca con esta familia. Un testimonio de la época indica que Tudanca era "discípulo de Gregorio Fernández"21.

Como hemos dicho, a pesar de seguir, a su manera, el estilo de Fernández, Tudanca no pasaba de ser un mediocre escultor. Este hecho no parecía importar a sus comitentes, ya que fue el escultor más demandado en Valladolid en el tercio central del siglo XVII. A esto se unía la circunstancia de que poseía el taller más solicitado a la hora de formar a nuevos aprendices y oficiales. La reputación que mantenía como maestro la vemos claramente definida al comprobar como Felipe del Rincón, hermano de Bernardo del Rincón acude a formarse al taller de Tudanca en lugar del de su pariente, y eso que por las pocas obras que tenemos documentadas de Bernardo éste se nos presenta un escalón por encima de Tudanca. La confianza que le mantenía la familia Rincón continuó tras el fallecimiento de Bernardo, ya que en 1661 su viuda pone por aprendiz de Tudanca a su hijo Bernardo ${ }^{22}$.

Fernández del Hoyo piensa que esta posición de superioridad respecto al resto de escultores de la ciudad se vio favorecido por la desaparición en 1660 de "Francisco Alonso y Bernardo del Rincón, la única figura importante que le podía disputar clientela era Juan Rodríguez. Honrado en su trato, falto de arrogancia y exigencias económicas, contó con una clientela fiel constituida en su mayor parte por iglesias de pueblos, cofradías y particulares, poco exigente y conservadora al solicitar continuamente la pervivencia de modelos anteriores que impidió el desarrollo de la imaginación creadora del artista. No tuvo trato con ningún cliente destacado pero tampoco la sociedad vallisoletana de la segunda mitad del siglo, sumida en una profunda crisis demográfica y económica podía exigir o propiciar grandes obras"23.

Además de formarse bajo la tutela de Tudanca, Ávila completaría su formación mediante la directa observación de las numerosas obras que Gregorio Fernández había legado a distintas iglesias y conventos de la ciudad. De Fernández tomará, como veremos a la hora de analizar su estilo, diversas poses, rasgos, modelos iconográficos, pero sobre todo su naturalismo, en ciertas ocasiones idealizado. Todo esto llevó a perpetuar la manera de hacer de Fernández hasta comienzos el siglo XVIII. Juan de Ávila, bajo mi punto de vista, se convirtió en el escultor que mejor supo interpretar los modos del gallego y a su vez actualizarlos, sobre todo mediante el cambio de los pliegues.

A continuación, se realizará un bosquejo biográfico y artístico de Francisco Díez de Tudanca y del pintor Gabriel de Palacios.

$20 \quad$ Ídem, p. 373.

21 En 1656 el cura párroco de Cogeces del Monte (Valladolid), anotaba en su libro de Bautismos, al hablar de los relieves de la portada de la iglesia "alábolos Tudanca, discípulo de Gregorio Fernández". Ibídem.

22 Ídem, p. 381.

23 Ídem, p. 388. 
Como ya hemos dicho en varias ocasiones, Francisco Díez de Tudanca ${ }^{24}$ fue un escultor vallisoletano que gozó de gran renombre en su época a pesar del escaso mérito de su obra. Señala la profesora Fernández del Hoyo que el caso de Tudanca "es representativo de un fenómeno sociológico hoy frecuente pero que rebasa la consideración temporal: la supervaloración de un determinado artista por encima de sus merecimientos. El paso del tiempo y el mejor conocimiento de su obra revelan, a veces, la falta de una base cierta para ello" 25 . A pesar de sus evidentes limitaciones no podemos negar que mantuvo un papel muy relevante en la escultura vallisoletana del tercer cuarto del siglo XVII. Desconocemos con quién se formó, aunque lo más probable es que fuera en el taller de algún discípulo de Gregorio Fernández. Poseemos un testimonio, poco fidedigno, que hace a Tudanca discípulo del maestro gallego: en unas anotaciones realizadas en 1656 por el cura de Cogeces del Monte, don Juan Rodrigo, en el libro de bautismos figura lo siguiente: "Se hicieron los nichos y santos de la portada de la Concepción, la han alabado todos, por cosa rarísima y excelente; San Frutos, San Clemente y todos los demás hízolas el famosísimo maestro Francisco de Isla Coterón y alábolos Tudanca, discípulo de Gregorio Fernández y éste de Juan de Juni que

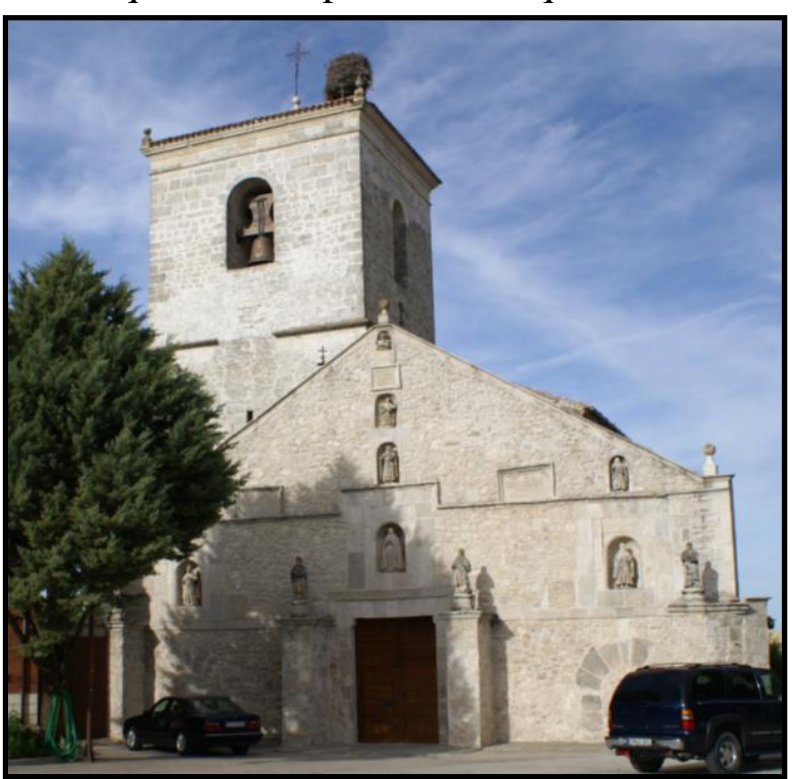

Il. 3- Iglesia parroquial de la Asunción. Cogeces del Monte (Valladolid).

hizo el retablo mayor" 26 . Como vemos el testimonio no merece demasiada credibilidad viendo que sitúa a Gregorio Fernández como discípulo de Juan de Juni, y a este último como autor del retablo mayor de dicha iglesia parroquial.

\footnotetext{
$24 \quad$ El primer acercamiento al escultor lo realiza Esteban García Chico. Posteriormente Tudanca ha contado con un buen puñado de revisiones y actualizaciones, siendo fundamental el artículo realizado por la profesora Fernández del Hoyo. GARCÍA CHICO, Esteban: Documentos para el estudio del arte en Castilla. 2..., op. cit., pp. 297-307; GARCÍA CHICO, Esteban: “Artistas Montañeses. Francisco Díez de Tudanca, escultor", Altamira. Revista del Centro de Estudios Montañeses, tomo XII, 1954, pp. 38-56; MARTÍN GONZÁLEZ, Juan José: Escultura barroca castellana ..., op. cit., pp. 283-287; PARRADO DEL OLMO, Jesús María: "El retablo mayor de el Salvador de Boadilla de Rioseco (Palencia)", B.S.A.A., tomo XLII, 1976, pp. 472-476; LLAMAZARES RODRÍGUEZ, Fernando: "El escultor Francisco Díez de Tudanca...”, op. cit., pp. 55-57; MARTÍN GONZÁLEZ, Juan José: Escultura barroca en España..., op. cit., pp. 74-75; FERNÁNDEZ DEL HOYO, María Antonia: "El escultor vallisoletano Francisco Díez de Tudanca...”, op. cit., pp. 371-388; PÉREZ DE CASTRO, Ramón: "La huella de Gregorio Fernández...", op. cit., pp. 169-173; BALADRÓN ALONSO, Javier: op. cit., pp. 153-170.

25 FERNÁNDEZ DEL HOYO, María Antonia: "El escultor vallisoletano Francisco Díez de Tudanca...", op. cit., p. 371.

26 VALDIVIESO, Enrique: Catálogo Monumental de la provincia de Valladolid. Tomo VIII..., op. cit., p. 72.
} 
Acabado su aprendizaje abre taller en la Plaza Mayor, donde recibirá a numerosos discípulos, muchos de ellos completamente desconocidos en la actualidad. Su producción escultórica, aunque numerosa, ha desaparecido casi en su totalidad. Destaca por la realización de copias de los modelos creados por Gregorio Fernández: Inmaculadas, Yacentes, etc... Asimismo descolló por ser un especialista dentro del campo de la escultura procesional, en la cual también dirigió sus ojos a Fernández, pero también a Bernardo del Rincón, y más concretamente a su Cristo del Perdón, del cual realizo dos copias. Sus obras más importantes, conservadas en la actualidad, son el Paso del Descendimiento encargado por la Cofradía de la Soledad de Medina de Rioseco (para la cual ejecutó también el Paso del Santo Entierro), la parte escultórica del retablo de la iglesia de la Asunción de Bercero (trabajó conjuntamente con el escultor Juan Rodríguez), y el Yacente realizado para la iglesia parroquial de Martín Muñoz de las Posadas.

Las palabras que mejor definen el estilo de Tudanca son tosquedad y mediocridad. Sus pliegues, generalmente muy burdos, en algunas ocasiones no tienen el mínimo sentido. Dada esta carta de presentación es un verdadero milagro que supiera encauzar el talento del joven Ávila. Sus esculturas suelen caracterizarse por los tipos achaparrados y las cabelleras ensortijadas, presupuesto este último que retomará su discípulo, aunque ejecutándolas de una manera más realista y pormenorizada. Un rasgo que se aprecia en la mayoría de sus obras es el excesivo remarque de los huesos, especialmente las costillas y las rodillas. Finalmente habría que referirse al escaso movimiento del que hacen gala sus imágenes, así como la nula expresividad de sus rostros, los cuales suelen caracterizarse por el ceño fruncido y los ojos abultados.

García Chico supuso, juzgando su apellido como topónimo, que "debió de nacer en Tudanca, humilde pueblecito de la montaña"27, tesis que también expuso Martín González $^{28}$. No debemos descartar que su familia pudiera provenir de ese pueblecito. Francisco Díez de Tudanca nació en Valladolid, muy probablemente en su Plaza Mayor, a finales del mes de mayo de 1616, siendo el cuarto hijo del matrimonio formado por Diego Díez de Tudanca, mercader de joyería, y María Gómez. El día 29 de aquel mes fue bautizado en la parroquia de Santiago ${ }^{29}$.

La familia debió de gozar de una posición económica desahogada. Dentro de la crisis generalizada que experimenta Valladolid a partir de 1606, especialmente rigurosa en el mundo de los mercaderes y artesanos, el gremio de "paños y joyas" era el más próspero de la ciudad. Probablemente el padre tendría tienda abierta en la Plaza Mayor de la ciudad "a la cera de San Francisco", lugar en donde vivía la familia.

Cuando en 1644 murió el padre ${ }^{30}$, el escultor probablemente poseería taller propio. En octubre del año anterior había contraído matrimonio con Francisca Ezquerra, diez años

27 GARCÍA CHICO, Esteban: Documentos para el estudio del arte en Castilla. 2..., op. cit., p. 324.

28 MARTÍN GONZÁLEZ, Juan José: Escultura barroca castellana ..., op. cit., p. 283.

29 FERNÁNDEZ DEL HOYO, María Antonia: "El escultor vallisoletano Francisco Díez de Tudanca...", op. cit., p. 371.

$30 \quad$ Ídem, p. 373. 
más joven que el artista. Las relaciones con su familia política, particularmente con el suegro, debieron ser estrechas sin que faltasen, en ocasiones, las lógicas desavenencias. Así, por ejemplo, será padrino en el bautizo de Juana Ezquerra, hija de Romualdo Ezquerra, el 11 de julio de $1660^{31}$. Posiblemente el escultor tenía su taller en la Plaza Mayor $^{32}$. En diciembre de 1647 renovó por un año el arrendamiento de una casa propiedad de $\mathrm{D}^{\mathrm{a}}$ Jerónima de Camargo "de alto abajo sin exentar ni reservar cosa alguna y las rejas segunda y postrera de la dicha casa y su portada es para mí (...) y la reja primera queda para la dicha Jerónima", pagando 500 reales. Sin embargo, en el ánimo del escultor existía el propósito de cambiar de domicilio porque en abril de 1648 pagó a un maestro albañil por las reformas que había hecho "en unas casas que están en el pasadizo de don Alonso Niño de Castro" (actual calle de la Pasión). El edificio, que no le pertenecía, disponía de entresuelo y dos pisos "cuartos primero y segundo", hablándose también de alcobas, dormitorios, sala y estudio ${ }^{33}$.

Esta última vivienda sería excesivamente grande para el artista ya que el pintor Gabriel de Palacios arrendó "el cuarto primero de la casa", durante un año y por 10 ducados, mientras que otra inquilina alquiló "el cuarto segundo". Tudanca se reservó "un cuarto bajo" quizás con el estudio que se menciona. Existen pruebas que permiten asegurar las buenas relaciones que existieron entre los vecinos ${ }^{34}$.

Cuando en enero de 1653 se procede a inventariar y tasar los bienes del difunto Conde de Benavente, se designa a Tudanca para tasar la escultura, junto con Pedro Salvador, el discípulo de Fernández. Sin embargo, en el momento de realizarse su nombre está tachado. Cuando en 1656, Pedro Salvador y Juan Rodríguez "tasadores que fueron de los condes de Benavente" reclaman un dinero, en nombre de Tudanca no aparece ${ }^{35}$.

En las fiestas del Corpus Christi del año 1660 le veremos trabajando en ellas por orden del Ayuntamiento de la ciudad. En este año se encarga de "los reparos de los gigantes y otras cosas para la fiesta del Corpus",36, además de hacer otros nuevos "los gigantes y tramoya de pasta" 37 . Por todo ello se le abonaron 2.050 reales en varios libramientos, siendo el último de ellos el efectuado el 24 de mayo "por cuenta de las cabezas y manos de los gigantes y demás cosas de su cargo" "38. En estas mismas fiestas le veremos trabajando junto a su amigo el pintor Alonso Mayo, el cual trabajaba en "aderezar los gigantes" "enlenzar los carros", y en "poner lienzo, clavarlo y aparejarlo para los

\footnotetext{
31 A.G.D.V., San Miguel, 1644B, f. 285.

32 En realidad, toda su vida parece haber transcurrido en torno a este núcleo que lo viera nacer y donde todavía vivía en 1647. En los libros parroquiales de Santiago consta que la familia tenía casa en la Plaza Mayor al menos desde 1621; allí murió el padre, en 1644, y en 1651 María Gallo, su viuda cobraba por el arrendamiento de casas en el mismo lugar. FERNÁNDEZ DEL HOYO, María Antonia: "El escultor vallisoletano Francisco Díez de Tudanca...”, op. cit., p. 374.

33 Ibídem.

Ibídem.

Ídem, p. 388

A.M.V., CH. 65-7, p. 19.

A.M.V., CH. 65-7, p. 20.

A.M.V., CH. $65-7$, p. 20.
} 
cuatro medios carros nuevos y las tramoyas", labores por las que percibiría 800 reales ${ }^{39}$.

En 1663 realiza un arco a la Puerta del Campo por mandato de la Cofradía de Cristo Resucitado y Virgen de la Alegría, radicada en una capilla propia de la iglesia de Santiago Apóstol -actualmente dedicada a Nuestra Señora de Loreto-. El día de la fiesta principal de la cofradía, el Domingo de Resurrección, se celebraba la procesión del Señor Resucitado. Con la imagen de Jesús Resucitado, se daba vuelta a la Plaza Mayor y se iba hasta la puerta del Campo donde, en el arco mencionado, estaba la Virgen. Ambos regresaban posteriormente hasta la iglesia de Santiago ${ }^{40}$.

En aquellos años el escultor debía de tener una holgada situación económica, hasta el extremo que se permite conceder algún préstamo. Así, el 21 de junio de 1664 el escultor presta a don Juan Alejandro Díaz Hurtado, regidor de Valladolid y patrono del convento de monjas trinitarias de San Bartolomé, 2.500 reales de vellón "que por me hacer merced y buena obra me ha prestado hoy día de la fecha para la cosecha de los frutos". El regidor, que se obligaba a devolverle toda esa cantidad "en una paga para el día de Todos los Santos de este dicho año puesto en esta dicha ciudad en casa y poder del dicho Francisco de Tudanca o de quien el suyo hubiere" 41 , hipotecaba "los frutos de pan que cogiere este dicho año de cien obradas de tierra poco más o menos que tengo en término del lugar de Olmos de Valdesgueva que son mías propias y arrendadas libres de todo censo perpetuo ni al quitar aniversario capellanía obligación hipoteca especial ni general'. Dos días después Tudanca testifica en la postura que hizo el ensamblador Pedro de Cea para la obra del retablo mayor de la iglesia de San Lorenzo $^{42}$, de Valladolid, según condiciones de Cristóbal Ruiz de Andino.

El 15 de febrero de 1672 firma como testigo en la carta de pago que otorgan Juan de Ávila y su esposa Francisca Ezquerra a favor de las memorias para casar huérfanas que había fundado María del Milagro y Mateo Tristán de Abellaneda sitas en la Cofradía de la Virgen del Pilar radicada en el Monasterio de Santa Ana ${ }^{43}$. Tres días después, el 15 de marzo, Tudanca se obliga a pagar al licenciado don Juan de Caviedes, "presbítero vecino de esta ciudad de Valladolid", 200 reales de vellón que ese mismo día le había prestado "por me hacer merced" 44 . El escultor se comprometía a pagárselos en un plazo de dos meses.

El 15 de junio de 1672 Tudanca y su esposa, Francisca Ezquerra, "hija legítima de Francisco Ezquerra y Juana Fernández de Geria sus padres y mis suegros difuntos y sus herederos cuya herencia tenemos aceptada y de nuevo aceptamos con beneficio de inventario", dan poder a Pedro Ezquerra "vecino de la villa de Medina de Pomar o a la

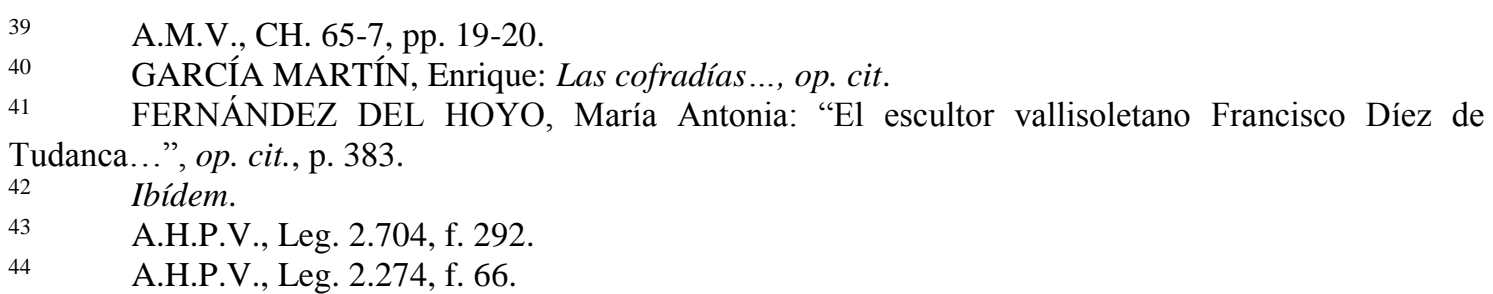


persona o personas que por él fuere sustituido" para que en nombre de ambos "pueda pedir y demandar recibir haber y cobrar de Pedro Ortiz de Otero vecino de la villa de Arioquelo y sus herederos y de Pedro Fernández escribano real y del número y ayuntamiento de la dicha villa y de otra cualquier persona (...) todas las cantidades de maravedies que quedaron debiendo al dicho Francisco Ezquerra nuestro padre como heredero de Francisco Ezquerra y Juliana de Rueda nuestro abuelos como poseedores de la hacienda que tocó a dicho Francisco Ezquerra nuestro padre y suegro como uno de tres herederos como constará por las cuentas y particiones e hijuelas a los cuales les pida cuenta de toda la dicha herencia, frutos y rentas de ello haciéndoles embargo de este todo el tiempo que los han tenido y poseído y gozado y recibiéndoles en data lo que legítimamente hubieren pagado sacando de su poder todos los dichos bienes" ${ }^{\prime 45}$.

El 21 de julio de 1673 Francisco Díez de Tudanca, su esposa, María Ezquerra, su discípulo el escultor Juan de Ávila y la esposa de éste, así como el propio Tudanca "como tutor de las personas y bienes de Juana y Jacinta Ezquerra hijas que fueron de Romualdo Ezquerra alguacil que fue de esta ciudad y de Ana González del portal su mujer difuntos vecinos" venden "una heredad de viña que está descepada y hecha erial" que habían heredado de Francisco Ezquerra, padre de Romualdo y Francisca ${ }^{46}$. Dichas viñas, unas ocho alanzadas "poco más o menos" se localizaban en el pago "que llaman Huerta del Moro", las cuales lindaban "con viña del Colegio de San Ambrosio y viña de Andrés Fernández escribano real por la parte de abajo y por la de arriba con viñas fueron del licenciado Antonio Ramírez clérigo y con la senda que baja al dicho pago de Huerta del Moro". Al no haberlas dado "las labores se ha hecho erial y no tiene cepas ni otros plantíos de manera que no ha sido ni es de ningún provecho", por lo que decidieron vendérselas al mercader Matías Martínez por 450 reales.

El 3 de enero de 1674 Tudanca y su esposa, Francisca Ezquerra, se obligan a pagar al maestro dorador Pedro de Mondragón 822 reales de vellón "que nos ha presentado en diferentes ocasiones para algunas necesidades y socorros que se nos ha ofrecido". Se comprometían a devolverlos "en una paga para el día fin de mayo que viene de éste presente año de seiscientos y setenta y cuatro puestos en su casa y poder de dicho Pedro Mondragón ${ }^{47}$ ". El 31 de agosto de 1674 de ese mismo año el anciano escultor da poder a "a Manuel Gallardo procurador del número de esta ciudad y a Juan Santín y Juan Calvo procuradores del número de esta Real Chancillería" para que le defiendan en "todos los pleitos y causas así civiles como criminales que tengo al presente y tuviere adelante así demandando como defendiendo en todos juicios, instancias y tribunales" $" 48$.

\footnotetext{
$45 \quad$ A.H.P.V., Leg. 2.756, ff. 117-118.

46 A.H.P.V., Leg. 1.977, ff. 163-165.

47 GARCÍA CHICO, Esteban: Documentos para el estudio del arte en Castilla. 2..., op. cit., pp. 306-307.

$48 \quad$ A.H.P.V., Leg. 2.626, f. 324.
} 
Por el testamento de Manuel de Sierra, tratante en fruta, fechado el 7 de agosto de 1677, sabemos que Díez de Tudanca le era deudor de 144 reales "que le di para hacer unos ángeles y de una colcha que le entregué, mando se cobren"49.

En 1681 retoca y realiza "las piezas que le faltaban" a las tres imágenes que formaban el retablo mayor de la capilla universitaria ${ }^{50}$. En el Libro de Cuentas hay un claro fallo y es que se le llama Manuel de Tudanca. No es que hubiera un escultor que se llamara así, es que cambió Francisco por Manuel. Manuel de Tudanca, hermano de Francisco, era un conocido escribano de la ciudad.

El 8 de marzo de 1683 el escultor realiza un apartamiento de la querella, puesta "ante el señor licenciado don Diego Colón de Larreátegui alcalde del crimen de esta corte y Francisco Rodríguez escribano de sala", que le había incoado a "Andrés González. hermano del trabajo (...) en razón de ciertas palabras que entre los dos hubo"51.

La última noticia que poseemos sobre Tudanca data del 10 de junio de 1684, fecha en que tasa las esculturas que dejó al fallecer el licenciado don Francisco Martínez Polo y Palacios, abogado de la Audiencia ${ }^{52}$. Desconocemos la fecha del fallecimiento del escultor, esto puede deberse fundamentalmente a tres motivos: que falleciera en un hospital, que falleciera en algún pueblo o que el libro de difuntos de la parroquia en la que hubiera fallecido hubiera desaparecido. Tan sólo sabemos que el día en que falleció su esposa, el 4 de abril de 1689, ya había muerto puesto que se señala en la partida de defunción que era viuda ${ }^{53}$.

\section{$\underline{\text { Discípulos }}$}

Dada la gran cantidad de aprendices a los que formó, lo que conllevó que su taller fuera el más concurrido de la ciudad, creo oportuno dedicarles un pequeño espacio. Ninguno de ellos cuenta con obra documentada a excepción de José Mayo y Juan de Ávila. Fernández del Hoyo dio ya noticia de algunos de ellos ${ }^{54}$, por lo que me centraré en los que causan novedad:

- Diego González Caballero. El 23 de abril de 1649 se firma ante el escribano Antonio de Brizuela la escritura de asiento de aprendiz por la cual Tudanca le

49 A.H.P.V., Leg. 2.735/4, ff. 189-190.

$50 \quad$ Obras de escultura. "Más se le reciben en data a dicho tesorero cincuenta reales de vellón que se dieron a Manuel de Tudanca escultor por razón de haber retocado todas las piezas que le faltaban a las tres hechuras de los santos que están en el altar de la capilla hacen maravedíes mil y setecientos". A.U., Libro de cuentas no 436. REDONDO CANTERA, María José: “El edificio...”, op. cit., p. 656.

51 FERNÁNDEZ DEL HOYO, María Antonia: "El escultor vallisoletano Francisco Díez de Tudanca...", op. cit., p. 388.

$52 \quad$ Ibídem.

53 "Se enterró en esta iglesia en sepultura propia Francisca Ezquerra viuda de Francisco Tudanca en la calle de Zúñiga. Recibió los sacramentos no testó por ser muy pobre". Ibídem.

$54 \quad$ Antonio Brizuela (1645), Felipe del Rincón (1647), Pedro Baños (1655), José Mayo (1656), Martín Gutiérrez de Perusillo (1660), Juan González (1661), Bernardo del Rincón “el joven” (1661). Ídem, pp. 374, 378, 379, 381. 
recibía en su taller. El documento, así como los papeles de la escribanía de Antonio Brizuela han desaparecido, por lo cual no podemos conocer todos los pormenores del acuerdo. En cambio, si se conserva un testimonio, fechado el 7 de agosto de 1650, por el cual sabemos que Diego González se había despedido "de casa del dicho Francisco de Tudanca y por excusarse de pleitos y diferencias se han convenido en que dando el dicho Diego González Caballero cincuenta reales al dicho Francisco Díez de Tudanca por el trabajo que ha tenido en enseñarle lo que al presente sabe del dicho oficio de escultor, le soltura la dicha escritura"55. Tras abonarle los 50 reales Díez de Tudanca consintió "que el dicho Diego González Caballero entre en casa de cualquier maestro de su arte a que le acabe de enseñar el dicho oficio, o en otro cualquiera que quisiere elegir (...) y se obligó de no le poner impedimento en ello como va dicho". Según ese mismo documento, Diego González se había "obligado a estar en casa y servicio del dicho Francisco Díez de Tudanca por tiempo y espacio de tres años que habían de correr y contarse desde el día de la fecha de la escritura (...) para que el dicho Tudanca le ensañase el arte de escultor sin hacerle falta en su casa y que al fin de los dichos tres años le había de dar enseñado el dicho oficio a vista de oficiales y maestros peritos".

- Juan Pérez. Natural del "lugar de Gallegos", su llegada al obrador se debió de producir en una fecha cercana a marzo del año 1665. Su aprendizaje tendría una duración de cinco años. No se ha logrado encontrar dicha escritura, en cambio sí se ha localizado un documento, fechado el 7 de octubre de 1666, por el cual Juan Pérez pedía a su maestro que le dejara marchar, sin aclarar las "causas que le mueven y habérselo pedido (...) sin embargo de faltar tres años y medio de servir dicho oficio" "56. Tudanca no puso objeciones al respecto y "dijo destrataba y destrató la dicha escritura de asiento de aprendiz y siendo necesario la daba y dio por nula rota y cancelada como si no se hubiera hecho ni otorgado y se obligó con su persona y bienes habidos y por haber de que ahora ni en tiempo alguno ni pedirá ni demandará cosa alguna sobre lo dicho al dicho Juan Pérez. ni a sus herederos y le daba y dio por libre de la dicha escritura".

- Manuel Gómez Otero. Se puso bajo la égida de Tudanca hacia el año 1673. Sabemos que fue discípulo de Tudanca gracias al testamento de Gabriel Gómez Otero, padre de Manuel, otorgado el 23 de abril de 1683. En él afirma que "habrá diez años poco más o menos que yo puse por aprendiz del oficio de escultor a Manuel de Otero mi hijo con Francisco Tudanca maestro del dicho oficio por cierto tiempo de que se hizo escritura ante Matías Pérez escribano real y me obligué a pagarle doscientos reales de moneda de vellón por dicha 
enseñanza los cuales se los tengo pagados y satisfechos declárolo así para que en todo tiempo conste" ${ }^{\mathrm{N}}$.

- Juan de Paz. El 20 de agosto de 1674 Juan de Paz "vecino de esta ciudad" asentaba por aprendiz del arte de escultor a su hijo José, el cual permanecería bajo sus enseñanzas durante cinco años "que han de comenzar a correr desde hoy veinte de agosto de este presente año"58. En este mismo año también tenemos constancia de que tenía como aprendices a Ventura Fernández, importante escultor burgalés de finales del siglo XVII, y a Andrés López"59.

- Manuel González. El 5 de agosto de 1678 llega al estudio de Tudanca el que fuera el último aprendiz conocido. Durante cinco años debía de aprender el oficio de escultor, estando al final de dicho plazo "hábil para lo usar y ejercer a vista de dos maestros que se han de nombrar para el dicho efecto uno por cada parte ${ }^{60}$. Tudanca ingresaría por este nuevo aprendizaje 800 reales de vellón, la cifra más alta lograda por el escultor, síntoma de que se encontraba en el cénit de su carrera y que gozaba de gran prestigio como preceptor entre los muchachos aspirantes a escultores.

\section{OBRA DOCUMENTADA}

1642. El Salvador. Iglesia del Salvador. La Bañeza (León) ${ }^{61}$. Desconocemos porque al final no se llevó acabo, ya en 1659 se le encargará la misma escultura al astorgano Lucas Gutiérrez.

Hacia 1650. Paso del Azotamiento de la Cofradía de Ntra. Señora de la Pasión (Fig. 1). Museo Nacional de Escultura y Monasterio de San Quirce. Valladolid ${ }^{62}$.

1650. Santa Lucía. Iglesia de Santa María del Castillo. Lomoviejo (Valladolid) ${ }^{63}$. Desaparecida.

1650. La Asunción para el licenciado Francisco Santos del Castillo. Tordesillas (Valladolid) ${ }^{64}$. Paradero desconocido.

1652. San Francisco de Asís y Santa Ana para la capilla de los Medina Prado. Iglesia de Santa Cruz. Medina de Rioseco (Valladolid) ${ }^{65}$.

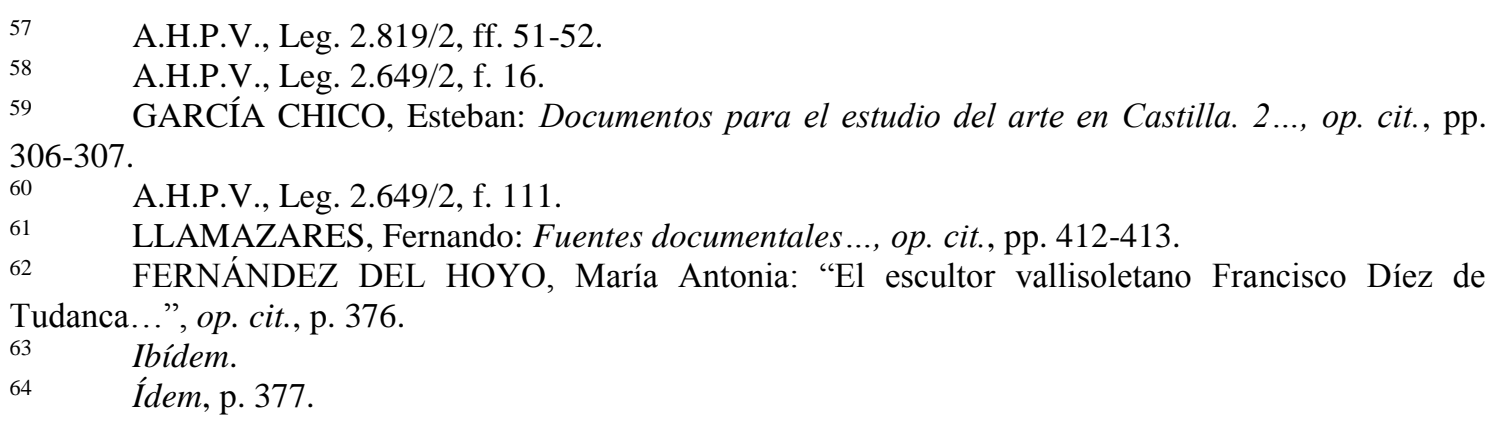


1652. Cristo Yacente para la Cofradía de Jesús Nazareno. Iglesia de Santa María de la Era. Villada (Palencia) ${ }^{66}$.

1653. Inmaculada Concepción para don Francisco Flores. Valladolid ${ }^{67}$. Paradero desconocido.

1653. Cristo Yacente (Figs. 2-3) para Manuel Izquierdo. Iglesia parroquial de Nuestra Señora de la Asunción. Martín Muñoz de las Posadas (Segovia) ${ }^{68}$.

1653. Esculturas para el retablo mayor (San Francisco, San Antonio, San Juan Capistrano, San Buenaventura, Cristo Crucificado, San Juan, Virgen María), Convento de Santa Clara, Cuenca de Campos (Valladolid) ${ }^{69}$.

1653. Relieve de la Transfiguración. Iglesia parroquial del Salvador. Boadilla de Rioseco (Palencia) ${ }^{70}$.

1655. Santiago Matamoros. Ermita iglesia de Santiago Apóstol. Ampudia (Palencia) ${ }^{71}$.

1655. Crucifijo para don Francisco de Arellano. León ${ }^{72}$. Paradero desconocido.

1656. Esculturas y relieves para el retablo mayor. Iglesia parroquial de la Degollación de San Juan Bautista. Ataquines (Valladolid) ${ }^{73}$. Al final debió de realizar una pequeña parte de toda la obra. No se conserva nada.

1657. Dos ángeles y una peana para la Virgen de la Pasión. Iglesia Penitencial de Nuestra Señora de la Pasión. Valladolid ${ }^{74}$. Desaparecidos.

1657. Esculturas para el retablo mayor (Figs. 4-7). Iglesia de la Asunción. Bercero (Valladolid $)^{75}$. Se repartió toda la escultura del retablo con el escultor Juan Rodríguez.

1661. Inmaculada Concepción. Convento de San Francisco. Mayorga de Campos (Valladolid) $^{76}$.

1661-1666. Reforma del retablo mayor. Iglesia parroquial de Santa María. Villamayor de Campos (Zamora) ${ }^{77}$.

65 PÉREZ DE CASTRO, Ramón: "La huella de Gregorio Fernández...”, op. cit., pp. 174-177.

66 FERNÁNDEZ DEL HOYO, María Antonia: "El escultor vallisoletano Francisco Díez de Tudanca...", op. cit., p. 377.

$67 \quad$ Ídem, p. 378.

$68 \quad$ Ídem, p. 377.

69 Ídem, p. 378.

70 PARRADO DEL OLMO, Jesús María: “El retablo mayor...”, op. cit., p. 474.

71 Díez de Tudanca debía de "hacer y acabar la hechura de Santiago apóstol que Pedro Salvador dejó comenzada". A.H.P.V., Leg. 2.397, f. 100 (1655).

72 GARCÍA CHICO, Esteban: Documentos para el estudio del arte en Castilla. 2..., op. cit., pp. 297-298

$73 \quad$ Ídem, pp. 298-299.

74 Ídem, pp. 300-301.

75 A.H.P.V., Leg. 2.105, ff. 440-441. FERNÁNDEZ DEL HOYO, María Antonia: "El escultor vallisoletano Francisco Díez de Tudanca...”, op. cit., p. 380.

76 Ídem, p. 382. 
1662. Inmaculada Concepción para la Cofradía de la Concepción. Melgar de Fernamental (Burgos) ${ }^{78}$. Paradero desconocido

1663. "Paso" del Descendimiento (Fig. 8) para la Cofradía de la Soledad de Nuestra Señora. Capilla de los Pasos Grandes. Medina de Rioseco (Valladolid) ${ }^{79}$.

1663. "Paso" del Santo Sepulcro (Fig. 9) para la Cofradía de la Soledad de Nuestra Señora. Medina de Rioseco (Valladolid) ${ }^{80}$. Desaparecido.

Antes de 1664. Cristo del Perdón (Fig. 10) para el desaparecido Colegio de Trinitarios Descalzos. Museo Diocesano y Catedralicio. Valladolid ${ }^{81}$.

1664. Cristo del Perdón. Colegio de Trinitarios Descalzos. Pamplona ${ }^{82}$. Desaparecido.

1664. Niño Jesús para don Diego de Villagómez. Valladolid ${ }^{83}$. Paradero desconocido.

1665. Túmulo en honor del rey Felipe IV para la Universidad de Valladolid ${ }^{84}$.

1667. San Miguel (Fig. 11). Iglesia de Santiago. Ávila ${ }^{85}$.

1667. "Paso" del Descendimiento. Benavente ${ }^{86}$. Paradero desconocido.

1667. Santa Águeda. Iglesia parroquial de San Martín. Bernuy de Zapardiel (Ávila) ${ }^{87}$.

1668. Águilas-atriles (Fig. 12). Iglesia de Santiago de los Caballeros. Medina de Rioseco (Valladolid) ${ }^{88}$.

1671. Águilas-atriles. Iglesia de Santa María. Torrelobatón (Valladolid) ${ }^{89}$.

1672. Cristo atado a la columna (Fig. 13). Ermita del Santo Cristo. Mojados (Valladolid $^{90}$.

1673. San Juan Bautista. Iglesia de San Juan Bautista. Pesquera de Duero

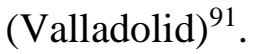

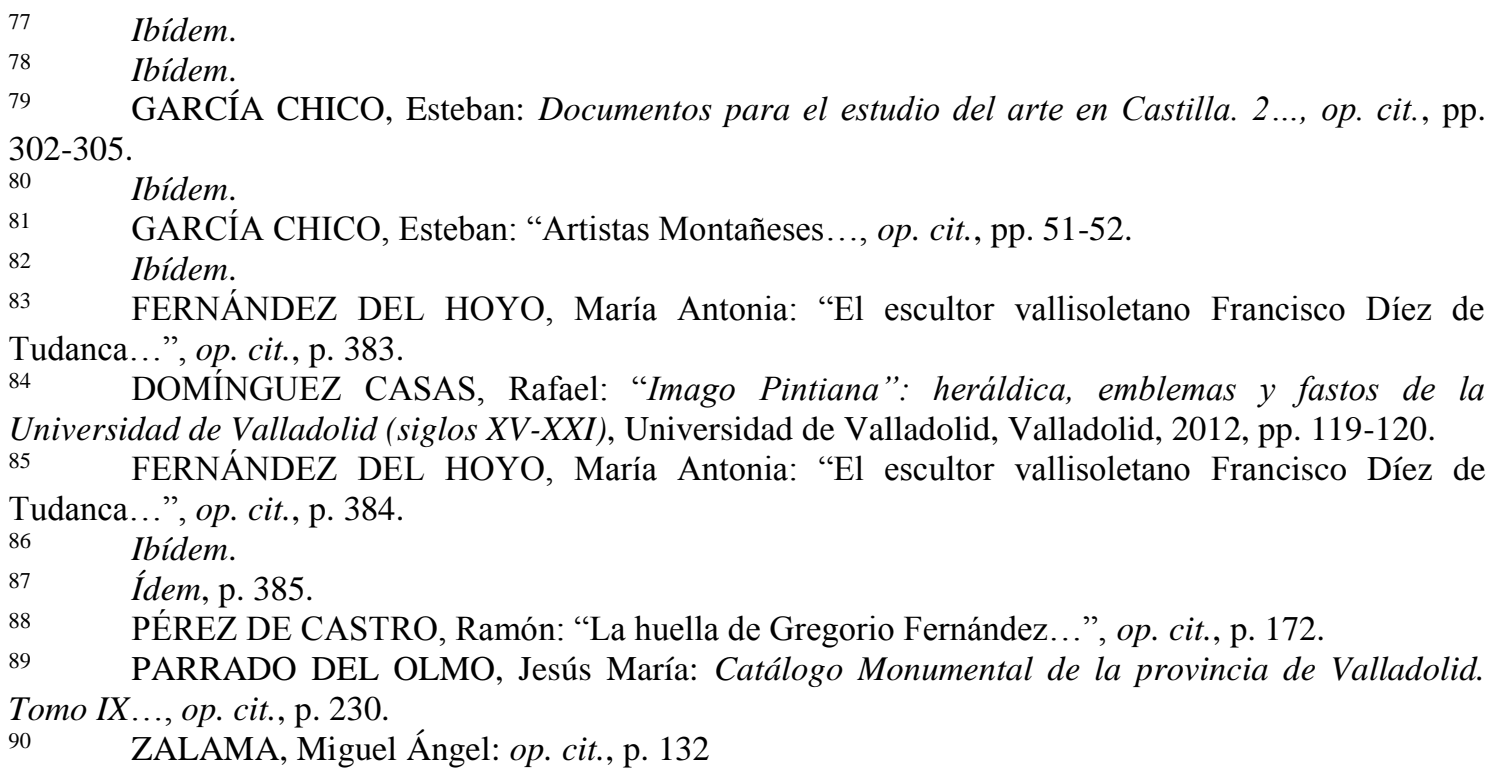


1674. "Paso" del Expolio (Fig. 14) para la Cofradía de Jesús Nazareno de León. León ${ }^{92}$.

1674. Cirineo para el paso de Jesús Nazareno de la Cofradía de Jesús Nazareno de León. León. Desaparecido ${ }^{93}$.

1675. San Agustín (Fig. 15). Iglesia parroquial de San Pedro. Villiguer (León) ${ }^{94}$.

1675. "Paso" de La Coronación de Espinas para la Cofradía de Jesús Nazareno. León. Desaparecido 95 .

1675. Centurión (Fig. 16) para el "paso" de la Crucifixión. Capilla de los Pasos Grandes. Medina de Rioseco (Valladolid) ${ }^{96}$.

1675. Retablos colaterales y escultura de San Fernando. Convento de San Francisco. Valladolid ${ }^{97}$. Desaparecidos.

1677. Cristo del Perdón (Figs. 17-18). Convento de Trinitarios Descalzos. Hervás (Cáceres) $)^{98}$.

1678. Jesús Nazareno y Nuestra Señora de la Soledad (Fig. 19). Iglesia parroquial de la Asunción. Montehermoso de Coria (Cáceres) ${ }^{99}$.

1678. Renovación de la imagen de San Pedro. Iglesia de San Pedro. Tiedra (Valladolid) ${ }^{100}$. Desaparecida.

1678. Esculturas para el retablo mayor. Iglesia parroquial de San Martín. Traspinedo

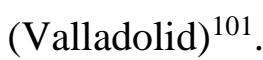

91 VALDIVIESO, Enrique: Catálogo Monumental de la provincia de Valladolid. Tomo VIII..., op. cit., p. 193. Fernández del Hoyo piensa que "la calidad de la obra es muy superior a la habitual de Tudanca y no se encuentra muy lejos del estilo de Ávila quien además hizo en 1678 el gran peñasco". FERNÁNDEZ DEL HOYO, María Antonia: "El escultor vallisoletano Francisco Díez de Tudanca...”, op. cit., p. 386.

92 Actualmente sólo subiste la figura de Cristo. Probablemente este paso fuese una imitación del paso del Despojo de Valladolid. Aunque esto no se diga explícitamente en el contrato, la descripción coincide perfectamente con el paso de Valladolid.

93 LLAMAZARES RODRÍGUEZ, Fernando: "El escultor Francisco Díez de Tudanca...”, op. cit., p. 55 .

94 La escultura ha sido muy trastocada, pues se le ha colocado tiara y unas llaves en la mano derecha, para convertirlo en un San Pedro, advocación de la iglesia de dicho pueblo. Ídem, p. 56; LLAMAZARES, Fernando: Fuentes documentales..., op. cit., p. 68.

95 LLAMAZARES RODRÍGUEZ, Fernando: "El escultor Francisco Díez de Tudanca...”, op. cit., p. 56.

96 PÉREZ DE CASTRO, Ramón: “La huella de Gregorio Fernández...”, op. cit., p. 172.

97 GARCÍA CHICO, Esteban: Documentos para el estudio del arte en Castilla. 2..., op. cit., pp. 305-306.

$98 \quad$ A.H.P.V. Leg. 2.342/5, f. 91.

99 BALADRÓN ALONSO, Javier: op. cit., p. 156.

100 PARRADO DEL OLMO, Jesús María: Catálogo Monumental de la provincia de Valladolid. Tomo IX..., op. cit., p. 200.

101 MARTÍN GONZÁLEZ, Juan José: Catálogo Monumental de la provincia de Valladolid. Tomo VI..., op. cit., p. 112. 


\section{OBRA ATRIBUIDA}

Hacia 1650. San José con el Niño. Convento de Santa Clara. Medina de Rioseco $(\text { Valladolid })^{102}$.

1657-1658. La Fe y la Caridad. Iglesia-Museo de San Antolín. Tordesillas $(\text { Valladolid })^{103}$.

1672. Esculturas del retablo mayor (San Juan y la Virgen María). Iglesia parroquial de San Pedro. Amusco (Palencia) ${ }^{104}$.

Último tercio del siglo XVII. Cristo Yacente. Iglesia Santuario de la Virgen del Socorro. Valderas (León) ${ }^{105}$.

\section{B- GABRIEL DE PALACIOS}

La otra parte de su formación, en este caso le deberíamos poner el adjetivo de "supuesta", fue junto al desconocido pintor Gabriel de Palacios. Como ya dijimos no sabemos si ese aprendizaje se llegó desarrollar, si el contrato se anuló al poco de hacerlo o bien se cumplió hasta que Ávila entró en el obrador de Tudanca. Que tanto Ávila como Palacios vivieran en la calle de Santiago como que el pintor tuviera contacto con Díez de Tudanca pueden hacernos sospechar que el joven aprendiz no progresara adecuadamente en el arte de la pintura y su maestro le aconsejara cambiar de disciplina y acudir al de su tal vez amigo Tudanca.

Pocas noticias poseemos sobre Gabriel de Palacios, todas ellas referentes a sus cambios de domicilio y a sus supuestas amistades. De lo que no cabe duda es de que debió de ser un pintor modesto, quizás englobado en los denominados "pintores de la calle de Santiago", vía en la que moró casi toda su vida ${ }^{106}$. Este hecho no es ninguna casualidad dado que la escasa actividad pictórica que se desarrolló en Valladolid durante los siglos XVII y XVIII se llevó a cabo fundamentalmente en dicha calle ${ }^{107}$.

Las escasas menciones que tenemos del pintor son las siguientes: en 1648 toma el alquiler de un "cuarto" de la casa que previamente había alquilado Francisco Díez de Tudanca "en unas casas que están en el pasadizo de don Alonso Niño de Castro"

102 VV.AA.: Clausuras: el patrimonio de los conventos de la provincia de Valladolid. 3, Medina de Rioseco - Mayorga de Campos - Tordesillas - Fuensaldaña y Villafrechós, Diputación de Valladolid, Valladolid, 2004, pp. 34 y 132.

103 PARRADO DEL OLMO, Jesús María: "Precisiones sobre el ensamblador José de Arroyo", B.S.A.A., Tomo LIV, 1988, pp. 433.

${ }_{104}$ GARCÍA CHICO, Esteban: Documentos para el estudio del arte en Castilla. 2..., op. cit., pp. 349-350.

$105 \quad$ VV.AA.: Semana Santa en León: pasos, Diario de León, León, 1996, p. 79.

106 En 1659 se le cita viviendo en unas casas sitas "a espaldas de la iglesia frente al Hospital de Juan Hurtado". FERNÁNDEZ DEL HOYO, María Antonia: Pintura y sociedad..., op. cit., p. 41.

107 Ídem, pp. 36-41. 
(actual calle de la Pasión) ${ }^{108}$. Entre sus discípulos se encontraba el pintor y religioso Jerónimo Benete ${ }^{109}$, al cual tomó por aprendiz en agosto de ese mismo año, testificando en el contrato de aprendizaje Tudanca, extremo que nos revela la cercanía entre ambos artífices $^{110}$. Ya en 1659 vemos a Palacios citado en las disposiciones testamentarias del pintor Francisco Jibaja. En ellas este último declaraba que Palacios le debía "un lienzo de vara y media que le di para pintar y 4 reales a cuenta" $" 11$.

\section{4-4 ESTILO}

A la hora de juzgar el estilo de Juan de Ávila nos topamos con algunas dificultades insalvables que nos impiden, por una parte, definir con claridad los rasgos que caracterizaban su trabajo y, por otra, trazar la lógica evolución que sufriría a lo largo de los años puesto que es raro el artista que se ha mantenido inmutable a lo largo de su carrera.

Estos problemas son fundamentalmente tres: la desaparición o extravío de obras acreditadas (Nuestra Señora de Gracia de Torrecilla de la Abadesa y las esculturas del retablo mayor del convento de San Juan de Dios de Valladolid): la falta de documentación, en muchas ocasiones debido a la falta de búsqueda en los archivos; y la similitud de estilo entre la mayoría de los escultores vallisoletanos de la época, dado que todos repetían las maneras, modos e iconografías de Gregorio Fernández. No vamos a insistir más en el carácter conservador de la escultura pucelana y, sobre todo, de los comitentes, que muchas décadas después de la muerte del genio de Sarria siguieron demandando réplicas fernandescas, lo que conllevó al estancamiento de la escuela. Ya señaló acertadísimamente Urrea sobre este hecho que "es difícil penetrar en este mundo de "fernandescos", aferrados en la repetición y copia de los modelos creados por Fernández. Desde el momento de su muerte -1636- hasta la segunda mitad del siglo, apenas conocemos el desarrollo artístico de los escultores vallisoletanos" $" 112$.

Relacionado con todo ello, viene bien recordar que Martín González dijo acerca de Juan de Ávila que hizo "resonar tardíamente el arte de Gregorio Fernández"113. La influencia de Fernández en Ávila lo podemos detectar constantemente. Por citar solo algunos ejemplos: el San Isidro labrador que talló para la cofradía homónima, los tres santos del retablo mayor de la colegial de Lerma (San Pedro en cátedra, San Andrés y San Pablo), la atribuida Inmaculada de Ataquines, los Calvarios etc... A continuación,

\footnotetext{
108 FERNÁNDEZ DEL HOYO, María Antonia: "El escultor vallisoletano Francisco Díez de Tudanca...", op. cit., p. 375.

109 Benete fue un pintor muy flojo, lo que indica el grado de calidad que tendría el maestro.

110 FERNÁNDEZ DEL HOYO, María Antonia: "El escultor vallisoletano...," op. cit., p. 375.

111 FERNÁNDEZ DEL HOYO, María Antonia: Pintura y sociedad..., op. cit., pp. 45-46.

112 URREA FERNÁNDEZ, Jesús: “El escultor Francisco Alonso de los Ríos...”, op. cit., p. 356.

113 MARTÍN GONZÁLEZ, Juan José: Escultura barroca ... op. cit., p. 322.
} 
desarrollaremos las problemáticas concernientes a la escasez documental y a las similitudes de estilo con otros artífices:

Tras una ardua búsqueda en los más diversos archivos, tanto a nivel provincial como nacional, y vistos los escasos resultados conseguidos en lo que a número de obras de arte documentadas, sospecho que hubo un importantísimo número de contratos de subarriendos de esculturas, de contratos verbales o incluso de compromisos privados entre escultor y comitente. No es normal la exigua cantidad de conciertos encontrados, pero no solo de Juan de Ávila sino de otros artistas contemporáneos: Alonso y José de Rozas, Juan Antonio de la Peña, Andrés de Pereda, Antonio Vázquez, Vicente Díez, etc... Apenas tenemos un par de contratos realizados por nuestro escultor. Si a eso sumamos que el escaso número de obras documentadas lo son solo por unas simples reseñas en los libros de fábrica de las parroquias nos da como resultado una escasa base sobre la que definir su estilo y por lo tanto poder realizar un correcto catálogo de su obra.

Es, además, con los citados escultores, sobre todo con José de Rozas y Juan Antonio de la Peña, con los cuales podemos confundir el estilo de Ávila. Los tres demuestran unas formas tan similares que ha hecho que en ciertos momentos algunas esculturas hayan sido atribuidas sucesivamente a algunos de ellos. Otras veces ha ocurrido que algunas esculturas habían sido atribuidas irrefutablemente a uno de ellos y han logrado ser documentados como obra de otro de esta terna. Un ejemplo de esto que hablamos lo tenemos en los grupos de San Joaquín con la Virgen y San José con el Niño sitos en el vallisoletano Oratorio de San Felipe Neri. Se atribuyeron en sucesivas ocasiones a nuestro escultor, pero años después la documentación ha fallado en favor de José de Rozas $^{114}$.

Estaremos de acuerdo en que Juan de Ávila es un epígono y un "discípulo en la distancia" de Gregorio Fernández. Como haría este último tras abandonar su época tardo manierista, Ávila basa su obra en un hondo naturalismo a la hora de modelar sus obras en el taller. Esta característica no es privativa de ambos escultores dado que toda la escultura castellana del momento, y la mayor parte de la española, se fundamentaba en ella.

A la vez que iban desarrollándose de manera satisfactoria los cinco años de aprendizaje junto a Tudanca, pienso que Ávila iría completando su formación visitando y, quizás, tomando apuntes de la obra de los grandes escultores que aquí vivieron y dejaron muestra de su arte: Alonso Berruguete, Esteban Jordán, Juan de Juni, Pompeyo Leoni, Francisco de la Maza, Adrián Álvarez, Francisco del Rincón, Gregorio Fernández... En su propia parroquia, la de Santiago Apóstol, dirigiría sus ojos al bello retablo de la Epifanía que Alonso Berruguete talló por orden del banquero don Diego de la Haya. Tampoco dejaría pasar por alto el desaparecido retablo mayor, que casualmente el propio Ávila sería el encargo de sustituir al final de su carrera, realizado en cerámica

114 URREA FERNÁNDEZ, Jesús: “El oratorio...”, op. cit., p. 18. 
vidriada, quizás procedente de los talleres florentinos de los Andrea Della Robbia ${ }^{115}$. En el templo existían otras obras de arte que quizás le interesaran: el grupo de Santa Ana, la Virgen y el Niño de Francisco del Rincón o el llamado Cristo de las Mercedes, hechura atribuida de manera mayoritaria a Pompeyo Leoni ${ }^{116}$.

Pero, sin ningún género de dudas, el escultor que más le interesaría estudiar fue Gregorio Fernández. No cabe duda de que el joven escultor sentiría una profunda admiración por el gallego dado que no solamente fue la cúspide de la estatuaria barroca castellana, sino que, además, su recuerdo permanecía aún latente en la ciudad. El genio de Sarria tenía embajadas en la mayoría de iglesias, penitenciales y conventos de la ciudad. No sabemos cuáles tuvo la oportunidad de visionar Ávila. Es factible pensar que, además de los pasos de Semana Santa, que le marcarían decisivamente, pudo observar la Inmaculada del Convento de San Francisco, el retablo mayor de la desaparecida iglesia de San Miguel Arcángel, las diversas tallas que fabricó para el Convento del Carmen Calzado, el Colegio de San Ignacio, el Convento de San Pablo, iglesia de San Martín, etc...

Pienso que Ávila asimiló como ningún otro escultor vallisoletano del momento o de los "herederos" de Fernández los modos y maneras del gallego. Partiendo de sus modelos iconográficos y estilemas, a los que añade una especial blandura de carnes y una multiplicación de paños, generalmente blandos y ondulados, crea un estilo mucho más moderno y movido. Parece que por fin el Barroco, en lo que se refiere a movimiento y dinamismo, ha llegado a la escultura vallisoletana, siendo su mejor ejemplo el Santiago Matamoros que talla para la hornacina principal del retablo mayor de la iglesia de Santiago.

Además de las enseñanzas recibidas de Tudanca y Fernández habría que sumar la influencia que pudo tener en su creatividad la gran cantidad de grabados que inundaban desde hacía tiempo los talleres de los artistas españoles. Los más utilizados, ya fueran estampas sueltas o en libros, fueron los de Adriaen Collaert (1560-1618) y Maerten de Vos $(1532-1603)^{117}$.

Como hemos dicho antes, la escasez de obras documentadas, algunas de las cuales han desaparecido, complica bastante el establecimiento de un marco cronológico adecuado para las diferentes etapas, por lo que deberemos conformarnos con establecer las características que exhibe Ávila tanto en sus primeros años como, sobre todo, en su etapa madura. Debido a su temprano fallecimiento no sabemos cómo habría evolucionado siendo ya un maestro consagrado, como así lo demuestra en su última creación, quizás su obra maestra: las esculturas del retablo mayor de la iglesia de Santiago de Valladolid, y más concretamente su imagen titular: Santiago Matamoros.

\footnotetext{
115 MARTÍN GONZÁLEZ, Juan José y URREA FERNÁNDEZ, Jesús: Catálogo Monumental de la provincia de Valladolid. Tomo XIV..., op. cit., p. 197.

116 Ídem, p. 193.

117 ALBARRÁN MARTÍN, Virginia: El escultor Alejandro Carnicero..., op. cit., p. 151.
} 
Para comenzar a hablar del estilo de nuestro escultor propiamente dicho hemos de partir de las pistas que nos ofrece Martín González en su libro Escultura barroca castellana. El ilustre historiador del arte diferenciaba la producción de Ávila en dos grandes etapas. Una primera en la que los vestidos suelen presentar "blandura de los paños, incurvados suavemente $y$ donde aparece desterrada toda dureza de talla" ${ }^{118}$, si bien ocasionalmente puede percibirse ciertas quebraduras ${ }^{119}$. En cambio, los pliegues de la segunda época señalada por Martín González se caracterizan por el "plegado blando y de líneas paralelas, acusando las formas corporales" ${ }^{120}$. Coincido plenamente con estos planteamientos si bien pienso que ya dentro de la primera época ensayó los plegados de líneas paralelas que exhibe en la segunda. Dada la escasez de obra documentada, como ya hemos referido en multitud de ocasiones pienso que es complicado establecer unas fechas concretas o aproximadas para encasillar cada estilo, si bien pienso que el punto de inflexión entre ambas debió de darse en fecha cercana a la realización de las esculturas para el retablo mayor de la Colegiata de San Pedro de Lerma (Burgos). Martín González piensa que la disyunción entre ambos momentos tuvo lugar en el retablo mayor del Convento de San Quirce. En estas esculturas aprecia que los pliegues "se han ido haciendo progresivamente más suaves, constituyéndose por unas líneas paralelas que se adhieren al cuerpo"121. Esta tendencia la ve ya consolidada en el San Francisco de Sales del Oratorio de San Felipe Neri. La evolución llevó al escultor a confinar los pliegues a la parte baja de las vestimentas.

Este es el planteamiento general, luego hay excepciones, concretamente dos: el Santiago Matamoros realizado para la sacristía de la iglesia homónima de Valladolid y el Crucifijo de Traspinedo, único resto conservado de su intervención en el retablo de la iglesia parroquial de dicho pueblo. En el primer caso extraña la forma de tallar los pliegues, el rostro y la barba. No tiene nada que ver con el escultor que poco antes había esculpido el paso del Despojo para la Cofradía de N. P. Jesús Nazareno. En el caso del Crucifijo, de configuración bastante basta no se aprecia la finura de pliegues y el blando modelado de los rostros que caracteriza a nuestro maestro. Pienso que la explicación pueda encontrarse en que ambas posean una amplia labor de taller, si bien el Crucifijo, además, se encuentra muy repolicromado y en un malísimo estado de conservación.

Sus figuras por lo general aparecen quietas pero con la clara intención de moverse, es como si dijéramos representa el inicio de una acción (los Bautistas, los tres santos del retablo de Lerma), en otros casos podemos verlas absortas esperando la inspiración divina (San Francisco de Sales del Oratorio de San Felipe Neri o los Santos Isidro y María de la Cabeza), o ya directamente capta el momento crucial de una maniobra (los sayones del paso del Despojo, Santiago Matamoros de la iglesia homónima). Marca a la perfección una diagonal barroca, generalmente con el movimiento de los brazos, ambos

\footnotetext{
118 MARTÍN GONZÁLEZ, Juan José: Escultura barroca castellana ..., op. cit., p. 320.

119 En las pocas ocasiones que podemos percibir estos pliegues, generalmente en obras atribuidas, su forma de tallarlos puede recordar la técnica de Juan Rodríguez o Alonso de Rozas, escultores que quizás pudo conocer.

120 MARTÍN GONZÁLEZ, Juan José: Escultura barroca castellana..., op. cit., p. 324.

121 Ídem, p. 323.
} 
se contraponen y complementan. Salvo en contadas ocasiones una de las piernas se encuentra adelantada, lo que favorece un leve contraposto.

A continuación, iremos desgranando el estilo de nuestro escultor en cuatro puntos básicos: anatomías, ropajes, postizos y relieves.

\section{A- ANATOMÍAS}

Sus esculturas poseen un gran naturalismo y un canon bastante estilizado, aunque con gran empaque, que deriva en una cierta monumentalidad. En algunas esculturas de Ávila, como por ejemplo en el San Isidro, Martín González percibe "el elegante ademán de las efigies de Gregorio Fernández" ${ }^{122}$.

Sus conocimientos sobre anatomía únicamente los podemos valorar a través de sus dos representaciones de San Juan Bautista ya que ni el Resucitado de Villasilos ni el Crucificado de Traspinedo los podemos tener en cuenta dado que la primera es clara obra de taller y la segunda se encuentra tan excesivamente policromada que no permite un estudio apurado. En las dos versiones del "Precursor" podemos advertir su calidad como anatomista vista su forma de representar las carnes fláccidas que presentan en el pecho, las articulaciones en piernas y brazos e incluso las rodillas y las espinillas.

Si hay dos lugares en los que los escultores ponen más énfasis y mimo a la hora de elaborarlas para así dotar a las esculturas de mayor realismo y sentimentalismo para que así lleguen antes al corazón del fiel que las observa son las cabezas y las manos. Nuestro escultor pone un gran cuidado a la hora de tallar ambos elementos, a los cuales llega a dotar de una gran expresividad. En este aspecto es digno heredero de Gregorio Fernández, si bien no se les puede comparar, ni tampoco lo pretendo puesto que no ha habido escultor que haya movido mejor la devoción popular a partir de característica forma de tallar rostros y manos que él.

Juan de Ávila tiene dos maneras de tallar las cabezas y las manos: en algunas ocasiones las realiza por separado del cuerpo, uniéndolas posteriormente mediante embones. Esta manera de trabajar es muy propia del barroco vallisoletano si bien en épocas anteriores, como por ejemplo el Renacimiento, habría sido impensable ya que tallaban todo el cuerpo en un mismo bloque. De esta última manera también le veremos trabajar. Así lo atestiguan el San Juan Bautista del Oratorio de San Felipe Neri, el Santiago Matamoros de la sacristía de la parroquial homónima o los tres sayones del paso del Despojo.

Las manos no suelen poseer un patrón único a la hora de disponer los dedos, modelo que si encontraremos en las talladas por sus hijos Pedro y Manuel. Las esculpe con gran finura, de forma pormenorizada. No son cinco dedos rígidos e iguales, diríase sin desbastar, sino que les moldea, les da forma, les individualiza. Los dedos tienen todas y cada una de sus divisiones en falanges perfectamente modeladas. Ávila es tan

122 Ídem, p. 321. 
perfeccionista que llega incluso a marcar con gran blandura las diferentes líneas de la mano y de los dedos. En determinadas ocasiones, como en sus Bautistas, podemos llegar a ver talladas con gran finura las venas e incluso los huesos (dada su delgadez y carácter de ascetas). Las uñas únicamente están perfiladas por una hendidura más profunda, y no llevan postizos. El movimiento de las manos está resuelto mejor en unos casos que en otros, destacando sin ninguna duda el San Juan Bautista y el San Francisco de Sales del Oratorio de San Felipe y San Isidro y Santa María de la Cabeza de la ermita de San Isidro. Son manos que ayudan a dar sensación de movimiento, característica muy propia del período en el que trabaja.

A las cabezas las imprime gran fuerza, claro ejemplo son las del San Pedro en Cátedra del retablo lermeño o el San Francisco de Sales que el escultor realiza para el oratorio de San Felipe Neri. Las suele elaborar anchas y alargadas, tendiendo a la forma ovoide. La blandura y el estudio de calidades en los rostros suele ser el patrón común. Así, por ejemplo, capta perfectamente las arrugas de la edad en el San Pedro en cátedra, la lozanía del rostro del San Juan Bautista del Oratorio de San Felipe Neri, o las venas en la frente del San Francisco de Sales del mismo templo.

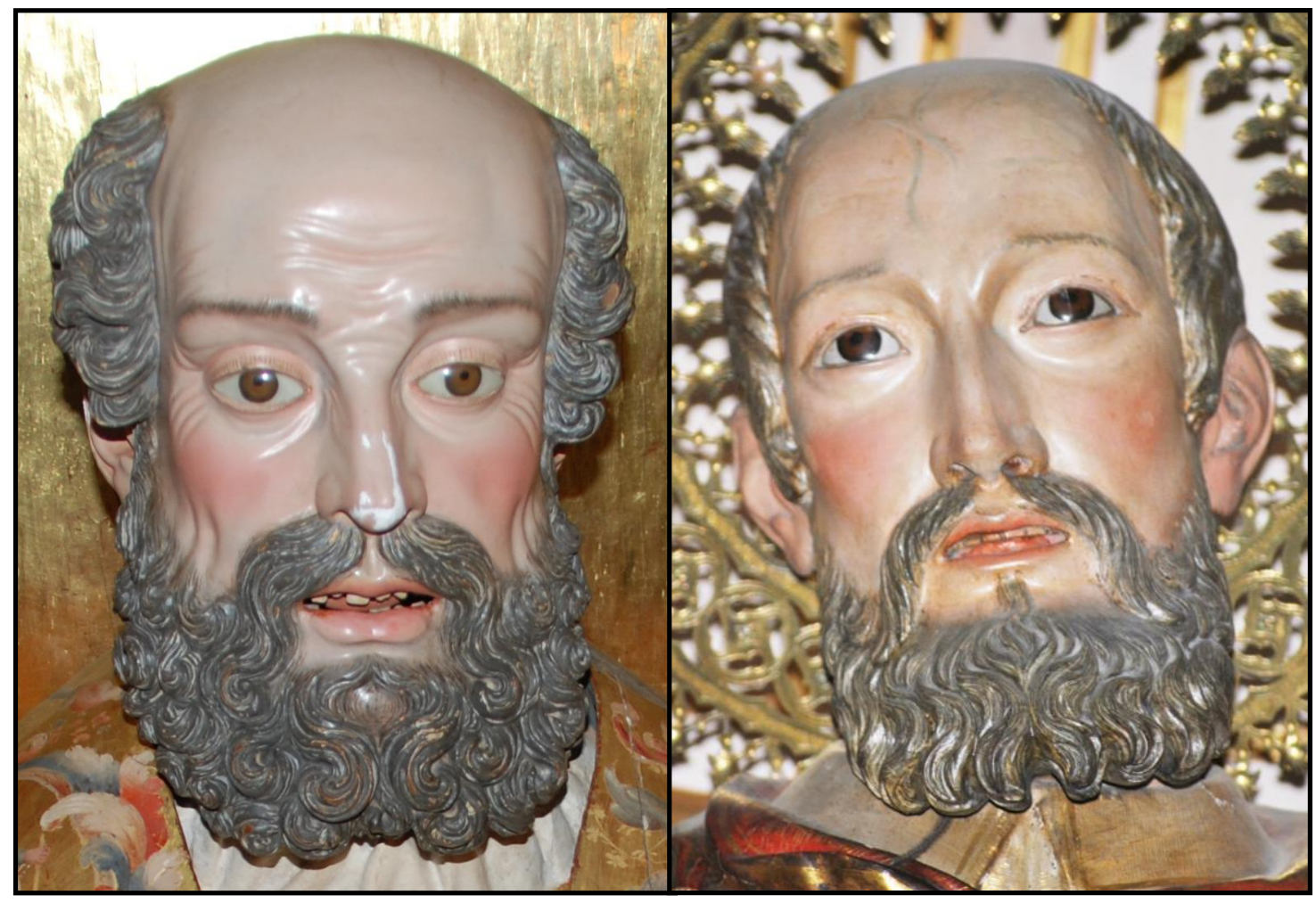

Il. 4- Juan de Ávila. Rostros del San Pedro en cátedra de Lerma y del San Francisco de Sales del Oratorio de San Felipe Neri de Valladolid. Fotografía del San Pedro @ Fundación del Patrimonio Histórico de Castilla y León.

Sus imágenes poseen unos rasgos faciales bastante profundos. Ojos almendrados rehundidos, en ocasiones tan cerrados que parecen achinados, característica que veremos en algunas obras de su hijo Pedro. Cejas arqueadas con una policromía muy naturalista que simula todos y cada uno de los vellos que las conforman. Abundan los ceños levemente fruncidos, aunque en otras ocasiones serán lisos. Nariz recta, simétrica,

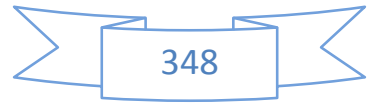


que se ensancha según descendemos hacia las aletas nasales, levemente pronunciadas. Las fosas nasales también están talladas. Sus bocas suelen ser pequeñas y entreabiertas dejándonos ver la fila de dientes superior, a veces las dos, y la punta de la lengua. Respecto a esto último hay una excepción: el San Pedro en Cátedra de Lerma, al cual talla la lengua completa, en bulto redondo, e individualiza los escasos dientes con que cuenta el primer papa. El surco nasolabial no suele tener cabida en sus obras dado que su espacio suele ocuparlo un bigote, si bien como estamos viendo siempre hay excepciones en Juan de Ávila: en este caso es el San Francisco de Sales de San Felipe Neri. Los pómulos no suelen estar muy desarrollados, solamente se les remarca por medio de la policromía rosada.

Sus tallas femeninas, que solo podemos juzgar por la Santa María de la Cabeza que se conserva en la vallisoletana ermita de San Isidro, no difieren demasiado de las masculinas, si bien los rasgos parecen más suaves, más finos. Asimismo, aparece de una manera más definida el surco nasolabial. La gran diferencia puede radicar en el mentón, que está mucho más marcado que en sus ejemplares masculinos. Este modo de hacer también lo tomará para sí su hijo Pedro.

Pone gran énfasis en la confección del cabello y las barbas, en los cuales nunca pierde la simetría. Para las barbas no tiene un modelo único, al menos contamos con cuatro diferentes: son los que vemos representados en el San Isidro Labrador (barba bífida profunda, con multitud de pequeños bucles y rematado en el mentón por dos cortos y

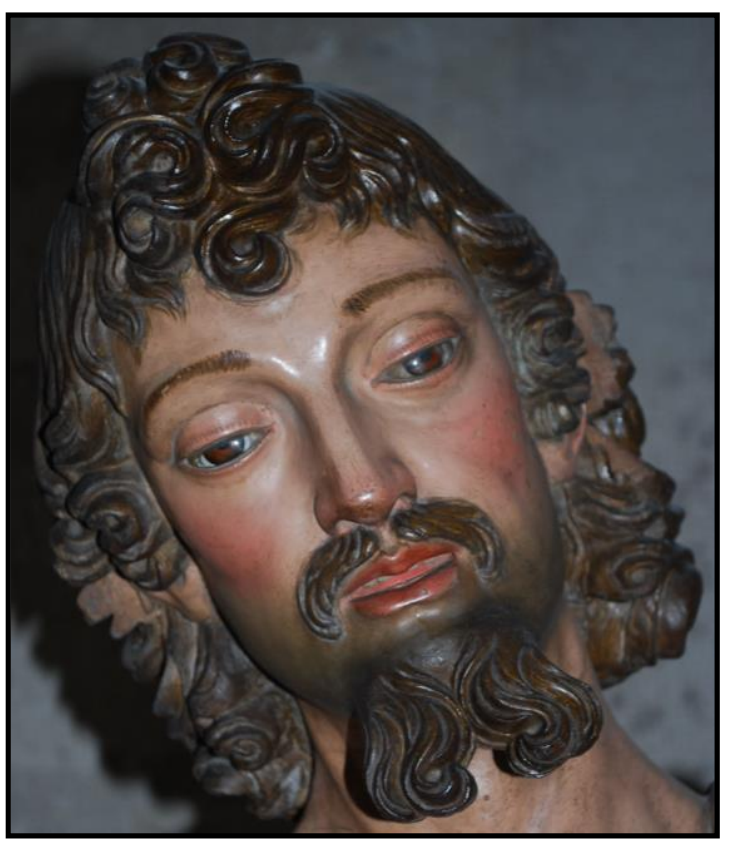

Il. 5- Detalle de la perilla del San Juan Bautista del Oratorio de San Felipe Neri de Valladolid. sinuosos mechones simétricos cuyos bucles miran hacia afuera); en el San Francisco de Sales (largos y sinuosos mechones compactos compuestos de una manera simétrica y muy virtuosa. Este tipo de barba calará en su hijo Pedro de Ávila, que lo utilizará en multitud de ocasiones. Claros ejemplos son los de los San Joaquines del Santuario Nacional de la Gran Promesa y del Convento de las Brígidas, ambos en Valladolid); en el San Pedro de la Colegiata de Lerma (barba muy poblada realizada a base de numerosos caracolillos y anchos bigotes), y en los San Juan Bautista que confecciona para la iglesia de Santiago y el Oratorio de San Felipe Neri (especie de perilla subdivida en dos mechones cortos retorcidos, también simétricos, con los bucles que lo rematan mirando hacia dentro).

En cuanto al pelo propiamente dicho lo talla muy pormenorizadamente, de una manera muy cuidada y delicada, en finas madejas. Martín González nos apunta dos características de los cabellos tallados por Ávila: primeramente, ve una similitud en la 
forma de ejecutarlos con Gregorio Fernández. Efectivamente, explica que Ávila conserva "todos los convencionalismos de éste [Fernández], incluso los cabellos caídos". Asimismo afirma: los "cabellos pegados como pelucas, característicos del estilo de Ávila" $" 123$.

Los cabellos suelen caer sobre la frente, algunas veces de manera simétrica (San Isidro) y otros de forma desordenada (San Andrés y San Pablo de la Colegiata de Lerma), pareciendo ambos tipos de pelos que estén mojados. Una tercera modalidad la conforma la especie de copete o cogollo de rizos abultados sobre la frente. Esta última modalidad y la forma de tallar los cabellos que caen a ambos lados de la cabeza reflejan a la perfección el excelente uso que daba del trépano, con el cual conseguía grandes volúmenes de pelo muy bien detallados, lo que provocaba un juego de luces y sombras que potenciaba sus formas. Estos últimos, los que podemos a ver a los lados de la cabeza suelen formarse a través de enormes rizos, todo lo contrario que los de la frente que tienden a la rectitud. Eso sí, tanto unos y como otros se disponen de manera simétrica siendo el punto de partida la parte del central del hueso frontal.

Desde sus primeras obras hasta las últimas vemos una evolución en su manera de tallar tanto barbas como cabellos. Si bien en un principio nos les presenta muy planos y poco singularizados, según va creciendo su maestría estos se irán abultando, creando grandes masas perfectamente perfiladas e individualizadas. En la mayoría de las ocasiones los cabellos cubren las orejas del personaje representado.

\section{B- ROPAJES/INDUMENTARIA}

Los ropajes suelen ser bastante realistas y en algunos casos incrementan la sensación de vitalidad y movimiento de la escultura, como es el caso del Santiago Matamoros que ejecuta para el retablo mayor de la parroquia de Santiago Apóstol. En éste sobresalen los pliegues de la capa que captan perfectamente el efecto del aire que incide sobre ella.

La indumentaria de la que hacen gala los personajes de Ávila no difiere en demasía de la que ya estudiamos en el capítulo dedicado a las características de la escultura barroca española. Usa dos tipos de ropajes: las vestimentas intemporales (túnicas, sayas, hábitos) para los personajes sagrados (Jesucristo, la Virgen, San José, padres de la Virgen, santos fundadores de órdenes y otros santos); y la moda de la época. Esta última la utilizará para los sayones del paso del Despojo, los moros de sus dos grupos de Santiago Matamoros, y para San Isidro y Santa María de la Cabeza. Estos dos últimos visten a la usanza de los labriegos de la época.

123 Ídem, pp. 321-322. 


\section{C- ICONOGRAFÍAS}

Juan de Ávila no destacó por ser un gran creador de iconografías, si bien su escaso catálogo no nos permite afirmar otra cosa. Su fuente de alimentación en este aspecto será fundamentalmente Gregorio Fernández. Así lo podemos comprobar en sus dos San Juan Bautistas; en San Pedro en cátedra, San Andrés y San Pablo del retablo lermeño, en el Crucificado de Traspinedo, o en el San Isidro de la ermita vallisoletana homónima. Tampoco parece que fuera el artífice de la iconografía del paso del Despojo ya que éste seguiría puntualmente la disposición que poseía un paso idéntico anterior que la Cofradía de N. P. Jesús Nazareno tuvo que devolver al Convento de San Agustín, su legítimo poseedor ${ }^{124}$.

Las únicas iconografías que pueden ser de su inteligencia son las de Santa María de la Cabeza y San Francisco de Sales, si bien no habría que descartar que hubiera tomado por modelo algún grabado, sobre todo en el caso del santo francés. En todo caso se trata de dos santos muy poco usuales en el medio castellano.

\section{D- POSTIZOS}

Apenas los utiliza. Para los ojos nunca usa el cristal, sino que o bien coloca una tapilla de vidrio o directamente los pinta sobre la madera. Tampoco destaca nuestro escultor por el uso de telas encoladas ni uñas postizas, todo lo contrario a lo que hizo Gregorio Fernández unas décadas antes, el cual destacó por utilizar una amplia gama de ellos. La tela encolada se utilizó bastante, sobre todo en el siglo XVIII, para conseguir mayor verismo en la representación de las vestiduras y del movimiento de las mismas.

\section{$\underline{\text { E- RELIEVES }}$}

Los relieves serán algo muy minoritario en su obra: tan solo tenemos constancia de que trabajó los dos que coronan los retablos colaterales del Oratorio de San Felipe Neri. También se le atribuyen los del retablo mayor del mismo templo. Creo que también le pueden pertenecer los que figuran en los áticos de los retablos colaterales de la iglesia del Monasterio San Quirce y Santa Julita. En ellos no consigue dar la más mínima impresión de profundidad, dinamismo y realismo. Ello se debe fundamentalmente a la total y absoluta falta de perspectiva. Ávila practica en ellos lo que Martín González definía como "falso relieve" 125 , que consiste en adherir al tablero del fondo figuras de bulto redondo o casi completas, con lo cual no cumple una de las características de los relieves: tallar las figuras en el propio tablero.

Además, los relieves son bastante arcaizantes. En ellos solamente da cabida a unas pocas figuras, el resto, si el historiado lo requiere, aparecen pintadas en el fondo del

$124 \quad$ VVAA.: Pasos restaurados, Museo Nacional de Escultura, Valladolid, 2000, p. 65.

125 MARTÍN GONZÁLEZ, Juan José: Escultura barroca castellana..., op. cit., p. 24. 
panel. El hecho de que se combine pintura y escultura ayuda a dar cierta perspectiva a la escena. La inclusión de tan pocas figuras esculpidas puede ser tomada como una pobreza en cuanto a los recursos o como un afán de simplificación, lo que está claro es que es un recurso barroco pues se funden varias disciplinas artísticas en una misma obra $^{126}$. Las figuras en relieve de Ávila se caracterizan por ir talladas en bajorrelieve, a excepción de las cabezas y brazos que son casi de bulto redondo. En ellas se advierte pesadez en los pliegues. 


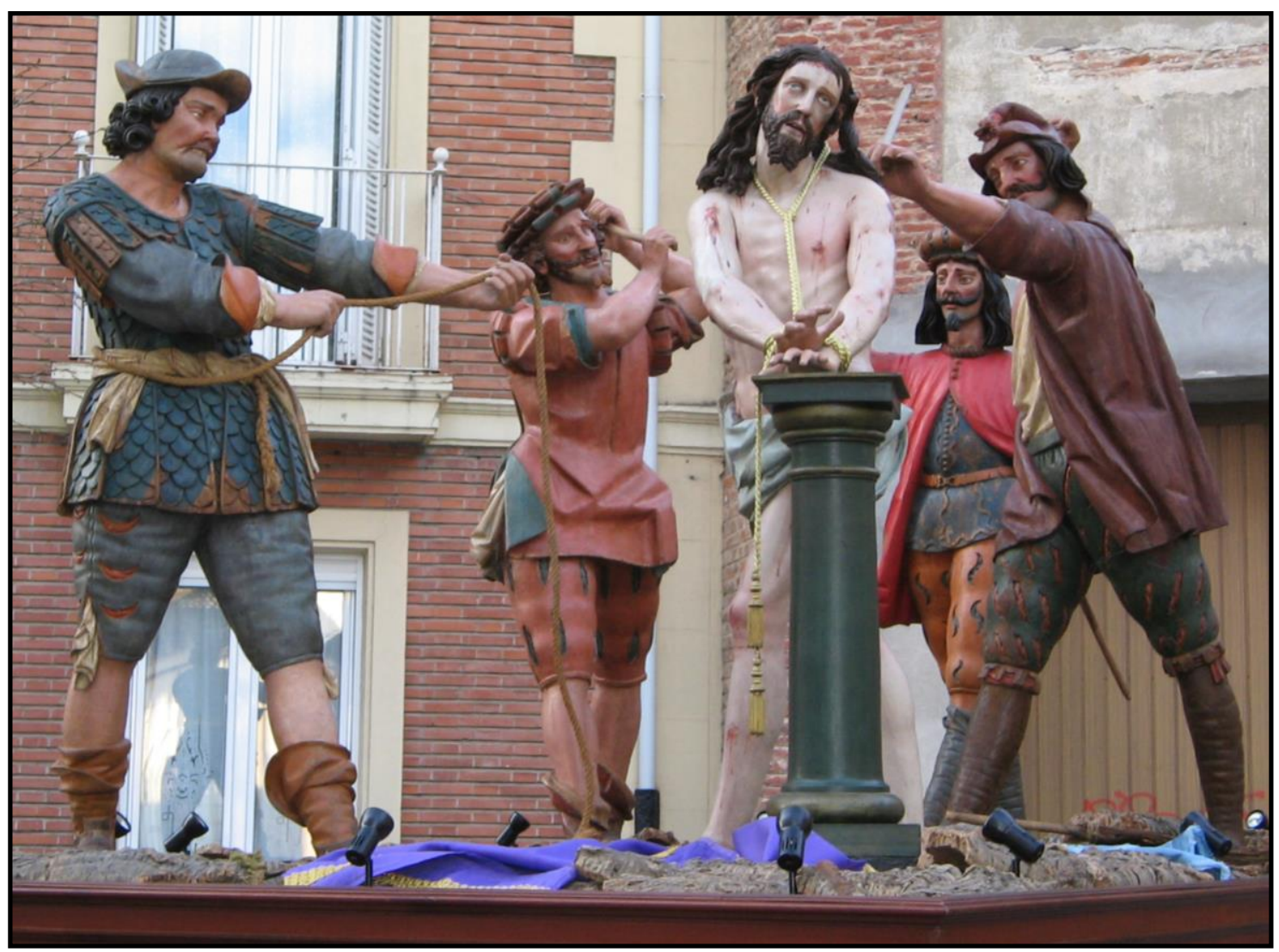

Fig. 1- Francisco Díez de Tudanca. Paso del Azotamiento de la Cofradía de Nuestra Señora de la Pasión. Museo Nacional de Escultura. Valladolid.

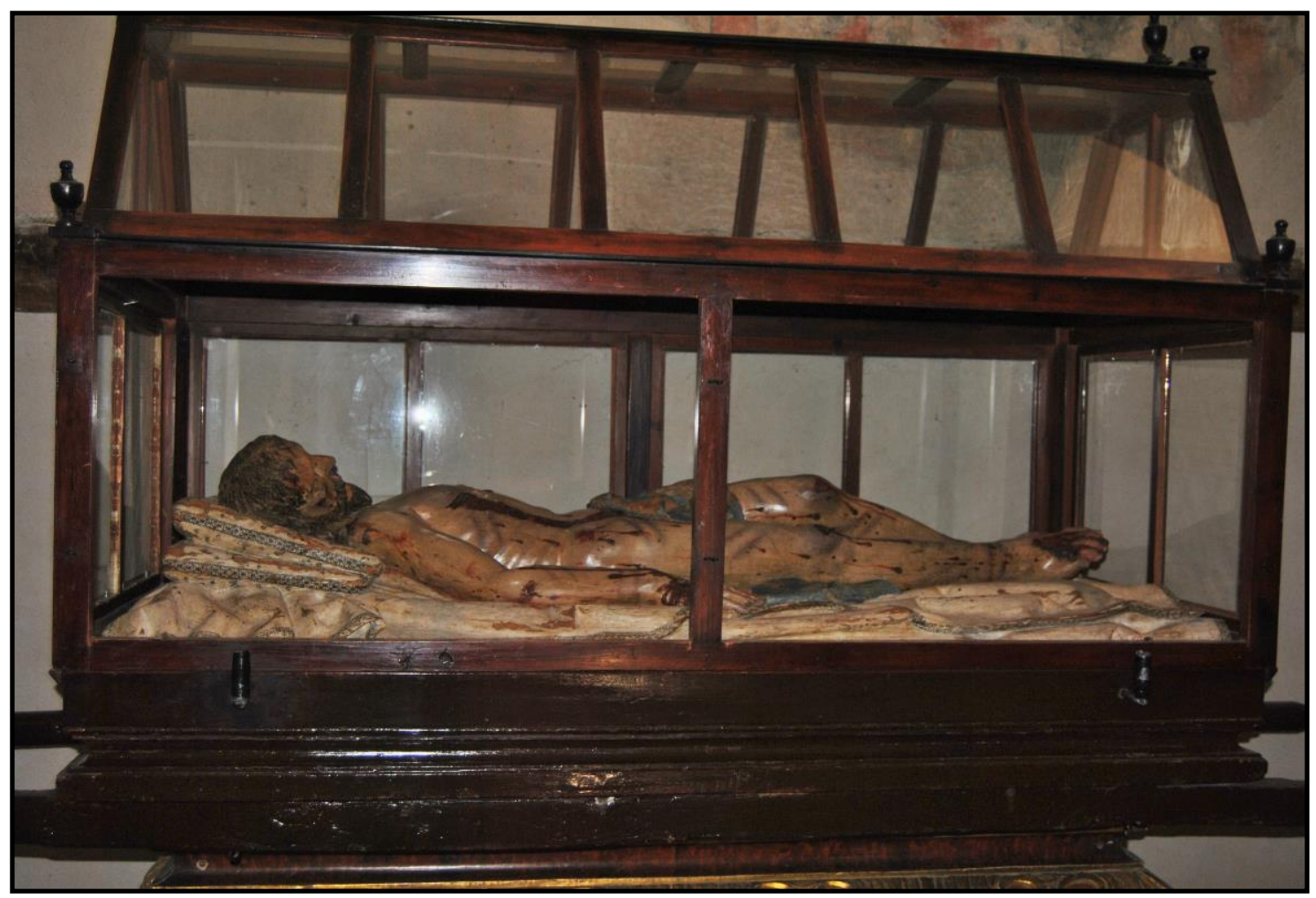

Fig. 2- Francisco Díez de Tudanca. Cristo Yacente. Iglesia parroquial de la Asunción. Martín Muñoz de las Posadas (Segovia).

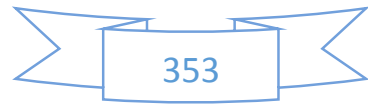




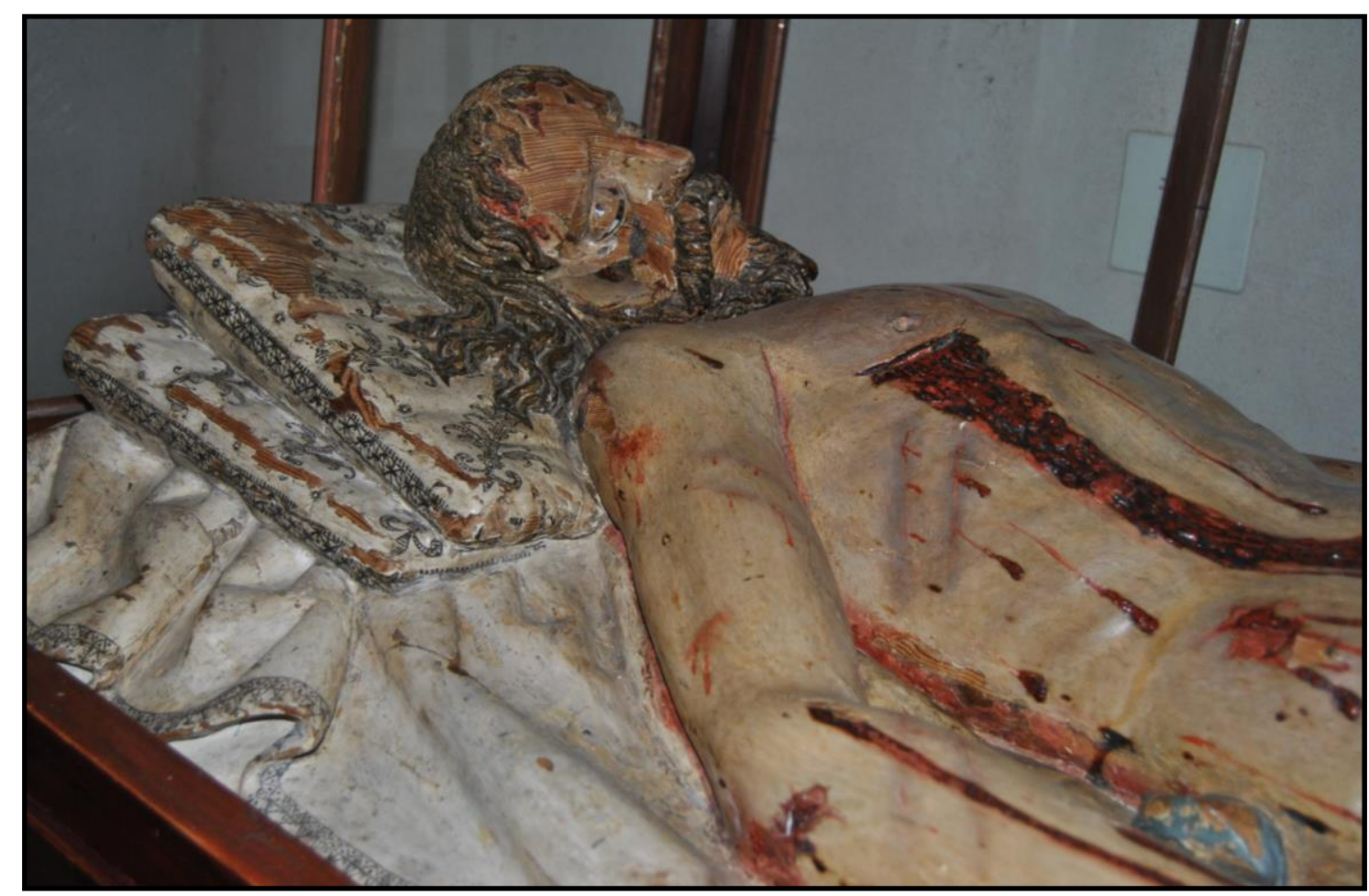

Fig. 3- Francisco Díez de Tudanca. Detalle Cristo Yacente.

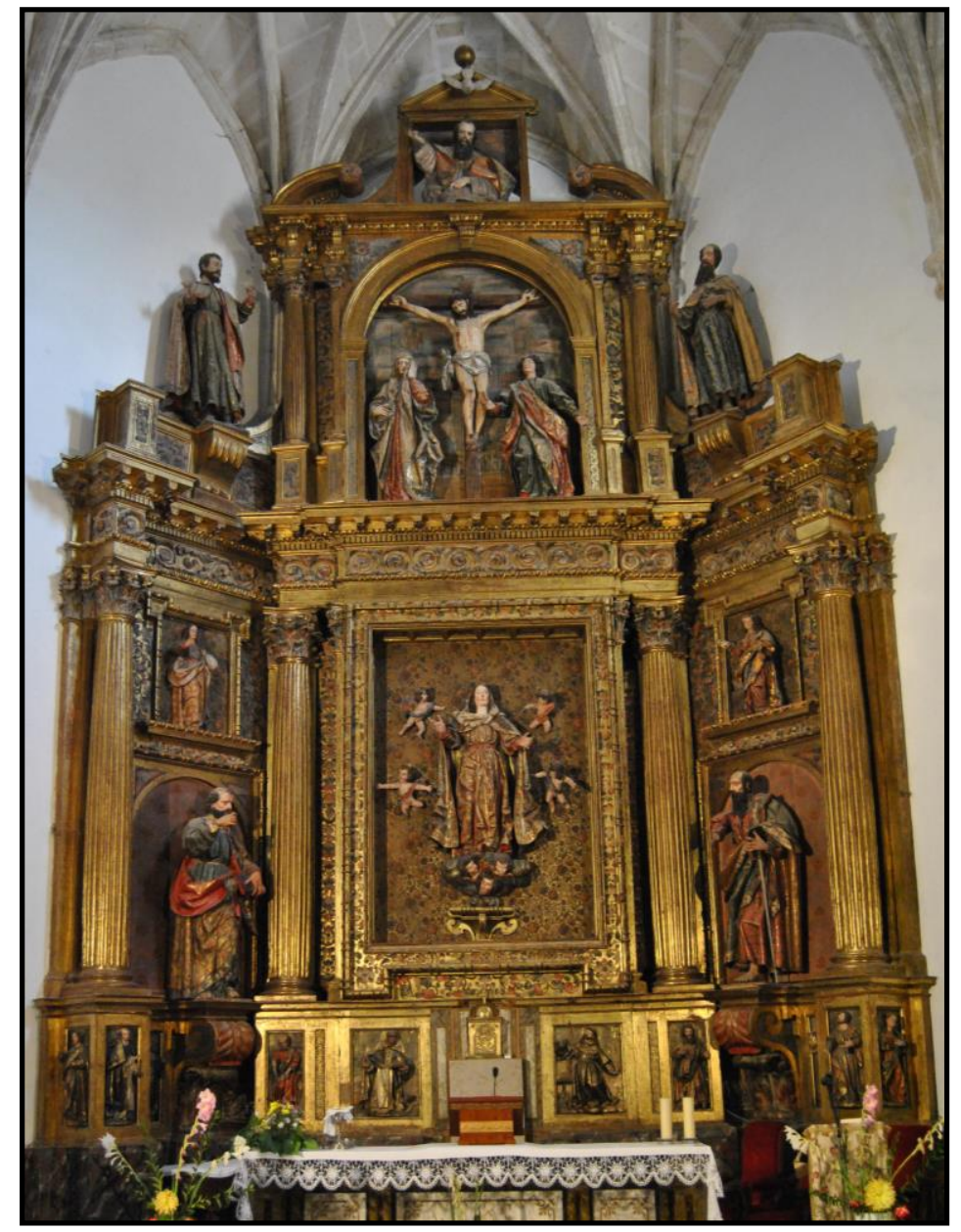

Fig. 4- Francisco Díez de Tudanca y Juan Rodríguez. Esculturas del retablo mayor. Iglesia parroquial de la Asunción. Bercero (Valladolid).

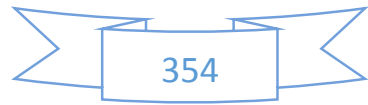




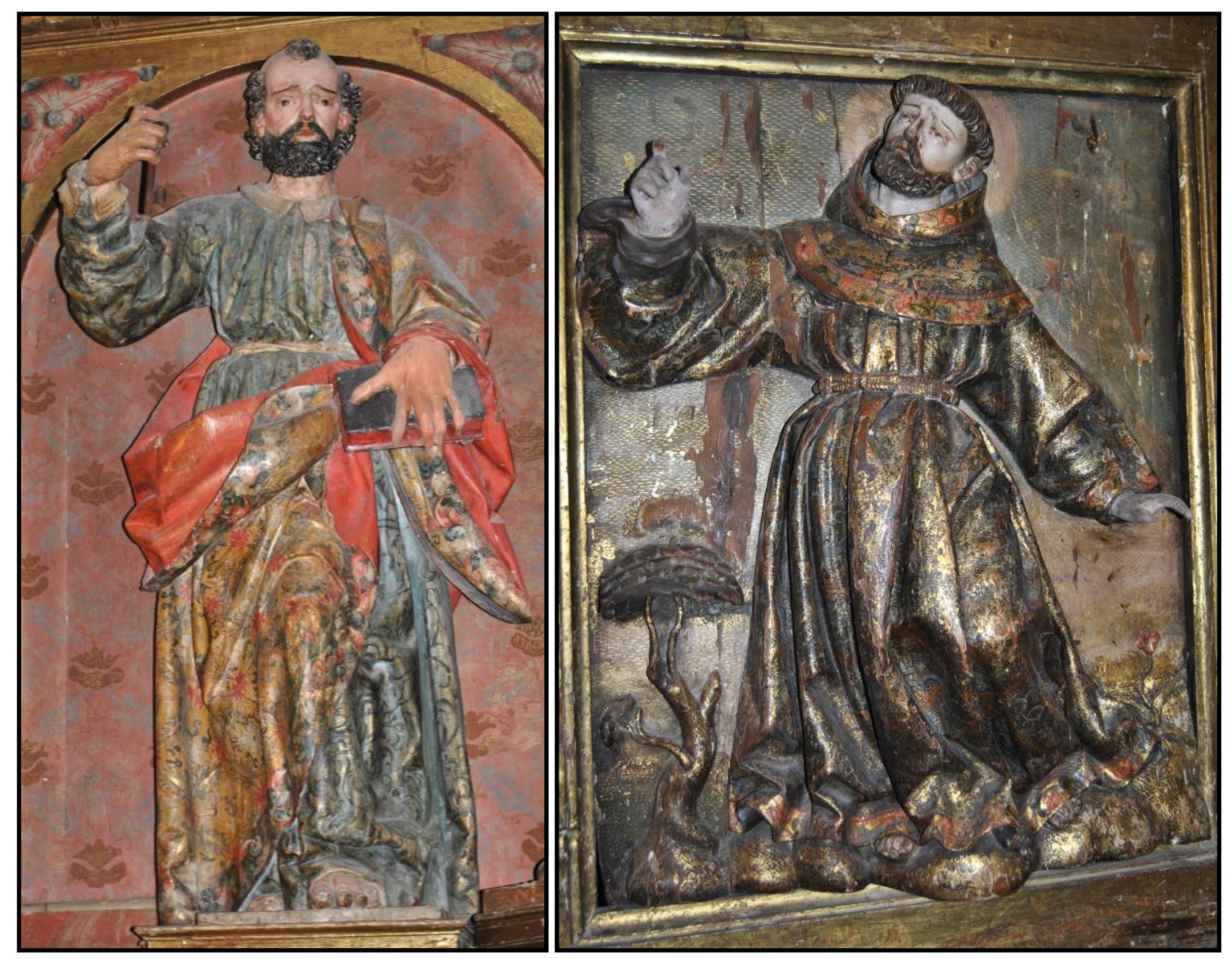

Figs. 5-6- Francisco Díez de Tudanca. San Pedro y Relieve de San Francisco del retablo mayor. Iglesia parroquial de la Asunción. Bercero (Valladolid).

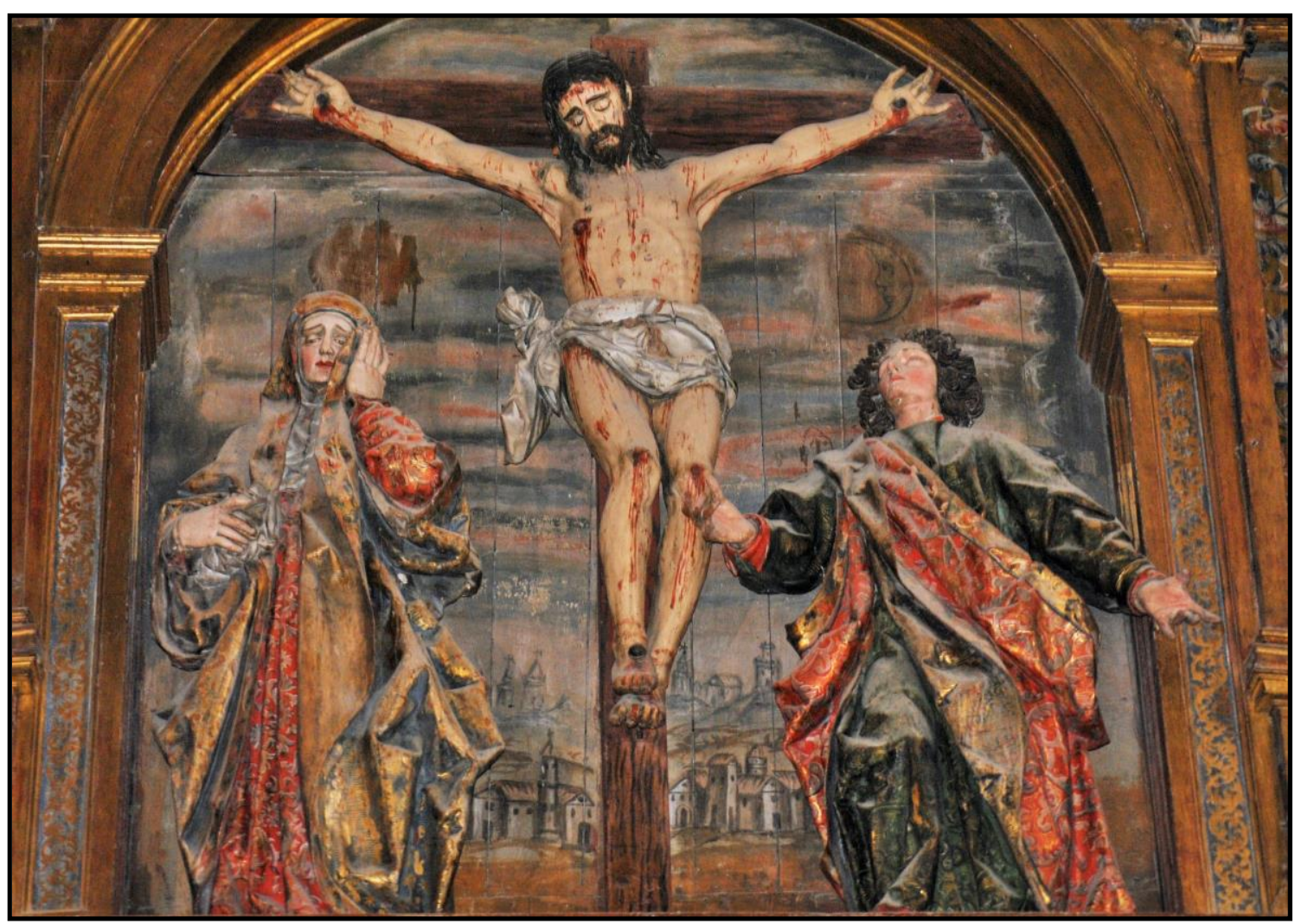

Fig. 7- Francisco Díez de Tudanca. Calvario del retablo mayor. Iglesia parroquial de la Asunción. Bercero (Valladolid).

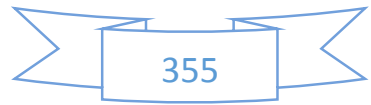




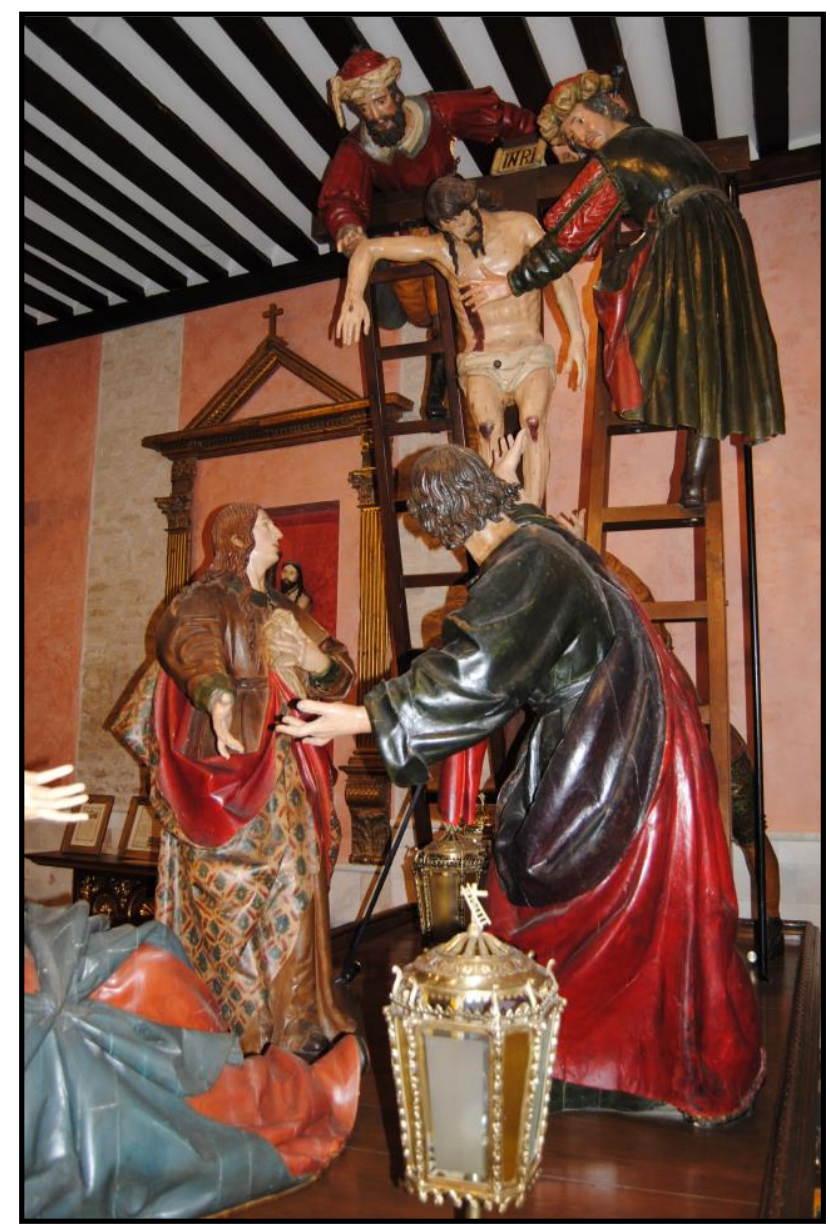

Fig. 8- Francisco Díez de Tudanca. Paso del Descendimiento. Capilla de los Pasos

Grandes. Medina de Rioseco (Valladolid).

Fig. 9- Francisco Díez de Tudanca. Paso del Santo Sepulcro

(Desaparecido). Medina de Rioseco (Valladolid).
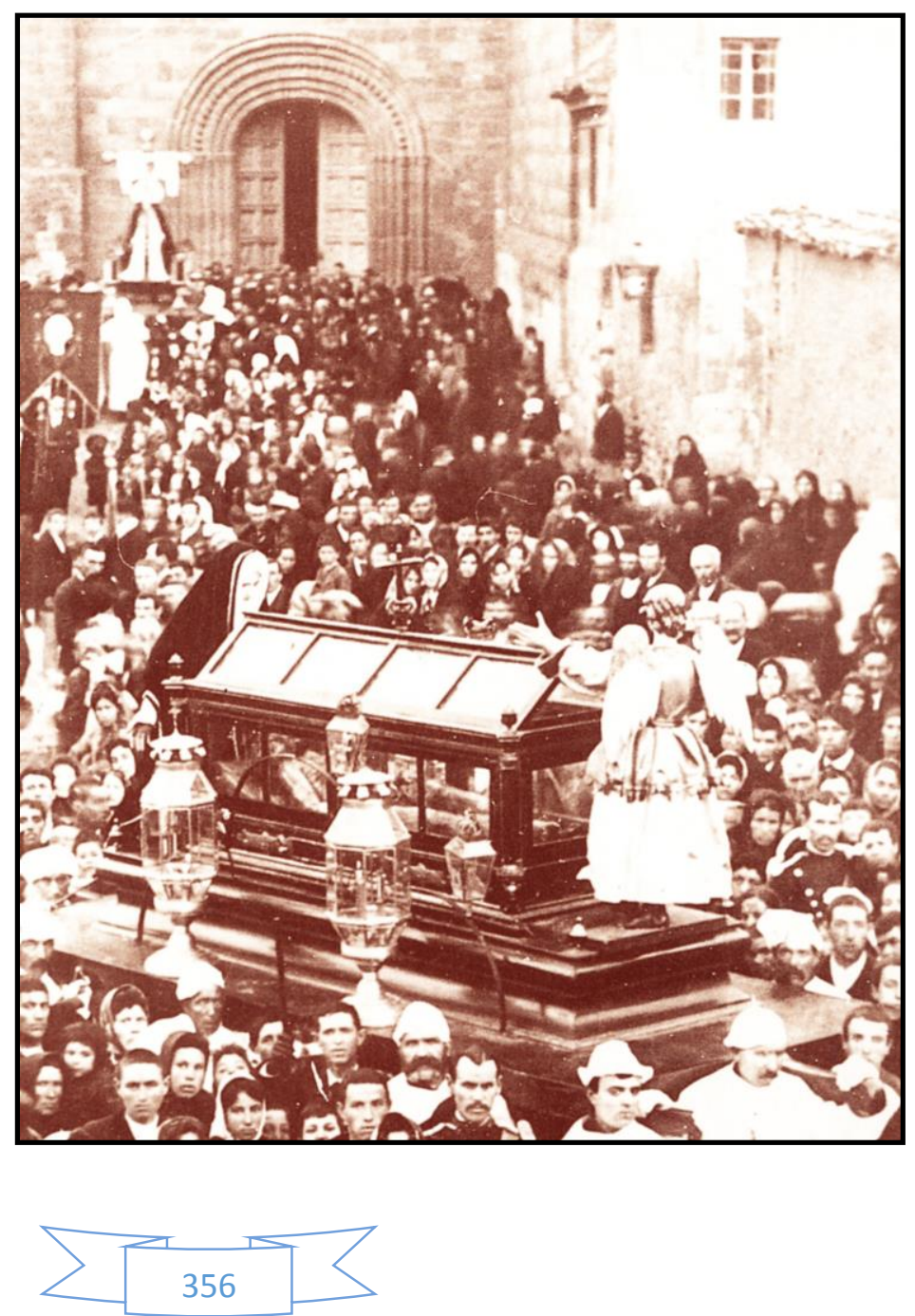


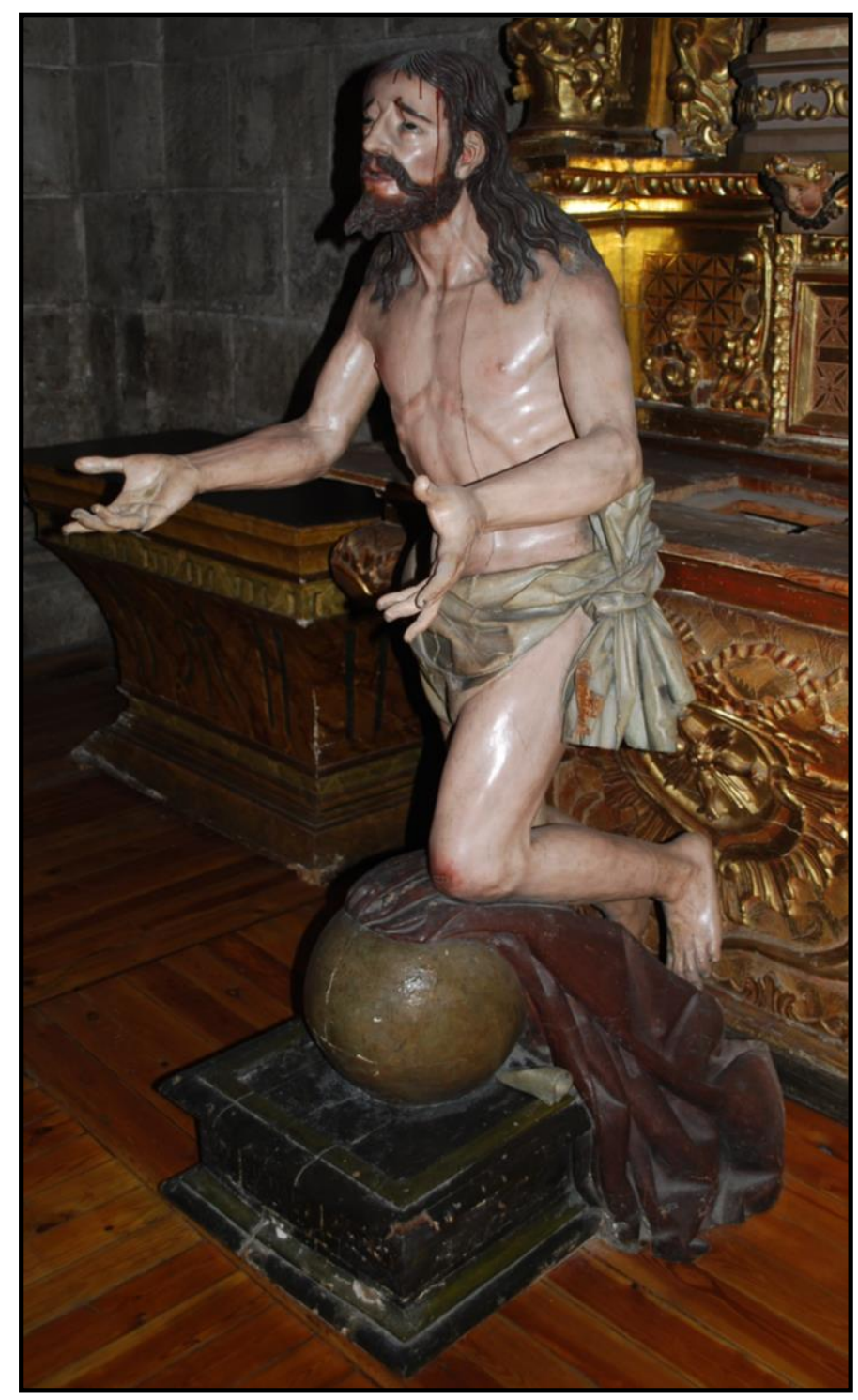

Fig. 10- Francisco Díez de Tudanca. Cristo del Perdón. Catedral. Valladolid.

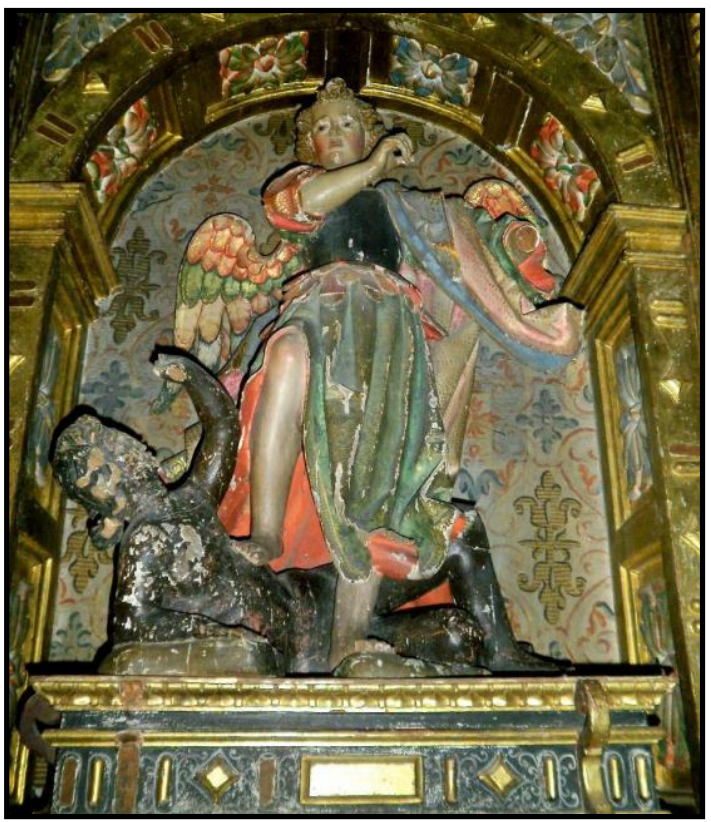

Fig. 11- Francisco Díez de Tudanca. San Miguel. Iglesia de Santiago. Ávila.

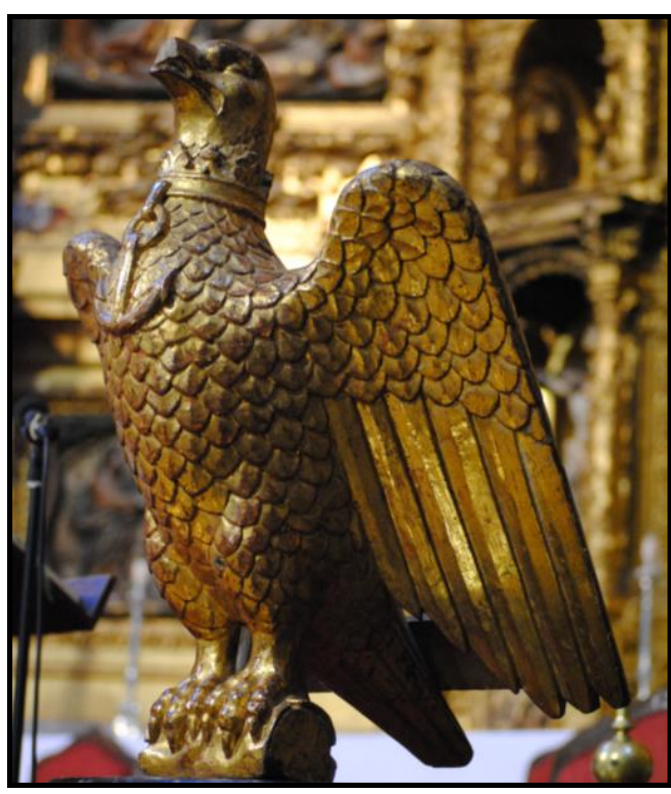

Fig. 12- Francisco Díez de Tudanca. Águilaatril. Iglesia de Santiago de los Caballeros. Cigales (Valladolid).

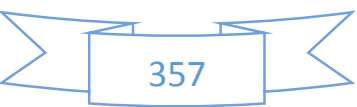




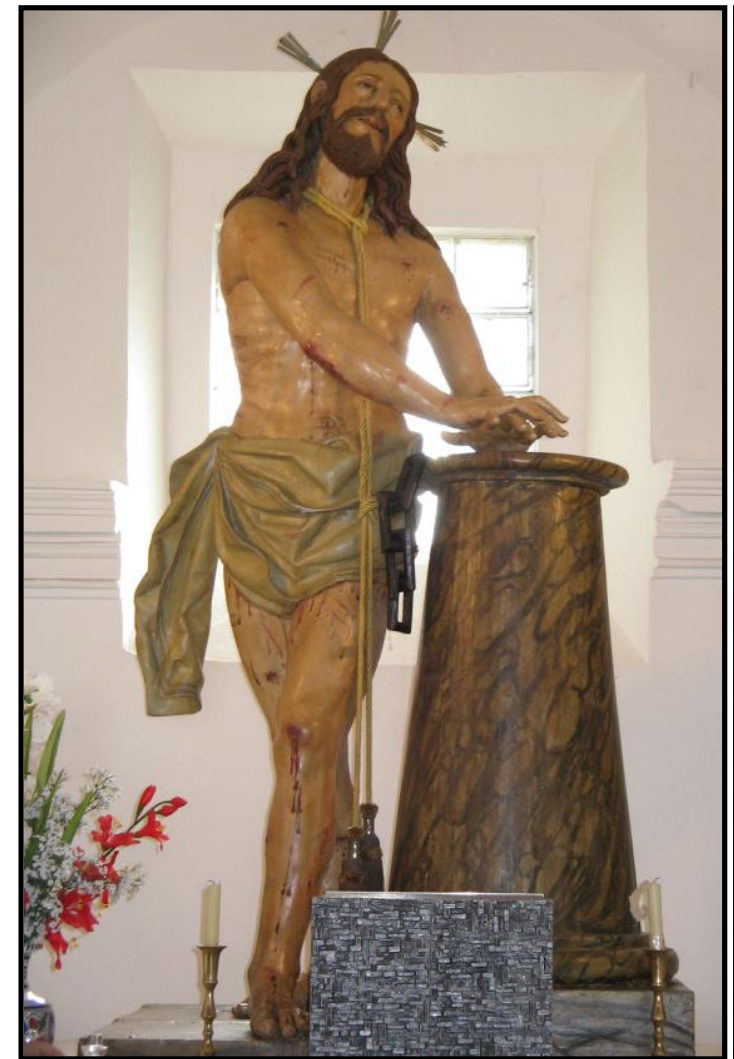

Fig. 13- Francisco Díez de Tudanca. Cristo atado a la columna. Ermita del Santo Cristo. Mojados (Valladolid).

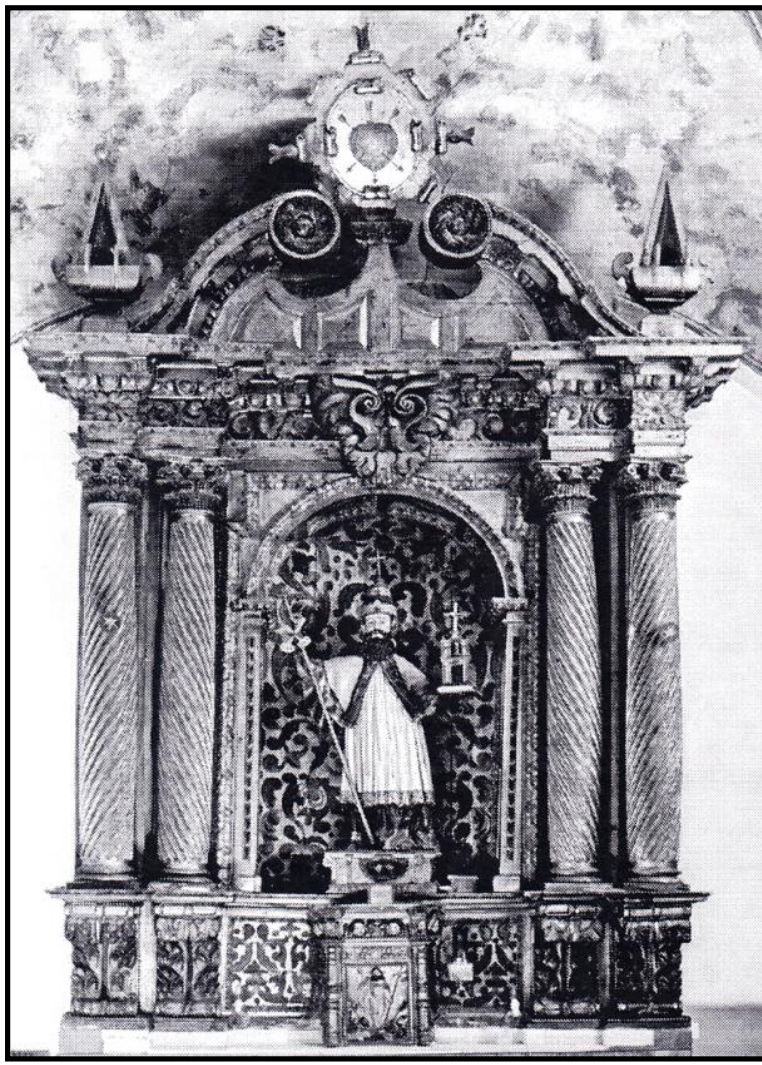

Fig. 15- Francisco Díez de Tudanca. San Agustín. Iglesia parroquial de San Pedro. Villiguer (León).

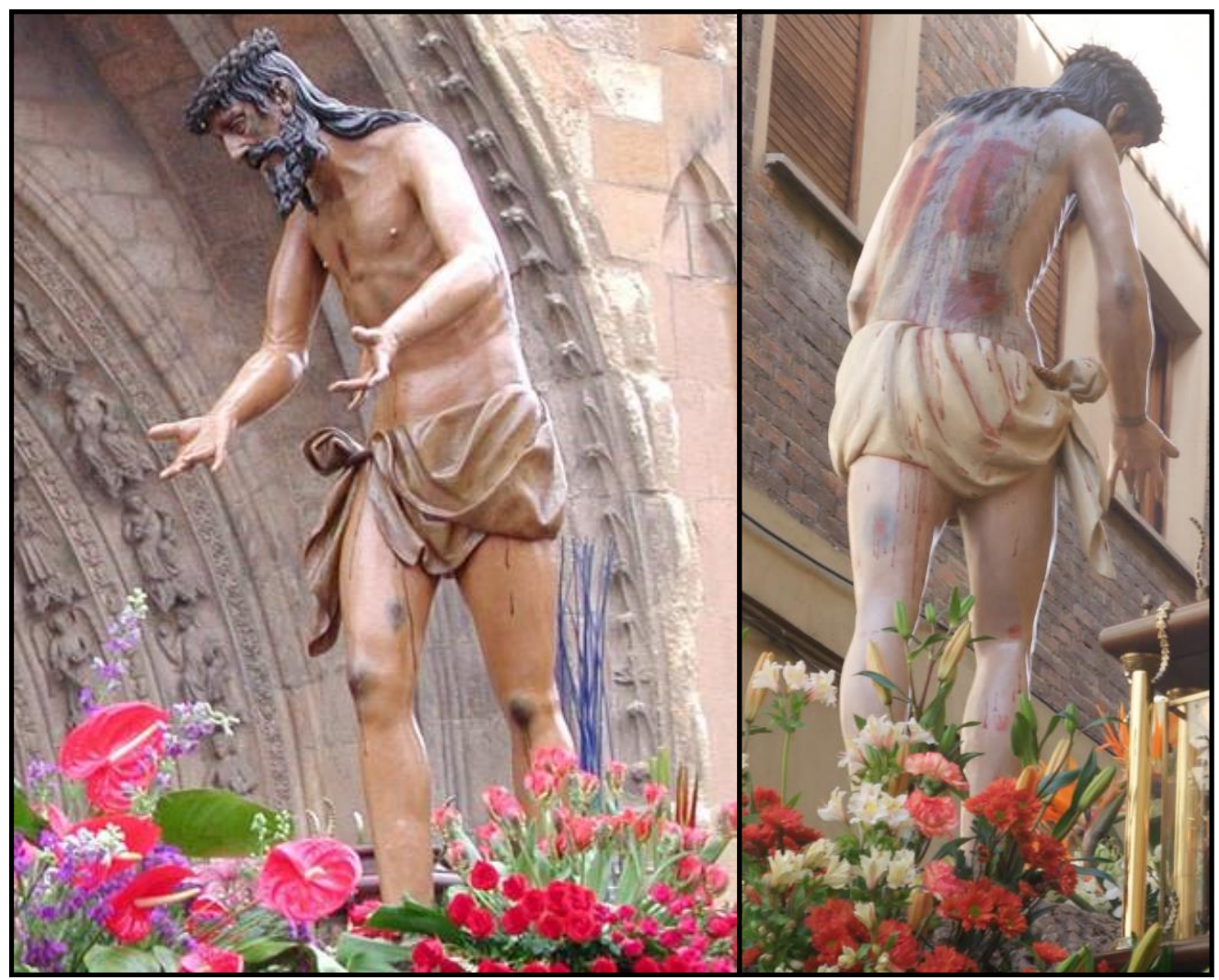

Figs. 14- Francisco Díez de Tudanca. Paso del Expolio. Capilla de Santa Nonia. León.

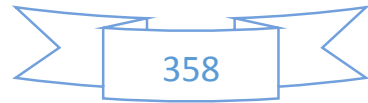




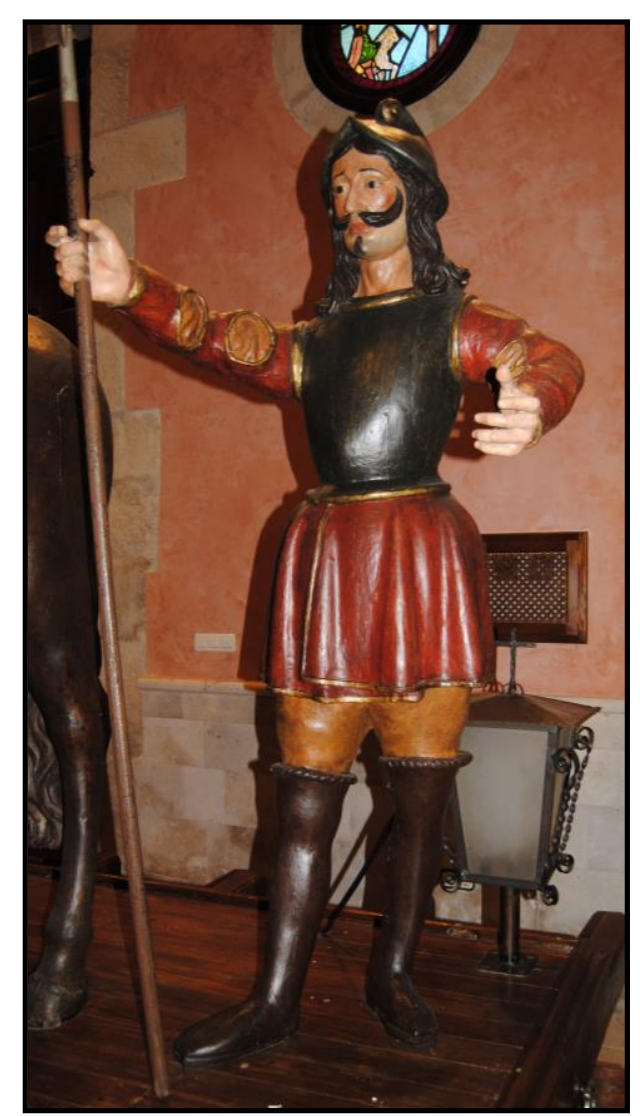

Fig. 16- Francisco Díez de Tudanca. Centurión de La lanzada de Longinos. Capilla de los Pasos Grandes. Medina de Rioseco (Valladolid).

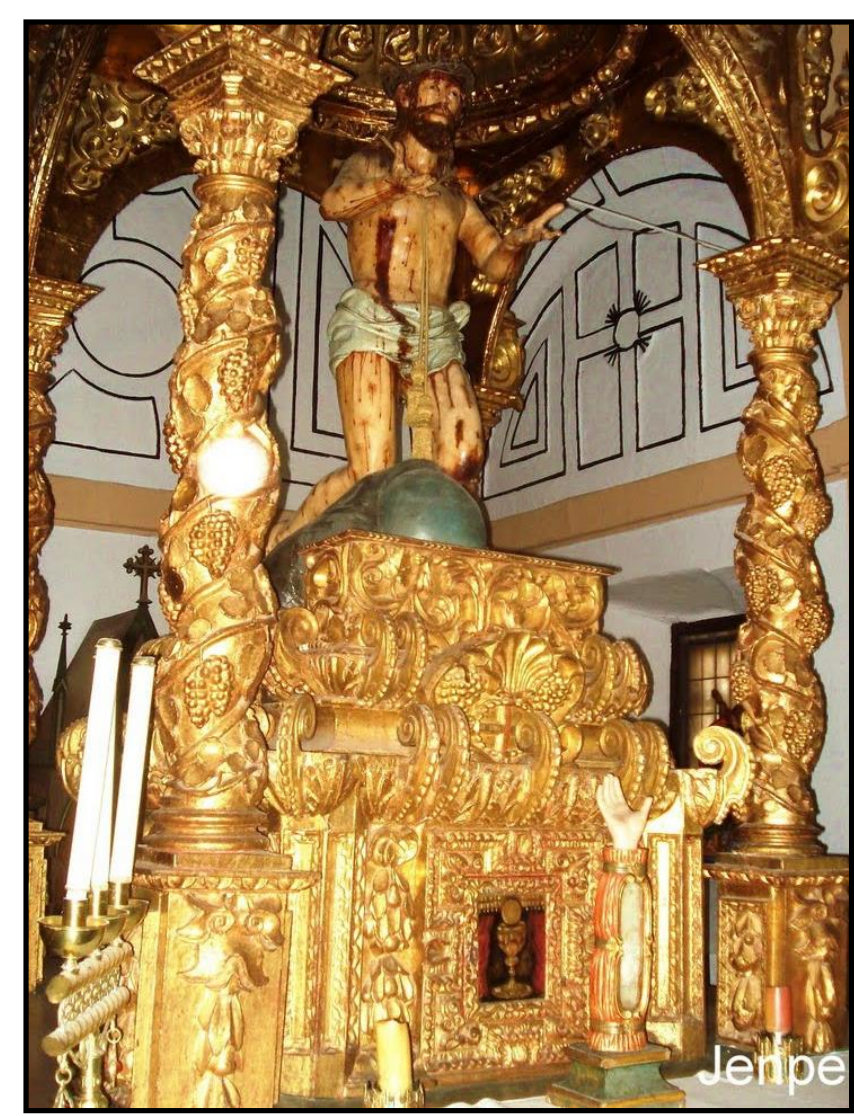

Fig. 17- Francisco Díez de Tudanca. Cristo del Perdón. Iglesia de San Juan Bautista. Hervás (Cáceres).

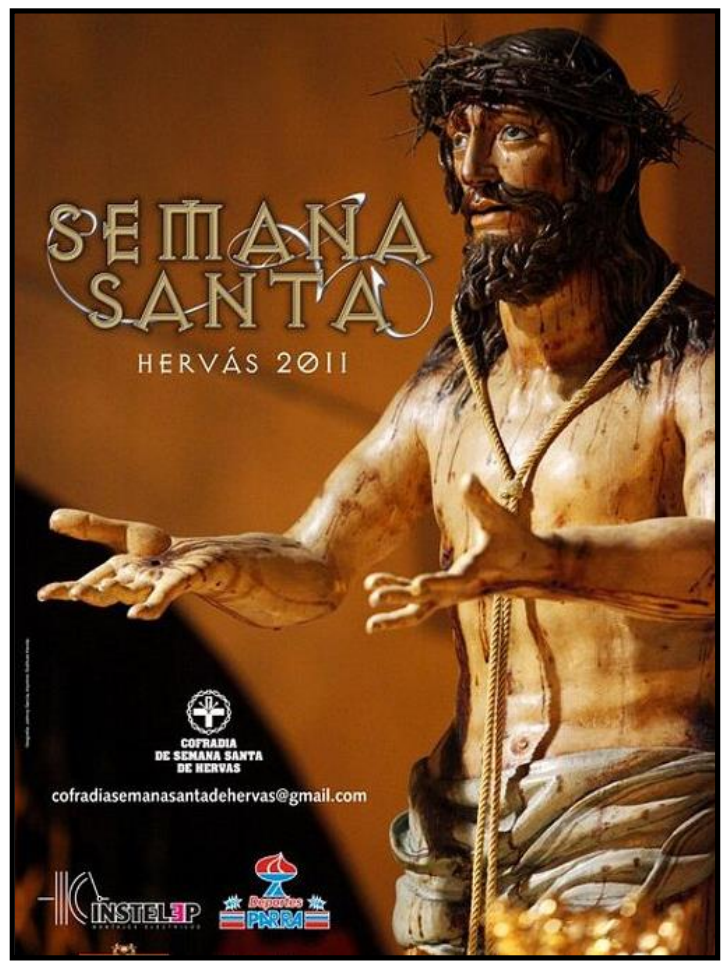

Fig. 18- Francisco Díez de Tudanca. Cristo del Perdón. Iglesia de San Juan Bautista. Hervás (Cáceres).

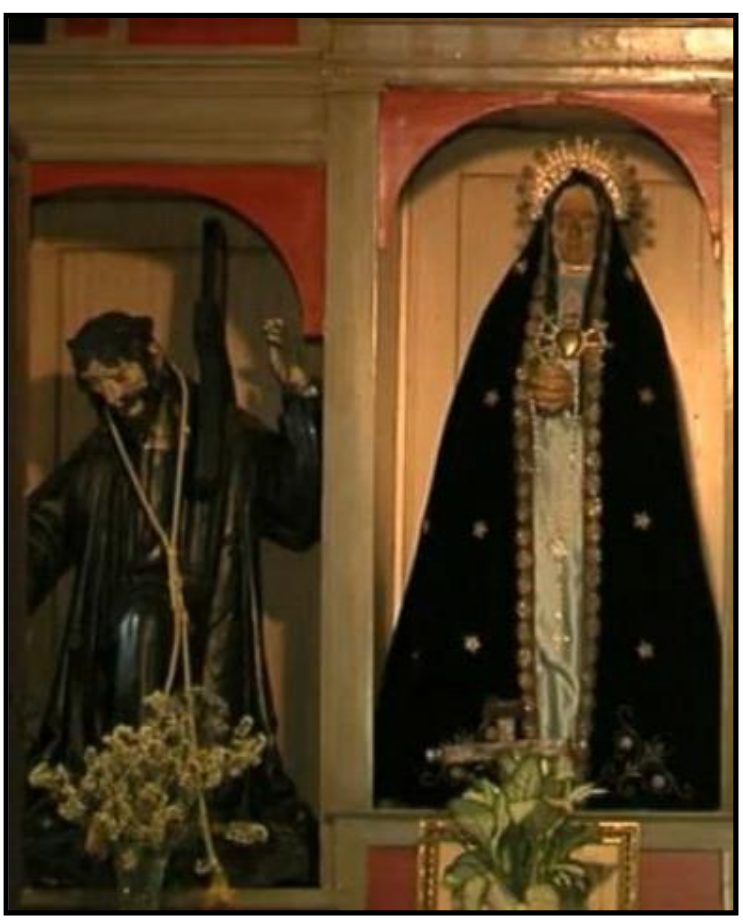

Fig. 19- Francisco Díez de Tudanca. Jesús Nazareno y Virgen de la Soledad. Iglesia parroquial. Montehermoso (Cáceres). 
$\sum[360 \leq$ 


$$
\frac{\text { 5- JUAN DE ATILA. }}{\text { CATALOGO }}
$$




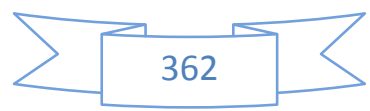


En el presente capítulo vamos a ir desgranando poco a poco el catálogo que puede relacionarse con Juan de Ávila. La presente clasificación se subdivide en cuatro apartados claramente diferenciados: obras documentadas, obras atribuidas, obras relacionadas y obras descatalogadas.

Obras documentadas. Son aquellas de las que tenemos constancia de su autoría ya sea porque conservamos los contratos de ejecución, por reseñas en libros de cuentas o de fábrica, etc...

Obras atribuidas. Son aquellas que sin tener constancia documental podemos adscribir al escultor mediante la mera comparación estilística con sus obras indudables. Muchas de las atribuciones que realizo son inéditas, no sé si con mayor o menor fortuna. El resto están recogidas de diferentes libros, si bien las dos fuentes principales han sido el Inventario artístico de Valladolid y su provincia $(1970)^{1}$, dirigido por don Juan José Martín González, y los veintiún tomos del Catálogo Monumental de Valladolid.

Obras relacionadas. Se incluirán aquellas esculturas o conjuntos escultóricos que, sin poder ser adjudicados directamente a Ávila por sus características, bien podemos decir que han salido de su taller o bien que el escultor que las ha realizado se ha basado parcial o completamente en su forma de hacer. No pueden considerarse del propio escultor, pero tampoco se pueden relacionar con los estilos de otros.

Obras descatalogadas. En esta última sección se incluirán aquellas que alguna vez han sido atribuidas a nuestro escultor y que ya sea porque han salido a la luz nuevos datos que desechan tal autoría o porque no resisten una comparación con el estilo de Ávila, no pueden seguir figurando en el apartado de atribuciones.

No todas las obras serán tratadas con la misma extensión ya que hay algunas de las que carecemos por completo de dato alguno. Además, una vez que se explique la iconografía de un santo no se volverá a hacer para así evitar repeticiones reiteradas.

La ordenación de las obras sigue un criterio cronológico en el caso de las "documentadas" y "atribuidas", mientras que las "relacionadas" y "descatalogadas" he preferido colocarlas en el orden alfabético de las localidades en que están situadas.

1 MARTÍN GONZÁLEZ, Juan José (dir.): Inventario artístico de Valladolid..., op. cit. 


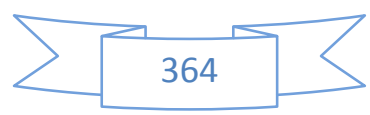




\section{5-1 OBRAS DOCUMENTADAS}




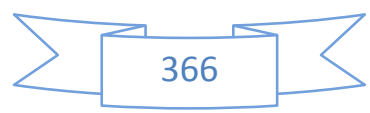




\section{VALLADOLID. IGLESIA DE SAN JUAN BAUTISTA}

\section{MARCOS PARA CUADROS (1675)}

Con motivo de la inauguración de la iglesia de la Pasión en el año 1675 se solicitó una serie de lienzos a determinados pintores locales con el fin de embellecer los desnudos muros de la iglesia. A cambio de este "favor" los pintores recibirían honores de diputados en la Cofradía Penitencial de la Sagrada Pasión de Cristo. Los lienzos desarrollarían tres ciclos, siendo el principal el dedicado a la vida de San Juan Bautista (patrón de la cofradía). Los otros dos aluden a la Pasión de $\mathrm{Cristo}^{2}$ y a la vida de la Virgen. Los pintores encargados de llevar a efecto tal tarea fueron Manuel Juárez ${ }^{3}$, Agustín Bara ${ }^{4}$, Amaro Alonso ${ }^{5}$ y Diego Díez Ferreras. Según Martí y Monsó "estas obras pertenecen a la decadencia pictórica aun siendo del último tercio del siglo XVII',

A pesar de lo dicho, no todos los cuadros fueron donados puesto que consta que algunos fueron pagados con el dinero aportado por ciertos benefactores. Así, por ejemplo, los cofrades Luis de San Juan y Juan Ruiz del Árbol entregaron 100 ducados cada uno para ayuda "de los cuadros que se han de poner en la iglesia"7.

2 En la ciudad existe otro ciclo artístico dedicado al Precursor. Se trata de la serie de relieves realizados por el escultor Claudio Cortijo para la iglesia de San Juan de Letrán. MARTÍN GONZÁLEZ, Juan José y URREA FERNÁNDEZ, Jesús: Catálogo Monumental de la provincia de Valladolid. Tomo $X I V . . .$, op. cit., p. 316. En la provincia podemos señalar un ejemplo más: el desarrollado en el retablo mayor de San Juan de Villalón de Campos, atribuido al Maestro de Palanquinos. URREA FERNÁNDEZ, Jesús y BRASAS EGIDO, José Carlos: Catálogo Monumental de la provincia de Valladolid. Tomo XII..., op. cit., p. 129; URREA FERNÁNDEZ, Jesús (coord.): Patrimonio restaurado..., op. cit., p. 237.

"6 de marzo de 1675 (...) el señor Manuel Juárez pintor (...) dará de limosna dos cuadros grandes que llenen los dos huecos de la capilla mayor y uno largo del testero a donde eligiese la Cofradía (...) acordose (...) que los dos cuadros de la capilla mayor sea el uno el Levantamiento de la Cruz y otro Cristo con la Cruz a cuestas (...) y que para fin de julio han de estar acabados en toda perfección. Aceptó el Manuel Juárez y dio las gracias [Porque le concedieron honores de diputado como a los demás]. MARTÍ Y MONSÓ, José: Estudios histórico-artísticos..., op. cit., p. 502.

$4 \quad$ "6 de marzo de 1675 (...) el señor Agustín Bara (...) dará dos lienzos para la iglesia y un testero a satisfacción (...)". Ibídem.

5 "18 de mayo de 1675. Manuel de Antecha Alcalde dijo (...) se había dado principio a poner en dicha iglesia la vida de San Juan Bautista en pinturas grandes con marcos dorados de mucha costa y otras sobre ellas más pequeñas con los mismos marcos (...) y había solicitado con el dicho señor Amaro Alonso pintor de que diese dos pinturas grandes la una de la Cena y la otra de la Degollación de San Juan que se han de poner (...) en correspondencia de las dos que están puestas a la izquierda y que el susodicho había ofrecido de darlos acabados (...) para el mes de agosto de este año... Se aprueba dando al dicho Amaro Alonso las dichas dos pinturas a satisfacción de D. Gregorio Rodríguez Gavilanes”. Ibídem.

6 Ibídem.

$7 \quad$ "Ofrecimientos para costear los cuadros que habían de ponerse en la iglesia de la Pasión. 6 de marzo de 1675. El señor Luis de San Juan, cofrade de la penitencial ofreció en el cabildo de ese día, cien ducados para que se distribuyesen en uno de los cuadros que se han de poner en la iglesia, con la condición de quedar reservado de oficios penosos; y el señor Juan Ruiz del Árbol, ofreció por su parte otros cien ducados que habían de convertirse en hacer un cuadro para la iglesia como los que al presente se estaban haciendo, con tal de que le diesen honores de diputado". MARTÍ Y MONSÓ, José: "Efemérides inéditas. Marzo. Ofrecimiento para costear los cuadros que habían de ponerse en la iglesia de la Pasión”. En VV.AA.: Boletín de la Sociedad Castellana de Excursiones, Tomo III (1907-1908), Grupo Pinciano, Valladolid, 1984, p. 369. 
Tras la marcha de la cofradía penitencial de su iglesia a comienzos del siglo XX los cuadros fueron retirados y parte de ellos trasladados a la recientemente inaugurada, por entonces, iglesia de San Juan Bautista. Allí fueron a parar tan solo los lienzos referidos a la vida del Precursor ${ }^{8}$. Asimismo, los de la vida de la Virgen, no todos, marcharon a la clausura del Convento de San Quirce y Santa Julita ${ }^{9}$. Sobre los cuadros relativos al ciclo de la Pasión no quedan noticias. Ignoramos si han desaparecido para siempre o bien se encuentran en alguna otra iglesia o institución.

Pues bien, a lo largo de ese año de 1675 la Cofradía Penitencial de la Sagrada Pasión de Cristo y San Juan Bautista Degollado encomienda a Juan de Ávila la ejecución de unos marcos para los cuadros, los cuales son entregados por el escultor el 6 de marzo de $1675^{10}$. El encargo constituía un paso más dentro del proceso de amueblamiento interior de la iglesia, la cual por entonces estaba sufriendo una importante remodelación barroca $^{11}$. Es probable que al realizar dichos marcos también nuestro escultor obtuviera el honor de diputado de la penitencial.

Los marcos, que debían de ser grandes y "estar tallados en el estilo de la época", van decorados con motivos vegetales (Figs. 1-2), materializados en las típicas hojas carnosas que podemos observar en los retablos de aquel momento. Desconocemos si Ávila hizo los marcos para todos los cuadros puesto que tan solo tenemos constancia de que realizó los de la "capilla mayor y otro para la iglesia". Todos son similares, lo que no ayuda a dilucidar dicha cuestión. Tan solo escapa de esta uniformidad el del cuadro de San Juan Bautista niño, que en vez de adoptar el formato rectangular posee en su parte central inferior un importe recorte para poder situarlo encima de una puerta o vano.

Martín González define de la siguiente manera la simbiosis entre cuadros y marcos: "Los cuadros de historia de San Juan Bautista presentan también marcos de hojas carnosas. Es, en suma, la iglesia que mejor señala el giro hacia el barroquismo en Valladolid"12.

$8 \quad$ La primera piedra se colocó el 16 de julio de 1930, inaugurándose el 23 de junio de 1932. MARTÍN GONZÁLEZ, Juan José y URREA FERNÁNDEZ, Jesús: Catálogo Monumental de la provincia de Valladolid. Tomo XIV..., op. cit., p. 75.

$9 \quad$ REBOLLO MATÍAS, Alejandro: "Acerca de nuestra historia: la iglesia de la Pasión y su patrimonio ( $3^{\mathrm{a}}$ parte), Pasión Cofrade, $\mathrm{n}^{\mathrm{o}} 8$ (segunda época), 2012, pp. 38-41.

$10 \quad$ "6 de marzo de 1675. Juan de Ávila (...) dará los marcos tallados grandes para la capilla mayor y otro para la iglesia. [Son buenos marcos, tallados en el estilo de la época]". MARTÍ Y MONSÓ, José: Estudios histórico-artísticos..., op. cit., p. 502.

${ }_{11} \quad$ La construcción de la portada de la iglesia de Nuestra Señora de la Pasión se llevó a cabo en dos plazos. Se comenzó contratando en 1670 el primer cuerpo de la portada (A.H.P.V., Leg. 2.311, ff. 915917) y seguidamente los cuerpos segundo y tercero. Con posterioridad, en 1671, se contrataría la talla decorativa que debería recorrer los dichos cuerpos segundo y tercero (A.H.P.V., Leg. 2.312, ff. 459-461), con lo cual quedaría acabada exteriormente la iglesia.

12 MARTÍN GONZÁLEZ, Juan José: “Arquitectura, urbanismo...”, op. cit., p. 125. 


\section{PESQUERA DE DUERO. IGLESIA PARROQUIAL DE} SAN JUAN BAUTISTA

\section{PEÑASCO PARA SAN JUAN BAUTISTA (1678)}

La primera obra de relativa importancia dentro del campo de la escultura, ya que los marcos anteriores eran una labor más propia de un ensamblador o artesano, fue el peñasco sobre el que asienta la efigie de San Juan Bautista predicando en el desierto que preside la hornacina central del retablo mayor de la iglesia parroquial de Pesquera de Duero.

Desconocemos el nombre del escultor que talló la imagen del Precursor, aunque ciertos pagos a Francisco Díez de Tudanca podrían indicarnos que fue el escultor vallisoletano, maestro de Juan de Ávila, el que la llevó a cabo. Se trata de unas cantidades abonadas a Tudanca por parte de los ensambladores del retablo, Juan Fernández y Pedro de Fuertes $^{13}$. No creo que sea casualidad que ambos escultores, Ávila y Tudanca, aparezcan juntos trabajando en una misma obra, a pesar de que la imagen del santo se realizó hacia 1672, año en que se estaba dorando y estofando, mientras que para el peñasco hubo que esperar hasta 1678.

Pienso que el santo fue contratado por Francisco Díez de Tudanca, el cual por entonces seguía siendo uno de los maestros más populares en los territorios vallisoletano y adyacentes, mientras que Ávila todavía se encontraba bajo sus órdenes en el taller o bien acababa de establecerse por su cuenta, aunque este extremo lo desconocemos. A pesar de que Tudanca contratara la obra el autor de la misma sería su aprendiz, Juan de Ávila, puesto que la escultura estilísticamente se encuentra más cerca del primer estilo de Ávila que de lo demostrado por Francisco Díez de Tudanca a lo largo de su dilatada carrera. Las esculturas de este último suelen tener una calidad bastante inferior a las de su aprendiz, extremo que ya apuntó la profesora Fernández del Hoyo, la cual afirma que "la calidad de la obra es muy superior a la habitual de Tudanca y no se encuentra muy lejos del estilo de Ávila quien además hizo en 1678 el gran peñasco"14. A pesar de todo, la sequedad de los paños, de las facciones del rostro y la somera forma de tallar la perilla lo alejan bastante de Ávila.

El motivo que llevaría a Tudanca a ceder la elaboración de la escultura a su discípulo más aventajado se debería a la acumulación de trabajo en el taller ${ }^{15}$ y a no querer que se demorasen en demasía los plazos de entrega de las obras contratadas.

\footnotetext{
13 "Pedro de Fuentes. Más se le pasa en cuenta novecientos y treinta y cinco reales que por cartas de pago parece haber pagado a Pedro de Fuentes maestro de talla por cuenta del dinero que se le está debiendo de la obra del retablo en que esta incluso en dicha cantidad treinta y cinco reales que por su mandato se dieron a Francisco de Tudanca vecino de Valladolid”. VALDIVIESO, Enrique: Catálogo Monumental de la provincia de Valladolid. Tomo VIII..., op. cit., p. 193.

14 FERNÁNDEZ DEL HOYO, María Antonia: "El escultor vallisoletano Francisco Díez de Tudanca..., op. cit., p. 386.

15 En este año tenemos documentadas dos obras: un Cristo atado a la columna para la localidad vallisoletana de Mojados y, posiblemente, las esculturas del retablo mayor de la iglesia de San Pedro de
} 
Antes de analizar la escultura de San Juan Bautista lo haremos del peñasco, puesto que es el verdadero objeto de este estudio. A simple vista extraña que se le encomendara una labor de tan escasa importancia como es el dicho peñasco a un escultor que acababa de firmar, o dentro de poco firmaría, un contrato con la Cofradía de N. P. Jesús Nazareno de Valladolid para realizar el paso procesional del Despojo. Esto era un indicio de su prestigio, pero sin embargo Ávila no querría dejar escapar ninguna oportunidad de trabajo, pues estaba al comienzo de su carrera y no le sobrarían los encargos. Pienso que uno de los motivos que llevó a la iglesia a encargarle el peñasco a Ávila tendría que ver con Tudanca, el cual recomendaría a la iglesia a su discípulo predilecto. Otra teoría, si aceptamos que el santo lo llevó a cabo Ávila, sería la de que la parroquial querría que tanto el peñasco como el santo que asentaría sobre él fueran del mismo autor. Es decir, la iglesia habría quedado satisfecha con la hechura del Bautista realizada años antes, supuestamente por Ávila.

El peñasco (Fig. 3) se adapta perfectamente a la parte inferior de la hornacina, llegando a ocupar todo su ancho y casi la mitad de su altura. Es posible que después de colocar al San Juan Bautista en la hornacina principal los encargados de la iglesia vieran que el conjunto quedaba muy desproporcionado: era muy poca escultura para una hornacina tan alta, debido a lo cual decidieron realizar un peñasco que realzara y otorgara monumentalidad al santo patrón de la iglesia. Además de servir de soporte al Bautista también actúa como referente paisajístico, ayudando a los fieles a encuadrar mejor la escena.

La ejecución del peñasco, el cual le reportó a Ávila la nada desdeñable cantidad de 700 reales $^{16}$, lo conforman un amasijo de restos vegetales, maderas y piedras, a los que hay que sumar dos pequeños arbolillos, cada uno a un lado del santo. Todo está distribuido de manera simétrica, estando separadas ambas partes por una especie de riachuelo. Hay detalles anecdóticos como pueden ser un trozo de muralla, flores y varias serpientes. La representación de los arbolillos es claramente deficiente en cuanto a su verosimilitud, recordando por su forma algunos que podemos contemplar en representaciones de San Juan Bautista niño o de la Magdalena que se conservan en la capital del Pisuerga ${ }^{17}$. Se trata de una obra menor dentro de la producción del escultor.

La escultura de San Juan Bautista (Fig. 4) es la única obra escultórica de todo el retablo, además de ser la titular del templo. La iconografía del santo corresponde a una tipología muy usual en el territorio vallisoletano y en las zonas anejas: se le representa de pie sobre un tronco, con una pierna adelantada. En una mano sujeta una vara crucífera

Amusco (Palencia) contratado por el ensamblador Pablo de Freiría y en el que salieron por fiadores Pedro Salvador "el joven" y el propio Tudanca. ZALAMA, Miguel Ángel: op. cit., pp. 93-94; FERNÁNDEZ DEL HOYO, María Antonia: “El escultor vallisoletano Francisco Díez de Tudanca..., op. cit., p. 380.

16 "Peñasco. Recibensele en data doscientos reales que dicho mayordomo pagó a Juan de Ávila vecino de la ciudad de Valladolid por cuenta de setecientos en que se concertó un peñasco de un San Juan que era de hacer para dicha iglesia. Constó de recibo que exhibió dicho mayordomo". VALDIVIESO, Enrique: Catálogo Monumental de la provincia de Valladolid. Tomo VIII..., op. cit., p. 194.

$17 \quad$ Uno de estos ejemplares, un San Juan Bautista atribuido al escultor Juan Rodríguez, se conserva en la sacristía de la iglesia de San Miguel y San Julián. MARTÍN GONZÁLEZ, Juan José y URREA FERNÁNDEZ, Jesús: Catálogo Monumental de la provincia de Valladolid. Tomo XIV ..., op. cit., p. 126. 
mientras que con la otra nos señala el cordero, el Agnus Dei. San Juan porta el típico sayo de piel de camello que le deja al descubierto brazos y piernas; así nos lo indica San Marcos: "Llevaba Juan un vestido de pelos de camello, y un cinturón de cuero ceñía sus lomos, y se alimentaba de langostas y miel silvestre" (San Marcos: 1, 6). Sobre su hombro izquierdo cuelga un manto rojo, elemento que retomará Ávila en sus Bautistas, en el caso que éste no fuera también suyo. Cabeza cuadrada con cabellera de pelo hirsuto, bigotes y pequeña perilla bífida. Según Réau, el tronco vendría a ser el púlpito improvisado desde el que el santo predicaba a las masas en el desierto ${ }^{18}$. Nuevamente, San Marcos relata este instante: "Apareció en el desierto Juan el Bautista, predicando el bautismo de penitencia para remisión de los pecados. Acudían a él de toda la región de Judea, todos los moradores de Jerusalén, y se hacían bautizar por él en el río Jordán, confesando sus pecados. (...) En su predicación les decía: Tras de mí viene uno más fuerte que yo, ante quien no soy digno de postrarme para desatar la correa de sus sandalias. Yo os bautizo en agua, pero Él os bautizará en el Espíritu Santo" (San Marcos: 1, 4-8).

El retablo (Fig. 5) fue contratado el 1 de junio de 1671 en la propia villa de Pesquera de Duero por los ensambladores Juan Fernández ${ }^{19}$ y Pedro de Fuertes ${ }^{20}$ (DOCUMENTO 36). Los artífices del retablo, que se obligaban a realizarlo con madera de pino de Canicosa, articularían el retablo con "columnas estriadas se han de entender que han de ser salomónicas y vestidas de talla entera y en el último cuerpo a los lados las pinturas que tiene la traza han de ser enjutas de talla". Por cuenta de ambos maestros tan solo correría la ejecución de la arquitectura del retablo, teniendo que poner la iglesia y el obispo de la diócesis de Palencia "lo necesario para las pinturas y bulto de San Juan". Los lienzos contenidos en la traza serían "de pintura a arbitrio del cura, mayordomo y beneficiados de la iglesia en cuanto a las historias y en cuanto a su bondad de la pintura hayan de corresponder a la obra con la misma decencia y proporción". Por su parte, la escultura de San Juan Bautista "que va en la caja del medio ha de ser de escultura de buena mano que corresponda decentemente a la obra del retablo". El contrato imponía que los maestros, que recibirían 26.000 reales, tenían que realizar el retablo en la propia villa de Pesquera, debiendo de tenerlo acabado y asentado "dentro de veinte meses del día de la fecha a vista y satisfacción de maestros peritos en el arte".

18 RÉAU, Louis; Iconografía de la Biblia. Antiguo testamento, Ediciones del Serbal, Barcelona, 1999 p. 506.

19 Se tratará del ensamblador riosecano que trabajó tanto por tierras vallisoletanas como salmantinas en la segunda mitad del siglo XVII. Su obra maestra fue el monumental retablo mayor de la Clerecía de Salamanca, realizado en 1673.

20 "Más se le pasan en cuenta dieciocho mil y trescientos y dieciocho reales que por carta de pago firmada por Pedro de Fuentes y de Juan Hernández pareció tenerles pagado por cuenta de la obra del retablo y ajuste de cuenta entre los susodichos y los señores Ldo. Gaspar Bodigos y Tomás Cardenal, en primero de diciembre del año pasado de setenta y dos". VALDIVIESO, Enrique: Catálogo Monumental de la provincia de Valladolid. Tomo VIII..., op. cit., p. 193.

La única obra que se le conoce, aparte de este retablo, es la talla del segundo y tercer cuerpo de la portada de la iglesia de la Pasión. En el contrato para la ejecución de dicha decoración se le titula de "maestro de ensamblaje y talla". A.H.P.V., Leg. 2.312, ff. 459-461. 
El encargado de realizar el dorado de tan imponente máquina fue el prestigioso dorador y estofador vallisoletano Pedro de Mondragón, el cual se obligó el día 21 de abril de 1678 a ejecutarlo según las condiciones que previamente había redactado Bartolomé Duque Gómez, asimismo dorador de la misma vecindad (DOCUMENTO 37). Los trabajos se dieron por finalizados en 1679 , año que aparece escrito en el ático.

El retablo, típicamente prechurrigueresco, consta de banco, cuerpo principal y ático. El cuerpo principal se articula a través de cuatro columnas salomónicas con decoración de escaso resalte. Éstas apean sobre cuatro potentes ménsulas situadas en el banco. En el centro del banco iría dispuesta la desaparecida custodia. Sobre la hornacina principal, donde se encuentra la citada talla de San Juan Bautista, aparece una gran tarjeta tallada con unas formas vegetales muy carnosas. El ático se dispone en semicírculo, ostentando en su parte central una portada flanqueada por dos machones. A los lados dos grandes rameados completan el conjunto. El retablo dispone, asimismo, de una serie de pinturas que ayudan a completar el discurso iconográfico del mismo. En el banco, flanqueando la custodia se encuentran dos santos de gran de devoción popular (San Sebastián y San Roque), a los extremos del mismo se sitúan dos escenas de la infancia de Cristo ( $L a$ Adoración de los Pastores y La Adoración de los Reyes Magos). En las calles laterales del cuerpo principal se disponen dos cuerpos de pinturas, todas ellas relativas a la vida del santo titular de la iglesia (La Visitación, El Nacimiento de San Juan Bautista, El Bautismo de Cristo y La Degollación del Bautista) (Fig. 6). En el centro del ático corona el retablo el Calvario, remate típico de los retablos, si bien este suele ser mayoritariamente escultórico.

Referente a la autoría de las mismas tan solo sabemos que Baltasar de la Puente, pintor natural de Curiel de los Ajos (actual Curiel de Duero), fue el encargado de realizar las pinturas de San Roque y San Sebastián. Enrique Valdivieso le atribuye el resto de lienzos en función de la similitud en los rasgos anatómicos de los personajes ${ }^{21}$.

$21 \quad$ VALDIVIESO, Enrique: Catálogo Monumental de la provincia de Valladolid. Tomo VIII..., op. cit., p. 178. 


\section{VALLADOLID. MUSEO NACIONAL DE ESCULTURA}

\section{PASO “PREPARATIVOS PARA LA CRUCIFIXIÓN" (1678-1680)}

El paso procesional comúnmente denominado del Despojo (Figs. 7-8) viene escenificar el momento previo a la crucifixión. El conjunto debía ser el resultado de la fusión de dos acontecimientos: el de Cristo en solitario esperando a que los sayones que le rodean terminen de preparar la cruz en la que será elevado y crucificado $^{22}$, y el de la arrancadura de la túnica de Cristo por parte de sus verdugos.

Si bien esta iconografía, en lo que se refiere al mundo de la escultura no fue ni de las más antiguas en ser representadas ni de las populares bien pronto comenzó a gozar de gran éxito debido fundamentalmente a dos motivos: la acción de la escena concuerda perfectamente con los postulados barrocos, en especial con el de la captación de un instante concreto. Por otra parte era una de las escasas ocasiones en la que un escultor castellano podía recrearse en un desnudo erguido ${ }^{23}$.

Las escenas comentadas no están recogidas por los Evangelios canónicos, solamente se hace referencia al momento en que, una vez crucificado Jesús, los soldados se disputan sus vestimentas. Escribe San Juan (19: 23-24): “Los soldados, una vez que hubieron crucificado a Jesús, tomaron sus vestidos, haciendo cuatro partes, una para cada soldado, y la túnica. La túnica era sin costura, tejida toda desde arriba"24. Para conocer algunos detalles de este pasaje hemos de consultar otros textos. Así, el primero, cronológicamente hablando, es el apócrifo Evangelio de Nicodemo. En él se describe la Pasión de Cristo. Llegados al momento que nos interesa, señala: "Y Jesús salió del pretorio, y los dos ladrones con él. Y, cuando hubo llegado al lugar que se llama Gólgota, los soldados le desnudaron de sus vestiduras y le ciñeron un lienzo, y pusieron sobre su cabeza una corona de espinas, y colocaron una caña en sus manos (...). Y ellos se repartieron sus vestiduras" ${ }^{25}$. Como vemos, tampoco es mucha información la que aporta. Tan solo que le quitaron las vestiduras y le colocaron un paño de pureza para cubrir el sexo.

Desde entonces, y como muy bien señala Pérez de Castro, "la literatura mística fue enriqueciendo el parco relato con detalles sumamente expresivos, terminando por conformar un tema fundamental en el ciclo de la Pasión, que en el barroco se plasmó

\footnotetext{
22 Según Réau la espera que hace Cristo a que los sayones terminen de preparar la cruz viene prefigurada en el Antiguo Testamento en el episodio de "Job sentado sobre el estercolero (in sterquilinio) y rascándose las úlceras”. RÉAU, Louis: Iconografía de la Biblia. Nuevo testamento, Ed. del Serbal, Barcelona, 2000, p. 488.

23 PÉREZ DE CASTRO, Ramón: "La cofradía penitencial de la Pasión y el primitivo conjunto procesional de El Redopelo, del escultor Manuel Borje Zayas (1665)”. En PÉREZ DE CASTRO, Ramón y RUBIO DE CASTRO, Alfonso (coord.): Hermandad de Nuestro Señor de la Desnudez. Medina de Rioseco. Valladolid, Gráficas Iglesias, Palencia, 2010, p. 36.

$24 \quad$ NACAR FUSTER, Eloíno y COLUNGA CUETO, Alberto (O.P.): Sagrada Biblia. Versión directa de las lenguas originales, Biblioteca de Autores Cristianos, Madrid, 2003, p. 1.373.

25 PÉREZ DE CASTRO, Ramón: “La cofradía...", op. cit., p. 34.
} 
con un realismo conmovedor" 26 . De comienzos de la Edad Media datan dos buenos ejemplos de místicos que "reviven" esta escena en sus meditaciones: Santa Brígida y el Pseudo-Buenaventura. Ambos relatos nos ofrecen visiones muy patéticas de aquel acontecimiento, si bien contradictorias. Efectivamente, mientras que la monja sueca señalaba que fue el propio Cristo quien se desnudó una vez aceptado el martirio ${ }^{27}$, el Pseudo-Buenaventura refiere que fueron los soldados quienes se los quitaron ${ }^{28}$. Fue en estos momentos en los que tuvo gran predicamento en el campo de la escultura la iconografía denominada "Cristo sobre la piedra fría", en la cual podemos ver a Jesús sentado sobre una piedra, con la mirada perdida, pensando en lo que lleva padecido y lo que todavía le queda por soportar. Unas veces se le representa con las manos atadas y otras con la cabeza apoyada sobre una de ellas.

La literatura mística posterior se centrará en dos momentos fundamentales: la desnudez de Cristo, y el tremendo dolor por él sufrido tras arrancarle la túnica, la cual se encontraba pegada a los cuajos de sangre, al "redopelo". El momento de aquella arrancadura debió de ser tremendamente cruel ya que las heridas volvieron a manar sangre a borbotones. Dos grandes místicos recogen este pasaje: Juan de Padilla "el Cartujano" y Fray Luis de Granada. Padilla (1468-1522) en su obra Retablo de la vida de Cristo (1485) relata que "cuando al calvario con Cristo llegaron era llegada la hora de sexta; y luego la gente cruel deshonesta las vestiduras alli le quitaron. Al redopelo muy fuerte tiraron tal que las carnes de Cristo llagadas salieron con las vestiduras pegadas las cuales recientes allí se pegaron" 29 . Por su parte, Fray Luis de Granada en su Libro de la oración y Meditación reflexiona lo siguiente: "Mira pues como llegado ya el Salvador a este lugar aquellos perversos enemigos, porque fuese más vergonzosa su muerte, le desnudan de todas sus vestiduras, hasta la túnica interior, que era toda tejida de alto a bajo sin costura alguna. Mira, pues, aquí con cuanta mansedumbre se deja desollar aquel inocentísimo Cordero, sin abrir su boca, ni hablar palabra contra los que así le trataban, Antes, de muy buena voluntad consentía ser despojado de sus vestiduras y quedar a la vergüenza desnudo, porque con ella se cubriese. Mejor que con las hojas de higuera, la desnudez de aquellos que por el pecado habrían perdido la vestidura de la inocencia y de la gracia recibida. Dicen algunos doctores que para desnudar al señor esta túnica, le quitaron con grande crueldad la corona de espinas que tenía en la cabeza, y después de ya desnudo, se la volvieron a poner de nuevo, e hincarle otra vez las espinas por el cerebro, y hacer nuevas aberturas y llagas en él (...) y como la túnica estaba pegada a las llagas de los azotes, y la sangre estaba helada y abrazada con la misma vestidura, al tiempo que se la desnudaron, como eran tan ajenos de piedad aquellos malvados, despegáronsela de golpe, y con tanta fuerza, que

\footnotetext{
$26 \quad$ Ibídem.

$27 \quad$ Ibídem.

28 "Ahora se le desnuda (...) renovándosele las llagas producidas por arrancársele los vestidos pegados a la carne. Ahora la Madre ve por vez primera a su Hijo tan maltratado y dispuesto a ser atormentado con mortal dolor. Apodérase de ella una grandísima tristeza y rubor por verlo completamente desnudo, pues no le dejaron ni aún los paños de honestidad. Ella se adelanta, apresuradamente, se acerca a su Hijo, lo abraza y envuelve su desnudez con el velo de la cabeza". Ibídem.

$29 \quad$ Ibídem.
} 
la desollaron y renovaron todas las llagas de los azotes; de tal manera que el santo cuerpo quedó por todas partes abierto, como descortezado, y hecho toda una grande llaga, que por todas partes manaba sangre (...) Ea pues, ánima mía, aprende tú también aquí a seguir a Cristo pobre y desnudo; aprende a menospreciar todo lo que puede dar el mundo, para que merezcas abrazar al señor desnudo con los brazos desnudos, y ser unida con él por amor, que también ese desnudo, sin mezcla de otro peregrino amos".

Volviendo al paso vallisoletano, el cual ha recibido numerosos nombres o apodos a lo largo de la historia, tales como el "Expolio" o el "Redopelo" o, el más actual, "Preparativos para la Crucifixión", hay que señalar que ha sido uno de los conjuntos procesionales con una historia más azarosa (pleitos, cambios de esculturas, incendios...). Fue la primera gran obra contratada por Juan de Ávila. Su razón de ser no fue otra que la necesidad que detentaba la vallisoletana Cofradía de Nuestro Padre Jesús Nazareno de contar con un paso propio de esta iconografía al haber tenido que devolver el primitivo conjunto al Convento de San Agustín, su legítimo poseedor. Quién sabe si de no haber devuelto el paso no hubieran tenido también que renovarlo, ya que según palabras de Agapito y Revilla se encontraba "tan estropeado y maltratado, quizá, por lo que padecían las figuras al ser armado y desarmado"30.

La Cofradía de Nuestro Padre Jesús Nazareno se fundó en el Convento de San Agustín el 16 de noviembre de $1596^{31}$ según consta en su Regla, aprobada el 16 de mayo de 1600 por Bartolomé de la Plaza, primer Obispo de Valladolid, bajo el nombre de "Cofradía de la Cinta de Nuestro Padre San Agustín y Santa Mónica, de Nuestra Señora de la Consolación de Bolonia, Ánimas de San Nicolás de Tolentino y Jesús". En las reglas y constituciones se establecía la obligación de que sus cofrades debían de "seguir fieles a Jesús con la cruz a cuestas" ${ }^{\prime 2}$. La Cofradía se instalaría en una de las capillas de la iglesia conventual para celebrar sus cultos y guardar los pasos procesionales ${ }^{33}$.

Con el paso del tiempo la cofradía y el convento tendrían diversas rupturas ${ }^{34}$, siendo la definitiva la acaecida en 1676 con motivo del traslado de la cofradía a su propio templo penitencial sin haber avisado a los religiosos. Efectivamente, el Viernes Santo, 3 de abril, de ese año "salió la procesión de Viernes Santo de convento de San Agustín calzado, y se quedó en la ermita de Jesús nazareno con todos los pasos y estandartes y guiones" 35 . Este hecho indignó enormemente al convento que decidió interponer un

\footnotetext{
$30 \quad$ AGAPITO Y REVILLA, Juan: Catálogos del Museo de Bellas Artes..., op. cit., p. 93.

31 BURRIEZA SÁNCHEZ, Javier: Cinco siglos de cofradías y procesiones: Historia de la Semana Santa en Valladolid, Ayuntamiento de Valladolid, Valladolid, 2004, p. 25.

$32 \quad$ Ibídem.

33 La cofradía utilizaba la Capilla de Jesús Nazareno (o de Santa Mónica) que era "la capilla postrera del cuerpo de la iglesia, al lado de la epístola, en que tiene los pasos para la procesión que saca la dicha cofradía de este convento el viernes santo por la mañana y las cruces para los que vienen con túnicas moradas en la capilla de los Peñaranda". FERNÁNDEZ DEL HOYO, María Antonia: Patrimonio perdido..., op. cit., p. 278.

$34 \quad$ Existe en la Real Chancillería un pleito entre ambas partes en relación a la posesión de unas casas. Archivo de la Real Chancillería. Pleitos Civiles. Alonso Rodríguez (F). Caja 2188.0004.

35 MARTÍ Y MONSÓ, José: Estudios histórico-artísticos..., op. cit., p. 497.
} 
pleito a la cofradía, litigio que se resolvió a favor de los monjes. La sentencia condenaba a la cofradía a devolver los pasos al convento, al cual se reconoció como su legítimo poseedor. Viéndose privada de los pasos que hasta entonces procesionaba, la penitencial tuvo que encargar una reproducción de aquéllos. Para ello solicitó los servicios de los escultores vallisoletanos más importantes del último cuarto del siglo XVII: Juan de Ávila y Juan Antonio de la Peña. Los pasos a renovar eran el de Jesús Nazareno (desconocemos la autoría del actual Nazareno, que quizás se deba a Alonso de Rozas), el del Despojo, y el denominado paso grande de la Crucifixión (actual Sed Tengo), del cual solamente se reemplazó el Crucificado, que es el actualmente conocido como Cristo de la Agonía, tallado en 1684 por Juan Antonio de la Peña.

La composición del primitivo paso del Despojo, esculpido con anterioridad al año 1622, nos es conocida gracias a la descripción realizada en el contrato para el policromado del paso homónimo de la Cofradía de Nuestra Señora de la Misericordia de Medina del Campo, copia del vallisoletano ${ }^{36}$. Desconocemos al autor del conjunto primitivo, verdadero "autor intelectual" del tallado por Ávila, aunque por las fechas en que tenemos constancia de su existencia, antes de 1622, quizás habría que situarlo en la órbita de Gregorio Fernández o de sus colaboradores ${ }^{37}$. También se podría plantear la hipótesis de que a cargo de Fernández, absoluto renovador de la escultura procesional vallisoletana en el primer tercio del siglo XVII, corriera el diseño/modelo del paso, mientras que uno de sus oficiales de confianza o discípulos fuera el autor material del mismo. Desconocemos el destino que tuvieron las esculturas del primitivo paso. Lo más probable es que desaparecieran o que fueran vendidas antes de la Desamortización, quizás a alguna parroquia rural, puesto que de no ser así hubieran pasado a engrosar los fondos del Museo de Bellas Artes.

El autor del conjunto medinense fue el escultor local Melchor de la Peña, el cual lo tenía finalizado en el año 1629. Nada se ha conservado de aquél. El paso era idéntico al primitivo vallisoletano tanto en la composición como en el número de personajes. Sirva como ejemplo la descripción del Cristo medinense: en las condiciones para el policromado se dice que debía de dársele "encarnación mate y ha de estar maltratado en codos rodillas y espaldas, con sus desollones, puestos como en Valladolid" (DOCUMENTO 38). Según el referido contrato las imágenes que formaban el primitivo conjunto vallisoletano eran: Cristo, el sayón de la lanza, el sayón que barrena,

\footnotetext{
36 Aún antes de este primitivo paso, que fue copiado en numerosas localidades cercanas a Valladolid, e incluso debió de servir de modelo a Juan de Ávila, hubo otro, construido en papelón, a comienzos del siglo XVII. Efectivamente, Javier Burrieza refiere que por estas fechas la penitencial contaba con tres pasos de papelón, entre ellos uno efigiando el Despojo: "un Cristo con la cruz a cuestas, que vaya delante y todos siguiéndole y los más cercanos los niños. En medio otro Cristo caído con un sayón que le está sosteniendo y Nuestra Señora que le ayuda a levantar. Atrás de la procesión otro, con una cruz en el suelo y un sayón despojando a Cristo que no le falte de desnudar para quedar en carnes más de las mangas y con un velo cubierto". BURRIEZA SÁNCHEZ, Javier: Cinco siglos de cofradías..., op. cit., p. 38.

$37 \quad$ Si aceptamos que el paso del Despojo que en 1621 realiza Antonio de Amusco para la localidad de Villalón es copia del vallisoletano podríamos retrasar unos años la ejecución del pucelano. PÉREZ DE CASTRO, Ramón: "La cofradía...", op. cit., pp. 36-37. Tampoco habría que descartar el hecho de que fuera un paso de papelón.
} 
el sayón que quita la vestidura y el sayón del azadón; es decir, poseía un sayón más que el paso actual, el cual, además, representaba la acción principal del paso: arrancar la túnica, pegada a las heridas, al redopelo (expresión utilizada para nombrar este paso, aludiendo a un violento tirón). De las condiciones del contrato se deduce que el vestido, además de estar ya en manos del sayón, sería de tela puesto que Cristo debía estar "maltratado en codos y rodillas y espaldas con sus desollones puestos como en Valladolid y la llaga de las espaldas ha de ir con su corcho y sangre cuajada"38.

La Cofradía de Nuestro Padre Jesús Nazareno procesionaria este antiguo paso hasta 1677 año en que, como hemos visto, el Convento de San Agustín sale victorioso del juicio contra la penitencial y recupera la propiedad de los pasos procesionales. Fue entonces cuando la cofradía se decide a encargar uno para suplirle. El 21 de febrero de 1678 comienzan las gestiones para "que se hiciese un paso nuevo en lugar del Despojo (...) y se trajo un modelo o traza del paso hecho por Juan Antonio, Maestro escultor de esta ciudad" 39 . La intención de la cofradía era tenerlo acabado en poco tiempo para así procesionarlo en la Semana Santa de ese mismo año, tiempo a todas luces insuficiente. El referido Juan Antonio no es otro que Juan Antonio de la Peña, el cual modeló un boceto que no debió gustar a la cofradía o bien que el precio solicitado por el imaginero gallego era excesivo. Sea como fuere, cinco días después se trató en cabildo la oferta presentada por nuestro escultor, asimismo cofrade de la penitencial. Ávila se obligaba a realizar "el paso nuevo que en el cabildo antecedente estaba propuesto hacer que lo haría. Y como otro de su arte. Y con más comodidad"40. A cambio solicitaba que se le reservase de los oficios menores y que, además, se le nombrase diputado de la misma. El día 5 de marzo la cofradía decidió aceptar la oferta de Ávila y se comisionó a los alcaldes de la cofradía y a Francisco García Carrión ${ }^{41}$ para que rubricaran el contrato con Ávila.

Hasta que se documentó la autoría del paso siempre se barajó la posibilidad de que hubiera sido hecho por algún escultor de la órbita de Gregorio Fernández, no descartando tampoco que lo hubiera tallado el propio maestro. No debe extrañarnos este hecho ya que ha sido bastante usual en Castilla atribuirle cualquier escultura o paso que gozara de cierta calidad. Efectivamente, en el caso de nuestro paso al menos ha habido dos atribuciones, las realizadas por Martí y Monsó y por Agapito y Revilla. Mientras que el primero sostenía que el paso había salido de la propia "Factoría Fernández" ${ }^{2}$, el segundo afirmaba que fue realizado por "discípulos y contemporáneos de Gregorio Fernández, por creer que si en esas esculturas puso la mano el maestro, lo hizo con

\footnotetext{
$38 \quad$ VV.AA.: Pasos restaurados, op. cit., p. 65.

39 AGAPITO Y REVILLA, Juan: Catálogos del Museo de Bellas Artes..., op. cit., p. 93.

$40 \quad$ Ibídem.

$41 \quad$ ARRIBAS ARRANZ, Filemón; La Cofradía Penitencial..., op. cit., p. 77.

42 "Paso del Cristo del Despojo. Tiene las figuras siguientes: el que tira de la soga y tiene su espada con una barra que le atraviesa, la figura que barrena, la figura del azadón. Fácilmente pueden verse algunas de estas figuras en el Museo, y aun cuando no hayamos encontrado información respecto a sus autos, no estará desacertado la opinión tradicional, al suponer que hayan salido de los talleres de Gregorio Fernández”. MARTÍ Y MONSÓ, José: Estudios histórico-artísticos..., op. cit., p. 496.
} 
mucha parquedad de trabajo"43. Además, para Agapito y Revilla no había ninguna duda de "que el estilo, la escuela del maestro, seguía; se conservaba fresco el recuerdo $y$ se trataba de continuar su arte, pero sin poder llegar a él"44. Finalmente consideraba que las esculturas del paso seguían "las influencias y tendencias de Gregorio Fernández; pero separándose ya mucho del maestro y, lo que es peor, bajando el mérito de su inspiración y arte. De la técnica no hay para qué hablar, que aquella morbidez y suavidad en los desnudos, aquel realismo en la expresión, aquel acentuado claro oscuro de los ropajes, terminaron en estas tierras al bajar Fernández al sepulcro". En cualquiera de los casos lo fechaban en el primer tercio del siglo XVII.

Resulta bastante enigmático el hecho de que la cofradía procediera a encargar un cometido de tanta importancia, como era un paso procesional, a un escultor novel. Esto puede deberse a dos motivos: o su propuesta combinaba un magnífico proyecto y una mejor oferta económica, además del hecho de ser cofrade de la propia penitencial; o bien el talento de Juan de Ávila era ya de sobra conocido a través de ciertas obras que en la actualidad o no conservamos o se encuentran sin documentar. Por desgracia, de momento, no conocemos ninguna escultura tallada por Ávila con anterioridad a éstas, aunque seguro que las debió haber ya que no es asumible que con 26 años no hubiera realizado ninguna, excluyendo, por supuesto, las actuaciones secundarias anteriormente comentadas.

La construcción del paso se dilató más de lo pensado puesto que no sólo no estaría acabado para ese mismo año, sino que no estuvo listo para procesionarse hasta la Semana Santa de 1680. Durante los dos años en que se ausentó la representación del Despojo su posición en la procesión nazarena fue ocupada por unos estandartes. Así, tras el paso de Jesús Nazareno y un claro de cruces venían "los estandartes que habrán de ocupar el puesto del paso del Despojo"45. Ya en la planta procesional del año 1680 se le cita como "paso nuevo" 46 .

El conjunto salido de las gubias de nuestro escultor no es una copia idéntica al que anteriormente procesionó la cofradía, el devuelto al Convento de San Agustín, puesto que en esta nueva composición no figuran ni el sayón de la lanza ni el que arrancaba de un tirón (a redopelo) la túnica a Cristo. Este último ha sido suplido por una túnica de tela tirada a los pies de Cristo. Asimismo se añadiría uno que no existía con anterioridad: el sayón que tira de la soga, cuya inclusión se deberá al importante significado que poseía la maroma para la cofradía ya que en un cabildo celebrado en el año 1603 se acordó que todos los cofrades "por humildad se lleven soga a la garganta" $"$. Los otros dos sayones fueron reproducidos con total fidelidad tanto en lo que respecta a la postura como en el físico. Así lo comprobamos en las condiciones para policromar el paso de Medina del Campo: "el que barrena ha de llevar barba y cabello

43 AGAPITO Y REVILLA, Juan: Las cofradias..., op. cit., pp. 45-46.

$44 \quad$ Ídem, p. 15.

45 MARTÍN GONZÁLEZ, Juan José y URREA FERNÁNDEZ, Jesús: Catálogo Monumental de la provincia de Valladolid. Tomo XIV..., op. cit., p. 223.

$46 \quad$ ARRIBAS ARRANZ, Filemón; La Cofradía Penitencial..., op. cit., p. 77.

$47 \quad$ VV.AA.: Pasos restaurados, op. cit., p. 65. 
entrecano (...) y el del azadón la encarnación algo moreno encendido, bigotes castaños y el cabello más negro" 48 .

La sincronía de los sayones de la barrena y el azadón con los del primitivo conjunto llevó a Filemón Arribas a sopesar la posibilidad de que Juan de Ávila solamente tallara el Cristo y el sayón de la soga ${ }^{49}$. Esta opción queda totalmente descartada por dos razones: primero, porque Ávila presenta un modelo completo y, segundo, porque estilísticamente los tres sayones denotan la misma mano. Según Hernández Redondo los tres sayones son hermanos en estilo, tienen "unidad tanto en la composición general como en los detalles de acabado" ${ }^{\text {. A }}$. Asimismo, señala que la rudeza de los rostros se aleja de la producción conocida del escultor, el cual suele dotar a los rostros de cierta blandura. Creo que llegados a este punto hay que pensar que esta rudeza quizás se deba a un motivo que apuntamos antes: el de dotar a los sayones de la máxima fealdad. También hay que tener en cuenta que estas esculturas son las más antiguas que conocemos de su mano, por lo que hay que entender que su estilo "clásico" no estaría plenamente configurado, siendo, asimismo, deudor, en parte, de su etapa formativa. Además, el tener que realizar una copia más o menos exacta de un paso anterior le obligaría a sacrificar su estilo en pos de la imitación. Años después le ocurrirá otro tanto al tener que copiar el San Pedro en cátedra que Gregorio Fernández había tallado décadas antes para el desaparecido convento franciscano del Abrojo ${ }^{51}$.

Los tres sayones, concebidos de manera monumental, poseen un gran naturalismo, si bien pecan de tener unas anatomías algo secas y rígidas. Están completamente tallados en madera, careciendo por completo de postizos. Seguramente el Cristo original del paso los tuviera, al igual que los posee el Cristo del Despojo realizado por Claudio Cortijo, dado que las imágenes que se destinaban al culto diario en la iglesia debían de poseer un mayor verismo que moviera a la devoción. Las vestimentas poseen unos paños muy blandos y redondeados, si bien en ocasiones se percibe cierta dureza, como pueden ser los de las mangas del "barrena". Es de destacar el magnífico modelado de las caras, sobre todo de la del sayón de la soga, en la cual capta a la perfección las numerosas arrugas que surcan su rostro.

Los modelos utilizados por Juan de Ávila a la hora de concebir los sayones fueron los judíos vallisoletanos. Siempre se ha señalado la inspiración que proporcionaban los rasgos de la raza judaica (nariz corva y barba puntiaguda) a los imagineros del siglo XVII. Los tipos escogidos sobresalen por su fealdad, nota característica a la hora de representar a los sayones en los pasos procesionales, lo que provocaba la irrisión y el odio del público, el cual en alguna ocasión llegó a apedrearlos. La fealdad estaba asociada a la maldad, cuanto más horribles y deformes eran los personajes peor condición encarnaban.

\footnotetext{
48 GARCÍA CHICO, Esteban: Valladolid: Papeletas..., op. cit., p. 63.

49 ARRIBAS ARRANZ, Filemón; La Cofradía..., op. cit., p. 79.

$50 \quad$ VV.AA.: Pasos restaurados, op. cit., p. 70.

51 URREA, Jesús: “Gregorio Fernández en el Convento de Scala Coeli...”, op. cit., p. 29.
} 
A pesar de que los sayones de este paso han sido siempre minusvalorados y considerados como los peores de toda la serie vallisoletana ${ }^{52}$, cuenta Palomino que un inglés ofreció casi 100 doblones por la cabeza de uno de ellos ${ }^{53}$, negocio que por suerte no se llegó a concretar. También en ocasiones se ha aludido a la flojedad de la composición, más si la comparamos con otros pasos de nuestra Semana Santa. Hemos de tener en cuenta que Ávila debía de idear una disposición que pudiera ser contemplada desde múltiples puntos de vista, lo que implicaba situar a los sayones de tal manera que no estorbaran la visión de la figura principal, pero que a la vez el espectador tuviera una idea global del tema desarrollado en el conjunto procesional. No cabe duda de que Juan de Ávila a pesar de que copiaría con bastante fidelidad el paso primitivo se vería auxiliado de estampas y grabados ${ }^{54}$. Para este caso en concreto manejaría dibujos que representaran el "Enclavamiento", como por ejemplo uno realizado por Durero en el cual un sayón barrena la cruz en una postura similar a la dispuesta por Ávila en el paso. Otra fuente de la que pudo beber fue el lienzo de $E l$ Expolio del Greco, en el que aparece el "barrena" en primer término. Para Hernández Redondo $^{55}$ estas mismas fuentes fueron las que utilizó Felipe Gil de Mena para su lienzo Cristo y la Virgen intercesores por la humanidad, conservado entre los fondos de la Diputación Provincial de Valladolid ${ }^{56}$.

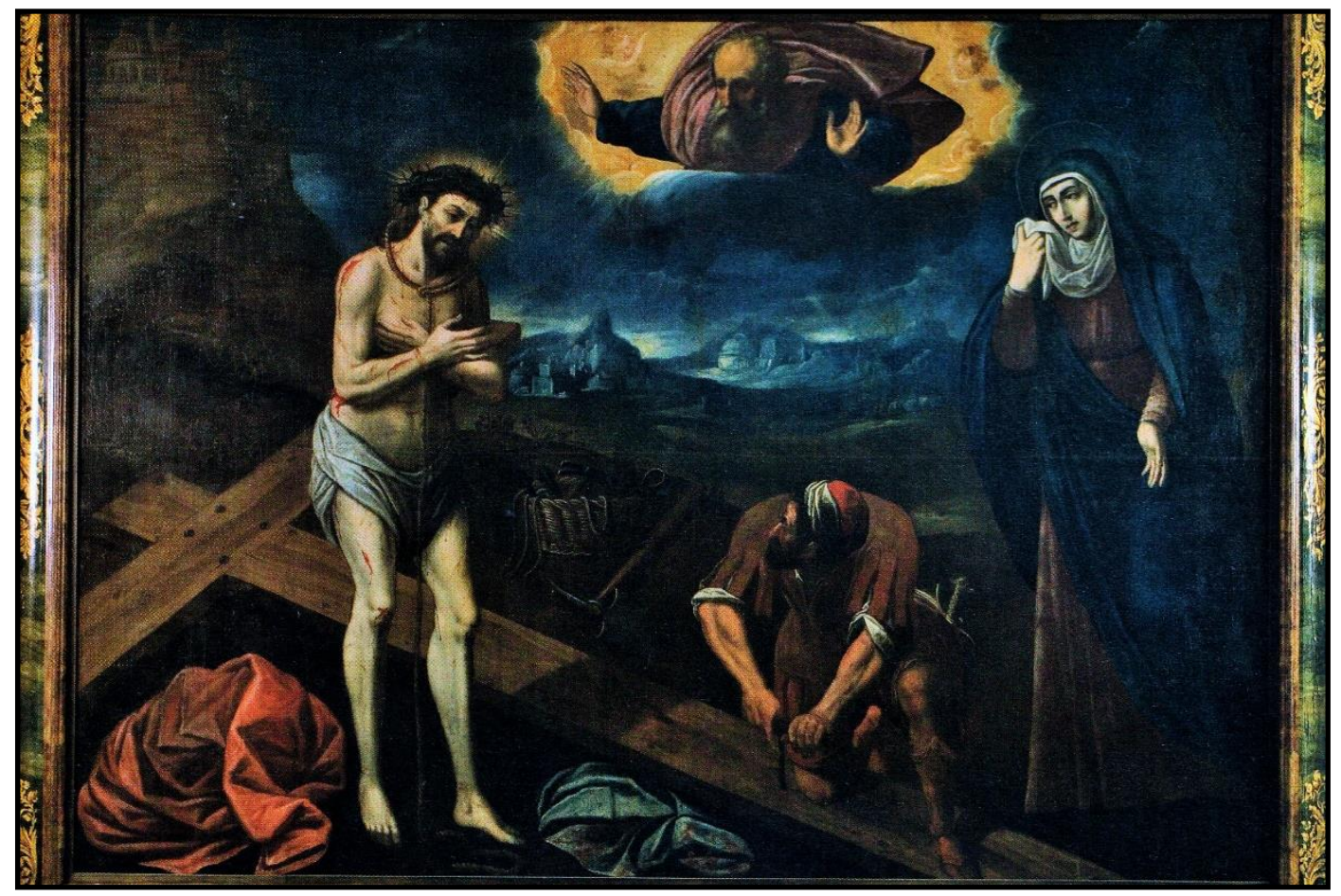

Il. 1- Felipe Gil de Mena. Cristo y la Virgen intercesores por la humanidad. Diputación Provincial. Valladolid.

\footnotetext{
52 ARRIBAS ARRANZ, Filemón; La Cofradía..., op. cit., p. 79.

53 AGAPITO Y REVILLA, Juan: Las cofradias..., op. cit., pp. 82-83.

$54 \quad$ Pérez de Castro señala las versiones de Lieven de Witte y de Giorgio Ghisi, entre otras muchas. PÉREZ DE CASTRO, Ramón: "La cofradía...", op. cit., p. 36.

$55 \quad$ VV.AA.: Pasos restaurados, op. cit., p. 70.

$56 \quad$ La pintura, procedente del desaparecido Hospital de Esgueva, está atribuida a Felipe Gil de Mena. ÁlVAREZ VICENTE, Andrés y GARCÍA RODRÍGUEZ, Julio César: Damnatus..., op. cit., p. 84.
}

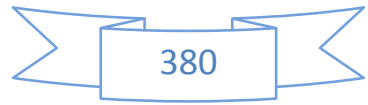



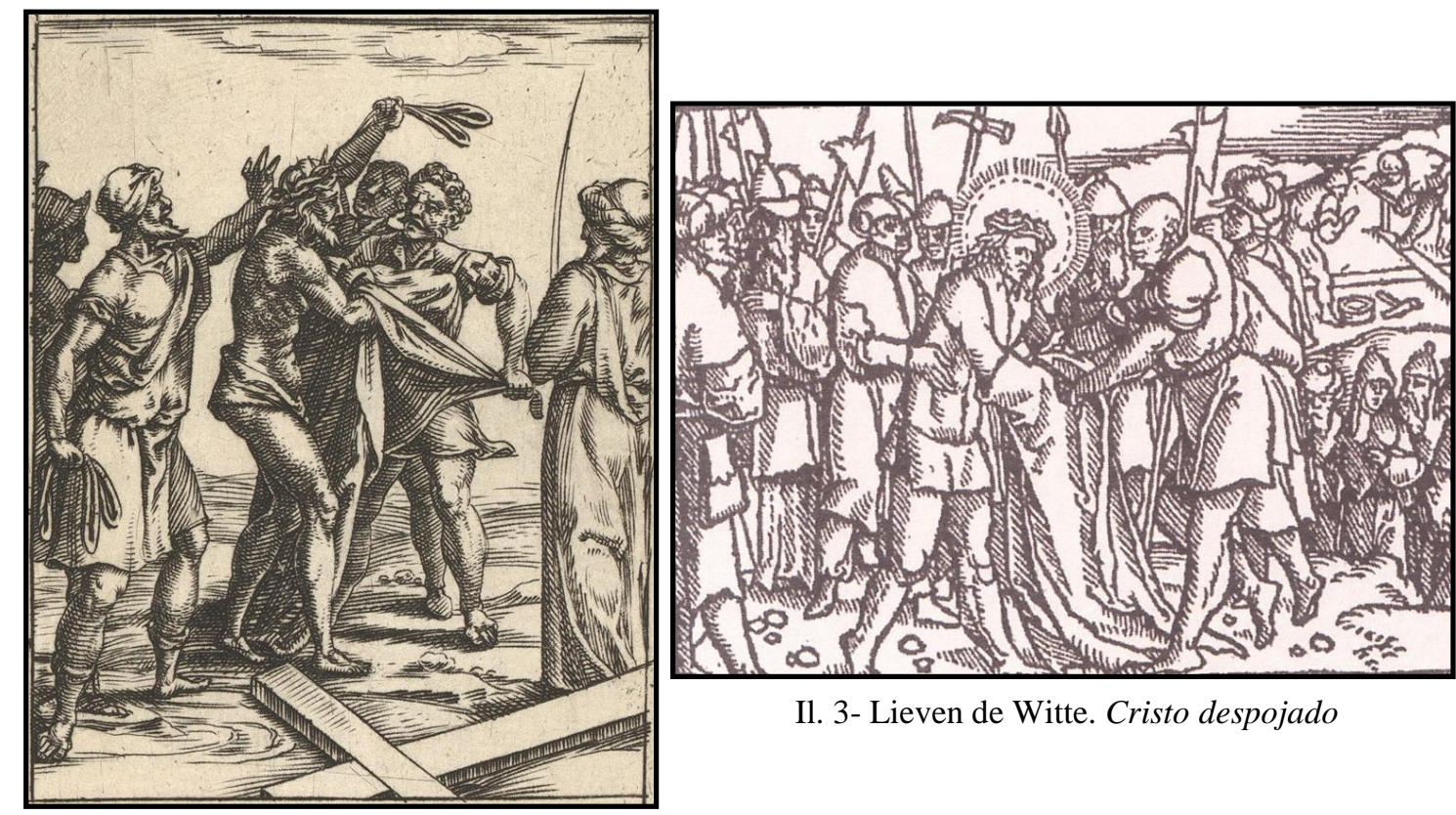

Il. 3- Lieven de Witte. Cristo despojado

Il. 2- Giorgio Ghisi. Cristo despojado.

A lo largo del tiempo tanto el Cristo Despojado como los sayones sufrieron numerosos reparos debido a las desperfectos, mayores en el caso de estos últimos dado que todo el año, salvo la Semana Santa, eran apilados de cualquier manera en los cuartos de las penitenciales Así, la imagen de Cristo fue recompuesta en 1734 por el escultor Antonio de Gautúa, y en 1700 el pintor José Díez de Prado retocó la policromía de los sayones, los cuales fueron nuevamente pintados en 1795 por Ramón Olivares ${ }^{57}$. En el año 2000 el paso fue completamente restaurado por el Museo Nacional de Escultura, lo que ayudó a recuperar la rica y colorida policromía original ${ }^{58}$.

A raíz de la decadencia de la Semana Santa vallisoletana a mediados del siglo XVIII muchos pasos procesionales dejaron de desfilar, otros se simplificaron, caso del de la Oración del Huerto, dado que en ocasiones no había hombres suficientes para transportarlos, con lo que ello implicaba: el almacenamiento de las figuras secundarias en lugares poco adecuados. No todas las imágenes que conformaban los pasos procesionales corrieron la misma suerte: mientras que las titulares seguirían dispuestas en los altares de las iglesias para el culto diario, las que formaban parte del historiado (sayones, personajes secundarios, cruces, etc...) se almacenaron sin ningún cuidado en los sótanos de las penitenciales, lo que a la postre contribuyó a su deterioro y, en algún caso, a su desaparición. La Real Academia de Bellas Artes de la Purísima Concepción de Valladolid quiso poner freno a este deterioro. Así, en 1842 decidió recoger las figuras del historiado, pasando estas a engrosar los fondos del recién creado Museo Provincial de Bellas Artes ${ }^{59}$.

57 ARRIBAS ARRANZ, Filemón; La Cofradia ..., op. cit., p. 81.

$58 \quad$ VV.AA.: Pasos restaurados, op. cit.

$59 \quad$ Ídem, p. 18. 
A pesar de que en el museo las tallas estarían mejor cuidadas hubo un problema: las esculturas se hallaban desordenadas y sin catalogar. Todo cambió en la década de 1920 en la que se produjo un resurgimiento de las procesiones vallisoletanas, lo que trajo consigo la reconstrucción de los antiguos pasos procesionales ${ }^{60}$. El principal encargado de dicha tarea fue Juan Agapito y Revilla, el cual se encontró con la dificultad de que las imágenes provenientes de las diferentes penitenciales estaban mezcladas con el resto de esculturas del Museo, con lo cual la tarea que se le presentó fue bastante ardua. Poco a poco consiguió resultados, no sin algunas pequeñas confusiones, hasta que llegó al paso del Despojo, en el cual cometió un grave error: incluyó un sayón (conocido como sayón "de la guedeja") perteneciente al paso de La Flagelación del Señor de la Cofradía de la Pasión (Fig. 9) ${ }^{61}$. El sayón en cuestión, uno de los azotadores del Cristo atado a la columna, al tener un brazo extendido pensó que era el que estaba arrancando las vestiduras al Señor (como ocurría en el paso primitivo, motivo que pudo inducir a error a Agapito y Revilla).

Otra de las intervenciones llevadas a cabo por Agapito y Revilla para la reconstrucción del paso fue la incorporación de una nueva imagen de Cristo despojado ya que la titular permanecía al culto en el retablo de su penitencial (como veremos más adelante la escultura original tallada por Ávila se quemó durante un incendio acaecido en la iglesia penitencial en el año 1799, y la hizo nueva dos años después Claudio Cortijo). Finalmente decidió incorporar a la escena un Ecce Homo, atribuido a Francisco Alonso de los Ríos, conservado en el actual Museo Nacional de Escultura, titulado "Cristo próximo a la Crucifixión", proveniente del Convento de los Agustinos Recoletos ${ }^{62}$. Una vez finalizada la reconstrucción, Agapito y Revilla se refirió a él como el "más flojo de composición de todos los reconstituidos; pero las figuras no se prestan a más de lo que se ha hecho"63.

Años después el paso sufrió ciertas modificaciones ya fuera en la disposición de las esculturas en el tablero (una de ellas, para mí la más acertada, en aquella en la cual Cristo ocupaba la parte delantera del paso, estando situados tras de él los sayones), o por los cambios de la figura del Cristo, ocupando este puesto durante algunos años la imagen titular tallada por Cortijo (Figs. 10-11). La disposición actual es: en la parte delantera del paso, a la izquierda el "barrena" perforando la parte inferior de la cruz, a su derecha el sayón de la azada; en la parte posterior, a la izquierda Cristo y a la derecha el sayón que le sujeta con una cuerda. La ausencia de otros personajes en la escena, como pudieran ser la Virgen, San Juan o la Magdalena incrementa el sentimiento de angustia en el espectador al ver al Redentor tan solo acompañado por los sayones.

El primitivo paso nazareno del Despojo, como ocurrió con otros muchos vallisoletanos, se convirtió en el modelo para una amplia serie de copias y réplicas que inundaron toda

$60 \quad$ Ídem, p. 73.

61 Se piensa que fue realizado hacia el año 1650 por los escultores Francisco Díez de Tudanca y Antonio de Ribera. La Cofradía de la Santa Vera Cruz poseía un paso homónimo, tallado por Gregorio Fernández, el cual fue el modelo para el anteriormente citado. Ídem, pp. 45-52.

62 Ídem, p. 70.

63 AGAPITO Y REVILLA, Juan: Las cofradias..., op. cit., p. 47. 
Castilla. Una de las primeras reproducciones, si no la inicial, fue la que el escultor Antonio de Amusco talló en 1621 para Villalón de Campos. Este conjunto lo integraban Cristo y dos sayones, el que le quitaba la túnica y el que barrenaba la cruz. Estas tres imágenes componen lo que podíamos llamar la composición más básica de esta escena. A este grupo seguirían el de Melchor de la Peña para la Cofradía de la Misericordia de Medina del Campo (1629), los de Manuel Borje para Medina de Rioseco (1665) y Benavente (1668), el de Francisco Díez de Tudanca para los Nazarenos de León (1674), y los de Palencia, Sahagún y Villada ${ }^{64}$. El último de ellos fue la copia que Juan de Ávila realizo para los Nazarenos vallisoletanos con objeto de sustituir al primitivo paso que tuvieron que devolver al Convento de San Agustín. Por desgracia hemos perdido la mayoría de ellos, tan solo conservamos, de forma total o parcial, los de Valladolid, Sahagún y León.

A continuación, pasamos a analizar las esculturas que componen el grupo procesional:

\section{Cristo Despojado}

Desconocemos por completo como era el Cristo Despojado (167 x 80 x $46 \mathrm{cms}$.) tallado por Juan de Ávila ya que no poseemos ninguna descripción ni testimonio gráfico. Para imaginarnos como pudiera haber sido esta imagen tenemos dos "fuentes", ya que el resto de "Expolios" o "Despojos" han desaparecido: el Cristo del Despojo tallado por Claudio Cortijo tras la destrucción del de Juan de Ávila y el que el maestro de este último, Díez de Tudanca, tallara en 1674 para la Cofradía de Jesús Nazareno ${ }^{65}$. Viendo estos dos podríamos imaginar que el ejemplar de nuestro escultor presentaría a Jesús de pie, con la pierna derecha adelantada. La cabeza levemente inclinada hacia delante y mirando a su derecha. Los brazos extendidos en actitud de súplica. Anatomía completamente al descubierto a excepción del paño de pureza, anudado también al lado derecho. Policromía que hace poco hincapié en la sangre, es un Cristo poco "maltratado". Es probable que a los pies estuviera arrojada una túnica de tela. A todo ello podríamos añadir la descripción que se hace del paso de Medina del Campo, copia del vallisoletano, en el contrato para su policromado: "Es condición que la figura del santísimo cristo ha de ser la encarnación mate y ha de estar maltratado en codos rodillas y espaldas, con sus desollones, puestos como en Valladolid, y la llaga de las espaldas a de ir con su corcho y sangre cuajada, el paño dorado y rajado, y sus cardenales con limpieza y los ojos de cristal. Y en el cuerpo derramada alguna sangre

64 PÉREZ DE CASTRO, Ramón: “La cofradía...”, op. cit., pp. 36-37.

65 En el contrato para la ejecución de este paso Tudanca se obligaba a que el Cristo lo haría "a imitación de mucha humildad, la hechura bien puesta de escultura y encarnado como le toca las llagas de hombros y espalda, codos y rodillas muy llagadas, la cabeza peleteada de oro, conforme la del azotamiento, con sus ojos de cristal y dientes de marfil y como que se le arranca el pellejo, la estatua del natural, conforme a la del azotamiento". LLAMAZARES RODRÍGUEZ, Fernando: "El escultor Francisco Díez de Tudanca..., op. cit., p. 55. 
en parte que convenga y el cabello de color de avellana madura con su claro y oscuro" ${ }^{\text {"66. }}$.

El único dato cierto que tenemos que es ocupaba el retablo colateral del evangelio de la iglesia penitencial de N. P. Jesús Nazareno. Ignoramos el autor de los primitivos retablos colaterales, los segundos sabemos que fueron hechos en 1706 por el acreditado ensamblador Blas Martínez de Obregón ${ }^{67}$. Tanto el Cristo del Despojo como su retablo desaparecieron en el transcurso del pavoroso incendio acaecido en la iglesia penitencial en el año 1799. En cabildo celebrado después de la procesión del Corpus de 1801 se delegó al pintor Anastasio Chicote y al escultor, ensamblador y tallista Eustaquio Bahamonde (1757-1830/1837), la gestión para realizar una nueva imagen de Cristo que sustituyera a la malograda de Ávila. El encargado de tal tarea fue el mediocre escultor vallisoletano Claudio Cortijo, si bien debía de seguir puntualmente el modelo elaborado por el escultor y tallista Pedro León Sedano. La policromía corrió a cargo de Anastasio Chicote, mientras que las tres potencias de plata de la cabeza fueron confeccionadas por el platero Manuel Torices ${ }^{68}$. El resultado fue un Cristo que aún mantiene las formas barrocas pese a lo avanzado de la fecha (1801), siendo uno de los últimos ecos de este periodo. También hubo necesidad de sustituir la mayoría de los retablos. En el caso que nos ocupa no fue hasta 1811 cuando los hace el ensamblador José Bahamonde, último miembro de una extensa familia de escultores, ensambladores y tallistas ${ }^{69}$. Se trata de un sencillo retablo neoclásico formado por un solo cuerpo flanqueado por dos columnas corintias. En el entablamento figura una grisalla efigiando a la Sagrada Familia, a ambos lados, ángeles de escultura.

El Cristo tallado por Cortijo (Fig. 12) procesionó desde el momento de su ejecución hasta la desaparición de las procesiones a finales del siglo XIX. Posteriormente, desfiló de manera intermitente durante el siglo XX: en un principio presidiendo el paso para el que fue realizado y posteriormente, en la procesión de regla de la cofradía, de manera individual.

El Ecce Homo, que hace las veces de Cristo del Despojo, que actualmente preside el paso, y que como hemos visto fue el utilizado por Agapito y Revilla para la reconstrucción del paso, está atribuido al escultor vallisoletano Francisco Alonso de los Ríos, el cual debió tallarlo hacia el año 1641 (Fig. 13). La escultura, que posiblemente fue sufragada gracias a las limosnas del hermano Andrés de San Nicolás ${ }^{70}$, procede del altar mayor de la capilla del Ecce Homo del desaparecido Convento de Agustinos Recoletos, desde donde fue trasladado, a raíz del proceso desamortizador, al Museo Provincial de Bellas Artes. La escultura ofrece una gran similitud con la imagen

66 GARCÍA CHICO, Esteban: Valladolid: Papeletas..., op. cit., pp. 61-63.

67 Asimismo, artífice de la labor arquitectónica del retablo mayor de la iglesia penitencial. El retablo de la epístola estaba presidido por la Virgen de la Soledad. Ambos colaterales estaban distribuidos en dos pisos, estando el superior ocupado por sendos lienzos del pintor Ignacio de Prado. ARRIBAS ARRANZ, Filemón; La Cofradía..., op. cit., pp. 44-45.

$68 \quad$ Ídem, pp. 81-82.

69 PARRADO DEL OLMO, Jesús María: “Precisiones...”, op. cit., pp. 343-361; REDONDO CANTERA, María José: Los Bahamonde..., op. cit., pp. 287-316.

70 FERNÁNDEZ DEL HOYO, María Antonia; Patrimonio perdido..., op. cit., p. 523. 
homónima que, procedente de la iglesia de San Juan de Letrán, se expone en el Museo Diocesano y Catedralicio. Ambas han compartido funciones procesionales sin haber sido creadas con ese fin, esta última talla fue alumbrada durante muchos años en la noche del Miércoles Santo por la Cofradía de las Siete Palabras en la denominada Procesión de Paz y Reconciliación. Aunque durante muchos años esta última imagen también estuvo atribuida a Francisco Alonso de los Ríos en la actualidad se ha optado por relacionarla con Alonso de Rozas.

Ambas esculturas parecen estar inspiradas en el Ecce Homo que Gregorio Fernández tallara por mandato de don Bernardo de Salcedo, cura de la iglesia de San Nicolás ${ }^{71}$, el cual también se conserva en el Museo Diocesano y Catedralicio.

\section{$\underline{\text { Sayón del azadón }}$}

El sayón del azadón (185 x 74 x 92 cms.) (Figs. 14-15) copia el modelo del primitivo paso, ya que en el contrato de copia que se encarga para Medina del Campo se especifica que "el del azadón ha de llevar la encarnación algo moreno encendido, bigotes castaños, y el cabello más negro, montera verde con forro amarillo, ropilla azul, forro dorado, calzones rosados, con los forros naranjados, medias caídas verdes, zapatos negros, medias amarillas, con su azadón de color de yerro, petrina con yerros pavonados, el puñal al natural..."

Aparece de pie, con una pierna adelantada, como haciendo el movimiento para encorvarse y comenzar a cavar el hueco en el que se sujetará el sagrado madero. Con las dos manos ase con fuerza el azadón que le da nombre. Hubiera sido más correcto para representarle de una forma más natural el que apareciera más encorvado, y es la figura más rígida del conjunto. Viste chaqueta marrón con pespuntes azules y pequeños motivos rojos; las mangas las tiene recogidas lo cual permite ver la camisa rosa. Le cruza el pecho un cinturón negro y dorado que no parece tener función alguna. La cabeza se encuentra tocada por un extravagante gorro, que en las citadas condiciones se nombra como "montera". Calzas con rayas horizontales multicolores hasta la rodilla que ocultan otras ropas, y finalmente unas botas altas. Es un personaje del todo estrafalario en su forma de vestir. Muestra un gran exotismo, como prueba el turbante y el gran colorido de los ropajes

Éste sayón es muy distinto a los otros en su físico; su rostro y su complexión tan atlética parecen haberse inspirado en un hombre de origen africano, quizás en la de algún esclavo que hubiera en la ciudad, puesto que la esclavitud era aún algo bastante común. La inclusión de un personaje de raza negra pudo estar motivada para aludir a la maldad, encarnada en dichos sayones, o bien para referirse a que el padecimiento de Cristo fue para redimir los pecados de todo el mundo, es decir, de todas las razas.

71 URREA FERNÁNDEZ, Jesús: “Un Ecce Homo de Gregorio Fernández”, B.S.A.A., Tomo XXXVIII, 1972, pp. 554-556.

72 GARCÍA CHICO, Esteban: Valladolid: Papeletas..., op. cit., pp. 61-63. 
Hay que destacar que este sayón fue exhibido en la sala $n^{\circ} 14$ de la Exposición Histórica-Europea de 1892 (Fig. 16). Esta sala fue en la que expusieron sus mejores obras las Comisiones de Monumentos de Huesca y Toledo, diversas instituciones de Valladolid, el museo provincial de Guadalajara, la Junta provincial del Centenario en Sevilla y el Cabildo de la catedral de Burgos. Esta exposición, al igual que la HistóricoAmericana, tuvo lugar con motivo de la celebración del IV Centenario del Descubrimiento de América. La presente exposición, desarrollada en la planta alta del entonces Palacio de Biblioteca y Museos, fue inaugurada el 11 de noviembre de $1892^{73}$.

\section{$\underline{\text { Sayón del barreno }}$}

El sayón (115 x 82 x 145 cms.), popularmente conocido como "el barrena" (debido al instrumento que porta) (Figs. 17-18) figuraba también en el primitivo paso de la cofradía. En el contrato para el policromado del conjunto medinense se le describía como con "encarnación plomada, barba y cabello entrecano, valona algo azulada coleto imitando al natural de ante guarnecido con tres pasamanos contrahechos por el natural encarnado; los calzones de color violeta o morado las cuchilladas doradas y rajadas y en las puntas por el natural, su barrena del color del yerro"74. Aparece arrodillado, mirando desafiante al espectador, apoyando la rodilla derecha en la cruz para hacer más fuerza y que el barreno, que sujeta con las dos manos, penetre en la madera de la cruz con mayor facilidad. Es la maldad personificada dentro del paso, en clara contraposición con la figura de Cristo. Es sin duda el sayón más feo y grotesco del conjunto. Si bien la figura está bien compuesta los pliegues de los brazos no están muy logrados, además de ser bastantes duros para lo que nos tiene acostumbrado nuestro escultor. Ávila efigia a este esbirro con una prominente calvicie, tan solo detenida gracias a unas originales patillas. Nariz muy prominente, ojos casi saltones, desdentado, labios muy gruesos y bigotes muy característicos, mentón rehundido y frente arrugada. Las patillas, el bigote y el cabello son canosos. Viste chaleco azul con varios botones desabrochados, lo que deja entrever el pecho velloso. Por debajo un blusón de color rojizo, del que solo podemos ver las mangas, asimismo abotonadas. Además, por la parte trasera se le sale la camisa. Calzón color ocre hasta las rodillas, zapatos marrones y calzas rojas con una especie de motivo decorativo.

"El barrena" es un personaje popular en la escultura castellana, los antecedentes se remontan a Juni. Señala Martín González que este personaje es muy habitual en la pintura, siendo uno de sus precedentes uno de los personajes que figuran en un grabado de la Crucifixión, obra de Durero, y que posteriormente utilizará El Greco para su Expolio $^{75}$.

\footnotetext{
73 http://ceres.mcu.es.

74 GARCÍA CHICO, Esteban: Valladolid: Papeletas..., op. cit., pp. 61-63.

75 MARTÍN GONZÁLEZ, Juan José: Escultura barroca castellana ..., op. cit., p. 124.
} 


\section{$\underline{\text { Sayón de la soga "el bizco" }}$}

El sayón de la soga (182 x 80 x 117 cms.) (Figs. 19-20) es el único de los sayones que debemos completamente a Ávila, en el sentido de que no está copiado del paso precedente, sino que posee una iconografía diferente. Viene a sustituir al que amenazaba a Cristo con una lanza. En este caso le agrede poniéndole una soga al cuello y tirando de él. El motivo de su inclusión puede deberse al simbolismo que, como hemos dicho, tenía la soga para la Cofradía de N. P. Jesús Nazareno, dado que en un cabildo del año 1603 se acordó que por humildad llevaran en procesión la soga a la garganta.

El sayón de la soga es, para mí el de mayor calidad del conjunto, al menos en lo que respecta a la composición del rostro. Se caracteriza por la blandura de sus pliegues, levemente curvados, que en nada se parecen a los de su compañero "el barrena". Representa a la perfección a un hombre de raza judaica: nariz curva y aguileña y barba puntiaguda. En este sayón veremos la característica forma de Ávila de tallar el pelo en masas compactas y las barbas, en este caso perilla, con bucles. Buen estudio de calidades en lo que respecta a las arrugas que surcan su rostro. Cabeza cubierta por un estrafalario gorro de colores, en cuya parte superior hay botones. Viste chaleco amarillo con numerosas aberturas cerradas por lazos azules, mangas verdes. Pantalón rojo hasta la rodilla, con aberturas a los lados. Botas negras. Ciertamente, su vestimenta es, al igual que la de sus compañeros, estrafalaria y exótica. Gusta Ávila de introducir numerosos detalles que enriquezcan los atavíos de sus malvados. Al igual que veíamos con "el barrena" destacan por su originalidad las patillas, partidas y llenas de rizos. 


\section{VALLADOLID. IGLESIA DE SANTIAGO APÓSTOL}

\section{GRUPO DE SANTIAGO MATAMOROS Y ARCO-HORNACINA (1681)}

Encima de la cajonería de la sacristía, alojada dentro de una "hechura de un arco grande que hizo [Juan de Ávila] para dicho santo", se encuentra una escultura de Santiago Matamoros (Figs. 21-23), titular de la iglesia. El grupo procesional realizado por Ávila en $1681^{76}$, que venía a sustituir al tallado en 1622 por el escultor Juan Imberto $^{77}$, le reportó 650 reales. El carácter procesional de Santiago Matamoros, con lo que ello conllevaba: la labor de montarlo y desmotarlo de la plataforma en la que saldría en procesión el día de su fiesta, el 25 de julio, llevaría a que con el tiempo el grupo sufriera un deterioro considerable. Pero no solamente se la sacaría en procesión el referido día, también debió ser asidua de los desfiles del Corpus Christi, y quizás formó parte de alguno de los muchos altares efímeros que se hicieron en las calles de Valladolid con motivo de las más diversas celebraciones, fundamentalmente canonizaciones y beatificaciones. Gracias al testimonio de Telesforo Medrano sabemos fehacientemente que el santo salía el día del Corpus: "El 1 [de agosto de 1853] a las ocho de la tarde se hizo también traslación del Santísimo Sacramento de Santiago a la iglesia de Jesús Nazareno, como más inmediata y por ser penitencial de Santiago. Se hizo procesión pública y se trasladó con el Santísimo a la Virgen del Pilar y a Santiago el que sacan en procesión el día del Corpus. Sólo vino por la calle de Santiago y arroyo de la Plaza a Jesús, saliendo al recibimiento la cofradía con sus insignias y corporación" $"$.

Es significativo señalar, pues lo considero importante, que este encargo es el primero documentado de la fructífera relación laboral entre el escultor y la iglesia de la cual era hijo de pila, y fue parroquiano a lo largo de toda su vida. Gratiniano Nieto llegó a dudar de la autoría del presente Santiago Matamoros, creyendo que en realidad se trataba del de Imberto $^{79}$. Sin embargo, un análisis estilístico nos descarta por completo su paternidad.

76 “1682-1683. Más pagué a Juan de Ávila del Santiago que hizo de talla con un peñasco sobre que se pone para la fiesta de Santiago y de hechura de un arco grande que hizo para dicho santo todo tallado con sus remates seiscientos y cincuenta reales en que se concertó todo". A.G.D.V., Santiago. Libro de fábrica 1673-1707, f. 147. MARTÍN GONZÁLEZ, Juan José y URREA FERNÁNDEZ, Jesús: Catálogo Monumental de la provincia de Valladolid. Tomo XIV..., op. cit., p. 202.

77 "Ítem se le reciben cincuenta reales en pago a Juan Imberto escultor a buena cuenta de Santiago que hizo para las procesiones". GARCÍA CHICO, Esteban: Documentos para el estudio del arte en Castilla. 2..., op. cit., p. 279. Juan Imberto fue un escultor que propagó el estilo y las iconografías de Gregorio Fernández en tierras segovianas. HERAS GARCÍA, Felipe: "Marcos de Garay, Juan Imberto y el retablo de Matilla", B.S.A.A., Tomo XXXIX, 1973, pp. 261-268; MORENO ALCALDE, Mercedes: "Noticias sobre el escultor Juan Imberto", B.S.A.A., Tomo XLVII, 1981, pp. 456-463; URREA FERNÁNDEZ, Jesús: "Escultores coetáneos y discípulos de Gregorio Fernández en Valladolid I", op. cit., pp. 355-357.

78 FERNÁNDEZ DEL HOYO, María Antonia: "Valladolid en el siglo XIX según el manuscrito de Telesforo Medrano. Noticia de Urbanismo, arquitectura y arte”, B.R.A.C., Tomo XLII, 2007, p. 80.

$79 \quad$ "Al entrar en la sacristía, pendiente del muro que hay frente a la puerta está el Cristo de Escobar, y dentro de ella, en rica hornacina barroca, escultura de Santiago, obra de Juan Imberto". NIETO GALLO, Gratiniano: Guías artísticas de España. Valladolid, Barcelona, 1954, p. 27. 
Santiago el Mayor era hijo de Zebedeo, y hermano primogénito de San Juan Evangelista. El epíteto de "El Mayor" le viene dado por ser uno de los primeros apóstoles que siguieron a Jesucristo. Desconocemos como desarrolló su apostolado, se piensa que lo realizó por Siria y Judea, y que en el año 44 regresó a Jerusalén, y sería entonces cuando Herodes Agripa lo mandó decapitar.

La tradición española cuenta que Santiago habría venido a España para predicar. Desembarcó en Cartagena, y ya en Zaragoza se le apareció en lo alto de una columna de jaspe la Virgen del Pilar rodeada de un coro de ángeles. Después del martirio, el cuerpo del apóstol habría navegado hasta Galicia en una barca conducida por un ángel. Señala Réau que "esta leyenda se explica por el deseo que animó a todos los países de la cristiandad de vincular la fundación de sus iglesias locales con uno de los discípulos de Cristo, Italia vindicaba a san Pedro, Grecia y Rusia a san Andrés. La España cristiana quiso hacerse con el apóstol Santiago (...) en realidad, nunca estuvo en España y sus reliquias jamás fueron trasladadas a Galicia. Esta leyenda nació de la cruzada contra los moros (Reconquista) y de la peregrinación a Santiago de Compostela"80.

Dicha peregrinación, organizada por los monjes de Cluny parar socorrer a los cristianos durante la Reconquista, se remonta al siglo X. Fue entonces cuando se forjó la leyenda española del apóstol Santiago. Se pretendió datarla con un documento apócrifo, presentado como un texto del siglo VII, que afirmaba que Santiago había llegado a España para evangelizarla ${ }^{81}$. Posteriormente, en el 830 se creyó que se había descubierto la tumba del apóstol en Galicia. Fue en el año 834 cuando aconteció el primer suceso por el cual se puede hablar de la protección del apóstol Santiago a España. Efectivamente, en ese mismo año, durante la batalla de Clavijo, se apareció ante al rey Ramiro I (842-850) en sueños venciendo a los moros montando un caballo blanco (símbolo de la victoria) mientras blandía su estandarte. A raíz de todos estos hechos, Santiago se convirtió en el patrón de los peregrinos y de los caballeros. Señala Andrés Ordax que "esta noticia fue recogida por Ximénez de Rada quien dice que el rey venció al grito de "Adiuva nos D. et Ste. Iacobe". Y, por su parte, Alfonso X explica que "Y Santiago con una espada en la mano desbarata el ejército de los infieles". Un voto del rey en Clavijo originó el "voto de Santiago", aunque hay que advertir que el "Privilegio de los Votos o Diploma de Ramiro" no fue redactado hasta mediados del siglo XII"82.

El grupo procesional tallado por Ávila y el peñasco (o no se conserva o bien la escritura se refiere a la peana sobre la que está colocado, si bien esta parece dieciochesca dada la decoración de rocalla) sobre el que asienta el santo ecuestre fueron estofados y dorados por el pintor José de Estrada ${ }^{83}$. Ávila no solamente se encargó de tallar el grupo

80 RÉAU, Louis: Iconografía de los santos. P-Z, Ed. del Serbal, Barcelona, 1998, p. 170.

81 Ídem, p. 171.

82 ANDRÉS ORDAX, Salvador: Iconografía jacobea en Castilla y León, Real Academia de Bellas Artes de la Purísima Concepción, Valladolid, 1993, p. 36.

83 "1682-1683. Mas pagaron a Joseph de Estrada de estofar y dorar el dicho Santo y peñasco y dorar todo el dicho arco de oro limpio setecientos y cincuenta reales”. A.G.D.V., Santiago. Libro de fábrica 1673-1707. 
escultórico, sino que también confeccionó la "hechura de un arco grande", que será el que está asentado sobre la cajonería de la sacristía. En realidad, se trata de una hornacina poligonal empotrada en la pared, que remata en forma de cascarón sobre cuya clave hay una venera, reafirmando nuevamente la presencia de Santiago Apóstol, advocación de la iglesia y del santo que exhibe el hueco. El frente de la misma lo forman dos pilastras con una ménsula en su parte de superior, las cuales a su vez sirven de apoyo a un arco totalmente cuajado de decoración vegetal y de entrelazos. Completan el conjunto sendas volutas y guirnaldas al lado de las pilastras. El conjunto arquitectónico posee unas formas bastante clásicas, y por lo tanto retardatario, más propio de la década de 1650 o 1660. Esta labor, entre otras que veremos, nos induce a pensar que Juan de Ávila desarrolló a lo largo de su carrera otros quehaceres además de los puramente escultóricos, dado que esta obra es más propia de ensambladores o tallistas.

El escultor nos presenta al apóstol en su modalidad de "Santiago Matamoros", iconografía que fue muy difundida durante la Reconquista por la orden de Santiago. Es un tipo ecuestre. Santiago aparece representado atacando en el aire sobre un caballo blanco, y derrotando a los moros en la batalla de Clavijo. Figura tal cual lo relata la leyenda, la cual dice, como hemos visto, que el rey Ramiro I vio al santo en sueños en vísperas de una batalla contra los moros ${ }^{84}$. Monta en un caballo blanco, arremete contra los moros con una espada en la mano, los derrota y los pone en fuga. Existen dos versiones del tema según el santo cabalgue sobre la tierra o en el cielo, en éste caso el ataque es terrestre. Años después, en el retablo mayor de la misma iglesia, veremos a Ávila materializar el segundo tipo: atacando a los moros desde el cielo.

El conjunto, realizado en madera policromada y tela (los jaeces del caballo), está integrado por las esculturas de Santiago a caballo y un moro en el suelo, recién caído de su equino. Tanto la temática de la obra, como su composición, nos bridarán una ocasión única para establecer una evolución de Ávila entre los comienzos de su carrera y su final. $\mathrm{O}$, dicho de otra manera, entre este grupo procesional y el del retablo mayor de la misma iglesia, realizado por el escultor ya en las postrimerías de su vida. Santiago Matamoros, de tamaño menor al natural, se encuentra en plena batalla, empuñando la espada en alto con su mano derecha mientras que con la otra sujeta el caballo -blanco, a la manera tradicional- ofreciéndonos una composición ciertamente inestable, aunque resuelta un tanto defectuosa al tallar a Santiago en una posición bastante rígida. Santiago se dispone a dar el golpe de gracia, al moro caído, sobre su caballo encabritado. Existe además una desproporción entre el tamaño del santo y el caballo, notablemente inferior a cómo debería habérsele representado. Por la posición de la otra mano cabe pensar que portaría el típico estandarte con el que se suele representar la tipología de Santiago Matamoros. Para dar una sensación de movimiento al conjunto, como buen escultor barroco, ha desplegado la capa, de una manera ciertamente teatral, con numerosas quebraduras que vienen a simular la acción del viento y la rapidez de la acción ejecutada por el santo.

84 RÉAU, Louis: Iconografía de los santos. P-Z..., op. cit., p. 173. 
El pelo y la barba están tallados en grandes mechones simétricos y no de una forma más o menos individualizada como hará el escultor en obras posteriores. De todas formas, el tallado difiere del resto del catálogo conocido del escultor, y si no lo tuviéramos documentado sería muy difícil atribuírselo. El santo gira la cabeza mirando hacia el suelo donde se encuentra el moro a batir. Tiene el rostro ensimismado, nariz y cejas rectas, boca entreabierta.

Viste túnica, sujeta mediante un cordón en la cintura, y por debajo se entrevén unas calzas con botonadura de color rojizo y una franja dorada. Calza unas pequeñas botas marrones con el envés hacia afuera, lo que nos permite ver una pequeña porción de la pierna del santo. La manga del brazo derecho, el que levanta para atacar al moro, queda recogida lo que nos permite ver la botonadura de la camisa. Encima de la túnica porta una esclavina, con el ribete dorado, en la que se han colocado dos veneras metálicas, elemento típico de la iconografía del santo. Son muy interesantes los dobladuras de la esclavina tanto en el pecho como en el lado derecho que los resuelve con suaves pliegues muy característicos del escultor. Cabe destacar que no siempre se le representó con esta vestimenta, pues las imágenes más antiguas nos le presentan a veces vistiendo armadura $^{85}$. Desconozco si el casco metálico que actualmente exhibe se hizo en la época o es un añadido posterior.

La escultura del moro, bastante difícil de analizar dada su posición, baja bastante en calidad respecto al santo. La talla es bastante plana. Podemos ver al moro tocado con un turbante muy colorido. En una mano porta un escudo y en la otra una especie de cimitarra. El grupo se encuentra en un deficiente estado de conservación, siendo necesaria una restauración.

\section{PERSPECTIVA PARA LA FIESTA DE SANTIAGO APÓSTOL (1681)}

El mismo año que contrata la ejecución del grupo procesional hace lo propio con una perspectiva que se iba a utilizar como decorado durante la fiesta de Santiago Apóstol ${ }^{86}$. La arquitectura efímera constaba de tres arcos con una grada en medio de otras tres. Por este trabajo Ávila recibiría 100 reales. Del policromado se ocupó su amigo el pintor Amaro Alonso ${ }^{87}$, mientras que otros artistas serían los encargados de dar los últimos retoques a la arquitectura efímera ${ }^{88}$. Desconozco si las fiestas que celebraba la iglesia de

\footnotetext{
$85 \quad$ VV.AA.: Iconografía de Santiago y de los santos burgaleses vinculados a la peregrinación, Fundación para el Desarrollo Provincial de Burgos, Burgos, 1993, p. 12.

86 "1682-1683. Gastos menudos y extraordinarios. Más pagaron a Juan de Ávila de una perspectiva que hizo de tres arcos con su grada en medio de tres gradas para dicha fiesta cien reales". A.G.D.V., Santiago, Libro de fábrica 1673-1707, s/f.

87 "Más pagaron a Amaro Alonso de pintar los tres arcos de la perspectiva y el respaldo de ella y la tramoya para encerrar a su majestad ciento y ochenta reales”. A.G.D.V., Santiago, Libro de fábrica 16731707, s/f.

88 "Más se pagaron a Diego de Millares latonero de doce cirialicos de bronce que hizo para dicha perspectiva a quince reales el par noventa reales". "A Juan de Reinoso de platear dichos cirialicos a ocho reales el par cuarenta y ocho". "Más pagué de veinte jarras de madera pequeñas para dicha perspectiva y de dorarlas cincuenta y dos reales". "Más pagaron de veinte ramilletes y trece rosas para dicha
} 
Santiago el día de su advocación (25 de julio) contaban siempre con arquitecturas efímeras o bien se realizaron ex profeso ese año para celebrar el estreno del nuevo paso procesional.

Debido a lo parquedad de los datos con que contamos, simples reseñas, es imposible hacernos una idea de cómo sería, de sus medidas, donde iría colocado etc.... Lo importante es que volvemos a ver a Juan de Ávila en una faceta diferente a la de simple escultor, en este caso como diseñador de arquitecturas efímeras, lo cual casa bien con el documento en el que se le citaba como "maestro de arquitectura" (DOCUMENTO 23). Si con la hornacina de la sacristía dijimos que ejerció de ensamblador, en este caso lo volvemos a refrendar pues eran ellos los que levantaban las arquitecturas efímeras, en algunas ocasiones bajo el plan previo llevado a cabo por los pintores.

perspectiva y alrededor del arco principal noventa y siete reales”. A.G.D.V., Santiago, Libro de fábrica 1673-1707, s/f. 


\section{CIGALES. IGLESIA PARROQUIAL DE SANTIAGO APÓSTOL}

\section{ESCULTURA PARA EL RETABLO DE DON FRANCISCO PINACHO Y PAREJA (1685)}

El 30 de agosto de 1685 Blas Martínez de Obregón, como principal, y Juan de Ávila, como fiador, firman una escritura de contrato para la realización de un retablo para don Francisco Pinacho y Pareja, canónigo de la Catedral de Palencia ${ }^{89}$, con destino a la iglesia parroquial de Santiago Apóstol de Cigales (DOCUMENTO 28). Como es lógico pensar, Martínez de Obregón se encargaría de la parte arquitectónica mientras que Ávila haría lo propio con la escultórica. Esta es la primera ocasión en que ambos artistas aparecen relacionados a la hora de contratar un retablo. Posteriormente, les veremos juntos en otras ocasiones: documentalmente nos consta su participación en el retablo mayor de la iglesia de Santiago (Obregón proporciona la traza); mientras que en obras atribuidas su colaboración se hace patente en los retablos mayores de las iglesias conventuales de las Brígidas y San Quirce, entre otros.

Además, se obligaban a "hacer el marco en blanco y tallado y un escañito con dos asientos". Todo ello debía de entregarlo antes del día de San Juan del año siguiente. El coste del retablo, el cual sería elaborado en Valladolid, ascendía a 4.000 reales, siendo abonados los primeros 500 reales el mismo día del otorgamiento de la escritura.

Este retablo debe ser el que aparece citado en el Catálogo Monumental del Antiguo Partido Judicial de Valoria la Buena como situado en el baptisterio, que se encuentra en el hueco de la torre del lado de la Epístola. Este retablo era descrito por Urrea como "salomónico, sin dorar, con pintura de la Virgen del Carmen con San Elías y Santa Teresa, igualmente de Diego Díez Ferreras. En el banco, pinturas de San Lorenzo, del mismo pintor. En el ático, un Santo, del momento del retablo"90. El retablo que vemos en la actualidad no es el que originariamente realizó Martínez de Obregón ya que en 1779 sus medidas se vieron reducidas de manera drástica, tanto en altura como en anchura, para poder situarlo dentro del baptisterio. El retablo, que se encuentra intitulado como de la "Virgen del Carmen", fue trasladado el 18 de agosto de 1986 a su actual ubicación: el muro del lado del Evangelio".

Martínez de Obregón exhibe en esta obra su habitual estilo, perteneciente al denominado "retablo churrigueresco". Éste se compone, en la actualidad, de un pequeño banco y un solo cuerpo. En el banco se incluye la pintura de San Lorenzo flanqueada por dos potentes ménsulas que sirven de apoyo a sendas columnas salomónicas, las cuales articulan el único cuerpo y enmarcan la hornacina de remate semicircular que lo

89 A.H.P.V., Leg. 15.030. URREA FERNÁNDEZ, Jesús: Catálogo Monumental de la provincia de Valladolid. Tomo XX..., op. cit., p. 50

$90 \quad$ Ídem, p. 46.

91 SAN JOSÉ DÍEZ, Mariano; La parroquia de Cigales, Ayuntamiento de Cigales, Cigales, 1992, p. 126. 
preside. Esta hornacina está ocupada por la referida pintura de la Virgen del Carmen con San Elías y Santa Teresa. En el ático se observa una escultura de una santa de factura romanista, por lo tanto, anterior a la realización del retablo. Es probable que también pertenecieran al originario retablo que salió del obrador de Martínez de Obregón otras dos pinturas que se encuentran repartidas en otros lugares del templo, los cuales, además de presentar el mismo estilo de Diego Díez Ferreras, tienen asimismo una iconografía carmelita. Se trata de los óleos de San José con el Niño Jesús y de San Joaquín con la Virgen ${ }^{92}$.

Partiendo de estos datos y de la escritura de obligación parece que el retablo tendría dos cuerpos, el inferior con tres hornacinas y el superior solo con uno, a manera de ático. Si tenemos en cuenta que en el contrato se especifica que el retablo contendría en el primer cuerpo una escultura del "Santo que elixiere el dicho señor Canónigo", para la cual se debería hacer su repisa, la distribución podría ser la siguiente: en el cuerpo inferior, a la izquierda, el cuadro de San José con el Niño; en la hornacina central, la escultura que del "Santo que elixiere el dicho señor Canónigo"; mientras que la hornacina de la derecha estaría ocupada por el óleo de San Joaquín con la Virgen, complementándose y contraponiéndose de esta manera ambos cuadros, tanto en actitudes como iconográficamente. En el ático iría el óleo de la Virgen con San Elías y Santa Teresa. Cabría la opción de que este lugar fuera ocupado también por la escultura y el de la escultura por este óleo. Finalmente, en el banco habría otras dos pinturas, completando de esta manera el actualmente conservado de San Lorenzo.

Desconocemos la advocación del santo que eligió el canónigo Francisco Pinacho y Pareja, y si éste se llegó a realizar, o bien el retablo quedó completamente decorado con las pinturas de Díez Ferreras. Dado que la mayoría del retablo tenía una iconografía carmelitana cabe pensar en una escultura relacionada con esta orden. Si bien, suponiendo mucho, debido a que el comitente de la obra se llamaba Francisco se podría proponer que el santo supuestamente elaborado por Ávila fue San Francisco de Asís, pues resultaba algo muy común que cuando un mecenas concertaba una obra la escultura

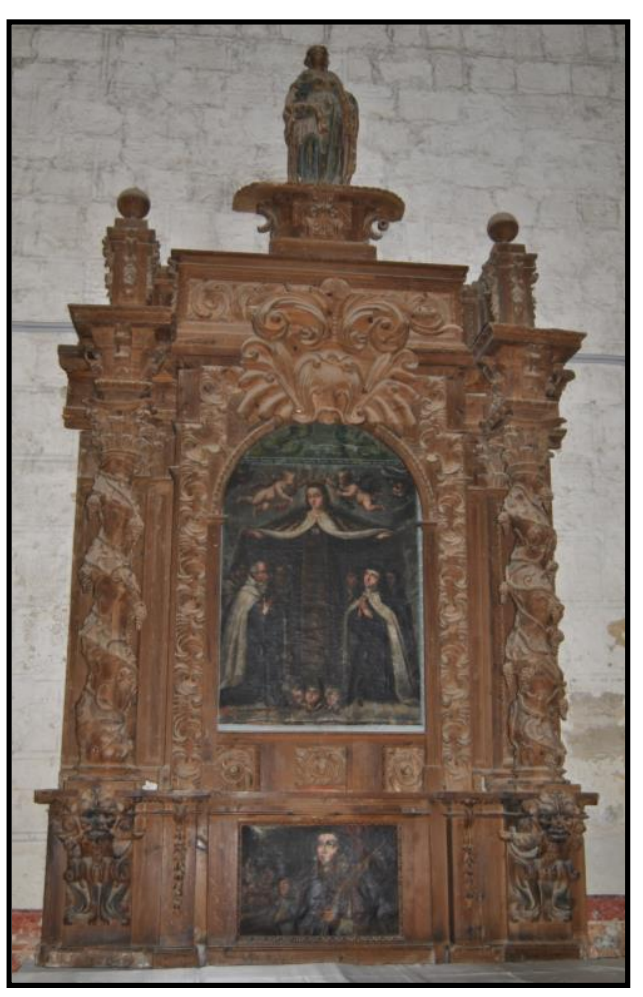

Il. 4- Blas Martínez de Obregón. Retablo. Iglesia parroquial de Santiago Apóstol. Cigales (Valladolid.) principal representara a un santo de su nombre. En la actualidad en la iglesia no se conserva ninguna escultura de esta época del santo franciscano. Tampoco podríamos descartar una imagen carmelitana (Santa Teresa, Virgen del Carmen, etc...) dada la iconografía de los diferentes óleos.

$92 \quad$ Ídem, pp. 98 y 128. 


\section{VALLADOLID. HOSPITAL DE SAN JUAN DE DIOS}

\section{ESCULTURAS DEL RETABLO MAYOR (1687)}

Al portugués Juan de Dios le cambió la vida el oír en Granada la predicación de San Juan de Ávila, dedicándose desde entonces a la penitencia, aunque con tal exceso que durante un tiempo fue recluido como demente. De esta forma pudo comprobar en sus propias carnes el maltrato que recibían los enfermos, lo que le llevó a fundar en el año 1540 en Granada una Congregación de Hermanos Hospitalarios dedicada a la asistencia de enfermos locos y niños deformes ${ }^{93}$. La Hermandad fue aprobada como Instituto por el Papa Pío V el 1 de febrero de 1571, bajo la regla de San Agustín, y Paulo V la declaró Orden regular, añadiendo a los tres votos habituales el cuarto de hospitalidad. Sus integrantes vistieron en un primer momento con "jerga blanca y parda, ceñida con correa", posteriormente, tras un decreto de la Sagrada Congregación de Obispos y Regulares dictado el 11 de septiembre de 1722, cambiaron a un hábito de color negro, con "túnica de mangas anchas y arrebujadas, escapulario, capuchón y cinturón de cuero colgando por el lado derecho" $"$.

El Hospital de San Juan de Dios de Valladolid sirvió, según Antolínez de Burgos, para "albergar a los enfermos que padecen enfermedades incurables". Este Hospital se identifica históricamente con el llamado de los Desamparados, que estuvo situado al norte del Campo Grande, saliendo de la ciudad por la Puerta del Campo hacia la derecha, en terrenos que hoy corresponden a la Academia de Caballería y casas militares, y que a fines del siglo XVI eran casas edificadas en parte de lo que fue la extensa huerta de la familia de los Niño de Castro. En 1591 la Cofradía de los Desamparados, cuyo hospital estaba situado frente a la iglesia de El Salvador, buscaba un local más adecuado para instalarse y, considerando que las afueras era el lugar conveniente, eligieron el citado sitio $^{95}$.

Sin embargo, el Hospital de los Desamparados no fue el primer edificio ocupado por los Hermanos de San Juan de Dios, sino que cuando estos llegaron a Valladolid regentaron el cercano Hospital de la Resurrección. En 1591 solicitaron de manera infructuosa la administración del Hospital de los Desamparados. No la lograron hasta el 14 de octubre de 1600, si bien no fue hasta el 30 de noviembre de 1603 cuando se les dio "la tenencia y posesión, gobierno y administración" del Hospital de los Desamparados o de San Juan de Dios ${ }^{96}$. Abandonaron el Hospital de la Resurrección en 1615, quedándose a partir de entonces solamente con el Hospital de San Juan de Dios. El hospital, que atendía a enfermos de ambos sexos, y dedicaba cuidado especial a lo incurables, contaba con una capacidad de 50 camas repartidas en dos pisos. Diez religiosos, uno de ellos sacerdote, además de algunas mujeres, atendían al servicio ${ }^{97}$. La advocación de San Juan de Dios

FERNÁNDEZ DEL HOYO, María Antonia: Patrimonio perdido ..., op. cit., p. 441. Ibídem.

FERNÁNDEZ DEL HOYO, María Antonia: Desarrollo urbano..., op. cit., p. 335.

FERNÁNDEZ DEL HOYO, María Antonia: Patrimonio perdido..., op. cit., p. 445.

CANESI ACEVEDO, Manuel: Historia de Valladolid (1750), Tomo III, op. cit., p. 414. 
del Hospital no es baladí puesto que desde el momento en que fue canonizado, en el año 1691, fue el patrón de los hospitales, de los enfermeros y de los enfermos.

La iglesia era simple, de una sola nave y sin capillas, según Canesi: "era muy buena, clara y muy capaz"98, calificando la sacristía como "tan espaciosa y tan bien adornada que puede apostar lucimientos con las mejores de la Religión". Descripción parecida es la que nos ofrecen los archivos de la institución: "La iglesia de este Hospital la hizo el P. Dionisio el año de 1628. No tiene patrón ni capilla alguna”. El interior, aparte del retablo mayor, se completaba con dos retablos colaterales: uno dedicado a San Carlos Borromeo y otro a Nuestro Padre San Juan de Dios ${ }^{99}$.

El retablo mayor, dedicado a Nuestra Señora de los Desamparados, fue contratado el día 7 de febrero de 1687, contando con la autorización del Padre Provincial de la Orden, por los ensambladores Alonso Manzano, Juan Correas y Bernardo de Carvajal, y nuestro escultor Juan de Ávila (DOCUMENTO 29). Éste venía a sustituir al que tenían "por estar el que al presente tiene muy antiguo". Es decir, los Hospitalarios deseaban hacer un nuevo retablo mayor que diera un "mayor realce y adorno del culto divino". El nuevo retablo debía de construirse, como era costumbre, en madera de Soria "seca y limpia lo más que se pudiere y de satisfacción traerla a su costa a esta ciudad". Tendría que estar finalizado y puesto en su sitio el día 15 de agosto de ese mismo año. Por el ensamblaje y escultura cobrarían 4.400 reales, precio que nos indica que el retablo no sería de grandes dimensiones. En esa cantidad también entraría la confección de la custodia. Ambas obras se habrían de "hacer y ejecutar dentro de este dicho convento donde ha de estar el obrador y taller y se ha de dar sitio para ello y para recoger lo que se obrase".

Unos meses después de colocarse el retablo en el altar mayor se contrató el dorado del mismo con los acreditados doradores y estofadores vallisoletanos Antonio Barreda y Alonso Gutiérrez. La escritura, otorgada el 11 de abril de 1688, contó como testigos con Manuel de la Torre y Ballesteros, Pedro Cerezal y Francisco Ibarra "vecinos de esta ciudad y los otorgantes que doy fe que conozco lo firmaron" (DOCUMENTO 39). Ambos artífices se obligaban a dorar el retablo "de oro limpio cuanto registrare la vista desde la iglesia y coro", y a dorar y estofar a los cinco santos y ángeles. No todo debía dorarse, pues algunas maderas se jaspearían "de diferentes jaspes y barnizado con barniz", y las puertas "en los claros se han de fingir unas perspectivas de tres términos y los perfiles que le cercan a la puerta y los festones han de ser de oro limpio".

En la parte baja de la máquina sacra debían de fingir la entrada a la sacristía. Los colores a utilizar serían "muy finos" y si no lo hacían de esta manera tendrían que "borrarlo y hacerlo nuevo y elegir dicho convento personas de su satisfacción que por cuenta de dichos maestros lo hagan". La suma pecuniaria que recibieron ambos pintores fue de 5.500 reales, precio que nuevamente nos hace suponer que el retablo no era muy grande. El trabajo debería de estar concluido para el día de Nuestra Señora de

$98 \quad$ Ibídem.

99 FERNÁNDEZ DEL HOYO, María Antonia: Patrimonio perdido..., op. cit., p. 450. 
agosto de ese mismo año, es decir, el día 15. La labor llevada a cabo por ambos doradores debió de ser óptima dado que Canesi comenta que "el adorno del retablo dorado muy precioso, y en medio de él está colocada la imagen de María Santísima de los Desamparados, como titular del convento, a quien otros llaman Nuestra Señora de la Piedad, y encima de él se ve el gran patriarca San Juan de Dios, y los colaterales se hicieron y doraron en nuestro tiempo" ${ }^{100}$.

Nada subsiste de este retablo, ni siquiera sus esculturas. Tan solo existe una reseña sobre una de ellas: en un inventario de bienes realizado en 1836 se hace referencia a que se recogieron de la iglesia dos esculturas de San Juan de Dios, posiblemente las que se encontraban en el retablo mayor y en uno de los colaterales. También se habla de dos "Nuestras Señoras", de las que quizá una fuera la titular del templo, Nuestra Señora de los Desamparados ${ }^{101}$. Las cuatro esculturas todavía se encontraban en el convento al año siguiente. El resto de esculturas se venderían o bien desaparecieron durante la Desamortización, aunque nunca hay que desechar la posibilidad de que hayan ido a parar a alguna iglesia o convento de la ciudad, o incluso a una parroquia rural, situación que se ha dado en otros casos similares.

Así pues, siguiendo al pie de la letra el contrato, el retablo estaba formado por un banco, dos cuerpos y el ático. El cuerpo inferior lo articulaban cuatro columnas salomónicas que descansaban sobre otras tantas repisas. En cada uno de los dos intercolumnios se situaba una hornacina que alojaba una escultura: en el lado izquierdo San José con el Niño en brazos y en el derecho Santo Domingo de Guzmán. En el nicho de la caja central, envuelta en un marco quebrado, se situaría la titular de la iglesia, Nuestra Señora de los Desamparados. Tras de ella un camarín al que se accedía mediante dos puertas situadas en el banco (a través de una de ellas también se pasaba a la lujosa sacristía). El cuerpo superior lo conformaban el Arcángel San Rafael, en la hornacina del lado del evangelio, y San Carlos Borromeo vestido de cardenal, en el lado de la epístola. El espacio central de este cuerpo lo ocuparía el titular de la Orden, San Juan de Dios. Tanto la imagen de Nuestra Señora de los Desamparados como la de San Juan de Dios, es decir, las dos de la calle central, provenían del primitivo retablo. El ático se resolvía mediante una "tarjeta con dos niños de bulto de todo relieve desnudos con sus bandas conforme el cabimiento que hubiese en dicho sitio". Además, en la referida tarjeta se debían de "poner las armas de la religión como lo demuestra la traza".

Me queda la duda de si Ávila no tallaría también una nueva imagen de San Juan de Dios, ya que en las condiciones para el dorado del retablo de las imágenes se alude a su policromado, o tan solo se trataba de un repolicromado, como debió ocurrir también con la escultura de Nuestra Señora de los Desamparados, la cual se debía "de dorar y lo mismo la caja que ha de ser de oro limpio".

El conjunto se veía enriquecido con una monumental custodia con "seis columnas en la misma conformidad [que el retablo] rebutidas y guarnecidas (...) con sus arbotantes

100 CANESI ACEVEDO, Manuel: Historia de Valladolid (1750), Tomo III, op. cit., p 414.

101 FERNÁNDEZ DEL HOYO, María Antonia: Patrimonio perdido..., op. cit., p. 451. 
que reciban los arcos y en los arcos en la clave tarjeta y arquillos tallados y en los arcos sus enjutas de talla y en la parte interior su anillo redondo de pechinas cuadradas y en ellas follaje de talla y para cerrarla han de subir seis cartelas adornadas de buena talla". Se remataba con una figura de la Fe con los ojos vendados.

A continuación, analizaremos de una manera más pormenorizada las esculturas que realizó Juan de Ávila para el retablo. Debido a que no se conservan, para hacernos una idea, recurriremos a los contratos del retablo y de su policromado, así como a la iconografía propia de cada santo. La descripción hecha en el contrato del dorado sobre las esculturas es tan exhaustiva que nos permite hacer una idea bastante aproximada a cómo serían. Antes de nada, pues lo considero importante, hay que señalar el hecho de que en estas imágenes se usaron postizos, algo infrecuente en la obra de Ávila: "Que todos los ojos de dichas hechuras han de ser de vidrio cristalino y se han de pintar para dentro".

\section{$\underline{\text { SAN JOSÉ }}$}

San José, padre nutricio de Jesús, sujetaría al pequeño en brazos. La iconografía seguida en esta escultura sería la dictada en el Concilio de Trento: un San José joven, de unos cuarenta años. Lo más probable es que apareciera de pie, sujetando con las dos manos un paño en el cual sostendría muy delicadamente a su hijo, algo similar a la escultura del mismo santo que atribuyo a Ávila en el Santuario del Domus Dei de La Aguilera (Burgos). Esa es la composición que nos deja entrever el hecho de que, según el contrato de dorado, Jesús apareciera con pañete, es decir, siendo todavía un bebe, puesto que de ser un niño figuraría representado de pie, vestido con una túnica, mientras que el padre le agarraría de la mano, teniendo la otra libre para portar una vara florida con lirios, símbolo de su matrimonio virginal con María. La capa que portaba San José era "encarnada y se ha de hacer en ella un brocado de diferentes colores sacando algunas labores y lazos de oro para picar de lustre y las labores que tuviere de colores picadas de diferentes grafios oscurecido y realizado y las orillas como las de los demás santos el forro morado claro y en él hecho una tela de diferentes colores oscurecido y realzado $y$ de diferentes grafios y en las orillas de dicho forro una orilla de dos dedos de nacho y en él se ha de hacer un sacado picado de oro la túnica del santo ha de ser verde y en él se ha de hacer un grutesco oscurecido y realzado". El pañete del niño sería "acambrayado y picado de grafio y en la orilla un sacado de oro". Su inclusión en el retablo se debe encontrar en relación a su carácter de padre y a que el hospital atendió a niños deformes, actuando por lo tanto como un padre para esos pequeños que eran rechazados de sus familias. 


\section{$\underline{\text { SANTO DOMINGO DE GUZMÁN }}$}

La descripción de Santo Domingo es muy parca, tan solo señala que aparecía "con su insignia". El fundador de la Orden de hermanos predicadores o dominicos se localizaba en el lado de la epístola del primer cuerpo. Su nacimiento, al igual que el de Cristo, habría tenido unos presagios, en uno de estos, la madre del Santo, embaraza, habría visto en sueños a su hijo con una estrella sobre la frente, y bajo el emblema de un perro blanco y negro que tenía en sus fauces una antorcha encendida, significaba que estaba llamado a defender la fe amenazada por la herejía (combatió contra los albigenses). Esta leyenda tiene su origen en el juego de palabras que forma la palabra dominico, perro del Señor (Domini canis).

Según la iconografía tradicional, Santo Domingo aparece vestido con el hábito bicolor de su orden, túnica blanca y manto negro. Su ancha tonsura está rodeada por una corona de pelo, normalmente lleva una barba en collar. Entre sus atributos destacan: La estrella, sobre su frente o encima de su cabeza; el perro blanco y negro, que aparece sentado a sus pies y que lleva una antorcha encendida en sus fauces, es además de un atributo del santo el emblema de los dominicos. Otros atributos con que se le suelen representar son el libro, ya sea cerrado o abierto; y el rosario, el cual se considera que se lo dio la propia Virgen. La escultura de este retablo se habría de "dorar como el San José y se ha de dar del color que requiere en la túnica blanca una tela de oro picado de lustre y en la capa un brocado de oro y guardado de dicho oro y las orillas como los demás".

Su inclusión en el retablo se encuentra en relación a la idea que se tenía de que tanto la religión dominica como la de San Juan de Dios eran dos partes de un mismo todo. Nos lo explica a la perfección fray Juan Santos, cronista oficial de la Orden de San Juan de Dios: "Que son las dos religiones en el paraíso de la militante iglesia, sino dos ramas del mismo árbol, radicado en la caridad, de a dónde tomando la religión de Santo Domingo los frutos de la vida para la salud de las almas, con su doctrina, y estudios, dejó a la ínclita religión de San Juan de Dios, lo medicinal y sus hojas, para los achaques del cuerpo; no siendo menos agradable a Dios un hijo de San Juan de Dios, sirviendo en los Hospitales a los pobres, que un hijo de Santo Domingo, en las librerías continuando sus estudios"102. Pero no se queda ahí, más adelante señala que "es la ocupación del estudio, la más decorosa en la iglesia, y quiere agustino dar a entender, cuando agrada a Dios la caridad, y hospitalidad con los enfermos, y llama librerías los hospitales, libros los enfermos, para que se sepa, no ser menos del divino agrado un maestro en una librería, que un hijo de San Juan de Dios en una sala de su hospital, un maestro desvelado sobre los libros, que un religioso arrodillado en un hospital, a servir un enfermo"103. Finalmente llega a la consideración de que "la razón que puede tener este lazo, de tan seguro, y recíproco cariño entre las dos religiones, cuando sus institutos parecen totalmente distintos, si no opuestos; hallo, que aunque los medios sean diversos, se aúnan en el sujeto, que entrambos miran, que es el bien del próximo,

102 SANTOS, Juan (O. H.): Lauros panegíricos en la solemne canonización del gran patriarca San Juan de Dios, Impenda de Bernardo de Villadiego, Madrid, 1693, s/p.

103 Ibídem. 
pues una, y otra miran unidamente todo el hombre; la de Santo Domingo, según las dolencias que puede contraer el alma; la de San Juan de Dios, según las enfermedades, que pueden adolecer el cuerpo. Está el hombre compuesto de dos mitades, de cuerpo, y alma, y según ambas partes, puede enfermar de peligro: en el alma, por las ignorancias, y pecados, que quitan la vida de la gracia; en el cuerpo, por las enfermedades que tiran a la vida corporal; y hermanadas las dos religiones, miran a la total reparación de todo el hombre; lo que no se podía lograr con felicidad por una sola"104.

\section{$\underline{\text { LA FE CON EL SANTÍSIMO EN LA MANO }}$}

La Fe, que remataba la custodia, es junto a la Esperanza y a la Caridad una de las hijas de Santa Sofía, encarnación de la Sabiduría divina. Se la representaría según su iconografía tradicional: “con el Santísimo en la mano, vendados los ojos de alta tercia de alto más o menos lo que le correspondiere". Si bien lo más común es que figure con un cáliz en la mano.

\section{ARCÁNGEL SAN RAFAEL}

San Rafael aparecería efigiado "con el escapulario y capilla de dicha orden". Dos son los motivos que justifican su inclusión en el retablo mayor. Por una parte, su consideración como patrón de los boticarios, y, sobre todo, por la aparición que tuvo San Juan de Dios del Arcángel San Rafael. Cuanta el cronista oficial de la Orden de San Juan de Dios, fray Juan Santos en sus Lauros panegíricos en la solemne canonización del gran patriarca San Juan de Dios que "cuando se le apareció el Arcángel San Rafael, ayudándole a llevar un pobre enfermo, no le negó el nombre que tenía. ¿Quién eres?, le preguntó el santo; y respondió el Arcángel: soy Rafael, destinado por Dios para ser tu compañero, guarda tuya, y de todos tus hermanos. Por el nombre propio responde a San Juan de Dios. Cotéjese esta aparición con otra que el mismo Arcángel hizo a Tobías, para acompañar a su hijo en su peregrinación; y preguntando el Santo Tobías por su nombre, le respondió, no por el propio de Rafael, sino por el apelativo Ego sum azarias ananie magni filius" ${ }^{105}$. Posteriormente señala que no es extraño "ver ideada la gloriosa Religión de San Juan de Dios en tan superiores Ángeles, cuando San Rafael le vio con el mismo hábito servir, y curar en los Hospitales de esta ínclita familia" ${ }^{106}$.

Según su iconografía tradicional, vestiría de peregrino con el bordón, la cantimplora y el zurrón. Su atributo más característico es el pez que hizo pescar a Tobías y el pote de remedios, emblema de los médicos, con el que curó al viejo Tobías cuando regresó. El

\begin{tabular}{ll}
\hline 104 & Ibídem. \\
105 & Ídem, p. 12. \\
106 & Ídem, s/p.
\end{tabular}


contrato de dorado nos informa que se policromaría "la frontera y los costados". La jaquetilla por su parte iría "encarnada y en ella echar una tela de diferentes colores que contrapongan con lo encarnado sacando alguna labor de oro y lo que está metido de color la labor picada de grafio y el campo rajado y el oro escarchado y todo oscurecido y realzado y en todas las orillas de jaquetilla y túnica se ha de hacer en la conformidad que la del santo en la tunicela se ha de hacer una tela de medias tintas y de diferentes grafios el forro verde y en él un chamelote de oro".

\section{$\underline{\text { SAN CARLOS BORROMEO }}$}

Nacido en 1538, Carlos Borromeo fue llamado a Roma por su tío, el papa Pío IV, que a la edad de 23 años lo nombró arzobispo de Milán y le promovió para ser creado cardenal. Canonizado en 1612 por el papa Pablo V, al poco tiempo se convirtió en uno de los santos más populares de la Contrarreforma. Enseguida se le tomó como patrón contra la peste, sustituyendo a los antiguos patrones medievales (San Sebastián y San Roque). Su patronazgo deriva de que en 1575 durante la peste de Milán se ocupó personalmente de curar a los apestados, organizar lazaretos y movilizar a los sacerdotes y monjes como enfermeros. Se le suele representar con una larga nariz aguileña, vestiduras litúrgicas de arzobispo o el capelo cardenalicio. Suele portar un crucifijo, la calavera y, a veces, una cuerda de penitente al cuello, la cual solía llevar en las procesiones durante las epidemias de peste. El episodio más representado es el de su caridad hacia los apestados, de ahí que esté representado en el retablo de la iglesia de un hospital. Además de lo dicho, su inclusión en el retablo se encuentra en relación a la protección que según fray Juan Santos, cronista oficial de la Orden de San Juan de Dios, ejercía sobre su orden. Hablando de la capilla que se le puso al santo italiano en la Basílica de San Juan de Dios de Granada refiere las siguientes palabras, bastante esclarecedoras al respecto: "La capilla que está enfrente, es de San Carlos Borromeo, protector de nuestra religión (...)"107. Es más, más adelante, hablando sobre la vestimenta que habían proporcionado a la escultura del santo que habría de ocupar esa capilla, explica: "San Carlos Borromeo, nuestro protector, que vistió ricamente el afecto de dos devotos suyos" 108 . Para continuar diciendo: "Y al Arcángel San Rafael, compañero de nuestro santo Patriarca, de hermosísima escultura, el cual dio a mi convento de esta corte la Excelentísima señora Duquesa de Frías"109. Como comprobamos tanto el santo italiano como el Arcángel estaban profundamente vinculados a la Orden de San Juan de Dios.

En la escultura tallada por Ávila figuraba con "vestiduras de cardenal y en la mano una cruz con un santo bulto". La muceta iría dorada, al igual que el chamelote, "roquete blanco y rajarlo el oro y abajo unas puntas y lo restante de la púrpura que corresponda

\footnotetext{
107 Ídem, p. 25.

108 Ídem, p. 45.

109 Ibídem.
} 
a la muceta y las orillas que corresponda a las del santo y el ángel diferenciando en algunas labores".

\section{$\underline{\text { DOS NIÑOS }}$}

Los dos niños irían dispuestos en el cerramiento del retablo sujetando una tarjeta en la que estaban puestas "las armas de la religión". Se trataba de dos esculturas de angelotes, en bulto redondo, vestidos tan solo con una banda. Angelotes similares, con una banda que les cruza el pecho y una palma del martirio, los podemos ver en el ático del retablo mayor del Real Monasterio de San Quirce y Santa Julita; en el ático del retablo mayor de la iglesia del Rosarillo portan la banda, pero en vez de una palma llevan las Arma Christi (lanza y palo con la esponja untada en vinagre). 


\section{VALLADOLID. IGLESIA DE SANTIAGO APÓSTOL}

\section{ADORNOS PARA LA CRUZ DEL CEMENTERIO (1688)}

En las cuentas relativas a los años 1688-1693 de la iglesia parroquial de Santiago Apóstol aparece registrada la siguiente obra documentada de Juan de Ávila. Se trata de tres remates para la cruz de piedra que presidía el cementerio parroquial (Figs. 2425) ${ }^{110}$. Esta obra es importante pues nos muestra a un Ávila que también labraba la piedra, cosa poco frecuente en el Valladolid de la época. Si bien es cierto que es una obra menor, la idea de que pudiera haber labrado alguna escultura pétrea ya no sería tan descabellada.

Para centrar lo más posible la fecha de su ejecución nos es de gran utilidad una escritura en la cual el maestro de cantería Tomás de la Riba contrata la ejecución de "la obra que se ha de hacer en el cementerio de señor Santiago", que se encuentra "cómo se va a la Puerta del Campo de esta dicha ciudad". En dicho contrato, realizado el 31 de enero de 1688, el cantero se obligaba a "hacer una cruz de siete pies de alto con sus brazos y cabeza" (DOCUMENTO 40). Es previsible, por lo tanto, que Juan de Ávila se encargara de labrar los referidos remates ese mismo año de 1688. Lo que desconocemos es si Ávila realizó solamente esos remates o bien el cantero le subarrendó la ejecución de toda la cruz. Pienso que el cantero sería el encargado de realizar la cruz dado que se ven diferencias entre la piedra utilizada para ella y la usada para los remates. Una vez finalizada la cruz, queriendo la iglesia embellecerla, encargó a "su escultor" que le añadiera unos remates decorativos. Pero no fue eso lo único que realizó Ávila, también esculpió en la peana "dos conchas y dos hábitos de Santiago".

En la actualidad es difícil visualizar tanto las conchas como los hábitos puesto que la piedra se encuentra muy desgastada. El caso es que se pueden observar cuatro conchas, dispuestas con un ritmo de concha-liso, dado que la base de la cruz tiene forma octogonal. No he logrado encontrar los "dos hábitos de Santiago", que seguramente fueran dos cruces de la Orden de Santiago. Lo que si se observa en una de las caras es una especie de crucifijo, aunque muy consumido, apenas apreciable. En cuanto a los remates de la cruz se sitúan en los extremos de los brazos cortos y en el superior del largo. Los tres son iguales, parten de una especie de taza de la que surge un nuevo cuerpo de cuyo interior brota un elemento cilíndrico, todo ello decorado con motivos de conchas y vegetales.

Volviendo al contrato suscrito por Tomás de la Riba; la cruz, que debía medir siete pies de alto, tendría "sus brazos y cabeza conforme la tocare y correspondiere a la altitud la cual ha de ser ochavada con su pedestal que lleve su basa y capitel de dos pies y medio de alto y dos de grueso y ha de llevar dicho pedestal en la cara que mira a la calle de

110 "1688-1693. Ítem da en data doscientos y cuarenta reales que valen ocho mil ciento y sesenta maravedíes pagados a Juan de Ávila maestro escultor por hacer tres remates de piedra para la cruz que se puso en dicho cementerio en dicho tiempo y abrir en la peana dos conchas y dos hábitos de Santiago entrega recibo". A.G.D.V., Santiago, Libro de fábrica 1673-1707, f. 286. 
Santiago su encomienda de Santiago". Para su ejecución se usaría "piedra de la cantera de Campaspero". El plazo de ejecución finalizaba el 15 de julio de dicho año, cobrando por dicha obra 3.600 reales. Sin embargo, en el libro de cuentas de la iglesia figura la cantidad de 6.340 reales, diferencia que seguramente se deba a que el cantero realizó alguna otra obra además de las especificadas en el contrato ${ }^{111}$.

Como ocurrió con la casi totalidad de los atrios de las iglesias vallisoletanas y sus respectivas cruces de piedra, no siendo menos el de Santiago, acabó desapareciendo. En el año 1889 había voces que comentaban que se deseaba derribar los atrios de las iglesias de Santiago y de la Magdalena. No sería ese año, sino seis después, cuando se eliminaría el atrio de la iglesia de Santiago, concluyéndose las obras en poco tiempo. En el mes de abril ya había sido derribado puesto que un periódico escribía: "Hace тиy poco tiempo desapareció el atrio de Santiago que caracterizaba mucho la entrada a la iglesia"112. Por suerte la cruz se salvó y se trasladó a la plazoleta existente a los pies de la iglesia, instalándose justo enfrente de la entrada trasera de la misma. En la actualidad se conserva frente a la fachada de la iglesia conventual de San Pablo, siendo junto a la de La Antigua las únicas que subsisten ${ }^{113}$. Por fotografías antiguas y grabados conocemos también, entre otras, las de las iglesias de la Magdalena y San Juan Bautista.

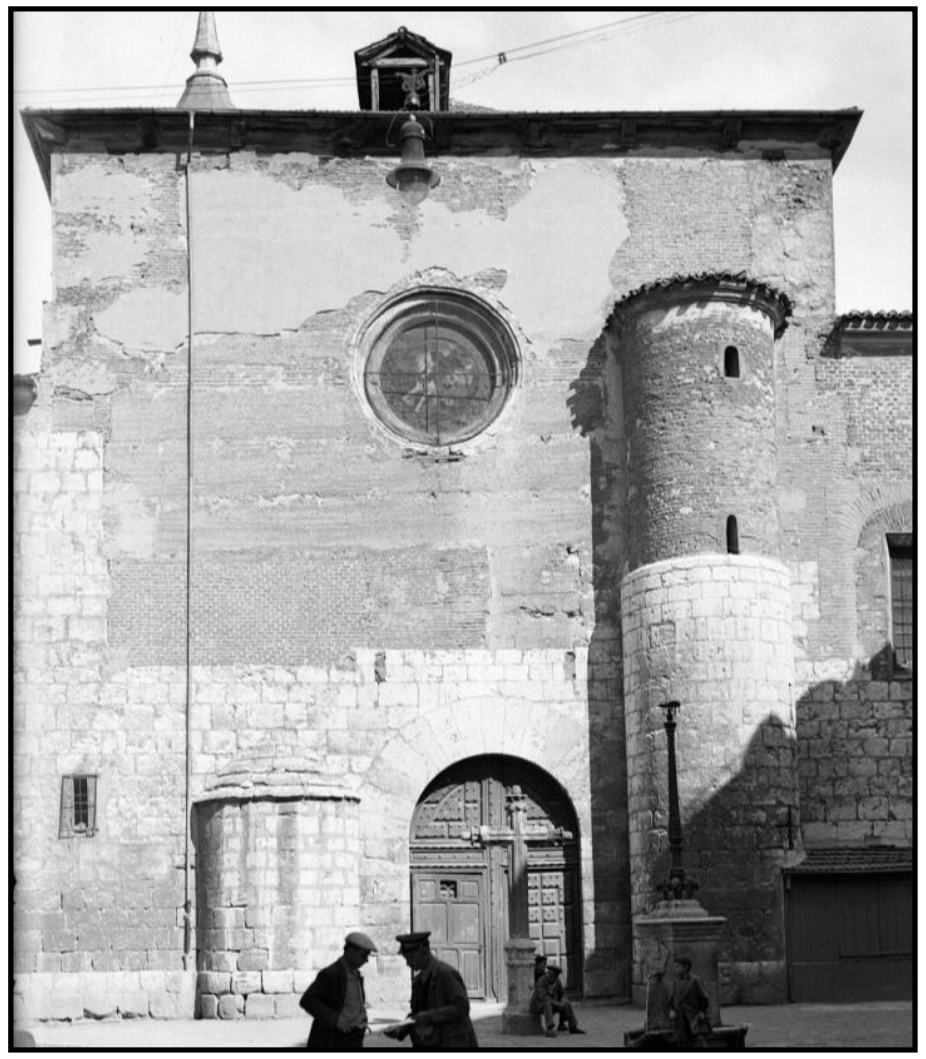

Il. 5- La cruz en el Atrio de Santiago, poco antes de que se trasladara a la

Plaza de San Pablo. Valladolid.

111 "1688-1693.- Obra del cementerio. Ítem son en data seis mil trescientos y cuarenta reales que valen doscientos y quince mil quinientos y sesenta maravedíes pagados a Tomás de la Riba maestro de cantería los mismos tuvo de costa la obra del cementerio de dicha iglesia la cual se hizo en el transcurso de los seis años de ésta cuenta entregó recibo". A.G.D.V., Santiago, Libro de fábrica 1673-1707, ff. 285286.

112 ORTEGA DEL RÍO, José Miguel: El siglo en que cambió la ciudad. Noticias artísticas de la prensa vallisoletana del XIX, Ayuntamiento de Valladolid, Valladolid, 2000, p. 226.

113 La de Santa María de la Antigua es la original de su iglesia.

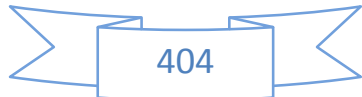




\section{VALLADOLID. AYUNTAMIENTO}

\section{INTERVENCIONES EN LOS GIGANTES DEL CORPUS (1691-1692)}

A medida que se van localizando documentos va difuminándose la idea de que Juan de Ávila, en particular, y la mayoría de los escultores españoles de la época, en general, tan solo se aplicaban a la escultura religiosa en madera policromada. Ya hemos visto como nuestro artífice practicó la escultura en piedra, realizó arquitecturas efímeras y pudo desarrollar labores de arquitecto y ensamblador. Pues bien, Juan de Ávila también trabajó la escultura profana. Efectivamente, el escultor labora en los años 1691 y 1692 para el consistorio vallisoletano realizando diferentes hechuras, de manera conjunta con su vecino y amigo el pintor Jacinto Mayo, para la Procesión del Corpus Christi de sendos años.

La fiesta del Corpus Christi ("Cuerpo de Cristo"), también conocida como Corpus Domini ("Cuerpo del Señor) o Solemnidad del Cuerpo y la Sangre de Cristo, estaba destinada a celebrar la Eucaristía. Su celebración tiene lugar 60 días después del Domingo de Resurrección, el jueves posterior a la solemnidad de la Santísima Trinidad, y a su vez el domingo siguiente a Pentecostés. En el Valladolid actual la celebración ha sido traslada al domingo siguiente.

El origen de esta fiesta, que se hunde en la plena Baja Edad Media, concretamente en el siglo XII, tuvo lugar en diversas ciudades de los Países Bajos, Renania y norte de Italia, dentro de un "nuevo contexto religioso seglar y especialmente femenino"114. Fue entonces cuando se organizaron grupos de mujeres, generalmente jóvenes y viudas que llevaban una vida de castidad, que se oponían a la vida de los monasterios, a la cual solamente accedían mujeres de la nobleza ${ }^{115}$. En uno de estos "Pseudo-monasterios", el de Mont-Cornillon, Juliana de Lieja tuvo una serie de visiones místicas relacionas con la Eucaristía, en una de las cuales el propio Jesucristo la instaba a que instituyera una fiesta de la Eucaristía. En 1246 el obispo de Lieja, de quien dependía el beaterio de Santa Juliana, aprobaba la visión que había tenido la santa y declaró la celebración litúrgica de dicha fiesta en su diócesis ${ }^{116}$.

Un impulso importante para el establecimiento de la fiesta litúrgica del Corpus Christi fue la conocida como "Misa de Bolsena" en el año 1263. En ella, cuenta la tradición, que al romper una hostia consagrada brotó sangre. Fue un año después, en agosto de 1264, cuando el papa Urbano IV, mediante la promulgación de la bula "Transiturus de hoc mundo", instituyó la solemnidad del Corpus Christi, su celebración tendría lugar el

\footnotetext{
114 SIGAUT, Nelly: "La fiesta de Corpus Christi”. En GALÍ BOADELLA, Montserrat y TORRES AGUILAR, Morelos: III Colegio Musicat. Lo sagrado y lo profano en la festividad de Corpus Christi, Universidad Nacional Autónoma de México, México, 2008, p. 27.

115 Ídem, p. 28.

116 VIZUETE MENDOZA, J. Carlos: "Teología, liturgia y derecho en el origen de la fiesta del Corpus Christi”. En FERNÁNDEZ JUÁREZ, Gerardo y MARTÍNEZ GIL, Fernando (coord.): La fiesta del Corpus Christi, Ediciones de la Universidad de Castilla-La Mancha, Cuenca, 2002, p. 29.
} 
jueves anterior a la fiesta de la Trinidad ${ }^{117}$. Sin embargo, habría que esperar hasta comienzos del siglo XIV para hallar el origen de las procesiones del Corpus Christi tal cual las conocemos hoy. En España las primeras fueron las de Pamplona (1317), Calahorra y León (1318), Gerona (1319) y Barcelona (1322) ${ }^{118}$. Según una bula papal, dicha fiesta sería "una celebración reverente frente a la institución de la eucaristía, pero también alegre" "119. Como comprobaremos la fiesta del Corpus fue adquiriendo con el paso del tiempo un carácter tanto profano como religioso en el que ambos elementos estaban entremezclados.

La procesión del Corpus solía comenzar con la llamada Tarasca, un horrible monstruo, mitad dragón mitad serpiente, que venía a ser una personificación del mal, contraponiéndose a ella el Santísimo Sacramento, que culminaba el desfile y era el encargado de vencerle. En muchas ocasiones la Tarasca solía tener siete cabezas, número nada baladí ya que aludía a los siete pecados capitales. Posteriormente salían los gigantes y gigantillas. Agrupados en parejas, representaban según Sigaut "las distintas partes del mundo o las distintas etnias que se rendían ante la presencia del Santísimo Sacramento". La misma investigadora encuentra dos fuentes con los que relacionar su origen: por una parte con un texto de los Salmos (71: 10-11): "Los reyes de Tarsis y de las islas ofrecerán presentes, los reyes de los árabes y de Saba traerán regalos y todos los reyes de la tierra lo adorarán, todas las naciones lo servirán"; $\mathrm{y}$, por otra, con una cita del Apocalipsis (20: 7) en la cual se les relaciona "con las imágenes de Gog y Magog, asimilados por algunos Padres de la Iglesia (San Agustín, San Ambrosio y San Jerónimo) con los turcos y los celtas orientales, que por su conexión con el anticristo asumen la estatura de gigantes". Detrás de todos estos personajes profanos le tocaba el turno a las danzas que representaban "escenas bíblicas, mitológicas e históricas; las danzas tradicionales, de espadas, moro y cristianos, de lazos y enramadas, y en algunos casos se incorporaron danzas de indios, negros y mulatos". Finalizaba esta parte de la procesión con el desfile de los gremios acompañados con sus respectivos santos patronos y con carros representando autos sacramentales ${ }^{120}$.

A continuación, comenzaba la segunda parte de la procesión, la plenamente religiosa. Comenzaba con las distintas órdenes religiosas y parroquias, colocadas según su antigüedad, cada una escoltando a su santo patrón. Finalizaba el cortejo con el cabildo catedralicio esparciendo incienso para purificar el recorrido que debía realizar el Santísimo Sacramento, que procesionaba generalmente bajo palio. Alrededor de todo el recorrido se colocaban altares.

Volviendo con nuestro escultor, en la celebración del Corpus del año 1691 corre a su cargo la restauración de algunas de las figuras de los gigantes que desfilaban en la procesión y la realización de cabezas nuevas para otros gigantes, dado que estas se

\footnotetext{
117 SIGAUT, Nelly: op. cit., p. 28.

118 VIZUETE MENDOZA, J. Carlos: op. cit., p. 33.

119 SIGAUT, Nelly: op. cit., p. 32.

120 Ídem, pp. 36-37.
} 
encontraban especialmente maltratadas ${ }^{121}$. Al año siguiente, también en compañía del referido Mayo, realiza dos cabezas nuevas para los gigantes y otra para la gigantilla, además de tallar nuevas manos y reparar alguno de los referidos gigantes ${ }^{122}$.

Como vemos, el hecho de estar realizados con materiales muy débiles, lo que las hacía obras efímeras, ocasionaba continuas reparaciones, cuando no modificaciones o sustituciones de diferentes partes de los cuerpos de estos: gigantes, gigantillas, tarascas, etc... Se cree que de estas esculturas efímeras proceden las "fallas" y otras tipologías similares.

121 Cuenta de relación jurada que doy yo Juan Francisco Canesi mayordomo de Propios de esta ciudad del que ha importado las fiestas de Corpus del presente año de mil y seiscientos y noventa y uno de que fueron comisarios los señores don Francisco Gutiérrez del Mazo y don Manuel Vallejo la cual doy en la forma siguiente:

$n^{\circ} 4$ Pintar carros. "Más quinientos reales pagados a Francisco Roldán y Joseph Parral pintores por los mismos en que se concertó pintar los carros y lienzos de ellos, naves y demás tramoyas para los autos". $\mathrm{n}^{\mathrm{o}} 24$ Aderezar gigantes. "Más trescientos reales pagados a Jacinto Mayo y Juan de Ávila con quien se concertó hacer las cabezas para los gigantes retocar y aderezar los demás”. A.M.V., CH. 175-29, ff. 1-3.

122 Relación y cuenta jurada que doy yo Juan Francisco Canesi mayordomo de Propios de esta ciudad de lo que han importado los gastos de las fiestas del Corpus de este presente año de mil seiscientos y noventa y dos de que fueron comisarios los señores don Diego Nuño de Valencia y don Juan Francisco de Rivera la cual doy en la forma siguiente:

“Aderezar gigantes. Más quinientos y cincuenta reales pagados a Jacinto Mayo y Juan de Ávila pintor y escultor en que se ajustó hacer dos cabezas nuevas de dos gigantes y una de la gigantilla y reparar los demás y retocarlos y hacer algunas manos nuevas consta de libranza”. A.M.V., CH. 175-29, f. 8. 


\section{LERMA. IGLESIA COLEGIAL DE SAN PEDRO}

\section{ESCULTURAS DEL RETABLO MAYOR (1692)}

El 7 de abril de 1692 Juan de Ávila contrata una de las obras más importantes de su carrera, y a la vez una de las que mayor prestigio le reportará: las esculturas del retablo mayor de la iglesia colegial de San Pedro de la Villa Ducal de Lerma. Se trataba de "hacer seis hechuras de esculturas a vista de maestros" "23, si bien a la postre Ávila tallaría siete, como veremos más adelante. En el contrato se especificaba que debía tallar las imágenes de San Pedro en cátedra, sentado y vestido de pontifical; San Pablo y San Andrés "de altura de dos varas"; y las personificaciones de tres Virtudes: Fortaleza, Justicia y Fe, sentadas y con sus respectivos atributos. Antes de decidir si le encargaba todas las esculturas, el cabildo colegial solicitó al escultor que primero tallara y les entregara una cabeza de San Pedro. Como vemos los religiosos quedaron muy satisfechos de la "prueba" que les mostró el escultor vallisoletano ${ }^{124}$. El precio total de la obra ascendió a 3.500 reales, cantidad, bajo mi punto de vista, bastante exigua.

Unas décadas antes había existido ya un intento de dotar a la capilla mayor de la iglesia colegial de un retablo que estuviera a la altura de tan insigne templo, el cual correría a expensas del Duque de Lerma. Las esculturas que lo ornarían saldrían de las gubias del escultor castellano más importante del momento: Gregorio Fernández. El 14 de julio de 1615 los ensambladores vallisoletanos Francisco Velázquez y Melchor de Beya contratan, fiados por el pintor Marcelo Martínez y el rejero Pedro del Barco, un primer retablo mayor para la colegiata, además de la sillería de coro, por la cantidad de 950 ducados (10.450 reales) ${ }^{125}$. Para materializarlo, se obligaron a seguir las trazas del arquitecto real Juan Gómez de Mora. El retablo tendría unas medidas de 45 pies de alto y 23 de ancho $(=12,60 \times 6,64 \mathrm{~m} .)^{126}$.

Al día siguiente, 15 de julio de 1615, tras contratar la parte arquitectónica se escritura con Gregorio Fernández la escultórica, la cual constaba de "nueve figuras al natural para el retablo de la capilla mayor de la iglesia colegial de San Pedro de la villa de

123 "Digo yo, Juan de Ávila, escultor en la ciudad de Valladolid, que me obligo a hacer seis hechuras de esculturas a vista de maestros.

La dicha hechura ha de ser de San Pedro vestido de Pontifical, sentado en una silla con los demás atributos que le corresponden al dicho Santo, de alto y tamaño como el que está en el Abrojo, de Padres Recoletos de San Francisco, que me obligo para que vea su V., los señores abad y cabildo de esta Colegial de Lerma la cabeza de dicho Santo, encarnada de mano de Manuel de Estradas, para que ella se reconozca en la forma que ha de corresponder toda la escultura del retablo y de no contentar se le volverá dicha cabeza y no pueda pedir nada por ella.

Las otras dos figuras, que corresponden a los intercolumnios, han de ser San Pablo y San Andrés, de altura de dos varas. En el segundo cuerpo se han de poner las tres Virtudes que son fortaleza, justicia y en medio la fe; han de ser de altura lo que corresponde estando sentadas con todos sus atributos, y han de corresponder en la obra de ellas a la de San Pedro, y está concertada dicha obra en tres mil quinientos reales. Lerma en 7 de abril de 1692. Juan de Ávila”. CERVERA VERA, Luis: La iglesia colegial..., op. cit., p. 205.

124 PAYO HERNANZ, René Jesús: El retablo..., op. cit., Tomo II, p. 293.

125 CERVERA VERA, Luis: La iglesia colegial..., op. cit., p. 84.

126 URREA, Jesús: "La escultura barroca en la comarca de Aranda de Duero", Biblioteca Estudio e Investigación, Tomo XIX: Dueros del Barroco, Aranda de Duero, 2004, p. 260. 
Lerma cuyo patrón es su Excelencia el señor Duque de Lerma". Las esculturas representarían un Calvario (es decir, Cristo Crucificado, San Juan y la Virgen), que iría situado en el ático (DOCUMENTO 41); "dos figuras para los lados en el remate del retablo", y otras cuatro "de la advocación que su excelencia [el Duque de Lerma] mandare", con destino a otras tantas hornacinas situadas en dos pisos diferentes. Todas las esculturas estarían "bien proporcionadas y que quepan en los nichos y remate donde se han de poner, bien movidas y con mucho aire que haga buen efecto para las partes donde se han de asentar". Al escultor gallego se le abonarían "sesenta ducados por cada una que con todas montan quinientos y cuarenta ducados". Para la custodia se comprometía a tallar el relieve de la puerta, que representaría "un misterio del Sacramento", y tres esculturitas: "la una para el remate de la dicha custodia y las dos para dos nichos". Gregorio Fernández se obligaba a tener finalizadas todas las tallas en el plazo de un año, momento en que se las entregaría a los ensambladores "porque las han de llevar y asentar por su cuenta en Lerma". (DOCUMENTO 41). Por toda esta obra se le abonaría 540 ducados (= 5.940 reales): 60 ducados por cada escultura, no habiéndosele "de pagar nada por las de la custodia".

El motivo principal del retablo no le sería encargado a Fernández sino que tenían pensado reaprovechar otra escultura, o bien colocar un lienzo ${ }^{127}$. Hay que tener en cuenta que tanto la Corte como sus satélites siempre tuvieron predilección por los retablos presididos por un gran lienzo, a imitación de las grandes palas de altar italianas, en vez de los escultóricos, más típicamente castellanos, puesto que consideraban a la pintura un arte más intelectual y elevado. En todo caso, esa pintura o escultura reaprovechada, tendría como motivo principal a San Pedro, titular de la Colegiata.

Urrea plantea dos posibilidades. La primera, la más probable, es que el retablo estuviera presidido por un gran lienzo con algún pasaje de la vida de San Pedro, como por ejemplo el "cuadro grande, de más de tres varas de largo (2,50 m.), de San Pedro crucificado al revés, con unos sayones que le están crucificando, de pintura, con marco dorado" que el Duque donó al convento lermeño de San Blas y que tal vez fuese el mismo que aún se conserva en la iglesia colegial. El lienzo es copia, seguramente la mejor conservada en España, del original que pintó Guido Reni en 1604 para la iglesia romana de la Decapitación de San Pablo, sita en la Abadía delle Tre Fontane. La otra hipótesis que sostiene es que este motivo principal del retablo fuera "un San Pedro crucificado de bulto, con una cruz embutida, pintado todo, que está en la iglesia mayor de la villa de Lerma" que esculpió el escultor ciudadrealeño Juan Solís por orden del Duque de Lerma ${ }^{128}$.

Este retablo no debió de llegar a materializarse dado que resulta difícil de creer que solamente 80 años después las esculturas realizadas por Gregorio Fernández fueran sustituidas por un emulo suyo, que si bien fue un buen escultor jamás podría haber competido con el gran maestro gallego. Desconocemos los motivos que llevaron a que ni el retablo ni las esculturas se llegaran a realizar. El profesor Urrea plantea la hipótesis 
de que ante la caída en desgracia del Duque de Lerma el interés mostrado hacia su iglesia Colegial decayó, por lo que la iglesia no dotó de retablo a su capilla mayor hasta que tuvo fondos suficientes para llevarlo a cabo. Que el retablo no se llegó a levantar nos lo confirma una noticia acaecida el 7 de octubre de 1617. Ese día se celebró el traslado del Santísimo Sacramento a la nueva iglesia Colegial, al cual asistieron el Duque de Lerma y el rey Felipe III. Allí se hace mención a que no había retablo alguno en la capilla mayor ${ }^{129}$. Asimismo, el citado profesor apunta, de una manera muy acertada, que "el cambio de gusto habría afectado al retablo pero no hubiese provocado la desaparición de los originales de Fernández, en el caso de haberse hecho, sino su traslado o venta a alguna población vecina" ${ }^{130}$. Efectivamente, es difícil de creer que se pudieran haber cambiado las tallas del gran Gregorio Fernández por las de Juan de Ávila, escultor que, a la sazón, tomaba como modelo para las suyas al genio de Sarria.

A lo largo de la segunda mitad del siglo la situación económica de la colegiata no debía ser muy boyante, por lo que era difícil asumir un reto tan importante como fabricar un retablo que debido a las medidas de la capilla mayor sería muy grande; además de eso, habría que costear la escultura, el policromado y el dorado. Es decir, algo totalmente imposible para la colegiata lermeña. Esta mala situación pecuniaria lo reflejan tanto los libros de cuentas como el libro de acuerdos capitulares. De hecho el relativo al año 1681 aludía a que la situación era tan crítica que durante unos meses se tuvo que recortar el salario de los ministros y los músicos ${ }^{131}$.

Poco a poco las arcas de la colegiata debieron de tomar oxígeno ya que en el año 1684 se comienzan a realizar algunas obras en la iglesia, entre las que se encontraba la composición de vidrieras para las tribunas del altar mayor. Todo esto parece indicar que el momento de plantear el retablo era ya cercano ${ }^{132}$.

El primer paso para la realización del majestuoso retablo mayor tiene lugar en el año 1690, fecha en que el "maestro de dorador y estofador" vallisoletano Manuel Martínez de Estrada, miembro de una extensa dinastía de doradores, diseña la traza y redacta las condiciones con las cuales se habría de ejecutar el nuevo retablo mayor de la Colegiata $^{133}$, previendo la inclusión de dos elementos anteriores: el tabernáculo y el llamado "Cristo de junco". Se le conocen numerosas intervenciones en retablos, fundamentalmente en la actual provincia de Valladolid, pero sin embargo es esta la primera noticia que tenemos sobre su faceta como tracista. El coste de la obra proyectada por Martínez de Estrada, sin incluir el precio del dorado, ascendía a 25.000 reales ${ }^{134}$. Entre las condiciones dadas por el vallisoletano tenemos algunas muy típicas en este tipo de contratos como que "toda la madera que hubiere de gastar sea seca y

\footnotetext{
129 Ibídem.

$130 \quad$ Ibídem

131 GÓMEZ ROBLES, Lucía: Estudio histórico-artístico del retablo y la custodia de la Colegiata de San Pedro de Lerma, Fundación del Patrimonio Histórico de Castilla y León, Valladolid, 2010, p. 16.

132 Ibídem.

133 CERVERA VERA, Luis: La iglesia colegial..., op. cit., p. 115.

134 PAYO HERNANZ, René Jesús: El retablo..., op. cit., Tomo II, p. 146.
} 
limpia de tea, y, si acaso no se pudiese remediar, que se saque los nudos (...) y se metan piezas muy bien ajustadas". Una condición específica para este retablo era que "si acaso se hubiere de poner la custodia que dicha iglesia tiene, por ser rica se pueden poner tres gradas, si acaso con las dos no alcanzare" ${ }^{135}$.

El encargado de llevar a cabo la obra, según las condiciones dictadas por el vallisoletano, fue el ensamblador burgalés, aunque de procedencia cántabra, Diego Alonso de Suano ${ }^{136}$, si bien desconocemos la fecha concreta en que la colegiata y el artista se ajustaron. Sea como fuere tuvo lugar en el año 1692, año en el que se concertó a hacerlo por 19.000 reales, cifra bastante inferior a la que demandaba el artífice vallisoletano $^{137}$. Por aquellas mismas fechas el libro de acuerdos del cabildo recogía la "satisfacción del Cabildo acerca del proyecto" llevado a cabo por Suano ${ }^{138}$.

Para el mes de octubre de 1694 la parte arquitectónica del retablo ya se encontraba finalizada puesto que el día 22 de ese mismo mes Martínez de Estrada fue requerido por el cabildo de la Colegiata "para ver y reconocer y declarar lo obrado en el retablo que ha hecho en la capilla mayor de dicha iglesia Diego Suano, en virtud de las condiciones de arriba y la traza que se le entregó" ${ }^{139}$. El juicio del dorador vallisoletano fue bastante favorable, aunque sacó algunos pequeños fallos: por ejemplo, "en el pedestal principal le faltan todos los pendientes que consta por traza, que penden de repisa a repisa, no los ha ejecutado, aunque es cosa que no hace mucha falta", o que "falta en alzado detrás de los estípites una traspilastra en correspondencia de todas las demás, las cuales no se deben haber hecho por no picar la piedra". Entre los testigos de este escrito figuró, además del arcediano de la Colegial de Lerma, el "padre guardián que al presente era en el convento de la Aguilera, que llaman el padre Lara". Este hecho puede tener su importancia en el tema de las esculturas realizadas por Ávila, y lo trataremos más adelante. El cabildo quedó tan satisfecho del trabajo llevado a cabo por Suano que en agradecimiento le abonaron 1.100 reales "de guantes"140.

No toda la talla del retablo fue realizada por Suano puesto que de los dos ángeles de la parte inferior del mismo se encargó el escultor José Quintana, tarea por la que percibió 150 reales en el año $1692^{141}$.

El éxito del retablo fue tal que el ensamblador Félix Fresco solicitó el 15 de marzo de 1697 la traza del retablo a la colegiata para realizar uno similar en la iglesia parroquial

\footnotetext{
135 CERVERA VERA, Luis: La iglesia colegial..., op. cit., p. 206.

136 Para profundizar el conocimiento de este interesante ensamblador: PAYO HERNANZ, René Jesús: El retablo..., op. cit., Tomo II, pp. 141-161.

137 Retablo. "Primeramente se concertó el retablo en blanco con Diego de Suano maestro de arquitectura en diez y nueve mil reales y que valen”. GÓMEZ ROBLES, Lucía: op. cit., p. 32.

$138 \quad$ Ídem, p. 21.

139 CERVERA VERA, Luis: La iglesia colegial..., op. cit., p. 206.

140 Guantes. "Mil y cien reales que se dieron de guantes a dicho Diego de Suano [sic] además del concierto principal del retablo que valen”. GÓMEZ ROBLES, Lucía: op. cit., p. 32.

$141 \quad$ Niños de repisas. "Más ciento y cincuenta reales que se dieron a Joseph Quintana escultor por la escultura de los niños que están en la primera repisa de dicho retablo que valen”. Ibídem.
} 
de Herrera de Valdecañas (Palencia) ${ }^{142}$. Finalmente, dicho retablo fue realizado entre 1698-1699 por el propio Diego de Suano. En su traza podemos ver una clara similitud con el retablo lermeño.

Hubo que esperar seis años a que las arcas de la Colegiata se repusieran después del gran desembolso que supuso la fábrica del retablo para poder afrontar el dorado de la gran máquina lígnea. El 9 de mayo de 1700 el también dorador vallisoletano Leonardo Martínez de Estrada, hermano de Manuel Martínez de Estrada, presenta las condiciones con las cuales pretendía dorar y policromar aquel descomunal retablo ${ }^{143}$. Se debía dorar "desde la mesa del altar hasta la coronación de las armas (...) sin imperfecciones". En el pedestal debían de imitarse "pórfidos, lapislázuli y otros mármoles, atendiendo que se han de pintar al óleo, y luego de oreados se barnizarán dos manos con barniz de charol". La hornacina de San Pedro "por ser cosa más importante, el otro se quedará en limpio para que salga la efigie de San Pedro". La caja que resguarda al Crucificado "después de dorada, se pintará debajo del brazo derecho tres o cuatro ángeles, unos llorando y otros con otros sentimientos, y debajo del brazo izquierdo se pintará un ángel luchando con la muerte, y abajo la ciudad de Jerusalén, el sol y la luna se verán medio en sombras, y luego se sacará el oro conforme el arte"144. Además del dorado del retablo se obligaba a realizar, por vía de mejora, el policromado de "la salida desde el arco toral a la bóveda que circunda el suelo, la fachada de la pilastra de piedra y modillones, como son los que están a los finales de la cornisa. También declaro por mejora lo de la Capilla del Trascoro, como es encarnar el Santo Cristo y pintar San Juan y María, y demás adornos que allí están hechos" ${ }^{145}$.

El precio fijado por toda aquella ingente tarea ascendió a 28.000 reales. Unos días después, el 21 de junio de 1700, el escultor vallisoletano José de Rozas, Manuel Martínez de Estrada, José Garzón y Manuel Hernández firman un documento en Valladolid por el cual salían como fiadores de Leonardo Martínez de Estrada en la obra del "dorar un retablo que está en la santa iglesia colegial de señor San Pedro de la villa de Lerma en precio de veinte y ocho mil reales de vellón" (DOCUMENTO 42). Los cuatro se comprometían a que Leonardo "hará y ejecutará el dorado en dicho retablo con todo arte y perfección y cumplirá con todas las calidades y condiciones que para ello tuviere hechas y ajustadas sin faltar en cosa alguna a vista de maestros", y en caso de que así no lo hiciera "se nos pueda obligar y a cada uno in solidum a su paga y cumplimiento", para ello hipotecaban sus respectivas casas.

\footnotetext{
142 Memorial de Félix Fresco. "Leyose otro memorial de Félix Fresco, escultor en que pide al Cabildo se sirva de mandarle entregar la traza del retablo de esta Colegial para tomar la forma de otro que quiere ejecutar en Herrera de Valdecañas y que le volvería a entregar con puntualidad y siendo necesario daría fianza de ello. Y se acordó no había a lugar". Ídem, p. 38.

143 CERVERA VERA, Luis: La iglesia colegial ..., op. cit., p. 115.

144 Ídem, pp. 206-207.

145 Ibídem.
} 
La obra fue a buen ritmo puesto que el 6 de agosto de 1701 estaba ya concluida ${ }^{146}$. Al año siguiente se da por finalizado el retablo y se procede al traslado del Santísimo Sacramento a la custodia monumental incorporada al centro del mismo ${ }^{147}$. Recientemente, el retablo se ha visto sometido a una profunda restauración que le ha

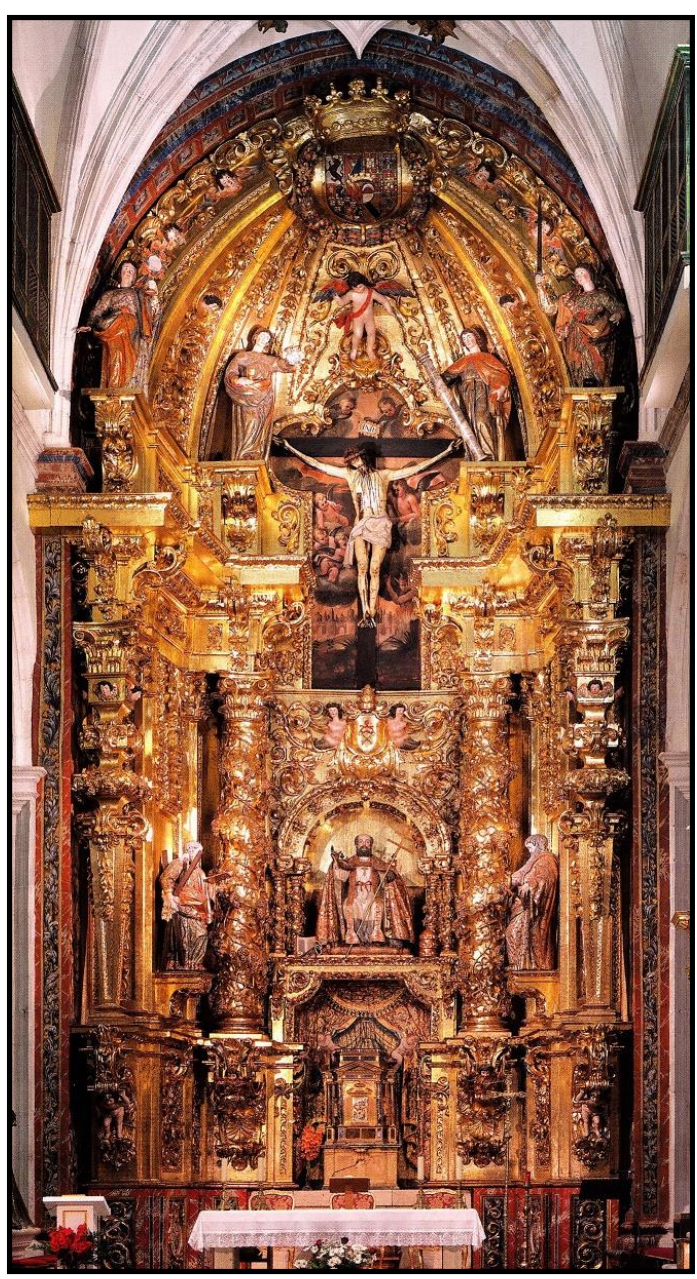

Il. 6- Diego Alonso de Suano. Retablo mayor.

Colegiata de San Pedro. Lerma (Burgos). devuelto su antiguo esplendor. Aunque por lo general presentaba un buen estado de conservación a nivel estructural, existía una gran cantidad de polvo además de algunos pequeños desprendimientos de oro. También se localizaron quemaduras y salpicaduras de cera en la superficie retablística. En lo referente a las esculturas éstas se encontraban sucias y ennegrecidas por el humo de las velas, amén de algunos pequeños desperfectos. Tras la restauración el retablo se asemeja a una gigantesca gruta incandescente ${ }^{148}$.

El gigantesco retablo (15 x 6 m.) se adapta perfectamente a la complicada forma del presbiterio: estrecho y muy alto. Se organiza mediante un banco, un solo cuerpo con tres calles, las dos de los extremos redobladas, y un ático en forma de cascarón cuyos nervios culminan en el escudo heráldico de don Juan de Dios de Silva y Haro y Mendoza, VI Duque de Pastrana, VII Duque de Lerma, y X Duque del Infantado ${ }^{149}$. Toda la superficie del retablo se encuentra recubierta de

146 "Digo yo, Manuel Martínez de Estrada, maestro dorador y estofador, vecino de la ciudad de Valladolid, y habiéndome llamado vuestra santidad para ver y reconocer si ha cumplido en el dorado y estofado según condiciones Leonardo Martínez de Estrada, juro a Dios y a una cruz que tiene cumplido y hecho todo cuanto conviene para su mayor lucimiento y firmeza conforme arte y Dios manda, y después hallo por mejora, como es la salida desde el arco toral a la bóveda que circunda el suelo, la fachada de la pilastra de piedra y modillones, como son los que están a los finales de la cornisa. También declaro por mejora lo de la Capilla del Trascoro, como es encarnar el Santo Cristo y pintar San Juan y María, y demás adornos que allí están hechos.

También declaro como, en el retablillo del Martirio de San Pedro, ha cumplido según condición, y halló de mejora todo lo pintado de pared que le circunda.

También digo que habiendo visto el retablo de San Juan está ejecutado según su obligación y tiene de mejora lo pintado en la pared, y la imagen del coro y otras cosas menudas que no lo pongo nombre, y por verdad lo firmo en esta villa de Lerma, a 6 de agosto de 1701 años". Ídem, p. 116.

147 LEÓN, Alfonso: "Tesoros para una Colegiata: restauración del retablo mayor y tabernáculo de San Pedro de Lerma”, Patrimonio. Fundación del patrimonio histórico de Castilla y León, no 36, 2012, p. 30 .

148 La restauración la llevó a cabo la Fundación del Patrimonio Histórico de Castilla y León entre noviembre de 2010 y julio de 2011. Ibídem, pp. 30 y 34.

149 GÓMEZ ROBLES, Lucía: op. cit., p. 50.

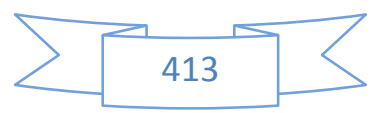


decoraciones geométricas, vegetales y cabezas de angelitos.

El banco, partido por el centro debido a la inclusión del tabernáculo reutilizado, lo componen cuatro repisas con otras tantas ménsulas decoradas con hojarasca, las extremas más adelantadas y con dos pequeños atlantes que simulan sostenerlas, los netos se encuentran decorados con cardinas.

El cuerpo se articula en tres calles separadas mediante dos columnas salomónicas de orden gigante, en los extremos. Flanqueando las calles laterales se sitúan dos estípites gigantes, lo que otorga al retablo una gran variedad y diversidad de recursos. La calle central no respeta las divisiones de banco, cuerpo y ático ya que el espacio dedicado a la custodia enlaza banco y cuerpo, y la hornacina del Cristo, situada en el ático hace lo propio también en el cuerpo. También en el cuerpo, aunque respetando su lugar, se encuentra la hornacina con el santo titular del retablo y del templo. Esta hornacina se encuentra sustentada por cuatro pequeñas columnas salomónicas repletas de racimos de uvas, las extremas más adelantadas, sobre las que asienta un remate semicircular cuyo interior contiene cuatro casetones decorados cada uno de ellos con decoración vegetal. Sobre esta hornacina vemos un panel ornado profusamente de roleos, y en el centro dos seres sireniformes que sujetan el escudo papal tocado con la tiara pontificia. Las calles laterales la conforman simples peanas con pequeñas ménsulas de decoración vegetal que sirven de asiento a San Pablo y a San Andrés; encima de los santos aparecen sencillas decoraciones basadas en marcos de tarjetillas geométricos.

Como acabamos de decir el cuerpo y el ático, en forma de cascaron, se encuentran "fusionados" por la hornacina del Santo Cristo, rectangular aunque con el remate superior trilobulado, de manera que los extremos de la cruz se adaptan a la perfección; sobre éste un angelillo con las alas desplegadas y una banda que cruza su pecho; todavía más encima el citado escudo del Duque de Lerma. Delante de todo este conjunto, justo en la vertical de las columnas y los estípites, se hallan unos pequeños entablamentos mensulados sobre los que apoyan las cuatro Virtudes.

El retablo responde a un modelo claramente ascensional, sensación que surge del hecho de que son pocas las líneas divisorias horizontales existentes en el retablo ${ }^{150}$. Esta sensación queda reforzada porque el cascarón, en su parte central, se une directamente a la calle principal, habiendo sido cortado el entablamento ya que el nicho donde se encuentra el "Cristo del Junco" une ambas partes. El Crucifijo, de origen mejicano, está tallado en pasta de maíz y conserva pelo natural. Sería la profunda devoción de los lermeños lo que llevó a la colegiata a reutilizarlo para este nuevo retablo. La primera referencia que tenemos sobre él se remonta a 1609, año en que se le menciona en el inventario como "un cristo grande" situado en el altar mayor. Unos años después, en 1615, se le nombra como "cristo de junco", e incluso dos años antes un inventario le citaba como "Cristo grande" ubicado en la iglesia de San Juan ${ }^{151}$. Todo ello apunta a que el Crucifijo fue traído a España con anterioridad al año 1609. Se trata de un Cristo

$150 \quad$ PAYO HERNANZ, René Jesús: El retablo..., op. cit., Tomo II, p. 146.

151 GÓMEZ ROBLES, Lucía: op. cit., p. 6. 
de tamaño monumental, pero a su vez de una extraordinaria ligereza derivada de los materiales en que fue esculpido. Según la restauradora Suárez Inclán, la cabeza es "hueca, aparece en primer lugar el papel amate, seguido por un casquete de tela de lino y colas, luego la estructura de cañas de maíz y finalmente la pulpa de la misma caña de maíz"152. Los brazos y piernas, realizados en cañas de maíz húmedas, son macizos, recubiertos de la pulpa de caña de maíz. Asimismo, la citada restauradora afirma que "en el cilindro interno del anclaje del brazo, ya en el cuerpo, la estructura está constituida (igual que el resto del cuerpo) por papel, caña de maíz y la pasta de cáñamo que termina de modelar la figura, dejando una superficie apta para recibir la preparación que es un estrato blanco de unas de 250 micras de espesor constituido por yeso con trazas de calcita y cola"153. Sorprende que a pesar de estar hecho con unos materiales tan modestos (cañas de maíz, papel amate y pasta de maíz), típicos todos ellos de la imaginería mejicana, el anónimo escultor haya logrado una imagen tan excelsa.

Payo Hernanz define este retablo como "una interesantísima obra tanto desde una perspectiva estructural como desde una perspectiva decorativa. Aunque no sea una obra diseñada por Suano, que se convirtió en mero ejecutor de la misma, Suano se nos presenta como un interesante y cualificado profesional capaz de llevar a buen término un trabajo de tan grandes proporciones. Esta producción se convertirá en un hito en la retablística provincial"154.

Entrando ya de lleno en lo que nos ocupa, como ya dijimos, Juan de Ávila se concierta con la iglesia colegial el día 7 de abril de 1692 para esculpir "seis hechuras de esculturas" (San Pedro en cátedra, San Andrés, San Pablo y tres Virtudes: Fortaleza, Fe y Justicia). Sin embargo, una modificación del proyecto, quizás motivado por el programa iconográfico y la búsqueda de simetría en el conjunto, provocó que las Virtudes pasaran a ser cuatro, pagándosele esta última en un momento posterior ${ }^{155}$. De esta manera las Virtudes efigiadas fueron: Justicia, Fortaleza, Templanza y Fe.

Desconocemos los motivos que llevaron al cabildo de la colegiata a elegir a Ávila. Se nos ocurren diversas hipótesis: decidieron recurrir al maestro más acreditado de la escuela más importante que había en Castilla: la vallisoletana; otra posibilidad es que fuera recomendado a la colegiata por el dorador Manuel Martínez de Estrada, tracista del retablo, ya que entre ellos debió de existir amistad, además de un gran número de colaboraciones en empresas artísticas como ya vimos en su momento; una última conjetura, a la que doy mayor verosimilitud, es la de que fuera promocionado por los franciscanos del cercano Convento del Domus Dei de La Aguilera (Burgos), para el cual debió de ejecutar un año antes las esculturas principales de su iglesia (Traslación de San Pedro Regalado, San José con el Niño, San Antonio de Padua). Hay un dato que puede

152 SUÁREZ INCLÁN, María: Memoria final de la Restauración del retablo mayor y custodia de la Iglesia Colegial de San Pedro de Lerma (Burgos). Anexo 1: Estudios previos, Fundación del Patrimonio Histórico de Castilla y León, Valladolid, 2011, p. 16.

153 Ibídem.

154 PAYO HERNANZ, René Jesús: El retablo..., op. cit., Tomo II, p. 146.

155 GÓMEZ ROBLES, Lucía: op. cit., p. 30. 
hacer verosímil esta hipótesis y que además relaciona a aquel cenobio con la realización de este retablo: entre los testigos de la escritura en la que Martínez de Estrada debía de dar el visto bueno a lo obrado por Suano figura, como ya vimos el "padre guardián que al presente era en el convento de la Aguilera, que llaman el padre Lara" "156.

La persona que contactó con Ávila para encargarle la realización de las esculturas fue el Racionero de la colegiata, don Cristóbal de Arce, puesto que se sabe que estuvo en Valladolid supervisando la traída de las imágenes a Lerma ${ }^{157}$. Además es a él a quien se le toman las cuentas el 15 de marzo de 1692 por parte del Cabildo "para a hacer pago a Juan Dávila maestro escultor y vecino de Valladolid de lo que se le estaba debiendo de la escultura de los santos y Virtudes del retablo que dicho Maestro ha hecho" y también "para pagar a Leonardo de Estrada dorador el coste del dorado de San Pedro"158.

Juan de Ávila percibió ese mismo año de 1692 "tres mil y quinientos reales de la escultura de San Pedro, San Pablo, San Andrés y Virtudes" 159 . Posteriormente se le abonaron "quinientos reales de una escultura de otra virtud" 160 . El cabildo quedó tan contento con nuestro escultor que le entregó, en concepto de guantes, "trescientos reales que se dieron a Juan de Ávila maestro de escultura quien hizo los Santos por reconocer merecía algo más el trabajo que valen"161. El escultor trabajó rápidamente ya que ese mismo año se llevaron las imágenes a Lerma ${ }^{162}$.

A pesar de que se dice que la totalidad del importe de las esculturas se le abona en 1692, en años sucesivos $\left(1693^{163}-1694^{164}\right)$ figuran diferentes partidas en los libros de fábrica a

156 CERVERA VERA, Luis: La iglesia colegial..., op. cit., p. 206.

157 Salario. "Más setenta y dos reales del salario de seis días que se ocupó dicho Señor Racionero en la ida a Valladolid para dichos santos”. GÓMEZ ROBLES, Lucía: op. cit., p. 32.

$158 \quad$ Dorado de San Pedro. "Más ochocientos que pago a Leonardo de Estrada del dorado de San Pedro y valen". Ibídem.

$159 \quad$ Escultura. "Tres mil y quinientos reales de la escultura de San Pedro, San Pablo, San Andrés y Virtudes que valen”. Ídem, p. 33.

$160 \quad$ Ídem. "Quinientos reales de una escultura de otra virtud que sea detrás y que valen (digo que se debería)". Ibídem.

161 Ídem. "Trescientos reales que se dieron a Juan de Ávila maestro de escultura que hizo los santos por reconocer merecía algo más el trabajo que valen”. Ibídem.

$162 \quad$ Coste de traer los santos y Virtudes. "Cuatrocientos y diez y nueve reales que por menos sea justo haber tenido de costa la traída de los apóstoles y Virtudes de la ciudad de Valladolid a esta villa que valen". Ibídem.

163 Juan de Arce. "Más entrego dicho señor Juan Rodríguez Sánchez a Juan de Arce vecino de la ciudad de Valladolid para libranza del canónigo para pagar a Juan de Ávila por cuenta de la escultura del retablo mayor". Ídem, p. 34.

164 Retablo. "Más ochocientos y treinta y tres reales y once más que entregó el Señor Racionero Cristóbal de Arce para pagar la escultura de los santos del retablo a Juan de Ávila vecino de Valladolid entrego recibo de dicho Señor Racionero Arce y valen".

Ídem. "Más mil reales por libramiento de la contaduría pago Don Francisco Solís al dicho Señor Racionero Arce por cuenta de los dos mil ducados, que tiene de renta la fábrica sobre los estados de Lerma para haberlos suplido en Valladolid la mesa capitular para pagar la escultura de dichas imágenes entrego dicho libramiento y recibo y valen".

Ayuda de costas al Señor Dávila y Juan de Estrada. "Más se le pasan a dicho Señor Maestrescuela Don Francisco de Arellano siete doblones de a dos escudos que hacen cuatrocientos y veinte reales y ellos; que los Señores Arcediano Don Juan Garrido y Chantre Don Lucas de Caniego comisarios nombrados por el cabildo mandaron dar a dicho Señor fabriquero para Juan Dávila maestro escultor y Manuel de Estrada 
favor del escultor; hemos de imaginar que las arcas de la colegiata volvían a estar maltrechas y se tuvo que ir pagando poco a poco. La suma total de la retribución se fraccionó en cuatro pagos, de los cuales se conservan los respectivos recibos en el Archivo Diocesano de Burgos. Todos ellos están fechados en Valladolid: el primer recibo, entregado el 17 de septiembre de 1692, tiene un valor de 1.000 reales; el segundo, entregado el 1692, vale 500 reales; el tercero, de 17 de noviembre de 1693, importa 1.000 reales; y el cuarto, de 27 de abril de 1694, asciende a otros 1.000 reales ${ }^{165}$. La virtud contratada con posterioridad aún se le estaba abonando en el año $1696^{166}$.

A continuación, analizaremos de forma individualizada las siete esculturas realizadas por Ávila, y veremos cómo en los tres santos, no solamente en San Pedro, la dependencia de Fernández es bastante cercana:

\section{$\underline{\text { SAN PEDRO EN CÁTEDRA }}$}

Lo primero que llama la atención al observar el retablo es la imagen de San Pedro en cátedra, versión del realizado hacia 1630 por Gregorio Fernández para la capilla de San Pedro Apóstol de la iglesia del convento franciscano del Scala Coeli del Abrojo (Figs. 26-28), próximo a Laguna de Duero (Valladolid) ${ }^{167}$. No solamente se inspiró en esta magnífica talla, sino que la copió puntualmente. Este hecho vuelve a probar lo que tanto venimos recalcando: la pervivencia y el éxito del que aún gozaban los modelos impuestos por Gregorio Fernández hacía ya más de medio siglo. Por ello no es extraño que cuando la iglesia colegial de Lerma se concierta con Juan de Ávila para la ejecución de las referidas imágenes le pidan que a la hora de representar al Príncipe de los Apóstoles lo haga según el afortunado modelo de Fernández: "vestido de pontifical, sentado en una silla con los demás atributos que le corresponden al dicho santo, de alto y tamaño como el que está en el Abrojo, de Padres Recoletos de San Francisco"168.

La imposición de esta cláusula a Ávila nos lleva a preguntarnos cómo conocieron los comitentes lermeños la escultura realizada por Fernández para el Scala Coeli del Abrojo, si bien ya está acreditada la extensa fama de la que gozaba. El profesor Urrea aporta dos hipótesis: la primera consiste en que Fernández ensayó en Lerma un modelo que no pudo llevar a cabo en el retablo mayor de la Colegiata y que posteriormente aprovechó para el convento franciscano del Abrojo; la otra estriba en que los padres franciscanos del cercano convento ribereño de La Aguilera animaron al cabildo de la

dorador para ayuda de costas y guantes por lo bien que habían ejecutado escultura y dorado de San Pedro y valen". Ídem, p. 36.

165 CERVERA VERA, Luis: La iglesia colegial..., op. cit., p. 115.

166 Retablo. "Seiscientos y setenta y seis reales que por libramiento de la contaduría entrego al Señor Canónigo Larios mayordomo de mesa por los mismos que el capitán Don Juan Rodríguez pago de la letra debían a Juan de Ávila maestro y escultor de Valladolid. Con que se le acabó de pagar la escultura de las Virtudes y en se le entregó el dicho libramiento con recibo". GÓMEZ ROBLES, Lucía: op. cit., p. 38 .

167 URREA, Jesús: “Gregorio Fernández en el Convento de Scala Coeli...”, op. cit., p. 23.

168 CERVERA VERA, Luis: La iglesia colegial..., op. cit., p. 205. 
Colegiata de Lerma a copiar para su retablo mayor la escultura que poseían sus hermanos de religión del convento del Scala Coeli, lo que nos indicaría el prestigio que la imagen poseía dentro de la Orden Franciscana ${ }^{169}$. Personalmente, creo que la opción más plausible sería la segunda, es decir, que los franciscanos de La Aguilera recomendaron al cabildo lermeño la ejecución de una copia del San Pedro. Además, como ya supuse antes, serían los propios franciscanos de La Aguilera los que recomendaron a Juan de Ávila al cabildo lermeño, dado que un año antes había trabajado para el propio Domus Dei ${ }^{170}$.

Lo que no está tan claro es de dónde tomó Fernández esta iconografía. Se piensa que su inspiración pudo llegar a través de algún grabado italiano o flamenco; lo indiscutible es que la composición parece derivar de algún retrato de pontífice o prelado ${ }^{171}$. Los retratos de la serie de obispos vallisoletanos iniciada en el año 1600 con el de don Bartolomé de la Plaza, pintado por Enrique Trozo, adoptan una disposición similar, lo que hace sospechar de la existencia de una misma fuente de inspiración que quizás pueda remontarse al modelo creado por Rafael en el fresco del Vaticano que representa a Gregorio IX publicando su Código, en la que el pontífice aparece coronado por la tiara. Por lo tanto, esta iconografía hunde sus raíces, como poco, en el Renacimiento, puesto que en las iglesias dedicadas al santo solía existir una estatua sedente del que fuera primer Papa, siendo la más conocida conservada en la Basílica de San Pedro del Vaticano, obra de Arnolfo di Cambio. En Valladolid existe una representación similar, en este caso pictórica, en la iglesia de la Magdalena ${ }^{172}$. El lienzo forma parte del retablo de la Virgen de los Remedios, cuyas pinturas fueron realizadas en 1676 por los hermanos Felipe y Manuel Gil de Mena y Muga, hijos del gran pintor barroco Felipe Gil de Mena. Curiosamente, el lienzo que estamos tratando se encuentra firmado y fechado. El santo aparece sentado en un sillón frailero de una forma muy forzada, en la mano izquierda sujeta las dos llaves, mientras que con la izquierda bendice. Viste de la misma manera con la que le representan tanto Fernández como Ávila. Tras de él, apoyado en el sillón, la cruz patriarcal, mientras que sobre una mesa situada a su derecha figura un libro que sirve de apoyo a la tiara papal. La composición la enmarca una tosca

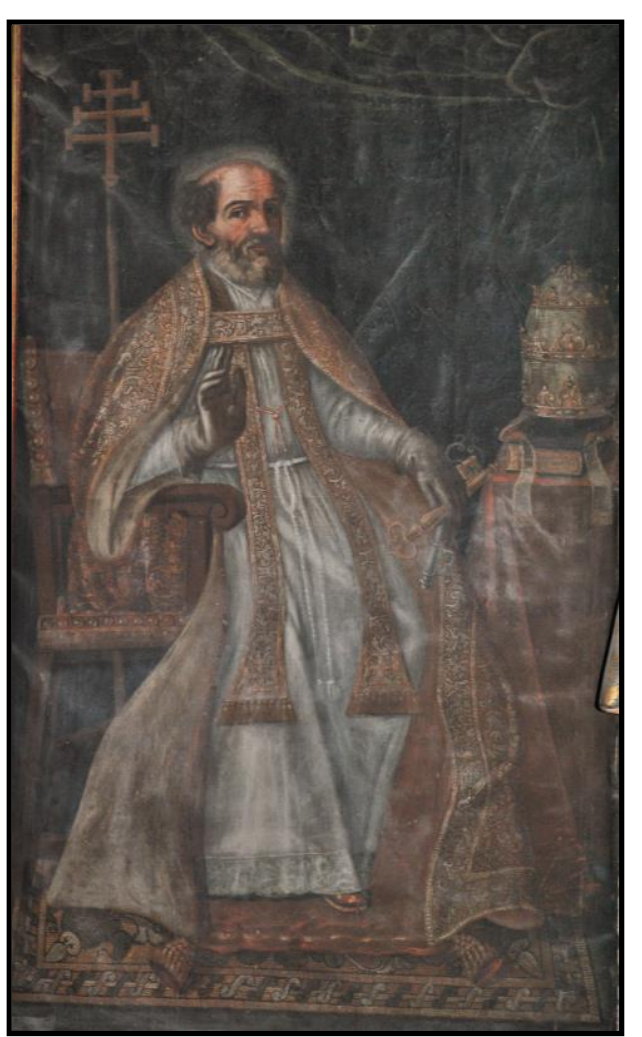

Il. 7- Felipe y Manuel Gil de Mena. San Pedro en cátedra. Iglesia de la Magdalena. Valladolid.

\footnotetext{
169 URREA, Jesús: “Gregorio Fernández en el Convento de Scala Coeli...”, op. cit., p. 29.

170 GARCÍA VEGA, Blanca: op. cit., p. 404.

171 URREA, Jesús: “Gregorio Fernández en el Convento de Scala Coeli...”, op. cit., p. 29.

172 VALDIVIESO GONZÁLEZ, Enrique: op. cit., p. 177.
} 
cortina, recurso típicamente barroco, y una alfombra y un cojín sobre el que apoya los pies el anciano pescador.

La talla de San Pedro en cátedra realizada por Fernández ingresó en el Museo de Valladolid a raíz de la Desamortización de Mendizábal, aunque se desconoce dónde fueron a parar el resto de esculturas que conformaban el retablo de la capilla de San Pedro del convento del Abrojo. Esta se encontraba "muy adornada y toda pintada de oro y azul con mucha curiosidad y coste", poseía un retablo del que se decía que era "de las obras más perfectas que se hallan en nuestra Castilla”. El retablo estaba compuesto de un único cuerpo y ático. En el banco había dos relieves efigiando La Adoración de los Reyes y La Adoración de los Pastores. En el nicho principal había "un arco grande de labores muy primas y en medio el príncipe de los Apóstoles San Pedro sentado vestido de pontifical con capa pluvial y sitial delante con su misal abierto en forma de predicar al pueblo, de estatura algo más que la común, obra tan perfecta y de tanta valentía que cualquiera que la mira le causa pavor" "173. A los lados de San Pedro, en los intercolumnios, dos esculturas de San Sebastián y San Antonio; sobre los extremos del entablamento San Luis y San Vicente, mientras que en la caja del ático figuraba un Crucificado. El conjunto se completaba con seis ángeles y la gloria ${ }^{174}$. Se desconoce el paradero de toda la obra escultórica, salvo el San Pedro, su bien Urrea plantea la posibilidad de que una escultura de San Sebastián, atribuía con toda seguridad a Fernández, custodiada en el Museo Nacional de Escultura, pudiera haber pertenecido a dicho retablo ${ }^{175}$.

Las diferencias entre las esculturas de Fernández y Ávila son escasas en lo iconográfico, si bien en lo técnico existe mayor distancia, la hechura de nuestro escultor es ciertamente más rígida e idealizada. San Pedro aparece sentado en un sillón frailero, elevado sobre una almohada con flecos en sus laterales, revestido de pontifical mediante una amplia capa pluvial policromada con unas ricas decoraciones vegetales, realizadas en dorado conjugado con rojos, azules y verdes, y alguna escena figurativa, como puede ser una que representa a su hermano San Andrés con la cruz espada cogida con una mano, mientras que con la otra sujeta un libro. Todas estas decoraciones quedan remarcadas por una preciosa cenefa vegetal que es bastante usual entre los doradores y policromadores vallisoletanos de finales del siglo XVII y comienzos del XVIII. Comparando estas policromías con las del ejemplar de Fernández, Lucía Gómez Robles señala que "las vestiduras presentan una decoración similar de tipo vegetal con escenas figuradas que en el San Pedro de Fernández quedan enmarcadas como escenas aisladas mientras que en el trabajo de Estrada, autor del dorado y la policromía, las figuras se funden con el fondo general". Finalmente destaca "el preciosismo en el dibujo de unos paños que quedaban a varios metros del espectador y, por lo tanto,

\footnotetext{
173 MARTÍN GONZÁLEZ, Juan José: El escultor Gregorio ..., op. cit., p. 242.

174 URREA, Jesús: “Gregorio Fernández en el Convento de Scala Coeli...”, op. cit., p. 27.

175 Ídem, p. 30.
} 
completamente invisibles a él"176. Según Martín González, el hecho de que San Pedro vista una capa pluvial quiere venir a significar que nos está hablando ex cátedra ${ }^{177}$.

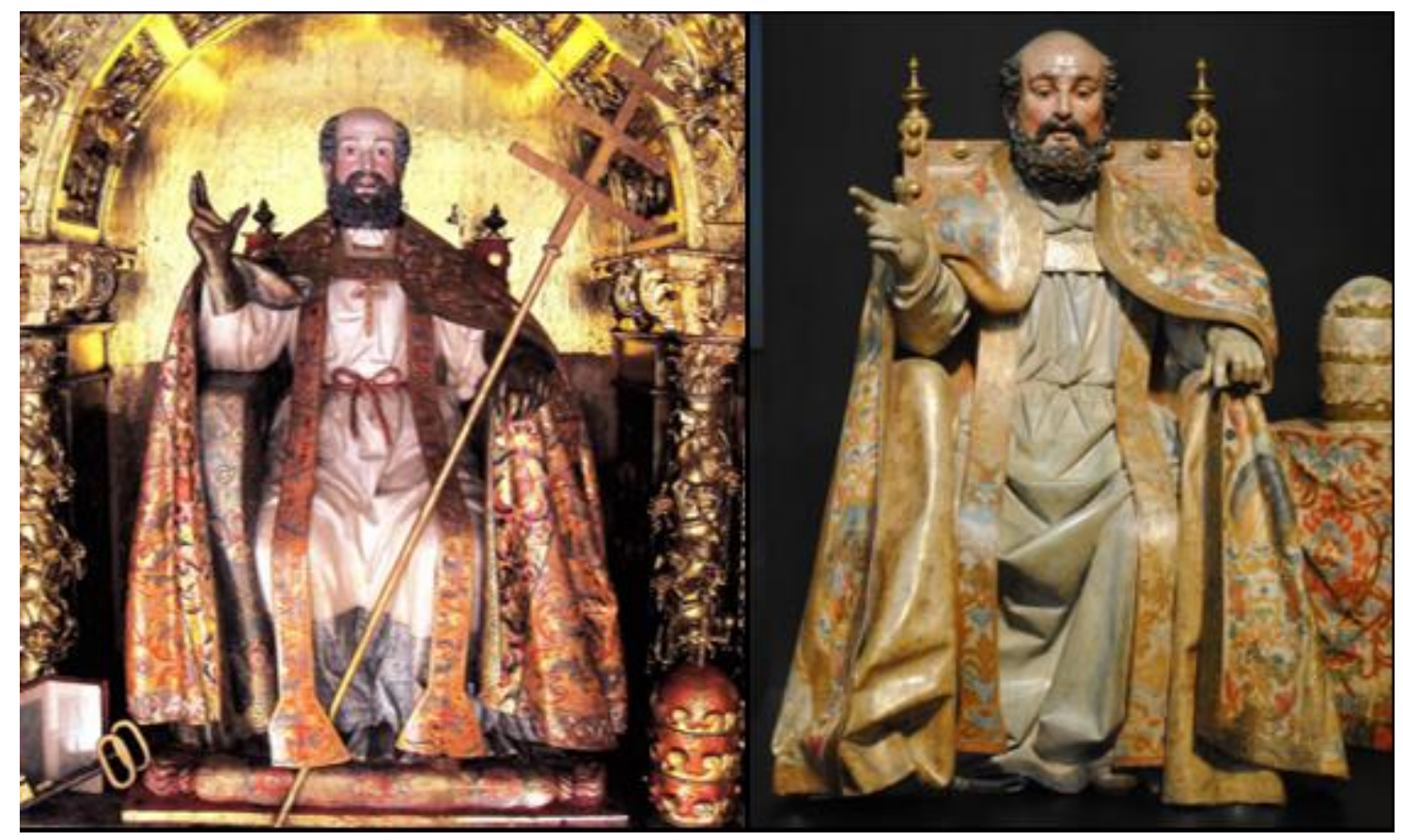

Il. 8- Comparación de los San Pedro en cátedra de Juan de Ávila y de Gregorio Fernández.

Por debajo de la capa pluvial viste un alba blanca, con imitación de labores de brocado en su parte inferior, atada a la cintura con un cíngulo rojo. Entre el alba y la capa se sitúa la estola, también ricamente policromada con los mismos motivos vegetales; en los extremos se ensancha hasta adoptar una forma trapezoidal en cuyo interior se encuentra inserta una cruz latina roja. La finura que consigue Ávila a la hora de tallar la estola a base de finas láminas de madera es una buena prueba de su maestría. Del cuello le cuelga una cruz dorada con piedras preciosas que encuentra perfecto acomodo entre las diferentes. Ambas manos las tiene resguardadas por sendos guantes marrones con una orla remarcada en dorado. En el dedo corazón de su mano izquierda se aprecia una especie de anillo, que será el del "pescador". Tiene el brazo derecho elevado, disponiéndose a impartir la bendición con los dedos pulgar, índice y anular extendidos. Con esa misma mano sujetaba anteriormente a la restauración las dos llaves, tan características de su iconografía, si bien en la actualidad se ha decidido dejarlas a sus pies junto a un libro. El brazo izquierdo lo apoya sobre el respectivo brazo del sillón, otorgando al santo una posición más naturalista. Antiguamente portó en dicha mano la cruz patriarcal, hoy en día está apoyada sobre su rodilla izquierda. Como hemos ido diciendo, el primer papa aparece rodeado de sus otros atributos: la cruz patriarcal, el libro abierto, las dos llaves y, por supuesto, la tiara papal, compuesta por tres coronas. Estas tres coronas hacen relación a que, según relata Santiago de la Vorágine, "la cátedra de Pedro fue regia, sacerdotal y magisterial; regia, porque Pedro fue príncipe

176 GÓMEZ ROBLES, Lucía: op. cit., p. 65.

177 MARTÍN GONZÁLEZ, Juan José: El escultor Gregorio ..., op. cit., p. 242.

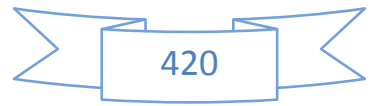


de todos los reyes; porque fue pastor de todos los sacerdotes y clérigos; y magisterial, porque fue maestro de todos los cristianos" $" 178$.

La cabeza, como es habitual en la obra de Ávila, está labrada independientemente del cuerpo, atizonada mediante un vástago cilíndrico. El rostro está tallado mórbidamente, acusando bien las calidades de la piel. La blandura del rostro la comprobamos en las arrugas de la frente y las mejillas, las cuales dan buena prueba de la avanzada edad del santo. Los ojos son de tapilla vítrea, nariz recta, cejas arqueadas, mejillas sonrosadas. Calvicie pronunciada, con grandes mechones de pelo en los laterales de la cabeza. Barba muy poblada realizada a base de numerosos caracolillos y anchos bigotes. La boca es pequeña y entreabierta, lo que nos permite ver los dientes e incluso la lengua, algo excepcional en la obra de Ávila. El grado de dependencia de esta escultura respecto a la de Fernández es tan grande que incluso están imitadas con gran maestría las formas deformes de los dientes del santo. Pienso que este aspecto no es baladí puesto que aporta al santo, sobre todo en la escultura de Fernández, cierto grado de campechanía y de humanidad a tal figura sacra.

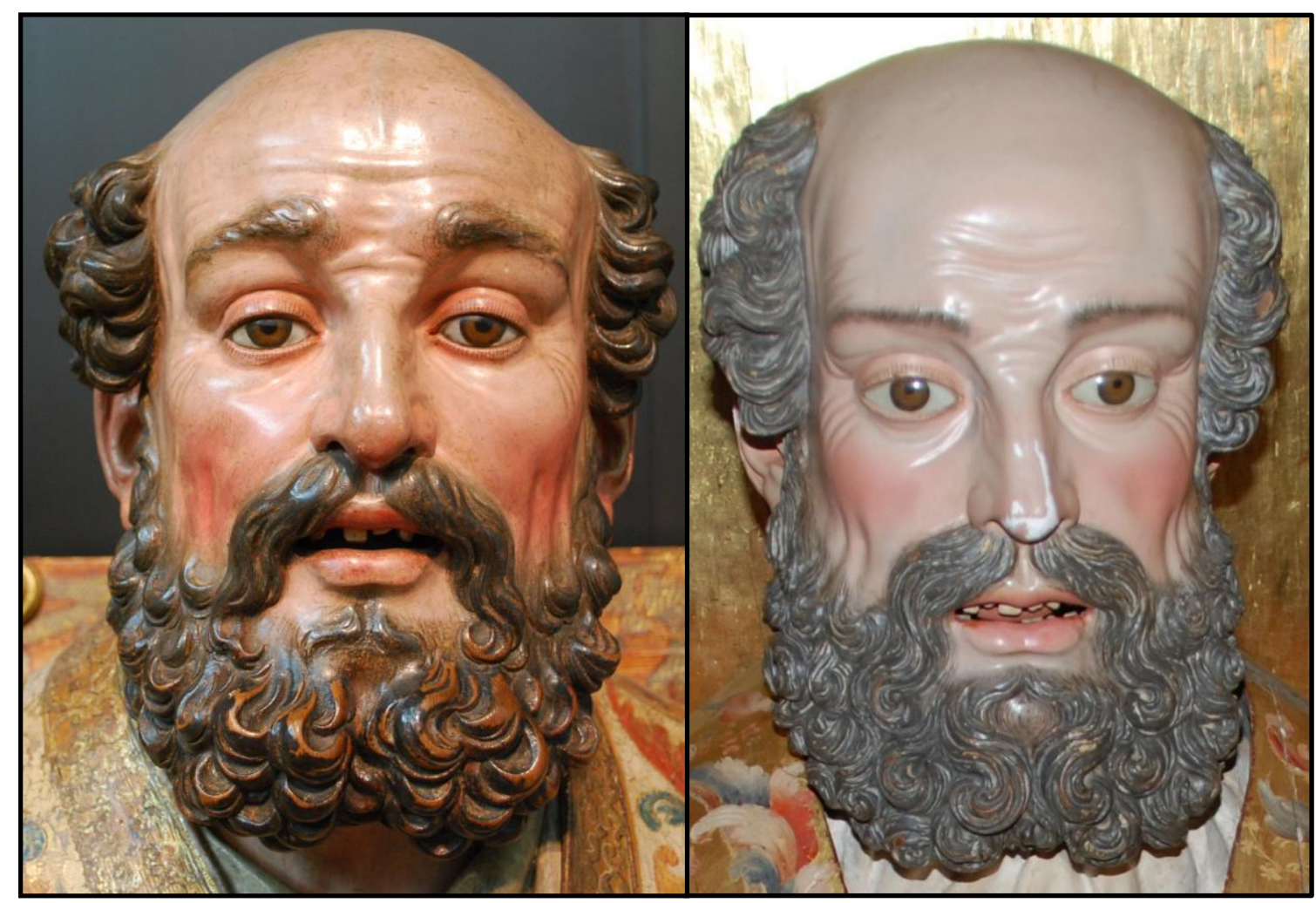

Il. 9- Comparación de las cabezas de los San Pedro en cátedra de Gregorio Fernández y de Juan de Ávila.

Los pliegues de sus vestimentas los podemos dividir en dos grupos: los más característicos de su estilo son los suaves y redondeados que caen casi de manera vertical que podemos apreciar en la capa pluvial; y los que son más ajenos a su obra. Estos últimos son los que presenciamos en el alba, mucho más duros y quebrados de lo que nos tiene acostumbrados. Pienso que en este caso ha querido copiar literalmente los de la escultura de Fernández, si bien no llega a tal grado de alatonamiento. Juan de

178 VORÁGINE, Santiago de la: La leyenda dorada, Tomo I, Alianza Forma, Madrid, 1982, p. 175.

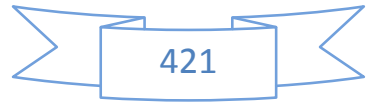


Ávila realizó una copia dignísima de la escultura homónima labrada por Gregorio Fernández. La finura con que talla la estola y la capa pluvial, y la bondad que refleja su rostro convierten a esta talla en una escultura señera dentro de su producción.

Del dorado de la imagen, primera escultura del retablo que fue policromada, se ocupó en 1692 Leonardo Martínez de Estrada, el cual percibió por tal tarea 800 reales $^{179}$. Extraña ver que en los libros de fábrica tan solo figura el policromado/dorado de esta talla, no existiendo ninguna referencia a los de las otras. El cabildo quedó tan satisfecho con el pintor vallisoletano que le obsequió con "ciento y cuarenta y dos reales que se dieron de guantes y regalo al maestro que doró a San Pedro que valen"180.

Durante la restauración del retablo y sus esculturas entre los años 2010-2011 se actuó con gran profusión en el santo ya que se encontraba en muy mal estado de conservación, habiendo sido necesario incluso reponerle algunos dedos perdidos, así como ciertos de sus atributos iconográficos. La restauradora, María Suárez Inclán, describe de la siguiente forma las intervenciones llevadas a cabo en la imagen: "Reconstrucción volumétrica y reposición de volúmenes. Se han reparado y reintegrado las llaves y los adornos que rematan la silla. Cruz patriarcal. Se han hecho de la mano izquierda dedos segundo y tercero empezando por la izquierda. De la derecha dedos uno y dos de la derecha"181.

Que el modelo fernandesco tuvo éxito lo prueba no solo esta copia de Lerma, quizás la mejor, sino otras muchas. Para no ser exhaustivos podemos citar los siguientes ejemplos: los de las parroquiales de Aguasal (Valladolid) ${ }^{182}$, Castronuevo de Esgueva (Valladolid) ${ }^{183}$, La Pedraja de Portillo (Valladolid) ${ }^{184}$, Serrada ${ }^{185}$ e Itero de la Vega (Palencia) ${ }^{186}$, o el de la Basílica de Nuestra Señora de los Remedios de Ágreda (Soria). Todas ellas son anónimas a excepción de la de Itero de la Vega, realizada en 1664 por el mediocre escultor vallisoletano Andrés de Oliveros (DOCUMENTO 43) ${ }^{187}$.

\footnotetext{
179 Dorar a San Pedro. "Ochocientos reales que tuvo de costas el dorar al Señor San Pedro los cuales se pagaron al maestro Estrada y valen”. GÓMEZ ROBLES, Lucía: op. cit., p. 33.

$180 \quad$ Más guantes. "Ciento y cuarenta y dos reales que se dieron de guantes y regalo al maestro Estrada que doró a San Pedro que valen”. Ibídem, p. 33.

181 SUÁREZ INCLÁN, María: $o p$. cit.

182 BRASAS EGIDO, José Carlos: Catálogo Monumental de la provincia de Valladolid. Tomo X..., op. cit., p. 13.

183 URREA FERNÁNDEZ, Jesús: Catálogo Monumental de la provincia de Valladolid. Tomo $X X \ldots$, op. cit., p. 35.

184 BRASAS EGIDO, José Carlos: Catálogo Monumental de la provincia de Valladolid. Tomo X..., op. cit., p. 108.

185 MARCOS VILLÁN, Miguel Ángel y FRAILE GÓMEZ, Ana Mª; Catálogo Monumental de Valladolid. Tomo XVIII..., op. cit., p. 407.

186 URREA, Jesús: “Gregorio Fernández en el Convento de Scala Coeli...”, op. cit., p. 30.

187 El 8 de julio de 1664 se concierta junto al ensamblador carrionés Manuel de Salceda para construir el retablo de la capilla del obispo de Málaga. Mientras que éste se ocuparía de la parte arquitectónica, por cuenta de Oliveros corrió la escultórica. El vallisoletano debía de tallar "un San Pedro de seis pies de alto como el que está en el Convento del Abrojo y un San Antonio de Padua con su Niño de cinco pies y medio de alto y una Magdalena de cinco pies y medio de alto y un Santo Cristo Crucificado de cuatro pies de alto, San Juan y María de tres pies y medio de alto y un San Pedro y San Pablo de pie y medio de alto, una Resurrección de medio relieve para la puerta de la custodia con dos
} 


\section{SAN ANDRÉS}

Situado sobre una simple peana en el lado del evangelio se encuentra San Andrés (Fig. 29). Ocupa el lugar que, por regla general, pertenece a su hermano menor Pedro dado que a este último se le suele situar frente a San Pablo, ambos "Príncipes de la Iglesia", puesto que en los retablos siempre figuran colocados de manera simétrica. En este caso, al ocupar San Pedro la presidencia del retablo se ha optado por que su lugar sea ocupado por su hermano mayor.

San Andrés, al igual que San Pedro, era pescador de Galilea. Su nombre es griego y significa "viril". Fue el primero en ponerse bajo el apostolado de Cristo, por ello los griegos le apodaron "Protokletos" o "Protoclite" (el primer llamado) ${ }^{188}$. Tras el fallecimiento de Cristo marchó a evangelizar los territorios que actualmente componen Rusia. Este hecho, unido a su crucifixión en Patras (Grecia), y a la leyenda narrada por el cronista Néstor que decía que el santo había clavado una cruz en Kiev y predicho la prosperidad de esa urbe, hizo que con el tiempo se convirtiera en el patrón de Rusia y Grecia $^{189}$. Como vemos, su culto estuvo más desarrollado en el oriente europeo, sin duda para competir con el que profesaba occidente a su hermano Pedro, cuyas reliquias se hallaban en Roma.

Juan de Ávila exhibe en este apóstol la mayoría de las características presentes en su estilo. Nos lo presenta de pie, con la pierna derecha levemente adelantada. Visto por el lateral, la imagen parece ciertamente rígida, el movimiento de la rodilla flexionada no está muy bien conseguido. Aparece absorto en la lectura del libro abierto que sostiene en su mano izquierda, haciendo con ello referencia a su condición de apóstol. Con la otra mano sujeta la cruz aspada, símbolo de su martirio; la sujeción no es directa, sino que lo hace por medio de un paño blanco. Este tipo de cruz es el atributo más común de San Andrés: se trata de una cruz aspada de brazos oblicuos en forma de X, la llamada Crux decussata (de decem o decussis: diez, en números romanos, X), y que posteriormente adquirió el nombre de cruz de San Andrés ${ }^{190}$. También se la conoce como cruz de Borgoña debido a que el duque Felipe el Bueno, el cual recibió en Constantinopla un fragmento de la cruz en que fue crucificado el apóstol en Patras (Grecia), la convirtió en la insignia de su Orden del Toisón de Oro.

Según Réau, la crucifixión de San Andrés, de la que se habla por primera vez en los Hechos Apócrifos de Andrés, fue "imaginada para igualar a la de su hermano San Pedro", pero a la vez era necesario diferenciarla, por ello se le atribuyó un modo diferente de crucifixión, y al mismo tiempo diferente a la de Jesucristo ${ }^{191}$. Se supuso, aunque no existen pruebas, que fue crucificado en un madero en forma de $\mathrm{X}$, letra que era la inicial del nombre de Cristo en griego. Hasta el siglo XV se le representó sobre

\footnotetext{
judíos y un sepulcro". Una vez más volvemos a ver la referencia al San Pedro en cátedra tallado por Fernández para el Convento del Abrojo.

188 RÉAU, Louis: Iconografía de los santos. A-F, Ed. del Serbal, Barcelona, 1997, p. 86.

189 Ídem, p. 87.

$190 \quad$ Ídem, p. 89.

191 Ídem, p. 91.
} 
una cruz latina de brazos horizontales (similar a la de Cristo), fue, a partir de entonces, cuando la cruz en forma $\mathrm{X}$ se convirtió en parte indispensable de su iconografía. Probablemente, tuvo mucha culpa de ello la influencia del Toisón de Oro.

La hermosa cabeza tiene claros ecos fernandescos. De él imita la forma en que resuelve la barba. Ávila añade una característica suya muy propia, también utilizada por Fernández: los finos y descuidos mechones de pelo que caen sobre la frente. Pelo canoso conseguido con el método del peleteado. Noble rostro con piel tersa, tan solo interrumpida por las hendiduras del ceño fruncido, y mejillas sonrosadas. Anchos bigotes que desembocan en una larga y espesa barba que finaliza en dos mechones simétricos a la manera de Ávila. Las manos poseen una posición en los dedos muy típica en Ávila, y que posteriormente veremos en sus hijos: dedos semidoblados, estando el corazón y el anular casi unidos. Además, esa forma de tenerlos doblados con el dorso hundido está tomado de Fernández ${ }^{192}$.

Viste túnica verde con distintos motivos decorativos de rameados vegetales. Por encima de esta un gran manto azul con pinceladas doradas con una preciosa orla dorada en el extremo, a la manera del San Pedro, y que veremos también en San Pablo. Por dentro el manto está policromado con tonos rojizos y motivos decorativos geométricos dorados. Como vemos nuevamente hay una combinación del color dorado con los verdes, azules y rojos. El manto produce quebraduras a la altura del abdomen del santo; asimismo le cae sobre el hombro izquierdo, motivo que veremos repetir a Ávila en sus representaciones de San Juan Bautista para el Oratorio de San Felipe Neri y para la iglesia de Santiago. Son pliegues muy suaves, levemente incurvados, no hay rastro de acartonamiento ni dureza. Los de la túnica son más menudos, sobre todo en la parte superior. En la parte inferior nos presenta los típicos pliegues de Ávila: redondeados y paralelos que caen verticalmente hacia el suelo, sin duda producidos por el choque de la prenda sobre el suelo, a la manera de las túnicas de los cofrades.

Martín González alabó mucho tanto esta imagen como la frontera de San Pablo. Las llegó a calificar como "dos esculturas nobilísimas, provistas de paños de fuertes dobladuras y con gran empaque". Según su opinión "nos hallamos ante las mejores repercusiones tardías de Gregorio Fernández" ${ }^{193}$. Pienso que también es de alabar la fastuosa policromía realizada por Leonardo Martínez de Estrada, el cual se ganó con creces la propina "de guantes" con que le obsequió la colegiata.

En esta escultura de San Andrés volvemos a comprobar la dependencia de Juan de Ávila de los modelos creados por Gregorio Fernández. En este caso el prototipo sería la imagen homónima tallada por el gallego para el retablo mayor de la iglesia parroquial de los Santos Juanes de Nava del Rey (1612). No se trata de una simple copia puesto que Ávila introduce novedades, como puede ser el haber invertido la composición: Fernández dispuso a su santo sujetando la cruz aspada con el brazo izquierdo, mientras que Ávila lo hace con el derecho. La otra mano, la hizo reposar Fernández de una

192 MARTÍN GONZÁLEZ, Juan José: El escultor Gregorio..., op. cit., p. 242.

193 MARTÍN GONZÁLEZ, Juan José: La escultura barroca en España..., op. cit., pp. 79-80. 
manera muy elegante sobre el pecho, por el contrario, Ávila la utiliza para sujetar un libro. Aunque en nada se le parece, Ávila pudo conocer, dada su función procesional, la escultura que del mismo santo realizó el acreditado imaginero vallisoletano Francisco Alonso de los Ríos en 1638 para la parroquia homónima ${ }^{194}$.

\section{$\underline{\text { SAN PABLO }}$}

La efigie de San Pablo (Fig. 30) suele ser una de las más habituales en los retablos barrocos, ocupando siempre la hornacina del lado de la Epístola, contraponiéndose, como hemos dicho a San Pedro, salvo en esta ocasión que se encuentra San Andrés por los motivos previamente analizados. La importancia de San Pablo en la religión católica es primordial, de hecho, según Réau, es después de Jesús "la mayor figura de la historia del Cristianismo"195. Saulo (el deseado), nombre que recibió el día en que fue circuncidado, fue un judío nacido en Tarso, posteriormente naturalizado ciudadano romano. Tras la conversión adoptó el nombre de Pablo (Paulus en latino, que significa pequeño, "ya por humildad a causa de su endeble apariencia, ya por rendir homenaje al procónsul romano de Chipre, Sergius Paulus, quien lo había escuchado con simpatía"196.

San Pablo, con un porte monumental, aparece de pie, con los brazos en una posición algo forzada, la pierna izquierda levemente flexionada y adelantada, contraponiéndose y complementándose de esta manera a la derecha de San Andrés. Su anatomía no se corresponde, como siempre, a lo que nos aseguran los testimonios de la época. Se decía de él que era "pequeño, de cuerpo esmirriado, y de una estatura por debajo de la media. Según parece, le cayeron en suerte todas las desgracias y desventajas: era calvo, legañoso, con nariz ganchuda, patizambo... Se hablaba de él como "una espina clavada en su carne", lo que ha hecho especular que estaba afectado por una enfermedad nerviosa" 197 .

Como San Andrés, también porta en sus manos, talladas de forma independiente, un libro y su atributo más característico. Con la izquierda sujeta un libro semicerrado, levemente abierto gracias a que el santo tiene colocado dentro el pulgar. También en este hecho se contrapone a su frontero San Andrés, ya que mientras que este lo tiene abierto, San Pablo lo tiene casi cerrado. Las actitudes también son opuestas dado que el primero aparece leyéndolo, por su parte Saulo ni siquiera parece tener intención de hacerlo. Tan solo es un atributo de apóstol, si bien esta calificación de apóstol es impropia dado que "no conoció a Jesús ni jamás formó parte del Colegio apostólico, ni siquiera después de la traición de Judas", aunque "se lo asimiló muy pronto a los discípulos" ${ }^{198}$. En la mano derecha sujeta de una manera muy elegante la espada, su

\footnotetext{
194 URREA FERNÁNDEZ, Jesús: “El escultor Francisco Alonso...”, op. cit., p. 355.

195 RÉAU, Louis: Iconografía de los santos. P-Z..., op. cit., p. 6.

196 Ibídem.

197 Ídem, p. 10.

198 Ídem, p. 6.
} 
atributo principal, que fue el instrumento con el que fue llevado a cabo su martirio: la decapitación.

Las facciones están modeladas con gran suavidad. La blandura del rostro también en este caso se ve levemente interrumpida por las arrugas del ceño. Carrillos abultados, boca pequeña entreabierta, ojos rehundidos y nariz recta que parece adelantar las que serán usuales en la obra de su hijo Pedro, La cabeza es majestuosa, de una gran calidad. La manera de disponer el pelo es la típica de nuestro escultor, con cabellos sinuosos descuidados cayendo sobre la frente, parecen estar como mojados. Largas y espesas barbas se esparcen sobre el pecho del santo, trayéndonos a la memoria las del Moisés de Miguel Ángel. También guardan gran parecido con las exhibidas por el San Pablo que Antonio Vázquez esculpió para el retablo mayor de la parroquial de Villalba de los Alcores ${ }^{199}$. Como en su frontero San Andrés, el policromador utiliza el peleteado. Las manos están talladas con gran delicadeza, podemos ver diferenciadas cada una de las falanges de sus dedos, así como las venas que los riegan.

La vestimenta es casi idéntica, así como la disposición del manto alrededor del abdomen y con uno de sus extremos cayendo sobre el hombro

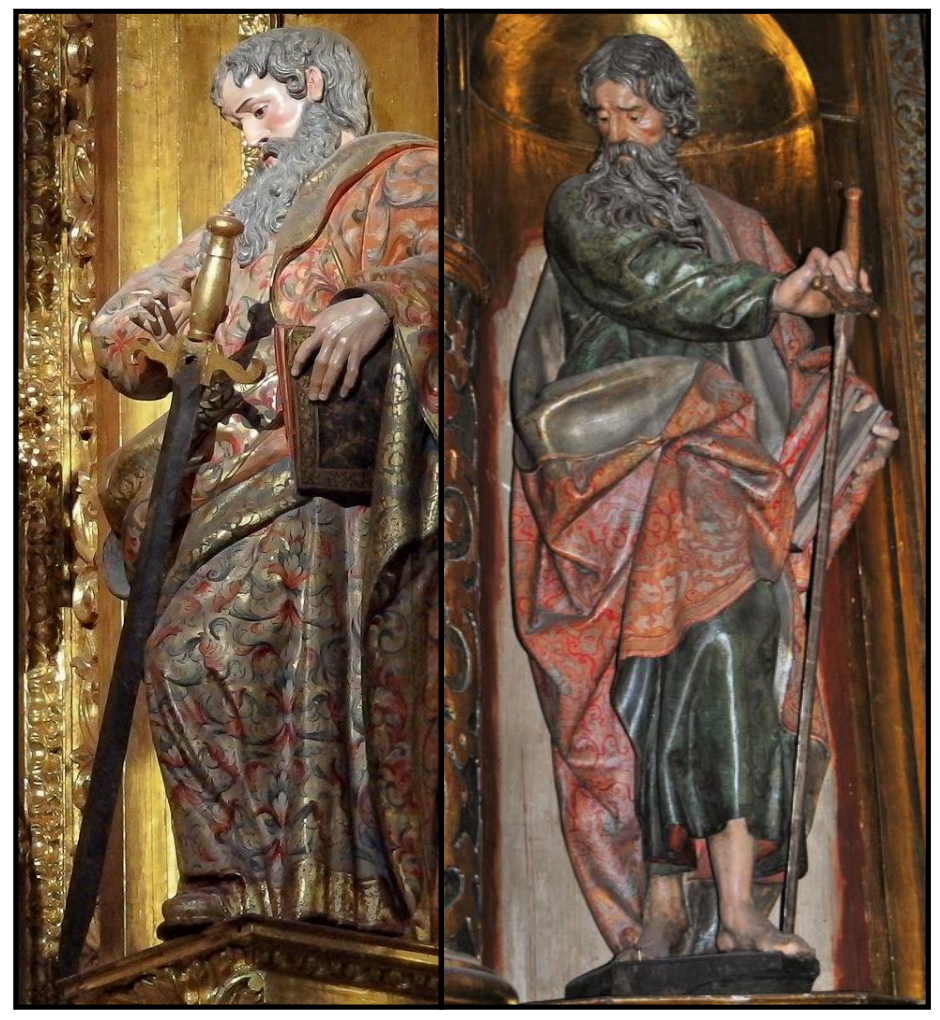

Il. 10- Comparación de los San Pablo de Juan de Ávila y de Gregorio Fernández. derecho. Abundan los tonos rojizos y dorados, así como las profusas decoraciones vegetales con azules y verdes. Asimismo, en el manto vuelve a aparecer la característica cenefa de la que hemos hablado con anterioridad y que se hacía patente tanto en San Pedro como en San Andrés. Para no repetirnos diremos que los pliegues de la túnica y del manto son en todo coincidentes con los exhibidos en el primer apóstol.

La escultura también está inspirada en Fernández. Parece llegar a una solución de conformidad entre su propio estilo y dos esculturas del maestro: el San Pablo que talló para los retablos mayores de la parroquial de Nava del Rey y de la Catedral de Plasencia. Mientras que del primero toma el detalle del dedo metido en el libro, del segundo copia la composición general (pierna adelantada, brazo derecho cruzado por delante del pecho, manto dispuesto atravesado sobre el abdomen, etc...), eso sí, en este

199 PARRADO DEL OLMO, Jesús María: Catálogo Monumental de la provincia de Valladolid. Tomo XVI..., op. cit., p. 351.

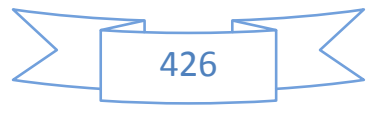


caso el santo no porta el libro. La cabeza ladeada con amplias barbas esparcidas por el pecho aparece en sendas imágenes. Hay un tercer San Pablo fernandesco que pudo ser el verdadero inspirador de la talla de Ávila puesto que éste sí que debió de verlo y estudiarlo con sus propios ojos. Se trata del que el gallego talló para el desaparecido retablo mayor de la primitiva parroquia de San Miguel de Valladolid, que después fue reutilizado para el retablo mayor de la iglesia de San Miguel y San Julián. Este San Pablo no solamente inspiró a Ávila, sino que fue el modelo para otros muchos escultores del siglo XVII y XVIII, como por ejemplo Pedro de Ávila. Algunas de estas versiones actualizadas del San Pablo fernandesco son las que podemos ver en los retablos mayores de Casasola de Arión, Cigales, Marzales, Torrecilla de la Abadesa (cuya escultura se atribuye al propio Ávila), Velilla, Villalba de los Alcores, Villanueva de Duero o el de la parroquia de Santa María de Pozaldez. La mayoría de las esculturas de estos retablos permanecen sin documentar. Tan solo sabemos que las de Cigales son obra de Andrés de Oliveros $(1668)^{200}$, las de Velilla de Pedro de la Cuadra (1613) ${ }^{201}$, el San Pablo de Villalba de los Alcores de Antonio Vázquez (1691-1693) ${ }^{202}$, y el de Pozaldez de Andrés de Pereda (1696) ${ }^{203}$. La disposición general de este San Pablo que inspiró a tantos artistas es sin duda el punto del que partió Ávila para crear el suyo, la gran diferencia con aquel es que nuestro escultor utiliza un canon más holgado.

Si comparamos esta escultura con la de San Andrés comprobamos que esta tiene una actitud más calmada y estática, si bien el rostro hace gala de fuerza contenida, podríamos hablar de una lejana "terribilità" practicada por Miguel Ángel. La talla aparece como retorcida sobre sí misma, recordando ciertas composiciones junianas.

\section{$\underline{\text { VIRTUDES }}$}

Las virtudes (Fig. 31) se ubican en el ático, y parecen escoltar al Cristo Crucificado. Aparecen situadas sobre simples ménsulas surgidas del entablamento que divide el ático del cuerpo del retablo. Todas ellas están situadas sobre la vertical de los diferentes soportes tectónicos del retablo (columnas para las centrales y estípites para las laterales). De izquierda a derecha efigian a la Fe, la Templanza, la Fortaleza y la Justicia. Como ya dijimos, en el proyecto inicial Juan de Ávila se obligaba a ejecutar "las tres Virtudes que son fortaleza, justicia y en medio la fe"204, a la cual se añadió posteriormente la Templanza. De esta manera conjugó tres de las Virtudes Cardinales (Fortaleza, Justicia y Templanza), descartando a la Prudencia, con una de las Virtudes Teologales: la Fe. Pero no queda ahí todo, pues hubo otra permuta: Ávila se

200 URREA FERNÁNDEZ, Jesús: Catálogo Monumental de la provincia de Valladolid. Tomo $X X \ldots$, op. cit., p. 161.

201 ARA GIL, Clementina Julia y PARRADO DEL OLMO, Jesús María: Catálogo Monumental de la provincia de Valladolid. Tomo XI..., op. cit., p. 354.

202 PARRADO DEL OLMO, Jesús María: Catálogo Monumental de la provincia de Valladolid. Tomo XVI..., op. cit., p. 351.

203 MARCOS VILLÁN, Miguel Ángel y FRAILE GÓMEZ, Ana Mª Catálogo Monumental de Valladolid. Tomo XVIII..., op. cit., p. 163.

204 CERVERA VERA, Luis: La iglesia colegial..., op. cit., p. 205. 
comprometió inicialmente a representarlas "sentadas con todos sus atributos"205, extremo que no cumplió puesto que aparecen de pie. Seguramente no habría sitio suficiente.

Las cuatro imágenes siguen el mismo patrón, de manera que si cada virtud no portara sus atributos personales no podríamos diferenciarlos, ya que, incluso, las vestimentas son casi idénticas. Apenas las diferencia el modo de tenerlas anudadas o colocadas. Visten túnica larga verde con esgrafiados dorados; por encima llevan un manto rojo, por su parte anterior, y verde, por la posterior, salvo la imagen de la Fortaleza que viste una capa roja. Las cuatro esculturas son muy rígidas, envaradas y lánguidas; no parece que tengan vida, como ocurre con los tres apóstoles; están como petrificadas. Los rostros son inexpresivos y estereotipados. La cabellera está tallada de forma muy sumaria, cayendo a ambos lados del rostro. Los pliegues son los típicos de Ávila, si bien se ven algo más secos y con ciertas durezas a la altura de las rodillas. Pienso que, en algunas de las Virtudes, como, por ejemplo, en la Templanza no ha sabido desarrollar los pliegues bajos de la túnica. Todo ello me lleva a pensar que estas cuatro tallas son obras de taller. El maestro daría el modelo, pero la ejecución corrió toda a cargo de sus oficiales y aprendices. Dada la altura a la que se encuentran, ya que desde el suelo los rostros y los detalles de los ropajes son casi imperceptibles, pienso que Ávila encomendó esta tarea "menor" a sus discípulos, quedándose para sí las esculturas de San Pedro, San Andrés y San Pablo, en las que se centró y recreó, logrando en ellas alguno de los grandes hitos de su carrera. A continuación, desgranaremos cada una de las Virtudes, comentándolas según su posición, de izquierda a derecha:

La Fe exhibe orgullosa en su mano izquierda, con el brazo bien levantado para que todos puedan verlo, un expositor con la sagrada hostia.

La Templanza es según Ripa "una especie de equilibrada moderación, guiada y determinada por un certero raciocinio, en todo cuanto respecta a los placeres o displaceres del cuerpo" 206 . Con su mano izquierda aparece vertiendo una jarra llena de agua sobre un aguamanil con vino, sujeto con la otra mano, con el fin de "mitigar lo que es demasiado excitante" 207 .

La Fortaleza ase enérgicamente la columna con su mano derecha, mientras que con la derecha hace lo propio con su manto. La columna es el atributo más característico de esta virtud porque, según Cesare Ripa, "de los elementos de un edificio éste es el más fuerte y el que sostiene a los otros" ${ }^{208}$. Si hacemos caso a Ripa, Ávila habría introducido una pequeña variación iconográfica ya que el italiano comenta que la personificación de la Fortaleza "se apoya" en la columna. En esta ocasión no se apoya en ella, sino que la sujeta con una de sus manos. En ocasiones la columna puede aparecer representada rota.

\footnotetext{
$205 \quad$ Ibídem.

206 RIPA, Cesare: Iconología, Tomo II, Akal, Madrid, 2007, p. 353.

207 RÉAU, Louis: Iconografía del arte cristiano, Ed. del Serbal, Barcelona, 2000, p. 227; http://www.arteiconografia.com/2011/05/las-virtudes-cardinales.html.

208 RIPA, Cesare: op. cit., Tomo I, p. 437.
} 
Finalmente, en el extremo derecho aparece la Justicia, la cual según Ripa es "aquel hábito según el cual el hombre justo, por su propia elección, es dador y dispensador tanto del bien como del mal, para sí mismo y los otros, o entre unos y otros en su caso, según su calidad y actuando de acuerdo con la proporción geométrica o la aritmética; teniendo como fin último la utilidad y la belleza, a la pública felicidad acomodada"209. La escultura figura levantando impetuosamente su brazo derecho, con cuya mano sujeta la espada. Con su otra mano, más relajada, sujeta las cuerdas de una balanza. Ambos son sus atributos más representativos junto con la venda en los ojos, elemento que en esta ocasión no posee ${ }^{210}$. 


\section{TRASPINEDO. IGLESIA PARROQUIAL DE SAN MARTÍN}

\section{RETABLO MAYOR (1678-1693/4)}

Gracias a los libros de fábrica sabemos que en 1678 ya se estaba realizando el retablo mayor $^{211}$, bajo la dirección de un maestro apellidado Muñoz ${ }^{212}$. Desde 1679 tenemos constancia de que Tudanca estaba relacionado con la obra ${ }^{213}$. En este último año se le pagan 60 reales por un trabajo que desconocemos. También se le abonan diferentes cantidades a Alonso Rodríguez Bote por un trabajo sin determinar ${ }^{214}$, a un maestro anónimo "por hacer las columnas del retablo"215, y a un tal Ribota por hacer el pedestal sobre el que asentar el retablo ${ }^{216}$. Durante años sucesivos se seguirán haciendo pagos a los maestros por razón del retablo, lo que nos indica que la obra se fue demorando, seguramente por la falta de liquidez en la parroquia.

De estas escasas noticias podemos colegir que de la parte arquitectónica del retablo se ocupó el "maestro Muñoz", al cual ayudarían otros maestros, como el que talla las columnas. Por su parte, Francisco Díez de Tudanca corrió con la escultórica. Desconocemos por completo las esculturas y/o relieves que se comprometió a tallar pues no se ha localizado la escritura de concierto y, además, el retablo desapareció en fecha indeterminada. A modo de anécdota hay que señalar que esta es, cronológicamente hablando, la última obra documentada del escultor.

Una nueva escritura nos permite conocer, en parte, los designios que tomó aquella accidentada obra. Fechado el 25 de octubre de 1694, se trata del documento por el cual los regidores de la villa acreditan que Juan de Ávila ha cumplido con su compromiso de finalizar el retablo (DOCUMENTO 32). Según relata la escritura, en una fecha indeterminada, Francisco Díez de Tudanca, como principal, y Juan de Ávila, como su fiador, se comprometieron con los regidores de la villa de Traspinedo, Sebastián de Olmedo y Manuel de Velicia, a continuar con la obra "de talla y hechuras de escultura" del retablo mayor. La expresión "de que proseguiría en la dicha obra y con efecto prosiguioo", unido a lo de que continuaría con la "obra de talla", nos deja la duda de si en realidad Tudanca no se hizo cargo, a partir de determinada fecha, de la maestría total del retablo, es decir, tanto de la arquitectura como la escultura. Tudanca no cumplió con su parte, puede que a causa de su fallecimiento, si bien no podemos descartar otras opciones como que su avanzada edad no le permitía desempeñar correctamente su oficio, que tuviera otros encargos simultáneos y no le diera tiempo a acabarlo, o bien que desistiera de hacerlo y quisiera que lo acabara su discípulo y sobrino Juan de Ávila.

\footnotetext{
211 MARTÍN GONZÁLEZ, Juan José: Catálogo Monumental de la provincia de Valladolid. Tomo VI..., op. cit., p. 113.

212 "6 reales que dio y gastó con Muñoz y su hijo, maestro del retablo". Ibídem.

213 "60 reales que pagó a Francisco de Tudanca, maestro del dicho retablo". Ibídem.

214 "200 reales a Alonso Rodríguez Bote, maestro que trabajó en la obra del retablo". Ibídem.

215 “150 reales a un maestro que trabajó en hacer las columnas del retablo". Ibídem.

216 "200 reales que pagó a Ribota, maestro que hizo el pedestal”. Ibídem.
} 
Tras la "renuncia" de Tudanca, Ávila "se convino y concertó (...) con la dicha villa como tal fiador de que proseguiría en la dicha obra". En efecto, prosiguió con la obra inacabada, pero, cosas del destino, no pudo finalizarla "como estaba obligado", si bien realizó "la mayor parte de talla y hechuras de escultura". Por excusarse de pleitos, ambas partes firmaron un nuevo concierto por el cual Ávila se comprometía a tallar "una hechura de un Santo Cristo y dos remates y dos festones que cuelgan a los lados de los arbotantes de dicho retablo y dos tarjetas que caen encima de las hechuras de Santa Teresa y Santa Catalina". Ávila cumplió perfectamente con lo acordado, por lo que el 25 de octubre de 1694 los regidores de la villa se "dieron por entregados a su voluntad y otorgaron carta de pago". No sabemos la fecha concreta en que Ávila terminó su trabajo, pero debió de ser a lo largo del año 1693, ya que es en ese año cuando se estaba efectuando el dorado del retablo, el cual corrió en su mayor parte a cargo del Concejo de la villa ${ }^{217}$.

Como vemos tampoco queda muy claro las esculturas que hizo Ávila, tan solo que corrió de su cuenta un Santo Cristo, es decir, un Crucificado, y dos remates y dos festones. Desconocemos si las imágenes de Santa Teresa y Santa Catalina las hizo el propio Ávila o fue parte de lo que dejó hecho Tudanca. El resto del programa iconográfico, como ya hemos dicho, nos es totalmente ignorado. Cabe pensar que siendo San Martín de Tours el patrón de la iglesia se hiciera una escultura suya que presidiera el retablo, a no ser que se reaprovechara una imagen anterior.

Tras una visita a la iglesia parece que lo único que puede relacionarse con el retablo mayor, del cual ha desaparecido la integridad de la arquitectura y parece que la casi totalidad de la escultura, es un Crucificado (Figs. 32-33) situado en la pared del presbiterio. No cabe duda de que este debe ser el Santo Cristo que Ávila se comprometió a tallar. Es una escultura ciertamente desconcertante puesto que, si el rostro puede ser relacionado plenamente con nuestro escultor, del cuerpo no puede decirse lo mismo, ya que la talla es bastante sumaria, con ciertos errores anatómicos y pliegues bastante duros localizados en la lazada del perizonium. No podemos ser categóricos en esta afirmación ya que el estado de conservación del Crucifijo es ciertamente lamentable, además de haber sufrido numerosos repintes poquísimamente afortunados, sobre todo en lo que concierte al rostro y a las numerosas gotas de sangre que para nada corresponderán a la policromía de la época en que Ávila talló la escultura.

Se trata de un Cristo de tres clavos que acaba de fallecer, ya que el cuerpo y los brazos todavía no se han desplomado a causa del óbito. La cabeza figura ladeada hacia el lado derecho y caída sobre el pecho, sobre el cual se apoya la barba. Perizonium anudado al lado derecho. Piernas flexionadas. Podríamos decir que este Crucifijo es la base sobre la que creará en un futuro Pedro de Ávila su característico Crucificado, del cual nos ha legado, al menos, cuatro ejemplares. A falta de retirar esa horrorosa policromía podemos observar un bellísimo rostro, muy típico de nuestro escultor: ojos levemente rehundidos, mejillas sobresalientes, anchos bigotes, barba bífida, potente melena a

217 "155 reales que ha gastado para ayudar de dorar el retablo, por cuanto el concejo hace todo el coste para dorar el retablo". Ibídem. 
manera "de peluca”, según las palabras de Martín González. Tampoco faltan sus característicos mechones simétricos y sinuosos cayendo sobre la frente, como si estuvieran mojados. A buen seguro una restauración nos proporcionará gratas sorpresas en lo concerniente a la cabeza del Santo Cristo.

Como desconocemos el destino que tuvo el retablo, si fue destruido o enajenado, tampoco tenemos constancia de qué ocurrió con el resto de las esculturas, de las cuales solo sabemos que había una Santa Teresa y una Santa Catalina. A manera de hipótesis, aunque sin ningún fundamento para asegurarlo, me gustaría señalar que la Santa Teresa pudiera ser una que se conserva en la moderna parroquia de Puente Duero, localidad cercana a Traspinedo. 


\section{VALLADOLID. ERMITA DE SAN ISIDRO LABRADOR}

\section{SAN ISIDRO Y SANTA MARIA DE LA CABEZA (1698)}

Cada oficio tenía su agrupación gremial y su santo patrón, los campesinos sentían una especial devoción por San Isidro labrador. Desde las postrimerías del siglo XV hasta principios del siglo XVIII los campesinos vallisoletanos celebraron los actos religiosos en la iglesia parroquial de San Andrés apóstol, puesto que por entonces los fondos gremiales eran muy reducidos, tanto que al parecer no les llegaba ni para sufragar los gastos de una Misa Mayor con panegírico y una modesta luminaria ${ }^{218}$. Los referidos campesinos se organizaron en 1494 en la denominada Cofradía de Nuestra Señora de la O y bendito Isidro labrador, teniendo su sede en la referida iglesia de San Andrés, por entonces la parroquia del barrio más rural ${ }^{219}$. Su regla tuvo que esperar algo más de un siglo para aprobarse, concretamente al año 1602. Posteriormente, tras la canonización del santo en 1622, los cofrades decidieron clavar una cruz "donde había de hacerse la obra y lo habían quedado en aquel estado" 220 .

Tras una serie de intentos de construir una capilla, o bien una ermita, en la que poder desarrollar cultos a su querido santo, los deseos se concretaron en 1692. Una de estas intentonas tuvo lugar hacia el año 1624, seguramente influidos todavía en el ánimo por la reciente canonización del santo. Cuenta Matías Sangrador que por entonces "la cofradía de Nuestra Señora de la O y San Andrés al cabildo de nuestra Santa Iglesia solicitando el competente permiso para construir una ermita fuera de las puertas de Tudela, en el paramillo, la cual había de dedicarse a San Isidro Labrador. El cabildo no dudó un momento en conceder esta gracia a la cofradía; pero la impuso la condición de que en el día de la festividad del Santo había de celebrar la misa un prebendado de la Santa Iglesia"221.

En el referido año de 1692 se volvió a tratar en un cabildo la posibilidad de fabricar una capilla en la iglesia de San Andrés, de similar manera a lo acontecido en Madrid, o construir "una ermita en el páramo sobre la fuente de la Salud a donde mejor se discurriese (...) donde llevaban las mieses a trillar los labradores". Finalmente triunfó la segunda tesis, por lo que se decidió fabricar una ermita "en dicho páramo cómo se va de esta ciudad a La Cistérniga a mano derecha". La cofradía, siempre apurada en lo económico, recibió ayuda del Ayuntamiento para poner en marcha la obra, concretamente 300 ducados, el resto deberían pagarlo los cofrades (DOCUMENTO 44). La ermita resultante fue un edificio muy pobre, realizado en piedra de cantería, ladrillo y tapial. Tiene planta de cruz latina, no proyectada al exterior. Consta de una sola nave, muy ancha, divida en dos tramos: el cuerpo de la iglesia y el altar mayor, este último es algo más ancho, además de estar rematado por una cúpula encamonada. Dicha

\footnotetext{
218 GARCÍA CHICO, Esteban: Valladolid: Papeletas..., op. cit., p. 105.

219 MARTÍN GONZÁLEZ, Juan José y URREA FERNÁNDEZ, Jesús: Catálogo Monumental de la provincia de Valladolid. Tomo XIV..., op. cit., p. 310.

$220 \quad$ Ibídem.

221 SANGRADOR Y VÍTORES, Matías: Historia de la Muy Noble y Leal Ciudad de Valladolid..., op. cit., Tomo II, p. 128.
} 
cúpula tiene decorado el centro de la misma y las pechinas con pinturas murales; también posee sencillas yeserías, como la bóveda de la nave, la cual, asimismo, tiene unos lienzos encastrados, práctica muy barroca. Poco más sabemos de su historia, como por ejemplo que en el año 1885 realizó funciones de hospital y lazareto para convalecientes a raíz de la epidemia de cólera, morbo que asoló la ciudad durante el verano $^{222}$.

Las limosnas y donativos a la cofradía no quedaron ahí, ya que en el año 1698 dos benefactores contactaron, de forma independiente, con Juan de Ávila para que este esculpiera las esculturas de los santos titulares de la cofradía y, por ende, de la ermita: el matrimonio formado por San Isidro y Santa María de la Cabeza. Estos bienhechores fueron el entonces obispo de Valladolid, don Diego de la Cueva y Aldana ${ }^{223}$, y don Luis de la Vega. Mientras que este último corrió con los gastos de la efigie de San Isidro, el prelado sufragó la de Santa María de la Cabeza ${ }^{224}$. Desconocemos de dónde era don Luis de Vega, pero, sabiendo que el obispo era madrileño, puede que la motivación de ambos fuera el tener unas esculturas en Valladolid de los patronos de su ciudad natal.

Las esculturas ya estaban concluidas en septiembre de ese mismo año, ya que Ortega y Rubio refiere que "en los últimos días de septiembre se celebraron fiestas con motivo de la traslación de San Isidro y Santa María de la cabeza a la iglesia que habían hecho los labradores y devotos junto a la fuente de la Salud"225. La primera vez que las tallas salieron en procesión fue la que se celebró el día de su fiesta del año 1700: "15 de mayo de 1700. Día de gran fiesta; primera procesión por los aledaños de la ermita. Confalón primoroso bordado con hilos de oro. Vistosos danzantes de tierra de Portillo. Carros con toldos engalanados con frutos de la tierra y repletos de viandas. Gente moza bailando a la rueda al compás de las notas alegres de la dulzaina y el tamboril aldeano

222 GONZÁLEZ GARCÍA-VALLADOLID, Casimiro: Valladolid..., op. cit., Tomo III, p. 39.

223 Nacido en Madrid en 1638, fue designado obispo de Valladolid en junio de 1682, si bien hasta el 10 de mayo de 1683 no tomó posesión de la diócesis vallisoletana. Dirigió los designios de la misma hasta 1707, año en que falleció. El mayor hito de su pontificado fue la beatificación de San Pedro Regalado. Su sucesor fue don Andrés Orueta Barasorda. DE CASTRO ALONSO, Manuel de: Episcopologio vallisoletano, Tipografía y casa editorial Cuesta, Valladolid, 1904, p. 292.

224 "Cabildo en 24 de abril de 1698 para la fiesta de San Isidro (...) se juntaron a cabildo los señores alcaldes, diputados oficiales y demás cofrades de la cofradía de Nuestra Señora de la O y el glorioso San Isidro sita en la parroquial de San Andrés de esta ciudad en su sala de cabildos como lo tienen de costumbre para tratar de las cosas tocantes al servicio de Dios Nuestro Señor bien y utilidad de dicha cofradía (...) estando juntos la mayor parte de los cofrades de los que al presente hay en ella se propuso por el señor Sebastián de Pesquera alcalde antiguo como se llegaba el día del glorioso santo que la cofradía dispusiese si se han de hacer fiesta respecto de que estaba la obra de la ermita en estado de que en todo este año se podía hacer la traslación y tenía noticia cierta de que el señor Obispo tenia mandado hacer a Santa María de la Cabeza mujer del glorioso Santo de talla para que aun tiempo se colocase con el Santo y la misma noticia tiene de que el señor don Luis de la Vega, tenía mandado hacer la efigie del glorioso Santo de talla y los hacia Juan de Ávila que la cofradía dispusiese lo que había de ejecutar y habiéndolo visto oído y entendido todos juntos unánimes acordaron se esté con el señor Obispo y con el señor don Luis de la Vega y se los de las gracias y se les tenga en esta cofradía como bienhechores y al dicho don Luis de la Vega por cofrade y se le llame a los cabildos para sí quisiese asistir a ellos (...). Esto acordaron y lo firme por el escribano de la cofradía”. GARCÍA CHICO, Esteban: Documentos para el estudio del arte en Castilla. 2..., op. cit., pp. 371-372.

225 ORTEGA Y RUBIO, Juan: Historia de Valladolid, Tomo II, Imprenta y Librería Nacional y Extranjera de Hijos de Rodríguez, Valladolid, 1881, p. 114. 
(...) A los pies del cerro, camino abajo, la fuente de agua milagrera que ningún romero deja de beber (...)"226.

Los dos patronos siguieron saliendo en años sucesivos, como podemos comprobar en el Diario de Valladolid de Ventura Pérez: El día 15 de mayo de 1742, "día de Pascua del Espíritu Santo, cayó San Isidro, y celebraron su fiesta en su ermita, y le quedaron en novenas por los buenos temporales; y el domingo siguiente, día de la Santísima Trinidad, le sacaron en procesión con Santa María de la Cabeza, su mujer, y le bajaron la cuesta abajo y volvieron a subir por el camino detrás de su ermita. Asistió la cofradía sacramental de San Andrés; iba delante la cofradía del santo con su guion blanco y con los dos santos en la tarjeta, y llevaban los mozos de la labranza a Santa María de la Cabeza y después iba la sacramental con su guion, y llevaban asimismo los mozos a San Isidro y detrás iba la parroquia cantando los salmos" ${ }^{227}$. Pero no solo han salido en procesión el día 15 de mayo de cada año, ambas imágenes formaron parte de la procesión celebrada el 8 de septiembre de 1758 con motivo de la colocación del Santísimo Sacramento en el recién inaugurado retablo mayor de la iglesia parroquial de San Andrés. Así lo recoge Ventura Pérez: “Año de 1758, día 8 de Setiembre, colocó en la parroquia de San Andrés el Santísimo Sacramento en su retablo nuevamente dorado. Salió la procesión de San Andrés por la Mantería, en donde al salir al Campillo hubo en la bocacalle de la Mantería un arco triunfal, por donde salió la procesión. Anduvo alrededor del Campillo, y a la puerta de San Felipe de la Penitencia había un muy lucido altar, que le pusieron los tablajeros; prosiguió la procesión por la calle de Zurradores, y a la puerta de un labrador, panadero, frente de la alhóndiga, había muy pulido altar, en donde tenían a San Isidro y Santa María de la Cabeza, su mujer, los mismos de su ermita (...)".

Las dos imágenes gozaron de gran popularidad y devoción, puesto que se llegaron a imprimir estampas efigiando a los dos santos labradores de la ermita. Quizás este sea uno de los motivos por los que se popularizaron tanto ambas imágenes en los territorios cercanos a Valladolid, particularmente en la zona sur de la actual provincia de Valladolid, casualmente por donde marchaba el camino de Valladolid a Madrid. Uno de los grabados nos muestra a ambos santos ubicados en una especie de hornacinas u arquitecturas fingidas, y tras ellos se abren sendos paisajes. Divide ambas hornacinas una especie de estípite sobre el que se sitúa un escudo con los atributos de los santos. Las imágenes siguen con más o menos fidelidad las esculturas de Ávila, sobre todo Santa María de la Cabeza. Debajo de cada santo uno de ellos se sitúa un letrero. Debemos leer ambos para completar el mensaje: "S. ISIDRO LABRADOR Y S MARÍA DE LA CABEZA. Como se venera en su Hermita extramuros de esta ciudad de Valladolid"228. Desconocemos tanto la fecha de ejecución como al grabador que lo hizo.

Por fortuna, ambas imágenes se han conservado en el retablo mayor de la ermita, el único que se ha conservado. El retablo es a la par simple pero bello, de hecho para

226 GARCÍA CHICO, Esteban: Valladolid: Papeletas..., op. cit., p. 108.

227 PÉREZ, Ventura: op. cit., p. 197.

228 GARCÍA VEGA, Blanca: op. cit., pp. 404-405. 
González García-Valladolid era lo "único que merece citarse" de toda la ermita ${ }^{229}$. Se organiza mediante banco, un solo cuerpo con tres calles, y ático rematado en una especie de peineta. El cuerpo principal se articula mediante cuatro estípites que flanquean las calles laterales, en cuyos intercolumnios, sobre sendas peanas, se sitúan otros dos santos labradores: San Laurenciano y San Emeterio de Barcelona ${ }^{230}$. Se desconoce el autor de ambas imágenes. Me gustaría apuntar el nombre del semidesconocido escultor vallisoletano José Fernández como posible autor de las dos tallas, dado que los rostros de ambos santos se acercan bastante a su escasa producción conocida $^{231}$. La hornacina principal, donde se encuentran San Isidro y Santa María de la Cabeza, está rematada en su parte superior por dos arcos de medio punto tapados por una decoración realizada a base de nubes y cabezas de querubines que recuerdan las creaciones de Pedro de Sierra $^{232}$. Las dos imponentes esculturas fueron definidas por García Chico como "esculturas esbeltas, bien plantadas, llenas de sentido humano y movidas con cierta gracia", acusando "la influencia de un aprendizaje en contacto directo con las obras de Gregorio Fernández"233. El ático, también articulado mediante dos estípites más pequeños, está presidido por un interesante lienzo del Arcángel San Rafael junto a Tobías, de cuya inclusión en el retablo desconozco la motivación. Remata el ático una peineta y a los lados,

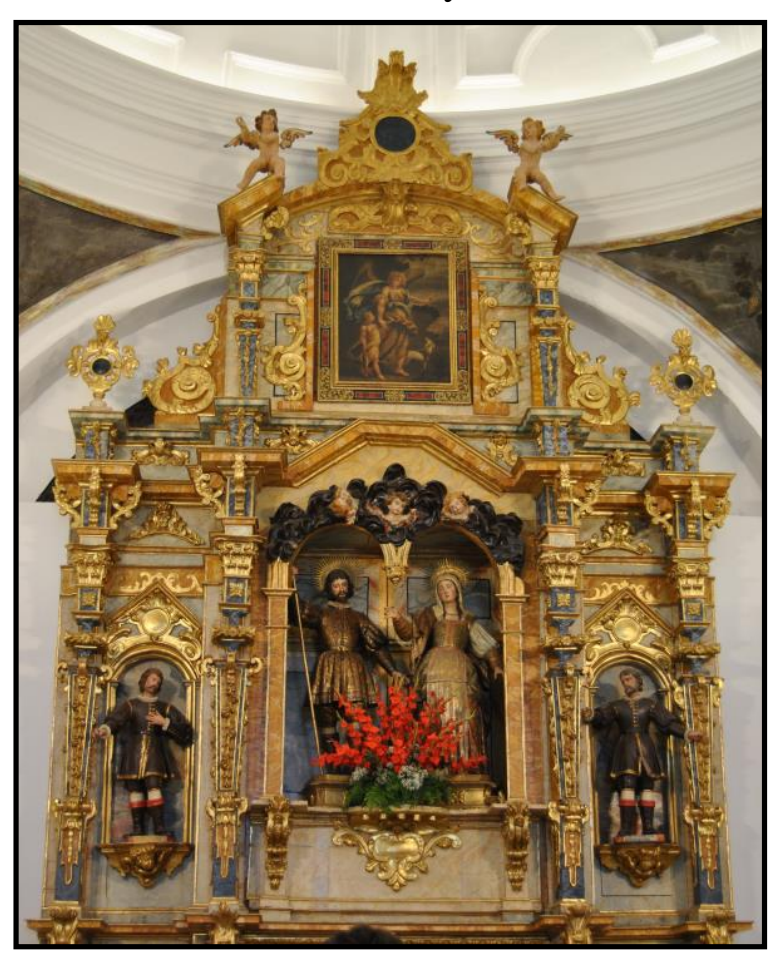

Il. 11- Anónimo. Retablo mayor. Ermita de San Isidro. Valladolid. montados sobre dos trozos de entablamento, sendos angelotes que bien pudieran haber portado entre sus manos algún objeto. Al encontrarnos en una fecha tan avanzada el dorado no lo inunda todo, sino que va ganando cada vez más peso el fingimiento de

229 GONZÁLEZ GARCÍA-VALLADOLID, Casimiro: Valladolid..., op. cit., Tomo III, p. 37

$230 \quad$ En la peana de San Emeterio se puede leer perfectamente "S.HEMETERIO JUE(...) DEBARZELONA", en cambio en la del otro santo ha desaparecido el letrero.

231 Tan solo le conocemos la ejecución de unas pocas esculturas: en 1741 realiza para la capilla de la Universidad de Valladolid las imágenes de San Juan, San Nicolás y Santa Catalina (desaparecidas); en 1749 contrata una María Santísima de los Dolores para la Hermandad del mismo nombre sita en la iglesia de San Pedro; en 1764 una Virgen del Rosario para Corcos del Valle; y en 1775 las imágenes de la Inmaculada, San Simón y San Judas para la parroquial de Valoria la Buena. REDONDO CANTERA, María José: "El edificio de la Universidad durante los siglos XVII y XVIII" en Historia de la Universidad de Valladolid, tomo II, Universidad de Valladolid, Valladolid, 1989, p. 657; MARTÍN GONZÁLEZ, Juan José y URREA FERNÁNDEZ, Jesús: Catálogo Monumental de la provincia de Valladolid. Tomo XIV ..., op. cit., p. 167; URREA FERNÁNDEZ, Jesús: Catálogo Monumental de la provincia de Valladolid. Tomo XX..., op. cit., pp. 58 y 128.

232 La disposición de los dos arcos de medio punto encima de los santos de la hornacina principal del retablo recuerda bastante a los retablos de doble advocación tan típicos en la zona burgalesa. En Valladolid y su área de influencia no existen muchos ejemplos.

233 GARCÍA CHICO, Esteban: Valladolid: Papeletas..., op. cit., p. 107.

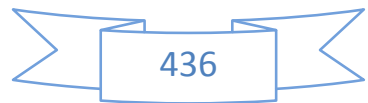


mármoles de diferentes colores. Pienso que el retablo podría fecharse hacia los años 1750-1760.

\section{$\underline{\text { SAN ISIDRO }}$}

Isidro de Merlo y Quintana (1082-1172), San Isidro Labrador, fue un santo español nacido en el Madrid dominado por los musulmanes (Mayrit). Si bien aún se duda de su veracidad histórica, se supone que fue un labrador mozárabe que trabajaba de peón de granja al servicio de la familia Vargas. Su vida y milagros fueron recopilados en el siglo XIII por Juan Diácono. Se dice que solía interrumpir su trabajo para rezar. En una de aquellas ocasiones fue sorprendido por su patrón, si bien un ángel terminó de arar las tierras por él mientas él seguía con sus plegarias ${ }^{234}$. Otro de sus numerosos milagros fue el de hacer brotar una fuente con su laya, elemento que será característico de su iconografía. Considerado como la personificación de las Virtudes de los campesinos, se le sacaba en procesión en los momentos de mayor necesidad: langosta, sequías o lluvias torrenciales $^{235}$. Su carrera hacia los altares estuvo jalonada por dos momentos: Pablo $\mathrm{V}$ lo beatificó en 1619, y Gregorio XV lo canonizó en 1622, junto a otros santos españoles: San Ignacio de Loyola, San Francisco Javier y Santa Teresa de Jesús. Su fiesta se estableció el 15 de mayo, en primavera, en la estación de la siembra.

Como ya hemos dicho, la escultura de San Isidro fue encargada a nuestro escultor por Luis de Vega en el año 1698, el cual posteriormente se la regalaría a la Cofradía de San Isidro, la cual, agradecida, acordó "se les tenga en esta cofradía como bienhechores y al dicho don Luis de la Vega por cofrade y se le llame a los cabildos para sí quisiese asistir a ellos" ${ }^{\prime 236}$.

Juan de Ávila concibió una escultura monumental (Figs. 34-35), con un porte distinguido. El santo, que posee un tamaño cercano al natural, sigue de cerca el modelo creado por Gregorio Fernández, cuyo cabeza de serie, según la opinión de Martín González, es la escultura de San Isidro labrador tallada en 1629 para la iglesia parroquial de Santa María de Dueñas (Palencia) ${ }^{237}$. Hay que subrayar que Ávila la toma como ejemplo, pero no la copia literalmente. En realidad, a partir de ella crea un modelo nuevo que tendrá gran repercusión en muchos pueblos de la actual provincia de Valladolid, sobre todo en los cercanos a Olmedo, y que a su vez sirvió como patrón a diversas esculturas del santo que fueron talladas por sus hijos Pedro y Manuel, si bien la mayor parte de ellas están atribuidas. Entre las documentadas contamos con la que su hijo Manuel esculpe para el retablo mayor de la iglesia de Fuentes de Valdepero

\footnotetext{
234 RÉAU, Louis: Iconografía de los santos. G-O, Ed. del Serbal, Barcelona, 1997, p. 130.

235 MARTÍN GONZÁLEZ, Juan José: "San Isidro Labrador". En VV.AA.: Las Edades del Hombre. El contrapunto y su morada [Exposición. Salamanca, 1993-1994], Las Edades del Hombre, Valladolid, 1993, p. 265.

236 GARCÍA CHICO, Esteban: Documentos para el estudio del arte en Castilla. 2..., op. cit., pp. 371-372.

237 MARTÍN GONZÁLEZ, Juan José: “San Isidro Labrador”, op. cit., p. 265.
} 
(Palencia) (DOCUMENTO 97). En definitiva, podíamos hablar de esta imagen de la ermita como el origen de una extensa serie de copias.

Como hemos dicho, la influencia de Fernández todavía se deja sentir en esta obra, tan alejada en el tiempo, sobretodo en el elegante ademán y en los convencionalismos del rostro del santo, como pueden ser los cabellos caídos sobre la frente propios de Fernández ${ }^{238}$. Isidro figura de pie, con la pierna izquierda adelantada. Ávila concibe los brazos del santo en diagonal, recurso muy barroco. Mientras que el derecho lo sitúa hacia abajo para agarrar el arado, el izquierdo lo levanta para sujetar el cayado. Viste a la usanza de los labriegos acomodados de la época ${ }^{239}$ : jubón con hombreras, ceñido en la cintura con un cinturón. Botonadura entre la gorguera y el cinturón. Amplias mangas, con pliegues suaves muy naturalistas, y bocamangas con botonadura. Calzas ajustadas al muslo hasta la rodilla. Polainas y zapatos. La mayoría de los pliegues son suaves y redondeados, destacan por su calidad los de la parte inferior del jubón.

La cabeza aparece tocada por una corona de tipo sol, de rayos rectos y curvos colocados alternativamente. El rostro es el usual en Ávila. Hay que subrayar el hecho de que los rizos que caen sobre la frente, de manera simétrica, no acaban todos en punta, sino que algunos lo hacen en forma de caracolillos. Destacan las grandes masas de pelo ensortijado con numerosos bucles y guedejas a ambos lados del rostro del santo, lo que indica una importante utilización del trépano. Como en otras ocasiones, las menos, los ojos son de pasta vítrea, no están pintados directamente en la madera, con lo cual aumenta su sensación de realismo. Le dan una especial vivacidad al rostro del santo. La delicadeza y elegancia con que Ávila concibe las manos del santo, y también de la santa, nos retrotrae de nuevo a la producción de Gregorio Fernández. Sin duda Ávila en esculturas como ésta se nos muestra como su mejor epígono.

Desconocemos el nombre del policromador, pero hizo un gran trabajo. La imagen se encuentra perfectamente policromada y estofada. La encarnación es mate. La totalidad de las ropas son de color marrón con numerosos esgrafiados en dorado realizando decoraciones vegetales y geométricas. Destaca la cenefa situada en la parte inferior del jubón, en ellas se dan cita verdes y rojos.

\section{SANTA MARIA DE LA CABEZA}

Nacida en una fecha indeterminada en la localidad de Uceda (Guadalajara), fue la mujer de San Isidro, al que conoció en Torrelaguna (Madrid) cuando éste intentaba huir de la conquista almorávide. Santificada con posterioridad a su marido, la iglesia confirmó su culto mediante un breve apostólico el 11 de agosto de 1697. Aunque su festividad se celebra de manera compartida con la de su marido el día 15 de mayo, la suya propia tiene lugar el 9 de septiembre. El nombre con el que fue santificada, "Santa María de la

238 MARTÍN GONZÁLEZ, Juan José: Escultura barroca castellana ..., op. cit., p. 321.
239 Ibídem. 
Cabeza”, es debido a que se guardó su cabeza relicario, la cual era procesionada por los campesinos como rogativa para que lloviera.

La escultura de la santa (Figs. 36-37) fue encargada y costeada en 1698 por el obispo de Valladolid, don Diego de la Cueva y Aldana, la cual posteriormente fue regalada a la cofradía titular. Llaman la atención dos cosas: por una parte, la premura con que se encargó una imagen de la santa, puesto que había sido canonizada apenas hacía unos meses; y también que fuera encomendada al escultor incluso antes que la de su marido, San Isidro.

Si de la imagen de San Isidro dijimos que Ávila se había inspirado en un modelo previo de Gregorio Fernández, no podemos decir lo mismo de la de Santa María de la Cabeza, la cual es invención propia del escultor vallisoletano radicado en la calle de Santiago ${ }^{240}$. Se trata de uno de los pocos modelos o iconografías creados durante el barroco en Castilla que no tiene a Gregorio Fernández como inventor.

Ávila concibe a la santa de manera parecida a su marido: de pie, mirando al frente, y vuelve a utilizar el recurso de colocar los brazos en diagonal. A diferencia de San Isidro, la santa tiene los pies a la misma altura, no adelanta ni atrasa ninguno de ellos. No sabemos que pudo sostener en sus manos: la derecha, levantada, y la izquierda, en posición relajada. Aunque en la actualidad está desposeída de estos atributos, seguramente con la derecha agarraba un huso de hilar, mientras que con la otra sostenía una lámpara de aceite ${ }^{241}$. Si hacemos caso del grabado anteriormente citado, que no concuerda con elementos que en realidad porta San Isidro, la santa tendría agarrada en su mano derecha una hoz.

Viste la indumentaria típica de una campesina española: corpiño ceñido al pecho mediante cordones, faldón, mandil y un manto caído sobre el hombro derecho, recurso típico de nuestro escultor. Los brazos se cubren mediante las mangas de una blusa blanca. La cabeza está tocada por un velo blanco que apenas deja vislumbrar su cabellera, tan solo unos finos mechones que caen por los laterales de su rostro. Leve inclinación de la cabeza hacia la derecha, en contraposición a su marido que la ladea a la izquierda. El rostro, al igual que el de San Isidro está modelado de forma muy blanda $^{242}$. Ojos azules de pasta vítrea, nariz amplia, boca entreabierta y mentón prominente.

La figura es mucho más voluminosa que la de su marido, mucho más elegante, quizás en ello influye el mandil y la dureza de los pliegues del faldón. Los pliegues del mandil son los típicos de Ávila: suaves, levemente curvos y paralelos. La policromía es mucho más alegre, y recuerda bastante a la que Leonardo Martínez de Estrada practicó con los tres santos del retablo de Lerma. Destacan los bellos motivos vegetales en el corpiño y en el faldón, así como las cenefas del mandil y del manto, esta última idéntica a las de los referidos santos de Lerma.

240 MARTÍN GONZÁLEZ, Juan José: La escultura barroca en España..., op. cit., p. 80.

241 GARCÍA VEGA, Blanca: op. cit., p. 405.

242 MARTÍN GONZÁLEZ, Juan José: Escultura barroca castellana ..., op. cit., p. 321. 


\section{TORRECILLA DE LA ABADESA. IGLESIA}

\section{PARROQUIAL DE SAN ESTEBAN PROTOMÁRTIR}

\section{NUESTRA SEÑORA DE GRACIA (1698)}

La Virgen de Gracia es una advocación mariana, fundamentalmente arraigada en tierras levantinas. Tiene sus orígenes en la frase pronunciada por el Arcángel San Gabriel durante la Anunciación a María: "Dios te salve María, llena eres de gracia". Su festividad tiene lugar el primer domingo del mes de agosto.

En el libro de cuentas de la Cofradía de Nuestra Señora del Rosario y del Nombre de Jesús, sita en la iglesia parroquial de San Esteban protomártir, se encuentra la escueta noticia que nos avisa de que en el año 1698 Juan de Ávila realizó una "hechura que hizo nueva de Nuestra Señora de Gracia" ${ }^{243}$. Nada más sabemos sobre la imagen, salvo algunos datos accesorios: en 1699 el platero vallisoletano Pedro Garrido le confeccionó una corona nueva; ese mismo año, la "Madre Luisa, religiosa del Convento de la Laura", realizó "un rostrillo que hizo nuevo para la imagen"; en 1699 un pintor se ocupa de "renovar el rostro de la Imagen de la Virgen", y el platero vallisoletano Marcos Ibáñez le retoca la corona; ya en 1705 el pintor tordesillano Juan López se encargó de "echar un ojo a Nuestra Señora de Gracia"244. Como podemos comprobar la renovación de la imagen fue constante, lo que nos lleva a pensar en su probable función procesional, extremo que se confirma en una partida del año 1712 en la que el dorador Manuel Barreda se obliga a "dorar y pintar las andas nuevas"

Es muy difícil imaginar cómo sería la imagen, pero el hecho de que Juan de Ávila cobrara por su hechura la escasa cantidad de 2.856 maravedíes (= 285 reales) lleva a pensar que o bien se trataba de una escultura de escaso tamaño o bien era una imagen de bastidor en la cual el escultor solamente se ocupó de tallar la cara y las manos. Para establecer una hipótesis de qué tipo de escultura mariana estaríamos tratando habría que entrar a fondo en la iconografía de la Virgen del Rosario, puesto que el nombre de Nuestra Señora de Gracia no era más que una advocación de aquella. Según cuenta la tradición, la devoción al Rosario, que según el diccionario es el "rezo de la Iglesia en que se conmemoran los quince misterios principales de la vida de Cristo y de la Virgen, recitando después de cada uno un Padre Nuestro, diez Avemarías y un gloriapatris" ${ }^{246}$, parte de Santo Domingo, y por extensión de la Orden de Predicadores. Dice la leyenda, que Santo Domingo tuvo una aparición en 1210 en la ciudad francesa de Albi en la que vio a la Virgen ofreciéndole un rosario, "que él llamó "corona de rosas de Nuestra

\footnotetext{
243 "Más 84 reales que pagué a Juan de Ávila, escultor y vecino de la ciudad de Valladolid, por la hechura que hizo nueva de Nuestra Señora de Gracia, que exhibió carta de pagos de dicho maestro, que valen más 2.856 maravedís". ARA GIL, Clementina Julia y PARRADO DEL OLMO, Jesús María: Catálogo Monumental de la provincia de Valladolid. Tomo XI..., op. cit., p. 347.

244 ARA GIL, Clementina Julia y PARRADO DEL OLMO, Jesús María: Catálogo Monumental de la provincia de Valladolid. Tomo XI..., op. cit., p. 347.

245 Ibídem.

246 DÍAZ VAQUERO, María Dolores: La Virgen en la escultura cordobesa del barroco, Monte de Piedad y Caja de Ahorros, Córdoba, 1987, p. 109.
} 
Señora”, como medio de vencer la herejía albigense"247. Esta vinculación con la Orden Dominica se acrecienta en el caso de esta Virgen ya que una religiosa del vallisoletano convento de La Laura (O. P.) le realizó, como acabamos de decir, un rostrillo a la imagen.

La popularización de la devoción a la Virgen del Rosario tuvo lugar con la creación de las Cofradías del Rosario. La primera de ella se fundó en 1470 en la ciudad de Douai (Francia). Relata Díaz y Vaquero que la plasmación artística de la Virgen del Rosario surge de la tipología de la Virgen protectora. Añade Réau que "la devoción de la Virgen del Rosario se relaciona estrechamente con el culto a la Virgen de Misericordia de la cual no es, desde cierto punto de vista, más que una prolongación" ${ }^{248}$. Según la referida Díaz y Vaquero, la Virgen del Rosario tiene tres iconografías diferentes: la primera, "deriva del modelo de la Virgen de Misericordia que abre su manto bajo el cual se cobijan los santos de la Orden Dominica. Sobre su cabeza dos ángeles sostienen una triple corona de rosas", la segunda, "recoge la introducción de la meditación de los misterios en el rezo del Rosario. Así se representa a la Virgen inserta en una mandorla formada por un rosario compuesto, frecuentemente, con rosas blancas para las Avemarías y rojas par los Paternóster. En él se intercalan medallones en los cuales se representan los diferentes misterios meditados"; y, la tercera, "es el modelo que se impone, tras haber perdido todas las "contaminaciones". Se trata de la figuración de la Virgen Madre, es decir, con el Niño, en actitud sedente, que ofrece, o bien Ella o bien el Niño, el rosario a Santo Domingo o a los fieles en general" 249.

Vistas las tres tipologías, lo más factible es que la escultura que talló Juan de Ávila para la cofradía fuera una de las del tercer tipo: Virgen con el Niño, de carácter sedente, que sostuviera en sus manos la Virgen del Rosario. Tampoco habría que descartar que estuviera de pie. Desconocemos tanto la fecha como las circunstancias en las que desapareció, puesto que sería impensable concebir que una imagen de tanta devoción fuera vendida, a no ser que se la sustituyera por otra. Lo más lógico es darla por destruida.

La imagen de la Virgen pudo servir de carta de presentación del escultor ante la iglesia, la cual, satisfecha del trabajo realizado, le confió la elaboración de la parte escultórica del retablo mayor (h.1698-1704), cuyas hechuras se le vienen atribuyendo desde hace tiempo. Y es más, la relación laboral se prolongaría hasta Pedro de Ávila, hijo de Juan, quien sabemos que talló en 1714 un bello Crucifijo ${ }^{250}$.

\footnotetext{
$247 \quad$ Ibídem.

$248 \quad$ Ídem, p. 112

249 Ibídem.

250 PARRADO DEL OLMO, Jesús María: Datos histórico artísticos ..., op. cit., pp. 104-106.
} 


\section{VALLADOLID. IGLESIA DE SANTIAGO APÓSTOL}

\section{ESCULTURAS DEL RETABLO MAYOR (1698-1702)}

El encargo de las esculturas del retablo mayor de la iglesia parroquial de Santiago Apóstol, su parroquia de toda la vida, resulta ser el colofón a su carrera truncada a los 50 años, una edad no muy madura ni aún para el siglo XVIII. No sólo será el broche de oro por ser su última gran obra sino también porque en ella nos legará su obra maestra: el grupo central de Santiago Matamoros.

La iglesia de Santiago, la más antigua de la ciudad, tiene su origen en una humilde ermita dedicada al Santo Cristo del Escobar. El cambio de advocación en favor del apóstol tuvo lugar hacia el año 1360, fechas en las que la ermita se hallaba servida por una cofradía dedicada a Santiago. Fue hacia el año 1400 cuando la ermita se convirtió en iglesia parroquial. Nada subsiste del aquel humilde templo ya que fue totalmente reconstruido. Primeramente, hacia 1490 se reedificó el cuerpo de la iglesia, y, seguidamente, entre 1497-1500 se llevó a cabo la obra de la capilla mayor ya que en el primero de esos años se había derrumbado, al igual que la torre. Se ocupó de su reconstrucción el arquitecto Juan de Arandía, si bien las obras fueron sufragadas por el parroquiano más relevante de dicha iglesia: el rico banquero/mercader don Luis de la Serna, el cual se quedó con el patronato de la capilla mayor para sí y sus herederos, convirtiéndola de esta manera en una especie de panteón familiar ${ }^{251}$.

Finalizada la obra de la capilla mayor decidió dotarla de un suntuoso retablo mayor. Al parecer, el retablo fue traído por don Luis de la Serna desde Florencia. Así lo atestiguaba el sacristán de la iglesia en el año 1588 en el transcurso de un pleito entre el templo y el nieto del referido don Luis, llamado de forma homónima: "[he] oído decir públicamente (...) que Luis de la Serna abuelo (...) había hecho traer el dicho retablo a su propia costa de Florencia". Otro testigo del mismo juicio nos aporta más información acerca de lo valiosísimo que era: "estando en plática con otros en dicha iglesia vio que el dicho Luis de la Serna dijo a los que con él estaban que le costaba más aquel retablo que si fuera de plata lo cual dijo porque los que con él estaban alababan mucho el dicho retablo" 252 .

Son muy esclarecedores otros dos testimonios que nos lo describen, a la vez que nos hablan desde dónde pudo llegar. El padre Fray Matías de Sobremonte, en su Historia inédita del convento de San Francisco de Valladolid (1660), al tratar sobre un retablo similar que presidía la capilla de Nuestra Señora del citado convento refería: "en el sitio principal de ella está una imagen muy hermosa de la madre de Dios sentada con su hijo

251 GONZÁLEZ GARCÍA-VALLADOLID, Casimiro: Valladolid..., op. cit., Tomo I, p. 768; MARTÍN GONZÁLEZ, Juan José y URREA FERNÁNDEZ, Jesús: Catálogo Monumental de la provincia de Valladolid. Tomo XIV..., op. cit., p. 188.

$252 \quad$ AGAPITO Y REVILLA, Juan: "Valladolid. La capilla mayor de la parroquia de Santiago. I". En VV.AA.: Boletín de la Sociedad Castellana de Excursiones (1913-1914): Castilla artística e histórica. VI, Grupo Pinciano, Valladolid, 1986, p. 247; URREA FERNÁNDEZ, Jesús: La iglesia de Santiago de Valladolid, Parroquia de Santiago, Valladolid, 1977. 
precioso en los brazos. Imagen silla y un arco de adorno es de barro cocido y vidriado de diferentes colores con tanto primor que parecen de pincel muy bueno". El otro testimonio, también acerca del retablo franciscano, nos lo aporta el polifacético pintor Diego Valentín Díaz. El que fuera patrono del Colegio de Niñas Huérfanas llegó a afirmar que este retablo procedía de la ciudad toscana de Pisa "y que es del mismo artífice que hizo el retablo del altar mayor de la Parroquial de San Iago que es de la misma materia y labor".

El nunca bien ponderado historiador local Manuel Canesi, que también llegó a conocerlo, lo describe en su Historia de Valladolid de la siguiente manera: "Luis de la Serna estampó en la capilla mayor y torre sus armas, y trasladó a la nueva de la antigua los bultos de sus progenitores ilustres, y la adornó de un retablo misterioso de ladrillo de azulejos, que entonces se usaba mucho, que llegó hasta nuestros días" ${ }^{253}$.

El costo que tuvo debió ser altísimo. De hecho, García Chico refiere que era una "pieza de tan subidos quilates que a pesar de estar fabricada en material deleznable costó más

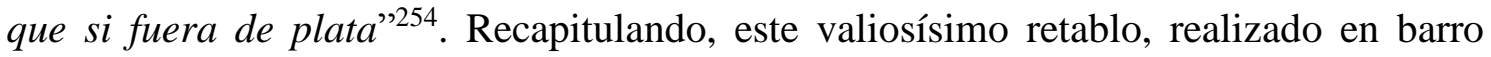
cocido y vidriado (mayólica), fue mandado traer desde la Toscana, no sabemos si desde Florencia o Pisa, por don Luis de la Serna. No cabe duda de que quería lo más exquisito para "su" iglesia". Martín González y Urrea piensan que pudo fabricarse en el taller florentino de Andrea della Robbia (1435-1525) 255 .

¿Qué esculturas conformaban este misterioso retablo? En los inventarios antiguos se le describía como "de talabera fina, y en el primer cuerpo sobre la custodia del Santísimo está una imagen de Santiago de bulto y en el segundo cuerpo un Santo Cristo con la Virgen y San Juan a los lados también de bulto"256. Debido a la fragilidad del material, algunas piezas del retablo fueron repuestas o reparadas en multitud de ocasiones, una de ellas fue llevada a cabo por el escultor vallisoletano Francisco Alonso de los Ríos en $1650^{257}$. La referida fragilidad unida al cambio de gusto llevaría a la parroquia a renovar el retablo mayor de la iglesia.

La retirada del retablo, si aceptamos el testimonio de Canesi, tuvo lugar en 1698. En dicho año se le apartó "para formar un nuevo retablo en la Capilla mayor que adornarse su magnitud, según la práctica y estilo de hoy; y habiendo conseguido su

\footnotetext{
253 CANESI ACEVEDO, Manuel: Historia de Valladolid (1750), Tomo I, op. cit., p. 335.

254 GARCÍA CHICO, Esteban: Valladolid: Papeletas..., op. cit., p. 101.

255 MARTÍN GONZÁLEZ, Juan José y URREA FERNÁNDEZ, Jesús: Catálogo Monumental de la provincia de Valladolid. Tomo XIV..., op. cit., p. 197.

$256 \quad$ Ídem, pp. 197-198.

257 "Diferentes aderezos de cosas de madera y el retablo. Debe la dicha fábrica ocho ducados que pagué a Francisco Alonso escultor del aderezo que hizo en el retablo del altar mayor el año de 1650 de dos cabezas de alabastro que hizo la una para Santiago otra para San Joseph un brazo para el Ángel de la Salutación y otro para un moro y otras piezas que ha hecho en dicho retablo y de limpiarle, pegar dichas piezas y componerlas de que hay carta de pago". A.G.D.V., Santiago, Libro de fábrica 1651-1654, f. 148. URREA FERNÁNDEZ, Jesús: “El escultor Francisco Alonso...”, op. cit., pp. 367-368.
} 
celoso proyecto a costa de muchos desvelos, quitaron el antiguo que tenía de azulejos el año de 1698, y en su elevado espacio construyeron otro muy primoroso" 258 .

El nuevo retablo no podía ser sufragado completamente por la propia parroquial, a pesar de la "sagrada opulencia y lustroso culto [en que] estaba esta parroquia de Santiago cuando siendo cura párroco D. Juan Fernández de Salazar". Fue este clérigo el que "solicitó vigilante que sus feligreses y vecinos de esta Ciudad contribuyesen finos devotos con algunas cantidades pecuniarias" ${ }^{259}$. Por lo tanto, el retablo fue construido gracias a las numerosas y generosas limosnas que le ofrecieron donantes particulares, cofradías radicadas en la parroquia, el Gremio de Herederos de Viñas (2.200 reales) y la propia ciudad de Valladolid (1.600 reales).

Los bienhechores particulares fueron don Alonso de Aguayo, patrón de la capilla mayor y regidor perpetuo de la ciudad (4.400 reales); don Antonio Rodríguez de Vera, regidor de la ciudad (1.100 reales); el ¿escribano? don Lope Quevedo (1.000 reales); el médico don Sebastián Martínez (500 reales); los mayordomos de fábrica Juan de Aragón (1.500 reales) y José Guerra (1.500 reales); y Manuel Recio (2.200 reales), que envió su donativo por manda testamentaria. Mientras que las cofradías que colaboraron en la construcción del nuevo retablo fueron: la Sacramental (4.400 reales), la de San José de maestros de obras (4.400 reales), la del Santo Ángel de la Guarda (600 reales), la del Santo Cristo (250 reales), la de la Concepción y Santos Mártires (200 reales), y la de Ánimas (2.200 reales). Asimismo, la propia parroquia puso de sus arcas 1.800 reales. Todas estas cantidades y sus donantes aparecen perfectamente detallados en los libros parroquiales (DOCUMENTO 45). Puede llamar la atención de que varios regidores de la ciudad participaran con su pecunio en esta recogida de fondos para el nuevo retablo, pero no es nada extraño ya que, según testimonio de Canesi, "el párroco [de esta iglesia] es capellán mayor de la Ciudad, por pertenecer a su jurisdicción las casas Consistoriales y por esto sus Regidores asisten en forma de ella a los sermones que tienen los miércoles y viernes de Cuaresma en esta Iglesia" ${ }^{260}$.

El nuevo retablo, realizado por Alonso de Manzano y Juan de Ávila, debió comenzar a construirse en 1698, año en que, según Canesi se retiró "el antiguo que tenía de azulejos el año de 1698, y en su elevado espacio construyeron otro muy primoroso"261. El cambio de retablo aparece perfectamente reflejado en dos visitas realizadas con tan solo con once años de diferencia. La visita del año 1693 refiere que sobre el altar mayor, que "es patronazgo de Luis de la Serna de que al presente es patrón D. Alonso Aguayo caballero del orden de Calatrava vecino y regidor perpetuo de esta ciudad y está dotada (...) en cada un año y el retablo de dicha capilla es de Talavera fina y en el primer cuerpo sobre la custodia nueva del Santísimo está una imagen de Santiago de bulto y en el segundo cuerpo un Santo Cristo con la Virgen y San Juan a los lados"262.

CANESI ACEVEDO, Manuel: Historia de Valladolid (1750), Tomo I, op. cit., p. 341. Ibídem.

Ibídem.

Ibídem.

A.G.D.V., Santiago. Libro de fábrica 1673-1707. Visita del año 1693.
} 
Por el contrario, en la visita del año 1704 el panorama había cambiado sustancialmente. Se relata que "el retablo de dicha capilla es nuevo, y está por dorar y del coste que tuvo y en qué caudal se fabricó está firmada cuenta en éste libro por el dicho Juan Fernández de Salazar cura de esta iglesia en la cual parece que alcanza a dicha fábrica en diez y seis mil y noventa reales" 263 .

El encargado de retirar el viejo retablo de alabastro en el año 1698 fue el afamado ensamblador y arquitecto vallisoletano Pedro de Ribas, el cual además se ocupó de "quitar las gradas de piedra y un pedazo de pared y volver a poner el presbiterio", cobrando por todo ello la cantidad de 390 reales $^{264}$.

La construcción del nuevo retablo se sacaría a subasta pública, acudiendo con sus trazas y condiciones varios ensambladores, entre los cuales solo tenemos noticia de Blas Martínez de Obregón y Alonso Manzano. La primera traza fue realizada por Martínez de Obregón, la cual fue finalmente desestimada, si bien se le abonaron 600 reales por el trabajo que tuvo en confeccionarla ${ }^{265}$. Sea como fuere, el encargado de construir el retablo fue el ensamblador vallisoletano Alonso Manzano, si bien no sabemos si lo levantó con su propia traza, con la de Obregón o con otra. Es frecuente que los ensambladores de la época a veces se sometan a la traza de otro maestro. Manzano, que trabajó en una casa aparte de su taller ${ }^{266}$, seguramente por las colosales dimensiones del retablo, percibió por su magnífico trabajo la crecida cantidad de 25.000 reales $^{267}$.

Juan de Ávila se encargó de la parte escultórica, cobrando por ella 11.000 reales de vellón "por toda la escultura que hizo para el retablo que se compone de la historia de Santiago Nuestra Señora del Pilar y seis ángeles"268. Como vemos, el programa iconográfico del retablo nos presenta dos de los hechos más importantes de la tradición jacobea: la aparición a Santiago y sus discípulos de la Virgen del Pilar, y la de Santiago en la batalla de Clavijo. Al no haberse hallado la escritura de concierto del retablo no sabemos si lo contrataron de manera conjunta Ávila y Manzano, a la manera del retablo mayor del Convento de San Juan de Dios, o bien cada uno contrató de forma individual

\footnotetext{
263 A.G.D.V., Santiago. Libro de fábrica 1673-1707. Visita del año 1704.

264 Pagado a Pedro de Ribas cantero. "Ítem son data trescientos y noventa reales que valen trece mil doscientos y sesenta mil los mismos que pagó a Pedro de Ribas cantero por quitar el retablo viejo las gradas de piedra y un pedazo de la pared y volver a poner el presbiterio de que entrega recibo". (DOCUMENTO 45)

265 Pagado a Blas Martínez de Obregón por la traza del retablo. "Primeramente son data seiscientos reales que valen veinte e mil y cuatrocientos maravedíes que en dicho Señor don Juan Fernández de Salazar pagó a Blas Martínez de Obregón maestro arquitecto por la traza que hizo de dicho retablo y no sirvió". Ibídem.

266 Pagado por la casa en que se fabricó el retablo. "Ítem son data cuatrocientos reales que valen trece mil y seiscientos maravedíes los mismos que pago por la casa en que se fabricó dicho retablo". Ibídem.

267 Pagado a Alonso Manzano maestro que hizo el retablo. "Ítem son data veinte y cinco mil reales que valen ochocientos y cincuenta mil maravedíes los mismos que pagó a Alonso Manzano maestro que hizo el retablo de que entrega recibo". Ibídem.

268 Pagado a Juan de Ávila escultor por todas las esculturas que hizo. "Ítem son data once mil reales de vellón que valen trescientos y setenta y cuatro mil maravedíes los mismos que pagó a Juan de Ávila escultor por toda la escultura que hizo para el retablo que se compone de la historia de Santiago Nuestra Señora del Pilar y seis ángeles de que entrega recibo". Ibídem.
} 
la obra de su arte. En este caso cabría preguntarse si la participación de Ávila se debe a una imposición de Manzano o bien al deseo de la parroquia de que fuera su hijo más ilustre el que dotara de imaginería a su retablo mayor, la obra de mayor lustre que acometería la iglesia de Santiago durante el siglo XVIII.

Finalizado el retablo, el encargado de policromar y estofar las imágenes fue Manuel Martínez de Estrada ${ }^{269}$. En el libro de fábrica solo se dice que estofó "el San Juan que se puso en correspondencia de San Joseph", aunque es lógico pensar que hizo lo propio con el resto de las esculturas. Como ya analizamos en su momento, la colaboración entre los hermanos Martínez de Estrada y nuestro escultor fue continua.

Las arcas de la parroquia quedaron tan exhaustas que hasta el año 1729 no pudo acometer el dorado del retablo. Se encomendó tan ardua tarea a Cristóbal Martínez de Estrada $^{270}$, otro miembro más de la prolija familia de doradores. Antes de que este principiara su trabajo el retablo sufrió una modificación. En las cuentas de los años 1728-1729 se anota un pago al ensamblador y escultor vallisoletano Pedro Correas por "la obra que hizo en el cascarón del retablo mayor"271. No se especifica que trabajo realizó, y tampoco hay nada en el cascarón que denote haber sido modificado el plan original de Manzano. Desconocemos en qué consistieron esas obras y la razón por la que fueron hechas; quizás se debiera a una reestructuración, a algún problema estructural o una simple restauración. Tan solo poseemos una descripción del retablo, muy somera, anterior a la intervención de Correas. Se trata de la que se realizó con motivo de la visita del obispo a la iglesia en el año 1711: “Capilla mayor: el retablo es de talla y en el primer cuerpo sobre la custodia está una hechura de bulto de Santiago, y el remate del dicho retablo es un hábito del apóstol Santiago y una corona imperial y la mesa del altar"272.

Pienso que la referida intervención pudo estar relacionada con los seis ángeles que Juan de Ávila se obligó a esculpir. En la actualidad tan solo existen cuatro, todos ellos montados sobre volutas o pedestales en el ático. Los dos restantes también tuvieron que estar colocados aquí puesto que en el resto del retablo no hay espacio, a no ser que formaran parte de la custodia. Además, existen otros ocho pequeños angelitos, cuyos rostros denotan el estilo de Ávila, pero que seguramente nada tienen que ver con los seis referidos. Son los situados sobre las puertas y hornacinas laterales del retablo; los superiores sostienen escudos con la cruz de la Orden de Santiago, mientras que los

269 Pagado a Manuel de Estrada dorador. "Ítem son data quinientos reales pagados a Manuel de Estrada maestro dorador y estofador por estofar el San Juan que se puso en correspondencia de San Joseph de que entrega recibo". Ibídem.

270 Dinero pagado a Cristóbal de Estrada maestro dorador. "Ítem son data ocho mil y quinientos reales que valen doscientos y ochenta y nueve mil maravedíes que pagó a Cristóbal de Estrada maestro dorador por cuenta de la obra del dorado del retablo mayor consta de recibos del susodicho". A.G.D.V., Santiago, Libro de fábrica 1708-1730.

271 Dinero a Pedro Correas. "Ítem son data seiscientos y cincuenta reales que dio a Pedro Correas maestro ensamblador con que se le acabó de pagar la obra que hizo en el cascarón del retablo mayor de dicha iglesia consta de recibo y valen veinte y dos mil y cien maravedíes". A.G.D.V., Santiago, Libro de fábrica 1708-1730.

272 A.G.D.V., Santiago, Libro de fábrica 1708-1730. 
inferiores hacen lo propio con una especie de espejos. Retomando el tema del ático, puede que el trabajo de Correas consistiera en retirar dos de los seis ángeles, probablemente situados sobre los pequeños pedestales anejos al grupo de la Aparición de la Virgen a Santiago. Estos asientos son exactos a los que sirven de apoyo a los ángeles de los extremos. Quizás dificultaran la visión del referido grupo, o bien estaban causando problemas de estabilidad al ático, y debido a esto hubo que retirarlos $\mathrm{y}$ asegurar el cascarón. Los ángeles serían sustituidos por simples hojas de acanto, motivo que hoy podemos ver allí situado.

Ese mismo año se finalizó el dorado del retablo y se procedió a su inauguración. Efectivamente, el 2 de junio de 1729 "los comisarios nombrados por la parroquia del señor Santiago de esta ciudad para la próxima fiesta que se ha de celebrar a la colocación del Santísimo Sacramento han dorado el retablo" pidieron licencia al Ayuntamiento vallisoletano para la celebración de las fiestas y "una corrida de toros después de la que la ciudad tiene acordada" en la Plaza Mayor, petición que fue aprobada por el consistorio (DOCUMENTO 46). El retablo fue solemnemente inaugurado el 8 de septiembre del año 1729, día en que se colocó nuevamente el Santísimo Sacramento. Con motivo de esta celebración se organizó una gran procesión y función religiosa que duró tres días: "salieron los gigantones; hubo danza de volantes y cinco altares, uno en el Ochavo, que le hizo la cofradía de Jesús, otro a la puerta de San Francisco, que le hizo la cofradía de San Antonio de mancebos sastres: estuvieron las calle y plaza muy colgadas y adornadas, en especial la plaza que la colgaron uniforme el primer alto de balcones de tapices, el segundo de varias colgaduras y el tercero de tafetanes. En la calle de Santiago pusieron su toldo; la pusieron también uniforme de abanicos y casa de Austria, igualando con maderos las casas que eran bajas para que estuviesen con simetría"273. Otra versión de estos acontecimientos nos lo proporciona el diarista vallisoletano Ventura Pérez ${ }^{274}$.

\footnotetext{
273 GONZÁLEZ GARCÍA-VALLADOLID, Casimiro: Valladolid..., op. cit., Tomo I, p. 768.

274 "Retablo de Santiago y el Santísimo en Jesús. Año de 1729, día 8 del mes de septiembre, se trasladó y colocó el Santísimo Sacramento en el retablo dorado nuevamente en la parroquia de Santiago, como asimismo colocaron de nuevo a S.M. en la iglesia de Jesús Nazareno. Celébrose una procesión a dos intentos, y fue que de camino pusieron el Sacramento en Jesús Nazareno. Hubo soldadesca de los de la manzana; salieron los gigantones; hubo danza de volantes y cinco altares, uno en el Ochavo, que le hizo la Cofradía de Jesús, otro a la puerta de San Francisco, que le hizo la cofradía de San Antonio, de mancebos sastres. Al llegar S.M. a éste altar vino una recia tempestad de agua, y se metió la procesión debajo de los portales de la Acera y allí se cantó el villancico, y después que se sosegó prosiguió la procesión por la Lencería al Ochavo, Especería y a Jesús, y pusieron allí a S.M., y prosiguieron por el peso a la Pasión, donde a la puerta había otro altar de la cofradía, y de allí a Santa Ana, donde había otro altar, de allí a Santa Cruz, en donde había a la puerta de la iglesia otro altar y bajaron por la calle del Campo a su casa.

Hubo en Santiago tres días festivos: asistieron las dos músicas de la Catedral y la suya; estuvieron las calles y plaza muy colgadas y adornadas, en especial la plaza que la colgaron uniforme el primer alto de balcones de tapices, el segundo de varias colgaduras y el tercero de tafetanes. En la calle de Santiago pusieron su toldo; la pusieron también uniforme de abanicos y casa de Austria, igualando con maderos las casas que eran bajas para que estuviese con simetría.

En Jesús Nazareno hubo otros tres días de fiesta; colgaron muy bien la iglesia, y en las cuatro boquillas de las pechinas pusieron los cuatro guiones de las otras penitenciales". PÉREZ, Ventura: op. cit., p. 99.
} 
El retablo, que a primera vista parece gigantesca gruta de oro incandescente, "pregona su claro carácter churrigueresco, estando emparentado con el de San Esteban, de Salamanca", según las palabras de Martín González ${ }^{275}$. El mismo profesor aseveraba que "debe considerarse este retablo como uno de los más espléndidos del Barroco"276. Sin lugar a dudas estamos ante uno de las obras cumbres del periodo churrigueresco. Adopta planta semicircular, adaptándose a la perfección a la forma del ábside gótico. Se articula mediante un amplio banco, un único cuerpo gigante con tres calles y el ático en forma de cascarón.

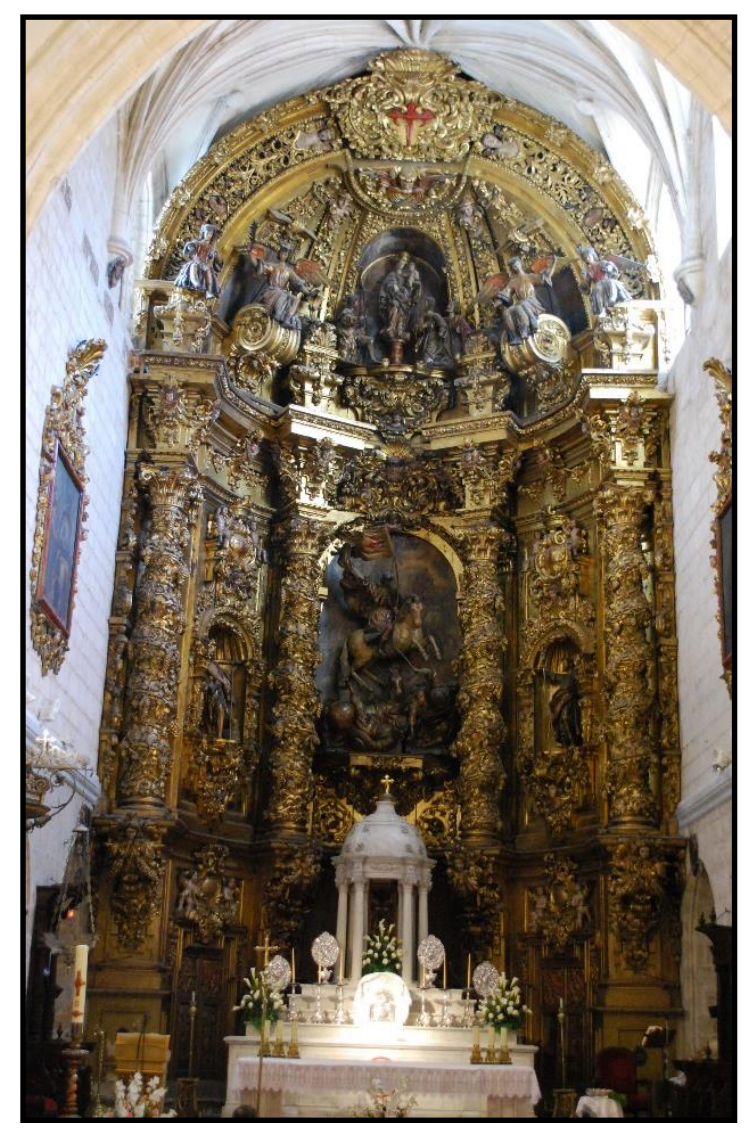

Il. 12- Alonso Manzano. Retablo mayor. Iglesia de Santiago Apóstol. Valladolid.
El banco, muy alto para dar cabida a dos puertas laterales, sobre las cuales se sitúan dos pares de ángeles sosteniendo espejos, sirve de asiento a cuatro grandes ménsulas decoradas con ornamentación vegetal muy carnosa y una cabeza de querubín. Sobre éstas apoyan las columnas salomónicas de orden gigante, repletas de pámpanos $\mathrm{y}$ racimos de uvas, que articulan el cuerpo del retablo. Estas cuatro crean la calle central, en la cual se dispone el grupo principal del retablo -Santiago Matamoros en plena acción-, y las laterales en los intercolumnios, en cada uno de los cuales se abre una hornacina, flanqueada por estípites, con remate superior en forma de venera con la charnela hacia afuera. No es casual que este remate adopte esta apariencia ya que la concha es uno de los atributos más usuales del apóstol Santiago. La hornacina del lado del evangelio está ocupada por San Juan Bautista, mientras que la de la epístola contiene a San José. Ambas concavidades asientan sobre unas imponentes ménsulas con una decoración de hojas crespas, mucho más abultadas aún que las que sostienen las columnas salomónicas. Por la parte superior se desarrolla una pseudo-guirnalda conformada por decoraciones de flores, frutas, cabezas de querubines y rematando todo un espejo, con la cruz de la Orden de Santiago pintada en su interior, escoltado por dos angelotes que a su vez sustentan una corona.

El ático, muy desarrollado, se resuelve con una forma avenerada. Posee también una decoración muy profusa, estamos hablando de puro horror vacui, con motivos vegetales y angélicos. Este ambiente está presidido por una hornacina central, en la cual se

275 MARTÍN GONZÁLEZ, Juan José: Escultura barroca castellana ..., op. cit., p. 314.

276 Ídem, p. 71. 
representa el momento de la aparición de la Virgen del Pilar a Santiago y sus discípulos, y a los lados, cabalgando sobre trozos de entablamento y volutas, unos ángeles que sobrevuelan el conjunto. El detalle de colocar las piernas de los ángeles colgando, produciendo un efecto de inestabilidad muy barroco ${ }^{277}$, procede del retablo que Esteban Jordán talló para la capilla del Santo Cristo de la desaparecida iglesia vallisoletana de San Antón, actualmente conservado en el Santuario Nacional de la Gran Promesa ${ }^{278}$. Los distintos paneles que conforman el cascarón del ático se completan con torsos de querubines que lindan con el remate del retablo que consta de un arcángel sobre el que se desarrolla un gran medallón vegetal en cuyo interior se encuentra esculpida, una vez más la cruz de la Orden de Santiago.

El gigantesco mueble lígneo se completaba con una mesa de altar, sagrario, gradas y tabernáculo barroco, todo lo cual fue sustituido en el año 1883 "por otros nuevos de mármol blanco (...) ejecutada en los talleres de la acreditada casa de Macael"279.

La parte escultórica del retablo, como ya hemos dicho, fue realizada por Ávila. Documentalmente, nos consta su paternidad de las esculturas de seis ángeles (dos de ellos desaparecidos), además de las historias de la Virgen del Pilar y de Santiago Matamoros. Piensan Martín González y Urrea que en la ejecución de estas esculturas "probablemente le ayudaría su hijo Pedro" 280 , extremo que parece tener visos de realidad si tenemos en cuenta que en la cercana iglesia del Convento de las Comendadoras de Santa Cruz, en su retablo mayor, aparece un Santiago Matamoros casi idéntico, el cual esta atribuido a Pedro de Ávila ${ }^{281}$.

Nada se dice en el libro de fábrica sobre las esculturas de San Juan Bautista y San José, tan solo que el dorador Manuel Martínez de Estrada estofó "el San Juan que se puso en correspondencia de San Joseph de que entrega recibo" (DOCUMENTO 45). Dicho esto, queda claro que el Precursor fue tallado por Juan de Ávila al mismo tiempo que el resto de imágenes del retablo. ¿No figura en las partidas porque fue donado por algún benefactor? Otro tema bien diferente es el de San José, ya que vista esa cita parece claro

277 Ejemplos similares, aunque cambiando a los Ángeles por los Padres de la Iglesia o por Apóstoles, los podemos ver en los retablos mayores de la iglesia parroquial de Herrín de Campos (Valladolid) o en iglesia de Santiago de los Caballeros de Medina de Rioseco (Valladolid), ambos debidos a la gubia del escultor Tomás de Sierra. Ídem, pp. 382-383. En la iglesia de San Martín de Valladolid existió un retablo dedicado a la Asunción en cuyo ático se disponían de similar manera los cuatro Evangelistas. Tras el derrumbe de la iglesia, que le afectó gravemente, se perdió el paradero de las esculturas supervivientes.

$278 \quad$ Ídem, p. 66.

279 "En el año 1883 y con motivo de la consagración de esta iglesia, solemnemente hecha el día 22 de Julio de dicho año por el Excmo. señor Dr. Don Benito Sanz y Forés, Arzobispo de la diócesis, se han sustituido su antigua mesa de altar, sagrario, gradas y tabernáculo de madera, por otros nuevos de mármol blanco, obra de muy buen conjunto, ejecutada en los talleres de la acreditada casa de Macael, en la provincia de Valencia. GONZÁLEZ GARCÍA-VALLADOLID, Casimiro: Valladolid..., op. cit., Tomo I, p. 769.

280 MARTÍN GONZÁLEZ, Juan José y URREA FERNÁNDEZ, Jesús: Catálogo Monumental de la provincia de Valladolid. Tomo XIV..., op. cit., p. 198.

281 URREA FERNÁNDEZ, Jesús (dir.); La pequeña escultura en Valladolid: siglos XVI-XVIII: (exposición) del 9 al 26 de marzo de 1983, Caja de Ahorros Popular de Valladolid, Valladolid, 1983. 
que fue reutilizada y, además, estilísticamente hablando, se encuentra bastante lejano de nuestro escultor.

Las referidas hornacinas han sufrido a lo largo del tiempo un baile de imágenes que complica más el asunto. Por diferentes testimonios, tanto escritos como fotográficos, sabemos que la imagen de San José presidió durante cierto tiempo el retablo colateral del Evangelio ${ }^{282}$, si bien ignoramos que imagen ocuparía su sitio en el retablo mayor. Bien pudo ocupar este espacio una imagen de Santa María Magdalena, que también atribuyo a Ávila y que en la actualidad ocupa el ático del retablo del colateral del evangelio $^{283}$. La iglesia quizás decidió sustituir la efigie de San José por esta, de manera que ambas hornacinas laterales estuvieran en concordancia con sendos santos ascetas (Bautista - Magdalena). De esta manera San José quedó relegado al referido retablo y nos da buena prueba de que no se realizó ex profeso para el retablo de Alonso Manzano.

También durante el siglo XX se vio desplazada del retablo mayor el San Juan Bautista, cuya hornacina fue invadida por el grupo de Santa Ana, la Virgen y el Niño de Francisco del Rincón ${ }^{284}$, que en la actualidad preside el retablo colateral del evangelio, el mismo que, como acabamos de decir, ocupó la imagen de San José). La hechura del Precursor fue desterrada a la capilla de San Jerónimo, en donde presidió un retablo plateresco procedente del entonces Museo Provincial ${ }^{285}$. Así nos lo describe Casimiro González García-Valladolid a comienzos del siglo XX: "La quinta capilla es la de San Jerónimo, cuya escultura se ve en el retablo principal. Está dedicada a bautisterio y al lado derecho tiene otro retablo con la estatua de San Juan Bautista: este retablo procede del Museo de pinturas y esculturas" ${ }^{286}$. Aún se encontraba el santo en el referido retablo en el año $1954^{287}$. En la actualidad el mueble se encuentra en la capilla de Nuestra Señora de Loreto, sita a los pies de la iglesia, al lado del Evangelio. Lo preside una imagen moderna de dicha advocación, sin ningún valor artístico. Comentan Martín González y Urrea que el retablo "viene siendo atribuido a Gaspar de Tordesillas. El retablo se articula mediante dos esbeltas y abalaustradas columnas sobre basamentos respaldadas por contrapilastras, y está decorado con labores

\footnotetext{
282 "El colateral del mismo lado se halla dedicado hoy a San José, y el de la epístola a la Purísima Concepción”. GONZÁLEZ GARCÍA-VALLADOLID, Casimiro: Valladolid..., op. cit., Tomo I, p. 769. 283 MARTÍN GONZÁLEZ, Juan José y URREA FERNÁNDEZ, Jesús: Catálogo Monumental de la provincia de Valladolid. Tomo XIV..., op. cit., p. 199.

$284 \quad$ Ídem, p. 196.

285 El retablo fue atribuido por Agapito y Revilla al entallador vallisoletano Gaspar de Tordesillas, aunque sospechaba de ciertos elementos de clara raigambre berruguetesca. Años después, Constantino Candeira comenta que el retablo en realidad no es una obra homogénea, sino que se trata de "un amasijo de elementos de uno y otro escultor. CANDEIRA PÉREZ, Constantino: "Los retablos de Gaspar de Tordesillas", B.S.A.A., Tomo VIII, 1941-1942, p. 121.

286 GONZÁLEZ GARCÍA-VALLADOLID, Casimiro: Valladolid..., op. cit., Tomo I, p. 772.

287 "En la capilla bautismal, al lado de la Epístola, hay un retablo interesante armado a base de elementos de distintas procedencias atribuidos a Gaspar de Tordesillas y alguno a Berruguete. El San Juan que se aloja en su nicho es de buena escultura del siglo XVII". NIETO GALLO, Gratiniano: op. cit., p. 26.
} 
típicamente renacentistas a base de roleos, cabezas de ángeles, cintas, etc. Hay que advertir que ha sido remodelado en diversas ocasiones y tiene elementos nuevos" ${ }^{288}$.

Relacionado con este baile de imágenes podemos recordar que en 1954 Gratiniano indica que "en los intercolumnios se ven esculturas de San Pedro y San Pablo" ${ }^{\text {"289 }}$. No creo que hubiera tales imágenes, más bien creo que es un simple error. A continuación iremos desgranando cada una de las piezas escultóricas del retablo, en las cuales, según Martín González, "se aprecia una gran blandura de modelado, imitando a Fernández"290.

\section{GRUPO DE SANTIAGO MATAMOROS}

A pesar de ser obra documentada de nuestro escultor, antes de que esto se conociera, Casimiro González García-Valladolid y otros eruditos no dudaron en asignar la imagen ecuestre de Santiago a la gubia de Gregorio Fernández. Pienso que este hecho nos da buena muestra de la gran calidad de la obra, siendo sin ninguna duda la obra maestra de Ávila ${ }^{291}$. El primero que negó la paternidad de Fernández fue García Chico, para el cual la atribución realizada por Alcalde Prieto y González García-Valladolid a Gregorio Fernández era " a todas luces errónea y hecha con notoria ligereza, pues tanto la arquitectura como la escultura guardan el mismo ritmo y tienen las características de las obras de principios del siglo XVIII" ${ }^{292}$.

El tipo de Santiago aquí representado es el Matamoros (Figs. 38-40), cuya tipología ya explicamos al tratar del otro Santiago ecuestre que Ávila esculpió para la sacristía. El santo aparece tal y como lo vio el rey Ramiro I en sueños: montando en un caballo blanco (símbolo de la victoria), derrotando a los moros, ambos caídos ya de sus respectivos caballos. En sus manos blande un estandarte con la cruz de la Orden de Santiago, mientras que con la otra hace lo propio con la espada con la cual pone en fuga a los enemigos.

Como comentamos con el anterior grupo de Santiago Matamoros, existen dos versiones del tema: pueda aparecer atacando a los moros desde el cielo o desde la tierra, en este caso parece que el santo viene a derrotarlos desde el cielo, aunque tampoco queda

\footnotetext{
288 MARTÍN GONZÁLEZ, Juan José y URREA FERNÁNDEZ, Jesús: Catálogo Monumental de la provincia de Valladolid. Tomo XIV..., op. cit., p. 191.

289 NIETO GALLO, Gratiniano: op. cit., p. 26.

290 MARTÍN GONZÁLEZ, Juan José: Escultura barroca castellana ..., op. cit., p. 322.

291 "Su altar mayor, de tres cuerpos, dorado y de columnas con emparrados, ofrece de notable la efigie del Santo titular, obra del escultor Gregorio Hernández, y en su término la Virgen del Pilar, también de talla". GONZÁLEZ GARCÍA-VALLADOLID, Casimiro: Valladolid..., op. cit., Tomo I, p. 769.

"Contiene de notable en su altar mayor una efigie de Santiago, de Gregorio Fernández". RUBIO Y BORRÁS, Manuel: Nueva guía de Valladolid, Valladolid, 1895, p. 102.

"Su altar mayor, recargado de talla, no contiene cosa de mérito si se exceptúa la efigie del Apóstol, que ocupa el centro, y que generalmente se cree sea obra de Gregorio Fernández". ALCALDE PRIETO, Domingo: op. cit., p. 177.

292 GARCÍA CHICO, Esteban: Valladolid: Papeletas..., op. cit., p. 102.
} 
demasiado claro. La composición está marcada por una clara diagonal que une los rostros del santo y del moro que intenta levantarse para atacarle, si bien en realidad comenzaría en el extremo superior de la capa de Santiago y finalizaría en las patas del caballo del moro referido. Hay una clara contraposición de actitudes entre los moros, uno caído que mira al suelo y el otro que intenta reincorporarse a la batalla mientras dirige sus ojos al santo; también la podemos percibir entre los gestos de los caballos y, también, entre los brazos del santo y del moro que porta la daga.

Es una escena puramente barroca ya que a la inestabilidad de la misma y la captación del momento en que Santiago se dispone a dar el golpe de gracia al moro que se intenta levantar, añade un interesantísimo contraposto en ambos moros. El barroquismo se ve acrecentado por la aparición en el fondo de una pintura que muestra un paisaje con personajes. Ésta pretende aportar mayor verismo a la escena, al igual que la sensación de movimiento que ha imprimido nuestro escultor al grupo; éste lo podemos comprobar fácilmente en el violento ondear de la capa del santo y del estandarte, el cual incluso se ve doblado en el palo. La referida escena parece representar la Batalla de Clavijo. En ella podemos ver tres espacios claramente diferenciados: en el lado inferior derecho una serie de moros con sus caballos, completando de esta manera a los dos tallados; en el lado izquierdo caballeros cristianos vistiendo armaduras contemporáneas del escultor, no de la época del rey Ramiro I; y en la parte superior derecha figura una gloria con cabecitas de ángeles aladas y nubes, en una de ellas parece inscribirse una cruz roja de la Orden de Santiago. Este recurso de incluir un lienzo o pintura tras las esculturas volveremos a verlo en los relieves que nuestro escultor talla para los áticos de los retablos colaterales del Oratorio de San Felipe Neri, si bien en esta ocasión se tratará de relieves y no de bulto redondo como en este caso.

En el centro aparece el monumental conjunto de Santiago Matamoros. Es una imagen de lo más teatral, como por otra parte corresponde al barroco y, seguramente en la escuela vallisoletana sea el culmen de este período en cuanto a movimiento y teatralidad. La composición ha sido hábilmente trazada, posee un gran dinamismo. Juan de Ávila ha tenido la osadía de colocar a Santiago con el busto en un violento escorzo, si bien también lo ha utilizado para las cabezas de los caballos (recurso que su hijo utilizará en el equino del retablo de las Comendadoras) y para los cuerpos de ambos moros. Santiago, espada en mano, se dispone a dar el golpe de gracia a sus enemigos, que aparecen en el suelo, descabalgados e indefensos, si bien uno de ellos intenta incorporarse para atacar al santo con una daga o puñal.

El santo viste túnica ceñida al abdomen por un cíngulo que se abre en las rodillas dejando éstas visibles. Las mangas están dobladas. Por encima, una bella esclavina negra, con profusa decoración de rameados dorados, misma técnica y color que vemos en la orla que la remata, y una capa blanca completamente desplegada por efecto del viento; también esta posee una orla, si bien en este caso es multicolor. Calza botas marrones. En toda esta vestimenta volvemos a ver sus característicos pliegues incurvados y suaves que dan gran verosimilitud a la escena, pues parece que se están moviendo debido a la rapidez de la acción representada. Hay algún rastro de dureza en 
los de la capa, en su centro parece como estrujada, si ben en el extremo, pero es bastante comprensible si lo que quería es similar el violento choque del viento sobre la misma.

Como ya dijimos, con las manos sujeta fuertemente la espada, en la derecha, y el estandarte, en la izquierda. La anatomía está bellamente modelada, si bien pienso que la pierna derecha no es muy verosímil. El rostro es muy hermoso, aunque no posee las cualidades mórbidas de los tres santos de Lerma, no sería descartable la tuviera y que nos lo impidiera ver la suciedad que posee el santo, en particular, y el retablo, en general. Posee las características típicas de Ávila: pelo mojado con mechones que caen sobre la frente, boca pequeña entreabierta, ceño fruncido, ojos almendrados, grandes masas de pelo a los lados del rostro, barba bífida, etc... Unas hendiduras en la parte superior del cráneo del santo me hacen pensar en que en algún momento pudo estar tocado con una corona. Un defecto que se le puede achacar a Ávila en casi todas sus esculturas, pero es más grave en esta ocasión por tratarse de una escena de acción, es el ensimismamiento con el que concibe los rostros, pareciera como si el santo hubiera sufrido un arrobamiento.

Hay que destacar, sin lugar a dudas, la composición del caballo y el verismo con el que ha sido reproducida su anatomía, aspecto que no solía ser muy bien representado por los artistas, y hasta Velázquez en sus retratos ecuestres de los reyes tuvo sus problemas. Cabeza y crines son de una calidad excelente, a excepción de las crines de la cola que son demasiado rígidos, aunque haya un intento por ondularlos. Estas referidas crines tienen otro defecto: si el santo se encuentra en pleno ataque $\mathrm{y}$, como vemos, el estandarte y la capa se ondulan violentamente, estas también deberían hacerlo. No es el caso pues aparecen caídas, totalmente verticales.

Los moros ocupan la parte baja de la escena, y para nada interrumpen la visión del santo. Visten ropa militar, coraza, calzas y turbante en la cabeza, todas ellas representadas con gran realismo y una bella policromía. Ambos han sido ya descabalgados de sus caballos, uno de ellos todavía con una pierna cayendo de la silla de montar, lo que le da mayor teatralidad a la escena. El otro intenta rechazar la acometida del santo intentando recomponerse y atacar al santo con una especie de daga. Ambos, en palabas de Martín González, se "disponen en atrevidos escorzos, al paso que jinete y caballo se mueven con suma valentía"293. Los moros no hacen sino completar uno de los mejores ejemplos españoles de escena teatral de finales del siglo XVII y principios del XVIII.

Ya señalamos que este grupo escultórico sirvió de modelo a su hijo Pedro, el cual pudo ayudarle, para ejecutar un conjunto similar para el primitivo retablo del cercano Convento de las Comendadoras de Santiago, si bien este es bastante más simple.

Aunque el estado de conservación no es demasiado deficiente, el polvo no permite ver el grupo con el detalle que merecería. Una restauración incrementaría el interés que ya

293 MARTÍN GONZÁLEZ, Juan José: Escultura barroca castellana ..., op. cit., p. 321. 
de por sí posee el conjunto. Lo mismo se puede decir del resto de esculturas, en particular, y del retablo, en general.

\section{$\underline{\text { SAN JUAN BAUTISTA }}$}

Como ya dijimos en su momento, no hay dudas acerca de su paternidad y cronología. Si aun así las tuviéramos no tendríamos más que compararla con la que aparece en el relieve que ejecutó para el Oratorio de San Felipe Neri, y también con la exenta que talló para ese mismo retablo, que es casi exacta.

La talla de San Juan Bautista (Fig. 41) ocupa la hornacina del lado del evangelio. Sigue de cerca, como dijimos, una tipología muy usual en el territorio vallisoletano y en las zonas anejas: se le representa de pie sobre un tronco, con una pierna adelantada. En una mano sujeta un báculo mientras que con la otra nos señala el cordero, el Agnus Dei. Los orígenes de este modelo parecen remitirnos nuevamente a Gregorio Fernández. Aun así, hay otros ejemplos que pudieron servir de nexo entre Fernández y Ávila, como es el tallado por Francisco Díez de Tudanca, o por el propio Juan de Ávila, para el retablo mayor de la parroquial de Pesquera de Duero (Valladolid). Entre los tallados por Fernández, hay dos que pudieran ser el prototipo: el del retablo mayor de la iglesia de los Santos Juanes de Nava del Rey (1612) y el del retablo mayor del Monasterio de las Huelgas Reales de Valladolid (1613). Este último pudo ser visionado directamente por nuestro escultor. Las diferencias entre ambos Santos Juanes (el de las Huelgas Reales y el de la iglesia de Santiago) son mínimas en cuanto a concepción y composición. Tan solo les diferencian ciertos detalles en la indumentaria y en la posición que ocupa el cordero, los cuales por cierto son casi idénticos. Refiere Martín González sobre la imagen de las Huelgas Reales, y pienso que bien podría valer para la tallada por Ávila, que San Juan Bautista "ofrece una composición manierista, de armoniosas curvas, cuerpo macizo y cabello

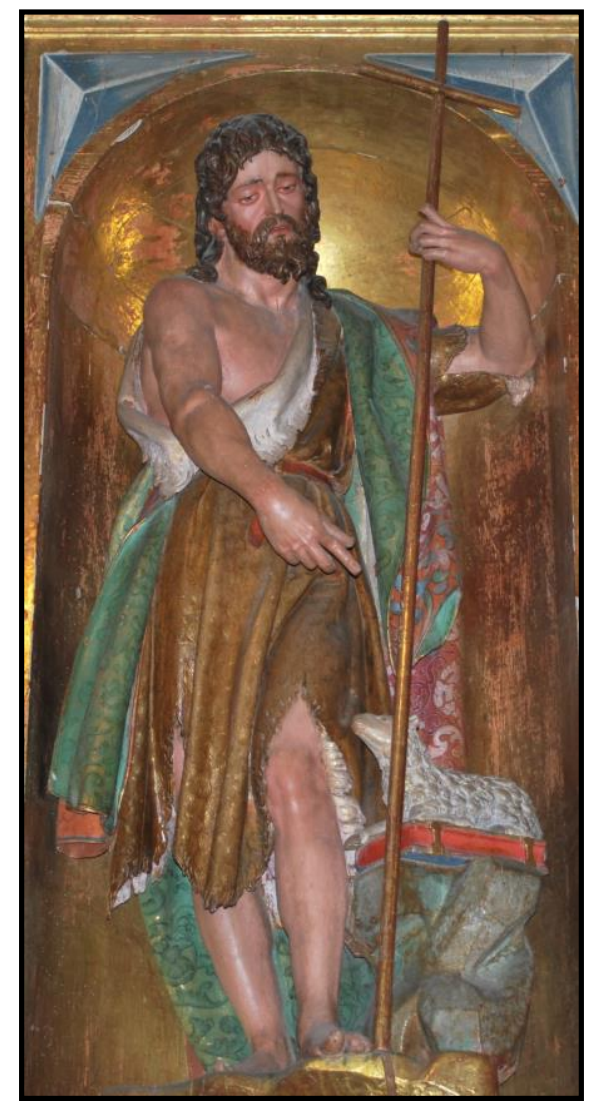

Il. 13- Gregorio Fernández. San Juan Bautista. Monasterio de las Huelgas Reales. Valladolid. espeso"294. Si comparamos ambas imágenes, la escultura modelada por Ávila resulta mucho más delgada, huesuda e incluso enjuta; nada tiene que ver con la belleza clásica propugnada por Fernández en la suya.

294 MARTÍN GONZÁLEZ, Juan José: El escultor Gregorio..., op. cit., p. 104.

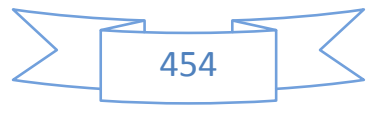


El "Precursor" aparece de pie, vestido con su típica piel de camello. El pellejo del animal, solamente anudado por el lado derecho, permite al escultor realizar un apurado estudio anatómico, dejándonos ver los brazos, las piernas, parte del torso y también de la cadera. Porta un manto rojo, con labores doradas a punta de pincel, sobre el hombro izquierdo que cae por la espalda. Como vemos, este recurso es muy utilizado por nuestro escultor, pero también lo vemos en el Bautista de Fernández. El borde del tejido lo adorna una rica cenefa decorada con motivos vegetales, aspecto también muy repetido dentro de los policromados de las esculturas de Ávila.

El rostro es casi idéntico al de Santiago, con la excepción de que las puntas bífidas de la barba no apuntan a los lados, sino que se resuelven mediante dos guedejas en forma de $\mathrm{S}$ cuyas puntas se rematan hacia dentro. También le diferencia la forma de resolver el pelo, en este caso no tenemos los frecuentes pelos mojados que caen sobre la frente, sino que aparecen recogidos en un gran mechón circular hecho a base de grandes rizos.

Con la mano derecha señala un cordero que hay a sus pies, mientras que con la izquierda sostiene un báculo. El cordero, que se encuentra sentado con las patas flexionadas, es todo él un conjunto de mechones de pelo circulares. Parece representar el momento relatado por San Juan: "Al día siguiente vio venir a Jesús y le dijo: He aquí el Cordero de Dios, que quita el pecado del mundo. Este es aquel de quien yo dije. Detrás de mi viene uno que es antes de mí, porque era primero que yo. Yo no le conocía; más para que Él fuese manifestado a Israel he venido yo, y bautizo en agua. $Y$ Juan dio testimonio diciendo: Yo he visto al Espíritu descender del cielo como paloma y posarse sobre Él. Yo no le conocía; pero el que me envió a bautizar en agua me dijo: Sobre quien vieres descender el Espíritu y posarse sobre Él, ese es el que bautiza en el Espíritu Santo. Y yo vi, doy testimonio de que éste es el Hijo de Dios" (Juan: 1, 29-34). Además del Agnus, situado a la derecha, sobre un pequeño peñasco, a la izquierda había una decoración arbórea, perdida en una fecha indeterminada del siglo XX.

La composición mantiene la típica diagonal barroca: parte de los ojos del santo, continúa por el brazo con que señala al cordero, y finaliza en éste, que mantiene la cabeza levantada como observando al santo, es decir, le corresponde con su mirada. Si por algo destaca la imagen es por el naturalismo y realismo que ha logrado Ávila en la anatomía del santo. Capta a la perfección el ascetismo del santo, retratándolo delgado, huesudo, con la piel pegada al hueso. Destaca la morbidez de la piel del pecho, en él podemos ver y contar cada una de las costillas. También ha representado las venas del brazo. Seguramente sea en este Bautista, y en el otro que talla para el Oratorio de San Felipe Neri, en los cuales Ávila nos muestra sus grandes cualidades como anatomista, puesto que representa a la perfección el cuerpo huesudo del santo (capta todas y cada una de las clavículas, las costillas y las falanges), los tendones del cuello, de las manos y de los pies, así como las venas de los brazos y la flacidez del pecho. La imagen es todo un alarde naturalista. 


\section{$\underline{\text { SAN JOSÉ }}$}

La talla de San José (Fig. 42), que preside la hornacina del lado de la epístola, no concuerda con los postulados pregonados por nuestro escultor. La escultura, que parece bastante anterior a la fecha de ejecución del retablo, fue reutilizada. Es probable que la imagen fuera la titular de la Cofradía de San José de maestros de obras ${ }^{295}$. Esta corporación fue fundada por los maestros de obras en 1614. No hay que confundir esta cofradía con la de San José de maestros entalladores sita en la iglesia penitencial de Nuestra Señora de las Angustias. El motivo que llevó a colocarla en el retablo mayor puede estar relacionado con que casi todas las cofradías radicadas en la parroquia tenían su propia capilla. Dado que la de San José no poseía ninguna se decidiría de manera mancomunada el colocar la imagen en el retablo. De lo que no cabe duda es que se pensó en ella desde un primer momento para ocupar una de las hornacinas laterales del retablo.

San José se nos presenta de pie, con una pierna adelantada. Con la mano derecha agarra la vara florida, elemento típico de su iconografía y que alude a su matrimonio virginal con María. Con la otra mano parece hacer un gesto que indica mesura. La escultura sigue de cerca el modelo creado por Gregorio Fernández. Tanto el tipo de paños como la forma de modelar el cuello, el rostro y los cabellos lo alejan por completo de nuestro escultor. Pienso que debió ser ejecutada en alguno de los múltiples talleres vallisoletanos del segundo tercio del siglo XVII, si bien dada la altura a la que se encuentra y que no pueda visionarse con más exactitud puede hacer que nuestro análisis sea equivocado, sobre todo en lo concerniente al rostro.

\section{APARICIÓN DE LA VIRGEN DEL PILAR A SANTIAGO Y SUS DISCÍPULOS}

La escena de la Aparición de la Virgen del Pilar a Santiago y a sus discípulos (Figs. 4344), que es una leyenda puramente española ${ }^{296}$, se popularizó a partir de la segunda mitad del siglo XVI ${ }^{297}$. Cuenta la tradición que hacia el 2 de enero del año 40 la Virgen se le apareció a Santiago y a sus discípulos zaragozanos en la, por entonces, ciudad de Caesaraugusta. La visión que tuvieron estos fue la de la Virgen María situada sobre una columna de jaspe, posteriormente conocida como "El Pilar"; ésta animó al apóstol a predicar el mensaje de Cristo por Hispania. Justo en este lugar fue en el que Santiago y los siete primeros discípulos de esta ciudad que le siguieron, fabricaron una capilla muy humilde.

La escena se incluye dentro de una hornacina de remate semicircular. El fondo de la misma, al igual que ocurre con la escena de Santiago Matamoros, va completamente pintado, queriendo aportar un grado mayor de ilusión y verismo. Las pinturas parecen

\footnotetext{
295 MARTÍN GONZÁLEZ, Juan José y URREA FERNÁNDEZ, Jesús: Catálogo Monumental de la provincia de Valladolid. Tomo XIV..., op. cit., p. 198.

296 ANDRÉS ORDAX, Salvador: Iconografía jacobea ..., op. cit., p. 34.

297 VV.AA.: Iconografía de Santiago..., op. cit., p. 13.
} 
representar, ya que la altura y la posición de las imágenes no dejan visionarlas con claridad, un paisaje en su parte inferior y en la superior una especie de rompimiento de gloria, con una multitud de cabezas de ángeles aladas, mismo motivo que vemos en el trono de la Virgen y también utilizado en las pinturas del semicírculo de la hornacina. Ese ilusionismo y teatralidad barroca se vería incrementado por la posición que goza este grupo, ya que se encuentra situado entre las dos ventanas laterales de la nave gótica, lo que haría que a determinada hora del día el sol iluminara la escena, con lo cual la Aparición a Santiago y sus discípulos se vería extendida al resto de fieles que estuvieran presentes en la iglesia. La combinación de escultura y luz solar ya fue utilizada por Bernini en sus transparentes, pero éste no sería un transparente propiamente dicho.

Juan de Ávila ha concebido la escena con un calculado juego de gestualidades por parte del apóstol y de los discípulos; pero también de diagonales, todas ellas parten de los ojos de los "humanos" y finalizan en el rostro de la Virgen y el Niño. Nuestro escultor impone una simetría en el conjunto. En centro lo ocupa la Virgen del Pilar con el Niño, situada sobre un trono con tres cabezas de ángeles, que pudiera ser el germen de los tronos angélicos que su hijo Pedro utilizará en todas sus representaciones de la Inmaculada, y éstos a su vez sobre el famoso pilar, toscano, pintado de rojo y oro, y con una Cruz de Jerusalén dorada, quizás de la de la Orden de Santiago, inscrita. A los lados de esta figuran Santiago (izquierda del espectador) y dos de los discípulos de este (derecha del espectador). La Virgen va tocada con una corona imperial.

La Virgen, como dijimos, sujeta con su brazo derecho al Niño Jesús desnudo, pero no directamente, sino intermediando un paño blanco. El Niño, con unas proporciones bastante regordetas, interactúa con su madre acariciándola suavemente el cuello. Con su otra mano agarra con fuerza una paloma, quizás símbolo del Espíritu Santo dado el ambiente celestial que simulan las pinturas de la hornacina. El rostro del infante es muy ancho, con carrillos prominentes, ojos pequeños y flequillo ladeado sobre la frente, nada que ver a la usual forma de tallar el pelo de nuestro escultor. María viste túnica roja, por encima tiene echado un manto que le llega a tapar la totalidad del cuero cabelludo, dejando solamente a la vista el rostro, muy clásico. El manto, realizado a base de estrechos y delicados pliegues redondeados se ve más arrugado y con pliegues más anchos y profundos en su zona media, sin duda provocados por el tirón al que se ve sometido por la Virgen con su otra mano, la cual, por cierto, está concebida con mucha elegancia. Este grupo de madre e hijo pasan por ser una de las obras más clásicas e idealizadas de Ávila.

Santiago viste de peregrino. En su mano izquierda porta el bordón. Aparece semiarrodillado, con la mano derecha extendida en actitud de sorpresa ante dicha aparición. Sus dos discípulos muestran su asombro con ademanes similares: uno de ellos, que ha perdido una mano, la otra se la lleva al pecho como en actitud de sometimiento devocional; mientras que el segundo levanta levemente las dos como encontrándose arrobado. Visten túnicas con manto por encima, y los pliegues son dulces y curvos. No hay quiebros bruscos, salvo en las zonas en que las vestimentas chocan 
contra el suelo. Sobre los rostros de Santiago y los apóstoles no hay mucho que decir, son los usuales en Ávila, además, son similares al de Santiago Matamoros. El del santo no se ve puesto que está girado para admirar a la Virgen y los de los apóstoles son los usuales de nuestro escultor. La policromía es la vista en otras ocasiones: a través de un color base (azul, rojo, verde o marrón) se hacen una serie de dibujos geométricos o vegetales en dorado u otro color de esa gama, además de utilizar un característico tipo de cenefa. El interés del grupo se centra en sus actitudes, de lo más movido y teatral de nuestro escultor.

\section{ÁNGELES}

Completan la decoración escultórica del cascarón los ángeles (Fig. 45) que campean sobre volutas y entablamentos a ambos lados del grupo de la Virgen. Ya comentamos que nuestro escultor talló seis ángeles, de los que en la actualidad solo se conservan cuatro, desconociendo el paradero de los dos restantes. La lógica lleva a pensar que los otros dos también se encontraban en el cascaron, el cual fue reformado por Pedro Correas en 1728-1729, y, quizás, fue entonces cuando se retiraron. Otras posibilidades mucho menos plausibles es que el escribano confundiera de número de ángeles. Tan solo el hallazgo del protocolo notarial nos sacaría de dudas, y eso en el caso de que se hubiera hecho.

Los ángeles, que adoptan unas posiciones ciertamente movidas, los podríamos agrupar en dos tipos: los dos más cercanos al grupo de la Aparición de la Virgen del Pilar, y los dos más lejanos. Los del primer grupo son de un tamaño ligeramente superior. Las cabezas se encuentran ligeramente inclinadas hacia los laterales del retablo. Las alas las tienen completamente desplegadas En una de sus manos portan una palma mientras que el otro brazo le mantienen extendido con la palma hacia arriba. Visten túnicas rojas con el interior de las mangas azul. Los del segundo grupo, es decir los de los extremos del retablo, poseen una composición más cerrada. Las alas no están desplegadas, y su tamaño es ligeramente inferior. Colocan las piernas ladeadas de forma que giran su cuerpo y cabeza para mirar hacia el centro del retablo. Cada uno de ellos porta una maza mientras que con la otra mano no sabemos qué acción desarrollarían pues se encuentran seccionadas. Visten túnica roja con decoraciones doradas a punta de pincel, mientras que el interior de la misma también es de color azul.

Las cabezas de los cuatro ángeles, casi idénticas, están tocadas como por un bonete con florecillas. Ciertas durezas en los plegados de las túnicas y en la forma de esculpir los rostros me obliga a pensar en la existencia de una alta participación del taller del maestro, al modo de las Virtudes del ático de Lerma. También influiría en la tosquedad de estos ángeles la altura a la que se encuentran. A pesar de estar al mismo nivel que el grupo de la Virgen, Ávila prefirió echar el resto en este misterio, dejando los ángeles, figuras secundarias del conjunto, en manos de sus discípulos. No sería descartable la participación de su hijo Pedro ya que la configuración del rostro, su característica nariz ancha y cuadriculada y la manera de tallar el pelo lo acercan a su magisterio. 


\section{VALLADOLID. ORATORIO DE SAN FELIPE NERI}

\section{ESCULTURAS PARA RETABLOS (1699)}

En el año 1699 la Congregación de San Felipe Neri contrata con Juan de Ávila la ejecución de un San Francisco de Sales y de los relieves de San Juan Bautista predicando en el desierto y San Francisco de Sales predicando. El escultor recibirá 500 reales por la escultura del santo y otros 500 reales por los dos relieves, es decir 250 reales cada $u_{n o}^{298}$. Se conserva el recibo otorgado por Juan de Ávila ${ }^{299}$. Estas tres piezas tenían como destino los dos retablos colaterales que la Congregación acababa de construir. El de la derecha dedicado a San Francisco de Sales, ocupando la hornacina principal el santo y el relieve en el ático. En el izquierdo ocurría lo mismo, pero con la presencia de San Juan Bautista. Aunque la escultura de este santo no aparece citada en el libro de cuentas no hay ninguna duda de que también fue esculpida por nuestro escultor Como podemos comprobar la elección de ambos santos para los colaterales no fue baladí: se eligió a dos grandes oradores y predicadores, acciones declamatorias en las cuales les podemos ver representados en los relieves, e incluso en las esculturas de bulto redondo.

La Congregación de sacerdotes puesta bajo la advocación de San Felipe Neri fue una institución creada por los sacerdotes seculares de la ciudad que tenía como objetivo, según las palabras de Rebollo Matías, "el sostenimiento del clero más pobre mediante la fundación de hospitalidad y socorro" 300 . En definitiva, se trataba de que este clero tuviera una ayuda cuando enfermaba, envejecía o fallecía. Su origen tiene lugar el 26 de febrero de 1645 en una de las capillas de la iglesia de Santiago, la cual les fue donada por el Hospital de Esgueva. Concretamente era la primera, contando desde el crucero, del lado de la Epístola. Allí realizó la Congregación sus cultos hasta el año 1658. En la actualidad se conserva en la referida capilla una imagen del santo, costeada por la propia iglesia ya que la Congregación una vez que abandonó la capilla y le vendió el

\footnotetext{
298 "1698-1699. 1.000 reales que pagó a Juan de Ávila maestro escultor por la hechura de San Francisco de Sales y de las dos historias de la Degollación de San Juan Bautista y un milagro de San Francisco de Sales. Los 500 por la dicha hechura de San Francisco y los otros 500 por dichas historias". URREA FERNÁNDEZ, Jesús: “El oratorio...”, op. cit., p. 19.

299 "Recibí del señor licenciado don Felipe Sánchez Flores de Paz presbítero capellán mayor de la capilla mayor de santa María Magdalena de esta ciudad mil reales de vellón que es la misma cantidad en que se ajustó la hechura de la efigie del señor san Francisco de Sales y las historias de san Joan Bautista y los dichos Francisco de Sales que todo lo he hecho de orden de la Congregación de nuestro padre San Felipe Neri para la iglesia de dicha Venerable Congregación y dicho señor don Felipe me lo ha pagado como testamentario del señor licenciado don Pedro Sinobas depositario que fue de dicha Congregación el año de mil y seiscientos noventa y nueve..." GARCÍA CHICO, Esteban: Documentos para el estudio del arte en Castilla. 2..., op. cit., p. 372.

300 REBOLLO MATÍAS, Alejandro: La Iglesia-Oratorio de San Felipe Neri de Valladolid: breve guía de su historia y patrimonio, Congregación de San Felipe Neri y de Nuestra Señora de la Presentación, Valladolid, 2008.
} 
retablo de la misma, se lo traspasó con la condición de que esta hiciera una hechura del "Apóstol de Roma"301.

El propósito lógico de la Congregación fue asentarse en una iglesia y hospital propio. El primer paso para lograrlo tuvo lugar el 14 de octubre de 1656, fecha en que se le concede la licencia para edificarla. Hubo que esperar hasta el año 1675 para que comenzara la construcción del templo, bajo la dirección del maestro de obras Antonio de la Iglesia. La finalización de las obras tuvo lugar en 1683, siendo el 24 de julio de ese año bendecida ${ }^{302}$. Con posterioridad llegó el embellecimiento del interior: pinturas para la nave y lienzos encastrados para las bóvedas, construcción de retablos provisionales, del cancel, del retablo mayor y finalmente, al borde del año 1700, de los retablos colaterales, que venían a culminar la decoración de la iglesia, a falta de que un cuarto de siglo más tarde se abrieran y ornamentaran las seis capillas del cuerpo de la iglesia.

Los retablos colaterales fueron realizados, como ya se venía pensando acertadamente ${ }^{303}$, por Francisco Billota. Ajustados el 7 de octubre de $1698^{304}$, no debió de darlos por fenecidos hasta el mes de mayo del año siguiente. En la Congregación celebrada el 18 de mayo de 1699 se acuerda buscar maestros para reconocer los retablos y ver si estaban ejecutados conforme a la traza y condiciones suministradas por el propio artista ${ }^{305}$. Con anterioridad a estos dos retablos debió de haber dos provisionales, el altar del lado del Evangelio lo presidía una pintura del Descendimiento de la cruz y el del lado de la Epístola otra de Santa Rosalía de Palermo ${ }^{306}$, ambos con marcos dorados.

Los retablos son gemelos; la única diferencia es que el de San Juan Bautista tiene el banco y una de las columnas perforadas en su parte inferior para permitir la entrada a la sacristía. Se estructuran en banco, único cuerpo y ático. En el banco se localiza el sagrario, a cuyos lados hay dos netos con decoraciones vegetales. El cuerpo del retablo se organiza a través de cuatro columnas salomónicas, dos columnas a cada lado, las centrales algo más salientes que las otras extremas, con lo cual se crea un efecto claroscurista típicamente barroco y también movimiento en planta. En medio de este cuerpo está la hornacina principal, con remate semicircular, que está rodeada por una especie de marco de tarjetillas con decoración vegetal. Justo encima, irrumpiendo tanto en el cuerpo como en el ático, se encuentra una gran tarjeta cactiforme con hojas crespas. El ático se conforma a partir de una caja que da cabida al altorrelieve, a cuyos lados hay sendas columnas salomónicas que sostienen un entablamento partido, en cuyo

\footnotetext{
301 MARTÍN GONZÁLEZ, Juan José y URREA FERNÁNDEZ, Jesús: Catálogo Monumental de la provincia de Valladolid. Tomo XIV ..., op. cit., p. 199-200.

$302 \quad$ Ídem, pp. 291-292.

303 Ídem, p. 293; URREA FERNÁNDEZ, Jesús: "El oratorio...”, op. cit., pp. 9-23.

304 MARTÍN GONZÁLEZ, Juan José y URREA FERNÁNDEZ, Jesús: Catálogo Monumental de la provincia de Valladolid. Tomo XIV..., op. cit., p. 293.

$305 \quad$ Congregación de 18 de mayo de 1699: "Decretose que para efecto de reconocer la obra de los dos colaterales ejecutados por Francisco Billota se diese comisión a los señores don Felipe Sánchez de Paz y Juan de Salazar y don Pedro de Rozas para que buscasen maestros viesen las condiciones y planta si estaban conforme a ellas y se diese cuenta a dicha Congregación que en esta forma se acabó dicha junta y lo firmó dicho señor Ministro y el presente secretario de que doy fe". A.S.F.N., Caja $14,2^{\circ}$ Libro de acuerdos (1690-1740), f. 42.

306 URREA FERNÁNDEZ, Jesús: “El oratorio...”, op. cit., p. 18.
} 
centro hay otra tarjeta cactiforme rematada por una corona y una cruz. La decoración es la principal protagonista de ambos retablos, y los llena por completo; es un verdadero "horror vacui".

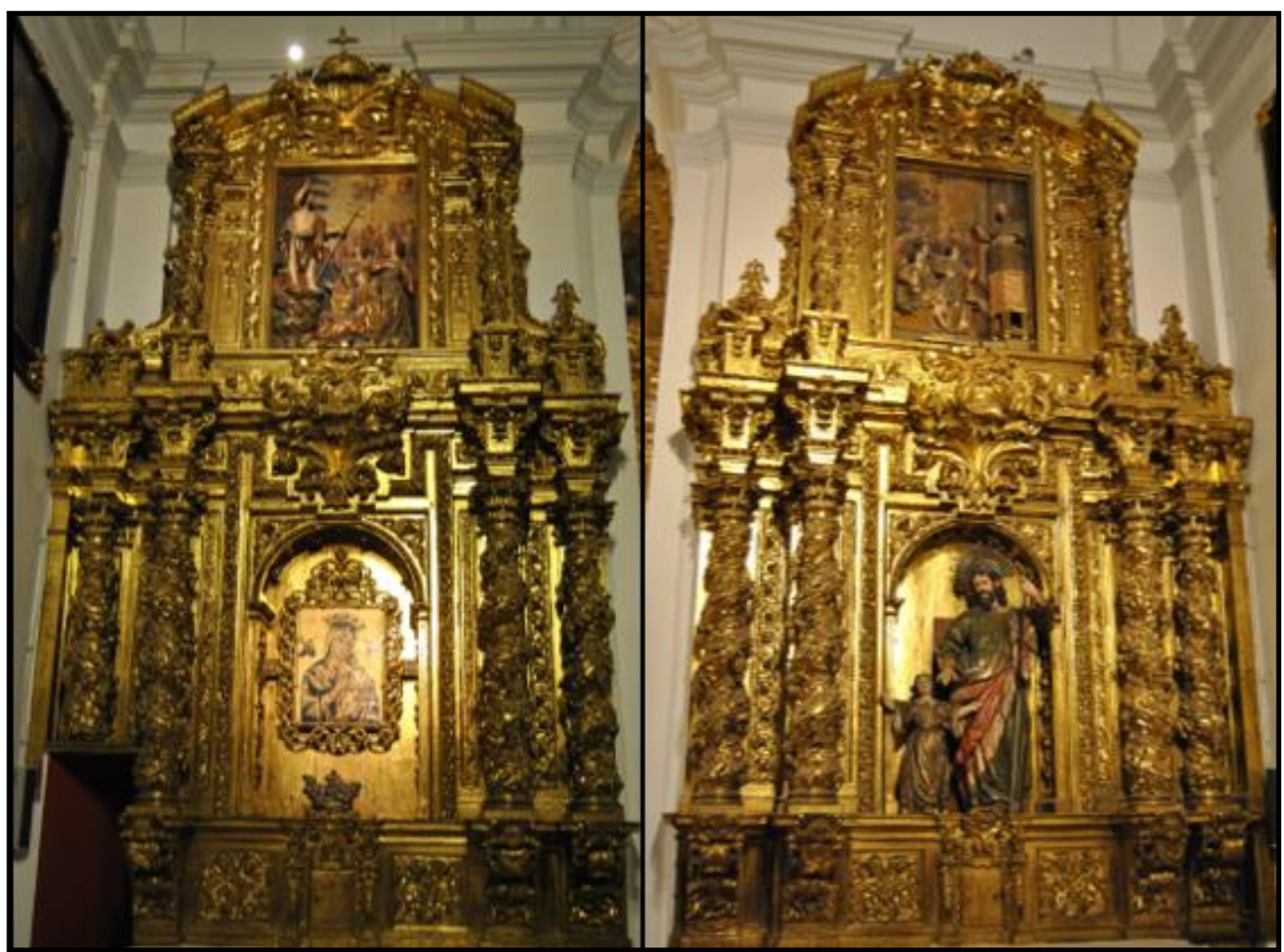

Il. 14- Francisco Billota. Retablos colaterales. Oratorio de San Felipe Neri. Valladolid.

Ambos retablos se encontraban aún sin dorar en 1701, puesto que el día 3 de agosto de ese año la Congregación pide ayuda económica a sus miembros para afrontar dicha tarea $^{307}$. Del dorado se encargó el mismo artífice que realizó el del retablo principal: Manuel Martínez de Estrada, con el cual Juan de Ávila ya había colaborado en el retablo mayor de la Colegiata de Lerma. Como vemos los destinos de esta familia de artistas y Juan de Ávila estuvieron permanentemente unidos. Los retablos se doraron a lo largo del año 1702, terminando de cobrar su trabajo ese mismo año ${ }^{308}$.

Antes de entrar a comentar la obra realizada por Juan de Ávila para ambos retablos hay que hacer referencia al trasiego que ha llevado a que las dos esculturas de San Francisco de Sales y San Juan Bautista no se encuentren en sus respectivos retablos: en el año 1964 se comenzó a desmantelar los retablos de la iglesia, lo que condujo a que las

307 "Pagar y satisfacer los dos colaterales que están hechos y fabricados de talla y escultura correspondientes al dicho y puesto en el altar mayor el uno al lado del evangelio con la hechura de San Juan Bautista en el desierto y el otro el de la epístola con la hechura de San Francisco de Sales, los cuales se hallan en blanco y necesitan de dorarse para la correspondencia... en la ciudad de Valladolid a tres de agosto de mil setecientos y un año...". A.H.P.V., Leg. 2.644, ff. 570-575.

$308 \quad 17$ de julio de 1702. "Recibí noventa y siete reales con que me acabó de pagar los mil ducados en que se concertaron los dos colaterales de la iglesia de (...) Firmado: Manuel Martínez de Estada". Archivo de San Felipe Neri, Legajo número 1. Recado de cuentas. MARTíN GONZÁLEZ, Juan José y URREA FERNÁNDEZ, Jesús: Catálogo Monumental de la provincia de Valladolid. Tomo XIV..., op. cit., p. 303.

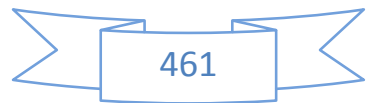


imágenes de las seis capillas laterales fueran cambiadas de sitio o arrinconadas, siendo sustituidas por esculturas modernas de nula calidad, situación que aún no se ha corregido en su totalidad ${ }^{309}$. Lo mismo sucedió con los retablos colaterales: El San Francisco de Sales fue sustituido por un grupo de San José con el Niño, obra de José de Rozas, que anteriormente se encontraba situado en el retablo de la tercera capilla del evangelio $^{310}$, pero que en origen fue tallado para el retablo mayor ${ }^{311}$. La escultura del fundador de los salesianos fue a parar a la iglesia del Monasterio de la Visitación de las Salesas. Por su parte, el San Juan Bautista fue sustituido por una pintura de Nuestra Señora del Perpetuo Socorro. Sería deseable que tanto los dos retablos colaterales como los de las seis capillas recuperaran las esculturas que en su día se pensó para ellas, a excepto de una de ellas que dicen que pereció en un incendio ${ }^{312}$. Todo esto, como sentencia Urrea, no deja de ser una "falta de respeto por las ideas que originalmente presidieron la mentalidad religiosa de los que concibieron el ornato de este templo"313. A continuación, hablaremos de las obras realizadas por Juan de Ávila para los referidos dos retablos colaterales, no sin antes reseñar que la colaboración entre los hijos de Juan, Pedro y Manuel, continuaría durante el primer tercio del siglo siguiente. Este fenómeno no será exclusivo de este templo ya que habrá otros lugares para los que había trabajado el padre y para los cuales también trabajarán los hijos: la Cofradía Penitencial de N. P. Jesús Nazareno de Valladolid o la iglesia parroquial de San Esteban Protomártir de Torrecilla de la Abadesa (Valladolid).

\section{$\underline{\text { SAN JUAN BAUTISTA }}$}

La escultura de San Juan Bautista (Figs. 46-48), que durante mucho tiempo se dio como "irremisiblemente perdida" ${ }^{14}$, se realizó para presidir la hornacina principal del colateral del Evangelio; si bien en la actualidad se encuentra expuesta en el Museo Diocesano y Catedralicio de Valladolid. En concreto ocupa uno de los nichos de la primera sala del museo, que se corresponde con la antigua capilla de San Llorente de la desaparecida colegiata vallisoletana. La "vida" de esta escultura no ha sido fácil ya que en el mes de junio de 1947 estuvo a punto de ser vendida a la iglesia de San Juan Bautista. El párroco de esta iglesia se dirigió al Ministro de la Congregación deseando adquirirla para su parroquia, estando dispuesto a pagar por ella las 1.500 pesetas en que la había tasado una "persona competente" 315.

\footnotetext{
309 URREA FERNÁNDEZ, Jesús: “El oratorio...”, op. cit., p. 10.

$310 \quad$ Ídem, p. 12.

$311 \quad$ Ídem, p. 18.

312 Diferentes fuentes me han informado que la Virgen Niña que acompañaba a San Joaquín, grupo tallado en un principio para el retablo mayor, se quemó en un incendio acaecido en la iglesia.

313 URREA FERNÁNDEZ, Jesús: “El oratorio...”, op. cit., p. 12.

314 Ídem, p. 10.

315 "Rvdo. Sr. Ministro de la Congregación del Oratorio de San Felipe Neri de Valladolid: Teniendo conocimiento de que esa Congregación que V. R. dignamente preside posee una imagen de San Juan Bautista retirada del culto, valorada en mil quinientas pesetas por persona competente; el que suscribe, párroco de la de San Juan Bautista de esta ciudad desea adquirirla para esta parroquia si le facilitan el pago entregando quinientas pesetas al contado y las mil restantes en dos anualidades sucesivas.
} 
Como hemos dicho, la escultura no está documentada, aunque su autoría en favor de Ávila no está en discusión. La problemática radica en el por qué no figura en el libro de cuentas. Lo más probable es que algún particular se ofreciera a sufragarla. Estilísticamente, todo en ella nos conduce hacia la paternidad de nuestro escultor. Si aun así quedaran dudas no habría más que compararla con la imagen del santo que Ávila talla para el relieve superior de ese mismo retablo, o con el San Juan Bautista que modela un año antes para el retablo mayor de la iglesia de Santiago apóstol de Valladolid. Esta última y la presente son casi idénticas, tanto en la concepción general del cuerpo, la posición de los brazos, la túnica de piel, la forma de caer el manto sobre el hombro, la forma de tallar el pelo y la barba, y hasta la forma de concebir el cordero que se encuentra a sus pies. En definitiva: en todo. La escultura no ofrece demasiadas novedades respecto al San Juan Bautista de la iglesia de Santiago, tan solo algunos pequeños detalles: el principal es la aparición a los pies del santo de un reducido peñasco, que viene a ser una rememoración, en pequeño tamaño, del que años antes había esculpido para asentar al santo titular de la parroquial de Pesquera de Duero; las dobleces del manto no son tan secas, son más dulces; esa misma aspereza en la facciones del rostro y en la manera de tallar el pelo se torna en esta ocasión en blandura en la piel y en una cabellera no tan geometrizada, por lo que sin duda es un rostro más vivo. En definitiva, el tratamiento del cuerpo está más apurado y ofrece mayor calidad y morbidez. No hay más que comparar ambos pechos y brazos, sin lugar a dudas porque el de Santiago iría en una hornacina muy alta y esta se encontraría casi frente a frente con los devotos.

Durante cierto tiempo llevó corona, lo que derivó en ciertos desperfectos en la cabellera. En un inventario del año 1806 se la citaba como "Retablo de San Juan Bautista y con él lo siguiente (...) 151. Primeramente la efigie de dicho santo con corona de plata"316.

\section{RELIEVE DE SAN JUAN BAUTISTA PREDICANDO EN EL DESIERTO}

El relieve del ático representa la Predicación de San Juan Bautista en el desierto (Fig. 49). San Juan se sitúa a la izquierda sobre un peñasco con rocas y serpiente, su particular púlpito natural. Con su mano izquierda sujeta un báculo rematado en forma de cruz, mientras que el otro brazo lo mantiene levantado en actitud de predicar con vehemencia. Este pasaje nos es relatado por San Lucas: "Después, pues, a las muchedumbres que venían para ser bautizadas por él: Raza de víboras. ¿Quién os ha enseñado a huir de la ira que llega? Haced, pues, dignos frutos de penitencia y no andéis diciéndoos: Tenemos por padre a Abraham. Porque yo os digo que puede Dios suscitar de estas piedras hijos a Abraham. Ya el hacha está puesta a la raíz del árbol; todo árbol que no dé buen fruto será cortado y arrojado al fuego. Las muchedumbres le preguntaban. Pues ¿qué hemos de hacer? Él respondía: El que tiene dos túnicas, dé

En espera de la resolución, que esa Congregación, que desearía fuera pronto (...). Valladolid 10 de junio 1947. Fdo: Delfino Molpeceres”. A.S.F.N., Papeles sueltos.

316 A.S.F.N., Inventario de los bienes y alhajas del año 1806. 
una al que no la tiene, y el que tiene alimentos haga lo mismo. Vinieron también publicanos a bautizarse y le decían: Maestro, ¿qué hemos de hacer? Y les respondía: No hagáis extorsión a nadie ni denunciéis falsamente y contentaos con vuestra soldada. Hallándose el pueblo en ansiosa expectación y pensando todos entre sí de Juan si sería él el Mesías, Juan respondió a todos, diciendo: Yo os bautizo en agua, pero llegando está otro más fuerte que yo, a quien no soy digno de soltarte la correa de las sandalias; Él os bautizará en el Espíritu Santo y en el fuego. En su mano tiene el bieldo para limpiar la era y almacenar el trigo en su granero, mientras la paja la quemará con fuego inextinguible" (San Lucas: 3, 7-17).

Viste a la usanza con la que le suele representar Ávila, además de la misma manera: típico ropaje hecho de piel de camello, y por encima del brazo izquierdo le cae un manto rojo con labores doradas. Los asistentes a la predicación del Bautista figuran a la derecha. Los hay de dos tipos, esculpidos y pintados. Del primer grupo hay tres personas con actitudes muy variadas y dinámicas subrayadas por la posición de los brazos.

Como de costumbre en nuestro escultor la composición posee una clara línea diagonal que va desde la mirada de los fieles al rostro y brazo derecho del santo. Los pliegues son los habituales: dulces, levemente curvados; aquí no aparecen los verticales de desarrollo paralelo hasta chocar contra el suelo. No existen las dobleces rectas. Hay que achacar al escultor la simplificación que ha hecho de su modelo de Bautista ya que ni las anatomías, ni el manto ni la piel de camello están tan elaborados ni apurados en su detalle.

El relieve, como comentamos en la introducción, no es donde mejor se desenvuelve Ávila. Tienden a un gran ingenuísimo y a una falta de perspectiva y proporción. Un claro ejemplo de esto lo tenemos en el canon achaparrado del santo, así como los errores de perspectiva en el grupo de los tres fieles. Como también comentamos, estos relieves en realidad no lo son, ya que son casi bultos redondos pegados al tablero, sobre el cual, además, se desarrolla la citada pintura que completa la escena con paisaje y dota a la obra de cierto empaque. La pintura, bastante abocetada, representa a su izquierda un paisaje con árboles, que enmarca la figura del santo; mientras que a la derecha aparecen una multitud de fieles que acuden a la plática del "Precursor", completando de esta manera a los tres tallados; en la parte superior, unas nubes y cabezas aladas de angelitos rematan la escena. Por la factura abocetada del óleo, recuerda bastante a las pinturas realizadas, supuestamente, por Manuel Peti en 1700 en los fondos de los relieves del desaparecido retablo mayor de la iglesia de San Ildefonso de Valladolid ${ }^{317}$. Aunque sea un recurso ciertamente pobre y nos muestre la escasa talla artística de los escultores vallisoletanos en lo que concierne a los relieves, el conjunto es bastante armonioso.

317 MARTÍN GONZÁLEZ, Juan José y URREA FERNÁNDEZ, Jesús: Catálogo Monumental de la provincia de Valladolid. Tomo XIV..., op. cit., p. 69. 


\section{$\underline{\text { SAN FRANCISCO DE SALES }}$}

San Francisco de Sales (1567-1622) sobresale por su faceta de gran predicador, puesto que consiguió rescatar a un gran número de católicos que se habían convertido en calvinistas en Chablais (Francia). Su gran aportación al cristianismo fue la fundación en Annecy, en el año 1610, junto con Juana Francisca de Chantal, de la congregación de las hijas de la Visitación, no en honor de la Visitación de la Virgen sino en alusión al hecho de que una de las labores de estas hermanas era la de visitar enfermos. También son conocidas como salesianas en honor a su fundador ${ }^{318}$. Era un santo muy reciente, pues acababa de subir a los altares en 1665. Tres años antes, el mismo papa que le había canonizado, Alejandro VII, también le había concedido la consideración de beato. Destacó como escritor, siendo su obra más conocida la Introducción a la vida devota (1608), la cual se convirtió enseguida en uno de los textos más populares del siglo XVII.

La hechura de San Francisco de Sales (Fig. 50-52) se realizó para presidir la hornacina del retablo colateral de la epístola. En la actualidad ocupa otro, fechable hacia el año 1900, en la iglesia de los Sagrados Corazones, de las Salesas ${ }^{319}$. El santo aparece en pie, con una rigidez en los pliegues de las vestimentas que le resta bastante naturalismo. Viste túnica, sobrepelliz, capa corta y muceta. La policromía imita a la perfección el brocado de la sobrepelliz, por lo demás es la típica a la que nos tiene acostumbrados la imaginería de Ávila, pero no obstante fue realizada por uno de los Martínez de Estrada. No falta la típica cenefa en el borde de la capa ni las labores vegetales doradas.

Ávila efigia al santo con la cabeza elevada, mirando a los cielos, justo en el momento en que recibe la inspiración divina. Según el parecer de Martín González, el santo se encuentra en "actitud de predicar" 320 . Con su mano derecha sujeta una pluma, referencia a su faceta de escritor, predicador y Doctor de la Iglesia, mientras que con la izquierda hace lo propio con un libro cerrado que serviría de apoyo a una maqueta de iglesia, que aludiría a su vertiente como fundador de una Orden. Es probable también que sobre el libro no apareciera la citada maqueta sino un corazón, como así lo deja entrever un inventario del año 1806, en clara alusión a su promoción del culto al Sagrado Corazón de Jesús ${ }^{321}$.

Ávila retrata al santo según su iconografía tradicional: calvo, con una pequeña barba y sin mitra, a pesar de su condición de obispo. El rostro, de gran dulzura, presenta grandes similitudes con el del San Isidro que había tallado un año antes para su ermita de Valladolid. Ojos vivaces, bien abiertos, nariz amplia, boca entreabierta que permite ver parte de la dentadura y la punta de la lengua. Sobre la frente ha plasmado una serie de

\footnotetext{
318 RÉAU, Louis: Iconografía de los santos. A-F..., op. cit., p. 568.

319 MARTÍN GONZÁLEZ, Juan José y DE LA PLAZA SANTIAGO, Francisco Javier: Catálogo Monumental de la provincia de Valladolid. Tomo XV..., op. cit., p. 199.

320 MARTÍN GONZÁLEZ, Juan José: La escultura barroca en España..., op. cit., p. 80.

321 "Altar de San Francisco de Sales (...) 198. Primeramente, la imagen de dicho santo colocada en el trono principal tiene corona de plata y la iglesia y corazón”. A.S.F.N., Inventario de los bienes y alhajas del año 1806.
} 
venas. El tipo de barba aquí desarrollada es novedoso ya que está compuesto de largos y sinuosos mechones compactos dispuestos con total simetría. El gran parecido del rostro tallado por Ávila con otras pinturas de la época evidencia que nuestro escultor manejó grabados o estampas.

La disposición de las manos es muy elegante. Destaca la derecha, encargada de sostener la pluma, la cual está presionada por solo dos dedos, estando el resto desplegados, sobre todo el meñique. La mano izquierda se encuentra doblada para abarcar y sostener con mayor fuerza el libro, el pulgar presiona la parte superior del mismo, mientras que el índice lo sostiene con una de las tapas, el resto por debajo. Individualiza cada una de las uñas, dedos y falanges, así como la piel tensionada de los tendones al estar separados los dedos. También talla las venas, algo muy típico del escultor. La colocación de los pies muy juntos, formado un ángulo de unos 90 grados, será una de las características típicas de su hijo Pedro de Ávila.

Referente a esta imagen comentó Martín González que "apreciamos en el arte de Juan de Ávila una disyunción en el modo de hacer los pliegues. Estos se han ido haciendo progresivamente más suaves, constituyéndose por unas líneas paralelas que se adhieren al cuerpo. Esta tendencia se acusa ya en el San Francisco de Sales de la Oratorio de San Felipe Neri. Pero es curioso que al mismo tiempo sigue utilizando los pliegues con quebraduras, típicos del siglo XVII'322.

\section{$\underline{\text { RELIEVE DE SAN FRANCISCO DE SALES PREDICANDO }}$}

El relieve nos presenta a San Francisco de Sales (Fig. 53) en el momento de predicar desde un púlpito octogonal con labores vegetales brocadas, emparentando de esta manera con el de San Juan Bautista, Interesa resaltar la faceta de grandes oradores. Gesticula con los brazos, los cuales han perdido las manos. Los fieles, situados a la derecha escuchan atentamente, unos sentados y otros incorporados. En este último Ávila ha resuelto muy mal el contraposto. Concretamente efigia a tres personas, igual que en el relieve del Bautista; de la misma manera el resto de oyentes aparecen plasmados en el fondo pictórico. Son tallas bastante más toscas y rudas que la figura de San Francisco de Sales, la cual denota una gran calidad, sobre todo en rostro. Hay una clara diferencia de calidad entre esta imagen y la frontera de San Juan Bautista, menos cuidada. Pareciera como si Ávila se hubiera encargado completamente de esta talla y en la otra hubiera dejado más libertad a su taller.

El fondo pictórico emparenta completamente con el del Bautista. Tras el santo figura un paisaje, en este caso arquitectónico. La parte de los fieles se ve aumentada por gran número de ellos en las más diversas actitudes. Sobre ellos nubes y cabezas aladas de ángeles.

322 MARTÍN GONZÁLEZ, Juan José: Escultura barroca castellana ..., op. cit., p. 323. 


\section{VILLASILOS. IGLESIA DE SAN ANDRÉS APÓSTOL}

\section{RETABLO DE LA RESURRECCIÓN ¿h. 1702-1711?}

El retablo dedicado a la Resurrección de Cristo de la iglesia parroquial de San Andrés Apóstol de Villasilos (Burgos) fue seguramente el último trabajo realizado por el escultor vallisoletano. Es una obra llega de interrogantes puesto que se le abonan los pagos en 1711, fecha en que nuestro escultor llevaba nueve años fallecido. Por otro lado, en las esculturas parecen advertirse dos estilos, ninguno de los cuales parece coincidir exactamente con el de nuestro escultor. Dada esta situación, el abanico de posibilidades de lo que pudo ocurrir es muy amplio: pudo darse el caso de que falleciera al poco de contratarla, no pudiendo haberla comenzado, o bien no llegó a acabarla; teniendo que finalizarlo su taller, en cuya cúspide se situaría su hijo Pedro, ya que por entonces Manuel no era más que un niño. En este caso cabe la probabilidad de que Juan tan solo tallara el Resucitado y que Pedro se ocupara del resto de esculturas y el relieve. Tampoco descartaría la posibilidad de que el escribano se equivocara de nombre y en vez de Juan fuera Pedro ya que en algunas esculturas se percibe su influjo. Sea como fuere, Juan o Pedro, la labor de taller en la mayoría de las imágenes es abrumadora.

Las imágenes que talló Ávila para el retablo fueron: un Cristo Resucitado que presidiría el conjunto en la hornacina principal; cuatro pequeñas imágenes de santos (San Antonio Abad, San Antonio de Padua, San Pedro y San Pablo); un relieve de la Ascensión para el centro del ático; y cuatro representaciones de las Virtudes Cardinales. Por toda la obra cobró la crecida cantidad de 6.380 reales de vellón ${ }^{323}$. La razón del elevado precio que abonó la iglesia al escultor no sería otro que el prestigio del que gozaba Juan de Ávila en el medio castellano y sobre todo por tierras burgalesas, como ya hemos comentado. En ningún caso podemos valorar que tan alto precio tenga relación con la cantidad de esculturas dado que la calidad de las mismas, y en especial el del titular de retablo es muy baja. Es sin duda lo más flojo de su producción.

Apunta, de manera acertada, Payo Hernanz que es muy extraño que un maestro de primera fila del foco vallisoletano, se enfrascara en la ejecución de "una obra claramente secundaria dentro de la parroquia" 324 . Desconocemos quien recomendaría a los encargados de la iglesia contactar con Ávila. Quizás este anónimo personaje tenga relación con el Convento del Domus Dei de La Aguilera o con la Colegiata de San Pedro de Lerma, instituciones que habían quedado muy satisfechas con el trabajo de nuestro escultor y que, además, no se encontraban muy lejos de Villasilos, particularmente el cenobio franciscano.

El retablo se encuentra situado en la nave de la epístola, casi a los pies de la iglesia. La parte arquitectónica fue realizada por el "maestro de arquitectura" burgalés Joaquín de

323 PAYO HERNANZ, René Jesús: El retablo..., op. cit., Tomo II, p. 570.
324 Ídem, p. 171. 
Villandiego ${ }^{325}$, al cual se le comienzan a abonar los pagos en 1711, año en que percibió 1.280 reales por la ejecución del retablo. Pese a que el retablo tenía la advocación de la Resurrección de Cristo, en la actualidad la hornacina principal la ocupa una imagen de la Soledad, habiendo quedado desplazado el Resucitado fuera del retablo. Por estas mismas fechas se le pagaron a Gabriel Balluerca 3.100 reales por dorarlo.

El retablo tiene una planta convexa, al igual que la hornacina central, lo que da al conjunto un movimiento que anticipa los esquemas generales del rococó. La arquitectura se organiza mediante banco, cuerpo con una calle y dos entrecalles y ático. El retablo se sustenta a través de cuatro columnas corintias alzadas sobre ménsulas con los dos tercios inferiores tallados y el superior estriado. Estas columnas están separadas del retablo, quedando detrás de cada columna un machón a modo de pilastra dotando al retablo de un juego de soporte y retrosoporte; se trata de un alabeamiento borrominesco. La calle principal contiene una hornacina con remate semicircular avenerado; a los lados, en las entrecalles, dos pisos de hornacinas que copian la tipología de las referidas hornacinas, pero en un tamaño más reducido. El entablamento no está corrido homogéneamente sino que en los lugares donde se ubican las columnas aparece saliente, mientras que en el resto del retablo aparece justamente siguiendo la línea de los retrosoportes. En la parte central, el arquitrabe se convierte en convexo, igual que ocurre en la hornacina principal. El friso está decorado con cabezas de serafines, motivo típico del siglo XVI. El remate, no es el típico cascarón, sino que se adapta a un arco preexistente en la pared.

La parte central de este remate contiene el relieve de la Ascensión en una especie de baldaquino $^{326}$.

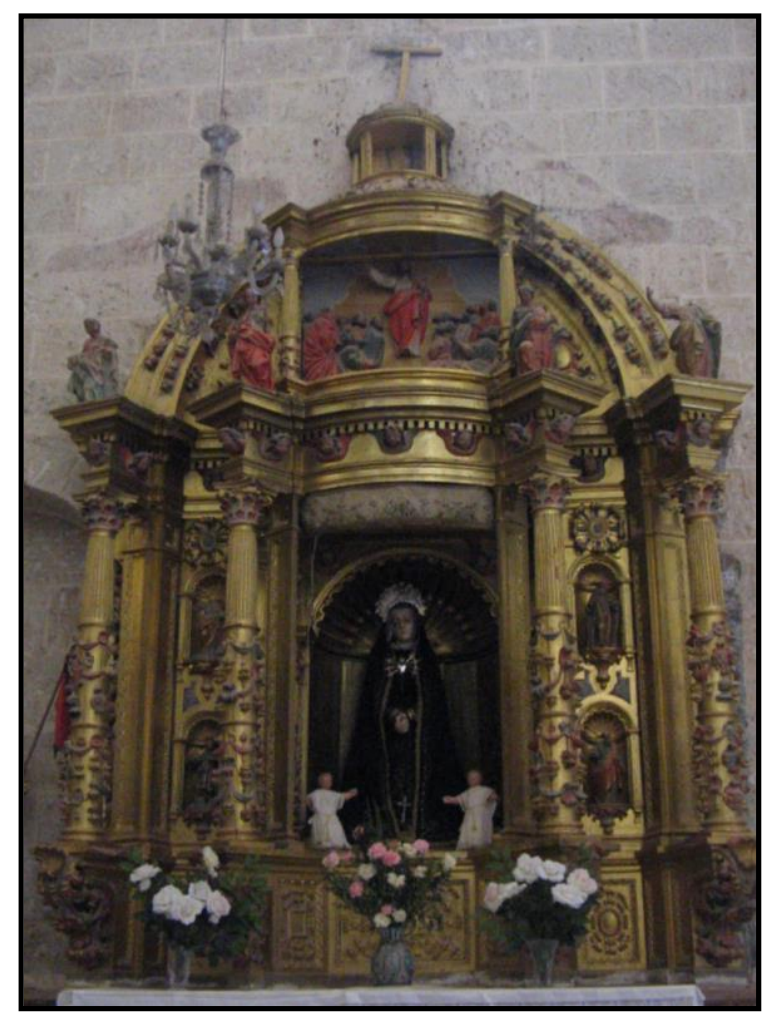

Il. 15- Joaquín de Villandiego. Retablo de Cristo Resucitado. Iglesia parroquial de San Andrés. Villasilos (Burgos).

A continuación, analizaremos las diferentes esculturas y relieve de que se compone el trabajo llevado a cabo por nuestro escultor, su taller o su hijo Pedro. Preside el conjunto el Resucitado en la hornacina de la calle principal, advocación que daba nombre al retablo. En las cuatro hornacinas de las entrecalles se sitúan cuatro santos: San Pedro y San Pablo, los Príncipes de los Apóstoles, los dos santos más importantes de la

\footnotetext{
325 Se poseen escasas noticias acerca de este interesante ensamblador nacido en 1666 en la localidad burgalesa de Sasamón. Debió de fallecer hacia 1736, fecha en que realizó su última obra conocida, el retablo mayor de Tabanera de Cerrato (Palencia). Ídem, pp. 161-181.

$326 \quad$ Ídem, pp. 172-173.
} 
cristiandad; y San Antón y San Antonio de Padua, dos de los santos más populares entre la ciudadanía del momento. Pienso que la disposición original ha sido modificada puesto que lo lógico sería que aparecieran colocados en correspondencia. Es decir: en el piso alto San Pedro y San Pablo, y en el bajo San Antonio de Padua y San Antón Abad. La colocación que a día de hoy rige es: en el cuerpo superior San Pedro y San Antón Abad, y en el inferior San Antonio de Padua y San Pablo. A pesar de lo ciertamente mediocres que son estas esculturas, por su formato, hacen venir a la memoria las numerosas esculturitas que Tomás de Sierra talló para los retablos de la capilla del Relicario de la Colegiata de San Luis de Villagarcía de Campos (Valladolid) ${ }^{327}$. Ya en el ático se desarrolla un relieve de la Ascensión, y las personificaciones de las Virtudes Cardinales (Prudencia, Justicia, Fortaleza y Templanza), si bien en alguna ocasión han sido erróneamente identificadas con los evangelistas ${ }^{328}$. Según Payo Hernanz, las esculturas perpetúan, a pesar de lo avanzado de la fecha, los modos de hacer y los elementos creados tiempo atrás por Gregorio Fernández, sobre todo en lo que concierne a las angulosidades y las quebraduras de los vestidos ${ }^{329}$. Si bien en otras ocasiones hemos visto como Ávila se inspiraba en los modelos del maestro gallego, en esta ocasión los modelos de los santos poco tienen que ver con los suyos.

\section{CRISTO RESUCITADO}

La efigie de Cristo Resucitado (Fig. 54) presidía el retablo, el cual se encontraba bajo su advocación, si bien en la actualidad se encuentra desplazado de él, estando ocupado ese lugar por una imagen de bastidor de la Virgen de la Soledad que cuenta con gran devoción popular. A día de hoy, el Resucitado se sitúa junto al retablo sobre una pequeña peana de piedra.

El pasaje de la Resurrección es uno de los temas más desconocidos de su Pasión, Muerte y Resurrección, ya que los evangelistas pasan muy por encima de él y además no se ponen de acuerdo entre ellos ${ }^{330}$. Este desconocimiento unido al enriquecimiento proporcionado por otros textos como son la literatura mística y los autos sacramentales hizo que los artistas gozaran de gran libertad de acción para interpretar el tema ${ }^{331}$. Señala Álvarez Vicente al respecto que "esta falta de descripción precisa en las Escrituras deja campo libre a la interpretación creativa de los artistas y a los requerimientos de quienes les encargaban las obras" 332 .

El Resucitado es, sin duda, la obra más floja del conjunto, especialmente en lo concerniente al rostro. Aparece según la representación más extendida a partir del

\footnotetext{
327 PARRADO DEL OLMO, Jesús María: Catálogo Monumental de la provincia de Valladolid. Tomo XVI..., op. cit., p. 342.

328 PAYO HERNANZ, René Jesús: El retablo..., op. cit., Tomo II, p. 172.

329 Ídem, p. 570.

330 ÁLVAREZ VICENTE, Andrés (et. al.): Resurrexit, Ayuntamiento de Valladolid, Valladolid, 2010, p. 73.

$331 \quad$ Ídem, p. 82.

332 Ídem, p. 73.
} 
Concilio de Trento: de pie, vestido únicamente con el perizonium y un manto rojo. Muestra las llagas, especialmente la lanzada, pero ya no como signo de la Pasión sino como triunfo. En su mano izquierda porta un estandarte, mientras que con la otra hace un gesto de bendición. Flexiona levemente una de las piernas, como avanzando, pero la anatomía es tan seca y rígida que esa sensación de avance se ve frenada.

El rostro, que sigue las pautas generales de los modos de hacer de nuestro escultor, aunque a buen seguro es obra plenamente de taller, posee esa expresión ensimismada tan típica de Ávila. A partir de ahí comienzan las diferencias: ni la manera de tratar el pelo y la barba, la forma de solucionar los labios ni la nariz corresponden a sus obras autógrafas. Aquí el pelo es mucho más plano, no vemos los mechones cayendo sobre la frente, apenas es un esbozo de aquellos, el pelo que rodea el rostro no es compacto, sino que se ve diferentes guedejas quebradas sueltas. Y, además, los labios están sellados, los paños son muy secos e incongruentes, y la barba está tallada muy sumariamente, apenas se encuentra abocetada, no hay volumen. Se podría decir que no estuvo afortunado ni siquiera el policromador dado el resultado de los ojos.

Puede que nuestro escultor, los artífices de su taller, o su hijo Pedro, se inspiraran a la hora de hacerlo en el Cristo Resucitado conservado en la iglesia de Santiago, aneja al taller de Ávila y que visitaría casi a diario. Se piensa que este Cristo fue la imagen titular de la Cofradía de la Resurrección, la cual se tiene constancia de su existencia entre mediados del siglo XVI, cuando se encargaría la referida imagen, y mediados del XVIII.

Hay que hacer notar el lamentable estado de conservación de la pieza, tanto de la talla como de la policromía ya que existen numerosas quebraduras tanto en el cuerpo como en la pérdida de dedos.

\section{$\underline{\text { SAN PEDRO }}$}

La escultura de San Pedro (Fig. 55), situada en la hornacina superior del lado izquierdo, es la peor conservada del conjunto ya que ha perdido la cabeza, el brazo derecho y parte de la mano izquierda. En las manos portaría alguno de sus atributos más significados: las dos llaves y la cruz de patriarca e, incluso, su cabeza pudo ir tocada con la tiara pontificia.

Aparece de pie, con una pierna adelantada, cuya rodilla se marca en los pliegues del manto. Porta túnica verde y manto amarillo, ambos policromados con colores planos y motivos decorativos a punta de pincel en tonos dorados, la cenefa en este caso también es con elementos vegetales dorados no existe la riqueza cromática que hemos visto en el resto de obras de Ávila. La escultura presenta un gran juego de volúmenes desarrollado a partir de los pliegues. Por la rigidez de ciertos paños, que parecen prefigurar los de "tipo cuchillo" usados por su hijo Pedro, y el detalle de la rodilla derecha en actitud de 
avance, también muy típico de este, la obra puede ser perfectamente relacionada con el mayor de los hijos de Juan de Ávila.

\section{$\underline{\text { SAN PABLO }}$}

Se ubica en la hornacina inferior del lado derecho. San Pablo (Fig. 56) aparece representado según la manera tradicional, con la prominente calva y una ampulosa barba, la cual está tratada de una forma muy sumaria, en apenas cuatro largas y sinuosas guedejas. También esta imagen ha perdido sus atributos. En la mano derecha portaría una espada, su elemento más característico, y símbolo de su martirio. Con la mano izquierda sujeta, de una manera ciertamente elegante, el manto. Viste una túnica verde larga que solo permite verle uno de los pies y un manto rojo que le cruza el cuerpo, desde el hombro izquierdo hasta la pierna izquierda, con la cual hace ademan de caminar. La policromía sigue las directrices vistas en el San Pedro. Los pliegues de la túnica, dejan entrever la pierna adelantada, y caen rígidos hacia el suelo; se puede hablar también de "pliegues a cuchillo". Tampoco sería descabellado pensar en que su autor fuera Pedro de Ávila puesto que esta imagen nada tiene del estilo de su padre.

\section{SAN ANTÓN}

San Antonio Abad (Fig. 57) aparece efigiado en la escultura localizada en la hornacina superior del lado derecho. San Antón (251-356) fue un monje cristiano, fundador del movimiento eremítico. Dice la leyenda, la cual se asemeja bastante a la de Buda, que tuvo una serie de tentaciones diabólicas en el desierto ${ }^{333}$. El santo está representado como un anciano barbudo, viste sayal con capucha, prenda común de los monjes de su orden, los antonitas. Esta orden hospitalaria, fundada en el siglo XI, tenía como función el sanar las enfermedades contagiosas: el fuego sagrado, o de San Antón, la peste y la sífilis. Gracias a la gran cantidad de establecimientos abiertos por esta orden, el culto a su "fundador" se extendió con rapidez durante la Edad Media ${ }^{334}$.

Aparece de pie, con la pierna derecha adelantada en actitud de caminar, movimiento intuido por los pliegues del sayal. Encima del sayón una gran capa con capucha, del mismo color que este. También a esta imagen le faltan los brazos, con lo cual ha perdido los atributos que le distinguían. Seguramente en una mano portaría un bastón con la tau, y en la otra un libro. La tau o cruz potenzada era el símbolo de la vida futura en el antiguo Egipto (lugar donde nació San Antón) ${ }^{335}$, ese bastón lo utilizaba como báculo abacial. De este bastón pendería una esquila, atributo de los ermitaños, que la empleaban para rechazar los ataques de los demonios, los cuales huían espantados al

\footnotetext{
333 RÉAU, Louis: Iconografía de los santos. A-F..., op. cit., p. 108.

334 Ídem, p. 110.

335 Ídem, p. 113.
} 
escuchar su ruido. En cuanto al libro, alude al libro de Regla de los antonitas; en algún caso, cuando el libro aparece abierto, de él nacen las llamas del fuego de San Antón.

Es probable que también le acompañara un marrano, el elemento más común de su iconografía, su compañero inseparable. El cerdo se suele frotar contra el santo como símbolo de fraternidad. La razón de representar al marrano junto al santo proviene de una leyenda: al parecer, el rey de Cataluña suplicó al santo que exorcizara a su esposa e hijos, los cuales se encontraban poseídos por demonios ${ }^{336}$. San Antonio accedió, y abandonó la Tebaida montado sobre una nube. Al poco desembarcó en Barcelona. Se dirigió a la casa del preboste Andrés, y cuando traspasaba la puerta una marrana le acercó en sus fauces un lechoncillo que había nacido sin ojos ni patas. Andrés intentó expulsar a la intrusa, pero San Antonio se lo impidió, diciéndole que la marrana sólo le quería implorar, igual que lo hacía el rey, la curación de su progenie. Tomó la mano de Andrés y para transmitirle su poder de exorcismo hizo con ella el signo de la cruz sobre el cochinillo que adquirió la vista y los miembros que le faltaban de nacimiento. Después de ello, Andrés exorcizó de la misma manera a la reina de Cataluña.

Tanto los pliegues como la policromía siguen los rasgos generales vistos en las otras tallas. La cabeza, el rostro y la forma de tallar la espesa barba son idénticos a las de San Pablo.

\section{$\underline{\text { SAN ANTONIO DE PADUA }}$}

San Antonio de Padua (Fig. 58) ocupa la última de las hornacinas, la inferior del lado izquierdo. Fernando "de Lisboa" fue un santo portugués nacido en la capital de este reino en 1195. Fue el segundo en importancia de la Orden Franciscana tras el propio San Francisco de Asís. La denominación con la que le conocemos se formó en dos momentos diferentes: en 1220 adoptó el nombre de Antonio al ingresar en la Orden de Frailes Menores, mientras que el apodo "de Padua" proviene de que allí fue donde pasó los últimos años de su vida ${ }^{337}$. Destacó como profesor de teología y, sobre todo, como predicador, motivos que llevaron a nombrarle Doctor de la Iglesia. Si bien su canonización fue rápida, ya que tuvo lugar en 1232, tan solo un año después de su fallecimiento, su historia y leyenda permanecieron en la oscuridad hasta que San Bernardino de Siena, a través de sus sermones, las rescató ${ }^{338}$.

Ávila nos representa al santo de pie, con un pie avanzando. Viste hábito franciscano, con amplio cuello y bocamangas, ceñido a la cintura por el característico cordón franciscano. A pesar de llevar pelo corto e ir sin barba, la configuración general del rostro es similar a la de los de San Pablo y San Antón. Como sucede con otros santos, la fisionomía con la que se le representa poco tiene que ver con la que poseyó en realidad. Cuenta Réau que "según un cronista paduano, no tenía nada de la ascética delgadez de

\footnotetext{
$336 \quad$ Ídem, p. 109.

337 Ídem, p. 124.

338 Ídem, pp. 124-125.
} 
San Francisco. Por el contrario, era de talla inferior a la media y muy corpulento, con una cabeza redonda y un vientre de hidrópico. Pero el arte no ha tenido en cuenta esos testimonios y le concedió el mismo aspecto demacrado que San Francisco. El dominico Santo Tomás de Aquino, que también era obeso, fue idealizado de la misma manera"339.

En la mano izquierda sostiene un libro de una manera muy elegante. Sobre este pudo estar situado un Niño Jesús, ya sentado, ya de pie. Este atributo alude a una aparición de la Virgen con el Niño que tuvo el santo en su habitación. En ella la madre le entregaba a su querido hijo. Al parecer este hecho es una transposición de la Aparición de Cristo Serafín a San Francisco de Asís. En su mano derecha, que la mantiene elevada, bien pudo exhibir una rama de lirios, símbolo de pureza ${ }^{340}$. Esta representación fue muy popular tras la Contrarreforma.

Los paños no son tan rígidos como en las otras tallas, y en esta ocasión son algo más suaves, incurvados. En la parte inferior del hábito, justo encima del pie, podemos observar que los pliegues hacen una forma parecida a un corazón. Este detalle, tomado seguramente de Gregorio Fernández, lo veremos continuamente en las representaciones del santo salidas del taller de los diferentes escultores vallisoletanos del siglo XVII. Podemos poner como ejemplos el San Antonio atribuido a Ávila en la iglesia del Domus Dei de La Aguilera; o los tallados por Alonso de Rozas para el retablo mayor del Convento de Santa Clara de Medina de Rioseco ${ }^{341}$, para uno de los retablos colaterales de la capilla de don Gabriel López de León, en la iglesia de San Pedro y San Ildefonso de Zamora ${ }^{342}$, y para el Convento de la Concepción Francisca de Zamora, actualmente en el Museo Catedralicio de la referida ciudad ${ }^{343}$.

\section{$\underline{\text { LAS VIRTUDES }}$}

Se sitúan sobre las partes sobresalientes del entablamento (Fig. 59). A pesar de que se ha dicho que eran las Virtudes Cardinales no las podemos identificar dado que la mayoría han perdido los brazos y los atributos que ayudaban a definirlas. La situada al extremo izquierdo parece sostener bajo uno de sus brazos una especie de recipiente dorado, y quizás aluda a la Templanza, virtud que ya analizamos en el retablo de la colegiata de Lerma. A su derecha hay una Virtud que debió sostener algo con su mano derecha, la cual solo conserva un paño blanco. Más a su derecha se encuentra la única Virtud que podemos identificar correctamente. Se trata de la Justicia dado que en su mano derecha sujeta la empuñadura de una espada, la cual también se ha perdido. Finalmente, en el extremo derecho, hay una última Virtud que levanta su brazo 
izquierdo, mientras que el derecho lo tiene vuelto como sujetando algo. Una hipótesis es que fuera la $\mathrm{Fe}$, dado que ese brazo levantado pudiera exhibir un ostensorio.

Son esculturas muy flojas, de pequeño tamaño, vestidas con túnica y manto, cada una de las cuales las tiene dispuestas de manera diferente, sin duda para dar mayor variedad al conjunto. Algunas recuerdan a los asistentes a los sermones de los relieves de los retablos colaterales de San Felipe Neri. Los paños son bastante duros, están mal resueltos, y poco tienen que ver con los de Juan de Ávila, y tampoco observamos los incipientes de "a cuchillo" de Pedro que si veíamos en otras esculturas del conjunto. Si bien, el carácter casi cúbico del rostro me lleva a pensar en una posible intervención o ayuda del propio Pedro de Ávila. La policromía es similar a la vista en el resto de esculturas del retablo, a excepción del Resucitado: colores planos con pequeños motivos dorados y algunas cenefas del mismo color.

\section{RELIEVE DE LA ASCENSIÓN DEL SEÑOR}

Se sitúa en el centro del remate, dentro de una especie de baldaquino (Fig. 60). La Ascensión fue el último capítulo de la Resurrección, acaecido cuarenta días después de este momento. Tuvo lugar en el Monte Olivete "en la parte del mismo que mira hacia Betania" 344 . Esa fue la segunda ocasión en que se les apareció: la primera había tenido lugar cuando los once se encontraban comiendo en el Cenáculo, que era el mismo en el que Jesús había oficiado la Última Cena. "Previamente Cristo había ordenado a sus discípulos que se concentrarán en la referida colina (...) cuando ya estaban reunidos en el sitio en que los había citado, se les apareció de nuevo, respondió a algunas cuestiones impertinentes que le plantearon, y luego, tras de levantar las manos y bendecirlos, comenzó a levantarse ante los ojos de ellos y subió al cielo" ${ }^{345}$. San Lucas es todavía más parco en la descripción de ese momento: "Los llevó hasta cerca de Betania, y levantando sus manos, les bendijo, y mientras los bendecía se alejaba de ellos y era llevado al cielo. Ellos se postraron ante El y se volvieron a Jerusalén con grande gozo" (Lucas 24, 50-52).

Efectivamente, tal cual ha representado Ávila el momento. Cristo aparece ascendiendo a los cielos, los pies ya se han elevado en el aire. Con las manos les bendice, siendo más ostensorio el realizado con el brazo derecho. Viste túnica blanca y manto rojo. A este respecto, dos ángeles "preguntaron a Cristo: ¿Cómo es que tus vestiduras son de color rojo semejante al de los que pisan la uva en el lagar?" Él les respondió que "estaba enrojecido a causa de la sangre que había derramado y conservaba sus cicatrices al subir al cielo" ${ }^{" 346}$.

Completan la composición doce apóstoles, si bien la Leyenda Dorada indica que eran once, y que en los Hechos de los Apóstoles la elección del duodécimo, San Matías,

\footnotetext{
344 VORÁGINE, Santiago de la: op. cit., Tomo I, p. 301.

$345 \quad$ Ibídem.

346 VORÁGINE, Santiago de la: op. cit., Tomo I, p. 304.
} 
tiene lugar después de la Ascensión de Cristo. La elección del sustituto de Judas Iscariote se realizó por sorteo: "Echaron suertes sobre ellos, y cayó la suerte sobre Matías, que quedó agregado a los once apóstoles" (Hechos de los Apóstoles 1, 26). Los apóstoles aparecen en el altorrelieve distribuidos de manera simétrica, seis a cada lado de Cristo. Unos están arrodillados, otros caídos en el suelo, otros de pie, lo que une a todos es que se encuentran asombrados mirando a Cristo que ya está por los aires. Se trata de un relieve bastante arcaico, ya que a pesar de la referida diversidad los rostros están estereotipados y los cuerpos no se encuentran individualizados, sino que están superpuestos unos a otros. Los rostros y la policromía son pobrísimos. El fondo no es mucho mejor, e ilustra un rompimiento de gloria. Tras Cristo una serie de rayos dorados, mientras que a los lados hay dos nubes blancas. 


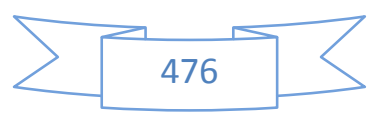




\section{5-2 OBRAS ARIBUIDAS}

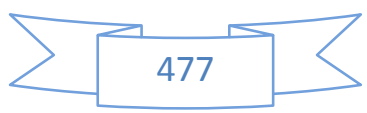




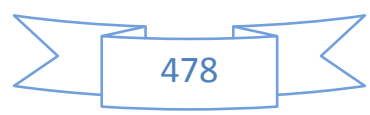




\section{VALLADOLID. IGLESIA DE SANTIAGO APÓSTOL}

\section{SANTO ÁNGEL DE LA GUARDA (h. 1672-1677)}

El bello grupo escultórico del Santo Ángel de la Guarda (Fig. 61-62) de la iglesia parroquial de Santiago Apóstol también ha sido relacionado con la producción de nuestro escultor. En concreto, Martín González y Urrea en el respectivo tomo del Catálogo Monumental dicen que su autor fue "probablemente el escultor Juan de Ávila con cuyo estilo se relaciona" ${ }^{\text {347 }}$. Asimismo, lo fechaban a finales del siglo XVII.

Pero, ¿y de dónde procede dicha imagen? Como hemos visto antes, Valladolid contó con dos cofradías advocadas bajo la protección del Santo Ángel de la Guarda. Si de la anterior desconocíamos la fecha y el lugar de su fundación, en esta ocasión no tenemos ese problema. La Cofradía del Santo Ángel de la Guarda fue fundada en el año 1625 en el Convento de la Santísima Trinidad. Se trataba de una cofradía de tipo gremial; sus cofrades fueron, en un principio, los maestros toqueros (aquellos que tejían tocas). Uno de los hechos más importantes de la cofradía fue la aprobación de su Regla en 1698, año en que ya se encontraba radicada en la iglesia de Santiago ${ }^{348}$. Así comienza: "Regla y Ordenanzas de la Hermandad y Cofradía del glorioso Ángel de nuestra guarda hecha por los maestros toqueros vecinos de esta ciudad de Valle de Olid que adelante irán declarados, año de mil y seiscientos y veinte y cinco, y anidida por los cofrades que hay vivos de este presente año de mil y seiscientos y noventa y ocho sita hoy en la parroquia de Santiago, y antes cuando se fundó en el Convento de la Santísima Trinidad Calzada". En la regla se hace referencia a que los santos protectores de la misma eran "la Virgen Santísima nuestra Señora con la advocación de su Santísima Asunción, y de los gloriosos Arcángel San Miguel, Ángel de Nuestra Guarda, Santa Úrsula y las once mil vírgenes y las benditas ánimas del Purgatorio a quienes tomamos por especiales patronos y abogados". La función de la cofradía era, según la regla, "que las personas de nuestro oficio (toqueros) conserven y conservemos la paz entre nosotros y para juntarnos en algunas festividades a vacar a Dios en santos ejercicios y piadosas obras". Como vemos el cometido de ambas cofradías del Santo Ángel de la Guarda era de lo más dispar, puesto que, recordemos, la otra tenía como misión socorrer a los enfermos sin recursos. La decadencia de la cofradía a finales del siglo XVIII la llevó a romper con su pasado gremial, permitiendo la entrada de personas de otras profesiones. A pesar de ese intento de supervivencia, desapareció en $1785^{349}$.

Anteriormente a esta imagen la cofradía poseyó otra, ya que en el año 1655, al tratarse una capitulación entre la cofradía y don Francisco Gibaja, se habla de instalar en la capilla que este último poseía en la iglesia de Santiago la imagen titular del Ángel de la

\footnotetext{
347 MARTÍN GONZÁLEZ, Juan José y URREA FERNÁNDEZ, Jesús: Catálogo Monumental de la provincia de Valladolid. Tomo XIV..., op. cit., p. 202.

348 El documento, conservado en la Biblioteca Histórica del Colegio de Santa Cruz, se puede consultar de manera on-line: http://uvadoc.uva.es/handle/10324/551

349 http://gloriasdevalladolid.blogspot.com.es/2015/03/cofradia-del-santo-angel-de-la-guarda.html
} 
Guarda $^{350}$. Cuando se realizó la escultura que estamos estudiando la cofradía ya contaba en la iglesia con una capilla en la que celebraba sus cultos. Se trataba de la cuarta del lado del Evangelio, anteriormente puesta bajo la advocación de las Once Mil Vírgenes. Durante largos años del siglo XX recibió el nombre de "San Antonio de Padua".

Aquí debió de ocupar un primitivo retablo que desconocemos. Debido al cambio de gusto, o a que el retablo se encontraba ya muy maltratado, se decidió dotar a la escultura de uno nuevo. Como en otras ocasiones, Manuel Canesi y Ventura Pérez no se ponen de acuerdo en las fechas. Efectivamente, según el diarista, la colocación del grupo en su nuevo retablo acaeció el 14 de abril de $1743^{351}$. Sin embargo, Canesi fecha aquel acontecimiento un día después ${ }^{352}$. Ambos coinciden en que para la celebración se realizó una procesión bastante concurrida. Por fortuna, el retablo se conserva tal cual en la capilla para el que fue tallado. El Catálogo Monumental de Valladolid lo describe como "de tipo hornacina, con profusa talla barroca pero de poco resalto. En su segundo cuerpo se colocó una pintura en tabla, obra de mediados del siglo XVI, representando a Santa Úrsula y sus compañeras. El retablo se doró y

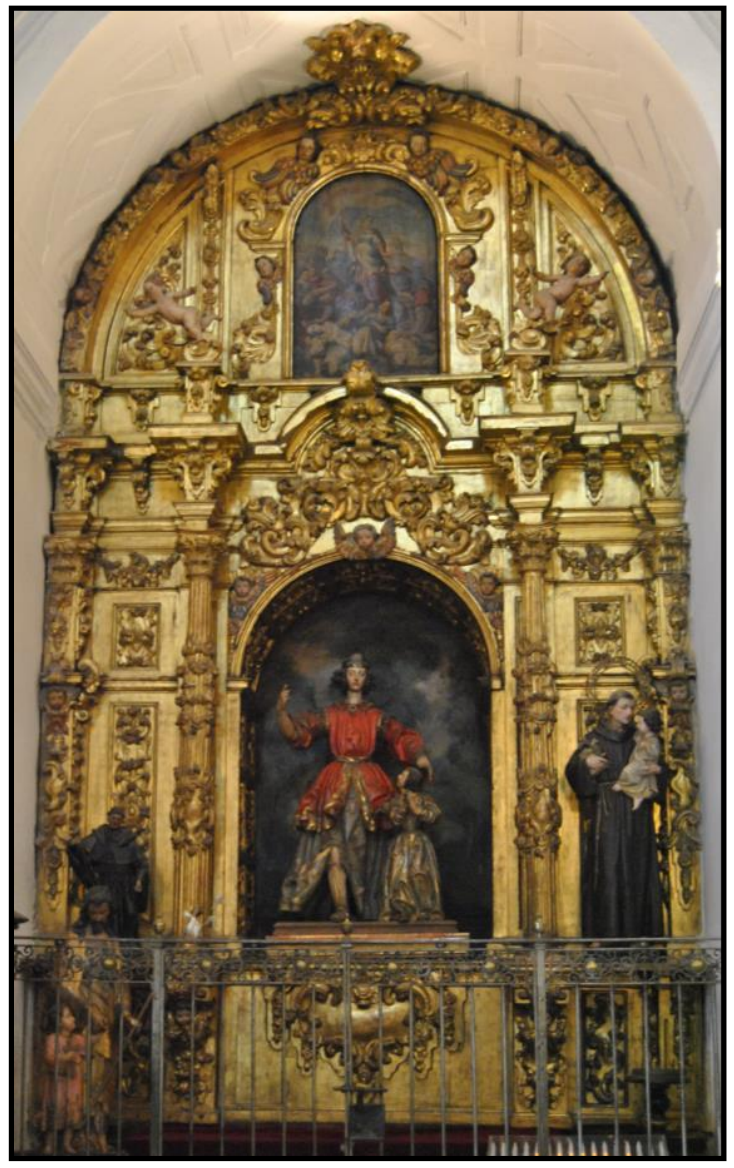

Il. 16- Anónimo. Retablo del Ángel de la Guarda. Iglesia de Santiago Apóstol. Valladolid. policromó en el año 1743 y la fecha de su ejecución no será muy anterior" ${ }^{\text {'53 }}$. Como vemos la pintura hacía referencia a la advocación primitiva de la capilla, Santa Úrsula y las Once Mil Vírgenes. Desconocemos al nombre del ensamblador o tallista que pudo realizar este bello retablo.

\footnotetext{
350 MARTÍN GONZÁLEZ, Juan José y URREA FERNÁNDEZ, Jesús: Catálogo Monumental de la provincia de Valladolid. Tomo XIV..., op. cit., p. 192.

351 Colocación del Ángel de la Guarda. "Año de 1743, día 14 de abril, se colocó el Santo Ángel de la Guarda en su retablo nuevo y dorado en la parroquia de Santiago: hubo procesión con asistencia de todas las cofradías de la parroquia y muchos niños vestidos de ángel con muchas joyas, y al otro día hubo fiesta de iglesia con sermón y S. M. patente”. PÉREZ, Ventura: op. cit., p. 209.

352 "Más adelante está la del Sto. Ángel de la Guarda, que antiguamente estuvo dedicada a Sta. Úrsula y las 11.000 vírgenes, y hoy tiene una cofradía del título del Santo Ángel, y en su día consagra reverentes cultos a su festividad y en ellos se esmera el año de 1743, volviéndose a colocar en un nuevo retablo de preciosa escultura con una solemnísima procesión, formada el día 15 de abril de las cofradías que autorizan este templo". CANESI ACEVEDO, Manuel: Historia de Valladolid (1750), Tomo I, op. cit., p. 339.

${ }_{353}$ MARTÍN GONZÁLEZ, Juan José y URREA FERNÁNDEZ, Jesús: Catálogo Monumental de la provincia de Valladolid. Tomo XIV..., op. cit., p. 192.
}

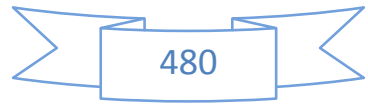


El Santo Ángel de la Guarda no se ha mantenido de manera inalterada en este retablo ya que a comienzos del siglo XX fue a parar a la capilla de San Jerónimo, lugar en el que quedó arrinconada, acompañando en su "destierro" al San Miguel que durante siglos había presidido una de las fachadas del Arco de Santiago ${ }^{354}$. Se daba de esta manera un doble ostracismo angelical. Su puesto en el retablo lo ocupó una moderna imagen de San Antonio de Padua, sin ningún valor ni interés artístico. Por fortuna, en el año 2013 una serie de cambios llevados a cabo en los altares de la iglesia ha llevado a que el Santo Ángel de la Guarda volviera a recuperar la presidencia del retablo que nunca debió de abandonar.

Si aceptamos la teoría de que nuestro escultor talló la imagen del Ángel de la Guarda podemos trazar una hipótesis que resuelve varios dilemas. Dado que Ávila perteneció a la referida cofradía sin ser maestro toquero, y dado que esta no admitió a personas que realizaban otros oficios hasta finales del siglo XVIII ${ }^{355}$, no cabe otra posibilidad que la de que la pertenencia a la misma hubiera sido un obsequio de la propia cofradía en agradecimiento a haberles esculpido la imagen titular. Lo que ya desconocemos es si fue de manera remunerada o desinteresada. Para cimentar esta hipótesis hemos de tener en cuenta que esta misma situación le ocurrió años después con la Cofradía de San Isidro cuando esculpió las tallas de los santos patrones de la misma. Si, además tenemos en cuenta que existen noticias de que ya era miembro de la Cofradía del Santo Ángel de la Guarda al menos desde el año 1677 llegamos a la conclusión de la que la escultura debió de tallada hacia 1672-1677 ${ }^{356}$. Dado que el escultor frecuentaría casi a diario la parroquia, y que esta misma le encargó diferentes obras y tareas a lo largo de su vida, el trato entre Ávila y los miembros de la cofradía sería habitual, y el conocimiento mutuo. Sea como fuere, de confirmarse tal atribución, estaríamos ante la obra conocida más antigua de nuestro escultor, y seguro que una de las primeras que salieron de su recientemente inaugurado taller.

El grupo presenta una disposición idéntica al conservado en la iglesia de San Martín; sin embargo, por los pliegues, muchísimo más quebrados y angulosos, cercanos a los practicados por los maestros del segundo tercio del siglo, y más concretamente por su mentor, podemos llegar a la conclusión de que es una obra bastante anterior. Ambos personajes aparecen de pie adelantando la pierna derecha, sin embargo, apenas se percibe la del niño, la cual permanece semi-oculta entre capas de gruesos pliegues. El ángel realiza el mismo gesto de acariciar la cabeza del niño, aunque en esta ocasión el brazo parece mucho más rígido. Con el otro brazo, que tiene la una manga arremangada parecía sujetar un báculo que no se conserva, y también ha perdido los dedos. Quizás no portara nada y se dedicara solo a señalarle el camino hasta el cielo al pequeño. El rostro está mejor trabajado, aunque es también bastante rígido. Por lo general, se intuye mayor intención de movimiento en el grupo de San Martín, si bien éste le gana en el aspecto monumental, es mucho más rotundo e, incluso diría, mucho más adecuado para su

\footnotetext{
354 http://gloriasdevalladolid.blogspot.com.es/2015/03/cofradia-del-santo-angel-de-la-guarda.html 355 Ibídem.

356 A.H.P.V., Leg. 2.757/6, f. 26.
} 
carácter procesional. El Niño, asimismo, también es mucho más naturalista, gira el rostro para ver lo que le indica su compañero, al mismo tiempo que junta las dos manos en actitud orante.

La vestimenta es similar en ambos grupos, aunque hay claras diferencias. El Ángel viste también dos túnicas, una más larga blanca, con bella decoración de flores en diferentes colores, y una más corta roja y con una amplia cenefa dorada con otros motivos, ceñida a la cintura por un cintillo dorado. Las diferencias se encuentran en la concepción de las mismas: mientras que la larga solo tiene una abertura, que nos permite ver tan solo una de las piernas del santo, la talla de San Martín tenía abiertas las dos; asimismo, la túnica corta tiene también una abertura en la parte central, mientras que la otra escultura no poseía ninguna, era toda completa. En el resto son idénticas: cuello vuelto, hombreras almenadas, manga derecha recogida, etc... Lleva la cabeza tocada por un casco, lo que es otro punto de diferenciación entre ambas tallas, así como la tipología del calzado, mientras que el de San Martín calzaba simples sandalias éste utiliza borceguíes. El Niño viste una amplia túnica blanca, con decoraciones florales similares a las del ángel, igualmente ceñida a la cintura.

El rostro es bastante inexpresivo, a la manera de su maestro Tudanca, si bien la calidad es bastante superior a su homólogo de San Martín. La concepción de la cabeza tiende a la elipsis, ojos amplios almendrados, nariz ancha y recta, fosas nasales talladas, boca entreabierta. Es muy interesante la manera en que Ávila ha resuelto la cabellera, muy suelta, con amplias masas de rizos acaracolados, que como siempre tiende a la simetría. La labor de trépano es encomiable. Esta solución capilar parece tomada de su maestro, el cual, supuestamente, la llevó a efecto en el San Juan Bautista de Pesquera de Duero, y en el Santiago de la ciudad de Ávila. Este mismo recurso, aunque mejor elaborado debido a la pericia que adquirió en el oficio lo veremos en sus dos Bautistas para las iglesias de Santiago y de San Felipe Neri. También guarda ciertas concomitancias con el del San Isidro de la ermita del mismo nombre. En todas estas esculturas, mucho posteriores, estas cabelleras tienden a la homogeneidad; sin embargo, estas cabelleras del Ángel de la Guarda tienen una forma triangular. Este primer Ávila parecía tender más a la idealización que al naturalismo, del cual será también un gran maestro.

El Niño tiene el cuello demasiado torcido, es una posición ciertamente antinatural. Su rostro es regordete, sensación incrementada por sus amplios pómulos y mentón. Ojos cándidos, nariz y boca similares a los del ángel. El pelo es también parecido si bien no alcanza tanto despliegue, pues está más pegado a la piel, aunque con los mismos rizos acaracolados. Sobre la frente vemos uno de los motivos característicos de nuestro escultor: los mechones simétricos deslizándose sobre ella. El tierno infante emparenta directamente con el Niño Jesús de la Sagrada Familia que Gregorio Fernández esculpe para la Cofradía de San José de la vallisoletana iglesia de San Lorenzo. Ávila intenta copiar tanto la forma de tallar el cabello como la técnica de los paños, algo más quebrados y rectos que los del gran maestro. Este es el claro ejemplo de cómo el primer Ávila partió de las formas y modelos fernandescos, a los cuales iría poco a poco imprimiendo su estilo, aunque sin llegar a despegarse nunca de ellos. Por todo ello, 
pienso que la cronología 1672-1677, que resulta ser los primeros años en que ejerció su maestría "en libertad", es correcta. Desconozco si es esta imagen, o bien la primitiva, a la que se alude en la visita que hizo el obispo a la parroquia en el año $1673^{357}$.

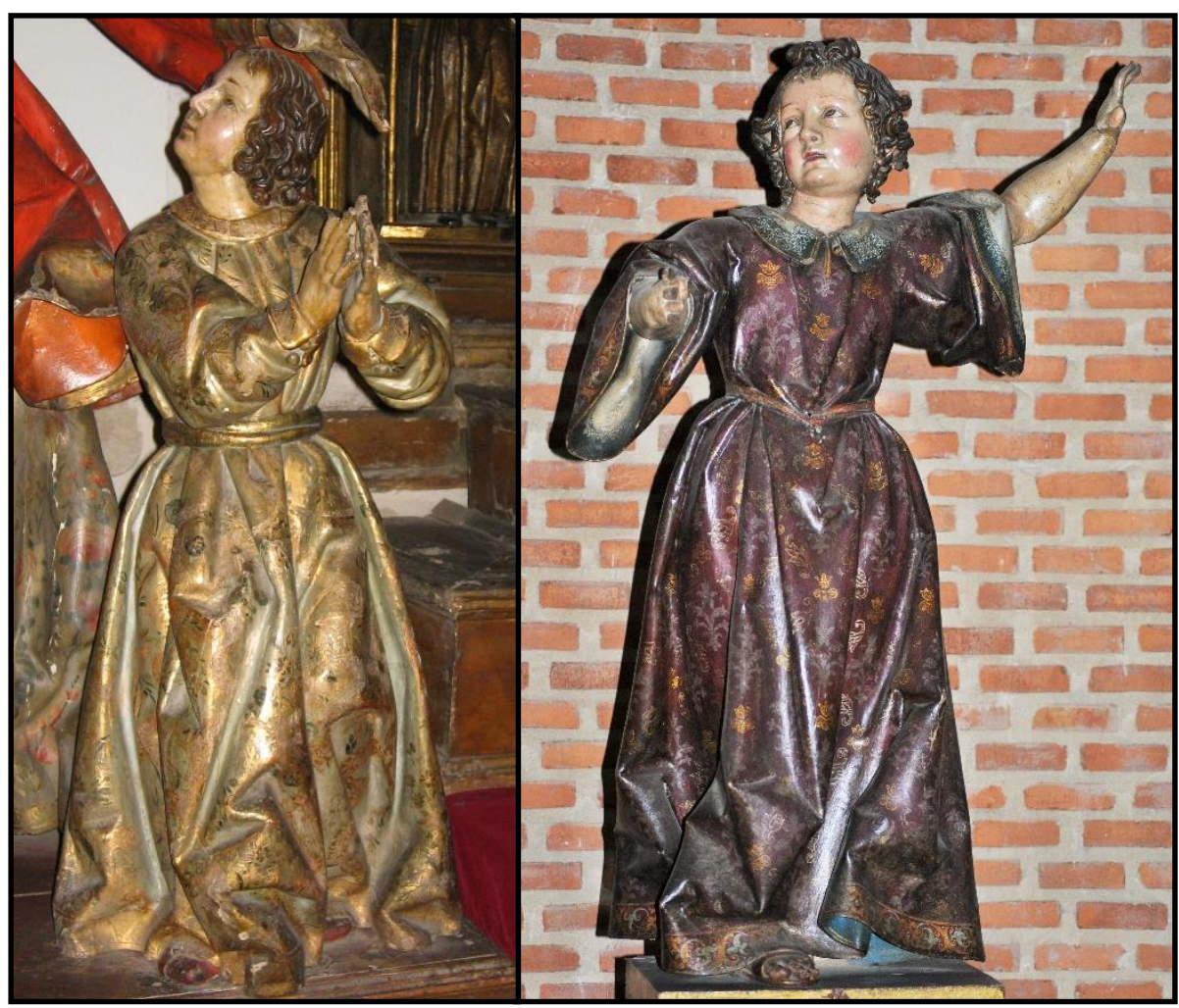

Il. 17- Comparación del Niño del Ángel de la Guarda atribuido a Juan de Ávila y el Niño de la Sagrada Familia de Gregorio Fernández.

\section{SANTA ROSA DE VITERBO (h. 1672-1690)}

En el ático del retablo colateral de la Epístola figura una escultura que parece obra indubitable de nuestro escultor. Se trata, supuestamente, de una María Magdalena. En el Catálogo Monumental así se la identifica, sin posibles atribuciones o cronologías. Tan solo añade que vino a sustituir "a la Santa Lucía que vio Canesi"358.

La escultura es casi idéntica, tanto en la composición como en los rasgos faciales, a otras dos que más adelante atribuiremos a nuestro escultor: las ¿Magdalenas? conservadas en el Real Monasterio de Santa Clara de Tordesillas (Valladolid) y en el Museo de San Francisco de Ampudia (Palencia). De todas ellas, tan solo esta última fue

$357 \quad$ "Once mil vírgenes: Otrosí visitado su Ilustrísima la capilla y altar inmediato a los referidos que es de la advocación de las Once mil vírgenes y tiene el primer cuerpo la hechura del Santo Ángel de la Guarda de bulto con su retablo y encima una pintura de Santa Úrsula y sus compañeras que pareció ser fundación de $\mathrm{D}^{\mathrm{a}}$ Constancia de Peñalosa y que está dotada en tres mil maravedíes de renta en cada un año que se cobran por la fábrica de esta dicha ciudad en diferentes censos en virtud de cesión que de ellos tiene, y el altar estar con su ara, manteles y frontal con toda decencia”. A.G.D.V., Santiago, Libro de fábrica 1673-1707, Visita de 1673.

358 MARTÍN GONZÁLEZ, Juan José y URREA FERNÁNDEZ, Jesús: Catálogo Monumental de la provincia de Valladolid. Tomo XIV..., op. cit., p. 199.

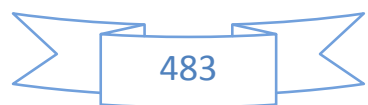


relacionada con Juan de Ávila. El autor de esta atribución fue Martín González, que ya es toda una garantía ${ }^{359}$. Vistos los tres ejemplos, y analizadas sus idénticas vestimentas, no cabe duda de que las santas van ataviadas con un hábito franciscano ceñido por el típico cordón que utiliza esta orden. Este hecho hace que me incline por desechar que su identidad sea la de Santa María Magdalena, y creer que, en realidad, se trate de Santa Rosa de Viterbo, cuya iconografía, exhibiendo un Crucifijo en su mano, se asemeja a la observada en estas obras, si bien no figura su atributo más característico: las rosas, ya en un cesto sujetado por la mano, ya recogidas en un pliegue de su hábito ${ }^{360}$. Para cimentar esta identidad hay que señalar la relación existente entre la Santa Rosa de Viterbo y el San Diego de Alcalá, también atribuido a Ávila y de la misma factura que ésta, conservados en el referido museo de Ampudia. Como vemos ambos coinciden en un determinado pasaje de su vida: los dos santos entregaban caritativamente mendrugos de pan a los pobres, hasta que una vez sus compañeros de cenobio les pillaron y justo cuando iban a verles el pan que portaban en su manto éstas se transformaron en flores (San Diego de Alcalá) o rosas (Santa Rosa de Viterbo). En algunas ocasiones he llegado a pensar en que pudiera tratarse incluso de Santa Rita de Casia, que posee una iconografía similar y tuvo una capilla en la iglesia ${ }^{361}$. Sin embargo, el tipo de hábito descarta esta idea por completo ${ }^{362}$.

Rosa de Viterbo fue una terciaria franciscana (1235-1252) canonizada en 1457. Cuenta Réau que entre sus milagros se encuentran los de resucitar a una de sus tías con tan solo trece años de edad, y el de "convertir al cristianismo a una maga, ascendió a una hoguera cuyas llamas se apartaban de su cuerpo"363. Esta niña santa, glorificada por la Orden Franciscana, pese a no haber profesado como monja clarisa dada su corta edad, vistió el hábito de las Damas Pobres e hizo privadamente los votos propios de la vida cenobítica. De ahí que las manifestaciones artísticas la representen con el hábito, llevando, en algunas ocasiones, el velo, aunque lo más frecuente es que no lo tenga puesto $^{364}$. Sus atributos más comunes son las rosas (ya sean en un cesto que porta en una de sus manos, en el manto o en forma de corona) y, como ya hemos dicho, el Crucifijo, el cual ase con una de sus manos. Según Ribadeneira, solía llevar un crucifijo en las $\operatorname{manos}^{365}$, y a veces con él predicaba suspendida en los aires ${ }^{366}$, que bien podría

359 URREA FERNÁNDEZ, Jesús y MARTÍN GONZÁLEZ, Juan José: Inventario artístico de Palencia y su provincia I..., op. cit., p. 60.

360 RÉAU, Louis: Iconografía de los santos. P-Z..., op. cit., p. 156.

361 En la actualidad no existe ninguna representación escultórica de esta santa en la iglesia.

362 MARTÍN GONZÁLEZ, Juan José y URREA FERNÁNDEZ, Jesús: Catálogo Monumental de la provincia de Valladolid. Tomo XIV..., op. cit., pp. 199-200.

$363 \quad$ Ibídem.

364 CASTRO BRUNETTO, Carlos Javier: "Iconografía de Santa Clara de Asís y Santa Rosa de Viterbo en Canarias", Revista de Historia Canaria, № 179, 1997, pp. 92-93.

365 "Tuvo que ella la Soberana Reyna de los Ángeles, María Santísima (...) varios coloquios; y al fin la mandó, que por la mañana fuese a la Iglesia, y allí se hiciese cortar el cabello, y se vistiese el hábito de San Francisco. Y habiéndose desnudado de las ricas galas, que se hallaron en Viterbo enviadas a Rosa por las mismas Señoras, juzgándose muy dichosas en que Rosa las vistiese; cortados los cabellos, vestido su santo Habito, y cilicio, descalzos los pies, con un Crucifico en las manos, alabando los Santísimos nombres de Jesús y María, predicando penitencia, alabando los diamantinos corazones de los pecadores, causando admiración, espanto y horror a los enemigos de la Fe Católica, se volvió a su casa, seguida de todo el Pueblo, con admirable devoción. Y aunque no consiguió entrar en el Monasterio de Santa María 
ser la iconografía representada en dicha talla, si bien el estatismo de la misma la convierte en una predicación más terrestre.

Santa Rosa de Viterbo (Fig. 63) figura de pie, con la pierna izquierda levemente adelantada, como así podemos intuirlo por la marca de la rodilla en la túnica. En su mano derecha debió de portar un Crucifijo, hoy en día perdido, mientras que la izquierda la mantiene extendida, como si estuviera sufriendo un éxtasis al contemplar al crucificado. A esto ayuda el rostro ensimismado. Larga melena ondulada y oscura, elemento que puede aludir a su condición de virgen. El tipo de rostro, muy blando, es en todo coincidente al estilo de Juan de Ávila, asemejándose, en términos generales, con el de la Virgen del grupo de la Aparición de la Virgen a Santiago del retablo mayor de la misma iglesia. Los pliegues son bastante menudos y paralelos en las zonas adyacentes al cíngulo, quebrándose mucho más en las mangas y en la parte de las piernas. En cierto modo nos recuerda a lo exhibido por Ávila en sus primeros momentos, y, en concreto, a los pliegues de las túnicas del Ángel de la Guarda y, sobre todo, del Niño que le acompaña del grupo procesional conservado en la misma iglesia. Creo, por lo tanto, que su fecha de ejecución rondará los años 1672-1690.

La escultura acusa cierta rigidez, característica, por otra parte, de este primer momento de nuestro escultor. Volvemos a ver una vez más la diagonal que suele marcar con los brazos de sus esculturas. Se trata de una imagen de bastante calidad, que necesita una profunda restauración dado que su policromía apenas se aprecia, pues tiene la mayor parte de los dedos partidos y rostro y cuello presentan suciedad y quizá desgaste del encarnado.

Desconocemos el origen de esta imagen, pero, al tratarse de Santa Rosa de Viterbo, sería bastante factible que procediera del Convento de San Francisco, tras cuya demolición muchas de las obras de arte que custodiaba fueron a parar a otras iglesias de la ciudad. Tenemos noticia de que existía al menos una escultura de esta santa en el grandioso cenobio franciscano, la cual, al parecer, era asidua de las procesiones organizadas por la comunidad. Ventura Pérez nos refiere dos de ellas: una celebrada el 11 de junio de 1722 en honor del "glorioso San Antonio de Padua, por la cofradía de los maestros sastres; hubo grande quimera entre el cabildo menor y los frailes de San Francisco". "Llevaron a San Francisco, San Buenaventura y San Pedro Regalado, San Diego de Alcalá y Santa Rosa de Viterbo; y en la Santa Iglesia se dijo una misa con grande solemnidad" 367 ; y la otra el 5 de junio de 1740 tras la elección del nuevo general de la orden, cuyo capítulo general se celebró en el propio monasterio: “Año de 1740 se

de las Rosas, con todo se sujetó a los tres votos de Castidad, Pobreza, y Obediencia, y a todas las demás obligaciones de la Religión; e hizo profesión de observar la Regla de Santa Clara, debajo la del Seráfico Francisco". Ibídem.

$366 \quad$ “(..) no siendo el menor el que sucedió infinitas veces; y era, que como la santa era tan Niña, y acontecía muchas veces ponerse a predicar en las plazas, sin prevención de silla, o bufete, no alcanzando a verla el numerosísimo concurso de la gente, lo remediaba el Altísimo, levantándola en el aire sobre la piedra misma en que se hallaba; la cual permanecía así todo el tiempo que duraba el Sermón; y en acabándose, se volvía la piedra a su centro, y la Niña con ella a tierra". Ibídem.

367 PÉREZ, Ventura: op. cit., p. 55. 
celebró el capítulo general en San Francisco. Se empezó en esta forma (...) El día de Pascua [del Espíritu Santo (5 de junio)], a las ocho de la mañana, se celebró la procesión de toda la orden seráfica, que anduvo las calles de la procesión del Corpus; (...). Llevaban en el cuerpo de la procesión muchos santos, como fueron San Luis, mártir, donado, que llevaban los donados, San Pedro Regalado, San Antonio de Padua, San Bernardino de Sena, San Pedro Alcántara, San Luis, obispo, San Luis rey de Francia, Santa Rosa de Viterbo, Santa Isabel, reina de Hungría, San Buenaventura y San Francisco, con su bandera, y detrás de cada santo iba un religioso vestido con capa pluvial, y la última iba la Purísima Concepción, la que tienen en el coro, y detrás iba vestido con capa pluvial el general nuevo, y fueron a la Santa Iglesia Catedral $(\ldots)^{\text {"368 }}$. 


\section{CEVICO DE LA TORRE. IGLESIA PARROQUIAL DE SAN MARTÍN}

\section{SAN MIGUEL (h. 1672-1690)}

El presente San Miguel (Fig. 64), ubicado en una peana del lado del Evangelio, fue puesto en relación con el estilo de Juan de Ávila por Urrea y Martín González al redactar el Inventario Artístico de Palencia: "Esculturas de San Juan Bautista y San Miguel, del siglo XVII, del estilo del escultor Juan de Ávila" ${ }^{369}$. Desconozco si es este mismo San Miguel el citado por Ramón Revilla en el primer tomo del Catálogo Monumental de Palencia ${ }^{370}$. En él se indica que presidía un retablo churrigueresco en el lado del Evangelio de la Ermita de Santa Ana de la propia localidad de Cevico de la Torre.

San Miguel aparece efigiado, al igual que en el caso de Ataquines, como guerrero, vencedor del demonio. El Arcángel figura de pie, en una posición ciertamente acrobática puesto que la pierna derecha la tiene flexionada para pisar la cola del demonio, mientras que la otra la mantiene recta, aunque también la utilizada para pisotear al diablo. Los atributos que portaba en sus manos han desaparecido. Se le ha colocado una espada en su mano derecha, pero nada tiene que ver con la configuración inicial. Vista la empuñadura que aún se observa en su mano izquierda, parece que la espada la cogía con ésta, mientras que, con la derecha, quizás, haría lo propio con una lanza, de manera similar al San Miguel de Ataquines. A los pies de San Miguel está el demonio, derrotado. Es una mezcla de torso humano y cola serpentiforme. Su rostro es espantoso.

Viste una larga túnica verde, abierta en ambas rodillas, dejándonos verle las piernas; por el interior la túnica es roja con motivos dorados. Las mangas son cortas, pues tan solo le llegan hasta el codo. Abunda la labor de esgrafiado. El torso va cubierto por una thoracata dorada con decoraciones esgrafiadas que se ajusta al cuerpo, debido a lo cual su anatomía queda perfectamente marcada; en la parte baja penden una serie de pulseras o "torquex" rojos. Sobre el hombro izquierdo cuelga un manto rojo muy volado, cuyo borde está recorrido por una cenefa del tipo de las que hemos hablado en tantas y tantas esculturas. El motivo del manto rojo sobre el hombro de un determinado personaje lo hemos visto en muchísimas esculturas de Ávila, tanto documentadas como atribuidas: podemos recordar, por ser el ejemplo más sobresaliente, el caso de los Bautistas. Los pies van calzados por unas sandalias muy simples.

Los pliegues corresponden a los que Ávila desarrolló dentro de su primera etapa: aquellos que eran descritos por Martín González como blandos, suavemente incurvados,

\footnotetext{
369 URREA FERNÁNDEZ, Jesús y MARTÍN GONZÁLEZ, Juan José: Inventario artístico de Palencia y su provincia I..., op. cit., p. 136.

370 REVILla VIELVA, Ramón: Catálogo monumental de la provincia de Palencia. 1, partidos de Astudillo y Baltanás, Diputación Provincial de Palencia, Palencia, 1951, p. 60.
} 
y, en los cuales no aparece ningún rastro de dureza. Por lo tanto, podríamos fechar la escultura en el periodo comprendido entre 1672-1690, aproximadamente.

A pesar de que la cabeza posee numerosos estilemas de Juan de Ávila, éstos no me permiten realizar una atribución indubitable. Lo que no me termina de convencer es la forma que adopta la boca, entreabierta pero sin tener los dientes tallados, la cual cae dentro del estilo de José de Rozas. En cambio, sí que entran de lleno en el arte de nuestro escultor los ojos almendrados rehundidos, que casi parecieran achinados; la nariz recta, simétrica, ensanchada en su parte inferior, y con aletas nasales levemente pronunciadas; los dos mechones simétricos de pelo mojado que caen sobre su frente; $y$, sobre todo, las voluminosas masas de bucles y rizos que se disponen a ambos lados del rostro, en las cuales el escultor muestra sus dotes en la talla con el trépano. Este tipo de cabellera también está presente en otras obras del artista. Sin embargo, repito, no podría descartarse el nombre de José de Rozas. 


\section{VALLADOLID. IGLESIA DE SAN MARTÍN}

\section{SANTO ÁNGEL DE LA GUARDA (h. 1675-1685)}

El grupo escultórico del Santo Ángel de la Guarda (110 cm.) (Figs. 65-66) ha sido, desde hace tiempo, relacionado siempre con Juan de Ávila. El primero en asignar la posible paternidad a nuestro escultor fue Jesús Urrea, el cual se refería a él como "obra de Juan de Ávila y es una versión reducida de otro similar existente en la parroquia de Santiago"371. Poco tiempo después, el propio Urrea y Martín González, en el respectivo tomo del Catálogo Monumental de Valladolid lo calificaron como "próximo a Juan de Ávila”, desmarcándose un poco de aquella primera apreciación ${ }^{372}$.

Esta escultura que vemos tan descontextualizada fue, en origen, la imagen titular de la Venerable Hermandad del Santo Ángel de la Guarda, con el título de la Limpieza ${ }^{373}$. Desconocemos todo acerca del origen de esta institución: ni el lugar en que fue creada ni la fecha de la misma. La función de esta institución consistía en socorrer a los pobres enfermos, sin tener en consideración si eran vecinos, o no, de Valladolid. La importancia de esta cofradía fue capital ya que a ella debemos, según afirma José de Tiedra, la construcción del Hospital de la Resurrección ${ }^{374}$, del que gozaba del vice patronato, siendo el patrono el obispo de Valladolid.

Tras el cierre del hospital comenzó un largo periplo tanto para la cofradía como para su imagen titular. El primer destino que tomaron fue, según nos relata González GarcíaValladolid "la Capilla del Hospital Municipal de Santa María de Esgueva el año 1889"375. Efectivamente, el 2 de septiembre de 1889 la cofradía se dirigió al ayuntamiento vallisoletano para solicitarle el traslado al citado hospital "con objeto de darle culto a la Efigie, y con los enseres que pertenecen a dicha Hermandad, con el carácter de interinidad y hasta tanto que en el Hospital Provincial se construya y habilite la Capilla proyectada para el culto público, según disposición del Excmo. Sr. Arzobispo de esta Diócesis" 376.

Durante el tiempo que estuvo radicada en Santa María de Esgueva, la cofradía siguió realizando sus cultos y procesiones con total normalidad: "Los años que aquí estuvo, siguiendo su antigua y tradicional costumbre, celebraban con solemnidad, y Jubileo de Cuarenta Horas, la fiesta del Santo Ángel de la Guarda, el día $1^{\circ}$ de Marzo, y en la Dominica del Buen Pastor en que se lleva solemnemente la comunión a los enfermos, tomaba parte activa, dando más esplendor al acto y obsequiando después a los

371 URREA FERNÁNDEZ, Jesús: Guía histórico-artística de la ciudad de Valladolid, Valladolid, 1982, p. 41.

372 MARTÍN GONZÁLEZ, Juan José y URREA FERNÁNDEZ, Jesús: Catálogo Monumental de la provincia de Valladolid. Tomo XIV..., op. cit., p. 101.

$373 \quad$ En el hospital existía una Cofradía de la Limpieza.

374 TIEDRA, José de: El Hospital de Santa María de Esgueva de Valladolid. Fundación gloriosa y secular del conde don Pedro Ansúrez y doña Eylo su mujer, Imprenta-Librería Casa Martín, Valladolid, 1937, p. 94.

375 GONZÁLEZ GARCÍA-VALLADOLID, Casimiro: Valladolid..., op. cit., Tomo I, p. 279.

376 TIEDRA, José de: op. cit., p. 96. 
enfermos con un extraordinario desayuno" ${ }^{377}$. Asimismo, el grupo del Santo Ángel de la Guarda siguió participando, como hacía desde tiempos pretéritos, en la procesión del Corpus Christi. Su última salida fue en el año 1925, "último año en que se permite la salida de imágenes en la Procesión del Corpus Christi",378.

La cofradía y su titular tendría otros dos traslados: en 1932 "trasladó sus reales al Convento de Descalzas Reales sin contar con nadie y haciendo acto de soberana independencia. No quiso vivir bajo la férula del Garrote"379. Allí permaneció unos pocos años ya que en 1945 la cofradía se traslada definitivamente a la iglesia de San Martin, lugar en el que actualmente radica la cofradía y se encuentra su imagen. El traslado se produjo mediante una procesión en la que figuraba "la cofradía del Santo Ángel con su estandarte, presidida por su Hermano Mayor Honorario don Gilberto Villar, en representación del Cuerpo de Policía Armada, y don Mariano Escribano, que representaba al Cuerpo General de Policía" ${ }^{380}$. Fue en ese momento en el que la imagen comenzó a ser honrada por el Cuerpo Nacional de Policía, cultos que aún se mantienen.

Recién llegada a la iglesia de San Martín, la escultura fue situada dentro de la capilla del obispo Fresno de Galdo ${ }^{381}$. Gracias a unas fotografías antiguas comprobamos que tenía su asiento al lado derecho del retablo de la capilla. Tras el hundimiento sufrido por la iglesia en el año 1965 se la decidió reubicar en el retablo en el que actualmente se encuentra. Se trata de un retablo de la segunda mitad del siglo XVIII que debió de estar dedicado a Santo Tomás de Villanueva, dado que este mismo santo figura en el relieve del ático. Este retablo se encuentra situado en la primera capilla del lado de la Epístola.

El culto al Santo Ángel de la Guarda surgió a principios del siglo XVI en la ciudad francesa de Rodez gracias al apoyo de su obispo, el bienaventurado François d'Estaing $(1460-1529)^{382}$. Su devoción comenzó a extenderse y popularizarse gracias a la acción, como en otras ocasiones, de los jesuitas, "que en su calidad de educadores de la juventud, estimularon la creación de cofradías del Ángel de la Guarda" ${ }^{383}$. Fue, precisamente, un jesuita, Francesco Albertini di Catanzaro, con su Trattato dell'Angelo Custode, publicado en Roma en el año 1612, uno de los grandes "culpables" del éxito que estaba cosechando el culto a los Ángeles Custodios. No podemos desdeñar tampoco el papel decisivo que tuvieron los grabados, entre ellos los diseñados por Hieronymus Wierix, para la propagación de esta devoción ${ }^{384}$. Señala Mâle al respecto que "su devoción se propagó en el siglo XVI en medio de las luchas religiosas; los católicos se

\footnotetext{
$377 \quad$ Ibídem.

378 http://gloriasdevalladolid.blogspot.com.es/2013/09/venerable-hermandad-del-santo-angelde.html

379 TIEDRA, José de: op. cit., p. 96.

380 http://gloriasdevalladolid.blogspot.com.es/2013/09/venerable-hermandad-del-santo-angelde.html

381 MARTÍN GONZÁLEZ, Juan José y URREA FERNÁNDEZ, Jesús: Catálogo Monumental de la provincia de Valladolid. Tomo XIV..., op. cit., p. 101.

382 RÉAU, Louis: Iconografia de la Biblia. Antiguo..., op. cit., p. 78.

383 Ibídem.

384 URREA FERNÁNDEZ, Jesús: “Ángeles napolitanos”, B.S.A.A., Tomo L, 1984, p. 444.
} 
consagraron a ella tanto como Lutero y Calvino los condenaron. En el siglo XVII llegó a estar tan generalizada que Clemente X (en 1670) la impuso a la Iglesia universal"385

La iconografía del Santo Ángel de la Guarda surge de las representaciones de San Rafael acompañado al pequeño Tobías. No podemos olvidar al respecto que, según Réau, en Florencia "era moda que al salir el hijo de un rico comerciante, mandara pintar un exvoto donde se hacía retratar con los atributos el joven Tobías, conducido por el arcángel Rafael que lo lleva de la mano"386. El motivo de que el acompañante del ángel sea un niño, símbolo del alma, es que "el niño está en esa edad en la que idea del mal empieza a insinuarse en el alma". En otras ocasiones se representa a un niño mucho más pequeño, un tierno infante, debido a que, según Mâle, "el Ángel de la Guarda era enviado al hombre en el mismo momento de su nacimiento" 387 . Los dos suelen aparecen avanzando por un camino, el de la vida. El ángel levanta el brazo señalando al niño el cielo, la meta de aquel largo transcurrir.

Nuestro escultor ha seguido fielmente el modelo iconográfico. El Santo Ángel figura de pie, con la pierna derecha adelantada. En la mano derecha porta un báculo con forma de cruz, mientras que, con la izquierda, en acción de protección, acaricia suavemente la cabeza del joven. El Niño, que aparece representado "en esa edad en la que idea del mal empieza a insinuarse en el alma", también adelanta su pierna derecha, mientras que sus manos las tiene colocadas frente al pecho en actitud de oración, a la vez que mira al ángel, como preguntándole si ese es el modo correcto de alcanzar el destino.

El ángel aparece ataviado con dos túnicas superpuestas de diferentes medidas y colores, diadema y sandalias. La túnica larga es blanca-azulada al exterior, con una serie de motivos dorados a punta de pincel, y roja y dorada al interior. Llega hasta los tobillos, pero posee sendas aberturas a la altura de los muslos que nos permiten verle las piernas. Por su parte, la túnica corta es roja con diferentes motivos en colores dorados, verdes y lilas. Le llega un poco por encima de las aberturas de la túnica larga, encontrándose ajustada por un cintillo azul en la cadera. La manga derecha se encuentra arremangada hasta el codo. El Niño utiliza una simple túnica larga blanca, con decoraciones florales, con abertura en uno de sus lados, dejándonos también ver una de sus piernas.

La indumentaria, con esas dos túnicas superpuestas, el cuello vuelto, la decoración de las mangas y el detalle de que la derecha se encuentre recogida, es un claro calco del Ángel del paso de la Oración del Huerto que Andrés de Solanes había tallado hacia 1629 para la Cofradía Penitencial de Nuestra Señora de la Vera Cruz ${ }^{388}$.

\footnotetext{
385 ZURIAGA SENENT, Vicent Francesc: "Entre la tierra y el cielo: el tipo iconográfico del Ángel Custodio". En VV.AA.: Entre cielos e infiernos. Memoria del V Encuentro Internacional sobre Barroco, Fundación Visión Cultura, La Paz, 2010, p. 283.

386 RÉAU, Louis: Iconografía de la Biblia. Antiguo..., op. cit., p. 78.

387 ZURIAGA SENENT, Vicent Francesc: op. cit., p. 286.

388 URREA FERNÁNDEZ, Jesús: "Nuevos datos y obras del escultor Andrés Solanes (+ 1635)", B.S.A.A., Tomo LV, 1989, pp. 483-484.
} 
El rostro del ángel presenta las características típicas de nuestro escultor, si bien la ejecución es bastante tosca, por lo que seguramente hubo bastante labor de taller. No parece que fuera una de las esculturas por las que más dinero percibió. Ojos almendrados de tapilla de vidrio, nariz larga y recta, boca cerrada, cabellera distribuida simétricamente a ambos lados del rostro distribuido en amplias masas de rizos. Son similares a los exhibidos en el Niño Jesús de la Sagrada Familia del Colegio de los Ingleses, o en los Bautistas, si bien en esta ocasión bajan bastante en calidad. El rostro presenta el ensimismamiento que solemos observar en buena parte de la obra de Ávila. El escultor no ha conseguido que la cara muestre una correcta interactuación con el niño. La anatomía presenta una factura muy sumaria, pues no encontramos el detallismo demostrado en otras piezas. La escultura del niño es muy estática, y a ello no ayuda la rudeza de su talla y el escaso movimiento de los pliegues, casi planos. Esta imagen es completamente obra de talla a excepción del rostro, muy bello, mejor que el del ángel. El pelo está también compuesto por numerosos rizos Pienso que, por la blandura percibida en sus paños, levemente incurvados, la escultura pudo ser realizada dentro de su primera etapa productiva.

En ocasiones especiales el grupo escultórico se ve enriquecido por una serie de postizos. En la actualidad le podemos ver engalanado con ellos el día de la fiesta de los Santos Ángeles Custodios. Efectivamente, en día tan señalado se le colocan unas espléndidas alas plateadas extendidas y el báculo con forma de crucifijo que el resto del año no empuña. Asimismo, tanto el Santo Ángel como el Niño reciben sendos fajines ceñidos a la cintura y coronas en la cabeza.

Se puede decir que el ángel ideado por Ávila es el resultado de la fusión de la iconografía de San Rafael con Tobías y la indumentaria del Ángel del paso de la Oración del Huerto. Asimismo, guarda numerosas similitudes con un grabado de Hieronymus Wierix en el que efigiaba al Santo Ángel de la Guarda acompañando al niño (el alma) por un camino acechado de numerosos monstruos, entre ellos uno que tiene dentro de sus fauces un esqueleto que intenta atacarles con una fecha. El ángel, de rostro bonachón, le señala el cielo, en el cual se desarrolla un rompimiento de gloria en el que podemos observar a la Santísima Trinidad coronando

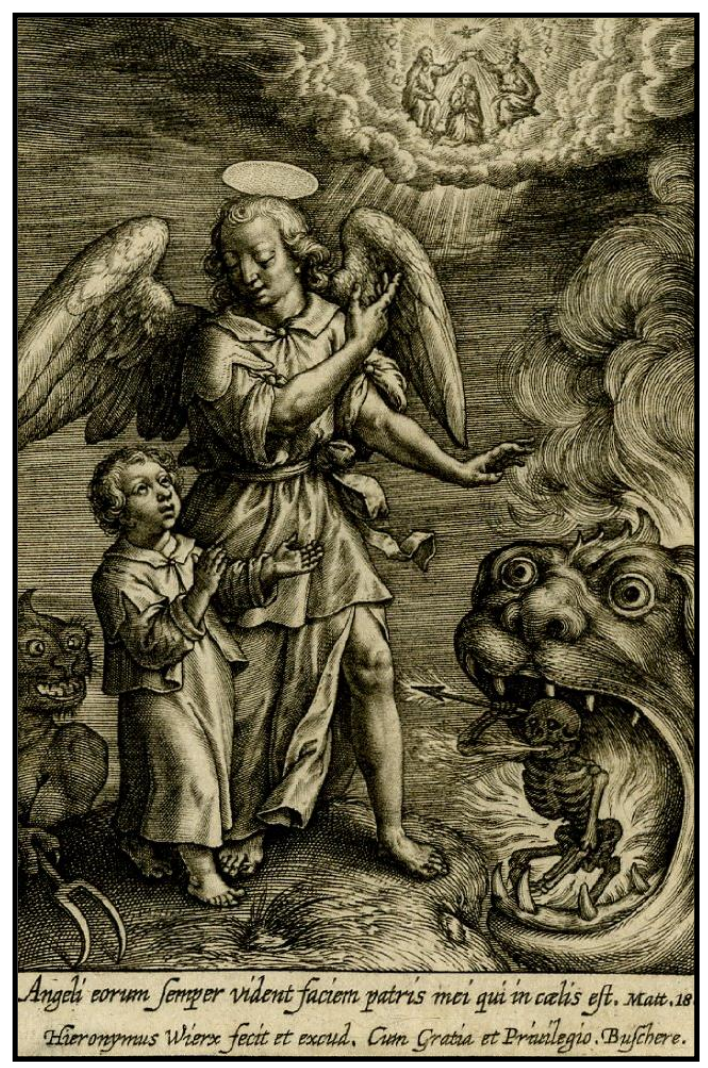

Il. 18- Hieronymus Wierix. Ángel custodio. a la Virgen María. El grabado, realizado en 1619, posee la siguiente leyenda: "Angeli eorum Semper vident faciem patris inei qui in caelis est. Hieronymus Wierix fecit et excud. Cum Gratia et Privilegio. Buschere". 


\section{VALLADOLID. CONVENTO DE SANTA CLARA}

\section{SANTA CATALINA DE BOLONIA (Último cuarto del siglo XVII)}

En la clausura del Convento de Santa Clara de Valladolid se conserva una interesantísima escultura que efigia a Santa Catalina de Bolonia ${ }^{389}$, aunque también cabría la posibilidad de que se tratara de Santa Inés de Asís ${ }^{390}$, que pienso procede atribuir con seguridad a nuestro escultor. Se encuentra guardada en la hornacina que preside una especie de retablo pedestre tallado en uno de los muros del coro. El retablo, totalmente decorado con pinturas murales vegetales y de angelitos, está flanqueado por

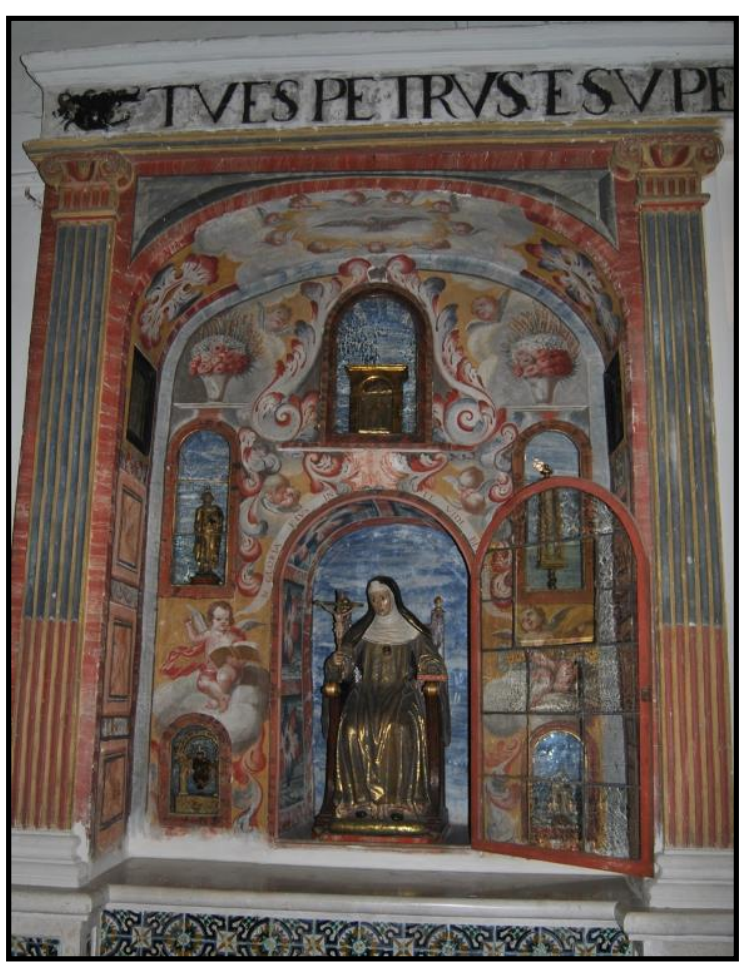

Il. 19- Anónimo. Retablo de Santa Catalina de Bolonia. Convento de Santa Clara. Valladolid. dos pilastras, y el remate lo conforma un arco carpanel. Contiene seis hornacinas, la central y otras cinco que la rodean. En ellas se pueden ver pequeñas esculturas y una reliquia, destacando una deliciosa representación de la Traslación de San Pedro Regalado, similar a las que tallarían el propio Juan de Ávila para el Convento del Domus Dei de La Aguilera y su hijo Pedro para la iglesia vallisoletana del Salvador.

Catalina Vigri había nacido en Bolonia en el año 1413. Destacó por haber practicado la pintura y la música, lo que le llevó a ser nombrada patrona tanto de la Academia de Pintura de su ciudad natal como, en general, de las artes liberales. Su milagro más conocido, transcurrido durante la Navidad, tuvo como protagonista a la Virgen, la cual se le apareció y le puso en sus brazos al Niño Jesús fajado. A raíz de este suceso, su iconografía más popular es representarla con el Niño en brazos ${ }^{391}$. Sin embargo, el escultor no ha elegido esta modalidad para su efigie.

Si aceptamos que la escultura es obra de Juan de Ávila, hemos de tener en cuenta que éste falleció en 1702, y la santa no fue canonizada hasta el año 1712. No sería un motivo suficiente para descartar su paternidad puesto que en multitud de ocasiones el pueblo se ha adelantado a la oficialidad en lo que concierne a elevar a los altares a determinadas personas virtuosas. No podemos tener un ejemplo más cercano que el de

389 MARTÍN GONZÁLEZ, Juan José y DE LA PLAZA SANTIAGO, Francisco Javier: Catálogo Monumental de la provincia de Valladolid. Tomo XV..., op. cit., p. 70.

$390 \quad$ En el Convento de Santa Clara de Villafrechós (Valladolid) se conserva, en uno de los retablos colaterales de la iglesia, una escultura dieciochesca similar a la del convento vallisoletano. En este caso se ha propuesto que dicha escultura efigia a Santa Inés de Asís. VV.AA.: Clausuras: el patrimonio de los conventos de la provincia de Valladolid. 3..., op. cit., p. 212.

391 RÉAU, Louis: Iconografía de los santos. A-F ..., op. cit., p. 283. 
Pedro de la Costanilla, San Pedro Regalado. Son innumerables las esculturas y pinturas que le efigiaron antes de que en 1746 fuera canonizado por el Papa Benedicto XIV.

La santa (110 cms.) (Fig. 67) aparece sentada sobre un sillón frailero, reposa sus pies sobre un cojín con borlas doradas en las esquinas. Con su mano izquierda sujeta un libro sobre el reposabrazos, con la derecha sujeta un Crucifijo por su parte baja, en actitud de mostrárnoslo y que nos postremos y oremos ante él. La escultura es fiel reflejo del cadáver incorrupto de la santa, conservado en el convento boloñés del Corpus Domini. Este se encuentra dispuesto de esta misma manera: sentada en una silla, reposando sus pies en un cojín. Los dos brazos los tiene alargados sobre las rodillas, teniendo agarrados con las manos un libro (izquierda) y un Crucifijo (derecha). Como vemos, la exactitud del modelo respecto al original es total, y hasta coinciden los atributos en las respectivas manos.

Viste el hábito de clarisa: túnica franciscana ceñida por el cordón típico, y toca larga negra con "babero" blanco. A la altura del pecho una teca, en cuyo interior figura un busto de Ecce Homo, quizás realizado en cera. Esta teca podría ser en realidad la representación de una medalla. Los pliegues del hábito son bastante tenues, en algunas partes el cuerpo parece asomar a través de la ropa. El rostro es muy dinámico y expresivo, parece tener luz propia. Tiene la cabeza levemente girada hacia la izquierda, mirando con amor el Crucifijo. Ojos muy vivaces. Boca entreabierta en la que podemos ver perfectamente tallados cada uno de los dientes e, incluso, la lengua. La cara no tiene un juego de calidades demasiado correcto, la superficie es plana, tan solo resalta

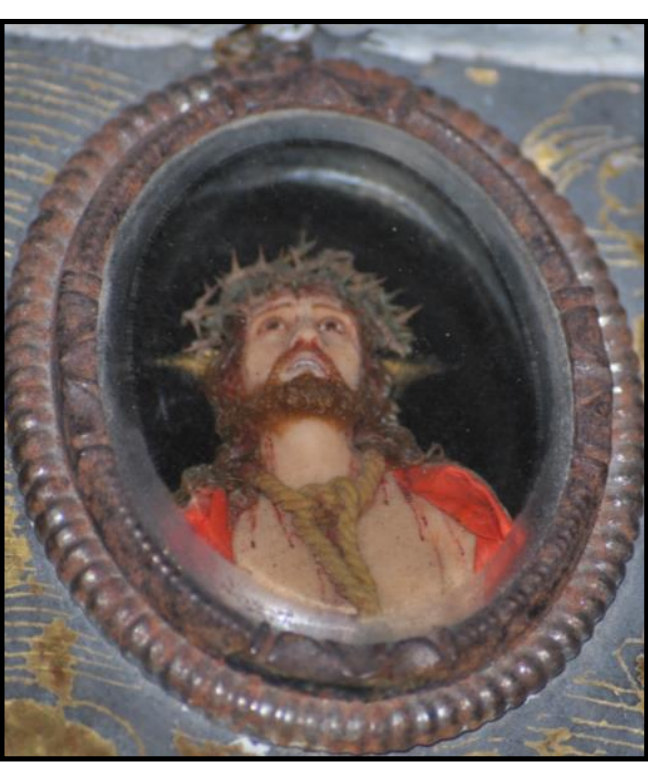

Il. 20- Detalle de la teca del pecho de Santa Catalina de Bolonia. Convento de Santa Clara. Valladolid. el mentón con el hoyuelo.

Es una escultura muy correcta e interesante dada la calidad de la misma y que se trata de una santa muy poco representada por estos territorios. En la provincia de Valladolid tan solo conozco una imagen similar, con la santa sentada, en la iglesia del Convento de Santa Clara de Villafrechós ${ }^{392}$.

392 PARRADO DEL OLMO, Jesús María: Catálogo Monumental de la provincia de Valladolid. Tomo XVI..., op. cit., p. 322. 


\section{VALLADOLID. PALACIO REAL}

\section{SAN PEDRO REGALADO (Último cuarto del siglo XVII)}

Desconocemos la procedencia de esta pequeña imagen que representa a San Pedro Regalado (83 cms.) (Fig. 68), aunque parece más que probable que provenga del desaparecido convento franciscano descalzo de San Diego, el cual estaba ubicado junto al Palacio Real, del cual realizó las funciones de Capilla Real. A esta suposición ayuda el hecho de que en el actual oratorio del palacio se encuentren otras esculturas "franciscanas" como son un San Diego de Alcalá o una Inmaculada, si bien la factura de todas ellas pertenece a diferentes artífices. Debido al reducido tamaño tampoco podemos descartar que presidiera algún oratorio particular dentro del propio palacio real.

La imagen del santo vallisoletano ocupa una pequeña peana situada a la izquierda del retablo mayor del oratorio. Fue fechada por Martín González en el siglo XVII ${ }^{393}$. Posteriormente, Carracedo Primo la creyó de la primera mitad de esa centuria ${ }^{394}$, cronología a todas luces errónea.

El santo aparece figurado en una de sus iconografías más sencillas, en la que, de no conocer su rostro, nos sería bastante complicado discernir su identidad. Vemos al Regalado vestido con el hábito franciscano ceñido por el típico cíngulo de esta Orden. Sobre los hombros una pequeña capilla, abierta por su parte delantera, por la cual se abrocha, que le llega hasta las rodillas. Debió calzar sandalias, extremo que no podemos llegar a confirmar dado que tiene seccionada la parte delantera de los pies. Este hábito debe ser el conocido como "sayalego", que es un "sayal basto de Aranda con el que se vestían los reformadores de Villacreces, por lo que se les conoció también como sayalegos, aunque a veces el paño podía recibir ricas labores de brocado"395. Aunque en algunas ocasiones la policromía puede imitar lo rudo de estas telas y los remendones de ella, en esta ocasión la policromía es muy rica, con decoraciones vegetales y geométricas; en la parte baja de la túnica se ve una amplia cenefa muy colorida.

San Pedro Regalado es representado de pie, con la pierna derecha levemente adelantada, como podemos verlo a través de su rodilla, insinuada a través del hábito. Los brazos muy abiertos, uno elevado y el otro en posición de sujetar algún objeto. Desconocemos qué atributos pudo llevar en ambas manos. La posición de los dedos de la mano derecha parece indicarnos que pudo sujetar una pluma, mientras que con la otra haría lo propio con un libro que se aprestaría a escribir. Refieren Redondo Cantera y Zaparaín Yáñez que "a menudo lleva un libro, abierto o cerrado, que hace referencia a su redacción de las constituciones que regían la vida de estas comunidades monásticas; también es consecuencia de los escritos que le atribuyeron sus panegiristas". Esto parece

393 MARTÍN GONZÁLEZ, Juan José (dir.): Inventario artístico de Valladolid..., op. cit., p. 14.

394 CARRACEDO PRIMO, José: Patrimonio histórico artístico del Palacio Real de Valladolid, Diputación Provincial de Valladolid, Valladolid, 1993, p. 39.

395 REDONDO CANTERA, María José y ZAPARAÍN YÁÑEZ, María José: op. cit., p. 78. 
confirmarse por la posición de la cabeza, mirando hacia el cielo, como buscando la inspiración, a la manera de Santa Teresa con el Espíritu Santo.

Los pliegues coinciden perfectamente con los laborados por Juan de Ávila en su segunda etapa: las dobleces son redondeadas, incurvadas levemente. Caen verticales y paralelas, hinchándose y ampliándose según van bajando. Si bien los pliegues de la túnica son algo rudos, todo lo contrario, se observa en los de la capa, muy finos y delicados, como podemos observar en los dobleces provocados a los lados del broche con que se la sujeta al cuello.

El estilo de Ávila también lo rastreamos en el rostro del santo, el cual guarda ciertas concomitancias con el de otros ejemplos del santo que se atribuyen al escultor, como son los de la iglesia penitencial de N. P. Jesús Nazareno de Valladolid y el del Domus Dei de La Aguilera (Burgos), especialmente con este último, sobre todo en lo concerniente a la blandura y juego de calidades del rostro, en el que acusa a la perfección la vejez a través de las arrugas y las pieles blandas. Ese rostro demacrado no tan solo por la edad, sino también por el riguroso ascetismo al que se obligó. Marcada calvicie en la parte delantera, que pudiera ser amplia tonsura, dado que alrededor tiene la coronilla con pelo, formado por estrechas y sinuosas guedejas, muy similares a las de las dos esculturas citadas. Las arrugas se hacen extensivas a su fino cuello, recordando lejanamente al San Pedro de Alcántara (Pedro de Mena, 1663) que se conserva en el Museo Nacional de Escultura de Valladolid. 


\section{VALLADOLID. SANTUARIO DE NUESTRA SEÑORA DEL CARMEN EXTRAMUROS}

LA VIRGEN DEL CARMEN NIÑA CON EL NIÑO JESÚS (Último cuarto del siglo XVII)

Esta curiosa imagen que representa a la Virgen del Carmen Niña con el Niño Jesús (Fig. 69) no ha sido citada nunca, ni en monografías del santuario, ni en inventarios ni en catálogos. La escultura es muy original puesto que no copia ningún modelo conocido, ni siquiera el del Carmen Calzado de Valladolid. En la actualidad se encuentra guardada en una especie de museo acondicionado en las instalaciones del Santuario, sacándose en procesión en la mañana del Lunes de Pentecostés por las cercanías de la iglesia.

Se trata de una imagen bastante pequeña, de alrededor de un metro de altura. Lo primero que llama la atención es lo dulce y bello que es el rostro de la joven Virgen, con piel muy tersa y que acusa calidades y blandura. Aparece de pie, con una rigidez evidente. Su mano izquierda la extiende, mientras que con la derecha sujeta a un Niño Jesús con vestimentas postizas. El Niño no es de la misma mano que la Virgen. Viste el típico hábito carmelita, en todo similar al que hemos visto en la Virgen del Carmen de Bercero, si bien la diferencia la ausencia de velo en la cabeza y la policromía, que en esta ocasión es de colores planos; no hay ni rastro de motivos ornamentales, a excepción de la estrecha cenefa dorada que encuadra el escapulario y el manto, con labores esgrafiadas. En el escapulario se halla pintado, en su parte superior, el escudo de la Orden del Carmen.

Por lo general la talla es muy tosca, en lo referente a la vestimenta, los pliegues son bastante duros, a excepción de los de la capa, que son suaves y redondeados, con leves quebraduras en las esquinas. Lo más destacable, como ya hemos dicho, es el rostro. Eleva su mirada hacia el cielo. Los ojos están levemente rehundidos. La nariz y la boca son las usuales en Ávila, al igual que el potente mentón. El pelo se distribuye de manera simétrica a ambos lados del rostro, si ben al caer sobre los hombros forma diferentes mechones sinuosos heterogéneos. 


\section{LAGUNA DE DUERO. IGLESIA PARROQUIAL DE LA ASUNCIÓN/}

\section{MILAGRO DE SAN PEDRO REGALADO RESUCITANDO PARA DAR DE COMER A UN POBRE (Último cuarto del siglo XVII)}

El presente grupo del Milagro de San Pedro Regalado resucitando para dar de comer a un pobre (125 x 148 cms.) (Figs. 70-72) no ha llamado mucho la atención de historiadores y curiosos, a pesar de lo extraordinario del tema que trata dentro del mundo escultórico. En el pictórico tenemos muchos más ejemplares, siendo el más conocido el que el pintor romano Plácido Constanzi (1688-1759) realizó en 1746 para la catedral vallisoletana, actualmente ubicado en la capilla de San Pedro Regalado de la seo $^{396}$.

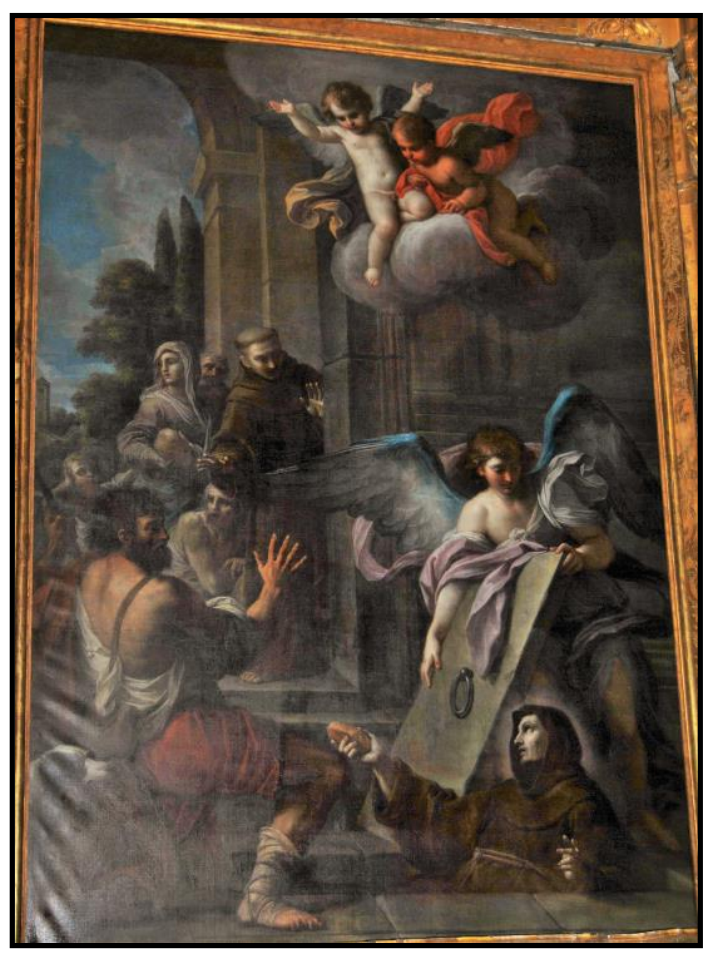

Il. 21- Plácido Constanzi. San Pedro Regalado resucitando para dar de comer a un pobre. Catedral. Valladolid.

El primero en hablarnos de él fue, como en tantas otras ocasiones, el gran investigador José Martí y Monsó. Éste en una de las salidas organizadas por la Sociedad Castellana de Excursiones, fechada el domingo 15 de julio de 1906, nos lo describe así: "En el muro del lado opuesto, frente a la puerta de entrada hay un grupo escultórico incluido dentro de una especie de hornacina con remate barroco, $y$ representa el milagro de San Pedro Regalado, resucitando desde el sepulcro para dar pan a un pobre. Este asunto, muy tratado ya en pintura, no le había visto ejecutado esculturalmente, y resulta aquí una composición sencilla y bien agrupada, de talla correcta, con gran unción religiosa, aunque sin la amplitud de estilo que hubiera tenido a estar hecha en época anterior, pues por sus caracteres debe pertenecer a ya avanzado el siglo XVII. Procede esta escultura de la iglesia conventual del Abrojo según investigaciones hechas por $D^{a}$ Nieves García de Agapito" ${ }^{397}$. Con posterioridad, tan solo se ha vuelto a tratar sobre él en dos ocasiones, ambas por Martín González. Primeramente, en el Inventario Artístico de Valladolid señala que se encontraba en la nave del Evangelio, datándolo en el siglo XVIII ${ }^{398}$. Tres años después, en la redacción

\footnotetext{
396 MARTÍN GONZÁLEZ, Juan José y URREA FERNÁNDEZ, Jesús: Catálogo Monumental de la provincia de Valladolid. Tomo XIV..., op. cit., p. 21.

397 MARTÍ Y MONSÓ, José: "Excursión a Laguna de Duero y el Abrojo. Domingo 15 julio 1906”. En VV.AA.: B.S.C.E. III (1905-1906), Grupo Pinciano, Valladolid, 1983, p. 443.

398 MARTÍN GONZÁLEZ, Juan José (dir.): Inventario artístico de Valladolid..., op. cit., p. 147.
} 
del Catálogo Monumental de Valladolid señala que se ubicaba en la nave de la Epístola, ratificándose en la fecha propuesta ${ }^{399}$.

Desconocemos que lugar pudo ocupar dentro de la iglesia de la Cartuja del Abrojo, de lo que no cabe duda es de que estuvo contra la pared. El marco arquitectónico dentro del cual se haya en la actualidad no fue el primitivo puesto que el grupo es fechable hacia el año 1700, y el Pseudo retablo parece hecho en las décadas de 1760-1770 dado que el estilo que exhibe es el de la transición del barroco a las formas neoclásicas.

Este retablo ha sufrido numerosas pérdidas desde que Martí y Monsó escribiera el artículo, en el cual insertó una fotografía en la cual observamos que éste era más alto y estaba más decorado. Efectivamente, podemos comprobar cómo han desaparecido las columnas laterales, parte de los relieves del banco y todas las rocallas y decoraciones situadas sobre el cuarto de esfera, el cual ha quedado ahora muy desornamentado. El retablo se estructura a través de un pequeño banco, el cuerpo y el ático. En el banco figuraban unos pequeños relieves, sobre los cuales aparece una hornacina cerrada con barrotes y culminada por una cruz. Esta hornacina, que irrumpe en el cuerpo del retablo, podría haber contenido alguna de las múltiples reliquias que del santo se conservan. En el cuerpo, que en su profundidad adopta una forma ovalada se hallaba articulada a través de dos pares de columnas rematadas por un trozo de entablamento y un pequeño frontón, un par a cada lado del grupo escultórico. Friso abombado. Por la parte posterior de éste se veían prolongados los entablamentos hasta unirse, los cuales iban sustentados por pares de pilastras. Justo detrás del grupo

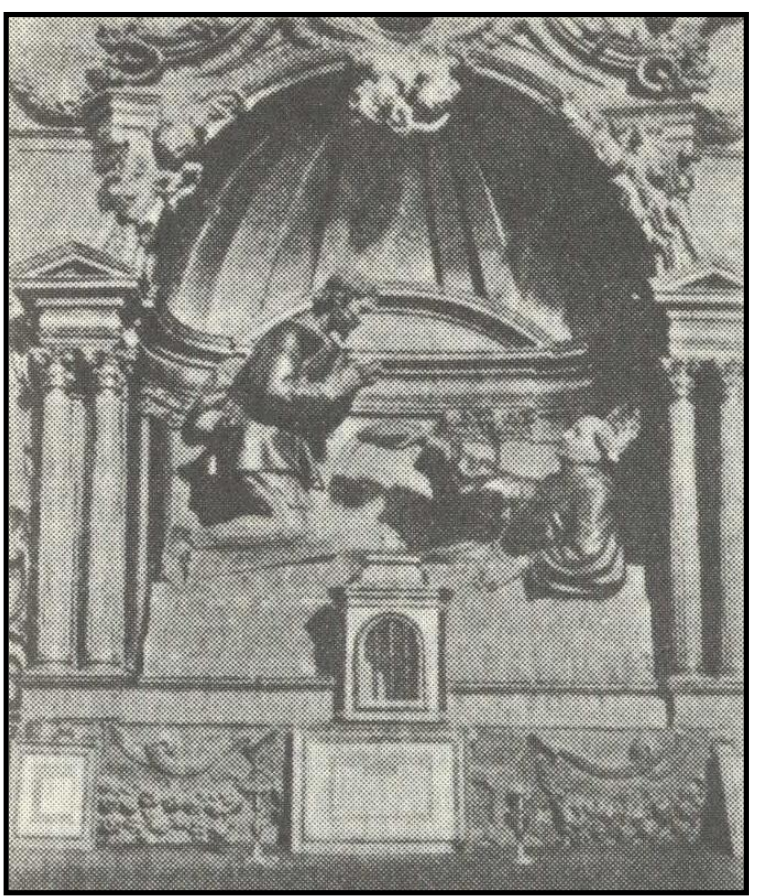

Il. 22- Aspecto del retablo cuando lo vio José Martí y Monsó. Iglesia parroquial de la Asunción. Laguna de Duero (Valladolid). escultórico, dos pares de estas pilastras sustentaban un frontón curvo, que servía de base al remate en forma de cuarto de esfera con múltiples nervios. Éste a su vez estaba decorado adornos rococós actualmente desaparecidos. Podemos percibir una lejana influencia del retablo escenario que Juan de Juni talló para fray Antonio de Guevara en el Convento de San Francisco de Valladolid.

No cabe duda de que el escultor que talló este grupo, quizás nuestro Juan de Ávila por los motivos que posteriormente trataremos, se basó para su composición en las

399 MARTÍN GONZÁLEZ, Juan José: Catálogo Monumental de la provincia de Valladolid. Tomo VI..., op. cit., p. 62. 
descripciones del milagro que realizaron tanto fray Antonio Daza como fray Manuel de Monzaval, los grandes hagiógrafos del "Santo Regalado".

La primera descripción del milagro nos la aporta el vallisoletano fray Antonio Daza (1627): "Llego un pobre a pedir limosna al Convento del Aguilera, en ocasión que el portero había dado toda la limosna a otros pobres que llegaron antes. Viéndose despedido, sin limosna, y sin consuelo, se fue al sepulcro del santo, y arrojándose sobre él, con grande ansia, y fatiga comenzó a dar voces diciendo: Oh santo bendito, si vos fuerais vivo no muriera yo de hambre, ni me fuera sin limosna de este monasterio. Caso admirable, abriose luego la sepultura, y alargando el santo el brazo con un pan en la mano se le dio al pobre, con que remedió su necesidad, y quedó hecho pregonero del milagro" 400 . Años después llegará la de fray Manuel de Monzaval (1684), hagiógrafo oficial del Regalado, algo más extensa y detallada: "Un anciano y pobre, entre otros menesterosos, a quienes se daba limosna en la portería del Aguilera, era socorrido con especial atención, porque el Santo Regalado movido de su necesidad, y años, con más caridad, viviendo le favorecía. Poco después de la muerte del santo, permitió Dios llegase a pedir la acostumbrada limosna a tiempo, que ya el portero la había repartido. Llegó tarde el pobre, con que el religioso no teniendo que darle, le despidió sin socorro. Quedó el necesitado desconsolado, y hambriento y, por esto, del portero quejoso. Entró en la iglesia, y puesto de rodillas ante la sepultura del santo con suspiros tiernos le dijo: Piadosísimo Padre, si tu vivieras, no me hubieran despedido sin limosna. En vos hallé siempre alivio, faltó vuestra vida, y se acabó mi socorro. Perezco de hambre, y no tengo quien con ojos de misericordia me mire. Hizo el pobre la petición en tono de queja amorosa, y fue para la caridad del Regalado riguroso cargo, a que satisfizo con el remedio. ;Oh asombro! La sepultura se abre, el cuerpo del difunto se incorpora, extiende el brazo, y da un pan a pobre quejoso. Está este milagro aprobado en las informaciones con testigos, aprobado con legales testimonios, y admitido por verdadero en la junta de cardenales, cuyo decreto confirmó el Pontífice. Es tal el prodigio, que sin estos fiadores, a escribirle no se atreviera la mano, para estamparle no tuviera alientos la pluma. Esta es aquella singular gracia con que Dios favoreció el cuerpo del Regalado difunto para que se singularizase entre todos, en este prodigio no hay otro, que se le parezca"401.

Efectivamente, el grupo aparece tal cual lo narran ambos hagiógrafos. El escultor ha dispuesto un conjunto en el que ambos personajes aparecen unidos por la mirada, siendo el pan el punto de fuga del mismo. A la derecha figura San Pedro Regalado, que se dispone presuroso a entregar un pan al pobre que le hace la plegaria. El santo aparece saliendo de su tumba, policromada con imitaciones de mármoles y jaspes. Su fuga de la

400 DAZA, Antonio: Excelencias de la ciudad de Valladolid, con la vida y milagros del Santo Fr. Pedro Regalado, natural de la misma ciudad, uno de los tres fundadores de la Santa Provincia de la Concepción, de la Regular Observancia de la Orden de Nuestro Seráfico Padre San Francisco, Casa de Juan Lasso de las Peñas, Valladolid, 1627, p. 103

401 MONZAVAL, P. Fr. Manuel de: Historia de las heroicas virtudes. Aclamación de los estupendos milagros. Vida, muerte y culto de San Pedro Regalado. Fundador de los Conventos de Domus Dei de Aguilera, y Scala Coeli del Abrojo primeros Santuarios de la Observancia en España, Impresor Felipe Francisco Márquez, Valladolid, 1684, pp. 276-277. 
tumba se ha saldado con la rotura de la losa que la cubría. A pesar de que figura extendiendo uno de sus brazos para dar el pan, mientras que con el otro hace el ademán de apoyarse en la tumba, la rigidez del rictus y la ausencia de emociones en su rostro nos indican que estamos ante un muerto. Su rostro es el típico que hemos visto en varias ocasiones: adelgazado a causa de los rigores a los que se sometía, plagado de arrugas, gran calva en la frente, tan solo acompañada por unos mechones de pelo sobre las orejas, etc... La cabeza parece un tanto pequeña para el cuerpo, que va vestido con el típico hábito franciscano, si bien su ejecución, un tanto burda, denota labor de taller.

A la izquierda del grupo se sitúa el pobre, sobre un trozo de la lápida de la tumba. Aparece arrodillado, encorvado, con las manos juntas realizando la plegaria al santo, que, como vemos, ha accedido a prestarle su ayuda. Viste según su condición de pobre: túnica corta con múltiples remiendos, perfectamente simulados por la policromía, la cual adopta tonos planos; pantalones cortos blancos con rayas verticales azules; y unas sandalias con los calcetines ró́dos, motivo por el cual podemos ver los dedos de sus pies. A la espalda, sujeto por una bandolera, lleva un capazo blanco con motivos azules. Al igual que ocurre con la labra del santo, la del pobre también es bastante burda, pero no solamente en la vestimenta, sino también en las manos. La cabeza es de mayor calidad, y en ella vemos más claramente alguno de los estilemas de Ávila: ojos estrechos y semihundidos, nariz amplia con el tabique nasal recto, boca entreabierta, barba rematada con dos mechones simétricos, etc... A pesar de todo, la simpleza y tosquedad de la que hace gala, tanto ésta como la del santo, me mueven a creerla como obra de taller. No hay más que comprobar que el rostro no posee la blandura de la que suele hacer gala nuestro escultor, las arrugas tampoco están tan bien logradas, son mucho más toscas. 


\section{NAVA DEL REY. IGLESIA PARROQUIAL DE LOS SANTOS JUANES}

\section{SANTA TERESA (Último cuarto del siglo XVII)}

En uno de los intercolumnios del retablo dedicado a San José en la iglesia parroquial de los Santos Juanes se encuentra una imagen de Santa Teresa (Fig. 73) que creo procede atribuir a nuestro escultor a la vista de los rasgos que podemos ver en su rostro. La escultura, que ocupa la hornacina derecha del dicho retablo, ubicado en la tercera capilla del lado del Evangelio, fue mandada realizar por la Cofradía de San José para el retablo que anteriormente poseía. Cuando en 1717 se decidió realizar este nuevo retablo se estableció en una de las condiciones de la escritura de contrato que se debían de reaprovechar dos hechuras "que tiene la dicha cofradía del tamaño de Santa Teresa que se ha de poner en dicho retablo". El anterior retablo fue construido en el año 1606 de manera conjunta por el entallador Pedro Rodríguez y el pintor Francisco Martínez. Su sustitución por el de Correas tuvo lugar a causa del desplome de la iglesia ${ }^{402}$.

Efectivamente, el 13 de septiembre de 1717 el ensamblador vallisoletano Juan Correas, fiado por Francisco Nuño, familiar del Santo Oficio, se concierta con Francisco García, mayordomo de la Cofradía de San José, sita en la iglesia parroquial de los Santos Juanes de Nava del Rey (Valladolid), para realizar "un retablo según la traza que para ello se ha elegido y se le ha entregado firmada de mí el dicho escribano la cual para reconocer si está obrada o no conforme lo demuestra dicha traza"403. Correas, que percibiría 4.150 reales vellón por su fabricación, debía de tenerlo acabado para el último día del mes de abril de 1718. El profesor Javier Castán los describe de la siguiente manera: "consta de banco, un cuerpo y tres hornacinas con columnas salomónicas y estípites, entablamento potente y movido y remate con relieve enmarcado $y$ coronamiento de gran desarrollo con elementos vegetales, flameros y penachos. Está ocupado por esculturas del siglo XVIII. En el nicho de la izquierda hay una imagen de la Magdalena penitente según el tipo de Pedro de Mena. La hornacina principal la ocupa un grupo de San José llevando al Niño de la mano. A la derecha está la escultura de Santa Teresa de Jesús en éxtasis, citada expresamente en el contrato como una de las piezas que habían de ser reutilizadas. En el ático hay un relieve del Sueño de San José, hecho para el retablo según las condiciones de la escritura de concierto" ${ }^{\text {"404 }}$.

Santa Teresa de Jesús, nacida Teresa de Cepeda y Ahumada, es una de las santas más conocidas y universales debido a sus múltiples facetas: reformó la Orden de los Carmelitas, llegando a fundar la Orden de las Carmelitas Descalzas; fue mística y

\footnotetext{
402 CASTÁN LANASPA, Javier: Catálogo Monumental de la provincia de Valladolid. Tomo XXI. Antiguo partido judicial de Nava del Rey, Diputación de Valladolid, Valladolid, 2006, p. 90.

403 GARCÍA CHICO, Esteban y BUSTAMANTE GARCÍA, Agustín: Catálogo Monumental de la provincia de Valladolid. Tomo V. Partido judicial de Nava del Rey, Diputación de Valladolid, Valladolid, 1972, pp. 83-84.

404 CASTÁN LANASPA, Javier: Catálogo Monumental de la provincia de Valladolid. Tomo XXI..., op. cit., p. 90.
} 
escritora; se la nombró como Doctora de la Iglesia Católica; y, junto a su compañero San Juan de la Cruz conforma una de las cumbres de la mística experimental cristiana $^{405}$.

Teresa de Cepeda nació en Ávila el 28 de marzo de 1515 en el seno de una familia de judíos conversos ${ }^{406}$. Con apenas 18 años abandonó la casa familiar y decidió ingresar en el Convento de la Encarnación de Ávila, profesando en 1534. A lo largo de su vida sufrió numerosos arrebatos místicos. Falleció en Alba de Tormes (Salamanca) el 4 de octubre de 1582; aunque, debido a la reforma gregoriana, en la cual se retiraron 11 días, su fiesta pasó a celebrarse el 15 de octubre ${ }^{407}$. Su proceso de ascenso a los altares fue bastante rápido puesto que el 24 de abril de 1614 el papa Pablo V la nombraba beata; y su canonización llegaba el 12 de marzo de 1622 de la mano de Gregorio XV.

En la escultura que nos interesa, Santa Teresa es efigiada en mitad del arrobo místico más destacado que experimentó: la Transverberación, Transfixión, o simplemente el "Éxtasis de Santa Teresa". Este hecho tuvo tal transcendencia que el papa Benedicto XIII instituyó su celebración el día 27 de agosto de 1726. La propia santa describe lo que le ocurría durante aquellos instantes: “Quiso el Señor que viese aquí algunas veces esta visión; veía un ángel cabe mí hacia el lado izquierdo en forma corporal, lo que no suelo ver sino por maravilla. Aunque muchas veces se me representan ángeles, es sin verlos, sino como la visión pasada, que dije primero. Esta visión quiso el Señor le viese así. No era grande, sino pequeño, hermoso mucho, el rostro tan encendido que parecía de los ángeles muy subidos, que parecen todos se abrasan. Deben ser los que llaman querubines, que los nombres no me los dicen; más bien veo que en el cielo hay tanta diferencia de unos ángeles a otros, y de otros a otros, que no lo sabría decir. Veíale en las manos un dardo de oro largo, y al fin del hierro me parecía tener un poco de fuego. Éste me parecía meter por el corazón algunas veces, y que me llegaba a las entrañas. Al sacarle, me parecía las llevaba consigo, y me dejaba toda abrasada en amor grande de Dios. Era tan grande el dolor, que me hacía dar aquellos quejidos; y tan excesiva la suavidad que me pone este grandísimo dolor, que no hay desear que se quite, ni se contenta el alma con menos que Dios. No es dolor corporal, sino espiritual, aunque no deja de participar el cuerpo algo, y aun harto. Es un requiebro tan suave que pasa entre el alma y Dios, que suplico yo a su bondad lo dé a gustar a quien pensare que miento. Los días que duraba esto, andaba como embobada; no quisiera ver, ni hablar, sino abrazarme con mi pena, que para mí era mayor gloria que cuantas hay en todo lo criado 408 .

Santa Teresa aparece totalmente sorprendida por la aparición de un pequeño ángel sobre ella. La santa figura de pie, con la pierna derecha levemente flexionada, por lo que el contraposto es muy suave. Extiende los brazos en ambas direcciones, con lo que el escultor ha decidido abrir la composición, quizás para que veamos con más claridad el 
corazón fulgurante que se halla tallado en su pecho. A su correcta visión también ayuda el hecho de que el escapulario se halle doblado por ciertas partes debido al movimiento que se presume en tal acción. Su cuerpo forma una "S" ya que gira levemente la cabeza hacia la izquierda, la cadera hacia atrás y las piernas hacia el mismo lado. Al movimiento de la acción también ayudan los pliegues de su capa, aunque son algo rígidos. Viste el típico hábito carmelita: túnica y escapulario marrón, capa blanca, velo negro y toca blanca que se adapta perfectamente a su rostro. La policromía de todas estas vestimentas es de colores planos; sin embargo, todas ellas, salvo la toca, llevan los bordes decorados con unas cenefas doradas y con decoraciones geométricas esgrafiadas. En definitiva, se trataba de un hábito muy humilde, hasta la propia Santa Teresa comentaba que "era tal la pobreza del hábito Carmelitano que incluso sufre epidemias de chiches por su mal estado. Santa Teresa relata este hecho tan penoso, no sin una gran dosis de humor" ${ }^{\prime 409}$. Los pliegues son muy naturales y amplios, movidos con mucha soltura; no existe la dureza en ellos, a excepción de los de la parte baja de la túnica, concebidos así por el efecto del choque de la misma con el suelo. La suavidad con que compone el manto. Es muy destacable la manera en que el escultor ha resuelto la doblez que se percibe en la parte alta del velo.

La imagen se encontraría en un buen estado de conservación si no fuera por la sección de muchos de los dedos de ambas manos. Las manos están talladas de manera exenta. Levanta la cabeza para observar al pequeño ángel que se le acerca. Le mira con un rostro muy dulce y bello, del que emana una gran expresividad tamizada de un profundo realismo. El artista ha captado a la perfección el justo momento en el que el ángel sorprende a la santa, el gesto que conforma su rostro así nos lo indica: mirada extasiada, boca entreabierta, etc... Como dijimos al presente, su faz presenta muchos de los rasgos presentes en el estilo de nuestro escultor: así, por ejemplo, vemos que su cabeza tiende al óvalo, que sus ojos son achinados y semihundidos, que su nariz es de tabique recto y ensanchada en su parte inferior, que su boca se encuentra entreabierta enseñándonos la fila superior de los dientes, y que su mentón es muy potente. Además, la piel acusa blandura.

Sobre el hombro izquierdo de la santa posa sus rodillas un pequeño angelito alado que ha perdido su brazo izquierdo, con el cual se dispondría a clavar una flecha de fuego en el corazón de la santa, el cual aparece "abrasado de amor". El angelito es también una figura muy dulce, con grandes pómulos, como suele ser habitual a la hora de representar a los niños pequeños. El pelo está tallado a grandes trazos.

409 TORRES SÁNCHEZ, Concha: La clausura femenina en la Salamanca del siglo XVII: Dominicas y Carmelitas Descalzas, Universidad de Valladolid, Valladolid, 1991, p. 164. 


\section{TORDESILLAS. REAL MONASTERIO DE SANTA CLARA}

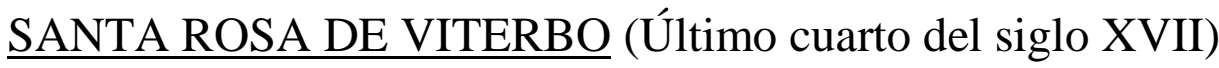

La única vez en que se habla sobre esta escultura (Fig. 74), y, además, muy de pasada, es en el libro Real Monasterio de Santa Clara de Tordesillas, realizado por Carmen García-Frías Checa. En él, la autora, se refiere a ella como "Una María Magdalena arrepentida. Escuela castellana. Siglo XVII"410.

Como ya dijimos, esta escultura es en todo similar a otra conservada en la iglesia de Santiago Apóstol de Valladolid y en el Museo de San Francisco de Ampudia (Palencia). Dado esto, y que se encuentra en un establecimiento franciscano, parece procedente pensar que no es tampoco una María Magdalena, sino otra Santa Rosa de Viterbo. Por otra parte, su atribución a Juan de Ávila viene dada de las semejanzas con la pieza palentina, la cual fue atribuida a nuestro escultor por Urrea y Martín González. Las tres esculturas difieren en poco, si bien esta pieza tordesillana es la que posee alguna diferencia con respecto a las otras: esta Santa Rosa posee un canon más achaparrado; unas melenas mucho más cortas y simplificadas; y, además, los pliegues de su vestimenta son algo más quebrados, lo que pudiera significar que es la más antigua de las tres. Ello me lleva a pensar en una datación aproximada del último cuarto del siglo XVII, probablemente más al comienzo de este periodo.

Esta imagen se encuentra dentro de una de las hornacinas del antecoro. Este espacio cuadrangular, realizado hacia 1401, sirvió de atrio a la iglesia provincial del Convento, que fue el actual coro largo ${ }^{411}$. Como hemos dicho, tanto la vestimenta como la composición de la escultura es completamente exacta a las otras dos: aparece ataviada con el hábito franciscano ceñido a la cintura por el típico cordón utilizado por la Orden. En su mano derecha debió de portar un Crucifijo, dado que parece conservarse restos de él entre los dedos; mientras que la izquierda la mantiene extendida, como si estuviera sufriendo un éxtasis al contemplar al crucificado. A esto ayuda el rostro ensimismado, el cual posee una abolladura en la frente, probablemente un desperfecto sufrido por la imagen. Larga melena ondulada y oscura, algo más simple y corta que las de las otras dos santas homónimas. El tipo de rostro, muy blando, es en todo coincidente al estilo de Juan de Ávila: ojos levemente hundidos, nariz recta, boca pequeña y entreabierta, mentón potente, etc... Los pliegues caen paralelos, aunque se van quebrando según van cayendo hacia el suelo; más suaves y menudos son los de la parte superior de la túnica. La escultura acusa cierta rigidez, característica, por otra parte, muy típica de este primer momento de nuestro escultor. Si las tres tallas fueran de nuestro escultor ésta bien

410 GARCÍA-FRIAS CHECA, Carmen. Real Monasterio de Santa Clara de Tordesillas, Editorial Patrimonio Nacional, Madrid, 1992, p. 42.

411 "Se compone de diez hornacinas enmarcadas por elegantes arcos de medio puto, que, hasta hace poco tiempo funcionaron como capillas confiadas al piadoso cuidado de las religiosas. Aparecen decoradas interior y exteriormente con pinturas murales del siglo XVII, cuyos temas dieron nombre a cada una de ellas". Ídem, p. 40. 
pudiera ser el modelo. La policromía es fastuosa, el dorado lo inunda todo, y sobre él múltiples decoraciones a base de esgrafiados. 


\section{VALLADOLID. IGLESIA PENITENCIAL DE NUESTRO PADRE JESÚS NAZARENO}

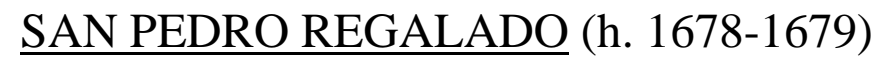

Aunque atribuida en repetidas ocasiones a Pedro de Ávila, esta escultura de bastidor de San Pedro Regalado (Fig. 75) sería más correcto incluirla dentro de la producción de su padre, Juan de Ávila ${ }^{412}$. El rostro puede asemejarse a los tallados por Pedro; sin embargo, en él no encontramos su característica nariz ancha con el tabique recto. Tampoco la cabeza posee su inconfundible composición cuadrangular. La escultura, de bastidor, es de tamaño natural. Tan solo tiene tallados la cabeza, cuello, manos y pies, siendo el resto un maniquí. Porta un libro y un manípulo blanco en su mano izquierda. En la cabeza tiene colocado un resplandor de plata con el escudo de la ciudad de Valladolid. Aparece efigiado casi calvo, con unas pequeñas matas de pelo a ambos lados de la cabeza, exhibiendo en el frontal una amplia calva. El rostro es muy bello, aunque sumamente demacrado, las arrugas surcan la frente, las mejillas, el cuello y hasta las zonas laterales de los ojos. Mira hacia el cielo, con la boca entreabierta, lo que nos permite verle los dientes. El rostro acusa blandura, pero nada tiene que ver con la exhibida en el Regalado de La Aguilera, mucho más real. Estas mismas facciones las encontraremos casi calcadas en otras representaciones del santo ejecutadas por el escultor, especialmente en el referido de La Aguilera. Si bien se verá en ellas la lógica evolución sufrida por nuestro escultor, en la que el mayor realismo y naturalismo serán los protagonistas.

La escultura perteneció en origen al cercano Convento de San Francisco, y llegó a la iglesia penitencial de Jesús Nazareno a comienzos del año 1837 tras el derribo del citado convento. Según el testimonio de Telesforo Medrano, el convento de San Francisco "se dio principio a arruinarle el día 18 de enero de este año de 1837". Los retablos "que le adornaban se ven puestos a pública subasta para el que los quiera comprar; sus hermosas efigies, que tanto se adornaban en otro tiempo, se ven arrastrar por las calles y conducirlas al convento de Clérigos Premostratenses, para ser vendidas al precio de seis cuartos por arroba, como si fuese madera destinada a ser quemada". Algunas de estas efigies "fueron recogidas por varios fieles y conducidas a otras iglesias donde puedan ser veneradas por el pueblo cristiano, tales fueron San Pedro Regalado, San Antonio el Pobre, la Virgen del Carmen, conducidas y colocadas en la Penitencial de Jesús Nazareno y otras a otras iglesias" ${ }^{413}$.

La llegada del santo franciscano a la iglesia penitencial se ve confirmada gracias a un documento conservado en el archivo de la cofradía. Se trata de una carta enviada por el secretario de la penitencial al Ayuntamiento en la que le expone la petición realizada en 1854 por el párroco de la iglesia de Santiago Apóstol de trasladar la imagen de San

412 MARTÍN GONZÁLEZ, Juan José y URREA FERNÁNDEZ, Jesús: Catálogo Monumental de la provincia de Valladolid. Tomo XIV..., op. cit., p. 222.

413 FERNÁNDEZ DEL HOYO, María Antonia: "Valladolid en el siglo XIX...”, op. cit., p. 72. 
Pedro Regalado a la citada parroquia, acción a la que se negó la cofradía ${ }^{414}$. A esta disputa alude Telesforo Medrano cuando relata que, tras las reformas acaecidas en la iglesia de Santiago, el 2 de febrero de dicho año, día de la Candelaria, se celebró una "muy solemne procesión con gran acompañamiento de hachas y luces de los de la Cofradía de Jesús, por invitación que para ello hizo el cura párroco a la Cofradía". En la procesión debió de haber tensiones, dado que Medrano comenta: "No me detengo a hacer el detalle de minuciosidades porque todo constará en actas en los libros de Santiago y de Jesús, y con más motivo en los de la iglesia de Jesús, por las ocurrencias que hubo entre unos y otros feligreses y diputados porque los de Santiago querrían llevar a San Pedro Regalado y los de Jesús se opusieron fuertemente, y por fin no la llevaron por entonces" ${ }^{\prime 4}$.

Desconocemos el motivo que llevó al cura a reclamar la imagen del Regalado para su iglesia. El caso es que tampoco es un hecho que debe extrañarnos mucho, ya que la iglesia Penitencial de Jesús Nazareno se encontraba bajo la jurisdicción de la parroquia de Santiago, y, además, en algunos momentos de la historia ciertos párrocos ambicionaron poseer el control de la penitencial. De hecho, según refieren RodríguezMonsalve y Muñoz González, durante la segunda mitad del siglo XIX y comienzos del XX el párroco de Santiago era de facto el Alcalde de la cofradía ${ }^{416}$. Gracias al citado documento también sabemos que el San Pedro Regalado se trasladaba todos los años al Ayuntamiento para que presidiera la festividad del Corpus Christi ${ }^{417}$. Desde el año 2013, en que se volvió a recuperar la costumbre de levantar altares en las calles por las que discurría la procesión del Corpus Christi, la cofradía ha vuelto a instalar al santo

\footnotetext{
414 "El fundamento del dcho. que cree tener la Cofradía a continua la Ntra. posesión se halla en los antecedentes siguientes:

Ya consta al I. Ayuntamiento que la efigie de San Pedro Regalado estaba colocada antes y aún algo después de la sabida exclaustración de regulares, en la Iglesia Conventual de San Francisco el Grande de esta ciudad. Acordado que fue el desmonte de aquella y del convento por la Junta de Enajenaciones de Bienes Nacionales los años de 1837 al 38, la Cofradía acudió ante la misma Junta solicitando se sirviera permitirla trasladar algunas imágenes y entre ellas la del referido Santo a la mencionada Penitencial de Jesús Nazareno; y así se verificó concedida que fue, sin condición alguna, la indicada solicitud, colocándola, a costa de inmensos sacrificios, desde la época hasta el día ha sido custodiado y venerado por la repetida corporación, sin que ni el Sr. Párroco, ni otra alguna la haya contestado con reclamación de ningún género". RODRÍGUEZ-MONSALVE PASTOR, Ernesto y MUÑOZ GONZÁLEZ, Alberto: "La imagen de San Pedro Regalado que se venera en nuestra Penitencial: Historia", Boletín informativo de la Insigne Cofradía Penitencial de Nuestro Padre Jesús Nazareno, Valladolid, No 31, 2014, p. 40.

415 FERNÁNDEZ DEL HOYO, María Antonia: "Valladolid en el siglo XIX...”, op. cit., p. 80.

416 RODRÍGUEZ-MONSALVE PASTOR, Ernesto y MUÑOZ GONZÁLEZ, Alberto: op. cit., p.

40.

417 "La Cofradía en cambio no desconoce que el I. Ayuntamiento de esta ciudad es el único que a cuál de la misma podría reclamar la citada efigie por la circunstancia del Patronato enunciado. Y tanto no desconoce el dcho. de esa Municipalidad que está dispuesta a respetar sus bellas intenciones según cree a trasladar a San Pedro Regalado a las Casas Consistoriales cuando se verifique la obra que en esta debe realizarse. Más entretanto que la obra se verifica, la Penitencial se considera acreedora a continuar poseyendo tranquilamente la imagen contra las exigencias del Sr. Párroco de Santiago o de las personas que lo secundan; y con el objeto de que VS. Ilma. se sirva proteger los racionales y religiosos deseos de la Cofradía, ésta se permite rogarla respetuosamente tenga a bien acordar que la efigie permanezca en la Iglesia de J. N. a disposición de la Penitencial, mientras que la Municipalidad no se digne trasladarla a las Casas Consistoriales concluidas que sean las obras". Ídem, pp. 40-41.
} 
franciscano en un altar bajo el balcón del consistorio, rememorando de esta manera aquellos tiempos no tan lejanos.

La respuesta del Ayuntamiento a la Cofradía, en la que se declara incompetente para valorar la propiedad de la imagen, nos vuelve a confirmar el hecho del traslado anual de la imagen de San Pedro Regalado al Ayuntamiento: "La única manifestación que el Ayuntamiento ha hecho sobre este particular ha sido la de que no le produce incomodidad de ningún género ni altera su práctica el traer a la Casa Consistorial en el día del Corpus Christi la imagen de dicho Santo Patrono de cualquiera de las dos iglesias que parece a disputar su ostentación y culto" "418.

Con posterioridad, la imagen siguió gozando de su función procesional, la cual fue perdiendo poco a poco. Por fortuna, en los últimos años la cofradía ha vuelto a retomar aquella costumbre. Así, por ejemplo, formó parte del altar que se levantó en la puerta de la iglesia penitencial el 3 de octubre de 2009 con motivo de la Coronación Canónica de la Virgen de las Angustias. Un hecho destacable fue el acaecido en la tarde del Jueves Santo del año 2010 cuando la Cofradía de la Santa Cruz Desnuda regaló a San Pedro Regalado un hábito franciscano, que es el que desde entonces suele vestir ${ }^{419}$.

En la iglesia penitencial debió de ocupar, según la descripción realizada por González García-Valladolid, un retablo situado a la izquierda del "consagrado al Santísimo Cristo de la Agonía"420. Es decir, se ubicaría entre el este retablo y el de San José. La imagen permaneció en dicho altar hasta que las reformas realizadas en la iglesia en la década de 1940 hicieron que pasara a instalarse en la Casa de Hermandad ${ }^{421}$.

A continuación, vamos a proponer una cronología para la imagen, partiendo del hecho de que tan solo se tiene constancia de la existencia de una única imagen de vestir de San Pedro Regalado en el Convento de San Francisco. En el inventario del convento realizado en 1809 se contabilizaban en la Capilla de Copacabana "cinco altares con todo lo necesario para celebrar. Tras el altar mayor (...) se halla el camarín de Nuestra Señora y en él dos arcas en la una se cuentan siete vestidos de la Virgen para todos tiempos y en la otra tres hábitos, uno de San Pedro Regalado, dos de San Buenaventura con un roquete rizado y tres mucetas de dicho Santo y juntamente un libro de madera forrado en carmesí con cantoneras de plata de San Pedro Regalado" $" 22$.

La capilla de Copacabana, anteriormente llamada de la Inmaculada, o de los Riveras, fue completamente transformada entre 1676-1679, años en los que se incrementaron sus dimensiones de forma considerable. La obra fue costeada, según relata Fernández del Hoyo "por el P. fray Hernando de la Rúa hijo del convento y Vicario Provincial de la

\footnotetext{
$418 \quad$ Ídem, p. 41.

419 Ídem, p. 43.

420 GONZÁLEZ GARCÍA-VALLADOLID, Casimiro: Valladolid..., op. cit., Tomo I, p. 636.

421 RODRÍGUEZ-MONSALVE PASTOR, Ernesto y MUÑOZ GONZÁLEZ, Alberto: op. cit., p.

39.

422 FERNÁNDEZ DEL HOYO, María Antonia: Patrimonio perdido..., op. cit., p. 76.
} 
Provincia de la Concepción, que había sido Comisario General de las Provincias de Nueva España donde desarrolló una fructífera labor fundacional; él mismo fue quien trajo de América la imagen titular de la capilla que se entronizó solemnemente en su camarín en el año 1679",423.

La obra no solamente constó de una ampliación del espacio de la misma sino que, además, se fabricaron, entre otras cosas, cinco retablos parar ornar la capilla. Efectivamente, el retablo mayor fue contratado el 26 de febrero de 1678 por el ensamblador Blas Martínez de Obregón, el cual se comprometía a realizar un retablo "donde se ha de poner a nuestra $S^{a}$ de Copacabana" $"$. Unos meses después, el 3 de diciembre, se ajustó nuevamente con el Convento para ejecutar los "cuatro retablos menores que el principal que se ha hecho en la forma de columnas y talla que el principal y lo demás ha de ir de concha y jaspes" ${ }^{25}$. Cada uno de estos cuatro retablos lo ocuparía un santo, cuyas identidades nos son reveladas por Canesi: relata que la capilla poseía el retablo principal, dedicado a la Virgen, y, además en "su circunferencia repartió quatro altares muy pulidos de San Buenaventura, San Joseph, Santa Teresa de Jesús y San Pedro Regalado"426.

Si tenemos en cuenta que la imagen custodiada en la iglesia de Jesús Nazareno procede del Convento de San Francisco, de que en este último tan sólo se conservaba una imagen de vestir de San Pedro Regalado, y que ésta, además, se encontraba en uno de los retablos de la capilla de Copacabana, nos da como resultado que la imagen debió ser realizada por nuestro escultor hacia los años 1678-1679, fechas en que se contratan los cuatro retablos menores y en que se entroniza a la Virgen de Copacabana en su camarín, momento en que lógicamente ya estaría toda la obra de la capilla finalizada.

La importancia de esta imagen fue enorme ya que protagonizó los actos religiosos que conmemoraron la llegada a Valladolid de la noticia de la canonización del Regalado, así nos lo indica Ventura Pérez: "Año de 1747, día martes 20 de Junio por la tarde, la seráfica religión de nuestro padre San Francisco acompañada de la comunidad de nuestro padre Santo Domingo, padres descalzos de San Diego, la comunidad del Abrojo, caballeros de esta ciudad y particulares, llevaron a la Santa Iglesia Catedral la imagen del Santo la que tienen los padres en la capilla de Copacabana"427. A lo largo de estos fastos fue procesionada hasta en cuatro ocasiones, siendo una de ellas llevada a la Catedral. Concretamente se la colocó "en el altar mayor, en donde con lucido adorno le tenían hecho de papeles de talco, que le hicieron unos maestros de Salamanca, con ochocientas luces, y los músicos estaban en un tablado fuera del coro hacia el lado de Nuestra Señora del Sagrario" 428 .

\footnotetext{
$423 \quad$ Ídem, pp. 73-74.

424 FERNÁNDEZ DEL HOYO, María Antonia: “El convento de San Francisco...”, op. cit., p. 418.

425 Ídem, p. 419

426 CANESI ACEVEDO, Manuel: Historia de Valladolid (1750), Tomo I, op. cit., p. 461.

427 PÉREZ, Ventura: op. cit., p. 245.

428 Ídem, p. 246.
} 
La imagen participaría en otras muchas procesiones y rogativas. Relata Ventura Pérez que una imagen de San Pedro Regalado, probablemente ésta, dada su popularidad, participó en la Procesión de San Pedro Regalado y Nuestra Señora el 7 de septiembre de $1702^{429}$. Asimismo, el 11 de junio de 1722 salió otra imagen del Regalado, acompañado de las de San Francisco, San Buenaventura, San Diego de Alcalá y Santa Rosa de Viterbo, en la procesión del "glorioso San Antonio de Padua, por la cofradía de los maestros sastres" $"$ 430.

Teniendo en cuenta de que fue la elegida para presidir las fiestas de la canonización, no sería descabellado plantear la posibilidad de que fuera esta imagen la que se trasladó el día 7 de noviembre de 1683 con motivo de la beatificación del Santo. Canesi refiere que la efigie iba "adornada de innumerable multitud de fina pedrería y de un vestido de tela de plata de singular estimación, guarnecido con muy costosos encajes de oro y diversos florones". Con esta descripción no cabe duda de que se trataba de una escultura de vestir, como la que nos ocupa La procesión transcurrió "desde este convento [de San Francisco] a la Santa Iglesia Catedral". Esa misma tarde se realizó otra procesión, en la que participaron todas las cofradías de la ciudad, cerrándola "la Ciudad y Real acuerdo de la Chancillería". Se dirigieron hacia el convento de San Francisco "donde colocaron al Santo y se finalizó tan sagrada función con copiosas centellas de fuego, que volando en alas de la devoción disparadas en toda la ciudad por la noche, si la plaza se encendía a rayos todo lo demás de ella se asombraba a truenos" $"$.

Volviendo a la capilla de Copacabana hemos de hacer un par de puntualizaciones más. Desconocemos si las esculturas que presidían los otros tres retablos (San Buenaventura, San José y Santa Teresa) colaterales eran reutilizadas o bien fueron ejecutadas en aquellos momentos, como la de San Pedro Regalado, por lo que cabría pensar que fuera nuestro escultor el que las llevó a cabo. Hemos de tener en cuenta, además, que la relación entre Martínez de Obregón y nuestro escultor fue muy fructífera, por lo que este trabajo sería un jalón más.

Aún hay otro tema que me gustaría reseñar, y que quizás ayude a explicar la supuesta continua relación de Ávila con los franciscanos, así como su presencia en La Aguilera tallando el grupo de la Traslación de San Pedro Regalado y las esculturas de San José y San Antonio. Como hemos dicho antes, el padre fray Hernando de la Rúa, hijo del convento de San Francisco, fue quien costeó la construcción de la capilla de Copacabana, y, quizás también, corrieron a su cargo los cinco retablos de la misma, además de ser la persona que trajo desde las Indias a la Virgen de Copacabana ${ }^{432}$. Pero

429 "En 7 de septiembre de 1702 sacaron a San Pedro Regalado en procesión para el altar que se le hizo en el Ochavo (...)". Ídem, p. 17.

$430 \quad$ Ídem, p. 55.

431 CANESI ACEVEDO, Manuel: Historia de Valladolid (1750), Tomo I, op. cit., p. 582.

432 Canesi nos aporta más datos sobre este generoso bienhechor: era "hijo del convento de Palencia, lector jubilado en Teología, vicario provincial de esta provincia de la Concepción por los años de 1676 sobre que tuvo muchas contradicciones por defender las inmunidades y privilegios reales y pontificios de los conventos de las Indias y ganó los pleitos con mucha gloria por ser persona de singular destreza en el majeo de los papeles, y llevó allá religiosos de la Santa Recolección de esta provincia y puso formal recolección con las mismas constituciones de la Aguilera y Abrojo en las provinciales del Santo 
no queda todo ahí, relata Canesi que la generosidad de fray Hernando de la Rúa fue todavía mayor, al igual que su cariño por San Pedro Regalado, puesto que "en la Aguilera también hizo el P. Rúa a San Pedro Regalado una maravillosa capilla para colocar sus reliquias de las celebradas de estos tiempos (...)"433. Si observamos los rostros de ambos Regalados comprobamos que fueron hechos por una misma mano: coinciden en todos los rasgos faciales al milímetro, hasta en la forma de tallar las ternillas de las orejas. De aquí podemos sacar la conclusión de que fuera el padre fray Hernando de la Rúa el que solicitara los servicios de Ávila para tallar, quizás las cuatro imágenes de los retablos colaterales de la capilla de Copacabana, al menos la efigie del Regalado; y que años después, siendo conocedor de las grandes aptitudes de Ávila le volviera a requerir, o quizás se lo recomendó a los frailes de La Aguilera, para que tallara al santo vallisoletano que años antes había esculpido para el convento vallisoletano.

Con todo ello despejaríamos las dudas sobre el origen de su continua relación laboral con los franciscanos, dado que se le atribuyen numerosas esculturas que tuvieron como destino conventos de esta orden religiosa. También podríamos decir que Juan de Ávila fue el encargado de codificar los modelos de San Pedro Regalado para un amplio territorio circundante, dado que muchos años después los escultores seguirían estos patrones, sin ir más lejos su propio hijo Pedro. Como veremos, aún hay otras esculturas del santo vallisoletano que pueden ser relacionadas con Juan de Ávila, por lo que, de confirmarse algún día todas ellas, podríamos denominarle como el "escultor del Regalado".

Evangelio de Méjico, Guatemala y Michoacán (según escribe el P. F. Matías Alonso tomo 1 libro 2 folio 347), y fue compasión general de aquel dilatado reino occidental; volvió a España y a su provincia en la que es y será su memoria muy gloriosa por haber empleado en obras pías algunos caudales que para este efecto trajo de bienhechores devotos, reedificó la capilla de nuestra Señora de Copacabana en este, obra muy suntuosa y mucha parte de ella está pintada y concluida, colocó en ella con grandes fiestas el año de 1679 tan soberana Señora en un retablo precioso matizado de varios colores y en la capacidad". CANESI ACEVEDO, Manuel: Historia de Valladolid (1750), Tomo II, op. cit., p. 461.

433 Ibídem. 


\section{VALLADOLID. REAL COLEGIO DE SAN ALBANO}

El Real Colegio de San Albano, vulgo "Colegio de los Ingleses" vino a ser uno de los espacios barrocos vallisoletanos que requirió la participación de un mayor número de artistas, tanto escultores como pintores, para poder dotar de imágenes a las múltiples capillas que se construyeron: la mayor y seis laterales, además de las múltiples habitaciones, sacristía, etc...

El origen de este Colegio se remonta a la llegada a Valladolid en el año 1600 de la imagen de la Vulnerata. La Virgen procedía de Cádiz, ciudad en la que fue mutilada en 1596 por los ingleses durante un asalto que sus tropas, al mando del conde de Essex y Sir Walter Raleigh, hicieron a la citada ciudad. Cuenta la leyenda que las tropas cogieron a la Vulnerata, la arrastraron por el suelo desde su iglesia hasta la plaza del mercado. Una vez allí la acuchillaron y partieron gran parte del rostro, de los brazos y arrasaron al Niño Jesús, del cual solo subsistió una pequeña porción de los pies.

Antes de arribar a Valladolid, la Virgen presidió la capilla que la condesa de Santa Gadea, esposa del Adelantado Mayor de Castilla, poseía en Madrid. Cuando los estudiantes del Colegio de los Ingleses de Valladolid tuvieron noticia de ella le solicitaron su donación a la noble madrileña, para así reparar el daño y la profanación a la que se había visto sometida la imagen por parte de sus compatriotas. Fue tras su llegada a la ciudad del Pisuerga cuando, según Javier Burrieza "en torno a ella se configuró una devoción barroca, profundamente relacionada con los conflictos religiosos. Un prestigio que se tradujo en milagros y en la necesidad de un espacio sacralizado de mayor tamaño"434.

Hubo que esperar al rectorado del padre Manuel de Calatayud, jesuita, para que se viera materializado el deseo de contar con un nuevo templo que satisficiera las necesidades del culto y fuera lo suficientemente digno para contener a la Virgen Vulnerata ${ }^{435}$. La falta de fondos fue un "hándicap" para llevar a cabo la construcción de la iglesia. Fue gracias a los sermones que el jesuita dio por toda España, en los que exaltaba la figura de la Virgen Vulnerata, se reunió el dinero necesario para costear la edificación del templo. Este consta de planta centralizada, un octógono alargado, con tres capillas a cada lado, además de la capilla mayor, presidida por la Vulnerata.

Cada una de las capillas debía de llevar su retablo, y estos ir decorados con esculturas, pues es lo que se demandaba en la tierra, no como en otras partes que se preferían los retablos pictóricos. Piensa Burrieza que el Padre Calatayud debía de conocer a los escultores más importantes de la escuela vallisoletana de la época (Juan Antonio de la Peña, Juan de Ávila, y Alonso y José de Rozas. Algo posterior es ya Pedro de Ávila), a 
quienes se sospecha que encargaría las imágenes que ornan los referidos retablos de las capillas laterales $^{436}$.

El primero en rastrear la gubia de Juan de Ávila en algunas de estas esculturas fue Martín González 437 . Años después volvía a ratificarse, relatando que ciertas "esculturas acusan el estilo de Juan de Ávila"438. Sobre los seis retablos de las capillas laterales se ha hablado en diversas ocasiones (Catálogo Monumental de Valladolid, Inventario Artístico de Valladolid, libros y guías artísticas diversas, etc...), no habiéndose puesto nunca de acuerdo sus autores en atribuciones concretas. Las esculturas de los seis retablos, a excepción del de la Piedad, cuya hechura se da casi unánimemente hecha que fue elaborada por Pedro de Ávila, se han atribuido indistintamente a los tres grandes maestros del último cuatro del siglo XVII: Juan de Ávila, José de Rozas y Juan Antonio de la Peña. Como ya dijimos, es muy complicado desligar el estilo de cada uno de ellos, por lo que discernir quien ejecutó las esculturas de cada retablo es tarea cuasi imposible, a no ser que la documentación nos aportara la luz que nos falta en estos momentos. Parece lógico pensar, dado el volumen de obra efectuada, que debieron de participar varios de ellos, quizás los tres. Partiendo de esta base, en que podríamos atribuir la escultura de los cinco a cualquiera de las tres gubias, incluida la de Ávila, pienso que nuestro escultor pudo intervenir en la imaginería del os retablos del Calvario, Sagrada Familia y Familia de la Virgen, si bien sobre el segundo de ello tengo ciertas reservas. Tampoco sería una locura atribuirle los de la Compañía y los Arcángeles, en los cuales creo detectar dos manos diferentes en cada uno de ellos, quizás las de Ávila y Rozas.

Desconocemos también el nombre del artífice o artífices que construyeron los seis retablos, quizás fuera Blas Martínez de Obregón, autor del retablo mayor; y la fecha en que fueron asentados tantos estos seis retablos como sus esculturas respectivas. La cronología aproximada no debe distar mucho del año 1679, como mucho finales de 1678, ya que el 22 de octubre de 1679 fue bendecida la iglesia, fecha en que todo debería estar ya perfectamente acabado ${ }^{439}$.

\section{CALVARIO (h. 1679)}

El grupo del Calvario, formado por Cristo Crucificado, la Virgen y San Juan, se halla ubicado en la capilla de los pies del Evangelio, junto a la entrada del templo. Se piensa que esta capilla fuera la sede de una congregación vinculada a la Compañía de Jesús, a la cual por entonces pertenecía la iglesia, establecimiento que regentaron hasta su expulsión de España en 1767. La hipótesis deriva de la inclusión en el remate del

\footnotetext{
$436 \quad$ Ibídem.

437 MARTÍN GONZÁLEZ, Juan José: La escultura barroca en España..., op. cit., p. 81.

438 MARTÍN GONZÁLEZ, Juan José: Guía histórico-artística de Valladolid, Miñón, Valladolid, 1972, pp. 144-145.

439 BURRIEZA SÁNCHEZ, Javier: Virgen de los ingleses, entre Cádiz y Valladolid. Una devoción desde las guerras de religión, Real Colegio de Ingleses, Valladolid, 2008, p. 335.
} 
retablo de un anagrama que consta de una $S$ atravesada por un clavo, cuyo significado puede ser el de "Esclavos""440.

El primero en atribuir este conjunto a Juan de Ávila fue Martín González en el Inventario artístico de Valladolid ${ }^{41}$, si bien con posterioridad él y Plaza Santiago en el Catálogo Monumental de Valladolid cambiaron su parecer y se decantaron porque su posible autor fuera Juan Antonio de la Peña ${ }^{442}$.

El retablo es muy sencillo, si bien se adapta a la perfección al escaso espacio del que dispone. Esto será común a los seis retablos colaterales, siendo más o menos iguales los de las capillas afrontadas, y en este caso se corresponde al de la Piedad. Ambos son los más pequeños del conjunto. Constan de un amplio banco, un único cuerpo con una calle y dos entrecalles y un ático, si bien este se encuentra unido al cuerpo a través de la hornacina del cuerpo. Las entrecalles van flanqueadas por sendas columnas salomónicas con gran número de emparrado. Estas dos hornacinas de las entrecalles en la actualidad exhiben dos bustos relicarios fechados hacia 1600 y atribuidos a Francisco del Rincón: los de los mártires San Abdón y el papa San Cleto ${ }^{443}$. Dado que estas hornacinas son bastante más altas que estos bustos, y que tienen el remate superior semicircular, cabe pensar en que estas tallas no estaban pensadas para estos sitios, pudiendo haber en su lugar unas esculturas que en la actualidad han desaparecido. También podría pensarse que en estas hornacinas pudieron estar metidas las imágenes de la Virgen y San Juan.

Sea como fuere, el escultor ha planteado una composición triangular en el que los ejes son las cabezas de los tres protagonistas. Las actitudes de la Virgen y San Juan se complementan y contraponen a partes iguales. Mientras que María mira hacia abajo, como queriendo evitar ver el sufrimiento de su hijo, con las manos juntas y la pierna derecha adelantada hacia el centro de la escena; el Discípulo Amado corresponde mirando hacia arriba, hacia Cristo, con las manos separadas y la pierna izquierda adelantada hacia el centro. El grupo está estructurado de una manera muy estudiada y equilibrada. Además, ambas esculturas se diferencian también en la concepción ya que mientras que María está concebida en una disposición cerrada sobre sí misma, la del apóstol es completamente abierta. Lo mismo se puede decir de sus actitudes, que parecen representar dos caras de la misma moneda: la Virgen, dolor contenido, resignación..., mientras, San Juan nos muestra un tormento de una manera más expresiva, si bien en sus gestos se puede ver cierta esperanza. Podría añadirse también la dicotomía idealismo (Virgen) - naturalismo (San Juan).

No cabe duda de que tanto la composición como los modelos proceden de Gregorio Fernández. Y, efectivamente, así es. Vemos que nuestro escultor se ha "inspirado" en

440 MARTÍN GONZÁLEZ, Juan José y DE LA PLAZA SANTIAGO, Francisco Javier: Catálogo Monumental de la provincia de Valladolid. Tomo XV..., op. cit., p. 271.

${ }_{441} \quad$ MARTÍN GONZÁLEZ, Juan José (dir.): Inventario artístico de Valladolid..., op. cit., p. 39.

442 "Asignable a Juan Antonio de la Peña, fiador de Blas Martínez de Obregón en el retablo mayor".

MARTÍN GONZÁLEZ, Juan José y DE LA PLAZA SANTIAGO, Francisco Javier: Catálogo Monumental de la provincia de Valladolid. Tomo XV..., op. cit., p. 271.

443 Ibídem. 
los Calvarios que el gallego talló para los áticos de los retablos mayores de las parroquiales de Nava del Rey (1612), si bien Ávila no ha incluido la Magdalena situada a los pies de este Crucifijo ${ }^{444}$, y Villaverde de Medina $(1612)^{445}$; y para los retablos mayores de los conventos vallisoletanos de las Descalzas Reales $(1612)^{446}$ y de las Huelgas Reales (1613-1614) ${ }^{447}$. Muy similares, aunque con algunas diferencias, son los de los retablos mayores de la iglesia de San Miguel de Vitoria $(1624-1625)^{448}$ y el de la Catedral de Plasencia (Cáceres) (1624-1625) ${ }^{449}$. En todos ellos podemos ver que los modelos de las tres figuras son idénticas a las de nuestro escultor, especialmente en lo que concierte a la Virgen y San Juan: las posturas de las cabezas, manos, piernas, etc... así nos lo demuestran.

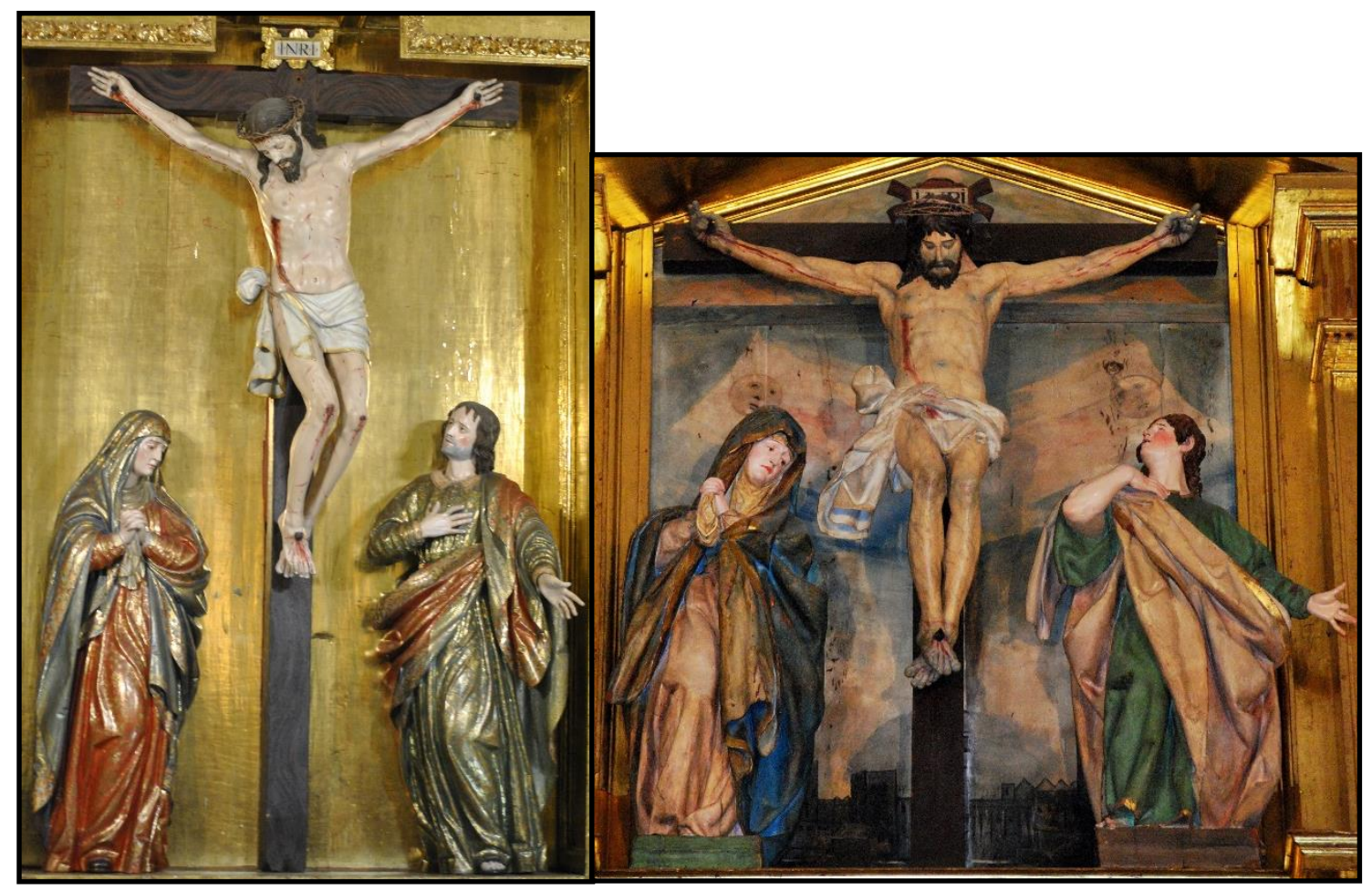

Il. 22- Comparación entre en Calvario atribuido a Juan de Ávila y el que Gregorio Fernández talló para el retablo mayor de las Descalzas Reales de Valladolid.

El Crucifijo (Fig. 76), algo menor del natural (142 cm.), nos presenta a un Cristo ya muerto, con la cabeza caída hacia el lado derecho. Cuerpo muy esbelto. Los ojos y la boca se mantienen entreabiertos. La cabeza se encuentra abundantemente regada de goterones de sangre que manan tanto de las heridas de la corona de espinas como de la boca. Corona de espinas natural. Rostro de facciones clásicas. Ojos de tapilla de vidrio. Tanto las facciones del rostro como la forma de tratar el pelo y la barba bífida son coincidentes con lo visto en la obra de nuestro escultor, si bien se puede observar un tratamiento algo más "biselado" de los cabellos, no es tan redondeado como en otras
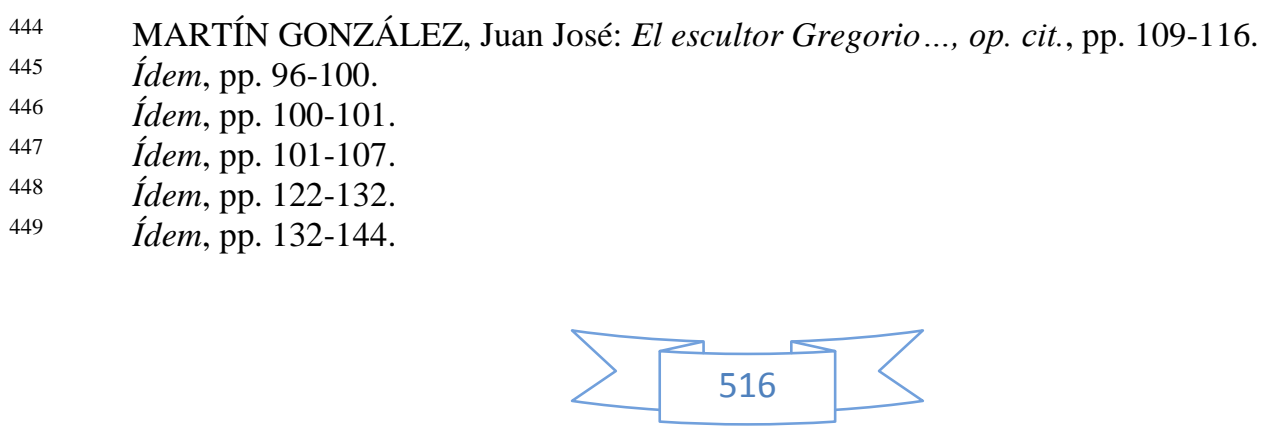
ocasiones. El pelo tan solo nos deja ver la oreja izquierda. Sobre el hombro derecho cae un mechón serpenteante.

Es un cristo muy sereno, nada expresionista. Perizonium blanco con ribete dorado anudado en la cadera derecha que permite ver a la perfección ese muslo. Los paños son muy suaves, redondeados, muy naturalistas, y no se percibe ningún quiebro ni dureza. Los pliegues están como pegados a la piel del fallecido. Ávila se ha recreado en el desnudo. Como ocurriera con el San Juan Bautista de San Felipe Neri nos vuelve a demostrar que es un gran anatomista. Capta a la perfección cada uno de los huesos y de los músculos. Modelado blando, sin exageraciones ni durezas. Los dedos extendidos comienzan, sin embargo, a doblarse mostrando el fallecimiento de Jesús. El tórax nos muestra la gran capacidad técnica de Ávila ya que ha sabido recrear perfectamente todas y cada una de las costillas, así como la cavidad torácica. Vientre hundido.

La policromía aumenta el valor de la talla. El cuerpo presenta un blanco mortecino tan solo interrumpido por los regueros de sangre que fluyen de las heridas de Cristo: cabeza, manos, costado, rodillas y pies. Es sin duda uno de los grandes crucificados tallados en Valladolid tras la desaparición de Gregorio Fernández, y será por su delicadeza un antecesor del modelo que utilizará y difundirá su hijo Pedro, cuya obra maestra es el "Cristo del Olvido". Podemos comprobar las numerosas similitudes existentes en la forma de disponer la cabeza, los bazos, las piernas y, sobre todo, los pies.

La Virgen (130 cms.) (Fig. 77) aparece de pie al lado izquierdo del Crucificado, según la vista del espectador. Adelanta la pierna derecha, la cual intuimos por los leves plegados de su ropa. Viste túnica roja hasta los pies, tan solo se le aprecia uno de los zapatos, manto azul echado sobre la cabeza que el cubre completamente el pelo. Tiene las manos entrelazadas frente al pecho, con ellas agarra con fuerza un pañuelo con el que se ha secado las lágrimas. María dirige su rostro, surcado de algunas lágrimas postizas, hacia el suelo. Boca entreabierta. Pliegues suaves y redondeados, si bien se quiebran con mayor dureza en la parte baja de la túnica, aportando a la talla una sensación de inmovilidad. En las mangas se desarrollan unos pliegues redondeados concéntricos que veremos en otras obras atribuidas a nuestro escultor. Destaca la preciosa cenefa que orla el borde del manto, es similar a otras tantas que hemos visto que los Martínez de Estrada aplican a las esculturas de Ávila, si bien desconocemos a su autor.

San Juan (138 cms.) (Fig. 78) figura de pie, contrapuesto a su "Madre". Dirige su mirada suplicante y dolorida hacia la de Cristo, sentimiento que se ve incrementado por la posición de sus manos: con la izquierda se toca el pecho, mientras que con la izquierda, que se encuentra tallada de forma exenta, la extiende hacia abajo, todo ello contribuye a un perfecto equilibrio en su composición, primero, y en la del grupo, después. Es, quizás, la escultura del conjunto más deudora de la tradición fernandesca ${ }^{450}$. Viste túnica verde anudada por un ceñidor en la cintura, es de ver la

450 BURRIEZA SÁNCHEZ, Javier: Gólgota, Ayuntamiento de Valladolid, Valladolid, p. 90. 
forma en que van decrecimiento y adelgazándose los pliegues según se llega a la referida cuerda. Cae hasta los pies, aunque en este caso si podemos verles, los cuales están resguardados por sandalias. Por encima de esta prenda tiene un paño rojo anudado a la cintura un extremo mientras que el otro cae sobre el hombro izquierdo, detalle que hemos observado en multitud de obras de nuestro escultor, especialmente en los Bautistas. Los pliegues son en todo coincidentes a los de la Virgen. El rostro nos presenta a San Juan según su iconografía tradicional: joven e imberbe, tan solo la policromía ha querido otorgarle una incipiente barba. En la cara podemos observar las características típicas de nuestro escultor, a lo que habría sumar los repetidos mechones mojados simétricos que caen sobre la frente. El pelo se organiza a ambos lados del rostro a través de grandes masas de pelo que discurren sinuosas, gran labor del trepano. El rostro parece anticipar el que utilizará, casi de manera seriada, su hijo Pedro de Ávila para muchas de sus esculturas, siendo especialmente característico el caso del San Juan que talla para una de las capillas de la catedral.

\section{LA SAGRADA FAMILIA (h. 1679)}

Con la atribución de las esculturas de este retablo sucede lo mismo que con las del retablo del Calvario. Martín González primeramente barajó el nombre de Juan de Ávila ${ }^{451}$, si bien posteriormente rectificó y se decantó por el de Juan Antonio de la Peña ${ }^{452}$.

El retablo ocupa la primera capilla del lado del Evangelio, junto a la capilla mayor. Es similar al que acabamos de analizar, si bien en este caso las medidas se han ampliado en lo que respecta a su longitud, las hornacinas laterales han desaparecido, y sobre la central se ha colocado un friso decorativo con cinco cabezas aladas de angelitos. En el ático se exhibe también un anagrama, en este caso "JMJ" que alude al motivo principal del retablo: "Jesús, María, José". En la hornacina central figuran San José, la Virgen y el Niño, en el pasaje de la Presentación en el templo, al igual que sucederá en el próximo retablo, que efigiará la Presentación de la Virgen en el templo. A los lados, sobre unas peanas situadas en los intercolumnios hay dos pequeñas estatuillas dieciochescas (49 cms.), atribuidas a Pedro de Ávila, que efigian a dos santos jesuitas: San Francisco de Borja y San Luis Gonzaga ${ }^{453}$.

En este grupo escultórico la influencia de los modelos de Gregorio Fernández es también muy clara. No cabe duda de que Ávila tomó como modelo la Sagrada Familia que el escultor de Sarria talló en 1620 para la Cofradía de San José y Nuestra Señora de Gracia y Niños Expósitos radicada en la iglesia parroquial de San Lorenzo (1620). Conjunto que, por cierto, urge de una restauración que le devuelva su primitivo

\footnotetext{
451 MARTÍN GONZÁLEZ, Juan José (dir.): Inventario artístico de Valladolid..., op. cit., p. 39.

452 MARTÍN GONZÁLEZ, Juan José y DE LA PLAZA SANTIAGO, Francisco Javier: Catálogo Monumental de la provincia de Valladolid. Tomo XV..., op. cit., p. 272.

$453 \quad$ Ibídem.
} 
esplendor ${ }^{454}$. Las semejanzas son evidentes: desde la forma de concebir las esculturas, hasta los gestos de las mismas e, incluso, los ropajes y la disposición de los pliegues de estos, si bien el tipo de quebradura nada tiene que ver. La gran diferencia entre ambos conjuntos es el dinamismo de las esculturas de Fernández y la cierta rigidez de las supuestamente elaboradas por Ávila.

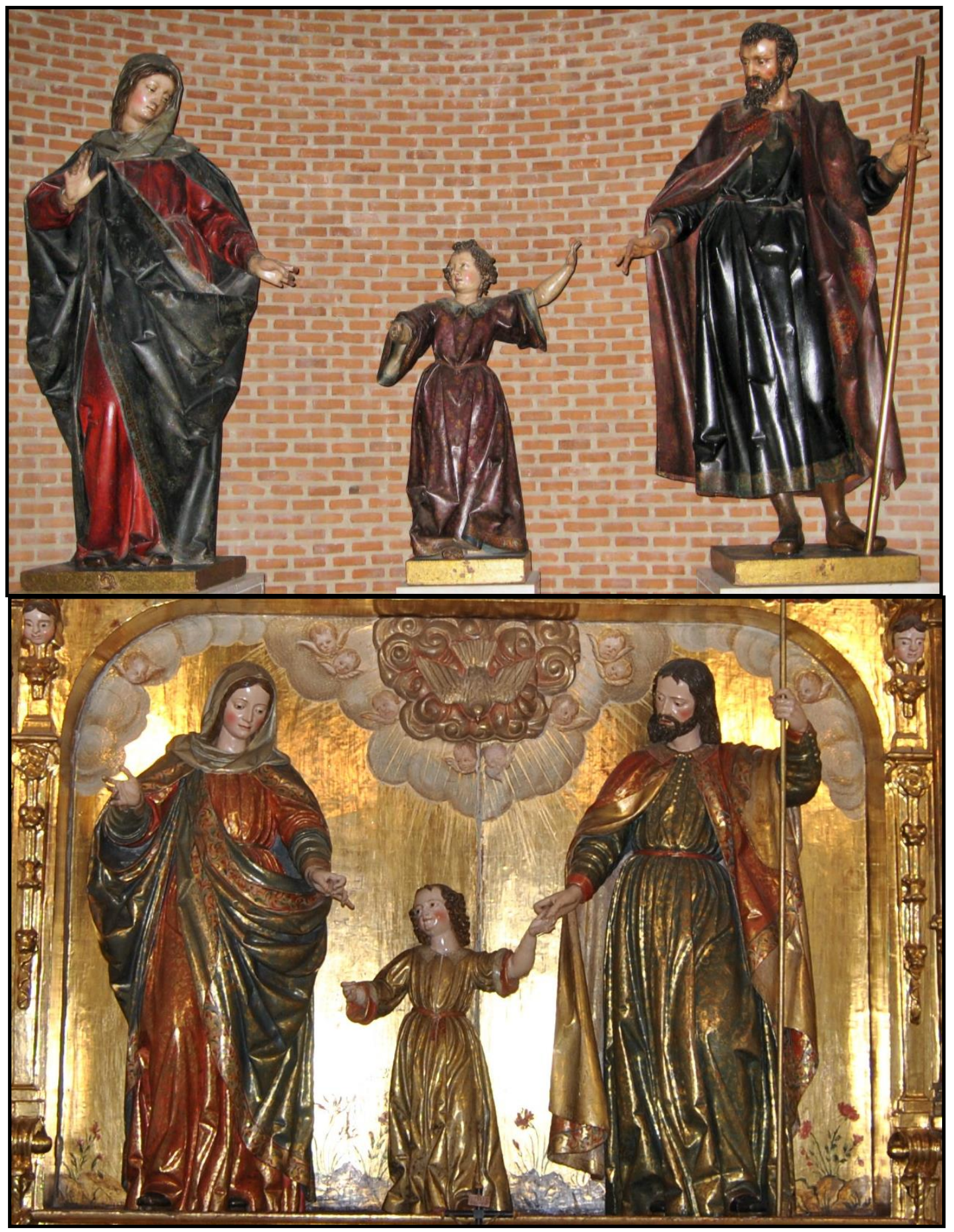

Il. 23- Comparación entre las Sagrada Familia de Gregorio Fernández y Juan de Ávila (atrib.).

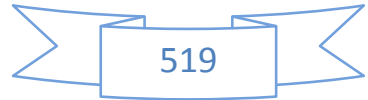


La Sagrada Familia fue una iconografía muy habitual durante el barroco. Su difusión fue ampliamente promocionada por la Contrarreforma, que estimuló el culto de la Trías humana: Jesús, María y José, también conocida como "Trinidad jesuítica", cuyo anagrama hemos visto que figura en el retablo. No extraña para nada que un grupo denominado de esa forma ocupara uno de los altares de una iglesia que, por entonces, era de propiedad jesuita. Esta Trinidad Terrestre está concebida a la imagen y semejanza de la Celestial, de la cual es un reflejo ${ }^{455}$. Asimismo, hay que señalar que en esta representación confluyen dos aspectos: la reducción de las Sagradas Parentelas medievales, ya que ahora solo aparecen los familiares más cercanos a Jesús ${ }^{456}$; y la revitalización del culto a San José a partir del Concilio de Trento.

El grupo se sitúa sobre un fondo dorado con una serie de flores a los pies de las tallas, y en la parte superior un rompimiento de gloria del cual surge la paloma del Espíritu Santo; a los lados nubes y cabezas aladas de angelitos.

La Virgen (136 cms.) (Fig. 79) figura al lado izquierdo del espectador, con la rodilla derecha adelantada en ademán de avanzar. Con su mano izquierda busca agarrar a su hijo, mientras que con la derecha hace un gesto bastante elegante. Viste túnica roja atada a la cintura por un ceñidor, hasta los pies, de los cuales podemos ver ambos zapatos; manto azul con una delgada cenefa a punta de pincel, como ya hemos visto en otras ocasiones; y un velo blanco en la cabeza, ocultando gran parte de su cabello. El rostro es en todo coincidente con el modelo de Ávila, a excepción de los labios, que parecen como sellados. En esta ocasión volvemos a ver esos pliegues concéntricos en las mangas que ya observamos en las esculturas del retablo anterior, y que también veremos en las de éste y en el próximo.

Las coincidencias con la obra de Fernández se encuentran tanto en la posición de las manos como en la elaboración de los pliegues, aunque en este caso los de Gregorio Fernández son más duros y acartonados, siendo los de esta Virgen más suaves, con unas formas más redondeadas. Contrastan los zigzagueantes del manto con los verticales de la túnica, que chocan contra el suelo generando ciertas durezas. También hay concomitancias en la forma de elaborar el velo blanco y el rostro, cayendo el pelo de manera simétrica a ambos lados de la cara.

El Niño Jesús (84 cms.) (Fig. 80) ocupa la posición central del conjunto. También figura en ademán de andar, con su pierna izquierda adelantada. Mientras que con su mano izquierda va a recoger la que su madre le tiende, la derecha ya se encuentra unida a la de su padre. Tiene el rostro levemente girado hacia su madre, y sonríe. Viste una túnica larga blanca, ajustada a la cintura con un ceñidor, con decoraciones doradas a punta de pincel. Tan solo podemos verle uno de los pies, concretamente el de la pierna adelantada, el otro queda sumido ante un amasijo de pliegues bastante duros que caen paralelos si bien a tramos se incluyen algunos diagonales. Estas quebraduras van en

455 RÉAU, Louis: Iconografía de la Biblia. Nuevo..., op. cit., p. 156.
456 Ídem, p. 153. 
aumento según van llegando al suelo, siendo los cercanos al ceñidor, muy dulces y con poco resalto.

La cabeza nos presenta una frente despejada sobre la cual caen dos pequeños rizos y, a los lados del rostro, dos espesas masas de pelo llenas de rizos, en la cual ha habido un amplio uso del trépano. Ambos detalles son en todo coincidentes con el estilo de Ávila. En concreto, este último nos recuerda a las cabelleras de los Bautistas tanto del Oratorio de San Felipe Neri como de la iglesia de Santiago. En esta ocasión las semejanzas con el Niño Jesús de Gregorio Fernández son totales. Tan solo les diferencia el dinamismo.

San José (139 cms.) (Fig. 81) se sitúa en el lado derecho de la composición. También intenta avanzar, si bien los pliegues le arrebatan buena parte de la sensación de movimiento. Con su mano derecha, cuyo brazo está oculto por parte de la capa, agarra la de su hijo, mientras que con la izquierda, con porte majestuoso, sujeta la vara florida; símbolo de su triunfo entre los pretendientes de la Virgen María. Viste túnica verde larga hasta el suelo, dejando entrever las puntas de los dos zapatos. Detalle que se desarrolla en las tres esculturas de manera similar. La prenda se encuentra sujeta en la cintura por un ceñidor. Sobre este se pueden observar unas abotonaduras en el pecho, las mismas que hay en las mangas. Encima de la túnica porta una elegante capa roja que cubre ambos hombros, si bien en el derecho cae por su parte delantera, particularidad que hemos visto muchas veces en las esculturas de Ávila. Los pliegues y la policromía son similares a los del San Juan del Calvario, si bien en las quebraduras de la túnica se asemeja más a los de la Virgen de este mismo grupo. En este caso destaca la delicadeza con la que están tratadas las dobleces de la capa; no hay rastro de durezas. Es la escultura menos influenciada por Fernández, si bien también tiene numerosas concomitancias, como puede ser la disposición de la capa o de las manos. La manera de configurar tanto el rostro como el pelo parece anticipar el que desarrollará su hijo Pedro de Ávila a la hora de efigiar a San José.

El rostro es muy similar al del Crucificado del anterior retablo y, también, al del San Joaquín que veremos en el próximo. Posee las características típicas de Juan de Ávila, si bien en este caso los dos mechoncillos simétricos que caen sobre la frente son muy escasos. El pelo cae en numerosos mechones ondulados a ambos lados del rostro. Tan solo nos permite entrever la oreja derecha. Barba bífida elaborada, al igual que el pelo, a través de numerosas curvas.

\section{SAN JOAQUÍN, SANTA ANA Y LA VIRGEN (h. 1679)}

Al igual que nos ha ocurrido con las imágenes que presiden los dos retablos referidos hasta el momento, las esculturas de éste fueron atribuidas a Ávila por Martín González $^{457}$, si bien posteriormente se decantó por Juan Antonio de la Peña ${ }^{458}$.

457 MARTÍN GONZÁLEZ, Juan José (dir.): Inventario artístico de Valladolid..., op. cit., p. 39. 
El retablo se ubica en la primera capilla del lado de la Epístola, junto a la capilla mayor, siendo, por lo tanto, frontero al de la otra "Trinidad" estudiada. El retablo es idéntico al de la Sagrada Familia, salvo en el anagrama del ático: este presenta las letras A/M (Ave María) superpuestas y, justo debajo, un corazón. En la hornacina central el grupo de San Joaquín, Santa Ana y la Virgen Niña, mientras que en las entrecalles hay dos peanas, similares a las del retablo anterior, sobre las que se sitúan las pequeñas imágenes (47 cms.) de San Ignacio de Loyola y San Francisco Javier, atribuidas a un seguidor de Gregorio Fernández del primer cuarto del siglo XVII ${ }^{459}$.

Es otra de esas iconografías surgidas a raíz de la Contrarreforma. Surge a manera de complemento de la Trinidad anterior, y viene a ser la Trinidad de la Virgen María. En ella tiene cabida ella y sus dos padres. El tema no es novedoso en la ciudad puesto que ya se contaba con otros ejemplos. El único conocido hasta el momento salido de las gubias de Gregorio Fernández es el que talló para la iglesia de los jesuitas de Lima, si bien poco tiene que ver con el que actualmente estamos tratando ${ }^{460}$.

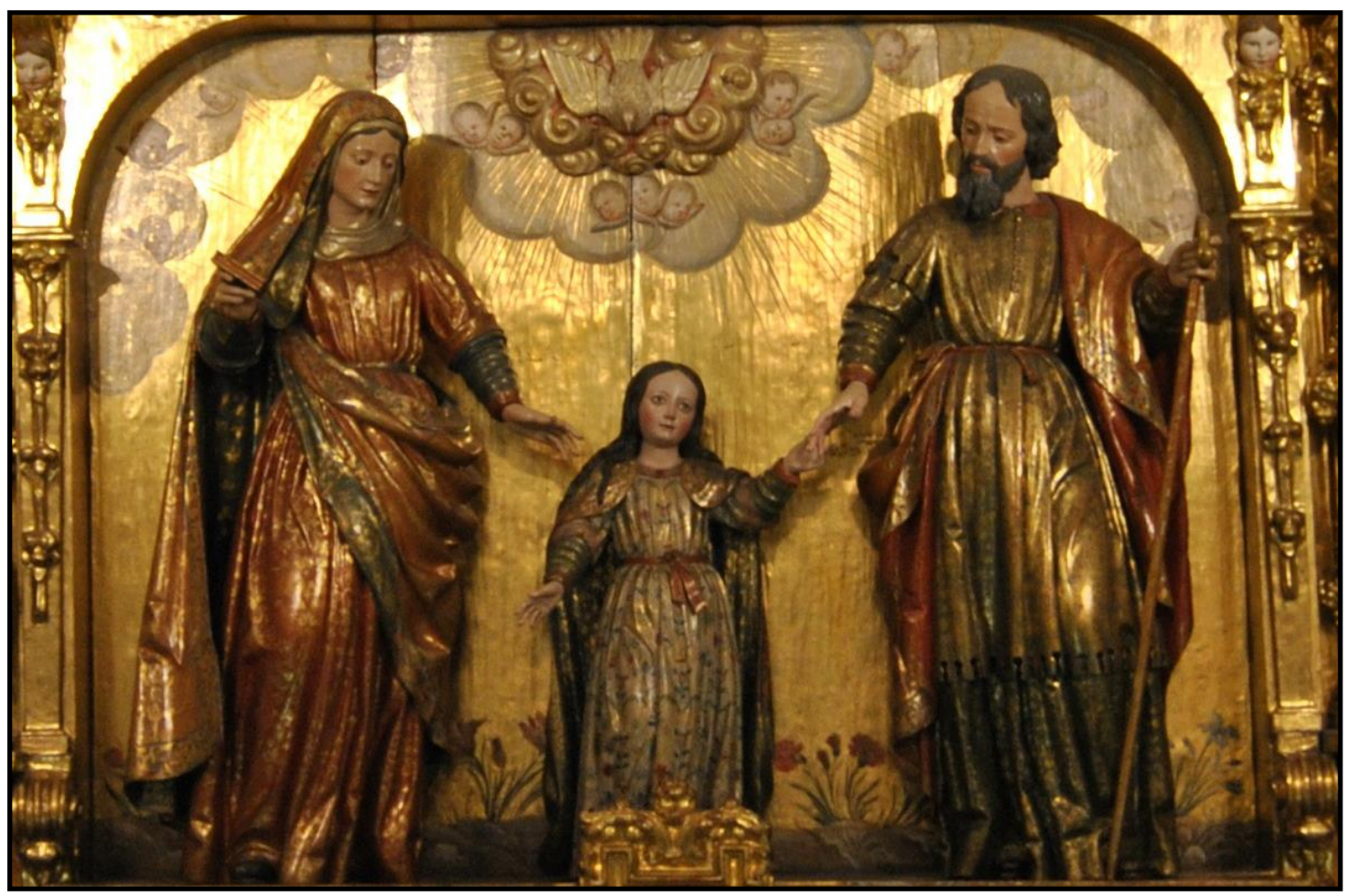

Il. 24- Juan de Ávila (atrib.). Sagrada Familia de la Virgen. Colegio de los Ingleses. Valladolid.

El presente conjunto es completamente idéntico en sus posiciones y actitudes al grupo anterior. La mujer, en este caso Santa Ana (Fig. 82), ocupa el lado izquierdo. Ésta tiende la mano a la Virgen Niña (Fig. 83), situada en el centro. A la derecha, San Joaquín (Fig. 84) sujeta con su mano la de su hija, mientras que con la otra hace lo propio con la vara. Tan solo han cambiado los tipos físicos y los rostros. El telón de

458 MARTÍN GONZÁLEZ, Juan José y DE LA PLAZA SANTIAGO, Francisco Javier: Catálogo Monumental de la provincia de Valladolid. Tomo XV..., op. cit., p. 273.

$459 \quad$ Ibídem.

460 MARTÍN GONZÁLEZ, Juan José: El escultor Gregorio..., op. cit., p. 219.

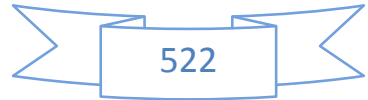


fondo, pintado y esculpido, es también calcado al del anterior grupo. Vista la paloma del Espíritu Santo se puede concluir que ambas fueron talladas por una misma mano.

No vamos a entretenernos en describir en profundidad cada imagen ya que, como acabamos de comentar, las vestimentas, por lo general, y las actitudes, pliegues y policromía son casi análogos a lo advertido en el grupo anterior. Tan solo hablaremos de los detalles característicos de este conjunto. Así, por ejemplo, Santa Ana (137 cms.) porta en su mano izquierda un pequeño libro, que pudiera simbolizar el "Ana leyendo" (Anna legens), "en relación con la antifona "Felix Anna quidam matrona legit", de la misa de la festividad de Santa Ana inspirada en los usos de la diócesis de París y contenida en un breviario de comienzos del siglo XIV" ${ }^{\prime 461}$. El rostro es el de una mujer madura. Ha captado, a través del blando modelado, las leves arrugas, si bien pienso que, al igual que ocurre en las otras dos tallas de este conjunto, la restauración ha sido un tanto excesivo en el rostro, y las ha hecho perder frescura. La Virgen Niña es la pieza que menos se parece a su correspondiente del grupo de la Sagrada Familia. Es una escultura menos movida, muy estática y compacta. No mira a su madre, como el Niño Jesús, sino que parece observar la paloma del Espíritu Santo. Destaca su túnica con policromía de florecillas y la pequeña capa sujetada con una cinta que pasa por delante del cuello. Su amplia frente, con el pelo dispuesto simétricamente a ambos lados del rostro, cayendo algún mechón sobre los hombros, la veremos en otras piezas que le atribuíamos al escultor, como la Virgen Niña conservada en el Santuario de Nuestra Señora del Carmen de Extramuros. El San Joaquín (140 cms.) viene a ser una representación madura del anterior San José. Tan solo les diferencia la blandura del rostro, surcado por leves arrugas, en especial en la frente, las amplias y más voluminosas cabelleras ya canosas y la mayor longitud de la barba. Un detalle interesante, y que veremos en otras piezas atribuidas a nuestro escultor, es la serie de entrantes y salientes que se ve en el borde del manto que porta sobre la túnica.

461 VV.AA.: Las Edades del Hombre. Paisaje interior, Fundación Las Edades del Hombre, Valladolid, 2009, pp. 401-403. 


\section{VALLADOLID. CONVENTO DE SANTA CATALINA}

\section{SANTA CATALINA DE ALEJANDRIA (h. 1680-1690)}

Esta pequeña imagen de Santa Catalina de Alejandría (65 cms.) (Fig. 85) se encontraba hasta la reciente clausura del Convento de Santa Catalina de Siena dentro de una de las hornacinas laterales del retablo que presidía la capilla de la Peña de Francia, localizada en una de las esquinas del claustro bajo. Desconozco su actual paradero ya que tras la marcha de las religiosas los bienes artísticos del convento, al igual que ocurrió con los de Las Lauras, han ido a parar a otros establecimientos de la Orden de Predicadores. En esta ocasión gran parte de ellos, no todos, se encuentran en la actualidad en los vallisoletanos conventos de San Pablo y de Corpus Christi.

Los únicos que han tratado sobre esta imagen han sido Martín González y Plaza Santiago, los cuales la han creído "cercana a Juan de Ávila", fechándola en el tercer cuarto del siglo XVII ${ }^{462}$. Dado que el estilo de las primeras obras de Ávila nada tiene que ver con el exhibido por esta talla, habría que retrasar su cronología hasta el último cuarto de siglo, concretamente a la octava década

La santa aparece de pie, estática, y su cuerpo parece formar un ángulo cóncavo. Va ataviada como una princesa real, coronada. Túnica blanca abotonada en el pecho y mangas, ceñida a la cintura por un cintillo abrochado por un elegante lazo, detalle que observamos en otras tallas asignadas al escultor. La decoración con motivos a punta de pincel es fastuosa. Similar es la del manto rojo que tiene echado por encima, dispuesto de una manera muy elegante. Este posee la cenefa que hemos observado en numerosas ocasiones. Los pliegues son los característicos de nuestro escultor, pero también los de los otros dos grandes maestros del momento (De la Peña y Rozas). La forma de componer la parte baja de la escultura, con una pierna levemente adelantada, con unos pliegues bastante duros y la disposición de los pies en un ángulo de $90^{\circ}$ parece anticipar los modos de hacer de Pedro de Ávila.

Tanto la escultura, en general, como el rostro, en particular, son ciertamente anodinos y secos. No hay ninguna sensación de movimiento, y el escultor no ha sabido infundirla vida. El rostro posee ciertos caracteres que hacen que la atribución a Ávila la haga con las máximas reservas, como son el prominente mentón y su marcado hoyuelo, la anchura de las aletas nasales y la disposición triangular de la nariz. El rostro se ve enmarcado por largas melenas simétricas que nacen de la frente. Los ojos parecen de cristal, aunque también podrían ser de tapilla de vidrio. Visto todo esto no había que descartar la paternidad de José de Rozas.

En una mano porta la palma del martirio y en la otra una espada (se encuentra partida, tan solo agarra el mango puesto que la hoja está caída). A sus pies se sitúa, en un lado,

462 MARTÍN GONZÁLEZ, Juan José y DE LA PLAZA SANTIAGO, Francisco Javier: Catálogo Monumental de la provincia de Valladolid. Tomo XV..., op. cit., p. 55. 
una rueda y, al otro, la cabeza cortada del Emperador Maximiano ${ }^{463}$. Tanto la espada como la rueda hacen referencia a los dos martirios que padeció la santa. Su iconografía se resume en un verso mnemotécnico: "O Katherina, tyrannum superans Doctos docens et rotas lacerans" ${ }^{\prime \prime 64}$

El primero de los martirios, que no se llegó a consumar, consistía en aserrarla entre dos ruedas erizadas de ganchos de hierro que hacían girar los verdugos. Santiago de la Vorágine en su Leyenda Dorada nos aporta más detalles acerca de este suceso: la forma en que sería torturada la santa fue ideada por uno de los prefectos del Emperador, ésta consistía en "cuatro ruedas cuajadas de agudísimos clavos y de pequeñas sierras dentadas. Será un instrumento de tortura verdaderamente horroroso; si lo aplicamos a esta doncella su cuerpo en poco rato quedará acribillado y hecho trizas por los pinchazos de los garfios y por las sajaduras de las sierras". Con este castigo, el prefecto pretendía conseguir otro objetivo: "los cristianos que contemplen este espectáculo, que resultará realmente atroz, quedarán aterrorizados, escarmentarán en cabeza ajena y abandonarán su religión”. Así se hizo. El Emperador, además, ordenó que montaran el artefacto "de tal modo que de las cuatro ruedas dos giraran en un sentido y las otras dos en sentido contrario, porque de esta manera, tendiendo a la víctima boca abajo, mientras unas laceraban la superficie inferior de su cuerpo, las otras lacerarían su superficie superior, y girando las ruedas en sentido opuesto e imprimiéndoles gran velocidad, al luchar fuertemente entre sí unas con otras, las rasgaduras que producirían en la carne de la joven serían más profundas y violentas". Antes de que se iniciara la tortura Santa Catalina comenzó a orar y a pedir a Dios que destruyese aquella horrible máquina. Y, en efecto, Dios le escuchó y "cuando el artefacto comenzó a girar a vertiginosa velocidad, un ángel hizo saltar las ruedas con tal fuerza que al dispersarse sus fragmentos en diversas direcciones y chocar violentamente contra los espectadores, mató a cuatro mil de ellos, todos los cuales eran paganos, 465 .

En el caso de la espada, ésta alude a su decapitación. Tras el suplicio de las ruedas dentadas, y el asesinato de la Emperatriz a manos de su marido, éste hizo comparecer ante él a Santa Catalina. La ofreció la dignidad de Emperatriz si renunciaba a su religión. La santa lo rechazó. Fue entonces cuando el mandatario decidió que ese mismo día sería decapitada. Y así lo hizo, "pero de sus heridas no brotó sangre, sino leche. Los ángeles recogieron su cuerpo y lo trasladaron al monte Sinaí distante veinte días de camino del lugar en que fue martirizada, y en el dicho monte lo sepultaron. Desde entonces, de los huesos de la santa emana permanentemente un delicioso aroma que devuelve la salud a cuantos enfermos lo aspiran" $" 66$.

\footnotetext{
463 RÉAU, Louis: Iconografía de los santos. A-F..., op. cit., p. 277.

464 Ídem, p. 276.

465 VORÁGINE, Santiago de la: op. cit., Tomo II, p. 770.

466 Ídem, p. 772.
} 
La cabeza cortada que se encentra a los pies de Catalina es la del emperador Maximiano, torturador y asesino de la santa ${ }^{467}$. Santiago de la Vorágine refiere que el verdugo también pudo ser el emperador Majencio ${ }^{468}$. La cabeza aparece con los ojos cerrados y tocada por un turbante, aludiendo a su carácter oriental, y una corona. Posee una espesa cabellera y barba. Está modelada blandamente. Las características faciales son similares a las que exhibe la santa.

En uno de los legajos que custodia el Archivo Histórico Provincial creo haber encontrado un dato que pudiera tener relación con esta obra, con el San Pablo que estudiaremos a continuación, con otra que no conocemos, o quizás con ninguna. En dicho documento figura el testamento de una religiosa del Convento de Santa Catalina llamada Jerónima de Ávila ${ }^{469}$. Si tenemos en cuenta que en el Valladolid de entonces el apellido no era demasiado común y que en el árbol genealógico del escultor figura una Jerónima de Ávila ${ }^{470}$, podemos llegar a la conclusión de que pudiera haber habido algún encargo al escultor por parte del cenobio auspiciado por la dicha religiosa, la cual conocía bien las dotes artísticas de su primo, ya que ésta, la referida Jerónima de Ávila, familiar de nuestro escultor, era hija de Juan de Ávila, tío paterno de nuestro Ávila. Dado que no existe la certeza absoluta de que la imagen fuera realizada por nuestro escultor habría que considerar otras opciones, siendo una de ellas, el que hubiera sido donada por un particular.

\footnotetext{
467 RÉAU, Louis: Iconografía de los santos. A-F..., op. cit., p. 277.

468 VORÁGINE, Santiago de la: op. cit., Tomo II, p. 772.

469 A.H.P.V., Leg. 2.768, f. 679.

$470 \quad$ "En doce de octubre de mil y seiscientos y cuarenta y ocho años bauticé e impuse los santos óleos conforme manda el Santo Concilio a Jerónima hija de Juan de Ávila y de Magdalena de Castro fueron padrinos el licenciado Francisco García clérigo presbítero capellán de esta iglesia y María Maldonado testigos Diego de Soto Beltrán y Santiago Fernández y lo firmé abogados a San Juan Bautista y Nuestra Señora”. A.G.D.V., Santiago, 1643B, f. 91.
} 


\section{COVARRUBIAS. COLEGIATA DE SAN COSME Y SAN DAMIÁN}

\section{SAN JOAQUÍN, SANTA ANA Y LA VIRGEN NIÑA (h. 1680-1690)}

En el museo de la Colegiata de San Cosme y San Damián de Covarrubias (Burgos) se conserva un delicioso grupo de la Sagrada Familia de la Virgen (Fig. 86) que viene a copiar puntualmente el conjunto de la misma iconografía conservado en el Colegio de los Ingleses de Valladolid, si bien en esta ocasión es de mucho menor tamaño, ya que se encuentra metido dentro de un pequeño escaparate.

Dada la exactitud entre ambos grupos no voy a entrar a comentar cada una de las imágenes, sino solo a señalar las similitudes y diferencias existentes entre ellos. Lo primero que cabe decir es que la composición del grupo, en general, y de cada una de las esculturas, en particular, es totalmente similar; a excepción de la Virgen Niña que, si en el Colegio de los Ingleses giraba levemente el rostro hacia la izquierda mirando a su padre, en esta ocasión la gira hacia la derecha observando a su madre. El cambio de posición del giro del rostro se ve continuado en el cambio de pierna adelantada: en aquélla era la derecha, en esta la izquierda.

Por lo demás las esculturas son puntuales, sus vestimentas y colores exactos, sus rostros parecen calcados, los pliegues son idénticos, etc... Tampoco difieren en los atributos que portan: Santa Ana, en su mano izquierda, un libro; y San Joaquín, en su derecha, un cayado. Asimismo, vuelve a aparecer un elemento que hemos recalcado en las muchas esculturas de San Joaquín que hemos atribuido a nuestro escultor y en las cuales nunca falta. Se trata de la decoración de la parte inferior de la sobre túnica, en la cual el borde está compuesto por una serie de entrantes y salientes que forman algo parecido a pequeños arcos de herradura. También son idénticos en todas las imágenes del padre de la Virgen la serie de pliegues redondeados concéntricos de la manga derecha de la túnica, elemento que también observamos en la de Santa Ana.

En cuanto a los rostros, éstos parecen más naturales y blandos que aquéllos; quizás los del Colegio de los Ingleses hayan sufrido una restauración demasiado concienzuda. Lo mismo podemos decir de la calidad de las barbas y cabelleras. Sin duda la mejor talla del conjunto es la de San Joaquín, pues su cabeza es simplemente magnífica. Estamos ante un gran ejemplo de lo que era la "pequeña escultura" producida por los talleres vallisoletanos, tan desconocida si la comparamos con la andaluza o la napolitana, también muy presente en Valladolid y en Castilla.

Desconocemos la procedencia de este grupo, aunque el hecho de se encuentre dentro de un escaparate parece indicar que pudo ser una donación de algún particular a la colegiata, quizás de algún clérigo. 


\section{SALAMANCA. MUSEO CATEDRALICIO}

\section{SAN JOAQUÍN CON LA VIRGEN NIÑA (h. 1680-1690)}

En la actualidad no tenemos noticia de ninguna obra documentada ni atribuida a nuestro escultor en la provincia de Salamanca. Pienso que se puede relacionar con su estilo un San Joaquín con la Virgen Niña (Fig. 87) conservado en la capilla de Santa Catalina del Museo Catedralicio de Salamanca, ubicada en el claustro de la catedral vieja. Mariano Casas Hernández nos explica la probable procedencia de esta escultura: con anterioridad a su inclusión en el museo catedralicio, había ocupado una de las dos hornacinas del lado largo de la capilla de la Virgen de la Cabeza, sita en el lado del Evangelio de la propia catedral $^{471}$. Allí permanecieron al menos desde el año 1867, en que Modesto Falcón describe que "en los arcos de frente están colocadas dos regulares estatuas de talla natural"; años después, en 1900, el padre Juan Antonio nos aporta la identidad de estas dos imágenes: "También es excelente escultura, de tamaño natural, un San Buenaventura que está en el arco contiguo a San Joaquín" ${ }^{472}$. El hecho de que la Virgen Niña vista el hábito carmelitano, como ya veremos, lleva a Casas Hernández a pensar este hecho unido al de que "en la catedral no quede noticia alguna de haber existido altar consagrado al santo patriarca Joaquín, y teniendo asimismo en consideración la alta estima y devoción que al padre de la Virgen se expandía desde el Carmelo, nos induce a considerar que su origen no haya que buscarlo en la catedral, sino en una comunidad desaparecida. Concretamente creemos que la imagen procede del convento de San Antonio, de carmelitas calzados" $"$ "773.

La base para su atribución es bien clara. Se trata de la total semejanza que guarda este San Joaquín con otros que hemos visto y atribuido al escultor tanto en el Monasterio de San Benito de Valladolid, el Colegio de los Ingleses de la misma localidad y la Colegiata de Covarrubias; todos ellos de diferentes tamaños y modalidades, puesto que en algunos aparece el santo solamente con la Virgen Niña y en otros formando la "Sagrada Familia de la Virgen". En este sentido la imagen salmantina viene a combinar elementos de todas ellas dado que no son totalmente exactas: del grupo de San Benito toma el elemento de tener a la Virgen recogida con uno de sus brazos, si bien en vez de estarlo en el derecho es en el izquierdo; de los ejemplares del Colegio de los Ingleses y de la Colegiata de Covarrubias toma el detalle de agarrar el cayado, puesto que no se tiene que preocupar por sujetar a la Virgen, dado que se sitúa en la posición central de la Sagrada Familia. A todo ello añade la composición inversa del cuerpo, puesto que mientras que todas las anteriores miran hacia la derecha, éste lo hace hacia la izquierda. La otra diferencia radica en la policromía, bastante distinta a la de las imágenes mencionadas; puesto que, mientras que las otras visten túnica y sobre túnica verde y manto rojo, esta salmantina va ataviada con túnica y manto rojo y sobre túnica dorada.

\footnotetext{
471 CASAS HERNANDEZ, Mariano: Escultura barroca en Salamanca: Imagen, discurso y culto en la catedral [Tesis doctoral], Tomo II, Universidad de Salamanca, Salamanca, 2013, p. 331.

$472 \quad$ Ibídem.

473 Ídem, p. 335.
} 
Por lo demás, tanto el ademán, vestimenta y rostro, es totalmente exacto a todos ellos. San Joaquín figura de pie, con una pierna adelantada formando un leve contraposto. El torso y la cabeza están levemente ladeados hacia la izquierda, observando amorosamente a su hija, a la cual sostiene con su brazo izquierdo, mientras que con el derecho sujeta un cayado. El rostro es un calco de los otros tres ejemplares, si bien no tiene unas arrugas tan acusadas. También el tipo de vestimenta es calcada: porta túnica, sobretúnica y manto. La túnica le llega hasta los pies, dejándonos ver tan solo la punta de estos; por su parte, la sobretúnica es algo más corta, extendiéndose hasta las rodillas, teniendo en la parte inferior un motivo muy característico del que ya hablamos al analizar las otras imágenes: el borde está compuesto por una serie de entrantes y salientes que forman algo parecido a pequeños arcos de herradura. Ambas túnicas están ceñidas por un cíngulo rojo, el cual sirve para sostener, de manera lateral, el manto que le cubre la espalda y le cae por el hombro izquierdo. Los pliegues también son semejantes, por lo que la fecha de ejecución oscilará entre las cronologías de las piezas anteriormente comentadas. Una fecha posible sería la que engloba los años 1680-1690. 


\section{VALLADOLID. IGLESIA DE SANTIAGO APÓSTOL}

\section{SAN JUAN BAUTISTA (h. 1681)}

Esta deliciosa escultura de San Juan Bautista (56 cms.) (Fig. 88) tan solo ha sido tratada en dos ocasiones: a raíz de una exposición titulada "La pequeña escultura en Valladolid: siglos XVI-XVIII", comisariada por Jesús Urrea; y poco después en el Catálogo Monumental de Valladolid. En la primera de estas ocasiones, Urrea la consideraba como el "boceto acabado del mismo Santo que hizo Juan de Ávila para el retablo mayor de la parroquia de Santiago entre 1698 y 1702. Sin embargo parece obra más avanzada por el tratamiento de su cabellera y barba así como por la elegancia de su gesticulación y la blandura de su modelado" ${ }^{474}$. Dos años después, Martín González y el propio Urrea en la redacción del Catálogo Monumental volvían a considerarlo como "el modelo que dio Juan de Ávila para el del retablo mayor" ${ }^{475}$. Por entonces la talla se encontraba en la sacristía. En la actualidad está guardado, junto a otras esculturas, en la casa parroquial.

San Juan Bautista, cuya figura parece trazar una helicoidal, está representado de pie sobre una peana que parece simular el desierto. A su izquierda una roca, sobre la que se encuentra un libro que sirve, a su vez, de peana a un cordero. La escultura del Precursor sigue de cerca el tantas veces aludido modelo común de la escuela vallisoletana y, asimismo, que Ávila utilizó para modelar sus Bautistas del retablo de la iglesia de Santiago y del colateral de San Felipe Neri. Las únicas diferencias que hayamos entre ellas son la ausencia del manto rojo que cae sobre el hombro y la añadición de un libro bajo el animalillo. El santo viste la típica piel de camello, coincidente con los otros ejemplares de Ávila hasta en las aberturas que tiene en sendas piernas a la altura de los muslos, y en la de la parte superior del vestido que nos permite ver una porción del tórax, apenas definido si lo comparamos con las otras tallas. En su mano derecha, cuyo brazo está dispuesto con suma elegancia, sujetaría una vara crucífera, mientras que, con el brazo izquierdo, que traza una diagonal, señala al cordero que tiene a sus pies. El dedo pulgar de su mano derecha está muy mal tallado, demasiado grande respecto al resto, muy desproporcionado. La anatomía es blanda, no hay más que comprobarlo en las piernas y en los brazos, pero no está tan apurada como en sus dos "hermanos mayores", si bien hace intención de marcar las clavículas, las rodillas y cada uno de los pies.

Sin descartar, para nada, la opinión sostenida por Martín González y Urrea de que esta escultura fuera el boceto que talló Ávila para el San Juan Bautista del retablo mayor de esta iglesia entre los años 1698-1702, me gustaría establecer una cronología diferente. Pienso que en realidad no se trata de un boceto, sino de una obra independiente bastante anterior, concretamente de hacia el año 1681. En este año, Ávila se compromete a realizar para esta misma iglesia un Santiago Apóstol procesionable, el que actualmente

\footnotetext{
$474 \quad$ URREA FERNÁNDEZ, Jesús (dir.): La pequeña escultura ..., op. cit.

475 MARTÍN GONZÁLEZ, Juan José y URREA FERNÁNDEZ, Jesús: Catálogo Monumental de la provincia de Valladolid. Tomo XIV..., op. cit., p. 203.
} 
preside la sacristía. Entre esta obra y el San Juan Bautista que tratamos ahora las coincidencias, sobre todo el rostro, pero también en los paños, saltan a la vista.

Poseen el mismo rostro estrecho, alargado e inclinado levemente hacia la derecha, así como una idéntica manera de tallar el pelo, muy sumaria, propia de sus primeros momentos (todavía no vemos sus famosos cabellos que parecen pelucas). También es coincidente la forma de llevar a cabo la nariz y la línea horizontal que marcan sus cejas, así como los ojos, la pequeña boca entreabierta, los bigotes y, sobre todo, esa barba minimizada a tan solo unos pocos mechones simétricos que se revuelven sobre sí mismos. Los pliegues verticales y paralelos a la altura de la cintura son también similares. Por el contrario, el Bautista parece una obra bastante más trabajada y moderna que el arcaico Santiago. Por todo ello creo que procede fecharla, con todas las reservas, hacia el año 1681.

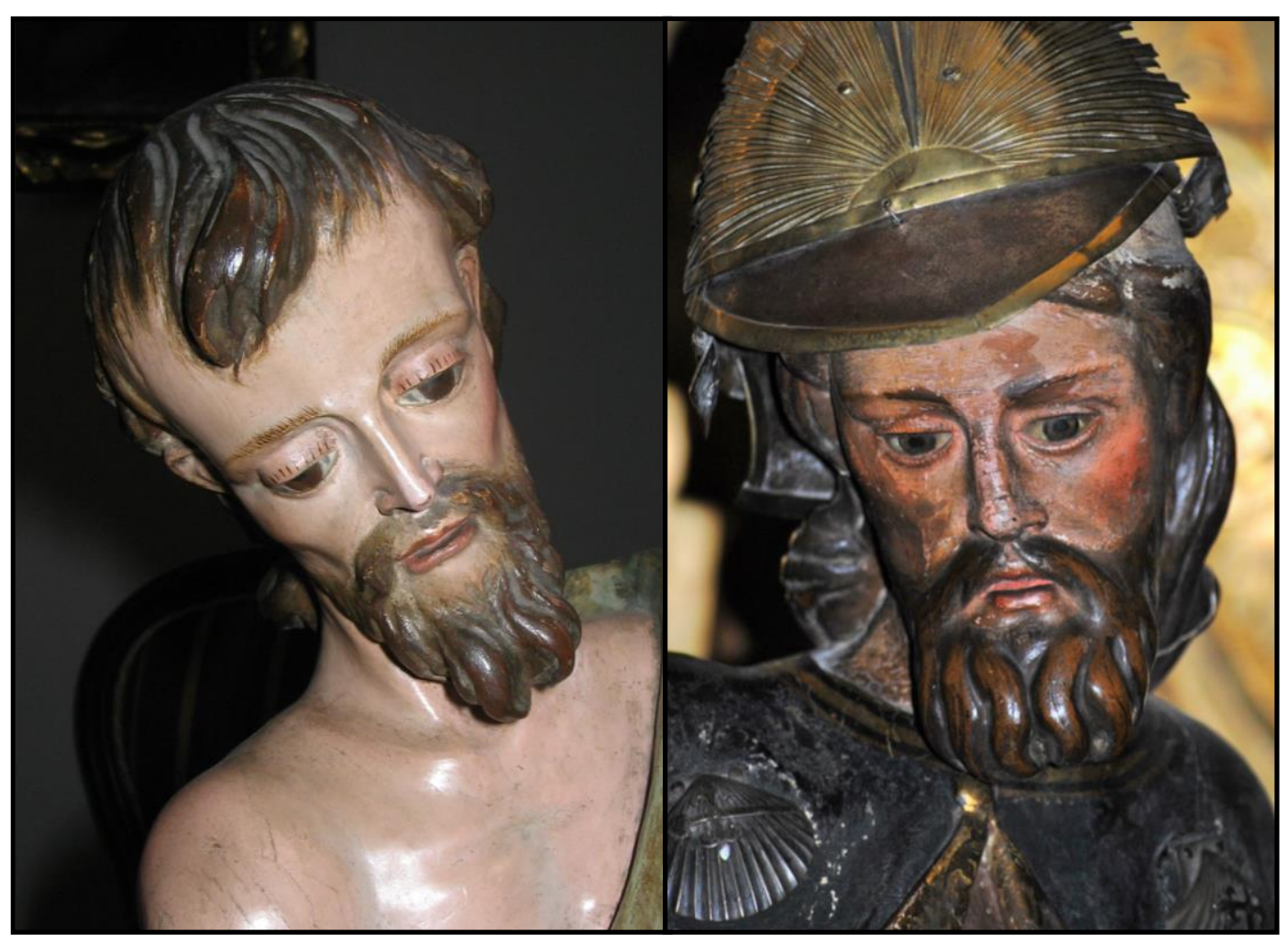

Il. 25- Comparación entre los rostros del San Juan Bautista (atrib. Juan de Ávila) y el Santiago Matamoros de Juan de Ávila. Iglesia de Santiago. Valladolid. 


\section{VALLADOLID. CAPILLA DE LA CONGREGACIÓN DE LA INMACULADA CONCEPCIÓN}

En la antigua capilla de la Congregación de la Inmaculada Concepción, actualmente conocida como Capilla de la Inmaculada Concepción o de la Congregación del Centro Diocesano de Espiritualidad, que formaba parte del amplísimo complejo jesuita del Colegio de San Ambrosio se hallan tres retablos cuyas esculturas pueden atribuirse a nuestro escultor, y de hecho así lo han hecho algunos expertos en la materia. Antes de analizarlas situemos un poco el lugar en el que se encuentran estas tallas.

El colegio de San Ambrosio fue la segunda de las fundaciones jesuíticas en la ciudad, tras el de San Ignacio. Explica Fernández del Hoyo que la compañía estableció este segundo colegio en el año 1567 "ocupando diversas casas contiguas, sitas en la calle del Salvador (hoy del Santuario) perteneciente a la parroquia de San Esteban, que los jesuitas adquirieron a la familia Cuadra Avellaneda primero y luego a los López de Calatayud"476. Posteriormente, en 1595 el colegio recibió un importante impulso económico gracias a los 7.000 ducados que les proporcionó don Diego Romano, arzobispo de Tlaxcala (Nueva España), y pariente lejano de San Ignacio de Loyola ${ }^{477}$. Siguió como establecimiento jesuita hasta la expulsión de estos en el 1767. A partir de entonces sus amplios edificios se destinaron a dos instituciones: la iglesia pasó a ser la parroquia de San Esteban el Real, demoliendo previamente la primitiva, y el resto pasó a ser el Colegio de los Escoceses, siendo la capilla que nos ocupa la iglesia de aquél colegio. Cuando en 1988 los escoceses marchan a Salamanca, la diócesis adquiere el inmueble y lo destina al Centro Diocesano de Espiritualidad del Sagrado Corazón de Jesús, siendo la capilla el oratorio del mismo.

La capilla debió comenzarse a construir en el segundo cuarto del siglo XVII, si bien sobrevino un largo que parón que no permitió reanudar las obras hasta noviembre del año 1680. Señala Fernández del Hoyo el hecho de que, por lo general, la arquitectura religiosa vallisoletana suela realizarse en dos etapas diferentes ${ }^{478}$. Efectivamente, el 4 de noviembre de 1680 los maestros de obras Juan Tejedor Lozano y Francisco García se conciertan con los "congregantes de la congregación de la Purísima Concepción de Nuestra Señora sita en el colegio de San Ambrosio de la Compañía de Jesús" que "tienen empezada la fábrica de la capilla de la dicha congregación y han acordado acabarla" (DOCUMENTO 52). Por encontrarse deteriorado el documento desconocemos la fecha en que se ajustaron entregar la obra. Sea como fuere percibirían 13.100 reales de vellón. Según Fernández del Hoyo, las condiciones a las que se comprometían los artífices se derivaba en "en el cerramiento exterior de la cabecera de la capilla -mientras que en el cuerpo de la misma estaría ya cerrado tiempo atrás-y al abovedamiento interior de todo el espacio" ${ }^{479}$. La citada profesora define la iglesia de la

\footnotetext{
476 FERNÁNDEZ DEL HOYO, Ma Antonia: "Notas sobre el Colegio...,, op. cit., p. 77.

477 Ibídem.

$478 \quad$ Ídem, p. 82.

479 Ídem, p. 83.
} 
siguiente manera: "de una sola nave, cuyo eje discurre paralelo a la actual calle de Alonso Pesquera (antes de San Esteban), dividida en cinco tramos más el presbiterio y coro alto a los pies. Se cubre con bóveda de cañón con lunetos y cúpula rebajada en la capilla mayor, y posee sacristía propia" ${ }^{480}$.

Para fechar las esculturas nos ayuda bastante el hecho de que en este año de 1680 se termine la obra de la capilla. Puesto que este dato unido al de que los retablos poseen una tipología propia de estos años nos conduce a que tanto éstos como sus imágenes fueron hechos poco tiempo después de acabadas las obras ${ }^{481}$. Además, no cabe duda de que ya tenían en mente realizar los retablos. Así podemos entreverlo en las condiciones: "y en el altar mayor se han de poner dos gradas de piedra y hacerse el altar de yeso y madera y su peana de madera con sus molduras y hacer el pedestal para el retablo de yeso y (...) en la parte que se juzgaren conveniente puerta para la sacristía y asimismo para los dos altares de los lados se han de hacer dos arcos de yeso y ladrillo y hacer dichos dos altares de yeso y madera con sus peanas guarnecidas de madera con sus molduras" $" 482$. Por lo tanto, la cronología aproximada sería hacia el 1681, año en que se acabaría la obra arquitectónica y se procedería al amueblamiento interior.

El retablo mayor, que encaja perfectamente en la cabecera del templo está completamente articulado a través de la columna salomónica, la cual se utiliza con profusión. El retablo tiene un pequeño banco, un solo cuerpo con una hornacina central y un ático con un relieve dentro de una portada, situada en la perpendicular de la hornacina comentada. El cuerpo está flanqueado por tres columnas a cada lado, dos inmediatas a la hornacina, la más cercana adelantada y la otra atrasada, mientras que la tercera se halla en el extremo. Todas ellas sujetan trozos de entablamento que hacen que la línea de imposta sea muy quebrada, con entrantes y salientes, un juego muy barroco. El ático, rematado en semicírculo, y coronado por una tarjeta vegetal, sigue la misma distribución que el cuerpo, con la exclusión de las columnas extremas ya que los lados se cierran en el cuerpo. Su construcción ha sido relacionada con la obra de Francisco Billota $^{483}$. La hornacina principal la ocupa una preciosa Inmaculada Concepción que sigue fielmente el modelo implantado por Gregorio Fernández. Por su parte, el relieve del ático presenta a la Santísima Trinidad y una gloria angélica.

Los dos retablos colaterales son idénticos. Apeados sobre un amplio zócalo de piedra, poseen un diminuto banco y un único cuerpo que se funde con el ático. El cuerpo se compone de una hornacina rematada con un arco de medio punto con el intradós decorado con flores. Lo sostienen dos columnas salomónicas que soportan el entablamento, el cual deriva en sus entremos en dos columnas salomónicas, algo más

\footnotetext{
$480 \quad$ Ídem, p. 82.

481 El Catálogo Monumental de Valladolid fecha tanto el retablo mayor como los dos colaterales indistintamente en el último cuarto del siglo XVII o a fines del mismo. MARTÍN GONZÁLEZ, Juan José y DE LA PLAZA SANTIAGO, Francisco Javier: Catálogo Monumental de la provincia de Valladolid. Tomo XV..., op. cit., p. 310.

482 FERNÁNDEZ DEL HOYO, Ma Antonia: "Notas sobre el Colegio...”, op. cit., p. 83.

483 MARTÍN GONZÁLEZ, Juan José y DE LA PLAZA SANTIAGO, Francisco Javier: Catálogo Monumental de la provincia de Valladolid. Tomo XV..., op. cit., p. 310.
} 
salientes que las anteriores. A partir de los laterales surge el ático, que no deja de ser sino una prolongación de cuerpo. Se va retranqueando hasta alcanzar la parte superior, curvada, en cuyo centro hay un gran medallón vegetal y una cabecita de ángel. En el interior de ambos retablos se disponen, afrontados, San Joaquín y Santa Ana.

Como vemos los tres retablos conforman un mensaje claramente mariano. Podríamos decir que, en cierto, modo, se trata de dos Trinidades. La celeste y la de María (San Joaquín, Santa Ana y la Virgen).

El primero en atribuir estas esculturas a un autor fue Martín González, el cual optó por Juan de Ávila, si bien solamente las de San Joaquín y Santa Ana. Tanto en el relieve de la Trinidad como la Inmaculada tan solo daba la cronología: fines del siglo XVII ${ }^{484}$. Con posterioridad, Urrea califica las esculturas de los retablos de la iglesia expresando ciertas dudas: "quizá sean obra de Juan de Ávila y se realizarían en el último cuarto del siglo XVII" ${ }^{485}$. Al no especificar a qué esculturas se refería cabe entender que englobaba en ellas al relieve e Inmaculada el retablo mayor. Finalmente, el propio Martín González y Plaza Santiago, en el Catálogo Monumental de Valladolid vuelven a las tesis del primero: San Joaquín y Santa Ana son del "estilo de Juan de Ávila", mientras que no proporcionan atribución al relieve e Inmaculada del retablo mayor ${ }^{486}$.

Comparto la atribución de las esculturas de los padres de la Virgen a Juan de Ávila. Además, creo que se debe a su gubia la Inmaculada puesto que, como veremos, poseen rasgos del estilo de nuestro escultor. De lo que me quedan más dudas es del relieve, muy tosco, incluso hasta para los poco agraciados relieves a los que nos tiene acostumbrado. Si bien las imágenes de Dios Padre y Dios Hijo mantienen cierta dignidad, la elaboración de la gloria angélica y las cabezas de estos es francamente vulgar y torpe. Todo ello me lleva a que, de momento, no pueda atribuirle este relieve a Ávila. Cabría la posibilidad de que el ensamblador acordara la realización del retablo mayor, teniendo la condición específica de entregar aquel relieve, obra que subcontrataría con algún maestro de segunda, o tercera, fila.

\section{SAN JOAQUÍN (h. 1681)}

San Joaquín (144 cms.) (Fig. 89) se sitúa en el retablo de la epístola. La talla tiene un porte monumental y elegante, incrementado por el suave contraposto. Aparece de pie, con la pierna izquierda adelantada, si bien el movimiento de la rodilla parece algo antinatural. Adelanta y recurva el brazo derecho, disponiendo la mano de una manera muy refinada, simulando que pudo sujetar algún objeto. Aunque tampoco es improbable que se trate tan solo de un gesto teatral, y que no agarraba nada con sus dedos. Podríamos suponer, dado que, como hemos dicho, la capilla posee un mensaje

\footnotetext{
484 MARTÍN GONZÁLEZ, Juan José (dir.): Inventario artístico de Valladolid..., op. cit., p. 35.

485 URREA FERNÁNDEZ, Jesús: Guía histórico-artística ..., op. cit., p. 56

486 MARTÍN GONZÁLEZ, Juan José y DE LA PLAZA SANTIAGO, Francisco Javier: Catálogo Monumental de la provincia de Valladolid. Tomo XV..., op. cit., p. 310.
} 
inmaculadista, que portara un cesto con dos palomas, la ofrenda ritual en el templo ${ }^{487}$. Con su mano izquierda agarra fuertemente el bastón que le ayuda a caminar. Viste túnica larga verde con labores doradas a punta de pincel. Por encima, un manto marrón anudado al ceñidor y que le cae por el lado contrario sobre el hombro derecho, anudándose en ese mismo brazo. Los pliegues son profundos, blandos e incurvados, pero a la vez parecen algo confusos.

La cabeza tiene gran fuerza. Es muy noble y distinguida. Dada la cronología que le atribuimos y sus grandes semejanzas con la escultura de San Andrés que talló para el retablo de Lerma podríamos decir que éste San Joaquín fue el modelo para aquél. Asimismo, se percibe en ella el fuerte influjo que Fernández ejercería sobre nuestro escultor. Cómo podemos observar, San Andrés y San Joaquín tienen en común la manera de disponer los cabellos sobre la frente, sinuosos, revueltos, mojados. Pelo tallado muy pormenorizadamente, de una manera muy cuidada y delicada, en finas madejas. Esta misma solución, que también está presente en el San Pablo de Lerma, será ampliamente utilizada por su hijo Pedro de Ávila (claros ejemplos son los de los San Joaquines del Santuario Nacional de la Gran Promesa y del Convento de las Brígidas, ambos en Valladolid). El cabello de los laterales también está revuelto, pero permite verle las dos orejas. Finalmente utiliza el mismo modelo de barba y bigote: bigotes anchos y barba larga formada por dos grandes mechones simétricos finalizados en dos caracolillos opuestos. El modelado es muy blando, y capta perfectamente la piel arrugada del anciano Joaquín. Boca pequeña, entreabierta, enseñando los dientes superiores. Ojos de tapilla. Ceño levemente fruncido. Nariz recta, simétrica, que se ensancha según descendemos hacia las aletas nasales, levemente pronunciadas. Las fosas nasales también están talladas. Pudiera ser que la cabeza hubiera sido esculpida aparte del cuerpo.

De confirmarse la atribución se convertiría en una de las piezas principales de su producción por la calidad exhibida en el modelado del rostro. La suciedad que posee resta parte de la elegancia que se le supone.

\section{SANTA ANA (h. 1681)}

Santa Ana (144 cms.) (Fig. 90) se sitúa en el colateral del Evangelio. La escultura sigue puntualmente las maneras vistas en el San Joaquín, con la excepción de que esta vez el contraposto se hace con la pierna derecha, de tal manera que se contrapone y complementa con el de su marido, realizado con la izquierda. Este mismo efecto de contraposición-complementación lo vemos reflejado en la manera de disponer el manto: si en San Joaquín se anudaba en la parte izquierda del ceñidor y le caía por el hombro de ese mismo lado, en Santa Ana ocurre todo lo contrario, se ciñe al lado derecho y cae por ese mismo hombro. Viste, asimismo, túnica larga blanca que solo nos permite verle las puntas de los zapatos y el citado manto, de color azul. Ambas prendas están ricamente

487 RÉAU, Louis: Iconografía de los santos. G-O..., op. cit., p. 153. 
policromadas con las tantas veces citadas cenefas. La cabeza y el pelo los cubre con un velo, que en la parte de la frente está suavemente ondulado. El escultor consigue una gran finura en la talla de esta pieza.

Adelanta y recurva el brazo izquierdo, mientras que el derecho simplemente lo estira levemente. Ambas manos, cuyos dedos están dispuestos muy elegantemente parece ser que también pudieron portar algún objeto o bien, como dijimos con San Joaquín, ser simples gestos teatrales, tan propios del Barroco. Aunque no lo dijimos al hablar de San Joaquín, éste giraba levemente su cabeza hacia la derecha, como observando a su hija en el retablo mayor. Gesto similar hace Santa Ana, si bien en este caso mira hacia su izquierda.

Como nos ocurre en otras ocasiones, Ávila no plasma tan bien los rostros de las figuras femeninas. Además, la vejez, representada a través de las arrugas y la flaccidez de la cara, no está tan bien conseguida como en el caso de San Joaquín. Santa Ana hace una extraña mueca apretando los labios, movimiento que vemos plasmado en las arrugas visibles en el surco naso labial y en las comisuras de los labios. Ojos de tapilla.

\section{INMACULADA CONCEPCIÓN (h. 1681)}

La Inmaculada (Fig. 91) que preside el retablo mayor de la capilla sigue fielmente el modelo establecido por Gregorio Fernández, si bien esta se presenta con unos pliegues mucho más movidos. En algo tenía que influir el tiempo que había transcurrido desde la muerte del gran maestro. La otra diferencia, más o menos acusada, es la forma general adoptada por la Inmaculada, algo más achaparrada y triangular que el común de las fernandescas.

A pesar de que esta pieza es ciertamente desconocida, al igual que lo es el propio oratorio, es, a no dudarlo, una de las mejores repercusiones de su Inmaculada. Dada su similitud creo procedente utilizar la explicación utilizada por Martín González para describir esta iconografía: "Tiene la cabeza redonda, cuello cilíndrico. Los largos cabellos se disponen simétricamente sobre el manto. Ordinariamente, como suelen ser imágenes procesionales, también se disponen por atrás. Las manos adorantes, levemente ladeadas. Túnica blanca, manto azul formando masas de pliegues muy quebrados en el tercio inferior. Hay dos variantes respecto al "trono": un grupo de cabezas de ángeles (normalmente tres), o un dragoncillo, símbolo del demonio". En este caso concreto que nos ocupa se trata del modelo de tres cabezas aladas de ángeles. Las dos de los lados tienen las alas extendidas, la cabeza ladeada y un mechón de pelo sobre la frente; mientras que la central mantiene la cabeza recta, las alas cerradas y la frente despejada. Los tres miran hacia la Virgen. Prosigue Martín González: "También figura la media luna (...) Por la parte posterior, el manto forma un gran nudo de pliegues, que estarían sujetos con alfiler (...) La túnica se pinta de blanco y cubre de flores. El manto se pinta de azul, pero se siembra de estrellas, bien pintadas o con tachones de bronce. Particular esmero se ponía en las orlas. Aquí figuraban escenas a 
punta de pincel, "piedras contrahechas", pero también "eses" metálicas, rosetas y otros adornos, de bronce, dorados y con piedras engastadas. En el borde se colocaba labor e encaje. En ocasiones el cintillo que ajusta el talle presenta lazo de tela con flecos" ${ }^{\text {"48 }}$. Cómo podemos comprobar, la Inmaculada que atribuimos a Ávila se ajusta a la perfección a lo narrado, si bien en esta ocasión no figuran postizos, como pudieran ser las "piedras contrahechas", "eses metálicas" ni los mencionados adornos de bronce o piedras engastadas. Es muy interesante la orla del manto, muy similar a las que llevamos aludiendo continuamente, si bien, en este caso, vemos a trechos figuras de angelitos afrontados que sostienen diversos elementos que aluden a la concepción virginal de María. Así, por ejemplo, en los ángulos inferiores, a ambos lados, vemos a una pareja de angelitos sostener el anagrama del "Ave María"; mientras tanto, a la altura de las rodillas, dos parejas de ángeles, una a cada lado, sostienen una especie de torre, ambas diferentes. Estas últimas sin duda aludirán al carácter de María como "fortaleza", Turris Davis cum propugnaculis ("Torre de David con baluartes") ${ }^{489}$. Además de estos detalles, cabe señalar que, en la túnica, entre los múltiples motivos vegetales, se pueden observar muchas coronas, que aludirán a su condición de Reina del Cielo, epíteto que, asimismo, aparece en el título de las letanías dedicadas a la Virgen por Sor María de Jesús de Ágreda: Letanía y nombres misteriosos de la Reina del Cielo, mi Señora.

A pesar de las numerosas Inmaculadas fernandescas, o de colaboradores suyos, habidas en la capital, no cabe duda de que Ávila tomaría como modelo la tan elogiada, y tristemente desaparecida, o en paradero desconocido, Inmaculada del Convento de San Francisco, que, además, se encontraba colindante a su taller, pudiendo visitarla todas las veces que le fuera necesario.

\footnotetext{
488 MARTÍN GONZÁLEZ, Juan José: El escultor Gregorio ..., op. cit., p. 224.

489 TRENS, Manuel: María: iconografía de la virgen en el arte español, Plus Ultra, Madrid, 1946,
} p. 153. 


\section{VALLADOLID. ORATORIO DE SAN FELIPE NERI}

\section{SAN FELIPE NERI (h. 1683)}

La escultura pétrea de San Felipe Neri (Fig. 92) que preside la hornacina de la fachada del oratorio del mismo nombre puede adscribirse a la gubia de nuestro escultor con bastante facilidad. Así lo vio ya hace unos años Rebollo Matías ${ }^{490}$. La cercanía del rostro de esta escultura, a pesar de estar realizada en piedra, con otras obras de Ávila es bastante llamativa. Así, por ejemplo, no hay más que compararla con el San Francisco de Sales, de esa misma iglesia, en la forma de resolver la nariz, los ojos, la elevación de las cejas, los bigotes e incluso la barba, con un pequeño mechón más ancho en el centro flanqueado por los ondulados. En esta ocasión no vemos sus típicos cabellos que caen sobre la frente, si bien, en esta ocasión, tampoco le venía bien ni al tema representado ni al material. Siempre se ha pensado que la escultura venía a representar una copia del San Felipe Neri del retablo mayor, pero más bien creo que es al revés: éste último es una versión del de la portada, dado que sería colocado poco antes de inaugurarse el oratorio en el año $1683^{491}$

"Pippo buono" (Felipe el bueno), fundador del Oratorio, había nacido en la capital de la Toscana en el año 1515. Conocido como el "Apóstol de Roma", falleció en esta ciudad en 1595. Su ascenso a los altares fue muy rápido ya que Pablo V le beatificó en 1615 y Gregorio XV le canonizó en 1622. Uno de sus hechos más extraordinarios fue la aparición, durante una de sus enfermedades, de la Virgen con el $\mathrm{Niño}^{492}$.

El santo aparece de pie, sobre una pequeña peana con hojas en las esquinas. Viste el hábito de la Congregación del Oratorio, compuesto por túnica y capa negra. La rigidez de la escultura, y en especial de los extremos de la capa, es máxima. Sin duda esto se deberá al material pétreo y a la escasa práctica del escultor en el trabajo de este elemento. Desde Francisco del Rincón no existió en Valladolid ningún artífice consagrado a la talla de la piedra o del mármol. También es verdad que no existieron muchas oportunidades porque apenas se fabricaron sepulcros y esculturas monumentales en esta época, y, además, la mayoría de las conservadas permanecen como anónimas. Aunque fue restaurada hace unos años, la escultura se encuentra en bastante mal estado (ha perdido la mitad de su mano derecha), al cual han contribuido de manera decisiva las palomas. En su mano derecha porta de una manera muy elegante, con la palma vuelta hacia arriba, un libro cerrado, que sirve de peana a una pequeña imagen de la Inmaculada Concepción, que aludirá a la aparición sufrida por el santo.

\footnotetext{
490 REBOLLO MATÍAS, Alejandro: La Iglesia-Oratorio ... op. cit.

491 MARTÍN GONZÁLEZ, Juan José y URREA FERNÁNDEZ, Jesús: Catálogo Monumental de la provincia de Valladolid. Tomo XIV..., op. cit., p. 292.

492 RÉAU, Louis: Iconografía de los santos. A-F..., op. cit., p. 514.
} 


\section{FUENTECÉN. ERMITA DE LA CONCEPCIÓN}

\section{INMACULADA CONCEPCIÓN (h. 1685)}

En la ermita de la Concepción se guarda una Inmaculada que, siguiendo el famoso modelo establecido por Gregorio Fernández, Payo Hernanz atribuye a Juan de Ávila o a José de Rozas. Dado que no he podido acceder a verla, tendremos que conformarnos con lo que escribe el referido investigador: "Un buen ejemplo [de Inmaculada] lo tenemos en la talla que preside el retablo de la ermita de la Concepción de Fuentecén que debió ser ejecutado después de 1685, fecha en la que Jerónimo Sanz costeó esta construcción y su mobiliario litúrgico. La calidad de esta talla, altamente fiel con el modelo vallisoletano, nos hace pensar que la obra pudo ser labrada en la propia ciudad de Valladolid. No hay que descartar la posibilidad de que fuera José de Rozas o Juan de Ávila quien realizó esta talla"493.

493 PAYO HERNANZ, René Jesús: "De los esplendores barrocos a las luces de la razón: retablos y esculturas del siglo XVIII en la Ribera del Duero", Biblioteca: estudio e investigación, No 20,2005 (ejemplar dedicado a: Ensenadas del Duero ilustrado), p. 317. 


\section{VALLADOLID. REAL MONASTERIO DE SAN QUIRCE}

\section{ESCULTURAS DEL RETABLO MAYOR (h. 1688-1689)}

Aunque no poseemos la escritura contractual o la reseña de la data en el libro de cuentas del convento, no hay ninguna duda de que el retablo fue realizado por Blas Martínez de Obregón, el más fecundo y prestigioso ensamblador vallisoletano del último tercio del siglo XVII, y primeros años del XVIII, el cual asimismo es el autor documentado de los dos retablos colaterales de la misma iglesia ${ }^{494}$.

A las más que fundadas sospechas se suma el hallazgo de la escritura otorgada el 9 de julio de 1689 por Blas Martínez de Obregón en la cual se obliga a realizar el retablo mayor de la iglesia de Nuestra Señora del Rosario (DOCUMENTO 50). Entre las condiciones que se impuso el ensamblador se encontraban varias en las cuales se ponían como modelos los retablos mayores del Convento de San Quirce y del Colegio de los Ingleses de San Albano ${ }^{495}$, este último realizado en 1677 por el propio Martínez de Obregón, a quien fiaron la obra los escultores Juan Antonio de la Peña y Pedro Salvador "el joven". Centrándonos en las referencias que se hacen del retablo de San Quirce en la citada escritura, se dice, por ejemplo, que "la custodia se ha de ejecutar conforme está en el Convento de San Quirce de esta ciudad y dentro de ella ha de haber su tramoya para descubrir el Santísimo Sacramento"; o que "el primer cuerpo ha de llevar cuatro columnas salomónicas con basas aticurvas y capiteles corintios compuestos y las pilastras lo mismo y estas columnas han de ser de cuatro vueltas revestidas y bien pobladas de hojas y vástagos y racimos de parra y los intercolumnios se han de ejecutar como lo demuestra la traza y está ejecutado en San Quirce". Por lo tanto, no cabe duda de que el retablo mayor de San Quirce fue realizado por Blas Martínez de Obregón en una fecha inmediatamente anterior al año 1689.

A pesar de todas estas razones, tampoco podemos descartar que fuera realizado por Francisco Billota, siguiendo la traza y las condiciones diseñadas por Blas Martínez de Obregón. Como acertadamente señala Martín González, este retablo es "análogo al retablo de las Brígidas", obra documentada de Francisco Billota ${ }^{496}$. Como vemos, los ensambladores vallisoletanos de la época utilizaban unas soluciones muy similares a la hora de trazar los retablos; también había muchas ocasiones en que se elegía la traza de un maestro, pero se concertaba su construcción con otro.

Un retablo tan espectacular solo era posible llevarlo a buen término si se contaba con numerosos recursos, como era el caso de este importantísimo cenobio. Cuenta Canesi que, en un principio, el convento sufrió “algunos atrasos y temporales trabajos,

\footnotetext{
494 Don Juan José Martín González descubrió que el autor de los retablos colaterales fue Martínez de Obregón mediante la lectura de los libros de cuentas del monasterio. MARTÍN GONZÁLEZ, Juan José: Escultura barroca castellana ..., op. cit., p. 318. Por suerte, se ha logrado localizar la escritura por la cual el ensamblador se obligaba a realizar sendos retablos colaterales. (DOCUMENTO 51).

495 MARTÍN GONZÁLEZ, Juan José y DE LA PLAZA SANTIAGO, Francisco Javier: Catálogo Monumental de la provincia de Valladolid. Tomo XV..., op. cit., p. 272.

496 MARTÍN GONZÁLEZ, Juan José: Escultura barroca castellana ..., op. cit., p. 311.
} 
teniendo una iglesia muy estrecha, hasta que tomó su hábito de la Excma. Señora $D^{a}$ María Coloma duquesa de Veraguas que murió en este convento santamente y otras muchas de realzada nobleza que le fueron enriqueciendo, con lo cual pudieron emprender una obra primorosa, reparando lo principal de él y fabricando la nueva iglesia que hoy tienen (...) y como cada día ha ido en aumento, hoy es de los más acomodados que tiene esta ciudad, de tal forma que las más de las religiosas tienen renta en particular, para su decencia, independiente de lo que es de comunidad, y así han podido adornar la iglesia con retablo nuevo dorado y sus colaterales cuya magnífica obra se feneció por los años de 1690"497.

El retablo, plenamente churrigueresco, sigue un modelo bastante popular en la escuela vallisoletana: se trata de un enorme retablo tetrástilo estructurado en un ancho banco, cuerpo con tres calles y ático semicircular con portada rectangular en el centro del mismo. El cuerpo principal está articulado a través de cuatro columnas salomónicas de orden gigante, apoyadas sobre ménsulas con hojas muy carnosas, entre las cuales encontramos mascarones, de cuyas bocas surgen festones de fruta. Entre las ménsulas se sitúan cartelas, delante de las cuales se han dispuesto las esculturas de San Quirce y Santa Julita, y el hueco para el sagrario.

La calle central alberga la imagen del titular del retablo, San Bernardo, y detrás

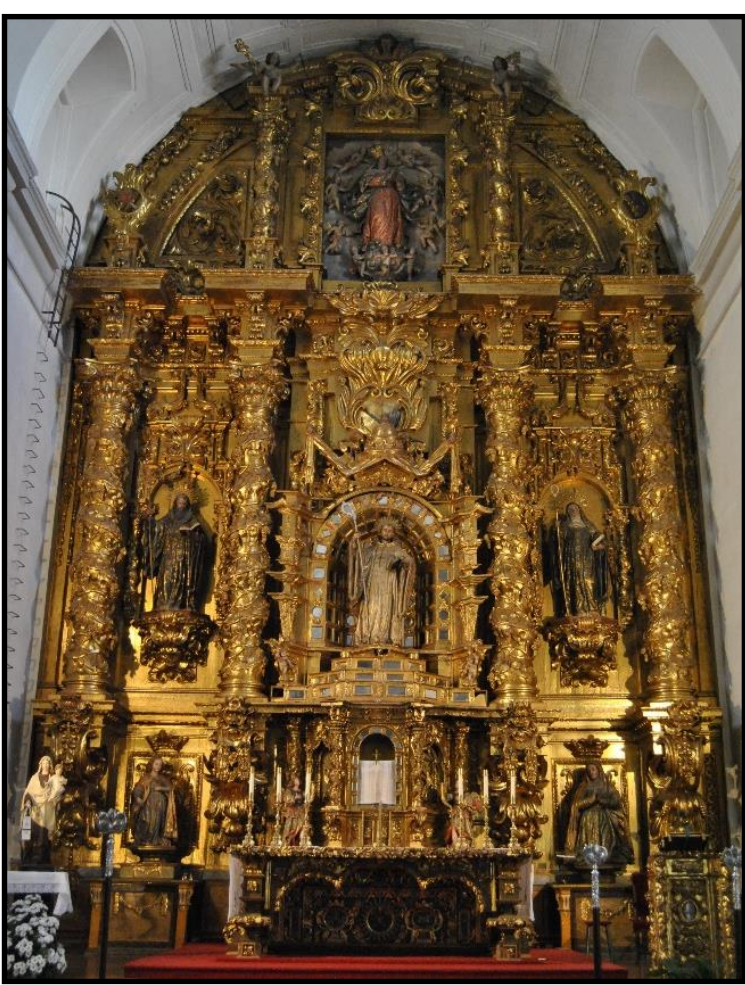

Il. 26- Blas Martínez de Obregón. Retablo mayor. Monasterio de San Quirce. Valladolid. de él una hornacina de espejos fechable en el segundo cuarto del siglo XVIII. A los pies del santo, y seguramente de la misma época que la hornacina, unas gradas escalonadas también decoradas con espejos. Asimismo, encima de la hornacina hay un pabellón y el escudo de la Orden del Císter. En los intercolumnios, flanqueados por sendas columnas salomónicas rematadas por un amplio trozo de entablamento, se encuentran las esculturas de San Benito y Santa Escolástica apeadas sobre simples ménsulas con decoración similar a las ménsulas del banco. Los marcos que rodean a los dos santos son quebrados, al modo de arrabá ${ }^{498}$.

El ático, que según Martín González es el usual de los Billota, tiene una portada flaqueada por columnas salomónicas coronadas por angelotes que portan palmas del martirio, seguramente en alusión a San Quirce y Santa Julita. A los lados dos grandes tableros decorados con rameados. La portada, encima de la cual hay una gran tarjeta

497 CANESI ACEVEDO, Manuel: Historia de Valladolid (1750), Tomo II, op. cit., p. 66.

498 MARTÍN GONZÁLEZ, Juan José: Escultura barroca castellana ..., op. cit., p. 311.

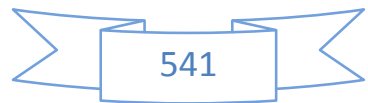


vegetal, está ocupada por un relieve de la Asunción de la Virgen. En los extremos del ático se sitúan sendas medallas decoradas con el Sol y la Luna. Ambos astros suelen aparecen en representaciones de temática mariana. Señalan Labrador González y Medianero Hernández que María "aparece en distintas representaciones de momentos muy significativos acompañada del Sol y de la Luna, por ejemplo en su Asunción, subiendo al cielo donde brillan el Sol y la Luna y donde espera Cristo rodeado del Tetramorfos $"{ }^{\prime 99}$. Efectivamente, en este retablo sucede esto mismo, salvo la espera de Cristo con el Tetramorfos.

El conjunto escultórico del retablo fue relacionado por primera vez con el estilo de Ávila por Martín González, el cual comentaba que "la parte escultórica del retablo entronca con el estilo de Juan de Ávila"500. Años después, este autor y Plaza Santiago, en el Catálogo Monumental, ratificaron este parecer pero también comentaban que " $\mathrm{el}$ estilo las aproxima también a José de Rozas"501. Martín González se reafirmó una vez más en lo dicho, afirmando que "son del mismo escultor [Juan de Ávila] las esculturas de los retablos mayores de Santa Brígida, San Quirce y otras varias en la iglesia del Colegio de Ingleses, de Valladolid. Su huella la hemos percibido en numerosos monumentos de la provincia de Valladolid" ${ }^{\text {502 }}$. Urrea y Brasas Egido han aportado un nuevo punto de vista, relacionado estas esculturas con la producción de Juan Antonio de la Peña ${ }^{503}$. Una vez más comprobamos la dificultad que entraña el separar las personalidades de los tres grandes maestros vallisoletanos de fines del siglo XVII.

Como ocurriera con la imagen de Santiago Matamoros del retablo mayor de la iglesia de Santiago, la alta calidad que exhiben las efigies de este retablo llevó a una gran personalidad, como fue Pascual Madoz, a atribuírselas a Gregorio Fernández. Madoz explicaba que el retablo "contiene buenas esculturas que se cree son de Gregorio Hernández"504. Para Martín González las esculturas del retablo son excelentes. Según él "no se puede hablar de decadencia de la escultura cuando se corta la madera con el encanto y la habilidad como en esta obra"505.

La parte escultórica consta de siete esculturas en bulto redondo (San Bernardo, San Benito, Santa Escolástica, San Quirce, Santa Julita y dos Ángeles que coronan la gran máquina lígnea) y un relieve (la Asunción). A estas imágenes habría que sumar dos Ángeles lampadarios, los cuales desconocemos si fueron realizados para el retablo, y en tal caso qué lugar ocuparían dentro del mismo, quizás sobre la custodia alumbrando a

\footnotetext{
499 LABRADOR GONZÁLEZ, Isabel María y MEDIANERO HERNÁNDEZ, José María: "Iconología del sol y la luna en las representaciones de Cristo en la cruz", Laboratorio de Arte, No 17 , 2004, p. 90

$500 \quad$ Ibídem.

501 MARTÍN GONZÁLEZ, Juan José y DE LA PLAZA SANTIAGO, Francisco Javier: Catálogo Monumental de la provincia de Valladolid. Tomo XV..., op. cit., p. 190.

502 MARTÍN GONZÁLEZ, Juan José: La escultura barroca en España..., op. cit., p. 81.

503 URREA FERNÁNDEZ, Jesús: Guía histórico-artística..., op. cit., p. 73; BRASAS EGIDO, José Carlos: Guía de Valladolid, Ediciones Lancia, León, 1984, p. 125.

504 MADOZ, Pascual: Diccionario geográfico-estadístico-histórico de Castilla y León. Valladolid, Valladolid, Ámbito Ediciones, 1984, p. 199.

505 MARTÍN GONZÁLEZ, Juan José: Escultura barroca castellana ..., op. cit., p. 311.
} 
San Bernardo. También desconocemos el lugar que tendrían las esculturas de San Quirce y Santa Julita en el retablo mayor. De lo que no hay duda es de que estaban en él, puesto que en contrato suscrito por Obregón para realizar los retablos colaterales se hablaba de que "los santos que intitulan San Quirce y Santa Julita que están puestos en el retablo del altar mayor se han de bajar y poner en el segundo cuerpo de cada uno de dichos dos colaterales" (DOCUMENTO 51). Es de suponer que los dos santos no estarían en el lugar que actualmente ocupan: sobre peanas entre las ménsulas del banco. La expresión utilizada en el referido contrato "se han de bajar" hace referencia expresa a que estaban asentados en el retablo. Me gustaría plantear la hipótesis de que las esculturas de ambos santos estuvieran situadas sobre los dos trozos de entablamento más cercanos al relieve de la Asunción, puesto que los otros dos están ocupados por sendos escudos con el Sol y la Luna. Hemos de tener en cuenta, además, que, según la perspectiva del espectador, San Quirce gira la cabeza hacia la derecha y Santa Julita hacia la izquierda, de manera que ambos parecerían estar observando la escena de la Asunción con gestos devotos: San Quirce con una mano el pecho y Santa Julita con las dos manos juntas, en idéntica posición a como las tiene colocadas la Virgen de la Asunción. Esta suposición se cimienta, además en la comparación con el relieve en piedra situado sobre la portada de la iglesia. Tanto las esculturas de San Quirce y Santa Julita, como las de Virgen y los ángeles que la rodean, son prácticamente exactos. Tan solo difieren en la posición de la mano derecha de San Quirce y en el punto de vista tomado para componer ambas imágenes de Santa Julita. Estas coincidencias ya fueron advertidas por Rebollo Matías, el cual, además, supone que las esculturas de la portada son "obra del tercer decenio del siglo XVII. Se trata de la misma factura y seguramente autoría que tienen las tallas de ambos titulares del retablo mayor"506. Nada tiene que ver el estilo de los de la portada con los del retablo, pues no hay nada más que ver los plegados y comprobar que los de la primera apuntan al primer cuarto del siglo XVII, y los del otro al último cuarto del mismo.

La inclusión en el retablo del Doctor Melifluo y de los dos santos gemelos (San Benito y Santa Escolástica) está más que justificada al tratarse de un convento acogido bajo la regla del Císter. Por otro lado, la incorporación de San Quirce y Santa Julita se hace en su calidad de santos patronos del convento. La incorporación en el ático de un relieve representando a la Asunción, y no un Calvario como era costumbre, tendrá relación con que San Bernardo, titular del retablo, fuera uno de los más fervientes defensores del culto a la Virgen María, llegándose a apodar él mismo como "fiel capellán" o "caballero sirviente" 507 .

506 REBOLLO MATÍAS, Alejandro y MINGO MACÍAS, Luis: “Acerca de nuestra historia: Real Monasterio de San Quirce y Santa Julita: arquitectura y patrimonio", Pasión Cofrade, no 11 (segunda época), 2015, p. 19.

507 RÉAU, Louis: Iconografía de los santos. A-F..., op. cit., p. 213. 


\section{$\underline{\text { SAN BERNARDO }}$}

San Bernardo de Claraval (1090-1153) fue un monje borgoñón nacido en el castillo de Fontaine-lès-Dijon. Sus padres fueron personas muy religiosas, lo que determinaría el camino que emprendió Bernardo: su padre fue un "caballero valeroso, vivió plenamente consagrado a su profesión militar y al servicio de Dios", mientras que su madre, cada vez que paría un nuevo hijo "tomábalos en sus manos, ofrecíalos a Dios y prometía al Señor que en cuanto alcanzaran la edad adecuada los consagraría a su servicio en algún monasterio"508. Así ocurrió con los siete hijos, seis varones y una hembra.

Santiago de la Vorágine nos da una explicación de su carácter a través del significado de su nombre: "Bernardo de "ber" (pozo, fuente) y de "nardo", nombre de una planta que según la Glosa del Cantar de los Cantares es humilde, cálida por naturaleza y muy aromática. San Bernardo fue también cálido por su fervorosa caridad, humilde en su conducta, fuente de doctrina, pozo de profunda ciencia y aromático por su excelente reputación extendida cual suave perfume por todas partes. Guillermo, compañero suyo y abad de San Teodorico, y Hernaldo, abad de Valbuena, escribieron su vida"509.

Su labor principal consistió en la reforma, y expansión, de la Orden del Císter, fundando en 1115 el monasterio de Claraval ${ }^{510}$; si bien también tuvo su importancia en aspectos tan dispares como el desarrollo del canto gregoriano, de la vida monástica y en la expansión de la arquitectura gótica. Tampoco podemos olvidar su faceta de místico, puesto que fue el primero que formuló los principios básicos de la mística ${ }^{511}$. Bernardo recibió dos grandes distinciones por parte de la Iglesia: en 1174 fue canonizado, y en 1830 fue nombrado Doctor de la Iglesia.

Con San Bernardo nos ocurre lo mismo que con otros santos, y es que la forma de representarlo no tiene nada que ver con su aspecto físico. Algunos testimonios de la época afirman que "era delgado, espiritualizado por el ayuno y las austeridades. Era pelirrojo de cabellera y barba"512. Aparece de pie, representando como abad de la orden del Císter, envuelto en una cogulla blanca de amplias mangas. En una mano porta el báculo abacial, y en la otra un libro cerrado, del cuello le cuelga una cruz. La vestimenta que porta para nada es la que utilizó, si hacemos caso a Santiago de la Vorágine: "Sus ropas fueron siempre pobres, pero limpias. Solía decir que la suciedad y desaliño en el vestir obedecían a una de estas tres cosas: o a negligencia, o a morbosa delectación personal de vanagloria, o al afán de granjearse fama de virtud ante los demás. A menudo citaba este proverbio adoptado por él como norma de conducta: "Si quieres pasar inadvertido a los ojos del prójimo, evita toda suerte de singularización”. (...) Mientras pudo hacerlo sin que nadie se diera cuenta de ello, llevó bajo sus hábitos, durante muchos años, una áspera túnica de pelo de cabra; pero tan pronto como se enteró de que sus monjes sabían que maceraba su cuerpo con

\footnotetext{
508 VORÁGINE, Santiago de la: op. cit., Tomo II, p. 511.

509 Ibídem.

510 RÉAU, Louis: Iconografía de los santos. A-F .., op. cit., p. 213.

511 http://es.wikipedia.org/wiki/Bernardo_de_Claraval

512 RÉAU, Louis: Iconografía de los santos. A-F ..., op. cit., p. 216.
} 
semejante cilicio, prescindió de él y lo sustituyó con ropa interior igual a la que usaban los demás miembros de la comunidad"513.

La escultura (Fig. 93) tiene un carácter monumental, el rostro está trazado mórbidamente, acusando bien las calidades de la piel, como por ejemplo las arrugas que se forman en la frente o en las ojeras. Boca entreabierta que permite ver los dientes. Ojos de cristal. Pelo muy escaso, tan solo un mechón sobre la frente y sobre las partes laterales. La barba está simplemente pintada. Según Martín González "en esta escultura se aprecia en Juan de Ávila una disyunción en el modo de hacer los pliegues. Estos se han ido haciendo progresivamente más suaves, constituyéndose unas líneas paralelas que se adhieren al cuerpo. Esta tendencia se acusa ya en el San Francisco de Sales del Oratorio de San Felipe Neri"514. Efectivamente, en esta imagen podemos ver unos pliegues que caen paralelos, en su origen está muy juntos y poseen poco resalto, pero según van cayendo se van ensanchando y quebrando, hasta golpear en el suelo que es donde vemos más angulosidades. A pesar de la amplia cogulla, los pliegues nos dejan entrever la rodilla derecha del santo. Las holgadas mangas están talladas con una delicadeza y finura maravillosa, a su preciosismo ayudan las fastuosas orlas que las ornan.

\section{$\underline{\text { SAN BENITO }}$}

Benito de Nursia (480-547) es considerado el iniciador de la vida monástica en Occidente. Hacia el año 500 comenzó a realizar vida de ermitaño en la gruta Sacro Speco, cerca del lago Subiaco ${ }^{515}$. Hacia el año 528-529 fundó la Abadía de Montecasino sobre las ruinas de un antiguo templo dedicado al dios Apolo, era muy frecuente que las primeras fundaciones cristinas se realizaran sobre antiguas construcciones paganas. Allí escribió la llamada "Santa Regla", que venía a regir la vida monástica de los monjes. Su éxito fue tal que sirvió de modelo para la de otras órdenes religiosas, como fue, por ejemplo, el Císter. Otros dos grandes hechos cuentan en su haber: la fundación de la Orden de San Benito (O.S.B.), y la creación de monasterios autosuficientes, empresa que fue ampliamente difundida durante la Edad Medina.

La inclusión de San Benito (Fig. 94) en el retablo se debe, como ya hemos dicho, a que el monasterio de San Quirce, perteneciente al Císter, se encuentra regido por la Regla de San Benito. Lo mismo acaece con la incorporación de su hermana Santa Escolástica.

El fundador de la orden de los benedictinos comparte los mismos planteamientos estéticos y formales que San Bernardo. Aparece de pie, con la pierna derecha levemente adelantada, movimiento percibido a través de las finas vestimentas. La figura posee un ligero contraposto como podemos en la posición de su cabeza y sus manos. Posee lejanos ecos de la Santa Escolástica que Juan de Juni talló para el retablo de San Juan

513 VORÁGINE, Santiago de la: op. cit., Tomo II, p. 515.

514 MARTÍN GONZÁLEZ, Juan José: Escultura barroca castellana ..., op. cit., p. 323.

515 RÉAU, Louis: Iconografía de los santos. A-F..., op. cit., p. 196. 
Bautista del Monasterio de San Benito el Real de Valladolid. En su mano derecha porta un báculo abacial, mientras que con la izquierda sujeta un libro abierto que lee atentamente, se trata de su "Santa Regla". El rostro es extremadamente expresivo y mórbido, captando muy bien la vejez del santo a través de las arrugas de la frente, de los laterales de los ojos y, sobre todo, de las mejillas. Barba muy poblada con numerosas guedejas sinuosas que terminan por confluir. En el pelo coincide con San Bernardo, es decir, un pequeño mechón en la frente y en los laterales. Viste una cogulla negra de benedictino, también de amplias mangas. Los pliegues son idénticos a los de San Bernardo.

\section{SANTA ESCOLÁSTICA}

Santa Escolástica (480-457) era la hermana gemela de San Benito; ambos nacieron y murieron en años idénticos. Como ocurre en el presente retablo, es muy frecuente que forme pareja con él ${ }^{516}$. Al igual que su hermano, fundó un convento, regido por la regla que éste había confeccionado. Se trata del de Piumarola, cerca de Montecasino. Escolástica tenía la costumbre de ir a visitar a su hermano una vez al año, encuentros que los hermanos dedicaban a orar. La última vez que le visitó, sintiéndose morir, le pidió que se quedara a su lado. San Benito no quiso romper las reglas de su monasterio y marchó. Escolástica pidió a Dios que no se marchara, y fue entonces cuando la divinidad la ayudó, haciendo estallar una fuerte tormenta que impidió a San Benito volver a su cenobio. Tras unos días la santa falleció, y San Benito que se encontraba orando tuvo una visión en la que el alma de su hermana subía al cielo en forma de paloma. Todo esto ha determinado que se invoque a Santa Escolástica contra las tormentas y truenos, y que parte de su iconografía la conforme una paloma ${ }^{517}$.

La escultura de Santa Escolástica (Fig. 95) no presenta novedades respecto a las dos anteriores, es, quizás, la talla más floja de las tres. También se encuentra de pie, podemos ver el mismo contraposto, sin embargo, al contrario que su hermano, adelanta la pierna izquierda, contraponiéndose de esta manera a su hermano y a San Bernardo. Aparece revestida de abadesa. Es la versión femenina de San Benito en el retablo. Al igual que él viste una cogulla negra benedictina de amplias mangas, ciertamente exageradas, las cuales dejan ver la botonadura de la vestimenta interior, al igual que en los otros dos santos. Porta en su mano derecha un báculo abacial y en la izquierda un libro. En este caso el libro no está abierto, sino cerrado. Dado que de los tres santos tan solo lo tiene abierto San Benito, pudiera tener el significado intrínseco de que tanto Santa Escolástica como San Bernardo siguieron fielmente la Regla escrita por el fundador de los benedictinos.

El rostro es más dulce e idealizado que los anteriores, pero sin embargo no llega a la calidad de estos. La piel de aquellos es muy fina y mórbida, y sin embargo esta es

\footnotetext{
$516 \quad$ Ídem, pp. 454-455.

517 http://es.wikipedia.org/wiki/Escol\%C3\%A1stica_\%28santa\%29
} 
demasiado lisa, destacando tan solo el prominente mentón. Ojos de cristal. Tiene la cabeza ligeramente girada hacia la derecha, mirando hacia el cielo, como observando una paloma, el atributo más generalizado de su iconografía, que no sabemos si llegó a existir sobre ella. Como acabamos de decir, sigue fielmente las características de las anteriores dos tallas con multitud de pliegues paralelos que se van quebrando según van bajando.

\section{RELIEVE DE LA ASUNCIÓN}

El tema de la Asunción (Fig. 96) no apareció hasta finales del siglo XIII, sustituyendo el de la Resurrección de la Virgen. Este pasaje no figura en los evangelios canónicos, sino que se trata, según Réau, "de una leyenda tardía, copiada en el siglo VI del Arrebatamiento del profeta Elías y de la Ascensión de Cristo. En el siglo VIII, la Iglesia de Roma todavía consideraba la Asunción corporal de la Virgen una opinión piadosa y no un dogma". El dogma de la Asunción no fue proclamado hasta 1950, en que lo hizo el papa Pío XII ${ }^{518}$.

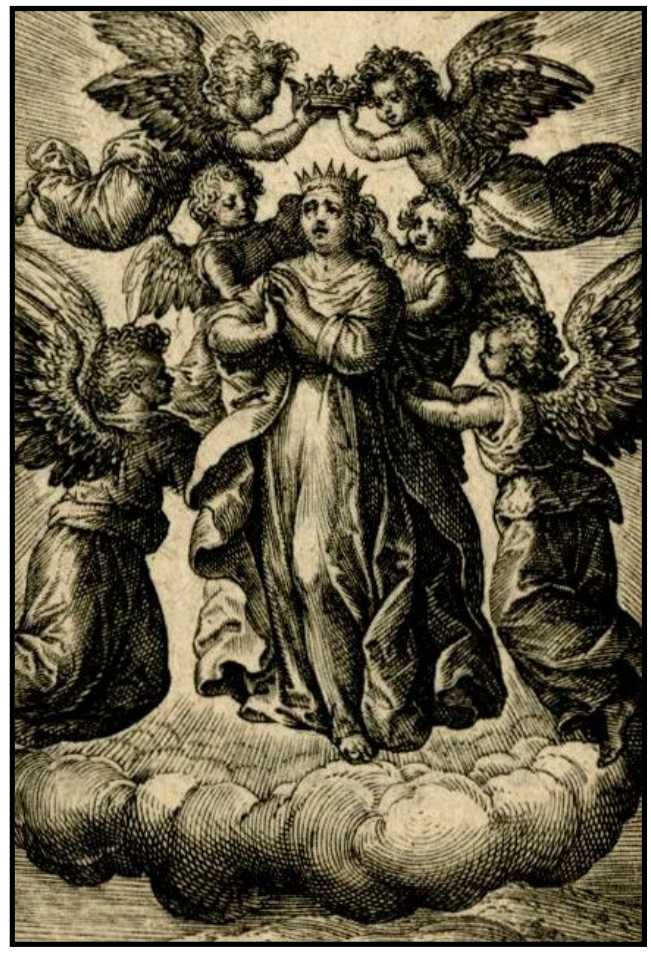

Il. 28- Johannes Wierix. La Asunción y la Coronación de la Virgen.

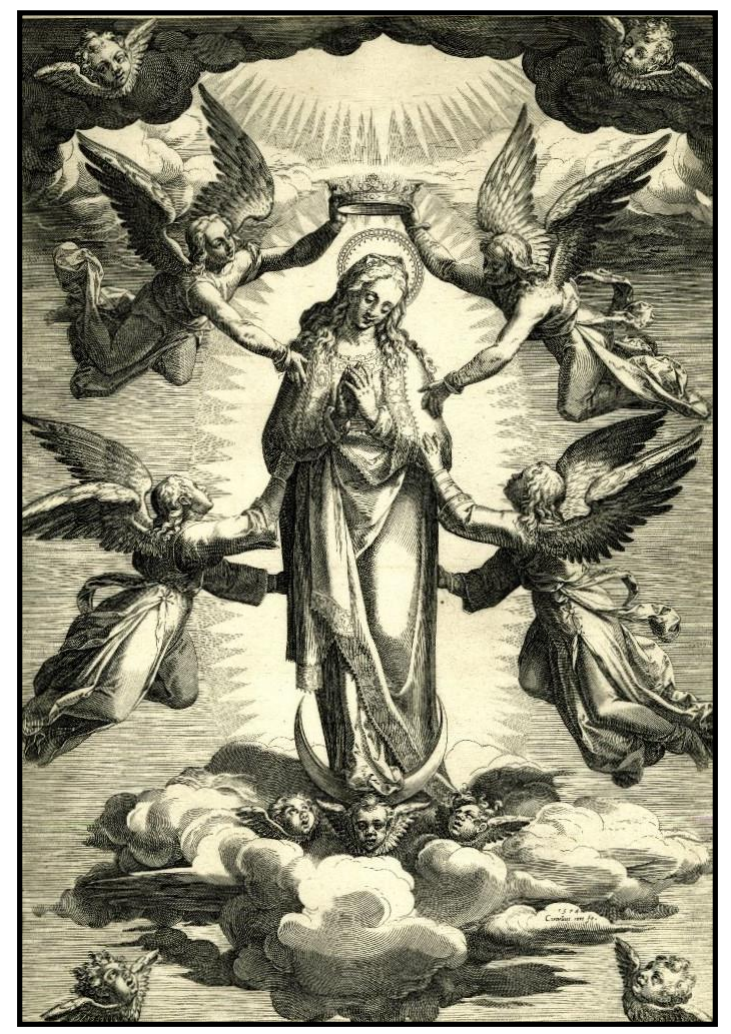

Il. 27- Federico Zuccaro. Asunción y Coronación de la Virgen.

Como hemos dicho antes, la presencia de la Asunción en el retablo tendrá su origen en la devoción que profesó San Bernardo a la Virgen. El santo "se había distinguido a lo largo de su vida por la promoción del culto a María, de la que no se cansaba de cantar sus alabanzas" ${ }^{519}$. La escena funde dos momentos diferentes: el de

\footnotetext{
518 RÉAU, Louis: Iconografía de la Biblia. Nuevo..., op. cit., p. 638.

519 https://www.museodelprado.es/enciclopedia/enciclopedia-on-line/voz/san-bernardo-y-la-virgenalonso-cano/
}

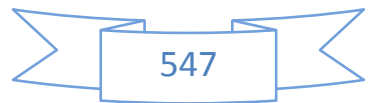


la Asunción de la Virgen y el de la Coronación. La composición goza de una total simetría ya que a cada lado de la Virgen figuran tres ángeles, con posiciones similares dos a dos. También los ángeles que sujetan la nube están situados de manera simétrica. Todos ellos se encuentran desnudos, pues tan solo tienen una banda de diferentes colores que les cruza el pecho. La composición estará inspirada en una estampa o grabado. Hay múltiples ejemplos que representan tanto la Asunción como la Coronación. Podemos citar uno realizado por Federico Zuccaro en 1574 y otro de Johannes Wierix en los albores del siglo XVII.

Situado en la portada que preside el ático, como en tantas ocasiones el relieve no lo es tanto ya que se trata de esculturas de bulto redondo pegados sobre el tablero de marco rectangular. La Virgen aparece de pie, con la socorrida posición adelantada de su pierna derecha, sobre una nube que ayudan a subir al cielo tres angelitos. El movimiento de la ascensión a los cielos lo percibimos por lo alborotado de los pliegues de su manto. Otros cuatro angelitos juguetean con el manto de la Virgen. Finalmente, otros dos ángeles la coronan. Las posiciones de los ángeles son muy variadas, les tenemos en contraposto, escorzo, etc..., todos ellos aportan gran frescura al relieve. La Virgen viste una túnica roja, que parece seguir el mismo sistema de pliegues de los tres santos del retablo, y un manto azul muy volado con unos pliegues mucho más quebrados, aunque suavizados por sus incurvaciones. Se encuentra juntando las manos en posición de oración, o de gracias a Dios por la corona que le está siendo impuesta. La cabeza mira levemente hacia el cielo.

\section{$\underline{\text { SAN QUIRCE }}$}

La escultura de San Quirce (110 cms.) (Fig. 97) como la de su madre Julita, como ya hemos dicho, sigue fielmente los relieves en piedra de estos mismos santos localizados en la parte superior de la portada de la iglesia monacal. San Quirico era hijo de Santa Julita, y padeció martirio en Tarso, junto a su madre, a la edad de tres años. Su pasión apócrifa le atribuye al menos seis suplicios, cada uno de los cuales rebotaba en sus verdugos: le azotaron con látigos guarnecidos de plomo, le cortaron la lengua, le sumergieron junto a su madre en un caldero lleno de pez y estopa encendida, le acostaron sobre una sartén, le quisieron trocear con una sierra, le hundieron tantos clavos en el cráneo y hombros como años tenía, y, finalmente, le cogieron de una pierna y le tiraron contra las gradas del tribunal, partiéndole la cabeza ${ }^{520}$. Al igual que otros mártires niños, como san Guido y santa Fe, san Quirico aparece representado más grande de lo que fuera.

Ávila representa a Quirico no como un tierno infante, sino de una edad aproximada a los 8-10 años. Es una escultura muy poco movida, pero ciertamente devota. Viste túnica azul, la cual le llega hasta el suelo, permitiéndonos tan solo ver la punta de los zapatos. Como en el resto de esculturas de este retablo los pliegues se pegan a la piel,

520 RÉAU, Louis: Iconografía de los santos. P-Z..., op. cit., pp. 108-109. 
permitiéndonos ver el leve avance de su pierna derecha, recurso muy utilizado por nuestro escultor. Los pliegues son similares también a los ya vistos en el resto de imágenes, sin embargo encontramos otro tipo en la capa roja que abrocha en su cuello mediante una especie de colgante. Estos pliegues son suaves, finos y redondeados, y no se aprecian quebraduras. Tanto el borde de la túnica como de la capa llevan la tan socorrida cenefa que por entonces debían practicar la mayoría de los doradores vallisoletanos. La policromía es muy bella.

En su mano derecha porta la palma del martirio, mientras que la izquierda la posa devotamente sobre el pecho. El tratamiento y la disposición de las manos, tanto en esta pequeña escultura como en el resto del retablo, es muy elegante y delicado, teniendo ecos lejanos de Gregorio Fernández, que es el escultor castellano que mejor ha expresado los sentimientos a través de esa parte del cuerpo. La cabeza, ligeramente inclinada hacia la izquierda, emparenta de lleno con Juan de Ávila, si bien la nariz puntiaguda no casa demasiado con sus postulados. Ojos de cristal, boca entreabierta, piel tersa, mejillas rosadas. También es muy propio de nuestro escultor las amplias cabelleras rizadas situadas a ambos lados del rostro, siendo el que se encuentra sobre la frente más liso y domado. Estos amplios bucles los encontramos en otras obras de Ávila, tanto documentadas como atribuidas, como pueden ser Ángel de la Guarda de la iglesia de Santiago de Valladolid, el San Isidro, el Niño Jesús del grupo de la Sagrada Familia del Colegio de los Ingleses, o el San Juan Bautista del Oratorio de San Felipe Neri. Tanto por la forma cuadrática del rostro, por la posición de los labios y sus comisuras, y la disposición de los rizos laterales parecen preludiar la obra de Pedro de Ávila. No hay más que comparar esta imagen con, por ejemplo, el San Miguel Arcángel que talla para la parroquial de Castil de Vela en $1714^{521}$.

\section{$\underline{\text { SANTA JULITA }}$}

Julita o Julieta (133 cms.) fue una santa mártir nacida en Capadocia. Junto con su bebe Quirico/Quirce fueron múltiplemente martirizados en tiempos de Diocleciano. La leyenda dice que se negó a ofrecer sacrificios a los ídolos, por lo que se la condenó a que le atravesaran con clavos, le sumergieran en un caldero de pez hirviente. Ninguna de estas torturas pudo con ella, por lo que los asesinos decidieron decapitarla y trocearla en numerosos pedazos que fueron dispersados. Unos ángeles se encargaron de reunirlos y darla sepultura ${ }^{522}$.

La santa (Fig. 98) aparece de rodillas, quizás para adaptarse a la altura que tiene su hijo. Quiero recordar la hipótesis de que ambos santos estuvieran colocados primigeniamente en el ático, sobre los trozos de entablamento más cercanos al relieve de la Asunción, de tal manera que interactuaran con ella, a la manera del citado relieve de la portada de la iglesia. A todo ello habría que añadir que, en la vertical de las esculturas, rematando el

521 URREA FERNÁNDEZ, Jesús y MARTÍN GONZÁLEZ, Juan José: Inventario artístico de Palencia y su provincia I..., op. cit., p. 123.

522 RÉAU, Louis: Iconografía de los santos. G-O..., op. cit., p. 217. 
retablo, hay dos angelotes con palmas del martirio, que sin duda aludirán al sufrido por madre e hijo. Es por ello que ambas esculturas fueron concebidas con un tamaño similar, y como Julita era una adulta se la decidió situar de rodillas. Esa interactuación con la Asunción la percibimos en esa cabeza ligeramente inclinada hacia la derecha, pero mirando lo que sucede sobre ella, mientras que sus manos aparecen unidas frente al pecho en acto de oración. Es decir, la santa queda admirada por la Virgen, a la cual se dispone a rezar, aunque también pudiera ser un signo de humildad, similar al que efectúa su hijo. Julita, a diferencia de este, no porta la palma del martirio.

El rostro es muy dulce, sin duda una de las más bellas creaciones de Ávila, o de quien al final se demuestre pertenecerle. Los labios levemente abiertos, marcadas comisuras. Las facciones vuelven a ser similares a las de Ávila, también en el caso de la nariz, no como ocurría con la de Quirico. Mejillas sonrosadas. El pelo apenas es perceptible en unas pequeñas porciones que delimitan el rostro, debido a que le cubre la cabeza un velo blanco, sobre el que a su vez tiene echado un manto ricamente policromado. Esta forma de disponer el pelo ya la hemos visto en la Virgen María del grupo de la Sagrada Familia del Colegio de los Ingleses. Asimismo, viste una larga túnica verde, con decoraciones doradas a punta de pincel, ajustada a la cintura por un ceñidor. Los pliegues son completamente diferentes a los vistos en las otras imágenes del retablo, debido, sin duda, a que la santa se encuentra arrodillada. En este caso los pliegues de la zona baja son muy quebrados pero redondeados, permitiéndonos intuir la pierna izquierda.

\section{$\underline{\text { ÁNGELES LAMPADARIOS }}$}

Desconocemos el lugar que ocuparían los dos ángeles lampadarios (Figs. 99-100) que en la actualidad se encuentra situados a ambos lados de la custodia. Tampoco tenemos la certeza de que hayan pertenecido al retablo. Podría pensarse en que escoltaran a la custodia, tal como hoy están, o bien que flanquearan a San Bernardo, situándose a los pies de éste, dado que ambos ángeles parecen mirar hacia arriba, uno hacia su derecha y el otro hacia su izquierda, es decir, se encuentran observando algo situado sobre ambos. La reforma a la que se vio sometida a mediados del siglo XVIII la hornacina de San Bernardo no nos permite contrastar esta hipótesis.

Existen ángeles similares, aunque algo anteriores, cronológicamente hablando, y de procedencia napolitana en la iglesia de Santiago el Real, de Medina del Campo (Valladolid); en el Convento de San Blas, de Lerma (Burgos); y en la Basílica de San Vicente, de Ávila ${ }^{523}$.

Ambos son idénticos, tanto en composición como en vestimenta, tan solo están diferenciados por la disposición del pelo. Están compuestos simétricamente, de tal

523 SÁNCHEZ DEL BARRIO, Antonio: “Ángeles lampadarios". En SÁNCHEZ DEL BARRIO, Antonio: Santa Teresa de Jesús y San Juan de la Cruz. El encuentro, Fundación Museo de las Ferias, Medina del Campo, 2014, pp. 186-187. 
manera que se contraponen a la perfección. El ángel situado a la izquierda de la custodia, según la visión del espectador aparece de pie, con la pierna izquierda adelantada. Se lleva su mano derecha, extendida, al pecho, en acto de devoción; mientras que con la izquierda sujeta un cuerno que serviría de lámpara. Su cabeza, levemente girada hacia la izquierda dirige su mirada hacia arriba. Por el contrario, el ángel de la derecha, adelanta su pierna derecha. La mano derecha la tiene dispuesta sobre el pecho, de la misma forma que el otro, del mismo modo que con la otra mano sujeta en cuerno, también con idéntica disposición del brazo. La cabeza la tiene levemente girada hacia la derecha, también mirando hacia arriba. Como vemos ambas figuras mirarían y flanquearían a una tercera escultura que se dispondría sobre ellos.

La vestimenta y disposición de sus pliegues son similares y, en cierta manera, viene a recordar la de los ángeles de la guarda que hemos estudiado antes, siendo por lo tanto deudores del Ángel tallado por Andrés de Solanes para el paso de la Oración del Huerto de la vallisoletana Cofradía de la Vera $\mathrm{Cruz}^{524}$. Visten dos túnicas, una más larga, decorada con motivos florales, abierta en una de sus piernas a la altura de la rodilla, lo que nos permite verle casi completamente esa pierna y parte de la otra; y otra más corta, en tonos violáceos, pero con la misma decoración. Está levemente abierta por la parte central, recurvándose suavemente esos pliegues, de manera similar a lo que acontece con la túnica larga. Por encima de ambas túnicas viste una coraza negra. Los puños de la túnica están remangados, permitiéndonos ver el envés rojizo. Pliegues blandos y redondeados. Los pliegues van resguardados por unas simples sandalias, casi idénticas a las del Ángel de la Guarda conservado en la iglesia de San Martín.

Las cabezas poseen rostros idénticos, tan solo levemente individualizados por la forma de disponer el pelo. Mientras que ambos peinan en los laterales de su rostro las típicas grandes masas de rizos, el de la izquierda mantiene la frente lisa y el de la derecha tiene una importante guedeja redondeada.

\section{CRISTO RESUCITADO (h. 1688-1694)}

Aun con ciertas reservas, pienso que también puede pertenecer a Juan de Ávila una escultura de Cristo resucitado (Fig. 101) que preside el ático de un retablo del último cuarto del siglo XVII, situado a los pies de la iglesia, entre el cancel de la puerta de entrada y la reja de la clausura. Este retablo, probablemente realizado al mismo tiempo que el Resucitado, tiene un solo cuerpo, ocupado por una gran hornacina, rematado en su parte superior por una tarjeta cactiforme. En dicha hornacina hay una especie de pabellón con las cortinas recogidas por dos angelitos, uno a cada lado, todo esto parece una añadidura posterior. En el ático, escoltado por sendas pirámides sobre jarrones, aparece la talla de Cristo Resucitado sobre una peana. Detrás de él una especie de hornacina de forma oval, calada por dentro, completamente decorada con elementos

524 URREA FERNÁNDEZ, Jesús: "Nuevos datos y obras del escultor Andrés Solanes...”, op. cit., pp. 483-484. 
vegetales. En la hornacina principal del retablo aparece un Calvario, con un gran Crucifijo de madera policromada, de fines del siglo XV. A los lados, la Virgen (124 cms.) y San Juan (132 cms.), realizados en el siglo XIV, pero repolicromados en el XVII ${ }^{525}$.

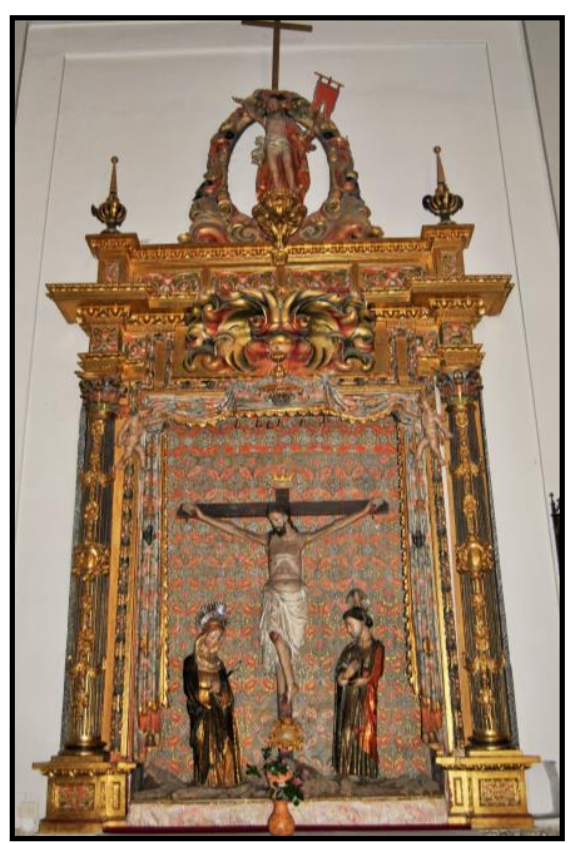

Il. 29- Anónimo. Retablo del Calvario. Monasterio de San Quirce. Valladolid.

Este Cristo Resucitado es una de las pocas representaciones escultóricas de ésta iconografía que se conservan en la ciudad ${ }^{526}$, y, quizás, una de las más desconocidas debido al lugar que ocupa dentro de la iglesia. Figura de pie, triunfal, con la pierna derecha levemente adelantada, en elegante y teatrero ademán. Con su mano derecha hace un gesto de bendecir, mientras que, con la izquierda sujeta, con los dedos elegantemente dispuestos, una bandera roja. Viste el perizonium, anudado a su lado derecho con un amplio lazo de pliegues redondeados, y también un manto rojo que, además de dar estabilidad a la escultura, se encuentra arremolinada en su brazo izquierdo. Aún tiene marcadas las heridas de la Pasión en manos y costado, lo que podría significar que Cristo se nos presenta triunfante sobre la muerte. La forma de caer del manto es similar a la observada, entre otras, en los Bautistas que talla para las iglesias de San Felipe Neri y Santiago Apóstol.

Nada tiene que ver esta escultura con su otro Resucitado, documentado, del pueblecito burgalés de Villasilos. Sin embargo, encuentro un gran parecido con el que su hijo Pedro de Ávila, supuestamente, realiza para Ampudia (Palencia); parece como si fuera el modelo en el que se inspiró. El modelado es blando, muy delicado, si bien no apura la representación anatómica tanto como en otras obras. El rostro posee una expresión bastante insulsa. El cabello, peleteado, está dispuesto simétricamente a ambos lados del rostro, con largos mechones sinuosos. Sobre la frente caen los típicos rizos de Ávila. La barba, también simétrica, termina en dos puntas. Ojos de tapilla, boca pequeña y cerrada. La escultura necesita una restauración que le devuelva el esplendor a la magnífica policromía, el abundante polvo y su altura dificulta bastante su estudio.

525 MARTÍN GONZÁLEZ, Juan José y DE LA PLAZA SANTIAGO, Francisco Javier: Catálogo Monumental de la provincia de Valladolid. Tomo XV..., op. cit., p. 189.

526 Apenas existen en Valladolid representaciones escultóricas del Resucitado. Tan sólo se conservan tres: uno atribuido a Francisco del Rincón en el Convento del Corpus Christi; otro atribuido a El Greco en el Convento de Porta Coeli; y otro anónimo del siglo XVI en la iglesia de Santiago, este último probable imagen titular de la antigua Cofradía del Resucitado y de la Virgen de la Alegría. Ya con una cronología posterior a la obra que estamos estudiando se conserva un ejemplar de finales del siglo XVIII en la Diputación Provincial, quizás proveniente del Hospital de la Resurrección; y otro en el Convento de Porta Coeli, obra de Ricardo Flecha, titular de la Cofradía de N. P. Jesús Resucitado y María Santísima de la Alegría. 


\section{VALLADOLID. CONVENTO DE LA CONCEPCIÓN}

\section{SAN JOSÉ CON EL NIÑO (h. 1690)}

En una hornacina horadada en uno de los pasillos que conducen al claustro del Convento de la Concepción de Valladolid se ubica una hermosa talla de San José con el Niño (76 cms.) (Fig. 102), que creo preciso atribuir a la gubia de Juan de Ávila. Con anterioridad, la imagen ya había sido calificada como del "estilo de Juan de Ávila", dándola una cronología del "último cuarto del siglo XVII"527.

Como parece lógico pensar, este lugar no fue su ubicación original. Partiendo de la base de que en el convento no hay más imágenes que efigien a San José, queda claro que esta fue la que presidía uno de los cinco retablos que, a principios del siglo XX, existían en la iglesia ${ }^{528}$. González García-Valladolid refiere al respecto de que la iglesia del convento era "bastante capaz, sencilla y de buenas luces, está formada por una sola nave gótica con cinco altares": el retablo mayor y cuatro laterales, dos a cada lado. El mayor poseía “imágenes de la Purísima Concepción, Santo Domingo de Guzmán y San Francisco de Asís en el primer cuerpo y un calvario en el segundo, todas de talla". Los del lado del evangelio estaban dedicados "a San Juan Bautista, escultura en madera y a San Francisco de Asís, pintura al óleo en lienzo"; mientras que los de la epístola "a San José, de talla, y al Descendimiento, también en pintura" ${ }^{\text {. }} 29$.

La iconografía presente en este san José alcanzó su apogeo después del concilio de Trento. Responde al rejuvenecimiento que le dieron los artistas a partir del siglo XVI, dejándole con el aspecto de un hombre de unos cuarenta años, y no de ochenta como en realidad debía de tener en el momento de desposarse con la Virgen.

San José aparece de pie sobre una peana de tarjetillas, que pudiera ser la original. Su cuerpo produce un ligero contraposto, con el torso levemente retrasado, y la cabeza y la pierna derecha sutilmente adelantados. El padre mira de manera muy amorosa a su hijo. Con el brazo izquierdo sujeta al Niño Jesús, que figura dormido y recostado sobre su pecho mientras agarra una bola del mundo; mientras tanto con su mano derecha, cuyo brazo lo levanta formando un ángulo de $90^{\circ}$, porta la vara florida, que alude a su victoria sobre los otros pretendientes de la Virgen, transformada en tallo de lirio, símbolo de su matrimonio virginal ${ }^{530}$. El relato en que se narra este acontecimiento se asemeja al de la designación de Aarón como sumo sacerdote ${ }^{531}$.

El rostro presenta la típica mirada ensimismada, barba corta, bífida y recurvada formada por pequeños rizos. Cabello ondulado cayendo simétrico a ambos lados del rostro. Difiere un tanto del estilo de nuestro escultor la forma de esculpir la nariz, más estrecha

\footnotetext{
527 MARTÍN GONZÁLEZ, Juan José y DE LA PLAZA SANTIAGO, Francisco Javier: Catálogo Monumental de la provincia de Valladolid. Tomo XV..., op. cit., p. 83.

$528 \quad$ En la actualidad solamente se conserva el retablo mayor.

529 GONZÁLEZ GARCÍA-VALLADOLID, Casimiro: Valladolid..., op. cit., Tomo II, pp. 289.

530 RÉAU, Louis: Iconografía de la Biblia. Nuevo..., op. cit., p. 168.

531 Ídem, p. 162.
} 
de lo normal, y la no aparición de la fila superior de dientes en la boca entreabierta; sin embargo, creo que no es óbice para creerla de Ávila. Viste túnica larga de color verde hasta el suelo, que deja entrever los dos zapatos. Ésta lleva botones en el cuello y en las mangas. En la parte inferior de la misma aparece una hermosa cenefa dorada con flores y otros motivos a punta de pincel. Encima de la túnica aparece, atado a la cintura, un prominente manto de color rojo, igualmente ornamentado con distintos motivos a punta de pincel. Diferencia a ambas prendas el tipo de plegado, mientras que los de la túnica caen paralelos y verticales, formando algunas durezas en la parte inferior de la misma; los del manto son muy suaves y redondeados, acusan perfectamente la anatomía del santo; es decir, son típicamente "Avilesinos". Por este tipo de pliegue paralelo podríamos fecharlo dentro del segundo estilo que Martín González ve en la producción de Juan de Ávila ${ }^{532}$. Aunque un poco más duros, estos pliegues recuerdan bastante a los de la Magdalena del Convento de las Lauras, asimismo atribuida al escultor vallisoletano. Debido a estos motivos parece procedente fechar esta bella imagen de San José con el Niño en la última década del siglo XVII, quizás hacia 1690.

Por su parte, el Niño Jesús aparece dormido sobre el pecho y el hombro del padre. Utiliza la mano paterna como una especie de silla. Su disposición es muy curiosa ya que utiliza de "reposabrazos" el pecho del santo y tiene la cabeza echada para atrás, para indicarnos que el sueño es verdaderamente profundo. A pesar de encontrarse dormitando, no por ello descuida la bola del mundo que sujeta con su mano izquierda. Viste una gran túnica, con los tres botones del cuello desabrochados. Los pliegues son algo duros. La policromía de la misma está completamente basada en rameados dorados y rojos a punta de pincel. La túnica nos permite verle las manos y los pies, miembros de aspecto bastante regordete, pero bien trabajados. La cabeza es muy bella y delicada, tendente a la forma cuadrada. El pelo se dispone en tres mechones sobre la frente y después unas grandes masas rizadas a los lados del rostro, a la manera de muchas esculturas documentadas y atribuidas al escultor. Los ojos los mantiene cerrados y la boca algo abierta, captando perfectamente el sueño. Los mofletes abultados y el mentón con el hoyuelo completan su faz.

532 MARTÍN GONZÁLEZ, Juan José: Escultura barroca castellana ..., op. cit., p. 324. 


\section{VALLADOLID. MONASTERIO DE SAN BENITO EL $\underline{\text { REAL }}$}

\section{SAN JOAQUÍN Y LA VIRGEN NIÑA (h. 1690)}

El grupo escultórico de San Joaquín y la Virgen $(160 \mathrm{~cm}$.) (Fig. 103) que actualmente contemplamos en el ábside del lado del Evangelio del Monasterio de San Benito el Real no perteneció en origen a este cenobio benedictino. Sangrador Minguela nos aporta valiosa información acerca de los orígenes del grupo. Relata que él llegó cedido a San Benito, junto con su retablo, en el año 1894 desde la iglesia del Santísimo Salvador, templo en el cual se encontraba instalado en la capilla de San Pedro Regalado.

La otrora iglesia benedictina, por entonces carmelita, se había reinaugurado el 15 de abril de 1893. Dado que su interior se encontraba completamente desamueblado solicitó obras a otras instituciones religiosas de la ciudad, a las cuales se sumaron diversos objetos regalados por algunos vallisoletanos durante el año en que la iglesia estuvo en obras $^{533}$. El propio Minguela indica que su primera ubicación en templo carmelita fue en la nave de la epístola: "junto a la verja hay otro lindo retablito, con una estatua muy regular, de escultura antigua, que represente al patriarca San Joaquín, padre de la Santísima Virgen la cual lleva sobre sus brazos" ${ }^{534}$. Posteriormente, el retablo con el que llegó, procedente de la iglesia del Salvador, fue eliminado; procediéndose en noviembre de 1895 a construirle otro más sencillo, el cual se ubicó en la segunda capilla de la nave del Evangelio ${ }^{535}$. En una fotografía de Antonio Passaporte, fechada entre 1927-1936, podemos ver el grupo escultórico presidiendo un sencillísimo retablo, casi diríamos una simple hornacina situada en el lado del Evangelio, justo a la derecha de la puerta de entrada al monasterio. Años después, en el Inventario Artístico de Valladolid, se le cita en la nave de la epístola ${ }^{536}$; finalmente ha acabado situado en el lugar en el que se encuentra en la actualidad: sobre una peana de piedra en el ábside del Evangelio.

Ahora que ya sabemos que la imagen procede de la capilla de San Pedro Reglado de la iglesia del Santísimo Salvador, vayamos a sus orígenes: la escultura fue mandada realizar hacia finales del siglo XVII por los sucesores del obispo don Diego de Soto para la capilla que éste poseía en la iglesia del Santísimo Salvador, "capilla intitulada de la Salutación (en la que se colocó a San Pedro Regalado) y al tiempo de dicha edificación estaba en el mismo sitio que al presente está" ${ }^{\text {537. }}$. Esta capilla se localizaba en el lado del Evangelio, en los terrenos que actualmente ocupa la de San Pedro Regalado. La fundada por el obispo Soto quedó arruinada al caérsele encima la torre de la parroquia. Este derrumbe debió producirse a mediados del año 1691, ya que el 12 de

\footnotetext{
533 ORTEGA DEL RÍO, José Miguel: op. cit., p. 263.

$534 \quad$ Ibídem.

535 RODRÍGUEZ MARTÍNEZ, Luis: Historia del Monasterio de San Benito el Real de Valladolid, Caja de Ahorros popular de Valladolid y Ateneo de Valladolid, Valladolid, 1971, p. 263.

536 MARTÍN GONZÁLEZ, Juan José (dir.): Inventario artístico de Valladolid..., op. cit., p. 26.

537 CALVO CABALLERO, Pilar: Fiesta y devoción popular: la Cofradía de San Pedro Regalado y Nuestra Señora del Refugio de Valladolid, Ayuntamiento de Valladolid, Valladolid, 2014, p. 62.
} 
agosto del referido año se reúne la junta parroquial del Salvador para iniciar una cuestación con la que reparar los daños producidos e intentar la reconstrucción de la torre $^{538}$. Los daños debieron ser tan graves que estaban empezando a dañar la capilla de los Reyes, el arco toral de la capilla mayor, y aún ésta.

La capilla del obispo Soto quedó abandonada, hasta que el 26 de mayo de 1709 fue solicitada por unos devotos del entonces beato Pedro Regalado para fabricar "una capilla donde se coloque en el sitio de otra que está totalmente arruinada, que se decía ser del Ilmo. Señor Obispo Soto, de que sobre ella tenía dicha fábrica tres mil y tantos maravedís de renta perpetua en cada un año, de que se debieran más de cien años como constaba de las cuentas, y asimismo se hiciese para ser mayor decencia y culto un nuevo camarín, que saliese al cementerio de dicha iglesia que cae a la plazuela con su transparente" ${ }^{\text {539. }}$.

Los sucesores del obispo Soto aceptaron ceder los terrenos de la capilla, si bien impusieron ciertos requisitos: "había de quedarse para dichos señores y sus sucesores en el camarín nuevo, que se hizo a expensas de los devotos, un arco a la espalda del altar del Santo en la pared maestra del grueso de ella, en donde dichos señores habían de poner una efigie de bulto de dicho señor obispo de alabastro, piedra o madera como les pareciere, y en él los escudos de sus armas, quedando asimismo para dichos señores y para su entierro y de sus sucesores el resto de dicho nicho, desde donde se había de poner la efigie de dicho señor obispo hasta el suelo, y otra sepultura en medio desde dicho nicho hasta el altar mayor de dicho camarín, y otra en la capilla al pie de dicho altar mayor, en las que pudiesen poner sus lápidas, con sus letreros y armas también para su entierro y de sus sucesores" ${ }^{\prime 540}$. Efectivamente, se les dieron las referidas sepulturas a los descendientes del obispo Soto, "detrás del retablo del Regalado, donde estaba su retablo altar familiar de San Joaquín en el hueco del camarín con nicho" ${ }^{541}$. Por si no quedaba claro, se repite "que quedan reservadas dos sepulturas en la dicha Capilla de San Pedro Regalado: una delante y otra pegada al altar de San Joaquín para el señor D. Fernando de la Mata, del Consejo de Valladolid y su oidor en esta Real Chancillería y al presente corregidor de la ciudad de Bilbao, y sus sucesores en el patronato de la dicha Capilla por el señor Obispo de Soto, que se le ofrecieron por razón del sitio en que se reedificó dicha capilla y altares a costa del dicho Gabriel de Medina y otros celosos de dicha Congregación" ${ }^{\text {"542. }}$.

Gracias al Libro de Alhajas de la Cofradía del Refugio, que un par de años antes se había fusionado con la del Regalado, conocemos la disposición original de la capilla ${ }^{543}$. Así, el 1 de enero de 1718, el camarín se hallaba dispuesto de la siguiente manera: "tiene en el camarín en su frontis un retablo de talla en blanco con una hechura de San Joaquín, una hechura de Nuestra Señora que tiene los brazos dorados y estofados al

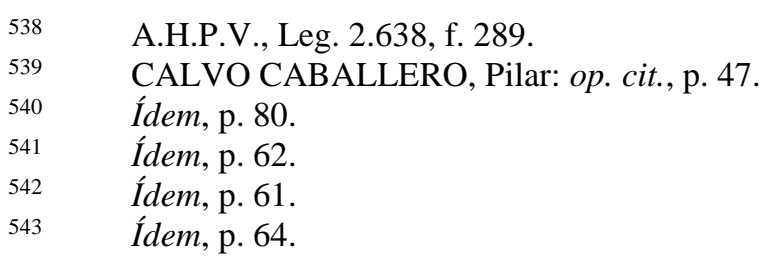


lado del evangelio de dicho Camarín, hay un colateral en blanco y en él el misterio de la Anunciación dorado y estofado" 544 . Otro documento nos aporta algún matiz más acerca de su posición dentro de la capilla de San Pedro Regalado, llamada así "por estar en medio de ella colocada en su altar la imagen de dicho santo y por una de las puertas que tiene dicho altar entramos a otro que en la testera de dicha capilla se halla con su retablo, y en él la santa imagen de San Joaquín de forma que viene a estar detrás del altar de San Pedro Regalado, y está formada otra capilla, aunque pequeña entre uno y otro altar" ${ }^{\prime 45}$. Tras la remodelación de la capilla en el año 1854 el retablo de San Joaquín abandona el camarín, pasando a ocupar el lado derecho de la entrada a la capilla, frente al retablo del Santo Cristo ${ }^{546}$.

En el año 1889 José Jover y Sans, uno de los empresarios vallisoletanos más importantes en este fin de siglo, se comprometió a reformar "decorosamente" la capilla de San Pedro Regalado, dada la devoción que profesaba hacia el santo pucelano ${ }^{547}$. Las diversas obras que tenía intención de realizar (poner vidrieras, pintar el techo y la cúpula, colocar un friso de madera en la pared para evitar roces, etc...) estaban solamente proyectadas, puesto que "para llevarlas a cabo en términos que sea conjunto que corresponda al pensamiento de embellecer aquel lugar, es absolutamente necesario que desaparezcan de la capilla los cuatro altares accesorios, no solamente porque allí no responden a ningún objeto de culto, sino a marcada irreverencia, pues no sirven más que para colocar sombreros durante las misas y ocupar un sitio que achica la capilla y estorban al desahogo, sino también porque son malísimamente tallados y no guardan armonía los unos con los otros, esto aparte de que las efigies carecen de mérito artístico y están muy mal tratadas por el transcurso del tiempo. También habría de suprimirse los dos altarcitos laterales del altar mayor que forman una especie de nicho de muy mal gusto, y así quedaría el altar de San Pedro mucho más esbelto (...) Solo así podré llevarla a cabo sufragando todos los gastos que ocasione, debiendo tener presente la cofradía que este proyecto de obra ha sido consultado a personas competentes: entre ellas a un señor académico de Bellas Artes y también al señor arzobispo de la Diócesis que lo han aprobado en todas sus partes (...) Valladolid, 4 de julio de 1889",548.

La propuesta no fue aceptada. El 9 de julio de 1889 la cofradía respondió negativamente a la desaparición de "los cuatro altares que en ella existen, porque los dos colaterales son de la propiedad de los sucesores de don Gabriel de Medina Mieses, vecino que fue de esta ciudad, así como la sepultura que está al pie de cada uno de ellos: el altar de

\footnotetext{
$544 \quad$ Ídem, p. 65. altar". A.H.P.V., Leg. 3.599, ff. 177-180.

546 CALVO CABALLERO, Pilar: op. cit., p. 135.

$547 \quad$ Ídem, p. 134.

$548 \quad$ Ídem, p. 135.
}

545 “y después de haber tomado agua bendita, y hecho oración al Santísimo Sacramento, pasamos a una capilla, que es la tercera del lado del evangelio, contando desde la puerta principal de dicha iglesia, cuya capilla se llama comúnmente de San Pedro Regalado por estar en medio de ella colocada en su altar la imagen de dicho santo y por una de las puertas que tiene dicho altar entramos a otro que en la testera de dicha capilla se halla con su retablo, y en él la santa imagen de San Joaquín de forma que viene a estar detrás del altar de San Pedro Regalado, y está formada otra capilla, aunque pequeña entre uno y otro 
San Joaquín y esta efigie corresponden a los sucesores del ilustrísimo señor don Diego de Soto, obispo que fue de Mondoñedo, a quienes pertenece el camarín de la capilla de San Pedro Regalado, donde anteriormente estuvo situado el indicado altar y efigie de San Joaquín" $" 549$.

Poco tiempo mantuvo esta postura la cofradía, ya que a finales de 1891 "prospera la propuesta por los deseos mutuos, de Leandro Jover de retomarla y de la Cofradía de impulsarla. La Cofradía, que vuelve a revolver en su archivo sobre los patronatos de los altares, baraja acudir al prelado de negarse el párroco a quitarlos; sus efigies podrían darse a iglesias pobres como la de Renedo. Su única condición fue no tocar la cabeza del Santo. Otro tanto Leandro Jover, que con su visita en noviembre de 1892 obtiene del provisor y arzobispo, Antonio María Cascajares, las órdenes para que los cuatro altares -dos salientes y dos enrasados-desapareciesen" 550.

Las obras de remodelación de la capilla comenzaron en 1893, por lo que los retablos y esculturas que consideraban prescindibles fueron desterrados del templo. El grupo de San Joaquín "que existió a la derecha de la capilla de nuestro patrono" fue entregado a la Hermandad de la Venerable Orden Tercera de Nuestra Señora del Carmen, sita en el Monasterio de San Benito el Real, cenobio que había sufrido mucho durante los efectos de la Desamortización. En el resguardo que dio el director espiritual carmelita, Anastasio Serrano, el 21 de febrero de 1894, se significa que habían recibido "un altar compuesto de una mesa de altar y retablo dorado con una hornacina, donde está colocado San Joaquín de talla de un metro y treinta y cuatro centímetros, con la imagen de la Santísima Virgen en el brazo, para colocarlo en la referida iglesia de San Benito" "551. El 25 de abril de ese mismo año la Cofradía de San Pedro recibió una nueva petición por parte del prior carmelita, Mariano Cidad, el cual "noticioso de que poseen un altar dorado que tenía un Santo Cristo y al pie Nuestra Señora de Refugio, que estaba a la izquierda de la entrada de la capilla de San Pedro Regalado, y de que en la actualidad no tiene servicio para la Cofradía, como corre peligro de perderse o mutilarse el mencionado altar, agradecería se dignasen concederle a la referida V.O.T. para colocarlo en el templo de San Benito el Real". Cinco días después, la cofradía aceptó la entrega, solamente, del "altar y mesa del mismo, pero sin efigie alguna"552.

Pero, ¿quién fue el obispo Soto? Don Diego de Soto y Vera, hijo de Luis de Soto y Catalina de Vera, había nacido en Valladolid. Tras acabar sus estudios eclesiásticos, obtuvo una canonjía en Palencia y, más tarde, un arcedianato en Santiago de Compostela. Trabajó durante 13 años como Oidor de las Chancillerías de Granada y Valladolid. En el año 1545 fue promovido para la diócesis de Mondoñedo ${ }^{553}$, obispado que rigió hasta el final de su vida, el 21 de agosto de 1549, momento en el que ya era obispo electo de Segovia. Fue enterrado "delante de la puerta principal de la catedral.

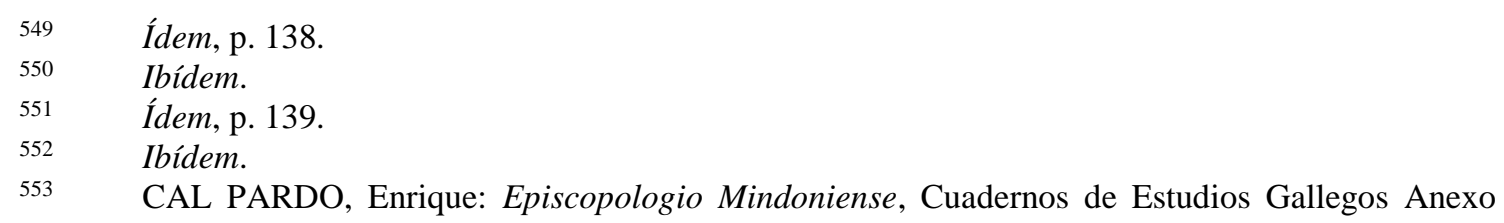
XXVIII, Santiago de Compostela, 2003, p. 300. 
El mismo, satisfecho por la obra realizada, quiso ser enterrado "en mitad" de dicha puerta" 554 .

El Padre Flórez en su España Sagrada nos aporta unos datos muy interesantes que unen la figura del obispo Soto a la iglesia del Salvador, en la cual se encuentra la capilla de la que estamos hablando. Relata el erudito agustino que Diego de Soto "fundó y dotó en la parroquia de S. Salvador de Valladolid (que sería la de su nacimiento) la Capilla dedicada a Santiago, nuestro Patrón, adornándola con pinturas, y dotando dos Capellanías con muchas Indulgencias. En el siglo siguiente se puso allí esta inscripción impresa por Gil González: “+ Esta capilla dotó y fundó el honrado Caballero D. Diego de Soto, del Consejo de su Majestad, y su Oidor que fue de las Chancillerías de Granada y Valladolid, y Obispo de Mondoñedo. Murió electo de Segovia en el 1549. Dejó por Patrón al Lic. Ramiro de Soto, su hermano, y a sus hijos, Corregidor que fue de Ponferrada, Arévalo, y Señorío de Vizcaya, y Alcalde Mayor del Adelantamiento de Burgos año de 1620. Dotó en ella dos Capellanías" ${ }^{555}$. Casimiro González GarcíaValladolid añade a todo esto un dato fundamental: en esa referida capilla de Santiago Apóstol, en la que el obispo Soto levantó su capilla de la Salutación, era en "donde se le bautizó; aquella es hoy la de San Pedro Regalado"556.

La escultura de San Joaquín con la Virgen Niña que estamos tratando ya fue relacionada con nuestro escultor por el Catálogo Monumental de Valladolid: "San Joaquín y la Virgen, madera policromada (160 cms.), último decenio del siglo XVII, estilo de Juan de Ávila"557; por su parte, el Inventario Artístico de Valladolid tan solo se refirió a él

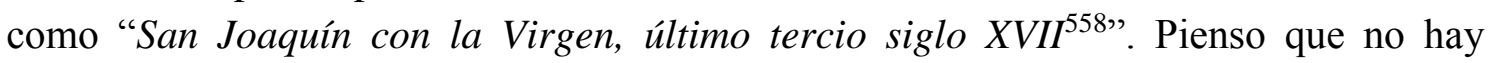
muchas dudas a la hora de atribuirle a Juan de Ávila esta pieza, como más adelante analizaremos. Por su parte, su cronología podría estar cercana al año 1690 dado el estilo de la misma y que tenemos el dato de que ya existía en 1691, año en que, como hemos visto, la caída de la torre provocó la ruina de la capilla. Otra cosa es la fecha en que se construyó el retablo, que debió ser posterior al año 1709, en que se levanta la capilla de San Pedro Regalado. Cabe destacar que nunca se procedió a su dorado, permaneciendo "en blanco".

Antes de analizar la escultura detalladamente, llama la atención el parecido que guarda este San Joaquín con otros que le han sido atribuidos o que posteriormente le atribuiré. Casos como los del San Joaquín del retablo de la Sagrada Familia de la Virgen, en el Colegio de los Ingleses; el de la Sagrada Familia del Museo de la Colegiata de Covarrubias; o el del Museo Diocesano de Salamanca, el cual, al igual que éste, lleva a la niña en sus brazos en una posición similar.

\footnotetext{
$554 \quad$ Ídem, p. 315.

555 FLÓREZ, Enrique: España Sagrada. Tomo XVIII. De las Iglesias Britoniense y Dumiense, incluidas en la actual de Mondoñedo, Oficina de Antonio Marín, Madrid, 1764, p. 237.

556 GONZÁLEZ GARCÍA-VALLADOLID, Casimiro: Datos para la historia biográfica ..., op. cit., Tomo II, p. 470.

557 MARTÍN GONZÁLEZ, Juan José y DE LA PLAZA SANTIAGO, Francisco Javier: Catálogo Monumental de la provincia de Valladolid. Tomo XV..., op. cit., p. 247.

558 MARTÍN GONZÁLEZ, Juan José (dir.): Inventario artístico de Valladolid..., op. cit., p. 26.
} 
San Joaquín aparece de pie, con la pierna izquierda adelantada. Típico contraposto que estamos viendo en casi todas las esculturas documentadas y atribuidas a Ávila. El torso y la cabeza están levemente ladeados también hacia ese lado, para poder observar mejor a su hija, a la cual sostiene con su mano derecha, mientras que con la izquierda intenta hacerle unas carantoñas. Esta última mano parece tallada de manera exenta. La cabeza es muy muy parecida a la de los San Joaquín referidos. El rostro acusa gran blandura. Ojos de cristal. Boca pequeña entreabierta, lo que posibilita que veamos los dientes superiores. La avanzada edad del santo está perfectamente representada en las arrugas que recorren su frente y sus pómulos. Luce frente una completamente despejada; amplias melenas a los lados; y una gran barba bífida con los mechones de pelo sinuosos típicos de Ávila. Parece vestir dos túnicas de igual color, verde con motivos dorados, si bien el polvo lo difumina bastante. La túnica inferior llega hasta los pies, dejándonos ver tan solo la punta de estos, detalle bastante típico de la escuela vallisoletana desde que lo introdujera Gregorio Fernández; mientras que la sobretúnica es algo más corte, le llega hasta las rodillas, teniendo la parte inferior de la misma un motivo que ya observamos en el San Joaquín del Colegio de los Ingleses, y que volveremos a ver en el resto de Joaquines: el borde está compuesto por una serie de entrantes y salientes que forman algo parecido a pequeños arcos de herradura. Ambas túnicas están ceñidas por un cíngulo rojo, el cual sirve para sostener, de manera lateral, un manto rojo que le cubre la espalda y le cae por el hombro izquierdo, también en una composición similar a los Joaquines referidos. Los pliegues de la túnica son exactos a los de las esculturas citadas, paralelos, verticales y redondeados. Otro detalle que nos acerca esta imagen a la producción de Ávila es la manera tan detallada de tallar las manos: con sus venas, uñas y falanges perfectamente delineadas.

Por su parte, la Virgen Niño está sentada en el brazo derecho de su padre. Viste una túnica blanca decorada con flores y emblemas que aluden a su Inmaculada Concepción, por encima un manto azul con motivos dorados a punta de pincel. En su mano derecha pudo sujetar algún objeto, mientras que con la izquierda se dispone a recoger la de mano de su padre. La cabeza de la Niña baja bastante en calidad a la del padre pues no se encuentra tan pormenorizada; sin embargo, sí que podemos ver los típicos ojos rehundidos de Juan de Ávila. La boca entreabierta, formando una especie de rectángulo será muy característica de Pedro de Ávila. Frente despejada, cabellera cayendo a ambos lados de la cabeza de manera simétrica en múltiples bucles sinuosos.

En definitiva, se trata de una obra de apreciable calidad que bien merecería una limpieza, puesto que parece no presentar daños que requirieran una restauración, y que fuera bajada de las alturas a las que se encuentra para poderla visionarla y darla culto de mejor manera. 


\section{VALLADOLID. CONVENTO DE SANTA CATALINA}

\section{SAN PABLO (h. 1690)}

La presente escultura de San Pablo (Fig. 104) también se encontraba localizada en una de las capillas del piso bajo del claustro bajo, concretamente en la del Santo Cristo. Su nombre hacía referencia al Cristo Yacente que la presidía. Se trataba de una imagen tallada según el modelo de Gregorio Fernández, autor al que se le ha venido atribuyendo desde hace mucho tiempo, si bien en la actualidad se relaciona más con su taller. Esta capilla era apodada por las propias monjas como la "Capilla Sixtina de Valladolid", debido a la multitud de obras de arte, tanto pictóricas como escultóricas, que contenía en su reducido espacio.

La pequeña escultura (106 cms.), que también pudo ingresar en el convento gracias a la donación de algún particular, fue atribuida a nuestro escultor por Martín González y Plaza Santiago, datándola en el último cuarto del siglo XVII ${ }^{559}$. Para mí, se trata de una de las esculturas con una atribución más segura.

El santo aparece representado en pie, con la pierna derecha adelantada, en ademán de avance. En su mano derecha porta un libro, el cual se encuentra abierto por las páginas por las que tiene metido un dedo el santo, que hace referencia a su carácter de apóstol, predicador y escritor de epístolas. Con la otra mano sujeta la espada de su martirio, la cual mantiene caída.

En caso de ser de nuestro escultor, la presente escultura no es tan arriesgada y monumental, como la realizada en Lerma. Es algo más convencional, pero, no por ello, carente de interés. El rostro del santo es muy similar al del San Joaquín que hemos visto en uno de los retablos del Colegio de los Ingleses. Coinciden en todo, a excepción de los mechones de pelo mojados sobre la frente y la mayor longitud de las barbas de este San Pablo. Los ojos, nariz, forma de boca, fruncimiento de ceño y arrugas que surcan la frente, mejillas y parte baja de los ojos son idénticos en ambas tallas. Podría decirse que las arrugas y la blandura del rostro están mejor conseguidas en esta pieza. Es admirable el realismo con el que Ávila consigue dotar de madurez al rostro del santo de Tarso. Hay, sin embargo, una pequeña diferencia entre ambas; se trata de la parte baja de la melena. Si en el San Joaquín se resuelve con cabelleras lisas pero sinuosas, en este caso de San Pablo observamos ciertos bucles, elementos utilizados por Ávila en otras muchas esculturas. Los ojos son de tapilla.

La vestimenta también es similar a la de San Joaquín, aunque hay mayores diferencias que con el rostro. Viste una larga túnica verde, ajustada por un ceñidor a la cintura, que le llega hasta los tobillos, permitiéndonos ver los pies calzados con sandalias. Por encima el típico manto rojo que, surgido de la espada, se sujeta por el ceñidor de la túnica, sube por la espalda y acaba enrollado en el brazo opuesto. La disposición del

559 MARTÍN GONZÁLEZ, Juan José y DE LA PLAZA SANTIAGO, Francisco Javier: Catálogo Monumental de la provincia de Valladolid. Tomo XV..., op. cit., p. 58. 
manto es idéntica a la observada en la Magdalena conservada en el Convento de Porta Coeli, si bien los pliegues son algo más redondeados y rígidos que aquéllos. Dado que en la parte baja de la imagen aparecen los manidos pliegues verticales habría que fecharlo cercano a finalizar su primera etapa y comenzar la segunda, es decir hacia 1690 .

Al igual que ocurre con Santa Catalina se trata de una escultura ciertamente anodina, pues el rostro no muestra sentimiento alguno, y el movimiento no está muy conseguido. 


\section{VALLADOLID. CONVENTO DE PORTA COELI}

\section{ESCULTURAS DEL ANTIGUO RETABLO DE LAS LAURAS (h. 1690)}

A finales del siglo $\mathrm{XX}$, cuando estaba a punto de ser derribado el convento, la iglesia conservaba en su altar mayor, como ya hemos dicho, un retablo neoclásico del primer cuarto del siglo $\mathrm{XIX}^{560}$. Anteriormente a éste hubo otro barroco. Según Canesi fue colocado en el año $1690^{561}$, al igual que sus colaterales. En lo que no acierta el diarista es en las fechas de dorado de los retablos ya que no aconteció entonces, sino en 1693. Los tres desaparecieron durante la Guerra de la Independencia, contienda que infringió gravísimos daños al patrimonio vallisoletano, cebándose especialmente con los retablística y la platería.

Por el contrato de ejecución del dorado del referido retablo mayor (DOCUMENTO 53) ${ }^{562}$ sabemos que este ya estaba construido en abril de 1693, mes en el que el dorador y estofador Alonso Gutiérrez se compromete a dorarlo y policromar las imágenes que se hicieron nuevas para él. Al parecer, el retablo poseía las siguientes esculturas: en el centro se encontraba Nuestra Señora de La Laura, titular del convento; a los lados de ésta Santa María Magdalena y Santa Rosa de Lima; ya en el ático se situaban dos ángeles ${ }^{563}$. Es de suponer que estos dos seres celestiales portaran alguna de las Arma Christi o, quizás, portaestandartes, según el modelo tan difundido y repetido en el área vallisoletana desde que Gregorio Fernández lo consolidara. Del retablo anterior se reaprovecharía la imagen de la Virgen que daba nombre al convento, mientras que las dos santas y los ángeles se fabricarían por entonces, motivo por el cual está incluido su dorado y policromado entre las condiciones redactadas por Gutiérrez.

El retablo pudo ser ejecutado por el prestigioso ensamblador vallisoletano Francisco Billota, pues consta que fue este artífice quien compuso el asiento sobre el que debía descansar la escultura de Nuestra Señora de La Laura ${ }^{564}$; además de ser la persona a la que se tenía que consultar la manera "que tengo de componer el pedestal" "565. Teniendo en cuenta la obra de Francisco Billota y la estrechez de la iglesia, este retablo estaría compuesto por un banco, un único cuerpo con tres calles, constituido a través de cuatro

\footnotetext{
560 MARTÍN GONZÁLEZ, Juan José y DE LA PLAZA SANTIAGO, Francisco Javier: Catálogo Monumental de la provincia de Valladolid. Tomo XV..., op. cit., p. 156.

561 "Este convento es de los más estrechos que hay en Valladolid. Por los años de 1690 pusieron nuevo dorado, retablo y colaterales, de suerte que es la iglesia es un aseado oratorio". CANESI ACEVEDO, Manuel: Historia de Valladolid (1750), Tomo III, op. cit., p. 509.

562 "En dicho contrato no solamente se compromete a dorar el retablo mayor, y a policromar y estofar las esculturas en él incluidas. También contrato el dorado de la custodia, de las cartelas de las lámparas de la iglesia, del remate del Santo Sudario, de la tabla donde se asientan los candeleros, además de componer el pedestal". (DOCUMENTO 53)

563 "Es condición que las dos efigies como son Santa María Magdalena y Santa Rosa se hayan de dorar las tres partes con el propio oro y después se han de estofar según y conforme a arte. Asimismo, los dos ángeles del último cuerpo se han de dorar y estofar en la misma conformidad que las santas referidas". Ídem.

564 "Es condición que he de dorar el asiento que hiciere Francisco Billota para Nuestra Señora y también los rayos que se han de hacer nuevos". Ídem.

565 "Es condición que tengo de componer el pedestal de la manera que dijere Francisco Billota con florones de oro". Ídem.
} 
grandes columnas salomónicas, y un ático con portada central. La Virgen y las dos santas presidirían cada una de las calles, mientras que los ángeles estarían colocados en los extremos del ático.

El dorado del retablo fue concertado el 3 de abril de 1693 por el referido Alonso Gutiérrez. Además, se comprometió con la priora del convento a dorar y policromar las cuatro imágenes (santas y ángeles); y a dorar los tres marcos de frontales (retablo mayor y colaterales), la custodia, el arca del Santísimo, el asiento y los rayos de Nuestra Señora, las dos cartelas de las lámparas, el remate del Santo Sudario y la tabla "donde se asientan los candeleros". Por todas estas tareas, que debería tenerlas concluidas para el último día del mes de julio de ese mismo año, Gutiérrez percibiría 9.500 reales. Hay que puntualizar a que, en lo referente a los colaterales, tan solo se debió de dorar sus frontales, ya que el de los retablos no se realizó hasta el periodo 1697-1700 según consta en uno de los libros de fábrica del convento.

Mis razones para atribuir a Juan de Ávila las imágenes de este retablo, salvo la de Nuestra Señora de La Laura, que fue reutilizada, se basan en la escultura de la Magdalena. Esta ya había sido relacionada con nuestro escultor por Martín González y Plaza Santiago: "María Magdalena, madera policromada, 125 cms., estilo de Juan de Ávila"566. Tras encontrar el contrato para el dorado del retablo, ver que en el que se hacía referencia a Santa Rosa, y comprobar que en el convento existía una escultura de dicha santa, y, además, con las mismas características que la Magdalena, me pareció lo más lógico atribuir la labor escultórica de este retablo a Ávila. Los ángeles han desaparecido, por lo que nunca sabremos a qué iconografía correspondían. Tras la destrucción del retablo barroco se reubicaría a las dos santas, mientras que los ángeles, si no fueron desbaratados, se desecharían.

Tampoco habría que descartar el hecho de que Francisco de Billota y Juan de Ávila trabajaron juntos en una serie de retablos. Tenemos documentada su coincidencia en los colaterales de la iglesia de San Felipe Neri; es probable que también concurrieran en los retablos del Domus Dei de La Aguilera (1690) y en el retablo mayor, y colaterales, del Monasterio de Santa Brígida. Además, en 1701 ambos artífices dieron el visto bueno conjunto a un retablo realizado por Manzano y De la Peña para la capilla de San Juan de Sahagún de la iglesia de San Martín.

Antes de analizar estas dos imágenes me gustaría aclarar que hablo sobre este retablo dentro del epígrafe del Convento de Porta Coeli dado que la Magdalena se conserva allí, desconociendo, sin embargo, el paradero de Santa Rosa de Lima.

566 MARTÍN GONZÁLEZ, Juan José y DE LA PLAZA SANTIAGO, Francisco Javier: Catálogo Monumental de la provincia de Valladolid. Tomo XV..., op. cit., p. 159. 


\section{MARÍA MAGDALENA}

Tras establecerse en una de las hornacinas laterales del retablo mayor barroco pasó, a consecuencia de la destrucción que supuso la Desamortización, a ocupar uno de los retablos colaterales del lado de la Epístola ${ }^{567}$, tal como pudo verla González GarcíaValladolid. Este mismo erudito la calificó como "escultura en madera muy aceptable". Una vez se derribó el convento a finales del siglo XX la escultura fue a parar, junto con otro lote de obras de arte, a la clausura del monasterio de Porta Coeli, concretamente a la sala donde se encuentra instalado el relicario.

Se trata de una escultura muy elegante que representa a María Magdalena $(125 \mathrm{cms}$.) (Fig. 105). La santa aparece llorando, como podemos ver por las lágrimas que surcan su bello rostro. Ese sentimiento seguramente le fuera provocado por la meditación sobre la Pasión de Cristo que le inducía la visión directa del Crucifijo que portaría en su mano izquierda. Tanto el Crucifijo como los dedos los ha perdido. Menos probable es que sostuviera en esa mano una calavera o un vaso de perfumes, que es su atributo más antiguo. El frasco de perfumes aparece en diferente ocasiones a lo largo de su vida: por ejemplo, cuando unge los pies de Cristo en la comida en casa de Simón el leproso, o cuando los lleva al Santo Sepulcro ${ }^{568}$. Con la otra mano, cuyo brazo tiene doblado, sostiene un paño blanco que se apoya sobre el pecho. El escultor ha sabido captar a la perfección el instante, ha parado el tiempo.

Al estar representada antes de su penitencia la vemos vestida con ricos atavíos. Estos, según Réau, hacen referencia a su pasado de vida mundana, son ropas de cortesana ("in habitu meretricio" ${ }^{569}$. La vestimenta la componen una amplia túnica de color verde con el ribete inferior con una cenefa dorada. Se ajusta a la cintura con un ceñidor rojo. Las mangas al estar acuchilladas nos permiten ver el forro interior de la túnica, de color amarillo y puños rojos. Por encima un manto muy sinuoso y quebrado. Situado tras la cintura, y recogido por el ceñidor, sube por la espalda cayendo por delante del hombro izquierdo. La disposición del mismo es bastante teatral, en correspondencia a la actitud de la santa. Los plegados del manto son amplios, suaves, redondeados, apenas si se percibe alguna quebradura; en cambio, los de la túnica son los que nos suele presentar Ávila en su segunda etapa: finos y paralelos, que al chocar con el suelo crean alguna pequeña dureza.

El rostro como ya hemos dicho es ciertamente bello. Su feminidad se ve incrementada por la inclusión de las largas melenas que le caen por la espalda y los dos finos, largos y sinuosos mechones que le caen por el pecho, llegando hasta la cintura. El pelo, que cae de manera simétrica a ambos lados del rostro, deja completamente visible la oreja

\footnotetext{
567 "Los retablos colaterales estaban dedicados: los del lado del Evangelio a la Oración en el Huerto y a la Soledad y los de la Epístola a San Agustín y Santa María Magdalena, siendo los primero y tercero pinturas en lienzo, la segunda de bastidor y la última escultura en madera muy aceptable". GONZÁLEZ GARCÍA-VALLADOLID, Casimiro: GONZÁLEZ GARCÍA-VALLADOLID, Casimiro: Valladolid..., op. cit., Tomo II, p. 359.

568 RÉAU, Louis: Iconografía de los santos. G-O..., op. cit., pp. 293-297.

569 Ídem, p. 297.
} 
derecha. La técnica de su talla es similar a la observada en el San Isidro. El rostro emparenta plenamente con los de Ávila: ojos grandes y rehundidos, nariz recta, amplia, boca entreabierta en la cual podemos ver parte de los dientes, e incluso intuir la lengua. Las mejillas sonrosadas y los labios acusan blandura. Los ojos parecen directamente pintados en la madera. También es característico de Ávila el leve adelantamiento de la pierna derecha, que apenas si se percibe a través del manto.

Pudiera ser que Ávila se hubiera inspirado a la hora de ejecutar esta talla en la Magdalena que Gregorio Fernández esculpió para el paso del Descendimiento de la Cofradía Penitencial de la Santa Vera Cruz (1623). En ella podemos ver una Magdalena con la posición de los brazos invertida: con el derecho se aprieta un paño sobre el pecho, mientras que el izquierdo le mantiene extendido, si bien en esta ocasión no porta atributo, aunque pudo llevar un vaso de perfumes. Tanto el movimiento del rostro como lo demás no conserva ninguna coincidencia. Esta escultura bien pudo servir de modelo a su hijo Pedro a la hora de tallar sus Magdalenas para la Catedral y para el Oratorio de San Felipe Neri. Desde luego, la forma en que compone con una pierna adelantada, la manera de disponer el manto y la sinuosidad con la que caen los cabellos sobre el pecho son buena prueba de ello.

Nuevamente en una escultura documentada, o atribuida, a Ávila la talla carece de postizos internos, tan solo reseñar la diadema de plata.

\section{SANTA ROSA DE LIMA}

El conocimiento que tenemos de esta escultura es menor puesto que, además de estudiarla solo por una pequeña foto en blanco y negro, desconocemos el lugar que ocupó en Las Lauras tras la destrucción del retablo mayor barroco, y también el destino que tomó tras el derribo del referido convento. Ya dijimos que las obras de arte que contenía este cenobio fueron a parar a diferentes establecimientos dominicos, siendo los que mayores cantidades recibieron los vallisoletanos de Porta Coeli y Corpus Christi y el de San Pedro Mártir de Mayorga de Campos (Valladolid).

La escultura de Santa Rosa de Lima (127 cms.) (Fig. 106) nunca había sido relacionada con Ávila. La única ocasión que se ha tratado de ella ha sido en el Catálogo Monumental de Valladolid, y en él se refería tan solo: "Santa Rosa de Lima, madera policromada, ojos de cristal, 127 cms., mediados del siglo XVII"570. Su inclusión en su retablo se debe a que es la patrona de las dominicas ${ }^{571}$.

La joven terciaria dominica (1586-1617) nacida en el Perú, aparece representada según su iconografía habitual: al igual que San Antonio de Padua, sostiene al Niño Jesús en

570 MARTíN GONZÁLEZ, Juan José y DE LA PLAZA SANTIAGO, Francisco Javier: Catálogo Monumental de la provincia de Valladolid. Tomo XV..., op. cit., p. 159.

571 RÉAU, Louis: Iconografía de los santos. P-Z..., op. cit., p. 154. 
una de sus manos, concretamente en la derecha ${ }^{572}$. En la otra mano parece que no tuvo ningún atributo. El proceso de elevación a los altares fue bastante rápido puesto que en 1668 fue beatificada y en 1673 canonizada, convirtiéndose de esa manera en la primera santa del Nuevo Mundo ${ }^{573}$. Mucha de su leyenda está relacionada con las flores: así, por lo visto, "las flores giraban sus cálices hacia ella", y, además, el día en que "se propuso su canonización al papa, éste respondió que no creería en la santidad de una india, incluso si lloviesen rosas. Apenas hubo pronunciado esas palabras, una lluvia de rosas cubrió el Vaticano y no cesó hasta que el pontífice decretó la canonización de la santa limeña"574.

Figura de pie. Se trata de una escultura muy estática, poco movida en contraposición a la Magdalena. A pesar de la escasa calidad de la fotografía parece que el rostro tampoco está tan trabajado como el de su compañera de retablo; lo mismo puede decirse de los pliegues que recorren el hábito. Éste parece ser el dominico, si bien la gran cantidad de motivos vegetales y la orla que recorre la capa pueden indicar lo contrario. La túnica se encuentra ceñida a la cintura. La cabeza se encuentra tocada por una esclavina que nos impide ver cualquier rastro de su cuero cabelludo. A falta de un correcto estudio de la pieza mediante la visión directa cabe atribuírsela a nuestro escultor, si bien los pliegues parecen denotar una cronología anterior a la propuesta.

\footnotetext{
572 Ídem, 1998, pp. 153-154.

573 Ídem, p. 154.

574 Ídem, pp. 153-154.
} 


\section{LEÓN. IGLESIA DE SANTA MARINA LA REAL}

\section{ESCULTURAS DEL RETABLO MAYOR (h. 1690-1691)}

El retablo de la antigua iglesia leonesa de San Miguel y de los Arcángeles de la Compañía de Jesús, actual parroquia de Santa Marina la Real, fue construido en 1690 por el ensamblador vallisoletano Alonso Manzano, el cual se concertó el 26 de mayo de dicho año con el Reverendo Padre Provincial Pablo Abarca, Rector del Colegio de la Compañía de Jesús de la ciudad de León, para realizar la "talla y ensamblaje del retablo de la capilla mayor de la iglesia de dicho colegio de León conforme a la traza que queda en poder del dicho Alonso Manzano firmada suya y del dicho Padre Rector" (DOCUMENTO 55).

Según las condiciones, el retablo debía de estar presidido por "la efigie de Nuestro Padre San Ignacio", mientras que "en la tarjeta que cierra la clave ha de ir el Jesús que harán la forma de tenerle con su corona encima y los dos Ángeles con sus alas y bandas que han de tener cuatro pies de alto y estos han de correr por cuenta del maestro que se encargare de su manufactura". Asimismo, Manzano se ocuparía de tallar la custodia, que tendría la "altura que el ancho pide a su proporción advirtiendo que el San Miguel ha de estar debajo de la cornisa principal y ha de ser ejecutada en la forma que demuestra la traza y planta y alzado". En su fachada habría de "quedar un marco fingido con su adorno de talla para que en este se ponga un lienzo que ha de ser de pintura para que el santo asiste allí y el Santísimo en el centro de la custodia". En el contrato también entraba la fábrica del marco de frontal de este retablo y los de los dos colaterales. Nos queda el interrogante de si antes de contratar este retablo había realizado también estos dos.

El colegio jesuita se comprometía a dar a Manzano un "taller suficiente y saludable para dicha ejecución y si se hiciere en otra casa particular lo haya de llevar el colegio a su cuenta", así como "un aposento con su cama de ropa para él solo y las pagas dando la cantidad que fuere necesario para pagar los oficiales cada semana y al maestro lo que fuere menester y tiempo suficiente que fuere necesario para acabar dicha obra". El plazo de ejecución del retablo, por el que se le abonarían 21.000 reales de vellón, sería de dieciocho meses "contando de San Juan de junio de mil seiscientos y noventa en adelante no faltando dinero a tiempo".

El retablo permaneció intacto hasta 1820, año en que se decidió adaptarlo a los nuevos gustos neoclásicos. Por lo visto, la reforma era necesaria porque tenía una fábrica antigua y estaba con la madera en su color, debido a lo cual se mandó que "se arreglase según arte con solidez y hermosura, conforme corresponde al orden que representa y su buena disposición, y que después se dorase y se pintase de un jaspeado imitando lo más posible al natural". Estos retoques fueron llevados a cabo por los escultores Ángel y Luis Álvarez y el pintor Francisco Quijano. A pesar de esta transformación el esquema arquitectónico barroco se mantuvo. Por desgracia, desapareció tras el hundimiento del 
ábside de la iglesia en el año 1970, si bien se conservan diversas fotografías que nos permiten su estudio ${ }^{575}$.

Gracias a dos inventarios realizados tras la expulsión de los jesuitas podemos conocer de manera detallada el aspecto del retablo tallado por Manzano. El primero de ellos indicaba "que el altar mayor tiene un retablo grande sin dorar, y con las efigies en primer lugar y más preeminente del ángel San Miguel, y a los lados las de San Gabriel y San Raphael, $y$ en un cascarón dorado sobre la custodia la imagen de Nuestra Señora de la Concepción de bulto más pequeña". En el segundo se apunta que "la (sic) altar mayor de madera por dorar con las imágenes de San Gabriel, San Miguel y San Raphael, de bulto, estofadas, y en lo superior del retablo otras dos de bulto y por estofar, la custodia dorada con una imagen de la Concepción en medio". Extraña que en ninguno de los dos inventarios se recojan el relieve de la Anunciación a la Virgen que se hallaba

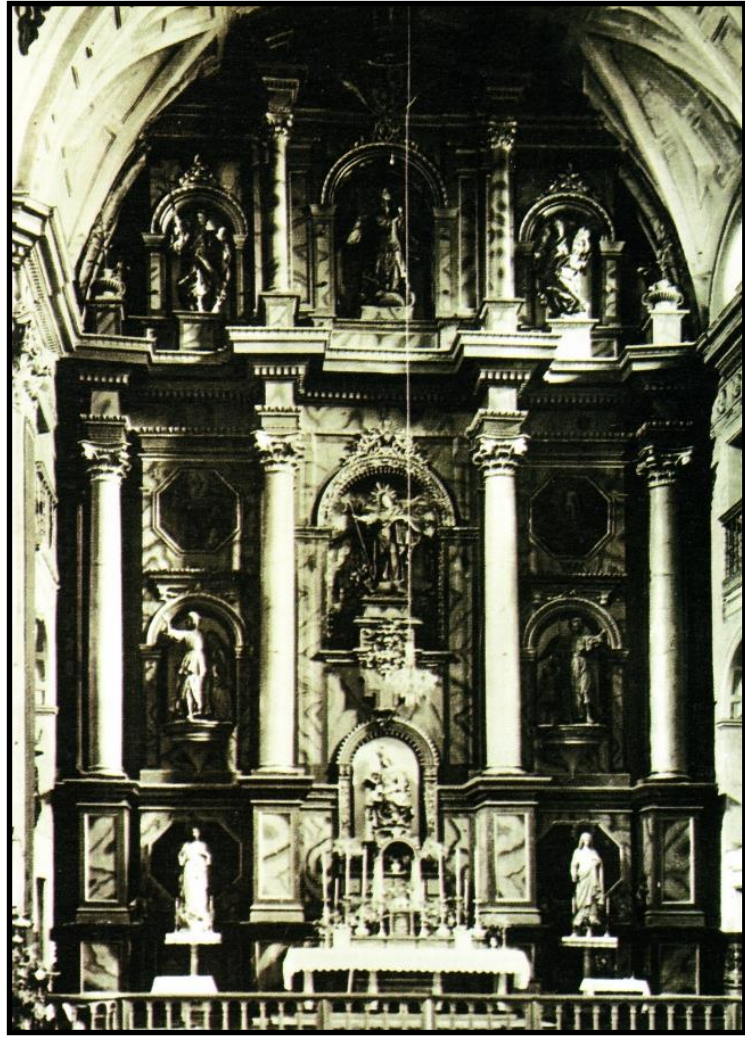

Il. 30- Alonso Manzano (y retocado en 1820 por Ángel y Luis Álvarez). Retablo mayor

(Desaparecido). Iglesia de Santa Marina. León. situada en la hornacina central del ático, ni los cuatro lienzos del Nacimiento, Adoración de los Reyes, Resurrección y Ascensión colocados en medio de los netos de la predela y en las calles laterales sobre las hornacinas de los dos ángeles ${ }^{576}$. Tras el hundimiento del ábside las cuatro pinturas, realizadas y firmadas por el vallisoletano Diego Díez Ferreras, se deterioraron bastante. Tres se conservaron en la iglesia mientras que la de la Resurrección pasó a engrosar la Colección Torbado.

Recapitulando, la parte escultórica estaba compuesta por San Ignacio, en la hornacina central; San Miguel en el trono de gloria; San Rafael y el Ángel de la Guarda, inventariado como San Gabriel. Además, en el centro del ático debió de existir un relieve de la Anunciación; y en las cajas laterales del mismo San Uriel y San Jehudiel, ambas realizadas en el segundo cuarto del siglo XVIII. El conjunto escultórico ha sufrido diversos avatares: la escultura de San Ignacio desapareció tras la expulsión de los jesuitas, mientras que el resto de ellas se vieron muy afectadas tras el hundimiento

575 LLAMAZARES, Fernando: "Un espacio barroco para la formación inicial de Lorenzana: la iglesia del Colegio de la Compañía de Jesús en León”. En PANIAGUA PÉREZ, Jesús (coord.): España y América entre el Barroco y la Ilustración (1722-1804), II Centenario de la Muerte del Cardenal Lorenzana (1804-2004), León, 2005, p. 63.

$576 \quad$ Ídem, p. 64. 
del ábside: solamente quedó intacto el Ángel de la Guarda; la efigie de San Rafael perdió los brazos y de los otros tres ángeles tan solo subsistieron las cabezas ${ }^{577}$.

Las efigies de los tres ángeles realizadas en la época en que se estaba fabricando el retablo (San Miguel, San Rafael y el Ángel de la Guarda) han sido atribuidas por Llamazares Rodríguez a José de Rozas ${ }^{578}$. Desconocemos si la imagen de San Ignacio se tallaría por entonces, por lo que también procedería asignársela al escultor que talló estas otras tres; o, quizás, se trataba de una escultura reutilizada.

Si bien creo que las esculturas denotan un influjo de José de Rozas, también veo ciertos estilemas presentes en la obra de Juan de Ávila, lo que vuelve a llevarnos a la situación repetida en tantas ocasiones: la similitud del estilo de ambos artistas y la consiguiente dificultad para poder delimitar sus personalidades artísticas.

Las esculturas del Ángel de la Guarda (Fig. 107) y San Rafael presentan una disposición y composición simétrica. Una se contrapone a la otra: aparecen los ángeles de pie, con una pierna adelantada; el brazo de ese mismo lado lo elevan al cielo, indicando al niño que les acompaña el camino que deben tomar, en el caso de San Rafael se trata del pequeño Tobías; el rostro ligeramente inclinado mirando a sus respectivos acompañantes; visten las típicas vestimentas que hemos visto en muchos de los ángeles vallisoletanos: los de las iglesias de Santiago y San Martín de Valladolid, el del relieve de Ataquines, el de la Oración del Huerto de Tordesillas, etc... Por este último motivo ya podemos asegurar que estas esculturas proceden de Valladolid. Las causas que me llevan a plantear una posible atribución a favor de Ávila, eso sí, con muchas reservas, se basan en el parecido de sus rostros, especialmente el de San Rafael con el de algunas esculturas atribuidas a nuestro escultor; asimismo, el parecido formal del niño que acompaña al Ángel de la Guarda es bastante exacto al del pupilo que hace lo propio con el mismo Ángel conservado en la iglesia de San Martín de Valladolid. Como podemos ver tanto los pliegues de la túnica, el detalle de la unión de las manos, y la forma de tallar el cabello son bastante aproximadas. También el cabello de ambos ángeles está construido de la misma manera, a base de amplios bucles en los laterales del rostro. A pesar de ello los grupos leoneses son de mayor calidad que el Ángel de la Guarda vallisoletano. No menos importante es el hecho de que Juan de Ávila y Alonso Manzano colaboraran en varios retablos, de los cuales tenemos noticia: el retablo mayor del Hospital de San Juan de Dios (1687) y el retablo mayor de la iglesia de Santiago Apóstol (1698-1702), ambos en Valladolid. No cabe duda de que en el amplio lapso de tiempo entre ambas obras indica que debieron de participar de manera conjunta en alguno más, quizás este leonés. La cronología más probable de la ejecución de estas esculturas será la 1690-1691. 


\section{AMPUDIA. IGLESIA MUSEO DE SAN FRANCISCO}

En el Museo de Arte Sacro ubicado en el antiguo convento de San Francisco se encuentran dos esculturas que pueden ser adscritas con bastante seguridad a nuestro escultor. Se trata de las de los franciscanos San Diego de Alcalá y Santa Rosa de Viterbo, si bien hay dudas acerca de la identidad de ésta última. Ambas ocupan en la actualidad las hornacinas laterales de un retablo barroco presidido por una escultura de la Estigmatización de San Francisco, obra relacionada con los Sierra, quizás Tomás de Sierra. Desconocemos el lugar de procedencia de ambas tallas, si bien parece bastante lógico pensar que pudieron hacerlo del propio Convento de San Francisco dada la temática franciscana de ambas piezas. Tras la Desamortización pasarían a la Colegiata, aneja al cenobio. Allí, en un retablo del siglo XVIII situado dentro de la Capilla de Santa Ana es donde la vieron tanto Martín González y Urrea como Parrado del Olmo ${ }^{579}$.

Su atribución a Ávila ha sido unánime hasta el momento. Los primeros en formularla fueron Martín González y Urrea, los cuales las creyeron "atribuibles a Juan de Ávila"; sin embargo, pensaban que se trataba de las efigies de San Diego de Alcalá y Santa María Magdalena ${ }^{580}$. Posteriormente, Parrado, coincidiendo en la identificación de las mismas, las definió como "próxima a Juan de Ávila"581.

Antes de pasar a analizar de forma individualizada las dos esculturas, me gustaría explicar los motivos que me llevan a pensar que se trata de Santa Rosa de Viterbo y no de Santa María Magdalena. Lo primordial que aduzco es la exactitud total que, como ya hemos señalado varias veces, poseen tanto esta escultura como las de las otras de esta santa conservadas en la iglesia de Santiago de Valladolid y en el Convento de las Claras de Tordesillas. Ambas esculturas, y esta también, han querido verse como Magdalenas, sin embargo, ya expliqué que lo más probable es que todas ellas efigien a Santa Rosa de Viterbo a la vista del hábito franciscano que portan y al origen franciscano que tienen todas ellas, incluida la vallisoletana. En el caso concreto de esta escultura de Ampudia pienso que el hecho de que aparezca junto a San Diego de Alcalá no es algo casual. Si echamos un vistazo a la historia de ambos santos, vemos que ambos coinciden en un determinado pasaje de sus vidas: los dos santos daban de comer pan a los pobres, hasta que un día sus compañeros de cenobio les descubrían y justo en ese momento el pan que portaban en el manto se transformaban en flores (San Diego de Alcalá) o en rosas (Santa Rosa de Viterbo).

579 URREA FERNÁNDEZ, Jesús y MARTÍN GONZÁLEZ, Juan José: Inventario artístico de Palencia y su provincia I..., op. cit., p. 60; PARRADO DEL OLMO, Jesús María: Ampudia: Iglesia de San Miguel, Diputación Provincial de Palencia, Palencia, 1991, p. 19.

580 URREA FERNÁNDEZ, Jesús y MARTÍN GONZÁLEZ, Juan José: Inventario artístico de Palencia y su provincia I..., op. cit., p. 60.

$581 \quad$ PARRADO DEL OLMO, Jesús María: Ampudia..., op. cit., p. 19. 


\section{SANTA ROSA DE VITERBO (h. 1690-1700)}

Como ya hemos referido en las otras dos ocasiones, las tres esculturas son prácticamente idénticas entre sí, tanto en lo referente a actitudes, iconografías y vestimentas. Pudiera ser que todas ellas copiaran un mismo modelo dada la exactitud entre ellas; o bien que una de ellas fuera el origen de todas estas copias. Lo lógico sería pensar que el modelo fuera la conservada en la iglesia de Santiago Apóstol, suponiendo que ésta procediera del Convento de San Francisco, cenobio franciscano que poseyó una serie de obras que fueron ampliamente copiadas para otros lugares. No hace falta señalar ahora la importancia de la que gozó este establecimiento.

Pues bien, como las otras dos, Santa Rosa de Viterbo (Fig. 108), aparece de pie, con la pierna izquierda levemente adelantada, creando así el tan manido contraposto. En su mano derecha porta un Crucifijo, mientras que la izquierda la extiende, como si estuviera sufriendo uno de sus tan característicos éxtasis al contemplar el sagrado madero. A esta suposición ayuda el gesto ensimismado y atento a la cruz que nos presenta su rostro. Viste el típico hábito franciscano ceñido por un simple cíngulo con los cinco nudos tradicionales en la Orden de San Francisco. El sayal de color pardo contiene pequeños motivos dorados esgrafiados; siendo el único adorno del hábito unas preciosas cenefas, del tipo de las que llevamos viendo en todas las esculturas, situadas en la parte baja del mismo y en los bordes de las mangas. Los paños presentan una total semejanza con los vistos en la Santa Rosa vallisoletana; también se asemeja más a ésta que a la tordesillana en el canon algo más estilizado y a la superior calidad artística de ambas, perceptible tanto en la forma de tallar los pliegues como en el énfasis puesto a la hora de crear el rostro y las cabelleras; en estas dos el escultor ha echado el resto.

La cabeza es muy "Ávila", pero tanto que hasta se parece a algunas de las esculturas que años después esculpirá su hijo Pedro. Así, por ejemplo, hay numerosas concomitancias entre esta cabeza y la que el propio Pedro talla en la Virgen de la Anunciación conservada en la actualidad en la iglesia parroquial de Renedo (Valladolid). El rostro acusa blandura, y es muy delicado y bello; quizás el más de los tres. Peina una preciosa y larga melena ondulada que le llega hasta la cintura, elemento que puede aludir a su condición de virgen. Esta melena es también la mejor de las tres esculturas dado el grado de individualización de guedejas que lleva; quizás esto se deba a que esta talla se encontraría más cerca de sus posibles espectadores que las otras dos, o simplemente hubo otros motivos que no vienen al caso. No insistiremos en su rostro puesto que lo dicho en los de las otras dos posee la misma validez para este caso. A pesar de su alta calidad, esta pieza también acusa cierta rigidez.

\section{SAN DIEGO DE ALCALÁ (h. 1690-1700)}

Fray Diego de San Nicolás, elevado a los altares como San Diego de Alcalá, fue un hermano lego de la Orden de los Frailes Menores de la Observancia. Nació el 14 de noviembre del año 1400 en la pequeña localidad sevillana de San Nicolás del Puerto. 
Dos facetas destacan en su personalidad: la de peregrino y la de misionero. Como peregrino, sabemos que en el año 1450 marchó a Roma para celebrar el Jubileo que había declarado el papa Nicolás V. También por entonces se celebraba en dicha ciudad la canonización de uno de los santos franciscanos más importantes: San Bernardino de Siena. Relacionado con esta vertiente hay que señalar que fue uno de los hombres más viajeros de su época puesto que visitó gran parte de España, incluidas las Islas Canarias, y algunos puntos de Francia e Italia. Como misionero fue enviado a Canarias al convento de Arrecife. Allí ocupó los cargos de cocinero, portero y hasta de guardián del convento. Es en este cenobio donde, a raíz de su trabajo de portero, ocurrió el milagro de la conversión de los panes en flores cuando los hermanos le pillaron entregando habitualmente mendrugos a los menesterosos.

Se le atribuyen numerosos milagros, siendo los más destacados el que hemos referido de la conversión del pan en flores: "a pesar de la prohibición de su superior, distribuía el pan del convento entre los pobres. Intentaron sorprenderle in fraganti pero el hermano portero que le revisó el delantal, sólo encontró rosas. Es la reedición del milagro de Santa Isabel de Hungría"582, el de "sus momentos de éxtasis, se elevaba en el aire de manera inconsciente. Durante uno de sus trances místicos, los ángeles lo sustituyeron en las faenas de la cocina" ${ }^{\$ 83}$. Falleció en Alcalá de Henares el 13 de noviembre de 1463. Su canonización llegó de la mano del papa Sixto V en 1588 a instancias del rey Felipe II $^{584}$. Posee las distinciones de haber sido el primer santo español de la Edad Moderna y, a su vez, el único santo canonizado en todo el siglo XVI. A raíz de haber sido el primer hermano lego franciscano canonizado fue tomado por patrono de esta Orden de los Frailes Menores de la Observancia ${ }^{585}$.

San Diego de Alcalá (Fig. 109) es representado en esta escultura de pie, con la pierna izquierda levemente adelantada. Al igual que su compañera de retablo, la imagen es bastante rígida. A ello contribuyen los pliegues rectos y paralelos que caen por su túnica, los cuales ayudan a fecharla dentro del segundo estilo de nuestro escultor; también figura este tipo de pliegues en la capilla. Viste un sayal buriel entallado hasta los pies, ceñido a la cintura por el usual cordón franciscano de cinco nudos; y una pequeña capilla sobre los hombros, abrochada a la altura del cuello. La monocromía de estas prendas se ve rota por las hermosas cenefas que recorren la parte baja de la túnica y el borde de la capilla; asimismo, por la parte inferior del interior se puede observar una cenefa diferente, realizada con esgrafiado.

El escaso movimiento de la escultura se ve protagonizado por la apertura de ambos brazos, lo que mueve muy suavemente la capilla. El brazo izquierdo lo flexiona para exhibirnos una cruz, que actualmente ha desaparecido. En la otra mano no debió de portar atributo alguno; la extensión de este brazo, similar al realizado por Santa Rosa, parece que también nos está efigiando al santo en uno de sus arrebatos místicos durante

\footnotetext{
582 RÉAU, Louis: Iconografía de los santos. A-F..., op. cit., p. 377.

583 Ibídem.

$584 \quad$ Ídem, p. 378.

585 http://es.wikipedia.org/wiki/Diego_de_Alcal\%C3\%A1
} 
los cuales se elevaba sobre la tierra mientras agarraba el Crucifijo. A esta hipótesis ayuda el rostro ensimismado que presenta. Si representara tal milagro sería el motivo de que San Diego figure tan rígido.

El rostro presenta numerosos golpes y pérdidas de policromía, especialmente en la zona de la nariz y de la frente. Aun así, emparenta totalmente con el de Santa Rosa, denotando la blandura típica que nuestro escultor exhibe en sus obras. Pareciera, no lo puedo asegurar, como si las manos y la cabeza hubieran sido talladas de manera exenta. 


\section{LA AGUILERA. CONVENTO DEL DOMUS DEI}

Cuando el 24 de julio de 1683 se beatifica a San Pedro Regalado hubo un notable desarrollo tanto de su culto como de su iconografía, aunque desde hacía ya tiempo se le venía representado tanto escultórica como pictóricamente. Fue entonces cuando se concedió el rezo propio para la orden franciscana y la ciudad de Valladolid. Después se extendió al resto de esta Diócesis y a los obispados de Osma y Palencia ${ }^{586}$. Cuando se obtuvo la referida beatificación los responsables del convento del Domus Dei decidieron construir una capilla en la que, acorde a la importancia que había tenido el santo para el propio cenobio, se le venerara de una manera más específica.

¿Cuáles son los orígenes de este monasterio y de la relación entre el vallisoletano y el referido establecimiento? Para explicar esta cuestión hay que remontarse a los siglos XIV-XVI, en los cuales los franciscanos españoles desarrollaron una serie de reformas, llamadas "observancias" que tenían como objetivo combatir la relajación que había sufrido la regla de San Francisco. Entre estos reformadores destacan los nombres de Juan de la Puebla, Juan de Guadalupe o Pedro de Villacreces ${ }^{587}$. Este último consiguió del Papa Benedicto XIII la firma, el 3 de noviembre de 1395, de la Bula "Sacre Religionis" por la que se le autorizaba a retirarse a cualquier lugar de Castilla (una de las tres provincias franciscanas en España, las otras dos eran Santiago y Aragón), en compañía de un máximo de siete frailes, para guardar de manera puntual la estricta observancia de la Regla. El primer "desierto" que creó fue en 1397 en una cueva en el Arlanza; posteriormente llegarían otras. El Convento que nos interesa, el Domus Dei de La Aguilera, no fue fundado hasta poco antes del año 1404. Villacreces debió conocer a Pedro Regalado de la Costanilla, futuro San Pedro Regalado, en Valladolid dado que "era un predicador muy demandado, y siempre mantuvo relaciones con el convento no reformado de San Francisco de Valladolid, en su paso por la villa debió de ganar a Pedro Regalado para su causa puesto que las estrategias del reformador se cifraban en reclutar niños y adolescentes, más fácilmente moldeables y a los que él mismo formaba" ${ }^{\text {588 }}$. Años más tarde, en 1415, ambos frailes fundan cerca de Laguna de Duero el Convento de Scala Coeli en El Abrojo ${ }^{589}$. Tras el fallecimiento de su mentor, en 1442 el vallisoletano le sucede en sus empresas reformadoras. Ya en 1454 sería nombrado vicario de ambos cenobios.

Aquella primera iglesia levantada en La Aguilera en 1404 debió de ser una construcción muy austera. No fue hasta 1492, año en que Isabel la Católica visita la tumba del santo, cuando el cenobio comienza a contar con una iglesia más adecuada. A finales del siglo

586 ZAPARAÍN YÁÑEZ, María José: Desarrollo artístico de la comarca arandina: siglos XVII y XVIII, Tomo II, Excma. Diputación de Burgos e Ilustre Ayuntamiento de Aranda de Duero, Burgos, 2002, p. 385 .

587 MUÑOZ JIMENEZ, José Miguel: "Barroco y Peregrinación: El Santuario de San Pedro Regalado en La Aguilera (Burgos), Goya: Revista de Arte, n 228, Madrid, 1992, p. 330.

588 EGIDO LÓPEZ, Teófanes: "Vida y milagros de San Pedro Regalado". En BURRIEZA SÁNCHEZ, Javier (coord.): La Ciudad del Regalado, Ayuntamiento de Valladolid, Valladolid, 2004, p. 26.

589 MUÑOZ JIMENEZ, José Miguel: op. cit., p. 331. 
XVI, en 1575, el virrey de Cataluña y Nápoles y primer duque de Peñaranda, don Juan de Zúñiga, patrocina la reconstrucción de la capilla mayor. Por desgracia, unos años después, en 1589, un incendio destruyó la iglesia, conservándose tan solo de aquel templo un estribo en el ángulo del Evangelio. La reconstrucción se inició cuatro años después. La nueva iglesia tendría una única nave con pilastras toscanas sobre el crucero. Estamos dentro del más puro clasicismo. En esta misma época se levantaron tanto el atrio de la iglesia como la portada que, presidida por la Virgen de la Asunción, ostenta el escudo de los Zúñiga y Sandoval ${ }^{590}$.

Fue ya a partir de la beatificación de fray Pedro Regalado (1683) cuando la gran afluencia de fieles que desean visitar su sepulcro obliga al convento a levantar un espacio más recogido en el que se le pudiera venerar en mejores condiciones. Fueron los propios franciscanos los que decidieron construir una capilla y un camarín dedicado al santo. Así, fray Ángel de Ceballos levantó “el camarín y capilla de San Pedro Regalado y lo adornó con pintura". Por su parte, fray Simón García "ayudó para la capilla en donde está el cuerpo del Santo" $" 591$.

Con el tiempo, las obras se fueron ralentizando. En marzo de 1687 el maestro de obras vallisoletano Pedro Vibanco se encontraba al frente de las mismas. Fue entonces cuando se obligó a proseguir y acabar la obra, pero sin embargo meses más tarde traspasa la construcción de los muros hasta la altura de la cornisa ${ }^{592}$. Una empresa tan ambiciosa necesitaba de benefactores que pudieran costear parte de la ingente cantidad de dinero que se necesitaba para concluirla. Efectivamente, gran parte de la obra fue sufragada por don Isidro López de Zúñiga, sexto duque de Peñaranda y décimo conde de Miranda, y el franciscano Simón García, a la sazón obispo de Tuy y Oviedo, el cual previamente había ocupado el cargo de guardián del Domus Dei ${ }^{593}$.

Una vez finalizada la parte arquitectónica, en 1691 se procedió al amueblamiento y decoración del interior, y para ello se trajeron cuadros y se levantaron altares y retablos ${ }^{594}$ Los tres retablos, remetidos dentro de hornacinas, que decoran el octógono son los dedicados a San Pedro Regalado (capilla mayor), a San José con el Niño (lado del Evangelio) y a San Antonio de Padua (lado de la Epístola). Desconocemos el nombre del ensamblador que los llevó a cabo, aunque Zaparaín Yáñez piensa que puedan proceder, al igual que las esculturas que los presiden, de los talleres vallisoletanos, más concretamente del de Francisco Billota ${ }^{595}$. Sin descartar esta afirmación, habría que tener en cuenta también los potentes talleres burgaleses, y concretamente los ribereños, dado que la forma en que se soluciona el ático con una

\footnotetext{
$590 \quad$ Ídem, p. 332.

591 ZAPARAÍN YÁÑEZ, María José: “Capítulo IV. Lo real maravilloso San Pedro Regalado y los testimonios artísticos", op. cit., p. 104.

$592 \quad$ Ídem, pp. 104-105.

593 MUÑOZ JIMENEZ, José Miguel: "Barroco y Peregrinación: El Santuario de San Pedro Regalado en La Aguilera (Burgos), Goya: Revista de Arte, no 228, Madrid, 1992, pp. 332-333.

$594 \quad$ Ídem, p. 333

595 ZAPARAÍN YÁÑNZ, María José: Desarrollo artístico..., op. cit., Tomo II, p. 390.
} 
especie de arco apuntado interior que cobija una pintura con marco angular no es muy frecuente en la retablística vallisoletana del momento.

La inauguración de tan magno recinto tuvo lugar el 13 de mayo de 1692 con la celebración del traslado de los restos del santo. La festividad la sufragó el referido fray Simón García, obispo de Oviedo, quien presidió la ceremonia junto a los obispos de Segovia y Osma, todos ellos franciscanos ${ }^{596}$.

La gran capilla del Regalado es de forma octogonal, cubierta con una gran bóveda de media naranja calada por una linterna, rematada por un chapitel de pizarra, muy del gusto de la arquitectura castiza madrileña. La planta del camarín es trebolada, la cual, según Zaparaín Yáñez, responde "a modelos de larga tradición en el ambiente castellano de la tipología funeraria, justificada en nuestro caso al concebirse como lugar de veneración de las reliquias del nuevo beato situadas en una urna "a espaldas del altar mayor" $" 597$. Aunque se desconoce al autor del proyecto se piensa que pudiera haber sido obra del jesuita Pedro Mato, dadas las relaciones existentes entre esta obra y el Colegio de San Albano de Valladolid ${ }^{598}$, del cual fue el artífice, si bien su realización corrió a cargo de Pedro Vibanco, asimismo participante en la construcción del Domus Dei.

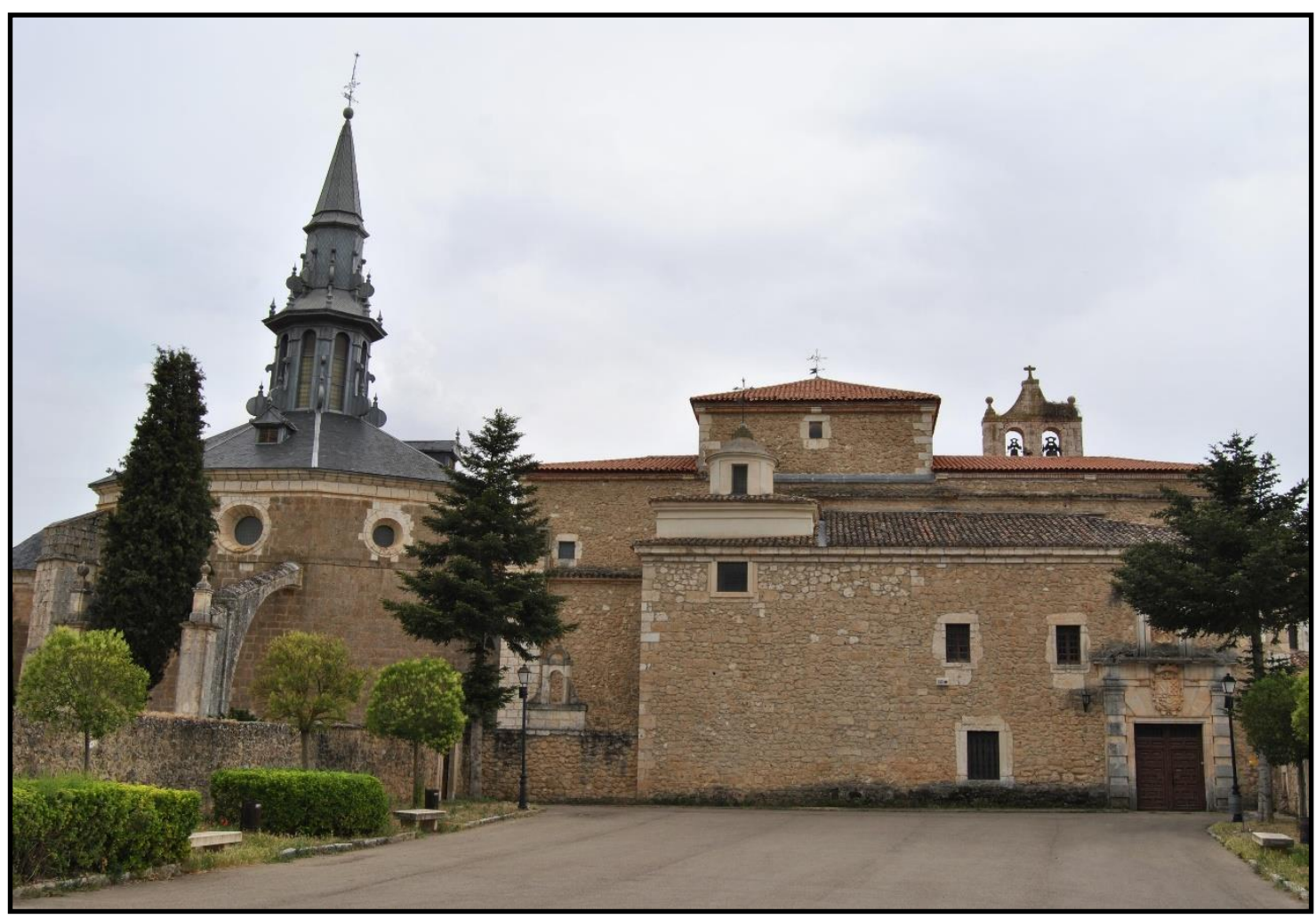

Il. 31- Convento del Domus Dei. La Aguilera (Burgos).

596 ZAPARAÍN YÁÑEZ, María José: “Capítulo IV. Lo real maravilloso San Pedro Regalado y los testimonios artísticos", op. cit., p. 105.

$597 \quad$ Ibídem.

$598 \quad$ Ídem, p. 106. 


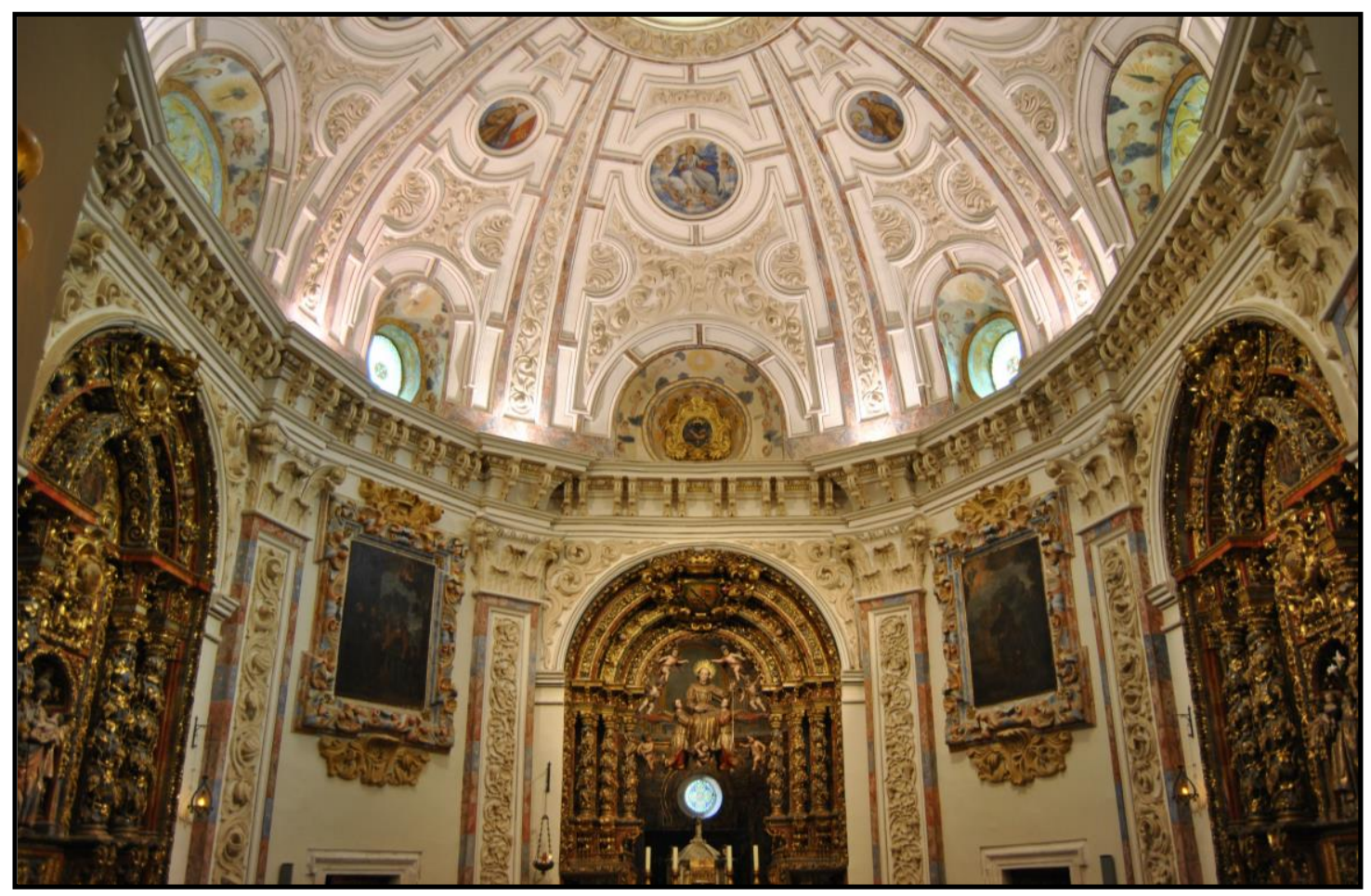

Ils. 32-33- Convento del Domus Dei. La Aguilera (Burgos).

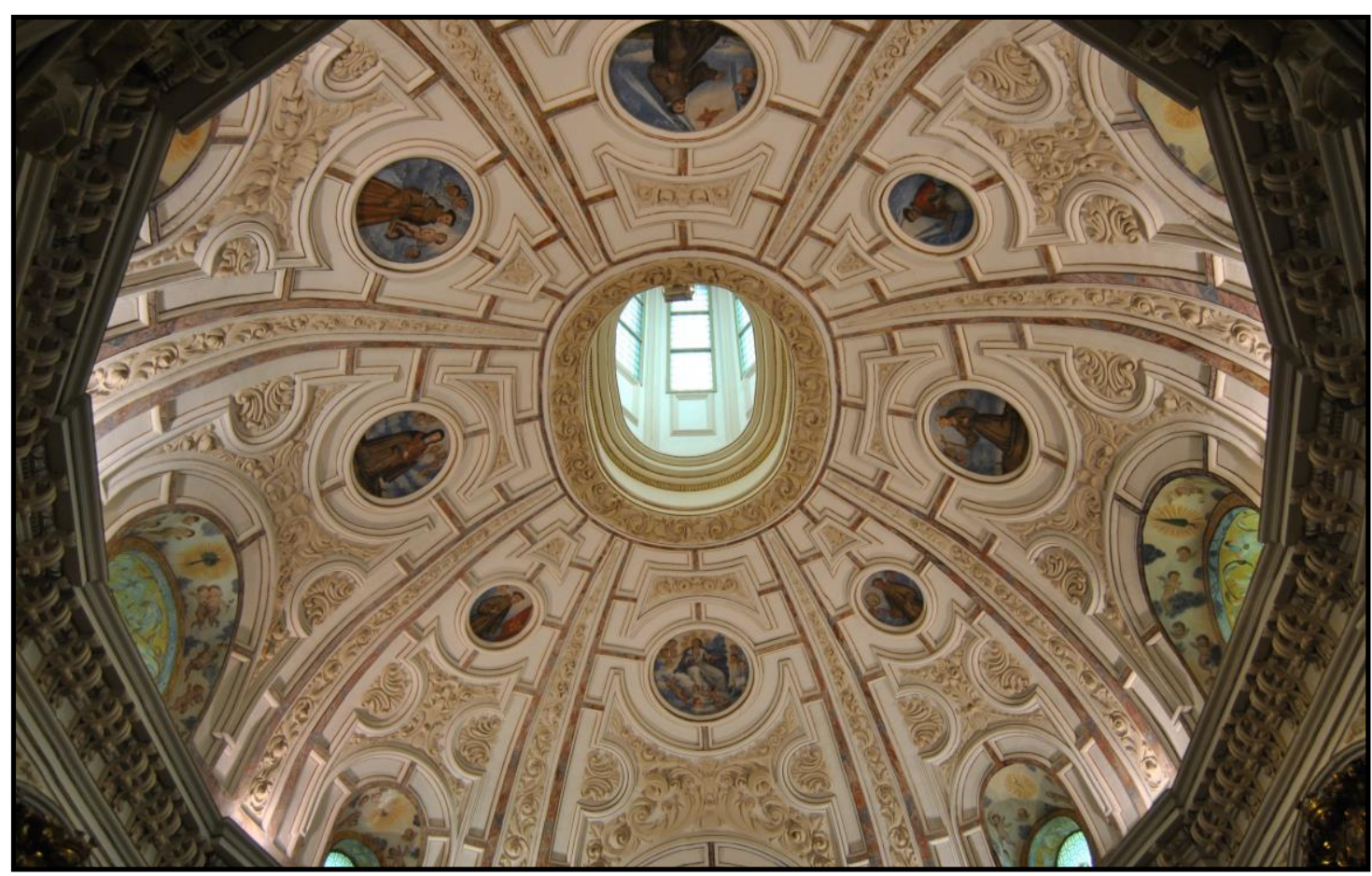

\section{TRASLACIÓN DE SAN PEDRO REGALADO (h. 1691)}

La localización del grupo de la Traslación de San Pedro Regalado (Figs. 110-113) en el altar mayor no es baladí. Representa al personaje por el cual se levantó la capilla, y asimismo viene a culminar el principal eje de visión que observa el espectador nada más entrar en la capilla. Desde allí lo contempla flotando, con lo cual la capilla se transforma en un espacio sobrenatural. El retablo se articula a través de tres columnas salomónicas

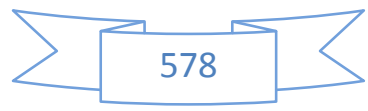


a cada lado, que se van retrasando según se van acercando al grupo escultórico. Debajo de cada grupo de columnas se sitúa una puerta para el acceso al camarín. El ático adquiere un cierre semicircular, en cuyo remate se sitúa la corona ducal sobre el escudo de los Zúñiga. La parte central del retablo está calada, permitiendo que la luz entre en el camarín. Antes de entrar a analizar este grupo y su iconografía vamos a hablar, de una manera más o menos extensa, de la figura que "propició" la construcción de esta capilla, retablos y esculturas: San Pedro Regalado.

Fray Pedro de la Costanilla nació en la vallisoletana iglesia de la Costanilla (actual c/ Platerías) hacia el año 1390, siendo bautizado en la iglesia más próxima a su domicilio, que era la del Santísimo Salvador; parroquia que años después difundiría, junto al Convento de San Francisco, la memoria de su ilustre hijo ${ }^{599}$. Refiere Teófanes Egido que el futuro santo recibió diversos nombres, tales como "Pedro de la Costanilla", "Pedro de la Regalada", "Pedro de la Costanilla y Regalado"; o, incluso, "Periquillo de Valladolid", apodo que le puso fray Pedro de Villacreces, y "Santo Regalado", nombre que le otorgaron tras su fallecimiento los humildes campesinos que le habían tratado ${ }^{600}$. Estos, además de los pobres y los enfermos conformaron el núcleo fundamental del cual partió la devoción del santo ${ }^{601}$. Al parecer, "se comprometió a los catorce años con el proyecto, que ya era realidad, de fray Pedro de Villacreces" ${ }^{\prime 62}$. Resalta Redondo Cantera y Zaparaín Yáñez que "su vida, según se recogía en la bula de canonización, se caracterizó por el ejercicio de la caridad, la penitencia, las ascesis y la pobreza, entre otras Virtudes" $" 603$.

Su culto debió de originarse en la segunda mitad del siglo XV en los alrededores del Convento de La Aguilera, puesto que era el lugar en el que reposaban sus restos, si bien no fue hasta 1520 cuando lo tenemos documentado. Con posterioridad, el culto se expandió, entre otros motivos, gracias al envío de "reliquias (fragmentos de huesos, de hábito, etc.) a diversos lugares, con lo que, además de propagar su devoción, se crearon nuevas sedes de culto. Entre éstas, la más importante fue la ciudad natal del santo, Valladolid" ${ }^{604}$. Fue en esta ciudad, la suya, desde la que surgieron los primeros intentos para lograr su canonización. Efectivamente, en 1626 el Convento de San Francisco comenzó a "promover la canonización de un monje perteneciente a una reforma eremítica que, si bien se situó, en un principio, al margen del sector conventual de la orden, había conseguido, más tarde, incorporar los conventos de la región a ella y formar así, la Provincia de la Purísima Concepción" ${ }^{605}$. También participaron en la propagación de su culto, y en la causa de su beatificación, personas pertenecientes a la nobleza y a la realeza; como, por ejemplo, Isabel la Católica, la reina Mariana de Austria, o los Condes de Miranda, patronos del convento de La Aguilera ${ }^{606}$. A partir de

\footnotetext{
599 EGIDO LÓPEZ, Teófanes: "Vida y milagros de San Pedro Regalado", op. cit., p. 25.

$600 \quad$ Ibídem.

601 REDONDO CANTERA, María José y ZAPARAÍN YÁÑEZ, María José: op. cit., p. 74.

602 EGIDO LÓPEZ, Teófanes: "Vida y milagros de San Pedro Regalado", op. cit., p. 26.

603 REDONDO CANTERA, María José y ZAPARAÍN YÁÑEZ, María José: op. cit., p. 73.

$604 \quad$ Ídem, p. 75.

605 Ibídem.

606 Ibídem.
} 
este momento los focos de su culto pasaron a ser dos: La Aguilera y Valladolid, ciudad en la que desde entonces su figura iría tomando mucha importancia.

El 17 de agosto de 1683 fue proclamado beato, si bien desde hacía tiempo sus paisanos le habían "subido a los altares", lo que trajo consigo la multiplicación de sus representaciones. Las celebraciones en Valladolid por la beatificación de su hijo fueron fastuosas, mezclando, como de costumbre, las fiestas profanas y las religiosas. Canesi describe a la perfección estos fastos que se sucedieron tras la llegada de la noticia de la beatificación al "convento y ciudad donde fue aplaudido con repetidos solemnísimos sagrados actos de júbilo y, previniendo festivas aclamaciones de tal declaración, dio cuenta de todo la comunidad al Real Ayuntamiento y otras Comunidades regulares, que explicando su gozo, quisieron interesarte en la función festiva"607. Cada una de estas comunidades decidió colaborar al gozo común con la construcción de un altar efímero a lo largo del recorrido por el que discurriría la procesión que se habría de celebrar en la tarde del domingo 7 de noviembre de 1683; si bien por la mañana se debía de proceder al traslado de "la efigie de San Pedro Regalado adornada de innumerable multitud de fina pedrería y de un vestido de tela de plata de singular estimación, guarnecido con muy costosos encajes de oro y diversos florones, desde este convento a la Santa Iglesia Catedral" 608 . Ya por la tarde, la procesión salió "con los realces de pompa y magisterio tan soberanos como de celebridad que tributaba decorosos aplausos a un hijo tan de su naturaleza y generoso amor en ella, fueron todos los Pendones y ricos estandartes de las muchas y graves cofradías que en esta dichosa ciudad están instituidas como por sagradas primicias de su devoto celo, luego las cruces de las Parroquias y Comunidades de Ilustrísimos y esclarecidos religiosos y detrás la clerecía, coronando el puesto de su nobilísimo Cabildo el Ilustrísimo señor D. Diego de la Cueva y Aldana su merecido Obispo, dando con su autorizada presencia más colmadas las veneraciones del culto, y cerró la solemne procesión la Ciudad y Real acuerdo de la Chancillería y así entraron todos en la Iglesia de este muy religioso convento donde colocaron al Santo y se finalizó tan sagrada función con copiosas centellas de fuego, que volando en alas de la devoción disparadas en toda la ciudad por la noche, si la plaza se encendía a rayos todo lo demás de ella se asombraba a truenos" ${ }^{609}$. Los altares efímeros levantados por las referidas comunidades religiosas fueron los siguientes: el recorrido comenzaba con el de "los padres Dominicos que erigió un portentoso altar en las Angustias, plazuela del Almirante, otra la de los padres de la Compañía de Jesús del colegio de San Ignacio, que levantó el suyo, con todo el adorno a que puede llegar lo primoroso delante del templo de la cruz, el tercero se debió al afectuoso tierno devoto cuidado de los monjes del Real Monasterio del Gran Patriarca San Benito, que colocó en las casas consistoriales, con todo el esmero en que pudo el gusto apetecer más grandeza; el cuarto quiso construir con arte ingenioso y profunda delicadeza la comunidad de los Padres Trinitarios Descalzos, en el sitio del caballo de Troya, otro

\footnotetext{
607 CANESI ACEVEDO, Manuel: Historia de Valladolid (1750), Tomo I, op. cit., p. 581.

608 Recordemos que esta escultura sería la imagen de vestir que, conservada en la iglesia penitencial de N. P. Jesús Nazareno, hemos atribuido a Juan de Ávila.

609 CANESI ACEVEDO, Manuel: Historia de Valladolid (1750), Tomo I, op. cit., p. 582.
} 
ejecutó como quien tenía tanta parte y obligación en las finas sagradas demostraciones la del convento del Abrojo frente al consistorio y el sexto y último se fabricó a disposición de los religiosos agustinos calzados" $" 610$.

Al tiempo que la Iglesia oficial elevaba al santo a los altares, también ascendió peldaños dentro del patronato de Valladolid. Así, el 23 de febrero de 1685 fue nombrado segundo patrón de la ciudad, quedando tan solo por detrás de la Virgen de San Lorenzo ${ }^{611}$. Años después, y coincidiendo casi cronológicamente con su canonización, en 1747 fue declarado patrono de la ciudad, sustituyendo en tal cargo honorífico a San Miguel Arcángel; el cual presidía una de las caras del Arco de Santiago, mientras que en el otro se encontraba la otra patrona: la Virgen de San Lorenzo.

Tras la beatificación hubo que esperar unos 60 años para que se produjera un acontecimiento, aún, de mayor magnitud para la ciudad: la canonización del beato Regalado. La noticia de que este acontecimiento era ya casi una realidad tuvo lugar el 18 de agosto de 1744, desatándose el furor de los vallisoletanos. Señala Lourdes Amigo que este hecho no era baladí, puesto que "los santos eran los grandes héroes en unos tiempos en que la religión impregnaba todos los aspectos de la vida cotidiana carente en sí misma de sentido y subordinada al más allá"612. La espera se demoró hasta el 25 de julio de 1746, día en que Benedicto XIV celebra la misa de San Pedro Regalado en la Basílica de San Pedro del Vaticano ${ }^{613}$; si bien la noticia no llegó a Valladolid hasta el 4 de octubre. Relata Canesi al respecto que "en este día llegó la noticia a Valladolid de haber el Papa confirmado la elección del patronato de esta ciudad y su obispado a favor de S. Pedro Regalado con octava de primera clase y día de fiesta de precepto; habiéndose publicado, empezaron las firmes expresiones de alegría las campanas y artificiales fuegos aquella noche" ${ }^{614}$. Estas celebraciones, calificadas como las "fiestas del siglo" por su brillantez y espectacularidad, nos son puntualmente narradas por el cronista Ventura Pérez ${ }^{615}$. Duraron más de quince días, durante los cuales se "sucedieron espectaculares fiestas en las que lo religioso y lo profano se entremezclaron en variopintas ceremonias" $"$.

Un tema que nos interesa particularmente es el de sus milagros. Desde su fallecimiento estos parecieron desencadenarse, siendo todos ellos anotados puntualmente por los monjes de La Aguilera. Tan solo en los seis meses que siguieron a su muerte se contabilizaron un total de 39 milagros, posteriormente incrementados hasta los 70 . Señala Teófanes Egido que "eran tantos, que los frailes, temerosos de que la concurrencia alterase el ritmo de su vida contemplativa, se cansaron de apuntarlos. Un

\footnotetext{
$610 \quad$ Ídem, pp. 581-582.

611 AMIGO VÁZQUEZ, Lourdes: “Capítulo III. El Santo celebrado por los vallisoletanos”. En BURRIEZA SÁNCHEZ, Javier (coord.): La Ciudad del Regalado, Ayuntamiento de Valladolid, Valladolid, 2004, p. 61.

$612 \quad$ Ídem, p. 63.

$613 \quad$ Ídem, p. 77.

614 CANESI ACEVEDO, Manuel: Historia de Valladolid (1750), Tomo III, op. cit., p. 558.

615 PÉREZ, Ventura: op. cit., pp. 245-252.

616 REDONDO CANTERA, María José y ZAPARAÍN YÁÑEZ, María José: op. cit., p. 78.
} 
siglo más tarde, cuando ya se hablaba de la beatificación se encargaron de hacer copias fidedignas de todos los casos allí contenidos"617. Hay que diferenciar entre los milagros que sus hagiógrafos relatan que realizó en vida, y los que se sucedieron tras su fallecimiento. La idea de la recopilación de estos últimos partió de su sucesor en la vicaría de los eremitorios del Abrojo y La Aguilera, fray Alonso de Valladolid ${ }^{618}$.

Parece que el primer tipo de milagros, los que realizó en vida, tuvieron relación con las personas que vivían "en las cercanías de la Aguilera o de Laguna de Duero, por las tierras aledañas de Valladolid, Palencia, Segovia", y contaban con un carácter taumatúrgico o terapéutico, dado que "todos ellos se refieren a sanaciones corporales, a curaciones de enfermos, entre los que abundan los tullidos" ${ }^{\prime 19}$. Sin embargo, estos milagros no fueron los que le otorgaron la fama, sino que fueron los que, según escribe Teófanes Egido, se "fabricaron por los hagiógrafos una vez que se rescató la memoria y se resucitó el entusiasmo por el Santo Regalado cuando se intentó ya en serio su beatificación o se celebró el reconocimiento oficial de su santidad"620. Los dos hagiógrafos más importantes del Regalado fueron fray Antonio Daza (1627) ${ }^{621}$ y fray Manuel de Monzaval (1684) ${ }^{622}$, ambos encargados de recopilar los milagros que, según la tradición oral, había realizó en vida; los cuales resultaban indispensables para cimentar su fama de milagrero y su posible ascensión a los altares. Puntualiza Teófanes Egido que estos milagros "responden más a la mentalidad barroca que a la del siglo $X V^{, 623}$.

Sin ningún género de duda, sus dos milagros más conocidos, y difundidos por las artes plásticas, fueron los de la Traslación entre los conventos de La Aguilera y el Abrojo, y el de su resurrección para dar de comer a un pobre anciano hambriento. Ahora tan solo hablaremos del primero de ellos puesto que del segundo ya se trató cuando se estudió un conjunto escultórico que representa este segundo milagro.

La Traslación del santo entre ambos conventos no deja de ser un episodio de bilocación, "un desafío a las leyes físicas", según Egido ${ }^{624}$. El propio cronista de la ciudad de Valladolid explica que "los viajes del santo eran entre la Aguilera y el Abrojo, pero en ambos conventos estuvo al mismo tiempo para celebrar el misterio de la Anunciación en la Domus Dei o capítulo de comunidad en el viernes de Lázaro en el Scala Coeli. Puesto a medir los tiempos, el cronista aquilata: "hecha la cuenta, no tardó un cuarto de hora; pero iqué mucho era si los ángeles le servían y acompañaban!”. Como es bien sabido, este angélico y aéreo transporte se convirtió en el símbolo iconográfico de San Pedro Regalado" ${ }^{\circ 25}$.

\footnotetext{
617 EGIDO LÓPEZ, Teófanes: "Vida y milagros de San Pedro Regalado", op. cit., p. 30. 618 REDONDO CANTERA, María José y ZAPARAÍN YÁÑEZ, María José: op cit., p. 75.

619 EGIDO LÓPEZ, Teófanes: "Vida y milagros de San Pedro Regalado", op. cit., pp. 30-31.

620 Ídem, p. 31.

621 DAZA, Antonio: op. cit.

622 MONZAVAL, P. Fr. Manuel de: op. cit.

623 EGIDO LÓPEZ, Teófanes: "Vida y milagros de San Pedro Regalado", op. cit., p. 32.

624 Ídem, p. 34.

625 Ibídem.
} 
Matías Sangrador, que consulta las obras de Daza y Monzaval, nos describe este episodio con mayor precisión: "En uno de estos días en que el Regalado acababa de celebrar capítulo en el eremitorio de La Aguilera, se despertó en él con vehemencia el deseo de asistir al que en la mañana de aquel mismo día, se había de celebrar también en el Abrojo; medía el santo desconsolado con la vista la inmensa distancia que le separaba de aquella casa (...). Sin embargo de tan insuperables obstáculos, lleno de fe cristiana, se resolvió a partir y tomando el sombrero y el báculo, salió a las siete de la mañana de La Aguilera y se encaminó presuroso al eremitorio del Abrojo. La hora de las ocho marcaba el cuadrante de esta santa casa y sus religiosos abandonaban las celdas para reunirse en la sala donde tenía ordinariamente lugar el capítulo, cuando se oyeron recios golpes en la portería que anunciaban la llegada de alguna persona. El religioso encargado abrió la puerta, y quedó extraordinariamente sorprendido, al ver entrar por ella al santo prelado (...). Asombrados quedaron los religiosos al verle aparecer en medio de ellos, cuando ninguna noticia habían tenido de su venida, y mucho más creció su admiración, cuando le oyeron decir que a la hora de las seis de aquella misma mañana había celebrado capítulo en La Aguilera y que Dios, por su misericordia infinita, le había dispensado la singular gracia de poder presidir el del Abrojo"626. Monzaval intenta explicar el milagro: "Pudo ser, que el Regalado, como cuerpo glorioso, con el favor divino tan veloz anduviese; pues como dicen los Auditores de la Rota en relación de sus virtudes: muchas veces ha concedido Dios a sus siervos en este mundo de los cuerpos gloriosos las excelencias; son testigos los Apóstoles cuando a la muerte de María Santísima milagrosamente vinieron; y San Antonio de Padua, cuando anduvo en tres horas de Padua a Lisboa el camino. Las pinturas, que copian este milagro llevan Ángeles al Regalado por el camino, el que así le anduviese, hacen creíble"627.

El grupo escultórico de la Traslación de San Pedro fue atribuido por Martín González sin ningún género de dudas al círculo vallisoletano de los Ávila, si bien con posterioridad se aclaró que sería con toda probabilidad de Juan de Ávila. El esquema compositivo está extraído de una estampa (158 x 117 cms.) diseñada por el grabador madrileño y presbítero Marcos Orozco $^{628}$, artífice especializado en la elaboración de grabados para portadas de libros, retratos y estampas de devoción. A Orozco se le encomendó la realización de la plancha de este grabado el mismo año de la beatificación del santo, el cual

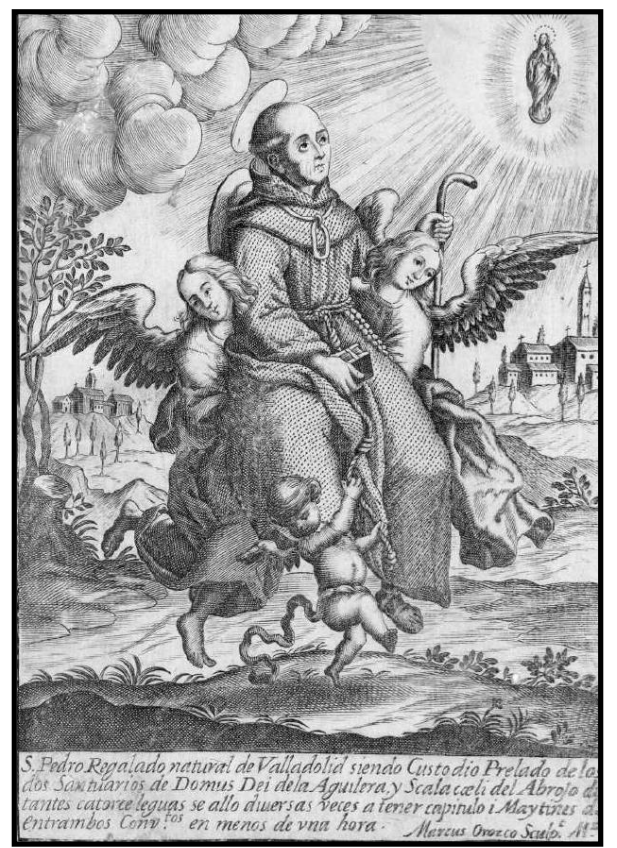

Il. 34- Marcos Orozco. La Traslación de San Pedro Regalado. tenía como destino la anteportada del libro de fray Manuel Monzaval Historia de las

\footnotetext{
626 CARRIÓN GONZÁLEZ, P. Fr. Luis (O.F.M.): op. cit., pp. 68-69.

627 MONZAVAL, P. Fr. Manuel de: op. cit., pp. 85-86.

628 Ídem, pp. 402-403.
} 
heroicas Virtudes aclamación de los estupendos milagros, Vida y muerte y culto de San Pedro Regalado $(1684)^{629}$. El grabado nos presenta al santo viajando por los aires, transportado por dos ángeles desde el convento del Abrojo hasta el de la Aguilera. Al fondo, en un rompimiento de gloria, muy propio del barroco, la Virgen contempla la escena desde el cielo. En la parte baja figura una inscripción: "S. Pedro Regalado natural de Valladolid siendo Custodio Prelado de los dos Santuarios de Domus Dei de la Aguilera y Scalacoeli del Abrojo distantes catorce leguas se halló diversas veces a tener capítulo y Maitines de entrambos Conv ${ }^{\text {tos }}$ en menos de una hora"630. Al igual que el modelo para este grupo escultórico fue el referido grabado, fue este grupo escultórico el que posteriormente se copiara puntualmente para efigiar este milagro del santo. El más claro ejemplo lo tenemos en el que Pedro de Ávila talló años después para la vallisoletana iglesia del Salvador.

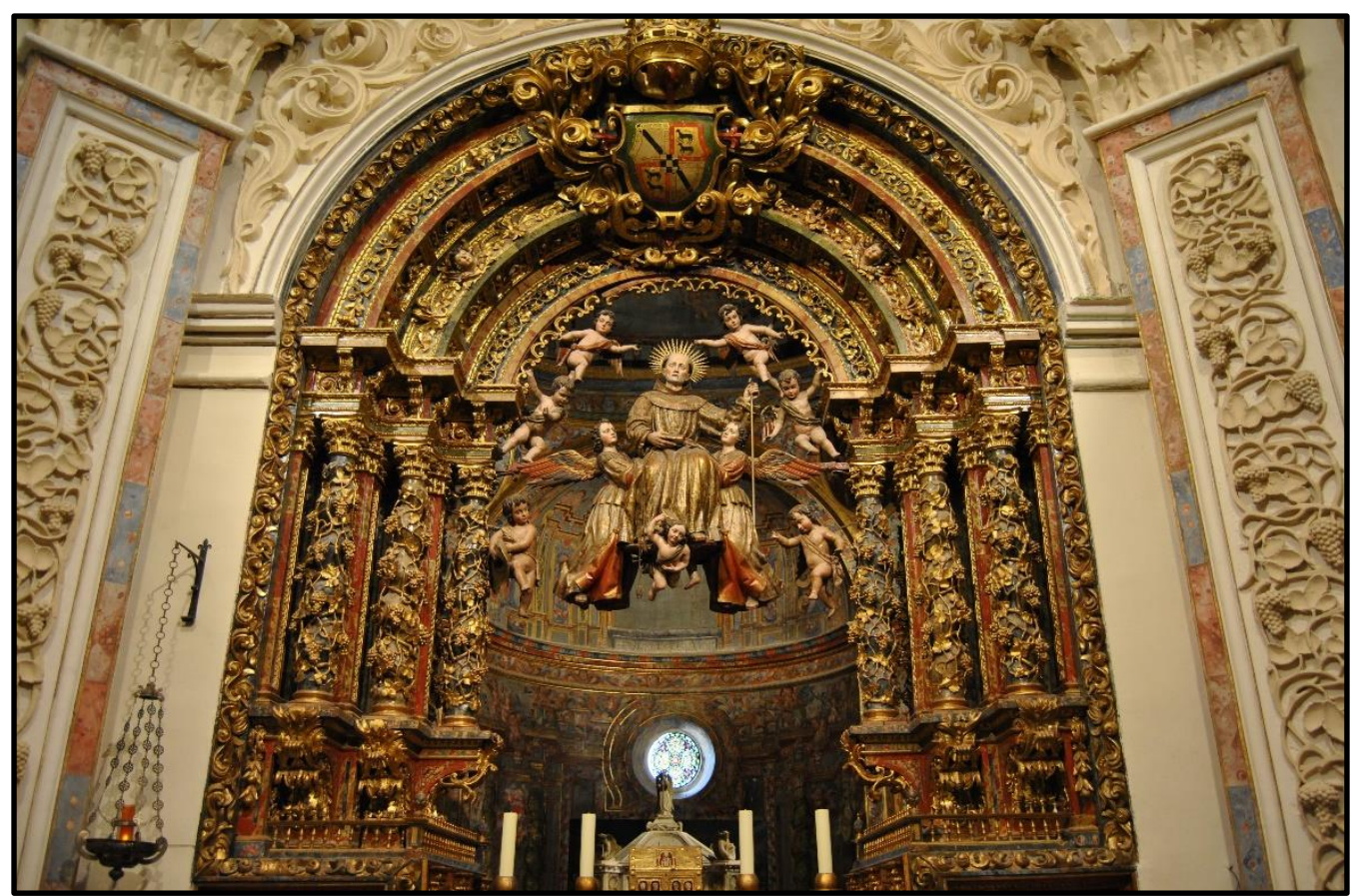

Il. 35- Anónimo. Retablo de la Traslación de San Pedro Regalado. Convento del Domus Dei. La Aguilera (Burgos).

San Pedro aparece siendo transportado por los aires por cuatro ángeles que forman una especie de "trono angélico": uno a cada lado del santo, agarrándole por las piernas y la espalda; otro a los pies, actuando de soporte; y uno último sosteniéndole las nalgas, que será el que propulsa al santo. El conjunto lo completan seis ángeles en diversas actitudes, y con cierta individualización de rostros y peinados, lo que aporta gran variedad y diversidad a la escena, rompiendo la monotonía; tres a cada lado, lo que da una simetría total a la composición; uno de ellos porta el sombrero del santo

629 Cabe destacar que este grabado no fue el primero que efigió el milagro de la traslación del santo; ya en 1634 se había realizado uno en la ciudad italiana de Milán para ilustrar la biografía que escribió acerca del santo Francisco de Ocampo. Según Redondo Cantera y Zaparaín Yáñez, "la estampa reproduce seguramente una pintura anterior, pues el marco superior corta la composición en el lugar donde habitualmente aparece la figura de la Virgen, de la que solamente se ve la aureola luminosa". REDONDO CANTERA, María José y ZAPARAÍN YÁÑEZ, María José: “op. cit., p. 76

630 GARCÍA VEGA, Blanca: op. cit., pp. 402-403.

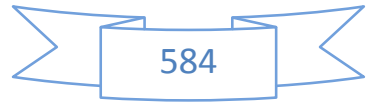


vallisoletano. Este tema se corresponde con el efectismo que se dio en el barroco, en el que también se desarrollaron los rompimientos de glorias; también es muy barroco el hecho de que los ángeles, convertidos en trono, ayuden a ascender a la Virgen o a otros santos. El conjunto es muy armonioso, tendente hacia la simetría, lo que le otorga un gran equilibro. Asimismo, goza de múltiples puntos de vista; así, por ejemplo, tendremos que entrar en el camarín para poder ver al ángel que le sujeta las nalgas, o el detalle de los dos ángeles laterales sujetándole la espalda y el capucho. Hay que señalar que todo el conjunto se halla situado bajo el retablo, en el arco que separa la capilla mayor del camarín, y nada hay ni debajo ni detrás de él que nos impida la vista, por lo que es de un efectismo total.

San Pedro Regalado viste hábito franciscano, concretamente el de los Menores de la Observancia que consta de "túnica, capilla y capuchón de color marrón"631. En ocasiones algunas esculturas poseen una policromía en la que se alude a las calidades pictóricas que "detallan la aspereza del sayal basto de Aranda con el que se vestían los reformadores de Villacreces, por lo que se les conoció también como sayalegos" ${ }^{632}$; este no es el caso dado que posee ricas labores de brocado en la parte baja y numerosas decoraciones vegetales y geométricas estofadas. Completa la vestimenta las sandalias, pese a que en su hagiografía se hacía referencia a que solía ir descalzo; el hecho de que las calce equivale a la descalcez; además de esto, apareció con ellas en su enterramiento. Los pliegues son muy blandos, y en ellos observamos las tradicionales líneas verticales paralelas, lo que es muy evidente en la túnica; también, aunque algo más curvos, son los situados a la altura del pecho y de los antebrazos.

De la fisionomía hay que señalar, como ya se ha apuntado en otros casos, que no es la verdadera puesto que no existen descripciones coetáneas, sino que el arte lo caracteriza de una determinada manera, como los casos, por ejemplo, de San Pablo o San Antonio de Padua. Figura representado con una amplia tonsura que "se convierte prácticamente en una calvicie, lo que le proporcionaba un aspecto de edad avanzada"633, y un rostro blando, enjuto, lleno de arrugas en el cual se "reflejan los sacrificios de una vida de penitencia y privaciones, trasladando la idea de "extrema delgadez" a la que llegó antes de morir, buscando impresionar el ánimo de los fieles" ${ }^{634}$. Está trazado tan mórbidamente que acusa a la perfección las calidades de la piel, y sobre todo las arrugas tanto del cuello como de los laterales de la boca.

En la mano derecha porta un libro cerrado que aludirá "a su redacción de las constituciones que regían la vida de estas comunidades monástica; también es consecuencia de los escritos que le atribuyeron sus panegiristas" 635 ; o bien a "las “Constituciones" que, según los hagiógrafos, elaboró para La Aguilera y el Abrojo,

\footnotetext{
631 REDONDO CANTERA, María José y ZAPARAÍN YÁÑEZ, María José: op. cit., p. 78.

$632 \quad$ Ibídem.

633 Ídem, p. 79.

634 ZAPARAÍN YÁÑEZ, María José: “Capítulo IV. Lo real maravilloso San Pedro Regalado y los testimonios artísticos", op. cit., p. 109.

635 REDONDO CANTERA, María José y ZAPARAÍN YÁÑEZ, María José: op. cit., p. 79.
} 
aunque fuera fray Pedro de Villacreces quien las preparó" ${ }^{636}$. Mientras tanto, con la mano izquierda sujeta un bastón, propio de su faceta de caminante, aunque cuando éste adopta forma de báculo abacial se refiere a su condición de vicario de los conventos de Domus Dei y Scala Coeli. También propio de su condición de caminante es el sombrero de ala ancha que porta uno de los angelitos que le flanquean, si bien en la mayoría de las ocasiones el sombrero suele llevarlo colgado del cuello o caído sobre la espalda ${ }^{637}$; como ocurre en el San Pedro Regalado que Pedro de Ávila talló, supuestamente, para la capilla que al santo se le dedicó en la vallisoletana iglesia del Salvador.

Los dos ángeles que sujetan al santo visten una larga túnica, abierta desde las rodillas, por encima de una sobre túnica. Esta vestimenta es bastante similar a la que portan los Ángeles lampadarios del vallisoletano Monasterio de San Quirce. El rostro de los ángeles, así como la caballera realizada a base de amplios bucles y rizos, posee ciertas concomitancias con otras obras de Ávila; estos también serán muy característicos en Pedro de Ávila. Tienen las alas completamente extendidas, exhibiendo un múltiple colorido: azules, rojos, dorados... Los pliegues de las vestiduras captan a la perfección el movimiento, agitándose con mayor intensidad en sus partes bajas. La posición de los pies y de la parte baja de las túnicas, que forma numerosas ondulaciones, simula a la perfección la levitación de ambos ángeles. Por detrás del santo, un tercer ángel ayuda a estos dos a transportar al Regalado; este ángel es similar a los otros seis que le rodean, pero sin embargo está mucho mejor tratado que éstos, que parecen obra de taller.

Como anécdota, se puede señalar que el grupo escultórico protagoniza la portada del libro Vida de San Pedro Regalado patrono de la M. N. M. K. y H. ciudad de Valladolid, realizada por Matías Sangrador Vítores, pero en la versión realizada años después "corregida e ilustrada con notas e índices" por el P. Fr. Luis Carrión González (O. F. M. $)^{638}$.

\section{SAN JOSÉ CON EL NIÑO (h. 1691)}

Desconozco la motivación exacta que llevó a los franciscanos de este cenobio a dedicar el retablo del Evangelio a San José en la capilla de San Pedro Regalado; en cambio, como veremos, si hay una posible suposición para la de su frontero, San Antonio de Padua. Podría pensarse que la presencia del esposo de María esté relacionada con la gran devoción que desde muy temprano le tuvieron los franciscanos. No podemos olvidar que entre los primeros panegíricos que se le dedicaron se encontraba el De Sancto Joseph Sponso Beatae Virginis del franciscano Bernardino de Siena; asimismo los franciscanos fueron la segunda orden religiosa que incorporó la fiesta de San José a

\footnotetext{
636 ZAPARAÍN YÁÑEZ, María José: “Capítulo IV. Lo real maravilloso San Pedro Regalado y los testimonios artísticos", op. cit., p. 110.

637 ANDRÉS ORDAX, Salvador: Iconografía de San Pedro Regalado, Junta de Castilla y León. Consejería de Cultura y Bienestar Social, Valladolid, 1991, pp. 61-62.

638 CARRIÓN GONZÁlEZ, P. Fr. Luis (O.F.M.): Vida de San Pedro Regalado patrono de la M.N.M.L. y H. ciudad de Valladolid, Librería Editorial Imprenta Pontificia, Barcelona, 1924.
} 
su calendario (1399), tan solo por detrás de los servitas (1324), y por delante de los carmelitas (siglo XV) ${ }^{639}$.

San José (Fig. 114) figura de pie con la pierna izquierda ligeramente flexionada, creando el típico contraposto en las esculturas de esta época, en general, y a las relacionadas con Ávila, en particular. Llama la atención el canon ciertamente alargado que ha tomado el escultor, la cabeza parece bastante pequeña en relación al cuerpo. Con ambas manos sujeta un paño blanco, decorado con una cenefa dorada y rayas azules y rojas, sobre el cual se aposenta el Niño Jesús. Los brazos están dispuestos en posiciones diferentes, mientras que el derecho tan solo lo tiene ligeramente flexionado para agarrar el paño a la altura de los pies del Niño; el izquierdo lo pasa por debajo de la cabeza del infante para así poder sostenerle mejor. Las manos emparentan directamente con las características que exhibe Juan de Ávila: perfección en su talla y simulación perfecta de las diferentes falanges, uñas y venas. El rostro presenta ciertas novedades respecto a lo que es habitual en nuestro escultor. Así, por ejemplo, la boca está cerrada y la barba está algo más prolongada y se remata en dos caracolillos afrontados, justamente como hará en la mayoría de las ocasiones su hijo Pedro de Ávila. Por el contrario, vemos sus característicos mechones mojados sobre la frente, desordenados, algunos curvos y otros más rectos; los ojos almendrados; su potente cabellera que llevó a Martín González a tacharlo de "peluca"; y la nariz ensanchada en su parte baja. También es muy sintomático de nuestro escultor el gesto dulzón y ensimismado con el que observa a su hijo; a pesar de estar el uno frente al otro no hay interactividad entre ellos.

El santo viste gran túnica verde hasta los pies, completamente llena de sencillos motivos decorativos vegetales; aunque en su parta baja encontramos la típica cenefa dorada y con múltiples colores efigiando también temas vegetales. Es admirable la finura que ha conseguido el escultor imprimir a los pliegues y las dobleces de esta parte inferior. Los pliegues parecen mostrar ese momento de transición entre los dos estilos puesto que, a pesar de la fecha, ya podemos ver los pliegues que caen horizontales y paralelos, tan solo interrumpidos y alterados por la rodilla adelantada. También porta un gran manto, bellísimo y fastuoso; su amplitud, que le lleva a llegar hasta el suelo parece explicarse, quizás, en un intento del escultor de dar mayor estabilidad a la imagen. El manto se sujeta por el cintillo que también le ciñe la túnica, pasando por detrás del santo y cayendo sobre el brazo izquierdo, justo debajo del paño con el que sujeta al Niño Jesús. Es de color marrón, con diversos motivos vegetales y geométricos en varios colores, incluido el dorado; todos los bordes poseen la cenefa que hemos referido con anterioridad; además, la parte interior es de color azul con amplias labores de esgrafiado dorado. Los pliegues del manto son muy movidos, aunque reinan las incurvaciones suaves, contrastando por lo tanto con la mayor rigidez de los de la túnica.

En esta ocasión no podemos ver al Niño Jesús con claridad ya que al estar girado para contemplar a su padre a nosotros nos da la espalda. Tan solo podemos decir que se trata

639 ARRIBA CANTERO, Sandra de: "San José", Revista digital de iconografía medieval, Vol. 5, No 10, 2013, pp. 66-67. 
de una figura rolliza, con las piernas movidas y con los brazos intentando tocar la barba de su padre.

A pesar de que la escultura pueda pecar de cierto estatismo y rigidez, tan solo contrarrestado por el movimiento que le otorga el manto con amplios pliegues, se trata de una escultura estupenda, y que, sin duda, de confirmarse su autoría se convertiría en una de las obras señeras de nuestro escultor; puesto que, además estaríamos hablando de que pudiera haber sido el modelo tomado por sus hijos Pedro y Manuel para confeccionar sus imágenes de San José. Si comparamos las versiones de ambos con ésta imagen podemos ver que la manera de disponer las manos con el paño para sujetar al Niño es casi idéntica; como también lo son el giro del rostro del padre para ver a su Hijo, y la manera organizar el manto. Llama la atención que Pedro ha utilizado también la caída de la ropa hasta el suelo para dar mayor estabilidad a la escultura.

\section{SAN ANTONIO DE PADUA (h. 1691)}

La elección de San Antonio de Padua como el otro santo que debía presidir el tercer y último retablo de la capilla pudiera estar relacionado con un hecho del que hemos hablado con anterioridad: la traslación de San Pedro Regalado. Referíamos que Monzaval al intentar explicar este acontecimiento tan milagroso decía que "muchas veces ha concedido Dios a sus siervos en este mundo de los cuerpos gloriosos las excelencias; son testigos los Apóstoles cuando a la muerte de María Santísima milagrosamente vinieron; y San Antonio de Padua, cuando anduvo en tres horas de Padua a Lisboa el camino"640. Es decir, que la inclusión en la capilla de San Antonio de Padua se deberá a que compartía junto a San Pedro Regalado el milagro de la Traslación, grupo que estaba efigiado en el altar mayor.

Como es usual en las representaciones castellanas, San Antonio (Fig. 115) aparece de pie, estático. Levanta su cabeza, dirigiendo la mirada hacia el cielo como si todavía estuviera viendo a la Virgen María, la cual le acaba de entregar al Niño Jesús. Éste se encuentra apoyado sobre un libro. Con su mano derecha realiza un gesto de bendición, mientras que con la izquierda sujeta la bola del mundo. Al igual que ocurría en el San José frontero, Jesús no reposa directamente sobre el libro, sino que les separa un fino paño, lo que nos indica la divinidad del Hijo de Dios. En su mano derecha, que la mantiene elevada, bien pudo tener unos lirios, símbolo de pureza ${ }^{641}$; la manera en que están dispuestos los dedos es muy elegante. Esta representación se hizo muy popular tras la Contrarreforma. Llama la atención que la escultura es muy similar en todos sus detalles a la del San Antonio que el propio Juan de Ávila, o alguien de su taller, realizó para el retablo de Villasilos (Burgos), si bien la composición se halla invertida.

El santo lisboeta viste el hábito típico de la Orden Franciscana, ceñido a la cintura por el cíngulo con cinco nudos. La túnica posee una policromía fastuosa, puesto que el color

640 MONZAVAL, P. Fr. Manuel de: op. cit., pp. 85-86.

641 Ídem, p. 127. 
pardo del fondo se ve enriquecido de numerosas flores multicolores y en el borde inferior una cenefa, asimismo con elementos vegetales; estos también aparecen a la altura del cuello y del pecho. Los pliegues son muy suaves, incurvados y redondeados. Apenas se perciben algunas leves quebraduras en la túnica, no hay lugar para los paños aristados. En la parte inferior del hábito, justo encima del pie izquierdo, podemos observar que los pliegues forman una figura parecida a un corazón. Este motivo lo vemos continuamente en las representaciones del santo salidas de los diferentes talleres escultóricos vallisoletanos del siglo XVII. Ya referimos, al hablar del San Antonio de Padua del retablo de la Resurrección de Villasilos (Burgos), unos cuantos ejemplos en los cuales aparece este "pliegue corazón"; concretamente a los San Antonio de Padua que Alonso de Roza talló para el retablo mayor del Convento de Santa Clara de Medina de Rioseco ${ }^{642}$, para uno de los retablos colaterales de la capilla de don Gabriel López. de León, en la iglesia de San Pedro y San Ildefonso de Zamora ${ }^{643}$, y para el Convento de la Concepción Francisca de Zamora, actualmente en el Museo Catedralicio de la referida ciudad ${ }^{644}$. Parece que el origen de este motivo, en particular, y el modelo de San Antonio, en general, se hallan como de costumbre en Gregorio Fernández. Desconocemos si el gallego talló algún otro San Antonio de Padua de tamaño natural (no contabilizamos aquí el conservado en la vallisoletana iglesia de San Miguel por ser figura de vestir), puesto que de no haberlo hecho el modelo tomado por todos estos escultores sería el relieve de San Antonio de Padua (en realidad es bulto redondo) del retablo de la Capilla de los Vargas en la iglesia parroquial de Brahojos de la Sierra (Madrid), realizado por Fernández en $1628^{645}$.

El rostro posee numerosas concomitancias con los de nuestro escultor, si bien la estrechez de la nariz y las orejas, un tanto despegadas, no es de lo más usual en él. El pelo, muy compacto y de poco se resalte, se resuelve a base de numerosas ondas muy bien unidas que no dejan ningún saliente. Como ya dijimos, los ojos se encuentran ensimismados, característica que, por otra parte, es bastante usual en Ávila. La policromía finge a la perfección la incipiente barba.

La figura del Niño Jesús es muy dulce y rolliza. Su rostro es bastante superior al del santo. Está lleno de frescura y lozanía. Presenta tres mechones mojados sobre la frente. Como no puede ser de otra manera, al tratarse de una representación infantil, Jesús es efigiado con amplios mofletes y mentón. Su posición, un tanto acrobática e inestable, añade mayor interés a la pequeña escultura.

\footnotetext{
642 GARCÍA CHICO, Esteban: Documentos para el estudio del arte en Castilla. 2..., op. cit., pp. 328-330

643 URREA FERNÁNDEZ, Jesús: "La capilla de D. Gabriel López de León en la iglesia de San Pedro de Zamora", B.S.A.A., Tomo LI, 1985, p. 505.

644 VASALLO TORANZO, Luis: “Arquitectura y patrimonio...”, op. cit., p. 136.

645 MARTÍN GONZÁLEZ, Juan José: El escultor Gregorio..., op. cit., pp. 144-147.
} 


\section{VALLADOLID. REAL MONASTERIO DE SAN QUIRCE}

\section{RETABLOS COLATERALES (1693-1694)}

En el crucero, escoltando al retablo mayor, hallamos dos retablos salomónicos gemelos. En sus respectivos áticos se encuentran otras obras que creo que pueden ser atribuidas a Juan de Ávila. Se trata de cuatro Virtudes y dos relieves.

El 30 de septiembre de 1693 Blas Martínez de Obregón, supuesto autor del retablo mayor, se concertó con doña Francisca María de Hinojosa, abadesa del monasterio, para realizar los retablos colaterales de la iglesia monacal. Entre las condiciones figuraba que el primero de ellos lo debería de tener finalizado para el día 1 de enero de 1694, mientras que el segundo estaría dispuesto para el mes de mayo de ese mismo año (DOCUMENTO 51). Martínez de Obregón percibiría por la construcción de ambas máquinas 3.500 reales de vellón. Debe de existir un error en los datos consultados por Martín González, en los cuales se decía que fueron realizados entre 1689 y $1691^{646}$, siendo la primera de estas fechas análoga a la del retablo mayor. No es factible que el mismo ensamblador realizara dos colaterales entre 1689-1691 y después los volviera a tallar entre 1693-1694. A continuación, en 1697, fueron dorados ${ }^{647}$.

Ambos retablos poseen una estructura idéntica, que, además, viene a ser una simplificación del retablo mayor. Están conformados por un estrecho banco, en el cual se localizan las ménsulas sobre las que apoyan las cuatro columnas salomónicas del cuerpo. Las extremas algo más retrasadas que las otras dos, creando un efecto de claroscuro y movimiento típicamente barrocos. En el centro, una hornacina. En el ático una portada escoltada por dos columnas salomónicas que soportan sendos trozos de frontón partido, sobre los cuales se encuentran tumbas unas Virtudes Cardinales. Mientras que estas dos columnas salomónicas están alineadas con las dos centrales del cuerpo, situados en los extremos del ático, coronando las columnas retrasadas del cuerpo, se encuentran "escudos" con "los cuatro hábitos de las cuatro órdenes militares que son Alcántara, Calatrava, Avis y Montesa” (DOCUMENTO 51).

Además de ser idénticos entre sí, son casi exactos a los colaterales del Oratorio de San Felipe Neri, retablos contratados el 7 de octubre de 1698 por Francisco Billota ${ }^{648}$, el cual los tenía ya finalizados el 18 de mayo de $1699^{649}$, fecha en que la Congregación pide buscar maestros que dictaminen si se habían realizado conforme a las condiciones y traza. Una vez más volvemos a comprobar las similitudes existentes entre las obras de Francisco Billota y Blas Martínez de Obregón. Las únicas diferencias entre ambos conjuntos son el retranqueamiento de las columnas extremas, la inclusión de las Virtudes rematando el frontón partido en los mismos retablos; y, finalmente, el formato alargado que adquieren los relieves de los áticos de los retablos de San Quirce.

\footnotetext{
646 MARTÍN GONZÁLEZ, Juan José: Escultura barroca castellana ..., op. cit., p. 318.

647 Ídem, p. 311

648 MARTÍN GONZÁLEZ, Juan José y URREA FERNÁNDEZ, Jesús: Catálogo Monumental de la provincia de Valladolid. Tomo XIV..., op. cit., p. 293.

$649 \quad$ A.S.F.N., Caja 14, $2^{\circ}$ Libro de Acuerdos (1690-1740), f. 42.
} 
Desconocemos qué esculturas contendrían las hornacinas de cada retablo, si bien una de ellas estaría ocupada por una Virgen, puesto que entre las condiciones redactadas por Obregón figura una que alude al "fondo de la caja de Nuestra Señora". Quizás ambas hornacinas auspiciasen a una Virgen en su interior. Actualmente están ocupadas por la Virgen de la Pasión (Epístola), titular de la cofradía penitencial del mismo nombre; y una escultura de la Asunción, de principios del siglo XVII ${ }^{650}$ (Evangelio). Quizás esta Asunción sea esa "Nuestra Señora" a la que alude la escritura.
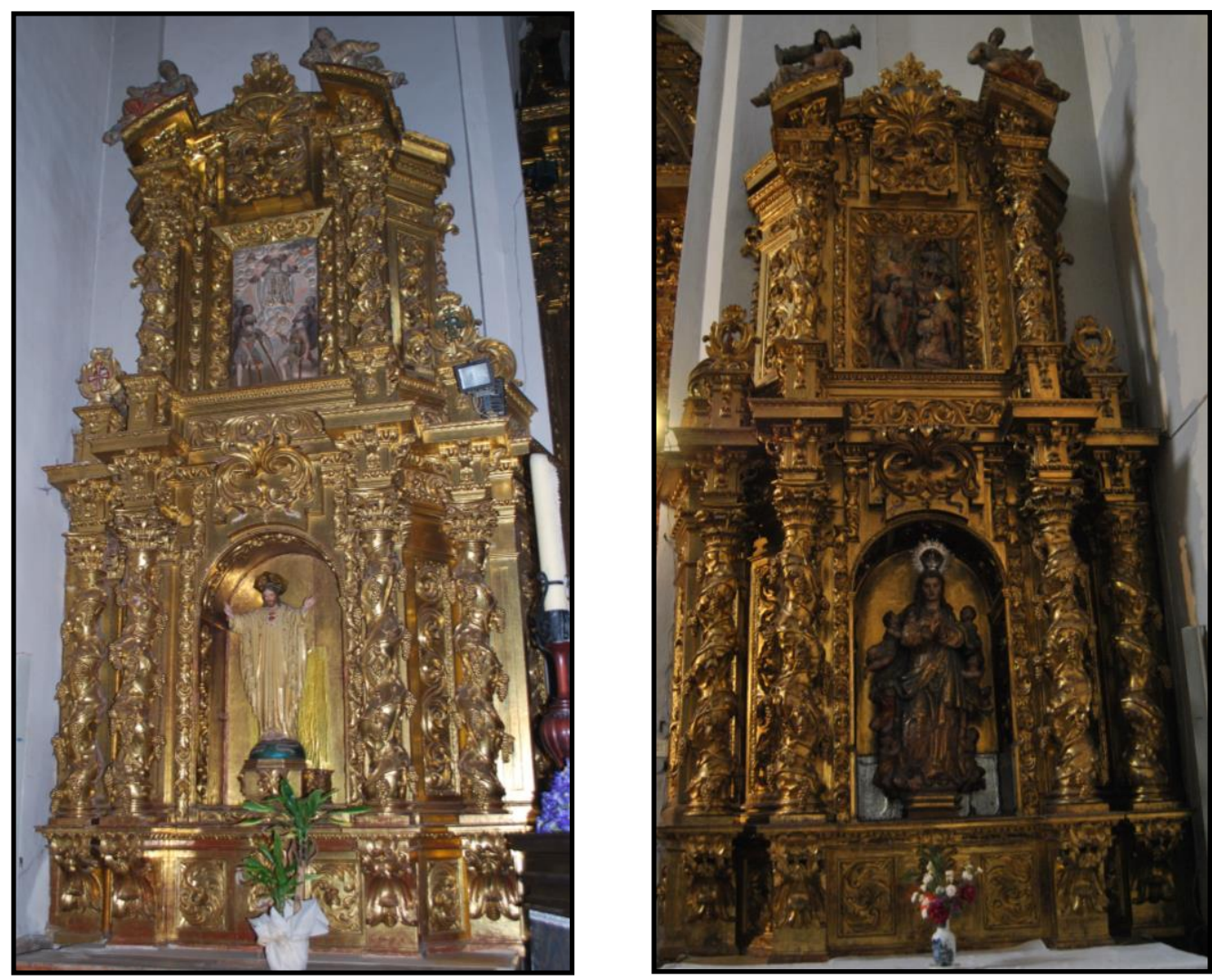

Ils. 36-37- Blas Martínez de Obregón. Retablos colaterales. Monasterio de San Quirce. Valladolid.

En un principio no estaría previsto colocar en los áticos sendos relieves, puesto que una de las condiciones de la escritura refiere que "los santos que intitulan San Quirce y Santa Julita que están puestos en el retablo del altar mayor se han de bajar y poner en el segundo cuerpo de cada uno de dichos dos colaterales". Esta cláusula sería impuesta por el propio convento con la intención de facilitar la visión y la devoción hacia los dos santos titulares de la casa, puesto que, al encontrarse, según hemos propuesto, tan altos en el retablo había dificultades para su correcta percepción. Desconocemos la razón que llevó al convento, o al ensamblador, a no cumplir con dicha condición y por lo tanto a colocar los relieves en vez de a los santos. Lo que ya no sabemos es si San Quirce y Santa Julita fueron a parar a las hornacinas del cuerpo de estos retablos, o bien se instalaron donde actualmente se encuentran, al pie del retablo mayor. Pienso que lo más probable es la primera opción.

650 MARTÍN GONZÁLEZ, Juan José y DE LA PLAZA SANTIAGO, Francisco Javier: Catálogo Monumental de la provincia de Valladolid. Tomo XV..., op. cit., p. 189. 
Las bases para atribuir a Ávila los dos relieves son varias. Primeramente, hemos de tener en cuenta que la técnica con la que están hechos es la misma que la exhibida en los de San Felipe Neri: no son relieves puros, en realidad, son figuras casi de bulto redondo pegadas al tablero, si bien en esta ocasión parece existir cierta gradación, puesto que las piernas de los tullidos parecen bajorrelieve; el fondo aparece pintado, y por el estilo de las pinturas no sería muy arriesgado decir que fueron hechos por el mismo autor que pergeñó las de San Felipe Neri, dadas las similitudes en tipos y cromatismo. También hay que señalar la cercanía existente entre la cabeza del tullido calvo del relieve del colateral izquierdo de San Quirce, y la de San Felipe Neri subido al púlpito.

Por su parte, las Virtudes Cardinales también caen dentro de la órbita de Juan de Ávila, si bien el tipo de nariz que exhiben acerca su ejecución también a José de Rozas. Sea como fuere, parecen obra de taller dado su modelado burdo y simplón.

\section{$\underline{\text { RETABLO COLATERAL DEL EVANGELIO }}$}

El relieve del ático representa la visión sufrida por unos tullidos (Fig. 116), en la cual observan la levitación, o ascensión a los cielos, de una santa cisterciense. La escena es plenamente simétrica: la santa ocupa el lugar central del tablero, arrodillada sobre una nube, parece que en su mano izquierda pudo portar un Crucifijo. Viste de manera similar a la Santa Escolástica del retablo mayor, cambiando, por supuesto, el hábito. La rodean tres cabezas de angelitos a cada lado, de los cuales son dos pintados y uno tallado; encima de la santa numerosas nubes. En la parte baja, a cada lado de la santa tres pobres y/o tullidos, dos pintados y uno esculpido. El personaje de la izquierda se apoya en dos muletas y, además, lleva una prótesis en la pierna, mientras que el otro tan solo sujeta la única muleta que utiliza bajo la axila izquierda. Ambos visten y son efigiados de manera similar, sus cabezas se diferencian tan solo en que uno de ellos va tocado con un turbante. La policromía recrea a la perfección los remiendos de la ropa de estos mendigos.

No queda claro a quién puede representar. Martín González y Plaza Santiago piensan que pueda ser "Santa Imelda remontada al cielo, contemplada su ascensión por pobres tullidos"651. Por su parte, Rebollo Matías cree que "representa, al parecer, la milagrosa aparición o ascensión de santa Eduvigis, caritativa princesa y monja cisterciense contemplada por unos tullidos, y no Imelda como se ha apuntado"652.

En los extremos del ático figuran dos de los "cuatro hábitos de las cuatro órdenes militares" que figuraban en las condiciones del retablo. Con hábito quiere referirse a la cruz que las distingue. La de la izquierda no coincide con ninguna de las cuatro, sin embargo, por el color, será la de Montesa; por su parte, la de la derecha es la de Avis. Coronando el ático, recostadas sobre sendos trozos del entablamento, seccionado por su

$651 \quad$ Ibídem.

652 REBOLLO MATÍAS, Alejandro y MINGO MACÍAS, Luis: “Acerca de nuestra historia: Real Monasterio de San Quirce y Santa Julita: arquitectura y patrimonio”, op. cit., p. 18. 
parte central, figuran dos Virtudes, que al haber sido desposeídas de sus atributos no las podemos identificar. Tanto por la posición que adoptan las mismas, como por situarse sobre superficies curvas, recuerdan o, quizás se inspiraron, en las cuatro esculturas recostadas, dos a dos, sobre los sepulcros fronteros de Giuliano y Lorenzo de Médici custodiados en la Sacristía Nueva de la iglesia de San Lorenzo de Florencia, realizadas todas ellas por Michelangelo Buonarroti. No hace falta decir el universo que separa a las creaciones de uno y otro maestro. Ni los pliegues, ni las facciones del rostro están muy tratadas, Ávila, o más bien su taller, no han puesto mucho énfasis en su realización, pero no cabe duda de que su localización tan alta ha influido en ella.

\section{RETABLO COLATERAL DE LA EPÍSTOLA}

El relieve del ático representa la decapitación de una santa por parte de un esbirro (Fig. 117), mientras que otro aguarda tras la santa; en el fondo, bajo un pabellón, se sitúa el monarca o tirano que ordenó el asesinato de la santa. Cómo podemos observar la composición es ciertamente floja, así como la plasmación de la perspectiva, muy defectuosa. El sayón degollador adopta una posición casi danzarina, con su particular cruce de piernas, disposición que repetirá, supuestamente Ávila, en otro verdugo similar representado en el relieve del martirio de San Esteban del retablo mayor de la iglesia de San Esteban Protomártir de Torrecilla de la Abadesa (Valladolid). La pintura del fondo nos introduce en una arquitectura, en la que delante del soberano se aprecian unas escaleras. A la izquierda del pabellón de éste se abre una especie de gloria en un cielo cubierto de nubes, de él nace una luz que apunta directamente a la santa, la cual, ya muerta, asciende a los cielos En la parte baja, tras el sayón asesino, aparecen pintados otros personajes, entre ellos un soldado. Son interesantes los motivos decorativos renacentistas que ornamentan las corazas del sayón de la lanza y del tirano; el primero con peto gris y decoraciones doradas, y el segundo con peto azul y decoraciones plateadas. Las ricas y variadas policromías remedian, en parte, la tosquedad con que el escultor ha plasmado la escena. El rostro del sayón degollador emparenta con los de los dos tullidos del otro relieve. Tampoco en esta ocasión hay mucha seguridad del pasaje que representa este relieve. Rebollo Matías piensa que podría tratarse del martirio de "Santa Taciana mártir, de especial veneración en el convento, o la degollación de Santa Julita, la madre de San Quirce" "653.

En los extremos del ático figuran los dos "hábitos" restantes. Se trata de los de Calatrava (izquierda) y, posiblemente, Alcántara, que es la que resta de las cuatro, aunque no lo podemos comprobar porque ha desaparecido todo resto de su cruz. Las dos Virtudes que coronan el ático aparecen dispuestas de la misma manera; sin embargo, en esta ocasión podemos reconocer a una de ellas; a la otra no, porque también ha perdido su atributo. La de la izquierda agarra con una de sus manos, de una forma muy elegante, como si no pesara, una poderosa columna, que sujeta sobre su hombro derecho y prosigue detrás de su cabeza. Es, a no dudarlo, la mejor pieza de las cuatro. Su rostro 
tiene ciertas similitudes con los ángeles que Ávila talló para el ático del retablo mayor de la iglesia de Santiago, de Valladolid.

\section{NUESTRO PADRE JESÚS CON LA CRUZ A CUESTAS (h. 1696-1697)}

Hasta hace poco tiempo la presente escultura de Jesús Nazareno (Figs. 118-119), actualmente con el nombre de "Nuestro Padre Jesús con la Cruz a cuestas", presidía un sencillo retablo compuesto por dos columnas dóricas en la capilla de Nuestra Señora de Belén del Santuario del Carmen de Extramuros. Allí fue inventariada por el Catálogo Monumental, describiéndola como "escultura policromada de Nazareno, de vestir (1,59 m.). Tiene las piernas talladas. La cabeza es hermosa y denota una buena mano de escultor, que la haría a mediados del siglo XVII" ${ }^{654}$. Por fortuna, a comienzos del año 2013, la Cofradía Penitencial de la Sagrada Pasión de Cristo, tras una larga serie de reclamaciones consiguió recuperarla, puesto que les pertenecía, ya que era la imagen central del paso Camino del Calvario. A partir de entonces, la cofradía, ejemplo donde las haya en cuanto a recuperación y conservación de su patrimonio, decidió restaurarla, puesto que se encontraba en muy mal estado debido al abandono sufrido en el Santuario del Carmen Extramuros. En la tarde-noche del Jueves Santo del año 2014, en la procesión de Oración y Sacrificio, su cofradía penitencial volvía a alumbrar a tan estimable imagen ${ }^{65}$, la cual se encontraba fuera de los desfiles procesionales de la Semana Santa vallisoletana desde el año 1927 en que realizó su última salida procesional. Esta tuvo lugar el mediodía el Viernes Santo, en la primera edición de la Procesión de Penitencia y Caridad ${ }^{656}$.

Este Nazareno vino a sustituir a otra similar, la original, que Gregorio Fernández había tallado para el paso Camino del Calvario ${ }^{657}$. Efectivamente, el 22 de noviembre de 1614 se comprometía con la Cofradía de la Sagrada Pasión de Cristo a realizar el citado paso por 2.000 reales ${ }^{658}$. Este se compondría de cinco imágenes: "Jesús Nazareno con la Cruz a cuestas, Simón Cirineo ayudándole a llevarla, un sayón tirando de la soga, un

654 MARTÍN GONZÁLEZ, Juan José y URREA FERNÁNDEZ, Jesús: Catálogo Monumental de la provincia de Valladolid. Tomo XIV..., op. cit., p. 276.

655 Su primera salida procesional relacionada con la Semana Santa fue la referida del año 2014, si bien la primera que protagonizó tras su restauración en el año 2013 fue la celebrada el día 28 de septiembre de ese año, con motivo de su traslado desde la Catedral hasta la sede canónica de la cofradía, el Real Monasterio de San Quirce y Santa Julita.

656 LUNA MORENO, Luis: “Acerca de nuestra historia: Nuestro Padre Jesús con la Cruza cuestas y su grupo procesional”, Pasión Cofrade, nº 10 (segunda época), 2014, p. 35.

657 Para profundizar en el estudio de este paso procesional: MARTÍN GONZÁLEZ, Juan José: Escultura barroca castellana..., op. cit.; MARTÍN GONZÁLEZ, Juan José: El escultor Gregorio ..., op. cit.; MARTÍN GONZÁLEZ, Juan José: "Los "pasos” procesionales de varias figuras en Castilla y León”, Primer congreso nacional de cofradías de Semana Santa, Diputación Provincial de Zamora, Zamora, 1987, pp. 123-133; DELFÍN VAL, José y CANTALAPIEDRA, Francisco: Semana Santa en Valladolid: Pasos - Cofradías - Imagineros. Lex Nova, Valladolid, 1990; VV.AA.: Pasos restaurados, op. cit.; VASALLO TORANZO, Luis: "El paso Camino del Calvario de Gregorio Fernández", Boletín del Museo Nacional de Escultura, No 11, 2007, pp. 16-21.

658 MARTÍN GONZÁLEZ, Juan José: Escultura barroca castellana ..., op. cit., p. 203. 
hombre armado y la Verónica" ${ }^{\circ 59}$. Desconocemos qué le pudo suceder al Nazareno tallado por el maestro gallego. El caso es que, a finales de ese mismo siglo, hacia 16901697, fue sustituida por el presente Cristo. Debió de ocurrirle alguna desgracia, aunque ningún documento aluda al cambio de imagen, puesto que no es comprensible que se supliera en tan escaso lapso de tiempo una obra del gran maestro por otra de similares características.

La fecha de 1697 no es baladí, puesto que en ese año se le confeccionaba una túnica nueva y se reparaban otras imágenes de la cofradía bajo la supervisión de los escultores Juan Antonio de la Peña y Juan de Ávila ${ }^{660}$, autores a los que se ha relacionado con la elaboración del Nazareno ${ }^{661}$. A raíz de la decadencia de las procesiones vallisoletanas a finales del siglo XVIII, la mayor parte de las esculturas, sobre todo las que componían el historiado (soldados, sayones, personajes secundarios), pasaron a engrosar los fondos del actual Museo Nacional de Escultura. Efectivamente, en 1828 la Real Academia de Bellas Artes trasladó todos estos personajes a su sede ${ }^{662}$. La composición y las tallas que conformaban el paso se "olvidaron", de tal manera que en el año 1922, cuando se reconstruyó, Agapito y Revilla y Francisco de Cossío "utilizaron como figura principal un Cristo Nazareno que "siempre acompañó en el Museo a la estatua del Cirineo", calificándolo aquél de "mediano", no correspondiente con la calidad de las restantes figuras y su mérito inferior a "lo que podía esperarse" de Gregorio Fernández"663. Este Nazareno, que aún hoy en día sigue presidiendo el paso procesional, se ha relacionado de manera fehaciente con Pedro de la Cuadra, siendo Luis Luna el primero en formular tan atribución. Asimismo, se ha descubierto que éste fue el primitivo Nazareno alumbrado por la cofradía penitencial homónima, el cual quedó guardado, tras el famoso pleito entre la cofradía y el Convento de San Agustín, en el cenobio agustino hasta la Desamortización ${ }^{664}$.

El Nazareno sobre el que estamos tratando permaneció en su sede. Así nos lo prueba el que en 1848 la Cofradía de la Pasión solicitara al Museo el préstamo del Cirineo para procesionarlo el Jueves Santo. Es más, en 1853 "un grupo de cofrades pide permiso para construir una Comisaría de "Jesús Nazareno el del Cirineo que se venera y se halla enclavado en el primer colateral de la derecha en esta Penitencial"665. Allí permaneció el Nazareno hasta el cierre de la iglesia en 1926, año en que se trasladó al Monasterio de San Quirce, si bien desconocemos el porqué de su traslado hasta aquí

\footnotetext{
659 MARTÍ Y MONSÓ, José: Estudios histórico-artísticos..., op. cit., p. 499.

660 LUNA MORENO, Luis: "Camino del Calvario". En VV.AA.: Gregorio Fernández y la Semana Santa, Ministerio de Cultura, Madrid, 1986, p. 51; MARTÍ Y MONSÓ, José: Estudios históricoartísticos..., op. cit., p. 499.

661 VV.AA.: Pasos restaurados, op. cit., p. 55; LLAMAZARES RODRÍGUEZ, Fernando: El "Nazareno" en la escultura barroca castellana. En IBÁÑEZ MARTÍNEZ, Pedro Miguel y MARTÍNEZ SORIA, Carlos Julián: La imagen devocional barroca, Ediciones de la Universidad de Castilla-La Mancha, Cuenca, 2010, p. 96.

$662 \quad$ Ídem, p. 95.

663 VV.AA.: Pasos restaurados, op. cit., p. 55.

664 Ibídem.

665 LUNA MORENO, Luis: “Acerca de...”, op. cit., p. 35.
} 
precisamente $^{666}$. Tras un supuesto incendio en el monasterio, que llevó a Agapito y Revilla a pensar la escultura se perdió, tenemos noticia de que pasó al Santuario Nacional de la Gran Promesa, lugar en el que se encontraba, al menos, desde $1943^{667}$. Finalmente, como ya hemos referido, la Cofradía de la Pasión logró recuperar la titularidad de la imagen, trasladándola en 2013 a su sede canónica, casualmente, el aludido Monasterio de San Quirce y Santa Julita.

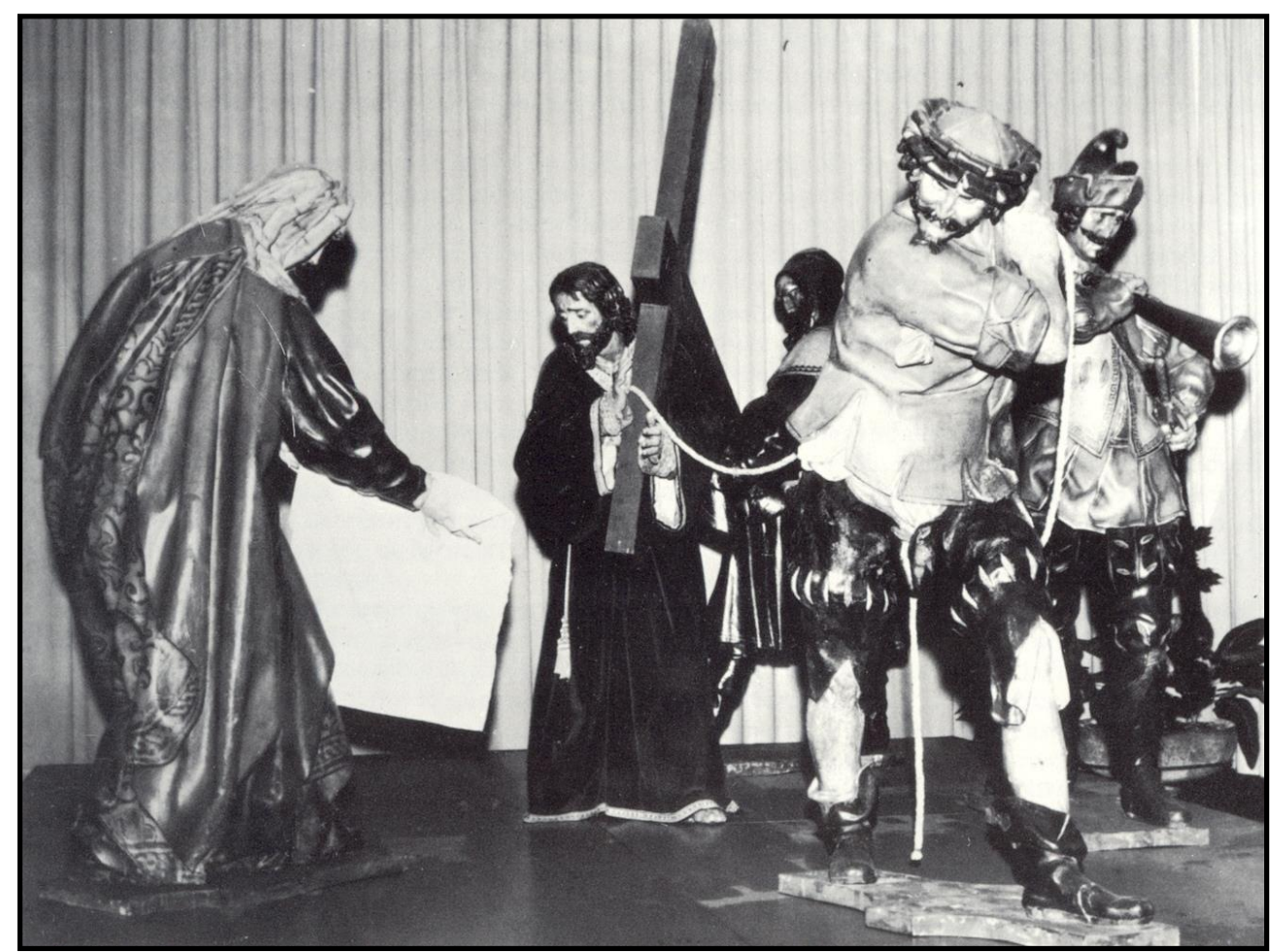

Il. 38- Reconstrucción del paso del Camino del Calvario realizada por Luis Luna en 1986.

La imagen permaneció ignorada en el Santuario del Carmen Extramuros hasta que en 1986 Luis Luna, con motivo de la exposición "Gregorio Fernández y la Semana Santa", la utilizó para conformar la hipotética reconstrucción del paso Camino del Calvario, ya que el Nazareno "corresponde fielmente al original perdido". Pensaba "que era esta misma figura, sino mediara un incendio en San Quirce; está tallada completa, con anatomía menos pormenorizadas en la parte que debe cubrir la túnica" ${ }^{\text {"668 }}$. Tan solo se equivocaba en una cosa: creía ver en ella el primer estilo de Gregorio Fernández, es decir, pensaba que era el Nazareno primigenio. Luna sigue manteniendo la idea de que la escultura es de Gregorio Fernández. Asevera que "diversas propuestas se han realizado para explicar la no-autoría de Gregorio Fernández de esta imagen; quizás la más curiosa es la "invención" de la noticia de una supuesta destrucción de la imagen original en el mismo siglo XVII, lo que motivaría la realización de una nueva talla que

666 BURRIEZA SÁNCHEZ, Javier: Varón de Dolores, Ayuntamiento de Valladolid, Valladolid, 2005, pp. 75-76. Hay que recordar que otras obras de arte pertenecientes a la Cofradía de la Pasión pasaron a la clausura de este monasterio. REBOLLO MATÍAS, Alejandro: “Acerca de nuestra historia: la iglesia de la Pasión y su patrimonio ( $3^{\mathrm{a}}$ parte), op. cit., pp. 38-41.

667 VV.AA.: Pasos restaurados, op. cit., p. 55.

668 LUNA MORENO, Luis: “Camino del Calvario", op. cit., p. 52.

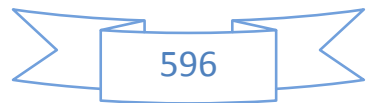


completase el conjunto; hay que señalar que no existe ninguna referencia documental que respalde esta "desaparición”. Incluso se ha supuesto que la imagen actual se debió realizar a finales del siglo XVII, insinuando la fecha de 1697, cuando se documenta, como ya se ha señalado, la confección de una túnica nueva para este Cristo; si, estilísticamente es difícil aceptar una cronología tan excesivamente tardía, resulta, al menos, peregrino, relacionar la realización de una túnica nueva con la talla de una nueva imagen (...). Las asignaciones que se han realizado a otros escultores, en mi opinión, no parecen estar amparadas por unas relaciones estilísticas evidentes" ${ }^{669}$. Todas estas correcciones y alusiones se refieren, en gran parte, al estudio del paso realizado por Urrea, uno de los grandes expertos sobre la obra fernandesca, para el catálogo de la exposición Pasos restaurados, celebrada en el año 2000 en el Museo Nacional de Escultura. Pienso, como Urrea, que de ninguna manera puede ser considerada esta escultura como la tallada por Fernández, ya que, según sus palabras, "por muchas y torpes restauraciones que haya sufrido, ni la falta de grandeza de expresión, ni los mechones de su cabeza y barba, ni la blandura de su rostro permiten reconocer en él los rasgos propios del gran maestro"670.

Los motivos que llevaron a confirmar que este Nazareno fue el que perteneció al paso del Camino del Calvario fueron varios, siendo, quizás, el más importante el que en su hombro derecho figure incisa la letra "P", lo que nos revela que procede de la Cofradía de la Pasión. A esto se sumó el hecho de que en las instrucciones para armar el paso se aluda a un sayón "que va metiendo la lanza por el costado de Jesús y ésta es de dos pedazos", precisamente el Nazareno del que estamos hablando poseía una "chapa metálica con rosca, precisamente en ese costado" 671.

De lo que no cabía duda es de que el Nazareno no estaba rodilla en tierra, como el que actualmente preside el paso, sino de pie, levemente inclinado por el peso de la cruz. Dos obras de arte ayudaron a confirmar este extremo: una pintura y un paso procesional. La primera es una "torpe y maltrecha pintura, de mediados del siglo XVIr" conservada en el Real Monasterio de San Quirce, quizás procedente también de la iglesia de la Pasión. El lienzo representa el Camino del Calvario, figurando en ellas unas imágenes bastante similares a las esculturas del paso vallisoletano. Esta similitud es aún mayor en el caso del Nazareno, puesto que adopta una posición idéntica a la adoptada por el Cristo que estamos tratando ${ }^{672}$. El apoyo es el grupo procesional Camino del Calvario que tallaron entre 1693-1696 los escultores vallisoletanos José de Rozas y Antonio Vázquez, y el riosecano Bernardo López de Frías "el viejo", para la Cofradía de Jesús Nazareno de Palencia $^{673}$. En este caso, el Nazareno, como en la pintura, también aparece de pie, es decir, de la misma forma en que se encuentra dispuesto nuestro Nazareno.

\footnotetext{
669 LUNA MORENO, Luis: “Acerca de...”, op. cit., p. 36.

670 LLAMAZARES RODRÍGUEZ, Fernando: "El "Nazareno" en la escultura barroca castellana", op. cit., p. 96.

671 VV.AA.: Pasos restaurados, op. cit., p. 60; VASALLO TORANZO, Luis: "El paso Camino del Calvario...", op. cit., p. 19.

$672 \quad$ VV.AA.: Pasos restaurados, op. cit., p. 60.

673 GARCÍA CUESTA, Timoteo; “La Cofradía...”, op. cit., pp. 111-112.
} 
El Nazareno que nos ocupa es una escultura de vestir, pero eso no quiere decir que sea de bastidor. Efectivamente, su cuerpo está completamente tallado. El escultor pone el máximo énfasis en el rostro, manos y pies, pero el resto también está esculpido. La anatomía que cubre la túnica es menos pormenorizada, pero ello no quiere decir que no esté tratada con toda corrección. El hecho de que en Valladolid desfilara un Nazareno vestido no ha de extrañarnos nada, al igual que las Vírgenes de la Soledad, cuyas dos iconografías, en su versión "de vestir" siempre se ha creído que son andaluzas. Como bien explica Luis Luna, se trata de "un evidente perjuicio historiográfico vallisoletano hacia las imágenes de vestir. Sin embargo, precisamente en el tema iconográfico que ahora nos ocupa, Jesús con la cruz a cuestas, Jesús Nazareno, lo habitual en Castila es, precisamente, que se represente mediante una imagen de vestir. Aparte que la estadística es abrumadora, en la época en que se contrata este paso, se contaba con significativos ejemplos: Medina del Campo, Nava del Rey y Cuéllar, precisamente con el cuerpo desnudo anatomizado, como la obra que ahora nos ocupa; además, conviene acordarse que, tanto se asocia la representación del Nazareno con la figura de vestir, que significativas y devotas imágenes, como la titular de su cofradía vallisoletana y la de Medina de Rioseco, por recordar unos ejemplos, pese a tener tallada la túnica, han sido vestidas, durante muchos años con ricos ropajes" 674 .

El rostro es muy bello, está captado perfectamente en su gesto el sufrimiento que está soportando al cargar con el madero. Mira al espectador buscando su ayuda y comprensión. Sea de Juan de Ávila o de Juan Antonio de la Peña, no cabe duda de que este rostro es el más fernandesco. Es, junto a otros como el Cristo de la Agonía tallado por el propio de la Peña, uno de los que mejor ha sabido fundir el legado de Gregorio Fernández y las corrientes vallisoletanas de finales del siglo XVII. Cristo tiene la cabeza levemente girada hacia la derecha, mirando hacia abajo, hemos de recordar que estaría observando su cara impresa en el paño de la Verónica. Mantiene los ojos, realizados en tapilla de vidrio, medio abiertos, todo lo que le permite el sufrimiento que está padeciendo. Ese mismo sufrimiento lo podemos observar en el arqueamiento de las cejas. El modelado del rostro es muy blando, pero se acrecienta en esta zona y en la de los labios. Tanto los ojos como la nariz entroncan de lleno con la plástica de Ávila y De la Peña. Boca entreabierta, dejando escapar el hálito, que permiten verle los dientes de la parte superior. Labios muy finos, perfectamente delineados. El bigote y la barba tienen poco resalte, mechones muy revueltos, la curva campa a sus anchas. La barba termina en dos puntas. El pelo es lo más novedoso de la escultura puesto que no se desarrolla en grandes bloques ni éstos son simétricos. Cada guedeja tiene autonomía propia deslizándose por el cuello cada una por su lado, destaca la que cae de manera muy sinuosa por su lado derecho, tapando la oreja. La corona es postiza, de espino natural, a la usanza de Fernández.

Las manos probablemente no sean las originales, y de serlo están muy desgastadas, no se aprecian casi restos de talla en ellas, apenas la zona que remarca las uñas. La sustitución, o las múltiples restauraciones, han determinado que estas manos sean

674 LUNA MORENO, Luis: “Acerca de...”, op. cit., p. 36. 
impersonales. Poco más o menos ocurre con los pies. La policromía enriquece grandemente a la escultura. Las gotas de sangre caen por su cara y cuello, no es abundante ni exagerada. Llaman, asimismo, la atención, los cardenales visibles a la altura de las muñecas y los tobillos, son la huella de unas previsibles cadenas.

El Nazareno, como hemos dicho, presidía el paso del Camino del Calvario. En él, interactúa con otros personajes: el Cirineo le ayuda a soportar el terrible peso de la cruz; la Verónica le seca la cara con un paño, en el cual queda impresa la faz del Redentor; por su parte, un sayón tira con fuerza de una cuerda anudada al cuello del Nazareno, otro anuncia el triste cortejo tocando una trompeta, y un tercer esbirro, que actualmente no existe, le hería con una lanza en el costado. La representación plástica de este paso procesional es el resultado de la fusión de los cuatro Evangelios canónicos y los textos piadosos medievales y modernos. A lo que habría que sumar la influencia del Vía Crucis y las visiones que tuvieron ciertos santos de Cristo con la cruz a cuestas camino del Calvario, si bien no fue una de las más frecuentes. El significado de estas contemplaciones venía a ser un apoyo a "soportar mejor la carga de su cruz de cada día de un modo más suave en su imitación a Cristo". Llamazares Rodríguez señala los siguientes: "San Bernardo de Claraval, entre los cistercienses; a San Juan de la Cruz y Santa Teresa de Jesús, entre la Orden del Carmelo; a Santa Clara de Montefalco entre la Orden agustiniana y a San Ignacio de Loyola entre los jesuitas" ${ }^{\prime 675}$.

Comenzaremos por los evangelistas. Mateo (27, 32-33) narra que una vez que Cristo abandonó el pretorio "encontraron a un hombre de Cirene, de nombre Simón, al cual requirieron para que llevase la cruz"; hecho que confirman Marcos (15, 21-22), al decir que "requisaron a un transeúnte, un cierto Simón de Cirene, que venía del campo, el padre de Alejandro y de Rufo, para que llevase la cruz", y Lucas (23, 26-27), que asimismo escribe que "le cargaron con la cruz para que la llevase en pos de Jesús". En cambio, Juan (19, 17-18) únicamente refiere que Jesús "llevando su cruz, salió al sitio llamado Calvario, que en hebrero se dice Gólgota, donde le crucificaron"676. Ninguno de los Evangelistas menciona a lo largo de su relato la presencia anecdótica de una mujer que apiadada del sufrimiento de Cristo enjugase el rostro de éste con un paño, tan sólo Lucas $(23,27-30)$ recuerda que en su camino al Calvario seguía a Jesús "una larga muchedumbre del pueblo y de mujeres, que se herían y lamentaban por El. Vuelto a ellas Jesús dijo: Hijas de Jerusalén, no lloréis por mí, llorad por vosotras mismas y por vuestros hijos...". Los primeros escritos que hablan sobre la Verónica, si bien no tratan sobre la subida al Gólgota sino identificándola con la hemorroísa, son los Evangelios Apócrifos de la Pasión y Resurrección ${ }^{677}$.

Por su parte, los textos piadosos y tratados ascéticos del siglo XVI fueron fundamentales para poder interpretar no solo este tema, sino otros muchos. Centrándonos en el pasaje del camino del Calvario, en la obra De imitatione Christi

\footnotetext{
675 LLAMAZARES RODRÍGUEZ, Fernando: "El "Nazareno" en la escultura barroca castellana", op. cit., p. 77.

$676 \quad$ Ídem, pp. 67-68.

677 Ídem, p. 68.
} 
(1418), de Tomás de Kempis, se recoge en el capítulo XII, titulado "Del camino de real de la Santa Cruz": "Esta palabra parece dura a muchos, que dice: "Niégate a ti mismo, toma tu cruz y sígueme” y sigue a Jesús (...) Toma pues la cruz y sigue a Jesucristo, e irá a la vida eterna. El vino primero, y llevó su cruz, y murió en la cruz por ti, porque tú también la lleves y desees morir en ella"678.

Señala Llamazares Rodríguez que dos de las obras místicas que más pudieron ayudar a los artistas a plasmar en obras de arte este pasaje fueron el Libro de Oración (1554) de fray Luis de Granada, y el Tratado de Oración y Meditación (1541-1551) de San Pedro de Alcántara ${ }^{679}$. Tan solo citaremos el primero de estos, puesto que el segundo recoge, más o menos, lo dicho por aquél. Efectivamente, en el capítulo X del libro de fray Luis de Granada, centrado en la Pasión y Muerte de Jesucristo, figura lo siguiente: "Estaba y a a las puertas aparejada la cruz, y asomaba por lo alto aquella temerosa bandera, amenazando a la cabeza del Salvador. Dada pues ya y promulgada la sentencia cruel, añaden los enemigos una crueldad a otra, que fue cargar sobre aquellas espaldas, tan molidas y despedazadas con los azotes, el madero de la cruz. No rehusó con todo esto el piadoso Señor esta carga (...) Camina, pues, el inocente con aquella carga tan pesada sobre sus hombros tan flacos, siguiéndole mucha gente y muchas piadosas mujeres, que son sus lágrimas le acompañaban" ${ }^{680}$. 


\section{VALLADOLID. CONVENTO DE PORTA COELI}

\section{VIRGEN DE LA SOLEDAD (h. 1697-1700)}

La presente talla de Nuestra Señora de la Soledad (130 cms.) (Fig. 120), que procede del desaparecido Convento de Nuestra Señora de la Laura, debe ser la que figura en los apuntes de uno de los libro de cuentas del convento ${ }^{681}$. Efectivamente, citada en el período 1697-1700, se dice que por ella se abonó al anónimo escultor, la cantidad de 1.390 reales, precio que incluía el coste de su diadema de plata y de 25 varas de tafetán para las cortinas. Si tenemos en cuenta que unos años antes Juan Antonio de la Peña había recibido 750 reales por una imagen de similar iconografía y tamaño, podemos hacernos a la idea de que el escultor de esta talla percibiría una cifra similar ${ }^{682}$.

La primera vez que esta Virgen es citada es en una exposición realizada en el año 1983 sobre el arte custodiado en las clausuras vallisoletanas. En el catálogo que se publicó con motivo de dicha muestra se calificaba a esta Soledad como obra de "autor vallisoletano de prestigio", barajándose dos nombres: José de Rozas y Juan de Ávila ${ }^{683}$. La cronología se establecía en el último cuarto del siglo XVII. Con posterioridad, en el respectivo tomo del Catálogo Monumental de Valladolid, Martín González y Plaza Santiago se reafirmaron en lo dicho, apostando decididamente por nuestro escultor, calificándola como "cercana a Juan de Ávila”. La cronología propuesta no varió ${ }^{684}$.

Desconocemos el lugar que ocuparía dentro de la iglesia. El hecho de que en el mismo periodo que se realiza la talla se procediese al dorado de los dos colaterales, y no hacia el año 1690 como relata Canesi ${ }^{685}$, lleva a pensar que pudo ocupar uno de ellos. La falta de documentación y la desaparición de la totalidad de los retablos barrocos existentes en la iglesia durante la Guerra de la Independencia provoca que este extremo no lo podamos confirmar o desmentir. Pudiera ser que el momento de la desaparición de estos retablos fuera en el año 1812. Francisco Gallardo y Merino relata que el día 4 de junio del dicho año las Lauras salieron de su convento: "En 4 (junio de 1812) se intimó orden por medio del Sr. Obispo a las monjas del convento de las Lauras para que le desalojasen, como lo hicieron, pasándolas al de Santa Ana. Esto fue para empezar

\footnotetext{
681 "1697-1700. 11.760 reales, que se han gastado en la iglesia en los tres años, en esta forma. De la hechura de Nuestra Señora de la Soledad y la diadema de plata y 25 varas de tafetán para cortinas a los colaterales, 1.390 reales. De dorar los dos colaterales y las varas del palio y el pulpito y de hacerle nuevo, 3.279 reales". MARTÍN GONZÁLEZ, Juan José y DE LA PLAZA SANTIAGO, Francisco Javier: Catálogo Monumental de la provincia de Valladolid. Tomo XV..., op. cit., p. 166.

682 URREA FERNÁNDEZ, Jesús: “La biografía al servicio del conocimiento...”, op. cit., p. 53.

683 MARTÍN GONZÁLEZ, Juan José y DE LA PLAZA SANTIAGO, Francisco Javier: El arte en las clausuras de los conventos de monjas de Valladolid (exposición), Museo Nacional de Escultura, Valladolid, 1983, nº 51.

684 MARTÍN GONZÁLEZ, Juan José y DE LA PLAZA SANTIAGO, Francisco Javier: Catálogo Monumental de la provincia de Valladolid. Tomo XV..., op. cit., p. 159.

685 CANESI ACEVEDO, Manuel: Historia de Valladolid(1750), Tomo III, op. cit., p. 509.
} 
hacer desde dicho convento hasta el de Filipinos (ambos en el Campo Grande por la parte de atrás) varias zanjas y maniobras de fortificaciones, etc..." ${ }^{686}$.

Acabada la Guerra de la Independencia las monjas procedieron a renovar el interior de la iglesia, construyéndose cinco retablos: el mayor y dos en cada uno de los lados de la nave. Estos cinco retablos neoclásicos, que seguían una misma traza, quizás pudieran haber sido ejecutados por Eustaquio Bahamonde, uno de los más acreditados artífices con que contaba Valladolid por aquellas fechas. Sabemos, gracias al testimonio de González García-Valladolid, el único que ha descrito el interior de la iglesia, que la Virgen de la Soledad ocupaba uno de los retablos del lado del Evangelio, el otro poseía un lienzo de la Oración en el Huerto ${ }^{687}$. La imagen debía de encontrarse vestida, lo que llevó a equívoco al erudito puesto que señala que era "de bastidores" 688 .

Tras el cierre del Convento y la dispersión de sus bienes artísticos entre diversos establecimientos de la Orden, principalmente los vallisoletanos de Porta Coeli y Corpus Christi de Valladolid y el de San Pedro Mártir de Mayorga de Campos (Valladolid), la Virgen de la Soledad ha ido a parar al relicario del Convento de Porta Coeli, espacio que comparte con una María Magdalena que, también procedente de este mismo Convento de Nuestra Señora de la Laura, se estudiará a continuación.

La presente advocación, en algunas ocasiones también conocida como "Virgen de la Paloma", representa uno de los casos más claros de la influencia de la pintura sobre la escultura. Aunque copia un lienzo, esta escultura "se puede considerar que supuso el inicio de una nueva tipología de imagen mariana" ${ }^{689}$. El modelo escultórico primigenio procede del genial baezano Gaspar Becerra. En 1565 la reina Isabel de Valois encarga a Becerra la ejecución de una imagen en bulto redondo de la Virgen de la Soledad, y bajo su maestría correría también su policromado. Con posterioridad la soberana regaló esta valiosísima y devotísima imagen al madrileño Convento de la Nuestra Señora de la Victoria, de los padres mínimos ${ }^{690}$. La relación de la reina con este cenobio fue muy estrecha ya que su devoción por San Francisco de Paula le llevó a patrocinar su construcción. Tras la Desamortización la Virgen pasaría a la capilla de San Isidro de la iglesia de San Andrés, lugar en el que fue destruida a consecuencia de un incendio en el año 1936.

El deseo de la reina al solicitar este encargo era poseer una "copia escultórica" de un cuadro de la Virgen de la Soledad y Angustias que había traído desde Francia y que

686 GALLARDO Y MERINO, Francisco: Noticia de casos particulares ocurridos en la ciudad de Valladolid Año 1808 y siguientes. Obra publicada, corregida, anotada y adicionada con un prólogo por D. Juan Ortega y Rubio Catedrático de esta Universidad, Imprenta y Librería Nacional y Extranjera de los Hijos de Rodríguez, Valladolid, 1886, p. 181.

687 GONZÁLEZ GARCÍA-VALLADOLID, Casimiro: Valladolid..., op. cit., Tomo II, p. 359.

$688 \quad$ Ibídem.

689 SÁNCHEZ DE MADARIAGA, Elena: "La Virgen de la Soledad. La difusión de un culto en el Madrid barroco". En CARLOS VARONA, María Cruz, CIVIL, Pierre, PEREDA ESPESO, Felipe y VICENT-CASSY, Cécile (coord.): La imagen religiosa en la Monarquía hispánica, Casa de Velázquez, Madrid, 2008, pp. 219-220.

$690 \quad$ Ibídem. 
conservaba en su oratorio. El proceso de elaboración llevado a cabo por Becerra fue arduo y prolongado. Relata Sánchez de Madariaga que "tardó un año en sacar una primera cabeza, que no satisfizo a nadie. No fue hasta el tercer intento, tras tener un sueño en el que una persona -no sabía si hombre o mujer- le decía que despertara, fuera a la chimenea, matase el fuego de un tronco de roble que se estaba quemando y lo preparase, porque de él sacaría la Imagen que deseaba, cuando finalmente realizó la imagen de Nuestra Señora de la Soledad. Becerra tuvo el caso "por milagroso, y cosa de revelación" 691 . La imagen se concibió para ser vestidera, y, efectivamente, así se hizo, con las ropas de la Condesa viuda de Urueña, Camarera mayor de la Reina ${ }^{692}$.

La milagrosa imagen recibió grandes vítores y elogios, siendo uno de los más exagerados el pronunciado por Palomino. El famoso pintor y tratadista cordobés, al hablar sobre Becerra en su conocido Parnaso español, pintoresco y laureado, comentaba que "la más heroica obra suya de escultura, y corona de sus estudios, fue la que hizo por mandato de la Serenísima Reina de España doña Isabel de Valois (llamada de la Paz) que es la imagen de Nuestra Señora de la Soledad"693. Señala Arias Martínez que llama la atención tan desmesurado elogio dado que se trataba de una "sencilla imagen de vestir, donde no era posible mostrar sutiles habilidades técnicas, y que sólo se puede explicar al rodearse su ejecución de misterio y de intervención sobrenatural, para llevar a cabo una verdadera imagen sagrada, que

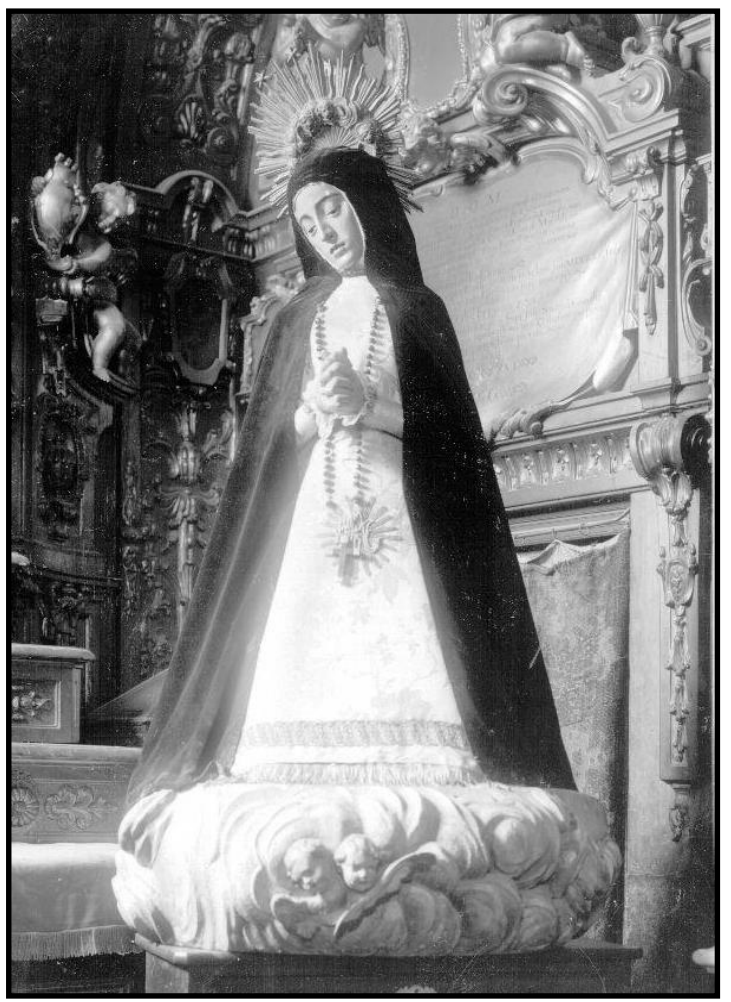

Il. 39- Gaspar Becerra. Virgen de la Soledad (Desaparecida). Madrid. trascendía cualquier planteamiento estético"694.

La escultura que nos ocupa es una imagen de bulto redondo en madera policromada. Llama la atención este hecho porque es de las pocas de este tipo que se conservan en Valladolid $^{695}$, puesto que, por lo general, solían ser de bastidor. No hay nada más que

$691 \quad$ Ibídem.

692 VV.AA.: Pequeñas imágenes de la Pasión en Valladolid [exposición abril-mayo 1987 Palacio de Villena], Ministerio de Cultura, Madrid, 1987, p. 71.

693 ARIAS MARTÍNEZ, Manuel: "La copia más sagrada. La escultura vestidera de la Virgen de la Soledad de Gaspar Becerra y la presencia del artista en el convento de Mínimos de la Victoria de Madrid”, B.R.A.C., Tomo XLVI, 2011, p. 33.

$694 \quad$ Ibídem.

695 Existen varias de pequeño tamaño en la ciudad, como son una conservada en el relicario de la iglesia de San Miguel y otra en el Convento de Sancti Spiritus. VV.AA.: Pequeñas imágenes de la Pasión en Valladolid..., op. cit., pp. 72-73. 
ver las Dolorosas que conservan las cofradías penitenciales de nuestra ciudad (Vera Cruz, Angustias, Piedad y Nazareno) o la de la iglesia de San Andrés ${ }^{696}$.

La talla descansa sobre una fina peana de tarjetillas. El escultor nos presenta a la Virgen arrodillada, y ataviada como una viuda, según el referido modelo. Este hecho lleva a que la imagen posea una bicromía blanco (túnica) - negro (manto) realizada a pulimento. La blancura del rostro torna casi en palidez. Las manos entrelazadas a la altura del pecho. La cabeza mira hacia el suelo, el escultor no ha resuelto bien la proyección de los sentimientos en el rostro de la Virgen, no es un rostro de tristeza, es más bien de ausencia, se encuentra impertérrita. Lleva como postizos una diadema y un rosario colgado de los brazos. Los pliegues son demasiados rígidos, en especial los de la túnica, como si el escultor los hubiera tallado de manera arbitraria, siendo, además, muy poco profundos.

La escultura es similar a una que había concertado el escultor Juan Antonio de la Peña el 12 de enero de 1682 con Santiago Rodríguez "vecino de la ciudad de León y abad de la Cofradía de Nuestra Señora de la Soledad que se sirve y canta en la parroquial de San Martín de ella". El escultor gallego se comprometía a tallar "una imagen de Nuestra Señora de la Soledad para dicha Cofradía para colocarla en dicha parroquia de San Martín donde está fundada"697. Las diferencias entre ambas estriban, sobre todo, en la calidad, siendo mucho mayor la concebida por De la Peña que la atribuida a nuestro escultor. Mientras que la del primero tiende a una composición, más o menos, piramidal, la segunda posee un contorno mucho más redondeado, diríamos casi de "cuerpo de botella". También les diferencia el hecho de que la imagen esculpida por De la Peña posee lágrimas de vidrio cristalino cayendo por el rostro. Que la ejecución de la talla atribuida a nuestro escultor es mucho más torpe la podemos ver en numerosos detalles, siendo los más significativos la nula expresividad del rostro y la nefasta forma de resolver el entrelazado de las puntas de la túnica a los pies de la imagen, mucho más delicada y singularizada en el ejemplar del artífice gallego.

A pesar de todo ello las facciones del rostro apuntan a una atribución a nuestro escultor, si bien la forma de tallar los labios y la tosquedad general de la talla inducen a pensar que el maestro dejo su elaboración en manos de su taller.

\section{¿SAN FELIPE BENIZZI? (h. 1698-1700)}

Desconocemos el santo efigiado y, aún más, la orden a la que pertenece, ya que la indefinición de la vestimenta hace que puedan asignársele varias, siendo las más probables la Orden de San Agustín y Orden la de los Servitas o de frailes Siervos de María. Tampoco serían descartables otras posibilidades. La falta de atributos y la descontextualización de la imagen no ayudan demasiado a despejar la incógnita. El

696 MARTÍN GONZÁLEZ, Juan José y URREA FERNÁNDEZ, Jesús: Catálogo Monumental de la provincia de Valladolid. Tomo XIV..., op. cit., p. 54.

697 URREA FERNÁNDEZ, Jesús: “La biografía al servicio del conocimiento...”, op. cit., p. 53. 
interrogante también se encuentra en su procedencia ya que no sabemos si pertenece a dicho convento o bien ha llegado procedente de otros establecimientos religiosos.

Pienso, a pesar de que normalmente se le represente sin barba, que el santo efigiado puedas ser San Felipe Benizzi (Fig. 121), superior general de la Orden de los Servitas, organización de tipo mendicante que seguía la regla de San Agustín. Fue fundada en Florencia en el año 1233, ciudad y año en que vino al mundo el referido Felipe Benizzi $^{698}$. Murió en esa misma ciudad en el año 1285. Hubo que esperar hasta 1671 para que el papa Clemente X lo canonizara ${ }^{699}$. Su iconografía es bastante sencilla puesto que se le suele representar con el hábito negro de su Orden y un crucifijo, o rama de lirio, en una de sus manos y a sus pies una tiara pontificia en alusión a sus rechazos de las dignidades de Arzobispo de Florencia y de Papa ${ }^{700}$. Acerca del Crucifijo señala Réau que "como San Buenaventura, no tenía otro libro que un Crucifijo" ${ }^{701}$.

Lo que podemos ver es a un santo de pie, con la pierna izquierda levemente adelantada. Viste un hábito negro ajustado a la cintura por un ceñidor. Las bocamangas son muy amplias, si bien no se han resuelto con demasiado realismo. Cabeza elevada, sus ojos parecen mirar hacia el cielo. Levanta el brazo izquierdo, y en su mano parece haber sujetado un Crucifijo ${ }^{702}$, aunque tampoco se podría descartar otro atributo. Su brazo izquierdo está colocado en una posición más reposada. En esa mano, dispuesta de manera bastante artificial, parece que pudo sujetar otro atributo.

La atribución a nuestro escultor viene dada por la semejanza que posee tanto el rostro como la forma de tallar la barba con el San Francisco de Sales que ejecutó para el Oratorio de San Felipe Neri. Además, los mechones mojados y sinuosos que caen sobre la frente es otra de las señales inequívocas de nuestro escultor. En este caso el parecido sería con el San Andrés del retablo de la colegiata de Lerma. Dadas también las semejanzas capilares con el San Isidro Labrador pienso que es oportuno fecharla hacia finales del siglo XVII, concretamente 1698-1700.

Los pliegues que podemos observar son muy suaves, sin apenas resalte, salvo en las bocamangas y en la parte baja de la vestimenta, agitada a causa del movimiento de la rodilla izquierda. Estos últimos producen algunas quebraduras, pero por lo general caen verticales hacia el suelo.

\footnotetext{
698 RÉAU, Louis: Iconografía de los santos. A-F ..., op. cit., p. 511.

699 Ídem, p. 512.

$700 \quad$ Ídem, p. 511.

$701 \quad$ Ibídem.

702 En la actualidad sujeta uno que nada tiene que ver con la escultura.
} 


\section{VALLADOLID. MONASTERIO DEL SANTÍSIMO SALVADOR DE SANTA BRÍGIDA}

\section{ESCULTURAS DEL RETABLO MAYOR (1697-1698)}

En el año 1696 se finaliza la construcción de la nueva iglesia conventual, lleva a cabo por el prestigioso maestro de obras vallisoletano Manuel Izquierdo. Cuenta Matías Sangrador que a finales del siglo XVII "se advirtió que la iglesia de este convento era demasiado mezquina para la importancia que sucesivamente había ido adquiriendo, por cuyo motivo se construyó otra de mayores proporciones que es la que hoy existe. La bendición del nuevo templo la hizo con grande solemnidad el Ilmo. Sr. D. Diego de la Cueva y Aldana, obispo de esta ciudad, el día 6 de mayo de 1696 en cuyo día celebró de pontifical; y se trasladó el Santísimo procesionalmente con asistencia del Ilustre Ayuntamiento y del Señor Corregidor, que lo era entonces el Señor D. Alonso de Pacheco, caballero de la Orden de Alcántara. La procesión recorrió toda la plazuela, en la cual se levantaron magníficos altares, y llevó el Santísimo debajo del palio el Señor D. Juan de Castro, capellán mayor del convento y canónigo de la Santa Iglesia" ${ }^{\text {703. }}$.

A continuación, se emprendió la tarea del amueblamiento interior de la misma. Lo primero que se hizo fue contratar en 1698 la hechura del retablo mayor y de los dos colaterales, cuya ejecución corrió a cargo del ensamblador vallisoletano Francisco Billota $^{704}$. Los tres retablos, así como el sagrario, monumento y púlpito, fueron dorados en 1703 por Manuel Martínez de Estrada, artífice que hemos visto en muchas ocasiones ligado a obras relacionadas con Ávila. Martínez de Estrada realizó tan magnífica labor en sus quehaceres que se le abonaron 500 reales en concepto "de guantes"

Una vez finalizados todos estos trabajos, el 19 de agosto de ese mismo año se procedió a trasladar el Santísimo a la iglesia. Ventura Pérez, testigo presencial de los hechos, lo describe así en su Diario de Valladolid: "en 19 de agosto de 1703 se trasladó el Santísimo a la iglesia nueva y retablo de las monjas de Santa Brígida, orden religiosa del Salvador; este día por la tarde hubo procesión (no hubo convite), asistió el Ilmo. Sr. D. Diego de la Cueva y Aldana, obispo de esta ciudad; llevaron el palio seis canónigos; el Santísimo le llevó el Dr. Cañizal, catedrático de esta real Universidad y confesor y capellán mayor de dichas religiosas; asistieron algunos religiosos del Convento de San Diego, descalzos de nuestro padre San Francisco: anduvo la procesión alrededor de la plazuela; había tres alturas; uno de San Diego, otro de San Ignacio y el otro de los

\footnotetext{
703 SANGRADOR Y VÍTORES, Matías: Historia de la Muy Noble y Leal Ciudad de Valladolid..., op. cit., Tomo II, p. 354.

704 MARTÍN GONZÁLEZ, Juan José y DE LA PLAZA SANTIAGO, Francisco Javier: Catálogo Monumental de la provincia de Valladolid. Tomo XV ..., op. cit., p. 38.

$705 \quad$ Ibídem.
} 
capellanes, y en cada uno hubo un villancico: la víspera tuvieron fuego de mano y un árbol" ${ }^{\prime 706 .}$.

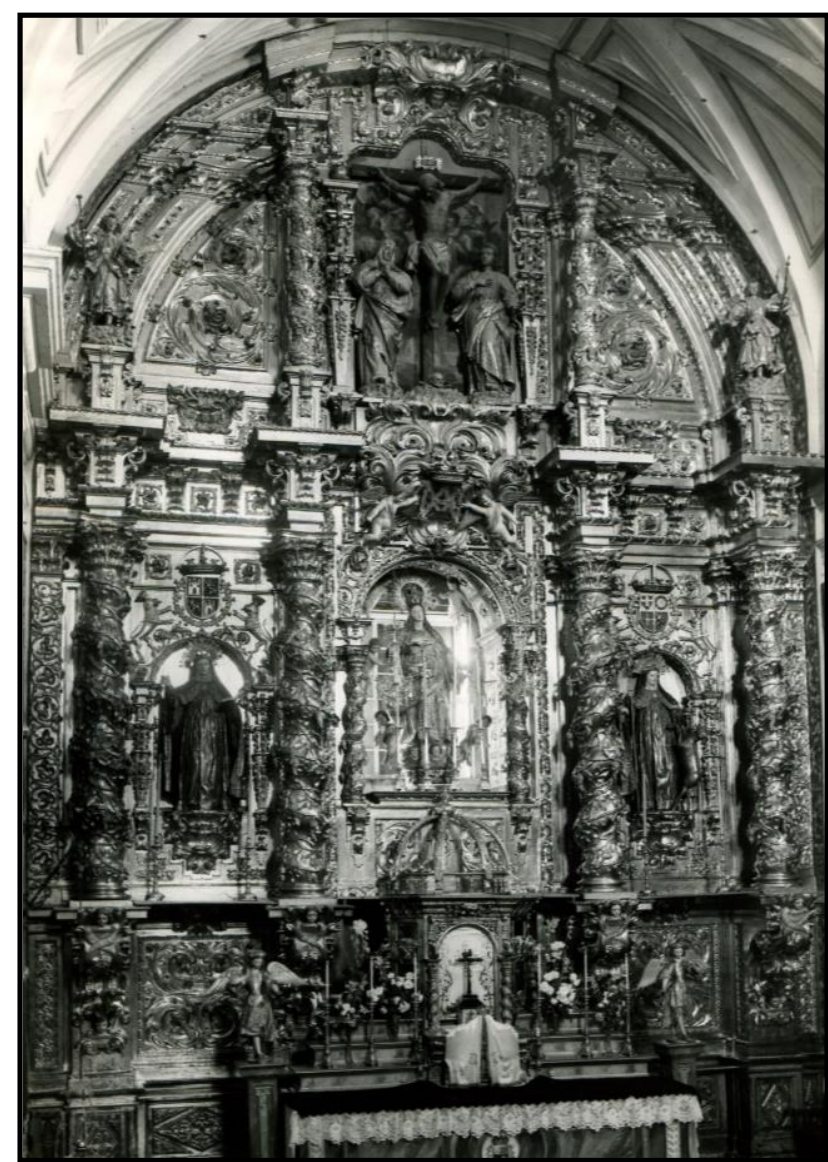

Il. 40- Francisco Billota. Retablo mayor. Monasterio de Santa Brígida. Valladolid. ( $)$ Departamento de Historia del arte de la Universidad de Valladolid.
Como ya dijimos, el retablo es casi idéntico al que preside el altar mayor del Monasterio de San Quirce y, asimismo, similar al de la iglesia de Nuestra Señora del Rosario. Las únicas diferencias reseñables las comentaremos a continuación. La calle central está presidida por una Asunción, detrás de la cual se abre un transparente, acompañada por angelitos que revolotean a su alrededor. Las hornacinas de los intercolumnios los ocupan Santa Brígida, patrona del convento y de la Orden del Santísimo Salvador; y Santa Catalina de Suecia, hija de Santa Brígida. Sobre la Asunción hay una tarjeta, con dos ángeles que portan el anagrama del Ave María. Por su parte, sobre las hornacinas de las dos santas se sitúan los escudos de Felipe IV y de la fundadora, Marina Escobar, soportados por leones tenantes. En la portada central del ático, mucho más desarrollado que en el de San Quirce, en este retablo casi ocupa el mismo espacio que el cuerpo, se abre una hornacina con la parte superior trilobulada. Dentro de ella encontramos un Calvario en el que sobresale el Crucifijo, y a ambos lados la Virgen y San Juan, que denotan una mano diferente. En sendos pedestales situados sobre sendos trozos de entablamentos en la parte superior de las columnas extremas se yerguen dos ángeles de clara raigambre fernandesca que portan los Arma Christi. González García-Valladolid nos describe el retablo de la siguiente manera: "se ven las imágenes de Nuestra Señora de los Ángeles, cuyo título lleva el convento, en el centro, y a sus lados Santa Brígida y Santa Catalina de Suecia; sobre las hornacinas que ocupan éstas están esculpidos los escudos de armas de la fundadora [Marina de Escobar] y del rey D. Felipe IV. En el segundo cuerpo y último término hay un Crucifijo con la Virgen y San Juan al pie de la cruz; todas estas esculturas son de madera, de cuerpo entero y tamaño natural"707.

\footnotetext{
$706 \quad$ PÉREZ, Ventura: op. cit., p. 19.

707 GONZÁLEZ GARCÍA-VALLADOLID, Casimiro: Valladolid..., op. cit., Tomo I, p. 521.
}

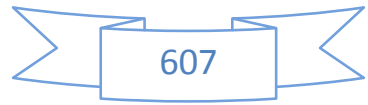


Tras la marcha de la comunidad a un nuevo monasterio a las afueras de la ciudad la iglesia sufrió numerosas pérdidas, muchas de ellas ventas completamente ilegales al margen de Patrimonio. Tan solo se conservó la arquitectura de los retablos por estar anclados a la propia estructura de la iglesia y por no haberse autorizado el traslado al nuevo edificio ${ }^{708}$. Por fotografías más o menos actuales sabemos que aparte de haber desaparecido alguno de los netos del banco, tampoco se encuentran ya en su sitio la magna custodia, los ángeles con el anagrama del "Ave María" que estaban sobre la hornacina central, y las dos columnas salomónicas que flanqueaban esta última hornacina. En cuanto a las pérdidas escultóricas, a su nuevo monasterio no llegaron ni los ángeles que revolotean alrededor de la Asunción, ni el ciervo que acompañaba a Santa Catalina de Suecia, ni los dos ángeles del ático, ni el San Juan ni la Virgen del Calvario. Tampoco hay noticias del paradero de dos ángeles más populares que flanqueaban la custodia. Es una lástima ver como los tres retablos de la iglesia, en particular, y el cenobio, en general, haya tenido una pérdida tan enorme de obras de arte que "nadie" sabe dónde fueron a parar tras el traslado de la comunidad. Preguntada la madre superior del convento me respondió en varias ocasiones que no tenía ni idea de que había ocurrido con las piezas escultóricas que "habían desaparecido" de la iglesia. Su risa nerviosa y el cambio de tema me lo dejaron claro.

Las esculturas del retablo poseen dos, o hasta tres manos diferentes: a Juan de Ávila se le han atribuido desde siempre el grupo de la Virgen de los Ángeles (Asunción) con los angelitos que la rodean, Santa Brígida y Santa Catalina de Suecia; a los que habría que sumar los dos ángeles que sujetaban el anagrama del "Ave María" y los otros dos que portan los Arma Christi. A su hijo Pedro de Ávila corresponderá el Crucifijo, mientras que la Virgen y el San Juan pudieran pertenecer a alguno de estos dos autores o a otro, extremo que no podemos confirmar por la lejanía de las fotos y porque tampoco podemos analizarlas por visión directa.

El primero en formular las atribuciones a Juan de Ávila fue Martín González, el cual veía en las esculturas del retablo "dos estilos, y es sin duda de Juan de Ávila"709. Con posterioridad, el gran investigador volvió a ratificarse en otras tres ocasiones: en el Inventario Artístico de Valladolid dijo que las esculturas eran "del estilo de Juan de Ávila" "110; mientras que en el Catálogo Monumental de Valladolid expresó que "estas figuras pueden corresponder a Juan de Ávila"11; finalmente, en su libro Escultura barroca en España 1600-1760 formuló que seguramente fueran "del mismo escultor [Juan de Ávila] las esculturas de los retablos mayores de Santa Brígida, San Quirce y otras varias en la iglesia del Colegio de Ingleses, de Valladolid"712.

\footnotetext{
708 MARTÍN GONZÁLEZ, Juan José y DE LA PLAZA SANTIAGO, Francisco Javier: Catálogo Monumental de la provincia de Valladolid. Tomo XV..., op. cit., p. 38.

709 MARTÍN GONZÁLEZ, Juan José: Escultura barroca castellana ..., op. cit., p. 310.

710 MARTÍN GONZÁLEZ, Juan José (dir.): Inventario artístico de Valladolid..., op. cit., p. 27.

711 MARTÍN GONZÁLEZ, Juan José y DE LA PLAZA SANTIAGO, Francisco Javier: Catálogo Monumental de la provincia de Valladolid. Tomo XV..., op. cit., p. 38.

712 MARTÍN GONZÁLEZ, Juan José: La escultura barroca en España..., op. cit., p. 81.
} 
Según el libro de gastos del convento, Juan de Ávila habría cobrado en febrero de 1698 la cantidad de 5.100 reales por las "imágenes del retablo, renovar los ángeles grandes, la Fe y los seis chicos del sagrario y la talla de la puertecita" $" 713$. Desconocemos a que "imágenes del retablo" se refiere dicha partida, puesto que solamente se ve la mano de Ávila, como hechos dicho, en las dos santas (Santa Brígida y Santa Catalina de Suecia) $\mathrm{y}$ en la Asunción rodeada de ángeles, y probablemente en los otros cuatro ángeles referidos. En cambio, dicha frase no puede referirse a las "imágenes" del Calvario puesto que ni la Virgen ni el San Juan poseen la factura típica del maestro vallisoletano, es más, en las fotografías conservadas se aprecia cierta tosquedad en su factura, algo impropio de nuestro escultor. Por otra parte, el Crucifijo fue realizado en 1703, cuando ya había muerto Juan de Ávila, siendo sin ninguna duda obra de su hijo Pedro ${ }^{714}$. En cuanto a la referencia de "renovar los ángeles grandes" no sabemos a cuáles se refiere, aunque con toda probabilidad sean los dos que portan las Arma Christi. "La talla de la puertecita" seguramente será la tabla con el relieve del Ecce Homo que todavía subsiste en el nuevo convento, atribuido asimismo a Ávila. Finalmente, no se conserva ni la imagen de la Fe ni los "seis chicos del sagrario".

Dada la dificultad que entrañan las esculturas de este retablo, por las múltiples vicisitudes sufridas, creo conveniente aclararlo con este cuadro:

\begin{tabular}{|c|c|c|}
\hline Asunción y ángeles & Atr. Juan de Ávila & Se conserva \\
\hline Santa Brígida & Atr. Juan de Ávila & Se conserva \\
\hline Santa Catalina de Suecia & Atr. Juan de Ávila & Se conserva \\
\hline Ángeles con Arma Christi & Atr. Juan de Ávila & Desaparecidos \\
\hline Ángeles del anagrama "Ave María" & Atr. Juan de Ávila & Desaparecidos \\
\hline Crucifijo "Calvario" & Atr. Pedro de Ávila & Se conserva \\
\hline San Juan y Virgen María "Calvario" & ¿? & Desaparecidos \\
\hline Seis ángeles del sagrario & ¿Atr. Juan de Ávila? & Desaparecidos \\
\hline La Fe & ¿Atr. Juan de Ávila? & Desaparecida \\
\hline Talla de la puertecita & Atr. Juan de Ávila & Se conserva \\
\hline
\end{tabular}

Es sintomático que en muchas de las instituciones para las que trabajó Juan de Ávila posteriormente lo hayan hecho sus hijos Pedro y Manuel. En este caso, se atribuyen sin ningún género de duda a su hijo Pedro un Crucifijo, un par de bustos de Ecce Homo y Dolorosa y una Inmaculada, amén de otras tallas.

\section{ASUNCIÓN DE LA VIRGEN "VIRGEN DE LOS ÁNGELES"}

La Virgen de la Asunción (170 cms.) (Fig. 122), conocida en el cenobio como "Virgen de los Ángeles", presidía el retablo, en cuya hornacina central se encontraba alojada hasta el abandono del primitivo monasterio. Allí, la rodeaban seis angelitos que

713 MARTíN GONZÁLEZ, Juan José y DE LA PLAZA SANTIAGO, Francisco Javier: Catálogo Monumental de la provincia de Valladolid. Tomo XV..., op. cit., p. 46.

$714 \quad$ Ídem, p. 39. 
revoloteaban, tres a cada lado, situados en tres niveles diferentes, y las posiciones de ellos eran muy variadas. Los dos de la parte superior parecían estar coronándola, a la manera del relieve de la Asunción del retablo mayor del Monasterio de San Quirce. La cabecita del ángel de la derecha posee grandes coincidencias con el que Ávila talla para la Virgen del grupo de la Aparición de la Virgen a Santiago Apóstol, en el retablo mayor de la iglesia de Santiago: tanto la forma de disponer el cabello, la manera de tallar el mentón y los mofletes, y la expresión misma. Detrás de la Virgen se abría una ventana con cristales que ejercía la función de transparente.

La Virgen aparece de pie sobre un trono conformado por una nube, realizada a base de espirales, en la que se encuentran tres pequeñas cabezas aladas de angelotes y una media luna, cuyos extremos enmarcan los pies de María. El detalle de colocar a los pies de la Virgen tres cabecitas aladas de angelotes fue tomado en préstamo por su hijo Pedro de Ávila, el cual diseña las "peanas" de sus Inmaculadas de la misma manera. Que Pedro pudo tomar esta Asunción como modelo para sus Inmaculadas nos lo demuestra también el detalle en que dispone el pelo, cayendo a ambos lados del rostro, la pierna izquierda adelantada y los pies.

El canon es bastante estilizado y refinado, como es frecuente en la obra documentada de nuestro escultor. Levanta levemente la cabeza hacia la derecha, dirigiendo su mirada hacia los cielos, adonde está siendo ascendida. El cuello y la cara son bastante alargados. Sin duda Ávila decidió alargar los miembros de la Virgen dado que se encontraba situada muy alto y que se trataba de la imagen más importante del conjunto. Si hubiera sido una figura "accesoria" no se habría tomado tantas molestias. El pelo nace en la frente y cae por los lados del rostro de manera casi simétrica. Las manos son muy teatrales, estando dispuestos sus dedos de una forma muy elegante. La derecha se la lleva al pecho, mientras que la otra la abre. Las manos, esculpidas de manera exenta, están talladas de una forma muy blanda, se aprecian hasta las arrugas de las líneas de las palmas.

Viste una túnica blanca abundantemente policromada con rameados dorados, verdes, azules y rojos y, de vez en cuando, una especie de floreros con las letras "MR" inscritos en ellos, es de suponer que aludirán a "María". La decoración es ofuscante; hay un verdadero horror vacui. La túnica se encuentra anudada a la cintura por un gran lazo rojo. Por encima porta un manto muy volado que aporta a la escultura unos perfiles bastante aristados, como prefigurando la escultura de pliegues de cuchillo que introducirá Pedro de Ávila en Valladolid a comienzos de la década de 1710. Sin embargo, no se trata de pliegues de cuchillo, están aristados pero doblados dulcemente; finalmente la redondez triunfa. El viento hace que el manto se le recoja bajo la cintura, para que no se le vuele, la otra parte del manto le cae sobre el hombro derecho, arremolinándose en la manga. La policromía del manto es azul, con labores doradas a punta de pincel representando una especie de soles destellantes rodeados de múltiples estrellas, asimismo también coexisten figuras geométricas. El borde de la túnica posee la cenefa que llevamos viendo a lo largo de casi todas las obras documentadas y atribuidas a nuestro escultor. En definitiva, a pesar de necesitar una restauración que 
avive más los bellos colores, la policromía es fastuosa, muy primorosa. Además, se ve enriquecida, por las puntillas de hilo que encontramos en las mangas y en los bordes del manto. Sería de las pocas veces en que Ávila utiliza postizos, amén de los ojos de cristal en limitadas ocasiones.

\section{SANTA BRÍGIDA DE SUECIA}

Santa Brígida de Suecia (1302-1373) fue una santa sueca nacida en Finstad. En el bautizo se le impuso el nombre de Brígida en honor a la santa irlandesa del mismo nombre. Casó con Ulf Gudmarsson, con quien tuvo ocho hijos, entre ellos a Santa Catalina de Suecia, cuya efigie también aparece en el retablo que estamos tratando. Tras quedarse viuda se retiró al convento cisterciense de Alvastra, donde sufrió unas visiones celestiales, las cuales las dejó escritas en su obra Revelationes sanctae Birgittae. En 1346 fundó la Orden de San Salvador, consagrada tanto a la veneración de la Pasión de Cristo como a la Compasión de la Virgen ${ }^{715}$, si bien hasta 1370 el papa no la aprobará 716 . Según Réau, "al menos en su origen, el monasterio presentaba la particularidad de ser mixto: monjes y monjas convivían bajo la autoridad de una abadesa". La insignia de la orden era "cinco pequeñas llamas rojas semejantes a gotas de sangre, que simbolizan las cinco llagas de Cristo"717.

Santa Brígida (160 cms.) (Fig. 123) ocupaba en el retablo, la hornacina de la izquierda. Figura de pie, con la pierna derecha ligeramente adelantada. La talla es muy estática, la leve sensación de movimiento es provocada por los pliegues del hábito, los cuales emparentan, en cierto modo, con los demostrados en los tres santos del cuerpo principal del retablo mayor del Monasterio de San Quirce. Pliegues blandos y paralelos pero que caen al suelo con cierta rigidez. Viste el típico hábito brigidino, compuesto por una túnica y manto gris, este último anudado al cuello. Las bocamangas son amplias, sin llegar a tan exageradamente holgadas como las de los tres santos referidos. En la cabeza "Sobre el velo se pondrá una corona de tela blanca, y sobre esta corona se coserán cinco pedazos de paño rojo con cinco gotas de sangre, la primera en la frente, la segunda en la nuca, la tercera y la cuarta sobre las orejas y la quinta en medio del cráneo como en el centro de una cruz. Esta corona será llevada tanto por las viudas como por las vírgenes"718. Estas cinco gotas vienen a ser similares a las cinco llagas franciscanas. Este hecho no hace sino demostrarnos que Santa Brígida se encontraba muy influenciada por San Francisco de Asís y por la Pasión de Cristo, de la cual tenía "ardiente devoción"719. En esta ocasión no aparece representada como abadesa, ya que no porta báculo, sino en su faceta de escritora. En su mano derecha sostiene una pluma,

\footnotetext{
715 RÉAU, Louis: Iconografía de los santos. A-F..., op. cit., p. 244.

716 Ídem, p. 245.

717 Ídem, p. 244

718 SÁNCHEZ HERRERO, José: "Pasión y Sangre: en torno al origen de las cofradías de Semana Santa hispana". En BALOUP, Daniel: L'enseignement religieux dans la Couronne de Castille: incidences spirituelles et sociales (XIIIe-XVe siècle), Casa de Velázquez, Madrid, 2003, p. 128.

719 RÉAU, Louis: Iconografia de los santos. A-F..., op. cit., p. 245
} 
con la que escribe el libro de las Revelaciones que sujeta con su mano izquierda. El libro, de color negro, está profusamente policromado con labores vegetales-geométricas doradas. Hay una contraposición de actitudes, mientras que con la mano que escribe tiene el brazo levantado, con el que sujeta el libro lo tiene levemente tendido.

La santa tiene la cabeza levemente levantada, mirando hacia el cielo, como si estuviera teniendo una de sus revelaciones, que rápidamente se dispone a escribir en el libro abierto. El rostro, de expresión insulsa, es ciertamente parecido al del San Francisco de Sales del Oratorio de San Felipe Neri. Ojos estrechos a medio abrir, boca entreabierta en la que se ven los dientes de la fila superior, etc... Los ojos son de tapilla. Sobre la cabeza una corona de plata. Que la escultura estaba hecha para un retablo nos lo indica la policromía de la parte trasera de la imagen, al llegar a esta zona las decoraciones doradas a punta de pincel y las cenefas desaparecen, dejando tan solo una amplia capa uniforme de color gris. En otras ocasiones esta zona queda "en blanco".

\section{SANTA CATALINA DE SUECIA}

Santa Catalina de Suecia (1331-1381) fue hija y continuadora de la obra comenzada por Santa Brígida de Suecia, su madre. Por lo tanto, en el retablo vemos escoltar a la Asunción a las dos cabezas de la Orden Brigidina o del Santísimo Salvador. Aunque casada desde muy joven con Edgar von Kyren, ambos observaron el voto de continencia y castidad. Tras el fallecimiento de su esposo, decide seguir los mismos pasos que su madre, de la cual será fiel compañera en todas sus empresas y peregrinaciones. Tras el fallecimiento de Brígida, Catalina llevó el cadáver de ésta a su patria, y en 1375 ingresó en el monasterio de Vadstena, del cual fue elegida abadesa en $1380^{720}$. Fue canonizada en 1484 por el papa Inocencio VIII.

Santa Catalina (160 cms.) (Fig. 124) ocupaba en el retablo, la hornacina de la derecha. La escultura sigue los mismos patrones que la de su madre, por lo que no nos extenderemos. Tan solo remarcar que los plegados centrales del hábito son un poco más quebrados, sin duda para introducir cierta diferenciación entre ambas. Lo único que las diferencia es que Santa Catalina no mira al cielo, sino a un ciervo, que actualmente no posee. El rostro es también muy trivial y apagado, en este caso ni siquiera abre la boca ni eleva los ojos hacia el cielo. Con su mano derecha agarra un báculo abacial, haciendo mención a su condición de abadesa del monasterio de Vadstena, el cual había sido organizado por su madre, la cual no llegó a ver acabado. En la actualidad, en su mano izquierda sujeta unas flores, ya que las monjas "perdieron" la escultura del ciervo que la santa acariciaba. Este animalillo se encontraba levantado sobre sus dos patas traseras. Era una escultura interesante por la escasez de estas imágenes en la plástica vallisoletana. Aparte de los caballos, y alguna que otra excepción, no es muy normal ver representados animales. Según Sgarbossa y Giovanni, este ciervo es bastante común

720 SGARBOSSA, Mario y GIOVANNI, Luis: Un santo para cada día, Editorial San Pablo, 1987, pp. 101-102. 
dentro de la iconografía de la santa, dado que, "según la leyenda, apareció varias veces misteriosamente para ponerla a salvo"721.

\section{$\underline{\text { RELIEVE DE ECCE HOMO }}$}

El presente relieve (Fig. 125) conforma la puerta de un sagrario. Por desgracia en las fotos antiguas no podemos verlo puesto que se encuentra tapado por una tela. De lo que no cabe duda es que de aquella custodia tan solo subsistió su puerta, la cual ha sido reutilizada para el nuevo sagrario, que parece hecho mediante la unión de varias piezas de retablo.

La elección del Ecce Homo para este sagrario no es baladí. Si bien lo normal es que la puerta del sagrario pueda contener un relieve que represente un Cordero Místico, un pelícano picándose el pecho para dar de comer a sus hijos, una Oración del Huerto, una Sagrada Cena o, incluso, la Resurrección; hay que recordar que estamos en un templo dedicado a Santa Brígida, y por lo tanto es normal que en la puerta se efigie un tema relacionado con ella, es decir, sobre la Pasión de Cristo. En la Revelación IX de su Libro I, la Virgen María describe a Santa Brígida sobre los tormentos a los que fue sometido su Hijo. En un pasaje de esta revelación redacta: "Pusiéronle la corona de espinas en su reverenda cabeza, y apretáronsela de tal suerte que con la sangre que caía, se llenaron sus ojos, se obstruyeron sus oídos, y toda su barba quedó afectada con la misma sangre que corría"722. Posteriormente, en la Revelación X señala que "a pesar de que mi cabeza estuviese toda atormentada con las espinas de la corona y la sangre corriese por todas las partes" ${ }^{723}$.

El tema del Ecce Homo no tuvo cabida dentro del primer Cristianismo "ante el intento de evitar el que se manifestaran los acontecimientos más sangrientos de la vida de Cristo, pues en la primitiva Iglesia se consideraba que esto era un escándalo a la hora de la misión entre los paganos" $" 724$. Surgió con fuerza a finales del siglo XV, dentro del tema de la Coronación de Espinas, en el cual se representaba a Cristo "sobre un estrado o en lo alto de la escalera, con la corona de espinas, el manto (o clámide) púrpura y el cetro de caña en las manos atadas; lastimosa imagen de un rey carnavalesco. Su pecho desnudo tiene las huellas de la Flagelación. Una cuerda pende en torno a su cuello. Desde sus párpados enrojecidos fluyen las lágrimas que caen sobre sus mejillas"725.

Este acontecimiento goza de una gran credibilidad histórica, según García Martín, puesto que todos los evangelistas hablan de él ${ }^{726}$. Los que más se extienden narrando el

\footnotetext{
$721 \quad$ Ibídem.

722 FRANCO MATA, María Ángela: "El Devot Crucifix de Perpignan y sus derivaciones en España e Italia”, Melanges de la Casa de Velázquez, No 20, 1984, pp. 192-193.

723 GARCÍA MARTÍN, Enrique: Imágenes de Ecce-Homo en Valladolid, Ayuntamiento de Valladolid, 2001, p. 11.

$724 \quad$ Ibídem.

725 RÉAU, Louis: Iconografía de la Biblia. Nuevo..., op. cit., p. 479.

726 GARCÍA MARTÍN, Enrique: Imágenes de Ecce-Homo..., op. cit., p. 11.
} 
pasaje son San Mateo y San Marcos: El primero de ellos relata que "Entonces los soldados del gobernador, tomando a Jesús, lo condujeron al pretorio y, reuniendo en torno a él toda la cohorte, y despojándole de sus vestiduras, le echaron encima una clámide de púrpura, y, tejiendo una corona de espinas, se la pusieron sobre la cabeza, y en la mano una caña; y doblando ante Él la rodilla, se burlaban diciendo: ;Salve, rey de los judios! Y escupiéndole, tomaban la caña y le herían con ella en la cabeza. Después de haberse divertido con Él, le quitaron la clámide, le pusieron sus vestidos y le llevaron a crucificar" (San Mateo: 27, 27-31). Por su parte, San Marcos: "Los soldados le llevaron dentro del atrio, esto es, al pretorio, y convocaron toda la cohorte, y le vistieron una púrpura y le ciñeron una corona tejida de espinas, y comenzaron a saludarle: Salve, rey de los judíos. Y le herían en la cabeza con una caña y le escupían, e hincando la rodilla, le hacían reverencia" (San Marcos: 15, 16-19).

Tuvo una gran importancia para las representaciones plásticas barrocas del Ecce Homo los textos de Fray Luis de Granada, el cual se centraba en los aspectos más cruentos de aquel momento: "Veo esta delicadísima cabeza, de que tiemblan los poderes del cielo, traspasada con crueles espinas. Veo escupido y abofeteado este divino rostro, oscurecida la lumbre de esa frente clara, cegados con la lluvia de la sangre esos ojos serenos. Veo los hilos de sangre que gotean de la cabeza, y descienden por el rostro, y borran la hermosura de esta divina cara"727. Posteriormente, añadió: "Cubierto con aquella púrpura de escarnio, la caña por cetro real en la mano, y aquella horrible diadema en la cabeza, y aquellos ojos mortales, y aquel rostro difunto, y aquella figura borrada con la sangre, y afeada con las salivas que por todo el rostro estaban tendidas" $" 728$.

El escultor nos presenta un busto de Ecce Homo prolongado hasta la cintura, puesto que se ve el perizonium, situado sobre unas nubes doradas. La talla es bastante plana y esquemática. El canon está desproporcionado, y la anatomía no está resuelta con demasiada corrección, especialmente en lo que atañe al pecho. La posición es muy rígida, si bien el relieve debe ocupar un espacio demasiado estrecho entre el extremo de la tabla y la abertura para introducir la llave. Tiene los brazos cruzados sobre la cintura, con las articulaciones muy rectas. Con su mano derecha sujeta la caña, elemento característico de esta iconografía; el otro, la corona de espinas, aparece ya ceñida a la frente. Parece intentar inspirarse en la posición de los brazos adoptada por el Ecce Homo (1620) tallado por Gregorio Fernández para la Cofradía Penitencial de la Santa Vera Cruz, pero nada más allá de la tentativa. Tiene la cabeza levemente girada hacia la derecha. El ejemplar brigidino es, asimismo, muy similar al busto de Ecce Homo, de bulto redondo, conservado en la clausura del vallisoletano convento de la Concepción, obra atribuida a José de Rozas ${ }^{729}$. De la corona de espinas mana abundantes regueros de sangre, tal y como explica la revelación de Santa Brígida; sin embargo, el resto del

\footnotetext{
$727 \quad$ Ibídem.

728 Ídem, p. 12.

729 MARTÍN GONZÁLEZ, Juan José y DE LA PLAZA SANTIAGO, Francisco Javier: Catálogo Monumental de la provincia de Valladolid. Tomo XV..., op . cit., p. 83; GARCÍA MARTÍN, Enrique: Imágenes de Ecce-Homo en Valladolid, Ayuntamiento de Valladolid, 2001, p. 32.
} 
cuerpo carece de ellos. Los ojos están directamente pintados sobre la madera. Pelo largo que cae en varios mechones sobre los hombros, dejando visible solamente una de las orejas. Barba bífida. 


\section{AMPUDIA. COLEGIATA DE SAN MIGUEL}

\section{SAN ROQUE (h. 1698)}

La presente escultura, que creo procedente atribuir a Juan de Ávila, debió de ser encargada por una cofradía homónima radicada en la localidad. Tanto en el Inventario Artístico de Palencia ${ }^{730}$, como en la pequeña monografía dedicada por Parrado del Olmo a la Colegiata de San Miguel $^{731}$, la imagen ocupaba una posición aneja a un retablo plateresco situado en la nave de la Epístola. Este mismo lugar es el que ocupa en la actualidad.

San Roque era uno de los santos más populares y tradicionales en las devociones cristianas, junto a otros como San Sebastián, San Blas o San Antonio Abad, todos ellos santos profilácticos. Y al igual que a San Isidro se le tenía gran devoción en las zonas rurales. A pesar del éxito de su culto, hay muchas dudas sobre la veracidad de la existencia de San Roque, y muchas veces se ha pensado que pueda tener un carácter legendario $^{732}$. Tampoco tenemos certezas de los años en que nació y murió el santo. Como posibles fechas de nacimiento se barajan 1295 y 1348/1350, mientras que como las de su fallecimiento las de 1317 y 1376/1379 ${ }^{733}$. Sea como fuera, Roque nació en Montpellier (Francia), en el seno de una rica familia. Al fallecer sus padres, Juan y Liberia, "distribuyó entre los pobres su cuantiosísima hacienda, renunció al título de nobleza que le correspondía, y se lo cedió a un tío suyo juntamente con el gobierno de los pueblos, villa y tierras que constituían los dominios que de su padre había heredado". Asimismo, "cambió sus ricas ropas por otras muy modestas y, con un sombrero en su cabeza, unas alforjas al hombro y un cayado en la mano, salió de su casa hacia Italia en viaje de peregrinación" ${ }^{\text {"734. }}$.

Al llegar a Italia Roque se encontró con un país "infestado por una terrible epidemia que causaba estragos entre la gente; muchas fueron las ciudades italianas, entre ellas Roma, Aquapendente y Cesena, liberadas de la peste por el piadoso peregrino sin más antídoto que el de trazar sobre ellas la señal de la cruz" ${ }^{, 735}$. En Roma se mantuvo entre 1367-1371, al cabo de lo cual marchó hacia Plasencia, ciudad que también sufría por entonces los efectos de la peste, y en la que además quedó infectado el propio santo " $a$ causa de una saeta que se le clavó en su pierna izquierda"736. Relata Réau al respecto de este capítulo de la vida de San Roque, y que es además el que ha concretado la iconografía tradicional del santo: "Una noche un ángel le advirtió que le había llegado la hora de sufrir. Aunque se sintió atravesado por el dolor, en vez de quejarse, dio gracias a Dios y se retiró en un bosque impenetrable para morir en soledad y no

\footnotetext{
730 URREA FERNÁNDEZ, Jesús y MARTÍN GONZÁLEZ, Juan José: Inventario artístico de Palencia y su provincia I..., op. cit., p. 63.

$731 \quad$ PARRADO DEL OLMO, Jesús María: Ampudia..., op. cit., p. 28.

732 RÉAU, Louis: Iconografía de los santos. P-Z..., op. cit., p. 147.

733 http://es.wikipedia.org/wiki/Roque

734 VORÁGINE, Santiago de la: op. cit., Tomo II, p. 954

735 Ibídem.

$736 \quad$ Ibídem.
} 
contagiar a nadie. Dios le envió un ángel consolador y curador para que lo asistiese en su soledad, el cual aplicó un bálsamo sobre su herida, y también hizo brotar una fuente para que Roque pudiera aplacar su sed febril. Además, lo aprovisionó de alimentos: cada día el perro de un señor de la región le llevaba un pan robado de la mesa de su amo. El perro proveedor tiene en esta leyenda la misma función que el cuervo que alimentó al profeta Elías y a San Pablo ermitaño"737.

Tras curarse de la enfermedad partió hacia su ciudad natal, Montpellier, en la que al llegar vestido con el hábito de peregrino no fue reconocido, siendo tomado por un espía, dado lo cual fue apresado y encarcelado. Tras pasar cinco años en prisión el santo falleció, supuestamente el 17 de agosto de 1327, con tan solo 32 años. Antes de morir, y según relata Santiago de la Vorágine en su Leyenda Dorada, el santo pidió a Dios "que en adelante se dignase, por su mediación, librar de la peste a cuantos se encomendasen a él”. Asimismo, "junto a su cuerpo se encontró una cédula con esta inscripción: "Se hace saber que toda persona amenazada de epidemia que se encomendase a Roque, se librará, por su intercesión, de contraer la perniciosa enfermedad" ${ }^{738}$.

San Roque (Fig. 126) ha sido efigiado de pie, con la pierna izquierda levemente adelantada. Ha sido caracterizado tal cual se puede leer en el texto que acabamos de citar. Con su mano derecha, cuyo brazo levanta, sujeta poderosamente el bordón de peregrino, a cuya condición también hacen referencia las vieiras pegadas sobre la parte delantera de la capa, a la altura de los hombros. Con la otra mano se recoge la túnica para mostrarnos la buba que ha nacido en su muslo izquierdo a causa de la infección de peste. Esta herida sanará pronto ya que se apresta a curársela un pequeño ángel "el cual aplicó un bálsamo". Al otro lado de San Roque, a sus pies, un perrito que le acerca un pan que trae en sus fauces: "Además, lo aprovisionó de alimentos: cada día, el perro de un señor de la región le llevaba un pan robado de la mesa de su amo". La composición bien pudo tomarse de algún grabado, estampa o dibujo. Existe un dibujo que a grandes rasgos coincide con el grupo de nuestro escultor en la Biblioteca Nacional de España: su autor es un tal Pedro Salvador, que lo ejecutó hacia 1640-1649 ${ }^{739}$.

Roque viste el típico atuendo de peregrino, conocido como sarrocchino ${ }^{740}$ : una túnica corta que le llega hasta la altura de las rodillas, ceñida a la cintura por un cinturón negro con toques dorados. Sobre los hombros va tocado por una amplia capa que también le cae hasta las rodillas; destaca la preciosa cenefa que orla su borde exterior, es el tipo de cenefa que hemos visto tantas veces, lo que nos pudiera hablar del origen vallisoletano de la pieza y, seguramente, de estudiarlo, nos indicaría hasta el posible pintor que la policromó.

Los motivos que me lleva a atribuir a esta pieza llegan a la hora de analizar el rostro del santo. Como podemos observar a simple vista, guarda un asombroso parecido con el del

\footnotetext{
737 RÉAU, Louis: Iconografía de los santos. P-Z..., op. cit., pp. 147-148.

738 VORÁGINE, Santiago de la: op. cit., Tomo II, p. 955.

739 http://bdh.bne.es/bnesearch/detalle/bdh0000088826

740 RÉAU, Louis: Iconografía de los santos. P-Z ..., op. cit., p. 150.
} 
San Isidro que Ávila talló para la cofradía vallisoletana homónima. Su afinidad no es meramente casual, es total. Desgranemos las múltiples semejanzas: la forma de construir los ojos, algo más cerrados en el caso de San Roque; la nariz, algo más fina en este último; la boca, más perfecta en el caso de San Isidro; el arqueamiento que producen las cejas, etc... Las similitudes llegan también, y de forma más clara, en el caso de la barba y la cabellera. Las formas sinuosas de los bigotes son idénticas, respetando la desnudez del surco naso-labial; la barba es igual de fina, si bien la de San Isidro es de mayor calidad, lo que nos pudiera indicar que el San Roque es obra de juventud o quizás existe la intervención del taller. La barba, muy corta, remata en dos caracolillos con las puntas hacia dentro; lo contrario que San Isidro, que apuntan hacia afuera. Los grandes mechones ensortijados que flanquean el rostro, compuestos de amplios bucles, también son plenamente coincidentes; al igual que los rizos sinuosos que caen sobre la frente. Se trata de cuatro rizos simétricos, dos a dos, que terminan curvados; por su parte los de San Isidro son algo más variados, puesto que poseen seis: los del centro y los extremos a la usanza del San Roque y los otros dos rectos. Hasta la corona, de tipo sol, es semejante. La gran diferencia entre ambas faces es el tratamiento un tanto seco del rostro de San Roque, que no posee la luminosidad y blandura de San Isidro. Solo hay que comprobar lo toscas que son las arrugas que bordean los ojos del santo antipestoso. Sin duda la cabeza, que se halla tallada de forma exenta, es lo mejor del conjunto, algo más esquemático que ésta.

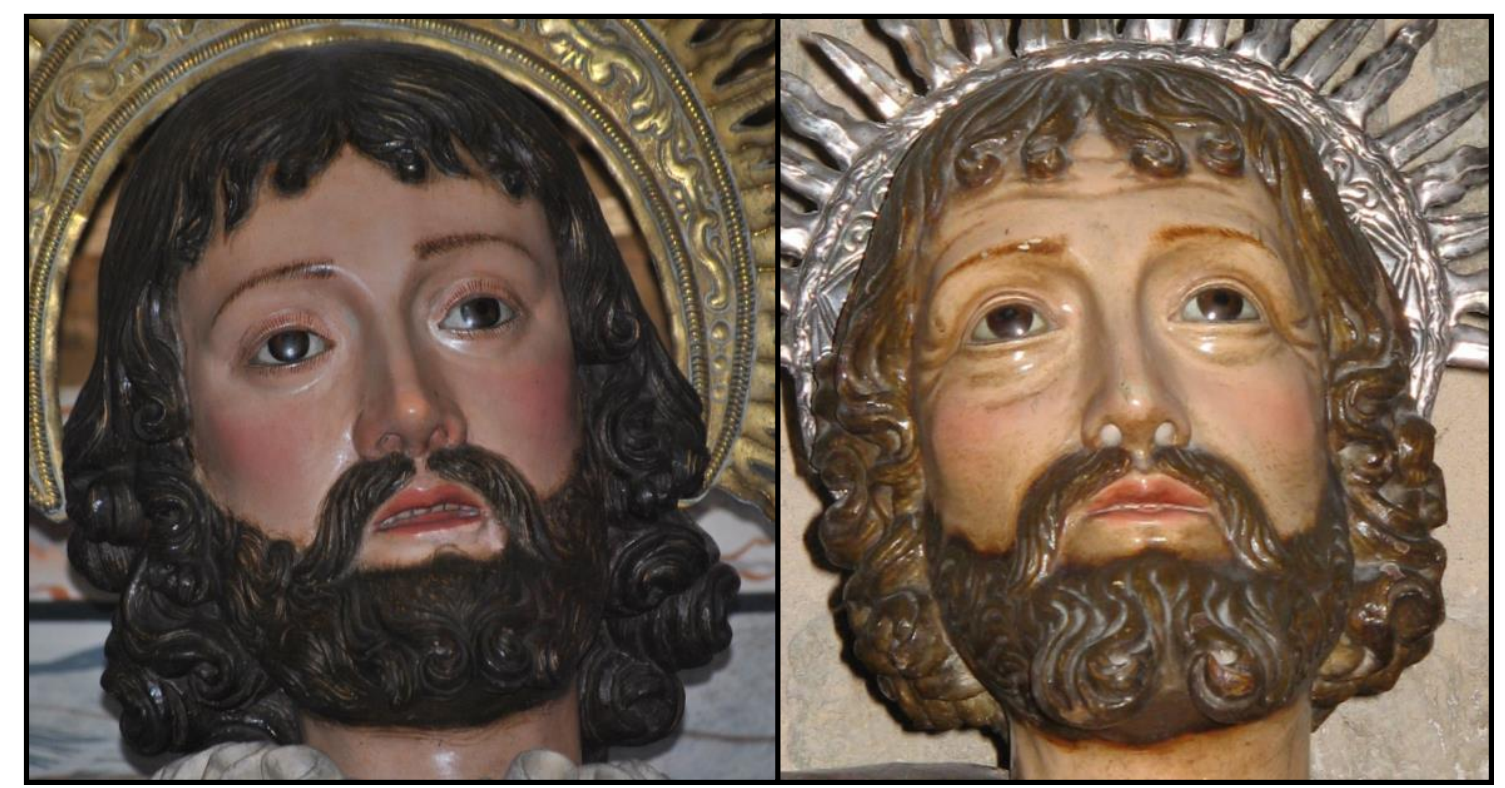

Il. 41- Comparación del San Isidro de Juan de Ávila y el San Roque que le atribuimos.

El ángel es una escultura bastante floja y rígida. Sus paños son muy toscos puesto que apenas hay gradación en los mismos. Figura adelantando una pierna, la cual podemos observar gracias a que se le abre la túnica por ese lado. El rostro posee un rictus intemporal, y parece estar totalmente ausente, no está en concordancia con la acción que se apresta a realizar. Le faltan la gran mayoría de los dedos. Señala Réau que el ángel 
enfermero apareció por primera vez en la iconografía de este santo en un grabado del año 1550 que venía a adornar la portada de su biografía ${ }^{741}$.

Sería deseable que, dado el interés que posee este grupo escultórico, se restaurara o limpiara, puesto que su estado de conservación es bastante deplorable. Los colores no se llegan a distinguir. 


\section{SANTILLANA DEL MAR. COLEGIATA DE SANTA JULIANA}

\section{SANTA JULIANA DE NICOMEDIA “O DE BITINIA” (1699)}

Hasta hace poco tiempo la presente escultura de Santa Juliana (Fig. 127) presidía la hornacina central del retablo mayor de la Colegiata de Santa Juliana de Santillana del Mar (nombre derivado de la propia santa), una imagen de la propia Santa Juliana que fue atribuida por Martín González a Juan de Ávila: “clasificable en la producción de Juan de Ávila, del último cuarto del siglo XVII"742. Esta asignación ha sido ratificada por otros investigadores, como por ejemplo Polo Sánchez ${ }^{743}$, al cual el rostro le recuerda al de la Inmaculada del relieve de la Asunción de Ataquines, obra fechada por aquellos mismos años ${ }^{744}$.

El retablo fue realizado durante el primer tercio del siglo XVI (h. 1520-1529), si bien todavía es deudor de las formas góticas, visibles sobre todo en los guardapolvos y doseletes $^{745}$. Su fabricación tuvo lugar por la necesidad con que contaba la colegiata de poseer un nuevo retablo que sustituyera a uno anterior, ya vetusto, que pudiera acoger las reliquias de Santa Juliana. En el banco se alojan cuatro grandes relieves de los evangelistas, dos a cada lado de la custodia barroca. El retablo se articula en tres cuerpos, tres calles y cuatro entrecalles: las calles laterales alojan seis pinturas representando el martirio de Santa Juliana (las dos de abajo: Santa Juliana ante el Juez y El Martirio de Santa Juliana) y cuatro episodios de la vida de Cristo: el Nacimiento, la Epifanía, la Entrada en Jerusalén y El Descendimiento o, mejor dicho, la Piedad; la calle central, de abajo arriba: una imagen de Santa Juliana, la Asunción de la Virgen y un Calvario; y, finalmente, en las entrecalles hay pequeñas peanas sobre las que descansan doce santos, coronados por otros tantos doseletes. Se ha llegado a decir que la arquitectura del retablo pudo ser realizada por el palentino Juan Ortiz el Viejo, sin embargo éste solo practicó la escultura; por su parte, la pintura se relaciona con el maestro que pintó las del retablo mayor de la parroquia de Llanes; y, finalmente, en lo concerniente a las esculturas, las imágenes bajo doselete y el Calvario se encuentran próximos a Gil de Siloé, mientras que el grupo de la Asunción es "de origen burgalés pero con influjos flamencos" $" 746$.

Este retablo llegó sin modificaciones hasta finales del siglo XVII; en el año 1606 un inventario lo describía de la siguiente manera: "Primeramente un retablo en el altar mayor de tabla y pincel dorado en esta forma. Una custodia antigua donde está el

\footnotetext{
742 HERNÁNDEZ DÍAZ, José, MARTÍN GONZÁLEZ, Juan José y PITA ANDRADE, Manuel: op. cit., p. 317.

743 POLO SÁNCHEZ, Julio Juan: Arte barroco en Cantabria: retablos e imaginería (1660-1790), Servicio de Publicaciones de la Universidad de Cantabria, Santander, 1991, p. 100.

$744 \quad$ Ídem, p. 281.

745 http://www.unican.es/NR/rdonlyres/B258786F-193F-456A-9716-

4142292B19E4/73401/Piezadelmes032012.pdf

746 http://www.unican.es/NR/rdonlyres/B258786F-193F-456A-9716-

4142292B19E4/73401/Piezadelmes032012.pdf
} 
Santísimo Sacramento, con cuatro ángeles de bulto, encima la imagen de Santa Juliana de bulto dorada y a los lados Santa Justa y Santa Rufina y más alto una imagen de Nuestra Señora de la Asunción dorada con ocho ángeles, y sobre un Cristo con María Virgen y San Juan, a los lados cuatro tableros de pintura y doce apóstoles de bulto y cuatro evangelistas. Encima de la custodia está una caja con dos puertas y dos llaves" "747. Pues bien, en el año 1699 se realizaron diversas transformaciones que afectaron al banco y a la hornacina central del retablo. En el centro del banco se insertó un "barroco templete del Sagrario, con su cúpula $y$ sus recargadas columnas" 748 . Asimismo, en la hornacina central, presidida hasta entonces por una Santa Juliana gótica, se colocó una santa de estirpe barroca traída desde Valladolid el referido año de 1699. En este mismo momento es cuando se reformó esta hornacina y se la colocaron unas "columnas salomónicas cargadas de pámpanos y racimos, que se dispondrían para instalar la imagen de la

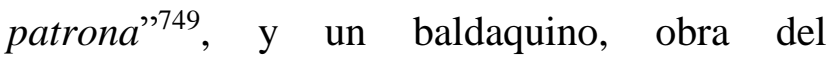
ensamblador Francisco de Barros en $1699^{750}$. En la actualidad la hornacina ha vuelto a su ser: se han eliminado tanto el baldaquino barroco como la escultura vallisoletana, volviendo a colocar a la Santa Juliana gótica.

Lafuente Ferrari cree que la Santa Juliana barroca, la que nos interesa en este estudio, es

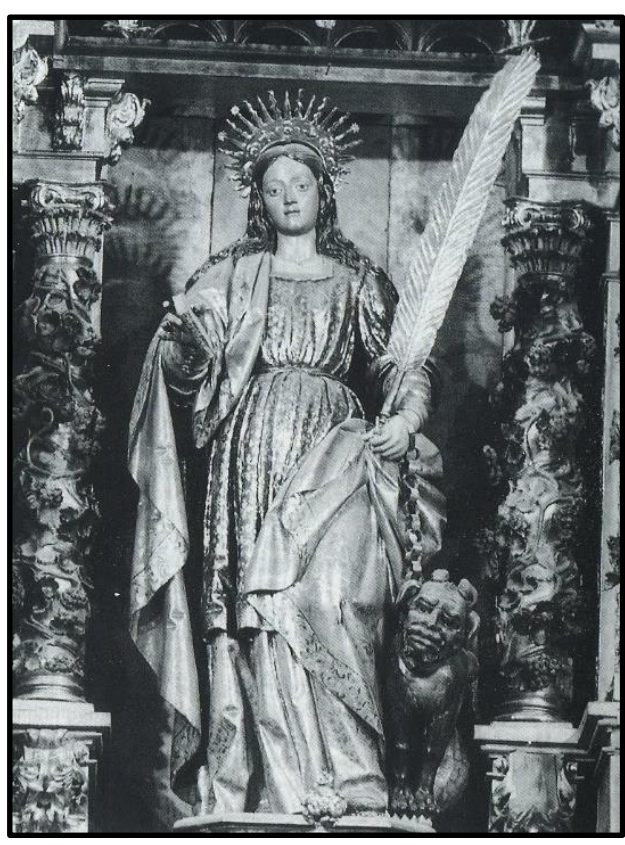

Il. 42- Juan de Ávila (atrib.). Santa Juliana. Colegiata de Santa Juliana. Santillana del Mar (Cantabria) una pieza sufragada por algún particular, dado que en aquella época la villa de Santillana y el cabildo de su colegiata recibió numerosas ayudas de indianos enriquecidos en México para sufragar algunas reformas que necesitaba el templo ${ }^{751}$. A Lafuente no le gustó demasiado la escultura, proyectando una imagen bastante negativa: "no es de gran calidad, el plegado de los paños, con el manto terciado sobre la rodilla izquierda, los candiles de la ropa, de un llano realismo sin afectación, y el detalle de hacer ostensible bajo al túnica el enterizo zapato que calza el pie de la santa, nos están indicando recursos muy empleados en la escuela de la ciudad del Pisuerga y acusan, especialmente en el manto, ecos del arte de Gregorio Fernández" ${ }^{, 752}$.

Santa Juliana de Bitinia, o de Nicomedia, ciudad del referido reino de Bitinia, fue hija de un padre pagano, que persiguió a los cristianos, y una madre agnóstica, por lo cual la

747 ORTÍZ DE AZUELA, Julián: Monografía de la antigua Colegiata (hoy iglesia parroquial) de Santillana del Mar, Santander, 1919, p. 96.

748 LAFUENTE FERRARI, Enrique: El libro de Santillana, Diputación Provincial de Santander, Santander, 1955, p. 178.

$749 \quad$ Ibídem.

750 POLO SÁNCHEZ, Julio Juan: op. cit., p. 281.

751 LAFUENTE FERRARI, Enrique: op. cit., p. 178.

752 Ídem, p. 179. 
propia Juliana tuvo que bautizarse en secreto. Un joven senador, de nombre Eleusio, quiso casarse con ella, a lo que el padre de Juliana dio el consentimiento. Juliana se comprometió a desposarse si Eleusio alcanzaba el cargo de juez y prefecto de la ciudad, logros que el joven consiguió. Fue entonces cuando la futura santa puso otra condición: convertirse al cristianismo. Eleusio comentó al padre de Juliana lo que le había propuesto su hija, a lo que éste exclamo: ¡Por Apolo y Diana! Más quiero verte muerta que cristiana». A lo que Juliana replicó: “mi Salvador es Jesucristo en quien tengo puesta toda mi confianza"753.

Con posterioridad se procedió a su tortura y posterior encarcelamiento, donde fue azotada con varas y colgada por la cabellera. Relata Réau, y nos interesa puesto que es la iconografía a la que pertenece esta escultura que "el diablo disfrazado de ángel quiso tentarla, pero ella lo castigó duramente, lo ató con la cadena que la sujetara y lo arrojó a las letrinas (in latrinam)" ${ }^{\text {"754 }}$. Tras ese acontecimiento, se la volvió a torturar sumergiéndola en un caldero de plomo fundido, el cual se transformó en agua tibia. Como no fallecía, se ordenó decapitarla, lo que acaeció el 16 de febrero del 304.

La santa es representada de pie, con la pierna derecha levemente adelantada, típico contraposto al que Ávila nos tiene acostumbrado. Con su mano izquierda sujeta un libro de plata, mientras que con la derecha hace lo propio con una palma del martirio, asimismo plateada, y una cadena con la que tiene agarrado a un pequeño demonio alado situado a los pies de la santa. Ya explicamos el motivo por el cual figura este demonio a su vera. Viste túnica marrón con decoraciones doradas esgrafiadas, sobre la cual se dispone una sobre túnica verde con motivos dorados, y un manto rojo con la misma decoración dorada y la típica cenefa que venimos viendo en la mayoría de esculturas.

La cabeza presenta las características de las que hace gala Juan de Ávila, aunque no conforma una de sus más felices creaciones, especialmente en lo concerniente al rostro: boca entreabierta, aunque no podemos ver los dientes; ojos achinados y semihundidos; nariz recta, potente y que acusa un enanche en su punta; cejas rectas; mentón potente; faz tendente al ovoide, etc... Además, los cabellos simulan estar mojados, nacen en la parte alta del cráneo, cayendo a los lados del rostro de manera más o menos simétrica, lo que lleva a que la frente esté muy despejada. El rostro no nos dice nada, es muy insulso, no deja traslucir ningún sentimiento. La manera de disponer la melena suelta por la espalda recuerda a la manera que utilizaba Gregorio Fernández para sus Inmaculadas. También hereda de Fernández, según Lafuente Ferrari, "el detalle de hacer ostensible bajo la túnica el enterizo zapato que calza el pie de la santa"755. Otras referencias que nos traen a la memoria esta escultura es la Santa Lucía que Francisco Díez de Tudanca esculpió para el retablo mayor de la iglesia de la Asunción de Bercero (Valladolid), si bien la talla en este último caso es mucho más basta, seca y vulgar, características de la mayor parte de la producción del maestro de nuestro Ávila.

\footnotetext{
753 http://es.wikipedia.org/wiki/Juliana_de_Nicomedia

754 RÉAU, Louis: Iconografía de los santos. G-O..., op. cit., pp. 215-216.

755 LAFUENTE FERRARI, Enrique: op. cit., p. 179.
} 
Los pliegues de su vestimenta corresponden a la perfección a la fecha en que se realizó, 1699, ya que presenta las características de la segunda etapa del escultor. Es decir: pliegues redondeados que caen verticales y paralelos, dejando entrever la anatomía a la que cubren. Sobre todo, los dobladuras del manto son bellísimos y dejan ver a las claras la mano de un buen escultor; solo así podemos explicar la finura que alcanza y la ausencia de cualquier dureza. La referida cenefa no hace sino acrecentar la belleza de esta ropa. A propósito de la policromía, la escultura necesita una importante restauración que limpie la suciedad que distorsiona los colores de la misma. Por lo demás, el estado de conservación parece bueno, a excepción de alguna pequeña rozadura en la cara del diablillo.

El referido diablillo que aparece a sus pies es un ser formado de por partes de diferentes seres: así, el rostro es el de un humano barbado, con orejas de animal y dos cuernecillos retorcidos sobre la frente; también es humano el pelo. El cuerpo es el de un dragón, a la vista de las dos garras delanteras y las alas visibles a ambos lados de su espalda, y la cola la de una serpiente, con sus escamas perfectamente simuladas por la policromía. El rostro del diablillo viene a recordar por la forma de su nariz, entrecejo y labios, al sayón del azadón del Paso del Despojo que Ávila esculpió para la Cofradía de N. P. Jesús Nazareno de Valladolid. 


\section{VALLADOLID. CONVENTO DE LAS DESCALZAS REALES}

\section{SANTA MARÍA MAGDALENA (Finales del siglo XVII)}

En el coro del Convento de las Descalzas Reales se hallaba una pequeña Magdalena (Fig. 128) en el desierto que en la actualidad se encuentra en paradero desconocido. Debido a su desaparición únicamente contamos con dos apoyos a la hora de poder estudiarla: una fotografía del Archivo Fotográfico del Departamento de Historia del Arte de la Universidad de Valladolid y la descripción realizada en el Catálogo Monumental de la Provincia de Valladolid. Este último refiere que se trataba de una hechura de "María Magdalena, como penitente, madera policromada sobre peana de paisaje, ojos de cristal, conforme a modelo de la iglesia de San Miguel, tercer cuarto del siglo XVII" ${ }^{756}$.

Gracias a la fotografía sabemos que estaba situada sobre la peana izquierda del gran conjunto de relicarios que cuelga en la pared norte del coro alto, en clausura. En la actualidad ese mismo lugar lo ocupa una imagen del Arcángel San Miguel venciendo al diablo, con toda probabilidad obra de José de Rozas, escultura que procede, junto con otra de San Gabriel, situado en la peana contraria en el coro, del retablo mayor de la iglesia. Allí flanqueaban la custodia ${ }^{757}$.

La Magdalena copia la imagen homónima conservada en la iglesia de San Miguel y San Julián (finales del siglo XVII), antiguo establecimiento jesuítico bajo la advocación de San Ignacio. Esta escultura a su vez tomaba como modelo la famosísima Magdalena tallada por Pedro de Mena para la Casa Profesa de los jesuitas en Madrid (1664). Pero esta iconografía no fue creación del genial andaluz, sino que este venía a copiar la Magdalena que, atribuida a Gregorio Fernández, se conserva en el madrileño Monasterio de las Descalzas Reales (h. 1615). Este debe ser el origen de toda la serie, si bien no hay ningún dato que lo confirme, como tampoco está confirmado que sea obra del escultor gallego. En Valladolid se conservan numerosos ejemplares tanto del siglo XVII como del XVIII repartidos por iglesias, museos y conventos.

La Magdalena del convento vallisoletano sigue puntualmente las citadas esculturas (finales del siglo), si bien nuestro escultor utiliza un canon más achaparrado; no es tan esbelta como las otras tres citadas. Además, el rostro no es alargado, sino que tiende al círculo. Hasta ahí las semejanzas, puesto que el tratamiento es mucho más rudo, si se compara la forma de tallar las largas melenas de la santa, con cabellos muy compactos, seriados y pegados al cuerpo; nada tiene que ver con los tallados, por ejemplo, por Mena, singularizados, con volumen, despeinados, despegados del cuerpo, etc... Tampoco consigue nuestro escultor la expresividad que sí logran los otros maestros en

\footnotetext{
756 MARTÍN GONZÁLEZ, Juan José y DE LA PLAZA SANTIAGO, Francisco Javier: Catálogo Monumental de la provincia de Valladolid. Tomo XV..., op. cit., p. 100.

757 La fotografía de los dos arcángeles custodiando el tabernáculo se puede ver en la lámina 300 del Catálogo Monumental de Valladolid. Ibídem.
} 
los rostros y manos de sus respectivas santas. No vemos por ningún lado el ascetismo que sí nos muestran los otros maestros.

María Magdalena, con un aspecto bastante juvenil, aparece retratada en un momento de intenso arrobo y oración ante el Crucifijo que sostiene en su mano izquierda. En este caso le resta la cruz; puede que ya entonces hubiera perdido el Crucifijo original, en caso de haberlo tenido. Su otra mano está posada delicadamente sobre el pecho, tapándoselo. Figura de pie, con la pierna izquierda levemente adelantada en ademán de caminar, sobre un delicioso paisaje formado por arbolillos, sobre uno de los cuales parece posarse una paloma. Viste un rígido sobretodo realizado con juncos entretejidos sujeto a la cintura por un cordón del mismo material y rematado por un gran lazo, algo basto si lo comparamos con sus modelos. El vestido le cubre desde la parte inferior del busto hasta los tobillos, dejándonos ver ambos pies. Los brazos están completamente desnudos, y el escultor intenta modelar los diferentes músculos del brazo, si bien no logra el realismo que sería preciso.

Su rostro concuerda bastante con los de nuestro escultor: ojos rehundidos, nariz recta, boca entreabierta, "como si le faltara aliento, abrumada por la compasión que siente por el sufrimiento de Cristo"758. Frente arrugada. Cuello muy corto y mal resuelto. Las largas melenas caen simétricamente a ambos lados del rostro, llegando hasta más allá de la cintura, elemento que, según Bray, evoca su feminidad ${ }^{759}$. Como ya dijimos, son mechones sinuosos muy compactos que caen paralelos, están sin individualizar.

En definitiva, por la similitud del rostro con los de otros tallados por nuestro escultor parece preciso atribuirle su ejecución en una fecha cercana a la última década del siglo XVII. Se trata de una obra bastante floja que no alcanza ni la genialidad y ni el misticismo logrados por Gregorio Fernández y, sobre todo, por Pedro de Mena.

758 BRAY, Xavier: “23. Pedro de Mena. María Magdalena”. En BRAY, Xavier: Lo sagrado hecho real. Pintura y escultura española 1600-1700, Ministerio de Cultura, Madrid, 2010, p. 150.

759 Ibídem. 


\title{
BRAGANCA. IGREJA DE SANTA MARÍA DA ASSUNCÃO O DE NOSSA SENHORA DO SARDÃO
}

\author{
SANTA MARÍA MAGDALENA (Finales del siglo XVII)
}

Juan José Martín González en su libro La huella española en la escultura portuguesa: renacimiento y barroco dio a conocer una serie de obras, probablemente españolas, que se conservan en conventos e iglesias portuguesas. Entre ellas existían algunas de clara procedencia castellana, y más concretamente vallisoletana. La Santa María Magdalena (Fig. 129) conservada en la iglesia de Santa María da Assunção o de Nossa Senhora do Sardão de Braganza (Portugal) es una de ellas ${ }^{760}$.

Refiere el investigador que se desconoce "cuándo pudo traerse de Valladolid -pues vallisoletana es-, ya que aun cuando la iglesia y el retablo en su forma actual datan del último tercio del siglo XVII, la imagen pudo haber estado antes en otra parte; es más, fue incorporada a dicho retablo en el siglo XVIII, como nos lo dice la hornacina en la que está colocada" ${ }^{\text {761. }}$. Me gustaría pues atribuírsela a Juan de Ávila, aunque con ciertas reservas.

La escultura sigue el denominado modelo de "Pedro de Mena". Ya hemos comentado en numerosas ocasiones que parece probable que el creador de esta iconografía fue Gregorio Fernández, y el prototipo del mismo la Magdalena conservada en el Monasterio de las Descalzas Reales de Madrid. En Valladolid el mejor ejemplar de los conservados, además de ser el de mayor tamaño, es el conservado en la iglesia de San Miguel y San Julián, antiguo templo del colegio jesuítico de San Ignacio. Al igual que de esta imagen, también desconocemos su autor. Argumenta Martín González al respecto del parecido con la Magdalena del colegio jesuita que ésta de Braganza posee "más punción dolorosa y mayor morbidez de carnes en la escultura braganzana. Pensando en ello se puede sentar varias hipótesis. Lo más lógico es imaginar que alguna dignidad eclesiástica de Braganza vería la escultura de San Miguel y mandaría sacar una copia. Desde luego no es frecuente que la copia supere al original, como habría ocurrido en este caso. Pudo existir también un modelo común para ambas imágenes, pues estamos acostumbrados a escribir una historia del arte sin contar con lo que ha desaparecido. Y una tercera hipótesis, prácticamente insostenible, es que la escultura ahora conservada en Braganza sea el original. Me inclino a creer, finalmente, que es una réplica -mejorando al original, a mi juicio-de la escultura vallisoletana de San Miguel"762.

Al seguir el citado modelo, estudiado en diversas ocasiones para otros ejemplos del mismo, no hace falta volver a describirlo. Solo puntualizar que en esta escultura el sentimiento que emana de su rostro es mucho mayor, y el detallismo alcanza grandes

\footnotetext{
760 MARTÍN GONZÁLEZ, Juan José: La huella española en la escultura portuguesa: renacimiento y barroco, Universidad de Santiago de Compostela, Santiago de Compostela, 1961, pp. 28-30.

761 Ídem, p. 30.

762 Ídem, p. 29.
} 
cotas, particularmente en lo demacrado de su faz. Asimismo, el pelo es de gran calidad, y los mechones están muy individualizados y trabajados.

Las razones que me llevan a atribuirle esta Magdalena, con muchas reservas como ya he comentado, son fundamentalmente los elementos que componen su cabeza. Lo primero que se puede indicar es que su cabeza adopta una forma ovoide; además, la pequeña boca entreabierta; los ojos "achinados" levemente rehundidos; la nariz recta, aunque se va ensanchando según se llega a la punta de la misma; mentón potente; pelo naciente de la parte alta del cráneo, dejando una prominente frente. Asimismo, la forma de tallar la cabellera es muy "avilesina": la hemos observado, como mayor o menor fortuna en las Magdalenas conservadas en el Monasterio de las Descalzas Reales y en el Convento de Porta Coeli de Valladolid, y en las tres esculturas que efigian a Santa Rosa de Viterbo (Valladolid, Tordesillas y Ampudia). De confirmarse tal atribución, y aún solo ratificándose su procedencia vallisoletana, estaríamos hablando de una de las mejores esculturas salidas de la capital pucelana a finales del siglo XVII. 


\section{VALLADOLID. MUSEO NACIONAL DE ESCULTURA}

\section{BUSTO DE ECCE HOMO (h. 1700)}

La única ocasión en la que se habla de este busto (Fig. 130) es en el libro El Monasterio de Nuestra Señora de Prado, y más concretamente en el capítulo que Urrea dedica a los bienes artísticos dispersos del cenobio. Entre las muchas obras con las que contó el centro jerónimo constaban, en el momento en que fue Desamortizado, acaecido en 1836, en la sacristía cuatro escultores: se trataba de una cabeza de San Pablo, atribuida a Felipe Espinabete; un Ángel, relacionable con Pedro de Sierra y/o Pedro Correas; y dos bustos, uno de Ecce Homo y otro de Dolorosa. En 1916 Agapito y Revilla identifica este busto entre los bienes del Museo Provincial, pero no sabemos que ocurrió con posterioridad dado que el de la Dolorosa desapareció, conservándose, por el contrario, las otras tres obras entre los fondos del Museo Nacional de Escultura.

Sería muy fácil establecer la hipótesis de que ambas imágenes formarían pareja, algo muy común en este tipo de representaciones. En contra de esta teoría se nos presenta la sensible diferencia de tamaño, mientras que la Dolorosa tan solo poseía una altura de 42 cms., el Ecce Homo mediría entre 63 cms. y 72 cms., según las estimaciones realizadas durante la Desamortización, y posteriormente por Agapito y Revilla. Ignoro el porqué de esa diferencia de tamaño del Ecce Homo, quizás en la época de Agapito la escultura llevara peana ${ }^{763}$. Otro enigma nos plantean estos dos bustos: Gratiniano Nieto refiere que en el año 1954 existían en el Monasterio de Nuestra Señora de Prado, cuando hacía las funciones de Instituto Psiquiátrico, dos "bustos de Ecce Homo y Dolorosa que a pesar de lo repintados y enmascarado que están, permiten reconocer la mano de un buen escultor del siglo XVII" ${ }^{, 764}$. ¿Serían estos dos bustos los mismos sobre los que estamos hablando?

Pasando ya a hablar de la obra que nos interesa, el Ecce Homo, lo primero que hemos de reseñar son las atribuciones que ha recibido. El primero, que sepamos, en tratar sobre ella fue Urrea, el cual se decantó por creerla "próxima al estilo del escultor Pedro de

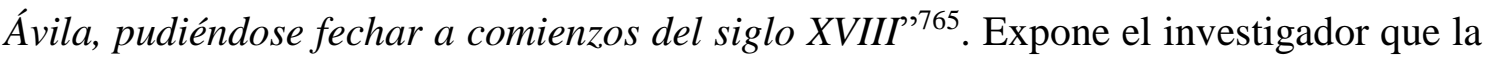
tipología de busto prolongado, que es el que exhibe el Ecce Homo, hunde sus raíces en el siglo XVII "dentro de las creaciones de Gregorio Fernández; éste es de una gran finura en su talla y aunque por la delgadez de su silueta y lo afilado de sus facciones podría recordar algunos prototipos andaluces, sin embargo se trata de una obra vallisoletana"766. Esta misma obra será la citada como restaurada por Carmen Wattenberg en el Boletín del Museo Nacional de Escultura del año 2005. La parquedad de su descripción nos impide conocer si se trata de la misma obra aunque la atribución a Pedro de Ávila puede ser definitiva: “Ecce Homo ( $\left.N^{o} R^{o} 236\right)$, madera policromada, de

\footnotetext{
763 URREA FERNÁNDEZ, Jesús: "Los bienes artísticos del Monasterio”, op. cit., p. 268.

764 NIETO GALLO, Gratiniano: op. cit., p. 109.

765 URREA FERNÁNDEZ, Jesús: "Los bienes artísticos del Monasterio”, op. cit., p. 268.

766 Ibídem.
} 
Pedro de Ávila"767. Pienso que la fecha más acertada sería el datarla hacia el año 1700 ya que concuerda perfectamente con el postrer estilo de Juan de Ávila y el primero de su hijo Pedro, el cual podremos ver en otras esculturas que le atribuiremos con casi total seguridad.

Bien es cierto que los rostros poseen ciertos estilemas de Pedro de Ávila, pero tampoco sería descabellado pensar en una posible atribución a su padre, Juan de Ávila. Por el tipo de pliegues y de barba me inclino más a pensar que sea de este último que de su hijo, aunque con muchísimas dudas puesto que el primer estilo de este último posee bastantes concomitancias con el de su padre, y no con el de Juan Antonio de la Peña o el de los Rozas, como se ha dicho en diversas publicaciones. No podemos olvidar que se formó con su padre y permanecería a su lado, por lo menos, hasta el año 1700 en que contrae matrimonio con la hija de De la Peña, con el cual colaboraría desde poco tiempo antes.

Se trata de un busto alargado que llega hasta un poco más abajo de la cintura. La base, que sería una estrecha cadera, se ve reforzada por la inclusión de la túnica roja, la cual además nos permite ver unos pliegues más característicos de finales del siglo XVII que de comienzos ya del XVIII, en el que poco a poco la redondez deja paso a las aristas. La composición es muy movida, mientras que el cuello y la cabeza giran ligeramente hacia arriba a la derecha, los brazos los sitúa con las manos juntas en su lado izquierdo. La anatomía no está muy apurada, sino que es bastante somera y seca, con algunas pequeñas manchas de sangre recorriéndola. Las manos son tremendamente expresivas, la posición y teatralidad de estos dedos son muy característicos de los Ávila. La túnica roja, que le envuelve la cintura y parte de la espalda, llegando a cubrir su hombro izquierdo y cayendo sobre ese brazo posee pliegues redondeados, aunque ciertamente toscos, sobre todo en la parte que cubre el hombro. Por su parte, el rostro es a no dudarlo de los Ávila, probablemente de Juan, o quizás de la primerísima etapa de Pedro. Los ojos, algo rehundidos, miran hacia el cielo, como suplicando clemencia a su Padre. La frente, despejada, está completamente encharcada de sangre, debido a las numerosas heridas provocadas por la corona de espinas, la cual pudo tener de manera postiza, al igual que la soga que anuda su cuello. Boca entreabierta que solo nos permite observarle los dientes de la fila superior. Barba de muy poco resalte resuelta de manera simétrica. La forma del pelo hace que la cabeza tienda a la forma cuadrada, típico de Pedro de Ávila, si bien no se desarrolla simétricamente, sino que a su derecha cae en varias guedejas separadas, y por la izquierda junta de manera recurvada, sorteando la amplia oreja.

Su estado de conservación debe ser bueno ya que, como hemos visto, parece que fue restaurado por los profesionales del propio Museo Nacional de Escultura. Sin embargo, por la única fotografía que se encuentra publicada vemos numerosos desconchones en los brazos, pérdida de dedos, roturas en parte de la túnica, etc...

767 VV.AA.: "Noticias. Taller de Restauración”, Boletín del Museo Nacional de Escultura, № 9 , 2005, Valladolid, p. 41. 


\section{SANTA RITA DE CASIA (h. 1700)}

Margherita Lotti, Santa Rita de Cascia, nació en la localidad umbra de Roccaporena (Italia) en el año 1381. Su nombre deriva del diminutivo de Margarita, Rita, y de la localidad en la que falleció, Cascia, también en Umbría. El hecho más destacado de su vida, y que ha conformado la iconografía con la que se la suele representar, es la de su estigmatización en el año 1428. Una madrugada de aquel año la santa oraba ante un crucifijo pidiendo a Cristo que le hiciera partícipe de sus padecimientos. Fue entonces cuando Jesucristo le dio una espina de su corona, la cual le quedó clavada a la santa en la frente, herida que no llegó nunca a cicatrizar. Posteriormente le extrajeron la espina y la guardaron como reliquia. El día de su muerte, en 1457, pidió una rosa, y le llevaron una que floreció milagrosamente en su jardín ${ }^{768}$. Fue beatificada en 1627 por Urbano VIII; sin embargo, su canonización fue mucho más reciente, concretamente el 24 de mayo de 1900, por lo que cuando se realizó la escultura era simplemente beata.

La escultura de Santa Rita de Casia (Fig. 131), actualmente conservada en el Museo Nacional de Escultura, procede del Convento de San Agustín de Valladolid ${ }^{769}$. Debe de ser la que se encontraba en la Capilla de Nuestra Señora de Gracia o de Santa Rita, situada en el lado del evangelio de la iglesia ${ }^{770}$. Sin embargo, según García Vega, la escultura estaba radicada en la tercera capilla del lado de la Epístola, en la cual "se veneraba a Santiago Apóstol (...) la que sin saberse porqué se fue o perdió desde el año 1715; y ahora se reverencia en dicha capilla la milagrosa imagen de Santa Rita de Casia" 771 .

La escultura figura en varios inventarios del convento: el primero fue el realizado el 12 de junio de 1808, tras el saqueo del convento de San Agustín por parte de la francesada, en el referido listado tan solo figuraban cuatro esculturas: Jesús Nazareno (el primitivo que procesionó la cofradía del mismo nombre y que actualmente preside el paso del Camino del Calvario), Santa Rita, San Antonio y San Agustín ${ }^{772}$; el segundo fue confeccionado en 1824, incluía los objetos que se estaban restaurando tras las exclaustraciones $^{773}$; y, finalmente, un tercero, fechado en 1837 , que trataba sobre las obras de arte que se encontraban en el convento tras la Desamortización ${ }^{774}$.

La escultura de Santa Rita tan solo ha recibido una atribución: la realizada por Federico Wattenberg a favor de Juan de Ávila, el cual señalaba que era "de autor anónimo del

\footnotetext{
768 RÉAU, Louis: Iconografía de los santos. P-Z..., op. cit., p. 136.

769 WATTENBERG, Federico: Guía del Museo Nacional de Escultura. Madrid, 1966, p. 70.

770 FERNÁNDEZ DEL HOYO, María Antonia: Patrimonio perdido..., op. cit., p. 274.

771 GARCÍA VEGA, Blanca: op. cit., p. 405.

772 REDONDO CANTERA, María José: "Los inventarios de obras de arte de los conventos vallisoletanos durante la Guerra de la Independencia", B.S.A.A., Tomo LVIII, 1992, p. 501.

773 "Echar los dedos de N.P. San Agustín, Santa Rita, San Judas Tadeo, San Antonio y Niño Jesús", y de "componer un Santísimo Cristo". FERNÁNDEZ DEL HOYO, María Antonia: Patrimonio perdido..., op. cit., p. 289.

774 "Un altar, ocho cuadros, tres colaterales; cuatro mesas de altar. Imágenes de bulto: dos de San Agustín; un san Antonio; tres Crucifijos; tres de San Juan; Un Santo Tomás; un Niño de Dios; cinco imágenes de Nuestra Señora; una santa Rita”. Ídem, pp. 289-290.
} 
siglo XVII y con caracteres que le harían conceptuar como de Juan de Ávila"775. Para lo que ha habido mayor variedad es para establecer su posible cronología. Por una parte tenemos la atribución a "autor anónimo del siglo XVII" que comparten Constantino Candeira $^{776}$ y Cecilio Barberán ${ }^{777}$; y, por otra, la formulada por Martín González que, estudiando "las mangas de los hábitos de los monjes, las cuales se hacen colgantes", la fecha en el último tercio del siglo XVII: "La cronología de esta anónima escultura puede deducirse del estudio de los pliegues. Acusan éstos el ablandamiento del postrer tercio del siglo, conservando cierta angulosidad en algunas partes"778.

Si bien el rostro me hace inclinarme por una atribución a favor de Juan de Ávila, el tipo de pliegue, algo más cortante que en otras ocasiones, como anticipando el "tipo cuchillo" que desarrollará su hijo Pedro, hace que todavía albergue ciertas dudas. La escultura es muy bella y movida. Se encuentra cargada de misticismo, como podemos ver en la observación fervorosa que hace la santa del Crucifijo que porta en una de sus manos. Como vemos la contemplación del Crucifijo es un tema muy barroco, que ya vimos, por ejemplo, en las numerosas Magdalenas que siguen el denominado "modelo Mena".

El anónimo escultor nos presenta a Santa Rita de pie, con la pierna izquierda ligeramente adelantada, como lo podemos observar por el suave contraposto de esa rodilla, que se marca en la vestimenta. El cuerpo de la santa está ligeramente recurvado hacia atrás, lo que, junto a la posición de sus brazos, abiertos, parece querer simular un éxtasis. Con su mano izquierda agarra un Crucifijo, que mira atentamente, teniendo el rostro levemente girado hacia ese lado. El brazo derecho, muy abierto. Viste el típico hábito agustino: túnica negra hasta los tobillos, que solo permiten verle la punta de los zapatos, ceñida a la cintura por un cinturón de cuero negro. Amplias bocamangas, como las vistas en las esculturas de San Bernardo, San Benito y Santa Escolástica del retablo mayor del Monasterio de San Quirce. La cabeza va cubierta por una toca blanca y encima un velo negro, ambos elementos hacen que tan solo podamos ver su rostro. La austera policromía negra tan solo se ve enriquecida por unas preciosas orlas doradas, con decoración vegetal, situadas en la parte baja de la túnica, y en los bordes de las mangas y del velo. El rostro posee una blandura extraordinaria, la expresión extática está perfectamente lograda. Los pliegues, como ya hemos dicho, son más aristados de lo que estamos acostumbrado en las imágenes relacionadas con nuestro escultor. A pesar de ello son suaves y finos, sobre todo los de las manos. Diferentes pliegues observamos en la parte baja de la túnica, los cuales coinciden más con Ávila, están algo más quebrados y redondeados, son los producidos por el choque de la ropa contra el suelo. La combinación de ambos tipos de pliegues me lleva a fecharla a finales del siglo XVII, quizás hacia el 1700.

\footnotetext{
775 WATTENBERG, Federico: Guía del Museo Nacional de Escultura. Madrid, 1966, p. 70.

776 CANDEIRA PÉREZ, Constantino: Guía del Museo Nacional de Escultura, Imprenta Gráficas Perdiguero Valladolid, 1945, p. 40.

777 BARBERÁN, Cecilio: Museo Nacional de Escultura, Valladolid, Afrodísio Aguado, Madrid, 1948, pp. 71-72.

778 MARTÍN GONZÁLEZ, Juan José: Escultura barroca castellana ..., op. cit., p. 21.
} 
La escultura gozó de gran popularidad y devoción, solo así se puede entender que se sacaran grabados de ella. García Vega dio conocer uno realizado en cobre en el año 1786, por Ventura de Agreda ${ }^{779}$. En él aparece la santa de manera idéntica a la escultura, si bien nos proporciona otra información, como es, que a sus lados se encontraban dos

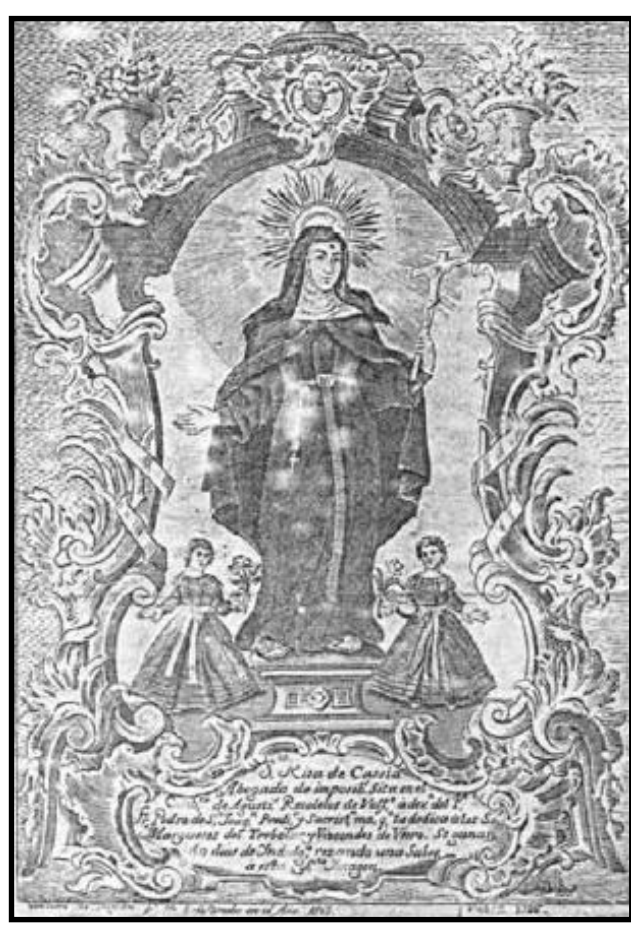
imágenes de niñas portando flores. La composición se halla enmarcada por un retablo rococó muy movido. En su parte superior figura un corazón, emblema agustino por excelencia En la parte inferior una cartela con rocalla, en cuyo interior figura esta leyenda: "Sta. Rita de Cassia Abogada de imposib., Sita en el Conb ${ }^{\text {to }}$, de Agust $^{\mathrm{s}}$, Recoletos de Valld., a dev ${ }^{\mathrm{n}}$, del $\mathrm{P}^{\mathrm{e}}$, Fr. Pedro de S. Joaq ${ }^{\mathrm{n}}$, Pred ${ }^{\mathrm{r}}$, y sacrist ${ }^{\mathrm{n}}, \mathrm{ma}^{\mathrm{r}}$, $\mathrm{q}^{\mathrm{n}}$, la dedica a los $\mathrm{Se}^{\mathrm{s}}$ Marqueses del Trebolar $\mathrm{y}$ Vizconde de Vtero. Se ganan 40 días de Yndulga, rezando una Salve a esta Sta. Ymagen".

Il. 43- Ventura de Agreda. Santa Rita de Casia.

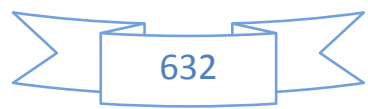




\section{ATAQUINES. IGLESIA DE LA DEGOLLACIÓN DE SAN JUAN BAUTISTA}

\section{RETABLO MAYOR (h. 1700)}

El retablo que actualmente preside la capilla mayor de la iglesia parroquial de Ataquines no es el originario que poseyó el templo. Este procede del Convento de la Encarnación de Arévalo; lugar en el que fue adquirido en cantidad de 900 reales por doña Petra Pérez, la cual en el año 1848 lo regaló a la parroquia de Ataquines ${ }^{780}$. Este retablo vino a sustituir a uno anterior, de estilo neoclásico, que llegó a ser visto y descrito por Madoz. Dice que formaba "una especie de trono con su cúpula semicircular sostenida por cuatro columnas de orden dórico, y la mesa separada de él, de modo que puede andarse cómodamente por detrás, teniendo colocado el tabernáculo encima de ella"781.

Desconocemos que retablo ocupaba el altar mayor a comienzos del siglo XVIII. Existieron dos proyectos para dotarle de un retablo, si bien parece que ninguno de los dos llegó a culminarse: el primero aconteció en 1656 con Francisco Díez de Tudanca, a la sazón maestro de Juan de Ávila; y el segundo en 1680 con Juan Antonio de la Peña.

El 13 de junio de 1656 Tudanca se concertó con el ensamblador José de Arroyo para realizar la escultura del retablo mayor de la villa de Ataquines (Valladolid), cuya arquitectura correría por parte del ensamblador segoviano. Arroyo se avino con la iglesia parroquial en "hacer y acabar un retablo para la capilla mayor de la dicha iglesia y en él ha de hacer (...) algunos cuerpos y figuras de escultura en conformidad de la traza y condiciones que el dicho José de Arroyo se obligó para el dicho Francisco Díez de Tudanca como va dicho sea convenido y concertado con el dicho José de Arroyo a tomar por su cuenta toda la escultura del dicho retablo en conformidad de las condiciones"782. Para el banco del retablo debía de realizar "los cuatro doctores y los cuatro evangelistas" para los netos, y las imágenes de Santa Lucía y Santa Águeda "en el dicho pedestal al macizo de los intercolumnios. Y en el alto cuerpo corteros y figuras de tres lados que se entiende de medio relieve con sus tableros". Para la custodia tallaría "un Salvador con su cordero del mismo relieve". En los intercolumnios del primer cuerpo figurarían seis tableros representando a los doce Apóstoles "de dos en dos los cuales han de ser cuerpos enteros conforme a los de pedestal". En la caja principal iría situado "un San Juan degollado que ha de ser figura redonda", y sobre éste, en la caja principal del ático, un "Descendimiento de la Cruz con todas las figuras enteras que le pertenecen". Escoltando este pasaje se situarían San Gregorio y San Nicolás, y San Nicolás y San Gregorio. Coronando el retablo aparecía un busto de Dios

\footnotetext{
780 "El retablo mayor de la iglesia, de estilo barroco, procede del convento de la Encarnación de Arévalo, y fue adquirido por $\mathrm{D}^{\mathrm{a}}$ Petra Pérez, en la cantidad de 900 reales, el año 1848: dicha señora lo regaló al mencionado templo". ORTEGA RUBIO, J: Los pueblos de la Provincia de Valladolid, Tomo II, Imprenta y Encuadernación del Hospicio Provincial Valladolid, 1895, p. 315.

781 MADOZ, Pascual: op. cit., p. 34.

782 GARCÍA CHICO, Esteban: Documentos para el estudio del arte en Castilla. 2..., op. cit., pp. 298-299.
} 
Padre. Dos años después, el 28 de junio de 1658, ambos artistas decidieron hacer un apartamiento, rompiéndose el compromiso laboral entre ellos ${ }^{783}$. Tudanca confesaba que aunque había recibido "diferentes cantidades de maravedies así en dinero como en libranzas en la dicha villa" por haber "comenzado a hacer y fabricar mucha parte" de la parte escultórica del retablo, no la pudo acabar "ni al presente tampoco por las muchas obras que tiene". Llegados a este punto se decidió que se tasara lo esculpido por Tudanca "por personas nombradas y el dinero recibido se ajustó valer lo que está fabricado con que el dicho José de Arroyo" se apartó de la escritura y en breve tiempo le encargaría a otro escultor la finalización de la parte escultórica del retablo. Las esculturas ya hechas quedaron en poder del ensamblador, ignorándose su posterior paradero y su posible utilización ${ }^{784}$. Ninguna de las esculturas que hoy se conservan en la iglesia guardan relación alguna con lo especificado en el contrato, de manera que no sabemos si se pudo aprovechar lo tasado, y en caso positivo donde fueron a parar las esculturas o relieves.

Posteriormente, en 1680 el escultor Juan Antonio de la Peña y el dorador Alonso Gutiérrez percibían una importante cantidad del alcalde de la villa de Ataquines, por lo que tal vez podría tratarse del cobro del retablo mayor de la iglesia ${ }^{785}$.

Volvamos al que nos ocupa. El actual retablo mayor ha sido relacionado con el ensamblador Alonso Manzano, fechándolo hacia el año $1700^{786}$. Tampoco sería muy descabellado proponer el nombre de Blas Martínez de Obregón, pues no hay más que ver el parecido que guarda con algunos de sus retablos, véase el de San Quirce de Valladolid. De lo que no hay muchas dudas es que tanto la arquitectura como sus esculturas proceden de talleres vallisoletanos.

El retablo es tetrástilo. Se dispone en banco, amplio cuerpo con tres calles y ático, este último seccionado para adaptarlo a la menor altura de este templo. En el banco aparecen cuatro ménsulas con

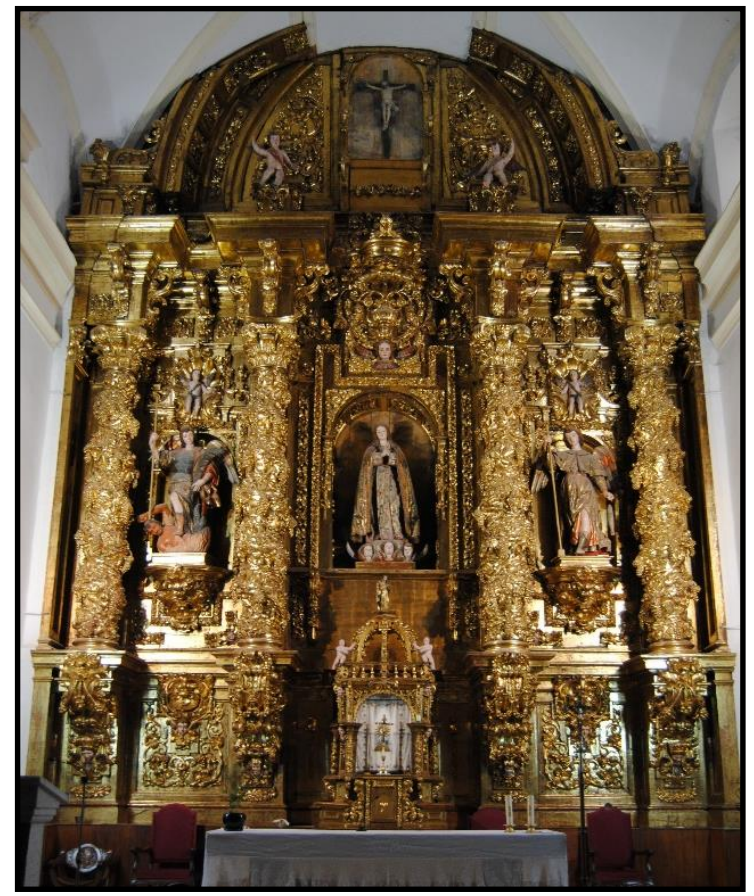

Il. 44- Anónimo. Retablo mayor. Iglesia parroquial de la Degollación de San Juan Bautista. Ataquines

(Valladolid).

\footnotetext{
783 Ídem, p. 299.

784 FERNÁNDEZ DEL HOYO, María Antonia: "El escultor vallisoletano Francisco Díez de Tudanca...", op. cit., p. 379.

785 "Juan Antonio de la Peña y Alonso Gutiérrez maestros escultor y dorador otorgan poder a Manuel Ordoñez para que en su nombre cobre de Joseph Nieto alcalde ordinario de la villa de Ataquines, Alonso Hurtado Bordón y otros vecinos en una escritura de obligación a nuestro favor otorgada 1.400 reales". BRASAS EGIDO, José Carlos: Catálogo Monumental de la provincia de Valladolid. Tomo X..., op. cit., p. 56.

786 MARTÍN GONZÁLEZ, Juan José: Escultura barroca castellana ..., op. cit., p. 323.
} 
mascarones, con decoración muy profusa y abultada. Entre las ménsulas se sitúan netos ricamente decorados, en cuyo interior figura una cabeza de ángel y sobre éste una especie de venera. En el espacio central, partido, se sitúa el sagrario. El cuerpo principal se articula a través de cuatro columnas salomónicas de orden gigante, decoradas con multitud de vides y pámpanos. En los intercolumnios se sitúan las tallas de San Miguel y San Rafael, y en la hornacina principal la Inmaculada. Las esculturas laterales se apoyan sobre unas peanas ricamente decoradas. En la parte superior de las tallas se sitúan unas hojas crespas y sobre ellas unos angelitos inscritos sobre veneras. El ático se encuentra muy modificado. Al parecer remataba de forma semicircular. Actualmente, en el centro hay una hornacina plana en la que se halla un Crucifijo. Sobre los entablamentos de las columnas salomónicas centrales campean dos angelitos con una banda roja cruzada sobre el pecho. Que el retablo está dedicado a la Virgen, y concretamente a la Inmaculada, nos lo indica el escudo coronado de una jarra de lirios existente sobre la hornacina principal del retablo, la cual nos habla de su concepción virginal.

Las tres esculturas de este retablo ya habían sido atribuidas a Juan de Ávila por Martín González en su libro Escultura barroca castellana ${ }^{787}$. Años después, en el Inventario artístico de Valladolid y su provincia prefirió definirlas como del "taller de los Ávila"788. Por mi parte, además de seguir la línea de Martín González, pienso que también podrían pertenecer a nuestro escultor el delicioso grupo de la Virgen con el Niño que culmina la custodia; y los dos ángeles que campean en el ático del retablo, muy similares a los del retablo del vallisoletano Monasterio de San Quirce.

\section{INMACULADA}

Con anterioridad la hornacina central del retablo estuvo ocupado por una horrenda escultura de mediados del siglo XVII que representaba a San Juan Bautista, titular del templo, imagen que quizás pueda relacionarse con la producción que Tudanca realizó para esta iglesia. Sin embargo, el "Precursor" vino a sustituir a la Inmaculada, verdadera titular de este retablo, puesto que actualmente ha vuelto a ocupar. Por su parte, la Inmaculada ha ocupado varios sitios dentro de la iglesia. Martín González, que acertó a verla al pie del retablo, la describe así: "copia tardía del conocido modelo de Gregorio Fernández. Está colocada sobre un trono de serafines que tienen el cabello apelmazado, como usa Ávila. Las formas del rostro están marcadas con dureza, en oposición a la blandura de que hace gala al esculpir los rostros masculinos" ${ }^{\text {789 }}$.

Esta Inmaculada (190 cms.) (Fig. 132), al igual que la vista en la Capilla de la Congregación del desaparecido Colegio de San Ambrosio de Valladolid viene a copiar, más o menos, fielmente el modelo creado y difundido por Gregorio Fernández; si bien ésta de Ataquines parece una versión un tanto más libre que la otra. Esta escultura

\footnotetext{
787 Ibídem.

788 MARTÍN GONZÁLEZ, Juan José (dir.): Inventario artístico de Valladolid..., op. cit., p. 81.

789 MARTÍN GONZÁLEZ, Juan José: Escultura barroca castellana ..., op. cit., p. 322.
} 
adquiere mayor corporeidad y movimiento que la fernandesca, así podemos verlo con el detalle del adelantamiento de su pie derecho, cuya rodilla parece doblarse; asimismo tiene unas proporciones algo más anchas. Otras diferencias con respecto al modelo original es que esta Virgen tiene atada la túnica con un cíngulo rojo a la altura de la cintura, elemento que jamás veremos en Fernández; y que las manos orantes no están levemente ladeadas, sino que el movimiento de estas es ya decidido, llegando las mangas a no caer de manera recta. El resto es en todo coincidente: tanto la vestimenta, como el color de éstas; la composición general y aún algunos detalles, como pueden ser el ladeamiento de la cabeza hacia la derecha, la mirada hacia abajo, la disposición de los cabellos o los pliegues rugosos del tercio inferior del manto, sin duda bastante más dulcificados que en las Inmaculadas de Fernández y en las copias más tempranas de éstas. El trono sobre el que se sitúa la Virgen lo conforma una masa nubosa que da cabida a tres cabezas aladas de angelitos, todas ellas mirando hacia Ella.

La escultura está tallada con delicadeza, especialmente en lo referente a los paños, muy dulces y finos; no la tiene tanto el rostro, algo duro. Parece como ausente, no posee vida interior como las fernandesca, es algo más distante. Tampoco destaca el tratamiento de los cabellos, bastante bastos; no les individualiza como hacía Fernández, y el escultor de esta Inmaculada los agrupa en mechones.

La policromía es fastuosa. La túnica blanca se ve regada de múltiples flores azules y rojas, y una imitación de brocado en la parte inferior de la misma. Por su parte la túnica es azul, con numerosas decoraciones vegetales doradas a punta de pincel. El borde de ésta se ve recorrido por la colorida cenefa que venimos viendo a lo largo de la mayoría de las obras relacionadas con los Ávila. Este detalle parece confirmarnos que se trata de una obra vallisoletana.

\section{ARCÁNGEL SAN MIGUEL}

Está situado en el intercolumnio izquierdo. San Miguel fue uno de los santos favoritos del barroco y de la contrarreforma, la cual dio un fuerte impulso a su culto y le tomó como el símbolo del "triunfo de la Iglesia católica contra el dragón de la herejía protestante: por esa razón se pusieron bajo su advocación magníficas iglesias en

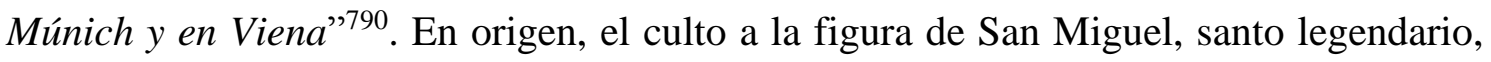
vino a reemplazar al de los dioses paganos; concretamente "al del dios egipcio Anubis y en particular al de Mercurio, el Hermes psicopompo, que en la mitología tenía una función análoga"791. Pero, no es esta la iconografía representada en la presente escultura, sino que se trata de un San Miguel guerrero, y vencedor del demonio; es decir, el episodio más conocido de su iconografía, especialmente en la época en que fue tallado.

790 RÉAU, Louis: Iconografía de la Biblia. Antiguo..., op. cit., p. 71.
791 Ídem, p. 68. 
Su condición de jefe de las milicias celestiales viene ya de antiguo, puesto que comentaba ya el profeta Daniel que sería él "quien, cuando el Anticristo venga a la tierra, aparecerá entre los hombres para defenderlos y protegerlos; él fue el que luchó contra el dragón y sus secuaces, los arrojó del cielo y obtuvo sobre ellos una imponente victoria; también fue él quien disputó con el diablo cuando este enemigo infernal trató de destruir el cuerpo de Moisés para hacerse parar por Dios y conseguir que el pueblo judio le adorara (...) Él es el abanderado de Cristo en el ejército de los Santos Ángeles y él será quien en cuanto el Señor le dé la orden, matará valientemente al Anticristo en la cima del monte Olivete, y quien dará la voz para que los muertos resuciten, y quien el día del juicio presentará ante el tribunal la Cruz, los clavos, la lanza y la corona de espinas" 792.

Como hemos dicho, San Miguel (Fig. 133) aparece venciendo al demonio. Este episodio está tomado directamente el Apocalipsis: "Hubo una batalla en el cielo: Miguel y sus ángeles peleaban con el dragón, y peleó el dragón y sus ángeles, y no pudieron triunfar ni fue hallado su lugar en el cielo. Fue arrojado el dragón grande, la antigua serpiente, llamada Diablo y Satanás, que extravía a toda la redondez de la tierra, y fue precipitado en la tierra, y sus ángeles fueron con él precipitados" (Apocalipsis: 12, 79). Este mismo acontecimiento lo narra Santiago de la Vorágine con más precisión en su famosa Leyenda Dorada. Se trata de la cuarta victoria que obtuvo sobre las hordas demoníacas: "Recordemos finalmente una cuarta victoria: la que el arcángel San Miguel obtendrá sobre el Anticristo cuando le dé muerte. En relación con esto leemos en el capítulo 12 de Daniel: "Entonces se alzará Miguel, el gran príncipe, el defensor de los hijos de tu pueblo”. Asi ocurrirá: se alzará, ejercerá su función de protector de los elegidos, y se opondrá valientemente al Anticristo, el cual, según dice la Glosa al comentar estas palabras del capitulo 13 del Apocalipsis "vi herida de muerte a una de las cabezas de la bestia", se hará el muerto, se ocultará durante tres días, y al cabo de ellos se presentará nuevamente ante el pueblo diciendo que ha resucitado, y con la ayuda de sus artes mágicas y la que le presten los demonios se elevará en el aire, conseguirá que las multitudes entusiasmadas le adoren, se trasladará posteriormente al monte Olivete y allí, en el mismo lugar desde el que Cristo ascendió a los cielos, montará su tienda; pero cuando esté dentro de ella sentado en su trono, llegará Miguel y le matará"793.

San Miguel aparece de pie, pisando al demonio, el cual se consume entre las llamas del infierno. La pierna con la que le presiona el pecho la tiene adelantada, creando un suave contraposto. Se encuentra alado por dos grandes alas desplegadas y muy coloreadas. Con su mano izquierda sujeta la palma de la victoria, y con la derecha una lanza que clava en la cabeza de Lucifer. El brazo con el que sujeta la lanza está dispuesto de una manera muy elegante, teniendo las mangas recogidas, lo que nos permite verle los brazos desnudos.

792 VORÁGINE, Santiago de la: op. cit., Tomo II, p. 621.
793 Ídem, p. 626. 
Viste como un guerrero, con una túnica larga, manto y sobre el torso una thoracata. La túnica le llega hasta los pies, si bien la tiene abierta desde las rodillas, lo que nos permite verle las piernas y las sandalias que protegen sus pies. Va policromada con motivos de flores. Como hemos dicho, las mangas de la túnica van recogidas, formando una importante masa de ropa a la altura del codo derecho. La coraza, que se ciñe a la perfección a la anatomía del santo, es de color azul con motivos floreados grises, como queriendo imitar la decoración de las armaduras de época romana, y ribetes dorados. De la parte baja de la coraza cuelgan una serie de pulseras o "torquex". Sobre el hombro derecho cuelga un manto rojo con motivos dorados a punta de pincel, y una cenefa con motivos vegetales multicolores, que se sitúa en la línea de las muchas que hemos visto en las esculturas relacionadas con nuestro escultor. Si bien los pliegues de la armadura y la túnica están tratados con gran naturalismo; la forma en que se arremolinan los del manto alrededor del brazo no están tan logrados, quedan algo acartonados, a excepción de los de los bordes que concuerdan perfectamente con los de la segunda etapa de Ávila por ser redondeados, suaves, finos, etc...

El rostro, que acusa gran blandura, exhibe muchas de las características presentes en la obra de Juan de Ávila: se trata de una faz alargada, tendente al ovoide; ojos almendrados semihundidos; nariz amplia con tabique recto que se ensancha en su parte baja; boca pequeña; mentón potente, etc... no concuerda tanto con su estilo el que la

boca permanezca cerrada. También es asignable a Ávila la amplia cabellera realizada a base de grandes rizos y mechones. Sobre la frente se sitúa un gran mechón en forma de "S", flanqueado por pelos mojados. Cae a ambos lados del rostro de manera simétrica. Las tapillas de los ojos están muy desgastadas, necesitando una urgente restauración.

\section{ARCÁNGEL SAN RAFAEL}

Preside el intercolumnio derecho, contraponiéndose de esta manera a San Rafael (Fig. 134). La contraposición no la observamos solamente en este hecho, sino en el que mientras San Miguel gira el cuello a su izquierda para mirar a la Virgen, San Rafael hace lo propio, pero hacia el lado derecho. Aparece representado según la iconografía que le une al pequeño Tobías, de quien fue guía; motivo por el cual se le tomó como protector de los adolescentes que dejaban la casa paterna, a los cuales protegía de las tentaciones y les impedía perderse en la primera escala, como el Hijo pródigo ${ }^{794}$.

San Rafael figura de pie. Al igual que San Miguel adelanta la pierna derecha, aunque de una manera mucho más sosegada, con lo cual el contraposto y la sensación de movimiento son mucho menores. Con su mano derecha, cuyos dedos están dispuestos con gran elegancia, sujeta un pez, que es el atributo que hizo pescar a Tobías. También relacionado con el joven se halla el atributo que sujeta con su mano izquierda: se trata de una cruz báculo, que alude al momento en que guio por el camino a Tobías. La composición viene a recordar, aunque de una manera bastante lejana, al Arcángel San

794 RÉAU, Louis: Iconografia de la Biblia. Antiguo..., op. cit., p. 77. 
Rafael que Gregorio Fernández talló para el retablo mayor de la antigua iglesia de San Miguel de Valladolid, y que en la actualidad se conserva en la iglesia de San Miguel y San Julián. Coincide con ella tanto en atributos como en vestimenta, sin embargo el acabado, movimiento y sensualidad no tienen nada que ver con aquél

Viste una túnica larga que le llega hasta los pies, aunque, al igual que en el San Miguel, aparece abierta desde las rodillas, lo que nos permite verle la pierna y las sandalias. La túnica, ceñida a la cintura por un cíngulo, posee una policromía a base de roleos vegetales y cabezas de angelitos, todo ello de colores, a lo que se suma un fondo dorado que le otorga mayor resalte. En la parte baja de la misma figura una cenefa con motivos vegetales y cabezas de angelitos. Sobre los hombros va tocado con una esclavina, atributo típico del arcángel. Los pliegues de la túnica y de la esclavina difieren, siendo los de esta última mucho más dulces y redondeados, lo que podemos observar en el doblez de una de sus partes. Los de la túnica son algo más duros, aunque se van suavizando según vamos bajando.

Tanto el rostro como las alas son plenamente coincidentes con los que exhibía el San Miguel, aunque los ojos de éste se encuentran en mucho mejor estado. Tanto los rasgos faciales como la amplia cabellera con bucles y mechón sobre la frente se vuelven a repetir.

\section{VIRGEN CON EL NIÑO}

Culminando la custodia se encuentra una pequeña y deliciosa escultura de la Virgen con el Niño (Fig. 135) que denota también el estilo de nuestro escultor, lo que puede indicarnos que pertenece al retablo mayor; es decir, ambos vinieron del Convento de la Encarnación de Arévalo (Ávila). Esta imagen nunca ha sido puesta en relación con él, lo contrario a lo que ocurre con las tres esculturas del retablo mayor y el relieve de la Anunciación que se encuentra en otro lugar de la iglesia.

La Virgen aparece de pie, con la pierna izquierda levemente levantada, introduciendo un contraposto, el cual se ve incrementado por el giro de la cabeza. La imagen se encuentra muy maltratada puesto que ha perdido la mano izquierda. Con la otra mano, la derecha, sujeta al Niño Jesús, que también presenta las pérdidas de sus brazos y piernas derechas. La Virgen viste una sencilla túnica dorada ceñida al cinto por un lazo; y un manto echado sobre la cabeza, del mismo color por la parte exterior, mientras que por la interior es azul. Llama la atención el hecho de que ambas policromías sean planas, no hay ningún motivo decorativo ni color adicional. Los pliegues son suaves, caen rectos y paralelos, acusando la anatomía, como podemos observar con la pierna de la Virgen. El manto adopta formas muy sinuosas y movidas, lo que contrasta, ciertamente, con la túnica. El Niño va desnudo, juguetea y acaricia el rostro de su madre, a lo que ella responde con una sonrisa, sonrisa que también corresponde su Hijo. Llama la atención el clavo que aparece sobre el pecho del pequeño Jesús. La talla del pelo es muy menuda, 
alejándose del modo de hacer de Juan de Ávila, aunque se acerca al de sus hijos Pedro y Manuel. Los rostros de ambos son deudores del estilo de nuestro escultor.

\section{$\underline{\text { ÁNGELES }}$}

Poco se puede decir de ellos debido a la altura en la que se encuentran. Tanto por su tipología como por el lugar que ocupan, recuerdan bastante a los que existen en el ático del retablo mayor del Real Monasterio de San Quirce y Santa Julita. Los ángeles van situados sobre unas penas, con las piernas caídas. Van desnudos, tan solo una banda cruza su pecho. Contraponen sus actitudes mediante la elevación de sus brazos, uno sube el derecho y el otro el izquierdo. Pudiera ser que en las manos de estos brazos hubieran portado algún atributo, quizás una palma, ya que los Arma Christi no tendrían sentido en este retablo.

\section{RELIEVE DE LA ANUNCIACIÓN (h. 1700)}

Anteriormente, este enorme relieve se encontraba ubicado en la nave de la Epístola, si bien en la actualidad está a los pies de la nave central, junto a la pared del coro. Se trata de un retablo salomónico, de finales del siglo XVII. El primero en relacionarlo con Ávila fue Martín González, el cual observó que "el arcángel San Gabriel es similar a los ángeles del retablo mayor de Santiago, y también la manera de hacer las nubes, en lineas espirales, pertenece al estilo de Ávila"795. Esta atribución ha sido años después compartida por Brasas Egido ${ }^{796}$.

Este relieve, que representa el pasaje de la Anunciación (Fig. 136), por su forma y decoración parece ser el remate de un retablo. Este hecho ya fue señalado por Martín González: "Retablo con remate del retablo mayor trasladado, último cuarto siglos XVII con relieve de la Anunciación"797. Pienso, por varios motivos, que pertenecería al retablo mayor de la iglesia. Lo primero que llama la atención del ático de este retablo es que ha sido totalmente seccionado en su parte superior para poderlo adaptar al testero de la capilla mayor, algo más bajo que lo que mediría el retablo completo. Segundo, el marco arquitectónico en que se halla embutido el relieve es bastante similar al que existe en el retablo mayor del convento de las Brígidas de Valladolid; si superpusiéramos la arquitectura de este relieve sobre el ático del retablo de Ataquines daría un resultado similar al del retablo citado, puesto que este también se cerraba en medio punto, forma a la que tiende la parte superior del ático y el propio ático del retablo de Ataquines. Tercero, el marco de tarjetillas que adorna el relieve es totalmente exacto al que exhibe la hornacina central del retablo, la que exhibe a la Inmaculada.

\footnotetext{
795 MARTÍN GONZÁLEZ, Juan José: Escultura barroca castellana ..., op. cit., p. 324.

796 BRASAS EGIDO, José Carlos: Catálogo Monumental de la provincia de Valladolid. Tomo X..., op. cit., p. 55.

797 MARTÍN GONZÁLEZ, Juan José (dir.): Inventario artístico de Valladolid..., op. cit., p. 81.
} 
Cuarto, el rostro de las esculturas de San Miguel y San Rafael es muy similar al de la Virgen de la Anunciación. Quinto, parece plausible pensar en que el retablo nos muestre a los tres grandes arcángeles realizando las acciones que mejor les representan: San Miguel venciendo al demonio, San Rafael con la historia del joven Tobías, y, finalmente, San Gabriel anunciando a María. Sexto, además de un retablo de clara

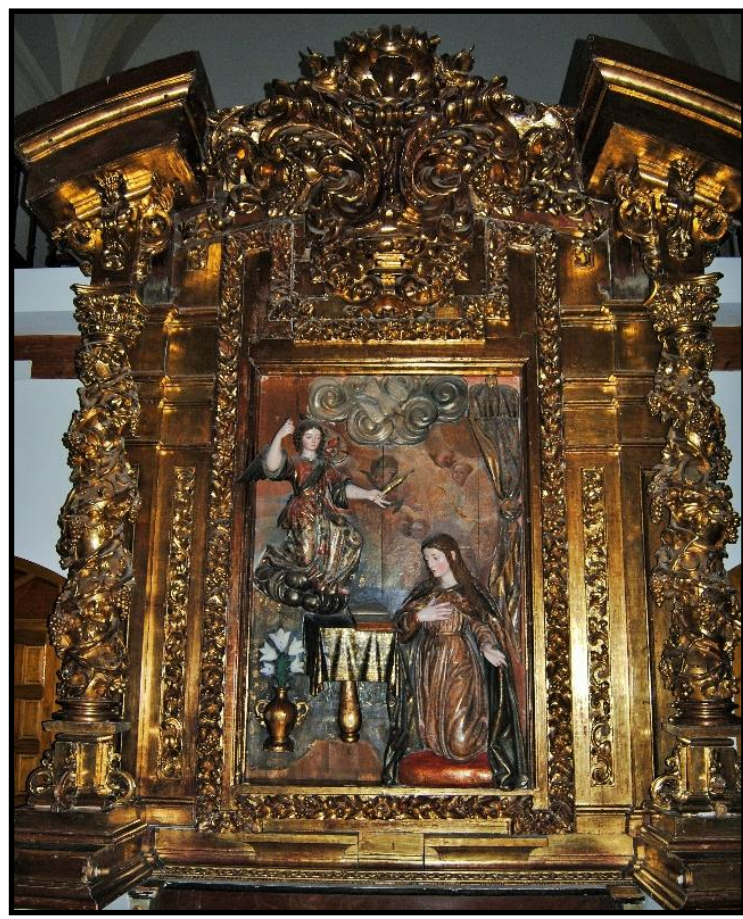

Il. 45- Juan de Ávila (atrib.). Anunciación. Iglesia parroquial de la Degollación de San Juan Bautista.

Ataquines (Valladolid). iconografía angelical, también lo es mariológica, dado que nos presentaría el momento en el que San Gabriel le anuncia que concebirá a su Hijo sin mancha, y justo debajo, en la hornacina central tendríamos a la Virgen como Inmaculada Concepción; a ello hemos de sumar el que tanto en el relieve, como en el escudo que hay sobre la Inmaculada aparezca el socorrido jarro de lirios, aludiendo a la pureza de la Virgen, con lo cual se completaría el círculo; el último paso, el de la Virgen con el Niño, lo tendríamos representando en la parte superior de la custodia.

Juan de Ávila, o el escultor que lo realizara, se basó para su ejecución en los evangelios, concretamente en el de San Lucas $^{798}$. Pero los escultores, dada la riqueza iconográfica que posee un tema como éste, necesitaron de otras fuentes. Efectivamente, muchos detalles de la Anunciación fueron proporcionados por los evangelios apócrifos, fundamentalmente el Protoevangelio de Santiago y el Evangelio de la Natividad de la Virgen; los cuales fueron divulgados en Europa por el Speculum Historiae de Vicent de Beauvais, y, sobre todo, por la Leyenda Dorada de Santiago de la Vorágine ${ }^{799}$.

Como es normal, la composición, que probablemente se inspire en algún grabado o estampa, se limita a tres personajes: la Virgen, San Gabriel y la paloma del Espíritu Santo. La escena se desarrolla en un interior, concretamente en la habitación de la Virgen puesto que a la derecha se observa un cortinaje descorrido. Completan el mobiliario una mesa, cuya perspectiva se haya bastante mal lograda, y un jarro con cinco lirios, atributo que alude a la pureza de la Virgen María, "y más especialmente de la virginidad de María, a quien San Bernardo llama inviolable castitatis lilium" ${ }^{800}$. Ésta aparece a la derecha, elevada sobre un pequeño cojín rojo, de rodillas. Se lleva una mano al pecho, mientras que la otra la extiende hacia un lateral, realizando un gesto

\footnotetext{
798 San Lucas: 1, 26-38.

799 RÉAU, Louis: Iconografía de la Biblia. Nuevo..., op. cit., p. 183.

$800 \quad$ Ídem, p. 192.
} 
como de sorpresa ante la llegada del ángel. Efectivamente, San Gabriel la ha sorprendido leyendo un libro abierto que se sustenta sobre la referida mesa. Réau especifica que la lectura que está realizando María es la Biblia, aunque según los Padres de la Iglesia podría tratarse de las predicciones de Isaías ${ }^{801}$. El ángel se sitúa en la parte superior izquierda. Como de costumbre, llega por la parte izquierda, aunque "con frecuencia se lo traslada hacia la derecha, especialmente a partir del Cinquecento" 802. Alas semidesplegadas. Monta sobre una pequeña nube, en la que realiza una ligera genuflexión. El hecho de situarlo sobre una nube, o volando, fue una reacción del Concilio de Trento para detener la "excesiva "familiaridad" del arte religioso del siglo $X V$, al cual la Contrarreforma se esforzó en devolver prestigio imprimiéndole mayor majestad"803. Gabriel empuña en su mano izquierda, de una manera bastante elegante, el bastón de mensajero, que, según Réau, viene a ser una transposición de la del dios Mercurio "mensajero de Júpiter, a quien el ángel Anunciador toma su vara de heraldo antiguo, bastón de mando confiado por el emperador celestial a su embajador extraordinario y plenipotenciario" ${ }^{804}$. El otro brazo lo levanta, señalando al cielo, o más bien a la paloma del Espíritu Santo. Este "gesto oratorio", según Réau, está tomado directamente de "las estatuas de los filósofos de la antigüedad, extiende la mano derecha hacia la Virgen, elevando el índice para subrayar sus palabras" ${ }^{\$ 05}$. En la parte superior de la escena figura la Paloma del Espíritu Santo, cuya silueta se recorta sobre unas nubes realizadas a partir de unas espirales. Está lograda muy bien la sensación de vuelo rápido, aprestándose a llegar a la Virgen. De él sale un haz luminoso que se proyecta sobre la cabeza de la Virgen. Remarca Réau que la paloma del Espíritu Santo tan solo tiene cabida en las Anunciaciones en las cuales interesa poner "el acento se pone en el misterio de la Encarnación" $"$. Completa la escena la pintura del fondo, puesto que no hemos de olvidar que este relieve es muy similar a los que hemos visto en San Felipe Neri o en San Quirce. Es decir, se trata de figuras de bulto completas pegadas sobre el tablero, cuyo fondo se encuentra pintado para dar mayor sensación de realismo y de perspectiva a la escena. Bien es cierto que en este caso sí que hay algunos elementos tallados en medio o altorrelieve: la nube, el Espíritu Santo, las cortinas, el jarrón con los lirios, la mesa y el libro. La pintura del fondo representa un escenario un tanto etéreo: un paisaje nuboso con tonos dorados y pequeñas cabecitas aladas de ángeles. El estilo de estas cabezas recuerda poderosamente a las de los relieves previamente citados.

La Virgen viste una túnica rojiza con motivos vegetales, ceñida en la cintura por un cíngulo rematado por un amplio lazo que hemos visto en otras ocasiones. Por encima, abrochada a la altura del cuello, porta una túnica azul con esgrafiados dorados y un ribete orlado por una cenefa vegetal similar a la ya vista tantas veces. Por su parte, el arcángel viste un atuendo muy similar a los que hemos visto en los Ángeles de la

$\begin{array}{ll}801 & \text { Ídem, p. } 188 . \\ 802 & \text { Ídem, p. } 190 . \\ 803 & \text { Ibídem. } \\ 804 & \text { Ídem, p. } 191 . \\ 805 & \text { Ibídem. } \\ 806 & \text { Ídem, p. } 193 .\end{array}$


Guarda de las iglesias vallisoletanas de Santiago y San Martín; del paso de la Oración del Huerto, de Tordesillas; etc...: se trata de dos túnicas; una larga, blanca y floreada, y una sobretúnica roja con una orla que recorre los bordes. Le cruza el pecho una banda azulada.

Los rostros y cabellos de ambas no son solo similares, sino que son plenamente coincidentes con los de San Miguel y San Rafael del retablo mayor de la misma iglesia, lo que nos colocaría en la línea de pensamiento de que este relieve también pertenecería a aquel conjunto. La Virgen concuerda con la Inmaculada anterior, aunque aquí predominan las líneas blandas. El arcángel San Gabriel es similar a los ángeles del retablo mayor de Santiago, y la manera de hacer las nubes, en líneas espirales es muy típica de Juan de Ávila ${ }^{807 .}$

807 MARTÍN GONZÁLEZ, Juan José: Escultura barroca castellana ..., op. cit., 324. 


\section{BERCERO. IGLESIA PARROQUIAL DE LA ASUNCIÓN}

\section{VIRGEN DEL CARMEN (h. 1700)}

La presente Virgen del Carmen (Fig. 137) preside un curioso retablo situado en la capilla mayor de la iglesia, al lado de la Epístola, entre el retablo mayor y el acceso a la sacristía. Este retablo ha sido fechado primeramente en el último cuarto del siglo XVII, por Martín González ${ }^{808}$, y, años después, hacia el 1700, por Ara Gil y Parrado del $\mathrm{Olmo}^{809}$. El único límite cronológico que poseemos es el año 1712, año en que el retablo es citado en una Visita y ésta nos informa de que era servido por la Cofradía homónima ${ }^{810}$.

El retablo está distribuido en banco, un cuerpo con una calle y el ático. El banco es muy estrecho. En su centro alberga el sagrario, cuya puerta está decorada con una pintura en la que se representa al Agnus Dei sujetando una bandera roja, a la manera de los Cristos Resucitados; mientras que en las orillas hay dos ménsulas, una a cada lado, que sirven

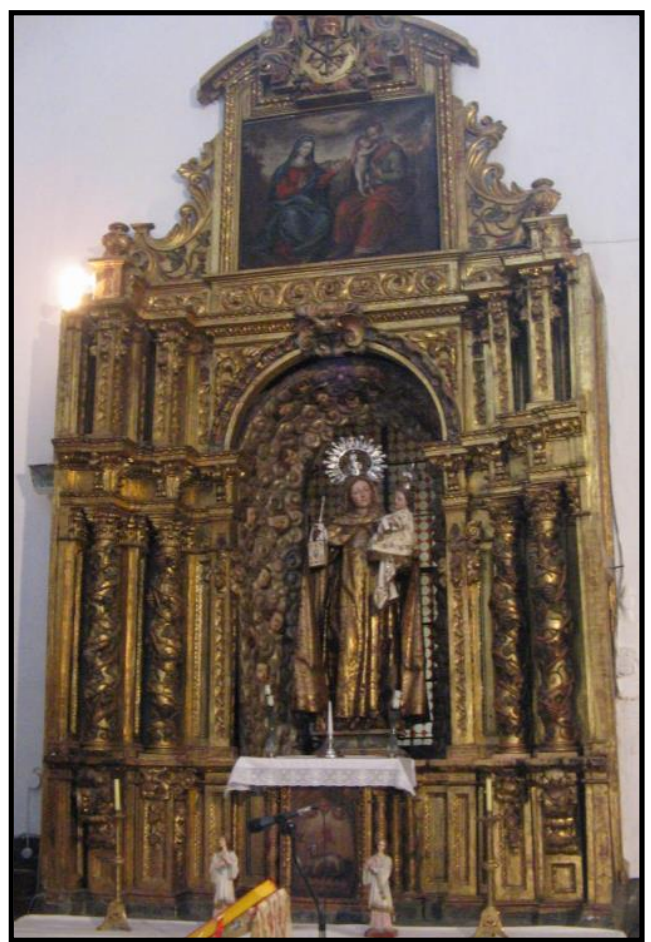

Il. 46- Anónimo. Retablo de la Virgen del Carmen. Iglesia parroquial de la Asunción. Bercero (Valladolid). para sujetar las dos columnas extremas del cuerpo. El cuerpo está presidido por una gran hornacina central, a cuyos lados hay dos espacios superpuestos, el inferior, articulado a través de dos columnas salomónicas a cada lado, las extremas algo más adelantadas, creando una sensación de movimiento en el retablo; mientras que el superior lo está por dos pequeños machones, también con los extremos más adelantados. El entablamento que divide ambos ámbitos está requebrado, partiéndose por la parte central para dar cabida a la hornacina central. Ésta tiene el remate semicircular, y el intradós del mismo está completamente forrado por una estructura adosada decorada con nubes y cabecitas de ángeles. En el interior del mismo la Virgen del Carmen. Finalmente, el ático está presidido por un gran cuadro que representa el Descanso en la Huida a Egipto, cuyo marco se prolonga por la parte superior, dando cabida al escudo de posible patrono que costeo el retablo, y quizás la Virgen del Carmen. El cuadro está flanqueado por sendos aletones que adquieren forma vegetal. El referido escudo posee una forma típicamente española y portuguesa: se trata de una forma rectangular con el borde inferior redondeado. El escudo está coronado. En el interior se desarrolla la cruz blanquinegra de los Dominicos delante de la cual se le cruzan en aspa

\footnotetext{
808 MARTÍN GONZÁLEZ, Juan José (dir.): Inventario artístico de Valladolid..., op. cit., p. 87.

809 ARA GIL, Clementina Julia y PARRADO DEL OLMO, Jesús María: Catálogo Monumental de la provincia de Valladolid. Tomo XI..., op. cit., p. 18.

$810 \quad$ Ibídem.
} 
una espada y una palma, o rama de olivo. Encima de esta cruz aparece la tiara papal roja con sus tres coronas superpuestas, y a cada lado una de las dos llaves de San Pedro. No cabe duda de que este escudo nos indica que el patrono del retablo, y quizás de la Virgen del Carmen, fue un personaje relacionado con los Dominicos, quizás un fraile de esta Orden, y a su vez con la Inquisición, dado que la espada y la rama de olivo flanqueando una cruz son los atributos de esta institución; la espada simboliza el trato a los herejes, mientras que la rama de olivo es la reconciliación con los arrepentidos ${ }^{811}$.

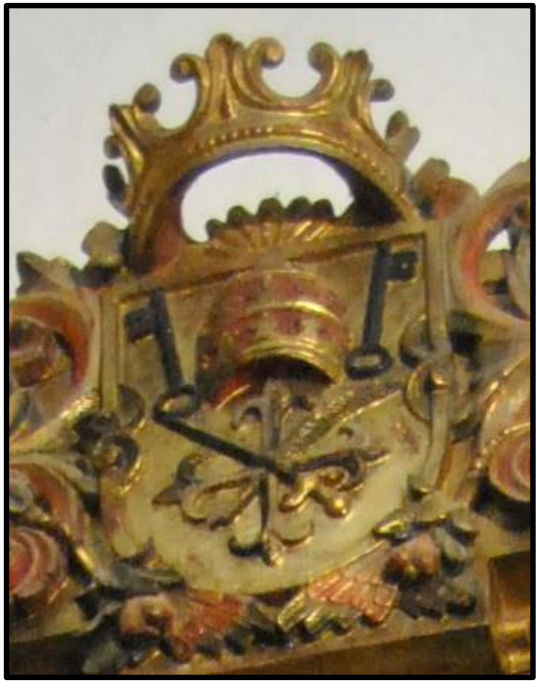

Il. 47- Detalle del escudo del Retablo de la Virgen del Carmen.

La Virgen del Carmen (135 cms.), al igual que otras esculturas sobre las que ya hemos hablado, sigue fielmente un modelo/prototipo creado por Gregorio Fernández en 1627. Concretamente se trata de la que el gallego talló para el retablo colateral del Evangelio del Convento del Carmen Calzado. Desconocemos su apariencia, tan solo conocida por la gran cantidad de réplicas que de ella se hicieron, incluso en su taller, y por sus discípulos más directos; y por dos grabados. El primero de estos grabados fue el referido por Martín González al hablar de esta escultura fernandesca. Decía que "el grabado muestra a la Virgen del Carmen dentro de un retablo con columnas jónicas. La imagen se alza sobre peana, en la que se ve una media luna y cabezas de ángeles. El grabado está firmado: “Tomás Solares la dibujó y grabó en Valladolid, año de 1813. Hujano la retocó, año de 1829”. La identificación se efectúa gracias al letrero: "Nuestra Señora del Carmen, como se venera en el colateral de Carmelitas Calzados de la Ciudad de Valladolid. Hay concedidas 160 días de indulgencias a todas las personas que rezaren u Ave María delante este imagen"812. Existe otro grabado, custodiado entre los fondos de la Biblioteca Nacional de Madrid, en el que la apariencia de la Virgen es totalmente exacta a la referida por Martín González, a excepción de las columnas jónicas del retablo, que se ven sustituidas por sendas cortinas recogidas, encima de las cuales se sitúa un escudo. En el de la derecha aparece un corazón y la leyenda "O morir o padecer. Santa Teresa"; mientras que en el de la izquierda figura una cruz rodeada de otra leyenda: "Padecer y ser menospreciado por ti. San Juan de la +". Un tercer escudo, más pequeño, el de la Orden del Carmen, se sitúa sobre la Virgen. Finalmente, debajo de la Virgen se sitúa la siguiente leyenda: "V $V^{o} \mathrm{RET}^{\mathrm{o}}$ de la milagrosa imagen de M., SS . del Carmen, venerase en el convento de Carmelitas descalzos de la ciudad de Valladolid dedicase al $S^{r} D^{n}$ Fran $^{\text {co }}$ Haro recibido y caballero del Orden de $S^{n}$ Juan. EL YLL ${ }^{m o} S^{r} D^{n}$ Julián Domínguez Toledo obispo de Valladolid, concede 40 días de indulg ${ }^{\mathrm{a}}$ a todas las pers ${ }^{\text {as }} \mathrm{q}$ rezr $^{\mathrm{n}}$ una salve $\mathrm{dl}^{\text {te }}$ desta $\mathrm{s}^{\text {ta }}$ imagen" ${ }^{\text {"813 }}$. Como vemos este grabado es casi un siglo más antiguo, dado que Domínguez de Toledo fue obispo de Valladolid entre 1728-1743, lo

\footnotetext{
811 http://es.wikipedia.org/wiki/Inquisici\%C3\%B3n_espa\%C3\%B1ola

812 MARTÍN GONZÁLEZ, Juan José: El escultor Gregorio ..., op. cit., p. 236.

813 http://bdh.bne.es/bnesearch/detalle/bdh0000184065
}

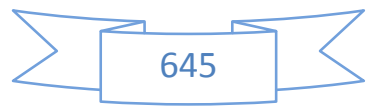


que nos confirma que desde muy pronto esta Virgen gozó de gran popularidad y devoción, y no solo entre los vallisoletanos.

La escultura original de Fernández desapareció, tal como nos relata Martín González: "Agapito y Revilla da cuenta del ingreso de la Virgen del Carmen en el Museo de Escultura y refiere las circunstancias de la entrega a persona particular. En efecto, don Manuel Safont, vecino de Madrid, solicitó en 1864 que le fuera cedida la imagen, a lo cual la Comisión Provincial de Monumentos contestó negativamente el 27 de noviembre de 1864. El demandante buscó apoyo en las altas esferas, y por una real orden de 5 de febrero de 1868 le fue entregada la Virgen del Carmen. Agapito y Revilla refiere la ventura de esta escultura. Logró averiguarse que iba destinada a la capilla que el citado señor tenía en una dehesa de la localidad de Piedrabuena (Ciudad Real). Pero el destinatario entró en dificultades económicas, no terminó la capilla y parece que la escultura durante algún tiempo siguió embalada; más adelante dícese que se pretendió venderla. La pista se pierde. Es creíble, no obstante, que exista, dado que era obra de muy reconocido valor" $"$.

El escultor que talló la imagen de Bercero bien pudo conocer, además de la original, la que preside el retablo mayor del Santuario de Nuestra Señora del Carmen Extramuros, antiguo Convento de Nuestra Señora del Consuelo, de carmelitas descalzos. No es de Fernández, aunque tampoco estará muy lejos de su taller. Visto todo esto las dos únicas diferencias existentes entre la Virgen del Carmen original y esta copia de Bercero son la peana de nubes y ángeles, inexistente en esta última, y el Niño Jesús, que en el grupo original aparece desnudo, y en este de Bercero se le han incorporado vestimentas, si bien también estará tallado desnudo.

La Virgen del Carmen es representada de pie, con una pierna levemente adelantada. Como vemos este último detalle figura en casi todas las esculturas documentadas o atribuidas a Ávila. En su mano derecha coge al Niño Jesús, el cual, asimismo, sujeta entre sus manos la bola del mundo. Aparece ataviado con unas ropas postizas, elemento accesorio dado que estará tallado desnudo. En su mano izquierda porta un escapulario que posee una imagen de la propia Virgen. La escultura carece de movimiento, es bastante rígida. Viste el típico hábito carmelita con túnica y escapulario marrón, este último ornado con el escudo de la Orden del Carmelo. Por encima una túnica blanca con múltiples decoraciones a punta de pincel y una magnifica cenefa con motivos vegetales. La cabeza está tocada por una cogulla blanca dispuesta de una manera muy elegante, deslizándose sobre su hombro derecho. Los pliegues son muy suaves, las quebraduras quedan relegadas a la parte baja de la túnica. Es admirable la manera en que consigue los pliegues de los extremos de la capa, en forma triangular, al igual que Fernández hacía en sus Inmaculadas. También, al igual que en éstas, el manto por su parte trasera forma un nudo de pliegues como consecuencia de su sujeción por un alfiler.

El rostro de la Virgen concuerda perfectamente con otros tallados por nuestro escultor. Así, por ejemplo, el parecido con el de la Virgen de la Sagrada Familia del Colegio de

814 MARTÍN GONZÁLEZ, Juan José: El escultor Gregorio..., op. cit., p. 235. 
los Ingleses de Valladolid es total. También similar, aunque algo diferente, es el de Santa María de la Cabeza, ubicada en el retablo mayor de la vallisoletana ermita de San Isidro. Los ojos se encuentran rehundidos y levemente abiertos. Nariz amplia que se ensancha según se llega hacia las fosas. Boca pequeña y entreabierta, mentón potente. El pelo, apenas visible por la cogulla, se distribuye simétricamente a ambos lados de la cara. Por la parte trasera caen unos pocos mechones sinuosos, de talla muy liviana. Por su parte el Niño Jesús, con su cabellera con grandes bucles es del todo similar a la exhibida por el Niño Jesús del referido grupo de la Sagrada Familia del Colegio de los Ingleses. 


\section{TORRECILLA DE LA ABADESA. IGLESIA} PARROQUIAL DE SAN ESTEBAN PROTOMÁRTIR

\section{RETABLO MAYOR (h. 1700)}

El retablo mayor de la iglesia fue realizado entre 1698 y 1704 por un ensamblador del que ignoramos su nombre. Parrado piensa que pudiera tratarse de Gregorio Díez de la Mata, el cual años después contrata, junto con su hijo José, la fabricación de los retablos laterales de la iglesia ${ }^{815}$. Las referidas fechas son los hitos cronológicos entre los cuales se realizó el retablo puesto que en 1698 es cuando lo manda realizar el obispo, y en 1704 cuando en una Visita a la parroquia se afirma que ya estaba concluido ${ }^{816}$.

También desconocemos al autor que dotó de esculturas a esta bella máquina salomónica. Si bien Martín González no se inclinó por apuntar el nombre de una personalidad concreta, concluyendo que éstas se debían al "último cuarto siglo XVII, de taller vallisoletano" ${ }^{\text {"17; }}$; Ara Gil y Parrado del Olmo, durante la redacción del respectivo tomo del Catálogo Monumental de Valladolid, creyeron que los más procedente sería atribuírselas a Juan de Ávila ya que por entonces trabajaba en la localidad realizando una imagen de Nuestra Señora de Gracia ${ }^{818}$; de esta misma manera seguían pensando en la segunda edición del catálogo: "Ya se insinuó en la primera edición del Catálogo la probable participación de Juan de Ávila en la escultura" ${ }^{\text {"819; }}$; una vez más se ratificó en esa opinión Parrado del Olmo en una nueva publicación: “cuyas esculturas ya hemos

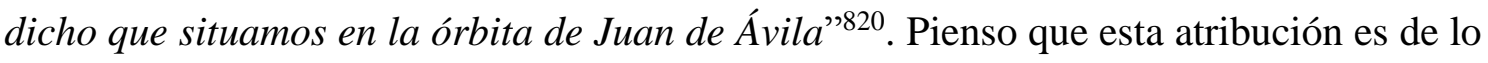
más acertada puesto que el estilo que denotan las esculturas se encuentra muy cercano al de nuestro escultor. Cabe señalar que años después la relación de los Ávila con esta iglesia continuaría puesto que Pedro de Ávila le tallaría un bello Crucifijo.

La iglesia debió pasar por unos momentos económicos bastante difíciles puesto que hasta el año 1712 no se realizan las posturas, remates y el contrato para el dorado y estofado del retablo. Efectivamente, el 9 de marzo de ese año Manuel Barreda Lombera, fiado por su padre Antonio Barreda y por Cristóbal Martínez de Estrada, se concierta con el licenciado don Francisco Reinaltos, vicario de la parroquia, el licenciado Santiago Crespo, cura de la misma, y Juan Crespo Ramos mayordomo de fábrica, para dorar el retablo mayor de la parroquia. Previamente se había pregonado "y en dos de este presente mes de marzo dicho Manuel Barreda Lombera hizo postura y condiciones en dicha obra en precio de diez y ocho mil reales que se habian de pagar en cierta forma y se admitió y pregonó y estando asignado el remate para el día de la fecha el dicho Manuel Barreda hizo mejora en razón de la paga de dicha cantidad para mayor

\footnotetext{
815 PARRADO DEL OLMO, Jesús María: Datos histórico artísticos ..., op. cit., p. 107.

816 ARA GIL, Clementina Julia y PARRADO DEL OLMO, Jesús María: Catálogo Monumental de la provincia de Valladolid. Tomo XI..., op. cit., p. 323.

817 MARTÍN GONZÁLEZ, Juan José (dir.): Inventario artístico de Valladolid..., op. cit., p. 290.

818 ARA GIL, Clementina Julia y PARRADO DEL OLMO, Jesús María: op. cit., p. 323.

819 Ídem, p. 526.

$820 \quad$ PARRADO DEL OLMO, Jesús María: Datos histórico artísticos..., op. cit., p. 107.
} 
seguridad de la obra y estándose pregonando para el remate que hicieron diferentes bajas y se remató dicha obra en el dicho Manuel Barreda Lombera en precio de diez y seis mil reales de vellón como parece del dicho pedimento condición postura pregón y demás diligencias y remate" (DOCUMENTO 54). Las referidas bajas fueron realizadas por Cristóbal Martínez de Estrada, que dejó la obra en 17.000 reales, y Joseph de Prado (se tratará del vallisoletano Joseph Díez de Prado), que la bajó hasta los 16.700 reales.

Gracias a estas condiciones para el dorado del retablo y estofado de las imágenes sabemos que éste poseía las siguientes imágenes: "Que las hechuras que tiene dicha obra de la historia de San Esteban, San Pedro, San Pablo, los dos ángeles, la Fe, San Juan y María y San Antonio de Padua y Santa Águeda y serafines". Todas ellas debian de dorarse "de oro limpio y las ropas y después se han de matizar de colores muy finos echando a cada hechura el color que corresponde y se han de echar orillas de oro de diferentes colores con sus niños y pájaros y adornos diferentes ejecutando en cada santo diferente orilla que no se parezca una a otra y para más lucimiento de dichas hechuras". A la vista de este párrafo podemos colegir que el San Antonio de Padua y Santa Águeda se reaprovecharon, puesto que son efigies de hacia el año 1600; y que de las esculturas que se realizaron al tiempo del retablo han desaparecido los dos ángeles, la Fe y los serafines. Quizás estos ángeles se situarían en el ático, uno a cada lado del calvario, sobre las columnas extremas, algo muy común en los retablos de la época; la figura de la fe remataría la custodia. Para apoyar esta tesis me baso en una fotografía antigua en la cual se puede observar que en el lado izquierdo del ático aparece una escultura que parece ser un ángel ${ }^{821}$; quizás fuera éste uno de ellos, en cambio, al otro lado aparece una escultura de San Sebastián, de época renacentista, que nada tiene que ver con este retablo, y que actualmente se encuentra en uno de los retablos laterales. Además de todo esto, también reaprovechada debía ser una escultura de San Esteban que se encontraba dentro de la custodia, la cual en el momento del dorado del retablo debía de ser renovada "la encarnación y el alba echándola su encaje de la parte de abajo, y la dalmática se ha de barnizar con espíritu de agua ardiente que es lo que necesita".

El retablo se articula a través de un amplio banco, un cuerpo tetrástilo con tres calles y un ático que se cierra de forma semicircular, adaptándose perfectamente a la bóveda de la capilla mayor. El centro del banco lo ocupan los restos del sagrario, que se encuentra muy modificado; a los lados de éste dos netos con paneles decorativos de hojarasca. Separando todos estos elementos se encuentran las ménsulas, profusamente decoradas, que sirven de apoyo a las cuatro grandes columnas que articulan el cuerpo principal, sobre las cuales, a su vez, se sustentan trozos de entablamento. El cuerpo se divide en tres calles: las laterales se encuentran presididas por dos hornacinas planas en las que asientan San Pedro y San Pablo; y la central, que da cabida a un gran relieve de la Lapidación de San Esteban, patrón de la iglesia. El relieve va enmarcado por dos estípites. El ático, que adopta un cerramiento semicircular es muy parecido a los vistos

821 ARA GIL, Clementina Julia y PARRADO DEL OLMO, Jesús María: op. cit., Lámina CLXXVII. 
en muchos retablos vallisoletanos de la época: la hornacina central va ocupada por un Calvario flanqueado por dos columnas salomónicas, algo más pequeñas que las del cuerpo, y a los lados dos paneles con amplios roleos. Asimismo, en la parte inferior y en la superior de esta hornacina figuran sendas tarjetas vegetales muy jugosas.

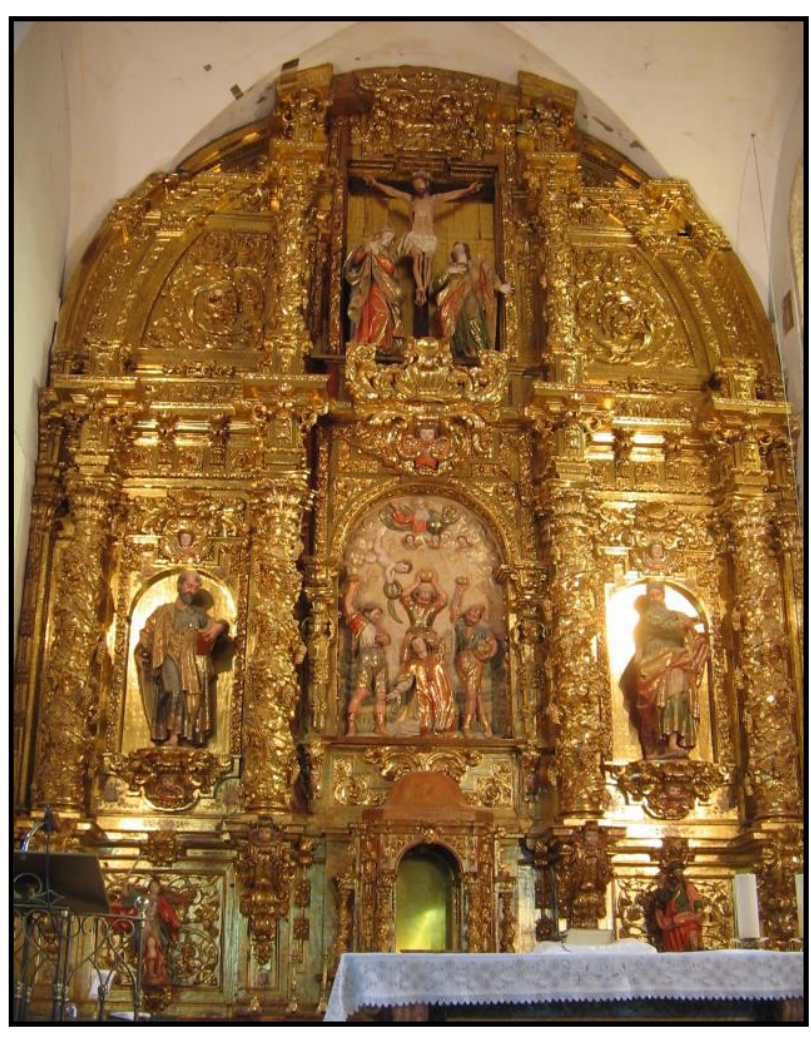

Il. 48- Gregorio Díaz de Mata (atrib.). Retablo mayor. Iglesia parroquial de San Esteban. Torrecilla de la Abadesa (Valladolid):
La reciente restauración del retablo, unida a la excelente conservación del mismo y de sus esculturas, nos permite conceptuarlo como uno de los mejores retablos de este momento. El fulgor del oro y de las policromías no hace sino aumentar el valor de esta pieza. Una lástima las pérdidas sufridas tanto en lo escultórico como en lo referente a la custodia.

Según bien señalan Ara Gil y Parrado del Olmo en estas esculturas "aún persiste la tradición de los modelos de Gregorio Fernández" ${ }^{222}$. Esta misma tradición la podemos percibir también en el Calvario y en el relieve de la Lapidación de San Esteban. También debían de seguirla los ángeles, aunque tan solo sabemos de ellos lo que se explaya el documento del dorado: "Que los ángeles han de llevar sus

telas de oro y colores en las jaquetillas y en las tunicelas hechas sus primaveras de flores de colores y oro con el color que a cada una corresponde". También gracias a este valioso testimonio conocemos que en el Crucifijo se habrían de "poner las llagas donde corresponde para más devoción", y ojos en de cristal en las esculturas de San Pedro, San Pablo, San Antonio y Santa Águeda, "y los pelos de todas las hechuras se han de meter de color que a cada una toca y se han de peletear de oro molido, y las cabezas de San Pedro y San Pablo de plata molida como corresponde por su ancianidad".

\section{LAPIDACIÓN DE SAN ESTEBAN}

Refiere Réau que San Esteban fue "uno de los siete diáconos ordenados por los apóstoles para que coadyuvaran en el apostolado mediante el ejercicio de determinadas funciones auxiliares" ${ }^{\$ 23}$. Efectivamente, así figura en el libro de los

\footnotetext{
$822 \quad$ Ídem, p. 323.

823 VORÁGINE, Santiago de la: op. cit., Tomo I, p. 60.
}

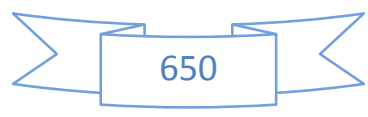


Hechos de los Apóstoles: "Por aquellos días, habiendo crecido el número de los discípulos, surgió una murmuración de los helénicos contra los hebreos, porque las viudas de aquéllos eran mal atendidas en el servicio cotidiano. Los Doce, convocando al pleno de los discípulos, dijeron: No es razonable que nosotros abandonemos el ministerio de la palabra de Dios para servir a las mesas. Echad el ojo, hermanos, de entre vosotros, a siete varones que gocen de reputación, llenos de espíritu y de sabiduría, a los que encarguemos este menester, pues nosotros debemos atender a la oración y al ministerio de la palabra. Fue bien recibida la propuesta por toda la muchedumbre, y eligieron a Esteban, varón lleno de fe y del Espíritu Santo, y a Felipe, a Prócoro, a Niconor, a Timón, a Pármenas y Nicolás, prosélito antioqueno: los cuales fueron presentados a los apóstoles, quienes, orando, les impusieron las manos. La palabra de Dios fructificaba, y se multiplicaba gradualmente el número de los discípulos en Jerusalén, y numerosa muchedumbre de sacerdotes se sometía a la fe" (Hechos de los Apóstoles: 6, 1-7). Añade a todo ello Santiago de la Vorágine que, entre los siete, fue "el primero, en un doble sentido: en cuanto que su persona fue la primera de las designadas por los electores, y en cuanto que a él encomendaron los apóstoles la presidencia o gobierno inmediato del grupo de los diáconos" $\$ 24$.

El relieve se basa en la narración de la lapidación de San Esteban (Fig. 138). Al parecer, San Esteban era conocido por los "muchos milagros y prodigios en beneficio del pueblo. Pero los judios, movidos por sentimientos de malevolencia hacia él, obsesionados por la idea de anular su labor y hasta de eliminarlo físicamente, decidieron atacarlo de estas tres maneras: por medio de debates públicos, calumniándole y sometiéndole a diversos suplicios" ${ }^{\text {"25 }}$. El momento exacto del martirio lo describe el libro de los Hechos de los Apóstoles: "Él, lleno del Espíritu Santo, miró al cielo y vio la gloria de Dios y Jesús en pie a la diestra de Dios, y dijo: Estoy viendo los cielos abiertos y al Hijo del hombre en pie, a la diestra de Dios. Ellos, gritando a grandes voces, tapándose los oídos y se arrojaron sobre él. Sacándole fuera de la ciudad, le apedreaban. Los testigos depositaron sus mantos a los pies de un joven llamado Saulo; y mientras le apedreaban, Esteban oraba, diciendo: Señor Jesús, recibe mi espíritu. Puesto de rodillas, gritó con fuerte voz: Señor, no les imputes este pecado. $Y$ diciendo esto, se durmió. Saulo aprobaba su muerte" (Hechos de los Apóstoles: 7, 55$60)$.

El escultor ha concebido el relieve como un gran panel rectangular terminado en su parte superior en forma de arco de medio punto, adaptándose a la perfección a la hornacina para la que ha sido tallado. Este relieve no es como los que hemos visto unas cuentas veces en los cuales se trata de figuras de bulto redondo pegadas sobre el panel del fondo, y en el que la pintura goza de un papel primordial. No, en esta ocasión hay figuras de bulto redondo, sí, pero también observamos que algunas partes de los asesinos del santo, e incluso, toda la parte superior del relieve, son eso: relieve, ya sea medio o bajorrelieve. A decir verdad, en este relieve la perspectiva y la proporción si

$\begin{array}{ll}824 & \text { Ídem, p. } 61 . \\ 825 & \text { Ibídem. }\end{array}$ 
están bien conseguidas, salvo algún pequeño error en la forma de conseguir los abdómenes de los sayones.

Dentro de la escena observamos dos acciones claramente diferenciadas, unidas ambas por un ángel que baja del cielo para entregar a San Esteban la corona y la palma del martirio: en la parte inferior acontece la lapidación del santo a cargo de tres verdugos, mientras que en la superior le espera el Dios Padre rodeado de nubes y cabezas aladas de ángeles. Comencemos por la escena importante: San Esteban se encuentra arrodillado, indefenso ante los tres verdugos que van a comenzar a lanzarle las piedras; el hecho de que justo sea el momento en que se va a iniciar la lapidación es una característica muy barroca puesto que se trata de captar un instante, un momento. San Esteban abre los brazos, subiendo el izquierdo y bajando el derecho, como intentando parar alguno de los proyectiles, o quizás no es más que una pose teatral del escultor; sea como fuere, los brazos forman una diagonal muy barroca. Dirige su mirada hacia el cielo, concretamente hacia el ángel que le desciende la corona y la palma que en unos momentos le acreditarán como mártir, mejor dicho, como el protomártir, primer fallecido a causa de un martirio por seguir a Jesús. Su rostro, y concretamente sus ojos, capta a la perfección la agonía y sufrimiento que está padeciendo al ver lo que le espera. El santo aparece efigiado como un joven imberbe, vistiendo la típica casulla de diácono. La casulla está ricamente policromada de rojo, con labores y cenefas doradas; y, en su parte inferior, un recuadro con un amplio dibujo vegetal.

Rodean al santo tres sayones, uno a cada lado y otro por su parte trasera. Todos ellos se disponen a lanzarle una piedra; los de los lados con una mano, mientras que con la otra sujetan otras piedras; por su parte, el de atrás, agarra una gran piedra con las dos manos para así golpear al santo con más fuerza y saña. Visten ropas burdas, a juego con su baja condición; y su aspecto es claramente desaliñado, como podemos observar en los sayones laterales: el de la izquierda tiene la chaquetilla desabrochada y el de la derecha nos muestra parte de su pecho; asimismo, ambos tienen las calzas caídas. Contrastan estos dos sayones entre sí por cuanto mientras el de la izquierda se asienta fuertemente con las dos piernas firmes el de la derecha pasa su pierna derecha por detrás de la izquierda, creando una posición bastante inestable, como si fuera un paso de baile. También confrontan bastante los rostros de estos verdugos, bastante feos y anodinos, con el del santo, que es particularmente sentimental y bello. Las anatomías son algo más robustas de lo que nos tiene acostumbrado Ávila, si bien podemos ver claramente su mano en la imagen del santo, especialmente en el rostro del mismo: sus ojos, su boca y su nariz delatan su estilo; aunque la manera de taller el pelo es novedosa puesto que no se estructura a través de su estilo de "peluca" sino que coloca un gran mechón sobre la frente y dos conjuntos de rizos a los lados del rostro.

En la parte superior, entre nubes y cabezas aladas de ángeles aparece Dios Padre, con la bola del mundo en su mano izquierda, mientras que con la derecha realiza un gesto de bendición dedicado al santo. Como dijimos, el nexo de unión entre ambos "mundos" lo efectúa un ángel que baja del cielo portando la corona y la palma del martirio (dos de sus atributos más comunes) que entregará a San Esteban. Respecto a su policromía, 
refería el contrato de policromado y dorado: "Que dicha historia de San Esteban se ha de dorar de oro limpio de hechuras y campo dando sus matices de colores como pide cada hechura con sus telas orillas y grutescos sacándolo de grafio como también se han de sacar todas las demás hechuras de la obra, y se han de sacar echando sus cabezas de serafines en la gloria de dicha historia y las encarnaciones a cada hechura como le toca" (DOCUMENTO 54).

\section{$\underline{\text { SAN PEDRO Y SAN PABLO }}$}

Como ya dijimos, y señalaron, Ara Gil y Parrado del Olmo en estas esculturas "aún persiste la tradición de los modelos de Gregorio Fernández" "26. Efectivamente, es en estas dos esculturas (Figs. 139-140) en donde mejor se perciben el estilo y, sobre todo, los modelos del genial maestro gallego. Efectivamente, a este hecho ya nos referimos cuando hablamos del San Pablo que Ávila había tallado para la Colegiata de Lerma; si bien en esta ocasión la copia es mucho más evidente puesto que en aquélla nuestro escultor había introducido ciertas novedades de su cosecha. En esta ocasión no, pues tanto el San Pedro como el San Pablo copian literalmente los modelos que creó Fernández y que utilizó en diversas ocasiones. Las versiones primigenias de ambos santos deben ser las que el gallego talló para el desaparecido retablo mayor de la primitiva iglesia de San Miguel (1606); actualmente conservadas en la iglesia de San Miguel y San Julián. Como ya dijimos, estas dos imágenes fueron ampliamente copiadas por los escultores, especialmente los vallisoletanos de todo el siglo XVII, y parte del XVIII (por ejemplo, Pedro de Ávila): podemos comprobarlo en los Santos Pedros y Pablos que figuran en los retablos mayores de Casasola de Arión, Cigales, Marzales, Velilla, Villalba de los Alcores, Villanueva de Duero o el de la parroquia de Santa María de Pozaldez. Algunas de ellas fueron realizadas por artistas tan dispares como Andrés de Oliveros, Pedro de la Cuadra, Antonio Vázquez (1691-1693) o Andrés de Pereda (1696), si bien la mayoría de ellos permanecen aún anónimos.

Estas dos esculturas, por lo tanto, coinciden en todo con aquellas fernandescas: composición, posición de los diferentes miembros del cuerpo, forma de disponer los pliegues, tipo y cantidad de pelo, etc... Es idéntica incluso la manera de disponer los dedos y los libros en ambas tallas. Las dos grandes diferencias residen en la pericia del escultor, mucho menor que el gran maestro, y en la dulzura de los pliegues, como no puede ser de otra manera a estas alturas del siglo; lo que en Fernández eran pliegues acartonados, en estas atribuidas a Ávila dominan los pliegues curvos, suavemente combados, y tan solo detectamos algunas durezas en el manto del San Pedro. También habría que reseñar la contraposición de actitudes: Simón Pablo avanza su pierna derecha, mientras Saulo lo hace con la contraria, la izquierda.

San Pedro figura de pie, con la pierna derecha levemente adelantada, formando un leve contraposto, remarcado aún más por el ladeamiento de la cabeza. En su mano derecha

$826 \quad$ Ídem, p. 323. 
sujeta las dos típicas llaves, tan comunes en su iconografía, mientas que en la otra porta un libro abierto; aparta una determinada página del libro metiendo el pulgar en él, detalle que procede también de Fernández. Como vemos, mientras un brazo reposa, el otro ejerce una acción. La cabeza la ladea hacia la izquierda como disponiéndose a iniciar la lectura el libro. El rostro presenta alguna de las características de Ávila, como pueden ser los ojos almendrados y rehundidos, el ceño semi-fruncido o el tipo de nariz y de barba, esta última muy relacionada con la del San Isidro Labrador. La cabeza del santo presenta una calvicie muy pronunciada; el pelo se reduce a unos mechones laterales y una pequeña isla redonda de pelo sobre la frente, debajo de la cual podemos percibir las arrugas que nos denotan su edad; a ello también ayudan las pieles blandas de sus mejillas. Viste túnica azul hasta los tobillos, y un manto por encima del hombro derecho que se recoge y sujeta gracias al libro.

Por su parte, San Pablo también es efigiado de pie, aunque con la pierna izquierda adelantada. En su mano izquierda portaba su atributo más personal: la espada, la cual ha desaparecido, conservándose tan solo su empuñadura; mientras que con la izquierda hace lo propio con un libro, en este caso cerrado, al contrario que el de San Pedro. También difiere bastante la acción que desarrolla puesto que mientras que San Pedro parece leer el libro, San Pablo no tiene intención de hacerlo, y su movimiento se centra más en la sujeción de la espada. Esta escultura está, a todas luces, compuesta con mucha mayor elegancia e intención de movimiento; la otra es más pausada y calmada. Las facciones están modeladas con gran suavidad y blandura, las arrugas con casi imperceptibles. La cabeza ladeada con amplias barbas esparcidas por el pecho.

El policromado de ambos santos es fastuoso. Cada apóstol lleva los colores con los que suele ser identificado: azul para San Pedro y verde para San Pablo. A ello se unen múltiples decoraciones vegetales, rameados, y de otro tipo tales como la tiara papal en el manto de San Pedro; éstos, al igual que las túnicas van orladas en su parte baja y en los bordes por unas preciosas cenefas. Destaca el profuso uso del dorado.

\section{$\underline{\text { CALVARIO }}$}

Al igual que el San Pedro y San Pablo, el Calvario (Fig. 141) también sigue de cerca las tipologías creadas por Gregorio Fernández; modelos que también fueron repetidos, con más o menos variaciones, hasta la extenuación por los escultores vallisoletanos de todo el siglo XVII. Podemos citar los casos de los Calvarios inscritos en los áticos de los retablos mayores del Oratorio de San Felipe Neri, iglesia de Nuestra Señora del Rosario o del Convento de Santa Brígida, etc..., todos ellos en la ciudad de Valladolid. Tampoco se nos puede olvidar el que se atribuye a Juan de Ávila en el Colegio de los Ingleses de la capital del Pisuerga. Todos ellos, como ya hemos dicho, proceden de los Calvarios que Gregorio Fernández talló para los áticos de varios retablos, teniendo en cuenta el mismo hecho de que el incluirlos en el ático es también invención suya: Nava del Rey (1612), Villaverde de Medina (1612); en Valladolid los de los conventos de las 
Descalzas Reales $(1612)^{827}$ y de las Huelgas Reales $(1613-1614)^{828}$; o los de la iglesia de San Miguel de Vitoria (1624-1625) y el de la Catedral de Plasencia (Cáceres) (16241625).

En todos ellos observamos que la disposición de las tres figuras es idéntica a las propuestas por Fernández y también a las exhibidas por nuestro Ávila. Copian hasta el más mínimo detalle: los gestos del rostro; las posturas de las cabezas, manos y piernas; y hasta los pliegues. Por todo ello no nos detendremos en su análisis más de la cuenta. Sin embargo, sí que podemos señalar un par de aspectos: llama la atención la profusión de la sangre que emana de la cabeza, manos, costado, rodillas y pies de Cristo. Los pliegues son los típicos de estas fechas, totalmente diferentes a los fernandinos; en la Virgen observamos un pliegue bastante agudo en la túnica que parece anticipar el de "cuchillo" de Pedro de Ávila. No podemos descartar que si estas esculturas fueron realizadas por Juan de Ávila le ayudara su hijo Pedro, el cual años después volverá a trabajar en esta iglesia. También podemos destacar la similitud que goza el rostro, y sobre todo la manera de disponer el cabello, con el del San Esteban del relieve principal del retablo. Sea como fuere, este Calvario no alcanza la calidad exhibida por el grupo homónimo del Colegio de los Ingleses; sin embargo, los paños están mucho más trabajados. Pienso que hay en ellas labor de taller puesto que el rostro de la Virgen es bastante anodino. 


\section{VALLADOLID. ORATORIO DE SAN FELIPE NERI}

\section{BUSTO DE ECCE HOMO}

Martín González atribuye a Juan de Ávila un busto de Ecce Homo que en la actualidad no se encuentra en ninguna de sus dependencias ${ }^{829}$. Desconozco si la talla ha desaparecido o bien ha ido a recalar a otra institución religiosa de la ciudad, como ya ocurriera con las de San Francisco de Sales, San Juan Bautista, San Joaquín con la Virgen Niña, etc... Este Ecce Homo debe ser el mismo que cita Gratiniano Nieto en el año 1954 en la capilla de la Soledad. La escultura, que flanquearía a la escultura principal del retablo, era "del siglo XVII cuyo modelado recuerda mucho el de Gregorio Fernández"; al otro lado se situaba una "Dolorosa pequeña inspirada en la de Juni", esta última se conserva en el tránsito a la sacristía ${ }^{830}$. Sea como fuere, este busto debió desaparecer entre 1959, año en que Martín González redacta su libro Escultura barroca castellana, y 1985, que es cuando se publica el tomo del Catálogo Monumental de Valladolid, en el cual se habla sobre el oratorio, puesto que en este ya no figura reseñada la escultura.

En la iglesia de Santiago Apóstol, muy relacionada como ya vemos visto con el Oratorio de San Felipe Neri, se conservaban hasta hace no mucho tres bustos de Ecce Homo. El Catálogo Monumental recoge que se encontraban en la sacristía, dos eran del siglo XVII y otro del XVIII ${ }^{831}$. Tras interesarme por ellos he descubierto que en la actualidad se guardan dos de ellos en dependencias parroquiales, sin haber noticia del tercero. De este tercero he conseguido, por fortuna, una fotografía en el Archivo Fotográfico del Departamento de Historia del Arte de la Universidad de Valladolid. Ninguno de los tres puede ser relacionado con nuestro escultor puesto que uno es de factura andaluza, otro de la segunda mitad del siglo XVIII, y el tercero, el que conocemos por fotografía, si bien es el más cercano a nuestro escultor, posee unos

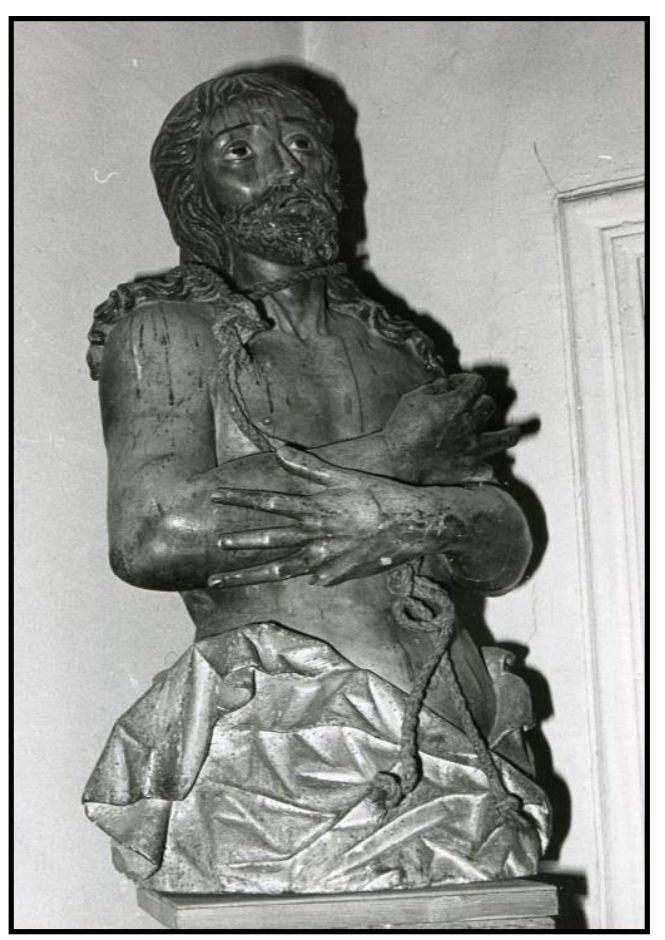

Il. 49- Anónimo. Ecce Homo. Iglesia de Santiago Apóstol. Valladolid. pliegues y una calidad muy diferente a la de

829 MARTÍN GONZÁLEZ, Juan José: Escultura barroca castellana..., op. cit., p. 322. Tanto el Rector de la Congregación como el sacerdote encargado del Oratorio me han asegurado que en la actualidad no existe ningún busto de Ecce Homo.

$830 \quad$ NIETO GALLO, Gratiniano: op. cit., p. 122.

831 MARTÍN GONZÁLEZ, Juan José y URREA FERNÁNDEZ, Jesús: Catálogo Monumental de la provincia de Valladolid. Tomo XIV..., op. cit., pp. 202-203.

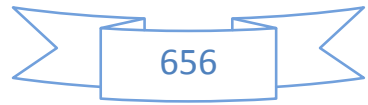


Ávila. En el caso de que uno de los tres fuera el del Oratorio de San Felipe Neri no hay dudas de que sería este último, puesto que es el más fernandesco.

Como no tenemos ninguna prueba para garantizarlo, ni tan solo sospecharlo, y no conservamos fotos del Ecce Homo del Oratorio tan solo podemos señalar que esta talla fue atribuida a nuestro escultor por Martín González, lo cual es ya bastante garantía, sin poder yo aportar nada más. 


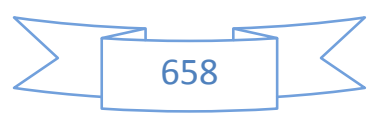




\section{5-3 OBRAS RELACIONADAS}




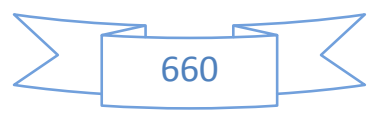




\section{VALLADOLID. CENTRO DIOCESANO DE ESPIRITUALIDAD}

SAN JOSÉ (h. 1672-1680)

En una hornacina situada en el primer piso de la caja de la escalera del Centro de Espiritualidad se encuentra un pequeño San José (59 cms.) (Fig. 142) que ha sido relacionado con Juan de Ávila en numerosas ocasiones, pero otras tantas lo han sido con José de Rozas. Este San José debe de ser el que antiguamente estaba situado en un desaparecido retablo de San Francisco Javier en el Oratorio del Colegio de San Ambrosio $^{832}$.

Los primeros en relacionar esta obra con nuestro escultor fueron Martín González y Plaza Santiago, los cuales lo creyeron "cercano a Juan de Ávila" 833 , fechándolo en el último cuarto del siglo XVII. A día de hoy, en un letrero situado a los pies del santo se le denomina como con "influencia de José de Rozas". Nuevamente volvemos a comprobar la cercanía de estilo entre los tres grandes maestros vallisoletanos de finales del siglo XVII, siendo en algunas ocasiones muy complicado discernir la autoría de las imágenes en disputa.

El pequeño tamaño de la obra sea quizás indicativo de que en origen pudo realizarse para el oratorio privado de un particular, y que después recaló en el colegio jesuítico mediante donación. La escultura sigue de cerca uno de los modelos fernandescos, cuyo mejor ejemplar es el realizado hacia 1620 para la Cofradía de San José y Nuestra Señora de Gracia y Niños Expósitos de la iglesia de San Lorenzo mártir de Valladolid ${ }^{834}$. La imagen del Centro de Espiritualidad sigue el modelo, pero no posee la delicadeza de la piel, la forma de tallar el cabello de aquél ni sus típicos paños.

El padre nutricio de Cristo está de pie sobre una rica peana de tarjetillas. Con una mano sujetaría la vara florida (actualmente desaparecida), la cual como ya se dijo alude a la victoria del santo sobre el resto de pretendientes de la Virgen, mientras que con la otra quizás diera la mano a un hipotético Niño Jesús, aunque pienso que no. Viste una amplia túnica de color verde, con motivos vegetales esgrafiados, mientras que la parte inferior de la misma se encuentra orlada por amplia cenefa similar a la vista en otras esculturas de Ávila. La túnica se anuda a la altura de la cintura con un lazo rojo. La larga túnica, que tan solo nos deja entrever los zapatos, posee una botonadura en el cuello y en las mangas, estas últimas de color rojo. Encima de la túnica porta una capa muy decorada y con igual cenefa; y un manto rojo que cae sobre su izquierdo, motivo que asimismo ha sido utilizado frecuentemente por nuestro escultor. Los suaves pliegues de la túnica, muy naturales y que traen al recuerdo los de Gregorio Fernández, contrastan con la rigidez de los de la túnica, sobre todo en su parte inferior.

\footnotetext{
832 "Retablo salomónico con pintura de San Pedro en el ático, y de la Inmaculada en el Sagrario; tiene tres esculturas: San Francisco Javier y un Santo franciscano, siglo XVIII; San José siglo XVII". MARTÍN GONZÁLEZ, Juan José (dir.): Inventario artístico de Valladolid..., op. cit., p. 35.

833 MARTÍN GONZÁLEZ, Juan José y DE LA PLAZA SANTIAGO, Francisco Javier: Catálogo Monumental de la provincia de Valladolid. Tomo XV..., op. cit., p. 310.

$834 \quad$ MARTÍN GONZÁLEZ, Juan José: El escultor Gregorio..., op. cit., p. 221.
} 
El rostro, bastante abocetado para lo que nos tiene acostumbrado Ávila, presenta una nariz amplia, cuyas aletas no concuerdan demasiado con las demostradas por nuestro escultor, si bien los mechones mojados y revueltos que caen sobre la frente si lo son. También deja bastantes dudas la técnica demostrada en la boca, que no tiene los labios separados. Todo ello, además del carácter anodino del rostro, me hacen pensar que pertenece a una etapa temprana dentro de la producción de Ávila. Más o menos entre su salida del taller de Tudanca y la ejecución del Santiago Matamoros de la sacristía de la iglesia parroquial de Santiago Apóstol, es decir hacia los años 1672-1680. Otra baza que juega a favor de una cronología temprana es que todavía no vemos los característicos pliegues largos y paralelos en la parte inferior de los ropajes; éstos son más duros y quebrados.

\section{VALLADOLID. IGLESIA DE SAN NICOLÁS DE BARI}

\section{SAN JOSÉ CON EL NIÑO (h. 1672-1685)}

La parroquia de San Nicolás de Bari fue con anterioridad la iglesia del Convento de los Trinitarios Descalzos. Durante este tiempo de iglesia conventual la escultura de San José con el Niño (Fig. 143) que presentamos en este momento estuvo ubicada en la Capilla del Niño de la Salud ${ }^{835}$. Tras la desaparición del Convento, y la conversión de la iglesia en parroquia de San Nicolás, se instaló en la capilla del Santísimo Cristo del Amparo. Tras una serie de cambios de lugar, uno de ellos motivado por un espantoso incendio, llegó al retablo que actualmente preside: un vulgar armatoste neoclásico del siglo XIX ubicado en el lado del Evangelio.

La única referencia a una posible autoría de esta imagen fue la formulada por Martín González y Urrea en el respectivo tomo del Catálogo Monumental. Ambos profesores la consideraron realizada hacia el año 1700, encontrándose "próxima al taller de Juan de Ávila" ${ }^{836}$. Esta misma atribución fue recogida por la profesora Fernández del Hoyo ${ }^{837}$. Con anterioridad, Martín González la había fechado en la "primera mitad del siglo XVII ${ }^{838}$.

El tratamiento general de la cabeza es bastante cercano a Ávila, sin embargo, pequeños detalles me mueven a creerlo de su taller o, quizás, de su círculo. Aspectos como el mayor alargamiento del rostro, la boca cerrada con labios gruesos, la estrechez de los ojos, la cabellera cayendo a ambos lados de la cabeza formando como un gran triangulo, cuando Ávila nos tiene acostumbrado a cabelleras más o menos estrechas, aunque voluminosas. Sin embargo, el tipo de pelo, de rizos, de nariz es bastante cercano a su estilo. La escultura presenta una notoria rigidez, acrecentada por los duros pliegues de la

835 FERNÁNDEZ DEL HOYO, María Antonia: Patrimonio perdido..., op. cit., p. 552.

836 MARTÍN GONZÁLEZ, Juan José y URREA FERNÁNDEZ, Jesús: Catálogo Monumental de la provincia de Valladolid. Tomo XIV..., op. cit., p. 143.

837 FERNÁNDEZ DEL HOYO, María Antonia: Patrimonio perdido..., op. cit., p. 552.

838 MARTÍN GONZÁLEZ, Juan José (dir.): Inventario artístico de Valladolid..., op. cit., p. 51. 
zona baja de la túnica. Por su parte, los pliegues de la túnica, muy horadados, aunque redondeados, también pecan de cierta dureza; no son muy verosímiles, especialmente los desarrollados bajo la mano izquierda del santo. La imagen forma una especie de triángulo, puesto que la túnica se va ensanchando progresivamente desde el cuello hasta los pies. En cuanto a su policromía, a pesar de lo meritorio de las labores a punta de pincel con motivos vegetales del manto, tampoco es muy destacable si la comparamos con la mayoría de las que recubren las esculturas relacionadas con nuestro escultor.

A pesar de todo ello, la creo una imagen de cierta calidad que tiene que deberse al círculo de Ávila o, si no, al de alguno de los mejores talleres de la ciudad de finales del siglo XVII, como el de Juan Antonio de la Peña. Respecto a su cronología, y partiendo de los duros pliegues comentados, pienso que habría que retrasarla bastante de la fecha del año 1700, puesto que en esta época dominan los suavemente incurvados; por todo ello, creo que su ejecución rondaría el séptimo decenio o mediados del siguiente del siglo XVII. Si nos atenemos a que Juan de Ávila comienza a trabajar de manera libre en el año 1672, la fecha se establecería entre 1672-1685.

\section{CABEZÓN. IGLESIA PARROQUIAL DE LA ASUNCIÓN}

$\underline{\text { SAN ROQUE (Finales del siglo XVII) }}$

En la iglesia parroquial de la localidad de Cabezón de Pisuerga, muy cercana a Valladolid capital, se encuentra una pequeña imagen de San Roque (93 cms.) (Fig. 144) que se acerca bastante a la producción de Juan de Ávila, si bien ciertos detalles nos impiden poder asignársela o atribuírsela con certeza a él mismo. Al tiempo de redactarse el Catálogo Monumental de Valladolid ésta se encontraba situada en el retablo del lado de la epístola. Urrea, autor de este tomo, la fechaba de manera genérica: "San Roque, del siglo XVII" ${ }^{839}$. Pudiera ser que la imagen del santo francés proceda del Convento de Nuestra Señora de la Victoria y que en 1965 pasó a engrosar los fondos del Museo Diocesano y Catedralicio, en cuyo catálogo, realizado por Martín González, se le citaba así: " $n$ o 65. San Roque. Muy repintada. Siglo XVII. Obra de imitador de Gregorio Fernández $\left(0,93 \mathrm{~m}\right.$.)" ${ }^{\$ 40}$. En la actualidad se localiza en la parte baja del coro, en una especie de museo parroquial perfectamente acondicionado.

San Roque se nos presenta de pie, con la pierna izquierda adelantada, en cuyo muslo presenta la típica buba. El santo se levanta la corta túnica para que se la podamos ver con mayor facilidad. Con su mano derecha sujeta el bastón de peregrino. A los pies del santo aparece el perro, sentado sobre sus patas traseras, con el pan en la boca. Todo según su iconografía tradicional.

839 URREA FERNÁNDEZ, Jesús: Catálogo Monumental de la provincia de Valladolid. Tomo XX..., op. cit., p. 18.

840 FERNÁNDEZ DEL HOYO, María Antonia: Patrimonio perdido..., op. cit., p. 323. 
Lo primero que destaca es la policromía de fondos planos pero muy fuertes: verde y dorado para la túnica; verde y negro para las botas; y rojo, negro y dorado para el manto. Desconozco si se trata de la policromía original o si bien fue repolicromada con posterioridad o, quizás, el restaurador ha ejercido su oficio con demasiado celo. Por lo general, la talla es bastante modesta, a excepción del rostro, en el cual se concentra las escasas gotas de calidad habidas en esta talla. La faz de Roque presenta una dulzura muy en línea con las obras de Juan de Ávila, a cuyo estilo también se asemeja la manera de tallar los ojos, almendrados y como rehundidos; la nariz; la amplia frente, o incluso el pelo. Donde vienen ya las diferencias, motivos por los cuales no puedo atribuírselo a Ávila, sino que parece procedente hacerlo a su círculo más inmediato, no descartando ninguna posibilidad, es en la forma de tallar la boca, levemente entreabierta y sin figurar los dientes; la barba, muy plana y rematada en dos caracolillos muy cortos; y, sobre todo en los sencillos pliegues que nada aportan a la vestimenta, son casi planos. La forma de la barba no deja de recordar bastante a las que utilizará su hijo Pedro de Ávila, véase el San José de la catedral vallisoletano u otros ejemplares San José que se le atribuyen, aunque de una manera mucho más simple.

\section{ÁVILA. CONVENTO DE SAN JOSÉ}

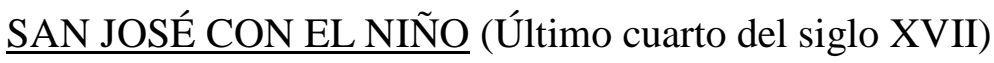

La presente escultura no he podido verla ni estudiarla, pero creo que el hecho de que una eminencia como Martín González la relacionara con nuestro escultor es suficiente. Hablando de la sala capitular del Convento de San José de la ciudad de Ávila refiere que existía una pequeña escultura de San José y el Niño $(66 \mathrm{cms}$.) "relacionable con el vallisoletano Juan de Ávila y datable del último cuarto del siglo XVII"841. Así, queda reseñada.

\section{BENAVENTE. HOSPITAL DE PEREGRINOS DE LA PIEDAD}

\section{TRÁNSITO O MUERTE DE SAN JOSÉ (Finales del siglo XVII)}

El grupo de Tránsito o Muerte de San José (Grupo: 148 x 110 x 120 cms; Cama: 148 x 56 cms.) (Fig. 145) es un tema muy extraño dentro del mundo de la escultura, y de hecho desconozco más ejemplares. Tampoco es muy usual dentro de la pintura, si bien en Valladolid contamos con el magnífico ejemplar que Francisco de Goya pintara para el Real Monasterio de San Joaquín y Santa Ana.

El grupo, que parece poseer un carácter procesional, a pesar de que no posee más que un punto de vista, fue realizado para el Hospital de San José de Convalecientes, fundación

841 MARTÍN GONZÁLEZ, Juan José: "El convento de San José de Ávila: (patronos y obras de arte)", B.S.A.A., tomo XLV, 1979, Valladolid, p. 356. 
realizada por don José de Vega y su esposa doña Jerónima Uña y Herrera en el año $1685^{842}$. Este mismo hospital, en el año 1962 se fundió con el Hospital de la Piedad, en cuya capilla mayor, sobre el retablo, se encuentra en la actualidad ${ }^{843}$. La aparición de un grupo con esta iconografía no es baladí, puesto que, según Fernando Regueras e Ignacio Blanco, "la postrera convalecencia de San José era, pues, un tema idóneo para representar al santo patrono de la casa (y de la buena muerte): refugium agonizantium. El icono funciona como un auténtico trasunto sacramental de la extremaunción: esto es, reflejo e invitación al mismo tiempo a la buena muerte de muchos de los enfermos que acabarían sus días en el hospital benaventano" 844.

El grupo se asemeja de una manera muy fiel a varios pasajes del evangelio apócrifo denominado Historia de José el Carpintero: "Y María, mi madre Inmaculada, fue a donde estaba José, y yo me senté a sus pies, mirándole. $Y$ vi que los signos de la muerte habían aparecido en su rostro. El bienaventurado anciano levantó la cabeza y me miró fijamente. No podía habla, por causa de los dolores de la muerte que le rodeaban, pero se quejaba mucho. Tuve sus manos entre las mías por espacio de una hora, y él, volviendo su rostro hacia mí, me hacía señales de que no le abandonara (...)"845. El grupo escultórico representa a San José en la cama. Su mano derecha es recogida por Jesús, situado en el lado izquierdo de la cama, mientras que la Virgen María, situado al otro lado de la cama se apresta a darle un paño.

Fernando Regueras e Ignacio Martín con motivo de la redacción de la ficha de este grupo para la exposición de las Edades del Hombre celebrada en la catedral de Zamora en el año 2001, de nombre "Remembranza", dejaron escrito que en base a los "pliegues suaves rectilíneos, ricos estofados de brocado, la propia configuración de las coronas y ciertos ecos lejanos de Gregorio Fernández en la imagen de María, recuerdan la obra

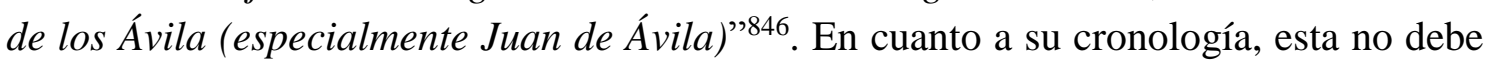
andar muy cercano al fin del siglo XVII, dado que, además, el hospital para el que fue tallado fue fundado, como ya hemos dicho, en el año 1685.

Bien es cierto que las esculturas emanan un aire a Juan de Ávila, como puede ser la concepción general de los rostros o la manera de tallar los ojos o el pelo; sin embargo, es imposible atribuírselos a su persona y si a un discípulo bastante inferior a su maestro: la forma de tallar la barba y los pliegues, muy secos, denotan la mano de un maestro poco diestro y mediocre. Los pliegues son insulsos, el canon resulta achaparrado, y la manera de tallar las barbas es muy rudimentaria. La figura más bella del conjunto es, sin duda, la Virgen María, cuyo rostro posee lejanos ecos de la Santa María de la Cabeza de la vallisoletana ermita de San Isidro. Sea como fuere, el verdadero valor del grupo reside en lo extraordinario de su temática dentro del arte de la escultura.

\footnotetext{
842 MARTÍN BENITO, Ignacio y REGUERAS GRANDE, Fernando: “9. Tránsito o Muerte de San José". En VV.AA.: Las Edades del Hombre. Remembranza, Edades del Hombre, Zamora, 2001, p. 550. 843 Ibídem.

$844 \quad$ Ídem, p. 551.

$845 \quad$ Historia de José el Carpintero. Capítulo XIX.

846 MARTÍN BENITO, Ignacio y REGUERAS GRANDE, Fernando: op. cit., p. 551.
} 


\section{GUIMARÃES. IGREJA DE SÃO DÁMASO}

\section{PASO "PREPARATIVOS PARA LA CRUCIFIXIÓN" (Siglo XVIII)}

Tan solo pretendo reseñar el eco que provocó el paso del "Redopelo", "Despojo" o "Preparativos para la Crucifixión", que como vemos trascendió fronteras. Solamente eso, puesto que la ejecución escapa tanto a Ávila como a cualquier escultor español, siendo obra de algún artífice local. Señala Martín González que, en una capillita aneja a la iglesia de San Dámaso, en Guimarães (Portugal), se guarda un conjunto escultórico, realizado en el siglo XVIII en madera policromada, que copiaba el referido paso vallisoletano: "El esbirro que perfora la cruz está copiado del que figura en el paso de los Preparativos para la Crucifixión, de Valladolid, labrado por Juan de Ávila. Es, por otra parte, grupo escultórico de escaso valor" ${ }^{847}$.

HERRERA DE PISUERGA. IGLESIA PARROQUIAL DE SANTA $\underline{\text { ANA }}$

SAN ROQUE (Finales del siglo XVII)

Al igual que me ocurre con la imagen de San José con el Niño del convento abulense de San José, tampoco he logrado conseguir fotografías del presente San Roque ni visionarle directamente, por lo que no he podido estudiarlo; pero, una vez más, las sospechas de Martín González y Urrea son un buen cimiento. Ambos escribieron en el Inventario Artístico de Palencia: "Escultura de San Roque del siglo XVII del estilo de Ávila" ${ }^{\prime 848 . ~}$

\section{ORENSE. CATEDRAL DE SAN MARTÍN}

\section{SAN JOAQUÍN, SANTA ANA Y LA VIRGEN (h. 1705)}

El presente grupo escultórico de San Joaquín, Santa Ana y la Virgen (Fig. 146) se ubica en uno de los altares colaterales de la capilla del Santo Cristo de la catedral de Orense; estos fueron ejecutados, junto con el baldaquino que preside este espacio, el 18 de marzo de 1696 por el escultor y ensamblador leonés Francisco de Castro Canseco $(1655-1724)^{849}$. Efectivamente, este grupo se localiza en el retablo colateral del

847 MARTÍN GONZÁLEZ, Juan José: La huella española ..., op. cit., p. 40.

848 URREA FERNÁNDEZ, Jesús y MARTÍN GONZÁLEZ, Juan José: Inventario artístico de Palencia y su provincia II..., op. cit., p. 95.

849 SEOANE PRIETO, José Raúl: La Catedral de Ourense. I, Patrimonio Histórico Gallego. 1, Catedrales, Xuntanza, Laracha (A Coruña), 1997, p. 334. Sobre este interesantísimo escultor y ensamblador que trabajó fundamentalmente en Galicia consultar: CARAMES GONZÁLEZ, Concepción: "El escultor y entallador Francisco de Castro Canseco (1693-1724), Boletín auriense, No 2, 1972, pp. 167-192; GARCÍA IGLESIAS, José Manuel: Francisco de Castro Canseco (Ca. 1655-1714), en la actividad artística de Galicia, Laboratorio de Arte, No 5, Fascículo 1, 1992, pp. 241-263. 
Evangelio, el cual está presidido por una bella talla de San José con el Niño, flanqueada por dos pequeños bustos de los Inocentes. En la parte inferior aparece el objeto de nuestro estudio: San Joaquín, la Virgen niña y Santa Ana ${ }^{850}$.

Sabemos que este grupo de la Sagrada Familia de la Virgen fue realizado en Valladolid, ciudad de la que llegó en 1705, año en que fue colocado en este lugar. Martín González se lo atribuyó a Juan de Ávila, aunque tampoco descartaba la autoría de José de Rozas: "hay dos escultores en Valladolid candidatos a la autoría: José de Rozas y Juan de Ávila. Este último ofrece más posibilidades de ser el autor. La obra está relacionada con las esculturas del mismo tema, en la iglesia del convento de Santa Brígida de Valladolid"851; además, también se pueden relacionar con otro grupo similar: el custodiado, como ya hemos visto, en la Colegiata de San Miguel de Aguilar de Campoó (Palencia). A la vista de estos datos cabe decir varias cosas: si se realizó en 1705 la autoría de nuestro escultor queda totalmente descartada puesto que falleció en 1702; además, poco tiene que ver el estilo que podemos percibir en estas tres tallas si lo comparamos con el de las referidas imágenes de las Brígidas, puesto que, mientras que en éstas no podemos discernir con claridad el nombre de su posible artífice, en cambio las del convento vallisoletano sí que caen plenamente dentro del último estilo de Juan de Ávila, o el primero de su hijo Pedro; finalmente, los motivos que me llevan a incluirle en "obras relacionadas" y no en "obras descatalogadas" es el hecho de que podemos percibir ciertos rasgos que le vinculan al taller de nuestro escultor: la manera de tallar las largas melenas onduladas de la Virgen; la disposición de las túnicas y mantos de San Joaquín y Santa Ana; el rostro de San Joaquín, muy con el del San Andrés que Juan de Ávila talló para el retablo mayor de la Colegiata de San Pedro de Lerma, etc... Por todo ello, como acabo de comentar, pienso que el autor de este bello grupo se halla en las proximidades de Juan de Ávila, descartando casi por completo a José de Rozas y, sobre todo, al otro gran artífice vallisoletano de la época: Juan Antonio de la Peña.

En esta misma capilla, concretamente en la parte trasera del tabernáculo se hallan otras dos piezas de procedencia vallisoletana: un pequeño Santo Cristo del Perdón y un busto de Dolorosa; y en otro punto de la catedral una pequeña representación de Santa María Magdalena según el difundido modelo vallisoletano ${ }^{852}$. También en estos tres casos hay muchas dudas acerca de sus paternidades, puesto que, por ejemplo, para la Dolorosa se han barajado nombres tan diversos como los de Tomás de Sierra o Pedro de Ávila. De

\footnotetext{
850 Sobre este grupo escultórico hay abundante bibliografía: MARTÍN GONZÁLEZ, Juan José: "Esculturas vallisoletanas en la Catedral de Orense", Cuadernos de Estudios Gallegos, Tomo XVI, Santiago de Compostela, 1961, pp. 253-254; CHAMOSO LAMAS, Manuel: La Catedral de Orense, Everest, Madrid, 1980; MARTÍN GONZÁLEZ, Juan José: "Lazos de arte entre Valladolid y Orense", En torno al arte auriense: homenaje a D. José González Paz. Universidad de Santiago, Santiago de Compostela, 1990, pp. 67-75; VILA JATO, Dolores: Cadernos no restauro, a capela do Santo Cristo de Ourense: Catedral de Ourense, Xunta de Galicia, Santiago de Compostela, 1996; SEOANE PRIETO, José Raúl: La Catedral de Ourense. I, Patrimonio Histórico Gallego. 1, Catedrales, Xuntanza, Laracha (A Coruña), 1997.

851 MARTÍN GONZÁLEZ, Juan José: “Lazos de arte...”, op. cit., pp. 72-73.

852 MARTÍN GONZÁLEZ, Juan José: “Esculturas vallisoletanas...”, op. cit., pp. 253-254.
} 
todas maneras, no nos detendremos en ellas puesto que no han sido, ni pueden ser, atribuidas ni puestas en relación con Juan de Ávila.

\section{TORDESILLAS. IGLESIA-MUSEO DE SAN ANTOLÍN}

\section{ÁNGEL DE LA ORACIÓN DEL HUERTO (Antes de 1680)}

En la iglesia museo de San Antolín de Tordesillas se haya la imagen de un Ángel (1,50 m.) (Fig. 147) que forma parte de un paso de la Oración del Huerto que pienso que, si bien no puede ser atribuido con mucha seguridad, puede relacionarse de manera bastante fidedigna con nuestro escultor ${ }^{853}$. El motivo fundamental para ello es el extraordinario parecido que guarda su cabeza con la del Ángel de la Guarda custodiado en la iglesia de Santiago Apóstol de Valladolid, hechura atribuida desde antiguo a Juan de Ávila. Tampoco podríamos descartar el nombre de su maestro, Francisco Díez de Tudanca, del cual sí que tenemos documentadas ciertas actuaciones en la localidad.

Empezando por la forma y composición que adopta la cabeza, tendente al rombo, hasta algunos nimios detalles, el parecido entre ambas piezas es más que evidente. Lo primero que llama la atención es la práctica identidad entre las cabelleras de ambas esculturas: un prominente mechón realizado a base de amplios rizos; y a los lados del rostro dos enormes masas ensortijadas de bucles que tienden a la forma triangular. También es más que evidente el parecido en el gesto estereotipado que denota su faz. Asimismo, son idénticas las bocas, con sus labios gruesos y rectos; se encuentran abiertas, a pesar de lo cual no vislumbramos los dientes. La nariz y los ojos son también muy similares, por no decir exactos. Lo único que las diferencia es la distinta tonalidad de la policromía; el mejor acabado del rostro del Ángel de la Guarda, cuya piel acusa blandura, y no la planitud del tordesillano; y la incipiente barbilla y papada del vallisoletano. A pesar de las similitudes, el Ángel del paso procesional es bastante más anodino.

Si entramos a hablar del cuerpo, las diferencias son ya abismales. Este ángel es de una factura mucho más seca y envarada. Sus pliegues tampoco tienen nada que ver ya que son más reducidos y poco naturales, pareciera como si el escultor no hubiera sabido resolverlos.

Esta escultura forma parte junto a un Cristo arrodillado, conservado en un retablo neoclásico ubicado en la nave del evangelio de la iglesia de San Pedro, del paso de la Oración del Huerto que la Cofradía de la Vera Cruz de Tordesillas había mandado realizar con anterioridad al año 1680. El Ángel y el Cristo no son de la misma época,

853 Hace años, tras la desaparición de la capilla de la Vera Cruz de la iglesia de San Pedro, la escultura del Ángel pasó a ocupar el baptisterio, lugar en la que la vieron los autores del Inventario Artístico de Valladolid y del Catálogo Monumental de Valladolid. MARTÍN GONZÁLEZ, Juan José (dir.): Inventario artístico de Valladolid..., op. cit., p. 285; ARA GIL, Clementina Julia y PARRADO DEL OLMO, Jesús María: Catálogo Monumental de la provincia de Valladolid. Tomo XI..., op. cit., p. 217. 
sino que este segundo es bastante posterior; Parrado del Olmo piensa que pudo ser tallado por el escultor vallisoletano Claudio Cortijo hacia el año $1800^{854}$.

Este paso es una más de las copias que se efectuaron de la Oración del Huerto que Andrés de Solanes talló entre 1629-1630 para la Cofradía Penitencial de la Santa Vera Cruz de Valladolid ${ }^{855}$. Las réplicas fueron numerosas, podríamos citar las de Medina del Campo, Medina de Rioseco o Nava del Rey. En todas ellas, y en esta tordesillana también, se dispone una formación más sencilla que la vallisoletana puesto que se prescinde del amplio historiado, que también incluía la escena del prendimiento, reduciéndolo a la acción principal de la historia: Cristo y el Ángel con el cáliz.

Andrés de Solanes debió de concebir el grupo escultórico tras leer los evangelios de San $\operatorname{Marcos}^{856} \mathrm{y}$, sobre todo, de San Lucas, puesto que solamente este último nos advierte de la presencia del ángel que interactúa con Jesús: "Saliendo se fue, según costumbre, al monte de los Olivos, y le siguieron también sus discípulos. Llegado allí, díjoles: Orad para que no entréis en tentación. Se apartó de ellos como un tiro de piedra, y, puesto de rodillas, oraba, diciendo: Padre, si quieres, aparta de mí este cáliz; pero no se haga mi voluntad, sino la tuya. Se le apareció un ángel del cielo que le confortaba. Lleno de angustia, oraba con más insistencia; y sudó como gruesas gotas de sangre, que corrían hasta la tierra. Levantándose de la oración, vino a los discípulos, y encontrándolos adormilados por la tristeza, les dijo: ¿Por qué dormís? Levantaos y orad para que no entréis en tentación" (San Lucas: 22, 39-46).

El escultor de este ángel de Tordesillas copia puntualmente al de Solanes, utilizando la misma disposición e indumentaria: de pie, con la pierna derecha adelantada; en la mano izquierda sujeta un cáliz, mientras que con la derecha hace lo propio con un báculo cruciforme. Viste doble túnica: una más larga de color blanco hasta los pies, abierta por una de sus piernas; y una sobretúnica más corta, ambas ceñidas con un cíngulo negro.

Sabemos que el Ángel existía ya en 1680, puesto que en ese año figura en un inventario de los ornamentos y alhajas que por entonces poseía la iglesia de San Pedro de Tordesillas. En él se dice al referirse a la capilla de la Vera Cruz: "La Cofradía de la Santa Vera Cruz en la iglesia de San Pedro tiene su capilla, que está junto al coro, y pegada a la puerta principal de dicha iglesia, y en dicha capilla dicha cofradía tiene un Santo Cristo en la Columna, y otro de Nazareno, otro de la Oración del Huerto y el ángel, que son los pasos para la procesión del Jueves Santo, y en dicha capilla con el título y renombre de la Cruz, está una cruz de talla, dorada y estofada, con que no

\footnotetext{
854 PARRADO DEL OLMO, Jesús María: “5. Oración del Huerto”. VV.AA.: Las Edades del Hombre. El árbol de la vida, Fundación las Edades del Hombre, Salamanca, 2003, p. 97.

855 URREA FERNÁNDEZ, Jesús: "Nuevos datos y obras del escultor Andrés Solanes...”, op. cit., pp. 483-484.

$856 \quad$ "Llegaron a un lugar cuyo nombre era Getsemaní, y dijo a sus discípulos: Sentaos aquí mientras voy a orar. Tomando consigo a Pedro, a Santiago y a Jun, comenzó a sentir temor y angustia, y les decía: Triste está mi alma hasta la muerte; permaneced aquí y velad. Adelantándose un poco, cayó en tierra y oraba que, si era posible, pasase de Él aquella hora". San Marcos, 14, 32-35.
} 
gradillas, y en dicha cruz un relicario con un Agnus y un Signum Crucis en un cristal ${ }^{857}$.

Piensa Parrado del Olmo que su ejecución pudo llevarse a cabo en el segundo tercio del siglo XVII, si bien el límite sería el referido año de 1680: "Presenta los habituales plegados quebrados de la escuela vallisoletana, más abultados hacia la zona inferior de la imagen. Tiene un rostro alargado, con melena de bucles abultados. Se puede indicar que todos estos aspectos son característicos de los seguidores de Gregorio Fernández. que trabajan a la muerte del maestro en el segundo tercio del siglo"858. También lo fecha por entonces José Enrique Martín Lozano: "La figura del Ángel corresponde al segundo tercio del siglo XVII"859. Si efectivamente aceptamos esta suposición de que fue tallada en el segundo tercio del siglo XVII, la atribución a Ávila quedaría totalmente desechada; sin embargo, si la creemos contemporánea al Santo Ángel de la Guarda de la iglesia de Santiago de Valladolid, y la fechamos por aquellas mismas fechas (16721677) en que creo que fue realizada, la atribución sería plenamente factible.

Aunque no se atreve a atribuírselo a Juan de Ávila, Margarita de los Ángeles González deja caer su posible actuación en la obra: "A pesar de su ya comentada deuda con el modelo creado por Solanes, en esta obra se hallan mayores similitudes con el Ángel de la Guarda de la iglesia vallisoletana de Santiago Apóstol, fechado a finales del siglo XVII y atribuido a Juan de Ávila. El contorno de ambos es muy similar, la cabellera es casi idéntica, y el volumen y disposición de las profundas quebraduras en las ropas, o el modo de elevar la bocamanga derecha de la túnica, presentan las mismas soluciones plásticas" ${ }^{\prime 860}$.

\section{ADDENDA}

Finalmente me gustaría solamente apuntar tres obras que pienso pueden atribuirse o relacionarse con nuestro escultor. Todas ellas representan a San José y se custodian en conventos de Carmelitas Descalzas. Se trata de las conservadas en el retablo del coro alto del Convento de la Concepción del Carmen o de Santa Teresa (MM. Carmelitas Descalzas), de Valladolid ${ }^{861}$; en el retablo mayor de la iglesia de San José (MM.

\footnotetext{
857 ARA GIL, Clementina Julia y PARRADO DEL OLMO, Jesús María: Catálogo Monumental de la provincia de Valladolid. Tomo XI..., op. cit., pp. 238-239.

858 PARRADO DEL OLMO, Jesús María: “5. Oración del Huerto”, op. cit., p. 96.

859 MARTÍN LOZANO, José Enrique: “Oración del Huerto". En ÁLVAREZ VICENTE, Andrés y GARCÍA RODRÍGUEZ, Julio César: Tradebatur, Ayuntamiento de Valladolid, Valladolid, 2007, p. 72

860 DE LOS ÁNGELES GONZÁLEZ, Margarita: “Ángel (del paso procesional "La oración del huerto"): En URREA FERNÁNDEZ, Jesús (coord.): Patrimonio restaurado de la provincia de Valladolid 1997-2003. Del olvido a la memoria (vol. 1). Pintura y Escultura, Diputación de Valladolid, Valladolid, 2008, p. 128.

861 MARTÍN GONZÁLEZ, Juan José y DE LA PLAZA SANTIAGO, Francisco Javier: Catálogo Monumental de la provincia de Valladolid. Tomo XV..., op. cit., p. 222.
} 
Carmelitas Descalzas), de Medina del Campo ${ }^{862}$; y en la iglesia del Convento de la Encarnación (MM. Carmelitas Descalzas) de la villa ducal de Lerma.

862 ARIAS MARTÍNEZ, Manuel, HERNÁNDEZ REDONDO, José Ignacio y SÁNCHEZ DEL BARRIO, Antonio: Catálogo Monumental de la provincia de Valladolid. Tomo XIX. Medina del Campo, Diputación de Valladolid, Valladolid, 2004, p. 188. Esta imagen fue atribuida por Jesús Urrea a José de Rozas. RODRÍGUEZ, Juan Luis y URREA FERNÁNDEZ, Jesús: Santa Teresa en Valladolid: historia de sus fundaciones hasta nuestros días. El arte en San José de Medina y en la Concepción de Valladolid, Caja de Ahorros Popular de Valladolid, Valladolid, 1982, p. 384.

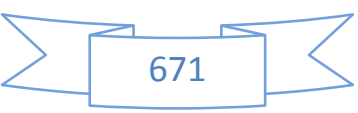




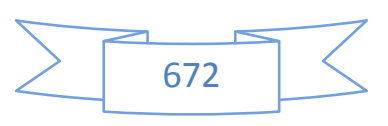




\section{5-4 OBRAS \\ DESCATALOGADAS}




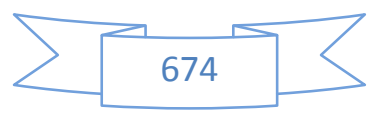




\section{VALLADOLID. CENTRO DIOCESANO DE ESPIRITUALIDAD}

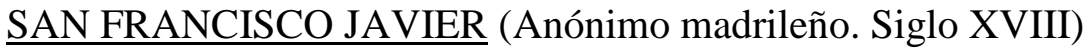

En una de las salas del actual Centro Diocesano de Espiritualidad, antiguas dependencias del colegio jesuítico de San Ambrosio, se encuentra una buena talla de San Francisco Javier (Fig. 148), en cuya cartela existe una leyenda por la que se le atribuye al "Círculo de Juan de Ávila"; fechándolo de una manera muy genérica: "siglo XVII'.

El primero que nos habló de la existencia de esta imagen fue Manuel Canesi, el cual, al hablar sobre la iglesia del Colegio de San Ambrosio, actual Santuario Nacional de la Gran Promesa, comentaba: "Luego depositaron el cadáver como se practica con todos en la retirada capilla del relicario que está al lado del colateral de San Francisco Javier, al pie de la peana del altar en que también yacen no menos canonizables las reliquias del V. P. Luís de la Puente, honor de este colegio, ilustre de su patria"863. Posteriormente, figura citada tanto en el Inventario Artístico de Valladolid como el Catálogo Monumental de Valladolid. En el Inventario, Martín González, lo inventaría en el Santuario Nacional de la Gran Promesa, antigua iglesia del Colegio de San Ambrosio, concretamente en el primer tramo del lado del Evangelio, dando como cronología el siglo XVIII ${ }^{864}$. La escultura cambió de lugar, puesto que en el Catálogo Monumental aparece reseñado en un retablo salomónico ubicado en el lado de la Epístola de la Capilla de la Congregación, también parte del antiguo Colegio de San Ambrosio, y aneja al actual Santuario. Los autores de este tomo del Catálogo, Martín González y Plaza Santiago pensaron que el San Francisco Javier denotaba el "estilo de Pedro de Ávila", fechándolo en el primer cuarto del siglo XVIII ${ }^{865}$.

Para nada puede ser asociado este San Francisco Javier a los catálogos de Juan ni Pedro de Ávila. Nada vemos en él que nos recuerde a estos dos escultores, pero ni siquiera a la escuela castellana. Probablemente se tratará de una obra madrileña de finales del siglo XVII, o seguramente de comienzos del XVIII. Algunos entendidos en la escultura barroca madrileña me han sugerido que el autor de esta imagen pudiera hallarse en el círculo más inmediato de Juan Alonso Villabrille y Ron, no descartándose tampoco que sea del propio imaginero asturiano.

\footnotetext{
863 CANESI ACEVEDO, Manuel: Historia de Valladolid (1750), Tomo III, op. cit., p. 388.

864 "Lado del Evangelio. En el primer tramo desde los pies: Retablo plateresco siglo XVI con diversas esculturas del siglo XVII: San José; Santa Teresa, primera mitad del siglo, copia de Fernández; Virgen de la cofradía de los plateros; Piedad; una Santa, principios de siglo. Escultura de San Francisco Javier siglo XVIII". MARTÍN GONZÁLEZ, Juan José (dir.): Inventario artístico de Valladolid..., op. cit., p. 60.

865 Lado de la Epístola. Retablo con columnas salomónicas. En la hornacina central, San Francisco Javier, madera policromada (105 cms.), primer cuarto del siglo XVIII, estilo de Pedro de Ávila. MARTÍN GONZÁLEZ, Juan José y DE LA PLAZA SANTIAGO, Francisco Javier: Catálogo Monumental de la provincia de Valladolid. Tomo XV..., op. cit., p. 310.
} 


\section{VALLADOLID. CONVENTO DE LA CONCEPCIÓN}

CRUCIFICADO (Anónimo. Segunda mitad del siglo XVII)

En 1960 Alfonso Santamaría en su artículo sobre la iglesia del Convento de la Concepción de Valladolid señalaba que el Cristo Crucificado (Fig. 149) ubicado en la hornacina del ático del retablo mayor sería obra de Juan de Ávila: "El Cristo del ático, por la postura del cuerpo, volviendo la cabeza hacia su derecha inclinándola suavemente sobre el hombro; por el nudo del paño de pureza; las piernas hacia su izquierda, recuerda al Cristo del retablo de la iglesia del Rosario, cuya escultura "será de Juan de Ávila", escultor que trabaja en los retablos de los Billota"866. Años después, Martín González, durante la redacción del Inventario Artístico de Valladolid señala tan solo que el Cristo sería de la misma época que el retablo, es decir, de finales del siglo XVII ${ }^{867}$.

Desconocemos si el Crucifijo era propiedad del convento o bien vino de manera conjunta con el retablo, puesto que en 1726 las religiosas de este convento se lo compraron al de Clérigos. Así nos lo relata Canesi: "En este estado, llegó el año de 1726, cuando a 25 de septiembre, se festejó en este convento la traslación del Santísimo Sacramento y María Santísima de la Concepción al nuevo retablo que compraron las religiosas a los padres Clérigos Menores, dedicado por ellos a San Cayetano, y por no concluirlo le acomodó este convento a su capilla mayor, con caudal que les dejó una

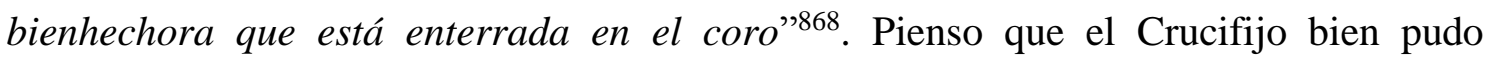
provenir del Convento de Clérigos Menores dado que se adapta a la perfección a la hornacina en la que se halla incluido.

A pesar de la altura y oscuridad en la que se encuentra, que dificulta bastante su estudio, pienso que para nada puede ser relacionado este Crucifijo con Juan de Ávila dado que no guarda ninguna relación con el único Crucificado que poseemos de su mano, el de Traspinedo, ni con otros que se le atribuyen; por ejemplo, el del Colegio de los Ingleses. Su canon, un tanto achaparrado, y la tosquedad de su talla nos mueven a no poder aceptar esta atribución.

\section{VALLADOLID. IGLESIA DE NUESTRA SEÑORA DEL ROSARIO}

ESCULTURAS DEL RETABLO MAYOR (José de Rozas y Antonio Vázquez. 1689)

Las esculturas de este retablo desde hace tiempo fueron puestas en el haber de Ávila. El primero en atribuirle las imágenes fue Martín González en su inconmensurable Escultura barroca castellana. En ella sentenciaba: "La escultura será de Juan de

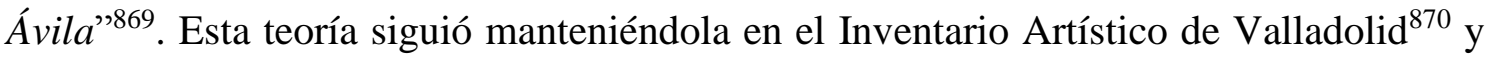

\footnotetext{
866 SANTAMARÍA, Alfonso R.: op. cit., pp. 184-185.

867 MARTÍN GONZÁLEZ, Juan José (dir.): Inventario artístico de Valladolid..., op. cit., p. 33

868 CANESI ACEVEDO, Manuel: Historia de Valladolid (1750), Tomo III, op. cit., p. 232.

869 MARTÍN GONZÁLEZ, Juan José: Escultura barroca castellana ..., op. cit., p. 311.

870 MARTÍN GONZÁLEZ, Juan José (dir.): Inventario artístico de Valladolid..., op. cit., p. 56.
} 
en una guía histórico-artística de la ciudad ${ }^{871}$. Esta misma atribución la sostuvo en un principio Urrea ${ }^{872}$, aunque con posterioridad pensó que quizás las esculturas se debieran a José de Rozas ${ }^{873}$. Como ya hemos dicho en varias veces, el parecido existente entre las obras de Juan de Ávila, Juan Antonio de la Peña y José de Rozas, ha llevado en muchas ocasiones a atribuir ciertas piezas a varios de ellos, y esta vez también fue así. Efectivamente, las esculturas son obra de José de Rozas, pero no todas, dado que compartió tareas con el vallisoletano Antonio Vázquez. Ambos escultores trabajaron en diversas ocasiones de manera conjunta. Por lo tanto, estas esculturas están perfectamente documentadas y su atribución a Juan de Ávila queda desechada.

En un contrato realizado el 13 de julio de 1689 (DOCUMENTO 56), José de Rozas y Antonio Vázquez se comprometen con Juan Blanco, quien representa a la Cofradía de Nuestra Señora del Rosario y Santos Mártires Cosme y Damián, a realizar “dos hechuras de bulto la una del glorioso Padre San Francisco y la otra de Santo Domingo para poner en el retablo que se está haciendo para la iglesia de Nuestra Señora del Rosario y Santos Mártires de esta dicha ciudad". Una condición interesante del contrato, y que nos demuestra la vigencia que mantenían los modelos de Gregorio Fernández (a pesar de llevar ya más de 60 años muerto), es que se comprometen a realizar la imagen de Santo Domingo "a semejanza de la que está en la capilla del Convento de San Pablo de esta ciudad en todos los movimientos excepto que no ha de tener al pie globo de nubes como le tiene el de dicha capilla sino es que ha de estar de planta firme". El resto de hechuras del retablo (relieve de San Cosme y San Damián, dos ángeles portaestandartes y el Calvario) aunque no figuran en el contrato serán suyas con toda seguridad. Lo que ya no acertamos a saber es cuales corresponden a cada uno.

\section{VALLADOLID. IGLESIA DE SANTIAGO APÓSTOL}

\section{GRUPO DE SANTIAGO MATAMOROS (Anónimo. Comienzos del siglo XVIII)}

El pequeño grupo escultórico de Santiago Matamoros (44 cms.) (Fig. 150) que se encuentra instalado dentro de una pequeña hornacina de la sacristía de la iglesia parroquial de Santiago Apóstol fue atribuido a Ávila por Jesús Urrea. El investigador sugiere que pudo ser "un boceto terminado para la escultura del santo titular que talló Juan de Ávila con destino al retablo mayor de su iglesia parroquial y en el que trabajó acompañado de su hijo Pedro que haría en 1732 un grupo similar para las Comendadoras de Santa Cruz"874. Prosigue diciendo que se trata de una "obra sumamente cuidada y pese a su pequeño formato produce el mismo efecto de teatralidad que la obra situada en el presbiterio del templo".

\footnotetext{
871 MARTÍN GONZÁLEZ, Juan José: Guía histórico-artística..., op. cit., pp. 109-110.

872 URREA FERNÁNDEZ, Jesús: Guía histórico-artística ..., op. cit., p. 27.

873 MARTÍN GONZÁLEZ, Juan José y URREA FERNÁNDEZ, Jesús: Catálogo Monumental de la provincia de Valladolid. Tomo XIV..., op. cit., p. 267.

$874 \quad$ URREA FERNÁNDEZ, Jesús (dir.): La pequeña escultura ..., op. cit.
} 
A raíz del descubrimiento del testamento de Santiago Manzano, presbítero capellán y músico de la catedral vallisoletana, podemos desechar tanto esta atribución como el que sea el modelo del grupo principal del retablo mayor. Este generoso religioso fue un cliente habitual de los talleres escultóricos y pictóricos vallisoletanos dado que poseía una gran cantidad de obras de arte, las cuales donó a múltiples instituciones tanto de la ciudad de Valladolid, como de otras localidades cercanas, como es el caso de la Colegiata de Toro (Zamora) ${ }^{875}$. Falleció en Valladolid el día 11 de enero de 1736, siendo enterrado en la catedral, "a la puerta de Nuestra Señora de los Dolores en sepultura de fábrica" ${ }^{\$ 76}$.

En su primer testamento, ratificado posteriormente en un codicilo y un segundo testamento, ordena entregar a "la iglesia de Santiago un santo con su caballo de escultura, y pintura del Descendimiento" "877. Esta cita por sí misma no nos daría las pistas necesarias para relacionarlo con la escultura que estamos tratando; sin embargo, a continuación, la describe: "y un escaparate y dentro el santo en su caballo de escultura". No hay dudas, se trata del pequeño escaparate de la sacristía. Santiago Manzano tenía más escaparates similares a éste, puesto que al Convento de la Merced Calzada entregaba "dos escaparates uno de San Juan y otro de la Magdalena de cera para la capilla de Nuestra Señora de la Cerca sita en él"878.

El grupo lo forma Santiago a caballo y un moro a los pies del caballo. Santiago aparece montando un caballo blanco, sosteniendo con la mano izquierda una bandera y a su vez las riendas del caballo, y con la derecha seguramente blandiera una espada. La capa totalmente extendida y con un buen tratamiento de los pliegues, haciéndonos patente el viento y el movimiento de Santiago. El caballo se apoya sobre las patas traseras, levantando las delanteras. En el suelo aparece tirado, quizás arrollado por el caballo, el moro, el cual levanta el brazo izquierdo, en cuya mano sujeta un escudo preparado para rechazar el inminente golpe de espada de Santiago. Quizás la figura del moro sea la que está tratada de una forma más esquemática. A pesar de ser un grupo de pequeño tamaño, las esculturas tienen un gran encanto.

Este tipo de "pequeña escultura", según Urrea, vino a divulgar y popularizar "las nuevas y tradicionales ansias religiosas, muchas veces cumpliendo el mismo papel que la

\footnotetext{
875 NAVARRO TALEGÓN, José: La Colegiata de Toro, Junta de Castilla y León, Valladolid, 2005, p. 113.

876 "En once días del mes de enero de mil setecientos y treinta y seis años, habiendo recibido los santos sacramentos con el de la extremaunción murió (...) del colegio músico don Santiago Manzano capellán y músico de ésta santa iglesia y se enterró en ella a la puerta de Nuestra Señora de los Dolores en sepultura de la fábrica, hizo su testamento debajo del cual falleció que pasó por testimonio de Joseph Sanz del Río escribano de la Real Universidad de ésta ciudad de Valladolid, su fecha once de octubre del año de mil setecientos y treinta y uno, por lo que manda se digan por su alma doscientas misas dejó por sus testamentarios al padre fray Santiago Barruelo doctor de la Real Universidad y su catedrático y lector de teología de su Convento de la Merced Calzada a don Juan Toro y a don Miguel Márquez prebendados de ésta santa iglesia y a estos dos por herederos (...) y lo firmé como cura que soy de ésta santa iglesia hecho ut supra”. A.G.D.V., Catedral, 1684D, f. 251.

$877 \quad$ A.H.P.V., Leg. 3.130, f. 611.

878 A.H.P.V., Leg. 3.130, f. 612.
} 
estampa o la imagen grabada" ${ }^{\text {879 }}$. Su pequeño formato, además de favorecer su transporte, las hacía "asequibles como objeto de ofrecimiento o de regalo. Aunque desconocemos cuáles fueron sus precios en origen, sospechamos que en algunas ocasiones forzosamente tuvieron que ser elevados dado el esmero que puso el artista. Es cierto que tenía que haber oscilaciones según el material empleado, pero la reducción del tamaño no significaría, ni mucho menos, abaratamiento del producto" ${ }^{880}$. Por lo general estas esculturas son anónimas, aunque a veces aparecen firmadas, circunstancia que, según Urrea, se debe al "cariño puesto en ellas por su autor o el deseo de que su arte fuese reconocido en la región para donde iban destinadas, con claros fines propagandísticos" $" 881$. No podemos olvidar que el fácil transporte de estas esculturas facilitaba la llegada de obras de otros lugares de España (Madrid, Andalucía, Murcia...) o del extranjero, como por ejemplo de Nápoles.

\section{VALLADOLID. MONASTERIO DE SAN BENITO EL REAL}

EL PROFETA SAN ELÍAS (Anónimo. Último cuarto del siglo XVII)

En el ábside de la nave de la Epístola se encuentra una gran escultura del profeta San Elías (Fig. 151) que Martín González y Plaza Santiago creen del estilo de Juan de Ávila ${ }^{882}$. Cabe reseñar que Floranes rizó el rizo llegando a atribuírselo a Gregorio Fernández ${ }^{883}$, atribución a todas luces imposible de aceptar y de mantener. En Valladolid se halla otro San Elías similar, concretamente en el Museo Nacional de Escultura, aunque desconocemos su procedencia.

La escultura no perteneció en origen a este monasterio sino que procede del convento del Carmen Calzado ${ }^{884}$, concretamente de la Capilla de San Elías ${ }^{885}$. Al parecer, tras la Desamortización, la escultura no la recogió el Museo de Bellas Artes, como así lo atestigua el hecho de que no figure ni en los inventarios de la Comisión de Monumentos ni en los del Museo. Desconocemos que ocurrió tras la Desamortización, el caso es que hasta el año 1893 estuvo en poder del Cuerpo de Ingenieros, el cual lo tenía totalmente abandonado, siendo su estado de conservación bastante deplorable. Este mismo año les es solicitado por la Orden Tercera del Carmen para así colocarlo en el Monasterio de San Benito, ya que tras el abandono del mismo éste se encontraba despojado de

\footnotetext{
879 URREA FERNÁNDEZ, Jesús (dir.): La pequeña escultura ..., op. cit.

880 Ibídem.

881 Ibídem

882 "Lado de la epístola. El Profeta Elías, madera policromada, tamaño superior al natural. Según el Padre Rodríguez procede del convento del Carmen Calzado. En razón a su gran tamaño, estaría en la parte superior de algún retablo. Está representado con vestido de piel de camello. Estilo de Juan de Ávila”. MARTÍN GONZÁLEZ, Juan José y DE LA PLAZA SANTIAGO, Francisco Javier: Catálogo Monumental de la provincia de Valladolid. Tomo XV..., op. cit., p. 248.

883 FERNÁNDEZ DEL HOYO, María Antonia: Patrimonio perdido..., op. cit., p. 360.

884 RODRÍGUEZ MARTÍNEZ, Luis: Historia del Monasterio de San Benito el Real de Valladolid, Caja de Ahorros popular de Valladolid y Ateneo de Valladolid, Valladolid, 1971, p. 279.

885 FERNÁNDEZ DEL HOYO, María Antonia: Patrimonio perdido..., op. cit., p. 360.
} 
cualquier obra de arte. Refiere el padre Rodríguez que la escultura estaba todavía en el Carmen Calzado "en cuyos sótanos se hallaba en completa destrucción".

Antes de exponerlo al culto, se procedió a su restauración, labor de la que se ocuparon Juan Rodríguez Carretero y Blas González García-Valladolid. Una vez completada y expuesta de nuevo al culto, la imagen gozó de gran predicamento, sobre todo por la cofradía de "viudas" que le tenía por patrón ${ }^{886}$. Por entonces no se encontraba en el ábside en el que está hoy, sino que se localizaba a los pies del primero tramo del lado del Evangelio ${ }^{887}$.

El profeta Elías es, después de Moisés, la mayor figura del Antiguo Testamento ${ }^{888}$. Su nombre significa Mi Dios (El) es Yahvé. Dedicó su vida a luchar por Yahvé, contra Baal. Su culto se debe al apoyo que recibió de los carmelitas, los cuales le tomaron por patrón, llegando a considerarle el fundador de su orden debido a que vivió en una gruta del monte Carmelo; puesto que, no hemos de olvidar, que el origen de la orden se halla en unos ermitaños establecidos en el propio monte Carmelo en las postrimerías del siglo XVII ${ }^{889}$. Reseña Rosario Fernández, que en el referido monte "existía ya una comunidad de anacoretas que, según la tradición, representaba la continuidad de una vida eremítica en el lugar desde los tiempos del profeta, manteniendo vivo su espíritu" 890 . El místico Juan de S. Sansón calificó a los carmelitas de "auténticos hijos de san Elías". De hecho la orden también se llama Ordo Elianus ${ }^{891}$.

San Elías aparece efigiado en esta escultura según su iconografía tradicional: De pie, revestido con piel de camello, tanto en túnica como en manto, y empuñando en una de sus manos una espada flamígera (hoy perdida) con la que venció a los profetas de Baal en el Monte Carmelo. En la otra mano sostiene un libro, atributo que nos habla de su carácter de "fundador" de la Orden Carmelita. También podría tratarse del libro de sus profecías, en el cual quizás se pueda leer: "Zelo zelatus sum pro Domino Deo exercituum" (Me consume el celo por el Señor, Dios de los ejércitos).

El rostro para nada se asemeja a los tallados por Ávila. El tratamiento de las arrugas parece algo más duro y acartonado a lo que nos tiene acostumbrados nuestro escultor; tampoco coincide la forma de tratar el pelo y la barba. El rostro enérgico es bastante anodino, incluso para lo que nos tiene acostumbrados el escultor. En un hipotético caso, vería más cerca este San Elías de Pedro de Ávila que de su padre Juan, pero no es de ninguno. La escultura pertenecerá a un buen escultor vallisoletano del último cuarto del siglo XVII: José de Rozas, Andrés de Pereda, Antonio Vázquez, Vicente Díez, etc...

\footnotetext{
886 RODRÍGUEZ MARTÍNEZ, Luis: op. cit., p. 279.

887 MARTÍN GONZÁLEZ, Juan José (dir.): Inventario artístico de Valladolid..., op. cit., p. 26.

888 RÉAU, Louis: Iconografia de la Biblia. Antiguo..., op. cit., p. 400.

889 FERNÁNDEZ GONZÁLEZ, Rosario: "San Elías". En URREA, Jesús: Teresa de Jesús y Valladolid. La Santa, la Orden y el Convento, Ayuntamiento de Valladolid, Valladolid, 2015, pp. 94-95.

$890 \quad$ Ibídem.

891 RÉAU, Louis: Iconografia de la Biblia. Antiguo ..., op. cit., pp. 401-402.
} 


\section{VALLADOLID. MUSEO NACIONAL DE ESCULTURA}

INMACULADA (Anónimo. Último cuarto del siglo XVII)

En el Museo Nacional de Escultura, en la antigua sala dedicada a la cabeza degollada de San Pablo, se encontraba un gran retablo presidido por una Inmaculada Concepción (Fig. 152) que tanto Federico Wattenberg como Eloísa García de Wattenberg relacionaron con la obra de Juan de Ávila. Concretamente se referían a ella con las siguientes palabras: "La Inmaculada que aparece en la hornacina central es obra anónima de finales del siglo XVII, con recuerdo de producciones de Juan de Ávila"892. Ningún detalle de la escultura (rostros, pliegues, manera de disponer los cabellos) nos permite relacionarla con nuestro escultor, y, probablemente, ni siquiera con la escuela vallisoletana; puesto que lo único que podría acercarla es la utilización del manido modelo de Gregorio Fernández. Esta Inmaculada, al igual que el retablo, fechado este último en 1753, procede del Convento de Madres Franciscanas de Salamanca ${ }^{893}$.

\section{VALLADOLID. ORATORIO DE SAN FELIPE NERI}

ESCULTURAS DEL RETABLO MAYOR (José de Rozas y Andrés de Pereda. 1689)

El primero en relacionar las esculturas y relieves del retablo mayor del Oratorio de San Felipe Neri con Juan de Ávila fue Gratiniano Nieto, el cual señalaba, refiriéndose al San Joaquín con la Virgen Niña (esta última desaparecida): "La última capilla está dedicada a San Joaquín; en su retablo se ve una buena talla de San Joaquín con la Virgen niña, atribuida a Juan de Ávila, y una pequeña cabeza de Cristo coronado de espinas, tallada en el siglo XVIII por un buen maestro" ${ }^{894}$. Esta misma atribución la sostuvo en diversas ocasiones Martín González. Primeramente, en su libro Escultura barroca castellana (1959), "En San Felipe Neri hace, sin duda de ningún género, las esculturas del retablo mayor (...). Lo deducimos de la comparación estilística de los relieves antes mencionados" ${ }^{995}$; y después en el Inventario Artístico de Valladolid (1970): "Retablo mayor de Francisco Billota, fines siglo XVII, con esculturas de Juan de Ávila: Calvario, San Pedro, San Pablo. Escultura de San Felipe Neri, siglo XVIII"896; y en Escultura Barroca en España 1600-1770: citando las obras que Ávila tiene documentadas en este oratorio, añade "por comparación estilística, además de estas obras, en el citado templo tienen que corresponderle las esculturas y relieves del retablo mayor" $" 897$.

Pues bien, también las esculturas deben ser eliminadas del grupo de obras atribuidas a nuestro escultor, dado que Jesús Urrea descubrió que los verdaderos artífices de ellas

\footnotetext{
892 WATtENBERG, Federico: Guía del Museo Nacional de Escultura, Madrid, 1966, p. 62; GARCÍA DE WATTENBERG, Eloísa: Museo Nacional de Escultura, Valladolid, 1984, p. 56.

893 WATTENBERG, Federico: Guía del Museo Nacional de Escultura, Madrid, 1966, p. 62.

894 NIETO GALLO, Gratiniano: op. cit., p. 122.

895 MARTÍN GONZÁLEZ, Juan José: Escultura barroca castellana ..., op. cit., p. 322.

896 MARTÍN GONZÁLEZ, Juan José (dir.): Inventario artístico de Valladolid..., op. cit., p. 37.

897 MARTÍN GONZÁLEZ, Juan José: La escultura barroca en España..., op. cit., p. 80.
} 
fueron José de Rozas y Andrés de Pereda ${ }^{898}$. Con la documentación de estas imágenes volvemos a confirmar dos axiomas: la cercanía y confusión que provocan los estilos de Juan de Ávila, José de Rozas y Juan Antonio de la Peña; y, la tendencia de artistas como Pereda, y el propio Rozas, a contratar obras de manera conjunta.

El retablo original poseía las siguientes esculturas: en el banco dos relieves (Predicación de San Pablo a Félix y Drusila, y Cristo con San Pedro); en el cuerpo las esculturas de San Joaquín con la Virgen Niña, San Felipe Neri y San José con el Niño; y, en el ático, el Calvario (Crucifijo, San Juan y la Virgen María) y otros dos relieves (la Oración del Huerto, y Cristo camino del Calvario). A todo esto, habría que añadir el desaparecido relieve del sagrario y los dos ángeles que campearían en los extremos del ático. Ya en 1720 los grupos de San Joaquín y San José fueron sustituidos por las colosales estatuas de San Pedro y San Pablo, obra de Pedro de Ávila. El licenciado don Pablo del Moral, visitador del obispo, nos lo describe de una manera bastante exacta el 28 de abril de 1692: se trataba "de un retablo ahora nuevamente hecho de toda hermosura a costa de los congregantes de dicha venerable Congregación, juntamente con la iglesia y oratorio, el cual está hecho una ascua de oro". El primer cuerpo se compone de "cuatro columnas salomónicas (...) donde está la efigie del Santo de bulto con su diadema de plata y a los lados y en el intercolumnio las efigies del patriarca San José con el Niño de la mano en el lado del evangelio y en el de la epístola el glorioso San Joaquín con la Virgen Santísima de la mano siendo niña, las cuales son asimismo de bulto". En su pedestal "dos historias de medía talla, la una la entrega de las llaves por Cristo a San Pedro y la otra la predicación de San Pablo a Félix y Drusila, doradas y estofadas". Finalmente, en el ático "un Cristo crucificado con María y San Juan y a los lados dos ángeles con diferentes instrumentos de la pasión de Cristo que dejan sobre las columnas de él, unos y otros de bulto dorado y estofados, y en dos enjutas Cristo nuestro bien en la calle de la Amargura y otra de la oración del huerto, de medía talla doradas y estofadas" ${ }^{\prime 899}$.

\section{SAN FELIPE NERI}

En la amplia sala capitular del Oratorio de San Felipe Neri encontramos un San Felipe Neri (Fig. 153), de factura bastante seca, que fue relacionada con los quehaceres de Juan de Ávila por Martín González y Urrea: la consideraban "obra de hacia 1700, que sigue el modelo de Juan de Ávila"900. El hecho que me ha llevado a situarla como "obra descatalogada" en vez "obra relacionada" es que Urrea documentó que la escultura del retablo mayor, incluido el San Felipe Neri que toma por modelo esta imagen que estudiamos, no es obra de Ávila sino de José de Rozas y Antonio de Pereda. Por lo tanto, no puede considerarse entonces que "sigue el modelo de Juan de Ávila". De todas

\footnotetext{
898 URREA FERNÁNDEZ, Jesús: “El oratorio...”, op. cit., p. 18.

899 URREA FERNÁNDEZ, Jesús: “El oratorio...”, op. cit., p. 18.

900 MARTÍN GONZÁLEZ, Juan José y URREA FERNÁNDEZ, Jesús: Catálogo Monumental de la provincia de Valladolid. Tomo XIV..., op. cit., p. 299.
} 
maneras, aunque no sea el modelo, este San Felipe Neri no posee ninguno de los estilemas presentes en la obra de Juan de Ávila; es más, me atrevería a decir que no me recuerda el estilo de ninguno de los escultores vallisoletanos de esta época, sino que me parece más bien obra madrileña. La Inmaculada que lleva encima del libro, de ser la original, tampoco presenta un modelo utilizado en Valladolid ni en Castilla. El cuerpo está tallado de una manera bastante tosca, con unos pliegues muy rígidos y nada vallisoletanos; siendo la cabeza lo único meritorio de la imagen.

Este San Felipe Neri preside un retablo al que no debió de pertenecer puesto que la hornacina es de mayores dimensiones, tanto en altura como en anchura. Además, para que no diera la impresión de pequeñez, la escultura ha sido subida a una peana con decoración vegetal. Si seguimos la clasificación de retablos barrocos trazada por Martín González, este pertenecería a la etapa pre-churrigueresca (1650-1690) ${ }^{901}$, dado lo conservador de su traza. A este momento, como hemos dicho al principio de este trabajo, pertenecen ensambladores como Pablo de Freiría (a.1613 - 1673), Cristóbal Ruiz de Andino (h.1625 - d.1687), Antonio Billota (h.1630 - 1687), Pedro de Cea (1633 - d.1684) y Juan Guerrero de Horna (1639 - d.1702). El retablo presenta un banco ornado con dos pinturas de San Pedro y San Pablo, encima del cual se desarrolla un arco vignolesco rematado por un entablamento curvo que recuerda a las tumbas mediceas. Desconocemos a qué lugar perteneció este retablo, quizás fuera el que se construyó de manera temporal para la capilla mayor mientras la Congregación cosechaba fondos para poder acometer la obra del que actualmente la preside.

\section{VALLADOLID. SANTUARIO NACIONAL DE LA GRAN PROMESA}

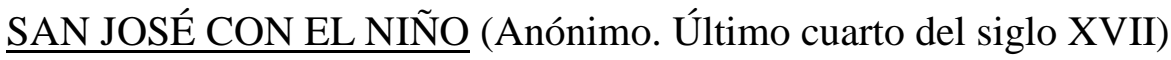

Desde siempre este San José con el Niño (145 cms.) (Fig. 154) ha sido relacionado con los Ávila. Efectivamente, Jesús Urrea lo calificaba como "del taller de los Ávila"902; mientras que los autores del respectivo tomo del Catálogo Monumental de Valladolid lo definen como "del último cuarto del siglo XVII, próximo a Juan de Ávila"903. Por su parte Brasas Egido pensaba que era "del último cuarto del siglo XVII y del estilo de Juan de Ávila"904. A pesar de colocar esta imagen en el apartado de "Obras descatalogadas", lo hago con muchas dudas. Aunque todavía tengo ciertos recelos sobre la posible autoría de Ávila, la mayor parte de las características de esta pieza me mueven a clasificarlo aquí.

\footnotetext{
901 MARTÍN GONZÁLEZ, Juan José: Escultura barroca castellana..., op. cit.; MARTÍN GONZÁLEZ, Juan José: El retablo barroco..., op. cit.

902 URREA FERNÁNDEZ, Jesús: Guía histórico-artística ..., op. cit., p. 50.

903 MARTÍN GONZÁLEZ, Juan José y URREA FERNÁNDEZ, Jesús: Catálogo Monumental de la provincia de Valladolid. Tomo XIV..., op. cit., p. 323.

$904 \quad$ BRASAS EGIDO, José Carlos: Guía de Valladolid, op. cit., p. 71.
} 
Desconocemos si la escultura perteneció al Colegio de San Ambrosio o fue depositado aquí por otra iglesia o cofradía; puesto que, no hemos de olvidar que, todavía aquí se conservan algunas obras de arte pertenecientes a la desaparecida iglesia de San Antón o a la Cofradía de Nuestra Señora de la Piedad. Recordemos que en el desaparecido retablo mayor de la iglesia penitencial de Nuestra Señora de la Piedad existió un San José.

En la actualidad se encuentra en el Santuario Nacional de la Gran Promesa, en la primera capilla, contando desde el crucero, del lado del Evangelio. Se aloja dentro de un retablo hornacina con el fondo pintado procedente del Museo Nacional de Escultura, institución en la que estuvo expuesto durante cierto tiempo en la escalera del mismo. La pintura del fondo es un paisaje con casas y angelitos plorantes en el cielo, lo que nos lleva a pensar que probablemente la hornacina estuvo presidida por un Crucificado.

También en el propio Santuario Nacional de la Gran Promesa, este San José ocupó uno de los dos retablos gemelos que, procedentes del desamortizado Monasterio de San Benito el Real ${ }^{905}$, se encontraban, en el Museo Nacional de Escultura, institución a la que han regresado. En este mismo retablo, cuando estaba situado en la última capilla del lado del Evangelio, lo acertó a ver Gratiniano Nieto ${ }^{906}$; y, aún, permanecía allí cuando se redactó el Inventario Artístico de Valladolid ${ }^{907}$.

Aunque, como ya he dicho, la talla posee ciertos estilemas de Juan de Ávila, la forma de tallar los ojos, redondeados y bastante juntos; y la boca cerrada me llevan a creerlo de otro autor de la misma época, o quizás algo anterior. Desde luego los pliegues también podrían asociarse con Ávila, sin embargo se detectan ciertas durezas y rudezas que me impiden pensar en la posible autoría de nuestro escultor.

\section{AGUILAR DE CAMPOO. COLEGIATA DE SAN MIGUEL}

\section{SAN JOAQUÍN, SANTA ANA Y LA VIRGEN (Finales del siglo XVII)}

En la Colegiata de San Miguel de Aguilar de Campoó (Palencia) se custodia un bello grupo de la Sagrada Familia de la Virgen (Fig. 155) que Martín González y Urrea asignan al círculo de Juan de Ávila, fechándolo a finales del siglo XVII o comienzos del XVIII $^{908}$. En la actualidad este conjunto se guarda en el museo de la colegiata, si bien

\footnotetext{
905 Estos dos retablos fueron realizados para el trascoro del Monasterio de San Benito el Real por Juan de Cambray y Cornieles de Holanda. http://ceres.mcu.es/pages/Main

906 "La última capilla del lado del Evangelio está dedicada a San José cuya representación es una buena escultura del XVII colocada en un retablo del XVI atribuido también a Berruguete". NIETO GALLO, Gratiniano: op. cit., p. 107.

907 "Lado del Evangelio. En el primer tramo desde los pies: Retablo plateresco siglo XVI con diversas esculturas del siglo XVII: San José; Santa Teresa, primera mitad del siglo, copia de Fernández; Virgen de la cofradía de los plateros; Piedad; una Santa, principios de siglo". MARTín GONZÁLEZ, Juan José (dir.): Inventario artístico de Valladolid..., op. cit., p. 60.

908 URREA FERNÁNDEZ, Jesús y MARTÍN GONZÁLEZ, Juan José: Inventario artístico de Palencia y su provincia II..., op. cit., p. 16.
} 
con anterioridad se encontraba en la capilla de los pies de la nave de la epístola. Desconozco si este lugar fue el originario de las tallas.

La disposición de las tres esculturas viene a copiar la de las mismas tallas que se encuentran en el Colegio de los Ingleses de Valladolid, atribuidas con mayor certeza a nuestro escultor, y de mucho mayor tamaño. El grupo de Aguilar de Campoo tiende de una manera más clara a la simetría, como así podemos comprobar al observar que mientras que San Joaquín levanta su brazo derecho, Santa Ana contesta haciendo lo propio con el izquierdo. Por su parte, la Virgen Niña levanta ambos brazos, dándoles las manos a sus padres. Mayor relación guarda este grupo con otro similar, incluso en tamaño, localizado en la capilla del Santo Cristo de la Catedral de Orense, asimismo atribuido a Juan de Ávila, pero que, debido a su avanzada fecha, también me obliga a colocar en el apartado de "obras relacionadas". La similitud de este grupo y el de Aguilar de Campoo es clarísimo en su disposición general, pero también en los rostros de la Virgen y de Santa Ana. De lo que no hay duda es que existía un patrón en la ciudad de Valladolid que servía de modelo para todas estas versiones. Aquí también cabría meter los ya vistos de Flores de Ávila (Ávila) y de Covarrubias.

Nada posee este grupo que pueda ser relacionado con Juan de Ávila: los rostros no poseen ninguna de las características, especialmente el de Santa Ana; la disposición de los cabellos es demasiado apelmazada; las arrugas de los rostros son demasiado duras, no poseen la blandura del que hace gala Ávila, las narices son más afiladas, y, también los pliegues son mucho más duros, especialmente los de la túnica de San Joaquín.

\section{CARRIÓN DE LOS CONDES. MONASTERIO DE SANTA CLARA}

SAN JOSÉ (Último cuarto del siglo XVII)

En la tribuna de la Epístola de la iglesia del Monasterio de Santa Clara de Carrión de los Condes, antiguo oratorio de la madre Luisa, se localiza una escultura de vestir, que representa a San José (Fig. 156), que recientemente ha sido atribuida a nuestro escultor por la doctora Lorena García ${ }^{909}$. Antiguamente, este San José formaba parte, junto a una Santa Inés del siglo XVII y un San Antonio atribuido a Tomas de Sierra, todas ellas esculturas de vestir, de un retablo neoclásico realizado hacia 1786; situado en el coro bajo de la iglesia. En la actualidad estas piezas han sido sustituidas por tres imágenes modernas de la Inmaculada, San Francisco y San José con el Niño ${ }^{910}$.

Lorena García define así el curioso San José articulado: "La otra pieza es un San José articulado del taller de Juan de Ávila. Está acompañado de un Niño Jesús que no se correspondería con el mismo autor, sino que se trataría de una pieza procedente de una peana, como así testimonian las oquedades de sus pies. Al parecer la figura de San José

909 GARCÍA GARCÍA, Lorena: op. cit., p. 644. Deseo dar las gracias a Lorena por haberme facilitado una fotografía de San José para poder estudiarlo.

$910 \quad$ Ibídem. 
fue serrada en un momento determinado, sustituyéndose el bastidor inicial de la parte inferior por otro, con calzado y faldilla tallados. Así lo evidencia la diversa policromía de esta parte con la del tronco superior y los brazos movibles"911. Aunque se trata de un San José articulado que se realizó para ser vestido, tiene tallado todo el cuerpo; eso sí, tan solo la cabeza, las manos y las piernas tienen calidad artística, el resto está esculpido de una manera muy somera. El motivo es claro: lo iba a tapar la ropa que le confeccionaran las monjas. La imagen posee un lejano parecido en su rostro con el del San José que se conserva en la vallisoletana iglesia de San Nicolás, y con el cual le relacionamos. A pesar de esta similitud, el ejemplar de Carrión de los Condes baja mucho, se trataría de una copia de inferior calidad, la forma de tallar el rostro y la cabellera es más burda y simple. Si la referida imagen vallisoletana tan solo se podía relacionar con nuestro escultor, ésta ni siquiera podemos aceptarla ni como atribuida ni como relacionada; pienso que será obra de algún escultor modesto.

\section{CARRION DE LOS CONDES. IGLESIA DE SANTA MARÍA DEL CAMINO}

\section{ESCULTURAS DEL RETABLO MAYOR (¿Tomás de Sierra? 1684)}

El retablo mayor de la iglesia de Santa María del Camino fue mandado construir en 1684 por el obispo Juan del Molino Navarrete, el cual se concertó para su realización con el prestigioso ensamblador Santiago Carnicero, vecino de Villada ${ }^{912}$. Su dorado, ejecutado en 1685, corrió a cargo de Alonso Gómez, vecino de Mazuecos de Campos, uno de los grandes doradores castellanos de esta época. Salió por su fiador Santiago Carnicero $^{913}$. El cuerpo tiene tres calles enmarcadas por cuatro columnas salomónicas, en las calles laterales se encuentran San Juan Bautista (160 cms.) (Fig. 157) y San Juan Evangelista (150 cms.), y en la central la Inmaculada Concepción $(157 \mathrm{cms}$.), que sigue de cerca el modelo implantado por Gregorio Fernández, aunque de una manera bastante libre. El ático lo preside San Francisco de Asís. Señala Lorena García que la inclusión de los Santos Juanes "se justificaría por la alusión al patrón, Fray Juan de Molino y a su madre, llamada Juana"914. Por su parte, la Inmaculada tendría relación con "la dedicación del templo a Santa María y la vinculación del obispo Molino a esta tipología, como custodio que fue de la provincia franciscana de la Concepción"915. Finalmente, el San Francisco del ático estaría relacionado con este último motivo, dado que "era franciscano y a esto hay que sumar el hecho de que su padre fue bautizado con el nombre de Francisco, de ahí la elección del santo de Asís" "916.

\begin{tabular}{ll}
\hline 911 & Ibídem. \\
912 & Ídem, p. 890. \\
913 & Ídem, p. 896. \\
914 & Ídem, p. 892. \\
915 & Ibídem. \\
916 & Ibídem.
\end{tabular}


Pues bien, estas cuatro esculturas que posee el retablo fueron atribuidas al círculo de Juan de Ávila por Martín González y Urrea ${ }^{917}$. Al igual que veremos en la siguiente escultura de San Juan Bautista de la parroquial de Cevico de la Torre, la figura del Precursor sigue el modelo utilizado tanto por Ávila como por la inmensa mayoría de los escultores de la escuela vallisoletana barroca; sin embargo, su ejecución está fuera de la órbita de Ávila. No tenemos más que comparar la escultura del San Juan Bautista con los otros que le tenemos documentados o atribuidos, y nada en ellos les asemeja. El resto de esculturas tampoco le pueden ser atribuidas, pues tanto los rasgos faciales, como los prototipos físicos y los plegados nada tienen que ver con nuestro escultor.

Pienso que las esculturas del retablo pudieran pertenecer al berciano de nacimiento, aunque riosecano de residencia, Tomás de Sierra, el cual trabajó de forma denodada para esta zona de la actual provincia palentina, y tierras cercanas. Para ello me baso en que Santiago Carnicero y Tomás de Sierra colaboraron en multitud de empresas artísticas para las más diversas iglesias, cofradías y ermitas; y, sobre todo, en la absoluta similitud existente entre el San Juan Bautista de este retablo y el del retablo mayor de la parroquial de Villaumbrales (Palencia), obra documentada del citado Sierra ${ }^{918}$.

\section{CEVICO DE LA TORRE. IGLESIA PARROQUIAL DE SAN MARTÍN}

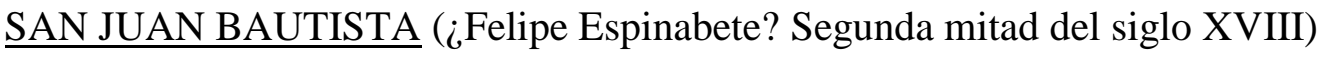

Tanto esta escultura como la del San Miguel de la misma iglesia están atribuidas a escultor Juan de Ávila por los autores del Inventario Artístico de Palencia: "Esculturas de San Juan Bautista y San Miguel, del siglo XVII, del estilo del escultor Juan de Ávila"919. Puede que esta talla fuera la imagen titular de la cofradía de San Juan Bautista sita en esta misma iglesia.

Esta escultura (Fig. 158) no posee ningún rasgo que lo vincule a Ávila, pues no hay nada más que compararlo con los varios Bautistas que le tenemos documentados o atribuidos. Quizás, tan solo, el detalle del manto caído sobre el hombro derecho; si bien este detalle es muy característico de los Bautistas que crearon los escultores vallisoletanos desde tiempos de Gregorio Fernández, su verdadero origen. La talla tiene un aspecto chato y musculoso que nada tiene que ver con Ávila. Lo único cierto es que la composición general del Bautista es idéntica a la utilizada por nuestro escultor, pero, como hemos dicho, era típica de la escuela vallisoletana, no solamente de Ávila. Esto nos indica que el escultor que la talló vivía y trabajaba a las orillas del Pisuerga. Pienso que el autor de la obra es, con toda probabilidad, Felipe de Espinabete, o su taller, puesto que tanto la forma de disponer el pelo, los ojos pequeños y juntos, y el

917 URREA FERNÁNDEZ, Jesús y MARTÍN GONZÁLEZ, Juan José: Inventario artístico de Palencia y su provincia I..., op. cit., p. 58.

$918 \quad$ Ídem, p. 307.

919 Ídem, p. 136. 
característico detalle de rematar la barba con dos caracolillos apuntan en esa dirección. Todos estos detalles los vemos en multitud de obras del escultor tordesillano; como, por ejemplo, la cabeza de San Juan Bautista que perteneció al Convento de La Laura de Valladolid, actualmente en el Monasterio de Sancti Spiritus de la localidad zamorana de Toro; eso sí, esta última posee un nivel escultórico muchísimo más alto; de ahí que el Bautista pueda ser obra de taller.

\section{HORNILLOS. IGLESIA PARROQUIAL DE SAN MIGUEL}

\section{CRISTO ATADO A LA COLUMNA (Anónimo. Comienzos del siglo XVIII)}

En una hornacina lateral de un retablo situado en el lado del Evangelio se encuentra una pequeña imagen de Cristo atado a la columna (Fig. 159) que Brasas Egido relaciona con Juan de Ávila: "de hacia 1700, copia el modelo de Gregorio Fernández relacionable con la obra del escultor Juan de Ávila ${ }^{920}$. Años antes este Crucifijo había sido fechado en el siglo XVIII ${ }^{921}$. Es rara la presencia de una escultura de tan escaso tamaño en hornacinas que nada tienen que ver con ella; quizá fue regalada por algún vecino del pueblo que lo tenía en su oratorio particular. Según me comentó la amable señora que me mostró la iglesia, la talla fue robada y, siete años después, apareció en Huelva junto a otras piezas usurpadas a la parroquia.

La escultura copia puntualmente la tipología de Cristo atado a la columna creada por Gregorio Fernández. Posee gran naturalismo, canon esbelto. Surge un contraposto en el modo de colocar las piernas, una de ellas avanza mientras la otra se encuentra en retroceso. Las manos sobre la columna están atadas por una soga. Rostro como ensimismado. Los cabellos se tratan de manera más o menos individualizada, con ciertas ondulaciones. Los ojos son postizos, de color negro, lo que le da aporta a la escultura mayor viveza. Aparecen pequeños restos de sangre en la frente y bajo la nariz, también hay sendos regueros en cada una de las rodillas. La talla se encuentra muy repolicromada, con colores planos, además de estar en muy mal estado de conservación, lo que impide un estudio pormenorizado. De todas maneras, poco tiene que ver esta escultura con el estilo de Juan de Ávila: el pelo y la barba poseen poco resalte, la anatomía no está demasiado pormenorizada, los paños son muy simples, etc... No me atrevo a dar ninguna atribución ni cronología.

\footnotetext{
920 BRASAS EGIDO, José Carlos: Catálogo Monumental de la provincia de Valladolid. Tomo X..., op. cit., p. 81.

921 MARTÍN GONZÁLEZ, Juan José (dir.): Inventario artístico de Valladolid..., op. cit., p. 143
} 


\title{
LEÓN. MUSEO CATEDRALICIO-DIOCESANO
}

\author{
BUSTO DE ECCE HOMO (Anónimo. h. 1657)
}

El primero en hablar del presente busto de Ecce Homo (Fig. 160) fue Martín González, el cual tan solo refirió que la escultura copiaba un modelo de Gregorio Fernández ${ }^{922}$. Posteriormente, Llamazares Rodríguez la ha relacionado con Juan de Ávila ${ }^{923}$. Aunque en la actualidad se encuentra expuesto en el Museo Catedralicio y Diocesano, con anterioridad, cuando lo estudió Martín González, se encontraba en la sacristía de la catedral; pero, éste tampoco fue su lugar primigenio. Según explica Llamazares Rodríguez, este busto se encontraba en la capilla de San Charles (Carlomagno), para ello se apoya en un acta capitular que fecha la colocación de este busto en la referida capilla en el año 1657: "Así mismo cometió el cabildo (...) la disposición del retablo de San Charles y reja para colocar la efigie del Ecce Homo que está tras del coro"924.

Como vemos, la temprana fecha en que consta que existía descarta por completo la atribución de este busto a nuestro escultor. De todas maneras, la forma de elaborar los pliegues es mucho anterior a la época en la que Ávila trabaja. Tampoco tiene nada que ver la manera de tallar la cabellera y barba, y ni siquiera los rasgos faciales. De lo que pienso que no hay dudas es que el busto procede de algún taller de la ciudad del Pisuerga.

\section{MEDINA DE RIOSECO. MUSEO DE SEMANA SANTA}

\section{CRISTO ATADO A LA COLUMNA (Anónimo. Mediados del siglo XVII)}

La presente escultura (Fig. 161), que copia de manera invertida la composición del Atado a la Columna que Gregorio Fernández talló para la Cofradía Penitencia de la Santa Vera Cruz de Valladolid, fue atribuida por Urrea a Juan de Ávila, refiriendo que se trata de una "copia muy blanda, seguramente de Juan de Ávila, sobre original de Gregorio Fernández" 925 . Nunca se ha propuesto otro nombre que no fuera éste, si bien, como veremos posteriormente, no se puede aceptar de ninguna manera que Ávila fuera el autor de este bellísimo Cristo. Anteriormente a Urrea, García Chico estudió en diversas ocasiones esta escultura. La primera vez, en 1945, señaló algo evidente, que "recuerda las efigies de Gregorio Fernández"926; para años después considerarla de "un

\footnotetext{
922 MARTÍN GONZÁLEZ, Juan José: Escultura barroca castellana. Segunda parte, op. cit., p. 155 923 LLAMAZARES RODRÍGUEZ, Fernando: Guía de León. Lancia, León, 2001, p. 70.

924 LLAMAZARES RODRÍGUEZ, Fernando: "Iconografías de los siglos XVI, XVII y XVIII en las capillas de la Catedral de León” en Entorno a la catedral de León (estudios), Universidad de León, León, 2004, p. 389.

925 URREA FERNÁNDEZ, Jesús: "Semana Santa”, Cuadernos Vallisoletanos, no 24, Caja de Ahorros Popular de Valladolid, Valladolid, 1987, p. 15.

926 "Escultura de extraordinario valor artístico, del extinguido convento de San Francisco. En su desnudo, parece de veras carne, sangre y nervios que laten y sufren. Recuerda las efigies de Gregorio Fernández". GARCÍA CHICO, Esteban: La ciudad de los Almirantes: su historia y tesoro artístico, Diputación Provincial de Valladolid, Valladolid, 1945, p. 200.
} 
discípulo de Gregorio Fernández" ${ }^{27}$. Finalmente, en el primitivo tomo dedicado a Medina de Rioseco en el Catálogo Monumental la consideró simplemente "de la escuela de Gregorio Fernández"928.

Es una copia a menor escala de la obra maestra que Gregorio Fernández talló para la Cofradía de la Vera Cruz de Valladolid, es una prueba más del éxito del que gozaron los modelos de Fernández desde el mismo momento de su creación. La gran diferencia respecto a ésta se encuentra en que la composición está invertida respecto al original, y en el tamaño, siendo ésta de mucha menor altura. Sigue el modelo en todos los sentidos: columna baja de tipo de Santa Práxedes, que obliga a hacer al cuerpo una leve flexión hacia adelante.

Este Atado a la Columna, conocido cariñosamente como "Ceomico" o "Ecceomico", se conserva en la iglesia de Santa Cruz, actual Museo de Semana Santa. La imagen procede de la capilla de San Andrés del Convento de San Francisco, que era la primera del lado de la Epístola, aunque con posteriormente se "mudó" a la capilla derecha del pórtico, que era propiedad de Juan de Calahorra. A raíz de este traslado esta capilla tomo el nombre de "capilla del Ecce Homo"929. Como podemos comprobar, la escultura no poseía un carácter procesional, si bien las circunstancias se dieron la vuelta tras la Desamortización, en que el Atado fue a parar a la iglesia de Santa Cruz, en donde fue ubicado en la hornacina del banco del retablo del Santo Cristo de la Pasión; momento en que se incorporó a los desfiles procesionales ${ }^{930}$.

El dato por el cual descartamos totalmente la autoría de Juan de Ávila es porque tenemos noticia de que ya existía en 1653. Cuentan Asensio Martínez y Pérez de Castro que "en 1653 tenemos noticia indirecta de su existente: Ese año Bartolomé Arango compra la capilla de San Andrés, la tercera del lado de la Epístola dentro de la iglesia franciscana, permitiendo que continuase allí una imagen del Cristo Atado a la Columna

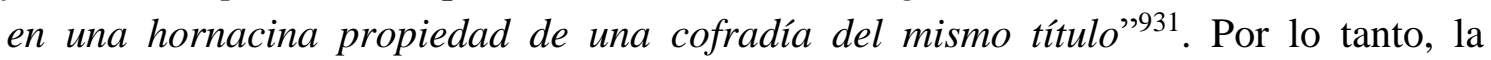
escultura debió de fabricarse en el segundo cuarto del siglo XVII, quizás hasta en vida

927 "De la iglesia conventual de San Francisco pasó en depósito una efigie algo menor del natural de Jesús atado a la columna, de un discípulo de Gregorio Fernández”. GARCÍA CHICO, Esteban: El arte en Castilla. Los templos riosecanos: el arte en Castilla, Diputación Provincial de Valladolid, Valladolid, 1955 , p. 53

928 "De la iglesia conventual franciscana pasó en depósito una efigie, algo menor del tamaño natural, de Jesús atado a la columna, de la escuela de Gregorio Fernández”. GARCÍA CHICO, Esteban: Catálogo Monumental de la provincia de Valladolid. Tomo I. Medina de Rioseco, Diputación de Valladolid, Valladolid, 1956, p. 118.

929 WATTENBERG GARCÍA, Eloísa: Catálogo Monumental de la provincia de Valladolid. Tomo XVII..., op. cit., p. 63.

930 ASENSIO MARTÍNEZ, Virginia y PÉREZ DE CASTRO, Ramón: "Semana Santa en Medina de Rioseco. Los conjuntos procesionales de Medina de Rioseco". En ALONSO PONGA, José Luis (coordinador): La Semana Santa en la Tierra de Campos vallisoletana, Sever-Cuesta, Valladolid, 2003, p. 177.

$931 \quad$ Ídem, p. 178. 
de Fernández. Así lo ve Martín González, para el cual "por las dobladuras del paño se deduce que sería hecho no mucho después que el de Fernández"932.

\section{VIRGEN DE LA ALEGRÍA (Anónimo. Último cuarto del siglo XVII)}

La Virgen de la Alegría (Fig. 162), en realidad una Inmaculada que sigue fielmente el modelo implantado por Gregorio Fernández, desfila procesionalmente en la mañana del Domingo de Resurrección, si bien no fue creada con ese propósito. En la actualidad se conserva en la iglesia de Santa Cruz, actual Museo de Semana Santa, aunque desconocemos el lugar del que procede. La atribución a Juan de Ávila, más bien a los Ávila en general viene dada por el profesor Ramón Pérez de Castro y por Virginia Asensio: "pero por su forma de tallar la consideramos realizada dentro del siglo XVII aunque ya bastante avanzado, seguramente en su segunda mitad, por ciertas semejanzas con la obra de los Ávila o el mismo Sierra, mucho más dulce y afilada la expresión del rostro" ${ }^{933}$.

A pesar de que el rostro pueda poseer un lejano eco de Juan de Ávila, tanto la anchura del mismo, como la boca cerrada, manera de disponer los cabellos y la rugosidad de los pliegues lo alejan bastante de nuestro escultor. Pienso que lo más probable es que esta Inmaculada se deba a Tomás de Sierra, puesto que la blandura del rostro de la Virgen como la propia concepción de los angelotes son muy similares a otras imágenes de este artista. Es más, estos “putti” recuerdan bastante a los que años después tallará Pedro de Sierra.

\section{NAVA DEL REY. IGLESIA PARROQUIAL DE LOS SANTOS JUANES}

\section{RELIEVE DEL SUEÑO DE SAN JOSÉ (Anónimo. 1717-1718)}

El relieve (Fig. 163) que preside el ático del retablo de San José de la iglesia parroquial de los Santos Juanes de Nava del Rey fue atribuido a Juan de Ávila por García Chico y Bustamante García durante la primera redacción del Catálogo Monumental del Partido Judicial de Nava del Rey ${ }^{934}$. Resulta imposible que sea de nuestro escultor dado que no

\footnotetext{
932 "El Cristo a la columna, de la penitencial de la Vera Cruz, se guarda en la iglesia de San Francisco. Es una copia en pequeño del de Fernández en la penitencial de la Vera Cruz, de Valladolid, bien que invertida la composición. Por los dobladuras del paño se deduce que sería hecho no mucho después que el de Fernández. No hay inconveniente en admitir que algunas copias fueron hechas en vida del maestro, por escultores ajenos a su taller. No existiendo la "propiedad artística", ninguna barrera impediría la copia. De todas formas, el que aparezca invertida la composición no deja de ser un ingenuo intento de ocultar el plagio". MARTÍN GONZÁLEZ, Juan José: Escultura barroca castellana ..., op. cit., p. 125.

933 ASENSIO MARTÍNEZ, Virginia y PÉREZ DE CASTRO, Ramón: op. cit., p. 229.

934 "Retablo de San José. Sirve de coronamiento, encuadrado en un espléndido marco, un relieve que narra la escena del sueño de San José, revelado por un ángel, posiblemente debido a la gubia del escultor Juan de Ávila, colaborador con el maestro en varios retablos. El retablo es de Juan Correas".
} 
coincide ni en estilo ni en cronología, puesto que el relieve fue realizado en mismo año en que se ejecutó el retablo. Efectivamente, el retablo fue concertado el 13 de septiembre de 1717 por el ensamblador vallisoletano Juan Correas; y en una de las cláusulas de dicho contrato se establecía que "en la parte que está el Padre Eterno se ha de poner un San José dormido y encima el ángel uno y otro de medio relieve y en el tablero han de estar también el Espíritu Santo y algunas cabezas de serafines"935. Por lo tanto, si el relieve se realiza en 1717, y nuestro escultor falleció en 1702, la atribución no tiene ningún fundamento.

\section{PEÑAFIEL. CONVENTO DE SANTA CLARA}

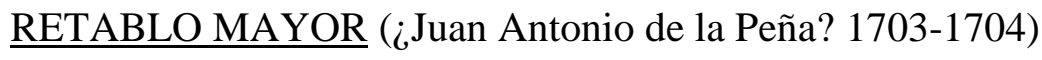

El retablo mayor de la iglesia del Convento de Santa Clara de Peñafiel fue realizado entre 1703 y 1704 por el ensamblador vallisoletano Alonso Manzano ${ }^{936}$. Efectivamente, el 14 de septiembre de 1703, fiado por su amigo el escultor Juan Antonio de la Peña, contrata la realización del retablo mayor del "Convento de la Encarnación del orden de San Francisco de dicha villa de Peñafiel" y los cuatro "colaterales del altar mayor de la iglesia" ${ }^{937}$.

Dos han sido las ocasiones en que las esculturas de este retablo han sido atribuidas a Juan de Ávila: primeramente, Martín González, que explicaba que caían "dentro del segundo estilo de Juan de Ávila, de plegado blando y de líneas paralelas, acusando las formas corporales, el retablo de las Claras de Peñafiel, contratado por Alonso de Manzano. El San Francisco de Asís responde en composición al de la iglesia del Rosarillo, de Valladolid; está en admiración, contemplando el Crucifijo; al otro lado vemos a San Bernardino de Siena. El relieve del ático muestra cierta coincidencia, sobre todo en composición, con el de Ataquines; el ángel se asemeja más al del relieve de la Oración del Huerto, de Sn Felipe de Neri, de Valladolid"938; y después Enrique Valdivieso ${ }^{939}$.

Las esculturas que conforman el retablo, y que fueron atribuidas a Ávila fueron las de San Francisco, San Bernardino de Siena y el relieve de la Anunciación. Hay que reseñar que la composición general de este relieve es completamente exacto al homónimo que

GARCÍA CHICO, Esteban y BUSTAMANTE GARCÍA, Agustín: Catálogo Monumental de la provincia de Valladolid. Tomo V..., op. cit., p. 27.

935 Ídem, pp. 83-84.

936 "Maestro de retablo. Más dan en data diez mil reales dados al maestro del retablo el cual se llama Alonso Manzano; los cuales son los mismos que tiene hecha escritura por todos ellos de que queda satisfecho; salvo si de parte de la comunidad se determinase cosa de guantes. 13.000". Archivo Histórico Nacional (en adelante A.H.N.), Sección Clero, Leg. 16.547, p. 272 (1701-1703); MARTÍN GONZÁLEZ, Juan José: Escultura barroca castellana..., op. cit., p. 314.

937 URREA FERNÁNDEZ, Jesús: “La biografía al servicio del conocimiento...,, op. cit., p. 56.

938 MARTÍN GONZÁLEZ, Juan José: Escultura barroca castellana ..., op. cit., p. 324.

939 VALDIVIESO, Enrique: Catálogo Monumental de la provincia de Valladolid. Tomo VIII..., op. cit., p. 170. 
vimos en la parroquial de Ataquines (Valladolid), si bien difieren en el estilo. En cuanto al San Bernardino de Siena, su identificación no ha sido siempre así: en ocasiones se ha pensado que se trata de San Pedro Regalado ${ }^{940}$, identificación que apoyo dado el parecido de su rostro con los de muchas de las esculturas que le efigian, por ejemplo la que hemos visto que se conservan en la iglesia penitencial de N. P. Jesús Nazareno.

La atribución a Juan de Ávila queda totalmente invalidada desde el momento que conocemos la fecha de contratación del retablo, septiembre de 1703, dado que Juan de Ávila había fallecido un año antes. Por el contrario, que Juan Antonio de la Peña salga por fiador de Alonso Manzano parece confirmarnos que el autor de las tallas fue el gallego afincado en Valladolid. De no contar con estos mínimos datos habría sido totalmente lógica su atribución a Ávila, puesto que el estilo es demasiado similar. Nuevamente vemos la conjunción de estilos entre Juan de Ávila, Juan Antonio de la Peña y José de Rozas.

\section{TORO. IGLESIA CONVENTUAL DE LA CONCEPCIÓN FRANCISCA}

ESCULTURAS DEL RETABLO MAYOR (Anónimo vallisoletano. h. 1705-1707)

José Navarro Talegón sitúa en el haber de nuestro artista las esculturas que componen el retablo mayor de la iglesia conventual de la Concepción Francisca (Fig. 164) de la localidad zamorana de Toro, si bien con anterioridad había formulado atribución a favor de Antonio Tomé, "pero hay que rectificarlo reconociendo que nada tienen en común con lo suyo, salvo, quizás, el haber servido la de san Félix de modelo a la homónima que entalló en maestro toresano para el hospital de la Convalecencia"941. Las esculturas que componen el retablo son: San Félix Cantalicio y Santa Teresa para las hornacinas laterales (la elección de estos dos santos se encuentra en relación a que dos de los grandes contribuyentes para la fabricación de este relieve fue el matrimonio formado por Félix de Ribera Velázquez y Teresa Sierra ${ }^{942}$; un relieve, casi bulto redondo, de la Estigmatización de San Francisco; y dos ángeles cabalgando sobre las ménsulas laterales del ático. Navarro Talegón alude a que estas "interesantes piezas salieron sin duda de Valladolid y seguramente se deban a Juan de Ávila"943. Lo único que tenemos documentado de esa posible relación entre este retablo y Valladolid es que del dorado del retablo, policromado de las esculturas y pintura de las decoraciones murales de la capilla mayor fueron realizados por vallisoletanos Miguel (será Manuel) y Agustín Estrada, forma abreviada con que a veces eran conocidos los "Martínez de Estrada"944.

\footnotetext{
940 MARTÍN GONZÁLEZ, Juan José (dir.): Inventario artístico de Valladolid..., op. cit., p. 230.

941 NAVARRO TALEGÓN, José: Inventario y catálogo..., op. cit., p. 22.

$942 \quad$ Ibídem.

943 Ídem, p. 23.

944 Ibídem.
} 
La atribución a Ávila de estas esculturas, calificadas por Navarro Talegón como "espléndidas", queda totalmente descartada por un motivo fundamental: las esculturas fueron realizadas, según el propio investigador comenta, entre los años 1705-1707 ${ }^{945}$, es decir, años después de la muerte del escultor vallisoletano.

\section{ZAMORA. IGLESIA DE SAN TORCUATO}

\section{SAN JUAN DE MATA Y SAN FÉLIX DE VALOIS (Anónimo. Finales del siglo XVII)}

En el retablo mayor de la iglesia de San Torcuato de Zamora, antigua iglesia del Convento de los Trinitarios Calzados, se conservan dos esculturas de santos trinitarios que han sido relacionados con Ávila. Se trata de San Juan de Mata y San Félix de Valois (Figs. 165-166). Efectivamente, Vasallo Toranzo, Almaraz Vázquez y Blanco Sánchez dijeron de ellas que "declaran su ascendencia vallisoletana por el tratamiento de las telas y la rigidez de las posturas, de manera que se acercan al círculo de José de Rozas y Juan de Ávila, maestros de perfiles todavía muy difuminados"946.

Para nada pueden adjudicarse estas esculturas a Juan de Ávila y ni siquiera a su taller, puesto que los rostros de ambos santos son muy convencionales, y nada poseen del vigor de Ávila. Las diferencias, aun solo en el rostro son más que evidentes: estas esculturas tienen unas narices estrechas; boca curva cerrada, barbas muy planas, secas, sin ningún resalte en los mechones; orejas saltonas, etc... tampoco la manera de tallar la cabellera tiene nada que ver con nuestro escultor. En cuanto a las vestimentas de los santos, estas poseen una rigidez acartonada nada usual en Ávila, al igual que los pliegues en zigzag que podemos ver tanto en sus túnicas como en los escapularios.

945 NAVARRO TALEGÓN, José: Catálogo monumental de Toro..., op. cit., p. 220.

946 VASALLO TORANZO, Luis, ALMARAZ VÁZQUEZ, María de las Mercedes y BLANCO SÁNCHEZ, José: “Antonio Tomé en el retablo de los Trinitarios de Zamora”, B.S.A.A., Tomo LXXI-2, 2005, p. 224. 


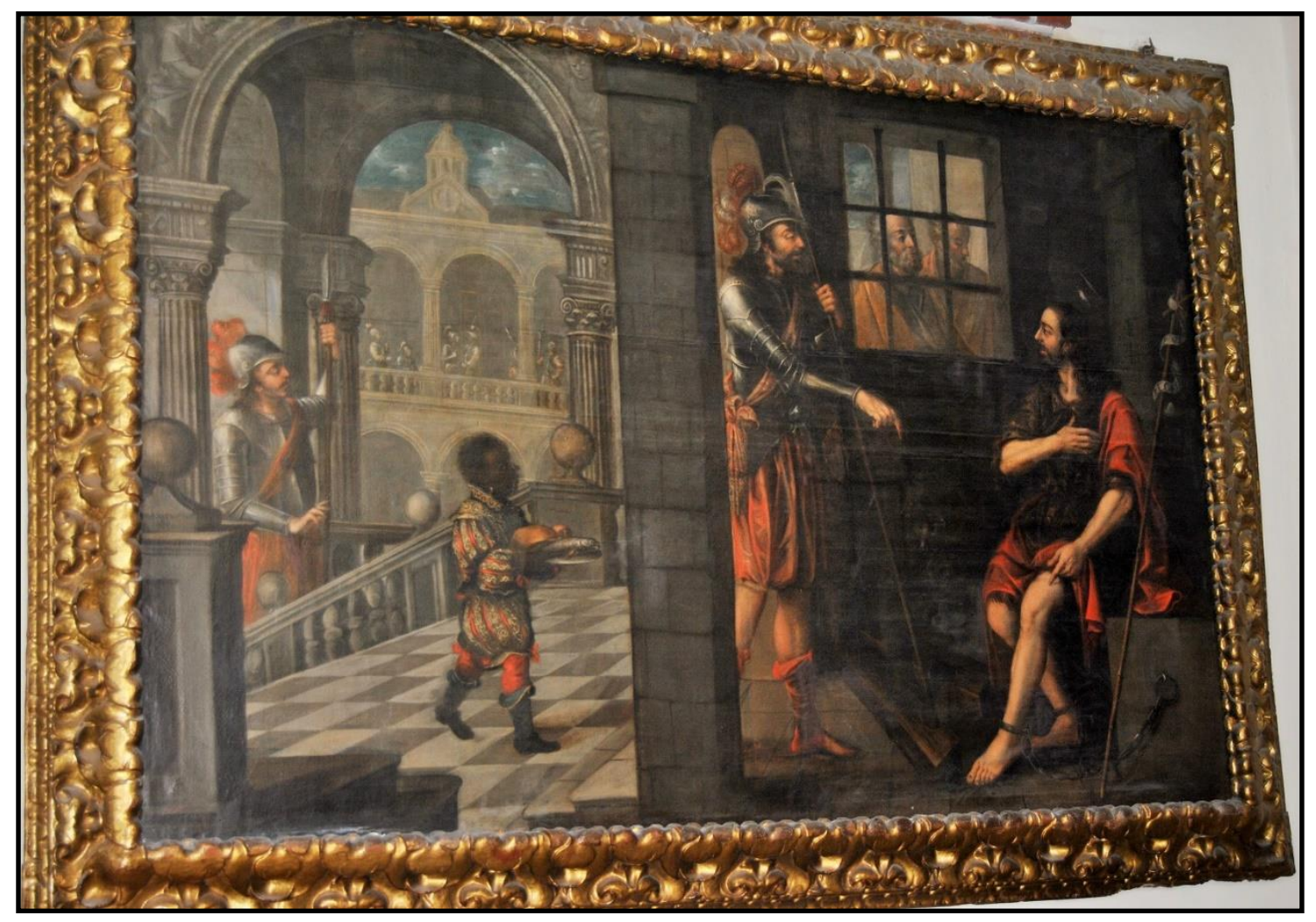

Fig. 1- Juan de Ávila. Marco. Iglesia de San Juan Bautista. Valladolid.

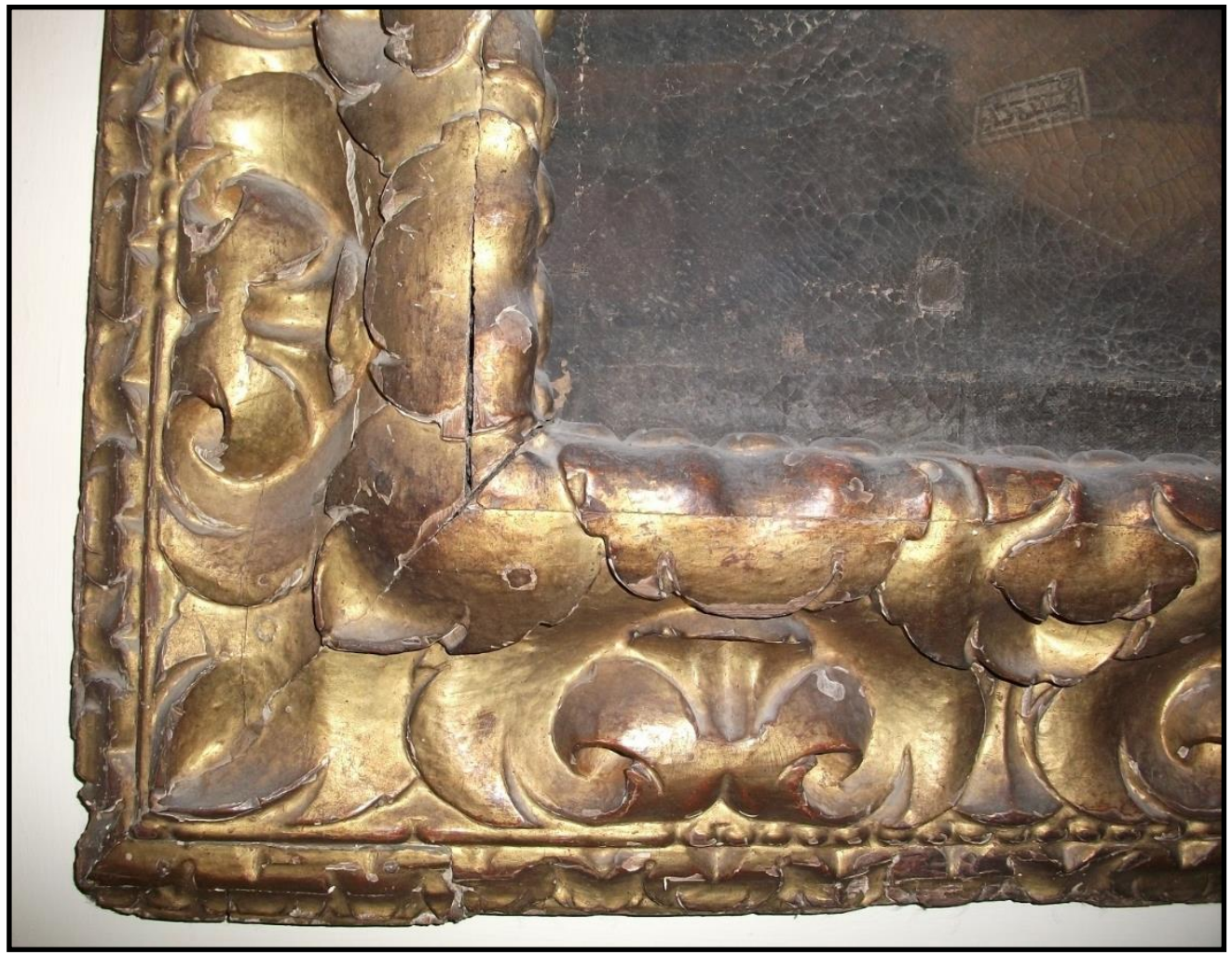

Fig. 2- Detalle del marco.

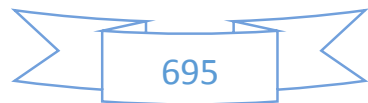




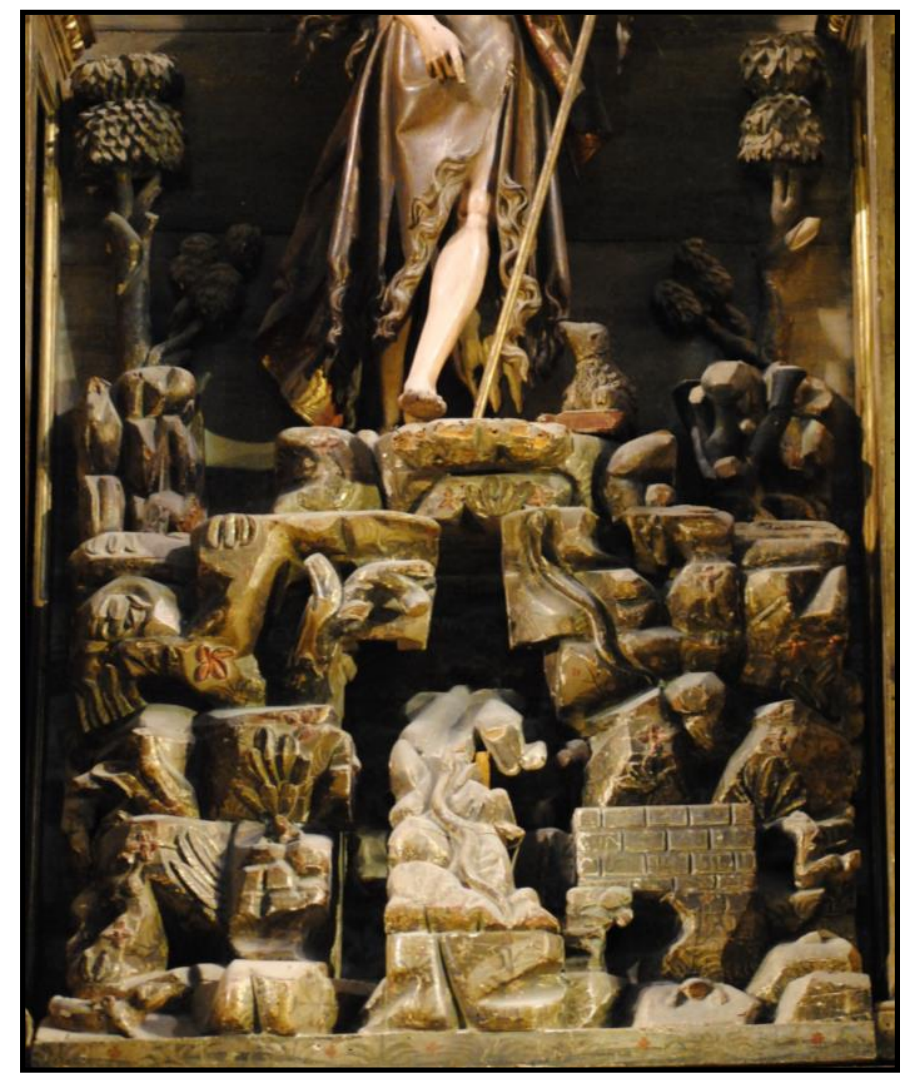

Fig. 3- Juan de Ávila. Peñasco. Iglesia parroquial de San Juan Bautista. Pesquera de Duero (Valladolid).

Fig. 4- ¿Francisco Díez de Tudanca o Juan de Ávila? San Juan Bautista. Iglesia parroquial de San Juan Bautista. Pesquera de Duero (Valladolid).
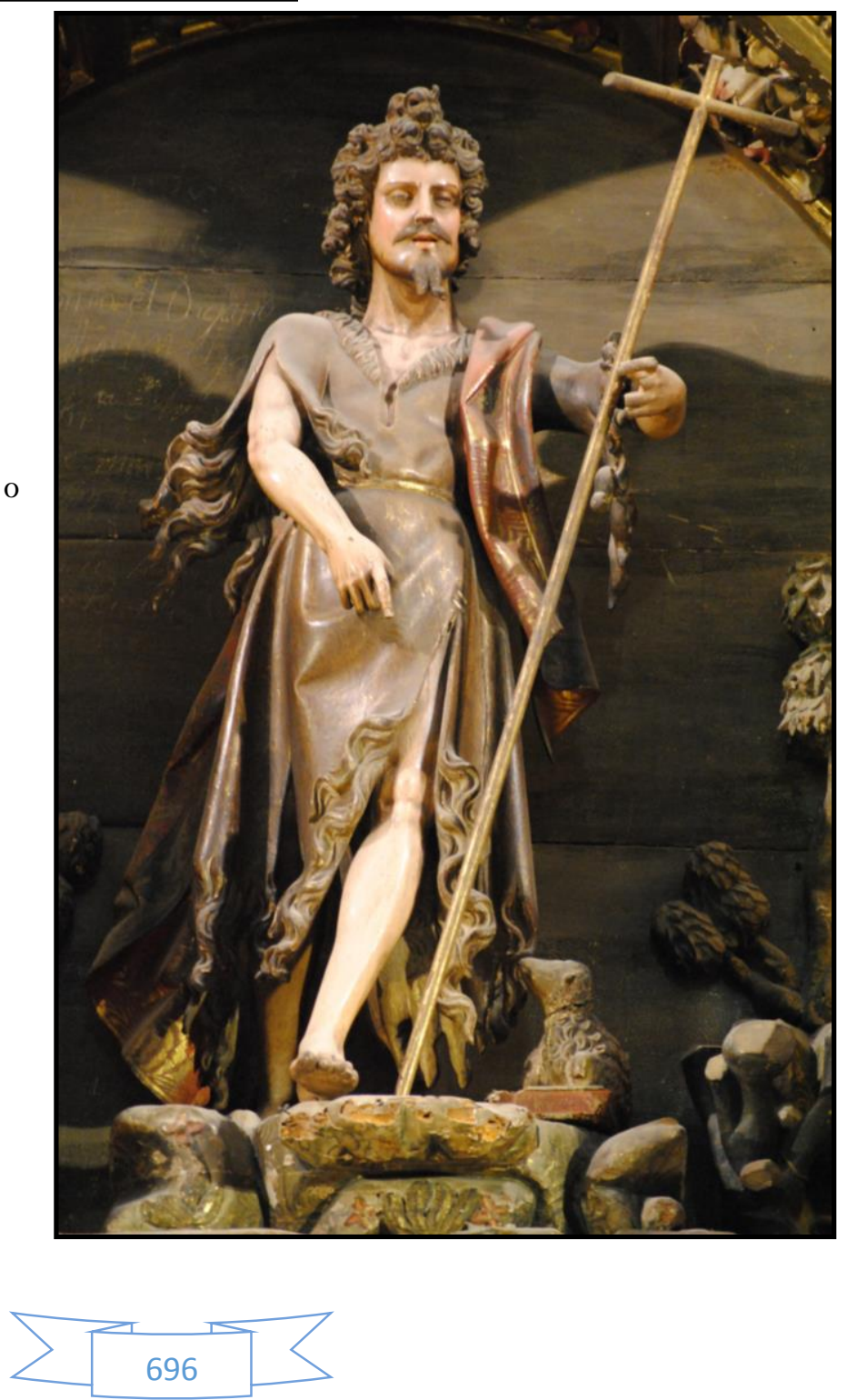


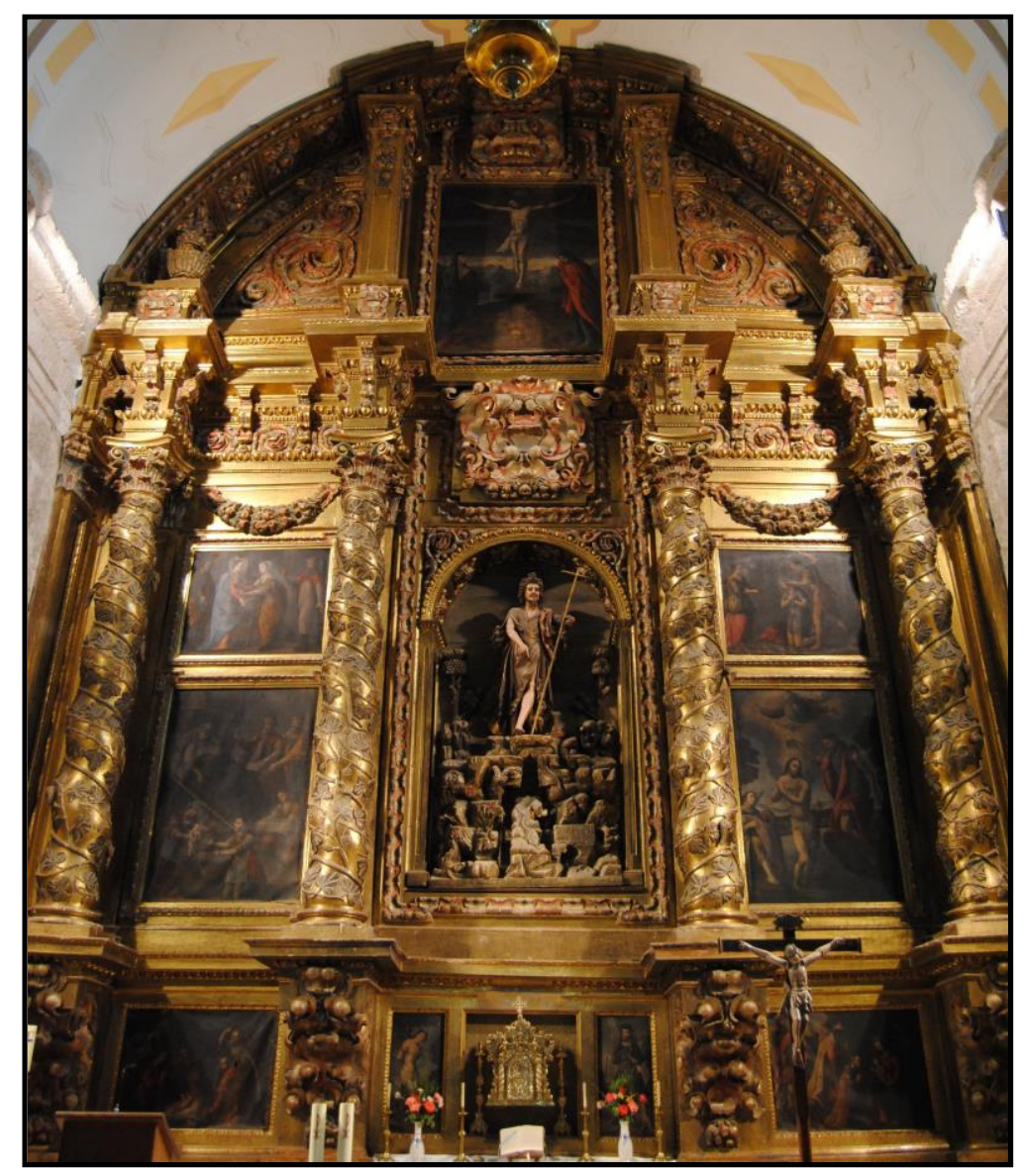

Fig. 5- Juan Fernández y Pedro de Fuertes. Retablo mayor. Iglesia parroquial de San Juan Bautista. Pesquera de Duero (Valladolid)

Fig. 6- Baltasar de la Puente. El Bautismo de Cristo. Iglesia parroquial de San Juan

Bautista. Pesquera de Duero (Valladolid).
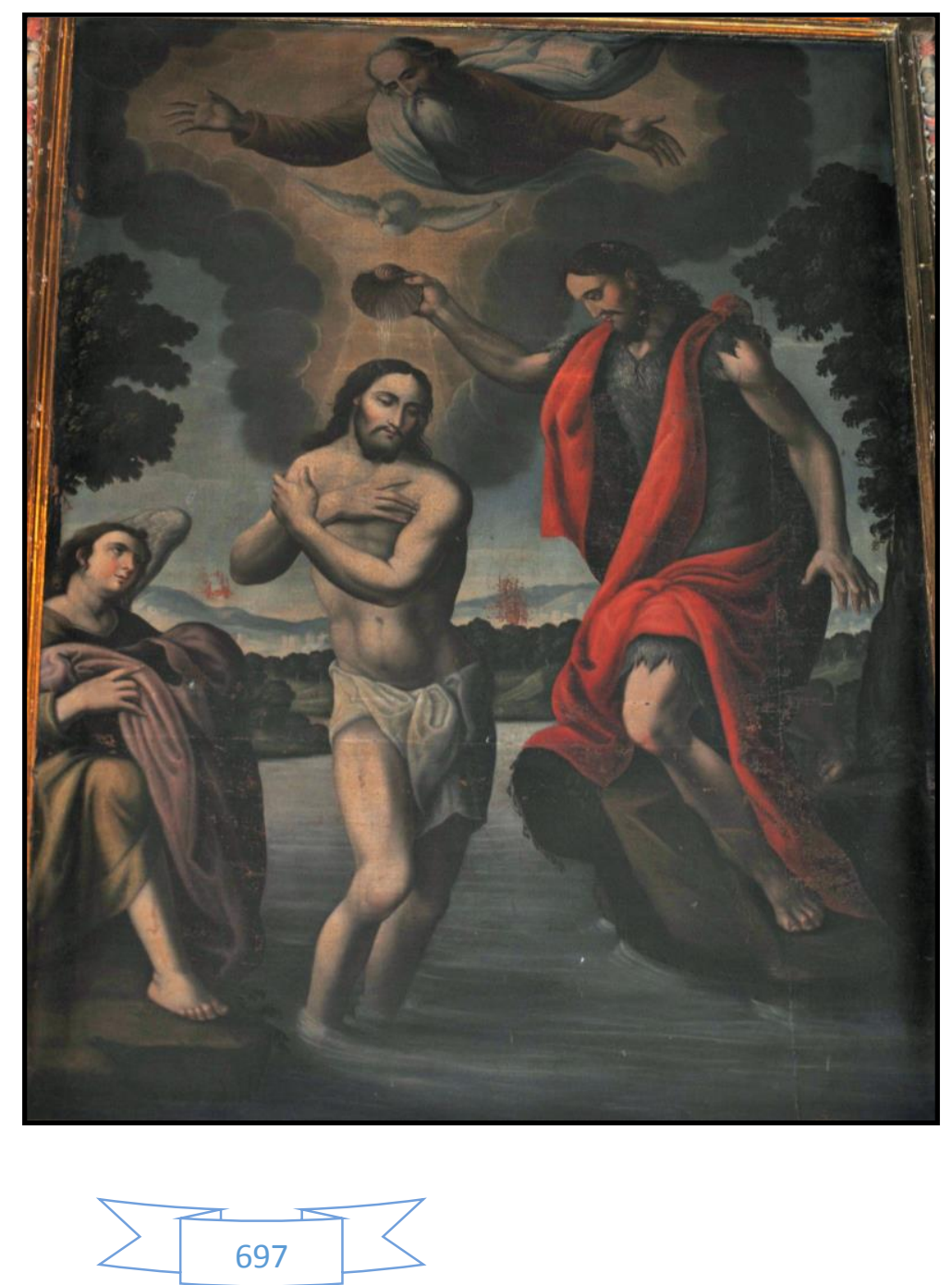


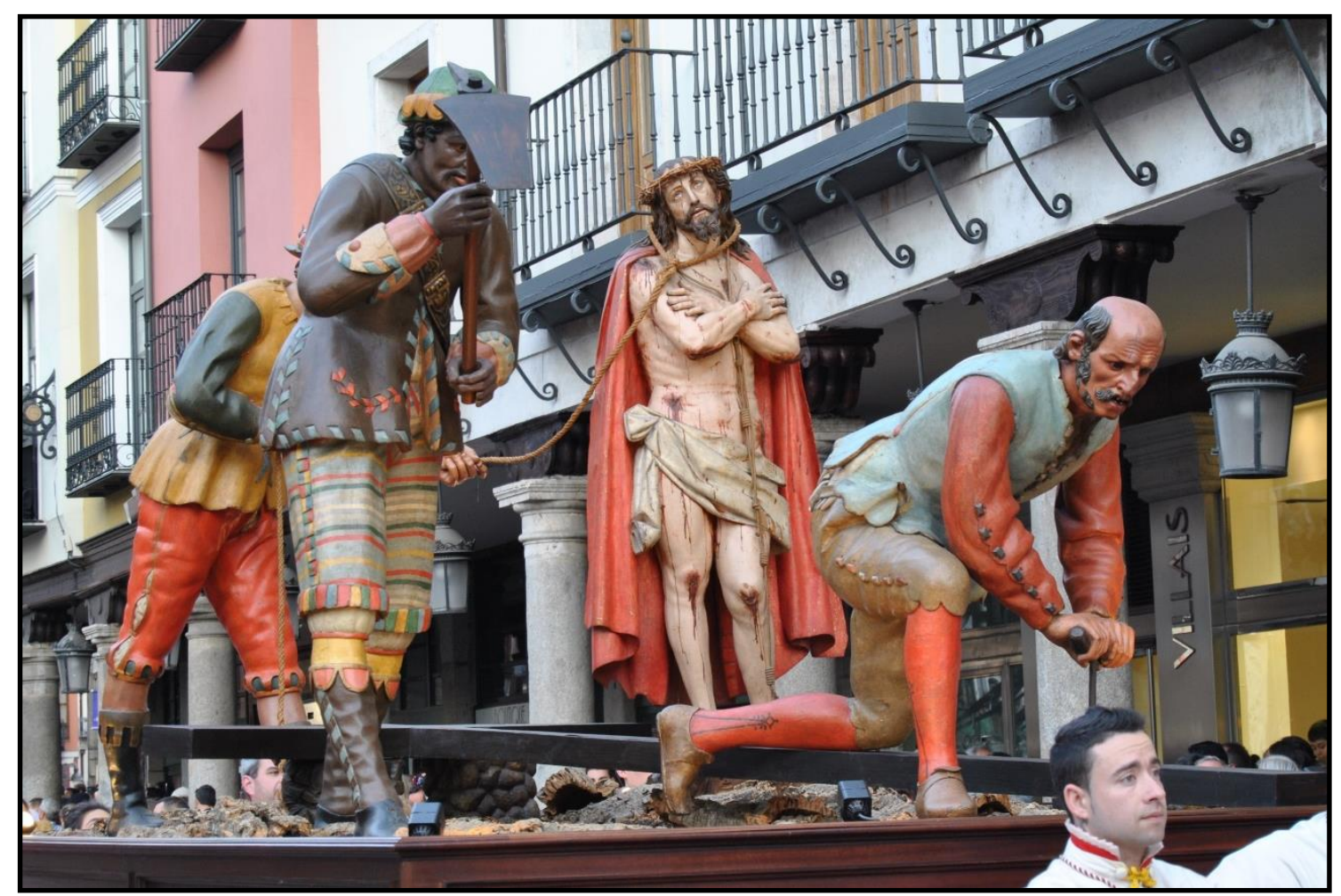

Fig. 7- Juan de Ávila. Paso "Preparativos para la Crucifixión” o "El Despojo". Museo Nacional de Escultura. Valladolid.

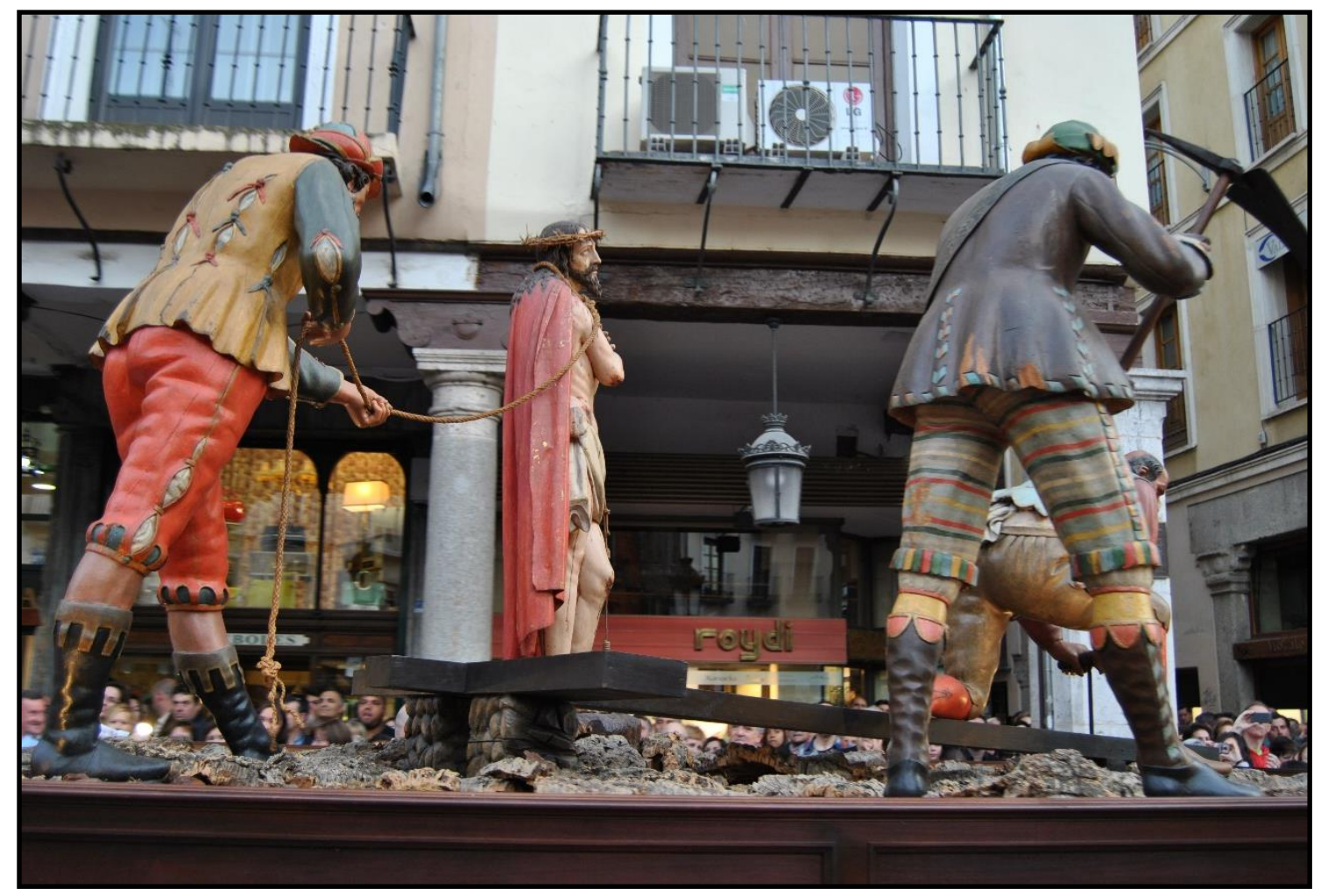

Fig. 8- Juan de Ávila. Paso "Preparativos para la Crucifixión” o "El Despojo". Museo Nacional de Escultura. Valladolid.

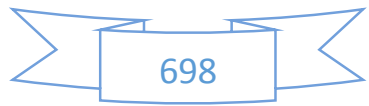




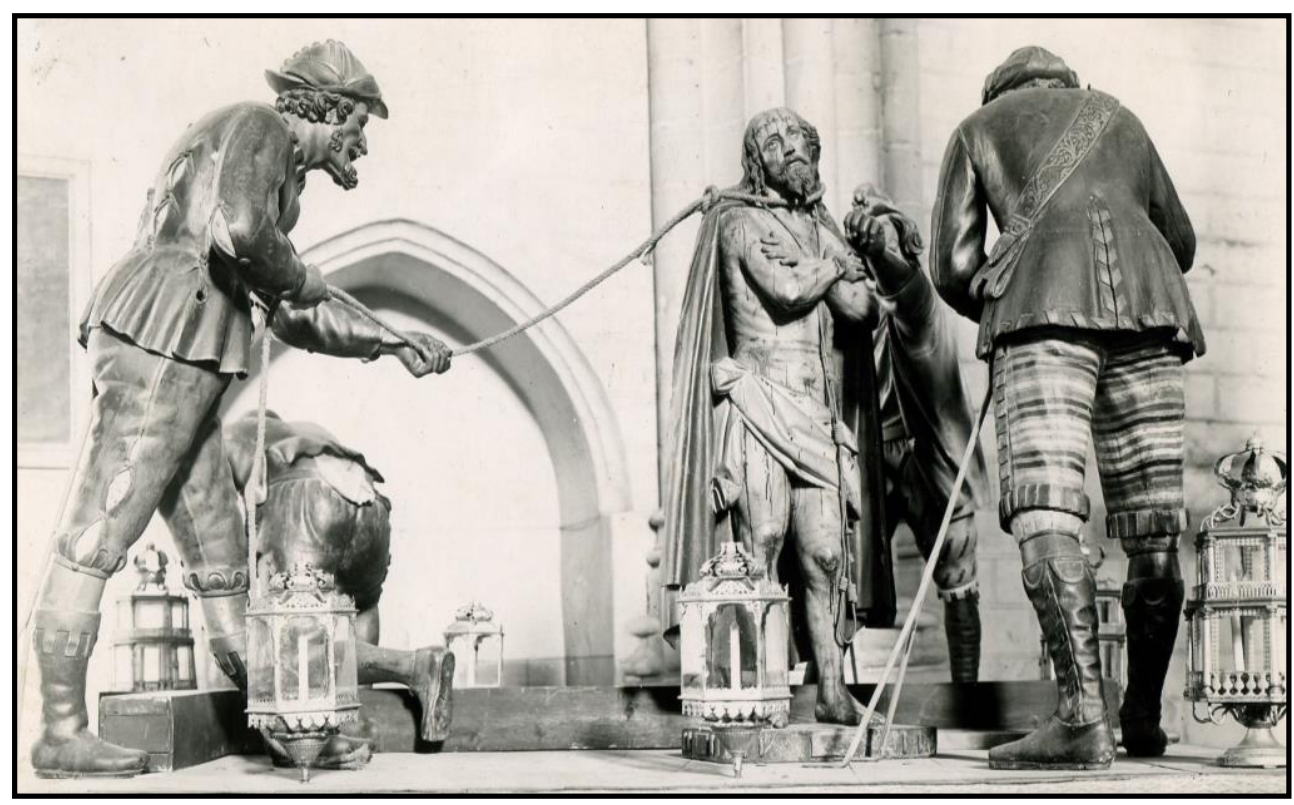

Fig. 9- Reconstrucción del paso del Despojo realizada por Agapito y Revilla con la errónea inclusión del "sayón de la guedeja" del Paso de La Flagelación de la Cofradía de la Pasión.

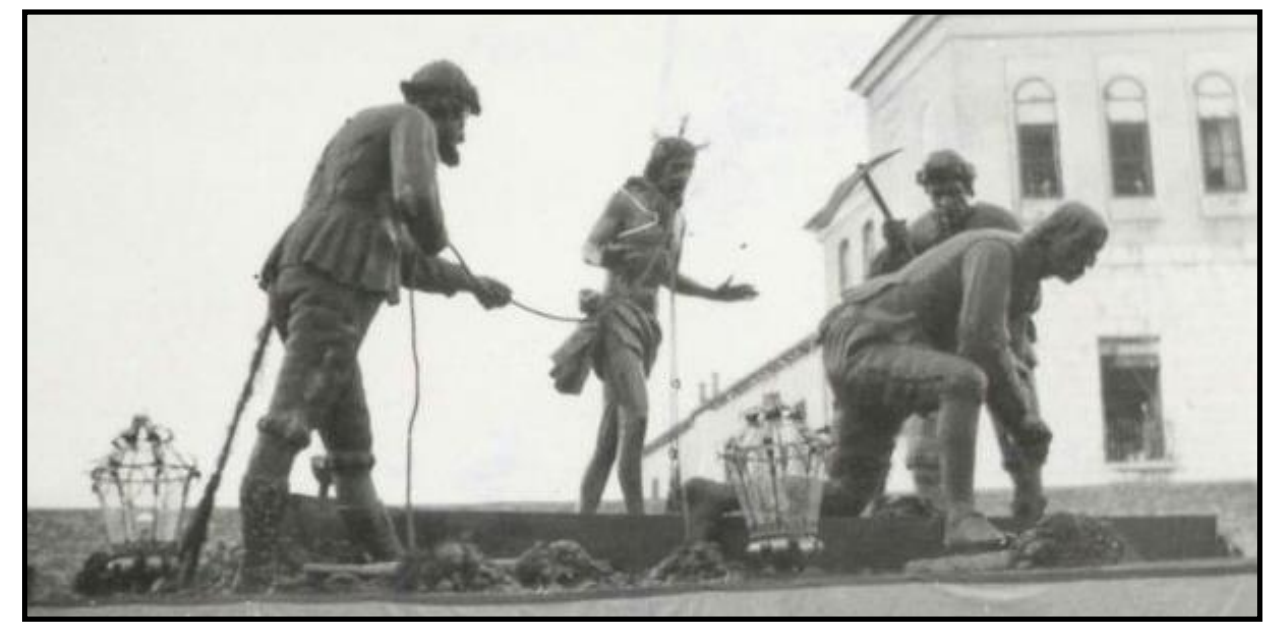

Fig. 10- Antigua disposición del paso del Despojo con el Cristo de Claudio Cortijo.

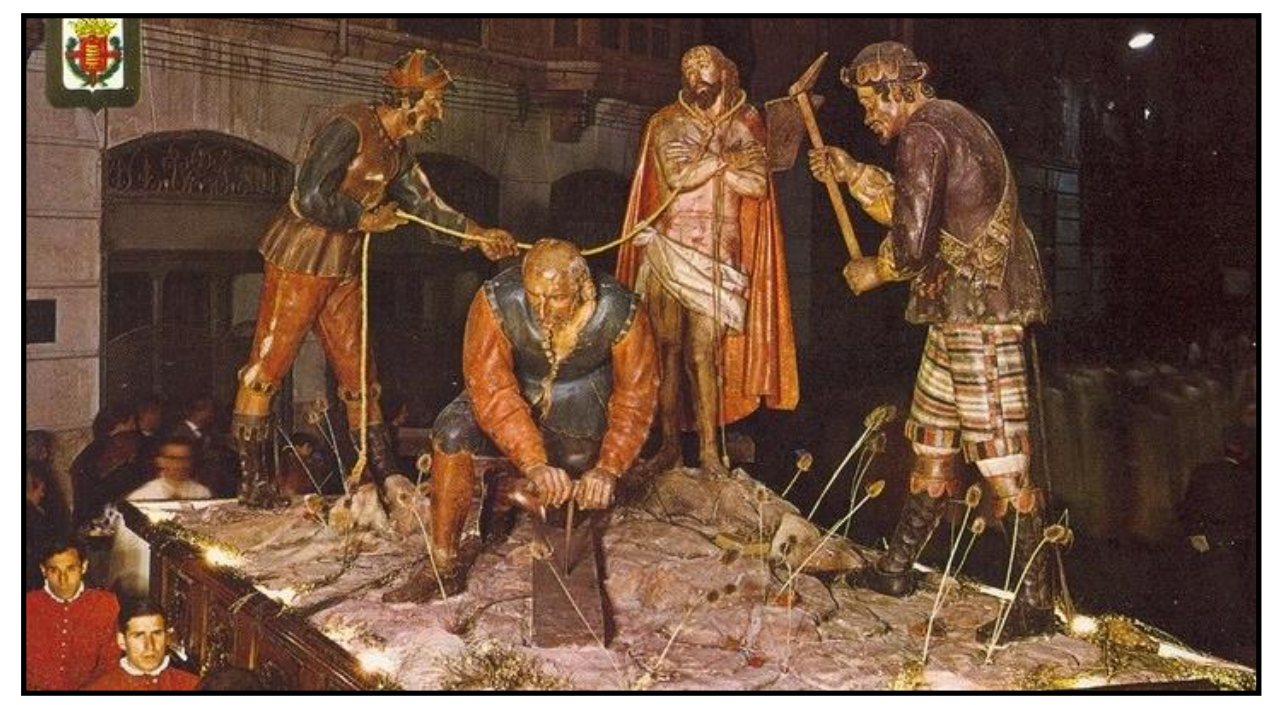

Fig. 11- Antigua disposición del paso del Despojo con el Cristo actual, atribuido a Francisco Alonso de los Ríos.

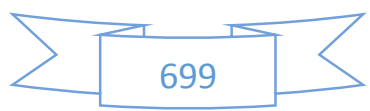




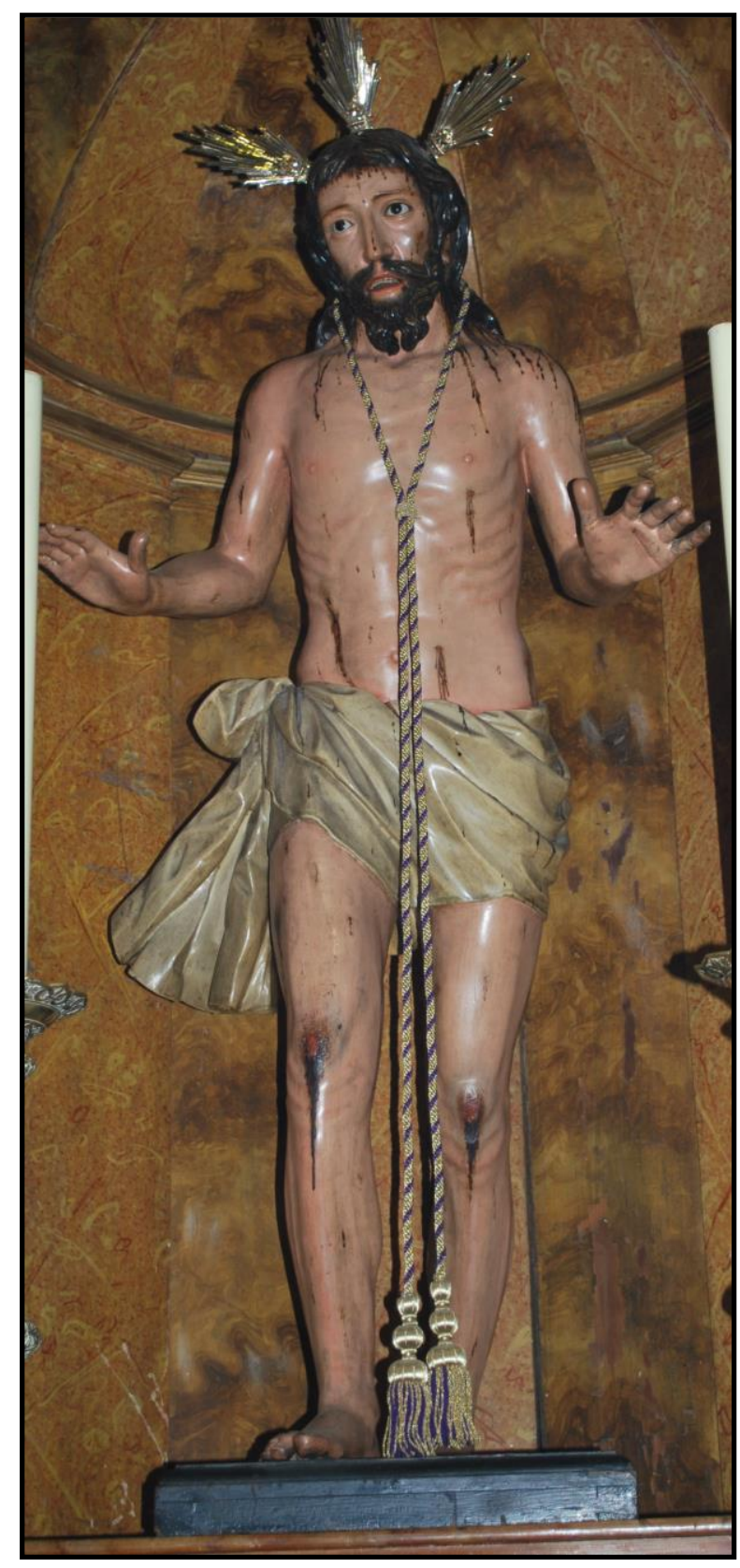

Fig. 12- Claudio Cortijo. Cristo del Despojo. Iglesia penitencial de N. P. Jesús Nazareno. Valladolid.

Fig. 13- Francisco Alonso de los Ríos (atrib.). Ecce Homo. Museo Nacional de Escultura. Valladolid. () Museo Nacional de Escultura.
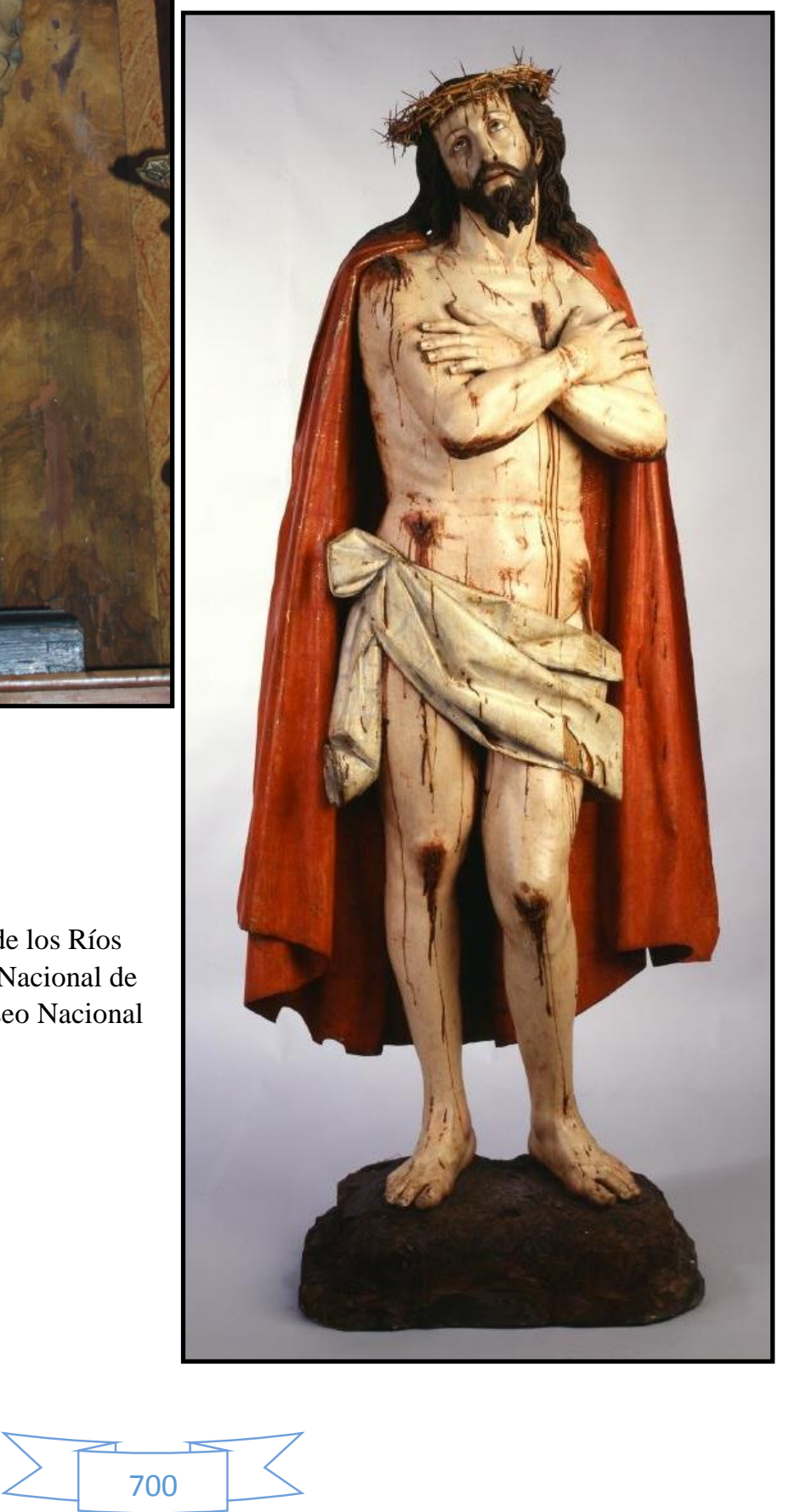


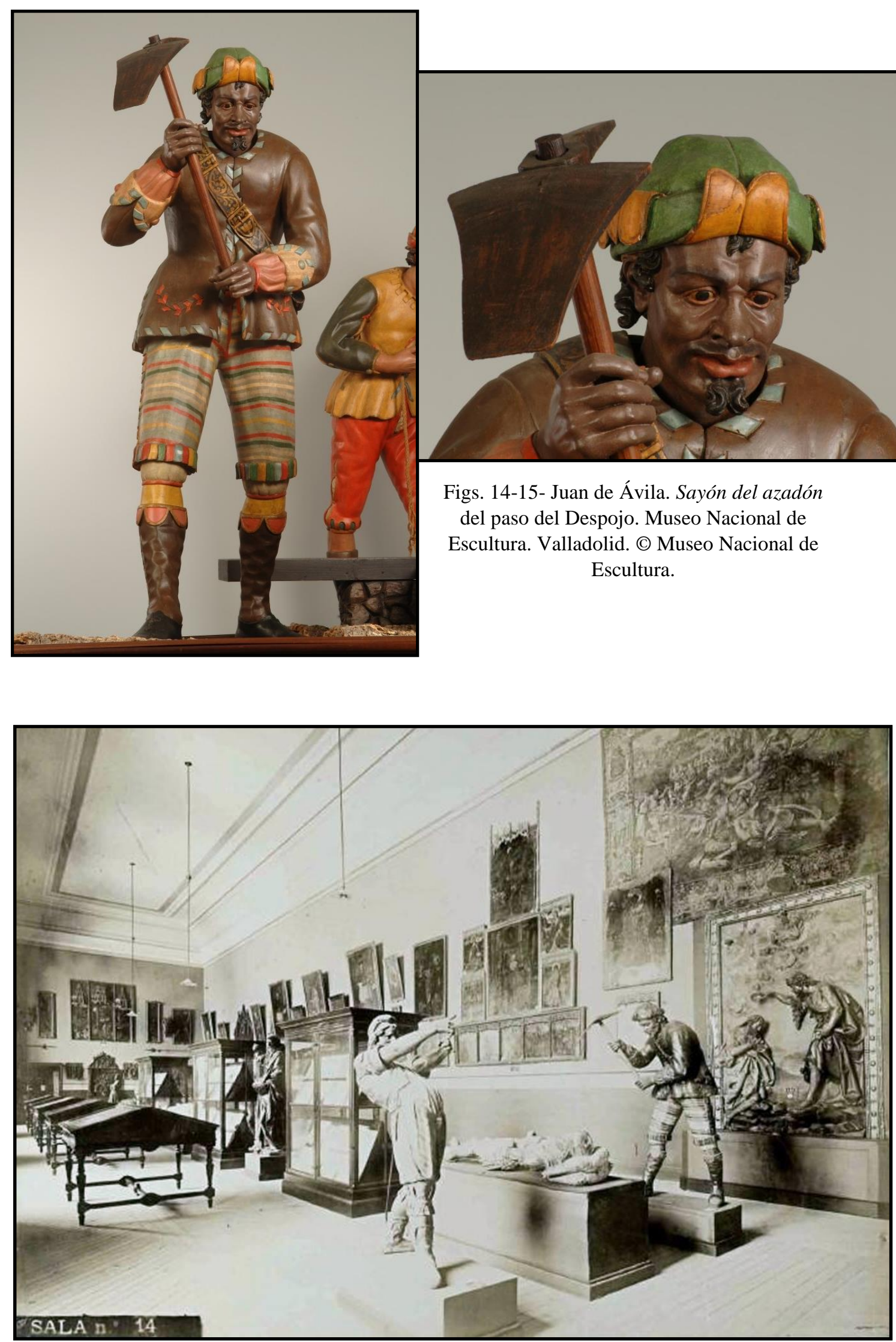

Fig. 16- Vista de la sala n ${ }^{\circ} 14$ de la Exposición Histórica-Europea de 1892. En ella se observa al sayón del azadón, y, además, otras piezas como uno de los sayones del paso de la Elevación de la Cruz, el Bautismo de Gregorio Fernández o la Estatua yacente del I Marqués de Villafranca.

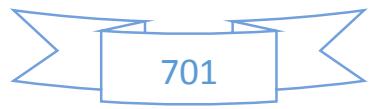



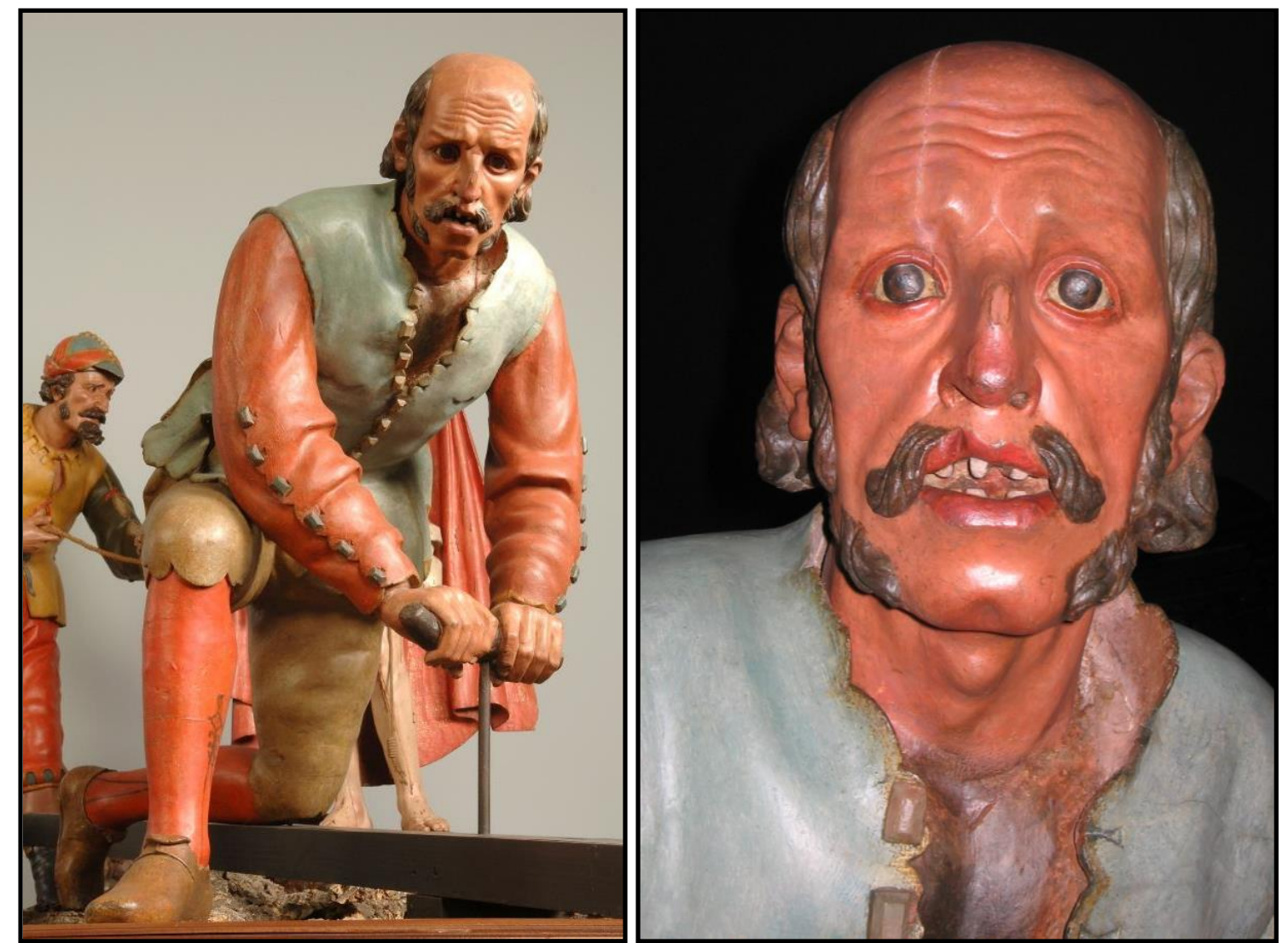

Figs. 17-18- Juan de Ávila. Sayón del barreno del paso del Despojo. Museo Nacional de Escultura. Valladolid. Fig. 17 (c) Museo Nacional de Escultura.

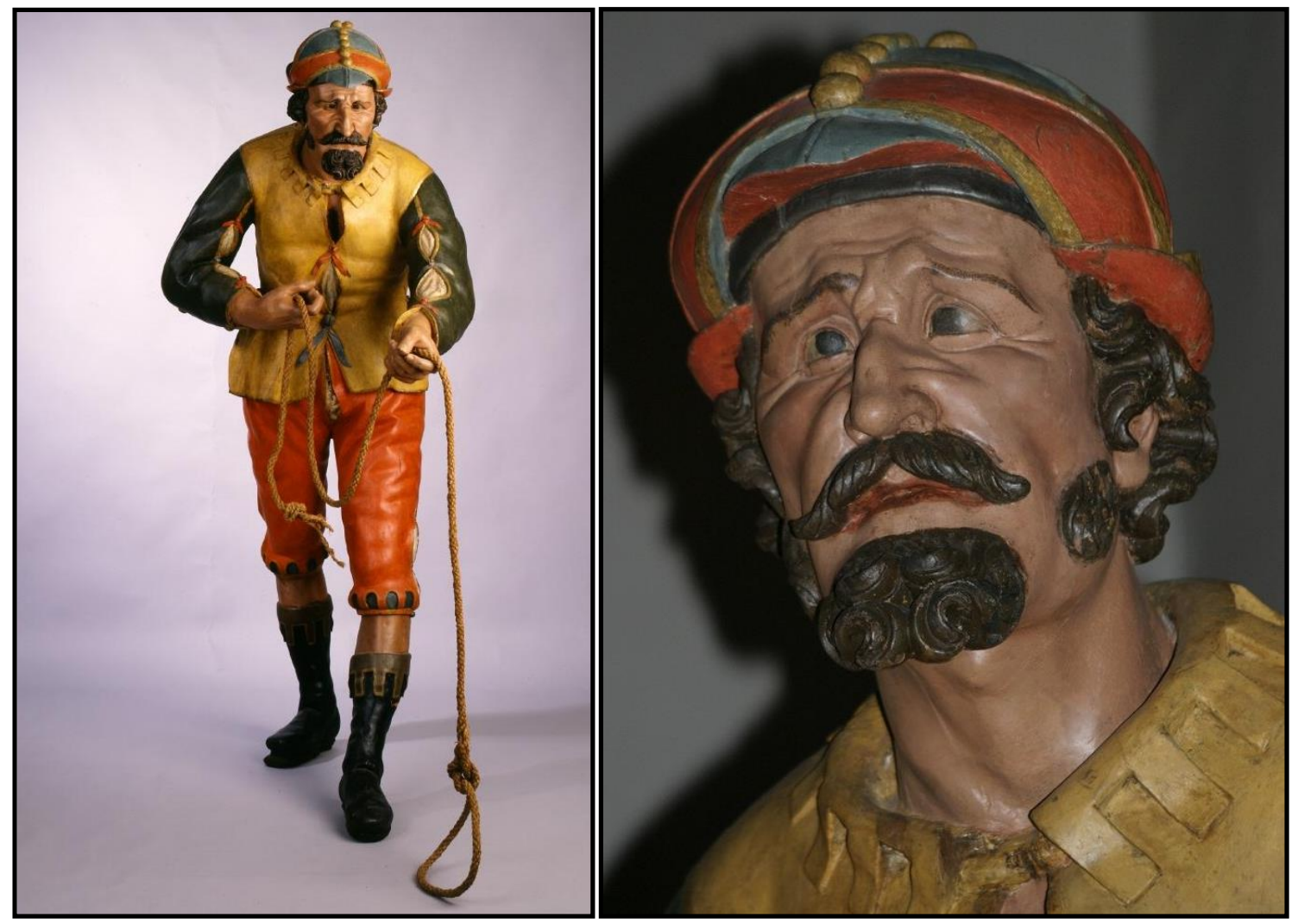

Figs. 19-20- Juan de Ávila. Sayón de la soga del paso del Despojo. Museo Nacional de Escultura. Valladolid. Fig. 19 (C) Museo Nacional de Escultura.

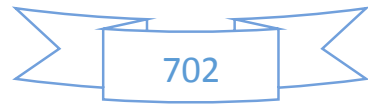



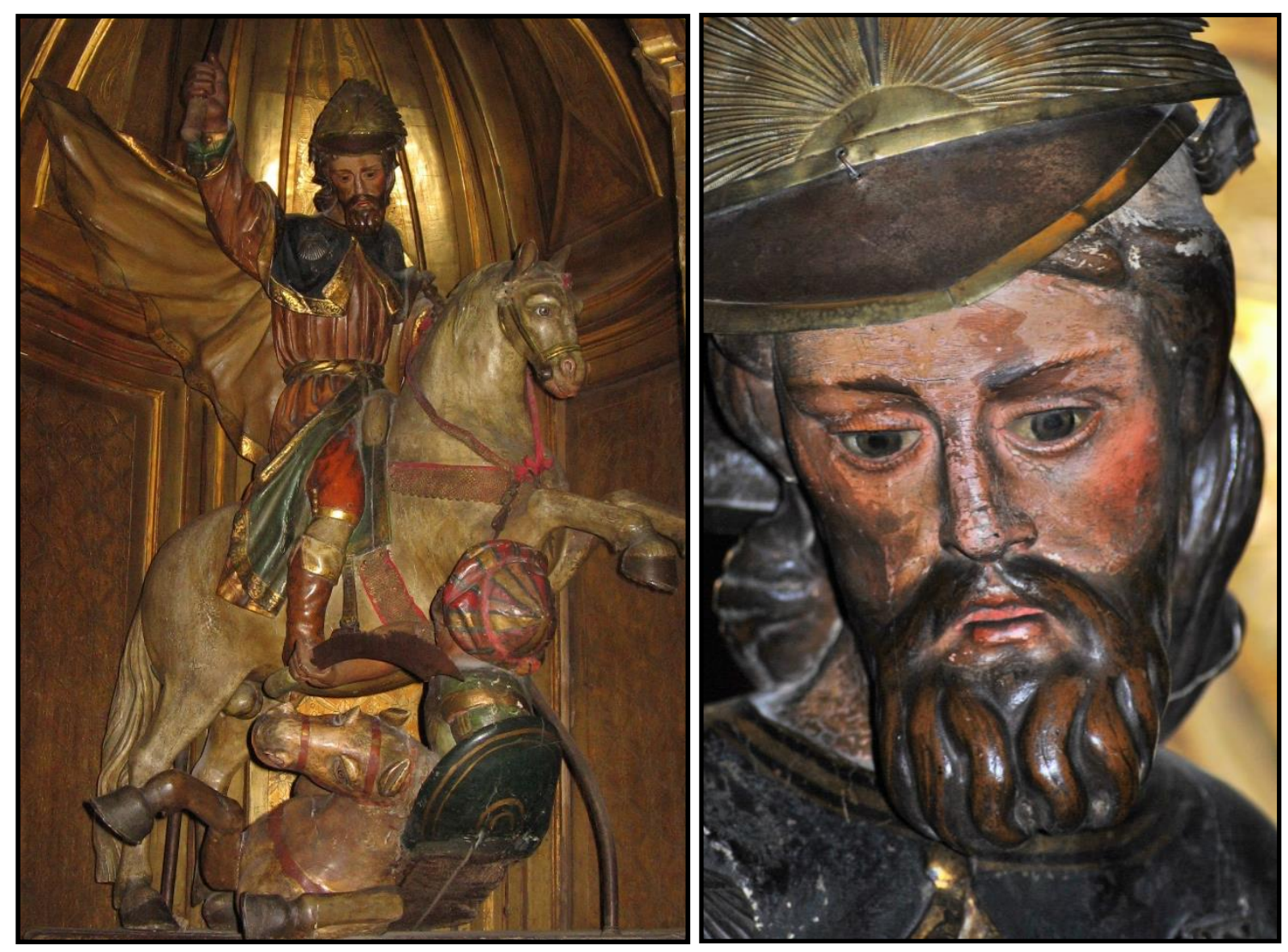

Figs. 21-23- Juan de Ávila. Santiago matamoros. Iglesia de Santiago Apóstol. Valladolid.
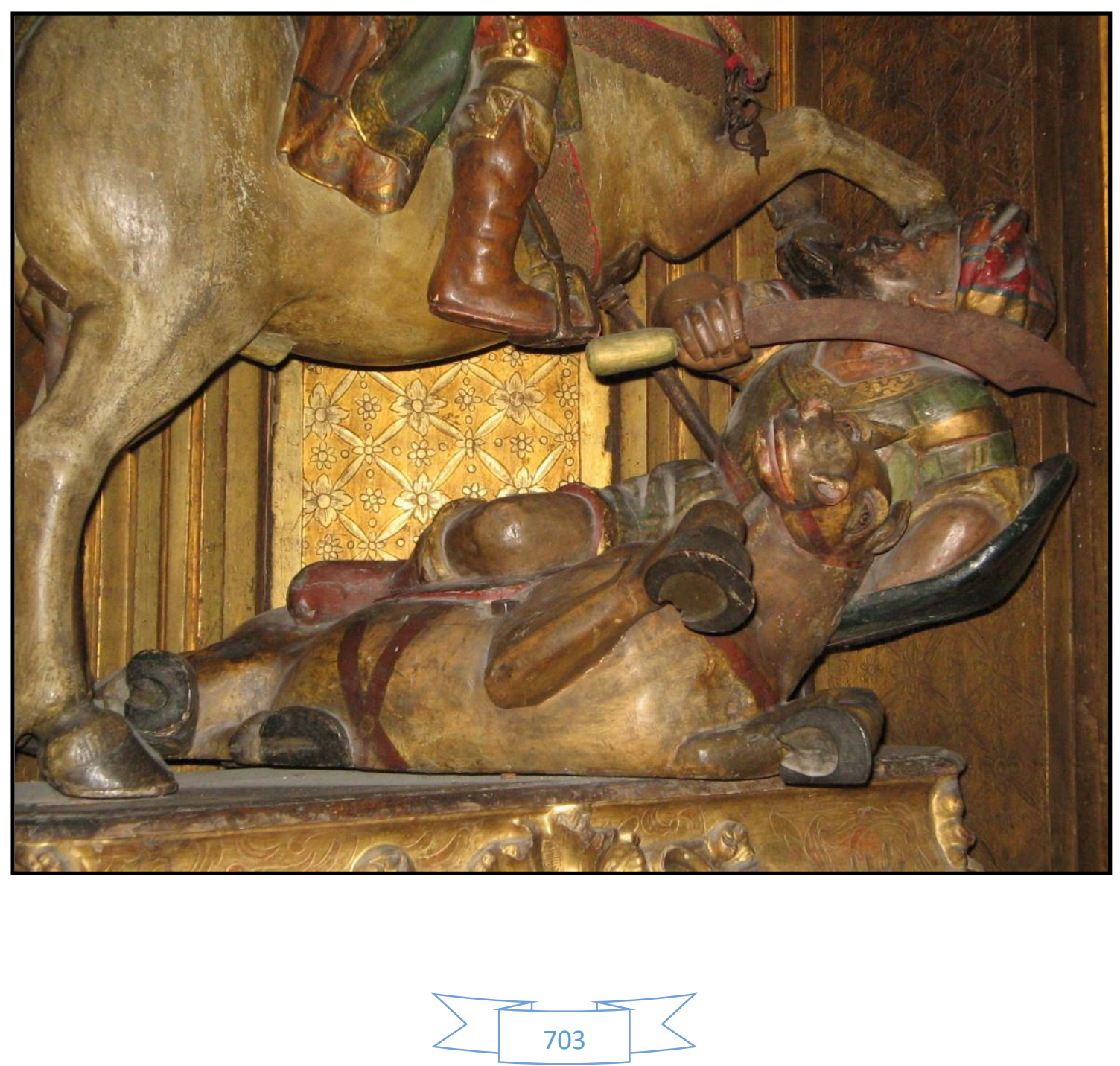


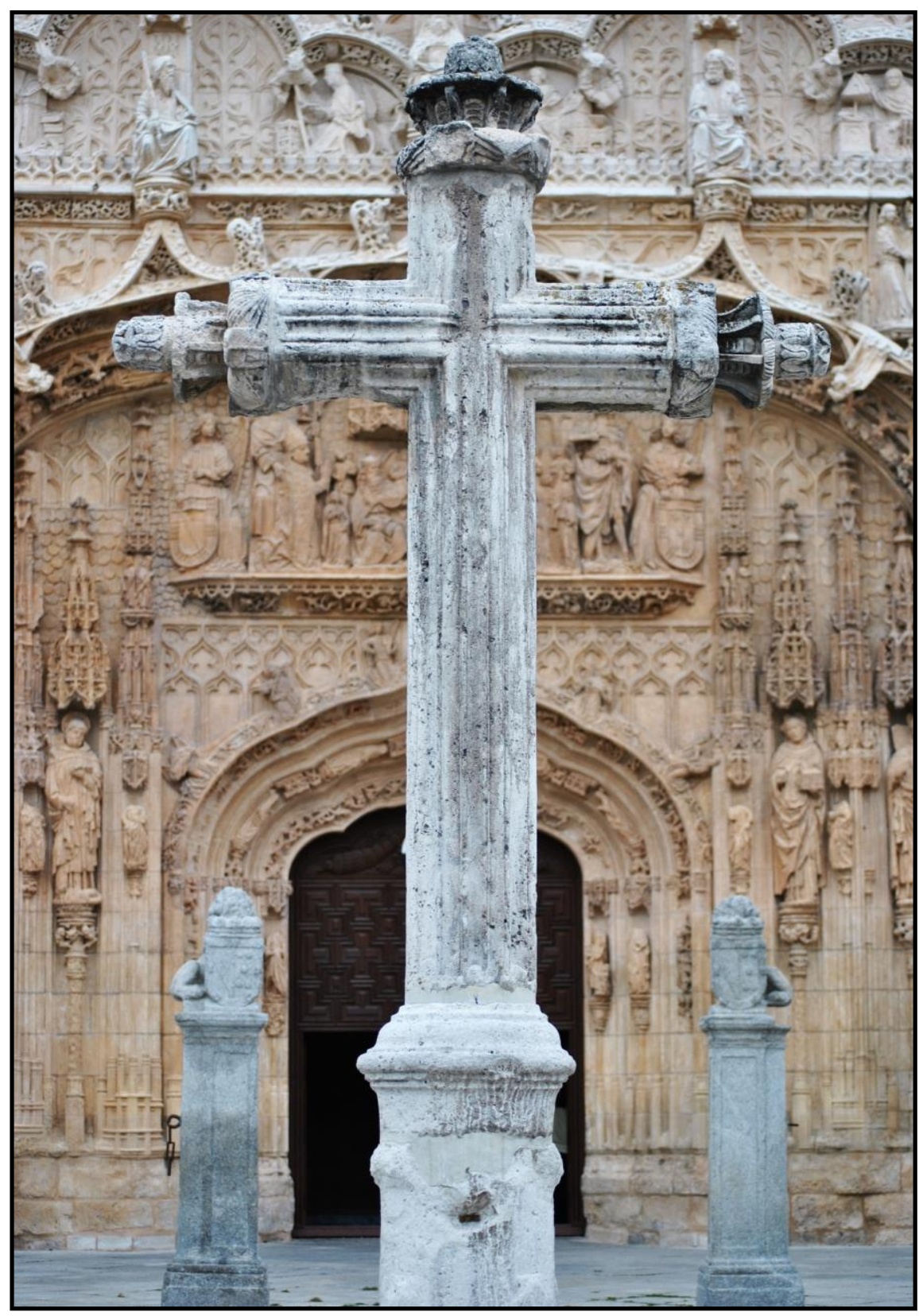

Figs. 24-25- Juan de Ávila. Adornos de la cruz del cementerio de la iglesia de Santiago Apóstol. Plaza de San Pablo. Valladolid.
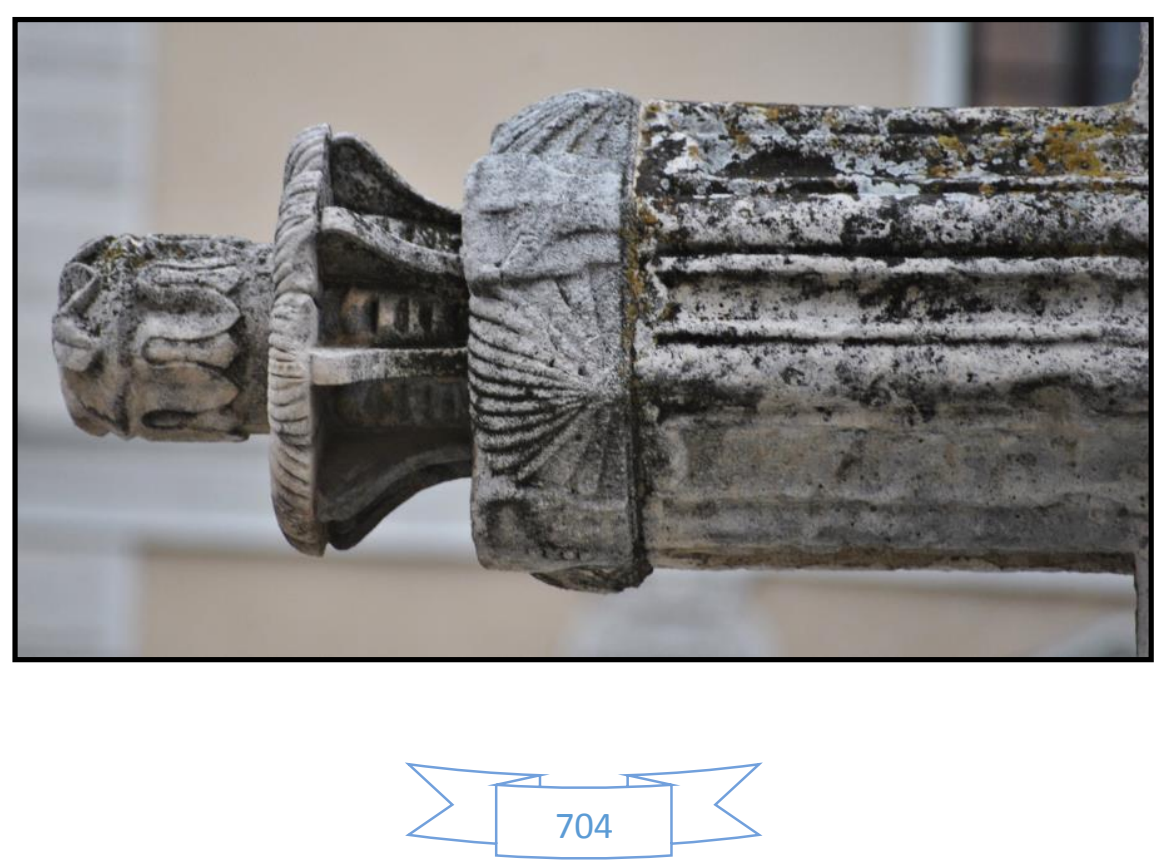


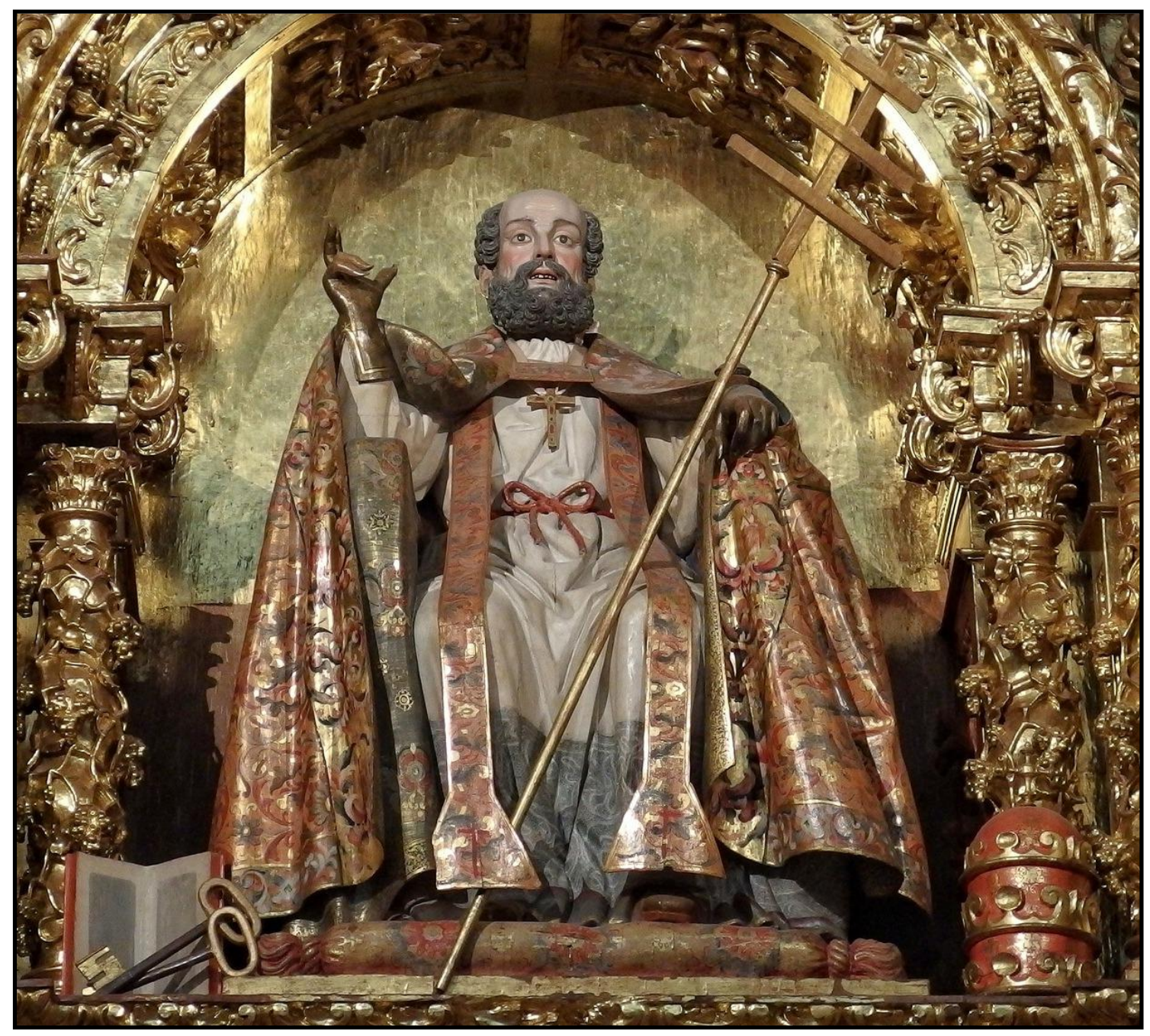

Figs. 26-28- Juan de Ávila. San Pedro en cátedra. Colegiata de San Pedro. Lerma (Burgos). (C) Fundación del Patrimonio Histórico de Castilla y León.
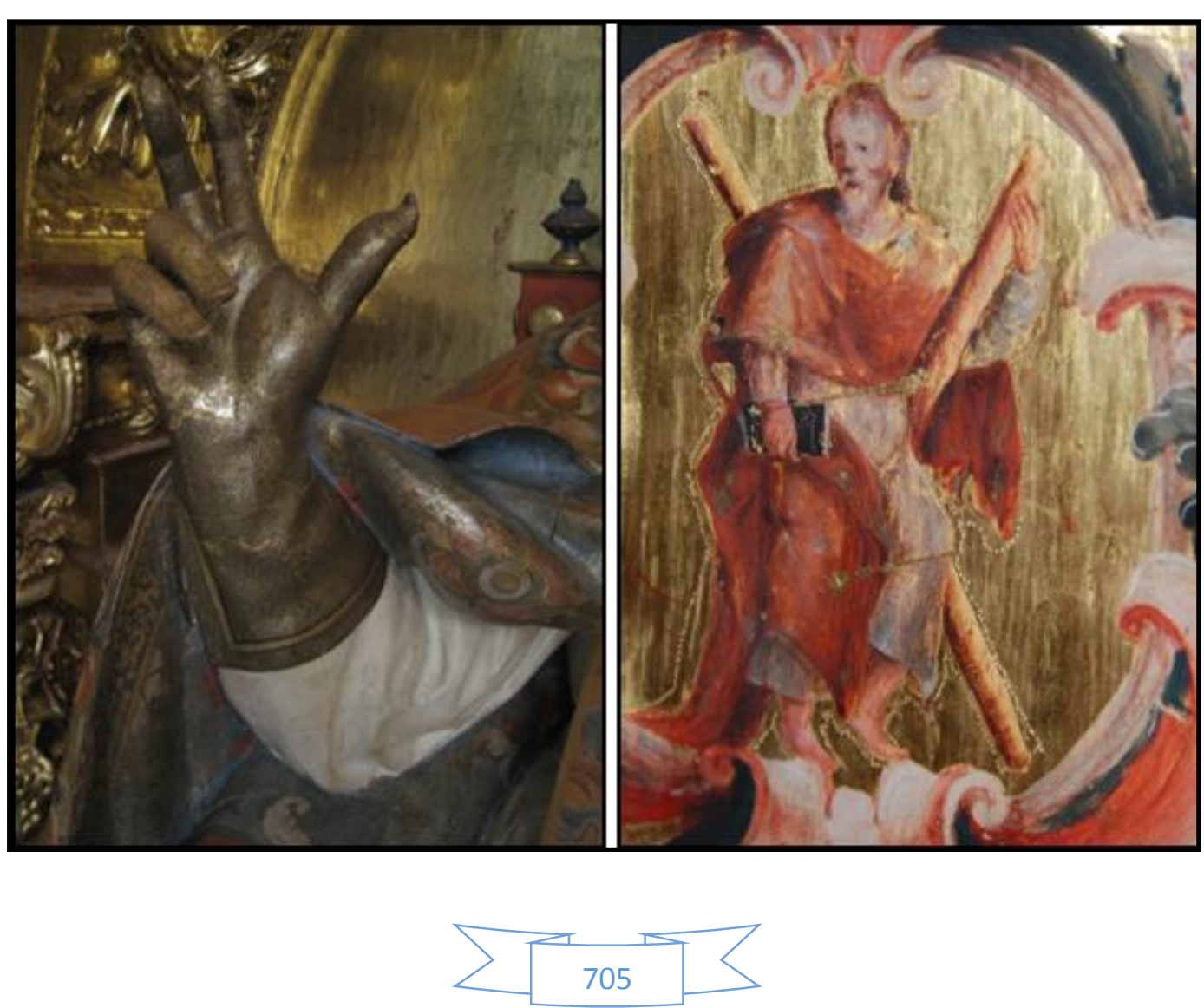

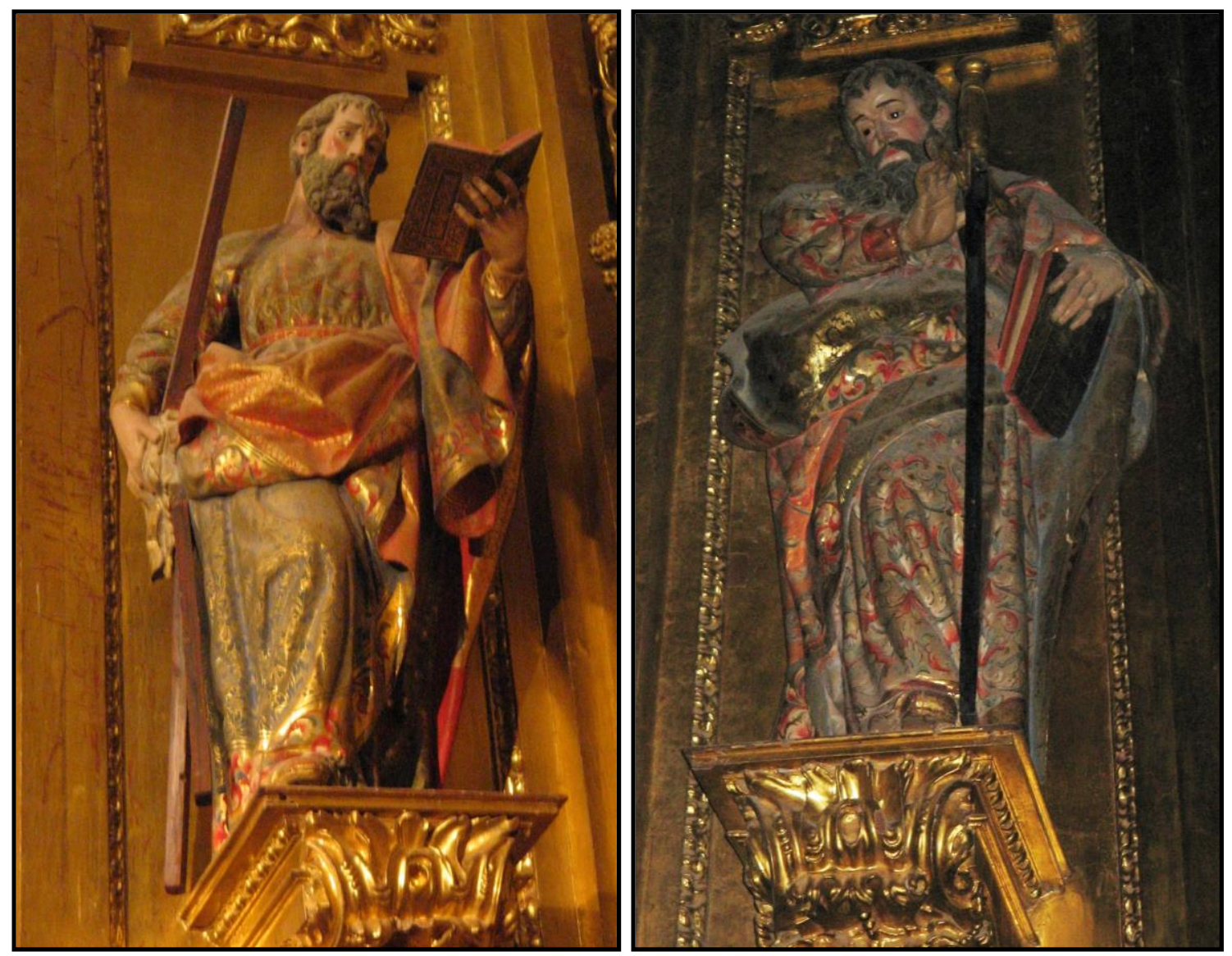

Figs. 29-30- Juan de Ávila. San Andrés y San Pablo. Colegiata de San Pedro. Lerma (Burgos).

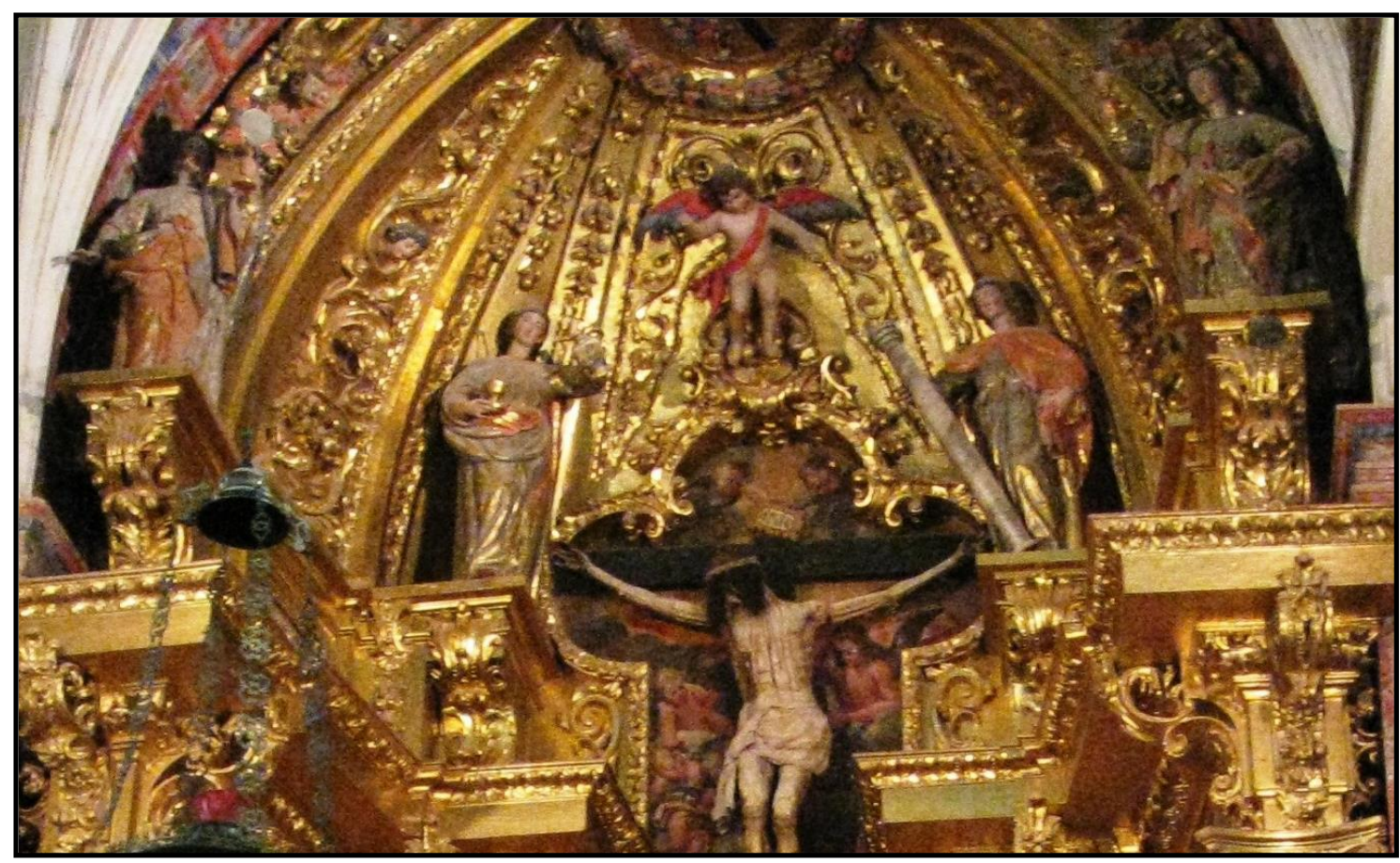

Fig. 31- Juan de Ávila. Virtudes. Colegiata de San Pedro. Lerma (Burgos).

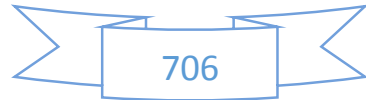




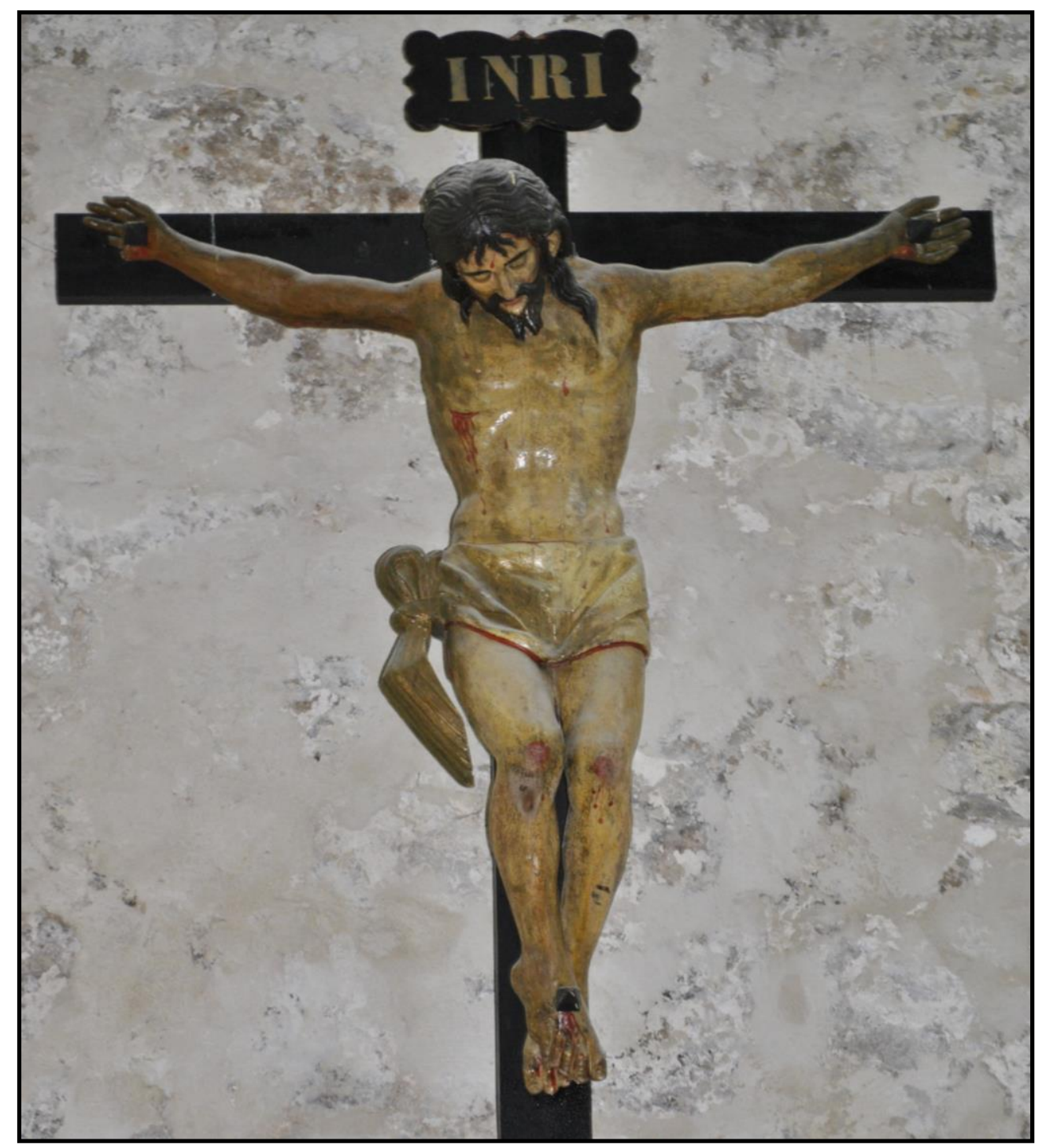

Figs. 32-33- Juan de Ávila. Crucifijo. Iglesia parroquial de San Martín. Traspinedo (Valladolid).
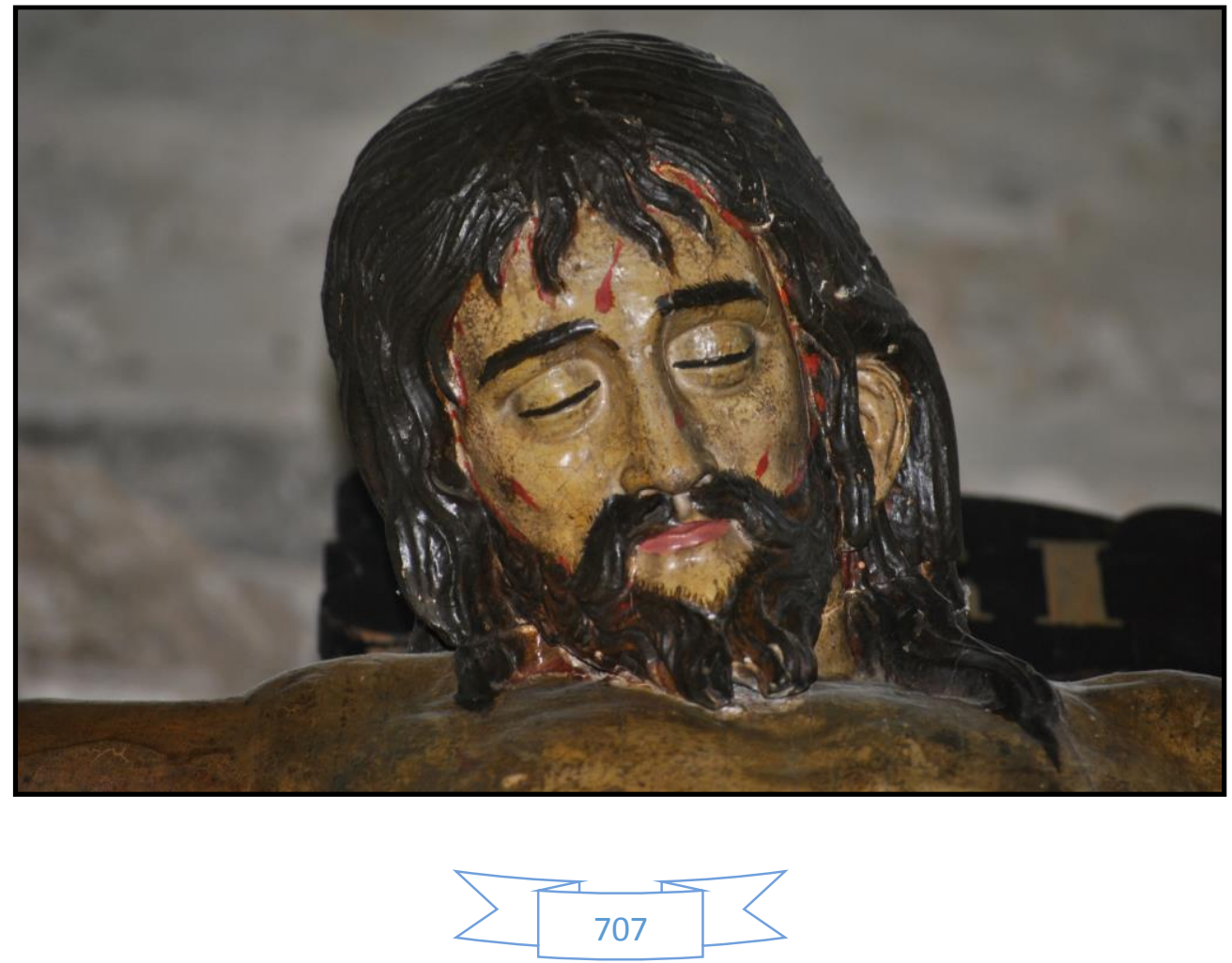

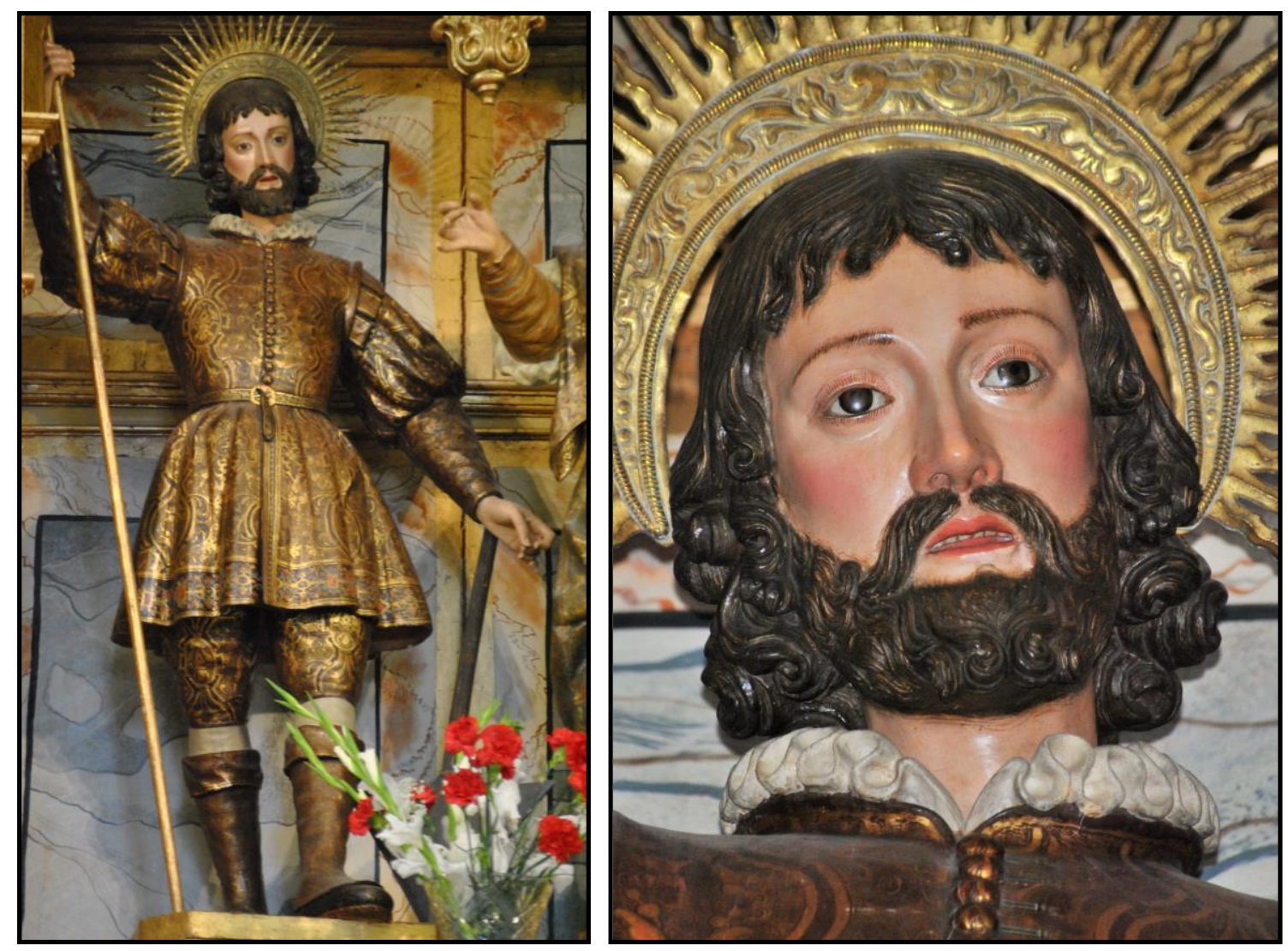

Figs. 34-35- Juan de Ávila. San Isidro Labrador. Ermita de San Isidro. Valladolid.
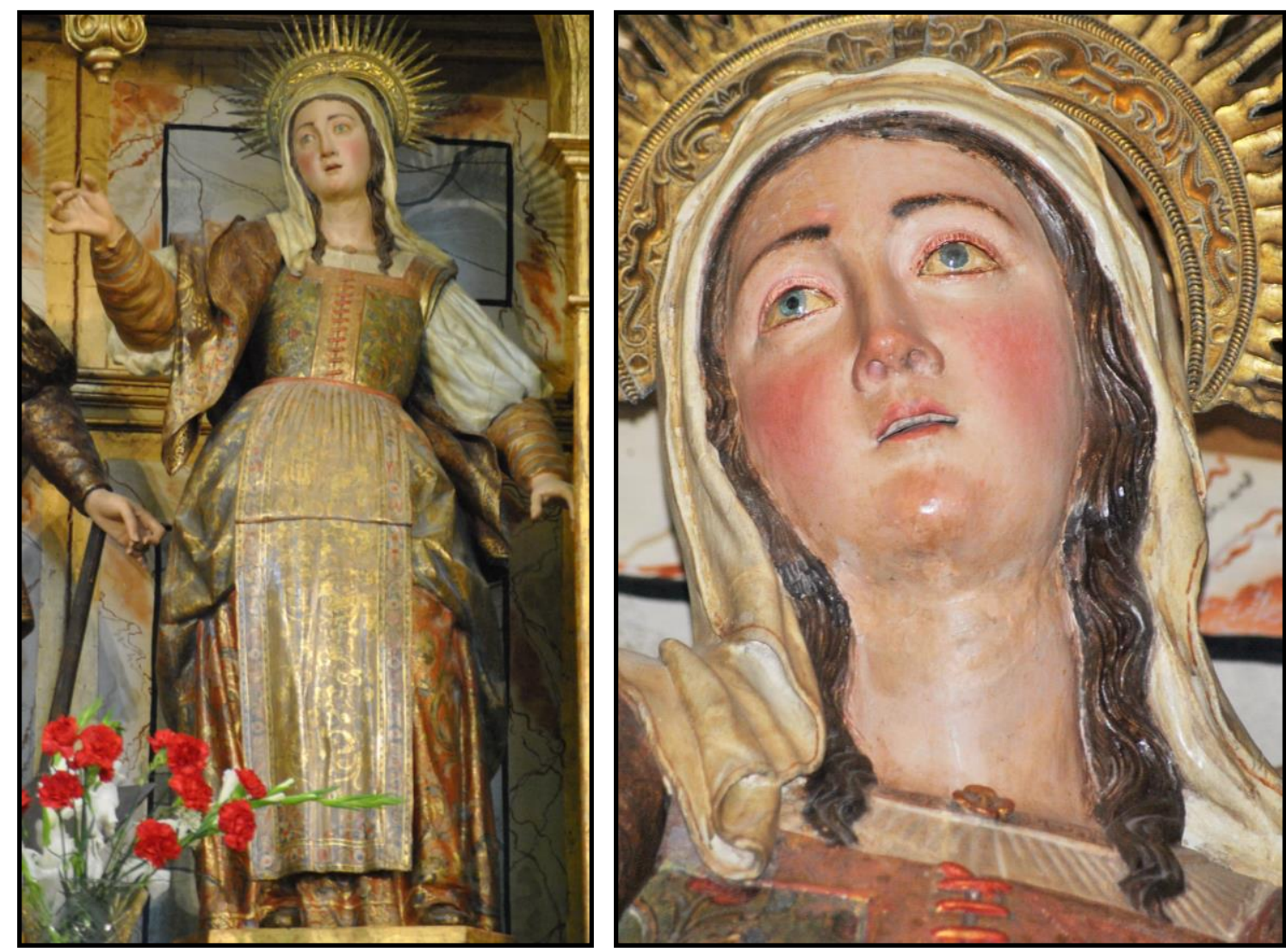

Figs. 36-37- Juan de Ávila. Santa María de la Cabeza. Ermita de San Isidro. Valladolid.

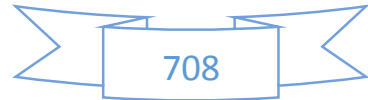




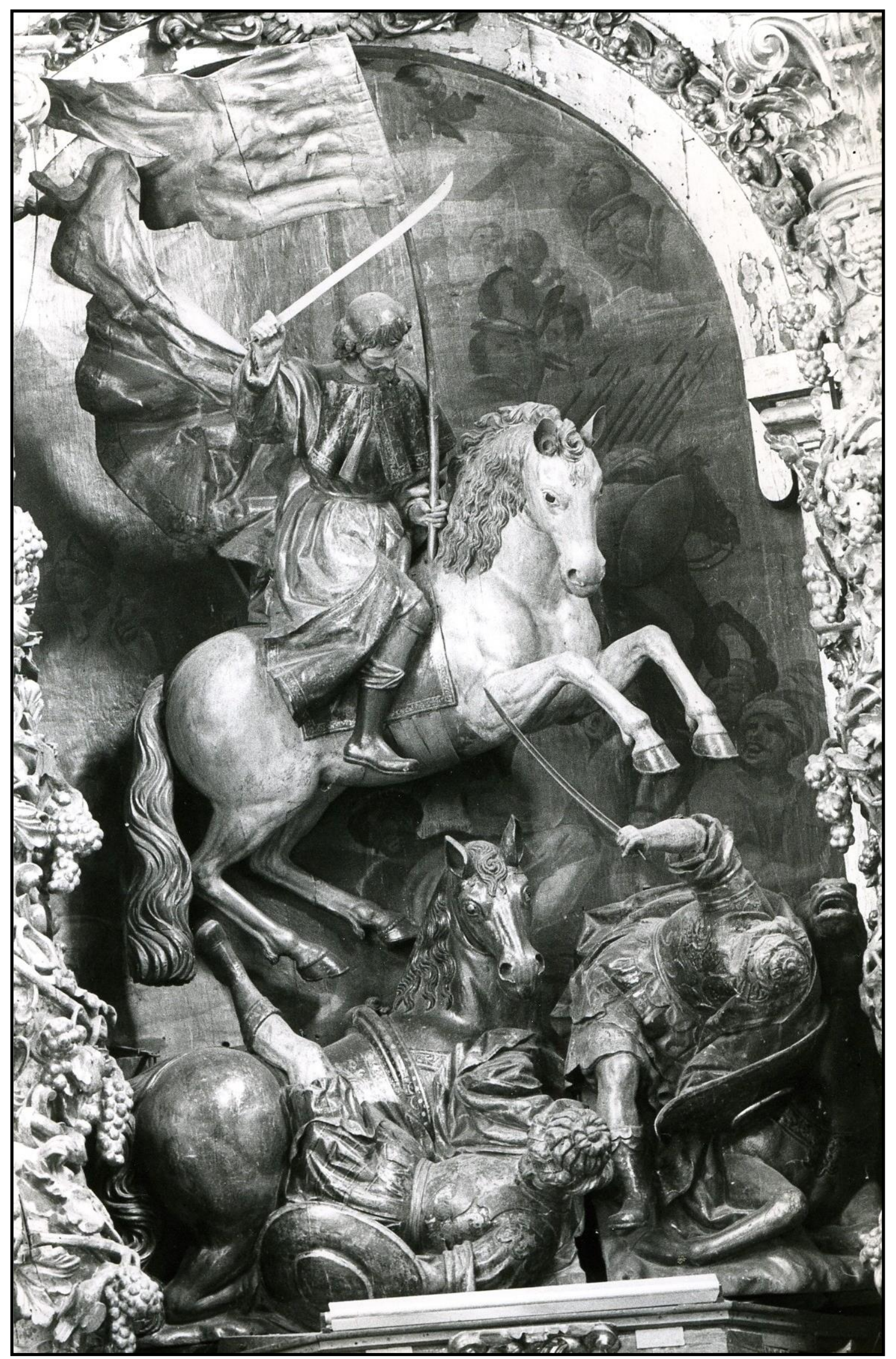

Fig. 38- Juan de Ávila. Santiago Matamoros. Iglesia de Santiago Apóstol. Valladolid. (C Departamento de Historia del Arte de la Universidad de Valladolid. 


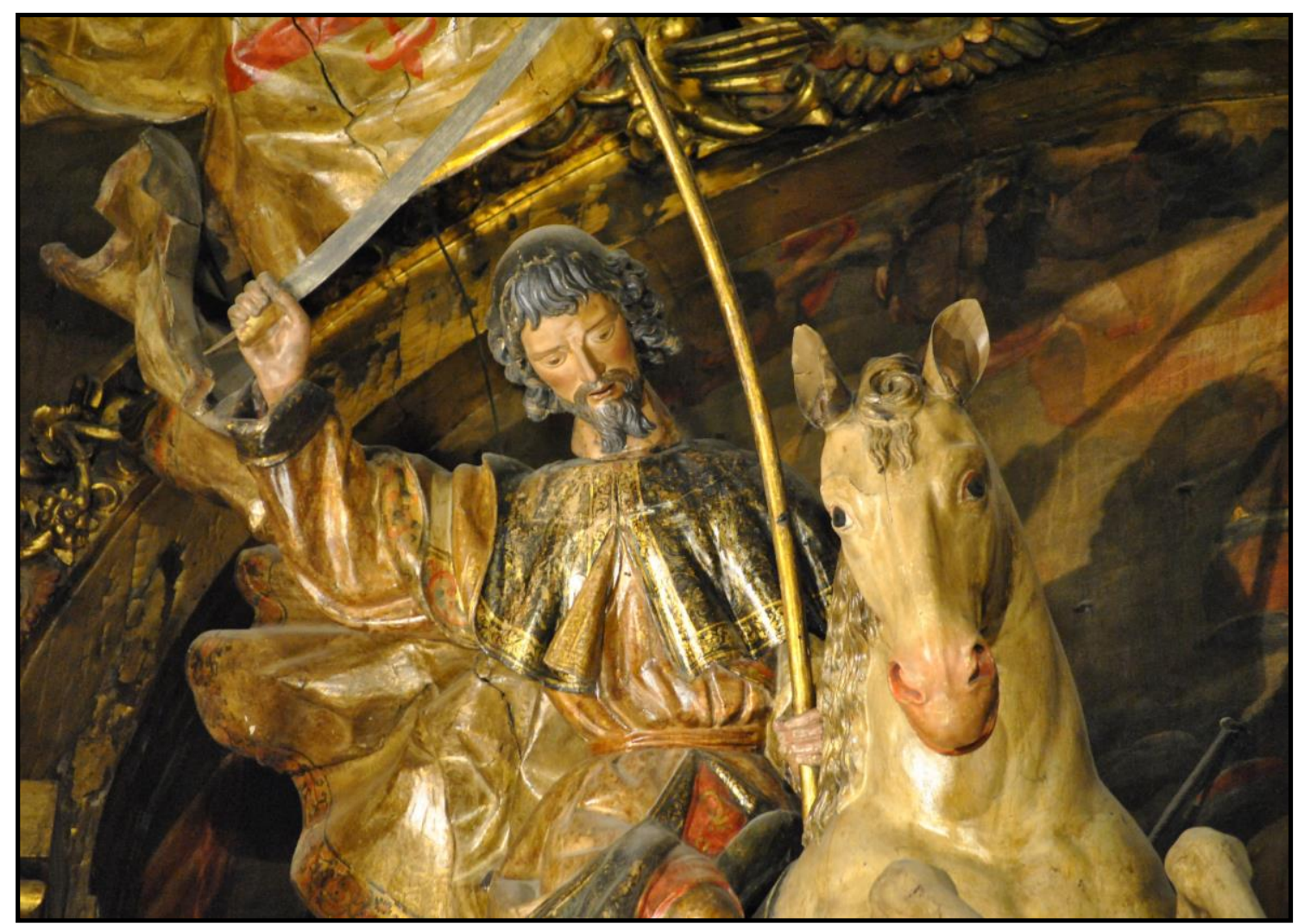

Figs. 39-40- Juan de Ávila. Santiago Matamoros. Iglesia de Santiago Apóstol. Valladolid.
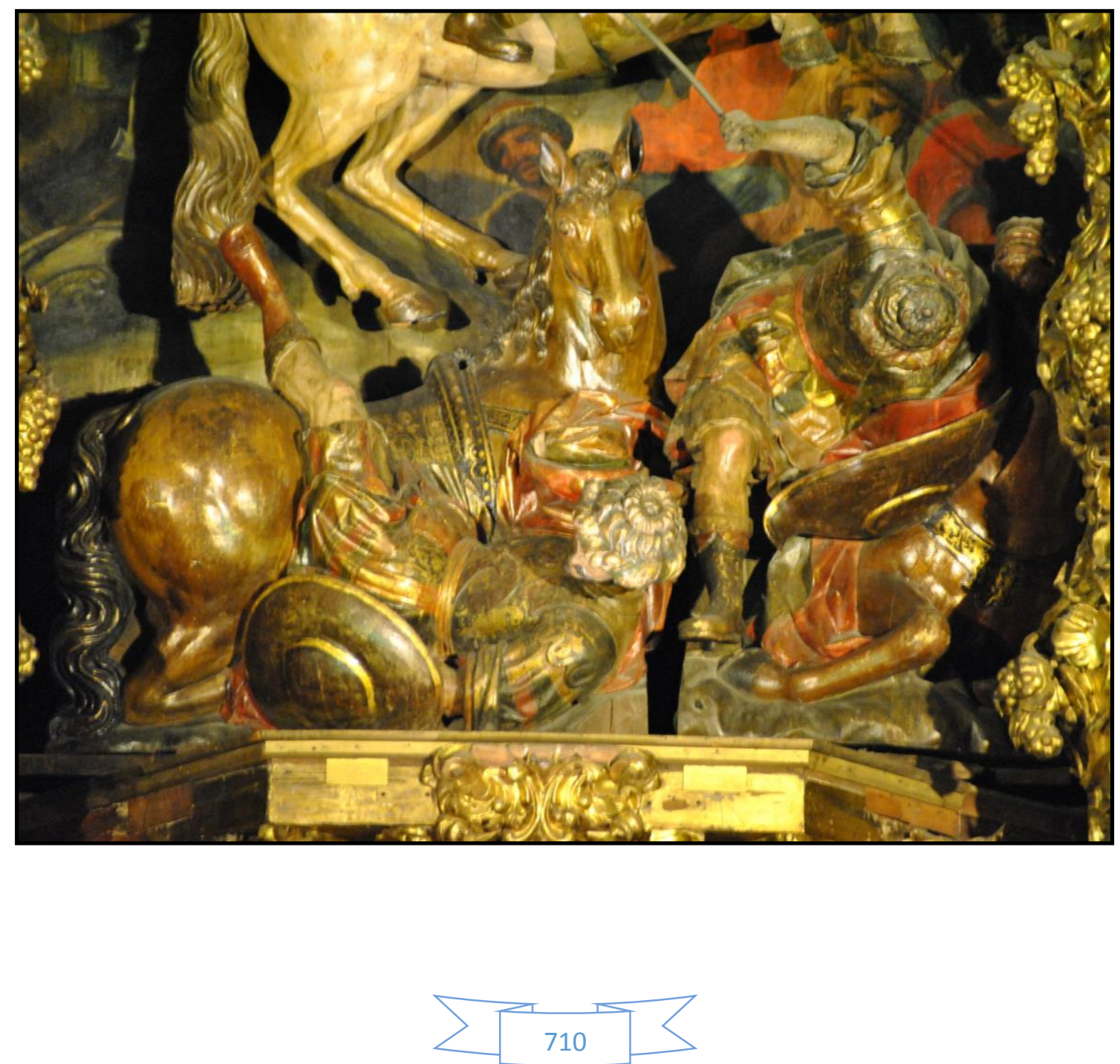


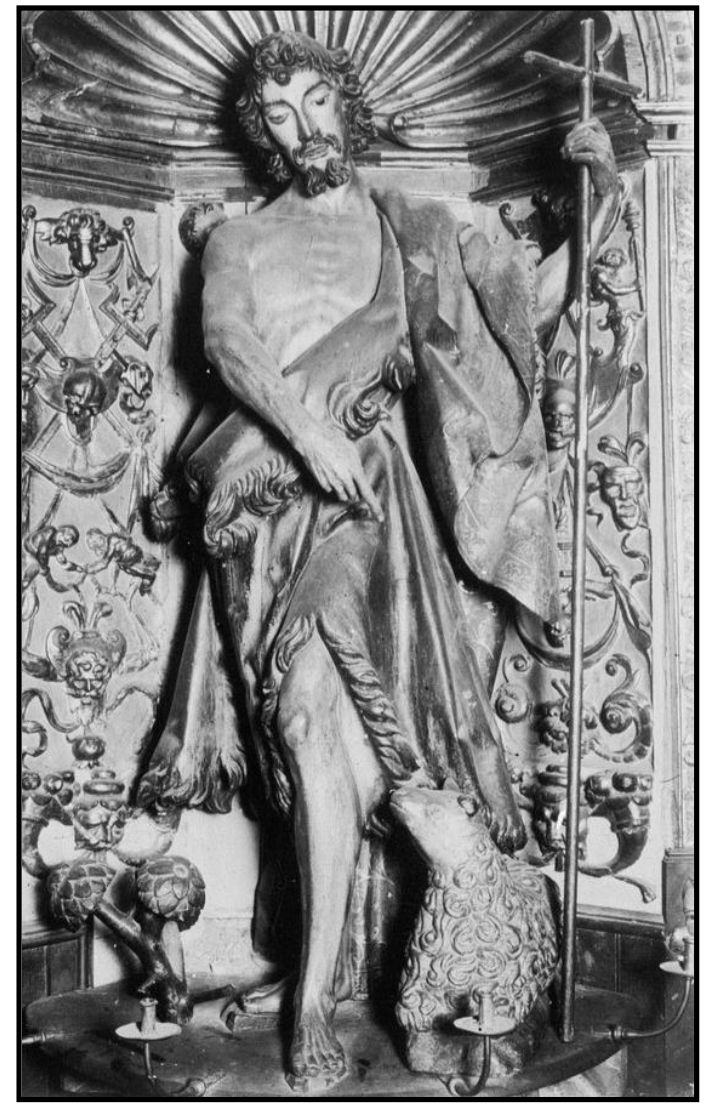

Fig. 41- Juan de Ávila. San Juan Bautista. Iglesia de Santiago Apóstol. Valladolid.

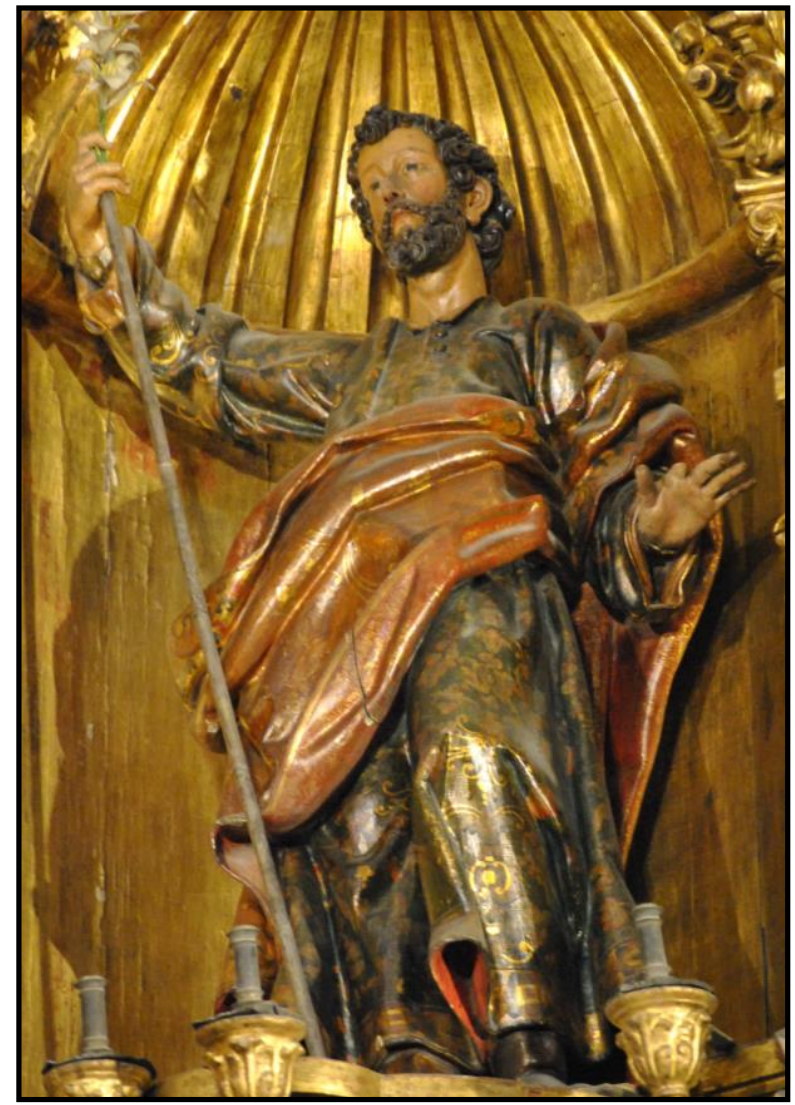

Fig. 42- Juan de Ávila. San José. Iglesia de Santiago Apóstol. Valladolid.

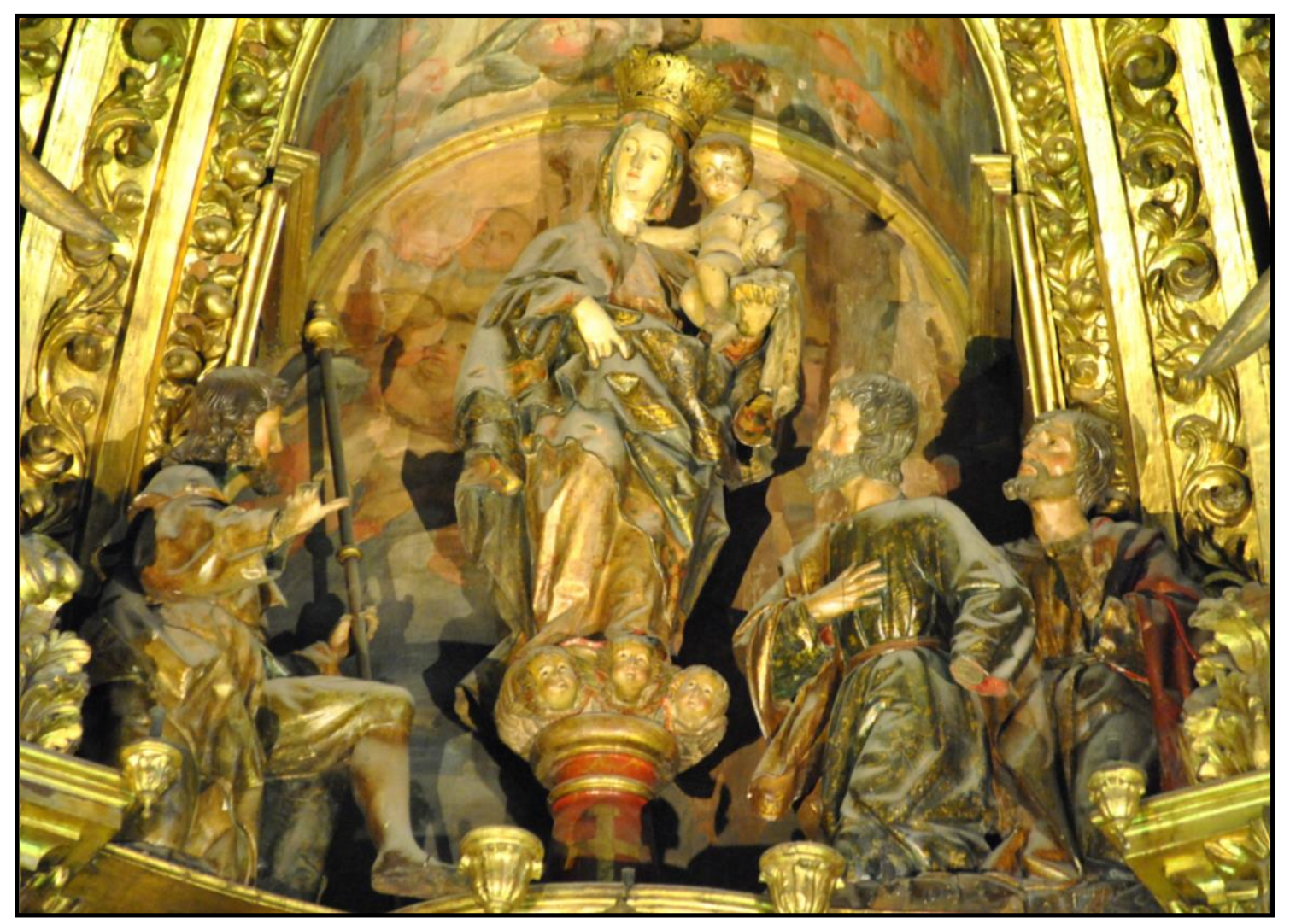

Fig. 43- Juan de Ávila. Aparición de la Virgen del Pilar a Santiago y sus discípulos. Iglesia de Santiago Apóstol. Valladolid.

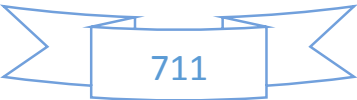




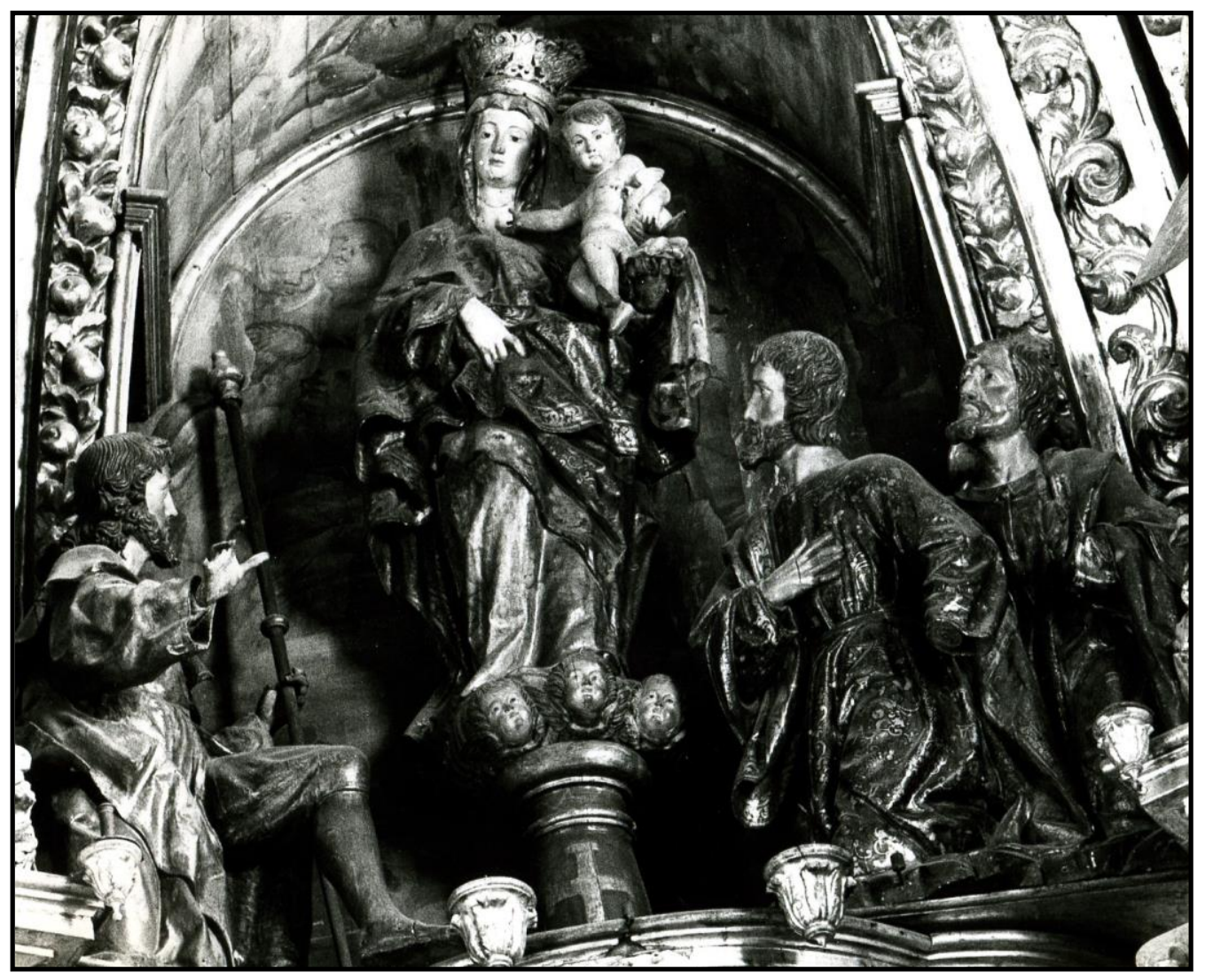

Fig. 44- Juan de Ávila. Detalle de la Aparición de la Virgen del Pilar a Santiago y sus discípulos.

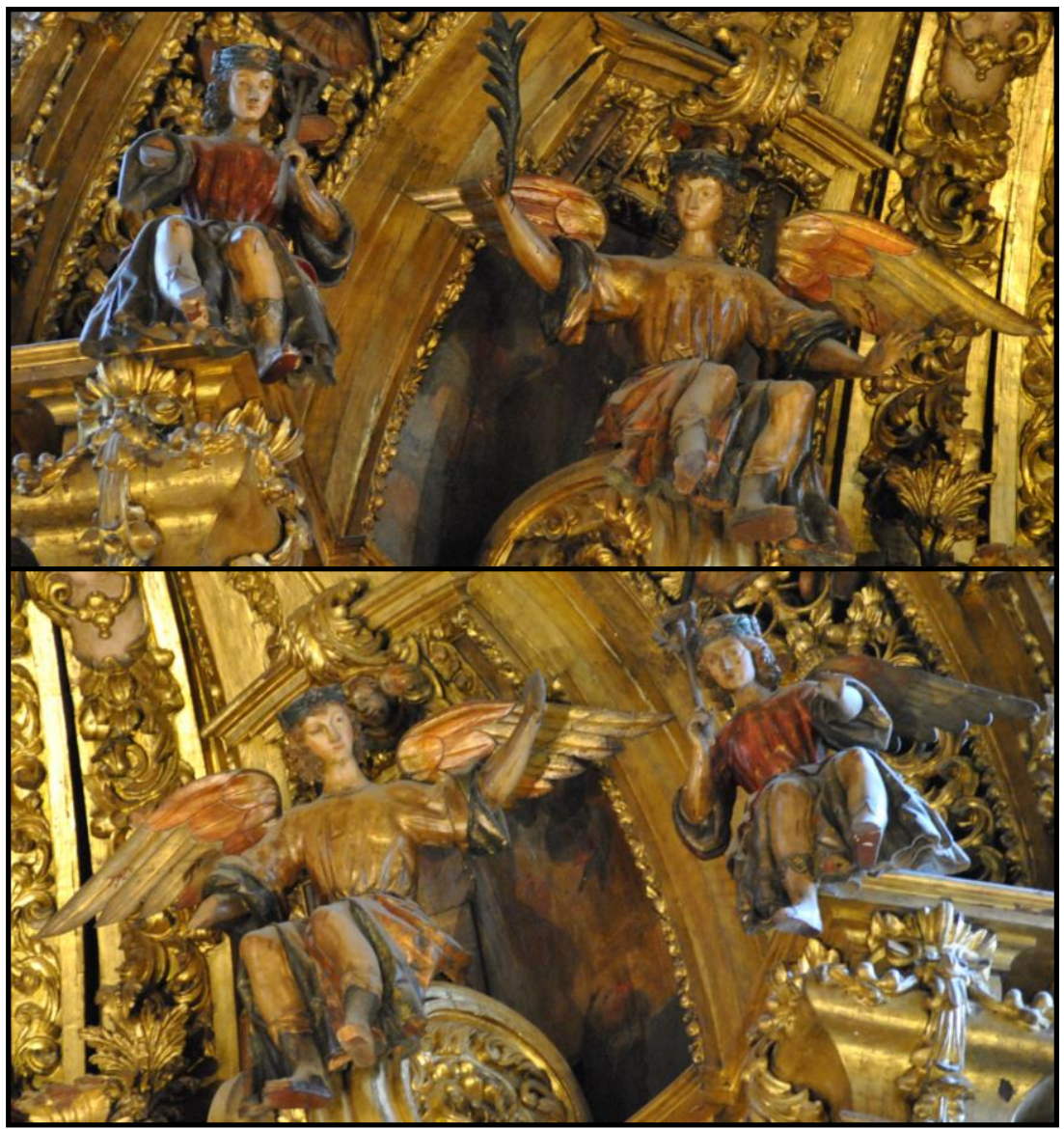

Fig. 45- Juan de Ávila. Ángeles. Iglesia de Santiago Apóstol. Valladolid.

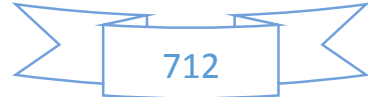



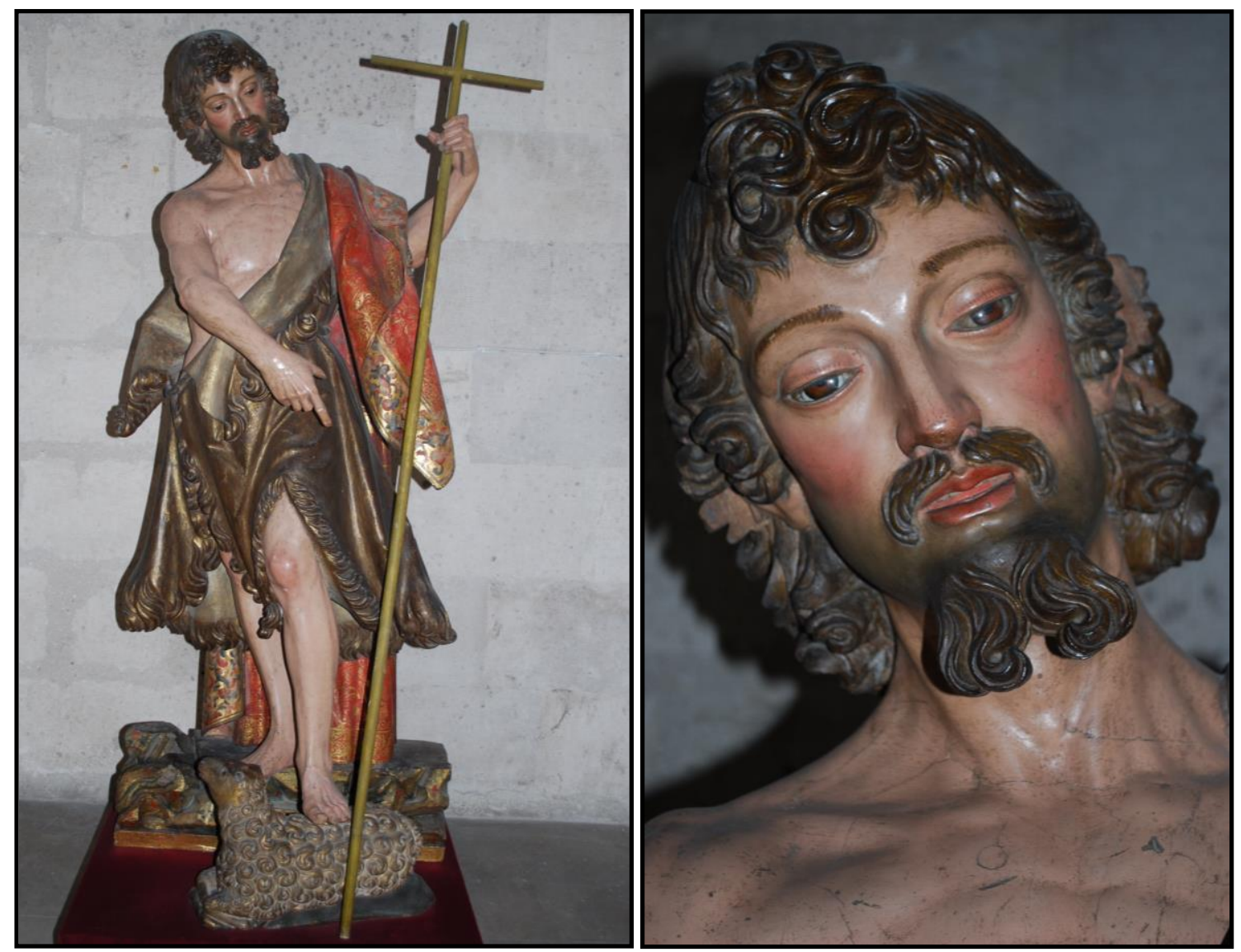

Figs. 46-48- Juan de Ávila. San Juan Bautista del Oratorio de San Felipe Neri. Museo Diocesano y Catedralicio. Valladolid.
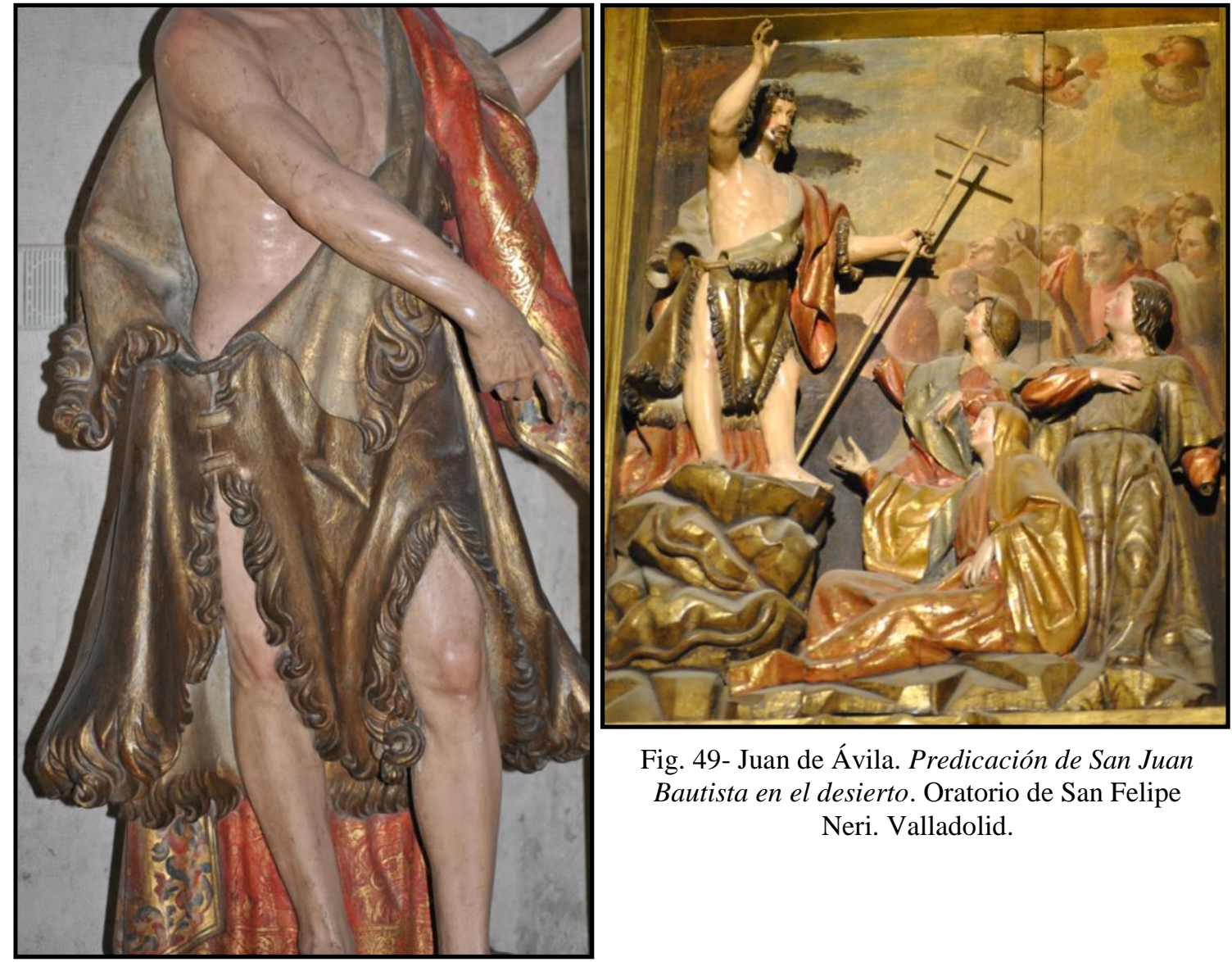

Fig. 49- Juan de Ávila. Predicación de San Juan Bautista en el desierto. Oratorio de San Felipe Neri. Valladolid.

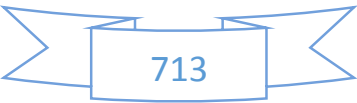



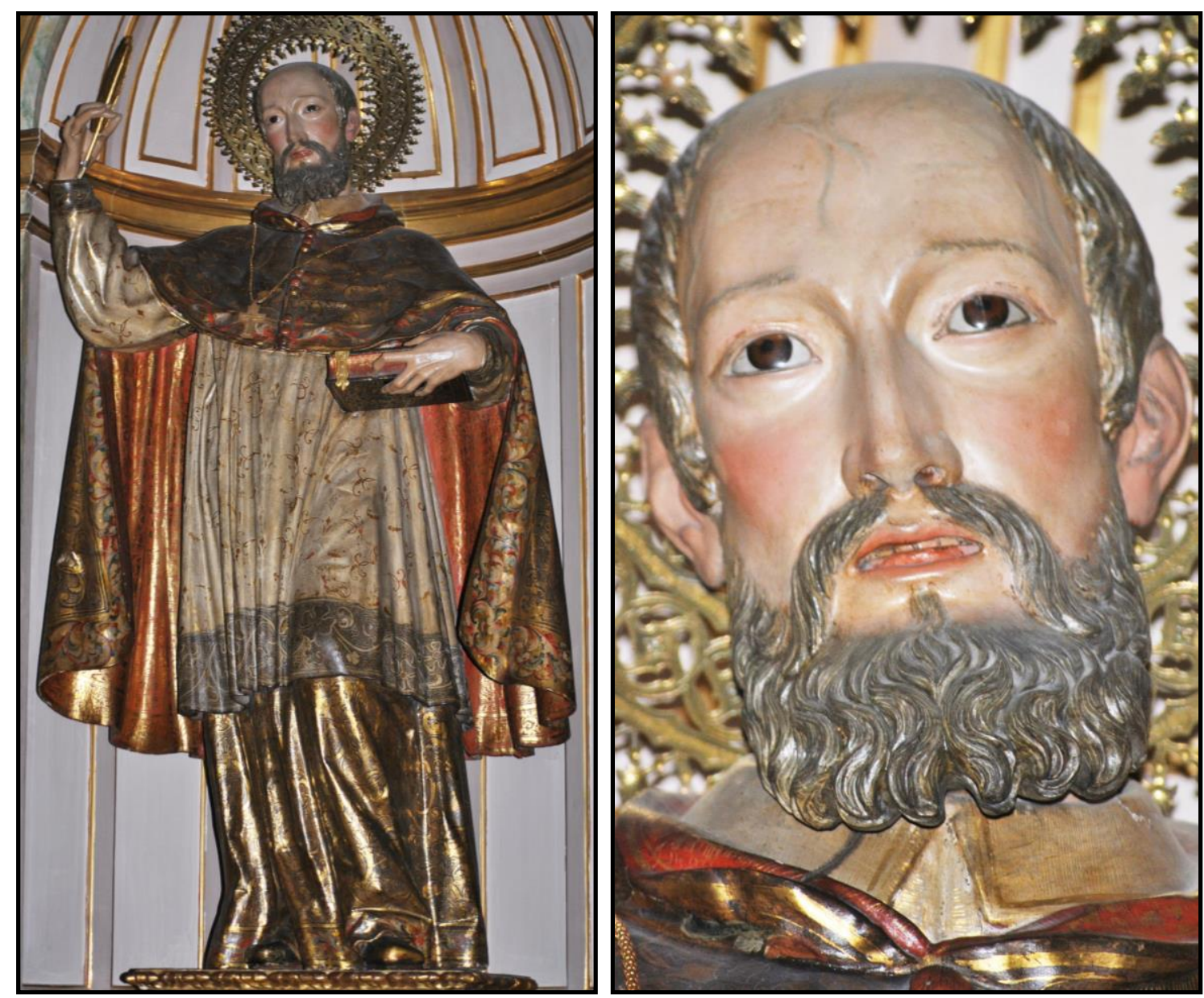

Figs. 50-52- Juan de Ávila. San Juan Bautista del Oratorio de San Felipe Neri. Iglesia de los Sagrados Corazones de las Salesas. Valladolid.

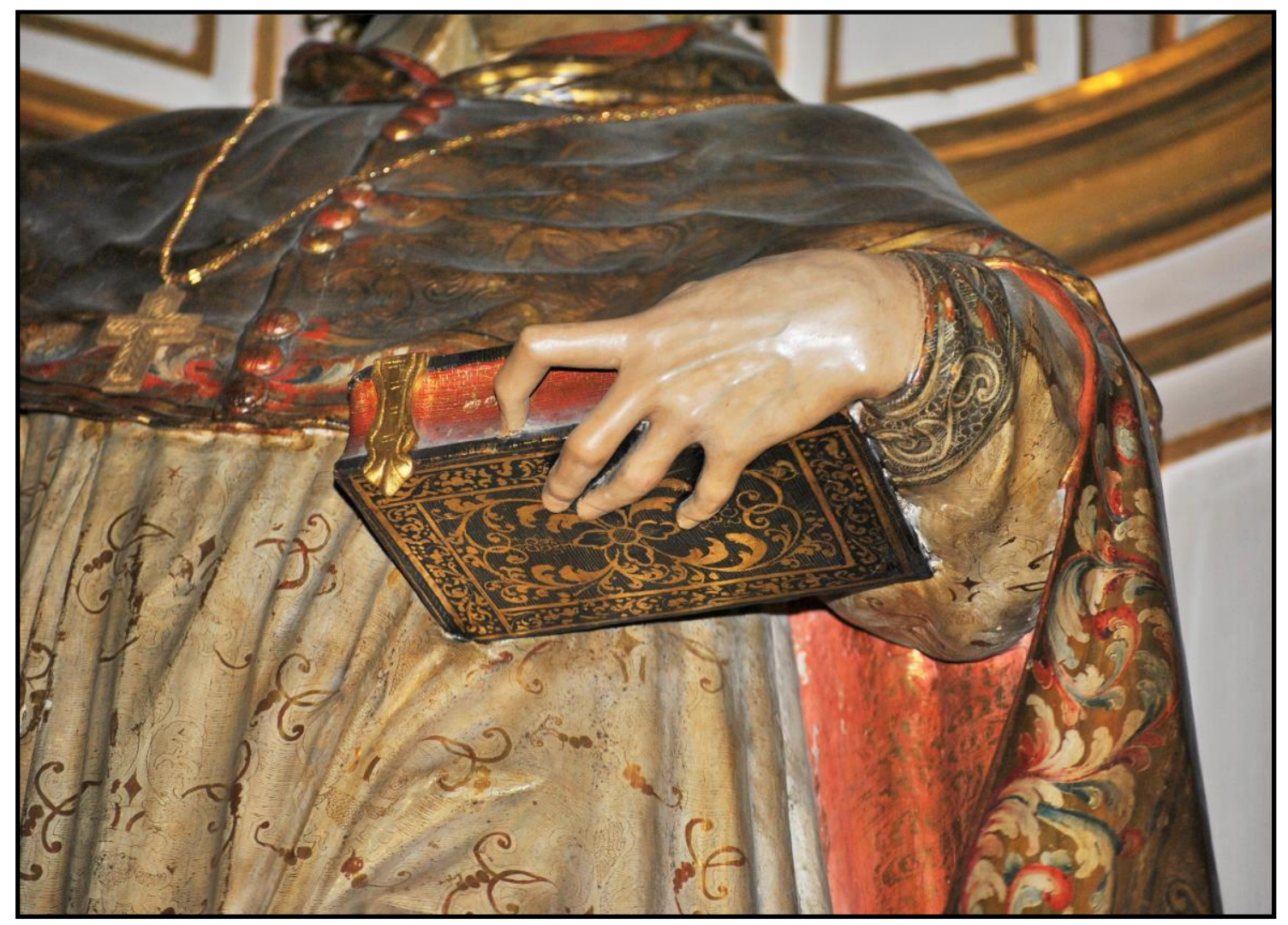




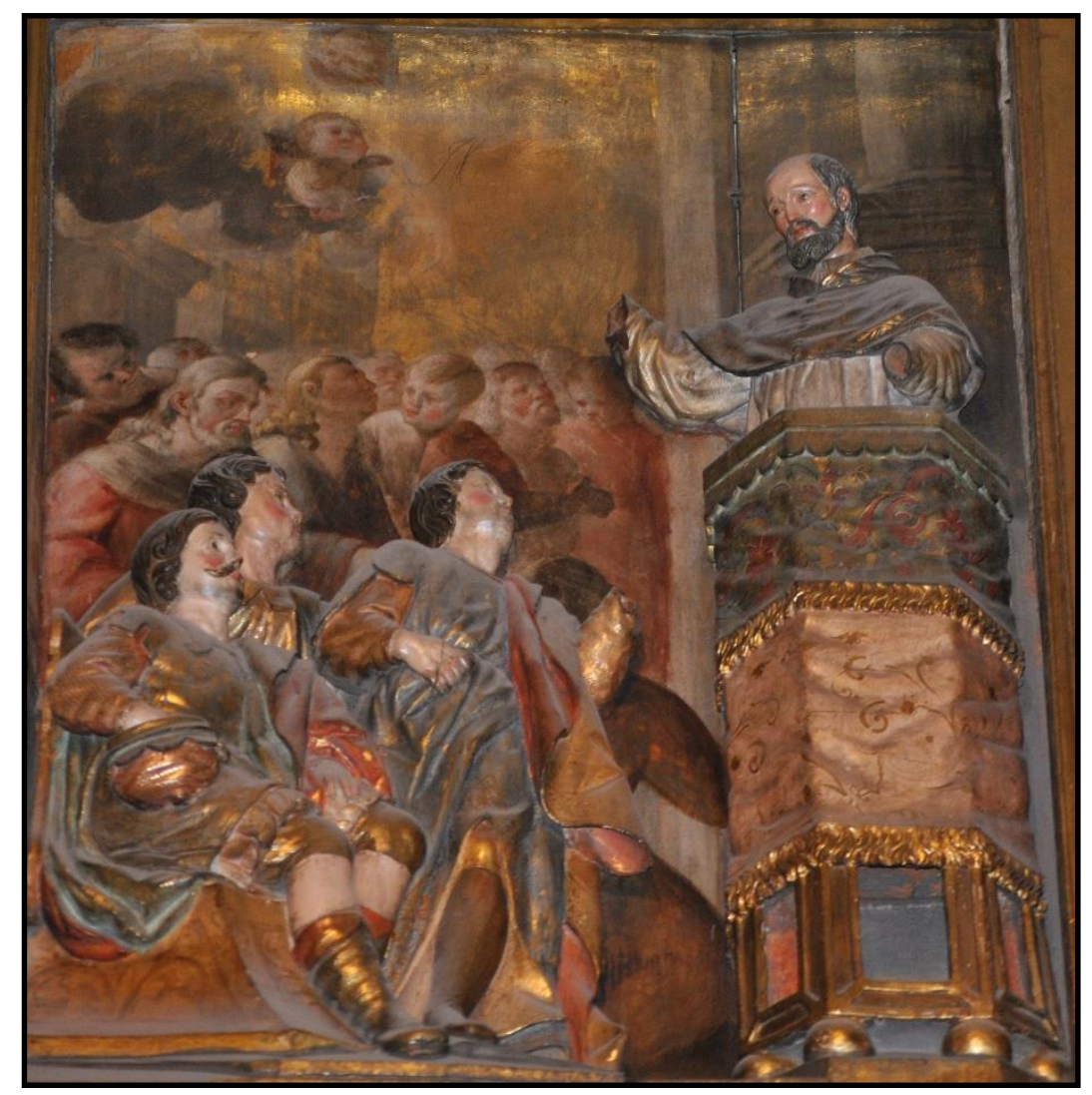

Fig. 53- Juan de Ávila. Predicación de San Francisco de Sales. Oratorio de San Felipe Neri. Valladolid.

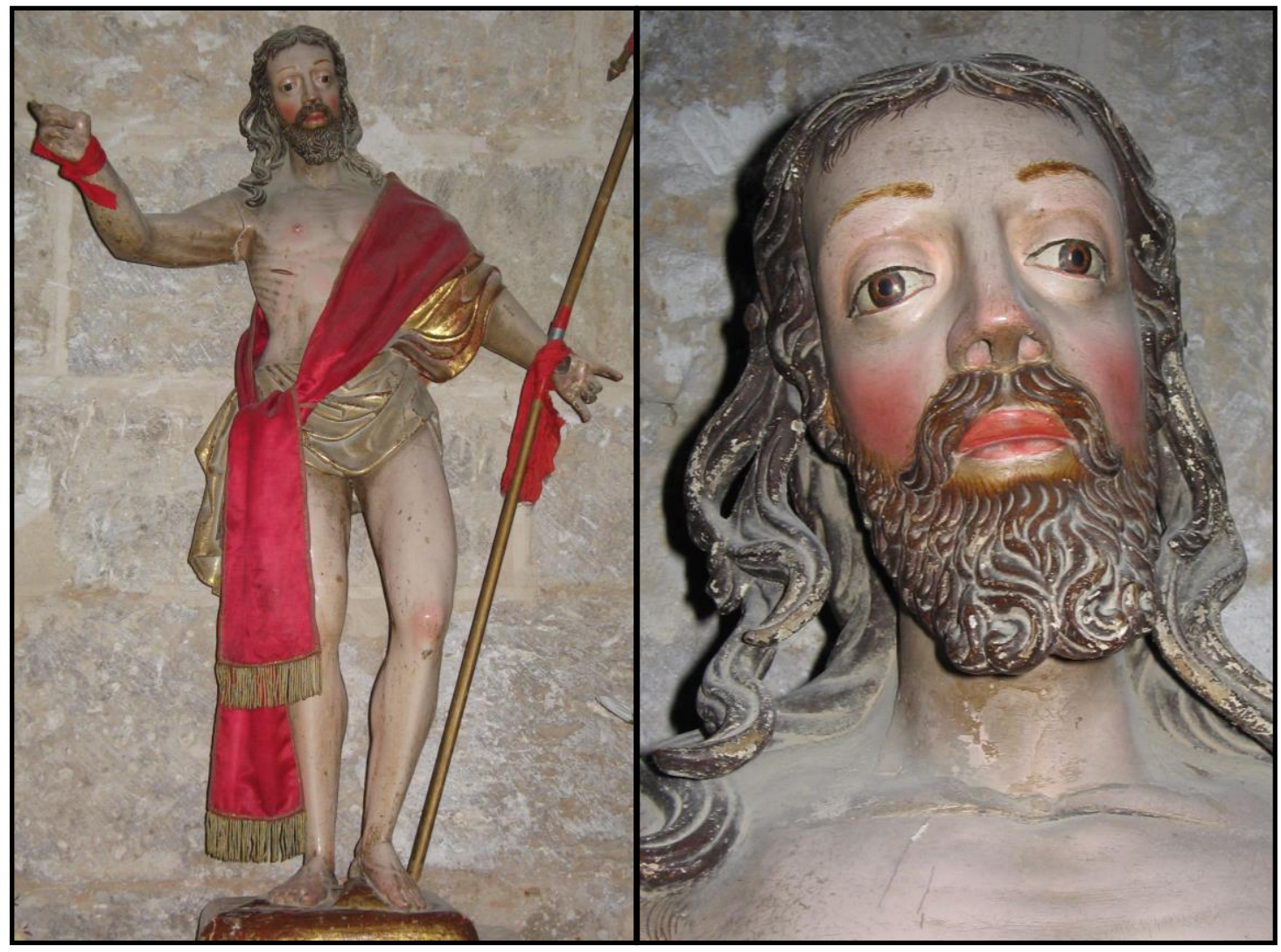

Fig. 54- Juan de Ávila. Cristo Resucitado. Iglesia parroquial de San Andrés. Villasilos (Burgos).

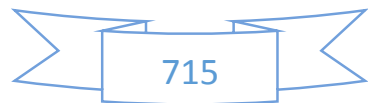




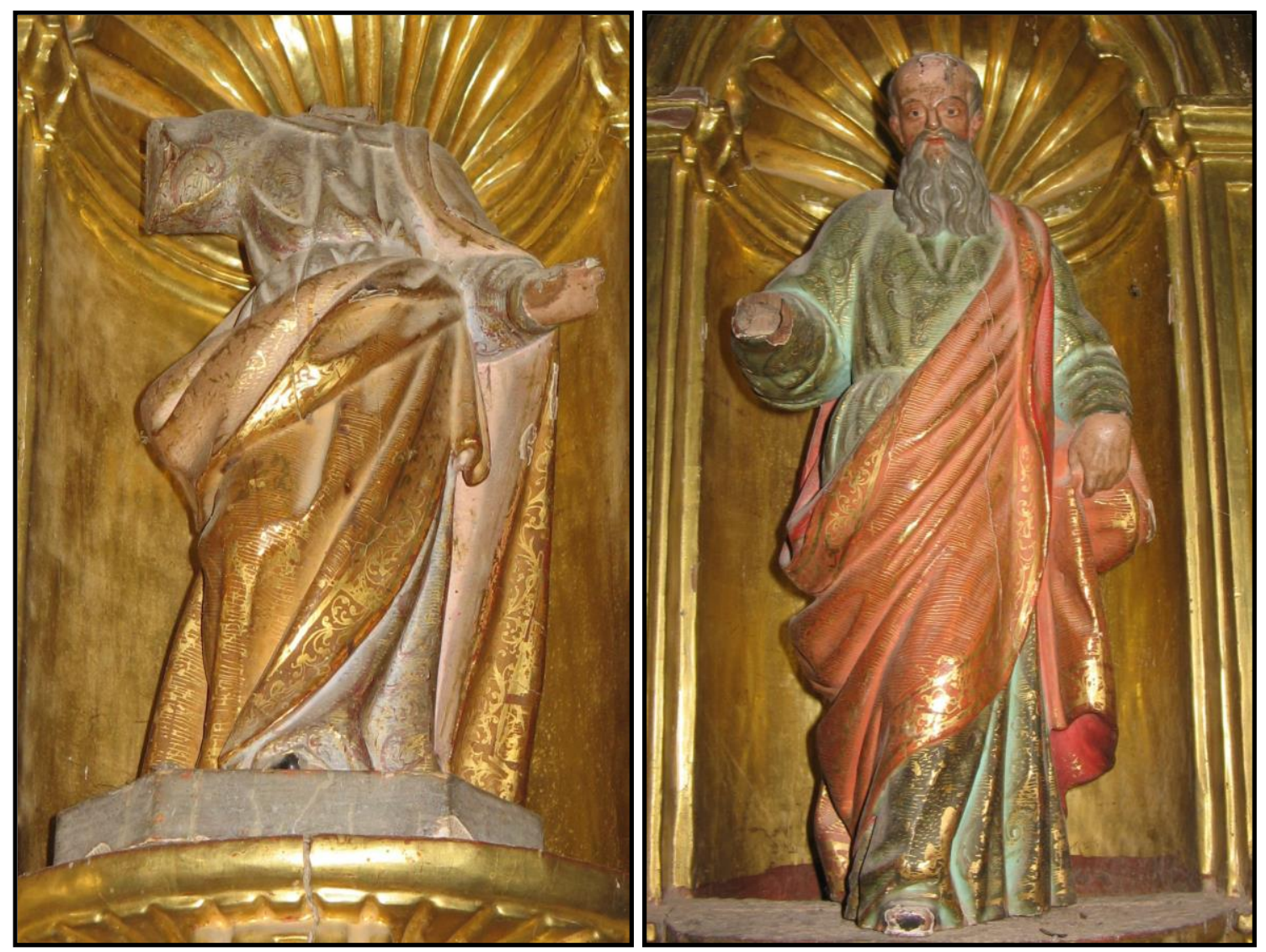

Figs. 55-58- Juan de Ávila. San Pedro, San Pablo, San Antonio Abad y San Antonio de Padua. Iglesia parroquial de San Andrés. Villasilos (Burgos).
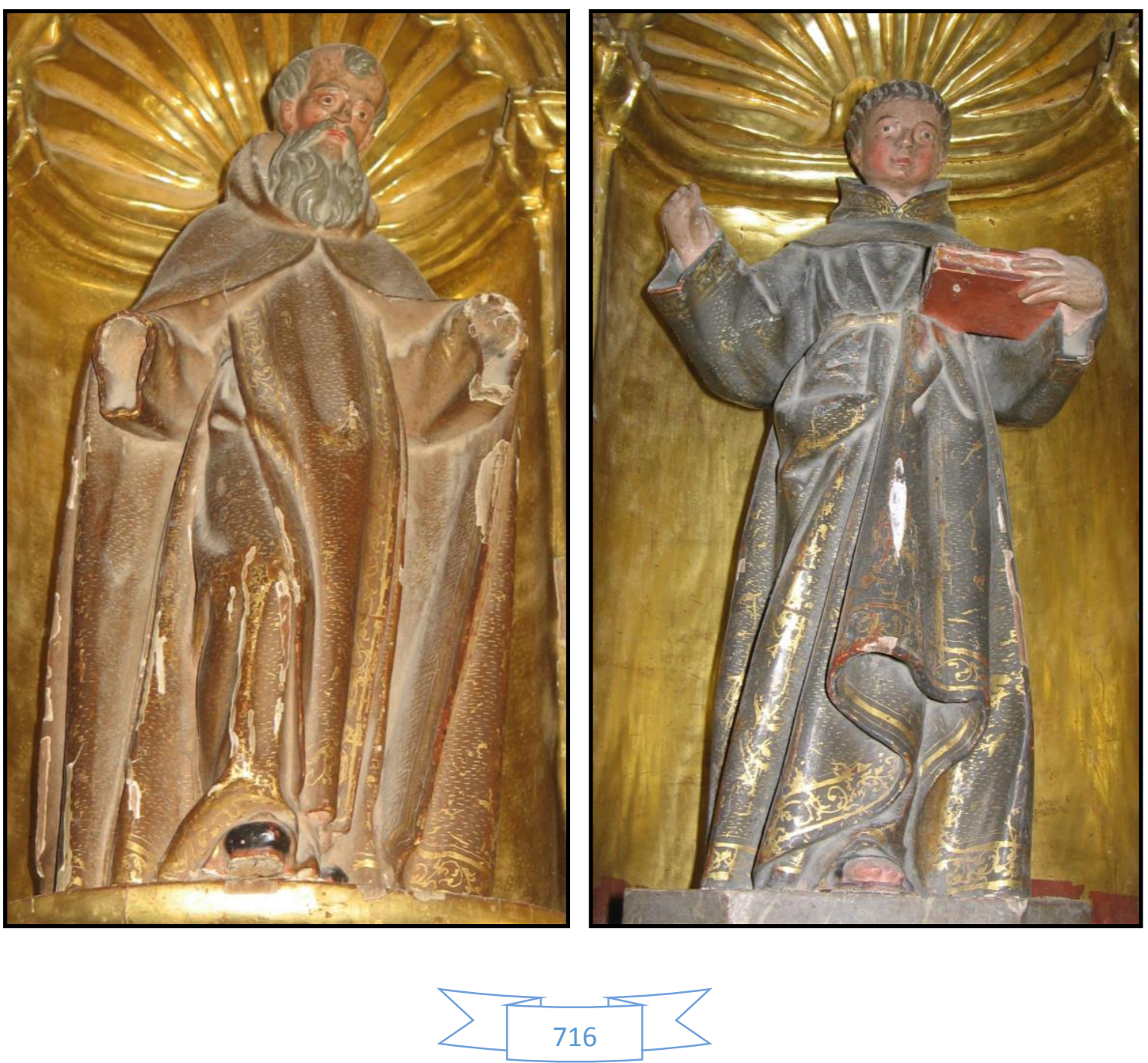


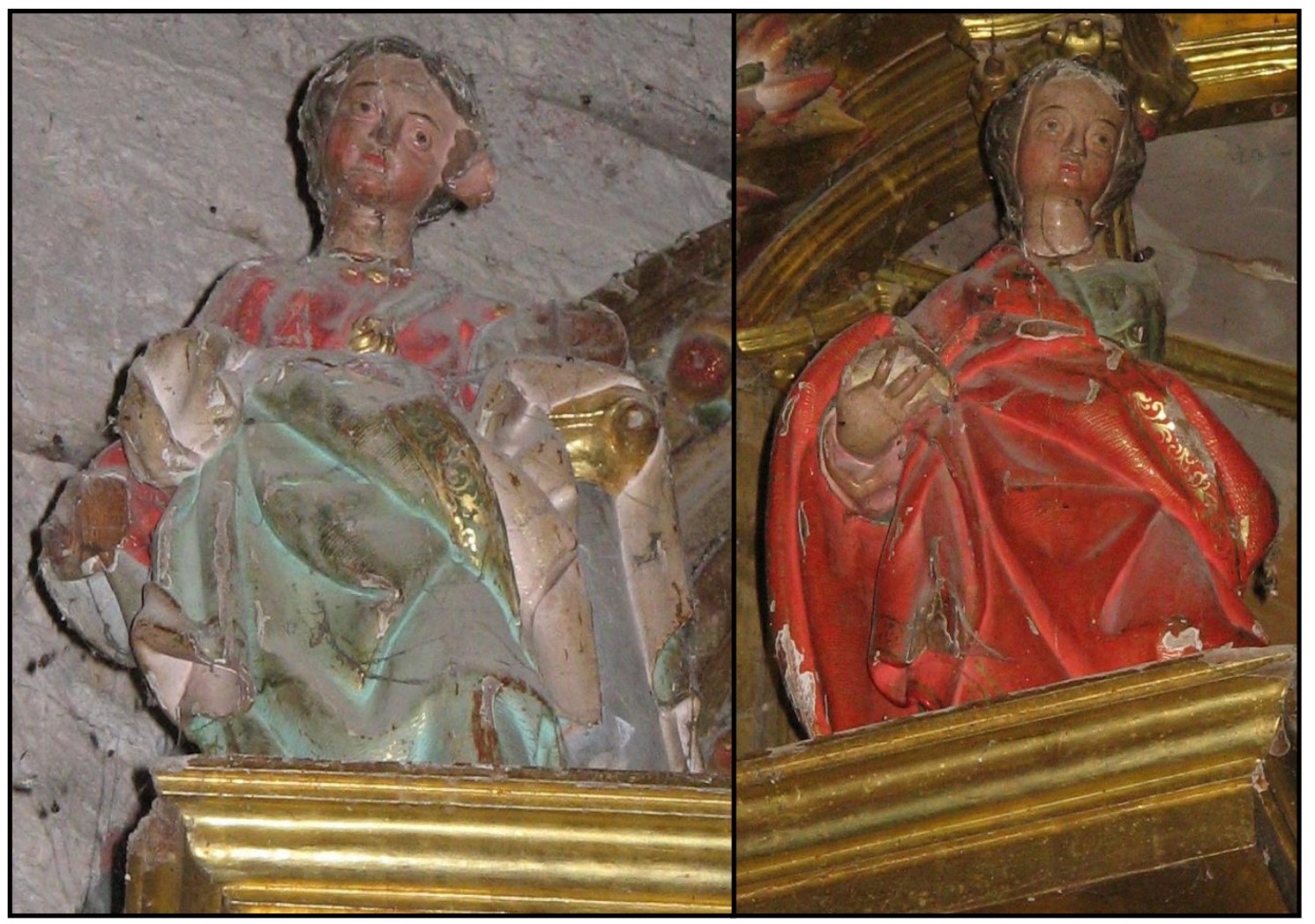

Fig. 59- Juan de Ávila. Las Virtudes. Iglesia parroquial de San Andrés. Villasilos (Burgos).

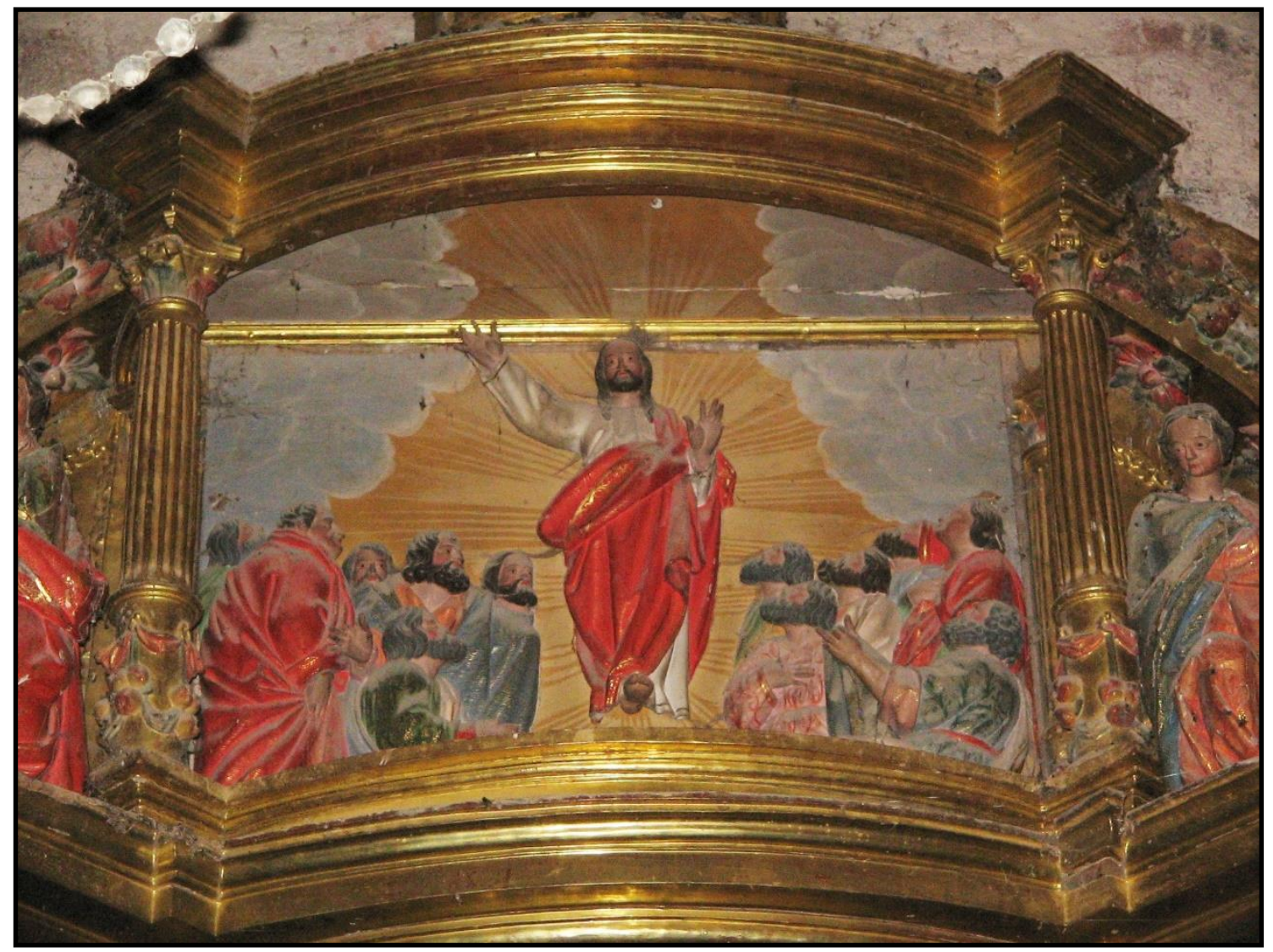

Fig. 60- Juan de Ávila. La Ascensión del Señor. Iglesia parroquial de San Andrés. Villasilos (Burgos).

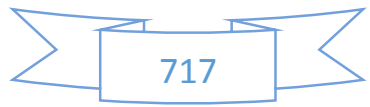



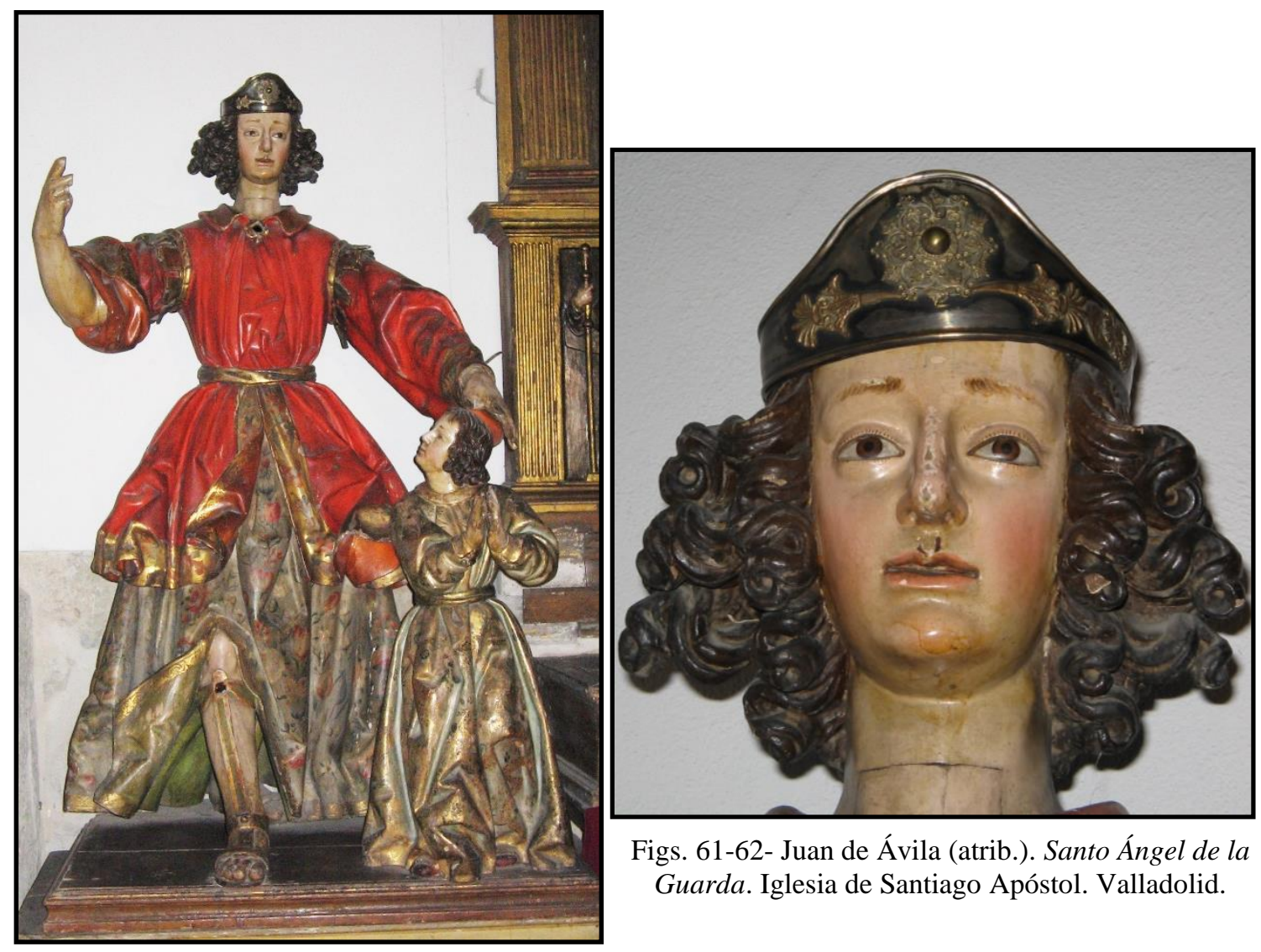

Figs. 61-62- Juan de Ávila (atrib.). Santo Ángel de la Guarda. Iglesia de Santiago Apóstol. Valladolid.

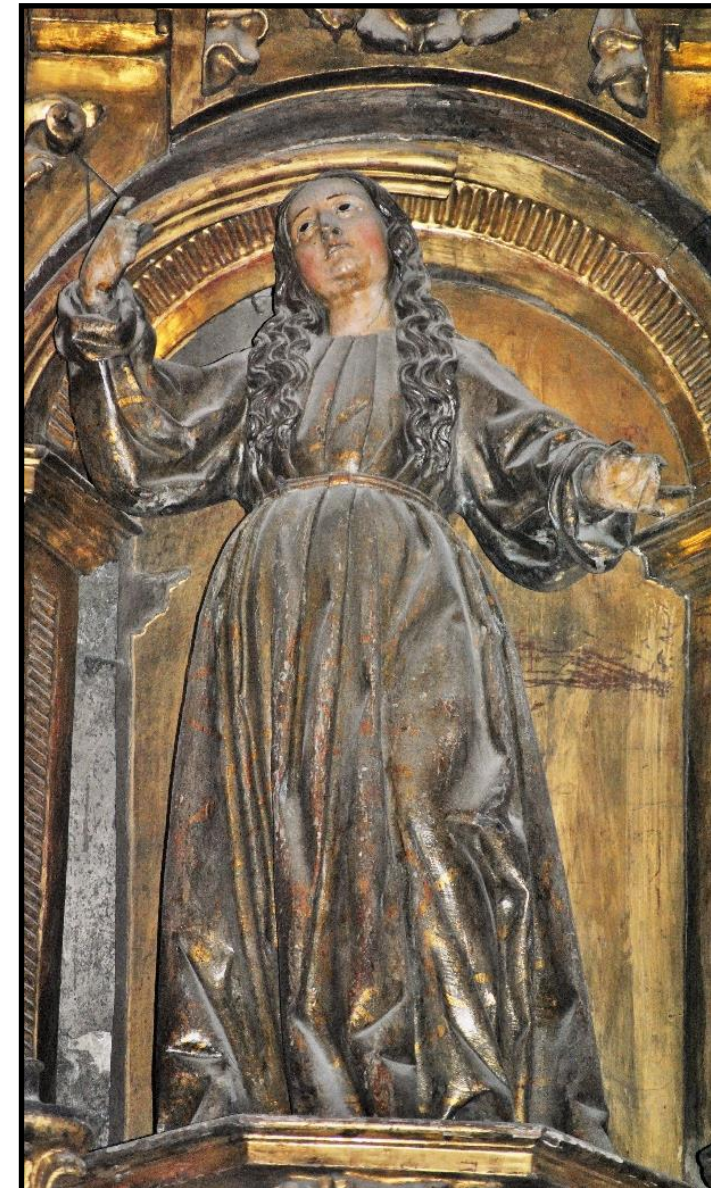

Fig. 63- Juan de Ávila (atrib.). Santo Rosa de Viterbo. Iglesia de Santiago Apóstol. Valladolid.

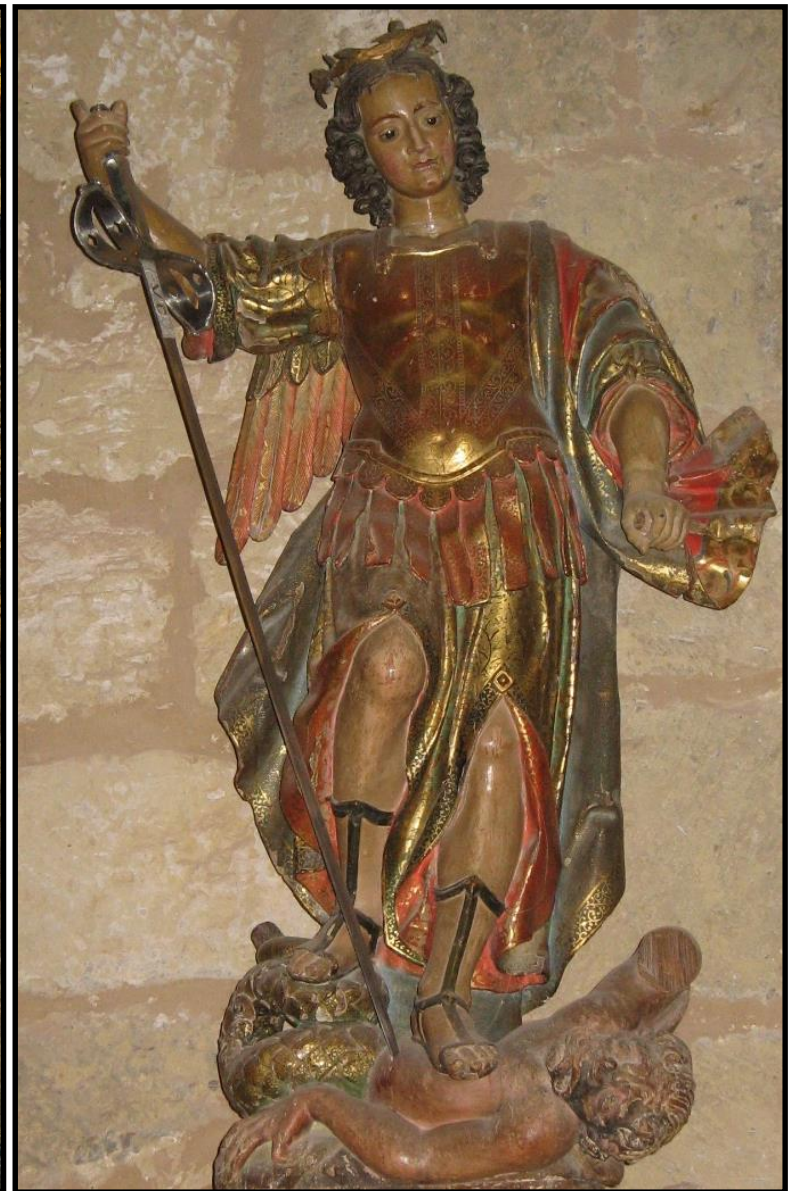

Fig. 64- Juan de Ávila (atrib.). San Miguel. Iglesia parroquial. Cevico de la Torre (Palencia).

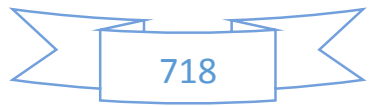




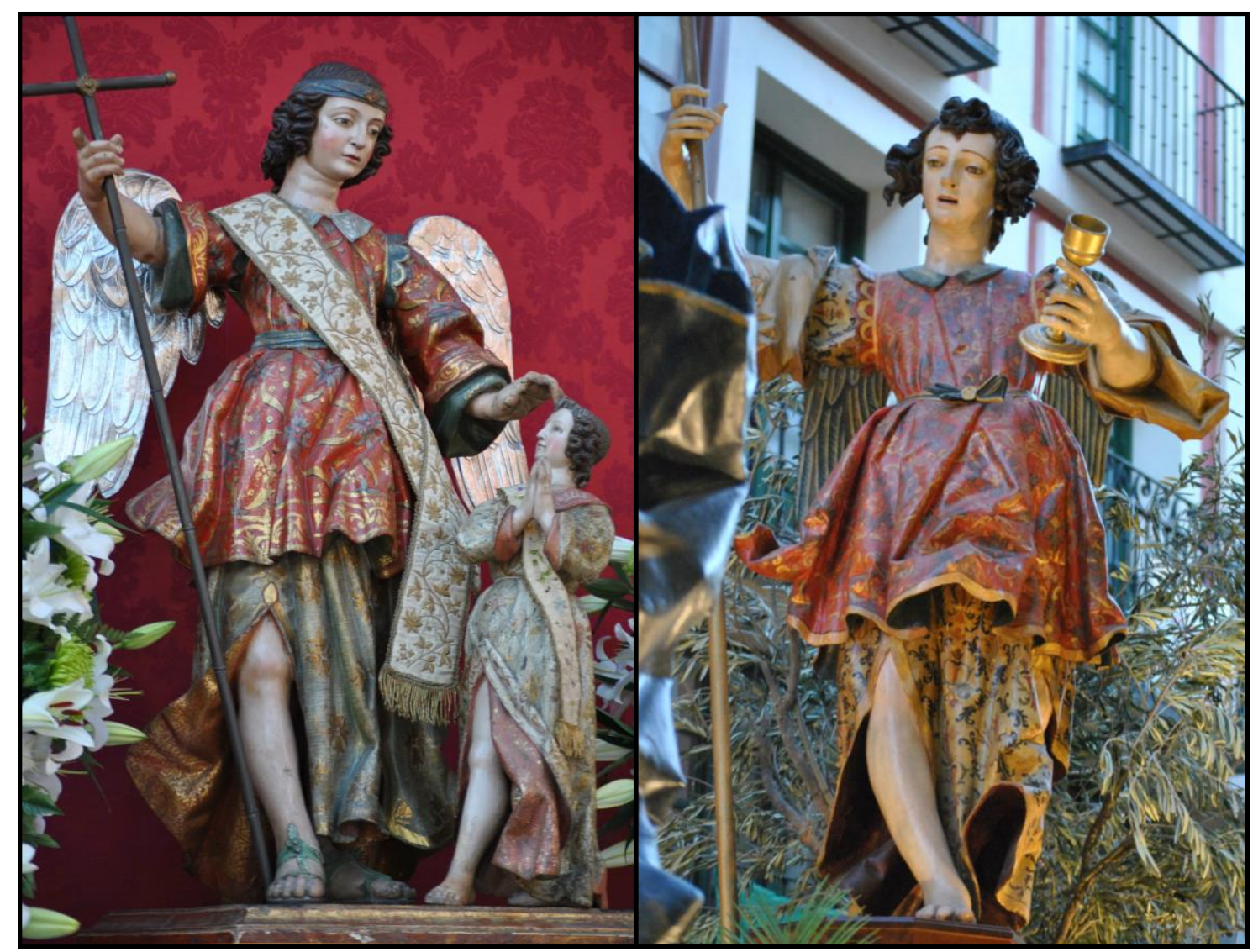

Fig. 65- Juan de Ávila (atrib.). Santo Ángel de la Guarda. Iglesia de San Miguel. Valladolid.

Comparación con el Ángel del paso de la Oración del Huerto realizado por Andrés Solanes para la Cofradía Penitencial de la Santa Vera Cruz.

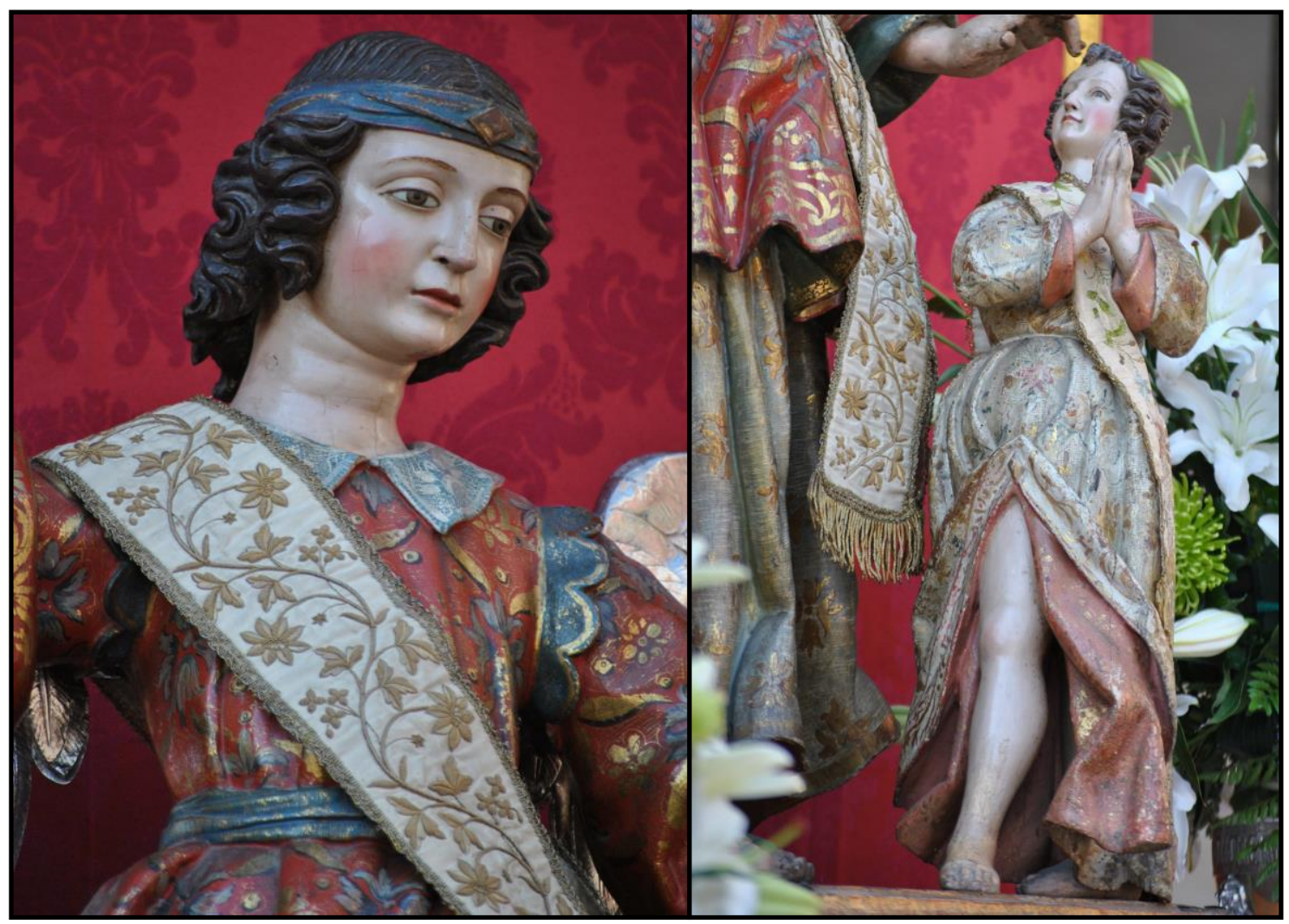

Fig. 66- Juan de Ávila (atrib.). Detalles del Santo Ángel de la Guarda.

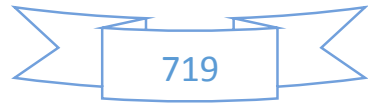




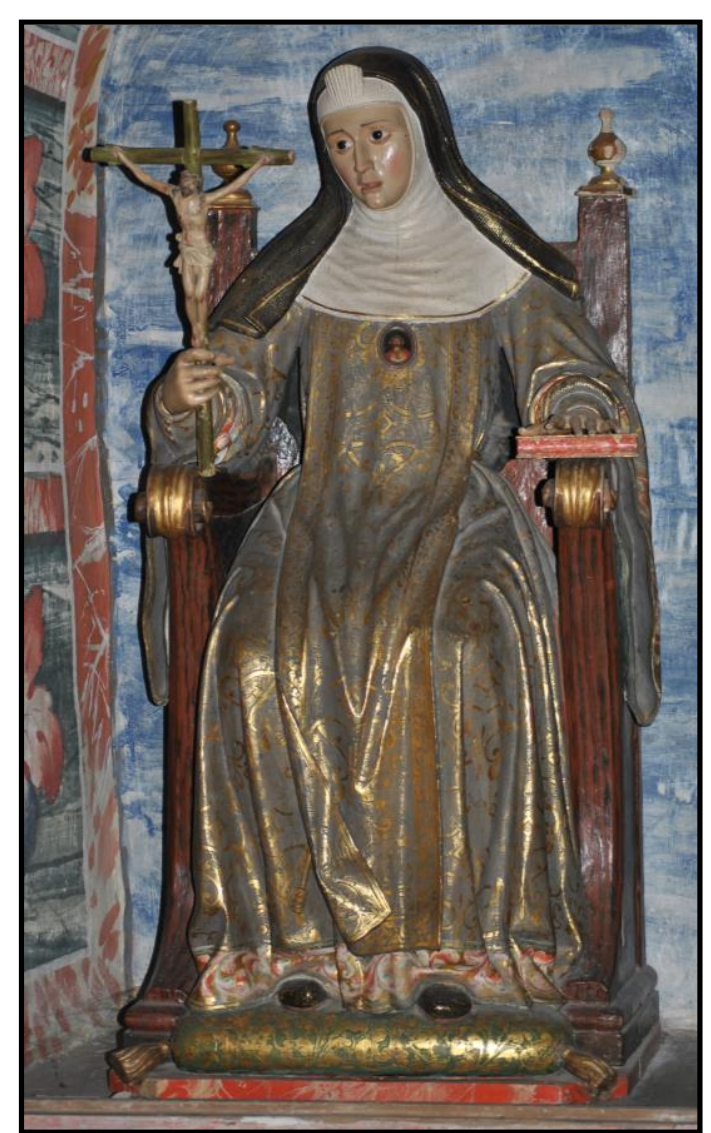

Fig. 67- Juan de Ávila (atrib.). Santa Catalina de Bolonia. Convento de Santa Clara. Valladolid.

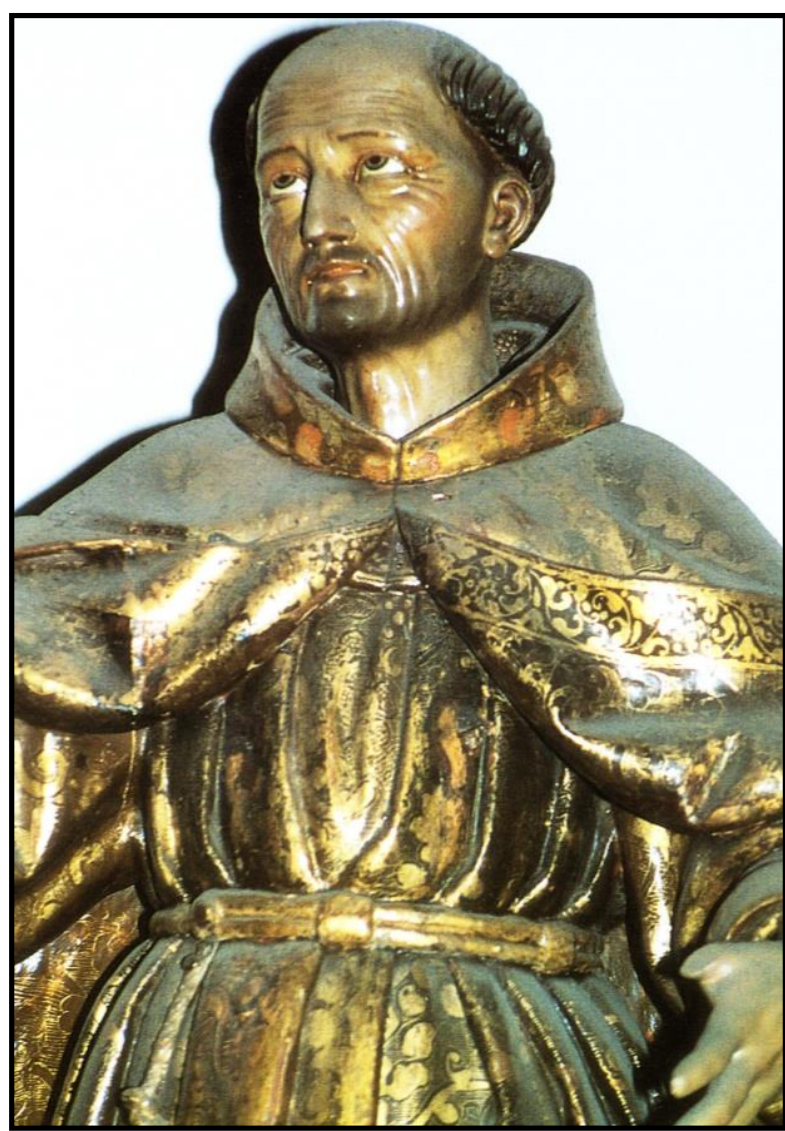

Fig. 68- Juan de Ávila (atrib.). San Pedro Regalado. Palacio Real. Valladolid.

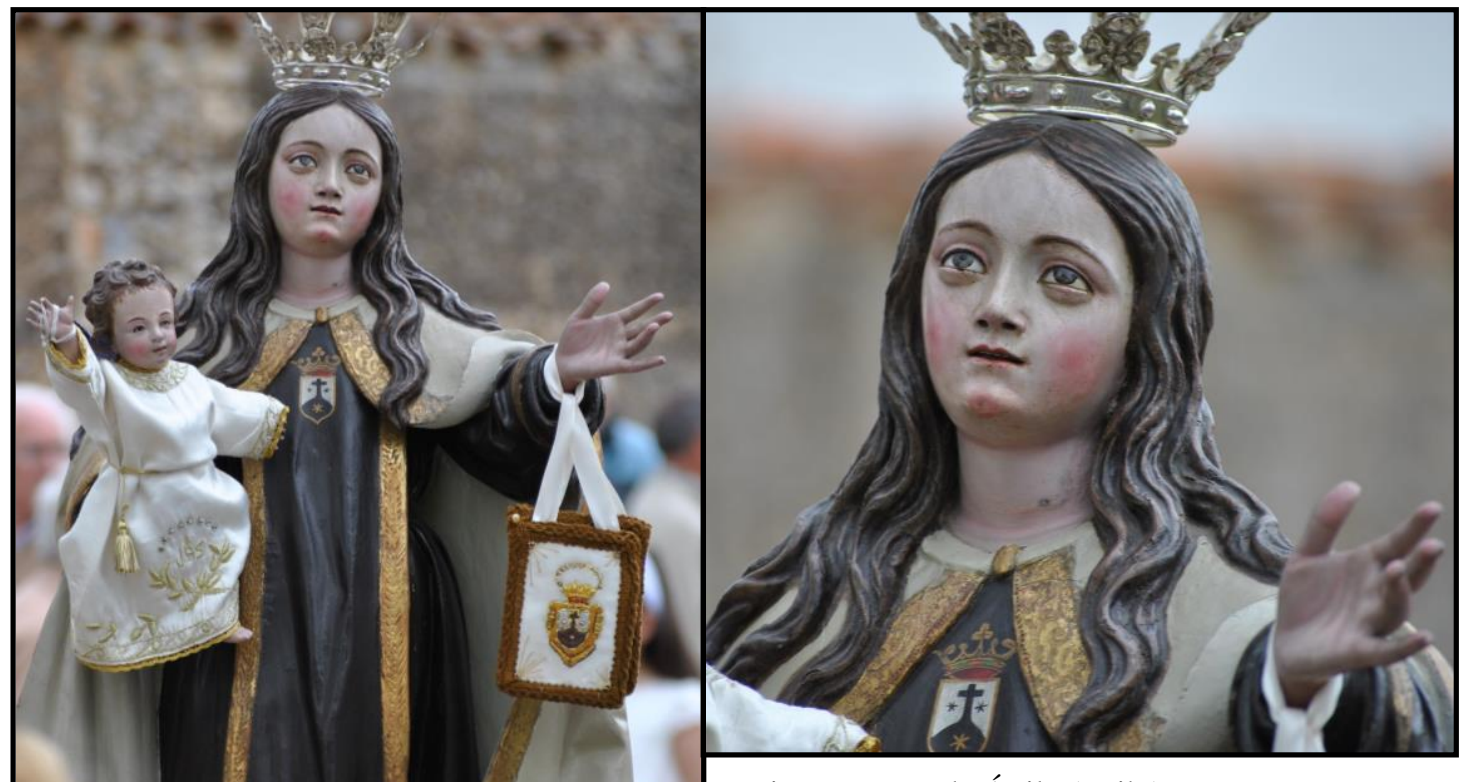

Fig. 69- Juan de Ávila (atrib.). La Virgen del Carmen Niña con el Niño Jesús.

Santuario de Nuestra Señora del Carmen Extramuros. Valladolid. 

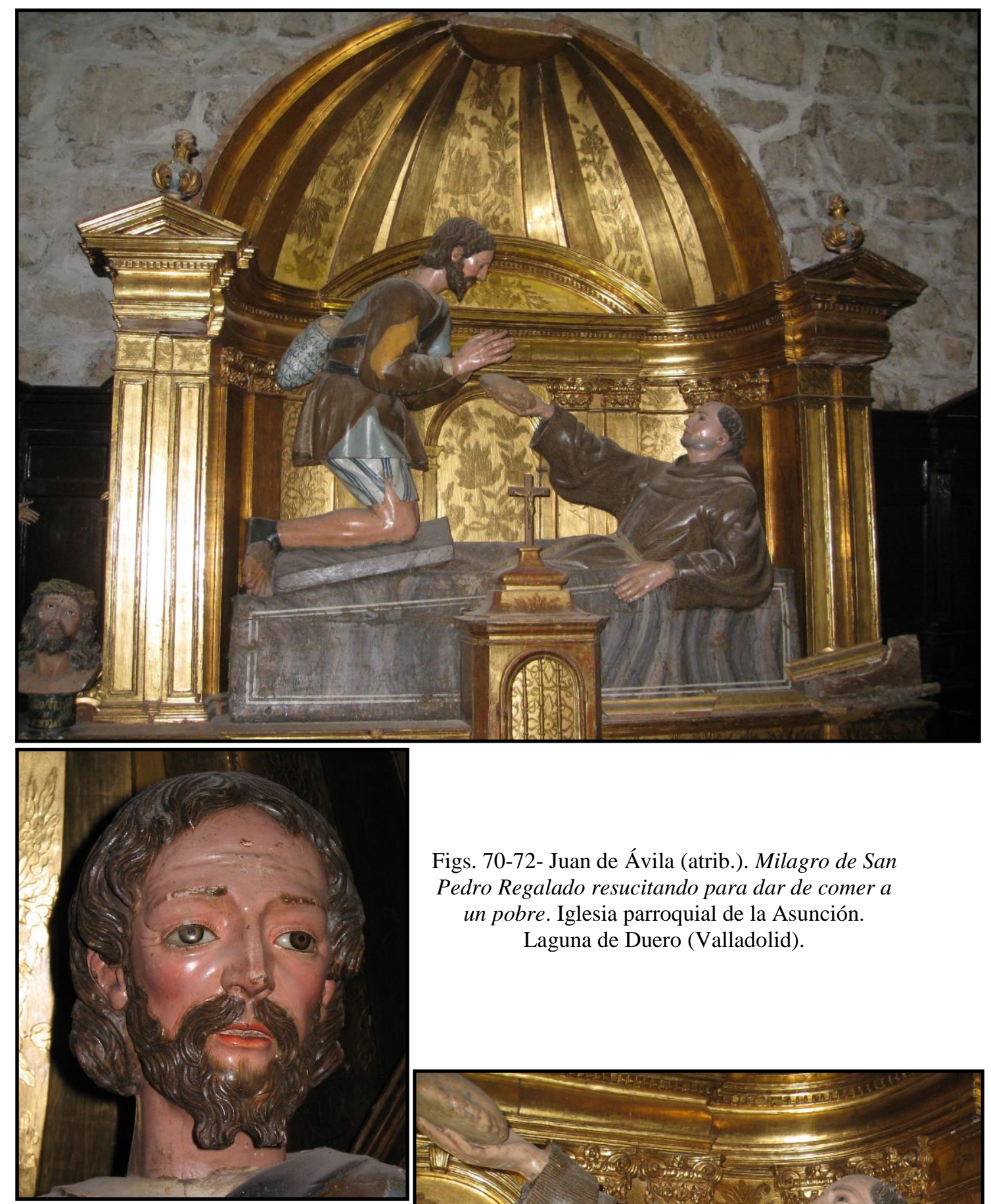

Figs. 70-72- Juan de Ávila (atrib.). Milagro de San Pedro Regalado resucitando para dar de comer a un pobre. Iglesia parroquial de la Asunción. Laguna de Duero (Valladolid).
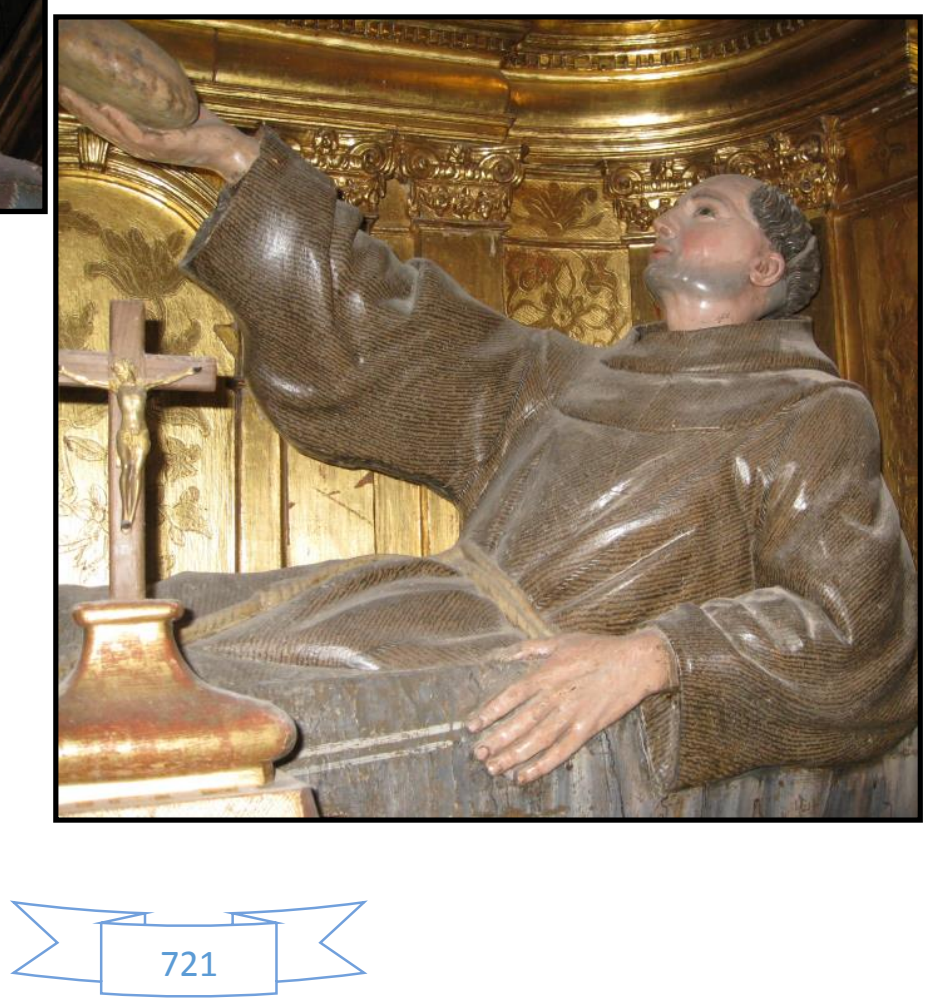


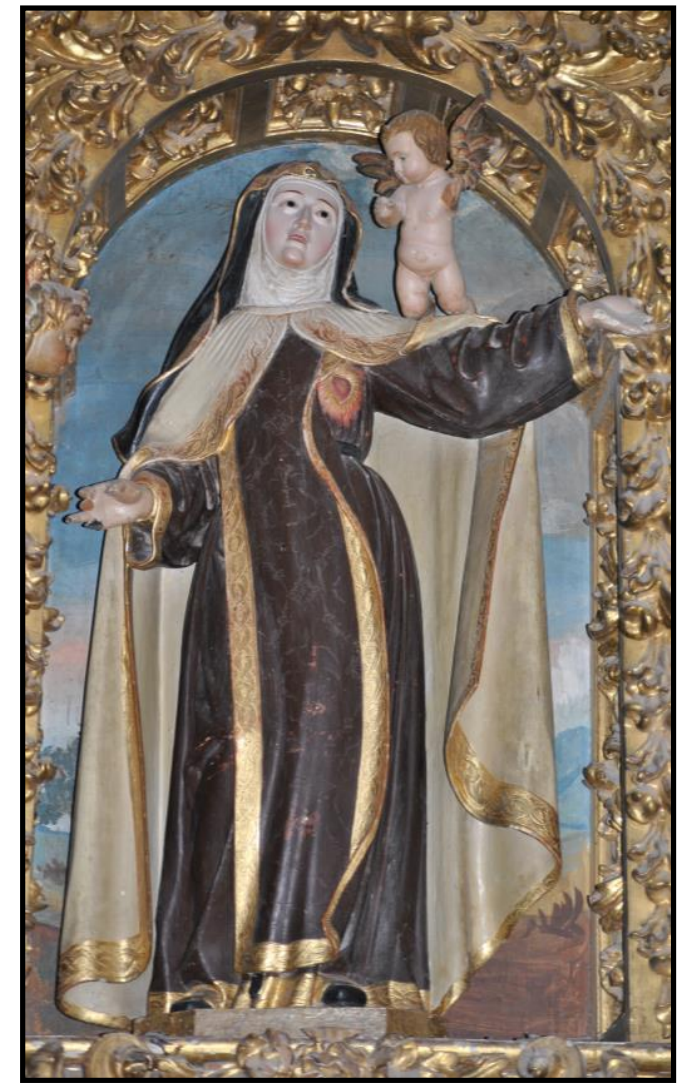

Fig. 73- Juan de Ávila (atrib.). Santa Teresa. Iglesia parroquial de los Santos Juanes. Nava del Rey (Valladolid).

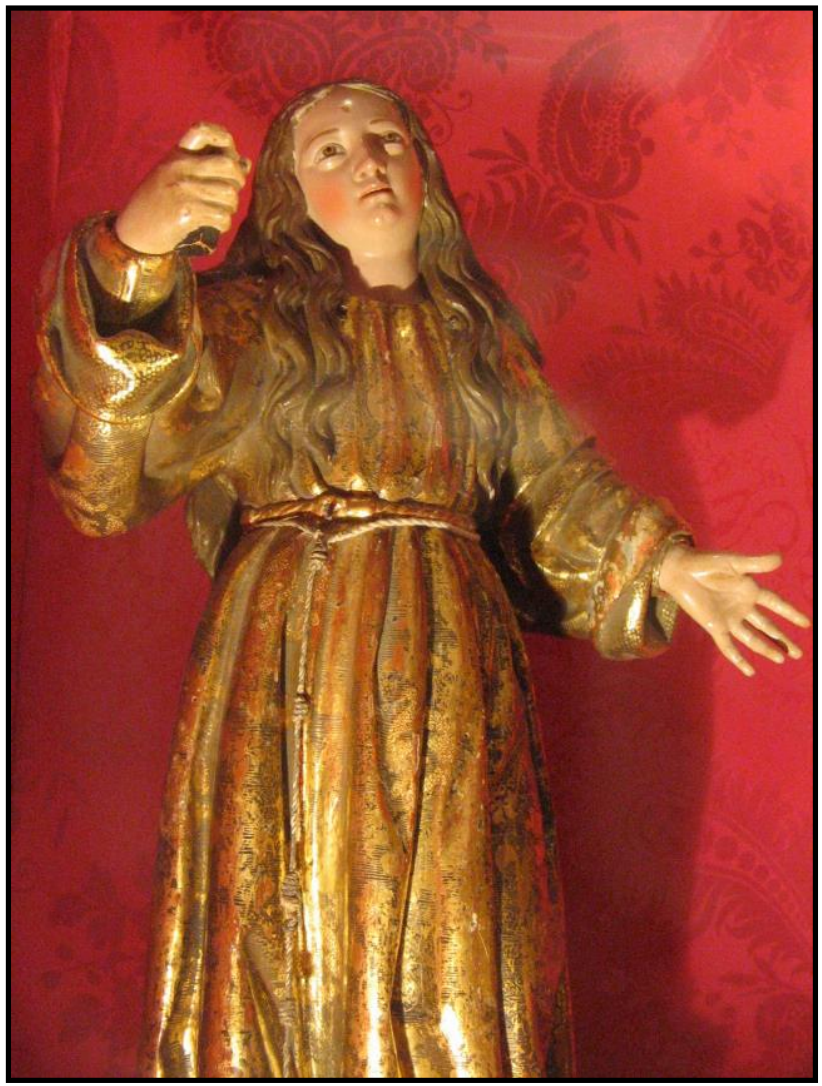

Fig. 74- Juan de Ávila (atrib.). Santa Rosa de Viterbo. Real Monasterio de Santa Clara. Tordesillas (Valladolid).

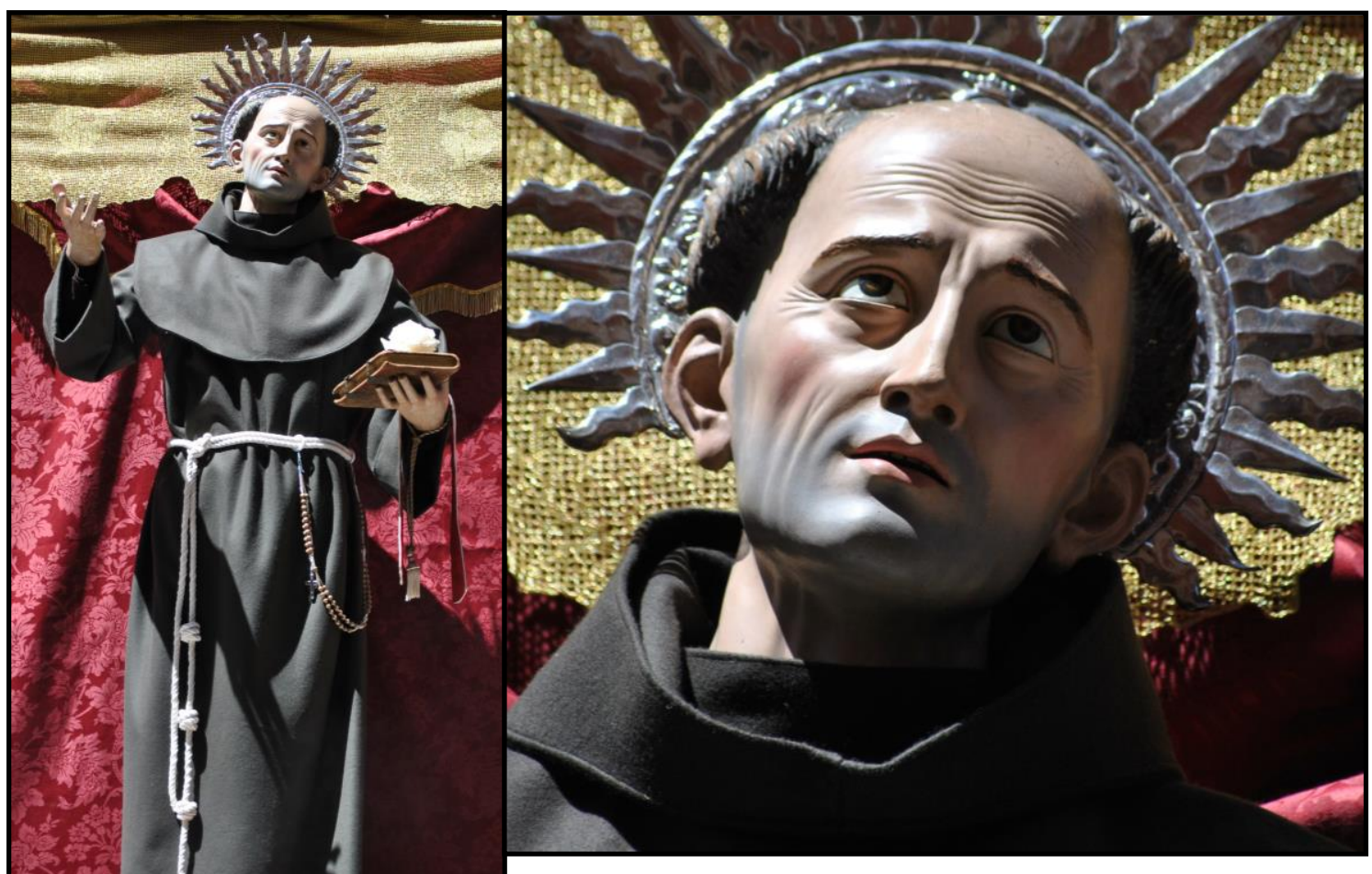

Fig. 75- Juan de Ávila (atrib.). San Pedro Regalado.

Iglesia penitencial de N. P. Jesús Nazareno. Valladolid.

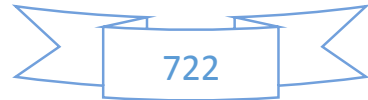




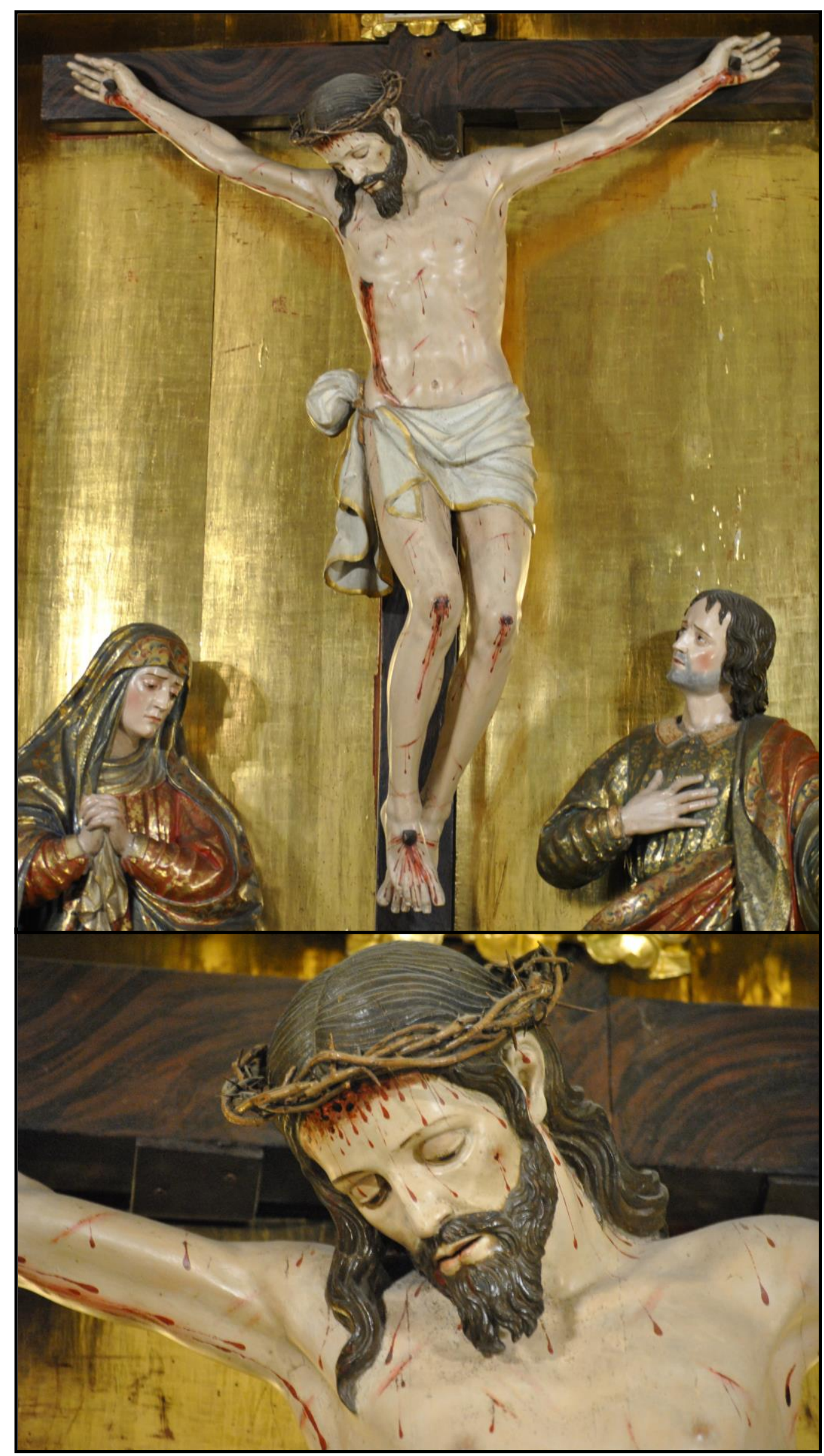

Fig. 76- Juan de Ávila (atrib.). Crucifijo del Calvario. Colegio de los Ingleses. Valladolid.

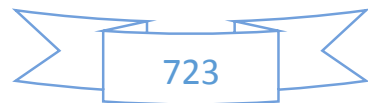




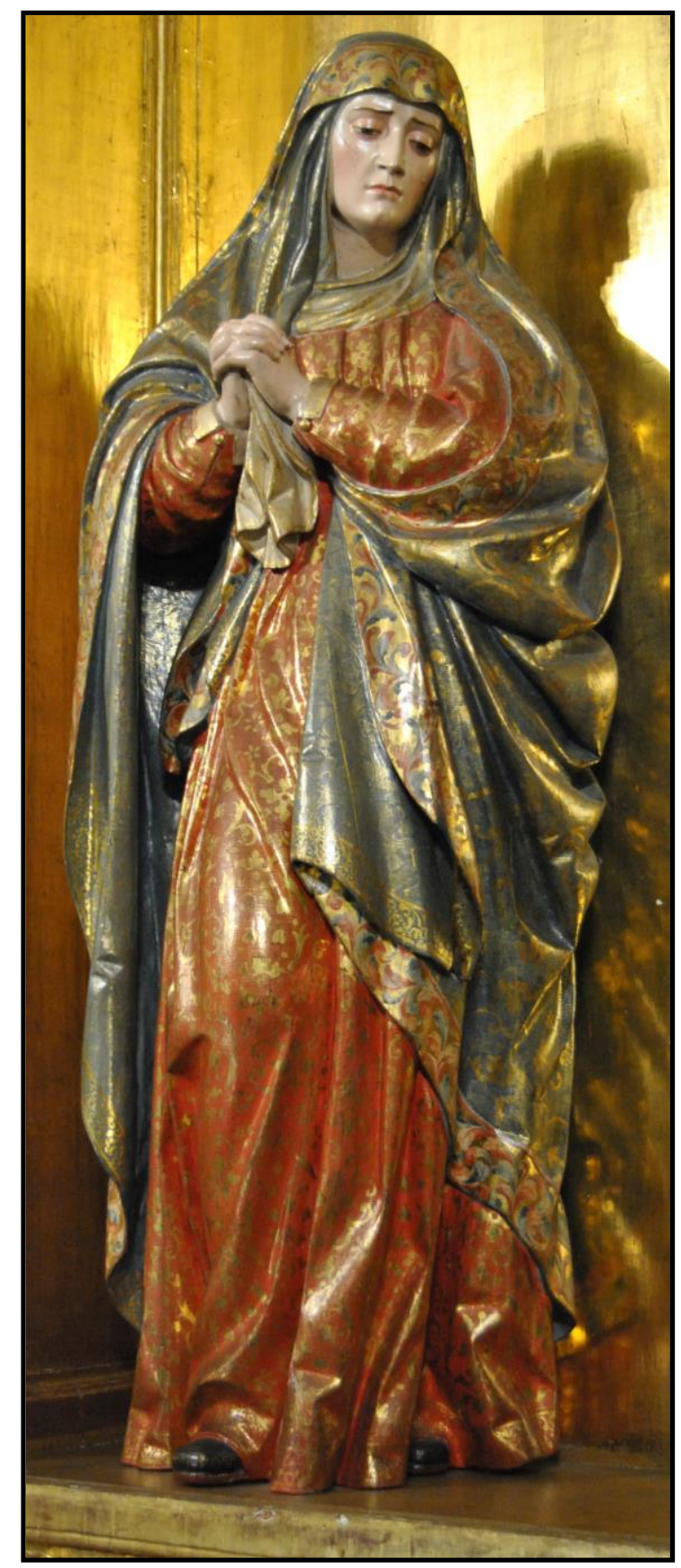

Fig. 77- Juan de Ávila (atrib.). Virgen del

Calvario. Colegio de los Ingleses. Valladolid.

Fig. 78- Juan de Ávila (atrib.). San Juan Evangelista del Calvario. Colegio de los Ingleses. Valladolid.
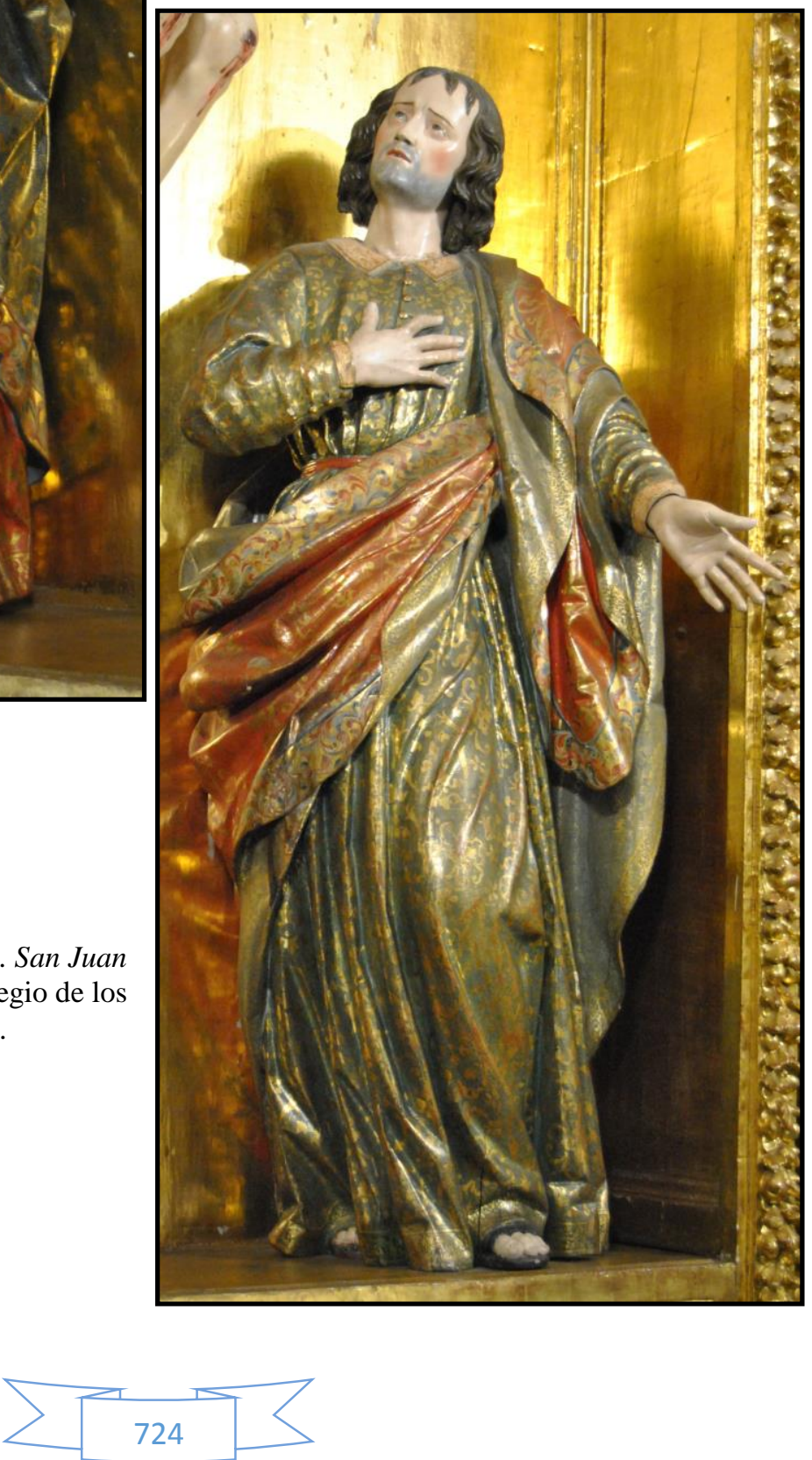

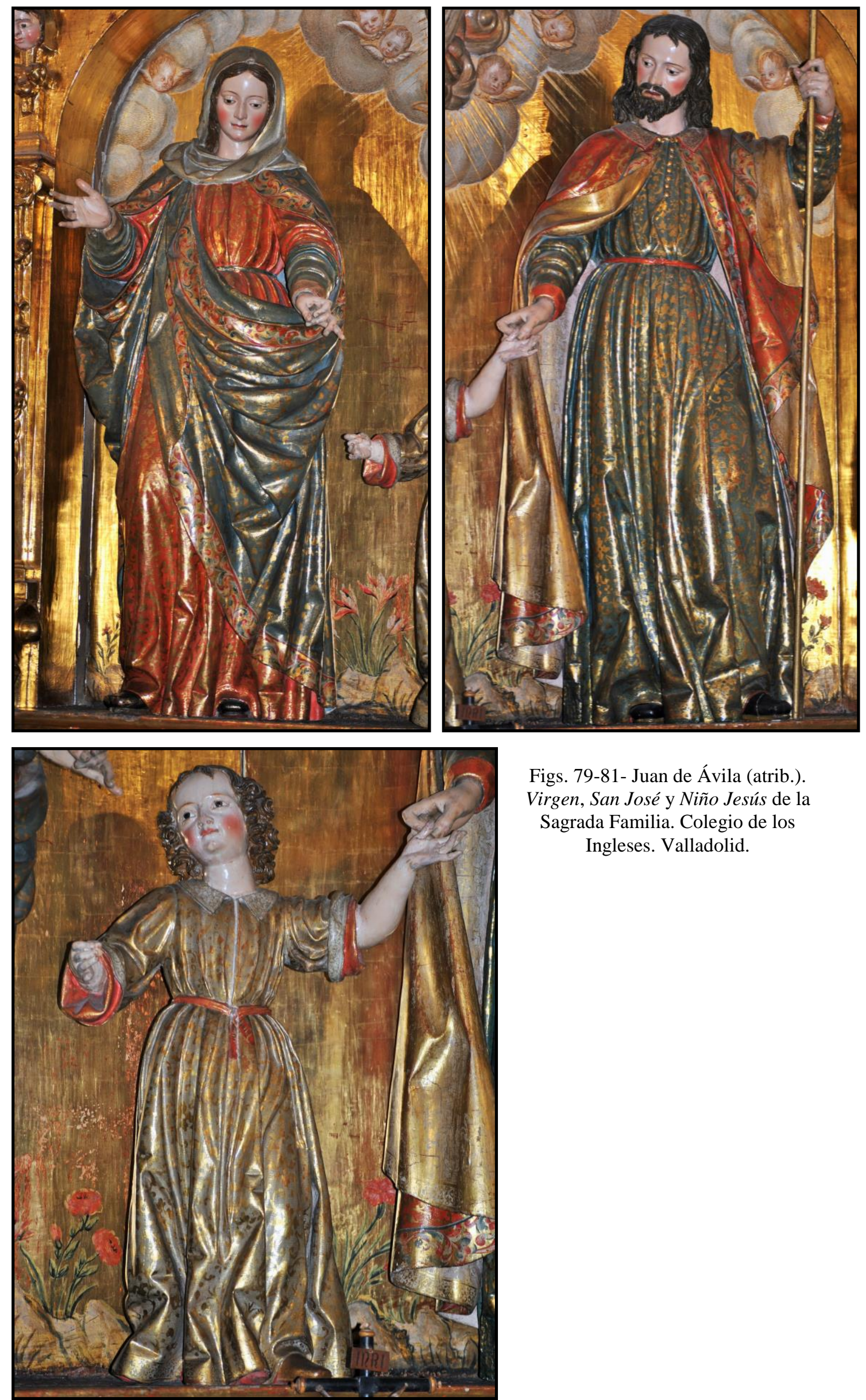

Figs. 79-81- Juan de Ávila (atrib.). Virgen, San José y Niño Jesús de la Sagrada Familia. Colegio de los Ingleses. Valladolid.

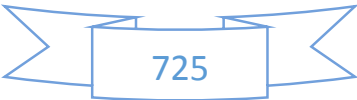



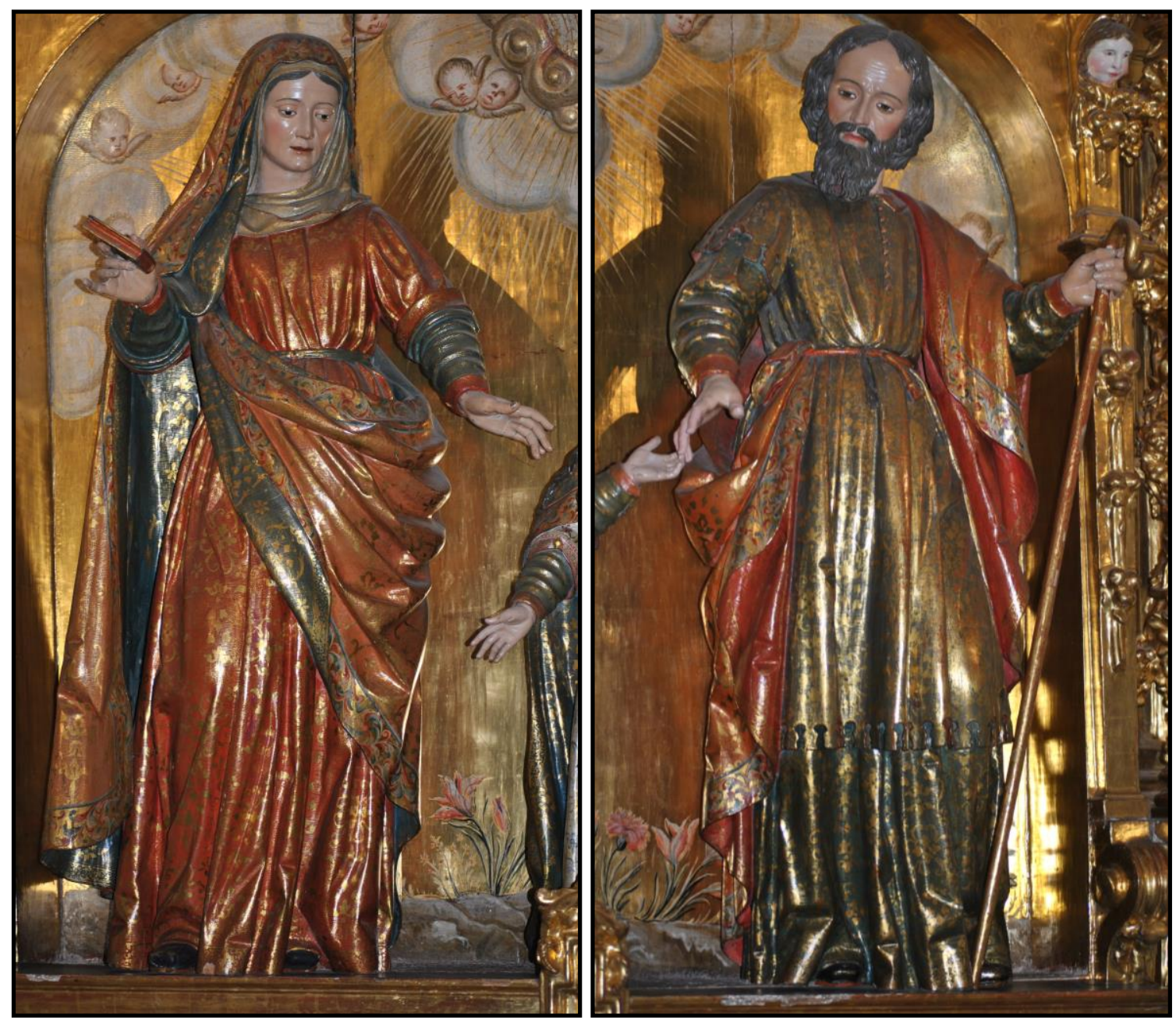

Figs. 82-84- Juan de Ávila (atrib.). San Ana, San Joaquín y la Virgen Niña de la Sagrada Familia de la Virgen.

Colegio de los Ingleses. Valladolid.
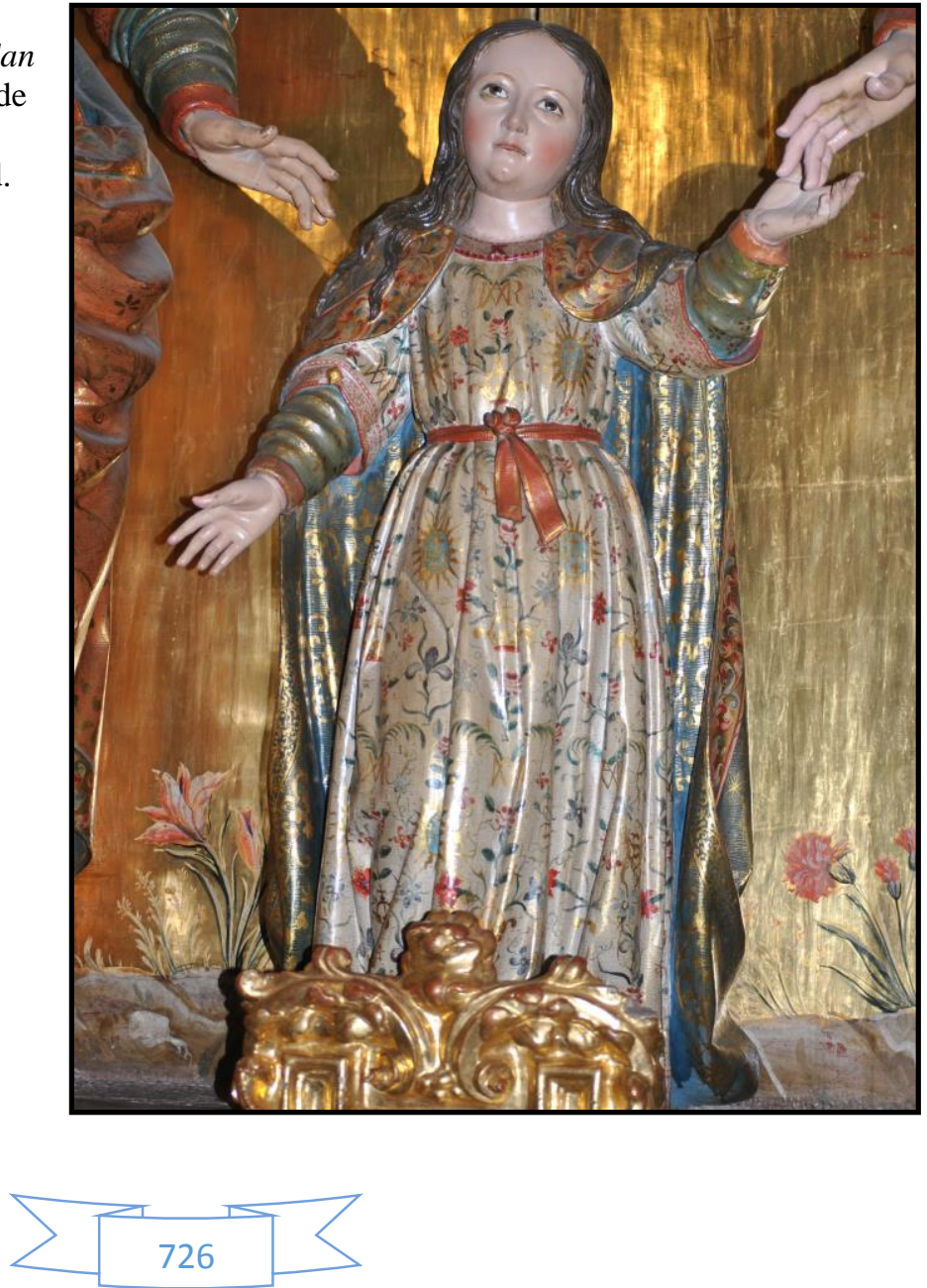


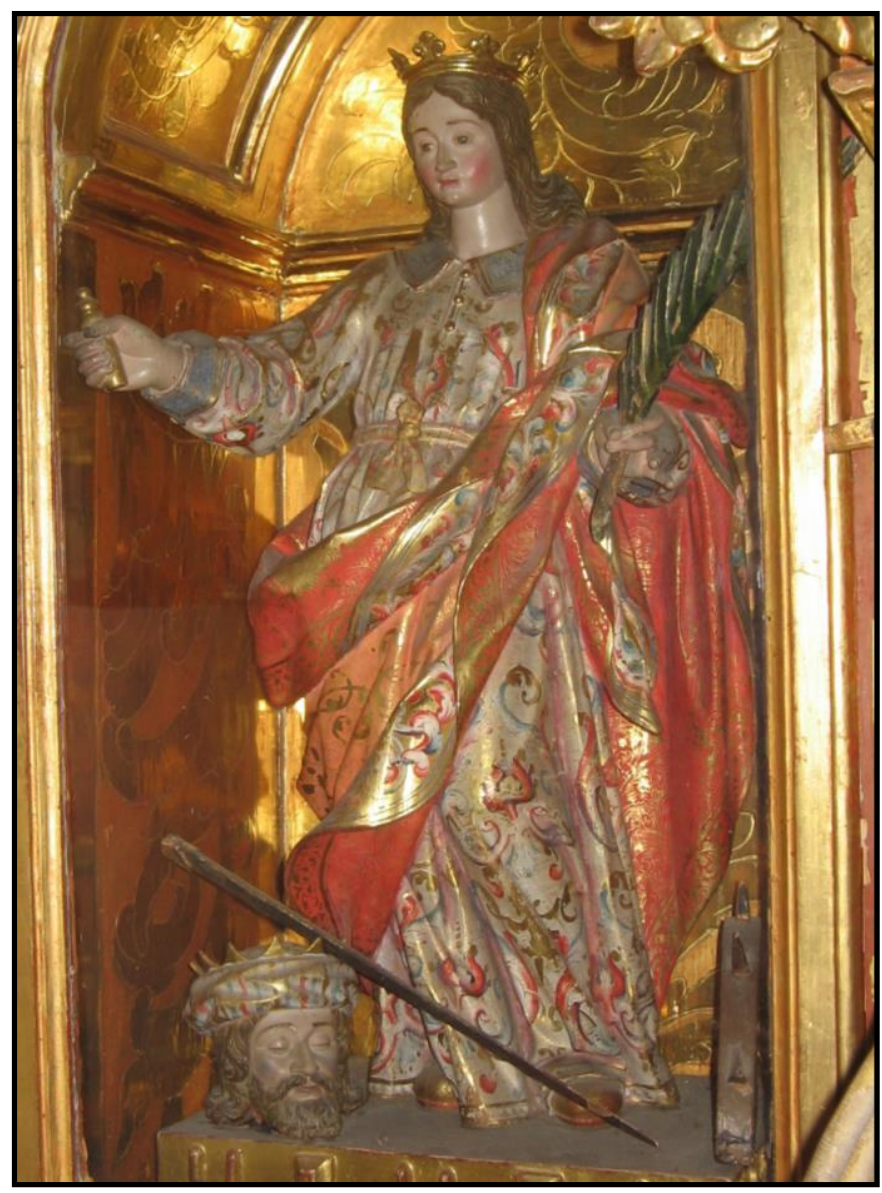

Fig. 85- Juan de Ávila (atrib.). Santa Catalina de

Alejandría. Convento de Santa Catalina. Valladolid.

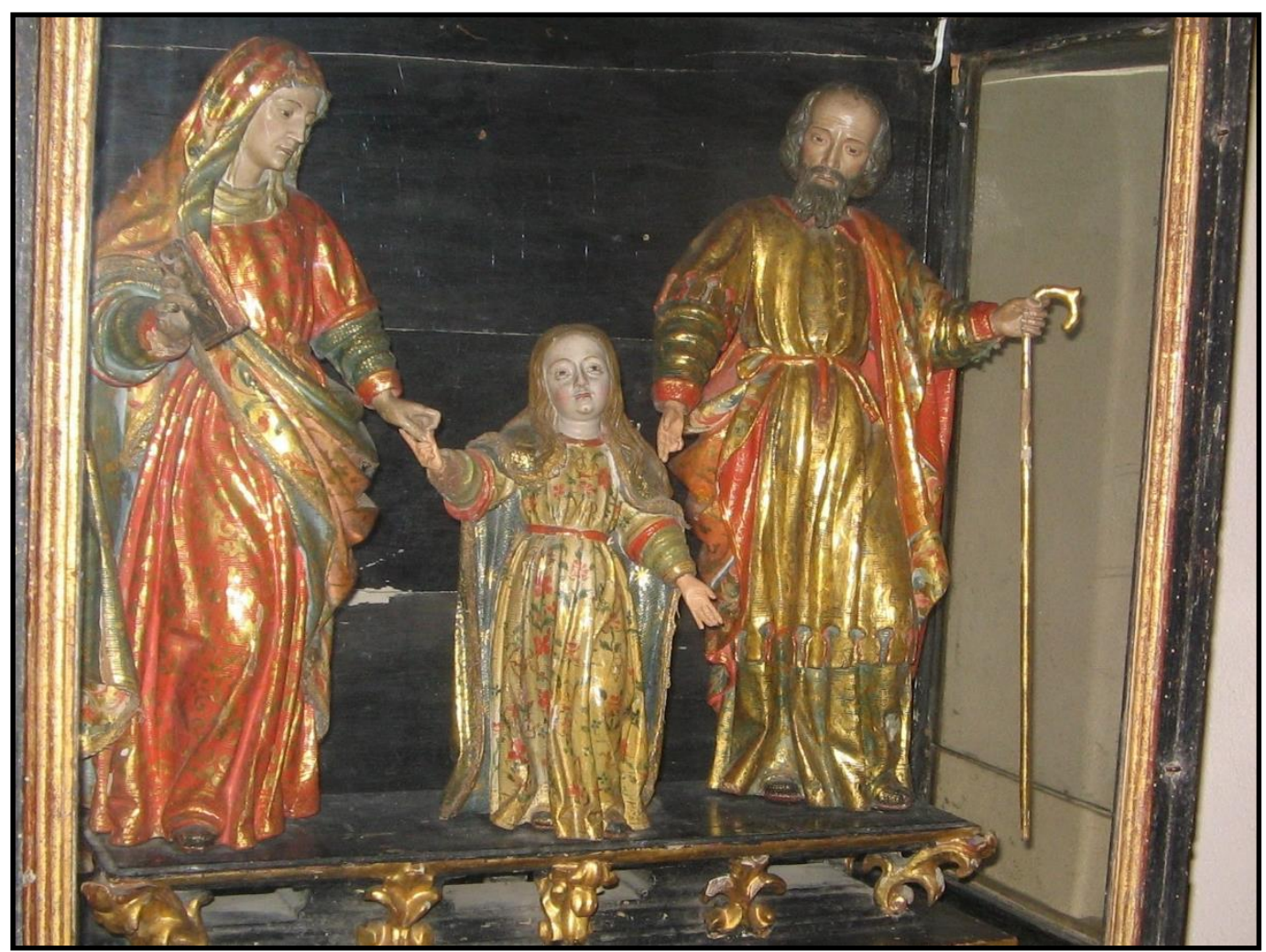

Fig. 86- Juan de Ávila (atrib.). San Joaquín, Santa Ana y la Virgen Niña. Colegiata de San Cosme y San Damián. Covarrubias (Burgos).

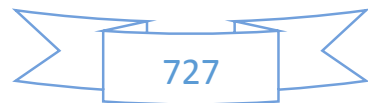




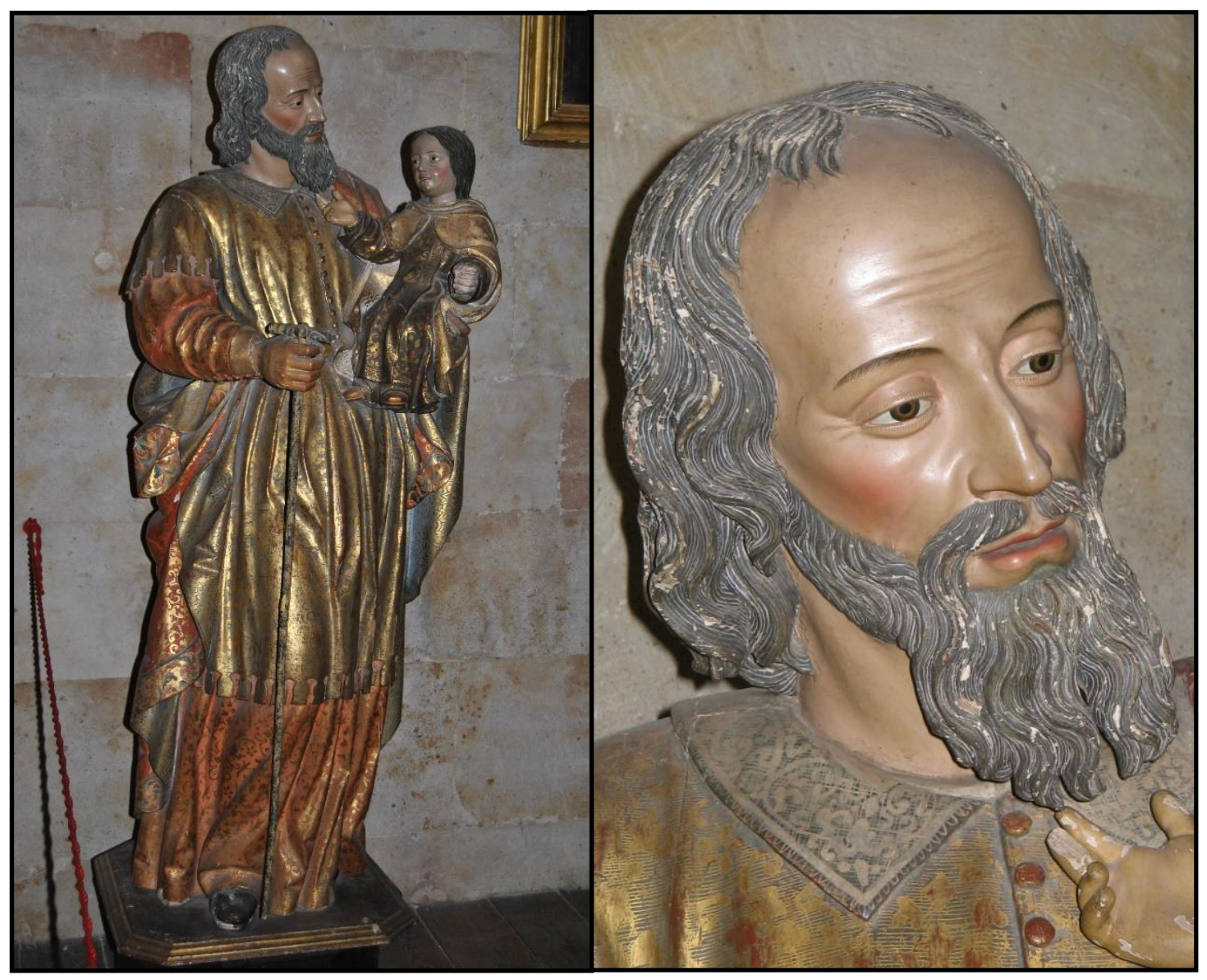

Fig. 87- Juan de Ávila (atrib.). San Joaquín con la Virgen Niña. Museo Catedralicio. Salamanca.

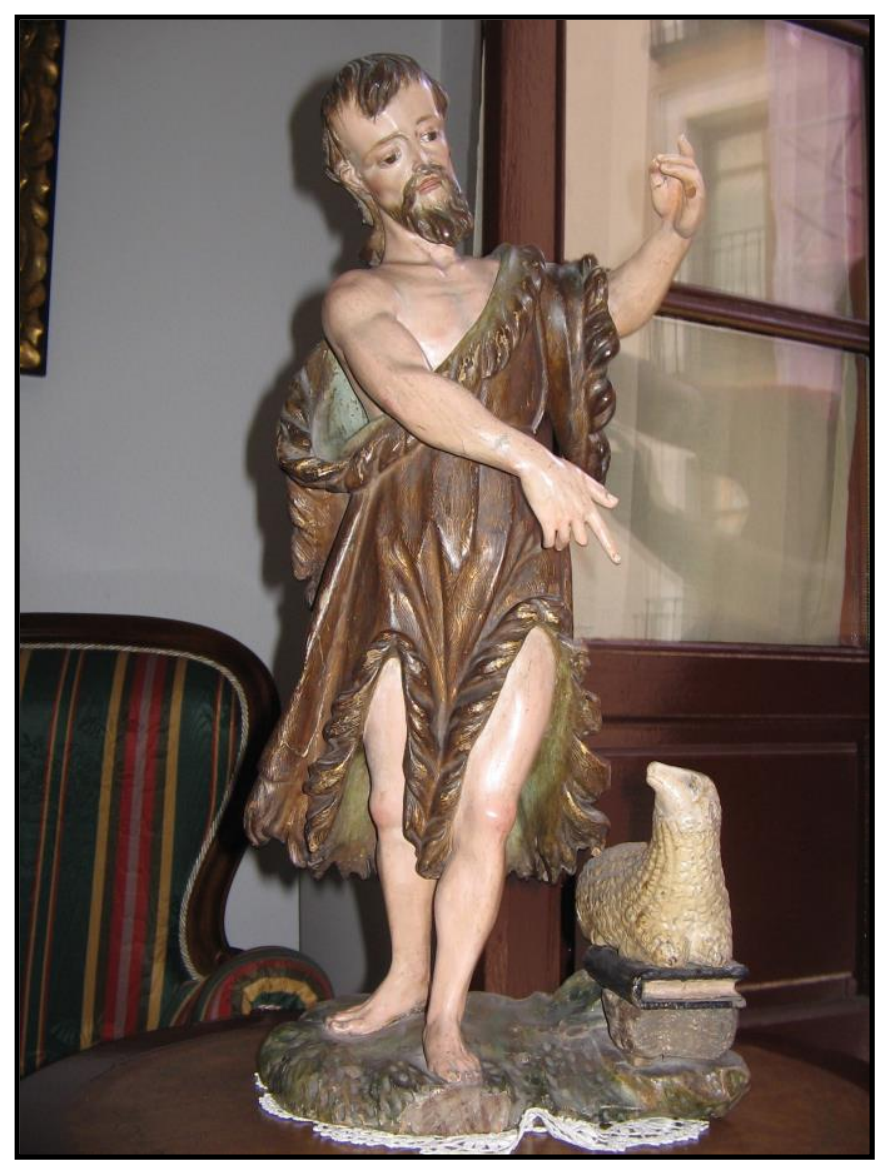

Fig. 88- Juan de Ávila (atrib.). San Juan Bautista. Iglesia parroquial de Santiago Apóstol. Valladolid.

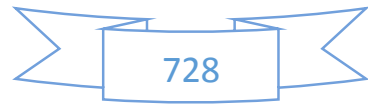




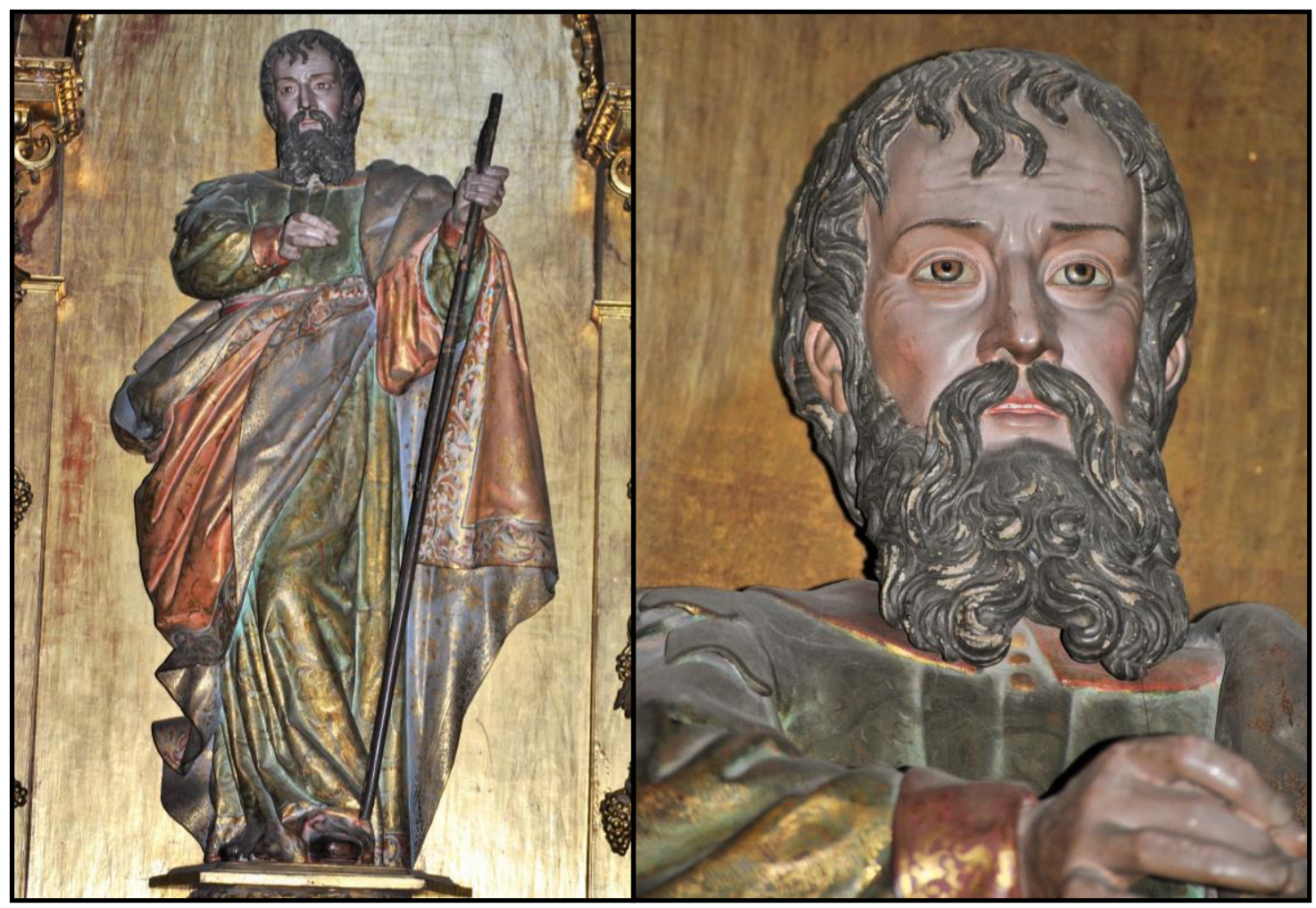

Fig. 89- Juan de Ávila (atrib.). San Joaquín. Capilla de la Congregación de la Inmaculada Concepción. Valladolid.

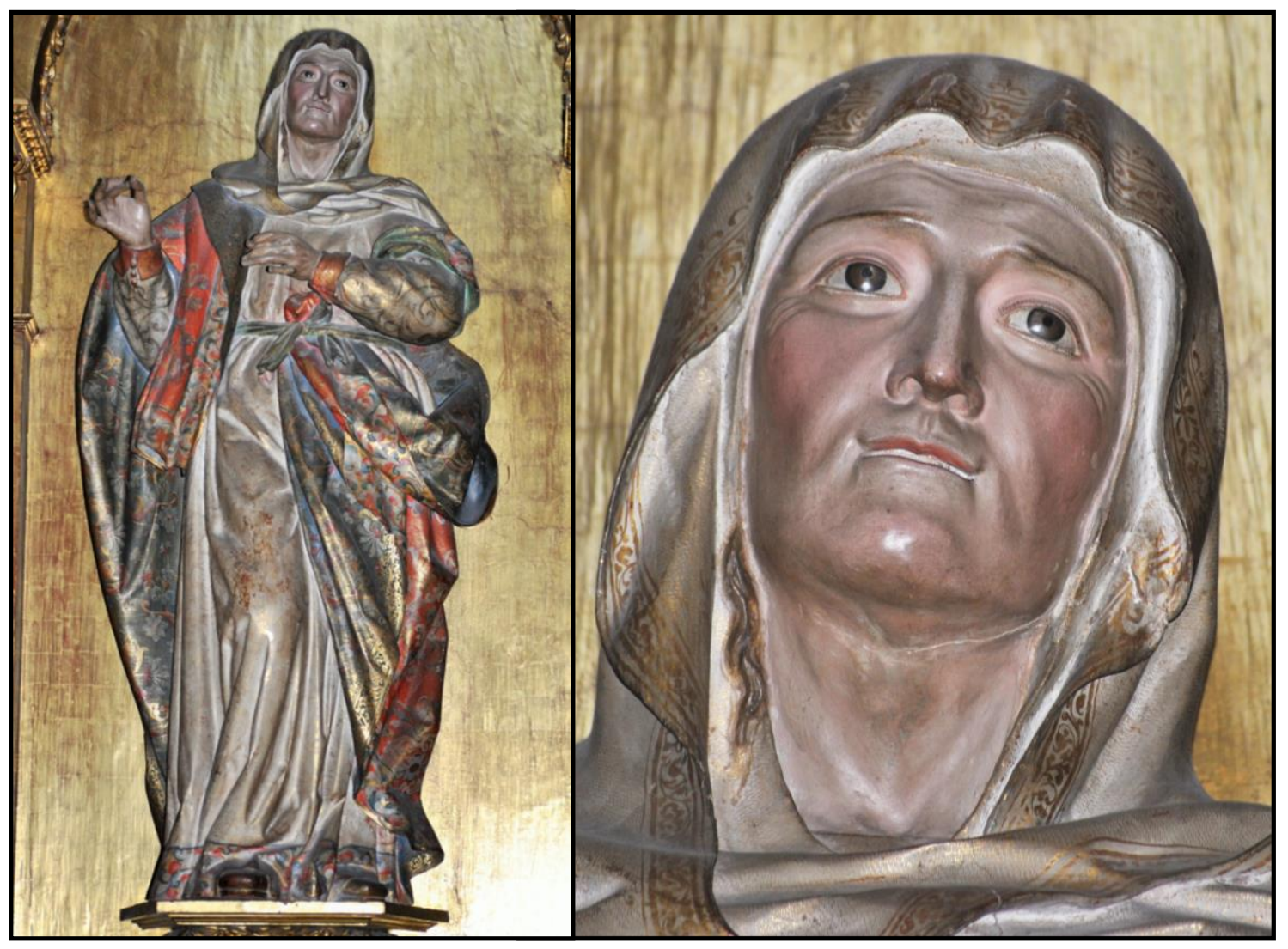

Fig. 90- Juan de Ávila (atrib.). Santa Ana. Capilla de la Congregación de la Inmaculada Concepción. Valladolid.

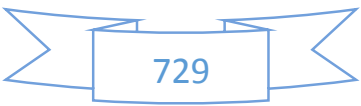




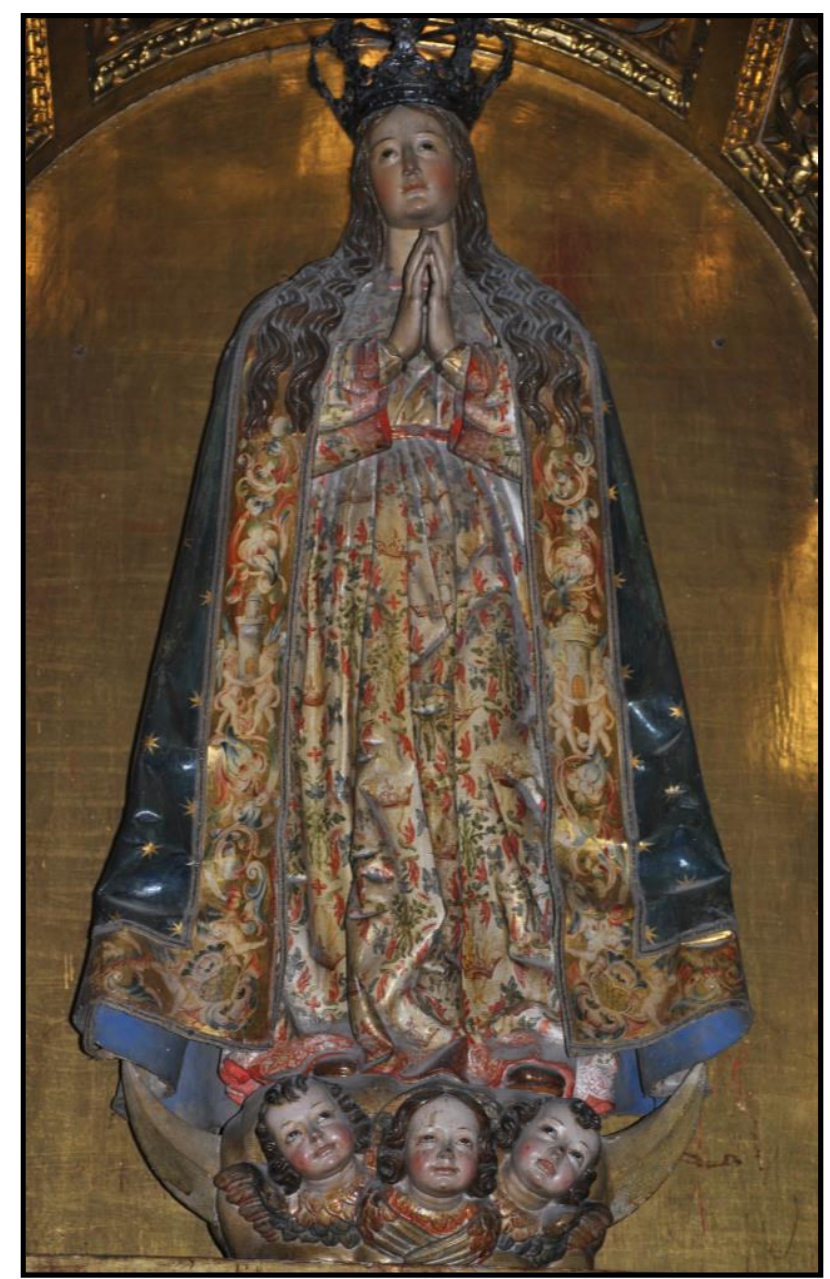

Fig. 91- Juan de Ávila (atrib.). Inmaculada.

Capilla de la Congregación de la Inmaculada Concepción. Valladolid.

Fig. 92- Juan de Ávila (atrib.). San Felipe Neri. Oratorio de San Felipe Neri. Valladolid.
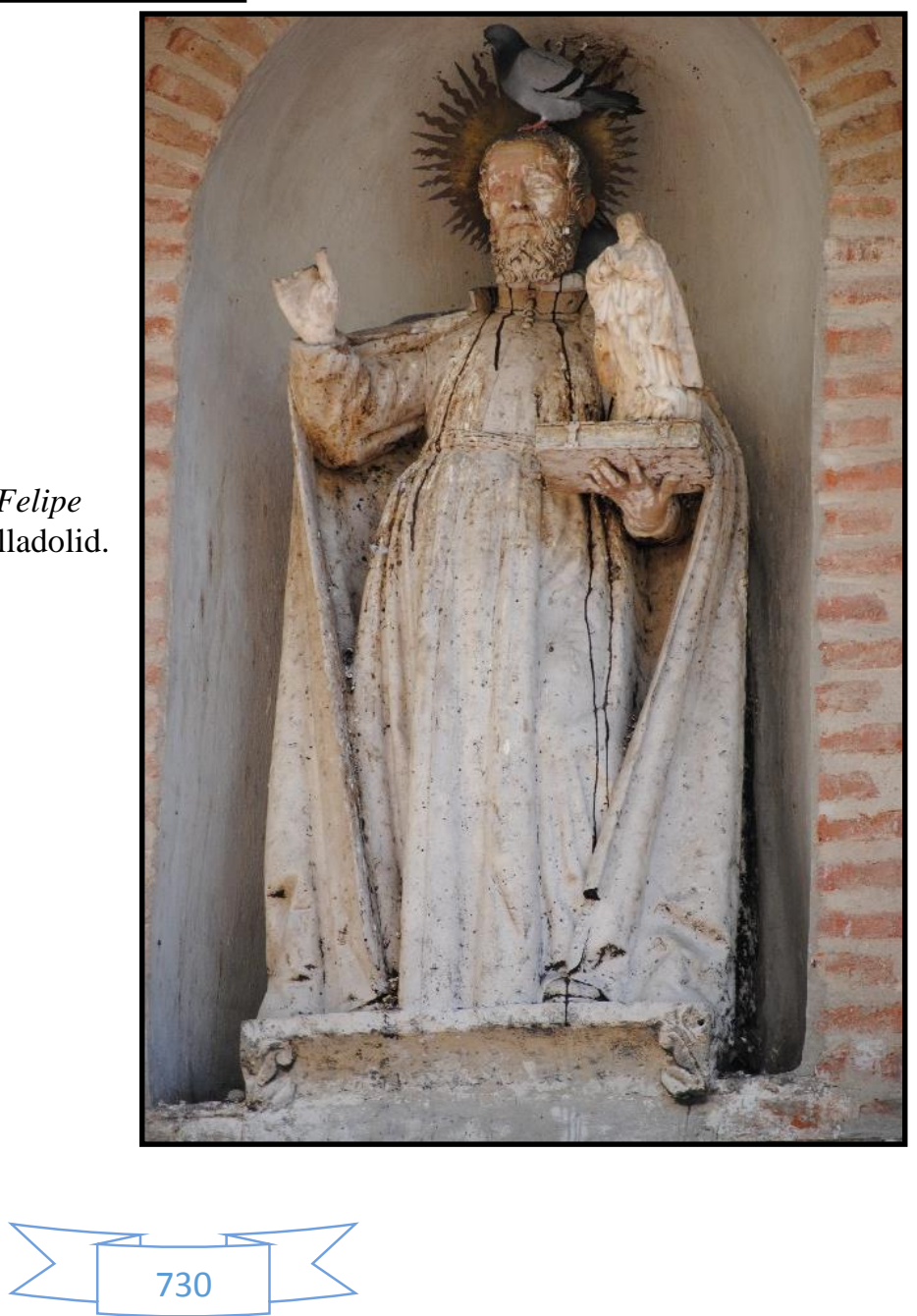


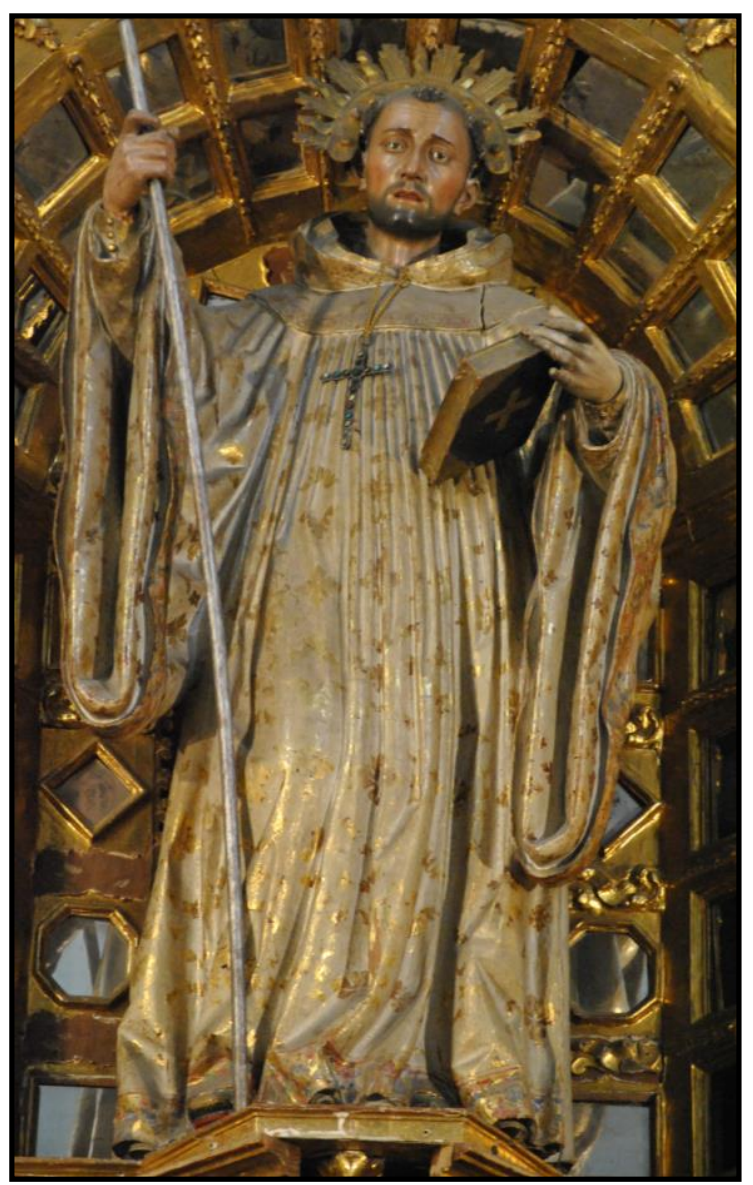

Fig. 93- Juan de Ávila (atrib.). San Bernardo. Monasterio de San Quirce. Valladolid.
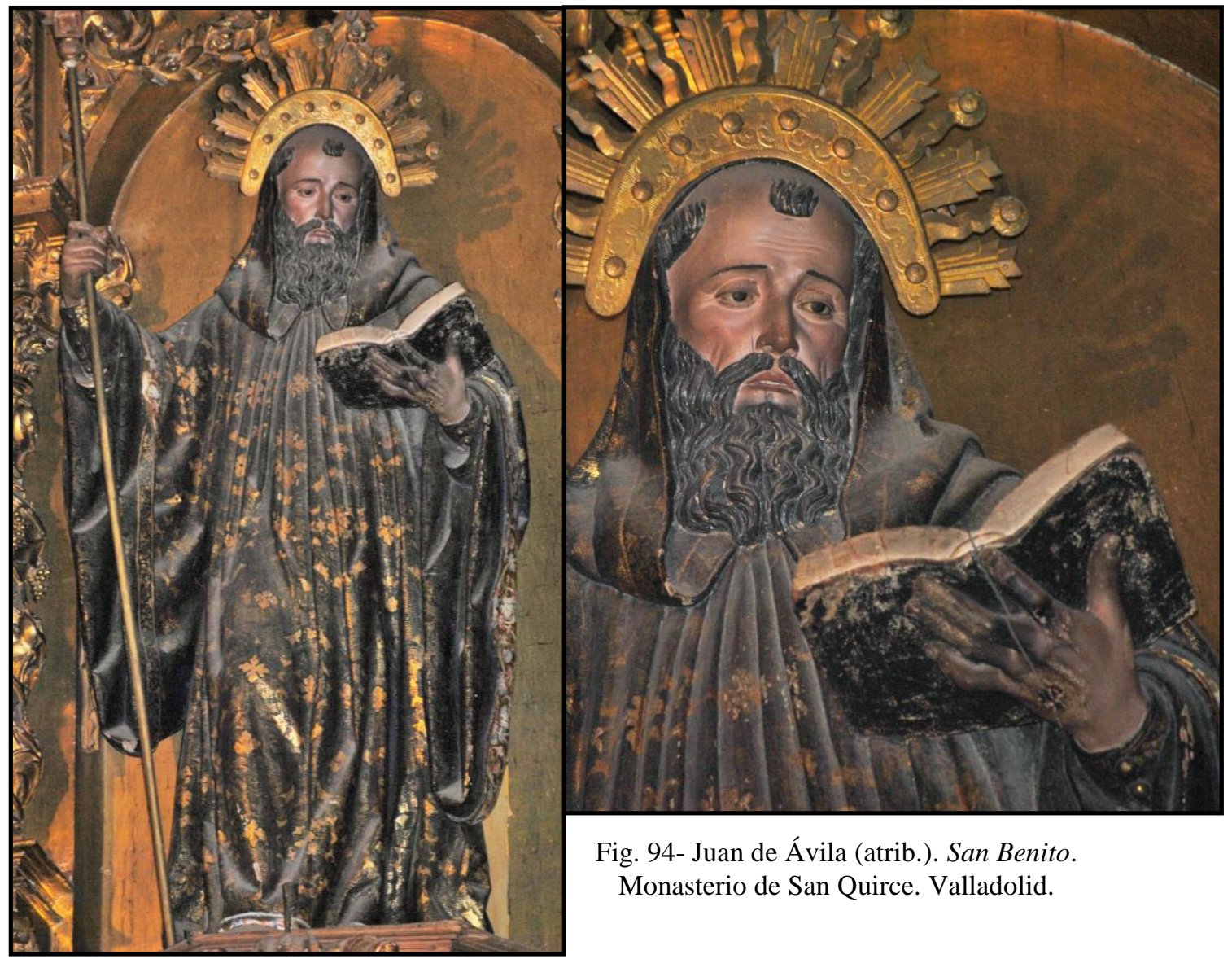

Fig. 94- Juan de Ávila (atrib.). San Benito. Monasterio de San Quirce. Valladolid.

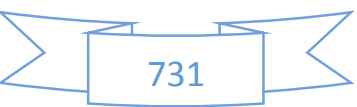




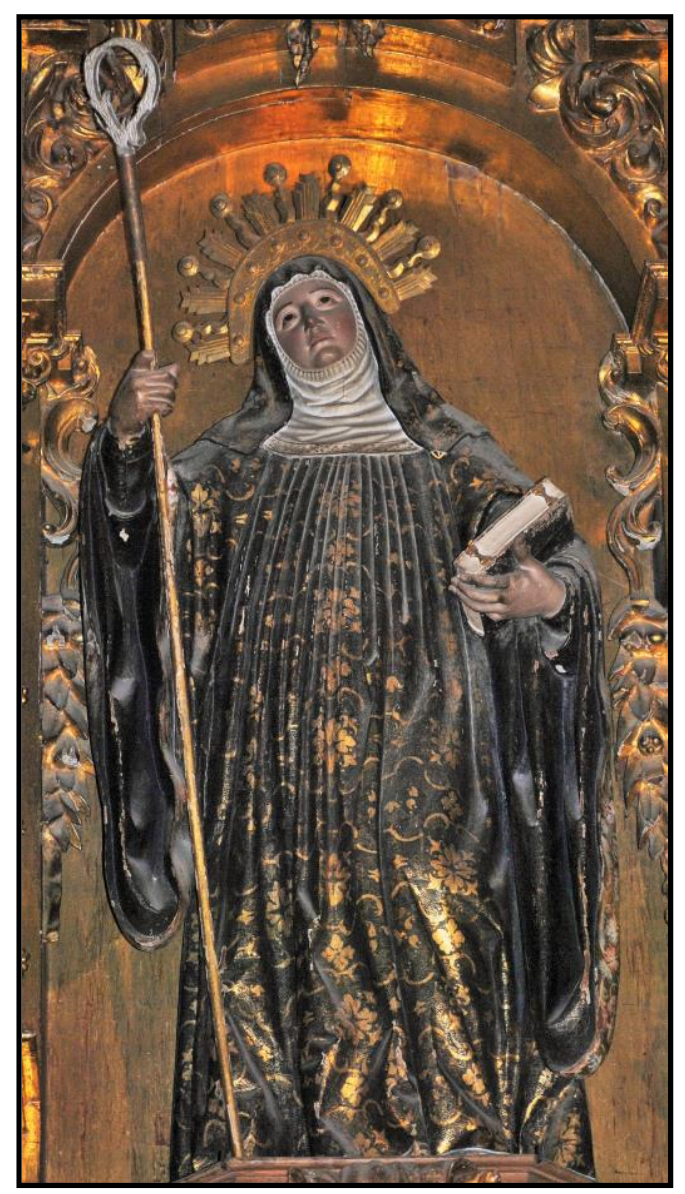

Fig. 95- Juan de Ávila (atrib.).

Santa Escolástica. Monasterio de San Quirce. Valladolid.

Fig. 96- Juan de Ávila (atrib.). La Asunción. Monasterio de San Quirce. Valladolid.
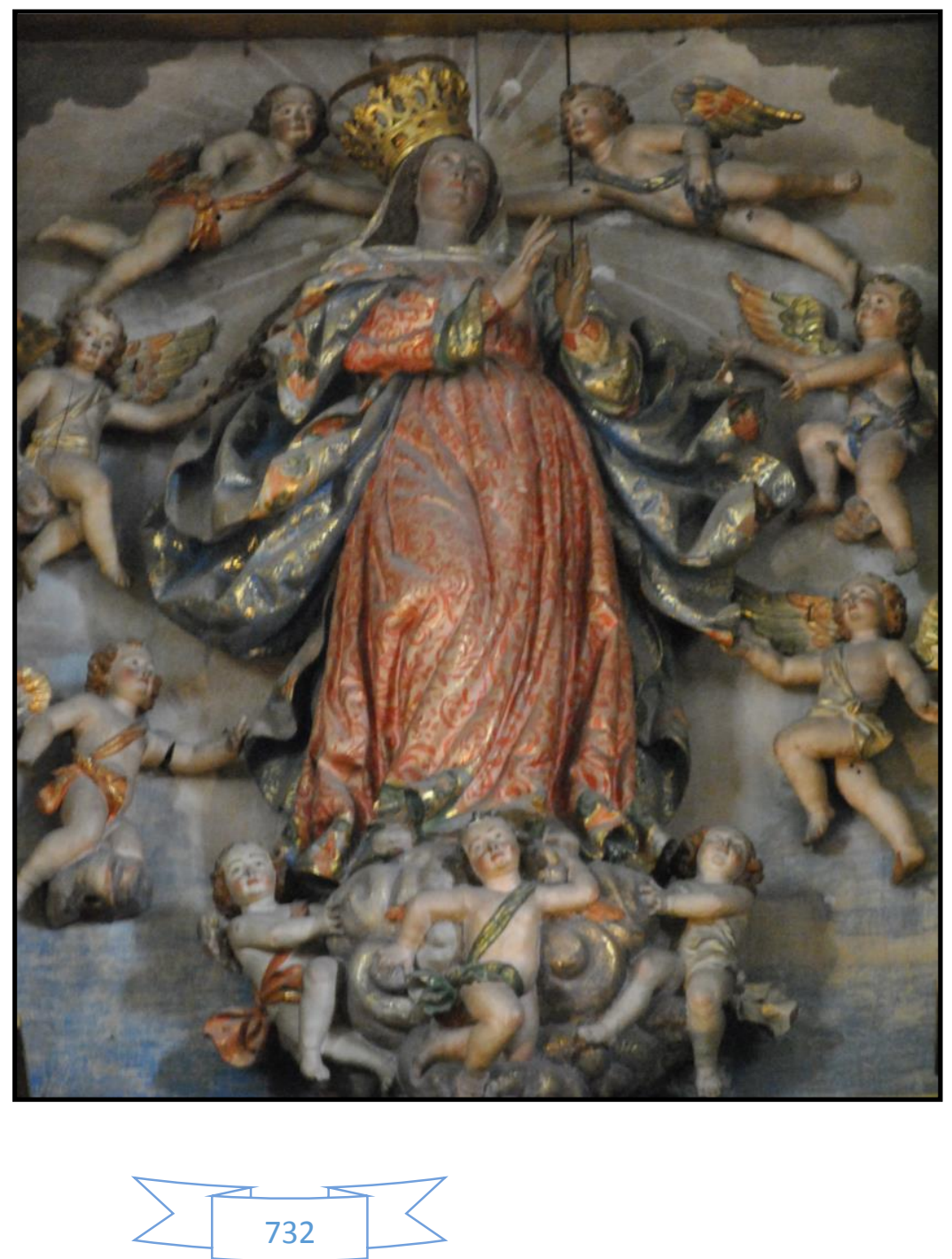

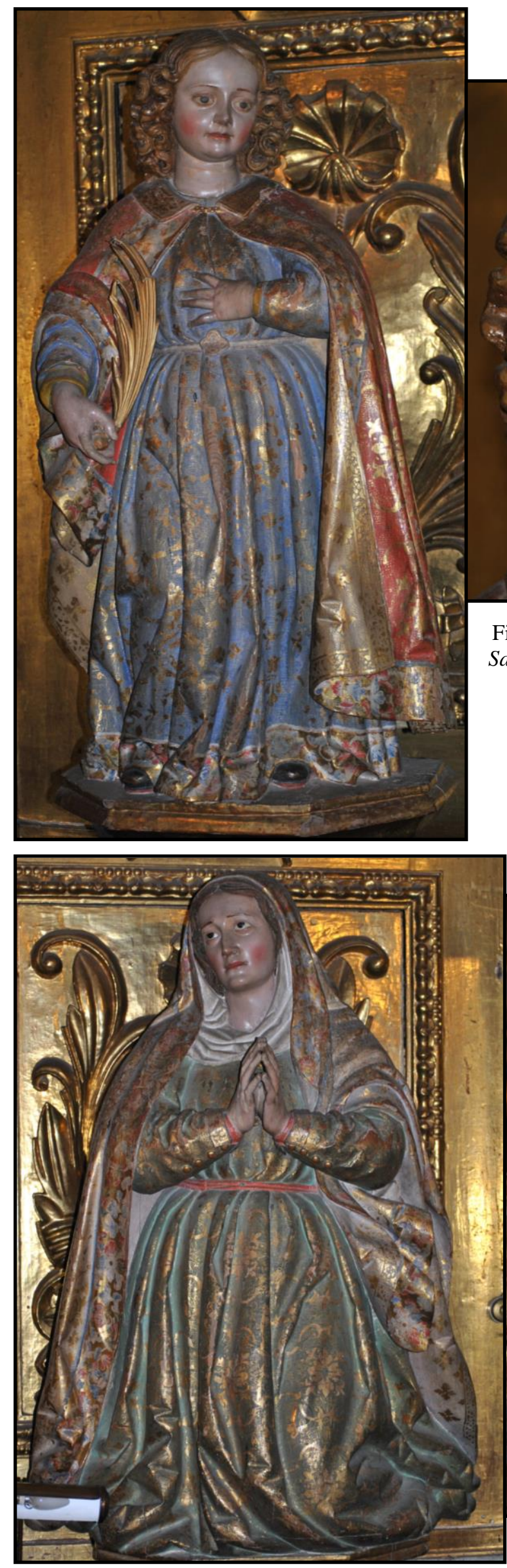

Fig. 98- Juan de Ávila (atrib.). Santa Julita.

Fig. 97- Juan de Ávila (atrib.).

San Quirce. Monasterio de San

Quirce. Valladolid.

\section{Monasterio de San Quirce. Valladolid.}
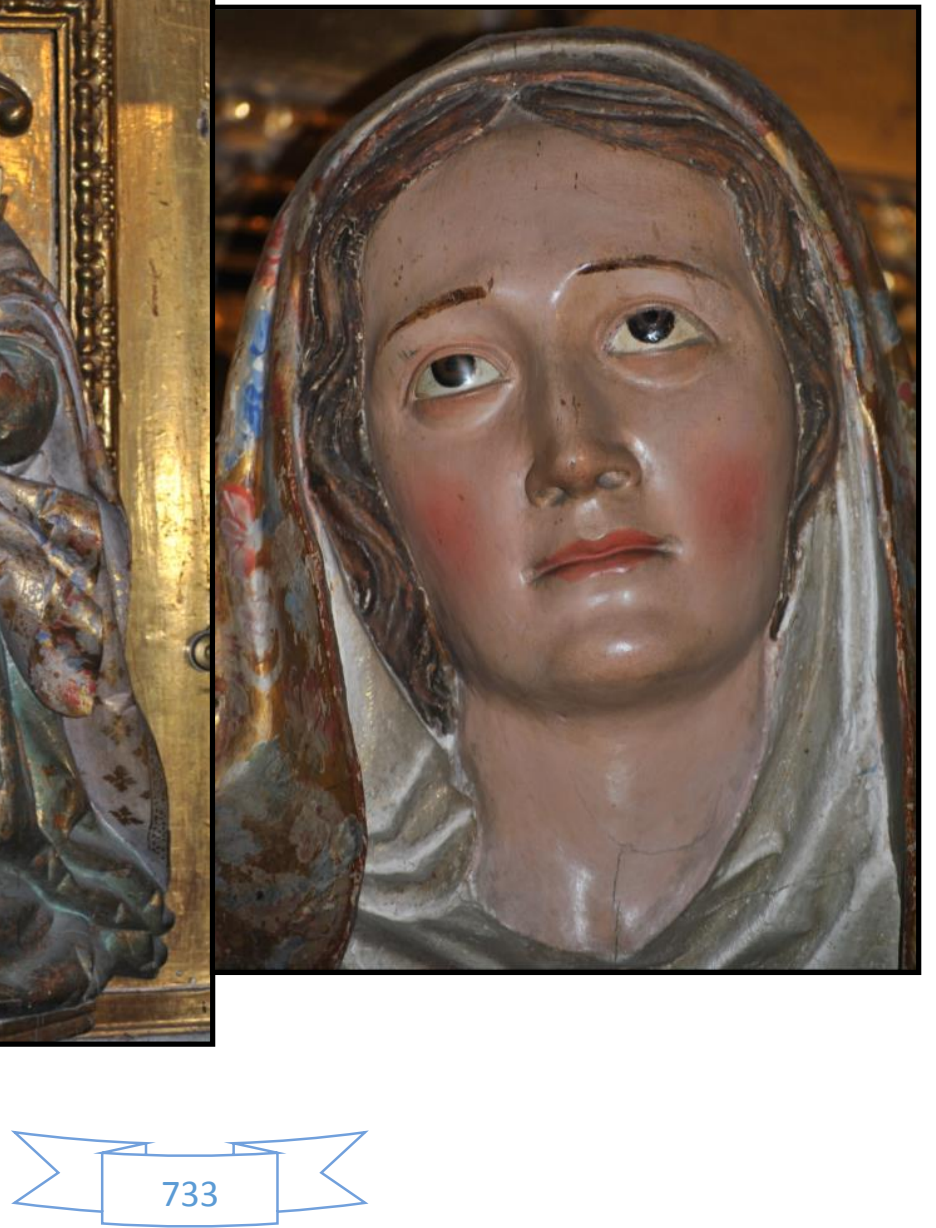


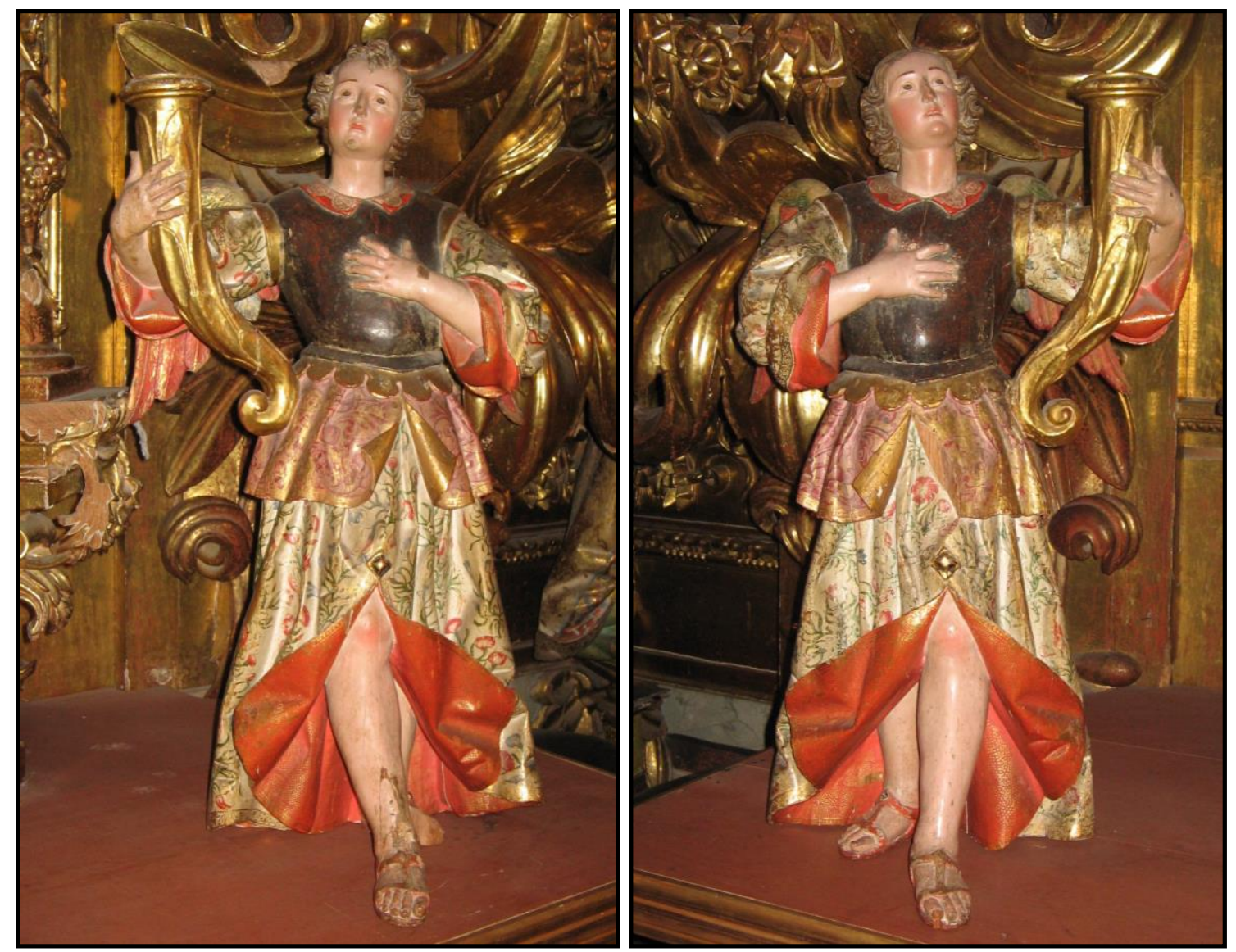

Figs. 99-100- Juan de Ávila (atrib.). Ángeles lampadarios. Monasterio de San Quirce. Valladolid.

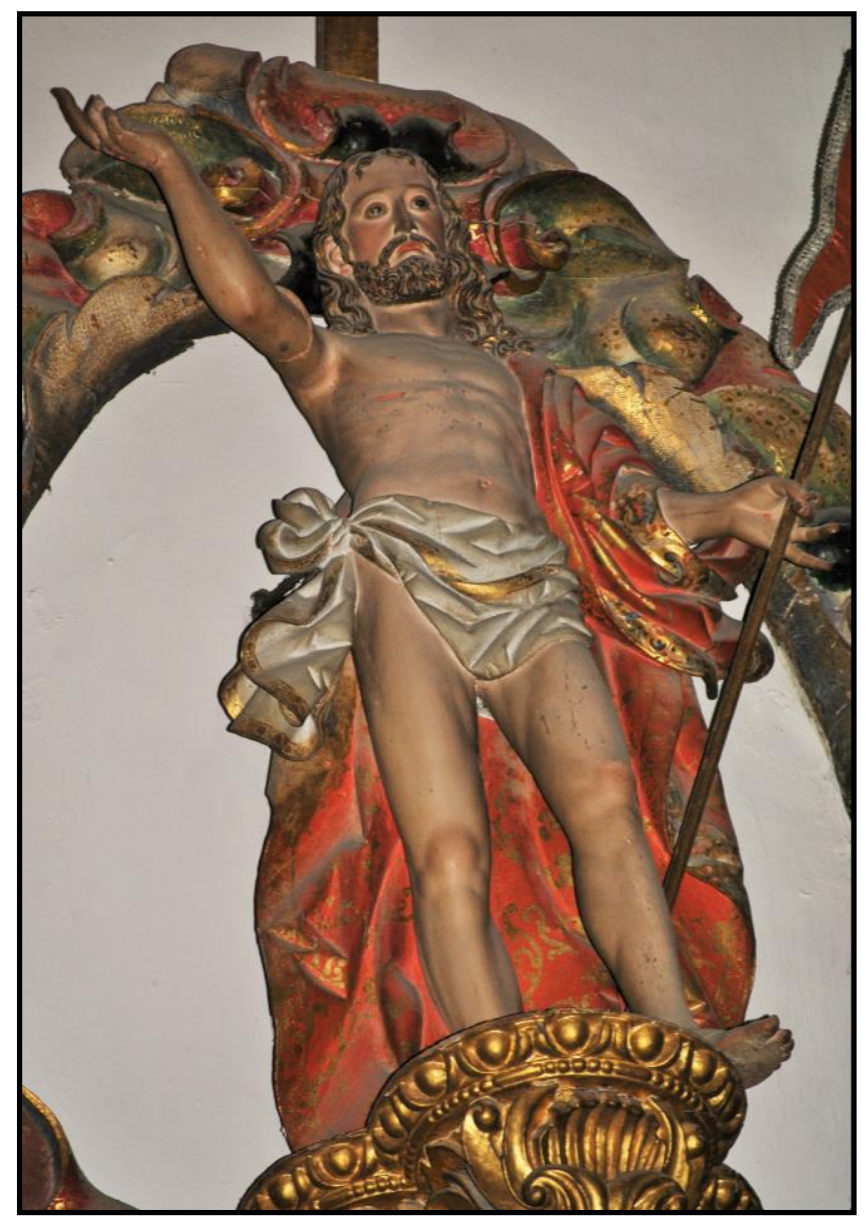

Fig. 101- Juan de Ávila (atrib.).

Cristo Resucitado. Monasterio

de San Quirce. Valladolid.

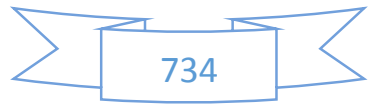




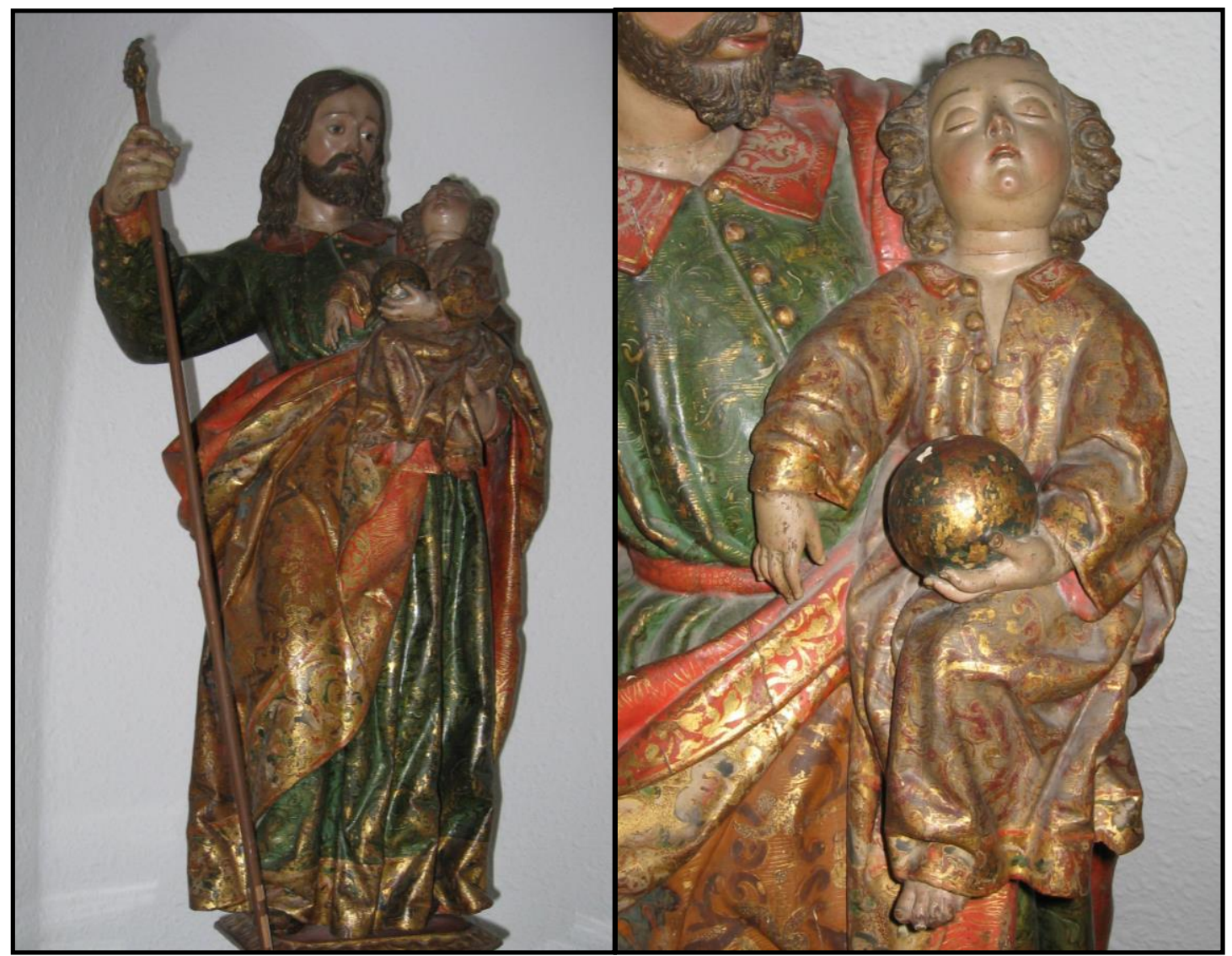

Fig. 102- Juan de Ávila (atrib.). San José con el Niño. Convento de la Concepción. Valladolid.

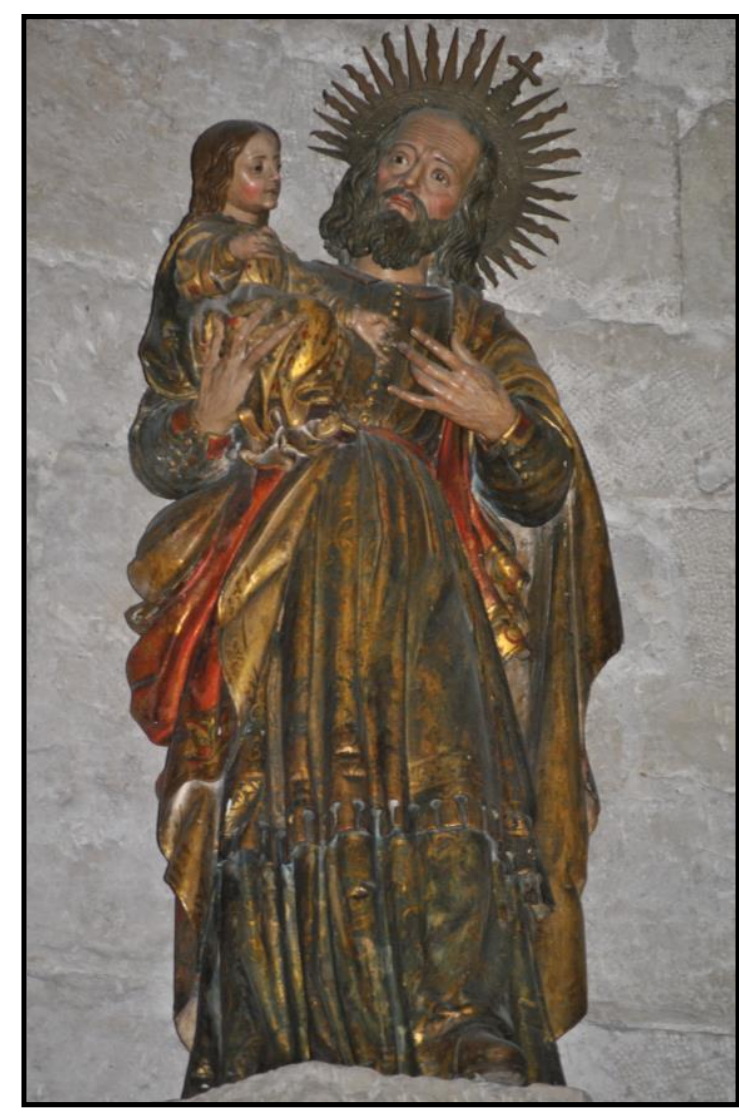

Fig. 103- Juan de Ávila (atrib.). San Joaquín y la Virgen Niña. Monasterio de San Benito.

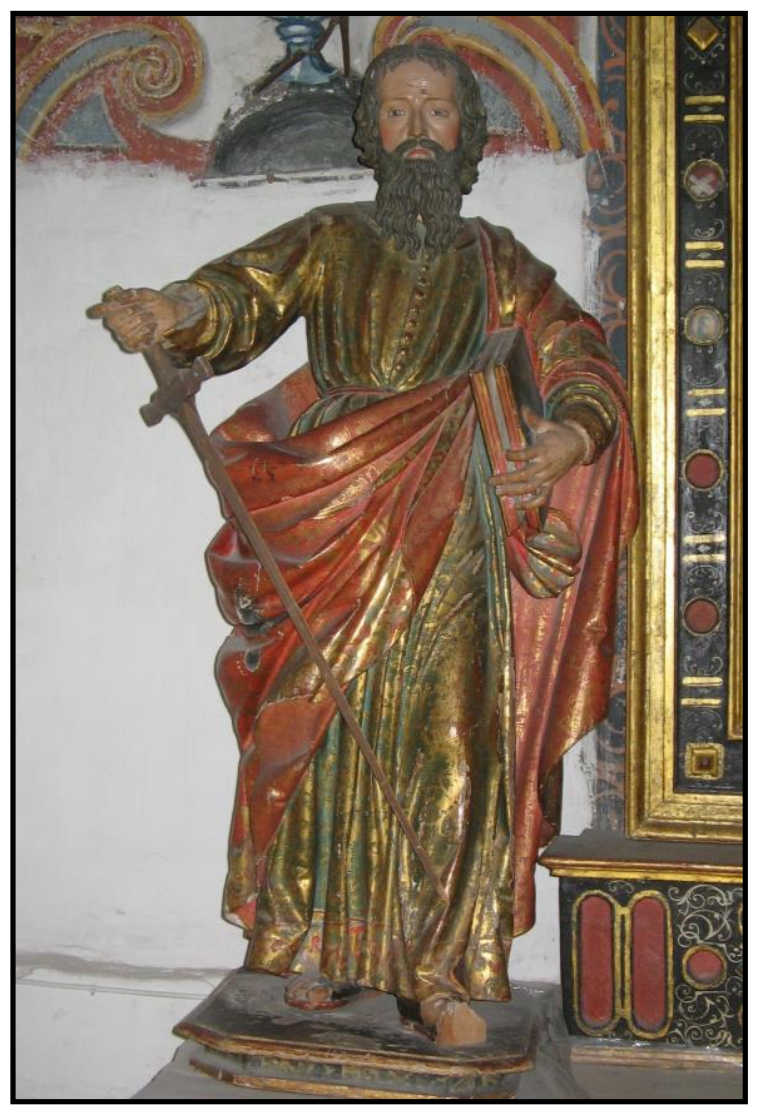

Fig. 104- Juan de Ávila (atrib.). San Pablo.

Convento de Santa Catalina. Valladolid. 


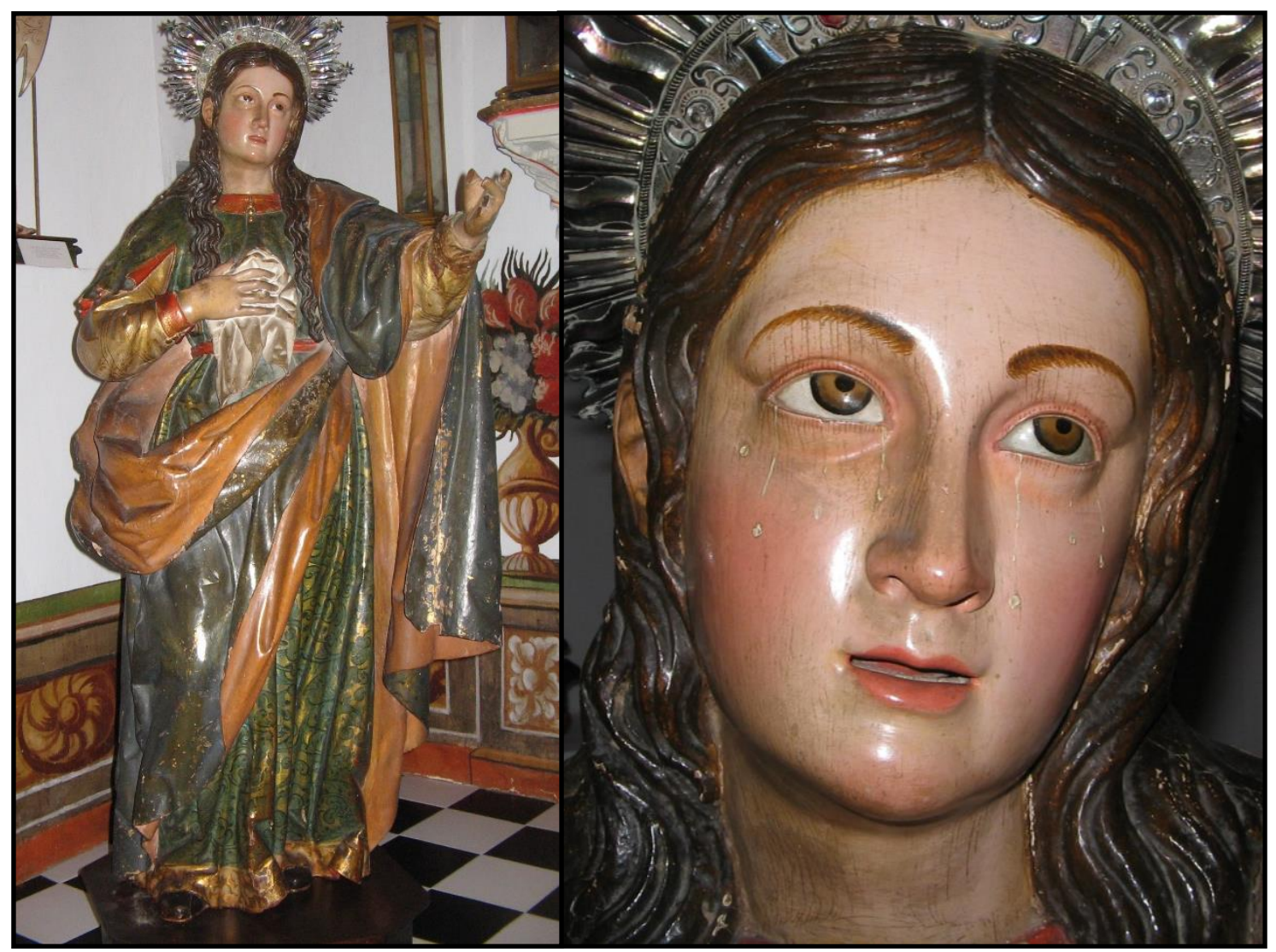

Fig. 105- Juan de Ávila (atrib.). Santa María Magdalena del antiguo retablo mayor de Convento de las Lauras. Convento de Porta Coeli. Valladolid.

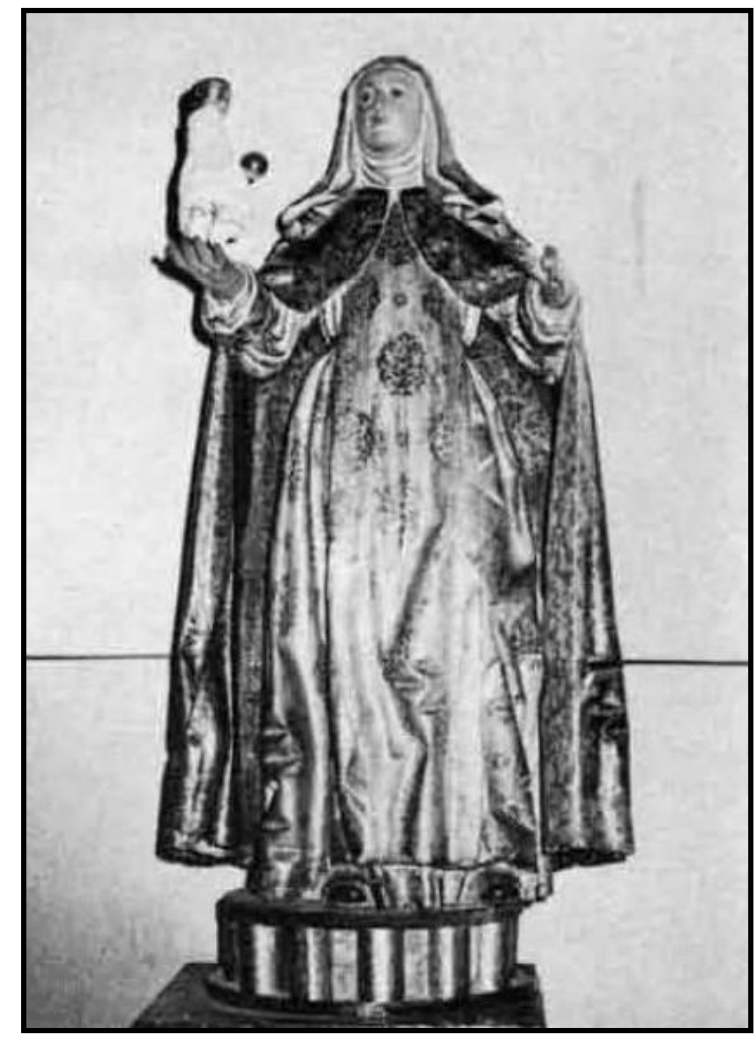

Fig. 106- Juan de Ávila (atrib.). Santa Rosa de Lima del antiguo retablo mayor de Convento de las Lauras. Convento de Porta Coeli. Valladolid.

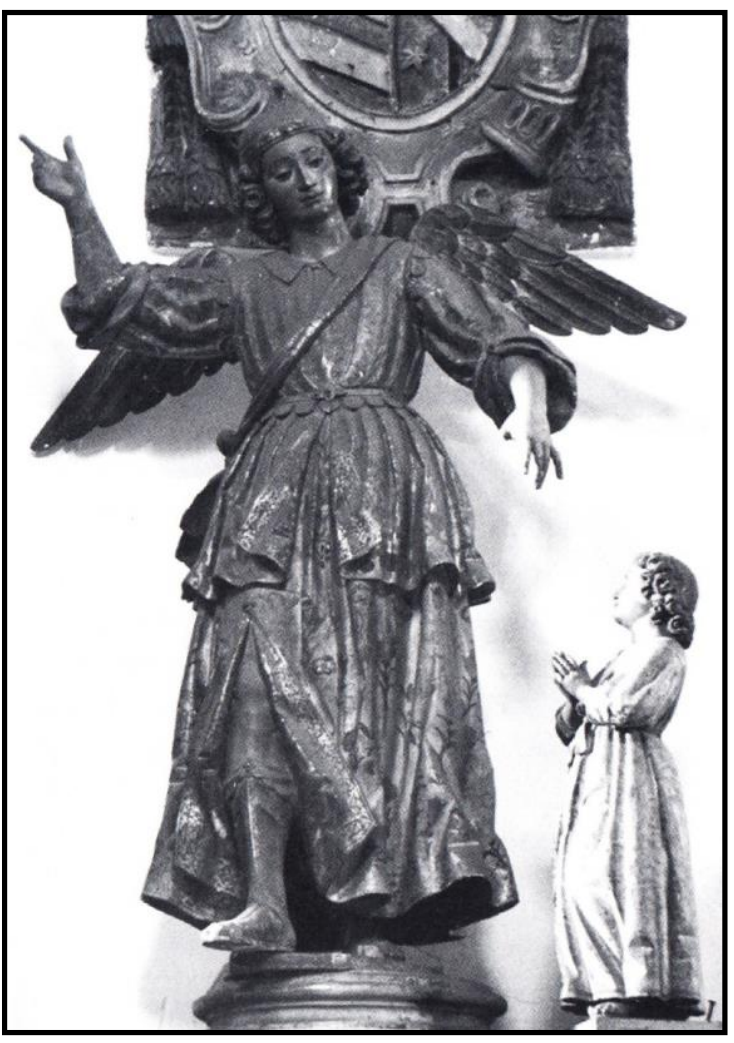

Fig. 107- Juan de Ávila (atrib.). Ángel de la Guarda. Iglesia de Santa Marina la Real. León. 

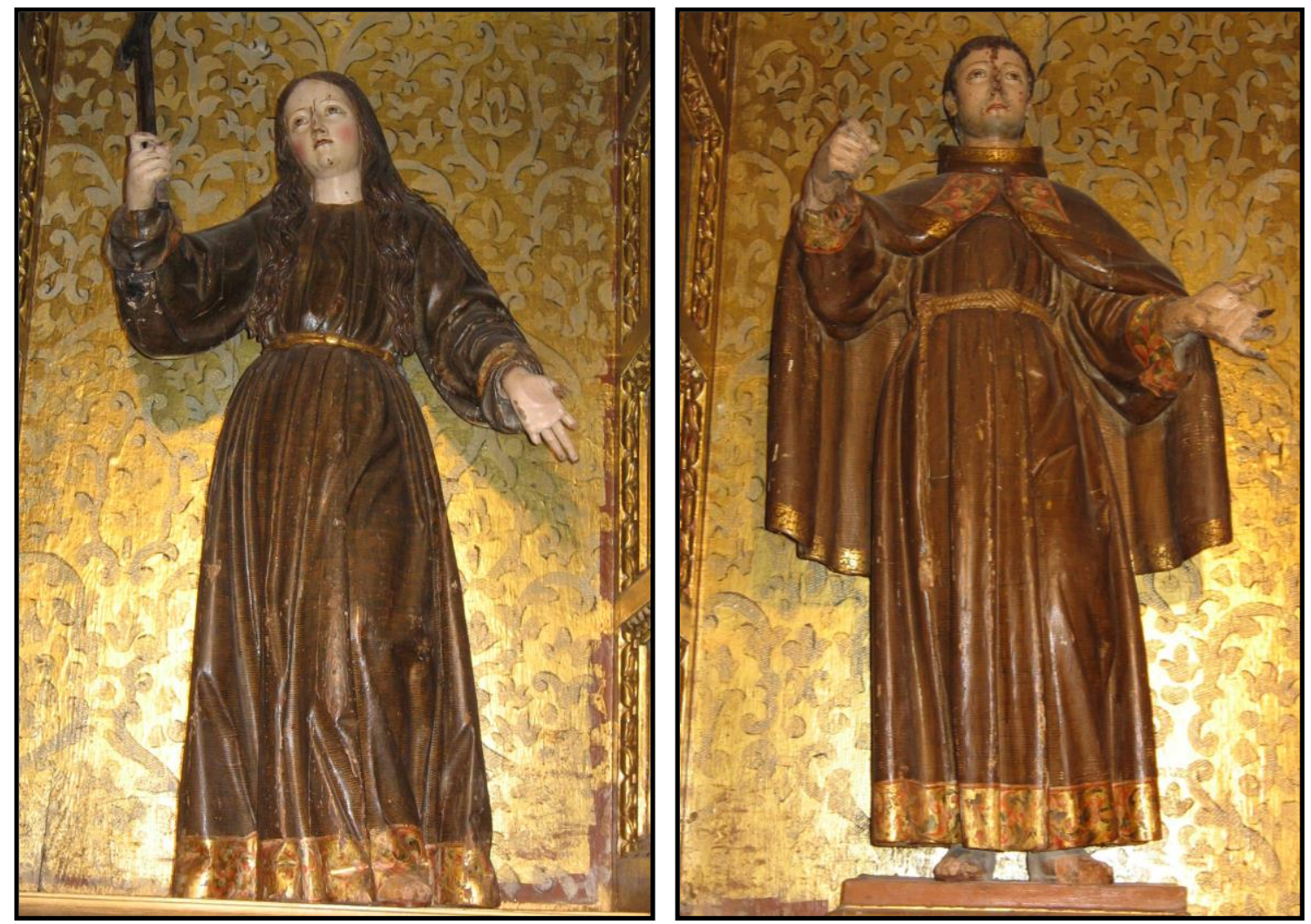

Figs. 108-109- Juan de Ávila (atrib.). Santa Rosa de Viterbo y San Diego de Alcalá. Iglesia museo de San Francisco. Ampudia (Palencia).

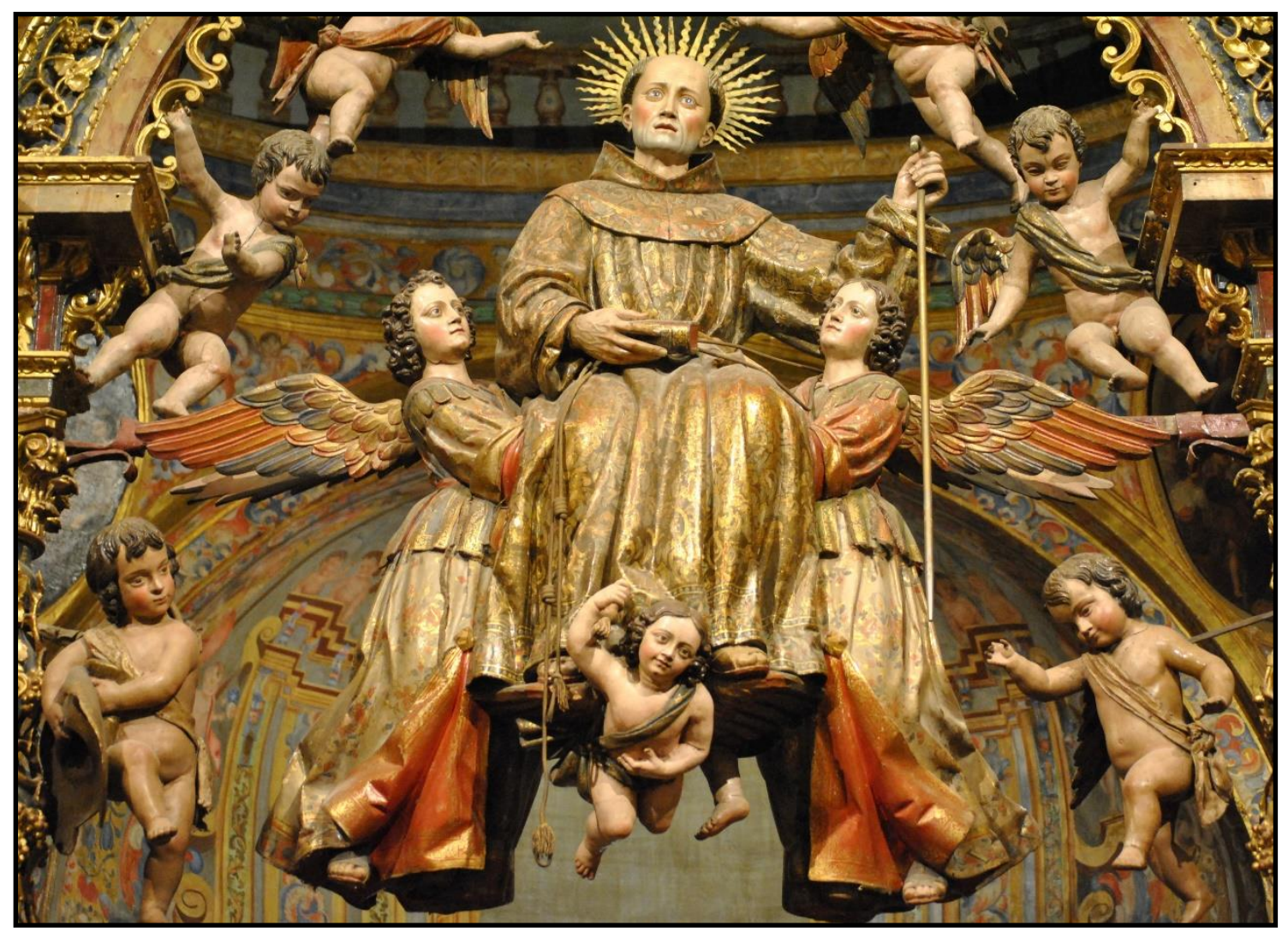

Fig. 110- Juan de Ávila (atrib.). La Traslación de San Pedro Regalado. Convento del Domus Dei. La Aguilera (Burgos).

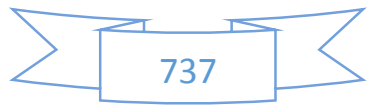




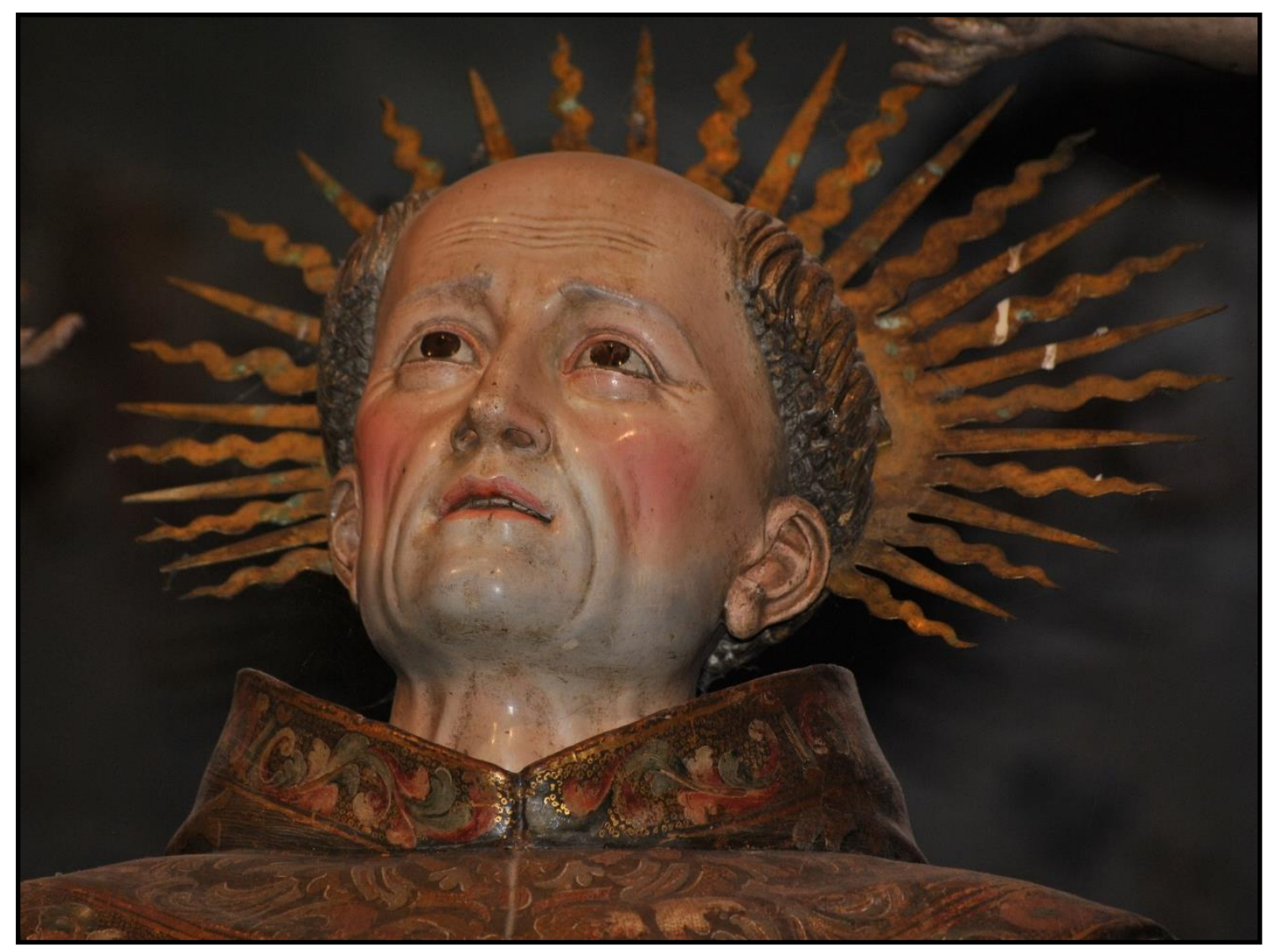

Fig. 111- Juan de Ávila (atrib.). Detalle de La Traslación de San Pedro Regalado.

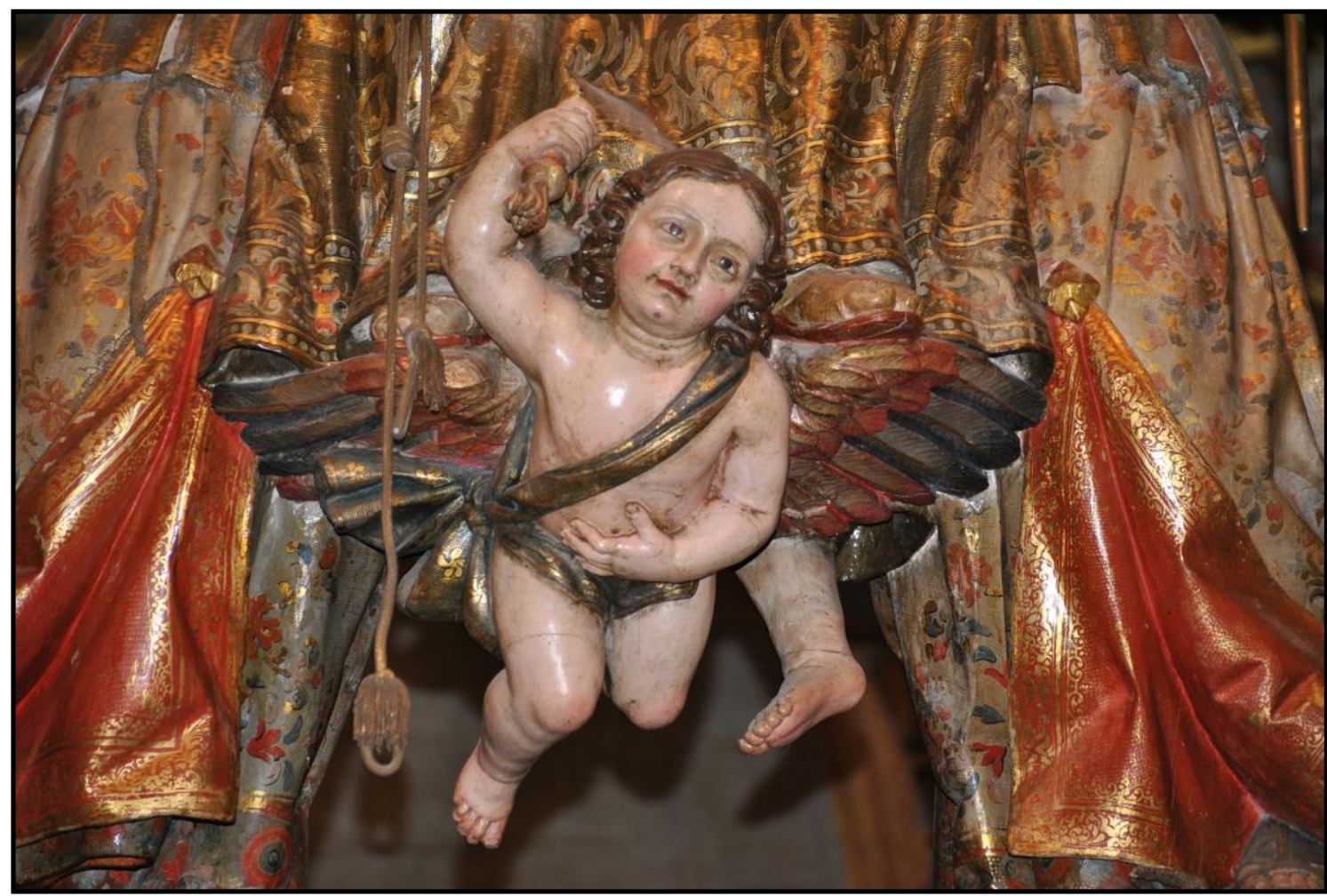

Fig. 112- Juan de Ávila (atrib.). Detalle de La Traslación de San Pedro Regalado.

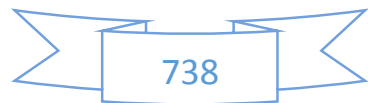




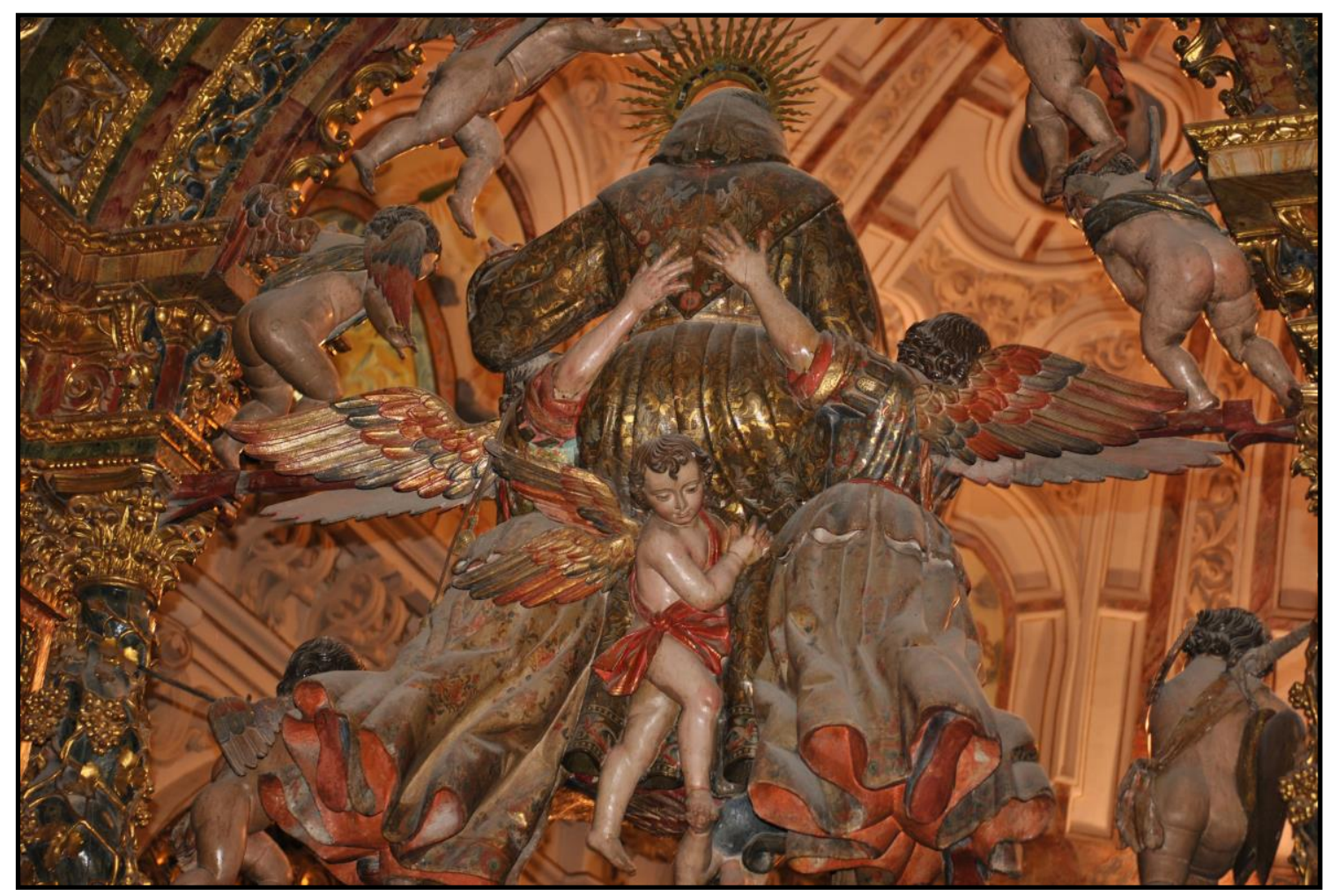

Fig. 113- Juan de Ávila (atrib.). Detalle de La Traslación de San Pedro Regalado.

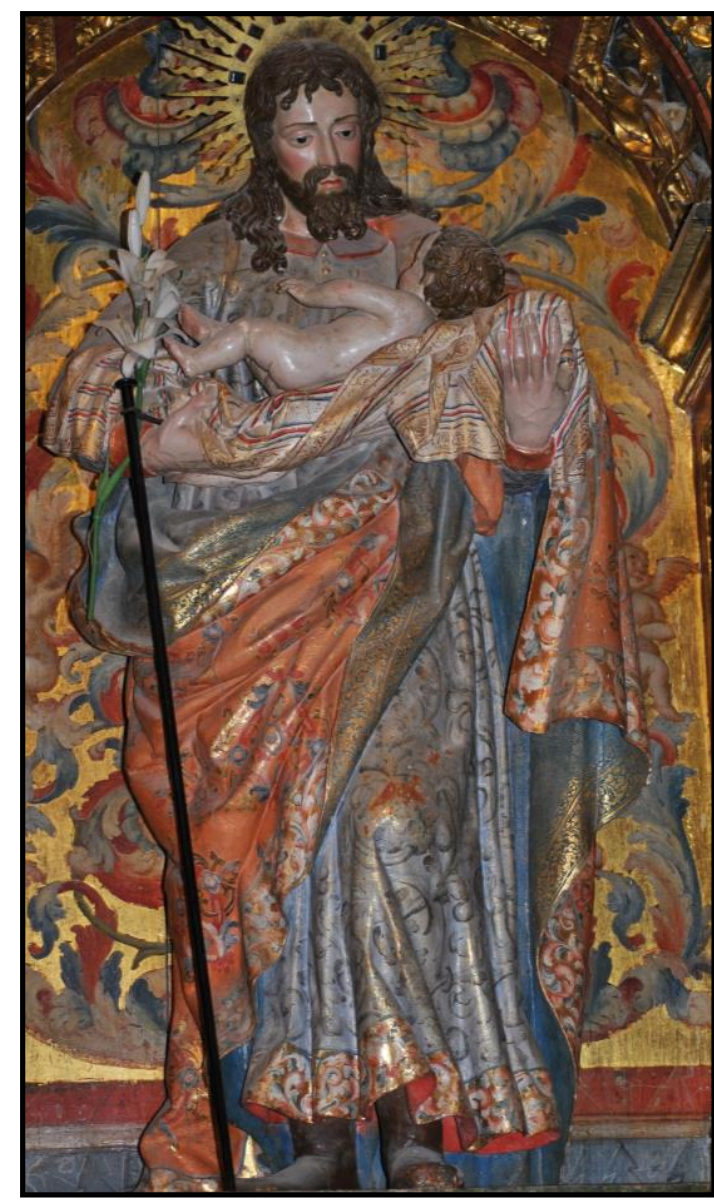

Fig. 114- Juan de Ávila (atrib.). San José con el Niño. Convento del Domus Dei. La Aguilera (Burgos).

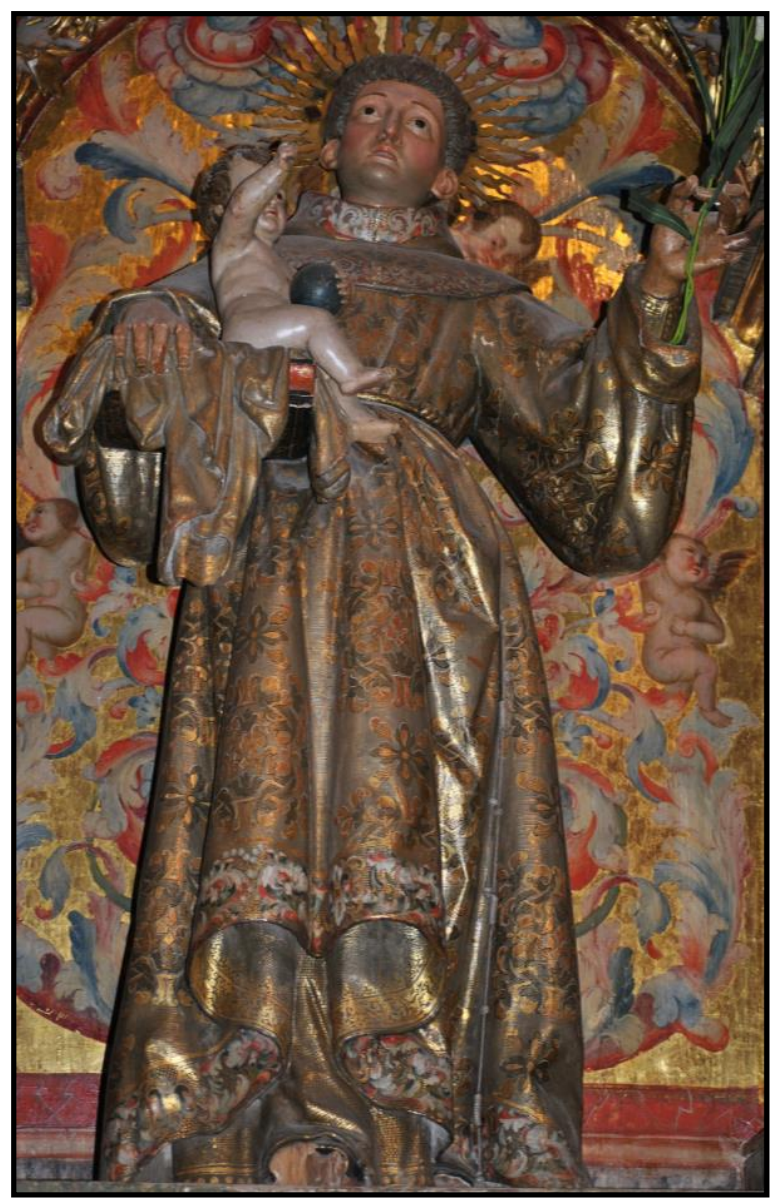

Fig. 115- Juan de Ávila (atrib.). San Antonio de Padua. Convento del Domus Dei. La Aguilera (Burgos).

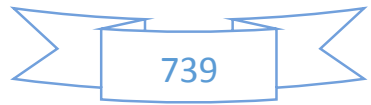




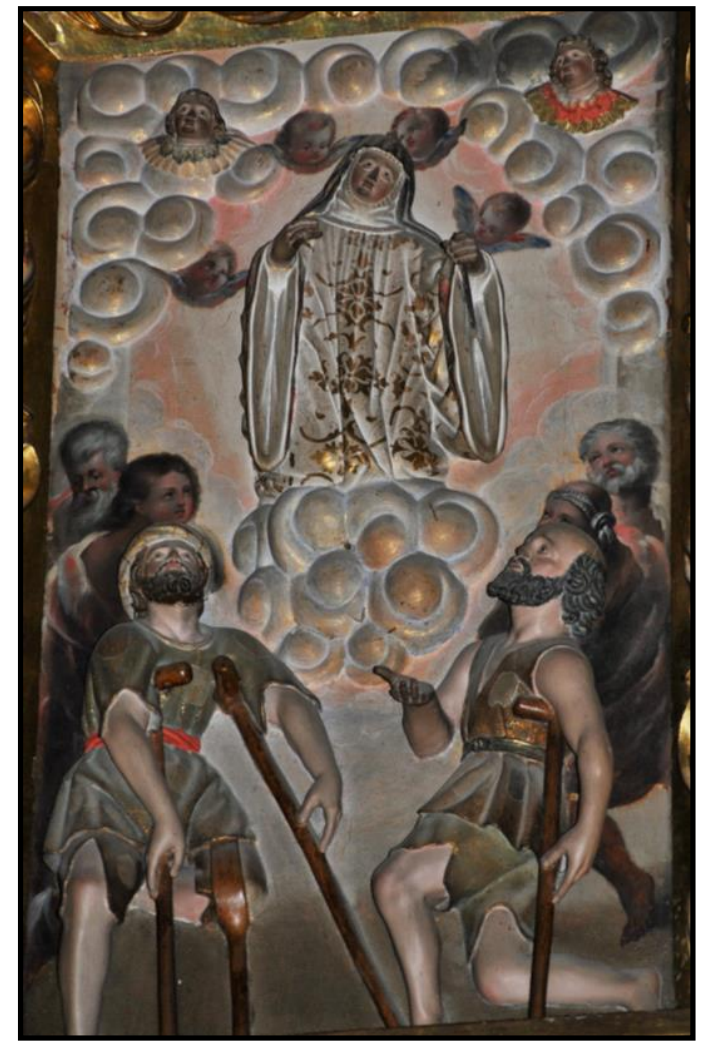

Fig. 116- Juan de Ávila (atrib.). Ascensión a los cielos de ¿Santa Imelda? Monasterio de San Quirce (Valladolid).

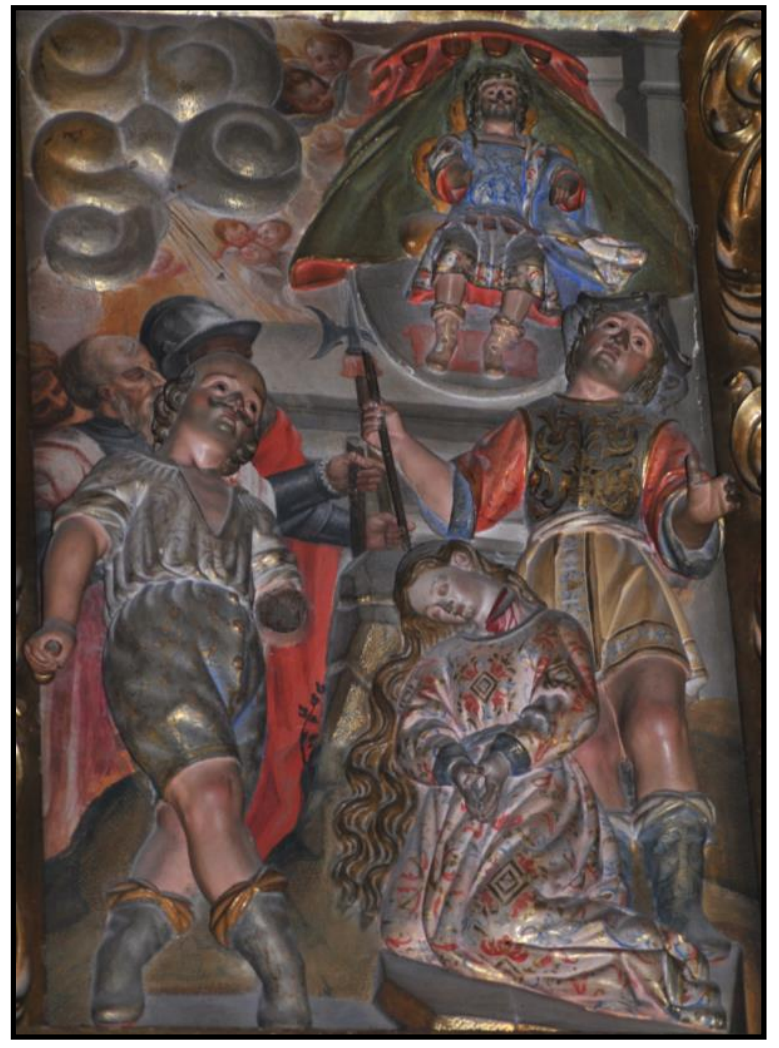

Fig. 117- Juan de Ávila (atrib.). Decapitación de una santa. Monasterio de San Quirce. Valladolid.

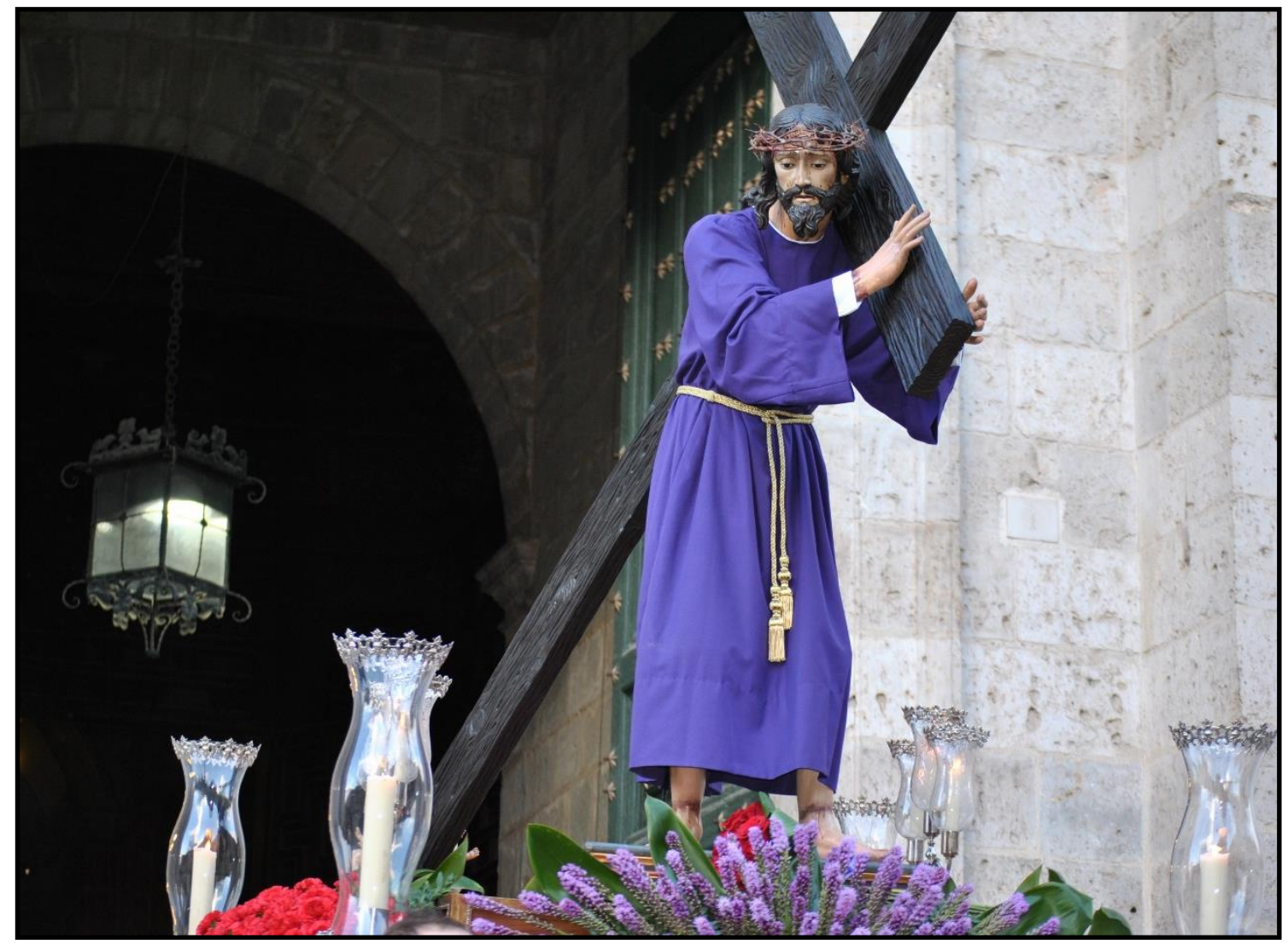

Fig. 118- Juan de Ávila (atrib.). Nuestro Padre Jesús con la cruz a cuestas. Monasterio de San Quirce. Valladolid.

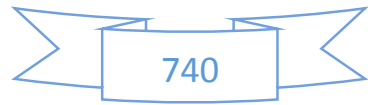




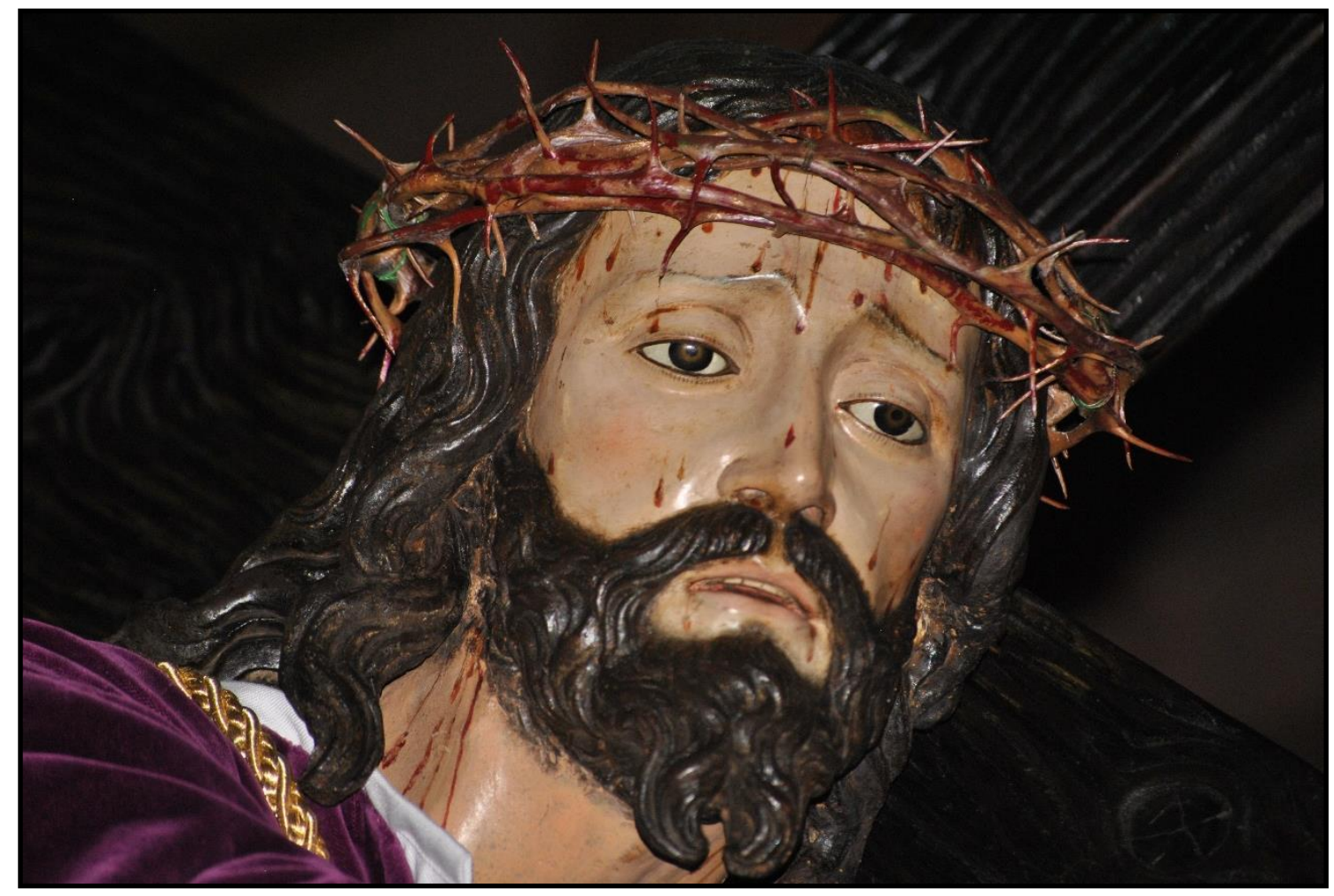

Fig. 119- Juan de Ávila (atrib.). Detalle de Nuestro Padre Jesús con la cruz a cuestas.

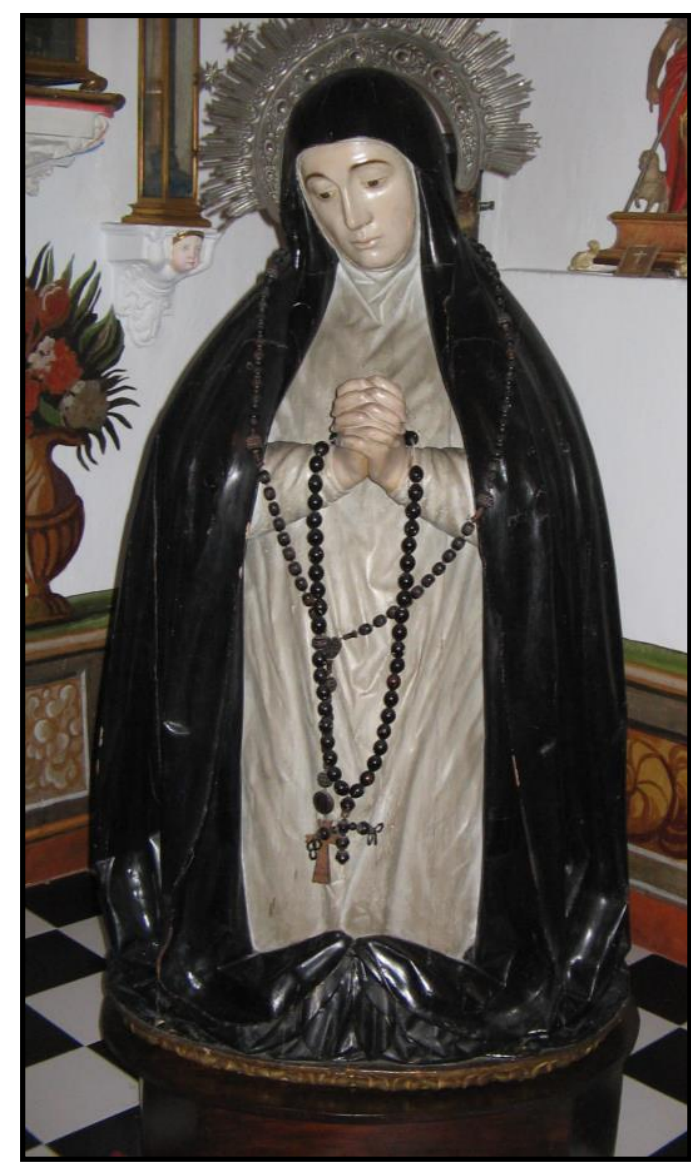

Fig. 120- Juan de Ávila (atrib.). Virgen de la Soledad. Convento de Porta Coeli. Valladolid.

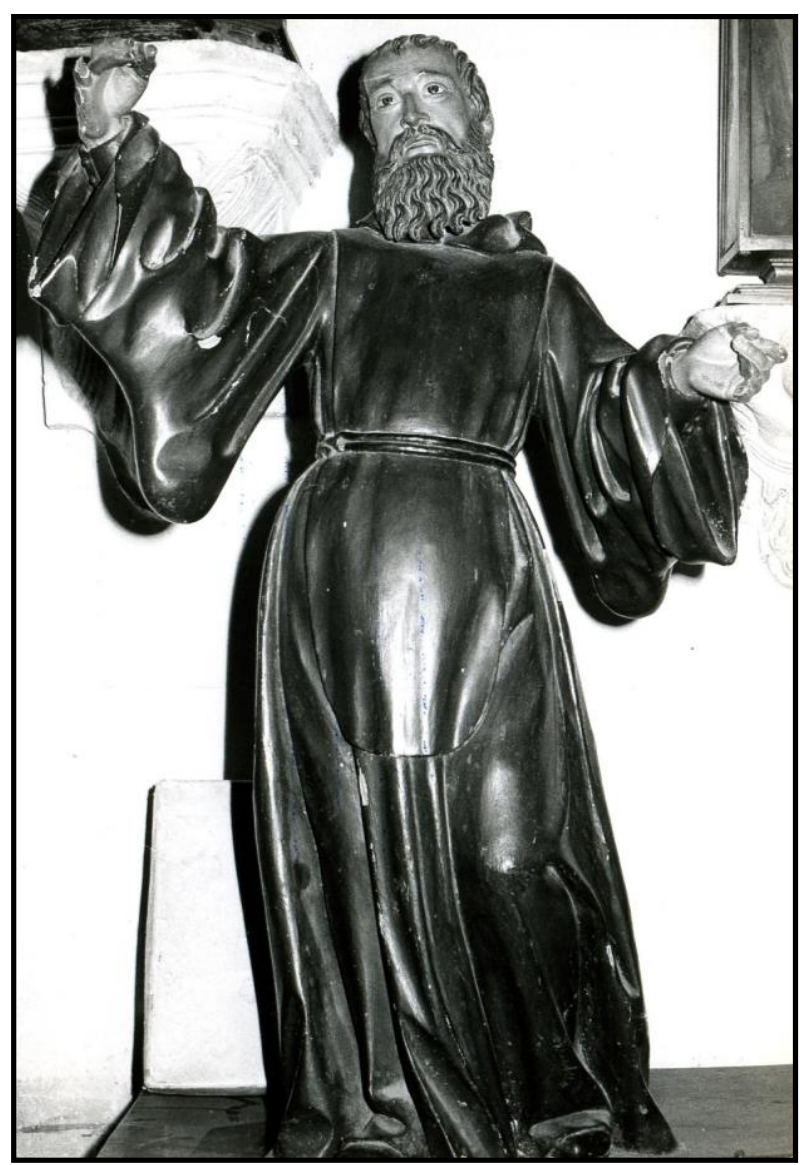

Fig. 121- Juan de Ávila (atrib.). ¿San Felipe Benizzi? Convento de Porta Coeli. Valladolid. (C) Departamento de Historia del Arte de la Universidad de Valladolid. 


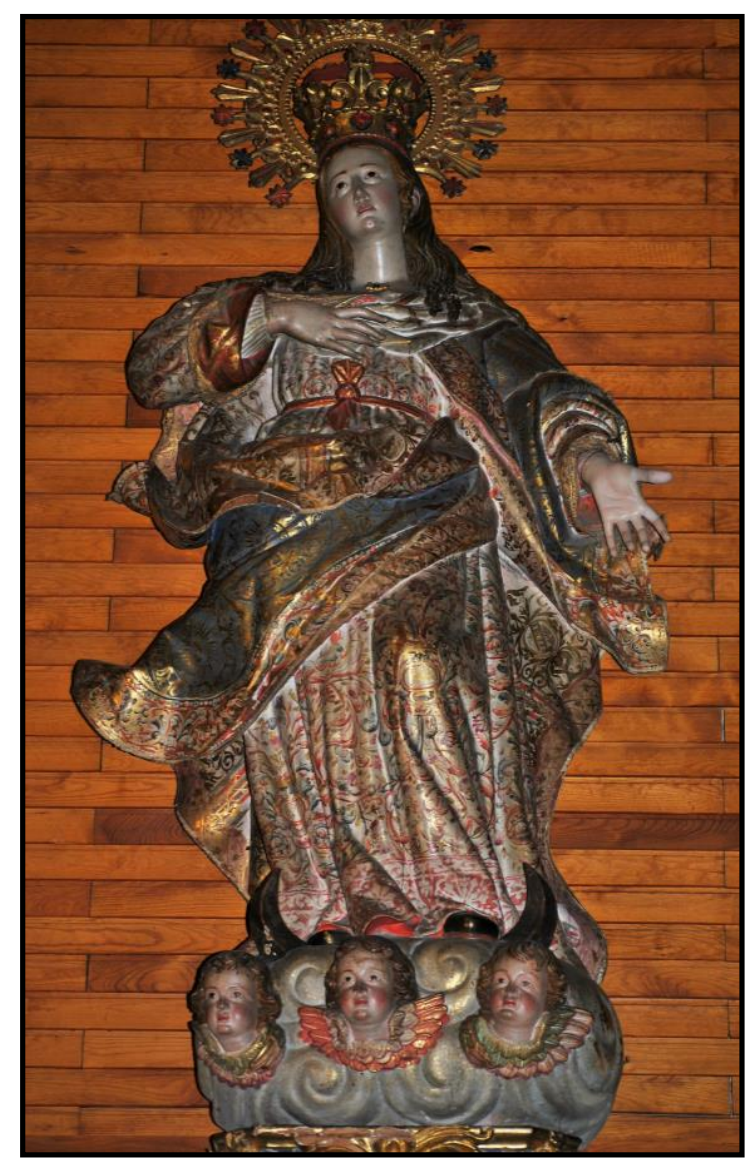

Fig. 122- Juan de Ávila (atrib.). Asunción. Monasterio de Santa Brígida. Valladolid.

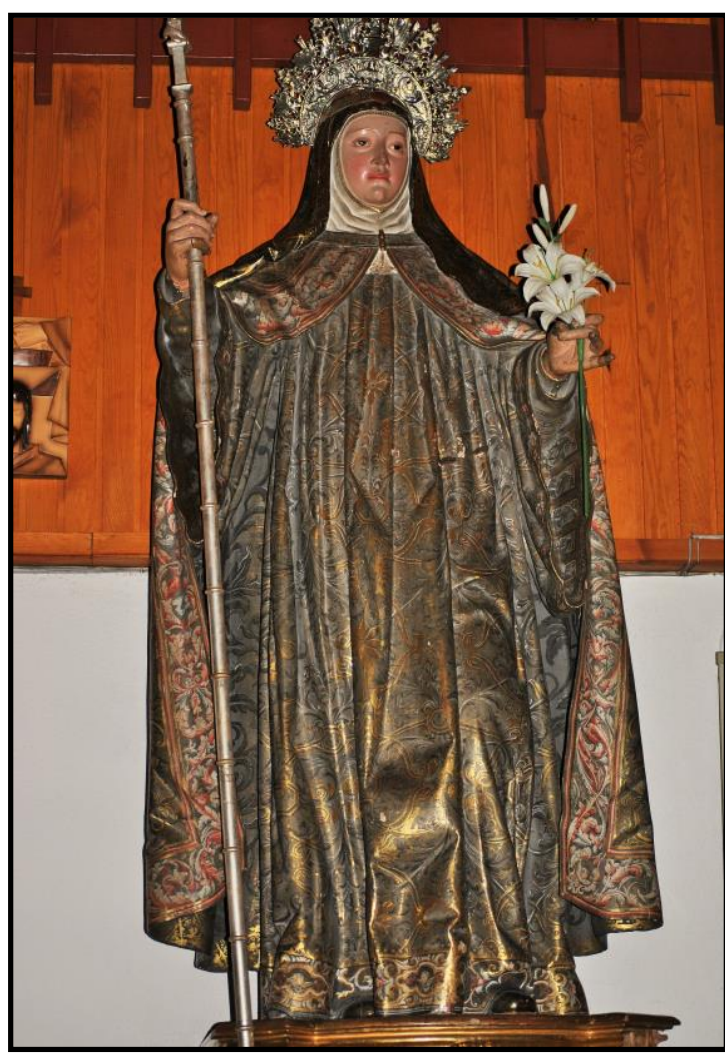

Fig. 124- Juan de Ávila (atrib.). Santa Catalina de Suecia. Monasterio de Santa Brígida. Valladolid.

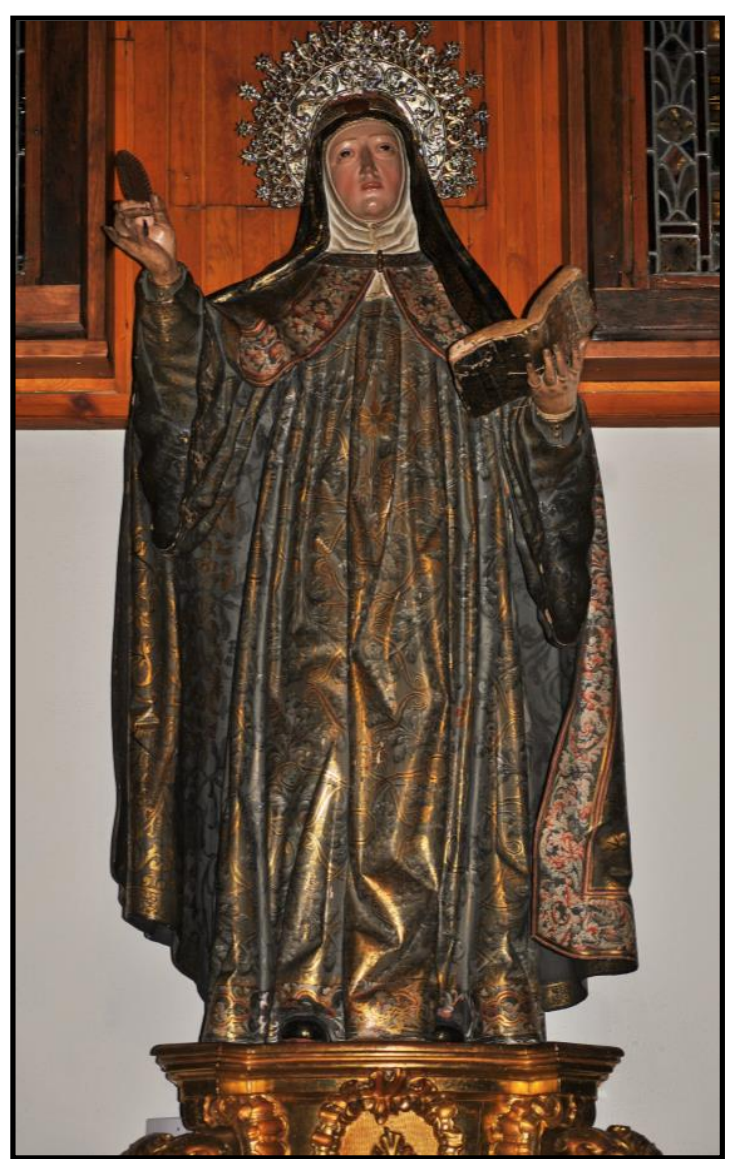

Fig. 123- Juan de Ávila (atrib.). Santa Brígida. Monasterio de Santa Brígida. Valladolid.

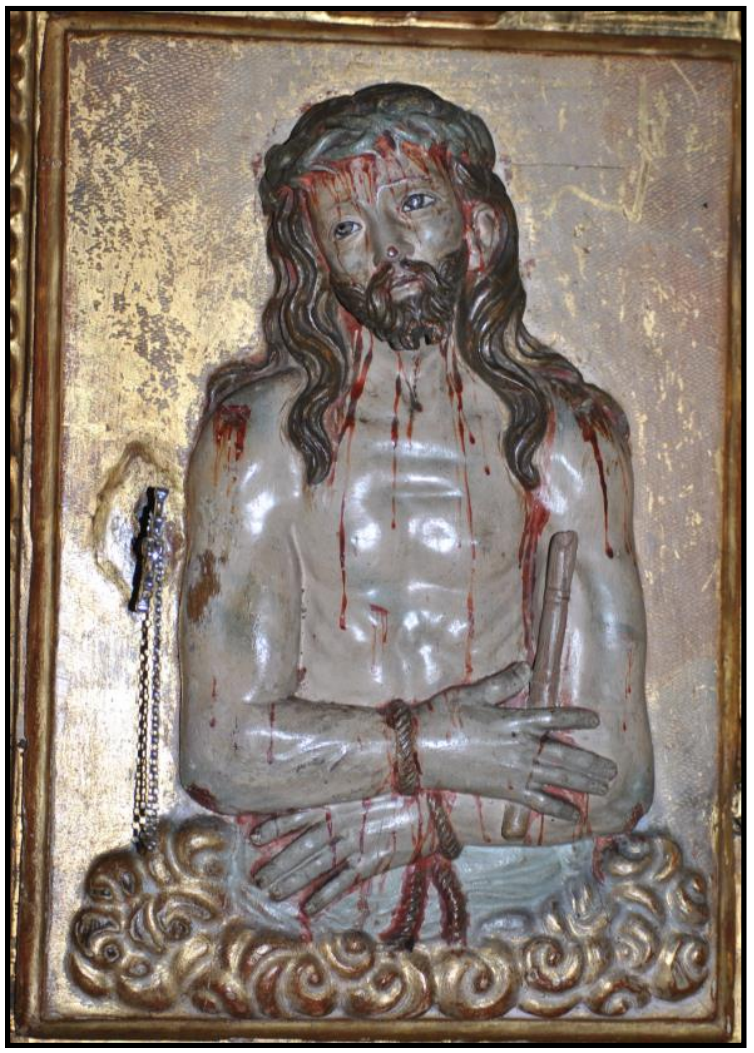

Fig. 125- Juan de Ávila (atrib.). Ecce Homo. Monasterio de Santa Brígida. Valladolid.

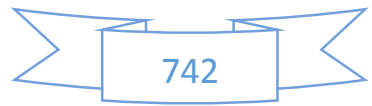




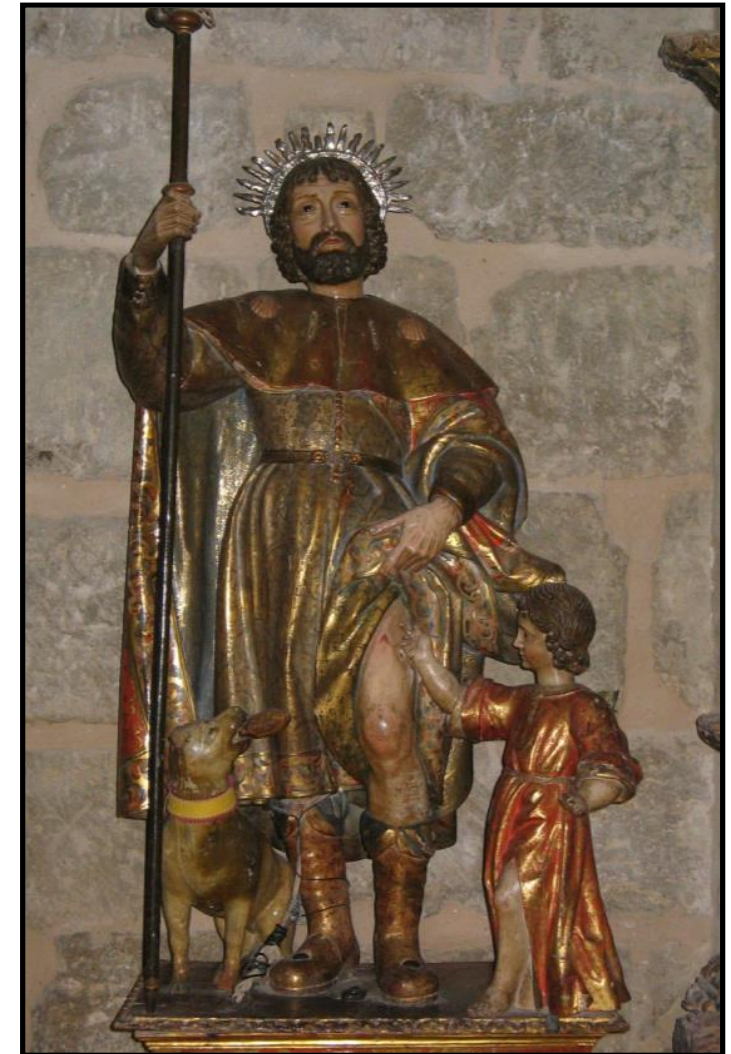

Fig. 126- Juan de Ávila (atrib.). San Roque. Colegiata de San Miguel. Ampudia (Palencia).

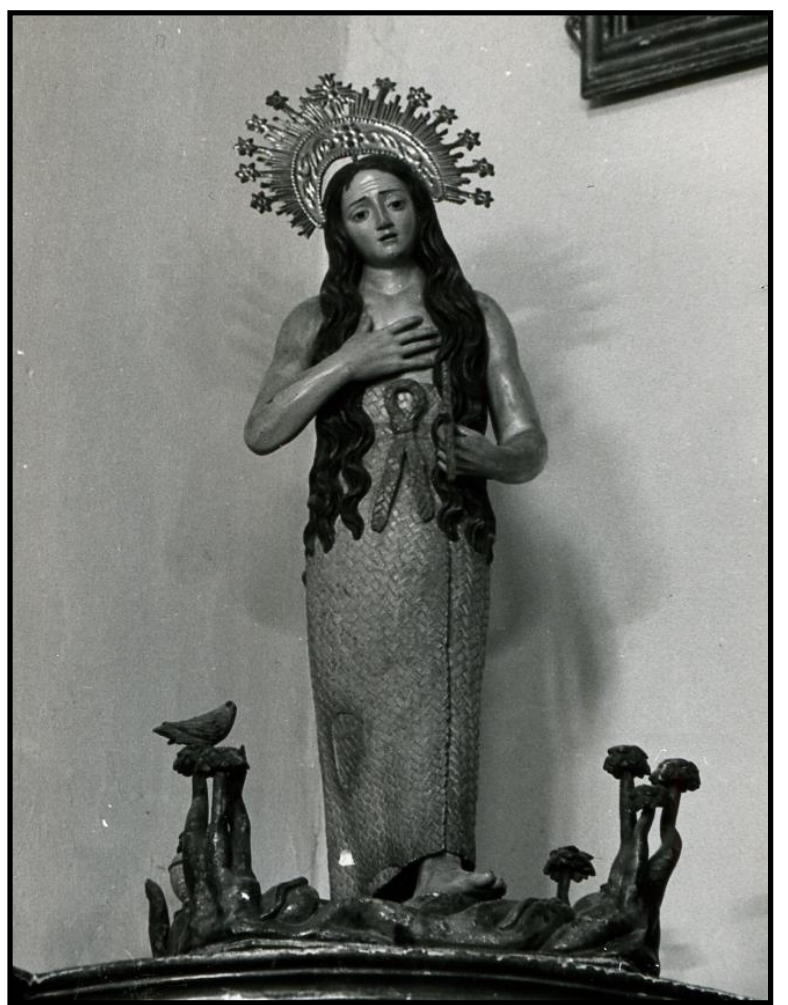

Fig. 128- Juan de Ávila (atrib.). Santa María Magdalena. Convento de las Descalzas Reales. Valladolid. (C) Departamento de Historia del Arte de la Universidad de Valladolid.

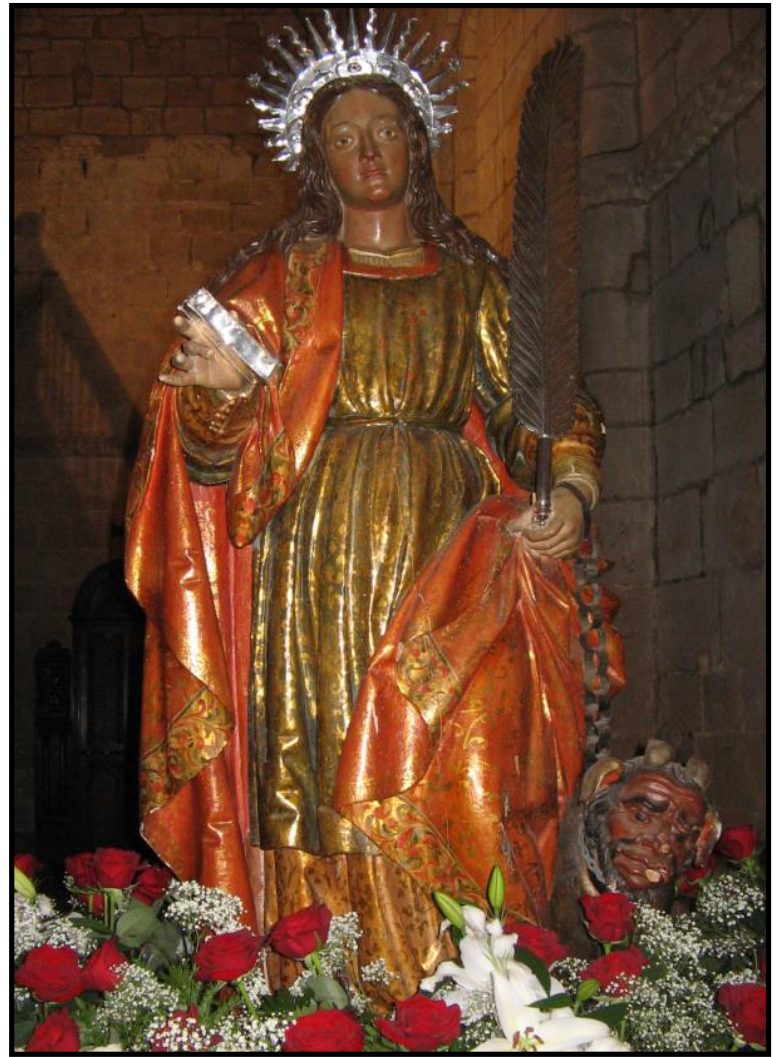

Fig. 127- Juan de Ávila (atrib.). Santa Juliana. Colegiata de Santa Juliana. Santillana del Mar (Cantabria).

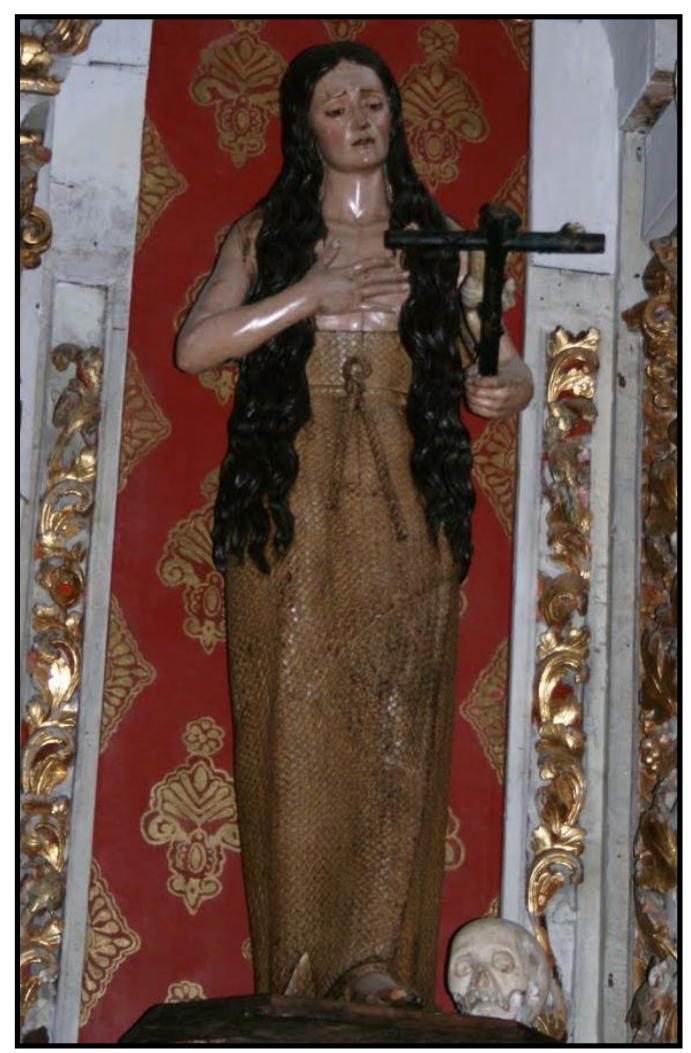

Fig. 129- Juan de Ávila (atrib.). Santa María Magdalena. Iglesia de Nuestra Señora de la Asunción. Bragança (Portugal).

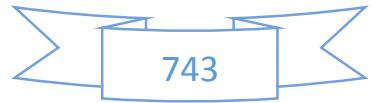




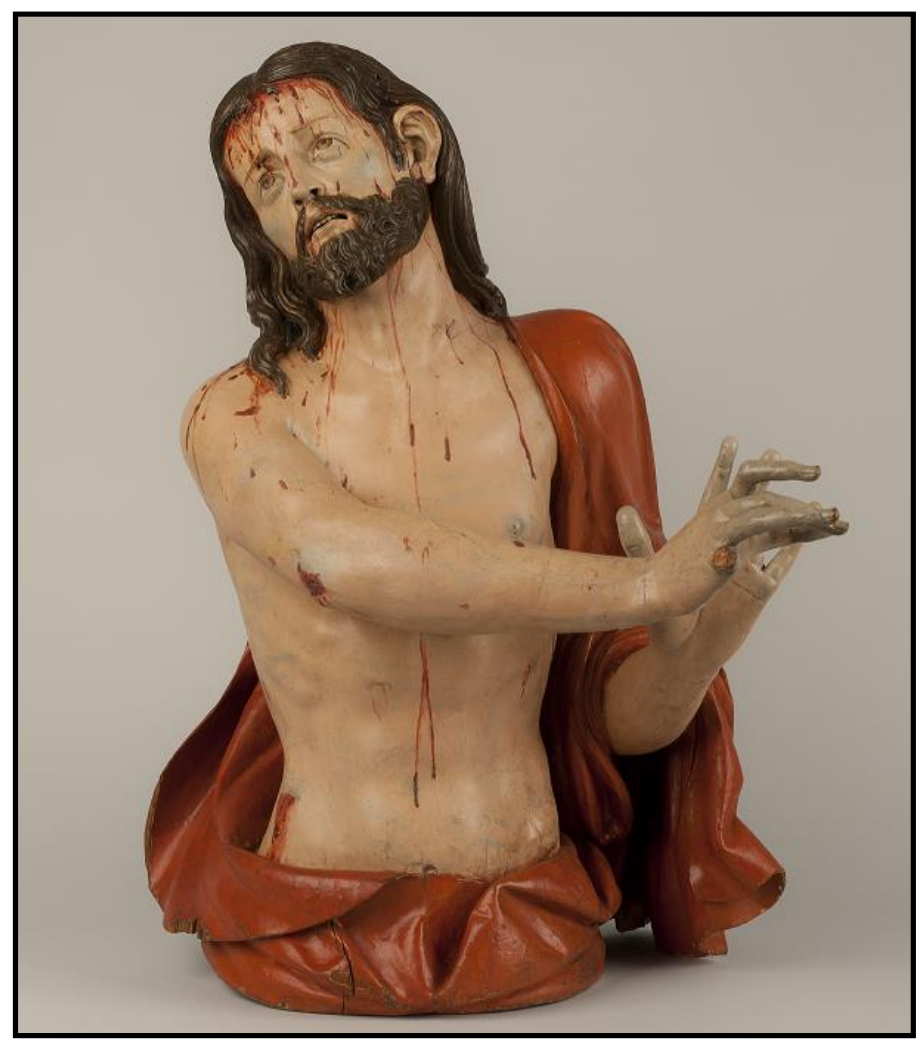

Fig. 130- Juan de Ávila (atrib.). Busto de Ecce Homo. Museo

Nacional de Escultura. Valladolid.

(C) Museo Nacional de Escultura.

Fig. 131- Juan de Ávila (atrib.). Santa Rita de Casia. Museo Nacional de Escultura. Valladolid. (C) Museo Nacional de Escultura.
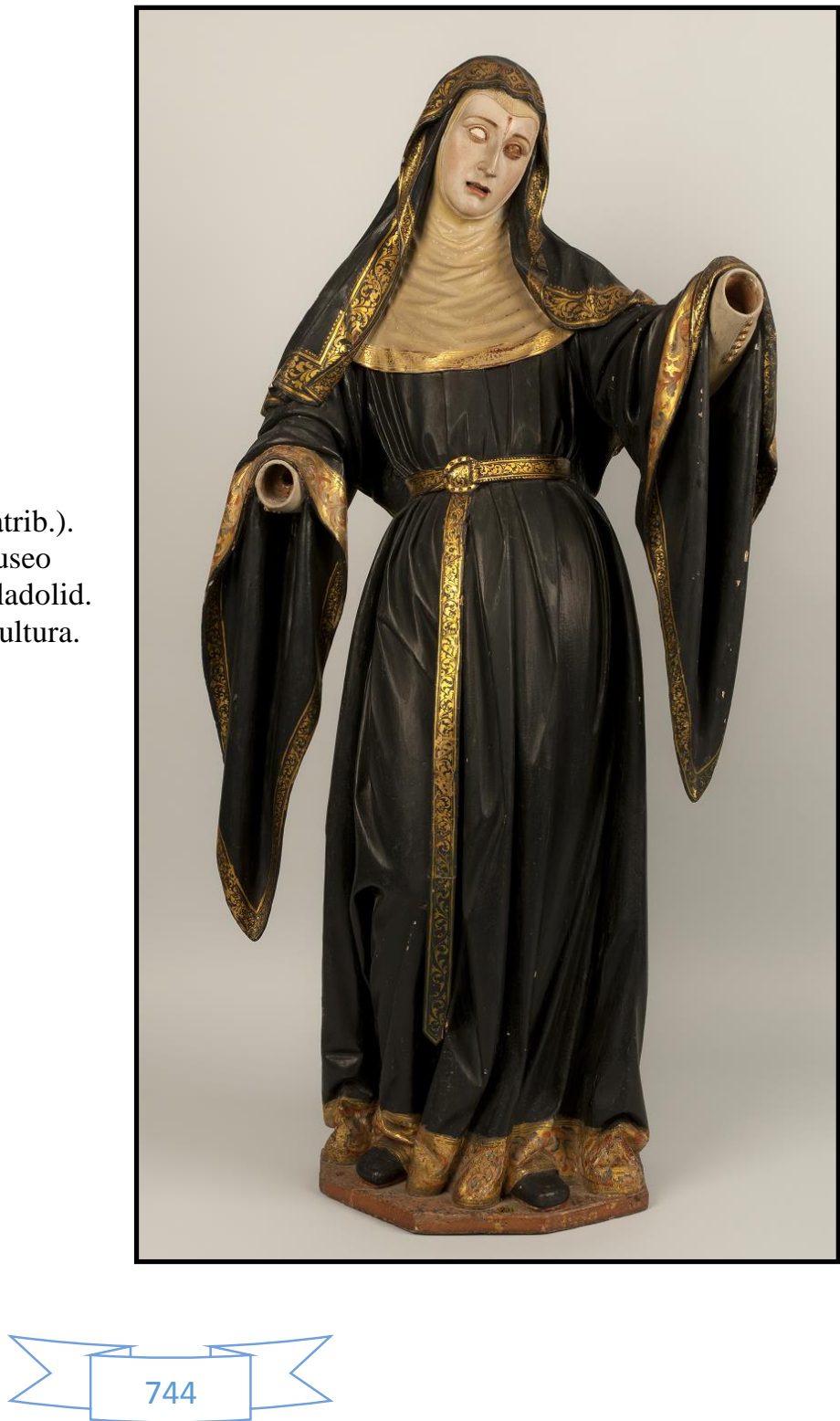


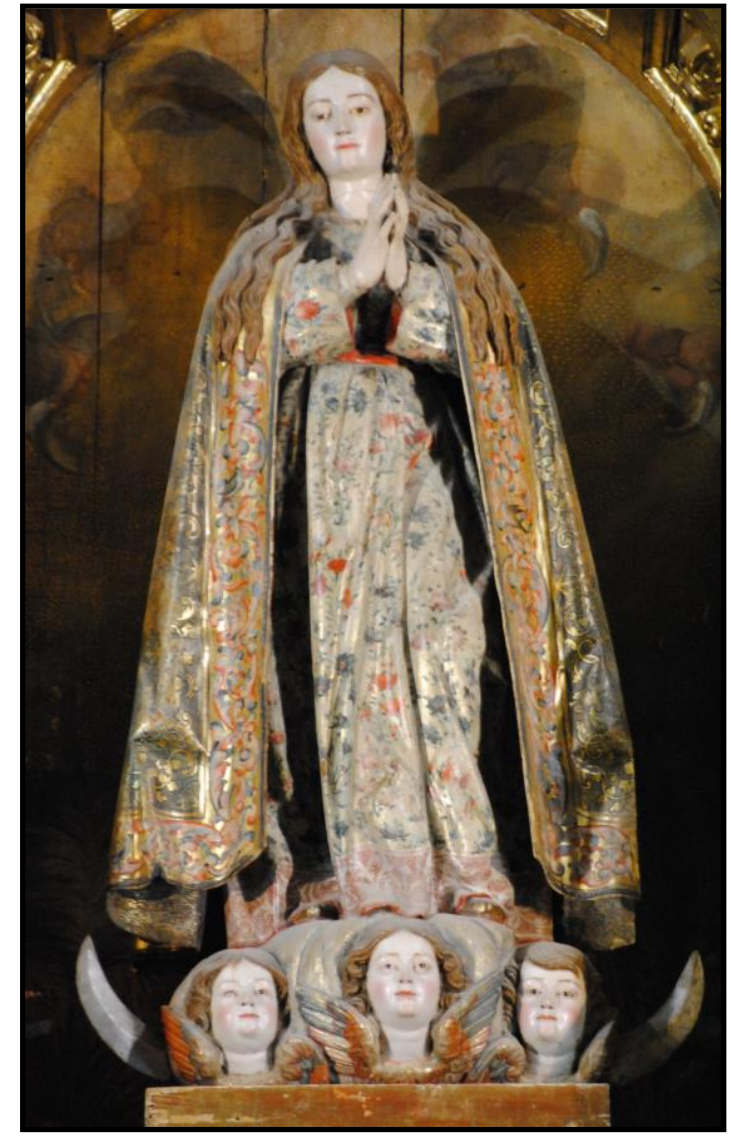

Fig. 132- Juan de Ávila (atrib.). Inmaculada. Iglesia parroquial de la Degollación de San Juan Bautista. Ataquines (Valladolid).

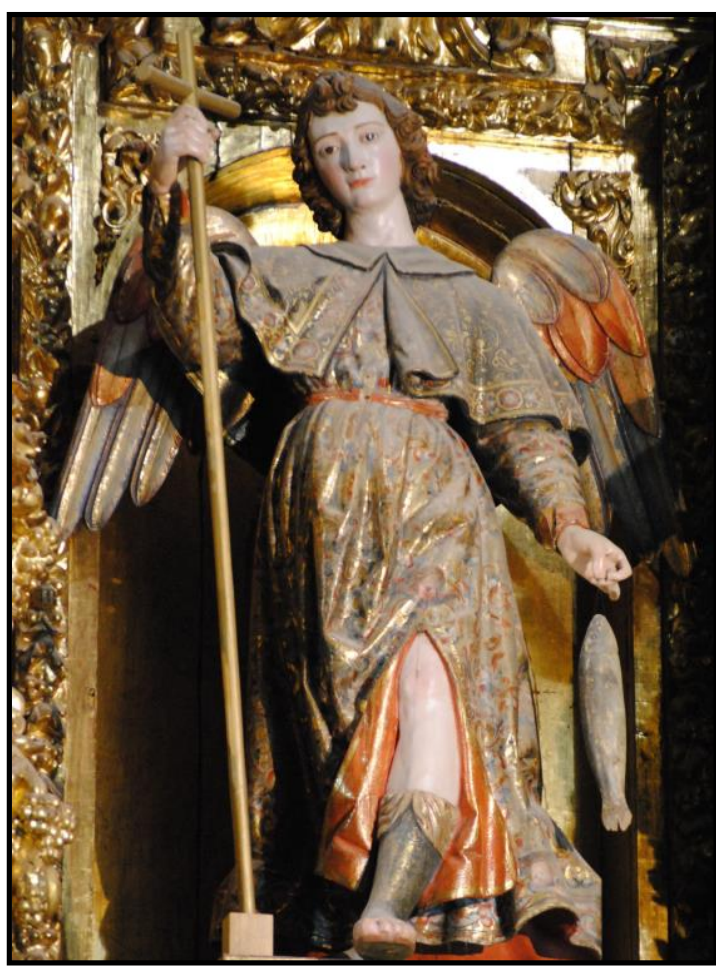

Fig. 134- Juan de Ávila (atrib.). San Rafael. Iglesia parroquial de la Degollación de San Juan Bautista. Ataquines (Valladolid).

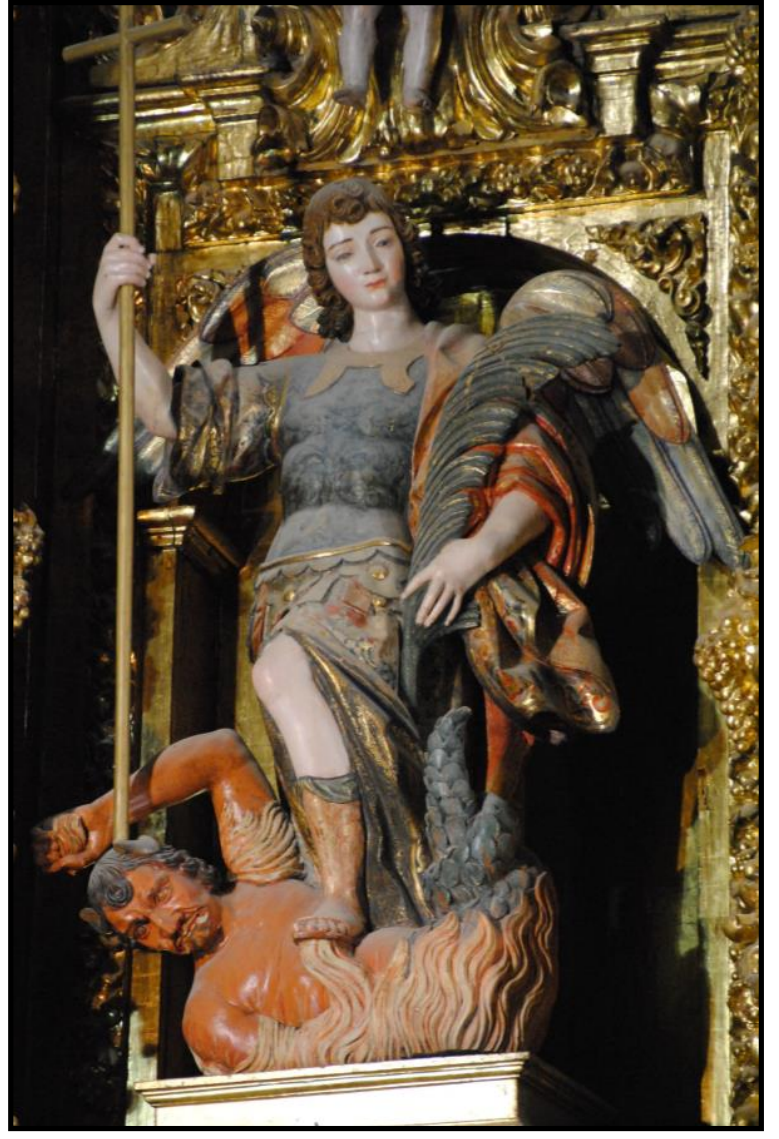

Fig. 133- Juan de Ávila (atrib.). San Miguel. Iglesia parroquial de la Degollación de San Juan Bautista. Ataquines (Valladolid).

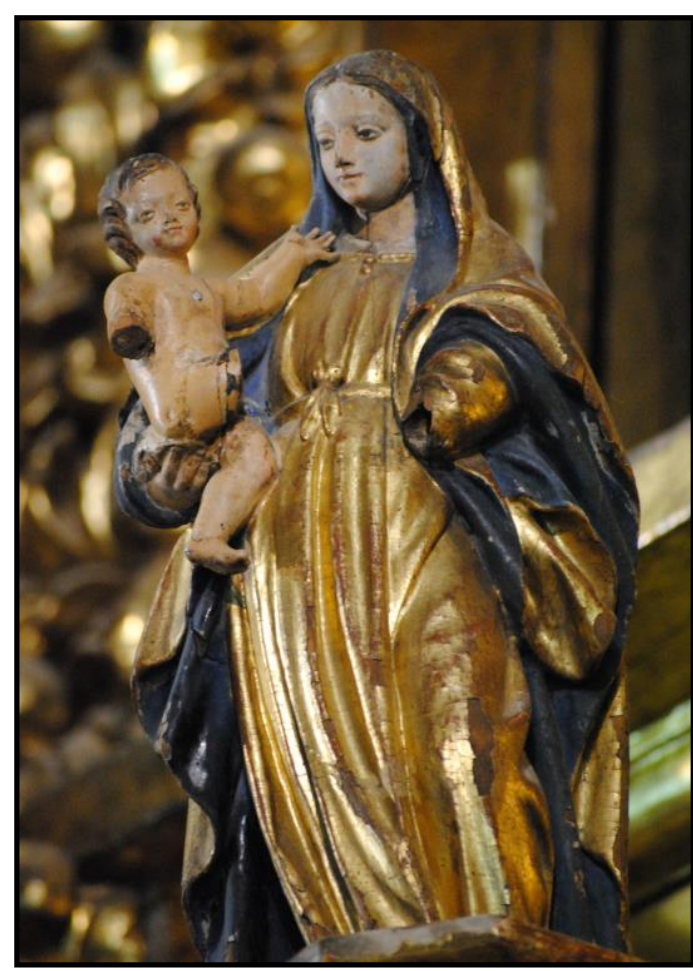

Fig. 135- Juan de Ávila (atrib.). Virgen con el Niño. Iglesia parroquial de la Degollación de San Juan Bautista. Ataquines (Valladolid). 


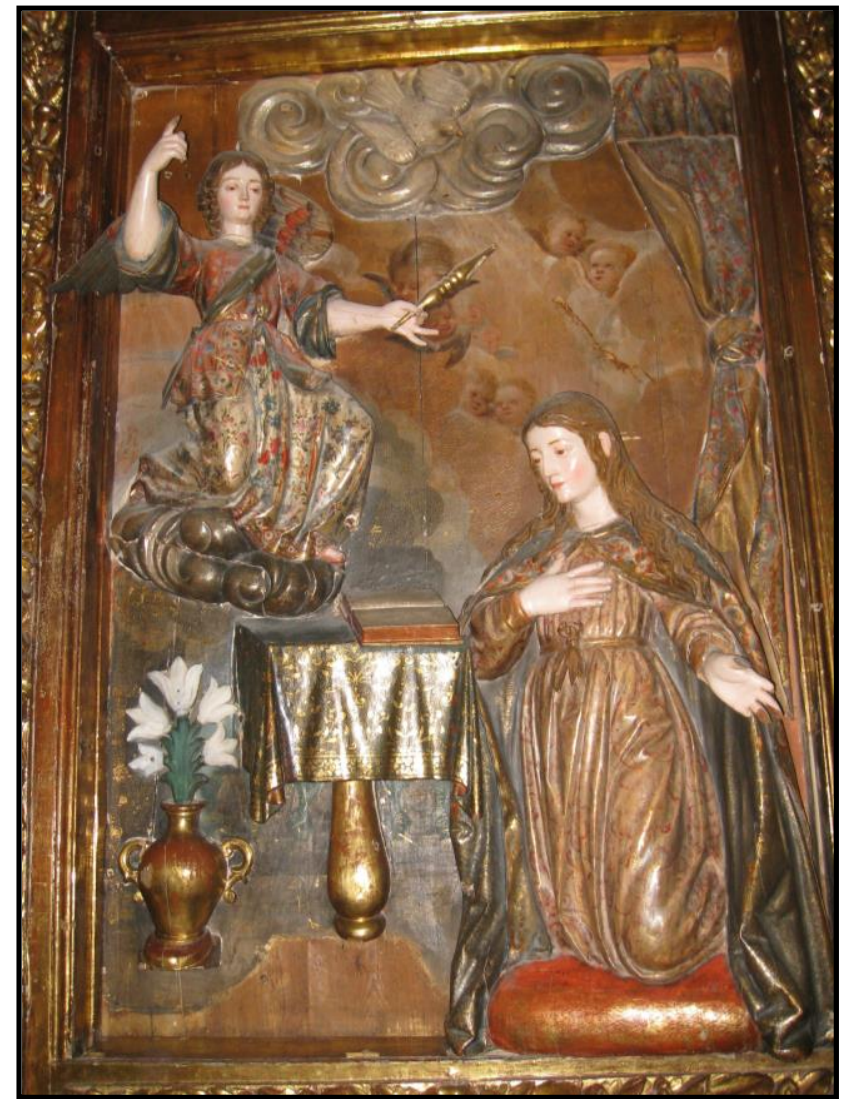

Fig. 136- Juan de Ávila (atrib.). Anunciación. Iglesia parroquial de la Degollación de San Juan Bautista. Ataquines (Valladolid).

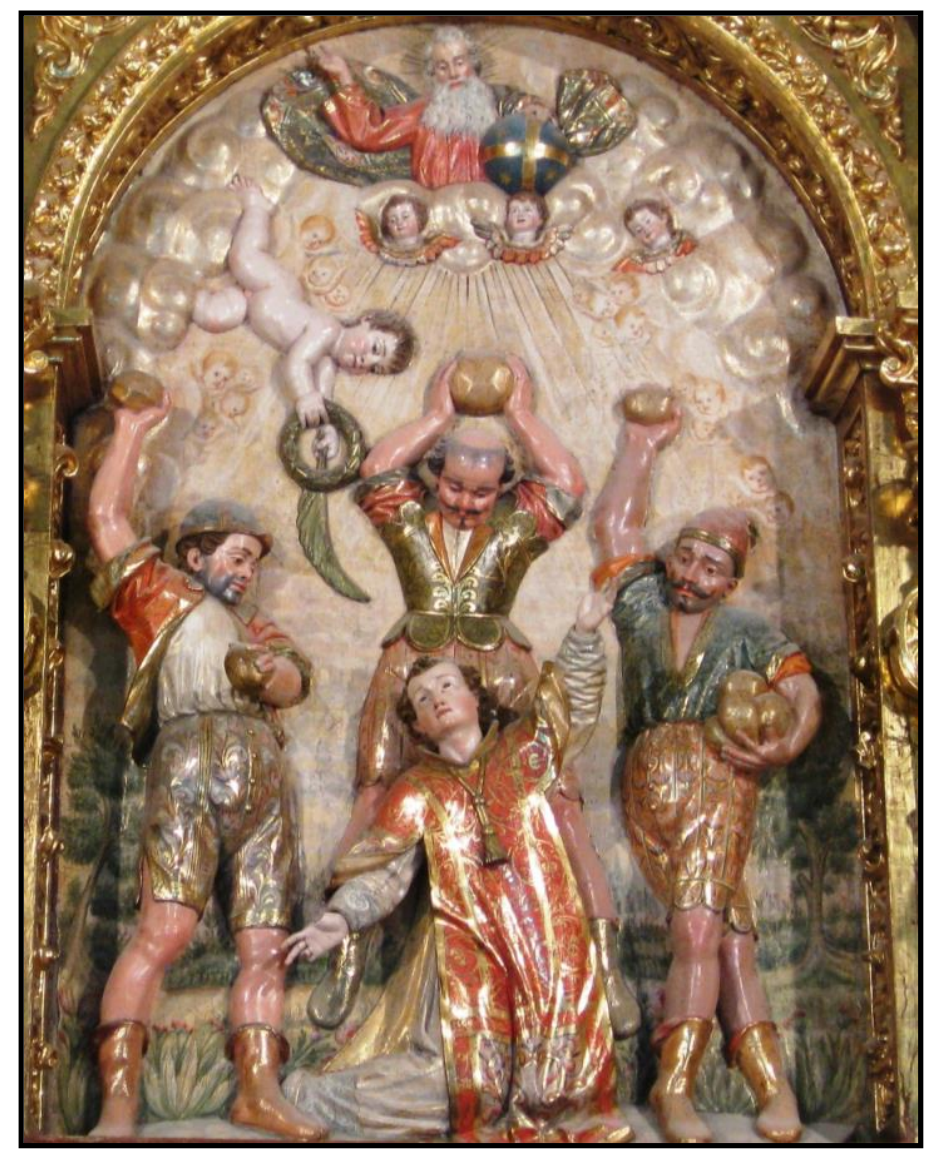

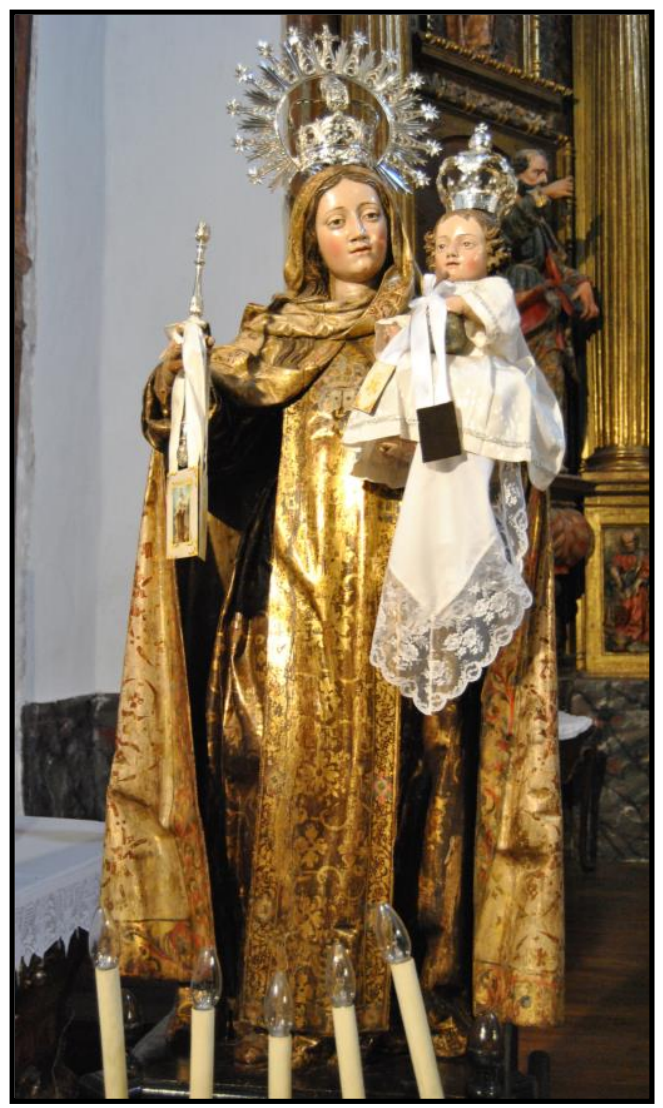

Fig. 137- Juan de Ávila (atrib.). Inmaculada. Iglesia parroquial de la Asunción. Bercero (Valladolid).

Fig. 138- Juan de Ávila (atrib.). Lapidación de San Esteban. Iglesia parroquial de San Esteban. Torrecilla de la Abadesa (Valladolid).

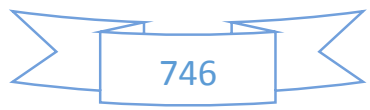



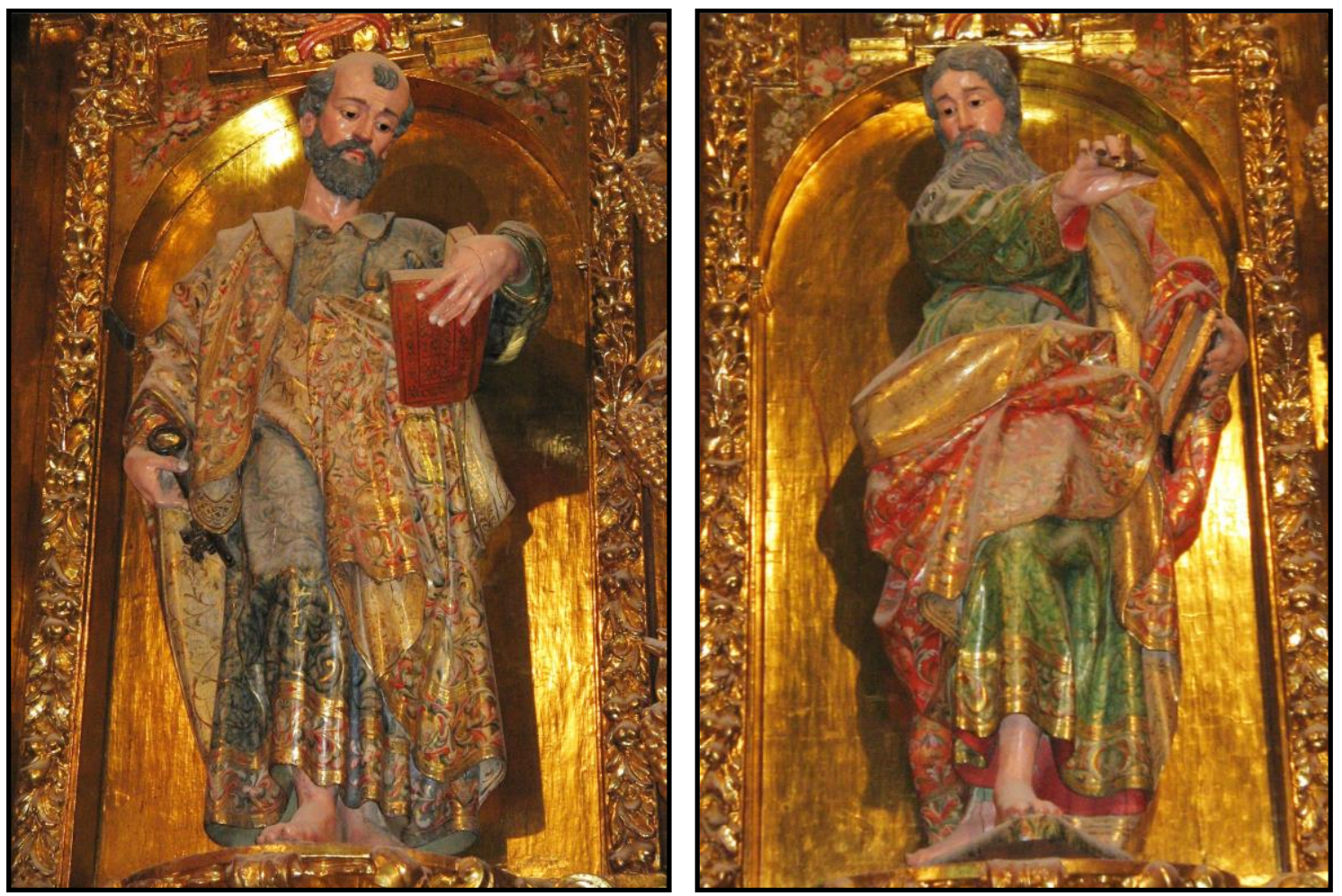

Figs. 139-140- Juan de Ávila (atrib.). San Pedro y San Pablo. Iglesia parroquial de San Esteban. Torrecilla de la Abadesa (Valladolid).

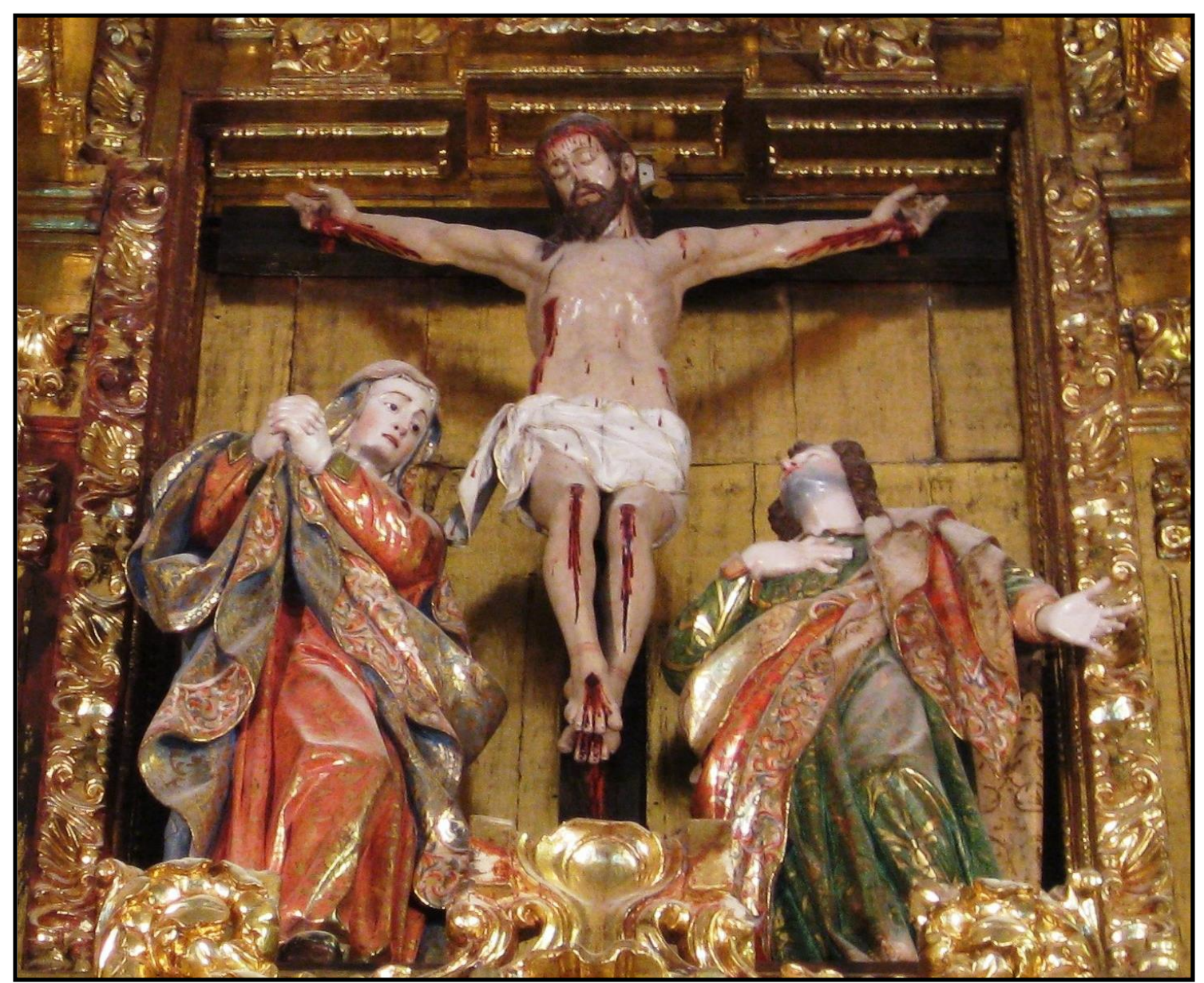

Fig. 141- Juan de Ávila (atrib.). Calvario. Iglesia parroquial de San Esteban. Torrecilla de la Abadesa (Valladolid).

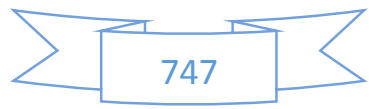




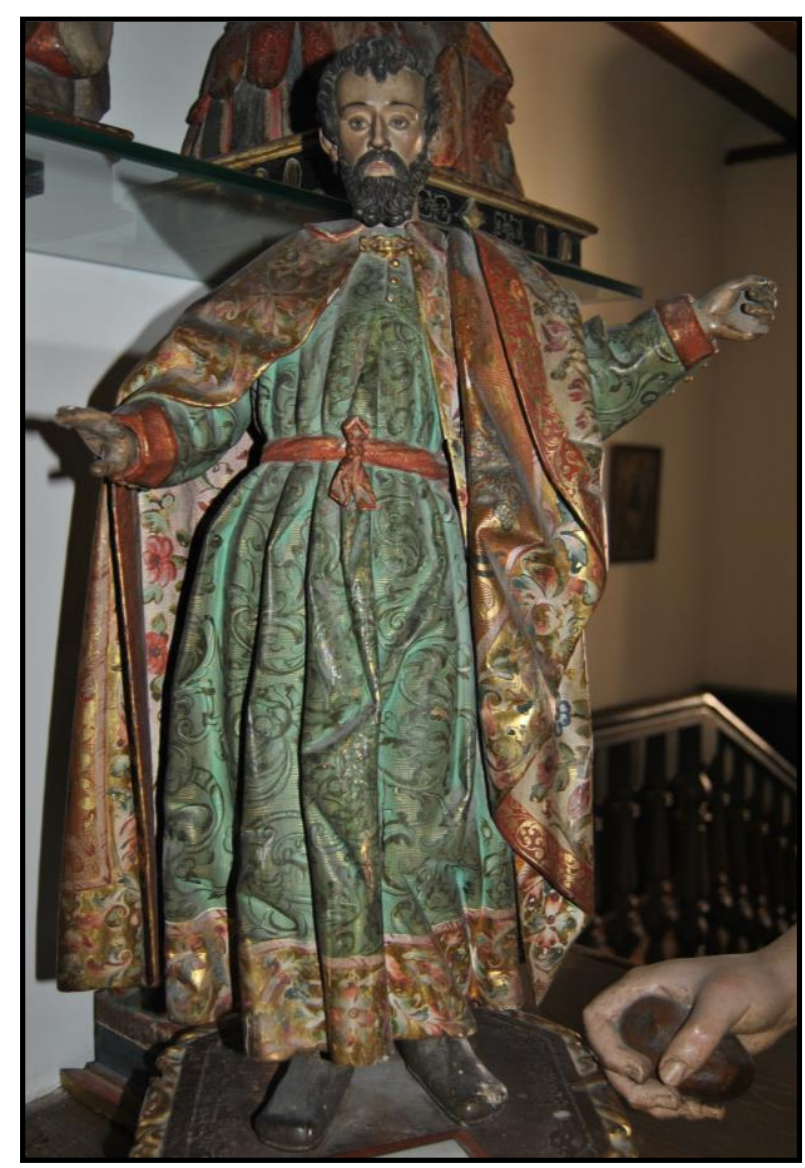

Fig. 142- Juan de Ávila (atrib.). San José. Centro Diocesano de Espiritualidad. Valladolid.

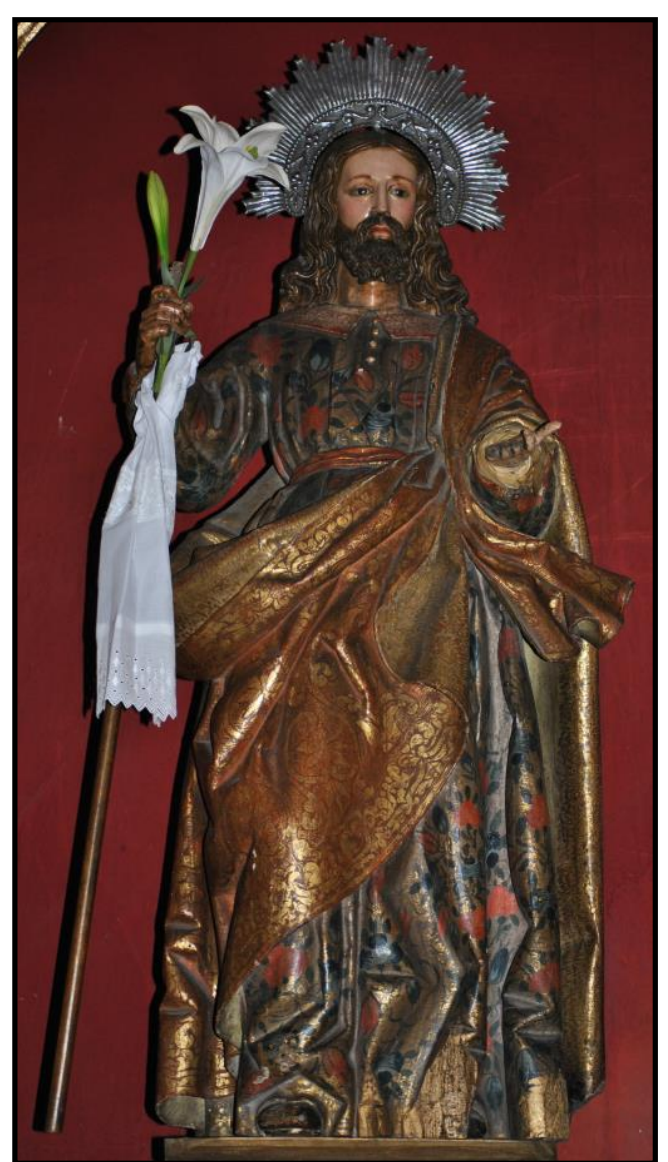

Fig. 143- Juan de Ávila (atrib.). San José. Iglesia de San Nicolás. Valladolid.

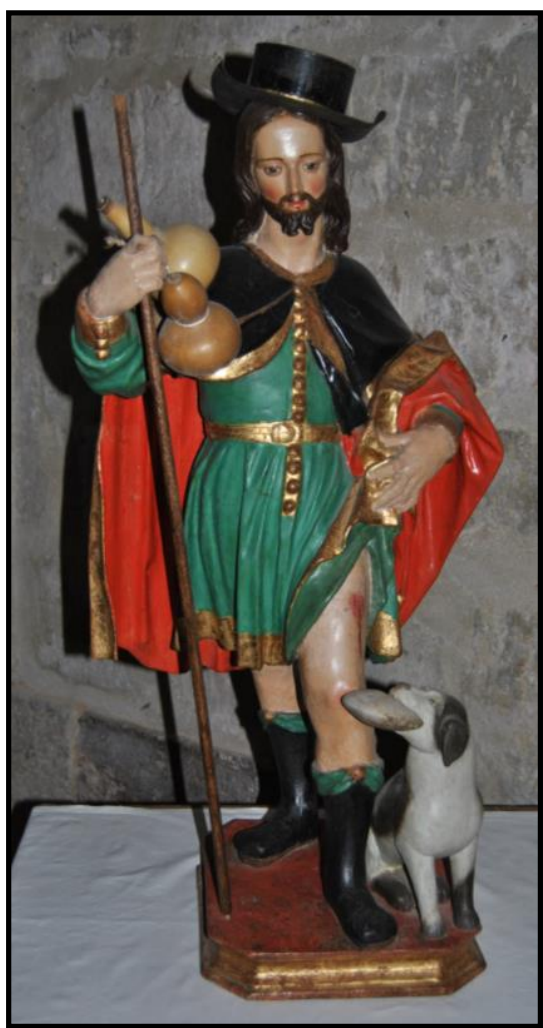

Fig. 144- Juan de Ávila (atrib.). San Roque. Iglesia parroquial de la Asunción. Cabezón (Valladolid).

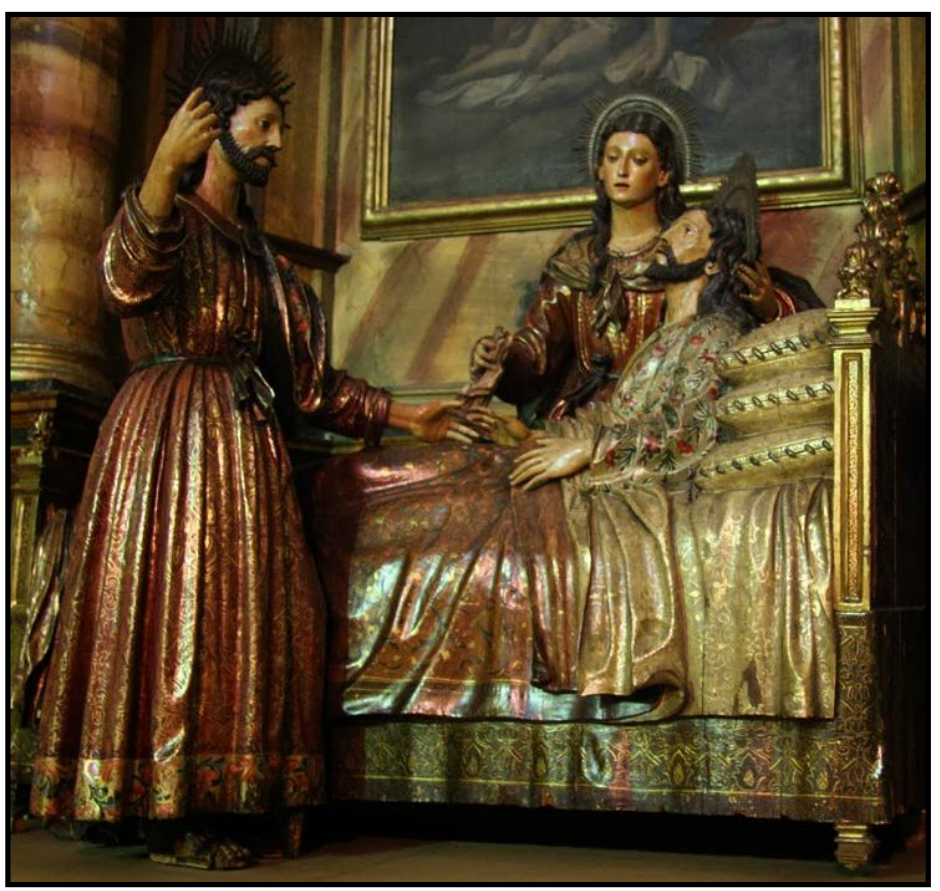

Fig. 145- Juan de Ávila (atrib.). Tránsito o Muerte de San José. Hospital de Peregrinos de la Piedad. Benavente (Zamora).

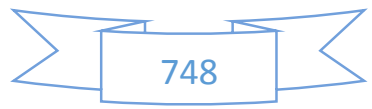




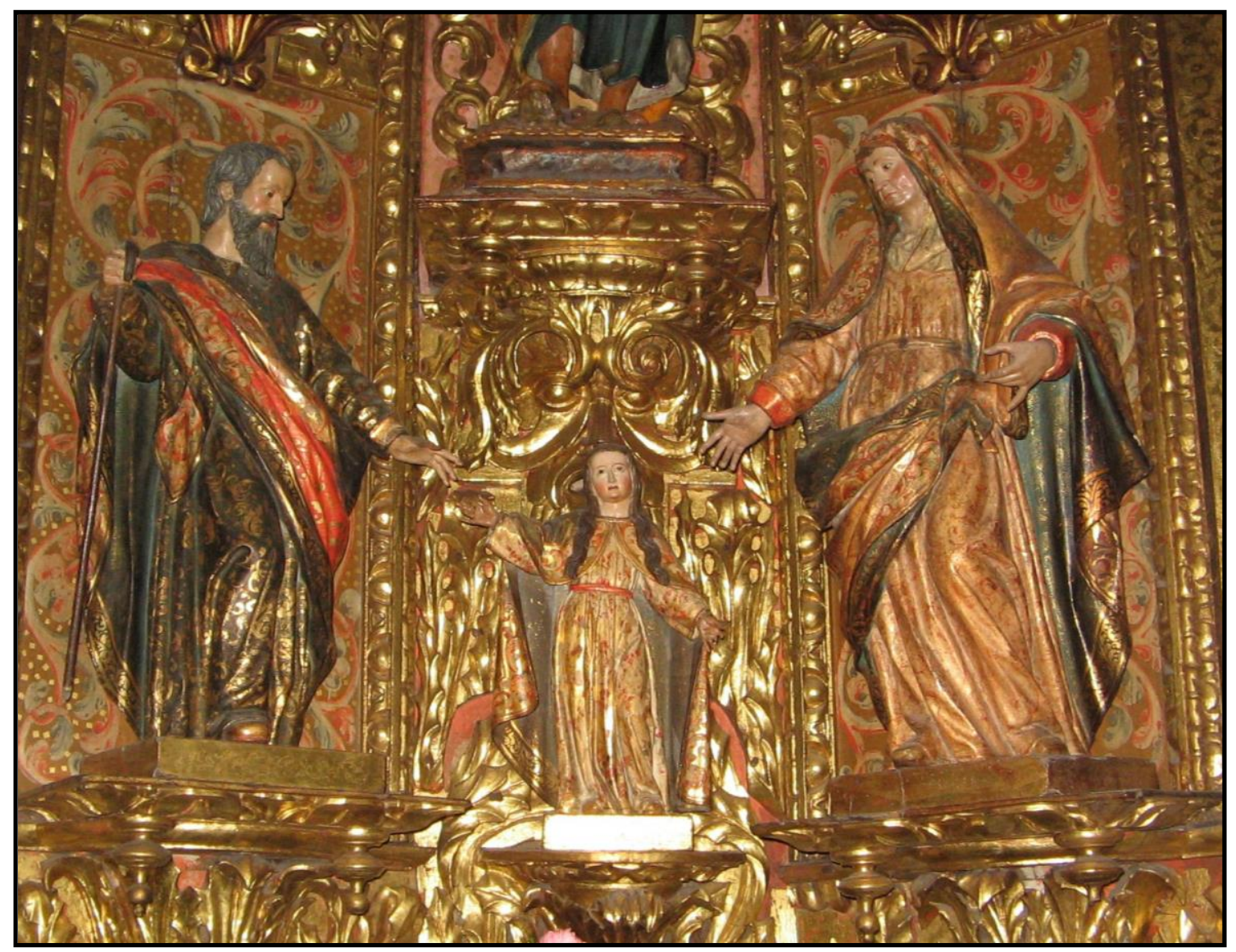

Fig. 146- Juan de Ávila (atrib.). San Joaquín, Santa Ana y la Virgen. Catedral. Orense.

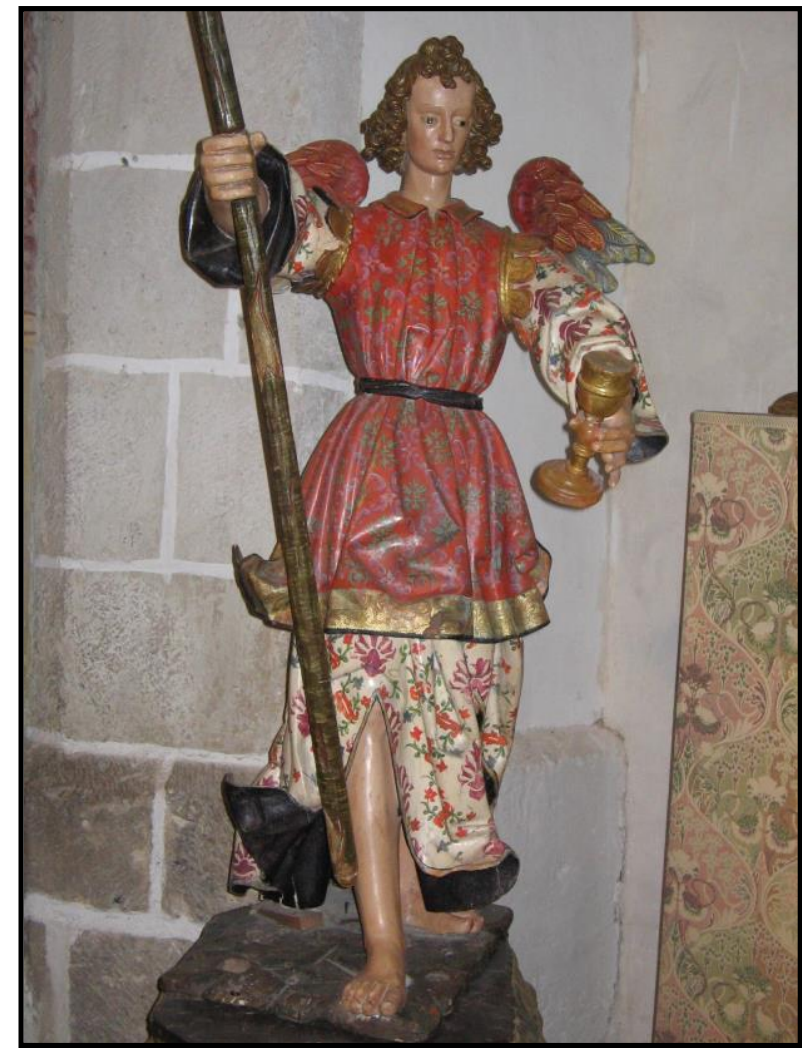

Fig. 147- Juan de Ávila (atrib.). Ángel del paso de la Oración del Huerto. Iglesia museo de San Antolín. Tordesillas (Valladolid).

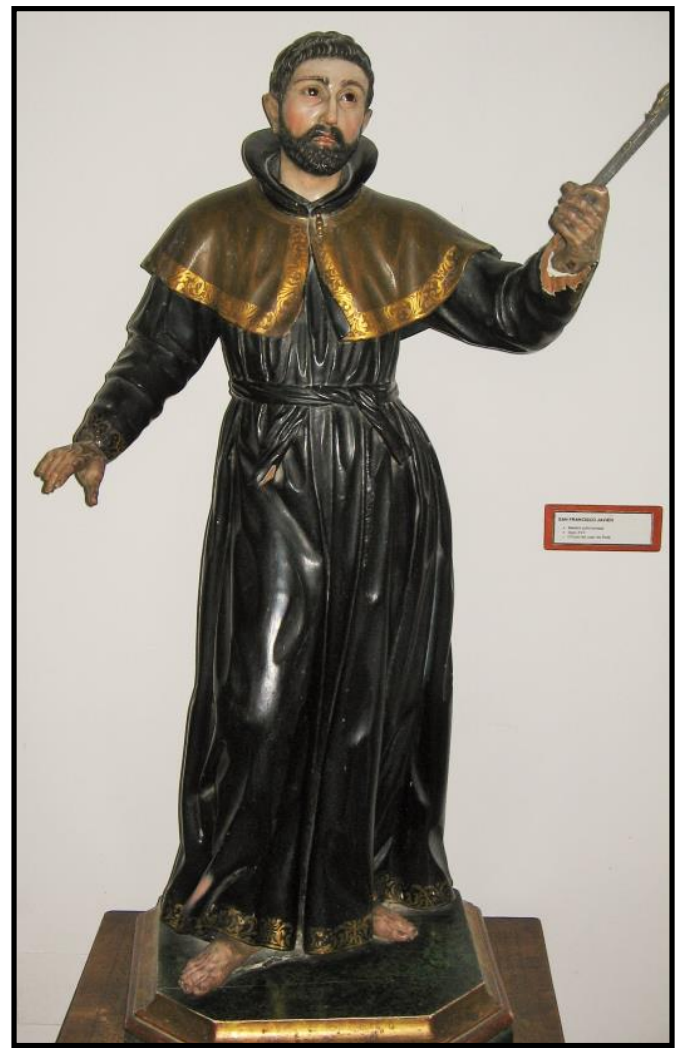

Fig. 148- Anónimo madrileño. San Francisco Javier. Centro Diocesano de Espiritualidad. Valladolid

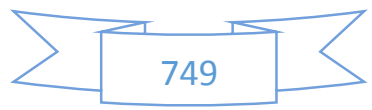




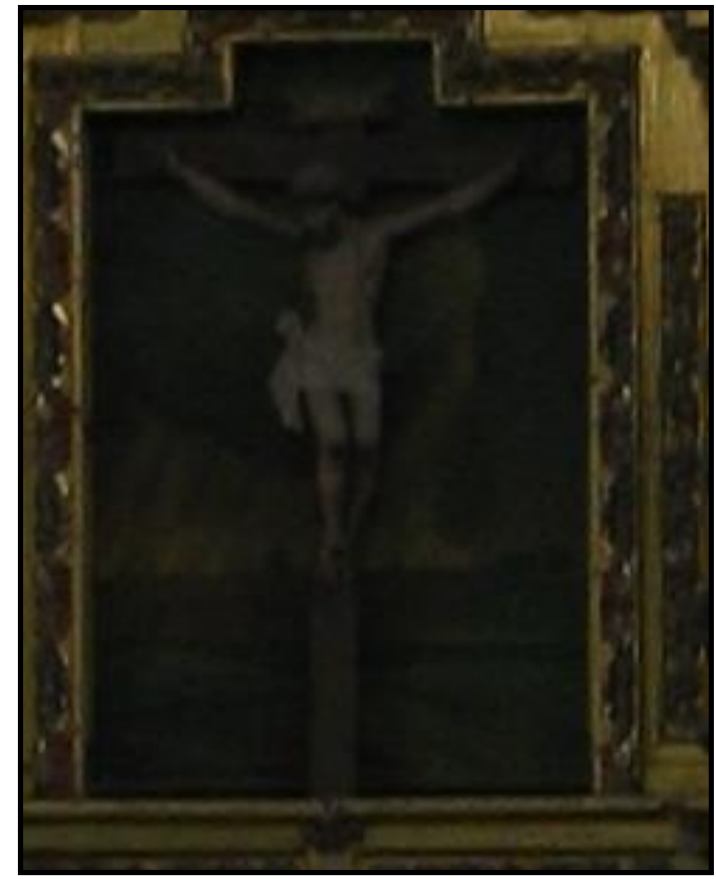

Fig. 149- Anónimo. Crucificado. Convento de la Concepción. Valladolid.

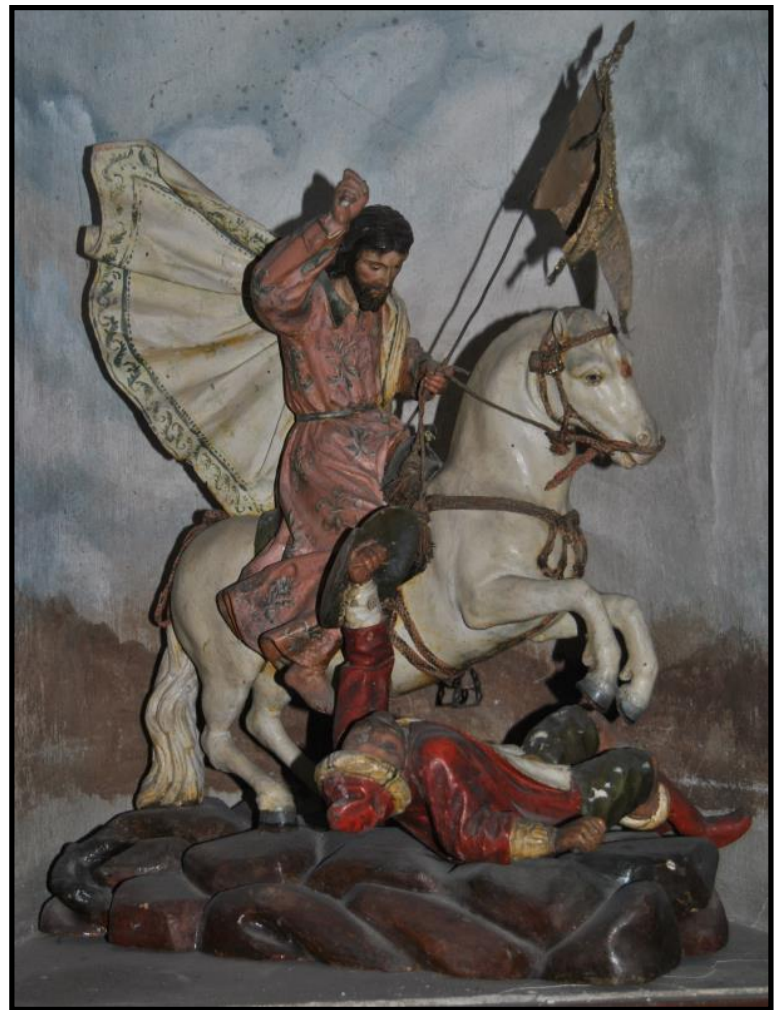

Fig. 150- Anónimo. Santiago Matamoros. Iglesia de Santiago Apóstol. Valladolid.

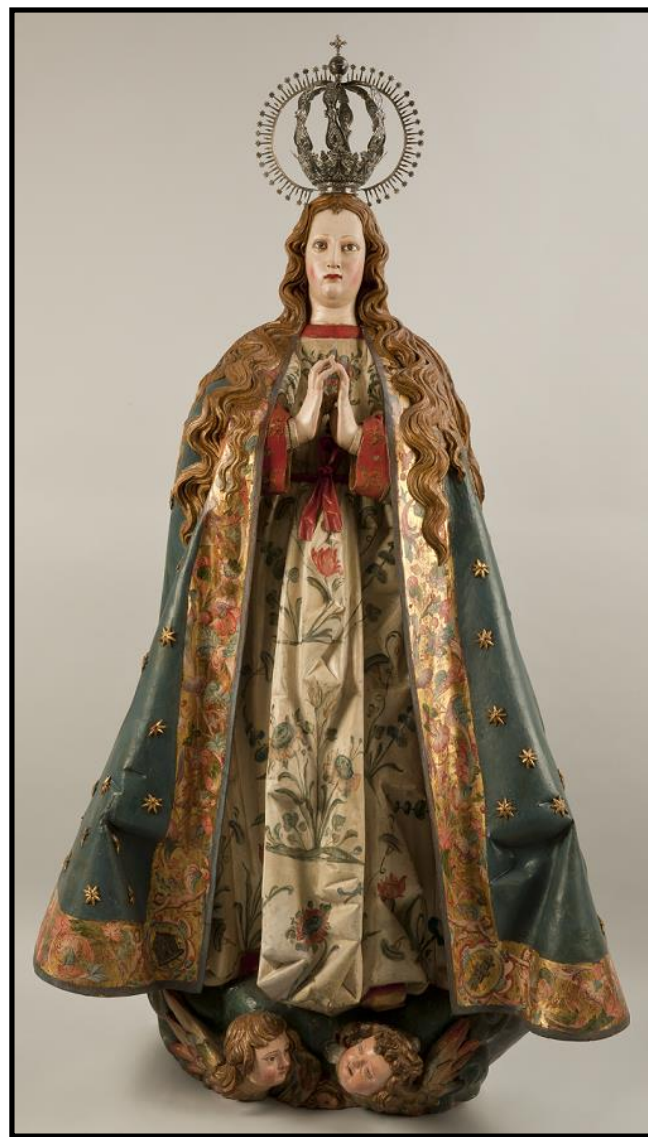

Fig. 152- Anónimo. Inmaculada. Museo Nacional de Escultura. Valladolid. (C) Museo Nacional de Escultura.

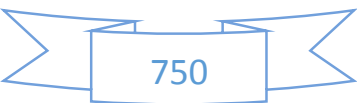




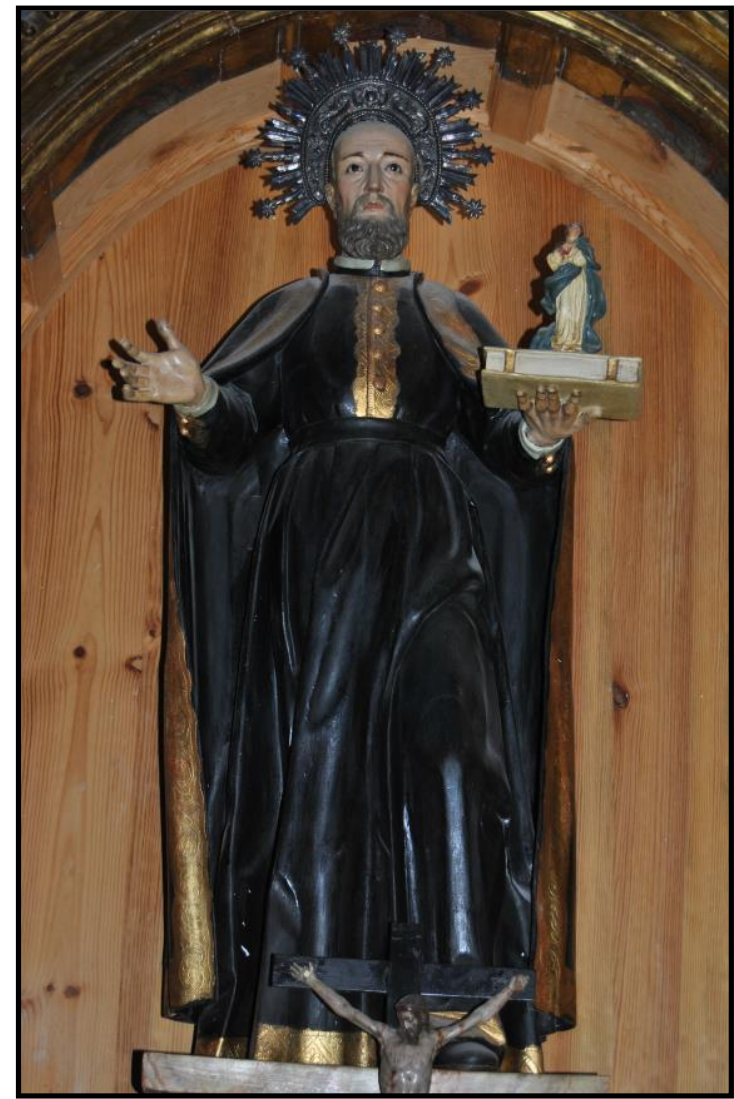

Fig. 153- Anónimo. San Felipe Neri. Oratorio de San Felipe Neri. Valladolid.

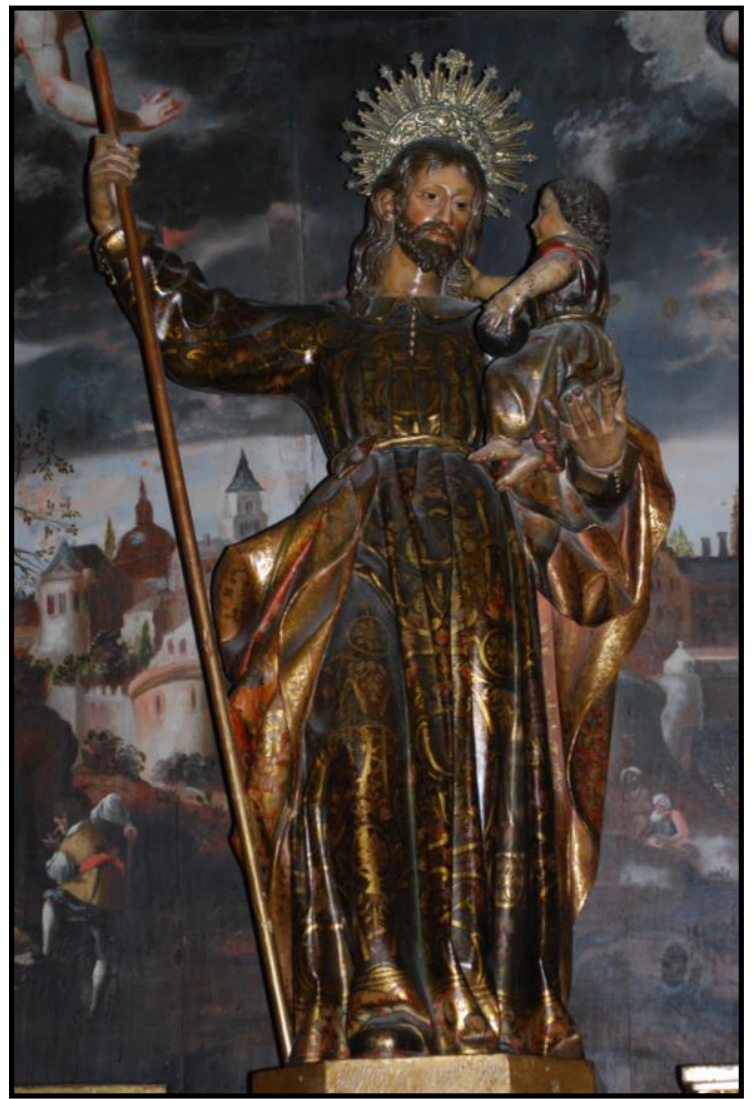

Fig. 154- Anónimo. San José con el Niño. Santuario Nacional de la Gran Promesa. Valladolid.

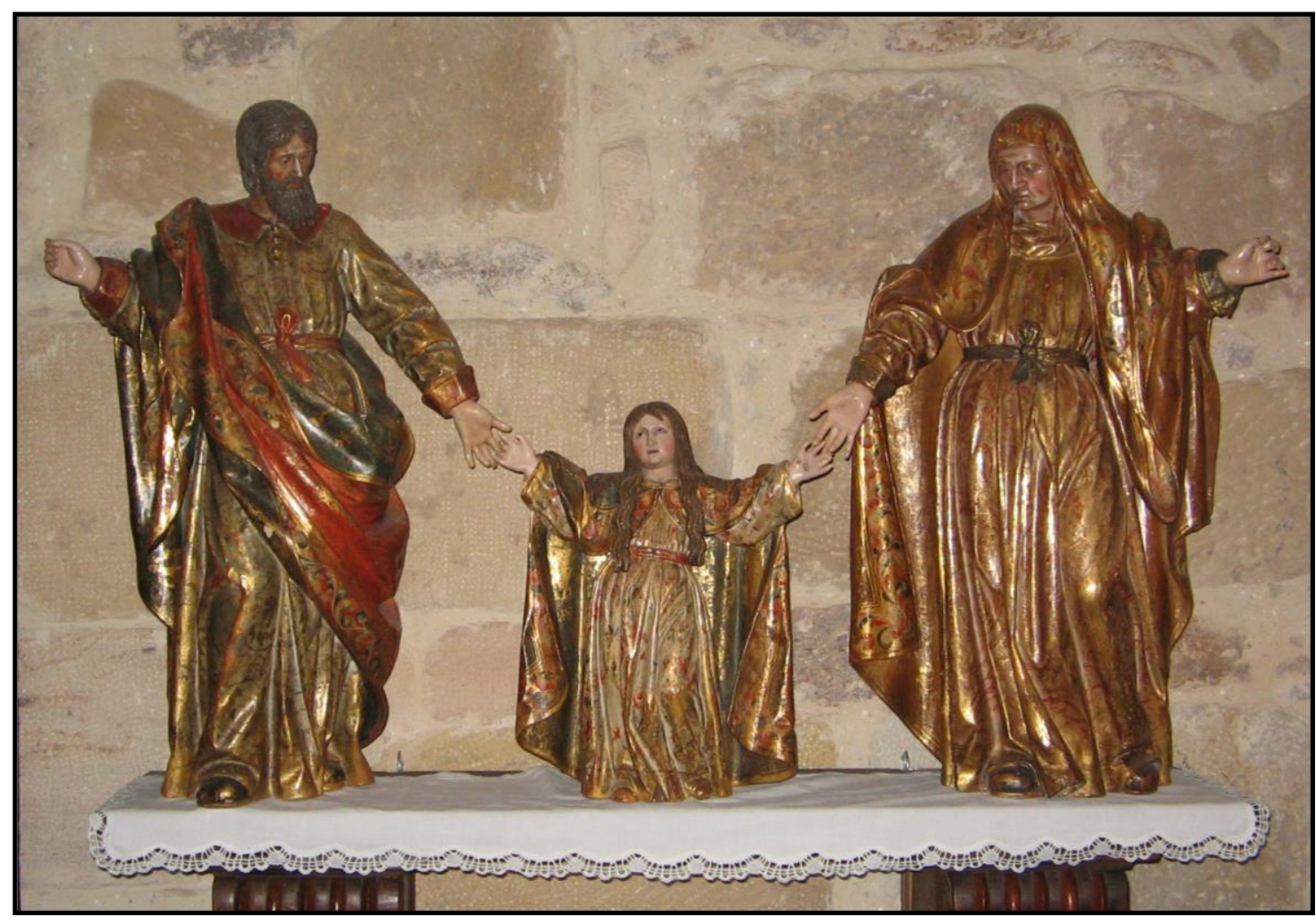

Fig. 155- Anónimo. San Joaquín, Santa Ana y la Virgen Niña. Colegiata de San Miguel. Aguilar de Campoo (Palencia).

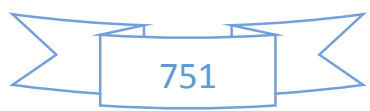




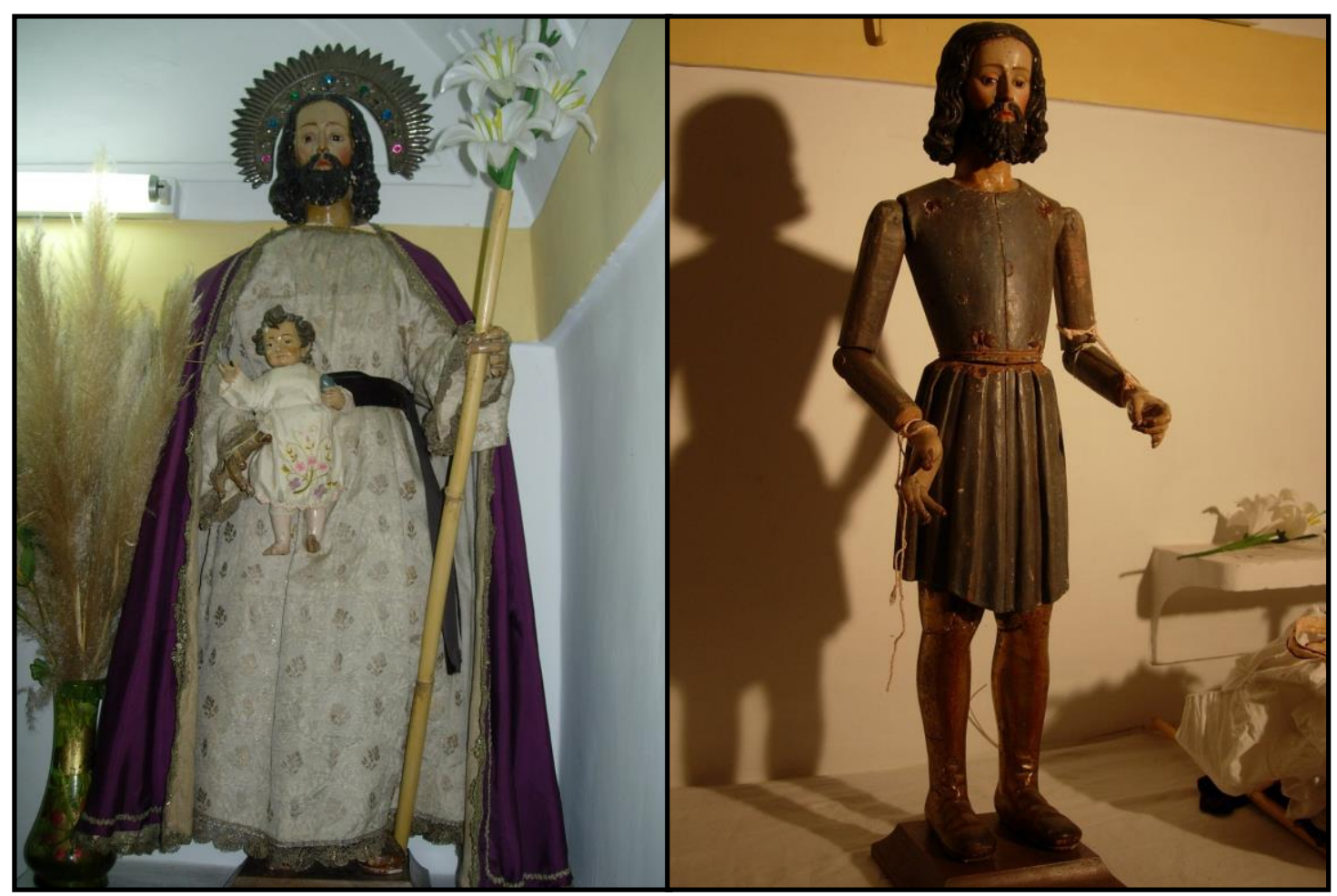

Fig. 156- Anónimo. San José. Monasterio de Santa Clara. Carrión de los Condes (Palencia). (C) Lorena García García.

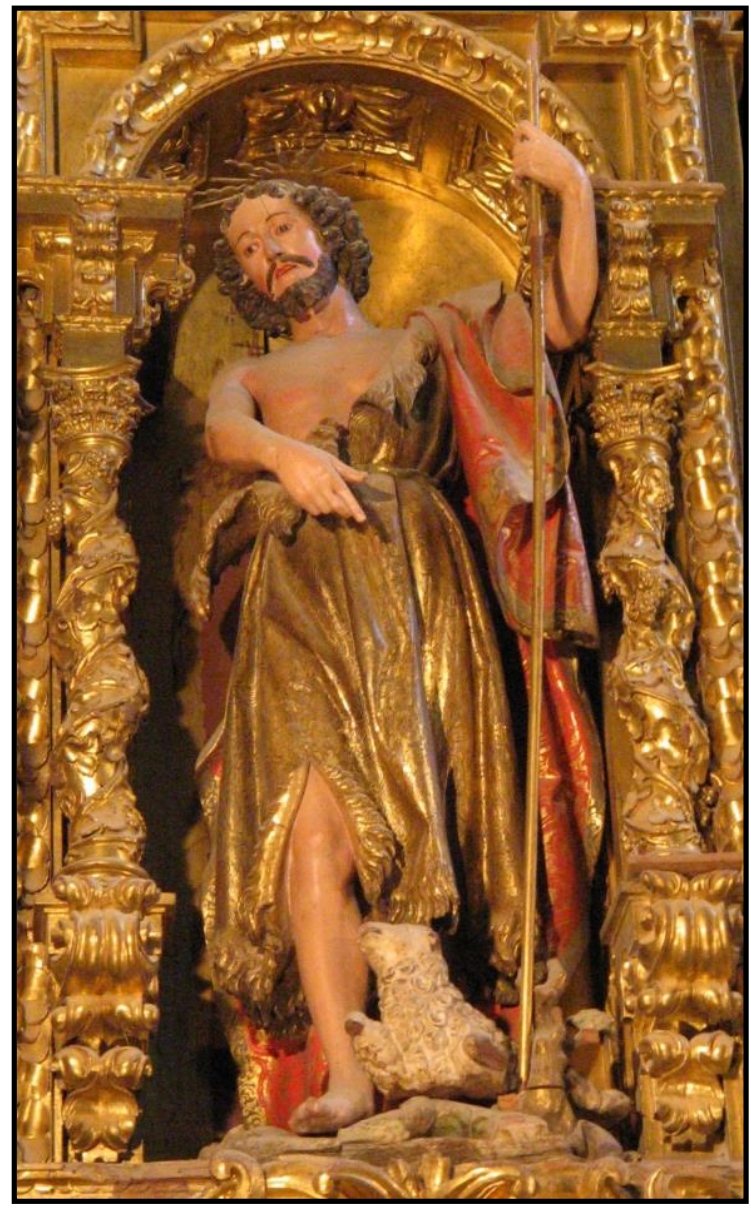

Fig. 157- ¿Tomás de Sierra? San Juan Bautista del retablo mayor. Iglesia de Santa María del Camino. Carrión de los Condes (Palencia).

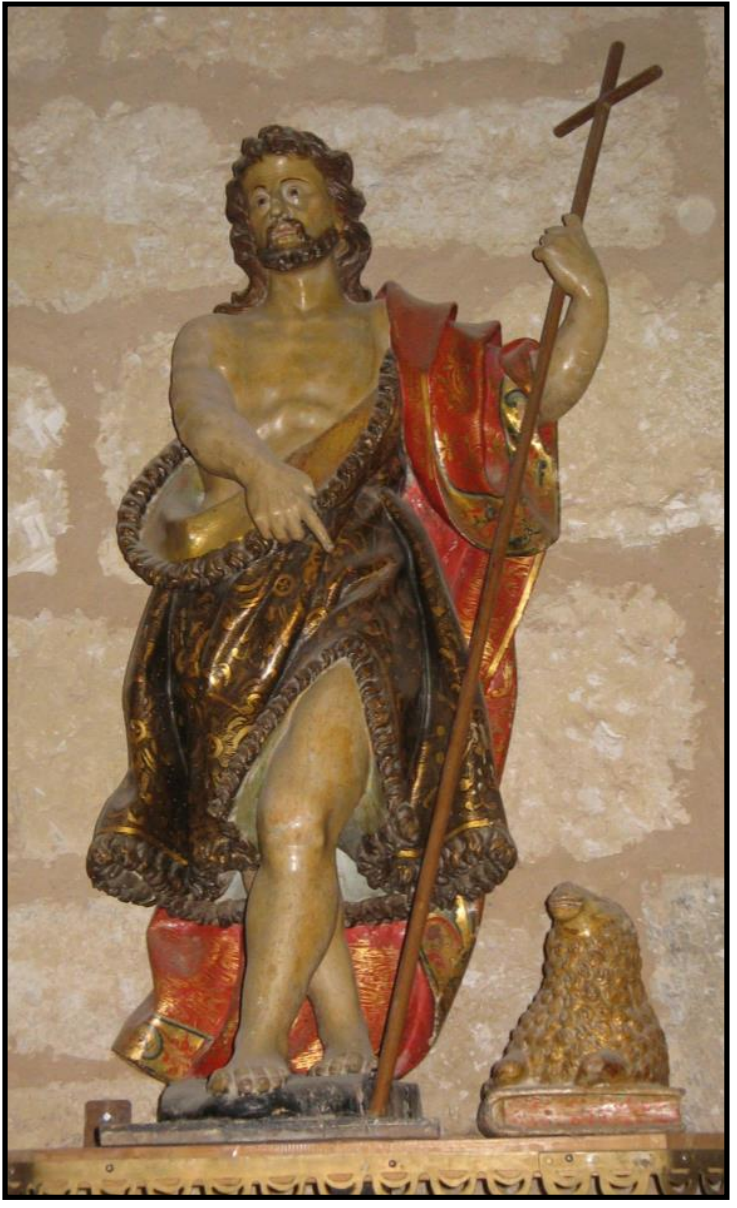

Fig. 158- ¿Felipe Espinabete? San Juan Bautista. Iglesia parroquial de San Martín. Cevico de la Torre (Palencia).

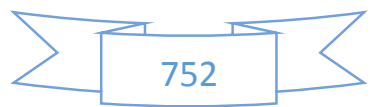




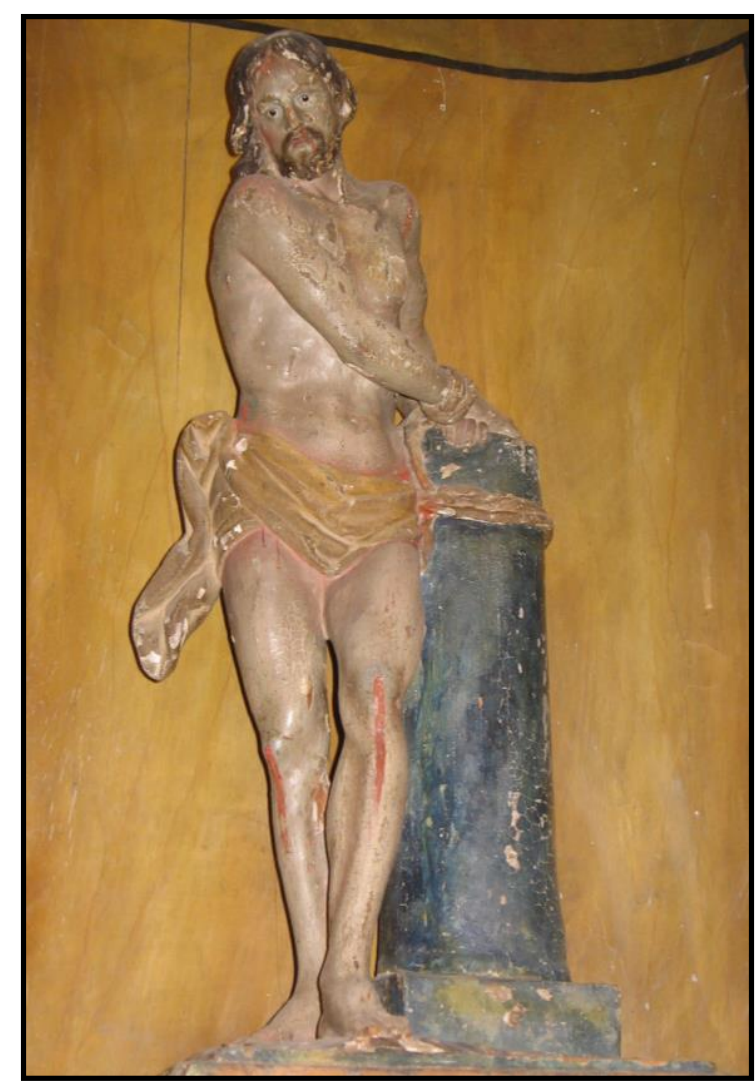

Fig. 159- Anónimo. Cristo atado a la columna. Iglesia parroquial de San Miguel. Hornillos (Valladolid).

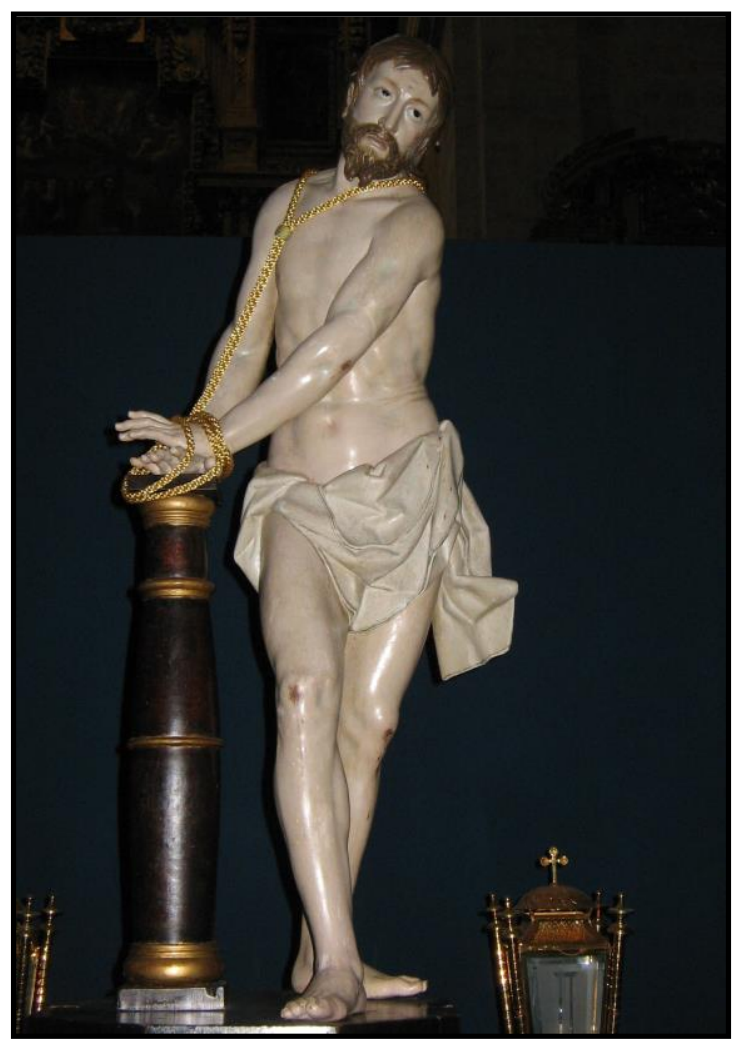

Fig. 161- Anónimo. Cristo atado a la columna. Museo de Semana Santa. Medina de Rioseco (Valladolid).

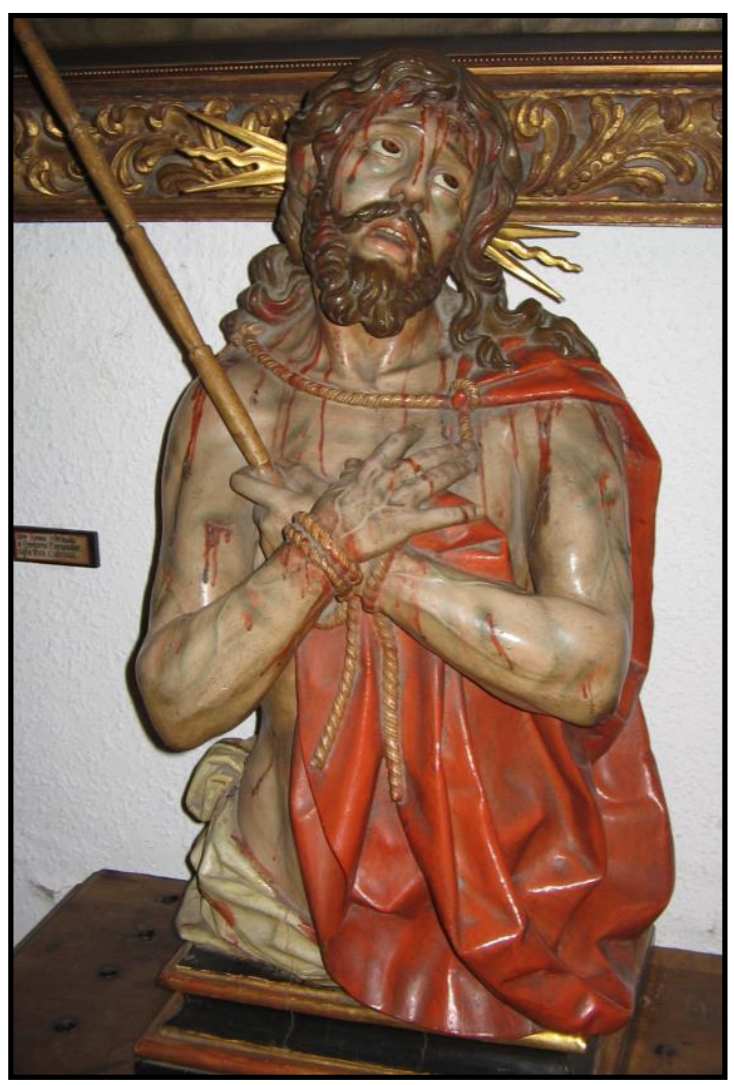

Fig. 160- Anónimo Busto de Ecce Homo. Museo Catedralicio-Diocesano. León.

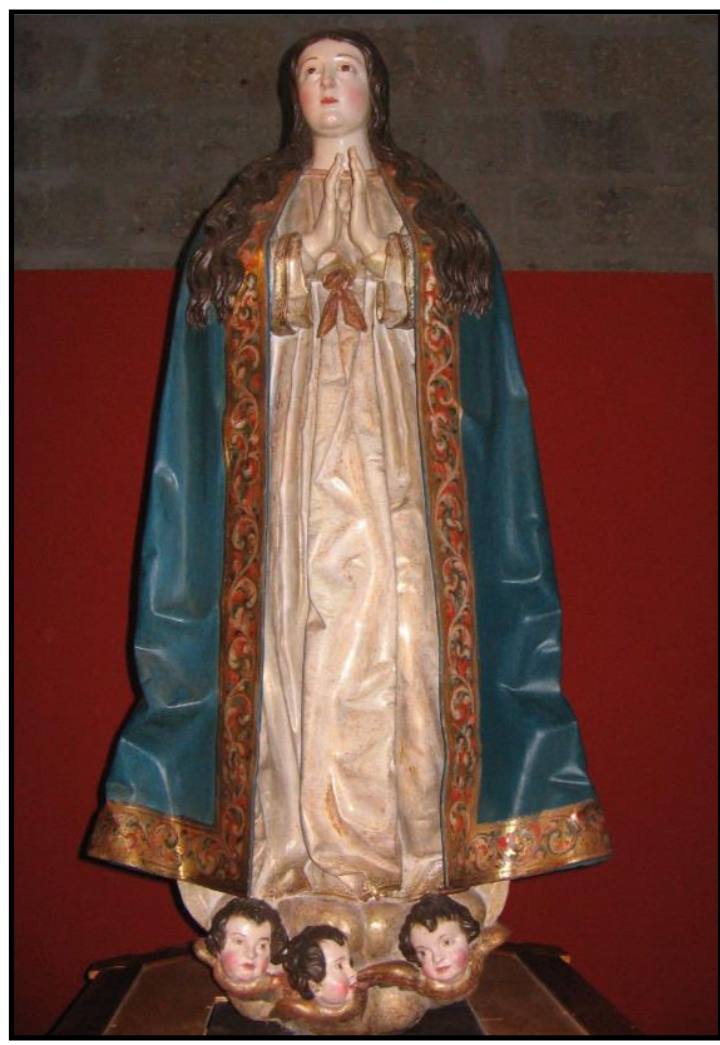

Fig. 162- Anónimo. Virgen de la Alegría. Museo de Semana Santa. Medina de Rioseco (Valladolid).

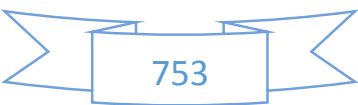




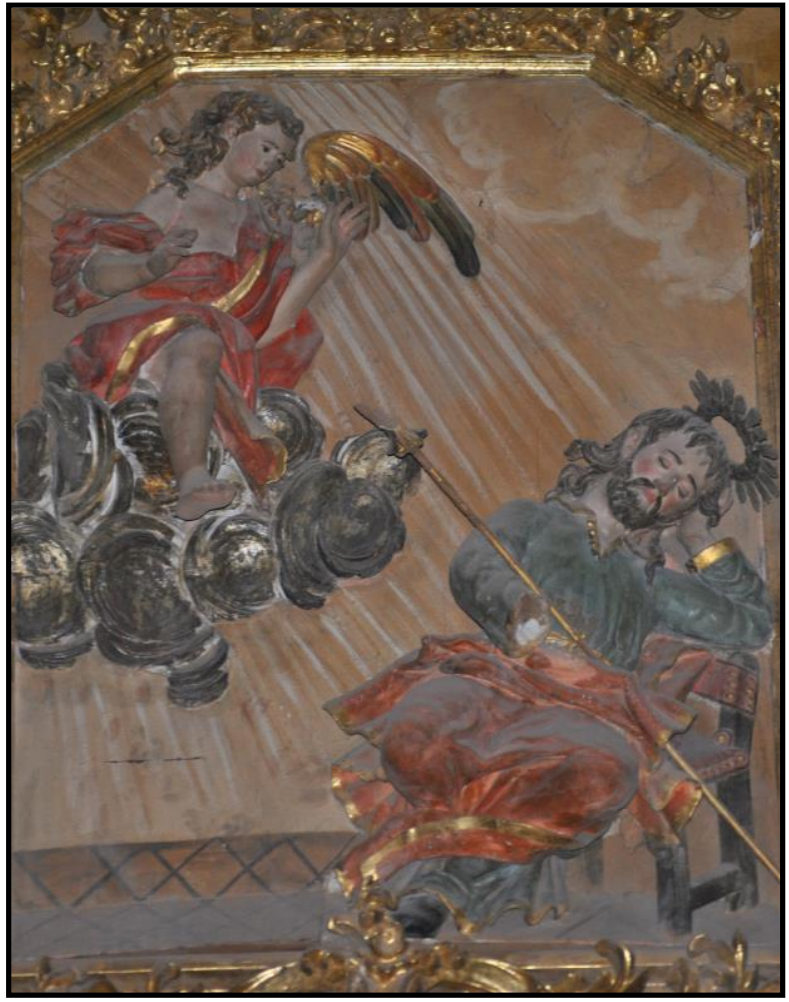

Fig. 163- Anónimo. El sueño de San José. Iglesia parroquial de los Santos Juanes. Nava del Rey (Valladolid).

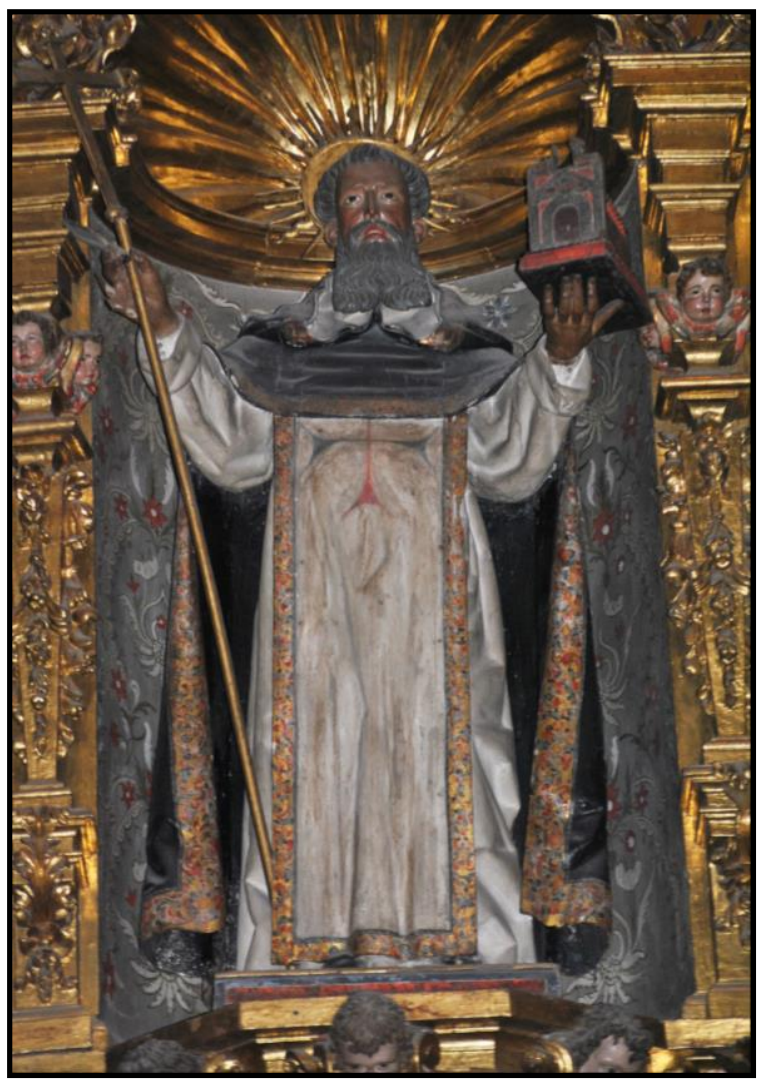

Fig. 165- Anónimo. San Félix de Valois. Iglesia de San Torcuato. Zamora.

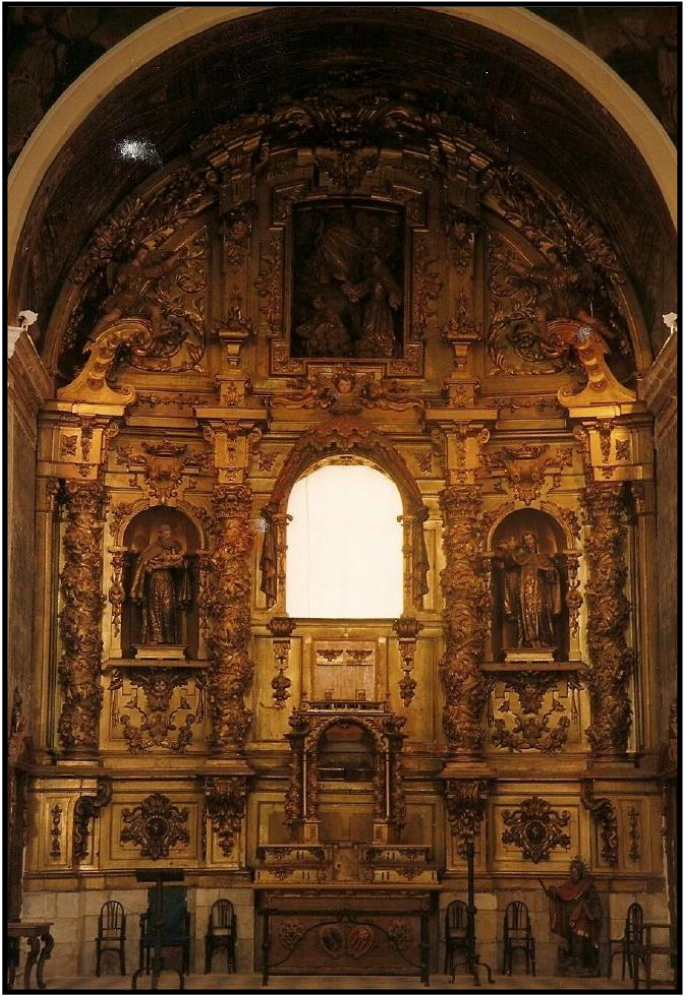

Fig. 164- Anónimo. Esculturas del retablo mayor. Iglesia conventual de la Concepción Francisca. Toro (Zamora).

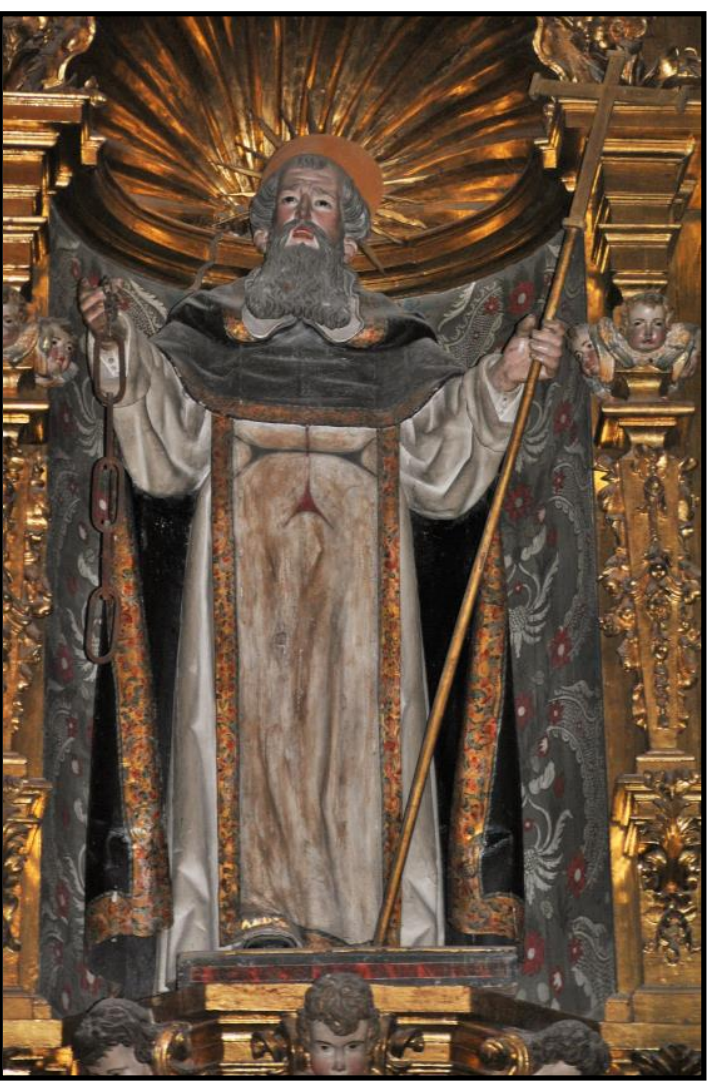

Fig. 166- Anónimo. San Juan de Mata. Iglesia de San Torcuato. Zamora.

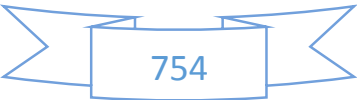




$$
\frac{\text { 6-DISCIPULOS DE }}{\underline{\text { JUAN DE ÁVILA }}}
$$


$\sum\left[\begin{array}{l}756 \\ 4\end{array}\right.$ 
Una escultura o pintura siempre es atribuida o documentada a favor de un solo artista, el maestro. Normalmente no corría por su parte la ejecución total de la obra, sino que delegaba en sus oficiales y aprendices. El maestro se encargaría de dar los modelos y finalmente de dar los trazos geniales al acabado. En otras ocasiones cuando el comitente era importante, el encargo correría totalmente a cuenta del maestro, pues no podía permitirse un fallo que le reportara malas opiniones. Los aprendices comenzaban a llegar al taller del maestro a la edad de 11 o 14 años, aunque siempre hay excepciones, generalmente por la fecha más alta. El grado de oficial, según Agulló Cobo, lo tendría completado hacia los 16-19 ${ }^{1}$. Por poner el ejemplo de Juan de Ávila: accedió al taller de Díez de Tudanca con 15 años, y finalizó su aprendizaje con 20.

El taller de Juan de Ávila debió de ser de medio tamaño puesto que, aunque poseamos muy pocas obras documentadas, no cabe duda de que fue uno de los talleres más solicitados y de mayor importancia en el Valladolid de finales del siglo XVII, los cuales seguían siendo los más prestigiosos del noroeste español. La importancia de este taller sería mucho mayor de confirmarse los numerosos encargos solicitados por parte de cenobios y particulares relacionados con la Orden Franciscana.

Por desgracia, tampoco son demasiados los aprendices que hemos podido documentar. Obviando la figura de su hijo Pedro, que lógicamente se formaría en el taller paterno, dos son los discípulos acreditados: Matías Ortiz y Francisco de la Vega. A estos me gustaría sumar, aunque no posea la escritura de asiento de aprendiz ni ninguna noticia que lo pueda confirmar, un nombre que pienso que con bastante probabilidad pudiera haberse formado bajo la tutela de Ávila. Se trata del vallisoletano Antonio de Gautúa, uno de los escultores más notables en el primer tercio del siglo XVIII en Valladolid, y que expandió su arte más allá de la misma; llegando incluso a la ribera arandina, comarca en la que se encuentra el Convento del Domus Dei de La Aguilera, para el cual trabajó Juan de Ávila. Además fue uno de los pocos artífices que fue capaz de esculpir la piedra, capacidad muy poco común entre los escultores vallisoletanos. A estos tres nombres habría que sumar José de Larra Domínguez que, en opinión de Albarrán Martín, bien pudo formarse con alguno de los "escultores de relevancia dentro del panorama castellano de la época, como Alonso y José de Rozas, Juan Antonio de la Peña o Juan de Ávila, activos en 1680"2. Cronológicamente hablando, el primero de ellos en llegar al obrador de Ávila fue Francisco de la Vega (4 de julio de 1674); a continuación llegaron Matías Ortiz (22 de febrero de 1677) y José de Larra Domínguez, por aquellas mismas fechas. Finalmente, Antonio Gautúa accedería al taller de nuestro escultor a mediados de la década de 1690. Un poco antes lo haría Pedro de Ávila.

1 AGUlló COBO, Mercedes: “El escultor Pedro Alonso de los Ríos...”, op. cit., p. 20. ALBARRÁN MARTÍN, Virginia: El escultor Alejandro Carnicero..., op . cit., p. 103. 


\section{6-1 FRANCISCO DE LA VEGA}

Francisco de la Vega, hijo de Pedro de la Vega, debió de nacer a comienzos de la década de 1660. El 4 de julio de 1674 el referido Pedro de la Vega y Juan de Ávila redactan la "escritura de aprendiz al oficio y arte de escultor", por la cual el primero de ellos metía en el taller de nuestro escultor a su hijo (DOCUMENTO 15). Ambas partes se convinieron en que el periodo de aprendizaje duraría cinco años que habrían de comenzar "desde hoy día de la fecha", al final de los cuales el aspirante debía estar "hábil a vista y declaración de dos oficiales del dicho oficio nombrados por cada parte el suyo". Ávila debía de mantener al aprendiz en su casa, es decir un aprendizaje interno, tiempo en el que le daría "de comer y cama a su costa". Francisco no podría ausentarse "de la casa y servicio del dicho Juan de Ávila su maestro y si lo hiciere se le haya de volver el dicho Pedro de la Vega dentro de ocho días de cómo hiciere dicha ausencia". Por el trabajo de enseñar el oficio Ávila percibiría 200 reales de vellón: 100 reales abonados ese mismo día y otra tanta cantidad "para el día del señor San Juan de junio del año que viene".

Con este escultor tenemos dos problemas: por un lado, no hemos logrado documentarle ninguna noticia biográfica ni artística; y por otro, hemos encontrado una serie de obras realizadas por un escultor, o varios, llamado, o llamados, Francisco de la Vega. Además, tampoco sabemos si ese escultor, o escultores, es el aprendiz de Juan de Ávila. A la espera de nuevos documentos que puedan dilucidar y separar las distintas personalidades, enumeraré las obras realizadas por estos escultores homónimos.

El primero de los "Francisco de la Vega" nos lo da a conocer Payo Hernanz. Este escultor, instalado temporalmente en los alrededores de Aranda de Duero (Burgos), procedía de Liérganes (Cantabria). Piensa el investigador burgalés que "debió probar fortuna en esta zona pero no decidió residir de continuo en ella,

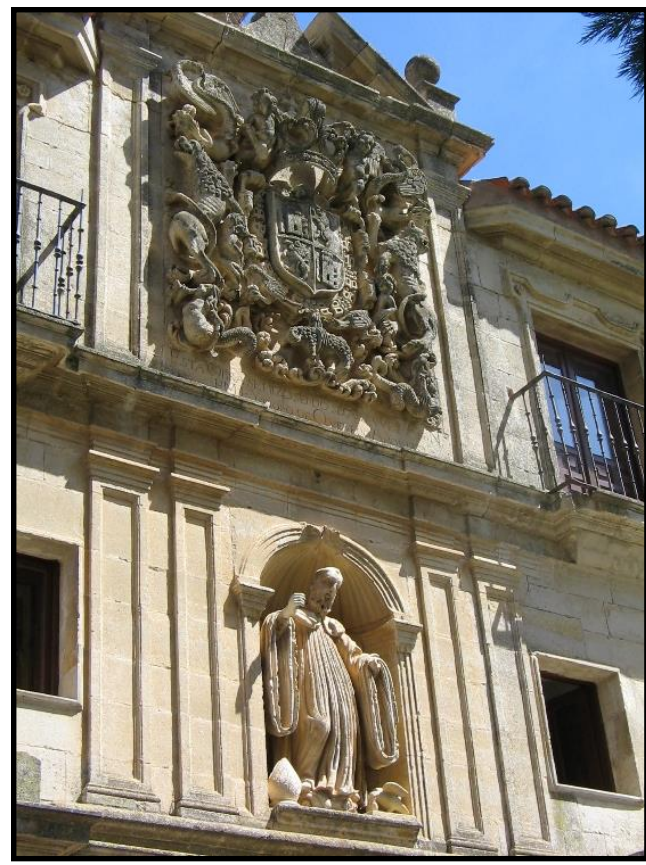

Il. 1- Francisco de la Vega. Santo Domingo y Escudo. Monasterio de Santo Domingo de Silos. Santo Domingo de Silos (Burgos). abandonándola, pues son escasas las producciones que de él hemos conseguido documentar" ${ }^{\prime 3}$. A este escultor, que debió de ser bastante diestro tanto en la talla de la madera como de la piedra, le pertenecerán un San Juan Bautista (1711) en la iglesia parroquial de San Juan del Monte (Burgos); un escudo (1722) de la fachada de la ermita de la Santísima Trinidad, de Fuentespina (Burgos); y otro escudo (1722) en el exterior del Monasterio de Santo Domingo de Silos, sito en la localidad burgalesa homónima.

3 PAYO HERNANZ, René Jesús: El retablo..., op. cit., Tomo II, p. 315. 
Por tierras cántabras trabajan otros escultores homónimos, que por la cronología de sus fechas podríamos llegar a pensar que se trata de la misma persona, la cual va vagando por la geografía norteña según va obteniendo contrato y sin poder establecerse en un lugar fijo. Efectivamente, en 1697 tenemos documentado que un tal Francisco de la Vega, vecino de Liérganes, esculpe una Asunción para la iglesia parroquial de Santa María de Miera (Cantabria). Además, en 1714, otro Francisco de la Vega, vecino de Solórzano "de la provincia de Trasmiera", se concierta con Pedro López, vecino de Limpias, para ejecutar el retablo mayor de la iglesia parroquial de Santecilla (Burgos), y en la misma, el retablo de la capilla de don Juan de Prieto Ahedo.

Resta una obra más realizada por un escultor llamado Francisco de la Vega, aunque la lejanía geográfica respecto a todas las anteriores apunta a que se trataba de otro artífice diferente. En definitiva, pienso que podríamos estar hablando de una horquilla de entre 2 ó 3 escultores homónimos. Dado que no sabemos si el aprendiz de Ávila fue uno de ellos, colocamos a continuación todas estas obras, seguidas de una breve reseña.

\section{$\underline{\text { Catálogo }}$}

1697. Asunción. Iglesia parroquial de Santa María de Miera (Cantabria). Se le pagaron por su ejecución 120 reales $^{4}$.

1705. Retablo mayor (Fig. 1). Iglesia parroquial de San Pedro. Estebanvela (Segovia). Este retablo fue realizado por los ensambladores y tallistas Juan Arauz y José Serna, y el escultor Francisco de la Vega ${ }^{5}$. El retablo, de clara raigambre churrigueresca, presenta las esculturas de San Pedro in cátedra (hornacina central), de un Santo obispo (lado del evangelio) y de San Antonio Abad, al cual acompaña el típico cerdito. Desconozco si las esculturas de la custodia también fueron realizadas por De la Vega. En ella aparecen un Santiago Matamoros rematándola, y en la puerta un relieve representando al Buen Pastor. Por fotografías, no por visión directa, podemos apreciar unas esculturas con una factura bastante seca y mediocre, y unos rostros muy anodinos. Sin embargo, llama la atención que en la hornacina central figure un San Pedro en cátedra, misma escultura que Juan de Ávila tuvo que tallar para el retablo mayor de la Colegiata de San Pedro de Lerma (Burgos).

1711. San Juan Bautista. Iglesia parroquial de San Juan del Monte (Burgos). Se trata de la imagen titular de la iglesia. Payo Hernanz la clasifica como una escultura de "caracteres claramente convencionales" .

1714. Retablo mayor y de la capilla de don Juan de Prieto Ahedo. Iglesia parroquial de Santecilla (Burgos). En 1714 don Juan de Prieto Ahedo, caballero de la Orden de

4 GONZÁlEZ ECHEGARAY, María del Carmen: Artistas cántabros de la edad moderna: su aportación al arte hispánico: diccionario biográfico-artístico, Institución Mazarrasa, Santander, 1991, p. 678.

5 http://www.pueblos-espana.org/castilla+y+leon/segovia/estebanvela/

6 PAYO HERNANZ, René Jesús: El retablo..., op. cit. Tomo II, p. 315.

$\begin{array}{r}759 \\ \hline\end{array}$ 
Santiago, del Consejo de Su Majestad y contador mayor de las órdenes militares, se concierta con Pedro López, vecino de Limpias, y Francisco de la Vega, vecino de Solórzano, para fabricar el retablo mayor de la parroquia de Santecilla, y el de la capilla que el propio noble poseía en dicho templo. Ambos artistas deberían hacer la obra en casa de este personaje ${ }^{7}$.

1722. Escudo. Ermita de la Santísima Trinidad. Fuentespina (Burgos). Zaparaín Yáñez lo describe de la siguiente manera: "sobre el arco de triunfo que protege el acceso puede verse un frontón semicircular interrumpido para acoger un bello escudo, excelentemente efectuado por Francisco de la Vega en 1722. Aparece enmarcado por un baquetón mixtilíneo que destaca del fondo fuertemente almohadillado e invade la rosca del arco inferior que prolonga el eje alrededor del cual se articula la portada, la corona real y el toisón que completan este elemento heráldico con las armas de la villa han hecho creer en la existencia de un patrocinio regio no constando documentalmente"8. El escudo presenta la corona real y el toisón, y las armas de Castilla, León y Fuentespina. Tradicionalmente se ha pensado que la monarquía pudo haber contribuido en esta obra, extremo que no se ha podido confirmar. Quizás, el escudo, pueda interpretarse como el del Concejo de Fuentespina, patrono de la ermita, que incorpora el toisón y la corona al ser una villa de realengo 9 .

1722. Santo Domingo y dos escudos y otras esculturas y relieves (Fig. 2). Monasterio de Santo Domingo de Silos. Santo Domingo de Silos (Burgos). En 1722 un tal Francisco de la Vega, acompañado de otro escultor anónimo, se encarga de esculpir para la portada del monasterio dos escudos y la imagen de Santo Domingo de Silos, por las cuales se les pagó 55 reales; poco después se le dieron otros 40 reales más por componer un tercer escudo seguramente originario de la construcción demolida- que se había quebrado. Finalmente, el conjunto se vio enriquecido con la labra, también por De la Vega de las esculturas de la beata Juana de Aza, un cautivo liberado, una imagen alegórica de la Fama y dos reyes benefactores de la abadía, por todo lo cual recibieron 650 reales más. Junto con ello abriendo dos cuadros en el muro maestro que no habían sido previstos en el proyecto original, donde se alojaron dos relieves de la vida del santo abad, labores por las que percibieron cinco reales diarios ${ }^{10}$.

\footnotetext{
7 MARTÍN GONZÁLEZ, Juan José: Escultura barroca en España..., op. cit., pp. 471-472.

ZAPARAÍN YÁÑEZ, María José: Desarrollo artístico..., op. cit., Tomo II, p. 418.

ZAPARAÍN YÁÑEZ, María José: Fuentespina: la villa y su arte, siglos XVII y XVIII, EMAN, San Sebastián, 1995, p. 117.

10 "Ítem pagué a Francisco de la Vega, escultor, por hacer los dos escudos y el santo, once doblones, y por componer el que se quebró cuarenta reales. Ítem al dicho y su compañero por hacer los dos reyes, Doña Juana, captivo y Fama, seiscientos y cincuenta reales. Ítem a los dichos por diez y seis días que se ocuparon en abrir los dos cuatros, a diez reales, ciento y sesenta reales. Y nuestro padre abad les dio de guantes setenta y cinco reales". PALACIOS PALOWDAR, César Javier: Patrimonio artístico y actividad arquitectónica del Monasterio de Santo Domingo de Silos (1512-1835), Universidad de La Laguna, La Laguna, 2000, p. 220.
} 


\section{6-2 MATÍAS ORTIZ}

Matías Ortiz debió de nacer hacia el año 1665, ya que cuando el 22 de febrero de 1677 firma el asiento de aprendiz contaba con “doce años, poco más o menos". El referido día, Juan de Ávila y Gregorio Partearroyo, quizás familiar o curador del muchacho, ajustan que el artista debía de enseñar a Matías Ortiz el oficio de escultor "por tiempo y espacio de siete años que han de comenzar a correr y contarse desde hoy día de la fecha" (DOCUMENTO 19). Ortiz debería residir en casa de su maestro ya que habría de "asistir en casa y servicio del dicho Juan de Ávila y le ha de dar de comer y ropa limpia y curarle las enfermedades que en el discurso del dicho tiempo tuviere"; además se especifica que Partearroyo proporcionaría a su joven un colchón y una manta. De la ropa necesaria para vestir y calzar se ocuparían las dos partes: los cuatro primeros años correrían a cargo de Partearroyo y los tres últimos de Juan de Ávila. Nuestro escultor percibiría por la instrucción del adolescente 400 reales de vellón, los cuales se le abonarían el día de Nuestra Señora del mes de marzo de ese mismo año. No tenemos más noticias acerca de su biografía ni de su carrera profesional. No le hemos podido documentar ninguna obra.

\section{6-3 ANTONIO DE GAUTÚA}

Si observamos los rostros, pliegues y modelos que utiliza Antonio de Gautúa a lo largo de su carrera, vemos que son plenamente deudores de los Ávila. En un principio tuve dudas acerca de si atribuir su formación a Juan de Ávila, o a su hijo Pedro; sin embargo, una vez localizada la partida de nacimiento de Gautúa, queda claro que de ser aprendiz de uno de estos lo fue de Juan puesto que nació tan solo cuatro años después que Pedro de Ávila.

A estas razones puramente formales habría que añadir otros datos puesto que no hemos logrado encontrar ningún documento en el que se nos insinúe tal aprendizaje. Me refiero al hecho de que en la iglesia de San Felipe Neri, cuando Pedro y Manuel de Ávila trabajaron en los retablos de las capillas de la iglesia, también lo hizo Antonio de Gautúa, el único escultor ajeno a esta familia que laboró en ellos. Si nos fijamos bien en estas esculturas que talló (cuatro santos y dos relieves de la vida de la Virgen), especialmente en ciertos detalles de los relieves podríamos creer, de no conocer que son de Gautúa, que fueron realizados por Pedro de Ávila. Me refiero, concretamente, al rostro de la Virgen de los Desposorios; al del San Joaquín y el ángel del Abrazo ante la Puerta Dorada; y, sobre todo, a los del Ángel de la Guarda y el niño que la acompaña. Todo ello me lleva a pensar que la participación de Gautúa se debía a una posible amistad con los hermanos Ávila, sobre todo con Pedro por evidentes motivos de edad, que se había fraguado en los años en que ambos coincidieron en el taller de Juan de Ávila.

Tampoco es desdeñable el hecho de que tanto Antonio de Gautúa como Pedro de Ávila se encargaran de tasar de manera conjunta las esculturas de un personaje fallecido. 
Concretamente, el 6 de junio de 1721 tasaron las imágenes que dejó el mesonero Juan Antonio Sanz de Cabezón ${ }^{11}$. Un último dato que nos podría hablar de la cercanía entre Gautúa y los Ávila es el relativo a la fabricación de unos ángeles para el órgano de la iglesia de San Pedro de Tordesillas en el año $1715^{12}$. En este caso Gautúa aparece contratando la obra junto a un tal José de Ávila. Al no tener documentado ningún escultor con tal nombre, he creído que pudo ser un error del escribano y en realidad tratarse de Pedro o de Manuel, que por aquellas fechas trabajaban en Tordesillas y en sus alrededores.

Sea como fuere, el estilo de Antonio de Gautúa viene a ser una mezcla de los de Juan y Pedro de Ávila, al que añade su propia impronta. Sus esculturas, por lo general, suelen ser bastante pausadas, no existiendo movimientos acentuados. A pesar de las fechas en que desarrolla su magisterio, en su obra no tienen cabida los pliegues "a cuchillo", tan

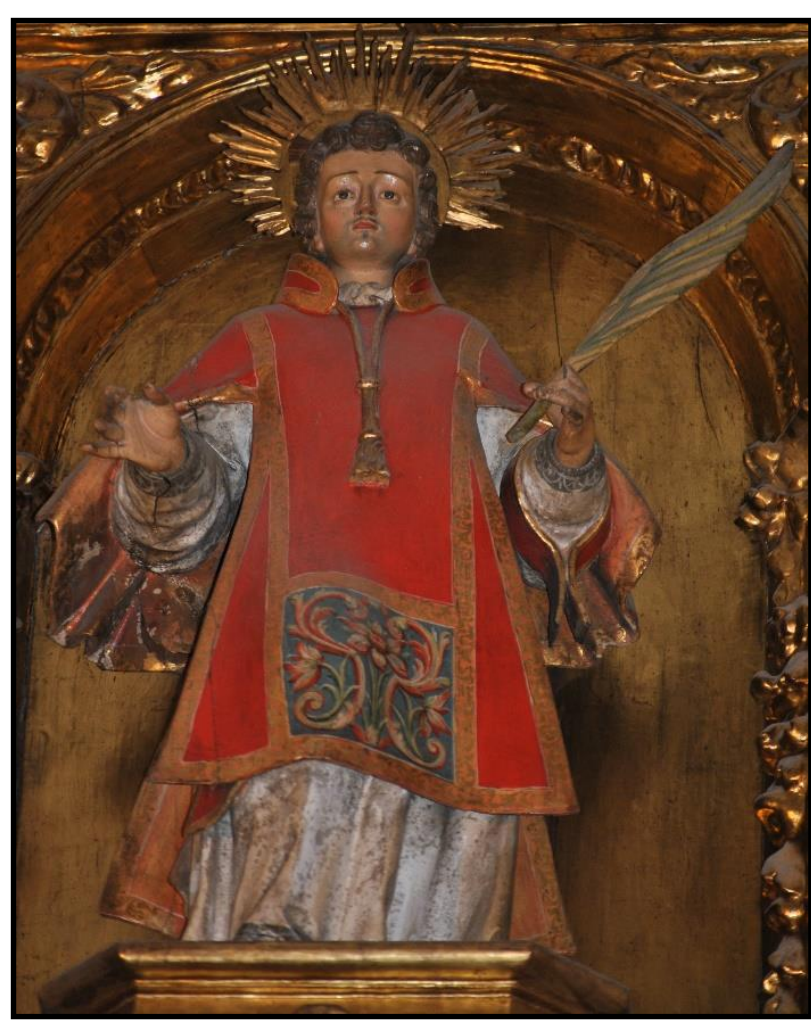

Il. 2- Antonio de Gautúa. San Lorenzo. Oratorio de San Felipe Neri. Valladolid. típicos, por otra parte, del estilo de su compadre Pedro de Ávila. Los pliegues utilizados por Gautúa derivan directamente de los utilizados por los escultores vallisoletanos de finales del siglo XVII, si bien en alguna ocasión podemos ver que coquetea con los de "cuchillo", pero sin llegar a completarlos. Un detalle presente en la mayor parte de su producción es el hecho de que sus personajes adelanten una pierna, motivo también presente en la obra de los Ávila.

Para las cabezas, gusta de amplias cabelleras con bucles, a lo Juan de Ávila; o con el pelo algo más liso a base de grandes líneas, como Pedro de Ávila. También de su supuesto maestro proceden los rostros, aunque en su caso no adoptan la forma ovoide sino que tienden más a un cuadrado un poco alargado. Asimismo, las narices talladas por Gautúa poseen un tabique nasal bastante más ancho que lo exhibido por su probable maestro, pero, asimismo, es totalmente similar a las de su amigo Pedro de Ávila. De todas formas, pareciera como si a largo de su carrera, Gautúa adoptara un "segundo estilo", en el cual los rostros se achaparraran un tanto. Algo más que una simple similitud podemos detectar cuando comparamos la barba de caracolas rizadas con que efigia a su San Pedro de la iglesia

$11 \quad$ A.H.P.V., Leg. 2.395, ff. 729-730.

12 ARA GIL, Julia y PARRADO DEL OLMO, Jesús María: Catálogo Monumental de la provincia de Valladolid. Tomo XI..., op. cit., p. 234. 
homónima de Tordesillas y los San Pedros que Pedro de Ávila talla para las iglesias vallisoletanas de San Felipe Neri y del Santísimo Salvador. Es más, parece una versión de este último, el que conforma el paso conocido como Las lágrimas de San Pedro. Otra similitud la tenemos en el rostro del San Isidro que talla para la localidad vallisoletana de Cervillego de la Cruz. De él podríamos decir que pareciera realizado por Pedro de Ávila pero con una calidad sensiblemente más baja, tal es su parecido.

Sus relieves tienen mayor interés que los de Juan de Ávila, aunque solo sea por el hecho de que en ellos hay mucho más valor escultórico, quedando la pintura muy diluida. En sus relieves vemos que las figuras son eso, relieves, y no bultos redondos pegados contra el tablero. Los dos que talló para otros tantos áticos de los retablos de las capillas del cuerpo de la iglesia del Oratorio de San Felipe Neri son muy sugestivos por la diversa gradación de los relieves y su policromía.

Que fue un escultor polivalente lo refleja el hecho de que trabajara tanto la madera como la piedra, cualidad muy importante puesto que, en esta ciudad, desde Francisco del Rincón, no habían existido escultores capaces de tallarla. A la vista del escueto catálogo, que seguramente se ampliará en tiempos venideros, podemos comprobar como las obras más destacadas de su producción son, precisamente, los Padres de la Iglesia que esculpió para la fachada de la seo vallisoletana. Da la casualidad de que en estas monumentales esculturas sí que aparecen los pliegues "a cuchillo"; asimismo el escultor varía su forma de componer las barbas, formándolas a partir de largas guedejas

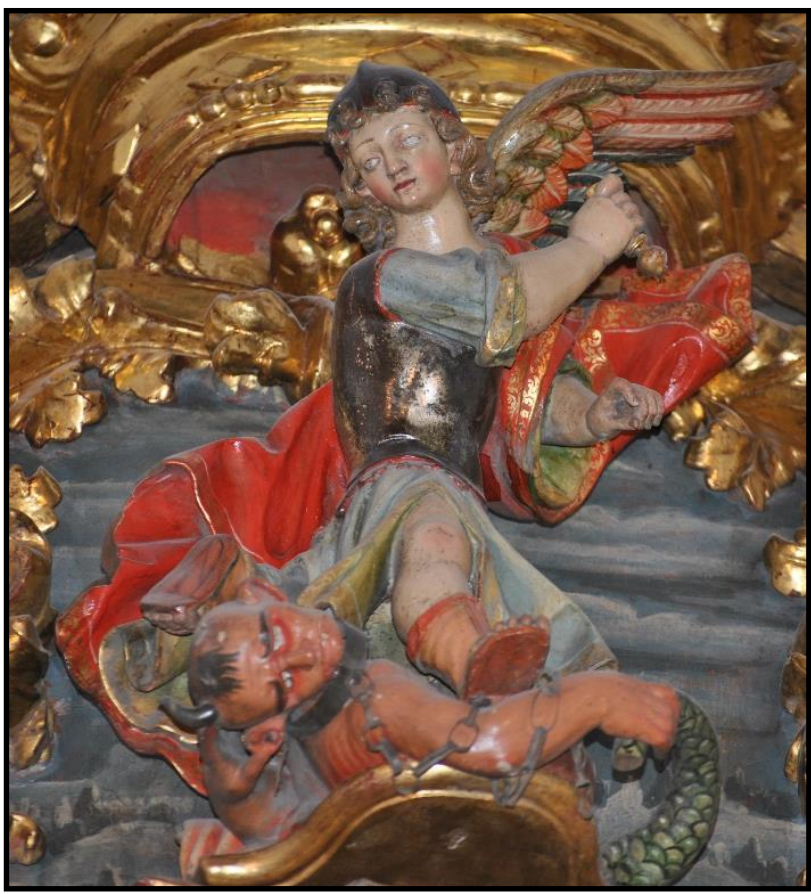

Il. 3- Antonio de Gautúa. San Miguel venciendo al demonio. Oratorio de San Felipe Neri. Valladolid. agrupadas que forman trazas sinuosas, y desaparecen los volúmenes compactos.

Una vez trazado su estilo a grandes rasgos, a la espera de que algún investigador se interese por estudiar la obra de este digno escultor vallisoletano, procedemos a mostrar los datos concretos que sobre él poseemos, que no son pocos:

Antonio de Gautúa nace en Valladolid el 8 de septiembre de $1682^{13}$, siendo bautizado el 11 de octubre de ese año en la iglesia de Santiago ${ }^{14}$. Sus padres fueron el tratante de fruta

13 Su primer apellido lo encontraremos escrito de formas muy diversas. Si bien lo más común es que aparezca "Gautúa", en otras muchas ocasiones es "Gaute". De manera muy minoritaria lo veremos como "Gautrías" o "Gautica".

14 "En once de octubre de mil seiscientos y ochenta y dos años yo Mateo González teniente de cura de la parroquial de señor Santiago de ésta ciudad de Valladolidbauticé e impuse los santos óleos como el 
Antonio Fernández de Gaute (otras veces nombrado simplemente como Antonio de Gautúa) y Francisca de Mendoza, los cuales eran moradores del Corral de Falaguer, también conocido como corral de los fruteros ${ }^{15}$. Antonio fue el hijo menor de una extensa serie de hermanos: la mayor era María (6 de diciembre de 1670), a quienes siguieron Antonio "primero" (21 de noviembre de 1671), Antonia (15 de febrero de 1675), Manuel "primero" (24 de diciembre de 1675), Bernardo (16 de marzo de 1677), Teresa (13 de abril de 1678), Manuel "segundo" (18 de mayo de 1679), Juan Antonio (27 de enero de $1681)^{16}$ y Manuela.

La cercanía entre la casa paterna de Gautúa y el taller de Ávila conllevaría a que el padre de éste y el escultor se relacionaran, lo que propiciaría que el pequeño ingresara hacia los años 1694-1696 en el obrador de nuestro artista. Por estas mismas fechas conocería a Pedro de Ávila, el cual estaría terminando su formación artística junto a su padre, o, quizás, se encontrara ayudándole en calidad de oficial.

La primera noticia que poseemos de nuestro escultor data de 1709, año en que Gautúa se encontraba preso en la cárcel real "de orden y mandado del señor licenciado D. Pedro Afán de Rivera del Consejo de su Majestad y su oidor de la Real Audiencia y Chancillería, juez de fraudes de la renta y estancos de tabaco de esta ciudad y sus partidos". El día 24 de mayo de ese año se ordena su liberación con la condición de que otorgara fianza carcelaria. Dos días después, Gautúa cumplió con la ley y dio como fiador al maestro sastre Francisco Martínez, el cual le "recibía de dicha prisión como carcelero conventariense", obligándose a devolver a Gautúa a prisión siempre y cuando "dicho señor don Pedro Afán de Ribera juez de su causa" se lo mandare ${ }^{17}$.

El 24 de mayo de 1714 tasa las esculturas que dejó al fallecer Juana Martín, mujer de Roque de Benavente ${ }^{18}$. Le volveremos a ver ejercer esta tarea en otras tres ocasiones: la primera de ellas el 6 de junio de 1721, de manera conjunta con Pedro de Ávila. Los bienes a valuar eran las esculturas que había dejado al fallecer el mesonero Juan Antonio Sanz de Cabezón ${ }^{19}$. Gautúa había sido nombrado tasador por parte de Josepha Novia y Juan Antonio Gago, mientras que Ávila lo fue por Juan Antonio Soto. Las otras dos tasaciones las realizó en el año 1728: el 14 de febrero estimó las "pinturas de bulto" que quedaron tras el fallecimiento de María Prieto de la Fuente ${ }^{20}$, otorgando cuatro días después carta

\footnotetext{
santo concilio manda a un niño hijo legítimo de Antonio Fernández de Gaute y doña Francisca de Mendoza parroquianos de ésta dicha parroquia al Corral de Fruteros pusieronle por nombre Antonio que nació en ocho de septiembre de éste presente año según me lo aseguraron sus padrinos que lo fueron el licenciado Juan de Mazuelas e Isabel Fernández dieronle por abogados a Nuestra Señora y a San José fueron testigos Nicolás Fernández y Antonio Ortiz y lo firmé”. A.G.D.V., Santiago, 1668B, f. 328.

15 A.H.P.V., Leg. 2.738, ff. 108-111.

16 A.G.D.V., Santiago, 1668B, ff. 56, 87, 167, 187, 217, 240, 259 у 294.

17 A.H.P.V., Leg. 3.014/1, f. 6.

18 A.H.P.V., Leg. 3.125, f. 121.

19 A.H.P.V., Leg. 2.395, ff. 729-730

20 A.H.P.V., Leg. 3.336, f. 81. 
de pago en razón de los 8 reales que se le abonaron por tal trabajo ${ }^{21}$. Ya el 27 de junio tasa las esculturas que le restaron a su muerte a Isidoro Pérez ${ }^{22}$.

En 1717 trabaja para el Ayuntamiento, como años antes lo había hecho su probable maestro. Efectivamente, le vemos colaborando en los preparativos para la celebración de la fiesta del Corpus Christi del año 1717, en concreto se ocupa de realizar "la cabeza de la tarasca las garras cola y las siete figuras que suban en ella"23.

El 27 de junio de 1722 contrae matrimonio con Clara Rodríguez en la parroquia de San Lorenzo $^{24}$, actuando como testigos sus amigos los ensambladores Juan y Pedro Correas. Posteriormente, el 13 de junio de 1723, la pareja fue velada en la misma iglesia, figurando nuevamente como testigo Juan Correas ${ }^{25}$.

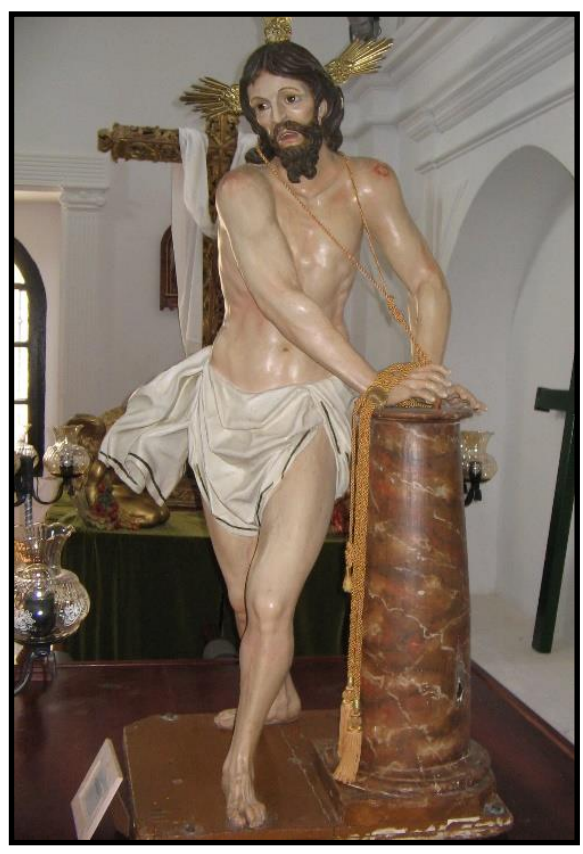

Il. 4- Melchor García. Cristo atado a la columna. Ermita de la Vera Cruz. Carrión de los Condes (Palencia).

El 8 de febrero de 1724 recibe en su taller como aprendiz a Melchor García, uno de los pilares de la retablística y escultura riosecana y terracampina de mediados del siglo XVIII ${ }^{26}$. La escritura de aprendizaje reglaba que el joven asistiría "en casa de dicho Antonio de Gautúa como aprendiz de dicho oficio de escultor por tiempo y espacio de cinco años", que empezarían a correr desde ese mismo día. Melchor debía de obedecer a su maestro en todo lo que "le mandare en lo tocante y perteneciente a dicho oficio y servidumbre de su casa según y cómo lo han hecho y hacen los demás aprendices". Durante el tiempo que estuviere bajo su aprendizaje, Gautúa se comprometía a darle "de comer y ropa limpia". Por el trabajo de enseñanza, Melchor García y su madre le abonarían 200 reales de vellón: la mitad "en que se regula una cama de ropa que lleva el dicho Melchor García en que ha de dormir", y los otros cien reales restantes "en los días y partidas que pudiere dentro de dichos cinco años".

El primer matrimonio sería breve ya que su mujer fallecería por estos años sin haber logrado descendencia. La viudedad no se prolongó demasiado ya que al poco tiempo contrajo segundas nupcias con la tordesillana Manuela García, seguramente en un momento en el que el escultor se encontraba trabajando en la villa, quizás en el San Pedro que preside el retablo mayor de la iglesia homónima ${ }^{27}$. El 28 de octubre de 1727 se firman

\footnotetext{
$21 \quad$ A.H.P.V., Leg. 3.350/3, f. 25.

22 A.H.P.V., Leg. 3.412, ff. 142, 149 y 151.

23 CALLEJA GAGO, Rosa María: Gobierno municipal, siglo XVIII, Ayuntamiento de Valladolid, Valladolid, 1993, p. 119.

$24 \quad$ A.G.D.V., San Lorenzo, 1671M, f. 131.

25 A.G.D.V., San Lorenzo, 1671M, f. 133.

26 A.H.P.V., Leg. 3.326/2, ff. 493-494.

27 ARA GIL, Clementina Julia y PARRADƠ DEEL OLMO, Jesús María: Catálogo Monumental de la provincia de Valladolid. Tomo XI..., op. cit., p. 213.
} 
las capitulaciones matrimoniales de la futura pareja ${ }^{28}$. Gautúa se comprometía a aportar al matrimonio 500 ducados "en obra que tiene hecha de escultura y bienes muebles" que habrían de ser tasados por personas peritas. Además "por ser la dicha Manuela García doncella y en cabello honesta virtuosa recogida y de loables costumbres y de honrados padres y parientes y por otras justas causas que a ello le mueven la dota y manda en arras proternúpcias ciento y cincuenta ducados de vellón". Tan solo un día después se celebran los desposorios en la iglesia de Santa María de Tordesillas ${ }^{29}$; posteriormente, el 10 de febrero de 1728, las velaciones tuvieron lugar en la iglesia de San Lorenzo de Valladolid $^{30}$, actuando nuevamente como testigo Pedro Correas. El matrimonio tuvo tres hijas: Teresa Rafaela (1731), Antonia Francisca (1734) ${ }^{31}$ y Manuela Dorotea Gautúa (1736), todas ellas bautizadas en la iglesia de San Lorenzo de Valladolid. Urrea sospecha que durante su estancia tordesillana bien pudo haber tenido por aprendiz u oficial a Felipe Espinabete $^{32}$.

El 18 de mayo de 1729 recibe en su taller como aprendiz a Manuel García, natural de la villa de Pozo de Urama (Palencia) ${ }^{33}$. El muchacho debía de permanecer bajo el magisterio de Gautúa seis años "que han de empezar a correr y contarse desde el día de San Juan de junio que viene de este año". Durante cinco de ellos se formaría como escultor, pudiendo así el sexto año "trabajar por mesero", pagándole su maestro 30 reales de vellón "al fin de cada mes, o en la forma que pueda el susodicho". Durante los seis años del aprendizaje Gautúa le daría de comer y ropa limpia "según es costumbre", cobrando asimismo por el trabajo de enseñanza del muchacho 250 reales de vellón.

Un mes después, el 16 de junio, ostentando el cargo de alcalde de la Cofradía de Jesús Nazareno, conjuntamente con el dorador y estofador Bonifacio Núñez, decide que "para

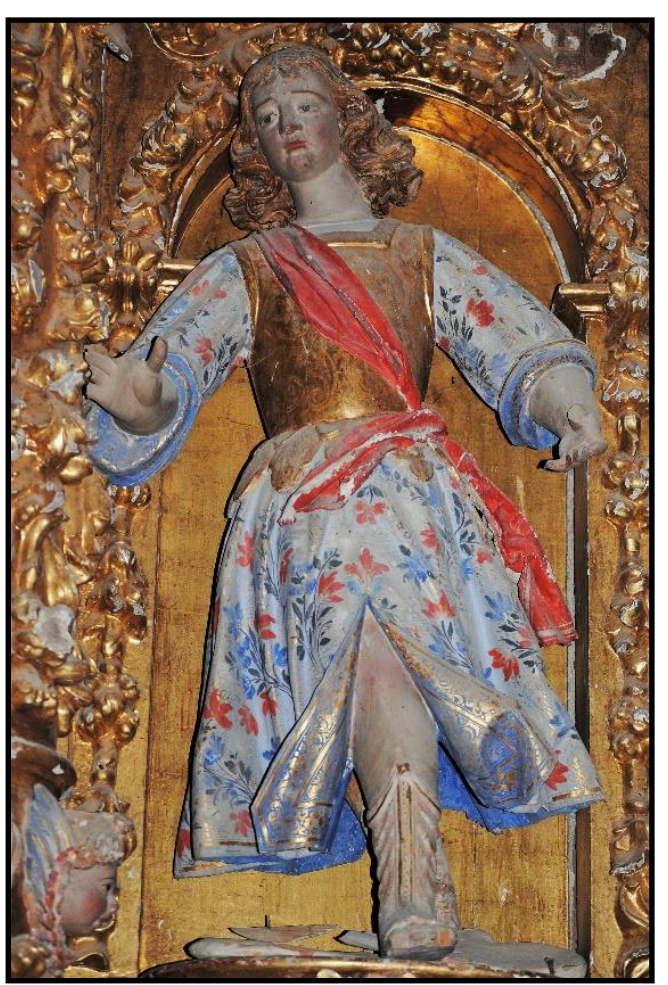

Il. 5- Antonio de Gautúa. Ángel Mancebo. Ermita de Castilviejo. Medina de Rioseco (Valladolid). que se extendiese más la devoción de Jesús Nazareno (...) tirar e imprimir unas estampas

\footnotetext{
28 A.H.P.V. Leg. 5.456, ff. 64-66 (1727).

29 A.G.D.V., Tordesillas, Santa María, 1691M, f. 138.

$30 \quad$ A.G.D.V., San Lorenzo, 1671M, f. 147.

31 A.G.D.V., San Lorenzo, 1728B, ff. 18 y 30.

32 URREA FERNÁNDEZ, Jesús: "Nuevos datos y obras del escultor Felipe de Espinabete (17191799), B.S.A.A., tomo LI, 1985, p. 508.

33 A.H.P.V., Leg. 3.326/2, ff. 777-778. Este escultor pudiera ser el importante escultor radicado en Palencia que talló obras tales como la interesantísima sillería y la cajonería de la iglesia de Santa Eufemia de Autillo de Campos en 1744. GARCIA CHICO, Esteban: Documentos para el estudio del arte en Castilla. 2..., op. cit., pp. 434-435.
} 
de su efigie, para lo cual se la puede pedirle lámina al señor Pablo López" ${ }^{34}$. Siendo todavía alcalde de Jesús Nazareno, el 2 de junio de 1730, realiza un pedimento al ayuntamiento en el cual le suplica "se sirva mandar que dicho mayordomo me dé la limosna que fuere su agrado por estar aplicado al culto y mayor adorno de dicha iglesia" 35 . En él dejaba entrever que la cofradía andaba escasa de fondos y necesitaba dinero para comprar la cera necesaria con la que adornar las funciones de sermones durante la Cuaresma. El ayuntamiento contestó a esta súplica concediendo a la cofradía ocho libras de velas. Finalmente, el 12 de junio Gautúa recibía de éste "cuatro libras de cera blanca o el precio de ellas en recompensa de la que dicha cofradía gastó en la cuaresma de este presente año con el motivo de la asistencia de esta ciudad en su iglesia a los sermones de ella". Años después, en 1734, trabaja para la referida cofradía reparando la talla de Cristo del Despojo del paso del Redopelo, que su posible maestro había esculpido hacía medio siglo ${ }^{36}$.

El 14 de octubre de 1731 actúa como testigo en el testamento que otorga el dorador Cristóbal Martínez de Estrada en virtud del poder que le había entregado su mujer, Agustina Hernández, por encontrarse muy grave y no poder testar por ella misma ${ }^{37}$. Debió de ser muy amigo del dorador puesto que en el testamento otorgado por este último se señala que le había prestado dinero a Gautúa, concretamente 135 reales de vellón que debía de devolverle a la máxima brevedad ${ }^{38}$.

El 31 de octubre de 1731 recibe a un nuevo aprendiz en su taller. Este día se ajusta con Joseph Rodríguez para instruir a su hijo Francisco Rodríguez, a lo largo de "tres años y medio que han de empezar a correr y contarse desde el día de Navidad de este presente año". Gautúa se comprometía a darle "enseñado todo lo perteneciente a dicho oficio hábil y capaz para poder trabajar como oficial", y a alimentarle y darle cama y ropa limpia "sin que por razón de dicha enseñanza se me haya de dar cosa alguna estándolo como ha de estar precisa y necesariamente asistiendo el dicho Francisco Rodríguez en mi casa y obrador como tal aprendiz, a dicho ejercicio y demás que se ofrezca"39. Entre los testigos de la escritura figuran los ensambladores Manuel Rodríguez y Cayetano Jiménez.

El 13 de abril de 1733 Antonio de Gautúa actúa como testigo en un pleito que sostiene el dorador Manuel Díez de Aragón a la hora de vender una casa que éste tenía en la plazuela de la Santísima Trinidad ${ }^{40}$.

El 6 de mayo de 1737 "estando enfermo en cama de la enfermedad corporal que Dios nuestro señor ha sido servido de me dar pero en mi sano juicio y entendimiento natural"

34 MARTÍN GONZÁLEZ, Juan José y URREA FERNÁNDEZ, Jesús: Catálogo Monumental de Valladolid. Tomo XIV ..., op. cit., p. 224.

35 A.M.V., Caja 51-1, f. 32.

36 ARRIBAS ARRANZ, Filemón: La Cofradía Penitencial..., op. cit., p. 81.

37 A.H.P.V., Leg. 3.328, ff. 895-596.

38 "Ítem declaro me debe Antonio de Gautúa vecino de esta ciudad ciento y tantos reales de vellón que resultará lo líquido del papel que me tiene hecho a mi favor mando se cobre". FERNÁNDEZ DEL

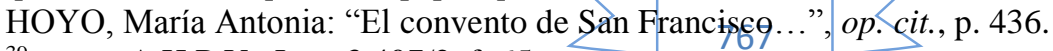

39 A.H.P.V., Leg. 3.407/2, f. 65.

40 A.H.P.V., Leg. 3.407, ff. 202-206 (1733). 
otorga testamento, extremo que, como veremos posteriormente, negará haber hecho ${ }^{41}$. En él ordenaba ser enterrado, "con el hábito de Nuestro Padre San Francisco", en la iglesia de San Lorenzo. El testamento nos aporta un dato interesante, y a su vez algo muy frecuente entre los artistas de la época: su militancia en numerosas cofradías, algunas de ellas de carácter penitencial: era diputado de la Cofradía de la Santa Vera Cruz, de la de Nuestra Señora de la Pasión y de la de Jesús Nazareno; también era miembro de la de San Lucas. Para cumplir el testamento nombraba como albaceas a su mujer y a su buen amigo Pedro Correas. Asimismo, instituía como herederas a sus tres hijas. Finalmente, dejaba ordenado que "por el mucho amor y cariño y satisfacción que siempre he tenido y tengo a dicha $D^{a}$ Manuela García mi mujer y este a las referidas mis hijas y suyas la nombro por tutora y curadora de las personas y bienes de las susodichas". Entre los testigos de la escritura figura nuevamente Cayetano Jiménez, que debía ser buen amigo del escultor, y el también ensamblador Bernardo Hernández.

Esta enfermedad no pudo con él ya que un mes después, el 26 de junio de 1737, el escultor y su mujer toman "en renta y arrendamiento" del Real Hospital de Santa María de Esgueva una casa "que a dicho Real Hospital frontero al Convento de Santa Ana pertenece en la que ha vivido Pedro Correas vecino de esta ciudad que hace esquina a dicho convento" ${ }^{42}$. El contrato tenía una duración de 4 años, pagando en cada uno de ellos 16 ducados de vellón.

Finalmente, Antonio de Gautúa muere el 30 de julio de 1744, siendo enterrado en la parroquia de San Lorenzo ${ }^{43}$. Murió "muy pobre".

\section{$\underline{\text { Catálogo }}$}

1712. Cuatro ángeles y tres marcos para el retablo mayor. Iglesia de San Lorenzo. Valladolid $^{44}$.

1714-1715. Nuestra Señora de la Consolación y dos ángeles mancebos (Figs. 3-5). Ermita de Nuestra Señora de Castilviejo. Medina de Rioseco (Valladolid) ${ }^{45}$.

1715. Ángeles para el órgano. Iglesia de Santa María. Tordesillas (Valladolid) ${ }^{46}$.

\footnotetext{
$41 \quad$ A.H.P.V., Leg. 3.425, ff. 508-509.

42 A.H.P.V., Leg. 3.425 , f. 493.

43 "En treinta días del mes de julio de mil setecientos y cuarenta y cuatro se enterró en esta parroquia Antonio de Gautúa en sepultura de la fábrica no hizo testamento por no tener de qué y haber muerto muy pobre y para que conste lo firmo dicho día, mes y año”. A.G.D.V., San Lorenzo, 1671D, f. 191.

44 URREA FERNÁNDEZ, Jesús: “Archivos parroquiales”, B.S.A.A., Tomo XXXVII, 1971, p. 516.

45 GARCÍA CHICO, Esteban: Catálogo Monumental de ta provincia de Valladolid. Tomo I..., op. cit., p. 191.

46 ARA GIL, Clementina Julia y PARRADO DEL OLMO, Jesús María: Catálogo Monumental de la provincia de Valladolid. Tomo XI..., op. cit., p. 234
} 
1718. San Francisco Javier y San Isidro Labrador. Iglesia parroquial de San Juan Bautista. Cervillego de la Cruz (Valladolid) ${ }^{47}$.

1722-1725. Esculturas y relieves para los retablos del cuerpo de la iglesia (San Miguel, San Rafael, San Lorenzo, San Esteban, Abrazo ante la Puerta Dorada y Desposorios de la Virgen) (Figs. 6-9). Iglesia de San Felipe Neri. Valladolid ${ }^{48}$.

1725. Santa Bárbara (Fig. 10) para la iglesia de San Benito el Viejo. Iglesia de San Martín. Valladolid ${ }^{49}$.

1726. Asunción para el retablo mayor. Iglesia parroquial de la Asunción. Mambrilla de Castrejón (Burgos) ${ }^{50}$.

1727. San Pedro en cátedra (Fig. 11). Iglesia de San Pedro, Tordesillas (Valladolid) ${ }^{51}$.

1729. El Salvador (Fig. 12). Iglesia del Salvador. Tiedra (Valladolid) ${ }^{52}$.

1731. San Millán (Fig. 13). Iglesia parroquial de San Millán. Velliza (Valladolid) ${ }^{53}$.

1732. Esculturas de San Jerónimo y San Gregorio (Figs. 14-15) para la fachada principal. Catedral. Valladolid ${ }^{54}$.

1736. Santísima Trinidad (Fig. 16) para la fachada. Ermita de la Santísima Trinidad. Fuentespina (Burgos) ${ }^{55}$.

A todas estas obras documentadas, y por comparación estilísticas, creo que se le podrían atribuir un San Roque en el Santuario del Carmen Extramuros ${ }^{56}$; un San Antonio en el retablo mayor de la parroquia de Cervillego de la Cruz (Valladolid) ${ }^{57}$; y una Inmaculada Concepción en la parroquial de Gumiel de Izán (Burgos) ${ }^{58}$.

47 WATtENBERG GARCÍA, Eloísa: Catálogo Monumental de la provincia de Valladolid. Tomo XVII..., op. cit., p. 69.

48 URREA FERNÁNDEZ, Jesús: “El oratorio...”, op. cit., p. 20.

49 MARTÍN GONZÁLEZ, Juan José y URREA FERNÁNDEZ, Jesús: Catálogo Monumental de la provincia de Valladolid. Tomo XIV..., op. cit., pp. 101 y 289.

$50 \quad$ PAYO HERNANZ, René Jesús: “De los esplendores barrocos...”, op. cit., p. 312.

51 ARA GIL, Clementina Julia y PARRADO DEL OLMO, Jesús María: Catálogo Monumental de la provincia de Valladolid. Tomo XI..., op. cit., p. 235.

52 PARRADO DEL OLMO, Jesús María: Catálogo Monumental de la provincia de Valladolid. Tomo IX..., op. cit., p. 199.

53 ARA GIL, Clementina Julia y PARRADO DEL OLMO, Jesús María: Catálogo Monumental de la provincia de Valladolid. Tomo XI..., op. cit., p. 401.

54 GARCÍA CHICO, Esteban: Documentos para el estudio del arte en Castilla. 2..., op. cit., pp. 386387; MARTÍN GONZÁLEZ, Juan José: Koticias đ̄ocumentales...”, op. cit., p. 194.

55 ZAPARAÍN YÁÑEZ, María José: Desarrollo artístico..., op. cit., Tomo II, p. 418.

56 MARTÍN GONZÁLEZ, Juan José y URREA FERNÁNDEZ, Jesús: Catálogo Monumental de la provincia de Valladolid. Tomo XIV..., op. cit., p. 281.

57 MARCOS VILLÁN, Miguel Ángel y FRAILE GÓMEZ, Ana Mª; Catálogo Monumental de Valladolid. Tomo XVII..., op. cit., p 65.

58 ONTORIA OQUILLAS, Pedro: “La iglesia de Santa María de Gumiel de Izán”, Boletín de la Institución Fernán González, no 205, 1985, p. 75. 


\section{6-4 JOSÉ DE LARRA DOMÍNGUEZ}

Virginia Albarrán Martín en su brillantísimo libro El escultor Alejandro Carnicero entre Valladolid y la Corte (1693-1756) señala, al hablar sobre el maestro de éste, José de Larra Domínguez (1665-1739), vallisoletano de nacimiento, que debió de formarse en la capital del Pisuerga al lado de alguno de los grandes maestros del último cuarto del siglo XVII: Alonso de Rozas, José de Rozas, Juan Antonio de la Peña o nuestro Juan de Ávila ${ }^{59}$. José de Rozas quedaría totalmente descartado de la terna de posibles maestros ya que es riguroso contemporáneo de Larra puesto que nació en 1662. Analizada la obra que Albarrán Martín documenta y atribuye a Larra, pienso que no hay muchos fundamentos para aceptar que Ávila fue el preceptor de Larra.

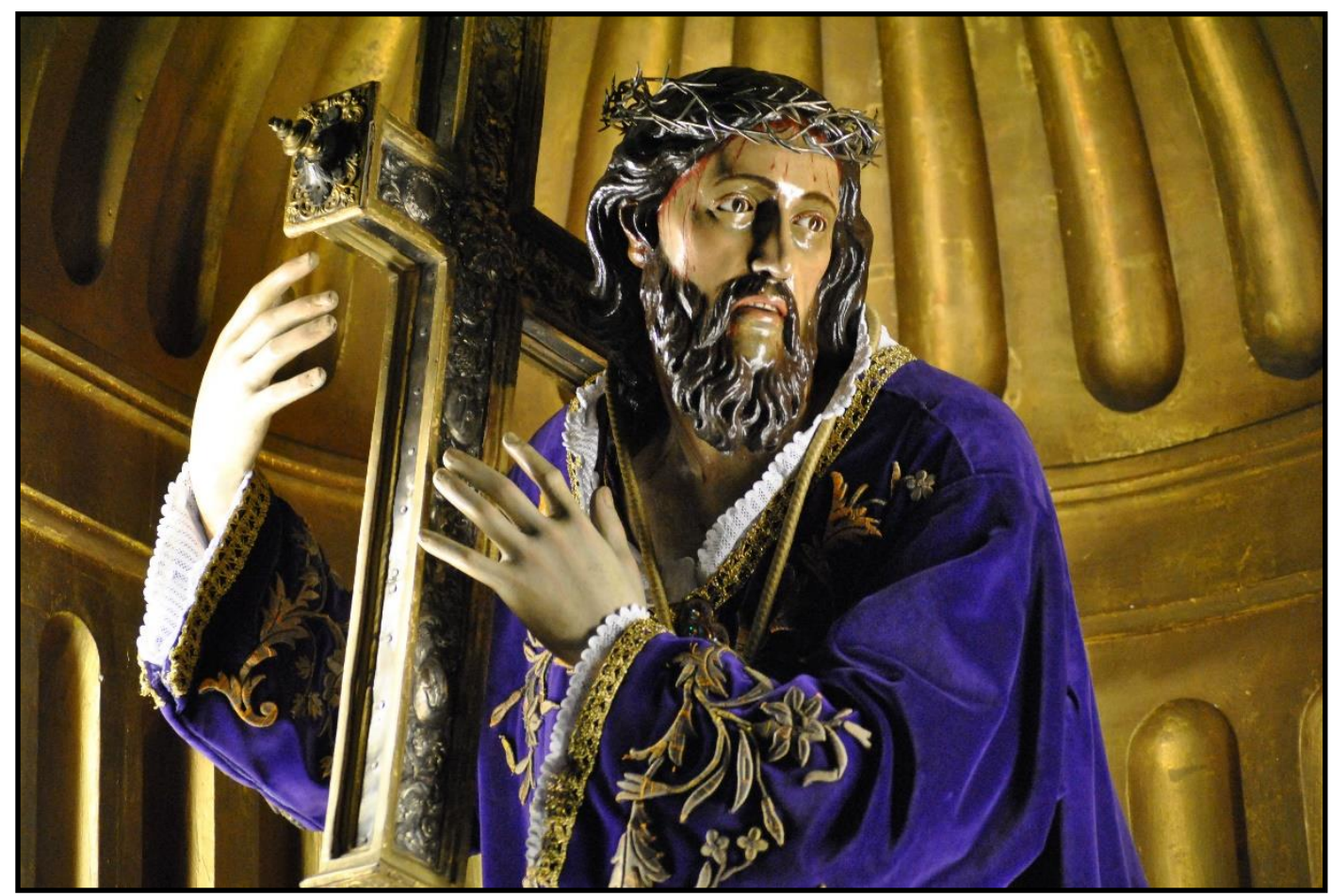

Il. 6- José de Larra Domínguez. Nazareno. Iglesia de San Julián. Salamanca.

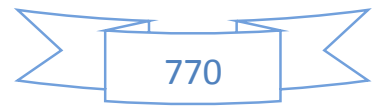




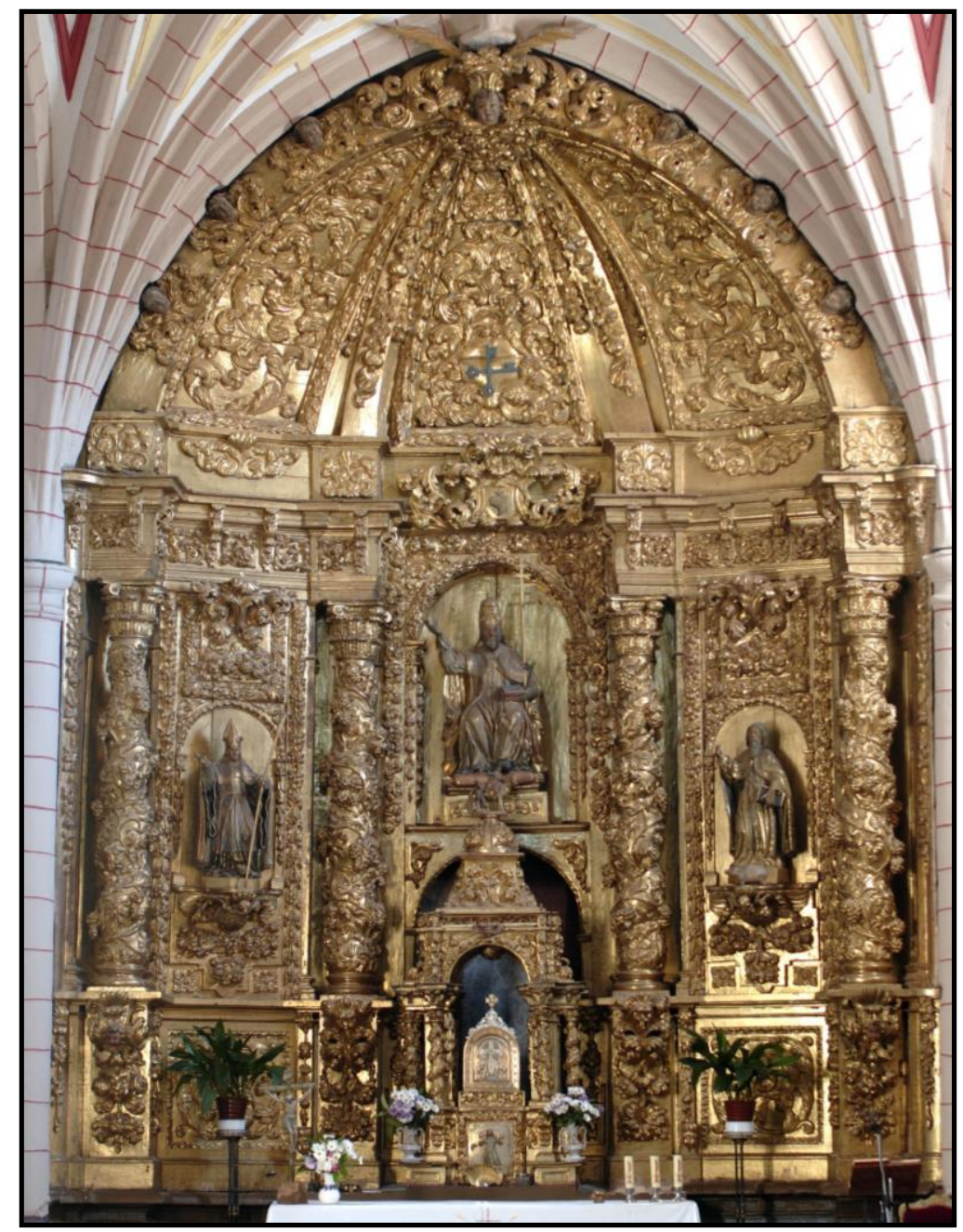

Fig. 1- Francisco de la Vega.

Esculturas del retablo mayor. Estebanvela (Segovia).

Fig. 2- Francisco de la Vega. Santo Domingo. Monasterio de Santo Domingo de Silos. Santo Domingo de Silos (Burgos).
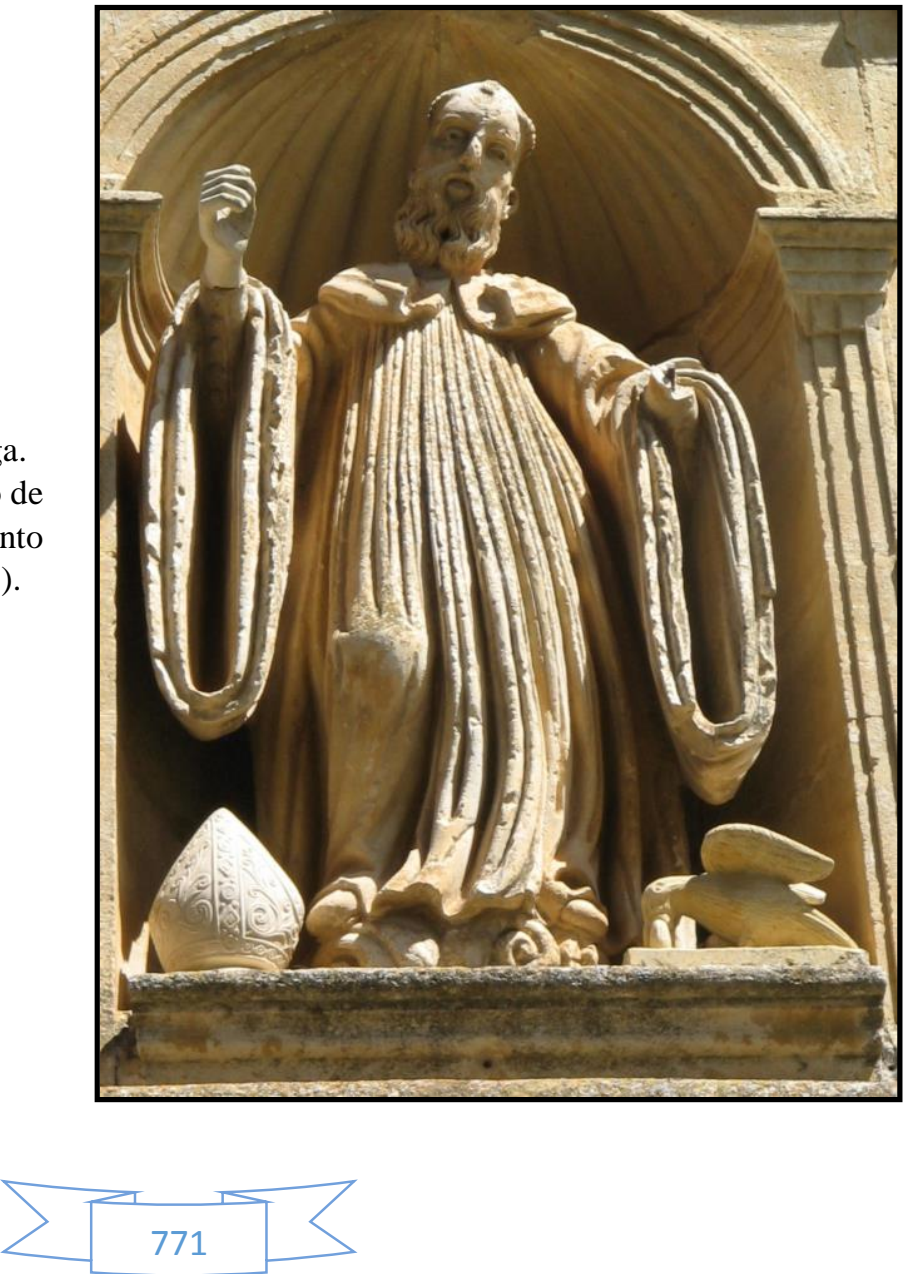


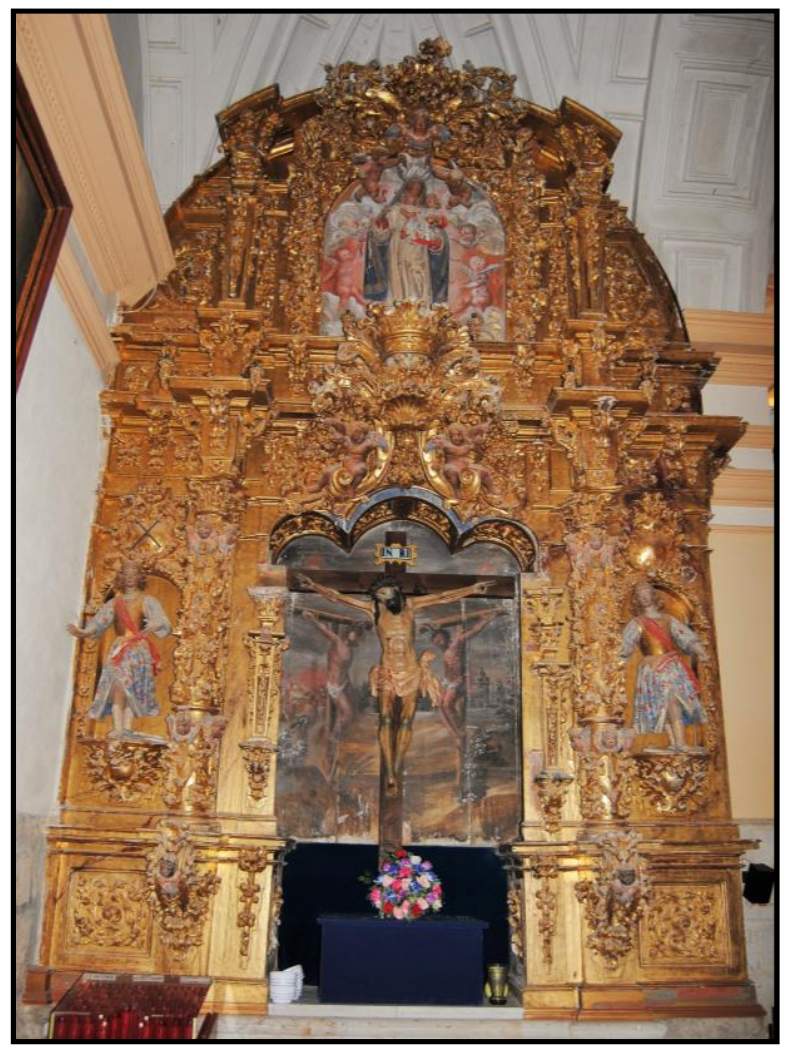

Fig. 3- Retablo del Santo Cristo. Ermita de

Castilviejo. Medina de Rioseco (Valladolid).
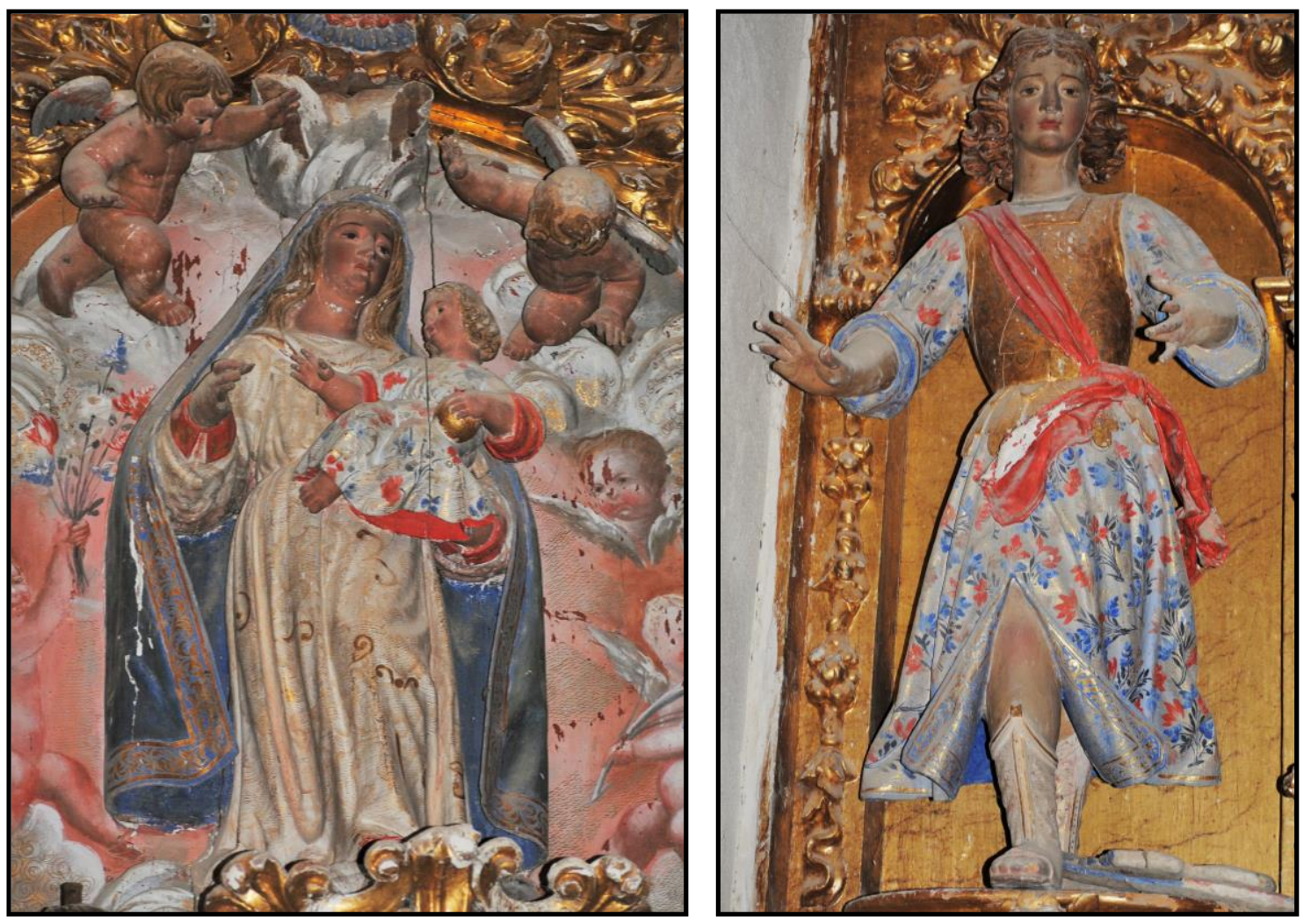

Figs. 4-5- Antonio de Gautúa. Virgen de la Consolación y Ángel Mancebo. Ermita de Castilviejo. Medina de Rioseco (Valladolid).

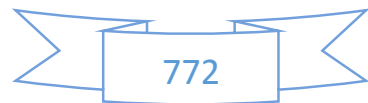



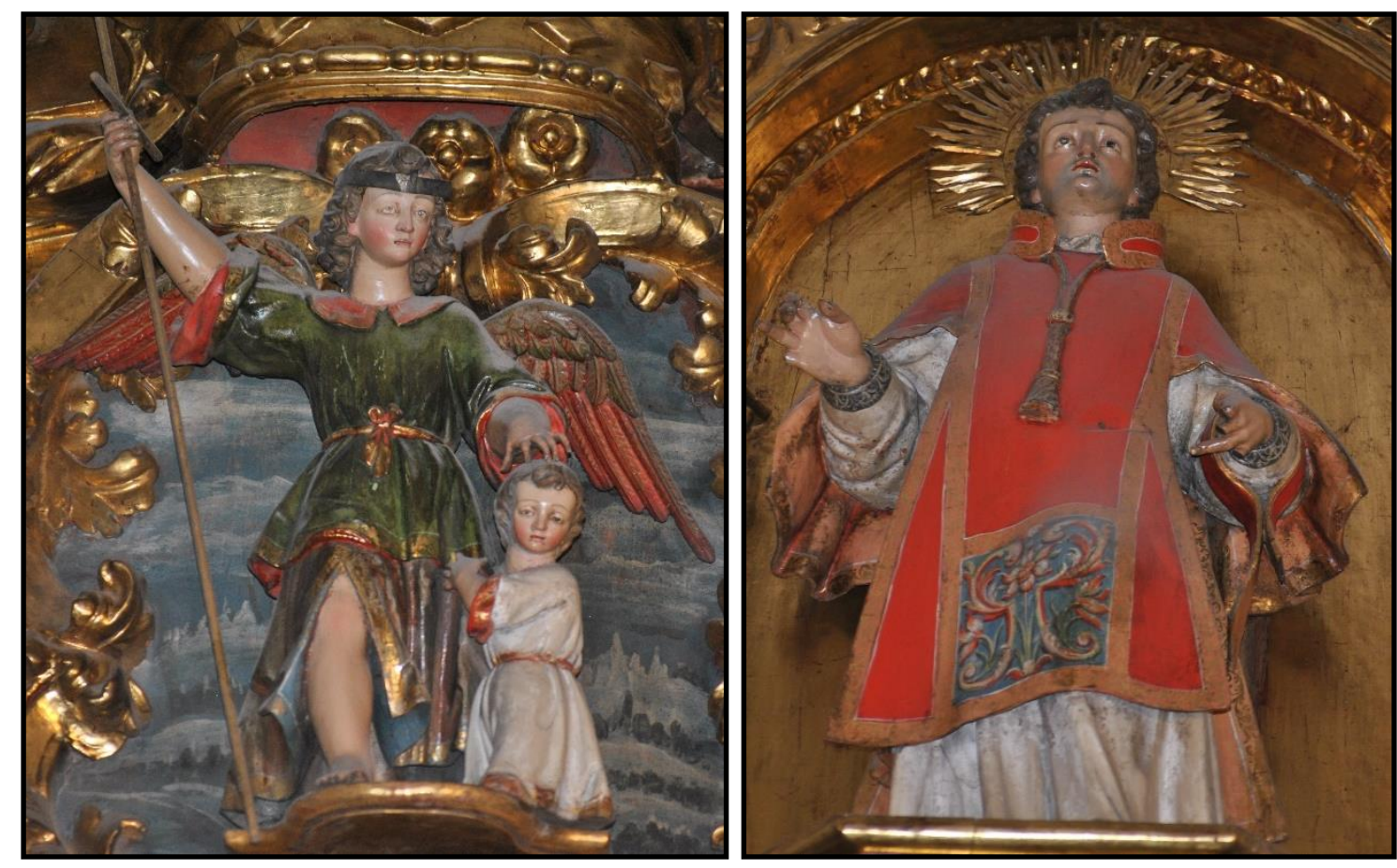

Figs. 6-7- Antonio de Gautúa. San Rafael con Tobías y San Lorenzo. Oratorio de San Felipe Neri. Valladolid.

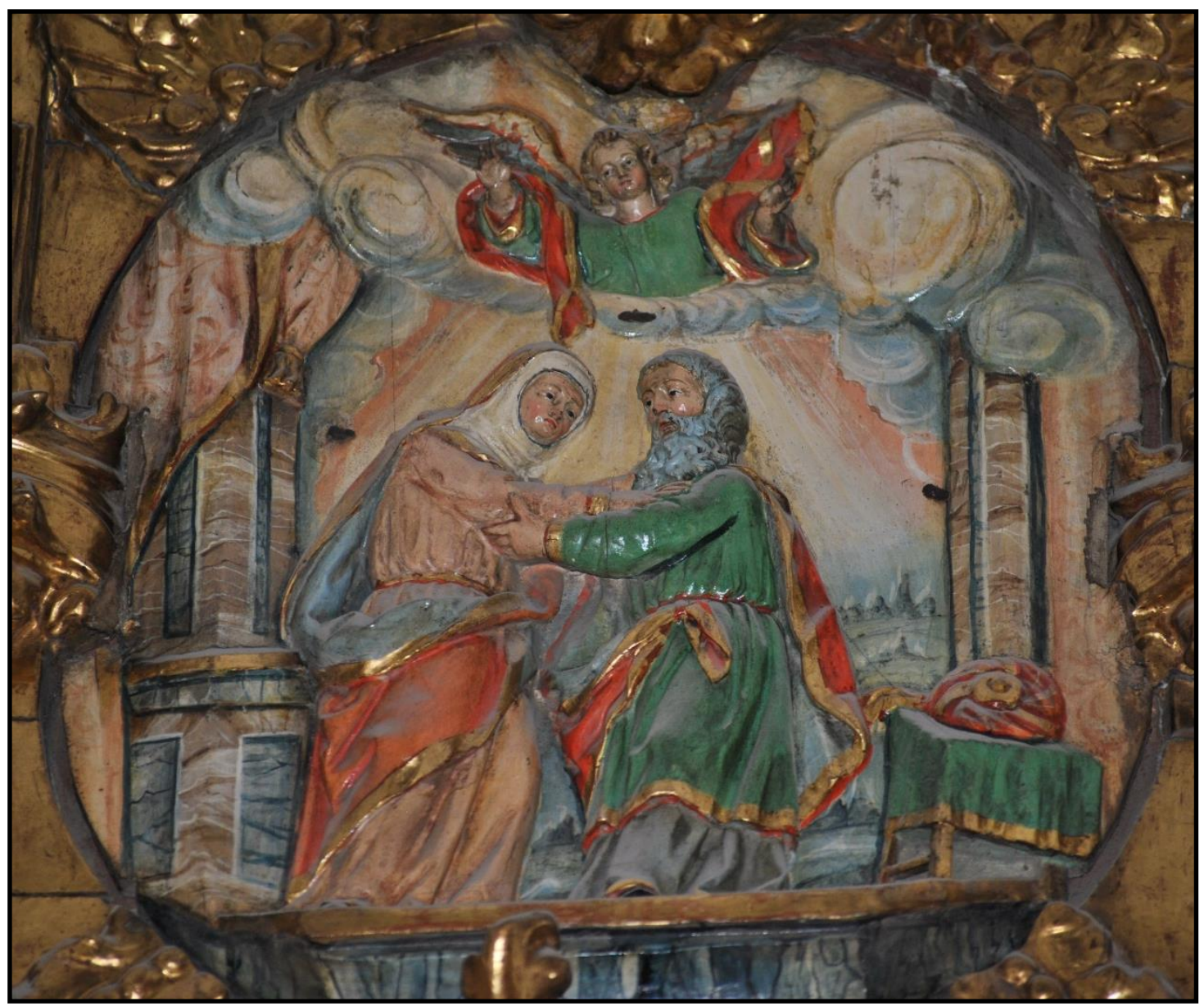

Fig. 8- Antonio de Gautúa. Abrazo ante la Puerta Dorada. Oratorio de San Felipe Neri. Valladolid.

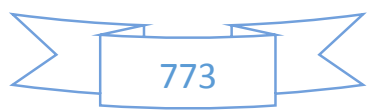




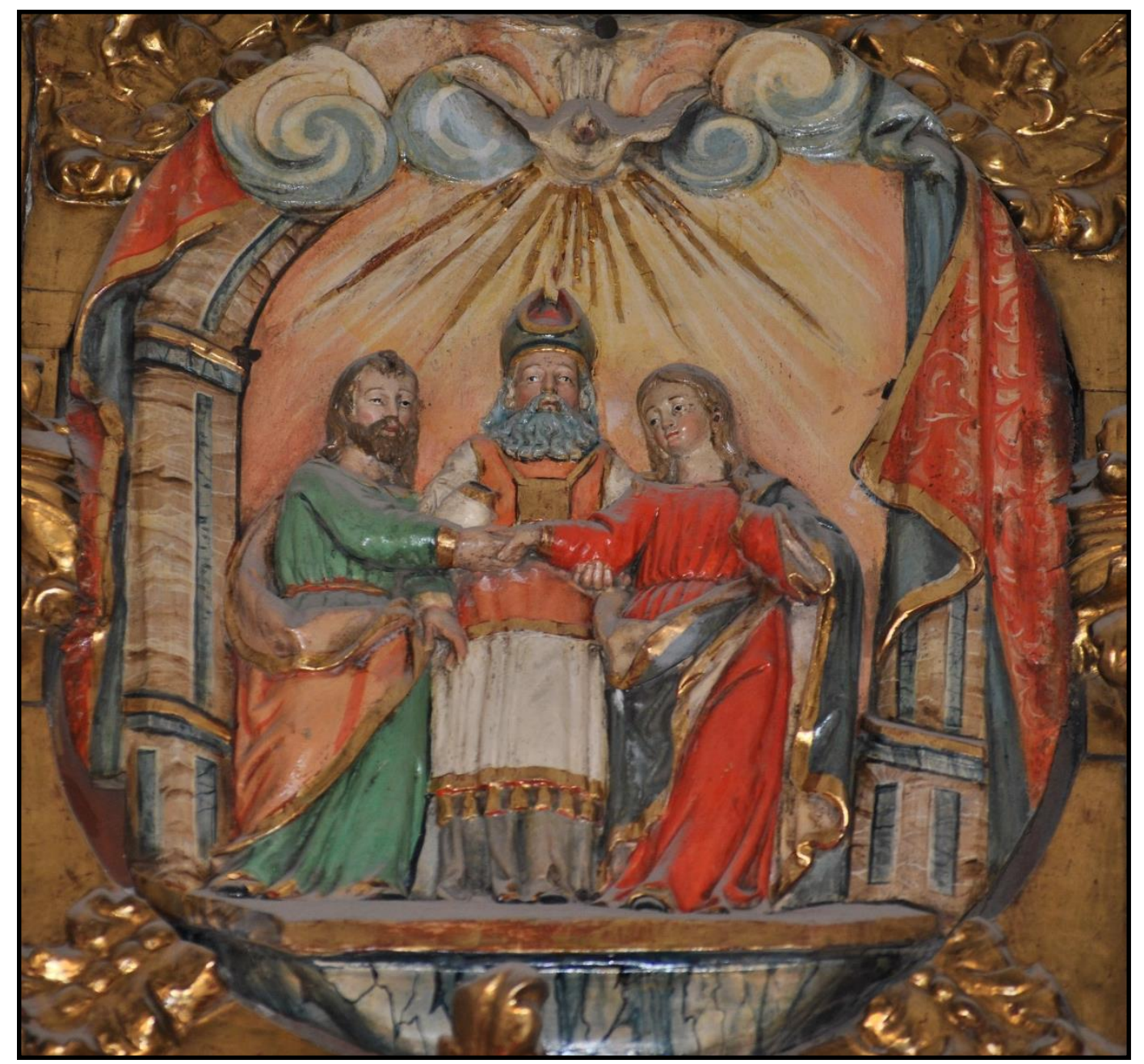

Fig. 9- Antonio de Gautúa. San Desposorios de la Virgen. Oratorio de San Felipe Neri. Valladolid.

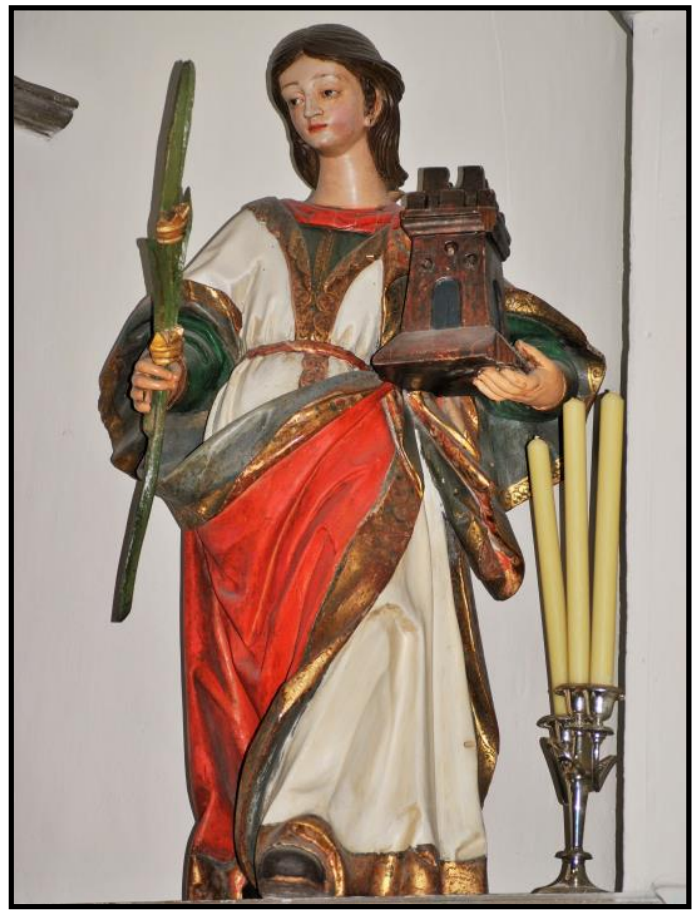

Fig. 10- Antonio de Gautúa. Santa Bárbara. Iglesia de San Martín. Valladolid.

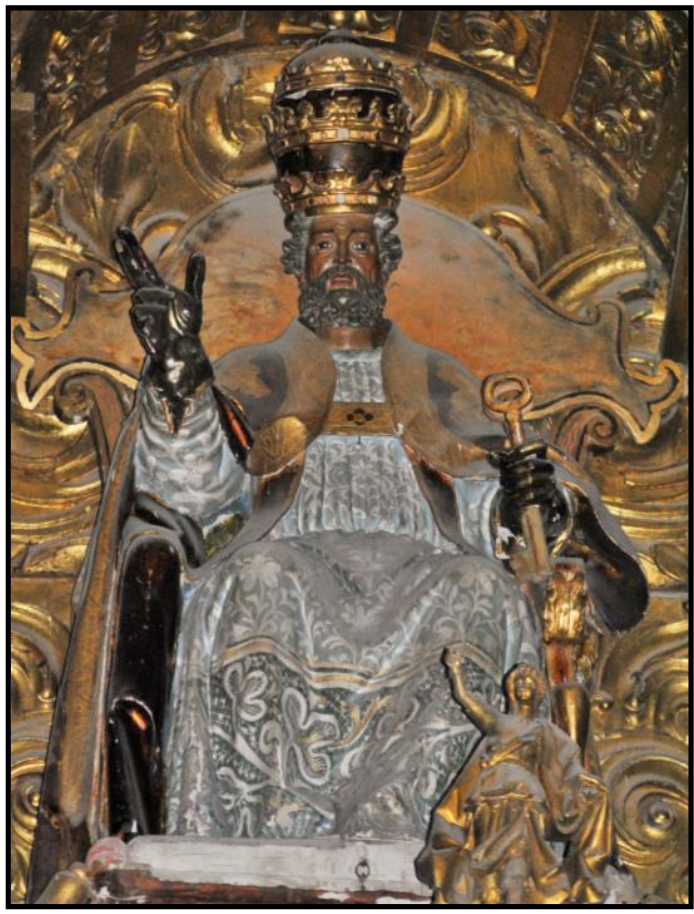

Fig. 11- Antonio de Gautúa. San Pedro. Iglesia de San Pedro. Tordesillas (Valladolid). 


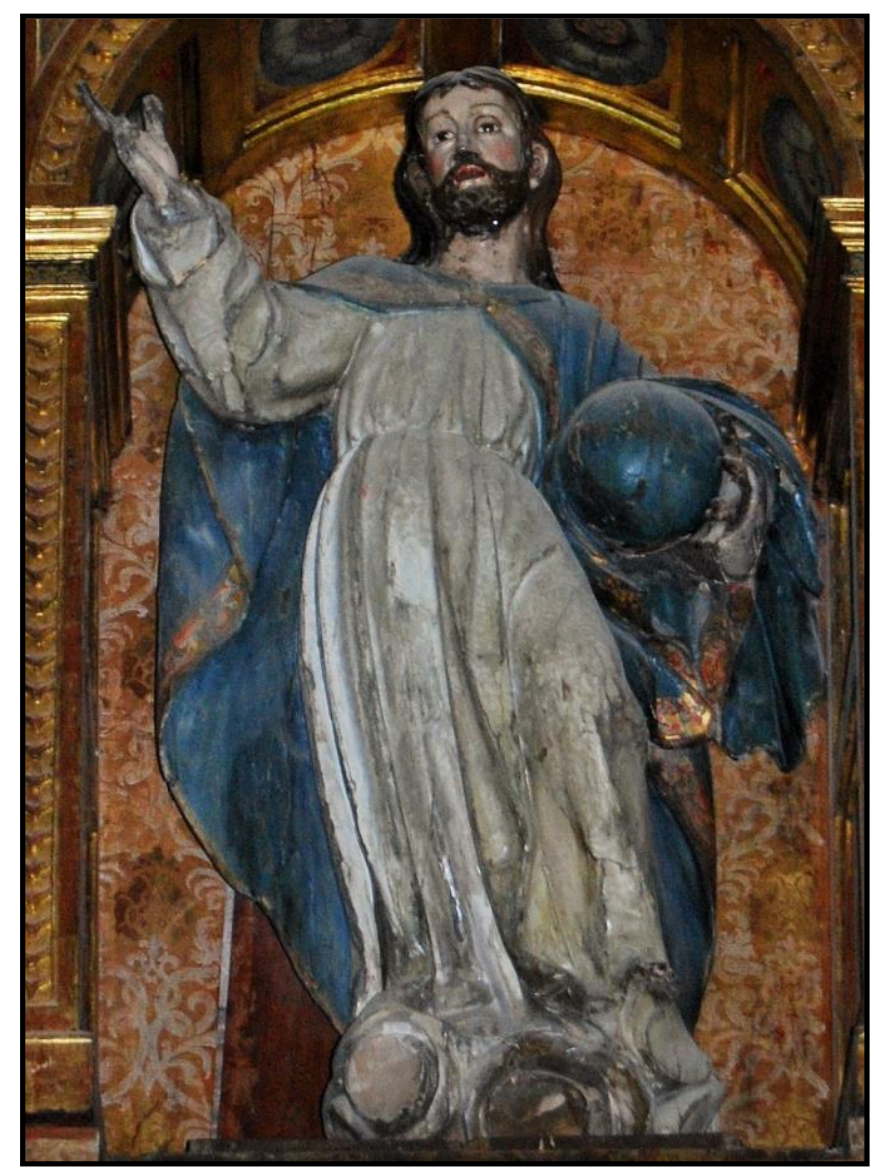

Fig. 12- Antonio de Gautúa. El Salvador. Iglesia del Salvador. Tiedra (Valladolid).

Fig. 13- Antonio de Gautúa. San Millán. Iglesia parroquial de San Millán. Velliza (Valladolid).
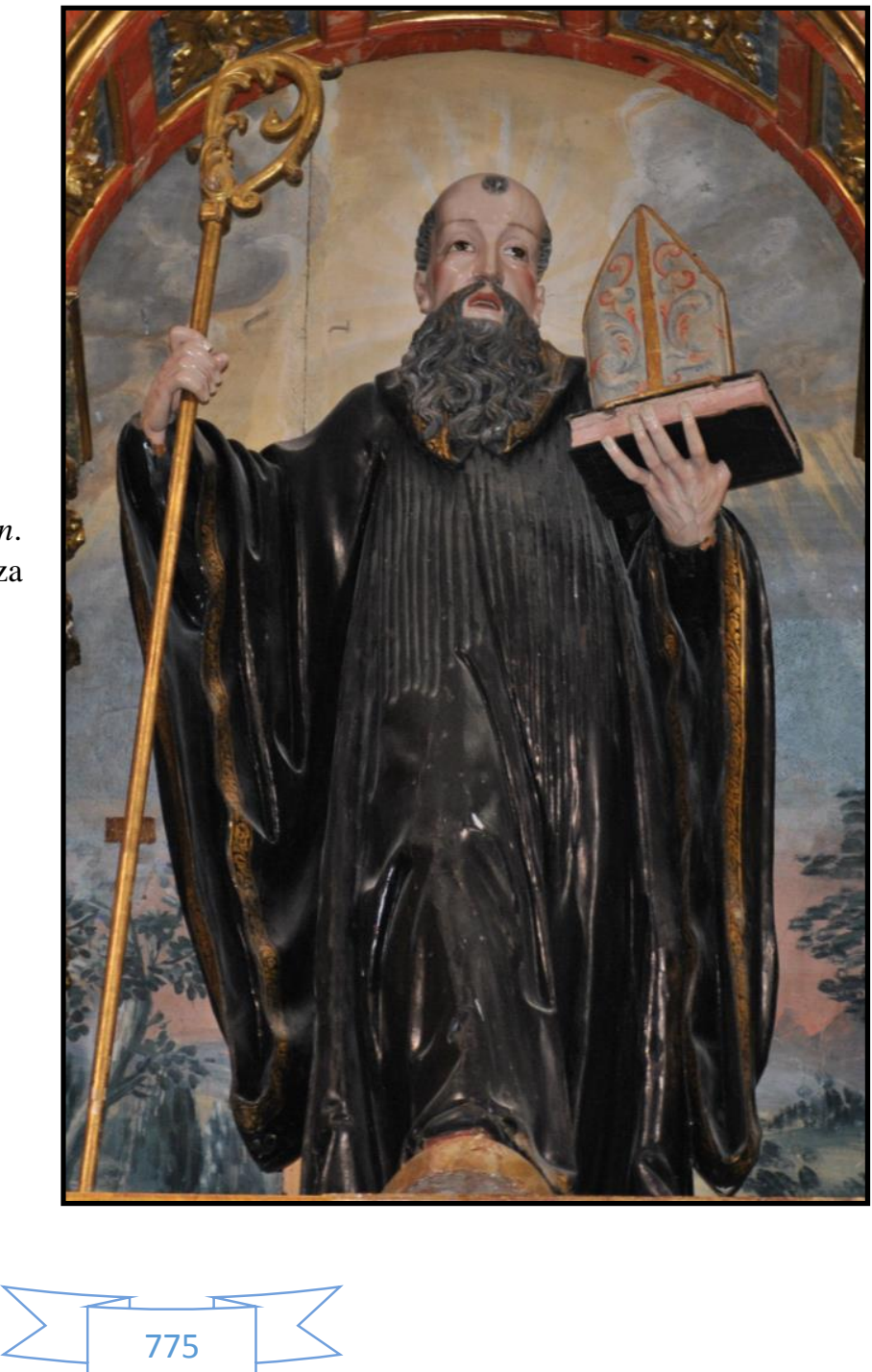

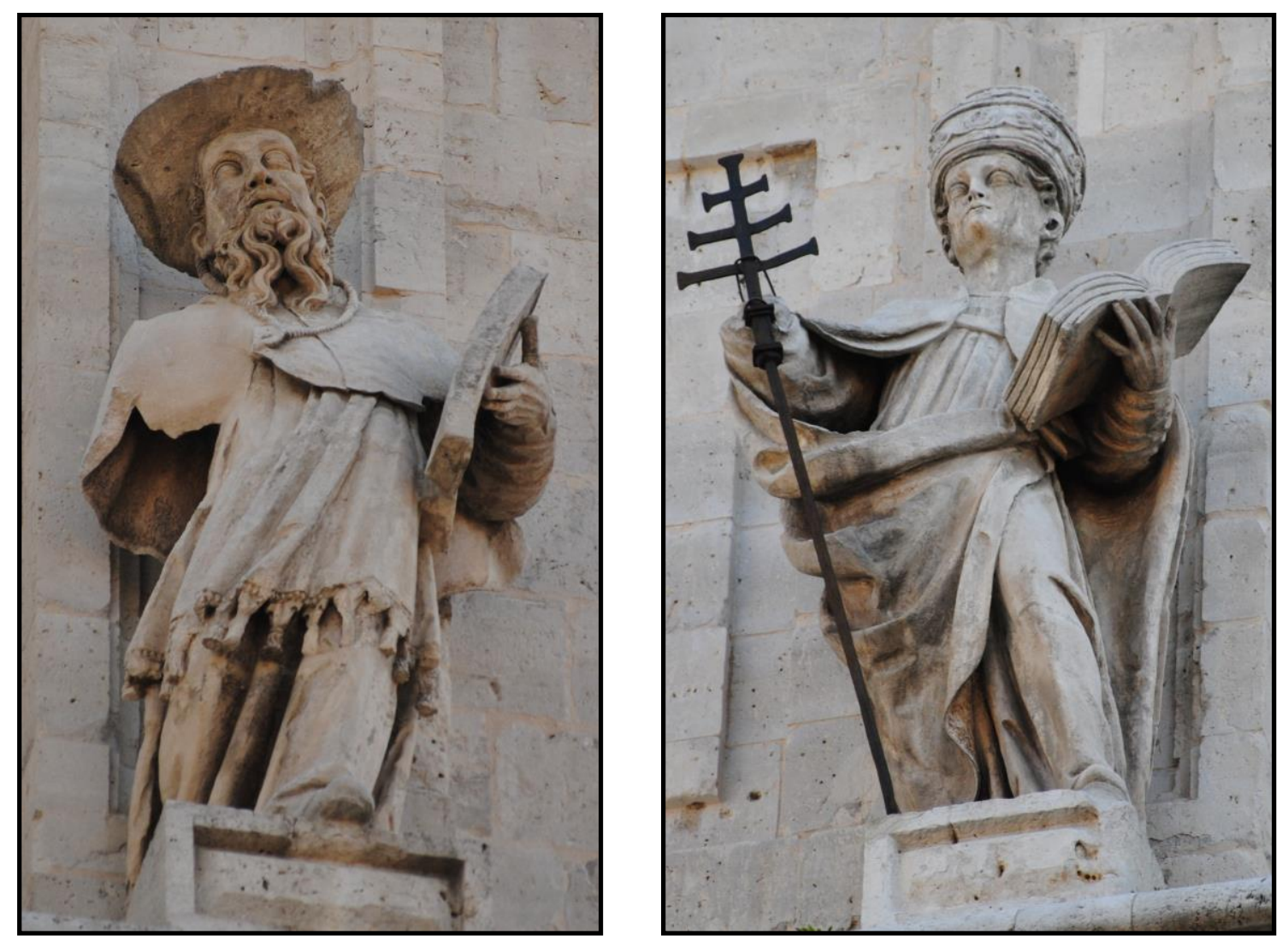

Figs. 14-15- Antonio de Gautúa. San Jerónimo y San Gregorio. Catedral. Valladolid.

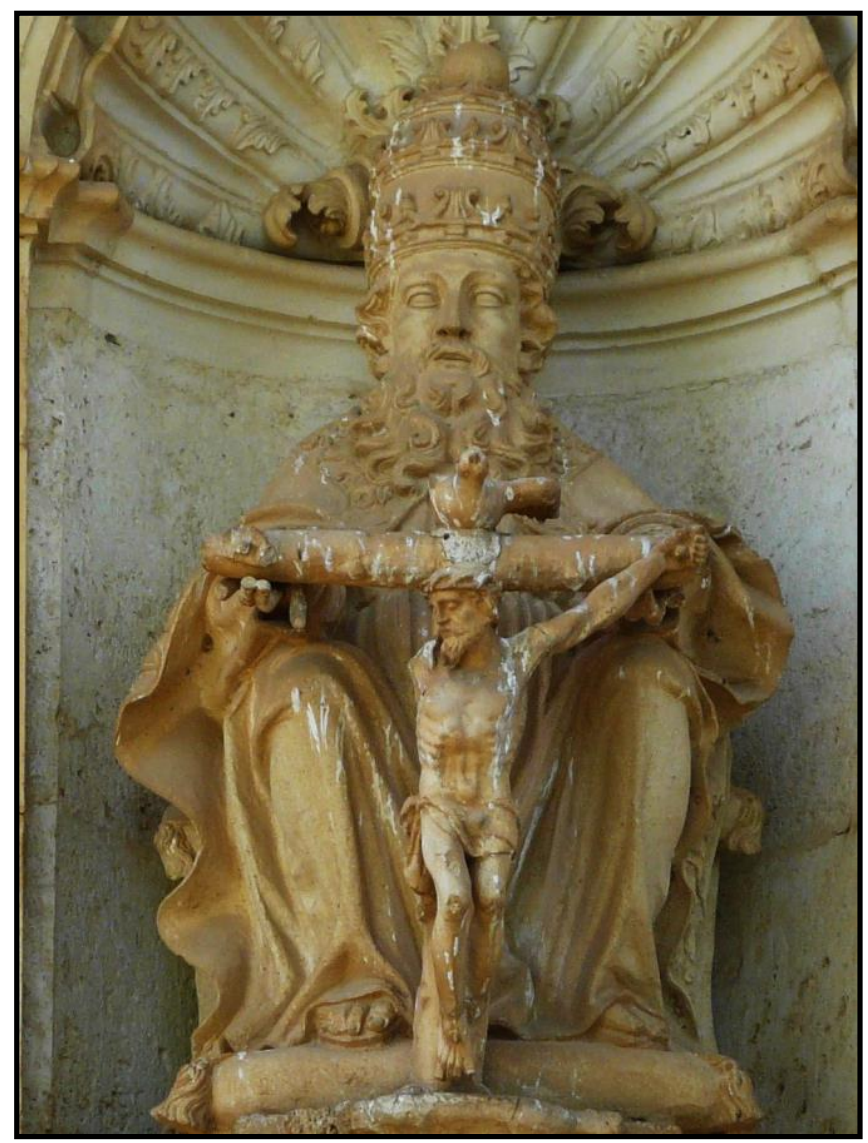

Fig. 16- Antonio de Gautúa. Santísima Trinidad. Ermita de la Santísima Trinidad. Fuentespina (Burgos).

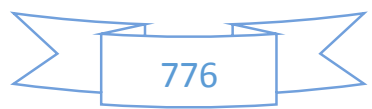




\section{Z-PEDRO DE ÁVILA. PERSONALIDAD}


$\sum \sqrt{778} \leq$ 


\section{7-1 BIOGRAFÍA}

\section{A- ETAPA JUVENIL Y APRENDIZAJE EN EL TALLER PATERNO (1678-1700)}

Pedro de Ávila Ezquerra nace en la calle de Santiago, o del Campo, de Valladolid el 30 de junio de 1678, siendo bautizado el 10 de julio de ese mismo año en la iglesia parroquial de Santiago Apóstol ${ }^{1}$. En el acto de imposición de este sacramento actúan como padrinos el matrimonio formado por el escultor Francisco Díez de Tudanca y Francisca Ezquerra, tíos de su madre; no deja de ser curioso que tanto su padre como su padrino fueran algunos de los escultores más importantes de la urbe. Al pequeño se le dieron por abogados a la Virgen y a San José. Ejercieron como testigos del feliz acontecimiento el escultor Manuel Gómez Otero $^{2}$, quizás compañero de aprendizaje de Juan de Ávila en el taller de Tudanca, y Bartolomé Sánchez ${ }^{3}$. Nuestro escultor no fue el primero de los hijos de Juan de Ávila y Francisca Ezquerra que poseyó el nombre de Pedro puesto que tres años antes un hermano suyo ya lo tuvo; su temprano fallecimiento llevaría a sus padres a querer bautizar a su siguiente hijo con ese nombre ${ }^{4}$.

Cuando Pedro viene al mundo, el hogar familiar se encontraba compuesto por sus padres, Juan de Ávila y Francisca Ezquerra, y por su hermana mayor Teresa $(1673)^{5}$, con la que mantuvo una excelente relación durante toda la vida de ésta, ya que falleció antes que nuestro escultor. Queda la incógnita de si por entonces vivía su hermana Josepha Antonia $(1672)^{6}$, la primogénita de sus padres. En años sucesivos Pedro vería nacer a sus hermanos Francisco $(1681)^{7}$, Joseph $(1682)^{8}$ y Ana $(1685)^{9}$. De ellos tres tan solo el segundo llegaría a la vida adulta.

1 "En diez días del mes de julio de mil y seiscientos y setenta y ochos años yo Juan de Carrión y Muñoz teniente de cura de esta iglesia parroquial de Señor Santiago de Valladolid bauticé e impuse los santos óleos como el Santo Concilio manda a un niño hijo legítimo de Juan de Ávila y Francisca Ezquerra moradores en la calle de Santiago pusieronle por nombre Pedro el cual nació en treinta del mes de junio pasado de este presente año según me lo aseguran sus padrinos que lo fueron Francisco de Tudanca y Francisca Ezquerra tía de la madre de dicho bautizado dieronle por abogados a Nuestra Señora y San Joseph fueron testigos Manuel Gómez Otero y Bartolomé Sánchez todos vecinos de ésta ciudad y lo firmé". A.G.D.V., Santiago, 1668B, f. 242. FERNÁNDEZ DEL HOYO, María Antonia: "El escultor vallisoletano Francisco Díez de Tudanca...", op. cit., p. 385.

2 Pocas noticias tenemos sobre el escultor Manuel Gómez Otero (1649-d.1683). Se debió de formar codo a codo con Juan de Ávila en el taller de Francisco de Tudanca. Gómez Otero figura en varias ocasiones fiando a su maestro, en calidad de oficial suyo. Efectivamente, le encontramos firmando la escritura de obligación que hace Tudanca para esculpir un Santo Cristo del Perdón para la localidad cacereña de Hervás. A.H.P.V., Leg. 2.342/5, f. 91.

Quizás se trate del escultor homónimo que en 1691 se encarga de engrapar "yendas que tenía el caballo de Longinos" del paso homónimo que ese mismo año habían tallado José de Rozas y Antonio Vázquez para la Cofradía de Jesús Nazareno, de Palencia. Desconocemos por completo a este escultor, quizás fuera oficial de alguno de estos dos. GARCÍA CUESTA, Timoteo: "La Cofradía...", op. cit., p. 120.

4 A.G.D.V., Santiago, 1668B, f. 176. FERNÁNDEZ DEL HOYO, María Antonia: "El escultor vallisoletano Francisco Díez de Tudanca...”, op. cit., p. 385.

5 A.G.D.V., Santiago, 1668B, f. 136. Ibídem.

A.G.D.V., Santiago, 1668B, f. 103. Ibídem.

A.G.D.V., Santiago, 1668B, f. 294.

A.G.D.V., Santiago, 1668B, f. 316. FERNÁNDEZ DEL HOYO, María Antonia: "El escultor vallisoletano Francisco Díez de Tudanca...”, op. cit., p. 385.

$9 \quad$ A.G.D.V., Santiago, 1683B, f. 63.

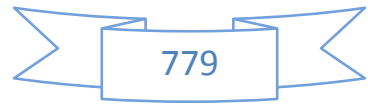


Nada más sabemos de su infancia salvo que a punto de cumplir 6 años, el 7 de mayo de 1684, celebra el sacramento de la confirmación junto a su hermana en la iglesia de Santiago Apóstol. La ceremonia fue oficiada por el obispo de Valladolid, don Diego de la Cueva y Aldana ${ }^{10}$, mientras que como padrinos del acto ejercieron doña María Antonia Pérez y el licenciado Juan Delfín. Tres años después, el 7 de septiembre de 1687, acude junto a su hermana y a su padre a la confirmación de su otro hermano Joseph. La ceremonia, al igual que la suya, fue llevada a cabo por el mismo prelado en la iglesia de Santiago Apóstol.

La niñez de Pedro transcurriría correteando por la calle de Santiago y el taller paterno, lugar en el cual, poco a poco, iría cogiéndole gusto a la práctica escultórica; asimismo, asistiría frecuentemente junto a sus padres a oír misa a la iglesia de Santiago Apóstol. Quizás las magníficas preseas artísticas que posee este templo fueran, al igual que en el caso de su padre, el detonante de su amor por la escultura.

$\mathrm{Su}$ infancia se cortaría abruptamente el 17 de noviembre de 1686 con el fallecimiento de su madre ${ }^{11}$. Tras el luctuoso acontecimiento, su padre quedó viudo muy joven, teniéndose que ocupar de sus cuatro hijos (Teresa, Pedro, Joseph y quizás Ana) y un taller en el momento de máxima expansión y reconocimiento. Es de creer que, por entonces, Teresa, la hermana mayor, ayudara a su padre a cuidar de los pequeños; quizás, fue por entonces cuando se forjó ese amor fraternal entre nuestro escultor y su hermana, la que posiblemente fue para él como segunda madre.

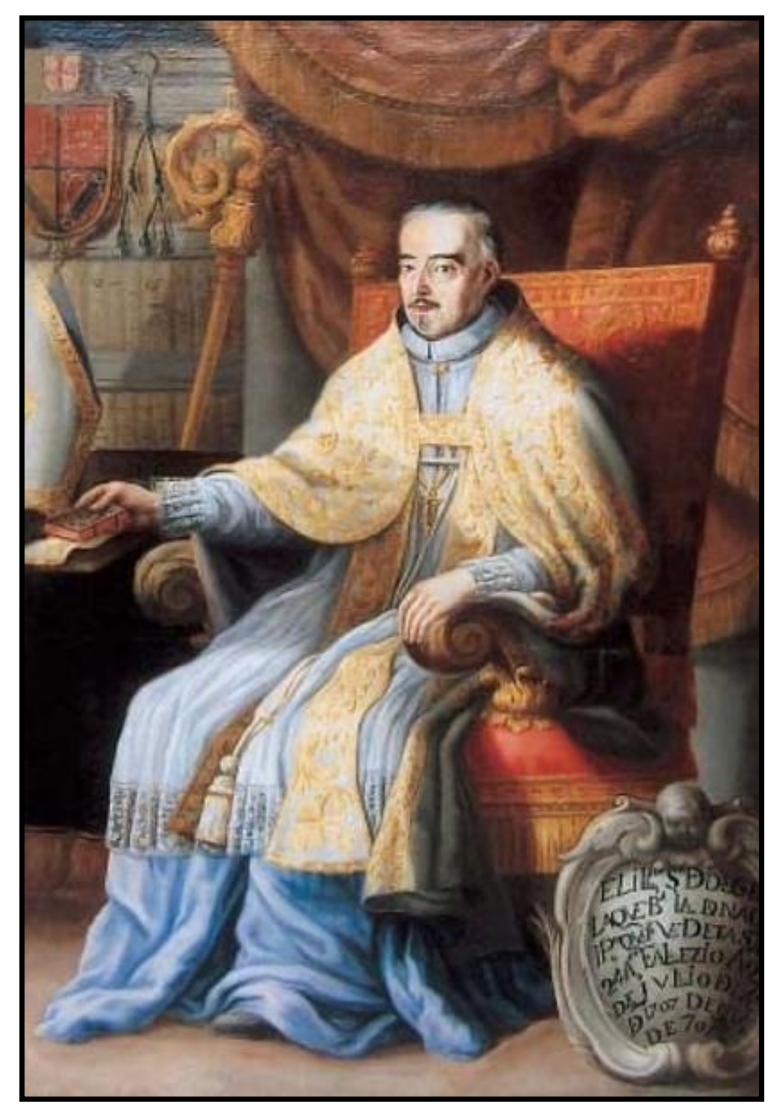

Il. 1- Manuel Peti Bander. Don Diego de la Cueva y Aldana. Catedral. Valladolid.

Es previsible que Pedro de Ávila desde muy pequeño trasteara por el taller paterno, en el cual desde jovencito aprendería a tallar figuritas ya fuera en barro o en madera con una pequeña navaja. El padre, viendo que su hijo poseía ciertas dotes y aptitudes, o bien

10 "En Santiago. En la ciudad de Valladolid a seis días del mes de mayo de mil seiscientos y ochenta y cuatro años el Ilustrísimo señor don Diego de la Cueva y Aldana obispo de esta ciudad de Valladolid celebró el santo sacramento de la confirmación en esta iglesia de señor (...) siendo padrinos Doña María Antonia Pérez y el licenciado D. Juan Delfín 7 de mayo de 1684. Pedro y Teresa hermanos: naturales de esta ciudad, hijos legítimos de Juan de Ávila y Francisca Ibarra a la calle de Santiago". A.G.D.V., Santiago, Confirmados, f. 26. No cabe duda de que el apellido de Francisca estaba mal escrito, puesto que no era Ibarra sino Ezquerra.

11 A.G.D.V., Santiago, 1673D, f. 576.

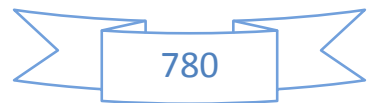


que deseaba que siguiera el oficio paterno y así asegurarse mejor la vida de lo que lo había hecho sus predecesores (modestos zapateros de viejo), decidió enseñarle el arte de escultor. Ya dijimos con anterioridad que los aprendices solían acceder a los talleres a una edad aproximada entre 11 y 14 años. Por lo tanto, Pedro realizaría su aprendizaje aproximadamente entre 1689-1692, convirtiéndose posteriormente en el mejor oficial con el que contó su padre.

Por entonces, el 6 de febrero de 1689, su padre contraía matrimonio en segundas nupcias con Bentura Sedano, hija del escultor palentino Mateo Sedano ${ }^{12}$. La ceremonia tuvo lugar en la iglesia del Santísimo Salvador, parroquia en cuyos límites tendría la casa la novia. Este nuevo matrimonio daría a Pedro, Teresa y Joseph dos hermanos más: Manuel (1690) $)^{13}$ y Manuela $(1691)^{14}$, si bien esta última fallecería al poco de nacer. La relación con su madrastra y la familia de ésta debió ser óptima puesto que un cuñado de ésta, Santiago Izquierdo (marido de la hermana de Bentura), ejerció el cargo de testigo en la boda de Pedro de Ávila y María Lorenza de la Peña. Además, conservamos numerosas pruebas del amor fraternal y de la colaboración laboral entre Pedro y su hermano Manuel. A pesar de todo, todavía existen muchas dudas e interrogantes relacionados con Bentura Sedano, los cuales esperemos que algún día se puedan resolver: por ejemplo, resulta extraño que en la partida de defunción de Juan de Ávila no se aluda a ella, puesto que tampoco tenemos noticia de que ella hubiera fallecido.

Seguramente en años sucesivos, Pedro comenzaría a ayudar a su padre de una manera mucho más activa en la confección de algunos encargos, si bien por el momento no podemos relacionar con su mano ninguna obra paterna. Es probable que a partir de 1696 la colaboración con su padre fuera "in crescendo" puesto que le llegarían numerosos pedidos: Virgen de la Soledad para el Convento de Porta Coeli (h. 1697-1700), esculturas del retablo mayor de las Brígidas (1697-1698), San Roque para la Colegiata de Ampudia (h. 1698), San Isidro y Santa María de la Cabeza para la Cofradía de San Isidro Labrador (1698), esculturas del retablo mayor de Santiago Apóstol (1698-1702), esculturas y relieves para los retablos colaterales del Oratorio de San Felipe Neri (1699), Santa Juliana para la Colegiata de Santillana del Mar (1699), etc... En los años que transcurren hasta el cambio de siglo no le hemos conseguido documentarle obra alguna, y tampoco podemos relacionarle con ninguna. Existe una excepción, aunque pienso que no tiene muchos visos de realidad: en la iglesia penitencial de N. P. Jesús Nazareno se conserva una bella imagen de Cristo Yacente atribuida a Pedro de Ávila, la cual tienen fechada en 1698. Desconozco el motivo de fecharla en este año, pues nadie ha dado una explicación. Además, en el catálogo realizado en el año 2014 con motivo de la exposición de Las Edades del Hombre "Eucharistia", exhibición de la cual formó

\footnotetext{
12 A.G.D.V., El Salvador, 1685M, f. 35.

13 A.G.D.V., Santiago, 1683B, f. 171.

14 A.G.D.V., Santiago, 1643B, f. 215.
} 
parte; Hernández Redondo la da una cronología entre los años 1720-1729 ${ }^{15}$; es decir, no hay ningún documento que permita fecharla en aquel año tan temprano.

En las postrimerías del siglo Pedro de Ávila conocería a María Lorenza de la Peña, hija del escultor Juan Antonio de la Peña y su futura esposa. Desconocemos como se fraguó esta amistad. Creo que tan solo caben dos hipótesis: que la conociera a raíz del trabajo desarrollado en el taller de Juan Antonio de la Peña, su futuro suegro; o bien que la conociera antes y a raíz de entonces su suegro le propusiera colaborar en su obrador. Sea como fuere, ambas hipótesis nos plantean un interrogante: ¿Por qué abandonó Pedro de Ávila el taller paterno para formar parte del de Juan Antonio de la Peña, uno de los dos máximos competidores de Juan de Ávila en la ciudad y en la región, por mucho que este fuera su suegro, o su futuro suegro? La pregunta se nos presenta bastante difícil de resolver, teniendo que entrar de nuevo en el terreno de las conjeturas. Pudo darse el caso de que el joven oficial quisiera volar solo y probar suerte en el taller de otro de los escultores más prestigiosos de la ciudad; con lo cual, además, completaría las enseñanzas paternas con las de Juan Antonio de la Peña; convirtiéndose de esa manera en un maestro mucho más completo y versátil gracias a los conocimientos tomados de ambos; otra hipótesis es la de una probable mala relación entre padre e hijo, si bien no hay ningún elemento que apunte en esta dirección; una última posibilidad es la de que Juan Antonio de la Peña, conocedor del "cariño" existente entre nuestro escultor y su hija, le propusiera trabajar en su taller para costear parte de los gastos relacionados con la boda y prometiéndole, quizás, heredarlo tras su fallecimiento.

\section{B- PRIMERAS OBRAS Y CAMBIO DE TALLER (1700-1708)}

Desconocemos la fecha en que Ávila comenzó a trabajar con su futuro suegro, aunque ésta debió ser con anterioridad al año 1700; de todas maneras, creo que lo más procedente es fechar el comienzo de esta segunda etapa de su vida en el 1700, año en que contrae matrimonio con la hija del maestro y da pátina de oficialidad a su colaboración con De la Peña; todo esto no quiere decir que desde hacía años no contratara obra por su parte.

La amistad y el amor entre Pedro y María Lorenza de la Peña desembocaron al poco de quebrar el siglo en boda. Efectivamente, la ceremonia tuvo lugar el 11 de agosto de 1700 en la desaparecida iglesia de San Miguel, bajo el altar mayor para el cual un siglo antes había tallado unas preciadas esculturas Gregorio Fernández ${ }^{16}$. Desde entonces, si

15 HERNÁNDEZ REDONDO, José Ignacio: "Nº 61 Cristo Yacente". En VV.AA.: Las Edades del Hombre. Eucharistia, Fundación Las Edades del Hombre, Valladolid, 2014, p. 246.

16 "En once de agosto de mil y setecientos yo el licenciado Don Juan Antonio González presbiterio de licencia de don Antonio Sangáriz cura propio de la parroquia de Señor San Miguel de esta ciudad de Valladolid habiendo precedido las tres canónicas municiones que el Santo Concilio manda y licencia del señor provisor de éste obispado desposé por palabras de presente según el Santo Concilio de Trento a Pedro de Ávila natural de esta ciudad, hijo legítimo de Juan de Ávila ambos escultores, y de doña Francisca Ezquerra con doña María Lorenza de la Peña, natural de esta ciudad hija legítima de Juan Antonio de la Peña, escultor, y de Francisca de Santiago ambos contrayentes solteros; asimismo el 
no antes, el futuro del escultor quedó ligado casi indisolublemente al de esta parroquia, en la cual viviría casi hasta el día de su muerte. En el enlace actuaron como padrinos Juan de Ávila e Isabel Santos; mientras que ejercieron de testigos Francisco Santiago, abuelo de María Lorenza, el médico Juan Crisóstomo de la Comba y Santiago Izquierdo, cuñado de Juan de Ávila. El matrimonio sería muy feliz, aunque por desgracia no lograría tener descendencia, por lo que se tuvieron que conformar con el amor de sus sobrinos, los hijos de Teresa y Manuel de Ávila, con los cuales mantendría una afectuosa relación. Como podemos comprobar, este en un caso más en el que dos familias de artistas emparentan entre sí; y en el que un escultor a falta de descendencia directa que pueda heredar su taller casa a su hija con un escultor al que legárselo.

Un día antes de celebrarse la boda se firmaron las capitulaciones matrimoniales. En ellas intervinieron de una parte Pedro de Ávila y su padre, Juan de Ávila; y de la otra María Lorenza de la Peña y los suyos, Juan Antonio de la Peña y Francisca de Santiago (DOCUMENTO 34). Como de costumbre, se declaraba que los futuros esposos se habrían de desposar "por palabras de presente que hagan legítimo y verdadero matrimonio y en tiempo debido se velarán según orden de la santa madre iglesia católica romana habiendo precedido las tres canónicas municiones que el santo concilio de Trento dispone y manda, o dispensándose en ello y con las demás". En lo referente a las dotes, Juan Antonio de la Peña y su esposa se comprometían a "dar y pagar en dote a la dicha María Lorenza de la Peña su hija para que lleve a dicho matrimonio con dicho Pedro de Ávila (...) para ayuda de sus alimentos cargas y obligaciones de dicho matrimonio y por capitales y caudales suyos propios y por cuenta de la herencia paterna y materna (...) quinientos ducados de vellón luego que tenga efecto el dicho matrimonio en dinero alhajas de por casa ropa blanca y alhajas de oro y plata". Por su parte, Pedro de Ávila, "atendiendo a la calidad y prendas personales de la dicha María Lorenza de la Peña", la ofrecía y dotaba en "en arras y dotación proternúpcias a la dicha María Lorenza de la Peña en doscientos ducados de vellón que confiesa caben en la décima parte de sus bienes con que al presente se halla". Finalmente, ambas partes acordaban que una vez que tuviera lugar el matrimonio y que Juan Antonio de la Peña abonara los 500 reales a Pedro de Ávila éste otorgaría carta de pago en favor de su suegro. Figuran como testigos de la escritura Francisco Santiago, abuelo de María Lorenza; Joseph de Ávila, hermano de Pedro de Ávila; y Joseph de Libarona.

Como acabamos de comentar, una vez consumado el matrimonio De la Peña debía de proceder a abonar a Pedro de Ávila los 500 ducados de prometidos en la dote; desconocemos qué ocurrió, pero el caso es que el pago no llegó a efectuarse. Dada la demora de más de dos años, el 16 de noviembre de 1702, Pedro de Ávila interpuso medidas legales contra su suegro (DOCUMENTO 59).

sobredicho día los vele in facie ecclesiae y di las bendiciones nupciales, siendo a todo ello presentes por testigos Francisco Santiago abuelo materno de la contrayente, el Dr. don Juan Crisóstomo de la Comba, médico y Santiago Izquierdo, vecinos de esta dicha ciudad; padrinos Juan de Ávila padre del contrayente e Isabel Santos. Y lo firmé con dicho cura fecha ut supra”. A.G.D.V., San Miguel, 1681M, f. 88. 
A partir de entonces se sucedieron diferentes episodios judiciales que culminaron con el pago de la dote. Primeramente, el 17 de noviembre de ese año, Juan Antonio de la Peña y su esposa dan poder a "Manuel de Peña María y a Luis Antonio Canedo procuradores del número de esta ciudad y a Pedro Álvaros de Velasco y Pedro de Velasco Barreda Lucas de Cantabrana y a Pedro Domínguez de Vargas procuradores del número de esta Real Chancillería" para que les defiendan "en un pleito ejecutivo que contra ellos ha pedido Pedro de Ávila (...) sobre la paga de quinientos ducados y otras cosas en el dicho pleito contenidas" (DOCUMENTO 57). Cinco días después, Pedro de Ávila sigue esos mismos derroteros y otorga su poder a "Luis Antonio Canedo y Joseph de Medrano procurador del número de ella y a Juan Pérez de Medina y Antonio Rodríguez Román que lo son de esta Real Audiencia" para que le "defiendan en un pleito ejecutivo que ante uno de los señores alcaldes del crimen (...) tengo pendiente contra los dichos Juan Antonio de la Peña y su mujer sobre la paga de quinientos ducados de vellón que me ofrecieron en dote (...) cuando casé con la dicha mi mujer" (DOCUMENTO 58). El acuerdo entre ambas partes no tardaría en llegar, lo que posibilitó a que la relación entre Ávila y su familia política no se deteriorara; es más, llegó incluso a ser buena durante el resto de la vida de Juan Antonio de la Peña y de su mujer. Así, al poco tiempo De la Peña abonó lo que debía a Ávila, y éste el 9 de diciembre de ese mismo año otorgaba carta de pago de dote en favor de su suegro (DOCUMENTO 59).

Una vez que nuestro escultor presentó la "ejecución por los dichos quinientos ducados contra la persona y bienes del dicho Juan Antonio de la Peña y los de la dicha Francisca de Santiago su mujer por más su legítima y costas" la justicia falló a su favor y ordenó trabar los "bienes de los susodichos a cuya ejecución salió y se opuso el dicho Juan Antonio de la Peña", el cual presentó un memorial "de distintas partidas de dinero que por cuenta de los quinientos ducados" ya había abonado a Ávila. De la Peña argumentaba que le había pagado ya 3.334 reales, además de otras sumas de dinero en razón de "diferentes obras de escultura que el otorgante hizo de orden del dicho su suegro": una imagen de Nuestra Señora de la Pasión para el Colegio de los Ingleses (350 reales); un Niño Jesús, del que desconocemos su destino (100 reales); dos Niños para la iglesia de San Martín (100 reales); y, finalmente le pagó 40 reales por acabar una escultura de Nuestra Señora de la Concepción, del cual tampoco sabemos su paradero. Una vez abonadas todas estas partidas, De la Peña adeudaba todavía a Ávila 2.166 reales de los 500 ducados de la dote (= 5.500 reales); cantidad que le abonó en dos pagas: la primera, por valor de 1.796 reales, el 18 de noviembre de ese año, y la otra, de 400 reales, el día 28 de ese mismo mes. Además, por su parte, Juan Antonio de la Peña solicitó a nuestro escultor que le devolviese "unos perendengues de oro y aljófar, una sortija de oro, una pintura de Nuestra Señora de la Soledad con manto a la florentina, y unos morrillos medianos de hierro" que le había entregado en "calidad de garantía el otorgante no saliese de las órdenes del dicho su suegro siendo licitas y decentes, y para ello pidió que el otorgante hiciese cierta declaración y con efecto la hizo y conforme a ella resulta que las dichas alhajas las dio y entregó al otorgante y a la dicha su mujer voluntariamente sin la dicha calidad". El hecho de que De la Peña le entregara a Ávila 
ciertos bienes para que no abandonase su taller podemos entenderlo como la enorme estima que tenía el viejo escultor de las excepcionales facultades de su "discípulo".

Poco antes de este litigio familiar, el 12 de agosto de 1702, Pedro de Ávila firmaba como testigo en la escritura de obligación que hicieron el ensamblador Juan Llorente, como principal, y el dorador Manuel Martínez de Estrada, como fiador, para la fabricación de un cancel con destino a la vallisoletana iglesia conventual de San Pablo ${ }^{17}$.

Apenas tres meses después le llegó uno de los momentos más duros de su vida: la muerte de su padre, Juan de Ávila. El progenitor de nuestro escultor falleció el 6 de noviembre, siendo sepultado en la iglesia de Santiago Apóstol ${ }^{18}$. Con anterioridad, había testado ante el escribano Francisco de Colinas, documento que no se ha conservado; en él dejaba nombrados como testamentarios al pintor Ignacio Díez de Prado y a Santiago Izquierdo, su cuñado (era el esposo de la hermana de su segunda mujer, Bentura Sedano). Es una verdadera lástima que no se haya conservado ni el testamento ni los inventarios y particiones de sus bienes puesto que nos habrían ayudado bastante a conocer datos muy concretos sobre su vida, su taller, sus intereses literarios, y sobre las obras que había ejecutado, o que por entonces se encontraba trabajando. Sea como fuere, queda claro que nombraría por herederos universales a sus cuatro hijos vivos: Teresa, Pedro, Joseph y Manuel. Es previsible que los tres hermanos se ocuparan de Manuel, el pequeño de la familia, que tan solo contaba con 12 años; si bien sería en Pedro de Ávila en el que recaería la mayor parte de su cuidado, dado que por estas mismas fechas comenzaría a formarle en el oficio familiar. No existe ninguna duda de que Pedro fue el maestro de Manuel, y si la hubiera no habría más que observar las obras de este último y comprobar como comparten un mismo estilo. De hecho, en alguna ocasión, como con las esculturas del retablo mayor de la iglesia de Fuentes de Valdepero (Palencia), se ha confundido la mano de ambos hermanos: siempre se creyó que eran de Pedro, hasta que salieron a la luz documentos que confirmaban la autoría de Manuel. Con el tiempo, Manuel se convertiría en el mejor oficial de Pedro, para posteriormente, quizás, independizarse y abrir un taller propio.

Juan de Ávila debió de dejarles una buena herencia por cuanto sabemos que a Pedro de Ávila le correspondió, al menos, una casa en la calle de Santiago, la cual lindaba "por una parte con casas del Colegio de San Gregorio y por otra casas de Francisco Sáenz. boticario vecino de ella sobre que la Cofradía de la Santa Espina sita en la Santa Iglesia Catedral de esta dicha ciudad tiene un censo perpetuo de dos ducados cada un año con derecho de veintena" (DOCUMENTO 73). Cabe pensar que a cada uno de los hijos le dejó una casa.

Como ya hemos visto, Pedro de Ávila por entonces trabajaba a las órdenes de su suegro, para el cual realizó las obras anteriormente comentadas: una Nuestra Señora de la Pasión para el Colegio de San Albano; un Niño Jesús del que desconocemos el destino; dos Niños para la iglesia de San Martín; también finalizó una imagen de Nuestra Señora

$17 \quad$ A.H.P.V., Leg. 3.005, ff. 471-472.

18 A.G.D.V., Santiago, 1673D, f. 576. 
de la Concepción que parece probable que comenzara a tallar el propio Juan Antonio de la Peña. Tan solo podemos identificar con una obra existente la Virgen de la Pasión, que seguramente sea la Piedad que preside una de las capillas de los pies de la iglesia del Colegio de los Ingleses de Valladolid; aunque el Cristo muerto sobre los brazos de la Virgen sigue dejándonos algunas dudas. De los "dos niños para la parroquia de San Martín" no tenemos ninguna pista de para dónde fueron realizados puesto que no sabemos si se trataba de Niños Jesús o bien de angelotes; sea como fueren parecen haber desaparecido. Si aceptamos que eran ángeles, quizás, como analizaremos en su momento, estos tuvieran como destino un retablo del que por entonces se encargaba en esta parroquia Juan Antonio de la Peña. Efectivamente, en 1699 el suegro de nuestro escultor contrataba la parte escultórica del retablo de la capilla de don Gaspar de Vallejo, la cual constaba, según Martín González y Urrea, de Santo Toribio de Mogrovejo, San Juan de Sahagún, Santo Tomás de Villanueva y relieve del martirio de San Bartolomé. Dado que hasta nosotros tan solo han llegado la de San Juan de Sahagún y el relieve de San Bartolomé, éste último pintado en época neoclásica de blanco imitando mármol, parece factible que tanto las otras dos estatuas como los niños pudieran haber desaparecido, aunque nunca hay descartar la posibilidad de su venta a una parroquia rural. Todas estas esculturas que hemos citados fueron realizadas a finales del siglo XVII, siendo la fecha límite el mes de agosto de 1700 puesto que es cuando se fechan las capitulaciones matrimoniales de Pedro de Ávila y María Lorenza de la Peña.

Unos años después, concretamente en 1703, debió de comenzar a trabajar para el vallisoletano Monasterio de Santa Brígida, para el cual laboró abundantemente. Hasta poco antes de su fallecimiento, su padre Juan de Ávila, se habría ocupado de dotar de imágenes al retablo mayor de este cenobio, tarea que no debió de acabar; debido a lo cual las monjas decidirían que su hijo, ante la supuesta proximidad de su estilo, acabara lo empezado. Efectivamente, Pedro de Ávila se ocupó de tallar el Crucificado del Calvario del ático del retablo mayor. También por estas mismas fechas debió de tallar el grupo de San Joaquín, Santa Ana y la Virgen que presidía el retablo colateral del Evangelio; quizás tallara el San José del colateral de la Epístola, pero es una mera suposición puesto que no he podido ver ni fotografías suyas. A todas estas habría que añadir una Inmaculada Concepción, bastante diferente de su modelo habitual, lo que me hace pensar que sería un "ensayo" del prototipo que popularizó en el Oratorio de San Felipe Neri; dos Bustos de Ecce Homo y Dolorosa y una Santa Escolástica, si bien estas últimas cuatro tallas parecen de años posteriores.

También en estos primeros años de carrera se inició una curiosa expansión de su arte hacia numerosas localidades del Antiguo Partido Judicial de Olmedo. Desconocemos el motivo de tal propagación; pienso que podría estar relacionado con el éxito que tuvo el San Isidro que su padre talló para la ermita vallisoletana del mismo nombre. La difusión de su culto tras su canonización y la devoción que se le tenía en el campo cristalizó en el deseo de diferentes parroquias rurales de poseer imágenes del santo agrícola por excelencia. Para ello decidirían acudir al maestro que talló la escultura vallisoletana; pero, ante el fallecimiento de Juan de Ávila, pensarían que lo más correcto sería 
encargárselas al hijo de éste, puesto que sería el artífice más cercano al creador del modelo. Parece que los primeros en efectuar sus pedidos fueron las parroquiales de Muriel de Zapardiel (h. 1700), Puras (h. 1702-1704) y, quizás, Aguasal (h. 1700). La iglesia de Puras quedó tan satisfecha que dos años después se decidió a encargarle un Cristo Resucitado (h. 1704-1706), que pienso que es una de sus obras más interesantes de esta primera época en la que todavía no ha conformado su verdadero estilo.

Sería entonces cuando la fama de Pedro de Ávila se extendería por la zona y le llegarían nuevos encargos: un San Juan Bautista (h. 1700) para la parroquial de Almenar de Adaja; San José y Santa Teresa para la de Fuente-Olmedo; y la Sagrada Familia de la Virgen para Flores de Ávila. Este grupo es casi exacto al que tallara por estas mismas fechas para el vallisoletano Monasterio de Santa Brígida. Años después volvería a trabajar para esta zona, concretamente para el Hospital de San Nicolás de Bari de Olmedo, para el cual talló la imagen de San Nicolás de Bari; dado que en esta escultura aparece ya el paño a cuchillo parece lógico fecharla con posterioridad a 1712, año en que comienza a trabajar con este tipo de pliegue. En definitiva, parece que el grueso de la producción de su "primer estilo" se encuentra por las tierras sureñas de la actual provincia de Valladolid. Es curioso el hecho de que todas estas localidades se encuentren casi en una línea recta cuyos extremos serían Valladolid y Flores de Ávila. Seguramente una búsqueda en profundidad por los pueblos de esta zona, tanto en el área vallisoletana, segoviana como abulense deparará nuevos descubrimientos. Parece que la expansión de la escultura de Pedro de Ávila por estas zonas estuvo en relación con sus esculturas de San Isidro, en las cuales versionaba el modelo de su padre Juan de Ávila.

Parece probable, como analizaremos en su momento, que Ávila pudo realizar un viaje a Madrid para con el objetivo de completar su formación o bien con la intención de un hipotético asentamiento y apertura de taller. Sea como fuere, la estancia fue muy corta, los límites los estableceríamos entre el año 1705 y finales de 1707. Allí recibiría muchas influencias (madrileña, andaluza, italiana), dado que por entonces la capital de España era un crisol; pero sin duda lo que le marcaría serían las esculturas de Pedro de Mena, José de Mora y algunas piezas napolitanas.

La siguiente noticia, que además sirve de fecha ante quem, es el fallecimiento de su suegra, Francisca de Santiago, el 9 de diciembre de 1707. Por aquel entonces Ávila se encontraba en Valladolid enterrándola en la iglesia de San Miguel; previamente la finada había otorgado dos testamentos: uno en 16 de julio de 1699 "encontrándose enferma de enfermedad natural tal cual Dios ha sido servido darme y en mi juicio y entendimiento natural" ${ }^{19}$, y otro, que en realidad era un poder para testar, pocos días antes de fallecer, el 27 de noviembre de $1707^{20}$. En este último testamento indicaba su deseo de ser sepultada en la capilla de Nuestra Señora de la Esperanza de la referida parroquia; asimismo instituía como herederos universales a sus tres hijos: María, Juana y Joseph.

19 A.H.P.V., Leg. 2.894/2, ff. 18-19.

20 A.H.P.V., Leg. 2.763, f. 233. Juan Antonio de la Peña cumplió con los deseos de su esposa y otorgó el testamento en su nombre el 9 de diciembre. A.H.P.V., Leg. 2.763/2, ff. 244-245. 
Tras la muerte de su esposa, la salud de Juan Antonio de la Peña empeoró, lo que le llevó también a dictar testamento, lo que acaeció el 29 de septiembre de 1707 ante el escribano Tomás de San Juan ${ }^{21}$. Poco viviría ya el escultor, que fallecería, al igual que Juan de Ávila, a una edad no demasiado avanzada (a los 50 murió Ávila y sobre los 58 De la Peña), el 2 de enero de 1708, "a cosa de las siete de la noche"; siento enterrado "con la pompa más moderada que se pueda, no faltando la decencia" en la iglesia de San Miguel ${ }^{22}$. Señala acertadamente Urrea que tras el fallecimiento de De la Peña "el panorama escultórico local pasó a ser dominado en un primer momento por José de Rozas, que contaba por entonces 46 años, siguiéndole a la zaga precisamente Pedro de Ávila, que no había cumplido aún la treintena. La escultura vallisoletana quedó repartida en manos de ambos. Ni Andrés Pereda (h.1655-1732) ni Manuel Ordónez, superviviente de la generación anterior, ni los más jóvenes Vicente Díez, José Pascual (1677-1714) o Antonio Gaute o Gautúa (1682-1744) les inquietaron y sería Pedro de Ávila quien terminó convirtiéndose en el escultor más sobresaliente y de mayor personalidad de este centro artístico al converger en él las enseñanzas recibidas de su padre, el escultor Juan de Ávila (1652-1702) y de su difunto suegro"23.

A la muerte de su suegro se dieron todas las circunstancias para que Pedro de Ávila asumiera el papel de "patriarca" de la familia. Hemos de tener en cuenta que en los últimos años suegro y yerno volvieron a mantener una relación muy estrecha y familiar. Solo así podemos explicar el que De la Peña le nombrara como uno de sus testamentarios, denotando así el aprecio que sentía por él, fraguado durante los años en que ambos compartieron taller, puesto que desde la muerte de Juan de Ávila, si no antes, Pedro trabajaría codo a codo junto a su suegro. Aparte de esta circunstancia, hay que tener en cuenta otras tres que apoyan esta tesis de la asunción de Pedro de Ávila del papel de "patriarca" de la familia. Las tres circunstancias derivan de las diferentes situaciones en que se encontraban los hijos de Juan Antonio de la Peña: primeramente estaba María Lorenza de la Peña, su esposa, de la que él sería el responsable; por otro lado se encontraba Juana Rosa de la Peña, que por entonces era menor de edad, y cuya custodia quedó en manos de Pedro de Ávila y María Lorenza; y, finalmente, tenemos a José de la Peña, el único hijo varón del escultor, que bien pudo ocupar el lugar principal de la familia si no fuera porque se encontraba fuera de España, concretamente en Portugal, en donde vivía con su esposa e hijos. Todas estas particularidades le convirtieron en el centro de la familia y en uno de los actores principales a la hora de la realización del inventario, cuenta y partición de los bienes de su suegro.

Si hubo una relación realmente importante tras el fallecimiento del escultor fue la de nuestro escultor con Juana Rosa de la Peña, hija menor del difunto maestro. Ésta había nacido en Valladolid a comienzos del mes de junio de 1686, siendo bautizada en la iglesia de San Miguel el día 16 de ese mismo mes $^{24}$. Entre los testigos del feliz

\footnotetext{
21 URREA FERNÁNDEZ, Jesús: “La biografía al servicio del conocimiento..., op. cit., p. 48.

$22 \quad$ Ibídem.

23 Ídem, p. 55.

$24 \quad$ "En diez y seis de junio de mil y seiscientos y ochenta y seis años yo el licenciado Manuel de Reinoso teniente de cura de la iglesia parroquial del señor San Miguel de esta ciudad de Valladolid
} 
acontecimiento se encontraba el dorador Alonso Gutiérrez. A la muerte de su padre, Juana Rosa contaba solamente con 21 años, siendo por lo tanto menor de edad ${ }^{25}$; motivo por el cual se le debía proporcionar un curador que administrara tanto su persona como sus bienes. El elegido para este cargo fue Pedro de Ávila, su cuñado, nombramiento que tuvo lugar el 29 de febrero de 1708 (DOCUMENTO 60). En tal papel, nuestro escultor suplicará, en nombre de Juana Rosa, a la autoridad competente la asignación diaria de una cantidad para poder "alimentarla y sustentarla"; por entonces la joven ya se hallaba viviendo en el Convento de San Nicolás. Pedro de Ávila lograría su objetivo, ya que el corregidor de Valladolid, don Bartolomé Antonio Badarán y Osinalde, le asignó “real y medio de vellón cada día para sus alimentos" (DOCUMENTO 61).

Las labores de Pedro de Ávila como curador de Juana Rosa de la Peña continuaron en, al menos, otras tres ocasiones, si bien todas ellas relacionadas con el mismo tema: el ingreso de Juana Rosa como "religiosa de velo y coro" en el Convento del Santísimo Sacramento y San Nicolás, de la Orden de San Agustín de Calzados. El primer documento, que data del 10 de mayo de 1708, trata sobre las capitulaciones para ingresar como religiosa en el sobredicho convento (DOCUMENTO 62). Por razón de ese ingreso, Pedro de Ávila y María Lorenza de la Peña abonaban al convento 8.800 reales de vellón, además de 200 ducados $(=2.200$ reales $)$ de propinas y otros 40 ducados $(=440$ reales $)$ por razón de los alimentos que gastara la joven durante su estancia en el convento. El siguiente documento, fechado el 14 de mayo de 1709, es la obligación que hacen Pedro de Ávila y su mujer para pagar al citado convento 2.000 reales de vellón que todavía le estaban debiendo por la dote de entrada al convento de Juana Rosa. Este dinero era el último plazo de la paga de la dote, debido a que esa misma semana Juana Rosa iba a hacer profesión solemne (DOCUMENTO 63). El último documento es la propia carta de pago de dote (DOCUMENTO 64), datada ese mismo día, otorgada por el convento a favor de Pedro de Ávila y su mujer.

\section{C- ÉPOCA DE LOS GRANDES CONTRATOS (1708-1720)}

El año 1708 es fundamental para nuestro escultor puesto que es en el que termina de independizarse artísticamente, si no lo estaba ya. Desconocemos si hasta el fallecimiento de su suegro trabajó solamente a sus órdenes; simultaneó el trabajo en el taller de éste con sus propios encargos; o bien se hallaba ya independizado. Sea como fuere, el fallecimiento de su suegro cortó los lazos artísticos que les unían. Otro hecho por dilucidar es si Pedro de Ávila trabajó hasta entonces en taller propio o bien en el de su suegro, el cual, tras su fallecimiento, quedó en manos de nuestro escultor.

bauticé e impuse los santos óleos según forma de nuestra santa madre iglesia a Juana hija legítima de Juan Antonio Peña y de Francisca de Santiago su legítima mujer; fueron sus padrinos el licenciado D. Juan Antonio González teniente de cura de la iglesia de Santiago y Juana de Llanos dieronla por abogados a Santa Rosa y San Fernando rey de España fueron testigos D. Antonio Sangáriz cura propio de dicha iglesia y Alonso Gutiérrez y lo firmé·. A.G.D.V., San Miguel, 1668B, f. 176. URREA FERNÁNDEZ, Jesús: "La biografía al servicio del conocimiento...", op. cit., p. 55.

25 La mayoría de edad estaba establecida por entonces en 25 años. 
Tras desaparecer el escultor gallego, el matrimonio formado por Ávila y su mujer, de la una parte; y el hijo de De la Peña, Joseph, y su familia, que acababa de regresar de Portugal, de la otra; tuvieron que compartir la casa del finado durante cierto tiempo. Señala Urrea que "durante año y medio las dos familias convivieron sin problemas" 26 ; sin embargo, el 30 de noviembre de 1710, ambas partes "deseando vivir con paz y quietud y excusar algunos inconvenientes", acordaron que un maestro de obras "viese, reconociese y midiese dicha casa y separase dichas viviendas dando y aplicando a cada uno su mitad y la vivienda correspondiente conforme a sus medidas sin perjuicio" (DOCUMENTO 69). La división de ambas viviendas, así como los reparos necesarios, deberían de hacerse "dentro de tres meses de la fecha de esta escritura". La historia de esta casa no quedaría aquí, puesto que el 8 de enero de 1714 Pedro de Ávila adquiere a su cuñado su mitad, quedándose por lo tanto con la totalidad del inmueble que les entregó De la Peña (DOCUMENTO 70). Desconocemos si Joseph de la Peña la vendió porque tenía problemas económicos; quiso trasladarse a otra casa; o bien quiso volver a Portugal, país del que era su esposa y en el que quizás nacieron sus hijos. Lo que no cabe duda es que entre ambos hombres existía una buena relación puesto que Joseph califica al escultor como "Pedro de Ávila mi hermano". Se me ocurre una hipótesis que quizás pueda explicar esta venta: pudiera ser que Ávila rogara a su "hermano" que le vendiera su parte de la casa para así contar con un inmueble mucho más grande en el que poder ampliar notablemente el tamaño de su taller; dado que es en este año en el que se le acumulan más pedidos y en el que parece que terminó de despegar su prestigio. Hemos de tener en cuenta que en este año de 1714 tenemos documentada gran parte de su producción conocida, tampoco demasiado abundante, a la que seguramente habría que añadir otras que no conocemos por el momento: las esculturas de San Juan Evangelista, San Pedro, San José y San Miguel para la Catedral; el San Miguel para Castil de Vela; y el Crucificado para Torrecilla de la Abadesa. Sea como fuere, la venta se hizo efectiva, y Pedro de Ávila pagó los 2.200 reales en que Joseph de la Peña tasó su casa; dos meses después, este último le otorgó carta de pago por la venta de la casa (DOCUMENTO 71).

Al mismo tiempo, otro asunto le unió a su cuñado, Joseph de la Peña. Se trataba de la entrega de los bienes que le había dejado su padre tras su fallecimiento. El 29 de octubre de 1709 Manuel de Peñamaría "en nombre y como defensor de Joseph de la Peña hijo y heredero que es y quedó de Juan Antonio de la Peña" pide que se le entregaran los bienes que había heredado, los cuales se encontraban depositados en Juan Antonio de Bahamonde "mediante que doña Juana de la Peña hermana de mi parte entró y está religiosa profesa en el Convento de San Bartolomé extramuros de esta ciudad con que sólo han quedado en el siglo mi parte y Pedro de Ávila como marido y conjunta persona de doña María de la Peña hermana asimismo de mi parte, quien se halla en esta ciudad a prevenir casa para traer y conducir a ella a su mujer hijos y familia para que cuando vengan tenga de pronto el caudal que le ha tocado a su Majestad pido y suplico mande que dando el dicho Pedro de Ávila fianza de tener de pronto el caudal que a mi parte se le adjudicó y tocó se le entregue el dicho Juan Antonio de Bahamonde

26 URREA FERNÁNDEZ, Jesús: “La biografía al servicio del conocimiento...”, op. cit., p. 55. 
despachándole para ello su libramiento en forma" (DOCUMENTO 67). Posteriormente se investigó si en realidad se trataba del verdadero Joseph de la Peña, para cuya identificación se interrogó a diversas personas, entre ellas su hermana María Lorenza y el escultor José de Rozas. Así, por ejemplo, María Lorenza llega a declarar que esa persona era "su hermano carnal le reconoce por cuya razón le tocan y pertenecen todos los bienes dinero y alhajas que se le adjudicaron en la cuenta y partición".

Joseph había solicitado que "el depósito de la cantidad que le tocó de su legítima se removiese en Pedro de Ávila su cuñado en el ínterin que mi parte trae y conduce a esta ciudad dicha su mujer hijos y familia que se hallan cuarenta leguas de esta ciudad y por verdad se mandó que mi parte justificase la identidad de su persona la que tengo justificada plenamente como consta de la información que presentó y juró". Una vez que llegó a la ciudad la familia de éste, Ávila salió por fiador de sus cuñados al respecto de que éstos "estarán en esta ciudad y no harán ausencia de ella ninguno de los referidos al dicho reino de Portugal de donde la susodicha es natural ni a otro reino ni parte que sea contrario y enemiga de esta corona de España pena de que se les pueda castigar y castigue en todo aquello que deben ser castigados los que hacen semejantes fugas a reino enemigo". Es decir, nuestro escultor se obligaba a "que los dichos sus cuñados se asentaren e hicieren fuga a tierra o reino contrario a esta dicha corona luego que tal lo conste dará y pagará a la elección y voluntad del señor corregidor de esta ciudad o de otro cualquier señor juez que lo sea competente cada y cuando que le sea mandado y pedido los diez y seis mil ochocientos y veintidós reales y medio de vellón la misma cantidad que al dicho Joseph de la Peña le tocó en su hijuela y hubo de haber en los bienes que quedaron por fin y muerte del dicho Juan Antonio de la Peña su padre". Pasados los años, y visto por los jueces competentes que el matrimonio no se ausentó de España ni hizo lo que en el texto se relaciona, Pedro de Ávila quedó "dado por libre (...) en virtud de auto del corregidor D. Francisco Joseph Montalbo y Huerta corregidor de esta ciudad" el 22 de marzo de 1714. Todo lo relativo a la entrega de los bienes que Joseph de la Peña había heredado de su padre quedó zanjado el 4 de diciembre de 1709 en que éste expidió carta de pago a favor de don Juan Antonio González Bahamonde (DOCUMENTO 68).

Volviendo a la línea cronológica de nuestro Ávila, hemos de retroceder nuevamente hasta comienzos del año 1708. El 29 de febrero de este mismo año de 1708, Ávila y su mujer renuevan y reconocen un censo perpetuo que recaía sobre una de las casas que "quedaron por fin y muerte de Juan Antonio de la Peña asimismo escultor y de Francisca de Santiago su mujer difuntos vecinos que fueron de esta dicha ciudad". El censo, que ascendía a 100 reales anuales, había sido fundado por el carpintero Toribio González de Linares y su mujer Inés Gutiérrez en favor del Convento de San Pablo. Tras los fallecimientos de De la Peña y su mujer, la casa fue adjudicada "entre otros bienes (...) adjudicaron a mí la dicha María de la Peña como uno de sus hijos y hermanos fue la mitad de la dicha casa de que procede el dicho censo perpetuo y la otra mitad se adjudicó a Joseph de la Peña nuestro hermano con la carga del censo 
perpetuo referido". Esta casa hacía "esquina a las dichas dos calles de San Miguel y la otra que sube por detrás de la dicha iglesia del Cristo de la Cruz a la calle de las Damas de ésta ciudad" (DOCUMENTO 65).

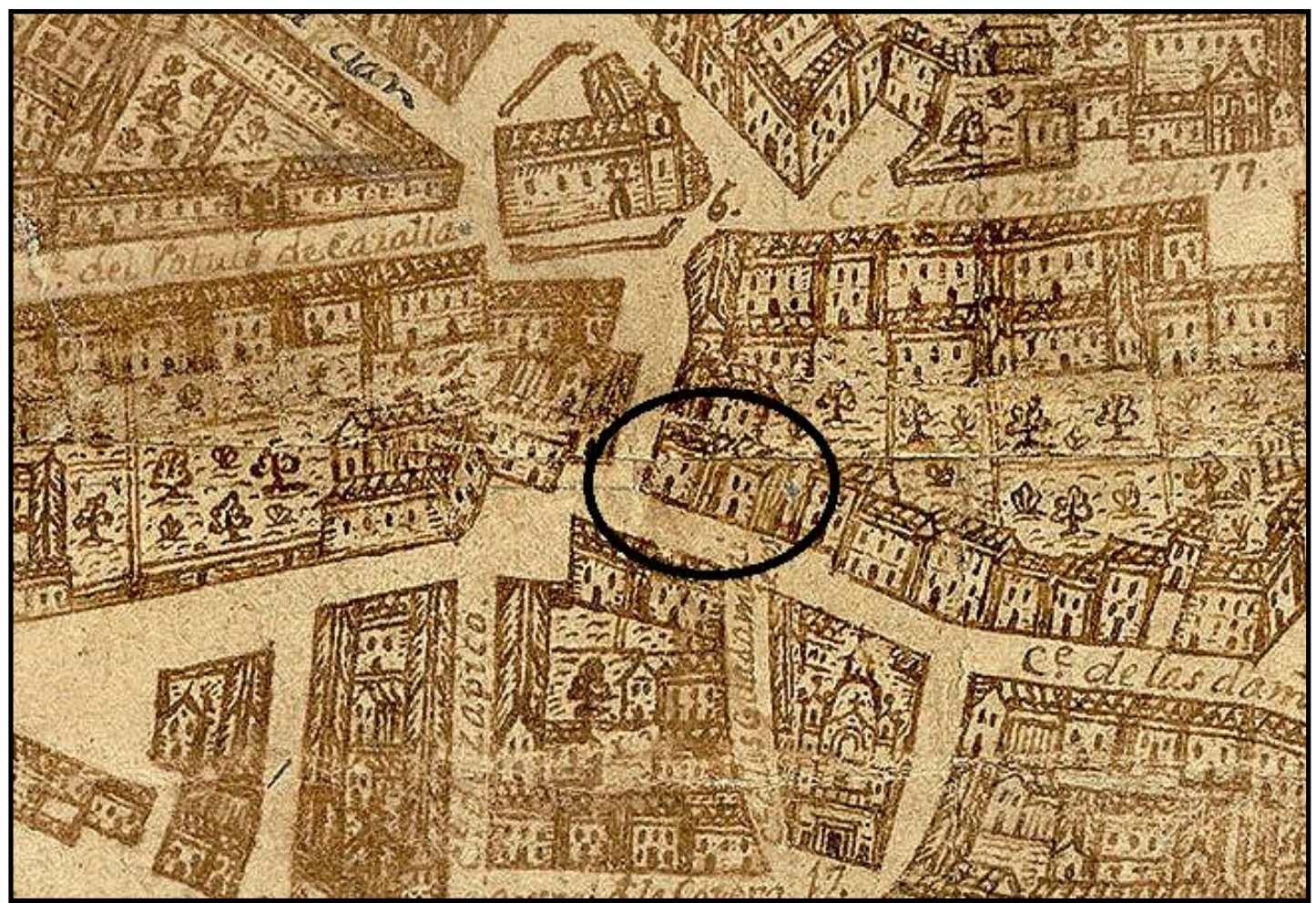

Il. 2- Localización de la casa de Juan Antonio de la Peña que fue dividida tras su fallecimiento entre sus hijos Joseph y María Lorenza, esposa de Pedro de Ávila. Mapa de Bentura Seco de 1738

Unos días después, el 7 de marzo, Pedro de Ávila y su mujer, "a pesar de no encontrarse enfermos, se otorgan un poder recíproco para testar" (DOCUMENTO 66). Seguramente les debió afectar muchísimo el fallecimiento tan seguido de los padres de María Lorenza y quisieron "ordenar las cosas" por si acaso les sucedía alguna desgracia similar. Ese poder recíproco se lo daban "para que llegando el caso de que uno de los dos otorgantes muere el que de los dos sobreviviere al otro; pueda por el que falleciere y en su nombre hacer y otorgar su testamento última y postrimera voluntad en el término que le da el derecho y en el hacer las mandas legados y disposiciones que quisiere y que tenemos comunicadas entre los dos". Asimismo, ordenaban ser sepultados en la desaparecida iglesia de San Miguel, concretamente en "la sepultura donde está enterrado Juan Antonio de la Peña nuestro padre y suegro como se entra en la sacristía en la capilla mayor no habiendo embarazo justo y habiéndole en la parte que eligieren nuestros testamentarios". Además, como no podía ser de otra manera al no tener descendencia, "nos dejamos e instituimos por nuestros herederos legítimos y universales también el uno al otro y del otro al otro". Este testamento quedaría en papel mojado puesto que ambos redactaron otros nuevos hacia el final de sus vidas.

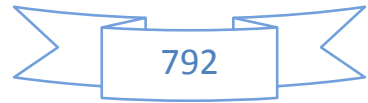


El 14 de agosto de 1708 fallece su hermano Joseph, el cual por entonces se encontraba soltero viviendo en algún domicilio del área territorial de la catedral por cuanto se le entierra allí al día siguiente a su óbito ${ }^{27}$.

Por estos mismos momentos se encontraba tallando una de sus esculturas más míticas, aunque por desgracia todavía no la hemos podido documentar, si bien no existe ninguna duda acerca de su autoría: el grupo de la Traslación de San Pedro Regalado que le encargó en 1709 el escribano Gabriel de Medina Mieses para la capilla que se le fabricó al santo en la iglesia del Santísimo Salvador de Valladolid ${ }^{28}$. No cabe duda de que la elección de Pedro de Ávila para realizar este prestigioso encargo, por cuanto era la primera gran imagen del santo vallisoletano en su ciudad natal, y en la parroquia en la que recibió las aguas bautismales, vino a confirmarnos su posición de superioridad con respecto a los otros escultores del foco vallisoletano; y muy especialmente con José de Rozas, el último gran artífice vivo de la generación capitaneada por él mismo, Juan de Ávila y Juan Antonio de la Peña. No sabemos si al mismo tiempo, o algún tiempo después, aunque con fecha límite en el año 1716, el propio Medina Mieses debió de encargar a nuestro escultor las imágenes que ocuparían los dos retablos colaterales de la capilla del Regalado; los cuales, también costeados por Medina Mieses, se situarían sobre las tumbas familiares que le fueron adjudicadas al escribano ${ }^{29}$. Estos dos retablos estaban dedicados a la Anunciación en el misterio de la Encarnación y a los Celos de San José. El primero de ellos lo conforma un grupo de la Anunciación, mientras que el segundo, que en un principio constaba de una imagen de San José (desaparecida en fecha ignorada), en una fecha anterior a 1716 fue sustituida por un Ecce Homo. Desconocemos si ese San José fue realizado por entonces, o bien estaba reaprovechado. Ambos conjuntos se encuentran en la actualidad en la parroquial de Renedo.

El grupo de San Pedro Regalado es importante desde otro punto de vista: el de la evolución del estilo de nuestro escultor. Si algo es consustancial al arte de Pedro de Ávila es la utilización del paño "de cuchillo", que fue creado por Bernini, aunque nuestro artífice parece que fue el primero en utilizarlo en Castilla. Efectivamente, el uso del paño de cuchillo no fue algo instantáneo, sino progresivo. Podemos ver cierta evolución desde el grupo de la Traslación de San Pedro Regalado (1709) de la iglesia del Salvador de Valladolid, en que comenzamos a intuirlo; hasta que aparece ya plenamente configurado en el año 1712, como podemos comprobar en imágenes tales como Nuestra Señora de las Nieves de Alaejos, San Pío V del vallisoletano Convento de San Pablo o el San José de Morales de Toro. Sin embargo, Ávila siguió evolucionando este tipo de paño, puesto que cada vez logró una mayor labor de filigrana.

\footnotetext{
27 "En 14 de agosto de 1708 habiendo recibido los santos sacramentos con el de la extremaunción murió en esta parroquia de la catedral Joseph de Ávila soltero mi parroquiano hijo de Juan de Ávila y de Manuela Ezquerra vecinos de esta ciudad difuntos no hizo testamento (...) enterrose en 15 de este dicho mes en Valladolid". A.G.D.V., Catedral, 1684D, f. 160. El nombre de la madre es erróneo puesto que era Francisca y no Manuela.

28 CALVO CABALLERO, Pilar: op. cit., p. 71.

29 Ídem, p. 61.
} 
La consolidación del prestigio del escultor derivó en una serie de encargos, cada vez con mucha mayor asiduidad, tanto en la ciudad como en las zonas cercanas. La repercusión en la ciudad fue inmediata: la Ilustre Cofradía Penitencial de Nuestra Señora de las Angustias le encargó en 1710 la ejecución de las tallas de Cristo atado a la columna y Ecce Homo para los retablos colaterales de la recién construida capilla camarín de las Angustias; mientras que hacia 1712-1713 el convento dominico de San Pablo, con objeto de celebrar la canonización de uno de los personajes más ilustres de la Orden, decide confiarle la realización de una imagen de San Pío V. Por su parte, entre las localidades cercanas a la capital vallisoletana, le comisionaron obra las iglesias de la Asunción de Geria (Santa Catalina de Alejandría, h. 1711-1712), la de Santa María de Alaejos (Santa Bárbara, h. 1712), la de los Santos Juanes de Nava del Rey (Nuestra Señora de las Nieves, h. 1712), y la de San Juan Bautista de Morales de Toro (San Ildefonso y San José, 1712) ${ }^{30}$.

El 22 de mayo de 1712 se celebra la boda de su hermano Manuel de Ávila con María Martínez, hija del platero vallisoletano Joseph Martínez $^{31}$. Pedro acudiría a la ceremonia, acaecida en la iglesia del Santísimo Salvador, el mismo recinto en el que se había celebrado el segundo matrimonio de su padre Juan de Ávila. La relación con su hermano era fraternal como nos lo demuestra los numerosos documentos, prueba de ello es que el 13 de abril de 1714 figura como testigo, junto a los plateros Damián Cortés y Joseph Martínez, en el bautizo de su sobrina María Teresa de Ávila, primogénita de su hermano Manuel ${ }^{32}$. La cercanía entre los matrimonios de ambos hermanos llevó a que María Lorenza de la Peña ejerciera de madrina, junto a Juan Sangáriz, de otra hija de Manuel de Ávila, Feliciana, bautizada en la iglesia de San Miguel el 2 de diciembre de $1725^{33}$.

Llegados a estas alturas, nuestro escultor conocería a la mayoría de los artífices vallisoletanos contemporáneos: arquitectos, escultores, pintores, policromadores, etc... Entre ellos se encontraba el batidor de oro Antonio Canesi, con quien parece que mantuvo una excelente relación. Este hombre era hermano ni más ni menos que del famoso escribano e historiador vallisoletano Manuel Canesi Acebedo, cuya obra cimera es, según sus propias palabras, la "Historia Secular y Eclesiástica de mi patria de Valladolid"; la cual tenía finalizada con anterioridad a su testamento otorgado el 5 de abril de 1750, en el que declaraba su deseo de venderla "por mi heredero y su importe se convierta en sufragios por mi alma, la de dicha mi mujer y demás personas que tenga obligación" ${ }^{34}$. Pues bien, la amistad entre el batidor de oro y Ávila la entrevemos en el legado que hace a nuestro escultor en uno de sus testamentos: "Mando yo el dicho don Antonio Canesi y Acebedo a Pedro de Ávila escultor vecino de esta ciudad una

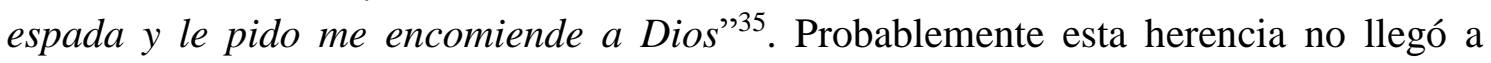

NAVARRO TALEGÓN, José: Catálogo monumental de Toro..., op. cit., p. 343.

A.G.D.V., El Salvador, 1685M, f. 229.

A.G.D.V., Valladolid, San Miguel, 1705B, f. 82.

A.G.D.V., Catedral, 1681B, f. 372.

A.H.P.V., Leg. 3.660/1, ff. 31-33.

A.H.P.V., Leg. 3.083, ff. 191-192. 
culminarse puesto que en testamentos posteriores ya no cita a Ávila, aunque este hecho tampoco es excluyente. De lo que no cabe duda es que la amistad entre ambos artistas continuó en el tiempo, puesto que en 1726 Ávila se encarga de inventariar y tasar las esculturas que poseía el batidor de oro antes de que contrajera matrimonio en segundas nupcias con doña Isabel de Mata $^{36}$. Pudiera ser que alguna de éstas hubiera sido tallada por Ávila, aunque es una hipótesis sin fundamento alguno. A la vista de todo esto colegimos dos cosas: la generosidad y el poderío económico de Antonio Canesi. Ambas percepciones las volvemos a confirmar tras leer su testamento redactado en 1727, en el cual mandaba entregar tras su fallecimiento a la Cofradía de Nuestra Señora del Val "el Rey Felipe Quinto y la Soberana que tengo con marcos dorados los cuales se pongan en la capilla mayor de la iglesia de dicha cofradía sin que se saquen de ella por vía de empréstito vendan ni enajenen" 37.

Otra buena amistad de Pedro de Ávila debió ser su colega de oficio José Pascual, hijastro del también escultor José de Rozas; puesto que en su testamento, fechado el 28 de mayo de $1713^{38}$, declara deber a "Pedro de Ávila vecino de esta ciudad de oficio escultor diez y ocho reales de vellón mando se le paguen". No sabemos en concepto de que figuraba esta deuda, quizás fuera de un préstamo. No debe extrañarnos esta cercanía dado que el escultor, rigurosamente contemporáneo de Ávila, vivía también en el barrio de San Miguel.

El 22 de junio de 1714 Ávila se encarga de tasar las esculturas que dejó al fallecer don Juan Antonio de la Rumbe y Elizalde ${ }^{39}$, regidor que fue de la ciudad de Valladolid $^{40}$.

36 "Antonio Canesi Acebedo batidor de oro vecino de esta ciudad de Valladolid viudo de doña Teresa Monje, digo que para el servicio de Dios nuestro señor estoy tratado casarme con doña Isabel de Mata natural de esta dicha ciudad y para que en todo tiempo conste los bienes que llevo y se sepa su valor desde luego nombro por tasadores en lo tocante (...) para escultura a Pedro de Ávila (...), a su majestad pido y suplico los haya por nombrados y se les notifique lo acepten y mediante hallarse menor de veinte y cinco años la dicha doña Isabel de Mata para que dicho inventario se haga sin vicio ni nulidad se notifique a su curador ad litem y cite para ello y nombre si quisiere de su parte tasadores en que recibiere merced". Tasación de escultura. "En Valladolid dicho día yo el escribano estado en dichas casas con asistencia y en presencia de dicho curador pareció ante mí Pedro de Ávila escultor vecino de ella tasador nombrado por lo tocante a dichas alhajas del cual tomé y recibí juramento por Dios nuestro señor y una señal de cruz en forma de derecho y habiéndole hecho como se requiere prometió decir verdad debajo de lo cual hace la tasación siguiente:

- Un Niño de Pasión que está en un escaparate y un San Juan uno y otro de bulto a mil y cien reales cada uno dos mil y doscientos.

- Un Niño de bendición que está en otro escaparate doscientos y cuarenta reales.

- Una Nuestra Señora de las Angustias o Dolores mil y trescientos reales.

Con lo cual se feneció y a cada uno el inventario y tasación de alhajas de escultura los cuales según ella importan tres mil setecientos y cuarenta reales que se quedaron en poder del dicho Antonio Canesi y dicho tasador declaro haberla hecho bien la verdad para el juramento que lleva hecho en que se afirmó y ratificó y lo firmó declaro ser declaro ser de edad de cincuenta y dos años poco más o menos fírmolo dicho curador y el expresado Antonio Canesi y en fe de ello yo el escribano". A.H.P.V., Leg. 3.160, ff. 418-420 (1726).

37 A.H.P.V., Leg. 3.160.

38 GARCÍA CHICO, Esteban: Documentos para el estudio del arte en Castilla. 2..., op. cit., pp. $362-363$.

39 Tenemos documentado que ejerció el cargo de regidor vallisoletano, al menos, entre 1678 y 1690. Además, en el año 1690 fue nombrado comisario de las fiestas organizadas con motivo del 
Como veremos más adelante, no será la única tasación que realice. El inventario de las esculturas del regidor nos aporta datos interesantes: por lo visto poseía un pequeño Nacimiento; además de las tan frecuentes pequeñas esculturas de San Juan Niño y Santa María Magdalena con sus respectivos peñascos. El toque exótico, y que nos da buena cuenta de los posibles del regidor, lo ponían los dos Niños Jesús importados desde Nápoles "el uno de Gloria y el otro de Pasión", cada uno de los cuales lo valuó Ávila en la nada despreciable cantidad de 400 reales $^{41}$.

Justo un mes después se celebraron las capitulaciones matrimoniales entre su hermana Teresa y Santiago Barba, acto del cual Pedro es testigo, junto con Juan de Aldaba y Lorenzo Negral (DOCUMENTO 6). Para Santiago Barba fue el segundo matrimonio ya que previamente había estado casado con Juliana Meléndez, la cual había muerto en 1703 , otorgando testamento en ese mismo año ${ }^{42}$. Ese mismo día se celebró la boda en la iglesia de San Miguel, siendo madrina de la misma María Lorenza de la Peña ${ }^{43}$, cargo que volvería a ejercer el 24 de septiembre, fecha en la que se veló al matrimonio en la catedral $^{44}$.

El año 1714 fue mágico para nuestro escultor desde el punto de vista artístico, puesto que le comisionan uno de los encargos más importantes de su vida: las esculturas que debían de presidir los retablos de las cinco capillas de la catedral que no poseían un

casamiento de Carlos II con María de Neoburgo en la propia ciudad. A.H.P.V., Leg. 2.376, f. 845; A.M.V., CH. 91-6.

$40 \quad$ Tasación escultor. "En la ciudad de Valladolid a veinte y dos de junio de mil setecientos y catorce años, estando en la casa donde vivía y murió don Juan Antonio de la Rumbe Elizalde vecino y regidor perpetuo que fue de esta ciudad yo el escribano, con asistencia del señor don Manuel Junco (del Consejo de su Majestad) y demás herederos tomé y recibí juramento por Dios y una cruz e forma de derecho de Pedro de Ávila escultor tasador nombrado para efecto de tasar lo tocante a su ejercicio, y habiendo hecho como se requiere dijo hacer dicha tasación bien y fielmente y sin agravio de partes la cual hace en la forma y manera siguiente:

- San Joseph. Un San Joseph, la Virgen y el Niño de vestidura del Nacimiento, en cien reales.

- San Juan. Un San Juan con su peñasco en cuatrocientos reales.

- Magdalena. Una Santa María Magdalena con su peñasco en cuatrocientos reales.

- Santo Cristo. Un Santo Cristo de marfil, en doscientos y cuarenta reales.

- Ídem. Otro Santo Cristo de madera en ochenta y ocho reales.

- Niños. Dos Niños de Nápoles el uno de Gloria y el otro de Pasión a cuatrocientos reales cada uno ochocientos reales.

En dicha conformidad el dicho Pedro de Ávila maestro escultor tasador nombrado para dicho efecto dijo haber hecho bien y fielmente dicha tasación, y sin agravio de partes so cargo del juramento que lleva hecho en que se afirmó y ratificó y dijo ser de edad de treinta y cuatro años poco más o menos y lo firmó y en fe de ello yo el escribano". A.H.P.V., Leg. 2.394/3, f. 58. URREA FERNÁNDEZ, Jesús: "El oratorio...", op. cit., p. 19.

41 En el Monasterio de la Concepción del Carmen (Monasterio de Santa Teresa) se conserva un Niño Jesús con las Arma Christi de procedencia napolitana que bien podría ser el citado "Niño Jesús de Pasión". Casado Paramio se lo ha atribuido recientemente a los hermanos Aniello y Michele Perrone. Aunque esta escultura sería donada por un particular, seguramente no tenga nada que ver con la del regidor, pero al menos nos da buena muestra de la incesante llegada de obras napolitanas a la ciudad. No cabe duda de que fue donación. CASADO PARAMIO, José Manuel: "Niño Jesús con los Arma Christi". En REBOLLO MATÍAS, Alejandro: Signa Christi. Símbolos y emblemas de la Pasión, Ayuntamiento de Valladolid, Valladolid, 2015, p. 62.

$42 \quad$ A.H.P.V., Leg. 2.954, ff. 323-326.

43 A.G.D.V., San Miguel, 1681M, f. 88.

44 A.G.D.V., Catedral, 1695M, f. 131.

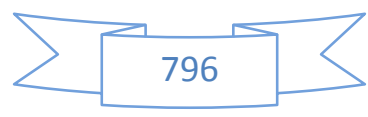


patronato privado, sino que eran propiedad de la seo: las de San Juan Evangelista, Santa María Magdalena, San José, San Pedro y San Miguel ${ }^{45}$. Este encargo le sirvió para codificar los modelos de estos santos, alguno de los cuales volverá a realizar con posterioridad y con un alto grado de similitud. Efectivamente, ese mismo año nuestro escultor talló un San Miguel idéntico para la iglesia parroquial de San Miguel de Castil de Vela $\left(\right.$ Palencia) ${ }^{46}$. El encargo catedralicio parece que le proporcionó el nombramiento de maestro mayor del obispado si tenemos en cuenta la expresión con la que se refieren al escultor en el libro de fábrica de la referida iglesia de Castil de Vela, o quizás solo se refiera al hecho de que por entonces se encontraba trabajando en la seo: "Pedro de Ávila maestro escultor en Valladolid y de la Santa Iglesia de dicha ciudad" "47. Para apoyar la tesis de que pudo ser nombrado maestro mayor del obispado me baso en que en uno de sus testamentos, el fechado el 23 de abril de 1747, Ávila explica que el obispo de Valladolid, Julián Domínguez de Toledo, le "había dado consignado por vía de limosna a razón de tres reales cada día y eran de veinte meses devengados hasta la muerte del dicho Ilustrísimo señor" (DOCUMENTO 79); esto pudiera probar que trabajó para el obispado, y el obispo en nombre de la institución que presidía decidió otorgarle una pensión ante la imposibilidad del escultor para trabajar debido a su ceguera.

Todavía en este año de 1714 tenemos documentada otra obra: un Cristo Crucificado

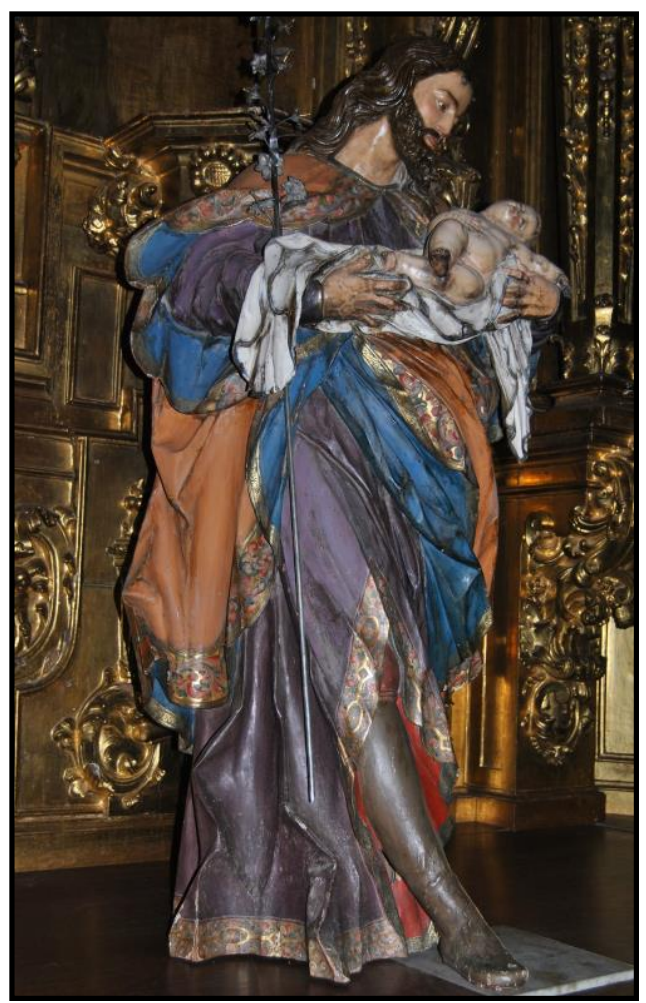

Il. 3- Pedro de Ávila. San José con el Niño. Catedral. Valladolid. para la iglesia parroquial de San Esteban Protomártir de Torrecilla de la Abadesa (Valladolid $)^{48}$. Hay que recordar que su padre había trabajado años antes para esta misma iglesia esculpiendo una imagen de Nuestra Señora de Gracia (1698) y, posiblemente, las esculturas del retablo mayor (1700). Este encargo será trascendental puesto que en él fijará su modelo definitivo de Crucificado. Ya no tendrá nada que ver con el del retablo mayor de las Brígidas, ni siquiera en el tamaño. Este nuevo tipo de Crucificado será notablemente más pequeño y delicado, y con unas pautas tan características que nos ayuda a atribuirle otros Crucificados. Será, por lo tanto, el prototipo que utilice para crear años después el Crucificado del Oratorio de San Felipe Neri (1720) y, quizás, un Crucificado que hemos localizado en la iglesia parroquial de Bernuy de Coca (Segovia). Otra sorpresa nos deparó la

45 URREA, Jesús: "Capillas y patronos de la catedral de Valladolid”, B.R.A.C., Tomo XL, 2005, p. 123.

46 A.D.P., Castil de Vela, San Miguel, Caja 32, f. 87.

$47 \quad$ Ibídem.

48 PARRADO DEL OLMO, Jesús María: Datos histórico artísticos ..., op. cit., pp. 104-106. 
documentación de este Crucificado de Torrecilla de la Abadesa como obra de Pedro de Ávila, y es la posibilidad de asegurar sin ningún género de dudas de que Pedro y Manuel de Ávila eran hermanos; ya que durante cierto tiempo se creyó que pudieron haber sido padre e hijo ${ }^{49}$.

Por estas mismas fechas Ávila se encontraría trabajando para don Pedro de Rábago, cura de la vallisoletana iglesia del Salvador, tallándole al menos las imágenes de la Virgen del Refugio y de Las lágrimas de San Pedro. El sacerdote fue un gran benefactor para su iglesia. Así, entre otras cosas, "con el fin de la mayor honra y gloria de Dios Nuestro Señor y de los Santos de quien he tenido y tengo particular devoción" hizo adornar "de mi propio caudal", los "tres altares hechuras y retablos, como al presente están por no haberlos en dicha iglesia con la ruina de la torre vieja". El primero se situaba en el lado del Evangelio, debajo del arco toral de la capilla mayor, en correspondencia del altar del Santísimo Cristo que está al lado de la epístola de Nuestra Señora del Consuelo. Otro era el de "mi padre San Pedro apóstol en el sitio y capilla de Nuestra Señora del Descendimiento de la Cruz que dicha torre arruinó que es de los Señores Condes de Alba Real". El tercer altar y retablo era el de "Nuestro Padre San Francisco de Paula en el sitio y arco como se entraba a la capilla que era del señor obispo Soto que también arruinó dicha torre cuyo sitio pertenece a la Cofradía de las Ánimas de dicha parroquia". También ordenaba que si algún bienhechor "hiciere alguna dotación memoria o fundare capellanía en dicho altar de Nuestra Señora del Consuelo" se le habría de dar el "dicho altar hechura de Nuestra Señora retablo que esta dorado y pintado con el niño Jesús de Pasión recostado en una cama todo hecho con gran primor y vidrieras cristalinas que Nuestra Señora tiene y el niño según y cómo al presente todo ello está para él sus herederos y pueda poner en él sus armas y letrero que le pareciere de poner como de cosa suya propia y mediante haber hecho todo ello a mi costa pido" (DOCUMENTO 88).

La Virgen del Refugio la podemos fechar con cierta precisión entre finales de 1716 o comienzos de 1717, puesto que el día 7 de noviembre de 1716 es cuando se firman las capitulaciones para fusión entre la Cofradía de San Pedro Regalado y la Cofradía del Refugio, sita hasta entonces en el Convento de la Santísima Trinidad ${ }^{50}$. Tras la unión, la cofradía naciente se radicó en la nueva capilla que se le había construido a San Pedro Regalado años atrás en la iglesia del Salvador. Al estar el altar de esta cofradía presidida por el santo Regalado, el cura de la iglesia querría que también figurara allí la otra advocación de la nueva cofradía: la Virgen del Refugio, por lo que se decidiría a costearla. Y quien mejor para llevarla a cabo que el escultor más prestigioso de la ciudad, y que ya había dado buenas muestras de su arte en la propia iglesia que él dirigía. Recordemos que años atrás había realizado las imágenes de la Traslación de San Pedro Regalado, la Anunciación y el Ecce Homo. 
Por su parte, la escultura del San Pedro Apóstol, conocida actualmente como Las lágrimas de San Pedro, nos trae más complicaciones para dilucidar su cronología aproximada. Aunque sea un periodo bastante amplio, podríamos fijar la fecha post quem a mediados de 1691, año en que se derrumba la torre ${ }^{51}$, por cuanto esta escultura formaba parte del "lote" costeado por Rábago de "tres altares hechuras y retablos, como al presente están por no haberlos en dicha iglesia con la ruina de la torre vieja"; por su parte, la fecha ante quem sería el 19 de julio de 1720, día en que Pedro de Rábago dicta el testamento en el cual figuran descritas todas las esculturas y preseas que había donado a la iglesia. Un análisis estilístico, en el que la presencia del pliegue "de cuchillo" es muy leve todavía nos permitiría fecharla hacia 1709-1712, puesto que el referido pliegue aparece ya plenamente configurado hacia 1712-1713 en su San Pío $V$. A raíz de esta cronología podríamos plantearnos una cuestión: ¿Qué escultura fue la "embajada" del

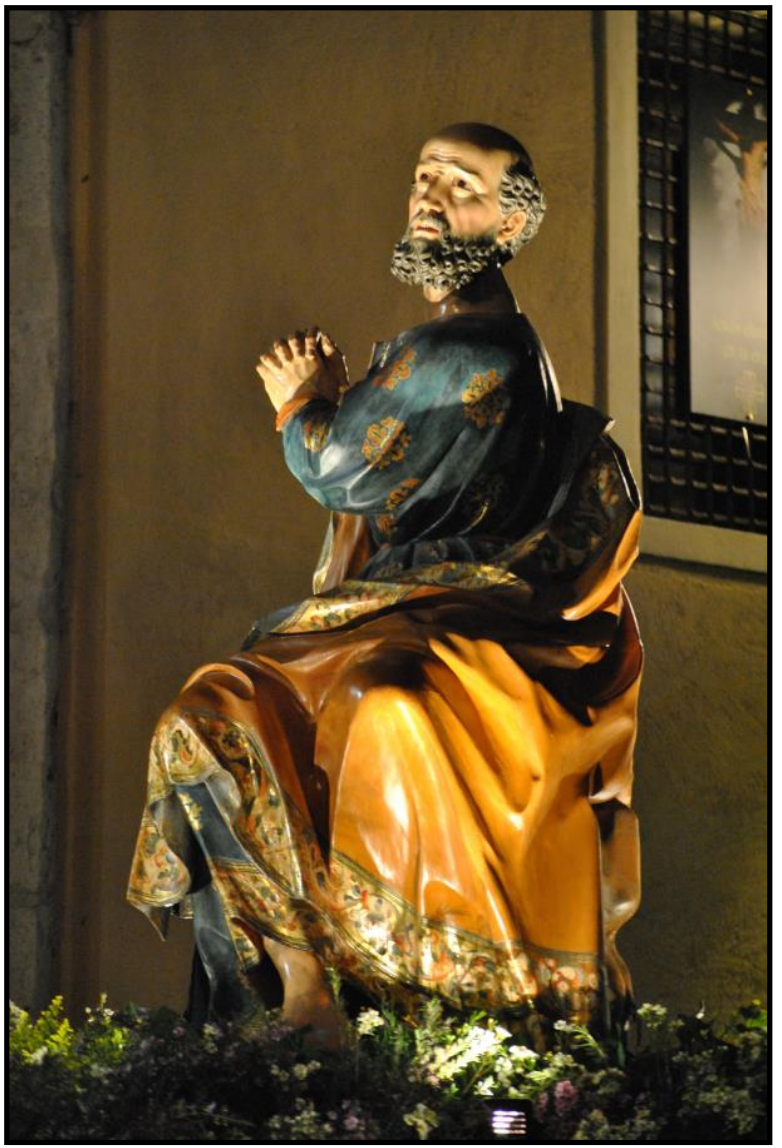

Il. 4- Pedro de Ávila. Las lágrimas de San Pedro. Iglesia del Salvador. Valladolid. arte de Pedro de Ávila en la iglesia del Salvador y que desencadenó el resto de pedidos: éste San Pedro plorante o la Traslación de San Pedro Regalado? Hay que recordar otros dos motivos por los cuales se pudo contar con Ávila para tallar estas imágenes: Juan de Ávila pudo haber trabajado ya para la iglesia realizando el San Joaquín con la Virgen Niña para el camarín de la capilla del Regalado; y, también se piensa que fue Juan de Ávila el que concibió por vez primera la representación escultórica de la Traslación de San Pedro Regalado, concretamente en el ejemplar realizado para el Convento del Domus Dei de La Aguilera; por lo tanto, qué mejor que fuera el hijo de éste el que tallara una versión de aquella. Si tenemos en cuenta esto parece claro que la "embajada" de Pedro de Ávila fue el grupo que representa el milagro del santo vallisoletano.

El 15 de abril de 1717 nace su sobrina María Barba, hija de Teresa de Ávila y Santiago Barba, a la cual querrá tanto, llegándola incluso a instituir en uno de sus testamentos como heredera universal. Fue madrina de su bautizo la esposa de nuestro escultor, María Lorenza de la Peña ${ }^{52}$.

\footnotetext{
$51 \quad$ A.H.P.V., Leg. 2.638, f. 289.

52 A.G.D.V., Catedral, 1656B, f. 82.
} 
El 6 de noviembre de este mismo año de 1717 vende la casa que había heredado tras la muerte de su padre. Ésta estaba ubicada en la calle de Santiago "que al presente linda por una parte con casas del Colegio de San Gregorio y por otra casas de Francisco Sáenz boticario vecino de ella" (DOCUMENTO 73). Los compradores fueron Manuel Rodríguez y Martina Chapón, a los cuales Ávila daba "en venta real y enajenación perpetua por juro de heredad desde ahora para siempre jamás (...) para ellos, sus hijos herederos y sucesores y quien su derecho tuviere la dicha cada aquí declarada y deslindada con todo cuanto la toca y pertenece sin reservar cosa alguna". El precio estipulado por nuestro escultor para la venta fue de 200 ducados de vellón, los cuales se comprometían a pagárselos en varios plazos: en mano le entregaron "en doblones de a cuatro y de a dos reales de a ocho y de plata de a dos y sencillos reducidos a vellón" (= 1.000 reales). Los 1.200 reales restantes se los pagarían en cinco plazos: "a razón de doscientos y cincuenta reales en cada uno que importan mil reales y los doscientos restantes otro tal día de Navidad del siguiente del setecientos y veinte y dos". Dos días antes de esta venta, Pedro de Ávila pidió permiso a la Cofradía de la Espina para poder venderla, ya que esta cofradía poseía un censo perpetuo de dos ducados ( $=22$ reales) en cada año. El consentimiento le llegó el 9 de noviembre de ese mismo año.

Los años 1719-1720 configuran otra de sus grandes etapas productivas, puesto que entre ambos años recibirá una "lluvia" de encargos para el Oratorio de San Felipe Neri, templo anejo, casualmente, a la iglesia del Salvador. ¿Casualidad? Efectivamente, entre estos dos años tanto la propia Congregación del Oratorio como diversos particulares solicitarán obra a nuestro escultor para alhajar los retablos que por entonces se estaban fabricando para las nuevas capillas abiertas en el cuerpo de la iglesia. Parece que el primero en contratar los servicios de Ávila fue don Antonio Arenas, antiguo ministro de la Congregación; el cual le encargaría un San Antonio de Padua que dona al Oratorio en julio de 1719. Un año después don Santiago Manzano, presbítero capellán y músico de la catedral vallisoletana, haría lo propio con las de un Cristo Yacente y un Niño Jesús. Ambas serían talladas por Ávila en 1720. En este último año le llegaría el otro gran contrato: la Congregación le solicita la ejecución de las esculturas de San Pedro, San Pablo, Santa María Magdalena, Cristo Crucificado, y la Inmaculada Concepción. Este es el último gran impulso constructor de retablos e imágenes que vería la ciudad.

Pero, para el oratorio no solamente talló imágenes, también desarrolló otras tareas, como fue la de tasador. Así, en la Congregación celebrada el 10 de mayo de 1720 se expone que "por cuanto dicha parroquia de San Miguel necesitaba de una hechura de escultura de dicho santo y hoy al presente dicha Venerable Congregación tenerla en una de dichas capillas se había de servir de donársela ahora fuese de limosna o por su justo valor tasándola por maestro que lo entendiese, y oída y entendida dicha proposición por todos los señores presentes dijeron que para dicho efecto nombraban y nombraron a los señores don Manuel Suárez y don Manuel Argain Ylloldi para que estos tratasen y conferenciasen con dicha parroquia o con la persona o personas que para este efecto tuviesen comisión estando con Pedro de Ávila, maestro escultor, y éste 
declarase la estimación que podía tener dicha hechura de San Miguel"53. Desconocemos a qué imagen se refiere, y si al final la parroquia de San Miguel la adquirió y por cuánto lo hizo. El antiguo templo dedicado a San Miguel Arcángel desapareció, pero gran parte de sus bienes fueron a parar a la iglesia del colegio jesuita de San Ignacio; que a partir de entonces adquirió el nombre de iglesia de San Miguel, San Julián y Santa Basilisa. Ventura Pérez nos narra en su Diario de Valladolid que " $a$ mediados de septiembre de este presente año [1777] empezaron a demoler las iglesias de San Miguel y San Julián"54; y que el 11 de noviembre de 1775 ya se estaban trasladando algunas de las imágenes de estos dos templos "a la iglesia de San Ignacio" "55. En esta nueva parroquia se conservan tres esculturas de diferentes tamaños que efigian a San Miguel que bien pudieran ser ésta de San Felipe Neri: la primera se encuentra situada en la sacristía, dentro de una hornacina situada encima del gran retablo fingido, esta imagen "de gran calidad, datable del último cuarto del siglo XVII" ha sido atribuida a José de Rozas ${ }^{56}$; otra, muy pequeña, corona el retablo del relicario: "estatua de San Miguel de madera policromada, del siglo XVIII" última (0,92 m.) que actualmente reposa sobre la cajonería de la sacristía, si bien cuando se redactó el respectivo tomo del Catálogo Monumental de Valladolid estaba guardada dentro de una vitrina de la sacristía: "San Miguel, madera policromada, con excelente policromía, comienzos del siglo XVIII; en vitrina de cristales"58.

Por estas mismas fechas tallaría el Cristo Resucitado que actualmente se conserva en el Museo de Arte Sacro de Ampudia, instalado en el antiguo Convento de San Francisco. Dado el carácter procesional que parece que posee, es probable que la escultura fuera contratada por la Cofradía de la Cruz puesto que muchos años antes esta misma cofradía se había concertado con el también escultor vallisoletano Pedro Salvador "el joven” para esculpir una serie de pasos a imagen y semejanza de los vallisoletanos: "Pedro Salvador se obliga de dar hechas y acabadas (...) cuatro hechuras de escultura, la una de un Santo Cristo a la columna, otro un Santo Cristo sentado para la coronación, otra hechura de un Cristo en la oración del huerto y la otra el ángel en la embajada con su

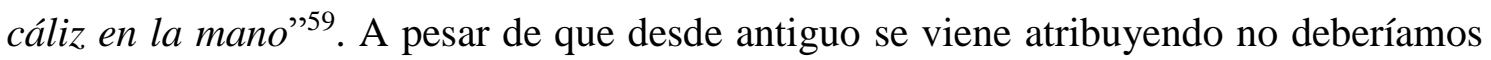
descartar que pudiera ser obra de su hermano Manuel de Ávila, puesto que solamente de este último poseemos obras documentadas en las cercanías de la ciudad de Palencia, concretamente en Fuentes de Valdepero; localidad, por otra parte, no muy lejana a Ampudia.

53 A.S.F.N., Caja 14, $2^{\circ}$ Libro de acuerdos (1690-1740), ff. 152-153. MARTÍN GONZÁLEZ, Juan José y URREA FERNÁNDEZ, Jesús: Catálogo Monumental de la provincia de Valladolid. Tomo XIV..., op. cit., p. 302.

54 PÉREZ, Ventura: op. cit., p. 490.

$55 \quad$ Ídem, p. 480.

56 MARTÍN GONZÁLEZ, Juan José y URREA FERNÁNDEZ, Jesús: Catálogo Monumental de la provincia de Valladolid. Tomo XIV..., op. cit., p. 124.

$57 \quad$ Ídem, p. 126.

$58 \quad$ Ibídem.

59 BALADRÓN ALONSO, Javier: op. cit., p. 170. 


\section{D- ÚLTIMA ETAPA PRODUCTIVA (1721-1742)}

Esta última etapa productiva tan amplia se nos presenta árida de noticias relacionadas con su oficio puesto que no poseemos más que una obra documentada: la Virgen de las Angustias que talla para la iglesia de San Miguel de la cercana localidad de Íscar (Valladolid). Tampoco son muy numerosos los datos biográficos que hemos conseguido, si bien es cierto que tampoco tenemos muchos en las otras etapas. Los límites cronológicos de este periodo no están puestos de manera baladí, sino que se corresponden al año posterior al que esculpió las esculturas del Oratorio de San Felipe Neri y al año en que se fecha el segundo testamento del escultor, en el cual declara que se encontraba ciego, y por lo tanto ya no podía trabajar en su oficio.

El 6 de junio de 1721 tasa, de manera conjunta con Antonio de Gautúa, las esculturas que dejó al fallecer el mesonero Juan Antonio Sanz de Cabezón ${ }^{60}$. Gautúa fue nombrado tasador por parte de Josepha Novia y Juan Antonio Gago, mientras que Ávila lo fue por la de Juan Antonio Soto.

El 12 de agosto de 1721 su hermana Teresa, sintiéndose enferma, otorga un poder para testar a su marido para que cuando ésta muriera poder realizar un testamento por ella (DOCUMENTO 7). En el dicho poder nombra por sus testamentarios a su marido, Santiago Barba, y a Pedro de Ávila. También dejaba encargado que se debía de entregar María Lorenza, mujer de Pedro, "tres casacas, la una de nobleza, otra de fondo, y otra de lamparilla negra y un manto y un zagalejo blanco". Teresa fallecería dos días después, siendo enterrada en una sepultura propia que tenían ella y su marido en el Convento de San Francisco, dejando por heredera a su hija María Barba ${ }^{61}$. El día 30 de ese mismo mes Santiago Barba otorgaría el testamento que Teresa de Ávila le había comunicado ${ }^{62}$.

60 "En Valladolid dicho día, mes y año en prosecución de dicho inventario y tasación dicho ministro tomó y recibió juramento a Dios y una cruz en forma de derecho de Pedro de Ávila maestro escultor nombrado por la dicha Josepha Novoa y Juan Antonio Gago y de Antonio Gautúa asimismo escultor nombrado por el dicho Juan Antonio Soto por ante mí el escribano y habiéndole hecho como se requiere y prometido decir verdad y de hacer la dicha tasación sin agravio alguno y se inventarían los bienes siguientes:

- Un Santo Cristo de bulto con su doselito en veinte reales.

- Un Niño Jesús de bulto con su peana de tres cuartas de alto que está en un escaparate con su mundo de cristal en la mano en doscientos y cuarenta reales.

- Una Nuestra Señora del Nacimiento para vestido en ciento y veinte reales.

- Un San José del mismo tamaño en ciento y veinte reales.

- Un Niño Jesús de alabastro en su cama de palosanto todo en ciento y veinte reales.

- Un Niño Jesús de una cuarta con su peana dorada en sesenta reales.

- Dos cornucopias doradas a tres reales.

La cual dicha tasación declararon haberla hecho sin agravio de las partes a lo que Dios nuestro señor les ha dado a entender so cargo de sus juramentos en que se afirmaron y lo firmaron y que son de edad dicho Pedro de Ávila de cuarenta y dos años y dicho Antonio Gautúa de treinta y tres poco más o menos los cuales dichos bienes se quedaron en el sitio donde estaban y se depositaron con los demás en este día inventariados y que se inventariaren y lo firmó dicho ministro y en fe de ello yo el escribano. A.H.P.V., Leg. 2.395, ff. 729-730.

61 A.G.D.V. San Miguel, 1684D, f. 193.

62 A.H.P.V., Leg. 2.962, ff. 624-625. 
El año 1723 comenzará con una nueva propuesta de trabajo de la Congregación de San Felipe Neri a nuestro escultor. Efectivamente, en cabildo de 23 de febrero de 1722 la Congregación acordó que para "los segundos retablos se necesitaban de hacer dos ángeles, los que dicha Venerable Congregación mandó se ejecutasen, haciendo el uno San Miguel y el otro el Ángel de la Guarda, cometiendo a dichos señores comisarios la ejecución de ellos con cuyo decreto se feneció dicha Congregación"63. Apenas dos semanas después, en un nuevo cabildo celebrado el día 9 de marzo la Congregación da noticia de que nuestro escultor "Pedro de Ávila había tomado las medidas de los huecos para hacer los ángeles y que quería por ellos mil reales dicha Venerable Congregación mandó se suspendiese por ahora dicha ejecución" ${ }^{64}$. Es decir, la idea que tenía la Congregación es que la parte escultórica de los seis nuevos retablos (a excepción de dos de ellos que recibirían del altar mayor los grupos de San José y San Joaquín), además de las esculturas de San Pedro y San Pablo del altar mayor fuera por completo realizada por los hermanos Ávila; puesto que Pedro talló todas las referidas imágenes y Manuel, por su parte, se ocupó de tallar una serie de ángeles para adornar dos de estos retablos.

A pesar de haber medido ya los huecos en los que debía de colocar las imágenes de San Miguel y del Ángel de la Guarda, la candidatura de Pedro de Ávila quedaría desestimada por la Congregación tras la propuesta monetaria realizada por el escultor. Los 1.000 reales debieron de parecerles excesivo, seguramente tendría algo que ver las exhaustas arcas de la Congregación tras las numerosas obras acometidas en los últimos años, por lo que decidieron buscar otro escultor más económico: Antonio de Gautúa. Bien es cierto que para el tamaño de ambas imágenes el precio era excesivo; sin embargo, también es verdad que por entonces Pedro de Ávila era el escultor más prestigioso de Valladolid y su zona de influencia.

El 23 de marzo de 1723 se vuelve a celebrar un cabildo en el que se aborda el tema. En esta ocasión la Congregación acuerda que se ejecuten "los dos Arcángeles San Miguel y San Rafael", para lo cual da comisión a "los señores doctor don Roque García Quiñones, don Antonio Herrera para que lo pusiesen en ejecución en aquella forma que sea más conveniente según se hizo donde se determinó el ponerlos que fue en los remates de los dos retablos" ${ }^{65}$. Finalmente, el elegido fue Antonio de Gautúa, escultor que si bien no posee la calidad de Ávila empezó a gozar desde entonces de un prestigio que se afianzaría en años sucesivos con el encargo catedralicio de las esculturas de los Padres de la Iglesia para la fachada de la seo, empresa en la que colaboraría con Pedro Bahamonde. Ya comenté con anterioridad la hipótesis, a partir del análisis de estas pequeñas esculturas del Oratorio, de que Gautúa pudiera haber sido discípulo de Juan de Ávila; pues bien, ante la falta de acuerdo monetario con la Congregación, Pedro de Ávila recomendaría a ésta a su amigo Antonio Gautúa, con el cual habría coincidido en el taller paterno; y, además, habría expuesto a la Congregación la similitud del estilo de ambos, de tal manera que los retablos presentarían unas esculturas con un estilo más o

\footnotetext{
63 A.S.F.N., Caja 14, $2^{\circ}$ Libro de acuerdos (1690-1740), f. 175.

64 Ibídem.

65 MARTÍN GONZÁLEZ, Juan José y URREA FERNÁNDEZ, Jesús: Catálogo Monumental de la provincia de Valladolid. Tomo XIV ..., op. cit., p. 303.
} 
menos uniforme. Desconocemos la fecha exacta en la que la Congregación se ajustó con Gautúa, lo único que sabemos es que debió de acabarlas hacia mediados de septiembre de 1724, puesto que en el cabildo celebrado el 10 de septiembre la Congregación daba comisión a algunos de sus miembros para ajustar el dorado de los retablos, símbolo inequívoco de que ya estaban todas las esculturas colocadas ${ }^{66}$. Pero, para entonces no solamente había realizado las de San Miguel y el Ángel de la Guarda (San Rafael), sino que también le habían comisionado las de San Lorenzo, San Esteban y los relieves del Abrazo ante la Puerta Dorada y los Desposorios de la Virgen. Es decir, había decorado los áticos de los seis retablos del cuerpo de la iglesia. Ignoramos el montante total de la operación, tan solo sabemos que el 29 de mayo de 1725 le liquidaban los últimos 720 reales que se le adeudaban ${ }^{67}$.

La fama de Pedro de Ávila debía de encontrarse por entonces en su cenit, lo que incremente nuestro pesar de no poseer ninguna obra documentada de todos estos años. Parece que siguió trabajando incesantemente para las poblaciones situadas en el sur de la actual provincia vallisoletana: en 1723 la iglesia de San Francisco de la V.O.T. de La Seca le debió de encargar un San Francisco de Asís para su retablo mayor; y tan solo un año después, en 1724, la parroquial de Matapozuelos hace lo propio con una Santa María Magdalena, patrona de la iglesia y de la localidad.

Un trabajo de especial relevancia, y que no hacía sino afirmar el prestigio del que gozaba nuestro escultor, parece ser la exquisita efigie de San José que le encarga hacia el año 1729 el canónigo vallisoletano don Marcos Ibáñez, la cual posteriormente donará al Santuario de Nuestra Señora del Henar de Cuéllar (Segovia). Aunque no podamos constatar documentalmente que sea obra de nuestro escultor, la mera observancia estilística y el hecho de que el comitente esté relacionado con la catedral, institución con la que mantuvo una relación tan cercana Ávila, parecen confirmarlo. Como comprobamos una y otra vez sus modelos más solicitados eran los que representaban a la Magdalena, a San José, a Cristo Crucificado y a la Inmaculada.

Un año después, en 1730, parece que contrató las esculturas del retablo mayor del Convento de Nuestra Señora de la Victoria, cuya parte arquitectónica fue realizada por el ensamblador vallisoletano José Díaz de Mata ${ }^{68}$. Sabemos que contenía las siguientes imágenes, además de la reutilizada Virgen de la Soledad rodeada por ángeles portadores de los instrumentos de la Pasión: San Francisco de Paula, San Juan ¿Bautista o Evangelista?, San José, San Joaquín y Santa Ana; todas ellas debieron surgir de las gubias de nuestro escultor ${ }^{69}$. Como veremos más adelante, parece que todas estas tallas, a excepción de la de San Juan, se conservan en diferentes recintos religiosos de nuestra ciudad. A todas ellas habría que sumar un Santo Mínimo, también procedente de este

66 A.S.F.N., Caja 14, $2^{\circ}$ Libro de acuerdos (1690-1740), f. 191.

67 "Se pagaron a Antonio Gautúa 720 reales de resta de las hechuras de San Miguel, el Ángel, San Lorenzo y las dos hechuras”. URREA FERNÁNDEZ, Jesús: “El oratorio...”, op. cit., p. 20.

68 PÉREZ, Ventura: op. cit., p. 104.

69 REDONDO CANTERA, María José: "Los inventarios de obras de arte de los conventos vallisoletanos durante la Guerra de la Independencia”, B.S.A.A., Tomo LVIII, 1992, p. 498. 
convento, que se conserva en dependencias catedralicias junto al San Francisco de Paula.

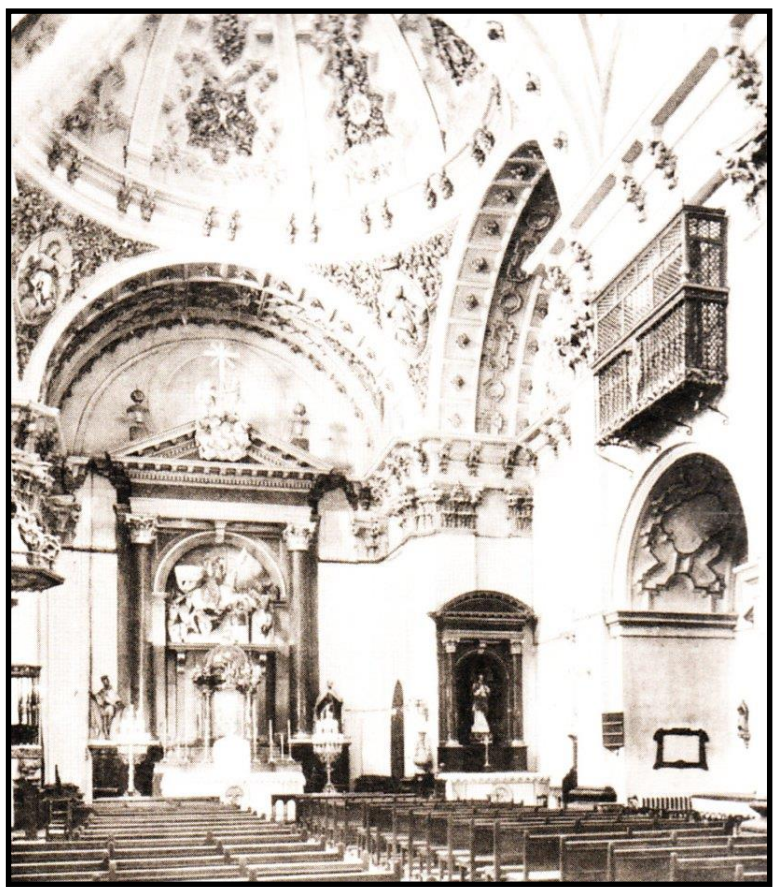

Il. 5- Convento de las Comendadoras de Santa Cruz a comienzos del siglo XX. Valladolid.

Otro convento vallisoletano que pudo requerir sus servicios por estos años será el de las Comendadoras de Santiago: en 1732 parece que le solicitan las esculturas pétreas de la portada de la iglesia: San Agustín, Santa Mónica y la Inmaculada Concepción; y, en 1734, las esculturas del desaparecido retablo mayor barroco de la iglesia. De estas, tan solo se conserva en la actualidad el grupo central que representa a Santiago Matamoros, en todo similar al que años atrás había tallado su padre para el retablo mayor de la cercana iglesia de Santiago Apóstol; también debieron de pertenecer a dicho retablo dos esculturas de San Francisco de Borja y San Fernando que hasta hace unas décadas estuvieron situadas a los lados de actual retablo mayor neoclásico.

Volviendo a su faceta personal. El 21 de mayo de 1731 se celebran en la Santa Iglesia Catedral los desposorios de su sobrina María Barba con el librero Juan Ceano, celebración de la que ejercerá de madrina María Lorenza de la Peña, y de testigo el propio Pedro de Ávila. Una vez más comprobamos el cariño que profesaba el matrimonio hacia su sobrina ${ }^{70}$.

El 4 de septiembre de 1733 es nombrado por su hermano Manuel como uno de sus dos testamentarios, el otro lo fue su mujer. Efectivamente, ese día Manuel de Ávila, encontrándose "enfermo en la cama de enfermedad corporal que Dios nuestro señor sea servido darme aunque en mi sano juicio y entendimiento natural", decide redactar un poder para testar a favor de su esposa María Martínez (DOCUMENTO 95). No hemos logrado encontrar el testamento redactado por ésta. Finalmente, Manuel falleció en su casa de la calle de San Miguel el día 27 de ese mismo mes, siendo sepultado en la iglesia parroquial homónima ${ }^{71}$

La muerte de Manuel debió de ser un golpe tremendo para nuestro escultor ya que además de perder al último de sus hermanos, al cual vería a diario dado que vivían tan solo a un par de calles de distancia; también perdía a uno de sus "discípulos" y colaboradores más eficaces, con el cual es probable que mantuviera relaciones labores.

$70 \quad$ A.G.D.V., Catedral, 1695M, f. 82.

71 A.G D V., Valladolid, San Miguel, 1711D, f. 105.

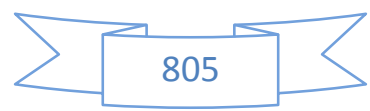


Aunque es poco probable, quizás hasta pudieran haber compartido taller, el cual se encontraría a cargo de Pedro.

Señala muy acertadamente Virginia Albarrán en su monografía sobre Alejandro Carnicero que el artífice iscariense tal vez pudo esculpir "alguna de las esculturas que, según el diarista Ventura Pérez, se instalaron en esos años en varias iglesias de la ciudad, como la de San Luis para su retablo del Convento de San Francisco (28-IV1737) ${ }^{72}$, un San Francisco de Regis destinado a la Compañía de Jesús (20-IV-1738) ${ }^{73}$ o el San Miguel costeado por la cofradía del santo y las Ánimas de la parroquia de San Juan $(19-X-1738)^{74}$. No obstante, la falta de noticias al respecto impide que pueda asignarse con seguridad ninguna de ellas a Carnicero" 75 . Es factible pensar que alguna de ellas pudiera haber sido realizada por Pedro de Ávila dado que por entonces seguiría siendo la estrella más luminosa el panorama artístico vallisoletano, aunque por poco tiempo ya que Pedro de Sierra y Felipe Espinabete estaban a punto de entrar en escena; tan solo el hallazgo de estas esculturas nos despejaría las dudas.

Antes de que nuestro escultor quedara ciego, en el periodo delimitado entre los años 1739-1742 (no sabemos si por enfermedad o por accidente) y tuviera que abandonar la práctica de la escultura, su arte volvió a expandirse a los territorios cercanos a Olmedo, concretamente a Íscar. Es curioso este hecho puesto que en apenas tres años le podemos documentar y atribuir tres obras: parece ser que en 1737 talla un San Ramón Nonato, actualmente conservado en la iglesia de Santa María de los Mártires; hacia 1737-1739 un San Antonio de Padua (h. 1737-1739) para la desaparecida iglesia de San Pedro; y en 1739 una Virgen de las Angustias (1739), su última escultura documentada.

El 7 de septiembre de 1741 el anciano escultor recibirá un nuevo golpe en forma de pérdida, la más grave que podía esperar: el fallecimiento de su esposa María Lorenza de la Peña. Tal y como había ordenado en el testamento que ambos habían otorgado de manera conjunta en 1708, su cuerpo fue sepultado "en la sepultura donde se enterró Juan Antonio de la Peña su padre sita en la Parroquial de San Miguel de esta ciudad"76. En virtud de aquel testamento, que en realidad era un poder para testar, a

72 "Colocación de San Luis. Año de 1737, día 28 de abril, en la nave de Santa Juana, en San Francisco, colocaron a San Luis, obispo de Tolosa, en un retablo nuevo que para este efecto se hizo: tuvieron misa y sermón, S.M. patente y gran función”. PÉREZ, Ventura: op. cit., p. 144.

73 "Fiestas de San Juan Francisco de Regis. Año de 1738, día 20 de abril, se comenzaron las fiestas que los padres de la Compañía hicieron en San Ignacio a la canonización de San Juan Francisco de Regis, y se continuaron por tres días". Ídem, pp. 152-153.

$74 \quad$ “Colocación de San Miguel Arcángel en San Juan. Año de 1738, día 19 de octubre, se colocó en la parroquial de San Juan Bautista la imagen de San Miguel Arcángel, nueva, costeada y puesta en su retablo, compuesto por su cofradía del santo y ánimas de los pobres que entierran en el cementerio de dicha parroquia. Hicieron una procesión muy solemne por toda la parroquia y barrio; asistieron todas sus cofradías; iba en la procesión San Juan, el que llevan el día del Corpus, después San Miguel y después Nuestra Señora de la Concepción, y después S.M. Sacramentado”. Ídem, p. 159.

75 ALBARRÁN MARTÍN, Virginia: El escultor Alejandro Carnicero..., op. cit., p. 59.

76 "En siete de septiembre año de mil setecientos y cuarenta y uno, habiendo recibido los santos sacramentos murió doña María Lorenza de la Peña, mujer que fue de don Pedro de Ávila, y moradora a la calle de San Miguel. Enterrose en la capilla mayor de esta parroquial de dicho Santo Arcángel en sepultura propia la primera hacia la sacristía línea primera. Su marido en virtud de poder otorgó testamento ante Joseph Rodríguez, escribano del número de esta ciudad, en veinte y cuatro de octubre de 
Pedro de Ávila le tocó formar el testamento en virtud de aquel poder. Efectivamente, el 24 de octubre de ese mismo año el escultor lo redactaba (DOCUMENTO 75). En él, además de figurar las típicas clausulas relativas a su entierro y a las misas que quería que se la dedicasen, María Lorenza volvía a ratificar que Pedro de Ávila sería tanto su testamentario como su universal heredero.

Pedro de Ávila, que por entonces se hallaba "privado de vista", ante la imposibilidad de poder vivir solo, marchó a vivir a casa de sus sobrinos María Barba y Juan Ceano, los cuales le habían "convidado me fuese a su casa y compañía" (DOCUMENTO 79). El escultor debió de ver muy mermados su ánimo y su salud a raíz del enorme disgusto que le supuso la pérdida de María Lorenza. Al igual que ocurrió en 1708 tras la muerte de su suegro, nuestro escultor decidió redactar un nuevo testamento tras la privación de su mujer. Efectivamente, el 11 de enero de 1742, Pedro de Ávila "maestro escultor vecino de esta ciudad, hijo legítimo de Juan de Ávila y Francisca Ezquerra difuntos vecinos que fueron de ella", encontrándose "en sana salud aunque privado de la vista y con algunos achaques habituales y en mi juicio y entendimiento natural pues conozco a los que me tratan y me comunican" redactaba sus últimas voluntades (DOCUMENTO 76). Es muy interesante la circunstancia de que el propio escultor nos informe de que se encontraba totalmente ciego, ya no solo por el hecho en sí, sino porque nos establece un límite cronológico a su obra ya que desde entonces no podría desarrollar su oficio.

Entre sus últimas voluntades, Ávila solicitaba que su cuerpo fuera sepultado en la iglesia de San Miguel "en la sepultura que me pertenece en ella" o en la Santa Iglesia Catedral. La elección de este último lugar se explica fácilmente por hallarse viviendo en casa de su sobrina María Barba, la cual estaba localizada en la calle de la Librería, es decir, frontera a la fachada gótica de la Universidad. A su sepelio deberían de acudir las cofradías "Sacramental del Hospital General extramuros de esta ciudad y la Penitencial de Nuestra Señora de la Pasión donde soy diputado y cofrade”. Asimismo, nos confirmaba que durante su matrimonio con María Lorenza de la Peña "no tuvimos ni tengo sucesión legítima así lo declaro para descargo de mi conciencia y para que siempre conste". Declaraba tener diversas deudas, las cuales tenía declaradas a su sobrina María Barba y al marido de ésta, Juan Ceano, el cual, como veremos, parece que fue protagonista de unos pasajes bastante sórdidos contra nuestro escultor; era voluntad de Ávila el que "se paguen dichas deudas del valor de los bienes que quedaran por mi fallecimiento y así lo declaro para descargo de mi conciencia y para que siempre conste". Finalmente, nombraba como testamentarios y albaceas al presbítero don Juan Calvo, a don Alonso de la Rumbe y Elizalde, regidor perpetuo de Valladolid (una vez más volvemos a comprobar la amistad que le unía a esta saga de regidores vallisoletanos), y a su sobrino político Juan Ceano; por su parte, instituía como heredera universal del "remanente de mis bienes, derechos, acciones y por cualquier título o causa legítima y me tocan y pertenecen puedan tocar y pertenecen" a su sobrina María Barba. Fueron testigos de las últimas voluntades del escultor Manuel

este año. Mando cien misas por la expresada $D^{a}$ María, de quien se instituyó por heredero. Y como cura propio de dicha iglesia lo firmé en Valladolid”. A.G.D.V., San Miguel, 1711D, f. 153. 
de la Peña, Matías Cortés, Manuel Barcenilla y Mateo Negral. No pudo firmar el testamento debido a la sobredicha "privación de la vista", y a su ruego lo firmaron "dos de dichos testigos".

\section{E- LA ÉPOCA OSCURA (1742- 1755)}

Esta última etapa que conformamos englobaría los años 1742, en que ya sabemos de manera fidedigna que el escultor no podía trabajar en su oficio debido a su condición de ciego, y el de 1755 en que otorga el que seguramente fue su último testamento, falleciendo poco después.

Poseemos una noticia anecdótica fechada pocos días después de haber redactado el testamento. El 5 de febrero de 1742 su cuñado Santiago Barba, viudo de su hermana Teresa de Ávila, otorgaba un codicilo en el cual declaraba que "le está debiendo Pedro de Ávila vecino de esta ciudad trescientos y cuarenta y cinco reales de vellón que prestó mando se cobren"77.

Este postrer periodo de la vida de nuestro escultor comenzó con otra malísima noticia, una más. Esta vez se trataba de la pérdida de su querida sobrina y heredera universal, María Barba. Su óbito se produjo el 9 de febrero de 1744 en el domicilio familiar que ésta poseía en la calle Librería ${ }^{78}$, siendo enterrada por expreso deseo en el Convento de los Padres Mercedarios Calzados. Previamente, el 31 de enero de 1744, la joven había dado poder a su marido para que éste pudiera otorgar el testamento en su nombre dado que la gravedad de la enfermedad se lo impedía a ella (DOCUMENTO 77). En él instituyó por herederos universales a sus dos hijos Vicente y María Manuela.

No sabemos si fue por tanto fallecimiento en su familia, el caso es que desde entonces a nuestro escultor le entró una verdadera fiebre por hacer testamentos. Desde este momento hasta el supuesto año de su fallecimiento, 1755, realizó nada más y nada menos que otros cuatro testamentos, a sumar a los otros dos que hasta entonces había otorgado solo y de manera conjunta.

El primero de estos nuevos testamentos fue otorgado el 26 de julio de 1745 (DOCUMENTO 78). En él apenas hay novedades y datos de interés. Pedro vuelve a insistir en sus deseos de que su "cuerpo sea sepultado en la iglesia parroquial de San

\footnotetext{
77 A.H.P.V., Leg. 3.346, f. 16.

78 "En nueve de febrero de mil setecientos y cuarenta y cuatro murió en esta parroquia de la Santa Iglesia Catedral de esta ciudad de Valladolid, habiendo recibido los santos sacramentos, con el de la extremaunción a la calle de la Librería Doña María Barba y Dávila, que estaba casada con Juan Ceano, a quien dio poder para testar, que se hizo por testimonio de Manuel Padillo y García notario de la conservaduría de la real universidad de esta dicha ciudad y escribano real de su majestad, por el cual mandó enterrarse en el Convento de Padres Mercedarios Calzados de esta dicha ciudad en sepultura propia y que por su alma se dijesen cien misas rezadas, la cuarta en la Parroquia y el dicho Juan Ceano usado del citado poder dispuso lo mismo por el testamento, que hizo ante el dicho Manuel Padillo, y nombró por sus testamentarios, a el dicho Juan Ceano, al señor D. Francisco Varredo canónigo lectoral de esta Santa Iglesia, y por sus herederos, a Vicente y María Ceano, sus hijos legítimos, y del citado Juan Ceano, y en fe de ello lo firmo como cura dicha parroquia”. A.G.D.V., Catedral, 1684D, f. 277.
} 
Miguel de esta dicha ciudad en la sepultura que me pertenece en ella o en la Santa Iglesia Catedral de esta dicha ciudad donde al presente soy parroquiano, en la que eligieren y como les pareciere a mis testamentarios; y con el hábito de Nuestro Padre San Francisco". La primera diferencia con respecto al anterior testamento tiene relación con que ahora es solamente Juan Ceano, viudo de María Barba, el que conocía las deudas que tenía contraídas Ávila. Asimismo, elegía como testamentarios a los mismos que ya tenía nombrados: "don Juan Calvo presbítero en esta ciudad, don Alonso de la Rumbe y Elizalde regidor perpetuo de ella y al dicho Juan Ceano mi sobrino". Finalmente, al haber fallecido su sobrina María Barba, a quien había instituido por su universal heredera, le tocó cambiar de sucesor y nombrar al marido de ésta, Juan Ceano "mi sobrino en atención a que éste ha estado y está manteniendo, vistiendo y calzando de todo lo necesario y asistidome en mis enfermedades supliendo y pagando el susodicho el importe de cuantos gastos se han ocasionado por una y otra razón y con su propio caudal de más de cuatro años a esta parte sin que yo le haya podido satisfacer cosa alguna por mi imposibilidad que es notoria ni lo poder ganar por hallarme sin la vista natural". Como tal heredero a "todos mis bienes, derechos y acciones, entre los cuales lo es una casa que tengo a la calle de San Miguel de esta dicha ciudad que hace esquina y vuelve a la calle de las Damas bajando de la iglesia de San Miguel con toda su vivienda, oficinas altas y bajas y servidumbre que la corresponde sin reservar cosa alguna". Finalmente, el anciano escultor esperaba "del bueno celo y cristiandad del referido Juan Ceano continuará en mantenerme, vestirme, calzarme y asistirme como hasta aquí lo ha hecho sin que yo tenga otro medio, modo ni arbitrio de poderlo remunerar lo mucho que le debo y gastos que conmigo ha hecho y espero haga en los restantes días de mi vida". Pienso que este testamento fue una pantomima ideada por Juan Ceano en la cual un viejo ciego atemorizado le hacía entrega "por su propia voluntad" de su casa. Llama la atención de que Ávila en su testamento no entregara ningún bien, por nimio que fuera, a sus sobrinos, los hijos de su querido hermano Manuel.

El segundo testamento que Pedro de Ávila compone en esta última etapa se fecha el 23 de abril de 1747 (DOCUMENTO 79). Este documento sí que nos aporta algo más de información sobre la vida privada del escultor, si bien el tema que nos da a conocer es bastante desagradable, como ahora veremos. Pedro de Ávila vuelve a informarnos que se hallaba "levantado y bueno por la misericordia de Dios y en mi sano juicio y entendimiento natural"; y que deseaba ser enterrado con el hábito franciscano en la iglesia de San Miguel en la referida sepultura en la que se hallaba su esposa María Lorenza. Tras enumerar los asistentes que deseaba acudieran a su sepelio y las misas que se deberían decir por su alma, comenta que no podían faltar al entierro las "cofradías de la Sagrada Pasión de Cristo donde soy diputado y la de la Sacramental del Hospital General de esta dicha ciudad por ser cofrade de ella".

A continuación es cuando nos habla sobre un problema familiar que llevaba sufriendo durante bastante tiempo: se trataba del chantaje, extorsión y robo que le venía perpetrando su sobrino político Juan Ceano, a quien en el testamento anterior dejaba 
nombrado como heredero universal. No cabe duda de que éste se aprovechó de la edad, ceguera y soledad que padecía nuestro escultor. A la vista de las palabras que el escultor le dedica parece más que probable que Ceano pudo haberle amenazado con algún tipo de represalia, como ya dijimos, si no le nombraba como su único heredero. Pues bien, declara Pedro de Ávila que "después que falleció dicha mi mujer, por Juan Ceano librero vecino de esta ciudad marido de doña María Barba mi sobrina ya difunta y por hallarme privado de vista me convidó me fuese a su casa y compañía, y con efecto lo ejecuté, y me mantuvo cinco años poco más o menos, de cuyo mantenimiento no le debo maravedies algunos mediante haberlo hecho en caridad, y ofreció me lo haría así y sin embargo de lo referido, todos los bienes muebles con que entonces me hallaba los llevó dicho Juan Ceano a su casa y los vendió sin haber percibido yo maravedies". Pero esto no quedó así, Ceano también sustrajo a nuestro escultor "mil y ochocientos reales que el Ilustrísimo señor don Julián Domínguez Toledo ${ }^{79}$, obispo que fue de esta dicha ciudady su obispado me había dado consignado por vía de limosna a razón de tres reales cada día y eran de veinte meses devengados hasta la muerte del dicho Ilustrísimo señor"; unos 1.500 reales que Ávila había conseguido con el arrendamiento de la casa "que tengo sita en esta dicha ciudad en dicha parroquia de San Miguel frontero a la que tienen los señores Arces por habérmela mandado la referida doña María de la Peña mi mujer y nombrado por su único y universal heredero"; y 375 reales "que también percibió y cobró dicho Juan Ceano del valor de una cruz de diamantes propia de dicha doña María de la Peña mi mujer, sin que de esto ni de lo demás que va referido haya recibido ni entregándoseme maravedíes algunos por el susodicho ni dicha su mujer mi sobrina, quienes al tiempo y cuando falleció la referida mi mujer por haberme reinado irme a su casa y compañía solicitaron marido y mujer con dicho Ilustrísimo señor no me contribuyese con la limosna de los referidos tres reales diariamente que me tenía

79 Julián Domínguez de Toledo fue el décimo octavo Obispo (1728-1743) de la diócesis vallisoletana, sucediendo en el cargo a José de Talavera Gómez de Eugenio (1716-1727). Nació en Talavera de la Mancha en 1680; siendo sus padres, Jerónimo Domínguez de Escudero e Isabel de Ayllón, miembros de las más ilustres familias de la villa. Comenzó sus estudios en el Colegio Imperial que la Compañía de Jesús poseía en Madrid; posteriormente los continuó en Universidad de Alcalá de Henares, en donde cursó Filosofía y Teología. A los 18 años consiguió la cátedra de Filosofía y a los 22 consiguió el grado de Doctor en Teología, con unánime aplauso de profesores y alumnos. Una vez que se le ordenó sacerdote, completó sus estudios de Derecho en la Universidad de Salamanca; universidad en la cual ejerció posteriormente como Catedrático de Escritura y Canónigo Lectoral. También ocupó el cargo de Canciller mayor de la Universidad de Valladolid. Fue tal su fama que llegó hasta la Corte, de tal manera que el rey Felipe V le presentó el 31 de enero de 1728 para el cargo de obispo de Valladolid. Entre los logros de su apostolado se encuentra la ordenación como sacerdote del beato jesuita Bernardo Francisco de Hoyos en 1735, primer y principal apóstol en España de la devoción al Sagrado Corazón de Jesús. También destacó Domínguez de Toledo durante su obispado en Valladolid por su gran caridad hacia los pobres. Falleció en 1743 víctima de la gangrena, siendo enterrado en la Catedral, en cuya sepultura se colocó la siguiente inscripción: "¡Hen mortalis! en luta oeternitatis via, hoc signat illam in lapide, egenus sibi, multis dives, liberalis ómnibus Illss. D. D. D. Julianus Dominguez Toledo, indivi Ildephonsi Complutens y Collegio alumnus, illius Universitatis Artium Caletrae moderatur, Salmantinae Sanctae Ecclesiae Canonicus Lectoralis, ac illius etiam Universitatis Cathedrae Scripturae Interpres. Prior et Dominus de Junquera de Ambía, a consiliis suce Maiestatis, hujus Pintianae Academiae Cancellarius Regius, ac tándem nullis avidus honoris, in ac sacra Vallisoletana Cathedrali Ecclesia dignissimus praesul et Antistes. In pace, quam amavit, dormiat et requiescat a die 2 Junii anno Domini 1743". Le sucedió Martín Delgado Cenarro y Lapiedra (1743-1753). GONZÁLEZ GARCÍA-VALLADOLID, Casimiro: Datos para la historia biográfica..., op. cit., Tomo I, pp. 379-380; CASTRO ALONSO, Manuel de op. cit., pp. 305-308. 
señalados y por no perderlos me reduje, como va declarado a estarme con los susodichos bajo de las promesas que me hicieron de mantenerme en caridad sin que por esta razón les diese cosa alguna lo que es público y notorio y lo declaro así para el paso en que estoy, y que siempre conste".

Finalizaba el testamento nombrando como testamentarios al historiador Manuel Canesi Acebedo $^{80} \mathrm{y}$, nuevamente, a don Alonso de la Rumbe y Elizalde, regidor perpetuo de Valladolid. Asimismo, instituía como sus únicos herederos a María, Clara y Manuel de Ávila sus "sobrinos carnales hijos legítimos y de legítimo matrimonio de D. Manuel de Ávila mi hermano ya difunto y de doña María Martínez su mujer vecina de esta dicha ciudad, para que los referidos mis sobrinos lo hayan y hereden y partan por iguales partes con la bendición de Dios y la mía y les pido me encomienden a Dios". Un último dato nos interesa de este testamento: se trata de la identidad de uno de los testigos que lo firmaron: "Francisco Xavier Pérez su arte tallista". Este totalmente desconocido artífice sobre el que no tenemos ninguna clase de noticia ni artística ni biográfica, ¿pudo haber sido discípulo de Pedro de Ávila? No lo sabemos, pero aquí queda señalado; quizás futuras investigaciones puedan responder esta cuestión. A la vista de este testamento nos queda otra incógnita: ¿En qué casa se encontraba por entonces viviendo nuestro escultor, y en qué compañía? Lo lógico sería pensar que volvió a su morada del barrio de San Miguel, pero la incapacidad de poder vivir solo y la falta de recursos para disponer de una sirvienta dificulta bastante la resolución de esta pregunta.

Apenas tres meses después de haber redactado el testamento anterior, el 12 de julio, realiza el tercero que firma en esta última época (DOCUMENTO 80). En él, además declararse "levantado y bueno por la misericordia de Dios y en mi sano juicio y entendimiento natural", vuelve a repetir puntualmente todo lo referente a su entierro y las misas por su alma. También vuelve a referirse a las malas pasadas que le provocó su sobrino político Juan Ceano, aunque en esta ocasión amplía el número de bienes que le enajenó, e incluso involucra en dicha estafa a su propia sobrina María Barba, a la cual tanto amó: "me convidó [María Barba] me fuese a su casa y compañía y con efecto lo ejecuté y me mantuvo cinco años poco más o menos de cuyo mantenimiento no le debo maravedies algunos mediante haberlo hecho en claridad y ofrecidome lo haría así y sin embargo de lo referido todos los bienes muebles con que entonces me hallaba los llevó dicho Juan Ceano a su casa, como fueron: taburetes de vaqueta encarnada, sillas de lo mismo, dos escritores con sus mesas, sábanas apuntadas que fueron seis, y otra ropa blanca, unos pendientes de perlas netas tasados en diez o doce pesos, unas sortijas de oro con piedras ordinarias que tenía en sus manos dicha doña María mi mujer cuando murió, dos casacas de terciopelo, la una y la otra de damasco, un guardapiés de persiana nuevo, un dengue de grana nuevo con guarnición de seda, un manguito y dos mantos de diferentes piezas de espetera, cofres, arcas y otras cosas hasta que me

80 La amistad y cercanía de Canesi a Pedro de Ávila la podemos percibir en las palabras que le dedicó el historiador al hablar sobre las imágenes que el escultor había tallado para el Oratorio de San Felipe Neri en 1720. Comenta en su Historia de Valladolid que "los santos que las adornan, hechuras de Pedro de Ávila, estatuario insigne, vecino de esta ciudad". CANESI ACEVEDO, Manuel: Historia de Valladolid (1750), Tomo III, op. cit., pp. 560-561. 
quedaron sin camisa, vendieron dicho Ceano y su mujer sin haber percibido yo maravedíes algunos de las referidas alhajas vendidas". Asimismo, vuelve a referir que el matrimonio se había quedado con el dinero procedente de la limosna que le había consignado el obispo Julián Domínguez de Toledo (1.800 reales de vellón), del derivado de los sucesivos alquileres de su casa del barrio de San Miguel (1.500 reales de vellón), y del valor de una cruz de diamantes que era propiedad de su esposa difunta (375 reales).

En esta ocasión volvía a nombrar como testamentarios a don Alonso de la Rumbe y a Manuel Canesi; pero, la importancia de este testamento radica en el hecho de que prescinde de sus sobrinos, los hijos de Manuel de Ávila, como sus universales herederos; cambiando tal nombramiento por el de una viuda llamada Francisca López. Muy fuerte debía de ser la "amistad" con esta mujer para realizar tal cambio.

No sabemos desde cuándo se conocían nuestro escultor y Francisca López, a los cuales unía el estado de viudedad. Una mera hipótesis sería la de que esta mujer fuera una especie de asistenta del anciano escultor, ya que por su ceguera y avanzada edad no podía valerse por sí mismo, y que pasado el tiempo ambos se enamoraron. Lo primero es una suposición, lo segundo es una afirmación, puesto que el 4 de septiembre de 1747 contraen matrimonio "en la ermita de Nuestra Señora de las Angustias". La ceremonia fue oficiada por don Francisco Alonso Blanco "cura de la parroquial de San Juan Evangelista inclusa en la santa iglesia catedral"81. Los dos testigos del feliz acontecimiento fueron don Juan de Alba y don Alonso de la Rumbe; cómo podemos comprobar al escultor y al regidor perpetuo de la ciudad les debía de unir una sólida amistad ya que este último figura de testigo en todos y cada uno de los testamentos del escultor

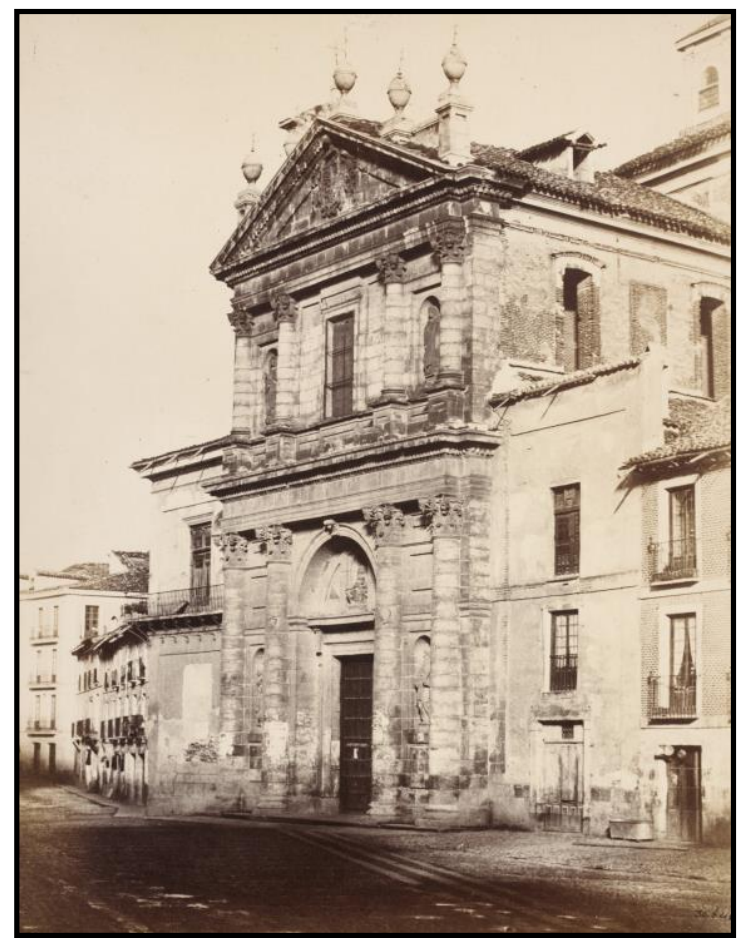

Il. 6- Iglesia penitencial de Nuestra Señora de las Angustias. Valladolid. de esta última época. Esta amistad debió ser extensible a toda la familia puesto que no

81 "En la ciudad de Valladolid a cuatro días de septiembre de mil setecientos y cuarenta y siete años yo D. Francisco Alonso Blanco cura de la parroquial de San Juan Evangelista inclusa en la santa iglesia catedral de ella con licencia del señor D. Antonio Manuel de Villanueva y Ribera provisor y vicario general de este obispado refrendada de Pedro Martínez Salazar por Villalpando en tres de dicho mes, y no habiendo resultado impedimento alguno desposé por palabras de presente que hicieron verdadero matrimonio, velé in facie ecclesiae dije la misa y di las bendiciones nupciales en la forma que prescribe el ritual romano en la ermita de Ntra. Sra. de las Angustias a Pedro de Ávila viudo de doña María de la Peña con Francisca López viuda de Gregorio González mis feligreses y viven en la calle de los Baños, fueron testigos D. Juan de Alba y D. Alonso de la Rumbe vecinos de esta ciudad, y en fe de ello lo firmo". A.G.D.V., Catedral, 1695M, f. 287. 
podemos olvidar que en 1714 Ávila tasó las esculturas que dejó al fallecer Juan Antonio de la Rumbe y Elizalde, quizás padre de don Alonso.

Este matrimonio fue una segunda oportunidad para ambos, los cuales quizás pensaron en envejecer juntos y felices ante la ausencia de una familia que les asistiera. Así debió ser, los sinsabores provocados en los últimos años por la muerte de todos sus familiares y el timo y robo perpetrado por su sobrino político se tornaron en una felicidad que quizás se prolongara hasta sus últimos días. Gracias a la partida de matrimonio sabemos que por entonces la pareja vivía en la calle de los Baños (actual c/ Echegaray), vía aneja a la Penitencial de Nuestra Señora de las Angustias ${ }^{82}$. No parece muy arriesgado pensar que esta casa sería propiedad de Francisca. Cabe reseñar que en este segundo matrimonio tampoco lograron tener descendencia; algo por otra parte lógico dada lo avanzado de sus edades.

El cambio de domicilio de nuestro escultor contribuyó a que se deshiciera de la casa en la que había vivido desde que contrajo matrimonio con su primera mujer, María Lorenza de la Peña. La venta de la casa aconteció el 21 de agosto de 1747 (DOCUMENTO 82). En ese día, Pedro de Ávila "heredero que soy y quedé de doña María de la Peña mi legítima mujer difunta instituido en el poder que recíprocamente de conformidad otorgamos (...) digo que a la referida doña María de la Peña como a hija única y heredera de Juan Antonio de la Peña su padre también difunto vecino que fue de esta misma ciudad la perteneció en ella una casa que hace esquina a las calles de San Miguel y las Damas linda al presente por esta con casa de Benito Oriz, y por la de San Miguel con otra del Convento de San Pablo Orden de Santo Domingo el cual tiene sobre la citada que va deslindada y me pertenece (...) cien reales vellón de censo perpetuo en cada un año con derecho de veintena y tanteo". El comprador de la casa fue don Joseph Plaza Jaén, el cual abonó por ella 3.500 reales; además, tendría que ocuparse en adelante de pagar la "carga y gravamen" que tenía impuesta el Convento de San Pablo. En definitiva, Ávila vendía y daba en "venta real y enajenación perpetua por juro de heredad para ahora y siempre jamás según dicho es, al expresado don Joseph Plaza Jaén, sus hijos y a quien en su derecho suceda la referida casa antes de ahora deslindada en el principio de esta escritura toda ella con sus entradas, salidas, usos, costumbres, derechos y servidumbres cuantas tiene y la pertenecen sin exceptuar cosa". La primera paga, de 1.500 reales, se la entregó "ahora a presencia de la de dicho

82 La actual calle de Echegaray, nombre puesto en honor del insigne dramaturgo José Echegaray, tuvo un origen medieval. El nombre de calle "de los baños" le venía por la existencia de unos baños que al menos databan de mediados del siglo XIII. Estaban situados "cerca del ramal Norte del Esgueva, de los cuales no se tienen noticias detalladas y concretas, ya de su disposición, ya de su funcionamiento. Lo más probable es que dada la proximidad del sitio al Esgueva, de este se tomaran las aguas, si es que no servían para su uso las de algún manantial o fuente que por allí brotase, pues estaban también muy próximos los baños al "Cañuelo", cuyo nombre expresaba una fuente, un caño pequeño, y su agua habría de utilizarse, seguramente, por el pueblo. Lo que sí habría de ser cierto es que los desagües de los baños habían de ir al Esgueva, pues que sus cauces recogieron siempre todas las aguas sucias de la villa que le salían al paso (...) Antolínez [de Burgos] conoció algunas dependencias del edificio antiguo destinado a baños, y se conformó con decir, refiriéndose a la calle comprendida entre las Angustias y Portugalete, "que hoy permanecen algunas piezas de ellos [de los baños] en una casa a mano siniestra poco antes de entrar en el puente de la Belería", sin añadir más". AGAPITO Y REVILLA, Juan: Las calles de Valladolid..., op. cit., pp. 148-151. 
escribano y testigos de esta escritura de que le pio de fe, y yo el dicho escribano la doy de que en la suya y mía se contaron en especie de oro y plata que reducida a vellón al precio que hoy corre y vale lo sumaron y montaron y pusieron en mano del nominado don Pedro de Ávila quien los guardó y pasó a su parte y poder realmente y con efecto; y no contó por hallarse ciego". Los 2.000 reales restantes se le abonarían a Ávila "en fin de mayo del año que viene de mil setecientos cuarenta y ocho". Ocho días después de esta venta, Ávila completó la operación pagando al Convento de San Pablo 175 reales en concepto de los "derechos de la veintena parte en que vendió la casa que poseía en representación de su mujer doña María de la Peña de que fue y es único heredero a don Joseph Plaza Jaén vecino de esta misma ciudad en precio de tres mil y quinientos reales".

Una nueva laguna documental nos deja sin noticias de nuestro escultor hasta los que parecen los momentos previos de su fallecimiento. En su último testamento conservado, fechado el 10 de junio de 1755, se declara por primera vez "enfermo en cama de la enfermedad que Dios nuestro señor ha sido servido darme y en mi juicio $y$ entendimiento natural creyendo" (DOCUMENTO 83). Asimismo, variaba el lugar de su entierro: declaraba su deseo de ser sepultado "en el Santo Convento Hospital de Nuestra Señora de los Desamparados, Orden de Nuestro Padre San Juan de Dios en donde al presente me hallo enfermo". Lo más interesante, sin lugar a dudas, es el hecho de que nos hable de una escultura que pudiera ser de su mano: "Declaro tengo por mío propio empeñado un San Antonio en ocho ducados vellón, es mi voluntad se traiga a dicho convento hospital pagando la referida cantidad y vendido que sea les mando cien reales vellón para mi entierro". El dinero sobrante lo dejaba a "disposición de la referida Francisca López mi mujer". Finalizaba el testamento nombrando como testamentaria y heredera a su esposa, Francisca López; además una breve cita nos habla de la pobreza en la que se hallaba inmerso nuestro escultor: "distribuido a dicho convento hospital en papel de oficio por pobre y sin derechos los que tampoco se pagaron de este original por la notoria pobreza del otorgante, de que doy fe". Sin duda esa pobreza estuvo provocada por la falta de medios para lograr ingresos, no podemos olvidar que hacía más de 13 años que no trabajaba; y, además, había sufrido por parte de su sobrino político el robo de la casi totalidad de su patrimonio, tanto material como monetario

Dada la avanzada edad y la enfermedad que por primera vez declaraba tener es probable que falleciera poco tiempo después en el Hospital del Convento de San Juan de Dios, lugar en el que se encontraba ingresado y en el que sería sepultado según sus propios deseos. Esta es sin duda la explicación de que no hayamos encontrado su partida de defunción en ninguna de las parroquias de la ciudad, si bien el libro de registros de difuntos de estos años de la iglesia de San Ildefonso, casualmente la parroquia más próxima al Convento de San Juan de Dios, ha desaparecido. Es una pena comprobar como una de las cimas más importantes de la estatuaria vallisoletana tuvo una última parte de su vida tan penosa y lastimosa; llena de amargura por los fallecimientos de sus seres más queridos; por el robo y, quizás, maltrato psicológico de sus sobrinos María 
Barba y Juan Ceano, con los cuales vivió cerca de cinco años; y aquejado por la ceguera, enfermedad mucho más lamentable en el caso de un escultor, puesto que le conllevó al cierre del taller y, por consiguiente, de su única fuente de ingresos. Todo ello derivó en un anciano que falleció ciego y pobre. Penoso final para una personalidad artística tan importante en nuestra ciudad.

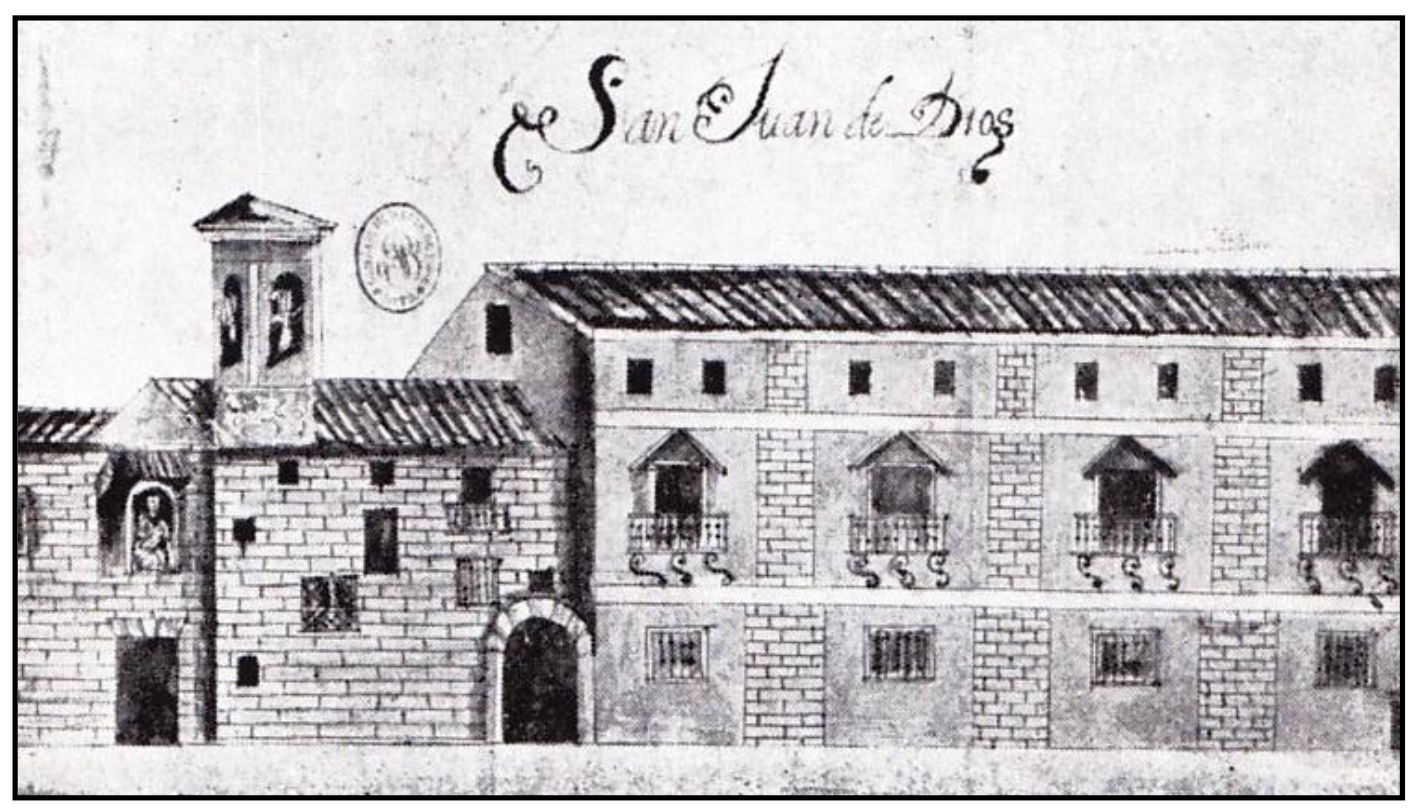

Il. 7- Diego Pérez Martínez. Hospital de San Juan de Dios. Ilustración de la "Historia de Valladolid" de Juan Antolínez de Burgos.

\section{7-2 LA FAMILIA}

A continuación, nos vamos a referir, exclusivamente, a la familia de Pedro de Ávila. En ningún caso se va a hacer referencia a la vida de su padre ni de sus hermanos, puesto que de esto ya nos hemos ocupado al hablar de la familia de Juan de Ávila. Tampoco pondremos ningún dato acerca de sus mujeres que ya haya sido tratado en la biografía de nuestro escultor, por lo que nos ceñiremos a otros nuevos.

\section{A-SUEGRO: JUAN ANTONIO DE LA PEÑA}

Ya tratamos sobre su vida y obra en la sección dedicada a los escultores contemporáneos a nuestros artistas de la familia Ávila.

\section{B- PRIMERA MUJER: MARÍA LORENZA DE LA PEÑA}

La vida de María Lorenza de la Peña es de lo más tranquila, pues no existen sobresaltos que nos haga tener muchos documentos sobre su existencia. Al revés, apenas contamos con los justos: fechas del nacimiento, del bautizo, del matrimonio y de la muerte.

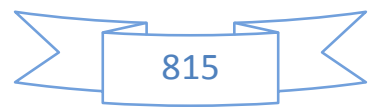


María Lorenza de la Peña nace el 9 de agosto de 1682 en la casa que sus padres, el escultor Juan Antonio de la Peña y Francisca de Santiago, poseían en la calle Cantarranas de la capital castellana. Su bautizo tuvo lugar en la primitiva iglesia de San Miguel el día 16 de agosto de ese mismo año ${ }^{83}$. El encargado de dispensárselo fue el cura ecónomo de la parroquia, don Juan de Carrión Muñoz. Fueron sus padrinos el pintor y religioso Jerónimo Benete, que también fue padrino de otros hijos de Juan Antonio de la Peña y de otros artistas, y Juana de Llanos. Se le dieron como abogados a Nuestra Señora de la Esperanza, cuya efigie se veneraba en la parroquia y a San José. Finalmente, ejercieron el cargo de testigos los licenciados Andrés Merino, beneficiado de dicha iglesia, y Juan Fernández de Villate.

Cuando su madre procede a dictar testamento el 9 de diciembre de $1707^{84}$, ella y sus hermanos Joseph y Juana quedan instituidos como herederos.

La relación con su familia política debió de ser excelente puesto que no tuvo reparos en ser madrina de Feliciana de Ávila, hija de su cuñado Manuel de Ávila, el 2 de diciembre de $1725^{85}$; también ejerció el cargo de madrina en la boda contraída entre su cuñada Teresa de Ávila y Santiago Barba el 22 de julio de 1714 en la iglesia de San Miguel ${ }^{86}$, y en las velaciones del referido matrimonio, celebradas el 24 de septiembre de ese mismo año en la santa iglesia catedral ${ }^{87}$.

\section{C-SOBRINA: MARÍA BARBA}

Aunque no fue la única sobrina que tuvo Pedro de Ávila, sí que fue la más cercana. María Barba era hija de su hermana Teresa de Ávila y el marido de ésta, Santiago Barba. Nació en Valladolid el 15 de abril de 1717, siendo bautizada el día 22 de ese mismo mes en la parroquia de San Juan Evangelista, sita en la capilla homónima de la catedral $^{88}$.

83 "En diez y seis de agosto de mil y seiscientos y ochenta y dos años yo Juan de Carrión Muñoz cura ecónomo de ésta iglesia parroquial del señor San Miguel de esta ciudad de Valladolid bauticé e impuse los santos óleos como el Santo Concilio manda a una niña hija legítima de Juan Antonio de la Peña escultor y Francisca Santiago parroquianos de dicha iglesia a Cantarranas pusieronla por nombre María Lorenza la cual nació a nueve de este presente dicho mes según me lo aseguraron sus padrinos que lo fueron Jerónimo Benete y Juana de Llanos, dieronla por abogados a Nuestra Señora de la Esperanza y San José fueron testigos el licenciado Andrés Merino beneficiado de dicha iglesia y el licenciado Juan Fernández de Villate vecinos de esta ciudad y lo firmé”. A.G.D.V., San Miguel, 1669B, f. 140. URREA FERNÁNDEZ, Jesús: "La biografía al servicio del conocimiento..., op. cit., p. 55.

84 A.H.P.V., Leg. 2.763/2, ff. 244-245.

85 A.G.D.V., Catedral, 1681B, f. 372.

86 A.G.D.V., San Miguel, 1681M, f. 88.

87 A.G.D.V., Catedral, 1695M, f. 131

88 "En veintidós de abril de mil setecientos y diez y siete años yo Don Francisco del Álamo cura propio de la parroquial del Señor San Juan Evangelista inclusa en Santa Iglesia Catedral de esta ciudad de Valladolid bauticé (...) a María hija legítima de Santiago Barba y de Doña Teresa de Ávila mis feligreses (...) dieronla por abogados a Nuestra Señora del Sagrario, San José y Santa Basilisa testigos D. Juan de Toro, Tomás Rodríguez y Jerónimo Vázquez y lo firmé.” A.G.D.V. Catedral, 1656B, f. 82. 
Nada más sabemos de la joven hasta que con tan solo 14 años contrae matrimonio con el librero Juan Ceano, éste tuvo lugar en la santa iglesia catedral el 21 de mayo de $1731^{89}$. Unos días antes, el 1 de mayo de 1731 se redactan las capitulaciones matrimoniales. En ellas se especifica que María era "doncella virgen y en cabello e hija de padres conocidos y cristianos viejos" (DOCUMENTO 74). El 5 de agosto de 1731 Juan Ceano otorga carta de pago en favor de Santiago Barba ${ }^{90}$. El matrimonio tuvo cuatro hijos: María Micaela $(1736)^{91}$, Vicente $(1737)^{92}$, Manuel Justo (1739) ${ }^{93}$ y María $(1740)^{94}$.

$89 \quad$ "En la ciudad de Valladolid (JHS) a veintiuno de mayo de este año de mil setecientos y treinta y un años, yo D. Manuel Velandía sacristán mayor de la Santa Iglesia Catedral de esta ciudad (...) desposé por palabras de presente que hicieron verdadero matrimonio según dicho Santo Concilio a Juan Ceano Martín natural de la villa de Becerril de Campos diócesis de Palencia hijo legítimo de Francisco Ceano y María Martín difuntos, con María Barba Ávila natural de esta ciudad hija legítima de Santiago Barba y Teresa de Ávila difunta fueron testigos don Iván de Toro y Manuel Ceano y Joseph Meléndez y el día siguiente yo dicho D. Manuel velé in facie ecclesiae en la ermita de Nuestra Señora de los Inocentes a los dichos y en el altar mayor de ella dije de la misa nupcial e hice las demás ceremonias que proviene el manual romano a que fueron padrinos Narciso Barba María de la Peña y fueron testigos D. Manuel Ceano, Joseph Meléndez y Pedro de Ávila vecinos de esta dicha ciudad y para que conste lo firmé con dicho señor cura fecho ut supra". A.G.D.V., Catedral, 1695M, f. 82.

$90 \quad$ A.H.P.V., Leg. 2.968, ff. 148-151.

91 "En la ciudad de Valladolid a seis días del mes de febrero de este presente año de mil setecientos y treinta y seis yo don Gabriel Dominguez del Cid cura propio de la santa iglesia catedral de esta dicha ciudad habiendo precedido los santos exorcismos bauticé solemnemente en ella puse los santos óleos y crisma según forma de Nuestra Santa Madre la Iglesia de Roma a María Micaela nació el día dos del dicho hija legítima de Juan Ceano natural de la villa de Becerril de Campos diócesis de Palencia y de doña María Barba natural de esta dicha ciudad, su legítima mujer y mis parroquianos que viven a la Librería fueron padrinos Santiago Barba su abuelo de dicha bautizada y Teresa, digo Francisca de Ávila, digo Barba tía de dicha bautizada, dile por abogados a Nuestra Señora de las Candelas, San Blas y San Antonio de Padua testigos Manuel Barrigón, don Juan Díez y Manuel de San Pedro y lo firmé en esta dicha ciudad, fecho ut supra”. A.G.D.V., Catedral, 1681B, f. 435.

$92 \quad$ "En veinte y tres días del mes de diciembre de este presente año de mil setecientos y treinta y siete yo don Gabriel Dominguez del Cid cura propio de la santa iglesia catedral de esta dicha ciudad de Valladolid habiendo precedido los santos exorcismos bauticé solemnemente en ella puse los santos óleos y crisma según forma de Nuestra Santa Madre la Iglesia de Roma a Vicente Domingo Ignacio el día veinte del dicho hijo legítimo de Juan Ceano natural de Becerril de Campos d y de doña María Barba natural de esta dicha ciudad, su legítima mujer y mis parroquianos que viven a la Librería (...) fueron padrinos dicho Santiago Barba y Francisca Barbe, dile por abogados a Nuestra Señora de las Mercedes, San Miguel y Santo Tomás Apóstol fueron testigos don Miguel González, Manuel Barrigón y Andrés de Vega y lo firmé fecho ut supra". A.G.D.V., Catedral, 1681B, f. 448.

$93 \quad$ "En la ciudad de Valladolid a dos días del mes de junio de mil setecientos y treinta y nueve años yo don Manuel Ceano presbítero con licencia de don Joseph Pérez de Aliende cura de la santa iglesia catedral, exorcicé, impuse el santo óleo y crisma a Manuel Justo Germán a quien había bautizado en casa por necesidad don Sebastián de Medina capellán del número de dicha santa iglesia el día veintiocho de mayo próximo pasado en que nació, hijo legítimo de Juan Ceano natural de Becerril de Campos y de doña María Barba natural de esta ciudad, feligreses de dicha parroquia que viven a la Librería (...) fueron sus padrinos dicho Santiago Barba y Francisca Barba abogados San José, San Miguel y San Fernando, testigos don Sebastián de Medina, don Joseph Rodríguez y Manuel Barrigón y para que conste lo firmo con dicho señor cura". A.G.D.V., Catedral, 1681B, f. 458.

94 "En la ciudad de Valladolid a veinte y siete días del mes de diciembre de mil setecientos y cuarenta años yo don Joseph Pérez de Aliende cura de la parroquial del señor San Juan inclusa en la santa iglesia catedral de esta dicha ciudad habiendo echo los santos exorcismos, bauticé solemnemente e impuse el santo óleo y crisma según forma de nuestra santa madre iglesia a María, que dijeron había nacido el día veinte y dos del mes arriba dicho hija legítima de Juan Ceano natural de la villa de Becerril de Campos y de doña María Barba natural de esta dicha ciudad mis feligreses, que viven a la Librería (...) fueron sus padrinos Miguel González y Francisca Barba su tía, y testigos Gregorio Fernández, Joseph 
Un nuevo salto cronológico nos la sitúa el 11 de enero de 1742, día en que Pedro de Ávila firma uno de sus testamentos, como heredera universal de su tío (DOCUMENTO 76). El final se acercaba, y María no heredaría nada de su tío, pues a la buena salud, con excepciones, de Pedro de Ávila se sumó el fallecimiento de la propia María. Éste se produjo el 9 de febrero de 1744 en su casa de la calle Librería ${ }^{95}$, siendo enterrada, por expreso deseo, en el Convento de los Padres Mercedarios Calzados. Previamente, el 31 de enero de 1744 María da poder a su marido para que otorgara el testamento por ella, dado que la gravedad de su enfermedad se lo impedía (DOCUMENTO 77). Finalmente, Juan otorgaba el testamento en virtud de poder el 17 de marzo de ese mismo año ${ }^{96}$.

\section{D- SEGUNDA MUJER: FRANCISCA LÓPEZ}

Francisca López fue la segunda mujer de Pedro de Ávila, matrimonio que hasta el momento permanecía inédito puesto que se pensaba que el escultor falleció en 1742 poco después del óbito de su primera esposa, María Lorenza de la Peña. No tenemos muchas noticias sobre su vida, pasamos a exponerlas:

Francisca nació el 22 de agosto de 1697 en la localidad vallisoletana de Cigales, en cuya iglesia parroquial de Santiago Apóstol fue bautizada el día 9 de septiembre de ese mismo año ${ }^{97}$. Sus padres fueron Andrés López y Bernarda García. Desconocemos el momento en que llegó a Valladolid. Sea como fuere, el 27 de junio de 1717 contrae matrimonio con un tal Gregorio González en la iglesia de San Juan Bautista de la capital vallisoletana ${ }^{98}$.

Rodríguez y Joseph de Rozas dila por abogados a Nuestra Señora del Sagrario, San José y San Joaquín, y en fe de ello lo firmé ut supra". A.G.D.V., Catedral, 1681B, f. 466.

95 "En nueve de febrero de mil setecientos y cuarenta y cuatro murió en esta parroquia de la Santa Iglesia Catedral de esta ciudad de Valladolid, habiendo recibido los santos sacramentos, con el de la extremaunción a la calle de la Librería Doña María Barba y Dávila, que estaba casada con Juan Ceano, a quien dio poder para testar, que se hizo por testimonio de Manuel Padillo y García notario de la conservaduría de la real universidad de esta dicha ciudad y escribano real de su majestad, por el cual mandó enterrarse en el Convento de Padres Mercedarios Calzados de esta dicha ciudad en sepultura propia y que por su alma se dijesen cien misas rezadas, la cuarta en la Parroquia y el dicho Juan Ceano usado del citado poder dispuso lo mismo por el testamento, que hizo ante el dicho Manuel Padillo, y nombró por sus testamentarios, a el dicho Juan Ceano, al señor D. Francisco Varredo canónigo lectoral de esta Santa Iglesia, y por sus herederos, a Vicente y María Ceano, sus hijos legítimos, y del citado Juan Ceano, y en fe de ello lo firmo como cura dicha parroquia”. A.G.D.V., Catedral, 1684D, f. 277.

96 A.H.P.V., Leg. 3.542, ff. 46-47.

97 "Certifico yo el licenciado Manuel Álvarez cura y beneficiado de la parroquial del señor Santiago de la villa de Cigales que en nueve días del mes de septiembre de mil seiscientos y noventa y siete bauticé y puse los santos óleos según forma de nuestra madre iglesia a Francisca hija legítima de Andrés López vecino de esta y natural de la villa de Villanubla y de Bernarda García vecina de dicha villa y natural de la villa de Dueñas obispado de Palencia y ambos mis parroquianos, fueron sus padrinos Manuel Díez y Luisa Sanz Lopo, testigos Tomás Reoyo y Francisco Álvarez todos vecinos de dicha villa nació en veinte y dos de agosto de dicho año abogada Nuestra Señora y por verdad lo firmé dicho día ut supra”. A.G.D.V., Cigales, Santiago Apóstol, 1691B, f. 80.

98 En veinte y siete de junio año de mil setecientos y diez y siete yo don Joaquín Pérez cura propio de la parroquial iglesia de San Juan Bautista de esta ciudad habiendo precedido las tres canónicas municiones que el Santo Concilio tridentino manda y licencia in scriptis del señor doctor don Juan 
El 28 de mayo de 1742, encontrándose aún casada con Gregorio González, decide dictar testamento, si bien al final de la redacción del mismo se especifica que "lo otorgo así ante el presente escribano en este dicho Real Hospital a veinte y uno de mayo" (DOCUMENTO 81). Por entonces se hallaba ingresada en el Real Hospital de Santa María de Esgueva debido a una enfermedad que no especifica. En sus últimas voluntades exhortaba que su "cuerpo sea sepultado en el cementerio de la Antigua de esta dicha ciudad y con el hábito de Nuestra Señora del Carmen, asistiendo la Cofradía de las Ánimas Pobres de la parroquial, y con la demás disposición que es costumbre a los demás pobres que mueren en este dicho Real Hospital". También deja claro que, aunque casada con Gregorio González, el matrimonio no había tenido descendencia. Tras inventariar una serie de deudas, tanto a favor como en contra, relata que su voluntad era "que todos los trastos que hay en la casa en que he vivido lo haya y goce para sí y como propio el dicho Gregorio González mi marido, excepto un brasero, un velón y una palmatoria". Finalmente, dejaba nombrados como testamentarios y albaceas a Manuel Saavedra "presbítero capellán de este dicho Real Hospital" y a Joseph Villar "su mayordomo".

Las últimas noticias que sobre ella tenemos, ya que no hemos conseguido localizar la fecha de su fallecimiento, son las que nos aporta el que creemos postrimero testamento de Pedro de Ávila, otorgado el 10 de junio de 1755 desde el Hospital de Nuestra Señora de los Desamparados, inserto dentro del Convento de San Juan de Dios (DOCUMENTO 83). En él dejaba nombra a Francisca, su esposa, como testamentaria y como única y universal heredera.

\section{7-3 RELIGIOSIDAD}

El caso de la religiosidad de Pedro de Ávila es bastante curioso puesto que, al contrario que su padre y que la mayoría de los artistas de su época, tan solo tenemos constancia que perteneció a una cofradía; concretamente a la Cofradía Penitencial de Nuestra Señora de la Pasión, tal y como sabemos gracias a la lectura de sus múltiples testamentos, en todos los cuales deja reflejado que ocupaba puesto de diputado (DOCUMENTO 76). Llama la atención el hecho de que no tengamos documentada ninguna obra suya, o actuación sobre el patrimonio de esta cofradía, puesto que la mayoría de los artistas ligados a una cofradía trabajaron para ella.

Manuel de Acítores provisor y vicario general de esta ciudad y su obispado refrendaba de Antonio López Ramírez notario de asiento, desposé por palabras de presente que hicieron verdadero matrimonio por no haber resultado impedimento alguno a Gregorio González residente en esta ciudad hijo legítimo de Baltasar González y de Antonia Martín naturales de la villa de Bembibre y obispado de Astorga con Francisca López natural de la villa de Cigales y residente en esta dicha ciudad hija legítima de Andrés López y de Bernarda García, fueron testigos Blas García, Alonso Cea Gago y Blas de Yado, asimismo recibieron las bendiciones de la iglesia y para que conste lo firmo en Valladolid fecha ut supra. A.G.D.V., San Juan Bautista, 1657M, p. 171. 
Aunque tampoco tengamos noticia alguna, es bastante probable que también perteneciera a la Cofradía Penitencial de Nuestro Padre Jesús Nazareno, para la cual parece que trabajó, y de la que fueron miembros tanto su padre, Juan de Ávila, como su hermano, Manuel de Ávila. Al contrario de lo que sucede con la Cofradía de la Pasión, para la Cofradía de N. P. Jesús Nazareno sí que talló un precioso yacente ubicado en el retablo de la Virgen del Sacro Monte Calvario, aunque por desgracia no lo tenemos documentado.

También es plausible que pudiera haber pertenecido a otras como la Sacramental del Hospital General extramuros, dado que en sus numerosos testamentos refleja que esta cofradía debería de acudir a su entierro; y, quizás, a la sacramental de la iglesia de San Miguel, en cuya parroquia moró la mayor parte de su vida. 


\section{8-EI ARTE DE \\ PEDRO DE AVILA}


$\sum[822]$ 


\section{8-1 MARCO DE TRABAJO}

Su marco, o más bien marcos, de trabajo se establecen en dos lugares: primeramente, en la calle Santiago junto a su padre; y hacia el año 1700 o un poco antes, en el de San Miguel, cuando accede como oficial al taller de su suegro, que posteriormente dirigirá él mismo. Del barrio de Santiago ya hablamos al tratar este punto en Juan de Ávila, así que nos entraremos en el de San Miguel

La plaza de San Miguel fue, junto con la del Rosarillo, uno de los centros fundacionales de la urbe. Según Agapito y Revilla "constituyó esta plaza el centro geométrico de la villa en su primitiva formación, cuando aparece ya cercada con su primera muralla, la más antigua de las conocidas. En ella, como es de suponer, estaría el núcleo más importante en la vida de la población"1.

El obrador de Juan Antonio de la Peña se hallaba en la "esquina a las calles de San Miguel y las Damas" (DOCUMENTO 82); concretamente en "la calle de San Miguel que hace esquina a la que sube por detrás de la ermita del

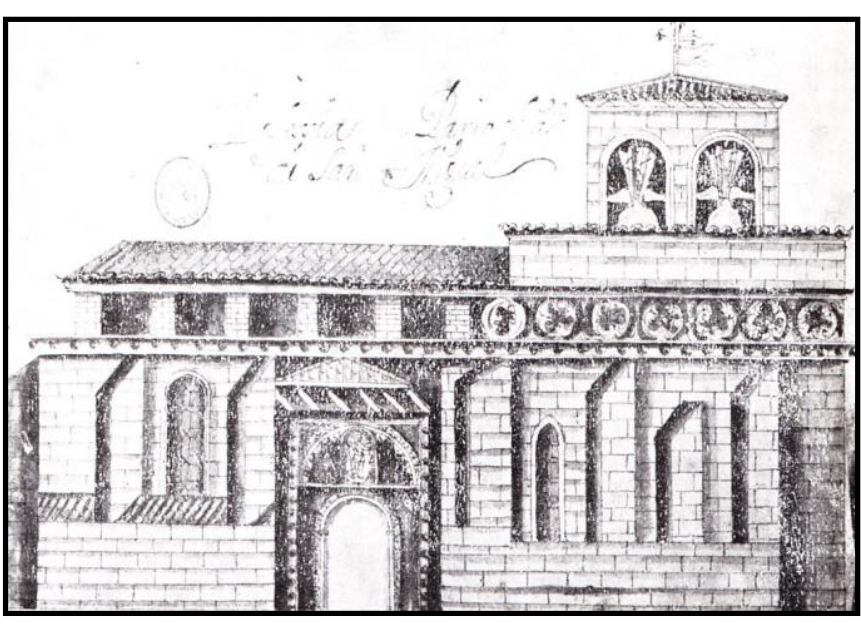

Il. 1- Diego Pérez Martínez. Iglesia de San Miguel. Ilustración de la "Historia de Valladolid" de Juan Antolínez de Burgos. santo Cristo de la Cruz a la calle de las Damas, y linda al presente con las dichas dos calles y con casas hacia la parroquia de San Miguel" (DOCUMENTO 65). Tras el fallecimiento de De la Peña la casa se subdividió en dos, yendo a parar una a María Lorenza de la Peña y Pedro de Ávila y la otra a Joseph de la Peña, el otro hijo del escultor. Si tenemos en cuenta tanto la localización que nos dice la descripción, como este último hecho, y lo trasladamos al plano de Bentura Seco de 1753, año en que Ávila ya no vivía allí, podríamos colegir que en verdad se trata de las dos casas que hacen esquina a la calle las Damas; encontrándose asimismo al final de la calle Guadamacileros y al principio de otra sin nombre que desemboca en la iglesia de San Miguel; podría colegirse que estaban en la plaza de los Condes de Niebla. En la actualidad estas casas se encontrarían en la Plaza de los Arces, en la esquina que divide la calle de San Antonio de Padua de la prolongación de la de Leopoldo Cano.

Esta zona pasaba por ser la más poderosa de la ciudad puesto que en ella moraban algunos de los personajes más influyentes de la urbe; también tenían cabida la mayor parte de los palacios que los nobles construyeron en siglos anteriores, si bien la mayoría de sus propietarios ya no vivían en ellos dado que se trasladaron a Madrid tras la marcha de la Corte en 1606. Esta es la gran diferencia con respecto al barrio de Santiago, en el

1 AGAPITO Y REVILLA, Juan: Las calles de Valladolid..., op. cit., p. 432. 
que tan solo existía una casa noble, la del Conde de Monterrey. Mientras que aquél era un barrio fundamentalmente artesanal y, en parte, artístico, puesto que allí se hallaban establecidos gran parte de los pintores y algún escultor; en este de San Miguel menudeaban los nobles, los regidores de la ciudad, los plateros y la mayor parte de los escultores, configurándose de esta manera como el "barrio de los escultores" en el siglo XVIII. Efectivamente, en él vivían, y vivieron, entre otros: Alonso de Rozas, Andrés de Pereda, Antonio Vázquez, Damián Díez, José de Rozas, Juan Antonio de la Peña, Andrés Carballo, Pedro León Sedano, José Pascual, Antonio Bahamonde y, quizás, José Fernández. Tampoco era nada despreciable el número de ensambladores, tallistas y artífices relacionados con el mundo de la arquitectura.

Como acabamos de comentar, las casas nobles eran multitud por esta zona, si bien la piqueta y la especulación han acabado con la mayoría de ellas. El taller de Pedro de Ávila se hallaba rodeado: la Casa de los Arenzana o del Conde de Fuentenueva de Arenzana (calle de San Ignacio, $\left.n^{\circ} 9\right)^{2}$, la Casa del escultor Alonso Berruguete (calle General Almirante) ${ }^{3}$, la Casa del licenciado don Francisco Butrón (plaza de Santa Brígida) ${ }^{4}$, la Casa del licenciado Francisco González Cacho Villegas (calle

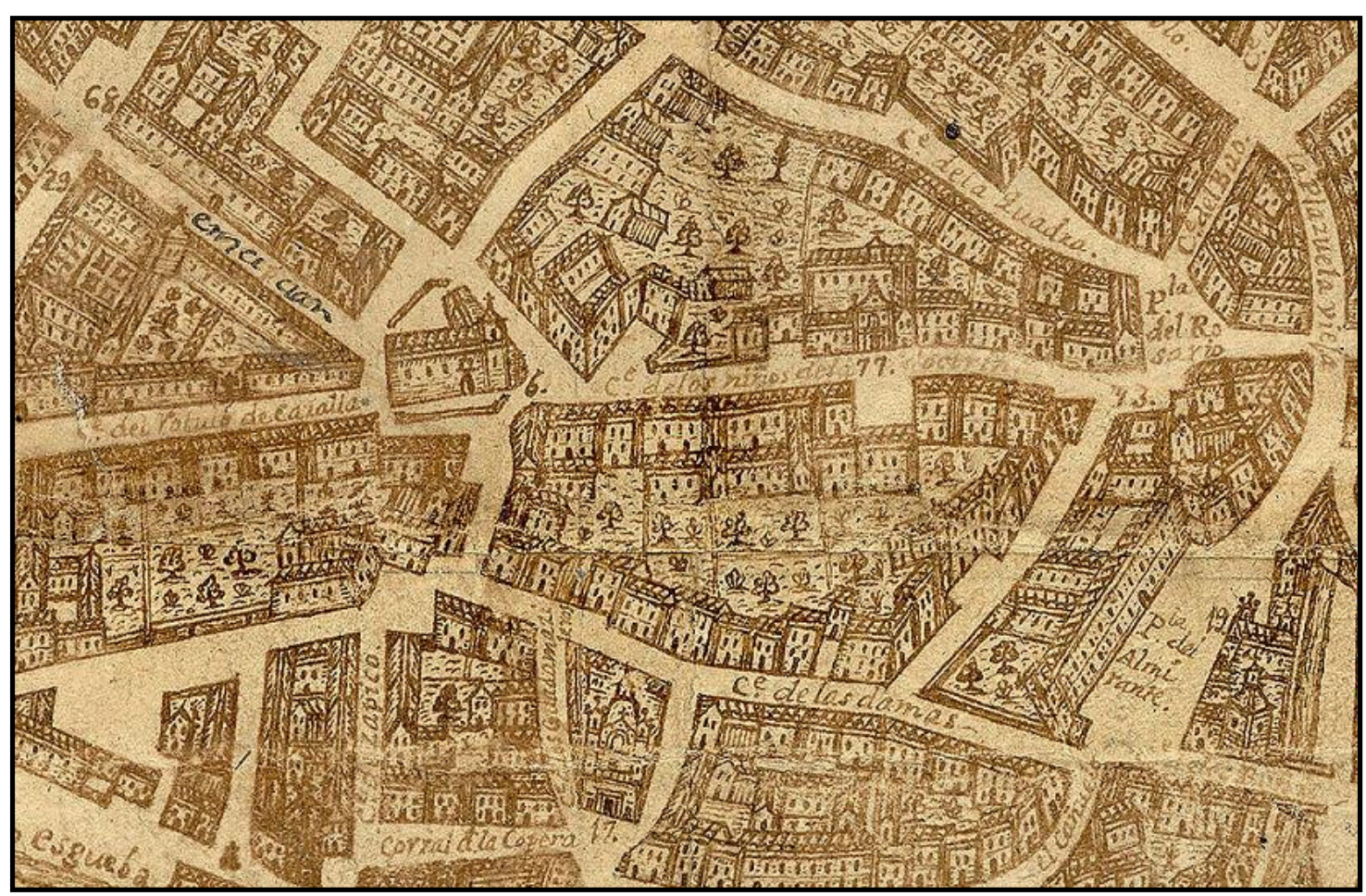

Il. 2- Inmediaciones de la calle de San Miguel en el mapa de Bentura Seco de 1738.

Guadamacileros, $\left.n^{\circ} 9\right)^{5}$, el Palacio del banquero Fabio Nelli de Espinosa o del Marqués de la Vega de Boecillo (plaza de Fabio Nelli) ${ }^{6}$, la Casa del Marqués de Valverde de la Sierra (calle San Ignacio, $\left.\mathrm{n}^{\mathbf{0}} 11\right)^{7}$, la Casa del Marqués de Villasante (actual Palacio

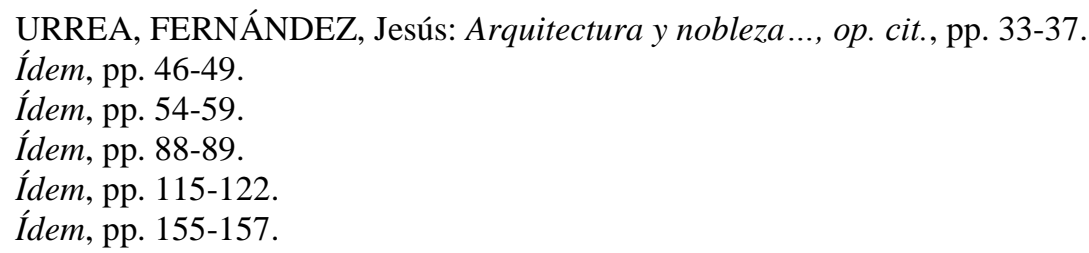


Arzobispal. Calle de San Juan de Dios, $\left.\mathrm{n}^{\mathrm{o}} 5\right)^{8}$, la Casa de don Antonio de Pesoa o del Marqués de Castrofuerte (calle de San Ignacio, $\left.n^{\circ} 5\right)^{9}$, el Palacio del Conde de Fontanar o de la familia Gardoqui (antes Plaza de San Miguel) ${ }^{10}$, la Casa del Marqués de Frómista (antes Plaza de San Miguel) ${ }^{11}$, la Casa del Conde de Nieva o del Montijo (antes calle General Almirante y Plaza de los Arces) ${ }^{12}$, la Casa del Conde de Ribadeo y Salinas (antes Plaza de las Brígidas y calle San Quirce) ${ }^{13}$ y la Casa del regidor don Francisco Rubín de Celis (antes calle de San Blas) ${ }^{14}$. También se hallaba bastante cerca el Palacio del Almirante de Castilla, sito en la plazuela del mismo nombre frente a la iglesia penitencial de Nuestro Señora de las Angustias, para la que es probable que nuestro escultor trabajara.

Tampoco faltaron en los alrededores del taller de Ávila los establecimientos religiosos, la mayor parte de ellos situados entre los de mayor importancia, tradición y abolengo de la ciudad: a misa asistiría a diario a la iglesia de San Miguel, la más antigua de la ciudad, situada a tan solo unos pasos de su casa-taller; tampoco se encontraban muy lejos la iglesia penitencial de la Santa Vera Cruz o la ermita de Nuestra Señora del Val; un poco más distantes, pero tampoco demasiado, estaban el Monasterio de San Benito el Real, el Colegio de San Ignacio de jesuitas (actual iglesia de San Miguel y San Julián), el Convento de la Concepción (calle de la Concepción), el Monasterio de Santa Brígida (Plazuela de los Leones), el Hospital de la Misericordia o de los Niños de la Doctrina con su iglesia de San Blas (calle de los Niños de la Doctrina), y el Hospital de Nuestra Señora del Rosario, conocida vulgarmente como "el Rosarillo". Parece que la proximidad de su taller tan solo cristalizó en los encargos que le realizó el Monasterio del Santísimo Salvador de Santa Brígida.

También existían dos paraderos reseñables y muy peculiares en las cercanías del obrador de nuestro escultor: el Malcocinado (situado en la calle del Malcocinado, actual calle de Francisco Zarandona), que eran "una serie de casas que se comunicaban unas con otras, cerca de la ermita de Nuestra Señora del Val, y que vendían el menudo de las reses y carne más barata, generalmente de oveja, pero no cruda, sino cocida. Esto era lo permitido; pero infringiendo las leyes se vendía todo tipo de carne" y se llegó incluso a "vender carne de reses muertas, no sacrificadas"15; y el ramal norte de la Esgueva.

Ídem, pp. 176-180.

Ídem, pp. 218-220.

Ídem, pp. 271-273.

Ídem, pp. 274-275.

Ídem, pp. 304-306.

Ídem, pp. 313-314.

Ídem, pp. 315-316.

MERINO BEATO, María Dolores: op. cit., Tomo I, p. 285. 


\section{8-2 EL OFICIO DE ESCULTOR}

Pedro de Ávila fue escultor. Esta afirmación es tan simple como contundente. Si bien de su padre sabemos que realizó algunas labores propias de ensambladores, arquitecturas efímeras, etc...; de Pedro de Ávila no tenemos noticias que apunten en estas direcciones. Los pocos datos que poseemos sobre su obra aluden tan solo al mundo de la escultura. También al contrario que su padre no tenemos ninguna duda de si pudo policromar sus esculturas, pues no lo hizo; si bien con Juan de Ávila siempre nos quedará la incertidumbre de si su posible formación pictórica cristalizó en algún policromado de sus imágenes, con Pedro de Ávila no ocurre esto, puesto que conocemos la inmensa mayoría de los policromadores y doradores que dieron color a sus hechuras.

Una de sus ocupaciones como escultor fue la de tasador de esculturas y otro tipo de objetos de madera; labor, esta última, más propia de ensambladores: por ejemplo las "dos cornucopias doradas" que poseía el mesonero Juan Antonio Sanz de Cabezón. Tenemos documentadas tan solo tres tasaciones, fechadas en el corto espacio comprendido entre 1714-1726; no cabe ninguna duda de que un maestro tan prestigioso debió de estar mucho más solicitado y pudo realizar bastantes más. Parece que estas tres personas debieron de tener una posición acomodada si cotejamos las esculturas que cada uno poseía: además del regidor vallisoletano Juan Antonio de la Rumbe y Elizalde ${ }^{16}$; se encontraban el mesonero Juan Antonio Sanz de Cabezón, propietario de importantes preseas ${ }^{17}$; y el batidor de oro Antonio Canesi Acebedo ${ }^{18}$, miembro de una ilustre familia pues su padre fue Juan Francisco Canesi, recaudador de los Propios de la ciudad, y su hermano fue el famoso historiador Manuel Canesi.

El prestigio del que gozo Pedro de Ávila como escultor fue reconocido en propia vida del artista, puesto que era muy celebrado por sus conciudadanos. Su amigo Manuel Canesi, el historiador local, llega a decir de él al hablar sobre las esculturas que esculpió para el Oratorio de San Felipe Neri que eran obra de "Pedro de Ávila, estatuario insigne, vecino de esta ciudad"19. Habría que llegar al siglo XX para leer nuevas alabanzas hacia nuestro escultor. Así, Gratiniano Nieto en su Guía artística de Valladolid refería sobre la Santa María Magdalena del Oratorio de San Felipe Neri que ésta "demuestra el rango que llegó a alcanzar la escultura de Valladolid en esta centuria" ${ }^{20}$. Años después, Durruty Romay hacía la siguiente disertación, en la cual ponderaba de una manera muy positiva a Pedro de Ávila: "El siglo XVIII, fecundo en el arte barroco, dio en Castilla una pléyade de escultores de gran interés, aun no muy conocidos ni divulgados. Tal vez la fama y la gloria magnífica de maestros como Berruguete, Francisco del Rincón, Juni, Fernández, etc., proyectada en prolongación interminable a todas las épocas, contribuye a oscurecer en cierto modo, a artistas

16 A.H.P.V., Leg. 2.394/3, f. 58. URREA FERNÁNDEZ, Jesús: “El oratorio...”, op. cit., p. 19.

17 A.H.P.V., Leg. 2.395, ff. 729-730.

18 A.H.P.V., Leg. 3.160, ff. 418-420 (1726).

19 CANESI ACEVEDO, Manuel: Historia de Valladolid (1750) Tomo III., op. cit., pp. 560-561.

20 NIETO GALLO, Gratiniano: op. cit., p. 122. 
posteriores -aunque no muy lejanas a ellos en ciertas analogías-, que sin llegar a ser astros de primera magnitud, tienen luz y valor propio de gran intensidad; este es el caso de Pedro de Ávila"21. Finaliza su breve artículo señalando que "por sus contrastes, por la maestría de su técnica, por sus méritos artísticos, Pedro de Ávila bien merece ocupar un puesto de honor entre los escultores del siglo XVIII y que su nombre y obra se divulgue en la proporción que sus cualidades le alcanzan"22.

Su escaso catálogo nos le muestra aplicado a tan solo los tipos de escultura. Este limitado listado se ampliaría de forma notable si tuviéramos en cuenta las imágenes que se le atribuyen sin ningún género de dudas. Sea como fuere, la escultura destinada a retablos la comprenden: la Piedad del Colegio de los Ingleses de Valladolid, el San Miguel para Castil de Vela, los cuatro santos para otros tantos altares de la Catedral vallisoletana, las cinco imágenes para el Oratorio de San Felipe Neri; mientras que las imágenes de devoción tan solo la compondrían el Crucificado para Torrecilla de la Abadesa y la Virgen de las Angustias para Íscar. Nos queda la duda de si el San Ildefonso y el San José de Morales de Toro fueron realizadas para un retablo o no.

Otras dos facetas que le diferencia de su padre es que no hemos logrado documentarle ningún relieve, siendo por lo tanto un escultor "de bulto redondo", ni ninguna escultura de carácter profano, pues todas son religiosas.

No debió de dedicarse en exclusiva a la talla de madera, puesto que hay al menos cuatro esculturas en piedra que podemos relacionar con mayor o menor fortuna con él. Se trata de las tres que conforman la portada del Convento de las Comendadoras de Santiago de Valladolid (San Agustín, Santa Mónica y la Inmaculada Concepción), en el que si nos dejamos llevar por el modelo de Inmaculada caben pocas dudas de su autoría; y la Santa María Magdalena que preside la hornacina de la fachada de la parroquia vallisoletana homónima. Ya remarcamos en este mismo punto al hablar de Juan de Ávila, el cual debió de practicar la talla en piedra de manera excepcional, puesto que tan solo le documentamos la cruz del cementerio de la parroquia de Santiago, que "de la escultura en piedra o en mármol no podemos hablar mucho ya que en aquella época ni en los años inmediatamente anteriores o posteriores hubo en Valladolid escultores especializados en la talla de estos materiales. Tampoco es que existieran muchas oportunidades para aplicarse a ellas". En la madurez de Pedro de Ávila este panorama había cambiado, puesto que a este momento pertenecen, además de las que le hemos atribuido, las que Antonio de Gautúa y Pedro de Bahamonde realizaron para la fachada de la catedral vallisoletana, si bien hubieron de seguir los modelos dados por el escultor vallisoletano, aunque salmantino de adopción, José de Larra Domínguez, cuñado de Alberto de Churriguera, el cual por entonces se ocupaba de la construcción del segundo cuerpo de la fachada de la seo; y las que los Tomé esculpieron para las fachadas de la iglesia de San Martín (San Martín partiendo la capa para dársela a un pobre) y de la Universidad.

21 DURRUTY ROMAY, Inés: "El Cristo del Olvido. Escultura de Pedro de Ávila”, B.S.A.A., Tomo VII, 1940-1941, pp. 205-209, p. 205.

22 Ídem, p. 209. 


\section{8-3 FORMACIÓN}

No cabe duda de que Pedro de Ávila aprendió el oficio desde bien pequeñito en el taller paterno, en el cual se encontraría trasteando desde su más tierna infancia. Su formación propiamente dicha llegaría, como era costumbre en la época, entre los 11 o 14 años, finalizándola a los 15 o 19 años. Al cabo de este tiempo, hacia el año 1695, proseguiría su aprendizaje en el taller de su padre pero en calidad de oficial, auxiliándole ante el creciente número de encargos; y, un poco más tarde, quizás, contrataría alguna obra por su parte, extremo que no podemos confirmar.

Otro punto que ignoramos es el concerniente a la fecha de emancipación paterna y pase al obrador de su suegro, o futuro suegro, Juan Antonio de la Peña. Cuando se casa con la hija de éste, en 1700, ya había trabajado para él, lo que nos indica que Ávila estaba a sus órdenes desde tiempo antes. Desconocemos las motivaciones que le llevarían a cambiar de taller, como ya dijimos con anterioridad, pero quizás se debiera a un interés en profundizar sus estudios y no conformarse con lo enseñado por su padre, siendo de esta manera un maestro mucho más completo puesto que habría tomado lecciones de los dos talleres más importantes de la ciudad, si excluimos de esta lista al de José de Rozas.

\section{8-4 ESTILO}

Al igual que nos ocurría con Juan de Ávila, y nos pasará con Manuel de Ávila, la escasez de obra documentada de todos ellos nos dificulta bastante la labor de poder establecer una serie de características concretas con las que definir de manera precisa el estilo de nuestros escultor. Por fortuna, el caso de Pedro de Ávila es distinto puesto que posee un estilo tan particular que unas pocas obras documentadas nos han servido perfectamente para poder atribuirle otras muchas sin problema; esto en lo referente a su "segundo estilo" puesto que el primero hasta el día de hoy había permanecido casi inédito dado que tan solo contábamos con una obra de este periodo. Sin embargo, un análisis profundo de estos primeros años nos ha llevado a poder atribuirle una serie de piezas que están fuera de toda duda y que además nos permite configurar el puzle que a día de hoy se nos presenta con las características de la primera etapa. Hemos de decir que a estas dificultades, también se nos añade otra: la similitud de su "segundo estilo" con el de su hermano Manuel, el cual le copia fielmente. Pero, como decíamos, el "segundo estilo" de Ávila, que es con el cual habitualmente identificamos al escultor, es tan característico que no cabe error a la hora de atribuirle obras; se puede decir que este segundo estilo nos presenta al Pedro de Ávila más íntimo. En definitiva, las características exhibidas en su segunda etapa, sobre todo en lo concerniente a rostros y pliegues, son tan personales que no podemos presentar otras "candidaturas" a las obras que se le van atribuyendo; es decir, todo lo contrario a lo que nos ocurría con Juan de Ávila, en que los escultores de su época poseían un estilo más o menos cercano derivado del influjo fernandesco. 
Dicho todo esto, cabe señalar ciertas excepciones: algunas esculturas que creemos que corresponden a la primera etapa de Pedro pueden ser indistintamente atribuidas a su padre Juan de Ávila, puesto que por entonces el estilo de ambos parece ser bastante similar. Por ejemplo, esto nos ocurre con el desaparecido grupo de San Joaquín, Santa Ana y la Virgen del Monasterio de Santa Brígida de Valladolid. Ya en la segunda etapa, como hemos dicho, sobre algunas de sus obras atribuidas podemos tener la duda de si le pertenecen a él o bien a su hermano Manuel; o, incluso, quizás a Antonio de Gautúa, si bien las esculturas de este último bajan bastante la calidad con respecto a Pedro. Pero lo cierto es que su estilo y el de otros escultores vallisoletanos contemporáneos (el citado Antonio de Gautúa, Joseph Pascual, José de Rozas, Pedro Bahamonde), que tampoco abundaban, poco o nada tienen que ver. Tan solo con Pedro de Sierra compartirá la utilización de los "pliegues a cuchillo" tan característicos de nuestro escultor, si bien éste último sabemos que lo aprendió en los talleres franceses establecidos en el Palacio Real de La Granja de San Ildefonso ${ }^{23}$.

Si no fuera por el estilo tan característico que posee nuestro escultor, sobre todo en su segunda época, aunque también en parte de la primera, tendríamos casi los mismos problemas para definir su estilo que tuvimos con su padre. Estos son: la escasez de obras documentadas, más grave en este caso que en el de Juan de Ávila puesto que conocemos el prestigio que tuvo Pedro en su época y del liderazgo que mantuvo durante largos años en la escultura vallisoletana, por su parte Juan de Ávila tuvo que compartirlo con José de Rozas y Juan Antonio de la Peña. El otro problema sería la desaparición de alguna de sus escasas obras documentada; por fortuna, en el caso de Pedro de Ávila tan solo nos falta la Virgen de las Angustias que talló para la localidad de Íscar. A pesar de que tan solo hemos de lamentar la pérdida, o extravío, de una de sus obras, esta ausencia es muy dolorosa por cuanto nos mostraría bien a las claras las características escultóricas que pregonaba Pedro de Ávila en el final de su magisterio, puesto que un par de años después quedaría ciego y tendría que jubilarse prematuramente.

A continuación pasaremos a explicar los dos estilos que engloban la producción de nuestro escultor. Cambiaremos el método respecto a cómo lo tratamos cuando hablamos de Juan de Ávila puesto que en su caso tan solo se trató de una evolución de las características; en este caso no, las dos etapas de Pedro de Ávila son tan diferentes que estamos hablando de dos estilos casi completamente distintos, por lo que en cada uno de ellos explicaremos sus singularidades. Además, intentaremos aportar una hipótesis que explique el porqué de ese cambio tan radical que sufrió su arte a mediados de la primera década del siglo XVIII.

23 MARTÍN GONZÁLEZ, Juan José: Escultura barroca castellana..., op. cit., p. 383; MARTÍN GONZÁLEZ, Juan José: Escultura barroca en España, 1600-1770 ..., op. cit., p. 460. 


\section{$\underline{\text { A- PRIMER ESTILO }}$}

A pesar de que nuestro Pedro es uno de los renovadores de la escultura vallisoletana y castellana a partir de la década de 1710, su formación trascurre al lado de su padre y su suegro, escultores que aún se encontraban imbuidos dentro de la prolongada tradición fernandesca que se llevaba dando en la plástica vallisoletana desde la misma muerte de Gregorio Fernández en 1636. Muchos estudiosos e investigadores han incidido en este hecho. Por ejemplo, Durruty Romay, la única que ha dedicado un artículo en exclusiva a nuestro escultor, y más concretamente a su "Cristo del Olvido", señalaba que "la escuela de Gregorio Fernández, debió ser mentor y guía de su inspiración y posiblemente la contemplación y quién sabe si hasta las normas de las obras de éste, decidieran su desarrollo artístico" ${ }^{24}$. Asimismo, añadía que en su estilo demostraba estar "imbuido del espíritu de los grandes imagineros castellanos del siglo XVII y especialmente de Gregorio Fernández" 25 . Finamente, y refiriéndose también al "Cristo del Olvido", comentaba su cercanía a "escultores anteriores y con la escuela de finales del XVI y del XVII, especialmente con Gregorio Fernández; el patetismo, la sobriedad, la belleza delicada de la forma y la serenidad tranquila de la expresión, producto de un acendrado misticismo o bien reflejo de los de Gregorio Fernández"26.

Otros investigadores han querido ver en el estilo inicial de nuestro escultor otras relaciones, además de las ya conocidas de Juan de Ávila y Juan Antonio de la Peña. Recientemente, la profesora Porras Gil ha llegado a comentar al respecto que "su estilo en poco hace recordar el de su padre, mucho más anclado en las austeras formas castellanas derivadas de la tradición iniciada por Gregorio Fernández y que él lleva a una extrema rigidez. Su obra, al menos en sus inicios, se adapta más a las formas del escultor Juan Antonio de la Peña, en cuyo entorno realiza sus primeros encargos" 27. Por su parte, Martín González llegó a señalar, tomando como base la Piedad/Virgen de la Pasión que talló para el Colegio de los Ingleses de Valladolid, que las obras de la primera época denunciaban "su formación bajo la égida de los Rozas" ${ }^{28}$. Sin embargo, años después, y refiriéndose a esa misma escultura, cambió de idea y pensó que más bien nos presentaba "el primer estilo del maestro, todavía muy influido por el de su padre $^{29}$.

Es lógico pensar que a lo largo de los años de aprendizaje junto a su padre y De la Peña ocurriera lo que comentamos también con Juan de Ávila: que el joven Pedro fuera visitando y tomando apuntes de diferentes esculturas repartidas por las múltiples iglesias, conventos, monasterios y hospitales repartidos por la ciudad. No volveremos a repetir lo dicho con Juan de Ávila, pero seguramente le impresionaran las tallas que legaron a lo largo de los siglos Alonso Berruguete, Esteban Jordán, Juan de Juni,

\footnotetext{
24 DURRUTY ROMAY, Inés: op. cit., p. 206.

$25 \quad$ Ídem, p. 208.

$26 \quad$ Ídem, p. 209.

27 PORRAS GIL, María Concepción: "Cristo Resucitado". En VV.AA.: Las Edades del Hombre.

Passio, Fundación Las Edades del Hombre, Valladolid, 2011, p. 376.

28 MARTÍN GONZÁLEZ, Juan José: Escultura barroca castellana..., op. cit., p. 324.

29 MARTÍN GONZÁLEZ, Juan José: Escultura barroca en España, 1600-1770 ..., op. cit., p. 447.
} 
Pompeyo Leoni, Francisco de la Maza, Adrián Álvarez, Francisco del Rincón, Gregorio Fernández, etc... Nuevamente, las maravillas escultóricas que viera desde pequeñito en la parroquia de Santiago serían las que surtieron mayor efecto en el futuro artista.

Al contrario que su padre, Pedro de Ávila no partió de los modelos y maneras propugnadas por Fernández, sino de las del propio mentor, Juan de Ávila, que en definitiva venía a ser un "fernandismo" evolucionado y mucho más movido y barroco. Esto no quiere decir que no copiara modelos de Fernández, como veremos más adelante. Entre otros muchos, para el San Pablo que talló para el retablo mayor del Oratorio de San Felipe Neri se inspiró en el que Gregorio Fernández había ideado un siglo atrás para el retablo mayor de la desaparecida iglesia de San Miguel. También debió de copiar, o tomar por modelo, a Juan de Juni cuando se le encargó realizar una Virgen de las Angustias para la localidad vallisoletana de Íscar; no sabemos si la idea partió del propio Pedro de Ávila o bien fue una imposición de los comitentes.

En las esculturas de este "primer estilo" la quietud y el movimiento sosegado son la constante. La ilusión de movimiento en la mayoría de las ocasiones se debe al concebir las esculturas con un ligero contraposto, resuelto con el adelantamiento y ligera flexión de una de las rodillas. En este primer momento el movimiento de sus esculturas es más "conservador" que el que logró su padre en sus últimas esculturas. Son figuras plantadas. Aunque en ocasiones intenta formar diagonales mediante la composición y complementación de las posturas de los brazos, estas suelen resultar algo forzadas. A continuación analizaremos las anatomías, ropajes y postizos.

\section{Anatomías}

Sus esculturas denotan una gran calidad técnica. Son figuras con movimientos muy pausados. Tienden al naturalismo, aunque en algunas ocasiones con un canon demasiado estilizado, casi diríamos praxiteliano. Podemos conocer su competencia anatómica gracias al Resucitado de la localidad vallisoletana de Puras, al Crucificado del Monasterio de Santa Brígida y, en menor medida, al San Juan Bautista de Almenara de Adaja. Llama la atención la diferencia existente entre las esculturas del Resucitado y del Precursor, por un lado, y la del Crucificado, por otro. Las dos primeras poseen unas anatomías bastante planas y poco apuradas, aunque no dejan de ser correctas. Sin embargo, la del Crucificado es mucho más potente, realista y de mayor calidad. Cabe pensar si en realidad el verdadero Pedro de Ávila sea el de las dos primeras tallas,

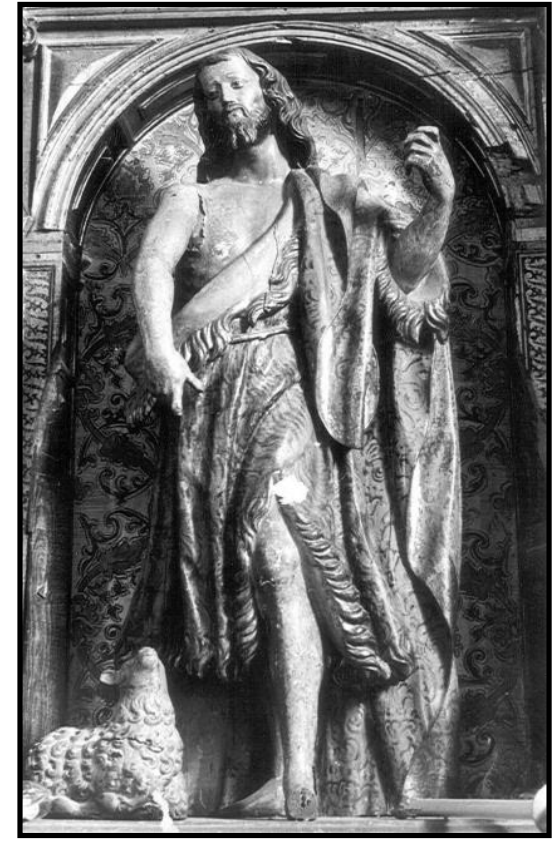

Il. 3- Pedro de Ávila. San Juan Bautista. Iglesia parroquial de la Asunción. Almenara de Adaja 
mientras que del Crucificado tan solo se ocupó de rematar ciertos detalles, habiendo corrido el grueso de su ejecución a cargo de Juan de Ávila hasta que se vio sorprendido por la muerte. Además, podemos comparar este San Juan Bautista con los documentados de su padre. Las diferencias son muy claras, a pesar de utilizar el mismo modelo. En el ejemplar de Pedro no observamos las carnes fláccidas en el pecho, la perfecta definición de las rodillas, espinillas y demás huesos. También hay que tener en cuenta el lamentable estado de conservación en que se encuentra, así como las fracturas a la altura del hombro del brazo derecho y de ambos pies.

Como es normal, Pedro de Ávila pone el mayor énfasis a la hora de tallar las cabezas y las manos, a las cuales dota de gran teatralidad. Cuando logra la maestría a la hora de expresar verdaderos sentimientos través de la gestualidad de las manos es durante su "segundo estilo", en este primero podemos decir que las concibe simplemente con una parte más del cuerpo, y no entra en poéticas. Al igual que ocurre con su padre, Pedro de Ávila tiene dos maneras de tallar las cabezas y las manos: en algunas ocasiones, cuando se trata de esculturas con los brazos desnudos, sin vestimenta, las realiza por separado del cuerpo, uniéndolas posteriormente mediante embones. Como ya dijimos, esta manera de trabajar es muy propia del barroco vallisoletano; aunque anteriormente, en el Renacimiento lo usual era tallar todo el cuerpo en un mismo bloque. De esta última manera también le veremos trabajar, concretamente en las esculturas que tienen la vestimenta tallada, a excepción del Bautista; que, aunque lleva su característico atuendo, el cuello y los brazos se encuentra a la vista del espectador y se encuentran tallados junto al cuerpo. Así lo podemos comprobar en el referido San Juan Bautista de Almenara de Adaja, el Resucitado de Puras y el Crucificado de las Brígidas.

Salvo un par de excepciones, los rostros masculinos de esta primera etapa se encuentra estereotipados, y siguen un mismo patrón que se repetirá en la mayor parte de sus personajes. Las excepciones son el supuesto San José que tallara para Fuente-Olmedo y el Crucificado de las Brígidas. En lo referente a los rostros femeninos no podemos establecer un juicio dado que no poseemos más que la Virgen de la Pasión, en realidad Piedad, que tallara por orden de su suegro para el Colegio de los Ingleses de Valladolid. Lo único que queda claro es que este rostro es plenamente deudor del que años antes tallaron Juan de Ávila o Juan Antonio de la Peña para la Virgen del Calvario de ese mismo recinto. Como comprobaremos, la evolución sufrida por sus rostros femeninos será total en su "segundo estilo", compartiendo buena parte de sus características con los masculinos.

A excepción del rostro de la Piedad, que intenta transmitirnos pena y duelo; y el del Crucificado, que figura ya sereno tras el fallecimiento; el resto son de gran fuerza expresiva, incluso podríamos decir que sonrientes. Representa a personajes durante su vida normal o bien, como el caso del Resucitado, tras haber vencido a la muerte, momento de alegría que queda patente en su rostro.

Concibe las cabezas de una manera muy similar a su padre, aunque algo más estrechas y alargadas. Sin embargo, en vez de adoptar forma ovoide como las de aquél, las de Pedro 
suelen tender al rectángulo, extremo que se terminará de definir y acusar con mucha mayor claridad en su segunda etapa. Sin embargo este hecho es importante, puesto que es una de las escasas características propias que se mantuvieron inalterables a lo largo de toda su carrera. Sin embargo, este tipo de cabeza no la observamos en la Virgen de la Pasión de los Ingleses, lo que me ha llevado en multitud de ocasiones a dudar de su autoría. Los rostros acusan blandura y un incipiente estudio de calidades que irá perfeccionando a lo largo de su magisterio. De ser suyo el desaparecido grupo de la Sagrada Familia de la Virgen del Monasterio de Santa Brígida de Valladolid, con el rostro de San Joaquín se nos mostraría como un digno sucesor de su padre a la hora de captar a la perfección las arrugas propias de la vejez, las cuales surcan la frente, mejillas y laterales de los ojos del santo.

Estas esculturas iniciales poseen unos rasgos, bastante profundos, completamente heredados de su padre. Pareciera como si a la hora de representar las facciones de los rostros durante esta primera etapa, nuestro escultor se hubiera inspirado en las del San Isidro que su padre tallara para la cofradía homónima; las similitudes con ella son totales.

Los ojos suelen ser almendrados, rehundidos, y en la parte inferior de los mismos aparece sin excepción un potente abultamiento muy característico, lo que hace que el ojo aparezca más cerrado de lo que debiera; sin embargo no se produce el "achinamiento" del que hablábamos en las esculturas de Juan de Ávila. Cejas levemente arqueadas. El ceño aparece completamente liso. La forma de componer las narices es similar a la paterna aunque algo más pequeñas. Se trata de narices rectas y simétricas, con el tabique nasal redondeado (esto es importante puesto que será una de las grandes diferencias durante su segunda etapa, en la cual el tabique estará aplastado y geometrizado), que se ensanchan en su parte inferior, aunque las aletas nasales no están muy pronunciadas. Las fosas nasales se encuentran perforadas, detalle que aporta mayor verismo a la imagen. Las bocas son anchas y entreabiertas, a pesar de lo cual no llega a tallar los dientes. Los labios parecen formar una especie de mueca, que se repetirá y se hará aún más pronunciada en su segunda etapa; es, por lo tanto, otra de esas pocas características que no se cortarán súbitamente en su segundo estilo, sino que evolucionarán. El surco nasolabial no suele tener cabida dado que la totalidad de imágenes de esta primera etapa poseen barba y no hay espacio. Los pómulos no están muy desarrollados, y tan solo se les insinúa por medio de la policromía.

Como dijimos, su manera de realizar los rostros femeninos tan solo la podemos juzgar por la Virgen de la Pasión de los Ingleses, y eso en el caso de que sea la supuestamente documentada. Su rostro poco o nada se parece a los masculinos: la cabeza tiende al óvalo; los ojos son grandes y no poseen ese característico abultamiento en la parte inferior de los mismos; la nariz es muy ancha y no se expande en su parte inferior; las cejas son curvas; la boca es pequeña y entreabierta, aunque en este caso sí que talla unos minúsculos dientes, etc... Como vemos se trata de un modelo completamente diferente, pero no solo a las esculturas masculinas de esta primera etapa, sino a las de ambos géneros de la segunda. 
Para tallar el cabello y las barbas sigue fielmente las reglas de la simetría, solo rota en alguna ocasión por un mechón ladeado. Para las barbas cuenta con tres modelos que prolongará y perfeccionará en su segunda etapa. La primera se trata de barbas realizadas a base de numerosos y sinuosos mechones profundos a ambos lados del rostro, que se prolongan de la misma manera por el bigote y por la parte inferior del labio. La barba se prolonga en el mentón a través de dos o cuatro mechones curvos, largos y simétricos cuyos bucles miran hacia el interior. A este grupo pertenecen los San Isidro de Puras y Muriel de Zapardiel, el San Juan Bautista de Almenara de Adaja y el Resucitado de Puras; e, incluso, con algunas dudas, el Crucificado de las Brígidas. El segundo tipo de barbas tiene como único representante al San José de Fuente-Olmedo; se trata de una barba similar, aunque la resolución en el mentón se hace por numerosos caracolillos redondeados que conforman una barba bífida corta, esta tipología se la veremos utilizar mucho en los San José de su segunda etapa; también usará este recurso su hermano Manuel. La tercera tipología parece derivada del San Francisco de Sales que su padre ejecutara para el Oratorio de San Felipe Neri. Se trata de largos y sinuosos mechones compactos compuestos de una manera simétrica y muy virtuosista. Este tipo de barba hace su acto de aparición en el San Joaquín que supuestamente talla, puesto que hay dudas de que pertenezca a Juan de Ávila, para el grupo de la Sagrada Familia de la Virgen de las Brígidas. Sin embargo, esta misma barba la volverá a utilizar en el San Joaquín que se conserva en el Santuario Nacional de la Gran Promesa, motivo por el cual he decidido atribuirle el grupo anterior.

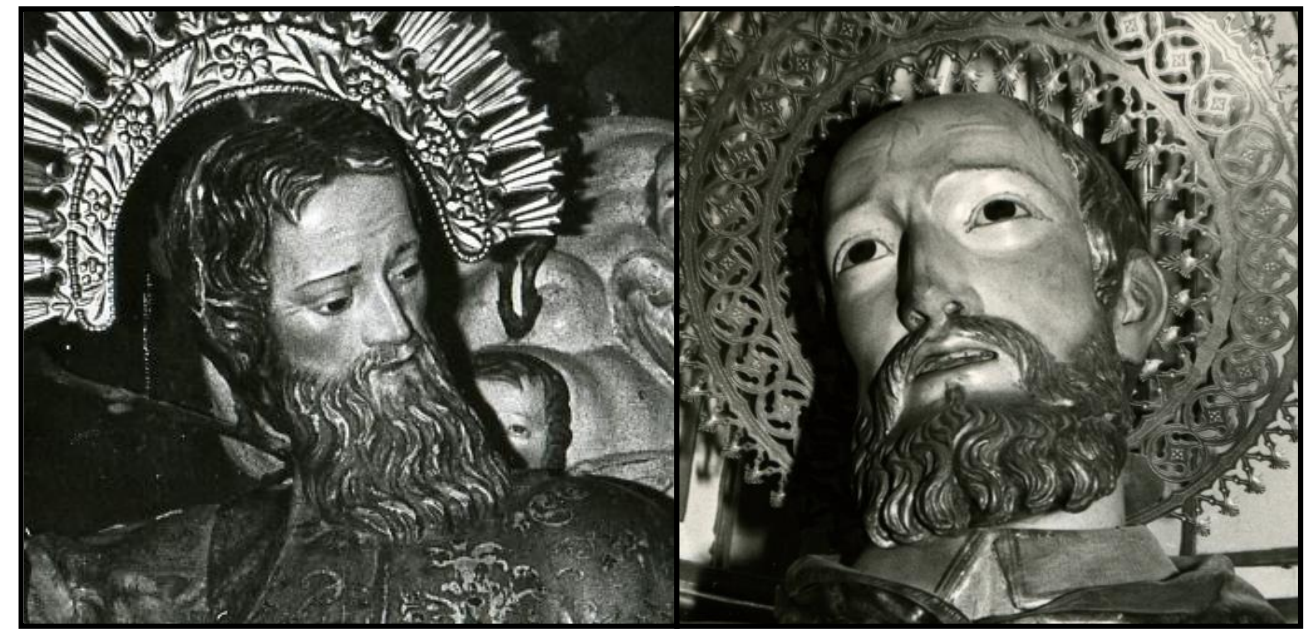

Il. 4- Comparativa de las barbas del San Joaquín atribuido a Pedro de Ávila y del San Francisco de Sales de Juan de Ávila.

Pasando a hablar de las cabelleras, lo primero que hay que decir es que todas las esculturas que le hemos atribuido en esta primera etapa, a excepción de la Virgen de la Pasión de los Ingleses y del supuesto San Joaquín de las Brígidas, siguen un mismo patrón. Se trata de amplias y sinuosas cabelleras conformadas a ambos lados del rostro, cuya forma rectangular parece quedar envuelto por estas. Por lo general suelen hacer dos ondas superpuestas, acrecentándose el volumen y anchura de las inferiores, es decir, hace adoptar a la cabeza una forma tendente al trapecio. Las melenas llegan como mucho a la altura de los hombros, nunca más allá. Este sería el prototipo general. Este modo de concebir la melena la veremos prolongada en numerosas obras de su segunda

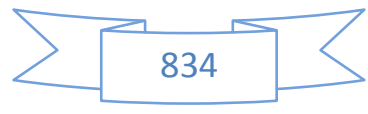


etapa: el busto de Ecce Homo de las Brígidas, el Ecce Homo de la parroquial de Renedo, los diversos ejemplares de San José, etc... en todos ellos parece como si la melena fuera concebida como un fondo para el rostro. Dos variantes suponen el Resucitado de Almenara de Adaja, en el que dispone de unos mechones más amplios y ondulados, dejándonos incluso verle una de las orejas, detalle que no observaremos en el resto de piezas; y el San Joaquín de la Brígidas, en el que el pelo es mucho más apelmazado, recordando "demasiado" a la maniera de Juan de Ávila.

Sin embargo, donde introduce mayor variedad es en la forma de resolver el peinado situado sobre la frente. Efectivamente, tendremos diversos recursos: la más usual, y la que se prolongará a lo largo de toda su carrera, sin excepción, es la de dos pequeños mechones simétricos con las puntas apuntando hacia el exterior (San Isidro de Muriel de Zapardiel, San Joaquín de las Brígidas, San Isidro de Puras); otra es la de un mechón mojado dispuesto de manera diagonal sobre la frente; y la última es la frente despejada, con lo cual tan solo observamos una amplia frente (San Juan Bautista de Almenara de Adaja), llegando casi a una incipiente calvicie (Resucitado de Puras). En la mayoría de las ocasiones los cabellos cubren las orejas de los personajes representados. Según vaya evolucionando y ganando en maestría irá individualizando mayormente cada una de las guedejas, bucles, etc... hasta llegar a tallarlos con verdadero naturalismo y mimo. No solo eso, sino que además irán ganando volumen y prestancia.

\section{Indumentaria y pliegues}

Al igual que en los personajes representados por Juan de Ávila, los ropajes suelen ser bastante realistas, sin embargo en la mayoría de las ocasiones de esta primera época parecen encapsular el posible movimiento iniciado por sus extremidades. De todas maneras, el movimiento de los mismos es muy natural.

La indumentaria de la que hacen gala los personajes de Ávila no difiere en demasía de la que ya vimos en los capítulos dedicados a las características de la escultura barroca española y a los ropajes utilizados por Juan de Ávila. Las tipologías de indumentaria se reducen a dos: las vestimentas intemporales (túnicas, sayas, hábitos) para los personajes sagrados (Virgen de la Pasión, Cristo Crucificado, Cristo Resucitado, San Joaquín, San Juan Bautista, San José); y la moda de la época. Esta última la utiliza de manera exclusiva para las dos representaciones de San Isidro, las cuales siguen fielmente el modelo utilizado por su padre, y que a la vez parece derivar lejanamente del que se le atribuye a Gregorio Fernández en Dueñas.

En cuanto al pliegue, ni por asomo encontraremos el famoso pliegue a cuchillo que observamos en su "segundo estilo". Durante esta primera etapa no hace sino prolongar los plegados que utilizaron en los albores del siglo XVIII todos los escultores vallisoletanos de la época, fundamentalmente Juan de Ávila, Juan Antonio de la Peña y José de Rozas; este hecho no debe extrañarnos puesto que se formó con los dos primeros y trató al segundo; y, además, la falta de novedades en el aislado territorio 
vallisoletano incidió en un continuo retorno al pasado. Podríamos utilizar para definir este tipo de paños la descripción que utilizó Martín González para referirse a los de la primera etapa de Juan de Ávila: "blandura de los paños, incurvados suavemente y donde aparece desterrada toda dureza de talla"30, si bien ocasionalmente puede percibirse ciertas quebraduras. Sin embargo, en algunas ocasiones también encontramos el "plegado blando y de líneas paralelas" propio de la segunda etapa de Juan de Ávila ${ }^{31}$. En definitiva, en ciertos casos utiliza el primero, en otras el segundo y en otro grupo, en el de los San Isidro, combina ambos.

\section{$\underline{\text { Iconografías }}$}

Al igual que su padre, Pedro de Ávila no destacó por ser un gran creador de iconografías durante esta primera etapa, al menos eso es lo que nos muestra su diminuto catálogo. Su fuente de alimentación en este aspecto serán Juan de Ávila y Gregorio Fernández, puesto que a ellos dos se debe la creación y evolución del San Isidro y del San Juan Bautista que veremos en el catálogo de nuestro escultor. También de su padre parece proceder el grupo de la Sagrada Familia de la Virgen del Monasterio de las Brígidas. Del resto de esculturas conservadas de este primer periodo tan solo podríamos pensar que es creación suya el Crucificado de las Brígidas. Es más, éste parece ser el cabeza de serie de una serie de ejemplares que en años sucesivos irá perfeccionando; siendo, sin embargo, el resto de ellos, de un tamaño mucho más pequeño y con un aspecto más delicado y refinado, dejándose sentir en ellos el preciosismo del que gozó el siglo XVIII cortesano y europeo.

\section{$\underline{\text { Postizos }}$}

Al igual que su padre y su hermano, apenas los utiliza. Para simular los ojos coloca una tapilla de vidrio o bien los pinta directamente sobre la madera. Si aceptamos identificar a la Piedad del Colegio de los Ingleses como la Virgen de la Pasión que para dicho establecimiento talla por orden de su suegro (de lo cual no estoy muy convencido), tendríamos que poner en el haber de Ávila la utilización de cristal para las lágrimas del rostro de la Virgen; en realidad se trataba de capilares de cristal fundidos, a través de los cuales se obtenían las gotas que van pegadas, algunas de las cuales se han perdido. Poco más podemos decir puesto que tampoco utilizó telas postizas, ni uñas, ni corcho.... En su segunda etapa sí que parece que usó en alguna ocasión la tela encolada para conseguir mayor verismo a la hora de representar las vestiduras y el movimiento de las mismas. 


\section{$\underline{\text { B- SEGUNDO ESTILO }}$}

Desde siempre se ha hablado de un "segundo estilo" que engloba la producción más personal de nuestro escultor; aquella que, sobre todo, se caracteriza por la utilización del "pliegue a cuchillo", elemento que le diferenció del resto de escultores vallisoletanos y castellanos durante una larga época; puesto que, además, como ya dijimos, fue el primero en utilizarlo por estos lares. Este "segundo estilo" llega a ser tan personal que apenas nos recuerda su etapa anterior y nada vemos en sus esculturas de lo aprendido al lado de su padre y de su suegro. La ruptura con la tradición castellana es total, y podríamos decir que Pedro de Ávila es el encargado de hacer evolucionar la escultura vallisoletana desde los últimos ecos fernandescos hasta la plástica propiamente dieciochesca; siendo, por lo tanto, el precedente de Pedro de Sierra, que se ocupará de terminar dicha tarea. Si de Sierra sabemos que la transformación de su arte y la ruptura

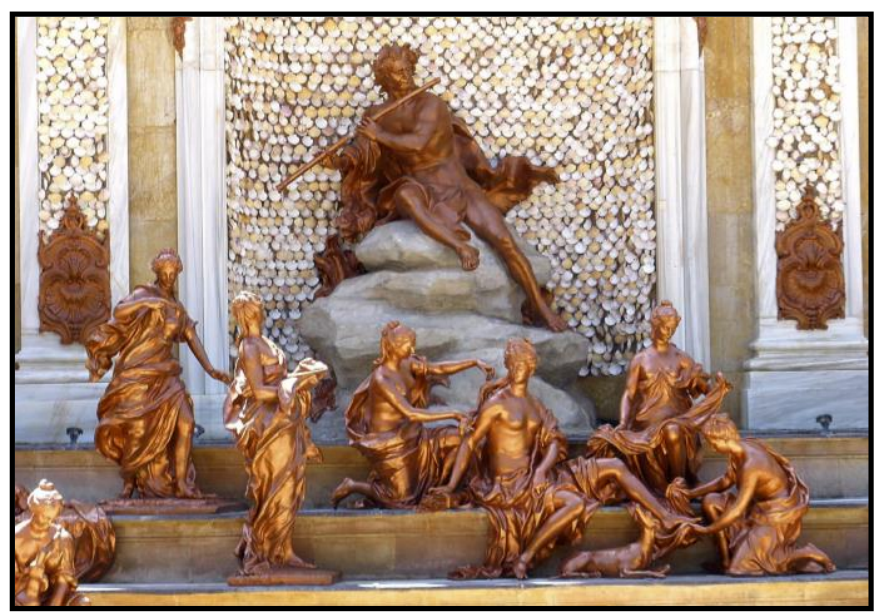

Il. 5- René Frémin. Fuente de los Baños de Diana. Palacio Real de La Granja de San Ildefonso. Real Sitio de San Ildefonso (Segovia). con las enseñanzas paternas tuvo lugar gracias a las enseñanzas recibidas en el Palacio Real de La Granja de San Ildefonso de manos de un grupo de escultores franceses capitaneados por René Frémin y Jean Thierry ${ }^{32}$, de Ávila desconocemos como pudo fraguarse ese cambio tan espectacular. No tenemos documentado que nuestro escultor saliera nunca de la ciudad, lo que complica la cosa, aunque es obligatorio pensar en un hipotético viaje a Madrid.

Llegados aquí cabe preguntarse: ¿A través de quién pudo aprender la técnica del "pliegue a cuchillo"? Por aquellas fechas pudo conocerlo a través de tres vías: la italiana, la francesa y la española. Las dos primeras quedan prácticamente descartadas puesto que no es factible ni probable que viajara a Francia ni a Italia; si bien, como veremos, pudo influirle decisivamente la escultura napolitana. Finalmente, en cuanto a la vía española, Pedro de Ávila tan solo pudo tomar las enseñanzas necesarias para derivar en su nuevo estilo de las escuelas madrileña y, sobre todo, andaluza. Si juntamos todas estas posibles influencias, la única posibilidad que podríamos aceptar es que nuestro escultor realizó un viaje a Madrid, puesto que allí se fusionaban diversos factores: la escuela madrileña, el poso dejado por diversos escultores andaluces que utilizaron el "pliegue a cuchillo", y la custodia en numerosas iglesias, conventos y hospitales de gran cantidad de obras llegadas desde tierras italianas.

32 Ídem, p. 383; MARTÍN GONZÁLEZ, Juan José: Escultura barroca en España, 1600-1770..., op. cit., p. 460. 
La segunda pregunta sería: ¿cuándo comienza a utilizar nuestro escultor el "pliegue a cuchillo", y por lo tanto a exhibir su "segundo estilo? Refiere la profesora Porras Gil al respecto que lo comenzó a utilizar a partir del San Miguel que en 1714 talló para la iglesia parroquial de San Miguel de Castil de Vela (Palencia) ${ }^{33}$. Ni mucho menos, puesto que si nos basamos en la totalidad de obras que se le tienen documentadas y atribuidas, observamos que su paño ya aparece plenamente configurado en el San Pío V que le comisiona el Convento de San Pablo de Valladolid entre los años 1712-1713. En años anteriores, si bien este paño no estaba plenamente desarrollado, contamos ya con esculturas que parecen insinuarlo: son los casos, por ejemplo, de la Traslación de San Pedro Regalado para la iglesia del Santísimo Salvador (1709); de la Santa Catalina de la iglesia parroquial de Geria (h. 1711-1712), de la Santa Bárbara de la iglesia de Santa María de Alaejos (h. 1712), y de la efigie de Nuestra Señora de las Nieves de la parroquia de los Santos Juanes de Nava del Rey (1712). En todas ellas vemos la evolución del pliegue "a cuchillo": en el grupo de la Traslación de San Pedro Regalado todavía muy incipiente, menudo y ancho, pero poco a poco irá estrechándose $\mathrm{y}$ afilándose. Es decir, la utilización de este pliegue y el supuesto viaje a Madrid tuvieron lugar con anterioridad al año 1709.

La tercera pregunta sería: ¿Existió un viaje a Madrid?, y de haberlo habido ¿cuándo sucedió? Como ya hemos dicho, no tenemos documentado ningún viaje de nuestro escultor, aunque quizás los hubo para contratar obra. De lo que no cabe duda es de que una evolución tan profunda no pudo partir de sí mismo y mucho menos si tenemos en cuenta el ambiente "pos-fernandesco" que aún se vivía en la ciudad. Por lo tanto, el viaje a Madrid, podría explicar el cambio de estilo, así como muchos detalles que veremos en su obra y que pudieran proceder de las escuelas andaluza y napolitana, pero nunca de la castellana. Si tenemos en cuenta los diversos datos tanto biográficos como artísticos, así como las esculturas atribuidas, parece claro que el supuesto viaje a la Corte debió de acontecer entre los años 1705, en que probablemente se encontraba tallando un San José y una Santa Teresa para la parroquial de Fuente-Olmedo (Valladolid) y 1707. El límite cronológico de este último año sería el mes diciembre puesto que es cuando fallece su suegra y él ya se encontraba en Valladolid. Por lo tanto, ese viaje fue muy corto, entre un año o año y medio.

La cuarta pregunta sería: ¿Pedro de Ávila viajó a Madrid con el deseo de ampliar sus conocimientos, acudiendo al que por entonces era el foco más avanzado del país, o bien intentó establecerse en la ciudad? Lo más lógico sería pensar que intentó hacerse un hueco en la Villa y Corte, siguiendo los pasos de su paisano Pedro Alonso de los Ríos, y el mismo camino que años después emprenderían con gran éxito Alonso de Grana, Alejandro Carnicero o Luis Salvador Carmona. Hasta el momento no hay ninguna noticia acerca de posibles intervenciones de Ávila en Madrid, aunque si estuvo lo lógico es pensar que algo haría, aunque no se ha documentado o no se conserva. De todas formas la saturación de grandes maestros con que contaba ese foco haría desistir a nuestro escultor.

33 PORRAS GIL, María Concepción: op. cit., p. 376. 
Y, la última cuestión sería: ¿A qué artistas y qué obras conoció en Madrid que le llevaron a modificar de una manera tan radical su estilo? A grandes rasgos podemos decir que fueron dos los elementos que pudo aprender allí: la utilización del "pliegue a cuchillo" y ciertos ademanes que posteriormente incluirá en sus esculturas, como por ejemplo la disposición de las piernas y los pies. Respecto al "pliegue de cuchillo" parece claro que las dos influencias más notables pudieron ser las de la escuela andaluza (fundamentalmente de Pedro de Mena y de José de Mora) y napolitana. Por otro lado, los referidos ademanes y posición de las extremidades inferiores, parece claro que las tomó, como ya veremos, de los escultores napolitanos.

El que nosotros llamamos "pliegue a cuchillo" fue concebido por Gian Lorenzo Bernini en la década de 1620, puesto que ya se lo vemos utilizar en la Santa Bibiana (16241626) que esculpió para la iglesia romana homónima Este tipo de paño, de configuración muy aristada, consigue una mayor sensación de movimiento, lo que implica un acrecentamiento del "barroquismo". En años sucesivos, y hasta el final de su carrera, seguirá utilizándolo, aunque no combinándolo con otros. Este tipo de paño tan barroco se lo veremos utilizar en algunas de sus obras más emblemáticas: en los Ángeles del Baldaquino de San Pedro (1623-1634) y en la Tumba de Urbano VIII (1628-1647) (Fig. 1), ambos monumentos conservados en la Basílica de San Pedro del Vaticano (Roma); en el Éxtasis de Santa Teresa (1647-1651) (Fig. 2), de la iglesia de Santa María de la Victoria (Roma); en la Verdad descubierta por el Tiempo (1652) (Fig. 3), de la Galería Borghese (Roma); en los cuatro Padres de la Iglesia de la Cátedra de San Pedro (1656-1666) (Fig. 4), de la Basílica de San Pedro del Vaticano (Roma); y en el Éxtasis de la beata Ludovica Albertoni (1671-1674) (Fig. 5), de la

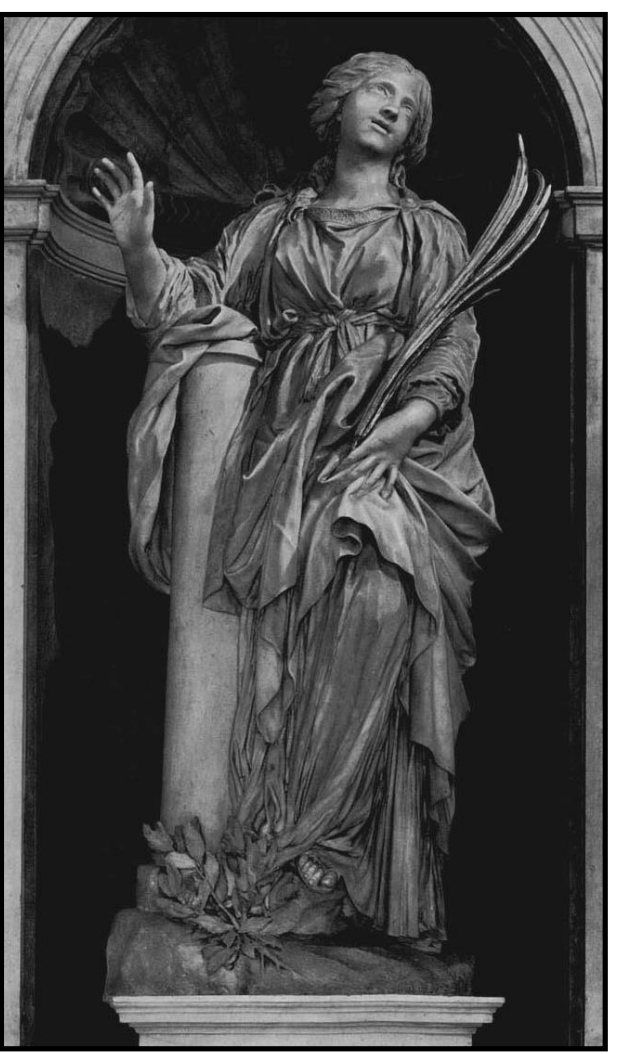

Il. 6- Gian Lorenzo Bernini. Santa Bibiana. Iglesia de Santa Bibiana. Roma. iglesia de San Francesco a Ripa (Roma). Desde el mismo momento en que Bernini concibió este pliegue, y como cada novedad que ingeniaba, se popularizó con tal rapidez que hasta sus "enemigos" artísticos, como Alessandro Algardi, lo tomaron como suyo y lo utilizaron abundantemente.

Como ya hemos dicho, hubo de transcurrir "casi medio siglo de retraso" para que Pedro de Ávila introdujera "en Castilla el paño dinámico y cortante usado por Bernini"34. Martín González señala que este "pliegue castellano" no es exactamente igual al berninesco, sino que es "menos profundo, y menos claroscurista: forma aristas fuertemente biseladas, como cortadas por rápidos golpes de gubia. Se suelen llamar

34 MARTÍN GONZÁLEZ, Juan José: Escultura barroca castellana..., op. cit., p. 19. 
paños cortados a cuchillos. Con esto adquiere la escultura un aire trepidante muy barroco; es decir, se entra en el período barroco por antonomasia de la escultura castellana" ${ }^{35}$. Asimismo, señala Martín González que Camón Aznar calificó de "impresionista la técnica de estos paños, diseñados en planos móviles, cargados de impactos luminosos, que confieren movilidad a la imagen". También sospechaba que, tal y como creemos, este tipo de paño surgiría "en Madrid, por efecto del influjo de las esculturas napolitanas, tan abundantes en esta ciudad"36. Pienso que, además del supuesto influjo napolitano, también tuvo importancia para la difusión de este paño el concurso de los granadinos Pedro de Mena y José de Mora.

En lo escultórico, el siglo XVII supuso para Madrid la llegada de diversas influencias dado que la escuela local no contaba con grandes artistas. Si durante la primera mitad de la centuria Madrid se vio dominada por la escuela castellana, todo cambió durante la segunda mitad, en el que la pujanza fue claramente andaluza. Allí no solamente llegaron obras de los mejores escultores andaluces del siglo XVII, sino que algunos de ellos residieron de forma más o menos prolongada en la Villa y Corte. Así ocurrió con Juan Martínez Montañés, Alonso Cano, la Roldana, Pedro de Mena o José de Mora. Tan solo analizaremos a continuación los casos de estos dos últimos por ser los que creemos que más pudieron influir, a través de sus esculturas, en nuestro Ávila.

El caso de Pedro de Mena es paradigmático puesto que, aunque su viaje a Madrid fue muy corto (debió de tener lugar en el año 1663, según Serrano Fatigati y el padre Llordén $)^{37}$, sin embargo fue el escultor español que más exportó y difundió su obra por todos los rincones del país, siendo Madrid una de las ciudades más afortunadas en ese aspecto $^{38}$. Comentaba al respecto el pintor y tratadista Antonio Palomino que "en este tiempo corrió de suerte su fama, que no pudo evadirse de tantos empeños como fueron de la Corte, y diferentes partes de España, solicitando lograr alguna cosa de su

\footnotetext{
$35 \quad$ Ibídem.

$36 \quad$ Ídem, p. 197.

37 El primero de estos señaló que "tuvo que ser anterior al año 1663, en que fue nombrado escultor de la catedral de Toledo. Llordén apoya la posibilidad de la estancia en Madrid, debido a que en nutridos hallazgos documentales hay un vacío en 1663, prolongado hasta el 6 de septiembre en que vuelve a aparecer en Málaga". Martín González añade años después que "es necesario aceptar la efectividad del viaje, aunque fuera de corta duración, de un año o año y medio. Las razones aducidas por Orueta, del impacto de la escultura del centro de la Península, son muy sólidas. Pero la más firme argumentación es el nombramiento del escultor de la catedral de Toledo, acordado por el cabildo el 7 de mayo de 1663. No podía justificarse su concesión sin un conocimiento personal de Mena por el cabildo". MARTÍN GONZÁLEZ, Juan José: "Pedro de Mena visto desde Castilla". En VV.AA.: Pedro de Mena. III Centenario de su muerte, 1688-1988 (exposición Catedral de Málaga, abril de 1989), Junta de Andalucía, Sevilla, 1989, pp. 65-67.

$38 \quad$ Valladolid también contó con obras de Mena. Con total seguridad ha habido dos: el busto de Dolorosa del Real Monasterio de San Joaquín y Santa Ana y un San Pedro de Alcántara en el Monasterio de las Brígidas, si bien este último fue vendido hace muchos años, como otras muchas obras. Se tiene noticias que pudieron existir algunas obras más de Mena en el citado Monasterio de San Joaquín y Santa Ana, sin embargo, tan solo podemos citar una Magdalena penitente, similar a su conocida imagen madrileña, actualmente en el Museo Nacional de Escultura de Valladolid. LUNA MORENO, Luis: "En torno a Pedro de Mena y la escultura castellana". En VV.AA.: Pedro de Mena y Castilla (Catálogo de exposición), Ministerio de Cultura, Valladolid, 1989, p. 14.
} 
mano"39. Sin duda esta expansión se vio favorecida por el hecho de que la mayoría de las esculturas exportadas eran de pequeño tamaño "e incluso de las de "medio cuerpo", es decir, de busto ${ }^{40}$.

La cantidad de obras de Mena en Madrid es enorme, si bien algunas se han perdido. Por citar unas cuantas: los bustos de Ecce Homo y Dolorosa del Monasterio de las Descalzas Reales $(1673)^{41}$, los desaparecidos bustos de Ecce Homo y Dolorosa del Convento de las Mercedarias de don Juan de Alarcón ${ }^{42}$; la Virgen de la Contemplación
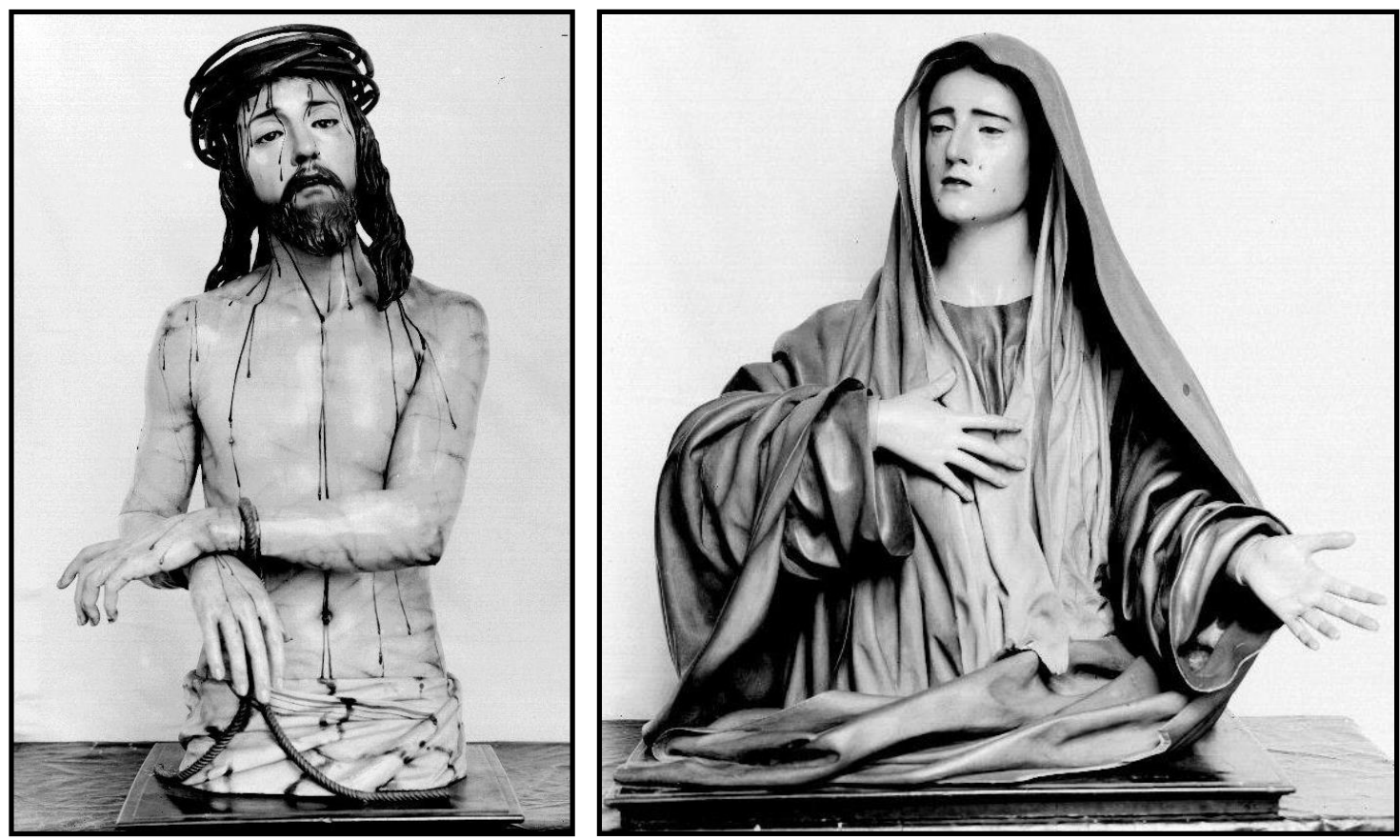

Il. 7- Pedro de Mena. Bustos de Ecce Homo y Dolorosa. Monasterio de las Descalzas Reales. Madrid.

en el referido Monasterio de las Descalzas Reales (Fig. 6), el busto de Dolorosa del Convento de las Maravillas, el Niño Jesús de la Pasión del Convento de las Capuchinas, etc... ${ }^{43}$. Sin embargo, estas no fueron las de mayor importancia ni las que pudo contemplar Pedro de Ávila dado que se custodiaban en clausura. Las dos imágenes, o más concretamente la escultura y el grupo escultórico, que le pudieron suponer un fuerte impacto fueron la Magdalena penitente (1664) de la Casa Profesa de los Jesuitas ${ }^{44}$, y el Calvario (1671) (Fig. 7-8) del Colegio Imperial, también de la Compañía de Jesús ${ }^{45}$. Este último grupo, compuesto por el Crucifijo (realizado por Pedro de Mena), la Virgen, San Juan y la Magdalena para la Capilla del Cristo, gozó de una gran popularidad desde

39 PALOMINO DE CASTRO Y VELASCO, Antonio: Museo pictórico y escala óptica. II, Práctica de la pintura, Aguilar, Madrid, 1988, p. 659.

$40 \quad$ MARTÍN GONZÁLEZ, Juan José: "Pedro de Mena visto desde Castilla". En VV.AA.: Pedro de Mena. III Centenario de su muerte, 1688-1988 (exposición Catedral de Málaga, abril de 1989), Junta de Andalucía, Sevilla, 1989, p. 65.

41 PORTELA SANDOVAL, Francisco José: "Panorama actual de la escultura religiosa en Madrid (1500-1750), Cuadernos de Historia y Arte IV, Tomo IV, 1986, p. 82.

$42 \quad$ Ibídem.

43 Ibídem.

44 MARTÍN GONZÁLEZ, Juan José: "Pedro de Mena visto desde Castilla", op. cit., p. 69.

$45 \quad$ Ídem, p. 73. 
el mismo momento en que Mena lo completó; por lo que, sin duda, fue una de las paradas obligatorias de Ávila durante su estancia madrileña. De no menos celebridad gozó la Magdalena de la Casa Profesa, por lo que su visita también debió de ser forzosa. También pudo conocer el Crucifijo que Mena talló para la iglesia de la Virgen de Gracia (Fig. 9) ${ }^{46}$. Por desgracia esta bellísima imagen ya no se conserva. Tras destruirse la referida iglesia pasó a la capilla de San Isidro en la iglesia de San Andrés, lugar en el que pereció durante la Guerra Civil. Si observamos las dobleces del paño de los Crucificados de Pedro de Ávila vemos que son totalmente deudores de éstos, aunque la composición del perizonium nada tenga que ver.

Parece que de Pedro de Mena y de José de Mora pudo "aprender" esa manera tan delicada y virtuosa que ambos tuvieron de adelgazar hasta lo máximo posible los paños, llegándolos a convertir en finas láminas. Ambas características las tenemos presentes en multitud de obras de Mena: la Virgen de Belén (1664. Destruida) (Fig. 10) y el Crucificado (1658-1662) (Fig. 11) del Convento de Santo Domingo de Málaga; los bustos de Ecce Homo y Dolorosa, y el busto de la Dolorosa de la Contemplación del Monasterio de las Descalzas Reales de Madrid, etc.

El otro escultor en cuestión, José de Mora, posee ciertos parámetros diametralmente opuestos a los de su paisano Mena; puesto que residió mucho mayor tiempo en Madrid, esculpió bastantes menos obras (quizás esta escasez no sea tal y haya tenido mucho que ver el efecto destructor de la Desamortización y de la Guerra Civil, amén de ventas varias) y logró ser nombrado Escultor del Rey. Residió en Madrid durante dos amplios periodos, aunque jalonados por numerosos idas y vueltas a Granada. La primera marcha tuvo lugar hacia 1666 "probablemente aconsejado por Alonso Cano (...) cabe pensar que él mismo animara a José de Mora a trabajar en Madrid, con su discípulo Herrera Barnuevo"47. Tras dos o tres años regresaría a su tierra ${ }^{48}$. El otro viaje aconteció en 1671, tras la muerte del referido Sebastián de Herrera Barnuevo, seguramente decidido a ocupar el

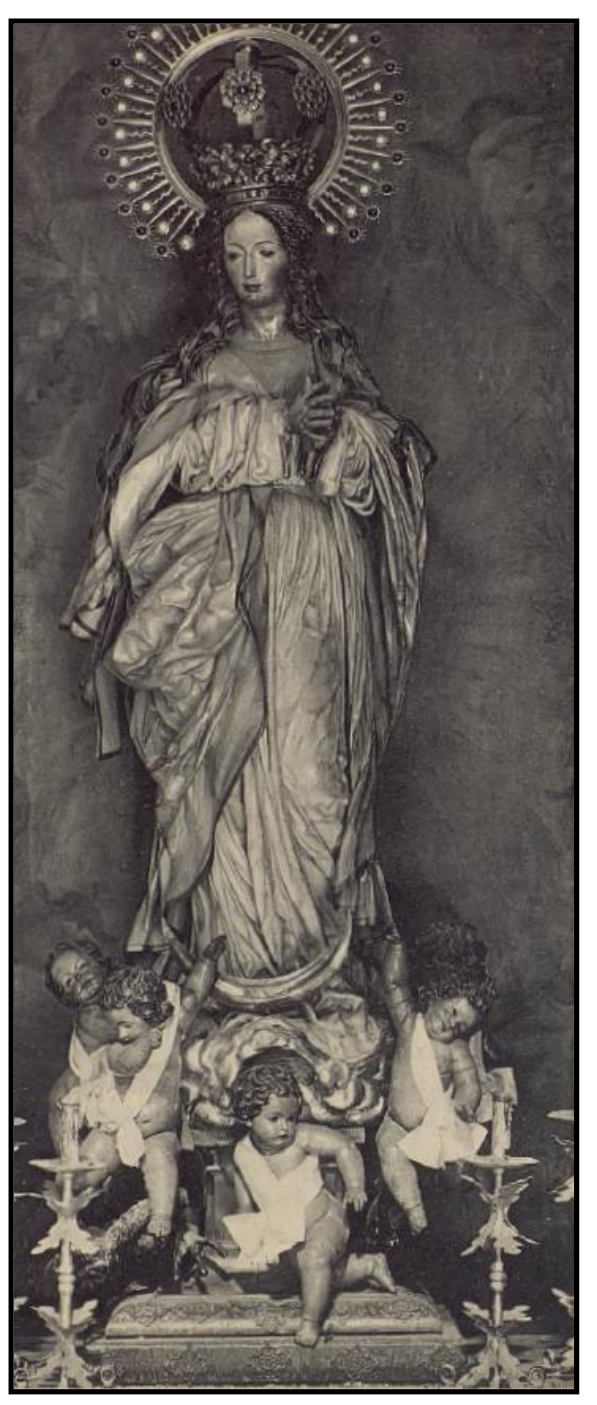

Il. 8- José de Mora. Inmaculada Concepción (destruida) Colegio Imperial. Madrid.

46 SERRANO FATIGATI, Enrique: "Escultura en Madrid, desde mediados del siglo XVI hasta nuestros días", Boletín de la Sociedad Española de Excursiones, Vol. 17, № 3, 1909, p. 218.

47 LÓPEZ-GUADALUPE MUÑOZ, Juan Jesús: José de Mora, Editorial Comares, Granada, 2000, p. 41.

48 MARTÍN GONZÁLEZ, Juan José: Escultura barroca en España, 1600-1770..., op. cit., p. 225. 
lugar que había dejado este. Un año después fue nombrado Escultor del Rey. Tras varias idas y vueltas, Mora regresó de manera definitiva a Granada en el verano de 1679. El encargo más importante que recibió en Madrid y que pudo conocer Pedro de Ávila fue la desaparecida Inmaculada Concepción del Colegio Imperial $(1670)^{49}$. Por fotografías antiguas podemos observar como Mora utiliza en ella abundantemente, muchísimo más que Mena, el pliegue a cuchillo; de una manera mucho más radical a como lo utilizará Ávila. También destaca la maestría con que se encuentran adelgazadas las ropas, llegando a parecer filos de cuchillos. Sin lugar a dudas esta Inmaculada debió de suponer un impacto para nuestro escultor. Podríamos incluso pensar que Ávila tomó ciertos estilemas de esta imagen para concebir su propio modelo de Inmaculada, si bien ni el concepto global ni la posición de sus manos son los mismos. Esta Inmaculada es

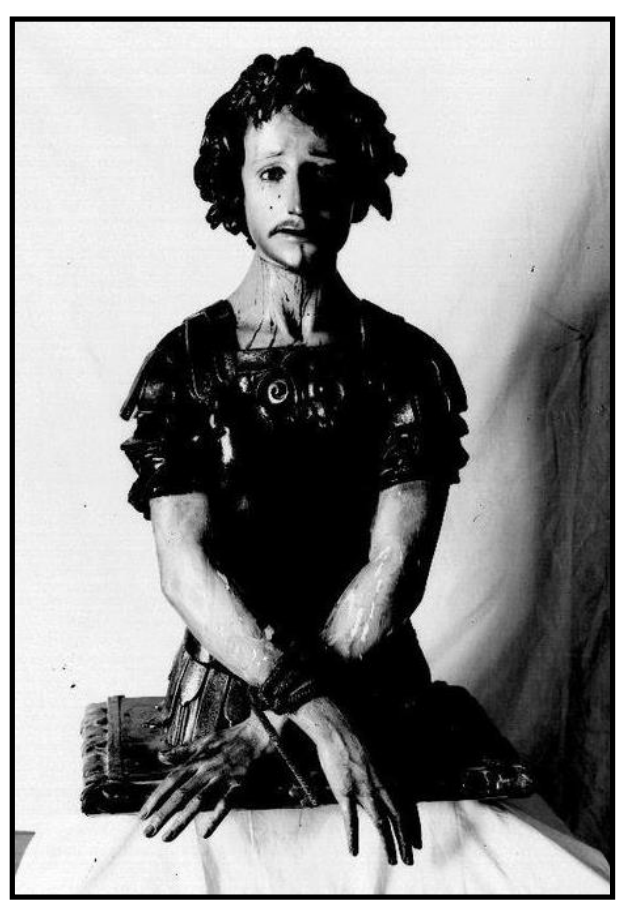

Il. 9- José de Mora. San Acisclo. Convento de las Trinitarias. Madrid. deudora del prototipo canesco, por lo que podríamos llegar a especular que las Inmaculadas de Ávila tienen un lejano poso del "racionero". Entre otras obras suyas para Madrid podemos citar los Bustos de Ecce Homo y Dolorosa del Convento de las Maravillas (1675) (Figs. 12-13), la Dolorosa de la Cofradía de San Fermín de los Navarros, y los bustos-relicarios de San Acisclo y Santa Victoria de la iglesia de las Trinitarias ${ }^{50}$.

Una vez analizados los dos escultores andaluces que pudieron tener incidencia sobre el cambio de estilo de Ávila, relataremos la posible influencia que quizás también pudo tener sobre su arte la escultura napolitana. A lo largo del siglo XVII la llegada de escultura italiana de calidad a Madrid fue enorme, fenómeno del que tampoco se libró Valladolid, aunque en mucha menor medida. Dejando a un lado las escasas obras maestras que llegaron procedentes de otros puntos de Italia, y de nombres tan importantes como los de Pietro Tacca, Gian Lorenzo Bernini, Alessandro Algardi o Domenico Guidi ${ }^{51}$, tenemos que hablar sobre la escultura napolitana, la cual llegó en crecido número y de los mejores talleres de la capital de la Campania: Nicola Fumo, Michele Perrone, Giacomo Colombo o Michelangelo Naccherino. Este hecho no debe de extrañarnos ya que su traída se vio favorecida por las estrechas relaciones que se mantenían con el reino de Nápoles puesto que no dejaba de ser un Virreinato español. Así, por ejemplo, de este último se conservaba un Cristo atado a la columna (1614) (Fig. 14) en el Convento de Trinitarios Descalzos, actualmente en el Museo Lázaro Galdiano; de Michele Perrone un pequeño Cristo Yacente en el coro del monasterio de la Encarnación (1690), del cual existe una copia de tamaño natural en la capilla del

49 LÓPEZ-GUADALUPE MUÑOZ, Juan Jesús: op. cit., p. 50.

50 PORTELA SANDOVAL, Francisco José: op. cit., p. 83.

51 Ídem, pp. 61-62. 
Sepulcro de la iglesia del Carmen. Estas no las pudo conocer nuestro escultor dado que, como ocurrió con algunas de Mena y Mora, se encontraban en la clausura; sin embargo, sí que pudo observar las magistrales imágenes del Nazareno con la cruz a cuestas (1698) de Nicola Fumo y el Cristo atado a la columna (1698) (Fig. 15) de Giacomo Colombo, ambas conservadas en la capilla del Cristo de la iglesia de San Ginés. También pudo conocer otras dos obras anónimas conservadas en la iglesia de la Enfermería de la Venerable Orden Tercera: una Inmaculada y un busto de Ecce Homo $^{52}$.

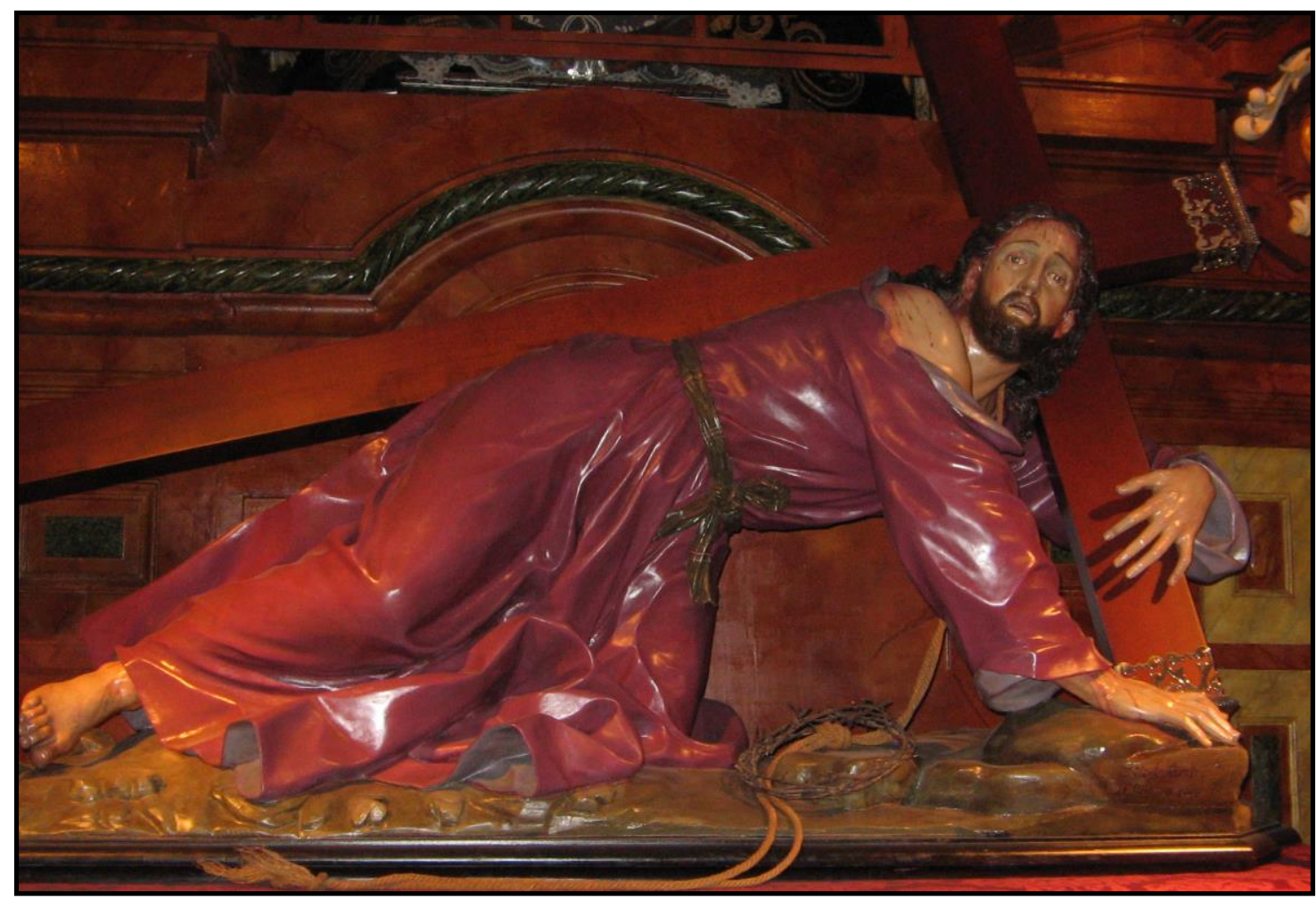

Il. 10- Nicola Fumo. Nazareno con la cruz a cuestas. Iglesia de San Ginés. Madrid.

Si observamos atentamente la cabeza del Nazareno de San Ginés comprobamos que tanto la forma que adopta el rostro como la manera de disponer los cabellos son muy semejantes a la manera en como los resuelve Ávila durante esta segunda etapa. Pero las coincidencias con el arte de Nicola Fumo no quedan aquí. Debió de conocer más esculturas de este brillante escultor, ya fuera en Madrid, en Valladolid o en otro lugar que desconocemos, puesto que ambos coinciden en tres detalles: El primero sería el pliegue a cuchillo. La forma en que ambos lo desarrollan se encuentra más cercana a la napolitana que la existente con los escultores andaluces. Se trata de un pliegue algo más aristado y no tan profuso; mientras que la segunda y la tercera similitudes irían unidas, puesto que se trata de la manera en que ambos conciben la piernas y pies: la pierna izquierda con la rodilla a medio flexionar, mientras que ambos pies forman un ángulo de $90^{\circ}$. Para comprobarlo podemos comparar imágenes de ambos artistas, por ejemplo, la Magdalena que Pedro de Ávila talla para la Catedral o el San Bernardo que se le atribuye sin ningún género de dudas en el Real Monasterio de San Quirce de Valladolid

$52 \quad$ Ídem, p. 63.

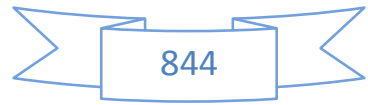


con la Virgen con el Niño, llamada "la Napolitana", obra de Nicola Fumo, que se conserva en el Convento de San José de Madres Carmelitas de Medina del Campo (Valladolid). Pero, es que estos mismos recursos no debieron ser privativos de Fumo, sino de la escuela napolitana en general. Efectivamente, podemos observarlos, entre otras, en el San Cayetano y el San Francisco Javier (Figs. 16-17) que Gaetano Patalano esculpe en 1692 para la iglesia de Santa Clara de Lecce (Apulia/Italia) ${ }^{53}$. En ambas imágenes se aprecia también el magistral adelgazamiento de la madera, hasta parecer casi papel.

Las coincidencias con la escultura napolitana durante el "segundo estilo" de nuestro escultor no quedan ahí. Por ejemplo, su modelo de Inmaculada se encuentra bastante cercano a otros realizados por imagineros napolitanos. Tanto por la disposición del paño como de las manos, la similitud es casi completa con la Inmaculada (Fig. 18) que Pietro Patalano talla tardíamente para la iglesia parroquial de Montesano Salentino $^{54}$. Asimismo, la Inmaculada de Pedro de Ávila que actualmente se conserva en el Seminario Diocesano de Valladolid es semejante tanto en su concepción, como en la gestualidad y en los angelitos del trono a una Inmaculada (Fig. 19) atribuida a Nicola Fumo conservada en una colección privada ${ }^{55}$. También posee ciertas similitudes con la Inmaculada (Fig. 20) que de Gaetano Patalano se conserva en la iglesia de Santa Clara de Lecce (Apulia/Italia) ${ }^{56}$. En las tres imágenes observamos el mismo ligero arqueamiento del cuerpo, como ocurre en las imágenes talladas en marfil, así como el detalle de llevarse la mano derecha al pecho. Posiblemente no se trate más que de causalidades, pero ahí queda apuntado. Una vez comentadas las influencias que pudo recibir Ávila en

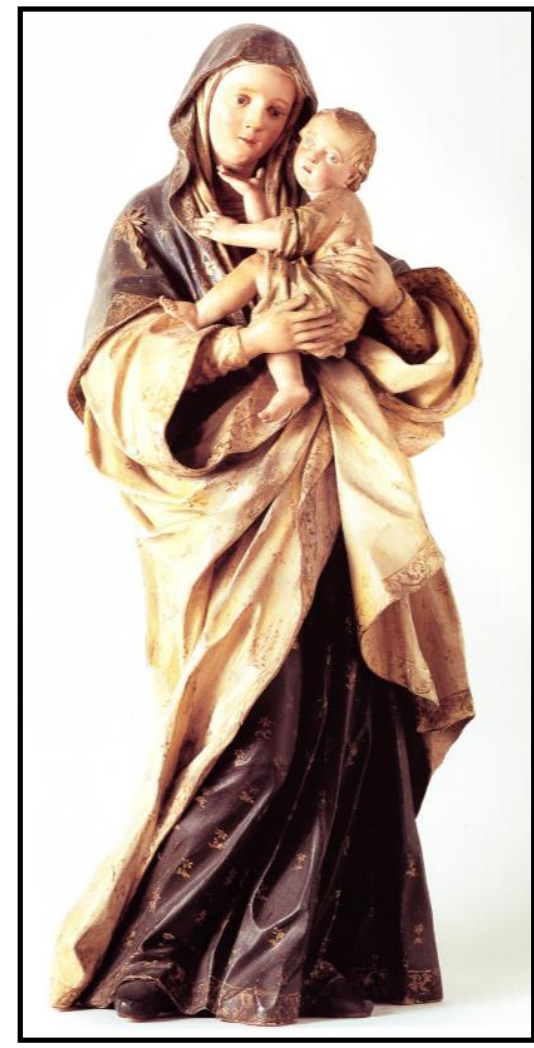

Il. 11- Nicola Fumo (atrib.). Virgen con el Niño. Convento de MM. Carmelitas. Medina del Campo (Valladolid). su probable viaje a Madrid desgranaremos las características que posee su "segundo estilo".

Las esculturas de este "segundo estilo" se caracterizan, según Martín González, por el ensanchamiento de los perfiles "como si se tratara de un relieve. Los pliegues se hacen muy movidos, ejecutándose con cortes de borde aguado (pliegues "a cuchillo"). La policromía se acomoda a tonos planos. Las cabezas tienen una composición casi

53 ALONSO MORAL, Roberto: "La Scultura lígnea napoletana in Spagna nell'età del barocco: presenza e influsso. En CASCIARO, Raffaele y CASSIANO, Antonio: Scultura di età barocca tra Terra d'Otranto, Napoli e Spagna, De Luca Editori d'Arte, Lecce, 2007, pp. 242-245.

$54 \quad$ Ídem, pp. 282-283.

55 Ídem, pp. 264-265.

56 Ídem, pp. 238-239. 
rectangular, cayendo de forma muy elegante los cabellos. Se usan ojos de cristal"57. Años antes Durruty Romay, partiendo del análisis del "Cristo del Olvido" señalaba que en este "segundo estilo" se observaban "dos tendencias bien definidas, el barroquismo del siglo, apenas esbozado en la profusión de la sangre, en cierta afectación académica y en la inclinación al realismo como producto de un neoclasicismo, y su contacto con escultores anteriores y con la escuela de finales del XVI y del XVII, especialmente con Gregorio Fernández; el patetismo, la sobriedad, la belleza delicada de la forma y la serenidad tranquila de la expresión, producto de un acendrado misticismo o bien reflejo de los de Gregorio Fernández, alejamiento de artistas contemporáneos suyos y personalidad artística" "58. Además, ve en sus obras "cierta serenidad melancólica y una extremada finura en conjunto y detalles que hace contraste vigoroso con la afectación del siglo" $"$.

En esta segunda etapa, observamos en sus esculturas "una sensibilidad diferente que conduce a un concepto plástico mucho más refinado y elegante en total sintonía con los principios propios del siglo XVIII" ${ }^{60}$. Esta evolución, según la profesora Porras Gil, ha llevado a nuestro escultor a destacar "con mayor eficacia los valores de elegancia en sus imágenes conseguidos por el ritmo postural dado a las extremidades de éstas, la suavidad del modelado anatómico, la definición de los rostros siguiendo un esquema tendente al rectángulo y la acentuación del ángulo cortante de los pliegues" ${ }^{\prime 61}$.

Ahora es cuando Pedro de Ávila se nos muestra más barroco, libre de las ataduras anteriores. Ese barroquismo lo observamos en multitud de detalles: el dinamismo que adoptan los perfiles de sus esculturas, hecho favorecido por el uso del pliegue berninesco; en la captación teatral del momento culminante, en la teatralidad de las acciones, en la utilización de diagonales, etc... A todo ello suma caracteres muy propios de la escultura dieciochesca cortesana y europea, como son la elegancia, el refinamiento, la recreación en las formas, las poses declaratorias y grandilocuentes, o las actitudes afectadas. Todas estas características las vemos resumidas a la perfección en los dos ejemplares de San Miguel que esculpió para la Catedral de Valladolid y la parroquial de Castil de Vela, y en las diversas Inmaculadas documentadas y atribuidas; estas últimas son, quizás, las que nos muestran al Ávila más innovador y abierto a las influencias cortesanas y europeas.

\section{$\underline{\text { Anatomías }}$}

Si en su primera etapa dijimos que sus esculturas denotaban una gran calidad técnica, ahora es cuando logra unas cuotas de virtuosismo especialmente reseñables. El canon

\footnotetext{
57 MARTÍN GONZÁLEZ, Juan José: Escultura barroca en España, 1600-1770..., op. cit., pp. 447448.

$58 \quad$ Ídem, p. 209.

$59 \quad$ Ídem, p. 206.

60 PORRAS GIL, María Concepción: op. cit., p. 376.

61 Ibídem.
} 
sigue siendo muy estilizado, aunque el naturalismo se ve matizado en este periodo por una incipiente preocupación por la elegancia. Ahora es cuando Ávila alcanza sus mejores cuotas de brillante anatomista, como así podemos comprobarlo en multitud en los Crucificados; los Ecce Homo de la parroquial de Renedo, del Monasterio de Santa Brígida y de la Cofradía de las Angustias de Valladolid; el Atado a la columna de esta misma penitencial; el Cristo Resucitado de Ampudia, los Yacentes de San Felipe Neri y de la Cofradía de N. P. Jesús Nazareno, etc. En todas estas imágenes, pero sobre todo en su "Cristo del Olvido" del Oratorio de San Felipe Neri y en el bellísimo busto de Ecce Homo que se custodia en la clausura del Monasterio de Santa Brígida de Valladolid es donde muestra su magnífica competencia a la hora de modelar con maestría, elegancia y finura las anatomías; la corrección es total a la hora de captar e individualizar cada músculo, hueso o vena, pero no por ello deja de incluir cierta idealización propia de la escultura clásica. Son especialmente impresionantes por su verismo y por su juego de calidades las venas de las manos y brazos de algunos de los referidos ejemplos. Este asombroso naturalismo y realismo le lleva a conseguir ciertos detalles como la extensión de los músculos de la axila o el hundimiento del vientre del Crucificado.

Acabamos de referir que el canon utilizado por Ávila en este periodo es algo más corto que en la etapa anterior. Sin embargo, cabe decir que a raíz de la comparación de ciertas obras atribuidas observamos que podría haber utilizado dos tipos de cánones, puesto que al que usa con frecuencia, el más alargado, parece añadir en ciertas ocasiones otro algo más achaparrado, como podemos comprobarlo en el Ecce Homo y el Atado a la Columna de la Cofradía de las Angustias y en el Atado a la Columna de la parroquial de Tudela de Duero. En ellos, además, observamos que la reproducción del natural tiene una situación total de primacía sobre la elegancia presente en las obras de estos años. Quizás la explicación a este asunto tendrá relación con el hecho de que las citadas imágenes no son fruto de su diseño sino que se limita a copiar modelos preexistentes: los dos Atados siguen fielmente el ejemplar fernandesco de la Cofradía de la Santa Vera Cruz; por su parte, el Ecce Homo no deja de ser también una copia de ese modelo aunque con ciertas variaciones. Resulta bastante extraña esta iconografía de Ecce Homo en la que figura un Atado a la Columna tañido con el manto púrpura.

También hay que llamar la atención de que no utilizaba un mismo concepto anatómico para sus figuras, generalmente tendentes a la delgadez, sobre todo en las esculturas que representan a Cristo en alguno de los pasajes de la Pasión. Así lo podemos comprobar en el Crucificado del Oratorio de San Felipe Neri o en el Ecce Homo de Renedo. Relacionado con su concepción anatómica encontramos ciertos estilemas que, como ya dijimos, pueden poseer influencia napolitana. Estos son el adelantamiento de una de las piernas, generalmente la derecha, con la consiguiente doblez de la rodilla; así como la colocación de los pies formando un ángulo de $90^{\circ}$.

Al igual que sucede en su primera etapa, Pedro de Ávila seguirá tallando las manos y las cabezas, pero sobre todo las manos, de las dos maneras referidas anteriormente; si bien cabe señalar que habrá mayor número de piezas con el cuerpo tallado en un solo bloque. Así lo podemos comprobar en todas y cada una de las esculturas documentadas que 
realizó para las capillas de la catedral vallisoletana y del Oratorio de San Felipe Neri. De los escasos ejemplares de la primera modalidad, la de las manos separadas del cuerpo, podemos citar el San José que se conserva en la iglesia de la Victoria, las esculturas de San Joaquín y Santa Ana del Santuario Nacional de la Gran Promesa o el San Francisco de Asís de la parroquial de La Seca. Asimismo, al todavía más reducido grupo de las cabezas talladas por separado pertenece esta última imagen del santo italiano y el San Ramón Nonato de Íscar.

Ahora no solamente talla las manos como una parte más del cuerpo sino que concibe las esculturas como un todo, valoriza y mima cada parte del cuerpo o de las vestimentas. Ahora, en esta segunda etapa, es cuando nuestro escultor dotará de vida propia a las manos, dejando de ser meros apéndices para convertirse en uno de los "motores" por los cuales sus esculturas expresarán sentimientos. Llama la atención que en la inmensa mayoría de las ocasiones las manos suelen estar estereotipadas; es como si tuviera un modelo al que recurre constantemente. En otras ocasiones, cuando la acción que desarrolla el personaje necesita de una tensión especial es cuando las individualiza, logrando que se complemente con el rostro sufriente, devoto o ascético del individuo en cuestión. El referido modelo estereotipado sigue la siguiente secuencia: el pulgar y el meñique no los mueve, siguen un movimiento natural; en cambio, con el índice y el medio realiza una "V", teniendo el primero de ellos algo doblado y el segundo estirado; por su parte, el anular lo dobla hacia abajo. También hemos encontrado que las venas y los tendones de las manos siguen un mismo patrón. Este mismo ritmo también está presente en las manos del San José que su hermano Manuel talla para la Cofradía de N. P. Jesús Nazareno.

Los rostros acusan un perfecto juego de calidad. En los rostros jóvenes se percibe blandura mientras que en los de los ancianos, como el San Pedro del Oratorio de San Felipe Neri, capta a la perfección las carnes fláccidas y las arrugas propias de la vejez, las cuales surcan la frente, mejillas y laterales de los ojos del santo. En este sentido la tez avejentada del santo emparenta totalmente con la del San Pedro en Cátedra que su padre talla años antes para la Colegiata de Lerma.

En lo referente a las cabezas hay un cambio sustancial puesto que la práctica totalidad se encuentran estereotipados, todos ellos poseen una serie de elementos tan sumamente característicos que nos facilitan mucho la identificación de nuevas obras. Es decir, existe un mismo modelo al cual en ocasiones introduce ciertas variantes dependiendo de si el personaje representado es masculino o femenino, pero en el fondo las singularidades son las mismas. En las féminas veremos como la parte inferior del rostro abandona la rectitud del rectángulo para convertirse en una curva pronunciada con algo de papada y un potente mentón (algunas veces con hoyuelo, caso de la Inmaculada de San Felipe Neri), características que también observamos en el San Juan Evangelista de la Catedral. Además de todo lo dicho, ese rectángulo que compone la faz se ve tamizado por las ondas laterales del pelo. Si anteriormente aún quedaba un cierto poso de la forma "ovoide" propugnada por su padre, ahora la tendencia rectangular será la norma. Las frentes son amplias y anchas. 
Los ojos siguen siendo almendrados y rehundidos, con el característico abultamiento de la parte inferior de los mismos, aunque en esta nueva etapa no lo utilizará de manera generalizada. Una de las excepciones la encontramos en algunos rostros femeninos, en los cuales ese abultamiento no hace acto de presencia. Las cejas pueden aparecer rectas o bien levemente levantadas formando una diagonal de poca pendiente. Para el ceño encontramos también dos tipologías: o liso o arrugado, dependiendo de la tensión que adopta la expresión del santo; esas arrugas también pueden aparecer pero no en función de la expresión sino de la avanzada edad del personaje representado (así lo vemos en el San Pedro y San Pablo del Oratorio de San Felipe Neri, o en Las lágrimas de San Pedro, entre otros.

La forma de tallar las narices difiere bastante de la que ejecutó en la primera etapa. En este segundo estilo realiza unas narices tan características que se convierten en uno de los elementos fundamentales con que contamos para realizarle nuevas atribuciones sin apenas problemas. Se trata de narices rectas, potentes, geometrizadas, con el tabique nasal ancho y aplastado; desde el nacimiento de la nariz hasta su desembocadura en las fosas nasales va creciendo en anchura, formando algo parecido a un triángulo isósceles. Las aletas nasales están levemente pronunciadas, mientras que las fosas nasales van perforadas, detalle que aporta un mayor grado de realismo. Las bocas parecen estrecharse respecto a su anterior etapa, aunque sigue concibiéndolas entreabiertas. Y, como novedad, introduce la talla de los dientes e incluso, en algunas ocasiones, de la punta de la lengua. Los labios, muy finos y con las comisuras pronunciadas, siguen repitiendo esa especie de mueca de la que hablábamos en la primera etapa, aunque ahora se destaca aún más. El surco nasolabial va perfectamente modelado, lo que contribuye a valorizar el rostro; cuando el personaje representado posee barba. Ávila suele dejar una estrecha franja para colocar el referido surco. Por regla general, los pómulos pueden estar algo abultados, aunque en otras ocasiones no aparecen; y, en las menos, figuran demacrados para expresarnos el sufrimiento del personaje, caso de los Ecce Homo; o por la abstinencia, caso del San Pedro Regalado. Lo que no termina de faltar en los pómulos es la entonación rosada.

El cabello y las barbas de este periodo también tienden a la simetría, como ocurría en la etapa anterior, conservando, asimismo, similares estilemas también. Eso sí, parece que según va ganando maestría y seguridad en sus facultades va individualizando y otorgando mayor detallismo a cada una de las guedejas, bucles, etc...; es decir, el paso del tiempo se ve reflejado en sus obras en una mayor perfección técnica.

Para las cabelleras utiliza una gama muy variada de soluciones, si bien hay una que será la predominante: se trata de las largas cabelleras a ambos lados del rostro, las cuales parecieran servir de "marco" al rostro. Estas amplias y sinuosas cabelleras se encuentran compuestas por amplias ondas que se prolongan hasta la base del cuello, cayendo, en ocasiones, alguno de los mechones sobre el pecho. La largura y amplitud de estas madejas trae como consecuencia la total ocultación de las orejas. Esta modalidad ya la comentamos en la primera etapa, sin embargo ahora es cuando el escultor acrecienta el volumen y la definición de las cabelleras. Podríamos decir que en esta segunda etapa, 
consciente de su valía, el escultor se recrea a la hora de su talla. Entre el inmenso número de obras en que utiliza esta solución destacamos por la calidad y elegancia de sus cabelleras las siguientes: San José de la catedral vallisoletana, busto de Ecce Homo de las Brígidas, Crucificado "del Olvido", Inmaculada del Oratorio de San Felipe Neri y Ecce Homo de la parroquial de Renedo. Cabe destacar que en las figuras femeninas, como por ejemplo las dos Magdalenas (Catedral y San Felipe Neri), prolonga la cabellera con cuatro largos mechones hasta la cintura, que en realidad se trata de dos finas guedejas recurvadas a cada lado del rostro. Tanto en las figuras masculinas como en las femeninas, la cabellera se resuelve por la parte trasera con una amplia y extendida melena que ocupa una buena porción de la parte superior de la espalda. Hemos observado que según transcurre el tiempo este tipo de cabellera se va "barroquizando", aumentando considerablemente su volumen. De confirmarse este hecho, observado a través de la comparación de los Crucifijos y de alguna otra obra, nos ayudará a poder datar algunas esculturas que le tenemos atribuidas con total certeza pero de las cuales no poseemos una cronología aproximada.

Pero, como hemos dicho, este tipo de caballera prototípica, que utilizará tanto para personajes masculinos como femeninos, no será la única variante, sino que concibe muchas de sus esculturas con una amplia gama de alternativas capilares, en algunas ocasiones en función del personaje representado.

Las otras dos soluciones del cabello más difundidas son la cabellera realizada a través de numerosos y amplios bucles compactos que traen consigo un volumen de masa muy importante, y también nos da buena prueba de su destreza a la hora de la utilización del trépano. Este tipo de cabellera no fue inventada por él puesto que ya la vemos presente en escultores de las generaciones inmediatamente precedentes como lo fueron su padre o José de Rozas. La tenemos presente en los dos ejemplares de San Miguel (Catedral y parroquial de Castil de Vela), en el San Lorenzo de la iglesia homónima y en el San Juan Evangelista de la Catedral. La tercera gran "solución" es la que presenta al santo con las patillas afeitadas, teniendo pelo solo en lo que es el casco craneal (parece simular una tonsura, es propia de santos frailes); la talla es muy plana, sin apenas resalte; en el extremo inferior está configurada por un sinfín de pequeñas guedejas en forma de "S". Esta tipología la encontramos en el San Francisco de Asís de La Seca, y en el San Ramón Nonato y San Antonio de Padua de Íscar. Sin ánimo de ser exhaustivos hablaremos de otros tipos de peinados dando algún ejemplo de cada uno de ellos: la calvicie la tenemos presente en personaje de avanzada edad, como San Pedro Regalado y el apóstol San Pedro. Una variante de este último, aunque con la inclusión de un mechón circular sobre la frente, la tenemos en el San Bernardo del Monasterio de San Quirce y en el Santo Mínimo conservado en la catedral. La última modalidad reseñable es la "cabellera no tallada", que es aquella que dado que la cabeza aparece cubierta por un gorro o una capucha no se ve (Santa Escolástica del Monasterio de Santa Brígida, San Pío V del Convento de San Pablo, San Nicolás de Bari de Olmedo o San Francisco de Paula de la catedral). 
Íntimamente relacionado con la caballera se encuentra la forma de resolver el peinado situado sobre la frente. Tendremos una gama algo más limitada, aunque seguirán un mismo patrón con variantes, se trata de dos o cuatro rizos o pelos simétricos enfrentados uno a uno o dos a dos. Las dos variantes más comunes, que a su vez proceden de su etapa anterior, son la de dos pequeños mechones rectos simétricos con los extremos apuntando hacia el exterior (San José de Morales de Toro, San Pablo del Oratorio de San Felipe Neri, Nazareno de Tudela de Duero y Atado a la Columna y Ecce Homo de la iglesia penitencial de Nuestra Señora de las Angustias; y la de dos mechones que apenas se separan de la cabellera pero que en su extremo se retuercen formando dos caracolillos simétricos. Tampoco faltarán algunas esculturas que lleven la frente despejada. Por su extrañeza y poca utilización podemos citar los dos voluminosos rizos en forma de "S" del San Juan Evangelista de la catedral; y las cuatro guedejas mojadas simétricas, dos a dos, del San Joaquín conservado en el Santuario Nacional de la Gran Promesa.

Finalmente toca hablar de la manera de concebir las barbas, eso en el caso de que los personajes no sean imberbes, como por ejemplo el San Juan Evangelista de la Catedral o los San Antonio de Padua de Íscar y La Seca. Cabe decir que las soluciones coinciden, a groso modo, con tres modelos que ya utilizó en su primera etapa, aunque ahora las perfeccionará y complicará gracias a su mayor pericia técnica. La primera se trata de barbas realizadas a base de numerosos y sinuosos mechones profundos a ambos lados del rostro. La barba se prolonga en el mentón a través de dos o cuatro mechones curvos, largos y simétricos cuyos bucles miran hacia el interior. A este grupo pertenecen los Crucificados, algunas de las imágenes de San José, el busto de Ecce Homo de las Brígidas y el Ecce Homo de cuerpo entero de la parroquial de las Renedo. El segundo tipo de barbas es bastante similar a la anterior, aunque la resolución en el mentón se hace por numerosos caracolillos redondeados que conforman una barba bífida corta. Esta tipología la vemos presentes, entre otros, en los San José de la iglesia de la Victoria y del Santuario del Henar (Segovia). La tercera tipología, que como ya dijimos en la primera etapa, deriva del San Francisco de Sales que su padre ejecuta para el Oratorio de San Felipe Neri; esta se resuelve con largos y sinuosos mechones compactos compuestos de una manera muy virtuosa y simétrica, no hay una cantidad exacta de mechones ni de la largura de los mismos, como podemos comprobar en el San Joaquín que se conserva en el Santuario Nacional de la Gran Promesa, en el San Nicolás de Bari de Olmedo y en el San Pablo del Oratorio de San Felipe Neri. A todas estas heredadas de su etapa anterior hemos de añadir una cuarta tipología, directamente heredada del San Pedro en Cátedra que su padre había tallado para la Colegiata de Lerma. Se trata de la barba realiza a base una gran cantidad de pequeños bucles compactos. Lo podemos observar en sus tres efigies de San Pedro.

Cabe señalar, al igual que ocurría con uno de los tipos de cabellera, una evolución que nos podría permitir fechar algunas obras sin cronología precisa. Comparando esculturas documentadas de los albores de este periodo que poseen la barba bífida con otras similares atribuidas, y que pertenecen a la etapa final de su magisterio, observamos que 
a comienzos de este nuevo estilo las barbas son algo más alargadas, estrechas y con los dos bucles apenas curvados; en cambio, en otras obras más avanzadas esa barba es ligeramente más corta, se ha ensanchado y los bucles han tomado un aspecto más redondeado.

\section{$\underline{\text { Indumentaria y pliegues }}$}

Pocas novedades en cuanto a indumentaria podemos añadir a lo que explicamos en el denominado "primer estilo", quizás se puede señalar que algunas de sus esculturas parece ir ataviadas con ropas lujosas, propias de los altos estamentos sociales; así lo podemos observar en sus hechuras de San José. Tampoco parecen vestimentas humildes las que portan las Magdalenas del Oratorio de San Felipe Neri, de la Catedral y de la parroquial de Matapozuelos. El hecho de que estos San José los conciba Ávila con una pierna casi descubierta podría tener relación con esa alta sociedad, como así lo indicaba Martín González: "Los descotes, brazos y piernas descubiertos, actitudes desenvueltas, adornos (...) son reveladores de esta preeminencia social" 62 .

En lo referente a los pliegues, todas y cada una de las obras que engloban este "segundo estilo" llevarán el sello inconfundible de Ávila durante este periodo: el tantas veces repetido "pliegue a cuchillo" o "pliegue berninesco". También explicamos con anterioridad que este pliegue no lo realizó de la misma manera en sus primeras obras de esta época que según fueron avanzando los años. Efectivamente, parece que comenzó a utilizarlo, que nosotros podamos asegurarlo, a partir del año 1709 en que realiza el grupo de la Traslación de San Pedro Regalado para la iglesia del Santísimo Salvador. Entonces esta doblez era un "paño a cuchillo" en formación, como si todavía no dominara la técnica, que dada la finura que requería no debía ser fácil. Al cabo de uno años, concretamente hacia 1712-1713 cuando realiza el San Pío V para el Convento de San Pablo de Valladolid, parece que ya sí domina a la perfección su ejecución y le vemos el pliegue plenamente configurado. Pero su progreso no se detuvo puesto que con los años siguió incidiendo aún más en el adelgazamiento de los paños así como en el movimiento violento de los mismos. Uno de los mejores frutos de estos momentos es la estrecha tela que cuelga del cuello del San Miguel de Castil de Vela. Ahí observamos que los pliegues adquieren unas aristas cortantes, como cuchillos, ya no se percibe la redondez que había caracterizado la práctica de los escultores vallisoletanos previos. Pero, no porque los paños adopten formas voladas, violentas y cortantes dejan de ser movimientos naturales. Todo lo contrario, el naturalismo guía el proceder de nuestro escultor. La perfección en cuanto a la unión de la finura de este tipo de pliegues, casi como hojas de papel, y el movimiento que podemos denominar "barroco" lo hallamos en dos creaciones algo más tardías: la Magdalena y la Inmaculada del Oratorio de San Felipe Neri. En ellas los finos cortes agudos de la madera han llegado a su máxima expresión.

62 MARTÍN GONZÁLEZ, Juan José: Luis Salvador Carmona: escultor y académico, Alpuerto, Madrid, 1990, p. 40. 
Muchas de sus esculturas, sobre todo en la de mayor empeño, suele arremolinar grandes porciones del manto alrededor del brazo o por debajo de él, con lo cual consigue una mayor complejidad formal y un claro ensanche. También con el manto suele formar diagonales, o incluso cruzar un par de ellas, como podemos observar en muchas de sus obras documentadas. Los mantos llegan a poseer tantos finas dobleces y tal perfección técnica que en ocasiones puede parecer tela encolada, mucho más maleable y dúctil que la madera. En sus años postreros el pliegue a cuchillo llegará a ser tan agudo y cortante que llegará a concebir las esculturas con unos perfiles puramente geométricos, como así lo observamos en el San Joaquín que se conserva en el Santuario Nacional de la Gran Promesa. Esto conlleva a que se abran los perfiles de las imágenes y que exista cierta inestabilidad, en ocasiones paliada por el ensanchamiento inferior de los mantos o túnicas.

\section{$\underline{\text { Iconografías }}$}

Durante esta segunda etapa parece que su capacidad creativa ganó muchos enteros, posiblemente a raíz de las experiencias vividas durante su viaje a Madrid, aunque tampoco hemos de descartar su ingenio ni la utilización de una serie de estampas y grabados que no hemos logrado localizar. No cabe duda de que creó numerosas iconografías, lo que conllevó la casi total ruptura con los modelos fernandescos imperantes desde que Gregorio Fernández los impusiera a comienzos del siglo XVII. Que fue un escultor de éxito nos lo indica la excelente fortuna que llegaron a lograr algunas de estas iconografías, lo que supuso nuevos encargos de imágenes casi idénticas y la consiguiente expansión de la influencia de nuestro escultor por los territorios adyacentes.

Las iconografías propias de Ávila que lograron mayor difusión fueron las de San José, San Miguel, María Magdalena, Inmaculada (relacionado con ésta parece encontrarse la imagen de Nuestra Señora de las Nieves conservada en la parroquial de Nava del Rey, que también es iconografía propia de nuestro escultor), Cristo Crucificado (que si bien su cabeza de serie pudo ser el realizado en 1703 para el retablo mayor de las Brígidas si aceptamos que es suyo y no de su padre- el Crucificado realizado en esta época tendrá algunas diferencias: tamaño mucho más pequeño y un aspecto más delicado y refinado) e, incluso, el San Pedro. De este último hemos de diferenciar entre el San Pedro del Oratorio de San Felipe Neri, en que sigue modelos fernandescos, y el de la Catedral y el denominado Lágrimas de San Pedro de la iglesia del Salvador. De este último pasaje apenas existen ejemplares escultóricos por lo que hemos de darle a Ávila todo el mérito de su creación, sin minusvalorar el posible papel del mecenas; sin embargo, sí que pudo inspirarse en uno de los muchos lienzos que de este tema se conservaban en Valladolid, por ejemplo el situado en uno de los retablos del camarín de la Virgen de las Angustias en la iglesia penitencial homónima. Pudiera ser que Ávila hubiera conocido alguno de los diversos lienzos que de ese tema realizó El Greco, puesto que éstos y la escultura de Ávila son muy similares. 
Me gustaría destacar que la iconografía con que concibió a San José alcanzó tal popularidad que fue copiada por otros artistas. A la versión ya conocida de su hermano Manuel para la vallisoletana Cofradía de N. P. Jesús Nazareno, hemos de añadir otra existente en la iglesia de Santa María de Curiel de Duero (Valladolid). Este San José con el Niño es prácticamente idéntico a todos los conocidos de nuestro escultor tanto en disposición, vestimenta, etc... pero el estilo no es el suyo.

Aunque bastantes escultores del foco vallisoletano habían tratado ya el tema de los bustos de Ecce Homo (desde Alonso Berruguete y Juan de Juni hasta Gregorio Fernández y otros escultores barrocos de segunda fila) no ocurrió así con los de Dolorosa; de los cuales se conservan algunos ejemplares ya tardíos de finales del siglo XVII, y mucho menos con la pareja formada por ambos. El hecho de que Pedro de Ávila realizara una serie de bustos de estas características podría tener su origen en la influencia granadina de Pedro de Mena y José de Mora que le quedó tras el supuesto viaje a Madrid. La escuela granadina había destacado desde comienzos del siglo XVII por la difusión de los bustos de Ecce Homo y Dolorosa, siendo sus primeros artífices los hermanos Miguel y Jerónimo García. No llegó sin embargo la popularización de estas iconografías hasta que Mena y Mora los trabajaron de manera múltiple, hasta casi la obsesión, para exportarlos a numerosos puntos del país e incluso de Sudamérica.

También será creación suya la tipología de San Juan Evangelista, cuya prototipo, probablemente transformado en el siglo XIX, conservado en la Catedral, será sin lugar a dudas el modelo que tomó su hermano Manuel para las copias que realizó con destino a los retablos mayores de las iglesias de Santa María de Colaña de Castromocho (Palencia) y de Santa María la Antigua de Fuentes de Valdepero (Palencia).

Otros muchos de sus santos, Cristos y Vírgenes pudieron ser creaciones suyas. Por evitar prolijidad tan solo reseñaremos, por su novedad la Virgen del Refugio que talló para don Pedro Rábago, cura de la iglesia del Salvador de Valladolid. Esta Virgen no se parece a ninguna otra de esta advocación por cuanto la inmensa mayoría de ellas son esculturas de bastidor. Pudiéramos pensar que para su concepción llegó a fusionar su propia inventiva con la Dolorosa de la Vera Cruz de Gregorio Fernández y la de las Angustias de Juan de Juni; puesto que, en realidad, esta Virgen del Refugio no deja de ser una dolorosa.

A su riqueza creativa también añadió la inspiración, o directamente copia, de iconografías creadas, o generalizadas por su padre. En esta categoría cabe citar la Traslación de San Pedro de la iglesia del Santísimo Salvador, copia del grupo homónimo que Juan había concebido para el Domus Dei de La Aguilera (Burgos); las numerosas imágenes de San Isidro, que tienen como modelo el "creado" por Gregorio Fernández para Dueñas, aunque popularizado a raíz de la imagen del santo que Juan de Ávila talló para la cofradía gremial vallisoletana; y el Santiago Matamoros que preside el retablo mayor del ex-convento de las Comendadoras de Santiago, reproducción literal del que Juan esculpió para el altar mayor de la cercana iglesia de Santiago Apóstol. También parece que proceden de su padre los modelos que Pedro de Ávila se encargaría 
de evolucionar de San Joaquín y Santa Ana, siendo los prototipos los conservados en uno de los retablos del Colegio de los Ingleses.

Otra de las iconografías que tomó para sí fue la Anunciación, cuyo grupo conservado en Renedo (Valladolid) parece inspirarse en los conjuntos conservados en la parroquial de Ataquines (atribuido a Juan de Ávila) y en el ático del retablo mayor del Convento de Santa Clara de Peñafiel (atribuido a Juan Antonio de la Peña).

Tampoco faltó la copia de obras de Gregorio Fernández, característica tan propia de la escuela castellana incluso en vida del genio gallego. Desconocemos si esta imitación la hacía Ávila de "motu proprio" o bien era, como lógicamente parece, una exigencia de los comitentes. Como ya dijimos, seguiría extendida la mentalidad de que si no se puede tener una obra del gran maestro al menos poseer copias. Efectivamente, los Yacentes de la Cofradía de N. P. Jesús Nazareno y del Oratorio de San Felipe Neri, los Atados a la Columna de la Cofradía de las Angustias y de la parroquial de Tudela de Duero (Valladolid), los San Francisco Javier de las iglesia de Santa Marina la Real de León y de Santa María de Pozaldez (Valladolid), y los San Pedro y San Pablo del Oratorio de San Felipe Neri dan buena cuenta de ello.

Tampoco faltará la copia de otro de los grandes genios con que contó en siglos antecedentes la capital del Pisuerga -Juan de Juni- del cual copió la Virgen de las Angustias en menor tamaño para una de las iglesias de la villa de Íscar. Aunque existieron numerosas copias de esta Virgen casi desde el momento en el que el francés la creó, podríamos decir que Pedro de Ávila fue uno de los precursores de lo que Martín González considera la influencia de Juan de Juni sobre la escultura castellana dieciochesca: "En el siglo XVII predominan sobre todo las copias de Gregorio Fernández; en el XVIII, más barroco, las de Juni"63.

\section{$\underline{\text { Postizos }}$}

Si en la anterior etapa vimos que apenas los utilizaba, en esta la tónica será prácticamente la misma. Para simular los ojos seguirá más o menos lo realizado anteriormente. Si en la primera etapa vimos que los pintaba sobre la madera o bien colocaba una tapilla de vidrio; en esta nueva etapa parece que tan solo utilizó esta segunda opción, si bien en alguna ocasión se ha referido a que las esculturas que talló para el Oratorio de San Felipe Neri poseían ojos de cristal. Esto no se puede admitir y todas ellas siguen la tónica habitual de estos momentos y llevan sus correspondientes tapillas de vidrio. También utilizó resinas para simular la sangre coagulada en el cuerpo de sus Crucificados. Y, como en la primera etapa, también en esta le veremos usar capilares de cristal fundidos para crear lágrimas, como así podemos verlo en la Magdalena de la Catedral. Aunque ya las utilizara con anterioridad a su viaje a Madrid, pudiera ser que su uso se generalizase tras recibir la influencia de Mena y Mora, dos

63 MARTÍN GONZÁLEZ, Juan José: Escultura barroca castellana..., op. cit., p. 249. 
escultores que las utilizaban con asiduidad. Finalmente cabe destacar el uso por parte de Pedro de Ávila de la tela encolada. Esta parece que la utilizó para completar las esquinas de algunas vestiduras, con el objeto de conseguir mayor verismo a la hora de representarlas y otorgarlas un movimiento más violento. Observamos tela encolada en los pliegues que caen sobre el brazo izquierdo del busto de Ecce Homo del Monasterio de Santa Brígida de Valladolid, o en el paño que sujeta el busto de Dolorosa conservado en el Museo Nacional de Escultura. 


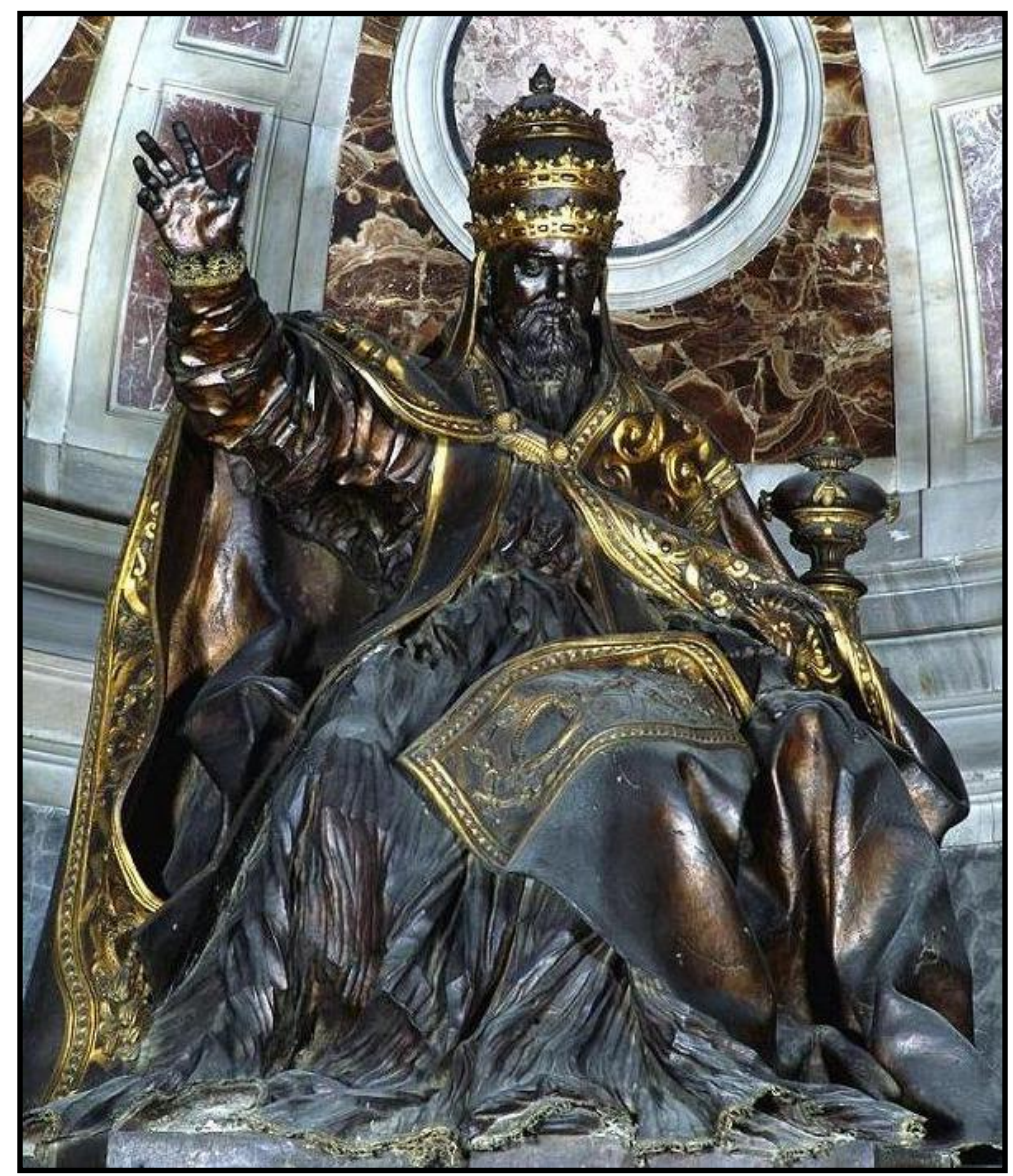

Fig. 1- Gian Lorenzo Bernini.

Tumba de Urbano VIII.

Basílica de San Pedro del Vaticano. Roma.

Fig. 2- Gian Lorenzo Bernini. Éxtasis de Santa Teresa.

Iglesia de Santa María de la Victoria. Roma.
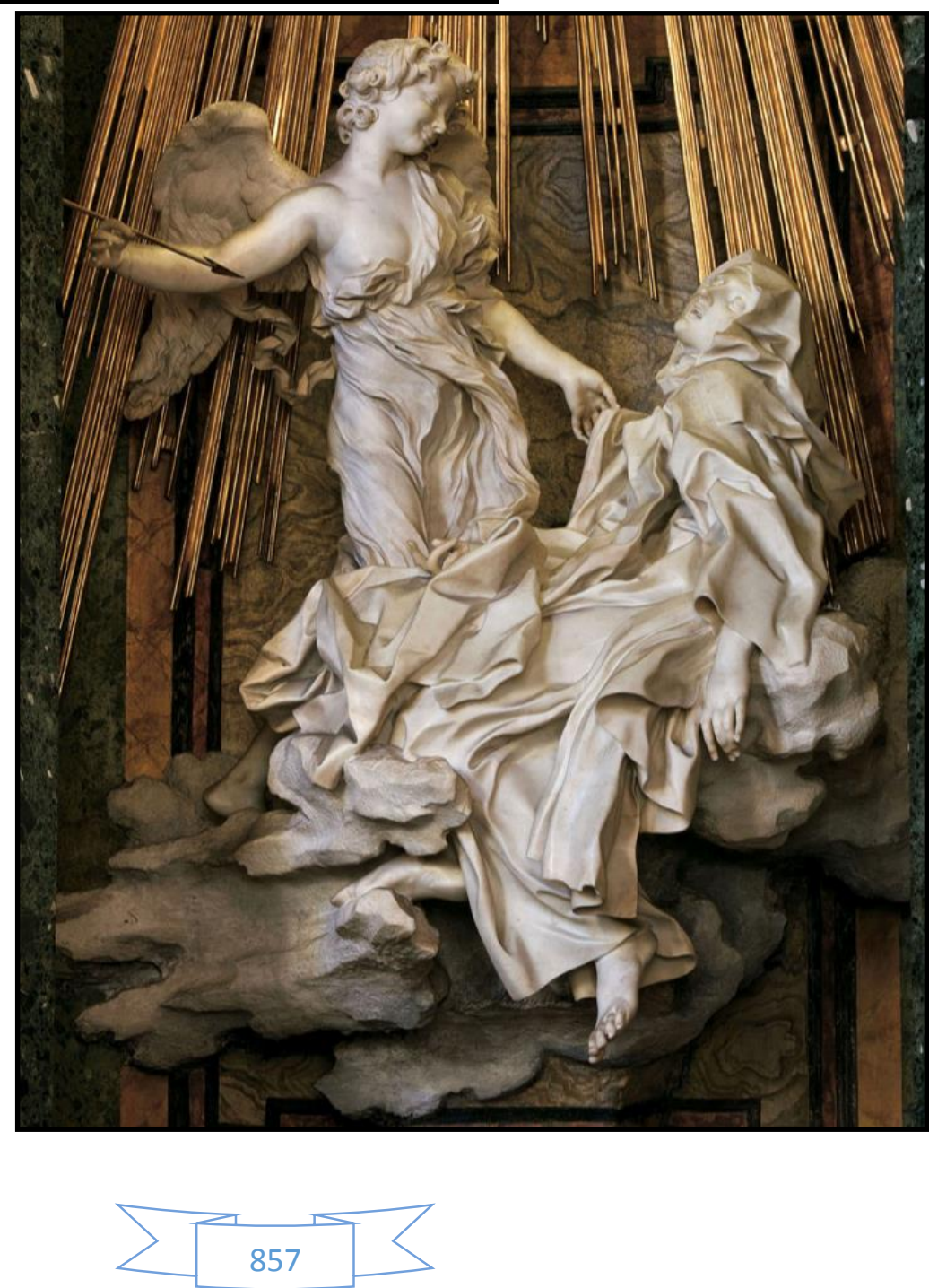


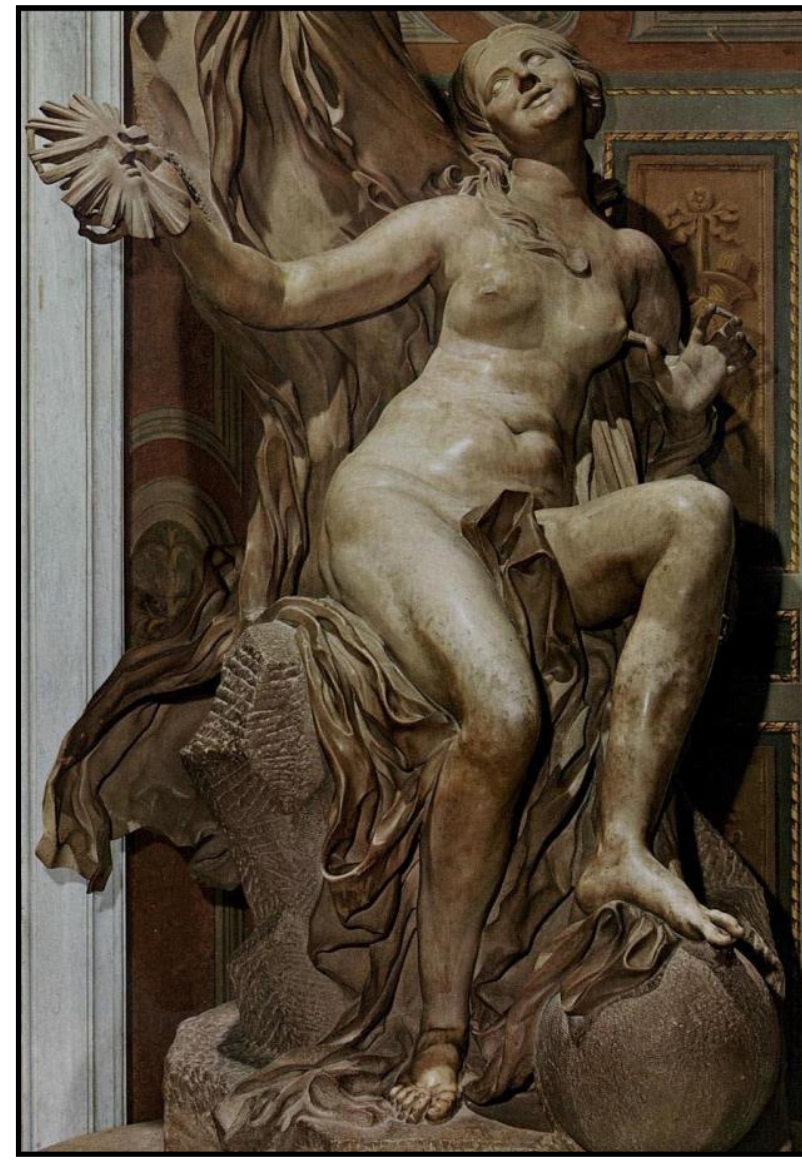

Fig. 3- Gian Lorenzo Bernini. La Verdad descubierta por el Tiempo. Galería Borghese. Roma.

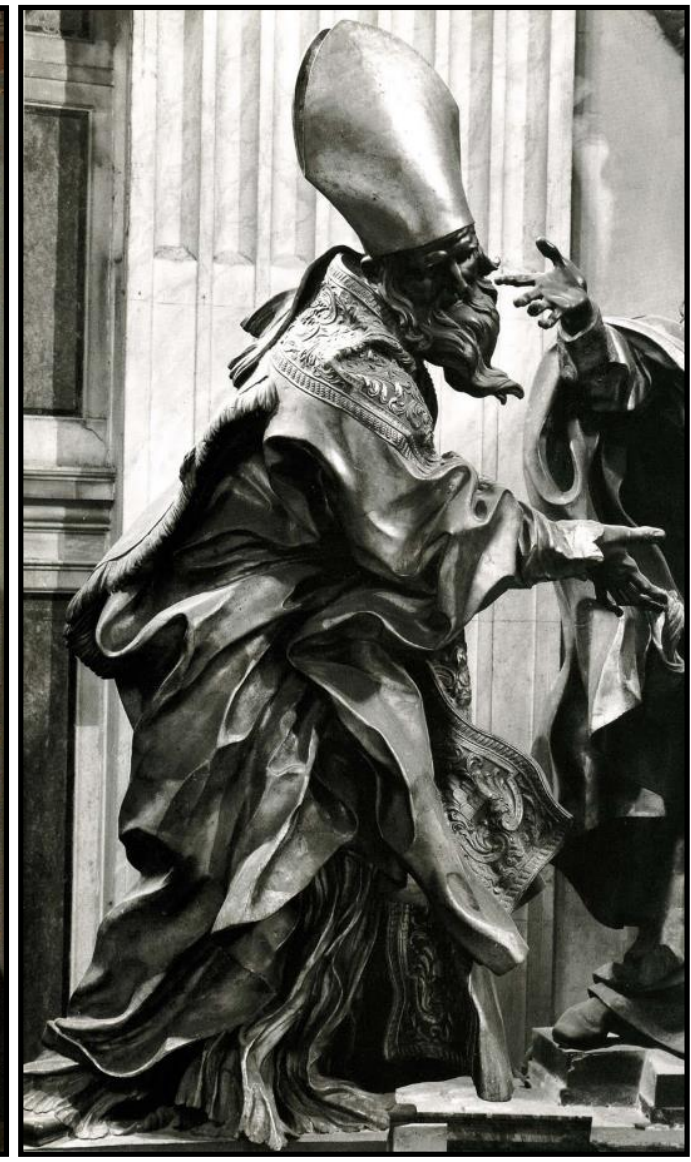

Fig. 4- Gian Lorenzo Bernini. Cátedra de San Pedro. Basílica de San Pedro del Vaticano. Roma.

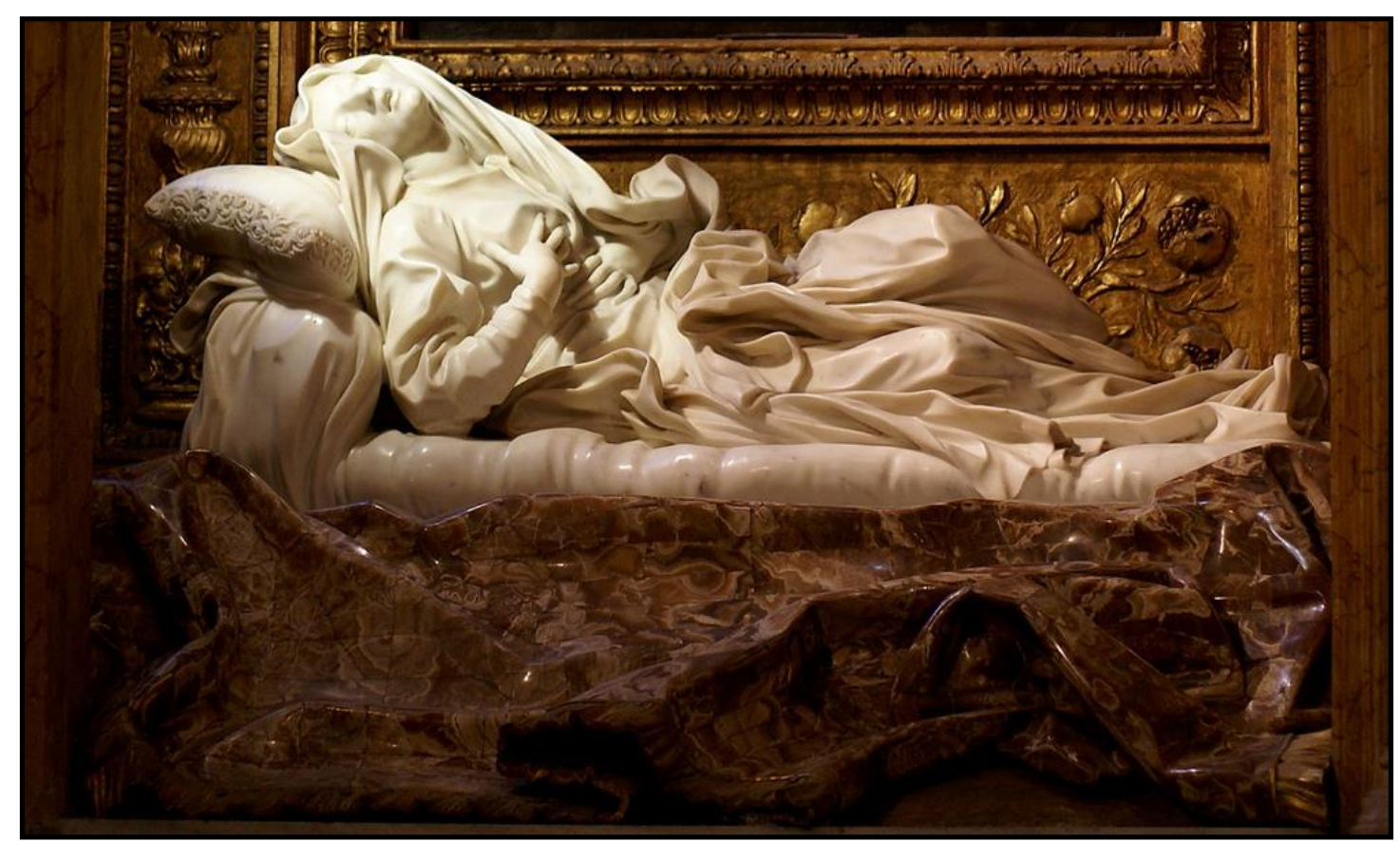

Fig. 5- Gian Lorenzo Bernini. Éxtasis de la Beata Ludovica Albertoni. Iglesia de San Francesco a Ripa. Roma.

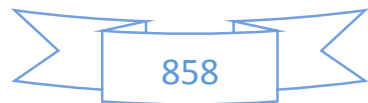




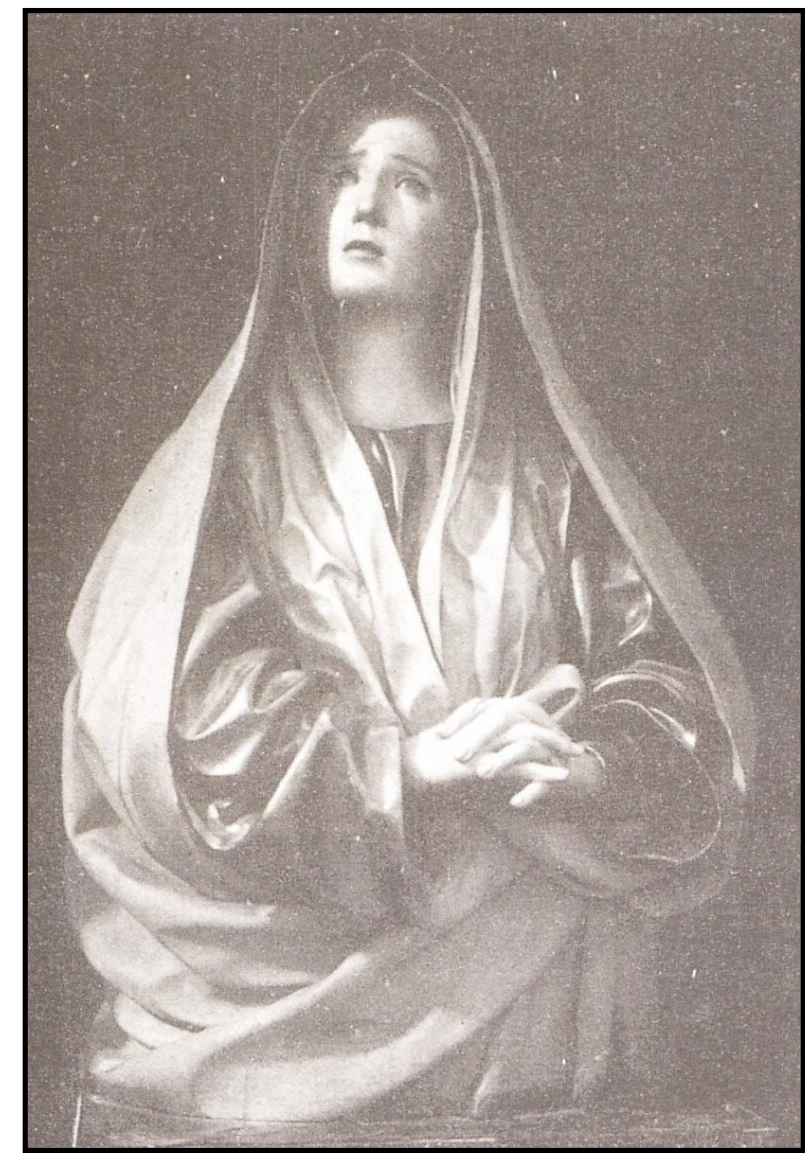

Fig. 6- Pedro de Mena. Virgen de la Contemplación. Monasterio de las Descalzas Reales. Madrid.

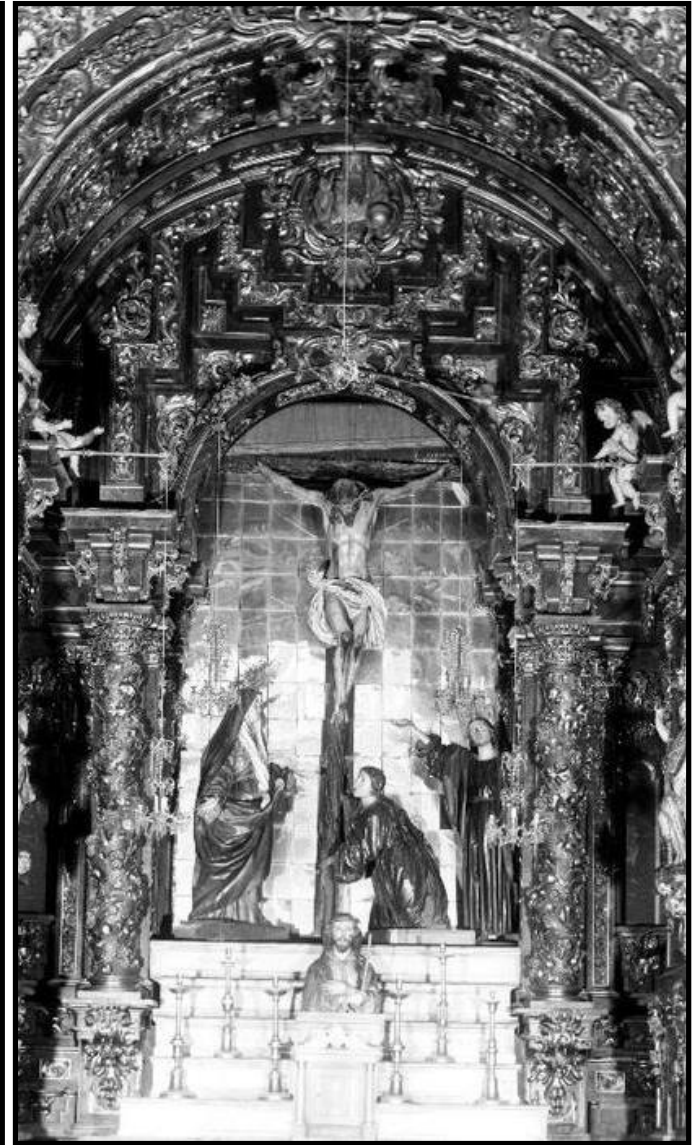

Fig. 7- Pedro de Mena. Calvario (destruido. El Crucifijo se atribuye a Juan de Mesa) Colegio Imperial. Madrid.

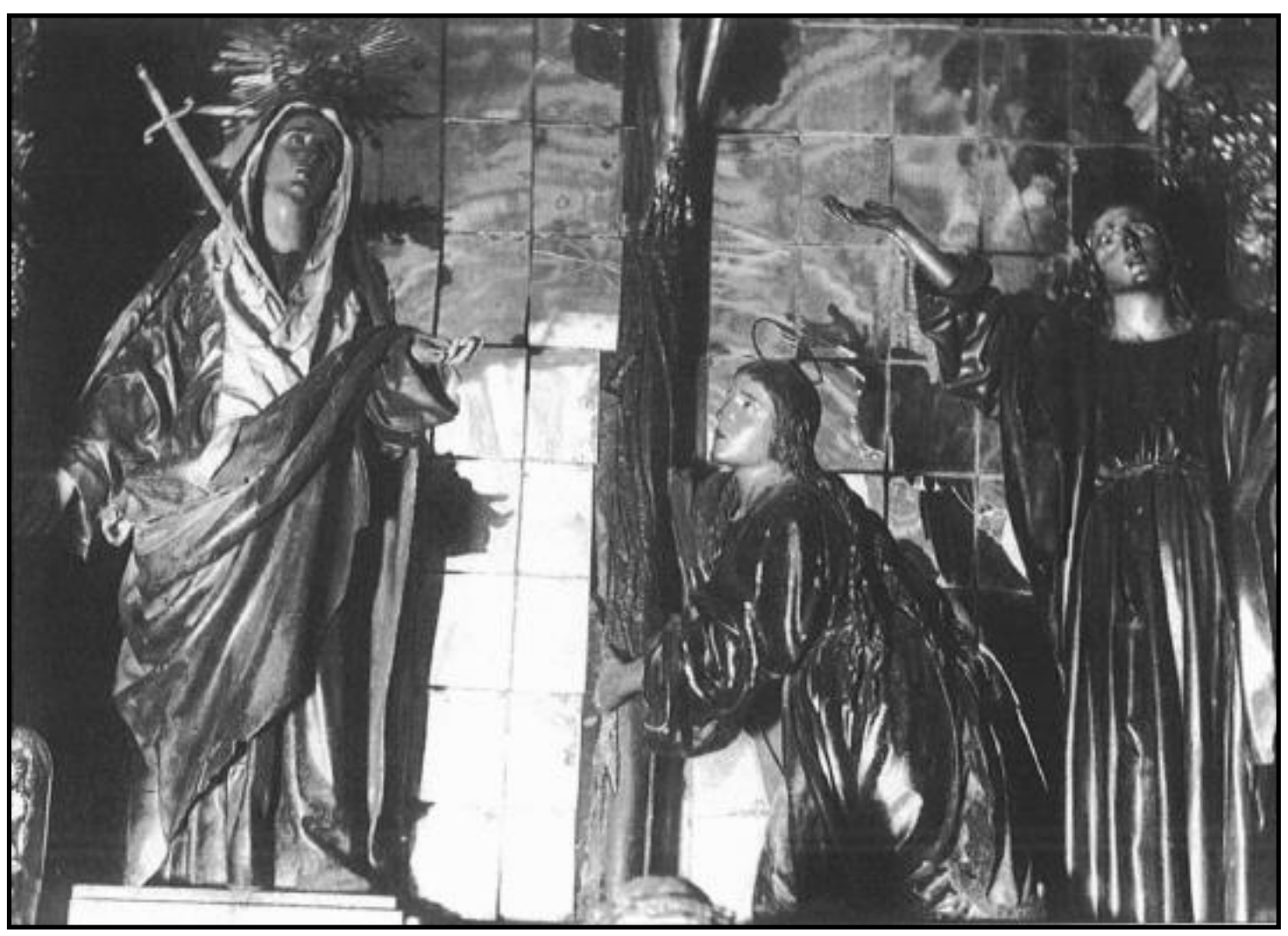

Fig. 8- Pedro de Mena. Detalle Calvario.

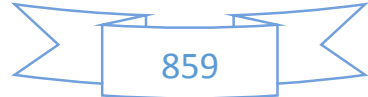



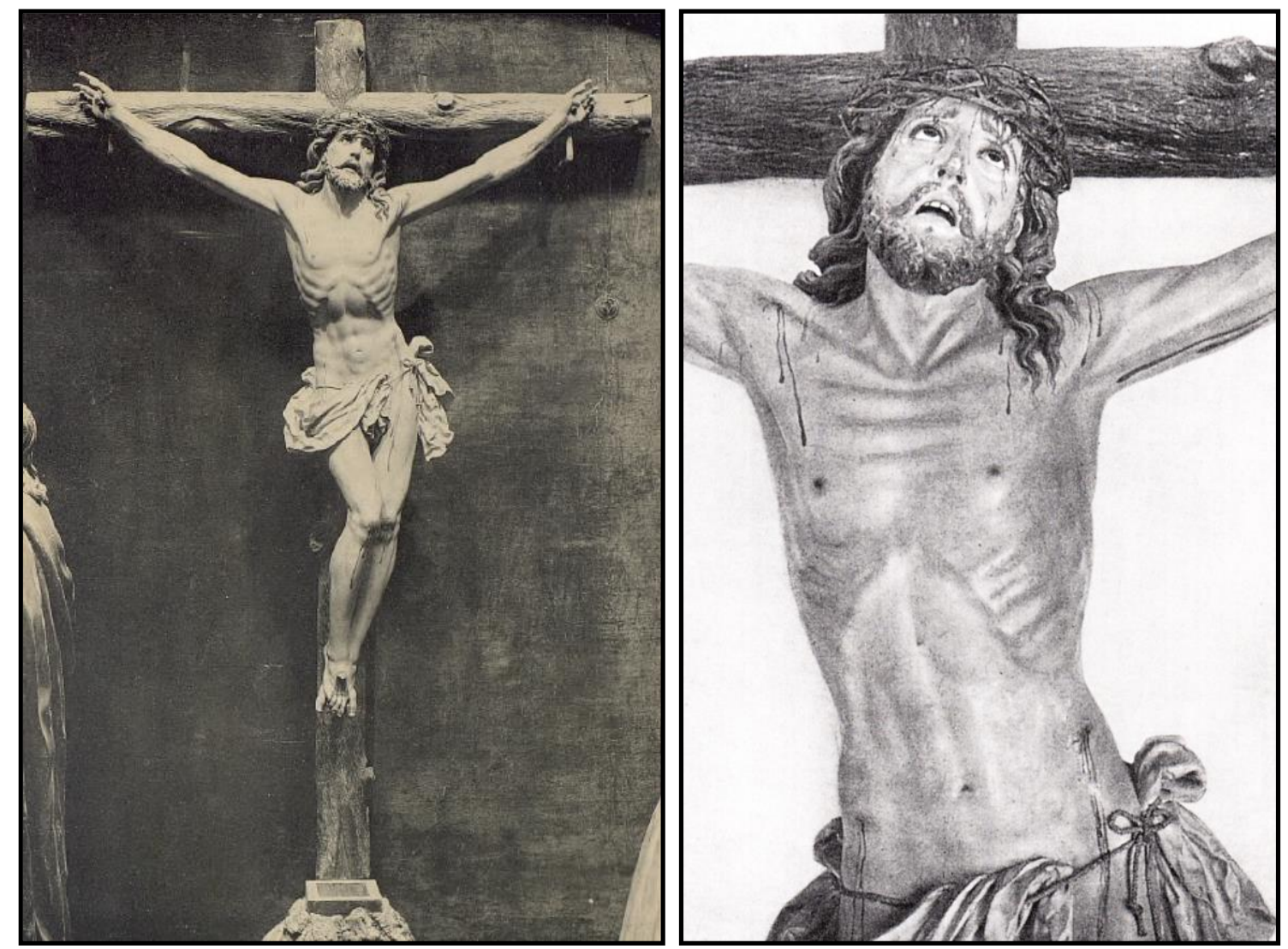

Fig. 9- Pedro de Mena. Crucifijo de la iglesia de la Virgen de Gracia (destruido) Iglesia de San Andrés. Madrid.
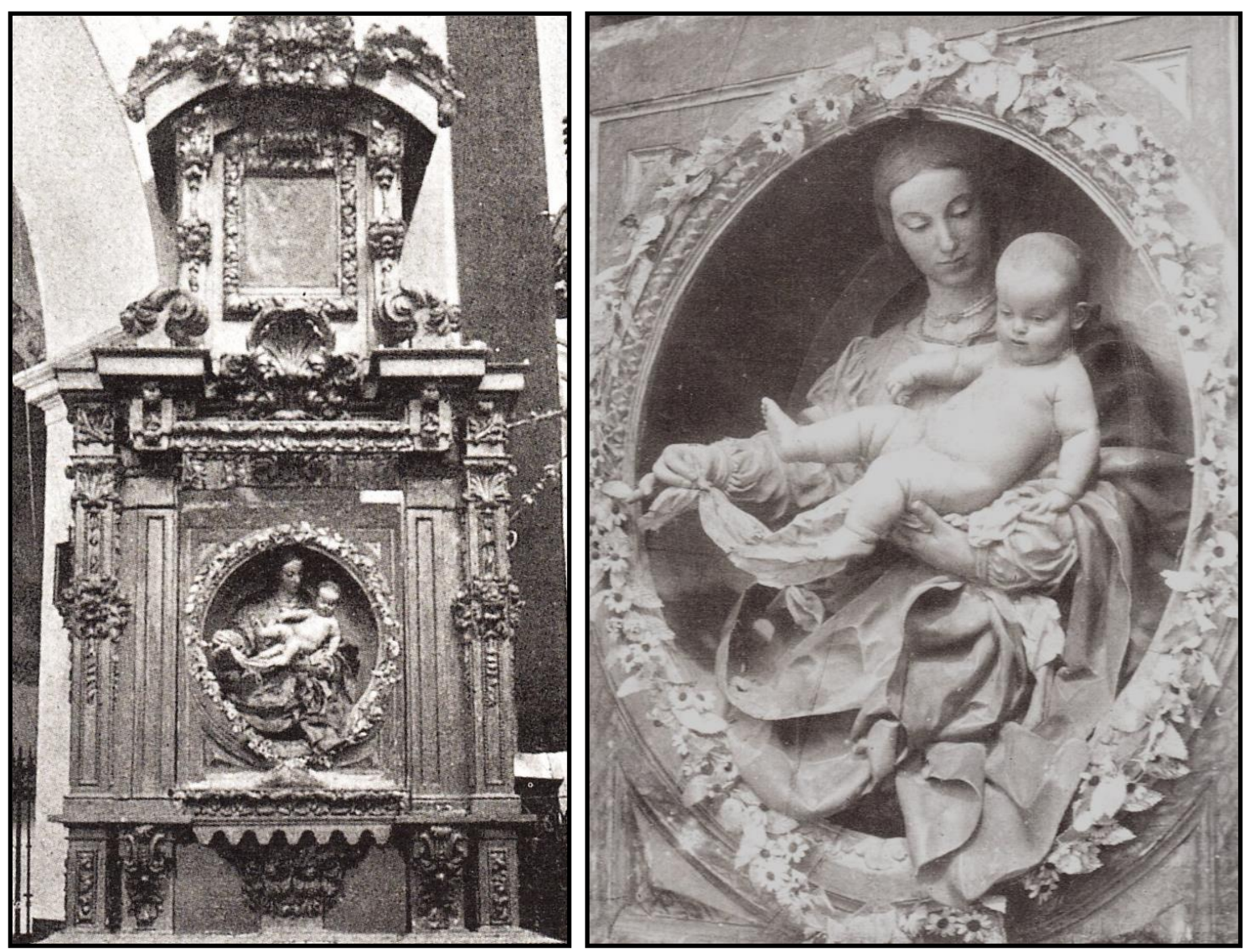

Fig. 10- Pedro de Mena. Virgen de Belén (destruida). Convento de Santo Domingo. Málaga.

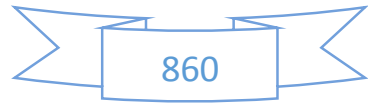




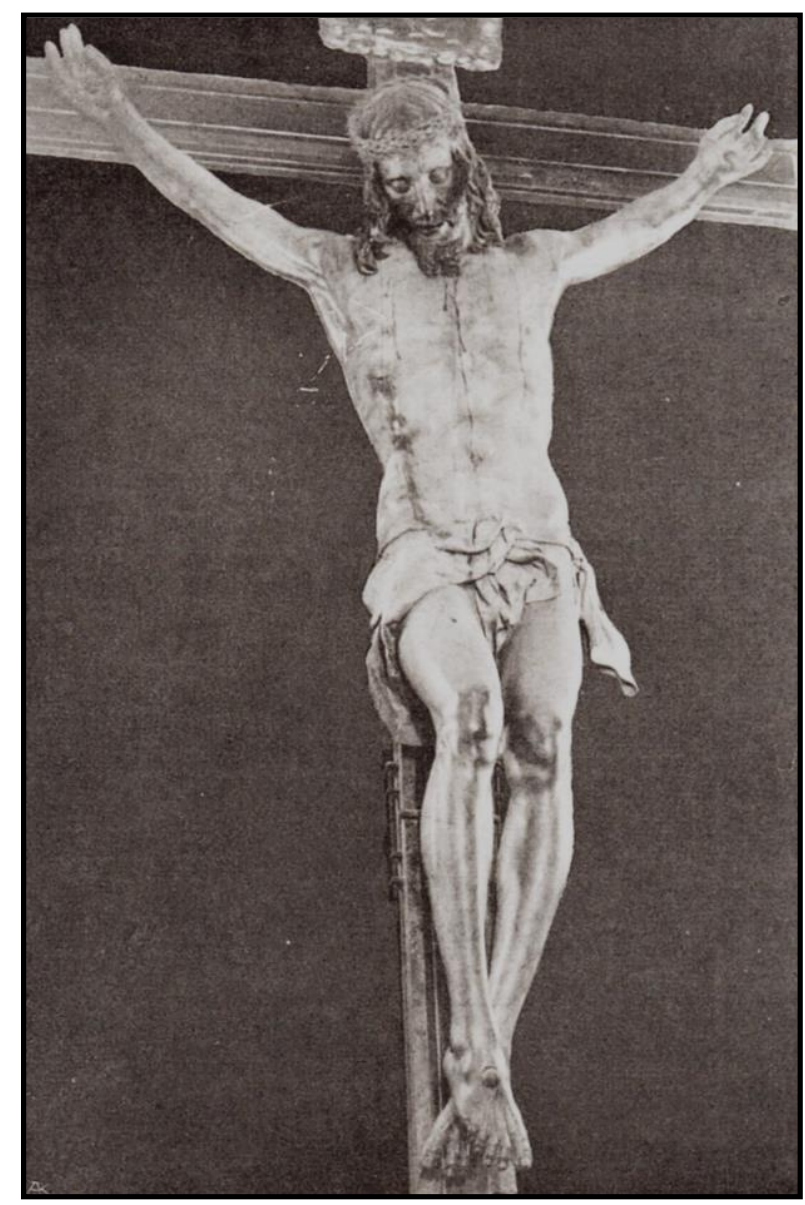

Fig. 11- Pedro de Mena. Crucificado (destruido). Convento de Santo Domingo. Málaga.

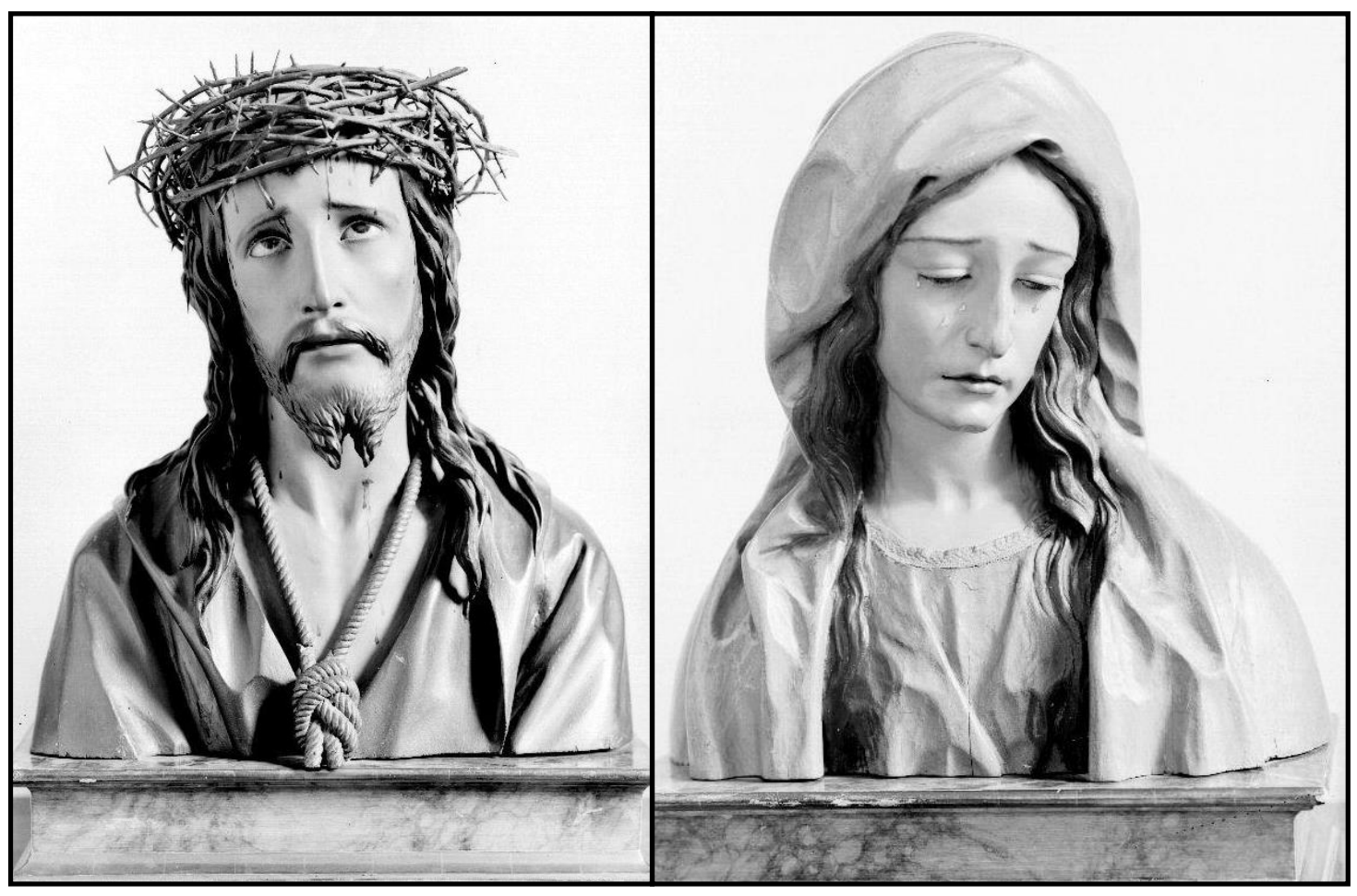

Figs. 12-13 José de Mora. Bustos de Ecce Homo y Dolorosa. Convento de las Maravillas. Madrid.

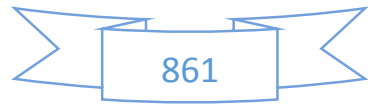




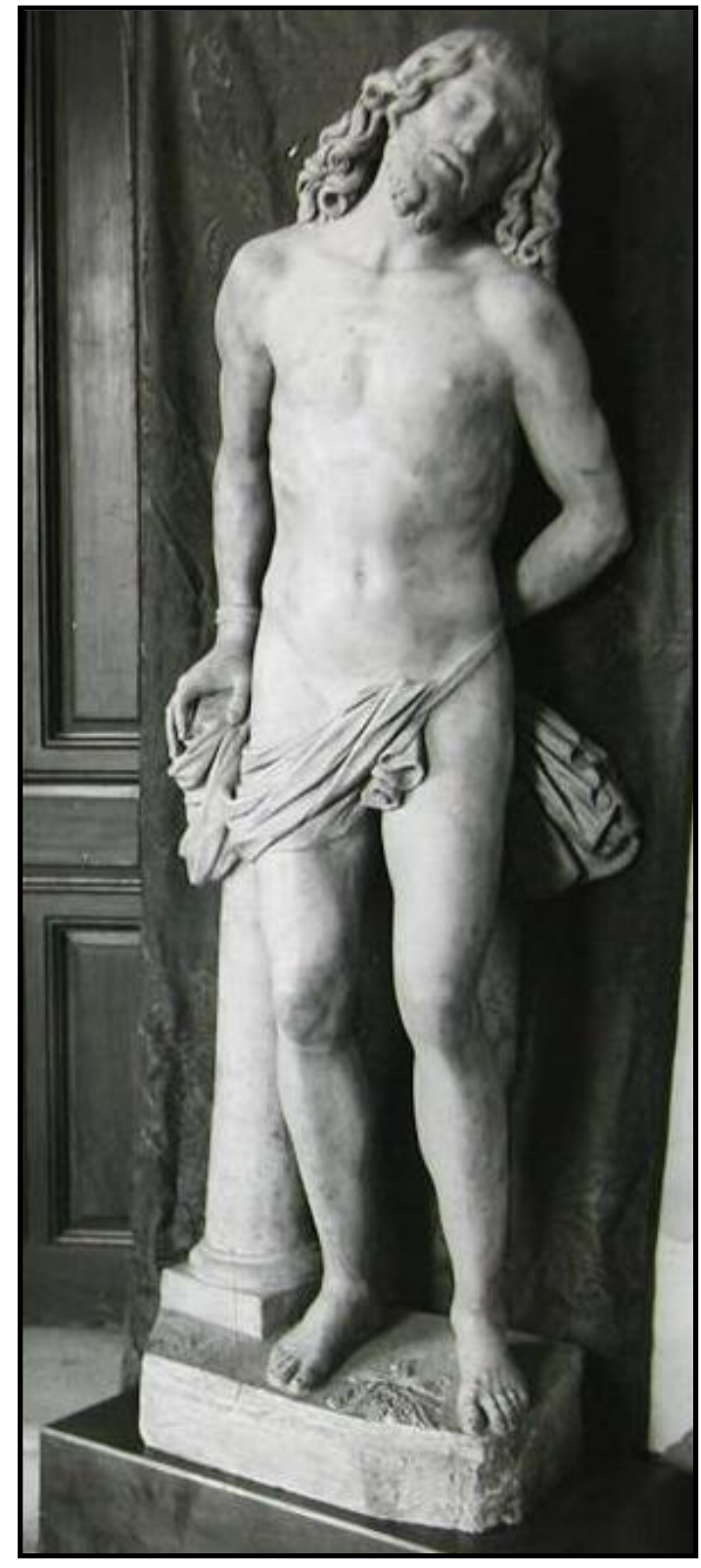

Fig. 14- Naccherino. Cristo atado a la columna. Museo Lázaro Galdiano. Madrid.

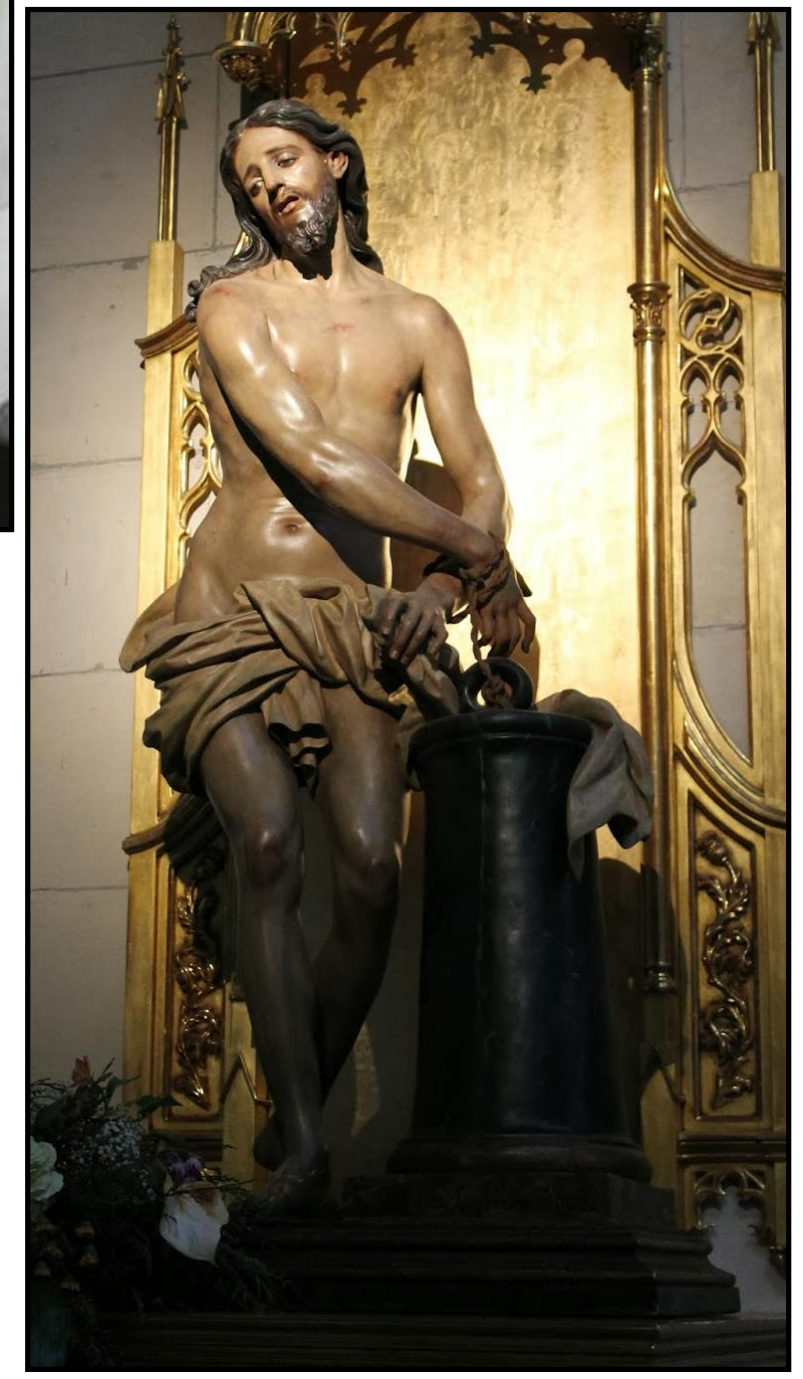

Fig. 15- Giacomo Colombo. Cristo atado a la columna. Iglesia de San Ginés (actualmente en depósito en la Catedral de la Almudena). Madrid.

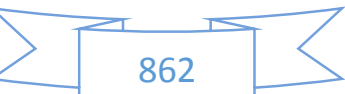




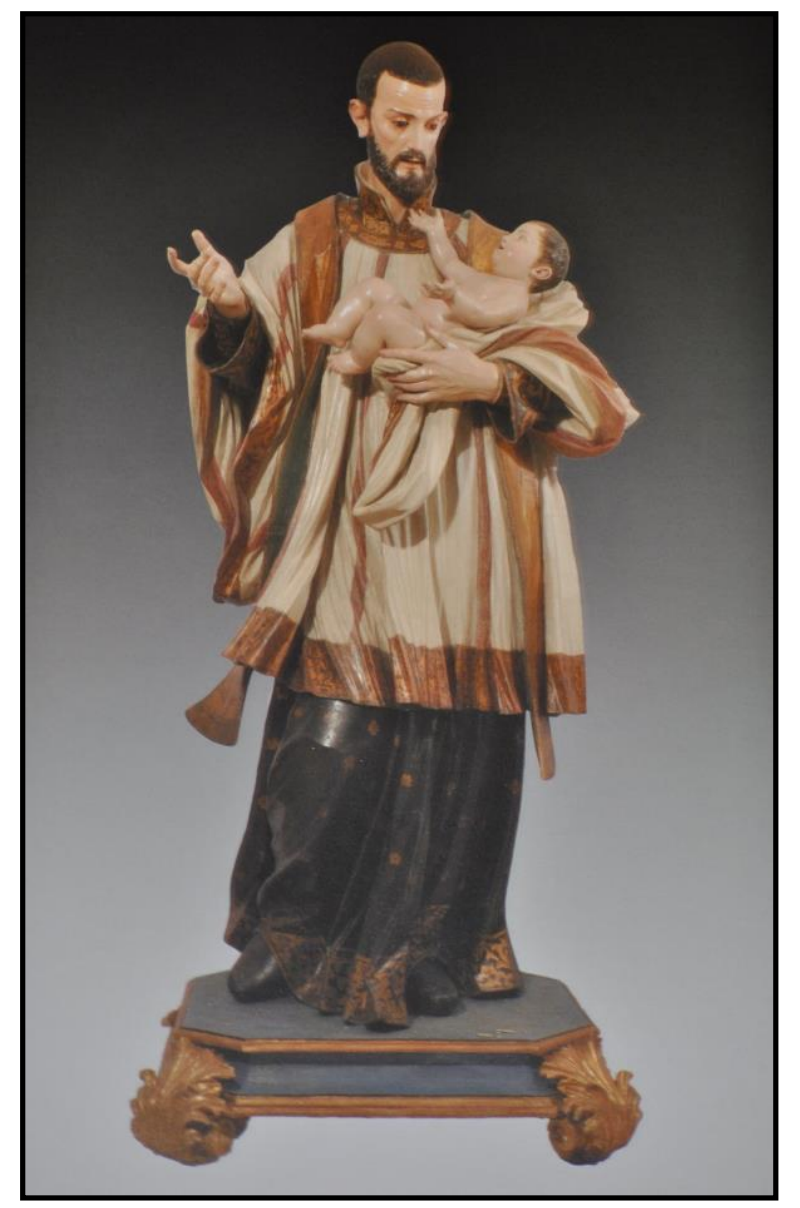

Fig. 16- Gaetano Patalano. San Cayetano. Iglesia de Santa Clara. Lecce (Apulia/Italia).

Fig. 17- Gaetano Patalano. San Francisco Javier. Iglesia de Santa Clara. Lecce (Apulia/Italia).
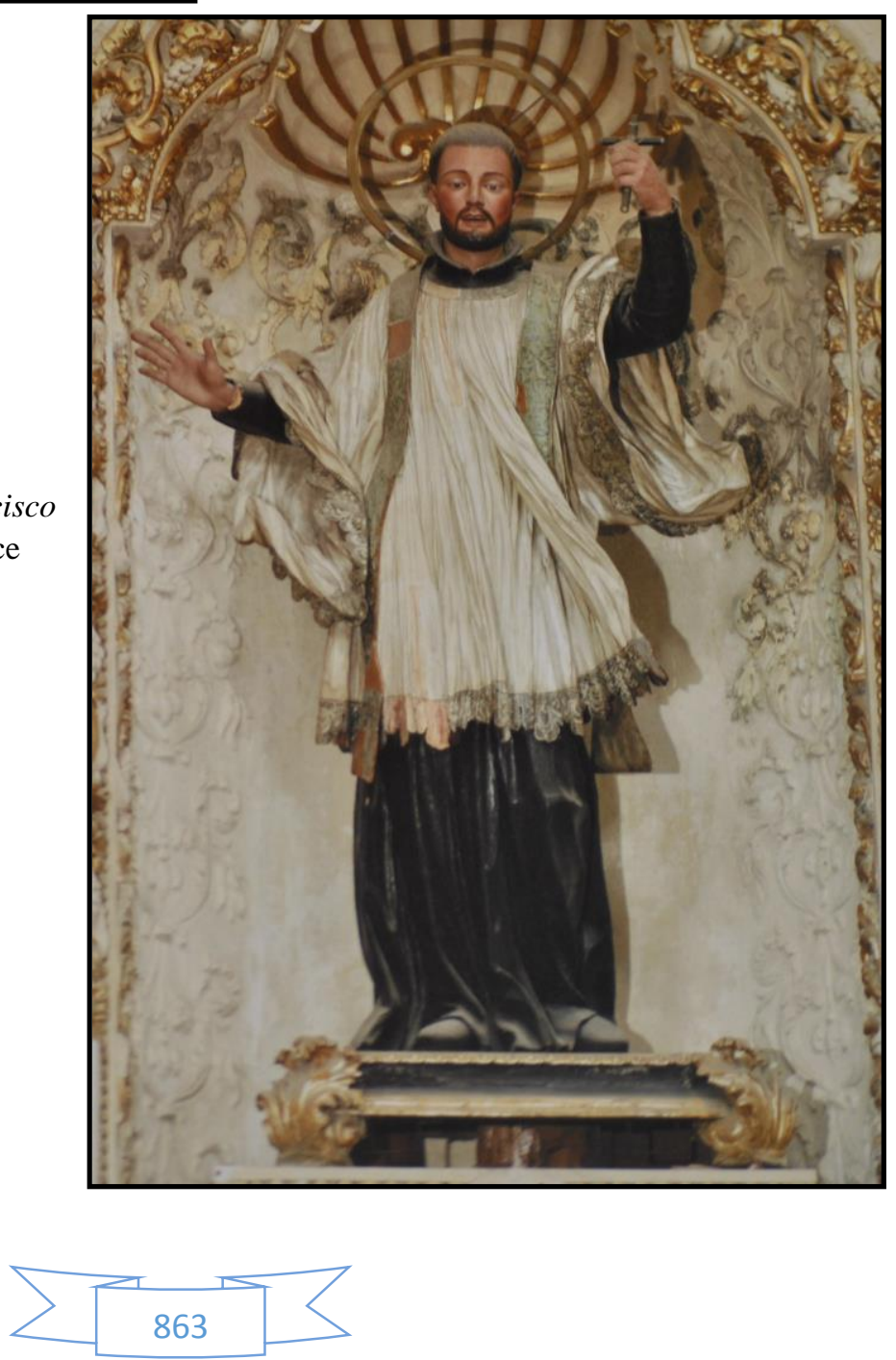


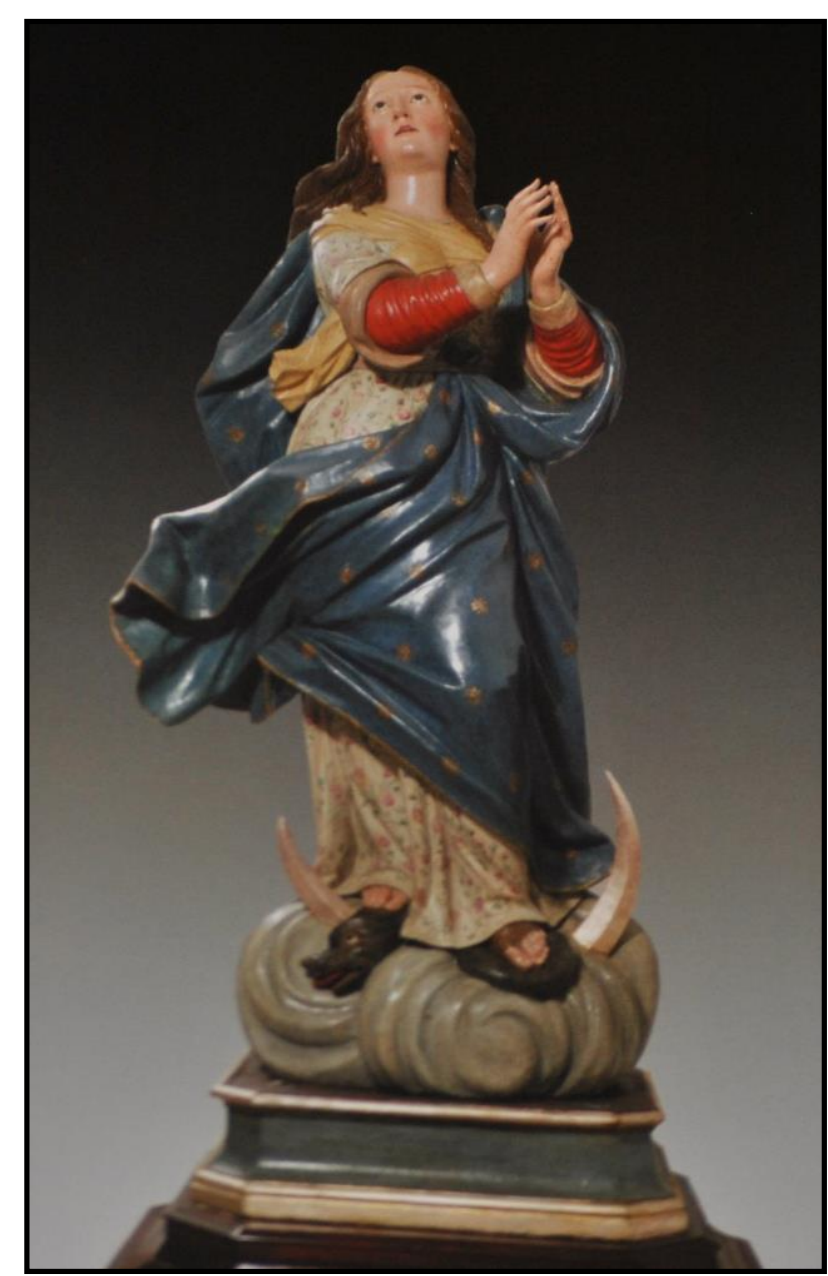

Fig. 18- Pietro Patalano. Inmaculada. Iglesia matriz. Montesano Salentino. Lecce (Apulia/Italia).

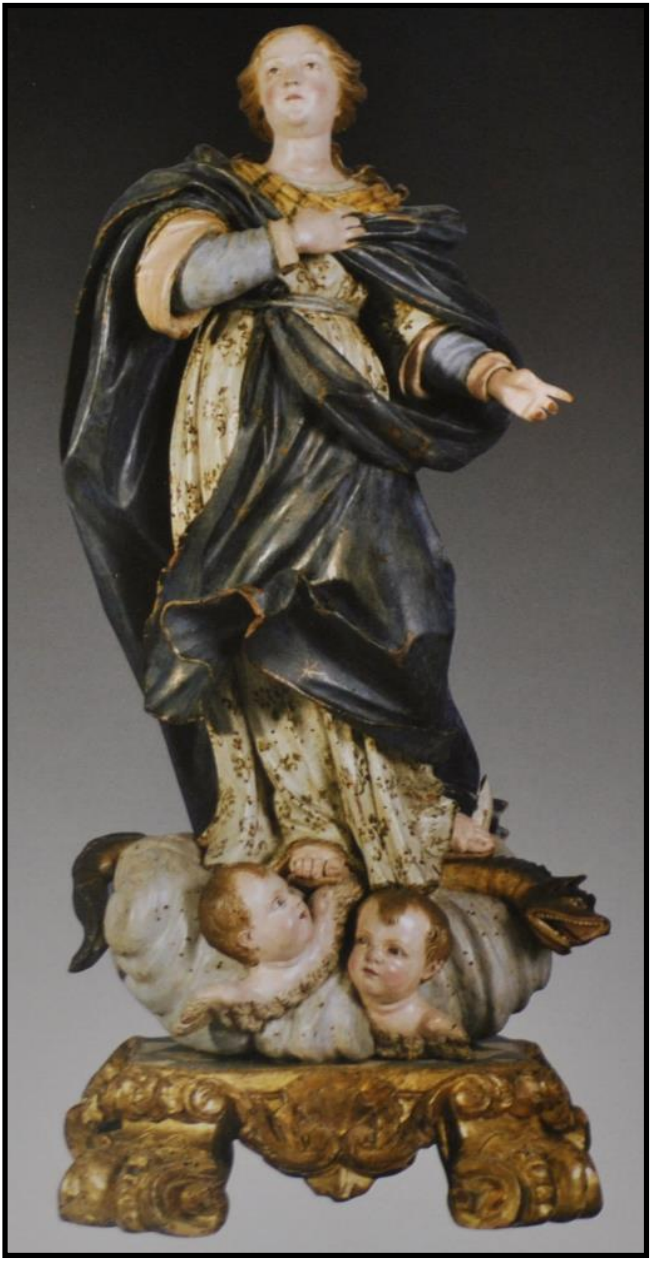

Fig. 19- Nicola Fumo (atrib.). Inmaculada. Colección privada.

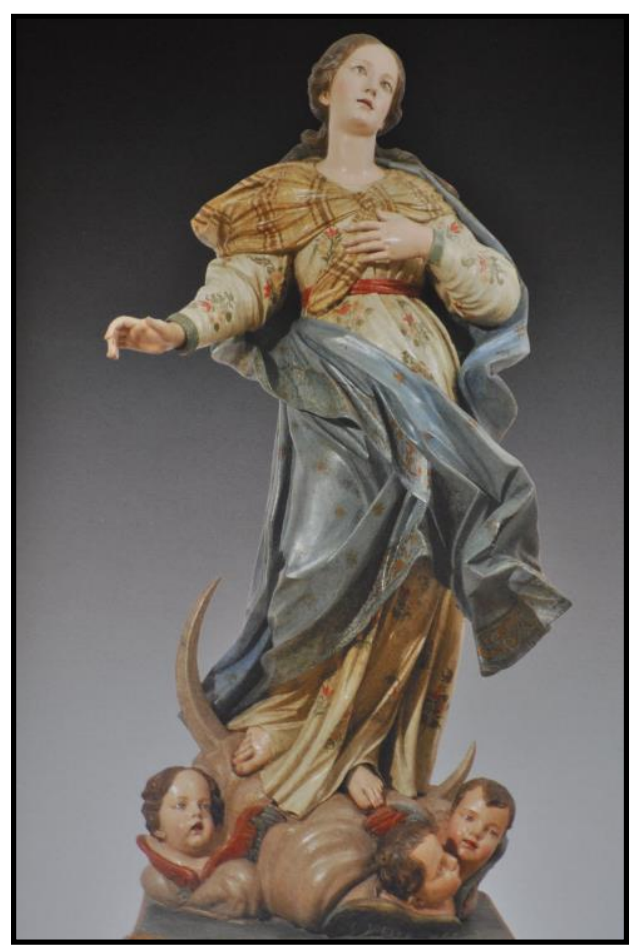

Fig. 20- Gaetano Patalano. Inmaculada. Iglesia de Santa Clara. Lecce (Apulia/Italia).

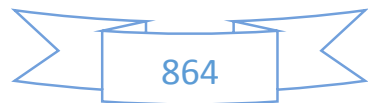




$$
\frac{\text { 9- PEDRO DE AVILA. }}{\text { CATALOGO }}
$$




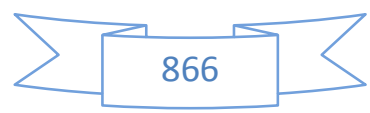


El presente capítulo lo estructuramos igual que hicimos al tratar sobre el catálogo de Juan de Ávila, puesto que también contamos con obras documentadas, otras atribuidas, algunas relacionadas e incluso algunas que procede descartar de su producción:

Obras documentadas. Son aquellas de las que tenemos constancia de su autoría ya sea porque conservamos los contratos de ejecución, por reseñas en libros de cuentas o de fábrica, etc...

Obras atribuidas. Son aquellas que sin tener constancia documental podemos adscribir al escultor mediante la mera comparación estilística con sus obras indudables. Muchas de las atribuciones que realizo son inéditas, no sé si con mayor o menor fortuna. El resto están recogidas de diferentes libros, si bien las dos fuentes principales han sido el Inventario artístico de Valladolid y su provincia (1970) ${ }^{1}$, dirigido por don Juan José Martín González, y los veintiún tomos del Catálogo Monumental de Valladolid.

Obras relacionadas. Se incluirán aquellas esculturas o conjuntos escultóricos que sin poder ser adjudicados directamente a Ávila por sus características, bien podemos decir que han salido de su taller o bien que el escultor que las ha realizado se ha basado parcial o completamente en su forma de hacer. No pueden considerarse del propio escultor pero tampoco se pueden relacionar con los estilos de otros.

Obras descatalogadas. En esta última sección se incluirán aquellas que alguna vez han sido atribuidas a nuestro escultor y que ya sea porque han salido a la luz nuevos datos que desechan tal autoría o porque no resisten una comparación con el estilo de Ávila, no pueden seguir figurando en el apartado de atribuciones.

No todas las obras serán tratadas con la misma extensión ya que hay algunas de las que carecemos por completo de dato alguno. Además, una vez que se explique la iconografía de un santo no se volverá a hacer para así evitar repeticiones reiteradas.

La ordenación de las obras sigue un criterio cronológico en el caso de las "documentadas" y "atribuidas", mientras que las "relacionadas" y "descatalogadas" he preferido colocarlas en el orden alfabético de las localidades en que están situadas.

1 MARTÍN GONZÁLEZ, Juan José (dir.): Inventario artístico de Valladolid..., op. cit. 


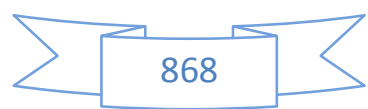


9-1 OBRAS DOCUMENTADAS 


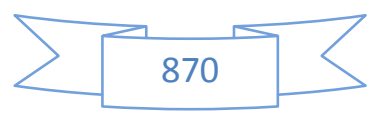




\section{VALLADOLID. IGLESIA DE SAN MARTÍN}

\section{DOS ESCULTURAS DE “NIÑOS” (1699)}

Las primeras obras que tenemos documentadas de Pedro de Ávila no corresponden a trabajos contratados de forma autónoma sino mandados realizar por su suegro, que es quien en realidad los había concertado. Sabemos de la existencia de esta breve serie de obras gracias a la carta de pago de dote otorgada por Ávila a su suegro en el año 1702. La que ahora nos ocupa figura en el referido documentado citada como "cien reales por dos niños para la parroquia de San Martín”. (DOCUMENTO 59).

La descripción es tan vaga y somera que no sabemos a ciencia cierta si se trataba de dos Niños Jesús o bien de angelotes; sea como fuere parecen haber desaparecido. Si aceptamos que eran ángeles lo más probable es que tuvieran como destino un retablo de dicha parroquia para el cual su suegro, casualmente, estaba realizando la parte escultórica del mismo. Se trataba del retablo de la capilla de don Gaspar de Vallejo. Esta máquina salomónica, contratada en 1699, por el ensamblador vallisoletano Alonso del Manzano, contendría en sus hornacinas una serie de esculturas talladas por De la Peña: Santo Toribio de Mogrovejo, San Juan de Sahagún, Santo Tomás de Villanueva y un relieve del Martirio de San Bartolomé $e^{2}$ De aquel retablo tan solo han llegado a nuestros días la imagen de San Juan de Sahagún y el relieve de San Bartolomé, éste último pintado, en época neoclásica, de blanco a imitación del mármol. Quizás los niños tallados por Ávila sirvieran de acompañamiento a alguno de estos santos, puesto que en sus hagiografías hay capítulos relacionados con ellos, o bien fueran angelotes distribuidos por alguna parte del retablo.

Si aceptamos esta teoría, tendríamos que retrasar algo la cronología que actualmente se viene otorgando a esta serie de piezas fechadas en 1702 por ser esa la fecha de la carta de pago de dote. Por la tanto la cronología correcta sería el año 1699, que es cuando De la Peña se encuentra laborando en las hechuras del referido retablo. Además, la aceptación de esta tesis supondría tener que aceptar la desaparición tanto de las esculturas de los santos, obra de De la Peña, como la de los "niños" tallados por Ávila, con la excepción de las dos referidas. Tampoco podemos descartar en ningún caso, salvo en aquellos en los que esté confirmada la destrucción de las imágenes, el hecho de que se puedan haber enviado a otras instituciones religiosas, parroquiales rurales, museos y hasta colecciones privadas.

En la actualidad, en la iglesia tan solo se conservan dos esculturas de niños ángeles y un Niño Jesús que porta un San Antonio de Padua. Ni los primeros, pertenecientes a un retablo rococó dedicado a Santo Tomás de Villanueva, aunque actualmente presidido por el Santo Ángel de la Guarda; ni el Niño que porta el santo pueden ser relacionados con los que estamos hablando por el mero hecho de que todos ellos parecen pertenecer a la segunda mitad del siglo XVIII.

2 MARTÍN GONZÁLEZ, Juan José y URREA FERNÁNDEZ, Jesús; Catálogo Monumental de la provincia de Valladolid. Tomo XIV..., op. cit., p. 101. 
Además, cabría otra hipótesis, bastante improbable. Pudiera ser que estos dos "niños" estuvieran relacionados con una Virgen de la Asunción que existió en una de las capillas del lado de la Epístola ${ }^{3}$, y que desapareció en la década de 1960 tras el hundimiento del techo de la iglesia. En fotografías antiguas apreciamos que la Virgen, del tercer cuarto del siglo XVII y de autoría desconocida ${ }^{4}$, estaba rodeada de seis ángeles niños, tres a cada lado. Los dos superiores parecen ser algo diferentes al resto: pudiera ser que con el tiempo dos de ellos se estropearan y se decidiera encargarle la realización de dos nuevos a De la Peña; el cual, agobiado por su crecido trabajo en la parroquia, decidió delegar en nuestro Ávila.

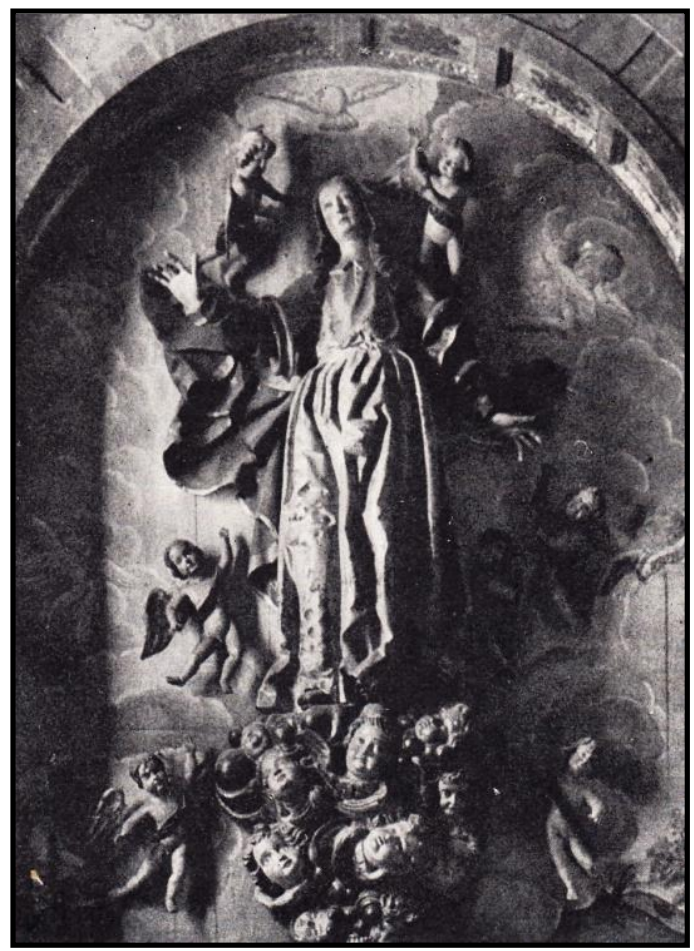

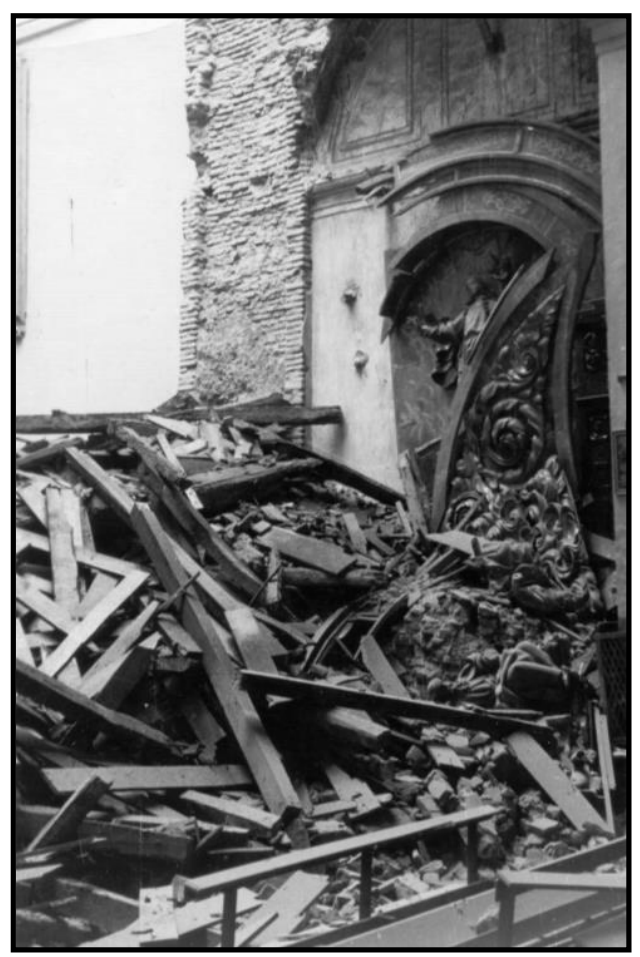

Il. 2- Situación de la Asunción tras el derrumbe del techo de la iglesia.

Il. 1- Anónimo. Virgen de la Asunción

(desaparecida). Iglesia de San Martín.

Valladolid.

\footnotetext{
3 Según refiere Manuel Canesi, esa capilla debía de pertenecer a don Gaspar de Uriarte, procurador de la Real Chancillería de Valladolid; el cual, además, había fabricado a su costa la escultura de la Asunción "También hay en la iglesia un retablo y en él colocada la imagen de Nuestra Señora de la Asunción, fabricado a costa de Gaspar de Uriarte, procurador de la Real Chancillería, y en él fundó algunas memorias y capellanías y dejó el patronato a una de las salas de lo civil de ella y se doró este retablo año de 1744”. CANESI ACEVEDO, Manuel: Historia de Valladolid (1750), Tomo I, op. cit., p. 404.

$4 \quad$ Martín González se la atribuyó al ensamblador Pedro de Cea, creyendo que este maestro pudo ejercer también labores de escultor, extremo que en la actualidad está totalmente descartado. También apunta a una similitud con la Asunción que Alonso de Rozas esculpió para el desaparecido retablo del Monasterio de Santa Clara de Medina de Rioseco. MARTÍN GONZÁLEZ, Juan José: Escultura barroca castellana..., op. cit., p. 292.
}

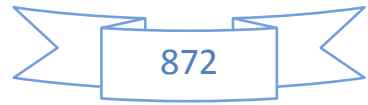




\section{VALLADOLID. REAL COLEGIO DE SAN ALBANO}

\section{VIRGEN DE LA PIEDAD “NUESTRA SEÑORA DE LA PASIÓN” (1702)}

El conocimiento de esta obra también nos viene dado por la carta de pago de dote que otorga nuestro escultor a su suegro Juan Antonio de la Peña el 9 de diciembre de $1702^{5}$ (DOCUMENTO 59). En el citado documento se hace referencia a que Ávila percibió de su suegro, en cuyo taller trabajaría como oficial, "trescientos y cincuenta reales por la hechura de una imagen de Nuestra Señora de la Pasión para el Colegio de San Albano de la compañía de Jesús de esta dicha ciudad". Aunque la referida carta de pago de dote fue descubierta en 1941 por García Chico, no fue hasta la redacción del Tomo XV del Catálogo Monumental de Valladolid ${ }^{6}$, que corrió a cargo de Martín González y Plaza Santiago, cuando se identificó esta Piedad con la que alude aquel documento ${ }^{7}$. De hecho, cuando Martín González redacta el Inventario artístico de Valladolid y su provincia aún no había caído en la cuenta de este hecho, por cuanto define esta imagen como "escultura de la Piedad, fines siglo XVII, tal vez de Juan de Ávila". En 2006 esta Piedad formó parte de una de las muestras que se vienen realizando en las salas municipales de exposiciones con motivo de la Semana Santa, concretamente en la titulada "Dolor y Gloria"; Julio César García Rodríguez se ocupó de redactar su fícha para el catálogo 9 .

Aunque tanto en el citado documento como en los libros de registro del Colegio figura como "Nuestra Señora de la Pasión" en realidad se trata de una Virgen de la Piedad. Señala Manuel Trens que la Piedad representa a la Virgen dolorosa (Virgen de la Pasión) después de la Crucifixión de Jesucristo. Es el momento en el que una vez se ha consumado la muerte de Jesús, su madre se reúne con él y lo recoge en sus brazos. Es un momento de soledad puesto que "es un momento de trágica dispersión (...) desaparecen los personajes históricos (...). La Virgen, pues, se quedó sola, víctima de su grandeza y sumergida en su dolor, entregada exclusivamente a la piadosa contemplación de sus devotos" ${ }^{\prime 10}$. La Piedad viene a ser una representación en la que se ensalza el papel dual de la Virgen como Madre y como Redentora de la humanidad. A veces se ha pensado que esta iconografía es una simplificación del "Llanto sobre Cristo muerto", si bien para Réau "la Virgen de la Piedad deriva más bien del tipo tradicional de la Virgen sentada, por simple sustitución del Niño Jesús por el Crucificado"11.

La representación de la Virgen de la Piedad hunde sus raíces en la Alemania medieval, concretamente entre los siglos XIII-XIV. Allí se la denomina Vesperbild, que significa

5 GARCÍA CHICO, Esteban: Documentos para el estudio del arte en Castilla. 2..., op. cit., pp. 369-371.

6 Ibídem.

7 MARTÍN GONZÁLEZ, Juan José y DE LA PLAZA SANTIAGO, Francisco Javier: Catálogo Monumental de la provincia de Valladolid. Tomo XV..., op. cit., p. 273.

$8 \quad$ MARTÍN GONZÁLEZ, Juan José (dir.): Inventario artístico de Valladolid..., op. cit., p. 40.

9 GARCÍA RODRÍGUEZ, Julio Cesar: "Piedad". En ÁLVAREZ VICENTE, Andrés y GARCÍA RODRÍGUEZ, Julio César: Dolor y Gloria, Ayuntamiento de Valladolid, Valladolid, 2006, p. 52.

10 TRENS, Manuel: op. cit., p. 204.

11 RÉAU, Louis: Iconografía de la Biblia. Nuevo..., op. cit., p. 111. 
“imagen vesperal”, según Trens debido a que "fue el viernes por la tarde cuando María recibió en sus brazos a su Hijo desclavado de la cruz" "12. Este pasaje no figura en los Evangelios sino que es una más de las creaciones de la mística medieval, como lo fueron la Virgen de la Misericordia o el Varón de Dolores. Esta temática en concreto, "realista y visionaria a la vez", surge a raíz de las Meditaciones del Pseudo Buenaventura, de las Efusiones del beato dominico Enrique Susón (Heinrich Seuse) y, como no, de las Revelaciones de Santa Brígida ${ }^{13}$. En todas ellas se refería a que la Virgen tenía sobre sus rodillas a Cristo muerto. Susón en su Minnebüchlein (atribuido) describe a Cristo en ese instante con "sus ojos, que brillaban como carbunclos, ahora están apagados. Sus labios, que parecían rosas rojas recién abiertas, están secos y su lengua pegada al paladar. Su cuerpo sangrante ha sido tan cruelmente estirado sobre la cruz que pueden contarse todos sus huesos". Por su parte, Santa Brígida relata este momento según las palabras que, según ella, le había dictado la Virgen: "Lo recibí sobre mis rodillas como un leproso, lívido y magullado, porque sus ojos estaban muertos y llenos de sangre, su boca fría como la nieve, su barba rígida como una cuerda"14.

Las primeras representaciones de Piedad proceden de Alemania, concretamente de los "conventos de monjas místicas del valle del Rin", algo muy lógico dado que se trata de un "tema tan femenino y maternal". Ya con posterioridad, el tema se extendió por toda Francia gracias a las cofradías de Nuestra Señora de la Piedad que "encargaron grupos para la decoración de sus capillas" "15. Los primeros ejemplos escultóricos se fechan en 1320, siendo por lo tanto "muy anteriores a las Visiones del Pseudo Buenaventura y de Santa Brígida (1303-1373)"16. Las más antiguas conservadas son una localizada en Coburgo (h. 1330) y otra en el Convento de las Ursulinas de Erfurt (h. 1340) ${ }^{17}$. Señala Réau dos maneras de disponer el cuerpo muerto de Cristo sobre las piernas de su madre: "A veces el cadáver está dispuesto horizontalmente, como el cuerpo de un nadador que flota de espaldas, con la herida del costado bien visible; otras, por el contrario, se presenta oblicuamente, en diagonal, apoyando los pies magullados en el suelo"18.

En Valladolid, la primera representación de la Virgen de la Piedad hace su acto de aparición en el Monasterio de San Benito el Real, concretamente en la capilla que poseía en el claustro (actual capilla de los Condes de Fuensaldaña) don Sancho de Rojas, obispo de Palencia. La escultura, actualmente conservada en el Museo Nacional de Escultura, era propiedad del rey Juan II de Castilla, el cual accedió a la petición del prelado palentino para que se la entregara. El grupo, realizado en piedra policromada, no es obra autóctona sino que procede de Centroeuropa, en alguno de cuyos talleres fue esculpida entre $1406-1415^{19}$. A partir de entonces las representaciones de la Piedad se

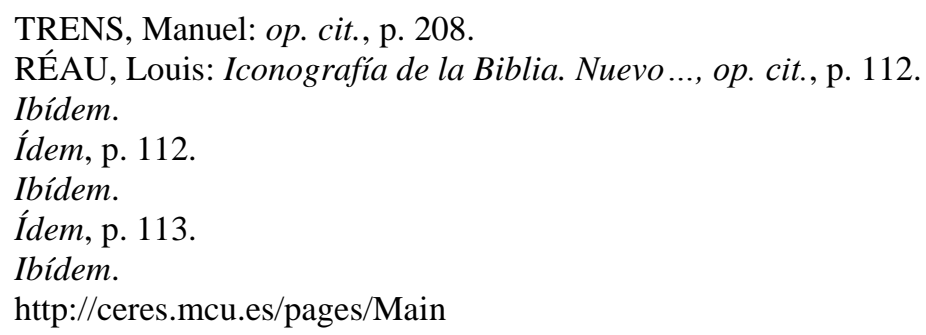


multiplicaron, siendo la obra sobre la que tratamos una de las piezas señeras del barroco vallisoletano, a pesar de su escaso conocimiento. Cabe señalar que en cuanto a la Virgen de la Pasión, la más conocida y difundida fue la titular de la Cofradía Penitencial de la Sagrada Pasión de Cristo, una pequeña talla de mediados del siglo XVI atribuida por Parrado del Olmo a Francisco Giralte con la que comparte composición la tallada por Pedro de Ávila ${ }^{20}$.

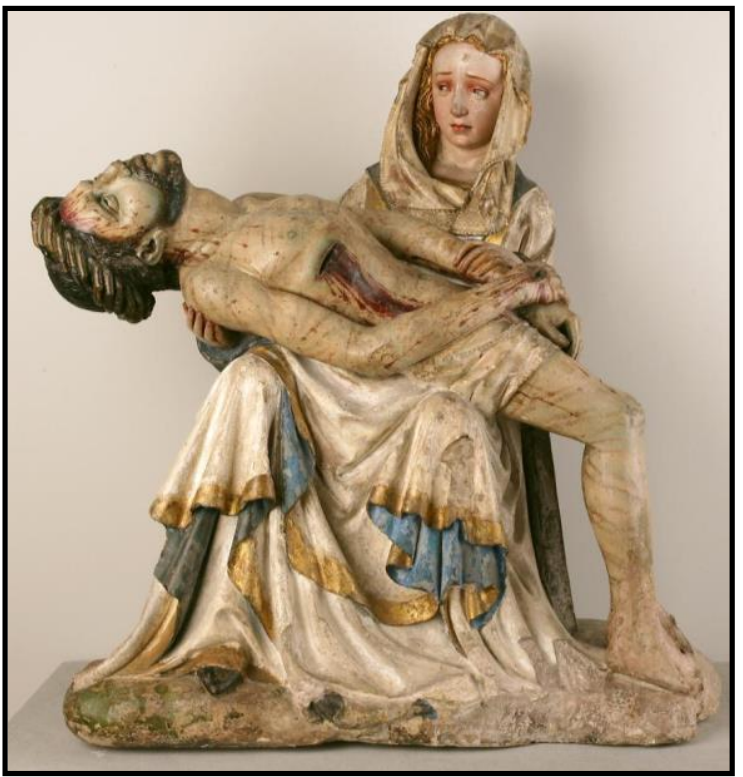

Il. 3- Anónimo alemán. Piedad. Museo Nacional de

Escultura. Valladolid. (C) Museo Nacional de Escultura.
La Piedad (138 cms.) (Figs. 1-4) del Colegio de los Ingleses se encuentra instalada en la primera capilla, contando desde la puerta de entrada a la iglesia, del lado de la Epístola. El retablo es muy sencillo, casi idéntico al frontero, que es en el que ya vimos que estaba expuesto un Calvario que se atribuye a Juan de Ávila. Tan solo difieren en que aquél tenía unas hornacinas laterales levemente insinuadas, mientras que éste no las posee, sino que han sido sustituidas por una serie de festones de frutas. En el ático figura un anagrama, del cual pende un corazón, en extremo similar al que campea en el ático del retablo de la Sagrada Familia de la Virgen: las letras A/M (Ave María)

superpuestas. No en vano son los dos retablos en los que predomina la temática mariana; pues, aunque la Virgen figure también en el Calvario y en la Sagrada Familia, no es el elemento central de la devoción. El grupo de la Piedad, que descansa sobre una rica peana con motivos vegetales (indicio que nos puede indicar su probable función procesional), se haya inclusa en la hornacina centra del retablo, que adopta la forma de una amplia caja cuadrada con un leve resalte en el centro de la parte superior.

Lo primero que llama la atención al analizar el grupo, detalle que nunca ha sido reseñado, es que la Virgen y el Cristo Yacente no son de la misma mano. Pero es más, parecen realizados en diferentes épocas y por diferentes talleres/escuelas. Efectivamente, tras un minucioso examen de la anatomía, facciones del rostro y del tipo de policromía, parece claro que el Cristo Yacente procede de tierras andaluzas; al igual que la titular del colegio en el que ambas se hallan: la Virgen Vulnerata. Si de esta última sabemos que su origen se encontraba en la ciudad de Cádiz, de la Piedad no tenemos el más mínimo dato, si bien la anatomía y el rostro parecen remitirnos a finales del siglo XVI o principios del siglo XVII; es decir, se trata de un Yacente romanista. Lo que ya no podemos especificar es de qué taller procede, siendo, por entonces, los más

20 PARRADO DEL OLMO, Jesús María: "La obra de Francisco Giralte en Valladolid", A.E.A., Tomo 82, No 326, 2009, p. 198. 
pujantes en Andalucía los de Sevilla y Granada ${ }^{21}$. Podríamos pensar que llegó desde Cádiz, al igual que la Vulnerata, aunque no tenemos ni un solo dato que apuntale esta tesis. Tampoco sabemos en qué fecha llegó al colegio, aunque parece probable que o bien fuera o regalo o que lo trajera el padre Calatayud tras uno de sus viajes en los que buscaba recaudar fondos para la construcción de una iglesia lo suficientemente decente para la Vulnerata.

Sea como fuere, lo que tenemos claro es que los padres jesuitas encargaron a De la Peña, y éste delegó en su yerno Pedro de Ávila, la realización de una Virgen de la Piedad, pero en el sentido de Virgen, para que con el Cristo conformaran un solo grupo. Parece claro que el Yacente perteneció a otro grupo de la Piedad puesto que la disposición de los brazos descarta la posibilidad de que haya sido un Cristo Yacente aislado. Este último hecho me hace creer que pudiera provenir de Cádiz y por lo tanto ser otra de las imágenes ultrajadas y destrozadas por los ingleses durante su asalto; es decir, los hijos de la pérfida Albión destruirían la imagen de la Virgen pero no la del Cristo, por lo que una vez que este último arribó a Valladolid, o años después (la falta de una cronología exacta sobre su llegada a la ciudad nos complica las cosas), se decidió completar el grupo con la talla de una Virgen. A pesar de todo, la prueba del buen trabajo de Pedro de Ávila no se halla solamente en la calidad de la talla, bastante meritoria, sino en el hecho de que ambas imágenes no desentonen y la crítica no haya incidido en que ambas proceden de latitudes opuestas.

El Cristo posee una anatomía apurada aunque sin caer en excesos. La cabeza y el cuello están levemente ladeados, signo de que la muerte ha llegado, como lo es también, a la vez que teatral, el hecho de que su brazo derecho se desplome y caiga de manera vertical al cuerpo; el otro brazo lo sujeta la madre. El paño de pureza dorado, y la forma de tallar el bigote y cabellos nos vuelven a indicar que la fecha aproximada rondará el año 1600. La escasez de sangre, con la excepción de la que mana en abundancia de la llaga del costado, nos vuelve a situar en latitudes andaluzas.

La Piedad nada tiene que ver con las de época gótica, en la que el patetismo era la nota común. Sus parámetros discurren más por la belleza formal, la dulzura y, sobre todo, el teatralismo. A esto último ayuda el hecho de que la pieza no esté tallada de forma conjunta, sino que sea la unión de dos volúmenes independientes, con lo cual el grado de realismo es mucho mayor. Hay que volver a insistir en el perfecto encaje que tienen las dos esculturas a pesar de ser de artistas, momentos y escuelas diferentes.

La Virgen aparece sentada, con los pies juntos y las piernas abiertas, como en forma de tijera, para poder sujetar mejor el cuerpo de su Hijo. El torso le tiene levemente girado hacia el lado derecho, para ver de cerca el rostro de su Divino Hijo. Los brazos parecen formar una diagonal puesto que el izquierdo lo eleva para agarrar el cadáver de Cristo por su brazo izquierdo, mientras que el otro le pasa por debajo del cuerpo yacente para sujetarlo por la espalda, y que de esta manera no se le caiga. Llama la atención el hecho

$21 \quad$ En ciertos aspectos como la forma de tallar el bigote y las barbas es similar con algunas obras del alcalaíno, pero miembro de la escuela granadina, Pablo de Rojas (1549-1611). 
de que con ninguna de las manos llega a tocar directamente el cuerpo de Jesús; y parece que tampoco llega a reposar éste sobre las rodillas de la Virgen (efecto bastante barroco y teatral). Como es habitual en Ávila, las manos están talladas de forma independiente del cuerpo, se puede decir que están medio articuladas; sería la única opción para este caso puesto que de otra manera no se podría extraer del conjunto la escultura del Cristo por cualquier motivo que se necesitara. Asimismo, cada una de las dos manos está concebida de manera diferente puesto que mientras que la derecha está pormenorizada reflejando articulaciones, uñas, etc..., la derecha no figura tan rígida, sino que sus dedos se curvan, como si sufrieran el efecto de agarrar el brazo del Hijo. La vestimenta de la Virgen es totalmente concordante con la que exhiben las otras dos representaciones de María que existen en la iglesia (la de la Sagrada Familia y la del Calvario): a saber, túnica larga roja con motivos dorados a punta de pincel; por encima un amplio manto azul que le cubre desde la cabeza, pasando por el pelo y la espalda y llegando hasta las rodillas. Su policromía se ve enriquecida con multitud de motivos dorados vegetales a punta de pincel y una orla de lo mismo; finalmente, en la cabeza, por debajo del manto, parece llevar una especie de velo blanco.

A pesar de que el rostro de la Virgen se sitúa en los parámetros de los escultores vallisoletanos de hacia el año 1700, de no haber tenido el documento que nos dice que es obra de Pedro de Ávila, habríamos tenido hartas dificultades para saberlo puesto que en él no vemos los rasgos que definen el estilo de nuestro escultor, y ni siquiera del "primer estilo" que es el menos conocido. El único elemento que nos hace recordar las maneras de Ávila es la incipiente nariz de tabique ancho e igual de arriba abajo. Los ojos son grandes, pintados sobre la propia madera, y las cejas enarcadas (algo totalmente ajeno al resto de la producción de nuestro escultor); la boca, entreabierta, nos deja ver levemente unos pequeños dientes; los labios son más carnosos de lo que acostumbrará. Hay un detalle que, al igual que el Cristo, puede ser de procedencia andaluza dada la escasez con la que aparece en la escultura castellana: se trata de las lágrimas postizas que surcan las mejillas de la Virgen, algunas de las cuales se han desprendido. En definitiva, esta Piedad nos muestra a un escultor principiante, todavía bajo la egida de su maestro y que parecía no estar muy habituado al oficio, es decir, sería una obra de plena juventud. La fealdad y la ausencia de emotividad en el rostro, así como la composición de un cuerpo demasiado cerrado (podríamos decir que parece un mazacote en el que apenas se insinúan las formas de las piernas a pesar de que por encima tiene el manto), sin "conquistar el espacio" más que lo absolutamente necesario (los brazos), así nos lo sugieren.

Otro elemento que concuerda con su primer estilo es la aparición del pliegue curvo, blando, sin quebraduras, típico de los escultores vallisoletanos del último cuarto del siglo XVII, en especial de su padre Juan de Ávila y de Juan Antonio de la Peña, de quienes lo aprendió. Un detalle curioso, y que lo hemos visto en algunas obras de Juan de Ávila, y que parece haberlo tomado prestado Pedro, es la inclusión en las mangas de Virgen de unas suaves dobladuras que parecen forman una serie de círculos 
concéntricos. Este motivo lo observamos en casi todas las esculturas que se atribuyen a Juan de Ávila en esta misma iglesia.

El grupo, y fundamentalmente la Virgen, posee unos lejanos ecos de Gregorio Fernández y de Francisco del Rincón, si bien en la mayoría de "Piedades" de estos dos artífices el cuerpo muerto de Cristo se reparte entre la Virgen y el suelo. El ejemplar al que más se acercaría es al que Rincón talló en piedra para la fachada de la iglesia penitencial de Nuestra Señora de las Angustias de Valladolid; en ella observamos que la Virgen es la total tenedora del cuerpo de su Hijo. Pareciera que Ávila se hubiera inspirado en ella para esculpir su Virgen, si bien la composición de la misma es invertida. Tan solo hay diferencia reseñable entre ambas y es que el brazo izquierdo que en la Piedad de Ávila lo sitúa por encima del cadáver de Jesús, su correspondiente en la Piedad de Rincón, el derecho, la mantiene relajado, no intenta agarrar el brazo de su hijo como ocurre con la que estamos estudiando. También pudiera inspirarse en la Virgen de la Pasión de la Cofradía Penitencial de la Sagrada Pasión de Cristo, hermandad de la cual nuestro escultor fue miembro e incluso llegó a ser diputado. 


\section{VALLADOLID. PARADERO DESCONOCIDO}

\section{NIÑO JESÚS (1702)}

Al igual que las otras dos obras, pero sobre todo como los "dos niños para la parroquia de San Martín", sabemos de su existencia exclusivamente por la carta de pago de dote que otorga nuestro escultor a su suegro Juan Antonio de la Peña el 9 de diciembre de $1702^{22}$ (DOCUMENTO 59). En el citado documento se hace referencia a que éste último le abonó "cien reales por un niño Jesús", del que desconocemos cual fue su paradero, y por lo tanto si podría ser alguno de los muchos que se conservan en las iglesias, monasterios, museos o colecciones privadas. Dado que no especifica el destino de este Niño Jesús, al igual que hace con una Inmaculada Concepción que debía de acabar, parece probable que tuviera como destino alguna colección particular. Sea como fuere, desconocemos todo acerca de esta talla.

22 GARCÍA CHICO, Esteban: Documentos para el estudio del arte en Castilla. 2..., op. cit., pp. 369-371. 


\section{MORALES DE TORO. IGLESIA DEL SALVADOR}

\section{SAN ILDEFONSO Y SAN JOSÉ (1712)}

El primer encargo que contrata de manera autónoma que tengamos documentado fueron las esculturas de San José con el Niño y San Ildefonso que en 1712 esculpe para la iglesia de San Juan Bautista de la localidad zamorana de Morales de Toro, población muy cercana al territorio vallisoletano ${ }^{23}$. Por ambas tallas percibió 1.000 reales, escasa cantidad si tenemos en cuenta que ya gozaba de gran prestigio tanto en Valladolid como en sus alrededores y que tan solo dos años después percibirá 1.400 reales por un San Miguel para la localidad palentina de Castil de Vela. La explicación probablemente se halle en que el escultor no quería dejar pasar ningún contrato, si bien la exigua cuantía se reflejó en la calidad de ambas imágenes; el aspecto de ambas nos indica bien a las claras que la mayor parte de la talla corresponderá a sus oficiales y aprendices, solo así podríamos explicar el escaso dinero recibido y también las monstruosas diferencias existentes entre este San José y el bellísimo que tallará dos años después para la catedral vallisoletana; uno y otro corresponden a un mismo modelo, pero sin embargo la distancia de calidad entre ambas es sideral. La amplia intervención de su taller en estas dos obras se deberá a que no daba más de sí ante la avalancha de peticiones de obras que tendría por entonces, algunas de las cuales le interesarían más, ya fuera desde el punto de vista crematístico o del comitente. Son los casos de Las lágrimas de San Pedro para don Pedro de Rábago, Santa Catalina de Alejandría para la localidad de Geria, Santa Bárbara para la de Alaejos, Nuestra Señora de las Nieves para la de Nava del Rey, San Pío $V$ para el Convento de San Pablo de Valladolid, etc.... No parece casualidad que todas ellas sean muy superiores, artísticamente hablando. En definitiva, es de sus obras más flojas, y ello es debido seguramente a la amplia labor de taller, cuando no completa. Sin embargo, a pesar de que no se encuentren entre lo mejor de la producción de nuestro escultor, sea por el motivo que sea, bajo ningún concepto se puede aceptar la afirmación de que a Ávila "le faltaban dotes" dada por Navarro Talegón ${ }^{24}$.

Con el paso de los años, y tras el derrumbe de la iglesia para la que fueron talladas, a lo que habría que añadir el cierre del resto de templos de Morales de Toro, las esculturas fueron a parar a la iglesia del Salvador, la única que quedó abierta al culto en la localidad $^{25}$. Desconocemos el motivo que llevó a la iglesia a encargar la efigie de un santo (San Ildefonso) tan poco usual junto con la de San José. El motivo pudo ser la cercana relación que tiene San Ildefonso con la ciudad de Zamora.

\footnotetext{
23 NAVARRO TALEGÓN, José: Catálogo monumental de Toro..., op. cit., p. 343.

$24 \quad$ Ibídem.

$25 \quad$ Ídem, p. 336.
} 


\section{$\underline{\text { SAN ILDEFONSO }}$}

San Ildefonso de Toledo (606-667) fue un arzobispo toledano, designación que le llegó de manos del rey godo Recesvinto; y cargo que ocupó en reemplazo de su tío, San Eugenio $^{26}$. Se distinguió por su inmensa devoción hacia la Virgen y sobre todo por defender su virginidad. A este aspecto dedicó su obra De Virginitate Sanctae Mariae contra tres infideles (Sobre la virginidad perpetua de Santa María contra tres infieles). También relacionado con la Virgen se halla su milagro más conocido, aquél en el que María le entrega la casulla: "Tu eres mi capellán y fiel notario. Recibe esta casulla la cual mi Hijo te envía de su tesorería". Tras ello, la misma Virgen se la colocó y le indicó que debía utilizarla tan solo en las festividades relacionadas con ella ${ }^{27}$. A pesar de que toda su vida giró en torno a Toledo, sus milagrosos restos fueron trasladados a Zamora con motivo de la invasión musulmana. En la actualidad se custodian en la iglesia arciprestal de San Pedro y San Ildefonso de la citada ciudad castellana.

San Ildefonso (Figs. 5-6) aparece efigiado de pie, con la pierna izquierda levemente adelantada. El contraposto se ve aumentado por la flexión de la rodilla. Ambos detalles serán muy típicos de la "maniera" de Ávila. La cabeza del santo se desarrolla según los parámetros a los que Ávila nos tiene acostumbrados en su "segundo estilo": tendente al rectángulo, y con la nariz, ojos y boca característicos. Sin embargo, la rudeza con la que se encuentran tallados los ojos, pintados en la propia madera, boca y, sobre todo, el pelo, son un claro indicativo de la alta labor de taller.

La efigie de San Ildefonso diseña una diagonal entre su pierna izquierda y la mano derecha. Levanta su brazo derecho para realizar con la mano el usual gesto de bendición, con los dedos inferiores doblados, y el resto extendidos. Con su otra mano parece que sujetó un atributo, seguramente un báculo que hiciera referencia a su condición arzobispal. También relacionados con tal condición están las vestimentas y la mitra. Viste túnica larga hasta los pies, de tal modo que solo nos deja ver la punta de los zapatos; y sobretúnica blanca con una exquisita cenefa imitando labores de brocado azules y negras. Ambas van sujetas a la cintura por un cíngulo. Por encima tiene echada sobre los hombros la casulla, que es elemento más típico de su iconografía, que le entregó la Virgen; de los dos extremos superiores de la casulla parten sendas cintas (como si fueran estolas) que se cruzan sobre el pecho y se extienden en forma de " $X$ " hasta las rodillas. La policromía de esta es riquísima, sobre un fondo rojo se desarrollan múltiples motivos vegetales y geométricos dorados a punta de pincel, a excepción de la cenefa que recorre todo el borde de la misma que también tiene motivos botánicos, pero en varios colores. Por su interior la policromía es diferente, puesto que son motivos vegetales azules y blancos, similares a la imitación de brocado de la sobretúnica.

En lo referente a los pliegues, a pesar de que en estas fechas ya tenía dominado el "pliegue a cuchillo", como podemos observarlo en la parte baja de las vestimentas, en que llega a realizar unas quebraduras muy aristadas y poligonales entre ambos pies que

26 RÉAU, Louis: Iconografía de los santos. G-O..., op. cit., p. 105.

27 https://es.wikipedia.org/wiki/Ildefonso_de_Toledo 
será un detalle muy usual en su producción; vemos que también está presente el plegado suave, con incurvaciones y exento de durezas propio de finales del siglo XVII. También figura otro motivo que se hace universal en su "segundo estilo": se trata de la colocación de los pies en un ángulo de $90^{\circ}$.

El estado de conservación de la talla es bastante bueno, con la excepción de la rotura de un par de dedos y la gruesa capa de repintes oscuros. Una restauración seguramente ayudaría a valorizar la escultura.

\section{$\underline{\text { SAN JOSÉ CON EL NIÑO }}$}

La presente escultura de San José con el Niño (Figs. 7-8) tiene mucha importancia por diversos motivos, ninguno de los cuales tiene que ver con su calidad, bastante escasa vistas las imágenes que salieron de su gubia por estos mismos años. Su trascendencia radica en que es la representación documentada más antigua del patriarca San José; pero no solo eso, sino que también es la más antigua relacionable con Ávila (ya sea documentada o atribuida) dentro de su segunda etapa; puesto que en la primera tan solo podríamos incluir uno conservado en Fuente-Olmedo. Éste de Morales de Toro viene a representar una transición entre el referido de Fuente-Olmedo y el de la catedral vallisoletana, que será, no solamente el de mayor calidad que le podamos adjudicar, sino en el que ya aparece plenamente desarrollado su modelo de San José, pletórico de movimiento, naturalismo y calidad.

El presente San José es, por lo tanto, el prototipo que Ávila utilizará y perfeccionará durante el resto de su vida y que tanto su hermano Manuel como otros artífices anónimos le copiarán en diversas ocasiones, hecho muy reseñable puesto que hasta entonces el único escultor al que se seguía tomando por referente en cuanto a iconografías era Gregorio Fernández; y, en menor medida, Juan de Juni (fundamentalmente su Virgen de las Angustias).

Pedro de Ávila nos presenta a San José de pie, con la pierna derecha ligeramente adelantada, aunque adoptando una posición muy elegante, distinción aumentada gracias al ligero escorzo del torso y la forma de disponer inestablemente al Niño Jesús. Con su mano izquierda sujeta al Niño Jesús mientras que con la derecha portaría una vara florida, en la actualidad sustituida por un ramo de lirios natural. Viste una túnica oscura, con esgrafiados dorados, hasta los pies; de los cuales solo podemos ver la punta de uno, el otro parece haber desaparecido. Por encima un manto algo más claro y decorado con los mismos motivos, a los que habría que añadir una cenefa que también presenta decoraciones doradas y otros colores. El manto, que le cae sobre el hombro y parte del brazo derecho, le cubre toda la espalda y parte del abdomen, subiendo hasta recogerse con el cíngulo que también le sujeta la túnica. La forma de recoger el manto es muy elegante puesto que termina en una especie de lacito, algo deteriorado. La cabeza vuelve a presentar los rasgos típicos de los que Ávila hace gala, si bien la tosquedad y simplificación con que se encuentran resueltos parece volver a indicarnos que la obra de 
taller es amplia. Los ojos están pintados en la propia madera. Por su parte, el Niño Jesús aparece en una posición muy inestable, curiosa y con un valiente escorzo: mientras juguetea con ambas manos con la barba de su padre, intenta escalar por el pecho del mismo apoyando un pie sobre las dobladuras del manto y el otro, con el que intenta "trepar", ya sobre en el cíngulo.

La escultura presenta, a diferencia del San Ildefonso, ya en la totalidad de sus vestimentas el pliegue a cuchillo, si bien su resalte es diferente en unas partes y en otras. Las dobladuras del manto y de la parte baja de la túnica llegan a ser demasiado geométricas, lo que nos indica que los aprendices u oficiales que pusieron la mano en ella no eran tan diestros como el maestro en la consecución óptima de los mismos. Tampoco está muy conseguida la soltura de los pliegues, así como la complicación de los mismos que veremos posteriormente en otros San José, en este caso se limitan casi a encapsular al santo en vez de a mostrarse como elementos que le otorguen movimiento, elegancia y dinamismo.

El estado de conservación es bastante malo puesto que además de haber perdido varios dedos tiene algunas resquebraduras en el resto de ambas tallas. A ello hemos de sumar la amplia capa de polvo que impide vislumbrar de forma óptima las policromías. 


\section{TORRECILLA DE LA ABADESA. IGLESIA}

PARROQUIAL DE SAN ESTEBAN PROTOMÁRTIR

\section{CRISTO CRUCIFICADO (1714)}

Si del San José con el Niño de Morales de Toro señalamos su capital importancia por ser el prototipo que habría de seguir Ávila el resto de su vida para tallar imágenes del padre nutricio de Jesús, la misma situación tenemos esta vez con el Cristo Crucificado (Figs. 9-12) de Torrecilla de la Abadesa. Es decir, la importancia del presente Crucifijo radica en que es el primero documentado de una serie en la que el escultor apenas introducirá novedades, copiando el modelo de manera continua, síntoma de que el prototipo creado por Ávila consiguió fortuna. Asimismo, como ocurría con el San José, también existen obras anteriores relacionadas con nuestro escultor que representan esta misma iconografía; sin embargo, no poseían las características concretas del modelo que después se repetirá. En esta ocasión nos referimos al que puede ser el antecedente de sus pequeños crucificados, del cual éste es el más antiguo, se trata del Crucificado que talló en 1703 para el Calvario del ático del retablo mayor del Monasterio de Santa Brígida de Valladolid. Aquél difiere sustancialmente de éste que, como ya hemos dicho, será el modelo que se repetirá en al menos otras dos ocasiones, aunque no podemos descartar más sorpresas en lo referente a parroquias rurales a raíz del casual encuentro que tuve de un Crucificado exacto en la iglesia parroquial de Bernuy de Coca (Segovia). Para finalizar esta introducción cabe señalar que el Crucificado más perfecto de todos, y además el más tardío, es el que talló para el Oratorio de San Felipe Neri de Valladolid, que se encuentra bajo la advocación de "Cristo del Olvido".

El primero en ver la relación de este Crucificado con nuestra familia de escultores, aunque sin optar por atribuírselo a ninguno en concreto, fue Martín González, el cual en el Inventario Artístico de Valladolid lo describe en el Sotocoro como "Escultura de Cristo siglo XVIII, del taller de los Ávila" 28 . Sin embargo, fue el profesor Parrado del Olmo el que halló una carta de pago que confirmaba la pertenencia de esta obra a la familia Ávila y además que nos aportaba el nombre del autor: Pedro de Ávila ${ }^{29}$.

En 1714 Pedro de Ávila se concierta con la parroquial de Torrecilla de la Abadesa (Valladolid) para realizarles una hechura de un Crucificado de tamaño menor que el natural. No parece casualidad que esta iglesia pensara en Pedro de Ávila, ya no solo porque por entonces fuera el artífice más destacado del foco más atractivo de Castilla, Valladolid, sino porque ya había tratado con su padre, Juan de Ávila, el cual les había tallado una Virgen del Rosario de vestir y, quizás, también contaron con él para realizar las esculturas del retablo mayor de la iglesia. Todo ello conformaría la mejor carta de presentación de Pedro de Ávila. Esta "herencia" de comitentes la volveremos a ver en el Oratorio de San Felipe Neri, que también contó con Juan de Ávila y años después con 
sus hijos Pedro y Manuel para adornar de las más bellas imágenes los distintos altares de su templo.

Efectivamente, el 6 de noviembre de 1714 el dorador Manuel Barreda, quien asimismo realizó el dorado del retablo mayor del templo, escribía al párroco de dicha iglesia para presentarle a Manuel de Ávila, "hermano del escultor que ha hecho la hechura de Cristo", quien de paso por Tordesillas para "ajustar un poco de obra" se aproximaría a Torrecilla para que se le abonara "el resto que se le debe" por el Crucificado que había tallado su hermano Pedro, puesto que la imagen ya se encontraba en el taller del referido dorador "para encarnarla"30. Es probable que por entonces Pedro de Ávila se encontrara tan agobiado por la cantidad de encargos que tenía entre manos (San Miguel de Castil de Vela; San Juan Evangelista, Santa María Magdalena, San José, San Pedro y San Miguel para la catedral de Valladolid; y, quizás, el Crucificado de Bernuy de Coca) que no tuviera el tiempo necesario para poder acercarse a Torrecilla para cobrar el dinero que la adeudaban; lo que, unido a que su hermano Manuel se encontraba en la cercana localidad de Tordesillas, propició que fuera este último el que percibiera los reales por su hermano. Queda bien a las claras la excelente relación existente entre los hermanos. Lo que ya no tenemos tan claro, o mejor dicho no tenemos ninguna pista, es a que empresa haría referencia ese "ajustar un poco de obra" a que se refería Manuel Barreda, que asimismo tendría buenas fuentes de información pues sería amigo de Manuel de Ávila. Como veremos en su momento, tan solo hay un par de piezas en Tordesillas que podrían ser puestas en relación con este último, aunque también habría que tener en cuenta el enorme patrimonio que ha perdido la localidad tanto de sus iglesias como de sus hospitales y conventos.

Volviendo al momento en que Barreda escribe la carta hablando de la próxima llegada de Manuel de Ávila a Torrecilla para percibir la cantidad adeudada a Pedro de Ávila, ésta tuvo lugar un día después. Efectivamente, el 7 de noviembre el menor de los Ávila llegaba a la iglesia de Torrecilla y otorgaba carta de pago en favor del licenciado Santiago Crespo, párroco de la iglesia, en razón de haber recibido 120 reales "por cuenta de la hechura del Santo Cristo, que está fabricando en casa de Pedro de Ávila, vecino de dicha ciudad"31. Pero, todavía le restaba por percibir a Pedro de Ávila el último plazo, que a buen seguro coincidiría con la entrega del Crucifijo una vez que

$30 \quad$ "Al licenciado don Santiago Crespo, gracia de Dios, felices años, cura en la villa de Torrecilla. Muy Señor mío: Sr. Cura: me alegraré ésta halle a V. Md. con perfecta salud en compañía de todos ellos mis señores a quien participará mis encarecidas memorias correspondiendo la mía y de mi esposa en todo lo que V. M. fuese servido el mandarnos. El portador de éste es un hermano del escultor que ha hecho la hechura de Cristo, en que pasa a Tordesillas a ajustar un poco de obra y le encargué pasase a esa villa para que V. Md. le diese el resto que se le debe por tener la hechura ya en mi poder para encarnarla. De lo que toca a las alhajas de plata ya están acabadas y las llevaré en toda forma a últimos de esta semana, y así no soy más largo por estar de prisa y ruego a Dios le guarde a V. M. los años (...) Valladolid, y noviembre 6 de 1714 años. Fdo: Manuel Barreda". Ídem, p. 106.

31 "Señor don Santiago Crespo. Manuel de Ávila, maestro de escultura, vecino de la ciudad de Valladolid, confieso haber recibido de la mano del Licenciado Santiago Crespo, cura de Torrecilla, 120 reales, los setenta reales que dio Juan Crespo de la limosna que se sacaba por el lugar; los cincuenta dijo el cura de mi dinero, y es por cuenta de la hechura del Santo Cristo, que está fabricando en casa de Pedro de Ávila, vecino de dicha ciudad. Y por verdad lo firmé en Torrecilla de la Abadesa, a 7 de noviembre de 1714 años. Fdo: Manuel de Ávila”. Ibídem. 
Manuel Barreda hubiera terminado de encarnarlo y policromarlo. Sea como fuere, una vez más Manuel de Ávila arribó a Torrecilla apenas un par de semanas después, el 23 de noviembre, para otorgar la última carta de pago al "licenciado Santiago Crespo cura propio de la villa de Torrecilla de la Abadesa" en razón de "ciento y veinte reales de vellón con que se acabó de pagar la hechura de un Santo Cristo que hizo para dicha villa"32. Desconocemos si Manuel de Ávila se encargó de transportar el Crucifijo desde Valladolid o si bien se encontraría laborando en Tordesillas a raíz de haber conseguido hacerse con el contrato al que se aludía en la anterior carta de pago al decir que estaba en Tordesillas para "ajustar un poco de obra".

En uno de los libros de fábrica de la parroquia figura en el año 1726 una partida por valor de 34 reales "que tuvo de costa el pintar el frontis de la sacristía y encarnación que dio a un crucifijo"33. Aunque no es verosímil que se refiera al Crucifijo de Pedro de Ávila puesto que sabemos que ya lo había encarnado Manuel Barreda, ahí queda apuntado.

El Crucifijo ocuparía en origen uno de los dos retablos colaterales de la iglesia, los cuales fueron contratados el 24 de mayo de 1714 por los ensambladores vallisoletanos Gregorio Díaz de Mata y su hijo José ${ }^{34}$, saliendo por fiador el referido Manuel Barreda, a quien se debe el dorado de ambos retablos. Todo esto nos lleva a pensar que Barreda, los Ávila (Juan y Pedro) y los Díaz de Mata (Gregorio y José) fueron los encargados de la renovación de la casi totalidad de los bienes artísticos de la iglesia, especialmente del retablo mayor y de los colaterales.

Los dos retablos, por los que percibieron 2.200 reales, se fabricaron a lo largo de los años 1714-1715, durante los cuales ambos ensambladores fueron otorgando cartas de pago. El primero en finalizarse fue el del Santo Cristo, el cual se les acabó de abonar el 31 de agosto de 1715, por lo que en fechas inmediatas se asistiría a la colocación en él del Crucificado de Pedro de Ávila ${ }^{35}$. Según Parrado del Olmo, el retablo pudo realizarse para que lo ocupara un "Crucifijo hoy situado en el coro, de la segunda mitad del siglo $X V I$, de 1,30 m. de altura, que encaja con las medidas de la caja del retablo", que es efectivamente el tallado por nuestro escultor ${ }^{36}$. El otro retablo lo ocuparía la desaparecida Virgen del Rosario, casualmente tallada por el padre de nuestro artífice, Juan de Ávila.

\footnotetext{
32 "Digo yo Manuel de Ávila escultor y vecino de la ciudad de Valladolid que recibí de mano del Licenciado Santiago Crespo cura propio de la villa de Torrecilla de la Abadesa ciento y veinte reales de vellón con que se acabó de pagar la hechura de un Santo Cristo que hizo para dicha villa y por verdad lo firmé en Torrecilla a veinte y tres de noviembre de mil setecientos y catorce. Fdo: Manuel de Ávila". A.G.D.V., Torrecilla de la Abadesa, Iglesia de San Esteban, Legajo de papeles sueltos.

33 A.G.D.V., Torrecilla de la Abadesa, Iglesia de San Esteban, Caja 2, Cuentas de fábrica 17171830, Año 1726.

34 PARRADO DEL OLMO, Jesús María: Datos histórico artísticos..., op. cit., pp. 107-108.

35 "Digo yo, Gregorio Díaz de Mata, que recibí de mano del Licenciado Alonso Crespo, depositario de la limosna del Santo Cristo 550 reales vellón con que me acabó de pagar la obra del colateral de dicho Santo Cristo (...) en Torrecilla, a 31 de agosto de 1715". Ibídem.

$36 \quad$ Ídem, p. 107.
} 
Tras la realización de los retablos, las arcas de la iglesia debieron de quedar tan exhaustas que no pudieron afrontar el dorado de los mismos; tarea que hubo de esperar hasta 1729, año en que nuevamente Manuel Barreda se encarga de "dorar el colateral del Cristo de la Esperanza que está en dicha iglesia y pintar la capilla mayor encarnar

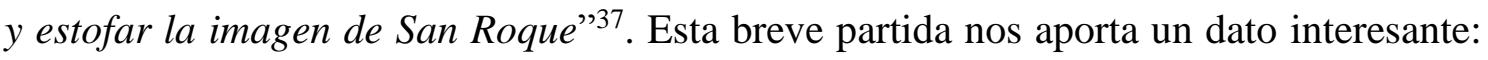
se trata de que el Crucifijo tallado por Ávila se encontraba bajo la advocación de "la Esperanza". Una vez que se acabaron de dorar los retablos se procedió a colocar las imágenes en ellos, momento para el cual se contrató un predicador que echara un sermón. En la actualidad aún se conservan ambos retablos, si bien sus hornacinas han sufrido una alteración ya que las dos imágenes originales han sido sustituidas por una moderna Virgen del Carmen y un San Sebastián del siglo XVI. Sería deseable que el Crucificado, que tras una serie de cambios de lugar ha acabado en el baptisterio, volviera al retablo para el que fue realizado.

El Crucifijo de Torrecilla de la Abadesa, que será el modelo a seguir en al menos otras dos ocasiones, tiene las siguientes características: Se trata de un Cristo de tamaño bastante inferior al natural, sujeto con tres clavos. Se nos presenta ya muerto, con la cabeza desplomada hacia el lado derecho, lo que hace que apenas le veamos el rostro si es que no nos situamos debajo de él, siendo lo más visible la potente melena con largos mechones curvos. Este último detalle, así como el de la cabeza desplomada hacia la derecha parecen remitirnos a algunos Crucificados de Gregorio Fernández, como por el ejemplo el de la Capilla de los Valderas en la iglesia de San Marcelo de León. El hecho de que aparezca ya muerto, además de los escasos regueros de sangre, hace que la imagen se nos muestre serena, tranquila e idealizada, nada que ver con otros Crucificados barrocos en los que se propugnaba por todo lo contrario: el patetismo llevado el extremo. Que esté algo idealizado no significa que no posea un fino estudio anatómico que permite observar cada músculo, hueso y vena del cuerpo. Las carnes tienen un blando modelado, aunque no tan perfecto.

Si comparamos los tres Crucificados podemos observar que este de Torrecilla parece poseer un canon ligeramente más corto que aquellos, a lo que puede ayudar el hecho de que sea también el que goce de una complexión ligeramente más corpulenta; si bien esto no quiere decir que estemos ante un Cristo musculado, sino que en comparación los otros dos están delgados y demacrados al extremo.

\footnotetext{
37 Dorar un colateral y adornar la capilla mayor. "Dos mil ciento y once reales que tuvo de costa el dorar el colateral del Cristo de la Esperanza que está en dicha iglesia y pintar la capilla mayor encarnar y estofar la imagen de San Roque la misma cantidad en que se ajustó con Manuel Barreda maestro de dorar y estofar vecino de la ciudad de Valladolid como consta de su recibo su fecha veinte y uno de noviembre de setecientos y veinte y nueve abonanse y valen setenta y un mil setecientos y setenta y cuatro maravedíes".

Sermón el día de la colocación de las imágenes. "Treinta y nueve reales y medio que se gastaron y dieron de limosna al predicador que predicó el día de la colocación de las imágenes en los retablos nuevos como consta del memorial de dicho cura y valen un mil doscientos y setenta y cinco maravedíes". A.G.D.V., Torrecilla de la Abadesa, Iglesia de San Esteban, Caja 2, Cuentas de fábrica 1717-1830, Año 1729. ARA GIL, Clementina Julia y PARRADO DEL OLMO, Jesús María: Catálogo Monumental de la provincia de Valladolid. Tomo XI..., op. cit., p. 334.
} 
La cabeza es muy hermosa, y en ella se pueden ver todas las características que conforman el "segundo estilo" de Ávila, con la excepción del tabique nasal ancho que en esta ocasión aparece más fino de costumbre; es, por lo tanto, una de escasísimas veces en que no utilice este rasgo. Su rostro es el prototipo que usa para las representaciones de Cristo. Así lo podemos comprobar, por ejemplo, en el Ecce Homo de Renedo o el busto de Ecce Homo del Convento de las Brígidas. La cabeza se inclina hacia el hombro derecho, indicándonos que ya ha debido de expirar, como así también lo advierten los ojos cerrados. Es una escena muy naturalista, nada forzada, y serena debido a que ya exhaló. La boca aparece entreabierta, dejando brotar algo de sangre, al igual que mana abundantemente de la frente. Lo más probable es que estos regueros de sangre no correspondan a la actuación que llevó a cabo Manuel Barreda, sino que se deban a algún repolicromado posterior; tal y como sucedió con el Cristo del Olvido del Oratorio de San Felipe Neri, en el cual tras una excelente restauración se comprobó que la mayoría de la sangre pertenecía a una burda intervención posterior y que la talla realizada por Ávila era muy parca en cuanto a los borbotones de sangre. Esa misma restauración descubrió el abundante uso del peleteado en el cabello que se encontraba oculto fruto de otro repinte; esto último también puede suceder con el Crucificado que tenemos ahora entre manos. En su rostro se observa que ni la mayor parte de la sangre ni de la policromía de los cabellos es la originaria de Barreda.

También la cabellera sigue las pautas del segundo estilo de nuestro escultor: abundante y ondulada melena, algunos de cuyos mechones caen sobre el hombro derecho. Lo que si nos interesa es la barba, por cuanto puede ayudarnos a datar ciertas obras de las que desconocemos la fecha aproximada. Si comparamos esta barba con la del Cristo del Olvido observamos que la del Cristo de Torrecilla es algo más larga, con los pelos menos individualizados y su forma es más hierática; sin embargo, en el Cristo del Olvido, esta barba bífida es algo más ancha, corta, con mayor detallismo a la hora de detallar cada mechón y, asimismo, goza de un mayor movimiento. Algo parecido nos ocurre a la hora de hablar de la melena: mientras que en el Crucificado de Torrecilla adopta una forma geométrica como si fuera un casco compacto, sin apenas sobresalir, a pesar de que vemos que tiene unos mechones bastante largos y voluminosos; en el "del Olvido" comprobamos que Ávila es más minucioso pues las curvas las ha ensanchado y complicado, con lo cual adopta una manera muy pictórica.

El relajamiento del cadáver lo vemos perfectamente reflejado en sus extremidades, las cuales también se vencen, si bien con ello no casa demasiado el hecho de que las manos se encuentren completamente extendidas, como si todavía se encontrara vivo y doliente. Sea como fuere, la muerte se ha apoderado de sus piernas, las cuales se doblan ante el peso del resto del cuerpo. Ese doblez en forma de ángulo es muy característico de nuestro escultor, y la perfeccionará aún más en el Cristo del Olvido. Tanto las piernas como los brazos vuelven a hablarnos muy bien del excelente conocimiento anatómico del que gozaba nuestro escultor. Dos detalles apoyan este extremo: el realismo que logra al tallar la línea axilar exterior completamente estirada, y la blandura que exhiben los bíceps femorales. Al ver estos dos detalles podemos decir que estamos delante de carne 
humana. En las piernas destacan dos aspectos: la excelente manera con que ha resuelto las llagas de las rodillas, y el maravilloso trabajo realizado por Barreda en la policromía puesto que aún se conservan alguna de las marcas de la flagelación; este mismo detalle fue descubierto en el Cristo del Olvido tras la restauración llevada a cabo en 2010.

El paño de pureza aparece anudado en el lado superior derecho, cayendo a ese lado una buena porción del mismo de una manera bastante natural. La parte que le cubre el sexo adopta unos pliegues en forma de dos "V" superpuestas tendentes al "cuchillo" pero no demasiado cortantes. A pesar de que la talla de este "perizonium" es bastante fina no puede ni compararse con la del que exhibe el Cristo del Olvido, en la que logrará tal movimiento de paños, siendo estos tan delgados, que lo convertirán en una de sus obras maestras. La policromía del perizonium se restringe a alguna línea vertical azul y una cenefa dorada muy estrecha en el borde del mismo. También referente a la policromía, aunque apenas se atisba, parece intuirse que en la espalda se ha simulado a la perfección el resultado del castigo recibido por Cristo durante la flagelación. Será similar a la espalda llagada de los Cristos atados a la columna de Gregorio Fernández. 


\section{CASTIL DE VELA. IGLESIA PARROQUIAL DE SAN MIGUEL ARCÁNGEL}

\section{SAN MIGUEL (1714)}

En 1714 realiza un San Miguel (Figs. 13-14) para la iglesia parroquial de Castil de Vela (Palencia), puesta bajo la advocación de dicho Arcángel ${ }^{38}$. Por su ejecución cobró la nada desdeñable cantidad de 1.400 reales, cifra muy subida debido seguramente al magistral trabajo realizado en ella y a que su por entonces su prestigio como escultor era enorme; de hecho, en el libro de fábrica de la citada iglesia se le cita como "maestro escultor en Valladolid y de la Santa Iglesia de dicha ciudad". Este extracto vendrá a referirse, quizás, a que era el maestro mayor de escultura de la diócesis, además de aludir al hecho de que por entonces se encontraba tallando cinco esculturas para otras tantas capillas de la catedral. El último plazo de la escultura se le terminó de abonar el 28 de mayo de $1715^{39}$. Durante ese mismo año el dorador vallisoletano Manuel Martínez de Estrada se encargaba de "estofar, encarnar y dorar y poner los ojos de cristal a dicha efigie", tareas por las que percibió 519 reales $^{40}$. Una vez acabadas estas últimas labores se procedería a subir al santo al retablo. De hecho, en las partidas del año 1716 figuran unos gastos "para la fiesta de la Traslación de San Miguel, para el predicador y refrescos y cohetes y colores para la peana del santo".

Desconocemos cómo sería y de cuándo dataría el retablo mayor primitivo. Sea como fuere, un cambio de gusto o el mal estado del retablo, la iglesia decidió realizar uno nuevo a mediados del siglo XVIII. Efectivamente, el 10 de noviembre de 1749 los maestros ensambladores riosecanos Manuel de Benavente y Gabriel Pérez, fiados por sus respectivas mujeres, se conciertan con "el señor cura mayordomo y oficiales de la iglesia parroquial del arcángel San Miguel de la villa de Castil de Vela" para realizar "el retablo de su capilla mayor" (DOCUMENTO 84). Por la ejecución de dicho retablo, para el cual utilizarían la traza y condiciones firmadas el día 19 de octubre, recibirían 4.000 reales "a toda costa, inclusa la colocación de la efigie del arcángel San Miguel, santos y niños que incluyen las precitadas condiciones". Además del retablo, ambos maestros deberían construir la mesa de altar, hacer una media naranja sobre la custodia antigua y, en el propio retablo, "hacer sus cajas de intercolumnios con sus peanas y demás adornos según está en la traza dejando el hueco para poner un San

$38 \quad$ Efigie de San Miguel a cuenta. "Más se le reciben en data mil doscientos y diez y ocho reales que ha dado a Pedro de Ávila maestro escultor en Valladolid y de la Santa Iglesia de dicha ciudad en cuenta de mil y cuatrocientos reales en que está concertada la talla del glorioso San Miguel titular de esta iglesia constó de recibo del susodicho y se hizo con licencia del Sr. D. Miguel Gómez de Escobar provisor de este obispado en respuesta a una misiva al cura su fecha veinte y tres de agosto de dicho año de catorce". A.D.P., Castil de Vela, San Miguel, Caja 32, f. 87.

39 San Miguel. "Más se le reciben en data ciento y ochenta y dos reales con que se acabaron de pagar los mil y cuatrocientos reales en que se ajustó la escultura de la efigie de San Miguel constó de recibo de Pedro de Ávila escultor vecino de Valladolid a 28 de mayo del dicho año de 1715". Ídem, f. 93.

$40 \quad$ Estofar dorar y encarnar dicha efigie. "Más se le reciben en data quinientos y diez y nueve reales que dio a Manuel de Estrada vecino de dicha ciudad dorador y estofador en que se ha ajustado estofar encarnar y dorar y poner los ojos de cristal a dicha efigie constó de su recibo de 28 de mayo de dicho año de 1715". A.D.P., Castil de Vela, San Miguel, Caja 32, f. 87. 
José en un lado con su Niño y también un San Isidro labrador al otro de estatura natural'. No cabe duda de que estas dos imágenes son riosecanas puesto que a la apariencia de la misma se uniría la lógica de que ambos maestros, también riosecanos, las solicitarían a uno de los talleres de la ciudad; siendo por entonces el más próspero y concurrido el del presbítero Francisco Sierra, hijo de Tomás de Sierra y hermano de Pedro, José y Jacinto, todos ellos escultores y ensambladores. Toda la obra la debían de tenerla finalizada y asentada para el día de San Miguel -29 de septiembre- del año siguiente de 1750. Me queda la duda de si la idea inicial de la iglesia no fue la de sustituir también el San Miguel de Pedro de Ávila puesto que entre las condiciones se puede leer una que dice: "y lo mismo de la del dicho arcángel San Miguel que ésta han de dar colocada y hecha según arte". La expresión "hecha según arte" parece entrever la idea de que estaban dispuestos a hacer una nueva talla del santo en consonancia con las otras dos que se iban a fabricar.

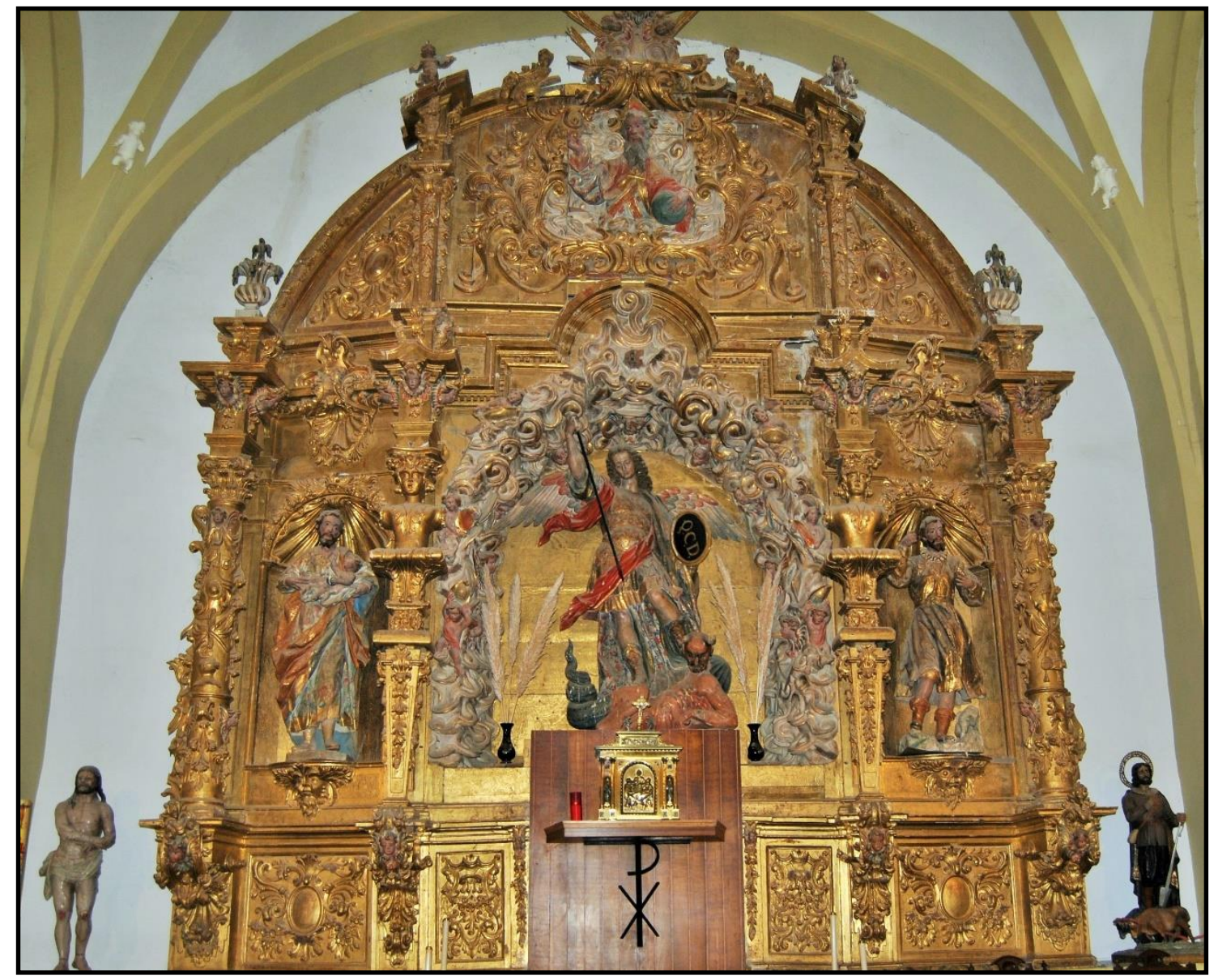

Il. 4- Manuel de Benavente y Gabriel Pérez. Retablo mayor. Iglesia parroquial de San Miguel. Castil de Vela (Palencia).

Lo primero que llama la atención al visualizar este San Miguel es que no tiene nada que ver con los que hemos relacionado con su padre. Aquellos, mucho más tranquilos y serenos, se basaban en una composición descriptiva, en los que se colocaba al diablo como si fuera un elemento más de la iconografía del Arcángel; sin embargo, en este San Miguel, Pedro de Ávila ha concebido la escena como un instante congelado, retratando el justo momento en el que el Arcángel se dispone a dar el golpe de gracia a Lucifer.

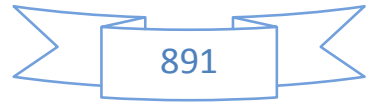


Pero no solo eso, sino que también ha sabido otorgar a la escena dinamismo y movimiento con la inclusión de la banda que le rodea el cuello, que parece agitarse violentamente por efecto del viento.

La composición es muy teatral puesto que tenemos al grupo alojado en la hornacina principal del retablo, la cual adopta una forma de cueva realizada a partir de nubes y cabezas de angelotes. Además de ello son muy características de este periodo las diagonales. En este caso tenemos tres, dos las conformarían las dos partes de la banda que agita el viento, las cuales se verían cortadas por la diagonal que dibuja la lanza que empuña el santo. Además de ello es un recurso muy barroco la interactuación de la escena con el espectador: mientras que el santo se centra en derrotar al demonio, es este último el que nos mira y nos introduce en la escena. Los perfiles y los paños son sinuosos.

San Miguel aparece de pie pisoteando a Lucifer; las piernas las mantiene abiertas, con lo cual consigue una posición de inestabilidad que casa bien con el gusto barroco. A esto habría que añadir el ligero contraposto que realiza con la pierna izquierda a medio doblar y el giro del cuello y cabeza para mirar hacia abajo. Se encuentra alado por dos grandes alas desplegadas y muy coloreadas. Extiende hacia arriba el brazo derecho de una manera muy elegante, teniendo las mangas recogidas, lo que nos permite verle los brazos desnudos, mientras que con esa mano sujeta una afilada lanza que se dispone a clavar al demonio. Este hecho nos vuelve a demostrar la concepción tan barroca del grupo, en el cual se ha querido captar el instante clave de la derrota de Lucifer, el momento anterior a que sea batido. Por su parte el brazo izquierdo lo mantiene replegado, con cuya mano empuña un escudo redondo para defenderse del posible ataque del enemigo; el escudo es negro con las letras "Q.C.D." (“Quién como Dios") grabadas en oro, el mismo material con el que se ha policromado el borde.

Viste como un guerrero, con una túnica dorada corta hasta las rodillas, sobre la cual porta una coraza thoracata de la que cuelgan una serie de pulseras o "torquex", a la manera del ejército romano. La coraza lleva un fondo dorado sobre el cual se desarrollan unas decoraciones vegetales en azul, rojo y verde. Colgado del cuello, y cayéndole por el brazo izquierdo y por toda la espalda y parte de atrás de las piernas lleva un amplio manto azul con decoraciones doradas por la parte anterior y motivos botánicos en azul y rojo sobre fondo blanco en la posterior. No cabe ninguna duda de que una buena policromía, y este es un claro ejemplo, aumenta la categoría y valoriza las esculturas. Finalmente, el otro elemento relacionado con la vestimenta que porta se trata de una especie de banda roja con un estrecho ribete con motivos geométricos dorados. Esta banda, que es la que proporciona mayor dinamismo y movimiento a la escena, la tiene colgada del cuello, si bien sus dos extremos rodean el cuerpo, saliendo una parte por encima del brazo derecho y termina tocando el ala de ese lado; y la otra le rodea la parte izquierda del torso y acaba a la izquierda del "torquex"; es decir, la misma banda forma dos diagonales paralelas. A sus pies se sitúa el demonio que viene a ser una combinación de cabeza humana con cuernos, cuerpo animal y cola de serpiente. 
Adopta una posición semi tumbada y con una manera de disponer los codos en el suelo bastante elegante. El rostro exhibe el ceño fruncido y gesto amenazador.

San Miguel, como ya dijimos, tiene una mezcla de perfiles sinuosos y de elegancia. Pedro de Ávila podría haberse inspirado para realizar su modelo de Arcángel en el San Miguel (1606) que Gregorio Fernández realizó para la parroquia homónima, justamente en la cual vivía desde hacía unos años el propio Ávila y que observaría muy a menudo. Las similitudes con este grupo las vemos, además de en la indumentaria, en la forma de disponer de esa manera tan elegante el brazo izquierdo subido mientras empuña con esa mano la lanza. También está presente en el San Miguel de Fernández el detalle del escudo en la otra mano. A pesar de todo, este grupo parece que guarda también bastante relación con el San Miguel (1613) que talló Juan Imberto para la iglesia del Convento de Santa Isabel de Valladolid; en este caso las similitudes se reflejan más en la posición de las piernas.

El rostro del santo evidencia ya claramente el segundo estilo de Pedro de Ávila, en el cual podemos ver los rasgos típicos: nariz de tabique ancho, ojos semi cerrados, cejas rectas, boca entreabierta en la que se atisba la punta de la lengua. A esto se añaden otros detalles característicos como la concepción rectangular de la cabeza, cuello alargado, y la aparición de uno de sus típicos modos de resolver el cabello: en la parte superior dos mechones simétricos y a los lados del rostro dos amplias cabelleras con multitud de bucles unidos. La labor del trépano es del todo meritoria. También concuerda con este "segundo estilo" la definitiva aparición del pliegue a cuchillo en el manto, en el torquex y, sobre todo, en la banda que le recorre el cuerpo; aquí Pedro de Ávila demuestra que ya lo domina a la perfección y que va adelgazando cada vez más las maderas, dándole a su vez quiebros sinuosos y aristas cortantes como cuchillos. Esto implica una mayor sensación de movimiento propiciado por el viento; a pesar de lo violento de estos movimientos es del todo naturalista, no incurre en exageraciones que le restarían verosimilitud. Esta simulación la ha logado a la perfección. Es sin duda una de sus obras maestras.

La importancia de esta escultura es similar a la que hemos visto con el San José de Morales de Toro o el Crucificado de

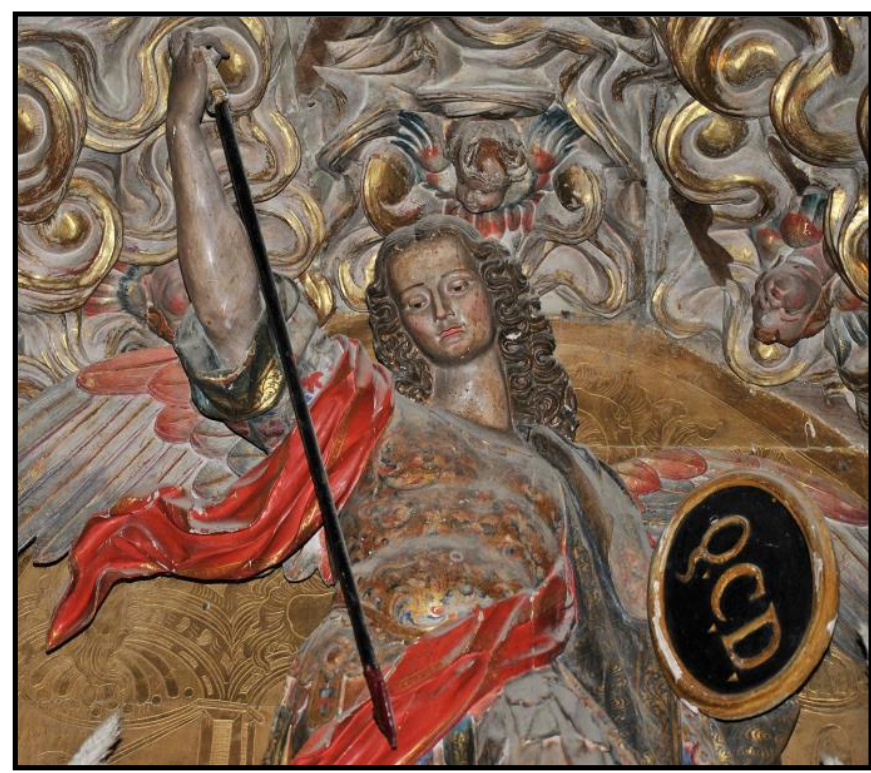

Il. 5- Pedro de Ávila. San Miguel. Iglesia parroquial de San Miguel. Castil de Vela (Palencia). Torrecilla de la Abadesa, y que posteriormente veremos en otras piezas como la Inmaculada y la Magdalena del Oratorio de San Felipe Neri; se trata de que son las esculturas-modelo sobre las que Pedro de Ávila volverá en nuevas ocasiones y copiará puntualmente o introduciendo 
alguna pequeña variante, pero sin embargo la composición general no variará en demasía. En este caso, parece ser que este San Miguel de Castil de Vela fue el primero de los dos que conocemos; el otro es el conservado en una de las capillas de la catedral de Valladolid. Aunque los dos se fechan en el mismo año, parece ser que este es algo anterior, puesto que cuando el 23 de agosto de este mismo año se le están abonando los honorarios a Ávila por esta escultura, en el libro de cuentas de la parroquia figura la reseña "maestro escultor en Valladolid y de la Santa Iglesia de dicha ciudad"; es decir, mientras que este debía ya de estar acabado, todavía se encontraba enfrascado en las esculturas de la catedral. Como desconocemos cual fue el orden que siguió para tallar las cinco imágenes de la seo, no podemos afirmar con rotundidad si ya estaba hecha o no. De todas maneras, es un dato anecdótico puesto que seguramente Ávila estaría por estos meses de 1714 en su taller trabajando en ambas esculturas; si bien cabe señalar que parece que se preocupó menos por la de la catedral puesto que su calidad es bastante inferior a esta de Castil de Vela, como así podemos verlo al analizar los pliegues e incluso las facciones del rostro, mucho más sumarias.

La gran calidad de la escultura no puede ser contemplada en todo su esplendor merced a la abundante capa de polvo que la cubre. No debería extrañarnos en un futuro encontrarnos en alguna parroquia rural de las provincias limítrofes a Valladolid con algún ejemplar similar a este puesto que, como ya hemos comentado, los modelos creados por Pedro de Ávila gozaron de gran predicamento. 


\section{VALLADOLID. CATEDRAL}

En el año 1714, o a finales de 1713, el cabildo de la catedral vallisoletana encomienda a Pedro de Ávila uno de los encargos más importantes de su carrera: la realización de cinco esculturas que debían de presidir otros tantos retablos, cada uno en la capilla de su advocación: cuatro de ellas se ubicaban en capillas del lado de la Epístola (Santa María Magdalena, San Pedro, San José y San Miguel), y la quinta en la situada a los pies del Evangelio (San Juan Evangelista). Por entonces, encima de esta última capilla se erguía la torre catedralicia, llamada "la buena moza". De todas ellas tan sólo una tuvo como destino una capilla que estaba bajo el patronato privado, la de la Magdalena, por lo que el resto tuvieron que ser dotadas por el propio cabildo catedralicio ${ }^{41}$.

El cabildo al encomendar las esculturas a Pedro de Ávila no se las encargaba a un escultor cualquiera, sino que lo hacía al que por entonces era el escultor más prestigioso del ámbito vallisoletano, y por lo tanto de gran parte del noroeste español. Ya dijimos a raíz de la expresión "maestro escultor en Valladolid y de la Santa Iglesia de dicha ciudad", contenida en el libro de cuentas de la parroquia de Castil de Vela, que no solamente era su importancia como escultor sino que también parecía que se trataba del maestro mayor de escultura del obispado. Esta importancia está en consonancia con la alabanza que le dedicó años después su amigo el historiador Manuel Canesi en su Historia de Valladolid: "estatuario insigne" 42 .

Como hemos referido antes, fue uno de los dos encargos más importantes de su vida, el otro sería el conjunto de otras cinco esculturas que le encargó la Congregación de San Felipe Neri para adornar tanto el retablo mayor como algunas capillas laterales. Ambos trabajos resultaron ser, sin lugar a dudas, las empresas de amueblamiento y decoración más importantes que se llevaron a cabo en Valladolid durante la primera mitad del siglo XVIII. En esta tarea catedralicia colaboró con otros dos artífices: los retablos corrieron a cargo del ensamblador Pedro de Ribas, mientras que el dorado de los retablos y, quizás, el policromado y encarnado de las esculturas lo realizó el dorador Santiago Montes. Sin lugar a dudas la catedral contó con parte de los mejores artífices en cada uno de sus respectivas artes.

Pedro de Ribas construyó los cinco retablos entre los años 1714-1715; de ellos tan solo han llegado hasta nosotros tres: los de San Pedro, San José y San Miguel. Los retablos debieron de obedecer a tres trazas diferentes, pues solo así se explica la disparidad de precios: en 3.400 reales se valoraron el de la Magdalena y el de San Pedro; 3.500 reales percibió por el de San José; mientras que por los que se hallaban en las capillas de los pies de ambas naves (San Juan Bautista y San Miguel) se le abonaron 5.200 reales, es decir, 2.600 por cada $u^{43}$. Por fortuna conservamos un retablo de cada tipo. Tanto los

$41 \quad$ URREA, Jesús: "Reflexiones sobre la Catedral de Valladolid y noticia de algunas de sus pinturas", II Curso de patrimonio cultural (2008-2009), Ayuntamiento de Valladolid, Valladolid, 2009, pp. 126-127.

42 CANESI ACEVEDO, Manuel: Historia de Valladolid (1750) Tomo III, op. cit., pp. 560-561.

43 1714-1715. "25.086 reales, de dos retablos para la capilla de la Magdalena y San Pedro, a 3.400 reales cada uno. Otro retablo para la capilla de San José en 3.500 reales; otros dos retablos para las 
retablos del primer tipo como los del segundo, por los cuales percibió similar cuantía, son casi idénticos, basados en una estructura de estípites. En cambio, los del tercer tipo, que podemos juzgar gracias al retablo de San Miguel, pudieron resultar más baratos debido a que se trata de un retablo completamente plano, sin resaltes, en contraposición a los otros que se prolongaban levemente por los lados, denotando que la pared tenía forma poligonal. Asimismo, es de resaltar que todos ellos en el centro de su ático se encuentra abiertos en forma de círculo que se superpone perfectamente a una vidriera que permite la iluminación del interior de la capilla puesto que de otra forma el tipo de arquitectura de la catedral las hubiera dejado a oscuras. Podríamos verlo como una especie de "transparente", pero muy simple.

Estos retablos no fueron bien considerados por el implacable ilustrado Ponz, el cual cada vez que podía demostraba su aversión hacia el barroco, al calificarlos como "ridículos maderajes, e invenciones, que dicen peor con el edificio (...). Si lo que se gastó (...) en aquellos, se hubiera invertido también en la continuación de la obra, ya puede usted ver adonde podría haber llegado. El caso es, que si aquella prosigue, y se concluye, como espero, es necesario que se quiten con el tiempo las expresadas fealdades" ${ }^{\prime 4}$.

Por su padre, Pedro de Ávila percibió por la ejecución de las cinco esculturas 8.000 reales de vellón, es decir 1.600 reales por cada una de ellas ${ }^{45}$, la cantidad más alta que tenemos documentado que se le pagara por una sola imagen; le sigue a la zaga los 1.400 reales del San Miguel de Castil de Vela. No cabe duda de la alta estima, y con razón, que tenía el cabildo catedralicio por nuestro escultor, el cual sin lugar a dudas echó el resto a la hora de fabricar las imágenes, alcanzando unas cotas de calidad (no en el caso del San Miguel) que nos llevan a afirmar con rotundidad que algunos de ellas figuran entre sus obras maestras, casos del San Pedro y San José.

Finalmente, como ya dijimos, del dorado de los retablos se ocupó Santiago Montes, si bien tan solo tenemos documentada su actuación en los retablos de la Magdalena y San José. Por el dorado de estos dos últimos, efectuado en el año 1716, se le abonaron 13.427, cantidad en la que entraban "otras cosas" ". Manuel Canesi en su Historia de Valladolid nos aporta la noticia de que Montes también se ocupó del dorado del retablo de la capilla de San Juan Evangelista: "Es la $1^{a}$ de mano izquierda la que sirve de parroquia y está dedicada a S. Juan Evangelista, adornada con nuevo retablo desde el año 1716 en que este y otros doró al uso de ahora Santiago Montes y se concluyeron

capillas debajo de las torres, en 5.200 reales; 8.000 reales los cinco santos para las cinco capillas. 200 reales a Pedro de Ribas por la traza de los últimos retablos". MARTÍN GONZÁLEZ, Juan José: "Noticias documentales sobre la Catedral de Valladolid", B.S.A.A., Tomo XXVI, 1960, p. 193.

44 PONZ, Antonio: Valladolid en el "Viaje a España" (1783), Grupo Pinciano, Valladolid, 1993, p. 43.

45 1714-1715. "8.000 reales los cinco santos para las cinco capillas". MARTÍN GONZÁLEZ, Juan José: "Noticias documentales sobre la Catedral de Valladolid", B.S.A.A., Tomo XXVI, 1960, p. 194.

$46 \quad$ 1716. "13.427 reales, a Santiago Montes por dorar los retablos de la Magdalena y San José y otras cosas". MARTÍN GONZÁLEZ, Juan José: "Noticias documentales sobre la Catedral de Valladolid", B.S.A.A., Tomo XXVI, 1960, p. 194. 
otras obras de menos entidad; pero todas primorosas y de mucha labor" ${ }^{" 4}$. Si no tuviéramos documentado el dorado de estos retablos gracias a los libros de fábrica la noticia aportada por Canesi poseería total verosimilitud dado que un hermano del diarista, el batidor de oro Antonio Canesi, sale como fiador de Montes en el dorado del retablo de la capilla de la Magdalena. A esto habría que sumar una supuesta relación de amistad con el dorador ya que le nombra en diversas ocasiones en su Historia, siendo uno de los pocos artistas contemporáneos a los que cita. Aunque no tenemos documentado al autor de los dorados de San Pedro y San Miguel, parece lógico pensar que también fue Santiago Montes. El del retablo de San Pedro se ejecutó en 1721 (el mismo año que el de San Juan Evangelista) ${ }^{48}$, mientras que dos años después se procedió con el de San Miguel $^{49}$. Los años transcurridos entre unos dorados y otros tendrán relación con el eterno problema de la seo vallisoletana: la falta de fondos de las arcas catedralicias.

Antes de que Urrea documentara estas cinco esculturas como obras de Pedro de Ávila, el peculiar estilo de nuestro artífice ya fue percibido por Martín González durante la redacción del Inventario Artístico de Valladolid; pero no en todas ellas. Mientras que sí lo vio con claridad en las esculturas de San José, San Pedro y la Magdalena ${ }^{50}$; no lo tuvo tan claro con la de San Miguel, sin lugar a dudas por la escasa calidad de esta imagen, de tal modo que prefirió adscribirlo a la "escuela de Pedro de Ávila"51. Finalmente, la de San Juan Evangelista tan solo la describió como escultura del siglo XVII ${ }^{52}$. Parece que el extraño cuerpo al que se colocó la cabeza de la escultura original tallada por Ávila despistó al profesor e investigador. Esta última problemática la analizaremos en profundidad más adelante.

Fue en 2005 cuando Jesús Urrea en su artículo "Capillas y patronos de la catedral de Valladolid" publicado en el Boletín de la Real Academia de Bellas Artes de la Purísima Concepción dio a conocer una partida por la cual quedó documentada la paternidad de Pedro de Ávila de todas estas esculturas: “ajustado un San Joseph, la Magdalena y San Pedro para las tres capillas en 1.600 reales cada santo y por cuenta pagué a Pedro de Ávila, 1.500 reales" ${ }^{\prime 53}$. De esta manera tendríamos documentadas tan solo tres de ellas, a 1.600 reales cada una, pero si esto lo unimos a una partida anterior por la cual se le pagaron 8.000 reales por las cinco esculturas, queda claro que ese escultor anónimo era Pedro de Ávila.

47 CANESI ACEVEDO, Manuel: Historia de Valladolid (1750), Tomo III, Grupo Pinciano, Valladolid, 1996, p. 335.

$48 \quad$ 1721.- "9.915 reales, que valen 337.110 maravedís, de dos retablos que se doraron, el uno de la parroquia y el otro de la parroquia de San Pedro". MARTÍN GONZÁLEZ, Juan José: "Noticias documentales sobre la Catedral de Valladolid", B.S.A.A., Tomo XXVI, 1960, p. 194.

49 1723.- "6.081 reales y 19 maravedís, en dorar el retablo de la capilla de San Miguel". MARTÍN GONZÁLEZ, Juan José: "Noticias documentales sobre la Catedral de Valladolid", B.S.A.A., Tomo XXVI, 1960, p. 194.

50 MARTÍN GONZÁLEZ, Juan José (dir.): Inventario artístico de Valladolid y su provincia, Ministerio de Educación, Valladolid, 1970, pp. 29 y 30.

$51 \quad$ Ídem, p. 30.

$52 \quad$ Ídem, p. 28.

$53 \quad$ URREA, Jesús: “Capillas y patronos de la catedral de Valladolid”, Boletín de la Real Academia de Bellas Artes de la Purísima Concepción, Tomo XL, 2005, p. 123. 
A continuación, pasaremos a analizar las esculturas empezando por la del lado del Evangelio y siguiente por las de la Epístola, desde la cabecera a los pies. En el caso de la capilla de la Magdalena, a pesar de no llamarse ya así y de no encontrarse allí la estatua, se seguirá el orden que tenía en tiempos de nuestro escultor.

\section{SAN JUAN EVANGELISTA (1714)}

La presente escultura (Figs. 15-16) parece ser la que ha tenido una historia más azarosa y confusa. La capilla, que durante siglos ejerció la función de parroquia catedralicia, se sitúa a los pies de la nave del Evangelio; era la de menores dimensiones, sin duda debido a que sobre ella se levantaba la antigua torre de la catedral.

El retablo primitivo ejecutado en 1714 por Pedro de Ribas ${ }^{54}$ y dorado en 1721 por Santiago Montes desapareció tras el hundimiento de la torre a media tarde del día 31 de mayo de 1841. De esta desgracia parece que tan solo se salvó la escultura titular del retablo, tallada por Ávila, aunque, como veremos, parece que esa afirmación no es del todo correcta. Pedro Alcántara Basanta en su delicioso Libro de curiosidades relativas a Valladolid (1807-1831) nos describe muy pormenorizadamente aquella desgracia: "En 31 de mayo de 1841 que fue $2^{\circ}$ día de Pascua de Pentecostés entre 4 y 5 de su tarde se arruinó la torre de la Santa Iglesia Catedral sin que sucediese desgracia alguna, ni en personas ni en los edificios contiguos, sólo si se arruinó la capilla de San Juan Evangelista, inclusa en la Santa Iglesia y era la parroquia así titulada y habiéndose hundido la habitación del campanero cayó su mujer entre las ruinas en la cama donde estaba durmiendo la siesta debajo de las cuales estuvo 22 horas que a puro celo y vigilancia de las autoridades, trabajo infatigable de los presidiarios y otras personas piadosas se la sacó viva con algunas lesiones y leves heridas que sanó completamente quedando un poquito coja. Y el marido tuvo el arrojo de bajarse de su habitación por una escalera de mano. Son muchas las circunstancias que se reunieron con esta desgracia por haber caído todo el campanario con el reloj; causando una explosión y ruido extraordinario, tomando toda la población de esta ilustre ciudad el mayor interés para acudir al alivio de tan grande desgracia y el Ilmo. Cabildo en unión con el Noble Ayuntamiento dispusieron a pocos días empezar la obra de desmonte de mucha parte de la torre que estaba ruinosa y todo se hizo sin que sucediese desgracia alguna más que haber caído un operario sin que se hiciese más daño que algunas contusiones, especialmente en el pecho el que sanó completamente a pocos días. Y constante el venerable cabildo en no perdonar fatiga hasta que se hallase el Copón con el Santísimo Sacramento de la parroquia que había quedado entre las ruinas, hallado este en la forma más admirable y sobre el Ara, dispuso hacer en acción de gracias una solemne procesión con asistencia de todas las Penitenciales, Cofradías Sacramentales, Clero, Autoridades local y provincial, Excmo. e Ilmo. Sr Obispo que llevaba el Santísimo en sus manos en el mismo Copón estando tendida toda la tropa de la guarnición de

54 MARTÍN GONZÁLEZ, Juan José: "Noticias documentales sobre la Catedral de Valladolid", B.S.A.A., Tomo XXVI, 1960, p. 193. 
Infantería, Caballería y Artillería y la de la Milicia Nacional, saliendo la procesión de dicha santa iglesia por la plazuela de Sata María, estando formada la Universidad en sus balcones de toda ceremonia y habiendo un hermoso altar en la puerta principal; continuando por la calle de la Librería, Plazuela del Colegio Mayor, calle de la Cárcava, Orates, Fuente Dorada, Platería, Cantarranas, Cañuelo hasta llegar a la Penitencial de las Angustias, donde se colocó el Santísimo Sacramento y en toda la carrera hubo muy hermosos altares y un concurso de gentes grandísimo $y$ piadoso, cuya procesión se verificó el día Domingo 18 de junio a las 10 de su mañana y el venerable cabildo continuó sus obras para habilitar la Santa Iglesia, y el día Domingo 2 de enero de 1842 tuvo la dicha e indecible gozo de hacer una solemne función e indecible gozo de hacer una solemne función de gracias con misa, sermón y Te-Deum y asistencia de todas las autoridades" $"$.

Inmediatamente el cabildo se apresuró a rehacer la bóveda de la capilla, "imitando su aspecto primitivo", y a construir un nuevo retablo mayor, el cual fue llevado a cabo en 1846 en estilo

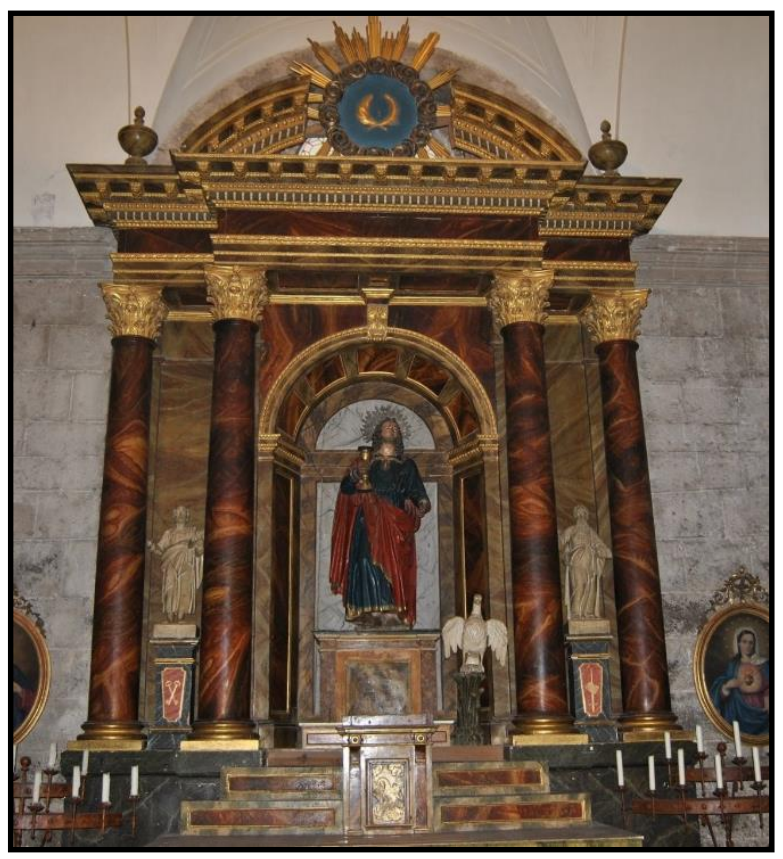

Il. 6- Jorge Somoza. Retablo de San Juan Evangelista. Catedral. Valladolid neoclásico por el prestigioso ensamblador vallisoletano Jorge Somoza ${ }^{56}$; se trata del que actualmente sigue presidiendo la capilla. Casimiro González García-Valladolid nos plantea ciertas dudas acerca de su fecha de ejecución y sobre su posible confusión con otro traído desde el Monasterio de Nuestra Señora de Prado. Señala que el "retablo corintio que tiene le hizo Jorge Somoza, y fue colocado en ella el año 1841, trasladado de la iglesia conventual de padres jerónimos de Nuestra Señora de Prado"57. Es decir, según el erudito el retablo no fue realizado en 1846 bajo los auspicios del cabildo, sino que se trajo en 1841 desde el referido monasterio desamortizado; en lo único que coincide es en la autoría del mismo.

La escultura de San Juan Evangelista no gustó para nada al referido Casimiro González García-Valladolid: "la efigie del Santo titular, escultura en madera de tamaño un poco mayor que el natural y de cuerpo entero, es muy regular" ${ }^{58}$; pero no es para menos puesto que la talla del cuerpo es muy basta, realizada por un maestro de tercera fila: los pies planos, casi sin desbastar; y los pliegues muy secos, sin orden ni concierto y

55 ALCÁNTARA BASANTA, Pedro: Libro de curiosidades relativas a Valladolid (1807-1831), Tipografía del Colegio Santiago, Valladolid, 1914, pp. 167-169.

56 URREA, Jesús: La Catedral de Valladolid y Museo Diocesano, Everest, Madrid, 1978, p. 21.

57 GONZÁLEZ GARCÍA-VALLADOLID, Casimiro: Valladolid, sus recuerdos y sus grandezas: religión, historia, ciencias, literatura, industria, comercio y política, Tomo I, Imprenta de Juan Rodríguez Hernando, Valladolid, 1900-1902, p. 351.

$58 \quad$ Ibídem. 
carentes de cualquier impulso naturalista. Desde hace tiempo tenía la sensación, la cual se ha acrecentado tras la reciente restauración de la imagen llevada a cabo este año de 2015 por un grupo de restauradores de la Escuela de Arte de Valladolid, capitaneados por Andrés Álvarez Vicente ${ }^{59}$, de que la cabeza no pertenecía a ese cuerpo. Pienso que, tras el derrumbe de la capilla, los únicos afectados no fueron el retablo y la capilla en sí, sino que también destruyó la escultura de San Juan Evangelista tallada por Pedro de Ávila. Parecería algo extremadamente raro y milagroso que tras tan pavoroso accidente la estatua hubiera quedado intacta. El cuerpo del santo quedaría tan afectado que no se pudo restaurar debido a lo cual, a la vista de que la cabeza sí que se conservó intacta, se contactaría con un escultor que tallara nuevos tanto el cuerpo como las manos, amén del cáliz que sostiene en una de ellas. Como podemos observar por los ropajes, el escultor en cuestión, del cual carecemos de cualquier pista para averiguar su identidad, no se nos muestra demasiado diestro a la hora de tallar los pliegues: las quebraduras bastas y sin sentido son la constante, sin nada que ver con el estilo elegante y refinado de nuestro escultor. Es extraño que no se haya reparado en esta diferencia de calidad entre el horroroso cuerpo y la estupenda y magnífica cabeza, que seguramente se encuentre entre las más bellas salidas del taller de Ávila.

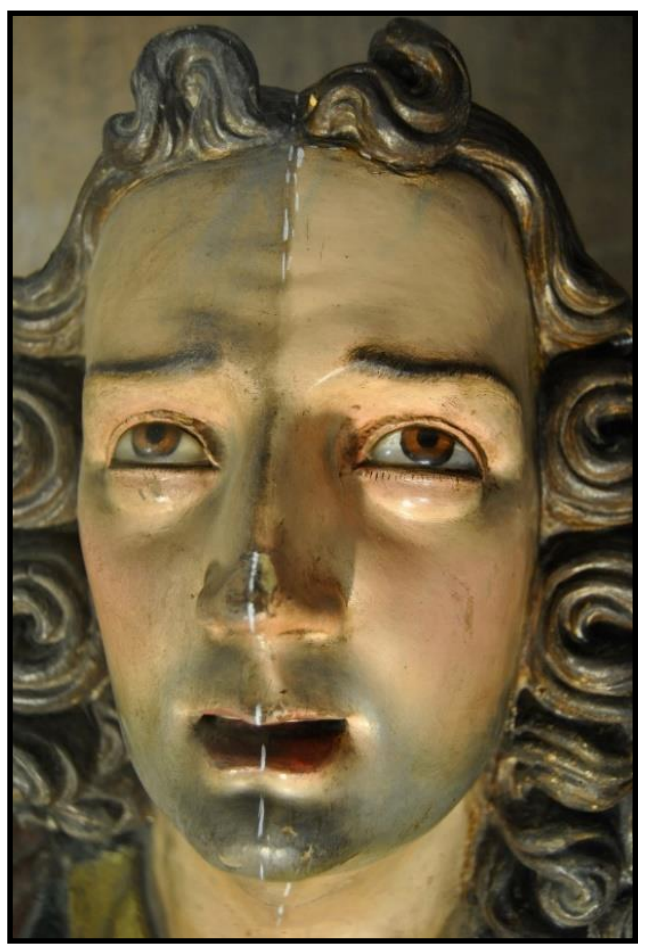

Il. 7- Detalle de la restauración del rostro de San Juan Evangelista.

La realización del nuevo cuerpo parece que trajo consigo un cambio en cuanto a la iconografía del santo puesto que tenemos algunas pistas que indican que no representaría, como ocurre ahora, el milagro de la copa de veneno, sino que en realidad Pedro de Ávila habría concebido al santo en su calidad de Evangelista. Para ello me baso en el hecho de que hay dos imágenes de este mismo santo que son idénticas entre sí. Se trata de la que hizo su hermano Manuel de Ávila para el ático del retablo mayor de Fuentes de Valdepero (Palencia) y otra que hemos descubierto en el retablo mayor de la iglesia de Santa María de Colaña de la localidad de Castromocho (Palencia), esta última sin autor concreto pero cuya autoría se debe sin lugar a dudas al propio Pedro de Ávila o a su hermano Manuel. Como hemos dicho, ambas son idénticas entre ellas (nos presentan al santo de pie, con la pluma en su mano derecha, el libro de su Evangelio en la izquierda y el

$59 \quad$ La restauración se llevó a cabo con motivo de la solicitud de la Cofradía del Discípulo Amado a la catedral para poder procesionar la imagen de San Juan, el Discípulo Amado, en la Procesión General de la Sagrada Pasión del Redentor. Efectivamente, ambas partes se pusieron de acuerdo, la talla se restauró de una manera impecable, dejándonos ver su magnífico rostro en todo su esplendor, y salió por primera vez en dicha procesión el día 3 de abril de 2015. Agradezco al citado Andrés Álvarez Vicente y a Juan Carlos Álvarez Sánchez, restauradores de la dicha imagen, por las facilidades para ver de cerca los progresos de la restauración. 
águila de su Tetramorfos a los pies; es decir, estamos hablando que el santo aparece en el pasaje en el que escribe su Evangelio en la Isla de Patmos), pero no solo eso, sino que el rostro, el pelo y la mirada elevada del santo también coincide con la del San Juan Evangelista que Pedro de Ávila talló para la catedral vallisoletana. En definitiva, este San Juan que estamos tratando, que en origen se le representaría en condición de Evangelista (seguramente también a sus pies se encontraría un águila puesto que la actual parece tallada también a mediados del siglo XIX), vendría a ser el modelo que sirvió años después a su hermano para tallar el San Juan de Fuentes de Valdepero y quizás el de Castromocho. O sea que estamos ante otra de esas esculturas clave que abren camino a una nueva iconografía creada por nuestro escultor, tal y como ocurrió con otras anteriormente reseñadas. Tampoco en este caso sería extraño el encontrarnos en alguna parroquia rural de Castilla con una imagen semejante, tal y como me sucedió hace poco tiempo con el San Juan Evangelista de Castromocho.

En definitiva, que el San Juan Evangelista tallado por Ávila para la catedral se nos presentaría de pie, con la pierna derecha levemente adelantada. En su mano izquierda portaría un libro abierto, con la derecha agarraría una pluma, mientras que el santo elevaría el rostro hacia el cielo buscando la inspiración divina. El santo vestiría una túnica verde hasta los pies y un manto rojo que le cubriría buena parte del cuerpo y le caería por el hombro y el brazo izquierdo. A sus pies se situaría un águila con la cabeza elevada mirando al santo y con las alas extendidas. No nos hemos referido antes a este detalle, pero es que las dos esculturas aludidas copian fielmente hasta las secuencias de rizos de la cabellera del original, motivo que ya hemos visto en los dos ejemplares de San Miguel Arcángel.

Por contra, el San Juan que actualmente vemos se nos presenta también erguido, con los dos pies bastante mutilados, y como pegados al inmenso bloque sin desbastar que conforman las vestimentas del santo (en la parte donde se unen los pies con el cuerpo se observa que el bloque de madera se encuentra totalmente macizo, sin desbastar ni policromar, algo totalmente impensable en Pedro de Ávila). Viste unos ropajes similares, signo de que el escultor se pudo guiar por los restos del cuerpo destrozado del santo: túnica larga verde y manto rojo recogido a la cintura. Como vemos es una simplificación, tanto de la manera de los ropajes como de los pliegues. En su mano izquierda sujeta el cáliz venenoso que, como hemos dicho, modifica el sentido e iconografía de la primitiva imagen, mientras que con la derecha hace un gesto como de agarrar algo.

El cáliz venenoso alude a un acontecimiento sucedido en Éfeso tras el fallecimiento del emperador romano Domiciano (51-96). Relata Réau que Aristodemo, a la sazón sumo sacerdote del templo de Diana en Éfeso, quiso poner a prueba a San Juan: "Si quieres que crea en tu Dios, te daré veneno a beber y si no te hace daño alguno es que tu dios es el verdadero Dios"60. Tras moler "reptiles venenosos en un mortero, en principio ensayó los efectos del veneno sobre dos condenados a muerte que sucumbieron de

60 RÉAU, Louis: Iconografía de los santos. G-O, Ed. del Serbal, Barcelona, 1997, p. 196. 
inmediato. Entonces llegó el turno del apóstol que tomó la copa y después de hacer la señal de la cruz, se bebió el veneno de un trago sin experimentar mal alguno. Luego resucitó a los condenados extendiendo su manto sobre ellos" ${ }^{\prime \prime}$. Sea como fuere la iconografía presente en la escultura estaría incompleta puesto que se suele colocar un pequeño dragoncillo saliendo del cáliz para indicaros que el líquido de su interior era veneno.

El rostro es brillante, precioso, parece reflejar la angustia del escritor que busca la inspiración divina para plasmar las palabras en el Evangelio. Nos presenta a un hombre joven que dirige sus ojos, realizados en tapilla, hacia el cielo. El gesto de angustia/sorpresa se ve acompañado por la boca entreabierta, de la cual podemos ver una estrecha franja de sus dientes superiores y la punta de la lengua. Los rasgos fisionómicos son los típicos en Ávila. Llama la atención la exquisita policromía, en especial la que nos muestra la incipiente barba. La caballera con amplios bucles que denota su manejo excepcional del trépano nos remite a las ya vistas en las efigies de San Miguel. El rostro parece emparentar con el del San Juan que probablemente talló su padre Juan de Ávila para el Calvario del Colegio de los Ingleses; además, este mismo rostro lo volverá a utilizar Ávila para la Magdalena que hizo para otra de las capillas de la catedral e incluso en la Virgen del grupo de la Anunciación conservado en la parroquial de Renedo, amén de otras muchas más.

\section{SANTA MARÍA MAGDALENA (1714)}

La actual capilla de San Pedro Regalado (la más cercana al altar mayor en el lado de la Epístola), estuvo anteriormente bajo la advocación de Santa María Magdalena; siendo, además, la única de las cinco capillas para las que Pedro de Ávila tallara una imagen que tenía patronato privado. La capilla había sido adquirida por doña Magdalena de Salcedo, esposa del Secretario de cámara don Juan de Santisteban, la cual dejaba ordenado en su testamento, otorgado el 27 de marzo de 1605, que poseía "en la Santa iglesia catedral de esta ciudad para mi entierro y de mis padres y del que yo quisiere la capilla del crucero de la dicha iglesia mayor nueva que se está haciendo, y en el entretanto que sea acabada la dicha capilla me dan los señores prior y cabildo de la dicha santa iglesia otra capilla que ahora está hecha en la iglesia vieja que está detrás del coro que es de la advocación de Santo Tomás de que tengo tomada posesión como consta por la escritura y autos que pasaron ante Amador de Santiago (...) en 12 de junio de $1595^{\prime \prime 62}$.

Asimismo, dictaba que si cuando falleciera "no estuviese acabada la dicha mi capilla que se acabe conforme está concertado por la dicha escritura de fundación y compra de ella y se haga el retablo y reja y ornamentos de plata que fuese necesario para ella y

\footnotetext{
$61 \quad$ Ibídem.

62 URREA, Jesús: “Capillas y patronos de la catedral de Valladolid”, Boletín de la Real Academia de Bellas Artes de la Purísima Concepción, Tomo XL, 2005, p. 113.
} 
se pongan mis armas y letrero de mis memorias en ella si yo no las dejare puestas y hecho lo susodicho y las dichas armas no se puedan mudar en ningún tiempo ni poner otras con ellas por mi patrón ni por otra persona alguna". Como al tiempo de morir, el 28 de octubre de 1608, la capilla "no está en estado de se poder acabar en muchos años sin mucho daño de ella por los temporales de ellos y haber de hacer trabazón la cantería y sillería de ella con las demás a que está junta" decidió que mientras se concluía ésta las memorias y el entierro de la difunta se celebraran en la capilla de Nuestra Señora del Populo radicada en el viejo templo catedralicio ${ }^{63}$.

Hubo que esperar hasta comienzos del siglo XVIII para que las obras de la seo se volvieran a reanudar. Efectivamente, entre los años 1708 y 1709 se construyeron las bóvedas de las capillas de la nave de la Epístola, terminándose la capilla que nos ocupa en 1712. Posteriormente, el rejero vitoriano Bartolomé Elorza se encargó de fabricar tres rejas similares para ellas que serían rematadas por copetes de madera dorada, obra del ensamblador Alonso del Manzano. Por último se contrataría la ejecución del retablo que presidiría la Magdalena de nuestro escultor; para ello el administrador de las memorias de doña Magdalena trató con el patrono don Francisco Herrera Villalobos para "que pusiese (...) retablo de mi gusto al modo de la capilla del santo Rey que abonaría en cuenta de su patronato" $"$. Como ya hemos visto con anterioridad, el retablo fue levantado en 1714 por el ensamblador Pedro de Ribas ${ }^{65}$. Posteriormente, el 27 de febrero de 1716 el dorador Santiago Montes se encargó de "dorar el retablo de la capilla de doña Magdalena de Salcedo y el marco de frontal", comprometiéndose a tener finalizada la obra en el mes julio de ese mismo año ${ }^{66}$. Hasta un par de años después las memorias de doña Magdalena no terminaron de abonar los honorarios al dorador, como así lo demuestran las cuentas del periodo 1717-1718; asimismo, también se demoró hasta el periodo 1719-1720 los pagos al ensamblador ${ }^{67}$.

El retablo no se ha conservado puesto que al llegar la época neoclásica el cabildo catedralicio decidió "poner al día" el aspecto de la capilla. Así, en el cabildo celebrado el 28 de julio de 1842, el canónigo lectoral refiere que "cuando se dio principio a quitar el altar de Santa María Magdalena, de cuya capilla es patrono, no se opuso a esta operación por ser de orden del Cabildo se pusieran mejores altares en todas las capillas". La estética neoclásica no afectó a más capillas (años atrás se habían realizado los dos colaterales y el retablo de la capilla de Nuestra Señora del Sagrario), por lo que al suspenderse esta operación se reclamó que "se continuase poniendo otro igual al de San Pedro Regalado (que se había colocado en la misma capilla) en la capilla de enfrente de San Fernando, y de lo contrario, se volviese a colocar el de la Magdalena". La petición buscaba conseguir una simetría decorativa, finalmente lo que acordó el

\footnotetext{
63 Ídem, p. 114.

64 Ídem, p. 115

65 MARTÍN GONZÁLEZ, Juan José: "Noticias documentales sobre la Catedral de Valladolid", B.S.A.A., Tomo XXVI, 1960, p. 193.

$66 \quad$ URREA, Jesús: "Capillas y patronos de la catedral de Valladolid”, Boletín de la Real Academia de Bellas Artes de la Purísima Concepción, Tomo XL, 2005, p. 115.

$67 \quad$ Ídem, p. 123.
} 
cabildo fue "suspender la operación de los demás altares hasta que se resuelva en un cabildo general" 68 .

Por otra parte, en el año 1843 se cambió la advocación de la capilla. Santa María Magdalena dejó paso al que hacía ya casi un siglo era el patrón de la ciudad: San Pedro Regalado, el cual había sido canonizado en 1746. Desde entonces el lugar de la escultura de la Magdalena lo ocupa un magnífico óleo del pintor italiano Plácido Constanzi regalado por el Convento de San Francisco que representa a San Pedro Regalado resucitando para dar de comer a un pobre ${ }^{69}$. El cambio de advocación de la capilla provocó la protesta del apoderado de doña Juliana Herrera y Salcedo, patrona de sangre, quien manifestó que se había enterado de "que se había quitado el altar e imagen de la Magdalena de la capilla de este nombre colocando en su lugar el de San Pedro Regalado, cometiendo el despojo contra la propiedad del patronato" y reclamaba "que inmediatamente volviese a colocar en dicha capilla y sitio que ha estado el altar e imagen de la Magdalena y que no hacerlo así iría a los tribunales de justicia"70. La capilla en la actualidad carece de culto y más bien parece un trastero, como muchas de las capillas catedralicias. Cuando la escultura abandonó el retablo mayor pasó a ocupar una hornacina lateral de piedra de la misma capilla ${ }^{71}$, y posteriormente recaló en otra similar situada en el vestuario de los canónigos, que es en donde se encuentra a día de hoy. Está por lo tanto, fuera del culto público.

Entre documentadas y atribuidas, tenemos relacionadas con nuestro escultor un total de tres Magdalenas, todas ellas similares pero con ligeras variantes que las hacen distintas unas de otras. La Magdalena que nos ocupa, a través de los atributos que porta, viene a fundir dos iconografías totalmente diferentes: por un lado tenemos la que alude a la muerte y resurrección de Cristo, presente en esta escultura a través del vaso de perfumes con el cual la santa se apresuró a ir a embalsamar el cuerpo de Jesús; y por otro lado está la calavera, que además de ser un atributo de la santa que viene a reflejarnos su penitencia y arrepentimiento, alude a su faceta de anacoreta y asceta meditabunda. Asimismo es un elemento muy característico del barroco que está presente en muchas representaciones y viene a invitar a la melancolía y a una reflexión sobre la fugacidad de la vida. Claro ejemplo de ello son las vanitas.

Pedro de Ávila nos dispone a la santa (Figs. 17-19) según el modelo que tanto repetirá: de pie, con la pierna derecha levemente adelantada formando un leve contraposto, el cual intenta aumentar con el remarcamiento de la rodilla adelantada, lo que también contribuye al dinamismo de la escultura. También dispone los dos pies en el

\footnotetext{
$68 \quad$ Ídem, p. 116.

69 URREA, Jesús: "Reflexiones sobre la catedral de Valladolid y noticia sobre algunas de sus pinturas". En VV.AA.: Conocer Valladolid. II Curso de patrimonio cultural 2008-2009, Ayuntamiento de Valladolid, Valladolid, 2009, p. 127.

70 URREA, Jesús: "Capillas y patronos de la catedral de Valladolid", Boletín de la Real Academia de Bellas Artes de la Purísima Concepción, Tomo XL, 2005, p. 116.

71 "Capilla de San Pedro Regalado. (...) En un nicho de esta capilla hay una buena talla del siglo XVIII, efigiando a la Magdalena”. CHUECA GOITIA, Fernando: La catedral de Valladolid: una página del Siglo de Oro de la arquitectura española, Instituto Diego Velázquez, Madrid, 1947, p. 203.
} 
característico ángulo de $90^{\circ}$ y además ambos separados por una porción de túnica con los pliegues muy afilados. Estos dos detalles los veremos continuamente a lo largo de toda su obra. Parecemos ver lejanos ecos de Gregorio Fernández, concretamente de la Magdalena que talló para el paso del Descendimiento de la Ilustre Cofradía de Nuestra Señora de las Angustias.

Con su mano izquierda, y ayudada por el antebrazo, sujeta muy elegantemente una calavera muy realista situada sobre un paño de movidos pliegues. Es decir, la santa no llega a rozar la calavera. Para dejarnos ver el peso del paño y de la calavera talla los dedos recurvados, como cediendo. Su otra mano se encuentra actualmente con la mayor parte de los dedos rotos, lo que ha implicado que no pueda seguir sujetando el vaso de perfumes con los que se iba a encargar de embalsamar el cuerpo de Cristo. Ante la rotura de los dedos se ha optado por colocarlo a sus pies. Urgiría una recomposición de estos dedos para que la iconografía volviera a tener sentido.

La cabeza y el rostro presenta todos y cada uno de los estilemas presentes dentro del segundo estilo de nuestro escultor. Llama la atención la presencia de una serie de lágrimas postizas en las mejillas de la santa. El rostro emparenta de una forma muy íntima con el de otras figuras femeninas como la Virgen de

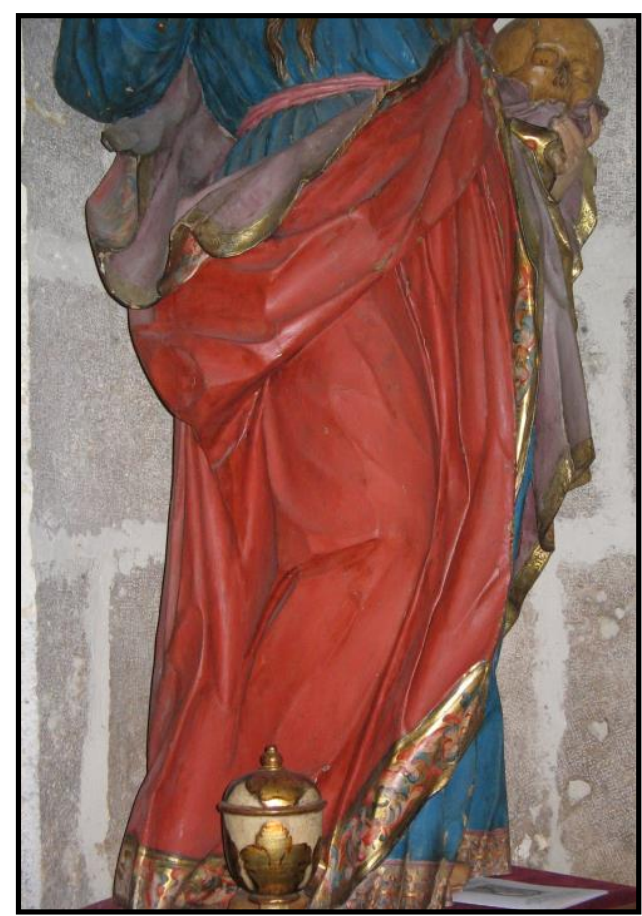

Il. 9- Detalle de los pliegues de Santa María Magdalena. la Anunciación conservada en

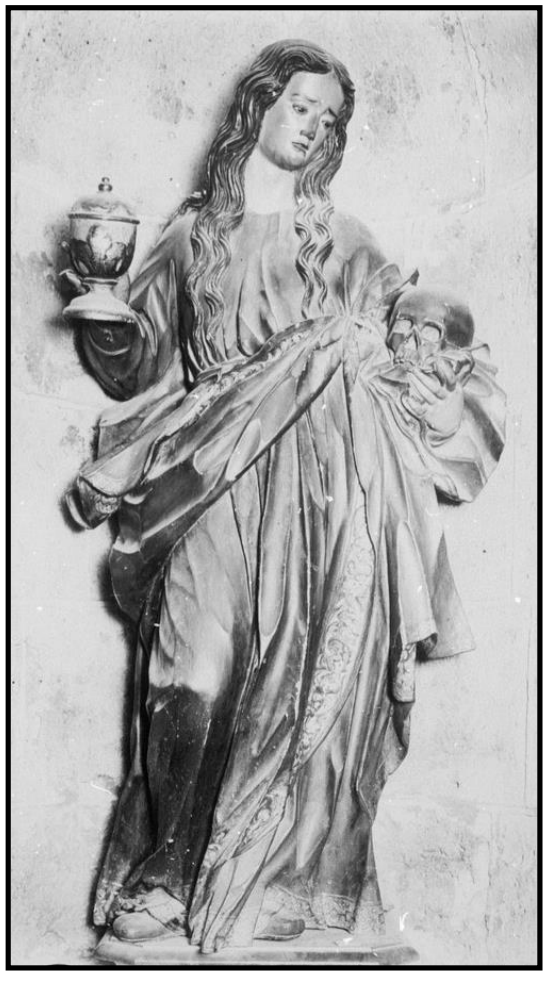

I1. 8- Fotografía de cuando Santa María Magdalena no tenía rotos los dedos y podía sujetar el vaso de los perfumes.
Renedo o el San Juan Evangelista de la catedral vallisoletana. Tiene larga cabellera que cae por la espalda y surca sinuosamente los dos lados del rostro hasta caer sobre el pecho con dos largas guedejas a cada lado. Sin duda con ello aludirá a su femineidad. El detallismo y volumen que poseen las guedejas incrementa el valor de la imagen.

Viste unos ricos atavíos compuestos por una túnica y un manto, ambos policromados con colores planos y unas ricas cenefas con decoraciones vegetales que parecen prolongar la tradición que vimos en la mayor parte de las esculturas de Juan de Ávila y que, por otra parte, era muy típica en la escuela vallisoletana a finales del siglo XVII y comienzos del XVIII. La 
túnica azul le cubre todo el cuerpo hasta los pies, dejándonos tan solo a la vista las manos y la punta de los zapatos. La mano derecha está tallada de manera independiente, y quizás debido a ello haya perdido gran parte de los dedos; por su parte izquierda parece resguardarse bajo la calavera entre las dulces dobladuras del paño. El manto rojo adopta una disposición que veremos en buena parte de su producción: parece recogerse en la parte izquierda del cinto que le ciñe la túnica, y a partir de ahí le cubre gran parte del abdomen, la pierna izquierda y buena parte de sus zonas traseras bajas. Con ello el escultor consigue simular una serie de diagonales que dinamizan la composición; otra diagonal, la más evidente, es la que une el rostro de la santa con la calavera. La meditación se hace presente.

Como en la mayoría de obras de esta segunda etapa, los pliegues a cuchillo abundan por doquier, y poco a poco va consiguiendo una finura asombrosa. Son especialmente remarcables las que definen el contorno de la escultura que parecen convertirla en una roca cortante, o los del interior del manto en el cual la sensación de movimiento es máxima.

\section{SAN JOSÉ CON EL NIÑO (1714)}

La capilla dedicada a San José, también denominada "de la familia Venero Leiva", nunca estuvo dotada económicamente, correspondiendo por lo tanto su cuidado y mantenimiento al cabildo catedralicio ${ }^{72}$. Como el resto de retablos estudiados fue tallado entre 1714-1715 por Pedro de Ribas $^{73}$, ocupándose de su dorado Santiago Montes en $1716^{74}$. El retablo no fue del gusto de Chueca Goitia que lo califica como "barroco, dorado, con un orden de estípites de escaso mérito" 75 , como tampoco lo fue la bellísima escultura de San José, que la consideró como una "talla del siglo XVIII, de poco valor"76. Craso error de apreciación.

La presente escultura de San José (Figs. 20-22) es, a no dudarlo, una de sus obras cimeras, en donde demuestra una técnica, un virtuosismo y

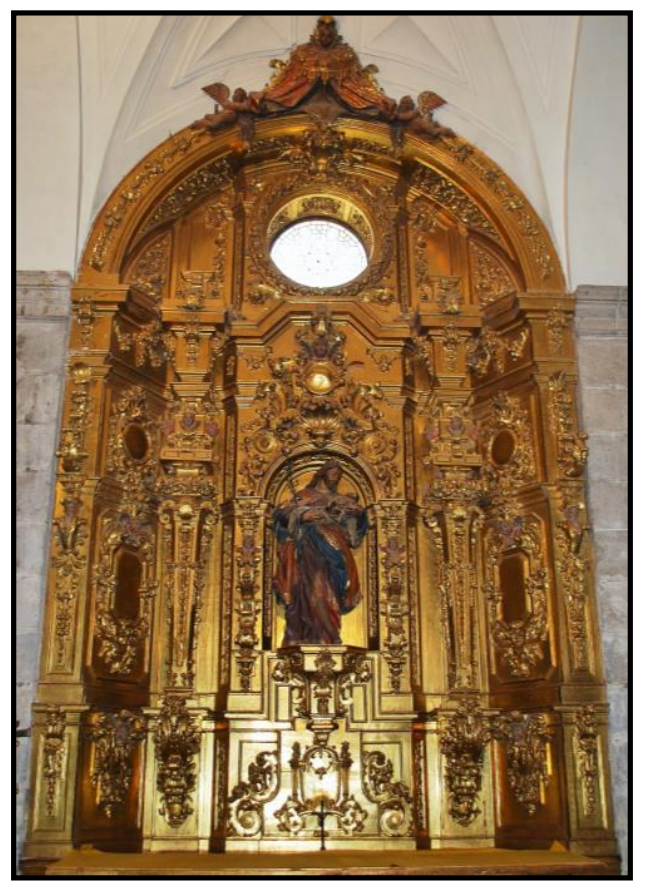

Il. 10- Pedro de Ribas. Retablo de San José. Catedral. Valladolid.

72 URREA, Jesús: “Capillas y patronos de la catedral de Valladolid”, Boletín de la Real Academia de Bellas Artes de la Purísima Concepción, Tomo XL, 2005, p. 120.

73 MARTÍN GONZÁLEZ, Juan José: "Noticias documentales sobre la Catedral de Valladolid", B.S.A.A., Tomo XXVI, 1960, p. 193.

$74 \quad$ Ídem, p. 194.

75 CHUECA GOITIA, Fernando: La catedral de Valladolid: una página del Siglo de Oro de la arquitectura española, Instituto Diego Velázquez, Madrid, 1947, p. 203.

76 Ídem, p. 204. 
una elegancia muy difícil de ver por estas fechas en España y en otros lugares que no fueran la Corte; es más, años atrás habría sido impensable este tipo de escultura en la que se conjuga una belleza y sensualismo en el que ya no tiene ninguna influencia la herencia fernandesca. Muchos detalles parecen remitirnos a la Corte, como son el uso de lujosas ropas, la delicadeza de los gestos o el incipiente influjo del rococó europeo singularizado en la utilización de una policromía con tonalidades planas y colores pálidos. Sin duda esta nueva forma de policromía ayuda a valorizar los distintos planos y el volumen de la talla; es decir estos colores revierten en pos de los valores puramente escultóricos, a pesar de que los bordes de la escultura tienden a un pictoricismo, elemento también muy extraño en tierras vallisoletanas.

Ya hemos dicho con anterioridad que este San José es el que podemos considerar como el modelo que posteriormente Pedro de Ávila repetirá en otras ocasiones con leves variantes, pero que alcanzará tanta popularidad que tanto su hermano Manuel como otros escultores se encargaron de copiar y difundir, y no precisamente para lugares secundarios puesto que una de las copias será la realizada por Pedro Correas para el retablo mayor de la iglesia de San Andrés de Valladolid. Sin embargo, y como también ya hemos remarcado, esta escultura viene a ser el final de una evolución, cuya estación primigenia pudo ser el San José de Fuente-Olmedo y la media el San José de Morales de Toro, en el cual están ya presentes la mayor parte de la composición y de los elementos, detalles y estilemas que componen este San José catedralicio.

Pienso que este definitivo modelo de San José pudo estar influido por el que supuestamente tallara su padre en la década de 1690 para la iglesia del Convento del Domus Dei de La Aguilera (Burgos). En aquella escultura observamos ciertas concomitancias en la manera de sujetar al Niño Jesús, así como en la presencia del paño que separa las manos del padre del cuerpo del Hijo. Estos dos elementos no aparecen en el que hemos denominado "fase intermedia" que es el San José de Morales de Toro, en aquél el Niño se apoya directamente sobre una de las manos del padre, y su posición no es tumbada, que da un aspecto mucho más delicado y bello, sino medio de pie y jugueteando con su padre; es decir es una versión algo más pintoresca y anecdótica.

Ávila nos presenta al santo de pie, ejerciendo un contraposto con el adelantamiento de la pierna derecha, movimiento muy elegante acrecentado por la apertura de la zona baja de la túnica lo que hace que podamos verle parte de la pierna y la bota. Nuevamente observamos la clásica disposición de ambos pies y entre medias el trozo de túnica separándolos. La forma de caer, como en tromba, de la túnica en el suelo parece querer establecer un punto de apoyo que ayude a la estabilidad de la pieza. Otra vez observamos cómo los perfiles bajos de parte de sus esculturas más bien parecen ser rocas cortantes. El santo gira levemente el rostro hacia abajo, mirando de forma muy amorosa a su hijo, el cual se encuentra tumbado sobre un paño que San José agarra con ambas manos. El Niño adopta una posición muy elegante, a la vez que perezosa puesto que parece no querer levantarse, y con su mano izquierda parece querer acariciar la mano izquierda del santo. Las manos del santo son un prodigio naturalista puesto que se curvan para acreditar el esfuerzo, lo que además incide en la morbidez de la carne; 
como de costumbre están perfectamente talladas con todas sus venas y huesos. En esta ocasión las manos forman parte del todo del cuerpo, no son independientes.

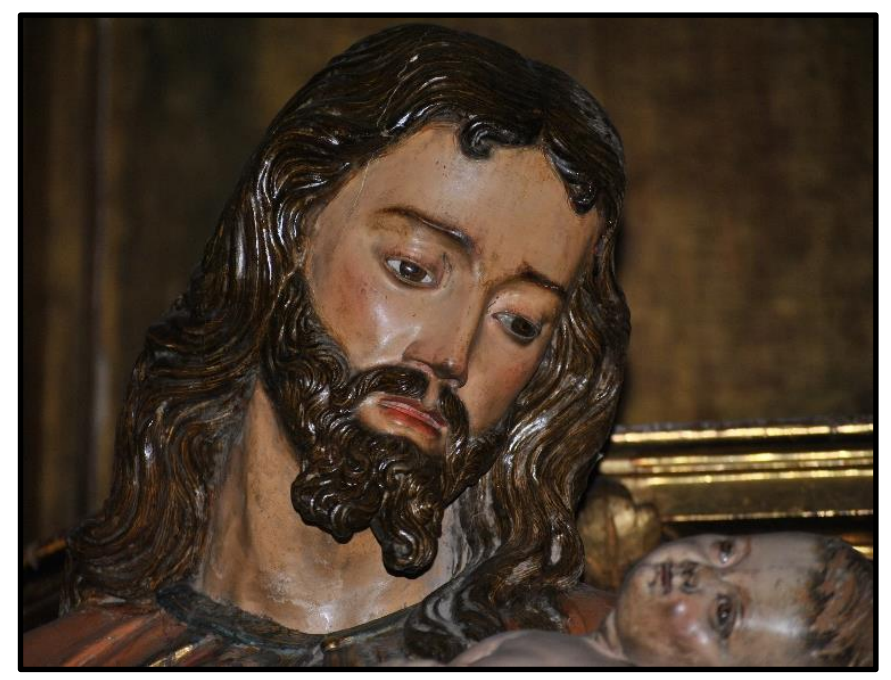

Il. 11- Pedro de Ávila. San José. Catedral. Valladolid.

El rostro del santo, que acusa blandura en las mejillas y morbidez en los labios, es el típico que utiliza para las representaciones del santo y las de Cristo. Nos presenta a San José con bigote y barba bífida realizada a base de pequeños mechoncitos recurvados. El peinado sobre la frente son otros dos pequeños mechones recurvados en su final, lo que hace que sean simétricos. A los lados del rostro se despliegan unas grandes melenas con ondas, muy individualizada cada guedeja. Tras la restauración de la escultura se observa mucho mejor el peleteado dorado. La forma de resolver la cabeza, tanto en lo referente al rostro como al peinado, es un prodigio técnico, lo que nos viene a demostrar la madurez del escultor.

Viste ropas muy ampulosas. La fina incisión de los pliegues implica la creación de numerosas diagonales, a la cual se une la formada por la mirada del santo al Niño Jesús. Porta una túnica morada abierta en una de sus piernas a la altura de la rodilla, con lo que nos permite verle la bota larga que le cubre uno de sus pies (este detalle se lo veremos copiar a los imitadores anónimos, no a Manuel de Ávila). Por encima viste una capa anudada al cuello que se despliega sobre los hombros, doblándose en ocasiones con mucha dulzura. El pliegue a cuchillo adquiere en esta escultura uno de sus cenits, pues observamos la composición de estas ropas a través de numerosos planos facetados e interrumpidos por finos pliegues que nos demuestran bien a las claras el virtuosismo adquirido por Ávila. La ampulosidad de las ropas convierte a la escultura en un clarísimo ejemplar de escultura barroca en la que el movimiento goza de una especial preferencia.

\section{SAN PEDRO APÓSTOL (1714)}

El retablo principal fue tallado en 1714 por Pedro de Ribas, percibiendo por él 3.400 reales $^{77}$. Siete años después fue dorado seguramente por Santiago Montes, encargado de realizar esta operación en los otros retablos ${ }^{78}$.

77 MARTÍN GONZÁLEZ, Juan José: "Noticias documentales sobre la Catedral de Valladolid", B.S.A.A., Tomo XXVI, 1960, p. 193.

$78 \quad$ Ídem, p. 194. 
San Pedro (Figs. 23-24) es representado de pie, parece avanzar con su pierna izquierda, aunque la rodilla de esa pierna no es tan abultada como en otras ocasiones. Ávila ha introducido un escorzo puesto que mientras que el santo parece dirigirse hacia la izquierda, gira el torso y la cabeza hacia la derecha. La escultura presenta los estilemas de Ávila que venimos repitiendo en todas estas imágenes "catedralicias", como son las de los pies.

En este santo, Ávila opta más por el carácter descriptivo que por la elegancia de la figura, aunque tampoco carece de ella. Ese carácter descriptivo lo vemos en que el escultor ha procurado introducir el máximo número de atributos que son consustanciales al primer Papa. Efectivamente, en esta ocasión a San Pedro, que porta en sus manos las típicas dos llaves y el libro que alude a su condición de apóstol, se añaden, a los pies del santo, dos angelitos apoyados a los lados de la peana. Ambos seres celestiales, parece que también tallados por nuestro escultor o sus oficiales,

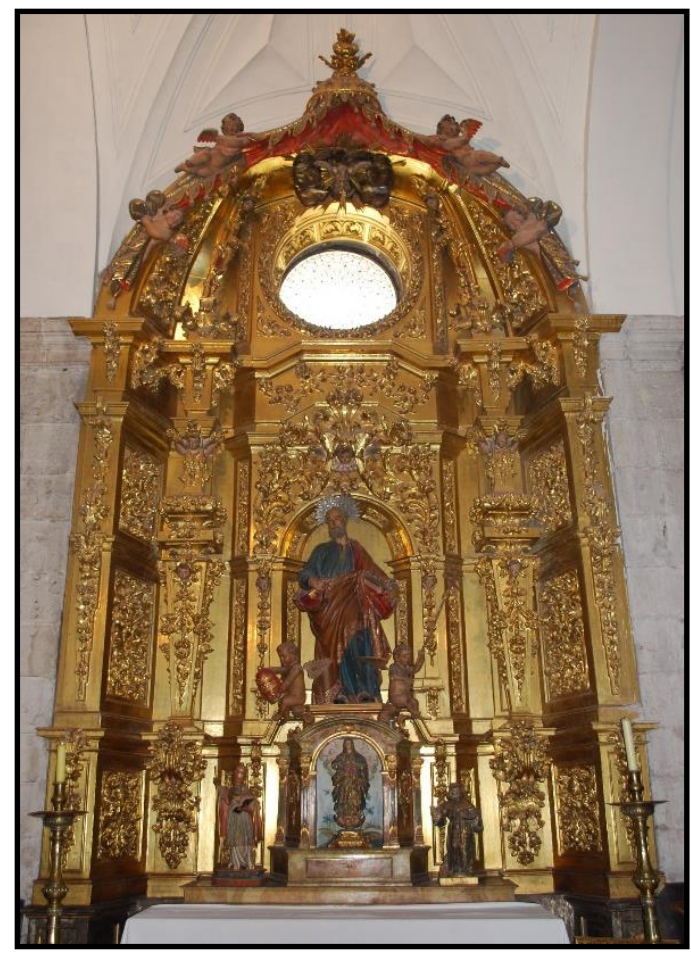

Il. 12- Pedro de Ribas. Retablo de San Pedro. Catedral. Valladolid. portan la tiara pontificia (el de la izquierda) y una cruz patriarcal (el de la derecha). Ambos "putti", de talla bastante ruda a excepción del rostro, llevan dos alas y una banda que les cruza el pecho. Este último detalle es bastante característico puesto que así les podemos ver caracterizados en la mayoría de los retablos en los que hacen acto de aparición: no hace falta recordar los retablos del Hospital del Rosarillo, Monasterio de San Quirce o el de la parroquial de Ataquines (Valladolid).

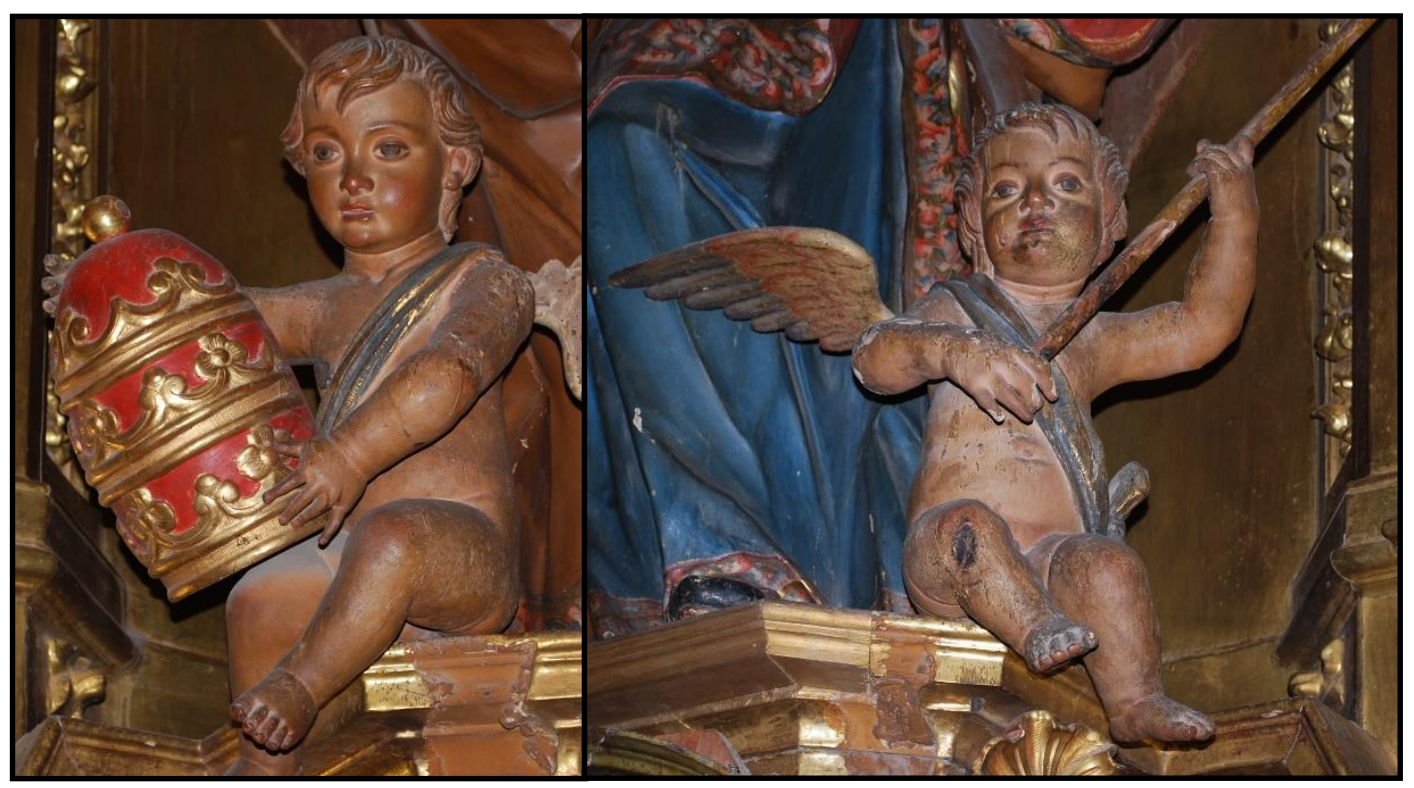

Il. 13- Detalle de los angelotes que portan los atributos de San Pedro.

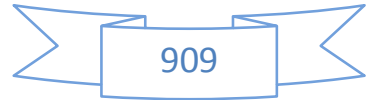


El rostro nos muestra bien a las claras que se trata del modelo que posteriormente utilizó para sus otras representaciones de San Pedro: el de las Lágrimas de San Pedro y el San Pedro del retablo mayor de San Felipe Neri. Sin embargo, muchos detalles parecen prestados por su padre. Efectivamente, señalaba Martín González sobre el San Pedro de San Felipe Neri, aunque también valdría en este caso, que "la cabeza [de San Pedro] sigue el tipo de Juan de Ávila para el San Francisco de Sales"79. Pero no solo eso, la forma de componer la barba, a base de numerosos caracolillos simétricos y uniformes nos remite a la barba del San Pedro en Cátedra que el propio Juan de Ávila talló de manera magistral para el retablo mayor de la colegiata de San Pedro de Lerma (Burgos). El rostro está tallado mórbidamente, acusando bien las calidades de la piel. La blandura del rostro la comprobamos en las arrugas de la frente, laterales del rostro, ceño y mejillas, todas las cuales dan buena prueba de la avanzada edad del santo y de la destreza de nuestro escultor para simularlas con tanta verosimilitud. Las facciones de ojos, nariz y boca son las usuales de Ávila en este periodo. Calvicie pronunciada, con grandes mechones de pelo en los laterales de la cabeza. Barba muy poblada realizada a base de numerosos caracolillos y anchos bigotes. La boca es pequeña y entreabierta, lo que nos permite verle los dientes.

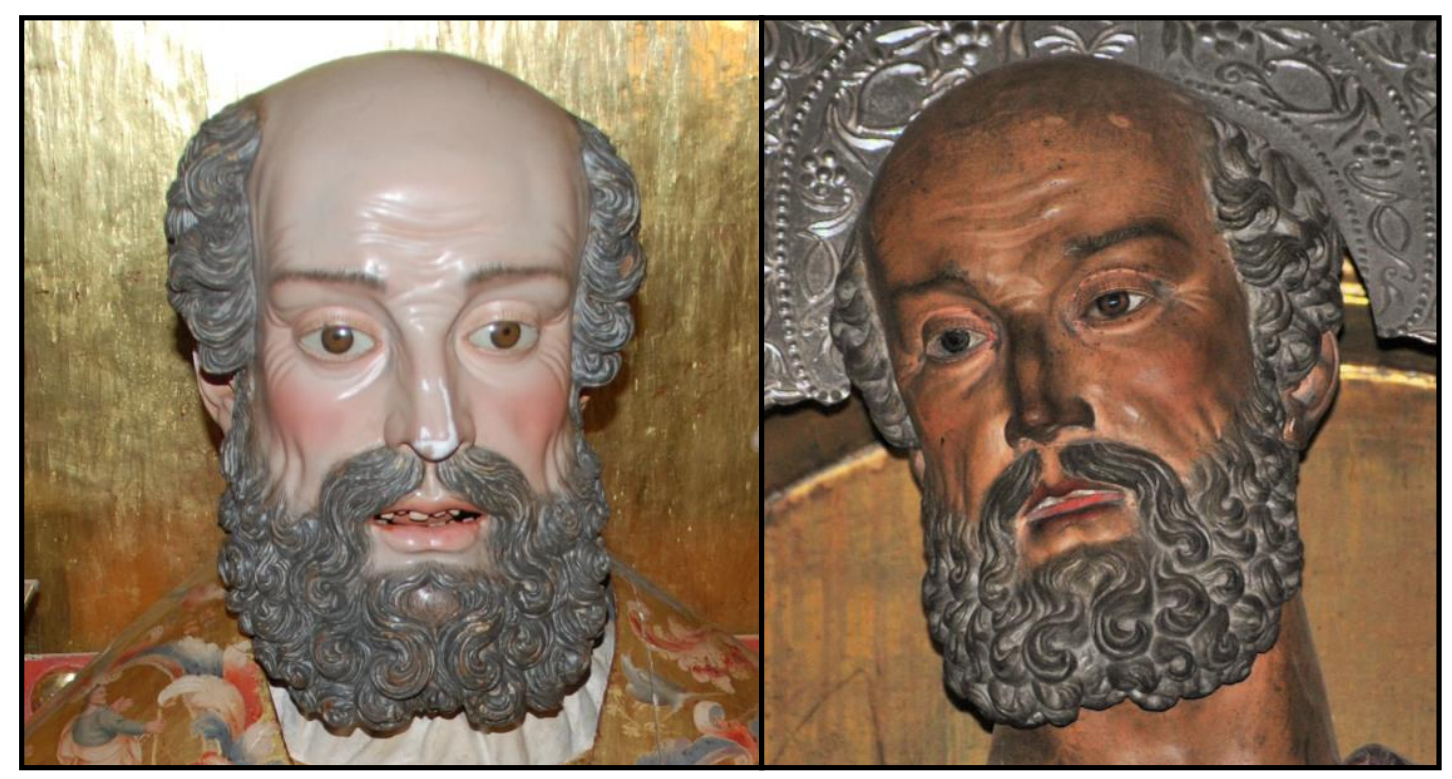

Il. 14- Comparación de las cabezas del San Pedro en cátedra de Juan de Ávila y el San Pedro de Pedro de Ávila.

Las manos, que portan los atributos ya comentados, son un prodigio de técnica y naturalismo, al igual que las del San José. Se recrea en la elegancia a la hora de componerlas, no hay más que ver la forma en que una mano coge la llave, poniendo unos dedos por encima y otros por debajo del referido; mientras tanto los dedos de la otra los distribuye tanto por los lomos del libro como por el borde de las páginas. No hace falta volver a señalar el detallismo de venas y articulaciones.

79 MARTÍN GONZÁLEZ, Juan José: Escultura barroca castellana, Fundación Lázaro Galdiano, Madrid, 1959, p. 325. 
Como todas las esculturas "catedralicias" viste doble indumentaria: por debajo una amplia túnica azul hasta los pies, cuyos pliegues caen rectos; y un manto marrón que desciende por el hombro izquierdo y que se enrolla en la cintura y en la pierna derecha, creando líneas diagonales y ensanchando la figura; con ello también consigue un choque entre estas diagonales y las verticales de la túnica. También en este caso los colores son planos y pálidos; tan solo rompen esta regla las preciosas cenefas con decoraciones vegetales que bordean las vestiduras. Los pliegues también presentan el acuchillamiento berninesco típico de esta segunda etapa. Sin embargo, en este caso no los lleva al extremismo del San José, lo que hace que la figura del primer Papa aparezca algo más reposada. Cabe una excepción, pues nuevamente aparece esa porción de túnica afilada en la parte baja separando los dos pies.

\section{SAN MIGUEL ARCÁNGEL (1714)}

La capilla de San Miguel es la localizada a los pies de la nave de la Epístola, frontera a la de San Juan Evangelista, y sobre ella se levanta la actual torre. El retablo fue tallado en 1714 por Pedro de Ribas, percibiendo por él 2.600 reales ${ }^{80}$. Su dorado fue el más tardío de los cinco retablos de los que hemos hablado puesto que no se realizó hasta 1723 , siendo con toda probabilidad su autor Santiago Montes ${ }^{81}$.

La talla de San Miguel (Figs. 25-26) es una copia exacta a la que hemos visto en el retablo mayor de la iglesia parroquial de Castil de Vela (Palencia). Por excusar repeticiones tan solo nos referiremos a los elementos que la diferencian de aquélla. Son pocas, aunque importantes, y quizás la más evidente es la baja calidad que posee esta escultura, evidente sobre todo en la talla del rostro, mucho más vulgar y esquemático, pareciera como si mientras Ávila tallaba el ejemplar palentino, un oficial se encargaba de ir repitiendo lo que hacía el maestro, y de ahí ese bajonazo cualitativo. También hay un cambio evidente en la forma de rematar los cabellos situados sobre la frente, solución más cercana al San Juan Evangelista catedralicio que al otro San Miguel; y en las armas que porta, o más bien que no porta, puesto que la lanza de su brazo derecho ha desaparecido; y el escudo del otro San

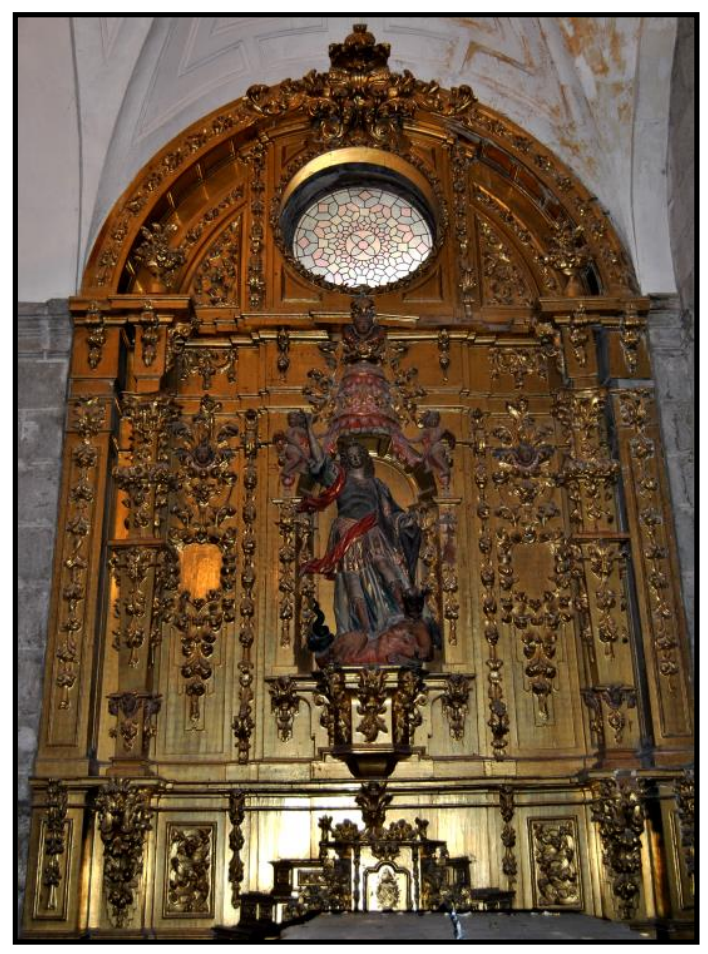

Il. 15- Pedro de Ribas. Retablo de San Miguel. Catedral. Valladolid. Miguel se cambia en esta ocasión por una cadena con la cual sujeta del cuello al 
demonio. Desconozco si este elemento salió del taller de nuestro escultor o bien también portaba escudo y ante la desaparición de ambas armas se optó por ponerle una cadena en esa mano. Otra diferencia bastante evidente es la falta de alas del Arcángel, tampoco sabemos si es porque se perdieron o bien porque no se las llegó a tallar. La última desemejanza es nimia y se trata del rostro de Lucifer, es muy parecido, pero no igual; las propias durezas que exhibe el demonio en el ceño fruncido parecen volver a ponernos en la pista de que la labor de taller en este grupo fue bastante importante.

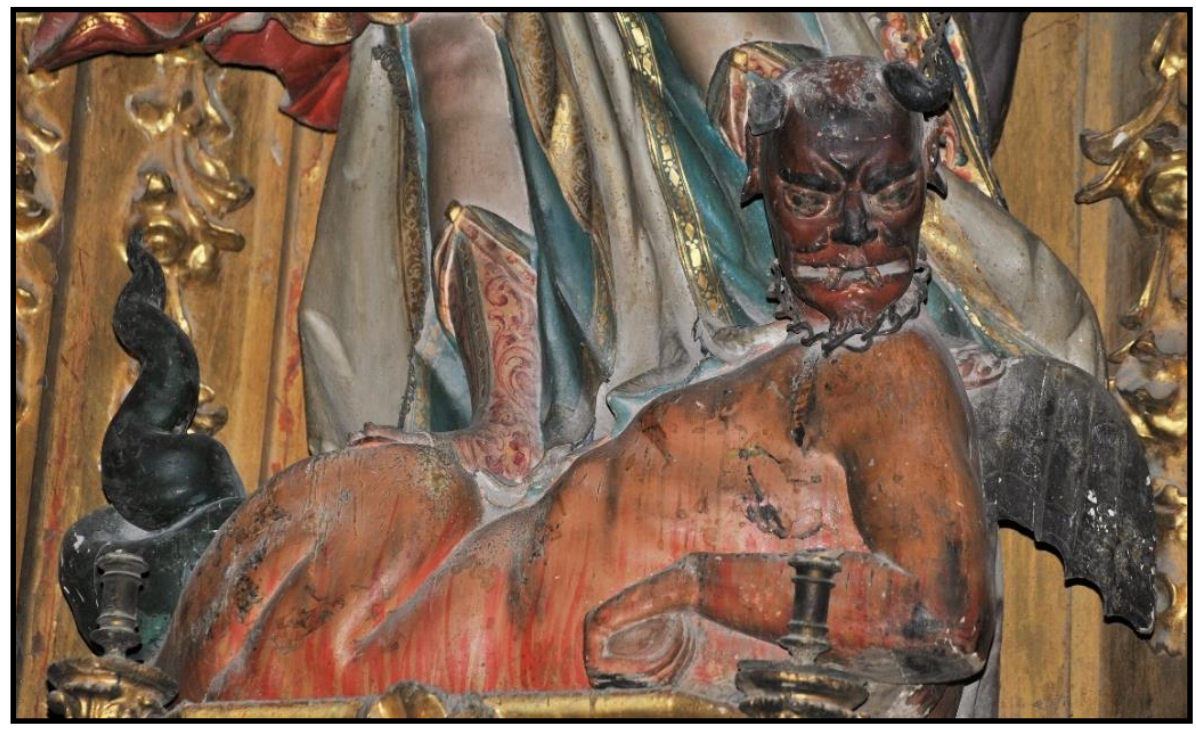

Il. 16- Detalle del demonio que derrota San Miguel.

También tenemos una diferencia respecto al ambiente que le rodea en el retablo. Si en el de Castil de Vela veíamos a San Miguel con una gruta a sus espaldas, en esta ocasión el decorado se limita a un pequeño pabellón ubicado sobre la cabeza del Arcángel que un par de angelotes se encargan de descorrer. No parece probable, vista la deficiente calidad de la talla, que estos dos "putti" salieran de las gubias de Pedro de Ávila, seguramente se deban al propio ensamblador, Pedro de Ribas. Finalmente me gustaría reseñar otro tema relacionado con la falta de la calidad: no deja de llamar la atención que por este San Miguel se le abonaran 1.600 reales y por el de Castil de Vela tan solo 1.400 reales cuando este último es obra de muchísimo mayor empeño y de

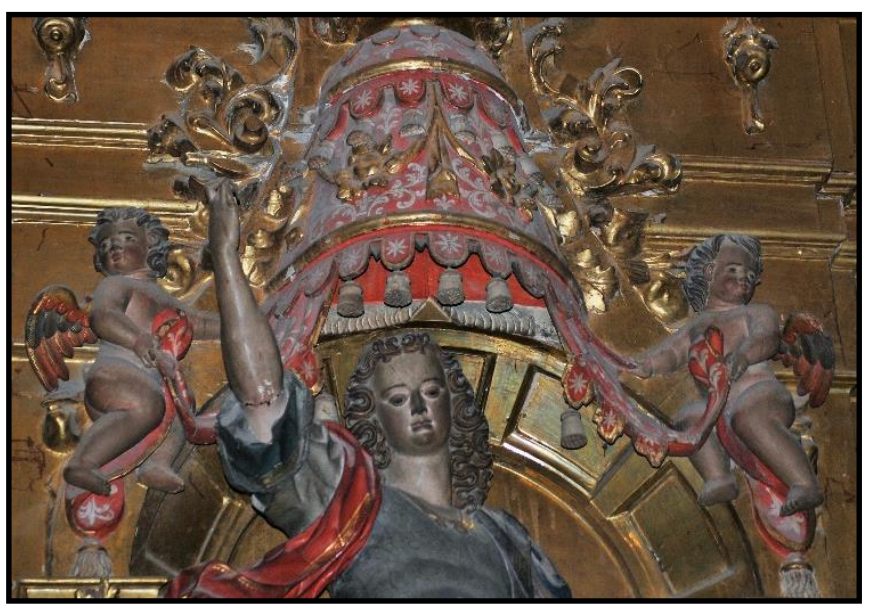

Il. 17- Detalle del pabellón que descorren los angelotes.

las más punteras de su catálogo. Quizás la explicación se encuentre en que Ávila contrató todas las esculturas de la catedral a un mismo precio; sin embargo, esta imagen no se corresponde con la excelente calidad de las otras cuatro. 


\section{VALLADOLID. ORATORIO DE SAN FELIPE NERI}

\section{ESCULTURAS PARA RETABLOS (1720)}

En 1720 o quizás a finales del año anterior, Pedro de Ávila se concierta con la Congregación de Sacerdotes de San Felipe Neri para tallar una serie de esculturas que sirvieran para adornar el retablo mayor y tres de las capillas del cuerpo de la iglesia. La Congregación ya debía de conocer las facultades artísticas de Pedro de Ávila puesto que además de haber trabajado para un enclave tan importante como era la Catedral, su padre había tallado unos años antes una serie de obras para el propio oratorio filipense. Quizás por entonces Pedro ayudara a su padre o simplemente Juan presentó a su hijo a los congregantes por si en el futuro necesitaban de un buen artífice que llevara a cabo algún proyecto escultórico.

Es en el acta de la Congregación celebrada el 26 de febrero de 1720 cuando encontramos la noticia de que Pedro de Ávila estaba fabricando "por orden de los señores comisarios nombrados por dicha Venerable Congregación" las imágenes de "San

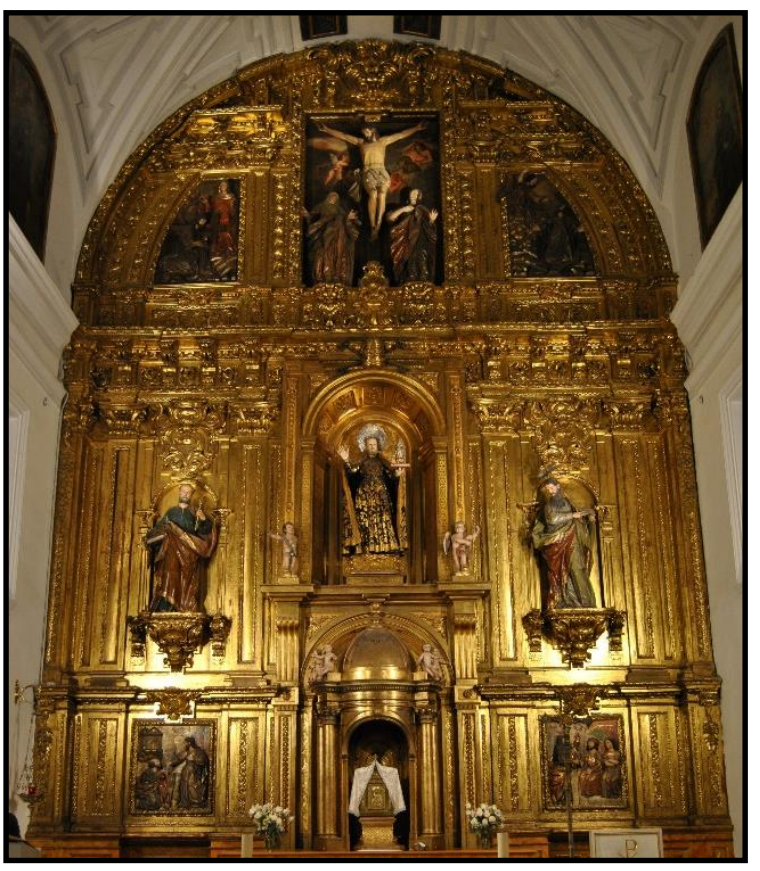

Il. 18- Francisco Billota. Retablo mayor. Oratorio de San Felipe Neri. Valladolid

Juan (es un error, se trata de San Pablo)

y San Pedro, Santa María Magdalena, Cristo Crucificado y Nuestra [Señora] de la Concepción". Las dos primeras esculturas (San Pedro y San Pablo) estaban destinadas al retablo mayor, las cuales venían a sustituir a los grupos de San Joaquín con la Virgen Niña y San José con el Niño Jesús; mientras que las otras tres (la Magdalena, Inmaculada y Cristo Crucificado) presidirían otras tantas capillas del cuerpo de la iglesia.

En esa misma Congregación se trató acerca de que era "necesario pagar a los maestros que actualmente estaban ejecutando dicha obra, como es ensamblador, cantero, otros oficiales y escultor". Para ello se ordenó a los señores "en cuyo poder paran las llaves del caudal de dicha Congregación den y socorran a dichos maestros con cuenta y razón, lo que por ellos fuese pedido; lo cual por todos los señores presentes en dicha junta se mandó se diese satisfacción". Finalmente, se puntualizaba que el precio que debía de percibir Ávila por cada una de las cinco tallas "en blanco" sería de 600 reales $^{82}$. Llama la atención el reducido precio cobrado por cada una de estas tallas, las

82 Congregación 26 de febrero de 1720. Proposición. "En la ciudad de Valladolid, a veinte y seis de febrero de mil setecientos y diez y nueve, junta y congregada la Congregación de Nuestro Padre San Felipe de Neri, en su sala, según lo tienen de costumbre para efecto de tratar y conferir cosas al servicio 
cuales podemos calificar como "obras maestras" de nuestro escultor; además, si las comparamos con las de la catedral, comprobamos que la estimación monetaria no puede encontrarse en función del tamaño puesto que unas y otras son similares. Según Martín González, "distingue a estas esculturas una perfectísima talla, hecha a base de cortes agudos, en arista, formando el típico pliegue barroco del siglo XVIII. Todas tienen policromía a base de tonos planos mates, sin doraduras. Son esculturas muy movidas"83.

En el mes de marzo de 1720 la Congregación le abona 1.000 reales de los 3.000 reales en que se concertaron ambas partes ${ }^{84}$. Ávila las tendría ya acabadas para finales del año 1721 puesto que el día 25 de enero de 1722 se documentan unos pagos al maestro que las estofó y pintó, y también los gastos derivados del "traer todos los seis santos (se tratarán de las cinco esculturas de Pedro de Ávila y probablemente una de las tres que donaron por entonces distintos mecenas: San Antonio de Padua, Cristo Yacente y Niño Jesús) en tres ocasiones de casa del pintor a la iglesia seis reales" ${ }^{" 5}$. Al anónimo maestro se le abonaron 550 reales por "estofar y pintar San Pedro y San Pablo", y la misma cantidad por "pintar la Magdalena, Cristo [Crucificado] y María"86.

Antes de profundizar en la historia de cada una de estas cinco tallas nos aproximaremos a las circunstancias que llevaron a la Congregación a encargárselas a Pedro de Ávila.

de Dios nuestro señor, y bien y utilidad de dicha Venerable Congregación, por especial llamamiento, que ante diem dio el señor don Manuel Martínez de Zamora, cura propio de Santa María Magdalena, y Ministro de dicha Venerable Congregación, Alonso Arrandez, nuestro llamador, por quien fuimos avisados para oír la plática que en dicho día y dicha sala hizo el señor don Pedro Manuel Dávila Canónigo, Magistral de la santa iglesia, y después de hecha y oída por dicho señor Ministro se propuso lo siguiente: que por cuanto según lo dispuesto y ordenado por dicha Venerable Congregación, en cuanto a la obra de retablos para las capillas del Oratorio era necesario pagar a los maestros que actualmente estaban ejecutando dicha obra, como es ensamblador, cantero, otros oficiales y escultor, y este ser Pedro de Ávila quien por orden de los señor comisarios nombrados por dicha Venerable Congregación para este efecto está haciendo las imágenes, que son un San Juan y San Pedro, Santa María Magdalena, Cristo Crucificado y Nuestra [Señora] de la Concepción, era necesario irles dando satisfacción, y para que no hubiese dilación en sus pagas dicha Venerable Congregación diese orden para que los señores, en cuyo poder paran las llaves del caudal de dicha Congregación den y socorran a dichos maestros con cuenta y razón, lo que por ellos fuese pedido; lo cual por todos los señores presentes en dicha junta se mandó se diese satisfacción, cada y cuando que por dichos señores comisarios fuese pedido, anotando su entrega en el Libro de saca que para en el arca de tres llaves y del caudal de dicha Venerable Congregación, y advierto dichas hechuras de escultura estar en precio cada una en blanco según asentó en dicha junta el señor don Jacinto Fernández comisario nombrado para este efecto en seiscientos reales de vellón". Archivo de San Felipe Neri (en adelante A.S.F.N.), Caja 13, 2 Libro de Acuerdos (1690-1740), f. 150. GARCÍA CHICO, Esteban: Documentos para el estudio del arte en Castilla. 2..., op. cit., p. 380.

83 MARTÍN GONZÁLEZ, Juan José: Escultura barroca castellana ..., op. cit., p. 325.

84 "Sírvase vuestra merced señor don Fabián Barriuso poderhabiente de la Venerable Congregación de Nuestro Padre San Felipe de Neri para el efecto de cobrar las cantidades de mes (por razón de refacción) a ella pertenecientes; mandar pagar un mil reales de vellón al señor Pedro de Ávila maestro de escultura, por cuenta de los tres mil reales en que por los señores Comisarios por dicha Congregación nombrados están ajustados cinco efigies a seiscientos reales de vellón cada una para los altares que se han de poner en las capillas de dicha Congregación y que por este libramiento y su recibo serán bien pagados y a vuestra merced se harán buenos en la cuenta que diese de los maravedíes del referido efecto Valladolid y marzo de mil setecientos y veinte". Ibídem.

85 MARTÍN GONZÁLEZ, Juan José y URREA FERNÁNDEZ, Jesús: Catálogo Monumental de la provincia de Valladolid. Tomo XIV..., op. cit., p. 305.

$86 \quad$ Ibídem. 
Desde el 14 de junio de 1675 en que se comienza la construcción de la iglesia por el maestro de obras Antonio de la Iglesia, la Congregación de sacerdotes de Nuestro Padre San Felipe Neri fue poco a poco, en la medida de sus posibilidades, amueblando el interior de la misma. Así, en 1688 fabrica el cancel de la puerta principal ${ }^{87}$; entre los años 1689-1691 el retablo mayor ${ }^{88}$; en el periodo 1698-1699 los dos retablos colaterales $^{89}$; y, finalmente, entre 1719-1722 los retablos de las seis capillas del cuerpo de la iglesia ${ }^{90}$. El artífice tanto del cancel como de los otros nueve retablos citados fue el ensamblador vallisoletano Francisco Billota, al que le auxilió su hijo Joaquín en la fabricación de los seis de las capillas. A todo esto hay que sumar los diversos encargos escultóricos y pictóricos que por fortuna, en su gran mayoría, se conservan en la iglesia, lo que la convierte en la actualidad en uno de los espacios barrocos mejor conservados de Valladolid, si no el que más, aunque es muy lamentable el baile de advocaciones habida en lo altares; es necesario la recuperación de la idea primigenia, pues lo contrario es una falta de respeto a aquel programa litúrgico. Comentemos brevemente la historia de los retablos para los que Pedro de Ávila talló las imágenes: a saber, el mayor y los de las capillas del cuerpo de la iglesia.

La historia del retablo mayor es muy azarosa. El 10 de agosto de 1685 Antonio Billota y su hijo Francisco redactaban las condiciones y elaboran la traza y planta con las cuales se comprometían a realizarlo (DOCUMENTO 48). El precio por su realización se ajustó en 15.000 reales de vellón "a toda costa excepto la escultura que llevare dicho retablo y que ésta ha de correr por cuenta del dicho señor cura y de la congregación" (DOCUMENTO 48). Asimismo, se obligaba a "hacer una custodia para dicho retablo conforme la planta hecha con doce columnas". Extraña que por entonces la Congregación de San Felipe Neri se propusiera llevar a cabo el retablo mayor puesto que se encontraba muy mal económicamente debido al continuo desembolso realizado, desde hacía muchos años, para la construcción de la iglesia.

Hubo que esperar tres años, hasta 1688, para que la Congregación se planteara de una manera más seria la construcción del retablo mayor. Concretamente, en la Congregación extraordinaria celebrada el 11 de marzo se habla de ir acopiando fondos de las más diversas maneras (refacciones a los congregantes, sisas municipales o reales, donaciones económicas de los nuevos congregantes o bienhechores) para "ayuda de fabricar el retablo que se pretende hacer para la iglesia de Nuestro Padre San Felipe Neri" "11. Las donaciones irán llegando poco a poco, de tal manera que en la Congregación de 30 de mayo se habla de que "fueron recibidos por congregantes de esta Congregación los señores don Manuel Blanco y don Gabriel de Terán y Mantilla, los cuales cedieron las

\footnotetext{
87 Ídem, pp. 300-301.

88 FERNÁNDEZ DEL HOYO, María Antonia: "El convento de San Francisco...”, op. cit., p. 436; MARTÍN GONZÁLEZ, Juan José y URREA FERNÁNDEZ, Jesús: Catálogo Monumental de la provincia de Valladolid. Tomo XIV ..., op. cit., p. 301; A.S.F.N., Caja 13, $1^{\circ}$ Libro de Acuerdos (16451690), f. 371.

89 MARTÍN GONZÁLEZ, Juan José y URREA FERNÁNDEZ, Jesús: Catálogo Monumental de la provincia de Valladolid. Tomo XIV..., op. cit., p. 293.

90 GARCÍA CHICO, Esteban: Documentos para el estudio del arte en Castilla. 2 ..., op. cit., p. 380.

91 A.S.F.N., Caja 13, $1^{\circ}$ Libro de Acuerdos (1645-1690), f. 364.
} 
refacciones para ayuda de la fábrica del retablo que se ha de hacer en esta iglesia"92. Unos días después los congregantes deciden que el retablo mayor se ha de hacer cuanto antes, por lo que dejan sin pagar 3.000 reales que debían de las obras del coro, capillas y portada de la iglesia, para poder afrontar la construcción del nuevo retablo. Para ello deciden que "se renovase la cesión que estaba hecha de todas las Sisas municipales hasta el año de noventa y dos y juntamente se otorgó poder hasta el año de setecientos y cesión y que las cobraren los depositarios actuales de la Congregación"93.

Finalmente, y tras conseguir los fondos necesarios, se deciden el 11 de julio de 1689 comisionar al "ministro, el vicario, el señor don Felipe Sánchez, el señor don Bernabé Gil, el señor don Juan Redondo, el señor don Juan Casado, el señor don Pedro de Rozas" para que "ajusten y concierten con la persona que les pareciere más a propósito" el referido retablo mayor ${ }^{94}$. Unos días después, en la Congregación del 8 de agosto se da la noticia de que los comisionados se habían concertado con el ensamblador Francisco Billota para que lo construya en precio de 10.500 reales $^{95}$.

En la construcción de la gran máquina lígnea, realizada en la sala capitular del Oratorio $^{96}$, no le ayudaría su padre puesto que había fallecido el 24 de marzo de 1687. El retablo construido por Francisco Billota, que como ya hemos dicho difiere bastante del actual, se articulaba a través de cuatro grandes columnas salomónicas, las cuales fueron posteriormente sustituidas por simples pilastras. El retablo ya estaba finalizado a mediados del mes de septiembre de 1690 ya que en la Congregación celebrada el día 19 se debatió "que medio se podía tomar para dorarle" puesto que una vez más las arcas estaban muy mermadas. La junta acordó "se pidiese por vía de empréstito a los señores veinte y cuatro de la Memoria del Sr. D. Andrés López Calderón la cantidad que fuese necesaria"97. También se comisionó a siete congregantes para que "hiciesen la escritura necesaria de parte de la Congregación a favor del maestro que le ha de dorar, y recibirla también de parte de dichos maestros a favor de dicha Congregación".

Unos días después, el 9 de octubre, los referidos señores comisionados se concertaron con el dorador y estofador Manuel de Estrada para que este dorara "un retablo de madera en blanco con sus columnas salomónicas (...) para mayor adorno y culto de la dicha iglesia" (DOCUMENTO 47). El dorador percibiría por tan magna empresa la crecida cantidad de 19.000 reales de vellón, teniendo como condición expresa el tenerla acabada en toda perfección para el día 20 de mayo de 1691. La escritura, en la cual figura como testigo el ensamblador Gregorio Díez de Mata, explica de una manera muy pormenorizada la forma en que debía ejecutarse el dorado del retablo y el policromado y

92 A.S.F.N., Caja 13, $1^{\circ}$ Libro de Acuerdos (1645-1690), f. 367.

93 MARTÍN GONZÁLEZ, Juan José y URREA FERNÁNDEZ, Jesús: Catálogo Monumental de la provincia de Valladolid. Tomo XIV ..., op. cit., p. 301. A.S.F.N., Caja 13, $1^{\circ}$ Libro de Acuerdos (16451690), f. 371.

94 Ibídem.

$95 \quad$ Ibídem.

96 Congregación de 13 de septiembre de 1689. “(...) se juntó la Venerable Congregación de Nuestro Padre San Felipe Neri en la sacristía de su iglesia por hallarse la sala capitular ocupada con la obra del retablo (...)”. A.S.F.N., Caja 13, $1^{\circ}$ Libro de Acuerdos (1645-1690), f. 371.

97 A.S.F.N., Caja 13, $2^{\circ}$ Libro de Acuerdos (1690-1740), f. 1. 
estofado de cada uno de los diferentes relieves y esculturas. Aparte de todo esto, la escritura nos es muy útil para conocer la forma y distribución primigenia tanto del retablo como de sus decoraciones escultóricas.

El 27 de junio de 1691 se trató en Congregación del momento en que debía de celebrarse "la fiesta de la traslación del Santísimo y de Nuestro Padre San Felipe Neri al retablo nuevo", síntoma de que las obras estaban ya finalizadas ${ }^{98}$. Que los problemas económicos de la Congregación de San Felipe Neri eran reales lo demuestra el que Francisco Billota no otorgara carta de pago y finiquito hasta el día 25 de agosto de 1694 (DOCUMENTO 49). En ella se daba por contento de las cantidades que le adeudaban "de la fábrica de dicho retablo y de armar y desarmar el monumento".

Nos podemos hacer una idea de cómo era la disposición original del retablo gracias a la pormenorizada descripción realizada por el licenciado don Pablo del Moral y Tejada, visitador del obispado, el 28 de abril de 1692, a la cual ya nos hemos referido al descatalogar las esculturas del retablo de la producción de Juan de Ávila ${ }^{99}$. El retablo no fue del gusto de Casimiro González García-Valladolid ${ }^{100}$.

Años después el retablo sufriría una importante modificación: la sustitución de las cuatro grandes columnas salomónicas que articulaban el cuerpo del retablo por unas simples pilastras. Este cambio otorgó al conjunto un esquema compositivo más plano y sencillo. En las hornacinas de los intercolumnios, actualmente ocupadas por el San Pedro y el San Pablo de Pedro de Ávila, se situaban los grupos de San Joaquín con la Virgen Niña y San José con el Niño Jesús realizados por José de Rozas y Andrés de Pereda $^{101}$. El cambio debió de acontecer entre 1719-1720 puesto que en febrero de este último año Pedro de Ávila se encontraba ya trabajando en las esculturas ${ }^{102}$. Los motivos que implicaron esta modificación en el retablo tendrían relación con problemas estructurales y el excesivo peso que suponían los citados dos grupos; motivo por el cual se decidió cambiar las columnas salomónicas por pilastras, y sustituir los pesados

98 Congregación en 27 de junio de 1691. Traslación del Santísimo y de Nuestro Padre que se ha de hacer. "También propuso el señor Ministro, como ya se iba llegando el tiempo, y así que determinase la Congregación la forma y disposición que había de tener dicha fiesta, y dicha Congregación acordó que se hiciesen tres días de fiesta con sermón y música, y otros cultos, en cada uno de los tres días con vísperas el primer día, y el señor Ministro se ofreció por sí solo y a su costa a hacer el primer día y decir la misa. Para el segundo día se ofreció el señor vicario y demás congregantes ayudando con sus propinas para lo cual se determinó que todo el dinero que procediese de las mandas que dichos señores hiciesen se entregasen al señor Juan Fernández Salazar cura de Santiago, con su cuenta y razón para su merced dispusiese y gobernase el gasto que se hiciese en dicha fiesta de dicho segundo día y el señor vicario se encargó de decir la misa. Para el tercero día se ofrecieron los señores curas y beneficiados del cabildo menor congregantes de dicha Congregación, y el señor D. Joseph de Sorribas se encargó de decir la misa. Y por último que los tres sermones fuesen a elección del señor Ministro". A.S.F.N., Caja 13, $2^{\circ}$ Libro de Acuerdos (1690-1740), f. 5.

99 URREA FERNÁNDEZ, Jesús: “El oratorio...”, op. cit., p. 18.

100 "El retablo mayor carece en absoluto de mérito: en los nichos que presenta tiene las estatuas del Titular y la de San Pedro y San Pablo, y termina con un gran Crucifijo, con la Virgen y San Juan a los pies”. GONZÁLEZ GARCÍA-VALLADOLID, Casimiro: Valladolid..., op. cit., Tomo I, p. 311.

101 URREA FERNÁNDEZ, Jesús: “El oratorio...”, op. cit., p. 18.

102 GARCÍA CHICO, Esteban: Documentos para el estudio del arte en Castilla. 2 ..., op. cit., p. 380. 
grupos escultóricos por dos imágenes algo más livianas. Otro motivo quizás pudo ser el que las columnas sobresalían tanto que estorbaban la entrada a la sacristía.

Para acabar con esta introducción hablaremos sobre los retablos de las capillas de la nave puesto que tres de ellos estarían presididos por esculturas de Ávila. El 27 de junio de 1719 Francisco Billota se obligaba a "hacer y ejecutar los seis retablos que necesitan las seis capillas de dicha iglesia" (DOCUMENTO 85). Francisco asoció a su hijo Joaquín a la escritura por si se daba la circunstancia de que "Dios nuestro señor fuese servido de llevarme antes que dicha obra se acabe y fenezca se haya de hacer y acabar, a costa de mi hacienda" "103. Primeramente, habría de fabricar los "dos primeros retablos ejecutados y arreglados según la planta traza y condiciones hechas", los cuales tenían como destino las dos capillas más cercanas al crucero. El ensamblador introdujo en el contrato una cláusula en la que solicitaba a la Congregación que les admitieran a él y a su mujer, Ángela del Álamo, como bienhechores de la misma, lo que conllevaba el derecho a poder ser enterrados en la iglesia. Billota a cambio se comprometía a hacer uno de los retablos a su costa, además de aportar una limosna de 3.000 reales. El día anterior, el 26 de junio, la Congregación aceptó el trato, recibiendo, además, como donativo del ensamblador "para la sacristía una fuente grande de plata dorada por dentro de peso de setenta onzas poco más".

La traza utilizada para los dos primeros retablos sirvió también de modelo para los otros cuatro, aunque se obligaba a introducir "diferencia de labores para más hermosura y lucimiento y en la misma forma los otros dos". Los dos primeros retablos debería de darlos "puestos y asentados para mediado de mayo del año que viene de setecientos y veinte", mientras que los cuatro restantes "dentro del término de los expresados tres años que corren desde hoy sin más dilación ni prorrogación”. La empresa era colosal, debido a lo cual Billota se hizo acompañar de un buen plantel de ayudantes que le facilitaran la tarea de decorar los retablos, entre ellos encontramos a los tallistas José Barroso de Ribera y Alonso Carnicero ${ }^{104}$. Por la hechura de los seis retablos se le abonaron 7.500 reales de vellón. Asimismo, Billota se ofreció a "dar dos mil reales de vellón a fin de que los sesenta que corresponden a su renta impuestos a censo se sirviese mandar decir las misas que les pareciere y no los entregando me obligué a dar y pagar dichos réditos con hipoteca de mi hacienda". Como de costumbre estos retablos no fueron del gusto de Antonio Ponz: "Y es lástima que en la del Oratorio de San Felipe Neri haya aquel conjunto de altares disparatados"105.

Una vez finalizados los retablos y con las esculturas titulares presidiéndolos, el siguiente paso fue encargar al escultor vallisoletano Antonio Gautúa cuatro pequeñas esculturas y dos relieves para colocar en los áticos. Las imágenes, realizadas entre los

\footnotetext{
103 Ibídem.

104 MARTÍN GONZÁLEZ, Juan José y URREA, Jesús: Catálogo Monumental de la provincia de Valladolid. Tomo XIV ..., op. cit., p. 294.

105 PONZ, Antonio: Valladolid en el “Viaje a España” (1783), Grupo Pinciano, Valladolid, 1993, p. 117.
} 
años 1722 y 1724 , fecha esta última en que se le acaban de pagar ${ }^{106}$, representan el Abrazo ante la Puerta Dorada (capilla de San Joaquín), San Esteban (capilla de la Inmaculada), San Miguel (capilla de la Magdalena), los Desposorios de la Virgen y San José (capilla de San José), San Lorenzo (capilla del Crucificado) y San Rafael (capilla de San Antonio de Padua). En relación con estas pequeñas esculturas y con Pedro de Ávila se encuentra la siguiente noticia: en el cabildo celebrado por la Congregación el 23 de febrero de 1722 se acuerda que para "los segundos retablos se necesitaban de hacer dos ángeles, los que dicha Venerable Congregación mandó se ejecutasen, haciendo el uno San Miguel y el otro el Ángel de la Guarda, cometiendo a dichos señores comisarios la ejecución de ellos con cuyo decreto se feneció dicha Congregación"107. Apenas dos semanas después, en un nuevo cabildo celebrado el 9 de marzo la Congregación informa de que "como Pedro de Ávila había tomado las medidas de los huecos para hacer los ángeles y que quería por ellos mil reales dicha Venerable Congregación mandó se suspendiese por ahora dicha ejecución"108. Es decir, la Congregación no aceptó la cantidad exigida por Pedro de Ávila, la cual considerarían sumamente elevada, por lo que decidieron buscar a un escultor que se amoldara mejor a su maltrecha economía.

Justo un mes después se celebra otro cabildo en el que se aborda este tema. En esta ocasión la Congregación acuerda que se ejecuten "los dos Arcángeles San Miguel y San Rafael", para lo cual dieron comisión a "los señores doctor don Roque García Quiñones, don Antonio Herrera para que lo pusiesen en ejecución en aquella forma que sea más conveniente según se hizo donde se determinó el ponerlos que fue en los remates de los dos retablos" $" 109$. Sería por entonces cuando se ajustaron con Gautúa, el cual debió de acabarlas hacia mediados de septiembre de 1724 puesto que en el cabildo celebrado el 10 de septiembre la Congregación daba comisión a ciertos miembros de la misma para ajustar el dorado de los retablos, signo de que ya estaban todas las esculturas puestas en sus respectivos lugares ${ }^{110}$. Como ya dijimos en su momento, no parece casual la elección de Gautúa en sustitución de Ávila, pues seguramente este último recomendaría a la Congregación la contratación de su amigo y antiguo compañero de taller.

La obra de los retablos se dio por concluida el 15 de junio de 1725, fecha en la que Manuel Barreda y Lombera termina de dorar los retablos ${ }^{111}$. El mismo maestro se

\footnotetext{
106 "Se pagaron a Antonio Gautúa 720 reales de resto de las hechuras de San Miguel, el Ángel, San Lorenzo, San Esteban y las dos hechuras”. URREA FERNÁNDEZ, Jesús: “El oratorio...”, op. cit., p. 20.

107 A.S.F.N., Caja 14, $2^{\circ}$ Libro de acuerdos (1690-1740), f. 175.

108 A.S.F.N., Caja 14, $2^{\circ}$ Libro de acuerdos (1690-1740), f. 175.

109 MARTÍN GONZÁLEZ, Juan José y URREA FERNÁNDEZ, Jesús: Catálogo Monumental de la provincia de Valladolid. Tomo XIV..., op. cit., p. 303.

$110 \quad$ A.S.F.N., Caja 14, $2^{\circ}$ Libro de acuerdos (1690-1740), f. 191.

111 "Año de 1725, día 15 del mes de junio, se acabaron de dorar los retablos de la capilla de San Felipe Neri; el dicho día colgaron toda la iglesia para las vísperas; al otro día hicieron función del santo y por la noche hubo mucho fuego, y el día 17 se celebró la función; dijo la misa el Sr. Dr. D. Roque García Quiñones, ministro actual que era predico el Sr. Dr. D. Pedro Manuel de Ávila y Cárdenas, canónigo magistral de esta Santa Iglesia; asistió a vísperas y misa la música de la Santa Iglesia”. PÉREZ, Ventura: op. cit., p. 75 .
} 
encargó por entonces de pintar las rejas de las capillas. Como vemos la decoración del interior de la iglesia fue amplia, variada y lujosa. La Congregación no escatimó en gastos, llegando a desembolsar hasta lo que ni siquiera tenía. A modo de resumen comentaremos como estaban dispuestos los seis retablos en el momento de su inauguración y también como se encuentran en la actualidad.

Lado del Evangelio:

- La capilla de los pies estaba dedicada a San Joaquín. En la hornacina central se encontraba el grupo de San Joaquín con la Virgen, procedente del retablo mayor; y en su parte superior, aludiendo a la referida escultura, el relieve del Abrazo ante la Puerta Dorada. Posteriormente, se colocó una imagen moderna de Santa Teresa, si bien actualmente la hornacina está ocupada por un San Antonio de Padua que, aunque ha sido atribuida en alguna ocasión a Pedro de Ávila, como veremos, pienso que puede ser relacionada con Gautúa.

- La segunda capilla es la dedicada a la Inmaculada. En su hornacina se encuentra la Inmaculada Concepción. Justo debajo de ella hallamos al Niño Jesús, y en el ático San Esteban.

- La tercera capilla, que es la aneja al crucero, fue la dedicada a la Magdalena, la cual actualmente se encuentra expuesta en el Museo Diocesano y Catedralicio. En el ático se dispone la escultura de San Miguel venciendo al demonio. Actualmente, el retablo está presidido por una vulgar escayola que representa a Santa Bárbara.

Lado de la epístola:

- La capilla de los pies estaba dedicada a San José y lo presidía el grupo de San José con el Niño. En el ático se encuentra el relieve de los Desposorios de la Virgen, temática que alude a la escultura de la hornacina. Actualmente, el retablo lo ocupa un moderno Santiago Matamoros.

- La segunda capilla está dedicada al Crucificado aunque durante algunos años ocupó su lugar una escultura de San Fernando, y anteriormente una Virgen de la Soledad de bastidor ${ }^{112}$. Debajo del Crucificado, metido en una urna-sepulcro, se expone un Cristo Yacente, también atribuido en alguna ocasión a Pedro de Ávila. En el ático se sitúa otro diácono, en correspondencia con el del retablo frontero: San Lorenzo.

- La capilla más próxima al crucero fue la dedicada a San Antonio de Padua, actualmente situado en otro de estos retablos. En el ático figura el arcángel San Rafael con Tobías. Actualmente el retablo se encuentra bajo la advocación de la Virgen de la Fuencisla.

112 MARTÍN GONZÁLEZ, Juan José y URREA, Jesús: Catálogo Monumental de la provincia de Valladolid. Tomo XIV..., op. cit., p. 294. 
Todavía en tiempos de Casimiro González García-Valladolid las capillas conservaban una distribución casi idéntica a como fueron concebidas ${ }^{113}$. Sería muy recomendable recuperar la disposición original de las mismas ya que las advocaciones de las capillas no fueron colocadas de manera baladí, el conjunto poseía un claro sentido litúrgico.

\section{SAN PEDRO Y SAN PABLO}

Tratamos estas dos esculturas de manera conjunta puesto que ambas fueron concebidas para el retablo mayor de modo que se complementaran y confrontaran sus actitudes: Pedro avanza su pierna derecha, mientras Saulo hace lo propio con la contraria, la izquierda. Ambas imágenes no hacen sino prolongar los modelos de Gregorio Fernández, tal y como ya habíamos visto en algunas hechuras realizadas por Juan de Ávila, como eran el San Pedro de la Colegiata de Lerma o los San Pedro y San Pablo que se le atribuyen en el retablo mayor de la parroquial de Torrecilla de la Abadesa (Valladolid). Ya dijimos con anterioridad que las versiones primigenias son las que Fernández talló para el desaparecido retablo mayor de la primitiva iglesia de San Miguel (1606); actualmente conservadas en la iglesia de San Miguel y San Julián. Estas dos esculturas gozaron de gran predicamento, como la mayoría de creaciones e

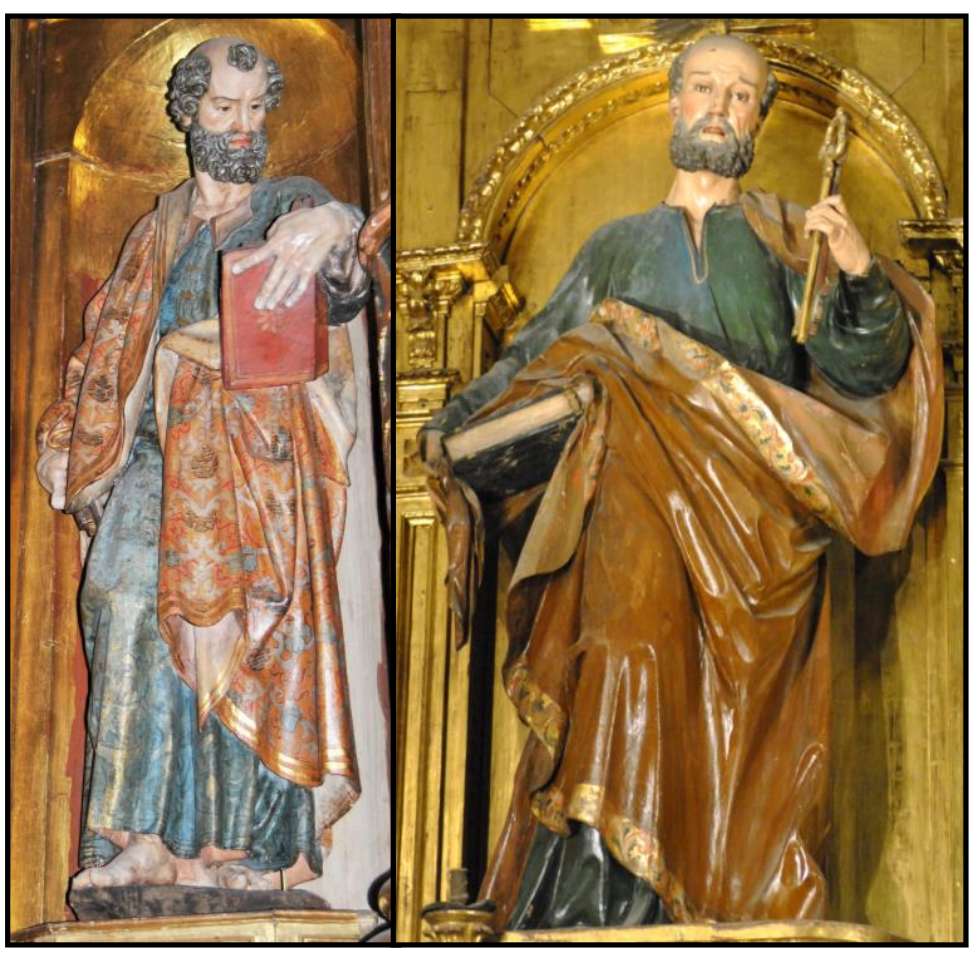

Il. 19- Comparación entre el San Pedro de Gregorio Fernández y el San Pedro de Pedro de Ávila. iconografías fernandescas, lo que conllevó a que fueran ampliamente copiadas por toda Castilla durante el siglo XVII y parte del XVIII, como vemos ahora en estas dos obras de Pedro de Ávila. No hace falta recordar los ejemplos de los retablos mayores de las parroquiales de Casasola de Arión, Cigales, Marzales, Villalba de los Alcores o Villanueva de Duero.

A pesar de que Pedro de Ávila se inspira en ellas más en el caso del San Pablo que en el San Pedrointroduce ciertas novedades que hace que no sean copias idénticas como las relatadas anteriormente. Así, por

\footnotetext{
113 "Mejores que lo anterior (el retablo mayor y colaterales) son los altares e imágenes de las capillas: las tres del lado izquierdo están dedicadas a la Magdalena, la Purísima y San Joaquín, y las del derecho a San Antonio, la Soledad y San José”. GONZÁLEZ GARCÍA-VALLADOLID, Casimiro: Valladolid..., op. cit., Tomo I, p. 312.
} 
ejemplo, en el San Pedro (Figs. 27-28) podemos ver que las similitudes son bastante escasas: mientras que el de Fernández en el rostro posee un mechón de pelo en la frente, la de Ávila luce prominente calva; si la del gallego porta en su mano izquierda un libro abierto que el santo parece leer y en la mano derecha sujeta unas llaves que parece ocultar, en el caso de Ávila, San Pedro nos muestra orgulloso las llaves levantadas en su mano izquierda, mientras que con la derecha sujeta un libro cerrado que ayuda a ensanchar la escultura. Por otro lado, los ropajes nada tienen que ver ni en tipología ni en cuanto a pliegues; lo que más nos puede llamar la atención es el hecho de que mientras que Fernández deja caer la túnica hasta los tobillos, dejándonos ver los pies del santo, Ávila por su parte la deja caer hasta el suelo, dejando al aire tan solo la punta de los zapatos. Una vez más volvemos a ver esa manera tan característica de Ávila de solucionar la posición de los pies separados por un trozo de túnica. Es más, parece que nuestro escultor no gusta de tallar los pies a las esculturas de los santos sino que prefiere resolverlo mediante la inclusión de la punta delantera de los zapatos y el resto oculto bajo la túnica. Tan solo talla los pies a las esculturas en las que prima es estudio anatómico, caso de Crucificados, del Atado a la columna y del Ecce Homo de la iglesia de las Angustias, del Ecce Homo conservado en Renedo o del Resucitado de Ampudia, si bien en esta ocasión tengo bastantes dudas sobre su pertenencia a Pedro o a su hermano Manuel.

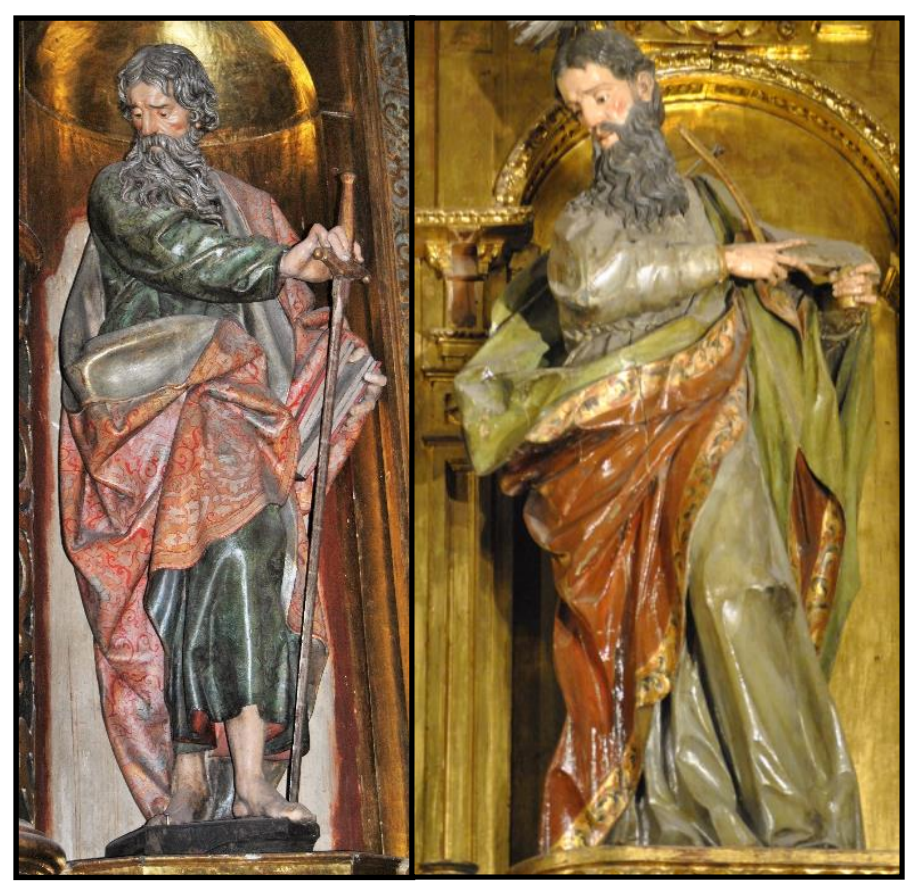

Il. 20- Comparación entre el San Pablo de Gregorio Fernández y el San Pablo de Pedro de Ávila.

Por su parte, el San Pablo (Figs. 29-30) sí que viene a ser una versión actualizada del original fernandesco. Tan solo cabría reseñar como diferencias el cambio de manos de los atributos: si Fernández concibe a su Saulo con la espada en la diestra y un libro a medio abrir en la siniestra; Ávila hace todo lo contrario, coloca en la izquierda la espada y en la derecha el libro; la otra desemejanza es similar a la vista en San Pedro y que nos confirma la teoría de que Ávila no gusta de dejar ver la parte baja de las piernas y los pies descalzos como Fernández sino que deja caer la túnica hasta los pies y tan solo nos deja ver la punta de los pies.

En definitiva, San Pedro figura de pie, con la pierna derecha levemente adelantada, formando contraposto y hasta podemos apreciar una cierta composición helicoidal entre el tronco, caderas y pierna derecha. En su mano derecha sujeta un gran libro cerrado, sobre el cual cae parte del manto; con la otra porta las dos llaves, las cuales exhibe en lo 
alto, como mostrándonoslas. Llama la atención la contraposición de actitudes: mientras un brazo reposa, el otro lo eleva con las llaves. La cabeza la ladea levemente hacia la izquierda, con lo cual introduce cierto dinamismo. El rostro es completamente exacto al que hemos visto en el San Pedro de la catedral, tanto en barba, cabellos, calidad de la piel, arrugas, etc... A pesar de esa total semejanza, tenemos la sensación de que este San Pedro que tratamos presenta un rostro algo más joven que el de la catedral, lo que quizás se deba a la reciente restauración a la que se le sometió. Como novedad, en el cuello llega a tallar hasta la incipiente nuez. En lo que no coinciden es en el modo de disponer la túnica y el manto, los cuales, a pesar de ser de las mismas tonalidades, son más ampulosos en este caso; dejando bien a las claras el propósito de querer ensanchar la escultura con los amplios pliegues y ondulaciones del manto sobre todo en la zona bajo el brazo izquierdo. A diferencia de aquel San Pedro, en este los pliegues son mucho más aristados, geométricos, cortantes y finos, pues parece que con el tiempo nuestro escultor fue perfeccionando cada vez más su técnica. Es sorprendente la delgadez que consigue en los bordes del manto, este detalle le emparenta de una manera muy cercana a Pedro de Mena y a Alonso Cano.

Por su parte, San Pablo también aparece erguido, aunque en este caso el contraposto es con el adelantamiento de la pierna izquierda. Como vemos la disposición de las piernas es idéntica pero invertida con respecto al San Pedro. El cuerpo también parece adoptar una disposición helicoidal, a lo que hay que sumar el valiente escorzo del torso y la cabeza, lo que unido al tratamiento de las ropas y sus pliegues la convierte en una de las tallas más barrocas de Ávila. En la mano izquierda porta su atributo más personal: la espada, la cual se ha colocado tras la restauración de la imagen de manera errónea puesto que la han puesto en la derecha. Por su parte, en su mano derecha, Ávila le dispuso un libro desencuadernado cerrado, con algunas páginas dobladas y arrugadas (nueva muestra del virtuosismo alcanzado por nuestro escultor), sin embargo tras la restauración se ha optado de manera totalmente errónea de colocarlo sobre la mano izquierda, en la cual se ve claramente que sostiene el mango de la espada, por lo que es incomprensible que se haya resuelto así.

El rostro está bellamente modelado puesto que capta con la misma maestría que lo hacía en los San Pedros las arrugas y las carnes blandas derivadas de la avanzada edad de San Pablo. Los rasgos faciales que presenta son los típicos de nuestro escultor, pero sin embargo esta es una de las pocas ocasiones en las que la boca abierta nos presenta la punta de la lengua bajo la fila superior de dientes. La barba se dispone en largos y sinuosos mechones compactos compuestos de una manera simétrica y muy virtuosista que también está presente en sus hechuras de San Joaquín y que parece derivar del San Francisco de Sales que tallara su padre. La cabellera está muy apelmazada por su parte superior, rematándose en dos mechones simétricos con las puntas orientadas hacia el exterior, mientras que a los lados se forman abultados bucles que tapan su oreja derecha. Para denotar vejez el policromador ha introducido el peleteado de tonos grises. En definitiva, se trata de una cabeza majestuosa. 
Tanto por el tipo de vestimenta, disposición de la misma y pliegues viene a ser un calco del San Pedro. Nuevamente hay que destacar tanto el ensanchamiento que se logra en la cadera con el manto, como el juego de diagonales que provoca este mismo elemento. También está presente esa misma finura. En este caso las entonaciones de las ropas son verde en la túnica y marrón en el manto, si bien este último presenta en el borde la típica cenefa que ya hemos visto en muchas ocasiones.

\section{MAGDALENA PENITENTE}

La talla de la santa ya estaba acabada el 18 de mayo de 1720, fecha en que fue bendecida, de manera conjunta con la de San Antonio de Padua, por el canónigo de la catedral don Tomás López de Castro ${ }^{114}$. Como ya vimos, esta escultura presidía la primera capilla del lado del Evangelio (Fig. 31), la más cercana al crucero. Este retablo, al igual que el frontero, el dedicado a San Antonio de Padua, tienen la particularidad de que llevan sobre la hornacina principal un pabellón descorrido (elemento muy del gusto del barroco) por dos angelitos, uno a cada lado, con lo cual parece que nos estuvieran descubriendo la imagen del santo titular de cada máquina, artificio muy barroquizante. Además, presentan otra particularidad: en las dos enjutas del arco que conforma el ático se sitúan otros dos angelitos, estos en posiciones más danzarinas. Sin ninguna duda estos ochos angelitos serán los realizados por su hermano Manuel de Ávila, al cual asociaría a la obra para que le descargara de trabajo. No sabemos cuánto percibió por ellos. En uno de los libros de la Congregación de San Felipe Neri se alude a que el 30 de enero 1720 se le abonaron "cien reales de vellón en cuenta de lo que ha de haber por las hechuras de los niños de los dos retablos que está ejecutado para dicha Congregación"115. Si nos fijamos en el rostro de todos estos "putti" el estilo de los hermanos Ávila está más que claro.

La Magdalena (Figs. 32-33) se encuentra en la actualidad en una de las hornacinas de la capilla de San Lorenzo de la antigua colegiata, una de las que actualmente conforman el espacio expositivo del Museo Diocesano y Catedralicio. Como ya hemos referido en diversas ocasiones, sería deseable que estas esculturas volvieran cada una a su retablo original, previa restauración dado que en el desafortunado traslado perdió gran parte de

114 Bendición de las dos imágenes de San Antonio y la Magdalena. "En diez y ocho de mayo de mil setecientos y veinte habiendo precedido comisión y licencia verbal a los señores don Antonio de Arenas, don Manuel Suárez y don Manuel Argain Ylloldi, congregantes para que los susodichos participasen al señor don Tomás López de Castro, canónigo de la santa iglesia como el Ilmo. Señor don fray Joseph de Talavera obispo de esta ciudad de Valladolid daba su permiso y dicha licencia a dicho señor don Tomás para efecto de bendecir las dos imágenes de San Antonio de Padua y Santa María Magdalena que están puestas en los dos primeros retablos de las capillas del Oratorio de la Venerable Congregación de Nuestro Padre San Felipe de Neri, y con dicho permiso y licencia dicho señor hoy dicho día y en dicho Oratorio hizo dicha bendición con la solemnidad que en semejante acto se requiere, y su ejecución fue entre cinco y seis de la tarde, con asistencia de dichos señores comisarios arriba nombrados, quienes asistieron con sobrepellices a acto tan serio, y para que conste yo el infrascrito escribano pongo esta nota y lo firmo". A.S.F.N., Caja 13, $2^{\circ}$ Libro de Acuerdos (1690-1740), f. 154; MARTÍN GONZÁLEZ, Juan José y URREA FERNÁNDEZ, Jesús: Catálogo Monumental de la provincia de Valladolid. Tomo XIV..., op. cit., p. 302.

115 GARCÍA CHICO, Esteban: Documentos para el estudio del arte en Castilla. 2..., op. cit., p. 375. 
los dedos, incluidos con los que sujetaba el Crucifijo, el cual se conserva en la actualidad en la sala de la congregación del Oratorio de San Felipe Neri sin ninguna indicación que nos refleje que no es una obra autónoma sino parte consustancial de la Magdalena, puesto que tal y como se encuentra actualmente esta talla sin el Crucifijo carece de sentido.

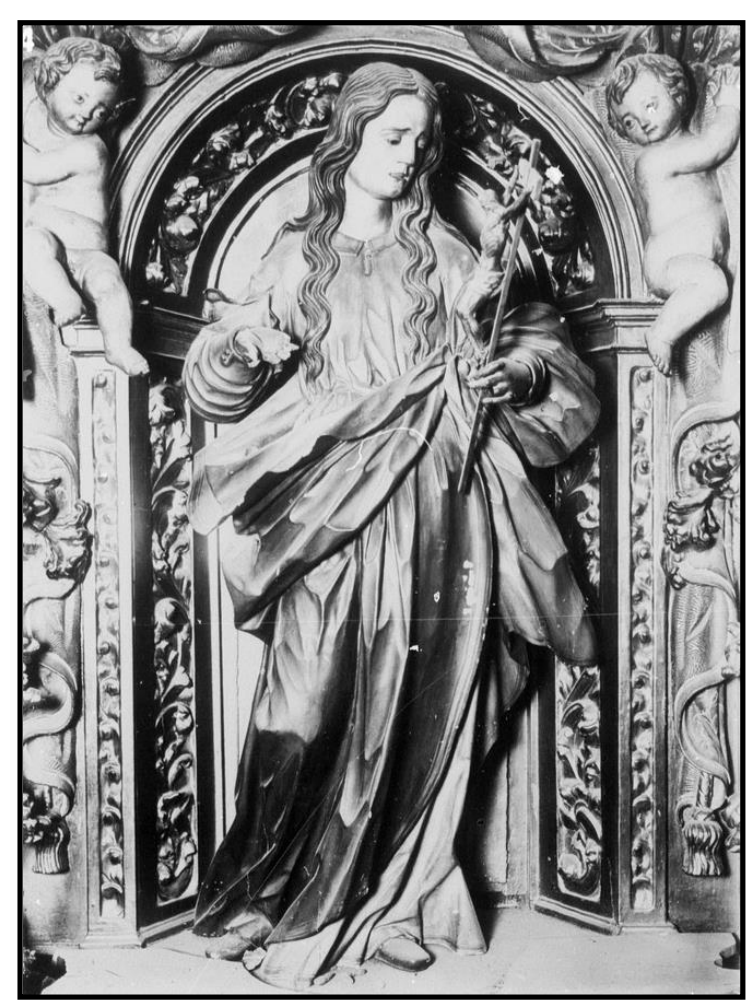

Il. 21- Santa María Magdalena cuando aún se encontraba en su retablo y donde sería deseable que volviera.

$\mathrm{Su}$ belleza la hizo merecedora de una aguda alabanza por parte de Gratiniano Nieto: "Al lado del evangelio, junto al crucero, la primera capilla que se encuentra está dedicada a la Magdalena cuya imagen es una gran escultura tallada asimismo por Pedro de Ávila la cual demuestra el rango que llegó a alcanzar la escultura de Valladolid en esta centuria" ${ }^{116}$. Esta afirmación es de la mayor importancia puesto que tanto la historiografía en general como la local y regional siempre ha minusvalorado la calidad de la escultura vallisoletana tras la muerte de Gregorio Fernández, como si no hubiera habido otros grandes maestros. Con posterioridad tan solo se ha rescatado del siglo XVIII a Pedro y Manuel de Ávila, Pedro de Sierra y Felipe Espinabete. Ya va siendo hora de que se otorgue su justo mérito a los componentes de la excelente escuela vallisoletana que suministró de buenas imágenes y retablos a las iglesias y conventos de la provincia pucelana y de las limítrofes durante la mayor parte del siglo XVIII. El tordesillano Espinabete se erige como el último gran maestro.

Santa María Magdalena aparece según la iconografía de penitente, pero sin embargo poco tiene que ver con la otra que vimos en la catedral, en la cual la alusión a la penitencia venía dada por la calavera que sostenía en una de sus manos. A pesar de esa diferencia, la disposición general de la escultura es similar tanto en el sentido helicoidal del cuerpo, el leve escorzo del torso, y la forma de disponer las piernas, pies, brazos y hasta las ropas. Las diferencias vienen dadas tan solo en el rostro, muchísimo más bello éste que aquél, y la distante colocación de la mano izquierda puesto que no debe sostener un paño con la calavera sino un Crucifijo que contempla con fruición. Por su parte, la otra mano realiza como la de la Magdalena catedralicia un típico gesto declamatorio. La forma de sostener el crucifijo es muy elegante. Otros elementos como las diagonales que forman los pliegues, también muy finos y delicados, y la propia mirada de la santa al Crucifijo vuelven a repetirse puntualmente. Cabe señalar que con

116 NIETO GALLO, Gratiniano: op. cit., p. 122.

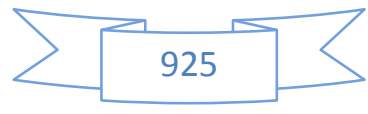


el paso del tiempo cada vez va logrando mayor estrechez en las láminas de madera y todavía afaceta más los diversos planos con los que compone los paños: podríamos decir que "barroquiza" su estilo. Sin embargo, la policromía nuevamente parece señalar la llegada del rococó y de la influencia cortesana: los colores siguen siendo planos, cada vez más pálidos, y encima han desaparecido aquellas hermosas orlas que han sido sustituidas por una simple franja dorada. La inclusión del color rosa palo y el verde suave parece reafirmar esta teoría. También es puramente cortesano el hecho de que la escultura, a pesar de presentar una especie de éxtasis ante la contemplación del Crucifijo, no se nos

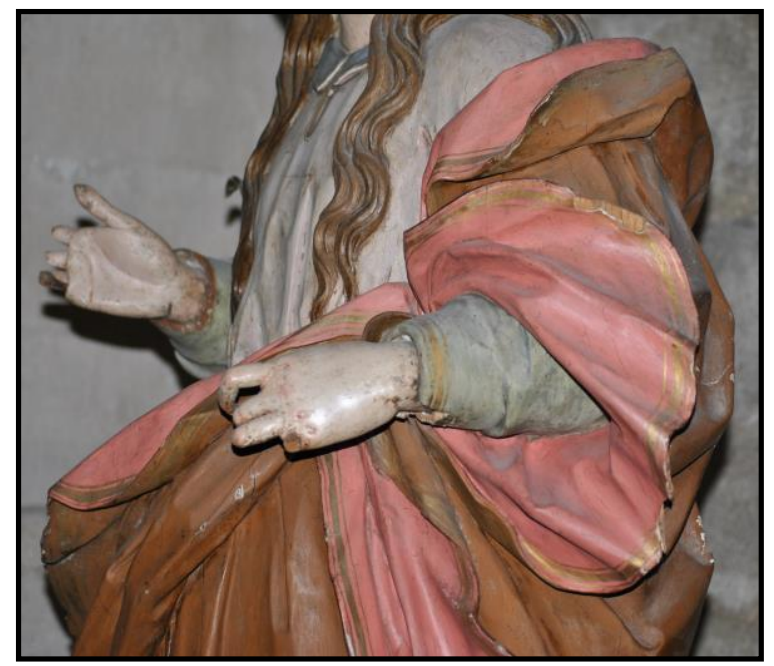

Il. 22- Detalle de los finos pliegues a cuchillo del manto de Santa María Magdalena. presenta a la santa sufriente, sino que prima ante todo la belleza formal y la elegancia en la composición.

En esta Magdalena nos interesa centrarnos en otros aspectos más novedosos como son el rostro y el Crucifijo. El rostro presenta los característicos rasgos faciales de Pedro de Ávila; sin embargo, en esta ocasión todos se encuentran mucho más apurados, finos;

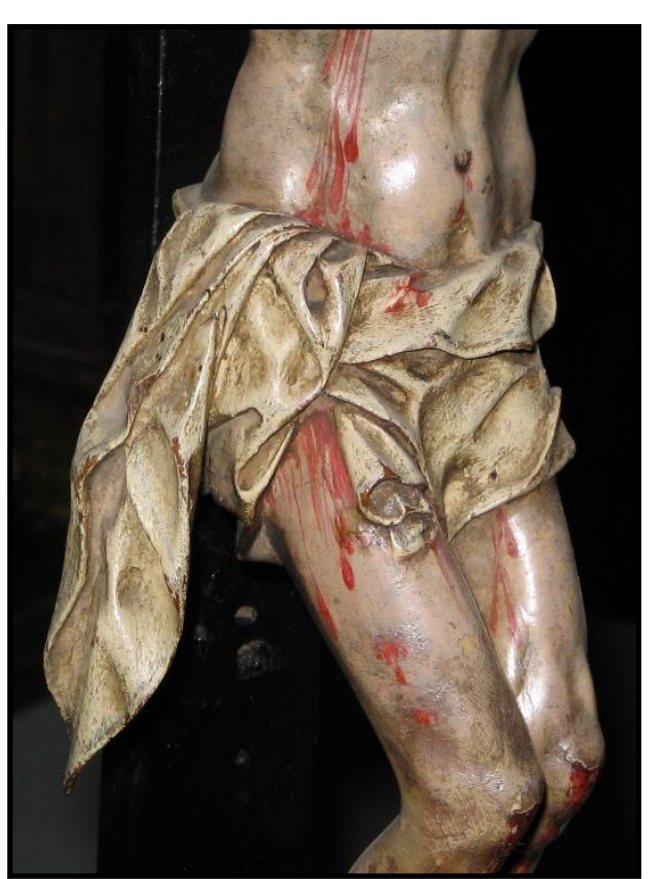

Il. 23- Detalle de los minuciosos pliegues a cuchillo del Crucifijo de la Santa María Magdalena. así, por ejemplo, están perfectamente perfilados los labios, dientes, punta de la lengua e incluso hace acto de aparición el surco nasolabial definido en su totalidad. Presenta novedad el hecho de que las cejas no sean rectas, sino que tiendan a una línea diagonal, lo que otorga a la santa una gestualidad cercana al arrobamiento místico ante el Crucifijo. El peinado se resuelve en largos y amplios mechones que caen hasta el pecho, dos guedejas a un lado del rostro y otros dos al otro; por la espalda seguramente se distribuyen sinuosos mechones en toda su anchura, como suele hacer en la parte trasera de las esculturas femeninas que hemos podido observar, como por ejemplo la Magdalena de Matapozuelos y alguna Inmaculada. Por su parte, el Crucifijo (Figs. 34-35) se encuentra en muy mal estado de conservación, casi peor que la propia Magdalena puesto que ha perdido gran parte de los dedos y tiene quebrado el brazo izquierdo a la altura del hombro, rotura que se ha intentado solucionar con un burdo pegamento que encima ha manchado de amarillo la fina y naturalista policromía. Cristo aparece ya muerto puesto que su cabeza 
parece caer hacia el hombro derecho, teniendo los ojos casi completamente cerrados; también las piernas se desploman a causa del óbito.

Los detalles generales del Crucifijo nada tienen en común con los cuatro Crucifijos de mucho mayor tamaño que le están documentados y atribuidos, y seguramente su diminuto tamaño tenga mucho que ver. Sin embargo, está fuera de toda duda la paternidad de Ávila pues no hay más que ver la forma en que resuelve el pelo situado sobre el cráneo y las ondulaciones que llegan a taparle una de las orejas. También es indicio de esto el hecho de que los paños del perizonium son de cuchillo, estando perfectamente modelados, con lo cual nos vuelve a demostrar su pericia para tallar minuciosamente hasta los detalles más nimios. Quizás el canon no sea tan correcto como el de los otros Crucificados puesto que torso y abdomen son excesivamente largos. Sin embargo, dado el tamaño de la pieza se trata de una obra excelente.

No deja de ser curioso el hecho de que la influencia de Mena que podemos ver en diversas características del estilo de Ávila no se haya traducido en la copia del modelo de Magdalena del granadino, imagen que debió de conocer seguro en su probable viaje a Madrid. Nuestro escultor, sin embargo, prefiere revestirla de lujosos ropajes de cortesana, con algunas dobleces en la túnica que la otorgan distinción.

\section{CRISTO CRUCIFICADO "DEL OLVIDO"}

El Cristo Crucificado fue bendecido el 26 de mayo de 1721, de manera conjunta con la Inmaculada de la capilla frontera, por el Ministro de la Congregación don Antonio Mansilla: "Otrosí dio comisión su Ilustrísima al señor Maestro Don Antonio Mansilla para que bendijese las dos imágenes de Cristo y María, que están en las dos capillas del medio, las cuales están benditas por dicho señor Maestro"117. Ese mismo día predicó en la iglesia don Roque García, catedrático de Prima de Filosofía en la Universidad.

Año y medio después, el 21 de enero de 1723, Juan Gil de Mesa "beneficiado de la parroquial del señor San Ildefonso y capellán del Real Convento de Santa Cruz de esta ciudad de Valladolid" declaraba en su testamento ser su voluntad que se entregara "a la Venerable Congregación de mi Padre San Felipe Neri de esta ciudad quien me ha de enterrar como llevo referido una urna pequeña pintada de chalor con flores de oro con su vidriera cristalina a la cara y en ella una imagen de ella de Nuestra Señora de los Dolores la cual es mi voluntad se ponga en la capilla del Santísimo Cristo de dicha iglesia en la primera grada que hay sobre el Santo Sepulcro o parte que más convenga en dicha capilla pido que me perdone y me encomiende a Dios" ${ }^{118}$. Esta Virgen de los Dolores que el beneficiado quería colocar a los pies del Crucifijo de Pedro de Ávila, y

117 A.S.F.N., Caja 14, $2^{\circ}$ Libro de acuerdos (1690-1740), f. 168. MARTín GONZÁLEZ, Juan José y URREA FERNÁNDEZ, Jesús: Catálogo Monumental de la provincia de Valladolid. Tomo XIV..., op. cit., p. 303.

118 A.H.P.V., Leg. 3.333, ff. 390-393. 
justo por encima de la urna del Cristo Yacente, pudiera ser una pequeña imagen que copia puntualmente a la Virgen de las Angustias de Juan de Juni que a día de hoy se encuentra situada sobre uno de los muros del espacio que comunica el altar mayor con la sacristía. La Virgen juniana tuvo un gran eco durante el barroco, al igual que la Dolorosa de la Vera Cruz, las cuales fueron copiadas en multitud de ocasiones; fundamentalmente para las parroquias rurales. En estas ocasiones se las solía asociar a un Crucifijo puesto que se las colocaba al pie de ellos, como ocurriría en este caso de San Felipe Neri; es decir, sería algo similar a la llamada tipología retablística del "Yacente-Dolorosa", en los cuales se colocaba al Yacente en una urna situada en el banco y una Virgen Dolorosa, generalmente de vestir, en la hornacina principal (en Valladolid capital tenemos varios ejemplos, como pueden ser los de las iglesias de Jesús Nazareno y la Magdalena o el más tardío de la parroquia de San Andrés). Pues bien, algunos ejemplos de lo que podríamos llamar "Crucificado-Dolorosa" o "Dolorosa al pie de la cruz" se conservan en las iglesias parroquiales de Bercero (el Crucificado es obra documentada de Alonso de Rozas) ${ }^{119}$ y Curiel de Duero o en el Humilladero del Santo Cristo de la cercana localidad de Villabáñez (el Crucifijo fue relacionado con Francisco de la Maza por Martín González) ${ }^{120}$.

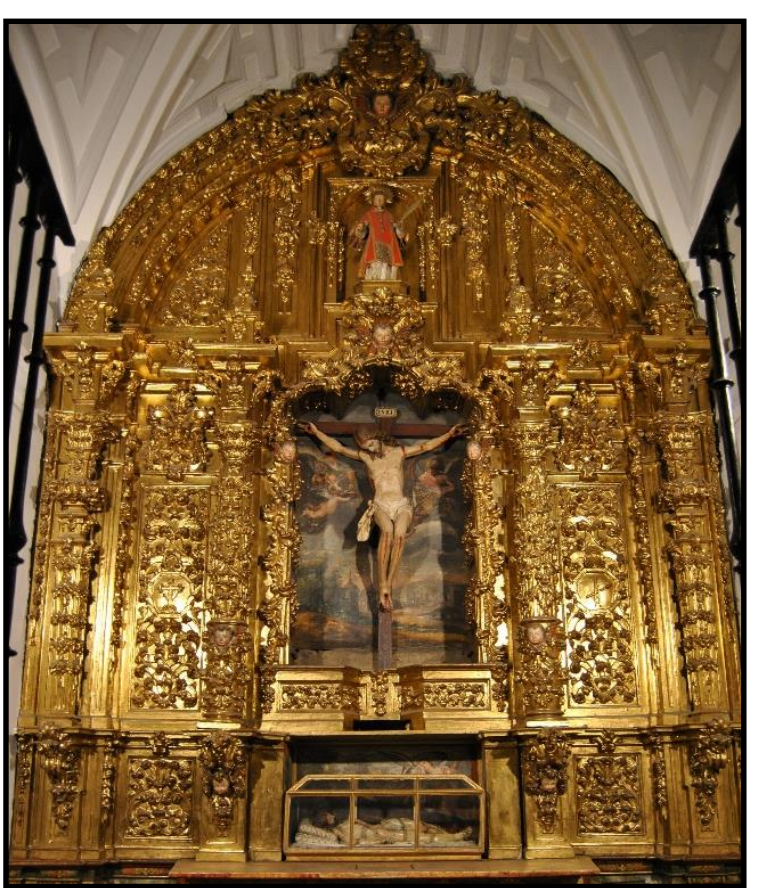

Il. 24- Francisco Billota. Retablo de Cristo Crucificado. Oratorio de San Felipe Neri. Valladolid.

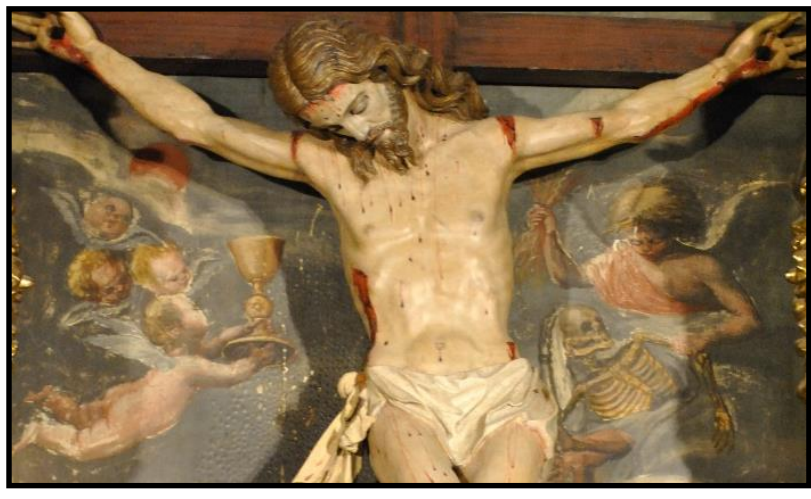

Il. 25- Detalle de los ángeles pintados en la hornacina del Retablo de Cristo Crucificado.

La hornacina en la que se encuentra el Crucificado (Figs. 36-38) adopta una forma trilobular en su parte superior, de tal manera que se adapta a la perfección a los brazos del madero. El fondo alberga una pintura que representa dos ámbitos claramente diferenciados: en la parte de abajo se desarrolla un paisaje compuesto por unas cuantas casas, árboles y todo cruzado por un riachuelo; y en la parte superior se sitúan dos grupos de personajes entre nubes a ambos lados del costado de Cristo: a la izquierda del

\footnotetext{
119 URREA FERNÁNDEZ, Jesús: “La capilla...”, op. cit., p. 506.

120 MARTÍN GONZÁLEZ, Juan José: Catálogo Monumental de la provincia de Valladolid. Tomo VI..., op. cit., p. 142.
} 
espectador tres cabezas de serafines aladas juntas y con ellos un ángel de cuerpo entero sosteniendo un cáliz que vendría a recoger la sangre que mana de la llaga del costado de Cristo; al lado derecho del espectador surgen de entre las nubes un ángel ya adulto que agarra del brazo a una representación de la muerte, tras de la cual hay una especie del diablo, a los cuales el demonio amenaza con los rayos que sujeta con la otra mano.

El presente Crucifijo es el mejor y más perfecto tanto de talla como de acabado de todos los que le tenemos documentados y atribuidos, de momento. No hace falta volver a citar que este Crucifijo sigue puntualmente el modelo creado por Ávila en el ejemplar de Torrecilla de la Abadesa, el cual hemos de considerar como el cabeza de serie. Cuando solamente se tenía documentado este Crucificado, Martín González comentó que este Cristo "-llamado del Olvido- representa la continuación del tipo creado por Juan de Ávila"121. Resulta un poco extraña esta afirmación puesto que en el año en que fue emitida esta opinión no teníamos documentado ningún Crucifijo de Juan de Ávila. Años después, en cambio, sí que se relacionó ya con el padre de nuestro escultor el de la capilla del Calvario del Colegio de los Ingleses de Valladolid.

No tenemos más remedio que recordar que Inés Durruty Romay dedicó a este pequeño Crucificado el artículo "El Cristo del Olvido. Escultura de Pedro de Ávila", que es el único monográfico que trata sobre la obra o biografía de todos nuestros escultores Ávila; sin embargo se trata de artículo que no trata tanto sobre el aspecto estilístico, sino que es más poético que otra $\operatorname{cosa}^{122}$. La propia Durruty Romay señala que en el Cristo se aprecian dos tendencias bien definidas: por un lado "el barroquismo del siglo, apenas esbozado en la profusión de la sangre, en cierta afectación académica y en la inclinación al realismo como producto de un neoclasicismo, y su contacto con escultores anteriores y con la escuela de finales del XVI y del XVII, especialmente como ya se ha indicado varias veces, con Gregorio Fernández; el patetismo, la sobriedad, la belleza delicada de la forma y la serenidad tranquila de la expresión, producto de un acendrado misticismo o bien reflejo del de Gregorio Fernández, alejamiento de artistas

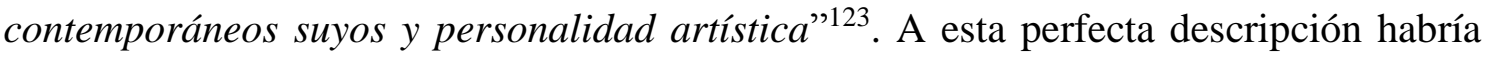
que realizar una corrección. Al hablar de que el barroquismo de la pieza se escenifica en la profusión de la sangre, cabe señalar que esta profusión sanguínea corresponde al repolicromado que se apreciaba cuando lo examinó Durruty; tras la restauración llevada a cabo en 2010 se ha recuperado la policromía original, la cual era mucho menos dramática. El propio restaurador, Andrés Álvarez, comenta que "al eliminarse el repolicromado, bastante mediocre, se ha recuperado la carnación original, que, aunque no está en perfecto estado tiene una calidad muy superior y multitud de detalles. También se ha recuperado el peleteado de oro, prácticamente intacto"124.

\footnotetext{
121 MARTÍN GONZÁLEZ, Juan José: Escultura barroca castellana..., op. cit., p. 325. DURRUTY ROMAY, Inés: op. cit., pp. 205-209.

Ídem, p. 209.

ÁLVAREZ VICENTE, Andrés: Imaginería ligera en Valladolid, Ayuntamiento de Valladolid, Valladolid, 2011, p. 82
} 
No volveremos a explicar las características del Crucifijo puesto que ya se hizo, y tan solo se señalarán las diferencias más importantes. Una de ellas será el uso de postizos, concretamente tela encolada, aunque no sabemos si lo realizó el propio Ávila, el policromador de la imagen o el que la repolicromó. Señala Álvarez Vicente al respecto que "la disposición del paño de pureza hacía que se le viese mucho la pierna y se optó por disimularlo parcheando con un trozo de tela encolada. Lo que por el momento no se puede precisar es si fue una actuación que se llevó a cabo en el momento de su realización, o con posterioridad. Otros crucificados del mismo autor tienen mejor resuelto este elemento, así que pudo haber sido él mismo o el policromador quienes lo modificaran, aunque por las estratigrafías sabemos que en algún momento entre finales del siglo XIX, principios del XX, se repolicromó, fecha que se podría haber aprovechado para realizar esta intervención y modificar el aspecto del paño de pureza"125.

Sin lugar a dudas Ávila había crecido como escultor desde que realizara los otros dos crucifijos similares en el año 1714 pues este lance lo podemos comprobar en el hecho de que la anatomía la ha apurado mucho más. Este Cristo posee un canon algo más alargado, a lo que sin duda ayuda su delgadez, y ya no es aquel Cristo potente pues ahora los huesos parecen salir a flote, y es una viva imagen del demacramiento que presenta un cuerpo múltiplemente torturado. Claro ejemplo de esa delgadez y también de la destreza de nuestro escultor es la forma de tallar el torso, con el vientre hundido, lo que hace que se le remarque el espacio intercostal de una manera mucho más naturalista y verídica, naturalismo aumentado por la talla incluso de los pezones, detalle que anteriormente no aparecía. También es remarcable la flaccidez que logra en la carne que pende de los brazos muertos y la verosimilitud de las venas, las cuales surcan todo su cuerpo. Como se suele decir en ocasiones de algunas imágenes de Cristo talladas por Gregorio Fernández, la madera se ha convertido en carne. Otra novedad será el tratamiento del paño de pureza, que se dispone de una manera similar, sin embargo los pliegues son muchísimo más pequeños y cortantes lo que implica una mayor agitación; una vez más nos vuelve a demostrar su portentosa técnica al cortar de una manera tan fina la madera que conforma el trozo de perizonium que cae verticalmente desde la lazada.

Sin lugar a dudas las mayores diferencias las encontramos en la cabeza, tanto en el rostro como en la cabellera. La cabeza es muy hermosa, y en ella aparecen de una manera mucho más clara todavía las características formales del "segundo estilo". Con diferencia de los otros dos, el rostro se ensancha, como también lo hace el volumen de las cabelleras dispuestas en los laterales, llegando a formar grandes ondulaciones en las que el escultor parece querer exhibir su talento, tanto por el tamaño de las mismas como por la finura y delicadeza con la que parece utilizar el trépano, puesto que intenta individualizar la cabellera por mechones. También hay diferencias en la forma de tallar los ojos y la barba. Los ojos no están cerrados, sino que aún podemos ver una estrecha franja de ellos, lo que, unido a la manera de tallar los párpados, en volumen, incrementa

$125 \quad$ Ibídem. 
la sensación de dramatismo y de realismo. Esta curiosa y veraz forma de tallar los párpados la volveremos a ver en el San Francisco de Borja del desaparecido retablo mayor del Convento de las Comendadoras de Santiago, de Valladolid, actualmente conservado en el Museo Nacional de Escultura. A este dramatismo y agotamiento final ayuda el detalle de la boca entreabierta con la punta de la lengua asomando. Por su parte, la barba se encoge en longitud, pero ensancha en amplitud. Asimismo, tiene mayor detallismo a la hora de detallar cada ambos mechones simétricos.

La policromía es mate. Especialmente destacable son los regueros de sangre y sobre todo los borbotones de sangre cuajada que adoptan una entonación más oscura. La restauración realizada en el año 2010 por Andrés Álvarez y su equipo de la Escuela de Restauración de Valladolid ha conseguido sacar a la luz el tremendo empeño que puso Ávila en esta pequeña obra maestra, cuya excelente calidad se encontraba oculta bajo un horroroso repinte. En la actualidad es procesionado por la Real y Venerable Cofradía de la Preciosísima Sangre de Nuestro Señor Jesucristo en la Procesión de la Buena Muerte que se realiza en la noche del Lunes Santo. Entre los aficionados a la Semana Santa de Valladolid se le conoce con el mote de "Crispín" debido a su pequeño tamaño.

\section{$\underline{\text { INMACULADA }}$}

Como ya dijimos, la Inmaculada fue bendecida conjuntamente con el Cristo Crucificado el día 26 de mayo de 1721 por el Ministro de la Congregación don Antonio Mansilla ${ }^{126}$. No quedan ahí las coincidencias entre ambas tallas puesto que esta imagen también se halla dentro de una hornacina con el borde superior trilobulado y bajo la hornacina hay otra en la que se encuentra un Niño Jesús, que aludiría a la Concepción Inmaculada de la Virgen. También se asemejan en que el fondo de la hornacina principal va pintada. En esta ocasión no tenemos ningún paisaje, sino que en la parte inferior se sitúan diferentes objetos y alegorías que aluden a su referida Concepción Inmaculada. Así, observamos de izquierda a derecha: un pozo (Puteus aquarum viventium, "Pozo de aguas vivas"); un árbol, quizás un cedro (Cedrus exaltata, "Alta como cedro); un olivo (Oliva spcesiosa, "Oliva vistosa"); una torre ("Turris Davis cum propugnaculis, "Torre de David con baluartes"); una fuente (Fons ortorum, "Fuente de huertos"); otro árbol sin identificar que aludirá a Virga Jesse floruit ("Floreció la vara de Jesé); y una especie de ciudad (“Civitas dei, "Ciudad de Dios”). En un nivel superior se sitúan dos ángeles, uno a cada lado, con una palma, que quizás aludan al triunfo de la Inmaculada. Finalmente, en la parte superior dos grupos de cabezas aladas de querubines sobre masas nubosas y en el centro, justo sobre la cabeza de la Virgen, la Paloma del Espíritu Santo irradiando un potente haz de luz sobre María.

126 A.S.F.N., Caja 14, $2^{\circ}$ Libro de acuerdos (1690-1740), f. 168. MARTÍN GONZÁLEZ, Juan José y URREA FERNÁNDEZ, Jesús: Catálogo Monumental de la provincia de Valladolid. Tomo XIV..., op. cit., p. 303. 
La base de la creencia de la Inmaculada Concepción o la Virgen Inmaculada "es la preservación del pecado original en ella misma" ${ }^{127}$. El origen se encuentra en la iglesia griega y en el Protoevangelio de Santiago, si bien dicho Protoevangelio "no propone la idea de la Inmaculada Concepción de María, parece ser que la implica. Se escribió como glorificación de la Virgen y contribuyó decisivamente al florecimiento de la Mariolatría durante la Edad Medía tardía cuando se reforzó considerablemente su posición como divinidad subordinada, tanto humana como divina" ${ }^{28}$. Según Manuel Trens, la fiesta de la Concepción de María se remonta al siglo VII, "bajo la denominación general de Concepción de Santa Ana, en 9 de diciembre. Esta fiesta solemnizaba la concepción pasiva de María en las entrañas de su madre, al paso que la Conceptio Maria Virginis aludía a la divina maternidad de la Virgen"129.

Uno de los primeros que defendió la causa inmaculadista fue el teólogo franciscano Duns Scoto, tarea que continuaron durante el final del periodo medieval los propios franciscanos en contraposición a los dominicos. Posteriormente "vendría el triunfo de la Inmaculada, para lo cual se contó con el apoyo popular y de clases tan influyentes como la Casa Real de España. La defensa acometida por los franciscanos hallaría soporte de los Jesuitas. Pero durante el siglo XVII los franciscanos canalizan el fervor

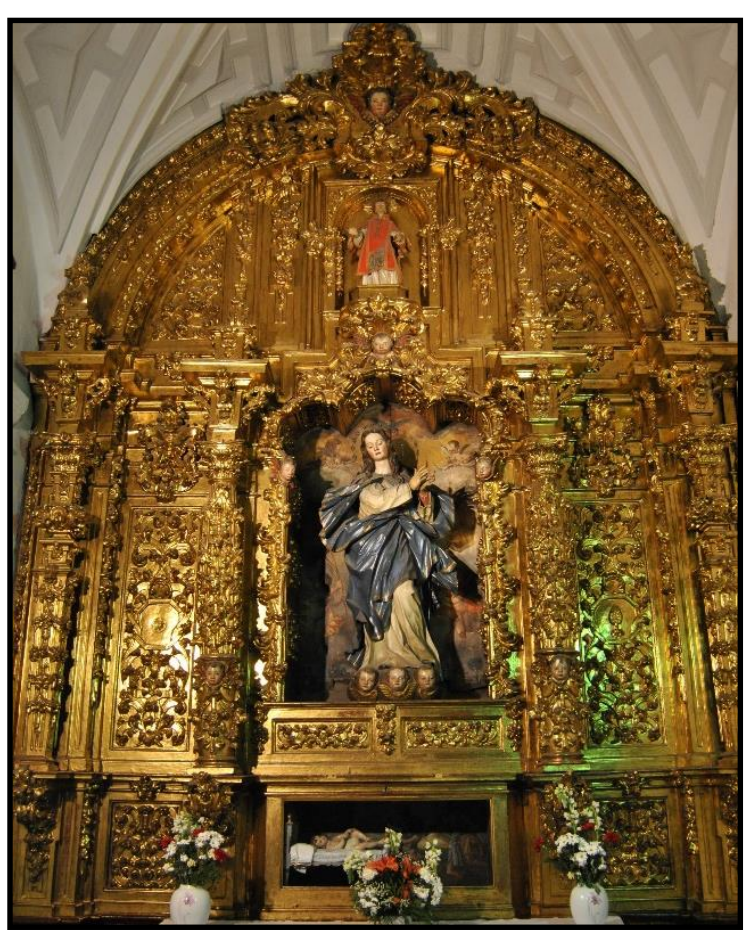

Il. 26- Francisco Billota. Retablo de la Inmaculada. Oratorio de San Felipe Neri. Valladolid. de las poblaciones y es en sus templos donde aparecen las imágenes de la Inmaculada más famosas. Son también las catedrales el cobijo de la devoción, pero en ellas contarán con el amparo del rey de España. Primero Felipe III y después Felipe IV se elevan a la categoría de campeones de inmaculadismo" ${ }^{130}$.

Aunque nuestra idea plástica de la Inmaculada Concepción es la que presenta a la Virgen María sola, con las manos orando sobre una luna o pisando al diablo, la iconografía ha cambiado mucho desde sus orígenes. La primera forma de representarse "la santidad sin mancilla de la Virgen" fue mediante el árbol de Jesé, que une lo descriptivo y lo genealógico ${ }^{131}$. Al parecer la idea de esta composición se encuentra en el abad Suger, el cual "mandó

127 MARTÍN GONZÁLEZ, Juan José: "Imágenes de escultura de la Concepción en Castilla y León de los siglos XVI al XVIII". En VV.AA.: La Orden Concepcionista: Actas del I Congreso Internacional, Tomo II, Universidad de León, León, 1990, p. 15.

128 STRATTON, Suzanne: La Inmaculada Concepción en el arte español, Fundación Universitaria Española, Madrid, 1989, p. 3.

129 TRENS, Manuel: op. cit., p. 165.

130 MARTÍN GONZÁLEZ, Juan José: “Imágenes de escultura de la Concepción...”, op. cit., p. 15.

131 TRENS, Manuel: op. cit., p. 96. 
ejecutarlo en un ventanal de su abadía de Saint Denis. Presenta varias formas, que se distinguen principalmente por sus mayores o menores dimensiones. Éstas dependen del espacio disponible. En la parte inferior se representa siempre a Jesé, el distinguido hacendado de Belén y padre de David. Se le representa tendido o sentado, pero casi siempre dormido (...) No es fijo el número de los antepasados de María que figuran en los árboles de Jesé (...) Por lo general, se les representa como reyes; algunos de ellos no lo fueron, pero todos eran de estirpe real. El remate es siempre la Virgen con el Niño Jesús, los cuales pueden aparecer representados indistintamente de pie, sentados o en busto. Puede figurársela con o sin el Hijo"132.

Con posterioridad llegó la llamada "Sagrada Parentela", que viene a ser una simplificación del "Árbol de Jesé” en el que la representación "toma un carácter de escena íntima, representándose en ella los próximos parientes contemporáneos de la Virgen. Externamente, parece que se trata de lo que vulgarmente llamamos un retrato de familia, pero la presencia del Espíritu Santo nos advierte que, en realidad, nos hallamos ante la admirable y sobrenatural Concepción de María" ${ }^{133}$. Lo normal es que aparezcan sentadas en sendos tronos la Virgen con el Niño y Santa Ana, y en medio en Espíritu Santo sobre ellas; sin embargo, en otras ocasiones pueden añadirse en los laterales "San José; al lado de Santa Ana, San Joaquín, los dos preclaros varones"134.

Una representación más explícita es el denominado "Encuentro de San Joaquín y Santa Ana ante la Puerta Dorada", cuyos detalles los narra Santiago de la Vorágine en su Leyenda Dorada. Después llegó la "Santa Ana Triple" que viene a "expresar indirectamente la concepción pasiva a María, es decir, de manera sobrenatural como fue concebida, consistió en ensalzar a su madre Santa Ana, en cuyo seno se consumó aquel gran misterio"135. El paso previo a la actual Inmaculada es la Virgen "Tota Pulchra" en la cual la única protagonista de la escena es la Virgen; María queda independizada de otra cualquier figura, y tan solo la rodean "emblemas, alegorías $e$ inscripciones", algunos de los cuales ya los hemos narrado al describir la pintura del fondo de la hornacina ${ }^{136}$.

Y al fin la Inmaculada prototípica del Barroco, pero también de parte del Renacimiento. Fray Juan Interián de Ayala explicó las características que tenían que tener las representaciones de esta nueva Inmaculada: "El que pintare mejor y con más viveza la señal (mujer) que describe el evangelista San Juan, éste será también el que pintará mejor y más propiamente a la Inmaculada Concepción de la soberna Señora". Además, debería representársela con unos 10 o 12 años, "con una túnica blanca y resplandeciente, bordada, si así se quiere, con flores de oro y con un manto cerúleo (azul), ancho y brillante cuanto sea posible. Pues de esta manera (además de representarse mejor a la vista la admirable dignidad del hecho) se apareció la purísima

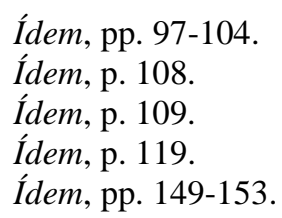


Señora, como lo notó el referido pintor (Pacheco), a la nobilísima virgen portuguesa Beatriz de Silva, fundadora de la Orden de la Purísima Concepción, que confirmó el Papa Julio II, el año 1511"137. La Virgen debe aparecer orante, sin el Niño Jesús. Y, además, como mujer apocalíptica y nueva Eva se la debe colocar bajos los pies el dragón del Apocalipsis o la "serpiente paradisíaca, que continúa ofreciendo entre sus mandíbulas el fruto de perdición" ${ }^{138}$. A esta imagen de Pedro de Ávila tampoco le falta una corona que exhibe doce estrellas, que es un atributo de la mujer apocalíptica. Asimismo se la debe colocar en el pedestal un cuarto de luna con las puntas de los cuernos hacia abajo ${ }^{139}$, a pesar de que en las esculturas puede entrañar mayor dificultad técnica.

La presente Inmaculada (Figs. 39-41), prototipo ideal de esta iconografía que parece que creó al comienzo de su carrera, ha conseguido múltiples alabanzas, sin ninguna duda merecidas. Por ejemplo, Gratiniano Nieto la calificó de "magnífica Inmaculada"140, y Martín González la llegó a considerar "entre las más primorosas de la plástica española"141. El propio Martín González también dijo de ella que se trata de "una de las más singulares Inmaculadas. La representación está influida por las representaciones pictóricas. De ahí que el modelo se haga ancho y los pliegues den la impresión de grandes pinceladas" ${ }^{142}$. No hay lugar a dudas de que es una de sus obras maestras.

No sabemos qué Inmaculadas pudo observar, quizás en ese viaje a Madrid, para elaborar esta iconografía tan novedosa en Valladolid que rompía completamente con el tipo de Inmaculada que se venía repitiendo hasta la saciedad desde principios del siglo XVII: la creada por Gregorio Fernández. No es baladí el éxito que tuvo el nuevo modelo iconográfico creado por Ávila puesto que logró romper con el monopolio fernandesco, llegando a ser también repetida en numerosas ocasiones. Años después se uniría a esta ruptura Pedro de Sierra. Quizás sean meras casualidades, pero el modelo de Inmaculada de nuestro escultor posee numerosas concomitancias con muchas Inmaculadas andaluzas, muchísimas más que con las castellanas, generalmente reducidas al referido prototipo simétrico fernandesco. Por ejemplo, hay no pocas coincidencias con la Inmaculada Concepción, vulgarmente conocida como "La cieguecita" que Juan Martínez Montañés talla en 1630 para la catedral de Sevilla: no hace falta más que observar el leve giro del cuello y la mirada hacia abajo, la posición que adoptan los brazos, que rompen toda simetría y las manos en oración, sin llegar a tocarse; el volumen que adopta el mano en su lado derecho, o el adelantamiento de la pierna izquierda. Con las de Cano y Mena compartiría el ensanchamiento producido a la altura del abdomen. No exactamente esta, pero otras Inmaculadas de Ávila veremos cómo

Ídem, p. 170.

Ibídem.

Ídem, pp. 174-175.

NIETO GALLO, Gratiniano: op. cit., p. 122.

MARTÍN GONZÁLEZ, Juan José: Escultura barroca castellana..., op. cit., p. 325.

MARTÍN GONZÁLEZ, Juan José: “Imágenes de escultura de la Concepción...”, op. cit., p. 14. 
coinciden también con algunos ejemplares realizados por escultores italianos y que parece que no pudo llegar a conocer.

Esta Inmaculada es la victoria del barroquismo de Pedro de Ávila. Así Martín González llega a decir que con ella "el escultor se ha adherido al pleno barroco y crea unos pliegues de borde muy agudo"143. Ávila dispone a su Virgen de pie sobre un trono formado por tres cabezas aladas de serafines, cada uno de ellos con una mueca para otorgar diversidad. Nuestro escultor ha decidido romper con la simetría y la tranquilidad que reinaba en las Inmaculadas castellanas, generalmente copias del modelo fernandesco. La Virgen adelanta la pierna izquierda, remarcándose en los ropajes el avance de la rodilla, detalle típico de nuestro escultor; como también lo es la disposición en un ángulo de $90^{\circ}$ de sus dos pies y la separación de ambos por un trozo de túnica con pliegues muy cortantes. Realiza un valiente escorzo con el torso, puesto que mientras sitúa la cabeza levemente girada para el lado derecho, los brazos los impulsa al izquierdo, para unir sus manos (talladas de forma independiente al cuerpo) en oración, pero sin llegar todavía a tocarse. La posición de las manos es elegante a la par que delicada. La rigidez del pasado no tiene cabida en esta Inmaculada "rompedora" de la tradición castellana.

El rostro posee los típicos rasgos faciales presentes en toda la segunda etapa de Ávila. Dirige los ojos hacia abajo, como mirando modestamente a las personas que se acercan a orarla. Su característica boca entreabierta nos muestra la punta de la lengua y la fila de dientes superior. La delicadeza con que trata Ávila este rostro le lleva a incluir un finísimo espacio nasolabial e incluso un curioso hoyuelo en la barbilla. El rostro acusa blandura, si bien parece tener un poco de papada. Las amplias cabelleras se ciñen a la cabeza y caen a manera de cascada de múltiples guedejas a ambos lados del rostro y aún por detrás. El tratamiento es muy minucioso, pues sin duda no quería que ningún detalle escapara a la perfección.

Viste túnica blanca hasta los pies, y como de costumbre no deja a la vista más que las manos y las puntas de los zapatos; y por encima una capa azul sujeta por un broche a la

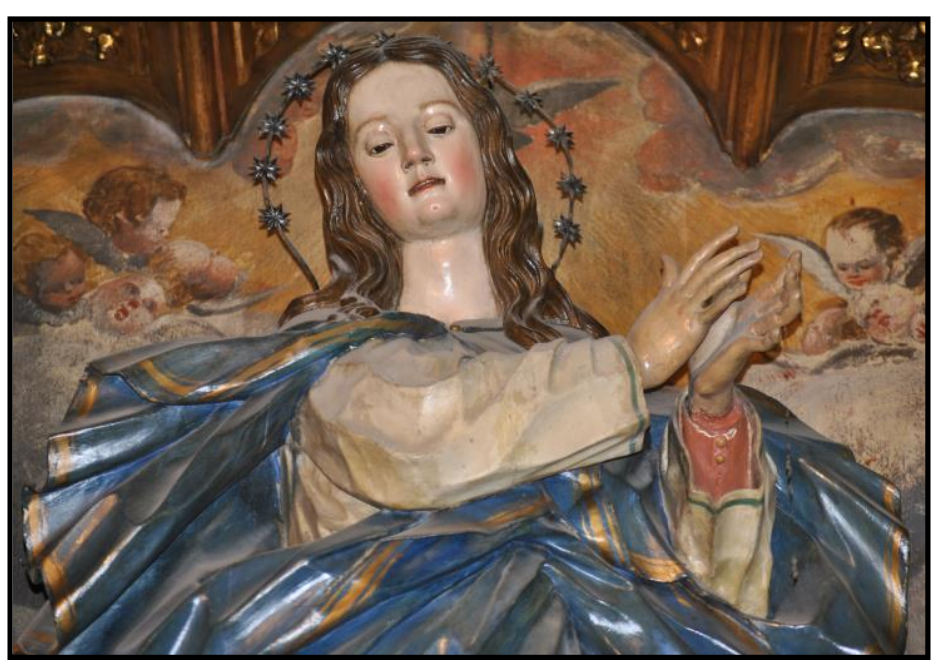

Il. 27- Pedro de Ávila. Detalle del rostro de la Inmaculada. altura del cuello. La policromía sigue los parámetros vistos en las otras tallas que realizó para el Oratorio, en la que los colores son planos, con lo cual se consigue una perfecta valorización de los volúmenes de la imagen; además de volvernos a remitir al incipiente rococó y a la influencia cortesana. Los colores son los usuales para la temática de la 
Inmaculada: el blanco para la túnica y el azul para el manto. Tan solo escapa a la rigidez la fina franja dorada que recorre el reborde. La encarnación es brillante, a pulimento, con lo que se consigue, según Echeverría Goñi, "la más adecuada para esa visión idealizadora"144.

El pliegue a cuchillo adquiere en esta pieza su cenit, así como la destreza de nuestro escultor en cortar finísimas láminas de madera y doblarlas a su antojo sin necesidad de engrosarlas; podemos comprobarlo en los rebordes de la capa, especialmente en los aristados del lado derecho tanto superior como inferior en los cuales es donde la ropa se pliega a voluntad del escultor, pura labor de filigrana. Mientras que la túnica posee unas dobladuras más tranquilas y sosegadas con un pliegue a cuchillo no tan potente; en la capa el aristamiento se acentúa con tal violencia que la prenda parece víctima de una fortísima racha de viento. Los pliegues adquieren un carácter pictórico, otorgando a la Virgen un perfil sinuoso y un ensanchamiento de su figura a la altura de los brazos y de la cadera, así como un juego de diagonales con los pliegues situados a los extremos de los brazos y bajo el brazo izquierdo. Es tal la utilización del pliegue berninesco en esta prenda que llega a crear superficies completamente afacetadas y geométricas al lado de grandes concavidades en las que queda desterrada por completo la línea recta.

Esta Inmaculada, que es la única que le tenemos documentada, no será probablemente el prototipo de la extensa serie que le podemos adjudicar, pero sin embargo es la más excelsa, y también la de mayor tamaño. Tenemos otras Inmaculadas de menor tamaño; pero, sin embargo, seguirán puntualmente este modelo que observamos en la de San Felipe Neri, lo que vuelve a demostrar que las iconografías creadas por Ávila gozaron de gran predicamento en su época. El resto de versiones introducirán sus pequeñas variantes; como, por ejemplo, la supresión en alguna de ellas de la peana angelical.

144 ECHEVERRÍA GOÑI, Pedro Luis: Policromía renacentista y barroca, Historia 16, Madrid, 1992. 


\section{ÍSCAR. IGLESIA DE SAN MIGUEL}

\section{VIRGEN DE LAS ANGUSTIAS (1739)}

En 1739 esculpe para la iglesia de San Miguel de Íscar la que es, a día de hoy, su obra documentada más tardía y parece que también la postrera en el global de obras relacionadas con su catálogo ${ }^{145}$. Es probable que poco tiempo después aconteciera su ceguera, la cual no sabemos si se debió a un accidente o a una enfermedad ocular o de otro tipo.

Desconocemos su actual paradero y tampoco hemos conseguido ninguna fotografía en la que se la pueda observar. La única noticia que tenemos al respecto es la que nos proporciona Martín González en el Inventario artístico de Valladolid. Al parecer, por entonces, en 1970, la escultura se encontraba arrinconada en una trastera de la iglesia ${ }^{146}$; siete años después cuando Brasas Egido redactó el tomo del Catálogo Monumental de Valladolid correspondiente al antiguo partido judicial de Olmedo la Virgen ya había desaparecido: "Entre algunas obras no conservadas de las que nos dan noticia los libros de cuentas de la parroquia, hay que destacar una imagen de la Virgen de las Angustias, que se hallaba sobre el sagrario del retablo mayor, y que hizo en 1739 el escultor vallisoletano Pedro de Ávila" "147. Dado que nunca se ha hablado de un hurto, podría tratarse de una de tantas ventas ilegales efectuadas por el clero.

Aunque en el libro de cuentas figura que era una Virgen de las Angustias, Martín González nos puntualiza que seguía fielmente el modelo impuesto por Juan de Juni: "Dolorosa siglo XVIII, copia de Juni""148. En definitiva, se trataba de una repercusión más de las múltiples que tuvo tanto en pintura como en escultura la Virgen creada por el artista francés ${ }^{149}$. Por esta escultura de pequeño tamaño, que se concibió para colocarla encima del sagrario del retablo mayor, percibió 837 reales; cantidad en la que se incluía el precio de la conducción de la escultura a la villa de Íscar. Sea como fuere, se trataba de una pieza que se la supone de un tamaño bastante reducido; esto quizás indicara la altísima calidad que poseía y también el crecido prestigio del que aún gozaba el escultor, lo que hace que lamentemos profundamente esa ceguera que le dejó inútil para el desempeño de su oficio.

\footnotetext{
145 "Más ochocientos y treinta y siete reales que importó la conducción y hechura de Nuestra Señora de las Angustias en la forma que hoy se halla sobre el sagrario del altar mayor en dicha iglesia como pareció del ajuste y memorial del Señor cura, con cuyo mandado lo pago (...) La hizo en Valladolid Pedro Dávila, maestro escultor". BRASAS EGIDO, José Carlos: Catálogo Monumental de la provincia de Valladolid. Tomo X..., op. cit., p. 97.

146 MARTÍN GONZÁLEZ, Juan José (dir.): Inventario artístico de Valladolid..., op. cit., p. 144.

147 BRASAS EGIDO, José Carlos: Catálogo Monumental de la provincia de Valladolid. Tomo X... op. cit., p. 92.

148 MARTÍN GONZÁLEZ, Juan José (dir.): Inventario artístico de Valladolid..., op. cit., p. 144.

149 Un estudio de buen parte de estas repercusiones, que se dieron tanto en Castilla como en otros puntos más alejados como Asturias, se puede consultar en el catálogo de la exposición "Civitatis Domina", redactado por Javier Burrieza, y celebrada con motivo de la Coronación Canónica de la Virgen de las Angustias: BURRIEZA SÁNCHEZ, Javier: Civitatis Domina. La Virgen de las Angustias y las gentes de Castilla, Ayuntamiento, Valladolid, 2009.
} 
La Virgen de las Angustias es una copia, según Manuel Trens, de la Virgen de la Piedad, "pero añadiendo a la Virgen unas espadas. Propiamente, la Virgen de los Dolores es la Virgen con o sin espadas, pero sin su Hijo difunto"150. Cuando aparece esta temática, en el siglo XIV, la Virgen tan solo aparecerá con una espada, si bien ya desde el siglo XIII se veneraban los cinco dolores de la Virgen ("la profecía de Simeón, la pérdida de Jesús en el templo, el prendimiento, la crucifixión y la Piedad, en la forma que hemos descrito. Entre los cinco dolores, algunos colocaron la huida a Egipto, lo que obligaba a suprimir el prendimiento o reunir los episodios de la Pasión en uno solo"151), lo que implicaba la representación con otras tantas espadas. Con el tiempo, estos se llegaron a multiplicar de manera desmesurada, llegando hasta los ciento cincuenta. Como vemos el número de dolores/espadas es muy variable dependiendo de muchos factores, sin embargo "Poco a poco prevaleció el número de siete, sin que hubiera unanimidad acerca de cuáles eran estos dolores. Para algunos, eran exclusivamente dolores de la Pasión, al paso que otros los extendían a toda la vida de María" ${ }^{152}$. Otra disputa fue la concerniente a los pasajes de la vida de Cristo y de la Virgen que hacían referencia a los dolores de María; según refiere Trens llegaron a haber hasta cinco grupos diferentes ${ }^{153}$.

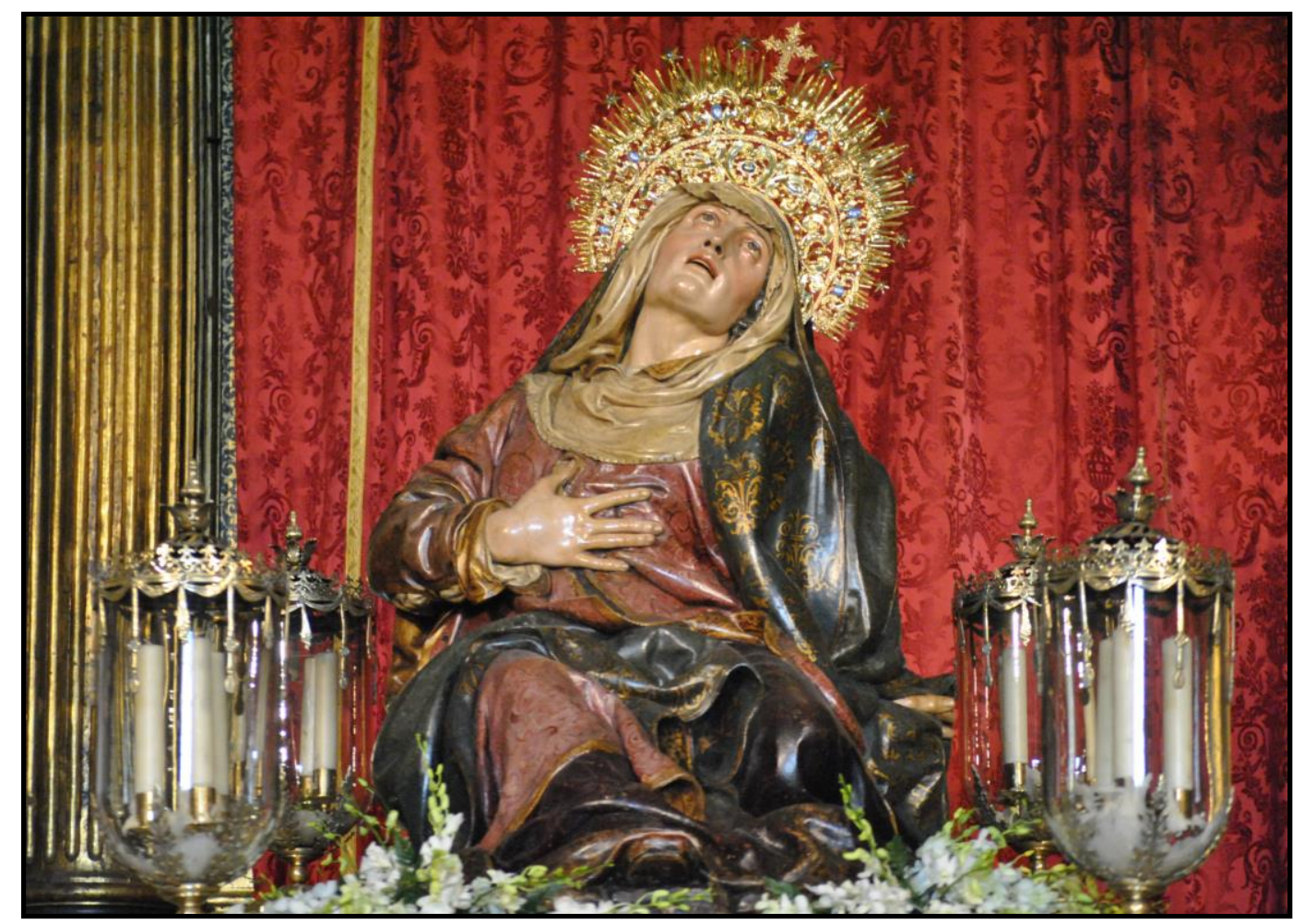

Il. 28- Juan de Juni. Virgen de las Angustias. Iglesia penitencia de Nuestra Señora de las Angustias. Valladolid.

TRENS, Manuel: op. cit., p. 223.

Ibídem.

Ibídem.

Ídem, p. 225.

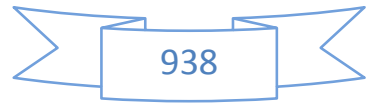




\section{9-2 OBRAS ATRIBUIDAS}




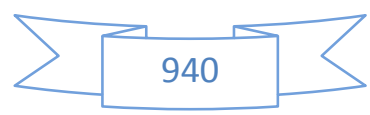




\section{SANTILLANA DEL MAR. FUNDACIÓN CAJA}

\section{CANTABRIA}

\section{BUSTO DE DOLOROSA (entre 1699-1739)}

La presente obra no la conozco ni siquiera por fotografías, sin embargo Juan A. Muñoz la fecha a principios del siglo XVIII, en "la estela de Luis Salvador Carmona y muy cercano a Pedro de Ávila"; además explica que se trata de "un magnífico ejemplo de la escultura tradicional castellana en madera policromada, una "Dolorosa" en busto, que si bien ha sido tradicionalmente atribuida a Gregorio Fernández, se encuentra a decir de investigadores como D. Enrique Campuzano, más en la línea de la escultura castellana" ${ }^{154}$. Dadas las referidas dificultades, no podemos asignarle una fecha aproximada, por lo que le pondremos las fechas extremas en que tenemos documentada la actividad de nuestro escultor; es decir, 1698-1739. Urrea pone en relación este busto con otros atribuidos a Pedro de Ávila como son los conservados en el Real Monasterio de San Quirce, en el Convento de las Brígidas y en el Museo Nacional de Escultura de Valladolid $^{155}$.

\footnotetext{
154 MUÑOZ, Juan A.: "Caja Cantabria. Santillana del Mar. Compromiso con el Patrimonio Cultura de Cantabria”, La revista de Cantabria, Caja Cantabria, No 135, 2009, p. 29.

155 URREA FERNÁNDEZ, Jesús: "Las esculturas de Villabrille y Ron del monasterio de San Quirce", Boletín de la Real Academia de Bellas Artes de la Purísima Concepción, Valladolid, Tomo XXXVI, 2001, p. 138.
} 


\section{VALLADOLID. REAL MONASTERIO DE SAN QUIRCE Y}

\section{SANTA JULITA}

\section{BUSTO DE DOLOROSA (h. 1700)}

El primero en tratar sobre este busto fue Martín González, el cual lo creó obra de un "artista imitador de Gregorio Fernández"156. Poco después, Gratiniano Nieto formuló una atribución que situaba el busto en las proximidades de nuestro escultor al creerla del "círculo de Pedro de Ávila" "157. Sería bastante años después cuando Martín González y Plaza Santiago matizaron este parecer, creyendo que lo más correcto era incluir el busto dentro de la primera etapa creativa de nuestro escultor ${ }^{158}$. El último que se ha pronunciado sobre la obra ha sido Jesús Urrea, el cual la cree realizada hacia el año 1700, cayendo su ejecución "dentro del estilo de Pedro de Ávila"; asimismo relaciona el busto con otros similares conservados en el Convento de las Brígidas, en el Museo Nacional de Escultura de Valladolid, en Santillana del Mar y en la catedral de Orense $^{159}$; los tres primeros se encuentra atribuidos a Pedro de Ávila mientras que el cuarto ha sido relacionada con diversos artífices, entre ellos Juan de Ávila y Tomás de Sierra. En la época en que el busto fue contemplado por Gratiniano Nieto y por Martín González éste se encontraba situado en el retablo situado detrás del cancel de entrada a la iglesia, justamente en el lugar que hoy ocupa un Calvario gótico del siglo XIV: "Cerca de la cancela de entrada hay un retablo del XVII y en él un buen Cristo, de la misma época, y a sus pies un busto de la Quinta Angustia del círculo de Pedro de Ávila" ${ }^{160}$.

En verdad este busto (91 cms.) (Fig. 42) pertenece a la primera etapa de Pedro de Ávila como así podemos comprobarlo por la presencia de pliegues redondeados, de unas anatomías todavía no apuradas y unos rasgos faciales que parecen preludiar lo que posteriormente veremos en su segunda etapa, en la que desarrolla su estilo plenamente personal. A pesar de estar realizado por las mismas fechas que la desconcertante Virgen de la Pasión del Colegio de los Ingleses, nada tienen que ver entre ambas, lo que no hace sino aumentar las dudas sobre aquélla. Además, cabe señalar que tanto por gestualidad como por la concepción de los diferentes ropajes puede ser el precedente del busto de Dolorosa conservado en el Museo Nacional de Escultura. Éste sería la base puesto que aquella es mucho más voluminosa, movida y elegante.

\footnotetext{
156 "Detrás de la cancela y dentro de un marco barroco, se venera un Cristo de buena mano, obra del siglo XVI, al pie del cual hay una Piedad hecha por artista imitador de Gregorio Fernández". MARTÍN GONZÁLEZ, Juan José: Guía histórico-artística..., op. cit., pp. 83-84.

157 NIETO GALLO, Gratiniano: op. cit., p. 112.

158 MARTÍN GONZÁLEZ, Juan José y DE LA PLAZA SANTIAGO, Francisco Javier: Catálogo Monumental de la provincia de Valladolid. Tomo XV..., op. cit., p. 192.

159 URREA FERNÁNDEZ, Jesús: “Las esculturas de Villabrille y Ron...”, op. cit., p. 138.

160 NIETO GALLO, Gratiniano: op. cit., p. 112; MARTÍN GONZÁLEZ, Juan José (dir.): Inventario artístico de Valladolid..., op. cit., p. 55.
} 
Pedro de Ávila nos presenta un busto cortado horizontalmente un poco por debajo de la cintura. La visión, a pesar de que la Virgen parece intentar realizar un escorzo, es totalmente frontal, de tal manera que tiene colocado el manto a manera de fondo. Dobla el brazo derecho para colocárselo sobre el pecho mientras que con la mano izquierda realiza un típico gesto declamatorio. Viste una túnica rojiza con el cuello y las mangas vueltas que nos indican que la parte interior es amarillenta. Le cubre la cabeza una toca blanca que se desliza por un lateral del rostro; y un manto azul que además de la cabeza le cubre el brazo izquierdo y el abdomen. Esta disposición del manto se lo veremos en gran número de ocasiones: la parte derecha del manto suele hacer un giro oblicuo debajo del brazo derecho para cubrirle el abdomen y sujetarse al lado izquierdo; mientras que el lado izquierdo suele enrollarse en múltiples ondas alrededor del brazo izquierdo. En esta ocasión las ondulaciones han sido simplificadas, de tal manera que tan solo se le recoge y cae la punta del manto hacia abajo. La policromía del manto es fastuosa puesto que recorre su borde una cenefa dorada y con motivos vegetales de diferentes colores muy similar a las que hemos visto en multitud de esculturas atribuidas a Juan de Ávila, y también al propio Pedro de Ávila.

El rostro adquiere las características propias que veremos en su segunda etapa si bien en este primer momento las facciones y los mechones no estarán tan trabajados. Gira el rostro hacia arriba, mirando al cielo. Los ojos son de tapilla, y bajo ellos surgen los consabidos abultamientos. Nariz ancha, potente, aunque todavía no aparece el tabique geometrizado. La boca es pequeña y entreabierta, dejándonos ver los dientes, si bien son demasiado básicos, bastante similares a los de la Virgen de la Pasión del Colegio de los Ingleses; siendo, de este modo, uno de los pocos elementos que las asemejan. 


\section{AGUASAL. IGLESIA PARROQUIAL DE SAN PEDRO}

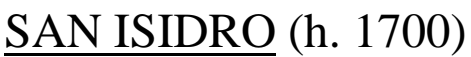

La presente escultura (Fig. 43) tan solo ha sido reseñada en dos ocasiones. El Inventario Artístico de Valladolid se refiere a ella como "copia del original de Fernández, siglo XVII"161, mientras que el Catálogo Monumental de Valladolid precisa que se trata de una escultura "muy interesante" y "atribuible al taller de los Ávila"162.

Efectivamente, la escultura fue realizada en los talleres de los Ávila, concretamente en el de Pedro de Ávila. Como podemos observar, sus características nos indican que es una obra de su primera etapa, en la que todavía no se ha desprendido de las enseñanzas paternas. Como ya hemos referido en su momento, pienso que este San Isidro pudo ser uno de los desencadenantes de los numerosos encargos recibidos por el escultor en las poblaciones cercanas a Olmedo (Valladolid), tal es así que Aguasal se encuentra a tan solo un par de kilómetros de distancia. Ya dijimos que el prototipo de San Isidro realizado por Juan de Ávila (aunque basado en el de Gregorio Fernández de la localidad palentina de Dueñas) para la ermita del mismo nombre de Valladolid llegó a cosechar tal éxito y popularidad que no solo se le dedicaron grabados, sino que fueron numerosas las poblaciones vallisoletanas que desearon disponer de una copia escultórica del patrón de los campos. Como quiera que Juan de Ávila falleció, los comitentes interesados decidieron encargárselas a su hijo Pedro. Solo así se puede explicar la proliferación de esculturas de San Isidro que pertenecen sin ningún género de duda a la primera etapa de nuestro escultor; y no solo eso, sino que además la inmensa mayoría de ellas, a excepción de una, se encuentran en localidades del antiguo Partido Judicial de Olmedo. La expansión del arte y del buen hacer de nuestro escultor por esta zona se vería refrendada por nuevos pedidos en esos mismos momentos como el San Juan Bautista de Almenara de Adaja (Valladolid) o el Resucitado de Puras (Valladolid). Sin duda este San Isidro de Aguasal (Valladolid) sería, si no la primera escultura que hiciera para la zona, una de las primeras puesto que debe ser fechada hacia el año 1700, al igual que el de Muriel de Zapardiel (Valladolid)

El presente San Isidro es completamente deudor del de su padre, puesto que copia fielmente tanto su ademan, como su vestimenta y la disposición de las diferentes partes del cuerpo. Si acaso cabe destacar que Pedro de Ávila no consigue un resultado tan elegante y proporcionado, el suyo es algo más achaparrado, con un rostro menos dulce y pliegues más duros. No hemos de olvidar que se trataría de una de sus primeras obras y que, por lo tanto, aún sido ya maestro escultor, no dejaba de ser un principiante. Aunque ambos San Isidros fueron realizados con los mismos fines - procesionales-, poseen dos tamaños muy distintos; puesto que, mientras que aquel es de tamaño del natural, este de Aguasal mide tan solo $90 \mathrm{cms}$. Quizás debido a este pequeño tamaño es por lo que se

\footnotetext{
$161 \quad$ Ídem, p. 66.

162 BRASAS EGIDO, José Carlos: Catálogo Monumental de la provincia de Valladolid. Tomo X..., op. cit., p. 13.
} 
decidió de dotar años después de un tabernáculo que le otorgara mayor porte y prestancia.

San Isidro figura erguido, adelanta decididamente la pierna izquierda creando el típico contrapposto al que nos tendrá habituado nuestro escultor desde el principio de su carrera. Dispone los brazos de tal manera que crea con ellos una diagonal: eleva elegantemente el derecho mientras que mantiene el izquierdo caído. Para excusar estos movimientos tan contrastados decide que con la mano derecha sujete un cayado mientras que con la izquierda haga lo propio con un manojo de trigo. No es descartable que en un principio Ávila le representara sujetando un arado, como en el prototipo de su padre. A sus pies figuran dos bueyes con un arado que serán un añadido posterior. Viste el atuendo de un labriego castellano pudiente: jubón con hombreras ceñido con un cinturón. Botonadura entre la gorguera y el cinturón, si bien muchos de sus botones se han perdido. Amplias mangas con pliegues algo acartonados, que no llegan a alcanzar la suavidad y dulzura lograda por su padre en este mismo elemento; lo mismo podemos decir de los pliegues de la parte baja del jubón, los cuales poseen unas quebraduras bastante duras. Calzas ajustadas del muslo hasta la rodilla. Polainas y zapatos. El tratamiento general denota una labra bastante plana y poco definida.

La cabeza es lo que más diferencia al ejemplar de Pedro de Ávila del de su padre puesto que ya no veremos en él los rescoldos de la influencia de Fernández, sino que estarán ya presentes muchos de sus propios estilemas. El rostro acusa ligera blandura. Así, su cabeza tiende a la usual forma rectangular. Los ojos, de tapilla vítrea, son almendrados, levemente rehundidos, llevando en su parte baja el potente abultamiento tan característico. Cejas levemente arqueadas y el ceño liso. La nariz, como es usual en estos albores de su primera etapa es completamente distinta a la que tanto le definirá: se trata de una nariz pequeña, recta, simétrica, con el tabique nasal redondeado, que se ensancha en su parte inferior. Fosas nasales talladas, y bajo ellas apenas hay sitio para el surco nasolabial. Boca cerrada con los labios apenas esbozados, al igual que los pómulos, que por el contrario se insinúan por medio de la policromía.

Barba construida a través de numerosos y sinuosos mechones muy planos a ambos lados del rostro que adquieren mayor corporeidad en el bigote y por debajo del mentón, llegando a crear una barba bífida compuesta por dos mechones curvos, largos y simétricos cuyos bucles miran hacia el interior. Frente amplia en el que el peinado se resuelve con dos pequeños mechones simétricos con las puntas dirigidas hacia el exterior. La cabellera la conforman amplias y sinuosas cabelleras a ambos lados del rostro, que ayuda a tamizar la forma rectangular de éste. Estas cabelleras se conforman a través de dos ondas superpuestas, cuyo volumen se acrecienta y adquiere mayor anchura en las inferiores. La melena es corta, hasta la altura de la nuca.

La imagen se conserva en la actualidad dentro un curioso baldaquino barroco en el que se le saca en procesión. El baldaquino está compuesto por cuatro columnas salomónicas, de cada una de las cuales parte un tallo vegetal oblicuo hacia la zona central que es en la cual se juntan todos y de la que surge un cogollo vegetal que hace 
las funciones de clave. Salvando las gigantescas distancias que diferencian a una y otra obra, este baldaquino no deja de recordar lejanamente por su aspecto y estructura al realizado entre 1623-1634 por Gian Lorenzo Bernini para la Basílica de San Pedro del Vaticano. Este de Aguasal debió de ser tallado en el año 1740 puesto que es la fecha que figura pintada en uno de los entablamentos que hay sobre las columnas salomónicas.

Antes de que se restaurara la iglesia hace un par de años, el templo se encontraba casi en ruinas. Dadas las debilidades que poseía entonces la iglesia, hubo un intento de robo de la escultura del santo, la cual estuvo a punto de ser sustraída de no ser porque se encontraba anclada al baldaquino, motivo por el cual los ladrones tuvieron que desistir. Tras descubrir los vecinos del pueblo el intento de robo decidieron guardar el baldaquino en una nave industrial y al santo agrícola en un domicilio privado de Olmedo. Tras la agradable e inesperada restauración de la iglesia, la talla ha vuelto a su lugar de origen. 


\section{VALLADOLID. IGLESIA DE SANTA MARÍA MAGDALENA}

\section{SANTA MARÍA MAGDALENA (Primer tercio del siglo XVIII)}

Aunque la atribución de esta escultura resulta problemática por el hecho de estar realizada en piedra, material en el que no tenemos documentado de Ávila ninguna obra (aunque parece probable que le pertenezcan las esculturas de la fachada del Convento de las Comendadoras de Santiago), esta Inmaculada presenta algunas características y detalles que parecen inclinarnos a creerla obra segura de nuestro escultor. En caso de confirmarse esta atribución, que por otra parte parece bastante probable, nos demostraría que Pedro de Ávila fue un escultor muy versátil puesto que fue el único capaz de tallar la piedra, junto con José de Rozas ${ }^{163}$, en el Valladolid de comienzos del siglo XVIII; y, además, sería su escultura pétrea más antigua, puesto que las del Convento de las Comendadoras datan de 1732, tal y como se puede leer en la peana de la Inmaculada. Esto nos abre las puertas a poder atribuirle alguna otra escultura pétrea conservada en las fachadas de las iglesias castellanas.

La escultura (Fig. 44) no ha recibido atribuciones, tan solo el Catálogo Monumental de Valladolid se refiere a ella como "una estatua en piedra de la Magdalena, del siglo XVIII" ${ }^{164}$. Esta imagen de Santa María Magdalena, patrona del templo, preside una hornacina situada en la fachada de la iglesia que sirve de tránsito entre las dos puertas de acceso al templo y el gigantesco escudo que campea en la parte alta. La hornacina se remata con una venera con la charnela hacia afuera. Esta hornacina, que datará de la misma fecha en que fue realizada la fachada, parece que contuvo con anterioridad a esta escultura otra similar realizada por entonces. Así parece indicárnoslo el detalle de que la escultura es algo menor que la hornacina; y que, además, no es verosímil que se esperara casi 150 años para colocar una imagen de la santa. El motivo que llevaría a reemplazarla sería el mal estado en que se encontraba, sin duda debido a los efectos meteorológicos. Algo similar ocurrió con la escultura del Salvador de la fachada de la iglesia parroquial de Simancas (Valladolid) ${ }^{165}$

Como hemos dicho, el estilo de nuestro escultor está más que presente en ella. No tenemos más que comparar esta talla con cualquiera de las dos Magdalenas que talló para Valladolid (Catedral y Oratorio de San Felipe Neri). Observamos la misma disposición general del cuerpo y el leve contraposto de su pierna derecha. También es idéntica la manera de colocar tanto las ropas como los pliegues, como así queda patente tanto en la túnica como en el manto que forma una diagonal a la altura de la cintura.

\footnotetext{
163 En 1712 realiza las esculturas de la fachada del Monasterio de San Pedro de Eslonza (León). RODICIO, Cristina: op. cit., p. 52.

164 MARTÍN GONZÁLEZ, Juan José y URREA FERNÁNDEZ, Jesús: Catálogo Monumental de la provincia de Valladolid. Tomo XIV..., op. cit., p. 149.

165 En 1551 los escultores Juan de Cambray y Miguel de Espinosa realizaron una primitiva imagen en madera del Salvador, la cual fue arrancada de su pedestal en 1731 por un violento temporal. Ese mismo año Pedro Bahamonde talló otra en piedra para sustituirla. DE LA PLAZA SANTIAGO, Francisco Javier: "El retablo de Nuestra Señora del Rosario...”; op. cit., pp. 296- 298.
} 
Otro de los detalles típicos de la segunda etapa de Pedro de Ávila que se encuentra presente en la escultura, amén de su característica forma de disponer el cabello sobre la frente, es la disposición de los dos pies, separados por un pliegue de la túnica, en un ángulo de $90^{\circ}$. Este motivo parece despejarnos la duda de la identidad del escultor que la talló.

Bien es cierto que también existen algunas diferencias, sobre todo en lo referente al estilo de la labra, pero sin duda se deberá al cambio de material puesto que la piedra es mucho menos dúctil. Quizás debido a ello no se molestó en formar ese característico remolino de pliegues alrededor del brazo izquierdo o el pliegue de manto que sale disparado en diagonal desde su cadera hacia la izquierda. También se deberá a este material la simplificación de los rasgos faciales y de los largos mechones que caen sobre la espalda, hombros y torso de la santa. Aunque en las dos esculturas en madera los mechones van de dos en dos, en esta de piedra son individuales; si bien parecen seguir las mismas direcciones. Los pliegues son a cuchillo, sin embargo no gozan de la finura que suele exhibir en la talla de la madera.

La santa aparece elevada sobre un peñasco formado por piedras que contienen en su interior un libro y una calavera, atributo muy típico de la Magdalena. Desconozco si el peñasco también fue tallado por Ávila o pudiera pertenecer al escultor que hipotéticamente talló una Magdalena primitiva en el siglo XVI. Ya dijimos la similitud casi total de esta escultura con las otras dos referidas de la catedral y del Oratorio de San Felipe Neri. En cuanto a los atributos que portaría, no lo podemos asegurar con totalidad puesto que han desaparecido. En su mano derecha, por su disposición con los dedos cerrados, quizás pudo asir un Crucifijo, aunque parece bastante improbable. Sin embargo, sobre la mano izquierda parece llevar un paño, de manera similar a la Magdalena de la catedral; y como aquella, quizás llevara encima una calavera. Sin embargo, sería bastante extraño por cuanto esta ya figura en la peana. Finalmente, hay que señalar que los ojos parecen conservar restos de pigmento azul, por lo que habrían estado policromados. 


\section{VALLADOLID. MONASTERIO DEL SANTÍSIMO SALVADOR DE SANTA BRÍGIDA}

El Monasterio del Santísimo Salvador de Santa Brígida fue una de las instituciones religiosas para las que más debió de trabajar la familia de los Ávila, sobre todo Juan y Pedro. Sin embargo, no tenemos constancia documental de ello, y solamente contamos con el análisis estilístico, que no es poco. Si Juan de Ávila se había ocupado de gran parte de la escultura del retablo mayor, Pedro fue el encargado de finalizarla con la ejecución del Crucificado del ático del referido retablo. Sería a raíz de aquello, y de la fama que por entonces ya poseía el escultor, cuándo las monjas decidieron seguir confiando en Ávila para que les realizara otras obras. Al citado Crucificado, hemos de añadir el desaparecido grupo de la Sagrada Familia de la Virgen que, atribuido indistintamente a Juan y Pedro, se conservaba en el retablo colateral del Evangelio. Además, también le corresponden una Inmaculada Concepción, dos bustos de Ecce Homo y Dolorosa y una efigie de Santa Escolástica. Cabe pensar si los bustos fueron encargados por el propio monasterio, fueron regalo de algún comitente o, incluso, resultado ser una donación testamentaria.

\section{CRUCIFICADO (1702-1703)}

Como ya vimos en su momento al tratar sobre el retablo mayor del monasterio, parece que Juan de Ávila se ocupó de la mayor parte de sus esculturas entre 1697-1698, pero sin embargo no se realizaron todas. Al menos quedó sin completar el Calvario puesto que tenemos noticia de que en 1703 se abonan ciertas cantidades a un escultor anónimo por desbastar el Santo Cristo, que no será otro que el Crucificado, lo que nos confirma que la parte escultórica del retablo quedó sin finalizar a finales del siglo XVII.

La empresa comenzada por Juan de Ávila se prolongaría en el tiempo, quizás debido a la contratación de otras obras, entre las que se encontraban las del Oratorio de San Felipe Neri y el retablo mayor de la parroquial de Santiago Apóstol. El inesperado fallecimiento del escultor propiciaría una interrupción en las obras, quedando sin finalizar el Calvario del ático; probablemente por entonces Juan de Ávila estaría tallando el Crucificado puesto que las esculturas de la Virgen y San Juan, las cuales podemos ver una fotografía antigua, nada tienen que ver con su estilo ni con el de su hijo Pedro. Desconocemos el paradero de estas dos imágenes, así como otras muchas tanto del retablo como del monasterio.

Las obras se retomarían al poco de fallecer Juan de Ávila, de tal manera que las religiosas decidieron encomendar la finalización del Crucificado (Figs. 45-46) a su hijo Pedro. En el pensamiento de ellas se encontraría la idea de contratar a un escultor que poseyera un estilo similar y pudiera dar uniformidad al conjunto de imágenes, sin resaltar sobre el resto; y para ello que mejor elección que el hijo de aquel artífice, Pedro de Ávila. Analizando los estilemas de este Crucificado no cabe ninguna duda de que el 
escultor anónimo al que en agosto de 1703 se le abonan 200 reales por "desbastar el Santo Cristo" es nuestro Pedro de Ávila ${ }^{166}$. Pero no solo eso, será también nuestro escultor al que se le abonan 1.000 reales por "los quatro ángeles de los colaterales" y otros 150 reales "por los dos de la María". En esas mismas cuentas figuran otras partidas por estofar y encarnar las esculturas y por dorar el retablo mayor, lo que nos indica que para dicha fecha el Crucificado ya estaba finalizado; y que, por lo tanto, su ejecución debió de acontecer entre finales de 1702 y mediados de 1703.

Los únicos que han atribuido el Crucifijo a Pedro de Ávila han sido Martín González y Plaza Santiago, los cuales expresan, sin ningún género de dudas, que su "estilo corresponde a Pedro de Ávila"167. Efectivamente, tanto la cabeza como el cuerpo posee todas y cada una de las características que podremos ver en su segunda etapa. A pesar de pertenecer a su primer estilo, nada tiene que ver ya con la Piedad del Colegio de los Ingleses, puesto que parece que ya por estos años había conseguido despojarse de parte de la herencia recibida por su padre y por su suegro, introduciendo ya lo que serán sus rasgos propios.

El Crucificado es de gran tamaño, como no podía ser de otra manera dada la altura a la que habría de colocarse, en el ático del retablo mayor. Las tres figuras del Calvario se hallaban insertas dentro de una hornacina flanqueada por dos estípites y rematada en

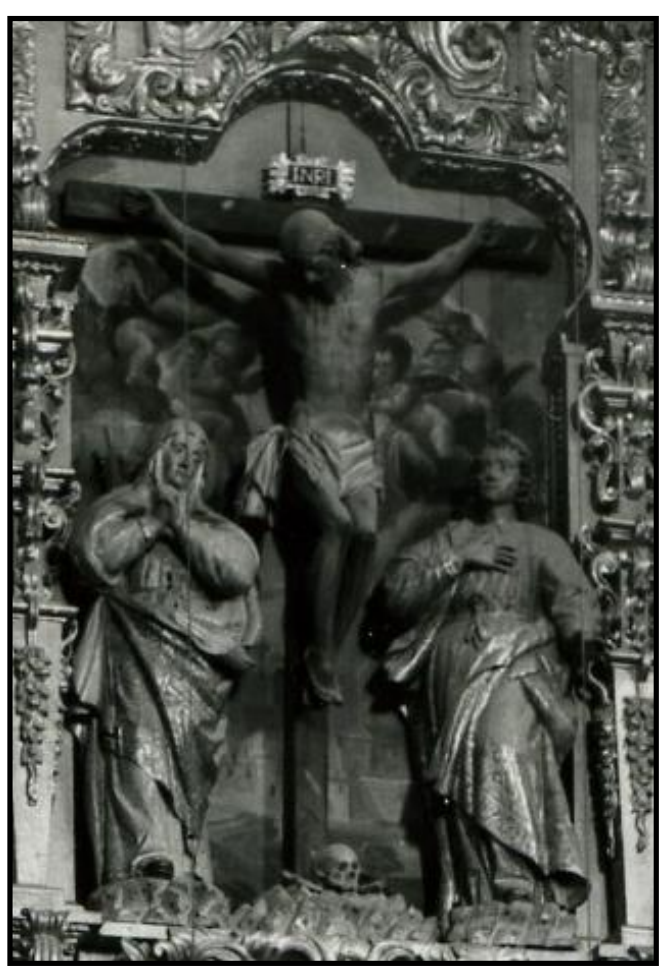

Il. 29- El Crucificado cuando aún formaba parte del Calvario del retablo mayor del Monasterio de Santa Brígida. forma trilobulada, de tal manera que los lóbulos extremos servían para colocar los brazos del madero y el superior para que cupiera el letrero con el "I.N.R.I.". En el panel situado tras las tres esculturas se desarrolla una pintura que parece efigiar en la parte inferior un paisaje urbano y en la superior nubes y ángeles, los cuales quizá llevaran un cáliz para recoger la sangre derramada por el Crucificado, de manera similar a como lo hemos visto en el Cristo del Olvido del Oratorio de San Felipe Neri.

Podríamos considerar a este Crucificado como el cabeza de serie de todos los que posteriormente realizaría (Oratorio de San Felipe Neri e iglesias parroquiales de Torrecilla de la Abadesa y Bernuy de Coca) si bien les diferencia tanto el tamaño como la constitución; puesto que estos tres últimos son mucho más pequeños y gozan de una anatomía mucho más delgada y enjuta, y nada tiene que ver con la potencia reflejada en este Cristo de las Brígidas. También le diferencia de los pequeños Crucifijos el hecho de

166 MARTÍN GONZÁLEZ, Juan José y DE LA PLAZA SANTIAGO, Francisco Javier: Catálogo Monumental de la provincia de Valladolid. Tomo XV..., op. cit., p. 47.

$167 \quad$ Ídem, p. 39. 
que los pliegues que recorren el paño de pureza son redondeados, no encontramos en ellos rastro alguno del pliegue berninesco que utilizará en su segunda etapa. Sin embargo, a pesar de estas diferencias, y de la distinta colocación de los dedos, que en este ejemplar brigidino están menos crispados y sin movimiento, el resto es en todo idéntico a sus hermanos pequeños.

Cristo se nos presenta ya expirado, con lo cual el cuerpo se encuentra totalmente relajado, lo cual lo podemos comprobar en los desplomes de la cabeza hacia el lado derecho y el cuerpo hacia adelante y las piernas contraídas ante el peso del cuerpo. Es un Cristo patético pero contenido, en contraste con la concepción ciertamente idealizada de los tres ejemplares más pequeños que nuestro escultor tallará con posterioridad. Los rastros de sangre son los justos y necesarios, los que salen de la cabeza y de las llagas. El cuerpo está perfectamente modelado con una anatomía muy apurada en la que logra captar cada uno de sus huesos, tendones y venas, lo que es buena prueba de la profesionalidad de nuestro escultor ya que a la altura a la que se colocaría la escultura estos detalles son completamente imperceptibles. La suciedad que actualmente acumula no nos permite comprobar la verdadera labor de la talla realizada por Ávila. Porta un perizonium blanco anudado en el lado superior derecho por una cuerda, cayendo a ese lado una buena porción del mismo, con pliegues suaves y curvados, nada que ver con los pliegues berninescos presentes en sus tres pequeños Crucifijos posteriores. El borde del paño y la cuerda que le sostiene llevan el borde policromado en tonos dorados. Destaca la finura lograda en los pliegues.

La cabeza no posee la calidad de sus tres creaciones posteriores, pero sin embargo en él se ven insinuadas ya las características que quedarán patentes en su segunda etapa, como es la adopción del rostro de una forma rectangular. Porta corona de espinas natural. Cristo aparece con los ojos completamente cerrados, con una nariz que se va ensanchando de abajo a arriba, aletas nasales remarcadas, boca entreabierta que permite ver la fila superior de dientes, cejas rectas, etc... En la cabellera es donde más coinciden sus esculturas del primer y segundo estilo: sobre la frente caen unos mechones sinuosos simétricos, barba rizada y largos y onduladas guedejas a los lados del rostro, que ayudan a enmarcar una de las orejas mientras la otra la ocultan completamente. Este tipo de ondulaciones, en las que verdaderamente nuestro escultor se gusta, con el paso del tiempo las irá detallando más y haciendo mucho más anchas y voluminosas; es sin duda uno de los elementos por los que se reconocen las esculturas de Ávila más fácilmente. Estas ondulaciones las veremos, por ejemplo, además de en sus Crucificados, en el Ecce Homo de Renedo o el busto de Ecce Homo del Convento de las Brígidas. Finalmente, tiene barba bífida, bastante diferente a lo que nos acostumbrará con posterioridad puesto que son dos mechones muy cortos y curvados en los que apenas se encuentran tallados los diferentes mechones, son dos "cuernos" capilares bastante bastos y someros. 


\section{PURAS. IGLESIA PARROQUIAL DE LA ASUNCIÓN}

En la iglesia parroquial de Puras se conservan dos esculturas que hasta ahora no han recibido la atención suficiente y que deben incluirse en el catálogo de Pedro de Ávila, concretamente dentro de su primera etapa. Estas tallas, conservadas en los retablos colaterales, efigian a San Isidro Labrador y a Cristo Resucitado, esta última especialmente interesante por la temática y por la posibilidad que nos abre para poder compararle con otro Resucitado que se le viene atribuyendo desde hace años en la localidad de Ampudia. Quizás también se deban a la gubia de Ávila los cuatro ángeles que se tallaron para los áticos de ambos retablos, aunque esta atribución la hago con todas las reservas. Un pausado examen de las facciones de ambas esculturas, y sobre todo de las del rostro del Resucitado nos indica que cae dentro de sus presupuestos artísticos; serían, por lo tanto, parte de sus primeras obras, en la cuales es deudor del espíritu de su padre.

El encargo de ambas tallas se encuentra íntimamente ligado con la construcción de los dos nuevos retablos colaterales de la iglesia. La noticia más antigua que conocemos sobre este tema es la visita realizada en el año 1700 por el obispo a la parroquial de Puras. Al comprobar que la economía de la parroquia se hallaba saneada, el prelado ordenó que se "hagan dos colaterales en correspondencia" con el mayor y que para ello se buscara "maestros de ciencia y conciencia y ajustándolos a mayor beneficio de dicha fábrica" "168. Con toda seguridad, los encargados de la fábrica de la iglesia solicitaron la realización de unos nuevos colaterales puesto que los antiguos se encontrarían muy maltratados; aunque tampoco podemos descartar un cambio de gusto. De los antiguos colaterales tan solo conocemos que uno estaba dedicado a San Roque ${ }^{169}$, imagen que actualmente se conserva en la hornacina derecha del colateral de la epístola.

La construcción de ambos retablos se demoró un par de años puesto que no figuran nuevas noticias hasta las cuentas de los años 1702-1704 en que se anotan diversos pagos. Las reseñas son escuetas puesto que solo hacen referencia a que fueron realizados por un ensamblador vallisoletano ${ }^{170}$ y a que el coste total de los mismos (en el que se incluían sus mesas de altar y el herraje para asentarlos) ascendió a 5.086

168 1698-1700. Mandatos. $3^{\text {o }}$ "Que respecto de ser tan considerable el caudal de dicha iglesia como consta del alcance que a su favor resultó de las cuentas últimas y necesitarse en dicha iglesia para mayor adorno suyo y decencia de que se hagan dos colaterales en correspondencia dio comisión su merced a dicho cura y licencia para que del caudal de dicha fábrica y con intervención del mayordomo de ella les hagan hacer buscando para este efecto maestros de ciencia y conciencia y ajustándolos a mayor beneficio de dicha fábrica sobre que se les encarga la convencía de dicho mayordomo y cura”. A.G.D.V., Puras, Iglesia de la Asunción, Caja 1, Cuentas de fábrica 1617-1899, Libro 1617-1707.

169 1698-1700. Mandatos. $3^{\text {o }}$ "Otrosí respecto que un colateral es de la advocación de San Roque y en donde está fundada cofradía y hermandad habiendo de ser dicha obra para mayor decencia del santo y siendo justo que la dicha hermandad ayude a ella mandó su majestad que todo el alcance que consta haber quedado a favor de la cofradía y contra el mayordomo que fue de ella lo entregue a dicho cura para ayuda de hacer los colaterales como está mandado". A.G.D.V., Puras, Iglesia de la Asunción, Caja 1, Cuentas de fábrica 1617-1899, Libro 1617-1707.

170 Quizás se deban a alguno de los grandes maestros que por entonces trabajaban en la ciudad: Blas Martínez de Obregón, Alonso Manzano, Gregorio Díez de Mata, Juan Correas, Pedro de Ribas, etc... 
reales $^{171}$. En los años siguientes los retablos se completarían con el encargo de las esculturas que les deberían presidir y de unos angelotes para los áticos, y de unas nuevas mesas de $\operatorname{altar}^{172}$. De los ángeles, por los cuales sabemos que se abonaron 350 reales ${ }^{173}$, sabemos que se realizaron en Valladolid; y justo en el mismo periodo en el que se hizo el de Cristo Resucitado. Como vemos, la evidencia de que las imágenes de San Isidro y de Cristo Resucitado fueron realizadas por Pedro de Ávila se refuerza aún más sabiendo que todas estas obras se encargaron a talleres vallisoletanos. Sin ninguna duda, el encargo de ambas hechuras a Ávila estuvo influenciado por el conocimiento que tuvieron los comitentes de las otras imágenes de San Isidro que el escultor había realizado, o estaba realizando por entonces, para parroquiales cercanas.

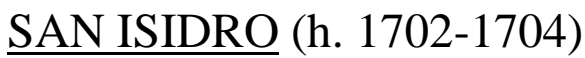

La imagen del santo madrileño (Fig. 47) fue realizada, supuestamente, por Pedro de Ávila entre los años 1702-1704, puesto que es en este periodo en el que se le abonan los 720 reales que costó tanto su hechura como la ejecución de la caja en que fue trasladado hasta Puras ${ }^{174}$. La cantidad pagada al escultor no es nada despreciable dada su condición de escultor novel. San Isidro preside el retablo colateral del Evangelio, al que le acompaña en los laterales una Virgen de la Merced del siglo XVIII y una Virgen de Fátima moderna y sin ningún valor y en el ático un santo dominico y en los extremos dos de los ángeles que se realizaron entre 1700-1702. A excepción de los ángeles, ninguna de estas esculturas perteneció en origen al retablo. Desconocemos qué imagen pudo ir dentro de la gran hornacina del ático puesto que el pequeño santo dominico que actualmente hay en ella es pieza reutilizada.

Poco podemos decir de la imagen de San Isidro que no hayamos ya comentado en el de Aguasal y sobretodo en el de Muriel puesto que es completamente idéntico a este último, de ahí que fechemos por estos mismos años a aquél. Lo bueno de este San Isidro

171 1702-1704. “Costa de hacer los colaterales. Más se pasan doscientos reales del porte de traer dichos retablos de la ciudad de Valladolid que hacen en maravedíes seis mil y ochocientos”. A.G.D.V., Puras, Iglesia de la Asunción, Caja 1, Cuentas de fábrica 1617-1899, Libro 1617-1707.

1702-1704. Colaterales. "Más da en data cinco mil y ochenta y seis reales que tuvieren de costa los dos altares colaterales que se han puesto en la capilla mayor en cuya obra entra las mesas de altar y herraje para asentarles como consta del remate de dicha obra y de carta de pago que exhibió dicho mayordomo del maestro que ejecutó dicha obra que hacen mil ciento y setenta y dos mil novecientos y veinte y cuatro se hizo en virtud de comisión”. A.G.D.V., Puras, Iglesia de la Asunción, Caja 1, Cuentas de fábrica 16171899, Libro 1617-1707.

172 1704-1706. Mesas de los colaterales. "Más da en data ciento y cinco reales que costaron las mesas de los altares colaterales de cal, ladrillo y yeso y maestro costó de su memorial hacen maravedíes". A.G.D.V., Puras, Iglesia de la Asunción, Caja 1, Cuentas de fábrica 1617-1899, Libro 1617-1707, p. 295. 173 1704-1706. Ángeles. "Más da en data trescientos y cincuenta reales del coste de los cuatro ángeles que están en los remates de los colaterales en que entra encarnarles y el porte de traerlos de la ciudad de Valladolid exhibió recibo hacen maravedíes”. A.G.D.V., Puras, Iglesia de la Asunción, Caja 1, Cuentas de fábrica 1617-1899, Libro 1617-1707, p. 295.

174 1702-1704. San Isidro. "Más da en data setecientos y veinte reales que tuvo de costa la efigie de San Isidro que está colocado en uno de dichos retablos en que entra la caja y porte de traer dicho santo desde la ciudad de Valladolid que hacen en maravedíes veinte y cuatro mil cuatrocientos y ochenta". A.G.D.V., Puras, Iglesia de la Asunción, Caja 1, Cuentas de fábrica 1617-1899, Libro 1617-1707, p. 288. 
es que posee la policromía original, y por lo tanto podemos imaginar cómo sería el de Muriel antes de que fuera repolicromado burdamente durante el siglo XVIII. La identidad entre ambas esculturas llega incluso a la cabeza, en la cual tan solo ha introducido tres novedades, meramente cosméticas y que en nada cambia el concepto general del rostro: en este San Isidro observamos que los abultamientos en las bolsas situadas bajo los ojos son algo mayores; también es diferente la barba puesto que finaliza en dos puntas y no en cuatro; y que los mechones que caen sobre la frente son más grandes; por lo demás, se trata de obras homónimas.

\section{CRISTO RESUCITADO (h. 1704-1706)}

La iglesia quedaría tan gratamente complacida con la escultura de San Isidro que deciden encargarle la del retablo frontero: Cristo Resucitado (Figs. 48-49). Éste figura citado en el Inventario Artístico de Valladolid muy de pasada: "Cristo Resucitado siglo XVIII"175; sin embargo, en el Catálogo Monumental ni aparece. Su ejecución se llevó a cabo entre los años 1704-1706, percibiendo por ella 638 reales, cantidad en la que entraba el coste de encarnar la efigie ${ }^{176}$. Por entonces también se confeccionaron "dos mantos de tafetán doble con sus encajes" para la imagen, lo que lleva a pensar que el Cristo se concibió con una clara función procesional ${ }^{177}$. El retablo lo completan a los lados del Resucitado un San Antonio de Padua moderno y de ningún valor artístico y un San Roque de comienzos del siglo XVII. En el ático un interesante San Sebastián del siglo XVI.

El valor de esta escultura es doble puesto que, además de representar una iconografía bastante poco utilizada como era la del Resucitado, nos sirve para compararla con otra efigie de Resucitado que se le atribuye en Ampudia; de tal manera que podemos observar las similitudes y diferencias que existen entre ambas épocas de nuestro escultor ya que ésta de Puras pertenece a la primera y la de Ampudia a la segunda. Sin ninguna duda, Pedro de Ávila hubo de inspirarse en los dos Resucitados ejecutados por su padre (el documentado de Villasilos y el atribuido del Real Monasterio de San Quirce y Santa Julita de Valladolid), con los cuales posee grandes semejanzas.

Lo primero que llama la atención de la presente escultura es su rigidez, así como su falta de estabilidad, lo que ha provocado que se le introdujesen tornillos y elementos metálicos en los pies y en la parte baja de la pierna para ajustarlo convenientemente a la plataforma. Ávila nos presenta al Resucitado según la forma usual: de pie, recio, sin

175 MARTÍN GONZÁLEZ, Juan José (dir.): Inventario artístico de Valladolid y su provincia, Ministerio de Educación, Valladolid, 1970, p. 246.

176 1704-1706. Cristo Resucitado. "Más da en data seiscientos y treinta y ocho reales que tuvo de coste la efigie de Cristo resucitado que está colocado en uno de los altares colaterales en que entra el coste de encarnar dicha efigie que hacen maravedíes”. A.G.D.V., Puras, Iglesia de la Asunción, Caja 1, Cuentas de fábrica 1617-1899, Libro 1617-1707, p. 295.

177 1704-1706. Mantos. "Más da en data ciento y cincuenta y cuatro reales que costaron dos mantos de tafetán doble con sus encajes para dicho Cristo consto de recibo". A.G.D.V., Puras, Iglesia de la Asunción, Caja 1, Cuentas de fábrica 1617-1899, Libro 1617-1707, p. 295. 
rastros de sangre (tan solo se utiliza policromía rojiza para destacar las llagas) y sujetando una banderola símbolo de su victoria sobre la muerte. Tan solo le cubre el cuerpo un perizonium blanco anudado al lado derecho surcado por unos pliegues redondeados que enlazan perfectamente con lo que aprendió a las órdenes de su padre y de su suegro; es decir, se trata del típico pliegue suave, redondeado, de los últimos años del siglo XVII y que los escultores con cierta edad (De la Peña, José de Rozas, Andrés de Pereda, etc...) seguirán utilizando en el siglo XVIII hasta su fallecimiento; todo lo contrario ocurre con los escultores jóvenes, como Pedro de Ávila, que solo lo utilizan durante la fase de aprendizaje y primeros años de maestría.

Adelanta levemente la pierna izquierda, logrando un interesante contrapposto que añade movimiento a la diagonal formada por sus brazos. La anatomía, que tiene patentes las llagas en manos, pies y costado, es blanda y más que correcta puesto que cada miembro está definido a la perfección. No hay incorrecciones, aunque quizás el torso se encuentre algo desproporcionado con respecto a las piernas. Como ocurrirá en años posteriores en los que su técnica alcanzará gran brillantez, representa a la perfección cada músculo, hueso, clavícula, articulación, dedos, etc... si acaso su tratamiento es algo plano lo que le resta brillantez. Especialmente destacable es la ilusión de la blandura de la carne situada a la altura del pecho y la representación de una serie de venas tanto en el muslo de la pierna derecha como en ambos brazos, lo que da la sensación de potencia contenida. Levanta el brazo derecho, con cuya mano sujeta la bandera de la victoria, mientras que el izquierdo lo baja. En esta mano también debió de tener algún elemento: es probable que, como otros Resucitados relacionados con Juan y Pedro de Ávila, la banderola la portara en su mano izquierda, mientras que con la derecha realizaría un gesto de bendición, extremo que no podemos confirmar puesto que se encuentra ocultos por la referida bandera.

Tanto la cabeza como el rostro siguen los planteamientos estéticos a los que nos tiene acostumbrados durante su primera época, si bien ya vemos en este rostro algunos elementos que anticipan su segundo estilo. Donde introduce novedades es en pelo y barba. En este caso la barba, bastante plana en los laterales del rostro, terminan en cuatro mechones simétricos y recurvados bajo el mentón. Es de sus soluciones más complicadas puesto que lo más usual es que sean solamente dos puntas. En cuanto al pelo, forma grandes masas curvas a ambos lados del rostro; especialmente ancha y trabajada es la del lado izquierdo, que le rodea la oreja y se desliza por el cuello y hombro. Este tipo de melena tan amplia y profunda, aunque mucho más trabajada, la veremos en algunas de sus esculturas de Cristo de la segunda etapa como pueden ser los Crucificados, el Ecce Homo de Renedo (Valladolid) o el busto de Ecce Homo de las Brígidas, entre otros. Por su parte, sobre la frente no aparece en esta ocasión ningún mechón o cabello, por lo que presenta una gran calva puesto que el pelo le nace bastante atrás. El rostro posee grandes similitudes con el del San Juan Bautista de la cercana localidad de Almenara de Adaja (Valladolid), lo que nos confirma que se haría por las mismas fechas; tan solo introduce leves novedades en el tipo de peinado que cae sobre la frente y en la disposición de las melenas. 


\section{ALMENARA DE ADAJA. IGLESIA PARROQUIAL DE LA ASUNCIÓN}

\section{SAN JUAN BAUTISTA (h. 1702-1705)}

Presidiendo el retablo mayor de la iglesia parroquial de Almenara de Adaja se encuentra una escultura de San Juan Bautista (Figs. 50-51), de tamaño ligeramente menor del natural, que debe ser inmediatamente añadida a las obras atribuidas a nuestro escultor. Se trata de una pieza más de ese grupo de obras fechables dentro de su "primer estilo"; y que, como ya hemos dicho en sucesivas ocasiones, se encuentran en territorios cercanos a Olmedo. En los libros de cuentas de la parroquia no hay ninguna referencia acerca a la imagen del Precursor. La única noticia relativa al retablo es bastante posterior a la fecha de ejecución de la obra. Se trata de la realización de un marco para el frontal del altar en el año 1741, el cual actualmente no se conserva ${ }^{178}$.

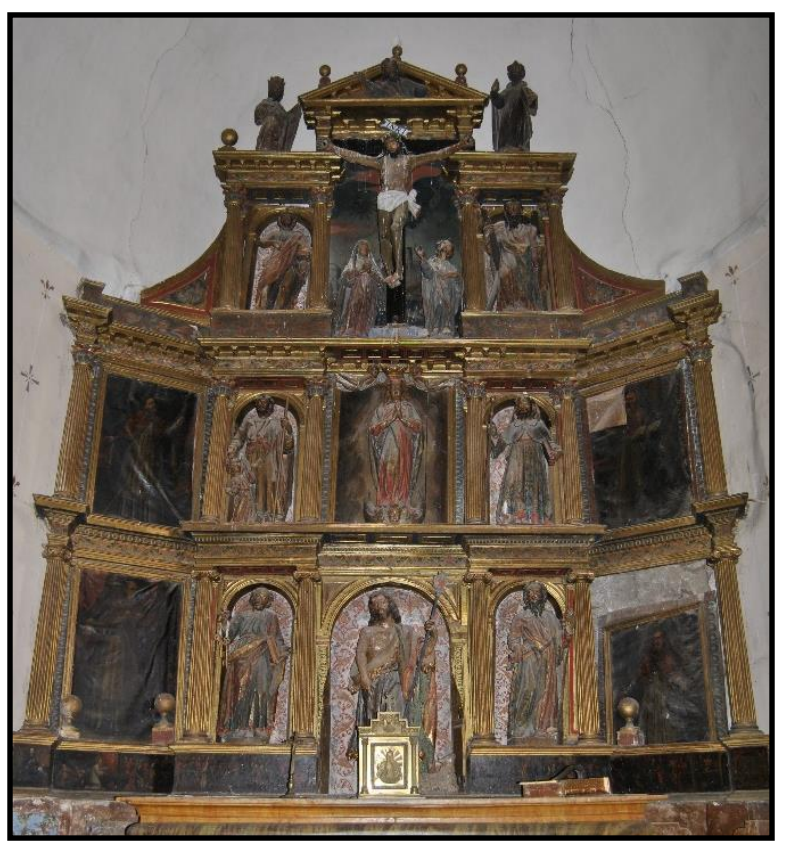

Il. 30- Anónimo. Retablo mayor. Iglesia parroquial de la Asunción. Almenara de Adaja (Valladolid).
El retablo fue construido en el año 1632. Conocemos este dato gracias a una inscripción conservada en el propio mueble. En él se dice que fue elaborado ese año gracias al patrocinio de un donante anónimo que ostentó la condición de clérigo: "Acabose esta obra año de 1632 en 30 de enero siendo cura el bachiller Juan Rodríguez y mayordomo Francisco López"179. Se trata de un retablo clasicista de tres cuerpos sustentados cada uno de ellos por un orden diferente (de abajo arriba: jónico, corintio y ¿compuesto?). Los dos primeros cuerpos poseen cinco calles, las extremas contienen lienzos y las tres centrales esculturas, mientras que en el último cuerpo las tres calles están ocupadas por esculturas. Tanto las esculturas como las pinturas son de diferentes épocas y estilos, siendo muchas de ellas muy mediocres. La mesa de altar se tallaría a finales del siglo XVIII. Sin duda, destaca por encima de todas las piezas del retablo el San Juan Bautista, patrón del retablo y de la iglesia; que presumiblemente fue encargado por la parroquia a Pedro de Ávila entre los años 1702-1705 aprovechando que se encontraba trabajando abundantemente para la zona. La concreción de un periodo tan pequeño se

\footnotetext{
178 "Sesenta y seis reales del coste de un marco para el frontal del altar mayor, consta de libramiento del señor cura y recibo". A.G.D.V., Almenara de Adaja, Iglesia de San Juan Bautista, Caja 2, Cuentas de fábrica 1741-1813, Libro 1741-1791.

179 BRASAS EGIDO, José Carlos: Catálogo Monumental de la provincia de Valladolid. Tomo X..., op. cit., p. 45.
} 
encuentra en relación al parecido del rostro del santo con el del San Isidro de Muriel de Zapardiel (Valladolid) o con los del San Isidro y Resucitado de Puras (Valladolid); siendo, por lo tanto, posterior a otras esculturas de esta zona, como por ejemplo el San Isidro de Aguasal (Valladolid). El retablo se encuentra en muy mal estado de conservación tanto en lo relativo a la arquitectura como a la escultura y pintura, con numerosas roturas, desprendimientos de los lienzos, suciedad... Urge una profunda restauración.

Como observamos a primera vista, Pedro de Ávila ha concebido a San Juan Bautista según un modelo muy repetido dentro del área vallisoletana, el cual ya había utilizado previamente su padre para realizar las diferentes esculturas de este santo que se le tienen documentadas y atribuidas. Se trata, como ya dijimos, de un prototipo ideado por Gregorio Fernández, el cual lo repitió en numerosas ocasiones con escasas variantes. Las dos primeras imágenes que tenemos constancia que talló fueron las de los retablos mayores de la iglesia de los Santos Juanes de Nava del Rey (1612) y del Monasterio de las Huelgas Reales de Valladolid (1613). Al igual que otras iconografías creadas por el maestro, esta de

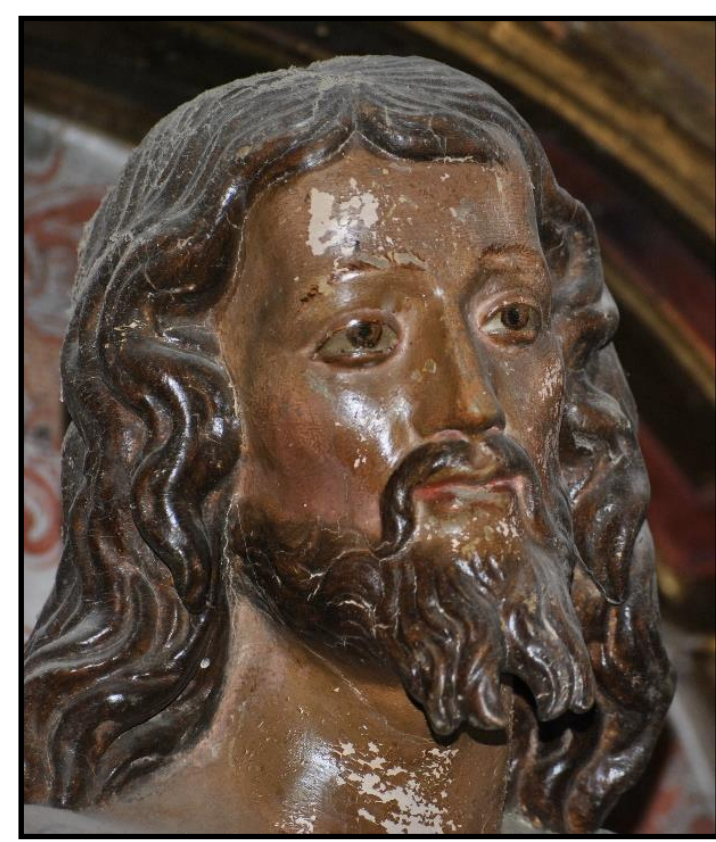

Il. 31- Pedro de Ávila (atrib.). Detalle de San Juan Bautista.

San Juan Bautista tuvo mucho éxito puesto que se siguió utilizando hasta bien avanzado el siglo XVIII. Así, tenemos, entre otras, las versiones que realizaron Antonio Bahamonde (1758-1759) para el retablo mayor de la iglesia de San Pedro de Valladolid y el también escultor vallisoletano José Fernández para uno de los retablos de la parroquial de Valoria la Buena (1775. No está documentada, pero es plenamente atribuible). A pesar de lo dicho, pienso que Pedro de Ávila no se inspiraría directamente en Fernández sino en su propio padre ya que habría visto sus esculturas en el taller; además de que una de ellas, la del retablo mayor de la iglesia de Santiago Apóstol, la vería frecuentemente cuando sus padres le llevaban a misa.

Efectivamente, sigue fielmente los modelos fernandesco y avilesino puesto que concibe a San Juan Bautista de pie, con una pierna adelantada formando contrapposto. Eleva la mano izquierda con la cual sujeta un báculo crucífero mientras que la derecha la baja para señalarnos el cordero, el Agnus Dei. El báculo lleva en su parte superior un medallón en que sobre fondo rojo se encuentra pintado una especie de custodia con el Corpus Christi. La unión de este elemento con el Cordero que figura a sus pies podría estar en relación con el binomio "Cuerpo de Cristo - Cordero de Dios. Este es el Cordero de Dios, que quita el pecado del mundo". Como en aquéllas, esta escultura 
también mantiene la composición en diagonal que une la mirada del santo con el cordero.

San Juan Bautista porta la típica piel de camello, la cual tiene anudada por el lado derecho, permitiendo a Ávila mostrar parte del torso y de las piernas del santo. Ávila tan solo ha tallado los pellejos de los bordes, que se encuentran dorados; mientras que el policromador se ha ocupado de simularlos en el resto del vestido. No falta el tan característico manto rojo colgado del hombro izquierdo, si bien por su interior es de color verde. En este caso no tenemos ni labores doradas en brocado ni una cenefa que recorra el borde del mismo. La anatomía desarrollada por Ávila es correcta sin florituras; aunque peca de ser un poco plana y carente de la vitalidad y blandura lograda en otras esculturas de estos momentos como el Cristo Resucitado de la parroquial de Puras (Valladolid). Hemos de tener en cuenta el mal estado de conservación de la imagen, que seguramente ayuda a empeorar nuestra contemplación. Por su parte, los pliegues del vestido están suavemente incurvados, recordando enormemente a los paternos, pero con una concepción algo más seca.

Lo mejor del conjunto es la cabeza, la cual parece que fue repolicromada lo que conllevó una pérdida de los valores escultóricos primigenios de la misma. El rostro es exacto al del referido Cristo Resucitado de la parroquial de Puras (Valladolid), la identidad entre ambos llega incluso a la forma de resolver la barba en cuatro puntas simétricas y recurvadas con las puntas dirigidas hacia el interior. Donde hay diferencia es en la concepción de los cabellos que caen sobre la frente (en esta ocasión aparece un mechón mojado dispuesto oblicuamente, a diferencia del Resucitado en el que luce una amplia frente desprovista de cualquier cabello) y en la melena a ambos lados del rostro (situadas dos amplias melenas que van creciendo en profundidad y anchura según descendemos, creando una forma trapezoidal de la que ya hemos hablado en los San Isidros que le atribuimos por estas mismas fechas). Hay que apuntar un dato importante: este rostro pudiera ser el antecedente del que observamos en gran parte de sus ejemplares de San José de la segunda etapa.

El cordero que se encuentra a sus pies es casi idéntico a los tallados por su padre: está sentado con las cuatro patas flexionadas y con la cabeza elevada mirando al santo. Su cuerpo está completamente cubierto por mechones de pelo circulares.

El estado general de la escultura es malísimo puesto que a la numerosa suciedad hay que sumar la fractura de ambos pies, de numerosos dedos de las manos, desconchones por todo el cuerpo y el desgarro del brazo derecho. Urge una profunda restauración. 


\section{MURIEL DE ZAPARDIEL. IGLESIA PARROQUIAL DE} LA ASUNCIÓN

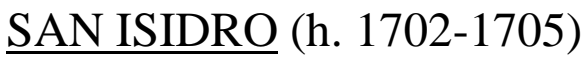

El presente San Isidro Labrador (Figs. 52-53) conservado en la iglesia parroquial de Muriel de Zapardiel (Valladolid) pertenece sin ningún género de dudas a la primera época de Pedro de Ávila. La imagen del santo labriego copia puntualmente el modelo creado por Fernández y popularizado por su padre, Juan de Ávila. Ya apuntó esta dependencia del modelo fernandesco Martín González, creyendo que fue realizada en el siglo XVII y repintada en el XVIII ${ }^{180}$. Sin embargo, Brasas Egido apuntó a que la imagen sigue el "modelo iconográfico creado por Juan de Ávila" "181, aunque como ya he referido en numerosas ocasiones, creo que lo más lógico es adjudicar el mérito del modelo a Gregorio Fernández (el San Isidro que supuestamente talló en 1629 para la parroquial de Dueñas). A Juan de Ávila se debe su popularización y a Pedro de Ávila su difusión por localidades cercanas a Valladolid capital y a poblaciones del área de Olmedo, como ocurre en este caso de Muriel. No podemos olvidar este hecho que venimos repitiendo en numerosas ocasiones, y es que al principio de su carrera, la obra de Pedro de Ávila se difundió ampliamente por los pueblos de esta zona gracias a las copias que realizó del San Isidro de su padre.

En cuanto a su cronología, Brasas señaló que se habría realizado en el último tercio del siglo XVII ${ }^{182}$. Esta fecha la hemos de retrasar hasta el primer lustro del siglo XVIII (1700-1705), puesto que es el momento en que se fechan todas estas obras olmedanas de su primera etapa, en la cual todavía observamos la clara influencia de su padre, así como la ausencia de los pliegues berninescos. Pero podríamos ajustar algo más su cronología: si creemos que la obra más arcaica de esta zona es el San Isidro de Aguasal, realizado hacia el año 1700, esta de Muriel habríamos de retrasarla un par de años puesto que posee mayor elegancia y definición en los rasgos corporales y sobre todo en el rostro y en la confección de las cabelleras. Asimismo, los pliegues son más redondeados y dulces, nada queda de aquella tosquedad. Debido a estos motivos, y a su enorme parecido con el ejemplar de San Isidro de la localidad de Puras, realizado en algún momento entre los 1702-1704, lo más lógico es creerla de estas mismas fechas; es decir, entre 1702-1705.

En la actualidad preside un retablo rococó situado en el lado de la Epístola del crucero. Este retablo y su frontero fueron realizados entre 1745-1750 por el escultor abulense Domingo Mariño ${ }^{183}$, pero su disposición original no es la actual sino que fueron

\footnotetext{
180 MARTÍN GONZÁLEZ, Juan José (dir.): Inventario artístico de Valladolid..., op. cit., p. 207.

181 BRASAS EGIDO, José Carlos: Catálogo Monumental de la provincia de Valladolid. Tomo X..., op. cit., p. 138.

182 Ibídem.

183 1745-1748. "Más 133 reales y 10 maravedíes pagados a favor de Domingo Mariño, maestro escultor, vecino de Ávila a cuenta de los 6.200 reales en que se remataron los dos retablos y sombrero de pulpito".
} 
proyectados como retablos colaterales en la capilla mayor, ocupando el espacio que dejan los ábsides laterales del templo. Como vemos, la gran altura de los retablos se encuentra en función de los altísimos ábsides mudéjares. Fueron retirados de su lugar original durante la segunda mitad del siglo XX quizás con el pensamiento de que la desnudez del templo favorecería la contemplación del primitivo templo mudéjar.

Sin ninguna duda San Isidro ocuparía uno de esos colaterales puesto que el retablo en el que se encuentra fue expresamente realizado para él, como así podemos comprobar por la presencia en el ático de un medallón que nos presenta al santo bajo una nube que le proyecta haces de luz. El retablo lo completan dos hornacinas laterales en las que se incluyen un San Francisco de Asís de comienzos del siglo XVII y una escultura dieciochesca de San Francisco Javier contemplando un Crucifijo que ha perdido. Por su parte, el retablo frontero auspicia en su ático un medallón representando la Anunciación, por lo que lo más probable es que la hornacina principal de ese retablo la ocupara una bellísima Asunción rodeada por ángeles fechada en $1673^{184}$. Desconocemos donde se localizaría antes la escultura de San Isidro; pero, de haber ocupado siempre uno de los colaterales del altar mayor, cabría considerar la posibilidad de que presidiera el primitivo colateral del Evangelio que se ejecutó entre los años 1715-1717 ${ }^{185}$.

La escultura de San Isidro es en todo similar al ejemplar de Aguasal, aunque posee ciertas diferencias, fundamentalmente en lo que concierte al estilo y a la apostura del santo. A pesar de ser más rígido que el de Aguasal, Ávila ha conseguido en esta ocasión mayor monumentalismo y elegancia, debido a lo cual emparenta directamente con el que realizara su padre para la ermita vallisoletana. La vestimenta también es idéntica, aunque el repolicromado posterior ha cambiado notablemente su aspecto, pero teniendo en cuenta al resto de imágenes de San Isidro que atribuimos a Pedro de Ávila e incluso el documentado a su padre, no cabe duda de que toda su vestimenta poseería colores marrones y por encima diferentes labores y decoraciones geométricas y vegetales doradas. Como aquél, también sujeta un cayado con la mano derecha mientras que el atributo que asiría con la izquierda ha desaparecido. Como de costumbre, a sus pies figuran dos pequeños bueyes con un arado, los cuales serán un añadido posterior. Donde más diferencias encontramos con respecto al San Isidro de Aguasal es en el rostro, el cual vemos que ya casi ha adquirido plenamente las formas y rasgos que utilizará hasta el final de su carrera con escasas variaciones. Los ojos se han hecho algo más pequeños; la boca se encuentra completamente tallada con los labios separados, aunque sin definir los dientes ni la punta de la lengua, de tal forma que logra esa mueca tan característica de la que hemos hablado en diversas ocasiones; el rostro en general ha adquirido mayor blandura y tersura; el pelo y la barba están más detallados y definidos, llegando a separar con minuciosidad cada una de las guedejas, de tal manera que el resultado es

1748-1750. "Más 1.162 reales que por la última paga dio a Domingo Mariño por la hechura de los dos retablos colaterales de la iglesia". "Más 225 reales que costó el portear de los carros que trajeron dichos retablos". Ídem, pp. 140-141.

$184 \quad$ Ídem, p. 138

185 1715-1717. "Más 2.784 reales que costó un colateral nuevo que se hizo en dicha iglesia y para el lado del evangelio". Ibídem. 
mucho más naturalista. Asimismo, las melenas laterales hacen que la forma rectangular del rostro se convierta en trapezoidal. Por su parte, los dos mechones que caen sobre la frente están más separados del cuero cabelludo y adquieren unas formas más redondeadas, pero sus puntas siguen señalando hacia el exterior. Finalmente, la barba también se encuentra muy modificada puesto que ha adquirido mayor profundidad y espesor, asimismo su punta ha pasado a tener cuatro mechones simétricos, dos a dos. Como vemos, en tan solo un par de años (los transcurridos supuestamente desde que realizara el ejemplar de Aguasal), la calidad lograda en el rostro ha sufrido una gran mutación, consiguiendo un acabado mucho más perfecto y realista. También hemos de apuntar el evidente parecido que goza este rostro con el del San Juan Bautista de Almenara de Adaja (Valladolid), entre otros. 


\section{VALLADOLID. MONASTERIO DEL SANTÍSIMO SALVADOR DE SANTA BRÍGIDA}

\section{SAN JOAQUÍN, SANTA ANA Y LA VIRGEN (h. 1703)}

El presente grupo escultórico (Figs. 54-55) presidía el retablo colateral del lado del Evangelio, según acertó a ver González García-Valladolid en el año 1900: "El retablo colateral del evangelio está consagrado a San Joaquín, Santa Ana y la Virgen y el de la epístola a San José, cuyas imágenes de talla ocupan sus tronos principales" ${ }^{\text {186; }}$ y Gratiniano Nieto en $1954^{187}$. Sin embargo, este último no se encontró con el San José en el retablo de la Epístola sino con "una buena talla de la Inmaculada". Pudiera ser que esta Inmaculada sea la que posteriormente le atribuiremos; sin embargo, a falta de documento fotográfico, no lo sabemos a ciencia cierta.

Los dos retablos colaterales fueron realizados, al igual que el mayor, por el ensamblador vallisoletano Francisco Billota, el cual debió de asentarlos a lo largo de la primera mitad del año 1703 puesto que en el mes de agosto de ese mismo año se le abonan los 12.000 reales por "los colaterales y púlpito ${ }^{188}$. También por entonces se pagaban 22.000 reales al maestro Manuel Martínez de Estrada por el "coste que ha tenido el dorar el retablo del altar mayor y monumento", a lo que habría que sumar el dorado de los retablos colaterales. Las religiosas quedaron muy satisfechas del trabajo del dorador puesto que le gratificaron con 500 reales "de guantes a Manuel Martínez de Estrada"189.

Estos dos retablos, que aún se conservan en la antigua iglesia conventual, siguen puntualmente la traza y disposición de los colaterales del Monasterio de San Quirce y del Oratorio de San Felipe Neri; los primeros realizados por Blas Martínez de Obregón, aunque parece que siguiendo la traza de Francisco Billota, y los segundos laborados por este último. Las únicas diferencias con respecto a los de estos dos templos es que la hornacina superior no adopta una forma rectangular sino que remata en semicírculo, y que a los lados de esta caja llevaría sendos ángeles; solo así se puede entender la partida de 1.000 reales pagados "al escultor por los quatro ángeles de los colaterales"190. Tanto estos colaterales como el retablo mayor, los únicos que debió poseer el templo, fueron definidos por González García-Valladolid como "dorados y del gusto dominante en la mayor parte de las iglesias de Valladolid, es decir, formados por columnas cubiertas con emparrado".

Tras el abandono del monasterio, y el posterior traslado de las religiosas a un chalet a las afueras de la ciudad, muchas esculturas y obras de arte del recinto desaparecieron. Entre las afectadas se encontraron algunas del retablo mayor y las esculturas titulares y ángeles de los colaterales. Del grupo que nos interesa, el de la Sagrada Familia de la

\footnotetext{
186 GONZÁLEZ GARCÍA-VALLADOLID, Casimiro: Valladolid..., op. cit., Tomo I, p. 520.

187 NIETO GALLO, Gratiniano: op. cit., pp. 125-126.

188 MARTÍN GONZÁLEZ, Juan José y DE LA PLAZA SANTIAGO, Francisco Javier: Catálogo Monumental de la provincia de Valladolid. Tomo XV..., op. cit., p. 47.

189 Ibídem.

190 Ibídem.
} 
Virgen, hay noticia de que en el año 1975 fue tasado por el Arzobispado en 300.000 pesetas $^{191}$, desconociéndose el paradero posterior, que seguramente fue la venta a algún particular.

El grupo de la Sagrada Familia de la Virgen, que presidía el retablo colateral del Evangelio, nos presenta multitud de interrogantes acerca de su paternidad puesto que bascula entre el "segundo estilo" de Juan de Ávila y los inicios de su hijo Pedro. El hecho de que ambos artistas trabajaran para el templo dificulta las cosas. Tampoco ayuda demasiado el que los retablos colaterales fueran realizados entre 1702-1703, fechas por las que también se haría este grupo escultórico, y momentos en que cualquiera de los dos escultores pudo realizarlo puesto que Juan de Ávila no fallece hasta finales del año 1702; es decir, que, si fuera obra suya, sería una de las últimas.

Martín González también se planteó esta dicotomía entre ambos artífices puesto que si primero pensó que las tres imágenes de este grupo escultórico poseían "formas deliciosamente bellas" que caían "dentro de este segundo estilo de Juan de Ávila, de plegado blando y de líneas paralelas, acusando las formas corporales"192. años después abrió un interrogante junto con Plaza Santiago al creer que podría tratarse de "obra de Juan de Ávila u obra temprana de su hijo Pedro de Ávila"193. Además, al encontrarse en "paradero desconocido" y contar tan solo para su estudio con dos fotografías, es muy complicado poder emitir un juicio fundamentado sobre estas imágenes. Asimismo, una de las dos citadas fotografías, una en la que solo figura el San Joaquín es bastante extraña puesto que no aparecen las otras dos. En ella San Joaquín aparece más centrado en la hornacina, ¿habrían sido ya vendidas entonces la Virgen y Santa Ana? Aunque no descarto, ni mucho menos, la posibilidad de que fuera Juan de Ávila el autor del grupo, pienso que la opción que cuenta con mayor verosimilitud es la que apunta a que fueran talladas por su hijo Pedro de Ávila. Para ello me fundamento en que, por una parte, desde el punto de vista estilístico, el rostro de San Joaquín presenta grandes similitudes con una imagen homónima sita en el Santuario Nacional de la Gran Promesa, y también con otro grupo idéntico a éste de las Brígidas conservado en la iglesia parroquial de Flores de Ávila, que también le atribuimos; y, por otra, que los San Joaquines que atribuimos a Juan de Ávila nada tienen que ver con éste. A ello podríamos añadir que el rostro de la Virgen, geometrizado y tendente al rectángulo casa mucho más con los de Pedro de Ávila que con los de su padre.

En las fotografías observamos que las tres esculturas se hallaban bastante constreñidas en la hornacina. La escena giraba en torno a la Virgen Niña, a la cual dirigen las miradas sus progenitores, conformando una composición triangular invertida. En la parte de atrás, sujeto al madero del fondo parecía haber una especie de nube con cabezas aladas de angelitos y unas ramas.

\footnotetext{
191 Agradezco este dato a don José Luis Velasco Martínez, Delegado de Patrimonio del Arzobispado de Valladolid.

192 MARTÍN GONZÁLEZ, Juan José: Escultura barroca castellana ..., op. cit., p. 324.

193 MARTÍN GONZÁLEZ, Juan José y DE LA PLAZA SANTIAGO, Francisco Javier: Catálogo Monumental de la provincia de Valladolid. Tomo XV..., op. cit., p. 38.
} 
Las tres imágenes están dispuestas de pie: la Virgen en el centro, de mucha menor altura que sus padres; mientras que San Joaquín se sitúa a la derecha y Santa Ana a la izquierda. Mientras que la Virgen dirige la mirada hacia su padre, éste realiza un contraposto y un escorzo con el torso hacia la izquierda para corresponder a la mirada de su hija. A la vez, Santa Ana es una imagen más plantada, menos movida, quizás para contraponerse al movimiento brusco de su marido.

San Joaquín viste una túnica hasta los pies, que nos permite ver parte de las botas, y por encima un mano anudado con el cíngulo con el que también se abrocha la túnica. Este manto le cubre parte de la espalda, del abdomen y finaliza cayendo hacia el suelo por la pierna izquierda. En su mano derecha porta un cayado y con la izquierda sujeta la mano de su hija. Los pliegues, al igual que los presentes en las otras dos esculturas de este grupo son redondeados, apenas vislumbradas quebraduras, lo que nos indica que estaríamos de lleno, como también nos indica la cronología, en plena primera etapa de Pedro de Ávila. Sin embargo, donde podemos ver ya elementos propios de nuestro escultor es en el rostro del santo el cual es el claro precedente del que utilizará años después para el San Joaquín conservado en el Santuario Nacional de la Gran Promesa y que pudo formar parte del desaparecido retablo mayor del Convento de la Victoria; y, en menor medida, para el San Pablo del retablo mayor del Oratorio de San Felipe Neri. Acaso la única diferencia con respecto al San Joaquín del Santuario sea que éste que tratamos ahora tiene una barba con unos mechones largos, sinuosos y compactos, mientras que el del Santuario exhibe barba bífida con mechones similares aunque algo más curvos y movidos. Sin duda esto se deberá a que este último lo realizó cuando ya era un escultor maduro y seguro de sus capacidades.

El modelo de Virgen Niña parece tomado del grupo de la Sagrada Familia de la Virgen que se le atribuye a Juan de Ávila en el Colegio de los Ingleses de Valladolid. Sin embargo, tanto los caracteres del rostro como los mechones de pelo largos y sinuosos cayendo a ambos lados del rostro son propios de Pedro de Ávila, así como el mayor dinamismo que adquiere. Como aquélla, viste túnica blanca floreada ceñida por un cíngulo y una capa colgada del cuello. Levanta la mano derecha buscando la de su padre, mientras que la izquierda la mantiene caída, sin duda para diversificar actitudes y no caer en la monotonía. Finalmente, Santa Ana viste una túnica hasta los pies, manto ceñido con el cíngulo y una toca alrededor del rostro. Es la escultura que peor se aprecia en la fotografía. Con su mano izquierda agarra un libro cerrado, con los dedos colocados muy elegantemente, recordándonos su posición a las que solía utilizar Gregorio Fernández; por su parte, con la mano izquierda se sujeta el manto. El rostro de Santa Ana acusa blandura, y los ropajes presentan los mismos pliegues suaves y curvados, sin duda un prodigio de técnica que nos recuerda fuertemente a la exhibida por su padre.

Desconocemos tanto el tamaño de las esculturas como su policromía, aunque pienso que serían similares al idéntico conjunto conservado en la iglesia parroquial de Flores de Ávila (Ávila). El parecido de ambos grupos es tal que en ocasiones he creído que se trataba del mismo, sin embargo les diferencia la posición del brazo izquierdo de San Joaquín. Por lo demás son dos conjuntos análogos hasta en los más mínimos. 


\title{
FLORES DE ÁVILA. IGLESIA PARROQUIAL DE SANTA MARÍA DEL CASTILLO
}

\author{
SAN JOAQUÍN, SANTA ANA Y LA VIRGEN NIÑA (h. 1703-1705)
}

En la parte delantera del lado del lado epístola de la iglesia parroquial de Santa María del Castillo de la localidad abulense de Flores de Ávila se encuentra un pequeño grupo escultórico (como de la mitad del natural) de la Sagrada Familia de la Virgen (Fig. 56) que debe ser inmediatamente puesta en el haber de nuestro escultor dada la altísima semejanza que guarda con el grupo homónimo del Monasterio de Santa Brígida de Valladolid. Ya comentamos que el parecido es tal que se confundirían con ser la misma obra de no ser por unos pequeños detalles localizados en el brazo izquierdo de San Joaquín. En cuanto a su cronología debe de fecharse aproximadamente entre los años 1703-1705. La primera fecha hace referencia a la del grupo de las Brígidas, mientas que la segunda marca el que consideramos fin de la primera etapa de nuestro escultor y su probable viaje a Madrid.

El grupo se localiza en el curioso retablo de la Soledad, el cual se encuentra metido dentro de una especie de hornacina realizada en yeso sobre el muro. Esta hornacina la forman dos pilastras, un friso superior y un ático triangular en los que en cada una de sus puntas hay un medallón. La parte interior del ático exhibe lo que parece ser una venera. Las típicas decoraciones renacientes lo ocupan todo. Lo que es el retablo propiamente dicho, de clara estirpe barroca, se divide en dos pisos: en el inferior se encuentra una Virgen de la Soledad de bastidor, mientras que en la superior está el grupo de la Sagrada Familia de la Virgen.

Dado que el grupo es completamente idéntico al citado de las Brígidas tanto en composición, rasgos físicos, pliegues y hasta casi el más mínimo de los detalles, no vamos a volver a explicar lo mismo. La única diferencia que tenemos con respecto a aquel grupo es que éste le hemos podido ver in situ y comprobar los colores de la policromía de cada una de las esculturas. San Joaquín viste una túnica verde con motivos esgrafiados dorados; y un manto verde por el exterior y rojo por el interior; por ambos lados vemos también motivos dorados e incluso una de las cenefas floridas que hemos visto en gran parte de la producción de Juan de Ávila. La Virgen porta una túnica blanca ceñida por un cíngulo a la cintura, con motivos botánicos en diversos colores (rojo, rosa, azul, verde); y un manto azul con diversos dibujos dorados. Finalmente, Santa Ana viste una túnica rosada con algunos elementos vegetales rojizos y una cenefa en la parte baja; asimismo sobre la cabeza y anudada también en la cintura con el mismo cíngulo que el que se ciñe la túnica, porta un manto azul con motivos dorados y la misma cenefa que en la túnica. Alrededor del rostro una toca blanca también con algún motivo decorativo dorado. 


\section{FUENTE-OLMEDO. IGLESIA PARROQUIAL DE SAN JUAN EVANGELISTA}

\section{SAN JOSÉ Y SANTA TERESA (1705)}

En el retablo mayor de la iglesia parroquial de San Juan Evangelista de Fuente-Olmedo se encuentran un San José (Fig. 57) y una Santa Teresa (Fig. 58) que pueden ser atribuidas a Pedro de Ávila con bastantes reservas, más en el caso de la santa abulense. Ambas esculturas denotan el primer estilo de nuestro escultor; además, ya dijimos que el San José parece ser el primero que realizó, y por lo tanto el precedente del que talló para la catedral vallisoletana. Si bien ambas imágenes poseen unos rasgos faciales que entran dentro de los presupuestos estéticos de Pedro de Ávila, así como otros detalles que casan con su estilo como la colocación de los pies en un ángulo de $90^{\circ}$, la imagen de Santa Teresa aún causa bastantes dudas. A pesar de todo, pienso que ambas tallas fueron las últimas que realizó durante su primera etapa antes del hipotético viaje a Madrid. Sin embargo, no son las últimas que le encargaron en las poblaciones del sur de la actual provincia de Valladolid puesto que, al menos, el Hospital de San Nicolás de Bari de Olmedo (Valladolid) le encargaría obra.

Brasas Egido dio a conocer en el respectivo tomo del Catálogo Monumental de Valladolid que en el año 1705 la parroquia tiene registrada en sus cuentas el pago por el retablo y las referidas esculturas de San José y Santa Teresa ${ }^{194}$. De esta misma época será el lienzo de la Asunción que figura en el ático del retablo, y bastante anterior el San Juan Evangelista que lo preside, el cual se encuentra representado barbado, iconografía bastante inusual. Por el

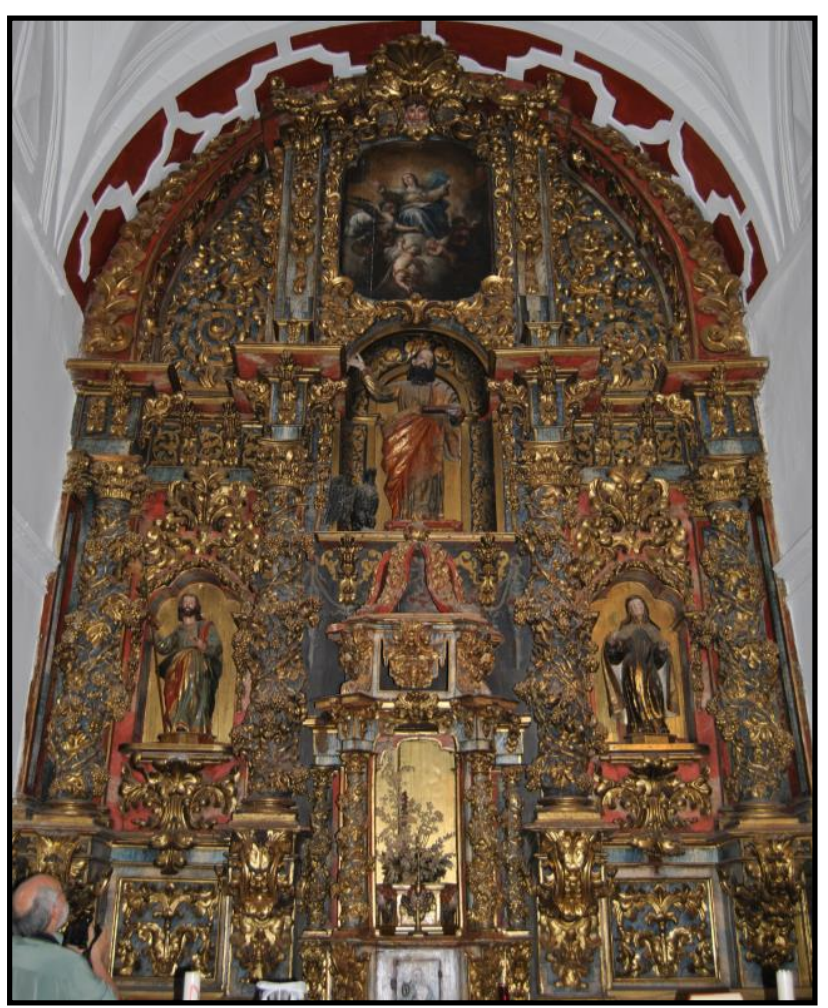

Il. 32- Anónimo. Retablo mayor. Iglesia parroquial de San Juan Evangelista. Fuente-Olmedo (Valladolid). retablo y su dorado, las dos imágenes y su estofado, así como por la "cerradura y llaves para el sagrario, grapas bisagras clavos y demás para el retablo, asentarle, pintarle y portes" se pagaron $10.924^{195}$. Restando todos estos conceptos de la cantidad total, por las esculturas se le debieron abonar entre 400 y 500 reales.

\footnotetext{
194 BRASAS EGIDO, José Carlos: Catálogo Monumental de la provincia de Valladolid. Tomo X..., op. cit., p. 75.

195 "1705-1707. Más 10.924 reales y medio del coste del retablo que se hizo nuevo para el altar mayor de dicha iglesia, los 3.800 que costó en blanco, los 6.000 de dorarle y lo restante de las efigies y
} 
Ambas esculturas son ciertamente toscas, y de pertenecer a Ávila sin ninguna duda habrán sido hechas en su mayor parte por el taller. Su canon es algo achaparrado y la talla demasiado superficial, no encontramos por ninguna parte la minuciosidad de la que suele hacer gala en la mayoría de sus obras. Las dos esculturas aparecen contrapuestas, San José adelanta la pierna derecha mientras que Santa Teresa hace lo propio con la izquierda. Asimismo, mientras que el primero mira hacia la izquierda, la santa lo hace a la derecha. Ambas esculturas comparten la posición de las manos puesto que mientras que con la derecha portan un atributo (una vara florida en el caso de San José y un elemento desaparecido en el caso de la santa), la izquierda la tienen con la palma vuelta como si estuvieran sujetan al Niño Jesús (San José) y un elemento indefinido (Santa Teresa). No sabemos qué motivos llevaron a la parroquia a elegir a estos dos santos para presidir las hornacinas laterales del retablo mayor, pero sin duda observamos una clara relación carmelita.

Ya hemos comentado que este San José es la imagen más antigua de todas las que representan al padre nutricio de Cristo; pero no solo eso, sino que también parece ser el modelo que en años posteriores evolucionará Ávila hasta conseguir el San José de la catedral, que luego será el que repetirá en diversas ocasiones y que además tomarán como ejemplo su hermano Manuel de Ávila y otros escultores anónimos. Viste una túnica verde con motivos botánicos dorados, mismo color que adoptan tanto el cuello como los botones y la parte baja de la misma. Por encima un manto rojo con la misma decoración vegetal dorada y una orla en el borde también dorada. El manto se le ciñe a la túnica en uno de sus extremos mientras que el otro le pasa por la espalda y le cae por el hombro izquierdo, motivo que le veremos repetir en infinidad de ocasiones. Ya está presente el detalle de los pies en un ángulo de $90^{\circ}$ y separados por un pliegue de la túnica. El rostro como vemos es el precedente inmediato al que exhibirán el resto de sus San José y buena parte de sus santos barbados: ojos almendrados, nariz ancha con tabique recto y aplastado, ojos de tapilla de vidrio, boca entreabierta, pómulos rosados, barba bífida construida a través de numerosas guedejas revueltas y el pelo simétrico y cayendo en amplias ondas a ambos lados de la faz. Sobre la frente sus dos típicos mechones curvos con las puntas dirigidas hacia el exterior. A excepción de la talla de la barba, el resto peca de dureza, especialmente la cabellera.

Por su parte, Santa Teresa aparece de pie vistiendo el típico hábito carmelitano con túnica y escapulario negros y capa blanca. Las tres prendas se hallan fastuosamente policromadas con motivos vegetales y geométricos dorados, especialmente la capa que además tiene una orla en el borde con diversos colores. La escultura peca de rigidez y su rostro no transmite nada, está totalmente estereotipado. También en esta ocasión vemos el detalle de la colocación característica de los pies. Aunque presenta los estilemas propios de Ávila en el rostro pienso que su ejecución corrió a cargo del taller. Los

hechuras de San José y Santa Teresa, estofarlas, unas gradillas para encima de la custodia, gasto que se hizo con el dorador y su familia, cerradura y llaves para el sagrario, grapas bisagras clavos y demás para el retablo, asentarle, pintarle y portes". Ídem, p. 76. 
pliegues presentes en ambas tallas son blandos y redondeados, aunque con algunas durezas, especialmente en la de la santa abulense.

En cuanto al estado de conservación, la escultura de San José presenta un buen estado general, aunque pueda tener algún repinte; sin embargo, la imagen de Santa Teresa presenta numerosas rozaduras y desprendimientos de policromía, amén de una alarmante suciedad. 


\section{VILLABÁÑEZ. IGLESIA PARROQUIAL DE LA}

\section{ASUNCIÓN}

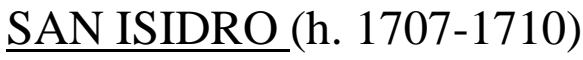

En la hornacina derecha de un retablo rococó situado en el muro de la Epístola se halla una escultura de San Isidro (Fig. 59), de tamaño menor del natural, que puede ser atribuida con ciertas reservas a Pedro de Ávila. En el Catálogo Monumental de Valladolid tan solo se alude a ella como copia del "original de Gregorio Fernández"196. Este retablo, realizado en 1762 para la Virgen de la Soledad lo compone además una escultura de un santo jesuita en la hornacina izquierda, un San Pedro en el ático y un pequeño San Antonio de Padua con el Niño en el banco ${ }^{197}$. Desconozco el anterior emplazamiento del San Isidro, si bien parece que no hay dudas de que pertenece a la parroquial. Comento esto porque sabemos que llegaron diferentes obras de arte procedentes de conventos desamortizados de Valladolid. La escultura vuelve a ser una copia casi exacta de todos los ejemplares de San Isidro que le hemos atribuido, especialmente de los de Muriel de Zapardiel (Valladolid) y Puras (Valladolid), debido a lo cual no volveremos a explicar sus características. Lo que hay que resaltar en esta ocasión es que se trata de un San Isidro bastante posterior, siendo el único que debe ser agrupado dentro de su segundo estilo. Los pliegues son algo más quebrados y tendentes a la arista que en las otras ocasiones, pero tampoco los paños a cuchillo son muy marcados, debido a lo cual se podría fechar en los albores de su referido segundo estilo, es decir, entre 1707-1710 aproximadamente. Comentaba al principio que atribuía esta pieza a Pedro de Ávila con ciertas reservas; efectivamente, ello se debe a que aunque el rostro presente las características típicas de Pedro de Ávila, se hallan realizadas de una manera tan tosca, y el pelo se presenta tan lacio y seco que me hace dudar si es obra suya (realizada en su mayor parte por su taller) o incluso pueda ser adscrita a su hermano Manuel de Ávila dadas las evidentes semejanzas que guarda con el San Isidro que éste realizó para el retablo mayor de Fuentes de Valdepero. Si comparamos ambos, vemos que las ondas laterales que forman los cabellos son igual de secas y rígidas, y no existe el esplendor y volumen del que suele hacer gala Pedro de Ávila. A pesar de todo, dado que apenas conocemos obras del pequeño de los Ávila y a que en esta misma parroquia se encuentra un San Francisco Javier que debe ser atribuido sin ninguna duda a Pedro de Ávila, prefiero, por el momento, ponerla en el haber de este último.

\footnotetext{
196 MARTÍN GONZÁLEZ, Juan José: Catálogo Monumental de la provincia de Valladolid. Tomo VI..., op. cit., p. 140.

197 "1762. 2.474 reales del coste del retablo de Nuestra Señora de la Soledad, con la efigie de San Ildefonso". Ídem, p. 160.
} 


\section{VALLADOLID. MONASTERIO DEL SANTÍSIMO SALVADOR DE SANTA BRÍGIDA}

INMACULADA (h. 1707-1713)

La presente Inmaculada Concepción (Fig. 60) es una imagen de madera policromada, de tamaño menor del natural (107 cms.). A simple vista, la Inmaculada presenta todos los rasgos de Pedro de Ávila, aunque esto no quiere decir que haya salido de sus manos. Así es como piensan Martín González y Plaza Santiago, los cuales la consideran obra de taller $^{198}$. Personalmente, la creo obra personal de Pedro de Ávila de los primeros momentos de su segunda etapa puesto que aparecen las características de este segundo estilo, incluido el incipiente pliegue a cuchillo; sin embargo, la utilización tan somera de este aconseja fecharlo entre su probable regreso a Valladolid hacia el año 1707 y el año 1713 puesto que a partir de 1714 vemos a Ávila desplegué el pliegue berninesco en todo su esplendor.

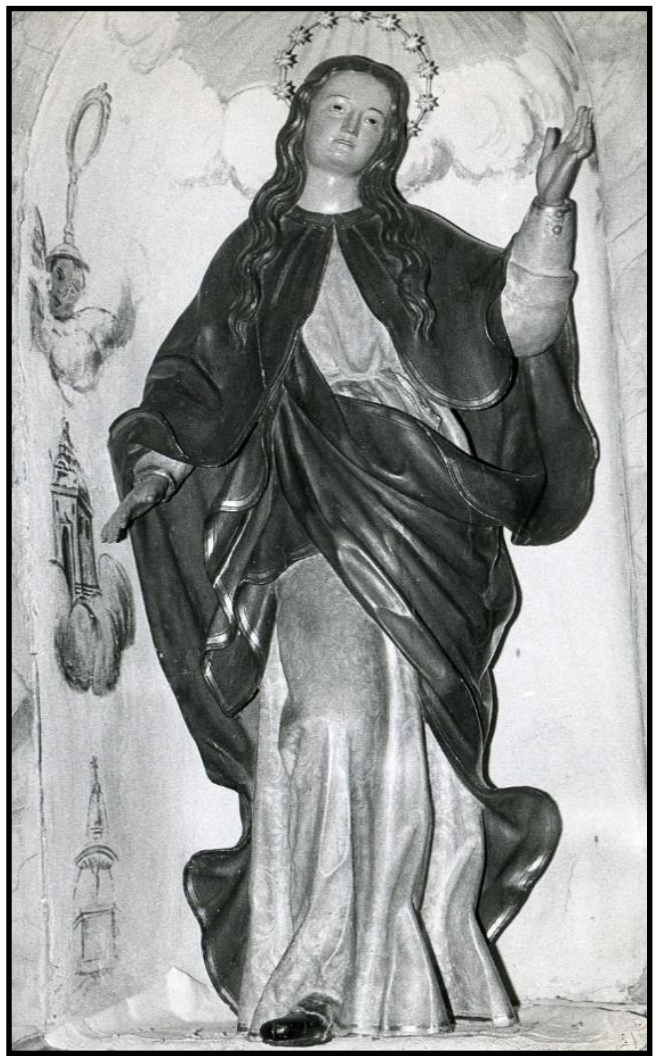

Il. 33- La Inmaculada cuando se encontraba en su anterior emplazamiento. (C) Departamento de

Historia del Arte de la Universidad de Valladolid.
Desconocemos el lugar que ocupó en el monasterio. Gratiniano Nieto refiere que en la iglesia, en el retablo colateral de la epístola, se veía "una buena talla de la Inmaculada"199. En ese mismo retablo se encontraba en 1970 cuando se redactó el Inventario Artístico de Valladolid $^{200}$. De todas maneras, no sabemos si esta Inmaculada a la que aluden ambos escritores es ésta sobre la que estamos hablando. En este mismo retablo hubo también una escultura de San José de la cual desconocemos todo por lo que no sabemos cuál fue la imagen titular de este retablo. En una fotografía conservada en el Archivo Fotográfico del Departamento de Historia del Arte de la Universidad de Valladolid podemos ver a la Virgen dentro de una especie de hornacina excavada en una pared. Las paredes de esta hornacina llevan pinturas alusivas a los dones de la Virgen: un espejo, una torre, un pozo, etc... No sabemos dónde se tomó esta fotografía, si en la propia iglesia o en algún lugar de la clausura. En la actualidad se guarda

\footnotetext{
198 MARTÍN GONZÁLEZ, Juan José y DE LA PLAZA SANTIAGO, Francisco Javier: Catálogo Monumental de la provincia de Valladolid. Tomo XV..., op. cit., p. 39.

$199 \quad$ NIETO GALLO, Gratiniano: op. cit., p. 125.

200 MARTÍN GONZÁLEZ, Juan José (dir.): Inventario artístico de Valladolid..., op. cit., p. 27.
} 
en la clausura del nuevo convento, situada sobre una simple peana localizada en un distribuidor.

Se trata de una curiosa Inmaculada dentro de la producción del maestro ya que no aparece sobre un trono angélico, es bastante rígida y no tiene las manos juntas en posición orante. A pesar de todo ello los rasgos propios del rostro y la composición de la parte baja de la túnica y de los pies no nos dejan dudas acerca de su paternidad.

La Virgen aparece de pie, con la pierna derecha levemente adelantada, rasgo que vemos continuamente en su obra. A pesar de la cierta rigidez de la imagen, observamos en ella un leve escorzo en la citada pierna, una composición helicoidal y una diagonal que une ambas manos, que se cruza con otra formada por el manto que cubre su abdomen. Un brazo lo baja, mientras que el otro lo sube realizando un gesto declamatorio, la diversidad de actitudes dinamiza la pieza. Viste túnica grisácea hasta los pies recorrida por una serie de motivos vegetales blanquecinos apenas visibles, quizás por la capa de suciedad que posee. La túnica es tan larga que tan solo deja ver la punta de los zapatos, como de costumbre, y también como nota habitual, los pies los tiene colocados en un ángulo de $90^{\circ} \mathrm{y}$ separados por un trozo de túnica aristado, aunque el hecho de que esa arista y las otras de esta parte baja no sean tan afiladas nos indica que todavía no pertenece al periodo más maduro del escultor, que comienza en el año 1714. Por encima de la túnica, un manto azul abrochado al cuello y abierto en dos partes desde ese mismo broche. El manto, cuyo borde se ve recorrido por una estrecha franja dorada, le cubre la espalda, los hombros, la mayor parte de los brazos e incluso le sube un trozo desde la cadera izquierda para ajustarse a la altura derecha del cíngulo con el cual se sujeta la túnica. En definitiva, es una disposición muy teatral. Los pliegues son redondeados y suaves en su mayoría, aunque ya vemos el incipiente acuchillamiento en algunas partes. También destaca la delicadeza y finura con que ha concebido los pliegues. Sin duda Ávila fue un maestro en lo concerniente al adelgazamiento inusitado de la madera.

El rostro posee los típicos rasgos faciales presentes en toda la segunda etapa de Ávila. Mira hacia el cielo con sus usuales ojos almendrados y rehundidos, y con el característico abultamiento de la parte inferior; ojos de tapilla que simulan ojos marrones; cejas rectas y pintadas, al igual que las pestañas; nariz recta, potente, geometrizada, con el tabique nasal ancho y aplastado; desde el nacimiento de la nariz hasta su desembocadura en las fosas nasales va creciendo en anchura; las fosas nasales van perforadas. Boca entreabierta con finos labios, en la cual podemos observar la fila superior de los dientes y la punta de la lengua. El surco nasolabial apenas está levemente apuntado. Mejillas tersas y coloreadas. El rostro acusa blandura, sobre todo en pómulos y mentón. Amplia frente y largas caballeras a los lados del rostro que caen a manera de cascada hasta más allá del pecho. A cada lado dos guedejas unidas, pero su talla no es tan pormenorizada como en ejemplares posteriores. 


\section{VALLADOLID. IGLESIA DEL SALVADOR}

\section{TRASLACIÓN DE SAN PEDRO REGALADO (1709)}

La capilla de San Pedro Regalado de la iglesia del Salvador de Valladolid se encuentra presidida por un sencillo retablo que alberga un bellísimo grupo escultórico que representa la Traslación de San Pedro Regalado, y que viene a ser una directa repercusión del realizado dos décadas antes para la capilla mayor del Convento del Domus Dei de La Aguilera. Si aquél grupo se atribuye con bastante seguridad a Juan de Ávila, este vallisoletano parece obra más que probable de su hijo Pedro. Antes de hablar sobre el grupo escultórico, trataremos sobre sus orígenes; es decir, la Cofradía de San Pedro Regalado y la capilla homónima que se le levantó en la referida iglesia del Salvador, parroquia en cuya pila fue bautizado el santo.

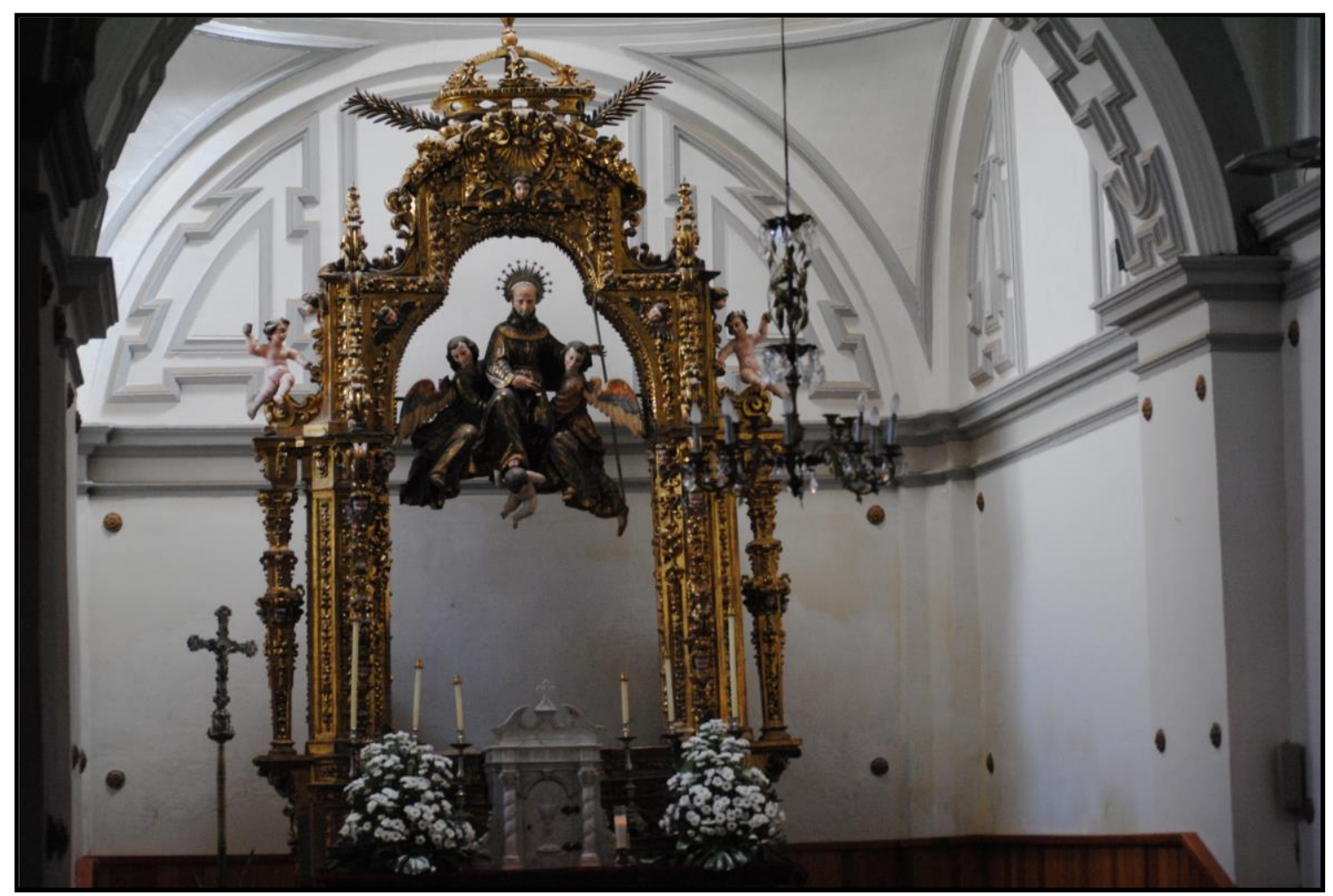

Il. 34- Pedro de Ribas. Capilla de San Pedro Regalado. Iglesia del Salvador. Valladolid.

En una fecha indeterminada del mes de mayo de 1709 un anónimo benefactor, que firma como "el más humilde y rendido devoto de San Pedro Regalado", decide que, "como amante y celoso de ella, dice ser de su particularísima devoción hacer a su costa un San Pedro Regalado (como está en el Convento del Aguilera) altar donde se coloque; y retablo para su mayor decencia, en dicha iglesia". Para ello suplica a la parroquia le concediera permiso para que "se haga dicho altar a la entrada de la capilla mayor, al lado del Evangelio en correspondencia del altar del Santísimo Cristo. Lo cual concedido, hará con otros devotos una fiesta muy solemne teniendo patente el Santísimo Sacramento (...) Ítem pide el acompañamiento de las cofradías sita en dicha parroquia y la solicitud de obtener las licencias que para todo lo dicho fueren necesarias que pues todo cede en mayor honra y gloria de Dios". Este anónimo

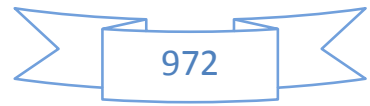


mecenas estaba convencido de que esta "demostración tan piadosa y tenida a tan gran santo, impetrara para todos sus parroquianos especiales auxilios para que le vean con mayor culto en la gloria" (DOCUMENTO 86). Pilar Calvo Caballero desvela que ese personaje anónimo no es otro que el escribano Gabriel de Medina Mieses, el cual no solamente costea el grupo de San Pedro Regalado y su retablo, sino que también sufraga los retablos colaterales y las esculturas que los presiden. Medina Mieses "contribuyó a la capilla, ideó la función de San Pedro Regalado y dota a la Cofradía de su sala y de esta Memoria, la primera recibida"201.

El 26 de mayo de ese mismo año "el cura y parroquianos de la iglesia parroquial del Salvador (...) estando especialmente nos el licenciado don Pedro de Rábago, cura propio de dicha iglesia, don Félix de Estefanía Ureta regidor, don Fernando Robredo, don Domingo Fernández del Val, don Francisco de Villegas, Jerónimo de Estrada, Juan Manuel Navarro Moreno, Juan de Mollinedo, Frutos Martínez, Julián García" otorgaban licencia a "dicho devoto (que es el escribano ante el que pasa esta escritura) para que coloque y ponga la efigie del señor San Pedro Regalado en dicha parroquia iglesia del Salvador donde está bautizado" ${ }^{202}$. Además, acordaron que se le dieran las gracias por tal ofrecimiento. En esa misma junta parroquial se resolvió fabricar una capilla propia a San Pedro Regalado "mediante decía ser propia causa de toda la parroquia por ser hijo de ella, y que lo razón se coloque en sitio el más decente que hubiere". El lugar elegido fue "el sitio de otra [capilla] que está totalmente arruinada que se decía ser del Ilmo. Señor Obispo Soto, de que sobre ella tenía dicha fábrica tres mil y tantos maravedís de renta perpetua en cada un año, de que se debieran más de cien años como constaba de las cuentas" $\mathrm{y}$, asimismo, "se hiciese para ser mayor decencia y culto un nuevo camarín, que saliese al cementerio de dicha iglesia que cae a la plazuela con su transparente".

Los comisarios nombrados para tal afecto también acordaron que "con gran regocijo y gusto por la mucha devoción que tenemos al dicho santo San Pedro Regalado y ser tal hijo de dicha parroquia le hemos votado por día festivo y de guarda en el día que le celebra la iglesia"; y que "se saque en procesión a dicho santo San Pedro Regalado por toda la dicha parroquia colgando las calles por donde pasare con la mayor decencia que se pudiere y tener a trechos sus altares y todo lo ofrecemos así; y que dichos señores comisarios soliciten para ello a la Venerable Congregación de Nuestro Padre San Felipe Neri y cofradías Sacramental, Ánimas, Nuestra Señora de la Guía, Buen Suceso, San Bartolomé, Santo Toribio y la Piedad, todas de dicha parroquia y a las demás personas que les pareciere y convenga para su mayor culto". La reunión parroquial acabó con el acuerdo de tener tres días de fiesta "de iglesia haciendo su altar y en él poner dicho santo y tener el Santísimo Sacramento patente, misas y sermones".

El día 4 de junio de 1709 se abrieron "los cimientos para la capilla camarín que a devoción de los devotos le consagran a su costa. Sea para el mayor servicio de Dios y mayor gloria del Santo". Asimismo, el día 28 de ese mismo mes se procedió a colocar

201 CALVO CABALLERO, Pilar: op. cit., p. 71.

202 Ídem, p. 47. 
"la primera piedra de la capilla camarín de San Pedro Regalado y en las tres piedras de las esquinas y medio de la pared principal se pusieron muchas reliquias y monedas de plata y cobre" ${ }^{203}$. La realización de la capilla marchó a buen ritmo puesto que a finales de agosto ya estaba acabada, y el día 29 de septiembre se procedió a colocar "al Santo en su retablo y capilla".

En la petición que hizo Manuel de Medina Mieses para hacer a su costa la efigie de San Pedro Regalado se podía leer la expresión "hacer a su costa", lo que nos viene a indicar que la imagen no estaba hecha por entonces. Por lo tanto, el encargo del escribano a Pedro de Ávila no se produciría pocos días después, tampoco se retrasaría mucho la contratación del retablo que presidiría el bulto del Regalado puesto que como ya hemos visto a finales de septiembre de ese mismo año ya estaba todo colocado en su sitio.

Un documento de poder a procuradores parece indicarnos que el autor del retablo fue el prestigioso ensamblador vallisoletano Alonso Manzano. Efectivamente, el 16 de septiembre del referido año de 1709, Manzano otorgaba poder a "Juan García Gago y a Manuel de Peñamaría procuradores del número de esta Real Chancillería" para que le defendieran de una demanda que le habían puesto "los comisarios nombrados por la parroquial del Salvador de esta ciudad para la traslación de San Pedro Regalado en su capilla de la iglesia de ella sobre suponer que el adorno que hecho y ejecutado según mi arte no está arreglado a la traza ni vale el precio en que lo ajusté y otras cosas contenidas en su pedimento". Manzano declaraba que esta afirmación era incierta "porque yo he cumplido con lo que ha sido de mi obligación" (DOCUMENTO 87). Lo que quedaría por confirmar es si con lo del "adorno" se refieren al retablo o no, sin embargo es lo más probable. El retablo es muy sencillo puesto que se trata de un simple arco exento con estípites a los lados. Va coronado por una gran corona y dos palmas a los lados. Por su interior, donde se encuentra el grupo de la Traslación de San Pedro Regalado, adquiere en su parte superior forma tribulada para adaptarse al citado grupo escultórico. El hecho de que una barra horizontal, oculta por las propias esculturas y las alas de los ángeles, sujete el grupo por las espaldas es un efectismo muy barroco puesto que a simple vista parece estar desarrollándose esa acción ante nuestros ojos.

Refería Manuel Canesi que la capilla se había terminado de fabricar y amueblar el día 26 de septiembre, y que había ayudado bastante en esta tarea "Gabriel de Medina Mieses, escribano del número de esta ciudad, y muy celoso y vigilante parroquiano y más de la extensión del mayor culto del santo a que coadyuvaron los mercaderes y plateros y otros muchos devotos". En la tarde de esa misma jornada, una vez preparados el retablo y trono nuevo se formó una procesión para conducir "el santo bulto (...) al convento de San Quirce de religiosas del orden de San Bernardo, donde el ilustrísimo señor D. Andrés de Urueta y Barasorda, obispo de esta ciudad, estaba confirmando a muchas de ellas". La procesión continuaría hasta el convento de las Brígidas, "en que cantaron la Salve a Nuestra Señora", y después prosiguió hasta el Convento de San

203 ZAPARAÍN YÁÑEZ, María José: "Capítulo IV. Lo real maravilloso San Pedro Regalado y los testimonios artísticos". En BURRIEZA SÁNCHEZ, Javier (coord.): La Ciudad del Regalado, Ayuntamiento de Valladolid, Valladolid, 2004, p. 107. 
Francisco. Al día siguiente, por la tarde, se celebró una nueva procesión, en esta ocasión entre el Convento de San Francisco, cenobio en el que había profesado el Regalado y su nueva capilla en la parroquia del Salvador, en cuya pila había sido bautizado ${ }^{204}$. Durante los tres días siguientes se exaltaron las virtudes del Regalado, y en el último, que fue el día 30, se realizó una nueva procesión en el que participaron algunas de las penitenciales colocando altares en la calle. Así, por ejemplo, la Cofradía de la Piedad puso el suyo en la calle de los Orates; mientras que la de la Vera Cruz dispuso uno "de cuatro caras muy vistoso" en el Ochavo; tampoco podía faltar el elaborado por el Convento de San Francisco, que se ubicó en la calle de la Sortija ${ }^{205}$.

Al relato de Canesi se contrapone el de Ventura Pérez (el cual en algunas ocasiones comete ciertos errores cronológicos) que fecha estos fastos por la conclusión de la capilla, procesión, etc... justo un año después, en septiembre de $1710^{206}$; relato que asimismo recoge Casimiro González García-Valladolid, el cual también en ocasiones comete fallos cronológicos: "La tercera capilla es la de San Pedro Regalado (...) El día 12 de junio de 1710 se acordó edificar una capilla dedicada a dicho Santo, en la iglesia parroquial del Salvador, en que fue bautizado: el día 28 del mismo mes se colocó la primera piedra y el 31 de agosto siguiente quedó terminada. Se eligió para su emplazamiento el lugar ocupado entonces por la pila bautismal, la que con este motivo fue trasladada a la capilla donde se encuentra hoy (...) El día 29 de septiembre se inauguró la nueva capilla y altar del santo, celebrándose al efecto un solemne triduo costeado el primer día por la Venerable Congregación de San Felipe Neri; ofició la misa el Dr. Cañizar, ministro de aquella y predicó el Sr. D. Pedro Dávila, canónigo magistral de esta Santa Iglesia: el segundo le costaron los feligreses de la parroquia; dijo la misa el párroco D. Pedro de Rábago y predicó el Rvdmo. P. Fr. Dionisio Carvajal, hijo de la parroquia y predicador mayor de la Orden de San Bernardo; el tercero fue hecho a expensas de la ciudad; predicó el predicador mayor de la Orden de San Francisco y asistieron el corregidor y los capitulares. "Este día salió por la tarde en procesión el santo; asistió la venerable congregación de San Felipe, la cofradía penitencial de la Cruz y Piedad, y todas la de la parroquia. La cofradía de la Piedad puso un altar muy lindo a los Orates. La cofradía de la Cruz puso otro en el Ochavo, que subía por encima del tejado. La congregación de San Felipe puso otro a la puerta de su iglesia; hubo muchos fuegos y luminarias todas las tres noches; hubo mojigangas y máscaras, y se concluyó con una corrida de toros. Se fundó al santo una congregación para enterrar a los pobres que mueren en la parroquia" 207.

Unos meses después, en mayo de 1710, los mismos parroquianos (animados por el inquieto don Pedro de Rábago, cura de la iglesia del Salvador) que dieron permiso a Medina Mieses para fabricar a su costa el grupo escultórico del Regalado, fundan la Congregación de San Pedro Regalado y Ánimas Pobres del cementerio de la referida parroquia. Su fundación tenía el propósito de subsanar la carencia de una cofradía

\footnotetext{
204 CANESI ACEVEDO, Manuel: Historia de Valladolid (1750), Tomo II, op. cit., p. 175.

205 Ídem, p. 176.

206 PÉREZ, Ventura: op. cit., pp. 32-33.

207 GONZÁLEZ GARCÍA-VALLADOLID, Casimiro: Valladolid..., op. cit., Tomo I, pp. 155-156.
} 
dedicada al santo vallisoletano (por entonces aún Beato) "y a la falta de sufragios de las Ánimas de los Pobres que recibe sepultura en el cementerio de la dicha Parroquial del Salvador"208. Esta cofradía, que tendría como misión el rezar por los pobres del cementerio parroquial "que no enterrarlos; asistir a los entierros de sus congregantes, esposas e hijos, brindarles la capilla y costearles las misas; pero éstas, a diferencia de las de aquellos sufragadas con limosnas, salen del peculio de cada congregante, lo que casaría con la norma de que sus miembros pertenezcan a los oficios más honoríficos y, por ende, más pudientes" ${ }^{209}$. La regla por la que debía regirse fue aprobada el 2 de mayo de 1711 por el vicario general don Andrés de Orbe y Larreátegui en nombre del obispo Andrés de Orueta Barasorda ${ }^{210}$. Asimismo, la cofradía se ponía bajo el patrocinio de don Baltasar de Zúñiga y Ayala, marqués de Aguilafuente, cuyo nombre encabeza la regla ${ }^{211}$. A pesar de ello, tal como y reseña Pilar Calvo Caballero, su protagonismo quedó eclipsado por los de "Pedro de Rábago, y de Gabriel de Medina Mieses, mayordomo y limosnero que fue del obispo Diego de la Cueva y Aldana, y escribano del número de Valladolid entre 1681-1721"212; puesto que al primero se debe la formación de la Congregación, y al escribano y su familia, que "son su alma como prueba la relación de firmantes de la Regla" ${ }^{213}$, parte de las esculturas y retablos de la capilla.

La historia constructiva de la capilla no acabaría ahí puesto que pocos años después se procedería a su ampliación. Relata Canesi que "no contenta la cofradía del santo y parroquianos con el demostrativo culto de su devota fineza ampliaron mucho más la capilla el año de 1726 y concluida el siguiente desde el día del santo que es a 13 de mayo" 214 . A este mismo acontecimiento se refiere Ventura Pérez: el 13 de mayo de 1727 "se colocó al santo San Pedro Regalado en su capilla nuevamente añadida la media naranja y lo correspondiente a ella: hubo tres días de fiestas" ${ }^{215}$. Entre las personas que contribuyeron al gasto de estas fiestas se encontraba el referido marqués de Aguilafuente, que aportó "un copiosa limosna (...) y otros muchos caballeros y particulares con que coronaron su grande amor" 216.

Efectivamente, el 30 de junio de 1726 la cofradía decide ampliar la capilla: "haciendo insinuación del gran deseo que tiene, mayor culto y veneración de San Pedro Regalado y decencia de su capilla y por no tener en ella comodidad bastante para la asistencia de dicha cofradía a las funciones que en ella celebra por lo cual pidió a dicha parroquia licencia para hacer un nuevo camarín en el sitio que con la nueva obra de la sacristía ha quedado junto al camarín que al presente tiene dicha capilla quedado este unido a ella para que todo sea capilla alargando para este fin dicho sitio" (DOCUMENTO

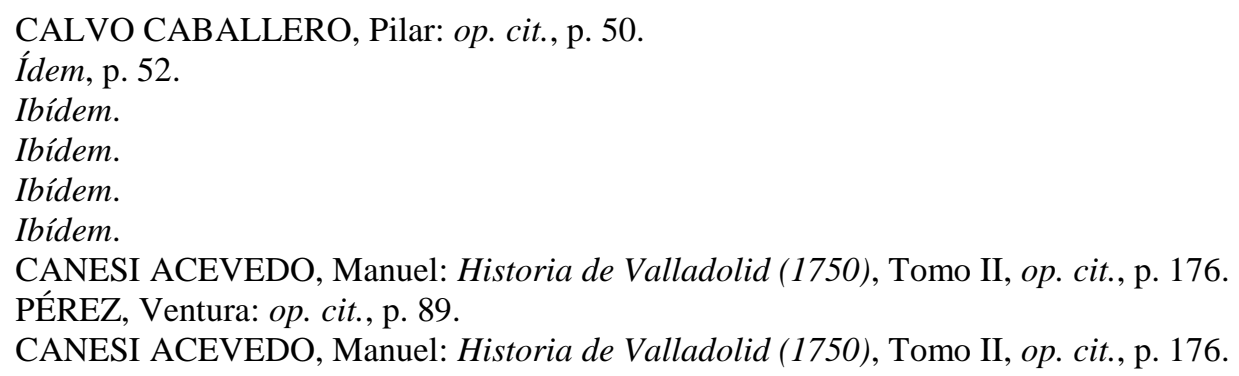


89). Esta ampliación de la capilla no supondría "ningún inconveniente ni perjuicio así a la sacristía nueva, capilla del santo". Sería el maestro de obras vallisoletano Matías Machuca el encargado de redactar un informe acerca de si se "podía seguir intervención a las luces y aguas de la sacristía de dicha iglesia y habiéndolo visto y reconocido todo ello muy por menor declaro no se sigue perjuicio alguno". En la obra también entraba la modificación de "las vidrieras, pintura de pechinas, bancos y una grada para elevar el retablo. Según María José Zaparaín, estas obras suponen notable transformación: se suprime el camarín y se añade media naranja y lo correspondiente a ella, privándose al retablo de la adecuada atmósfera lumínica que hubiera materializado la presencia de lo sobrenatural, limitando las sensaciones emotivas que de reclamo visual posee la escultura del Regalado suspendida en el retablo, concebido éste como suntuoso arco triunfal"217.

Desde que Martín González y Urrea expusieran en el respectivo tomo del Catálogo Monumental de Valladolid que este grupo "es probablemente de Pedro de Ávila, influido todavía por su padre Juan de Ávila"218, la atribución ha sido respaldada sin fisuras, y nunca se ha puesto en dudas. No hay muchas dudas acerca de su filiación puesto que tanto San Pedro Regalado como los ángeles laterales poseen unos rostros con los típicos estilemas propios de nuestro escultor. Lo primero que observamos es que se trata de una versión del que supuestamente realizó su padre veinte años antes para la capilla mayor del Convento del Domus Dei de La Aguilera. El grupo vallisoletano no copia puntualmente al burgalés puesto que, aunque posee los mismos elementos, parece mucho más movido.

San Pedro (Figs. 61-62) aparece siendo transportado por los aires por tres ángeles (y no cuatro como en el ejemplar burgalés puesto que en aquél figura un ángel que empuja al santo por la espalda) que forman una especie de "trono angélico": uno a cada lado del santo, agarrándole por las piernas y la espalda; y otro a los pies, actuando de soporte (Fig. 63). Todos muy similares a los burgaleses, aunque con gestos y disposiciones diferentes. No nos podemos hacer idea de cómo estaría colocado antiguamente puesto que tal y como está ahora carece de los múltiples puntos de vista que si tiene el grupo burgalés puesto que se puede acceder al camarín y verle la parte de la espalda al santo.

San Pedro Regalado figura como de costumbre con su típico hábito franciscano de la rama de los Menores de la Observancia que consta de "túnica, capilla y capuchón de color marrón" 219 . En ocasiones algunas esculturas poseen una policromía en la que se alude a las calidades pictóricas que "detallan la aspereza del sayal basto de Aranda con el que se vestían los reformadores de Villacreces, por lo que se les conoció también como sayalegos"220; este, al igual que el San Pedro de La Aguilera, posee ricas labores de brocado en la parte baja y en la capucha y el resto va decorado con labores vegetales

217 CALVO CABALLERO, Pilar: op. cit., p. 76.

218 MARTÍN GONZÁLEZ, Juan José y URREA FERNÁNDEZ, Jesús: Catálogo Monumental de la provincia de Valladolid. Tomo XIV..., op. cit., p. 34.

219 REDONDO CANTERA, María José y ZAPARAÍN YÁÑEZ, María José: op. cit., p. 78.

$220 \quad$ Ibídem. 
que apenas se pueden percibir en toda su grandeza y luminosidad por culpa del polvo y el paso del tiempo. Sería necesaria una restauración que recuperara la que seguramente sea una bellísima y colorida policromía. Los pies van calzados por unas sandalias rojas, las cuales tan solo las podemos vislumbrar si nos ponemos debajo del grupo escultórico dado que las oculta tanto el ángel inferior como la túnica del santo. Ya dijimos que, aunque se decía que solía viajar descalzo, las sandalias hacen referencia a la descalcez. Los pliegues son muy blandos, los heredados de su padre y su suegro, y sin embargo el tratamiento general de los mismos ya no es tan dulce y combado, sino que podemos percibir las quebraduras propias del pliegue a cuchillo, aunque todavía muy incipiente. Esto lo podemos observar en la parte baja de las túnicas del santo y los dos ángeles laterales. Lo que si se encuentra presente es ese adelgazamiento de las maderas que tanto gusta a nuestro escultor, y que nos trae a la memoria a Pedro de Mena y José de Mora.

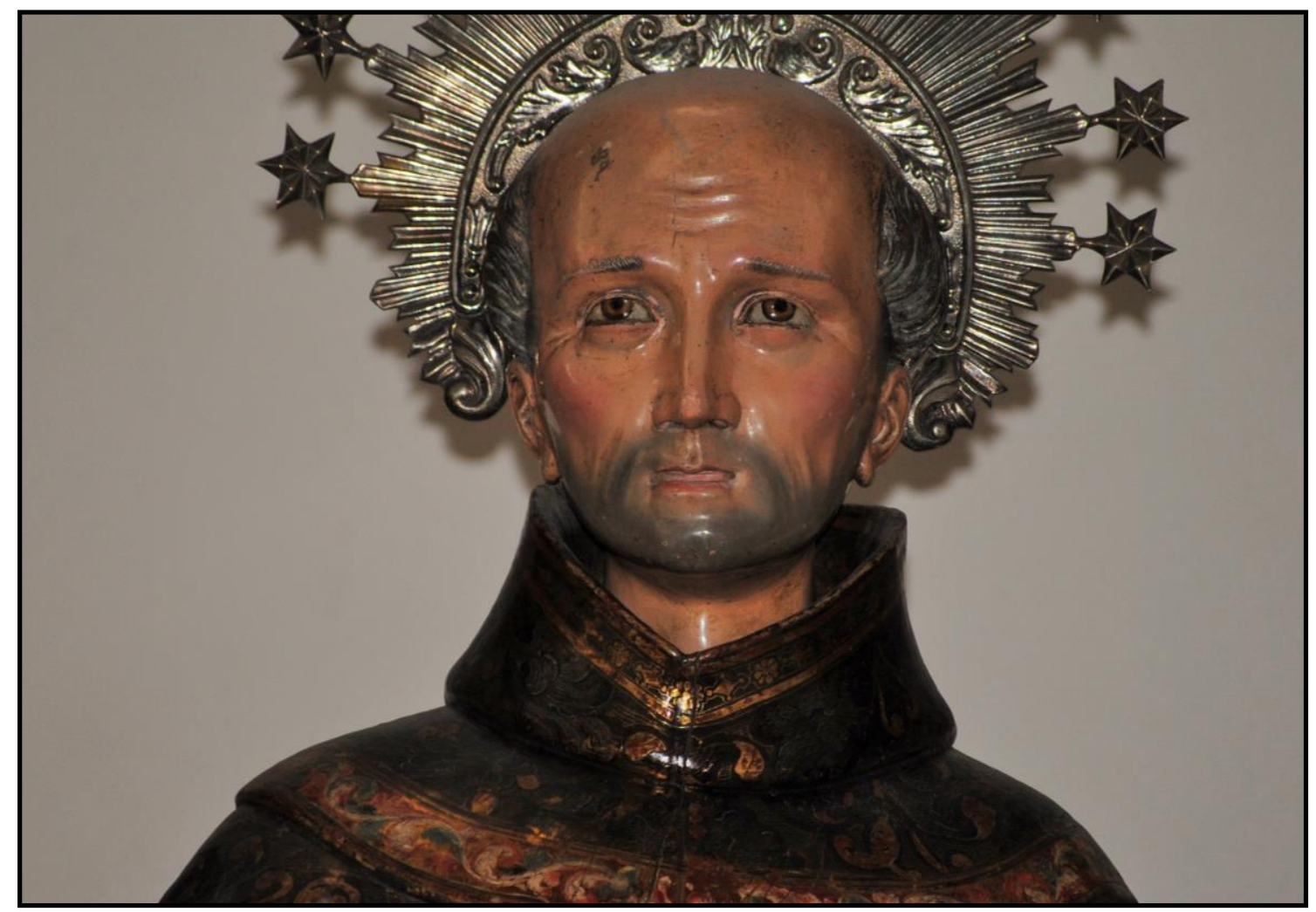

Il. 35- Pedro de Ávila (atrib.). Detalle de San Pedro Regalado.

El Regalado va "sentado" de una forma muy elegante puesto que tiene la pierna izquierda ligeramente adelantada, posándola sobre la cabeza del ángel inferior, mientras que la pierna derecha recae sobre la espalda del referido ser angélico. La posición de su cuerpo no es frontal puesto que, además, su torso se encuentra levemente girado hacia la izquierda. Por su parte, su brazo izquierdo lo extiendo hacia ese lado, mientras que con esa mano sujeta un cayado que alude a su condición de peregrino. El brazo derecho está relajado, y esta mano agarra un libro cerrado, aunque intenta meter uno de los dedos para separar las páginas, detalle que parece provenir de Gregorio Fernández. El libro alude "a su redacción de las constituciones que regían la vida de estas comunidades monástica; también es consecuencia de los escritos que le atribuyeron sus

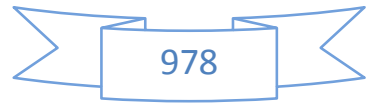


panegiristas"221; o bien a "las "Constituciones" que, según los hagiógrafos, elaboró para La Aguilera y el Abrojo, aunque fuera fray Pedro de Villacreces quien las preparó" $^{222}$. Pero, aún porta un tercer atributo: el sombrero de ala ancha, que le tiene colgado del cuello y caído sobre la espalda, que también alude a su condición de caminante.

El rostro nos presenta los rasgos típicos con los que se suele representar al Regalado, y asimismo las características propias del segundo estilo de Pedro de Ávila que hace que sus obras sean inconfundibles. Figura representado con una amplia tonsura que "se convierte prácticamente en una calvicie, lo que le proporcionaba un aspecto de edad avanzada"223, y un rostro blando, enjuto, lleno de arrugas en el cual se "reflejan los sacrificios de una vida de penitencia y privaciones, trasladando la idea de "extrema delgadez" a la que llegó antes de morir, buscando impresionar el ánimo de los fieles"224. Está trazado tan mórbidamente que acusa a la perfección las calidades de la piel, y sobre todo las arrugas del cuello, laterales de la boca y de la frente; esta última adopta la forma de doble onda superpuesta que hemos visto en otros santos. Nariz de tabique ancho, boca entreabierta, cejas rectas, ojos de tapilla, etc... La policromía es excelente, rosado para las mejillas y negruzco para simular una incipiente barba.

Los dos ángeles que sujetan al santo forman unos arriesgados escorzos, cada uno girando el torso hacia un lado, de tal manera que ambos nos miran de frente. Visten unas largas túnicas floreadas que les cubren todo el cuerpo, dejando tan solo al descubierto los pies, que van calzados con sandalias similares a las del santo. Por encima una sobretúnica, similar a la

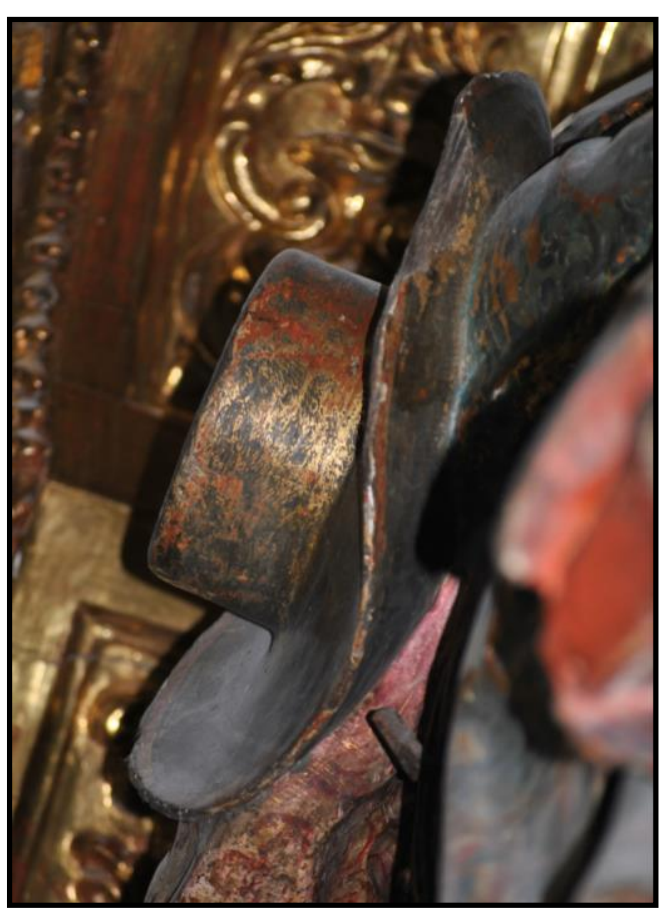

Il. 36- Pedro de Ávila (atrib.). Detalle del sombrero de San Pedro Regalado. que hemos visto en otros ángeles como los de la Guarda de las iglesias de Santiago Apóstol y San Martín, ambos atribuidos a Juan de Ávila. Esta sobretúnica, que va anudada a la cintura por un cíngulo, se abre a la altura de la propia cintura, llegando a doblarse con tal delicadeza y formando unas telas tan finas que parece como si el viento descorriera una cortina. Les diferencia la policromía puesto que la del ángel de la izquierda del santo es rosada y la de la derecha verde; eso sí, ambas llevan la misma decoración vegetal en tonos más oscuros que los referidos y también dorados. Las alas

\footnotetext{
221 REDONDO CANTERA, María José y ZAPARAÍN YÁÑEZ, María José: op. cit., p. 79.

222 ZAPARAÍN YÁÑEZ, María José: “Capítulo IV. Lo real maravilloso San Pedro Regalado y los testimonios artísticos", op. cit., p. 110.

223 ANDRÉS ORDAX, Salvador: Iconografía de San Pedro Regalado, op. cit., p. 79.

224 ZAPARAÍN YÁÑEZ, María José: “Capítulo IV. Lo real maravilloso San Pedro Regalado y los testimonios artísticos", op. cit., p. 109.
} 
de ambos ángeles, que se encuentran completamente extendidas y perfectamente policromadas en múltiples colores, son postizas puesto que están talladas aparte y sujetas a sus respectivos cuerpos por argollas. Los rostros de ambos ángeles son idénticos, y además presentan las respectivas características del segundo estilo de Ávila ya presentes en el propio Regalado. Hay que apuntar el hecho de que estos dos rostros emparentan de una manera muy cercana con los que nos tendrá acostumbrados Antonio de Gautúa, que como ya dijimos pudo ser compañero de taller de Pedro de Ávila en el taller del padre de este último. Las cabelleras rizadas con amplios bucles parecen anticiparnos las de sus esculturas de San Miguel o el San Juan Evangelista de la catedral.

Por último, el ángel de la parte inferior, que sirve para sujetar los pies del santo, está desnudo, mostrándonos en su plenitud su rolliza anatomía. Dado su rostro podría tratarse de una obra de taller.

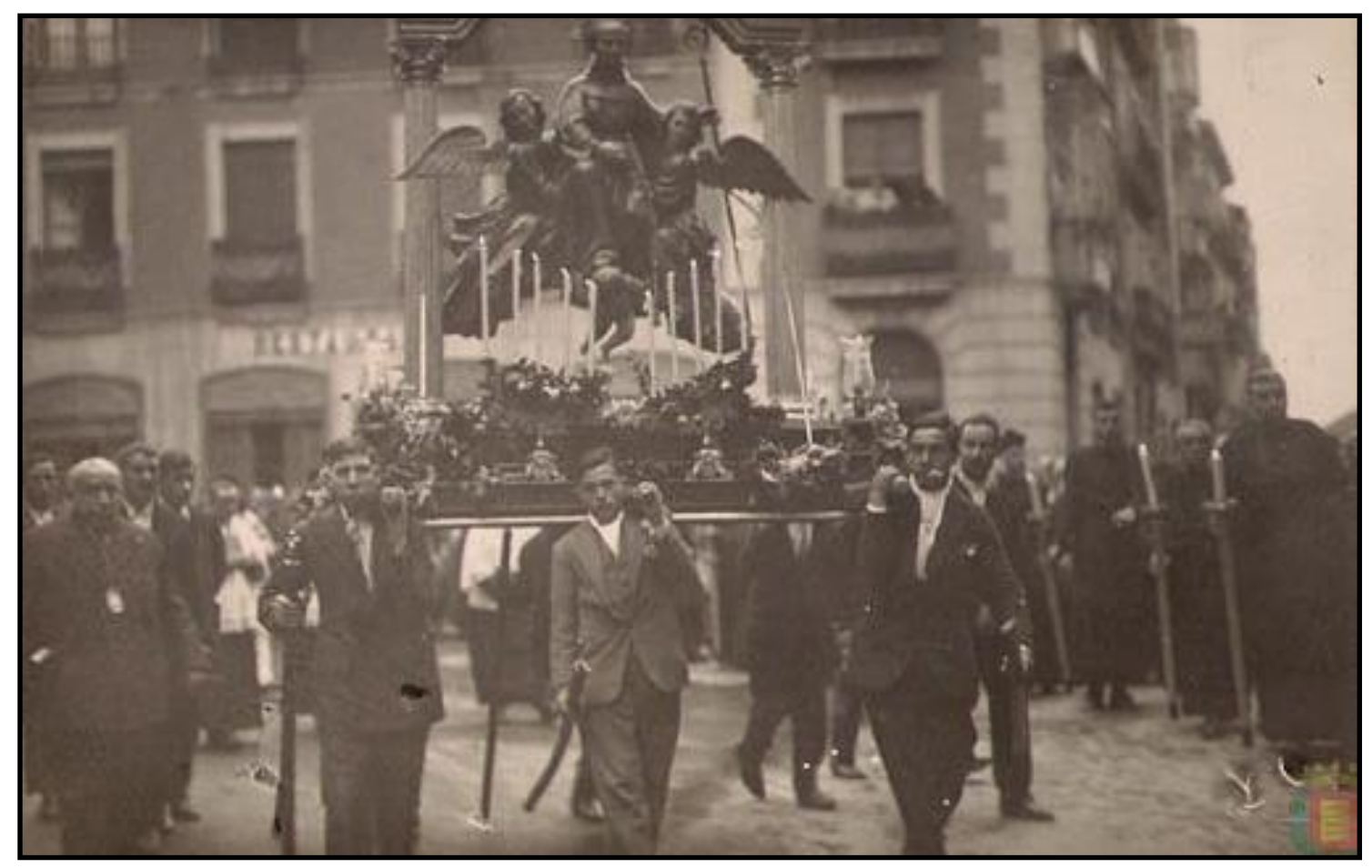

Il. 37- Procesión de San Pedro Regalado. Se ignora el año en que fue tomada la fotografía, será entre 1928 y 1930. (C) Archivo Municipal de Valladolid.

La escultura tuvo en el pasado una función procesional que en el día de hoy se ha perdido. Una de esas salidas extraordinarias fue la que aconteció el 2 de junio de 1808, en plena Guerra de la Independencia, con motivo de la proclamación de Fernando VII como rey de España. Francisco Gallardo nos narra este acontecimiento: "Conmoción en el pueblo. En el dos de junio [de 1808], sospechando el pueblo que no daban por el General y Ayuntamiento providenciales eficaces para la conducción de armas y municiones, se volvió a conmover; las salas del crimen franquearon las que tenían los reos, y el público pidió se proclamase a Fernando $7^{\circ}$ por rey de España y sus Indias, el Ayuntamiento convino en ello y así se ejecutó por su alférez mayor señor marqués de Revilla. A este tiempo se advirtió una nube en la plaza que formaba en rasgos con unos

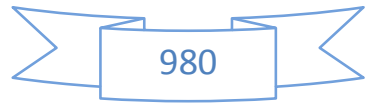


ramos de palma y después un circo u óvalo que en el medio contenía al sol; se desvaneció como a los treinta minutos, quedando algunas ráfagas; sacaron de la iglesia a Nuestra Señora del Pilar, y del Salvador a San Pedro Regalado, a quienes colocaron en el Consistorio y pusieron muchas luces"225. Las últimas veces que el santo salió en procesión fue en el periodo comprendido entre los años 1928-1930. La procesión fue recuperada, al igual que las de la Semana Santa, "a iniciativa del arzobispo Gandásegui". Señala Calvo Caballero que en 1928 "los cofrades quisieron que saliera la imagen del retablo de la Capilla, aunque pesase, por ser la conocida por los vallisoletanos. Alguna vez antes los devotos la sacaron fuera de El Salvador y fue la que más Novenarios presidió. Ésta sería su última salida, la última también que se bajó de su retablo al Santo" 226.

\section{LAS LÁGRIMAS DE SAN PEDRO (h. 1709-1711)}

Otra escultura conservada en la iglesia del Salvador que puede ser relacionada de manera inequívoca con nuestro escultor es la conocida como Las lágrimas de San Pedro (156 cms.) (Figs. 64-65); además esta imagen, al igual que la Virgen del Refugio, fue sufragada por el generoso párroco Pedro de Rábago. También en este caso, Rábago nos deja patente su patrocinio en su testamento, dictado el 19 de julio de 1720. Efectivamente, el religioso relata que el derrumbe de la torre de la iglesia provocó la ruina, entre otras cosas, de la "capilla y hechura de Nuestra Señora del Descendimiento de la cruz retablo y altar que es propio del mayorazgo que goza el Señor Conde de Alba Real", por lo que decidió costear "la efigie de San Pedro apóstol mi padre y puse el retablo que al presente tiene y el lienzo de Nuestra Señora del Descendimiento de la Cruz que está encima de dicho San Pedro todo lo cual por ser adorno para dicha Iglesia hice de mi voluntad y devoción y lo mando a dicho señor Conde y a sus sucesores perpetuamente con calidad y condición de que no lo puedan sacar ni quitar de dicho sitio con ningún pretexto" (DOCUMENTO 88). También Canesi alude a esa faceta de Rábago como patrocinador de obras de arte para su parroquia: "debiéndose el mayor cuidado al fervoroso celo de D. Pedro de Rábago su cura párroco, que también hizo blanquear y embaldosar toda la iglesia y fabricó la capilla de San Francisco de Paula y otros altares en la forma que hoy están, y dio otras efigies que adornan el templo y muchos ornamentos de que había necesidad que para todo da el beneficio curado porque es de los más pingües de esta ciudad"227.

Nuevamente fueron Martín González y Urrea los primeros en creerla obra de nuestro escultor. Afirmaban en el respectivo tomo del Catálogo Monumental que era "pieza asignable a Pedro de Ávila". Además señalaban que como la capilla en la que se encuentra es muy poco profunda, "podemos colegir su actitud: San Pedro contemplaría la escena de la Transfiguración, en el retablo mayor. Esto significa una concepción

\footnotetext{
225 GALLARDO Y MERINO, Francisco: Noticia..., op. cit., pp. 7-8.

226 CALVO CABALLERO, Pilar: op. cit., p. 512.

227 CANESI ACEVEDO, Manuel: Historia de Valladolid (1750), Tomo II, op. cit., p. 176.
} 
barroca de la composición, ya que enlaza puntos distantes en el espacio del templo"228. Hay que remarcar el error de apreciación cometido por Delfín Val y Cantalapiedra, los cuales creyeron que la escultura "fue tallada al parecer a fines del siglo XVI"229. Los mismos recogieron otra creencia: la de que "por hallarse en actitud sedente" pudiera haber pertenecido "a una Sagrada Cena desaparecida, pero el dato no ofrece ninguna garantía ya que no se ha documentado ninguna otra figura que pudiera pertenecer a un cenáculo"230. Efectivamente, es una suposición ilógica. En Valladolid tan solo han existido, que sepamos, dos Sagradas Cenas: una de papelón que acertó a ver Pinheiro da Veiga en el año 1605 en la procesión que salía del Monasterio de San Francisco: "El primer paso era la Cena, perfectísimo en todo"231; y la realizada entre 1942-1958 por el magnífico escultor vasco Juan Guraya Urrutia ${ }^{232}$.

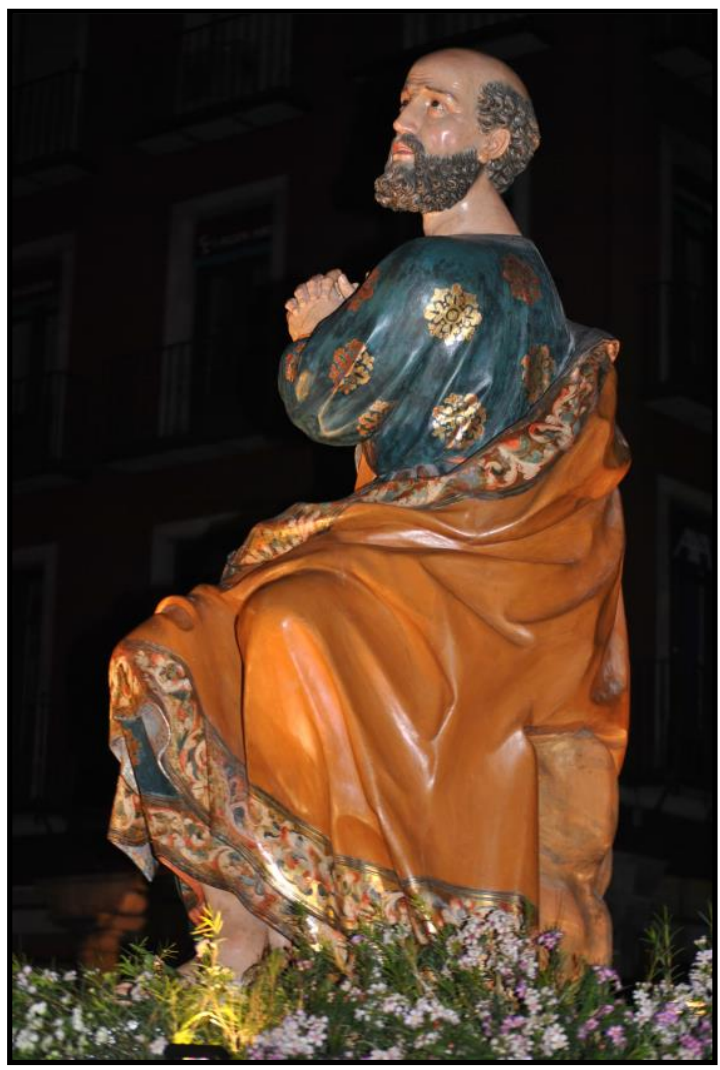

Il. 38- Pedro de Ávila (atrib). Las lágrimas de San Pedro. Iglesia del Salvador. Valladolid.
Es complicado otorgar a este San Pedro una cronología aproximada puesto que no tenemos ningún hito o documento accesorio que nos ayude. Tan solo contamos con el dato de que estaba realizada antes de 1720 , año en que ya hemos visto que Pedro de Rábago la reflejaba en su testamento. Partimos de la premisa de que pertenece a su segunda etapa; pero, sin embargo, la utilización del pliegue nos mueve a pensar que sería de los inicios de este momento; es decir, hacia 1706-1713. Pero, además, teniendo en cuenta que Rábago encargó la escultura y su retablo para ocupar una capilla que a la fuerza tuvo que ser reconstruida, al igual que la aneja de San Pedro Regalado, a causa del derrumbe de ambas a consecuencia de la caída sobre ellas de la torre de la iglesia, parece lógico pensar que este San Pedro se tallaría por las mismas fechas que el grupo de la

228 La escena de la Transfiguración es el único resto escultórico superviviente del primitivo retablo mayor tallado por Pedro de la Cuadra hacia el año 1602. En ella podemos ver a Cristo ascendiendo a los cielos flanqueado por los profetas Moisés y Elías y en la parte baja San Pedro, Santiago y San Juan. Como vemos el San Pedro barroco admiraría la escena y se volvería a ver sí mismo. MARTÍN GONZÁLEZ, Juan José y URREA FERNÁNDEZ, Jesús: Catálogo Monumental de la provincia de Valladolid. Tomo XIV..., op. cit., p. 33

229 DELFÍN VAL, José y CANTALAPIEDRA, Francisco: Semana Santa en Valladolid: Pasos Cofradías - Imagineros. Lex Nova, Valladolid, 1990, p. 49.

$230 \quad$ Ibídem.

231 VEIGA, Tomé Pinheiro da: Fastiginia: vida cotidiana en la corte de Valladolid, Ediciones Ámbito, Valladolid, 1989, pp. 45-46.

232 GARABITO GREGORIO, Godofredo: "Intrahistoria del paso de "La Sagrada Cena" de Juan Guraya: La cofradía, el escultor y las circunstancias", B.R.A.C., Tomo XLIII, 2008, pp. 65-80. 
Traslación de San Pedro Regalado o, quizás, un poco después; por lo que estaríamos barajando a grosso modo los años 1709-1711.

La escena efigiada en este San Pedro, su arrepentimiento, también conocido como "Las lágrimas de San Pedro", viene a representar el momento en el que el santo recuerda que se ha cumplido la predicción que le hizo Jesús de que antes de que cantara el gallo le negaría tres veces. Efectivamente, así sucedió según lo recuerda Réau: "En el atrio de la casa de Caifás, donde intentaba pasar inadvertido, una sierva lo reconoció, se acercó y le dijo: "Tú también estabas con Jesús de Galilea”. Él lo negó ante todos, con juramento, diciendo: "No conozco a este hombre". Poco después cantó el gallo. Entonces Pedro recordó lo que le predijera Jesús, salió de allí y lloró amargamente. La escena se repite dos veces más. Después de haber sido desenmascarado por la sierva, Pedro habría sido reconocido por su acento galileo por otro siervo (o sierva) y finalmente por un pariente de Malco a quien cortara la oreja. Por lo tanto, hubo tres negaciones de San Pedro, así como hubo tres tentaciones de Cristo" ${ }^{233}$. Sin embargo, cree el historiador del arte e iconógrafo francés que se trata de un relato bastante inverosímil puesto que "cuesta creer que Pedro, después de haber sido reconocido, cometiera la imprudencia de quedarse en el atrio en vez de marcharse"234.

El origen plástico de este tema se encuentra en los bajorrelieves de los sarcófagos paleocristianos, debido a que "la defección del Príncipe de los apóstoles era una excusa para la "caro peccatrix" del difunto". Sin embargo, poco después "este episodio fue desterrado del arte católico por el papado tanto como era posible"235. Recobró nuevos bríos en el Renacimiento y sobre todo durante el Barroco. Según Réau "el tema se volvió particularmente popular en la época de la Contrarreforma, como imagen del Sacramento de la Penitencia"236. En estos momentos se le representó solitario en medio de la noche, llorando sentado junto a la columna de la flagelación, y cerca también un gallo, el

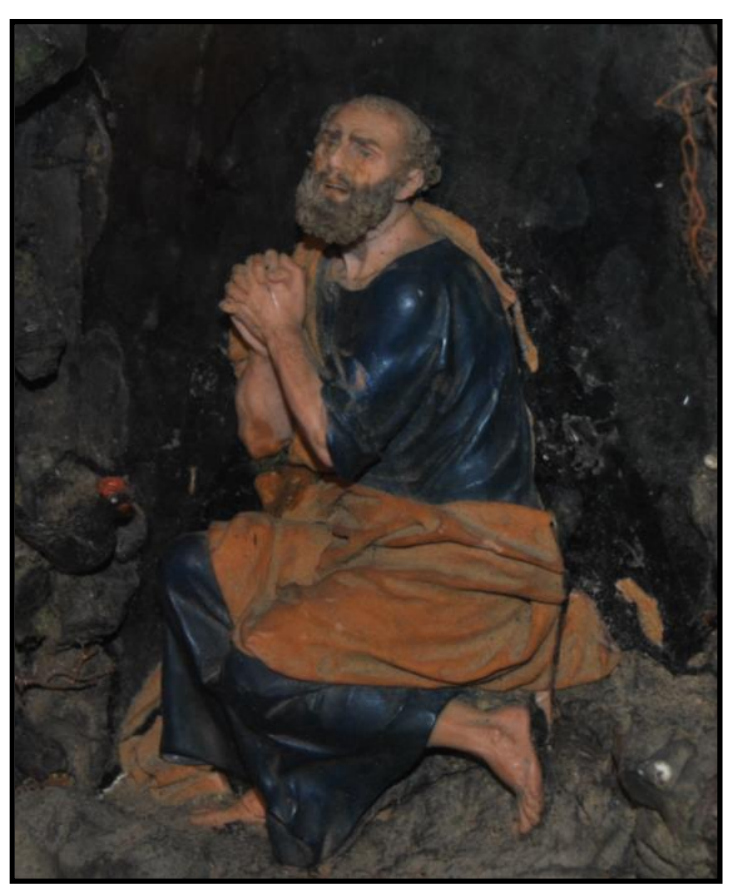

Il. 39- Anónimo Las lágrimas de San Pedro. Monasterio de las Huelgas Reales. Valladolid. cual en ocasiones puede estar en la parte alta de la columna, o a los pies del santo. Gran cantidad de pintores de primera fila han tratado esta temática: El Greco, Maíno, Velázquez, Tristán, etc... En Valladolid también hay numerosos lienzos si bien se deben a pinceles menos inspirados. Es muy destacable una pequeña representación escultórica $(20$ x 16 cms.), harto similar a la que

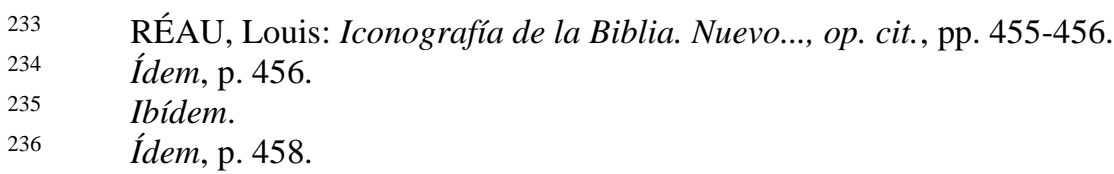


ahora nos ocupa de Pedro de Ávila, realizada en cera. Se conserva debajo del altorrelieve del Nacimiento de Jesús de Gregorio Fernández conservado en la capilla del Nacimiento del Monasterio de las Huelgas Reales de Valladolid. Lo más lógico sería pensar que Ávila manejara los mismos repertorios de grabados que los pintores, algunos de los cuáles serán los autores de las diversas Lágrimas de San Pedro que se hayan por algunas iglesias y clausuras vallisoletanas; pero, me gustaría apuntar al posible lienzo que pudo "inspirar" a nuestro escultor. Se trata del conservado en el ático del retablo del Ecce Homo de la capilla de las Angustias de la iglesia penitencial de Nuestra Señora de las Angustias. Como podemos comprobar tanto la manera de disponer el rostro como la de colocar las manos es completamente idéntica. Pero, lo que podría tratarse de una casualidad no lo es tanto puesto que la escultura que preside este retablo, realizado por Gregorio Díez de Mata en 1710, es un Ecce Homo que se atribuye con total acierto a Pedro de Ávila. Es decir, nuestro escultor conoció este lienzo de primera mano y, además, justamente por las fechas en que Pedro de Rábago debió de encargarle la ejecución del San Pedro.

Pedro de Ávila nos presenta al primer papa sentado sobre una roca, mirando al cielo

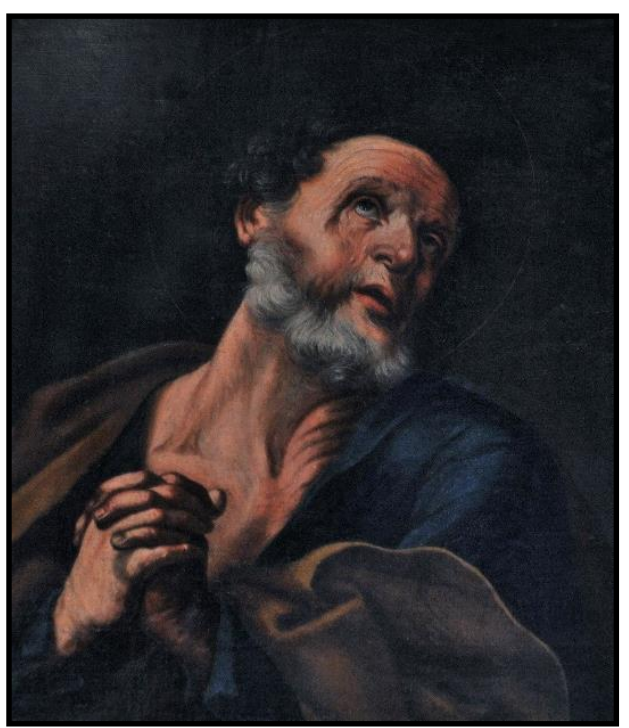
mientras implora el perdón tras las negaciones realizadas. San Pedro, que es figura de tamaño natural (156 cms.), se haya inserto en un sencillo retablo que no posee banco y se halla perfectamente encajado en la pequeña capilla hornacina. Se estructura a partir de dos pares de pilastras a los lados y el ático cerrado en semicírculo, el cual lleva en el centro una interesante pintura de la Piedad, que alude a la advocación de la capilla: "Nuestra Señora del Descendimiento", y a los lados sendos escudos idénticos (quizás los del Conde de Alba Real) ${ }^{237}$. La capilla, que es la más próxima al altar mayor Il. 40- Anónimo Las lágrimas de San Pedro. por el lado del Evangelio, también era conocida Iglesia penitencial de Nuestra Señora de las Angustias. Valladolid como la de "San Pedro ad Vincula" por motivos evidentes.

Como hemos dicho, San Pedro aparece sentado sobre una roca, con la espalda recta sin que se la sostenga ningún elemento. La imagen combina una disposición tendente a lo helicoidal con sendos escorzos tanto en piernas como en el torso puesto que las piernas las mantiene rectas, el torso lo gira hacia la derecha y la cabeza hacia la izquierda. Las piernas las cruza a la altura de los tobillos, posición harto teatral, al igual que lo son el desplazamiento de los brazos hacia la derecha con las manos unidas y entrelazadas implorando perdón, y la cabeza mirando al cielo mirando hacia el cielo mientras llora.

237 El condado de Alba Real fue concedido por Carlos II a Don Diego de Rivera y Vera el 2 de octubre de 1698. GONZÁLEZ DORIA, Fernando: Diccionario heráldico y nobiliario, Tomo I, Trigo ediciones, Madrid, 2000, p. 87. 
La referida helicoidal se ve subrayada por la posición del manto, pero también observamos una diagonal que parte de sus pies y culmina en el infinito proyectada a través de su cabeza. Tanto por el tipo de manto como de rostro emparenta cercanamente con los otros dos San Pedro que tenemos documentados de nuestro escultor (los de San Felipe Neri y la catedral). Sin embargo, los pliegues no son tan profundos y rectos como aquéllos, lo que nos mueve a pensar que se trata de una obra anterior. Viste una túnica verde larga, anudada a la cintura por un cíngulo, hasta el suelo, aunque al estar sentado nos deja verle los pies descalzos y parte de la pierna, el verde oscuro de la túnica contrasta con los motivos dorados estrellados de los que se ve surcada, y de la cenefa de motivos vegetales que surcan el borde inferior que viene a ser como las que veíamos en gran parte de las esculturas relacionadas con su padre. Por encima tiene echado un manto marrón, con similar cenefa, que le cubre las piernas, buena parte de la espalda y le cae por el hombro derecho, siendo interesante la curva que realiza al lado izquierdo de su cintura. El hecho de que las policromías sean planas, aunque todavía aparezcan algunos motivos decorativos como son las estrellas doradas de la túnica parece volver a incidir en que esta talla es levemente anterior a la de la

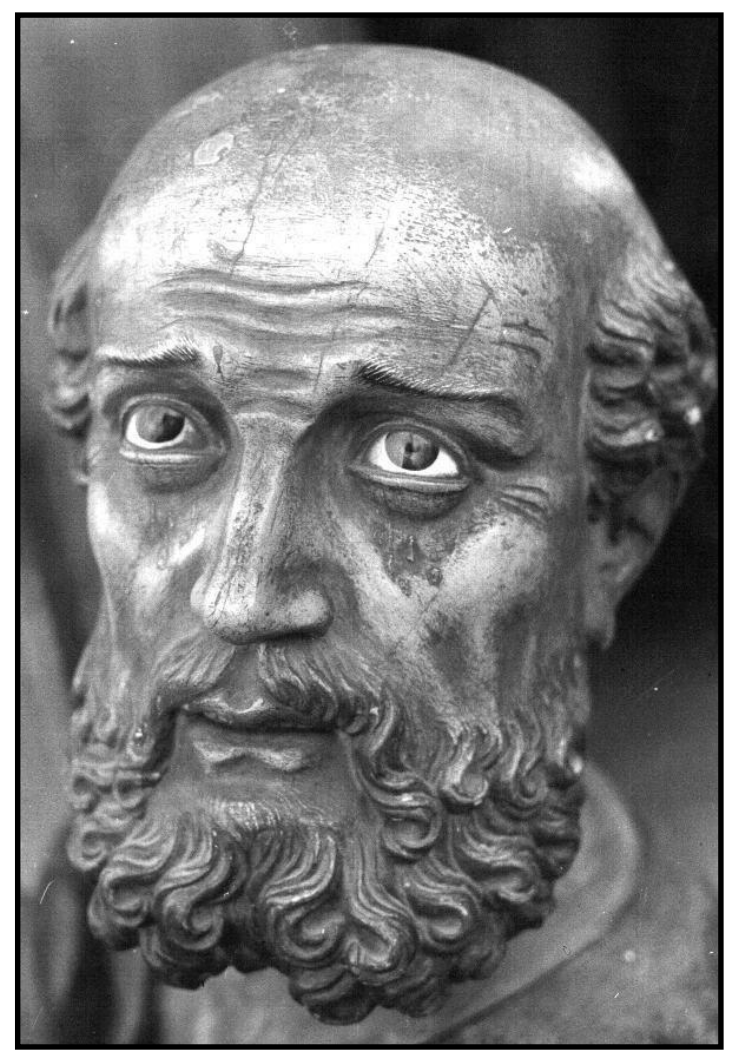

Il. 41- Pedro de Ávila (atrib.). Detalle de Las lágrimas de San Pedro. (๑) Archivo Municipal de Valladolid. catedral (1714).

Los pliegues son a cuchillo, pero producen concavidades bastante amplias, lo que nos mueve a pensar en un estadio bastante temprano puesto que con posterioridad se irán haciendo más pequeñas y se multiplicarán en cantidad. Además, no son tan cortantes como las que se verán en años posteriores, sino que todavía podemos ver formas redondeadas, suaves. Llama la atención que, a pesar de tratarse de una escultura supuestamente concebida para estar en un retablo, y por lo tanto no poder observarse su parte trasera, no solamente vaya policromada la espalda y la túnica sino que Ávila haya tallado perfectamente la roca y la túnica, e incluso ha colocado una suave y bella doblez en la parte superior. De no saber que era una imagen de retablo, estaríamos convencidos de que se realizó con fines procesionales por el perfecto acabado.

Ávila se ha esmerado mucho en representar la escasa anatomía visible puesto que en las manos podemos observar que están talladas a la perfección las venas, articulaciones, uñas y hasta los pliegues de ciertas arrugas. También es destacable el intento de individualización de cada uno de los dedos entrelazados, algo que en la mayoría de las 
ocasiones los escultores suelen realizar grosso modo. La cabeza del santo resulta ser un calco tanto en los rasgos faciales como en la barba y cabellera de las de las otras dos esculturas de San Pedro que le tenemos documentada (las de la Catedral y el Oratorio de San Felipe Neri). Si acaso, las únicas diferencias radican en la barba, puesto que en esta ocasión los mechones no son tan pequeños y redondeados, sino que parecen estirarse y adoptar una forma cercana a un gancho; el resto parece una reproducción lateral de las esculturas referidas. El rostro está tallado mórbidamente, acusando bien las calidades de la piel. La blandura del rostro la comprobamos en las arrugas de la frente, laterales del rostro, ceño y mejillas, todas las cuales dan buena prueba de la avanzada edad del santo y de la destreza de nuestro escultor para simularlas con tanta verosimilitud.

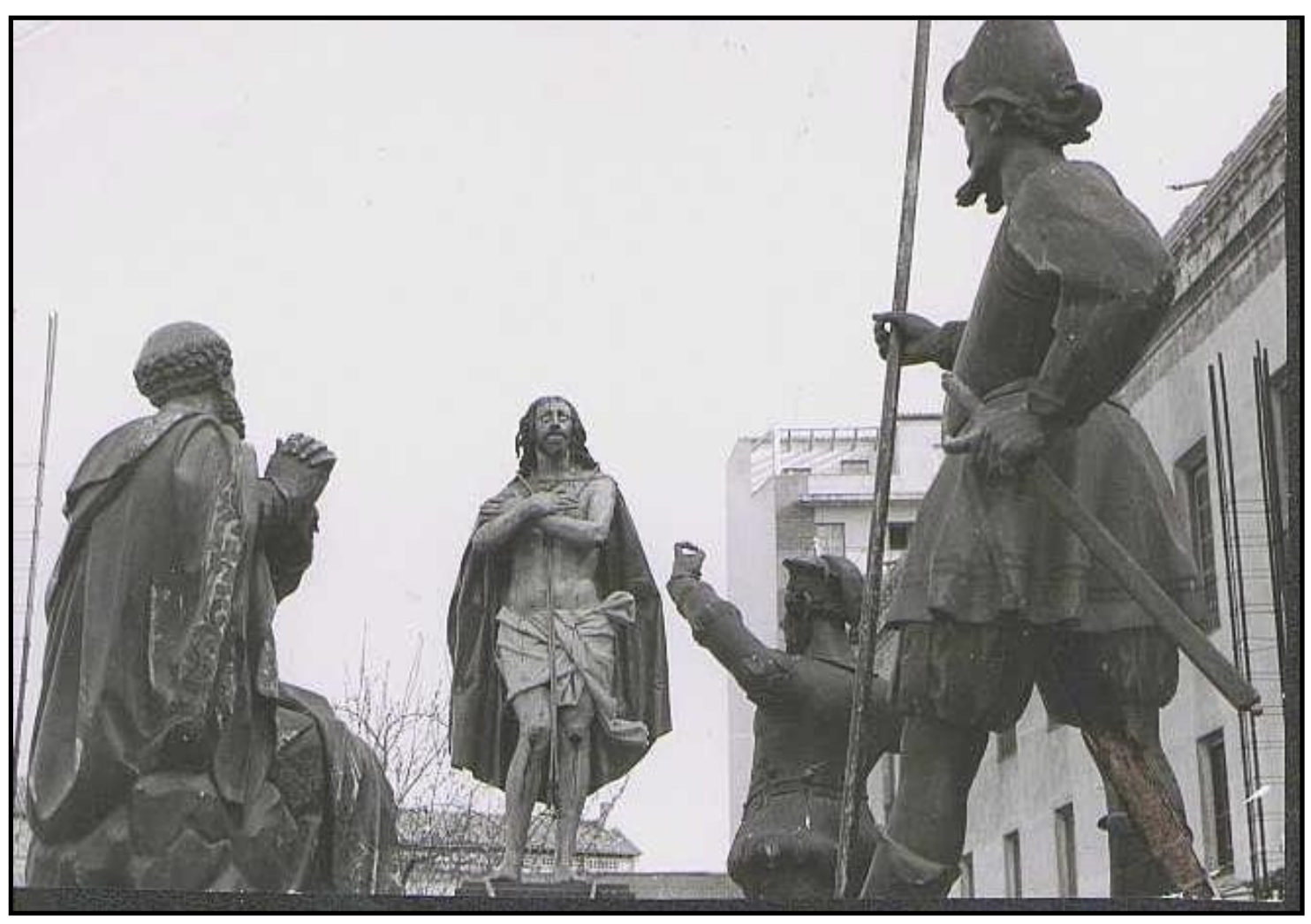

Il. 42- Las lágrimas de San Pedro cuando procesionó por primera vez en la Semana Santa de Valladolid. () Archivo Municipal de Valladolid.

La escultura de San Pedro se incorporó en el año 1965, de la mano de la Cofradía de Nuestro Padre Jesús Resucitado, a las procesiones de la Semana Santa de Valladolid, concretamente a la General de la Sagrada Pasión del Redentor celebrada en la tarde del Viernes Santo $^{238}$. Fue en aquel momento en el cual la imagen adoptó la advocación de "Las Lágrimas de San Pedro". A lo largo de este medio siglo de desfiles, San Pedro ha procesionado la mayor parte de las veces en solitario, si bien ha habido algunas excepciones: el año de su "debut" salió acompañado de un Ecce Homo y dos soldados que pertenecieron al paso de La Coronación de Espinas que Gregorio Fernández talló hacia 1624-1630 para la Cofradía Penitencial de la Santa Vera Cruz. Se trataba del sayón arrodillado y el de la lanza, ambos bastante vulgares y que seguramente ejecutaron en su mayor parte alguno de los múltiples aprendices que tenía el maestro

238 DELFÍN VAL, José y CANTALAPIEDRA, Francisco: op. cit., p. 49.

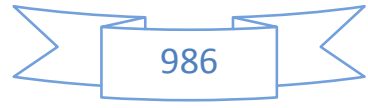


gallego en su taller. Por su parte, el Ecce Homo, que al parecer pertenece al Museo Nacional de Escultura, aunque en la actualidad se expone en el Museo Diocesano y Catedralicio, proceda de la iglesia de San Juan de Letrán. Durante mucho tiempo estuvo atribuido a Francisco Alonso de los Ríos por su parecido con el que actualmente desfila en el paso del Despojo (debido a que el Cristo original de Juan de Ávila pereció en un incendio en 1799), y que procede del Convento de Agustinos Recoletos ${ }^{239}$, pero desde hace unos años se ha modificado su atribución en favor de Alonso de Rozas. En 1966 se suprimieron los dos sayones, de tal manera que tal solo salieron juntas las imágenes de San Pedro y el Ecce Homo ${ }^{240}$. Ya en 1967 se sustituyó ese Ecce Homo por otro Cristo "propiedad del Museo Nacional de Escultura, obra de un autor anónimo del siglo XVII e inexacto en la interpretación del pasaje sagrado, pues Jesús no había sido flagelado aun cuando el galló cantó por tercera vez y Pedro lloró arrepentido" ${ }^{241}$. Desconocemos tanto al autor como la procedencia de este curioso Cristo atado a la columna que no aparece según el modelo tradicional de Gregorio Fernández, sino que se encuentra arrodillado. Todo parece indicar que llegaría al Museo Nacional de Escultura procedente de algún cenobio desamortizado.

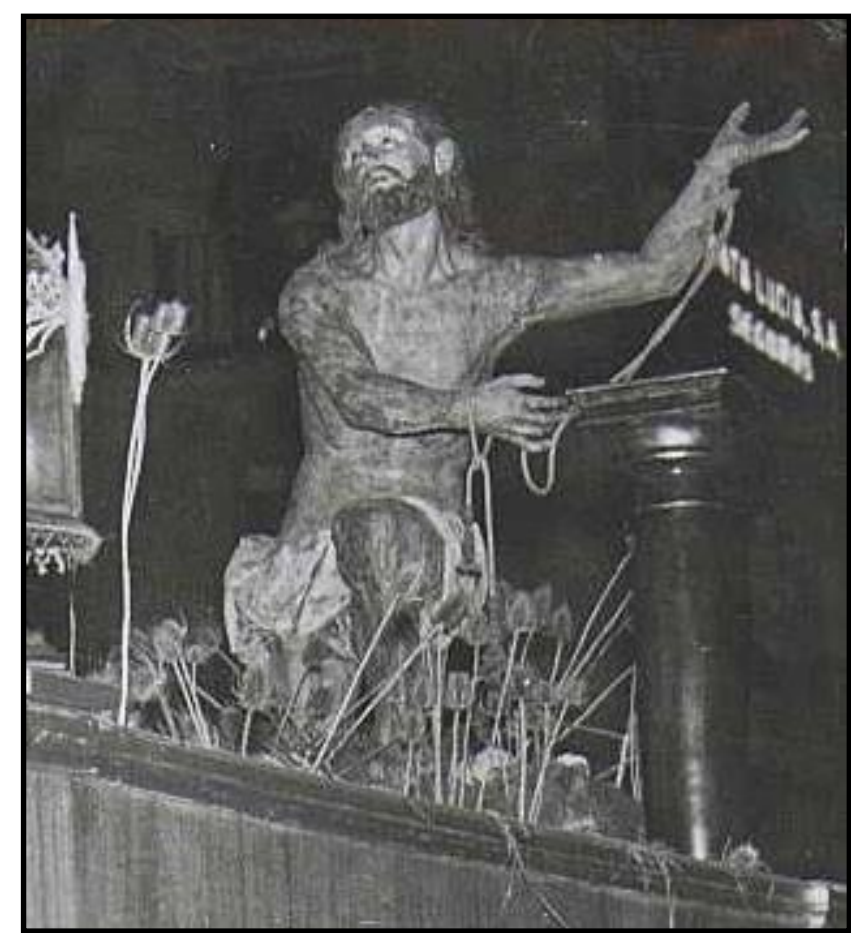

Il. 43- Cristo que acompañó a Las lágrimas de San Pedro durante la Semana Santa del año 1967. (C) Archivo Municipal de Valladolid. 


\section{VALLADOLID. IGLESIA PENITENCIAL DE NUESTRA SEÑORA DE LAS ANGUSTIAS}

\section{CRISTO ATADO A LA COLUMNA Y ECCE HOMO (h. 1710)}

La devoción que profesaban los vallisoletanos a la Virgen de las Angustias llevó a la Cofradía Penitencial de Nuestra Señora de las Angustias a tener que construir una capilla de mayores dimensiones en las que la sagrada imagen pudiera ser venerada por mayor número de personas. Fue por ello por lo que, a finales del siglo XVII, la cofradía comienza a hacer gestiones para construir una gran capilla. Así, lo primero que hizo la Cofradía fue acordar, en sesión de 21 de abril de 1699, la adquisición al Cabildo catedralicio de cinco casas colindantes a la iglesia para poder edificar ex novo la capilla de la Virgen. En el espacio conseguido no solamente se pudo levantar esa capilla sino que hubo terreno suficiente para construir la sacristía y la casa del capellán ${ }^{242}$. Por otro lado, como la construcción de la nueva capilla implicaba el derribo de la antigua, de la cual eran patronos los sucesores de los Aranzamendi, se hacía necesario la autorización de éstos, los cuales se comprometieron a darla a cambio de seguir siendo patronos de esta nueva capilla, eso sí sin ayudar económicamente a su construcción ${ }^{243}$. El acuerdo entre ambas partes se firmó el 20 de abril de 1703 en la notaría del escribano Lorenzo de Aguirre.

No obstante, antes de llegar a este acuerdo las obras ya habían comenzado, concretamente el 11 de junio del año 1700, tardando en realizarse casi una década. La causa de tal demora seguramente se deba a la falta de liquidez en las arcas de la cofradía. El resultado final fue una capilla dispuesta de manera perpendicular al eje de la iglesia en el colateral de la Epístola. Se abre a la nave mayor por medio de un gran arco. La capilla la conforman dos espacios centralizados: el primero de ellos con forma de octógono alargado, y que recibe luz a través de una linterna rematada en su exterior por una aguja revestida de pizarra, que sería el lugar reservado a los fieles que se acercaban a orar a la Virgen de las Angustias; mientras que el segundo de ellos adopta también otra forma octogonal, si bien está reservado por completo a la Virgen, la cual se encuentra en su tabernáculo y rodeada por siete lienzos colgados en la pared, de tal manera que este espacio se convierte en un camarín de tipo deambulatorio ${ }^{244}$. Estas pinturas, que efigian los Siete Dolores de la Virgen, son obra del pintor vallisoletano Manuel Peti Bander ${ }^{245}$.

A la vez que se iba finalizando la parte arquitectónica se emprendería la tarea de amueblar y decorar la capilla. Para ello se contó con numerosos artífices, entre los

\footnotetext{
242 ORDUÑA REBOLLO, Enrique: Cofradías y sociedad urbana: la ilustre Cofradía Penitencial de Nuestra Señora de las Angustias de Valladolid (1563-2002), Ciudad Argentina, Buenos Aires, 2003, p. 128.

243 Ibídem.

244 MARTÍN GONZÁLEZ, Juan José y URREA FERNÁNDEZ, Jesús: Catálogo Monumental de la provincia de Valladolid. Tomo XIV ..., op. cit., p. 233.

$245 \quad$ Ídem, p. 237.
} 
cuales destacan tres: los ensambladores Francisco Billota y Gregorio Díaz de Mata, y el dorador y estofador Santiago Montes. Billota tuvo a su cargo la tarea de labrar las puertas y ventanas de la capilla, pero su obra fundamental fue la de construir el tabernáculo en la que se entronizaría a la Virgen de las Angustias. Por desgracia desapareció a finales del siglo XVIII debido al cambio de gusto promulgado por la nueva fe neoclásica. Por su parte, Gregorio Díaz de Mata se encargó de construir los dos retablos ubicados en la primera estancia de la capilla y que sirven de marco a las esculturas del Ecce Homo y del Atado a la Columna que se atribuyen a nuestro escultor, pero también se ocupó de las otras dos hornacinas planas en las que se encuentran el San Juan y la Magdalena del Paso del Descendimiento tallado entre 1615-1617 por Gregorio Fernández; y, por último, los siete retablillos del camarín de la Virgen que enmarcan las pinturas de los Siete Dolores de la Virgen de Manuel Peti (la Circuncisión, la Huida a Egipto, Cristo entre los Doctores, el Camino del Calvario, la Crucifixión con la Virgen y San Juan, la Piedad y el Entierro de Cristo). Finalmente, en Santiago Montes recayó la labor del dorado y policromado de todos estos retablos y hornacinas, y seguramente también de otros elementos que decoran ambas capillas, como puede ser el arco de acceso al camarín ${ }^{246}$.

La decoración de la capilla se terminaría a finales del mes de agosto de 1710, fechas en las que se terminaban de abonar los emolumentos al dorador Montes ${ }^{247}$. Por entonces todo estaba ya preparado para la inauguración de la capilla. Ventura Pérez relata que en "este año de 1710 se colocó a María Santísima de los Cuchillos en su nueva capilla; estaba toda la ciudad muy adornada de altares y mucha alhaja de plata". También se refiere a que se rumoreaba por esos mismos días de la Guerra de Sucesión que "el señor archiduque estaba en España, se sonaba que venía a esta ciudad a causa de haber enviado a un tambor a pedir las llaves, y la ciudad haberle respondido que las llaves eran de Felipe V; sin embargo, que si las quería que viniese por ellas. Con este motivo la gente empezó a decir que venía el enemigo, y en una noche desnudaron toda la plaza que había en la calle y en su lugar lo adornaron de pasta. Y el archiduque no vino"248. Este relato lo complementa el realizado por Canesi, el cual explica que se celebraron en la ciudad festejos religiosos y profanos, y que entre los primeros destacó una procesión en la que participaron todas las cofradías de la ciudad. Este desfile, celebrado el 6 de septiembre de 1710, llevo a la Virgen desde la catedral hasta su iglesia penitencial puesto que antes había sido trasladada a la seo $^{249}$.

Antes de comentar las imágenes propiamente dichas hay que aludir a los retablos que presiden, los cuales se adaptan perfectamente a la forma cóncava del muro, siendo idénticos tanto en estructura como en decoración. Tienen un pequeño banco que se articula a través de netos y de las repisas de las columnas que articulan el cuerpo del retablo. Éste posee una hornacina central rematada en semicírculo y a los lados cuatro

\footnotetext{
$246 \quad$ Ídem, p. 237.

$247 \quad$ Ídem, p. 252.

248 PÉREZ, Ventura: op. cit., p. 30.

249 MARTÍN GONZÁLEZ, Juan José y URREA FERNÁNDEZ, Jesús: Catálogo Monumental de la provincia de Valladolid. Tomo XIV..., op. cit., p. 232.
} 
columnas salomónicas, dos a dos. Finalmente, el ático, que adopta forma semicircular, tiene en el centro un lienzo y a los lados dos tableros con decoraciones de rameados vegetales. La pintura del retablo del Evangelio (Ecce Homo) representa la Oración en el Huerto, mientras que el de la Epístola (Atado a la Columna) efigia las Lágrimas de San Pedro. Como observamos se trata de una iconografía plenamente pasionista. Ambos retablos se hallan embutidos en sendos arcos excavados en la pared, aunque el ensamblador ha concebido una especie de arco decorado con casetones que parece proteger al retablo. La decoración lo invade todo.

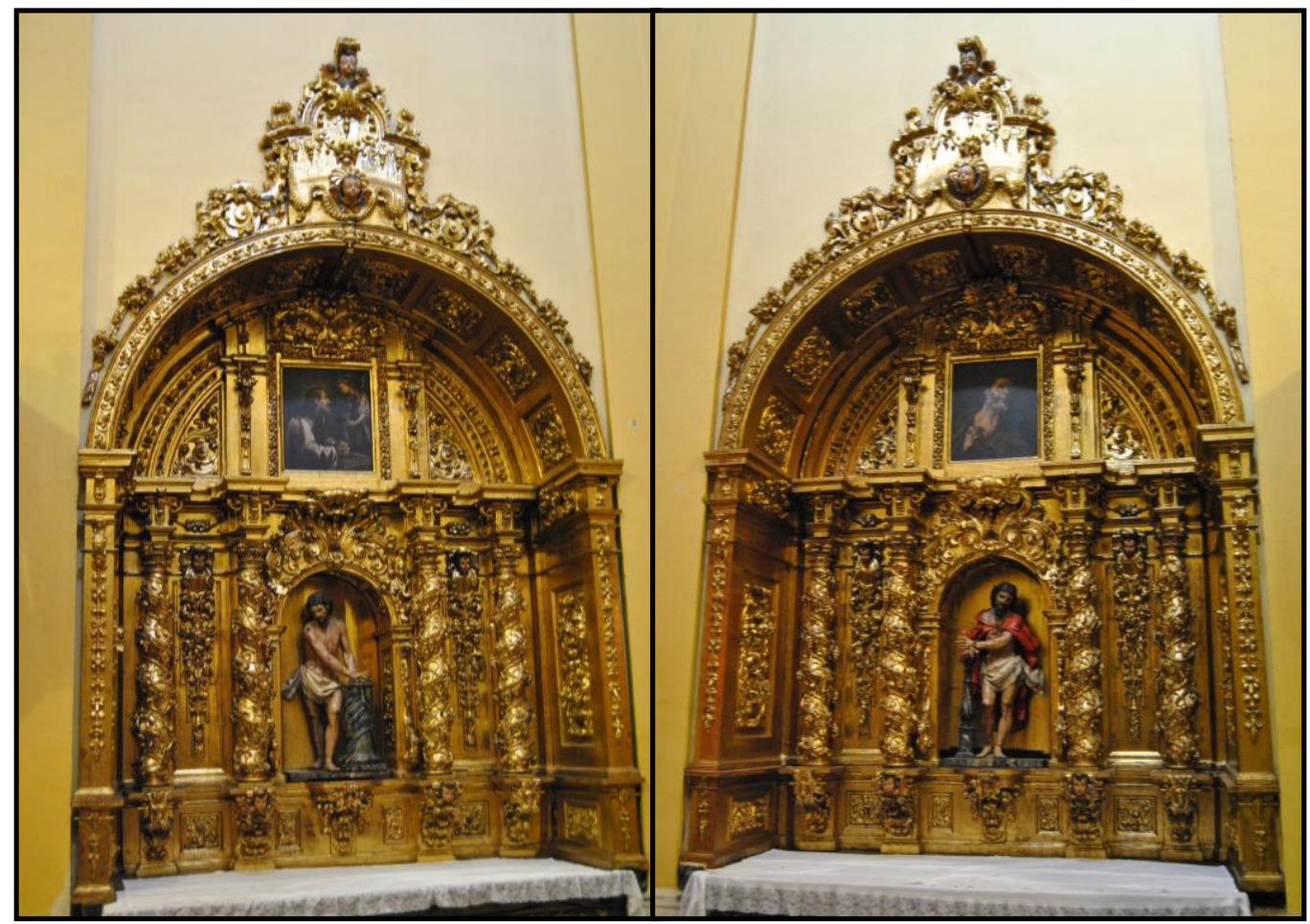

Il. 44- Gregorio Díaz de Mata. Retablos colaterales de la Capilla de la Virgen de las Angustias. Iglesia penitencial de Nuestra Señora de las Angustias. Valladolid.

El historiador neoclásico Isidoro Bosarte fue el primero en aludir a estas dos pequeñas esculturas que atribuimos con pleno convencimiento a Pedro de Ávila. El crítico señalaba en su Viage a España que en la capilla de la Virgen de los Cuchillos existía "un Señor a la columna, como de cinco cuartas de alto, cuya expresión es muy notable, y se atribuye a Gregorio Hernández no sin fundamento" 250 . Posteriormente, Matías Sangrador llegó a afirmar que "el Señor atado a la columna [es] obra de Gregorio Hernández"; misma atribución que realizara Casimiro González García-Valladolid: "a los costados del arco de entrada al camarín de la Virgen hay dos repisas con las estatuas, hermosísimas y de gran unción religiosa, de Santa María Magdalena y San Juan Apóstol y Evangelista, obras de Gregorio Hernández, así como las dos efigies de Jesús atado a la columna que ocupan los retablos laterales de esta capilla"251. En cambio, Agapito y Revilla no estaba de acuerdo con esas opiniones: "no creo, sin embargo, que esta talla sea del maestro. La considero una copia o imitación de los Cristos del mismo tema que

250 BOSARTE, Isidoro: Viage artístico a varios pueblos a España. 1, Viage a Segovia, Valladolid y Burgos, Imprenta Real, Madrid, 1804, p. 207.

251 GONZÁLEZ GARCÍA-VALLADOLID, Casimiro: Valladolid..., op. cit., Tomo I, p. 471.

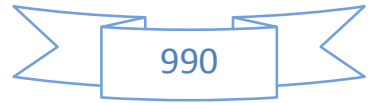


Fernández labró, del que formó tipo. Tiene, ciertamente, expresión parecida a los otros Cristos del artista en la Cruz y Pasión (éste ahora en el Museo), igual actitud y composición semejante a los mencionados; pero es más falto de proporciones, más grueso y el modelado de las carnes no tiene el jugo y suavidad de los desnudos más característicos de las obras de Gregorio. Es verdad que es buena escultura; más no puede pasar de una copia, como digo, ejecutada a la vista de otra y, quizá, por un oficial que hubiera trabajado a las órdenes del maestro" ${ }^{252}$.

Posteriormente, Gratiniano Nieto no aportó demasiada luz al tema puesto que simplemente se limitó a repetir lo dicho hasta el momento y también a datar el Cristo atado a la columna, de forma errónea, a "comienzos del XVIII"; mientras que el Ecce Homo lo conceptuaba como "obra posible de Gregorio Fernández"253. Por su parte, Martín González en su Guía histórico-artística de Valladolid (1972) se limitaba a aseverar que ambas piezas son "del tipo de la de Gregorio Fernández", sin llegar en ningún momento a atribuírselas a ningún escultor ${ }^{254}$.

Serían Martín González y Urrea los que darían una atribución certera que con el paso del tiempo no ha sido discutida. Efectivamente, ambos escribieron en el respectivo tomo del Catálogo Monumental de Valladolid que "pudieran ser obras tempranas de Pedro de Ávila"255. Dos años después esta atribución se vio reafirmada en el catálogo de la exposición "Pequeñas imágenes de la Pasión en Valladolid". En él Hernández Redondo atribuye a Pedro de Ávila la imagen de Cristo atado a la columna ${ }^{256}$, mientras que Luna Moreno hace lo propio con la del Ecce Homo ${ }^{257}$.

Finalmente, en cuanto a su cronología, parece claro que fueron encargadas a Ávila en 1710, año en que se contrataron todas las obras de amueblamiento de la capilla. Además, el estilo demostrado en ambas tallas, que nos retrotrae a comienzos de su segundo estilo, encaja a la perfección con aquella fecha. Que los únicos nombres que no figuran en el libro de cuentas de la penitencial sean los del escultor de estas dos imágenes y el del pintor de los dos lienzos de los áticos de estos dos retablos parece indicarnos que fue Gregorio Díaz de Mata, autor de ambas máquinas, el que subcontrataría ambas obras a sendos artífices. Este extremo ya fue apuntado por Martín González: "Sin embargo, como este maestro (Gregorio Díaz de Mata) es tallista, no sabemos puntualmente si las esculpió él o se encargó de ello algún otro maestro pagado a sus expensas" ${ }^{258}$.

252 AGAPITO Y REVILLA, Juan: La obra de los maestros de la escultura vallisoletana: papeletas razonadas para un catálogo. II, Fernández-adiciones y correcciones, Casa Santarén, Valladolid, 1929, pp. 90-91.

253 NIETO GALLO, Gratiniano: op. cit., p. 90.

254 MARTÍN GONZÁLEZ, Juan José: Guía histórico-artística..., op. cit., p. 39.

255 MARTÍN GONZÁLEZ, Juan José y URREA FERNÁNDEZ, Jesús: Catálogo Monumental de la provincia de Valladolid. Tomo XIV..., op. cit., p. 232

256 HERNÁNDEZ REDONDO, José Ignacio: "No 12 . Cristo atado a la columna". En VV.AA.: Pequeñas imágenes de la Pasión en Valladolid..., op. cit., p. 28.

257 LUNA MORENO, Luis: "No 34. Ecce Homo". En Ídem, p. 34.

258 MARTÍN GONZÁLEZ, Juan José: Escultura barroca castellana ..., op. cit., p. 241. 


\section{CRISTO ATADO A LA COLUMNA}

El pasaje de la Flagelación es narrado por los cuatro Evangelistas. Sin embargo, llama la atención el desarrollo que ha adquirido esta temática dados los pocos datos que se aportan en los evangelios, puesto que ni se dice que estuviera atado a la columna. Señala Réau que "la abundante iconografía de la Flagelación nació de esa mera palabra. No se puede citar otro ejemplo de una tan flagrante desproporción entre el laconismo de los textos y la prodigiosa riqueza de la imaginería que produjo"259. También comenta el historiador del arte francés que la Flagelación fue el castigo elegido por Pilato no para matarle sino para "salvarle la vida intentando apiadar a los judíos", puesto que le creía inocente ${ }^{260}$. Sin embargo esto no casa con lo relatado por Flavio Josefo y el filósofo Filón, los cuales señalaban que era el paso previo a la Crucifixión, puesto que se "desgarraba a los condenados a latigazos, antes de ejecutarlos: era un medio de arrancarles confesiones en una época que aún no había perfeccionado la técnica de las confesiones espontáneas"261. Según el Speculum Humanae Salvationis, los judíos pagaron a los soldados de Pilato para que Cristo recibiera más de los 40 azotes prescritos en la ley mosaica. Sin embargo, Santa Brígida en sus Revelaciones aumentó, como de costumbre, el suplicio sufrido por Cristo, aumentado el número de azotes a 4.475. La monja sueca llega a afirmar que las carnes se le desprendían con la sangre y las costillas "se dibujaban bajo la piel como una rejilla" ${ }^{262}$. Más cerca nos quedan las Meditaciones (1605) del jesuita Luis de la Puente, el cual describió la Flagelación de la manera siguiente: "Se puede considerar, que como algunos dicen, los soldados ataron fuertemente a Cristo Nuestro Señor a una columna, los brazos levantados en alto para poderle herir más a su placer, lo cual no sería pequeño tormento, porque le ataron por los pies, y por las muñecas con grande crueldad (...) Estando ya Cristo nuestro Señor desnudo en la columna, comenzaron los sayones a azotarle con extraordinaria crueldad. Los instrumentos del castigo, como algunos dicen, fueron tres diferentes que usaron diversos verdugos, hiriéndole unos después de otros, es a saber unas varas verdes, llenas de espinas, y unos ramales tejidos de nervios de bueyes, con sus abrojos de hierro al remate de ello, y unas cadenillas de hierro que herían y penetraban hasta los huesos. Con estos azotes comenzaron a descargar terribles golpes sobre las espaldas del Salvador, las cuales con la furia de los golpes, primero se encardenalaron, luego se desollaban del cuero delgado que tenían, después penetrando los azotes la misma carne, vertían arroyos de sangre que caían en el suelo, sin perdonar brazos ni hombros, y todo el pecho hasta descubrir los huesos" 263 .

Este pasaje ha sido uno de los más representados de toda la Pasión, si bien donde más éxito ha gozado ha sido en la escultura. Señala Hernández Redondo que esta iconografía

\footnotetext{
259 RÉAU, Louis: Iconografia de la Biblia. Nuevo..., op. cit., p. 470.

260 Ibídem.

261 Ibídem.

262 Ídem, p. 471.

263 BURRIEZA SÁNCHEZ, Javier: Varón de Dolores. Ayuntamiento de Valladolid, Valladolid, 2005 , p. 39.
} 
“cumplía con creces la finalidad de excitar la compasión del fiel al ofrecer un Cristo humillado, sangrante todo el cuerpo, especialmente la espalda, pero lleno de nobleza en su aceptación del sufrimiento. En la mayor parte de los ejemplares conservados se representa a Cristo en solitario atado aún a la columna tras el castigo, pero también es frecuente reflejar el momento del martirio, en ocasiones bajo la presencia de Pilatos" 264 .

Se tiene constancia de la existencia de dos reliquias de la columna totalmente diferentes: la conservada en la basílica de Santa Práxedes de Roma, la cual no se tuvo en consideración por los artistas durante varios siglos. Esta columna, que tiene forma de balaustre, fue llevada a la basílica romana en 1223 por el cardenal Giovanni Colonna desde el pretorio de Pilato. La otra era la conservada en la capilla de los franciscanos de la iglesia del Santo Sepulcro de Jerusalén (70 cms.), la cual había sido vista por San Jerónimo "todavía manchada de sangre, sosteniendo un pórtico". Ante la existencia de dos columnas diferentes, se buscó una explicación: "la que vio San Jerónimo sería la del pórtico del templo donde Jesús fue flagelado la noche de la Pasión. La segunda sería la columna baja del pretorio de Pilatos, en la que fue azotado por orden del procurador romano" 265 . Aunque la columna romana "no parecía ofrecer las mismas garantías de autenticidad que su rival de Jerusalén", después del Concilio de Trento "se le devolvieron los honores, y esta columna baja, cuya altura total es de sesenta centímetros, fue la que reprodujeron los pintores de la Contrarreforma en el siglo $X V I I^{\prime}$ y la que se popularizó en el mundo de la escultura ${ }^{266}$.

La evolución artística del tema se ha debido en gran parte al tipo de columna utilizada. Efectivamente, durante la Edad Media e inicios del Renacimiento se utilizó una columna muy fina y alargada que vendría a significar que Cristo fue azotado mientras se encontraba asido "a uno de los soportes de la estancia de Pilatos. Las manos pueden atarse al pilar o con independencia de éste, pero en cualquier caso la sujeción esencial se realiza a través de una cuerda con nudo corredizo, que rodea el cuello de la figura obligándola a abrazar el elemento sustentante"267. Durante el siglo XVI se produjo, según palabras de Hernández Redondo, una disputa "entre los partidarios de la corriente patética y los que, como consecuencia de la doctrina humanista, pretendían dotarle de un contenido clásico" 268 .

Fue a partir del Concilio de Trento cuando, deseando una representación más dramática, se prefirió utilizar "una columna baja y gruesa, hinchada como un balaustre o cilíndrica como un hito, que no ofrece apoyo ni protección alguna a la espalda de Cristo, de manera que los golpes llueven tanto sobre su espalda como sobre su

264 HERNÁNDEZ REDONDO, José Ignacio: “Cristo atado a la columna”. VV.AA.: Pequeñas imágenes de la Pasión en Valladolid..., op. cit., p. 19.

265 Ídem, p. 21.

266 RÉAU, Louis: Iconografía de la Biblia. Nuevo..., op. cit., p. 472.

267 HERNÁNDEZ REDONDO, José Ignacio: "Cristo atado a la columna". En VV.AA.: Pequeñas imágenes de la Pasión en Valladolid..., op. cit., p. 19.

268 Ibídem. 
pecho"269. Explica Hernández Redondo que esta última tipología debió conocerse ya en España por diversos grabados y sermones de la Pasión puesto que ya aparece reflejada en los Sermones cuadragesimales y de la Resurrección de Marín Peranza: "Atáronle a una columna no entera como son nuestras columnas, porque arrimado a ella excusara alguna parte del cuerpo al golpe, sino a una basa de columna que no se levantaba del suelo dos palmos, en ella estaba un anillo de hierro donde tuvieron presa la soga con que estaba por el cuello atado, quedando todo el cuerpo desnudo libre y desembarazado, para que los látigos y rebenques diesen vueltas al cuerpo. Esta columna en la forma dicha hemos visto y adorado en Roma"270.

El presente Cristo atado a la columna (108 cms.) (Fig. 66) sigue fielmente, aunque a menor escala, el realizado por Gregorio Fernández hacia el año 1619 para la Cofradía Penitencial de la Santa Vera Cruz. Como señala Martín González, este Cristo es "achaparrado y de formas abultadas, redondas, con paño anguloso, pero de aristas suavizadas"271. El grado de copia llega a tal punto que no se deja ningún detalle, ni siquiera el pliegue de la piel que se forma en la parte derecha del abdomen al acusar el contraposto realizado por estar tan baja la columna. Pero no solo eso, sino que Ávila intenta imitar hasta el tipo de plegados del paño de pureza, si bien adaptándolos al siglo XVIII. También es bastante similar el tipo de policromía, en el que las manchas sanguíneas no son muy profusas.

Cristo aparece de pie, con la pierna izquierda adelantada y la derecha atrasada, con lo cual consigue cierto equilibrio compositivo. Estira los brazos hacia la columna, teniendo sobre ella las manos atadas por una cuerda. Esta columna nada tiene que ver con la fernandesca de la Vera Cruz puesto que se trata de una troncocónica jaspeada imitando mármoles verdosos y negros. Cayendo del lado izquierdo de la columna se encuentran los eslabones de la cadena con la que debió tener las manos atadas en un principio. Gira la cabeza hacia el lado izquierdo, mirando al espectador con un rostro que mueve a la compasión. La anatomía es más magra que la del ejemplar de Fernández, pero también que la del Ecce Homo que supuestamente Ávila realizará años después para la capilla de San Pedro Regalado en la iglesia del Salvador y que actualmente se conserva en la parroquial de Renedo. Apurado estudio anatómico. Las carnes son blandas y reflejan a la perfección los conocimientos anatómicos de nuestro escultor puesto que representa bien cada uno de los huesos, articulaciones y venas del cuerpo. Especialmente destacables son las arrugas producidas en la parte derecha de la cadera, imitación de Fernández, y de la articulación del brazo izquierdo. Las manos son finas y delicadas y no llegan a tocarse.

El rostro es bellísimo, si bien se aparta ligeramente del canon que hemos establecido para las esculturas del segundo periodo de nuestro escultor puesto que, por ejemplo, no presenta la nariz de tabique ancho y recto, sino que no es tan rígida; asimismo, ésta es

269 RÉAU, Louis: Iconografía de la Biblia. Nuevo..., op. cit., p. 471.

270 HERNÁNDEZ REDONDO, José Ignacio: "Cristo atado a la columna". En VV.AA.: Pequeñas imágenes de la Pasión en Valladolid..., op. cit., p. 19.

271 MARTÍN GONZÁLEZ, Juan José: Escultura barroca castellana ..., op. cit., p. 241. 
de las pocas veces en que podemos observar las dos filas de dientes. Los ojos como de costumbre son de tapilla. Los dos moratones de las mejillas, producidos por sendos golpes, se ven secundados de sendas leves concavidades que aportan mayor verismo a la tortura de Cristo. La barba bífida es muy profusa, imitando el original fernandesco. Sobre la frente caen dos rizos curvos simétricos. La cabellera es abundante, de tal manera que cubre la oreja derecha y forma unos grandes remolinos alrededor de la izquierda. El resto de la melena caerá levemente por la espalda.

El paño de pureza tiene grandes pliegues que siguen fielmente los tallados por Fernández, si bien los de Ávila son algo más cóncavos. Aunque hay utilización del pliegue a cuchillo, todavía estamos en una fase bastante temprana. El borde del paño, que consigue afinar al máximo, va recorrido por una orla dorada. Podemos aseverar sin ningún género de dudas que se trata de una de las mejores repercusiones del modelo implantado por Fernández.

\section{$\underline{\text { ECCE HOMO }}$}

El Ecce Homo (Fig. 67), que tiene la misma altura que el Atado a la columna, se ha calificado en diversas ocasiones como "singularidad iconográfica"; y no es para menos puesto que parece fundir en una sola imagen los episodios de Cristo Atado a la columna y del Ecce Homo. Este Cristo, que ya aparece flagelado como podemos comprobarlo por las heridas de su espalda, no es tanto una imagen de sufrimiento, puesto que el suplicio del azotamiento ya ha pasado, como de meditación puesto que parece que el escultor nos le presenta para que seamos conscientes de los tormentos que ha sufrido. Es más, parece tratarse de la exposición del Ecce Homo ante el pretorio que de un Atado a la columna propiamente dicho. Como tal Ecce Homo aparece revestido con el manto púrpura anudado por un lazo a la altura del pecho, cubriéndole la espalda hasta la altura de los gemelos. Se trata de una imagen bastante más sanguinolenta. Al contrario que el Atado frontero, este Cristo no se encuentra levemente encorvado, sino recto, detalle al que sin duda favorece la introducción de una columna abalaustrada. Este tipo de columna se deberá seguramente al hecho de introducir variedad con respecto a la troncocónica, a ese mismo deseo de variedad corresponderán el detalle de que el paño de pureza se anude al lado izquierdo y no al derecho como en el Atado, y el que el rostro se gire a la izquierda en vez de a la derecha. Si no tenemos en cuenta ni el manto púrpura ni la columna abalaustrada, se trata sin ninguna duda de una composición invertida del Atado. El rostro es plenamente coincidente con el del Atado del retablo frontero si bien ha realizado una serie de cambios mínimos para introducir novedad: la barba es algo más ancha y corta; la boca se encuentra entreabierta, de tal manera que solo podemos verle los dientes superiores; el rastro sanguíneo es bastante mayor que en el Atado, el cual aparece más sereno y clásico; e, incluso, en vez de tapar con el pelo la oreja derecha, en esta ocasión tapa la izquierda, colocando también el pelo de una manera alternativa pero con los mismos mechones y grandes bucles. Por su parte las anatomías, y cada detalle de ellas, son parejas en ambos Cristos. 


\section{GERIA. IGLESIA PARROQUIAL DE LA ASUNCIÓN}

\section{SANTA CATALINA DE ALEJANDRÍA (h. 1711-1712)}

En la iglesia parroquial de la localidad vallisoletana de Geria existe una Santa Catalina de Alejandría (Fig. 68) que, aunque pasa bastante desapercibida por su localización en el ático de un retablo, debe ser inmediatamente incluida en el catálogo de nuestro escultor. Cuando se redactó el Inventario Artístico de Valladolid, en el cual se la definía como "Santa Catalina Virgen y Mártir, del siglo XVIII", estaba situada bajo el coro ${ }^{272}$. Palabras similares utilizó años después el propio Martín González en el correspondiente tomo del Catálogo Monumental de Valladolid ${ }^{273}$.

Santa Catalina preside la hornacina del ático de un retablo situado en el lado de la Epístola junto a la puerta de entrada al templo. El retablo, que se encuentra articulado a través de cuatro estípites, está compuesto por un pequeño banco, un cuerpo con tres calles (las laterales más estrechas) y un ático rematado en semicírculo. En la cúspide del ático se exhibe una medalla adornada en la cual figura un anagrama que aludirá a la Virgen decorado con tallos y una cabeza de angelote. El retablo puede ser fechado en el primer cuarto del siglo XVIII, si bien desconocemos que esculturas le integrarían en origen. Será este retablo el que figura reseñado en el Catálogo Monumental de Valladolid como "retablo barroco del siglo XVIII. Contiene una Virgen de vestir de este siglo"274. Si hacemos caso del anagrama del medallón del ático y a que Martín González refiere que el retablo estaba presidido por una Virgen de

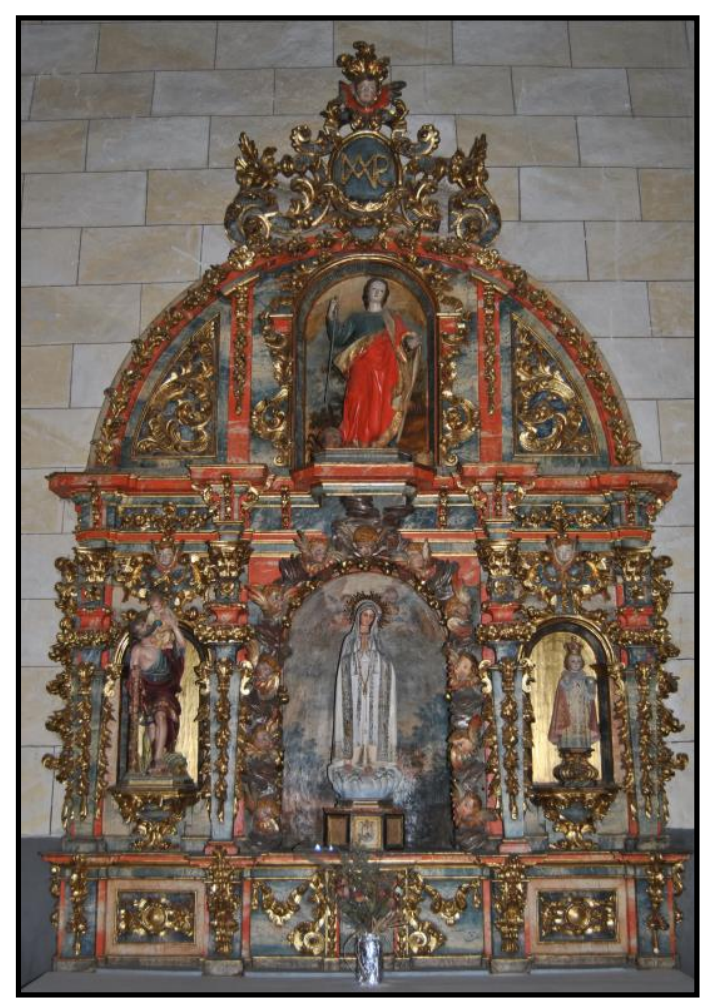

Il. 45- Anónimo. Retablo de la Virgen de Fátima. Iglesia parroquial de la Asunción. Geria (Valladolid). bastidor, parece claro que se realizó ex profeso para esta imagen mariana.

Llama la atención el hecho de que tanto en el fondo de la hornacina principal como en la del ático el fondo va pintado. La pintura del ático es un paisaje con árboles y un cielo con nubes; mientras que la de la hornacina principal es un paisaje parecido, aunque en el cielo aparecen unas cabezas aladas de serafines, lo que parece reforzar la idea de que esta hornacina la ocupara la referida Virgen de bastidor. Alrededor del hueco hay un marco formado por cabezas de angelotes separadas por sus propias alas. Es probable,

\footnotetext{
272 MARTÍN GONZÁLEZ, Juan José (dir.): Inventario artístico de Valladolid..., op. cit., p. 139.

273 MARTÍN GONZÁLEZ, Juan José: Catálogo Monumental de la provincia de Valladolid. Tomo VI..., op. cit., p. 45.

274 Ibídem.
} 
tanto por tamaño como por su adaptación al marco, que la escultura de Santa Catalina que tratamos fuera ubicada en la hornacina del ático. En la actualidad, completa el retablo una moderna Virgen de Fátima sin ningún valor en la hornacina principal, y en las de los lados otras dos imágenes modernas sin ningún valor artístico de San Cristóbal y el Niño Jesús de Praga.

Como decíamos, Santa Catalina es obra, a no dudarlo, de Pedro de Ávila a la vista de los estilemas que presenta en el rostro, además de la manera de disponer los pies y la presencia del característico pliegue a cuchillo. Este pliegue no se haya desarrollado en su totalidad, por lo que pertenecerá a los primeros años de su segunda etapa (17071713). Efectivamente, así parece confirmarlo uno de los libros de fábrica de la parroquia, el cual nos señala que su ejecución se efectuó en el año 1711 o a comienzos del siguiente. En 1711 el visitador general del obispo, don Andrés de Orbe y Larreátegui "colegial en el mayor de Santa Cruz de la ciudad de Valladolid", realiza una Visita a la parroquia durante la cual examina los diferentes retablos y señala que en el "altar de Santa Catalina halló que su efigie de talla por antiguo y deslucido no estaba de suerte que causare devoción al pueblo mandó se quitase y en su lugar y nicho se pusiese otra imagen de talla de la misma santa que se hiciese con la mayor brevedad a costa del caudal de la Cofradía sita en su altar y capilla"275. Esta antigua "efigie" de Santa Catalina que se encontraba en tal mal estado debía de estar situada, si hacemos caso de la visita realizada por el citado visitador el 2 de julio de 1702, en el colateral del Evangelio: "Altares. Visitó el altar mayor y halló ser de la advocación de Nuestra Señora de la Asunción y el altar con su ara, sábana y frontal con toda decencia. Visitó el altar colateral del lado del Evangelio que es su título de Santa Catalina y halló estar con su ara, sábana y altar y por ser el ara pequeña mando su merced que cuando se halla de decir misa en él se ponga otro portátil. Visitó el altar colateral del lado de la Epístola su título es de Nuestra Señora de la Purificación y halló estar con su ara, sábana y frontal con toda decencia"276.

Santa Catalina de Alejandría (que posee cierto parecido en su disposición con la santa homónima que hemos atribuido a Juan de Ávila en el vallisoletano Convento de Santa Catalina) aparece de pie, con la pierna derecha levemente adelantada, conformando el típico contrapposto al que nos tiene acostumbrado nuestro. Eleva su mano derecha, en la cual porta la espada con la cual fue martirizada mientras que el brazo izquierdo lo dispone oblicuamente. En esta última mano quizás portar la palma del martirio, al igual que el citado modelo de su padre al cual hemos aludido. A sus pies se sitúa una corona, que quizás la llevara puesta en la testa, y la cabeza cortada del Emperador Maximiano, su perseguidor y asesino. Ya comentamos que, según Santiago de la Vorágine, ese verdugo pudo ser también el emperador Majencio ${ }^{277}$. La cabeza apenas es visible debido a su posición y a la altura a la que se encuentra; a pesar de ello observamos que va coronada y que el rostro es el de un personaje bastante moreno con largos bigotes que

\footnotetext{
275 A.G.D.V., Geria, Iglesia de la Asunción, Caja 2, Cuentas de fábrica 1608-1720, f. 183.

276 A.G.D.V., Geria, Iglesia de la Asunción, Caja 2, Cuentas de fábrica 1608-1720, f. 99

277 VORÁGINE, Santiago de la: op. cit., Tomo II, p. 772.
} 
para nada se parece a la cabeza barbada y con turbante que ideó su padre, Juan de Ávila. Extraña que no figure su atributo más característico: la rueda con cuchillas en la cual fue martirizada.

Viste una túnica verde hasta los pies, de los cuales tan solo observamos las puntas. El cuello de la túnica tiene las solapas vueltas. Por encima un ampuloso manto rojo, recorrido por una esplendorosa cenefa dorada sobre la que figuran motivos botánicos en diferentes colores, que le cubre gran parte del cuerpo, sujetándose una parte en su axila izquierda y el otro extremo sobre el hombro derecho (este detalle lo observamos en muchísimas ocasiones, parece que lo pudo tomar de los San Juan Bautista de su padre y de Gregorio Fernández). Los pliegues son berninescos como podemos observar en el acuchillamiento presente en las dobladuras que forman la rodilla adelantada, los pliegues que chocan contra el suelo o los situados en la parte derecha a la altura de la cintura, los cuales se doblan sobre sí mismos dejándonos ver el envés. Concibe el manto a través de grandes concavidades situadas en diversos planos. También está presente el pliegue incurvado y redondeado $n$ la túnica y en ciertas partes del borde del manto. Sea como fuere, la combinación de ambos pliegues dota a la escultura de un movimiento muy naturalista y una apariencia delicada muy dieciochesca.

El rostro sigue los parámetros generales a los que nos tiene acostumbrados Ávila durante su segunda etapa. No posee ningún rasgo distintivo que merezca ser reseñado; tan solo podemos plantear la similitud existente entre la faz de esta santa y la de la Virgen de la Anunciación conservada en Renedo (Valladolid) e incluso con el del San Miguel de Castil de Vela (Palencia) y el San Juan Evangelista de la catedral vallisoletana. El pelo se distribuye simétricamente desde su nacimiento hasta las puntas, las cuales se recogen en la parte trasera de la cabeza, a la altura del cuello. Como en la mayoría de las ocasiones, las melenas se distribuyen a ambos lados del rostro en sinuosos mechones que ocultan ambas orejas. 


\section{ALAEJOS. IGLESIA DE SANTA MARIA}

\section{SANTA BÁRBARA (h. 1712)}

Santa Bárbara de Nicomedia fue una virgen y mártir cristina del siglo III cuya historia fue compilada en el siglo XV por Simeón Metafraste ${ }^{278}$, uno de los más destacados hagiógrafos bizantinos. Según Réau, en occidente la leyenda de la santa "se popularizó en Occidente en el siglo XVIII, gracias a Santiago de la Vorágine"279.

Bárbara, hija del sátrapa Dióscuro, estaba "dotada de tan extraordinaria hermosura corporal, que a su padre, movido por el intensísimo amor que a la hija profesaba, y para evitar que cualquier varón la viera, hizo construir una altísima torre y la encerró en ella" ${ }^{280}$. En ocasiones la leyenda varía y relata que en realidad la encerró para que no se convirtiera al cristianismo, esta torre tan solo tenía dos ventanas ${ }^{281}$. Sin embargo, ella "encontró el medio de recibir las enseñanzas de un sacerdote enviado por Orígenes que se hacía pasar por médico, y quien, después de haberla instruido en la religión cristiana le administró el bautismo" ${ }^{282}$. Fue entonces, cuando para explicitar su fe decidió realizar una tercera ventana en la torre, que simbolizaría a la Santísima Trinidad. Al enterarse Dióscoro del significado de las tres ventanas y de que su hija se había convertido al cristianismo la persiguió, aunque ella consiguió huir " $y$ se refugió en un peñón que se abrió milagrosamente para darle asilo. Pero fue denunciada por un pastor chivato que fue castigado por su traición con la metamorfosis de sus corderos en langostas" ${ }^{283}$. Una vez apresada, y visto que se negaba a renunciar a su fe y casarse con un pagano, se la juzgó y se la torturó de las más diversas maneras: "estirada en un potro fue azotada con vergajos, desgarrada con peines de hierro, rodeada de fragmentos de cerámica, quemada con hierros candentes; y al fin los verdugos le arrancaron los pechos con tenazas" ${ }^{284}$. Finalmente la pasearon desnuda por la ciudad y, aunque un ángel le cubrió con un velo, fue decapitada por su propio padre en la cima de una montaña. Dios castigó al asesino matándole con un rayo: "fue asaeteado y consumido de tal manera que de su cuerpo no quedaron polvo ni cenizas" 285 .

El primero en hablar de la presente escultura de Santa Bárbara fue Martín González en el Inventario Artístico de Valladolid, el cual tan solo la reseñó en el lado del Evangelio y la fechó en el siglo XVIII ${ }^{286}$. En la segunda edición del Catálogo Monumental de Valladolid, que corrió a cargo del profesor Javier Castán Lanaspa en 2006, la escultura ya presidía el retablo en el que se encuentra a día de hoy y que anteriormente ocupó Nuestra Señora La Morena. El citado docente atribuyó ya entonces la imagen a nuestro

RÉAU, Louis: Iconografía de los santos. A-F..., op. cit., p. 169.

Ibídem.

VORÁGINE, Santiago de la: op. cit., Tomo II, p. 896.

RÉAU, Louis: Iconografía de los santos. A-F..., op. cit., p. 169.

Ibídem.

Ibídem.

Ibídem.

Ídem., p. 170.

MARTÍN GONZÁLEZ, Juan José (dir.): Inventario artístico de Valladolid..., op. cit., p. 68 
escultor de manera tajante: "una escultura de Santa Bárbara, de Pedro de Ávila, del primer tercio del siglo XVIII, 287.

Es interesante la circunstancia de que Pedro de Ávila realizara una escultura para la localidad de Alaejos por el hecho de que de allí procedían sus antepasados, no en vano era el pueblo en el que había nacido su abuelo, Hernando de Ávila. Esto nos deja abierta la posibilidad de que el escultor tuviera algún familiar o conocido en la localidad que pensó en él para realizar la imagen. Tampoco sabemos si la escultura fue sufragada por la obra de fábrica o bien por un anónimo benefactor.

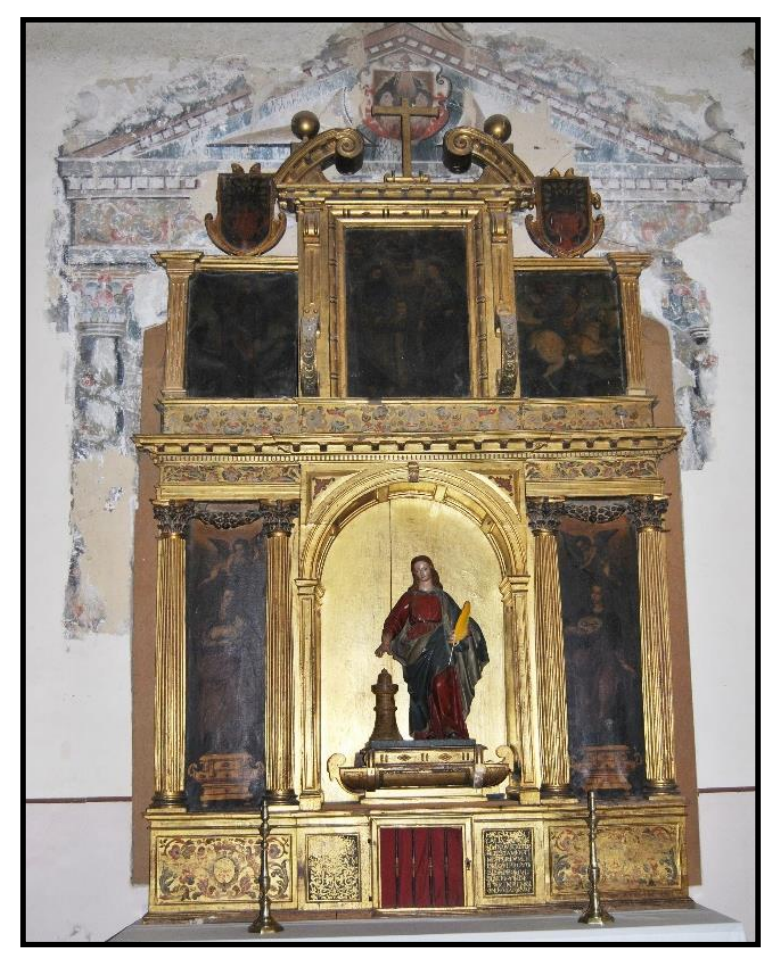

Il. 46- Joseph Castilla. Retablo de Santa Bárbara. Iglesia de Santa María. Alaejos (Valladolid).

Santa Bárbara (Fig. 69) preside un retablo que, si bien fue fechado por Castán Lanaspa en el primer tercio del siglo XVII ${ }^{288}$, hemos logrado documentar como obra del prolífico ensamblador "clasicista" Joseph Castilla; el cual se mantuvo fiel a los modelos retablísticos de las primeras décadas del siglo XVII. Efectivamente, el 7 de octubre de 1652 el ensamblador se presentó en Alaejos y se concertó con uno de sus vecinos, llamado Pedro de Carbajal, para "hacer y fabricar un retablo de madera de pino de Soria seca la más limpia que se hallare para el altar de Nuestra Señora del Carmen de la iglesia de señora Santa María de esta villa ajustándose así en el ancho como en el largo entre las columnas de yeso que tiene dicho altar conforme la traza que tiene dada y lleva dicho maestro firmada de ambos distribuyendo cada parte de por sí según manda Biñola"289. El retablo constaría de "cuatro columnas con sus pilastras entre calles y muros y su pedestal y en medio una caja en que sea como de un brazo con reliquias que tiene la dicha iglesia". En el medio iría "un arco para la caja de dicha imagen de Nuestra Señora". El retablo, por el cual percibiría 1.600 reales de vellón, debía de entregarlo acabado y asentado en un plazo de "ocho meses que corren desde hoy día de la fecha a vista de maestros de dicho arte". No le llegaron a pagar todo el dinero pactado puesto que una vez fallecido, el 5 de octubre de 1653, el referido Carbajal abonaba a su viuda 400 reales que aún se le adeudaban $^{290}$.

287 CASTÁN LANASPA, Javier: Catálogo Monumental de la provincia de Valladolid. Tomo XXI..., op. cit., p. 32.

$288 \quad$ Ibídem.

289 A.H.P.V., Leg. 13.817, ff. 109-110.

290 A.H.P.V., Leg. $2.509 / 2$, f. 206. 
Se trata de un retablo inserto sobre un muro abierto dentro del cual debió de haber otro anterior. Alrededor de este nicho figuran unas "pinturas murales del siglo XVIII que fingían un pórtico columnado de orden salomónico" ${ }^{291}$. El retablo presenta una distribución muy sencilla compuesta por un "banco, un cuerpo de tres calles definidas por columnas cortinitas, entablamento recto y ático con pilastras y frontón partido y curvo coronado por bolas" ${ }^{292}$. Acompañan a Santa Bárbara, en cuya hornacina anteriormente se encontraba Nuestra Señora La Morena ${ }^{293}$, cinco pinturas de mediana calidad que representan a Santa Inés, Santa Águeda, San Bartolomé, la Sagrada Familia, y Santiago Matamoros. Encima de las dos pinturas laterales del ático sendos escudos que exhiben dos jarros con lirios alusivos a la virginidad de María.

Sabemos, por una visita realizada por el abad de la Colegiata de Medina del Campo el 7 de marzo de 1588, que existía en el templo un altar dedicado a Santa Bárbara. Este se hallaba "dentro en la capilla mayor de dicha iglesia al lado de la Epístola". En él existía "un retablo dorado con ocho tableros pintados [...] y en el medio del dicho (...) pintado de pincel (...) Santa Bárbara (...) (y san) barme de bulto"294. A pesar de que el folio en el que se encuentran redactadas estas líneas está roto parece claro que no existía una escultura de Santa Bárbara, sino que se trataba de una pintura, y que otra de esas ocho tablas pintadas representaba a San Bartolomé; el cual, casualmente, también aparece efigiado pictóricamente en el retablo que actualmente preside la Santa Bárbara de Pedro de Ávila.

La escultura presenta las clásicas fórmulas de Pedro de Ávila tanto en rasgos faciales, tipo de pliegues como en la manera de disponer las piernas, pies y manto. Así, Santa Bárbara aparece de pie, adelanta levemente la pierna izquierda, creando el típico contrapposto y resaltando levemente la rodilla bajo la túnica. A su derecha figura su atributo más usual: una pequeña torre en la cual, efectivamente, podemos ver tres ventanas según narra la leyenda. Coloca en posición oblicua el brazo derecho, bastante rígido y con la muñeca fracturada, lo que hace que esa mano, con la cual se dispondría a tocar la torre, esté medio desprendida de la madera; puesto que además las manos han sido talladas de manera exenta. En la otra mano, en la cual debía de portar otro atributo dado la posición tan elegante que adoptan los dedos, quizás llevara una palma del martirio, que en la actualidad ha sido sustituida por una vulgar pluma de pájaro.

Viste una amplia túnica roja, ceñida a la cintura por un cíngulo rojo, que tan solo deja visibles las manos y los pies, los cuales se encuentran dispuestos según la forma habitual. Tiene el cuello vuelto. Por encima del hombro izquierdo tiene echado un manto azul que le cubre gran parte de la espalda, el brazo izquierdo, que es donde se recoge una parte, y la otra le atraviesa por el otro lado y se recoge en la parte derecha del cíngulo, de tal manera que dispone el manto sobre las piernas formando una

291 CASTÁN LANASPA, Javier: Catálogo Monumental de la provincia de Valladolid. Tomo XXI..., op. cit., p. 32.

292 Ibídem.

293 Ibídem.

294 Ídem, p. 23. 
diagonal que suele ser bastante típica en las composiciones de nuestro escultor; es, sin duda, otro de esos detalles que evidencian la personalidad de su gubia. Ambas prendas poseen colores planos que, aunque pudieran datar de la época de la escultura, creo que es producto de un repolicromado. Las dos vestimentas presentan unos pliegues ligeramente acuchillados, lo que nos lleva a fechar la imagen en una fecha cercana a 1712, año en que fue realizada la Virgen de las Nieves de la cercana localidad de Nava del Rey. Como vemos, los pliegues más minuciosos y aristados se encuentran en los alrededores del cíngulo, en la parte baja de la túnica y en la parte delantera y en el giro envés del manto. Por su parte, en la parte trasera del manto vemos amplias concavidades que gozan de gran finura.

El rostro posee las características típicas de Ávila, no presentando ninguna novedad que merezca reseñarse. Asimismo, también aplica las mismas soluciones al peinado, en el que deja la frente despejada y las cabelleras caen sinuosamente a ambos lados del rostro. No falta uno de los mechones sobre el pecho, mientras que el resto de guedejas se repartirán por la espalda. Lo usual es que el mechón caiga al lado izquierdo del cuello, en este caso lo hace al derecho, con lo cual introduce una mínima novedad. Su rostro guarda semejanzas, entre otras, con el de la Magdalena del Oratorio de San Felipe Neri; si bien sus rasgos son algo más estereotipados, no existe la delicadeza de aquella ni el rostro guarda su blandura y perfección técnica. 


\section{NAVA DEL REY. IGLESIA PARROQUIAL DE LOS SANTOS JUANES}

\section{NUESTRA SEÑORA DE LAS NIEVES (h. 1712)}

La imagen de Nuestra Señora de las Nieves (Figs. 70-73) de la iglesia parroquial de los Santos Juanes de Nava del Rey (Valladolid) posee todas las características típicas del segundo estilo de Ávila, por lo que su atribución se encuentra fuera de toda duda. El único hasta el momento en relacionar esta bellísima talla con nuestro escultor fue el profesor Castán Lanaspa, el cual juzgó el estilo que exhibe como "muy próximo al de Pedro de Ávila" 295 . En cuento a su cronología, parece lógico pensar que estaría acabada a mediados del año 1712 puesto que en el contrato para realizar su retablo, protocolarizado en agosto de ese año, se indica que este serviría "para poner la imagen de Nuestra Señora" ${ }^{296}$. Además, la presencia en la imagen de un pliegue berninesco sin demasiado resalte nos indica que la fecha citada es la más adecuada.

Como referíamos, el 10 de agosto de 1712 Pedro Castreño, mayordomo de la Cofradía de Nuestra Señora de las Nieves, y otros diputados de la misma, todos ellos comisarios encargados para la fábrica de un retablo "para poner la imagen de Nuestra Señora" que se habría de asentar en la iglesia parroquial de la villa, se concertaron con el ensamblador medinense Felipe Sánchez para que realizara "un retablo en dicha iglesia (...) que le ha de ejecutar arreglándose en todo a la traza que se ha exhibido; y guardarán en la dicha fábrica las condiciones que quedarán a continuación de esta escritura firmadas por el dicho Felipe Sánchez y Francisco Martínez de Arce maestro de dicho arte y vecino de la dicha villa de Medina del Campo" (DOCUMENTO 72A). Felipe Sánchez se comprometió en un principio a realizar la obra en un precio de 200 ducados (= 2.200 reales); sin embargo, tras una serie de bajas de Francisco Martínez de Arce, que la dejó en 1.700 reales de vellón, y del propio Sánchez, la obra quedó en 1.600 reales. Se daba como plazo para su entrega el último día de noviembre "que vendrá de este año de la fecha ocho días más o menos y pasados". Entre las condiciones figura una que dice que habría "de llevar segundo cuerpo para el Cristo de Burgos". Efectivamente, aún se conserva en el ático un lienzo del Cristo de Burgos.

Cinco años después, el 24 de enero de 1717, se procedió a su dorado. Así, la cofradía de Nuestra Señora de las Nieves se ajustó con el dorador y estofador de la villa Alonso de Neira, el cual tendría que tenerlo acabado "para el día de Santiago y Santa Ana que vendrá de este presente año" (DOCUMENTO 72B). El pintor siguió puntualmente las condiciones pactadas. Así por ejemplo comprobamos que realizó en el respaldo de la caja donde está la Virgen "una tela de lana encarnada o de cogollos en campo de oro".

Desconocemos exactamente para qué lugar fue proyectado el retablo ya que en las condiciones se habla de él como el "colateral de Nuestra Señora de las Nieves", lo cual

\footnotetext{
295 CASTÁN LANASPA, Javier: op. cit., p. 105.

296 GARCÍA CHICO, Esteban y BUSTAMANTE GARCÍA, Agustín: Catálogo Monumental de la provincia de Valladolid. Tomo V..., op. cit., pp. 84-86.
} 
es imposible dado que ya poseía dos retablos colaterales mucho anteriores que no han permanecido inalterables en sus sitios: en el lado del Evangelio figura el de la Virgen del Rosario, realizado por Pablo de Freiría en su parte arquitectura y en la escultórica Bernardo del Rincón ${ }^{297}$; mientras que en el de la Epístola se encuentra el de San Antonio Abad, realizado por el ensamblador Juan de Muniátegui y Gregorio Fernández ${ }^{298}$. Como señala Castán Lanaspa, el del Evangelio, que es unos años posterior, se realizó "en consonancia con el de San Antón"299.

El retablo de Nuestra Señora de las Nieves se halla situado "en la base de la torre, mirando hacia el coro" 300 . Se compone de un banco en el que se encuentran las ménsulas que soportan las cuatro columnas que sustentan el cuerpo principal, dos a cada lado, estando en el centro una hornacina con la Virgen de las Nieves. Finalmente, un amplio ático, de la misma altura que el cuerpo principal, que exhibe una gran pintura del Cristo de Burgos, en su parte superior remata un angelote y una forma avenerada. La totalidad del retablo está poblada de elementos vegetales. En la parte superior de la hornacina de la Virgen hay tres casetones. Señala Castán Lanaspa que el barroquismo del retablo se ve acentuado por "las pinturas murales que rodean el conjunto, con doseles y elementos vegetales en colores rojos y azules, del siglo XVIII"301.

Los orígenes de la advocación de la Virgen de las Nieves se remontan al siglo IV, concretamente al ministerio del papa Liberio $(352-366)^{302}$. Cuenta la leyenda que un rico

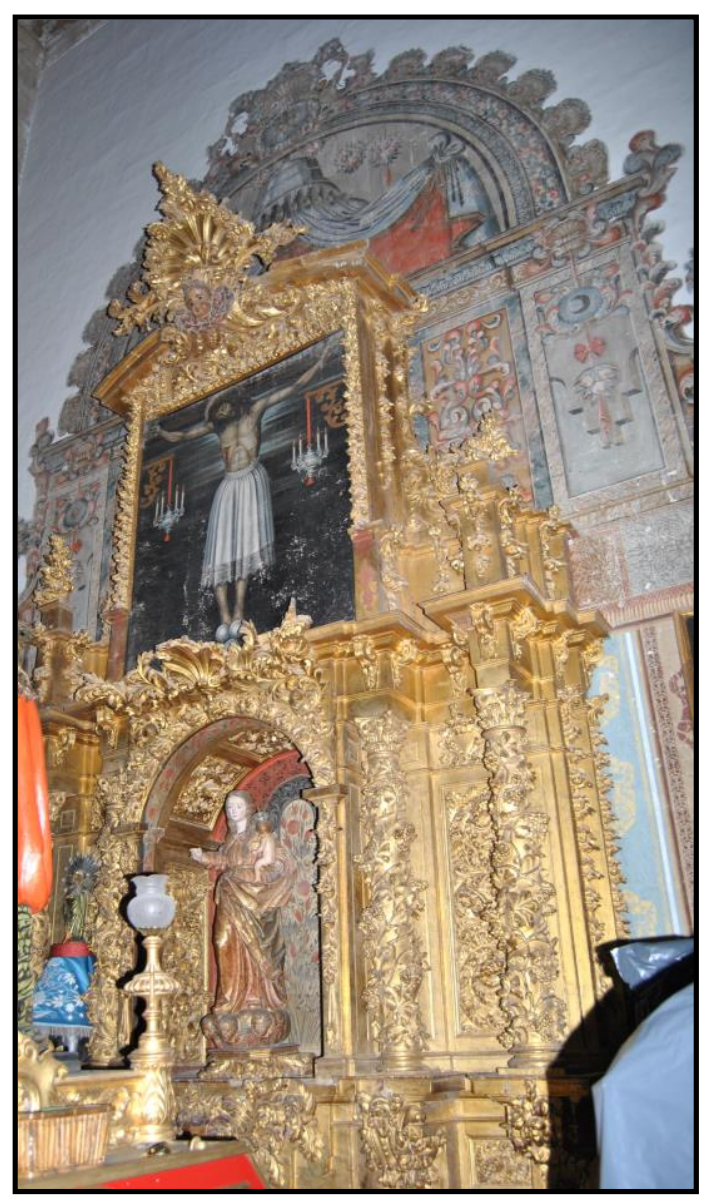

Il. 47- Felipe Sánchez. Retablo de Nuestra Señora de las Nieves. Iglesia parroquial de los Santos Juanes. Nava del Rey (Valladolid). matrimonio de patricios romanos, ya de avanzada edad y de acreditada caridad para con los demás, quiso "ofrendar a María sus tierras y, sin saber cómo hacerlo, pidieron a la Virgen que les revelase sus deseos" $"$ " La Virgen se les apareció la noche de un 5 de agosto indicándoles que le debían de construir un templo allí donde ella les indicara. A la mañana siguiente el monte Esquilino apareció milagrosamente nevado, lo que el matrimonio interpretó como la señal de que ese era el lugar elegido. El templo se

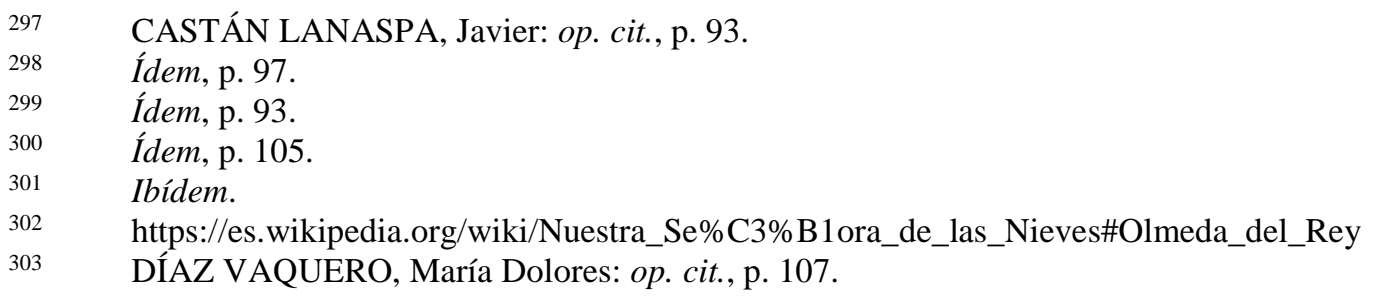


construyó rápidamente, si bien fue destruido no muchos años después ya que en el 434 el papa Sixto III levantó sobre esos mismos terrenos los fundamentos de la actual basílica de Santa María Maggiore. Como bien comenta Díaz Vaquero, el objeto de esta conmemoración mariana "no es otro que el de la conmemoración específica de la dedicación de esta iglesia de Roma, llamada también Basílica Liberiana en recuerdo del papa Liberio que fue su principal promotor" ${ }^{304}$. Sigue relatando que esta fiesta "contó con oficio propio a partir del siglo IX y entonces la basílica empezó a llamarse de Nuestra Señora de las Nieves. Desde este momento y hasta el siglo XIV, la fiesta se celebraba solamente en la citada Basílica, pero a partir de entonces el culto se extendió a las demás iglesias de la ciudad de Roma. Será Pío V quien la incluya en el calendario de la Iglesia Universal" 305.

Su iconografía es muy simple porque se la representa como una sencilla Virgen con el Niño. Castán Lanaspa refiere que esta imagen "parece corresponder a la iconografía de Virgen del Rosario o del Carmen"306. En su otra mano portó un atributo puesto que así parece indicárnoslo la posición de los dedos. Quizás sujetara un gran copo de nieve del que surge una flor que, además de aludir a la propia devoción de "Virgen de las Nieves", vendría a resaltar la pureza de la Virgen puesto que el color blanco siempre se ha asociado a ello. Otra teoría sería el rápido deshielo que aconteció en aquel mes de agosto en Roma tras indicarse el lugar en que debía ser levantada la basílica. La teoría de que pudiera ser ese elemento la realizo por cuanto en la iglesia de San Andrés de Valladolid hay dos representaciones de esta Virgen (una escultura del siglo XVI y una pintura) en las cuales parece tener en una mano el referido copo de nieve con la flor y en la otra al Niño Jesús. Dadas las evidentes semejanzas existentes con esta escultura de Nava del Rey, ¿pudo conocer Pedro de Ávila la escultura de la Virgen de las Nieves de la parroquia de San Andrés?.

Formalmente, Ávila ha concebido a esta Virgen de las Nieves a partir de su modelo de Inmaculada puesto que al igual que a éstas, ha colocado una peana cuyo frente lo ocupan tres cabezas aladas de serafines. Como podemos observar, este detalle es idéntico a la Inmaculada de San Felipe Neri, pero no solamente eso, sino que la postura general de la pierna y del cuerpo, a excepción de los brazos, es también exacta, con la diferencia de que es una composición invertida. Cabe plantearnos una pregunta ya que ninguna de las Inmaculadas que poseen una peana "angelical" y tenemos relacionadas con Ávila es anterior a esta Virgen de las Nieves: ¿Pudo servirse Pedro de Ávila de la Virgen de las Nieves como modelo para ejecutar este tipo de Inmaculadas, y más concretamente la del Oratorio de San Felipe Neri? Por el momento, la respuesta parece ser que sí dado que, como acabamos de comentar, ninguna Inmaculada con peana angelical realizada por nuestro escultor es anterior a esta Virgen navarresa.

La Virgen, que posee un tamaño menor que el natural, aparece efigiada de pie sobre la referida peana angelical en la cual observamos diversidad de gestos, de peinados y de

\footnotetext{
$304 \quad$ Ídem, p. 108.

$305 \quad$ Ibídem.

306 CASTÁN LANASPA, Javier: op. cit., p. 105.
} 
posición de alas, sin duda para crear multiplicidad. Adelanta levemente la pierna derecha para crear el típico contraposto al que nos tiene acostumbrado. Eleva levemente el brazo derecho, en cuyos delicados y elegantes dedos sujetaría un atributo que en la actual no conserva; mientras tanto su mano izquierda sirve de "trono" a un Niño Jesús coronado. Éste va desnudo y con las piernas flexionadas; con la mano derecha intenta acariciar el rostro de su madre, pero sin embargo en la actualidad ha perdido todos los dedos de ambas manos. Tanto anatómicamente como tipológicamente es similar a otros Niños Jesús que se le relacionan, como pueden ser los que portan algunos de sus San José.

Viste una amplia túnica rojiza con esgrafiados y motivos florales también rojos que le llega hasta los pies, de los cuales tan solo se ve la punta de los zapatos. En esta imagen tampoco falta la disposición de ambos pies en un ángulo de $90^{\circ}$ y separados por un trozo de túnica con pliegue más o menos cortante. Por encima de los hombros tiene echado un manto que se le ciñe en la base del cuello; éste es azulado por su exterior y rojizo por su interior, si bien ambas caras van profusamente decoradas con labores geométricas y vegetales en esgrafiado, y todo ello encuadrado por una bella cenefa con motivos botánicos de diversos colores. A partir de ahí se abre y le cubre ambos hombros, cayéndole por detrás y sirviendo de "fondo" al lado derecho de la imagen, mientras que el izquierdo le rodea la cadera y parte del abdomen hasta ceñirse en la parte derecha de la cadera mediante el cíngulo con el que se sujeta la túnica. Los pliegues presentes concuerdan a la perfección con los desarrollados en la época en que fue realizada la imagen (h. 1712) puesto que son de aristas vivas, cortantes, de cuchillo, pero no en su fase más aguda, sino que todavía son pliegues algo más calmados; son los inmediatamente anteriores a los que desarrollará en profundidad a partir del año 1714 en el que parecerán verdaderos filos de cuchillo. Los más agudos los sitúa en las zonas en las que el movimiento se presupone que es mayor: en la túnica en las zonas aledañas a su fruncimiento y en la parte baja, simulando el choque provocado con el suelo; mientras que en el manto los más acentuados se encuentran en la parte delantera, la más visible.

El rostro, cuya similitud es más que evidente con otras muchas imágenes femeninas, como es el caso de la Inmaculada del Seminario, la Magdalena del Oratorio de San Felipe Neri e incluso la Santa Bárbara de Alaejos (Valladolid), sigue fielmente los modos y maneras a los que nos tiene acostumbrado el escultor. Nos muestra a una Virgen muy juvenil, con la boca entreabierta, en la cual vemos una escasa porción de sus dientes y de la parte delantera de la lengua. Ojos de tapilla con el clásico abultamiento inferior de las bolsas. Especialmente destacable es el papel del policromador al pintar cada uno de los vellos de las cejas, y también van pintadas las pestañas. La nariz es la usual de Ávila, aunque en este caso pertenece a ese escaso grupo en el que el tabique nasal no se encuentra aplastado, sino que predomina una ligera curva. En la parte inferior del rostro está presente la incipiente papada tan característica. La cabellera, que deja completamente libre la frente, se desarrolla de la manera usual: en dos grandes melenas que flanquean el rostro de la Virgen; los mechones son más 
gruesos que en otras ocasiones, pero no por ello burdos ni poco trabajados. También como suele hacer nuestro escultor, un mechón cae sobre el pecho mientras que el resto se expande por su espalda, seguramente de forma similar a las Inmaculadas y Magdalenas, aunque en este caso no podemos comprobarlo por ser hechura de retablo. 


\section{VALLADOLID. CONVENTO DE SAN PABLO}

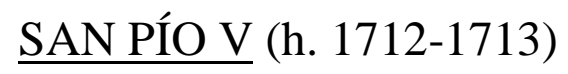

En la iglesia conventual de San Pablo encontramos la efigie de uno de los muchos dominicos que alcanzaron la santidad, con la diferencia de que éste además desempeñó el cargo de Papa. Se trata de Antonio Michele Ghislieri (1504-1572), San Pío V. Desde hace tiempo esta escultura ya fue relacionada con Pedro de Ávila. Efectivamente, Martín González en el Inventario Artístico de Valladolid la define como "San Pío V, principios siglo XVIII, de escuela de Pedro de Ávila"307; si bien años después en el Catálogo Monumental de Valladolid la creyó obra personal del escultor: "San Pío V, madera policromada (140 cms.), segundo cuarto del siglo XVIII, asignable a Pedro de Ávila ${ }^{308}$.

Pío V fue fraile dominico y comisario general de la Inquisición romana. Entre los logros más importantes de su pontificado se encuentran la imposición a los estados católicos de Alemania de cumplir las nuevas reglas dictadas en el Concilio de Trento, dando, por lo tanto, por iniciada la Contrarreforma; financió con los bienes del Vaticano las guerras santas contra los hugonotes en Francia, y la expulsión de los judíos; la reducción del gasto en la corte papal; la obligación de que los obispos vivieran en sus diócesis; y, artísticamente hablando, fue el que encargó al pintor Daniele da Volterra "Il Braghettone" que cubriera el sexo de los personajes del fresco del Juicio Final que Miguel Ángel Buonarroti había realizado para el altar mayor de la Capilla Sixtina ${ }^{309}$. El Papa Clemente X le nombró beato el 1 de mayo de 1672, siendo Clemente XI el que le canonizara el 22 de mayo de 1712.

Lo más probable es que la imagen del Santo Padre fuera encargada por la comunidad monástica de San Pablo a raíz de su canonización, por lo que la fecha de ejecución oscilaría entre los años 1712-1713. Quizás la imagen se encargó para que el 4 de agosto de 1713 presidiera el comienzo del novenario celebrado en el convento con motivo de su canonización, acto que nos es narrado por el diarista Ventura Pérez: "Año 1713, día 4 de Agosto, comenzó el novenario que hicieron los padres dominicos en el convento de San Pablo, en celebridad de la canonización de San Pío V; predicaron diversos oradores de distintas religiones; estuvo muy bien adornada la iglesia y retablo de luces" ${ }^{310}$. Además, esta fecha coincide perfectamente con el tipo de pliegue utilizado por Ávila, puesto que, aunque se vislumbra el cuchillo, todavía eran unas fechas bastante tempranas en las cuales no lo había desarrollado en su totalidad. Ese mismo año hubo en la ciudad otra celebración por la canonización de San Pío V. Según Canesi el festejo tuvo lugar el 24 de junio de 1713, siendo organizado por el Convento de San José de Capuchinos en honor de la "canonización de S. Félix de Cantalicio, religioso

\footnotetext{
307 MARTÍN GONZÁLEZ, Juan José (dir.): Inventario artístico de Valladolid..., op. cit., p. 52

308 MARTÍN GONZÁLEZ, Juan José y DE LA PLAZA SANTIAGO, Francisco Javier: Catálogo

Monumental de la provincia de Valladolid. Tomo XV..., op. cit., p. 265.

309 https://es.wikipedia.org/wiki/P\%C3\%ADo_V

$310 \quad$ PÉREZ, Ventura: op. cit., p. 39.
} 
lego capuchino, en la santa ciudad de Roma y de S. Pío V pontífice máximo de la religión dominicana" 311 . Esa noche se disparó en honor de los nuevos santos "un precioso fuego".

La efigie de San Pío V (Figs. 74-75) presidiría un retablo, no sabemos si reaprovechado o realizado ex profeso para la escultura de Pedro de Ávila, en la capilla del Rosario. Esta ubicación tendría toda la lógica puesto que este Papa se distinguió por ser un ferviente patrocinador del culto al Santísimo Rosario. Esta capilla del Rosario no es otra que en la que actualmente se encuentra el retablo en el que se expone la escultura del Papa, que hoy en día ha cambiado la advocación en favor del santo italiano: capilla de San Pío V. Refiere González García-Valladolid acerca de ella que fue "fundada por los señores Don Garci López de Madrid, del Consejo del rey Don Enrique IV, y Doña Juana de Herrera, su mujer, los cuales la dedicaron a la Virgen del Rosario y hoy está consagrada al Niño Jesús: en ella están enterrados los fundadores y Don Antonio de Espinosa, que costeó la fábrica del retablo y altar y sobre las estatuas de los fundadores, las cuales decian así: "Este retablo es de Antonio de Espinosa, que murió en esta villa, año de 1544. Está enterrado en esta capilla, que es doctor de Madrid y Juana de Herrera, su mujer, con consentimiento de sus herederos, Requiescat in pace. Amen". "Los bultos que están en esta capilla son de los honrados señores, el doctor García López de Madrid y Juana de Herrera, su mujer, el cual sirvió mucho tiempo en el Consejo del rey Don Enrique $4^{o}$ de gloriosa memoria, $y$ después fue del Consejo de los reyes Católicos Don Fernando y Doña Isabel, nuestros señores. El dicho doctor falleció en mayo de 1477. Dotaron esta capilla de pan y maravedies de juro, por salvación de sus almas" ${ }^{\prime 12}$.

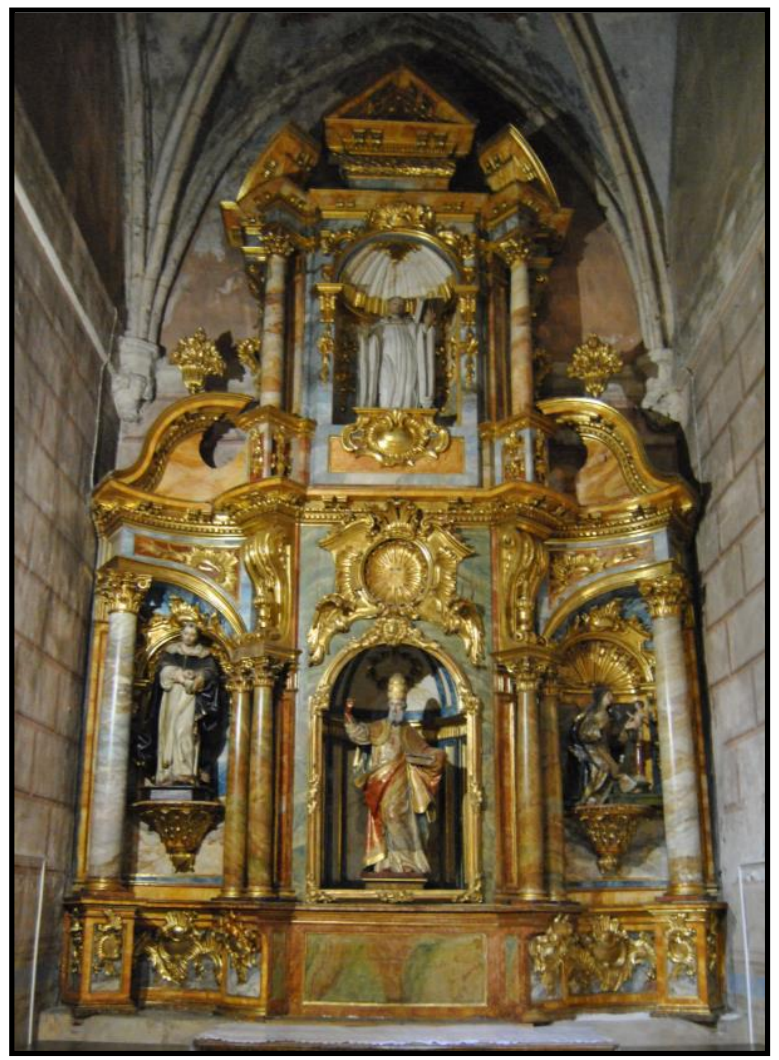

Il. 48- Anónimo. Retablo de San Pío V. Convento de San Pablo. Valladolid.

El retablo que actualmente preside la capilla es de estirpe rococó, como así lo demuestran las rocallas, pero también parece anticipar el neoclasicismo mediante la imitación de mármoles; por lo que su cronología se encontrará cercana al último tercio del siglo XVIII. Pudiera incluso haberse realizado a finales de la séptima década del citado siglo o en la octava puesto que esa imitación de mármoles pudiera estar en relación al decreto (1777) promulgado por el rey Carlos III en el que se prohibía realizar

311 CANESI ACEVEDO, Manuel: Historia de Valladolid (1750), op. cit., Tomo III, p. 556.

312 GONZÁLEZ GARCÍA-VALLADOLID, Casimiro: Valladolid..., op. cit., Tomo III, p. 504. 
retablos en madera, debiéndose utilizar piedras, mármoles y estucos. Sin embargo, como estos materiales eran bastante más caros muchos patronos decidieron seguir utilizando la madera, aunque policromándola de tal manera que parecieran materiales nobles (mármol, bronce, etc...).

Al tener que adaptarse a la capilla, el retablo adopta una forma estrecha y alargada. Tiene un solo cuerpo, con tres calles, y ático, rematado en un frontón curvo partido en tres trozos; el central es un triángulo mientras que los dos laterales tienden a las formas curvas. El diseño general del retablo es muy fantasioso. El elemento de sustentación de las hornacinas es la columna compuesta, si bien la hornacina superior la flanquean dos pilastras. Las cuatro hornacinas van rematadas por una venera, la de la central muy pequeña. San Pío V preside la hornacina principal del retablo, mientras que el resto de imágenes probablemente no pertenecieron en origen al mismo puesto que ni se amoldan a las hornacinas ni siempre se han encontrado ahí. Las hornacinas de las calles laterales presentan a dos santos dominicos de autores y escuelas diferentes. En la de la izquierda figura San Luis Bertrán ${ }^{313}$.y en la de la derecha a Santa Rosa de Lima ${ }^{314}$, esta última probablemente realizada a finales del siglo XVII en Nápoles. En el ático, San Bernardo, de la segunda mitad del siglo XVIII.

Pedro de Ávila nos presenta a San Pío V (140 cms.) de pie, marcando un fuerte contraposto con la rodilla izquierda, cuya pierna parece adelantar. La figura tiene un ritmo serpenteante que comienza en su mano derecha y acaba en la pierna izquierda, de la misma manera entre estos dos puntos se desarrolla una diagonal, que se cruza con la que forman los bordes del manto. Viste túnica blanca hasta los pies, dejándonos ver tan solo las características puntas de los zapatos, los cuales aparecen dispuestos según su forma característica (ángulo de $90^{\circ}$ y separados por un trozo de túnica, si bien en esta ocasión los pliegues afilados todavía no son tal, sino que son redondeados y blandos); por encima una sobretúnica blanca con una policromía que imita a la perfección en la zona baja las labores de encaje; colgada de los hombros, y uniendo ambos extremos por una cinta a la altura del pecho, viste una hermosa y complicada capa que le cubre la espalda, parte del torso y como es característico se le arremolina en el brazo y mano izquierdos. Por su interior es de color azul y por el exterior roja, teniendo ambos lados labores vegetales doradas esgrafiadas y los bordes una fina cenefa también dorada. Es admirable la manera que tiene de hacer los dobleces de la capa al contacto con la piel, la suavidad está presente; sin embargo, en otras partes comienza a tallar de una manera más cóncava, a la manera berninesca. Tampoco deja de aparecer un pliegue muy característico y rígido que sale como disparado en diagonal de su cadera hacia el lado izquierdo. Pero aún porta otras dos vestimentas típicas de su condición: la tiara papal y los guantes pontificales rojos.

313 Martín González y Plaza Santiago la adscriben a un seguidor de Luis Salvador Carmona, fechándola a mediados del siglo XVIII. Antiguamente presidía un desaparecido retablo neoclásico situado en la primera capilla del lado del Evangelio. MARTíN GONZÁLEZ, Juan José y DE LA PLAZA SANTIAGO, Francisco Javier: Catálogo Monumental de la provincia de Valladolid. Tomo XV..., op. cit., p. 265.

314 PARRADO DEL OLMO, Jesús María: “3.14. Santa Rosa de Lima”. En VV.AA.: Arte Americanista en Castilla y León [exposición], Junta de Castilla y León, Valladolid, 1992, p. 118. 
Eleva su brazo derecho con potencia y elegancia, y en esta mano portaría un atributo hoy desaparecido. Quizás exhibiera con fiereza un Crucifijo, elemento muy característico de su iconografía y que aludiría a su defensa de la Fe católica en su lucha contra los enemigos del catolicismo (hugonotes franceses, judíos, herejes, protestantes). Es decir, se nos muestra como un papa combativo. En su otra mano porta un libro que sujeta también con la capa y su cadera. La manera tan elegante de disponer los dedos sobre el borde central del volumen tiene ecos fernandescos.

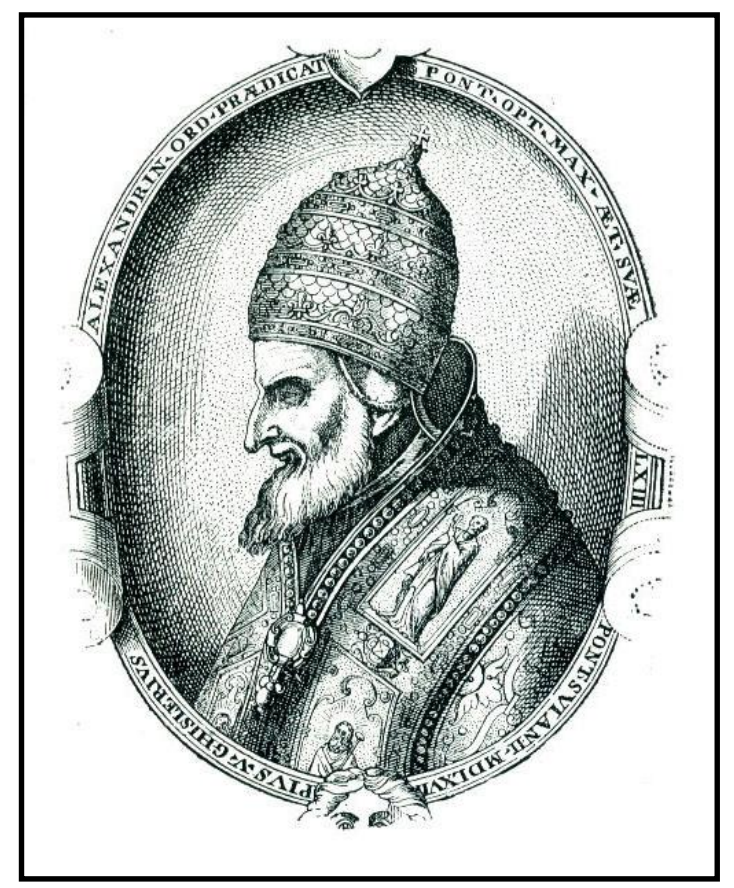

Il. 49- Mario Cartaro. Retrato de San Pío V.

Sin lugar a dudas lo más exquisito de la escultura es su enérgico rostro (que por otra parte casa a la perfección con su actitud combativa e inflexible), que acusa gran blandura y se encuentra plagado de arrugas indicadoras de su avanzada edad. Es sin duda uno de los mejor conseguidos por nuestro escultor. Podríamos decir que se trata del único rostro tallado por Ávila que en realidad nos muestra un retrato del efigiado, así parece indicárnoslo el hecho de que el estilo de Ávila haya quedado en esta ocasión, de manera completamente excepcional, diluido en favor del retrato del representado. No tenemos más que comparar la nariz que presenta San Pío V con las del resto de sus esculturas, tanto documentadas como atribuidas. La nariz recta de tabique nasal ancho ha dejado paso en esta ocasión a una nariz aguileña muy acentuada, así como a unas aletas nasales bastante pronunciadas. Sin ninguna duda detalles como este se deben al claro deseo de los dominicos de poseer una "Vera Efigie" del santo, y también al hecho de que Ávila o bien la propia Orden poseyeron un grabado o una estampa que utilizó el escultor para inspirarse. Uno de los más difundidos fue el realizado en 1567 por Mario Cartaro. Todos los grabados, pinturas, esculturas y estampas de la época reflejan los rasgos tan característicos del papa, como eran su peculiar nariz y la larga barba blanca, en muchas ocasiones bífida, tal y como le representa Ávila. La barba, en sus laterales, se organiza a través de una sucesión de "S" que partiendo de los lóbulos de las orejas, puesto que es lo único que se aprecia de ellas, van incrementándose en tamaño y anchura hasta desembocar en grandes mechones curvos que se afrontan bajo el mentón. Este tupido tipo de barba viene a ser una solución de compromiso de la exhibida por sus San Joaquines y el San Francisco de Sales que ejecutó su padre para el Oratorio de San Felipe Neri. Por lo demás, ojos bien abiertos mirando hacia arriba, boca entreabierta en la que podemos ver los dientes superiores, y cejas rectas. 


\section{AMPUDIA. IGLESIA MUSEO DE SAN FRANCISCO}

\section{CRISTO RESUCITADO (h. 1714)}

Una de las obras de más calidad que se le viene atribuyendo desde hace tiempo a Pedro de Ávila es un Cristo Resucitado (125 x 70 x $40 \mathrm{cms}^{315}$ ) (Figs. 76-78) que se conserva en el Museo de Arte Sacro de Ampudia (Palencia), ubicado en el antiguo Convento de San Francisco. La excepcionalidad de esta escultura queda patente por cuanto la profesora Porras Gil la define como "obra de sobresaliente factura"316. El origen de la escultura parece encontrarse, dado el carácter procesional que posee, en la Cofradía de la Cruz y por lo tanto en la ermita que esta poseía en la localidad. Hemos de recordar que muchas décadas antes esta misma cofradía se había concertado con el también escultor vallisoletano Pedro Salvador "el joven" para esculpir una serie de pasos a imagen y semejanza de los vallisoletanos: "Pedro Salvador se obliga de dar hechas y acabadas (...) cuatro hechuras de escultura, la una de un Santo Cristo a la columna, otro un Santo Cristo sentado para la coronación, otra hechura de un Cristo en la oración del huerto y la otra el ángel en la embajada con su cáliz en la mano"317.

En fecha indeterminada la imagen pasó a la Colegiata de San Miguel, en cuya capilla de Santa Ana la contemplaron Martín González y Urrea en 1977 cuando redactaron el Inventario Artístico de Palencia ${ }^{318}$. Fue además en esta publicación en la que se formuló por primera vez la atribución a favor de Pedro de Ávila ${ }^{319}$. Años después, Martín González dio ya por hecho que la escultura fue tallada por nuestro escultor: "una de las más singulares obras de Pedro de Ávila" ${ }^{320}$. Otros autores han recogido esta misma atribución, la cual no ha sido puesta en duda jamás ${ }^{321}$. A lo largo del tiempo, la escultura ha formado parte de varias exposiciones, siendo la más reciente la organizada en Medina del Campo y Medina de Rioseco en 2011 por Las Edades del Hombre bajo el título "Passio". Esta pieza en concreto se pudo ver en la sede riosecana, ubicada en la magna iglesia de Santiago de los Caballeros.

El presente Cristo Resucitado es una de las escasas ocasiones en que Pedro de Ávila tiene la posibilidad de mostrarnos sus conocimientos anatómicos, así como el dominio del desnudo; el cual, como podemos comprobar, es mucho más apurado y correcto que en su anterior versión del Resucitado que ejecutó para la localidad vallisoletana de

\footnotetext{
315 PORRAS GIL, María Concepción: op. cit., p. 376.

$316 \quad$ Ibídem.

317 BALADRÓN ALONSO, Javier: op. cit., p. 170.

318 URREA FERNÁNDEZ, Jesús y MARTÍN GONZÁLEZ, Juan José: Inventario artístico de Palencia y su provincia I..., op. cit., p. 60.

319 Ibídem.

320 MARTÍN GONZÁLEZ, Juan José: Escultura barroca en España ..., op. cit., p. 448.

321 MARTÍN GONZÁLEZ, Juan José, URREA FERNÁNDEZ, Jesús y BRASAS EGIDO, José Carlos: "VII- Del arte del Renacimiento al Neoclasicismo en Palencia". En GONZÁLEZ, Julio (coord.): Historia de Palencia II. Edades Moderna y Contemporánea, Excma. Diputación Provincial de Palencia, Palencia, 1984, p. 149; PARRADO DEL OLMO, Jesús María: Ampudia..., op. cit., p. 19; GÓMEZ, Enrique y MARTÍNEZ, Rafael: Semana Santa en Palencia. Historia, arte y tradiciones, Palencia, 1999, p. 99.
} 
Puras una década atrás. Ávila ha crecido mucho como escultor, si bien parece que en esta ocasión utiliza aquel modelo, al cual añade las enseñanzas aprendidas desde entonces. A diferencia de sus Ecce Homo y sus Crucificados en los que las anatomías suelen ser más delgadas y enjutas, este Resucitado se nos presenta ciertamente musculoso y magro. Por lo demás vuelve a demostrarnos que domina a la perfección la captación de los músculos, costillas, huesos, articulaciones, venas, uñas, etc... Las carnes acusan blandura y morbidez, especialmente destacable en detalles como los muslos o los brazos.

Ya dijimos al tratar sobre el Resucitado que le atribuimos en Puras (Valladolid) que Pedro de Ávila se debió de inspirar en los Resucitados ejecutados por su padre (el documentado de Villasilos y el atribuido del Real Monasterio de San Quirce y Santa Julita de Valladolid) para concebir el suyo. Pues bien, la similitud con ambos es total puesto que todos ellos disponen el cuerpo y los brazos de manera análoga (brazo derecho levantado bendiciendo y el izquierdo sujetando la banderola), pero aún más en el caso del ejemplar del convento vallisoletano puesto que ambos tienen tallado el manto en toda su plenitud, el cual les cubre completamente las espaldas y una buena porción del brazo izquierdo en el cual parece intentar enrollarse. La cercanía entre ambas piezas parece más que una mera casualidad.

Aunque estamos ante una escultura de bulto redondo podríamos afirmar sin riesgo a equivocarnos que la disposición del manto parece ejercer las funciones de fondo relivístico, de tal manera que la escultura queda pegada contra él y algunas partes del cuerpo como la pierna derecha se encuentran tan encajadas en el manto que parecen estar talladas en bajorrelieve. Asimismo, pienso que el manto sirve a Ávila para valorizar aún más la anatomía puesto que el potente rojo del manto contrasta con la blancura lechosa de la piel; pero, es más, también produce un fuerte choque la suave, elegante y curvilínea anatomía de Cristo con la rigidez, dureza y rectitud de los pliegues a cuchillo del manto. En definitiva, Ávila parece proponernos un juego de dualidades antagónicas pero complementarias. Este mismo detalle es reseñado por Porras Gil: "el artista compone una figura desnuda de bulto, que hace destacar sobre los pliegues ondulados y "a cuchillo" del manto. Éste, actuando como fondo, contribuye a expresar más eficazmente la delicadeza del modelado del cuerpo al contraponerla con el rígido aristado del plegado del manto y el paño de pureza" ${ }^{322}$. Y pienso que el manto aún aporta algo más y es que tal y como se encuentra dispuesto parece que transforma la verticalidad de la composición puesto que Cristo se halla en pie sin apenas movimiento, con una vista totalmente frontal, a una composición romboidal, dado que es la forma que parece que forman: el borde superior sería la cabeza, el inferior los pies y los laterales ambos lados del manto que parece llegar a ensancharse hacia la mitad del cuerpo de Cristo, de tal manera que desde ahí para arriba o para abajo se va estrechando. Este tipo de efecto puede recordarnos la forma "ahusada" con las que concebía sus esculturas el racionero Alonso Cano. Como vemos, la elegancia combinada con la importancia que otorga a la anatomía es primordial, y eso se demuestra en que el manto

322 PORRAS GIL, María Concepción: op. cit. 
apenas tapa el brazo de Cristo, dejando el resto al aire libre, algo infrecuente por cuanto normalmente los pliegues de los ropajes suelen ser muy ampulosos y lo cubren todo.

Cristo aparece erguido, con una pierna recta y la otra flexionada, como intentando avanzar, es justo el momento en el que despega el pie de la tierra y va a dar el paso, con lo cual aporta dinamismo y un contrapposto a la composición. Porras ve en esta postura una "conexión con la escultura clásica (...) notable tanto en el canon, como en la aludida postura"323. Aparece triunfante sobre la muerte, exhibiendo orgulloso las llagas de los pies, manos y costados, las cuales aparecen señaladas con el color rojo pero sin que en ningún momento mane sangre. Presenta una elegante serenidad. Su cuerpo aparece totalmente desnudo a excepción del paño de pureza y el manto rojo que le pende del hombro izquierdo y le cubre parte del brazo izquierdo y la totalidad de la parte trasera del cuerpo, dotándolo, como ya hemos dicho, de una especie de fondo "escultórico". El color rojo es totalmente plano a excepción de una pequeña banda dorada decorativa por el borde del interior del manto, mientras que por la orilla exterior la prenda se enriquece con una amplia y bella cenefa dorada con elementos botánicos de diferentes colores en la línea de otras tantas que ya hemos visto. El detalle de que el manto púrpura cubra una de sus hombros es visto por Luna Moreno como un "símbolo del martirio o como expresión de la realeza de Jesús" $" 324$. Los pliegues, que son profundos y a cuchillo, lo que nos pone como fecha más temprana el año 1714, forman amplias concavidades separadas por aristadas diagonales que van dividiendo en secciones lisas y recurvadas tanto el manto como el paño (este último posee unos pliegues algo más sencillos). Una vez más vuelve a impresionar la maestría y la pericia que tiene Pedro de Ávila para cortar la madera del manto en finísimas láminas. En su mano izquierda porta un estandarte, símbolo de su triunfo sobre la muerte, mientras que con la otra realiza un gesto de bendición mientras inclina levemente la cabeza para mirar atentamente al espectador. Este gesto de bendición con la mano izquierda puede interpretarse también como la muestra al fiel de la llaga de su mano para recordarnos que murió para redimir el pecado del mundo y vencer a la muerte, envite del cual salió triunfante tal y como nos lo demuestra al exhibir en la mano izquierda el estandarte de la victoria.

La cabeza no presenta ninguna novedad con respecto a todas las obras realizadas durante esta segunda etapa. Especialmente destacado es el tratamiento y definición lograda en la boca, que sigue el esquema de siempre: entreabierta con los dientes superiores y la punta de la lengua visibles. También ha puesto mucho empeño en la labra de la barba y la cabellera. Esta última se nos presenta como dos grandes masas onduladas simétricas que caen a ambos lados del rostro y que se van ensanchando según van cayendo de tal manera que otorgan a la cabeza un aspecto trapezoidal; sobre la frente caen dos de sus típicos mechones curvos con las puntas hacia afuera; este detalle parece ser una de sus "firmas" a falta del documento que acredite su autoría. Por su

\footnotetext{
$323 \quad$ Ibídem.

324 LUNA MORENO, Luis: "Cristo Resucitado", Apasionarte. Pasos de Palencia, Exposición Iconográfica, Cálamo, Palencia, 2006, p. 14.
} 
parte la barba es bífida y con un apurado minucioso como corresponde a una escultura que sería sacada en procesión y sería observada desde muy cerca. 


\section{BERNUY DE COCA. IGLESIA PARROQUIAL DE SAN VICENTE MÁRTIR}

\section{CRISTO CRUCIFICADO (h. 1714)}

La suerte de contar con dos Crucificados documentados de Pedro de Ávila y el hecho de que ambos sigan un modelo muy singular creado por el propio escultor hace que sea muy sencilla la identificación de nuevos ejemplares. Efectivamente, así ocurrió con un pequeño Crucificado, de tamaño aproximado a los del Oratorio de San Felipe Neri y de la parroquial de Torrecilla de la Abadesa, en la iglesia parroquial de San Vicente Mártir de Bernuy de Coca, localidad segoviana colindante con la actual provincia vallisoletana; $\mathrm{y}$, por otra parte, situada a tan solo unos kilómetros de poblaciones pertenecientes al área olmedana, que como ya sabemos fue el gran foco de irradiación de la obra de Ávila durante su primera etapa. Sin embargo, no podemos afirmar que este Crucifijo pertenezca a este primer momento puesto que en él están ya presentes muchos estilemas propios de la segunda etapa; sin embargo, los horribles y desastrosos repintes a los que ha sido sometido no nos permiten poder efectuar un estudio estilístico correcto que nos lleve a consignarle una cronología adecuada. En este sentido, seguramente ocurra como con el Cristo del Olvido del Oratorio de San Felipe Neri, en el cual, una vez que se le despojó del terrible repinte, se encontró una talla magnífica, muy delicada, y que no tenía nada que ver con las superficies planas y poco definidas que parecía tener aquella imagen repintada. Por lo tanto, en lo referente a su cronología, creo que lo más adecuado será fecharlo en torno al año 1714 dadas las evidentes similitudes que posee con el Crucificado de Torrecilla de la Abadesa; puesto que ambos, como se puede ver claramente, suponen un estadio anterior al Cristo del Olvido, en el que Ávila perfecciona al máximo ese modelo y le dota de gran delicadeza y calidad técnica.

Este Crucificado de Bernuy de Coca (Segovia) (Figs. 79-80) nos lleva a creer que el tipo de Crucificado ideado por Pedro de Ávila gozó de un gran éxito, puesto que solo así se puede explicar la presencia de estos tres Crucificados idénticos. Pero, es más, esto nos mueve a pensar en la posible existencia de otros ejemplares en poblaciones de esta zona, en particular, o de Castilla, en general. Nunca hay que olvidar la posibilidad de que alguno pudiera haber desaparecido por las más diversas vicisitudes.

Como decíamos, este Crucificado posee numerosas concomitancias con el de Torrecilla de la Abadesa (Valladolid), sobre todo en lo referente a la anatomía, dado que ambas son más magras que el de San Felipe Neri; el cual es más delgado y enjuto. Además, comparte otros detalles con el referido ejemplar de Torrecilla, los cuales a su vez les diferencian del de San Felipe Neri: observamos que la barbas de ambos son más alargadas, estrechas y con los mechones menos individualizados; es decir son más hieráticos y menos definidos que los del Cristo del Olvido, en el cual nuestro escultor detalla cada uno de los pelos y de los mechones de la barba. Algo similar ocurre a la hora de tallar la melena: mientras que en estos dos crucificados las caballeras adoptan una forma geométrica con ensanchamiento a la altura de las orejas, las cuales ocultan 
entre los mechones, en el ejemplar de San Felipe Neri, esta cabella se ensancha y adquiere unas ondas mucho más anchas y voluminosas. Comparadas, los dos Cristos precedentes tienen unos cabellos más secos y con una talla más gruesa.

Por lo demás, posee las mismas características que estos dos ejemplares, sobre todo la identidad es mayor con el de Torrecilla de la Abadesa, debido a lo cual no volveremos a repetirlas. Tan solo señalaremos un par de detalles y elementos que les diferencian: la cruz, policromada de verde y el letrero del I.N.R.I. parecen ser originales, algo que no ocurre en los otros Crucificados, los cuales son más modernos y sencillos. La definición anatómica en cuento a músculos, huesos, etc... no la vemos bien debido al referido grueso y burdo repinte que ha sufrido y que nos le muestra con una entonación verdosa que oculta todo signo de talla así como unas manchas de sangre que no poseen ningún realismo; sin embargo, parece observarse algún detalle que nos hablaría de esa hipotética buena talla oculta como es una serie de venas en la parte superior interna de las piernas, así como en los gemelos. Finalmente, aunque he comentado que podría fecharse por la misma época que el de Torrecilla de la Abadesa, el hecho de que los pliegues del perizonium no sean tan afilados como en aquél, y mucho menos todavía que en el de San Felipe Neri, me lleva a pensar que fuera levemente anterior, como de principios de la década de 1710; sin embargo, de momento, prefiero fecharlo en ese año de 1714.

A pesar de que el Crucifijo parece hallarse en buen estado de conservación sería preciso y urgente una profunda restauración que eliminara los gruesos y vulgares repintes que ha sufrido y sacara a la luz la brillante calidad técnica que a no dudarlo poseerá; como dijimos, seguramente nos llevaríamos una grata sorpresa al igual que ocurrió tras la restauración y eliminación de repintes del Cristo del Olvido; el cual, desde entonces, tiene que ser calificado sin ningún género de dudas como una de sus obras maestras, cosa que anteriormente no ocurría. 


\section{VALLADOLID. MONASTERIO DEL SANTÍSIMO SALVADOR DE SANTA BRÍGIDA}

\section{BUSTOS DE ECCE HOMO Y DOLOROSA (Hacia 1714-1720)}

En la clausura del Monasterio de Santa Brígida se conservan dos de las obras maestras de nuestro escultor, si bien no las tenemos documentadas. Se trata de la pareja de bustos de Ecce Homo (95 cms.) y Dolorosa (98 cms.). Ya hemos comentado que no sabemos si fueron encargados por las monjas o fueron un regalo o una donación testamentaria por parte de algún particular puesto que dan la sensación de haber sido imágenes de "escaparate".

El primero en ocuparse de estas dos magníficas obras de arte fue Martín González. El historiador del arte no tuvo ninguna duda de que su autor fue Pedro de Ávila, señalando, además, que "responden al modelo de Pedro de Mena, de busto muy prolongado" 325. Esta apreciación concuerda bien con el supuesto viaje a Madrid en el que conocería de cerca la obra de Pedro de Mena y José de Mora, entre otros. Esta atribución jamás ha sido puesta en cuestión, como no podía ser de otra manera por motivos evidentes. Los dos bustos fueron expuestos en sendas exposiciones ("Imágenes de Ecce-Homo en Valladolid" y "Virgen de Pasión") realizadas con motivo de la Semana Santa, en cuyos catálogos Enrique García Martín ha vuelto a confirmar la atribución ${ }^{326}$.

$\mathrm{Su}$ cronología debe rondar entre los años 1714-1720 aunque tampoco podemos descartar que sea posterior, aunque esto no podemos afirmarlo dado que no poseemos ninguna obra documentada con posterioridad al año 1720, a excepción de la desaparecida Virgen de las Angustias (1739) de Íscar (Valladolid). Las razones que exhibo para fecharlo en este lapso de tiempo son estilísticas: las facciones del Ecce Homo y la manera de disponer el pelo son muy similares a las del Cristo del Olvido del Oratorio de San Felipe Neri (1720); pero, es más, la forma de la cabeza, la disposición de cada mechón de cabellera y barba, así como de cejas, ojos, nariz, y todo lo demás es idéntica a la que exhibe el Ecce Homo conservado en la localidad vallisoletana de Renedo. Este Ecce Homo, que llegó procedente de la iglesia del Salvador de Valladolid fue tallado antes del año 1716. Por todo ello, y por la presencia en el busto de profundos pliegues a cuchillos, desarrollados a partir de 1714, la cronología dicha debe ser la aproximada. En cuanto al busto de la Dolorosa no podemos comentar semejanzas con ninguna otra pieza de nuestro escultor

Se trata de dos bustos prolongados hasta un poco más allá de la cintura, de tal manera que en el caso del Ecce Homo se puede observar aproximadamente la mitad del paño de pureza. Este tipo de bustos cortados a la altura más o menos de la cintura "tiene antecedentes italianos renacentistas, también era ya utilizado en el barroco

\footnotetext{
325 MARTÍN GONZÁLEZ, Juan José: Escultura barroca en España ..., op. cit., p. 448.

326 GARCÍA MARTÍN, Enrique: Imágenes de Ecce-Homo..., op. cit., p. 34.; GARCÍA MARTÍN, Enrique: Virgen de Pasión, Ayuntamiento de Valladolid, Valladolid, 2002, p. 32.
} 
andaluz, $^{327}$. La representación en busto del Ecce Homo tiene unos antecedentes muy remotos, tanto en la escuela vallisoletana como en la granadina, que es donde se formó Pedro de Mena. El modelo de Mena hunde sus raíces en las obras de Gaspar Núñez Delgado y en los hermanos Miguel y Jerónimo García, verdaderos especialistas en este tipo de representación, de la cual hicieron numerosas versiones, muchas de ellas en barro cocido y policromado. Por su parte, en Valladolid contamos también con numerosos ejemplares anteriores, si bien parece que Pedro de Ávila no debió de conocer ninguno, todo lo contrario que con algunos bustos de Pedro de Mena en el hipotético viaje a Madrid. Como decíamos, en Valladolid podemos citar el de Juan de Juni conservado en el Museo Diocesano y Catedralicio; el de Alonso Berruguete conservado en el Convento de Jesús y María aunque procedente de una clausura de Olmedo; el de Gregorio Fernández de Azcoitia; los atribuidos a José de Rozas en el Convento de la Concepción, a Alonso de Rozas en el Convento del Corpus Christi; y otros muchos ${ }^{328}$. No poseemos esa misma riqueza en el caso de los bustos de Dolorosa puesto que apenas podemos recordar dos casi idénticos conservados en el Museo Diocesano y Catedralicio y en el Convento de las Descalzas Reales; amén de los otros dos atribuidos a Pedro de Ávila (Monasterio de San Quirce y Museo Nacional de Escultura).

Lo que diferencia este par de bustos de buena parte de los anteriormente reseñados es que forman una pareja. Este detalle es importante puesto que en Valladolid no conservamos ninguna pareja de bustos de este tipo ${ }^{329}$, a excepción de las del Monasterio de San Quirce, obra del importantísimo escultor cortesano Juan Alonso Villabrille y Ron; y del antecoro del Convento de las Descalzas Reales de Valladolid; eso sí, no podemos asegurar que esta última pareja la hiciera el mismo autor. Todo lo contrario que ocurre en la escuela granadina y muy especialmente con Pedro de Mena y José de Mora que, si bien realizaron algunos ejemplares sueltos de uno u otra, la gran mayoría se trataba de parejas de bustos. Lázaro Gila Medina indica que Pedro de Mena esculpió al menos quince parejas ${ }^{330}$.

Como dijimos, este tipo de bustos iban dentro de escaparates situados sobre mesas, las cuales estarían colocadas en capillas u oratorios particulares, en los cuales el dueño iría a orar y meditar ante ellos. Es la "piedad" más próxima e íntima. Cuando estos personajes fallecían, era muy normal que por donación testamentaria lo legaran a conventos o monasterios, en los cuales, por fortuna, se han conservado un gran número de ellos. Este debe ser el caso de estos bustos de las Brígidas.

327 MARTÍN GONZÁLEZ, Juan José: Escultura barroca castellana ..., op. cit., p. 24.

328 Una buena cantidad de ellos formaron parte de la exposición "Imágenes de Ecce Homo en Valladolid" celebrada en el año 2001 en la Sala Municipal de Exposiciones del Teatro Calderón. GARCÍA MARTÍN, Enrique: Imágenes de Ecce-Homo..., op. cit.

329 No podemos contar la pareja de Ecce Homo y Dolorosa del Museo Diocesano y Catedralicio, y atribuidos a Pedro de Mena, puesto que no pertenecen a la ciudad, sino que llegaron procedentes de la cercana localidad de Valdestillas (Valladolid).

330 GILA MEDINA, Lázaro: Pedro de Mena escultor: 1628-1688, Arco Libros, Madrid, 2007, p. 187. 
Como tal pareja se contraponen y complementan a la vez tanto en actitudes como en movimientos. Ambos miran hacia el cielo, si bien mientras que Cristo gira su cabeza a la izquierda mientras mantiene los dos brazos levemente levantados, aunque uno más retrasado que el otro; la Virgen responde mirando hacia la derecha, levantando un brazo y bajando el otro. Ambos realizan gestos declamatorios. También hay un claro contraste entre el cuerpo desnudo del Cristo, en el que se ve que Pedro de Ávila ha querido apurar el estudio anatómico al máximo, el cual es sin duda excelente; mientras que en la Virgen, que va totalmente vestida, ha querido también mostrar sus dotes de laborioso y minucioso artífice al mover los ropajes a su gusto e interpretarlos con una variedad de pliegues berninescos como pocas veces veremos. Los pliegues a cuchillo aparecen en estas dos tallas en todo su esplendor, especialmente destacados son los realizados alrededor del cíngulo de la Virgen. En algunos casos Pedro de Ávila alcanza tal destreza en el adelgazamiento y la consecución de formas inverosímiles que pareciera como si fuera tela encolada. Contra lo que se ha dicho en ocasiones, no se trata de ojos de cristal sino de tapilla vítrea. Finalmente señalar que ambas tallas van policromadas con colores planos, no hay rastro de cenefas, tan solo podemos señalar sendas minúsculas franjas en los bordes del perizonium y del manto de Ecce Homo.

La altísima calidad de ambos bustos y su más que mejorable estado de conservación, puesto que muchos dedos se encuentran seccionados, así como desconchones a lo largo de los dos cuerpos y la nada favorecedora presencia de la espada clavada en el pecho de la Virgen, hace que fuera deseable y recomendable una restauración que les devolviera el esplendor. A pesar de que ya formaron parte de una exposición cada uno de ellos, sería deseable darlas a conocer para que se tuviera conocimiento del elevadísimo nivel escultórico que lograron algunos de los artífices de la escuela vallisoletana dieciochesca.

\section{$\underline{\text { ECCE-HOMO }}$}

El busto de Ecce Homo (95 cms.) (Fig. 81) aparece cortado a la altura del paño de pureza, del cual observamos la parte superior. Le cubre la espalda y parte de los hombros y de los antebrazos un manto rojo que cae recto por el brazo derecho mientras que, como es característico de nuestro escultor, se arremolina alrededor del izquierdo. Los gestos realizados con los brazos, ambos levantados, aunque en escorzo puesto que uno lo echa para atrás y otro lo adelanta, parecen sugerir súplica. A ese sentimiento de súplica sin duda ayuda el hecho de que mire hacia el cielo tiernamente con la boca entreabierta. Destaca García Martín el hecho de que ambas manos las mantenga extendidas y no "atadas ni sosteniendo la caña", como suele ser la iconografía habitual del Ecce Homo ${ }^{331}$.

En su mano derecha portó un cetro, el cual en la actualidad no le puede sujetar debido a la falta de algún dedo y alguna falange de otros. Lo verdaderamente destacable de este busto es su formidable anatomía tanto del busto como de la cabeza. El estudio

331 GARCÍA MARTÍN, Enrique: Imágenes de Ecce-Homo..., op. cit., p. 34. 
anatómico es de los más apurados que le veremos, solo comparable al Cristo del Olvido, puesto que veremos reflejados músculos, tendones, huesos, venas e incluso las arrugas de los dedos y las manos. Especialmente destacables son las venas de los brazos, y el rehundimiento de las clavículas y de la garganta. Pocas veces la escultura castellana ha llegado a tal grado de naturalismo. Por su parte, los dedos siguen la consabida distribución tan característica de Ávila. Los restos de sangre son muy pequeños, leves gotas tanto por el torso como por el rostro; algo más de cantidad en la frente debido a las heridas causadas por la corona de espinas, y también en el hombro izquierdo, lesión que obedecerá a los latigazos de la flagelación.

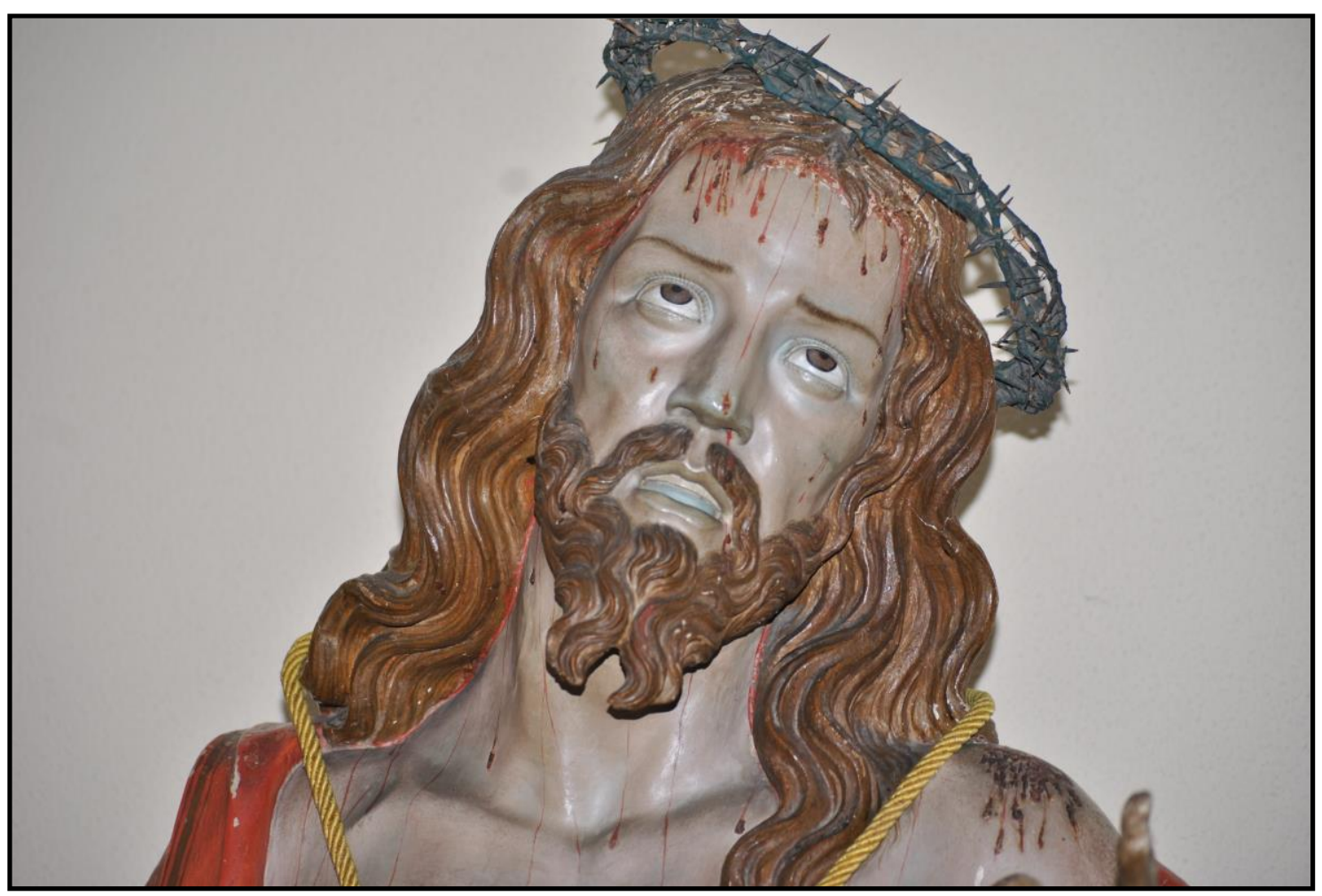

Il. 50- Pedro de Ávila (atrib.). Busto de Ecce Homo. Monasterio de Santa Brígida. Valladolid.

La cabeza es muy similar a la del Cristo del Olvido pero, sobre todo, a la del Ecce Homo de cuerpo entero conservado en la parroquial de Renedo (Valladolid) aunque procedente de la capilla de San Pedro Regalado de la iglesia del Salvador. Martín González definía la cabeza como "endeudada con Gregorio Fernández" 332 . La cabeza es bellísima, y en ella aparecen todos y cada uno de los elementos faciales típicos de nuestro escultor, no falta ni uno, empezando por el formato rectangular del rostro. Sin embargo, el plus de calidad puesto en esta obra es excepcional, y sin duda se deberá a la cercana contemplación a la que se vería sometido, de ahí el detallismo y lo apurado del rostro, de las cabelleras y de la anatomía, como ya dijimos. Las amplias melenas laterales ayudan a ensanchar el rostro. También la cabellera sigue las pautas del segundo estilo de nuestro escultor: abundante y ondulada melena, algunos de cuyos mechones caen detrás del hombro derecho y por delante del izquierdo. En cuanto a la barba es larga y bífida, en todo similar al Ecce Homo de Renedo y el Cristo del Olvido.

332 MARTÍN GONZÁLEZ, Juan José: Escultura barroca en España ..., op. cit., p. 448. 


\section{$\underline{\text { DOLOROSA }}$}

Al igual que el Ecce Homo, el busto de la Dolorosa (98 cms.) (Fig. 82) está cortado horizontalmente un poco por debajo de la cintura. Sin duda esta prolongación se deberá a la necesidad de espacio que tuvo el escultor para poder desarrollar correctamente el pliegue curvado del manto. Sin lugar a dudas, Pedro de Ávila se inspiró en la Dolorosa de la Vera Cruz realizada por Gregorio Fernández. De ella toma la manera de levantar la mirada hacia el Cristo muerto en la cruz, pero sin embargo en esta ocasión no tiene nada que ver con el Descendimiento; si bien esta mirada hacia el cielo se ve correspondida por otra similar del Ecce Homo. Como hemos visto en numerosas ocasiones, Pedro de Ávila se inspira bastante en el maestro, unas veces para partir de ahí y realizar sus propias composiciones y en otras ocasiones para hacer copias literales (Atado a la columna de la iglesia penitencial de las Angustias), si bien en este caso seguramente que se trató de una imposición del comitente.

Viste una túnica roja ceñida a la cintura por un cíngulo azul. Ya dijimos que Ávila simula a la perfección los numerosos pequeños pliegues formados por el ajustado entallado del cíngulo. Por encima un manto azul que le cubre la espalda y la cabeza; uno de los extremos se arremolina en numerosas ondas concéntricas alrededor del brazo izquierdo, detalle muy típico de nuestro escultor, mientras que la otra realiza una elipse desde el lado derecho, pasando por el abdomen hasta llegar a la axila izquierda. Por debajo del manto, le cubre la cabeza una toca que no termina por completo de ocultar los cabellos. Los pliegues a cuchillo son muy cortantes y las telas, sobre todo los paños volados del manto adquieren la típica finura a la que nos tiene acostumbrados. Tiene clavada una espada de plata en la parte derecha del pecho, pero sería deseable que para su mejor conservación se retirara puesto que los gestos que hace de por sí ya nos hablan del dolor de la Virgen. Sus manos forman una diagonal típicamente barroca. Levanta la mano derecha dando sensación sufriente mientras que la otra la extiende hacia el frente levemente realizando un gesto declamatorio. Ambas manos, realizadas de forma exenta, poseen la típica distribución de dedos que constantemente utiliza Ávila.

Si bien el rostro presenta los típicos rasgos fisonómicos a los cuales nos tiene acostumbrados Ávila durante su segunda etapa, la faz con que la ha representado poco tiene que ver con otras femeninas talladas por estas mismas fechas como pueden ser la Virgen de la Anunciación de la parroquial de Renedo, la Virgen del Refugio o las diversas versiones de la Magdalena; quizás las que sitúen más cerca sean los de la Inmaculada y la Magdalena del Oratorio de San Felipe Neri. Llama la atención el enarcamiento de las cejas, solución que utiliza en contadas ocasiones, que produce en el rostro un profundo sentimiento de dolor, al cual ayuda también la boca entreabierta y la mirada perdida en el cielo. Referente al rostro, refiere Martín González que "su rostro

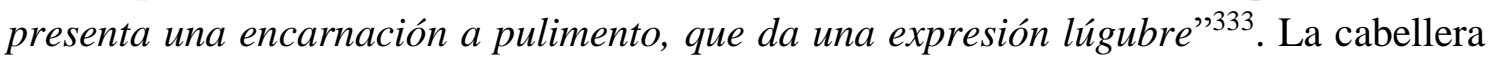
le deja la frente despejada, cayendo en largas melenas onduladas a ambos lados del rostro, la del lado derecho se pierde dentro de la toca, mientras la de la izquierda se

$333 \quad$ Ibídem. 
prolonga hasta el pecho. Como vemos, muchos de estos detalles los utiliza constantemente durante su prolongado "segundo estilo", lo que convierte a las esculturas de Ávila en obras fácilmente reconocibles, aunque difícilmente fechables si no contamos con ningún dato relacionado. El rostro acusa blandura, si bien no posee la perfección técnica presente en el Ecce Homo. Como ya dijimos, parece que Ávila se centró en el físico del Cristo y en los juegos de paños de la Virgen. Sea como fuere, en ambos casos logró dar buena muestra de sus capacidades.

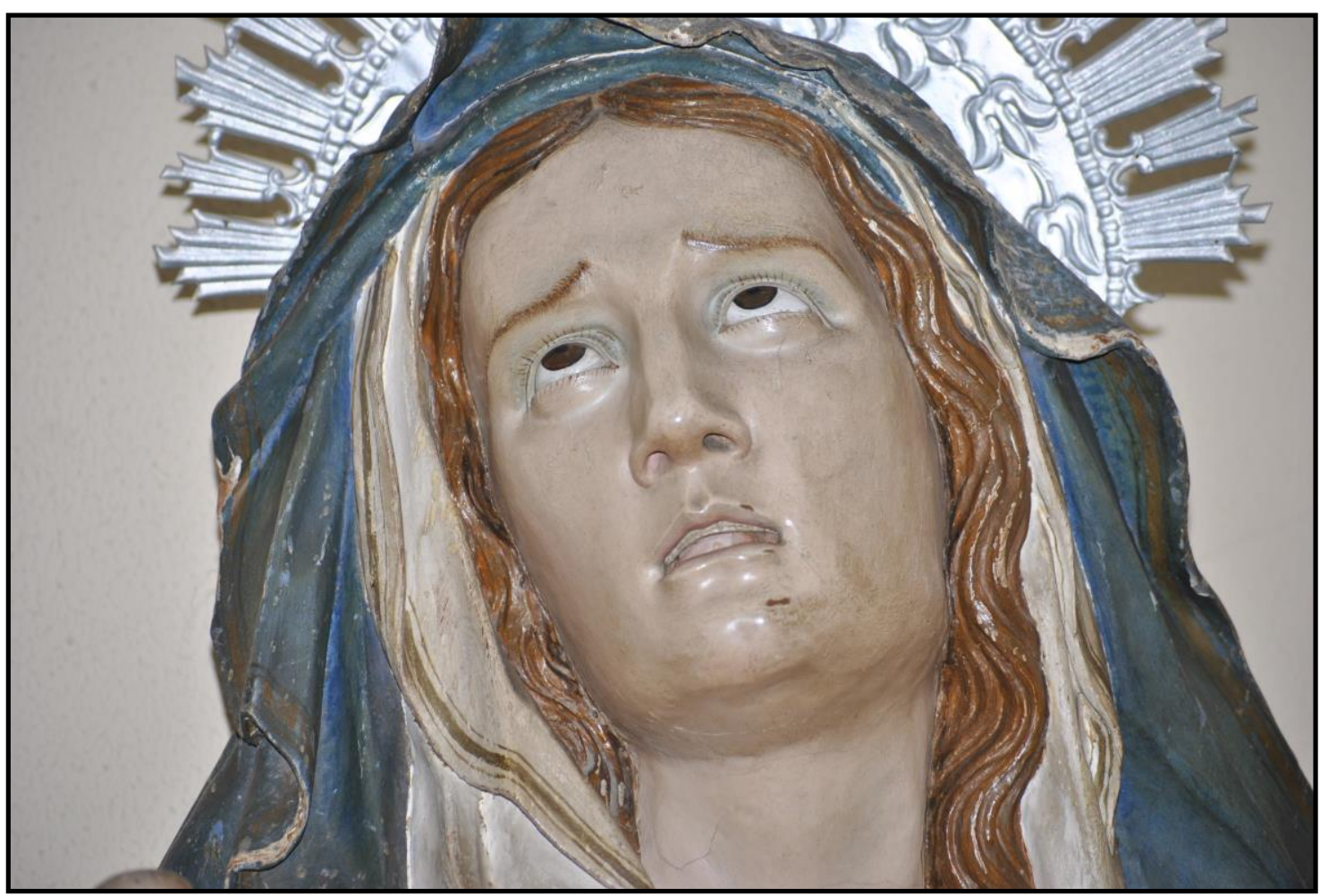

Il. 51- Pedro de Ávila (atrib.). Busto de Dolorosa. Monasterio de Santa Brígida. Valladolid.

\section{SANTA ESCOLÁSTICA (entre 1714-1739)}

La presente escultura no figura reseñada en el respectivo tomo del Catálogo Monumental, sin duda debido a que por entonces ya se había extraviado tras el abandono de las monjas del primitivo convento; sin embargo, sí que figura en el Inventario Artístico de Valladolid, realizado pocos años antes de la clausura del establecimiento. Martín González la pudo ver entonces en el lado del Evangelio, en el primer tramo después del coro ${ }^{334}$. La creyó obra del siglo XVIII, como así efectivamente parece por la única fotografía que hemos encontrado de ella, conservada en el Archivo Fotográfico del Departamento de Historia del Arte de la Universidad de Valladolid. Quizás esta escultura fuera una de las "dos religiosas de la orden, de tamaño mayor que el natural" que conformaban el altar de San Juan Bautista ${ }^{335}$, esta

\footnotetext{
334 MARTÍN GONZÁLEZ, Juan José (dir.): Inventario artístico de Valladolid..., op. cit., p. 27.

335 GONZÁLEZ GARCÍA-VALLADOLID, Casimiro: Valladolid..., op. cit., Tomo I, p. 521.
}

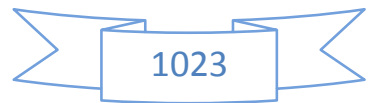


última escultura atribuida a Felipe Espinabete. Estas tres tallas también se perdieron tras la mudanza de las religiosas al nuevo convento.

Poco podemos comentar de la obra ya que tan solo contamos para su estudio con una pequeña fotografía. En ella observamos a la hermana gemela de San Benito de pie sobre una peana. Viste una cogulla negra benedictina de amplias mangas (que nos recuerdan a las del hábito cisterciense del San Bernardo del Monasterio de San Quirce), ciertamente exageradas; un velo negro y una toca que le rodea el rostro y le tapa toda la cabellera. En su mano derecha porta un báculo abacial y en la izquierda un libro cerrado. Ya dijimos al hablar de la Santa Escolástica que atribuimos a Juan de Ávila, en la cual pudo inspirarse su hijo Pedro para tallar esta dado los evidentes parecidos entre ambas, que el libro cerrado pudiera significar que no realizó una Regla propia sino que siguió fielmente la escrita por el fundador de los benedictinos. Las manos que sujetan ambos atributos, las cuales se hallan tallada de manera exenta, siguen fielmente la posición de los dedos que ya hemos dicho que nuestro escultor tenía estereotipada. Los pliegues son los típicos de cuchillo, y la finura lograda en las mangas nos habla del esmero puesto en la labra de esta imagen.

El rostro posee los típicos rasgos faciales presentes en su "segundo estilo". Mira hacia el cielo como buscando la inspiración divina. Ojos rehundidos de tapilla vítrea que adoptan la característica forma almendrada, y con el característico abultamiento de la parte inferior, mucho más pronunciado que en otras ocasiones; nariz recta con el tabique nasal ancho $y$ aplastado; fosas nasales perforadas. Boca entreabierta que forma una especie de mueca, de la que ya hablamos al exponer el estilo de nuestro escultor. No llegamos a apreciar si tiene tallados los dientes y la punta de la lengua como suele ser habitual. Tampoco llegamos a observar si los pies adoptan el ángulo de $90^{\circ}$.

La elección de la cronología 1714-1739 hace referencia a los dos hitos que hemos repetido en diversas ocasiones: 1714 es cuando comienza a presentar un pliegue a cuchillo mucho más pronunciado y depurado $\mathrm{y}$ un mayor adelgazamiento de las maderas; mientras que el año 1739 es en el que tenemos fechada su última obra ya que pocos meses después quedaría ciego. No se pueden afinar mucho más las fechas.

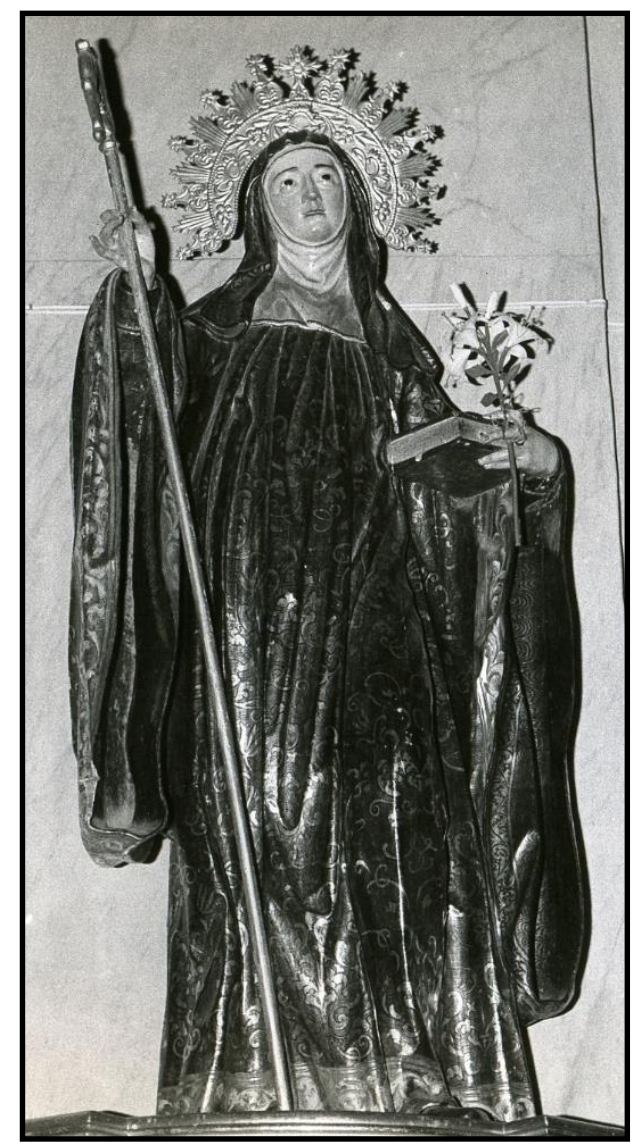

Il. 52- Pedro de Ávila (atrib.). Santa Escolástica. Monasterio de Santa Brígida. Valladolid. (C) Departamento de Historia del Arte de la Universidad de Valladolid. 


\section{VALLADOLID. MUSEO NACIONAL DE ESCULTURA}

\section{BUSTO DE DOLOROSA (entre 1714-1739)}

No tenemos ninguna noticia acerca del origen de este precioso busto de Dolorosa que se atribuye a Pedro de Ávila (Fig. 83). Tan solo que ingresó en el Museo Nacional de Escultura en 1985 tras su adquisición por el Ministerio de Cultura a la colección del Conde Güell ${ }^{336}$; el cual probablemente la adquirió de algún convento desamortizado o parroquia rural castellana, probablemente vallisoletana. En la actualidad se conserva en los almacenes del Museo Nacional de Escultura con el registro no 1.127. Quizás se encontrara dentro de un escaparate e hiciera pareja con un Ecce Homo, al igual que el par de bustos de las Brígidas, pero sin embargo no conocemos ningún busto de Cristo de características similares a esta Dolorosa. Tan solo cabe mencionar uno atribuido a Juan de Ávila que también se conserva en el Museo Nacional de Escultura, procedente del Monasterio de Nuestra Señora de Prado; si bien estilísticamente nada tiene que ver.

Hasta el momento nadie se ha ocupado de estudiar ni de citar este bello busto, por lo que se trata de una obra inédita para el público general. No es fácil determinar su cronología puesto que solo contamos con un elemento que nos puede delimitar un poco las fechas. Se trata del pliegue a cuchillo cortante, utilizado más o menos a partir de 1714. El otro límite cronológico sería 1739, año en que tenemos documentada su última obra. Podría pensarse que la fecha de ejecución del busto se encontraría más cercano a 1714 que a 1739 debido a la presencia de una cenefa decorativa en el manto de la Virgen, debido a que, como vamos viendo, según se avanza en el tiempo, las policromías adquiere tonalidades planas y las cenefas y otros elementos decorativos tienden a desaparecer; sin embargo, la presencia de estas cenefas en algunas obras atribuidas con total seguridad fechables en los últimos años de su magisterio nos impide poder afirmarlo con rotundidad.

El busto, realizado en madera policromada, es de tamaño natural (92,5 x 92 x $55 \mathrm{~cm}$.). Al igual que los otros dos bustos que se le atribuyen (los del Monasterio de San Quirce y del Monasterio de Santa Brígida) nos presentan una Dolorosa seccionada horizontalmente a una altura un poco inferior a la cintura. Este busto emparenta en el rostro y en el violento escorzo con el de la Virgen del Refugio y en cuanto a la composición y colocación de prendas y paños a los del busto de la Dolorosa de Santa Brígida. Además, al igual que esta última, posee lejanos ecos de la Dolorosa de la Vera Cruz de Gregorio Fernández.

Ávila nos presenta a la Virgen en una posición muy movida y barroca puesto que dispone el torso en escorzo y a la vez gira el cuello para mirar hacia el cielo infinito. Tiene el brazo derecho doblado, de tal manera que aplasta un paño que lleva en esa mano contra el pecho, mientras que con la mano izquierda realiza un típico gesto declamatorio. Ambas manos, que están realizadas de manera exenta, son muy delicadas,

336 Agradezco el conocimiento de esta pieza, así como los datos sobre su adquisición, a don Manuel Arias Martínez, subdirector del Museo Nacional de Escultura. 
especialmente la que sujeta el paño. Viste una túnica roja, con los puños vueltos, ceñida a la cintura por un cíngulo azul. Como en el busto de Dolorosa de las Brígidas, realiza la misma simulación de pequeños pliegues formados por el ajustado entallado del cíngulo. Los pliegues son aún más afilados. Por encima tiene echado sobre la cabeza y la espalda un manto azul con una cenefa dorada en el borde en la cual se explayan motivos decorativos botánicos de diferentes colores. Este manto realiza en la parte izquierda del busto el mismo giro sinuoso que la lleva a recorrer el abdomen y sujetarse bajo la axila izquierda; por su parte también aparecen los típicos finos paños en remolino presentes alrededor del brazo izquierdo. Por debajo del manto, le cubre la cabeza una toca blanca que le cubre parte de los cabellos. Las prendas presentan el consabido pliegue a cuchillo, y es especialmente destacable la consecución de las arrugas del pañuelo, en el cual llega a adoptar unos cortes tan agudos y unas formas tan intrincadas, inverosímiles y delgadas que parece labor de filigrana, en la que a la fuerza ha debido de utilizar el trépano para crear las diversas oquedades.

En cuanto al rostro, como ya dijimos, sigue los parámetros que son generales en Ávila, siendo su parecido casi total con el de la Virgen del Refugio, si bien en este caso los rasgos son algo más dulces y redondeados, la geometrización a la que nos tiene acostumbrados en esta ocasión deja paso a un relajamiento de las mismas. Además, al igual que la Virgen del Refugio última, y el busto de Dolorosa de las Brígidas, es una de las pocas tallas en las que no coloca las cejas rectas sino enarcadas. 


\section{VALLADOLID. SEMINARIO DIOCESANO}

\section{INMACULADA (entre 1714-1739)}

En una pequeña capilla del cuarto piso del Seminario Diocesano de Valladolid se custodia una maravillosa escultura de la Inmaculada Concepción (Fig. 84) que es obra indudable de Pedro de Ávila. El único que ha tratado sobre esta pieza es Enrique García Martín, el cual se la atribuyó sin reservas a nuestro escultor, afirmación con la que coincido totalmente ${ }^{337}$. Al parecer, según el propio García Martín, la pequeña imagen (78 cms.) procede de la iglesia de Santiago Apóstol, aunque se ignora la fecha en que llegó al seminario. Esta escultura podría tener la particularidad de ser la única que Ávila tallara para la iglesia en la que fue bautizado y para la cual trabajó ampliamente su padre.

El pequeño tamaño de la Inmaculada $(78 \mathrm{cms}$.) la invalida como imagen principal de cualquiera de los retablos de la iglesia, por lo que hemos de eliminar la opción de que presidiera el retablo de la capilla de la Inmaculada, cuya imagen titular era el lienzo atribuido a Juan Sánchez Cotán ${ }^{338}$; esta capilla, la segunda del lado del Evangelio si contamos la de la Virgen del Pilar, es descrita por Canesi de la siguiente manera: "toda pintada de azul, en que está el Santísimo Sacramento, y hay fundada en esta Parroquia una cofradía con el misterio de esta advocación" ${ }^{339}$. Probablemente tampoco se trate de la Inmaculada que refiere Casimiro González García-Valladolid en el retablo colateral de la Epístola ${ }^{340}$. Esta última posiblemente sea una de cartón piedra que hasta hace un par de años ocupó la hornacina principal de dicho retablo.

Una opción que creo más factible es que fuera una que estuvo situada sobre el sagrario barroco, el cual fue retirado junto con la antigua mesa de altar, gradas y tabernáculo el 22 de julio de 1883 con motivo de la consagración de la iglesia por parte del arzobispo Sanz y Forés. Todos estos elementos fueron sustituidos en aquel momento por otros de mármol blanco de Macael que para nada casan con el retablo barroco y que, además, nos privó de la contemplación del magno conjunto barroco creado por Alonso Manzano ${ }^{341}$.

En los libros de fábrica figuran unos datos que probablemente tengan que ver con nuestra Inmaculada: en el año 1749 se le abonan a un ensamblador, quizás Pedro Roldán, 146 reales por el coste del "arco donde está Nuestra Señora de la Concepción en el altar mayor consta de recibos" 342 . Ese mismo año el pintor Francisco de Prado,

337 GARCÍA MARTÍN, Enrique: El Seminario Diocesano de Valladolid. Notas de Historia y Catálogo Artístico, Diputación Provincial de Valladolid, Valladolid, 1998, p. 68.

338 MARTÍN GONZÁLEZ, Juan José y URREA, Jesús: Catálogo Monumental de la provincia de Valladolid. Tomo XIV..., op. cit., p. 201.

339 CANESI ACEVEDO, Manuel: Historia de Valladolid (1750), Tomo I, op. cit., p. 338.

340 GONZÁLEZ GARCÍA-VALLADOLID, Casimiro: Valladolid..., op. cit., Tomo I, p. 769.

$341 \quad$ Ídem, p. 768.

$342 \quad$ Arco de Nuestra Señora de la Concepción. "Son data ciento y cuarenta y seis reales coste que tuvo el arco donde está Nuestra Señora de la Concepción en el altar mayor consta de recibos". A.G.D.V., Santiago, Libro de fábrica 1731-1753, Año 1749. 
hijo del también pintor Ignacio de Prado, recibe 100 reales por dorar "un arco de espejos y rayos del altar mayor"; dicho arco no será otro que el de la partida precedente $^{343}$. Unos años después, en 1807, figura en otro libro de cuentas un pago al pintor Antonio Navarro "por el pintado y dorado de una repisa grande donde está colocada la Purísima Concepción en la sacristía"344. Dado que en la iglesia no hay constancia de que hayan existido otras representaciones escultóricas de la Inmaculada Concepción, cabe pensar que esta conservada en el seminario presidiera primero el arco a los pies del altar mayor y que con los años, y el cambio de gusto, pasara a la sacristía.

Aportar una cronología es muy complicado en esta ocasión puesto que no contamos con ninguna noticia o hito que nos permita delimitarla. Sin duda es posterior a 1714 debido a la aplicación del pliegue a cuchillo, y enero de 1740 que es cuando ya sabemos fehacientemente que se encontraba ciego; de hecho, su última obra conocida data de un año antes. Esta pequeña Inmaculada posee mayores similitudes con la de San Felipe Neri de las que tuviera la del Monasterio de las Brígidas puesto que a diferencia de esta última sí que cuenta con una peana angelical y posee en sus ropajes el pliegue berninesco. Sin embargo, también posee diferencias con la de San Felipe Neri puesto que no coinciden en la manera de disponer los ropajes ni en la forma de colocar las manos; mientras que aquélla une las manos en oración, esta se coloca la mano derecha sobre el pecho en gesto declamatorio.

La Virgen aparece de pie sobre un trono formado por tres cabezas de ángeles, cuyos rostros son bastante similares a los de la Inmaculada de San Felipe Neri. Para crear diversidad los dota de diferentes ejes de visión y peinados. Adelanta levemente la pierna izquierda, aunque en esta ocasión este hecho no tiene reflejo en la rodilla sobresaliendo por debajo de la túnica. La escultura rompe totalmente con la visión frontal puesto que mientras que el cuerpo está levemente arqueado, el torso realiza un ligero escorzo hacia el lado derecho, mucho más pronunciando en el caso de la cabeza. Dobla su brazo derecho para llevárselo al pecho muy devotamente, mientras que el izquierdo lo mantiene reposado. Las manos son muy delicadas y elegantes y siguen la ordenación de dedos a la que nos hemos referido en distintas ocasiones. Su factura es exenta, pues no están talladas en el propio cuerpo. La Virgen adopta una forma fusiforme que recuerda lejanamente las Inmaculadas talladas décadas atrás por el racionero Alonso Cano y su discípulo Pedro de Mena. Viste túnica blanca hasta los pies, los cuales en esta ocasión es una de las contadas veces en las que no aparecerán colocados en el ya sabido ángulo de $90^{\circ}$; asimismo tampoco figura el trozo de túnica que los divide, sino que los paños siguen un movimiento uniforme. Los pliegues caen verticales formando numerosas aristas, aunque no demasiado pronunciadas. Por encima porta un manto colocado de una manera muy artificiosa puesto que además de sujetárselo con la mano derecha a la altura

343 Dorado. "Son data cien reales pagados a Francisco de Prado por el dorado de un arco de espejos y rayos del altar mayor consta de su recibo”. A.G.D.V., Santiago, Libro de fábrica 1731-1753, Año 1749.

344 "Son data trescientos ochenta y ocho reales pagados a Anastasio Navarro maestro pintor y dorador en ésta forma: Primeramente por el pintado y dorado de una repisa grande donde está colocada la Purísima Concepción en la sacristía ciento veinte reales (...)”. A.G.D.V., Santiago, Libro de fábrica 1797, f. 277. 
del pecho, le recorre gran parte del abdomen, hasta pasar hacia la espalda, la cual cubre en casi su totalidad, y llega hasta el brazo izquierdo, en el cual forma un remolino alrededor de la mano. Este remolino ya le hemos visto en otras esculturas de nuestro artista. Los paños en esta ocasión son mucho más finos, aristados y volados. Utiliza los pliegues del manto para ensanchar la zona media y además para crear una diagonal que corte el acentuado verticalismo de la composición.

El rostro nos presenta a una Virgen mucho más aniñada que de costumbre, sus facciones son dulces y su piel acusa la típica blandura juvenil. Sus rasgos faciales son los típicos en nuestro escultor a excepción del cierto curvamiento del tabique nasal, el mantener la boca cerrada y el pronunciamiento excesivo de las comisuras. Como de costumbre, amplia frente y largas cabelleras que bordean los lados del rostro, ocultando una de las orejas y dejando la otra totalmente visible. Las guedejas son finas, por la espalda caerán expandidas, mientras que por la parte delantera algunas caen sobre los hombros y otra sobre el pecho. No son las típicas guedejas sinuosas, sino que los cabellos parecen ir entrelazados.

Sin duda todas las novedades habidas en esta talla con respecto a otras Inmaculadas obedecerían al deseo de que la parroquia en la que fue bautizado tuviera un ejemplar único y distinguido. Podríamos incluso especular que fuera un presente del propio escultor. Tan interesante escultura bien merecería una restauración y su vuelta a la iglesia de Santiago, recuperando parte de la utilidad para la que parece que fue concebida. 


\section{OLMEDO. IGLESIA DE SANTA MARÍA DEL CASTILLO}

\section{SAN NICOLÁS DE BARI (entre 1714-1739)}

San Nicolás de Bari (270-345/352) tiene la particularidad de que es un santo que ha tenido similar importancia en las dos iglesias cristianas: la Griega y la Latina. Aunque nació en Asia Menor, su culto llegó al sur de Italia gracias a sus reliquias. Señala Réau que el culto de San Nicolás "no padeció al cisma y ha seguido sirviendo como vínculo entre las dos mitades de la cristiandad. En tal sentido, puede decirse que es el más universal de los santos" ${ }^{345}$. Nicolás nació en el seno de una familia pudiente y cristiano, lo que conllevó que desde pequeño mamara la religión. Se dice que "su santidad se habría manifestado desde la cuna: los viernes, días de ayuno, se abstenía de mamar del pecho de su nodriza"346.

Fue un hombre muy caritativo, tal es así que cuando murieron sus padres repartió sus cuantiosos bienes entre los pobres. Pero no solo eso, sino que dos de sus milagros más conocidos tienen relación con la caridad: el primero es uno que se cuenta que dotó " $a$ tres jóvenes casaderas muy pobres a quienes la miseria empujaba al vicio", y el otro es el del "milagro de los tres monaguillos resucitados"347. Tras la referida renuncia de todos sus bienes marchó a la ciudad de Myra, en la cual fue nombrado obispo gracias a una casualidad, puesto que varios religiosos se encontraba allí intentando dilucidar quién sería el próximo obispo, y al no ponerse de acuerdo acordaron que lo fuera el próximo sacerdote que entrara en el templo, y ese fue San Nicolás ${ }^{348}$.

Su vida tiene otros acontecimientos curiosos: así, fue mandado apresar y que se quemara su barba por mandato del emperador Licinio, si bien al poco tiempo el advenimiento de Constantino trajo como consecuencia su liberación. El otro suceso reseñable es apuntado por Réau: "se contaba que había combatido la herejía arriana en el concilio de Nicea; llevado por su celo habría llegado a propinar a Arrio un puñetazo en el rostro" 349 .

La presente escultura de San Nicolás (Fig. 85), que sin ninguna duda pertenece a Pedro de Ávila, ha sido tratada en muy pocas ocasiones. De hecho, en el Inventario Artístico de Valladolid ni siquiera se cita. Brasas Egido la recoge en el Catálogo Monumental, si bien solamente la nombra ${ }^{350}$. Fueron Matamala y Urrea en su libro La nobleza y su patronato artístico en Olmedo los que desentrañaron la historia de esta bella imagen. Al parecer, el retablo llegó a la iglesia de Santa María de Olmedo en el año 1961 procedente del desaparecido Hospital de San Nicolás de Bari, cuya capilla presidiría. El Hospital de San Nicolás de Bari, también conocido como "La Copera" o "El

\footnotetext{
345 RÉAU, Louis: Iconografía de los santos. G-O..., op. cit., p. 428.

$346 \quad$ Ídem, p. 429.

347 Ibídem.

348 https://es.wikipedia.org/wiki/Nicol\%C3\%A1s_de_Bari

349 RÉAU, Louis: Iconografía de los santos. G-O..., op. cit., p 428.

350 BRASAS EGIDO, José Carlos: Catálogo Monumental de la provincia de Valladolid. Tomo X..., op. cit., p. 152.
} 
Hospitalillo", fue fundado por Francisca de Manzaneda, mujer en primeras nupcias del copero de la reina Isabel la Católica, Hernando de Cuellar, y posteriormente del licenciado Alonso de Montalvo, en sus propias casas. En su testamento, otorgado en 1485, deja nombrados como patronos a los sucesivos priores del monasterio de La Mejorada. Su función sería la de recoger a "los pobres dolientes y necesitados que hubiese en esta villa como peregrinos" 351 .

El 19 de junio de 2013 se recoge en prensa la reunión entre el subdelegado del gobierno en Valladolid, Pablo Trillo, y el Arzobispo de Valladolid, don Ricardo Blázquez, en la que se trata sobre "la posible transmisión de titularidad a una institución sin ánimo de lucro del retablo de San Nicolás ubicado en la iglesia de Santa María, de Olmedo, procedente de la próxima extinción de la 'Fundación Agregación de Fundaciones Benéfico Particulares de la Provincia de Valladolid', de cuyo patronato es presidente el delegado territorial de la Junta". Dicha Fundación fue constituida en el año 1965 por el Ministerio de Gobernación ${ }^{352}$.

Finalmente, el 5 de noviembre de ese mismo año el retablo pasa a poder de la Fundación de Las Edades del Hombre y se decide que continúe en la iglesia. El rumor previo de que el retablo podría abandonar la localidad causó un gran revuelo entre los parroquianos, debido a lo cual fueron necesarias unas palabras del secretario general de la Fundación para tranquilizarlos: "el retablo permanecerá dentro del templo como hasta ahora y no nos lo llevaremos a ninguna parte" ${ }^{353}$. Como anécdota señalar que el retablo fue tasado en 120.000 euros.

El retablo es claramente barroco y fechable en el primer cuarto del siglo XVIII debido al uso masivo del estípite y a la eliminación de la columna como elemento tanto sustentante como decorativo. Parece más que probable que el retablo fue hecho ex profeso para San Nicolás de Bari, cuya escultura preside la hornacina principal, situada en la parte baja del mismo. El resto del retablo lo completan y decoran ocho pinturas sobra tabla (la situada en el extremo derecho del banco ha desaparecido) que según Matamala y Urrea pudieran proceder de un retablo descabalado fechado hacia el 1500. Al estar una de estas tablas dedicada a San Jerónimo ambos investigadores sugirieron que el desaparecido retablo pudiera proceder del cercano monasterio de La Mejorada ${ }^{354}$. No sería nada extraño puesto que en la localidad se conservan otros muchos bienes procedentes de este cenobio jerónimo. Según Caamaño Martínez, estas pinturas presentan un estilo que fusiona los de Juan de Borgoña y Pedro Berruguete ${ }^{355}$. Los temas reflejados en ella son los siguientes: Santo Domingo, el Nacimiento, San

\footnotetext{
351 MATAMALA, Pilar y URREA, Jesús: La nobleza y su patronato artístico en Olmedo, Diputación Provincial de Valladolid, Valladolid, 1998, p. 111.

352 http://www.europapress.es/castilla-y-leon/noticia-junta-arzobispado-valladolid-estudíantransmision-retablo-iglesia-santa-maria-olmedo-20130619165751.html.

353 http://www.elnortedecastilla.es/20131106/local/valladolid/fundacion-simon-ruiz-recibe$201311062127 . \mathrm{html}$.

$354 \quad$ MATAMALA, Pilar y URREA, Jesús: op. cit., p. 111.

355 CAAMAÑO MARTÍNEZ, Jesús María: "Sobre la influencia de Juan de Borgoña", B.S.A.A., Tomo XXX, 1964, p. 301.
} 
Jerónimo, el Calvario, la Visitación, la Estigmatización de San Francisco, y el Nacimiento de la Virgen.

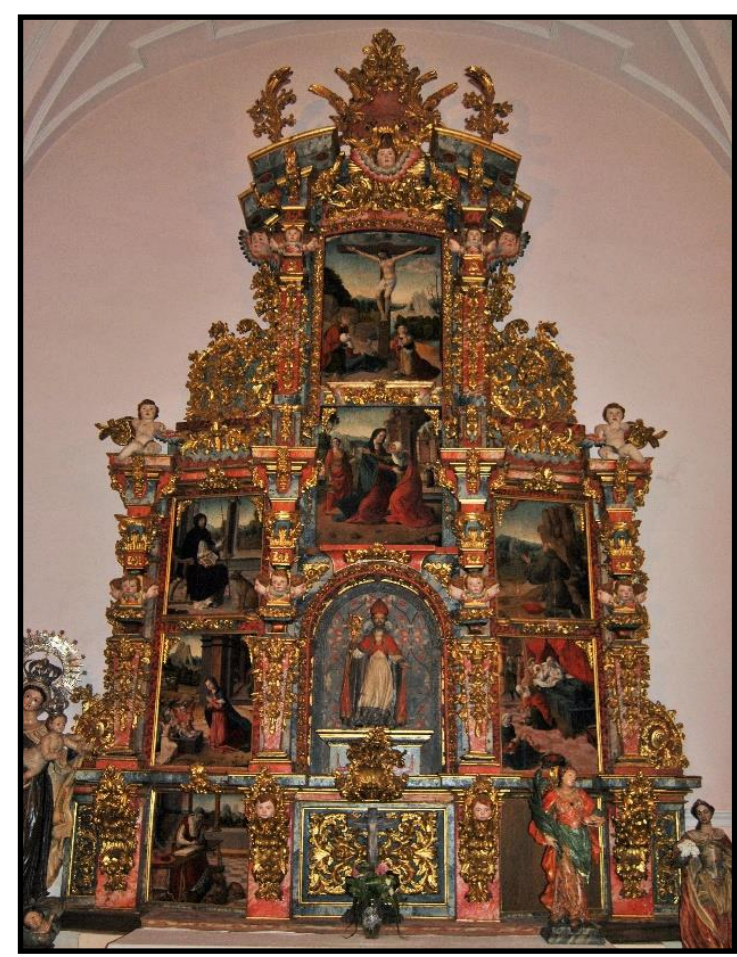

Il. 53- Anónimo. Retablo de San Nicolás. Iglesia de Santa María del Castillo. Olmedo (Valladolid).

El retablo $(450 \mathrm{cms}$. $\mathrm{x} 630 \mathrm{cms}$. sin el banco, el cual tiene de altura $100 \mathrm{cms}^{356}$ ) consta de banco, dos cuerpos, tres calles y ático; sin embargo la calle central rompe con el esquema de los cuerpos puesto que la hornacina principal es más alta que los cuerpos laterales; lo mismo ocurre con la hornacina dispuesta sobre ésta, la cual parte el entablamento; una última hornacina cumple las funciones de ático, a los lados de la cual hay sendos roleos vegetales. Remata el retablo un entablamento partido en cuyo centro hay una cabeza alada de serafín sobre el que se alza una especie de peineta con rocalla a la cual flanquean dos elementos botánicos. El retablo se estructura a través de estípites: cuatro en el cuerpo (sobre los extremos se sitúan sendos angelitos) y otros dos que flanquean el ático y la parte superior de la tabla situada bajo el ático. El mueble no se encuentra solamente dorado sino que el policromador le ha otorgado otros colores (azul y rojo) para dar mayor vistosidad, pero no son tonalidades planas sino que son jaspeados.

Pedro de Ávila dispone a San Nicolás según la postura que tanto le gusta al efigiarle de pie y con una pierna levemente adelantada, con lo cual crea un contrapposto y dota de cierto movimiento a la escultura, si bien la visión no deja de ser frontal. Podemos colegir que cuando nuestro escultor tenía que representar a un santo utilizaba esta "receta", la cual tan solo modificaba por medio de los ropajes y atributos que convinieran a cada uno de ellos. En este caso, San Nicolás levanta el brazo derecho, en cuya mano empuña un báculo, atributo que alude a su condición de obispo, al igual que la mitra con que se encuentra tocada su cabeza. En la mano izquierda, cuyo brazo mantiene levemente caído, también debió de sujetar algún elemento puesto que así parece indicárnoslo el hecho de que tenga la mano semi cerrada. Su cabeza, que mira al frente, posee los típicos estilemas de nuestro escultor ya en su segunda etapa, por lo que la imagen es posterior al año 1707: ojos de tapilla; nariz ancha, y con el tabique recto y aplastado; boca entreabierta, etc...; el rostro está modelado con gran blandura como podemos observar en su piel enjuta en ambos carrillos o en el hueso frontal, en el cual se llegan incluso a marcar los huesos; sobre la frente tiene dos arrugas que adoptan la

\footnotetext{
356 http://www.europapress.es/castilla-y-leon/noticia-junta-arzobispado-valladolid-estudían-
} transmision-retablo-iglesia-santa-maria-olmedo-20130619165751.html. 
forma tan característica que suele utilizar Ávila. La barba, trazada a base de largos y sinuosos mechones compactos simétricos y muy virtuosistas, procede del San Francisco de Sales que su padre ejecuta para el Oratorio de San Felipe Neri, y que el propio Pedro de Ávila pone en práctica en sus representaciones de San Joaquín, entre otros. Por ambos lados del rostro la barba es espesa y adopta esos mismos mechones alargados y sinuosos. Llama la atención de que nacen de una piel que se encuentra semi hundida a causa de la demacración propia de la avanzada edad. El pelo apenas es visible por cuanto tiene directamente tallada la mitra, tan solo pueden observarse los bucles que se forman entre la propia mitra y las orejas, las cuales no se hallan esculpidas del todo, puesto que el pelo le cubre la parte superior. Barba y cabellera son grisáceas.

San Nicolás va revestido como lo que era: un obispo. Viste una amplia capa blanca, con la parte inferior policromada con imitación de brocado en color azul, hasta los pies, de los cuales podemos ver tan solo la punta. Como de costumbre estos pies están dispuestos en un ángulo de $90^{\circ} \mathrm{y}$ separados por un pliegue cortante de la túnica. Sobre los hombros tiene echada una gran capa roja, con los ribetes recorridos por una lujosa cenefa dorada con diferentes motivos geométricos, que llega también casi hasta el suelo. No le cubre el pecho sino que toma formas redondeadas en ambos hombros y le cae por detrás; el movimiento de los brazos hace que las telas se tensen por detrás, formando una especie de fondo para el cuerpo del santo, y describen a los lados de la parte delantera dos triángulos isósceles con los pliegues curvados y recurvados a gusto del escultor. Este detalle recuerda lejanamente la disposición inferior de los mantos de las Inmaculadas de Gregorio Fernández. Bajo los trozos de capa de borde redondeado que están sobre los hombros salen sendas estolas rojas que se cruzan sobre el pecho y caen a los lados de las piernas hasta la altura de las rodillas. Estas estolas, cuyos extremos inferiores adquieren una forma tendente al triángulo, recuerdan mucho a la que porta el

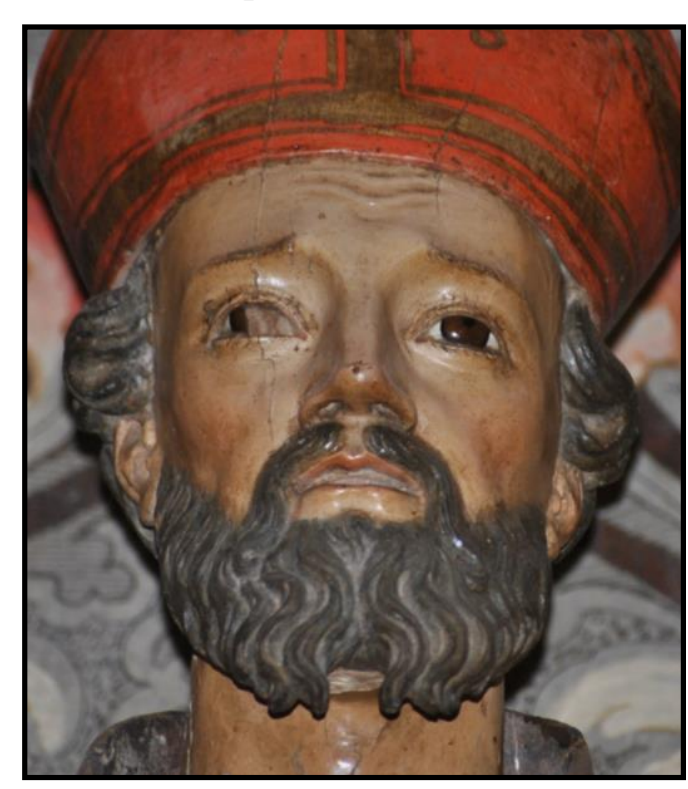

Il. 54- Pedro de Ávila (atrib.). Detalle de San Nicolás.

San Pedro en cátedra que Juan de Ávila esculpió para el retablo mayor de la Colegiata de Lerma, sobre todo en lo concerniente a la finura que logra al tallarlas. Los pliegues son muy suaves y redondeados en la capa, salvo en la parte inferior que llega a adquirir unos pliegues verticales quebradísimos que la doblan complemente. Por su parte, en la túnica son las típicas dobladuras a cuchillo, pequeñas a la altura de la cintura pero que se van ampliando y afilando más en su parte inferior, llegando a crear grandes masas que forman diagonales. La parte baja de la túnica adquiere esa característica forma como de roca aristada. En muy complicado otorgarle una cronología aproximada puesto que no poseemos más elementos de juicio que estos pliegues, debido a lo cual tan solo podríamos incluirla en el periodo 1714-1739. 


\section{VILLABÁÑEZ. IGLESIA PARROQUIAL DE LA}

\section{ASUNCIÓN}

\section{SAN FRANCISCO JAVIER (entre 1714-1739)}

En otro retablo dieciochesco, aunque en este caso de la primera mitad del siglo XVIII, encontramos una muy buena talla de San Francisco Javier; el cual copia, según indica Martín González "el conocido original de Gregorio Fernández de la iglesia de San Miguel de Valladolid" ${ }^{357}$. La efigie del santo navarro preside la hornacina principal, la cual exhibe en su parte trasera un rústico paisaje en el que nos muestra una pequeña porción de tierra y el resto un cielo pleno de estrellas. El mueble, que se encuentra "en blanco" a excepción de toda la calle central (incluida esa porción del banco y del ático) que va policromada en colores muy chillones, lo decoran dos cuatros de santos en las calles laterales y otro de la Trasverberación de Santa Teresa de Jesús en el ático. Quizás sea una propuesta algo arriesgada, pero el hecho de que Santa Teresa y San Francisco Javier fueran canonizados el mismo día (12 de marzo de 1622) podría indicarnos que el retablo se realizó para albergar a la escultura del jesuita. Sin embargo, el hecho de que este santo no figure en los libros de fábrica y que se trate de un santo no muy usual dentro de las iglesias parroquiales parece indicarnos que pudo ser sufragado por algún devoto del santo en la localidad; el cual conocía ya la imagen que Gregorio Fernández había tallado en el por entonces Colegio de San Ignacio y quiso una réplica para la parroquia de su pueblo.

San Francisco Javier (1506-1552), apóstol de la India y Japón, es el segundo jesuita más importante de la Orden tras San Ignacio. Nacido como Francisco Jasso Azpilicueta Atondo y Linares, adoptaría el nombre de San Francisco Javier en razón de haber venido al mundo en el castillo de Javier (Navarra). Aunque en sus años jóvenes intentó controlar el reino de Navarra, del cual fue su padre presidente del Real Consejo, finalmente se decidió por la carrera eclesiástica. En 1524 marcha a Paris para estudiar en la Sorbona. Cuatro años después conoce al que sería su gran amigo San Ignacio de Loyola, si bien al comienzo esta amistad no fue tal por parte de Francisco Javier ${ }^{358}$. En la capital francesa, junto con San Ignacio y otros cinco compañeros, funda el núcleo de la futura Compañía de Jesús. En Venecia es ordenado sacerdote el 24 de junio de 1537. Tres años después, y partiendo desde Lisboa, comienza su etapa de misionero. Llegó a la India y "de allí viajó a Goa y a Japón, fiel a su divisa: "Amplius"359. Tras una serie de problemas falleció el 3 de diciembre de 1552 en la isla de Shangchuan ${ }^{360}$. En 1554 su cuerpo fue llevado a la iglesia del Bom Jesús de Goa, lugar en el que aún se conserva su cuerpo incorrupto. Comenta Réau que "gracias a su apostolado en el Lejano Oriente, adquirió muy pronto fama de taumaturgo, halagüeña para los jesuitas, y mucho mayor que la de San Ignacio de Loyola, cuya vida se prestaba menos para la leyenda".

Ídem, p. 140.

https://es.wikipedia.org/wiki/Francisco_Javier

RÉAU, Louis: Iconografía de los santos. A-F..., op. cit., p. 569.

Ibídem. 
Además "se le atribuían numerosos milagros, sobre todo la resurrección de un muerto en la India. Pero la historia más popular es la de su crucifijo caído al mar que le fue devuelto por un cangrejo" 361 .

El presente San Francisco Javier (Fig. 86) copia puntualmente cada detalle de la hechura de Gregorio Fernández, si bien adolece de cierta rigidez. Además, es algo más estrecho y sus paños son menos ampulosos que los concebidos por el gran maestro gallego.

Viste sotana negra y manto del mismo color, ambos decorados tan solo por una cenefa que recorre la parte baja de la primera y el borde del segundo. Esta cenefa es dorada y con múltiples decoraciones vegetales en diversos colores; es decir, es la que solían ejecutar la mayor parte de los doradores y policromadores vallisoletanos del último cuarto del siglo XVII y primero del XVIII. Aparece en actitud de marcha, adelantando elegantemente la pierna izquierda en diagonal. Levanta el brazo derecho empuñando con fuerza una cruz parroquial, si bien en origen debió de asir un bordón de viajero, uno de los atributos más usuales de su iconografía. El otro brazo lo contrapone a éste teniéndolo hacia abajo, imitando también puntualmente la posición de los dedos del ejemplar de Fernández; esto es algo novedoso puesto que ya hemos visto como Ávila en la mayor parte de las ocasiones exhibe un determinado modelo estereotipado para colocar los dedos. No agarraría ningún elemento, y esta posición de los dedos obedecería tan solo a un deseo de dotar de elegancia a la talla. Por su parte, la cabeza presenta todos y cada uno de los estilemas de la segunda etapa de nuestro escultor: ojos de tapilla almendrados bajo los cuales se sitúan unas bolsas con bastante resalte; nariz de tabique ancho y aplastado; boca entreabierta en la cual podemos adivinar los dientes superiores y la punta de la lengua; blandura en el rostro, creada a través de la morbidez de los carrillos, de la dureza de los huesos orbitales y de la suave talla del surco nasolabial y del hoyuelo. En esta ocasión las cejas no son rectas, sino enarcadas, lo que dota al rostro de cierta preocupación o sorpresa. El pelo raso, como si fuera un pelo que le cubre toda la parte superior del cráneo y de los laterales, tapándole buena porción de ambas orejas. Barba rasurada, pero con la policromía simulando la sombra de la que le está volviendo a crecer. Esta solución capilar no es nada típica de nuestro escultor, y sin duda se deberá a la imposición por parte del comitente de que la copia del San Francisco Javier del colegio jesuita vallisoletano fuera lo más exacta posible; y como vemos lo fue, puesto que llega a copiar hasta la forma de doble curva que adopta la parte superior del cuello de la túnica, e incluso el detalle de que tanto las manos como la cabeza se hallan talladas por separado y se unen al cuerpo mediante un vástago.

La presencia de los pliegues a cuchillo en la mayor parte de las vestimentas, logrando crear perfiles aristados y profundos nos indicaría una cronología posterior al año 1714, pero sin la posibilidad de poder estrechar más el cerco. En la escultura conviven también los paños suaves incurvados tal y como podemos ver en los extremos del manto que caen bajo la mano izquierda.

361

Ibídem. 


\section{PAMPLONA. MONASTERIO DE SAN JOSÉ DE}

\section{CARMELITAS DESCALZAS}

\section{VIRGEN DEL CARMEN CON EL NIÑO (entre 1714-1739)}

En el Monasterio de Carmelitas Descalzas de San José de la capital de Navarra se conserva una Virgen del Carmen (Fig. 87) que puede ser perfectamente atribuida a Pedro de Ávila dadas las evidentes semejanzas que guarda con el estilo de nuestro escultor. En ella observamos ciertos detalles como la forma cuadrangular de la cabeza; los pliegues a cuchillo; el pliegue diagonal que sale disparado de su cadera izquierda; las ondulaciones del pelo; o la posición de los pies, separados por un pliegue cortante de la túnica, en un ángulo de $90^{\circ}$, que inducen a pensar seriamente que es obra de nuestro escultor. Además de todo ello, posee numerosas concomitancias con otras piezas documentadas o atribuidas con total seguridad a nuestro escultor como es el caso de la Virgen de las Nieves de Nava del Rey (Valladolid). Como vemos, ambas adoptan una postura similar tanto en la colocación de las piernas, con la derecha semi adelantada, o la posición de los brazos: recto el que sostiene al niño y levemente levantado el otro. Aunque sus rasgos parecen definitivos para esta atribución, el hecho de que tan solo conozca la obra por una pequeña fotografía en blanco y negro induce a tener cierta prudencia hasta que se pueda estudiar por mejores fotografías o incluso en directo. De todas maneras, la atribución queda establecida. En cuanto a su cronología, dadas las más profundas aristas de los pliegues parece más que apropiado fecharla entre 1714-1739; que como ya hemos dicho en otras ocasiones fue el periodo en el que los pliegues a cuchillo fueron más aristados.

Mercedes Orbe Sivatte en el tomo "5. III" del Catálogo Monumental de Navarra la describe de la siguiente manera: "Pieza interesante es la talla de la Virgen del Carmen, vestida con el hábito carmelita cuyos paños se agitan incorporando un movimiento propio del barroco del siglo XVIII Contemporánea a la imagen resulta la policromía de la túnica y el escapulario consistente en motivos floreados y en ces. El Niño apoya sobre la mano izquierda de su Madre y los dos cubren sus cabezas con coronas de plata decoradas con roleos vegetales y pedrería" 362 .

362 ORBE SIVATTE, Mercedes [et. al.]: Catálogo monumental de Navarra. 5. III, Merindad de Pamplona. Índices generales de la obra, Institución Príncipe de Viana, Pamplona, 1997, p. 305. 


\section{VALLADOLID. IGLESIA DEL SALVADOR}

\section{VIRGEN DEL REFUGIO (h. 1716-1717)}

La actual Cofradía de San Pedro Regalado poco tiene que ver con la original puesto que resulta ser la fusión de la anteriormente mencionada Congregación de San Pedro Regalado y Ánimas pobres del cementerio y la de Nuestra Señora del Refugio. La primera cofradía con la advocación de la Virgen del Refugio se fundó en Madrid en el año 1615, teniendo como objetivo los fines asistenciales: "albergar y alimentar a indigentes, sufragar la lactancia de niños de familias pobres, conducir a dementes a los establecimientos en que puedan ser atendidos, amparar expósitos, dotar doncellas, socorrer a madres abandonadas, ayuda a domicilio a pobres vergonzantes y costear baños y lavabos a menesterosos" ${ }^{\prime 363}$. La réplica vallisoletana nada tiene que ver con ella, y además sus orígenes nos son bastante desconocidos. El cometido de esta cofradía nada tenía que ver con el de la madrileña puesto que el de la vallisoletana era el propio de las cofradías de ánimas (hacer sufragios por todos los fallecidos sin confesión y enterrar a los pobres en la parroquia en la que radicara la hermandad) ${ }^{364}$. Desconocemos dónde se fundó, tan solo sabemos que en 1659 se encontraba radicada en el Convento de la Santísima Trinidad puesto que en el mes de septiembre de ese año se aprobaba su Regla $^{365}$. Parece que anteriormente estuvo en el Convento de San Juan de Dios, lugar del que marchó por no tener espacio para enterrar a los pobres ${ }^{366}$.

Tras algunos acercamientos, el 7 de noviembre de 1716 la cofradía se fusionó con la Hermandad de San Pedro Regalado, fecha en que se firmó la escritura de capitulación y concordia entre ambas congregaciones. En la referida escritura encontramos, entre otras, las firmas del escultor José de Rozas y del ensamblador Pedro de Ribas, los cuales signan en calidad de diputados de la Cofradía de Nuestra Señora del Refugio y Ánimas Pobres que sin confesión mueren ${ }^{367}$. Por parte de la Congregación de San Pedro Regalado compareció el cura de la iglesia del Salvador, don Pedro de Rábago, el cual "admite recibe une y congrega muy agradecido con todo gusto y estimación a la dicha cofradía y sus cofrades para que todos recíprocamente vivan como desean conformes en una sola congregación a mayor honra y gloria de Dios Nuestra Señora del Refugio, San Pedro Regalado bien y alivio de los que murieren desde hoy en adelante sin confesión". Ambas cofradías salieron ganando puesto que, como explica Calvo Caballero, "había satisfacción por ambas partes: la del Refugio entrevía por fin la posibilidad de enterrar pobres; la del Regalado, sobrevivir"; además "el mutuo interés hizo posible una fusión sin traumas ni perjuicios, el tándem era perfecto: la del Refugio supliría la falta de oficios, funciones y petitoria que mal cubrían los congregantes del Regalado, con lo que tendría manos libres en el gobierno de la nueva refundida, además de hallar la ansiada sede que, pertrechada de cementerio, le permitiría por fin

\footnotetext{
363 CALVO CABALLERO, Pilar: op. cit., p. 32.

364 Ídem, p. 33.

365 Ídem, pp. 35-37.

366 Ídem, p. 38.

367 Ídem, p. 56.
} 
cumplir plenamente como cofradía de ánimas, con el entierro de pobres"368. La Concordia no fue aprobada por las autoridades eclesiásticas, en este caso el obispo vallisoletano Julián Domínguez de Toledo, hasta el 17 de julio de $1730^{369}$.

Para conmemorar la fusión de ambas Hermandades, el inquieto cura de la iglesia del Salvador, don Pedro de Rábago, decide costear con su pecunio la imagen de Nuestra Señora del Refugio, la cual encargaría a Pedro de Ávila por aquellas fechas; de tal manera que tanto esta imagen como la de San Pedro Regalado que había sufragado el escribano Manuel de Medina Mieses compartirían una misma gubia, la de Pedro de Ávila. Sabemos de este mecenazgo gracias al testamento del propio Rábago, redactado el 19 de julio de 1720 (DOCUMENTO 88), en el cual expone lo siguiente: "como uno de los devotos de Nuestro Señor San Pedro Regalado asistí a la fábrica de su capilla y camarín retablo y colocación que está en dicha iglesia y solicité se formase como con efecto se formó congregación de diferentes parroquianos y devotos de donde soy congregante y por ser corto el número para que se aumentase la devoción solicité se uniese dicha congregación con la de Nuestra Señora del Refugio que estaba sita en el Convento de la Santísima Trinidad Calzada de esta ciudad como con efecto al presente está unida e incorporada y por no haber en dicha capilla ni tener la efigie de dicha advocación del Refugio hice a mi costa y expensa una de talla al pie de la Cruz y la puse y coloqué encima de el sagrario del altar de dicha capilla de San Pedro Regalado donde al presente esta cuya hechura e imagen mando a dicha cofradía de San Pedro Regalado y Nuestra Señora del Refugio sin que la puedan quitar ni promover de dicho sitio y capilla u otra ninguna parte con ningún pretexto y si lo que Dios no quiera ni permita dicha cofradía de Nuestra Señora desuniere y separase de la de San Pedro Regalado en este caso quede dicha imagen en dicha capilla y la mando a dicha cofradía de San Pedro Regalado".

Desde entonces ambas esculturas compartirían tanto cofradía como altar puesto que la Virgen del Refugio se situó bajo el grupo la Traslación de San Pedro Regalado. Conocemos la primitiva

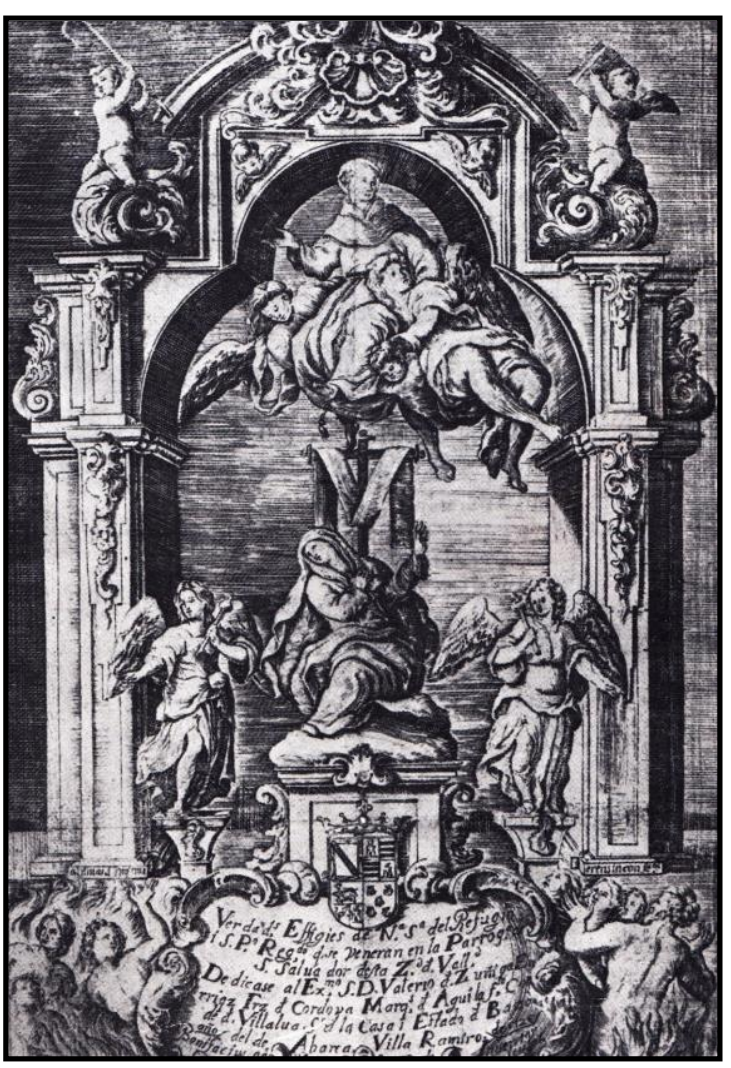

Il. 55- Bonifacio Quevedo Peti. Grabado del retablo de San Pedro Regalado. disposición de este retablo gracias al grabado realizado en 1726 por el pintor vallisoletano Bonifacio Quevedo Peti. En el grabado podemos ver que el retablo asienta

\footnotetext{
$368 \quad$ Ídem, pp. 57 y 59

369 Ídem, p. 63.
} 
sobre un banco en el que se representa a las Ánimas del Purgatorio a los lados de una cartela rematada por el escudo del marqués de Aguilafuente. Dentro de la cartela figura la inscripción "Verdaderas Efigies de Nuestra Señora del Refugio y San Pedro Regalado, que se veneran en la parroquia del Salvador de esta ciudad de Valladolid. Dedícase al Excelentísimo Señor Don Valerio de Zúñiga Enríquez Fernández de Córdoba, Marqués de Aguilafuente, Conde de Villalba, Señor de la Casa y Estado de Baza del de Abarca, Villa Ramiro". En la base de los pilares del retablo se puede leer otra inscripción: “Ánimas que mueren sin confesión”. Justo encima se sitúa la Virgen del Refugio flanqueada por dos ángeles maceros que actualmente no se conservan, y que quizás se debieran también a Pedro de Ávila. En un nivel superior observamos ya el grupo de la Traslación de San Pedro Regalado cuya figura se recorta sobre el arco trilobulado que forma el retablo, que es el que aún preside la capilla. Sobre las repisas laterales del retablo asientan sendos angelotes portando dos atributos del santo: el cayado y un libro. Hemos de señalar que tanto la representación de estos dos ángeles como la del grupo del Regalado es bastante fantasiosa, no se ciñe a la realidad de cómo son estas esculturas. El grabado se encuentra firmado por su autor: "Bonifacius a Queuedo Inventor / sculpsit año de 1726"370.

Desconocemos en qué momento se desplazó a la Virgen del Refugio del altar mayor. El caso es que sabemos que en abril de 1894, cuando el Monasterio de San Benito solicita a la cofradía la cesión del grupo de San Joaquín con la Virgen Niña, la Virgen del Refugio se encontraba a la izquierda según se entraba en la capilla ${ }^{371}$. Con posterioridad, se trasladó a la contigua capilla de los Reyes, a la sacristía y a otras capillas del templo. Ocasionalmente, durante alguna Semana Santa ha ocupado el retablo que preside el resto del año Las lágrimas de San Pedro. Tras la restauración a la que fue sometida en el año 2013, ha vuelto al retablo para el que fue realizada ${ }^{372}$.

Al igual que ocurre con el grupo de San Pedro Regalado, la Virgen del Refugio también fue atribuida a nuestro escultor por Martín González y Urrea ("obra asignable a Pedro de Ávila") en el Catálogo Monumental, y desde entonces no se ha puesto en duda tan acertada atribución ${ }^{373}$. En cuanto a su cronología parece lógico pensar que Rábago se la encargara al poco tiempo de que ambas se fusionaran, es decir, a finales de 1716, y ya estaría finalizada a lo largo de 1717.

La Virgen del Refugio (64 cms.) (Figs. 88-90), que parece recordarnos lejanamente a la Virgen de las Angustias de Juan de Juni y a la Dolorosa de la Vera Cruz de Gregorio Fernández, de las cuales es heredera, resulta ser un dechado de elegancia, delicadeza, finura y virtuosismo. Sin duda Pedro de Ávila ha puesto aquí todos sus conocimientos, creando una pequeña talla deliciosa y plagada de finísimos pliegues a cuchillo como jamás volveremos a ver en su obra, pues es un torbellino. Además, debido a su similar

\footnotetext{
$370 \quad$ Ídem, p. 506.

$371 \quad$ Ídem, p. 139.

$372 \quad$ Ídem, p. 176.

373 MARTÍN GONZÁLEZ, Juan José y URREA FERNÁNDEZ, Jesús: Catálogo Monumental de la provincia de Valladolid. Tomo XIV..., op. cit., p. 32.
} 
tamaño podemos hacernos una lejana idea de cómo sería la "desaparecida" Virgen de las Angustias de la localidad vallisoletana de Íscar.

Aparece sentada sobre un paraje rocoso en pendiente al pie de la Cruz, las rocas continúan por la parte trasera, de tal manera que la Virgen apoya la espalda. Adquiere una posición tan elegante como teatral. Extiende la pierna izquierda, cuya rodilla mantiene levemente flexionada debido a que por debajo se sitúa la pierna derecha, la cual tiene doblada en un ángulo de $90^{\circ}$. Tanto el torso como el cuello hacen sendos escorzos que diversifican los puntos de vista y dignifican aún más la técnica de nuestro escultor, puesto que gira el torso a la izquierda, al igual que las manos; mientras que la cabeza la dirige hacia su hombro derecho, echándola hacia atrás y mirando al cielo desconsolada, o quizás a su hijo aún crucificado. Por su parte, el brazo derecho lo levanta levemente realizando un gesto declamatorio con esa mano; mientras que la mano izquierda se la lleva al pecho de una manera muy elegante y transmitiéndonos una sensación de profundo dolor contenido, puesto que no hemos de olvidar que en el fondo se trata de una Dolorosa al pie de la cruz. Urrea la ha llegado a calificar acertadamente dada su movida composición como "gesticulante al máximo, sus elegantes proporciones se ven subrayadas por la multitud de pliegues "a cuchillo" que forman verdaderamente la túnica y manto de esta Virgen"374.

Viste los tradicionales ropajes con los que se la suele representar: una túnica roja ajustada a la cintura por un cíngulo, un amplísimo manto que le cubre gran parte del cuerpo, de la cabeza y aún del rocaje y una toca blanca concebida de una manera muy virtuosa que le encuadra el rostro y cae levemente por el pecho. El referido manto nos desvela una concepción triangular cuyos lados serían los finísimos pliegues del mismo que además parecen dotar de un fondo a lo que es propiamente la Virgen. Las policromías son totalmente planas, no existe gradación en las mismas y tampoco hay espacio para cenefas ni otros motivos decorativos. Estamos en la misma situación que ya comentamos con las esculturas de la catedral, y es que la aparición de estos colores planos parece indicarnos la influencia del arte cortesano o incluso del barroco avanzado y rococó europeo. Las tres prendas se encuentran totalmente surcadas por un número incontable de concavidades de diversos tamaños y calados ocasionados por la profusa utilización de pliegues a cuchillo, cuya finura llega a su máxima expresión en la cintura, en la cual simula a la perfección las arrugas producidas por el efecto del ceñimiento del cíngulo. Pocas veces podremos ver tal destreza a la hora de tal cantidad de pequeños pliegues tan aristados. Lo mismo podemos decir de los del manto, cuyas dos características (finura y aspecto cortante) aparecen presentes a lo largo de todo él y especialmente en los bordes superiores. Los paños la dotan de gran dinamismo y movimiento. Referente a este aspecto, no podemos aceptar de ninguna manera lo dicho en la ficha del catálogo de la exposición "Virgen de Pasión" celebrada durante la Semana Santa del año 2002, en la cual se dice que "la abundancia de pliegues a cuchillo que forman la túnica y el manto hacen que se la pueda atribuir sin dudas a la

374 URREA FERNÁNDEZ, Jesús (dir.): La pequeña escultura ..., op. cit. 
primera etapa de la producción del escultor Pedro de Ávila"375. Para nada, puesto que si precisamente algo diferencia las dos etapas de nuestro escultor es la presencia del pliegue a cuchillo en la segunda y no en la primera, en la cual aún se muestra totalmente deudor de las formas de su padre y de su suegro.

El rostro sigue los parámetros generales utilizados por Ávila para sus figuras femeninas de la segunda etapa. Tal es así que conserva gran parecido con el de la Virgen del grupo de la Anunciación conservado en la parroquial de Renedo, o con el de buena parte de sus Inmaculadas, etc... Tiene la boca entreabierta, dejándonos ver la punta de la lengua y los dientes superiores; ojos de tapilla, debajo de los cuales hay lágrimas simuladas por medio de la policromía; nariz de tabique ancho pero no tanto como en otras ocasiones, de tal manera que la rectitud habitual deja paso a ciertas redondeces; cejas algo levantadas, contrastando con la rectitud presente en la mayoría de sus obras; pelo simétrico que parte de la mitad del cráneo, con lo cual presenta amplia frente y potente mentón sin hoyuelo. Ávila ha logrado en esta pequeña pieza magistral la síntesis ideal de la belleza de los modelos fernandescos y el dinamismo y la delicadeza propios del siglo XVIII.

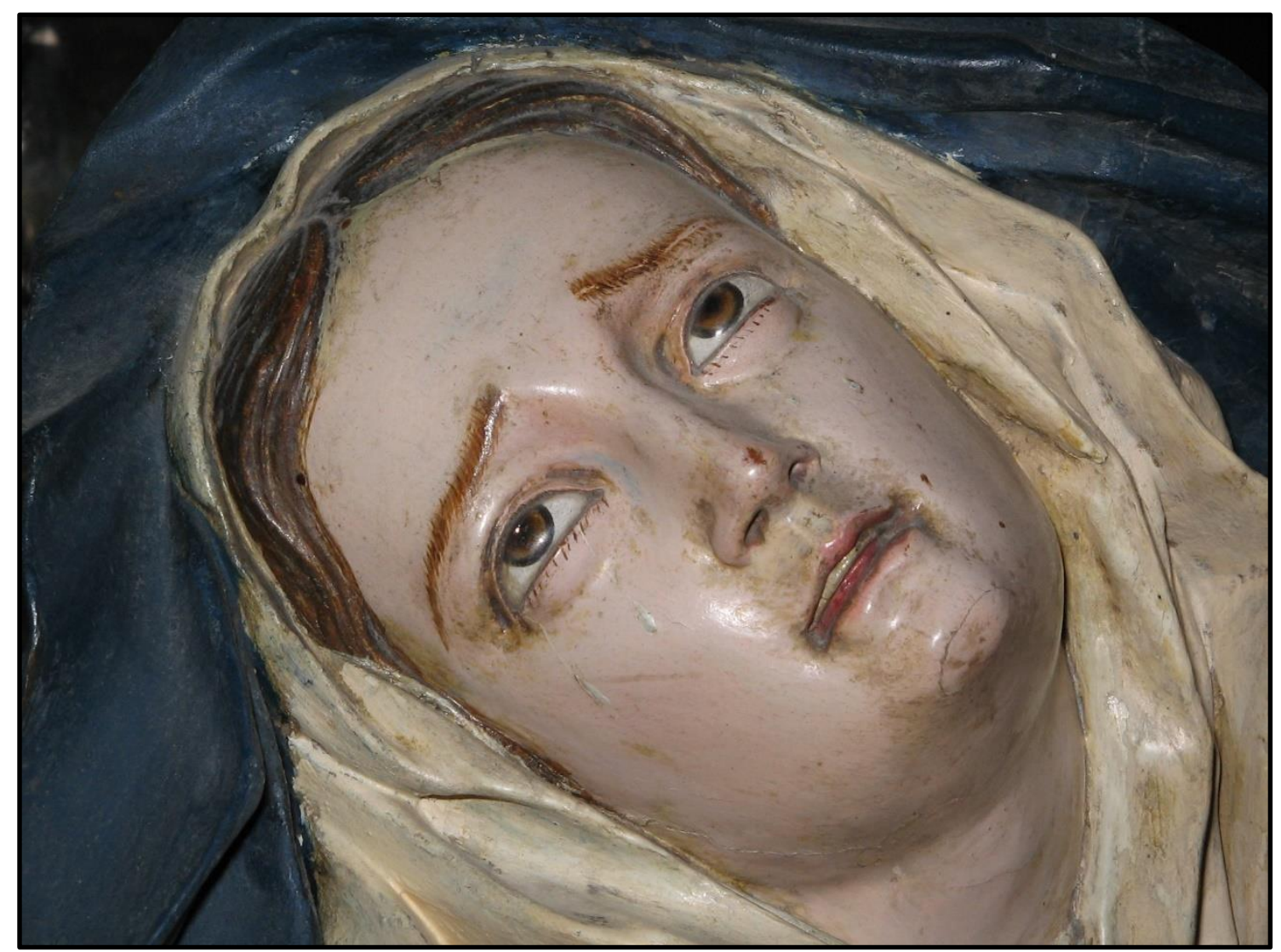

Il. 56- Pedro de Ávila (atrib.). Detalle de la Virgen del Refugio.

375 GARCÍA MARTÍN, Enrique: Virgen de Pasión, op. cit., p. 28.

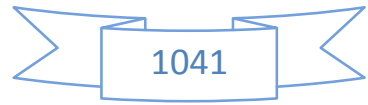




\section{VALLADOLID. IGLESIA DE SAN LORENZO}

\section{$\underline{\text { SAN LORENZO (h. 1716) }}$}

La presente escultura (Fig. 91), que atribuyo sin ningún género de dudas a Pedro de Ávila dados sus característicos rasgos faciales, se halla en la actualidad colocada sobre una peana a la izquierda del altar mayor de la iglesia. No aparece citada en ningún libro ni en el Inventario Artístico de Valladolid, si bien cabe señalar que por entonces la iglesia se encontraba cerrada ante su inminente ruina. En el Catálogo Monumental de Valladolid se hace referencia a un "San Lorenzo (en realidad es una escultura de santo jesuita revestido), del siglo XVIII" ${ }^{376}$. Este santo, de vestir, que nada tiene que ver con el del presente estudio, lo conocemos gracias a algunas fotografías antiguas en las cuales figura presidiendo un sencillísimo retablo neoclásico o dentro del baldaquino de plata en el que se procesiona a la Virgen de San Lorenzo. En la actualidad desconocemos su paradero; asimismo, ignoramos si la presente escultura que atribuimos a Pedro de Ávila pertenecía a la parroquia o llegó a la iglesia procedente de otro lugar.

Un nuevo enigma se nos plantea con la descripción que hace Canesi de esta iglesia. En ella hace referencia a "un retablico en que está el glorioso Mártir S. Lorenzo, que hace frente en ella, dádiva del Ilmo. Y Rmo. Señor D. F. Joseph de Talavera, Obispo que fue de Valladolid, es de las mejores piezas" ${ }^{\text {377 }}$. Por su parte, el retablo había sido donado a la iglesia, junto con otros ornamentos, alhajas y patrocinio de obras, por don Diego Álvarez Garcés en el año 1716. Lo primero que hemos de plantearnos es si la escultura donada por el obispo vallisoletano era ésta, hecho que parece bastante factible dado que el estilo que demuestra concuerda bien con los quehaceres de Pedro de Ávila por aquellas fechas. Asimismo, hemos de volver a recordar que nuestro escultor parece que fue el maestro mayor de escultura del obispado, y quizás seguía siéndolo, por lo que su trato con el obispo y los capitulares de la catedral sería bastante fluido; tal es así que años después otro de estos capitulares le debió de encargar un San José para el Santuario del Henar (Segovia).

Para acotar la fecha en que pudo ser realizado hemos de acudir al periodo en el que ostentó el obispado vallisoletano el referido José de Talavera Gómez de Eugenio ${ }^{378}$, que fueron los años 1716-1727. A la vista de estas fechas y de que el retablo del santo se

\footnotetext{
376 MARTÍN GONZÁLEZ, Juan José y URREA FERNÁNDEZ, Jesús: Catálogo Monumental de la provincia de Valladolid. Tomo XIV..., op. cit., p. 84.

377 CANESI ACEVEDO, Manuel: Historia de Valladolid (1750), Tomo I, op. cit., p. 317.

378 José de Talavera Gómez de Eugenio fue un fraile jerónimo nacido en 1664 en Navalmoral de la Mata (Cáceres). Desde joven se sintió atraído por la religión, debido a lo cual decidió ingresar en el Monasterio de San Lorenzo de El Escorial; lugar en el que estudió Filosofía, Teología y Derecho Canónico, alcanzando el grado de maestro de Sagrada Escritura en dicho cenobio. Fue elegido dos veces Prior del monasterio, y "desempeñó otros cargos como los de Calificador de la Suprema y General Inquisición, vicario y provisor general de la villa del Escorial, rector de su real Colegio, definidor dos veces de su religión y otros varios". Fue nombrado obispo de Valladolid en abril de 1716, aunque no tomó posesión hasta el día 30 de octubre en el que hizo su entrada solemne en la ciudad, "desde el Carmen y a caballo, según la costumbre y siendo el último que la hizo de esta manera". Murió en Valladolid el 5 de noviembre de 1727, siendo su cuerpo sepultado en la capilla de San Pedro de la catedral. DE CASTRO ALONSO, Manuel de: op. cit., pp. 301-304.
} 
realizó en 1716, parece claro que el obispo encargó la imagen de San Lorenzo a Pedro de Ávila al poco de llegar a la ciudad. No parece casualidad que solicitara una imagen de este santo puesto que era el patrón del Monasterio de El Escorial, cenobio en el cual el obispo de Valladolid había estudiado, había sido prior y había desempeñado diversos cargos.

San Lorenzo (h. 225-258) fue un mártir y diácono hispano nacido cerca de Huesca. Relata Réau que según los Hechos legendarios del santo, "por humildad lavaba los pies de los cristianos, habría curado a una viuda, Ciriaca, del dolor de cabeza y dado la vista a un ciego mediante el bautismo"379. Ejerció el cargo de tesorero durante el pontificado de Sixto II, el cual le había ordenado diácono. Tras el martirio del papa fue detenido por las tropas del emperador Decio, las cuales le obligaron a entregar el dinero de la iglesia, pero San Lorenzo no pudo hacerlo dado que lo había donado a los pobres $^{380}$. Este buen acto fue el desencadenante de su martirio y posterior muerte. Enfadado, el emperador Decio, "furioso por haber sido frustrado en su codicia, el emperador Decio ordenó que se lo flagelase con varas, se le quemaran las costillas con un hierro candente y que, por último, se lo extendiera desnudo sobre una parrilla dispuesta sobre un manto de brasas. Asado a medias, el mártir aún desafió a Decio. Mientras su carne chirriaba tuvo el valor de mofarse: "Muy bien, ya me has asado de un lado; dame la vuelta y así podrás comerme cocido a punto". Según Réau este tormento carece "de toda verosimilitud. Era extraño a la tradición romana asar a los condenados a las brasas, sobre una parrilla"381. Este martirio, que también existe dentro de la leyenda de San Vicente, pudiera no ser tal, sino deberse todo a un "un error de lectura: la expresión "passus est" habría sido transformada por un copista que omitió la letra inicial de "assus est" 382.

Pedro de Ávila nos presenta a San Lorenzo de pie como estático puesto que en esta ocasión no parece adelantar ninguna de las dos piernas. Tan solo podemos verle la punta del zapato derecho, el izquierdo estará bajo la túnica. En las manos porta sus dos atributos más significativos, realizados en platería: en la derecha una pequeña parrilla que alude a su martirio, y en la izquierda una palma que le acredita como mártir. Comenta Réau que aunque San Lorenzo "no tuvo la gloria de ser protomártir, como el diácono Esteban, en cambio se lo consideraba como el más meritorio de los mártires portadores de la palma a causa de la crueldad del suplicio que sobrellevó" ${ }^{383}$. Tanto las manos como la cabeza se hayan tallados de manera exenta.

Vista una túnica hasta los pies, que como ya hemos dicho le oculta completamente uno y la mayoría del otro. Es de color blanco, con la salvedad de la franja inferior que va policromada imitando labores de brocado de una manera muy veraz. Sobre ella una dalmática, otro de los elementos de su iconografía, aunque no privativo suyo. Se

\footnotetext{
379 RÉAU, Louis: Iconografía de los santos. G-O..., op. cit., p. 255.

380 Ibídem.

381 Ibídem.

382 Ídem, p. 256.

383 Ibídem.
} 
encuentra abierta a la altura de las axilas, por lo que nos permite ver la túnica inferior resguardando sus brazos y la misma policromía imitando puntillas en las mangas. Posee una rica policromía. En su parte interior es azul con decoraciones vegetales doradas; y por la exterior es roja con motivos botánicos en oro y diversos colores, además en su parte inferior presenta una maravillosa representación pictórica del martirio del Santo, obra sin duda de un buen pintor vallisoletano del primer tercio del siglo XVIII, quizás Manuel Peti Bander. Ambas vestimentas presentan pliegues diferentes: el suave, blando, incurvado y sin durezas más propio de fines del siglo XVII en la dalmática; y el berninesco en la túnica, estos pliegues, que parece como si se hubiera estrujado papel, están acuchillados, pero no en exceso.

El rostro es el de un joven imberbe. Presenta los típicos estilemas exhibidos por nuestro escultor durante su segunda etapa, y no hay en él ningún rasgo novedoso; si acaso el tipo de peinado, con numerosos bucles a los lados de la cara, y dos mechones rizados sobre la frente, disposición similar a la que podemos observar en el San Juan Evangelista y en el San Miguel de la Catedral. A pesar de que Ávila utiliza la misma receta, no por ello baja la calidad puesto que es admirable la manera de representar la boca entreabierta y en su interior los dientes superiores y la punta de la lengua. Los ojos, como de costumbre, son de tapilla de vidrio. 


\section{RENEDO DE ESGUEVA. IGLESIA PARROQUIAL DE LA INMACULADA CONCEPCIÓN}

En la iglesia parroquial de Renedo de Esgueva, realizada entre 1735 y 1738 por el arquitecto barroco vallisoletano Manuel Serrano ${ }^{384}$, se conservan dos obras (concretamente una escultura y un grupo escultórico) que sin ningún género de dudas habrán sido realizadas por nuestro escultor. Como comprobamos una y otra vez, el segundo estilo de Pedro de Ávila es tan característico que no presenta muchas dificultades para su identificación. Éste es el caso de ambas piezas, las cuales no pertenecen en origen a esta iglesia. La mayor parte del patrimonio artístico que poseía el templo parroquial pereció víctima de un pavoroso incendio acaecido el 16 de agosto de 1891. Al parecer, y según la crónica de Ortega y Rubio, el siniestro comenzó a eso de las 11 horas de la mañana por el altar mayor, en el cual se acababa de celebrar la misa. La catástrofe fue de tal magnitud que todo el templo quedó "lastimosamente destruido, hasta el punto de que ni las formas se salvaron". Tan solo se libraron "las ropas, efectos y alhajas que existían en la sacristía, sin que afortunadamente ocurriera desgracia alguna personal" 385 . Una vez reparados los desperfectos y retirados los escombros se procedió al amueblamiento de la iglesia puesto que había quedado completamente desornamentada de esculturas, pinturas y retablos. La escasez de fondos y el deseo de poseer piezas de calidad serían las motivaciones que llevaron al cura y parroquianos a solicitar la cesión de obras de arte con las que decorar la iglesia y restaurar el culto.

Por esos mismos años en la capilla de San Pedro Regalado de la iglesia del Salvador de Valladolid se estaban realizando una serie de "mejoras" patrocinadas por José Jover, a las cuales ya nos hemos referido al hablar del San Joaquín con la Virgen Niña de Juan de Ávila y de las de San Pedro Regalado y la Virgen del Refugio del propio Pedro de Ávila. Para llevar a cabo estas obras de "mejora" de la capilla, el empresario solicitaba que debían ser retirados "los cuatro altares accesorios no solamente porque allí no responden a ningún objeto de culto, sino a marcada irreverencia, pues no sirven más que para colocar sombreros durante las misas y ocupar un sitio que achica la capilla y estorban al desahogo, sino también porque son malísimamente tallados y no guardan armonía los unos con los otros, esto aparte de que las efigies carecen de mérito artístico y están muy mal tratadas por el transcurso del tiempo"386. Aunque en un principio la cofradía reaccionó de manera negativa a la solicitud dado que no estaba dispuesta a eliminar "los cuatro altares que en ella existen, porque los dos colaterales son de la propiedad de los sucesores de don Gabriel de Medina Mieses, vecino que fue de esta ciudad, así como la sepultura que está al pie de cada uno de ellos: el altar de San Joaquín y esta efigie corresponden a los sucesores del ilustrísimo señor don Diego

\footnotetext{
$384 \quad$ Ventura Pérez recoge la noticia de que la primera piedra fue colocada el 11 de octubre de 1735 , siendo previamente bendecida por el obispo de la diócesis don Julián Domínguez de Toledo. PÉREZ, Ventura: op. cit., p. 133.

385 ORTEGA Y RUBIO, Juan: Los pueblos de la Provincia de Valladolid, Tomo II, Imprenta y Encuadernación del Hospicio Provincial Valladolid, 1895, pp. 152-153.

386 CALVO CABALLERO, Pilar: op. cit., p. 135.
} 
de Soto, obispo que fue de Mondoñedo, a quienes pertenece el camarín de la capilla de San Pedro Regalado, donde anteriormente estuvo situado el indicado altar y efigie de San Joaquín"387; poco tiempo después ambas partes llegaron a un acuerdo "por los deseos mutuos, de Leandro Jover de retomarla y de la Cofradía de impulsarla. La Cofradia, que vuelve a revolver en su archivo sobre los patronatos de los altares, baraja acudir al prelado de negarse el párroco a quitarlos; sus efigies podrían darse a iglesias pobres como la de Renedo. Su única condición fue no tocar la cabeza del Santo. Otro tanto Leandro Jover, que con su visita en noviembre de 1892 obtiene del provisor y arzobispo, Antonio María Cascajares, las órdenes para que los cuatro altares-dos salientes y dos enrasados-desapareciesen"388.

Fue entonces cuando el párroco de Renedo solicita a la Cofradía de San Pedro Regalado dos retablos que "están como retirados [de la capilla de San Pedro Regalado] y sin aplicación en una capilla, y el otro a las puertas de la iglesia de El Salvador". E1 párroco de Renedo trató este asunto con Teodoro Lefler, coadjutor de la iglesia del Salvador y mayordomo de capilla de la Cofradía, la cual "acordó por unanimidad que los tres altares pertenecientes a esta cofradía con sus efigies, excepto la Santa Patrona que se reserva, se entreguen". Estos tres retablos y otros elementos que fueron entregados el 26 de octubre de 1896 a la parroquia de Renedo se especifican minuciosamente: "Dos retablos de cinco metros de alto por tres metros treinta y cinco centímetros de ancho, con sus correspondientes mesas de altar del orden barroco o Churriguera, forma hornacinas de medio punto. Otro ídem de cuatro metros de alto por dos metros ochenta centímetros de ancho del mismo orden de Churriguera con su mesa de altar, todo él dorado. Dos hornacinas de medio punto de dos metros de alto por un metro y veinticinco centímetros de ancho. Dos ídem doradas, forma de cascarón, también de Churriguera de un metro cuarenta centímetros de alto, por un metro de ancho. Una efigie que representa un Ecce Homo de un metro sesenta y cinco centímetros de alto. Uno de los dichos retablos con las efigies representando la Anunciación de Nuestra Señora con su ángel. Un crucifijo escultura que corresponde al retablo dorado. Cuyos tres altares se entregaron en este mismo día por don Basilio Zamora y don Victoriano Lucas Velasco al repetido señor cura don Jacinto Calvo Ortega, que los recibió a su satisfacción y los trasladó acto seguido en los carros preparados al efecto al mencionado pueblo de Renedo de Esgueva" ${ }^{389}$.

Los dos retablos a los que se alude como "del orden barroco o Churriguera, forma de hornacinas de medio punto" son los que albergaron en origen las esculturas que nos ocupan: el Ecce Homo y la Anunciación. Por fortuna, en fechas recientes Pilar Calvo Caballero ha logrado descubrir la identidad del anónimo benefactor que sufragó tanto los retablos (intitulados de la Anunciación y de los Celos de San José) como las dos esculturas que albergaron gracias a la Capitulación firmada entre las Cofradías de San Pedro Regalado y de la Virgen del Refugio por la cual acordaban fusionarse. Se trataba

\footnotetext{
$387 \quad$ Ídem, p. 138.

$388 \quad$ Ibídem.

389 Ídem, p. 152.
} 
del escribano Gabriel de Medina Mieses "por eso su escudo corona ambos retablos dorados, cuyas imágenes son las patronímicas de los nombres de su familia: Gabriel, de ahí la Anunciación y el arcángel San Gabriel, y José (en alusión a su hijo, el cual también desempeñó el oficio de escribano), cuya representación de los Celos de San José no se ha conservado. Este último solía acompañar a la Anunciación" ${ }^{390}$. Comenta al respecto Calvo Caballero que "Gabriel de Medina Mieses ve reconocido su constante trabajo y dispendio en pro de la Cofradía con el privilegio de dos sepulturas propias al pie de sus altares, con los dos nichos en la pared en los colaterales de la Capilla. Era el máximo reconocimiento e idéntica concesión que a los sucesores del obispo de Soto: otras dos sepulturas, delante y detrás del retablo del Regalado, donde estaba su retablo altar familiar de San Joaquín en el hueco del camarín con nicho, aunque por razón tan diferente cual fue la de ser los patronos que ceden la capilla donde se edificó la del Regalado" 391 .

Gracias al Libro de Alhajas sabemos el lugar que ocuparon estos dos retablos dentro de la capilla. En este libro, a fecha de 1 de enero de 1718 tan solo se hacía referencia a "un colateral en blanco y en él el misterio de la Anunciación dorado y estofado" ${ }^{392}$. Este detalle parece indicar que tan solo se había tallado uno de los dos retablos, y que su factura era reciente puesto que se encontraba "en blanco" a la espera de ser dorado y policromado. Además, tan solo se alude a la Anunciación, por lo que tanto el segundo retablo como el Ecce Homo debían de encontrarse en proceso de fabricación. Este segundo retablo, el intitulado de "los Celos de San José", fue llevado a cabo inmediatamente puesto que ya figura en el poder para testar que otorga Gabriel de Medina Mieses a sus hijos en el verano de 1720, si bien el testamento no fue redactado hasta siete años después. En él se dice que Gabriel de Medina Mieses "fue sepultado en la capilla de San Pedro Regalado de la iglesia parroquial del Salvador, está enterrado debajo del altar que en ella tenemos de los Celos de San José, frente del otro que también tenemos de la Encarnación de Nuestra Señora, que uno y otro hizo en su costa, con dicha capilla, retablo y santo dicho nuestro Padre; sin embargo de que por dicho poder se manda enterrar en el cementerio de la parroquia por la mucha devoción que siempre tuvo a las Ánimas Pobres de él" ${ }^{393}$. El retablo de la Anunciación estaba colocado en el colateral del Evangelio y el de los Celos de San José en el de la Epístola.

Que ambos retablos siguieron siendo los colaterales de la capilla de San Pedro Regalado nos lo confirma el testamento del presbítero Manuel de Medina Mieses, el último hijo de Gabriel de Medina Mieses; el cual, en su testamento, fechado en 1772, expresa su deseo de ser "sepultado en la iglesia parroquial del Salvador, donde soy feligrés, en una de las dos sepulturas que están al pie de los dos colaterales de la Capilla de San Pedro Regalado, inclusa en la misma iglesia". Un poco después vuelve a incidir en este hecho al hablar sobre las tres misas cantadas que fundaba en la capilla: "la una en el altar de dicho santo, en su día de octava, otra en el altar de San Gabriel, en su día, y la

$\begin{array}{ll}390 & \text { Ídem, p. } 61 . \\ 391 & \text { Ídem, p. } 62 . \\ 392 & \text { Ídem, p. } 65 . \\ 393 & \text { Ídem, p. } 68 .\end{array}$


otra en el altar del Santísimo Ecce Homo el día de San José a honra y gloria del Santo, uno y otro colaterales de la expresada capilla"394. Tan solo fue modificada su posición a raíz de la remodelación llevada a cabo en 1854, en la cual se decidió situar los cuatro retablos que por entonces tenía la capilla, amén del retablo mayor de la Traslación de San Pedro Regalado, afrontados dos a dos: cerca de la puerta de entrada a la capilla los de San Joaquín, a la derecha, y del Santo Cristo, a la izquierda; y más adelante, los de los Celos de San José y la Anunciación ${ }^{395}$. Finalmente, los retablos fueron retirados con motivo de la citada reforma, costeada por José Jover y llevada a cabo por el arquitecto diocesano Antonio Iturralde, de tal manera que para marzo de 1893 ya no se encontraban en la capilla para la cual fueron realizados ${ }^{396}$. Estos fueron los momentos previos a su marcha a la iglesia parroquial de Renedo.

Ambos retablos, de los cuales tan solo se conserva el armazón, resultan ser retabloshornacinas que por el interior adoptan en su parte superior forma de medio punto mientras que exteriormente se traduce en unas formas mixtilíneas que combinan las partes rectas con las curvas. A ambos lados de la base sendos roleos vegetales. En ambos coronamientos de las esculturas figuran sendos pabellones, aunque tan solo uno posee cuatro angelitos que intentan descorrerlos, del otro seguramente hayan desaparecido puesto que parece haber sido modificado con posterioridad (como podemos comprobar por la presencia de dos cabezas aladas de angelotes muy relacionadas con Pedro de Sierra) el coronamiento de las hornacinas aparece un pabellón. Culminan ambos retablos el escudo de los Medina Mieses, en cuya parte superior figura el torso afrontado de un guerrero con armadura y con el brazo en alto como si estuviera empuñando un arma.

En la actualidad, en uno de los retablos se ha vuelto a colocar el grupo de la Anunciación, como ocurriera antaño, mientras que en el otro se encuentran una Virgen de la Soledad de vestir y debajo de ella, en el banco, un Yacente moderno. Desconocemos qué retablo es el de la Anunciación y cual el de los Celos de San José; sin embargo, el hecho de que en el fondo del retablo en el que se encuentra la Dolorosa se conserve una pintura que parece representar el interior de una casa y a la izquierda un ángel descorriendo una ampulosa cortina roja nos hace pensar que este sea el que ocupó la Anunciación. Puesto que, además, las nubes pintadas a la derecha convienen perfectamente a la posición en que se encuentra el Arcángel San Gabriel (Figs. 92-93).

\section{ANUNCIACIÓN (1717)}

El presente grupo de la Anunciación (Figs. 94-96) ya fue relacionado con nuestro escultor desde hace tiempo. Fue Martín González el que en el Inventario Artístico de Valladolid lo incluyó dentro del "círculo de Pedro de Ávila" ${ }^{397}$. Posteriormente, el

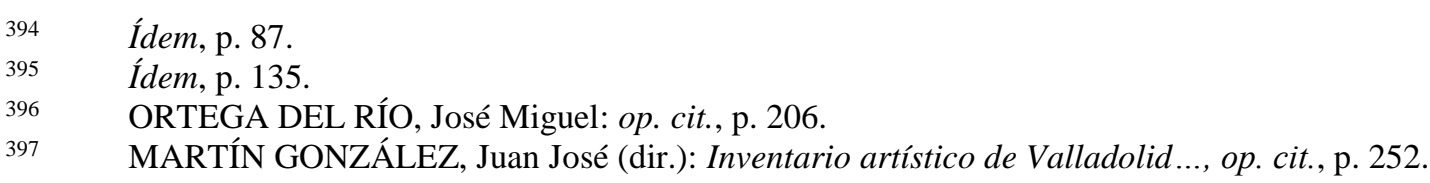


mismo Martín González, en el respectivo tomo del Catálogo Monumental de Valladolid la calificó de "obra del círculo de Pedro de Sierra. Las dos figuras están labradas por separado" 398 . Con toda probabilidad no se trate de un cambio de pensamiento sino de redacción.

En cuanto a su cronología, pienso que este grupo fue realizado en el año 1717, fecha que correspondería perfectamente a los pliegues acuchillados que exhibe (los cuales, como ya hemos repetido en muchas ocasiones, parece que se acentúan a partir del año 1714). Los motivos para fecharlo en el referido año, y que el estilo exhibido en él no parece desmentirnos, son los siguientes: creo que Gabriel de Medina Mieses propuso a la Cofradía de San Pedro Regalado y de la Virgen del Refugio, una vez fusionadas ambas hermandades el 7 de noviembre de 1716, el costear sendos retablos. El primero de ellos en llevarse a cabo sería el que contendría esta Anunciación, por lo que comenzaría a tallarse poco después, es decir, a finales de 1716 o comienzos de 1717. Y, por otra parte, sabemos, por el citado libro de alhajas de la Cofradía del Refugio, que a día 1 de enero de 1718 ya existían tanto el grupo escultórico como el retablo; el cual aún se encontraba sin dorar, es decir, "en blanco". Por lo tanto, el grupo de la Anunciación fue esculpido por Pedro de Ávila en 1717.

Para tallar el presente grupo escultórico, del que hay que destacar que se trata de figuras de bulto redondo, completamente exentas, parece que Pedro de Ávila pudo inspirarse en dos Anunciaciones con las cuales posee numerosos puntos de contacto. Se trata de las atribuidas a Juan de Ávila en Ataquines (Valladolid) y a Juan Antonio de la Peña en el retablo mayor de las Claras de Peñafiel (Valladolid). Sin embargo, hay que reseñar que tanto la de su padre como la de su suegro son altorrelieve, aunque en ocasiones parecen figuras exentas pegadas al tablero, pero no es así. Como ya hemos visto, es probable que el grupo escultórico perteneciera al otro retablo gemelo, el cual tiene pintado un fondo con diversos elementos que aluden al interior de una habitación. La composición y gestualidad de los dos grupos precedentes es idéntica al de Pedro de Ávila, sin embargo éste invierte la composición y la dota de mayor dinamismo, teatralismo, elegancia y delicadeza, elementos propios del siglo XVIII. Como vemos, los elementos son los mismos: San Gabriel se aproxima sobre una nube mientras eleva el brazo derecho; enfrente la Virgen se sitúa de rodillas sobre un cojín mientras se lleva la mano derecha al pecho. La escena se nos muestra muy teatral, con un juego de miradas que provoca una diagonal típicamente barroca; asimismo se contraponen la firmeza de la Virgen con la inestabilidad de San Gabriel.

La Virgen María figura arrodillada de una manera muy elegante sobre un cojín verde con una cenefa dorada puesto que tiene semi elevada la pierna derecha tal y como podemos comprobar por el alza de la rodilla; es más, a través de la túnica podemos intuir toda esa pierna. La forma de disponer esta pierna, así como sus pliegues y el hecho de que se intuya a través de la ropa es muy similar a la que podemos observar en el San Francisco de Paula conservado en el colateral de la Epístola de la iglesia del

398 MARTÍN GONZÁLEZ, Juan José: Catálogo Monumental de la provincia de Valladolid. Tomo VI..., op. cit., p. 75. 
Salvador de Valladolid, excelsa escultura de la que no se ha logrado adivinar todavía su paternidad, aunque sabemos que fue sufragada por el tantas veces citado cura de la parroquia, don Pedro de Rábago. Con el torso realiza un contrapposto ya que lo gira violentamente, como sorprendida, para ver la llegada de San Gabriel. Se lleva la mano derecha al pecho mientras que el otro brazo lo tiene ligeramente doblado realizando con esa mano una pose declamatoria. Ambas manos, que están talladas de manera exenta, son tremendamente delicadas. Pedro de Ávila ha cuidado cada uno de los detalles de ellas ya que esta escultura estaría a la altura del espectador, debido a lo cual dota a las manos de gran blandura, define las líneas de la mano, las articulaciones, etc... es muy expresiva especialmente la mano que se lleva al pecho, por cuanto los dedos que entran en contacto con el cuerpo acusan ese roce. Los dedos, como de costumbre, siguen su distribución habitual tan característica. Por su parte, el rostro, que también acusa gran blandura, nos presenta a una Virgen muy juvenil, en el cual están presentes todos y cada uno de los estilemas de nuestro escultor; hay que reseñar que las facciones son más redondeadas, incluso en la nariz que como ya sabemos suele tender en la mayoría de las ocasiones a ser más cuadrada, con líneas rectas. Especialmente acusadas son la mueca que realiza con la boca y las bolsas debajo de los ojos. Sobre la ancha frente nace el pelo que se distribuyen en dos masas de guedejas onduladas a ambos lados del rostro, perdiéndose bajo el manto que le cubre la cabeza, si bien no deja pasar la oportunidad para que uno de esos mechones serpentee hasta el pecho, otro de esos detalles que podemos considerar como la "firma" del autor. Los ropajes son los característicos en las representaciones de la Virgen: una amplia túnica que le cubre todo el cuerpo, ceñida a la cintura por un cíngulo, cuyo fruncimiento se haya perfectamente simulado por pequeños y agudos pliegues. Además, tiene un manto azul echado sobre la cabeza y los hombros, cayéndole por la espalda y formando una especie de "fondo para la escultura"; sin embargo, al lado derecho le pasa por debajo de la axila y el brazo de tal manera que forma una punta muy volada y con unos pliegues especialmente cortantes, intentando simular el movimiento del viento. El borde del manto lo recorre una preciosa cenefa dorada con motivos vegetales en diversos colores; es la típica banda que tanto abunda en la escultura vallisoletana desde finales del siglo XVII; aunque, sin embargo, el resto de la policromía, tanto el azul del manto como el rojo de la túnica son colores planos.

A la izquierda de la Virgen, derecha del espectador, y sirviendo de elemento de separación entre el mundo terrestre de María y el celeste del Arcángel San Gabriel, se sitúa una especie de mesa o reclinatorio sobre el cual se apoya un libro abierto por la mitad (se encuentra escrito este texto: "Ecce Virgo concipiet et pariet filium et vocabitur nomen eius Emmanuel) que la Virgen se encontraría leyendo cuando fue sorprendida por Gabriel. Por su parte, el Arcángel irrumpe en la escena por el lado derecho. Tiene unas grandes alas desplegadas con multitud de colores. Se sitúa sobre una deliciosa nube de formas muy caprichosas. El arcángel se sitúa de forma muy elegante puesto que tan solo apoya la pierna derecha, la cual tiene adelantada, mientras que la trasera la mantiene hacia atrás y en el aire; de tal manera que crea una inestabilidad propiamente barroca; además esta pierna adelantada forma una diagonal con el brazo derecho, que mantiene adelantado. Repliega su brazo izquierdo, cuya mano posee unos dedos 
encogidos que simulan estar agarrando algo, con lo cual es probable que portara un bastón de mensajero o una filacteria. Mientras tanto levanta la mano derecha en signo de salutación a la Virgen, y la elevación de este brazo trae consigo que se le repliegue la manga de la túnica. El rostro es muy similar al de la Virgen Maria, incluso en la manera en que su boca hace la característica mueca. Tan solo diferencia ambas cabezas el peinado. En esta ocasión sitúa dos pequeños rizos extendidos y simétricos sobre la frente, pero muy pegados al resto de la cabellera, y esta última cayendo a ambos lados del rostro en amplios bucles que llegan hasta la altura del cuello. Esta forma de resolver los cabellos parece recordarnos a la que exhiben el San Juan Evangelista que talló para la catedral, y a los dos San Miguel que esculpió para la referida seo y para la iglesia parroquial de Castil de Vela (Palencia). Viste una túnica grisácea muy movida en sus partes bajas, las cuales quedan a la altura de las rodillas. Recorren el extremo inferior, el cuello y las empuñaduras otras cenefas similares a la vista en la Virgen de este mismo grupo. Las piernas y los pies van cubiertas por unas sandalias azules y una raya marrón que tiene la parte delantera abierta, de tal manera que podemos verle los dedos.

Ambas esculturas presentan unos pliegues a cuchillo muy propios de estos momentos, que se van haciendo cada vez más agudos y minuciosos, creando unas superficies cóncavas muy naturalistas. Especialmente destacados son los paños que conforman la parte baja de la túnica del Arcángel, a la cual hacen adoptar una forma campaniforme, cuyos extremos inferiores se curvan y recurvan; lo que unido a la extrema finura de estas "telas" nos vuelve a mostrar a un escultor muy seguro de su potencial.

\section{ECCE HOMO (1718)}

Esta bella imagen de Ecce Homo (Figs. 97-98) tan solo ha suscitado tres reseñas de importancia, todas ellas realizadas por Martín González: en la primera de ellas le incluye entre las copias de esculturas de Gregorio Fernández, datándolo en el siglo $\mathrm{XVIII}^{399}$. En las otras dos ocasiones la ha situado, primeramente, en el "círculo de Pedro de Ávila" 400 y, después, como "del tipo de Pedro de Ávila"401. Vemos como poco a poco Martín González evolucionó desde una generalidad como era la "copia fernandesca" a creerla de un autor concreto.

En cuanto a su cronología, creo que fue esculpido, al igual que su retablo, en el año 1718; es decir, justamente a continuación de que se hubiera finalizado el otro y su escultura, la Anunciación; los cuales, como ya hemos comentado, estaban ya en la capilla el 1 de enero de 1718, si bien el retablo aún se encontraba sin dorar ni policromar. No podemos asegurar que fuera realizado en ese año de 1718, aunque parece lo más probable, puesto que los documentos que poseemos tan solo llegan a encuadrar el periodo en el que fue esculpido por Pedro de Ávila entre 1718-1726. Esta

\footnotetext{
399 MARTÍN GONZÁLEZ, Juan José: Escultura barroca castellana ..., op. cit., p. 241.

400 MARTÍN GONZÁLEZ, Juan José (dir.): Inventario artístico de Valladolid..., op. cit., p. 252.

401 MARTÍN GONZÁLEZ, Juan José: Catálogo Monumental de la provincia de Valladolid. Tomo VI..., op. cit., p. 75.
} 
última fecha no es baladí, sino que nos viene dada por la escritura, fechada el 30 de junio de 1726, en la cual la Cofradía de Nuestra Señora del Refugio y San Pedro Regalado decide ampliar su capilla para "mayor culto y veneración de San Pedro Regalado y decencia de su capilla y por no tener en ella comodidad bastante para la asistencia de dicha cofradía a las funciones que en ella celebra" (DOCUMENTO 89). En él se hace referencia al "sitio en que al presente se halla el del Santo Ecce Homo". Podríamos acotar aún más este periodo (1718-1720) si supusiéramos que el Ecce Homo se hizo al mismo tiempo que su retablo puesto que en el testamento de Gabriel de Medina Mieses, realizado en el verano de 1720, se menciona "el altar que en ella tenemos de los Celos de San José, frente del otro que también tenemos de la Encarnación de Nuestra Señora" ${ }^{402}$.

Tras la marcha del Ecce Homo a Renedo fue cambiado de retablo, al igual que la Anunciación, la cual pasó a ocupar el otro de los retablos colaterales idénticos que no era suyo. Por contra, el Ecce Homo no presidió el otro, sino que se le colocó en un retablo rococó dorado también procedente de la iglesia del Salvador. Este retablo fue adquirido en 1815 por la Cofradía de la Virgen del Refugio y San Pedro al Convento de Nuestra Señora de la Merced (Mercedarios Calzados) de Valladolid. La forma trilobular del remate de la hornacina nos indica que en su interior se alojaba un Cristo o un santo crucificado. Efectivamente, así era. La identidad de esta escultura queda desvelada por una inscripción, apenas visible, pintada en el óculo del ático: "S. EVLALIA D. BARCEL NA VIRGEN, Y M." ("Santa Eulalia de Barcelona virgen y mártir”). Esta escultura es, ni más ni menos, que la conservada en el Museo Nacional de Escultura, y cuya factura se atribuye a Luis Salvador Carmona entre 1760-1767 $7^{403}$ (Fig. 99). Este

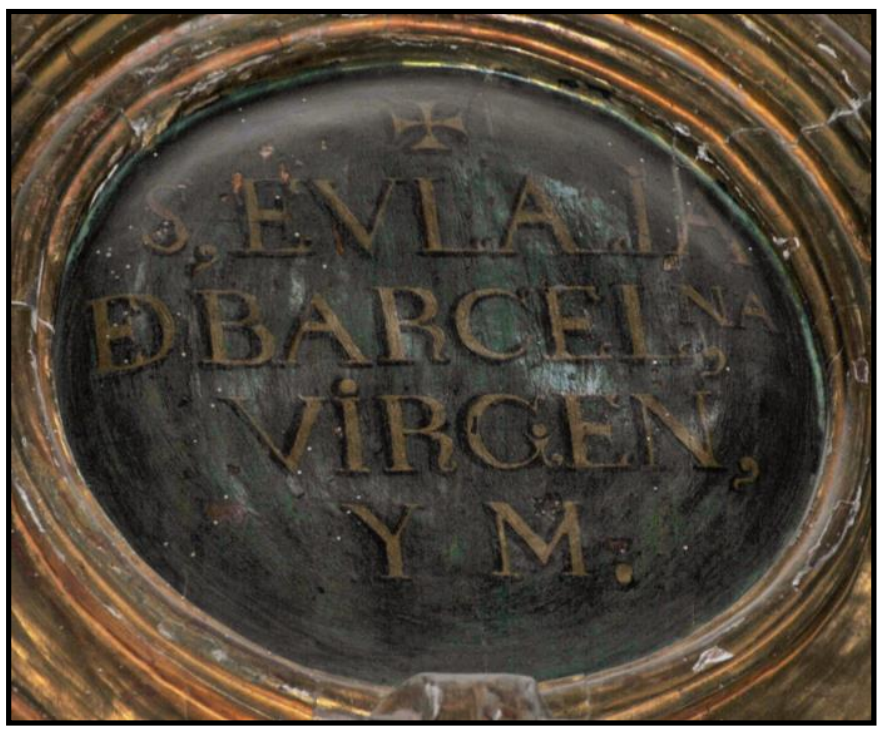

Il. 57- Detalle de la inscripción del retablo de Santa Eulalia, actual del Ecce Homo. retablo era el del colateral de la Epístola de la capilla de las Mercedes del referido Convento de Nuestra Señora de la Merced; capilla en la que se encontraba afrontado al del Evangelio, dedicado a San Dimas; es decir, se trataba de dos santos martirizados en la cruz. Esta capilla, según comenta la profesora Fernández del Hoyo, era "la más espaciosa del templo, su entrada se hacía por el testero del crucero de la epístola" ${ }^{404}$.

Como acabamos de comentar, fue adquirido al convento en 1815 "pero sin la imagen ni la mesa del altar, que se ha

\footnotetext{
402 CALVO CABALLERO, Pilar: op. cit., p. 68.

403 http://ceres.mcu.es/

404 FERNÁNDEZ DEL HOYO, María Antonia: Patrimonio perdido..., op. cit., p. 575.
} 
puesto en San Juan de Letrán a San Ramón". Con posterioridad, la escultura "figura en el inventario de bienes desamortizados de la Merced Descalza (San Juan de Letrán) en 1837, de donde fue trasladada al Museo. Allí se ha catalogado siempre, desde 1845, con la advocación de Santa Librada"405.

El presente Ecce Homo no deja de poseer una rara iconografía puesto que a diferencia de la mayoría de Ecce Homos este no porta la túnica morada ni la corona de espinas, y tampoco tiene las manos cruzadas sobre el pecho. Por el contrario, más bien parecería un Cristo a la columna por tener las manos sujetadas por una cuerda y levemente ladeadas hacia el lado izquierdo; sin embargo, el hecho de que esté erguido elimina toda posibilidad de que se trate de un Cristo de este tipo. También es un misterio el por qué Gabriel de Medina Mieses eligió la representación de un Ecce Homo para ocupar el altar advocado bajo el nombre de "los Celos de San José", el cual anteriormente parece que debió de tener una representación del padre nutricio de Cristo; si bien esta posibilidad no tiene ningún fundamento puesto que ni se tiene noticia de ello ni tampoco existió anteriormente a que se hiciera este Ecce Homo y el propio retablo, otro retablo en el que estuviera aquella escultura.

Pedro de Ávila ha reflejado en este Cristo lo que pondría en práctica unos años después en el Cristo del Olvido: la belleza patética, un Cristo sufriente pero que a la vez no se encuentra exento de gran belleza formal, delicadeza y cierta idealización. El canon es ciertamente alargado, cuasi praxiteliano, a lo que sin duda ayuda la delgadez extrema de su anatomía, en la que aciertan a verse cada uno de los huesos y venas que recorrer la enjuta piel de su maltrecho cuerpo.

Cristo aparece de pie. Tiene adelantada la pierna izquierda, a lo que responde la derecha retrasándose. Está en el momento en el que es sometido a juicio público en el pretorio de Pilato, de ahí que mantenga esa quietud tan absoluta tan solo rota por las piernas, cuya posición sin duda otorga estabilidad a la escultura. El brazo derecho lo tiene pegado sobre el pecho, de tal manera que las manos están atadas a la altura del costado izquierdo, lo que desplaza levemente el centro compositivo. Las manos a pesar de encontrarse atadas no están encapsuladas y "muertas"; por el contrario talla los dedos con gran elegancia y delicadeza que vuelve a recordar el "lenguaje de manos" de Gregorio Fernández. La captación de la anatomía es apurada y minuciosa puesto que define cada uno de los miembros del cuerpo; especialmente destacada es la labra de la clavícula, con las carnes rehundidas; y las finas piernas en las que se puede ver a la perfección las tibias o las diferentes venas que las riegan de sangre. El cuerpo tan solo se ve cubierto por un pequeño paño de pureza blanco que sigue fielmente el esquema que ya le hemos visto en los Crucificados: se trata de un paño muy aristado formando grandes concavidades que vienen a formar dos "V" superpuestas, la inferior más amplia, y cuyo punto inferior viene a coincidir con la parte baja del paño. Al lado izquierdo una lazada lateral de la que pende una gran masa y que a su vez deja descubierta una buena porción del muslo izquierdo, detalle con el que Ávila pretende valorizar la anatomía.

$405 \quad$ Ídem, p. 576. 
Especialmente interesante es la cabeza, la cual eleva levemente mientras mira hacia el cielo, como suplicando al Padre. Es sin duda una imagen de devoción. Tanto el rostro como las cabelleras son una copia puntual de los vistos en el busto de Ecce Homo de las Brígidas o el Cristo del Olvido, entre otros muchos. El rostro, que posee ciertos recuerdos del Cristo atado a la columna que Gregorio Fernández talló para la Cofradía Penitencial de la Santa Vera Cruz de Valladolid, presenta los típicos estilemas presentes en sus obras, si bien la minuciosidad es tal que dota de gran blandura a la piel y por el contrario dureza a los huesos orbitales. Hay un perfecto estudio de las calidades. Esa misma minuciosidad la tenemos también en la labra de la barba y la cabellera, en las cuales podemos observar cada uno de los pelos y guedejas pormenorizadas al máximo. La barba es bífida con dos guedejas sinuosas y simétricas cuyas puntas apuntan hacia adentro. La cabellera, que sobre la frente remata en dos mechones simétricos con las puntas hacia afuera, cae a ambos lados del rostro creando grandes masas capilares que se van ensanchando según van cayendo hacia los hombros; no falta el típico detalle del mechón estrecho que cae sobre el pecho. Me gustaría subrayar la absoluta similitud existente en la concepción de estas amplias y voluminosas cabelleras del Ecce Homo con las del Cristo Resucitado de Puras, perteneciente a su primera etapa. Como vemos, las melenas vienen a realizar los mismos movimientos y recurvamientos, sin embargo en su primera etapa no pormenorizaba tanto los cabellos, característica que fue adquiriendo con el tiempo. Esta es sin duda una evolución de aquella, lo que nos vuelve a reafirmar en dos ideas: en la de que el Resucitado pertenece a Ávila y en la de que en su primera etapa surgen estilemas que durante la segunda los perfeccionará y evolucionará.

Sin duda este Cristo es uno de los más sanguinolentos de cuantos tallara Ávila, los cuales si por algo se caracterizan es por la poca presencia de sangre en ellos. En éste en cambio la sangre mana abundantemente de la cabeza a causa de las heridas de la corona de espinas; del torso; seguramente de la espalda por el efecto de la flagelación (no lo podemos comprobar por la situación del Ecce Homo en el retablo); y sobre todo de los codos y las rodillas, de las cuales brota a borbotones e incluso hay restos de sangre coagulada. A pesar de que no fuera creado con esas intenciones, pienso que bien merecería ser imagen procesional. 


\title{
TUDELA DE DUERO. IGLESIA PARROQUIAL DE LA ASUNCIÓN
}

\author{
JESÚS NAZARENO (h. 1718-1720)
}

En una de las dependencias de la iglesia parroquial de Tudela de Duero se encontraba arrinconada una pequeña talla de Jesús Nazareno (Fig. 100) que debe ser incluida en el catálogo de nuestro escultor sin ningún género de dudas. Esta imagen representa un hito dentro de la obra de Pedro de Ávila puesto que se trata de una escultura "de vestir". A pesar ello no solamente tiene talladas la cabeza, manos y piernas, como suele ocurrir en la mayor parte de las ocasiones, sino que tiene esculpido todo el cuerpo; si bien las zonas que oculta la túnica presentan una anatomía más básica, muchos menos definida pero plenamente correcta. De hecho se incluyen ciertos detalles que nunca se verían salvo cuando se le retira la túnica, como son las rodillas sangrantes.

Este tipo de Nazareno ha gozado de gran éxito en Castilla, siendo uno de sus más felices cultivadores Francisco del Rincón, el cual debió de tallar varios Nazarenos de este tipo para localidades de la actual provincia vallisoletana (Nava del Rey, Medina del Campo, etc...). Pero estos Nazarenos tenían la cualidad de tener el cuerpo perfectamente tallado, son imágenes de vestir, pero de bulto completo. También tenemos el ejemplo del Nazareno esculpido en 1614 por Gregorio Fernández para el paso de Camino del Calvario de la Cofradía de la Sagrada Pasión de Cristo. Por la provincia se hallan numerosos ejemplares de Nazareno fechables a lo largo de la segunda mitad del siglo XVII y primeros años del XVIII, todos los cuales no tienen un autor asignado. Este pequeño ejemplar atribuido a Pedro de Ávila parece ser una de las últimas repercusiones (no podemos olvidar el que Felipe de Espinabete talló uno para la Cofradía de la Vera Cruz de Tordesillas) de aquellos nazarenos de principios del siglo XVII: una feliz recuperación.

Parece obvio comentarlo, pero se tratará de una escultura cuya función primordial sería la procesional; a la cual, quizás, acompañaran en los desfiles de Semana Santa por la localidad vallisoletana otras imágenes como un Cristo Atado a la Columna y un Ecce Homo conservamos en la misma parroquia. Como es habitual en los Nazarenos de este tipo, aparece de pie, aunque acusa cierta rigidez en cuerpo y piernas. Mantiene el brazo izquierdo subido y el derecho horizontal para poder sustentar la cruz. Gracias a una reciente restauración sabemos que la escultura está hecha en varias piezas, de tal manera que una de ellas es la cabeza hasta el cuello, teniendo en su interior un vástago que se inserta en el cuerpo de tal manera que apenas es visible el ensamblaje.

Toda la fuerza expresiva se concentra en la cabeza, bellamente modelada y acusando blandura, especialmente en los carrillos. Sigue el típico esquema de Pedro de Ávila: pelo ondulado a ambos lados del rostro cayendo en largas guedejas sinuosas; barba rematada en dos pequeños cuernos simétricos; nariz recta con tabique ancho y aplastado; ligero abultamiento bajo los ojos, los cuales son de tapilla; boca entreabierta; dos finos mechones simétricos sobre la frente; etc... Es admirable la minuciosidad con 
que trata los rasgos faciales, así como la melena y la barba. La profundidad y amplitud de las cabelleras entroncan plenamente con otras obras que representan a Cristo como son el Ecce Homo de Renedo (Valladolid), el busto de Ecce Homo de las Brígidas o el Cristo del Olvido de San Felipe Neri. La similitud con estas obras, así como los propios rasgos presentes en este Nazareno, nos hacen creer que lo esculpiría entre 1718-1720, pero sin descartar una fecha más tardía.

Cuando conocí la obra, se encontraba arrinconada junto a objetos que nada tenían que ver con el culto; es decir, estaba olvidada. Presentaba gran suciedad y un malísimo estado de conservación. Tras una restauración llevada a cabo en el año 2013 en dependencias catedralicias, la imagen ha recuperado parte de su esplendor; aunque por el contrario ha perdido cierta expresividad. 


\section{VALLADOLID. IGLESIA PENITENCIAL DE NUESTRO PADRE JESÚS NAZARENO}

YACENTE (h. 1718-1723)

En el banco del retablo de Nuestra Señora de la Soledad se conserva un pequeño Yacente (Figs. 101-102) que ha sido relacionado de manera muy acertada con Pedro de Ávila desde hace bastante tiempo. El primero en tratar sobre esta delicada escultura fue Arribas Arranz, el cual la definió como una "buena talla, especialmente del medio cuerpo superior", atribuyéndosela a "cualquiera de los aventajados artistas que trabajaban en Valladolid a fines del siglo XVII y principios del XVIII"406. Años después, Martín González, al tratar sobre las copias de modelos fernandescos en su libro Escultura barroca castellana ${ }^{407}$ no acierta a proponer un autor, sin embargo expone que podría fecharse en el primer tercio del siglo XVIII; años en los que también, según su parecer, se tallarían también los Yacentes del Oratorio de San Felipe Neri y de la Capilla de Nuestra Señora de los Dolores de la Catedral. Este mismo hecho, su deuda con los Yacentes fernandescos, lo volverá a señalar en el Inventario Artístico de Valladolid: "Escultura de Cristo Yacente en el banco siglo XVIII, copia de los de

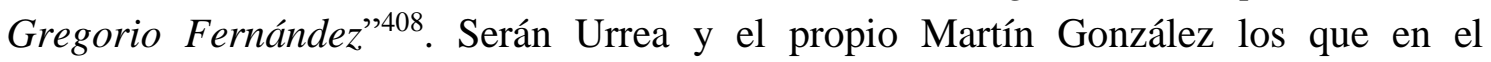
respectivo tomo del Catálogo Monumental de Valladolid se lo asignen finalmente a Pedro de Ávila. Según ellos, el Yacente es "una escultura de indudable adscripción a Pedro de Ávila" ${ }^{409}$. Esta atribución sigue vigente a día de hoy, como no podía ser de otra forma dada su completa similitud con otras esculturas de Ávila. La última ocasión en que se ha refrendado esta atribución ha sido en el año 2014, cuando el Yacente participó en la exposición "Eucharistia" de Las Edades del Hombre, cuya ficha de catálogo la realizó José Ignacio Hernández Redondo; el cual le definió como "digno ejemplo de la notable calidad de dicho taller [de los Ávila] en la primera mitad del siglo XVIII"410.

En cuanto a su cronología, la aproximación más acertada parece ser la realizada por Hernández Redondo que piensa que pudo ser realizado entre los años 1720-1729 ${ }^{411}$. Personalmente creo que el Cristo Yacente se tallaría en algún momento entre 17181723, años en que se contrata y se da por acabado el retablo. De este último acontecimiento nos da noticia Canesi ${ }^{412}$. Es decir, la devoción a la Virgen derivó en la construcción del retablo, y la construcción de éste desembocó en la contratación de un Yacente que viniere a completar un retablo del tipo "Yacente-Dolorosa".

\footnotetext{
406 ARRIBAS ARRANZ, Filemón; La Cofradia Penitencial..., op. cit., p. 92.

407 MARTÍN GONZÁLEZ, Juan José: Escultura barroca castellana ..., op. cit., p. 238.

408 MARTÍN GONZÁLEZ, Juan José (dir.): Inventario artístico de Valladolid..., op. cit., p. 43.

409 MARTÍN GONZÁLEZ, Juan José y URREA FERNÁNDEZ, Jesús: Catálogo Monumental de la provincia de Valladolid. Tomo XIV..., op. cit., p. 221.

410 HERNÁNDEZ REDONDO, José Ignacio: "Nº 61 Cristo Yacente". En VV.AA.: Las Edades del

Hombre. Eucharistia, Fundación Las Edades del Hombre, Valladolid, 2014, p. 246.

$411 \quad$ Ibídem.

412 CANESI ACEVEDO, Manuel: Historia de Valladolid (1750), Tomo II, op. cit., p. 51.
} 
Este tipo de retablos ("Yacente-Dolorosa") se comenzó a utilizar ya a lo largo del siglo XVI, aunque es durante el barroco cuando adquiere mayor protagonismo y desarrollo. Estos retablos, según expone Hernández Redondo, poseen un sentido eucarístico ${ }^{413}$, que en este caso particular se ve resaltado por la existencia en el ático de una escultura de la Fe y la aparición de un viril en el costado del Yacente. Como bien expresa la denominación "Yacente-Dolorosa", se trata de un retablo en el que el Yacente aparece situado en el banco, mientras que la Dolorosa, normalmente de la tipología creada por Gaspar Becerra para el madrileño convento de la Victoria, se sitúa en la hornacina principal. El de la iglesia de Jesús Nazareno le hallamos en el lado del Evangelio del crucero. El retablo se ejecutó según la traza presentada por el ensamblador José Díaz de Mata a la cofradía el 15 de mayo 1718. A la hora de su construcción Díaz de Mata se repartió la tarea con el también ensamblador Juan Correas. Desconocemos la razón de la demora que sufrió su ejecución puesto que no se da por concluido hasta febrero de 1723, ya que en los días 23 y 24 de febrero de ese año, tal y como relata Canesi, se "colocó a esta soberana Señora en su nuevo retablo que más parece de oro que dorado" "14. Esta fecha sería la correcta y no la de abril de 1729 que alude Arribas Arranz arguyendo las liquidaciones entregadas a Díaz de Mata y Correas por su trabajo $^{415}$. No es la primera vez que debido a problemas económicos una obra se acaba y tienen que pasar años para que sus artífices cobren lo estipulado en el contrato. Del dorado se ocupó Manuel Aragón en $1731^{416}$.

Es curioso comprobar como a la vez que ambos ensambladores realizaban este retablo, Juan Correas contrata por su parte el "retablo para un colateral de dicha iglesia donde se halla un Santo Cristo en cuyo sitio ha de quedar colocado"417. Se trataba de un retablo que colocaría "enfrente de Nuestra Señora de la Soledad" y que estaría presidido por el Santísimo Cristo de la Agonía, tallado en 1684 por Juan Antonio de la Peña. La historia del retablo de la Soledad, cuya ubicación original fue en este mismo lado donde se encuentra, aunque más cerca de la puerta de la iglesia, ha sido de lo más complicada ya que ha sobrevivido a varias incidencias. Así, fue el único retablo que se salvó del incendio acontecido en la iglesia en el año 1799418. Posteriormente, el 23 de febrero de 1853 el diarista Telesforo Medrano recoge que en la iglesia se provocó "un pequeño fuego (...) en el altar de la Virgen de la Soledad, por el pabilo de una vela mal apagada y que se fue introduciendo en la cerca seca que había sobre el sepulcro". Los daños fueron escasos pero "todos los pormenores constan en el libro de actas de la Hermandad puestas por mí como secretario que era de la Hermandad" "419. Sería a raíz de las reformas urbanísticas llevadas a cabo a finales del siglo XIX que tenían como objetivo ensanchar la calle de Jesús las que provocaron la sección de un trozo de la parte

\footnotetext{
413 HERNÁNDEZ REDONDO, José Ignacio: "Nº 61 Cristo Yacente" op. cit., p. 246.

414 CANESI ACEVEDO, Manuel: Historia de Valladolid (1750), Tomo II, op. cit., p. 51.

415 ARRIBAS ARRANZ, Filemón; La Cofradía Penitencial..., op. cit., pp. 131-132.

416 Ídem, pp. 52-54.

417 BRASAS EGIDO, José Carlos: "Noticias documentales...”, op. cit., p. 470.

418 MARTÍN GONZÁLEZ, Juan José y URREA FERNÁNDEZ, Jesús: Catálogo Monumental de la provincia de Valladolid. Tomo XIV..., op. cit., p. 220.

419 FERNÁNDEZ DEL HOYO, María Antonia: "Valladolid en el siglo XIX...”, op. cit., p. 80.
} 
delantera del templo. Estas se hicieron efectivas en 1885, año en que Joaquín Ruiz Sierra, el arquitecto municipal, levanta la actual fachada de ladrillo. Fue en estos momentos cuando se trasladó el retablo a su actual ubicación.

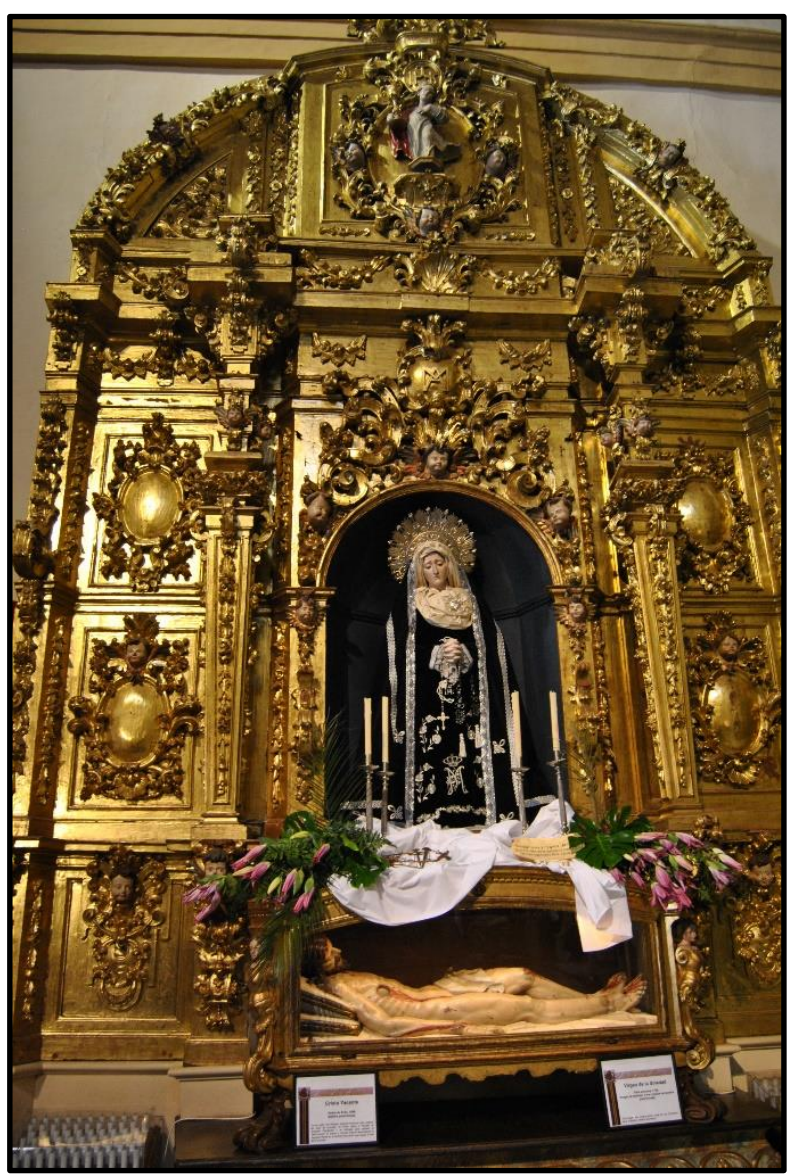

Il. 58- José Díaz de Mata y Juan Correas. Retablo de la Soledad. Iglesia penitencial de N.P. Jesús Nazareno. Valladolid.
El retablo $(679 \text { x } 406 \mathrm{cms} .)^{420}$ posee una disposición muy sencilla a la par que elegante. Asienta sobre un banco abierto en el centro para poder dar cabida a la urna de cristal que contiene al Cristo Yacente. Encima un único cuerpo, con tres calles, articulado por medio de cuatro estípites. Las calles laterales, más estrechas que la central, poseen dos pisos superpuestos adornados por cartelas, en las cuales podemos ver algunos agujeros que nos hacen creer que contuvieron algún elemento, quizás los Arma Christi; mientras que en la calle central se abre la hornacina en la que se encuentra la Virgen de la Soledad, sobre la que figura una rica decoración de hojarasca, cabezas de querubines y una cartela en la que se puede leer "A.M." (Ave María). El ático remata en forma semicircular, en cuyo centro exhibe un gran medallón en el que se encuentra una escultura de bulto redondo de la $F e$,

sobre ésta hay una cartela con las siglas "J.H.S.". Todo el retablo, que acusa gran planitud, se halla profusamente decorado con motivos vegetales y, en menor medida, de cabezas de angelotes. Recientemente, en el año 2002, el retablo fue restaurado, recuperando todo su esplendor perdido por el paso de los siglos y los dos incendios sufridos ${ }^{421}$.

La Virgen de la Soledad fue donada en 1706 por los cofrades Antonio de Jesús y José con el propósito de colocarla en el cuerpo de la iglesia, quizás sobre una simple mesa de altar. La gran veneración que se la tuvo desde el principio hizo que muy poco tiempo después se formara una Hermandad bajo su amparo. Efectivamente, relata Canesi que "en el año de 1722 se instituyó aquí otra cofradía con el título del Santo Monte Calvario y esclavos de María Santísima en su Soledad, con breve del Papa Benedicto

420 ARTE, CONSERVACIÓN Y RESTAURACIÓN S.L.: Memoria final de restauración. Retablo de la Dolorosa. Iglesia Penitencial de Jesús Nazareno Valladolid, Junta de Castilla y León, Valladolid, 2002, p. 11.

$421 \quad$ Ibídem. 
Décimo Tercio que la concedió muchas indulgencias" ${ }^{\prime 22}$. El nuevo retablo para la Virgen se acabó, como ya hemos dicho, en el año 1723 puesto que en los días 23 y 24 de febrero señala Canesi que se "colocó a esta soberana Señora en su nuevo retablo que más parece de oro que dorado y con amantes finezas de fuegos, sermón y misa, estando patente el santísimo demostraron sus individuos su cordial devoción que cada día se va aumentando más, pues en el de 30 y siguiente fue dorado éste y otro que está en correspondencia en el cuerpo de la iglesia y en 1 de abril de 31 volvió esta cofradía a colocar a María Santísima de la Soledad en su trono"423. La devoción hacia la Virgen de la Soledad llegó a tal punto que en 1780 el Papa Pío VI la concedió el título de altar privilegiado un día a la semana, el sábado, aplicable a las almas de los cofrades difuntos $^{424}$. Como ya dijimos, la Virgen sigue de cerca el modelo creado por Gaspar Becerra, vulgarmente llamado "de la Paloma". Se trata de una imagen de bastidor, únicamente se encuentran talladas las manos y el rostro. Viste a la usanza de las viudas de la época, con traje de terciopelo negro, aunque en su fiesta se la engalana con ropas blancas.

El origen de la iconografía del Cristo Yacente surge de la independización del citado Yacente del grupo del Santo Entierro, sobre todo a partir del Concilio de Trento, en que el Cristo en el sepulcro sufrió una "depuración compositiva por el que se desvinculó la imagen principal del resto de los personajes que asistieron al sepelio. A partir de dicho momento, se insiste en asociar la muerte de Jesús con el sacramento de la Eucaristía y la dramática exposición del Cristo yacente en solitario se convirtió en una iconografía que superaba lo narrativo para adquirir un alto contenido simbólico" "25. Además, según comentan Luna Moreno, el caso del Yacente es uno más de los ejemplos en que "la separación se produce en dos aspectos: grupos completos de los que sólo va quedando la imagen central, como imagen de devoción, o tallas ya concebidas independientes desde su origen" ${ }^{426}$. En Valladolid se conservan ejemplares de Yacentes aislados fechables ya en la primera mitad del siglo XVI. El primero en rigor es, según Martín González y Urrea, el conservado en el banco del retablo del Santo Sepulcro conservado en la iglesia de la Magdalena ${ }^{427}$, aunque procedente del Hospital de la Resurrección. Este retablo es un claro ejemplo de retablo Yacente-Dolorosa. En la provincia se conserva uno anterior en el Monasterio de Santa María la Real de Medina del Campo, cuya factura, de hacia 1516, se atribuye al Maestro de Covarrubias ${ }^{428}$.

En este Yacente y en otros conservados del siglo XVI ya se encuentra definido, según indica Luna Moreno, el tipo de Yacente que se utilizará en los siglos venideros en

\footnotetext{
422 CANESI ACEVEDO, Manuel: Historia de Valladolid (1750), Tomo II, op. cit., p. 51.

$423 \quad$ Ibídem.

424 ARRIBAS ARRANZ, Filemón; La Cofradía Penitencial..., op. cit., p. 91.

425 HERNÁNDEZ REDONDO, José Ignacio: "No 61 Cristo Yacente”, op. cit., p. 246.

426 LUNA MORENO, Luis: "Cristo Yacente". En VV.AA.: Pequeñas imágenes de la Pasión en Valladolid..., op. cit., p. 63.

427 MARTÍN GONZÁLEZ, Juan José y URREA FERNÁNDEZ, Jesús: Catálogo Monumental de la provincia de Valladolid. Tomo XIV..., op. cit., p. 150.

428 ARIAS MARTÍNEZ, Manuel, HERNÁNDEZ REDONDO, José Ignacio y SÁNCHEZ DEL BARRIO, Antonio: Catálogo Monumental de la provincia de Valladolid. Tomo XIX..., op. cit., p. 165
} 
Valladolid: "el Cristo, extendido sobre un lecho o una sábana (a veces tallado por separado, como en la primera obra citada), apoya la cabeza sobre una o varias almohadas, con lo que se consigue que la cara quede algo levantada para poderse ver" ${ }^{\prime 429}$. Sin embargo, el modelo que se impuso en Valladolid fue, como no podía ser de otra manera, el ideado por Gregorio Fernández, el cual se mantuvo hasta bien avanzado el siglo XVIII, como podemos observar en el Yacente del retablo de la Quinta Angustia de la iglesia de San Pedro.

Este pequeño Cristo Yacente ( 45 x 158 x 68,5 cms.) atribuido a Pedro de Ávila, que se encuentra metido dentro de una urna (173 x $96 \mathrm{cms}$.), sigue muy de cerca los modelos fernandescos; pero no el puramente barroco que adquirió gran predicamento, sino el primer tipo que refleja aún ecos manieristas, y que en Valladolid adquiere formas en el Cristo Yacente (h. 1610) del Convento de San Pablo de Valladolid, el cual fue donado a la comunidad dominica por el Duque de Lerma. Este Yacente de Gregorio Fernández junta dos características que no encontraremos unidas en ningún otro ejemplar: se trata de la corpulencia de su anatomía, presente en otros Yacentes de su primera etapa; y la existencia en el costado de un receptáculo o viril dispuesto para colocar la sagrada forma. No fue Fernández el primero en idear un Cristo que sirviera de expositor o de

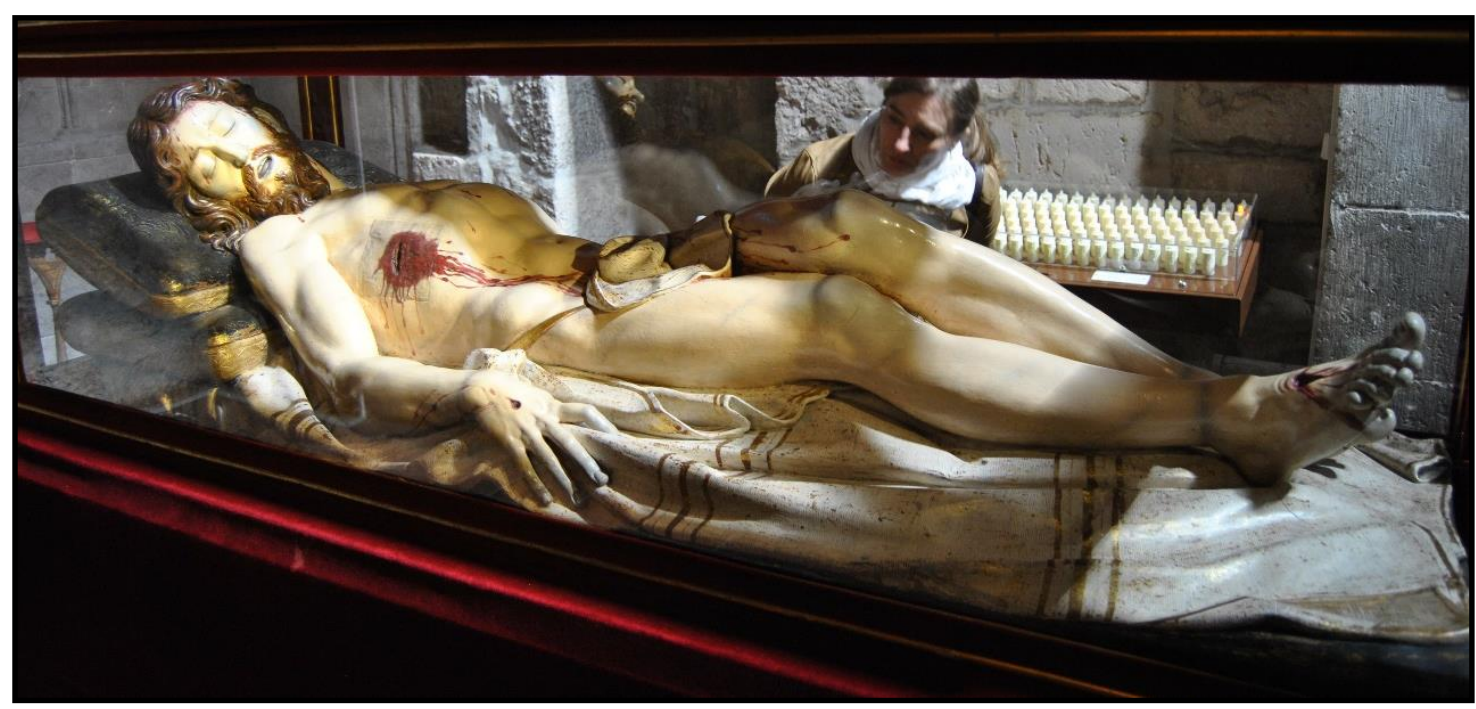

Il. 59- Gregorio Fernández. Cristo Yacente. Convento de San Pablo. Valladolid.

tabernáculo durante el Viernes Santo, pues este mérito parece corresponder al escultor Gaspar Becerra, el cual en los años centrales del siglo XVI esculpió un Yacente de este tipo para el Monasterio de las Descalzas Reales de Madrid. Explica Lorite Cruz que este Cristo "tiene un especial privilegio que se concede por influencia de la regente de las Españas Juana de Austria (hermana de Felipe II). La poderosa infanta es la que funda el convento y en él se instituye el extraño rito de procesionar el Santísimo el Viernes Santo (no se puede considerar como una estación de penitencia, sino de gloria). Hay que considerarlo algo insólito, porque por la conmemoración de muerte de Jesús el Viernes Santo no se puede consagrar, pues desde el momento en que se retira la

429 LUNA MORENO, Luis: “Cristo Yacente”. En VV.AA.: Pequeñas imágenes de la Pasión en Valladolid..., op. cit., p. 63. 
sagrada hostia el monumento creado para los oficios del Jueves Santo donde se ha conmemorado la Última Cena (a partir de la hora nona del viernes santo), Dios no está en la tierra, ha bajado a los infiernos a vencer al demonio y rescatar a la humanidad y las hostias por tanto son escondidas hasta la Vigilia Pascual, solo pudiendo comulgar aquellos que estén en peligro de muerte, para el resto de los católicos son las únicas horas del año en que no se puede recibir la comunión (recordemos que el Sábado Santo tampoco se celebra la Eucaristía), hay que esperar a que la luz sea encendida por el cirio pascual en la vigilia de pascua de resurrección; a partir de ese momento se podrá volver a consagrar" ${ }^{\prime 430}$.

Efectivamente, el Yacente de nuestro escultor también posee en el costado un viril (35 cms. de diámetro) en detrimento de la llaga. Durante mucho tiempo se había pensado que este viril o receptáculo habría servido para exponer el Santísimo Sacramento el Viernes Santo; sin embargo, el que el viril "no parecía pensado para ser practicable" llevó a Hernández Redondo a realizar un minucioso análisis, a través del cual descubrió hace poco tiempo que en realidad este viril no estaba realizado para insertar la Sagrada Forma sino que en su interior se encontraba "uno de los sellos de cera, conocidos como "Agnus Dei", que se realizaban en Roma con la cera de los cirios pascuales y que, tras la bendición papal, adquirían un rango de reliquia con propiedades milagrosas". Además, puntualiza que "en el interior del viril se puede apreciar junto a una minúscula cruz, el anverso del sello con la tradicional imagen del Cordero Místico sobre el libro de los Siete Sellos y portando el estandarte de la Resurrección. En realidad el significado sigue siendo eminentemente eucarístico, como muestra la inscripción "Ecce Agnus Dei, qui tollis pecata mundi" que todavía puede apreciarse en parte". Y finaliza explicando que lo raro "no es la existencia del sello sino su inclusión en una escultura" ${ }^{\prime 3}$.

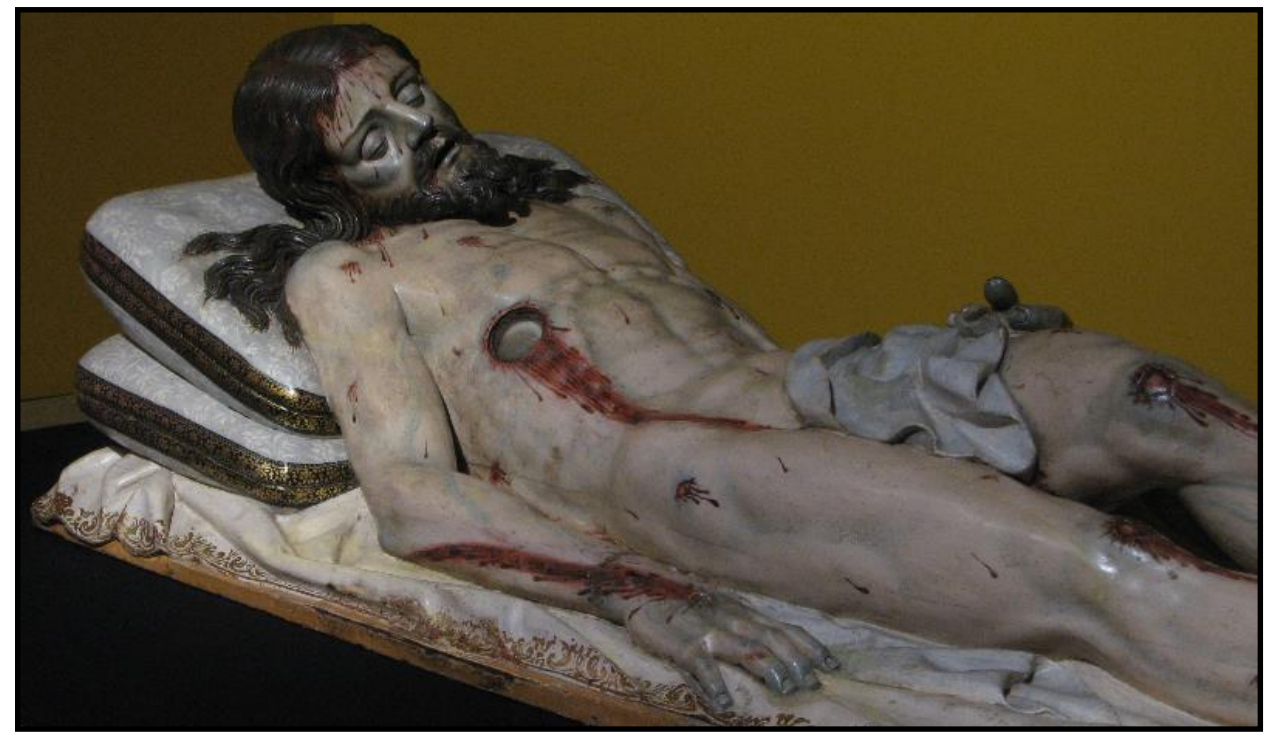

Il. 60- Pedro de Ávila ¿Atrib.?. Detalle del Cristo Yacente.

430 LORITE CRUZ, Pablo Jesús: "La figura de Cristo Yacente, ¿muerte o sacramentación?, Publicación digital de Historia y Ciencias Sociales, No 274, 2012, p. 7.

431 HERNÁNDEZ REDONDO, José Ignacio: "No 61 Cristo Yacente", op. cit., p. 246. 
Como ya hemos dicho, sigue puntualmente el modelo fernandesco del Convento de San Pablo, el cual además pertenece a la serie de Yacentes que están concebidos como si fueran altorrelieves, y no bulto redondo como es el caso del cercano Yacente de la iglesia de San Miguel. Sin embargo, a diferencia de ellos, este Cristo no mira hacia la derecha, sino que gira su cabeza hacia la izquierda, por lo que no la podemos ver en todo su esplendor. Además, como muchos de ellos, tan solo posee una vista lateral, si bien este en particular al estar dentro de una urna acristalada ligeramente exenta del retablo se le puede ver desde los dos lados cortos, con lo cual tenemos también una visión frontal.

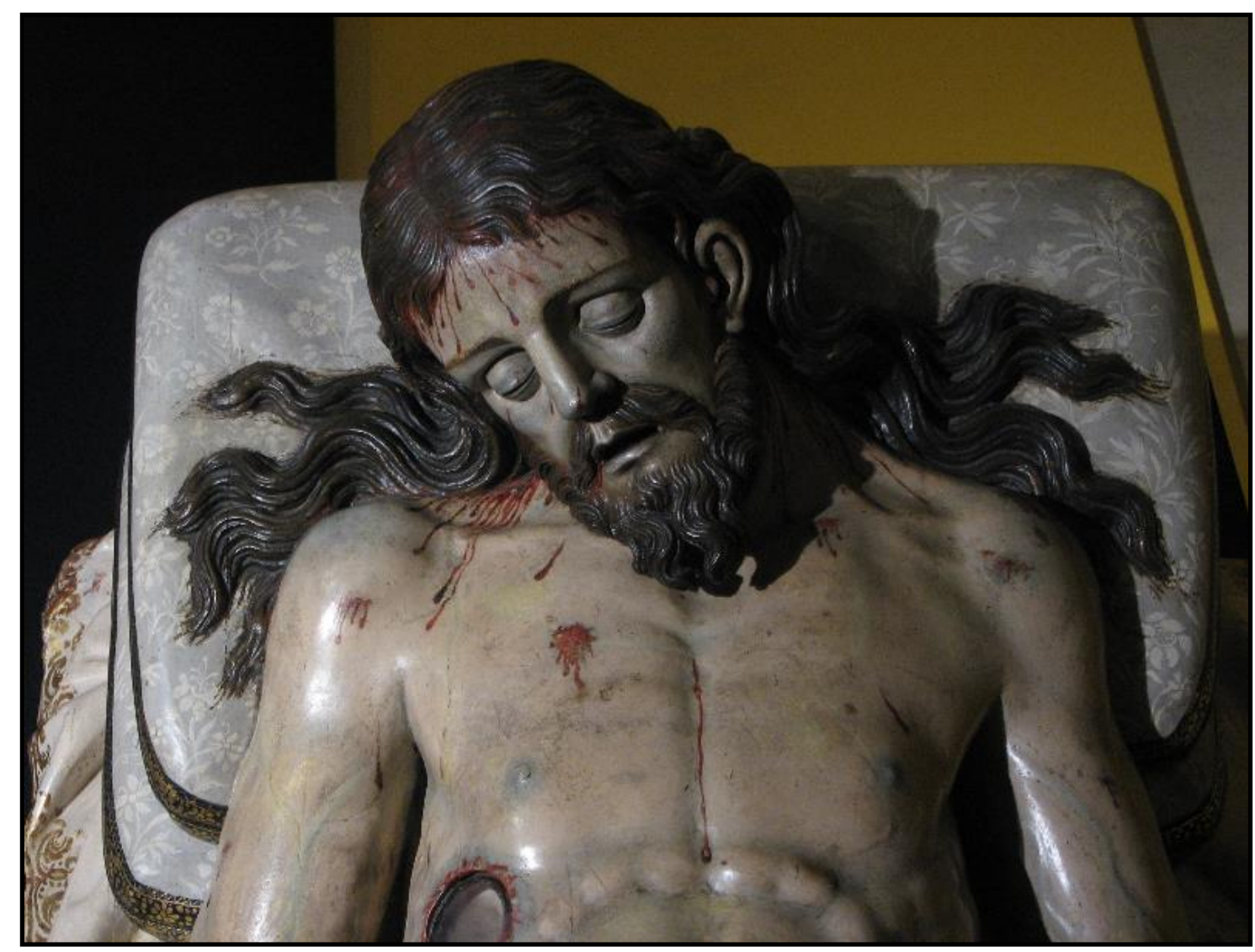

Il. 61- Pedro de Ávila ¿Atrib.?. Detalle del Cristo Yacente.

Cristo aparece tumbado, con las piernas estiradas, la derecha completamente en contacto con la sábana y la izquierda ligeramente flexionada y levantada. Para mostrar bien el viril, Ávila ha tenido que componer el torso algo más levantado de lo que sería usual e introducir dos amplios cojines, a la manera de su modelo, el Yacente de San Pablo. El paño de pureza le cubre el sexo y parte de la cadera izquierda, dejando libre la derecha, de tal forma que podemos contemplar mejor sus grandes dotes como anatomista. Este detalle también procede del citado Yacente, al igual que la colocación del brazo derecho en ángulo y la posición de los dedos de la mano como intentando agarrar la almohada. Sin embargo, lo que separa a ambos Cristos es la cierta planitud presente en la anatomía del Cristo de Ávila y lo ciertamente forzado que se encuentra tanto el torso como este brazo derecho. La parte que usualmente no se ve, el lado izquierdo del Cristo es muy interesante puesto que nos presenta el brazo ligeramente

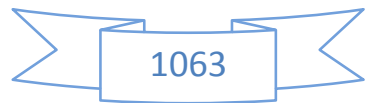


flexionado para colocarlo sobre la cadera, mientras que con esa misma mano sujeta fuertemente parte de la sábana hasta levantarla ligeramente, efecto que ha logrado Ávila simular a la perfección. Esta mano, al igual que la otra, se encuentra perfectamente detallada tanto en articulaciones como en venas, destacando su composición cerrada, que nos vuelve a recordar que estamos ante un difunto. Por su parte, la pierna ya dijimos que está levemente flexionada y levantada, pero hemos de verla por este lado para comprobar que Ávila ha dotado a esta pierna de todos y cada uno de los tendones y venas necesarios, el detallismo en esta escultura llega aquí a su máximo esplendor.

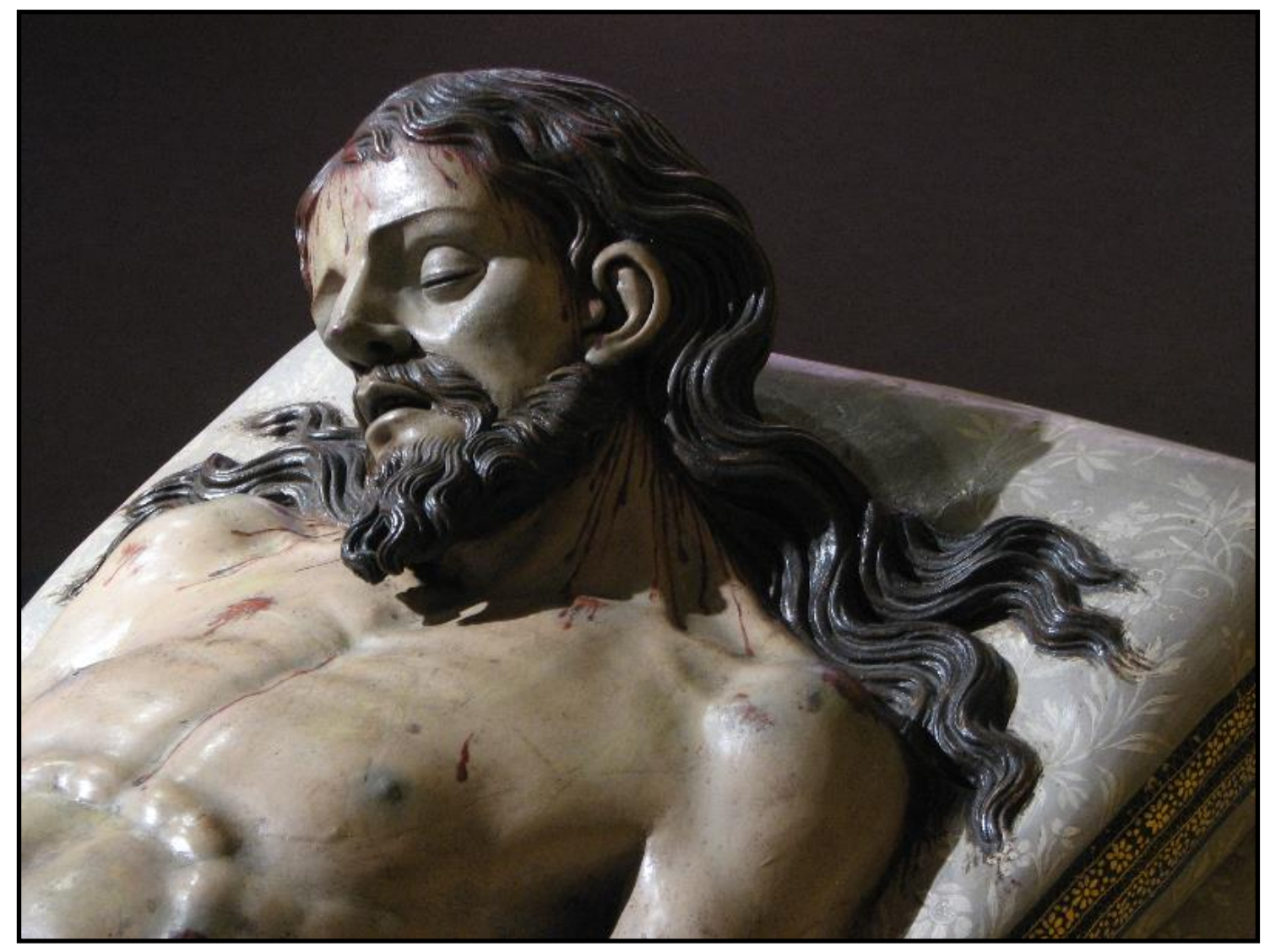

Il. 62- Pedro de Ávila ¿Atrib.?. Detalle del Cristo Yacente.

Sin duda lo mejor del Cristo es la cabeza que emparenta cercanamente con otras obras del escultor fechadas por estos mismos años, como pueden ser el Cristo del Olvido del Oratorio de San Felipe Neri, el San Francisco de Asís estigmatizado de la parroquial de La Seca o el busto de Ecce Homo del Monasterio de las Brígidas. La cabeza presenta una belleza muy serena. Cristo aparece con los ojos cerrados, aunque todavía se encuentran mínimamente abiertos; al igual que la boca, de la que sale sangre y en la cual observamos las dos filas de dientes y la lengua. Es una de las pocas esculturas de Pedro de Ávila en el que el interior de la boca se halla plenamente tallado, presentando la lengua y los dientes en volumen, puesto que en el resto de obras tan solo se insinúan, no se llegan a tallar completamente. La potente nariz de tabique ancho y recto es la usual de Ávila en estos años, al igual que las grandes melenas onduladas, barba espesa y barba sinuosa bífida. Los cabellos aparecen extendidos en diferentes guedejas a lo largo de la sábana, dejándonos oculta la oreja derecha y completamente visible la izquierda, la

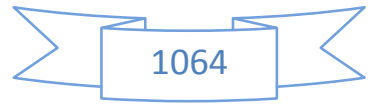


cual aparece rodeada de un espeso mechón que la circunda. Es muy destacada la talla de todos estos cabellos, puesto que los individualiza y los detalla hasta el extremo, al igual que el hecho de tener la boca completamente tallada en su interior puesto que el espectador le tendría a la altura de sus ojos a escasos centímetros de distancia.

Los paños de la sábana y del perizoma son los típicos de cuchillo, si bien no es de los ejemplos en que estos aparecen más afilados, pues la temática reposada de este Cristo no favorece la utilización masiva de pliegue tan nervioso y movido. Por su parte, el trozo de sábana situado a la izquierda del Cristo, la que éste intenta y logra levantar, posee unos pliegues a cuchillo combinados con los redondeados, y la composición triangular del perizoma es muy efectista.

La policromía a pulimento mortecina resalta aún más los valores de la escultura. El cuerpo apenas posee rastros de sangre, tan solo presentes en los regueros dejados por las llagas y en la cabeza, tanto en la frente como en la boca. Por su parte, los lados alargados de la sábana poseen en su borde una cenefa compuesta con grecas vegetales doradas. De la misma manera se encuentran motivos dorados sobre fondo negro en los ribetes de los cojines, mientras que el resto de los mismos se encuentran decorados con elementos botánicos blanquecinos que contrastan con el fondo grisáceo de los mismos.

Por último, hay que señalar que durante cierto tiempo el Yacente fue sacado en procesión por su cofradía; concretamente en la Procesión de Regla, celebrada en la madrugada del Jueves al Viernes Santo.

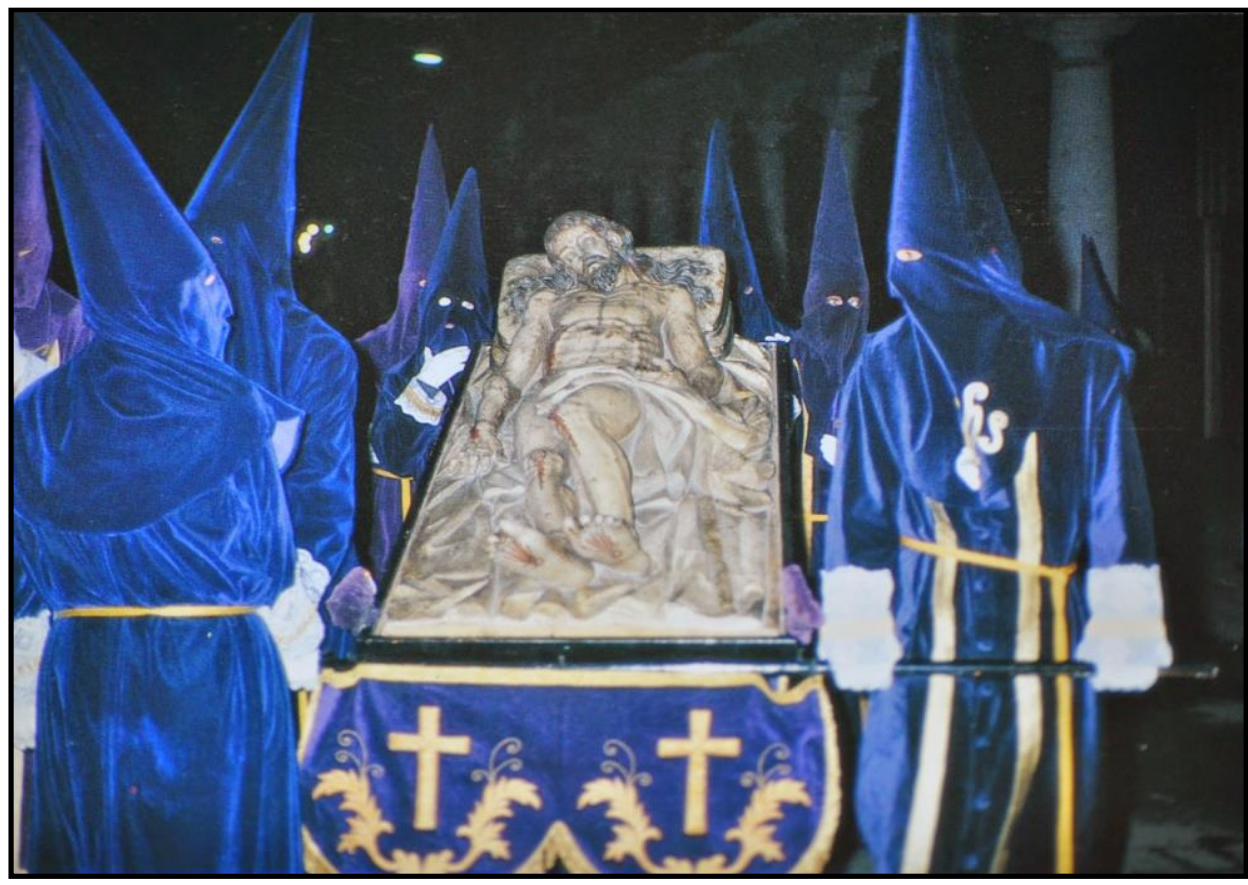

Il. 63- Instantánea de una de las salidas que efectuó el Cristo Yacente con su cofradía. 


\section{ALFARO. CONVENTO DE LA INMACULADA CONCEPCIÓN}

\section{INMACULADA CONCEPCIÓN (después 1720)}

En el Convento de la Inmaculada Concepción de Alfaro (La Rioja) se custodia una pequeña Inmaculada (85 cms.) (Fig. 103) procedente del convento de las Franciscanas de Fuensaldaña (Valladolid). No nos debe extrañar la relación laboral de Pedro de Ávila con la Orden Franciscana puesto que ya hemos hablado de que su padre mantuvo frecuentes contactos labores con diversos establecimientos de la Orden; y a ello hemos de sumar que los hijos (Pedro y Manuel) "heredaron" ciertos comitentes de su padre, Juan de Ávila.

La llegada de la comunidad fuensalina a Alfaro (La Rioja) se produjo en el año 2001 como consecuencia de la falta de vocaciones en el convento vallisoletano. A su vez, el inmueble que dejaron las hermanas en Fuensaldaña fue ocupado por unas religiosas Trinitarias procedentes de Extremadura. Investigando los avatares que pudo haber sufrido la imagen, la superiora de las Trinitarias me puso en comunicación con la que fue superiora de las Franciscanas cuando aún se hallaban en Fuensaldaña. Esta monja me comentó que había tenido que vender ciertas obras de arte, entre ellas la referida Inmaculada, para poder sufragar la mudanza al convento riojano. Sin embargo, un golpe de suerte me llevó a ver en la edición online de un famoso periodo riojano una entrevista realizada a esa referida monja, y justamente el texto se encontraba ilustrado con una fotografía en la que salía la citada religiosa y a sus espaldas, sobre una peana, la "desaparecida" Inmaculada Concepción. Hemos de considerar, por lo tanto, que esta escultura, y quizás otras muchas obras de arte del convento, salieron ilegalmente de la comunidad de Castilla y León.

Cuando la estudió Martín González para el Catálogo Monumental de Valladolid aún se

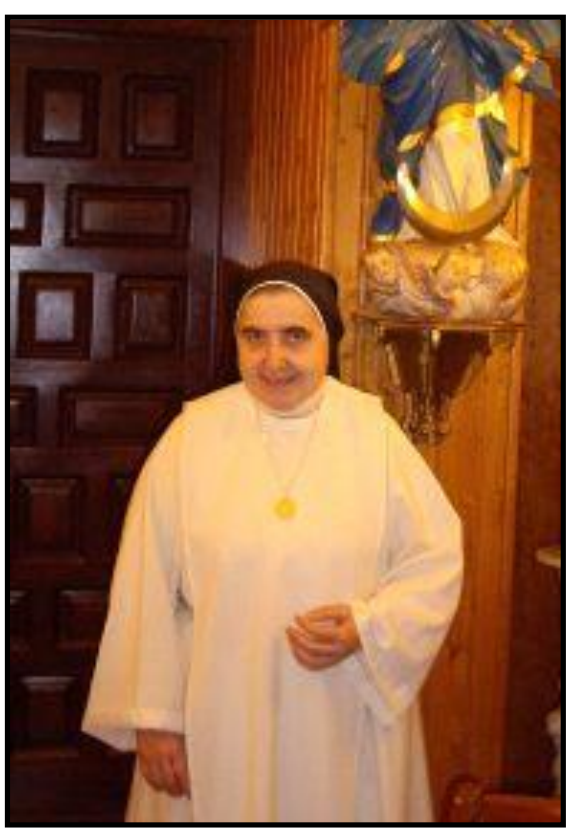

Il. 64- Fotografía que ilustraba el citado artículo y que demuestra que la

Inmaculada de Fuensaldaña se conserva en Alfaro (La Rioja). encontraba en el coro alto del convento de Fuensaldaña. Su dictamen fue meridiano: "es claramente una pieza dieciochesca de Pedro de Ávila, réplica de la que hay en la iglesia de San Felipe de Neri de Valladolid" ${ }^{432}$. Efectivamente, se trata de una copia bastante certera de la citada Inmaculada; aunque, sin embargo, introduce ciertos elementos que merece la pena reseñar: la Virgen parece concebida en una posición diagonal puesto que su cuerpo se

432 MARTÍN GONZÁLEZ, Juan José: Catálogo Monumental de la provincia de Valladolid. Tomo VI..., op. cit., p. 35 . 
encuentra mucho más inclinado, el movimiento se siente, es barroquismo en ebullición. En la peana, que la forman también tres angelitos, éstos no los presenta afrontados, sino que introduce un mayor dinamismo de tal manera que coloca el de la izquierda del espectador mirando al frente; el del centro ladeado mirando hacia los pies de la Virgen; y el de la derecha, que dirige su vista hacia arriba, tiene tapado medio rostro por una nube; como vemos, incluye una mayor variedad compositiva. También llama la atención el hecho de que Ávila ha ampliado ostensiblemente las superficies y anchuras del manto, de tal manera que la escultura misma se ensancha por las partes medidas. Este manto lo presenta con unos paños en los que el viento se ha vuelto mucho más violento, se agitan como ante un temporal. El escultor es consciente de su valía y quiere demostrarla aumentando y complicando estos paños con respecto a otras Inmaculadas, de tal manera que los hace adquirir un grado de finura pasmosa, parecieran hojas de papel; los cuales a su vez se recurvan sobre sí mismos, lo que da como resultado la multiplicación de pequeños pliegues y la formación de numerosas superficies cóncavas. También es destacable la radical utilización del pliegue a cuchillo en la parte baja de la túnica, de tal manera que ésta adquiere esa tan característica apariencia como de roca de puntas agudas, es la geometrización de la que hemos hablado en tantas ocasiones. Quizás donde más difiera esta Inmaculada de la de San Felipe Neri es en el rostro, puesto que no alcanza ni con mucho su calidad, siendo, sin lugar a dudas, lo más flojo del conjunto. Tampoco es especialmente destacable el tratamiento del cabello, que no posee la minuciosidad que le lleva en ocasiones a delimitar cada uno de los pequeños mechones que conforman las melenas. Por lo demás, la escultura es un calco de la que podemos considerar como el prototipo: la de San Felipe Neri.

En cuanto a su cronología, creo que debe asignársele una fecha avanzada debido a los afiladísimos y apretados pliegues aristados que figuran tanto en la túnica como en el manto, los cuales se encuentran en directa relación con los de la Inmaculada de San Felipe Neri. En esta ocasión, los de la parte baja de la túnica son incluso mucho más aristados y cortantes, con una finura en las láminas de madera que la convierte en una delicadísima pieza. Todo ello sumado al dinamismo, complicación de paños y dinamismo general de todos los elementos, hacen que se le pueda fechar con posterioridad al año 1720, pero sin poder establecer un periodo más cerrado dado que no poseemos ningún otro dato que nos ayude a hacerlo. 


\section{VALLADOLID. REAL MONASTERIO DE SAN QUIRCE Y}

\section{SANTA JULITA}

\section{SAN BERNARDO (década de 1720)}

La única referencia que tenemos de esta pequeña imagen $(65 \mathrm{cms}$.) (Figs. 104-105) realizada en madera policromada es la realizada por los autores del Catálogo Monumental de Valladolid, los cuales la describen como realizada en el "primer cuarto del siglo XVIII, estilo de Pedro de Ávila" ${ }^{33}$. En 2015 Rebollo Matías comentó que, según su particular punto de vista, San Bernardo denotaba el "estilo de Manuel de Ávila"434. Se trata de una atribución altamente arriesgada por cuanto apenas contamos con obras suyas con las que compararle. No estoy de acuerdo con ella y considero completamente acertada la opinión de Martín González y Plaza Santiago.

En el momento de ejecución de este catálogo la escultura de San Bernardo se custodiaba dentro de una hornacina situada en el coro. Pasados los años cambió de localización pues cuando accedí al monasterio para su estudio se encontraba sobre una mesa en una habitación de la clausura. En la referida hornacina del coro se ha sustituido al San Bernardo por una efigie de San Blas. Desconocemos si la escultura fue realizada para esa hornacina del coro o bien fue un regalo de algún donante anónimo puesto que la talla responde, tanto por su tamaño como por su grado de calidad, a las características de las imágenes de escaparate.

La escultura presenta las características y perfiles típicos con los que representa Pedro de Ávila a la mayoría de los santos durante su segunda etapa. San Bernardo aparece de pie, marcando el consabido contraposto con el adelantamiento de la rodilla izquierda. Eleva su brazo derecho empuñando un báculo abacial, aludiendo a su faceta de abad, mientras que el otro lo mantiene en reposo sujetando un libro abierto que hace referencia a su condición de fundador de una Orden religiosa, la del Císter. El libro es muy realista puesto que tiene escritas hasta unas líneas de texto. Las manos están talladas de manera exenta, tal y como me mostró una amable monja.

Viste la típica cogulla cisterciense blanca hasta los pies, dejándonos ver tan solo las características puntas de los zapatos, y amplísimas mangas muy del gusto del barroco. Sobre el blanco de la cogulla posee una riquísima y delicada policromía dorada consistente en diferentes motivos vegetales y orlas bordeando las mangas y la capucha. En la parte baja de la misma una cenefa de colores completa el conjunto. Sobre los hombros un escapulario redondeado y la capucha retirada, sobre la espalda. Los pliegues que surcan la prenda son los típicos a cuchillo, extremadamente finos, creando grandes concavidades longitudinales. Esto nos indica que estamos ante una obra de madurez, en la que domina a la perfección la técnica berninesca por la cual crea

\footnotetext{
433 MARTÍN GONZÁLEZ, Juan José y DE LA PLAZA SANTIAGO, Francisco Javier: Catálogo Monumental de la provincia de Valladolid. Tomo XV..., op. cit., p. 191.

434 REBOLLO MATÍAS, Alejandro y MINGO MACÍAS, Luis: “Acerca de nuestra historia: Real Monasterio de San Quirce y Santa Julita: arquitectura y patrimonio”, op. cit., p. 23.
} 
superficies muy aristadas, pero a la vez muy finas. Quizás pueda fecharse en la década de 1720. En la parte baja de la cogulla aparecen los estilemas característicos de nuestro escultor: los pliegues adquieren una forma rocosa aristada, siendo uno de los pliegues más cortantes el elemento divisor entre ambos pies, situados como de costumbre formando un ángulo de $90^{\circ}$. Son especialmente destacados los pliegues de las mangas, en los cuales las referidas características de los pliegues llegan aquí a su máxima definición y delicadeza. Los pliegues de la capucha quizás sean demasiado rígidos.

Su rostro presenta los rasgos habituales de Ávila, a pesar de que el santo figura con un gesto ciertamente anodino, algo no muy frecuente. Sin embargo, esto no impide para que el rostro esté muy logrado tanto en la captación de la blandura de la carne como en la consecuencia de las arrugas que denotan la avanzada edad del santo. Las arrugas de la frente vuelven a ser las dos "V" extendidas que tanto utiliza. La frente presenta amplia tonsura tan solo suavizada en el centro por un mechón circular, y en el exterior un borde de pelos cortos y sinuosos.

El resto de facciones, incluido el formato rectangular del rostro, obedece al estereotipo de Ávila: ojos almendrados y rehundidos, con el característico abultamiento de la parte inferior de los mismos; cejas rectas con ceño liso; nariz recta, potente, geometrizada, con el tabique nasal ancho y aplastado; desde el nacimiento de la nariz hasta su desembocadura en las fosas nasales va creciendo en anchura, formando un triángulo isósceles; las aletas nasales están levemente pronunciadas, mientras que las fosas nasales van perforadas, detalle que aporta un mayor grado de realismo. Boca entreabierta con finos labios, pero en esta ocasión no están tallados ni la lengua ni los dientes, apreciándose tan solo por estar simulado por la policromía la punta de la lengua. El surco nasolabial va perfectamente modelado, lo que contribuye a valorizar el rostro y a separar ambos lados del bigote. Ojos de tapilla que simulan ojos marrones. Cejas y pestañas pintadas. Pómulos rehundidos y arrugados en función de la edad, como ya hemos comentado. Barba con numerosos y sinuosos mechones profundos a ambos lados del rostro, prolongada en el mentón a través de dos mechones curvos y simétricos cuyos bucles miran hacia el interior. Este tipo de barba es similar a la que tienen los San José de la catedral y del Santuario del Henar, o en el busto de Ecce Homo de las Brígidas. 


\section{LA SECA. IGLESIA PARROQUIAL DE LA ASUNCIÓN}

\section{SAN FRANCISCO DE ASÍS ESTIGMATIZADO (1724)}

El San Francisco de Asís estigmatizado (Figs. 106-107) del que vamos a tratar a continuación constituye una obra de altísima calidad, conformándose sin ningún género de dudas en una de las obras maestras de nuestro escultor. A pesar de que no tenemos el dato concreto que nos la documente, no hace falta, vistas las características que exhibe el santo. Nunca se ha barajado el nombre de Pedro de Ávila entre los posibles autores de esta bellísima imagen. En 1910 fue atribuida por Elías Tormo a Luis Salvador Carmona; sin embargo, muchos años después esta asignación fue lógicamente desestimada ${ }^{435}$. A pesar de ello creo que no existe mejor alabanza a Pedro de Ávila y mayor reconocimiento a las altas cotas de calidad presentes en esta obra que se la haya creído como salida del taller cortesano más exquisito del barroco dieciochesco, como era el del escultor navarrés.

A día de hoy contemplamos la escultura del santo de Asís en una de las hornacinas laterales del actual retablo mayor de la iglesia parroquial de La Seca, concretamente en la izquierda. En la frontera se halla San Benito de Palermo y en la hornacina principal San Francisco de Asís muerto, según la famosa iconografía creada por Gregorio Fernández y difundida por Pedro de Mena. Finalmente, en el ático se encuentra presente un Crucifijo, que es la única pieza que resta de un Calvario, y a los lados en dos pequeñas hornacinas el Sol y la Luna. Remata el retablo el Padre Eterno dentro de un rompimiento de gloria, que viene a ser la "clave" del medio punto superior. Este retablo, junto con todas las esculturas mencionadas, no es el retablo mayor "histórico" de la iglesia parroquial sino que procede de la cercana iglesia de San Francisco de la V.O.T. Fue trasladado a su presente emplazamiento en la década de 1970 tras el hundimiento de la torre de la iglesia parroquial y la consiguiente ruina del retablo mayor del templo; además, también contribuyó a este traslado el cierre de la iglesia de la V.O.T. por peligro de derrumbe ${ }^{436}$. El actual retablo parroquial aún se encontraba en la iglesia de San Francisco, para la cual fue fabricado, cuando Martín González redactó el Inventario Artístico de Valladolid en el año 1970; es más, presentaba las mismas imágenes que hoy podemos ver en el retablo: "Retablo mayor, siglo XVIII, con esculturas: Calvario, el Cristo, principios, del XVII; la Virgen y San Juan, siglo XVIII; San Francisco, siglo XVIII; Estigmatización de San Francisco, siglo XVIII; San Benito de Palermo" ${ }^{437}$.

La V.O.T. de La Seca fue fundada en el año 1717, si bien la construcción de su iglesia no dio comienzo hasta febrero de 1725. Con anterioridad los congregantes habían intentado de manera estéril que la iglesia parroquial les cediera una capilla en la que celebrar sus cultos. Dadas las draconianas condiciones propuestas por ésta, decidieron adquirir unos terrenos anejos a la parroquia en donde edificar su propio templo. Las

\footnotetext{
435 MARCOS VILLÁN. Miguel Ángel y FRAILE GÓMEZ, Ana María: Catálogo Monumental de la provincia de Valladolid. Tomo XVIII..., op. cit., p. 348.

436 Ibídem.

437 MARTÍN GONZÁLEZ, Juan José (dir.): Inventario artístico de Valladolid..., op. cit., p. 156.
} 
obras se prolongaron bastante debido a una serie de dificultades económicas. Hubo que esperar al año 1751 para que el edificio, en su parte arquitectónica, estuviera acabado; con posterioridad se acometería el amueblamiento interior: realización del cancel, retablo mayor... ${ }^{438}$.

Por su parte, el retablo fue realizado en 1753 por el tallista vallisoletano Juan Macías, el cual lo dio por finalizado en 1755; si bien, su dorado no tuvo lugar hasta 1769-1773, labor de la que se ocupó el dorador vallisoletano Segundo del Río ${ }^{439}$. El retablo es descrito por el Catálogo Monumental de Valladolid como "de planta muy movida, se compone de banco, un único cuerpo con columnas corintias de fuste estriado y rocallas, y remate semicircular adaptado a la forma del ábside. San Francisco de Asís que junto con la de San Benito de Palermo en una de las hornacinas laterales deben atribuirse a Juan Macías" ${ }^{\prime 40}$.

Sabemos que la deliciosa escultura de la Estigmatización de San Francisco de Asís fue realizada en Valladolid en el año 1723, así consta en el libro de cuentas de la Venerable Orden Tercera"41: "Acuerdo para que se haga una hechura de San Francisco Nuestro

438 MARCOS VILLÁN, Miguel Ángel y FRAILE GÓMEZ, Ana María: Catálogo Monumental de la provincia de Valladolid. Tomo XVIII..., op. cit., p. 359.

$439 \quad$ Ibídem.

$440 \quad$ Ídem, p. 348

$441 \quad H e$ aquí el texto íntegro del acuerdo:

Acuerdo para que se haga una hechura de San Francisco Nuestro Padre. En 14 de noviembre de 1723.

"Junta la Congregación de oficiales de voz y voto de la Venerable Orden Tercera de la Penitencia de Nuestro Seráfico Padre San Francisco sita en esta villa de La Seca y su iglesia parroquial en ella a catorce días del mes de noviembre de mil setecientos y veinte y tres años estando en la sacristía de dicha iglesia lugar acostumbrado para semejantes juntas y siendo llamados por su portero según lo tienen de costumbre de que el presente escribano de dicha Orden lo certifica para tratar y conferir las cosas tocantes al servicio de Dios nuestro señor bien y utilidad de dicha Venerable Orden especialmente el señor licenciado don Fernando Moyano ministro, los hermanos Antonio de Pedrosa, Lorenzo Cantalapiedra y Lorenzo Martín discretos y Gregorio de Pedrosa presente escribano Leonardo de Pedrosa maestro de ceremonias Francisco Maestro limosnero mayor y Luis Hernáiz vicario del culto divino todos oficiales de voz y voto de dicha Orden y la mayor parte de los de voz y voto y así juntos por dicho señor ministro se hizo proposición a dicha junta de que siendo dedicada esta Venerable Orden para honra y gloria de Dios nuestro señor y de Nuestro Seráfico Padre San Francisco a cuyo fin se hacen en cada un año diferentes funciones y especial en la festividad de la Impresión de las Llagas de dicho santo en que se celebra con solemnidad de misa, procesión y sermón y es razón que para semejantes funciones dicha Venerable Orden tenga una hechura de Nuestro Seráfico Padre San Francisco para que se aumente más la devoción mediante hallarse al presente dicha Orden con caudales suficientes de sus limosnas que vista y entendida dicha proposición por dicha junta todos unánimes y conformes acordaron se ponga en ejecución el que se haga la referida hechura de San Francisco con la impresión de las llagas a cuyo fin en aquella vía y forma que más haya lugar dan poder y facultad en nombre de dicha Venerable Orden a dicho señor don Fernando Moyano ministro y al señor licenciado don Manuel Lorenzo Moyano hermano asimismo de ella para que en la ciudad de Valladolid o donde más convenga traten, confieran y ajusten con la persona o personas que sean de la facultad para que hagan la referida hechura de San Francisco Nuestro Padre ajustando por las cantidades, plazos y pagas que más les convenga haciendo de parte aparte para su seguridad la obligación con las calidades, condiciones y gravámenes necesarias y que convengan para que se consiga dicha pretensión que hechas y otorgadas que sean por dichos señores y maestros de esta Venerable Orden las aprueba y ratifica y a su paga se obligan en toda forma como si por ella misma fuese ejecutada con las costas que de no lo hacer y cumplir así se siguieren a cuyo fin obligaron el caudal y limosnas de dicha Venerable Orden y así lo otorgaron y acordaron por ante mí el dicho escribano en esta dicha villa de La Seca dicho día, mes y año dichos y lo firmaron excepto el dicho hermano Francisco Maestro que dijo no saber doy fe y lo firmé”. A.G.D.V., La Seca, Asunción de Nuestra Señora, Caja 4, Cuentas de la Venerable Orden Tercera de San Francisco 1717-1753, Libro 1, s/f. 
Padre: (...) en razón que para semejantes funciones dicha venerable orden tenga una hechura de Nuestro Seráfico Padre San Francisco para que se aumente más la devoción mediante hallarse al presente dicha orden con caudales suficientes (...) se haga la referida hechura de San Francisco con impresión de las llagas (...) que en la ciudad de Valladolid o donde más convenga se traten con la persona o personas que sean de la facultad para que hagan la referida hechura"442. Efectivamente, así se hizo, la ejecutó un escultor anónimo de Valladolid (nuestro Ávila) a cambio de 660 reales (precio más o menos intermedio entre los 500 reales que le pagó el Oratorio de San Felipe Neri por cada una de las cinco hechuras que les talló y los 1.600 reales que le abonó la seo vallisoletana por cada una de las cinco esculturas que les fabricó), tal y como nos lo hace saber el Acuerdo de un año después, 1724: "Que mediante por la junta antecedente de catorce de noviembre del año pasado de setecientos y veinte y tres se acordó que para honra y gloria de Dios Nuestro Señor y de Nuestro Seráfico Padre San Francisco se hiciese una hechura suya de bulto para las funciones de dicha orden la cual está ejecutada en la ciudad de Valladolid en cuya virtud acordaron se libre de lo más pronto y efectivo del caudal y limosnas de dicha orden seiscientos y sesenta reales de vellón en que parece se ajustó la referida hechura y asimismo el gasto de traerla desde dicha ciudad a esta villa y para colocarla en la iglesia de ella con la decencia y solemnidad que se requiere y todo ello se entregue para dicha paga y distribución a dicho señor ministro quien con recibo del escultor y memorial de dichos gastos se abonará todo lo que en ello gastare" ${ }^{\text {"43 }}$. Ese mismo año se libran 720 reales "para la paga y satisfacción de la hechura de Nuestro Padre San Francisco y gastos de traerle y otros que se habían ofrecer" ${ }^{\prime 44}$. Visto todo esto, y que la idea de fabricar la escultura parte de un acuerdo formado el 14 de noviembre de 1723, parece lógico fechar la imagen en 1724 puesto que entre que se pusieron de acuerdo con Ávila y éste terminara de tallarla nos habríamos puesto ya en los primeros meses de dicho año de 1724. Parece más que lógico que si quería una imagen de calidad acudieran a Valladolid y más concretamente al escultor más importante con que contaba la ciudad castellana en ese primer tercio del siglo XVIII: Pedro de Ávila.

En un primer momento la escultura se sitúo en la iglesia, si bien en 1725, tras no llegar a un acuerdo la V.O.T. con la parroquia para fabricar una capilla en la que dar culto a su sagrada imagen, la congregación decidió fabricar su templo propio. Por lo tanto, podríamos decir que la escultura de Pedro de Ávila fue el desencadenante para que la V.O.T. se independizara y construyera su magno templo.

San Francisco de Asís (1182-1226) es uno de los santos más conocidos de la cristiandad, por lo que no necesita presentación. El pasaje representado en esta escultura es, quizás, el más conocido del fundador de los franciscanos. Se trata de su Estigmatización. Se dice que en el año 1224 marchó solo al monte Albernia, lugar en el que el día que se celebra la Exaltación de la Cruz "tuvo la visión de un crucifijo aéreo

442 MARCOS VILLÁN, Miguel Ángel y FRAILE GÓMEZ, Ana María: Catálogo Monumental de la provincia de Valladolid. Tomo XVIII..., op. cit., p. 379.

$443 \quad$ Ibídem.

$444 \quad$ Ibídem. 
sobre el cual estaba clavado Cristo bajo la apariencia de un serafín de seis alas. De las heridas de Cristo irradiaban rayos que se imprimieron en su carne en forma de estigmas" 445 . Este hecho ya fue narrado por el biógrafo del santo, Tommaso de Celano: "Vio que encima de él había un hombre con seis alas, como un serafín, con los brazos extendidos y los pies juntos, fijado a una cruz. Dos de sus alas se elevaban por encima de la cabeza, otras dos se desplegaban para volar, las dos últimas le velaban todo el cuerpo (...). Su corazón estaba colmado con esta aparición, cuando en las manos y pies comenzaron a aparecer las marcas de los clavos, tales como acababa de verlas en el hombre crucificado, por encima de él"446.

Explica Réau que este pasaje fue copiado de la Visión de Isaías (Isaías 6, 1-14), la cual explica de una manera similar a los serafines de seis alas: "con dos se cubrían el rostro y con dos se cubrían los pies, y con las otras dos volaban". Además, añade el iconógrafo francés que el resto del milagro "se explica por el deseo de los franciscanos de subrayar la correspondencia de la vida del santo con la de Cristo. La Estigmatización sobre el monte Albernia está copiada de la agonía de Cristo en el monte de los Olivos. El serafín corresponde al ángel con el cáliz que se aparece a Jesús en oración. Detalle característico: durante el éxtasis doloroso de San Francisco, el hermano León se adormece, igual que los tres apóstoles" $" 477$.

Lo primero que hay que decir al hablar sobre esta escultura, y que es un hecho que ocurre con otros santos, es que la forma tradicional de representarle físicamente (cabeza y cuerpo) nada tiene que ver con la realidad. Según su biógrafo Tommaso Celano era "de endeble apariencia, baja estatura, con ojos de enfermo y una barba rala y descuidada"448. Aunque en algunas ocasiones se le representó así, el Concilio de Trento "prefirió representarlo con los rasgos de un asceta macilento y descarnado y expresión torturada, un espectro en sayal. Su hábito de franciscano fue reemplazado por otro de capuchino, sin duda porque los franciscanos reformados encarnaban con mayor fidelidad el espíritu de penitencia de la época"449.

Visto lateralmente, su cuerpo parece formar una helicoidal. El canon es algo más estilizado de lo normal. San Francisco figura de pie, adelanta levemente la pierna derecha, cuya rodilla flexionada se intuye bajo el sayal. Debido a la altura a la que se encuentra la escultura no podemos comprobar si tapa ambos pies o, como es usual, deja al aire libre la parte delantera, colocándolos además en un ángulo de $90^{\circ}$ y separados por un aristado pliegue del sayal. Tiene los brazos abiertos, con las palmas hacia arriba recibiendo los rayos del serafín que ya le han provocado los estigmas en ambas manos. Las manos, que están bellísimamente talladas y trabajadas con cada una de sus arrugas, falanges, etc..., están esculpidas aparte del cuerpo. También tiene impresa la llaga del costado, si bien en la actualidad tan solo podemos ver un gran hueco debido al mal

\footnotetext{
445 RÉAU, Louis: Iconografía de los santos. A-F..., op. cit., p. 545.

$446 \quad$ Ídem, p. 546.

$447 \quad$ Ídem, p. 545.

$448 \quad$ Ídem, p. 556

449 Ibídem.
} 
estado en que se haya la escultura. Es probable que, como en otras esculturas, podemos recordar una conservada en el Museo de San Joaquín y Santa Ana de Valladolid, de cada uno de los estigmas partiera una cuerda hacia el serafín simulando los rayos, mientras que del costado saldría un elemento más sólido que ayudara al serafín a simular el vuelo frente al santo.

Viste el típico sayal franciscano ajustado a la cintura por un cíngulo del que penden tres nudos que aluden a los votos franciscanos de pobreza, castidad y obediencia. Los pliegues que "acusan" el ceñimiento del cíngulo son muy pequeños y aristados, de tal manera que simulan la dicha acción a la perfección. Por su parte son todavía más cortantes y geométricos los de la parte baja del sayal, formando grandes masas cóncavas que como ya hemos dicho en numerosas ocasiones más bien parece una roca tallada, Ávila demuestra gran pericia en la concepción de estos paños tan aristados puesto que crea unos perfiles muy sinuosos y afilados. Totalmente diferente está concebido el cuello del hábito que es redondeado, aunque bastante rígido, algo que también veremos en los ejemplares San Antonio de Padua de esta misma iglesia y de la Íscar (Valladolid); sin embargo, en esta ocasión no parece tan almidonado como en el último ejemplar reseñado. Es probable que la cabeza también esté tallada de manera exenta y colocada después en el cuerpo.

La cabeza es muy bella y su gesto revela a la perfección el sufrimiento y la sorpresa ante el extraordinario milagro del que está siendo protagonista. Esa sorpresa queda patente en el ligero enarcamiento de las cejas y en la boca abierta, si bien este detalle es consustancial a la práctica totalidad de la obra de nuestro escultor. El rostro acusa gran blandura, se encuentra perfectamente modelado como podemos observar en los abultamientos en los

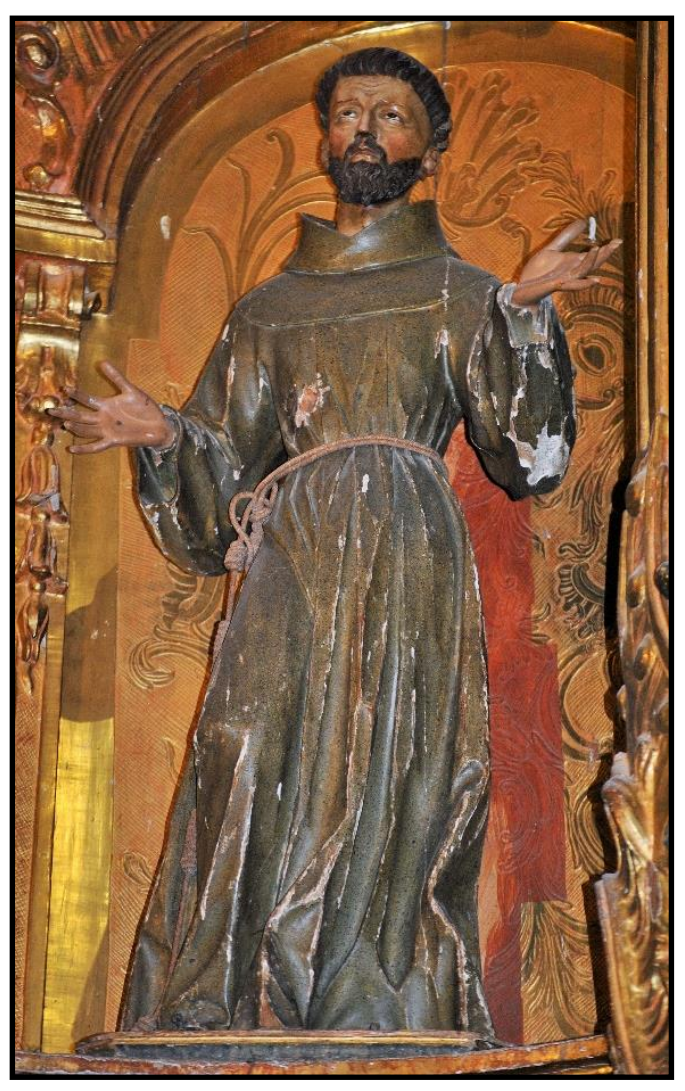

Il. 65- Pedro de Ávila (atrib.). San Francisco de Asís estigmatizado. Iglesia parroquial de la Asunción. La Seca (Valladolid). extremos de las cejas del hueso frontal. A esta suavidad de la piel contribuye las dos arrugas en la frente del santo, que tienen la forma tan manida que utiliza nuestro escultor, como de dos "V" estiradas y superpuestas. Los rasgos faciales también son los que podríamos llamar de receta que repite una y otra vez: ojos almendrados con abultamiento de la bolsa inferior, nariz de tabique ancho y aplastado, boca entreabierta que permite ver la fila superior de dientes y la punta de la lengua, etc... tampoco faltan los coloretes en los pómulos. Como Ávila ha concebido al santo con tonsura, le talla las dos orejas, recreándose en tallar los lóbulos y detallando cada una de las membranas de 
las mismas. La tonsura, como veremos en otros santos tonsurados (como los referidos ejemplares de San Antonio de Padua), la realiza a partir de una franja de cabellos que no es más que una sucesión de mechones en forma de " $S$ " que apenas se encuentran separados. En cuanto a la barba se trata de una barba bastante rala y que termina en punta bífida con cuatro mechones, dos a dos, sinuosos y con las puntas apuntando hacia dentro. Tanto el rostro como la barba los copiará puntualmente en el San Ramón Nonato que se conserva en la iglesia de Santa María de los Mártires de la localidad vallisoletana de Íscar. El presente rostro es uno de los más evocadores y sentidos de todos cuantos conforman su catálogo.

Por desgracia tan bella escultura se halla en un estado de conservación bastante deplorable que haría aconsejable una inminente restauración puesto que tiene desconchones por todo el cuerpo. Especialmente destacables son los del codo izquierdo y la llaga del costado; en cambio la cabeza parece no tener ningún daño reseñable.

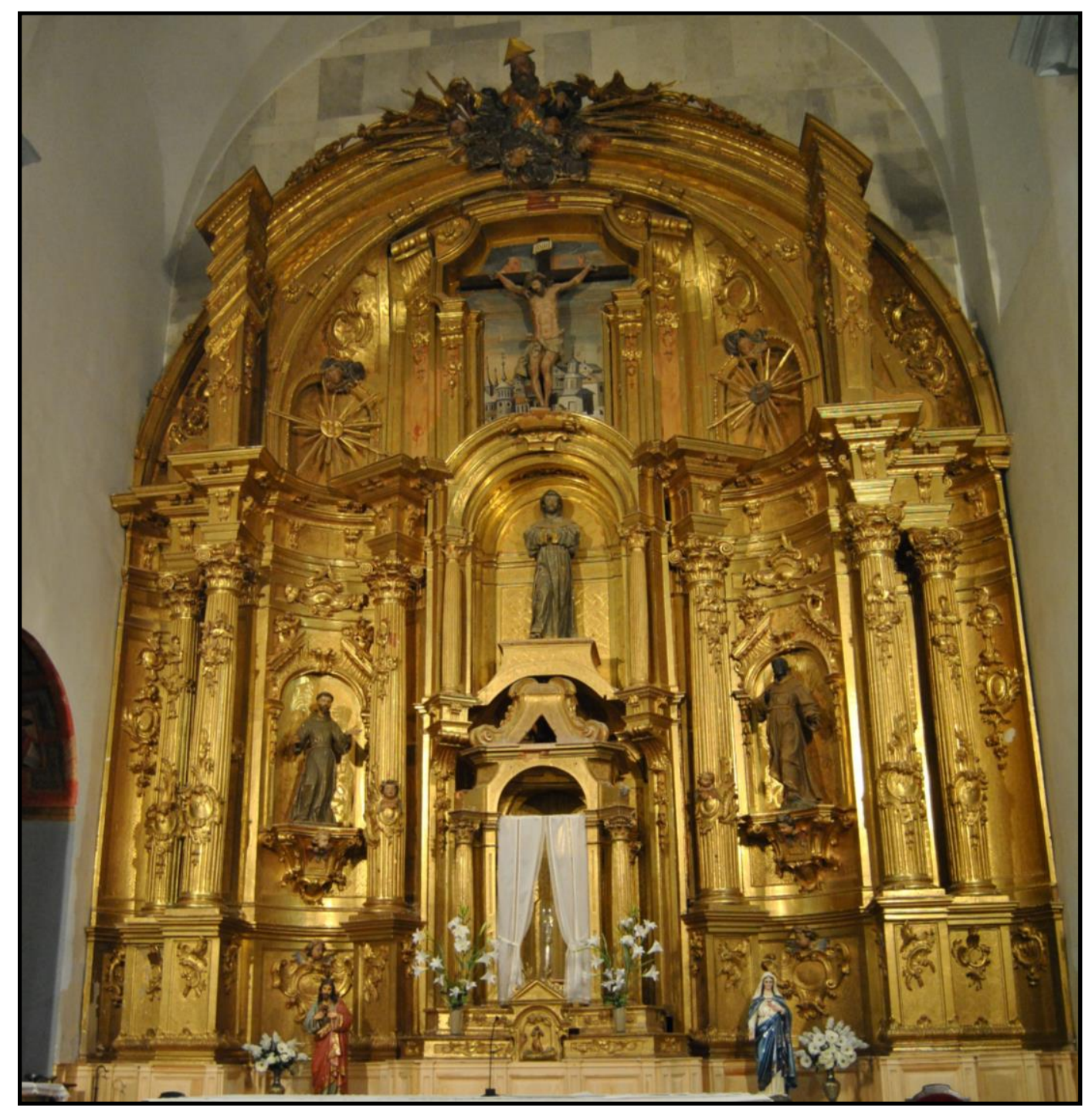

Il. 66- Juan Macías. Retablo mayor. Iglesia parroquial de la Asunción. La Seca (Valladolid).

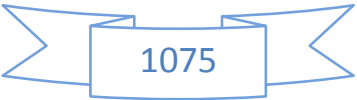




\title{
MATAPOZUELOS. IGLESIA PARROQUIAL DE SANTA MARÍA MAGDALENA
}

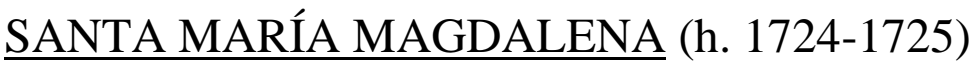

En la sacristía de la iglesia parroquial de Matapozuelos se conserva una escultura de la Magdalena (patrona del templo y de la localidad) (Fig. 108) de tamaño menor que el natural (102 cms.) que desde hace años viene siendo atribuida a Pedro de Ávila. Efectivamente, Martín González, cuando la vio en 1970 en la capilla de los pies de la iglesia acertó a adscribirla a la "escuela de Pedro de Ávila"450, opinión matizada tiempo después por Urrea que la creyó "obra indudable" de nuestro escultor. En cuanto a su cronología, el primero tan solo acertó a considerarla del siglo XVIII, mientras que Urrea apostó porque se realizaría en torno al año 1750. Como es evidente, esta última fecha es del todo imposible puesto que nuestro escultor había perdido la vista a finales de 1739 . Gracias a los libros de fábrica de la iglesia podemos acotar bastante la fecha de ejecución de la talla. La escultura de Santa María Magdalena estaba ya realizada en 1725 puesto que en este año se anotan pagos a Gregorio Penoz "El mudo" por pintar "el trono en que se colocó la imagen nueva de Santa María Magdalena"451. También en las cuentas de este mismo año figura un desembolso para el albañil que se ocupó de "abrir y componer el trono en que se colocó la imagen de Santa María Magdalena" ${ }^{452}$. Por lo tanto, podemos colegir que la escultura debía de estar hecha en ese mismo año de 1725 o quizás en el anterior.

El lugar que ocupó primitivamente fue la sacristía, justo el mismo en el que se encuentra en la actualidad, presidiendo un retablo rococó dorado en 1776 por Manuel Fernández de Navia ${ }^{453}$. Durante un periodo la imagen de la santa permaneció en la capilla bautismal, situada a los pies del lado de la epístola puesto que así lo reseñan tanto en el Inventario Artístico de Valladolid como en el respectivo tomo del Catálogo Monumental de Valladolid ${ }^{454}$.

La presente Magdalena viene a ser una especie de recapitulación de las otras dos que le tenemos documentadas, y por ende de la pétrea que le hemos atribuido en la fachada de la iglesia homónima de Valladolid, puesto que utiliza la misma composición, con la sola modificación de los atributos y otros pequeños detalles. Efectivamente, la disposición de las diferentes partes del cuerpo, vestimentas y pliegues es exacta a la de los otros

\footnotetext{
450 MARTÍN GONZÁLEZ, Juan José (dir.): Inventario artístico de Valladolid..., op. cit., p. 164.

451 "Ítem se le abonan ochenta y dos reales y medio que se pagaron a Gregorio Penoz "El mudo" por haber pintado el trono en que se colocó la imagen nueva de Santa María Magdalena (...)”. A.G.D.V., Matapozuelos, Iglesia de Santa María Magdalena, Libro de fábrica, Año 1725.

452 "Ítem se le abonan diez y seis reales que paga a Joseph Casado maestro albañil y en las obras que gastó en abrir y componer el trono en que se colocó la imagen de Santa María Magdalena”. A.G.D.V., Matapozuelos, Iglesia de Santa María Magdalena, Libro de fábrica, Año 1725.

453 URREA, Jesús: “Addenda. Matapozuelos". En BRASAS EGIDO, José Carlos: Catálogo Monumental de la provincia de Valladolid. Tomo X..., op. cit., p. 255.

$454 \quad$ MARTÍN GONZÁLEZ, Juan José (dir.): Inventario artístico de Valladolid..., op. cit., p. 164; URREA, Jesús: “Addenda. Matapozuelos”. En BRASAS EGIDO, José Carlos: Catálogo Monumental de la provincia de Valladolid. Tomo X..., op. cit., p. 255.
} 
ejemplares. A pesar de esta casi total similitud, tan solo rota por la disposición de los brazos en función a los distintos atributos que porta, observamos que esta Magdalena de Matapozuelos es la más floja de todas las realizadas en madera; la talla no parece tan fina, no hace falta más que ver el rostro, si bien pudiera haber influido decisivamente en este aspecto sucesivos repintes y la mala restauración a la que se le sometió hace unos años. Existe alguna fotografía antigua en la que observamos que, si bien el rostro y la cabellera no estaban esculpidos con el mismo esmero que en otras ocasiones, tampoco exhibía la inexpresividad de la que ahora hace gala, y el color y aspecto tan artificial que actualmente tienen sus cabellos.

Pedro de Ávila efigia a la santa según la forma dispuesta en los otros ejemplares: aparece de pie, con la rodilla derecha doblada creando la ilusión de avance, logrando dotar a la talla de un ligero contrapposto. Los pies, como de costumbre, adquieren el característico ángulo de $90^{\circ}$ y se encuentran separados por unos pliegues muy afilados. En su mano izquierda sujeta en la actualidad un paño blanco y encima el bote de los perfumes, pero sin embargo en origen esta disposición no sería así. Pedro de Ávila debió de concebir a la santa con el paño en la mano izquierda y el bote de los perfumes en la derecha (así lo vemos en fotografías antiguas), la cual actualmente la tiene girada mostrándonos la palma sin ningún sentido. Pero no solo eso, quizás sobre ese paño llevara una calavera, de manera similar a la Magdalena de la catedral vallisoletana, si bien no estamos muy seguros de ello. El paño puede tener un doble significado: o para limpiarse las lágrimas, si bien este elemento parece más propio de la Magdalena en el Calvario; o para utilizarlo junto con el bote de perfumes para lavar el cadáver de Cristo.

Viste una túnica azul con motivos florales plateados y con las mangas acuchilladas, debajo la cual se observa una prenda blanca que le cubrirá todo el cuerpo a excepción de las manos. La túnica, como de costumbre, le llega hasta los pies, dejándonos tan solo verle las puntas de los zapatos. Por encima tiene echado un amplio manto rojo que le cubre la totalidad de la espalda; y por delante desde el vientre hasta los pies, disponiéndose como en una amplia diagonal a su vez formada de las múltiples diagonales creadas por los profundos y aristados pliegues. La colocación del manto y de cada uno de sus pliegues viene a coincidir plenamente con los presentes en las otras Magdalenas. Tampoco faltan los pliegues arremolinados alrededor de su brazo izquierdo o el pliegue muy aristado que sale "disparado" en diagonal desde su cadera izquierda. A pesar de que los pliegues son bastante cortantes no poseen la calidad y la finura en la madera de la que hace gala en las otras Magdalenas. Esta falta de exquisitez puede no ser tal y deberse a los repolicromados y a la referida mala restauración, no lo sabemos; este mismo defecto está presente en rostro y cabellos, los cuales se disponen según la forma usual de dos sinuosas guedejas a cada lado del rostro que caen hasta el pecho. Los rasgos faciales son los típicos en Ávila, sin embargo son algo más secos de lo normal. Muy destacable es el ahuecamiento de la boca y la perfecta definición de los dientes superiores.

Que es imagen procesional, a la cual se saca por las calles del pueblo el día de su fiesta (22 de julio), nos lo demuestra el hecho de que tiene la parte trasera perfectamente 
tallada; siendo además una de las pocas esculturas de Pedro de Ávila que hemos podido conocer por detrás. Así, la cabellera la conforman múltiples y sinuosas guedejas muy extensas que apenas se encuentran separadas, llegando a cubrirle la totalidad de la espalda; esta manera de disponer los cabellos será la que utiliza para la gran mayoría de sus figuras femeninas, especialmente Magdalenas e Inmaculadas. Por su parte, los pliegues traseros del manto son muy secos; a grandes rasgos son tres grandes concavidades verticales que se van ensanchando y tan solo se ven interrumpidas por el arranque del pliegue curvo y recurvado que le pasa por el torso hasta enroscarse en el brazo izquierdo.

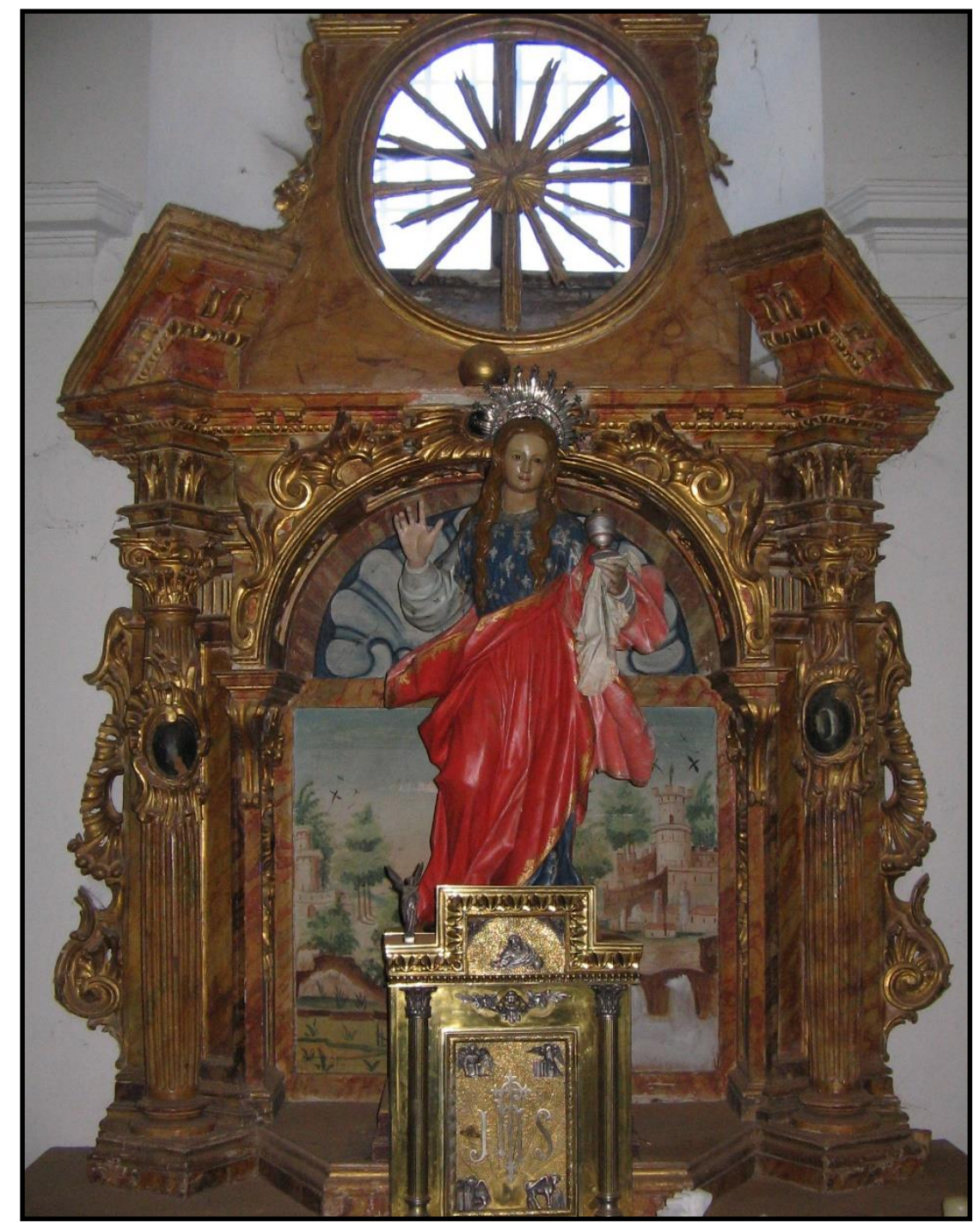

Il. 67- Anónimo. Retablo de Santa María Magdalena. Iglesia parroquial de Santa María Magdalena. Matapozuelos (Valladolid). 


\section{OÑATE. MONASTERIO DE LA SANTÍSIMA TRINIDAD DE SANTA CLARA DE BIDAURRETA}

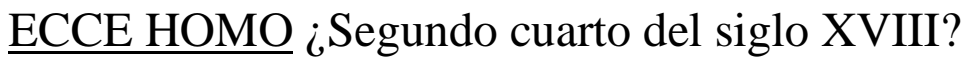

En el Monasterio de la Santísima Trinidad de Santa Clara de Bidaurreta en Oñate (Guipúzcoa) se conserva un Ecce Homo (Fig. 109) que pienso, con las reservas debidas, debe ser añadido al catálogo de nuestro escultor. Esta prudencia se debe a que no lo he estudiado in situ sino a través de dos fotografías no demasiado buenas; es decir, algo similar a lo ocurrido con la Virgen del Carmen de Pamplona. A pesar de estas reservas, la cabeza presenta una configuración unida a unos rasgos faciales, forma de disponer la melena y barba que entronca perfectamente con las pautas generales del arte de nuestro Ávila durante su segunda etapa.

El Ecce Homo (130 cms.) ocupa la hornacina lateral derecha de un retablo neoclásico dedicado a la Pasión de Cristo puesto que en ella se conservan otras tres esculturas procesionales de esta temática: en la hornacina central asienta un Nazareno de vestir, mientras que en su lateral izquierdo aparece un Cristo atado a la columna y, justo debajo del Nazareno, una Piedad. Este retablo, conocido como "del Nazareno" fue realizado entre 1786-1789 para la primera capilla del Evangelio de la iglesia monacal $^{455}$.

No cabe ninguna duda de que este Ecce Homo se inspira directamente en el del Ecce Homo del paso de la Coronación de Espinas que Gregorio Fernández talló hacia 1630 para la Cofradía Penitencial de la Santa Vera Cruz de Valladolid; y por ende también es deudora del Cristo de la Humildad que José de Rozas esculpió en 1691 para la Cofradía Penitencial de Nuestra Señora de la Piedad. Sin embargo, solamente se inspira en el modelo y en

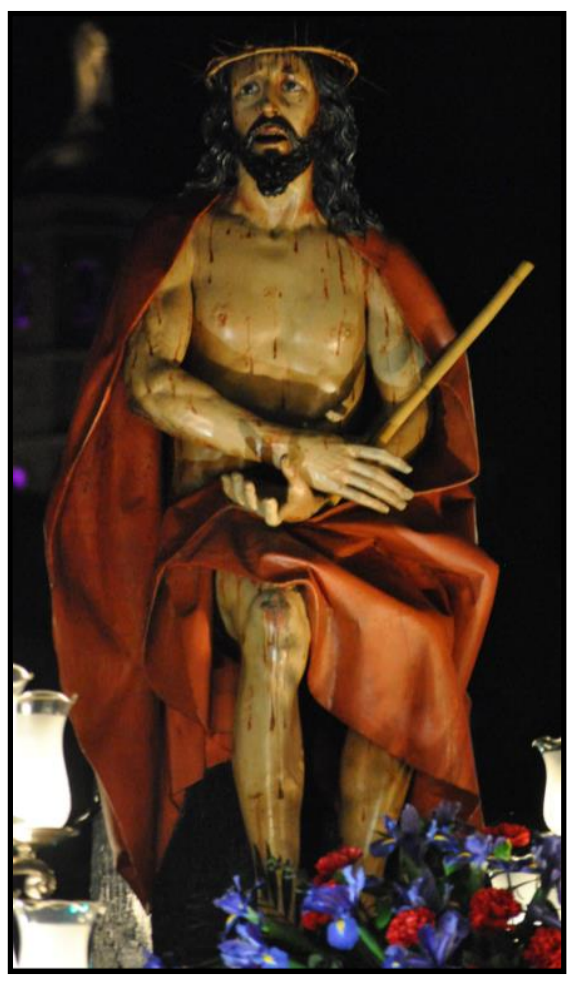

Il. 68- Gregorio Fernández. Ecce Homo. Iglesia penitencial de la Santa Vera Cruz. Valladolid. determinados rasgos de ambos, a los cuales añade otros elementos. Así, por ejemplo, si de Gregorio Fernández toma el arquetipo, de José de Rozas toma la rotura de la vista frontal puesto que Ávila hace mirar a su Cristo hacia el cielo (al contrario que Rozas, que mira hacia el suelo), la forma disponer los brazos levemente elevados enfrente del pecho, y el que el manto no le cubra toda la espalda y los muslos, sino que se caiga y le tape parte de los brazos.

455 CENDOYA ECHÁNIZ, Ignacio: La Semana Santa en Guipúzcoa. Estudio histórico-artístico, Sociedad de Estudios Vascos, San Sebastián, 1995, p. 91. 
Podemos ver al Ecce Homo sentado sobre un cajón, gira el brazo derecho hacia la izquierda para sujetar la caña que la acredita como "rey de los judíos" de tal manera que rompe la simetría y la rigidez de la composición. Ladea también hacia la izquierda el hombro derecho y eleva su cuello para mirar al cielo como esperando clemencia por parte del Padre. Viste tan solo el paño de pureza y un manto púrpura tirado por la espalda que le cubre el brazo izquierdo y una pequeña franja del derecho, de suerte que

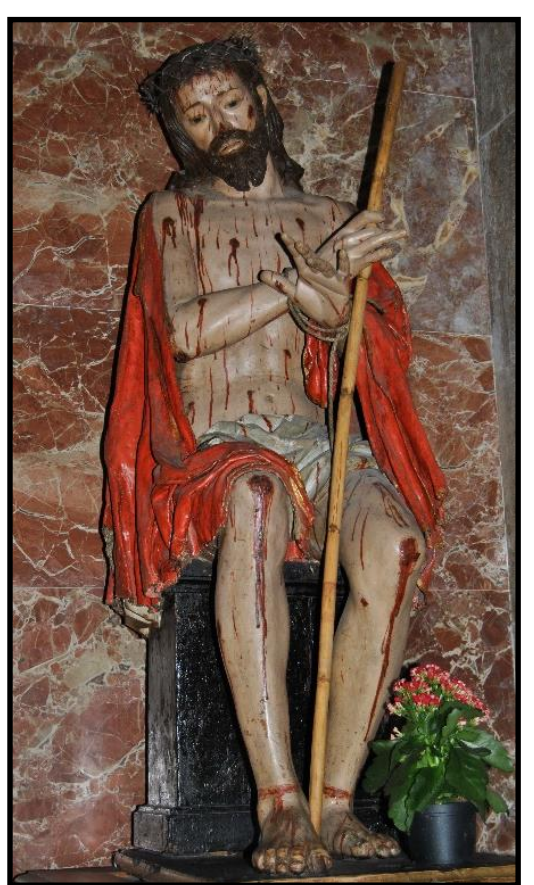

Il. 69- José de Rozas. Ecce Homo. le deba libre ese hombro y la mayor parte de su anatomía, de tal manera que el escultor se puede explayar demostrando sus conocimientos anatómicos. El rostro es doloroso, como resignado, intentando pedir ayuda a su Padre. La cabeza se encuentra tocada por una corona de espinas natural, la cual le provoca unas heridas que se van simuladas mediante gotas de sangre que le caen por la frente. Por lo poco que se observa en las fotografías que manejo, tiene barba bífida larga y simétrica; el pelo se dispone por la parte trasera formando numerosas ondulaciones, de manera similar a la que observamos en sus Crucificados; la nariz presenta un tabique ancho y aplastado, etc... en definitiva, presenta numerosas similitudes con nuestro escultor que me mueven a creerla como obra suya. Sin embargo, esta precaria situación no me deja asignarle una cronología correcta.

Santuario Nacional de la Gran Promesa. Valladolid.

Cendoya Echániz, el único que ha tratado sobre esta escultura, la cree obra del "taller de los Sierra" entre 1751-1753, si bien recalca que "es posible que en esta ocasión la participación de algún miembro de la familia sea mayor, si bien es difícil sostener tal extremo, por lo que tendremos que contentarnos con una autoría tan genérica como la propuesta" ${ }^{456}$. Bien es cierto que los Sierra trabajaron abundantemente en la zona según demostró el propio Cendoya Echániz ${ }^{457}$; sin embargo, el estilo presente en esta imagen parece desmentir la atribución a los Sierra o a su taller. Como vemos, las características de la escultura anulan, bajo mi punto de vista, la intervención de los Sierra; pero la cronología, también aparta de su autoría a Pedro de Ávila dado que a finales de 1739 quedó ciego. A este lío hemos de añadir que en el libro de recibo y gasto del convento figura la expresión "cuando se trajo de Valladolid"458. Si siguiéramos suponiendo que lo realizaron los Sierra, este dato eliminaría la posibilidad de que hubieran intervenido José y Francisco de Sierra, los cuales nunca mantuvieron taller abierto en Valladolid, siendo el único de los hermanos que trabajó de manera estable en esta ciudad Pedro de Sierra.

\footnotetext{
$456 \quad$ Ibídem.

457 CENDOYA ECHÁNIZ, Ignacio: "La aportación del taller de los Sierra a la escultura barroca en Gipuzkoa”, Ondare: cuadernos de artes plásticas y monumentales, № 19, 2000, pp. 521-531.

$458 \quad$ Ídem, p. 528
} 
Por lo tanto, estos datos y suposiciones nos abren más interrogantes que cuestiones cierra. Dado que está claro que el estilo de la escultura es profundamente más Ávila que Sierra: ¿podría haberla tallado con anterioridad a esos años y que las monjas no la encargaran sino que la adquirieran?; es más, ¿podría pertenecer este Ecce Homo a un anónimo discípulo de nuestro escultor del cual aún no conocemos su nombre? Como más adelante veremos, no sabemos el nombre de ningún discípulo de Pedro de Ávila, si bien no hay ninguna duda de que debió tenerlos y bastantes dada la extensa producción que se le adivina; sin embargo, entre ellos pienso que se encuentra Felipe Espinabete, uno de los grandes escultores barrocos castellanos de la segunda mitad del siglo XVIII. Todas las posibilidades quedan abiertas. 


\section{VALLADOLID. REAL COLEGIO DE SAN ALBANO}

\section{SAN FRANCISCO DE BORJA Y SAN ESTANISLAO DE KOSTKA (h.}

1726)

En los extremos del retablo dedicado a la Sagrada Familia se conservan dos pequeñas hechuras que según el Catálogo Monumental de Valladolid representan a San Francisco Javier (48 cms.) (Fig. 110) y a San Estanislao de Kostka (49 cms.) (Fig. 111). Sin embargo, hemos de hacer una corrección puesto que el primero de ellos no es el santo navarro, por cuanto ya figura en el retablo de la Sagrada Familia de la Virgen, en un tamaño similar, afrontado con San Ignacio de Loyola $(47 \mathrm{cms}$.). Parece lógico por lo tanto que estas pequeñas tallas de dos momentos diferentes representen a las cuatro grandes figuras de la Orden Jesuita. Según Martín González y Plaza Santiago estas dos últimas esculturas serían realizadas en el primer cuarto del siglo XVII por algún "seguidor de Gregorio Fernández" $"$ "59. Asimismo, estos mismos profesores fecharon las imágenes de San Francisco de Borja (y no San Francisco Javier) y San Estanislao de Kostka en el "primer cuarto del siglo XVII (será un error de redacción, queriendo decir siglo XVIII)”, y se las atribuyeron a Pedro de Ávila ${ }^{460}$.

Efectivamente, estas dos esculturas deben ser atribuidas con bastante seguridad a Pedro de Ávila dadas las evidentes semejanzas que guardan con la obra de nuestro artista. En ellas vemos algunos de sus estilemas como pueden ser los pliegues a cuchillo, la pierna levemente adelantada, la colocación de los pies en un ángulo de $90^{\circ}$, el manto arremolinado alrededor del brazo izquierdo, etc... Sin embargo, los rostros no poseen sus característicos rasgos faciales, tan solo la nariz y la forma de los ojos parecen recordarnos su estilo. A pesar de esto pienso que la atribución no corre peligro puesto que esta misma desemejanza de estilo también se encontraba en el documentado crucifijo de la Magdalena del Oratorio de San Felipe Neri. Por lo tanto, la explicación de estas diferencias con respecto al resto de las obras de nuestro artista tendrá relación con el escaso tamaño de las esculturas. Para su cronología tan solo podemos apuntar, como en otras ocasiones, el periodo 1714-1739. Quizás pudiéramos delimitar algo más si tenemos en cuenta que San Estanislao de Kostka no fue canonizado hasta el año 1726, si bien hemos de recordar que en muchas ocasiones el pueblo o las órdenes religiosas no esperaban a que determinada persona fuera beato o santo para encargar efigies suyas. A pesar de ello, pienso que los jesuitas del Colegio de San Albano encargarían ambas esculturas con motivo de la canonización del santo polaco ya que el otro santo elegido, San Francisco de Borja, se encuentra entrelazado en la historia de San Estanislao, como veremos a continuación.

San Francisco de Borja (1510-1572) fue un santo español que llegó a ser el III General de la Compañía de Jesús. Sus orígenes eran nobles puesto que fue IV duque de Gandía, marqués de Lombay e incluso virrey de Cataluña. De pequeño, sus padres lo enviaron a

459 MARTÍN GONZÁLEZ, Juan José y DE LA PLAZA SANTIAGO, Francisco Javier: Catálogo Monumental de la provincia de Valladolid. Tomo XV..., op. cit., p. 273.

$460 \quad$ Ídem, p. 272. 
la corte del rey Carlos $\mathrm{V}$ y posteriormente pasó a servir a la reina Juana a su palacio de Tordesillas $^{461}$. Uno de los episodios más conocidos de la vida del santo, y que tendrá vital importancia en su iconografía, es el del fallecimiento en 1539 de la reina Isabel de Portugal, la cual estaba considerada como una de las mujeres más bellas del mundo. Esta muerte le marcó tanto que desde entonces siempre comentó que fue el día de su conversión: "Por la emperatriz que murió tal día como hoy. Por lo que el Señor obró en mí por su muerte. Por los años que hoy se cumplen de mi conversión"462. Con posterioridad, organizó la comitiva que escoltó el cadáver de la reina hasta la Capilla Real de Granada. Antes de que este fuera sepultado, observó el rostro descompuesto de la reina, el cual será uno de sus atributos más recurrentes, y le preguntaron si juraba que aquella era la reina, a lo que respondió: "He traído el cuerpo de nuestra Señora en rigurosa custodia desde Toledo a Granada, pero jurar que es ella misma, cuya belleza tanto me admiraba, no me atrevo". Le insistieron en si juraba que aquel cadáver era el de la soberana, a lo que contestó: "Sí, lo juro, pero juro también no más servir a señor que se me pueda morir" 463 .

Por entonces comenzaría a colaborar con los jesuitas, y de hecho financió parte de la construcción del Colegio Romano (Roma) e incluso fundó el Colegio Jesuita de Gandía $^{464}$. Sin embargo, no sería hasta el fallecimiento de su mujer en el año 1546 cuando decidió ingresar en la Orden. Renunció a todos sus bienes y títulos, y también rechazó el título de cardenal que le habían ofrecido. Su ascenso en la Orden fue rápido ya que en 1554 fue nombrado Comisario General de los Jesuitas en España y en 1565 General de la Orden. Entre la multitud de acontecimientos de su generalato nos interesa especialmente el hecho de que fundara personalmente el noviciado de Sant'Andrea al Quirinale (Roma), en el cual se formó, entre otros muchos, San Estanislao de Kostka, cuya escultura hace pareja con la del santo español en este retablo del Colegio de los Ingleses. Fue canonizado en 1671 por el papa Clemente X.

Por su parte, San Estanislao de Kostka (1550-1568) fue un novicio polaco muerto a causa de la malaria sin haber cumplido los dieciocho años. La familia de San Estanislao, al igual que la de San Francisco de Borja, también pertenecía a la nobleza puesto que su padre fue senador del Reino de Polonia, y su madre hermana y sobrina de los Duques de Mazovia y, asimismo, tía del canciller polaco Félix Kryski ${ }^{465}$. Con tan solo 13 años su padre le envió a estudiar al colegio de jesuitas de Viena, en donde experimentó diversos éxtasis. Durante una enfermedad bastante crítica sufrió dos visiones: una en la que se le aparecía Santa Bárbara acompañada de dos ángeles, uno de los cuales le daba de comulgar; y otra en la que se le presentaba la Virgen para entregarle al Niño Jesús como signo de sanación. Este episodio, también presente en la historiografía de San Antonio de Padua, será uno de los más recurrentes en el mundo del arte; y, al parecer, sería el

\footnotetext{
461 https://es.wikipedia.org/wiki/Francisco_de_Borja

462 LEONARDI, C., RICCARDI, A. y ZARRI, G.: Diccionario de los santos, volumen 1, San Pablo, Madrid, 2000, p. 834.

$463 \quad$ AUCLAIR, Marcelle: La vida de Santa Teresa de Jesús, Palabra, Madrid, 1982, p. 98.

464 https://es.wikipedia.org/wiki/Francisco_de_Borja

465 https://es.wikipedia.org/wiki/Estanislao_Kostka
} 
tema elegido para representarle en la escultura que nos ocupa. Una vez repuesto, y en contra de la voluntad de su padre, viajó a Roma "para presentarse al general de la orden, San Francisco de Broja, quien lo recibió en el noviciado en 1567, donde murió en olor de santidad al año siguiente" ${ }^{\text {"66 }}$. Tras el fallecimiento fue sepultado en la iglesia de Sant'Andrea al Quirinale (Roma), donde años después el escultor Pierre Legros "el joven" realizaría una impresionante escultura del santo moribundo. Fue beatificado en 1605 y canonizado en 1726.

Ambos santos están concebidos de una manera similar, diferenciandoles tan solo las actitudes e interacciones con sus respectivos atributos. Aparecen de pie, con una pierna levemente adelantada, formando un contraposto. Cada santo adelanta una pierna diferente (San Francisco de Borja la derecha y San Estanislao la izquierda) para contraponerse y crear variedad. Viste la sotana negra con la que se suele representar a los jesuitas, así como una copa sobre los hombros. El cuello de la sotana es demasiado rígido. Los pliegues de la vestimenta son bastante aristados, dando la sensación de movimiento y llegando a crear unos perfiles ciertamente sinuosos; el pliegue a cuchillo es más que evidente pero sin llegar a estridencias como en otras ocasiones. La talla es muy fina y delicada, como así lo necesitan dos imágenes tan pequeñas. La forma de concebir la base (desde el tronco hasta los pies), e incluso el torso y los brazos de ambas esculturas es casi un calco de la que podemos ver en algunas de sus Inmaculadas (Oratorio de San Felipe o Convento de las Comendadoras de Santiago).

San Francisco de Borja sujetaría en la mano izquierda la cabeza descompuesta de la reina Isabel de Portugal, la cual a día de hoy ha desaparecido, mientras que la otra mano se la lleva al pecho indicando la conmoción sufrida por el santo y la correspondiente conversión sufrida en aquellos momentos ante la directa visión de los restos de la reina. La cabeza la gira hacia la izquierda dirigiendo su mirada a la perdida cabeza real. Como ya dijimos, y también sirve para el San Estanislao, los rostros no presentan los estilemas propios de Ávila a excepción de la nariz y los ojos; los cuales, además, nos recuerdan bastante a los de Antonio Gautúa; nada extraño como ya hemos comentado en numerosas ocasiones. Sobre la frente, pelo corto distribuido en unos cuantos mechones distribuidos al azar. San Estanislao de Koska sujeta con ambas manos un paño sobre el cual se situaría un desaparecido Niño Jesús que haría referencia a la la visión en la que la Virgen le entregaba su hijo para confirmar la sanación del santo. La cabeza corresponde con tal momento, ya que la baja para mirar al Niño Jesús, el cual quizás intentara acariciarle. El rostro y el peinado son similares a los de su compañero. Como vemos, ambos santos aparecen efigiados en una de sus historias más conocidas.

466 RÉAU, Louis: Iconografía de los santos. A-F..., op. cit., p. 458. 


\section{CUÉLLAR. SANTUARIO DE NUESTRA SEÑORA DEL HENAR}

SAN JOSÉ CON EL NIÑO (h. 1729)

En el Santuario de la Virgen del Henar, próximo a la localidad segoviana de Cuéllar, se encuentra una de las más bellas imágenes salidas de la gubia de Pedro de Ávila, si bien no la tenemos documentada. El único en llamar la atención sobre esta gran escultura y en formular la atribución a favor de nuestro escultor fue el carmelita Balbino Velasco Bayón, que en su Historia de Cuéllar admite que "quizá haya que atribuir a Pedro de Ávila el San José de la iglesia del Santuario de El Henar"467; si bien unos años antes tan solo había acertado a comentar que habría sido ejecutada "según parece, en la escuela de Gregorio Fernández" ${ }^{\prime 468}$.

También gracias a su labor investigadora sabemos que la imagen del padre nutricio de Jesucristo llegó al Santuario del Henar en el año $1729^{469}$. Según los libros conservados, el 27 de mayo de 1729 "llegó una efigie de estatura perfecta del glorioso Patriarca San José, con su Niño, en los brazos, que la dio de limosna el mismo referido canónigo de Valladolid don Marcos Ibáñez con don Cristóbal de Castañeda, vecino de dicha ciudad" ${ }^{\prime 470}$. Visto quien fue su donante, un canónigo de la catedral vallisoletana, no cabe duda de que este encargo partió del deseo de proporcionar al santuario carmelita una copia del San José con el Niño que en 1714 había tallado nuestro escultor para la seo vallisoletana. Además, hemos de recordar que Pedro de Ávila pudo ser el maestro mayor de escultura del obispado, con lo cual la relación con los canónigos sería fluida. En cuanto a que la escultura donada sea un San José parece más que lógico dada la devoción que sienten los carmelitas, Orden a la cual pertenece el santuario, hacia el padre nutricio de Jesús

Desconocemos para qué lugar dentro del Santuario estaba destinada la escultura, si bien parece lógico pensar que se colocaría en el mismo sitio en el que hoy se encuentra, en el colateral del Evangelio, pero presidiendo un primitivo retablo. Años después se le reubicó en uno de los nuevos retablos colaterales confeccionados hacia 1744, año en que se terminaron de dorar por el sepulvedano Francisco Casado ${ }^{471}$. Pero no sería el último retablo que conociera puesto que estos dos no se conservaron durante mucho tiempo dado que la llegada del neoclasicismo, cuyo gusto se impuso en los rectores del Santuario, llevó a fabricar unos nuevos. Efectivamente, estos retablos fueron vendidos a la iglesia de Montemayor y se procedió a construir dos nuevos que los $\operatorname{suplieran}^{472}$. El

467 VELASCO BAYÓN, Balbino (O. Carmelita): Historia de Cuellar, Diputación Provincial de Segovia, Segovia, 1974, p. 472.

468 IBAÑEZ, Manuel (O. Carmelita): Historia de la Virgen del Henar y su Santuario: estudio histórico crítico de la devoción a la Virgen del Henar en la villa y tierra de Cuéllar, Diputación Provincial de Segovia, Segovia, 1955, p. 130.

$469 \quad$ Ídem, p. 129.

$470 \quad$ Ídem, pp. 129-130.

471 Ídem, p. 141.

472 Ídem, p. 182. 
encargado de levantarlos fue el ensamblador y tallista vallisoletano Felipe Durán, el cual los tenía terminados en 1784; a continuación se procedió a su dorado y jaspeado, de tal manera que simularan estar realizados en materiales nobles (mármoles y bronce dorado), tarea de la cual se ocupó el también vallisoletano Gabriel Fernández de $\operatorname{Tovar}^{473}$. Estos dos artífices serían los que en 1784 ejecutaran el retablo mayor.

Como vemos, el canónigo debió exigir al escultor que se amoldara a su característico modelo de San José, del cual la mejor versión es la desarrollada para la Catedral, y la que asimismo llamaría la atención del religioso; pero, además de eso, le instaría a introducir una serie de novedades que le diferenciaran de aquél. Y, efectivamente, eso es lo que hizo Ávila puesto que, a pesar de seguir los mismos parámetros, vemos una serie de detalles innovadores. Lo primero que salta a la vista al comparar ambas esculturas es que en esta ocasión Ávila ha invertido completamente la composición; además de ello se trata de una imagen con una factura más erguida, seca y estrecha, y sus ropas no alcanzan la ampulosidad de la del San José catedralicio. También es más que evidente que los ropajes poseen una policromía más lujosa, completamente llena de motivos y decoraciones esgrafiadas y puntilladas a base de dorados sobre fondo marrón.

San José (Figs. 112-113) figura de pie, con la pierna izquierda recta y adelantada; es la única que podemos ver ya que la otra se oculta bajo los espesos pliegues de la túnica. En esta ocasión, y es algo que ocurre con pocas esculturas, observamos más allá de la punta de los zapatos ya que le podemos ver la bota completa y parte de la ropa interior que le cubre las rodillas. La forma de colocar la túnica formando un grueso bloque tras la pierna parece obedecer al hecho de querer establecer un punto de apoyo que ayude a dar estabilidad a la pieza ya que esta parte baja es bastante más estrecha que las superiores. San José observa a su Hijo, y para ello gira levemente el rostro hacia abajo a la derecha, mirando con extremado amor a su retoño, el cual se halla tumbado sobre un paño blanco que el santo sujeta con ambas manos. Nuevamente vemos que no es directo el contacto físico entre padre e hijo. El Niño Jesús, retoza sonriente sobre el paño, mira a su padre, correspondiente con su mirada e intentando con las manos tocarle la barba; asimismo juguetea con sus rollizas piernas, teniendo elevada una de ellas. Este Niño Jesús posee la particularidad de que se trata de una

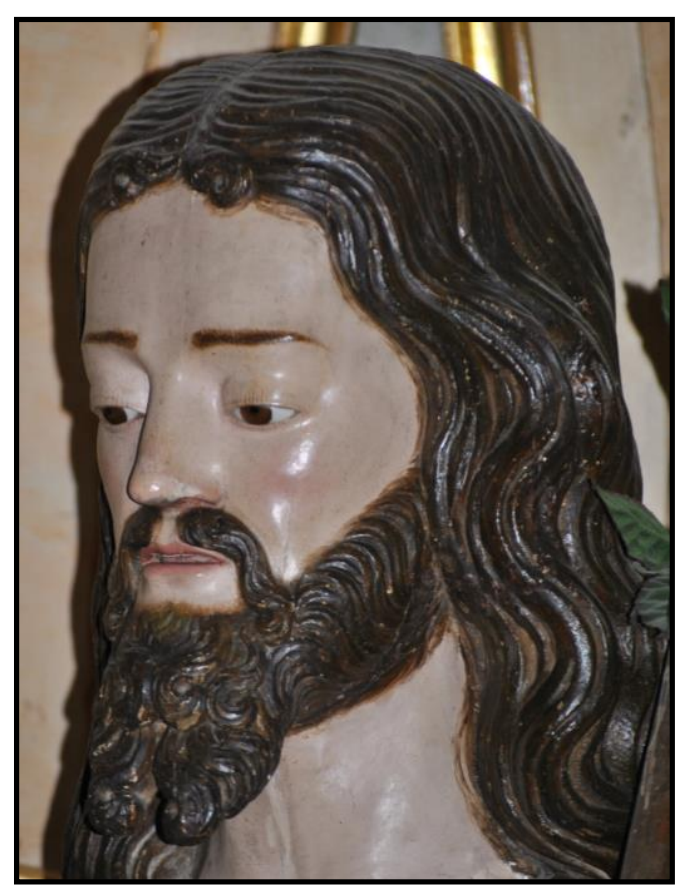

Il. 70- Pedro de Ávila (atrib.). San José con el Niño. Santuario de la Virgen del Henar. Cuéllar (Segovia). escultura exenta puesta sobre el paño, todo lo contrario que sucede con el San José de la catedral, en el cual el Niño forma parte del todo que conforman la escultura del padre y

473 Ídem, p. 181. 
el paño. En este sentido, posee mayores similitudes con el San José que tallaría un par de años después su hermano Manuel para la Cofradía de N. P. Jesús Nazareno; el cual, al igual que este del Henar, tiene el Niño Jesús tallado aparte; pero no solo eso ya que adopta la misma disposición corpórea en los gestos realizados con la cabeza, brazos y piernas. A pesar de todo ello, en ningún momento puede pensarse en una probable atribución de esta pieza a Manuel de Ávila ya que, a pesar de ser un buen escultor, la diferencia técnica entre ambos es abismal a favor de Pedro. Y si aún dudáramos, podríamos esgrimir que, a diferencia de los San José de Pedro de Ávila, el único conocido de Manuel no tiene una de las piernas al aire sino que ambas las tapa por completo la túnica; se trata de una característica propia del pequeño de la saga. Las manos del santo, una más elevada que otra, formando una pequeña diagonal con el paño que soporta al Niño, son un prodigio naturalista puesto que sus dedos se curvan para acreditar el esfuerzo del peso soportado. Además de ello, Pedro de Ávila las dota de una morbidez excepcional, tallando cada una de las venas, de las articulaciones, huesos, tendones y hasta simulando el hueco de las uñas. En esta ocasión no acierto a saber si se tratan de manos talladas aparte o en el propio cuerpo.

El rostro del santo, que acusa blandura en las mejillas y morbidez en los labios (los cuales se hallan perfectamente modelados) posee las características típicas que una y otra vez llevamos viendo en sus obras; acusando, por supuesto, mucho mayor parecido con las esculturas de San José; debido a lo cual no volveremos a repetirlas. Por su parte, exhibe una potente barba realizada a base de mechones sinuosos en los laterales del rostro y en la parte frontal remata bífidamente en dos amplios mechones realizados en su parte superior a base de caracolillos y en la inferior de dos guedejas recurvadas con las puntas hacia dentro. Pasa por ser una solución de compromiso entre las varias con que suele efigiar a sus personajes. Finalmente, la cabellera es simétrica; sobre la frente dos pequeños caracolillos que apenas se apartan de lo que es la melena, la cual discurre a ambos lados del rostro como dos grandes masas que forman sucesivas ondulaciones cada una de las cuales alcanza una mayor anchura y profundidad que la anterior; debido a esto le tapa ambas orejas. Este tipo de cabellera recuerda bastante a las utilizadas en el Cristo del Olvido, en el busto de Ecce Homo de las Brígidas y en el Ecce Homo de Renedo, entre otros.

Viste unos ropajes muy ampulosos, aunque con unos movimientos y volúmenes algo más contenidos que en el San José de la catedral. Porta un larga túnica que llega hasta el suelo, de color blanco por el exterior y azul por el interior, aunque sobre ambas entonaciones hay una serie de motivos dorados; por encima un manto abrochado al cuello que se distribuye por el cuerpo de las formas más caprichosas: alrededor de los brazos forma unos característicos remolinos de pliegues muy finas que incluso se recurvan sobre si mismos; de la cadera izquierda surge el no menos tradicional pliegue que sale disparado en diagonal; asimismo, habrá que achacar a ese virtuosismo el recurvamiento de finas láminas de madera con que se encuentra tallada la parte baja derecha del manto, que parece ascender con vida propia por la pierna del santo. Los pliegues, como podemos observar, son a cuchillo, aunque no tan pronunciados y 
aristados como en otras esculturas, pues en este caso son bastante más dulces; y no digamos ya los de la túnica que vienen a recordar los redondeados que usaban su padre y su suegro. Debido a estos dos últimos detalles relacionados con los pliegues, y al cierto hieratismo de la figura no sería de extrañar que la pieza hubiera sido comenzada por el taller dado que Ávila se encontraba enfrascado en otras esculturas y que después la retomó él, dándola mucho más vigor y fantasía puesto que hay bastante diferencia entre la parte baja de la talla y el resto.

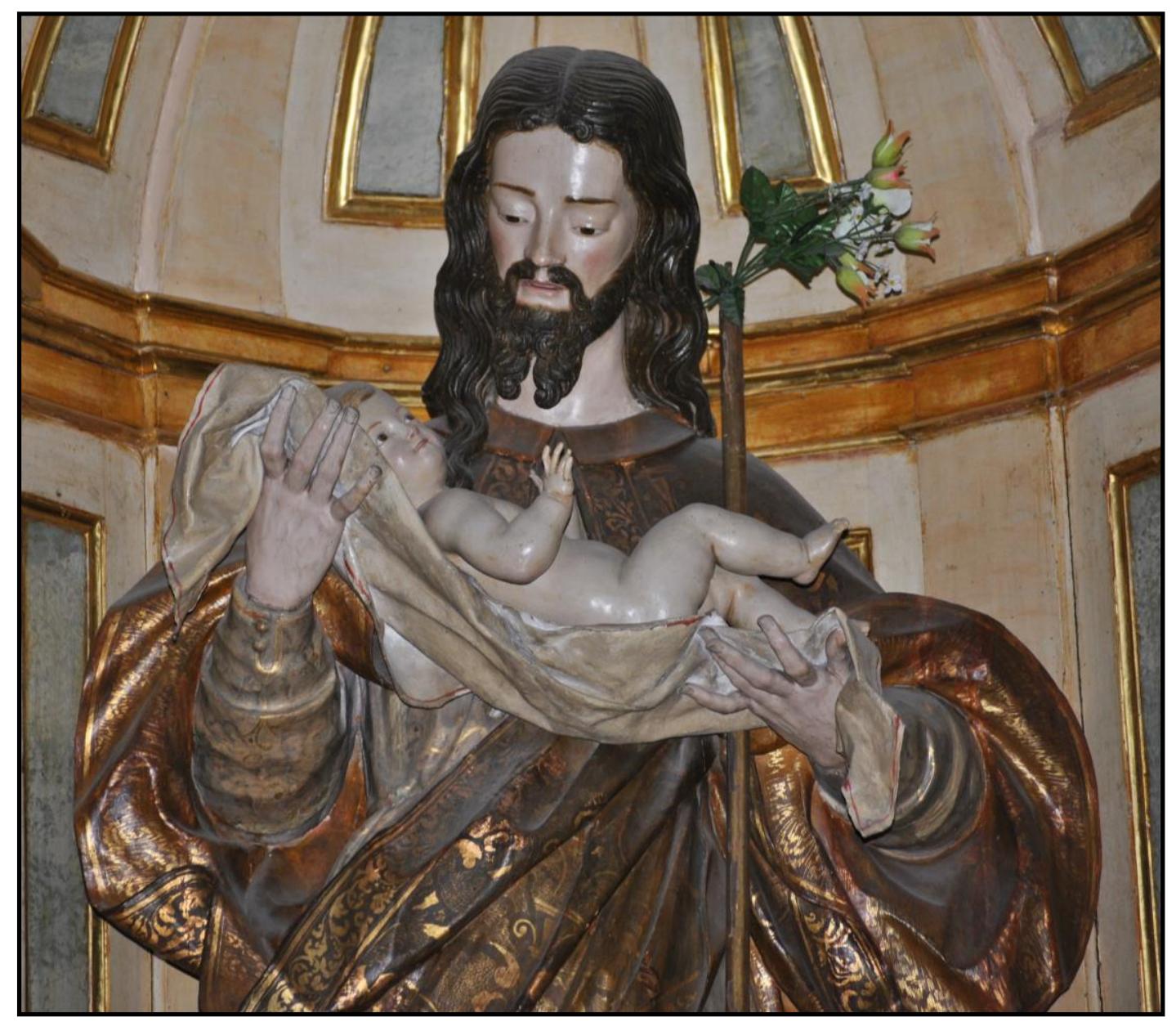

Il. 71- Pedro de Ávila (atrib.). Detalle de San José con el Niño.

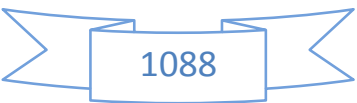




\section{VALLADOLID. CONVENTO DE NUESTRA SEÑORA DE LA VICTORIA (Desaparecido)}

\section{ESCULTURAS DEL ANTIGUO RETABLO MAYOR DEL CONVENTO DE NUESTRA SEÑORA DE LA VICTORIA (h. 1729-1730)}

En la capilla mayor de la iglesia del Convento de Nuestra Señora de la Victoria existió hasta finales del primer tercio del siglo XVIII un retablo del cual lo desconocemos todo. Tampoco sabemos si fue el primitivo del cenobio o bien uno que le sustituyó. Señala al respecto Fernández del Hoyo que "cuando en 1602 se habla de la dotación de la capilla mayor se ordena que debería estar presidida por un "retablo suntuoso y bueno de alto $y$ ancho que toda la pared de la frontera del altar mayor mostrare, conforme a la traza que los patronos dieren y en el dicho retablo en lo alto haya de poner dos escudos a los lados con las armas de los Zúñigas" ${ }^{474}$. Como vemos, este pequeño fragmento de documento tampoco clarifica demasiado el asunto.

Sea como fuere, ese retablo mayor que exhibía la iglesia conventual fue sustituido a mediados del año 1730. Efectivamente, el diarista Ventura Pérez recoge que " $a$ primeros de julio, se acabó de sentar el retablo de Nuestra Señora de la Soledad y San Francisco de Paula. Le hizo José Mata y se doró al folio" ${ }^{475}$. Cabe puntualizar que el tal José Mata no es otro que el ensamblador vallisoletano José Díaz de Mata, hijo del también ensamblador Gregorio Díaz de Mata.

Dicho retablo "de fábrica muy costosa" muy sufragado en su totalidad por doña Josefa Castellanos, segunda mujer que fue de don Lope de Quevedo; la cual, asimismo, dejó en su testamento 3.000 pesos para ayuda de su dorado ${ }^{476}$. Llama la atención que Ventura Pérez diga que en el referido año de 1730 "se doró al folio" y que ni veinte años después, en 1747, se vuelva a dorar, utilizando el legado dejado por doña Josefa Castellanos $^{477}$. El encargado de efectuar el dorado fue el riosecano Tomás de Sierra y Oviedo, hijo del escultor Tomás de Sierra Vidal. Efectivamente, el 25 de enero de 1737 Tomás de Sierra ${ }^{478}$, fiado por su hermano Pedro de Sierra y el batidor de oro Andrés Montes, se concierta con el "Reverendísimo Padre Corrector y religiosos del Convento de Nuestra Señora de la Victoria Orden de los Mínimos de San Francisco de Paula extramuros de esta nominada ciudad" para "dorar el retablo mayor que está puesto en su capilla mayor y estofar la escultura que en él hay, después de las efigies que hoy lo están" (DOCUMENTO 86). La subasta de la obra comenzó por 30.000 reales de vellón, aunque posteriormente la bajó hasta 28.000 reales; que era la misma cantidad en la que la puso el dorador palentino Francisco Rodríguez, "sin poner la mencionada

\footnotetext{
474 FERNÁNDEZ DEL HOYO, María Antonia: Patrimonio perdido..., op. cit., pp. 314-315.

475 PÉREZ, Ventura: op. cit., pp. 104-105.

476 CANESI ACEVEDO, Manuel: Historia de Valladolid (1750), op. cit., Tomo III, p. 273.

477 Ibídem.

478 El propio Tomás de Sierra “el joven” debía de haberse ocupado también del dorado del retablo mayor del Convento de Nuestra Señora del Consuelo (actual Santuario del Carmen Extramuros) puesto que a lo largo de toda la escritura no hace más que comparar aquél con este de la Victoria.
} 
Concepción en dichos vaciados de realce si no es con arreglo total a las condiciones puestas de orden de dicha comunidad". Finalmente, Sierra dejó el precio en 28.000 reales además de ser de su cargo "y cuenta el dorar todo el respaldo de los cajones de la sacristía y estofar el San Miguel del atril del coro, mandando que bajo de los propuestos aditamentos y condiciones y afianzando para el seguro quedase la expresada obra en el otorgante".

Entre las condiciones se refiere que debía de dorar el retablo "de oro limpio lo que alcanzase la vista del coro tribunal y capilla mayor sin que se pueda reservar nada más que los dichos y ha de bajar igualmente dorado desde el cuerpo de arriba hasta el fin del pedestal reservándolo y dorándolo como así corresponde". Por su parte, los "niños y cabezas de serafines se han de encarnar a pulimento con aceite de nueces y los pelos peleteados y los más de los sentidos que pertenece a dicha encarnación y toda esta a los que tuvieren y atributos se han de dorar y estofar de diferentes colores finos sacándolas de grafio de diversos géneros para más lucimiento". Finalmente, el pedestal se tendría que jaspear "al óleo con diferentes mármoles de colores muy finos barnizados con el espíritu del agua ardiente y todas las molduras se han de dorar al óleo y en los tímpanos de él se han de ejecutar diferentes adornos de oro para más lucimiento y duración". Toda esta obra debería de darla acabada para el último día de agosto de este mismo año. Las diferentes labores del retablo se dieron por concluidas el 13 de abril de 1749, fecha en que se procedió a colocar el Santísimo Sacramento ${ }^{479}$.

El retablo se encontraba compuesto de diferentes esculturas. La escultura titular del retablo, Nuestra Señora de la Soledad, se hallaba en la hornacina principal, constituida por un "entero camarín exquisitamente adornado" $" 480$. De esta Virgen, que no sabemos si es la que preside el actual retablo mayor de la moderna iglesia de Nuestra Señora de la Victoria ${ }^{481}$, dice Canesi que era "peregrina hechura y de suma devoción"482. La identidad del resto de imágenes la conocemos por un inventario de la época de la Guerra de Independencia dado a conocer por la profesora María José Redondo Cantera: por lo visto, a la Virgen de la Soledad rodeada por ángeles portadores de las Arma Christi; le acompañaban un San Francisco de Paula en la calle central; y, en las laterales, San Juan, San José, San Joaquín y Santa Ana ${ }^{483}$.

No tenemos muchos más datos sobre estas esculturas, por lo que todo lo que comentaremos a continuación será fruto de la unión de hipótesis y ciertas referencias. El San Francisco de Paula será, a no dudarlo, uno de los dos santos mínimos que, procedentes del propio Convento de la Victoria, fueron a parar en 1965 al Museo Diocesano y Catedralicio de Valladolid. Por su parte, el otro Santo Mínimo no sabemos si pertenecería al retablo mayor o se encontraba en otro lugar de la iglesia; dado que

\footnotetext{
479 FERNÁNDEZ DEL HOYO, María Antonia: Patrimonio perdido..., op. cit., p. 315.

480 CANESI ACEVEDO, Manuel: Historia de Valladolid (1750), op. cit., Tomo III, p. 273.

481 El actual retablo de la moderna iglesia, realizado por Esteban Jordán en 1594, procede de la antigua iglesia de San Ildefonso. FERNÁNDEZ DEL HOYO, María Antonia: Patrimonio perdido..., op. cit., p. 315.

482 CANESI ACEVEDO, Manuel: Historia de Valladolid (1750), op. cit., Tomo III, p. 273.

483 REDONDO CANTERA, María José: “Los inventarios...”, op. cit., p. 502.
} 
ambos santos denotan la misma factura y la misma disposición parece claro que estarían juntos y enfrentados. Quizás flanquearan a la Virgen de la Soledad, pero lo que resulta extraño es que ese santo mínimo no figure en el inventario que explicaba las imágenes que componían el retablo. Del San Juan no tenemos ninguna pista, y ni siquiera sabemos si se trataba de San Juan Bautista o de San Juan Evangelista, el cual se afrontaría en el retablo con la escultura de San José. El San José será el conservado en la moderna iglesia de Nuestra Señora de la Victoria; y, finalmente las de San Joaquín y Santa Ana, pudieran ser las que actualmente se encuentran en el Santuario Nacional de la Gran Promesa en calidad de depósito del Museo Nacional de Escultura, su verdadero poseedor. Parece claro que estas dos últimas llegaron a la institución museística tras la Desamortización, sin embargo allí no se tiene conocimiento ni noticia de qué convento o monasterio proceden.

Estas cinco esculturas que hemos comentado (San José, San Joaquín, Santa Ana, San Francisco de Paula y Santo Mínimo) tienen algo en común, y es que todas ellas fueron realizadas sin ningún género de dudas por Pedro de Ávila puesto que presentan cada uno de sus estilemas; y, además, la fecha de 1730 en que debieron ser realizadas concuerda perfectamente. Quedaría por encontrar el San Juan, en el caso de que no hubiera desaparecido durante la Guerra de la Independencia o en la posterior Desamortización. Sin embargo, existe un par de problemas, que no implican que esta teoría no pueda ser cierta. El primero de ellos es la diferencia de tamaño entre unas esculturas y otras: San Joaquín y Sana Ana miden 126 cms., el San Francisco de Paula 168 cms., el Santo Mínimo 150 cms., y el San José parece tener una altura cercana al natural. El otro problema, aunque más bien interrogante, sería: ¿El San José, cuyo tamaño parece ligeramente superior a las otras cuatro esculturas, pertenecía al retablo mayor o sería el que presidió el retablo colateral del Evangelio? Tan solo sabemos que este colateral "mostraba una escultura de San José y pinturas de la Asunción, San Sebastián y San Roque" ${ }^{484}$.

\section{SAN FRANCISCO DE PAULA Y SANTO MÍNIMO (Catedral)}

En la antigua capilla de don Pedro de Arce, actual sacristía de la Catedral, se encuentran dos imágenes de santos mínimos, siendo una de ellas San Francisco de Paula. Ambas esculturas proceden del desaparecido Convento de Nuestra Señora de la Victoria ${ }^{485}$, desde cuya iglesia llegaron en 1965 tras su demolición. Ya hemos dicho que pudieron haber pertenecido al retablo mayor a pesar de la considerable diferencia de tamaño entre ambas (168 y $150 \mathrm{cms}$.). Tras la desaparición de este retablo y su sustitución por el de Esteban Jordán, traído desde la parroquia de San Ildefonso, estos dos santos pasaron a

\footnotetext{
$484 \quad$ Ibídem. Puede que el referido retablo y sus pinturas sea uno conservado en la actualidad en la iglesia parroquial de Cubillas de Santa Marta (Valladolid). FERNÁNDEZ DEL HOYO, María Antonia: Patrimonio perdido..., op. cit., p. 316.

485 Ídem, p. 323.
} 
ocupar dos hornacinas abiertas en un zócalo que se construyó para elevar este nuevo retablo dado que era muy pequeño en relación a la gran altura de la capilla mayor.

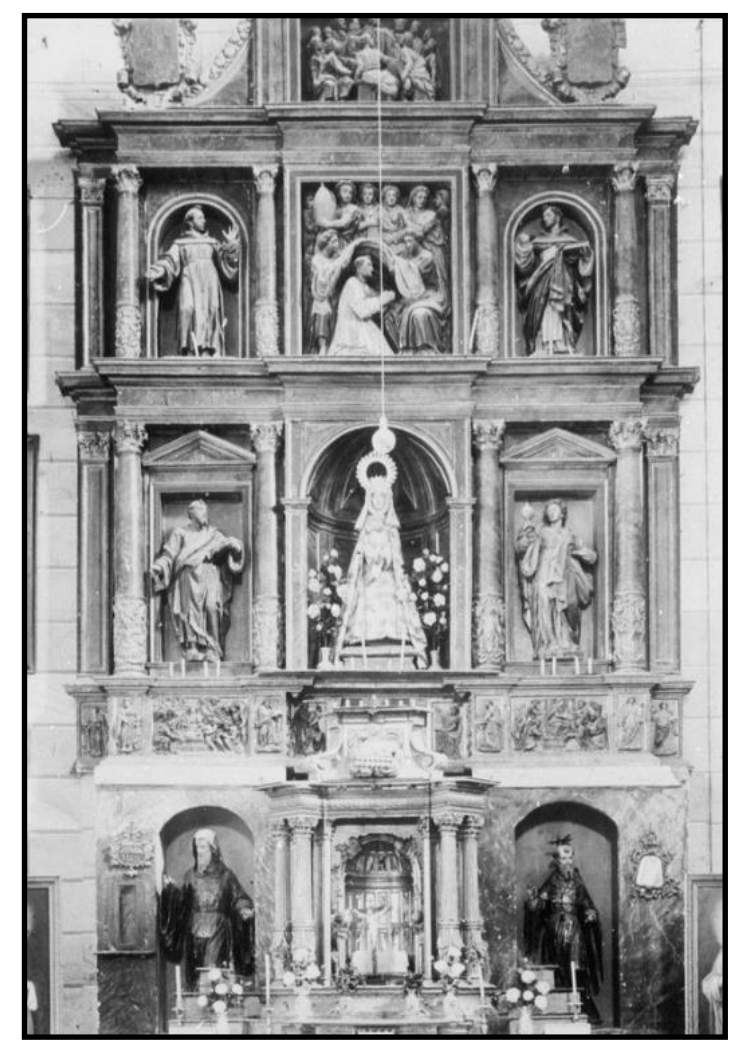

Il. 72- Antigua disposición del retablo mayor de la iglesia de la Victoria, en el que se observan a San

Francisco de Paula y al otro santo mínimo.

Ambas esculturas no son citadas ni en el Inventario Artístico de Valladolid ni en el tomo respectivo del Catálogo Monumental de Valladolid. Sin embargo, sí que son reseñadas en el Catálogo del Museo Diocesano y Catedralicio de Valladolid redactado en 1965 por Martín González. En él no realiza ninguna atribución, tan solo las fecha a finales del siglo XVII ${ }^{486}$.

San Francisco de Paula (1416-1507) fue el fundador de la Orden de los Mínimos o de los Ermitaños de fray Francisco de Paula, la cual se distinguía por añadir la humildad a los tres votos conventuales (caridad, obediencia y pobreza). El nombre de "Mínimos" se lo impusieron por considerarse a sí mismos como los "más pequeños de todos los religiosos" $" 487$. Nacido en la región de Calabria, adquirió reputación de taumaturgo, como lo demuestra el hecho de que le llamara el rey de Francia Luis XI en 1482 "quien esperaba curarse con sus plegarias" $"$. Su buena relación con la corona francesa llevó a que Francisco I solicitara su canonización, la cual le fue otorgada en 1519 por el papa León $X^{489}$.

Ambos santos aparecen revestidos con el típico hábito de los Mínimos con su túnica negra hasta los pies, ceñida a la cintura por un cíngulo, y un capucho. Las mangas son muy amplias, detalle muy del gusto del barroco. Aparecen de pie, disponiéndose de una manera semejante, lo que lleva a pensar en que estarían afrontados, de tal manera que las acciones realizadas por sus piernas, brazos y cabeza se complementaran. Adelantan la pierna izquierda, creando un suave contraposto, que en la escultura de San Francisco de Paula crea la sensación de movimiento.

\footnotetext{
486 MARTÍN GONZÁLEZ, Juan José: Catálogo del Museo Diocesano y Catedralicio de Valladolid, Dirección General de Bellas Artes, Madrid, 1965.

487 https://es.wikipedia.org/wiki/Orden_de_los_M\%C3\%ADnimos

488 RÉAU, Louis: Iconografía de los santos. A-F ..., op. cit., p. 564.

489 Ídem, p. 565.
} 
San Francisco de Paula (Fig. 114) será el que lleva el capucho cubriéndole la cabeza. Las suaves dobleces son muy naturales. El capucho remata en un pico sobre la frente que parece hecho en tela encolada, quizás por la dificultad que hubiera supuesto tallarlo en madera. A pesar de que le cubre la cabeza, podemos observar parte del pelo e incluso un mechón sobre la frente. El rostro, que acusa blandura tanto en la piel como en la consecución de las arrugas, presenta las típicas características del segundo estilo de Ávila. La barba es bífida, muy larga y simétrica, compuesta de largos mechones sinuosos que terminan en caracolillos redondeados. Tanto el pelo como la barba son canos, lo que señala su avanzada edad. Lleva las dos orejas talladas. Los ojos son de tapilla. Levanta la mano derecha, en cuyos dedos rotos portaría algún atributo, seguramente el que le caracterizara como San Francisco de Paula que es un sol en cuyo interior pondría la leyenda "CHARITAS"; mientras tanto, el brazo izquierdo lo baja, creando una diagonal entre ambos brazos y

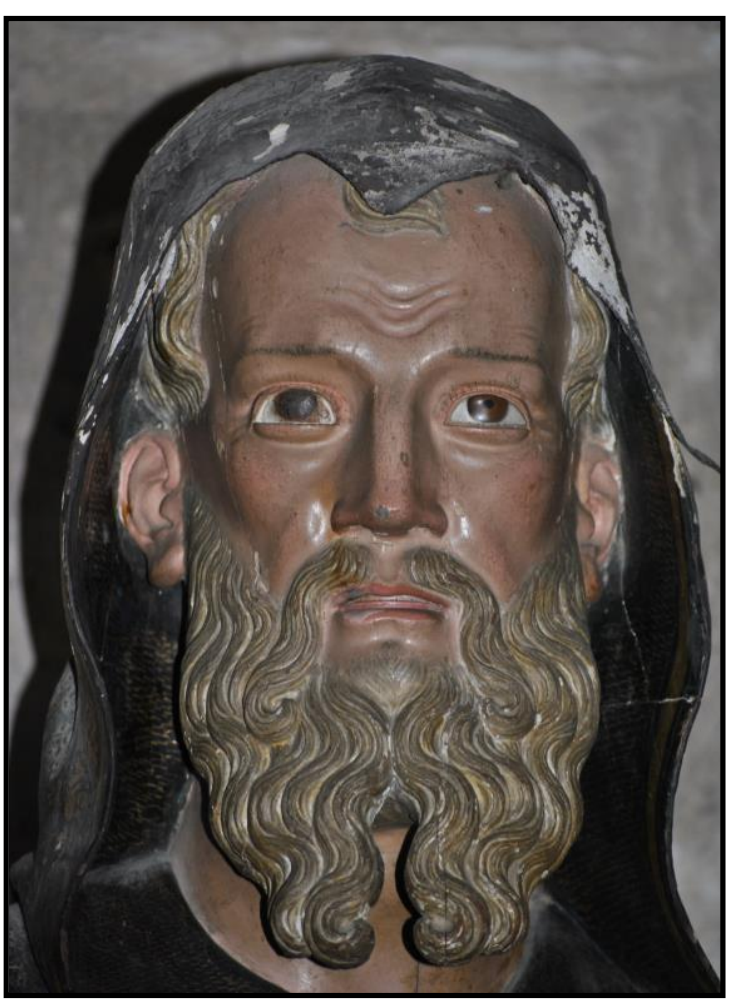

Il. 73- Pedro de Ávila (atrib.). Detalle de San Francisco de Paula.

en él llevaría otro atributo, quizás un báculo. Los pies también se encuentran seccionados, si bien observamos que siguen puntualmente la disposición que tanto gusta a Ávila de ponerlos en un ángulo de $90^{\circ}$ separados por un trozo del hábito con pliegues muy agudos. A pesar de que utiliza bastante el pliegue a cuchillo, éste le combina en esta ocasión con otros más redondeados y suaves, típicos de su padre; los podemos observar tanto en el capucho como en las mangas y el torso. La policromía es fastuosa puesto que al sobrio negro del hábito superpone una gran cantidad de decoraciones geométricas y botánicas esgrafiadas en oro. Es especialmente destacado el trabajo en el escapulario.

El otro santo Mínimo (quizás San Nicolás de Longobardi, si bien no fue beatificado hasta 1786 y canonizado a finales de 2014) (Fig. 115) sigue puntualmente la disposición y las características vistas en el San Francisco de Paula. Las diferencias las encontramos en la acentuación en todo el hábito del pliegue a cuchillo, el redondeado no hace acto de aparición; en la presencia de una esclavina; y en que el capucho le tiene caído sobre la espalda, con lo cual observamos su peinado que consiste en una amplia calvicie tan solo relajada por unos mechones laterales y otro sobre la frente. La similitud de los rostros de ambos es tal que se copian puntualmente dos arrugas superpuestas en forma de "V" estirada bajo el referido mechón. Los brazos siguen también la misma disposición, eleva el derecho y baja el izquierdo; y al igual que su compañero también tiene los dedos de 
las manos mutiladas, lo que ha conllevado a la pérdida de los atributos que portara. La policromía es exacta a la anterior. Ambas tallas urgen de una importante restauración.

\section{$\underline{\text { SAN JOSÉ CON EL NIÑO (Iglesia de Nuestra Señora de la Victoria) }}$}

La escultura de San José con el Niño (Fig. 116) que pudo pertenecer al antiguo retablo mayor del Convento de Nuestra Señora de la Victoria se encuentra situada actualmente en la capilla del bautisterio de la moderna iglesia de Nuestra Señora de la Victoria. Ya dijimos anteriormente que existían dos esculturas de San José en la antigua iglesia conventual: la del retablo mayor y la del retablo colateral de la epístola, intitulado de San Roque ${ }^{490}$. Desde hace tiempo la escultura se ha venido relacionando con Pedro de Ávila, primeramente en el Inventario Artístico de Valladolid: "Escultura de San José, siglo XVIII, de Pedro de Ávila"491; y, posteriormente, en la Guía histórico-artística de Valladolid (1972): "escultura de San José del siglo XVIII, obra de Pedro de Ávila"492.

La escultura sigue puntualmente el modelo habitual de Ávila para sus representaciones de San José; sin embargo, llama la atención el hecho de que los pliegues no son tan agudos como en el San José de la catedral, se ha moderado a la hora de su utilización. Esto lleva a que los perfiles no sean tan sinuosos sino más dulces y suaves a pesar de ser a cuchillo. No hay más que comparar los remolinos de la capa que se forman alrededor de ambos brazos: en esta escultura de la Victoria parecen como dos círculos, no existen los cortes agudos y nerviosos de aquel Pedro de Ávila. A diferencia de aquél, este San José tenía talladas las manos y el Niño de forma exenta; aunque las manos se conservan separadas del cuerpo previniendo de un posible robo, el Niño ha desaparecido. Al igual que el cuerpo, el rostro del santo tampoco posee una talla tan fina y apurada como la del ejemplar de la catedral; posee las mismas características faciales pero no es el mismo resultado, por lo que habrá que pensar en una amplia intervención de taller. Otras diferencias perceptibles es que la barba de este San José es bífida pero realizada a base de pequeños caracolillos, no de mechones. La entonación violácea tanto del rostro como de las ropas hace pensar en un posterior repolicromado que probablemente empeoró a la escultura, algo similar a lo que ocurrió con el Cristo del Olvido. También se percibe un retoque desafortunadísimo del ojo izquierdo.

\section{SAN JOAQUÍN Y SANTA ANA (Santuario Nacional de la Gran Promesa)}

Ambas esculturas llegaron al Museo Provincial de Bellas Artes, germen del Nacional de Escultura, procedentes de algún convento tras la Desamortización, aunque no hay noticias de cual; cabe la posibilidad de que lo hiciera, como es nuestra hipótesis, del de Nuestra Señora de la Victoria.

\footnotetext{
490 FERNÁNDEZ DEL HOYO, María Antonia: Patrimonio perdido..., op. cit., p. 316.

491 MARTÍN GONZÁLEZ, Juan José (dir.): Inventario artístico de Valladolid..., op. cit., p. 62.

492 MARTÍN GONZÁLEZ, Juan José: Guía histórico-artística..., op. cit., p. 107.
} 
Su estancia en el museo no sería muy prolongada puesto que en 1869, tras el pavoroso incendio sufrido (día 27 de octubre a las tres y media de la tarde) en la iglesia de San Esteban el Real (antigua iglesia del Colegio de San Ambrosio y actual Santuario Nacional de la Gran Promesa) ${ }^{493}$, todo su interior y la mayor parte de las obras de arte que atesoraba fueron destruidas; debido a lo cual el párroco de la citada iglesia, Gumersindo Océn, "envió un escrito a la Junta de Bellas Artes, que a su vez remitió al director de Instrucción Pública, en la que solicitaba varios lienzos y esculturas del Museo Provincial para el templo. La prensa apuesta por que se le niegue aunque, al final, algunas piezas llegarán hasta San Esteban"494. Las presentes imágenes de San Joaquín y Santa Ana fueron algunas de las escasas obras escultóricas que llegaron al templo, a las que se añadieron las de "San Lorenzo martirizado en la parrilla, San Miguel Arcángel, San Francisco Javier, Virgen niña, San José con el Niño, San Pedro Regalado, San Juan Bautista, Cristo crucificado, Inmaculada y varis santos como relicarios de medio cuerpo". A ellas se unieron una gran cantidad de pinturas, "todas ellas de autores anónimos y de mediana calidad"495.

En la actualidad, ambas esculturas se localizan en la capilla de los pies del lado del Evangelio, flanqueando un retablo que parece proceder de la antigua iglesia de San Ildefonso. Las atribuciones han sido casi siempre unánimes hacia nuestro escultor, si bien primeramente Martín González en el Inventario Artístico de Valladolid no aportó ninguna atribución, limitándose a fecharlas a "principios del siglo XVIII"496. Posteriormente, las adscribió sin lugar a dudas a Pedro de Ávila ${ }^{497}$, mismo parecer que tuvo Brasas Egido ${ }^{498}$, y el propio Martín González y Urrea cuando ambos redactaron el respectivo tomo del Catálogo Monumental: "asignable a Pedro de Ávila"499.

De confirmarse su pertenencia al desaparecido retablo mayor del Convento de la Victoria, estaríamos ante las dos mejores esculturas del conjunto, lo cual se podría explicar por ser las que se encontraban situadas en una zona más cercana al espectador, por lo que Ávila debió de cuidar todos y cada uno de los detalles, como así parece que hizo. No hay ninguna duda de que eran imágenes de retablo puesto que la espalda no está ni tallada ni policromada.

Al igual que las tallas de los dos santos Mínimos, San Joaquín y Santa Ana, que poseen un tamaño ligeramente menor (126 cms.), adoptan unas disposiciones complementarias que parecen indicarnos que estarían afrontadas. Mientras que San Joaquín dirige su mirada hacia la izquierda, Santa Ana lo hace a la derecha, como observando a su

\footnotetext{
493 ORTEGA DEL RÍO, José Miguel: op. cit., p. 207.

$494 \quad$ Ídem, p. 208.

$495 \quad$ Ibídem.

496 MARTÍN GONZÁLEZ, Juan José (dir.): Inventario artístico de Valladolid..., op. cit., p. 61.

497 "En el lado del Evangelio hay cuatro pinturas sobre tabla, obra de Jerónimo Vázquez y Gaspar de Palencia; y dos esculturas de San Joaquín y Santa Ana, de Pedro de Ávila". MARTíN GONZÁLEZ, Juan José: Valladolid, Ediciones Everest, León, 1991, p. 37.

498 "Dos buenas esculturas de San Joaquín y Santa Ana, adscritas a Pedro de Ávila". BRASAS EGIDO, José Carlos: Guía de Valladolid, op. cit., p. 71

499 MARTÍN GONZÁLEZ, Juan José y URREA FERNÁNDEZ, Jesús: Catálogo Monumental de la provincia de Valladolid. Tomo XIV..., op. cit., p. 324.
} 
marido; asimismo, mientras que el padre de la Virgen con el adelantamiento de su pierna nos ofrece sensación de movimiento, todo lo contrario ocurre con Santa Ana, que a pesar de adelantar la rodilla es figura más pausada.

San Joaquín (Fig. 117) aparece de pie, adelanta elegantemente la pierna izquierda, como cruzándola por delante de la derecha. El contraposto logra dotar de dinamismo a la escultura. La parte baja adopta la disposición típica de Ávila, los pliegues son tan agudos y aristados que nuevamente parece que nos encontramos ante una roca. Viste

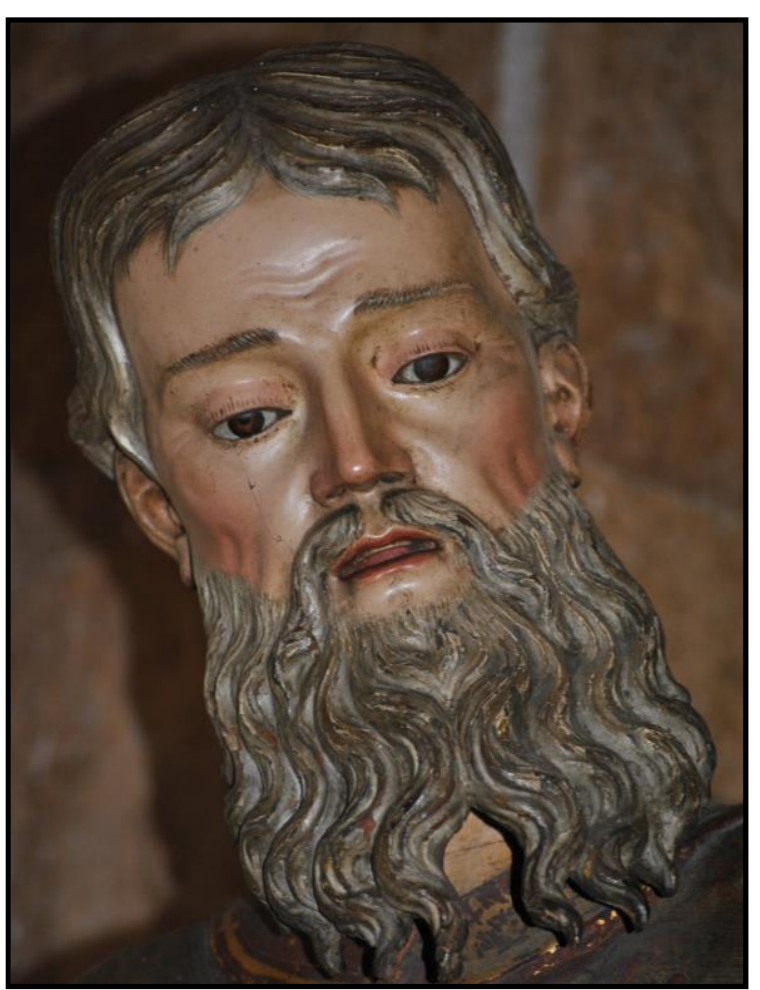
una bellísima túnica, ajustada a la cintura por un cíngulo, policromada y estofada con motivos botánicos; por encima porta un manto que le cubre la espalda, el hombro, el brazo izquierdo, y las piernas. Por su exterior es rojo, con franjas negras horizontales, y picado de lustre; mientras que por el interior domina el color azul con diversas franjas alternativas en las que podemos encontrar picado de lustre y cenefas vegetales. Los paños del manto son bastante suaves y redondeados, aunque también encontramos la utilización del pliegue a cuchillo; sin embargo, éste parece reservarse para dobladuras concretas y, sobre todo, como ya dijimos, para las zonas bajas. Como nos tiene acostumbrados, Ávila talla los Il. 74- Pedro de Ávila (atrib.). Detalle de San Joaquín. paños con tal finura que parece papel, así lo observamos en los bordes del manto, que además se doblan sobre sí mismo, lo que nos vuelve a hablar de su pericia. Detalles como estos son el mejor homenaje a Pedro de Mena.

La cabeza emparenta directamente con la del San Joaquín del desaparecido grupo de la Sagrada Familia de la Virgen del Monasterio de las Brígidas, atribuido indistintamente a nuestro escultor y a su padre; y al documentado San Pablo del retablo mayor del Oratorio de San Felipe Neri, con el cual incluso coincide en la disposición de los cuatro mechones irregulares sobre la frente. Sin embargo, a diferencia de ambos la resolución de la barba es distinta puesto que no son una serie de largos mechones sinuosos compactos sino que separa los mechones, convirtiendo la barba en bífida, lo que la hace mucho más ancha. El rostro es un prodigio técnico puesto que acusa a la perfección la avanzada edad del santo tanto debido al modelado blanco como a la aparición de unas arrugas hiperrealistas a la altura de las mejillas, muy acusadas, y de la frente, que es similar a la vista en las frentes de los santos Mínimos. Los rasgos faciales son los característicos de Ávila: boca abierta en la que podemos ver los dientes superiores y la punta de la lengua, ojos estrechos, nariz con tabique nasal ancho, cejas rectas, etc... 
Mantiene los brazos caídos. No sabemos si llegó a portar algún atributo puesto que no conserva las manos. Desconozco si es que han desaparecido o como ocurre con el San José de la iglesia de la Victoria se han guardado para que no sean robadas. Sin embargo, el hecho de que Santa Ana conserve una mano, muy deteriorada, parece apuntar a que tanto las dos de San Joaquín como la otra de su esposa han desaparecido.

Por su parte, Santa Ana (Fig. 118) se contrapone a su marido, al cual parece mirar. Aparece efigiada en el momento de adelantar la pierna izquierda, con la rodilla marcándose en la túnica, detalle muy característico de Ávila. Es una figura elegante pero menos movida. Parece adoptar una disposición helicoidal vista de lado. Viste de manera similar a San Joaquín con túnica hasta los pies y manto dispuesto de forma análoga, a esto hay que añadir que el manto le cubre la cabeza, y una toca blanca que le enmarca el rostro, impidiéndonos ver su cabellera. Con este detalle lo que consigue además es valorizar el rostro, en el cual vuelve a darnos muestra de su genialidad, puesto que al igual que San Joaquín modela muy blandamente su rostro, con arrugas en las mejillas y la característica arruga curva en la frente. Aunque el rostro sigue fielmente el modelo de Ávila hay que reseñar, por novedad, el que la nariz no sea de tabique ancho recto, sino que la nariz posee formas más redondeadas. El tipo de pliegues también es similar puesto que combina el redondeado con el de cuchillo, si bien la factura general de los pliegues de Santa Ana es algo más nerviosa, como podemos observar en el trozo de manto que sale disparado en diagonal bajo su brazo izquierdo. El brazo derecho lo dispone hacia abajo, mientras que el izquierdo lo abre poniendo el manto horizontal como si tuviera algún elemento sobre ella. Ya dijimos que ha perdido una de sus manos y la otra se conserva en bastante mal estado. Nuevamente volvemos a ver que la parte baja de la talla es la más aristada, entre uno de cuyos pliegues se sitúan ambos pies (uno ha desaparecido) en su característica disposición de $90^{\circ}$.

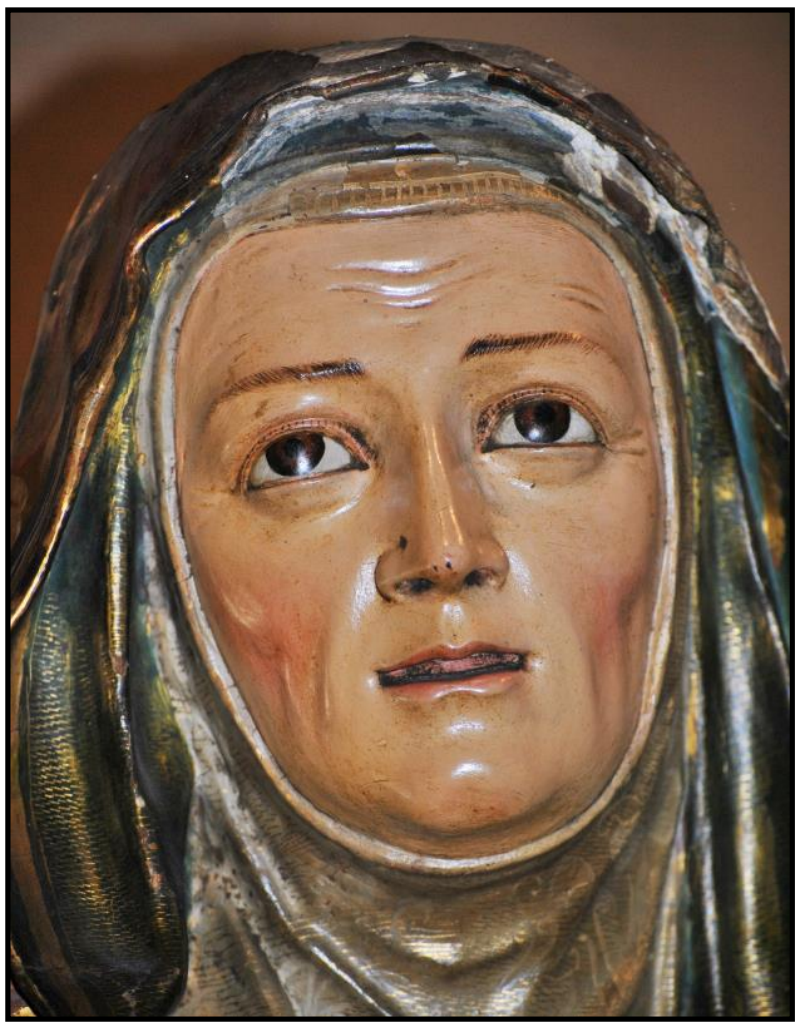

Il. 75- Pedro de Ávila (atrib.). Detalle de Santa Ana. 


\section{LA SECA. IGLESIA PARROQUIAL DE LA ASUNCIÓN}

\section{SAN ANTONIO DE PADUA CON EL NIÑO (década de 1730)}

En la misma iglesia, concretamente en la capilla de San Juan Bautista, se conserva un San Antonio de Padua con el Niño (Fig. 119) que también cabe atribuir a nuestro escultor, y concretamente a sus últimos años de producción dado lo encrespado y agudo de los filos de cuchillo que forman los pliegues de su hábito. En la actualidad preside un retablo rococó en la citada capilla, si bien no siempre estuvo ahí puesto que en el Catálogo Monumental de Valladolid se la cita en una de las hornacinas laterales, junto a Santa Teresa, del retablo de la capilla de San Basilio ${ }^{500}$.

A pesar de que ahora se conserve en la iglesia parroquial quizás también proceda, al igual que la Estigmatización de San Francisco, de la iglesia de San Francisco de la V.O.T. Al no poseer fotografías de la época no puedo afirmarlo con rotundidad pero quizás fuera el San Antonio inventariado por Martín González en la iglesia de la V.O.T. en un retablo rococó situado en el crucero, en el lateral de la Epístola ${ }^{501}$. Allí compartía intercolumnios con un San Francisco de Paula del siglo XVII y una Inmaculada del siglo XVII. Sin embargo, tenemos un problema para sostener dicha teoría y es que existía otro San Antonio de Padua en la iglesia parroquial, justamente en el retablo que actualmente preside: "En la misma [capilla]. Retablo rococó siglo XVIII, repintado con las esculturas siglo XVIII: relieve de San Francisco librando las Ánimas del Purgatorio. San Antonio con el Niño, San José con el Niño, con magnífica policromía, Santa Rita de Casia"502. El hecho de que a día de hoy en la iglesia parroquial tan solo exista un San Antonio de Padua, el que estamos estudiando, complica la tarea para discernir dicha cuestión.

El retablo en el que actualmente apea la escultura del santo lisboeta es de factura rococó. En el ático exhibe un medallón con San Francisco liberando a las Ánimas del Purgatorio. Marcos Villán y Fraile Gómez piensan que este retablo pudo ser el realizado en 1774 por el ensamblador y tallista Juan Macías para albergar una escultura de Santa Gertrudis en el crucero de la iglesia de la V.O.T ${ }^{503}$.

San Antonio de Padua conserva numerosos estilemas que me han llevado a creerla obra de Pedro de Ávila, si bien pienso que puede haber cierta labor de taller a juzgar por los rasgos un tanto rústicos del rostro; en el que, además, no encontramos esa blandura tan característica. El santo lisboeta ha sido concebido por nuestro escultor según su típico ademán: de pie, con una pierna adelantada, en este caso la izquierda, para provocar un ligero contraposto. La rodilla parece avanzar entre la amplia túnica del santo. La escultura está plantada sobre una pequeña y estrecha peana en cuyo ribete figura una

\footnotetext{
500 MARCOS VILLÁN, Miguel Ángel y FRAILE GÓMEZ, Ana María: Catálogo Monumental de la provincia de Valladolid. Tomo XVIII..., op. cit., p. 346.

501 MARTÍN GONZÁLEZ, Juan José (dir.): Inventario artístico de Valladolid..., op. cit., p. 156.

$502 \quad$ Ídem, p. 155.

503 MARCOS VILLÁN, Miguel Ángel y FRAILE GÓMEZ, Ana María: Catálogo Monumental de la provincia de Valladolid. Tomo XVIII..., op. cit., p. 351.
} 
leyenda que seguramente nos explicara quién o quiénes la mandaron esculpir, así como la fecha en que fue realizada. Dobla el brazo izquierdo para poder sujetar con ambas manos un gran paño en el que se situaría el Niño Jesús original, puesto que el actual está colocado de pie y poco tiene que ver con el estilo de Ávila. El pequeño se encuentra vestido con ropajes postizos.

Viste el usual hábito franciscano compuesto por un sayal que le llega hasta los pies y sandalias calzándoles. El sayal oscuro se ve tan solo alegrado por unas pequeñas decoraciones botánicas en la parte baja del mismo y en el cuello. Los pies como es usual aparecen colocados en un ángulo de $90^{\circ}$ y separados por una masa de pliegues bastante aguda. Ávila como de costumbre complica la parte baja de la escultura formando grandes pliegues aristados muy finos y cortantes. En este caso, esta distribución de pliegues será casi idéntica a la que utilizará en el San Antonio de Padua de Íscar (Valladolid). El resto de pliegues también son los típicamente berninescos, los cuales, en la década de 1730 que es en la que creo que fue realizado, tienden a ser mucho más aristados y con formas más complicadas y geométricas.

El rostro, que peca de estereotipado y poco trabajado, posee todas las características de la segunda etapa del escultor; pero, aunque no falta ninguna, el resultado no es el mismo. El peinado es tonsurado, similar al del San Francisco estigmatizado precedente, aunque sin la minuciosidad con la que ha representado cada mechón de aquél. 


\section{ORENSE. IGLESIA DE SAN FRANCISCO}

\section{INMACULADA CONCEPCIÓN (década de 1730)}

Hasta bien avanzado el siglo XVIII el influjo del arte vallisoletano siguió arribando a tierras orensanas; como bien demostró Martín González las relaciones artísticas entre ambas ciudades se remontaban a mediados del siglo $\mathrm{XVI}^{504}$. Si a Valladolid se encaminaron numerosos escultores gallegos con el fin de labrarse un futuro, entre los que podemos citar a Gregorio Fernández, Alonso de Rozas, Juan Antonio de la Peña o Pedro Bahamonde; a Galicia arribaron una serie de obras que llevaban el sello de la ciudad del Pisuerga, muchas de las cuales tuvieron como destino la catedral orensana (en la capilla del Santo Cristo se conservan una Sagrada Familia atribuida a Juan de Ávila, un busto de Dolorosa y un pequeño Cristo del Perdón, éstas dos últimas para el trasaltar).

En la iglesia orensana de San Francisco existe una Inmaculada Concepción (160 cms.) (Fig. 120) que no solamente posee los estilemas de nuestro escultor sino que además se trata de una copia casi exacta de la Inmaculada del Oratorio de San Felipe Neri; sin embargo, una serie de detalles como pueden ser la menor dulzura en el rostro o la falta de finura en la labra de la imagen nos hacen plantearnos la posibilidad de que se trate de una obra en la que la intervención del taller haya sido decisiva. La imagen, que no deja de tener cierto encanto, fue elogiada por Pascual Madoz en su Diccionario: "Su iglesia, bastante capaz con órgano y una bonita imagen de la Concepción" ${ }^{505}$. La atribución a Pedro de Ávila nos viene dada, como tantas otras veces, por Martín González, el cual en el año 1990 aseguraba con rotundidad que nuestro escultor sería "el autor de la Inmaculada que se conserva en la iglesia de San Francisco, de Orense" fecha su ejecución en la década de 1730 y propone que su llegada a la iglesia pudo deberse a "la misma orden franciscana, que contaba con importantísimo convento en Valladolid" $" 507$. Años después, el profesor seguía pensando que procedía atribuirsela a Pedro de Ávila, pero introducía el matiz de que no alcanzaba "la calidad de la de San Felipe Neri" ${ }^{\circ 08}$.

Dado que esta escultura copia puntualmente tanto en composición como en vestimentas e incluso en detalles como la colocación de brazos, cabellos, etc... a la de San Felipe Neri, por obviar repeticiones excesivas, tan solo comentaramos los elementos y detalles que las diferencian. Hay un motivo que singulariza esta piezas de las otras Inmaculads

504 MARTÍN GONZÁLEZ, Juan José: "Lazos de arte entre Valladolid y Orense", En torno al arte auriense: homenaje a D. José González Paz, Universidad de Santiago de Compostela, Santiago de Compostela, 1990, pp. 67-75.

505 MADOZ, Pascual; op. cit., p. 339.

506 MARTÍN GONZÁLEZ, Juan José: "Lazos de arte entre Valladolid y Orense", op. cit., p. 73.

507 Ibídem. Ya hemos dicho que hay otras obras de Pedro de Ávila que parecen haber sido encargadas por los franciscanos o congregaciónes relacionadas con esta orden, como la V.O.T. de La Seca (Valladolid); además, esta orden religiosa parece ser que tuvo una estrechísima relación artística con su padre, Juan de Ávila, al que encargarían numerosas obras desde diversos establecimientos: Convento de San Francisco de Valladolid, Convento del Domus Dei de La Aguilera (Burgos), etc...

508 MARTÍN GONZÁLEZ, Juan José: Escultura barroca en España ..., op. cit., p. 448. 
de nuestro escultor: la peana. Efectivamente, si en la mayoría de las versiones ésta aparece como una nube lisa o con tres cabezas aladas de serafines en el frente, en este caso la peana es un demonio de aspecto serpentiforme enroscado alrededor de una nube. Este diablo tiene las fauces abiertas, exhibiendo una potente dentición; por la parte de atrás su sinuosa cola adopta una posición vertical. La presencia de este demonio a los pies de la Inmaculada entronca con la visión de la Virgen apocalíptica; pero no solo eso, sino que también nos trae al recuerdo las Inmaculadas de Gregorio Fernández, las cuales se agrupan en dos categorías: las que su peana aparecían tres cabezas de angelitos y las que en ese mismo elemento figuraba un pequeño dragoncillo; es decir, justamente igual que las que exhibe Avila, con la añadición además de alguna que tan solo tiene la nube lisa a los pies.

Otra de las grandes diferencias con la de San Felipe Neri es que ésta es algo más estrecha y sus piegues no adquieren esos amplios y sinuosos volúmenes presentes en el ejemplar vallisoletano, esa falta de riesgo en la composición y la evidente sequedad de las facciones y pliegues parecen encaminarnos hacia la suposición de que se trate de una obra de taller. Circunstancia que pienso que lo confirma el rostro, el cual no posee ni la blandura ni la tersura de otros ejemplares. Aquí la piel parece tirante; sus rasgos son los típicos de Ávila pero no están tallados con la misma finura ni delicadeza de la que hacen gala las obras que están documentadas o las consideramos suyas fuera de toda duda. Podríamos decir que la ternura y la inocencia presente en el rostro de la Inmaculada de San Felipe Neri se ha tornado en el de la orensana en seriedad y ensimismamiento. Finalmente, los cabellos aunque realizan las mismas ondulaciones y discurren por los mismos senderos, parecen algo más toscos y estereotipados. A pesar de todo ello no me atrevo a asegurar que sea obra de taller por cuanto pudiera ser que la suciedad presente en toda la talla y el evidente repolicromado del rostro pudieran haber enmascarado la verdadera labra y calidad de la escultura. En esta ocasión parece que la Virgen posee los mismos colores que las otras imágenes (blanco para la túnica y azul para el manto); aunque en esta ocasión

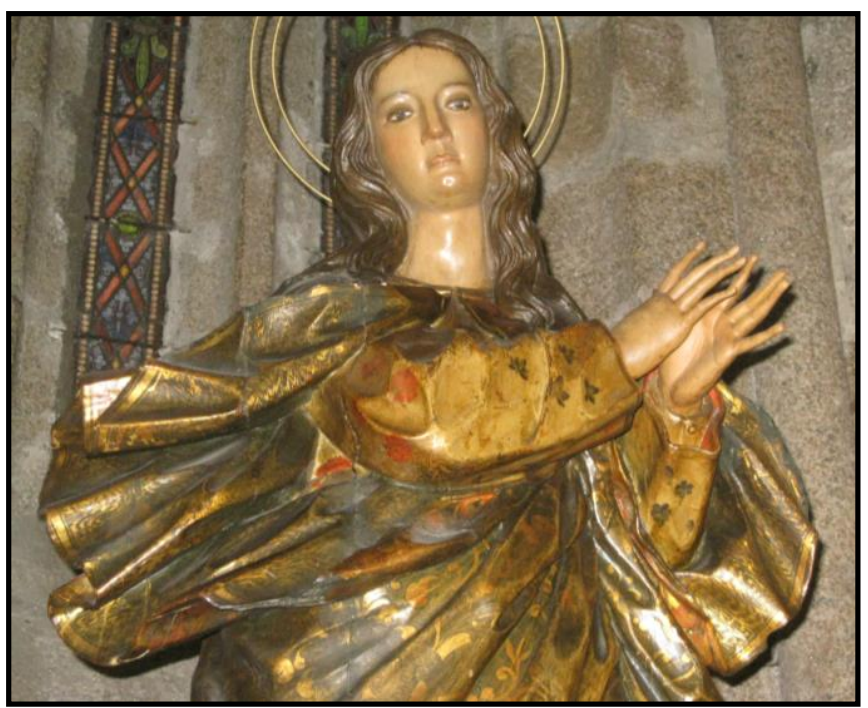

Il. 76- Pedro de Ávila (atrib.). Detalle de la Inmaculada. estos se ven enriquecidos por cuanto ambas prendas se hallan surcadas de diferentes elementos florales, así como una estrecha cenefa dorada en el borde del manto. Sin embargo, la suciedad presente ya hemos dicho que trastoca bastante su visión y una apreciación correcta. 


\section{VALLADOLID. IGLESIA DEL EX-CONVENTO DE SANTA CRUZ DE LAS COMENDADORAS DE SANTIAGO}

\section{ESCULTURAS DE LA PORTADA (1732)}

La fachada principal del Convento de las Comendadoras de Santiago fue uno de los últimos elementos que se fabricaron en el templo, cuya construcción se alargó durante casi un siglo debido a constantes problemas económicos. La finalización del templo se llevó a cabo gracias al mecenazgo de doña Teresa de Zúñiga y Pacheco, VI marquesa de Castrofuerte $^{509}$; que en 1729, previa renuncia de su título, profesó en el convento, dotándole con 3.000 ducados de renta ${ }^{510}$. Por entonces, también tendrían lugar el cerramiento de la cúpula y la decoración de las bóvedas que se encontraban "en blanco", así como la del coro y la del resto de la iglesia. Igualmente, se realizaría la notable portada principal, quizá aprovechando en parte lo realizado hasta 1719 . El templo se finalizó en 1734, por lo que se procedió a su inauguración, la cual tuvo lugar, según el testimonio del diarista Ventura Pérez, el día 2 de mayo: "colocaron en la iglesia nueva de señoras comendadoras de Santa Cruz el Santísimo Sacramento. Hicieron la procesión por dentro del convento desde la iglesia vieja a la nueva a puerta cerrada; tuvieron cinco días de función de iglesia que empezaron en día de la Cruz; trajeron de Madrid siete músicos, los tres capones, de voz, y los dos tocaban clarines y trompos de caza y los otros dos tocaban violines y uno el contrabajo: traslado a S.M. el Ilustrísimo Sr. Domínguez y bendijo la iglesia el día antes" $"$.

La fachada no daba directamente a la calle de Santiago, sino que se abría a un compás interior. El diseño de la portada utiliza elementos clásicos (columnas y entablamentos) organizados con un sentido barroco ${ }^{512}$. Podemos llegar a ver un influjo de Sebastiano Serlio en lo que respecta a la pureza de líneas con que ha sido concebida la parte baja de la portada; y, además, su forma de Arco del Triunfo emparenta con los modos del arquitecto italiano. Urrea define el diseño de esta portada como clásico y elegante "que no carece de movimiento ni de molduraciones barrocas" ${ }^{\prime 13}$. La traza de la misma

\footnotetext{
509 FERNÁNDEZ DEL HOYO, María Antonia: "El Convento de Comendadoras de Santa Cruz de Valladolid: Nuevos datos para su historia". En Valladolid: historia de una ciudad. Congreso internacional. 1, La ciudad y el arte Valladolid villa (época medieval), Ayuntamiento de Valladolid, Valladolid, 1999, pp. 109-110.

$510 \quad$ Ídem, p. 110.

511 PÉREZ, Ventura: op. cit., p. 123.

512 "Su hermosa fachada de piedra la forman dos cuerpos; el primero, de orden dórico, se compone de cuatro columnas estriadas que descansan sobre altos pedestales y sostienen la graciosa cornisa que corre a lo ancho de todo el frente y divide los dos cuerpos: en el centro se halla un esbelto arco de entrada y en los intercolumnios dentro de dos hornacinas parte superior tiene forma avenerada, las estatuas de dos santos. El segundo cuerpo es de orden jónico: consta de dos columnas estriadas y dos pilastras de menor elevación que las del primer cuerpo, que como éstas descansan en elegantes pedestales y sobre sus capiteles sostienen una segunda cornisa de la que se arranca un ático, abierto en su punto medio para dar lugar a un escudo de las armas reales, encima del cual se eleva una alta y caprichosa cruz: el centro de este cuerpo, almohadillado, contiene una hornacina de bellas proporciones, que ocupa una estatua de la Virgen de muy bien dibujo y correcta ejecución". GONZÁLEZ GARCÍA-VALLADOLID, Casimiro: Valladolid..., op. cit., Tomo I, pp. 76-77.

$513 \quad$ URREA FERNÁNDEZ, Jesús: Guía histórico-artística ..., op. cit., p. 58.
} 
recuerda a la de otras portadas del momento, o aún anteriores, como por ejemplo la de la iglesia parroquial de la Magdalena de Matapozuelos (Valladolid), como ya apuntó Martín González ${ }^{514}$. También se puede relacionar con otras fachadas columnarias cercanas: la del Monasterio de Nuestra Señora del Prado y la del Colegio de San Ambrosio, ambas en Valladolid; $u$ otras dos idénticas bastante anteriores como son las de las parroquiales de Villarramiel (Palencia) y Tudela de Duero (Valladolid).

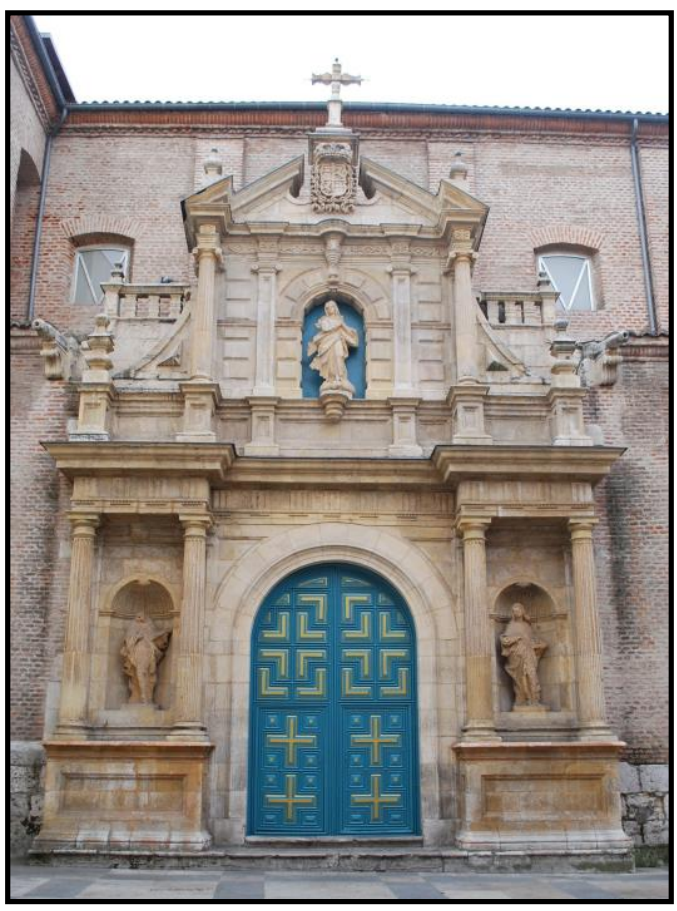

Il. 77- ¿Matías Machuca? Portada. Ex-convento de las Comendadoras de Santiago. Valladolid.

La fachada contiene tres buenas estatuas, aunque bastante maltratadas: en los nichos inferiores, a los lados de la puerta, Santa Mónica y San Agustín (cuya regla regía esta comunidad); mientras que en el nicho superior figura la Inmaculada Concepción, en cuya peana se puede leer la inscripción "Año de 1732", que aludirá a la fecha en que se realizaron tanto la fachada como las imágenes.

Las esculturas, que sin ningún género de dudas salieron del cincel de Pedro de Ávila, han sufrido a lo largo del tiempo numerosas atribuciones. El primero en formular una fue Martín González, para el cual "las esculturas acusan el estilo de Pedro de Bahamonde" 515. Años después en su libro Escultura barroca castellana, refiriéndose a la estatua de la Inmaculada, volvía a reafirmarse, aunque ya planteaba cierta relación con la estética de Ávila: "se aprecia en ella cierto recuerdo de Pedro de Ávila, pero es obra a no dudarlo de Pedro de Bahamonde, como las dos de abajo" 516 . En el mismo libro sentencia que las dos estatuas inferiores "ofrecen los caracteres inconfundibles de Bahamonde; véase la pierna avanzada y fuertemente marcada, la forma de pirámide invertida que tienen las esculturas y el arranque de las barbas, en armonía con la figura de San Pablo de la Catedral"; aunque, sin embargo, en la Inmaculada percibe que pudo ser "hecha bajo el influjo de Pedro de Ávila"517. Sería Urrea el primero en relacionar más decididamente las estatuas con el arte de Pedro de Ávila: "se encuentran próximas al estilo de Pedro de Ávila"518. Quizás esta formulación hizo cambiar de opinión a Martín González, el cual finalmente reconoció que "parecen obra del escultor Pedro de Ávila"519.

\footnotetext{
514 MARTÍN GONZÁLEZ, Juan José: Arquitectura barroca ..., op. cit., p. 159.

515 MARTÍN GONZÁLEZ, Juan José: Valladolid artístico. 3, Monumentos religiosos: iglesias y monasterios, Miñón, Valladolid, 1950, p. 8.

516 MARTÍN GONZÁLEZ, Juan José: Escultura barroca en España ..., op. cit., p. 453.

517 MARTÍN GONZÁLEZ, Juan José: Escultura barroca castellana ..., op. cit., p. 348.

518 URREA FERNÁNDEZ, Jesús: Guía histórico-artística..., op. cit., p. 58.

519 MARTÍN GONZÁLEZ, Juan José y DE LA PLAZA SANTIAGO, Francisco Javier: Catálogo Monumental de la provincia de Valladolid. Tomo XV ..., op. cit., p. 329.
} 
Aunque ambas opciones (Pedro Bahamonde y Pedro de Ávila) son igualmente válidas, e incluso se podría decantar la balanza a favor del primero por el hecho de que se le conocen obras en piedra por esos mismos años (esculturas de la fachada de la catedral de Valladolid) y a Ávila no, creo que es indudable que son obra de Ávila por la presencia de diversos detalles y estilemas propios de nuestro escultor. Además, parece, como ya hemos visto, que también Ávila pudo practicar la escultura pétrea.

\section{INMACULADA CONCEPCIÓN}

Para Gratiniano Nieto la Inmaculada (Fig. 121) es una obra muy destacable, "escultura muy airosa cuyos paños están movidos con gran elegancia"520. La Inmaculada viene a ser una copia puntual de la que realizó unos años antes en madera para el Oratorio de San Felipe Neri. Sin embargo, al igual que ocurre con la Magdalena pétrea de la parroquial homónima, parece que el hecho de que la escultura esté realizada en piedra ha influido en la simplificación de caracteres, detalles y paños. Referente a esto último, observamos que quizás no se encuentren tan profusamente aristados como en otras ocasiones, pero sin embargo los filos siguen siendo igual de cortantes y de delgados como así podemos comprobarlo en los bordes del manto que se agitan violentamente hacia el lado derecho.

En esta ocasión, y seguramente debido a la escasa visibilidad dada su altura, Ávila ha simplificado el trono, de tal manera que tan solo lo forman nubes, excluyendo en esta ocasión las típicas tres cabezas aladas de serafines. La Virgen adelanta la pierna izquierda, remarcándose en los ropajes el avance de la rodilla, detalle típico de nuestro escultor; como también lo es la disposición en ángulo de $90^{\circ}$ de sus dos pies y la separación de ambos mediante un trozo de túnica con pliegues muy cortantes. No faltan otros destalles característicos como la disposición del manto en diagonal sobre el vientre o el trozo de manto que surge de la cadera izquierda y sale disparado oblicuamente. Al igual que en la de San Felipe Neri, realiza un valiente escorzo con el torso puesto que gira levemente la cabeza hacia abajo a la derecha mientras que los brazos los impulsa a la izquierda, uniendo ambas manos en disposición orante. Tiene los brazos completamente pegados al cuerpo, por lo que nuestro escultor intenta reducir al máximo los salientes de la escultura que pudieran ser víctima de posibles desperfectos. En esta ocasión Ávila ha conseguido una Virgen con unos perfiles muy aristados, con muchos entrantes y salientes. Viste túnica hasta los pies, y como de costumbre no deja a la vista más que las manos y las puntas de los zapatos; por encima un manto y un velo que le cubre gran parte de la cabeza.

El rostro posee los típicos rasgos faciales presentes en toda la segunda etapa de Ávila. Dirige los ojos hacia abajo, como mirando modestamente a las personas que se acercan a orarla. Muestra un rostro bastante más inexpresivo. Sin embargo, este ejemplar posee diferencias con respecto a las esculturas inmaculadistas en madera: en esta ocasión no

$520 \quad$ NIETO GALLO, Gratiniano: op. cit., p. 46. 
tiene la boca abierta, sino que se mantiene cerrada; tampoco el pelo está suelto cayendo libremente por el torso y la espalda, sino que prefiere representarla con un velo que se lo resguarda y tan solo permite verle algunas de sus ondas características. El velo, tallado con gran maestría dada su finura, se dispone muy elegantemente, dejando caer una de sus puntas sobre el brazo izquierdo de la Virgen. El estado de la escultura es óptimo, si bien a pesar de su reciente restauración las palomas ya han empezado a ensuciarla.

\section{SAN AGUSTÍN Y SANTA MÓNICA}

Santa Mónica (330-387) fue la madre de San Agustín. Nacida en Tagaste (o Thagaste, actual Souk Ahras, provincia de Argelia), convirtió al cristianismo tanto a su marido como a su hijo ${ }^{521}$. Se la veneraba como "auténtico espejo de las viudas y protectora de las religiosas agustinas" $" 522$. Asimismo es junto a Santa Ana la patrona de las madres cristianas; y, además, se creía que su cinturón favorecía el correcto transcurrir de los $\operatorname{partos}^{523}$. Su presencia artística es abundante, si bien suele aparecer asociada a su hijo o a San Nicolás de Tolentino, los dos santos agustinos más importantes.

Por su parte, San Agustín de Hipona (354-430) fue obispo y uno de los doctores y padres de la Iglesia Latina. Se le considera como el máximo pensador del cristianismo durante el primer milenio, no va vano fue un gran intelectual además de escritor de temas teológicos y filosóficos. Su conversión al cristianismo no llegó hasta el año 385, sin duda influido por las ceremonias litúrgicas celebradas por el obispo Ambrosio en Milán (Italia), el mismo que dos años después le bautizó. Tras este trascendental acontecimiento, decidió regresar a África; sin embargo, antes de embarcar en el puerto de Ostia, su madre falleció. Al llegar a su Tagaste natal decidió vender todas sus posesiones y entregar el dinero a los pobres, hecho que como ya hemos visto es muy frecuente en las hagiografías de muchos santos. Fue ordenado sacerdote en Hipona en el 391 por el obispo Valerio y cuatro años después se le consagró obispo ${ }^{524}$. Durante su obispado su actividad fue frenética ya que predica contra la ortodoxia, interviene y preside concilios, y se enfrenta a diferentes herejías (donatistas, arrianos, priscilianistas). Su último gran logro fue la redacción de una regla para organizar la vida monástica, la "Regla de San Agustín”, entre los años 426-427.

Estas dos esculturas (Figs. 122-123) de las que Gratiniano Nieto dijera que no desdecían de la Inmaculada "a pesar de estar mutiladas" 525 se encuentran muy estropeadas a causa de los efectos atmosféricos, lo que dificulta un minucioso análisis de ambas; quizás también tenga alguna culpa la "francesada". La que se encuentra en mejor estado de conservación es Santa Mónica pues mantiene todos sus miembros, si bien muy desgastados y con los pliegues especialmente afectados. Sin embargo, San

\footnotetext{
521 RÉAU, Louis: Iconografía de los santos. G-O..., op. cit., p. 411.

522 Ibídem.

$523 \quad$ Ibídem.

524 https://es.wikipedia.org/wiki/Agust\%C3\%ADn_de_Hipona

525 NIETO GALLO, Gratiniano: op. cit., p. 46.
} 
Agustín ha perdido la cabeza, la mano derecha e igualmente se hayan muy desgastados sus pliegues. A pesar de todo, podemos observar algunos detalles como la disposición de los cuerpos con el clásico contrapposto mediante el ligero adelantamiento de la pierna izquierda, la formación de un ángulo de $90^{\circ}$ con los dos pies, la presencia del pliegue a cuchillo... La cabeza de Santa Mónica se halla también tan afectada que no es posible un reconocimiento de los estilemas faciales de nuestro escultor. La presencia de todos estos elementos en ambas esculturas, unido a que la Inmaculada del ático no presenta ninguna duda acerca de su atribución, hace que también sea indubitable la pertenencia de ambas al catálogo de Pedro de Ávila. Finalmente señalar que Santa Mónica viste túnica larga hasta los pies, manto y una toca de viuda en la cabeza; por su parte San Agustín porta los mismos elementos con la excepción de la toca. Como vemos ambas esculturas son casi idénticas tanto en composición como en indumentaria, y tan solo están diferenciadas por sus lógicas particularidades en cuanto al género (toca en Santa Mónica, barba en San Agustín) y por un elemento que ambos portan: el libro. Mientras que San Agustín lo lleva abierto seguramente queriendo simbolizar que era la Regla que él mismo había escrito; Santa Mónica también lo porta, pero cerrado.

\section{ESCULTURAS DEL ANTIGUO RETABLO MAYOR (h. 1732-1734)}

Las madres comendadoras también recurrieron a Pedro de Ávila para que esculpiera las tallas que debía alojar el desaparecido retablo mayor que se estaba construyendo por estas mismas fechas. Absolutamente anda sabemos de él, ni siquiera el año en que fue sustituido por el retablo neoclásico que aún continúa en la iglesia, aunque es de suponer que sería destruido durante la Guerra de la Independencia. La fecha de realización del retablo será posterior al de las esculturas de la fachada (1732) puesto que las religiosas esperarían a rematar el templo y todos sus elementos arquitectónicos antes de renovar el primitivo retablo mayor de la iglesia, que no debió de ser otro que el contratado en 1574 por Esteban Jordán. Este retablo fue adquirido en precio de 200 ducados por la iglesia parroquial de Ciguñuela en $1734^{526}$, fecha en la que probablemente ya estaría acabado el nuevo retablo mayor, el cual correría a cargo de un ensamblador que ignoramos, en su parte arquitectónica, y de Pedro de Ávila, en la escultórica. El que le encargaran las esculturas a Ávila es un indicio de lo satisfechas que habían quedado las religiosas tras la realización de las imágenes pétreas de la portada de la iglesia. El nuevo retablo estaría acorde con la nueva estética barroca de la iglesia.

No tenemos ningún documento que nos describa este retablo mayor dieciochesco o que nos hable sobre su autor o las esculturas que albergaría, por lo que tenemos que conformarnos con una descripción realizada del posterior retablo neoclásico por Elías Tormo a mediados del siglo XX. Por entonces tan solo se conservaban las esculturas de Santiago Matamoros, en la hornacina principal y de San Fernando y San Francisco de Borja a ambos lados del retablo. Comentaba Tormo que el retablo lo presidía "el gran

526 Esteban Jordán concertó las labores tanto de arquitectura, escultura como pintura. MARTÍN GONZÁlEZ, Juan José: Catálogo Monumental de la provincia de Valladolid. Tomo VI..., op. cit., p. 22. 
grupo de Santiago, el Apóstol, luchando, el "Santiago matamoros" a caballo, los vencidos moros derribados al suelo y caminando delante de él, y, cosa curiosa, no como enemigo, sino como contra religionario, un morito negro con tambor, redoblándolo, como animando a la batalla y marcando el paso de ataque: arte, el del grupo, no tan neoclásico comparado con la arquitectura que preside, y polícromo". Asimismo, se fijó en que la policromía no era "la castiza de los estofados y encarnados del siglo XVI y XVII de Castilla y Andalucía, sino la pintada en lustres y charolados de nuestro siglo XVIII" ${ }^{527}$. Sobre las esculturas de San Fernando y San Francisco de Borja decía que eran "artísticamente interesantes, y muy bella y sugestiva la última". Ambas se situaban a ambos lados del retablo, "pero en unidad artística con él, sobre pedestales". San Fernando vestía "el traje europeo de mediados del siglo XVI, el que a fines del XVII se le vistió a su cuerpo momificado en Sevilla cuando la canonización pontificia. Corona real, manto, espada, esferamundi, etc...". Por otro lado, la del San Francisco de Borja portaba "artística pero incongruentemente sotana y también manteo de jesuita y a la vez, encima, el manto de caballero santiaguista. Es ésta una ascética figura verdaderamente admirable: una de las esculturas españolas del siglo XVIII -el baladí siglo XVIII-de mayor sugestión; aparte de la escuálida, ascética cabeza, bello el conjunto, algo extraño".

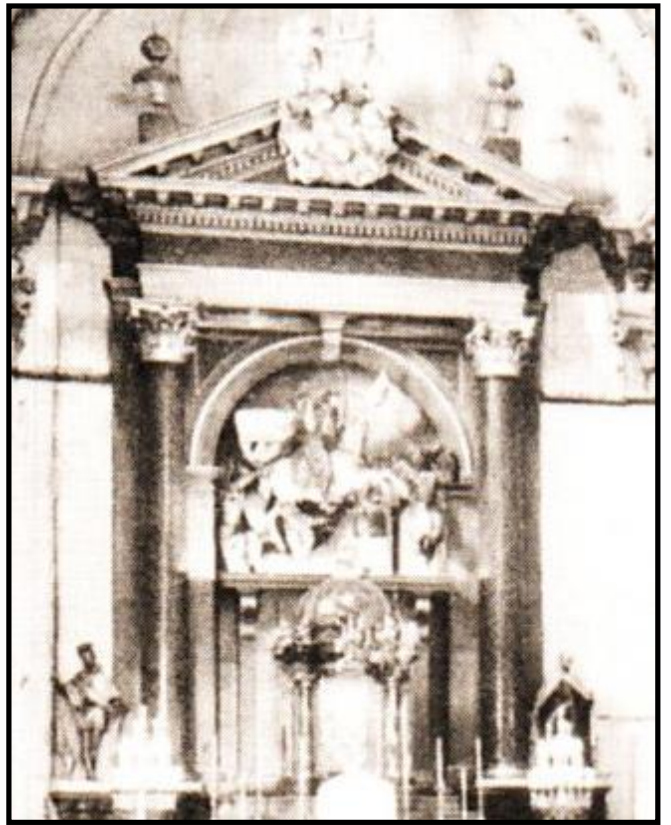

Il. 78- Fotografía de comienzos del siglo XX en el que se aprecian a los lados del retablo el supuesto San Fernando (izquierda) y a San

Francisco de Borja (derecha).
En la actualidad no se conserva en la iglesia más que el retablo neoclásico, muy mermado por la falta de la gran custodia cupulada que presentaba delante, y en la hornacina del mismo el grupo de Santiago Matamoros. No se puede decir lo mismo de las imágenes de San Fernando y San Francisco de Borja, las cuales aún se encontraban flanqueando el retablo cuando Martín González redactó el Inventario Artístico de Valladolid en 1970, si bien poco después fueron adquiridas por el Museo Nacional de Escultura (al menos el santo jesuita), en cuyo almacén se encuentran en la actualidad. Martín González no supo asignar las tres esculturas a ningún autor, tan solo se limitó a fecharlas: el San Fernando en el siglo XVII, mientras que el Santiago Matamoros y el San Francisco de Borja las veía del siglo XVIII $^{528}$. Años después, Urrea creyó que el Santiago Matamoros, única escultura que por entonces quedaba en el retablo, era “asignable también a Pedro de Ávila, réplica con algunas variantes al realizado por su

527 TORMO Y MONZÓ, Elías: "Las Comendadoras". En el colegio de mis nietas en Valladolid", B.S.A.A., Tomo VII, 1940-1941, pp. 158-159.

528 MARTÍN GONZÁLEZ, Juan José (dir.): Inventario artístico de Valladolid..., op. cit., p. 33. 
padre en 1699 para la parroquia de Santiago"529. Esta imagen ecuestre del patrón de España fue muy del gusto de Sangrador Vítores, el cual la alabó de manera conjunta con el San Francisco de Borja, pasando de largo del San Fernando: "muy notable la efigie de Santiago que ocupa el centro del retablo, y también son muy apreciables las esculturas de Virgen de la Paz y San Francisco de Borja que están en los colaterales"530. Si hacemos caso de esta descripción, parece que el San Francisco de Borja se encontraba a mediados del siglo XIX situado en uno de los dos retablos colaterales; situación que se repite cuando González García-Valladolid escribe Valladolid, sus recuerdos y sus grandezas: religión, historia, ciencias, literatura, industria, comercio y política: "también había en los colaterales de esta iglesia dos imágenes de Nuestra Señora de la Paz y San Francisco de Borja, bastante buenas" "531.

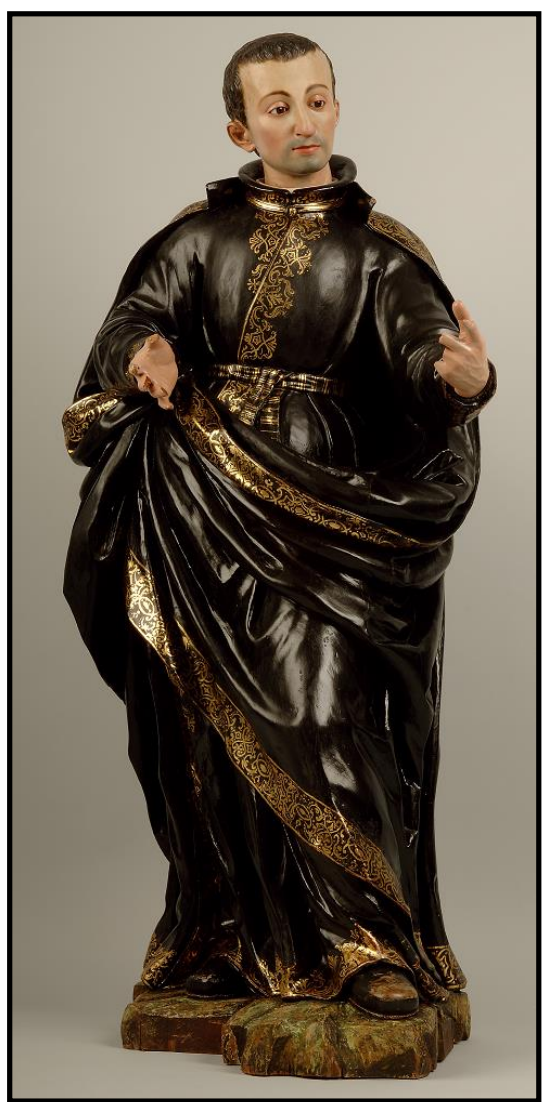

Il. 79- Anónimo. San Luis Gonzaga. Museo Nacional de Escultura.

Valladolid. (C) Museo Nacional de Escultura.

Acabamos de ver cómo tenemos muy pocas certezas sobre el retablo barroco y las esculturas que Pedro de Ávila pudo realizar para él. Lo único que está claro es que el Santiago Matamoros debió de presidir la hornacina principal, el resto está en el aire. A continuación expondremos los interrogantes. De las dos esculturas que hablan todos los autores anteriormente citados (San Fernando y San Francisco de Borja) tan solo se conserva en el Museo Nacional de Escultura el segundo de ellos, el cual no presenta ningún problema para atribuírselo a Pedro de Ávila. Del San Fernando no conocemos el paradero y además en el citado museo no se tiene constancia de ninguna escultura que represente al santo rey castellano; resulta algo extraño por cuanto gran parte del patrimonio de las comendadoras fue adquirido por la institución museística. Al no poseer tampoco una fotografía adecuada, no podemos saber si también cabe atribuírsela a Pedro de Ávila o no. Hasta aquí tendría lógica un retablo presidido por Santiago Matamoros y en el que estuviera San Fernando, por cuanto ambos combatieron a los moros durante la Reconquista; pero, ¿qué sentido tiene San Francisco de Borja en este retablo? Desconozco si esta escultura perteneció al retablo, seguramente el que constatáramos que el San Fernando fuera de Pedro de Ávila nos despejaría las dudas, las cuales no hacen más que acrecentarse ante la presencia también en el cenobio, y quizás procedente de este retablo, de una escultura de San Luis Gonzaga. Esta imagen, que también se conserva en el Museo Nacional de

\footnotetext{
529 URREA FERNÁNDEZ, Jesús: Guía histórico-artística..., op. cit., p. 58.

530 SANGRADOR Y VÍTORES, Matías: Historia de la Muy Noble y Leal Ciudad de Valladolid..., op. cit., Tomo II, p. 316.

531 GONZÁLEZ GARCÍA-VALLADOLID, Casimiro: Valladolid..., op. cit., Tomo I, p. 77.
} 
Escultura, posee una factura similar al San Francisco de Borja, por cuanto ambos visten la sotana jesuítica, si bien su ejecución escapa a la escuela vallisoletana, debiéndose englobar más bien en la madrileña. Por lo tanto, ¿pertenecieron en origen ambos santos jesuitas al retablo?, y si la respuesta fuera afirmativa, ¿por qué uno de los jesuitas es de Pedro de Ávila y la otra madrileña? No lo sabemos.

Tengo serias dudas sobre la pertenencia del San Francisco de Borja, no solamente debido a que no encuentro qué relación puede tener el jesuita con Santiago Matamoros y San Fernando, sino porque creo que pudiera ser una pieza reutilizada; solo así podemos entender que Elías Tormo, primero, y Gratiniano Nieto, después, se refirieran a ella como "artística pero incongruentemente sotana y también manteo de jesuita y a la vez, encima, el manto de caballero santiaguista"532. El manto santiaguista no era tal, sino que simplemente estaba simulado por la policromía, tal y como podemos ver en una lejana fotografía antigua. Entonces, ¿qué sentido tendría repolicromar un santo para adaptar su hábito a otra orden si no se tratara de una escultura reaprovechada? Creo que ninguno. Lo más lógico en este caso sería pensar que tanto el San Francisco de Borja como el San Luis Gonzaga fueron a parar al cenobio procedentes de alguno de los tres establecimientos jesuitas de la ciudad, pero sería demasiado aventurar.

A pesar de todo lo dicho, creo firmemente que el San Francisco de Borja pertenecería al retablo puesto que sería mucha casualidad que justamente hubiera ido a parar al altar mayor de las Comendadoras de Santiago una imagen de Pedro de Ávila que además es plenamente contemporánea, a la vista de los pliegues, del Santiago Matamoros que lo preside. Dicho todo esto, y ante la incógnita de si le pertenecerá o no el San Fernando a nuestro escultor (cuando sepamos su paradero y le analicemos podremos salir de dudas) tan solo analizaremos y creeremos que pertenecieron al retablo esas dos imágenes: Santiago Matamoros y San Francisco de Borja. En cuanto al San Luis Gonzaga desconocemos si perteneció al retablo, pero al no ser atribuible a nuestro escultor no tiene cabida en este estudio. Nuevamente hemos de mostrar la extrañeza de que en este cenobio figuren dos jesuitas de escuelas dispares.

\section{$\underline{\text { SANTIAGO MATAMOROS }}$}

El grupo principal del retablo representa, como no puede ser de otra manera, a Santiago Matamoros (Fig. 124), patrón de la orden militar de los Caballeros de Santiago, con quienes estaban vinculadas las Comendadoras de Santiago. A primera vista queda claro que Pedro de Ávila se basa para confeccionarlo en el que realizó su padre a principios de siglo para la cercana iglesia de Santiago Apóstol, en cuya ejecución seguramente le ayudó.

Aunque toma aquel conjunto por modelo, éste del cenobio no puede tener las mismas características; es decir, este adquiere un desarrollo horizontal en contraposición al de la

532 NIETO GALLO, Gratiniano: op. cit., p. 48. 
parroquia que es vertical; el motivo para este cambio está claro: el ábside gótico de la iglesia parroquial tiene muchísima mayor altura, con lo cual tanto el retablo, como la propia escena que lo preside, tienen que explayarse a lo alto; por el contrario, las dimensiones de la del convento son más modestas, por lo cual le conviene mejor un esquema horizontal. Esto en cuanto al grupo escultórico puesto que sigue siendo un enigma qué planta y distribución poseería el retablo. También coincide con el conjunto de su padre en el detalle de que tras del Santiago se halla una pintura en el tablón del fondo que ayuda a complementar la acción a la vez que la dota de mayor verismo. Apenas se puede ver debido a lo inaccesible del lugar además de la elevada altura y la interposición de las efigies; por lo poco que se observa parece una carga de las tropas cristianas a caballo espadas en mano contra las hordas musulmanas, las cuales empuñan lanzas. Desconocemos si en el retablo original había una pintura similar o no, lo que no cabe duda es de que esta fue ejecutada cuando se levantó el neoclásico puesto que se ve que fue realizada ex profeso para esta hornacina a la que se ajusta perfectamente. Llama la atención la existencia de numerosos rectángulos sobre la pintura, los cuales se pueden abrir; de alguno de ellos parten cuerdas para sujetar el grupo ecuestre.

En cuanto a las diferencias entre ambos grupos, la más reseñable es la que concierne al tipo de ataque del santo. Si en la iglesia parroquial veíamos que el apóstol atacaba a los moros desde el cielo, en esta ocasión los combate directamente desde la tierra. Asimismo, hay un cambio en cuanto a la composición, si la del grupo de la parroquia era diagonal; esta es triangular, siendo los vértices la cabeza del Santo Apóstol y los moros laterales, o incluso romboidal, añadiendo al moro situado bajo Santiago.

El santo aparece efigiado tal cual la visión que tuvo en sueños el rey Ramiro I: montado a lomos de un caballo blanco (color que simboliza el triunfo), mientras batalla y pone en fuga a los moros, los cuales han sido concebidos por Ávila en diversas actitudes para otorgar multiplicidad al conjunto; asimismo hay una contraposición de actitudes puesto que mientras que uno se encuentra de pie el otro se confronta arrodillado. El santo cabalga con el busto en escorzo y el brazo derecho levantado, espada en ristre, con intención de asestar el golpe de gracia a los moros; por su parte, el brazo izquierdo lo tiene retraído, habiendo perdido esa mano, en la cual seguramente blandiría un estandarte con la cruz de la Orden de Santiago de manera análoga al ejemplar de su padre; sin embargo, al igual que este, el barroquismo de la escena deriva de la captación del momento justo en que Santiago inicia la acción de derrotar al moro que le sale al encuentro, y de la inestabilidad que caracteriza la escena (principalmente al santo y al moro de la derecha). Si decíamos del grupo realizado por su padre que venía a ser una de las escenas más barrocas y mejor concebidas de la plástica vallisoletana, no podemos aseverar lo mismo de esta escena, la cual no deja de ser una copia adocenada (parece haber bastante participación de taller, pues no hace falta más que comparar las cabezas de los dos caballos presentes en la escena: el de Santiago posee un empeño mayor que el inferior) y carente de movimiento.

Santiago viste una túnica floreada en diversos colores oscuros ceñida a la cintura por un cíngulo rojo; la túnica le cubre la totalidad del cuerpo a excepción de las manos, la 
cabeza y la parte inferior de las piernas, en una de las cuales vemos que calza una bota marrón hasta la rodilla con una serie de motivos dorados. Sobre los hombros porta una esclavina negra con rameados dorados, el mismo color con el que se orlan las orillas. La tiene abrochada al cuello y abierto, de tal manera que nos deja ver parte de la túnica sobre el pecho al tener recurvada una de sus partes. Finalmente, entre esclavina y túnica tiene sujeta la amplia y volada capa blanca que ondea bravamente como si fuera una bandera. Su superficie se halla completamente arrugada y surcada de pequeños y finos pliegues a cuchillo. Aunque apenas se aprecian detalles, dada su altura e inaccesibilidad, parece que la capa sigue fielmente esas maneras tan típicas de Pedro de Ávila de tallarla en finísimas láminas. La cabeza del santo viene a ser una fusión, por un parte, del rostro del San José de la catedral de Valladolid (y también del ejemplar del Santuario del Henar, que es idéntico), y por otra, de las amplias masas de cabelleras rizadas de sus ejemplares de San Miguel o del San Juan Evangelista de la catedral. En cuanto a la barba bífida y creada a parir de numerosos caracolillos es una repetición de la que ostenta el San José segoviano que acabamos de citar. El rostro se encuentra perfectamente modelado y acusa la blandura de la que suele dotar Ávila a sus imágenes.

Por su parte, el caballo aparece en corveta, con las dos patas traseras apoyadas en tierra firme y las otras dos levantadas. Gira la cabeza en un violento escorzo para mirar directamente a los fieles que le ven desde la nave de la iglesia. La composición y la anatomía de su cuerpo están bastante bien conseguidas, siendo su calidad bastante alta, aunque no pueda compararse con la del caballo ejecutado por Juan de Ávila.

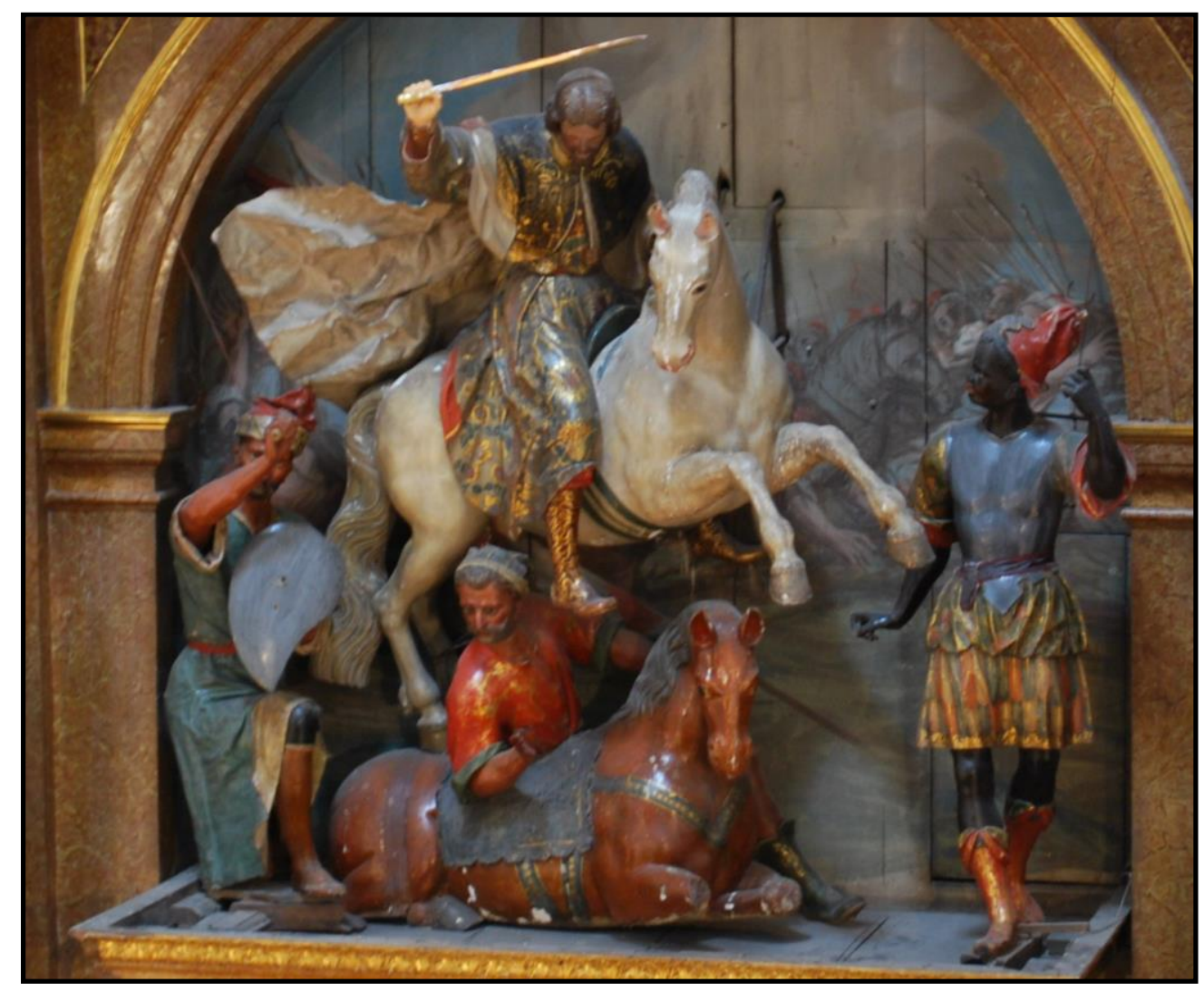

Il. 80 ¿Pedro de Ávila? Santiago Matamoros. Iglesia de las Comendadoras de Santiago. Valladolid. 
Finalmente hablaremos del acompañamiento de Santiago Apóstol, sin el cual la escena no tendría ningún sentido: los moros que rodean al santo. Hay tres: los que le flanquean a los lados son de mayor altura, encontrándose uno semi arrodillado y el otro de pie, mientras que el que se sitúa debajo de Santiago, ha sido representando como caído del caballo; todos están colocados de tal manera que no interrumpen la visión de lo que realmente importa: Santiago Matamoros a caballo. Vista la escena a gran altura, dado que difiere de la visión baja desde la nave, podemos observar que el moro inferior se ha caído del caballo, y tiene el cuerpo estirado formando una línea oblicua, de tal suerte que parece que Santiago Matamoros se dispone a saltarlo para no chocar. El caballo de este moro se halla completamente recostado con las cuatro patas recogidas, asimismo tiene perfectamente detalladas tanto la silla de montar como las bridas. El moro de la izquierda se halla con una rodilla en tierra y la otra flexionada, como intentando aguantar el envite al que le somete el santo; en una mano porta un escudo de curiosa forma parecida a una lágrima, mientras que en el otro brazo, que le tiene levantado, portaría una espada hoy perdida dado que se puede entrever entre sus dedos la empuñadura de la misma. El tercer moro, de piel negra y con los rasgos negroides del rostro perfectamente conseguidos (dada la verosímil caracterización de esta raza, no deja de recordarnos el San Benito de Palermo de principios del siglo XVII que, proveniente del desaparecido Convento de San Diego se expone en el Museo Nacional de Escultura) se sitúa de pie a la derecha del santo, y está concebido en escorzo, contrapposto, y de una manera ciertamente inestable dado que sitúa en la misma vertical la pierna derecha adelantada y la izquierda atrasada. Levanta un brazo y el otro le baja, sin embargo ha perdido los objetos que antaño portara, es probable que en la mano levantada llevara una espada; si bien Tormo parece que le vio un tambor según lo describe: "un morito negro con tambor, redoblándolo, como animando a la batalla y marcando el paso de ataque"533. Como vemos, hay una clara contraposición de actitudes entre los moros, uno caído que mira hacia los fieles, otro que intenta reincorporarse a la batalla y otro de pie que es el único en condiciones de enfrentarse al santo. En ellos destaca la variedad de vestimentas (túnicas en los dos soldados de tez más clara, y coraza y pantalones cortos en el negro) y de tocados (parecen un turbante, una cinta que ciñe el pelo y una especie de gorro frigio de composición fantasiosa), así como la amplia gama de colores que exhiben.

\section{$\underline{\text { SAN FRANCISCO DE BORJA }}$}

Ya hemos comentado que para Elías Tormo era "una de las esculturas españolas del siglo XVIII de mayor sugestión" "534, afirmación muy personal pero que aunque lleva algo de razón no deja de ser algo exagerada, según mi punto de vista. Lo que no puede ya aceptarse de ninguna manera es que, según su parecer, se le atribuya su ejecución a Felipe Espinabete en razón de las supuestas similitudes entre el rostro del jesuita y la

533 TORMO Y MONZÓ, Elías: op. cit., pp. 158-159.
534 Ibídem. 
cabeza degollada de San Juan Bautista conservada en la iglesia de San Andrés de Valladolid. Si confrontamos ambas vemos que nada tienen en común.

Sin ninguna duda este San Francisco de Borja (Fig. 125) es una de las esculturas más bellas, elegantes, místicas y de mayor empeño que realizara Pedro de Ávila, puesto que su autoría está fuera de toda duda viendo que están presentes todos y cada uno de sus estilemas, los cuales también se encuentran en el Santiago Matamoros. San Francisco de Borja (170 x 91 x 44 cms.) ingresó en la colección estable del museo junto con el San Luis Gonzaga el 13 de mayo de 1982 mediante el método de compra ${ }^{535}$. Actualmente posee el número de inventario "CE 1107".

San Francisco de Borja aparece de pie, quieto, meditabundo ante la calavera de la reina Isabel de Portugal, la cual para dar mayor verismo se trataba de una calavera real, no tallada. Se mantiene erguido, en contemplación, sin apenas movimiento, a pesar de que Ávila decide remarcar la pierna derecha bajo la ropa para crear su típico contrapposto que dinamiza la composición. Pero no solo eso, porque los giros de cabeza y cadera vienen a completar una serpentinata muy sutil. La mano izquierda la tiene vuelta para soportar la calavera de la reina emperatriz, mientras que la otra la mantiene abierta como expresando sorpresa ante el éxtasis místico que está sufriendo, puesto que se dice que fue en aquel justo momento en el que se "convirtió" y decidió formar parte de los jesuitas, momento que no se concretó hasta un cierto tiempo después. Las manos son muy delicadas y elegantes, con todos sus elementos perfectamente tallados y detallados tal y como podemos ver en el extremado realismo que acusan: como en todas aquellas esculturas de importancia o que iban a estar sometidas a un escrutinio visual cercano, tienen tallados todos los huesos, articulaciones, venas, rayas de las palmas e incluso los huecos simulando las uñas. La blandura y la carnosidad son plenas en estas manos que se encuentran unidas al cuerpo por un vástago puesto que al igual que la cabeza se hallan talladas de manera exenta. Viste la típica sotana negra jesuita y una amplia capa del mismo color sujetada en la parte trasera del cuello. A pesar de que ambos presentan una policromía negrísima, sobre ésta resaltan unas preciosas labores decorativas doradas con las que se ornan los bordes de ambas prendas. También se encuentra dorada una fina línea vertical en la parte superior de la sotana, que vendría a ser por donde se desabrocha. Como ya hemos visto en las representaciones de otros santos jesuitas atribuidos a Pedro de Ávila, nuestro escultor concibe los cuellos de las sotanas con gran dureza, como si estuvieran almidonados. Ya nos referimos a que en una fecha indeterminada las monjas santiaguistas decidieron repolicromarle la capa de color blanco para adaptarla a la orden santiaguista, pues así lo vio Tormo: "artística pero incongruentemente sotana y también manteo de jesuita y a la vez, encima, el manto de caballero santiaguista" ${ }^{\text {536. }}$.

Los ropajes están surcados por infinidad de plegados, la mayor parte de ellos berninescos, los cuales conforman unas superficies cóncavas y fuertemente aristadas en sus bordes. Cuando estos filos de cuchillo se curvan y se recurvan con total naturalidad

535 Debo estos y otros datos a doña Ana María Pérez, técnica del Museo Nacional de Escultura.

536 TORMO Y MONZÓ, Elías: op. cit., pp. 158-159. 
adquieren una finura sorprendente, y a la que ya nos tiene acostumbrados el escultor. Es especialmente destacable el conjunto de pliegues que componen la parte baja de la capa, los cuales son muy estrechos y arrugados, adquiriendo unas formas muy caprichosas a la vez que sorprendentes. No faltan tampoco los pliegues aprendidos durante el magisterio de su padre y su suegro: los suavemente incurvados, sin apenas movimiento que tienden a atemperar el movimiento de las esculturas, como a encapsularlas. En esta ocasión, éstos aparecen en la parte izquierda del manto, cayendo verticalmente a plomo sin apenas más vibración que unas levísimas ondas en el extremo. Estos pliegues están formados también a través de unas delgadísimas porciones de madera; la cual en ocasiones Ávila parece adelgazarla hasta el momento previo a que se parta o se transparente: no se puede apurar más; aunque ya lo hemos comentado en numerosas ocasiones, esta finura recuerda constantemente a Pedro de Mena, de quien debió aprenderlo "en la distancia". Además de éste no faltan los suavemente incurvados que aportan serenidad y reposo al santo. Hay otros dos detalles especialmente remarcables relacionados con los pliegues: la presencia habitual del aristado pliegue que separa ambos pies (colocados como de costumbre formando un ángulo de $90^{\circ}$ ); y la dulzura y naturalidad con la que impacta la parte inferior de la túnica sobre el zapato derecho, de tal forma que adquiere un requiebro formando un pico.

La cabeza es muy sugestiva, según la definiera Elías Tormo. Aparece meditabundo, con los ojos y la boca entreabiertos. Podríamos decir que es la versión masculina de alguna de las Magdalenas de nuestro escultor, puesto que ambos se encuentran transpuestos en la observación de una calavera mientras meditan acerca de la fugacidad de la vida. La cabeza y especialmente el rostro son de gran calidad; éste último parece cumplir las funciones de retrato: es decir; Ávila supedita su estilo, el cual sigue apareciendo claramente, en favor de la captación de los rasgos reales del santo; es decir, se vuelve a repetir lo ocurrido con la escultura de San Pío V del Convento de San Pablo. Pero este retrato va más allá de la captación de los rasgos faciales puesto que también le efigia con su característica cabeza alargada, la cual llega a adquirir una forma de óvalo. Este hecho es demostrable no solamente porque la mayoría de artistas (Martínez Montañés, Alonso Cano, Nicolás de Bussy, etc...) lo representaron así sino porque la mascarilla mortuoria que le sacaron así lo confirma. No cabe duda de que Ávila poseyó y/o utilizó alguna estampa o grabado del santo valenciano. También queda ajeno a Ávila, lo que vuelve a incidir en el carácter de retrato que posee esta cabeza, el tipo de solución que utiliza para la cabellera: una amplia calva con una serie de mechones blancos, curvos y de escaso resalte. La vejez no solamente la vemos reproducida en las canas sino también en las arrugas sobre la frente y sobre las cejas. Por lo demás, el rostro presenta las características típicas de Ávila: boca entreabierta completamente perforada en su interior, observándose los dientes superiores y la punta de la lengua; nariz ancha y con el tabique recto; ojos entreabiertos con una pasmosa reproducción de los pliegues del párpado; cejas levemente enarcadas y ceño fruncido. Incipiente barba simulada por la policromía, a la cual también se debe el nacimiento de los cabellos de la cabeza, lo que los hace más realistas. En la parte superior de la cabeza posee una incisión para sujetar un halo de plata. En definitiva, se trata de una de las tallas más excelentes de Pedro de 
Ávila, no solamente por la calidad y la finura de los plegados de la vestimenta sino también por la captación y delicadeza con que se encuentran tallados los rasgos fisionómicos del santo. 


\section{ÍSCAR. IGLESIA DE SANTA MARÍA DE LOS MÁRTIRES}

\section{SAN RAMÓN NONATO (1737)}

San Ramón Nonato (1203-1240) fue un santo mercedario catalán cuyo apodo "Non natus" (no nacido) deriva de que su "madre murió antes de parirlo y practicaron la cesárea sobre su cadáver" ${ }^{537}$. A raíz de este hecho se le consideró, según cuenta Réau, como el "protector particular de las mujeres embarazadas e incluso de las comadronas que las asistían durante el parto, y también de los recién nacidos" $" 538$.

Se hizo miembro de la Orden de los Mercedarios, la cual fue fundada por San Pedro Nolasco con el objetivo de rescatar a los cristianos cautivos de los musulmanes. Justo eso mismo es lo que le pasó a San Ramón cuando viajó al norte de África, dado que fue secuestrado por piratas berberiscos en Argel, los cuales "lo martirizaron atravesando sus labios con un hierro al rojo, luego pasaron un candado por los orificios, para impedirle que predicase el Evangelio"539. A raíz de este hecho se le tomó como protector de los esclavos. Tras ser liberado por su Orden volvió a España. Tiempo después el papa Gregorio IX lo nombró cardenal, si bien cuando el santo se dirigía a Roma falleció. Fue canonizado en 1657 por el papa Alejandro VII.

En la iglesia parroquial de Santa María de los Mártires de la localidad vallisoletana de Íscar se conserva una escultura de San Ramón Nonato (Fig. 126) que debe ser atribuida con total seguridad a nuestro escultor. Tan solo se la ha citado en dos ocasiones: en el Inventario Artístico de Valladolid, en el cual figura situado en el lado de la epístola de la iglesia de San Pedro (actualmente sin culto), fechándola en el siglo XVIII ${ }^{540}$; y en el respectivo tomo del Catálogo Monumental de Valladolid, el cual corrió a cargo de Brasas Egido. En esta última ocasión ya se encontraba en su ubicación actual, a los pies del lado de la epístola "junto a la puerta principal del templo". Brasas también la creyó del siglo XVIII ${ }^{541}$. Desconozco el porqué de la inconcreción cronológica puesto que su fecha figura escritura en una leyenda de la peana. Efectivamente, gracias a ella sabemos que fue realizada en 1737 gracias al dinero aportado por los devotos del santo en la villa: "Hizose con la limosna de los devotos de esta villa, siendo mayordomas $\mathrm{D}^{\mathrm{a}}$ Luisa Durango, Da María de Cieza y Heredia, Da Ana Rodríguez, año de 1737”.

La segura atribución de este San Ramón Nonato es importante por cuanto nos confirma que Ávila trabajó con asiduidad para Íscar en los últimos años de su magisterio ya que a su documentada Virgen de las Angustias (1739) hemos de añadir este San Ramón Nonato (1937) y un San Antonio de Padua (h. 1737-1739) realizado también para la iglesia de San Pedro, la misma en la que se encontraba el San Ramón. Además, dadas

\footnotetext{
537 RÉAU, Louis: Iconografía de los santos. P-Z..., op. cit., p. 121.

$538 \quad$ Ibídem.

539 Ibídem.

540 MARTÍN GONZÁLEZ, Juan José (dir.): Inventario artístico de Valladolid..., op. cit., p. 145.

541 BRASAS EGIDO, José Carlos: Catálogo Monumental de la provincia de Valladolid. Tomo X..., op. cit., p. 89.
} 
las cronologías de estas esculturas, parece ser que fue este San Ramón Nonato el que le dio a conocer en la villa.

Pedro de Ávila ha concebido a San Ramón de pie con un canon más alargado de lo normal. Como es usual, adelanta levemente la pierna izquierda si bien ni la rodilla se intuye bajo las ropas ni el contrapposto llega a serlo. Levanta el brazo derecho, en cuya mano porta la palma del martirio que alude a las torturas sufridas a manos de los musulmanes; mientras que en la mano izquierda sujeta una custodia, en cuyo centro figura la cruz flanqueada por dos árboles que suele ser el emblema de algunas cofradías de la Vera Cruz. Este atributo, la custodia, alude a la leyenda de que llegó a recibir el viático de manos de Cristo, aunque en otras ocasiones se dice que se lo dio un ángel ${ }^{542}$.

Viste túnica larga blanca hasta los pies, con lo cual volvemos a ver otras de las características típicas de nuestro escultor: tan solo se le perciben las puntas de los zapatos, los cuales figuran colocados en el usual ángulo de $90^{\circ}$ grados y separados por un pliegue muy cortante. La túnica tiene en su parte superior una capucha que el santo tiene retirada, caída sobre la espalda. Por encima una sobretúnica blanca que le llega hasta las rodillas; esta prenda no es de blanco uniforme puesto que en su parte inferior lleva una policromía azulada que imita labores de brocado; además, a la altura del pecho exhibe a todo color el escudo de la Orden de los Mercedarios. Además, porta una esclavina roja abierta al medio con los bordes decorados con motivos negros bastante bastos. Si esta escultura representara el nivel de complicación de los pliegues a cuchillo que mantuvo en sus últimos años, bien podemos decir que desde que comenzó a usarlos y hasta el final de su magisterio fue complicándolos de manera progresiva. Con el paso del tiempo los fue concibiendo más agudos y geometrizados, llegando a formar con los paños verdaderas rocas aristadas, como es el caso de la parte baja de la túnica del santo. También se encuentra muy facetada y surcada por amplias superficies cóncavas la sobretúnica. Por su parte, se muestra algo más relajado en la concepción de la esclavina, en la cual incluso vemos pliegues incurvados bastante suaves (sobre todo en la parte trasera de la misma, mientras que por la delantera observamos alguna ligera quebradura cortante). Con el ensanche de la parte inferior de la túnica y sobretúnica parece querer acentuar la forma piramidal de la composición. Como vemos, en sus últimos años, hay una gran tendencia en el escultor a la total geometrización del cuerpo y de los perfiles a base de los pliegues.

El rostro, que se encuentra bastante sucio, nos presenta las características que venimos repitiendo una y otra vez sin descanso, dado lo cual es tan fácil poder atribuirle esta imagen. Presenta blandura en la piel y arrugas en la frente que siguen su característica receta (dos "V" superpuestas alargadas). Boca entreabierta con labios finos y dientes superiores esbozados; ojos almendrados y con leve abultamiento de las bolsas inferiores; cejas rectas. Esta es de las pocas obras en que Ávila talla las dos orejas. En esta ocasión no tiene problemas para mostrarlas puesto que el santo no tiene el pelo largo, al revés una amplia calva rodeada de una tonsura que se conforma por una ancha

$542 \quad$ Ídem, pp. 121-122. 
franja de cabellos dispuestos en forma de "S" sin apenas separación entre unos y otros. La barba es muy rala, con unos pequeños mechones sobre los carrillos, bigote bífido en forma de "eses" y debajo también barba bífida corta. Es muy destacable la minuciosidad con que labra cada uno de los mechones que forman la barba y el bigote. Tanto el rostro como la forma de resolver la barba son coincidentes con los del San Francisco de Asís estigmatizado de la parroquial de La Seca (Valladolid), si bien este último posee bastante más calidad en cuanto al apurado técnico y al tratamiento de la piel.

La escultura se haya en el interior de un sencillo retablo del segundo cuarto del siglo XVIII. La hornacina central se haya flanqueada por dos estípites. En el ático campea un escudo que pudiera pertenecer al comitente que costeó el retablo. Desconozco si se talló exprofeso para albergar la imagen de San Ramón. El estado general de la escultura, con la excepción de la pérdida de algunos dedos, es muy buena, tan solo necesitaría una profunda limpieza. 


\section{ÍSCAR. IGLESIA DE SAN MIGUEL}

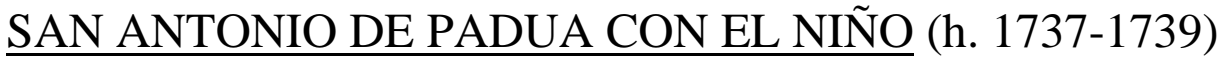

En la iglesia de San Miguel de Íscar (Valladolid) se conserva en un vulgar retablo moderno un San Antonio de Padua con el Niño (Fig. 127) que sin duda fue realizado por nuestro escultor; si bien sus rasgos generales, algo más vulgares que en otras ocasiones, me hacen pensar en una amplia labor de taller. También podría ser que la escultura perdiera sus valores originales a raíz de la reciente y brutal restauración a la que fue sometida.

Visto el tipo de pliegues, que son acuchillamientos bastante profundos, y que en 1737 parece que ejecutó el San Ramón Nonato conservado en la iglesia de Santa María y en 1739 la Virgen de las Angustias para la iglesia de San Miguel, parece lógico pensar que este San Antonio, que también fue realizado para la iglesia de San Pedro fue tallado por aquellas mismas fechas; es decir, en aquella época de intensa relación con las parroquias iscarienses. Además de todo ello, no parece casualidad el hecho de que tanto el San Ramón como, presumiblemente, este San Antonio de Padua, fueran costeados por los devotos de cada uno de ellos en la villa. Aunque no tengo datos concretos sobre este último me baso en el dato de que cuando en 1747 se realiza el retablo para el santo lisboeta se dice en el encabezamiento de la escritura del contrato que es sufragado por los "devotos de San Antonio de Padua de esta villa".

Efectivamente, el día 1 de octubre de 1747 los congregantes y "devotos de San Antonio de Padua de esta villa cuya efigie se halla en la iglesia de San Pedro" determinan hacer un altar y un retablo nuevo en el que colocar la sagrada imagen. Para ello unos días antes, el 6 de septiembre, el ensamblador Domingo Fernández Pedrosa, vecino de la villa, había realizado unas trazas y condiciones para el retablo; pero, además, debía de confeccionar un "trono correspondiente sobre el del santo a la misma similitud y mejor si cupiese para colocar a Nuestra Señora del Rosario". No fue hasta pasados unos meses, el 7 de abril de 1748 cuando, fiado por unos vecinos de la villa, el ensamblador se ajustó con la congregación para elaborar el retablo ${ }^{543}$. El retablo debía de colocarse "en la misma iglesia frente de su puerta principal, para que allí sea perpetuamente venerado de los fieles cristianos, por ser como es el sitio y parroquia más a propósito para ello", más concretamente "en el paraje donde se halla hoy Nuestra Señora del Rosario". El santo ocuparía la caja central del retablo, con un "adorno exterior de nubes, serafines, palmas, envuelto con dichas nubes y juntamente se han de repartir diferentes ráfagas circundando y adornando dicho adorno de nubes exterior, y se advierte que entre este adorno y el intercolumnio ha de bajar la cortina para encubrir dicho santo en su torno desembarazada y corriente". Teniendo en cuenta las características que se redactan en el contrato, pienso que este retablo se conserva actualmente en el muro del Evangelio de la iglesia de Santa María de los Mártires (Fig. 128).

543 A.H.P.V., Leg. 10.525, ff. 100-105 (1748). 
Al igual que ocurre con el San Ramón Nonato que Ávila talló para la localidad por estos mismos años concibe a San Antonio de Padua con un canon más alargado de lo normal, casi diríamos que praxiteliano. Aparece de pie, con la pierna izquierda ligeramente doblada, movimiento que deja entrever la túnica. Extiende ambos brazos con las palmas de las manos hacia arriba para sujetar al Niño Jesús, el cual iría tumbado sobre ellas; sin embargo, en la actualidad se ha colocado al infante incorrectamente puesto que figura sentado sobre la mano derecha de un modo artificial y que para nada casa con el espíritu general de la obra.

Viste el típico hábito franciscano compuesto por un sayal que le llega hasta los pies y sandalias en los pies; los cuales apenas podemos verlos debido a que les cubre la túnica. Los pies como es usual aparecen colocados en un ángulo de $90^{\circ}$ y separados por un pliegue muy cortante. Como de costumbre la parte baja de la escultura es muy aristada y geometrizada, con pliegues cortantes y grandes masas cóncavas que contribuyen a afacetar los perfiles del santo lisboeta. La túnica va ceñida con un cíngulo de cuerda natural. El cuello del capucho es demasiado rígido y amplio con lo cual pierde algo de naturalismo y parece indicar que la cabeza no está tallada junto al cuerpo sino que, al igual que las manos, fue tallada de manera exenta y posteriormente unidas mediante vástago. La policromía más que ser marrón parece jaspeada y muy pulida, logrando que la escultura de un aspecto como si estuviera realizada en piedra. La monocromía se ve rota por unas pequeñas decoraciones geométricas en la capilla, en el cuello y en los bordes de las mangas. Estas últimas en vez de tener un aspecto redondeado tiende más al rectángulo, con lo cual volvemos a comprobar la tendencia de Ávila en sus últimos años a simplificar las formas a cuerpos geométricos.

Lo que más llama la atención del rostro, que por otra parte exhibe los estilemas característicos a los que nos tiene habituados, es que la restauración ha sido tan excesiva que se nos presenta una tez demasiado brillante, habiendo perdido el juego de calidades y blandura de la piel original. Boca entreabierta mostrándonos la fila superior de dientes, nariz de tabique ancho y aplastado, ojos almendrados, cejas enarcadas, mentón potente, incipiente papada. Podemos considerar novedad el que talle las dos cejas, si bien en todos los santos a los que efigia con tonsura las suele esculpir con todo detalle. La forma de tallar la tonsura a base de una franja de pelo en forma de "eses" corridas es similar a las del San Francisco de Asís estigmatizado de la parroquial de La Seca (Valladolid) y al cercano San Ramón Nonato de la iglesia de Santa María de la misma localidad de Íscar (Valladolid). La barba y el bigote se encuentran en estado incipiente, debido a lo cual se ha preferido que fuese el policromador el que los insinuase. Por su parte, el Niño Jesús es similar a otros que hemos analizado, como el de la Virgen de las Nieves de Nava del Rey (Valladolid). Se trata de un infante rollizo, en el que destaca una anatomía surcada por arrugas adiposas. Semblante alegre, con las manos elevadas. También se encuentra excesivamente restaurado. 


\section{9-3 OBRAS RELACIONADAS}




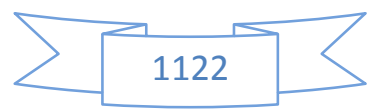




\section{ALDEAMAYOR DE SAN MARTÍN. IGLESIA DE SAN MARTÍN DE TOURS}

\section{SAN JOSÉ CON EL NIÑO (Anónimo. Primera mitad del siglo XVIII)}

En la iglesia parroquial de Aldeamayor de San Martín se conserva una interesante escultura de San José con el Niño (Fig. 129) que fue adscrita al círculo de Pedro de Ávila por Martín González en el Inventario Artístico de Valladolid ${ }^{544}$. Con posterioridad, Brasas Egido en el respectivo tomo del Catálogo Monumental de Valladolid tan solo la califica como "San José con el Niño, del siglo XVIII"545. Aunque debemos desechar por completo la atribución a Pedro de Ávila por motivos estilísticos más que evidentes, su inclusión en este apartado de obras relacionadas está vinculado por el hecho de que el escultor que la hizo copió fielmente el modelo de San José creado por Pedro de Ávila y continuado por su hermano Manuel. Pero tan solo eso, pues el resultado final es una escultura de una calidad muchísimo más modesta.

Efectivamente, teniendo en cuenta, por ejemplo, el San José que Pedro de Ávila talló para la catedral, vemos que ambas esculturas poseen unos parámetros similares. Nos presenta a San José de pie, con la pierna derecha adelantada con intención de caminar; de esa pierna podemos ver la parte inferior dado que la túnica se encuentra abierta en esta zona; con las manos sujeta un paño sobre el que figura tumbado el Niño Jesús en un estado entre dormido y desperezándose. En cuanto al rostro, parece intentar copiar la forma de la nariz; en el resto de rasgos faciales parece tender hacia la inspiración propia en vez de a la copia puntual; también se asemeja en el detalle de colocar en un ángulo de $90^{\circ}$ ambos pies. Otras enormes diferencias las encontramos tanto en la factura general de las tallas, mucho más apurada y de calidad en el caso de Ávila, y en la forma de resolver los pliegues: muy abultados, detallados y complicados en el caso de nuestro escultor y más vulgar en la escultura que nos ocupa. La modestia de este anónimo artífice la comprobamos también en la incapacidad que tiene para intentar lograr de manera verosímil los "pliegues a cuchillo", de los que Pedro de Ávila fue un consumado maestro.

El estilo que presenta esta escultura no concuerda con el de ninguno de los escultores vallisoletanos que conocemos actualmente. Tampoco podríamos descartar que hubiera sido hecha en alguno de los modestos, e ignorados, focos regionales que existieron en la actual provincia de Valladolid. Sea como fuere podemos plantear dos hipótesis: que el escultor pudiera haber sido discípulo de Ávila, aunque lamentablemente a día de hoy no conocemos el nombre de ninguno; o que, quizás, fuera un artífice que conociera la obra de Pedro de Ávila y sus esculturas de San José y decidiera copiarlo.

\footnotetext{
544 "Escultura de San José siglo XVIII, círculo de Pedro de Ávila”. MARTín GONZÁLEZ, Juan José (dir.): Inventario artístico de Valladolid..., op. cit., p. 75.

545 BRASAS EGIDO, José Carlos: Catálogo Monumental de la provincia de Valladolid. Tomo X..., op. cit., p. 37.
} 


\title{
ALMENARA DE ADAJA. IGLESIA PARROQUIAL DE LA ASUNCIÓN
}

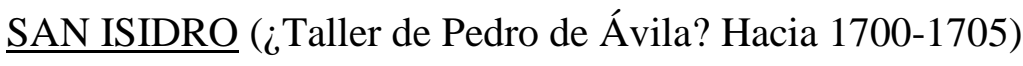

La presente escultura de San Isidro Labrador (Fig. 130) tan solo ha figurado citada, y de paso, en dos publicaciones. Se trata del Inventario Artístico de Valladolid, en el cual se dice de ella que es una "copia del original de Fernández. XVII"546; y del Catálogo Monumental de Valladolid, que acota algo más su cronología: "de fines del siglo XVII ${ }^{547}$. Esta hechura copia puntualmente tanto las vestimentas como el ademán del modelo creado por Fernández con su ejemplar conservado en la parroquial de Dueñas (Palencia), pero popularizado en buena parte del territorio vallisoletano a raíz de la escultura que Juan de Ávila talló para la ermita vallisoletana dedicada a este santo y su santa mujer. La talla presenta numerosos puntos en común con las obras de la primera etapa de Pedro de Ávila. Además, no podemos olvidar el hecho ya comentado en diversas ocasiones de que durante los primeros años del siglo XVIII detectamos la presencia del escultor en numerosas localidades del área de Olmedo, comarca a la que pertenece Almenara de Adaja, y en cuya parroquia se conserva una obra suya de esta época indubitable: el San Juan Bautista que preside el retablo mayor. Estilísticamente presenta parecidos con su primero estilo en la forma de concebir el rostro, tendente al rectángulo, y en la manera de resolver el peinado y la nariz. Sin embargo, la barba poco tiene que ver. Como no estoy en el total convencimiento de poder atribuírsela he preferido colocarla entre las obras relacionadas.

El santo aparece de pie, con la pierna izquierda adelantada. Se trata de una imagen bastante estática, pues no posee el movimiento del que hace gala el San Isidro de Juan de Ávila. Viste la típica indumentaria de labriego castellano con la que se le suele representar. En su mano derecha sostiene un cayado, mientras que con la derecha pudo sujetar un desaparecido arado. Tiene los dedos de esta última mano completamente rotos y desgastados. A sus pies se han colocado dos bueyes modernos. Cabe señalar, como ya dijimos, que la copia del modelo de Juan de Ávila es tan cercana que vemos presentes en esta talla tanto la botonadura, como la gorguera y el cinturón. Los pliegues redondeados, son los típicos exhibidos por los escultores vallisoletanos del último cuarto del siglo XVII. Todos estos parámetros me llevan a datarla entre 1700-1705.

\section{CURIEL DE DUERO. IGLESIA DE SANTA MARÍA}

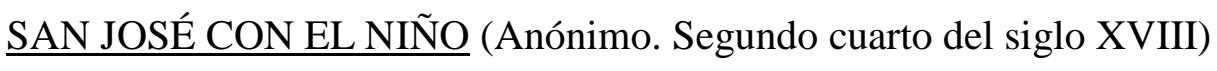

En un retablo barroco del lado de la Epístola de esta iglesia se conserva una escultura de San José con el Niño (Fig. 131) que copia puntualmente el modelo que Pedro de Ávila

\footnotetext{
546 MARTÍN GONZÁLEZ, Juan José (dir.): Inventario artístico de Valladolid..., op. cit., p. 77.

547 BRASAS EGIDO, José Carlos: Catálogo Monumental de la provincia de Valladolid. Tomo X..., op. cit., p. 45.
} 
utiliza en todas las representaciones de este santo; es decir, un caso similar al acaecido con la imagen homónima que hemos visto en la parroquial de Aldeamayor de San Martín. A diferencia de aquélla, esta escultura denota mayor calidad, amén de una mayor similitud, en el tratamiento de los paños, en los que se consigue a la perfección los "pliegues a cuchillo". Es decir, estamos hablando de un escultor más diestro que el de Aldeamayor. Amén de las múltiples similitudes, donde verdaderamente diverge de Ávila es en el rostro, que se encuentra totalmente lejano de los parámetros presentes en sus obras. Podríamos colegir, por lo tanto, que se trata de otro escultor que o bien se formó con Ávila o bien tomó prestado su exitoso modelo de San José. Por el momento, tampoco podemos relacionarlo con ningún artífice concreto. A este anónimo artista le deberán pertenecer también las dos esculturas con las que comparte hornacina, se trata de San Joaquín con la Virgen Niña. Es decir, tenemos presidiendo el retablo a las dos parentelas más difundidas. Cabe señalar que en el Inventario artístico de Valladolid se confunde a la Virgen Niña con Santa Ana: "Retablo barroco siglo XVIII con esculturas de San José con el Niño, San Joaquín y Santa Ana, y Santo Domingo - en el ático-de la misma época" ${ }^{548}$. El mismo error se vuelve a repetir en el respectivo tomo del Catálogo Monumental de Valladolid ${ }^{549}$.

\section{LA CISTÉRNIGA. IGLESIA PARROQUIAL DE SAN ILDEFONSO}

INMACULADA (Taller de Pedro de Ávila. Primer cuarto del siglo XVIII)

En la iglesia parroquial de San Ildefonso de la cercana villa de La Cistérniga se conserva una pequeña Inmaculada (Fig. 132) relacionada con el modelo creado por Pedro de Ávila. Martín González, el único que ha asignado una atribución a la talla, creyó oportuno definirla como "del círculo de Pedro de Ávila", y fecharla en el primer cuarto del siglo XVIII ${ }^{550}$. No le falta razón, pues el modelo, los recursos y las facciones son del maestro, pero la talla no es tan agradable y refinada como la de Ávila, por lo que no queda otra opción que creerla o bien "del círculo" o "del taller" de nuestro escultor. Por desgracia, como ya hemos comentado en varias ocasiones, el no conocer el nombre de ninguno de los discípulos u oficiales que trabajaron a las órdenes de Pedro de Ávila nos impide asignarles a estos anónimos artífices esculturas que imitan a las del maestro pero que no son suyas. La estructura y composición es idéntica a las documentadas y atribuidas con seguridad, sin embargo el acabado es mucho más deficiente, en los pliegues no se acusa la prolijidad, barroquismo ni finura que logra el maestro vallisoletano; y el rostro, y el pelo que le enmarca, carece de la vida que le infunde Ávila. En la peana puede leerse: "Se restauró a expensas de Francisco Olea". Mientras se restauraba la iglesia, la Inmaculada permaneció en los almacenes del Museo Diocesano, momento en la que la pude analizar por todos sus lados y comprobé que el

\footnotetext{
548 MARTÍN GONZÁLEZ, Juan José (dir.): Inventario artístico de Valladolid..., op. cit., p. 125.

549 VALDIVIESO, Enrique: Catálogo Monumental de la provincia de Valladolid. Tomo VIII..., op. cit., p. 92.

550 MARTÍN GONZÁLEZ, Juan José: Catálogo Monumental de la provincia de Valladolid. Tomo VI..., op. cit., p. 52.
} 
modo en que se expande su melena por la espalda en múltiples guedejas sinuosas es similar a la que podemos observar en muchas obras de Ávila, como por ejemplo la Magdalena de Matapozuelos.

Cuando Martín González redactó el correspondiente tomo del Catálogo Monumental de Valladolid la escultura se encontraba en la capilla del Santo Cristo, que es la primera del lado del Evangelio contando desde los pies de la iglesia ${ }^{551}$. En la actualidad ocupa la hornacina principal de un retablo rococó situado en el lado de la Epístola. Es probable que este retablo fuera realizado ex profeso para la Inmaculada puesto que en ella aparecen una serie de relieves relacionados con su iconografía: una fuente, un jarrón con lirios, etc... a todo ello se une la presencia en el ático de un santo franciscano, principal Orden que promovió el dogma de la Inmaculada Concepción de la Virgen. Debe tratarse de San Benito de Palermo. El santo aparece semiarrodillado sobre un trono de nubes, rayos y cabezas de serafines, estas últimas muy relacionables con otros angelotes vistos en la obra de Pedro de Ávila. En su mano derecha portaría un Crucifijo desaparecido, mientras que con la izquierda parece sujetar su atributo más característico: un corazón con siete gotas de sangre que aluden a las siete virtudes que poseyó (las tres teologales y las cuatro cardinales). Dada la iconografía franciscana es probable que este retablo proceda del cercano Convento de Santa María de Scala Coeli de El Abrojo, establecimiento franciscano próximo a Laguna de Duero. Hemos de recordar que ya Juan de Ávila debió de mantener una estrecha relación con esta Orden.

Quizás al escultor que talló la Inmaculada le pertenezca también el referido San Benito de Palermo, si bien la altura a la que se encuentra y el lamentable estado de conservación de la policromía nos impiden precisarlo con un mínimo de seguridad. Es más, a este anónimo discípulo, o seguidor, de Pedro de Ávila también pudieran corresponderle las esculturas que se alojarían en las hornacinas laterales puesto que las actuales nada tienen que ver en estilo, calidad ni dimensiones.

\section{MATAPOZUELOS. IGLESIA DE SANTA MARÍA MAGDALENA}

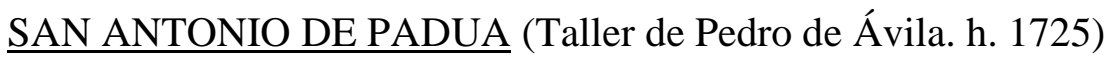

En el muro de la epístola, junto a un retablo diseñado en 1794 por el escultor vallisoletano Pedro León Sedano, se encuentra una talla que representa a San Antonio de Padua (115 cms.) (Fig. 133) que fue calificada por Urrea como relacionable "con el estilo de Pedro de Ávila"552.

San Antonio es figurado de pie, adelantando la pierna derecha, lo que le confiere un ligero contraposto, aumentado por el remarque que se hace de las formas de la rodilla. Los pies, como es habitual en Ávila, se disponen en un ángulo de $90^{\circ}$. Viste el típico

\footnotetext{
$551 \quad$ Ibídem.

552 URREA, Jesús: “Adenda. Matapozuelos”. En BRASAS EGIDO, José Carlos: Catálogo Monumental de la provincia de Valladolid. Tomo X..., op. cit., p. 255.
} 
hábito franciscano, el cual se encuentra surcado por numerosos pliegues a cuchillo muy cortantes. Tanto la cabeza como las manos parecen haber sido talladas de forma independiente del cuerpo. En las manos sujeta a un pequeño Niño Jesús del todo relacionable con los quehaceres de nuestro escultor. Lo que ya no casa tanto con el estilo de Ávila son los rasgos faciales del santo portugués, si bien es cierto que la nariz y los ojos se le acercan bastante. También las manos del santo cumplen la máxima que dijimos de las realizadas por Ávila, las cuales seguían una determinada combinación en los dedos. Otro motivo para relacionarla de manera fehaciente con la producción de Ávila es que la composición y disposición del santo es exacta, pero invertida, a otra escultura del mismo santo conservada en la iglesia de San Miguel de Íscar, y que le hemos atribuido a Ávila con total certeza. Como podemos observar tantos los pliegues como la posición de las rodillas, de las manos e incluso en la forma de tallar el cuello del hábito es completamente idéntica, pero invertida.

A raíz de todas estas semejanzas aunque a pesar de la baja de calidad del rostro respecto a las producciones más personales del maestro, y la escasa definición del pelo y las manos, me han llevado a creerla obra del taller del escultor. Además de todo ello se une el hecho de que en esta misma iglesia se conserva una hechura de la titular, Santa María Magdalena, que aunque no la tengamos documentada es obra atribuida con total certeza a nuestro escultor, y eso a pesar de su horrorosa restauración que le ha modificado sustancialmente los rasgos faciales. Teniendo en cuenta que esta última talla se fecha hacia 1724-1725, es probable que este San Antonio tenga una cronología similar, puesto que su estilo así lo nos lo confirma.

\section{SIMANCAS. IGLESIA PARROQUIAL DEL SALVADOR}

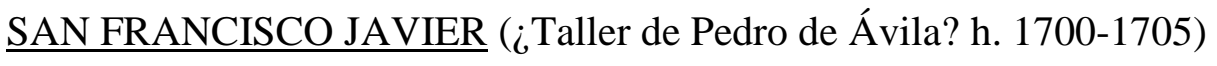

En la sacristía de la iglesia parroquial de Simancas se conserva un pequeño San Francisco Javier (Fig. 134) que debe ser inmediatamente puesto en relación con la producción de Pedro de Ávila. La escultura no figura ni en el Inventario Artístico de Valladolid ni en el posterior respectivo tomo del Catálogo Monumental de Valladolid, ambos realizados por Martín González. Ello puede llevarnos a pensar a que ha llegado en época reciente a la iglesia o bien que se encontraba perdido en alguna estancia de la misma; hecho, este último, nada extraño.

La presente escultura de San Francisco Javier sigue de cerca el modelo creado por Gregorio Fernández, y cuyo máximo exponente es el conservado en el retablo colateral del Evangelio de la iglesia de San Miguel de Valladolid, antiguo Colegio de San Ignacio. El santo figura con un ademán de avanzar, para lo cual adelanta la pierna izquierda. Su brazo derecho aparece estirado, con la mano en actitud de haber empuñado algún elemento desaparecido, quizás un báculo crucífero; por otro lado, el brazo izquierdo desaparece entre el mar de pliegues de la túnica, mostrándonos tan solo la mano, en la cual observamos que los dedos forman unos gestos muy elegantes, y con 
los cuales es probable que también pudieran haber sostenido algo. Hasta en un detalle tan nimio como es la posición de cada uno de estos dedos esta escultura copia puntualmente el referido prototipo de Gregorio Fernández. Se podría decir que es una perfecta copia punto a punto y detalle a detalle de aquél, pero pasado por el tamiz del primer estilo Pedro de Ávila, puesto que en las numerosas quebraduras de la túnica y del manto jesuita no aparece ni por asomo el pliegue a cuchillo; debido a ello debemos fecharla en los primeros años del siglo XVIII (1700-1705).

Que la escultura está relacionada de forma muy íntima con Pedro de Ávila lo evidencia la aparición en ella de los característicos rasgos faciales con los que dota nuestro escultor a sus personajes; sin embargo, la tosquedad en la talla del pelo y el aparente conservadurismo de los pliegues me lleva a considerarla como obra muy posible de Ávila aunque sin el suficiente convencimiento como para colocarlas entre el catálogo de atribuidas.

\section{VILLANUEVA DE DUERO. IGLESIA PARROQUIAL DE NUESTRA SEÑORA DE LA VISITACIÓN}

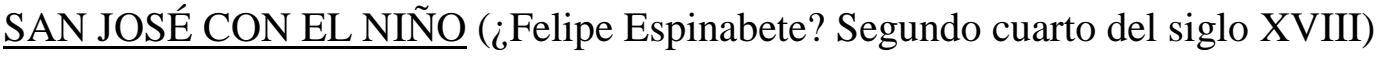

En la iglesia parroquial de Villanueva de Duero se conserva una escultura de San José con el Niño (140 cms.) (Fig. 135) que desde hace tiempo se viene situando en la órbita de nuestro escultor, y también en la de su hermano Manuel. Efectivamente, Urrea dijo de ella que "está emparentada con las creaciones de los hermanos Ávila"553; palabras similares a las que le dedicaron Marcos Villán y Fraile Gómez durante la redacción del respectivo tomo del Catálogo Monumental de Valladolid: "relacionado con las producciones de los hermanos Ávila" ${ }^{554}$.

La imagen no se realizó para la iglesia, sino que llegó a ella después de la Desamortización procedente de la cercana Cartuja de Nuestra Señora de Aniago. En efecto, en un inventario realizado en la Cartuja el 5 de septiembre de 1809, cuando todavía no había sufrido ninguna merma de carácter artístico, se hace referencia a una capilla de San José en la cual se conservaba "un retablo de talla dorado, con una imagen de talla de San Joseph, y su mesa de altar expuesta con sus toallas para celebrar, y un santo Cristo en bronce, la piscina con aguamanil de cobre, jarra y demás utensilios. Una alfombra al pie del altar de colores. El adorno de esta capilla se compone de ocho pinturas en lienzo" "555. Este inventario se realizó en presencia de un representante de la Real Hacienda y de otro de Bellas Artes, recayendo éste en el Padre

553 URREA FERNÁNDEZ, Jesús: "Noticia Histórica Artística de Villanueva de Duero (Valladolid)", Boletín de la Real Academia de Bellas Artes de la Purísima Concepción, Tomo XXXV, 2000, p. 106.

554 MARCOS VILLÁN. Miguel Ángel y FRAILE GÓMEZ, Ana María: Catálogo Monumental de la provincia de Valladolid. Tomo XVIII ..., op. cit., p. 459.

555 RICO DE LA FUENTE, Araceli: Monasterio de Nuestra Señora de Aniago: el sueño de una reina, Diputación de Valladolid, Valladolid, 2007, p. 96. 
Prior del convento ${ }^{556}$. Tras el saqueo de la Cartuja por parte de los franceses durante la Guerra de la Independencia y la posterior Desamortización los bienes que aún restaban en la iglesia se trasladaron a la cercana parroquia de Villanueva de Duero ${ }^{557}$.

Con esta escultura estamos ante la misma situación acontecida con los San José de Aldeamayor de San Martín y Curiel de Duero; es decir, se trata de una copia más del exitoso y conocido modelo creado y difundido por Pedro de Ávila. Sin embargo, a diferencia de aquellos, este San José es de mucha mayor calidad y con un grado de imitación casi exacto. La similitud es casi total con el San José que nuestro escultor talló en 1714 para la catedral de Valladolid. A tal grado de fidelidad llega la copia con respecto al modelo "avileño", incluso en la reproducción de los pliegues a cuchillo, que si no fuera por los rasgos faciales y la manera de resolver el pelo y la barba, que denota otra mano diferente, no habría ninguna duda para atribuírsela con total fundamento a Pedro de Ávila, ya que conserva hasta el detalle de verse la mitad inferior de la pierna derecha entre la abertura de la túnica; detalle que diferencia los San José de Pedro de Ávila de los de Manuel, puesto que el único San José conocido de este último, el de la iglesia penitencial de N. P. Jesús Nazareno, viste la túnica hasta los pies, no dejándonos ver ninguna parte de sus piernas.

Me gustaría proponer lo que considero una arriesgada atribución, y es que se trate de una obra de juventud de Felipe Espinabete, lo que de confirmarse daría carta de naturaleza a un hecho que expondremos más adelante: que el desconocido maestro de Felipe de Espinabete pudiera haber sido Pedro de Ávila. En tal caso, lo que ya no podríamos precisar es si Espinabete la contrató en sus primeros momentos como maestro independiente tras haber superado su proceso de aprendizaje en el taller de Ávila; o bien fue una obra contratada por Ávila y delegada a sus aprendices ante el crecido volumen de pedidos que por entonces tenía comprometidos, siendo por lo tanto Espinabete uno de esos aprendices, o quizás su oficial de confianza. Debido a que sería obra de juventud, es por lo que la escultura presenta rasgos faciales muy propios de Ávila, como son la nariz de tabique ancho y recto o los ojos; sin embargo, parecemos percibir la huella de Espinabete en su característica forma de tallar la barba, la cual repetirá posteriormente en la mayoría de sus obras, así como en el mechón que cae ladeado sobre la frente. Este último recurso lo observamos en algunas de sus cabezas degolladas de San Juan Bautista.

Aunque nada tenga que ver con esta pieza, por tratarse de una mera casualidad, cabe señalar que en la misma iglesia se conservan dos relieves-retablos de gran tamaño que representan sendos episodios de las vidas de San Juan de Sahagún y Santo Tomás de Villanueva. Estos relieves, atribuidos por Urrea al propio Espinabete, fueron adquiridos en 1817 al Convento de Agustinos Filipinos de Valladolid ${ }^{558}$.

\footnotetext{
$556 \quad$ Ídem, p. 93.

$557 \quad$ Ibídem.

558 URREA FERNÁNDEZ, Jesús: “Noticia Histórica Artística...”, op. cit., p. 104.
} 


\section{WAMBA. IGLESIA PARROQUIAL DE SANTA MARÍA}

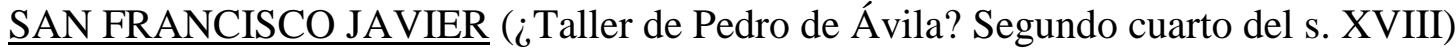

También podemos relacionar con Pedro de Ávila, nunca atribuirle directamente, un San Francisco Javier (Fig. 136) ubicado en el interior del último arcosolio gótico del lado de la Epístola de la iglesia parroquial de Santa María de Wamba. La escultura no aparece citada en el Catálogo Monumental de Valladolid, sin embargo en el Inventario Artístico de Valladolid figura en la sacristía junto a una Dolorosa de vestir ${ }^{559}$.

La escultura viene a ser una repetición algo más tardía de la que vimos en Simancas y por lo tanto del modelo fernandesco. Poseen el mismo tamaño, sin embargo esta nueva posee una anatomía algo más corpulenta y el canon es menos esbelto que aquélla. Su cronología más avanzada la comprobamos en la presencia del paño a cuchillo, aunque tampoco muy destacado. Las mayores diferencias las encontramos en el rostro, puesto que la boca no está entreabierta, sino que tiene los labios apretados, y la nariz no es tan ancha sino que se va ensanchando desde arriba hasta abajo; por lo demás las similitudes están claras. A pesar de la aceptable calidad de la talla, lo más prudente por el momento es situarla entre las obras relacionadas.

\section{GUMIEL DE IZÁN. IGLESIA PARROQUIAL DE LA ASUNCIÓN}

INMACULADA CONCEPCIÓN (¿Antonio de Gautúa? h. 1726-1736)

En el interior del arcosolio del sepulcro de los Gamarra, situado en la nave de la epístola de la iglesia parroquial de la villa de Gumiel de Izán (Burgos), se conserva una Inmaculada Concepción (Fig. 137) que copia fielmente el modelo creado y difundido por Pedro de Ávila. Según los datos que conservamos la imagen procede de la ermita de San Roque, lugar al que fue a parar desde el monasterio de San Pedro de Gumiel ${ }^{560}$.

Como hemos dicho la escultura resulta ser un calco de las de Ávila, tanto en las posiciones de los diferentes miembros del cuerpo como de las vestimentas. La única diferencia reseñable desde el punto de vista iconográfico es la supresión del trono con tres cabezas de angelitos por un globo terráqueo surcado por una serpiente. Este último motivo es completamente ajeno a todas las Inmaculadas documentadas y atribuidas a Ávila, y tampoco es muy frecuente dentro de la escultura vallisoletana y castellana. Las grandes divergencias de la escultura respecto a su modelo vienen dadas en lo referente al estilo, mucho más modesto a grandes rasgos. La cabeza y el cuello no poseen la misma elegancia, y las finas madejas de cabello no se encuentran individualizadas como en Ávila, aquí son algo más gruesas y pegadas a la cabeza. Por su parte, la cabeza no tiende al rectángulo sino a lo que podríamos llamar forma de "escudo español", que

\footnotetext{
559 MARTÍN GONZÁLEZ, Juan José (dir.): Inventario artístico de Valladolid..., op. cit., p. 360.

560 ONTORIA OQUILLAS, Pedro: "La iglesia de Santa María de Gumiel de Izán”, Boletín de la Institución Fernán González, no 205, 1985, p. 75.
} 
viene a ser un rectángulo con la parte inferior abombada hacia abajo. Finalmente, la ampulosidad, finura de los pliegues pictóricos que parecen cortar el aire debido a su afilado filo, vienen a simplificarse tremendamente en esta Inmaculada de Gumiel de Izán; motivo que hemos de buscar en la menor entidad del escultor con respecto a Ávila. No sabemos si es que no sabe o no se atreve a copiar los ángulos rectos que forman los paños a cuchillo en el lado derecho del manto, que verdaderamente parecen ondear de una manera muy violenta; en esta Inmaculada el manto se dobla, pero son pliegues más redondeados.

Si tenemos en cuenta la fidelidad respecto al modelo, lo que viene a significar que el escultor se hallaba dentro del círculo inmediato a Ávila, y que los rasgos faciales, que son similares a los de nuestro escultor pero para nada suyos, ya los hemos observado en piezas de un determinado artífice, la conclusión es clara: su autor es Antonio de Gautúa. Nuevamente volvemos a ver a Gautúa, supuesto discípulo de Juan de Ávila y compañero de taller de Pedro de Ávila en los años de aprendizaje de ambos, copiar un modelo creado por su amigo. Si tuviéramos dudas en cuanto a su atribución no tendríamos más que volver nuestros pasos sobre el rostro y el cuello de una escultura que hemos citado en varias ocasiones para a través de ella atribuirle otras imágenes: la Santa Bárbara conservada en la iglesia vallisoletana de San Martín.

También podríamos añadir razones de otra índole, como por ejemplo el hecho de que le tengamos documentado por la zona en, al menos, dos ocasiones: en 1726 realiza una Asunción para Mambrilla de Castrejón ${ }^{561}$, y diez años después la escultura pétrea de la Trinidad para la portada de la ermita de la Santísima Trinidad de la localidad burgalesa de Fuentespina ${ }^{562}$. La crecida cantidad que percibió por la Asunción, 2.000 reales, nos indica a las buenas el gran prestigio del que gozaba por aquellas tierras, lo que derivaría en otros encargos que hoy no tenemos documentados; siendo, quizás, esta Inmaculada conservada en Gumiel de Izán buen ejemplo de ello.

\section{VILLAVIUDAS. IGLESIA DE NTRA. SEÑORA DE LA ASUNCIÓN}

INMACULADA CONCEPCIÓN (Anónimo. Primer tercio del siglo XVIII)

En la hornacina central del retablo mayor de la iglesia, construido en 1704 por el ensamblador Lucas Ortiz de Boar, se conserva una imagen de la Inmaculada Concepción que fue tildada como "del estilo de Pedro de Ávila" por los autores del Inventario artístico de Palencia ${ }^{563}$. A sus lados figuran las esculturas de San Pedro y San Pablo; en el banco dos relieves de las Adoraciones de los Reyes y de los Magos, mientras que en el ático presenta un relieve de la Coronación de la Virgen.

\footnotetext{
561 PAYO HERNANZ, René Jesús: “De los esplendores barrocos...”, op. cit., p. 312.

562 ZAPARAÍN YÁÑEZ, María José: Fuentespina: la villa y su arte, siglos XVII y XVIII, San Sebastián, 1995, p. 116.

563 URREA FERNÁNDEZ, Jesús y MARTÍN GONZÁLEZ, Juan José: Inventario artístico de Palencia y su provincia I..., op. cit., p. 310
} 
El retablo fue contratado en 1702 por el ensamblador trasmerano Lucas Ortiz de Boar $^{564}$, el cual parece ser que lo acabó al año siguiente ${ }^{565}$. Por su trabajo percibió 9.000 reales. Del pedestal de piedra sobre el que asienta el retablo se ocupó Joseph de Larena ${ }^{566}$. En este miso momento se realizó un transparente en la hornacina central, tras la Inmaculada, lo que nos puede indicar que ya entonces estuviera tallada. De él se ocuparon Manuel Mathé, la parte arquitectónica, y Roque de la Ciudad, de la vidriera y de la red de transparente ${ }^{567}$. Ya en 1704 se dio por finalizado el retablo y se procedió a colocar al Santísimo ${ }^{568}$.

El retablo no fue dorado hasta el año 1733, tarea que acometió el maestro Fernando Guerra, vecino de Hornillos del Camino (Burgos). Los pagos por su trabajo se fueron retrasando, quizás debida a la mala situación de las arcas de la iglesia. En 1733 se le pagaron 3.302 reales y un cuartillo ${ }^{569}$; posteriormente, hubo que esperar hasta los años 1738 y 1739 para que le abonaran otros 1.198 reales $^{570}$, para un total de 5.000 reales.

En esta ocasión no puedo opinar sobre la obra puesto que no he logrado verla ni en directo ni por fotografías, debido a lo cual tendremos que fiarnos de la juiciosa valoración de dos personas tan acreditadas como Martín González y Urrea.

$564 \quad$ Escritura para hacer el retablo. "Más ocho reales y medio que pagó de la mitad de la escritura que se hizo para hacer el retablo". A.D.P., Villaviudas, Iglesia de Nuestra Señora de la Asunción, Libro de Fábrica 1695-1721, Cuentas de 1702, f. 55.

565 Retablo. "Más se le toma en data de nueve mil reales que es la cantidad que costó hacer el retablo como consta de licencia de su Ilustrísima para hacerle como consta de la escritura y carta de pago haber pagado a Lucas Ortiz de Boar que hizo dicho retablo valen". A.D.P., Villaviudas, Iglesia de Nuestra Señora de la Asunción, Libro de Fábrica 1695-1721, Cuentas de 1703, f. 61.

$566 \quad$ Pedestal. "Más cuatrocientos reales que costó de carta de pago haber pagado a Joseph de Larena por el pedestal de piedra que hizo para dicho retablo valen". A.D.P., Villaviudas, Iglesia de Nuestra Señora de la Asunción, Libro de Fábrica 1695-1721, Cuentas de 1703, f. 61.

$567 \quad$ Transparente. "Más ciento y diez y siete reales que constó de carta de pago haber pagado a Manuel Mathé vecino de la villa de Baltanás por abrir el transparente en el retablo que corresponde a Nuestra Señora".

Vidriera. "Más ciento y ochenta reales que constó de carta de pago haber pagado a Roque de Santa Clara vecino de la ciudad de Palencia latonero por la vidriera y red del transparente y paño para él y reja". A.D.P., Villaviudas, Iglesia de Nuestra Señora de la Asunción, Libro de Fábrica 1695-1721, Cuentas de 1703, f. 61.

568 Colocación del Santísimo. "Más seis reales que gastó cuando se colocó el Santísimo". A.D.P., Villaviudas, Iglesia de Nuestra Señora de la Asunción, Libro de Fábrica 1695-1721, Cuentas de 1704, f. 68 .

569 Retablo. "Ítem se le toma en data tres mil trescientos y dos reales y un cuartillo los mismos que constó de haber pagado a Fernando Gera maestro del doro del retablo que se ha dorado en virtud de licencia de los señores provisores valen”. A.D.P., Villaviudas, Iglesia de Nuestra Señora de la Asunción, Libro de Fábrica 1721-1740, Cuentas de 1738, f. 306.

570 Dorador. "Más se le abonan ochocientos y cincuenta reales vellón pagados a Fernando Guerra vecino de Hornillos del Camino en cuenta de mayor cantidad que dicha iglesia le debía de haber dorado el retablo de la capilla mayor consta de dos recibos el uno del susodicho de seiscientos y cincuenta reales su fecha en dicha villa en 13 de mayo de 1737, y el otro de Francisco Cenera su apoderado de doscientos reales su fecha en Palencia a 20 de octubre del año 1738”. A.D.P., Villaviudas, Iglesia de Nuestra Señora de la Asunción, Libro de Fábrica 1721-1740, Cuentas de 1738, f. 348.

Dorador. "Más trescientos cuarenta y ocho reales vellón que pagó a Fernando Guerra y en su nombre a don Francisco Cenera su apoderado la misma cantidad se le debía resto de mayor cantidad de dorar el retablo de dicha iglesia por cuya cantidad la ejecutó por el tribunal eclesiástico a donde declara el mayordomo esta presentada su carta de pago". A.D.P., Villaviudas, Iglesia de Nuestra Señora de la Asunción, Libro de Fábrica 1721-1740, Cuentas de 1739, f. 353. 


\section{9-4 OBRAS \\ DESCATALOGADAS}




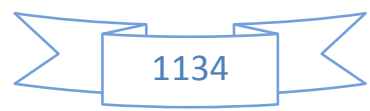




\section{VALLADOLID. CENTRO DIOCESANO DE ESPIRITUALIDAD}

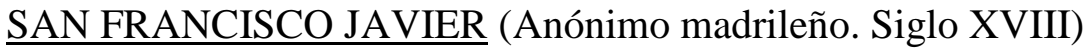

Esta escultura, de procedencia madrileña, ha sido atribuida indistintamente tanto a Juan como a Pedro de Ávila, hipótesis que como ya dijimos al hablar sobre las obras desclasificadas de Juan de Ávila son del todo incorrectas. Por no volver a hablar sobre temas ya tratados, tan solo citaremos que los únicos que han relacionado esta obra con "estilo de Pedro de Ávila" han sido Martín González y Plaza Santiago en el respectivo tomo del Catálogo Monumental de Valladolid ${ }^{571}$.

\section{VALLADOLID. IGLESIA DE SAN MIGUEL}

SANTA MARÍA MAGDALENA (Anónimo. h. 1666-1702)

La presente escultura de Santa María Magdalena (170 cms.) (Fig. 138), que sigue el modelo difundido por Pedro de Mena, pero cuyos orígenes parecen estar en la imagen que de Gregorio Fernández se conserva en el madrileño Monasterio de las Descalzas Reales, ha sido atribuida a diferentes escultores a lo largo del tiempo; sin embargo, aún en el día de hoy, no se ha llegado a una atribución certera y consensuada.

Para nada debe extrañarnos la presencia de la Magdalena en la iglesia de San Miguel si nos retrotraernos al momento en que fue ejecutada, justo cuando era un colegio jesuita. Como ya hemos hablado en diversas ocasiones, los colegios jesuitas del resto de España solían estar muy vigilantes sobre las "novedades" artísticas que se producían en los centros madrileños de esta orden. Efectivamente, la presente Magdalena no es más que una repercusión de la que Mena talló en 1664 para la Casa Profesa.

Entre las diferentes atribuciones realizadas, llegando incluso a creerse del propio Fernández (extremo del todo imposible con tan solo analizarla someramente) se encuentra la realizada a favor de Pedro de Ávila por Federico Wattenberg en su voluminoso libro sobre el Museo Nacional de Escultura editado en 1972 ${ }^{572}$ : "El tipo pudiera haberse inspirado en las creaciones ascéticas de Fernández o de su coetáneo Pereira, teniendo una gran difusión a lo largo del barroco, especialmente en la escuela castellana, en la que posiblemente Pedro de Ávila ejecutó una semejante para la iglesia de San Miguel, de Valladolid, que fue considerada de Fernández hasta que Martín descartó su atribución, siendo, a nuestro parecer, obra probable del citado Pedro en los comienzos del siglo XVIII, y recordando igualmente la ya mencionada de Juan Pascual de Mena, de mediados de siglo". En ningún caso podemos sostener aquella atribución a Pedro de Ávila puesto que en la santa no se encuentra ninguna de las características o estilemas propios de nuestro escultor.

571 MARTÍN GONZÁLEZ, Juan José y DE LA PLAZA SANTIAGO, Francisco Javier: Catálogo Monumental de la provincia de Valladolid. Tomo XV..., op. cit., p. 310.

572 WATTENBERG, Federico: Museo Nacional de Escultura, Aguilar S.A. Ediciones, Madrid, 1972, p. 325. 
Pienso que la atribución más lógica y comprensible fue la realizada por Martín González en favor del escultor berciano-riosecano Tomás de Sierra, iniciador de una extensa saga de escultores que ocupó casi todo el siglo XVIII ${ }^{573}$. El único dato que tenemos para poder delimitarla cronológicamente es la Memoria de los bienes que dejó al fallecer doña María Magdalena Pimentel, Marquesa de Viana. Gracias a ella, fechada el 8 de noviembre de 1702, sabemos que por entonces la escultura ya se hallaba en su retablo: "Lo segundo a que perpetuamente día y noche arda una lámpara que está delante del altar de Nuestra Señora de Loreto, mi madre y señora, en el que está también Santa María Magdalena, mi patrona"574.

\section{VALLADOLID. IGLESIA DE SAN PEDRO APÓSTOL}

QUINTA ANGUSTIA (José Fernández. 1749)

Gratiniano Nieto atribuyó al taller de Pedro de Ávila la imagen de la Quinta Angustia (Fig. 139) que preside el retablo de la Virgen de los Dolores ${ }^{575}$. "En el altar de la Virgen de los Dolores hay una buena talla de la Quinta Angustia de finales del XVII cuyo autor hay que buscarle en torno al taller de Pedro de Ávila, y otras de Jesús atado a la columna y de Jesús con la Cruz a cuestas, de la misma época".

El grupo escultórico, que no posee estilemas cercanos a Pedro de Ávila (más allá de la presencia del pliegue a cuchillo), fue documentado por Martín González y Urrea Fernández en el respectico tomo del Catálogo Monumental de Valladolid como obra del semidesconocido escultor vallisoletano José Fernández ${ }^{576}$.

\section{VALLADOLID. IGLESIA DEL SALVADOR}

SANTA ANA Y SANTA APOLONIA (¿Círculo de Pedro de Sierra? Hacia 1750)

Gratiniano Nieto al realizar su Guía artística de Valladolid relaciona dos esculturas de la iglesia del Salvador con los quehaceres de Pedro de Ávila. Se trata de la Santa Ana (115 cms.) (Fig. 140), en que observa "recuerdos de Pedro de Ávila", conservada en la capilla Sacramental, sita a los pies de lado del Evangelio; y una Santa Apolonia (102 cms.) (Fig. 141) "que hay en la capilla de enfrente"

\footnotetext{
573 ÁlVAREZ VICENTE, Andrés: “Magdalena penitente”. En ÁlVAREZ VICENTE, Andrés y GARCÍA RODRÍGUEZ, Julio César: Dolor y Gloria ..., op. cit., p. 112.

574 MARTÍN GONZÁLEZ, Juan José y URREA FERNÁNDEZ, Jesús: Catálogo Monumental de la provincia de Valladolid. Tomo XIV..., op. cit., pp. 133-134.

$575 \quad$ NIETO GALLO, Gratiniano: op. cit., p. 115.

576 1749.- "509 reales a Joseph Fernández y Manuel de Urosa maestros de escultoria y pintor por la imagen de Nuestra Señora de los Dolores, con sus andas y tornillos”. MARTÍN GONZÁLEZ, Juan José y URREA, Jesús: Catálogo Monumental de la provincia de Valladolid. Tomo XIV ..., op. cit., p. 169.

$577 \quad$ NIETO GALLO, Gratiniano: op. cit., p. 58.
} 
Según una relación fechada en 1792, estas dos esculturas y otra de Santa Lucía (102 cms.) presidían el retablo de la capilla Sacramental ${ }^{578}$. En él, la hornacina principal la ocupaba Santa Ana y las otras dos las laterales. Tras los numerosos cambios de localización sufridos por numerosas obras de arte de esta iglesia, llevados a cabo hasta fechas muy recientes, en la actualidad el retablo está presidido por una Virgen de la Soledad, y flanqueada por las de Santa Lucía y Santa Apolonia. Por su parte, la de Santa Ana se encuentra situada en la capilla del Buen Suceso. Siempre es deseable que las esculturas y pinturas se conserven en la capilla o retablo para el que fueron hechas, pero más todavía en esta iglesia que ha sufrido unas modificaciones tan continuadas a la par que arbitrarias.

Ninguna de las dos esculturas referidas puede atribuirse ni relacionarse con los quehaceres de Pedro de Ávila. Cabe señalar, además, que la Santa Ana es de una mano totalmente diferente a la que hizo la Santa Apolonia; que, a su vez, será del mismo artista que talló la Santa Lucía; puesto que son hermanas en cuanto a estilo, composición, indumentaria e, incluso, policromía. Lo único que poseen estas tallas relacionable con Ávila es la utilización del pliegue a cuchillo. Es probable que el autor de la Santa Ana se encuentra en el círculo de Pedro de Sierra, tal y como lo cree Martín González; el cual, asimismo, piensa que también la escultura de Santa Apolonia, y por lo tanto de la Santa Lucía, pertenece al círculo del artista riosecano ${ }^{579}$. Aunque ambos grupos de esculturas pertenezcan al círculo de Pedro de Sierra, la Santa Ana sería de un escultor y las otras dos de otro.

\section{VALLADOLID. MONASTERIO DE SAN BENITO EL REAL}

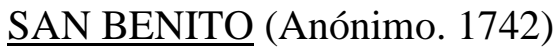

Martín González y Plaza Santiago en el respectivo tomo del Catálogo Monumental de Valladolid al hablar sobre la estatua de San Benito (Fig. 142) que existe en la hornacina ubicada sobre la portada principal del claustro procesional: "San Benito, que parece obra de Pedro de Ávila, del primer cuarto del siglo XVIII"580.

Bien es cierto que, a pesar de los desperfectos que exhibe su rostro, la escultura posee unas características que hacían factible su atribución a nuestro escultor. Sin embargo, Ventura Pérez nos da la noticia de que la el 6 de agosto de 1742 "se puso la estatua de San Benito de piedra, que está sobre la puerta de la portería seglar de dicho convento" ${ }^{581}$; lo cual, unido a que sabemos que el 11 de enero de ese mismo año Ávila se encontraba "privado de vista" (DOCUMENTO 79), nos da como resultado la descatalogación de esta pieza de la lista de obras relacionadas con nuestro escultor.

\footnotetext{
578 MARTÍN GONZÁLEZ, Juan José y URREA FERNÁNDEZ, Jesús: Catálogo Monumental de la provincia de Valladolid. Tomo XIV..., op. cit., p. 32.

$579 \quad$ Ibídem, p. 32.

580 MARTÍN GONZÁLEZ, Juan José y DE LA PLAZA SANTIAGO, Francisco Javier: Catálogo Monumental de la provincia de Valladolid. Tomo XV..., op. cit., p. 245.

581 PÉREZ, Ventura: op. cit., p. 199.
} 
No podemos aportar un nombre concreto como autor de esta pieza, si bien por aquellos años había en la ciudad diversos escultores que practicaron la talla de la piedra, como eran Antonio de Gautúa, Pedro Bahamonde, Pedro de Sierra; e, incluso, tampoco podemos perder de vista el de Felipe Espinabete, que por entonces debió de comenzar su carrera en solitario. Dicho todo esto, lo más probable es que la autoría de esta imagen se encuentre entre Bahamonde y Gautúa.

\section{VALLADOLID. ORATORIO DE SAN FELIPE NERI}

\section{SAN ANTONIO DE PADUA (¿Antonio de Gautúa? h.1718-1719)}

En el tomo XIV del Catálogo Monumental de Valladolid, Martín González y Urrea exponen que esta excelente talla de San Antonio de Padua (Fig. 143) pudo haberla "hecho también Pedro de Ávila"582. La escultura del santo portugués fue donada a la Congregación de San Felipe Neri el 7 de julio de 1719 por don Antonio Arenas, antiguo ministro que fue de ella ${ }^{583}$. La imagen fue bendecida junto con la de Santa María Magdalena el 18 de mayo de 1720 por el canónigo de la Catedral don Tomás López de Castro $^{584}$. En un principio ambas esculturas se localizaban en las capillas más inmediatas al crucero; sin embargo, tras el desmantelamiento sufrido en los altares de la iglesia en la década de 1960, San Antonio fue arrinconado en una estancia del oratorio junto con la Magdalena ${ }^{585}$. Sin embargo, parece que su retiro debió de producirse antes puesto que en una fotografía de Antonio Passaporte realizada entre 1927-1936 podemos ver la escultura en la parte superior de un retablo neoclásico situado en el lado del Evangelio de la iglesia del Rosarillo. En la actualidad, de vuelta en el oratorio, preside el retablo de la capilla de los pies del evangelio, el cual en un principio alojó el grupo de San Joaquín con la Virgen niña.

La excelente calidad de la imagen, unido a la similitud de rasgos con otras obras de Ávila de estos años, me han llevado en muchas ocasiones a dudar de si también atribuírsela o bien desecharla. Me he decidido por la segunda opción a la vista de un análisis minucioso de su rostro, así como del Niño Jesús, de los pliegues de la túnica y de la forma de componer las manos. Todo ello me ha llevado a descartar por completo su atribución. En cambio, creo que esta escultura debe atribuirse con bastante seguridad a Antonio de Gautúa, puesto que la gordura de los dedos y sobre todo la forma de componer el rostro emparenta de cerca con algunas esculturas documentadas de este

582 MARTÍN GONZÁLEZ, Juan José y URREA, Jesús: Catálogo Monumental de la provincia de Valladolid. Tomo XIV ..., op. cit., p. 294.

583 “Ofreció el señor Arenas un San Antonio de escultura. “(...) y en dicha Congregación el señor don Antonio de Arenas Ministro que había sido ofreció para uno de los dos primeros retablos un San Antonio de escultura y aceptada dicha oferta por dicha Venerable Congregación se le dio repetidas gracias". A.S.F.N., Caja 13, $2^{\circ}$ Libro de Acuerdos (1690-1740), ff. 145-146.

$584 \quad$ A.S.F.N., Caja 13, $2^{\circ}$ Libro de Acuerdos (1690-1740), f. 154; MARTÍN GONZÁLEZ, Juan José y URREA FERNÁNDEZ, Jesús: Catálogo Monumental de la provincia de Valladolid. Tomo XIV..., op. cit., p. 302.

585 URREA FERNÁNDEZ, Jesús: “El oratorio...”, op. cit., p. 10. 
escultor; como por ejemplo la Santa Bárbara que se conserva actualmente en la iglesia de San Martín de Valladolid. Hemos de recordar que años después, el propio Gautúa trabajó para la Congregación de San Felipe Neri, concretamente se ocupó de tallar las cuatro esculturas y dos relieves que coronan los retablos de las capillas de los cuerpos del oratorio.

\section{CRISTO YACENTE (¿José de Rozas? Hacia 1720)}

La pequeña escultura de Cristo Yacente (108 x 22 cms.) (Fig. 144), conservado en la parte baja del retablo dedicado al Cristo Crucificado, también fue una donación. El benefactor no se conformó con entregar esta delicada pieza, sino que lo hizo de manera conjunta con el Niño Jesús situado en idéntica posición que el Yacente, pero en el retablo frontero, el dedicado a la Inmaculada Concepción. El bienhechor no fue otro que Santiago Manzano, miembro de la Congregación y que, como ya vimos al hablar de Juan de Ávila, también había donado algunas esculturas y pinturas a la iglesia de Santiago, amén de otros conventos de la ciudad e incluso a la Colegiata de Toro. Manzano hizo entrega de ambas piezas en la junta celebrada por la Congregación el 14 de diciembre de 1720: "Otrosí en dicho día, mes y año se hizo saber a dicha Venerable Congregación como el señor don Santiago Manzano congregante de ella tenía ofrecido dar dos hechuras de bulto, la una de Cristo en el sepulcro y la otra de un Niño Jesús reclinado para que las pusiesen en los altares de las capillas de dicha Venerable Congregación donde se considerase pudiesen estar con lucimiento sin que se echasen a perder, y que los retablos quedasen con la arquitectura perfecta y que también ofrecía las urnas de dichas dos hechuras a dicha Venerable Congregación" ${ }^{586 .}$

La autoría de este precioso Yacente ha estado siempre muy discutida. El primero en hablar sobre él fue Martín González en su Escultura barroca castellana. En ella incluía entre las "copias de Fernández" tres pequeños Yacentes fechables en el primer tercio del siglo XVIII: el de la iglesia penitencial de N. P. Jesús Nazareno (obra atribuida con gran certeza a Pedro de Ávila), el situado en el retablo de Nuestra Señora de los Dolores de la Catedral (obra documentada de José Pascual), y éste que ahora nos ocupa. Sobre este último comenta "que si no fuera por la técnica del paño habría que creerle original" 587. Sin embargo, tras analizar las quebraduras del paño, en todo similares a las de Fernández, aunque con cierta incidencia del "pliegue a cuchillo", decide optar por "considerar autor de esta copia a Pedro de Ávila"588. Finaliza comentando que "el rostro se aproxima al de la Luz [Cristo de la Luz] y es detalle delator de copia la postura recogida de las manos, que Fernández acostumbra a extender. También el pecho está hinchado y levantado (como en el referido de San Miguel) y hundido en los

\footnotetext{
586 A.S.F.N., Caja 13, $2^{\circ}$ Libro de Acuerdos (1690-1740), f. 163. MARTÍN GONZÁLEZ, Juan José y URREA FERNÁNDEZ, Jesús: Catálogo Monumental de la provincia de Valladolid. Tomo XIV..., op. cit., p. 302.

587 MARTÍN GONZÁLEZ, Juan José: Escultura barroca castellana ..., op. cit., p. 238.

588 Ídem, p. 239.
} 
de Fernández" $" 589$. Con posterioridad la atribución a Pedro de Ávila ha recibido nuevos avales: así, Martín González y Urrea en el correspondiente tomo del Catálogo Monumental lo definen como "tardía copia de un modelo de Gregorio Fernández (...) está en relación con el estilo de Pedro de Ávila". También recogen esta atribución Luna Moreno en el catálogo de la exposición "Pequeñas imágenes de la Pasión en Valladolid"590, y García Martín en el de la de la muestra titulada "Cristos yacentes de Valladolid" $" 591$.

Nuevamente tenemos que rechazar frontalmente esta atribución puesto que ni la forma de tallar los ojos, la nariz ni la barba, entre otras cosas, es la que hace gala nuestro escultor. Por si fuera poco, no tenemos más que comparar este Yacente con otro similar conservado en la penitencial de Jesús Nazareno, el cual sí que se atribuye a Pedro de Ávila con total seguridad. Si comparamos ambas obras vemos que nada tienen que ver. Por no entrar en los estilemas, podemos observar que la serenidad de que hace gala el rostro de este último, se convierte en angustia y dolor en el de San Felipe Neri. No veo clara su atribución a un escultor concreto de la escuela vallisoletana, donde sin lugar a dudas fue realizado. Sin embargo, parece emparentar lejanamente con el Yacente que José de Rozas talló para el paso del Santo Sepulcro de la Cofradía de las Angustias, a pesar de la abismal diferencia de calidad existente entre ambas obras; sin lugar a dudas debido a que mientras que la de la cofradía apenas se observaría dada su altura y ostracismo dentro de la urna, todo lo contrario ocurriría con la de Santiago Manzano, cuya exquisita técnica y detallismo se deberán a la cercana contemplación a la que sería sometido.

NIÑO JESÚS (¿Anónimo vallisoletano o madrileño? Hacia 1720)

Como acabamos de comentar, el dulzón Niño Jesús (Fig. 145) conservado en el retablo de la Inmaculada Concepción fue donado, junto con el Yacente, por don Santiago Manzano el 14 de diciembre de $1720^{592}$. Santiago Manzano debió de ser un personaje bastante acaudalado, generoso, culto e interesado por el mundo del arte, en especial por el escultórico. Su profesión fue la de clérigo presbítero, capellán y músico de la catedral vallisoletana. Realizó donaciones a multitud de instituciones religiosas, en especial a la propia Congregación de San Felipe Neri, de la cual fue miembro. También recibieron generosas donaciones tanto la iglesia de Santiago Apóstol de Valladolid como la Colegiata de Toro.

\footnotetext{
$589 \quad$ Ibídem.

590 LUNA MORENO, Luis: "No 42. Cristo Yacente". En VV.AA.: Pequeñas imágenes de la Pasión en Valladolid..., op. cit., p. 66.

591 GARCÍA MARTÍN, Enrique.: Cristos yacentes de Valladolid, Ayuntamiento de Valladolid, Valladolid, 2000, p.12

592 A.S.F.N., Caja 13, $2^{\circ}$ Libro de Acuerdos (1690-1740), f. 163. MARTÍN GONZÁLEZ, Juan José y URREA FERNÁNDEZ, Jesús: Catálogo Monumental de la provincia de Valladolid. Tomo XIV..., op. cit., p. 302.
} 
Su testamento del día 11 de enero de 1723 nos proporciona alguna noticia más sobre su vida: Santiago Manzano era hijo legítimo de Santiago Manzano e Isabel Guerrero, vecinos de Toro; de ahí la vinculación que tenía con la Colegiata de dicha localidad, a la cual donó diversas obras. Asimismo, nos indica que tenía un sobrino, fray Santiago Maniela "religioso profeso del Convento de Nuestra Señora de la Merced Calzada de esta ciudad", del cual deseaba que se graduase "de licenciado en esta Real Universidad cuyo coste he de suplir yo llegando este caso". En este mismo testamento mandaba a "dicho Convento de la Merced Calzada una pintura en piedra de Santa Cecilia, y dos escaparates uno de San Juan y otro de la Magdalena de cera para la capilla de Nuestra Señora de la Cerca sita en él. Y a la fábrica de la iglesia parroquial de Santiago de esta ciudad una pintura del Descendimiento con marco dorado que es la única que al presente tengo; y un escaparate y dentro el Santo en su caballo de escultura. Asimismo mando un cuadro de Santa Cecilia de casi tres varas de alto con su marco negro para que se coloque en la capilla de Santa María Magdalena sita en dicha santa iglesia catedral donde como está dicho soy tal capellán" $" 593$.

Aunque tenemos constancia de otros testamentos y codicilos, lo que nos demuestra su preocupación por tener todos los intereses terrenales bien resueltos, nos interesa especialmente el dictado el 11 de octubre de 1731 por cuanto es el último que realiza, tal y como lo señala su partida de defunción en la santa iglesia catedral ${ }^{594}$. Gracias a estas últimas voluntades sabemos que su especialidad como músico era la de arpista, y que por entonces era "individuo del cabildo menor de la de Toro". En ellas nuevamente ordenaba que una vez que falleciese se entregara "al Convento de la Merced Calzada de esta ciudad una pintura de Santa Cecilia que tengo pintada en pórfido con marco de palosanto". Santiago Manzano murió en Valladolid el día 11 de enero de 1736, siendo enterrado en la catedral, " a la puerta de Nuestra Señora de los Dolores en sepultura de fábrica" ${ }^{, 595}$.

Esta deliciosa imagen fue atribuida sin ningún fundamento documental o estilístico por Alejandro Rebollo a nuestro escultor: "es atribuible al escultor Pedro de Ávila o a Manuel de Ávila, su hermano, que por entonces colabora con la Congregación realizando dos Niños" ${ }^{\$ 96}$. Seguramente el citado investigador no llegó a consultar la partida publicada hace décadas por García Chico en su fundamental obra Documentos para el estudio del arte en Castilla. 2, Escultores. Leyendo dicho resguardo de pago

\footnotetext{
$593 \quad$ A.H.P.V., Leg. 3.130, ff. 611-612.

594 A.H.P.V., Leg. 3.277/1, ff. 145-146.

595 "En once días del mes de enero de mil setecientos y treinta y seis años, habiendo recibido los santos sacramentos con el de la extremaunción murió (...) del colegio músico don Santiago Manzano capellán y músico de ésta santa iglesia y se enterró en ella a la puerta de Nuestra Señora de los Dolores en sepultura de la fábrica, hizo su testamento debajo del cual falleció que pasó por testimonio de Joseph Sanz del Río escribano de la Real Universidad de ésta ciudad de Valladolid, su fecha once de octubre del año de mil setecientos y treinta y uno, por lo que manda se digan por su alma doscientas misas dejó por sus testamentarios al padre fray Santiago Barruelo doctor de la Real Universidad y su catedrático y lector de teología de su Convento de la Merced Calzada a don Juan Toro y a don Miguel Márquez prebendados de ésta santa iglesia y a estos dos por herederos (...) y lo firmé como cura que soy de ésta santa iglesia hecho ut supra". A.G.D.V., Catedral, 1684D, f. 251.
}

596 REBOLLO MATÍAS, Alejandro: La Iglesia-Oratorio ..., op. cit. 
observamos que los citados "Niños" no eran ni Niños Jesús ni esculturas exentas, sino que se trataba de ángeles para dos retablos (los de la Magdalena y San Antonio de Padua): "Sírvase $V$ md señor Don Manuel de Oldi como depositario de nuestra Venerable Congregación de San Felipe de Neri manda entregar al señor Manuel de Ávila cien reales de vellón en cuenta de lo que ha de haber por las hechuras de los niños de los dos retablos que está ejecutado para dicha Congregación"597.

Por otra parte, desde el punto de vista estilístico, no hay ningún detalle o elemento en él que nos ayude a relacionarlo con ninguno de los dos hermanos. En caso de duda, no tendríamos más que comparar este Niño Jesús con los que conservan algunas de sus esculturas de San José. Bien es cierto que esta posee mayor calidad que aquéllas, pero, como dijimos con el Yacente, la contemplación cercana lo obligaba así. Por el momento no parece que esta pieza no encaja con el estilo de ningún escultor vallisoletano de la época, por lo que, de confirmarse su procedencia vallisoletana, estaríamos sin lugar a dudas ante unas de las más brillantes representaciones infantiles de la escultura pucelana del siglo XVIII. Tampoco habría que su posible importación, quizás desde tallares madrileños.

\section{SAN CEBRIÁN DE MAZOTE. IGLESIA PARROQUIAL DE SAN CIPRIANO}

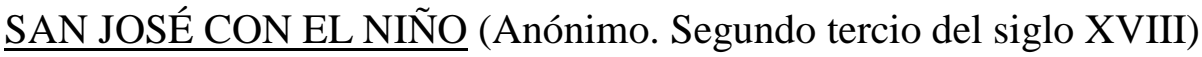

En la iglesia parroquial de San Cipriano de la localidad vallisoletana de San Cebrián de Mazote se encuentra una escultura de San José con el Niño (este último ha desaparecido) (Fig. 146) que fue incluida por Parrado del Olmo "dentro del círculo de Pedro de Ávila"598. Anteriormente, en el Inventario artístico de Valladolid, Martín González tan solo se había referido a ella como "escultura de San José con el Niño siglo XVIII ${ }^{, 599}$.

Para nada puede ser relacionada con nuestro escultor puesto que ni el rostro ni las vestimentas se asemejan a las exhibidas por Ávila en sus esculturas. Es más, ni siquiera se asemeja en cuanto a la disposición que adoptan todas sus esculturas de San José, prototipo que, como ya hemos visto, tuvo tanto éxito que fue tomado por otros artífices para tallar sus propias imágenes de San José, como son los casos de las piezas conservadas en las iglesias de Villanueva de Duero, Curiel de Duero o Aldeamayor de San Martín.

Desconocemos si la escultura perteneció siempre a la iglesia, antiguamente monasterio mozárabe, o bien procede del cercano Monasterio de la Santa Espina. Sea como fuere,

\footnotetext{
597 GARCÍA CHICO, Esteban: Documentos para el estudio del arte en Castilla. 2 ..., op. cit., p. 375.

598 PARRADO DEL OLMO, Jesús María: Catálogo Monumental de la provincia de Valladolid. Tomo IX..., op. cit., p. 158.

599 MARTÍN GONZÁLEZ, Juan José (dir.): Inventario artístico de Valladolid..., op. cit., p. 260.
} 
dentro de la propia iglesia ha tenido muchos cambios de posición dentro de la misma; puesto que tenemos noticia de que, además del sitio que ocupa en la actualidad (capilla del lado de la epístola en la cabecera), también estuvo en la sacristía y, por fotos antiguas, sabemos que estuvo expuesto en un sencillo altar colocado en la nave del evangelio.

\section{CARRIÓN DE LOS CONDES. ERMITA DE LA SANTA VERA CRUZ}

JESÚS NAZARENO (Anónimo. h. 1730)

En la ermita de la Santa Vera Cruz se conserva una escultura de Jesús Nazareno (Fig. 147) de hacia el año 1730 que ha sido relacionada con el "círculo de Pedro de Ávila" por Enrique Gómez y Rafael Martínez en un libro sobre la Semana Santa en la provincia de Palencia ${ }^{600}$; si bien posteriormente comentan que "el Nazareno carrionés se puede relacionar con la obra de Juan de Ávila, si tenemos en cuenta la práctica habitual de los encargos de las diferentes cofradías, que pedían copias de modelos famosos ya existentes, algo que aún hoy en algunos lugares se mantiene" ${ }^{601}$. Sea como fuere, no puede atribuirse ni a uno ni a otro, no ya tan solo por un mero análisis estilístico del rostro, sino porque, además, en el caso de Juan de Ávila llevaba más de dos décadas muerto.

El Nazareno, que en realidad no es tal puesto que se trata de un Cristo del Despojo, y aunque lleva una túnica, posee todo el cuerpo perfectamente tallado. Al parecer, será similar al que realizó para Valladolid Juan de Ávila y para León, Francisco Díez de Tudanca.

\section{CASTRILLO DE ONIELO. IGLESIA DE NUESTRA SEÑORA DE $\underline{\text { LA PAZ }}$}

VIRGEN CON EL NIÑO (¿Antonio de Gautúa? 1730)

Martín González y Urrea sitúan "próxima a Pedro de Ávila" la escultura de la Virgen con el Niño (Fig. 148) que preside el retablo mayor de la iglesia de Nuestra Señora de la Paz de Castrillo de Onielo (Palencia). Dicho retablo fue realizado en Valladolid en 1730 según la traza de Pedro de Portilla ${ }^{602}$, que será un ensamblador relacionado con los palentinos Gregorio y Miguel de Portilla.

\footnotetext{
600 GÓMEZ, Enrique y MARTÍNEZ, Rafael: op. cit., p. 58.

$601 \quad$ Ídem, p. 59.

602 URREA FERNÁNDEZ, Jesús y MARTÍN GONZÁLEZ, Juan José: Inventario artístico de Palencia y su provincia I..., op. cit., p. 127.
} 
Lo primero que cabe decir es que tanto la imagen de la Virgen con el Niño, con el relieve del ático que representa la Imposición de la casulla a San Ildefonso, como las esculturas de San Antonio de Padua y San Isidro Labrador que se sitúan sobre las hornacinas laterales fueron hechas por un mismo escultor; todas denotan una misma mano. Quizás a este escultor también pertenecieran las imágenes que debían alojarse en las referidas hornacinas laterales, actualmente ocupadas por dos horribles esculturas modernas de escayola de los talleres de Olot.

Aunque la escultura posee muchos puntos de contacto con la obra de Pedro de Ávila, como por ejemplo los rasgos faciales, no se puede sostener esta atribución si comparamos el rostro de la Virgen con el de algunas de las imágenes de Antonio de Gautúa; escultor con el que, ya hemos dicho, está íntimamente ligado Pedro de Ávila, quizás por haber compartido un mismo taller (el de Juan de Ávila) cuando se formaron en el oficio. Por ejemplo, las similitudes son absolutas con el rostro de la Santa Bárbara que se conserva en la iglesia de San Martín de Valladolid, o con los de la Virgen del relieve de los Desposorios y el San Miguel ubicados en uno de los retablos del Oratorio de la San Felipe Neri de la misma población. Además, en la ermita de Nuestra Señora de Castilviejo de Medina de Rioseco se conserva una Virgen de la Consolación, también obra documentada de Gautúa, que no solamente es semejante en el rostro sino en la concepción global de la talla.

\section{LEÓN. CONVENTO DE SAN FRANCISCO EL REAL}

\section{NAZARENO DE EN UNA DE SUS CAÍDAS (DAINOS) (Anónimo. Hacia 1700)}

En el Convento de San Francisco el Real de León se conserva una devotísima escultura que representa a Jesús Nazareno (Fig. 149) en una de sus caídas que se le conoce con el apodo del "Dainos". Para la paternidad de esta bella imagen han sido propuestos varios nombres, entre ellos los de José de Rozas o Pedro de Ávila. Para la atribución a José de Rozas se alude a sus "rostros de serena resignación invaden todas sus composiciones dentro de un pacífico aislamiento. La imagen de tranquilidad y de perfecto equilibrio del Nazareno encaja perfectamente con Rozas"; mientras que para la de Pedro de Ávila esgrime su parecido con el desaparecido grupo de la Sagrada Familia de la Virgen del Monasterio de las Brígidas de Valladolid y con la Magdalena del Oratorio de San Felipe Neri. Con ellas dos observa "ciertas analogías con el Nazareno de los Capuchinos de León (...). La iluminación de los rostros y sus cadenciosos movimientos nos colocan en una órbita común. La doble búsqueda en sus miembros, entre el apelmazamiento técnico y las directrices tensionadas de los músculos de sus manos lanzadas hacia un vacío angustioso, reflejarán ese espíritu inquietante de todas estas esculturas. Igual reflejo estético obtenemos en la mirada del Cristo Crucificado de la 
iglesia de San Felipe Neri, en Valladolid, obra también documentada de Pedro de Ávila" 603 .

Lejos de la poesía esgrimida para su atribución a Pedro de Ávila, ningún elemento técnico y estilístico presente en el rostro del Nazareno le liga a nuestro escultor. También es descabellada la opción de José de Rozas. Pienso que el escultor que realizó esta imagen no procedía de la capital castellanoleonesa.

\section{LEÓN. IGLESIA DE SANTA MARINA LA REAL}

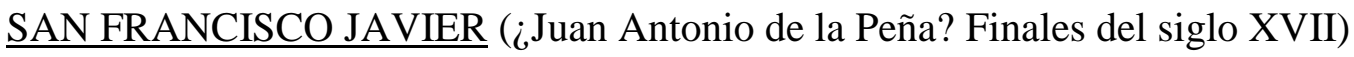

Como ocurre con otras tantas esculturas, esta vez también es Martín González en vislumbrar ciertos rasgos que ponen una escultura en relación con Pedro de Ávila. En este caso se trata de la escultura de San Francisco Javier (Fig. 150) conservada en la leonesa iglesia de Santa Marina la Real, antiguo templo de la Compañía de Jesús ${ }^{604}$. Posteriores estudios no han hecho sino seguir esta teoría: así ocurre con los diferentes libros que ha publicado Fernando Llamazares; el cual, asimismo, ha llamado la atención sobre otras esculturas conservadas en la antigua iglesia jesuítica que pueden ser atribuidos a otros escultores vallisoletanos como José de Rozas o Juan Antonio de la Peña ${ }^{605}$.

La escultura sigue al pie de la letra la imagen del santo navarro tallada por Gregorio Fernández para el Colegio de San Ignacio de Valladolid, actual iglesia de San Miguel y San Julián. Pero las similitudes no quedan ahí: San Francisco Javier presidía el retablo colateral de la Epístola, mientras que la de San Ignacio hacía lo propio con el del Evangelio $^{606}$. Es decir, de una forma similar a como se encuentran en Valladolid.

En uno de los inventarios se describe al retablo de San Francisco Javier de la siguiente manera: "Un colateral dorado a la mano izquierda del altar mayor, en medio la imagen de San Francisco Xavier, de cuerpo entero, diadema de plata con estrellas, y en cada una su piedra basta, una azucena en la mano izquierda de plata, y en la derecha una vara con cruz de plata, y al remate una paloma también de plata, y pendiente del pecho, de una cinta, un corazón de Jesús de lo mismo; en el segundo cuerpo del colateral una imagen de Nuestra Señora de la Portería de pintura; un crucifijo chico de marfil con cruz de ébano, una lámina de marfil (con cruz de ébano) digo con la imagen de Nuestra

\footnotetext{
603 VV.AA.: Semana Santa en León: pasos, Diario de León, León, 1996, p. 73.

604 CASASECA CASASECA, Antonio (et. al.): Historia del arte de Castilla y León. 6: Arte barroco, Editorial Ámbito, Valladolid, 1997, p. 286.

605 LLAMAZARES, Fernando: "Un espacio barroco...”, op. cit., p. 71; LLAMAZARES, Fernando: Fuentes documentales..., op. cit., p. 61.

606 LLAMAZARES, Fernando: “Un espacio barroco...,, op. cit., p. 67.
} 
Señora con el Niño en los brazos y San Joseph, con marco de ébano y cordoncillo de bronce dorado" 607 .

A pesar de que las quebraduras del hábito jesuítico pueden acercar esta obra a la órbita de nuestro escultor pienso que hay que descartar totalmente esta atribución. Creo que el San Francisco Javier fue realizado por algún escultor de la generación inmediatamente anterior a la de Pedro de Ávila. Quizás se deba a Juan Antonio de la Peña. En favor de la atribución a este último se encontraría el hecho de que sabemos que trabajó en León, concretamente realizó la imagen titular de la Cofradía de Nuestra Señora de la Soledad, sita en la iglesia de San Martín ${ }^{608}$. Además, hay que tener en cuenta de que en la misma iglesia donde se encuentra este San Francisco Javier se conserva el referido San Ignacio de Loyola, recientemente atribuido a Juan Antonio de la Peña por Fernando Llamazares, con el cual se confrontaría en los colaterales de la iglesia ${ }^{609}$.

\section{ORENSE. CATEDRAL}

BUSTO DE DOLOROSA (Anónimo vallisoletano. Hacia 1700)

En un interesante artículo realizado en el año 1990 por el profesor Martín González sobre las relaciones artísticas que han existido entre Valladolid y Orense, llama la atención sobre una serie de esculturas conservadas en la Capilla del Santo Cristo de la catedral orensana que denotan una clara procedencia vallisoletana. Una de ellas es un busto de Dolorosa (Fig. 151) que cree que pueda ser obra del riosecano Tomás de Sierra debido a su gran parecido con la Dolorosa del paso del Longinos, del que talló esa y otras esculturas en 1692. Asimismo señalaba que tampoco convendría "olvidar Pedro de Ávila, autor de una Piedad, en el Colegio de los Ingleses de Valladolid, con que guarda también estrecho parecido" ${ }^{610}$. Al parecer, el busto, realizado hacia el año 1700 , fue donado por entonces por un devoto llamado José María Martínez ${ }^{611}$. Las fuentes de la que parecen beber estas esculturas son la Virgen del paso del Descendimiento que en 1623 talló Gregorio Fernández para la Cofradía Penitencial de la Santa Vera Cruz; y, sobre todo, la Virgen del denominado "Paso nuevo de Nuestra Señora y San Juan" de la Cofradía de la Sagrada Pasión de Cristo, obra atribuida a Francisco Díez de Tudanca.

Esta bella escultura debe ser inmediatamente descatalogada del listado de obras relacionadas con nuestro escultor puesto que en nada se asemeja a sus obras. La forma de la cabeza, de la nariz y hasta de los ojos hace que tengamos que rechazar de pleno una atribución a favor de Ávila.

\footnotetext{
$607 \quad$ Ibídem.

608 URREA FERNÁNDEZ, Jesús: “La biografía al servicio del conocimiento...”, op. cit., p. 53.

609 LLAMAZARES, Fernando: "Un espacio barroco...", op. cit., p. 67.

610 MARTÍN GONZÁLEZ, Juan José: “Lazos de arte entre Valladolid y Orense”, op. cit., p. 72.

611 Ibídem.
} 


\section{PALENCIA. SEMINARIO MAYOR}

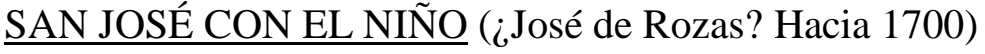

En la capilla del Seminario Mayor de Palencia se conserva un San José con el Niño (Fig. 152) que Urrea y Martín González no dudaron en atribuir a Pedro de Ávila: "Capilla. Escultura de San José con el Niño primer tercio del siglo XVIII que atribuimos a Pedro de Ávila"612. Para nada puede ser esta escultura relacionada con nuestro escultor, tan solo comparte con el estilo de Ávila la manera de tallar el pelo, el resto nada de nada.

Pienso que lo más lógico sería atribuir esta magnífica pieza a José de Rozas si tenemos en cuenta la total similitud que guarda con otro San José con el Niño guardado en el coro alto del vallisoletano Convento de las Descalzas Reales, el cual fue calificado de "próximo a José de Rozas" y fechado en el "último cuarto del siglo XVII" por Martín González y Plaza Santiago ${ }^{613}$. Como podemos observar todo en ellos es plenamente coincidente: la indumentaria y su forma de resolver los pliegues, la vestimenta del Niño Jesús con su bola y su característica cabellera realizada a base de bucles; e, incluso, el rostro y el peinado del santo. Sin embargo, parece obra de mucho mayor empeño esta escultura palentina.

612 URREA FERNÁNDEZ, Jesús y MARTÍN GONZÁLEZ, Juan José: Inventario artístico de Palencia y su provincia I..., op. cit., p. 46.

613 MARTÍN GONZÁLEZ, Juan José y DE LA PLAZA SANTIAGO, Francisco Javier: Catálogo Monumental de la provincia de Valladolid. Tomo XV..., op. cit., p. 100. 


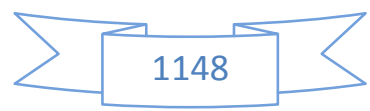




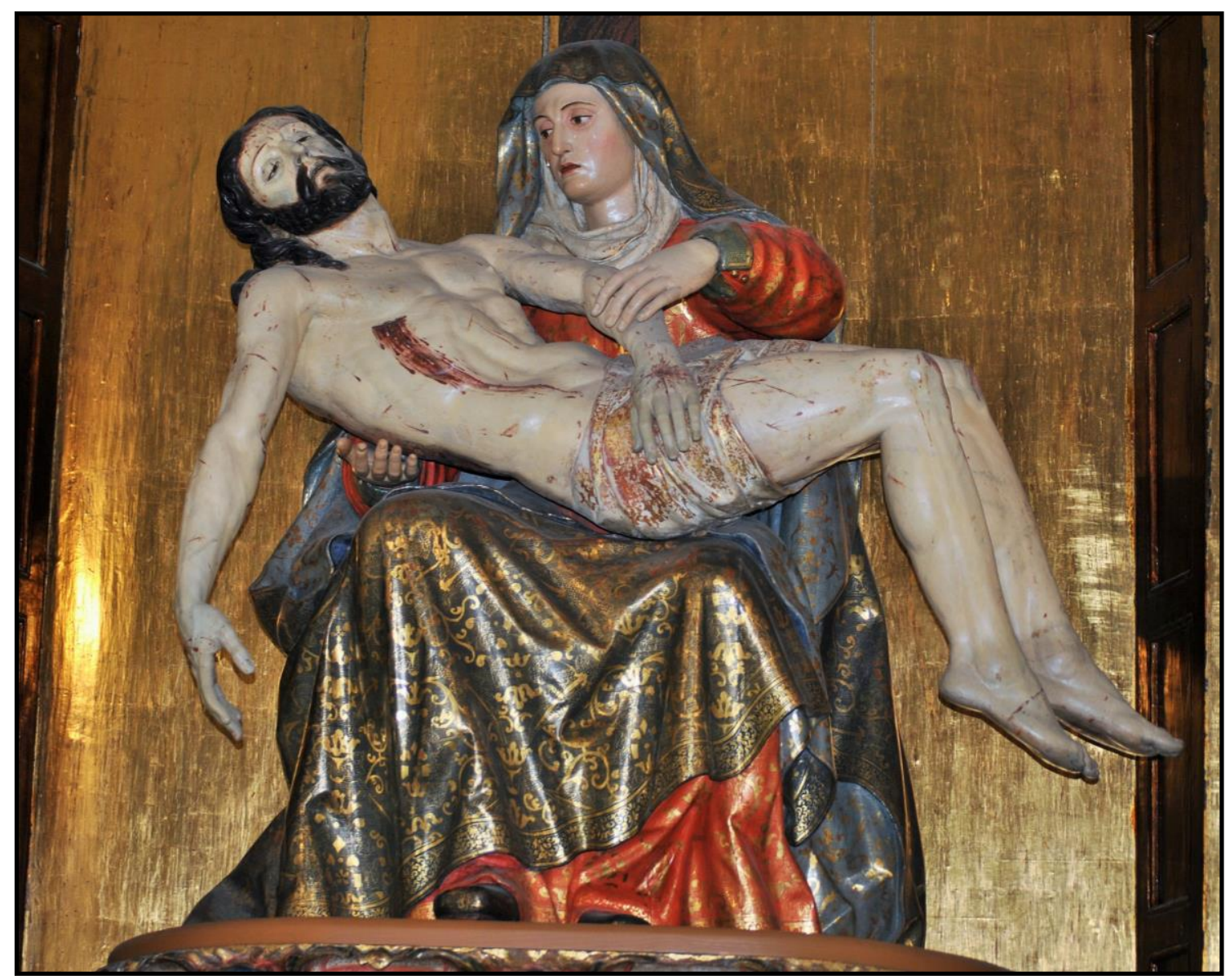

Fig. 1- Pedro de Ávila. Virgen de la Piedad. Colegio de los Ingleses. Valladolid.

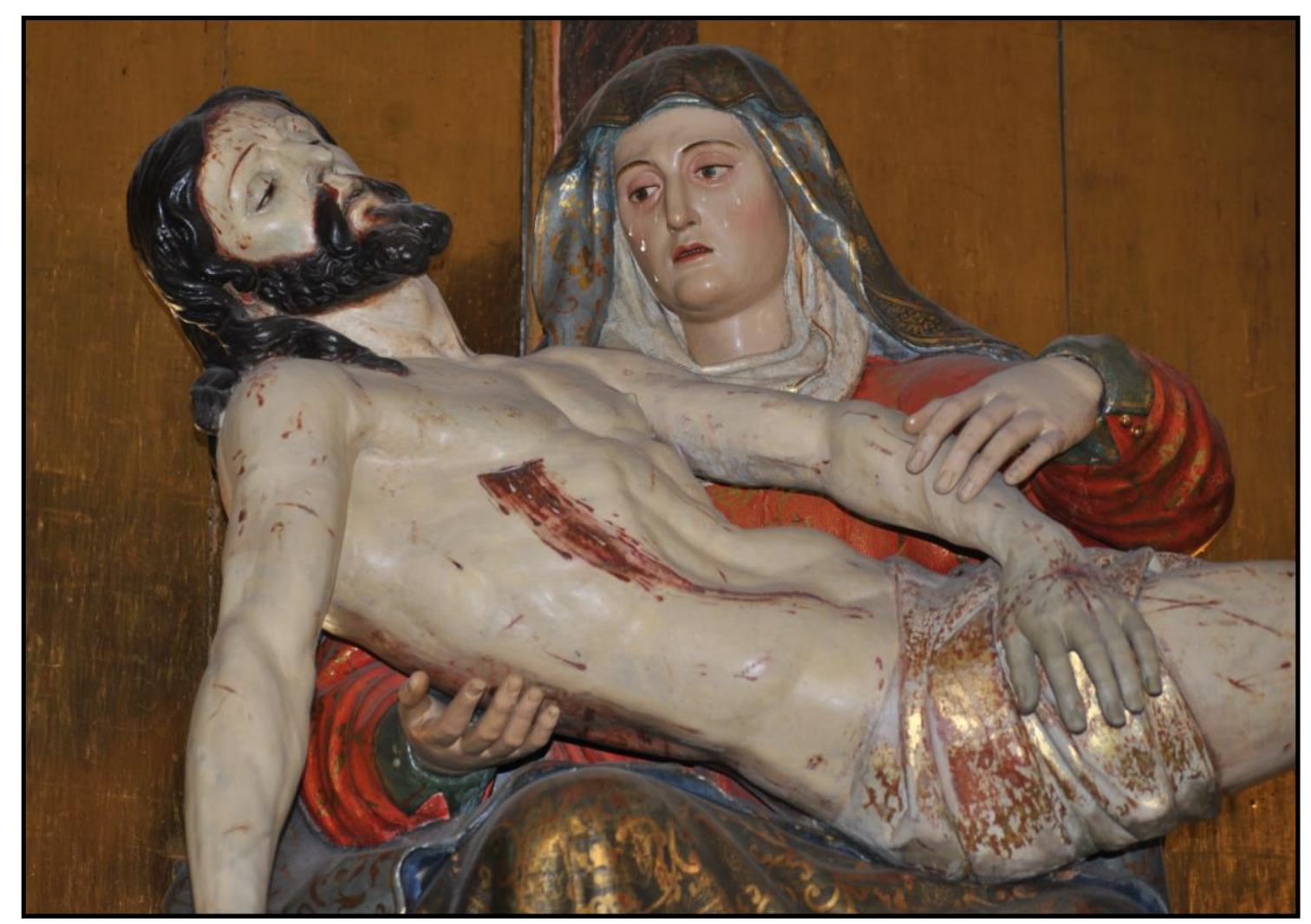

Fig. 2- Pedro de Ávila. Detalle de la Virgen de la Piedad.

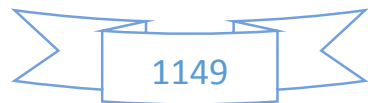




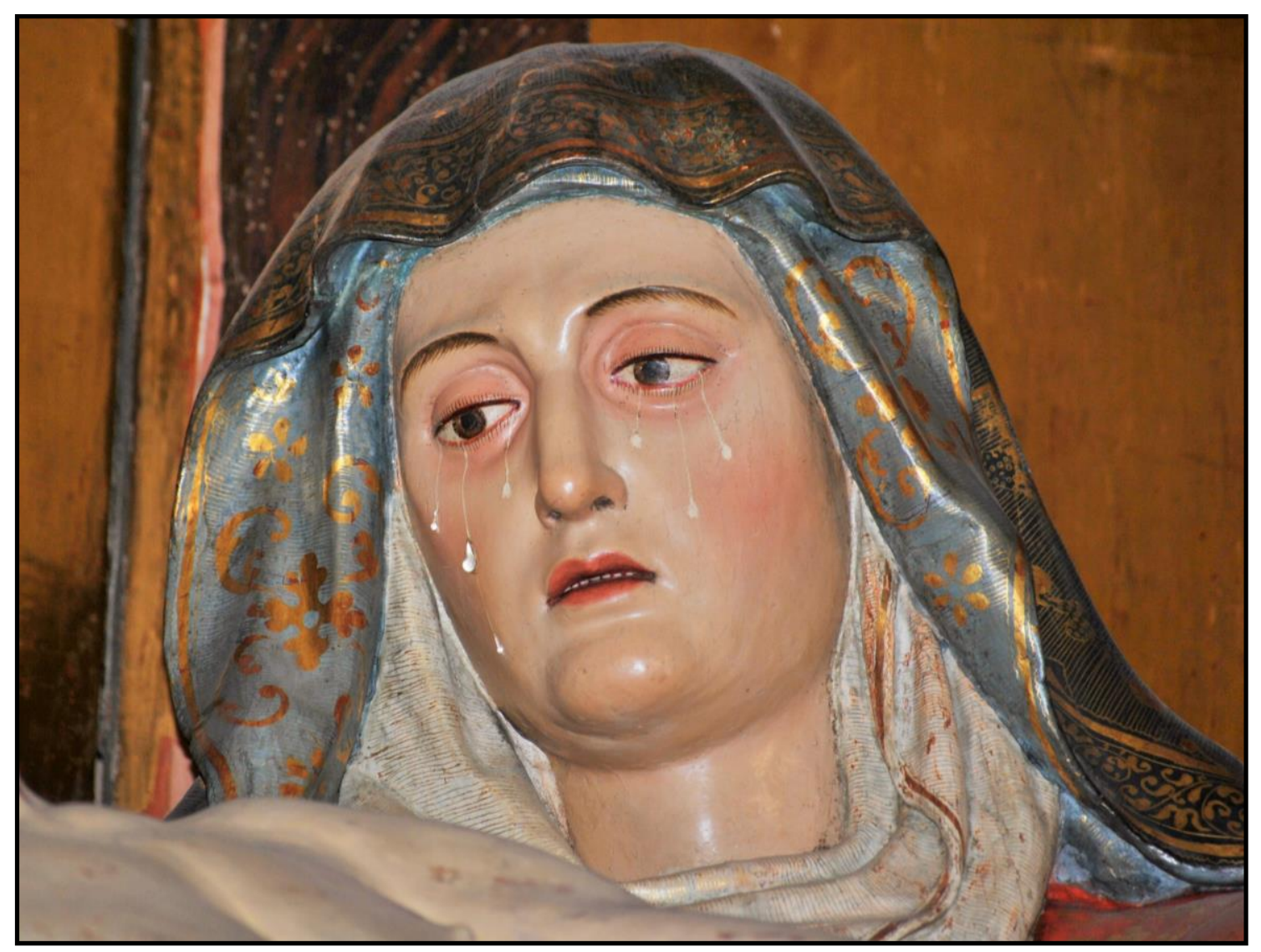

Fig. 3- Pedro de Ávila. Detalle de la Virgen de la Piedad.

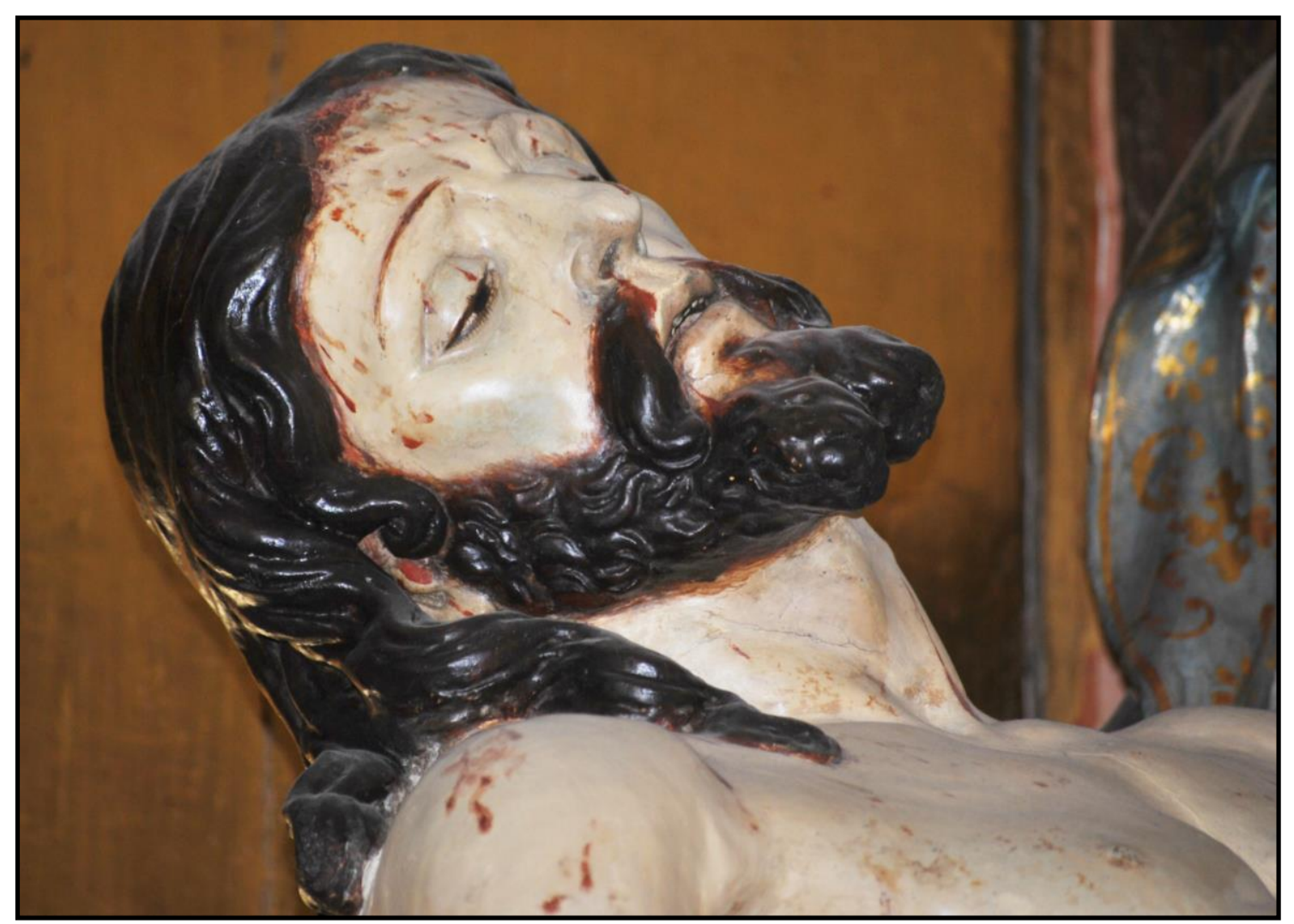

Fig. 4- Pedro de Ávila. Detalle de la Virgen de la Piedad.

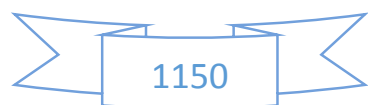




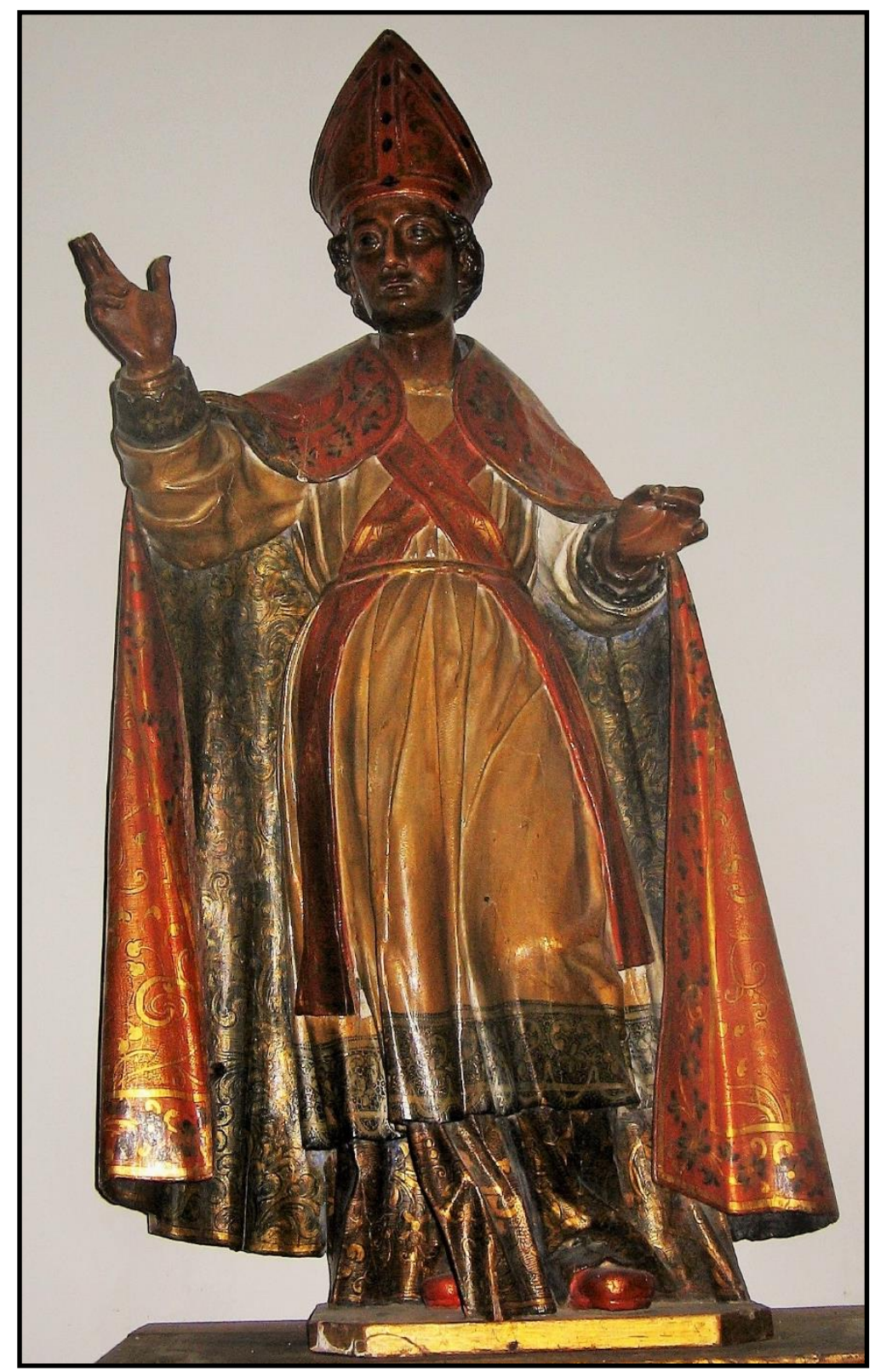

Fig. 5- Pedro de Ávila. San Ildefonso. Iglesia del

Salvador. Morales de Toro (Zamora).

Fig. 6- Pedro de Ávila. Detalle de San Ildefonso.
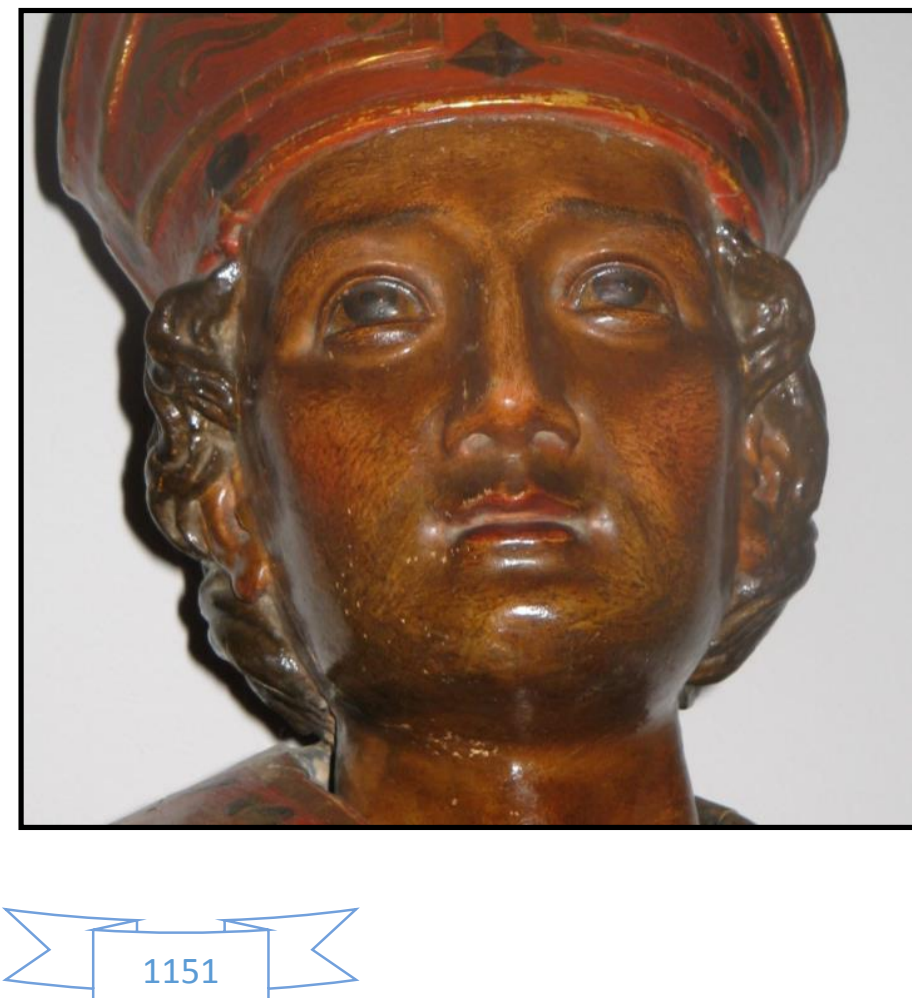


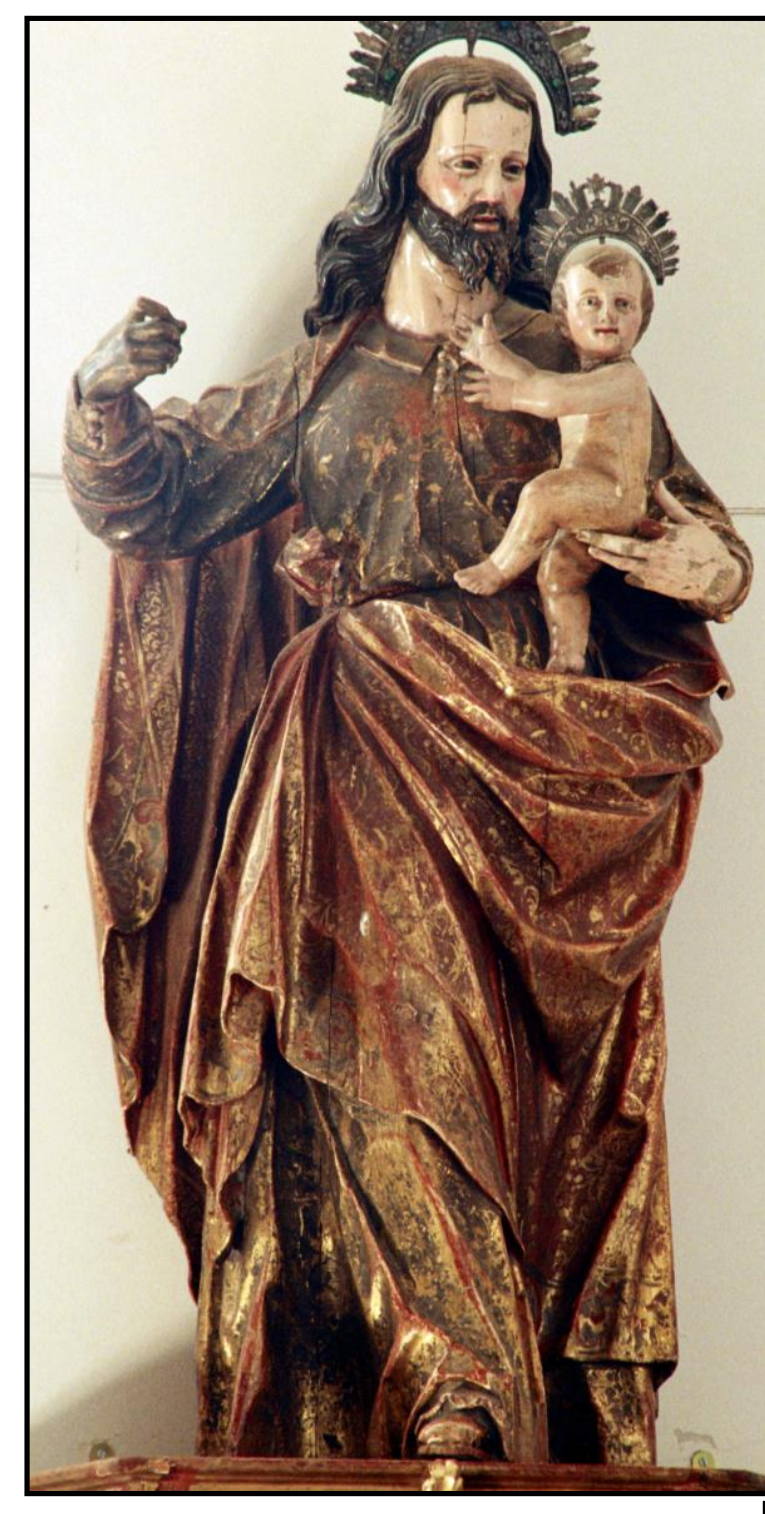

Fig. 7- Pedro de Ávila. San José con el Niño. Iglesia del Salvador. Morales de Toro (Zamora).

Fig. 8- Pedro de Ávila. Detalle de San José con el Niño.
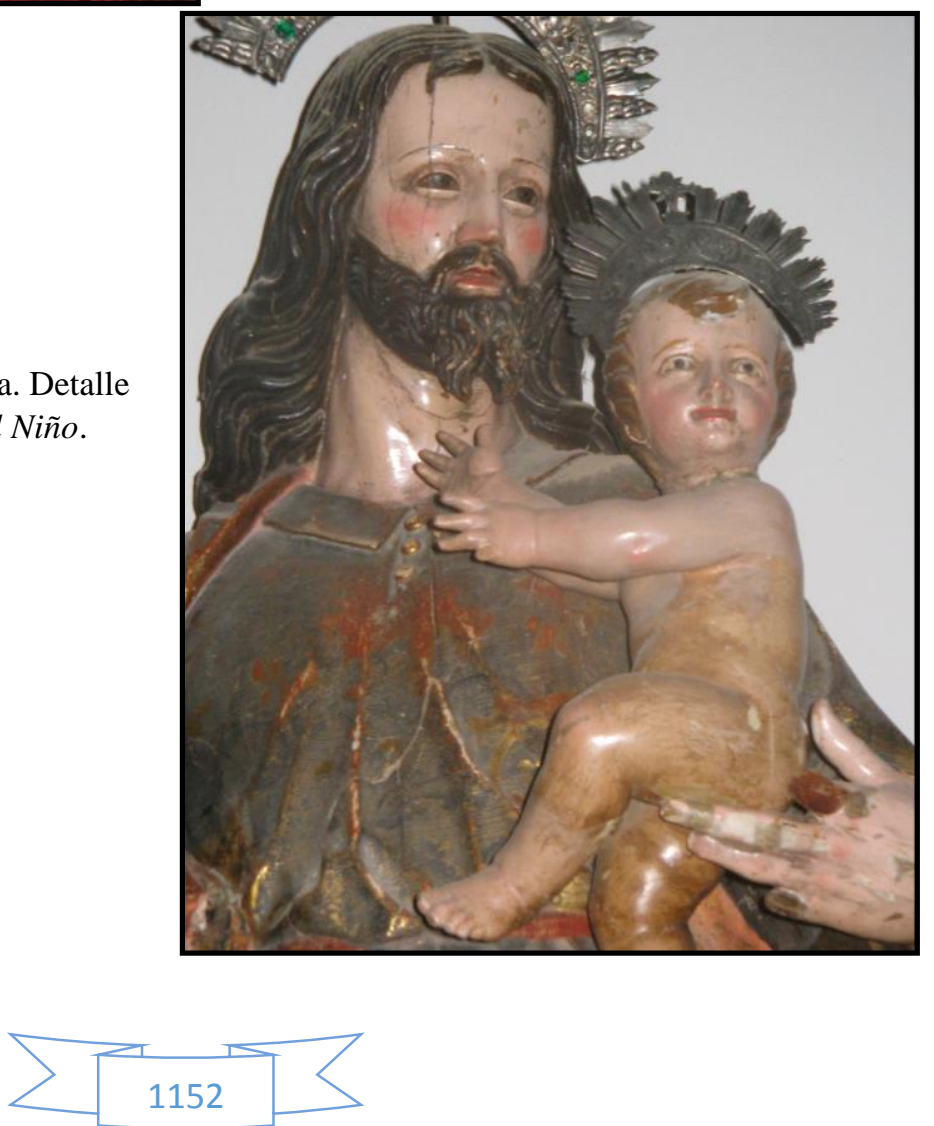


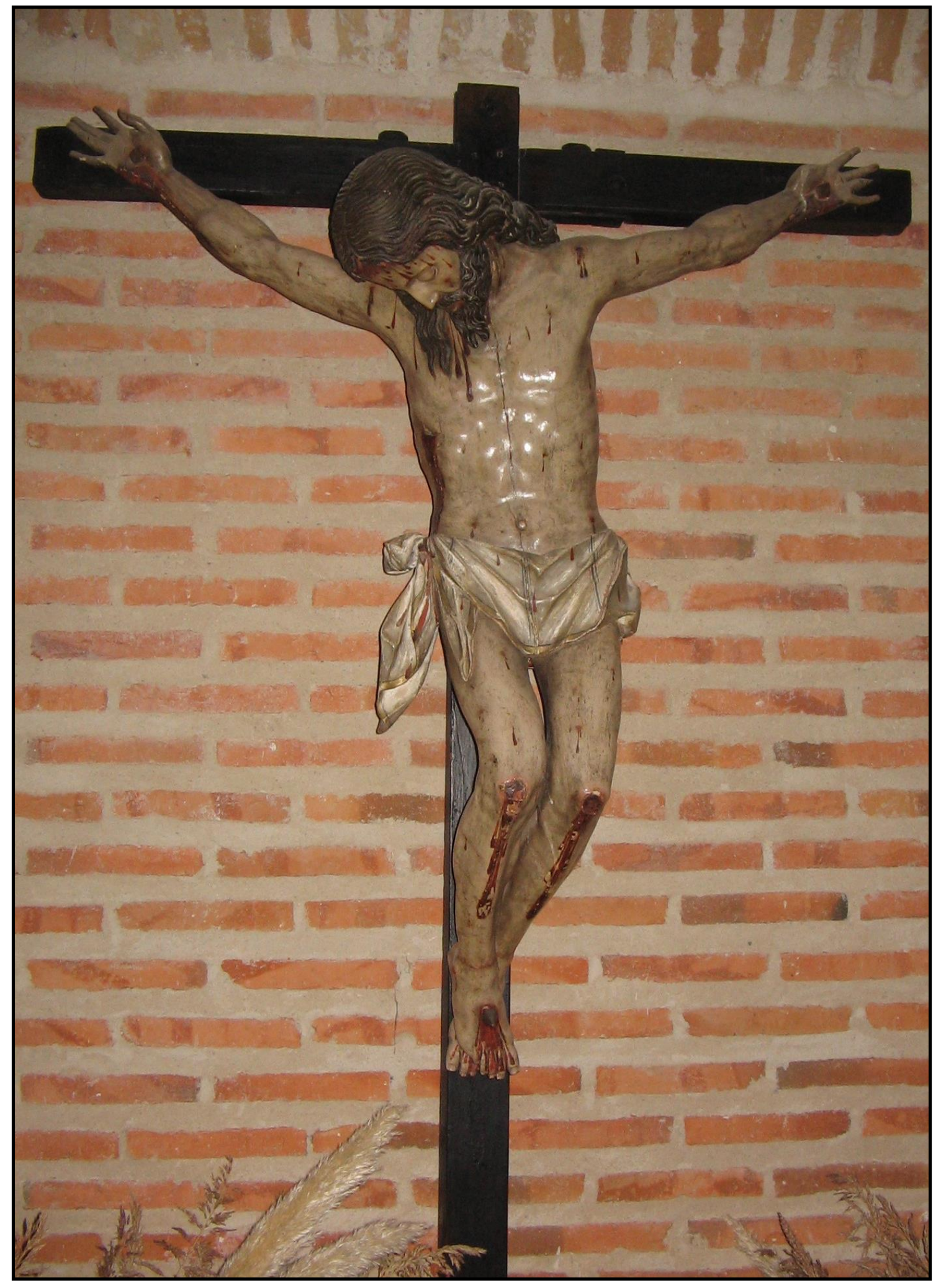

Fig. 9- Pedro de Ávila. Cristo Crucificado. Iglesia parroquial de San Esteban Protomártir. Torrecilla de la Abadesa (Valladolid).

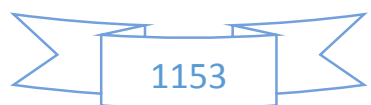




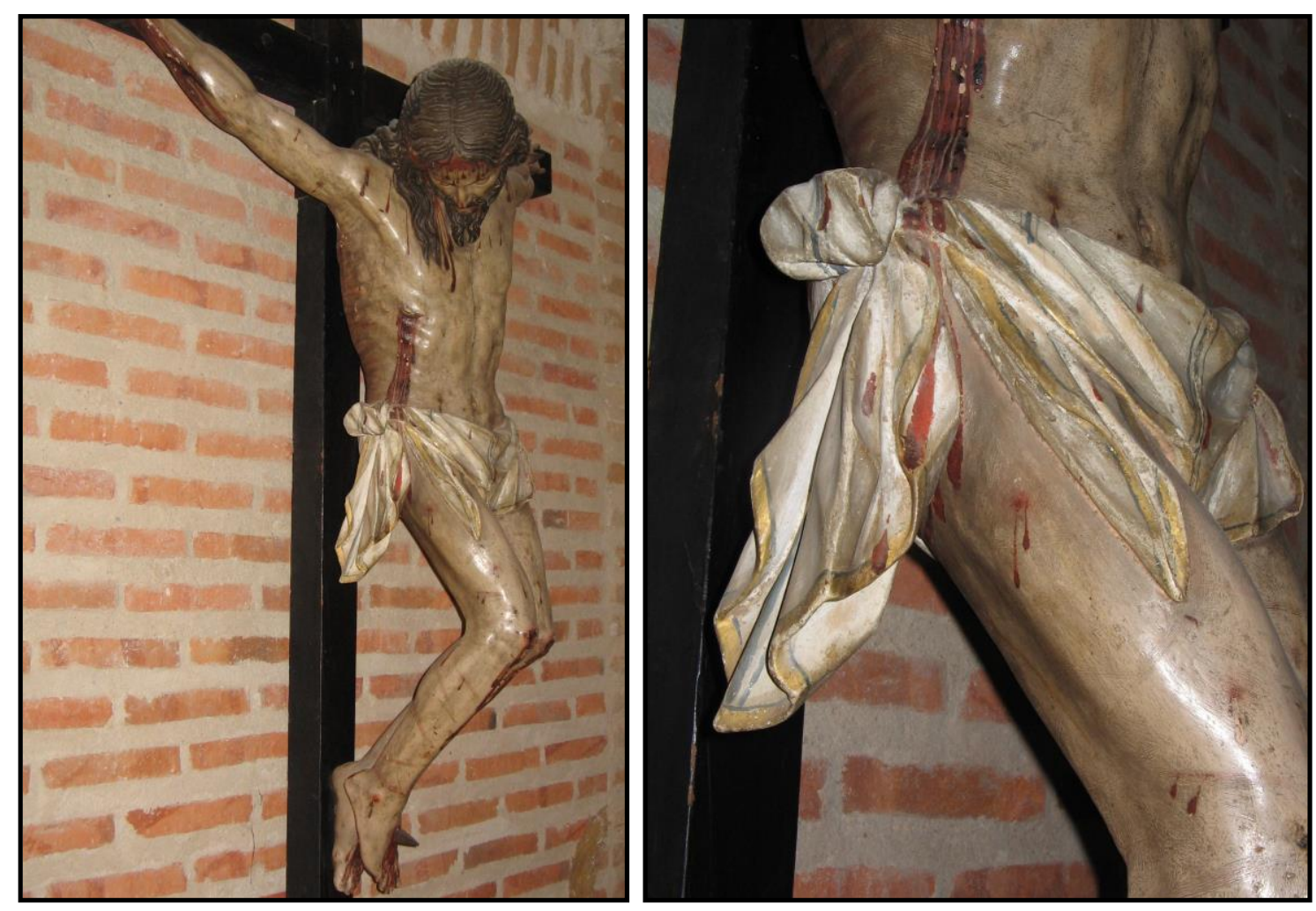

Figs. 10-12- Pedro de Ávila. Detalles del Cristo Crucificado.
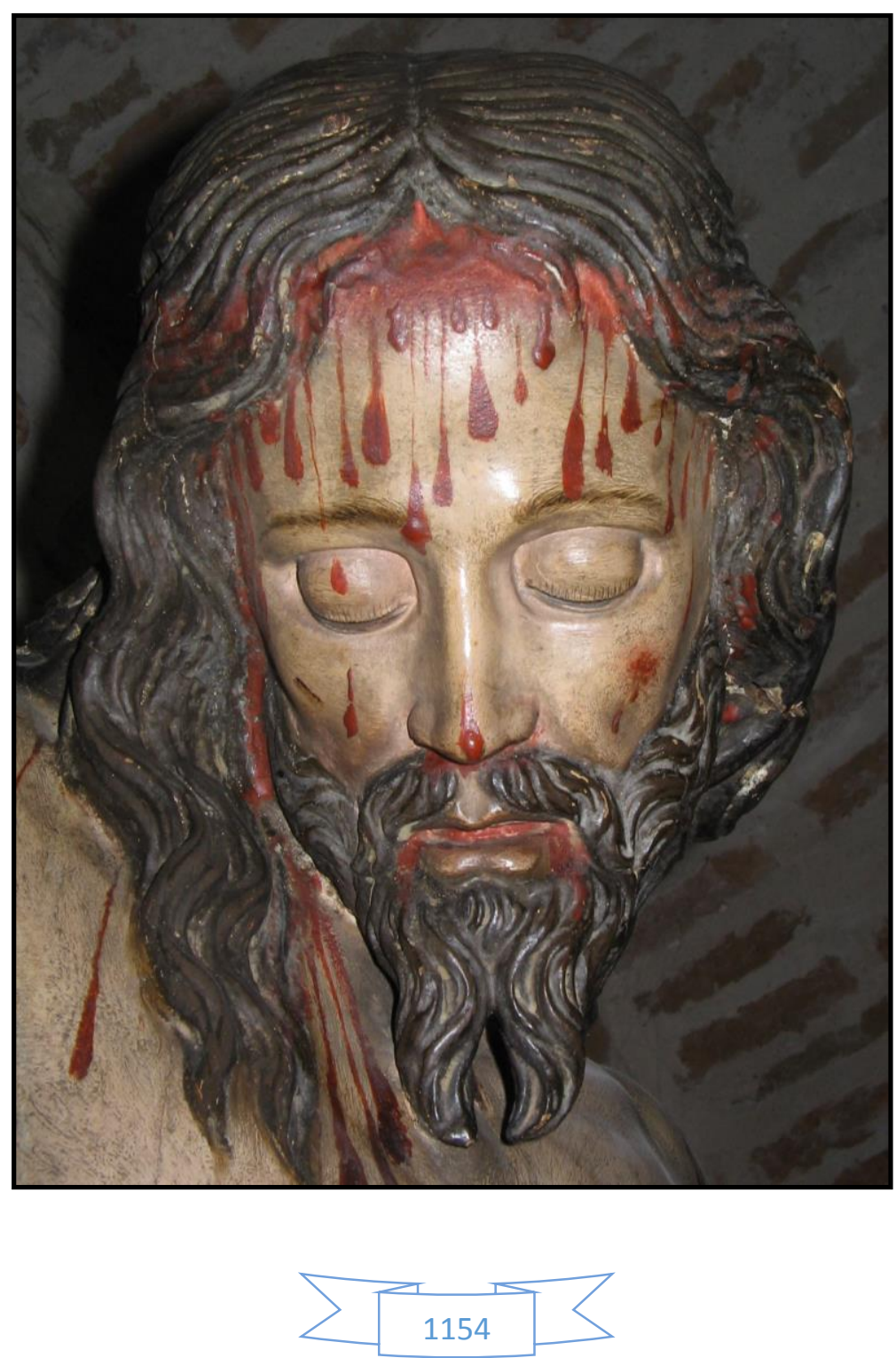


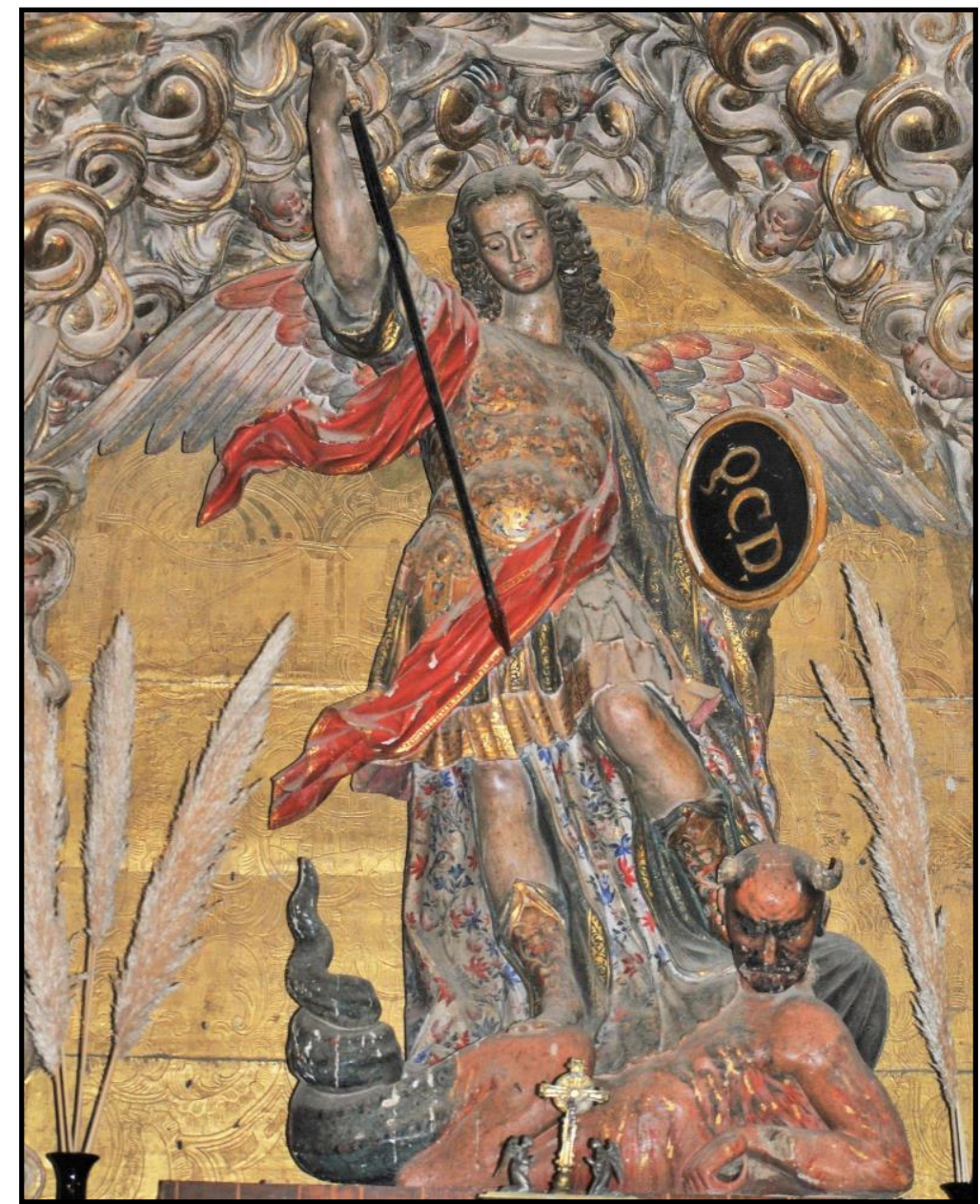

Fig. 13- Pedro de Ávila. San Miguel. Iglesia parroquial de San Miguel Arcángel. Castil de Vela (Palencia).

Fig. 14- Pedro de Ávila. Detalle de San Miguel.
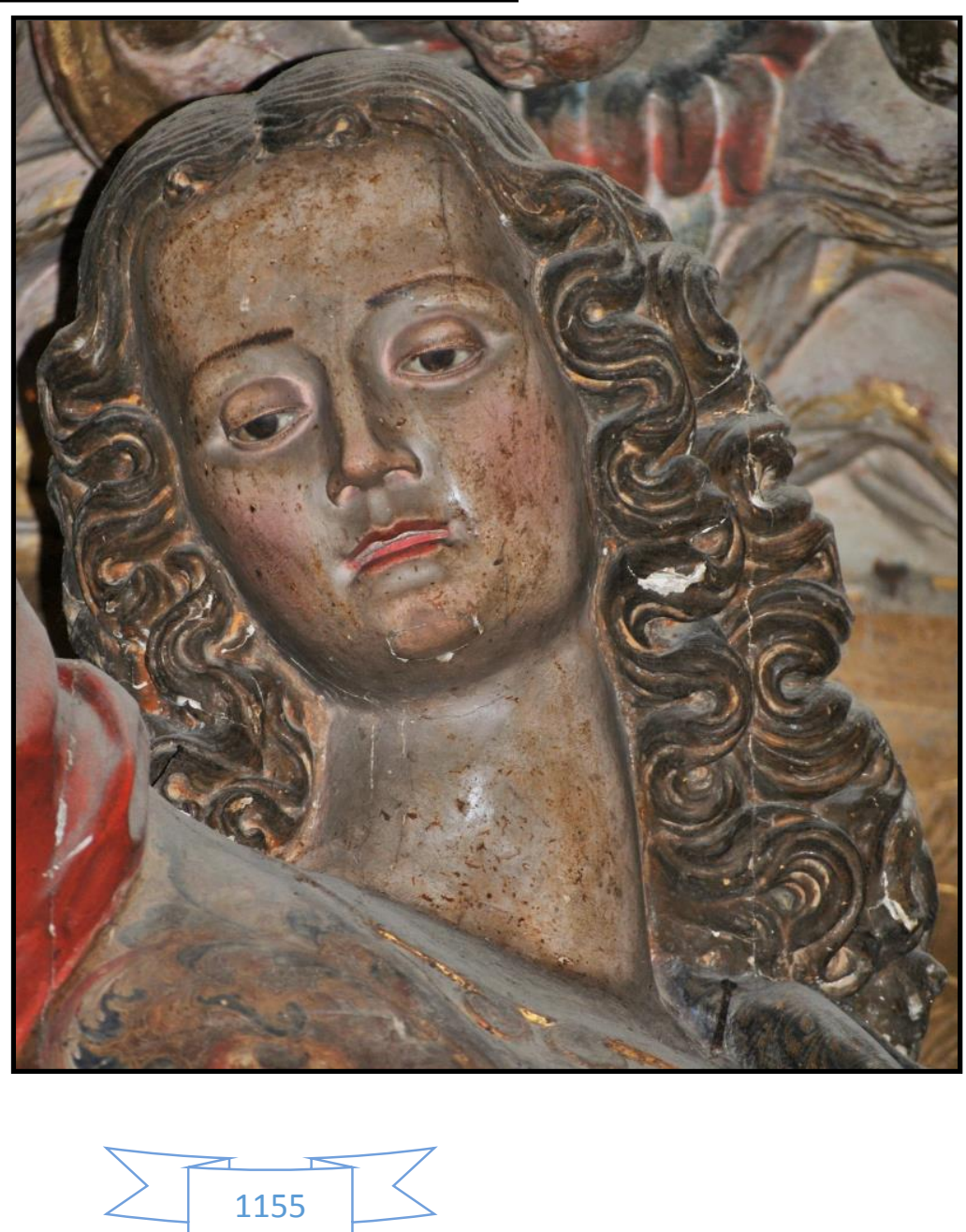


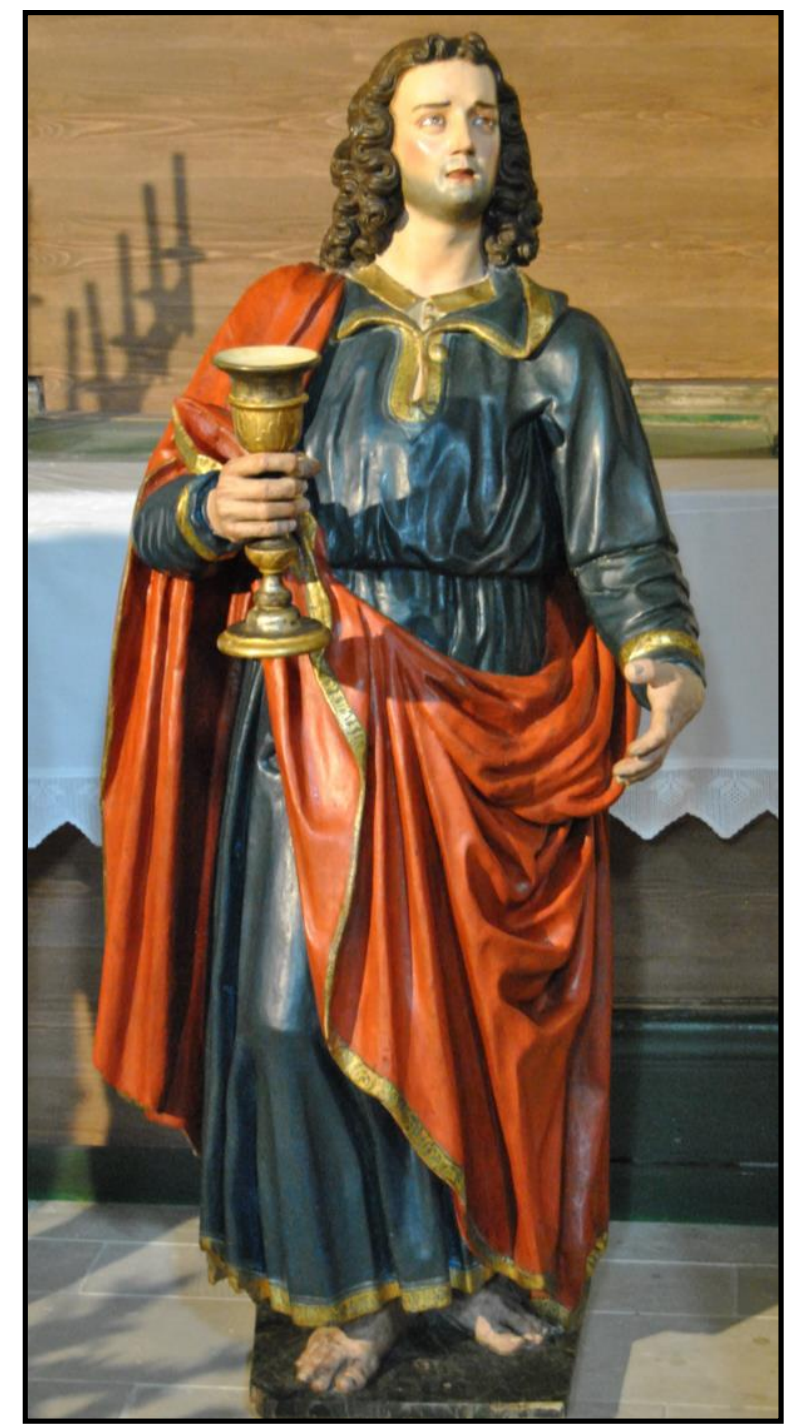

Fig. 15- Pedro de Ávila. San

Juan Evangelista. Catedral. Valladolid.

Fig. 16- Pedro de Ávila. Detalle de San Juan Evangelista.
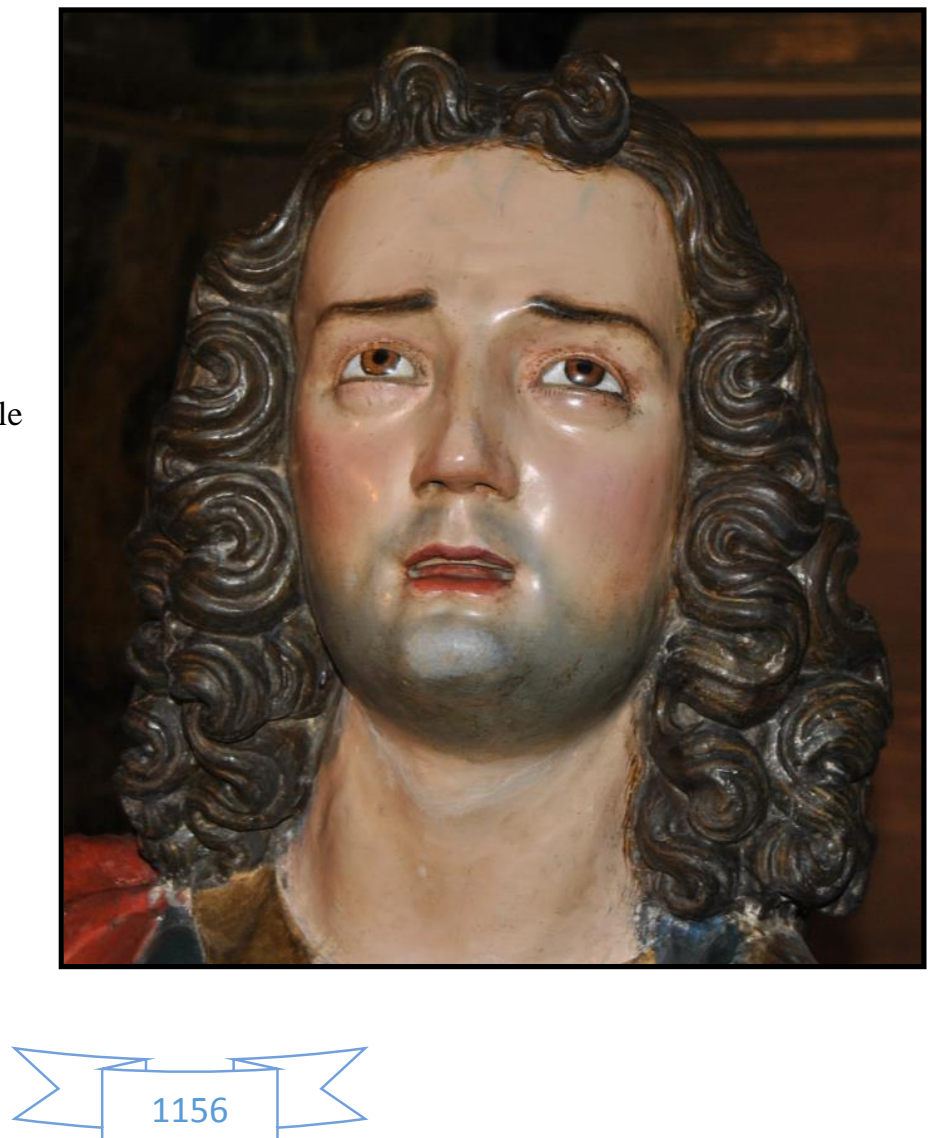


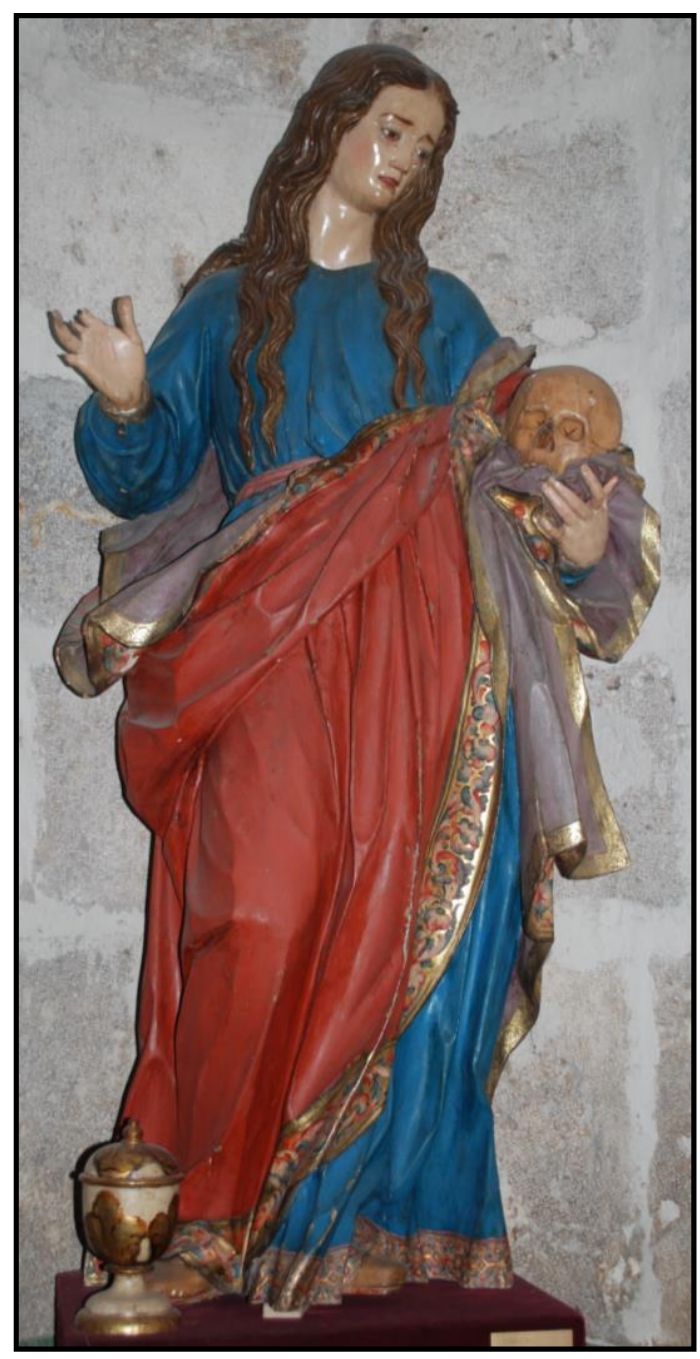

Fig. 17- Pedro de Ávila. Santa María

Magdalena. Catedral. Valladolid.
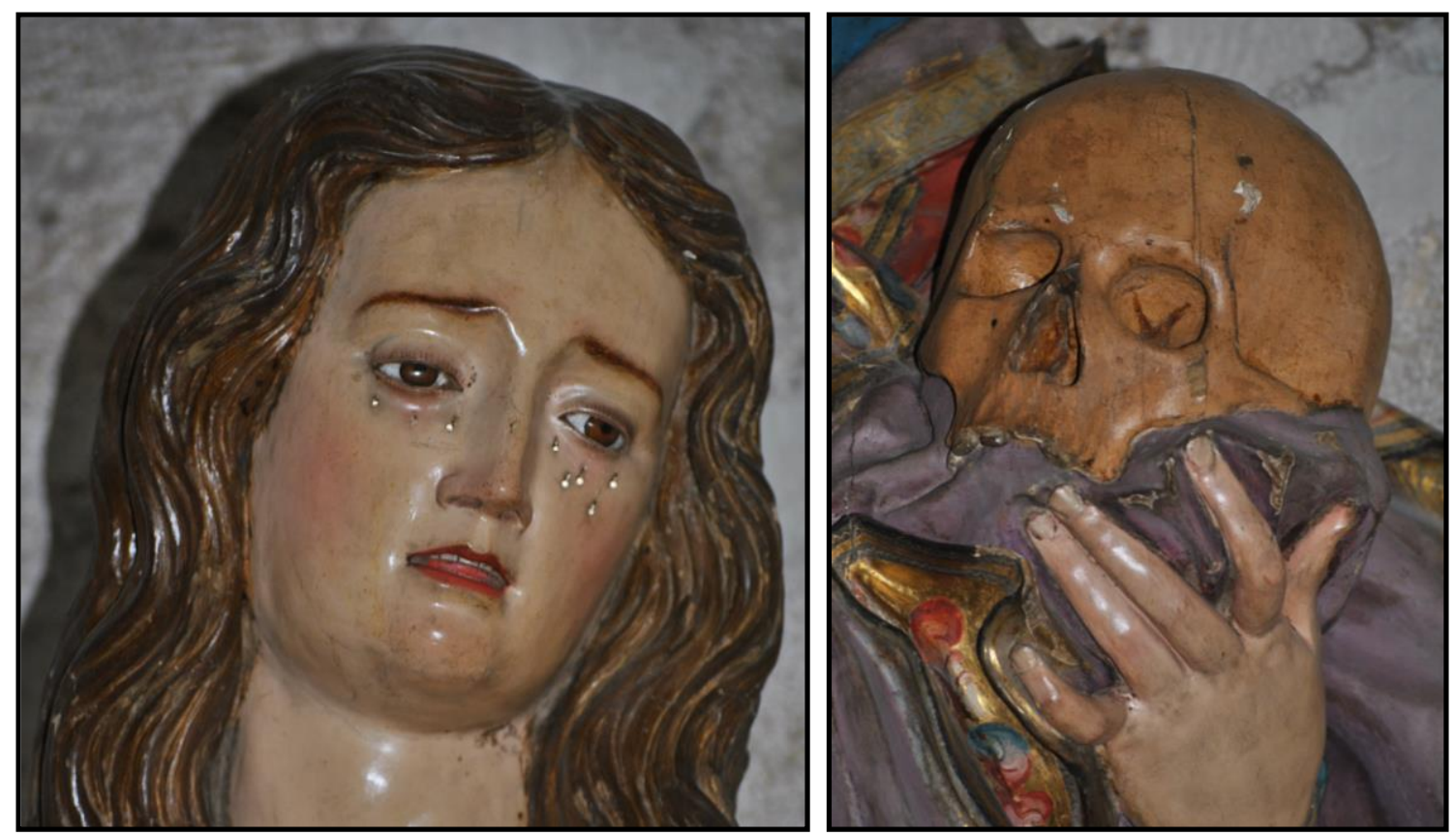

Figs. 18-19- Pedro de Ávila. Detalles de Santa María Magdalena. Catedral. Valladolid.

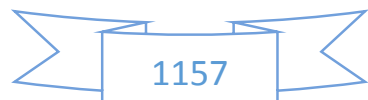




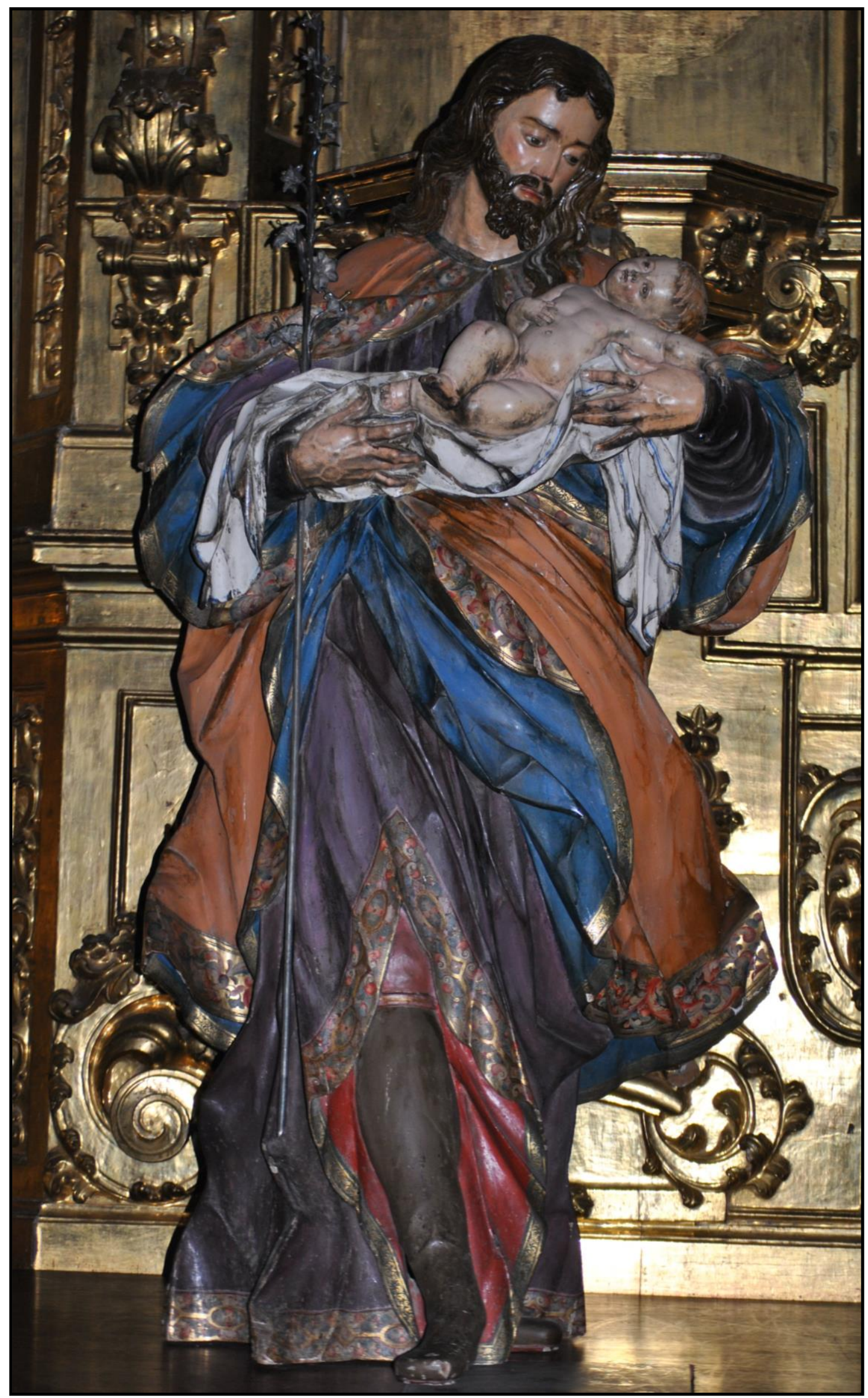

Fig. 20- Pedro de Ávila. San José con el Niño. Catedral. Valladolid.

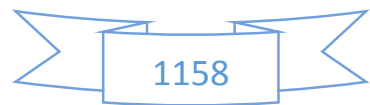




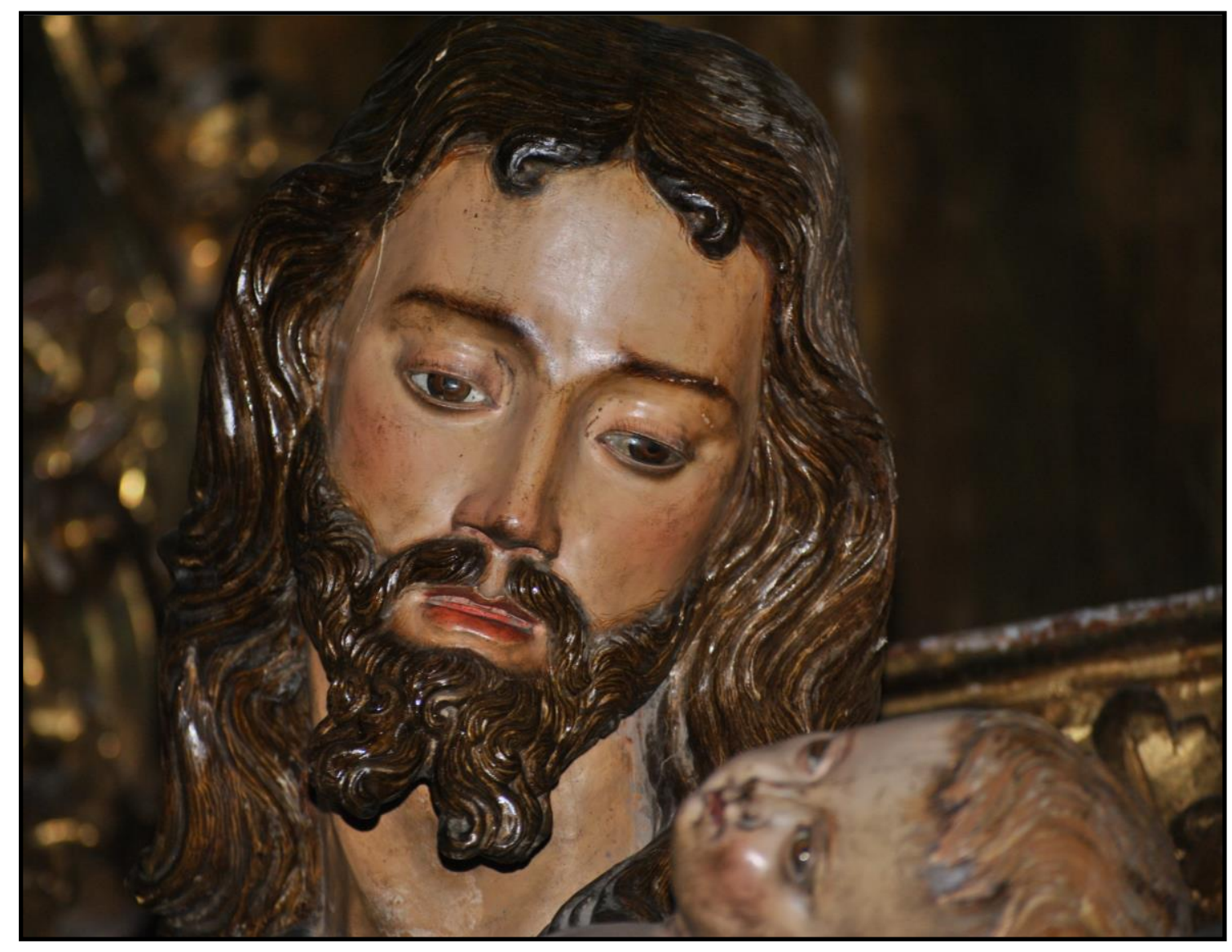

Figs. 21-22- Pedro de Ávila. Detalles de San José con el Niño.
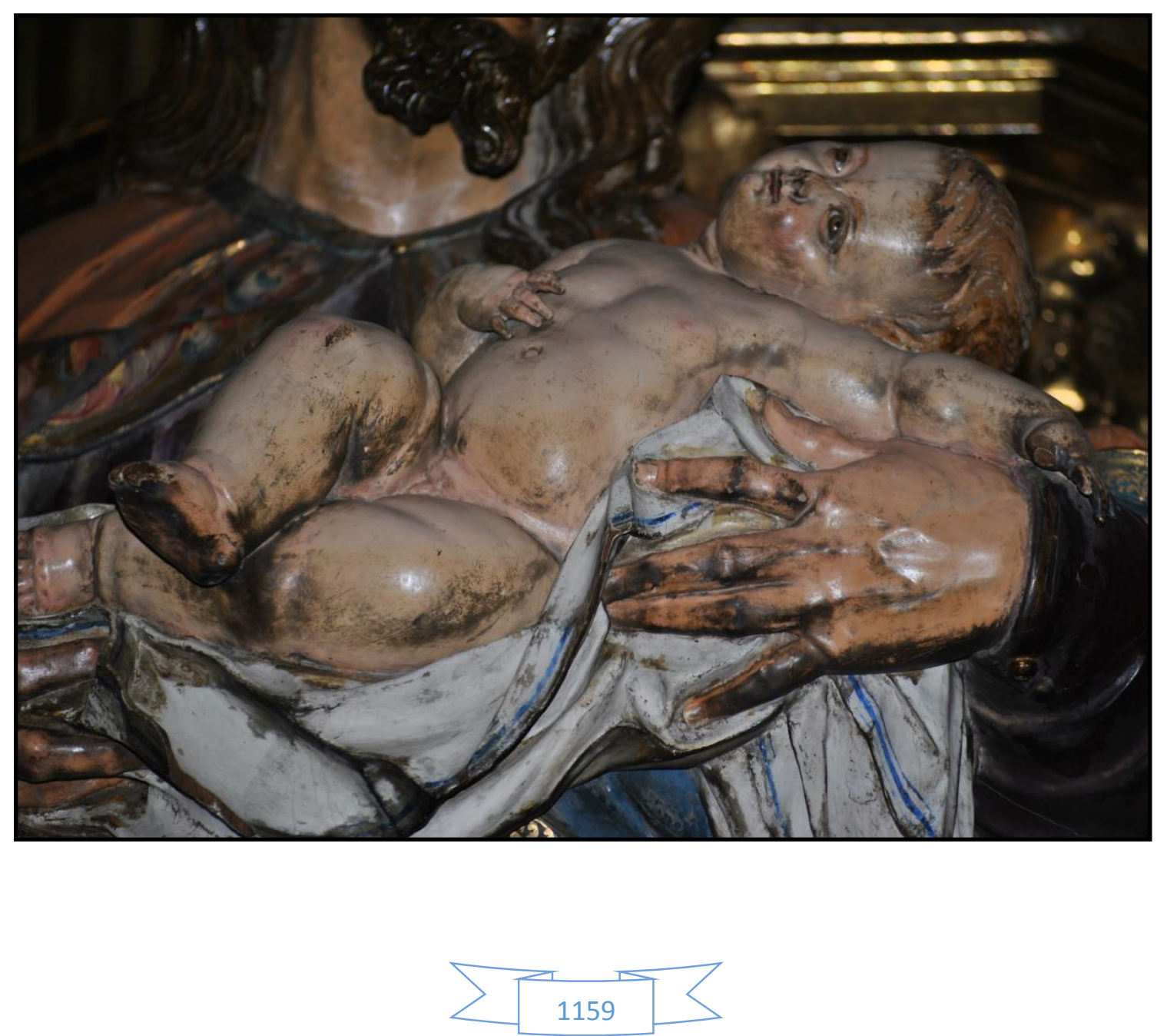


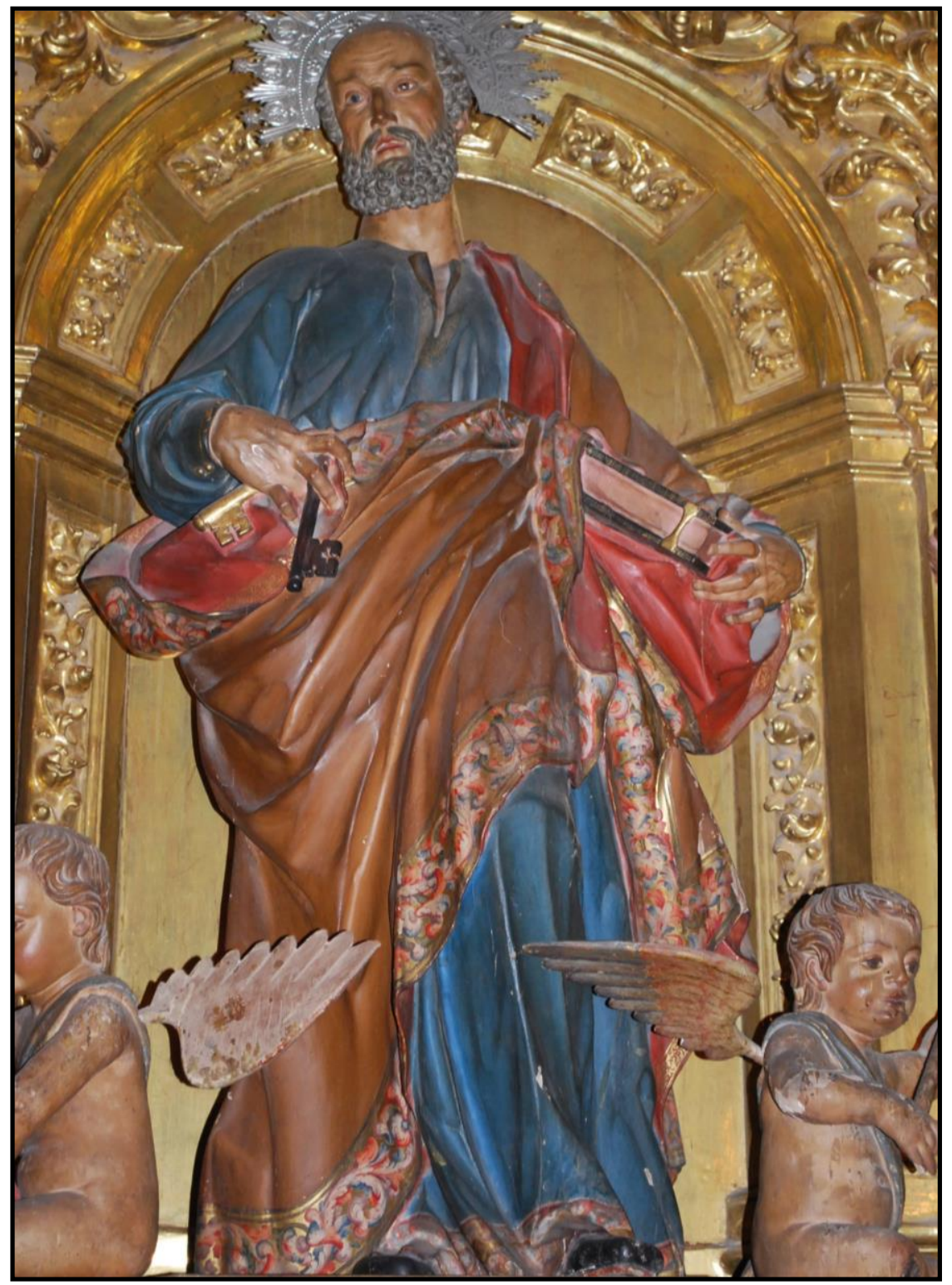

Figs. 23-24- Pedro de Ávila. San Pedro apóstol. Catedral. Valladolid.
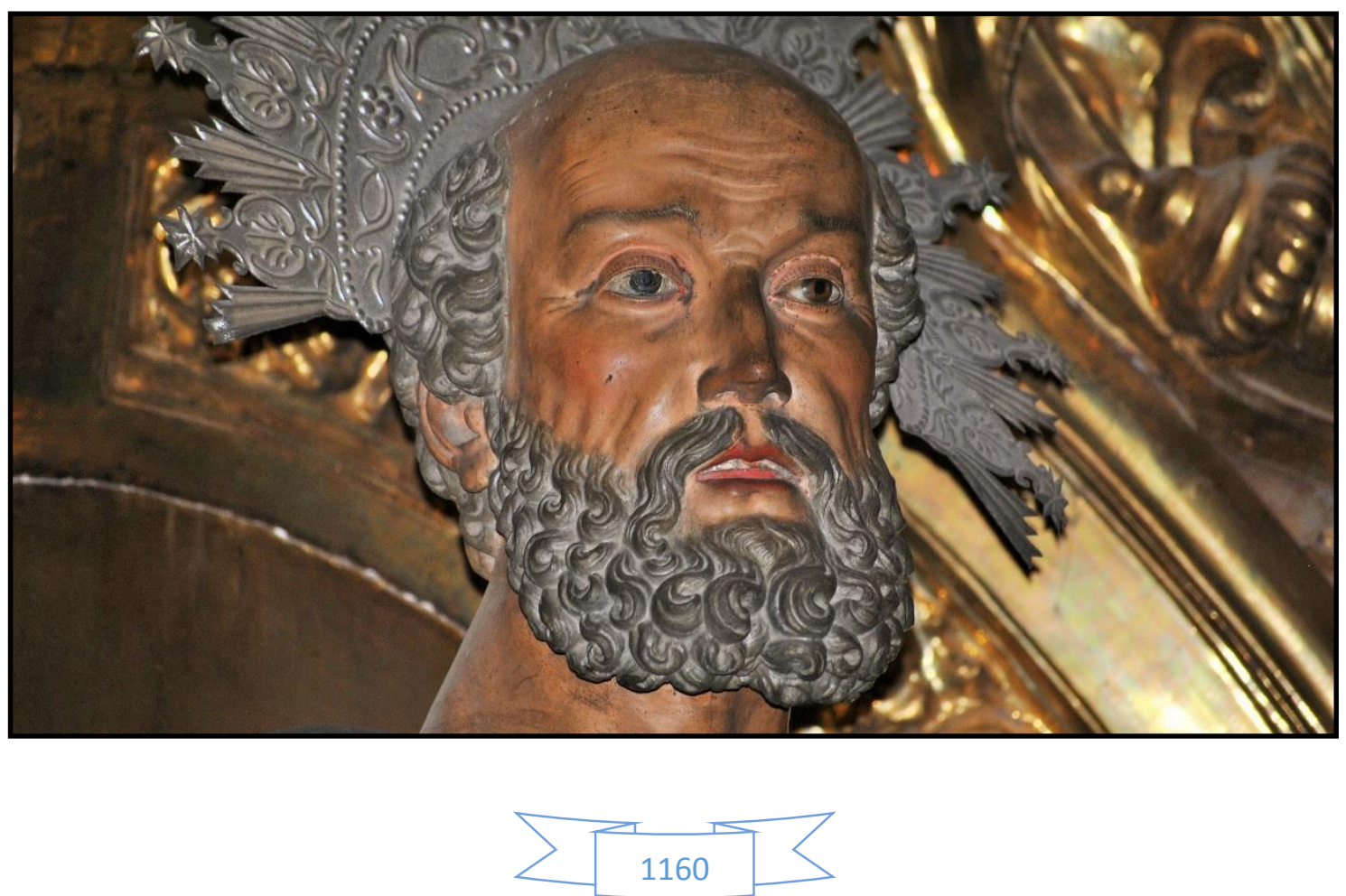


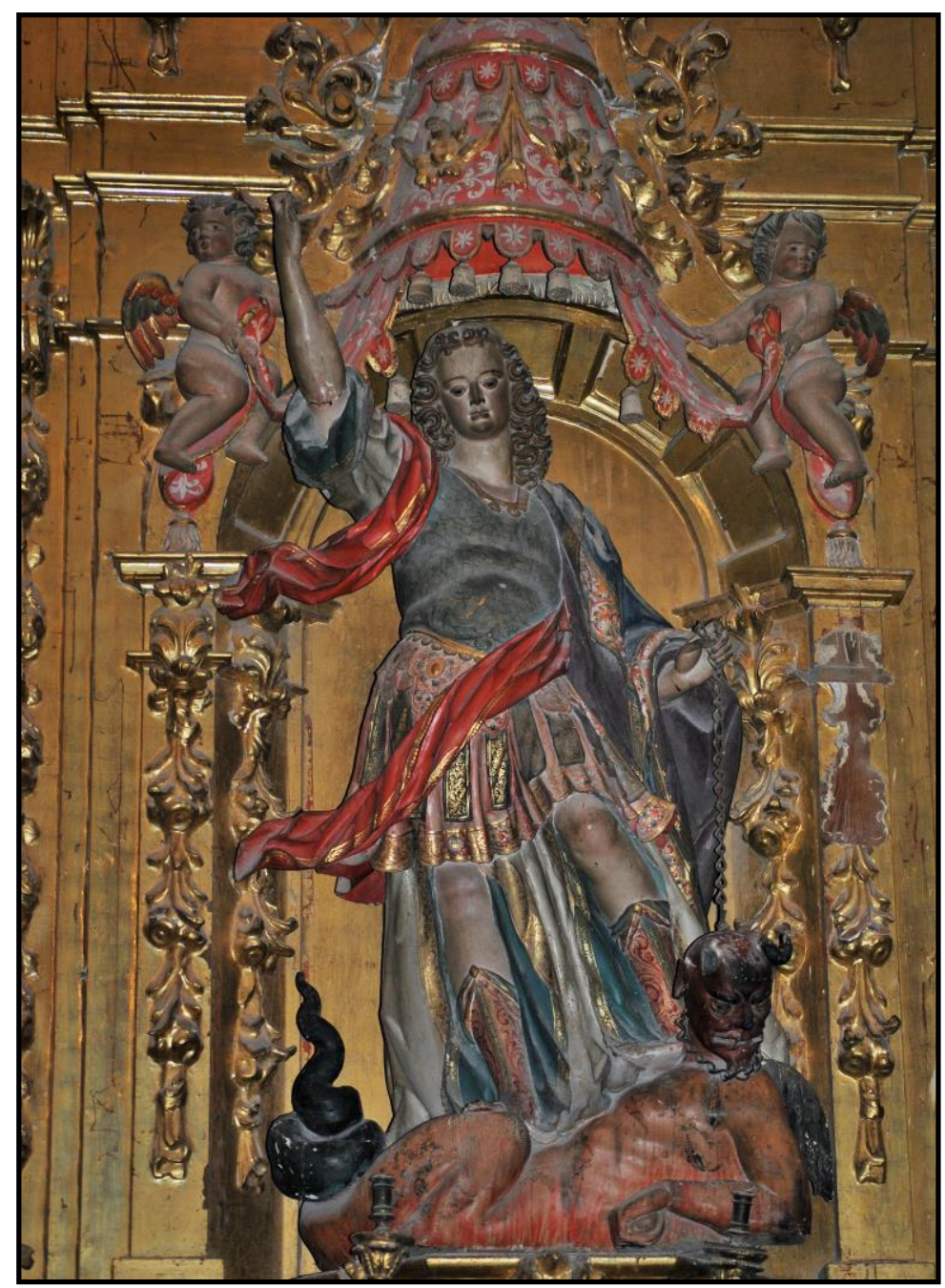

Figs. 25-26- Pedro de Ávila. Detalles de San Miguel. Catedral. Valladolid.
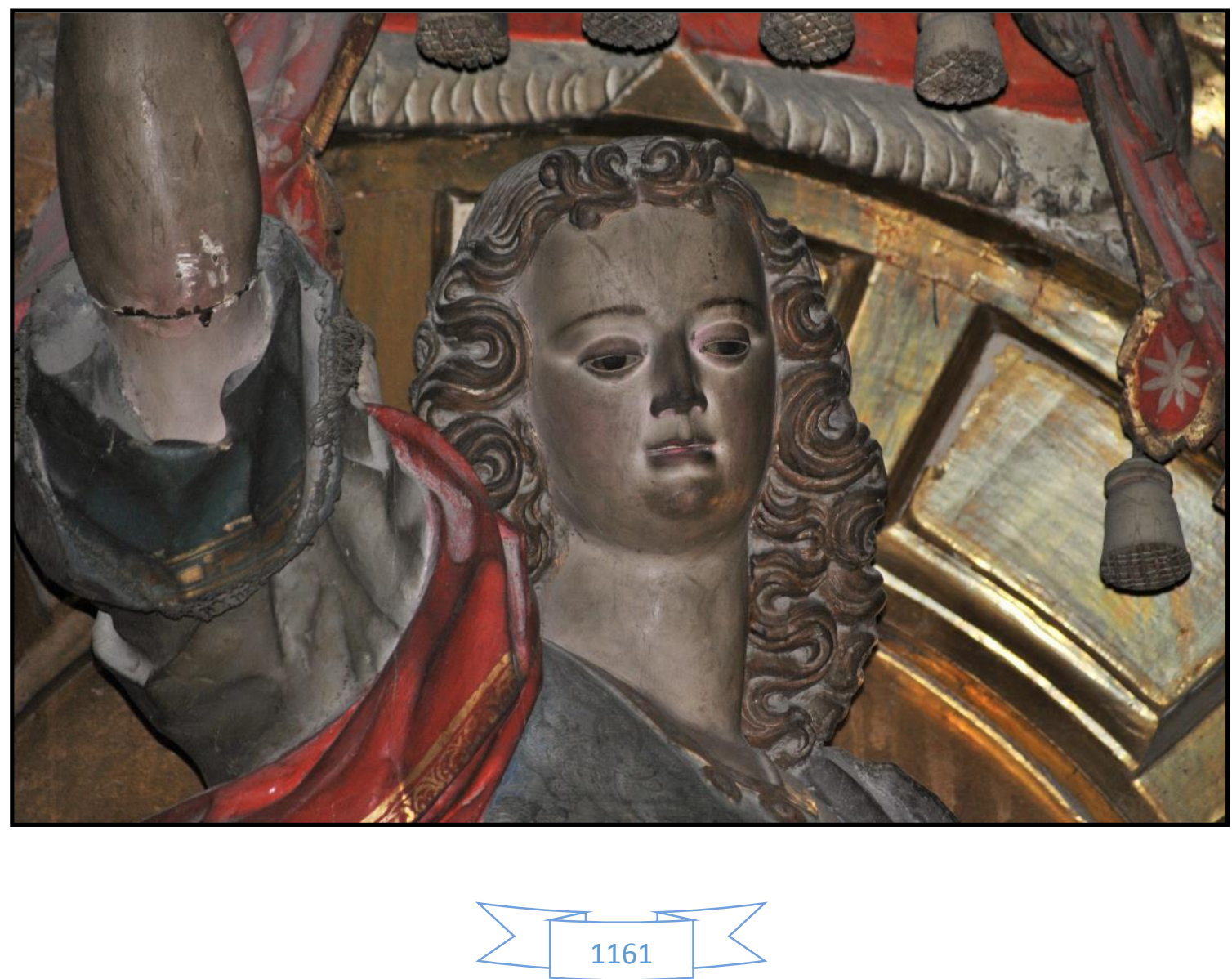


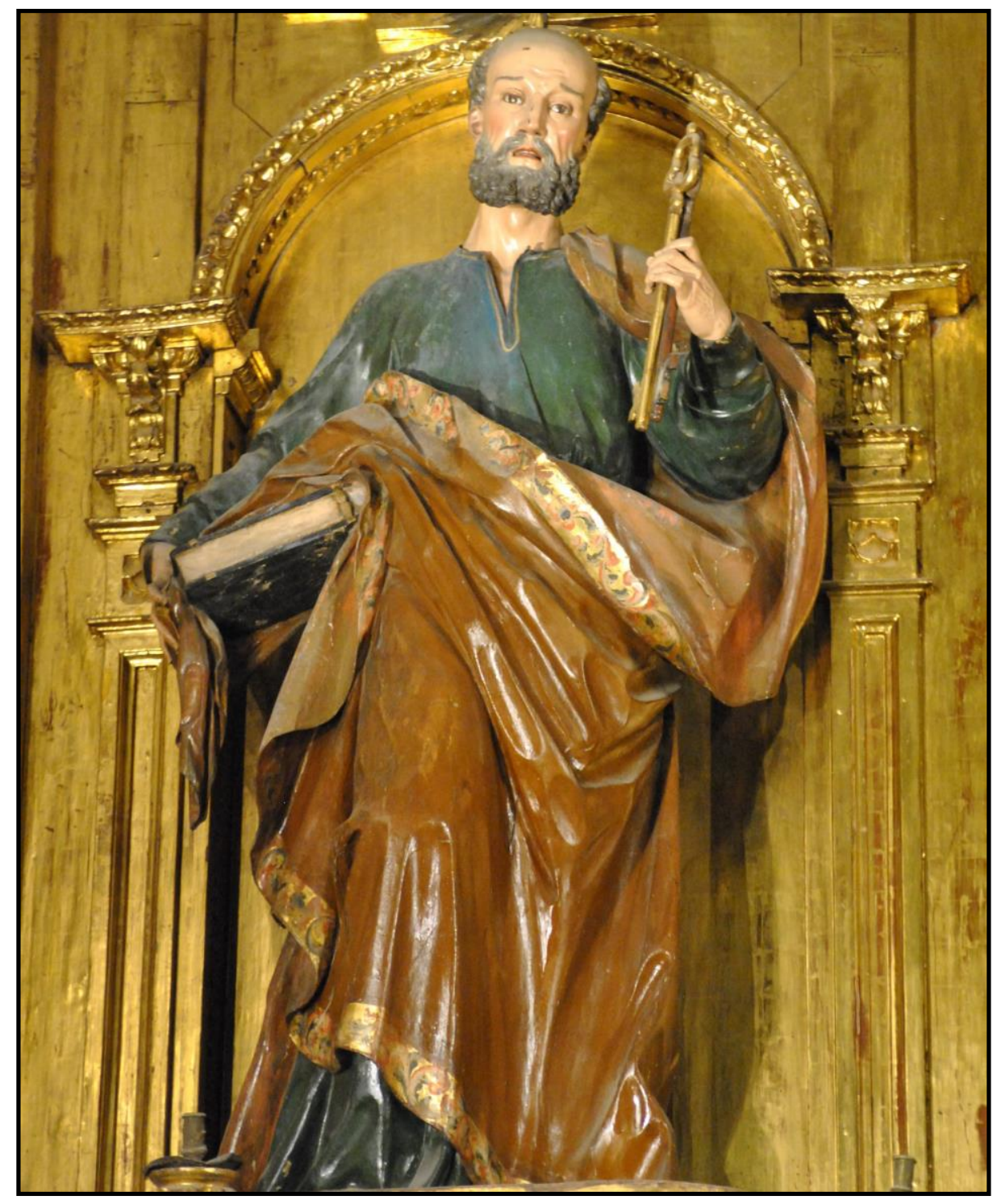

Figs. 27-28- Pedro de Ávila. San Pedro. Oratorio de San Felipe Neri. Valladolid.
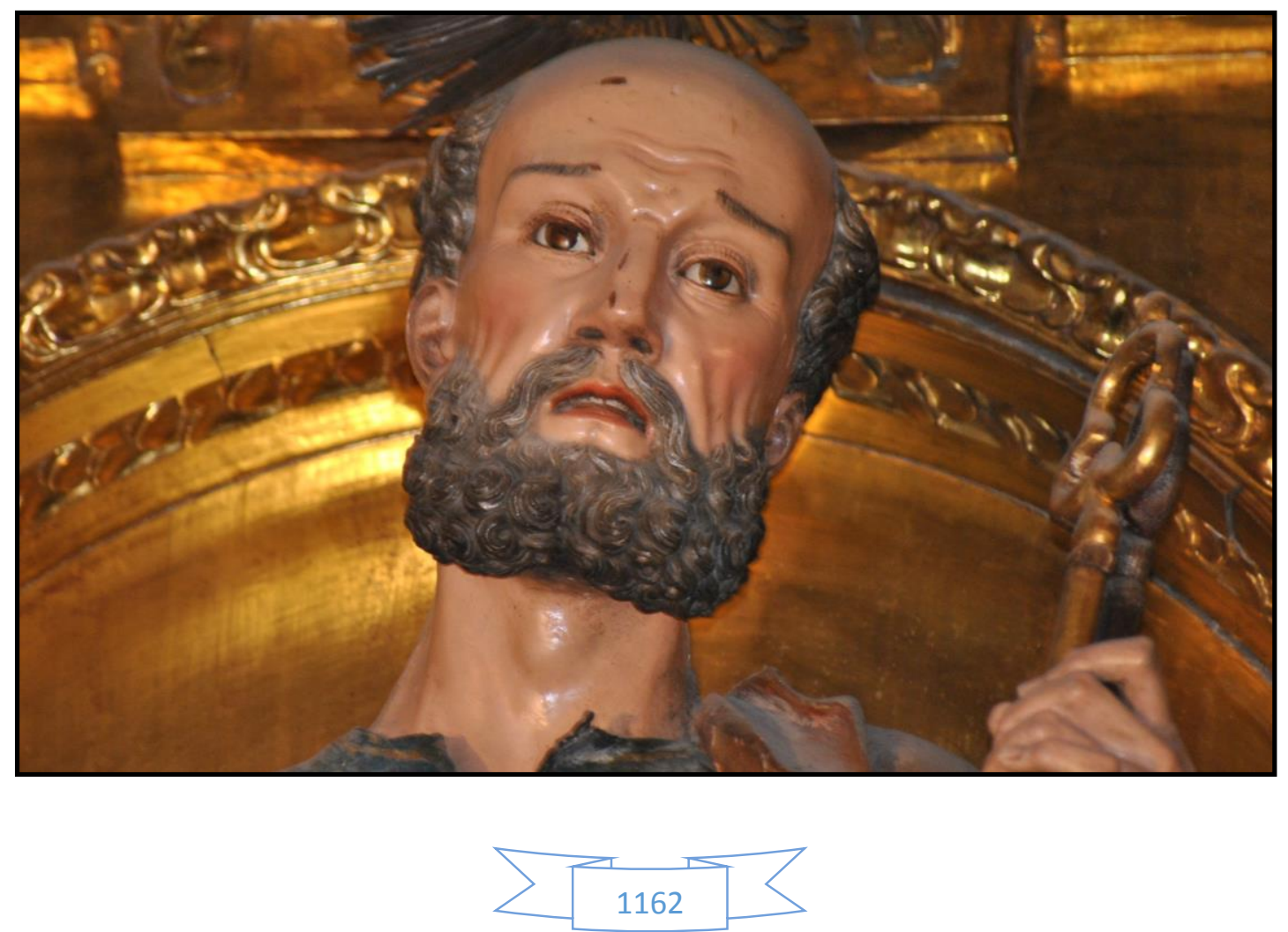


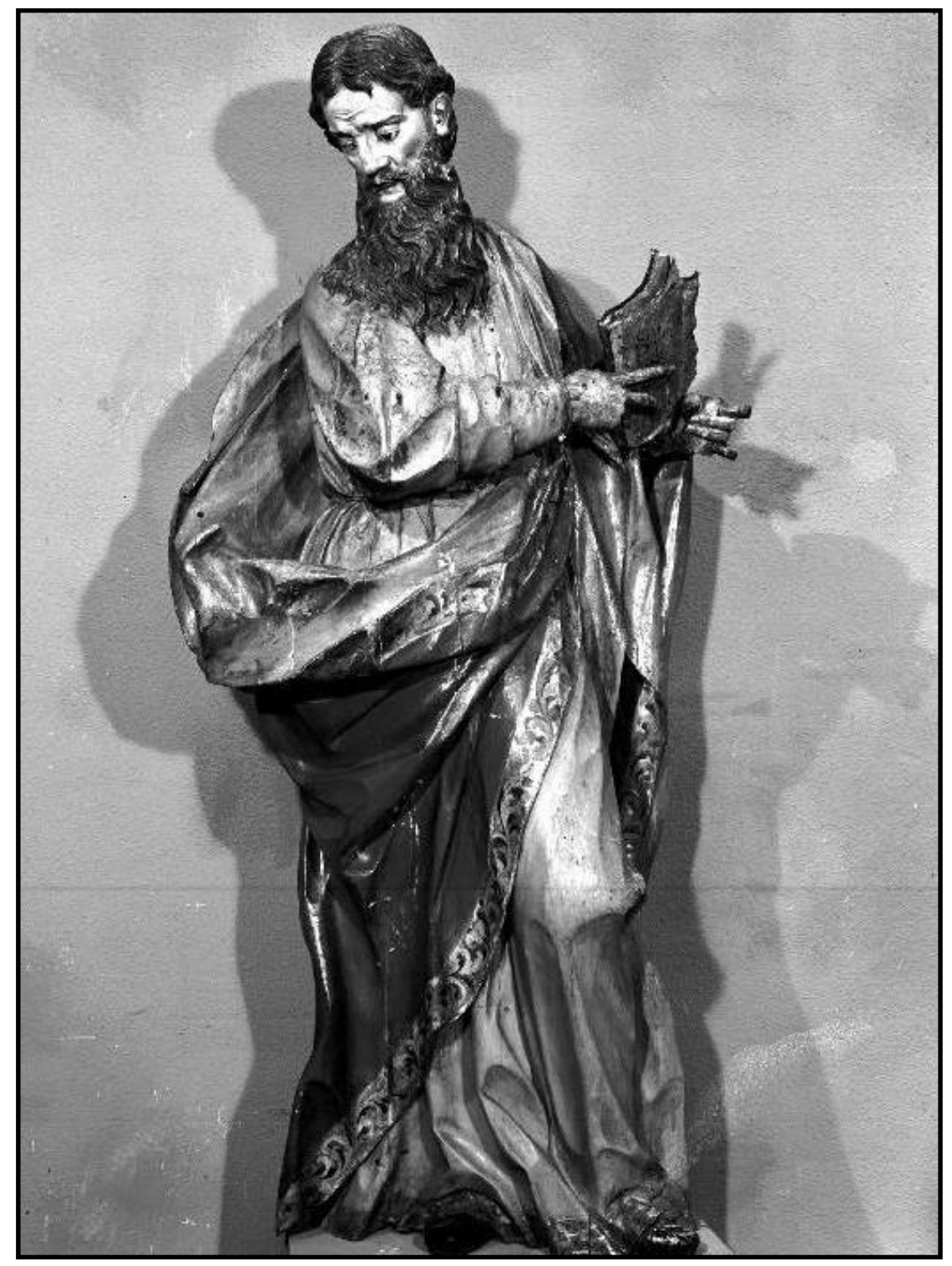

Figs. 29-30- Pedro de Ávila. San Pablo. Oratorio de San Felipe Neri.
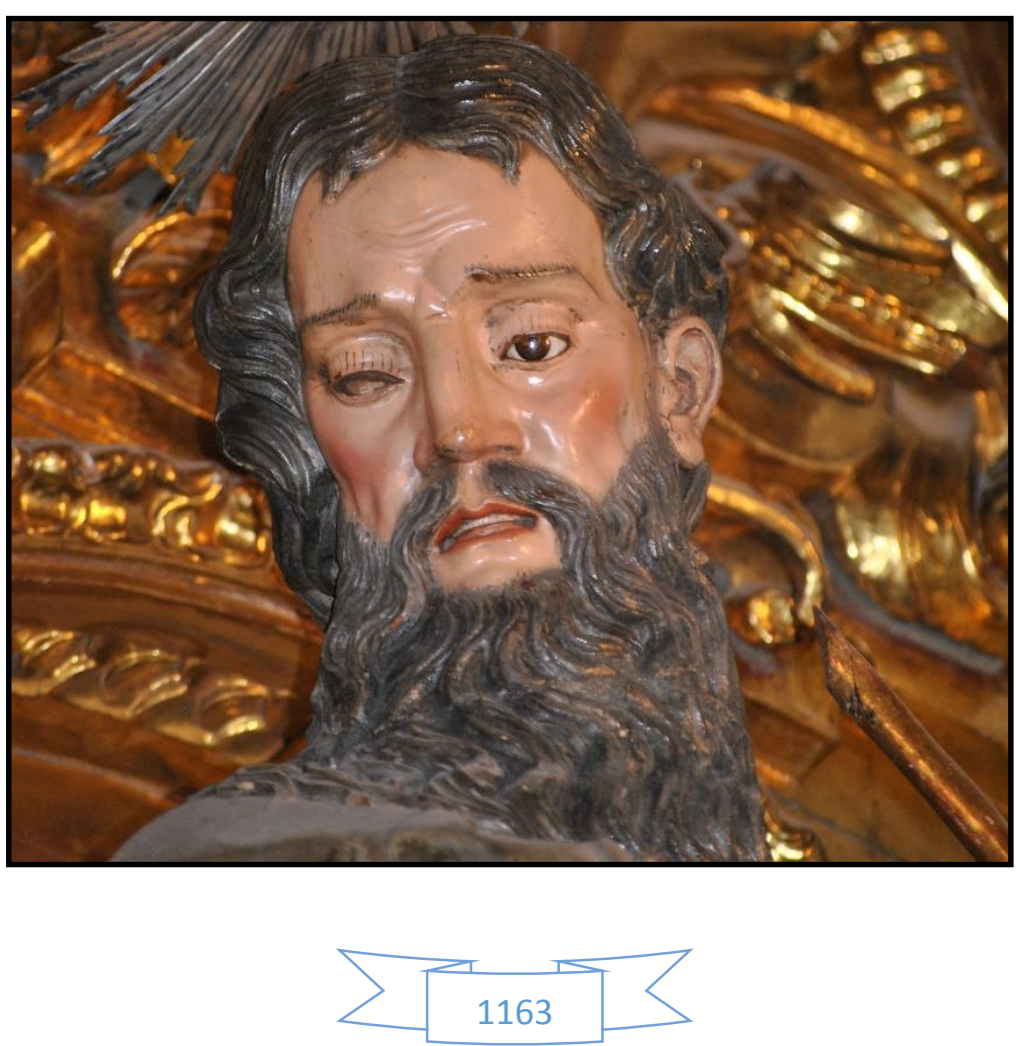


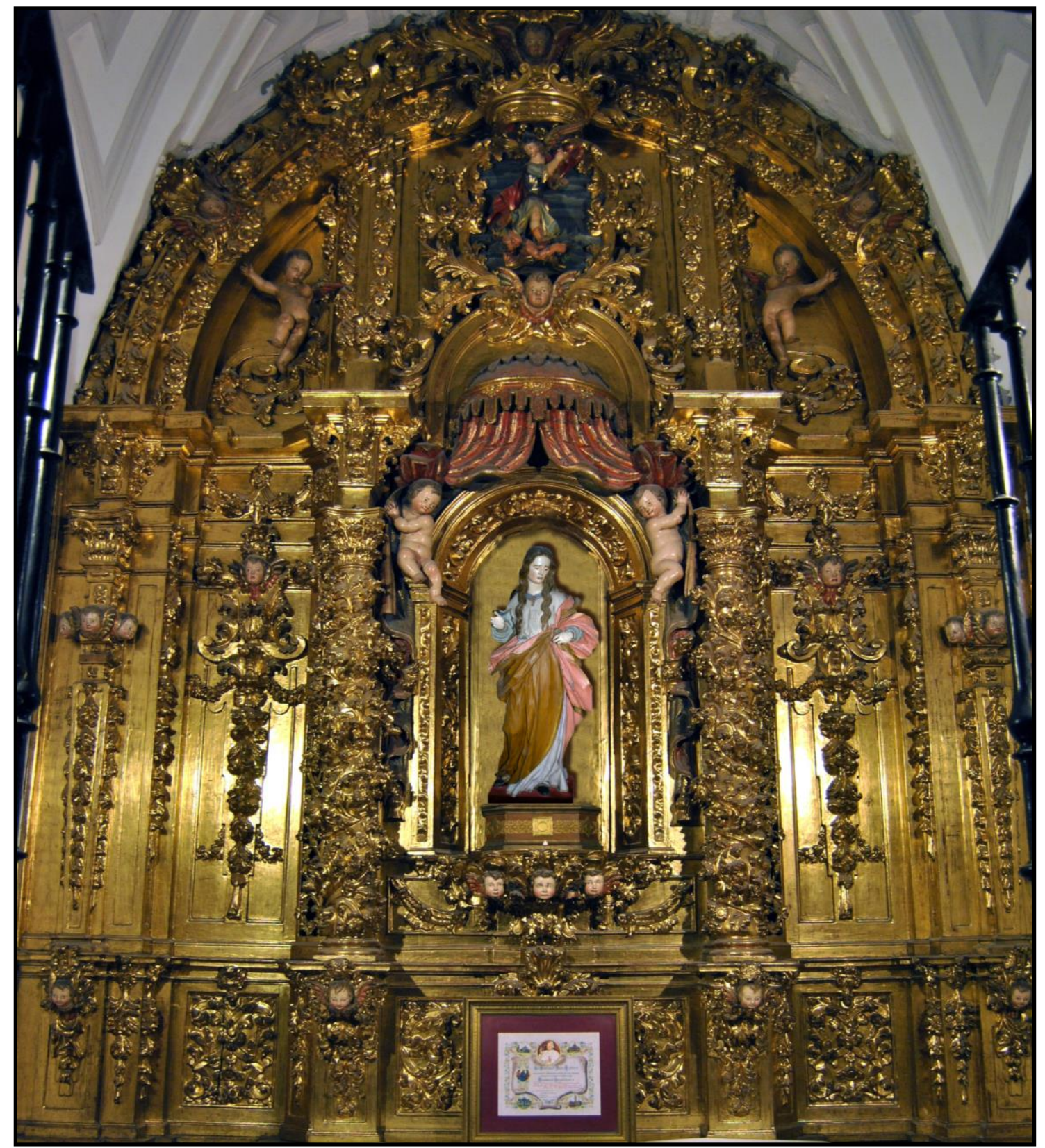

Fig. 31- Reconstrucción virtual del retablo de Santa María Magdalena. Oratorio de San Felipe Neri. Valladolid.

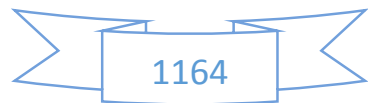




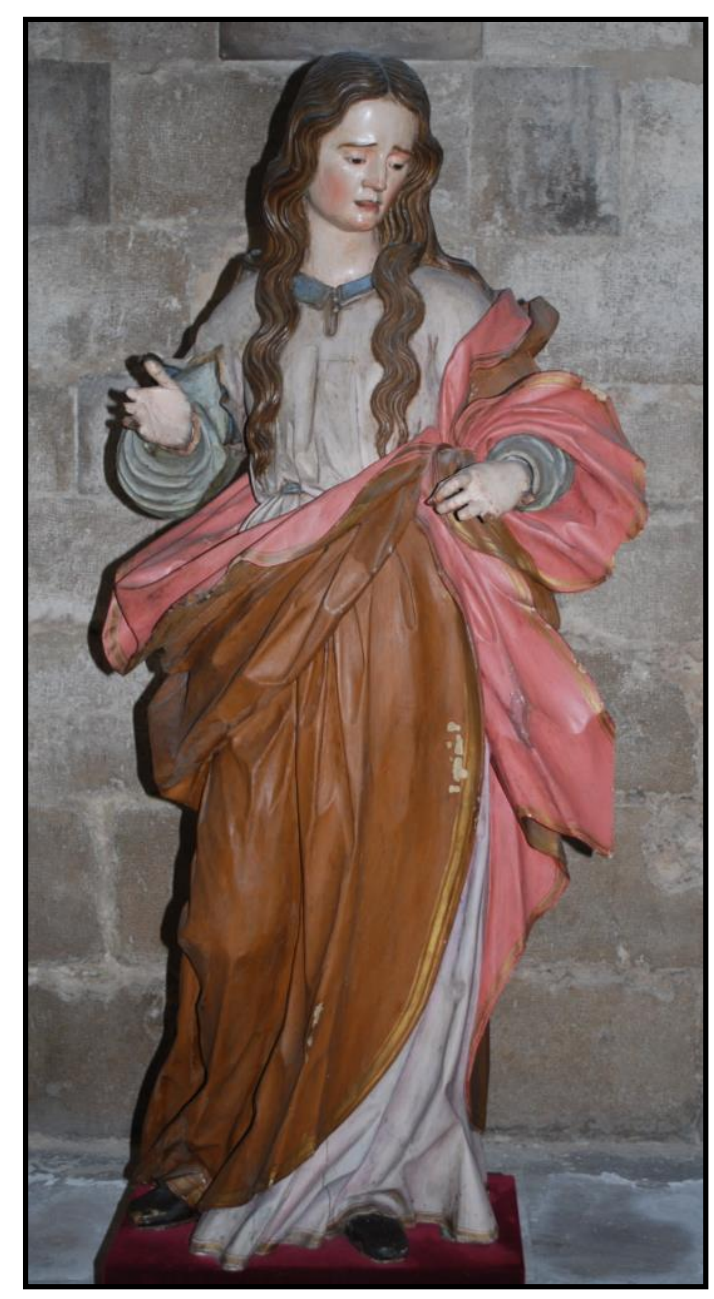

Fig. 32- Pedro de Ávila. Santa María Magdalena del Oratorio de San Felipe Neri. Museo

Diocesano y Catedralicio. Valladolid.

Fig. 33- Pedro de Ávila. Detalle de Santa María Magdalena.
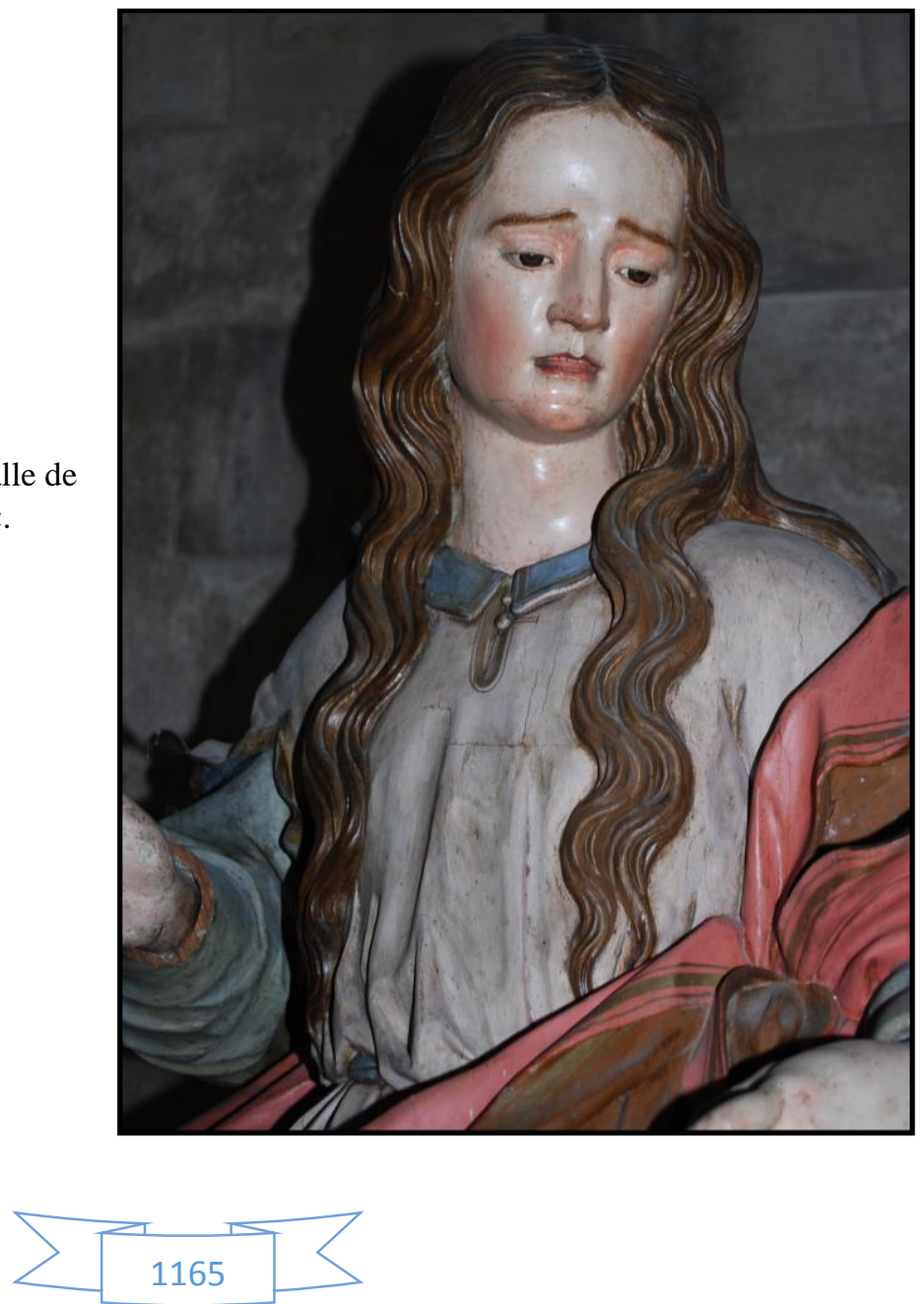


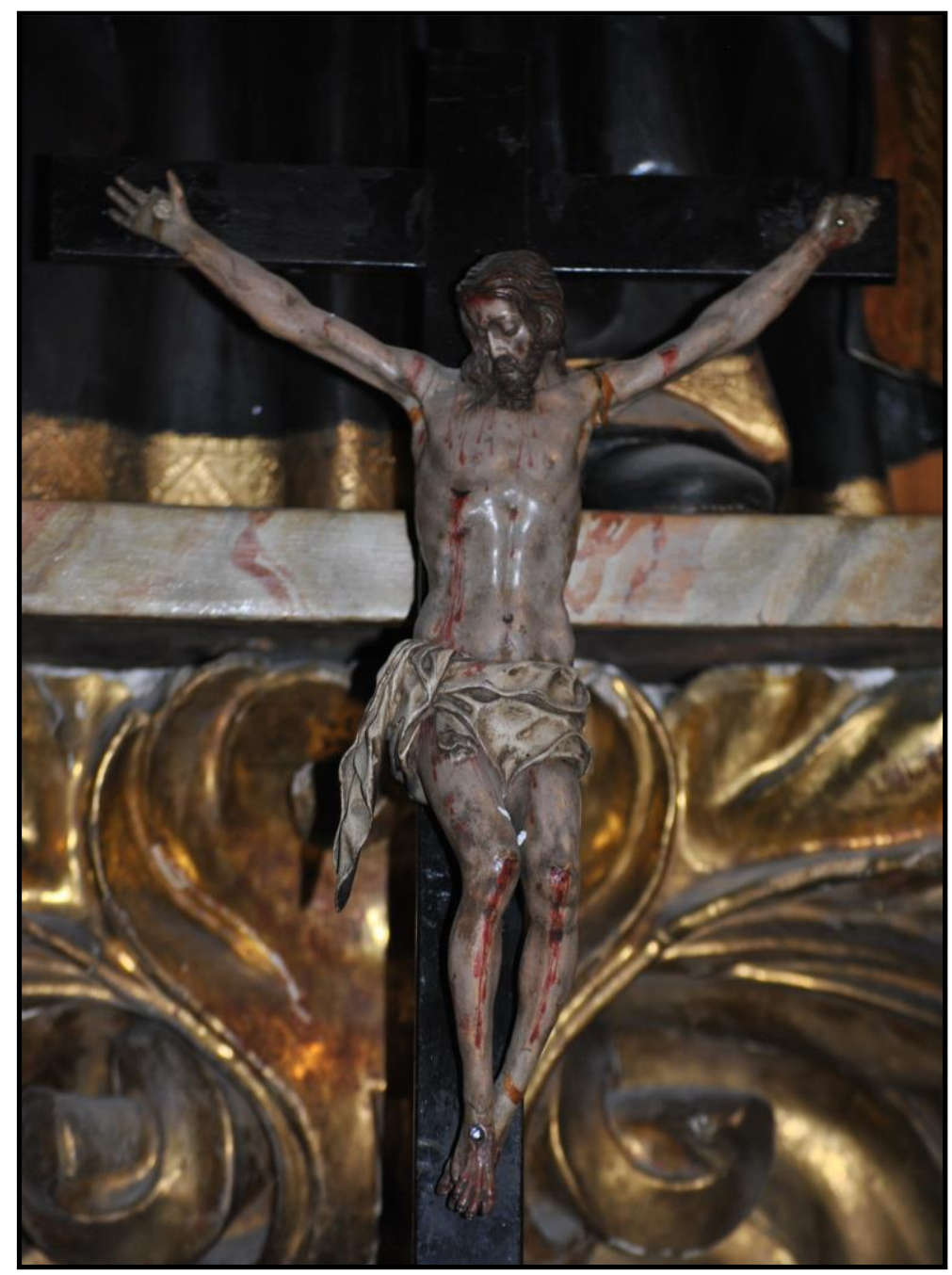

Fig. 34- Pedro de Ávila. Crucifijo de la Santa María Magdalena del Oratorio de San Felipe Neri. Oratorio de San Felipe Neri. Valladolid.

Fig. 35- Pedro de Ávila. Detalle del Crucifijo de Santa María Magdalena.
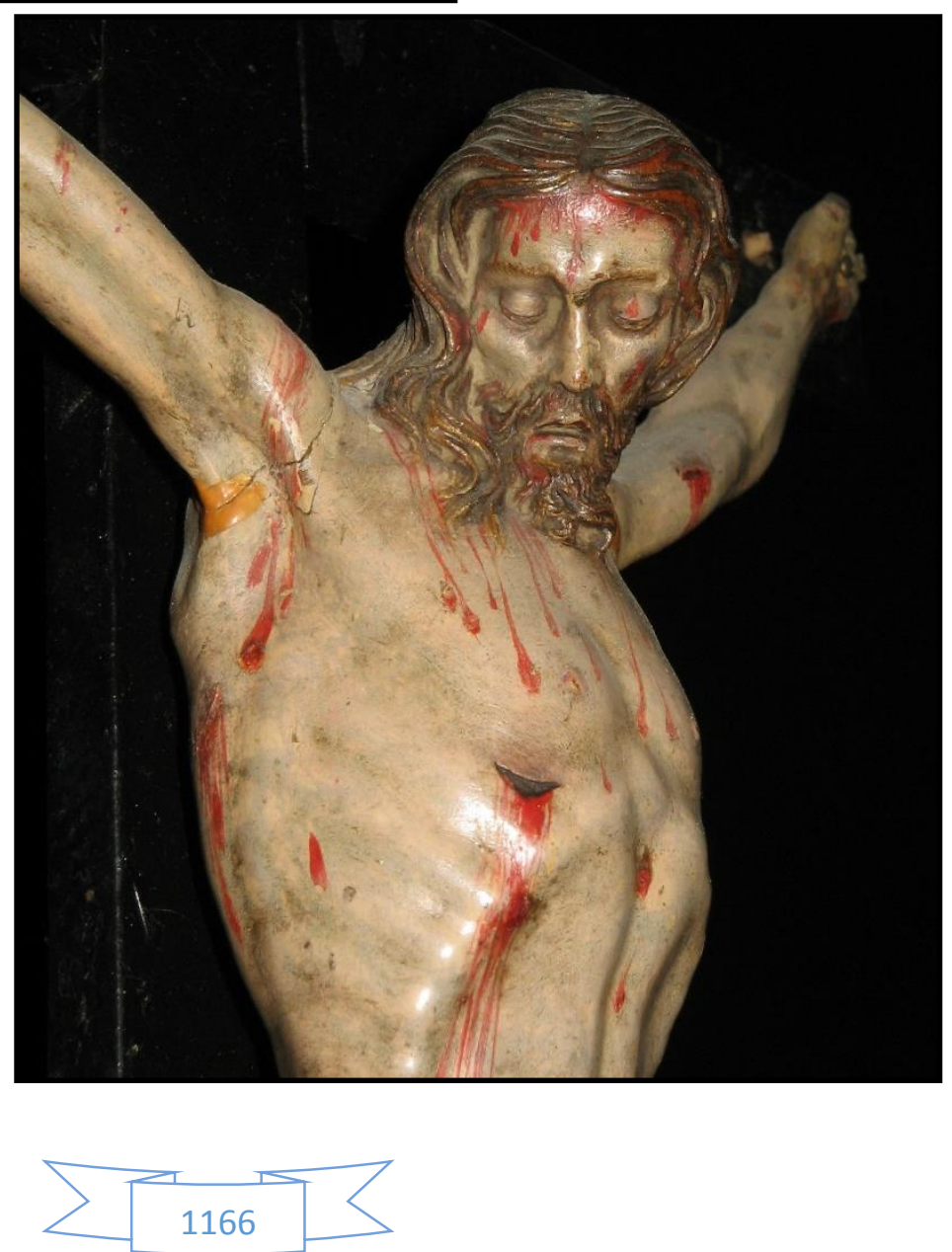


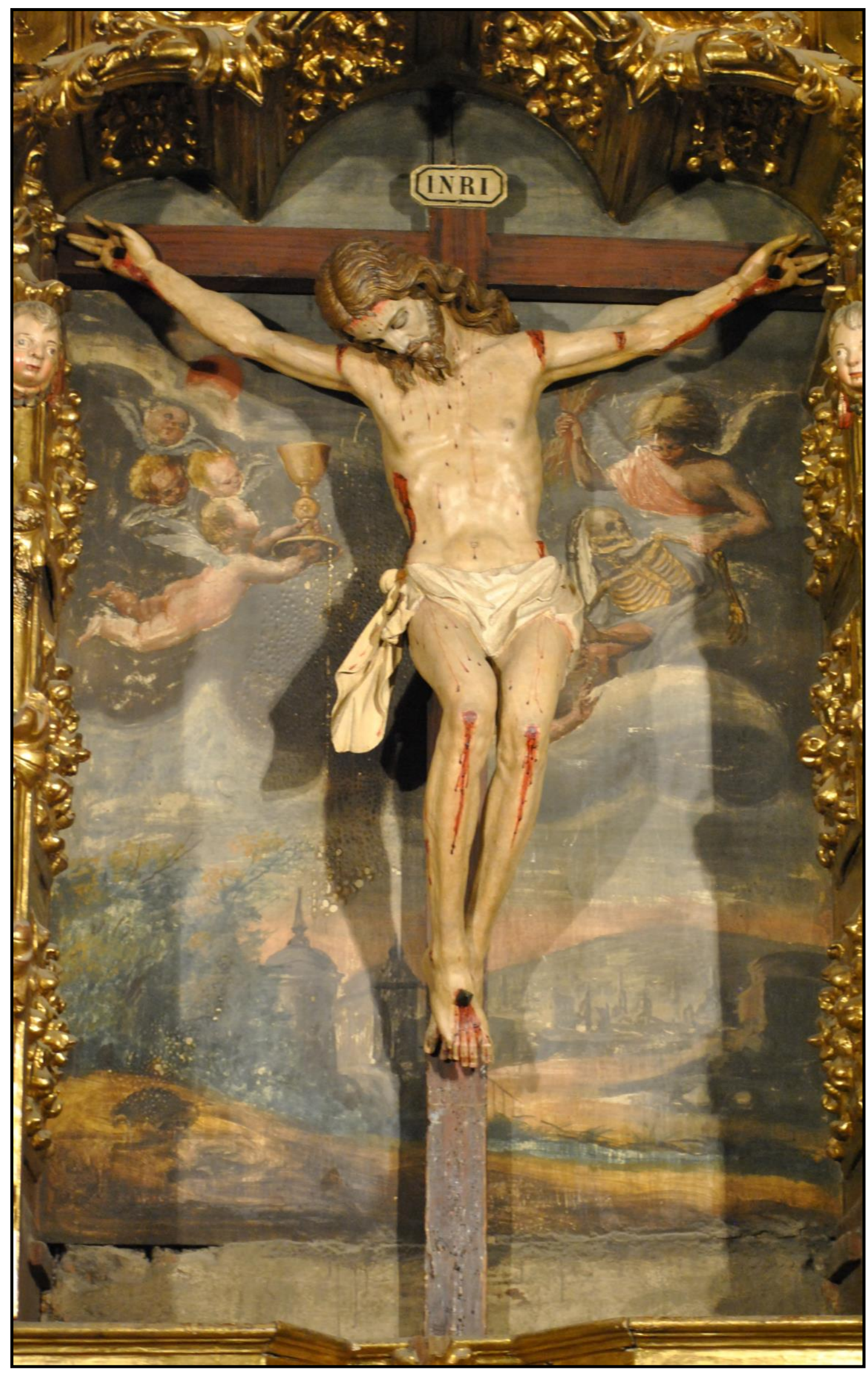

Fig. 36- Pedro de Ávila. Crucifijo (Cristo del Olvido). Oratorio de San Felipe Neri. Valladolid.

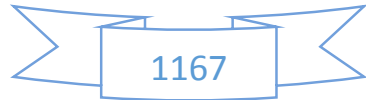




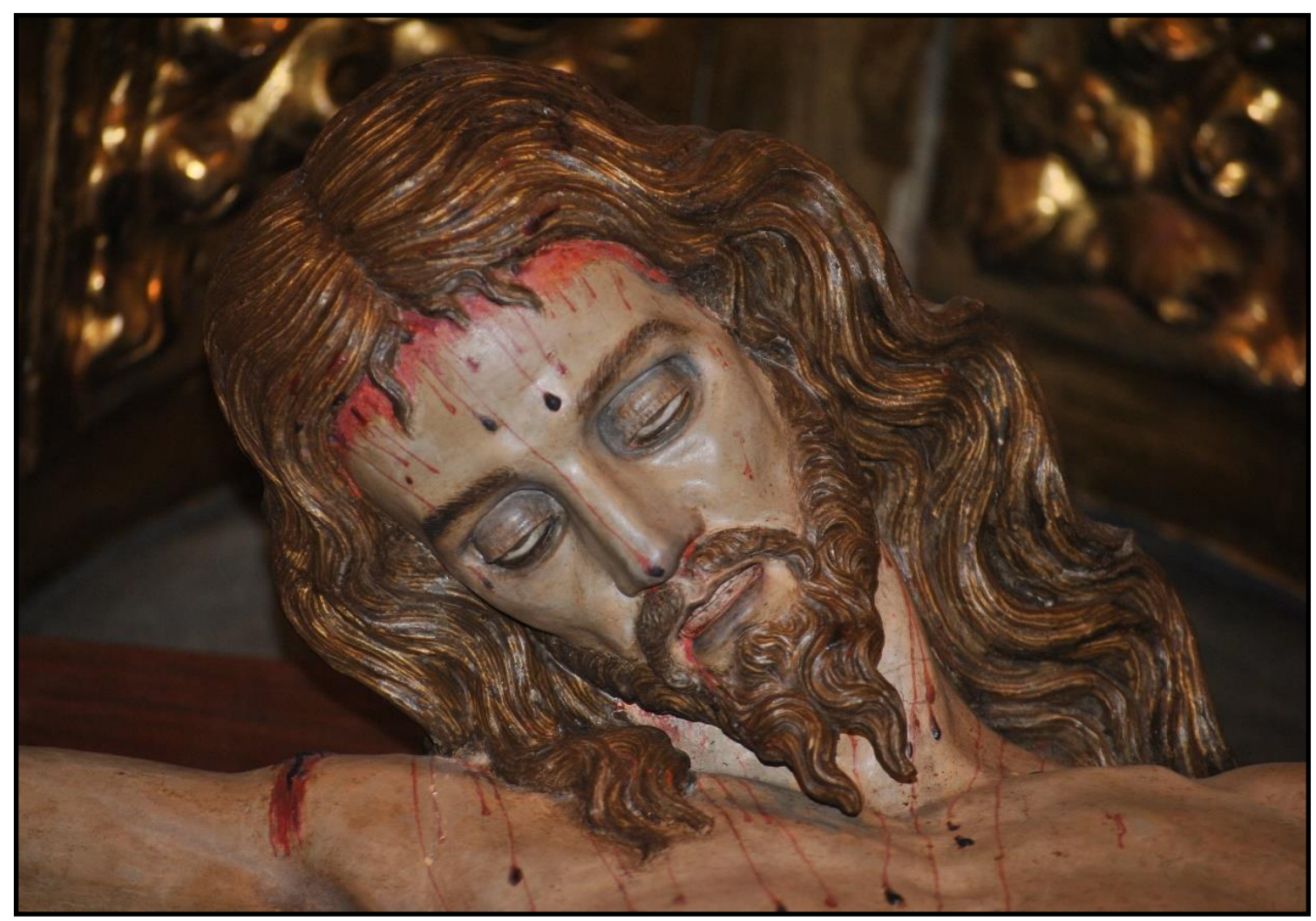

Figs. 37-38- Pedro de Ávila. Detalles del Crucifijo (Cristo del Olvido).
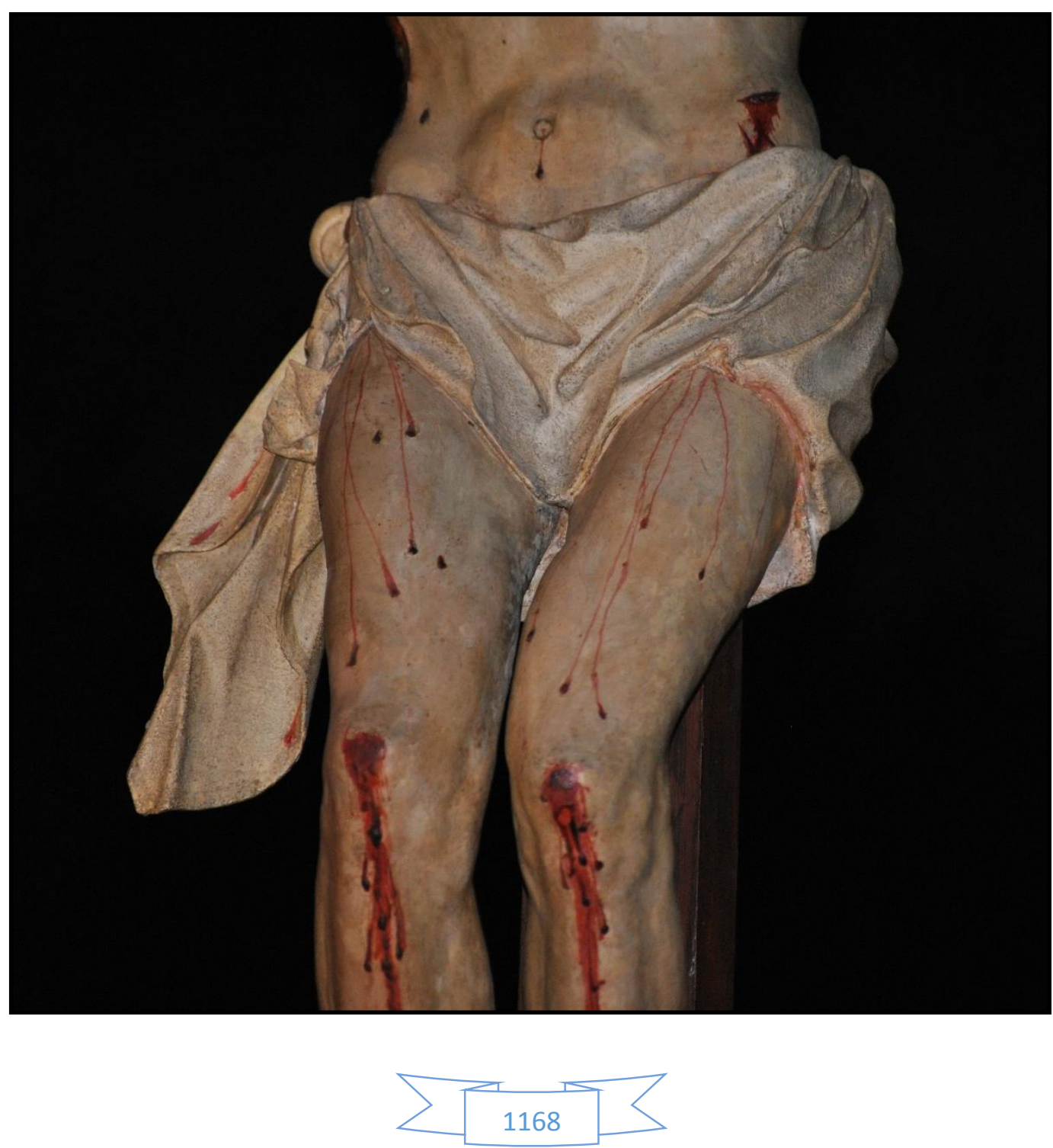


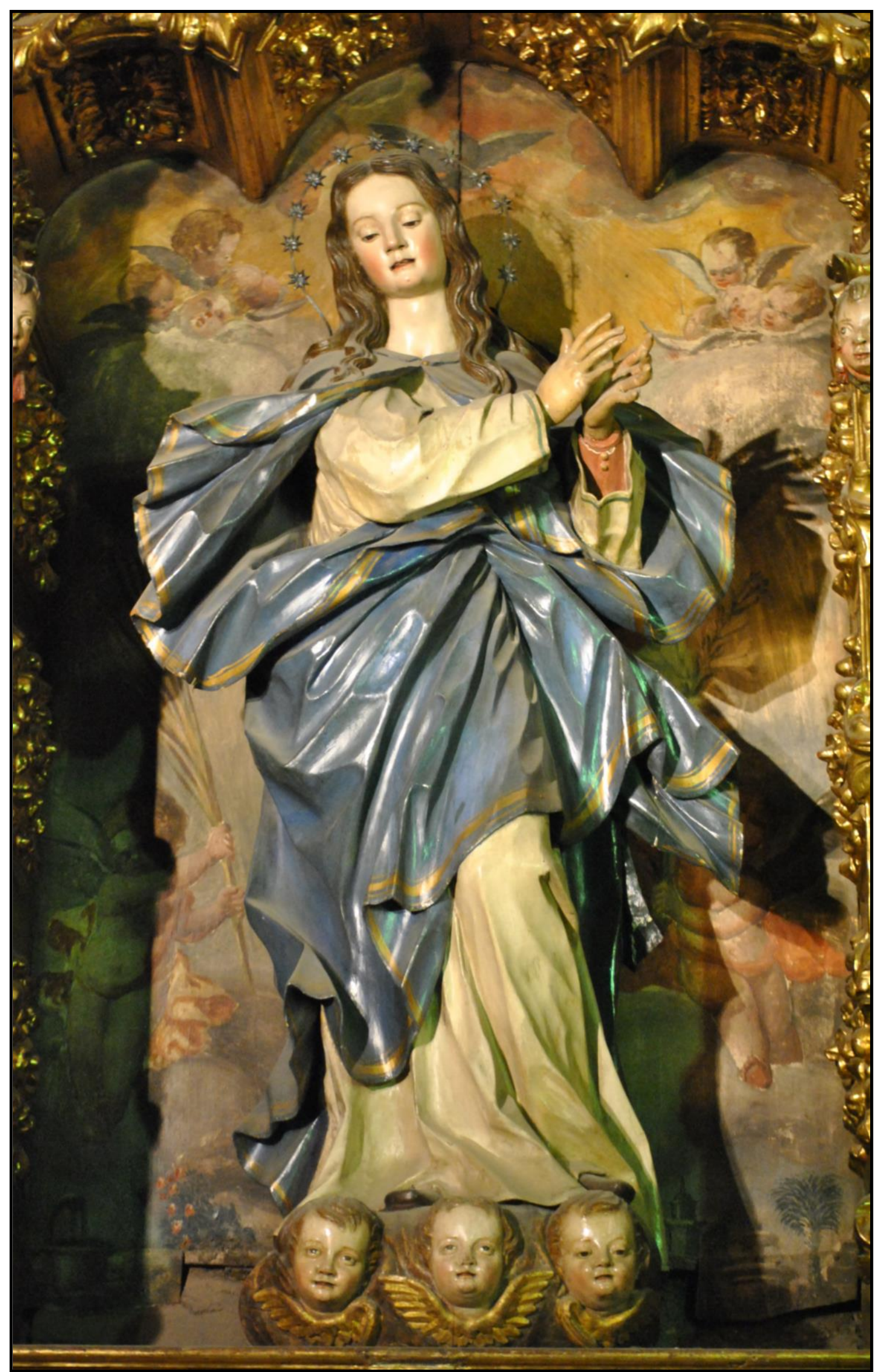

Fig. 39- Pedro de Ávila. Inmaculada Concepción. Oratorio de San Felipe Neri. Valladolid.

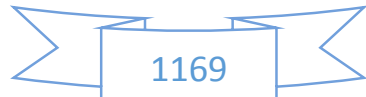




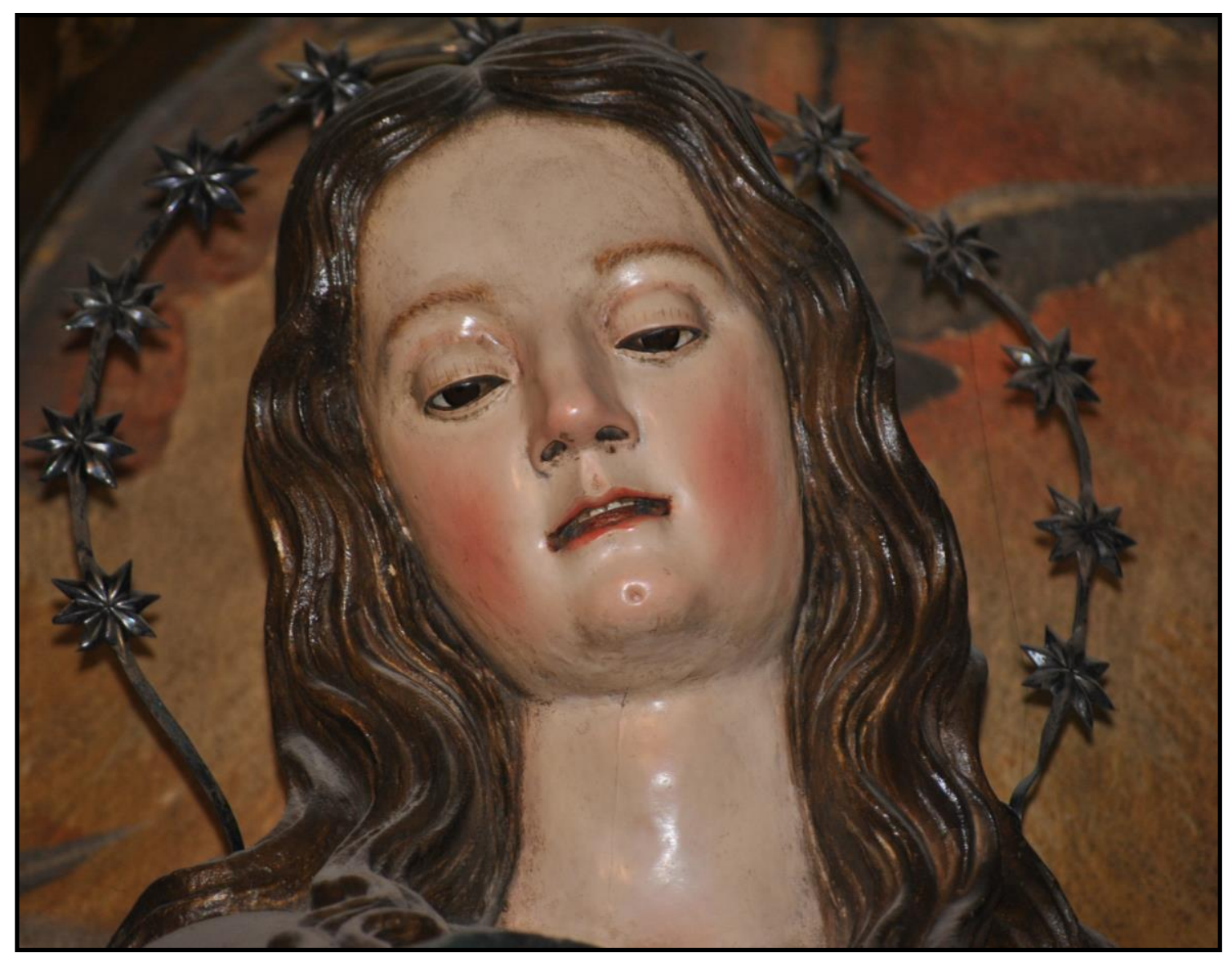

Figs. 40-41- Pedro de Ávila. Detalles de la Inmaculada Concepción.
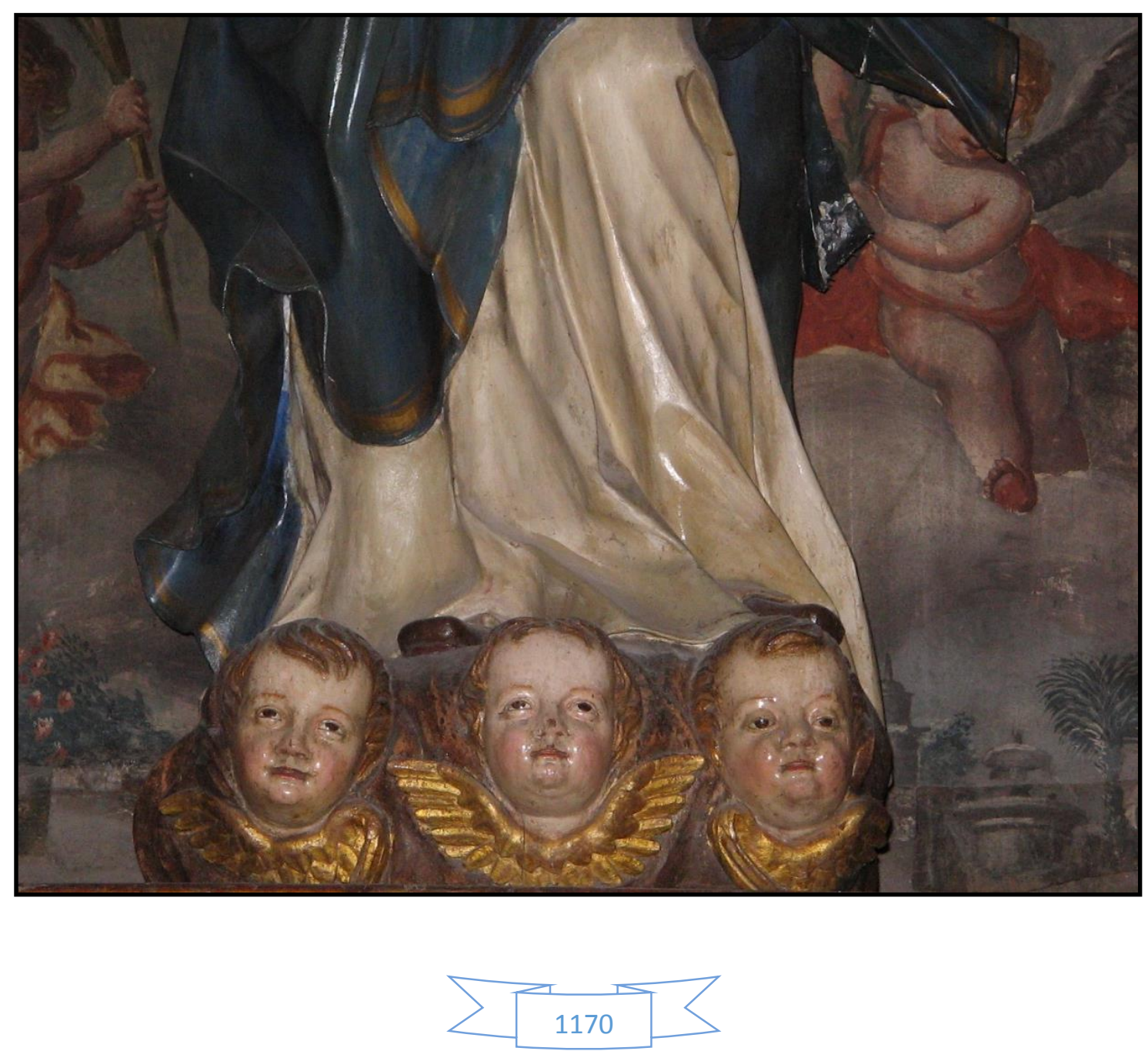


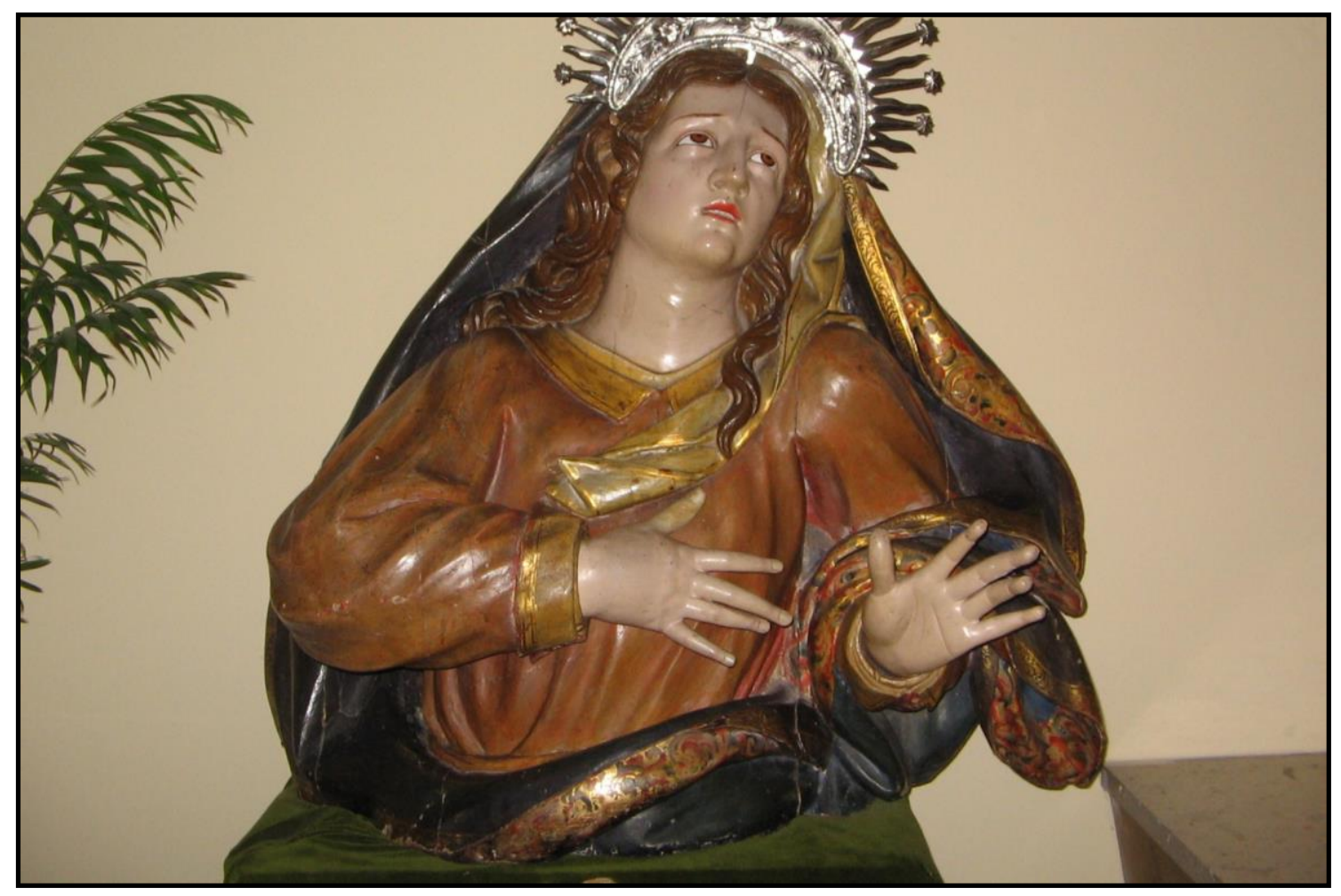

Fig. 42- Pedro de Ávila (atrib.). Busto de Dolorosa. Monasterio de San Quirce. Valladolid.

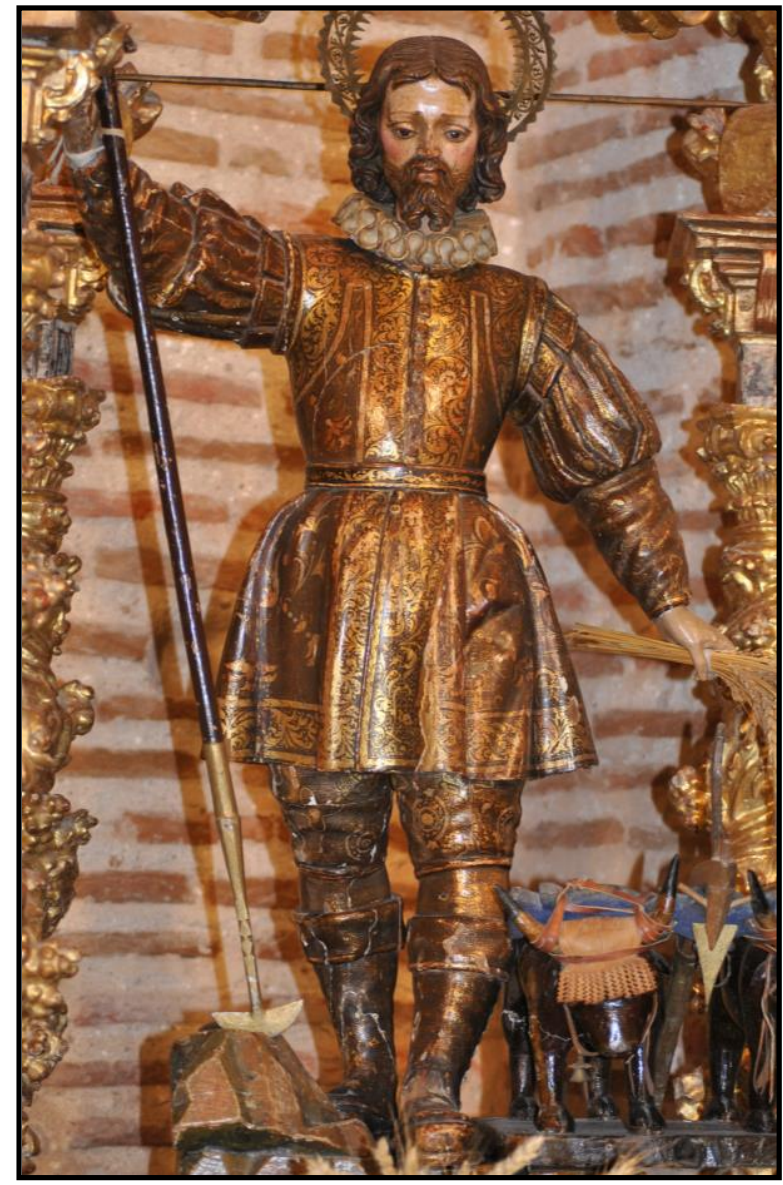

Fig. 43- Pedro de Ávila (atrib.). San Isidro. Iglesia parroquial de San Pedro. Aguasal (Valladolid).

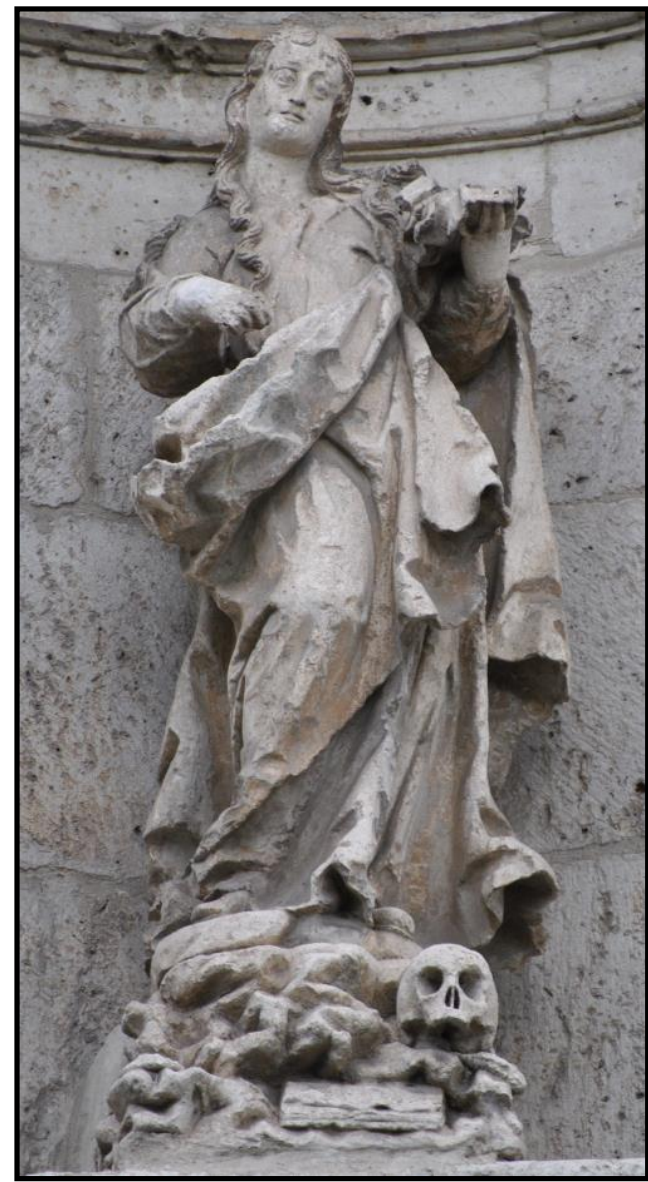

Fig. 44- Pedro de Ávila (atrib.). Santa María Magdalena. Iglesia de Santa María Magdalena. Valladolid. 


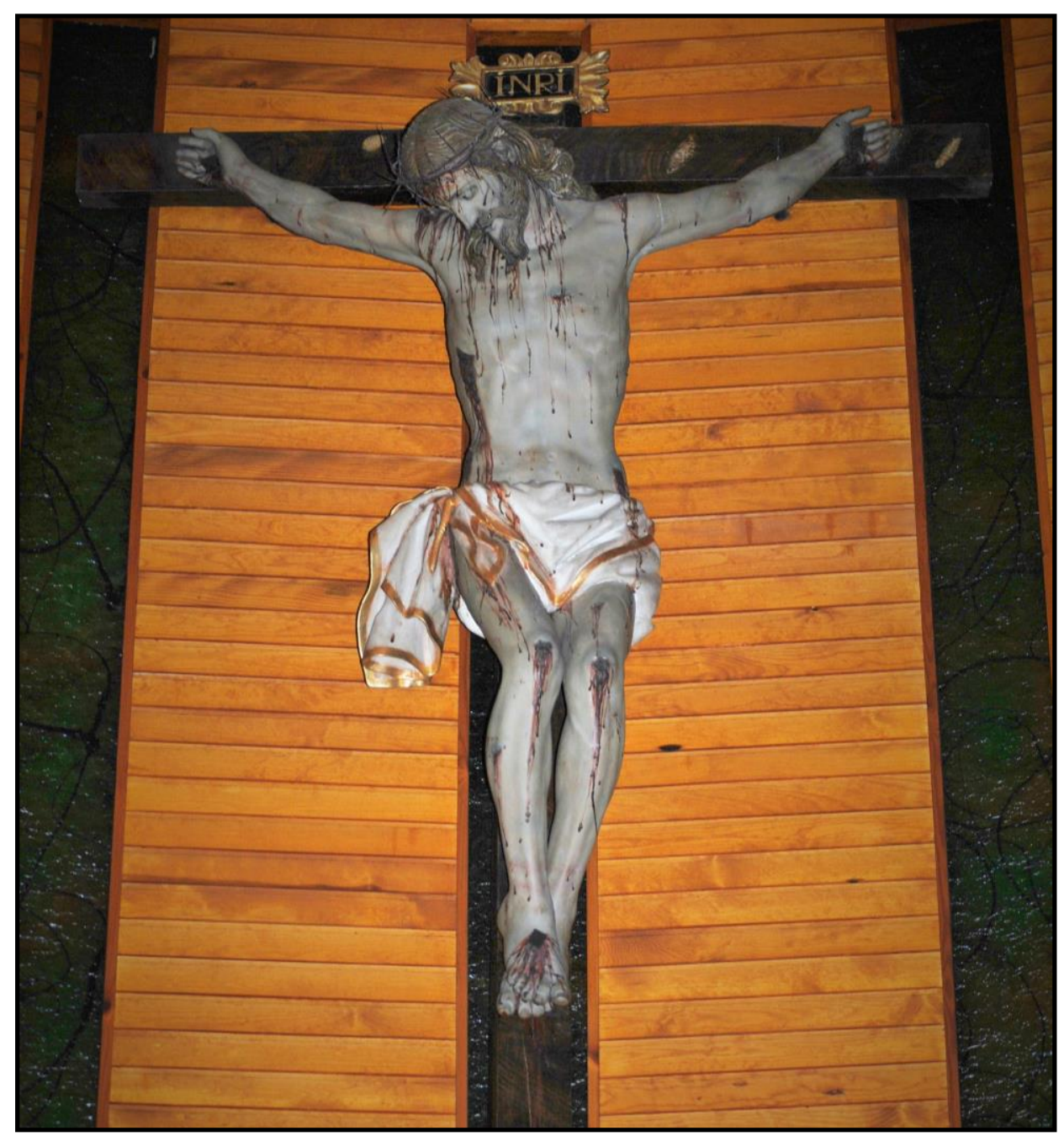

Figs. 45-46- Pedro de Ávila (atrib.). Crucificado. Monasterio de Santa Brígida. Valladolid.
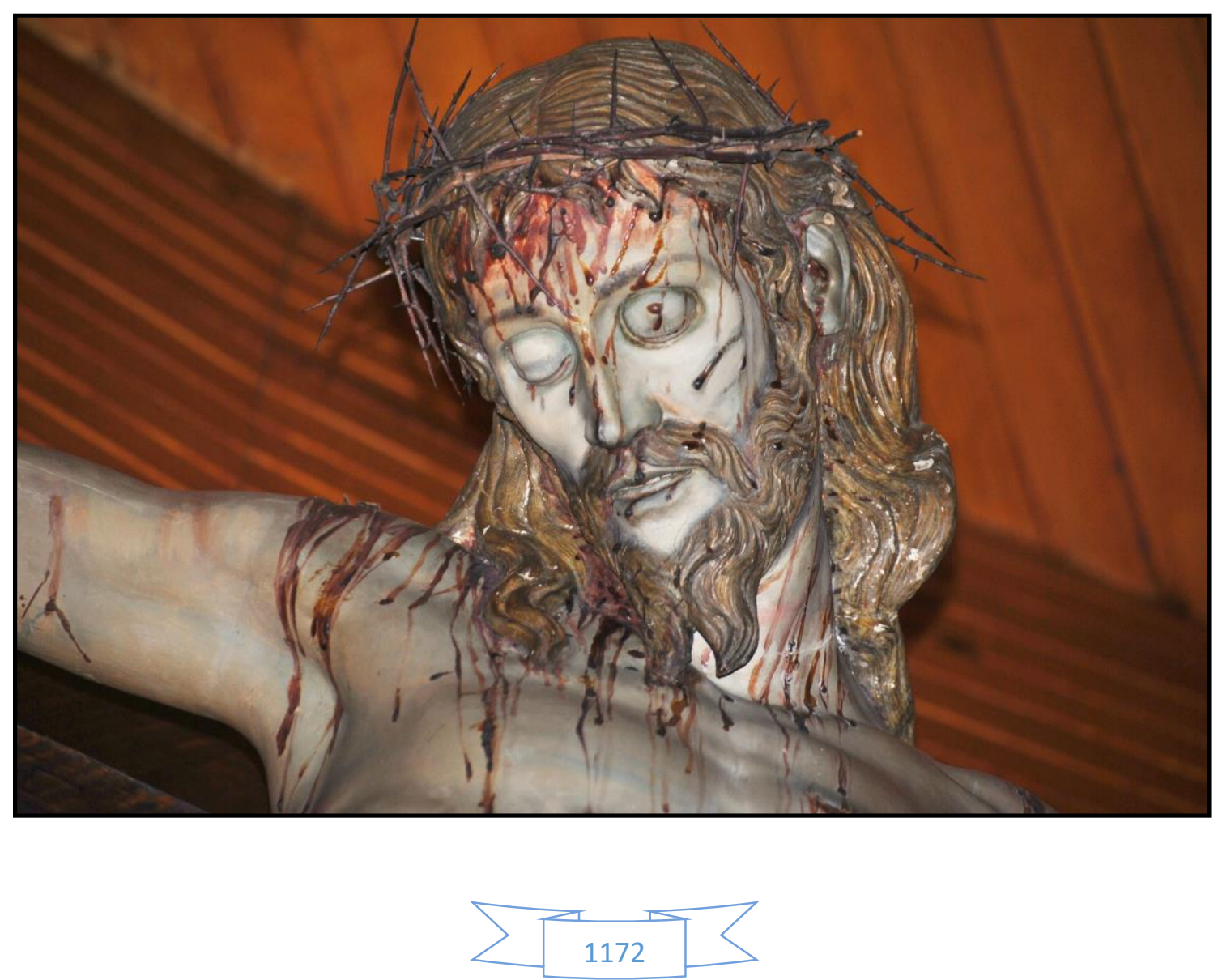


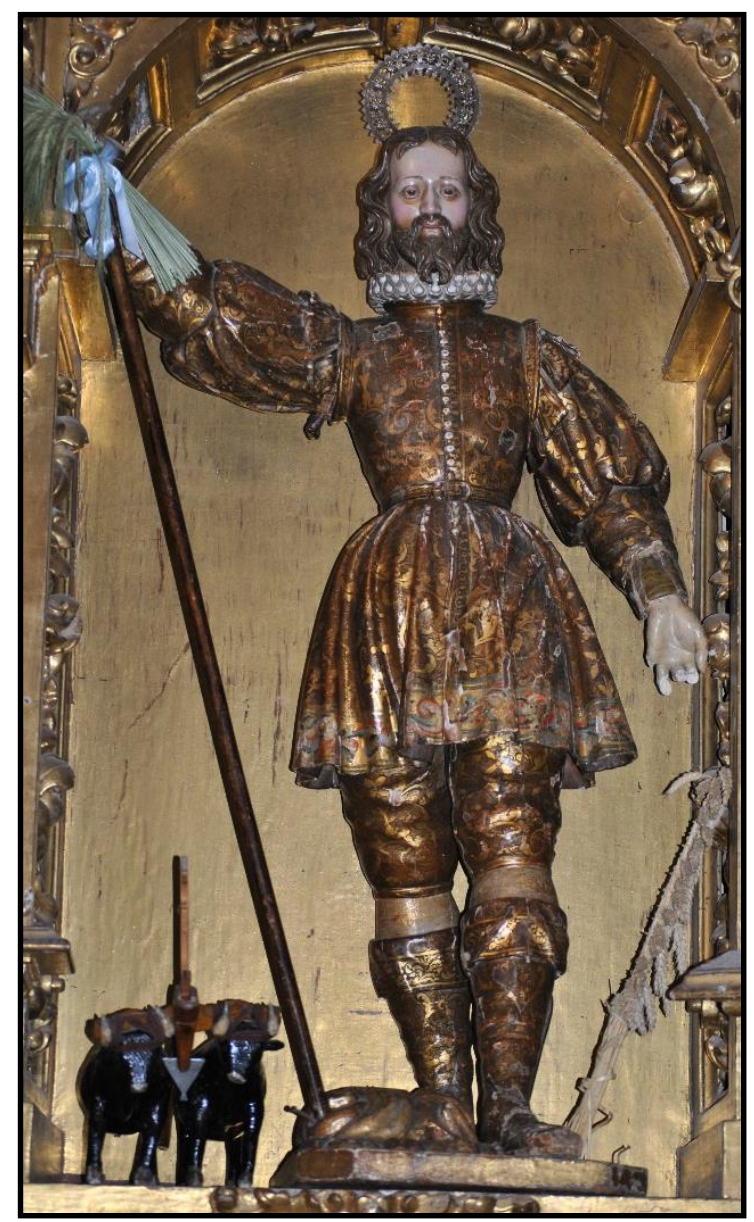

Fig. 47- Pedro de Ávila (atrib.). San Isidro. Iglesia parroquial de la Asunción. Puras (Valladolid).

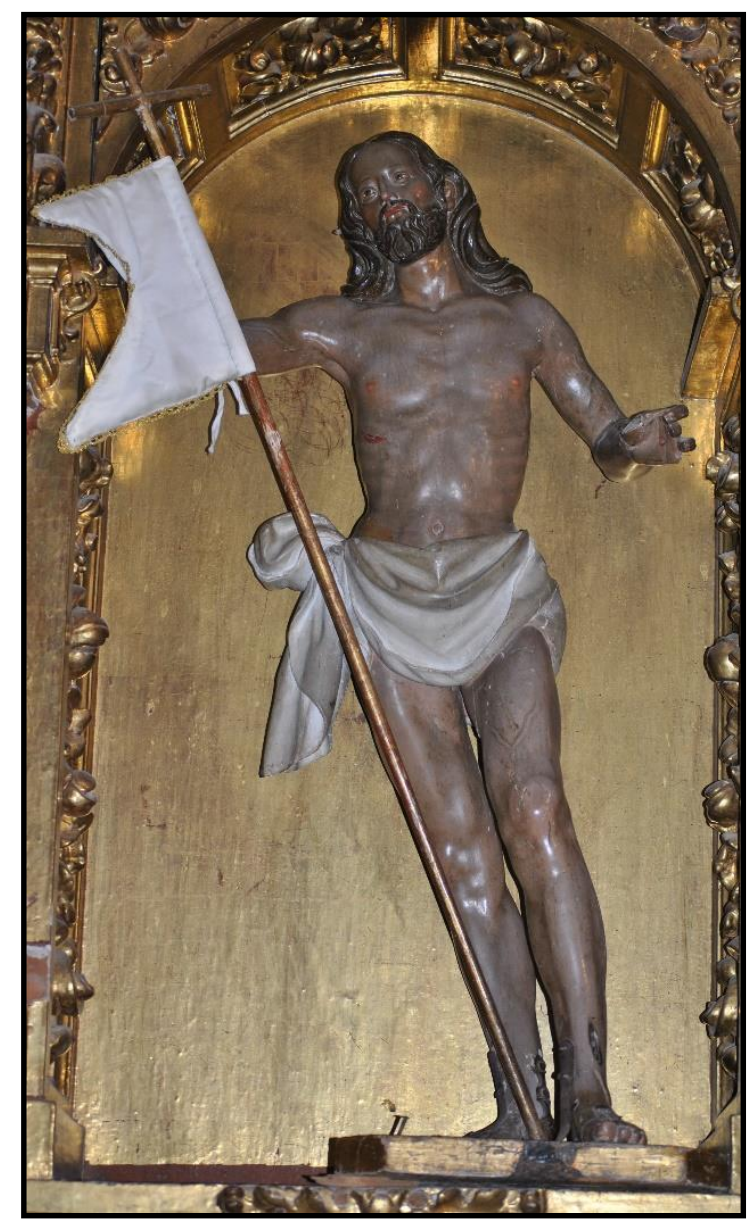

Fig. 48- Pedro de Ávila (atrib.). Cristo

Resucitado. Iglesia parroquial de la Asunción. Puras (Valladolid).

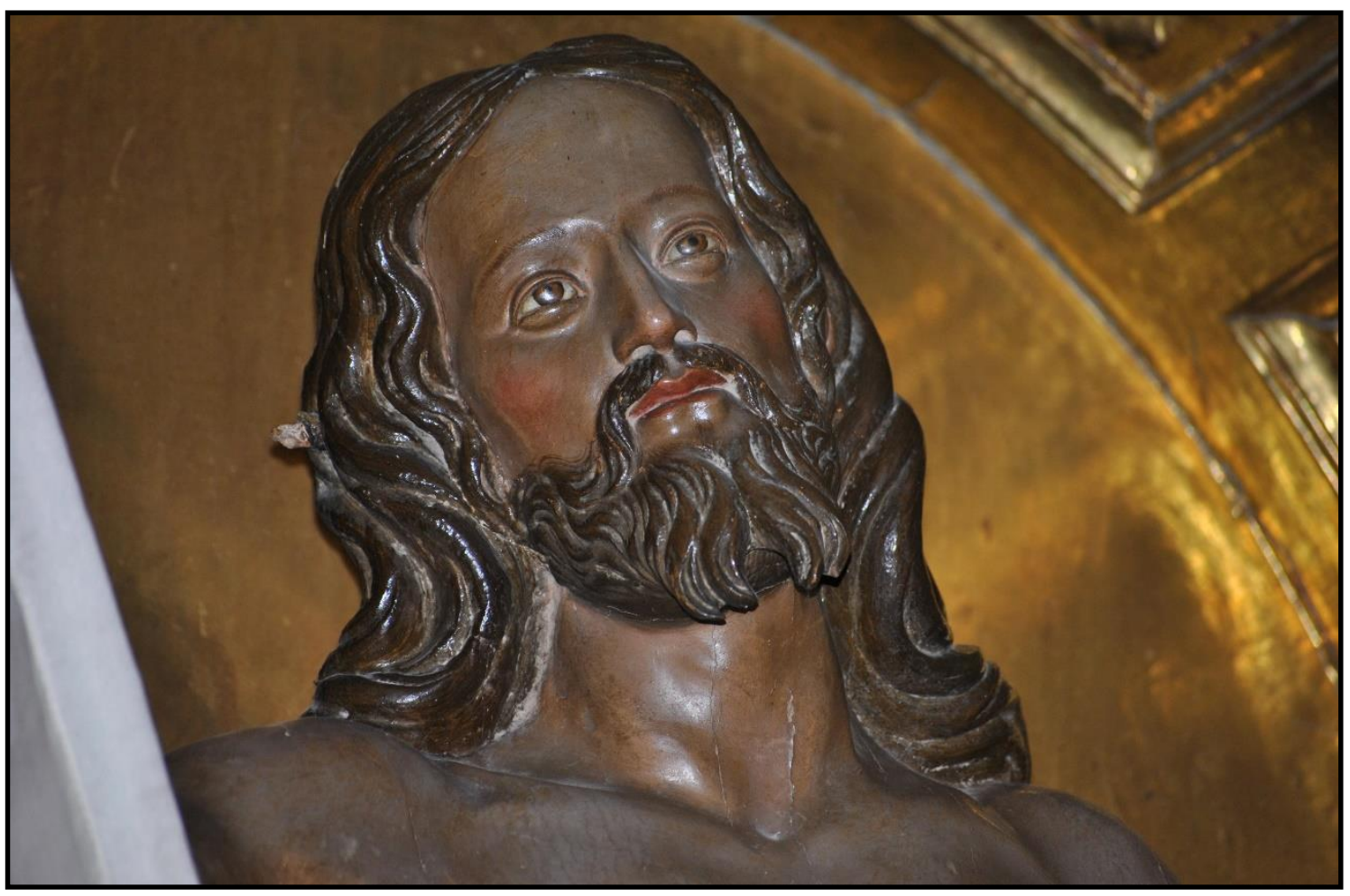

Fig. 49- Pedro de Ávila (atrib.). Detalle de Cristo Resucitado.

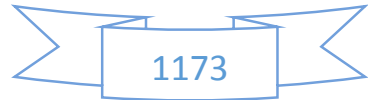




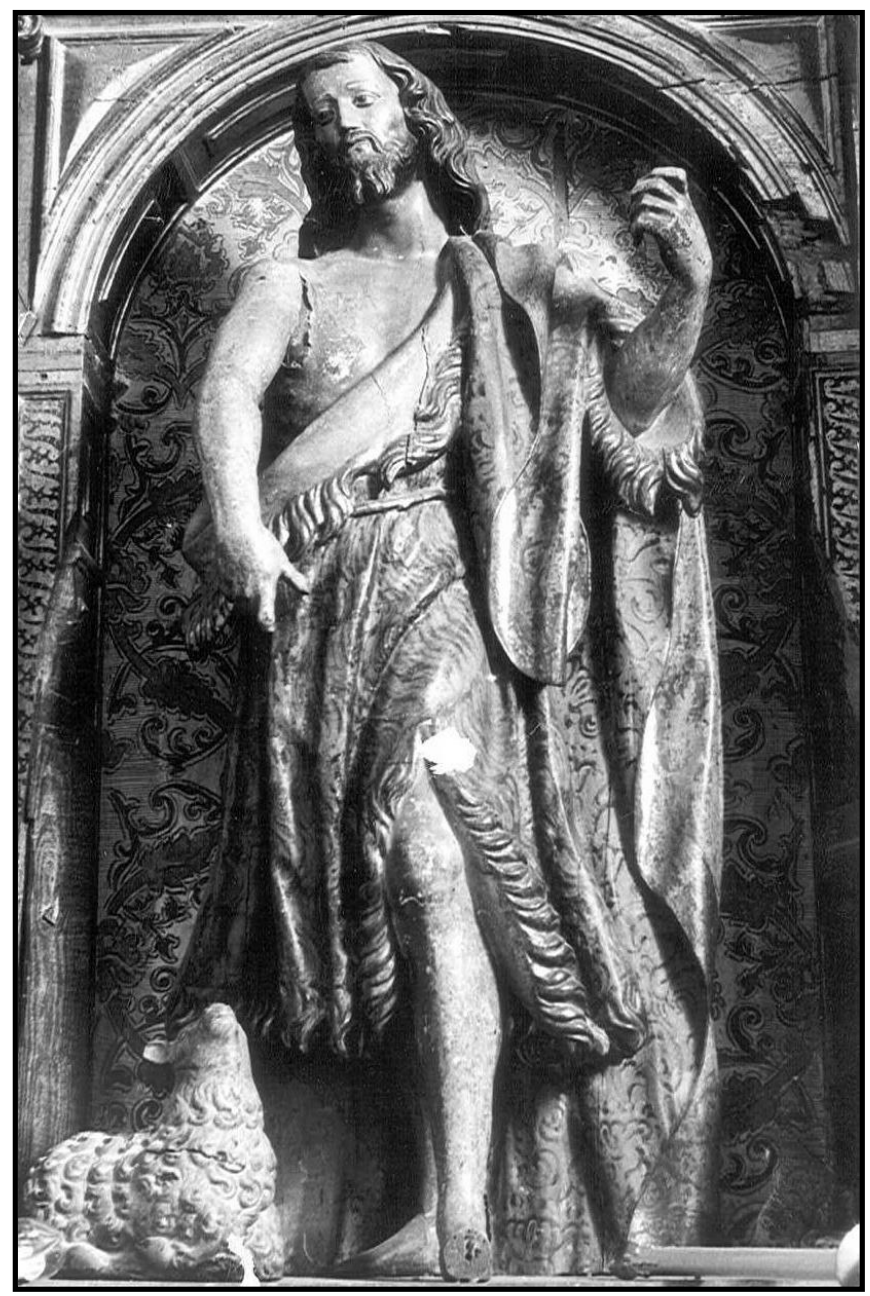

Figs. 50-51- Pedro de Ávila (atrib.). San Juan Bautista. Iglesia parroquial de la Asunción. Almenara de Adaja (Valladolid). Fig. 50 ๑ Departamento de Historia del Arte de la Universidad de Valladolid.
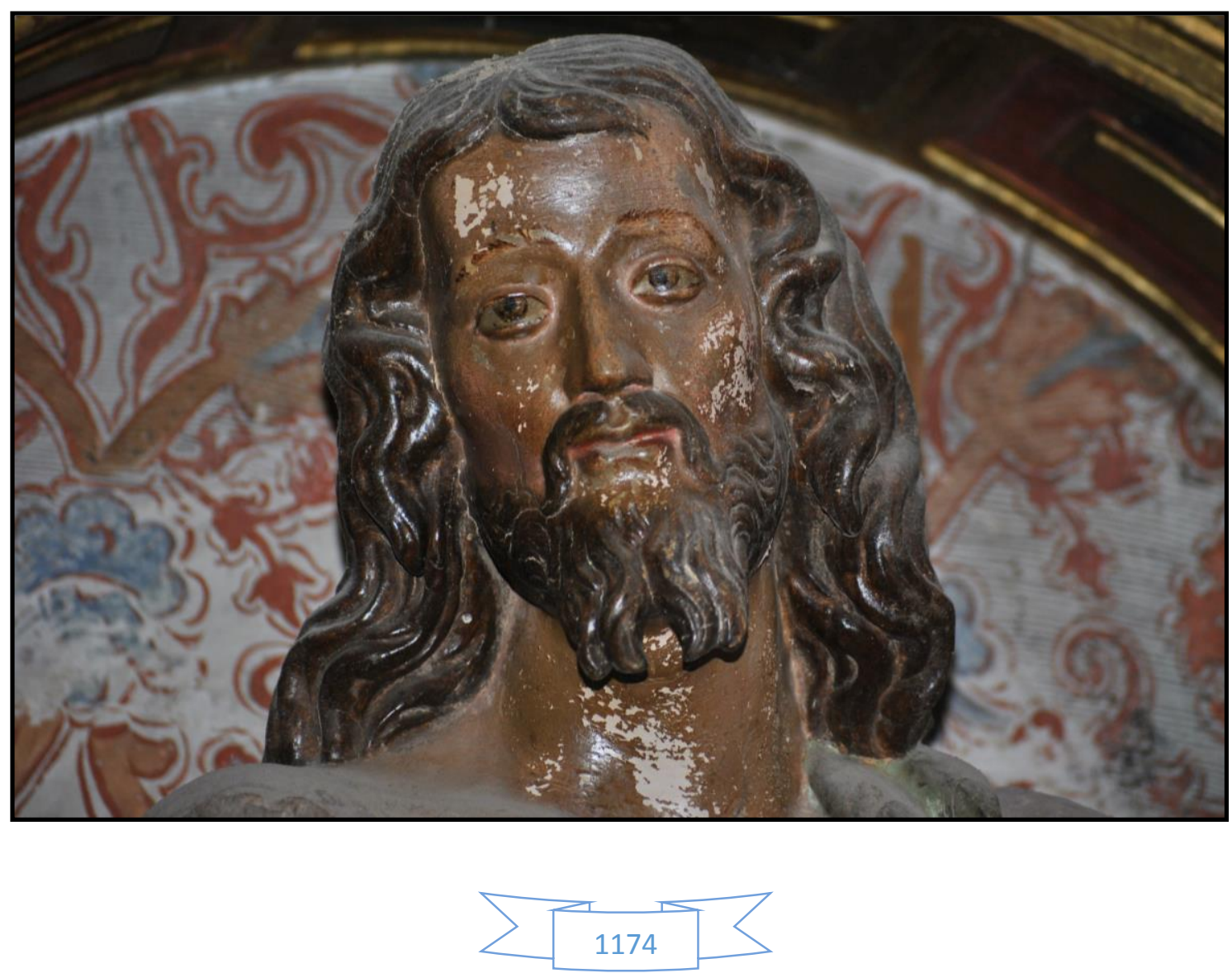


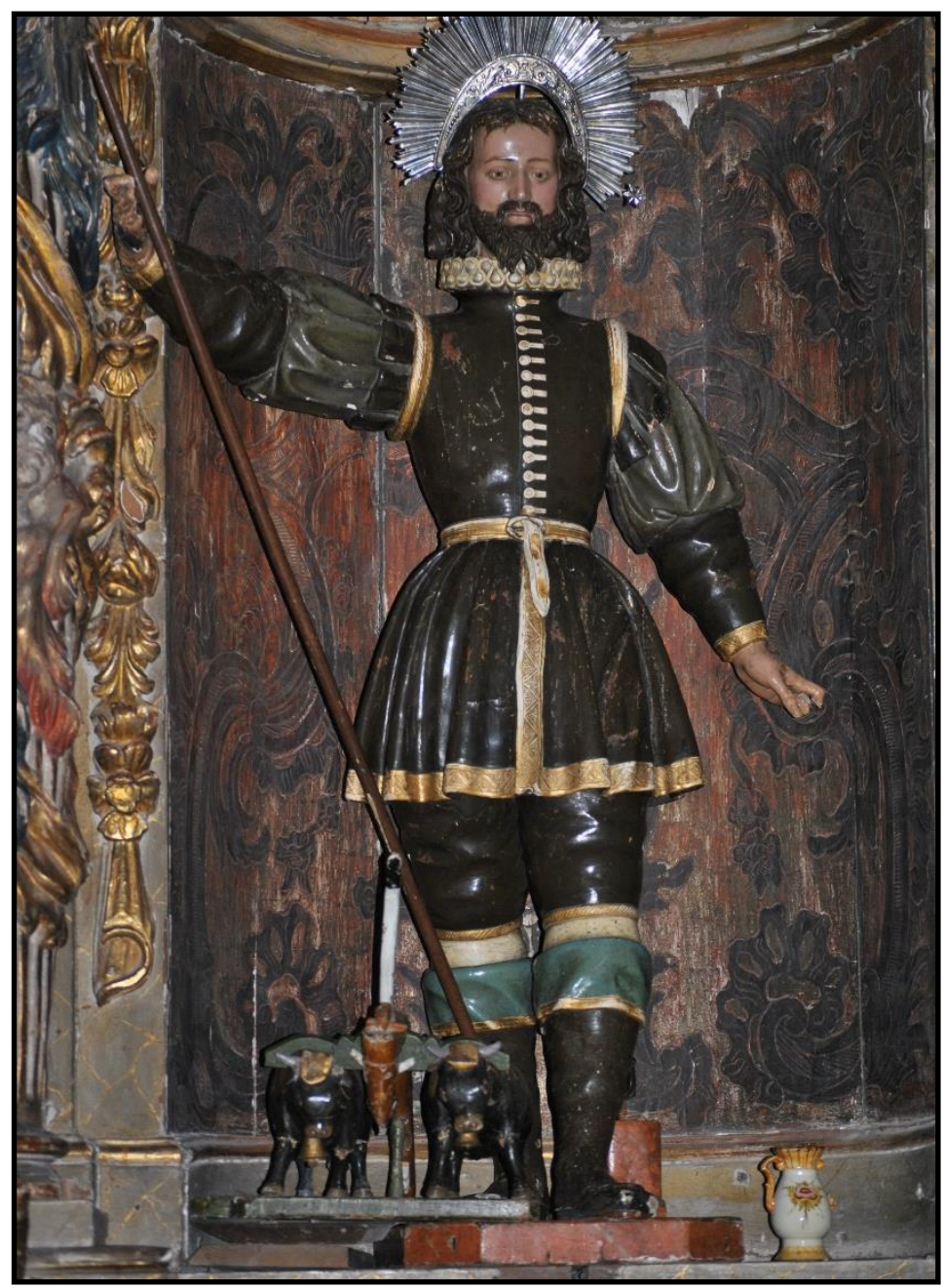

Figs. 52-53- Pedro de Ávila (atrib.). San Isidro. Iglesia parroquial de la Asunción. Muriel de Zapardiel (Valladolid).
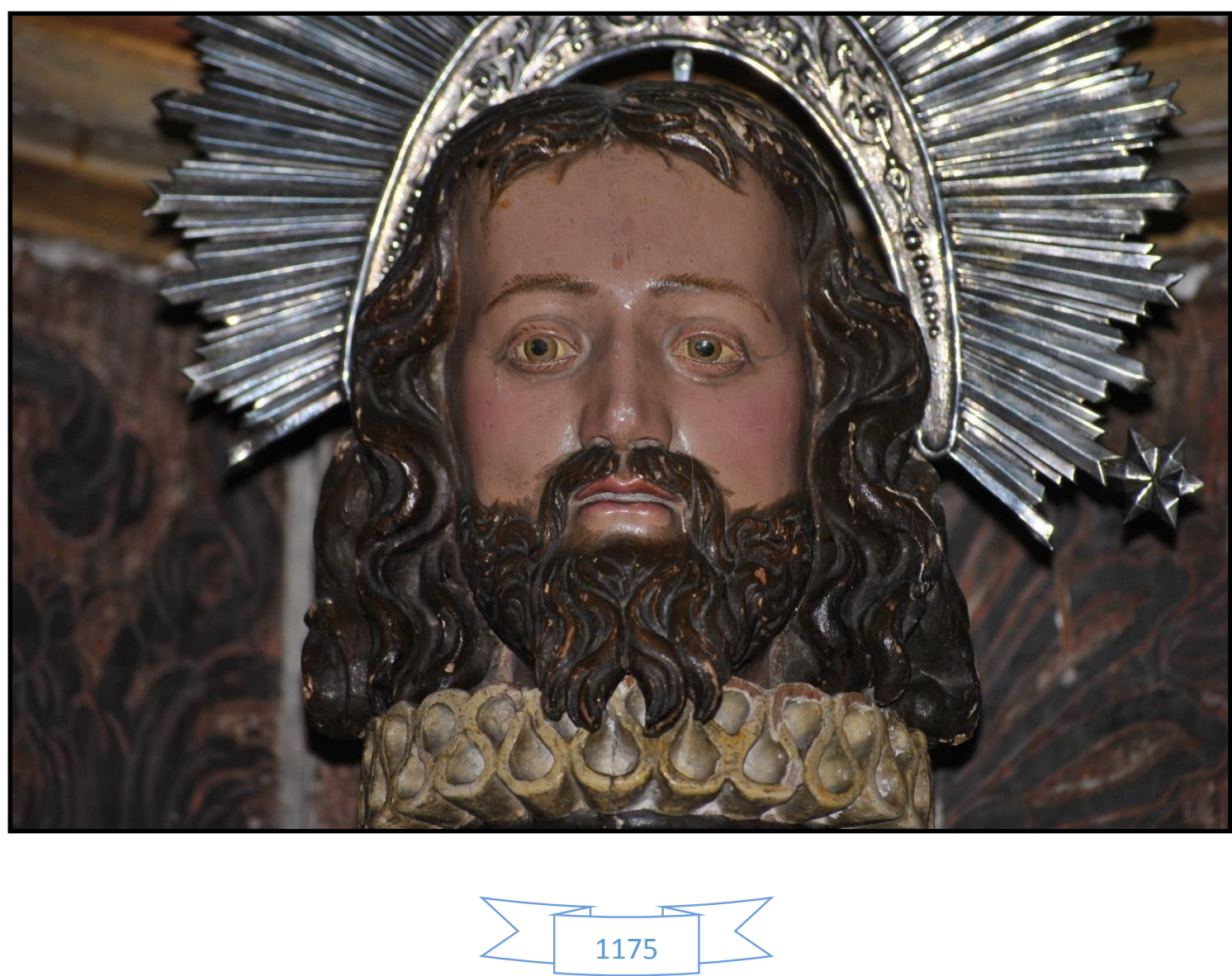


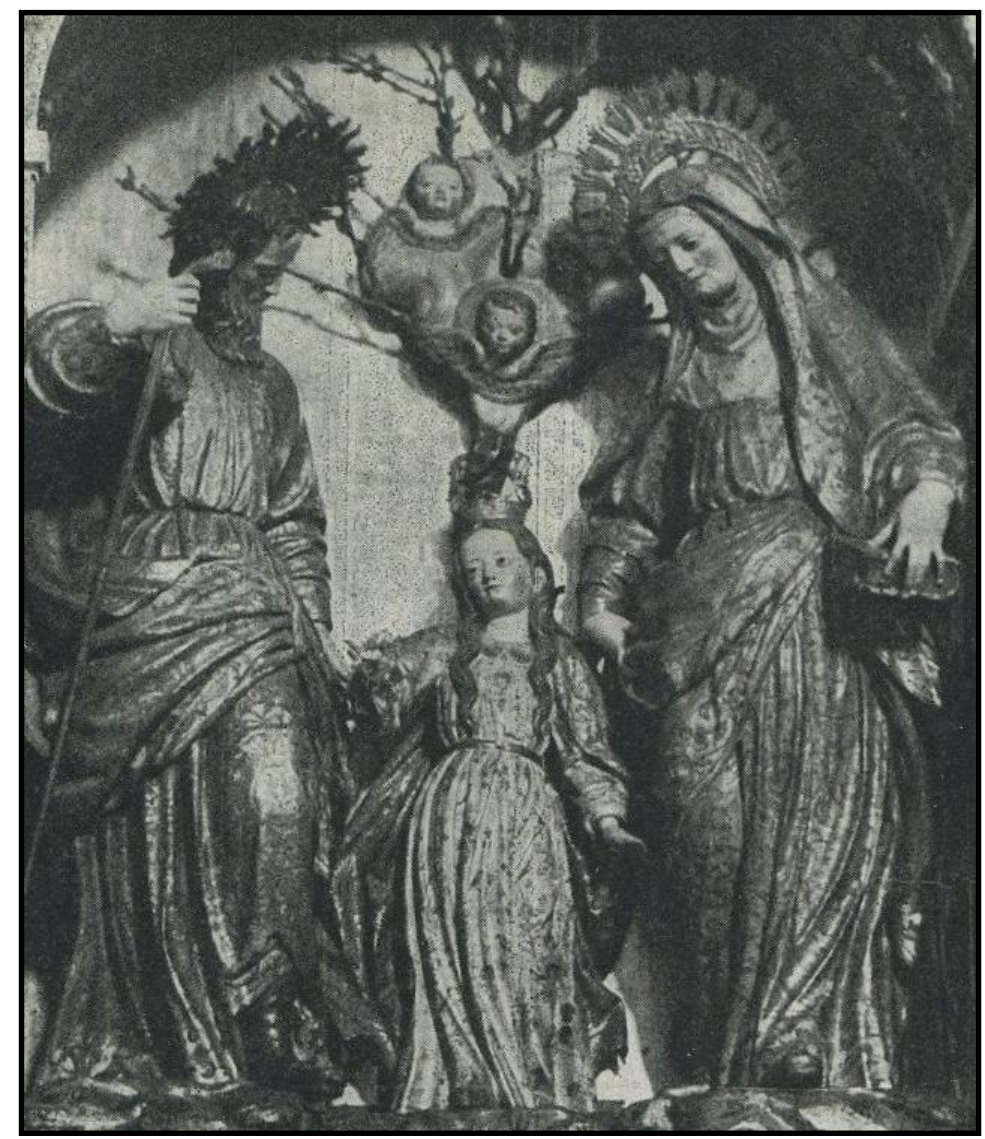

Figs. 54-55- Pedro de Ávila (atrib.). Grupo de San Joaquín, Santa Ana y la Virgen (desaparecido). Monasterio de Santa Brígida. Valladolid. (C) Departamento de Historia del Arte de la Universidad de Valladolid.
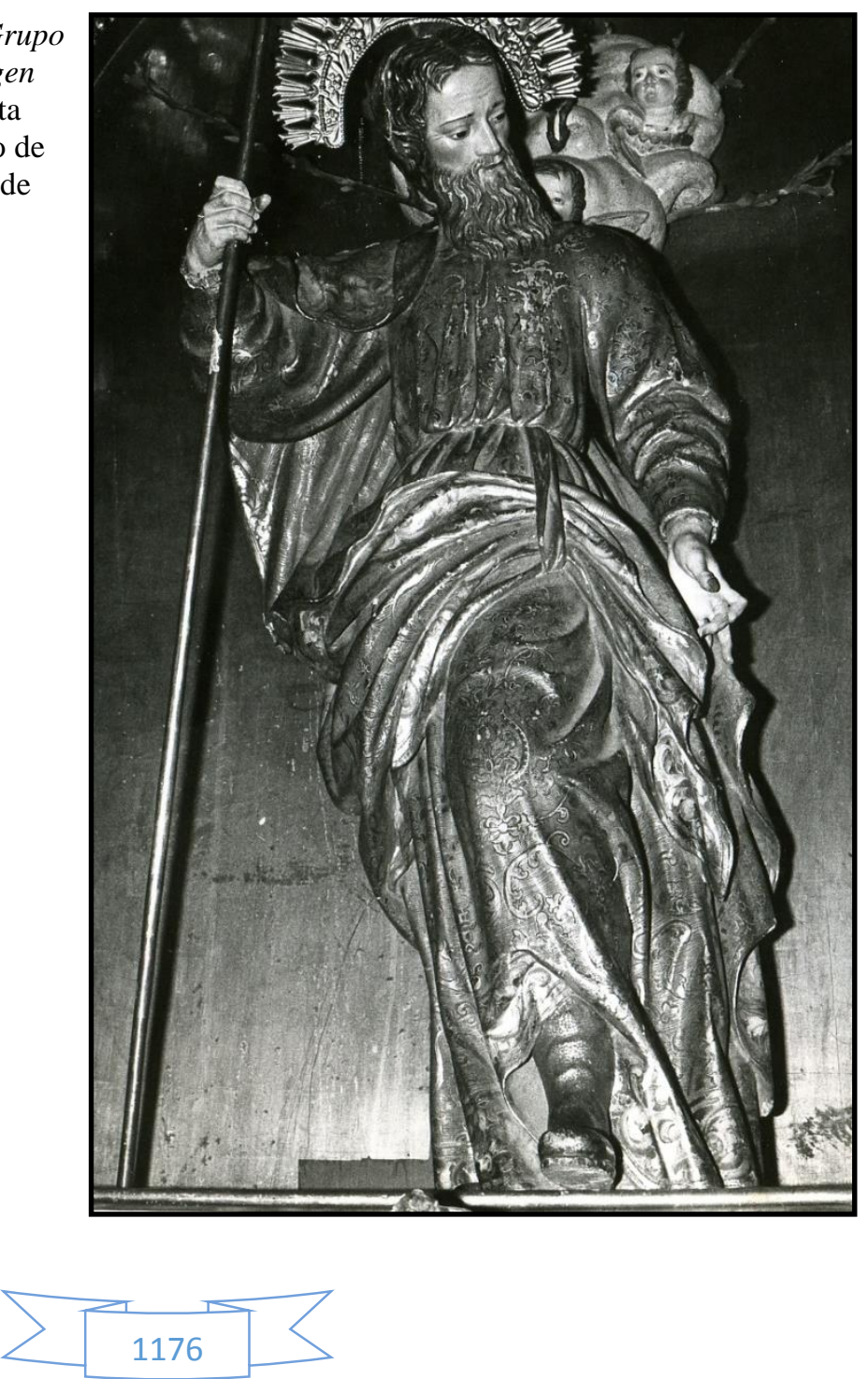


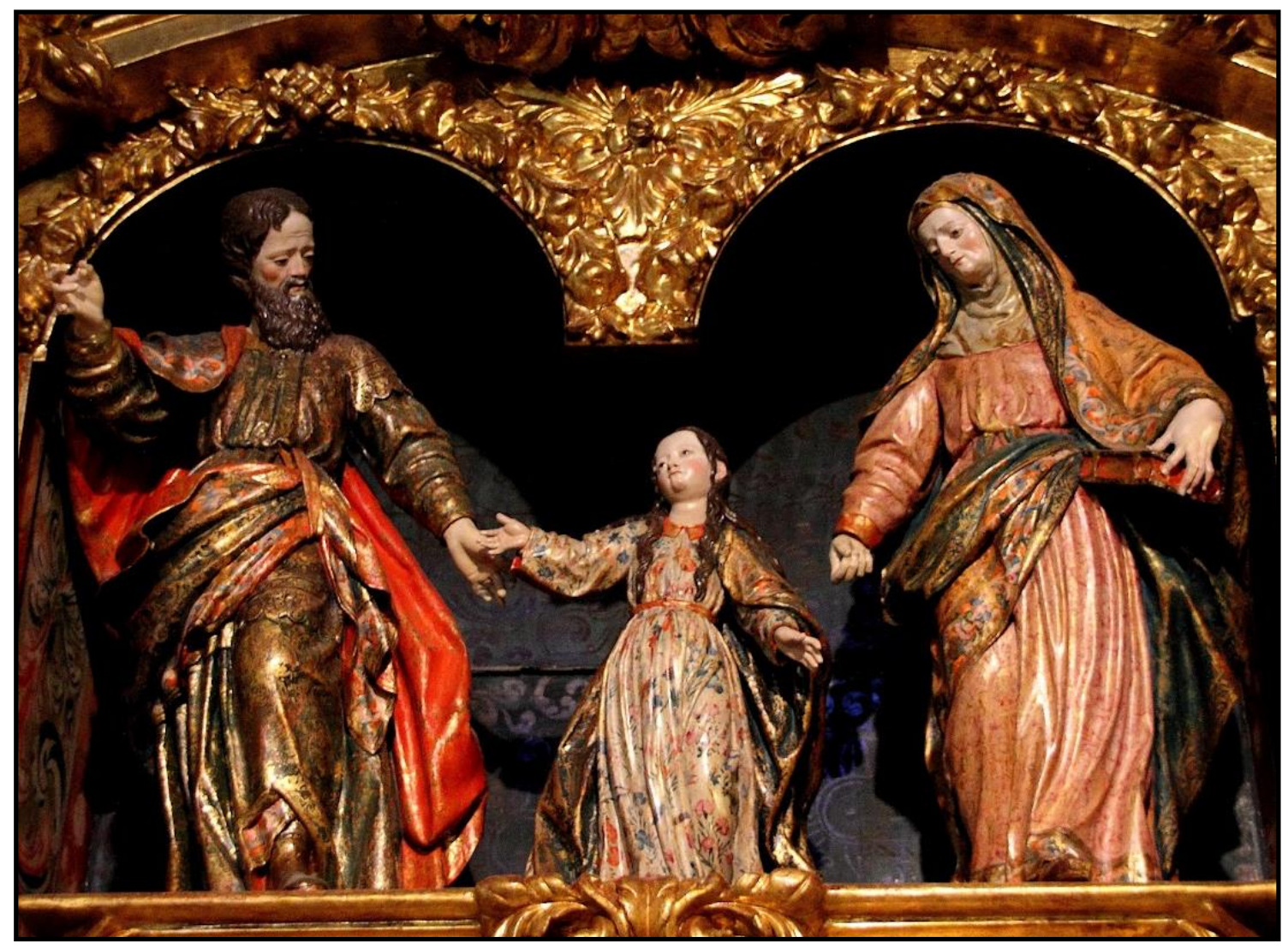

Fig. 56- Pedro de Ávila (atrib.). Grupo de San Joaquín, Santa Ana y la Virgen. Iglesia parroquial de Santa María del Castillo. Flores de Ávila (Ávila).
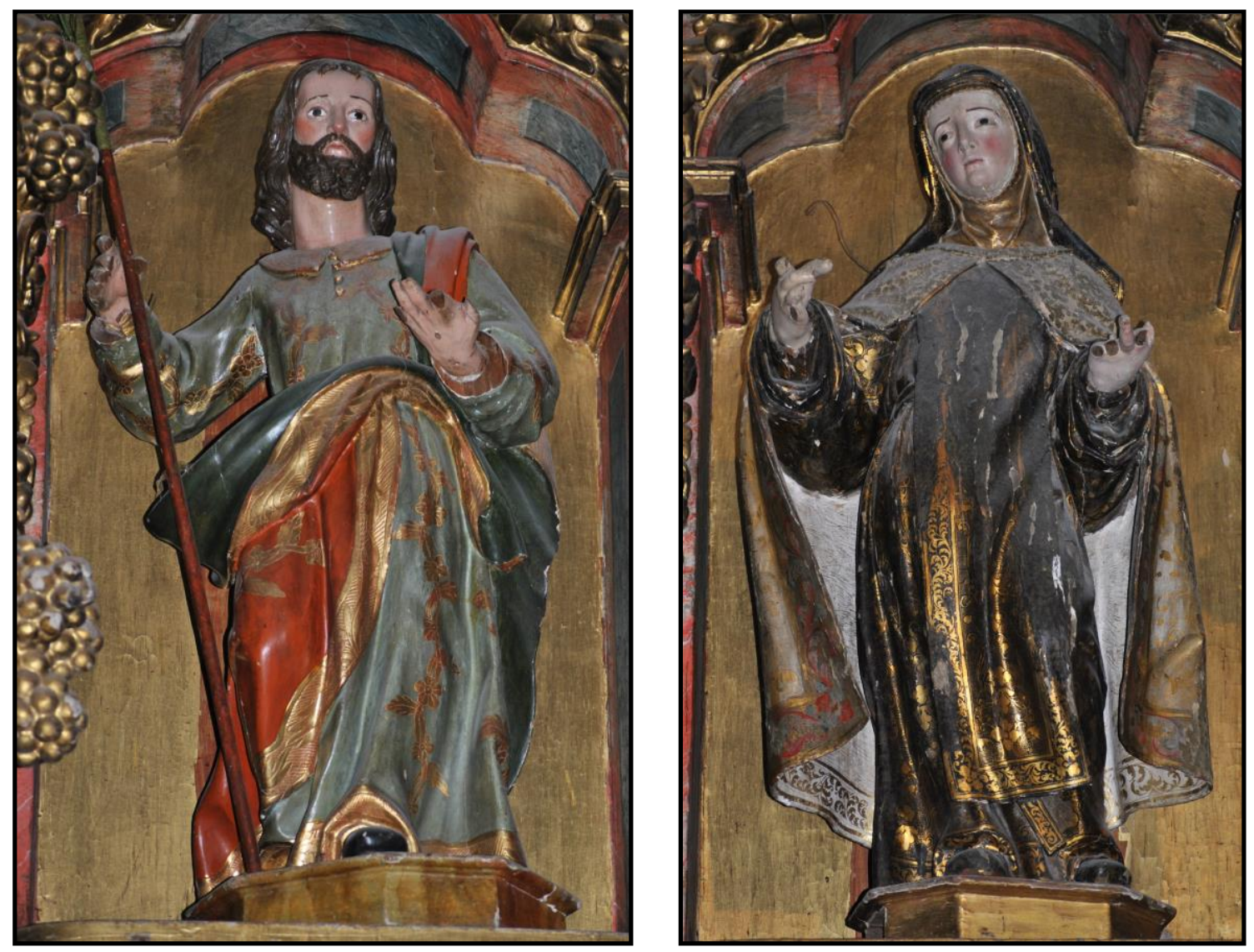

Figs. 57-58- Pedro de Ávila (atrib.). San José y Santa Teresa. Iglesia parroquial de San Juan Evangelista. Fuente-Olmedo (Valladolid).

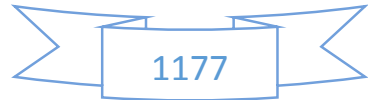




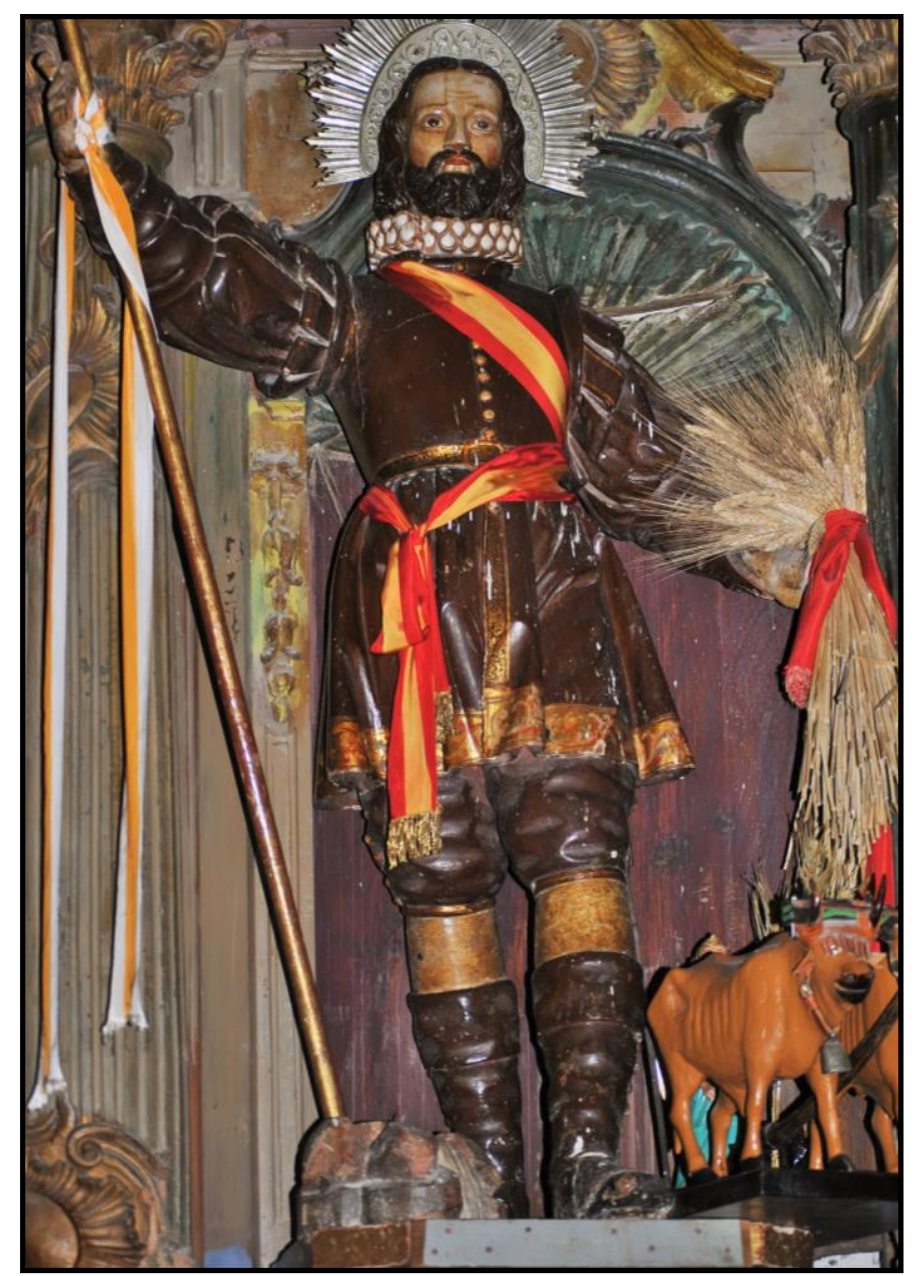

Fig. 59- Pedro de Ávila (atrib.). San Isidro. Iglesia parroquial de la Asunción. Villabáñez (Valladolid).

Fig. 60- Pedro de Ávila (atrib.). Inmaculada Concepción. Monasterio de Santa Brígida. Valladolid.
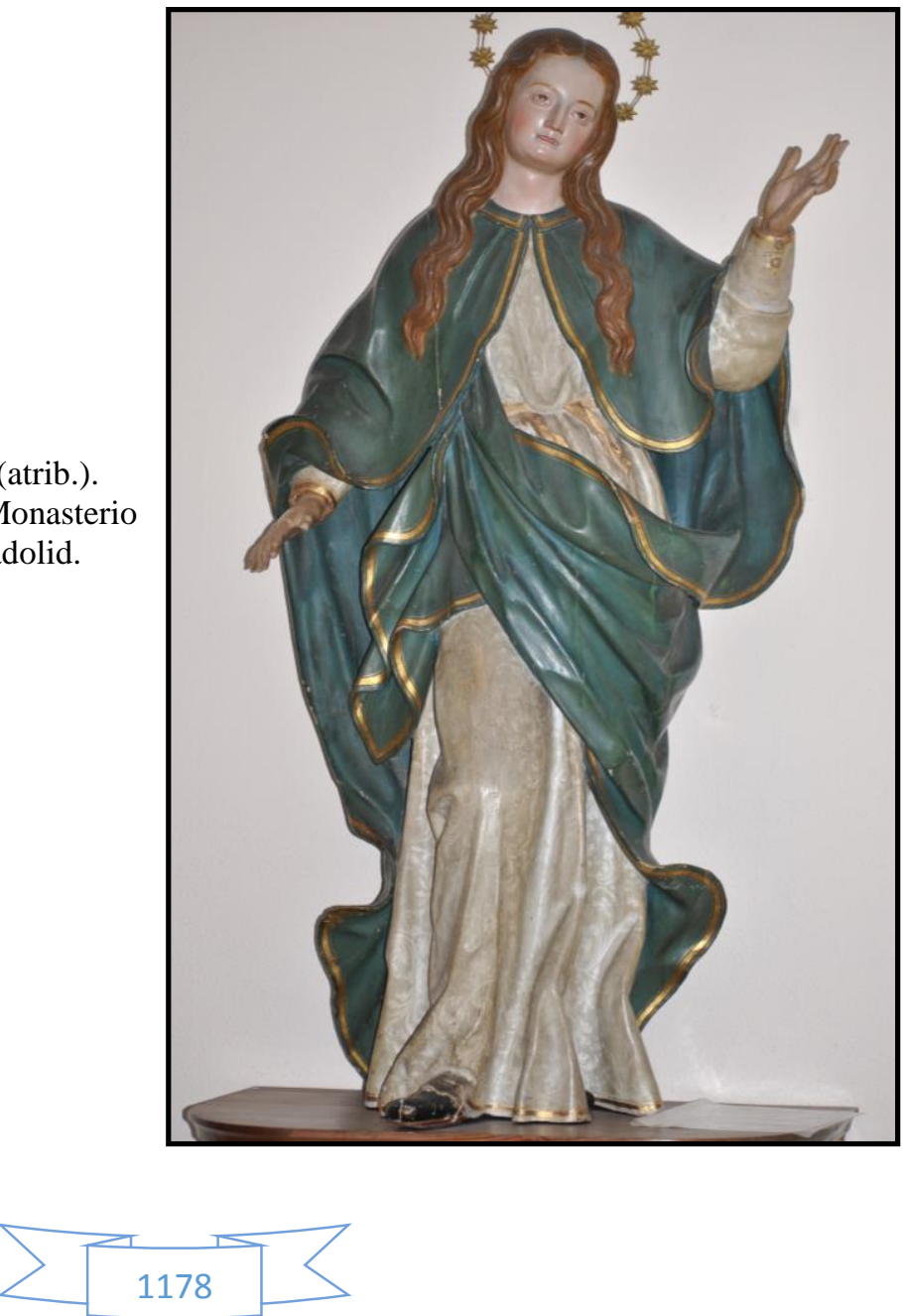


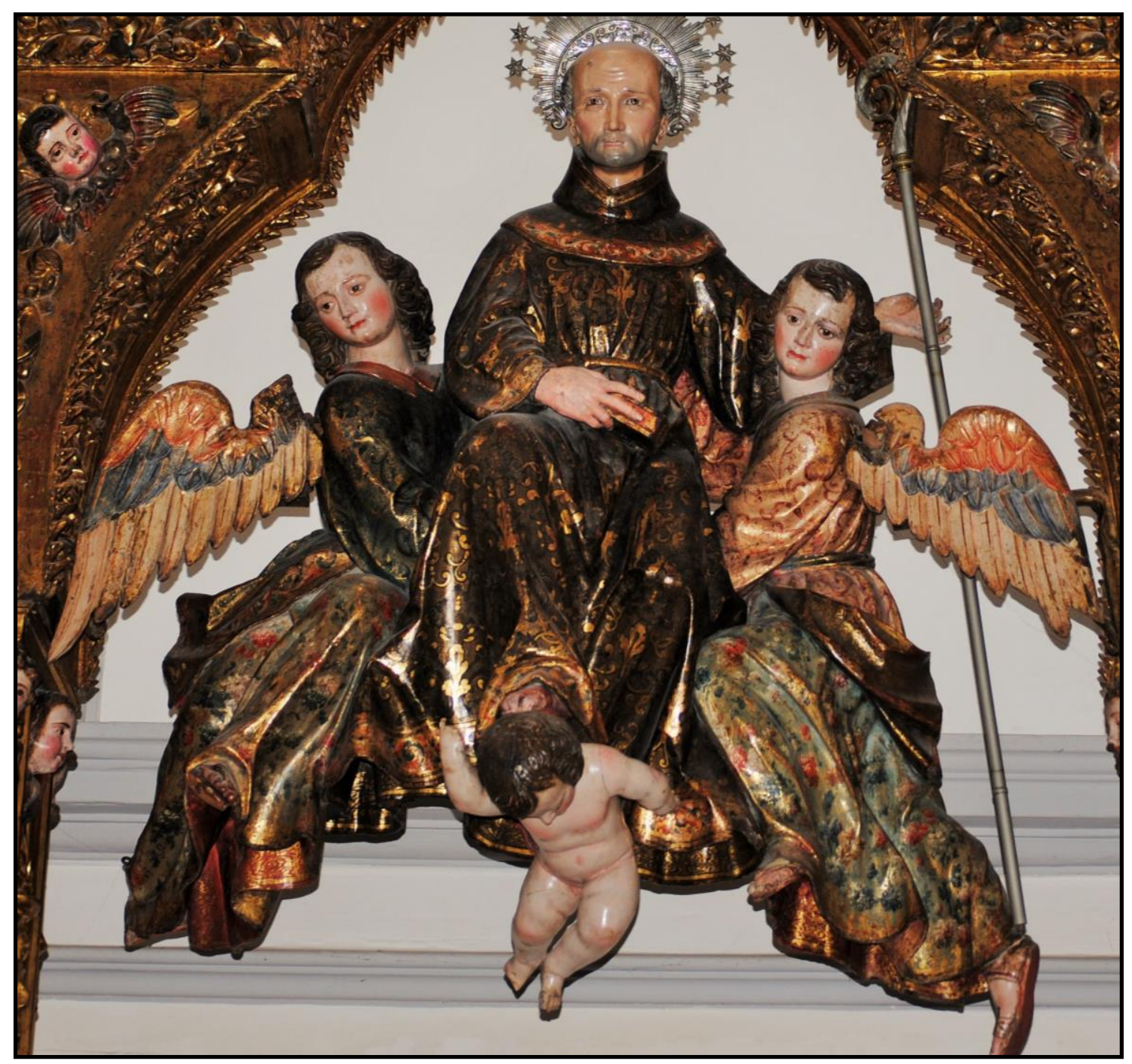

Fig. 61- Pedro de Ávila (atrib.). Traslación de San Pedro Regalado. Iglesia del Salvador. Valladolid.

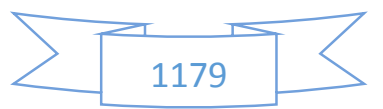




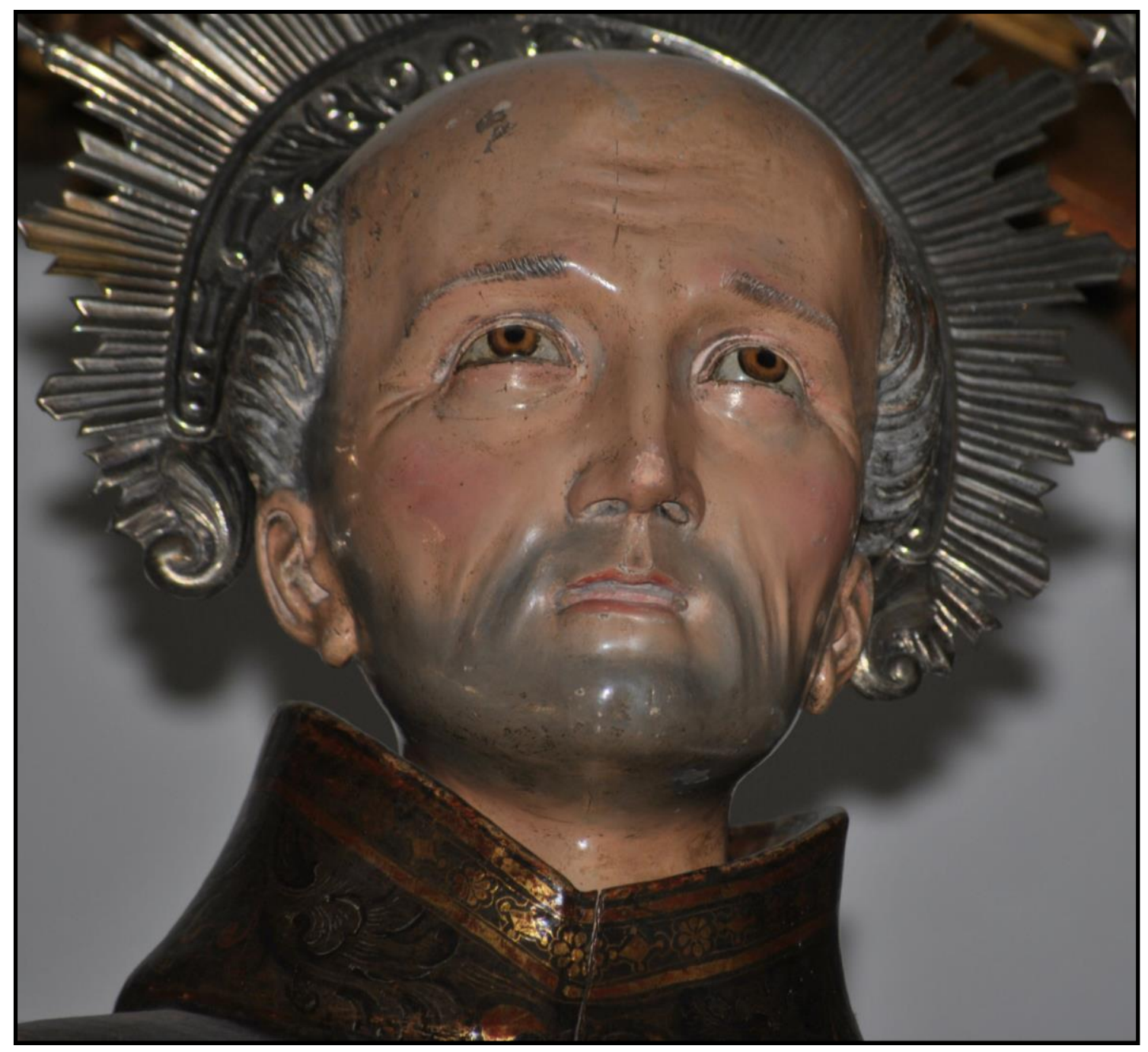

Figs. 62-63- Pedro de Ávila (atrib.). Detalles de la Traslación de San Pedro Regalado.
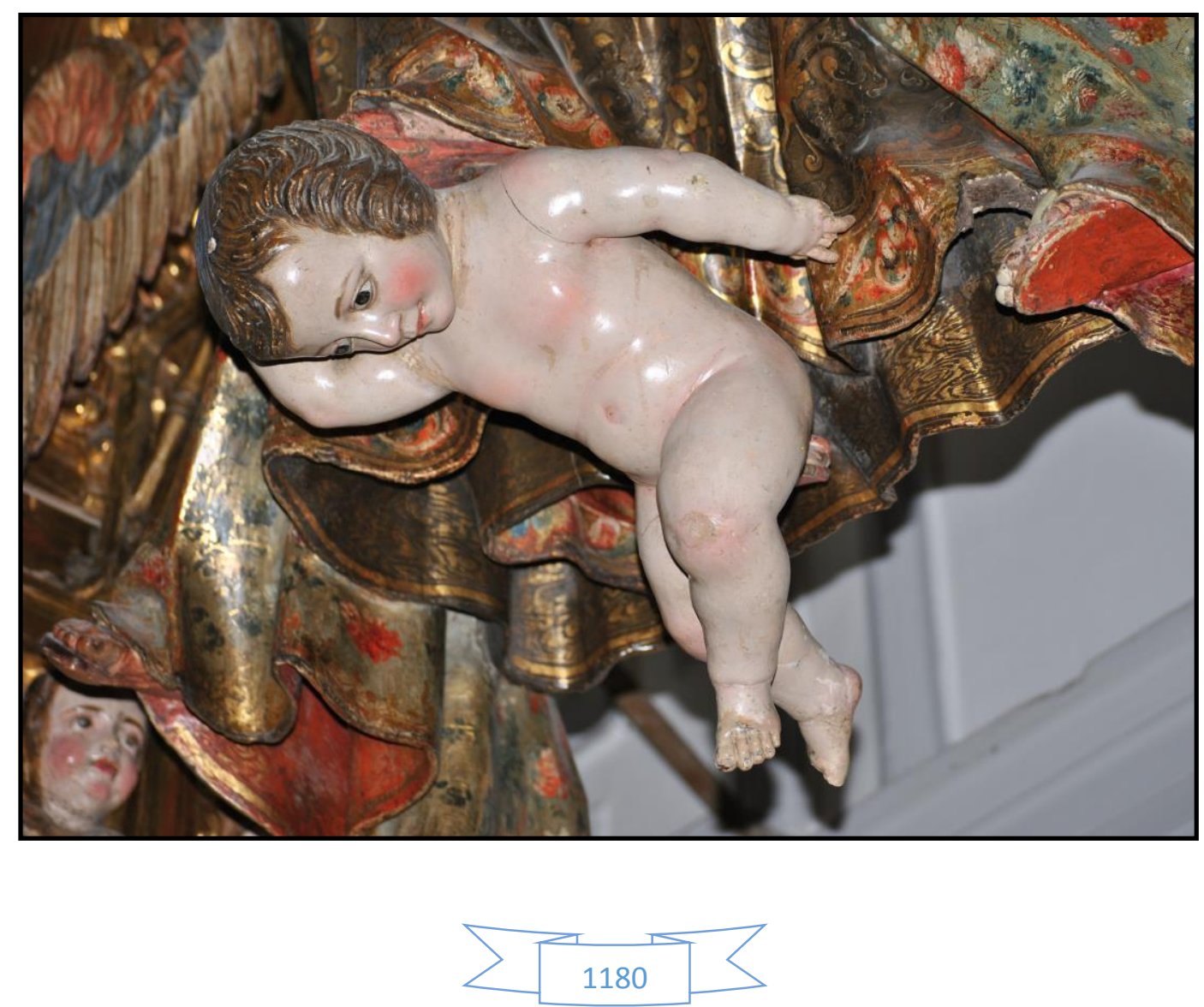


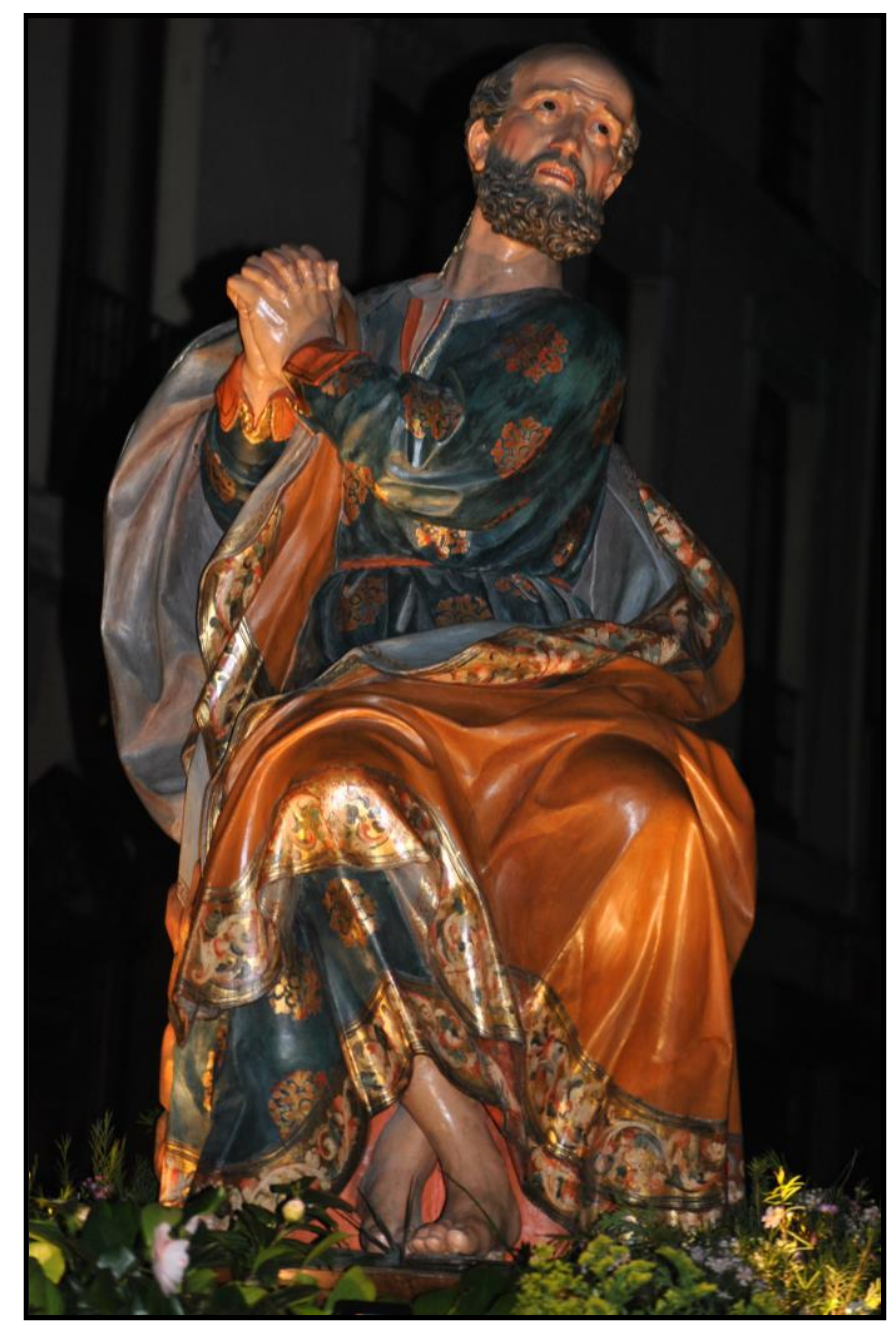

Figs. 64-65- Pedro de Ávila (atrib.). Las lágrimas de San Pedro. Iglesia del Salvador. Valladolid.
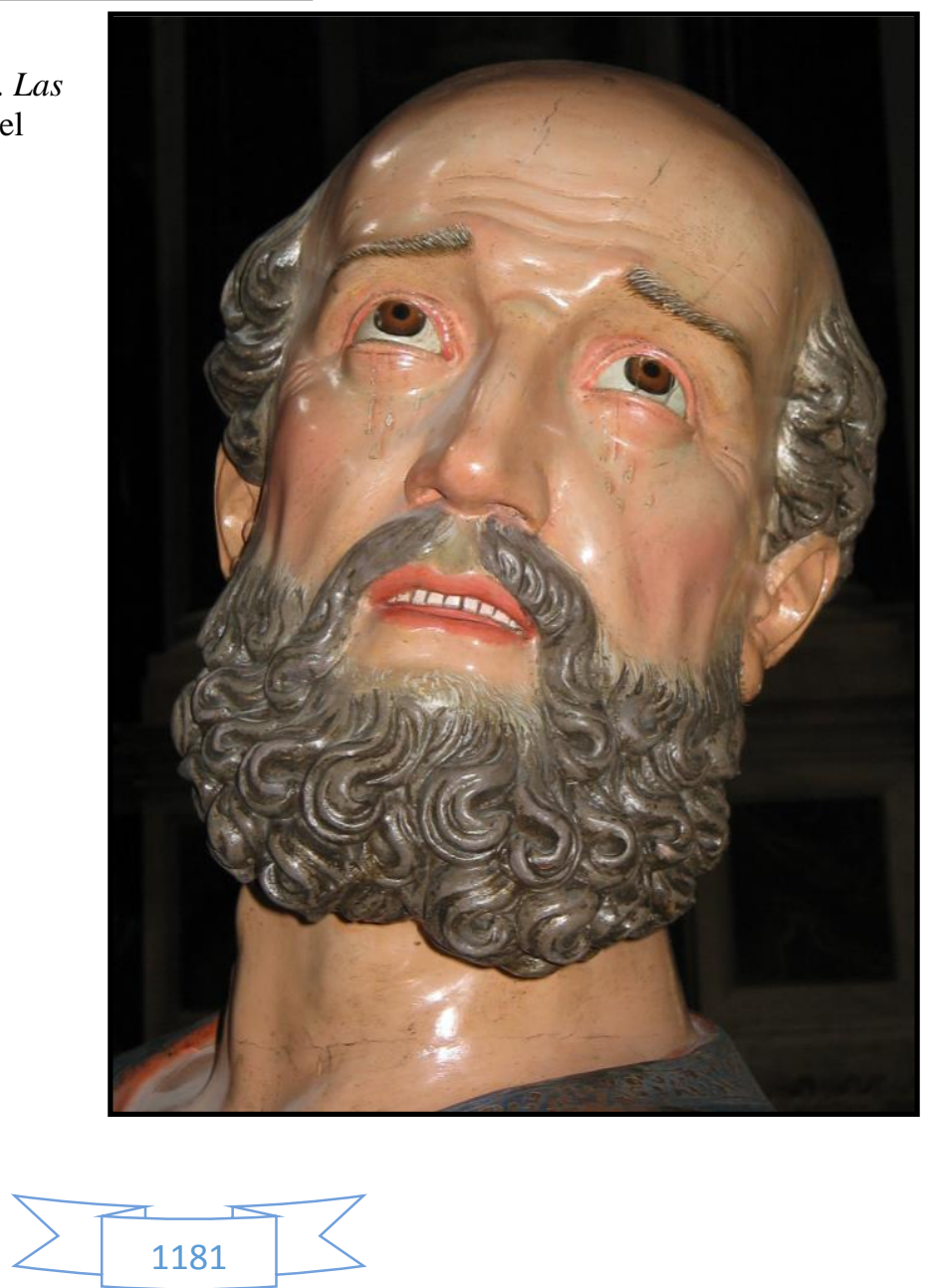


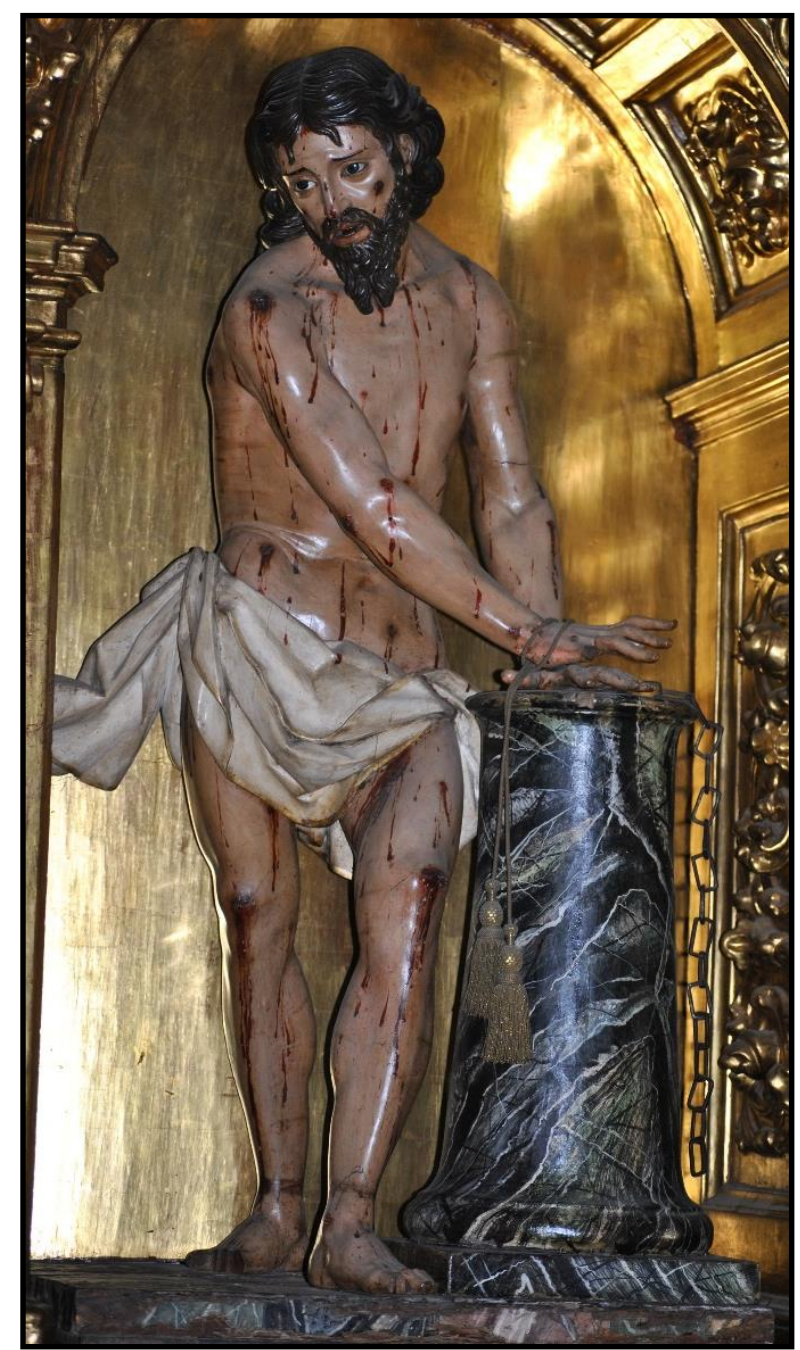

Fig. 67- Pedro de Ávila (atrib.). Ecce Homo. Iglesia penitencial de Nuestra Señora de las Angustias. Valladolid.
Fig. 66- Pedro de Ávila (atrib.). Cristo atado a la columna. Iglesia penitencial de Nuestra Señora de las Angustias. Valladolid.

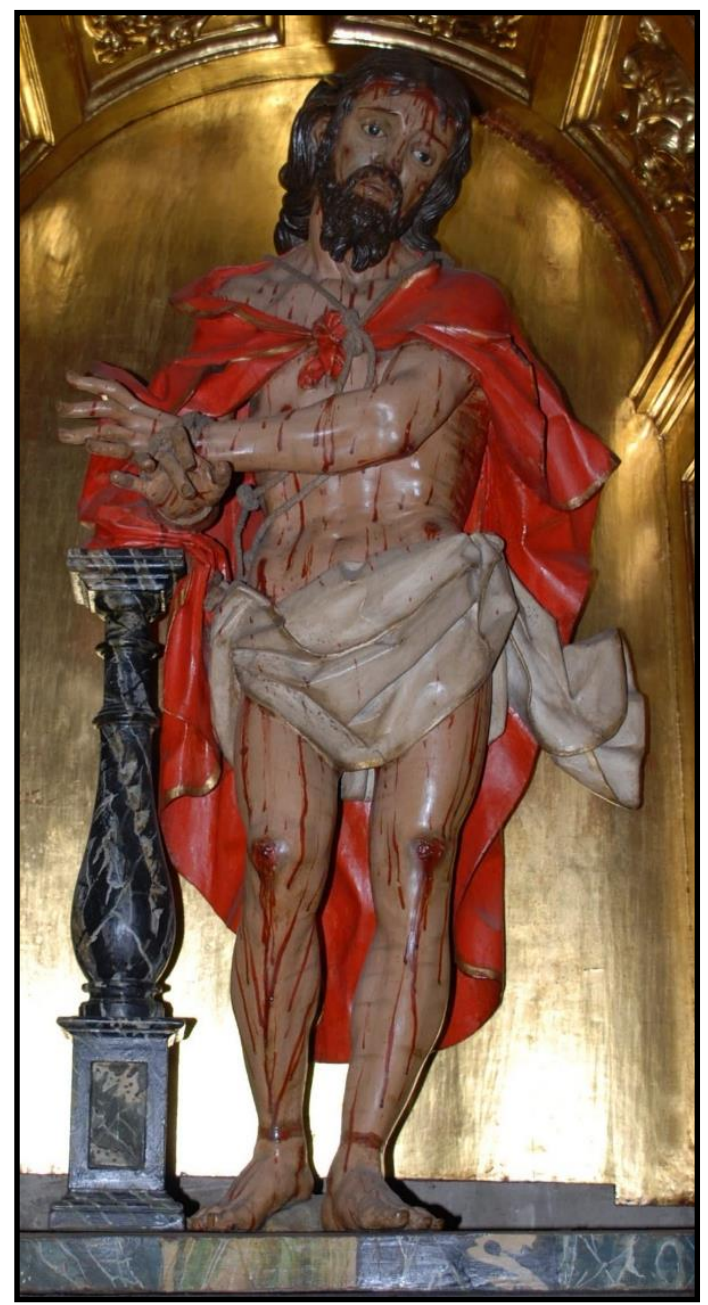

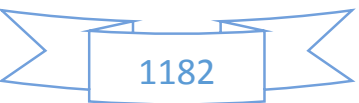




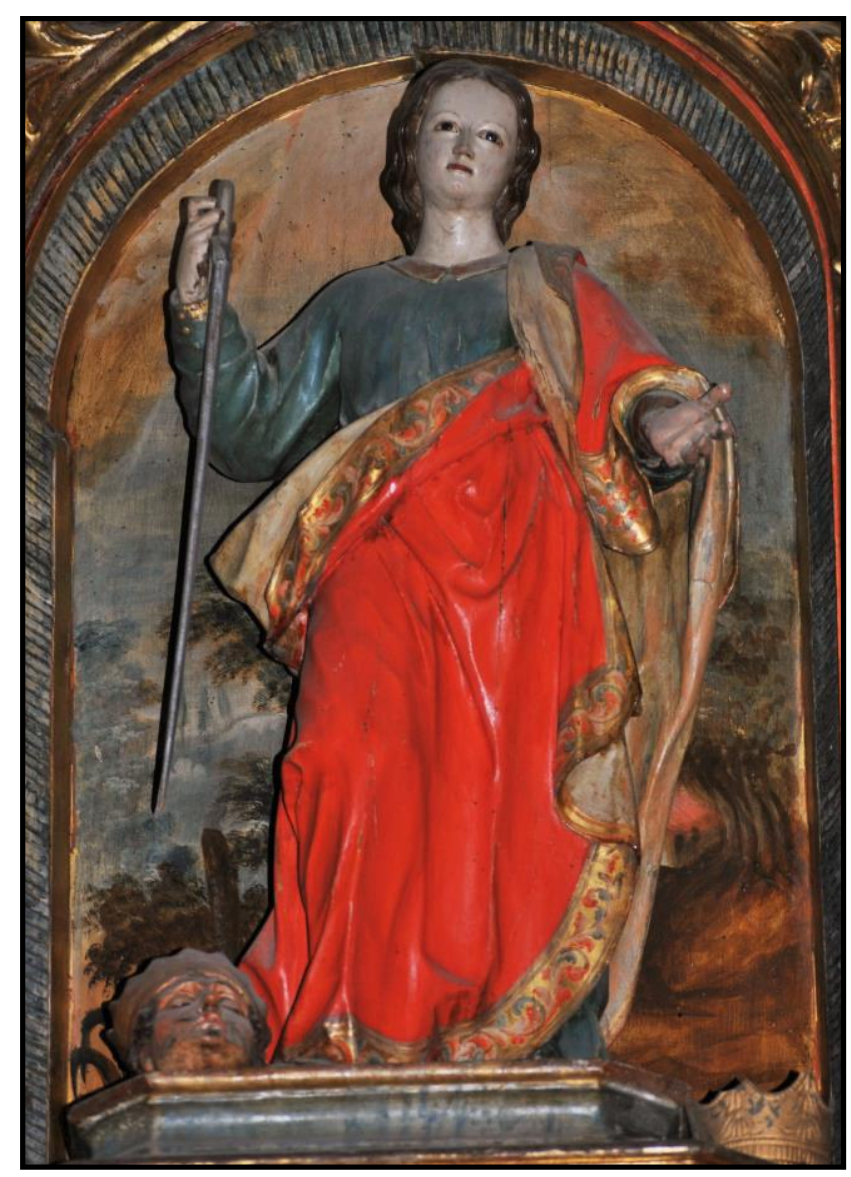

Fig. 68- Pedro de Ávila (atrib.). Santa Catalina de Alejandría.

Iglesia parroquial de la Asunción. Geria (Valladolid).

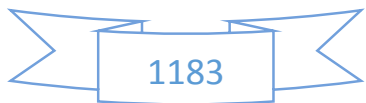


Fig. 69- Pedro de Ávila (atrib.). Santa Bárbara. Iglesia de Santa María. Alaejos (Valladolid).
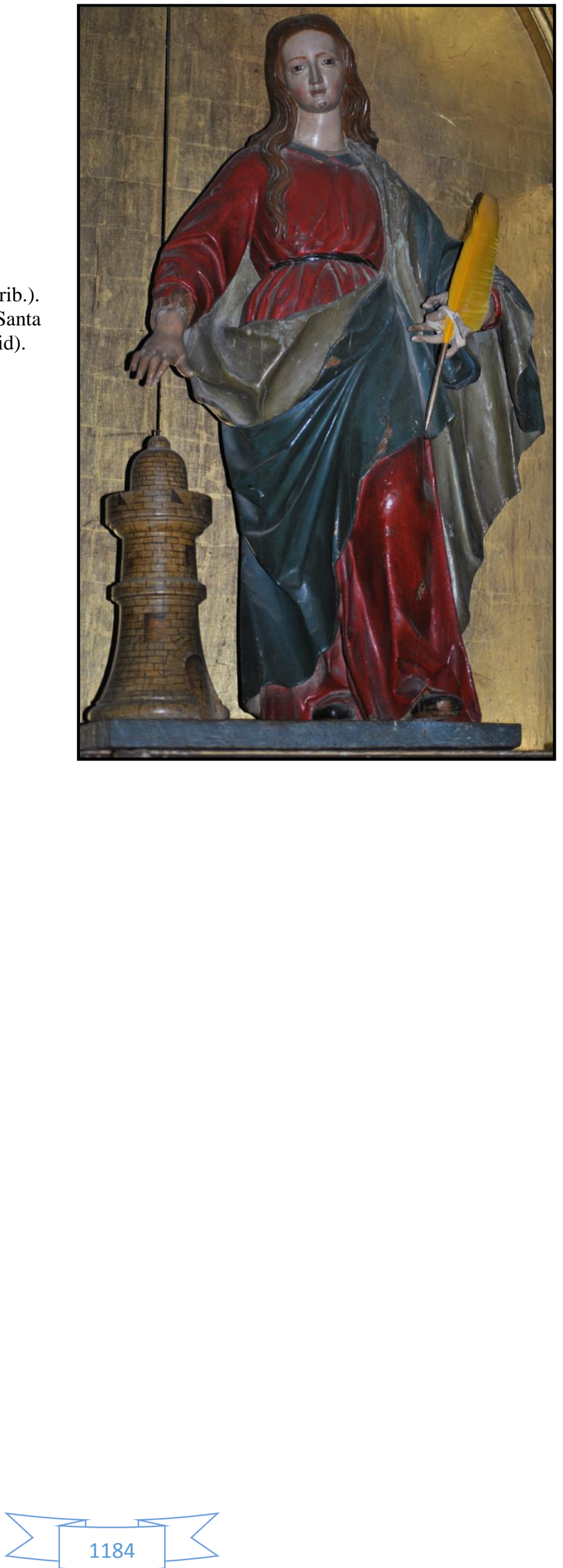


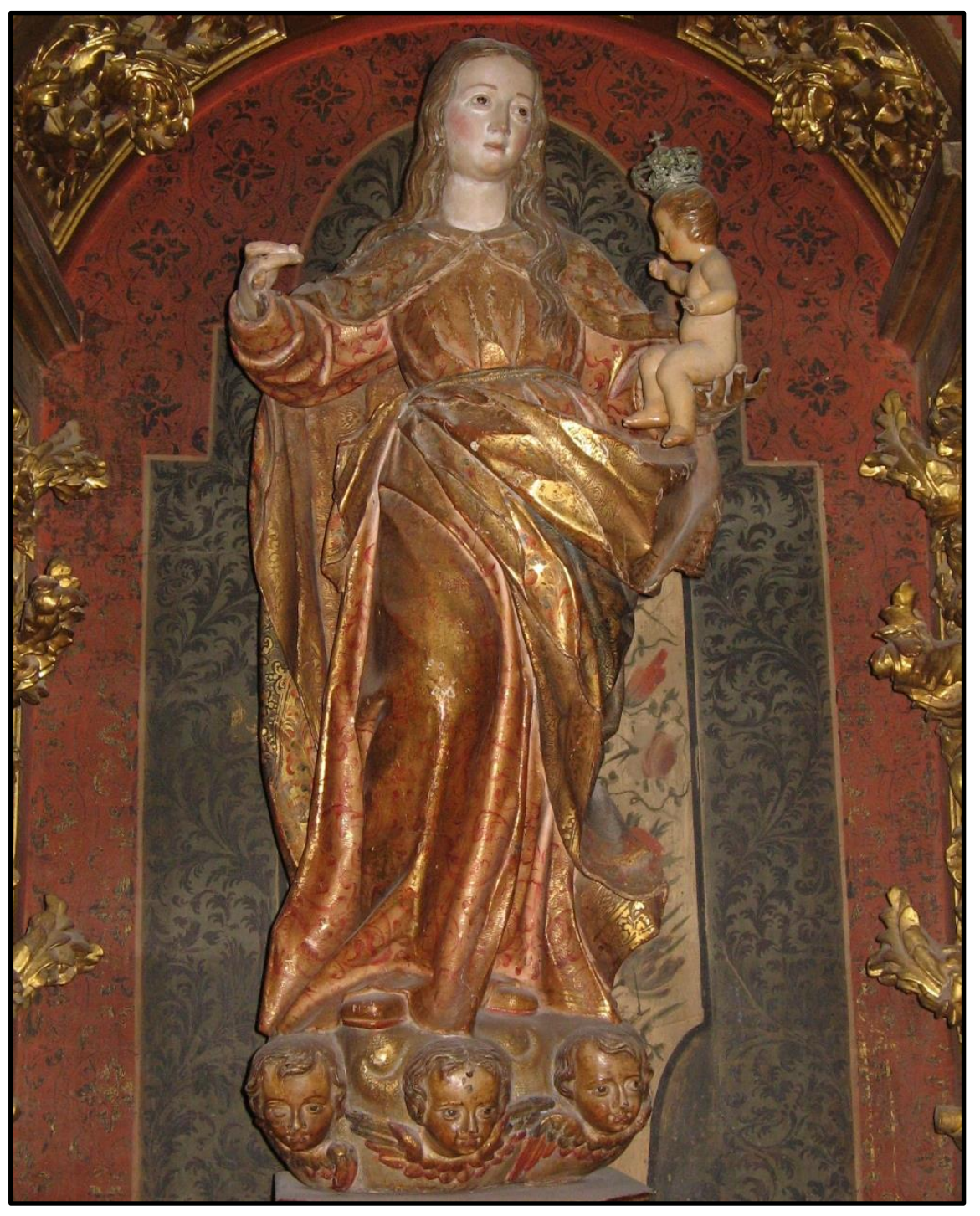

Figs. 70-71- Pedro de Ávila (atrib.). Nuestra Señora de las Nieves. Iglesia parroquial de los Santos Juanes. Nava del Rey (Valladolid).
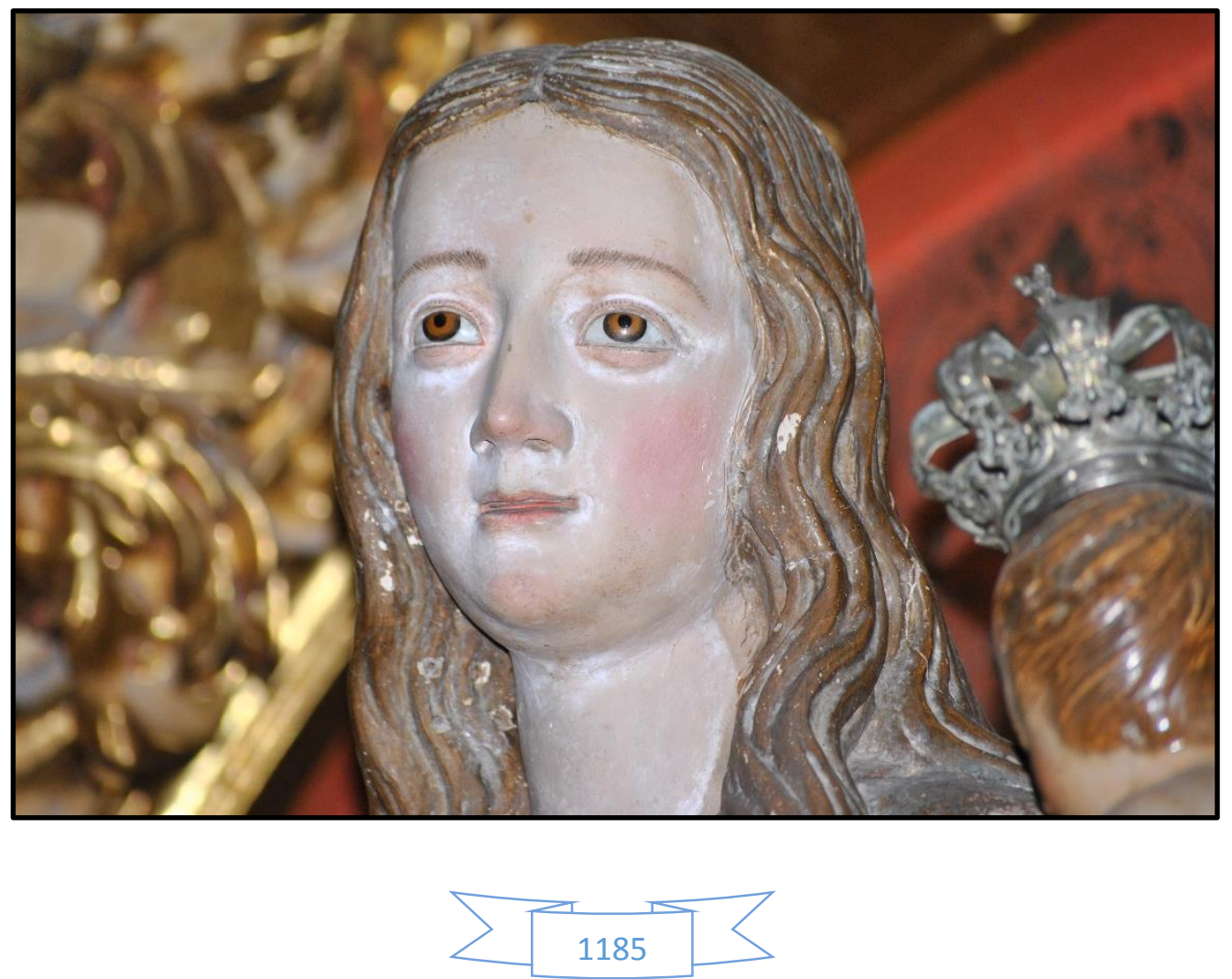


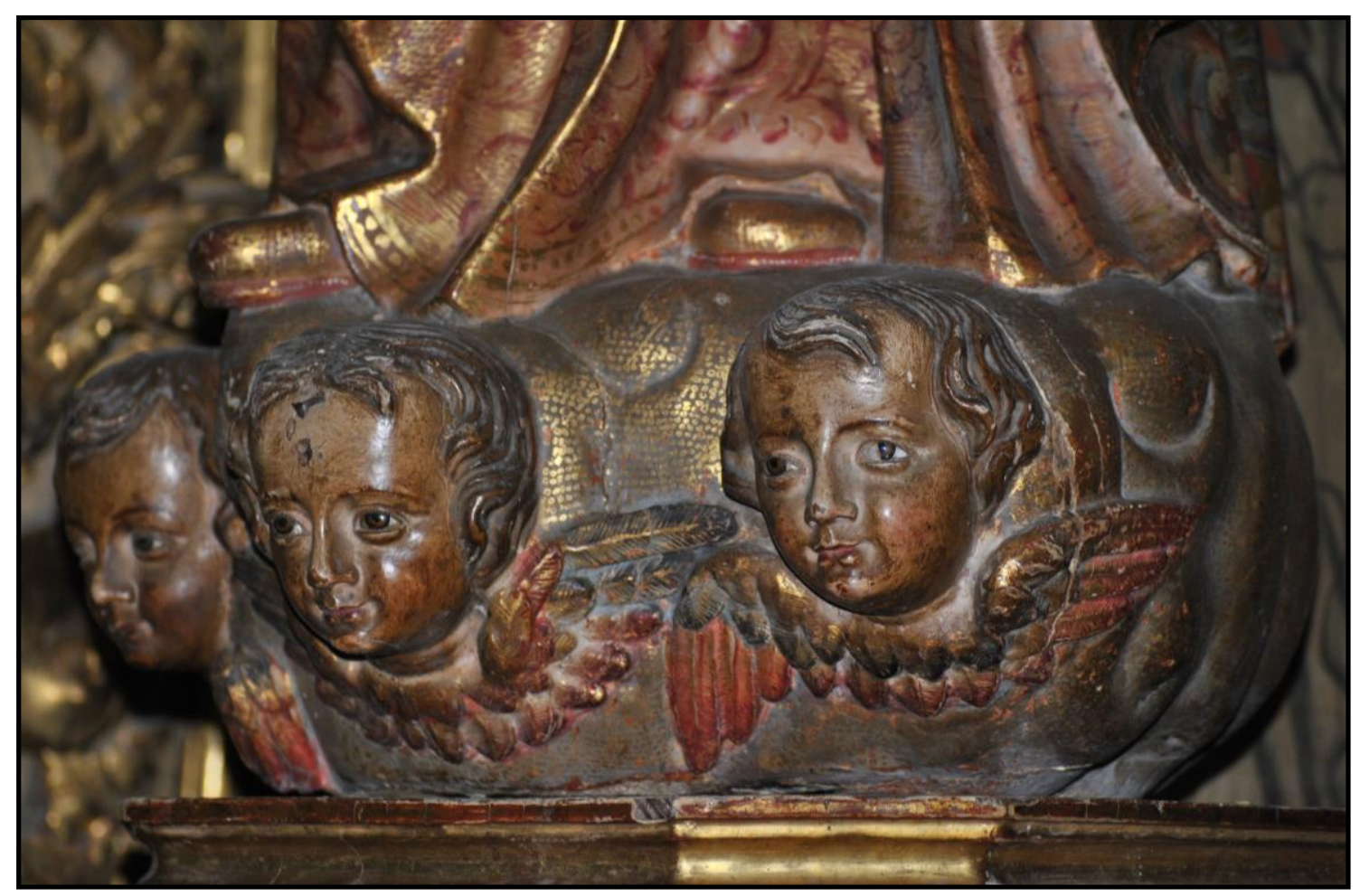

Figs. 72-73- Pedro de Ávila (atrib.). Detalles de Nuestra Señora de las Nieves.
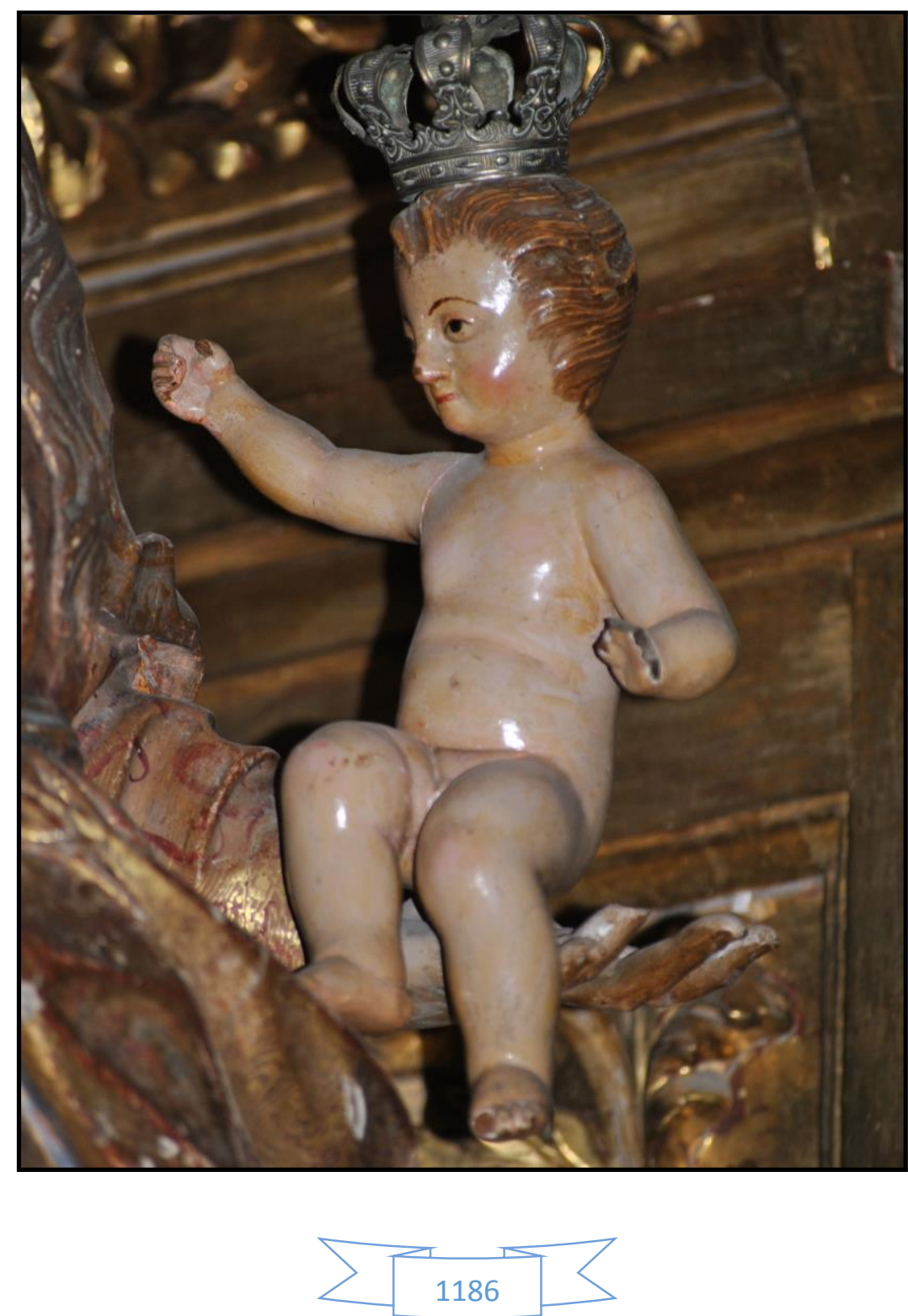


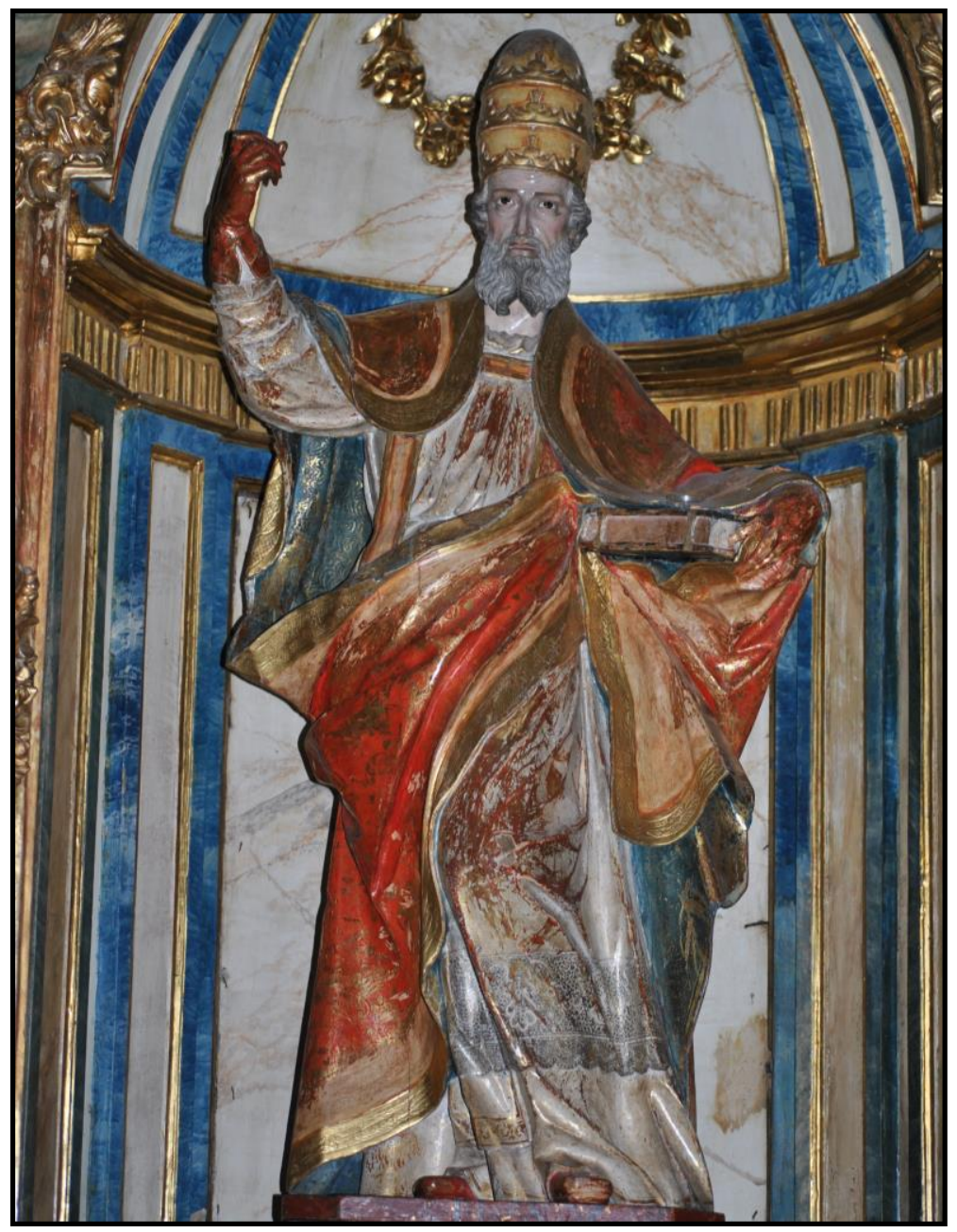

Figs. 74-75- Pedro de Ávila (atrib.). San Pío V. Convento de San Pablo. Valladolid.
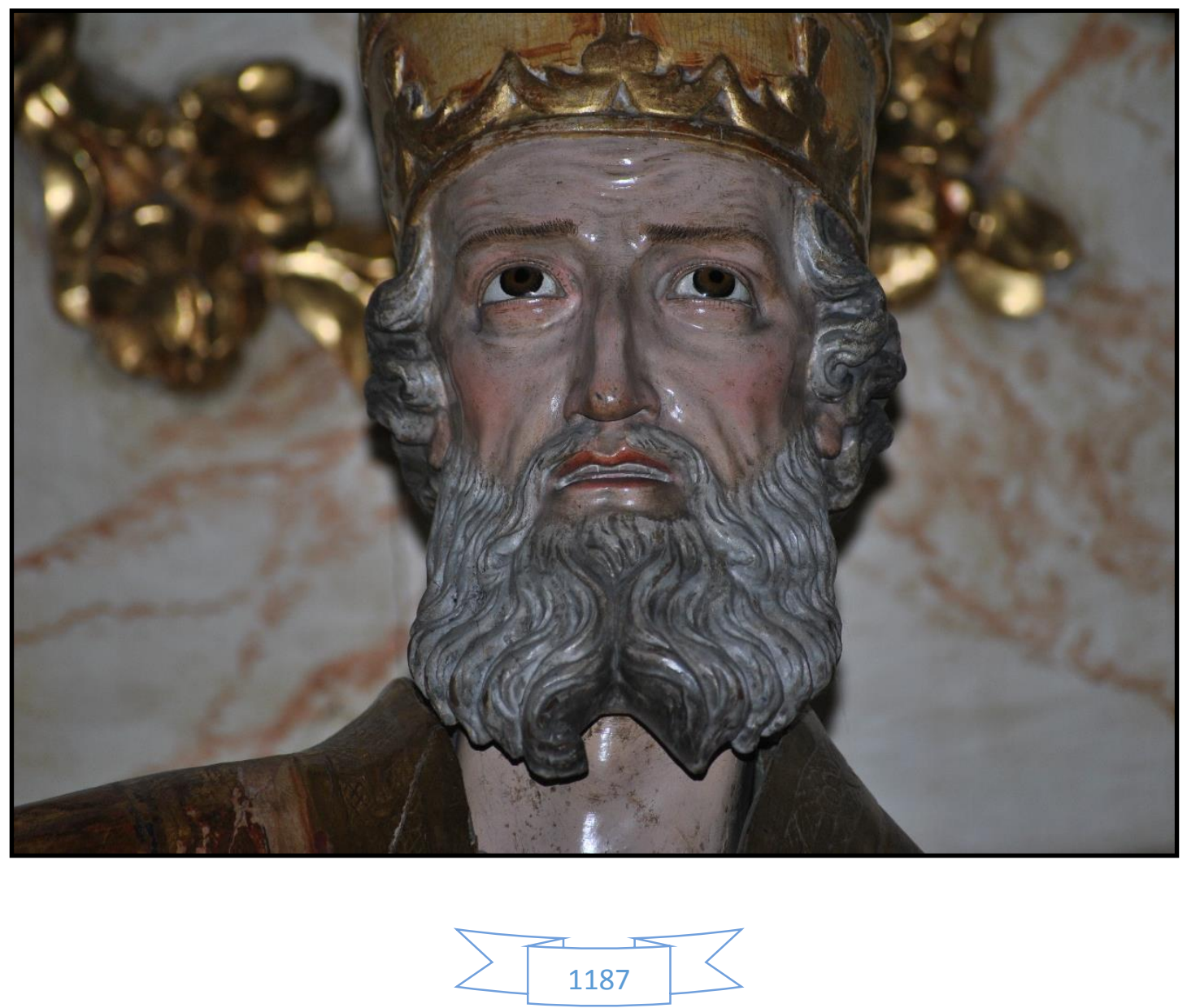


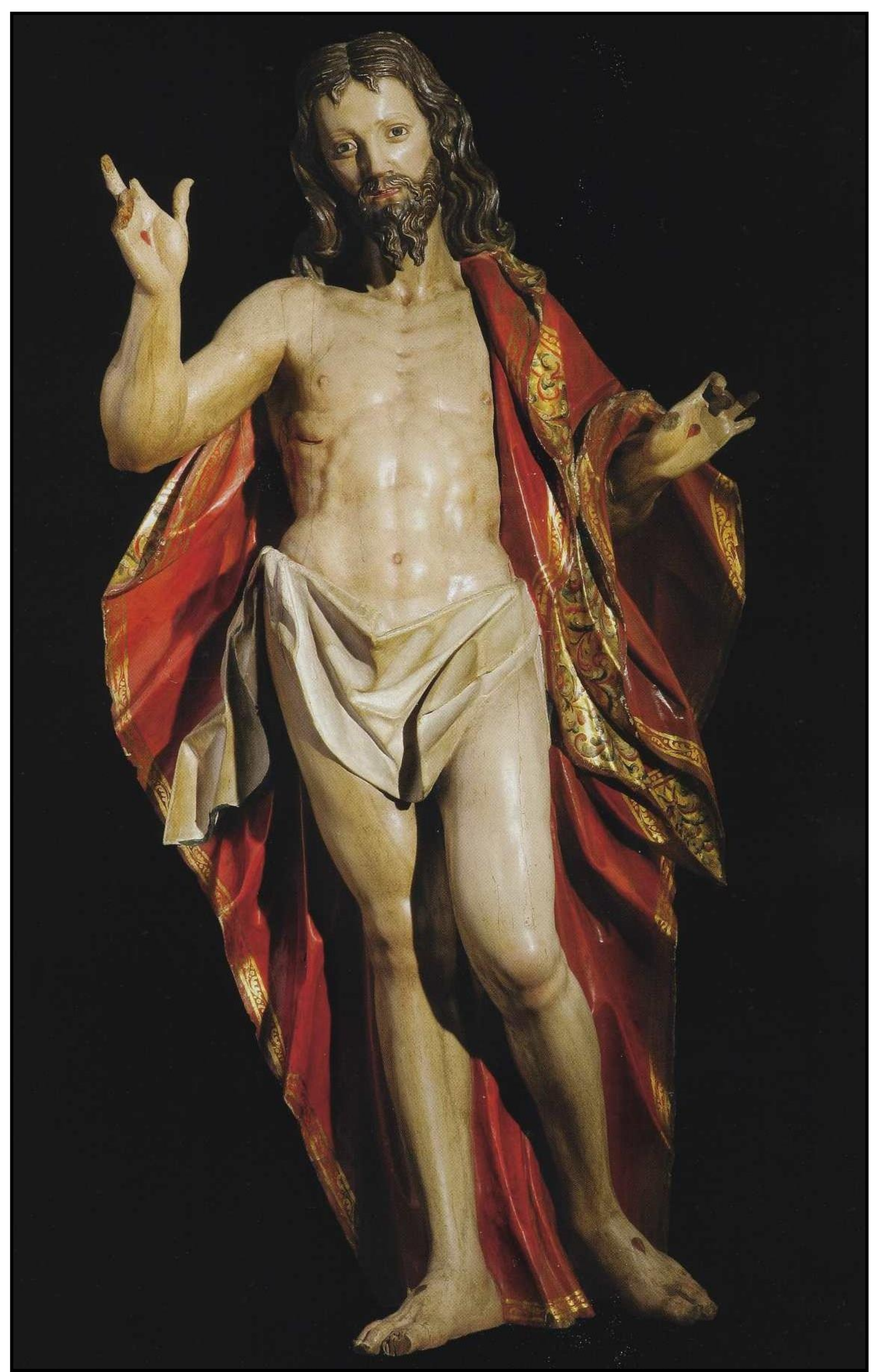

Fig. 76- Pedro de Ávila (atrib.). Cristo Resucitado. Iglesia Museo de San Francisco. Ampudia (Palencia).

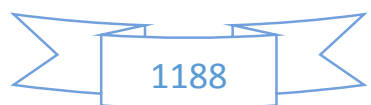




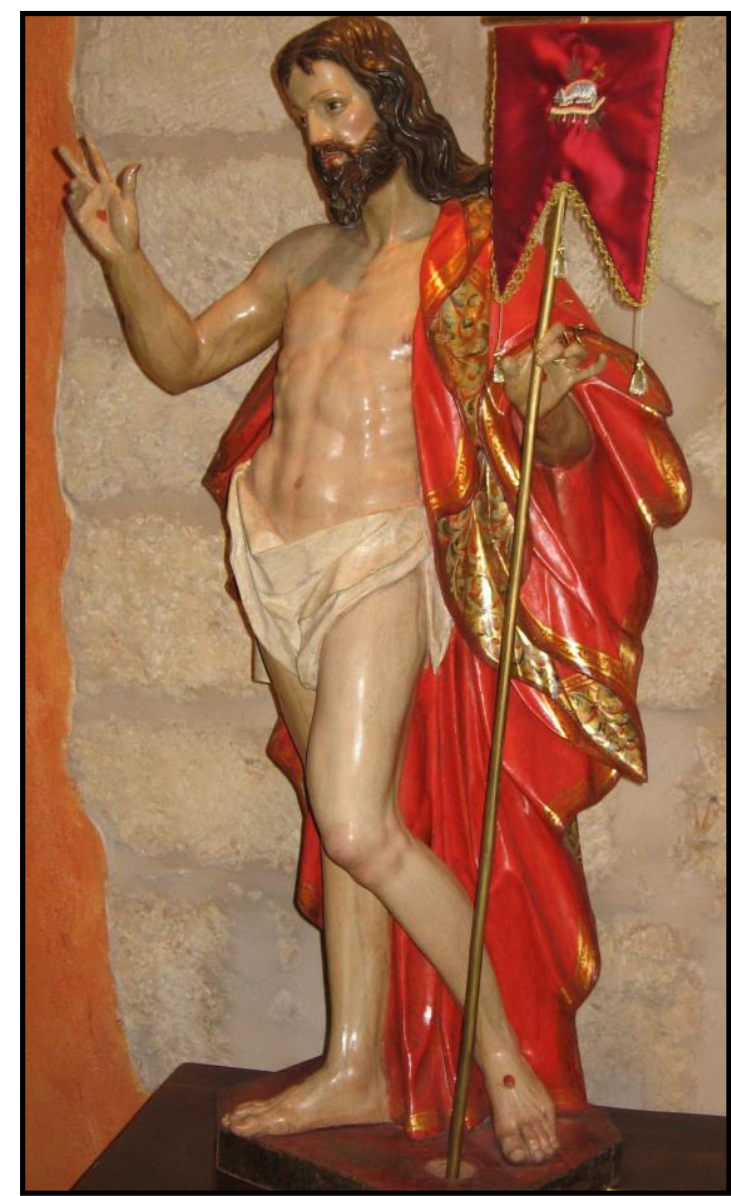

Figs. 77-78- Pedro de Ávila (atrib.). Detalles del Cristo Resucitado.
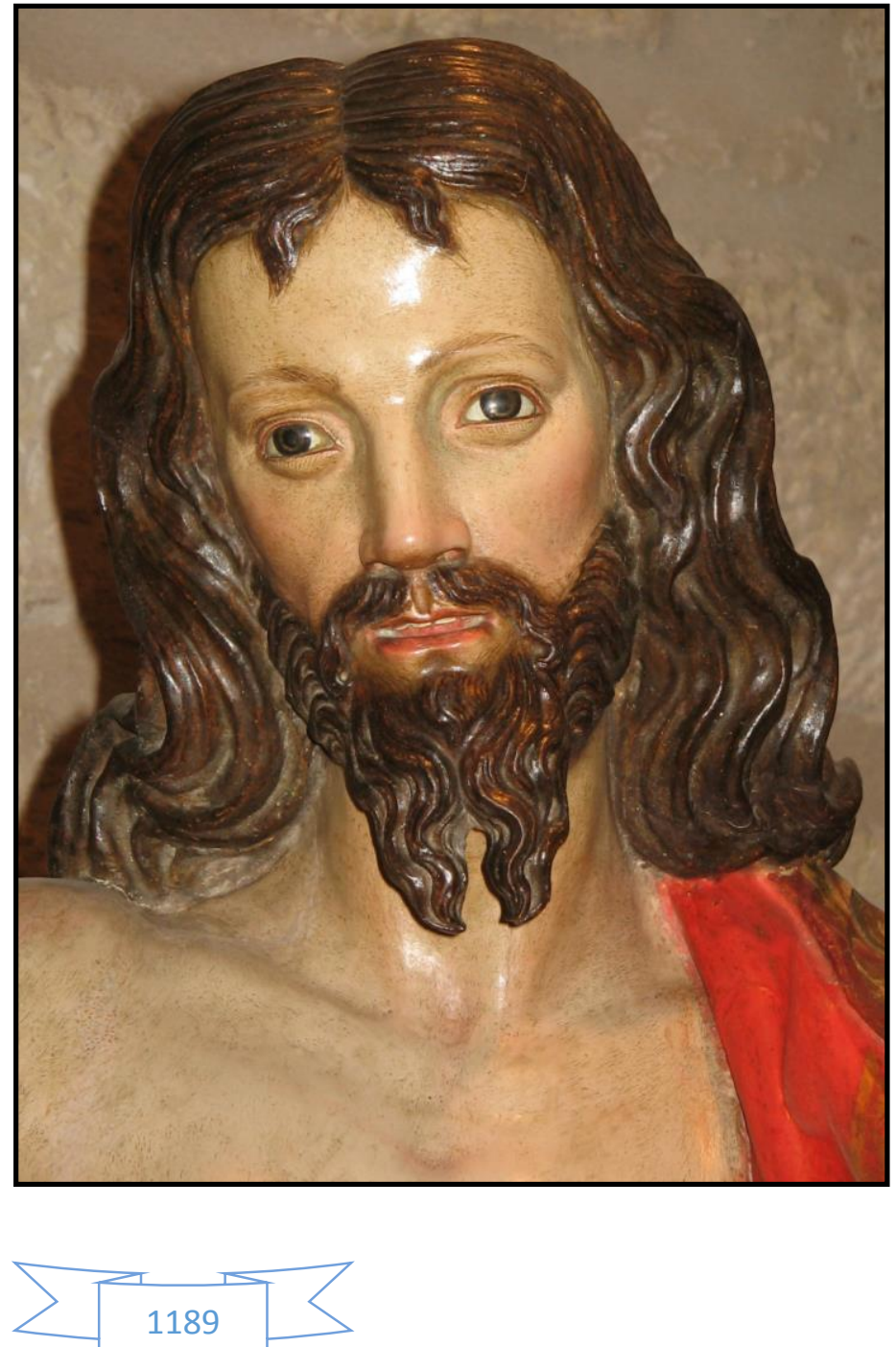

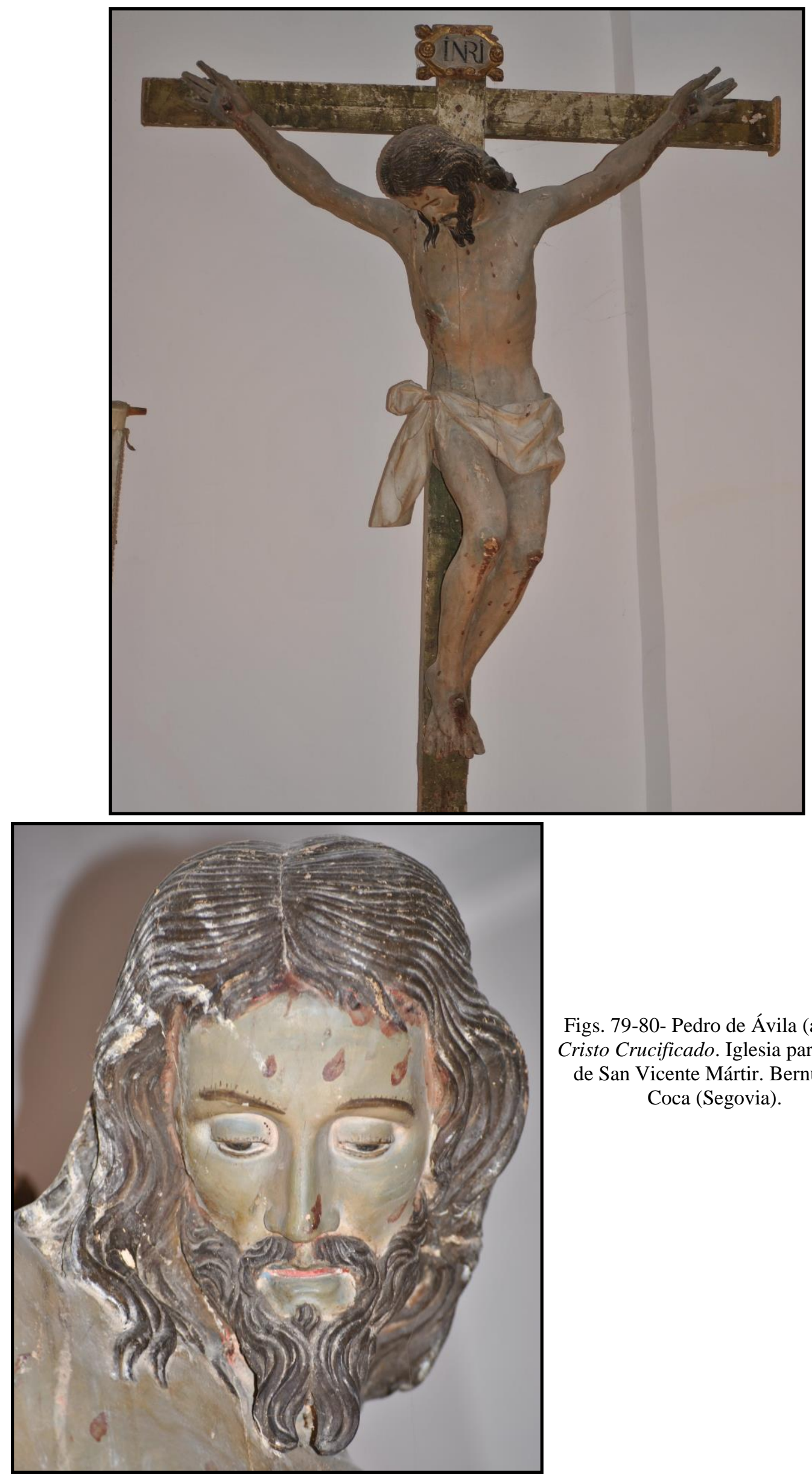

Figs. 79-80- Pedro de Ávila (atrib.). Cristo Crucificado. Iglesia parroquial de San Vicente Mártir. Bernuy de Coca (Segovia).

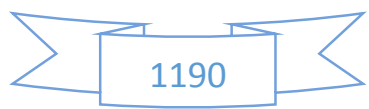




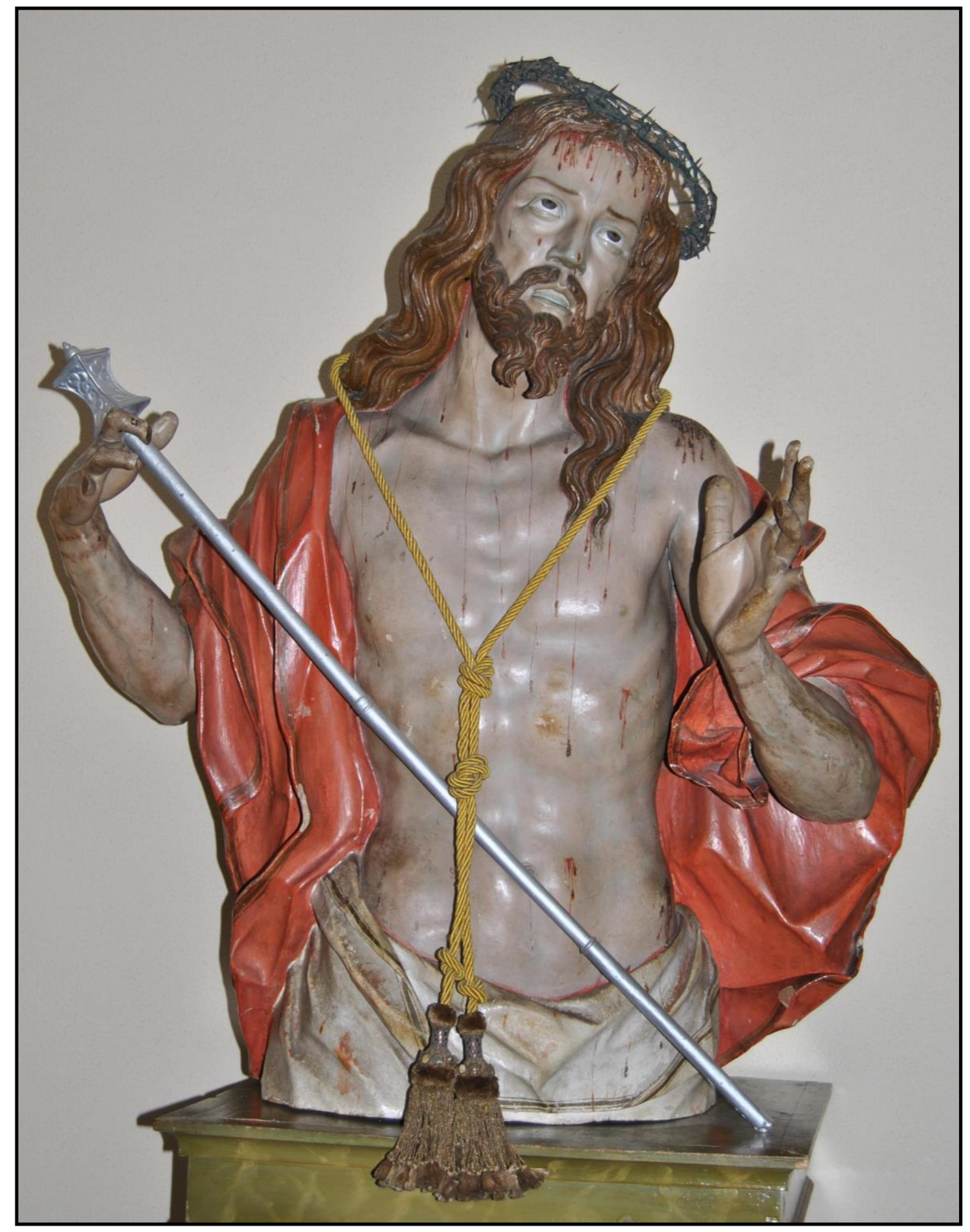

Fig. 81- Pedro de Ávila (atrib.). Busto de Ecce Homo. Monasterio de Santa Brígida. Valladolid

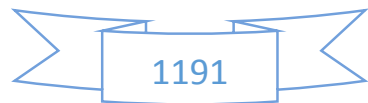




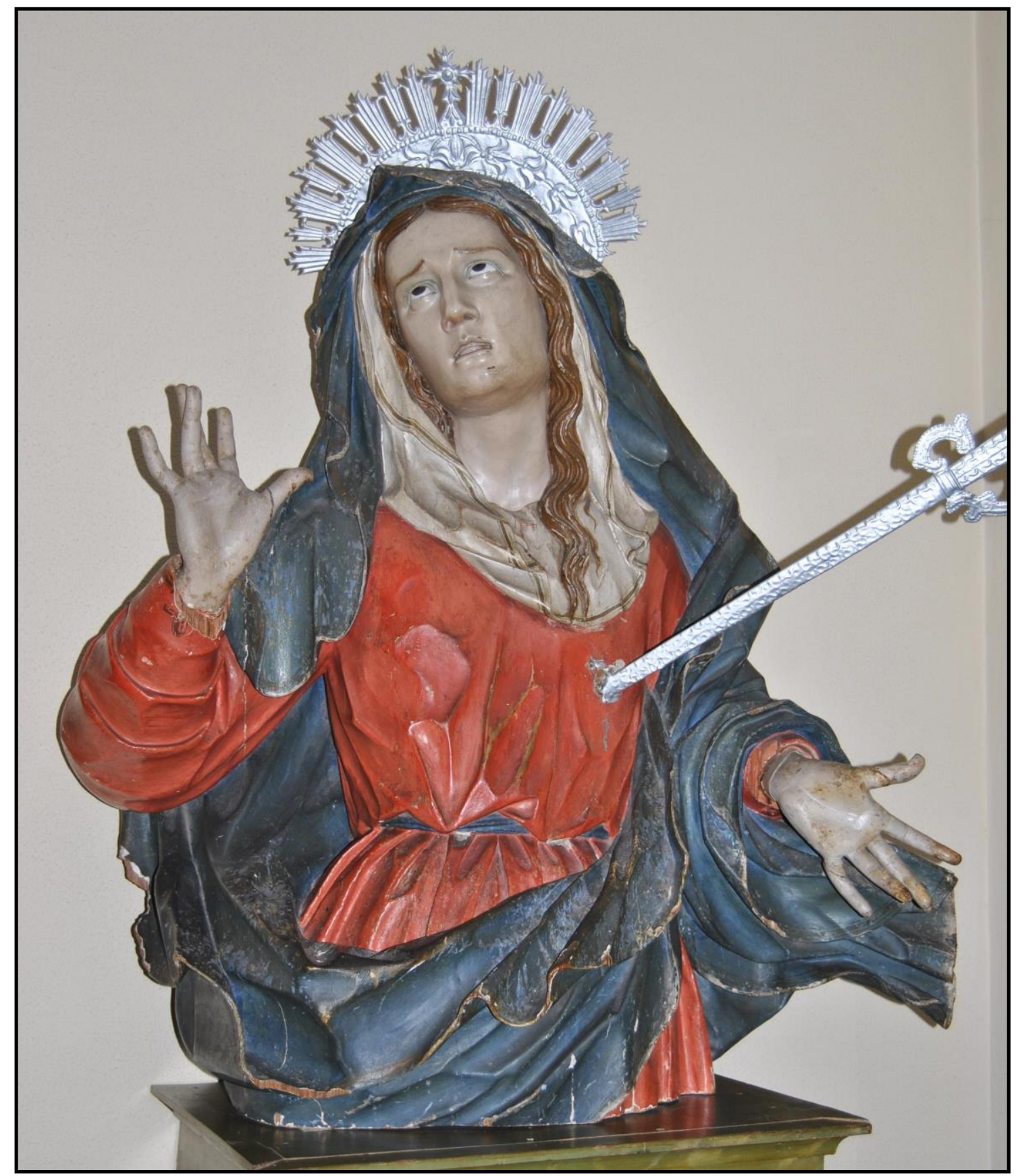

Fig. 82- Pedro de Ávila (atrib.). Busto de Dolorosa. Monasterio de Santa Brígida. Valladolid

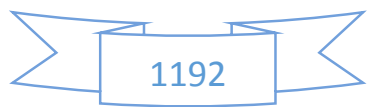




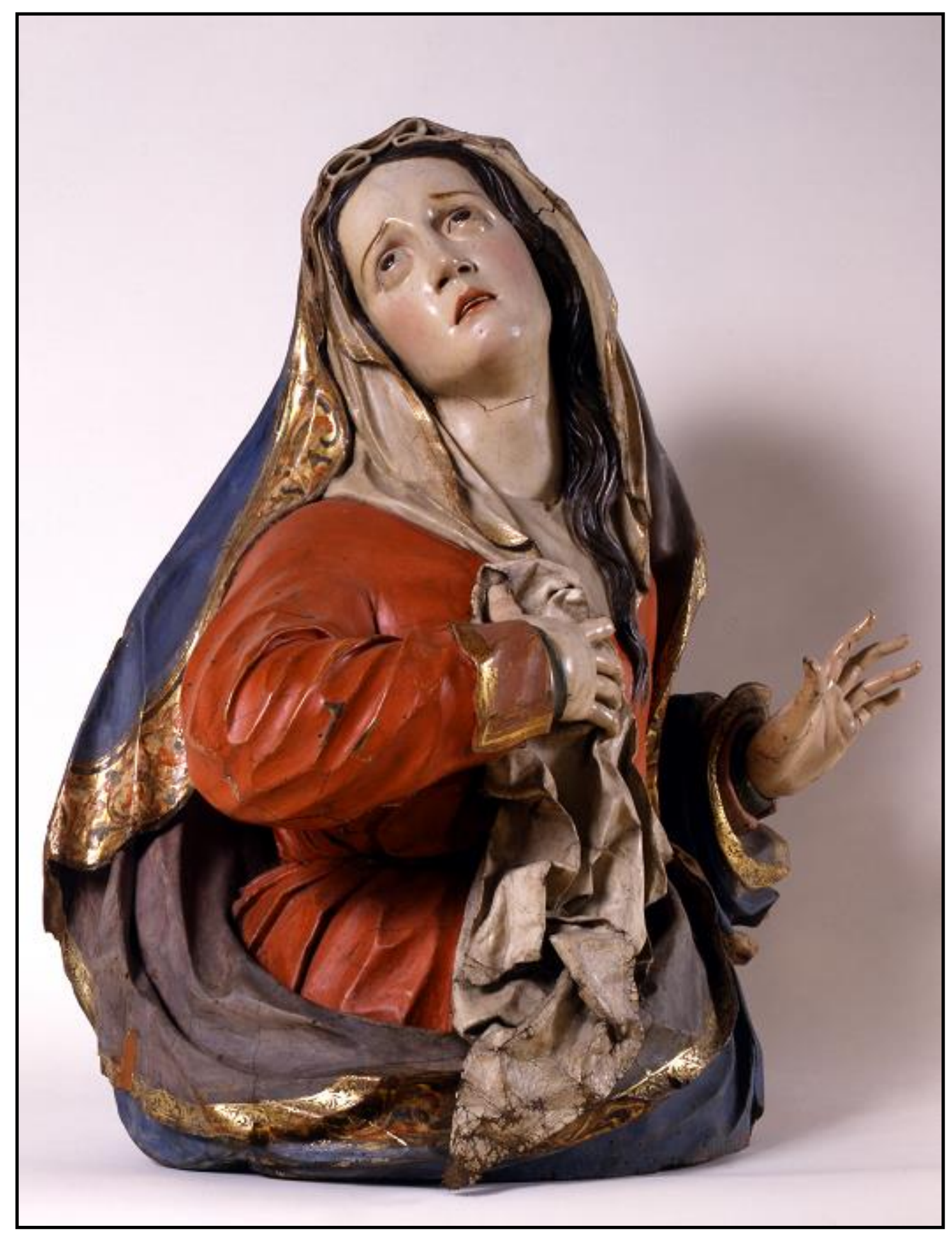

Fig. 83- Pedro de Ávila (atrib.). Busto de Dolorosa. Museo Nacional de Escultura. Valladolid. (C) Museo Nacional de Escultura.

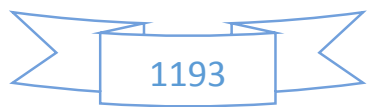




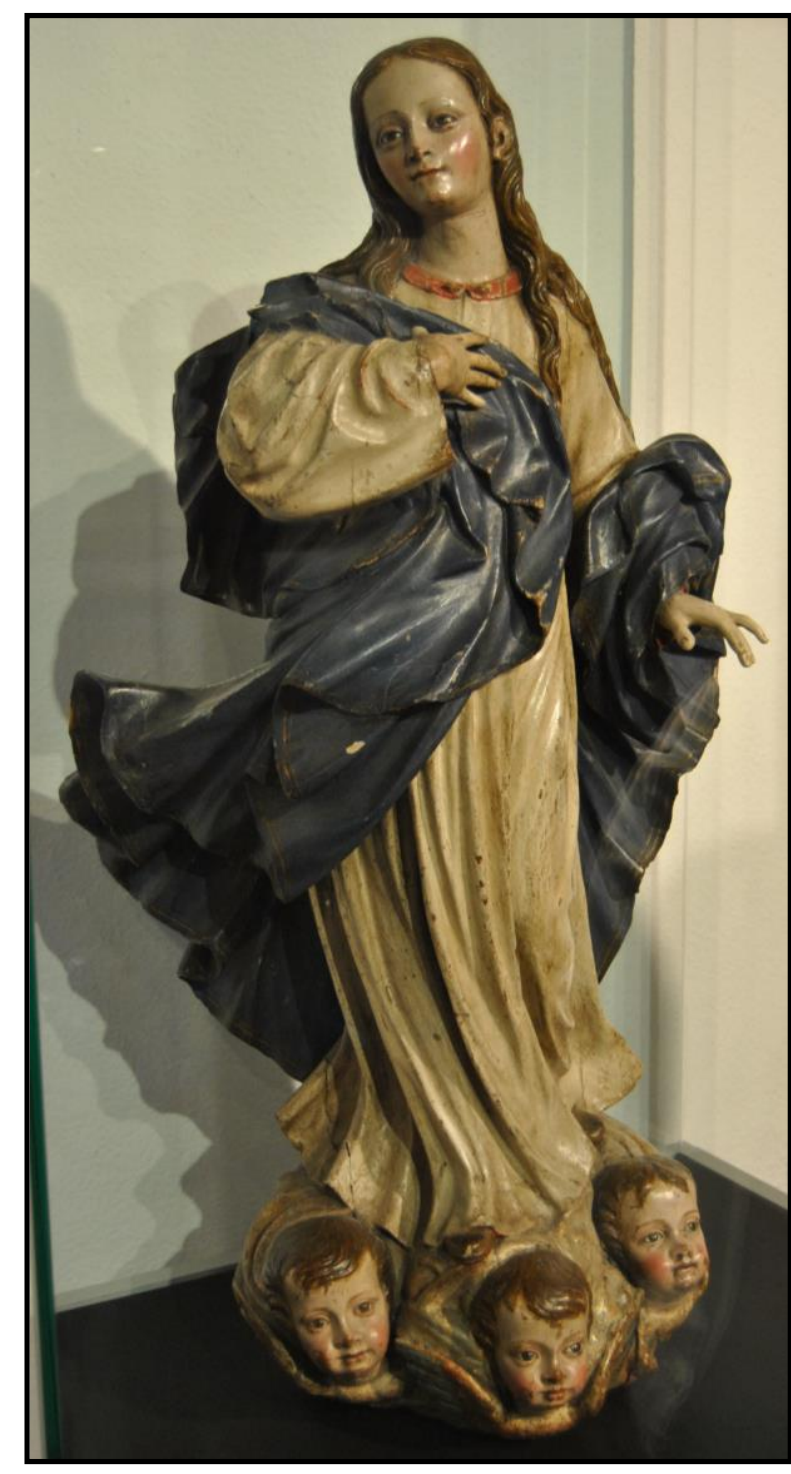

Fig. 84- Pedro de Ávila (atrib.). Inmaculada Concepción. Seminario Diocesano. Valladolid.

Fig. 85- Pedro de Ávila (atrib.). San Nicolás de Bari. Iglesia de Santa María del Castillo. Olmedo (Valladolid).
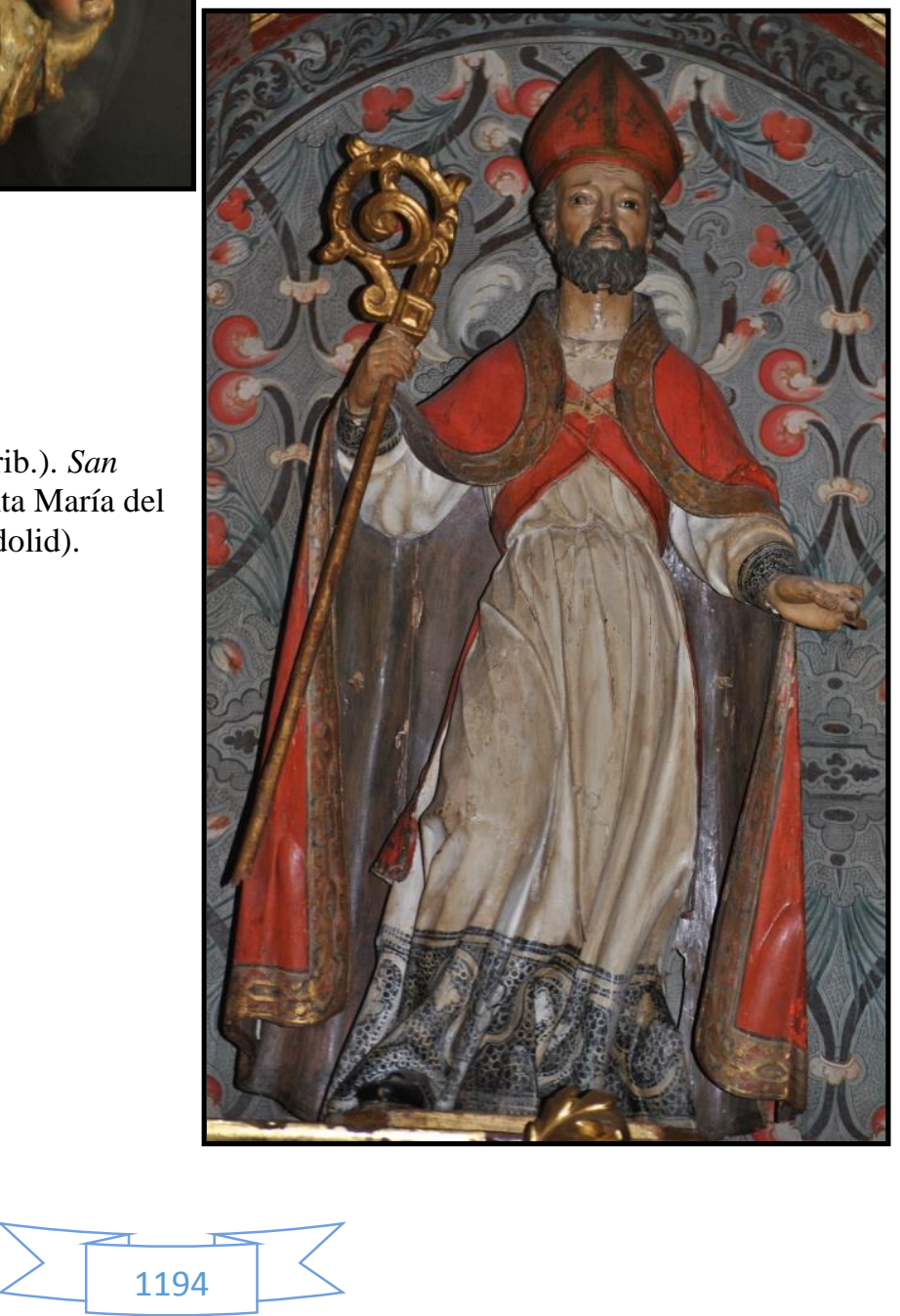


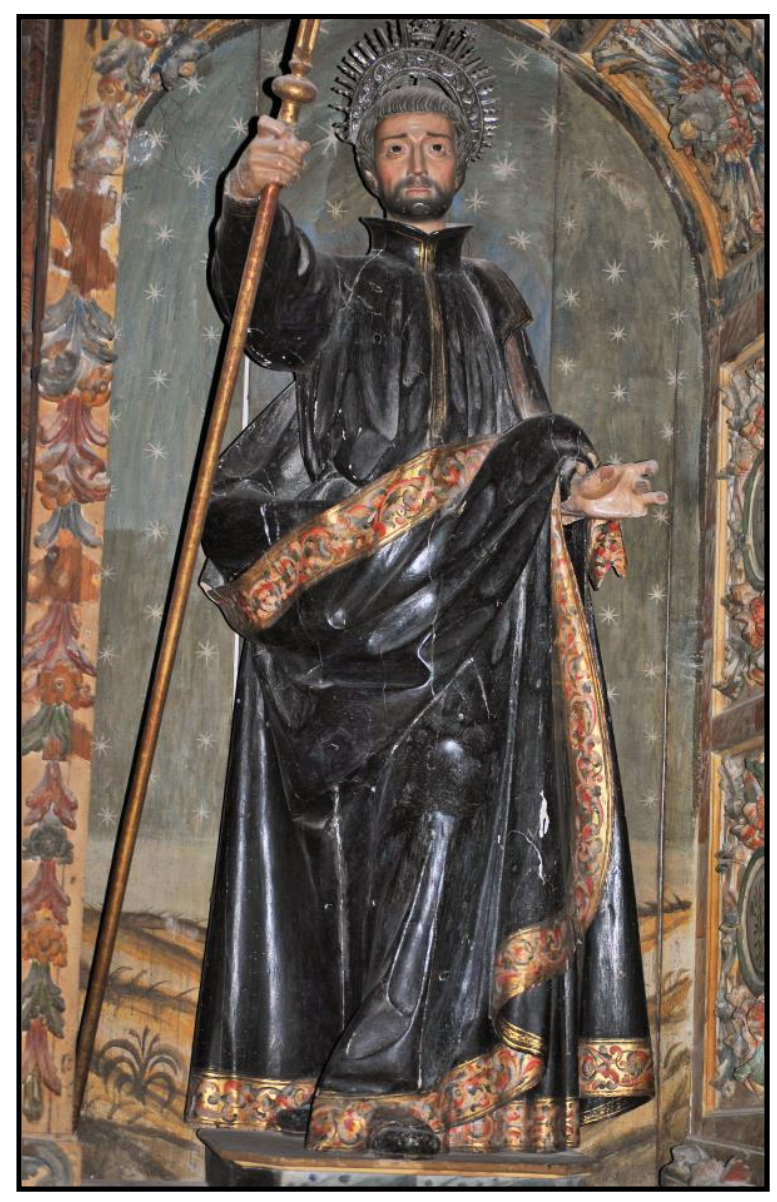

Fig. 86- Pedro de Ávila (atrib.). San Francisco Javier. Iglesia parroquial de la Asunción. Villabáñez (Valladolid).

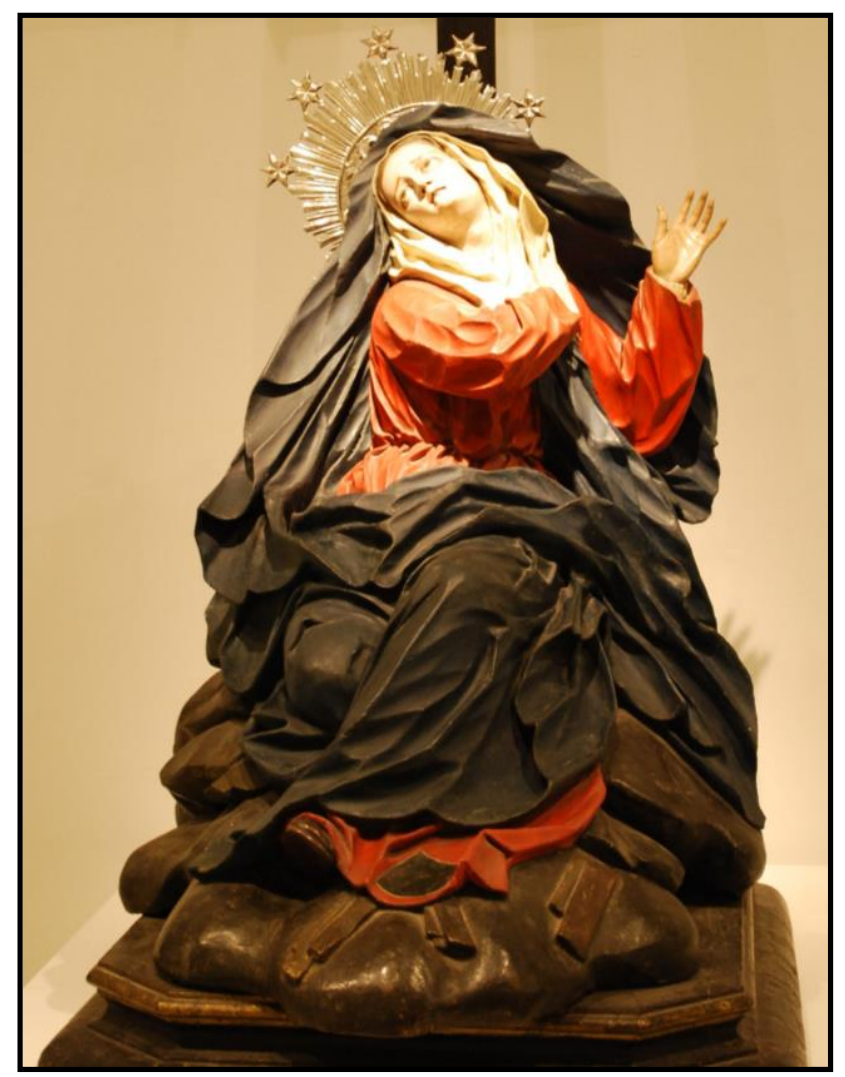

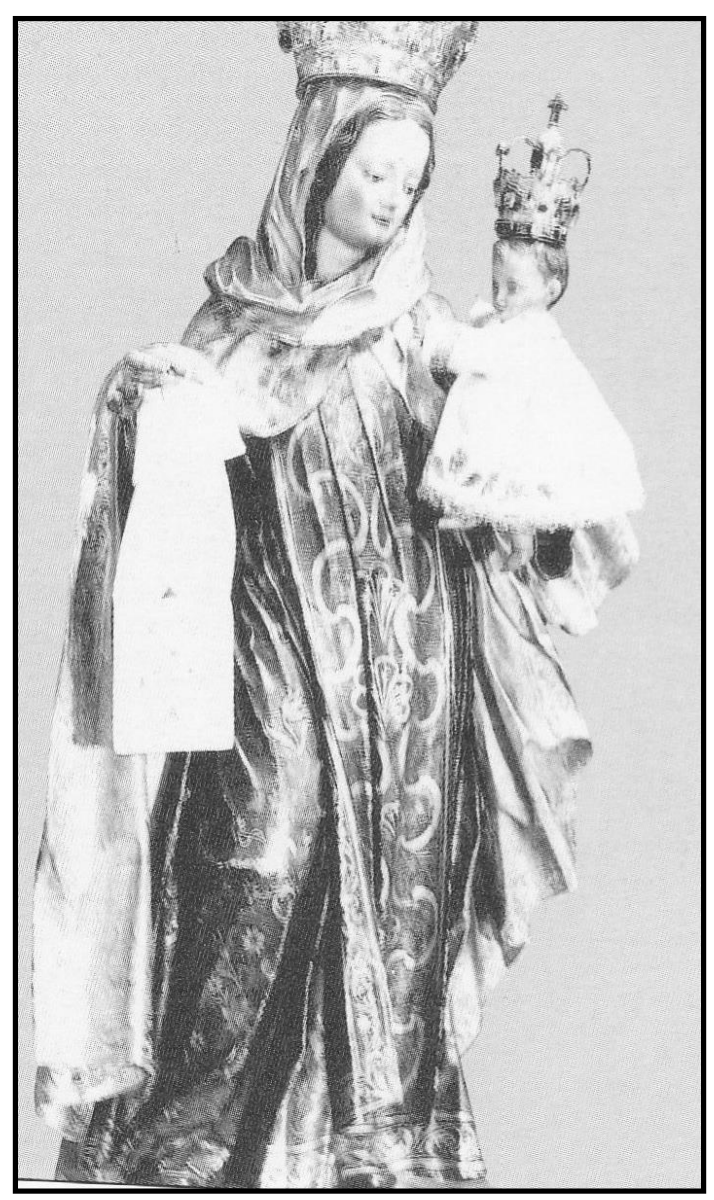

Fig. 87- Pedro de Ávila (atrib.). Virgen del Carmen con el Niño. Monasterio de San José. Pamplona (Navarra).

Fig. 88- Pedro de Ávila (atrib.). Virgen del Refugio. Iglesia del Salvador. Valladolid.

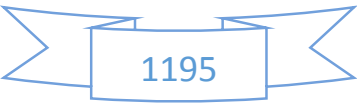




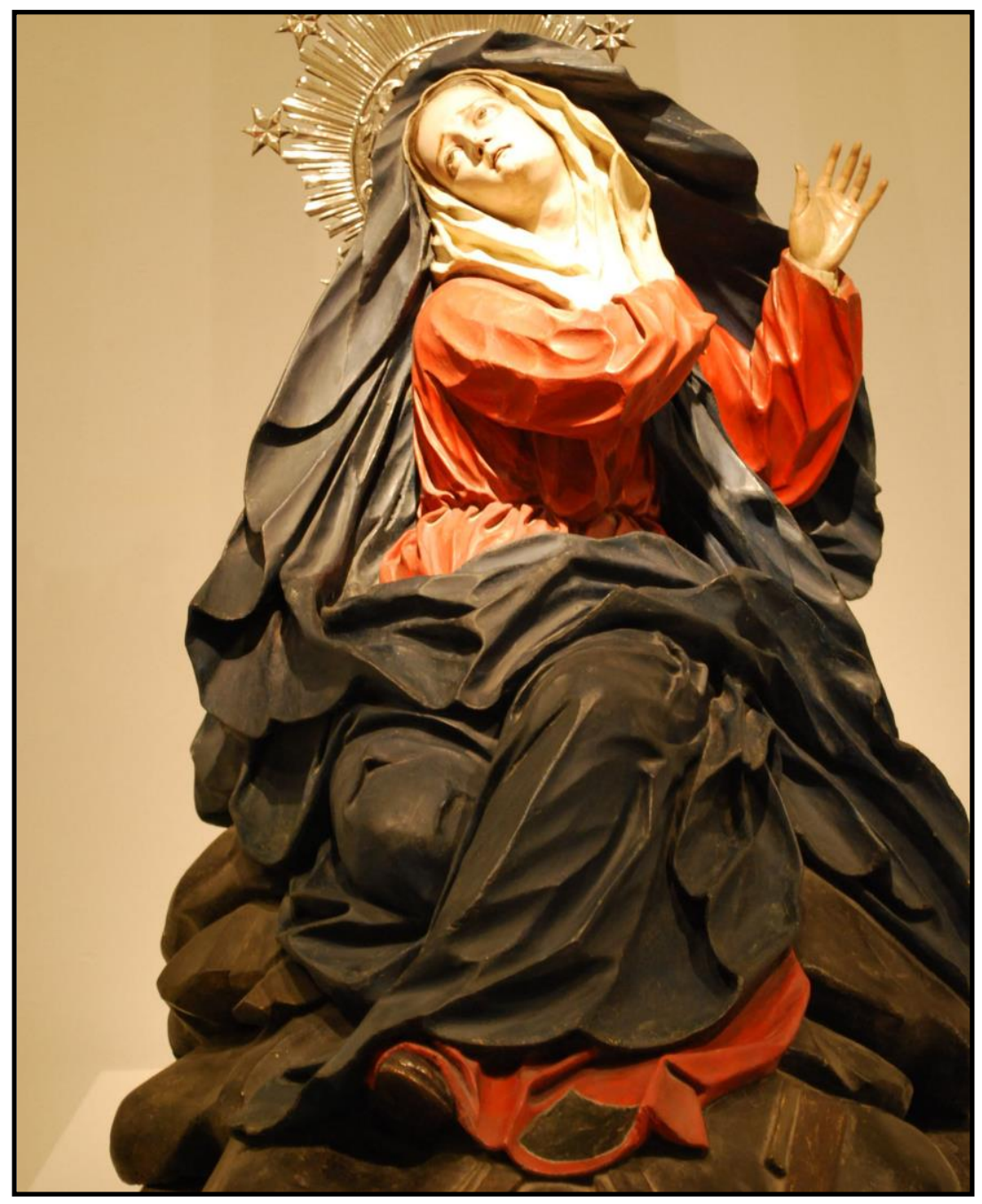

Figs. 89-90- Pedro de Ávila (atrib.). Detalles de la Virgen del Refugio.
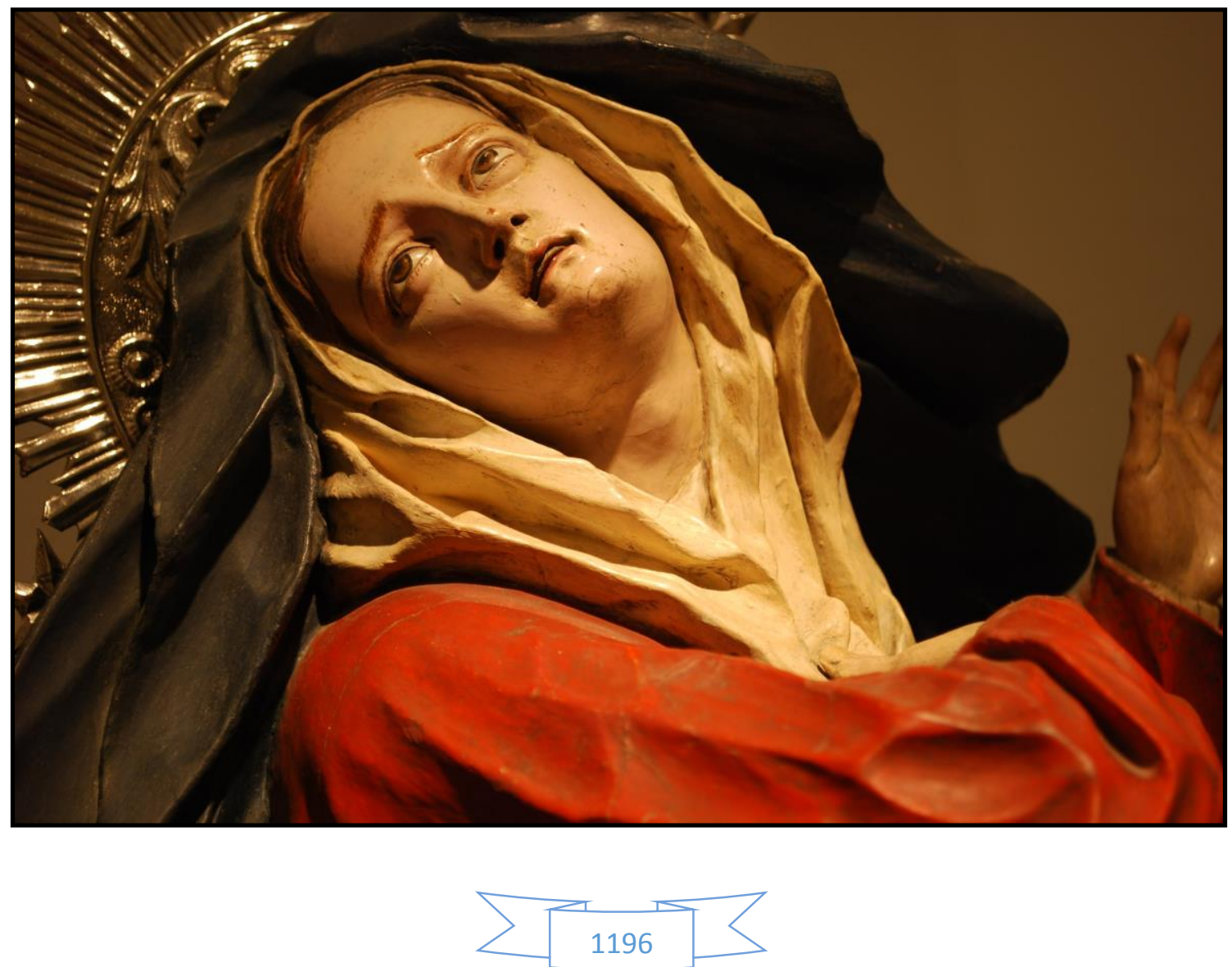


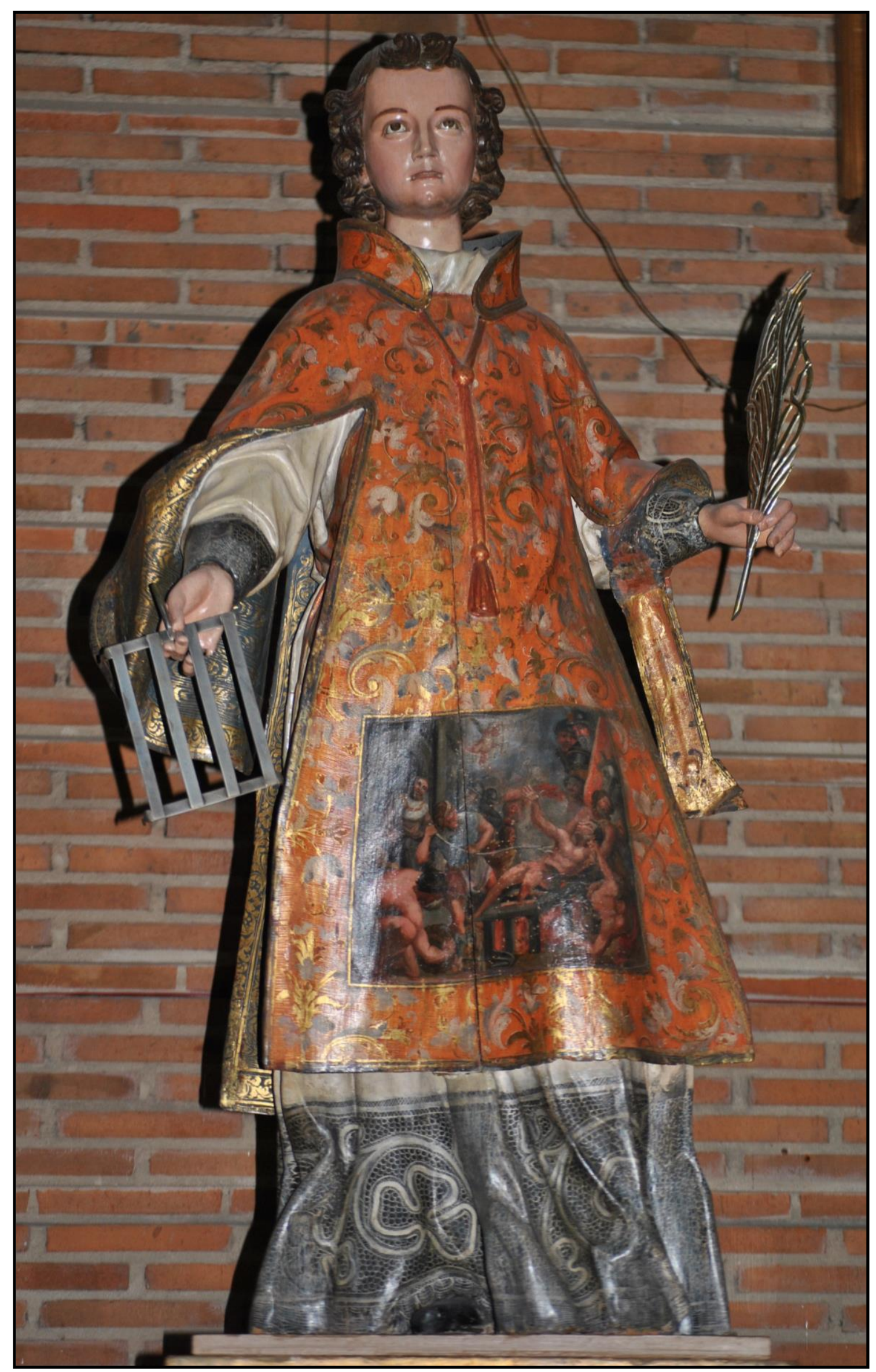

Fig. 91- Pedro de Ávila (atrib.). San Lorenzo. Iglesia de San Lorenzo. Valladolid.

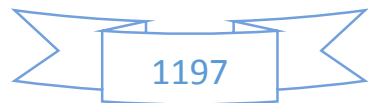




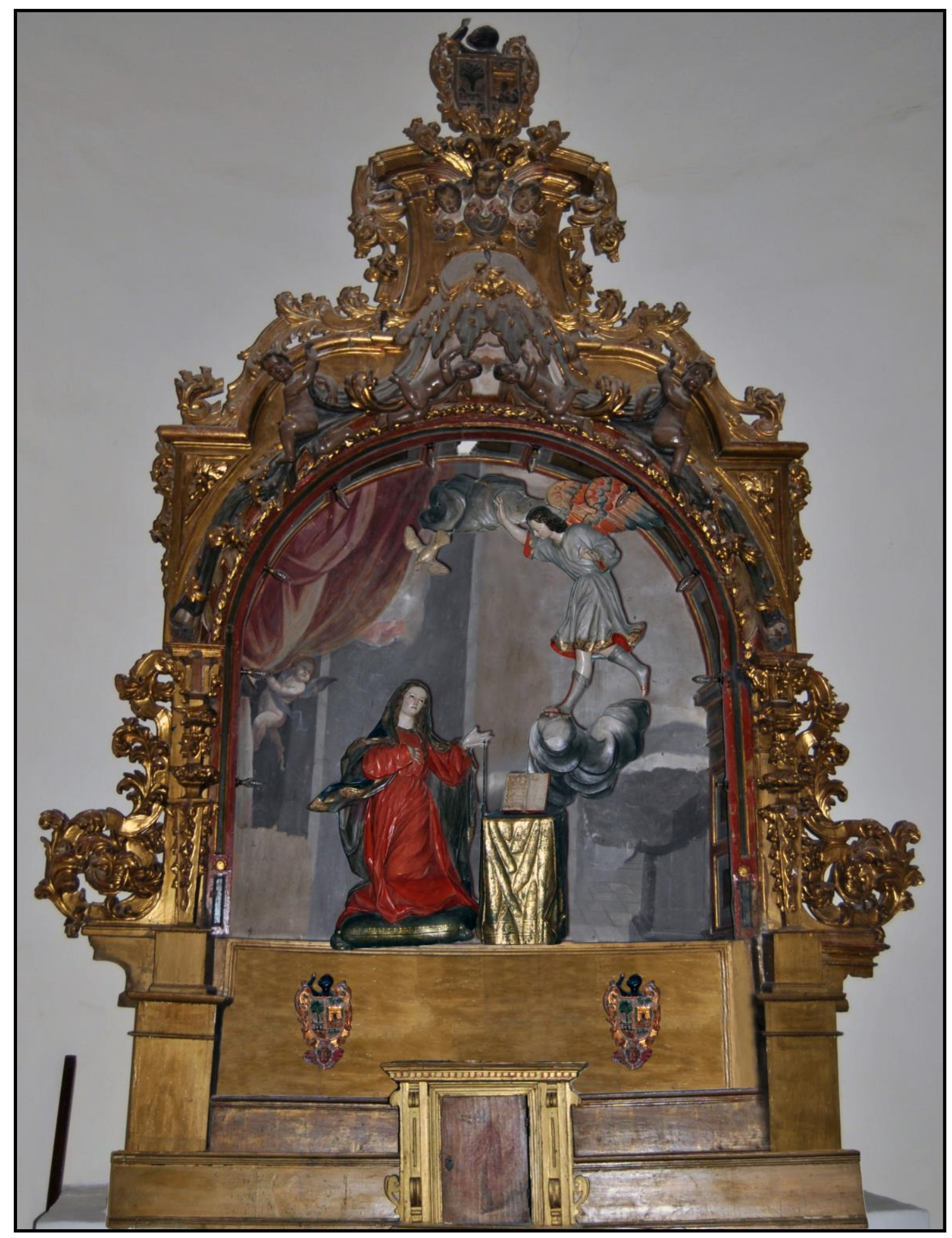

Fig. 92- Reconstrucción hipotética del retablo de la Anunciación. Iglesia parroquial de la Inmaculada Concepción. Renedo de Esgueva (Valladolid).

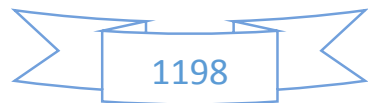




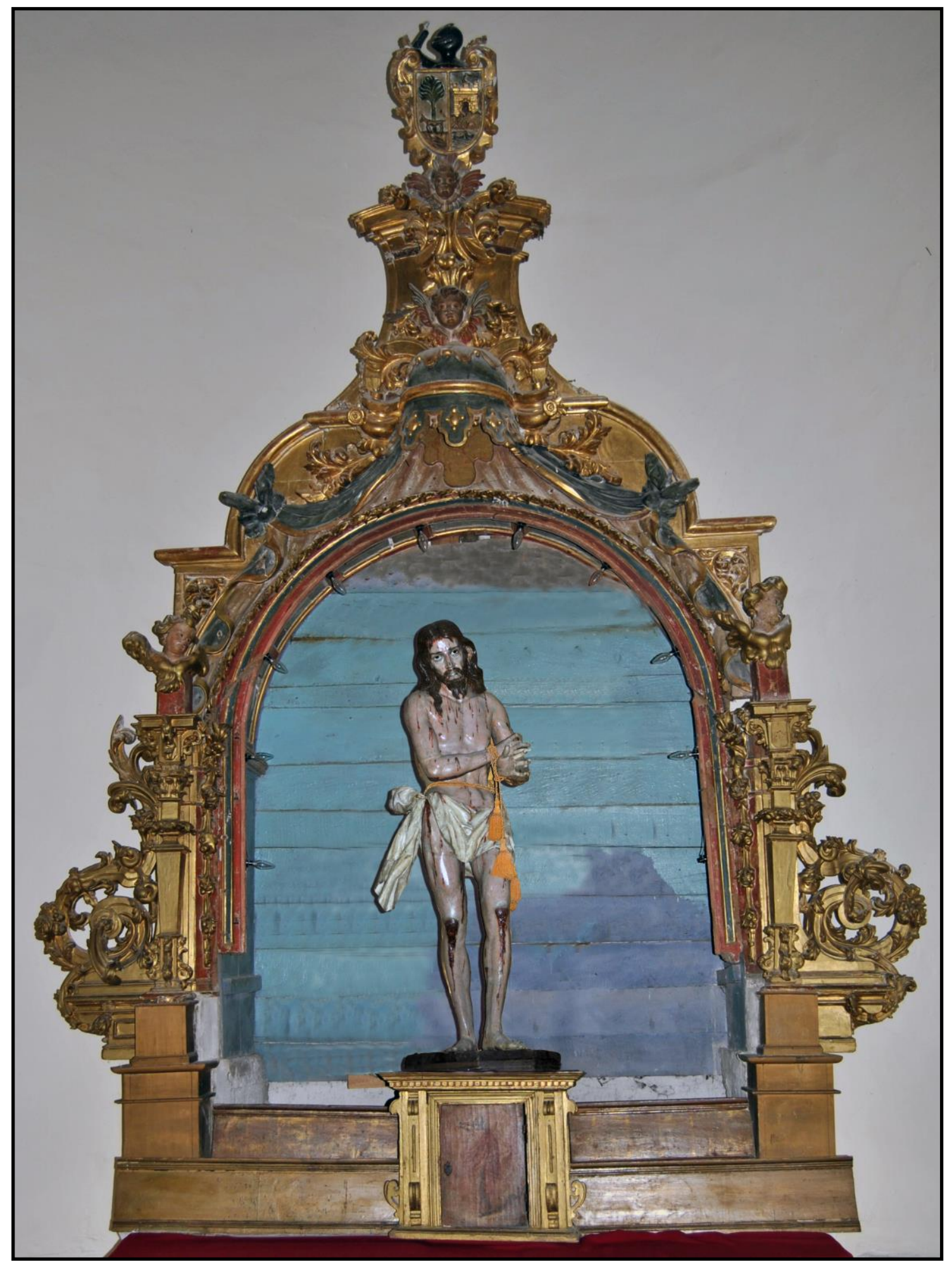

Fig. 93- Reconstrucción hipotética del retablo del Ecce Homo, antiguamente denominado como "Retablo de los Celos de San José". Iglesia parroquial de la Inmaculada Concepción. Renedo de Esgueva (Valladolid).

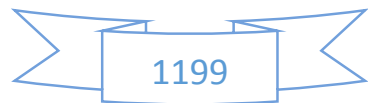




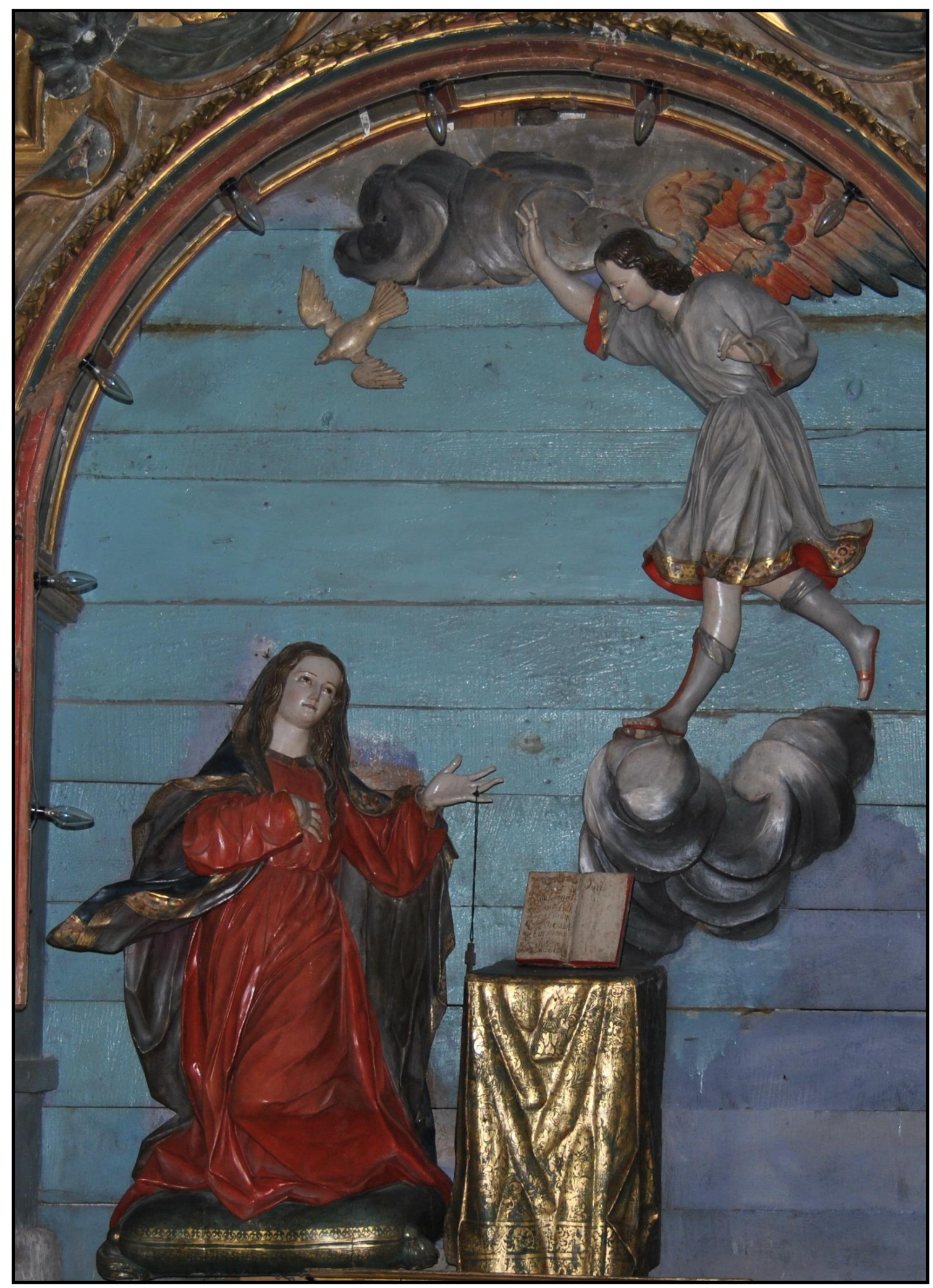

Fig. 94- Pedro de Ávila (atrib.). Anunciación. Iglesia parroquial de la Inmaculada Concepción. Renedo de Esgueva (Valladolid).

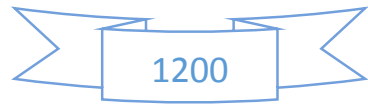




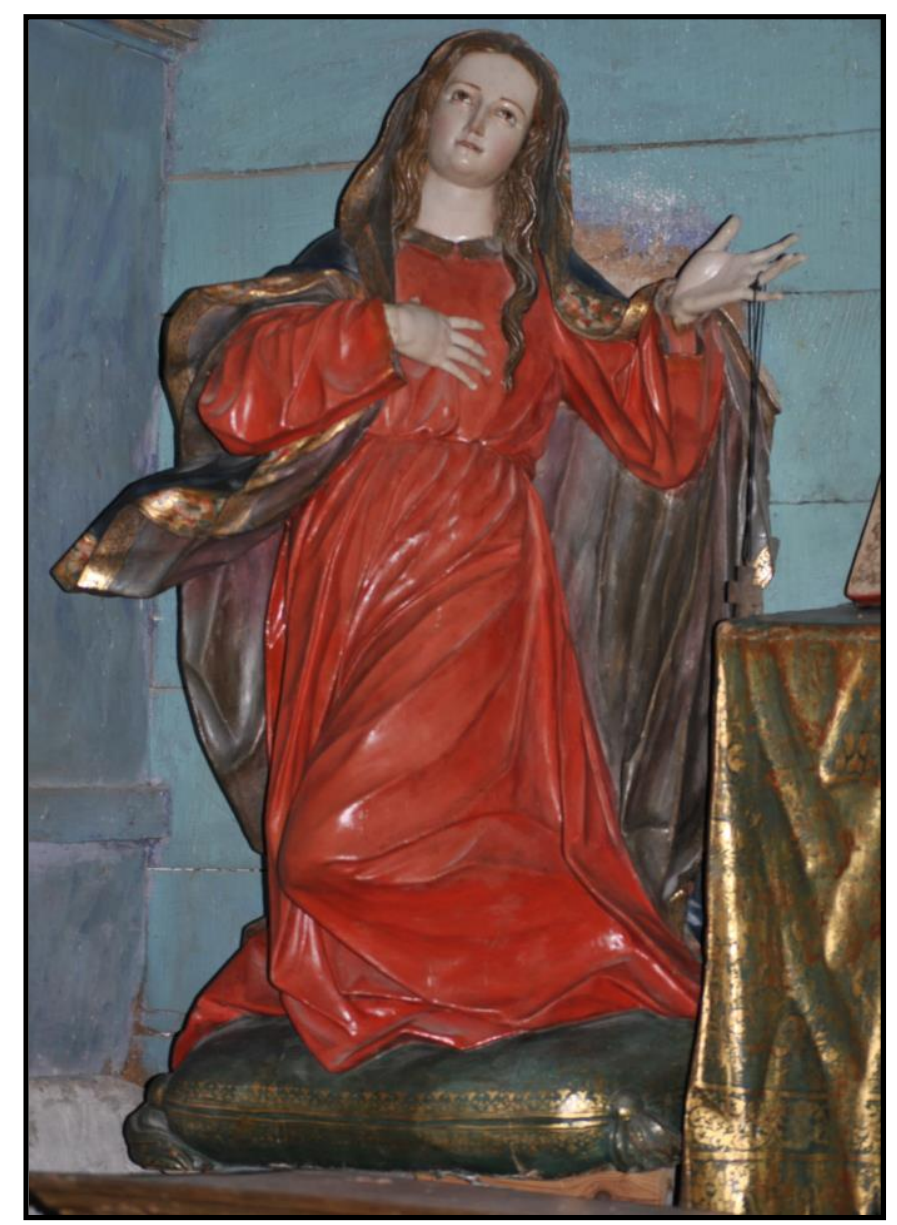

Figs. 95-96- Pedro de Ávila (atrib.).

Detalles de la Anunciación.
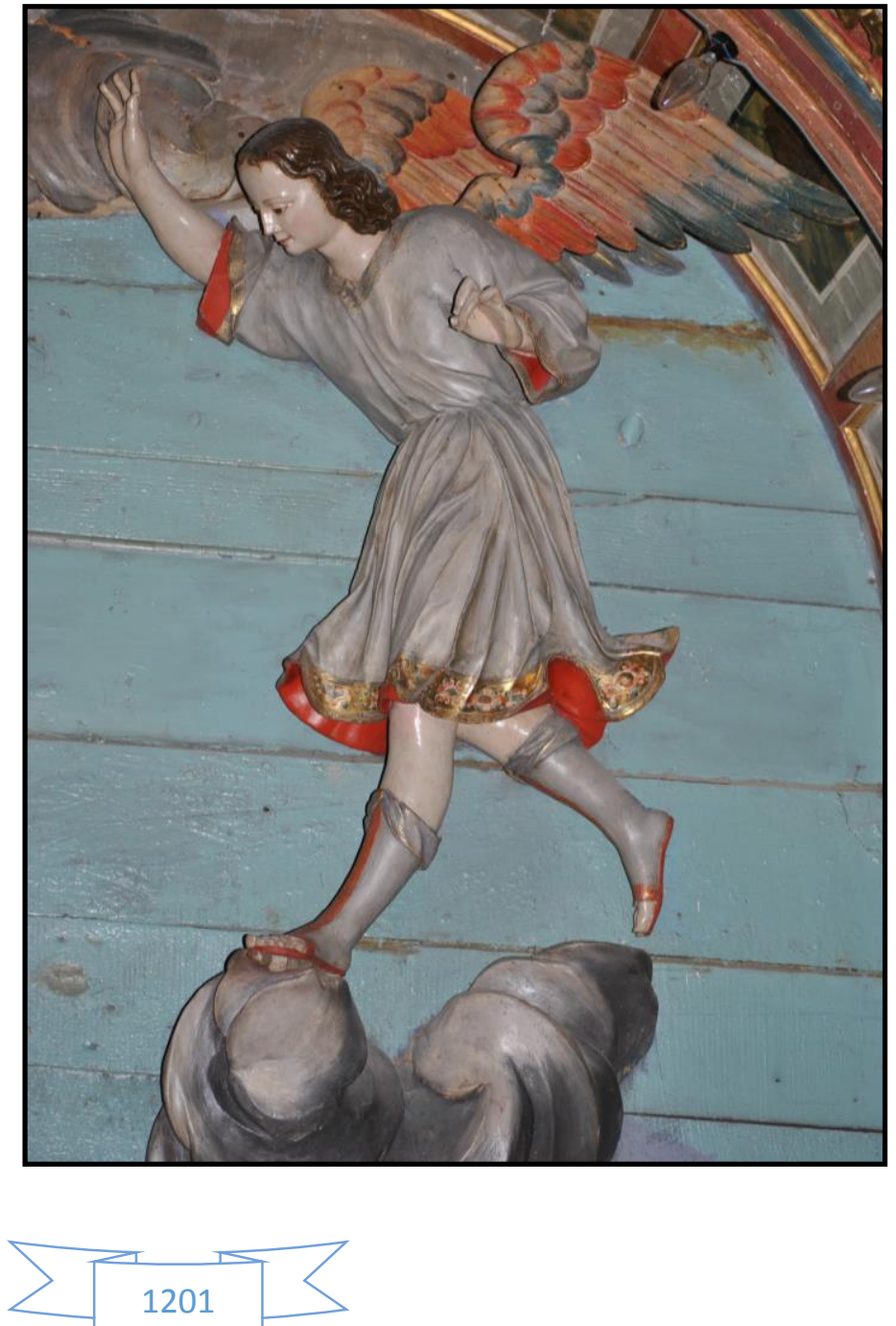

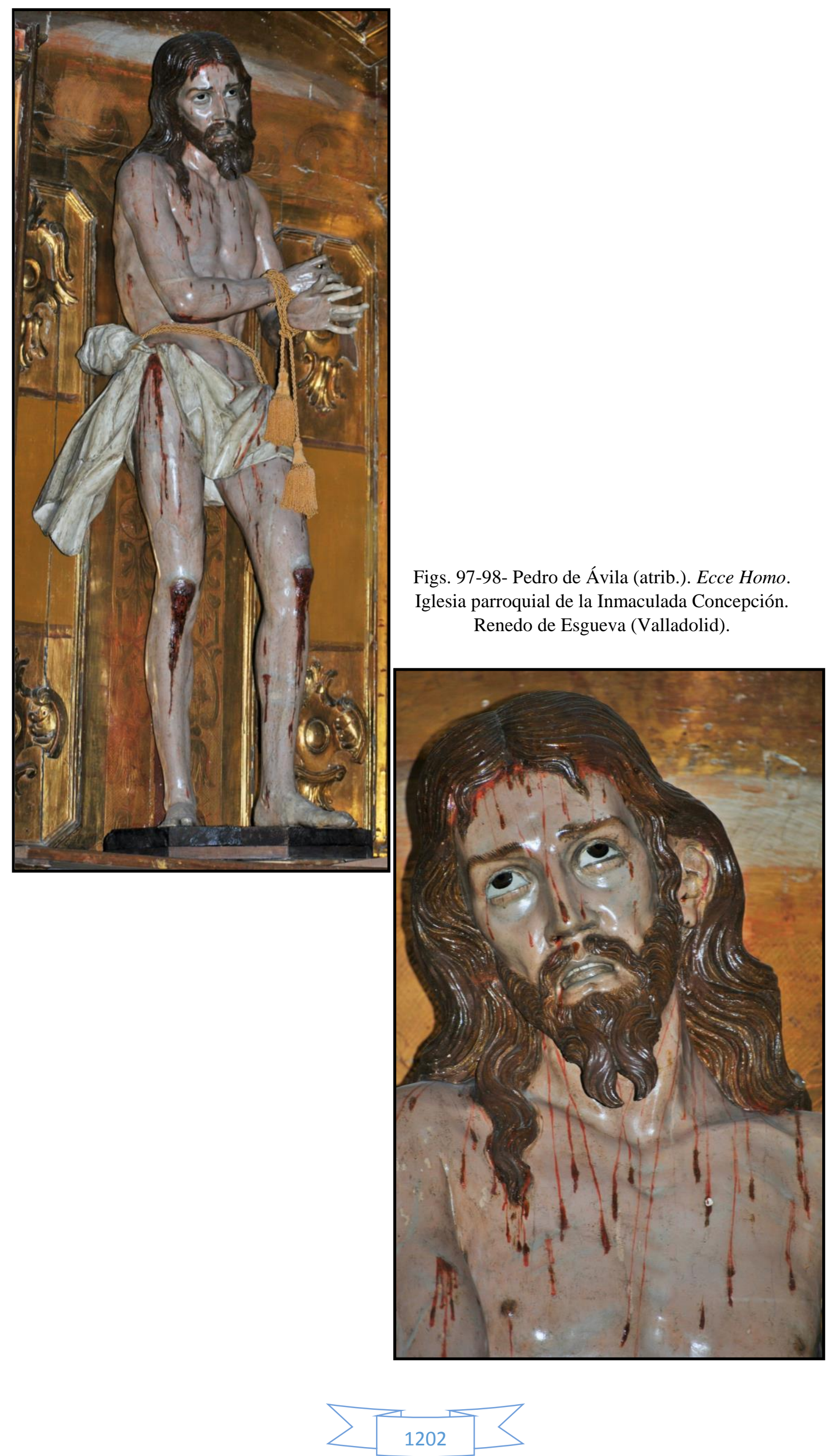


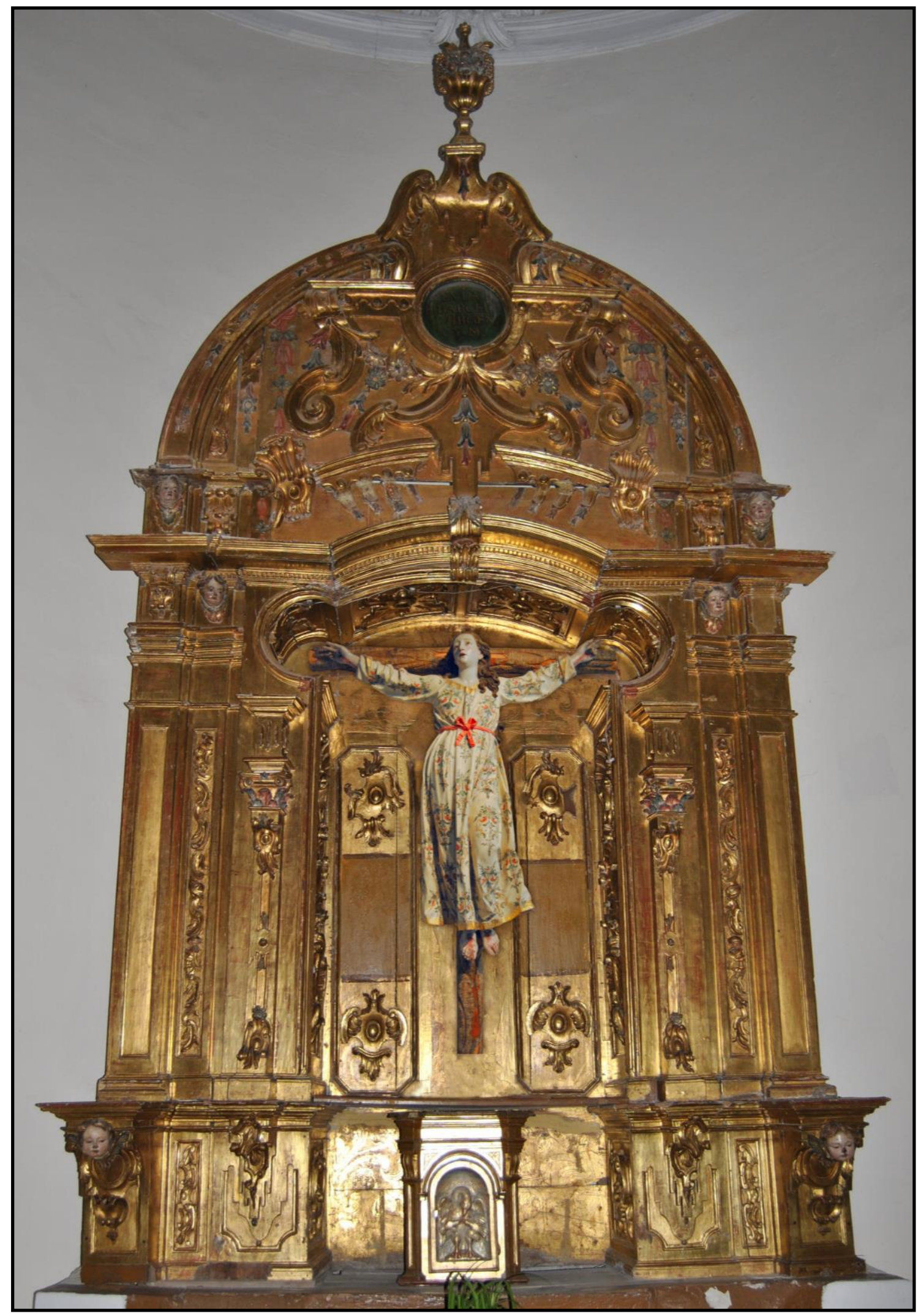

Fig. 99- Reconstrucción hipotética del retablo de Santa Eulalia. El retablo actualmente alberga al Ecce Homo en la Iglesia parroquial de la Inmaculada Concepción de Renedo de Esgueva (Valladolid).

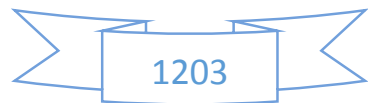




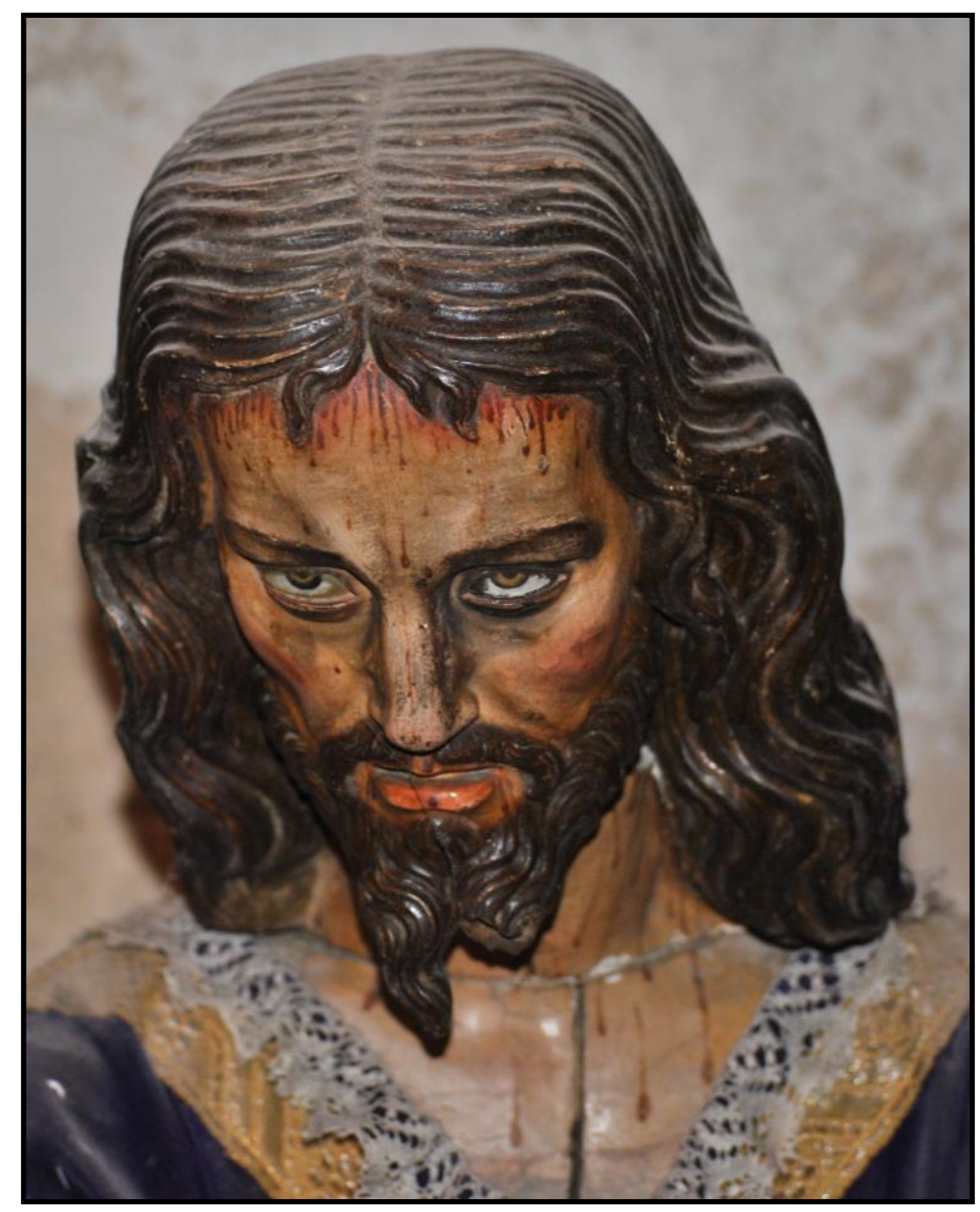

Fig. 100- Pedro de Ávila (atrib.). Jesús Nazareno. Iglesia parroquial de la Asunción. Tudela de Duero (Valladolid).

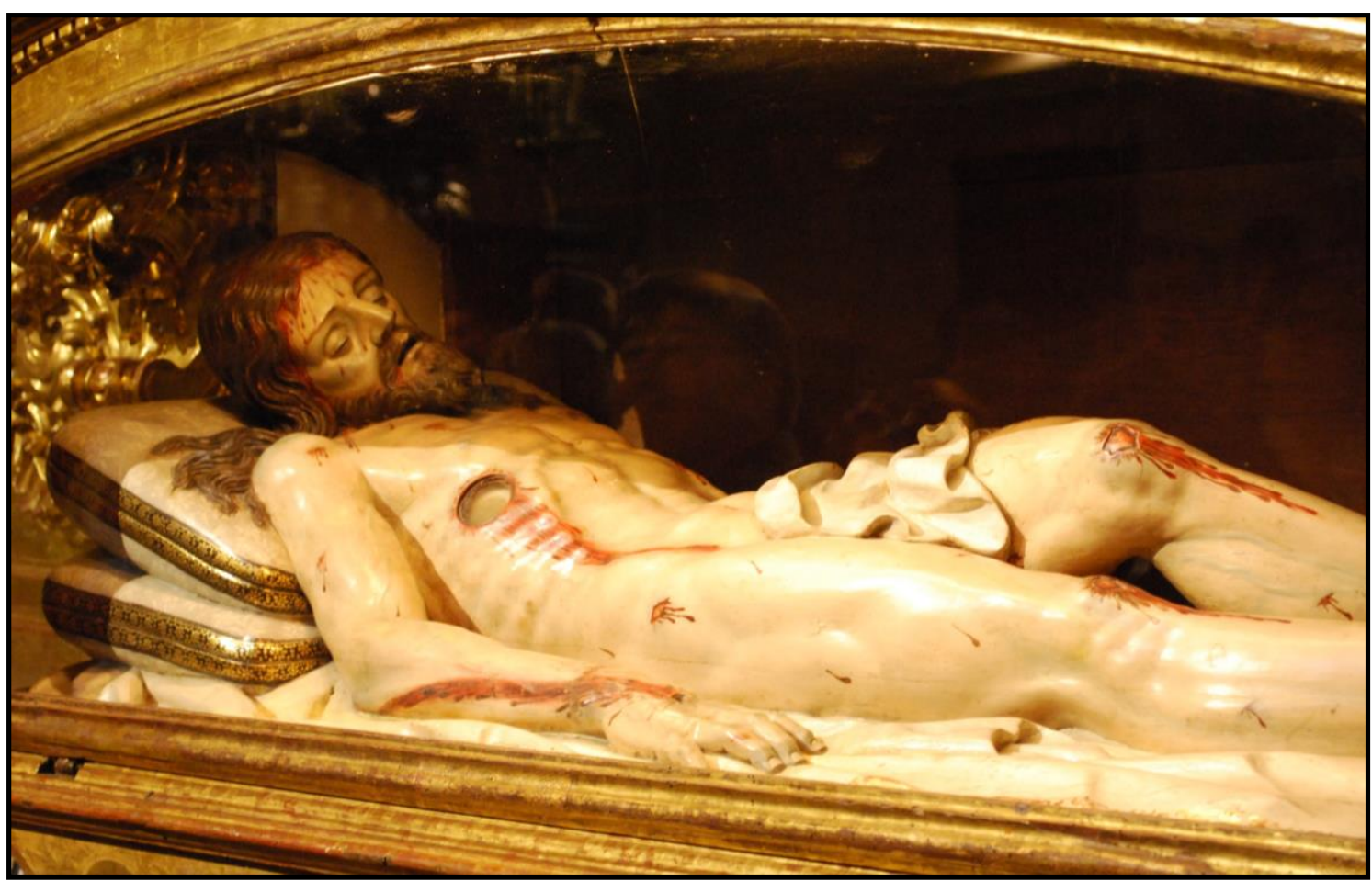

Fig. 101- Pedro de Ávila (atrib.). Cristo Yacente. Iglesia penitencial de N.P. Jesús Nazareno. Valladolid.

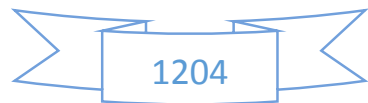




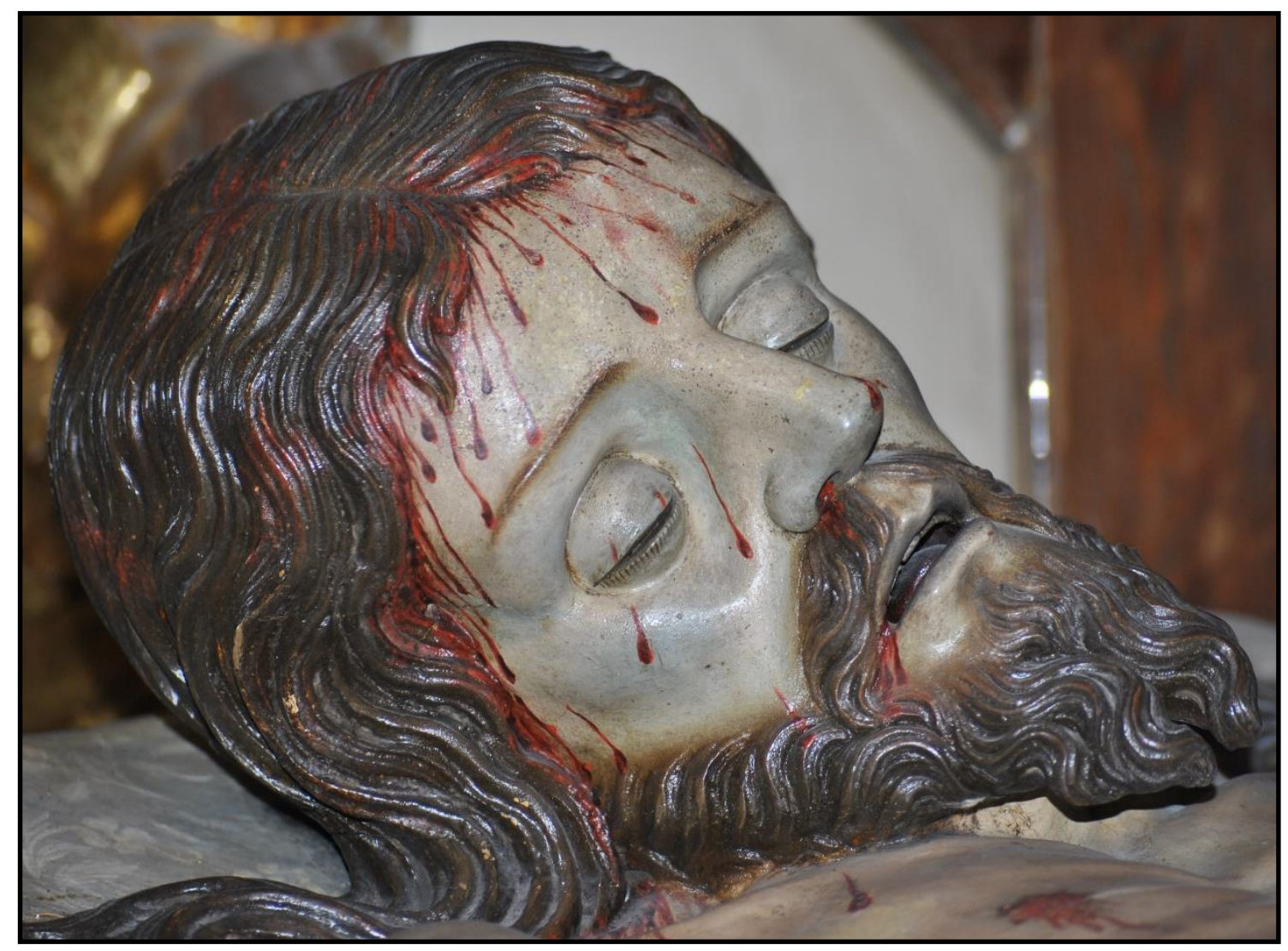

Fig. 102- Pedro de Ávila (atrib.). Detalle del Cristo Yacente.

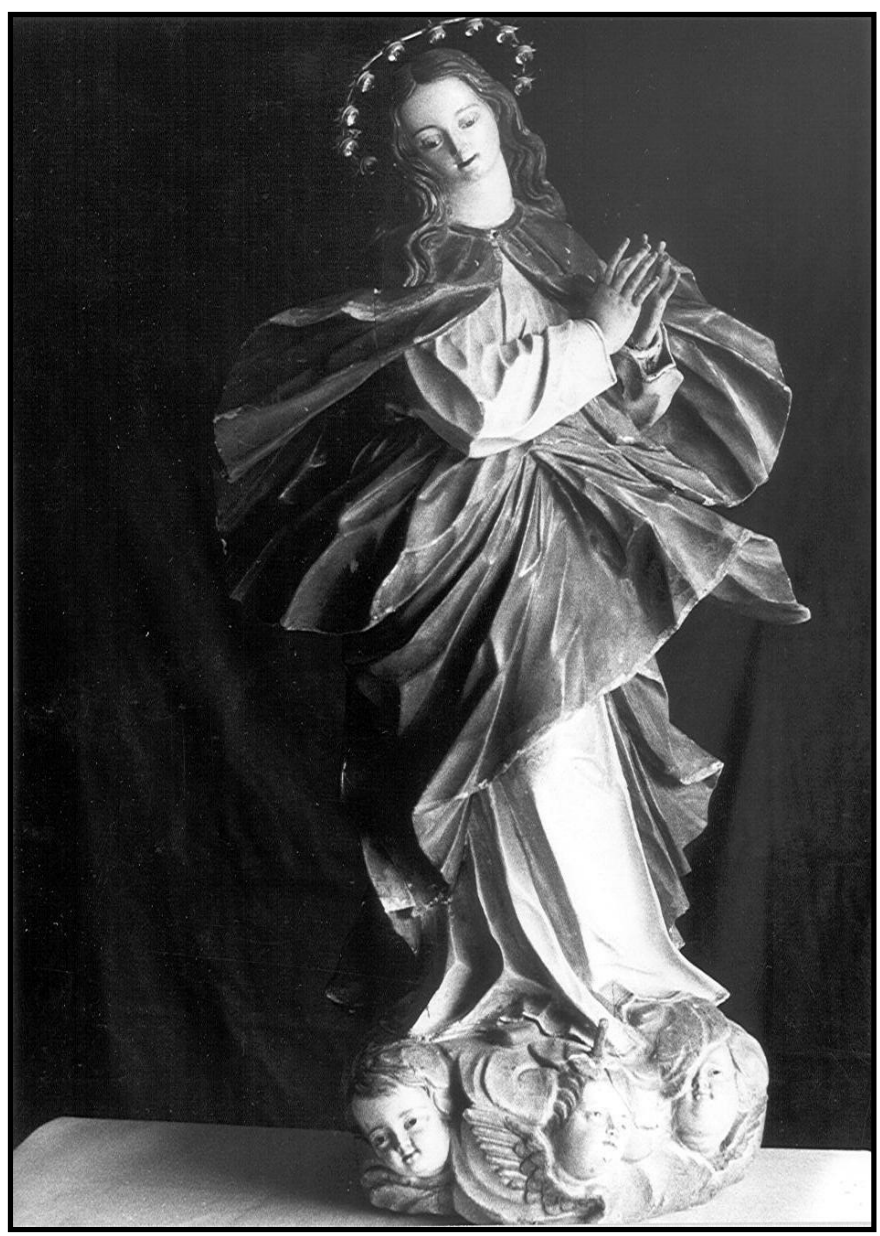

Fig. 103- Pedro de Ávila (atrib.). Inmaculada Concepción. Convento de la Inmaculada Concepción. Alfaro. (C) Departamento de Historia del Arte de la Universidad de Valladolid.

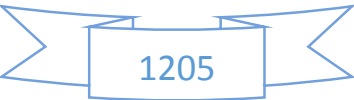



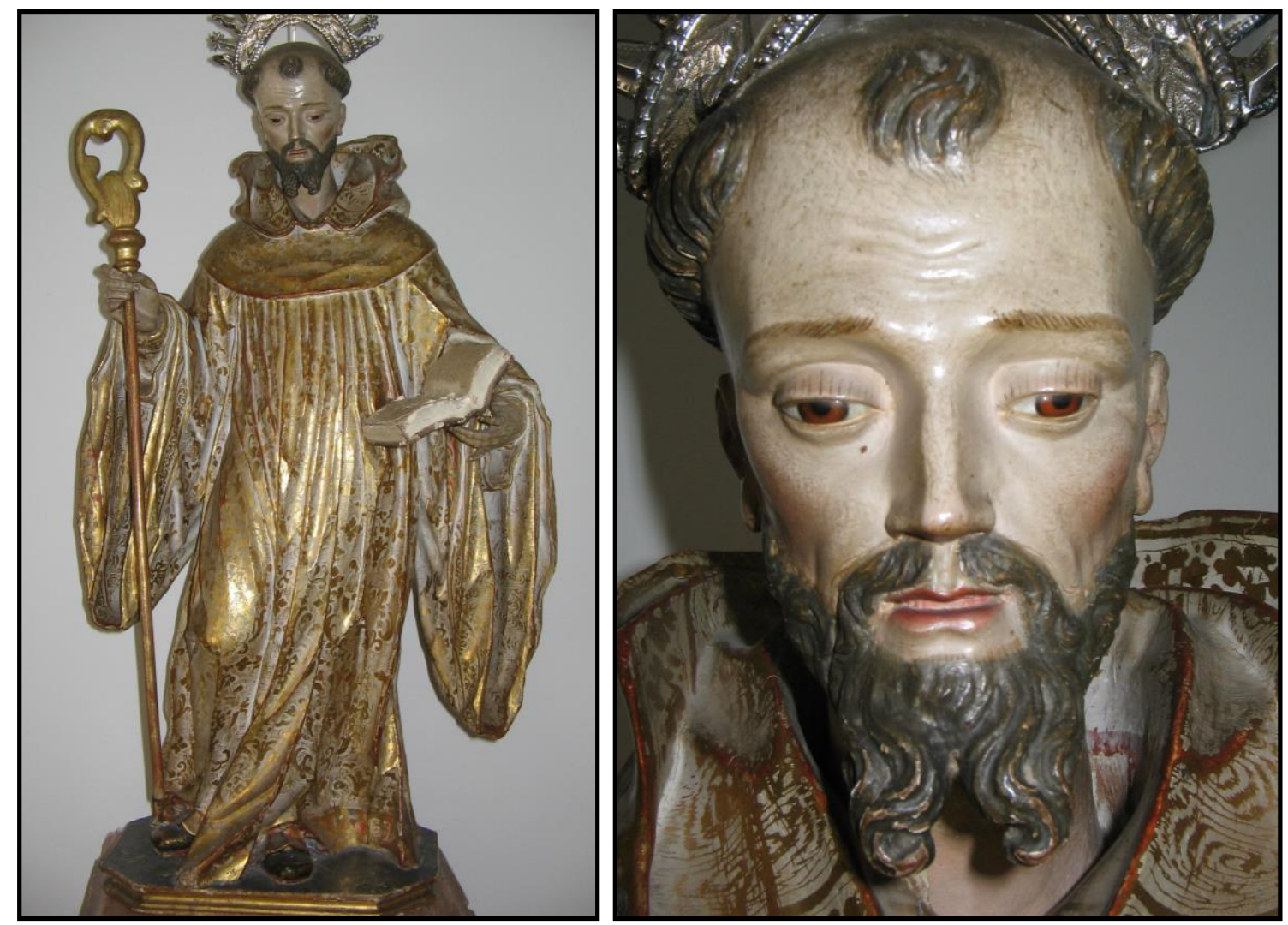

Figs. 104-105- Pedro de Ávila (atrib.). San Bernardo. Monasterio de San Quirce. Valladolid.
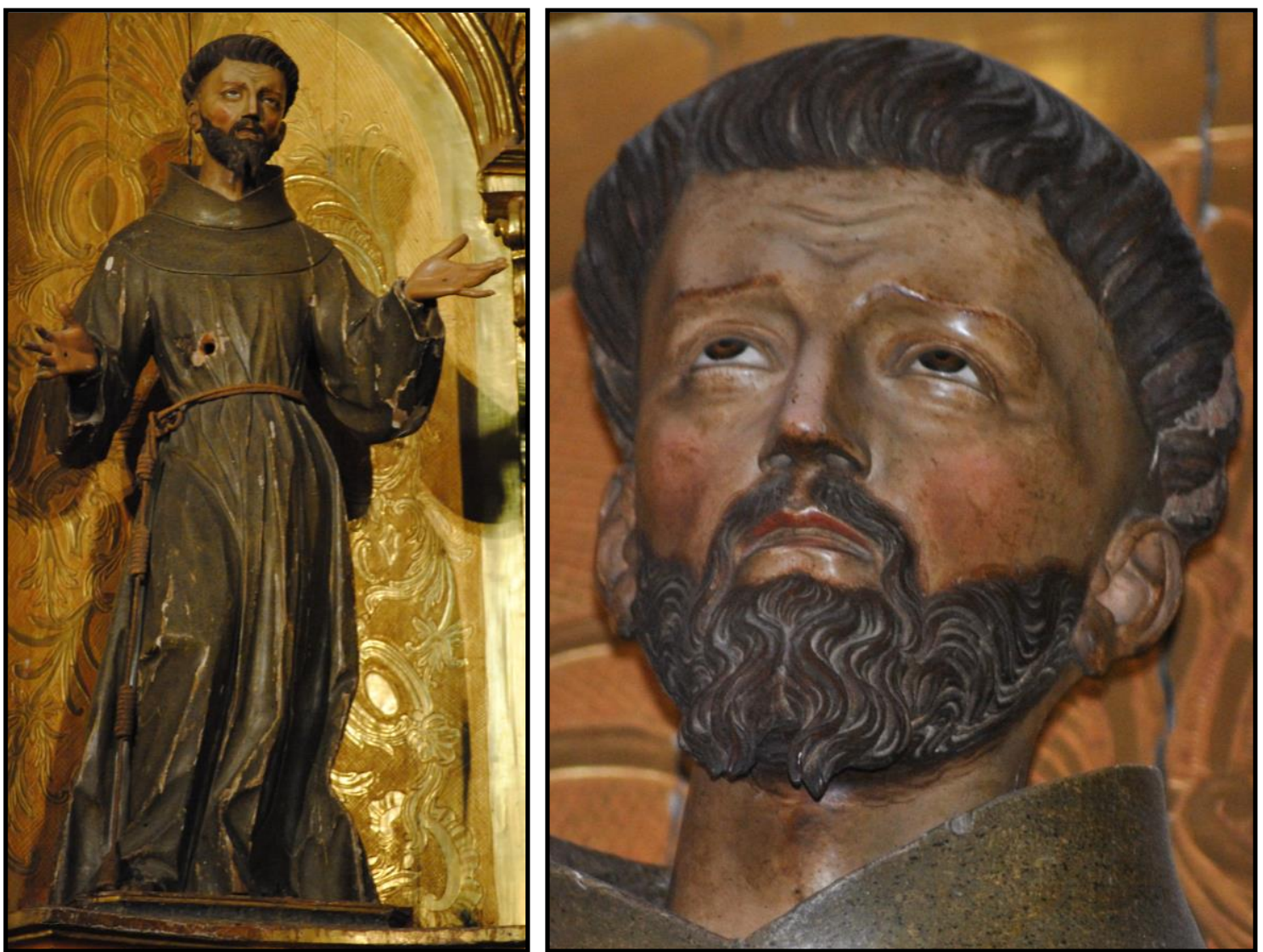

Figs. 106-107- Pedro de Ávila (atrib.). San Francisco de Asís estigmatizado. Iglesia parroquial de la Asunción. La Seca (Valladolid).

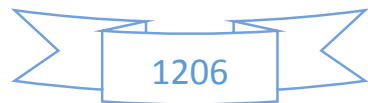




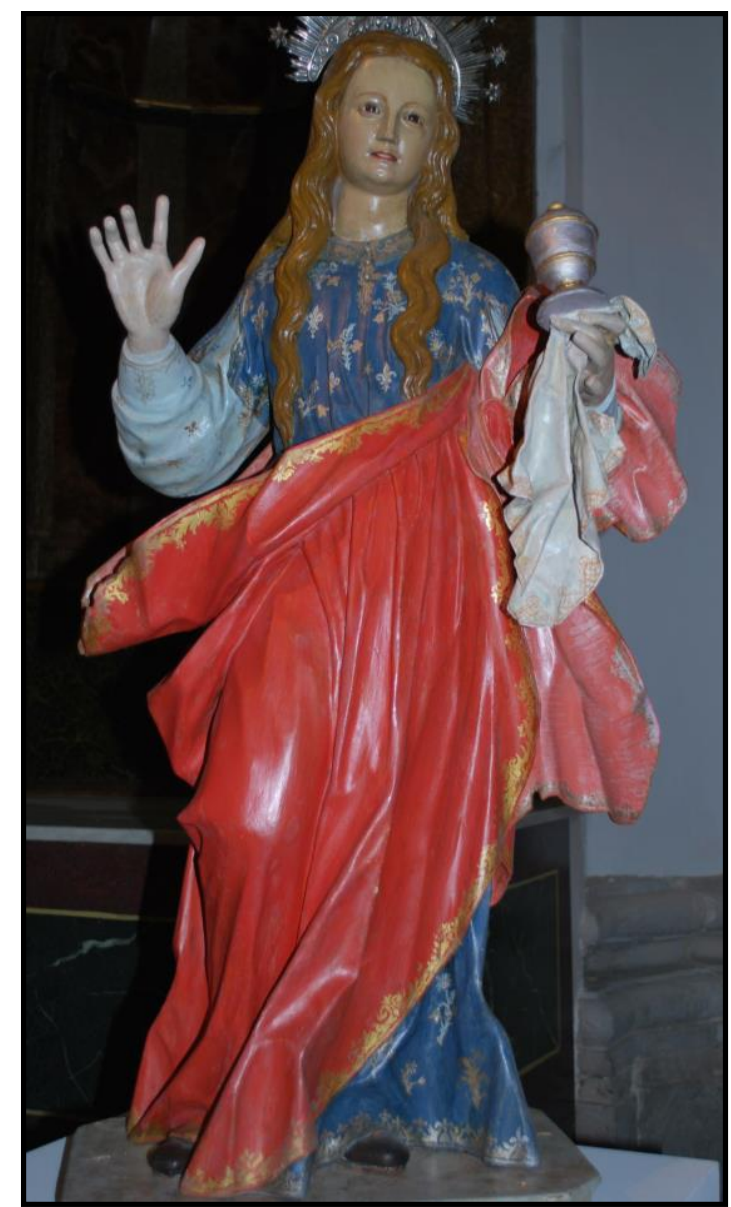

Fig. 108- Pedro de Ávila (atrib.). Santa María Magdalena. Iglesia parroquial de la Magdalena. Matapozuelos (Valladolid).

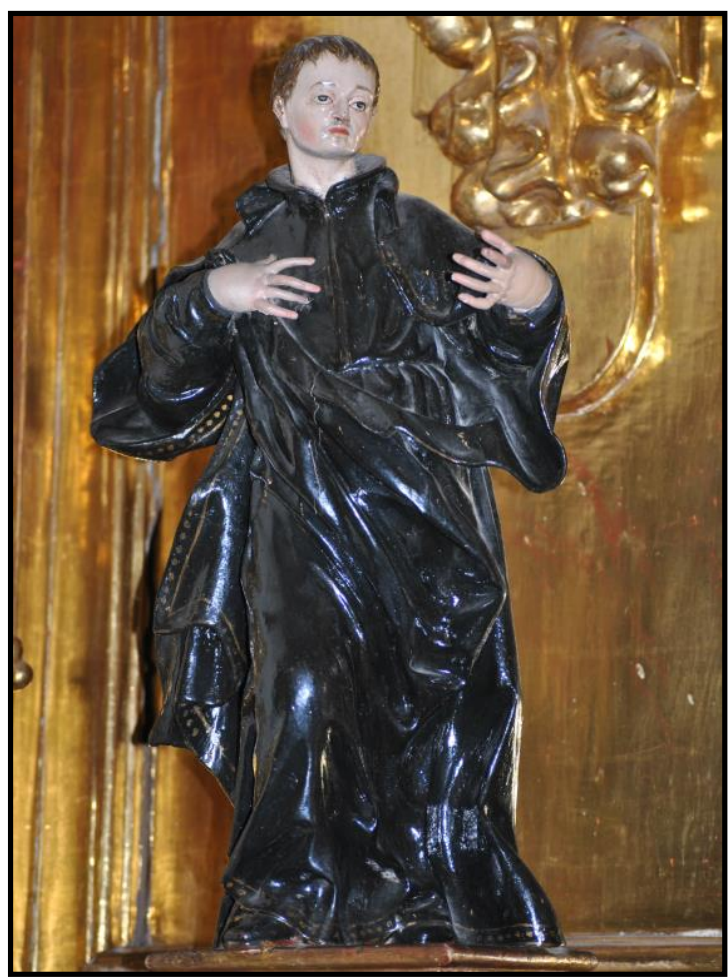

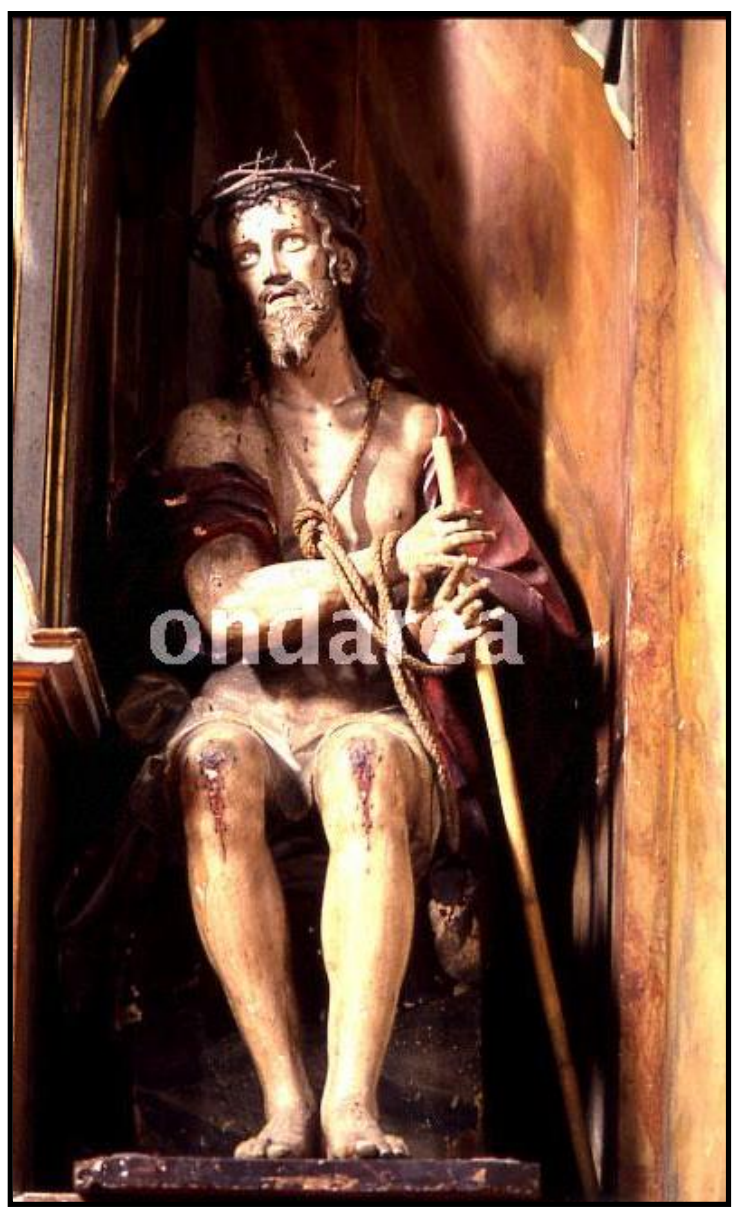

Fig. 109- Pedro de Ávila (atrib.). Ecce Homo. Monasterio de la Santísima Trinidad. Oñate.

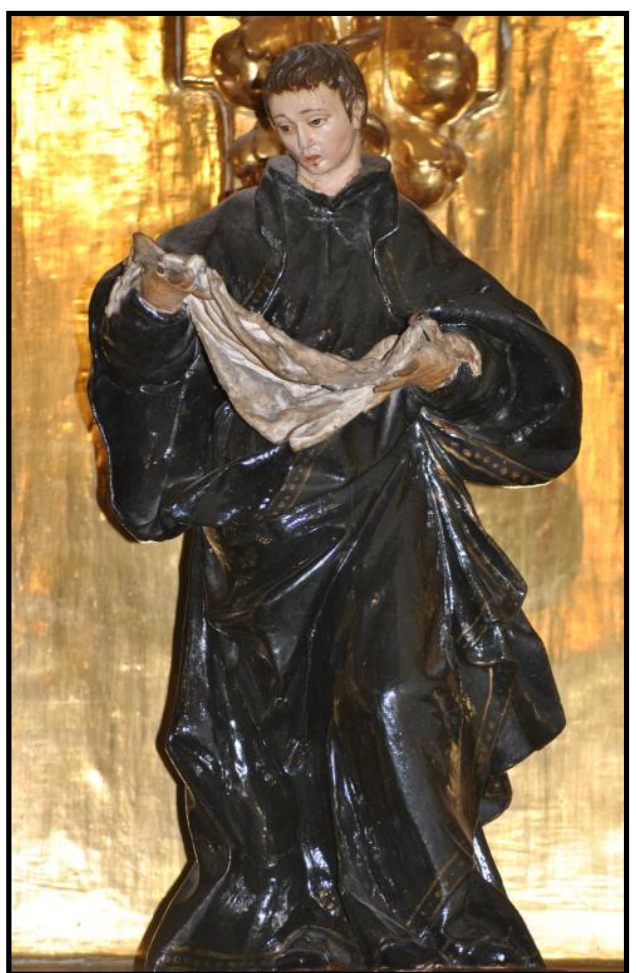

Figs. 110-111- Pedro de Ávila (atrib.). San Francisco de Borja y San Estanislao de Kostka. Colegio de los Ingleses de San Albano. Valladolid

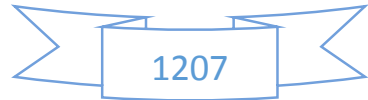




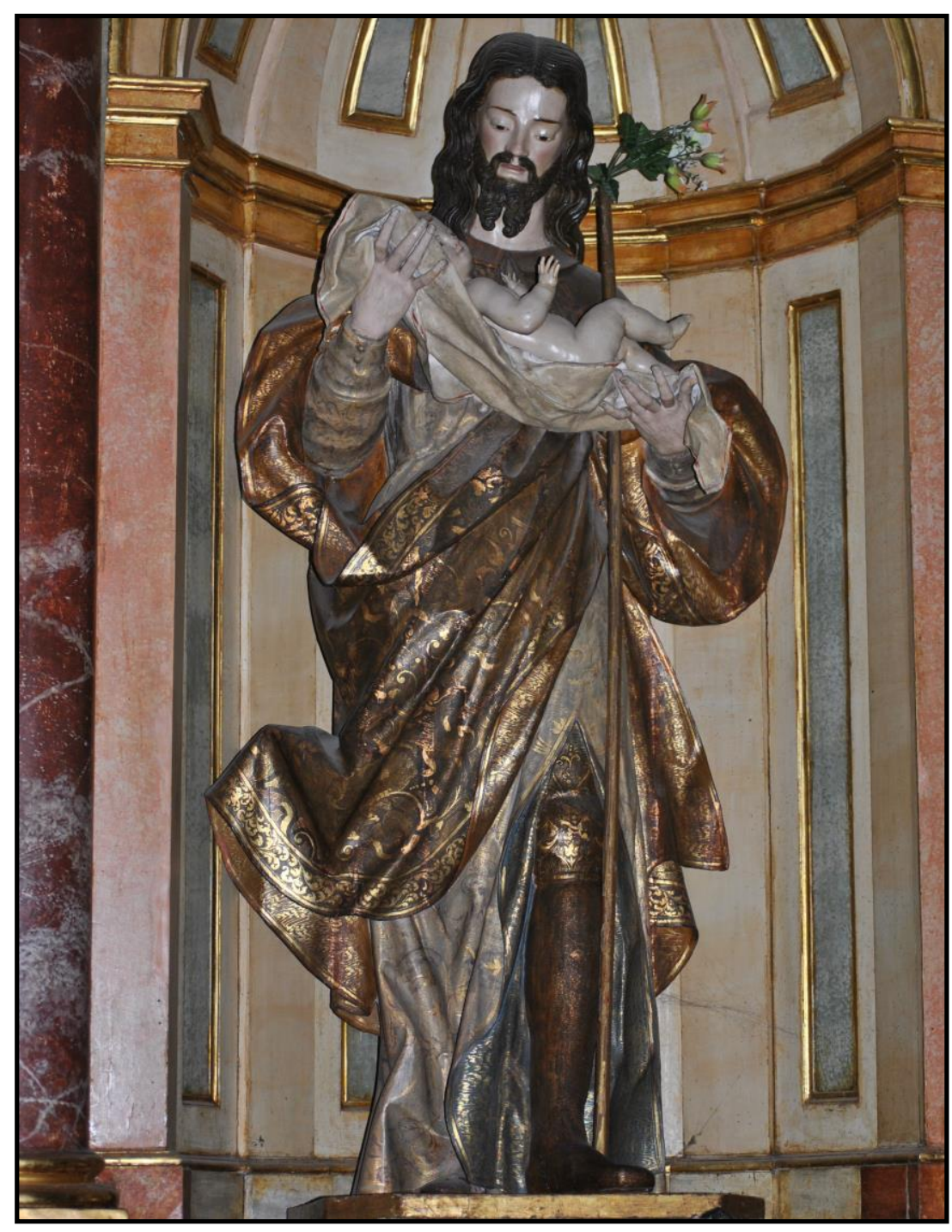

Figs. 112-113- Pedro de Ávila (atrib.). San José con el Niño. Santuario de Nuestra Señora del Henar. Cuéllar (Segovia).
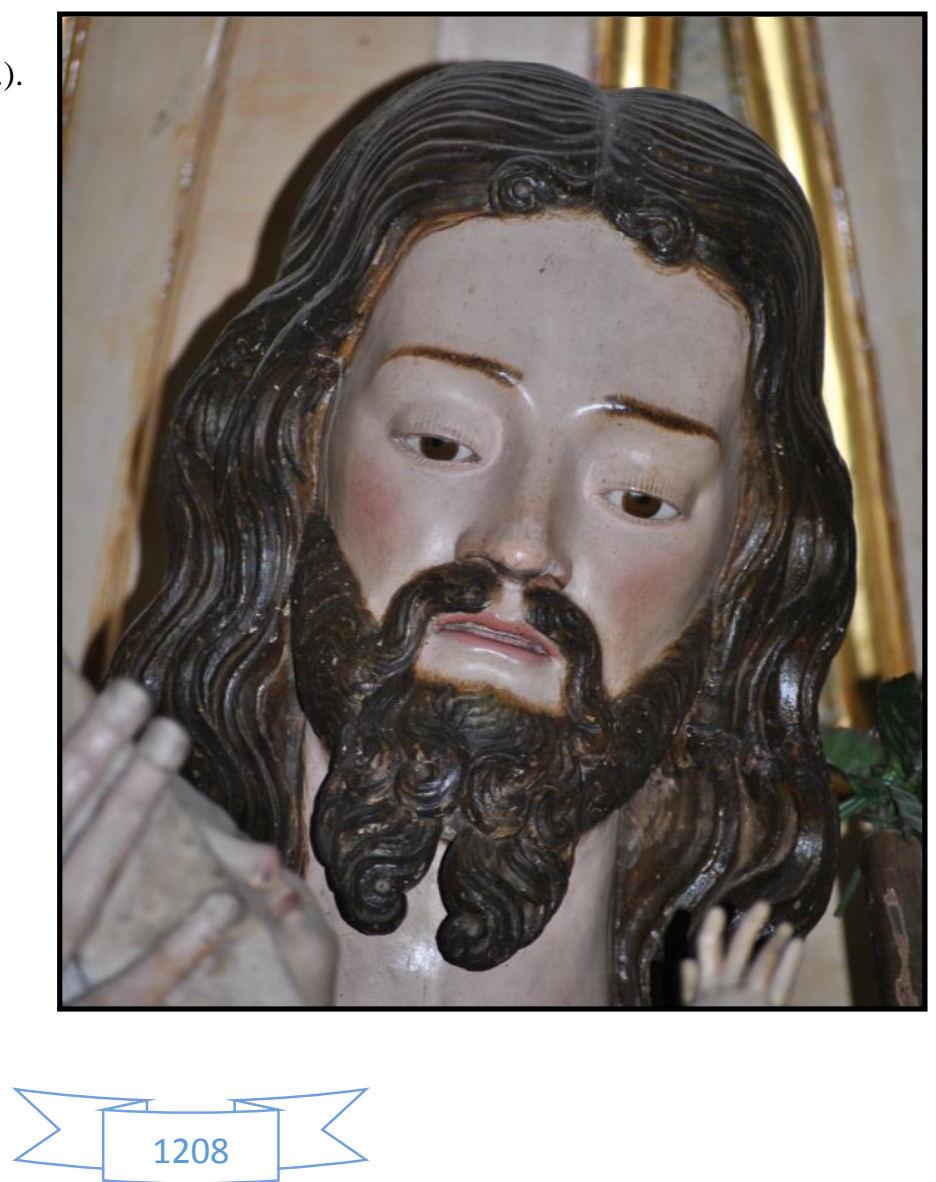

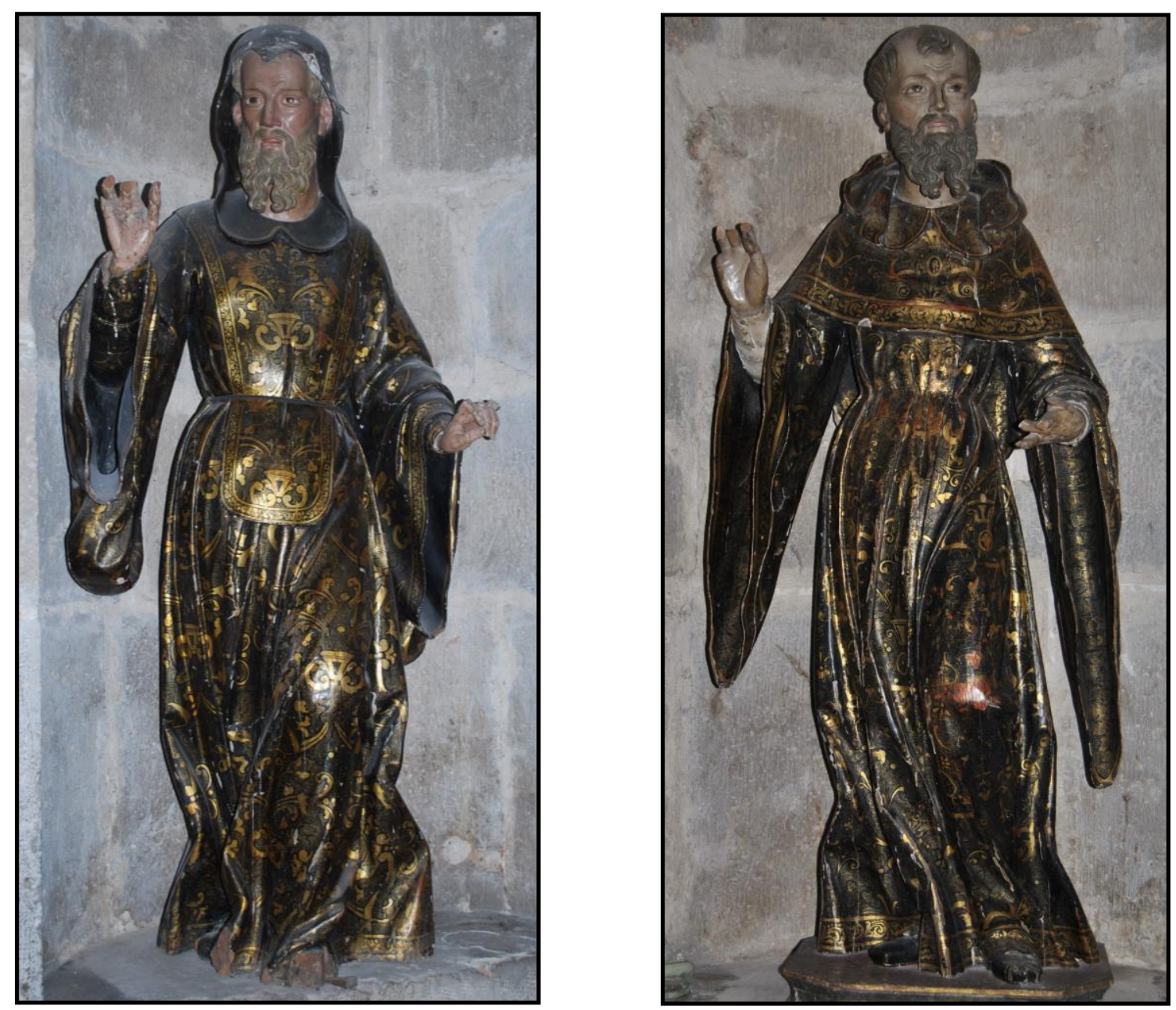

Figs. 114-115- Pedro de Ávila (atrib.). San Francisco de Paula y Santo Mínimo. Catedral. Valladolid.

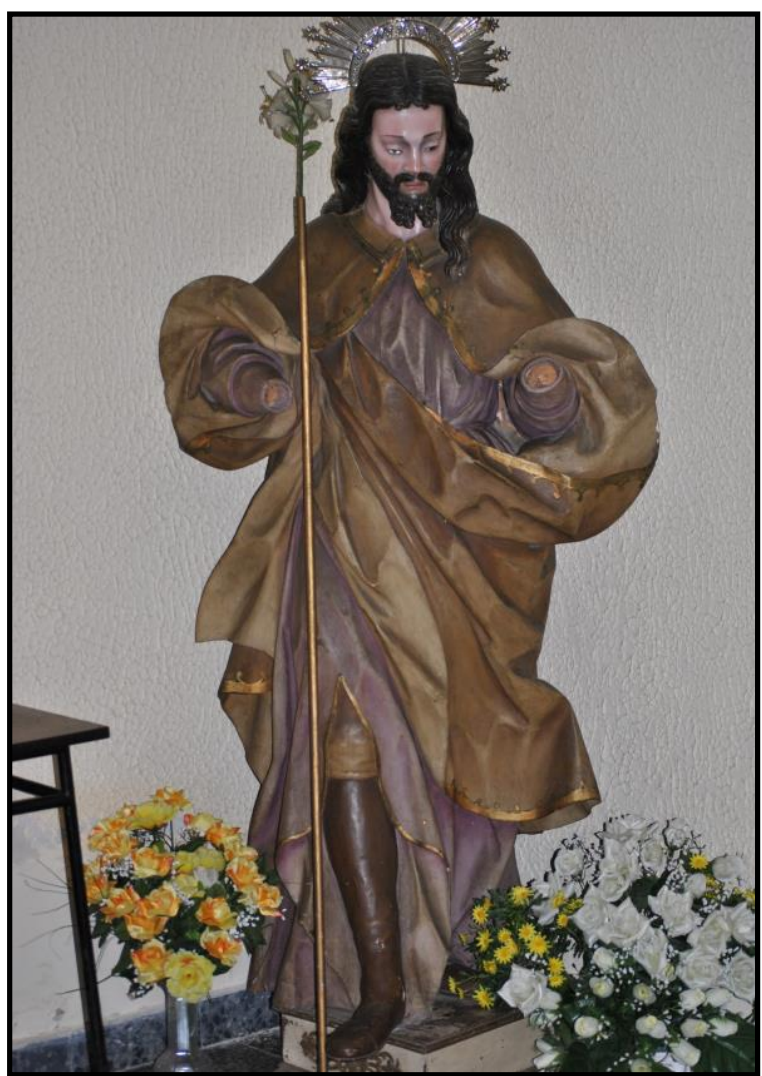

Fig. 116- Pedro de Ávila (atrib.). San José.

Iglesia de Ntra. Sra. de la Victoria. Valladolid.

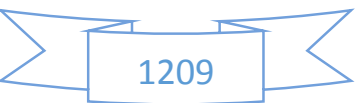



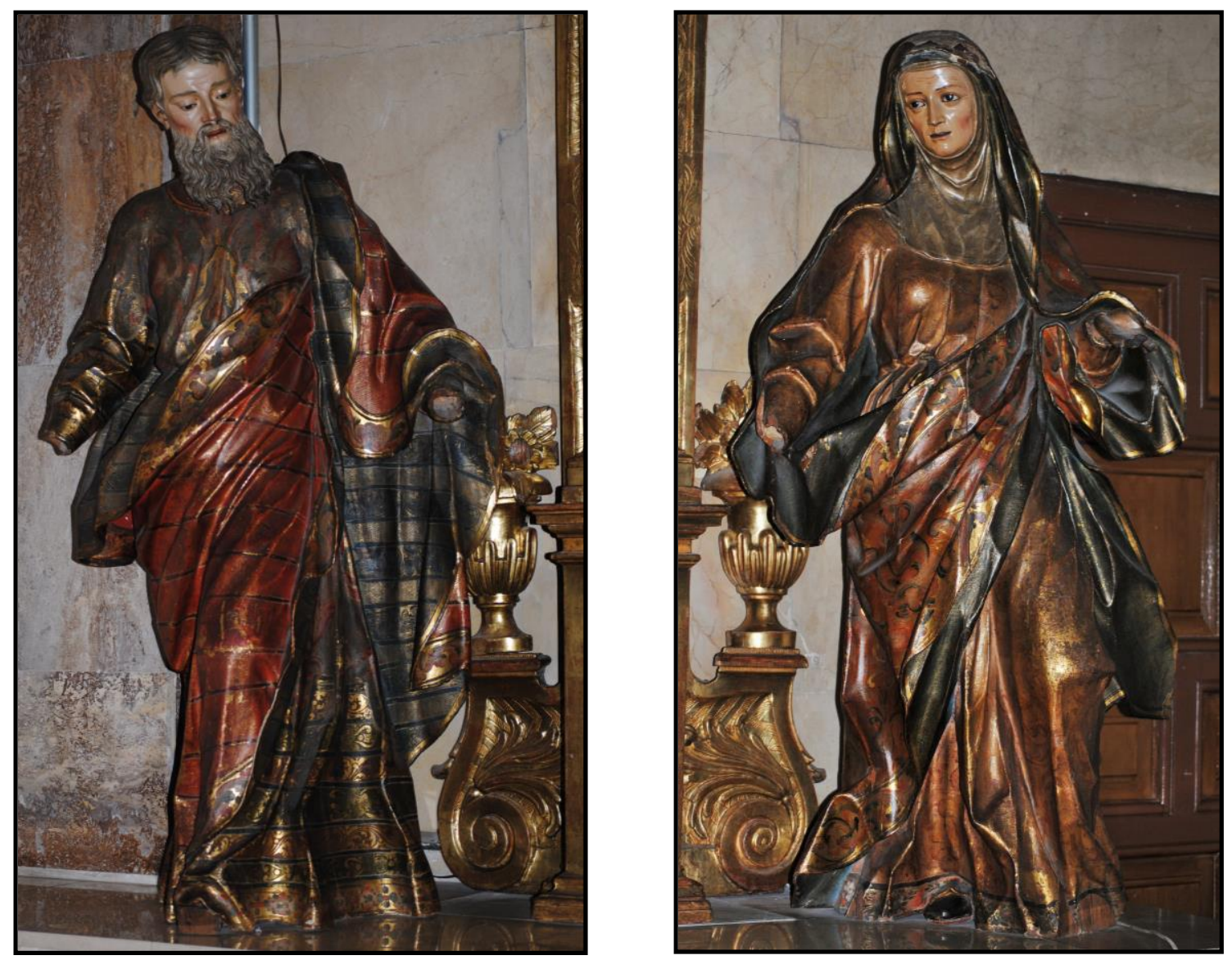

Figs. 117-118- Pedro de Ávila (atrib.). San Joaquín y Santa Ana. Santuario Nacional. Valladolid.

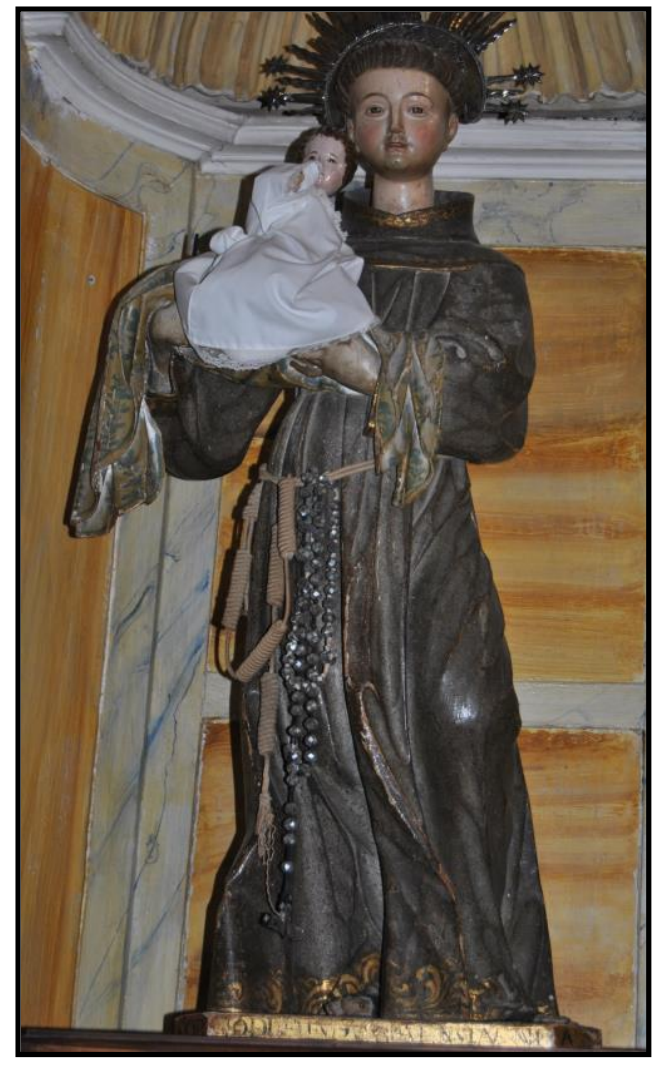

Fig. 119- Pedro de Ávila (atrib.). San Antonio de Padua. Iglesia parroquial de la Asunción. La Seca (Valladolid).

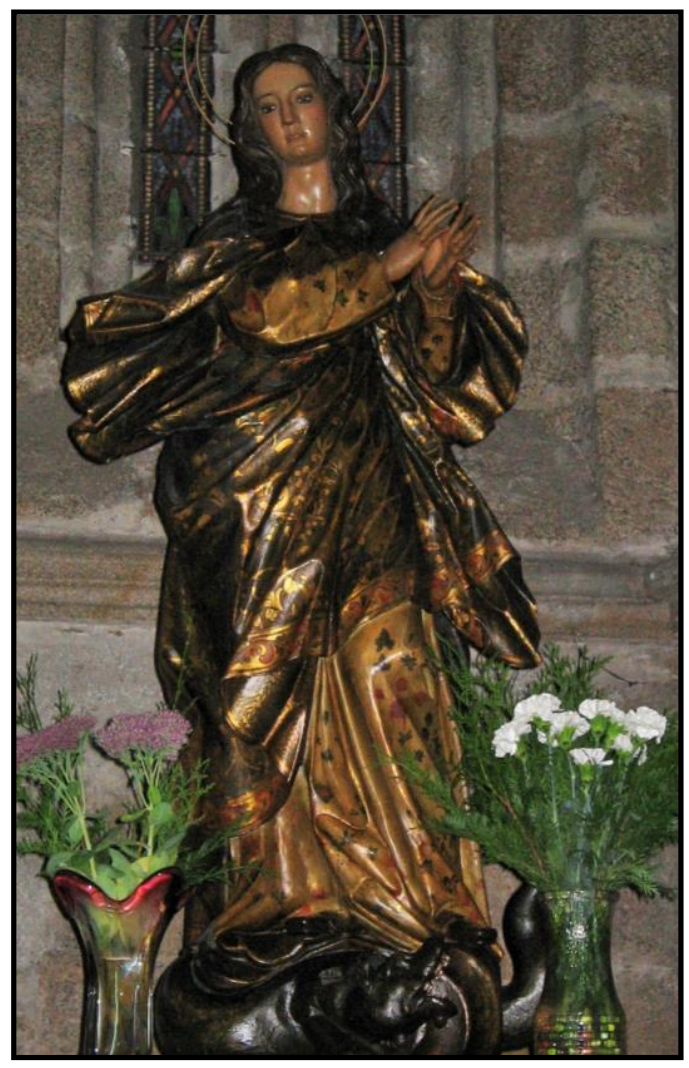

Fig. 120- Pedro de Ávila (atrib.). Iglesia de San Francisco. Orense. 


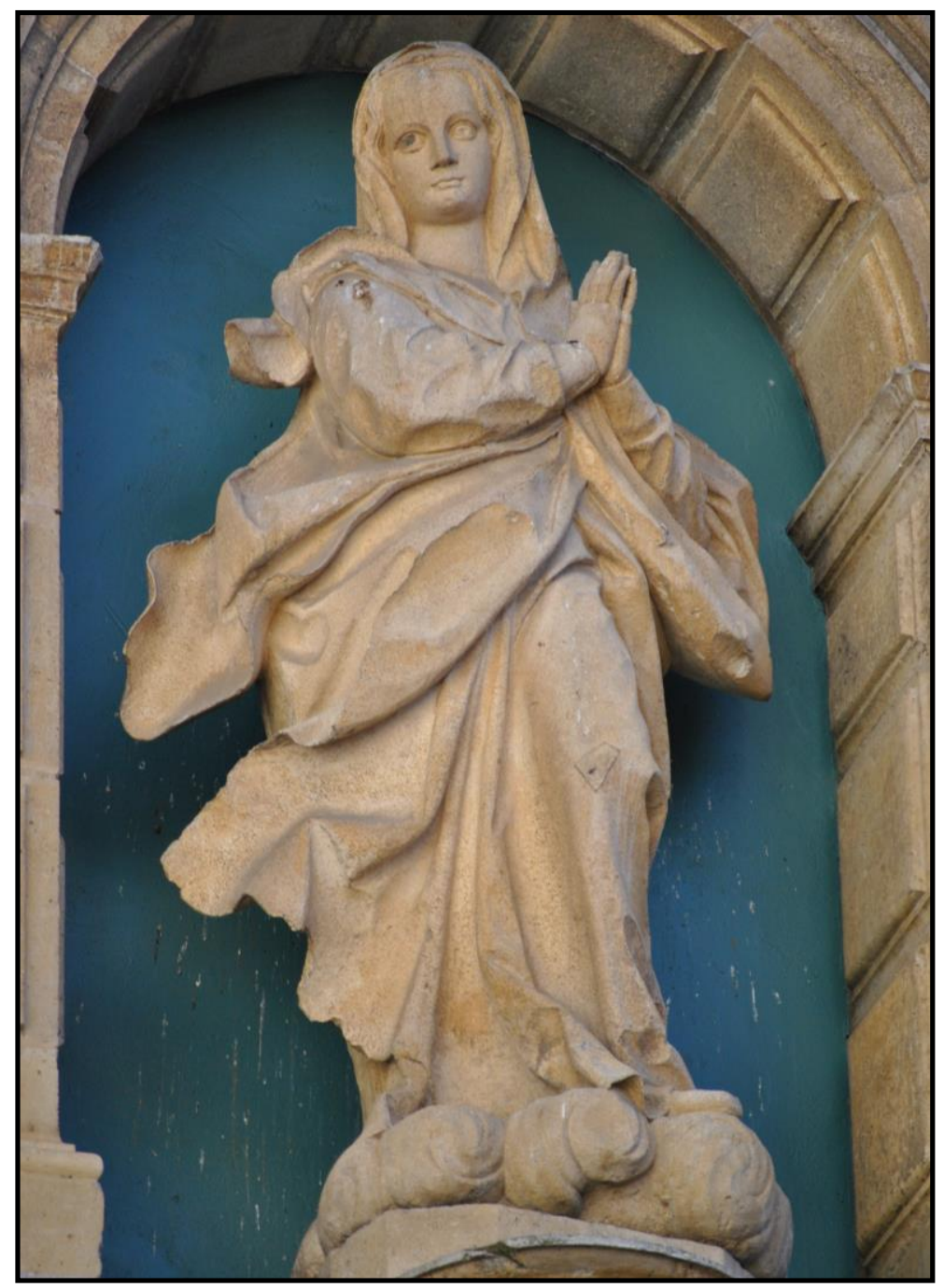

Figs. 121-123- Pedro de Ávila (atrib.). Inmaculada Concepción, Santa Mónica y San Agustín. Iglesia del Ex-convento de las Comendadoras de Santiago. Valladolid.
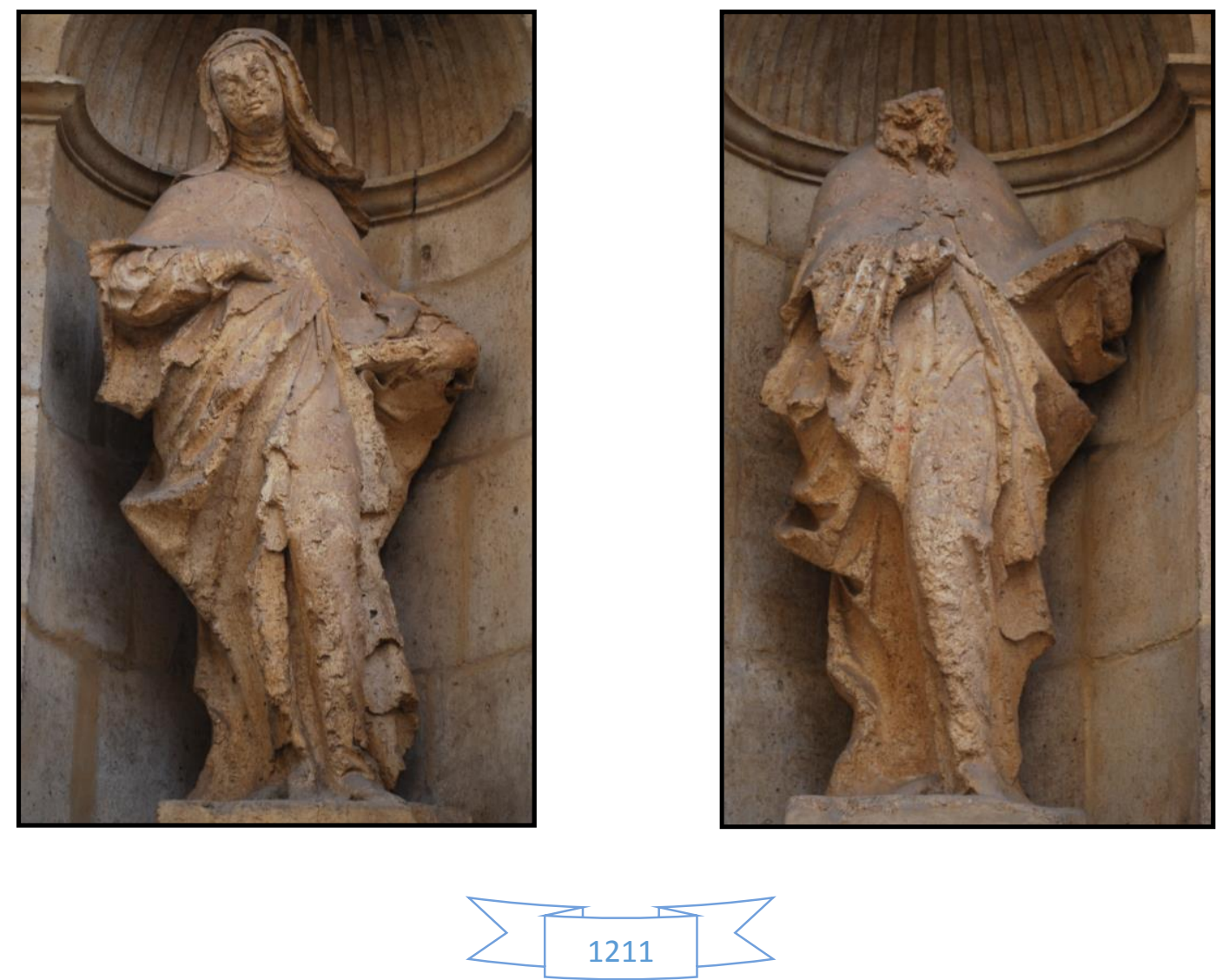


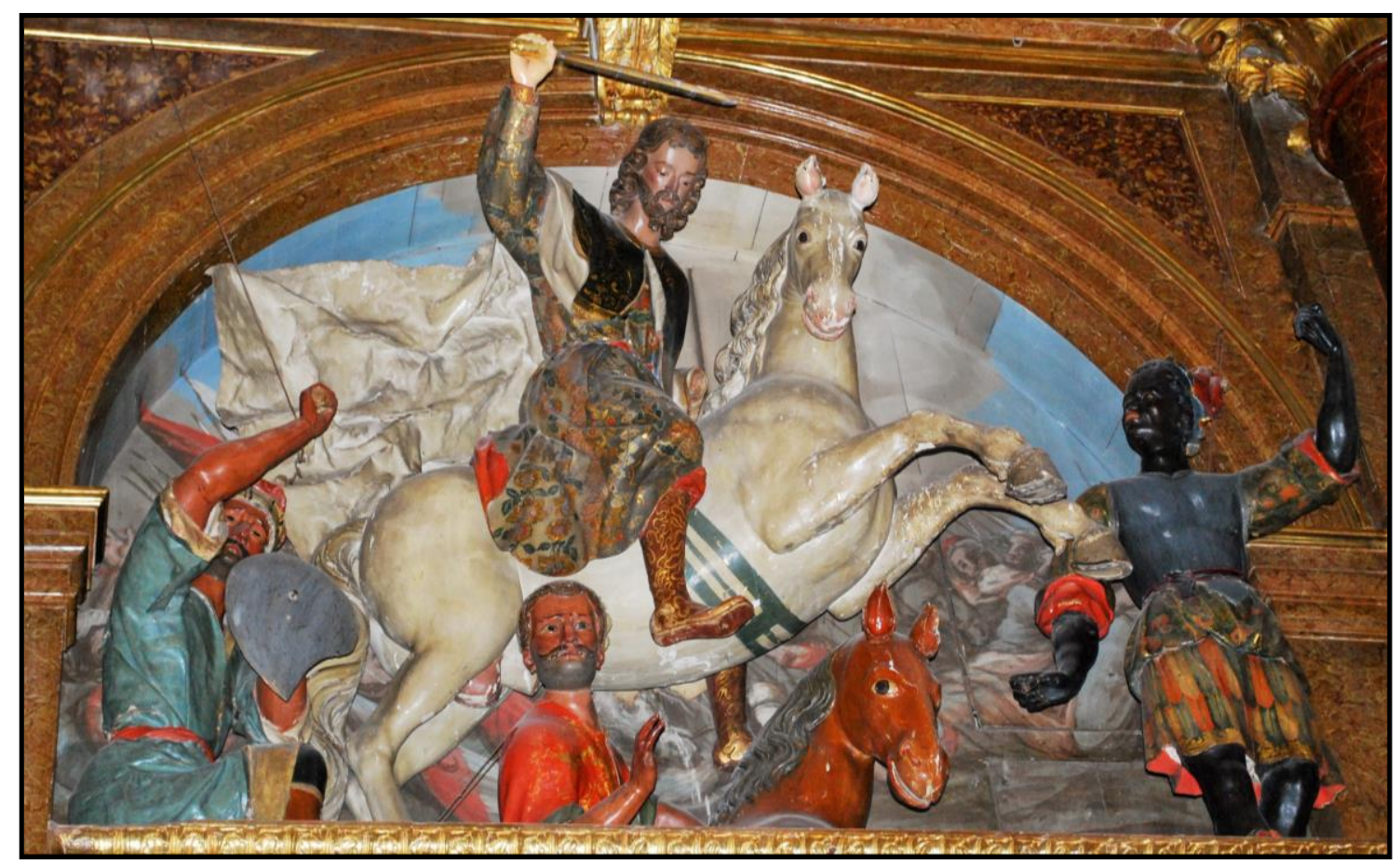

Fig. 124- Pedro de Ávila (atrib.). Santiago Matamoros. Iglesia del Ex-convento de las Comendadoras de Santiago. Valladolid.

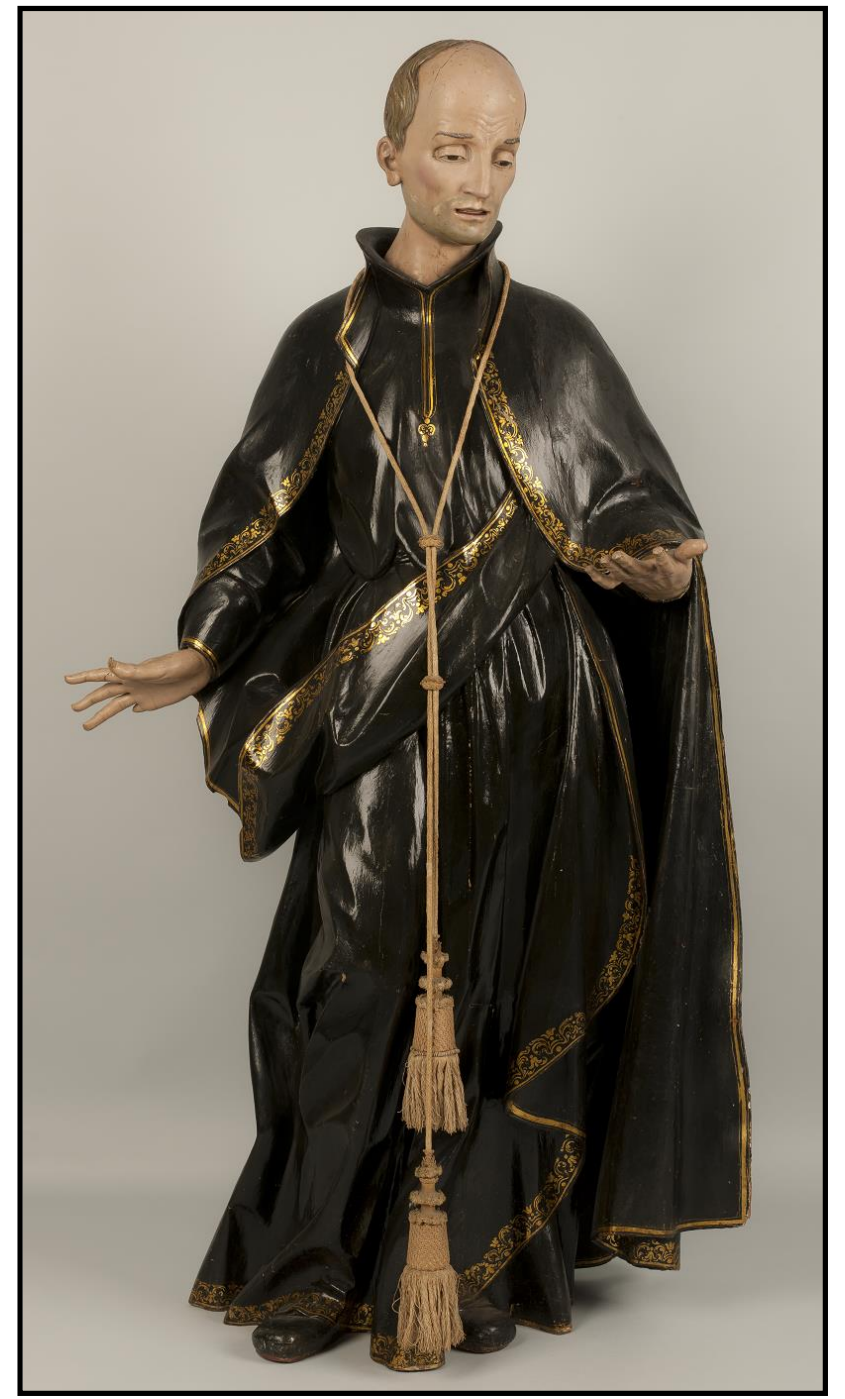

Fig. 125- Pedro de Ávila (atrib.).

San Francisco de Borja. Iglesia del Ex-convento de las Comendadoras de Santiago. Valladolid.

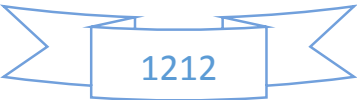




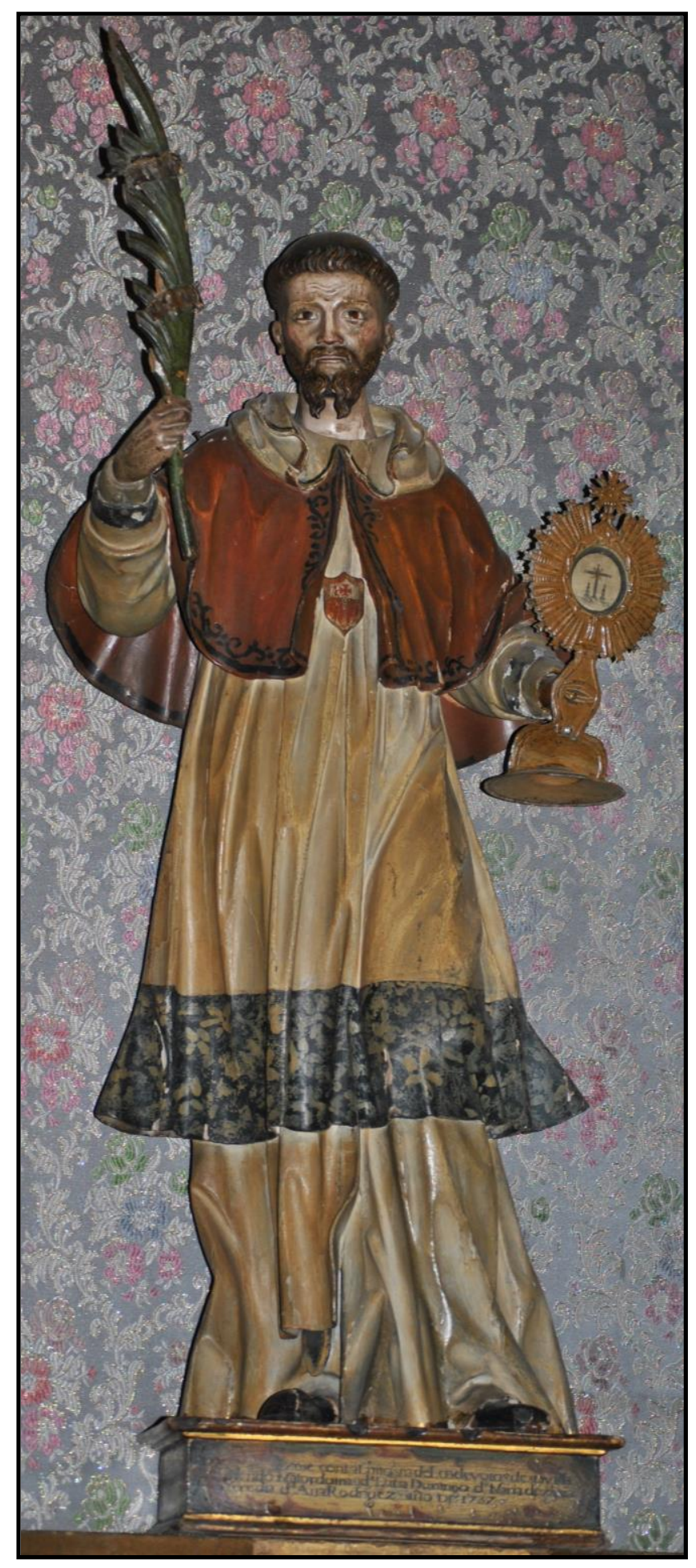

Fig. 127- Pedro de Ávila (atrib.). San Antonio de Padua. Iglesia de San Miguel. Íscar (Valladolid).
Fig. 126- Pedro de Ávila (atrib.). San Ramón Nonato. Iglesia de Santa María de los Mártires. Íscar (Valladolid).
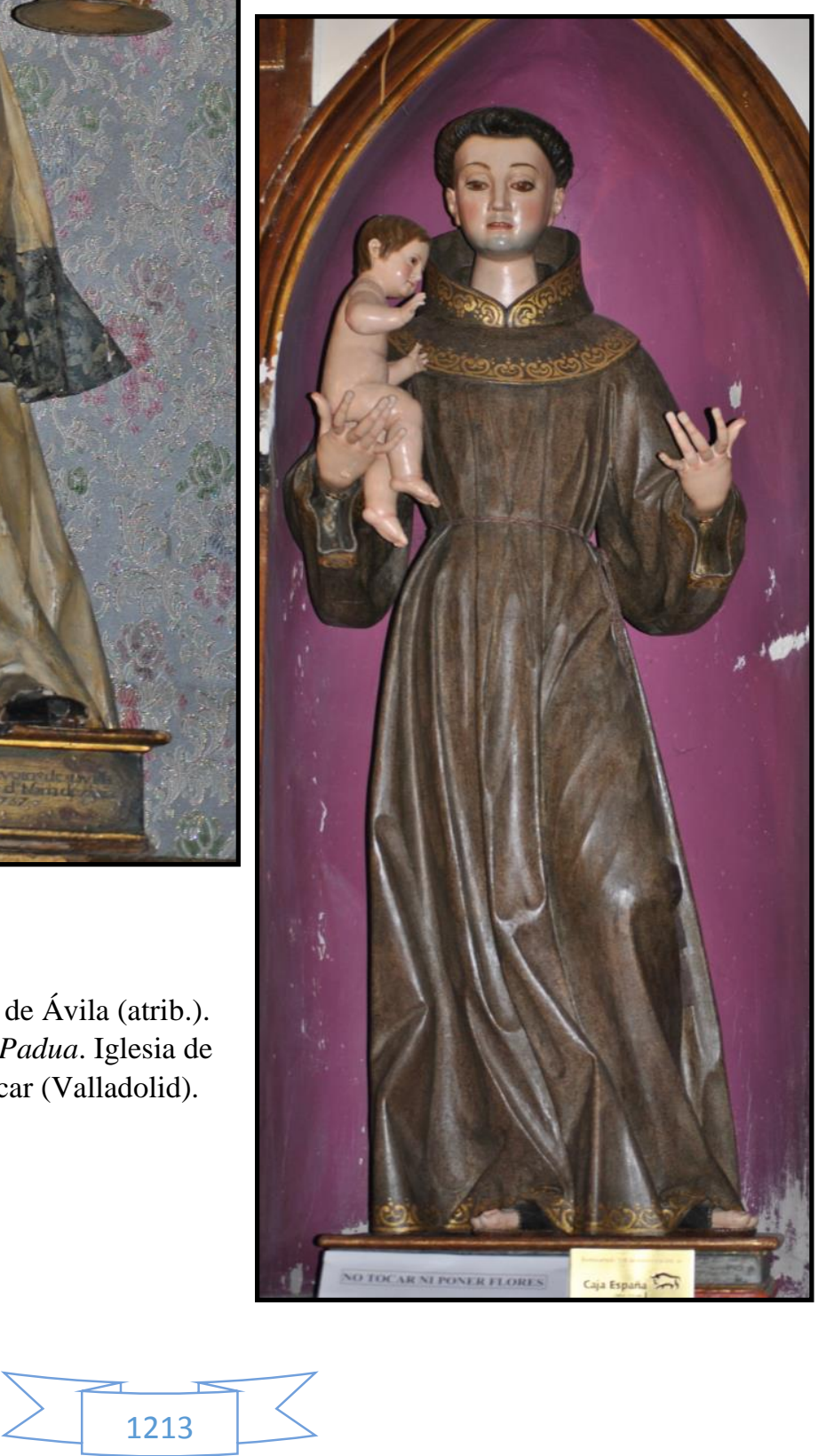


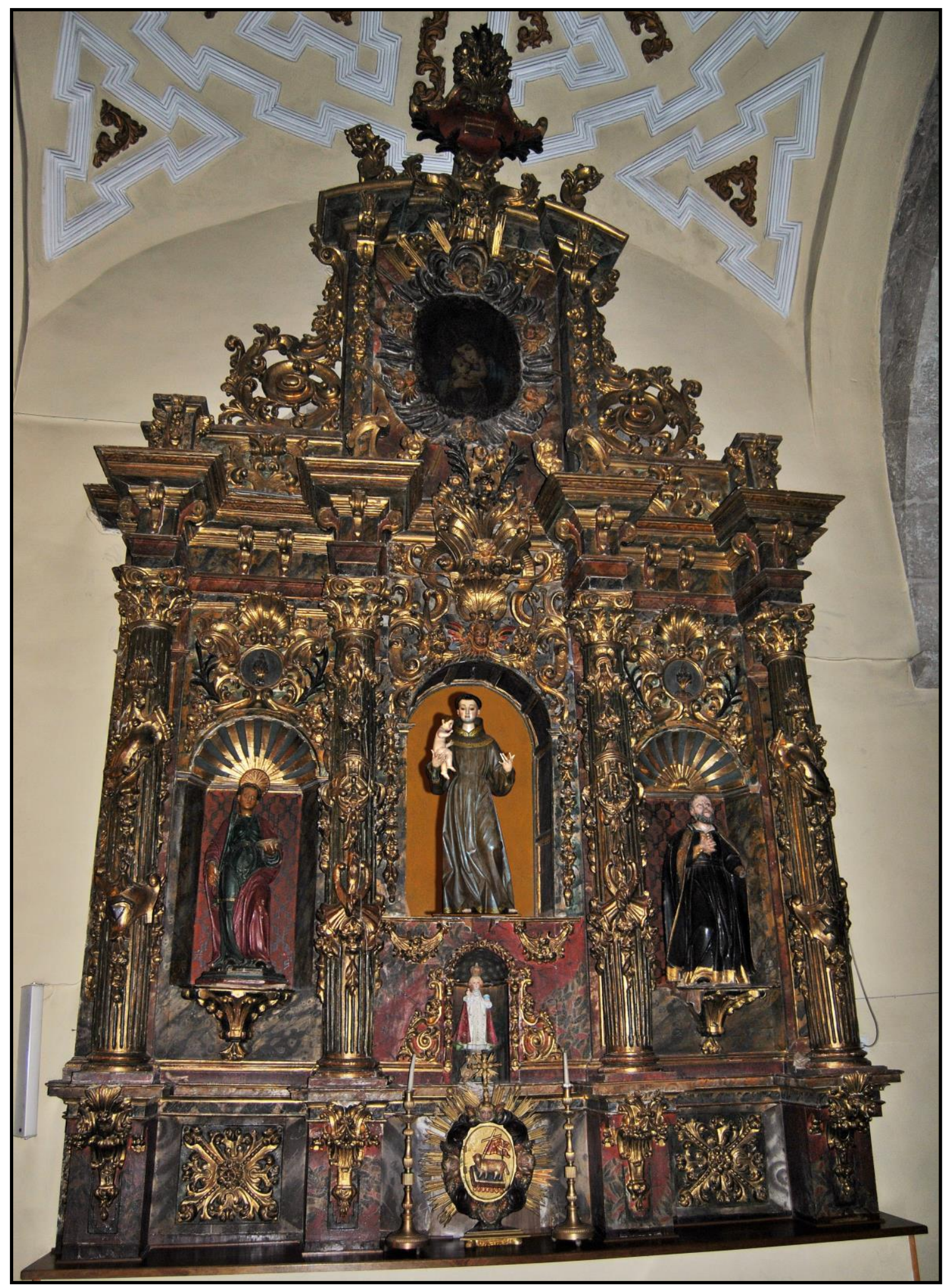

Fig. 128- Reconstrucción hipotética del retablo de San Antonio. El retablo actualmente se conserva en la iglesia de Santa María de los Mártires de Íscar (Valladolid), mientras que la escultura está en la iglesia de San Miguel de la misma localidad.

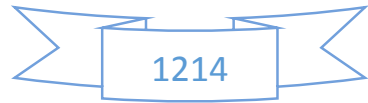




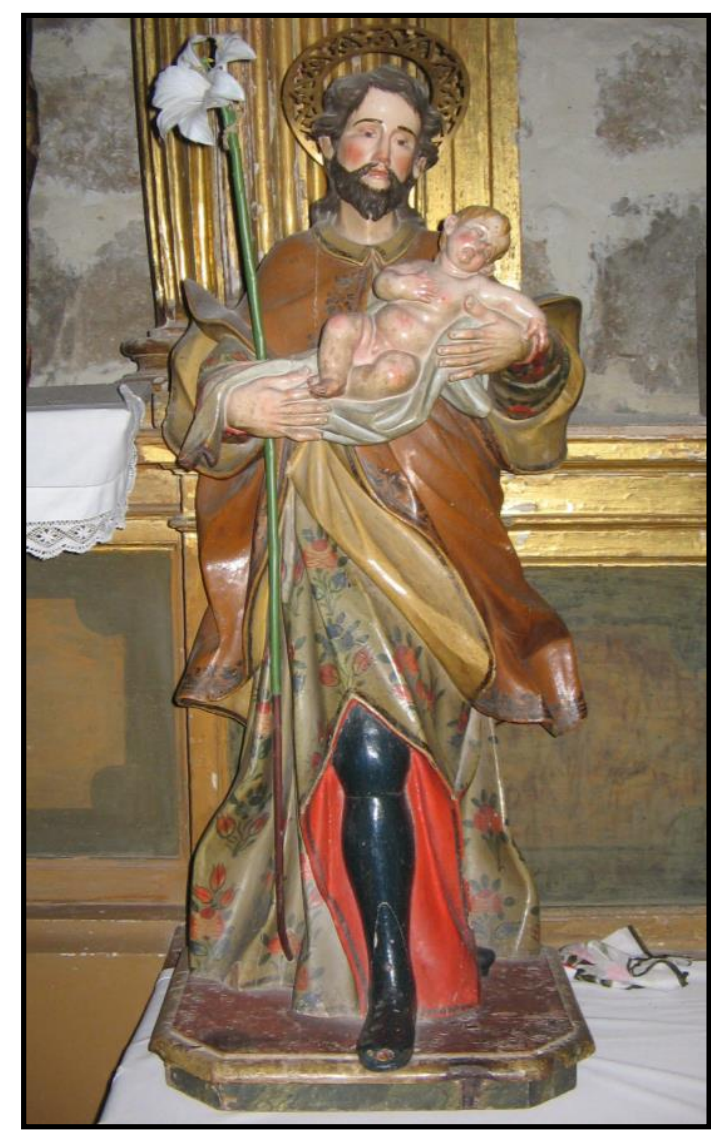

Fig. 129- Anónimo. San José con el Niño. Iglesia parroquial. Aldeamayor de San Martín (Valladolid).

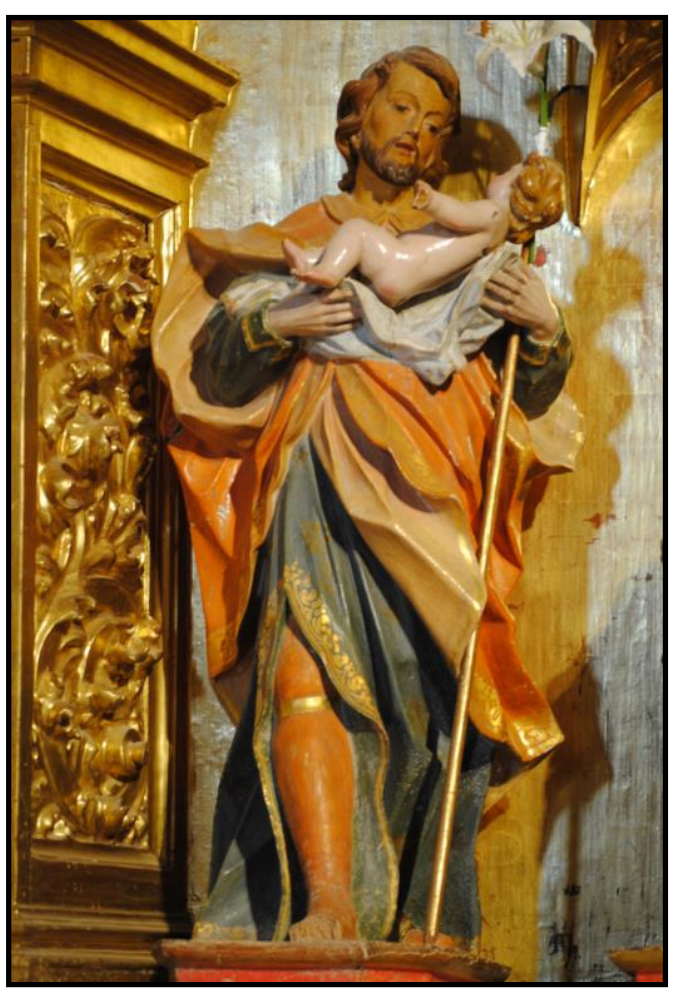

Fig. 131- Anónimo. San José con el Niño. Iglesia de Santa María. Curiel de Duero (Valladolid).

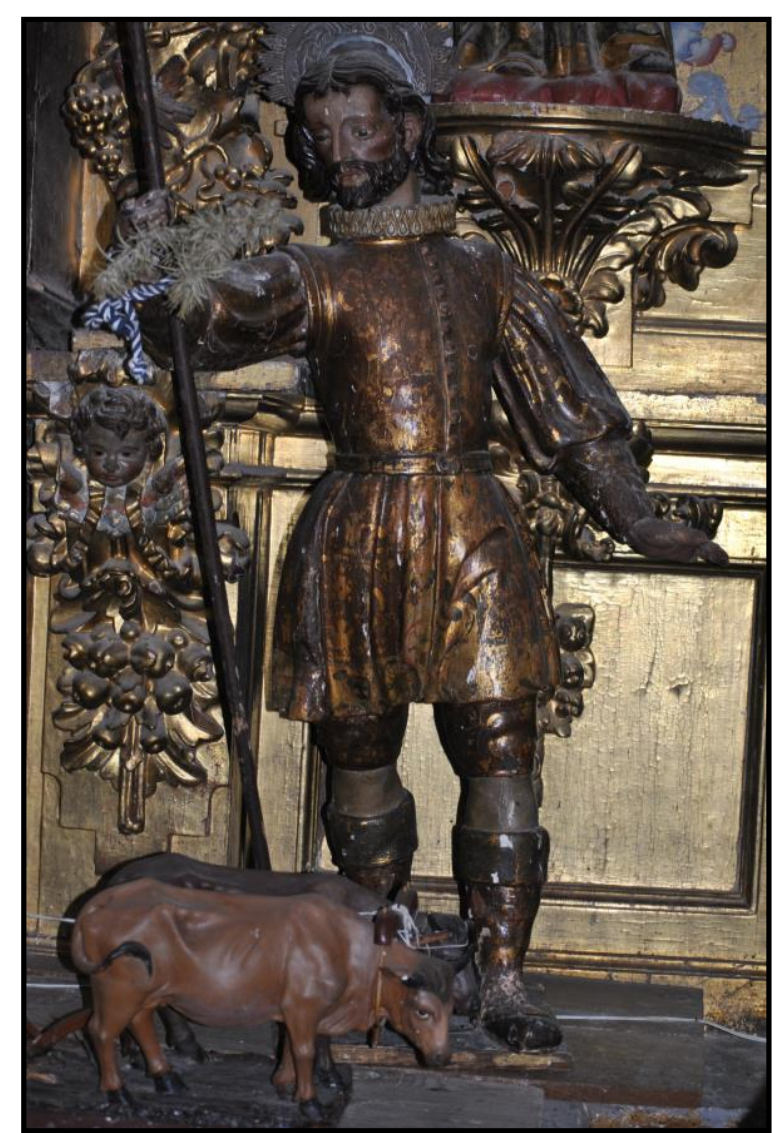

Fig. 130- ¿Taller de Pedro de Ávila? San Isidro. Iglesia parroquial de la Asunción. Almenara de Adaja (Valladolid).

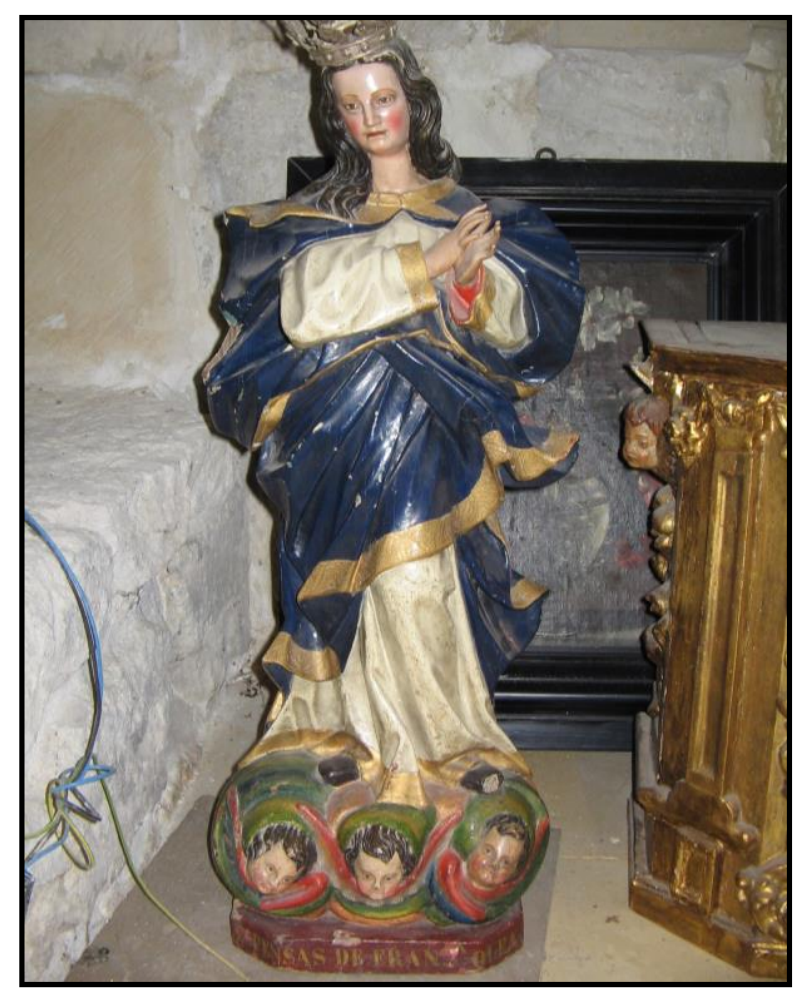

Fig. 132- Taller de Pedro de Ávila. Inmaculada

Concepción. Iglesia parroquial de San Ildefonso. La Cistérniga (Valladolid). 


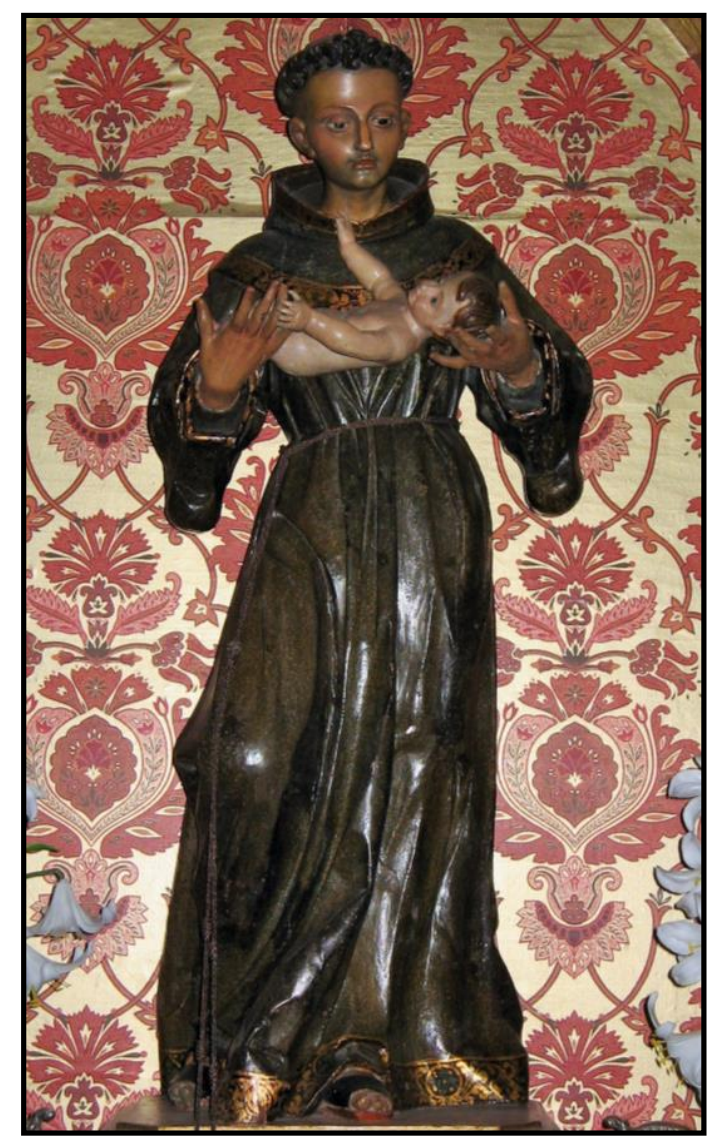

Fig. 133- Taller de Pedro de Ávila. San Antonio de Padua. Iglesia parroquial. Matapozuelos (Valladolid).

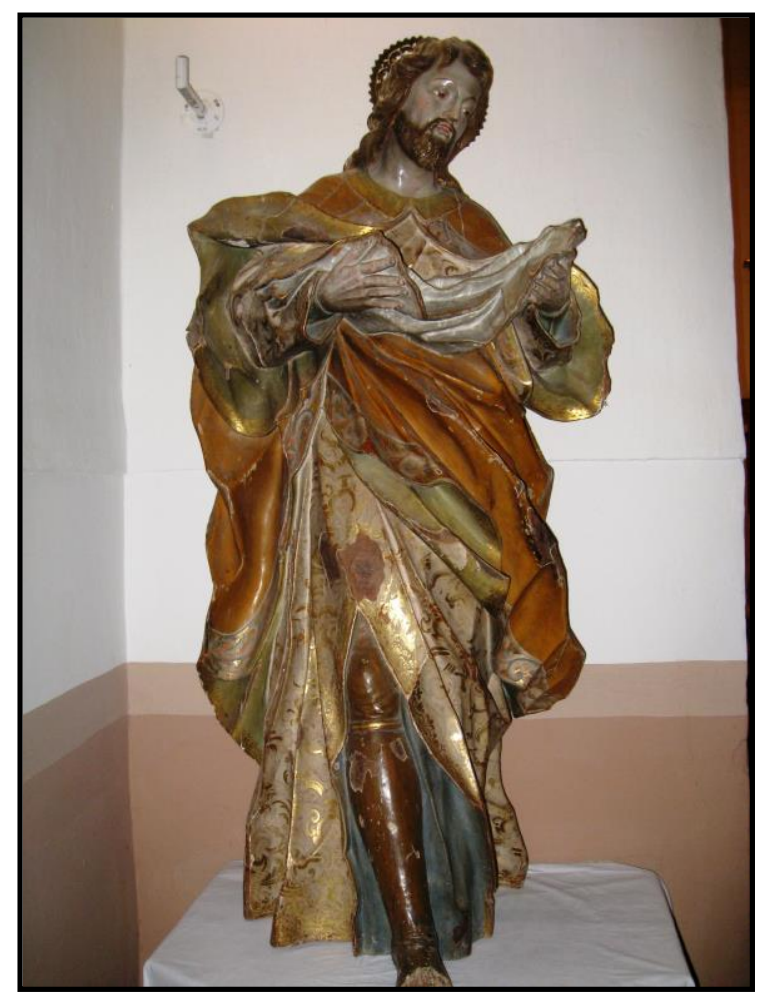

Fig. 135- ¿Felipe Espinabete? San José con el Niño. Iglesia parroquial. Villanueva de Duero (Valladolid).

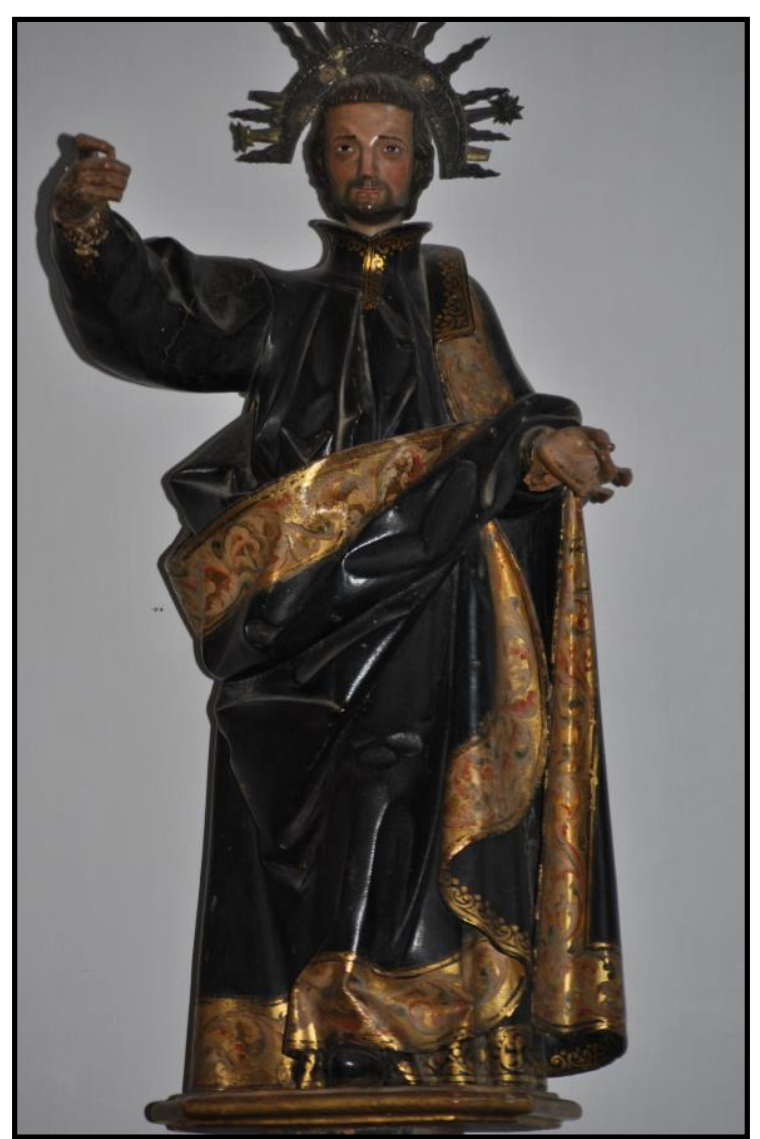

Fig. 134- ¿Taller de Pedro de Ávila? San Francisco Javier. Iglesia parroquial del Salvador. Simancas (Valladolid).

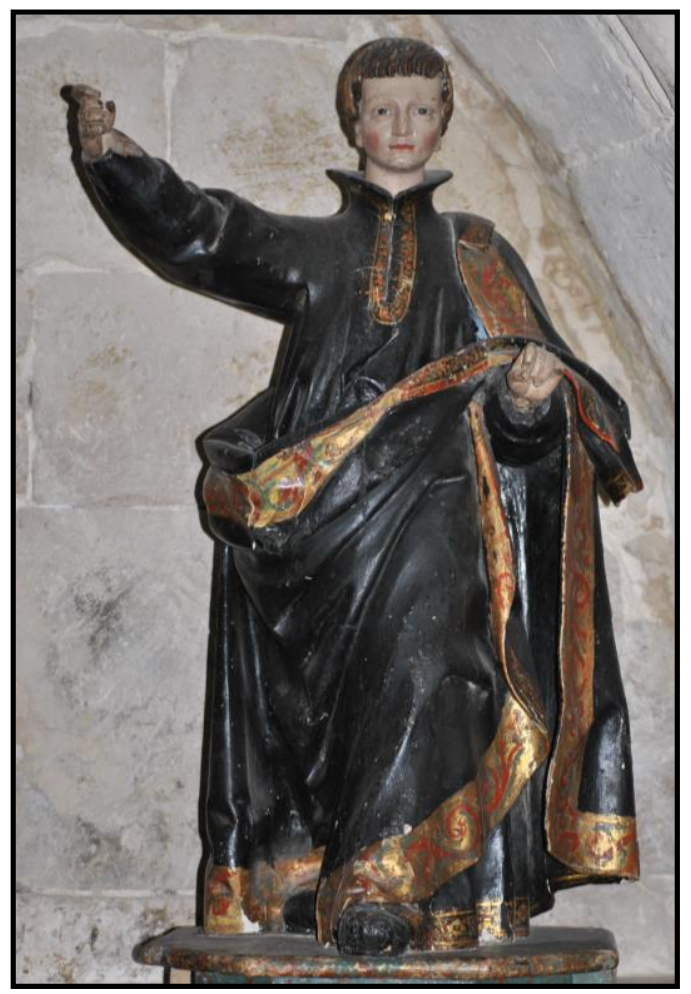

Fig. 136- ¿Taller de Pedro de Ávila? San Francisco Javier. Iglesia parroquial. Wamba (Valladolid). 


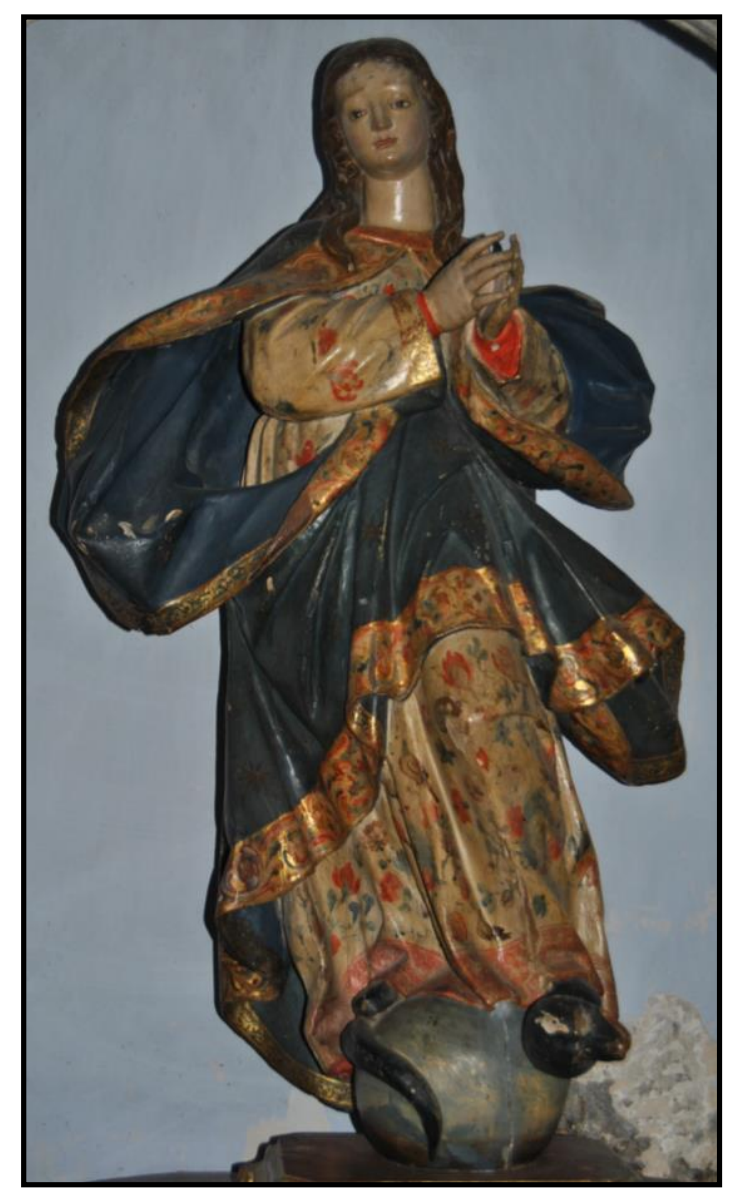

Fig. 137- ¿Antonio de Gautúa? Inmaculada Concepción. Iglesia parroquial de la Asunción. Gumiel de Izán (Burgos).

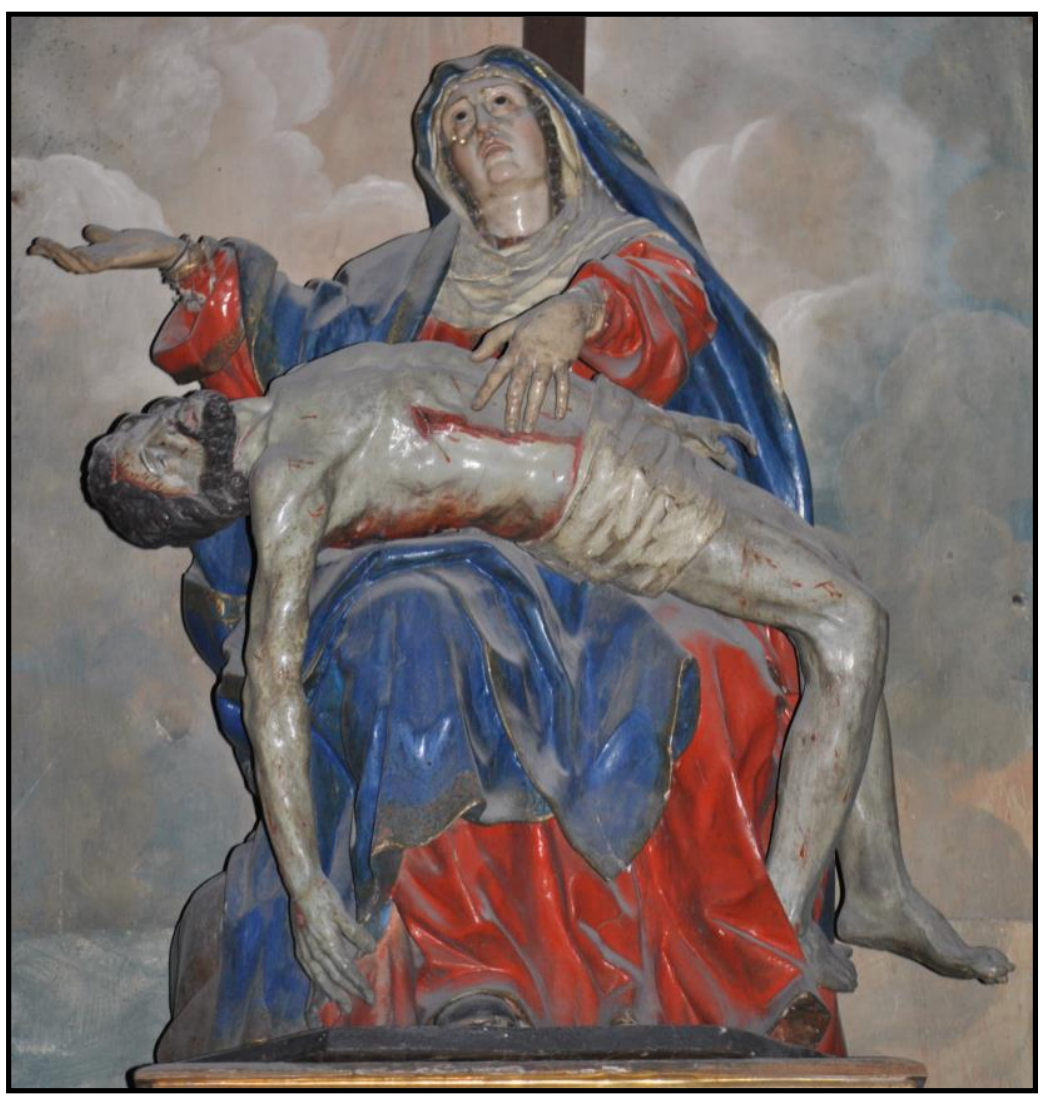

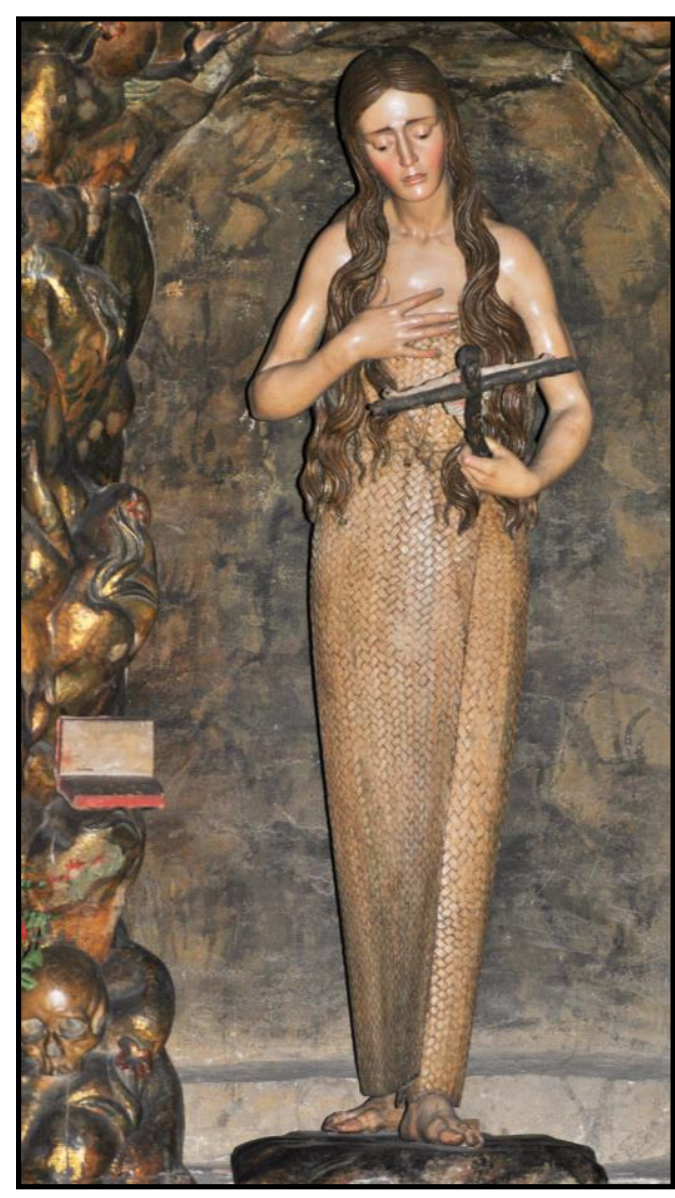

Fig. 138- Anónimo. Santa María Magdalena. Iglesia de San Miguel. Valladolid.

Fig. 139- Anónimo. Quinta Angustia. Iglesia de Pedro. Valladolid.

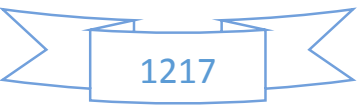



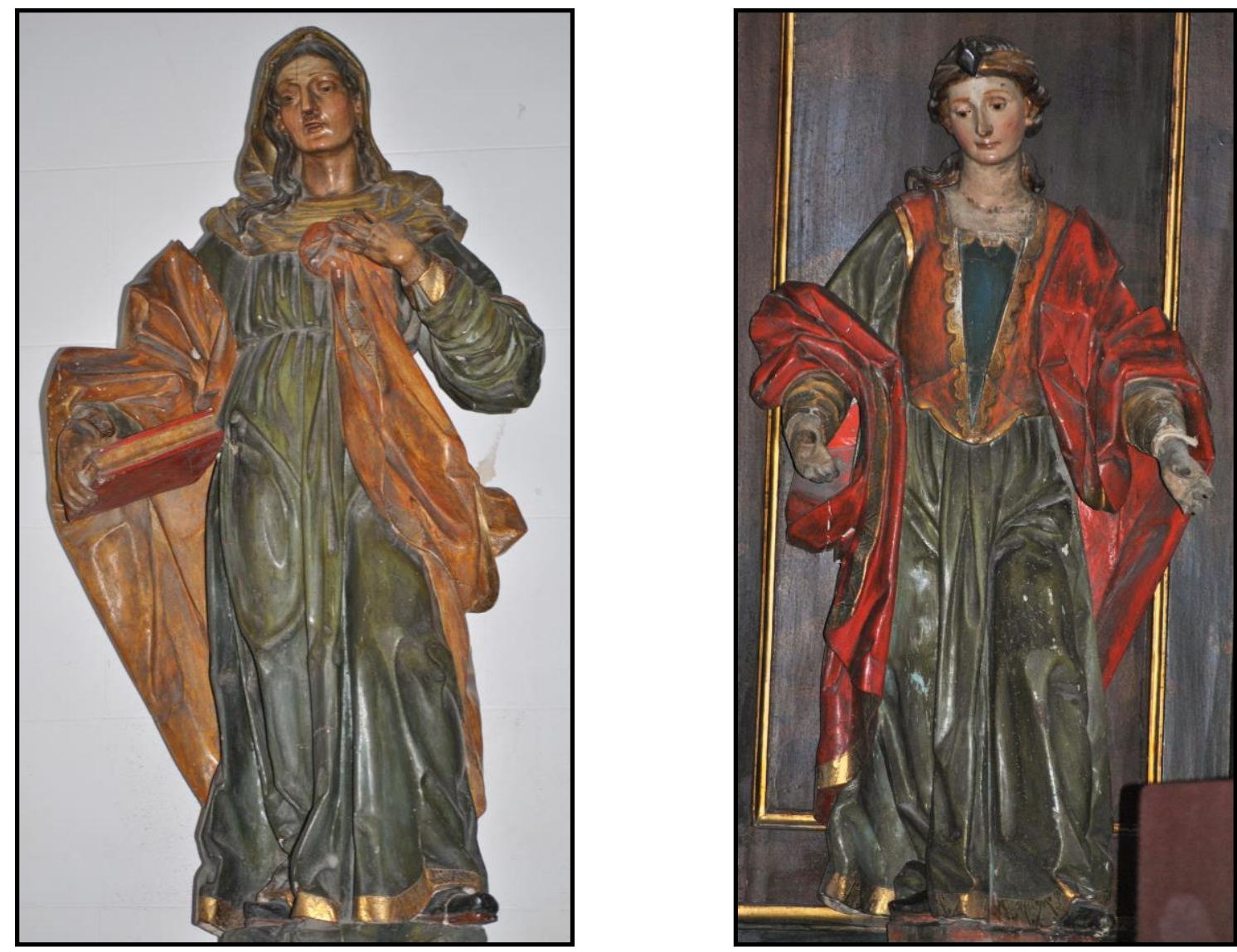

Figs. 140-141- ¿Círculo de Pedro de Sierra? Santa Ana y Santa Apolonia. Iglesia del Salvador. Valladolid.

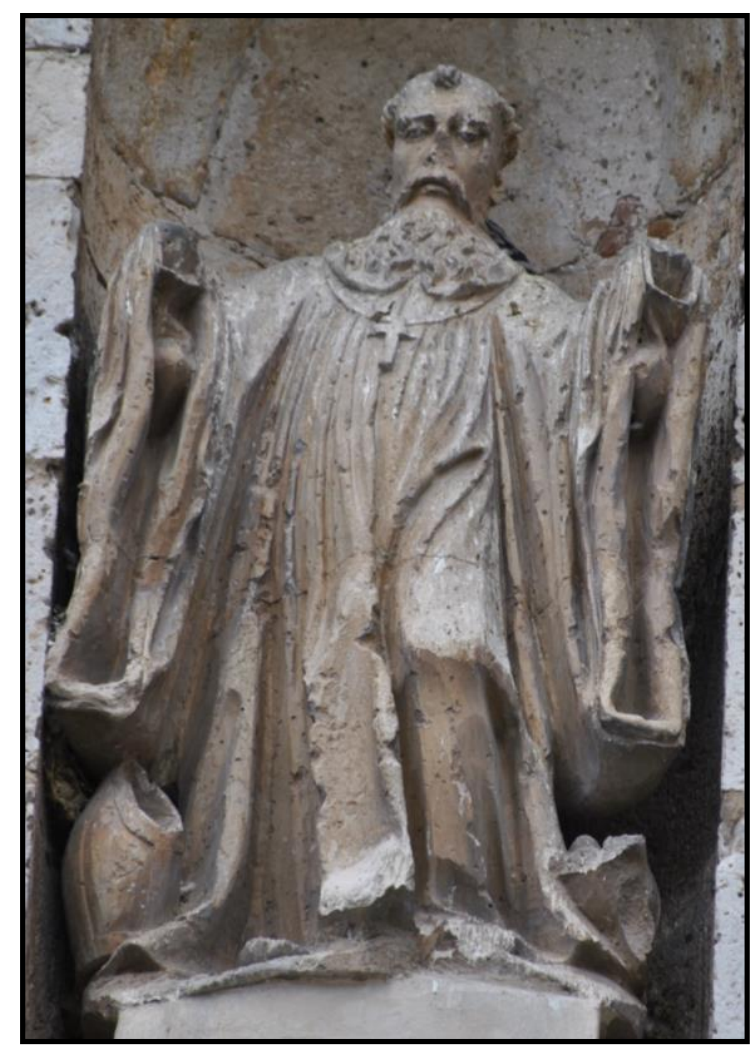

Fig. 142- Anónimo. San Benito. Monasterio de San Benito el Real. Valladolid.

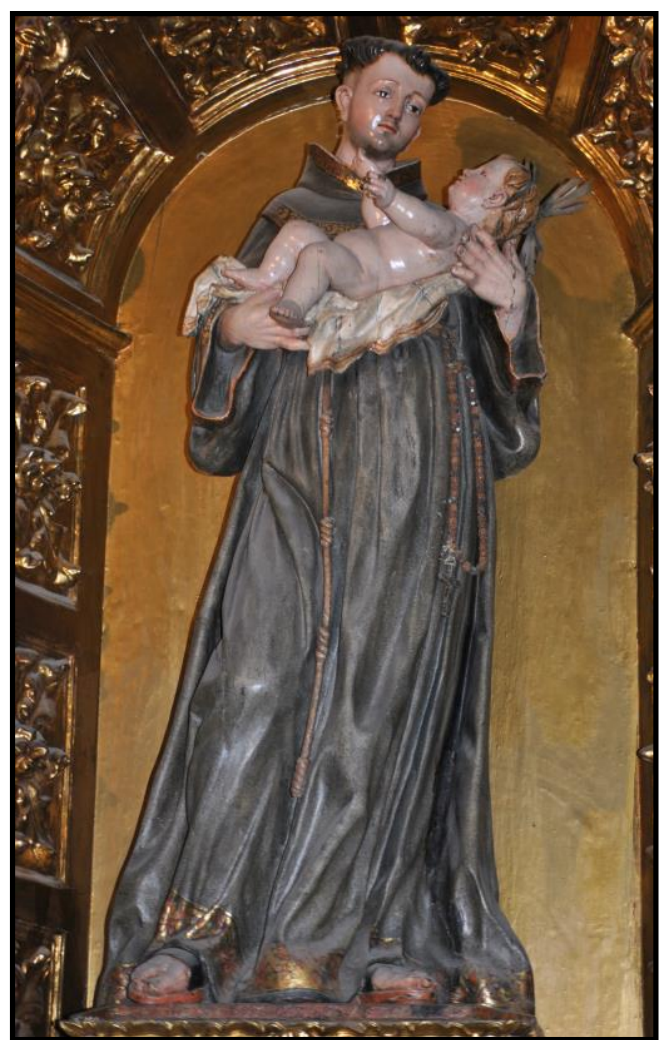

Fig. 143- ¿Antonio de Gautúa? San Antonio de Padua. Oratorio de San Felipe Neri. Valladolid.

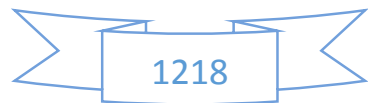




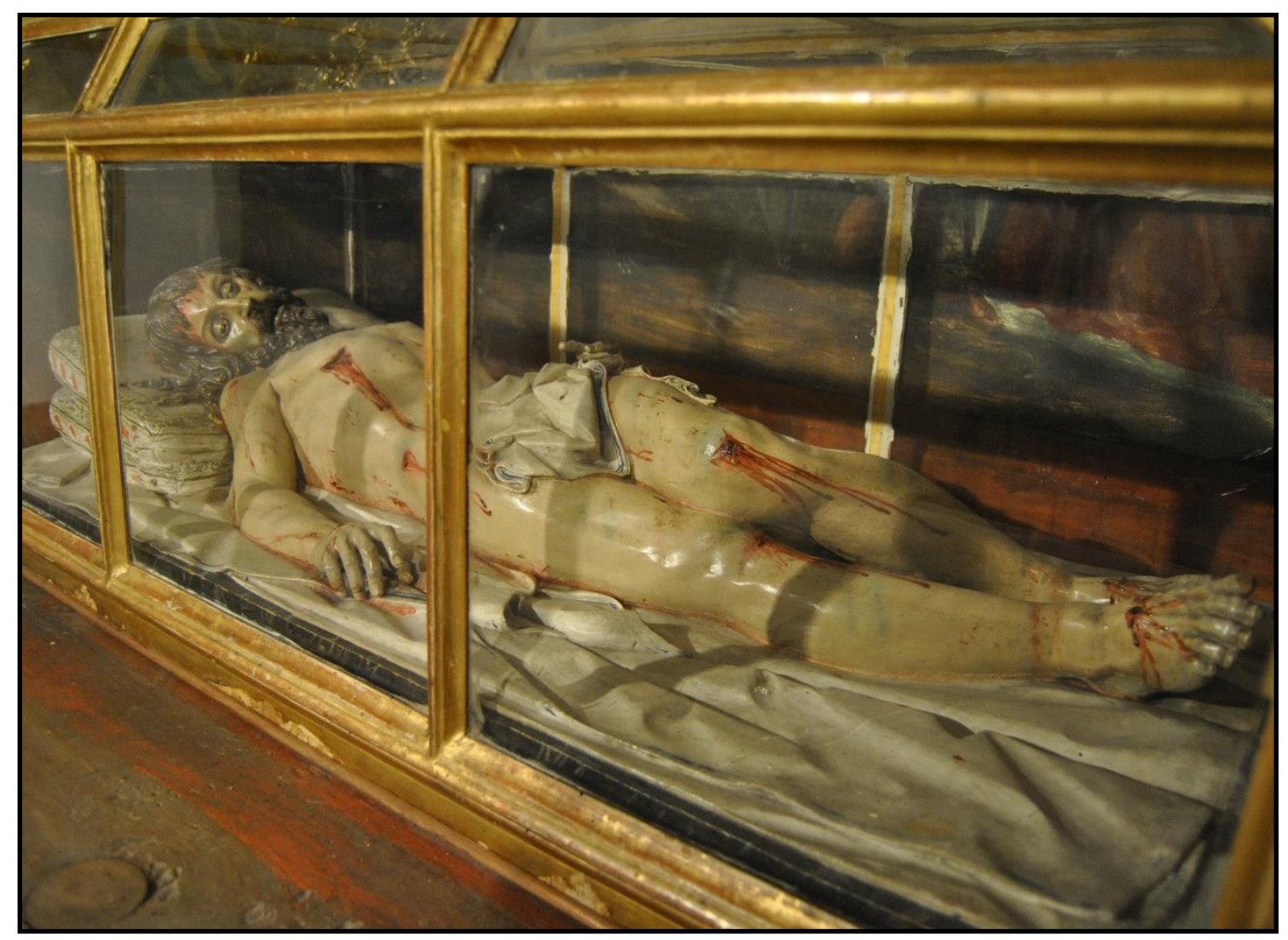

Fig. 144- ¿José de Rozas? Cristo Yacente. Oratorio de San Felipe Neri. Valladolid.

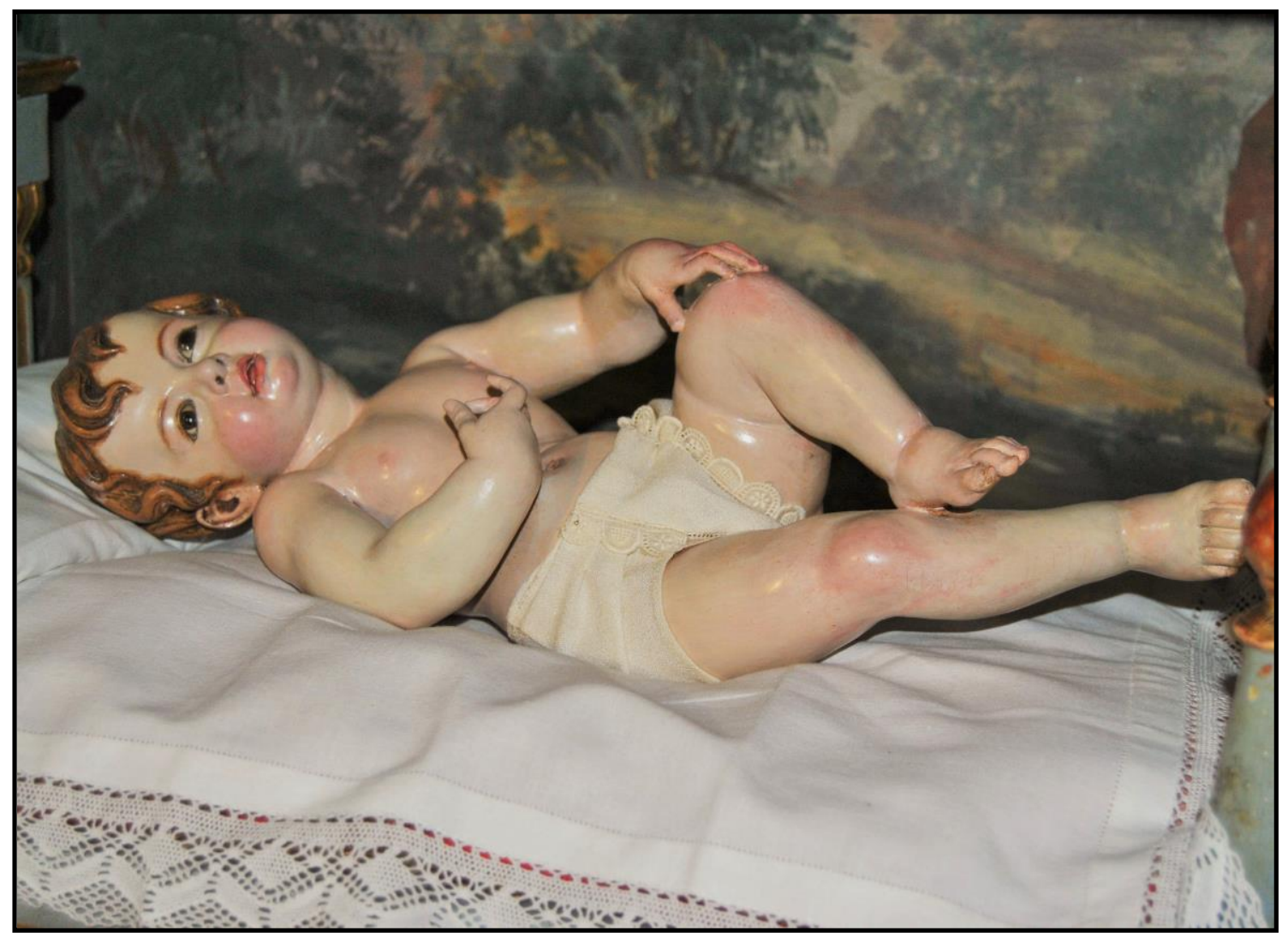

Fig. 145- ¿Anónimo vallisoletano o madrileño? Niño Jesús. Oratorio de San Felipe Neri. Valladolid.

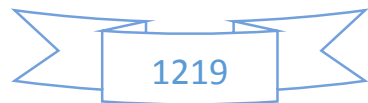




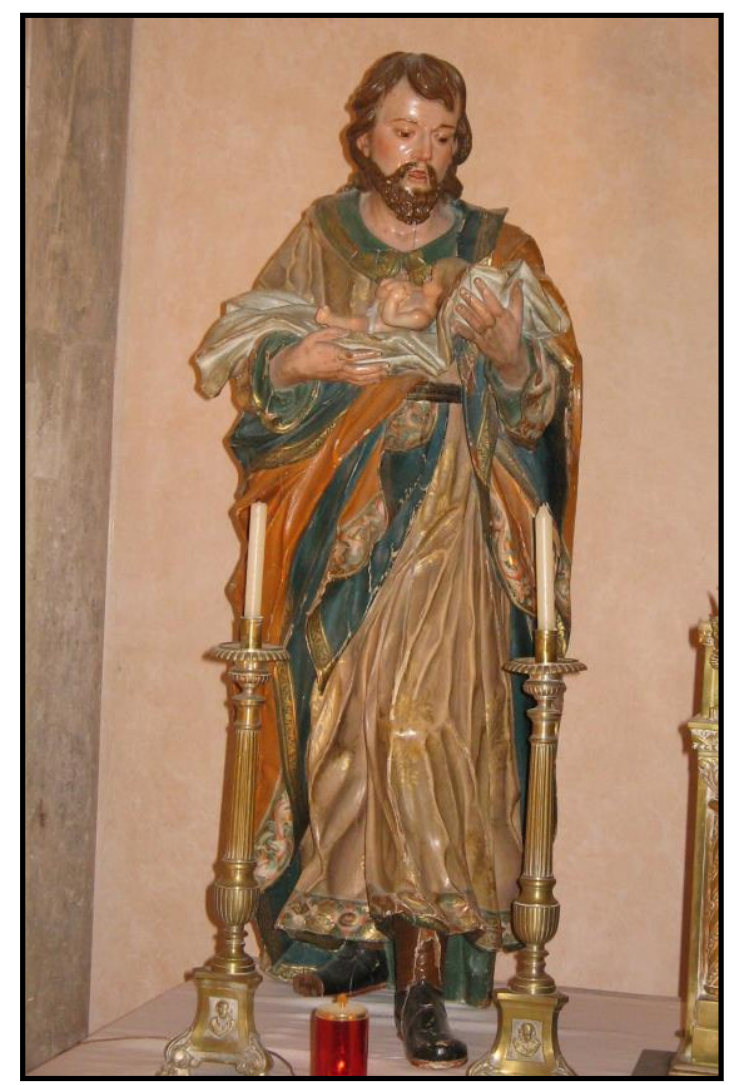

Fig. 146- Anónimo. San José. Iglesia de San Cipriano. San Cebrián de Mazote (Valladolid).

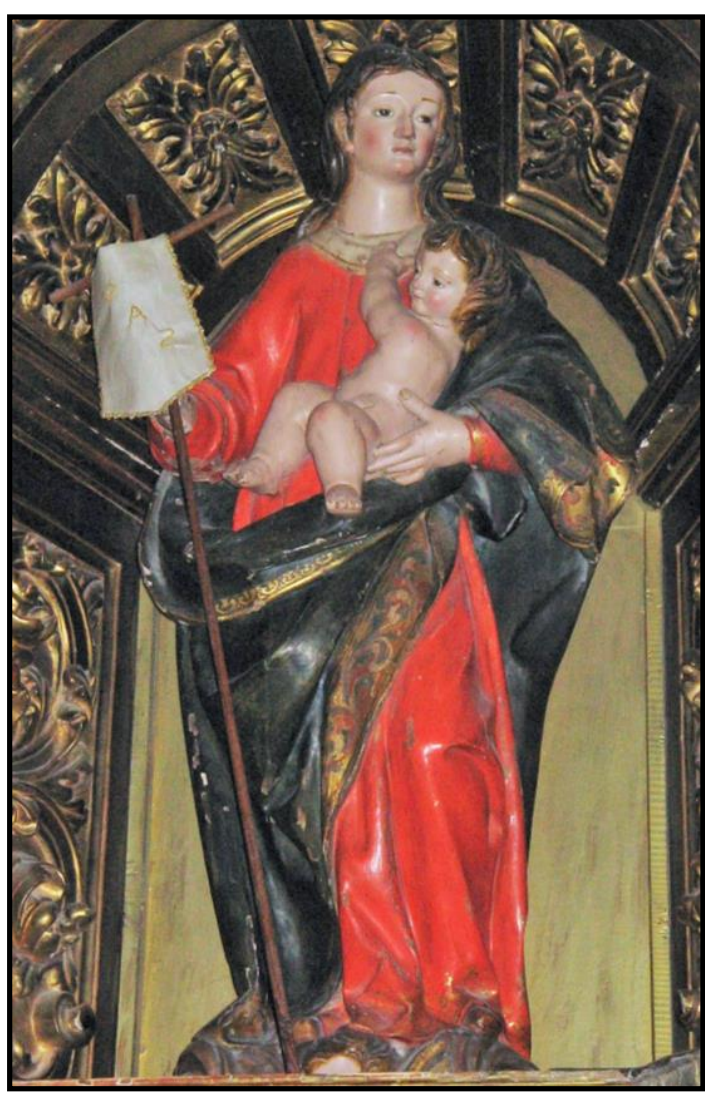

Fig. 148- ¿Antonio de Gautúa? Virgen con el Niño. Iglesia de Nuestra Señora de la Paz. Castrillo de Onielo (Palencia).

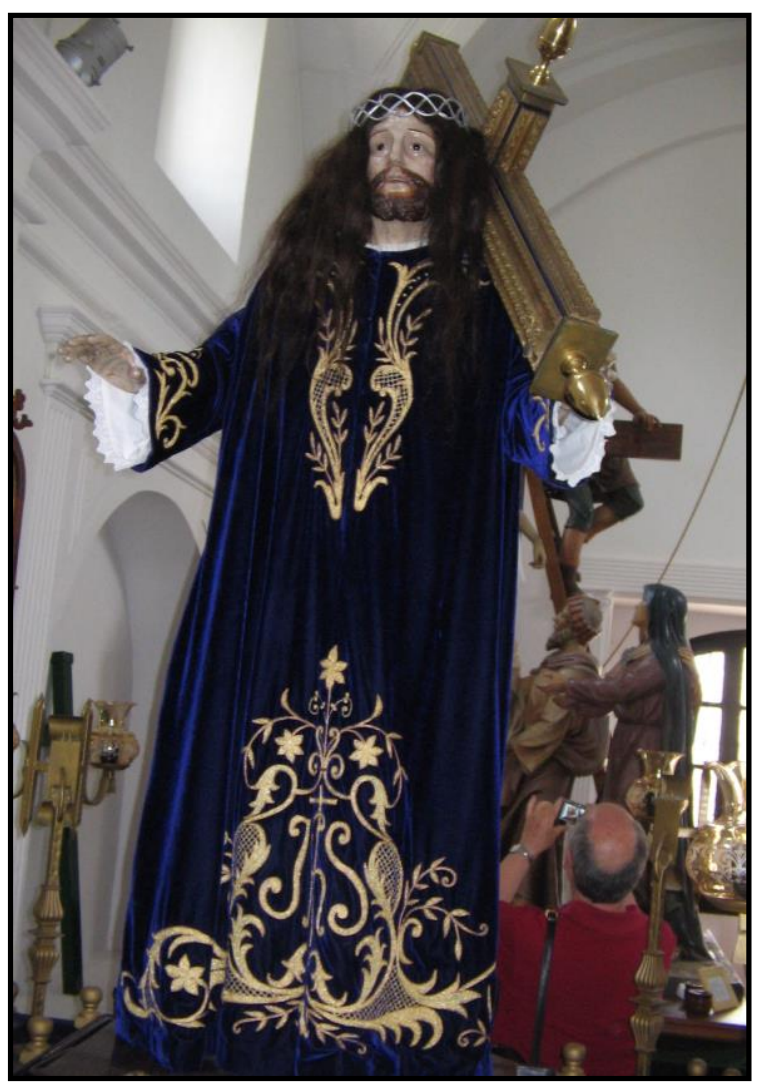

Fig. 147- Anónimo. Jesús Nazareno. Ermita de la Santa Vera Cruz. Carrión de los Condes (Palencia).

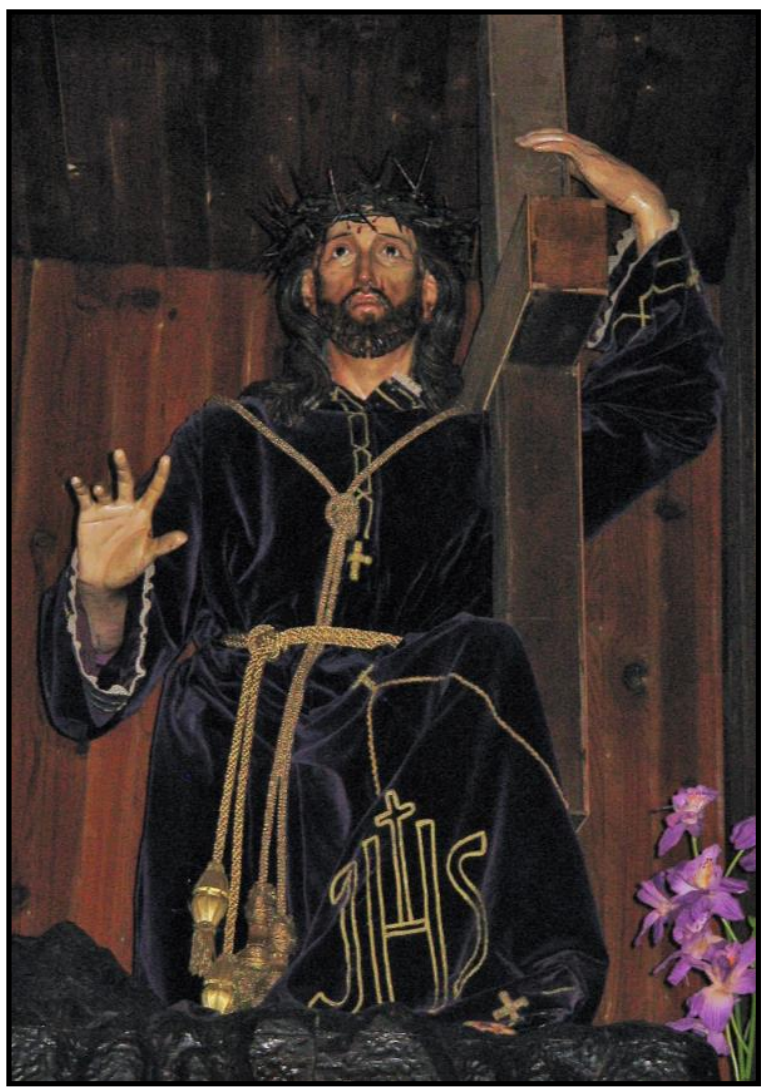

Fig. 149- Anónimo. Nazareno (Dainos). Convento de San Francisco el Real. León. 


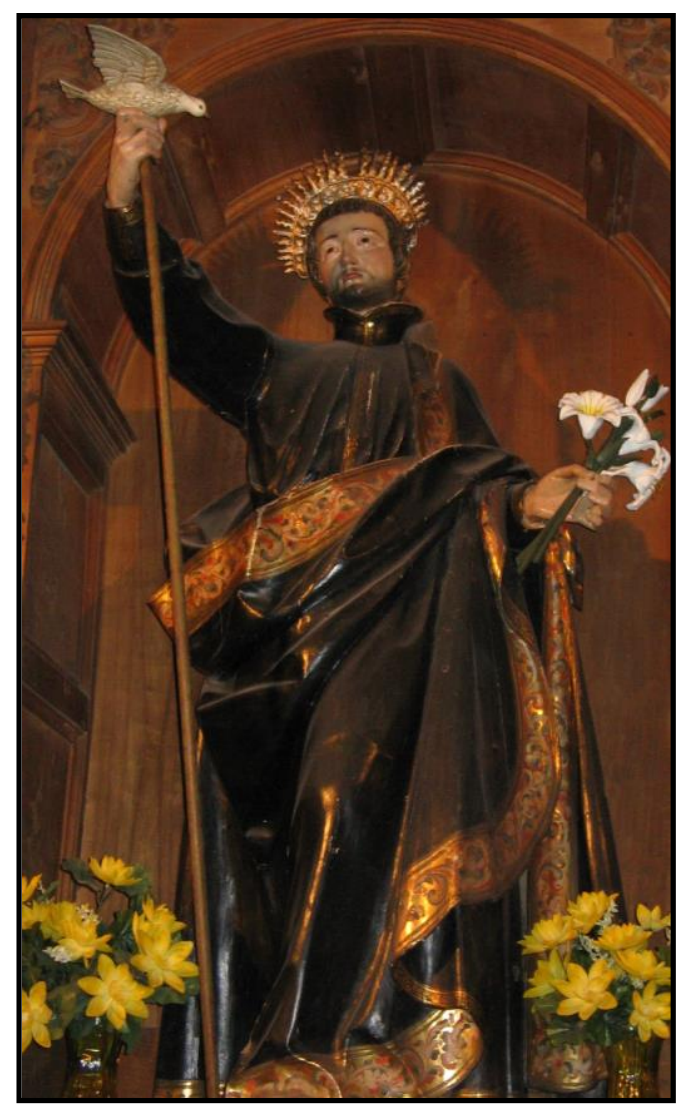

Fig. 150- ¿Juan Antonio de la Peña? San Francisco Javier. Iglesia de Santa Marina la Real. León.

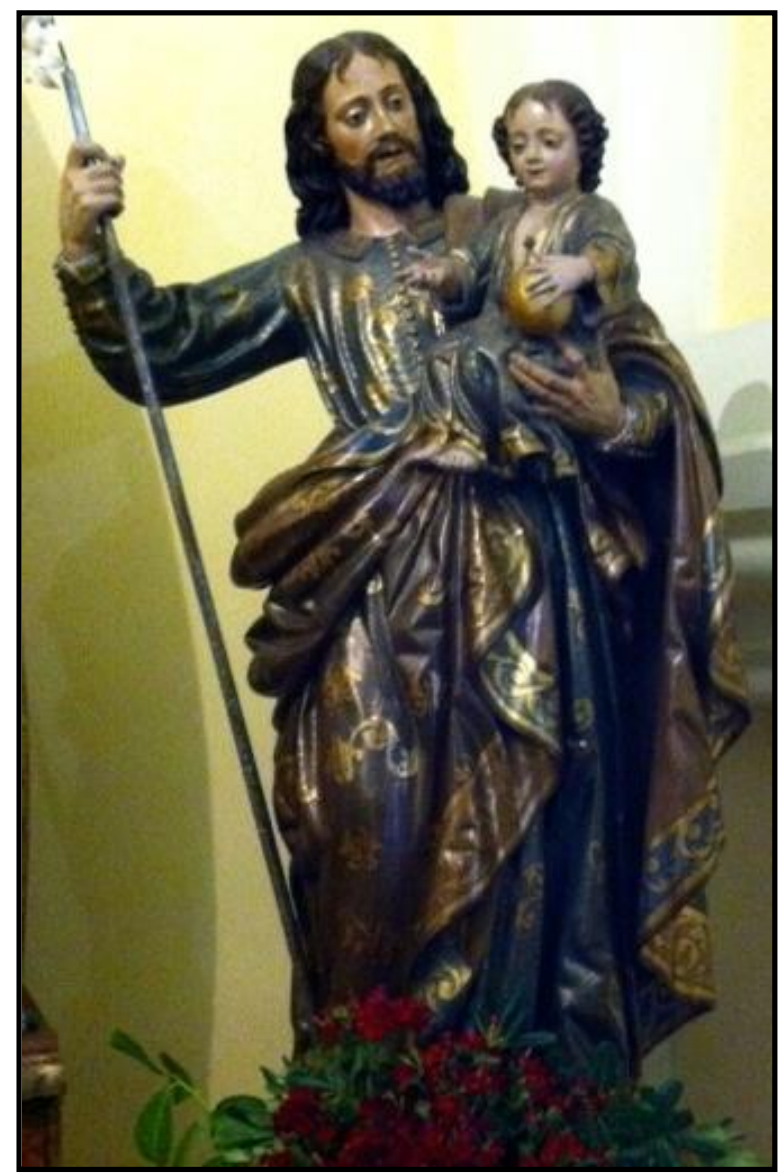

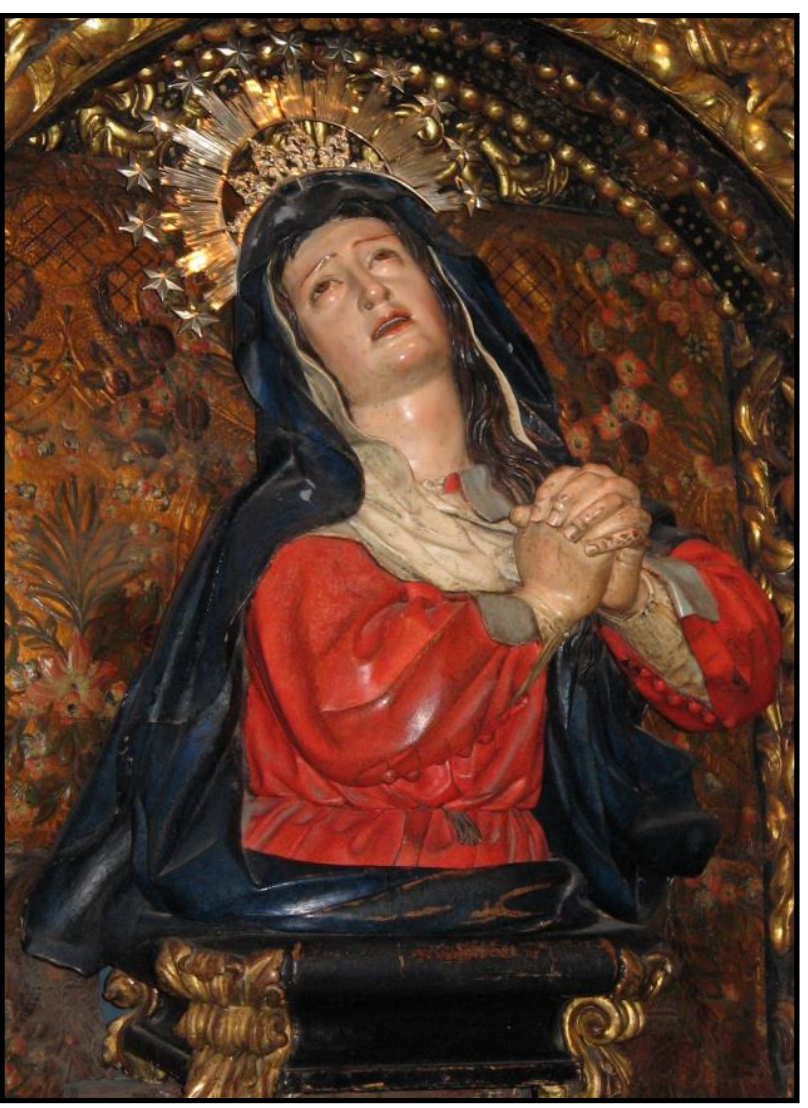

Fig. 151- Anónimo vallisoletano. Busto de Dolorosa. Catedral. Orense.
Fig. 152- ¿José de Rozas? San José con el Niño. Seminario Mayor. Palencia.

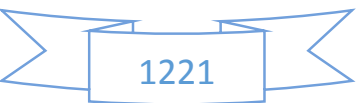




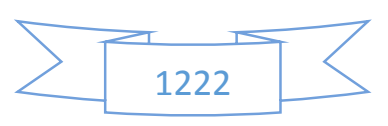




\section{0- DISCIPULOS DE PEDRO DE ÁVILA}




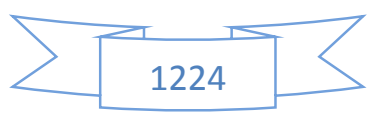


El taller de Pedro de Ávila debió de ser tan amplio como el de su padre, si no más, dado el volumen de obra que le atribuimos; mucha de la cual se concentra en periodos concretos que hace inexcusable la presencia de un amplio equipo que permitiera a nuestro escultor cumplir los plazos que se le imponían. El hecho de que le podamos atribuir tanta obra con seguridad y el que esta se encuentre bastante dispersa (hay que recordar que hemos localizados piezas suyas en Orense, Pamplona y quizás en Oñate) nos permite suponer que su fama era tal que todavía habrá bastante obra sin localizar, lo que vendría a convertir al taller de Pedro de Ávila en uno de los más importantes y productivos de la Castilla de la primera mitad del siglo XVIII. Sin embargo no conocemos a ningún integrante de este taller más allá de su hermano Manuel, el cual colaboraría con Pedro hasta que se independizó a mediados de la década de 1710. Además, al contrario de lo que nos sucedía con Juan de Ávila, no podemos atribuir a Pedro de Ávila la ascendencia escultórica sobre ningún artífice. Recordemos que a Juan de Ávila asignamos la formación sobre Antonio de Gautúa.

Dejando por descontado que debió de tener oficiales y aprendices "anónimos", los cuales no lograrían labrarse una carrera propia lejos del taller de Ávila, es probable que alguno de los pocos nombres de escultores vallisoletanos que conocemos del segundo y tercer cuarto del siglo XVIII pudieran haberse formado en su obrador; son los casos de José Fernández, Juan Macías o Andrés Carballo. Tampoco hemos de olvidar que había otros talleres que le harían la competencia, caso de los de Antonio de Gautúa, Pedro Bahamonde, José Pascual, José de Rozas, Andrés de Pereda; si bien solamente el de Pedro de Sierra podía igualársele.

La presencia a lo largo y ancho de la actual provincia de Valladolid de diversas esculturas anónimas que copian al milímetro los modelos creados por Ávila nos llevan a preguntarnos lo siguiente: ¿Fueron realizadas por discípulos de nuestro escultor o bien se trata de obras de artífices que tan solo se limitaron a copiar puntualmente alguno de los exitosos modelos del artífice vallisoletano? En esta lista cabrían muchas imágenes, pero tan solo reseñaremos por obviar prolijidad los ejemplares de San José que se conservan en las parroquiales de Aldeamayor de San Martín, Villanueva de Duero o Curiel de Duero. Además, habría que añadir que este mismo tipo de San José figura en el retablo mayor de la iglesia de San Andrés de Valladolid, el cual fue ejecutado tanto en la parte arquitectónica como en la escultórica por Pedro Correas. Como vemos la respuesta a la pregunta no es fácil puesto que si lo primero parece indicarnos que esas esculturas fueron hechas por discípulos del

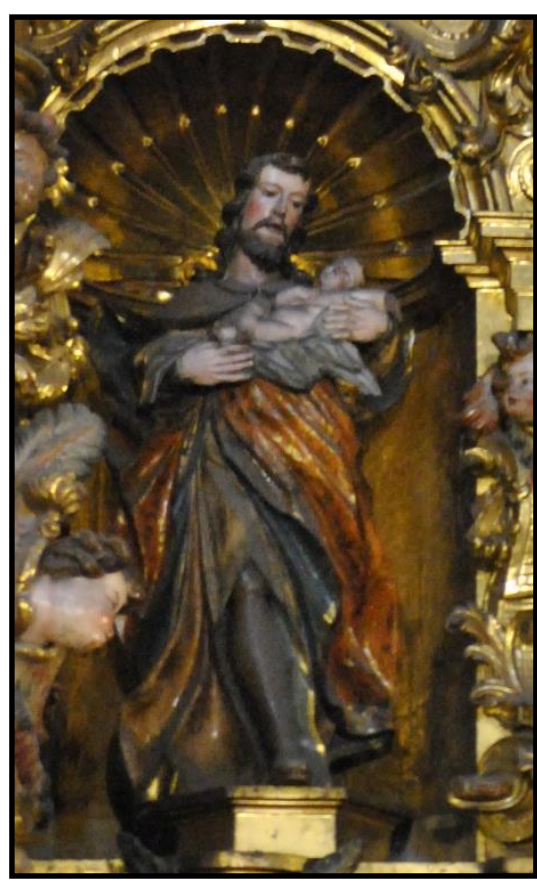

Il. 1- ¿Pedro Correas? San José del retablo mayor. Iglesia de San Andrés. Valladolid. maestro sin la necesaria capacidad de inventiva que les llevara a concebir sus propios 
modelos, lo segundo apunta a que los prototipos de Ávila gozaron de tal éxito que fueron copiados incluso por artistas de primer nivel, en lo que respecta al foco vallisoletano.

Me gustaría tan solo insinuar, puesto que no tengo pruebas documentales y las estilísticas son bastante débiles, que Pedro de Bahamonde pudo formarse en el taller de nuestro escultor: sus tipos humanos, así como la utilización del pliegue a cuchillo y la presencia de ciertos detalles como la manera de resolver las narices o las barbas así parecen pregonárnoslo. Sin embargo, el hecho de que Pedro Bahamonde fuera un gran retablista, disciplina que no pudo aprender de Pedro de Ávila ya que éste tan solo se dedicó a la escultura (hasta que nuevas pruebas documentales nos lo desmientan), parecen disipar esa posibilidad. A ello hemos de añadir el que desconocemos si vino a Valladolid ya formado, con tan solo unas nociones o bien con la intención de aprender el oficio.

Para finalizar, pienso que quien de verdad pudo formarse al lado de Pedro de Ávila, si bien es una hipótesis esgrimida con bastantes reservas, es Felipe Espinabete. La cautela exhibida se debe a que el artista tordesillano posee un estilo tan particular que parece no acomodarse al de ningún escultor vallisoletano de la época.

A día de hoy sigue siendo un verdadero misterio a las órdenes de qué escultor se formó Felipe Espinabete. Su aprendizaje debió de comenzar hacia 1730-1733; es decir, cuando contaba con unos 11-14 años. Por entonces no vivía en Tordesillas ningún maestro que pudiera enseñarle el oficio, por lo que lo más lógico es que tuviera que trasladarse hasta la capital vallisoletana para iniciar su formación. No es muy creíble la propuesta de Urrea de que Espinabete comenzara "estudiando con Antonio de Gautúa, escultor que en 1727 vivía y trabajaba en Tordesillas"1. Asimismo, supone que "con él permanecería, primero como aprendiz y luego como oficial, al menos, hasta 1740"2. Sabemos que Gautúa tuvo apariciones esporádicas en la villa, la última conocida en el referido 1727, año en que contrae matrimonio en segundas nupcias con la tordesillana Manuela García y en el que realiza la escultura de San Pedro en cátedra para la iglesia homónima. Sin embargo, parece demasiado precipitado pensar que un niño con apenas 8 años recién cumplidos comenzara a recibir lecciones de escultura por muy básicas que fueran.

Además de esta hipótesis se han barajado otras muchas sobre su supuesto aprendizaje. Piensa acertadamente Martín González que "su formación se efectuaría en Valladolid" y que sin ninguna duda le influyó de manera decisiva Pedro de Ávila, “cuyos pliegues imita"; pero también Pedro de Sierra, "que se había establecido en Valladolid"3. Por su parte, Brasas Egido, cree que probablemente "se formaría en Valladolid en relación con el riosecano Pedro de Sierra, con cuyo estilo se advierten algunas semejanzas". Finalmente, Urrea incide en la relación de Espinabete con los Sierra: "de lo que no se

1 URREA FERNÁNDEZ, Jesús: "Nuevos datos y obras del escultor Felipe de Espinabete", op. cit., pp. 510-511.

2 URREA FERNÁNDEZ, Jesús: "El escultor Felipe Espinabete (1719-1799)". En REDONDO, José, BAZÁN, Pedro y GARCÍA, Antonio María: Tordesillas a través de su Semana Santa, Diputación Provincial de Valladolid, Valladolid, 2000, p. 119.

3 MARTÍN GONZÁLEZ, Juan José: Escultura barroca en España ..., op. cit., p. 453.

BRASAS EGIDO, José Carlos: «NoticiasłäBre Espinabete”, B.S.A.A., Tomo XLV, 1979, p. 496. 
puede dudar es de la influencia ejercida por los hermanos Sierra-Francisco, Pedro, José y Jacinto-que mantenían en Rioseco un taller muy activo y que, junto con el vallisoletano Pedro de Ávila, eran en aquellos años, los escultores de mayor calidad de toda la comarca"; y en que probablemente el tordesillano ocuparía el espacio artístico dejado por Pedro de Ávila en Valladolid tras su fallecimiento ${ }^{5}$.

Aunque no nos consta que Espinabete viniera a Valladolid para aprender el oficio, no hay otra posibilidad, y este extremo tan solo podría ser resuelto con el hallazgo de la escritura de aprendizaje, la cual quizás todavía se encuentre entre los legajos de los diferentes escribanos tordesillanos. Sea como fuere, pienso que Felipe Espinabete se formó con Pedro de Ávila. Mis razones son tanto estilísticas como documentales.

Documentalmente, Pedro de Sierra quedaría totalmente descartado como posible maestro de Espinabete puesto que la fecha más temprana en que le tenemos documentado en Valladolid es en 1735 comenzando a fabricar la sillería del Convento de San Francisco; por su parte, en Medina de Rioseco parece que tan solo estuvo durante un corto lapso de tiempo entre 1726-1727 realizando las esculturas de la fachada de la iglesia de Santa Cruz. Ambas fechas le invalidarían como preceptor de Espinabete puesto que en este último periodo el tordesillano era muy niño y en 1735 ya habría acabado de formarse. El resto del tiempo, Pedro de Sierra se mantuvo viviendo y trabajando en Toledo.

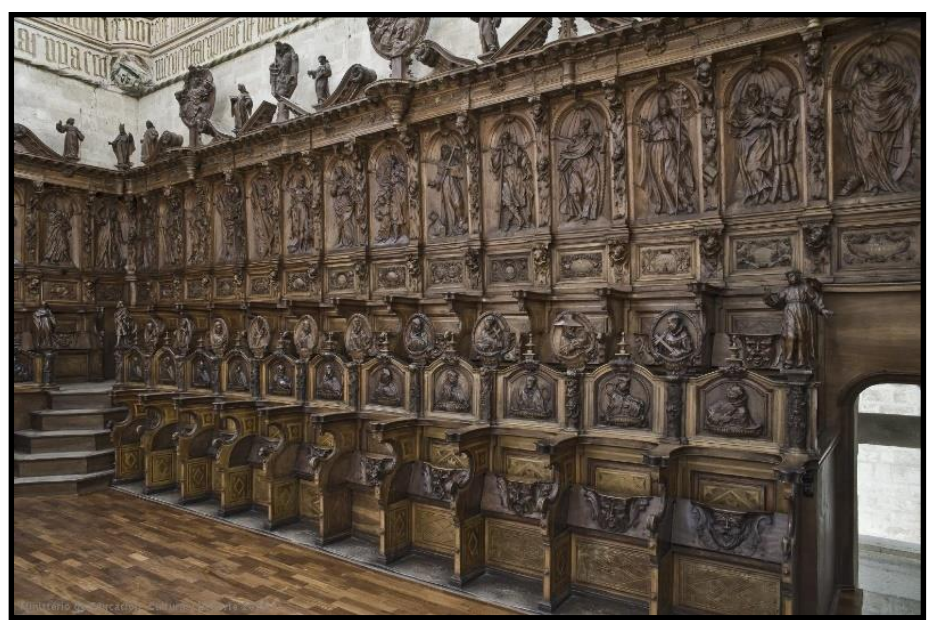

Il. 2 Pedro de Sierra y Jacinto de Sierra. Sillería del Convento de San Francisco. Museo Nacional de Escultura. Valladolid. (C) Museo Nacional de Escultura.

Dicho todo esto, me gustaría volver a incidir en la posibilidad de que Pedro de Ávila hubiera sido el maestro de Felipe Espinabete; sin embargo, no hemos de descartar otras posibilidades: que pudiera haberse formado con otro maestro vallisoletano, riosecano o, incluso, madrileño. Si aún creyéramos que su maestro fue Pedro de Sierra tendríamos que pensar en la posibilidad de que Espinabete marchara con él a aprender el oficio a Toledo puesto que era allí donde tenía abierto su taller por aquellas fechas.

5 URREA FERNÁNDEZ, Jesús: “El escultor Felipe Espinabete...”, op. cit., p. 119. 
$\sum[1228 \leq$ 


\section{II-MANUEL DE A VILA.}

PERSONALIDAD 
$\sum 1230 \leq$ 


\section{1-1 BIOGRAFÍA}

Durante mucho tiempo se dudó acerca de la relación familiar existente entre Manuel de Ávila y Juan y Pedro de Ávila. Las teorías eran dos: que fuera hijo de Juan de Ávila, o bien que lo fuera de Pedro de Ávila ${ }^{1}$. El dato que sirvió para desenmarañar esta problemática familiar fue uno aportado por el profesor Parrado del Olmo: se trataba de una carta de pago otorgada por Manuel de Ávila en relación con un Crucifijo que había tallado Pedro de Ávila para la iglesia parroquial de San Esteban de Torrecilla de la Abadesa. En ella Manuel se presentaba como "hermano del escultor (Pedro de Ávila) que ha hecho la hechura de Cristo". Otros datos que no han hecho sino confirmar este hecho han sido el hallazgo de sucesivos testamentos de Pedro de Ávila en los cuales asevera no haber tenido descendencia; y, por supuesto, el descubrimiento de su partida de bautismo, en la cual se puede leer que sus padres fueron Juan de Ávila y Bentura Sedano. Por lo tanto, Manuel es hijo de Juan, y hermanastro de Pedro.

\section{A- ETAPA JUVENIL Y APRENDIZAJE EN EL TALER DE SU HERMANO PEDRO (1690-1706)}

Manuel de Ávila Sedano nace en la calle de Santiago, o del Campo, de Valladolid el 12 de enero de 1690, siendo bautizado diez días después en la parroquia de Santiago Apóstol, al igual que todos sus hermanos y su padre ${ }^{2}$. Su padrino fue el licenciado Julián de Granda; se le adjudicaron por abogados a la Virgen, a San Juan y al Ángel de la Guarda. Por su parte, los testigos del bautizo fueron el licenciado Francisco Ortiz y Manuel Gómez (seguramente se trate del escultor Manuel Gómez Otero, que ya figuró como testigo en los bautizos de otros hijos de Juan de Ávila).

Manuel fue el primer hijo del reciente matrimonio formado por Juan de Ávila, para el cual se trataba de sus segundas nupcias, y Bentura Sedano. Si su hermano Pedro de Ávila había emparentado con uno de los mejores escultores de ámbito castellano, Juan Antonio de la Peña; en Manuel confluirán por vía de sangre dos de los más ilustres linajes escultóricos de la Castilla de la época: además de que su padre era Juan de Ávila; su abuelo materno, que por entonces ya había fallecido, fue Mateo Sedano, el escultor barroco palentino más importante del siglo XVII. Mateo había sido miembro de otra insigne estirpe de artífices, conformada por su padre Juan Sedano y por sus hermanos

\footnotetext{
1 Mientras que Arribas Arranz aseguraba que era hijo de Juan de Ávila (ARRIBAS ARRANZ, Filemón: La Cofradía..., op. cit., p. 94.), Martín González establecía la duda de que pudiera serlo de Pedro: "Manuel de Ávila será hermano o hijo de Pedro" (MARTÍN GONZÁLEZ, Juan José: Escultura barroca castellana..., op. cit., p. 325).

2 "En veinte y dos de enero de mil seiscientos y noventa años yo Alonso González teniente de cura de la parroquial de señor Santiago de ésta ciudad de Valladolid bauticé e impuse los santos óleos como el santo concilio manda a un niño hijo legítimo de Juan de Ávila y Bentura Sedano parroquianos de ésta iglesia a la calle del Campo pusieronle por nombre Manuel el cual nació en doce de dicho mes y año según me lo aseguraron sus padrinos que lo fueron el licenciado Julián de Granda beneficiado de presente de dicha iglesia abogados a Nuestra Señora y San Juan y el Ángel de la Guarda testigos el licenciado don Francisco Ortiz y Manuel Gómez y lo firmé”. A.G.D.V., Santiago, 1683B, f. 171.
} 
Juan y Carlos. Por lo tanto, nuestro Manuel será el último eslabón tanto de los Ávila, junto a su hermano Pedro, como de los Sedano.

Un año después de su nacimiento vendría al mundo su hermana Manuela, la segunda y última concebida por Juan de Ávila y Bentura $S$ dano $^{3}$, la cual fallecería al poco de nacer. Nada más conocemos de su niñez a excepción de que con 6 años, el 19 de mayo de 1696, celebra la confirmación de su Fe católica en la iglesia conventual de San Quirce y Santa Julita ${ }^{4}$, bajo el retablo para el cual su padre pudo tallar las esculturas. La ceremonia fue oficiada, al igual que la celebrada años antes para sus hermanos Pedro y Teresa, por el obispo de Valladolid, don Diego de la Cueva y Aldana; por su parte, actuaron como padrinos del acto Diego Vicente y doña Isabel Cañizar.

El 11 de agosto de 1700 acudiría acompañado de sus padres a la iglesia de San Miguel para ver casar a su hermano Pedro con María Lorenza de la Peña, hija de uno de los más afamados escultores vallisoletanos de la época, Juan Antonio de la Peña 5 .

Pienso que después de la boda, tras la marcha definitiva de su hermano Pedro del taller familiar, si es que no se había ido antes al de su suegro, Juan de Ávila pensaría que era apropiado ir enseñando a Manuel los rudimentos del oficio. Aunque el aprendizaje se solía comenzar entre los 11 y 14 años, como Manuel tenía la suerte de poseer un padre escultor, no sería nada extraño que este aprendizaje se adelantara hasta los 10 años; puesto que el pequeño conviviría entre "santos", maderas, garlopas y cinceles. De todas maneras, en el hipotético caso de que Juan de Ávila hubiera comenzado a enseñarle el oficio, poco es lo que pudo estudiar a su lado Manuel puesto que el progenitor falleció el 6 de noviembre de 1702. Ese día el patriarca de la familia es sepultado en la iglesia de Santiago Apóstol ${ }^{6}$. Con anterioridad, había testado ante el escribano Francisco de Colinas, documento que no se ha conservado; en él dejaba nombrados como testamentarios al pintor Ignacio Díez de Prado y a Santiago Izquierdo, su cuñado (era el esposo de la hermana de su segunda mujer, Bentura Sedano).

Manuel, el pequeño de la familia, quedaba huérfano, aunque todavía contaba con sus hermanos Teresa, Pedro y Joseph, si bien el segundo de ellos estaba ya independizado con su esposa. Desconocemos si la muerte de Juan de Ávila dejó completamente huérfano al joven Manuel puesto que ignoramos si por entonces había fallecido Bentura Sedano, su madre. Tras el nacimiento de Manuela de Ávila (1691) no volvemos a tener noticias de Bentura Sedano: en la partida de defunción de Juan de Ávila ni se la nombra, y en el expediente matrimonial del propio Manuel (1712) no se especifica si estaba viva o muerta, dato que en la mayoría de ocasiones se suele puntualizar.

A.G.D.V., Santiago, 1643B, f. 215.

"En diez y nueve de mayo de mil seiscientos y noventa y seis años el Ilustrísimo señor don Diego de la Cueva y Aldana obispo de ésta ciudad de Valladolid y su obispado celebró el santo sacramento de la confirmación en el Convento de San Quirce de Religiosas de San Bernardo (...) se confirmó en dicha iglesia padrinos dicho Diego Vicente y Doña Isabel Cañizar: Manuel hijo legítimo de Juan de Ávila y de Bentura Sedano moradores a la calle del Campo". A.G.D.V., Santiago, Confirmados, f. 49.

A.G.D.V., San Miguel, 1681M, f. 88.

A.G.D.V., Santiago, 1673D, f. 576. 
Ante esta incógnita se nos presenta la duda de ¿con quién vivió Manuel de Ávila tras el fallecimiento de su padre? Las opciones son varias: con su madre, en el caso de que todavía viviera; con sus hermanos Teresa y Joseph, que, dado que la primera no se había casado y el segundo era todavía joven, se habrían quedado viviendo juntos en el domicilio familiar; o con su hermano Pedro, el cual se ocuparía por entonces de comenzar, o continuar, con la enseñanza del joven Manuel. Ahí quedan expuestas las posibilidades, lo único que queda claro es que por entonces marcharía al taller de su hermano Pedro.

Ya hemos apuntado la posibilidad de que su padre pudiera haberle dado ciertas nociones sobre el oficio familiar, aunque en el caso de que esto hubiera sucedido muy pocas habrían sido éstas dada la escasa edad de Manuel al tiempo de la muerte de su padre. Esto no quiere decir que el taller paterno haya sido decisivo para que Manuel se inclinara a dedicarse al mundo de la escultura, ya que desde pequeño trastearía por el estudio y vería las imágenes que su padre estaba tallando para la iglesia de San Felipe Neri y para la vecina parroquia de Santiago Apóstol, lugar éste último al que iría muy a menudo a misa acompaño de Juan y de Bentura.

En definitiva, el grueso, o la totalidad, de la formación de Manuel corrió a cargo de su hermano Pedro. No hace falta más que comparar obras de ambos para ver que el estilo exhibido por Manuel deriva del de su hermano y no del de su padre. Por ejemplo, si confrontamos el San José que talla para la iglesia penitencial de N. P. Jesús Nazareno de Valladolid con el que su hermano talla años antes para la Catedral podemos comprobar como su parecido es más que razonable. El periodo de aprendizaje debió de extenderse hasta aproximadamente los años 1704-1706, momento en el que quizás comenzaría a trabajar como oficial de su hermano. Llegados a este punto llama bastante la atención el que no hayamos podido documentar ningún aprendiz de Pedro.

Por estas mismas fechas aconteció, el 31 de enero de 1704, su ingreso en la Cofradía Penitencial de Nuestro Padre Jesús Nazareno ${ }^{7}$. Dado que por entonces era poco menos que un niño habría que pensar que fue un adulto el que le quiso inscribir en la cofradía, a la cual había pertenecido su padre. Podríamos contemplar dos posibilidades: que le introdujera su madre, Bentura Sedano, o bien su hermano; aunque no tenemos ninguna constancia de que estos dos hubieran pertenecido a la penitencial.

\section{B- ETAPA DE MADUREZ (1706-1733)}

La elección del año 1706 para comenzar esta segunda etapa es más o menos aproximada, refiriéndose a la fecha en que más o menos debió de completar su aprendizaje de escultor al lado de su hermano. No sabemos qué ocurrió con posterioridad, caben dos opciones: que pudiera haber continuado un tiempo como oficial de su hermano o que directamente abriera taller. Pienso que aún continuaría unos

7 ARRIBAS ARRANZ, Filemón: La Cofradía..., op. cit., p. 94. 
años en el taller de su hermano, auxiliándole en sus encargos, hasta que contrajo matrimonio con María Martínez en 1712 y posiblemente se independizó. Queda claro que ya volaba solo en 1714, puesto que en una carta de pago que otorga al cura de Torrecilla de la Abadesa en nombre de su hermano Pedro se le cita como "Manuel de Ávila, maestro de escultura, vecino de la ciudad de Valladolid"8.

Tras el fallecimiento de su hermana Manuela al poco de nacer, el 14 de agosto de 1708 pierde a otro de sus hermanos. Efectivamente, ese día muere su hermano Joseph, el cual por entonces se encontraba soltero viviendo en algún domicilio del área territorial de la catedral por cuanto se le entierra allí al día siguiente a su óbito ${ }^{9}$.

$\mathrm{Su}$ siguiente hito biográfico son las capitulaciones matrimoniales, y posterior casamiento, con María Martínez. Las capitulaciones matrimoniales no se llegaron a redactar puesto que, según se dice en la carta de pago de dote, se "capitularon verbalmente". Para saber los extremos en que se concertaron Manuel de Ávila y sus suegros, Joseph Martínez y Andrea Cortés, hemos de acudir a la referida carta de pago, expedida por el escultor el 3 de octubre de 1721. Extraña bastante la demora de casi diez años, en todo caso debió de haber unos buenos motivos. Este caso es excepcional puesto que, por lo general, este documento se solía expedir días después del casamiento, o, bien, cuando el marido otorgaba testamento, apareciendo entonces la carta de pago como una de las cláusulas del mismo (DOCUMENTO 90).

Los padres de la "novia" se obligaban a llevar "a poder del otorgante por bienes dotales suyos propios y por cuenta en lo que hubiere de haber de las legítimas de los dichos sus padres" 3.450 reales de vellón "en bienes y alhajas de por casa tasados por personas nombradas cada parte la suya". Además, el platero se comprometía a tener al futuro matrimonio "en su casa y compañía cuatro años dándoles lo necesario para sus alimentos reputado cada año a trescientos y cincuenta reales empezando desde el día que tuviere efecto el matrimonio".

Por otra parte, Manuel de Ávila, dado que María Martínez era "doncella honesta y recogida y de buena vida y costumbres y caso honroso del matrimonio la ofreció en arras proternúpcias" 100 ducados de vellón (= 1.100 reales) "de cuya cantidad a mayor abundamiento por dichas razones la haré gracia y donación irrevocable con los requisitos necesarios". Dado que ya había "tenido efecto el matrimonio y el dicho Joseph Martínez cumplió con dar dichos alimentos de dichos cuatro años y le dio y entregó los dichos tres mil cuatrocientos reales y cincuenta reales" en diferentes bienes, Manuel de Ávila otorgó carta de pago de dote en favor de sus suegros. Los bienes que el

\footnotetext{
8 "Manuel de Ávila, maestro de escultura, vecino de la ciudad de Valladolid, confieso haber recibido de la mano del Licenciado Santiago Crespo, cura de Torrecilla, 120 reales, los setenta reales que dio Juan Crespo de la limosna que se sacaba por el lugar; los cincuenta dijo el cura de mi dinero, y es por cuenta de la hechura del Santo Cristo, que está fabricando en casa de Pedro de Ávila, vecino de dicha ciudad. Y por verdad lo firmé en Torrecilla de la Abadesa, a 7 de noviembre de 1714 años". A.G.D.V. Torrecilla de la Abadesa, Papeles sueltos de la parroquial. PARRADO DEL OLMO, Jesús María: Datos histórico artísticos..., op. cit., p. 106.

$9 \quad$ A.G.D.V., Catedral, 1684D, f. 160. El nombre de la madre es erróneo puesto que era Francisca y no Manuela.
} 
suegro entregó al yerno como parte de los 3.450 reales englobaban objetos de ropa blanca, de cobre, de madera, de plata y vestidos.

Así, la ropa blanca la englobaban la ropa de cama (un jergón, una manta, sábanas, colchas, almohadas) y la de mesa (paños, manteles, servilletas); los bienes de cobre eran en su mayoría objetos relacionados con la cocina (calderos, peroles, cazos, sartenes, una chocolatera, una parrilla, asadores, un almirez, un brasero, etc...). Los vestidos de la lista (basquiñas, guardapiés, anguarinas, un delantal, una mantilla, mantos, etc...) eran tanto para Manuel como para su esposa. Entre los bienes de madera encontramos, entre otros, las pinturas y esculturas que decorarían, primeramente, las estancias reservadas al matrimonio en la casa de su suegro; y, posteriormente, las diferentes viviendas en que morarían Manuel y María. Las pinturas representaban "países", a Nuestra Señora de Belén, a San Pablo, seis cuadros "con sus vidrieras y marcos"; mientras que la única escultura era un Niño Jesús "con escaparte". Además de elementos puramente artísticos este apartado de objetos lígneos lo completaba mobiliario de casa: taburetes, un escritorio, un bufete, etc... Finalmente entre los bienes de platería, oficio que profesaba su suegro, había objetos de poca monta: cucharas, una gargantilla, botones y pendientes, unos de plata y otros de aljófar. En caso de que el matrimonio se disolviera por cualquiera de los motivos que el "derecho permite", Ávila "volverá dicha dote con dicha dotación luego que lo otro suceda".

Una vez realizadas las capitulaciones matrimoniales se llevaría a cabo el enlace entre Manuel y María, el cual aconteció el 22 de mayo de 1712 en la iglesia del Santísimo Salvador ${ }^{10}$. La ceremonia fue oficiada por el presbítero don Pedro de Rábago, a quien la iglesia del Santísimo Salvador debe algunas de sus obras de arte más importantes. Los testigos

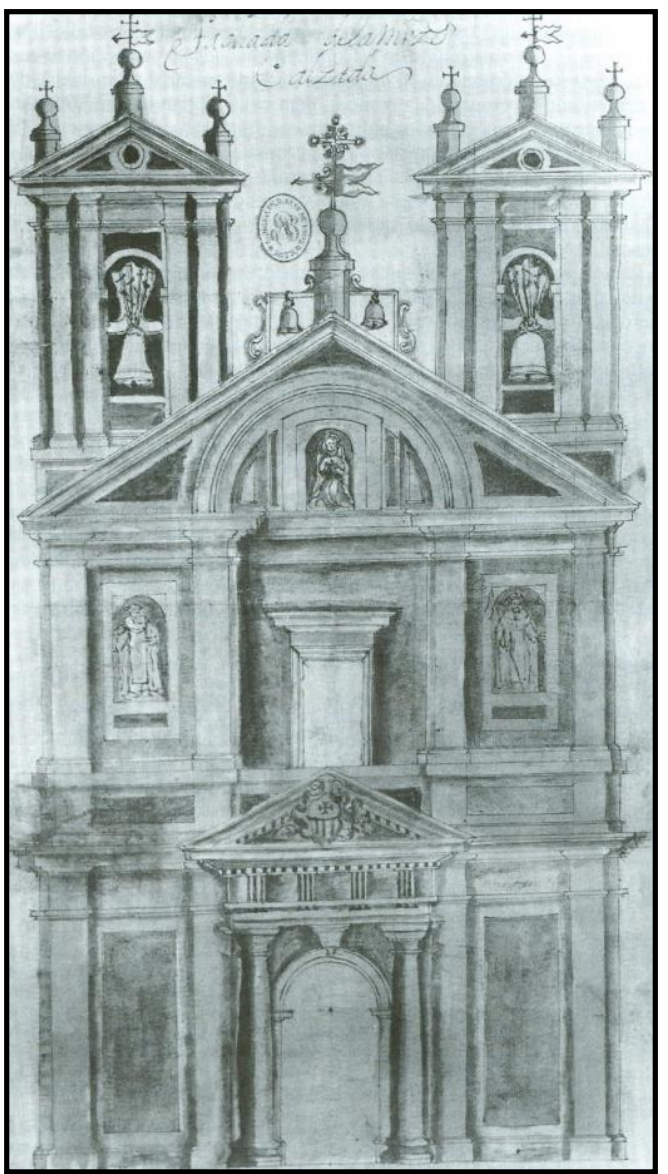

Il. 1- Diego Pérez Martínez. Convento de Nuestra Señora del Carmen. Ilustración de la "Historia de Valladolid" de Juan Antolínez de Burgos. del enlace fueron Santiago de Escobar, Jerónimo González y el platero Damián Cortés.

\footnotetext{
10 "En veinte y dos de mayo de mil setecientos y doce yo D. Pedro de Rábago cura propio de la iglesia parroquial del Salvador de esta ciudad de Valladolid habiendo precedido las tres canónicas municiones y licencia del señor provisor refrendada de Antonio López Ramírez notario de asiento su fecha en veinte de dicho mes desposé por palabras de presente que hacen verdadero matrimonio según forma de la santa madre iglesia a Manuel de Ávila natural de esta ciudad hijo legítimo de Juan de Ávila y Bentura Sedano con María Martínez natural asimismo de ella hija legítima de Joseph Martínez y Andrea Cortés fueron testigos Damián Cortés, Santiago de Escobar y Jerónimo González y lo firmé”. A.G.D.V., El Salvador, 1685M, f. 229.
} 
Tuvieron que transcurrir unos meses hasta que el matrimonio fue velado. La ceremonia, oficiada nuevamente por Pedro de Rábago, tuvo lugar el 15 de febrero de 1713 en el Convento de Nuestra Señora de la Merced ${ }^{11}$. El motivo de la elección de este cenobio quizás se debiera a que un tío de María Martínez, fray Francisco Cortés era "religioso de la Orden de Nuestra Señora de la Merced Calzada"12. Los padrinos del acto fueron los tíos de Manuel de Ávila, el matrimonio formado por María Sedano y Santiago Izquierdo; mientras que como testigos firmaron Joseph Marías, Jerónimo González y Joseph Martínez, padre de María. El matrimonio tuvo cinco vástagos, tres de los cuales llegarían a la edad adulta: María Teresa (1714), Clara (1715), Alfonsa María (1719), Feliciana (1725) y Pedro Manuel (1728).

Sería en este momento en el que Manuel se trasladaría desde la casa en que vivía por entonces, ya fuera el domicilio familiar o el de su hermano (doy casi por seguro que su madre no vivía), hasta la de su suegro, puesto que este último se había obligado en las capitulaciones matrimoniales a tenerlos "en su casa y compañía cuatro años dándoles lo necesario para sus alimentos reputado cada año a trescientos y cincuenta reales empezando desde el día que tuviere efecto el matrimonio". Este domicilio debía de estar situado en el Corral de la Copera, calle en la que, además, nació la primera hija del matrimonio: María Teresa (1714). Nos queda la duda de si por entonces Manuel tenía abierto taller propio o se encontraba trabajando en el de su hermano Pedro. El hecho de que Manuel compartiera casa con su suegro, el cual tendría allí instalado su taller parece indicarnos que el escultor aún no se habría independizado.

Como acabamos de comentar, dos años después, el 3 de abril de 1714, Manuel y María se ven bendecidos con la llegada de su primer hijo, en este caso hija, llamada María Teresa $^{13}$. Como testigos acudieron los plateros Damián Cortés (tío de María Martínez) y Joseph Martínez (abuelo de María Teresa) y Pedro de Ávila (tío de la recién nacida).

El 6 de noviembre de 1714, encontrándose de paso por "Tordesillas a ajustar un poco de obra", se acerca al lugar de Torrecilla de la Abadesa, localidad situada a unos pocos kilómetros de Tordesillas, para cobrar unas cantidades que le estaba adeudando esta parroquia a su hermano Pedro a cuenta de un Crucifijo que les había esculpido. Ese mismo día el dorador Manuel Barreda escribía al párroco de Torrecilla de la Abadesa para presentarle a Manuel de Ávila ${ }^{14}$. El Crucifijo, ya terminado, estaba en poder de Barreda, el cual estaría listo para proceder a su policromado. Al día siguiente, Manuel otorgaba en nombre de su hermano Pedro carta de pago por valor de 120 reales $^{15}$.

11 "En quince de febrero de mil setecientos y trece yo Pedro de Rábago cura propio de esta iglesia parroquial del Salvador de Valladolid en el Convento de Nuestra Señora de la Merced velé in facie ecclesiae y di las bendiciones nupciales según forma de la santa madre iglesia a Manuel de Ávila y María Martínez mis parroquianos cuya partida de desposorio está al folio doscientos y veinte y nueve de este libro fueron sus padrinos Santiago Izquierdo y doña María Sedano siendo testigos Joseph Martínez, Joseph Marías y Jerónimo González”. A.G.D.V., El Salvador, 1685M, f. 233.

$12 \quad$ A.H.P.V., Leg. 2.381, f. 281.

13 A.G.D.V., Valladolid, San Miguel, 1705B, f. 82.

14 PARRADO DEL OLMO, Jesús María: Datos histórico artísticos..., op. cit., p. 106.

15 "Manuel de Ávila, maestro de escultura, vecino de la ciudad de Valladolid, confieso haber recibido de la mano del Licenciado Santiago Crespo, cura de Torrecilla, 120 reales, los setenta reales que 
Finalmente, el día 23 del mismo mes, Manuel expidió una nueva carta de pago por los últimos 120 reales que se le debían a su hermano ${ }^{16}$. Dos cosas quedan claras: lo primero son las excelentes relaciones existentes entre ambos hermanos; $\mathrm{y}$, lo segundo, que Manuel de Ávila debió de permanecer en Tordesillas alrededor de dos semanas, seguramente durante el tiempo que se tardaba en adjudicar una obra para la que nuestro escultor había pujado. Por otro lado, no hemos podido documentar ese "poco de obra" a que se refiere Manuel Barreda. Es probable que esas obras fueran los cuatro Ángeles del órgano, realizados entre finales de 1714 y comienzos de 1715, cuyas hechuras contrató de manera conjunta con Antonio Gautúa ${ }^{17}$; y los Arcángeles San Miguel y San Rafael, todos ellos ubicados en la iglesia de San Pedro de Tordesillas.

A comienzos del año 1715 su esposa vuelve a quedarse embarazada, dando a luz el 12 de agosto de ese año a una niña a la que llamaron Clara ${ }^{18}$. No cabe duda de que sus padres eligieron ese nombre teniendo en cuenta que ese día se celebraba la festividad de Santa Clara de Asís (1194-1253), fundadora de la segunda orden franciscana o de hermanas clarisas, y asimismo hermana de San Francisco. En la actualidad la fiesta de la santa se celebra el día 11 de agosto, fecha en la que la Santa Clara falleció en Asís en el año 1253, a pesar de que antiguamente los fastos tenían lugar el 12 de agosto.

Hacia este mismo año de 1715 debía de encontrarse realizando las esculturas y relieves del retablo mayor de la iglesia de Nuestra Señora de la Antigua de Fuentes de Valdepero (Palencia). Aunque no poseemos ni el contrato de ejecución ni un pequeño registro en los libros de fábrica, creemos que esta fecha es la más aproximada puesto que en un poder otorgado por Tomás de Sierra a mediados de año 1715 se hace referencia a que el retablo "ha corrido y corre su ejecución a cargo de Alonso Manzano arquitecto y por lo que mira a la escultura para el mismo retablo está el susodicho la ajusto con mi el otorgante quedando a mi cuidado el hacerla" (DOCUMENTO 96). No sabemos qué sucedió, pero al final Sierra no fue el encargado de tallar las esculturas, tarea de la que se ocupó Manuel de Ávila. Parece lógico pensar que sería durante aquellos mismos momentos en los que el licenciado don Antonio Marcos, beneficiado mayor de la parroquia, le encargaría la imagen de Santa Bárbara que preside uno de los retablos de la cabecera de la iglesia.

dio Juan Crespo de la limosna que se sacaba por el lugar; los cincuenta dijo el cura de mi dinero, y es por cuenta de la hechura del Santo Cristo, que está fabricando en casa de Pedro de Ávila, vecino de dicha ciudad. Y por verdad lo firmé en Torrecilla de la Abadesa, a 7 de noviembre de 1714 años". Manuel de Ávila. Ibídem.

16 "Digo yo Manuel de Ávila escultor y vecino de la ciudad de Valladolid que recibí del Licenciado Santiago Crespo cura propio de la villa de Torrecilla de la Abadesa ciento y veinte reales de vellón con que acabó de pagar la hechura de un Santo Cristo que hizo para dicha villa y por verdad lo firmé en Torrecilla y 23 de noviembre de 1714. Vale 120 reales de vellón. Entregué yo el Licenciado a Don Santiago Crespo de éste recibo 117 reales y el cura 3 reales”. A.G.D.V., Torrecilla de la Abadesa, Iglesia de San Esteban, Legajo de papeles sueltos.

17 "195 reales que pagó a Antonio de Gaute, vecino de Valladolid, maestro escultor, por la hechura de cuatro niños que se pusieron en los arbotantes del órgano nuevo. Consta de recibos de dicho maestro y de Joseph de Ávila, también maestro de dicho arte". ARA GIL, Clementina Julia y PARRADO DEL OLMO, Jesús María: Catálogo Monumental de la provincia de Valladolid. Tomo XI..., op. cit., p. 234.

18 A.G.D.V., Valladolid. San Miguel, 1705B, f. 98. 
Pasados los cuatro años que Manuel y su esposa permanecerían viviendo en la casa del suegro y padre respectivamente, la pareja y sus dos hijas (María Teresa y Clara) se trasladarían a un nuevo inmueble. Desconocemos cual sería éste, quizás el mismo en el que vivían en noviembre de 1725 cuando nació su hija Feliciana: "junto a las Angustias". Esta misma casa será misma que se cita en 1728 en la partida de bautismo de su hijo Pedro Manuel: "que viven a la Plazuela del Almirante de Castilla". Ese "junto a las Angustias" sin duda hará referencia a que la casa lindaría pared con pared con la referida iglesia, por lo tanto, dos serían las opciones: el portal que hacía esquina entre la Plaza del Almirante y la calle de los Baños; o bien la casa situada justo a la derecha de la iglesia, es decir, frente a la portada de la denominada "Sala de Pasos" de la cofradía.

El 10 de marzo de 1717 vemos a nuestro escultor firmar como testigo en el testamento otorgado por Juana Fernández Andrade ${ }^{19}$. Desconocemos cuál sería su relación con esta mujer, pero seguramente se tratará de alguna vecina con la que mantendría amistad debido a que ambos vivían en el barrio de San Miguel.

El 23 de enero de 1719 Manuel y su esposa se ven bendecidos con la llegada de una nueva hija: Alfonsa María de la Paz, a la cual llevan a bautizar a la iglesia de San Miguel el 1 de febrero de ese año ${ }^{20}$. No cabe duda de que se la impuso el nombre de Alfonsa por haber nacido el día en que se festeja a San Ildefonso de Toledo (607-667), santo cuyo nombre es una variante de Alfonso.

En 1720 realiza unos "niños de los dos retablos" con destino al Oratorio de San Felipe Neri de Valladolid. Estos ángeles vendrían a decorar los retablos de la Magdalena y San Antonio, cuyas esculturas principales las había realizado su hermano Pedro ${ }^{21}$. No cabe duda de que la contratación de Manuel vino propiciada por Pedro de Ávila, ya fuera porque se lo recomendó a la Congregación de San Felipe Neri o bien porque era uno de los miembros de su equipo. El 18 de octubre de ese mismo año sale por fiador de su suegro, Joseph Martínez, en el arrendamiento que hace éste de una casa, propiedad del cabildo catedralicio, sita en "la calle de la Platería parroquia del Salvador que llaman la casa de Andrés Requejo"22.

El 12 de agosto de 1721 su hermana Teresa, sintiéndose enferma, otorga un poder para testar a favor su marido para que cuando ella muriera éste pudiera redactar su testamento (DOCUMENTO 7). En el dicho poder nombraba por sus testamentarios a su marido, Santiago Barba, y a Pedro de Ávila. También notificaba que entregaba a María Martínez, mujer de Manuel, "dos casacas de paño, una azul y otra negra y un guardapiés de droguete”. Extraña el hecho de ver a Teresa hablar de María Martínez

19 "el cual otorgo ante el presente escribano y testigos en la ciudad de Valladolid a diez días del mes de marzo de mil setecientos y diez y siete años siendo testigos Gregorio de Velasco Campo, Pedro Alonso maestro platero, Francisco Mozo, Manuel de Ávila y Francisco Ortega vecinos y estantes en esta ciudad". A.H.P.V., Leg. 2.961, ff. 33-35.

20 A.G.D.V., San Miguel, 1705B, p. 142.

21 GARCÍA CHICO, Esteban: Documentos para el estudio del arte en Castilla. 2..., op. cit., p. 375.

22 A.H.P.V., Leg. 3.023/2, f. 673. 
como "hija de Joseph Martínez", al mismo tiempo que al referirse a la esposa de Pedro de Ávila no la cita como "hija de Juan Antonio de la Peña", sino como "mujer de Pedro de Ávila”, que es lo que era.

Manuel vuelve a ser padre el 20 de noviembre de 1725. Este día nace su cuarta hija, a la que pusieron el nombre de Feliciana ${ }^{23}$. El motivo de este nombre tendrá relación en que este día se celebra la festividad del trinitario francés San Félix de Valois (1212-1262).

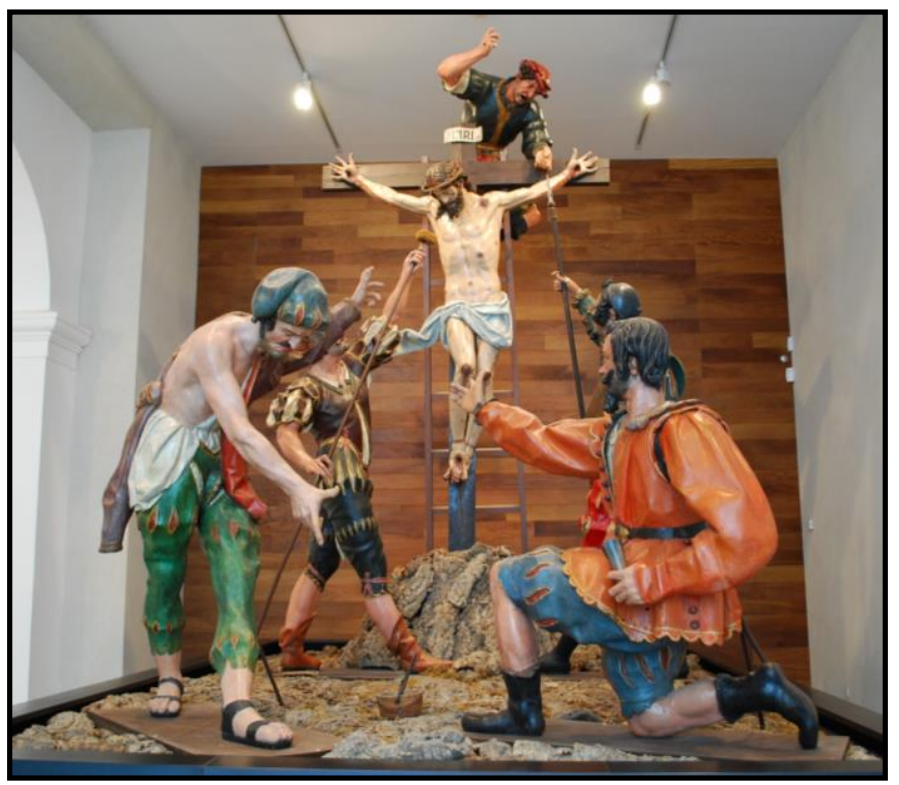

Il. 2- Gregorio Fernández. Paso de "Sed Tengo". Museo Nacional de Escultura. Valladolid.
Entre los años 1726 y 1733 efectúa diversos arreglos en las esculturas del paso de Cristo Crucificado (actual Sed Tengo). Es la primera ocasión en que le vemos trabajar para la Cofradía de N. P. Jesús Nazareno, de la cual era miembro. Se hicieron dos arreglos "en el sayón del caldero, incluso unos argollones que se le pusieron en la pierna derecha $y$ otro $n$ el de la escalera" 24 .

El 6 de mayo de 1728 nace su quinto hijo, y primer varón, Manuel Pedro ${ }^{25}$. Podríamos pensar que el nombre obedecía a la suma del nombre del padre y del hermano de éste (Pedro de Ávila). Pero también podría ser que se le pusiera ese nombre en honor a San Pedro Nolasco (ca. 1180-1245), cuya festividad se celebra el 6 de mayo. Tras este nacimiento, aunque en fecha imprecisa, si bien no debió ser muy posterior, la familia volvió a cambiarse de domicilio. El destino fue la calle de San Miguel, la misma en la que vivía su hermano Pedro y en la que murió Manuel en 1733, puesto que su partida de defunción se aludía a que era "morador a la calle de San Miguel".

El 22 de abril de 1730 volvemos a ver a Manuel de Ávila como testigo. En esta ocasión será en el arrendamiento de una casa, situada en "la callejuela de las cantarranas que mira al esgueva y afrenta a la espalda de la platería", que realizan Manuel Lorenzo y su mujer Isabel Fresca a la Venerable Orden Tercera del Convento de San Francisco ${ }^{26}$.

A.G.D.V., Catedral, 1681B, f. 372.

ARRIBAS ARRANZ, Filemón: La Cofradía..., op. cit., p. 89.

A.G.D.V., Catedral, 1681B, f. 388.

A.H.P.V., Leg. 3.187, f. 47. 
En este mismo año de 1730 comienza a labrar para la Cofradía Penitencial de N. P. Jesús Nazareno la escultura por la que será más conocido, y a la vez la única que se había documentado hasta hace unos pocos años: San José con el Niño ${ }^{27}$; en ella podemos ver claramente que se formó en el estilo de su hermano Pedro. El 16 de febrero de ese año el cofrade Pedro González expuso la conveniencia de que se hiciese "un San Joseph de bulto, del tamaño natural, con el Niño Dios en los brazos" $" 28$ para ponerle en el colateral del lado de la sacristía. Seguidamente, González hizo presente que un Manuel de Ávila, se ofrecía gratuitamente, comprometiéndose a hacerle "con todo primor por ser su habilidad bien conocida en esta ciudad" $^{29}$, si se le concedían honores de diputado. El hecho de que se ofrezca a realizar de manera gratuita la escultura a cambio de que se le concedan honores de diputado nos deja entrever a un escultor muy laborioso, circunstancia que no

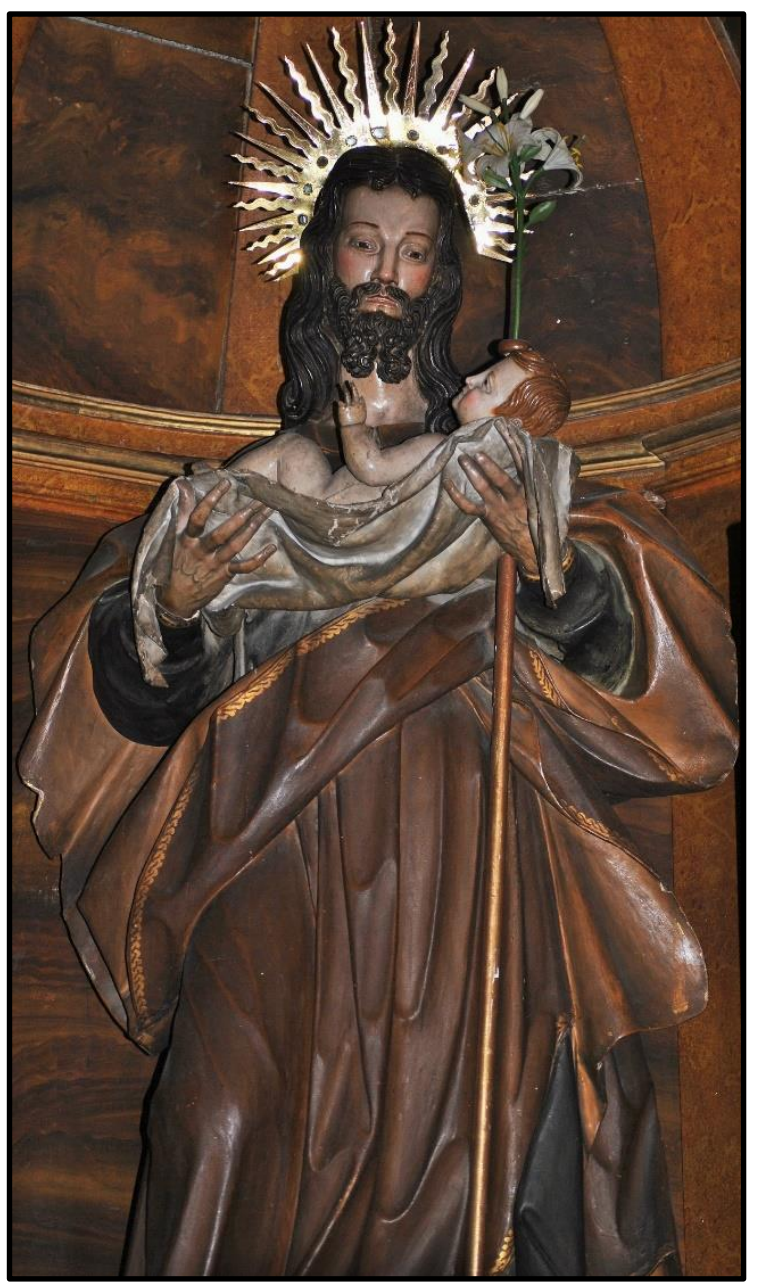

Il. 3- Manuel de Ávila. San José con el Niño. Iglesia penitencial de N. P. Jesús Nazareno. Valladolid. vemos reflejada en sus obras documentadas; puesto que esto venía a significar que deseaba que se le reservasen de los oficios menores de la cofradía, los cuales traían consigo un importante gasto de horas que tendría que restar de las dedicadas a su oficio.

A comienzos de septiembre de 1733, el día 4, Manuel, encontrándose "enfermo en la cama de enfermedad corporal y Dios nuestro señor sea servido darme aunque en mi sano juicio y entendimiento natural", ordena redactar un poder para testar a favor de su esposa María Martínez (DOCUMENTO 91) dado que la gravedad de la enfermedad que padecía era tal que no le permitía ni disponer testamento. En él ordenaba que su mujer fuera la encargada de otorgar el "testamento y última voluntad en mi nombre con la disposición de entierro misas y demás que la tengo comunicado y tratado con que no se entienda a señalar sepultura y testamentarios y herederos que esto lo reservo en mî". El lugar elegido por Ávila para su descanso eterno fue la iglesia de San Miguel, feligresía en la que vivió durante sus últimos años. Aunque en el poder no figura, y dado lo habitual de la cláusula, seguramente sería enterrado con el hábito de la Orden de

27 ARRIBAS ARRANZ, Filemón: La Cofradía..., op. cit., p. 133.

28 Ídem, p. 92.

29 http://nazarenovalladolid.com/nv/index.php/imagenes/otras-imagenes. 
San Francisco. En cuanto a sus testamentarios y albaceas, el escultor se decantó por su esposa, María Martínez, y por su hermano Pedro de Ávila; el único que aún le quedaba vivo y con el que había mantenido unos lazos estrechísimos tanto a nivel laboral como personal; no podemos obviar que ambos hermanos vivían a tan solo un par de calles de distancia, con lo cual el trato sería diario.

Como no podía ser de otra manera nombraba e instituía por herederos universales a Clara, María y Manuel "mis hijos legítimos y de legítimo matrimonio habidos con la dicha María Martínez mi mujer para que lo harán y hereden con la bendición Dios y la mía en iguales partes". Al encontrarse todos ellos en minoría de edad "desde luego valiéndome del derecho y por leyes de estos reinos me es concedido nombro por curadora de sus personas y bienes a la dicha $D^{a}$ María Martínez su madre a quien la relevo de toda fianza por la mucha satisfacción que de ella y su cristiandad tengo y pido y suplico a todos los señores jueces y justicias donde ocurriere a pedir el discernimiento se le conceda sin ella". Entre los testigos firmantes de la escritura figuran Manuel Rodríguez, que posiblemente se trate del ensamblador vallisoletano; y Alonso Carnicero, tallista de la misma vecindad con el que colaboraría en la obra de los retablos de San Antonio y la Magdalena del Oratorio de San Felipe Neri de Valladolid.

La agonía del escultor debió de ser larga puesto que no falleció en su casa de la calle de San Miguel hasta el día 27 de ese mismo mes. Tal y como deseaba fue sepultado en la desaparecida iglesia parroquial de San Miguel $^{30}$. Su viuda, que no volvería a contraer matrimonio, le sobreviviría bastantes años. Falleció el 14 de abril de 1756, siendo también enterrada en la iglesia de San Miguel $^{31}$. Por su sepultura se abonaron 33 reales y por el hachero y paño otros 8 reales.

Hemos de lamentarnos del temprano fallecimiento del benjamín de los Ávila puesto que su obra, aunque no llegara a las cotas de la calidad que alcanzó su hermano Pedro, nos mostraba a un excelente escultor que hubiera sido un dignísimo "rival" en el segundo tercio del siglo XVIII de Antonio de Gautúa, Pedro Bahamonde, Pedro de Sierra y Felipe Espinabete, los grandes dominadores de la escultura vallisoletana de esta época. Su temprana pérdida unida a la escasa obra que le tenemos documentada hace que nos duela más el no conocer las esculturas que talló que le hicieron merecer tales alabanzas como las que le dedicó un cofrade de Jesús Nazareno cuando Ávila propuso realizar de manera gratuita la escultura de San José: “con todo primor por ser su habilidad bien conocida en esta ciudad"32. La desaparición de muchos legajos, iglesias y conventos; además de la Desamortización parece que terminaron por enterrar su legado. Tampoco

$30 \quad$ "En veinte y siete de septiembre año de mil setecientos y treinta y tres habiendo recibido los santos sacramentos, murió Manuel de Ávila, marido que fue de María Martínez, y morador a la calle de San Miguel. Enterrose en esta parroquial de San Miguel y como cura propio de ella lo firme en Valladolid”. A.G D V., Valladolid, San Miguel, 1711D, f. 105.

31 "En catorce de marzo, año de mil setecientos y cincuenta y seis habiendo recibido los Santos Sacramentos de Penitencia y Comunión, murió María Martínez, viuda de Manuel de Ávila y moradora que fue a Cantarranas. Enterrose en esta iglesia parroquial de San Miguel (no hizo testamento) y como teniente cura que soy de dicha iglesia lo firmé en Valladolid". A.G.D.V., Valladolid, San Miguel, 1711D, f. 205.

32 ARRIBAS ARRANZ, Filemón: La Cofradía..., op. cit., p. 93. 
podemos pasar por alto el hecho de que, debido al parecido que guardaba su estilo con el de su hermano Pedro, algunas de las obras que hemos atribuido a Pedro puedan ser de Manuel. Una de dichas tallas quizás sea el Cristo Resucitado conservado en el Museo de Arte Sacro de Ampudia (Palencia), el cual desde antiguo se viene relacionando con Pedro de Ávila. El parecido que guarda su rostro con el del San José de la Cofradía de N. P. Jesús Nazareno; y el hecho de que Ampudia no se encuentre muy lejos de Fuentes de Valdepero (Palencia), localidad en la que se encuentra una de sus pocas obras documentadas, podrían apuntar en esa dirección.

\section{1-2 LA FAMILIA}

A continuación, nos vamos a referir, exclusivamente, a la familia de Manuel de Ávila. En ningún caso se va a hacer referencia a la vida de su padre ni de sus hermanos, puesto que de esto ya nos hemos ocupado al hablar de las familias de Juan y Pedro de Ávila.

\section{A-ABUELO MATERNO: MATEO SEDANO ENRÍQUEZ}

Parece que Mateo Sedano fue el escultor de mayor importancia en la ciudad de Palencia a lo largo del segundo y tercer cuarto del siglo XVII. Siguió de cerca los modelos creados por Gregorio Fernández tal y como lo podemos comprobar en su Inmaculada Concepción. Referente a este aspecto, Martín González definió su formación como realizada "bajo el influjo de Gregorio Fernández"33.

Desconocemos cuándo nació Mateo Sedano, si bien parece que debió suceder en Palencia con posterioridad a 1612, año en que nace su hermano mayor Juan Sedano. Sus padres fueron el escultor Juan Sedano, fallecido en 1636, y Catalina Enríquez ${ }^{34}$. El matrimonio dio otros dos hermanos a Mateo, los cuales también se dedicaron a la escultura: Juan y Carlos, si bien el primero de ellos parece que debió de practicar preferentemente el oficio de ensamblador.

Contrajo matrimonio en dos ocasiones. Su primera esposa fue Isabel Caballero, con la cual tuvo a su hija Isabel (se tratará de Bentura Sedano, segunda mujer de Juan de Ávila, padre de nuestro Manuel de Ávila); tras el fallecimiento de ésta casó en segundas nupcias con Inés de Osorno, que le dio otros dos hijos: María y Francisco.

El 20 de julio 1653 el cabildo palentino realiza el juramento en defensa del dogma de la Inmaculada Concepción de la Virgen María ${ }^{35}$. Aquella ceremonia no la pudo presidir

33 MARTÍN GONZÁLEZ, Juan José: Escultura barroca castellana. Segunda parte..., op. cit., p. 216.

34 GARCÍA CUESTA, Timoteo: "El retablo de la Inmaculada, de la Catedral de Palencia y noticia de los Sedano", B.S.A.A., Tomo XXVIII, 1962, p. 183.

35 Ídem, p. 182 
ninguna imagen dado lo apresurado del momento, y así lo evidencia un acuerdo catedralicio del día 9 de mayo de ese mismo año: "El tercero, que es si se trae a Nuestra Señora de la Calle [a la Catedral] para colocarla en nombre de Nuestra Señora de la Concepción, acordaron, habiéndolo votado por habas secretas, no sería posible poderse prevenir imagen de Nuestra Señora de la Concepción, conforme el deseo de todos" ${ }^{\prime 36}$. Finalmente le encargaron a Sedano la realización de una Inmaculada Concepción, que será una de sus escasas obras documentadas, aunque en la que puso mayor empeño. La escultura sigue fielmente el modelo creado por Gregorio Fernández.

El 2 de noviembre de 1664 sale por fiador, junto con Luis de Madrid y Joseph de Soto, de su hermano Juan en el contrato que hace este último para fabricar el "retablo mayor con dos colaterales a los lados" de la iglesia parroquial de Santervás de la Vega (Palencia) $^{37}$.

El 14 de marzo de 1679 contrata junto a su hermano Juan la realización del retablo de la capilla de la Cruz de la catedral de Palencia, retablo que iría presidido por la Inmaculada que el propio Sedano había tallado décadas atrás ${ }^{38}$.

El 25 de enero de 1681 los capitulares de la catedral palentina le otorgan el título de maestro de obras de la seo: "Sábado, 25 de enero de 1681. Este día se vio una petición de Mateo Sedano, escultor, en que representaba lo mucho que deseaba servir al Cabildo en todas las obras que en esta santa iglesia se ofreciesen, y así suplicaba le honrase con el título de ellas y su maestro, como le había tenido su hermano Juan Sedano, por cuya muerte había quedado a su cargo acabar el retablo que ambos tenían comenzado para la capilla de la Cruz y que estimaría

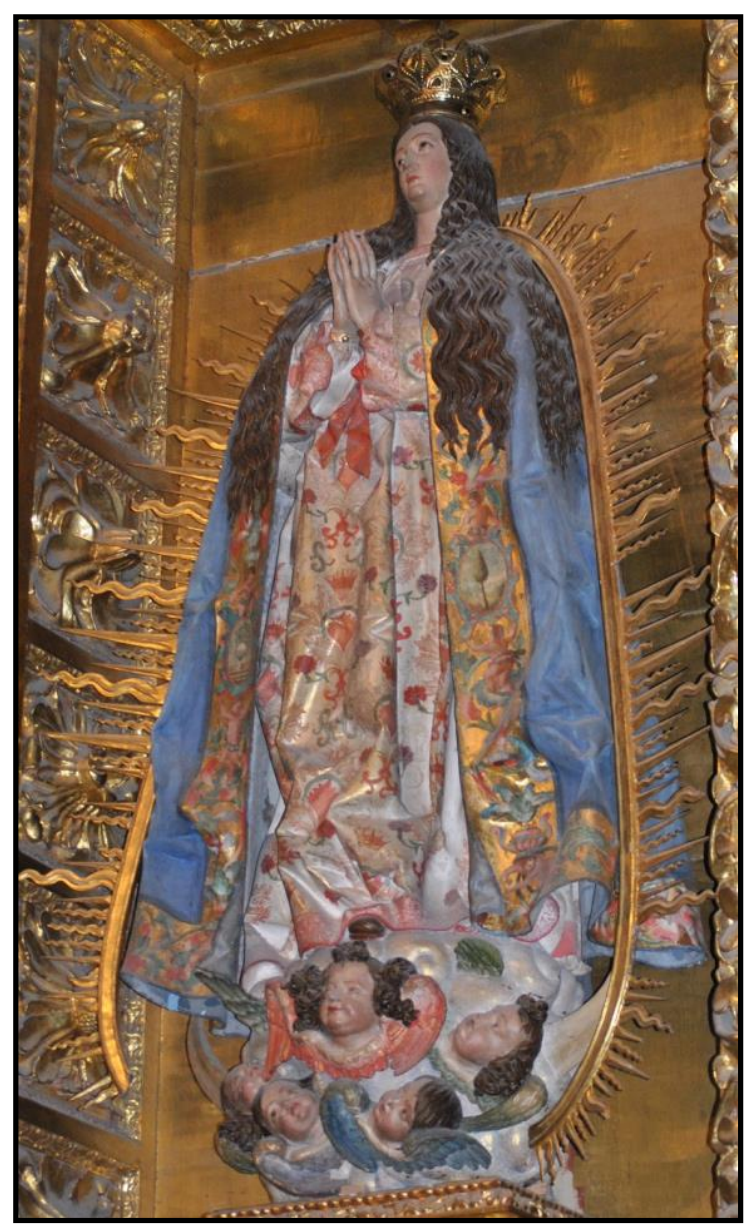

Il. 4- Mateo Sedano. Inmaculada Concepción. Catedral. Palencia. mucho este favor. Y entendida por el cabildo, respondió el señor don Andrés de Ysla, obrero de la fábrica, haber dado esta ocupación a Carlos Sedano que llegó primeo a pedírsela; pero que todo cabía en lo que el cabildo gustase. Y en esta consideración, el

\footnotetext{
$36 \quad$ Ibídem.

37 Ídem, pp. 197-200.
}

38 Ídem, pp. 203-208. 
Cabildo acordó que ambos, pues eran hermanos, tuviesen el título de maestros de las obras de la iglesia" 39 .

El 1 de mayo de 1684 Inés de Osorno, su mujer, encontrándose "enferma en la cama de enfermedad corporal que Dios nuestro señor ha sido servido de me dar sana de mi juicio y entendimiento natural temiéndome como me temo de la muerte que es cosa cierta a toda criatura" decide dictar testamento ${ }^{40}$. En él exponía su deseo de que su cuerpo, previamente revestido con el "hábito de Nuestro Padre San Buenaventura", fuera sepultado "en la iglesia catedral de esta ciudad en la sepultura que enfrente de Nuestra Señora la Blanca que tiene el dicho mi marido". En lo referente a los legados, mandaba se dieran "lutos enteros de bayeta de cien hilos al dicho mi marido y al licenciado don Bernardo Osorno mi hermano y a María Sedano mi hija"; y a su hijo Francisco "por el mucho amor y cariño que le tengo y hallarse como se halla manco y baldado el tercio de mis bienes y remanente del quinto de ellos en lo cual desde luego le mejoro en la mejor forma que puedo y me sea permitido por leyes de estos reinos por ser así mi voluntad". Finalmente, nombraba como testamentarios a su marido Mateo Sedano y a su hermano Bernardo de Osorno, y como herederos universales a sus dos hijos, María y Francisco.

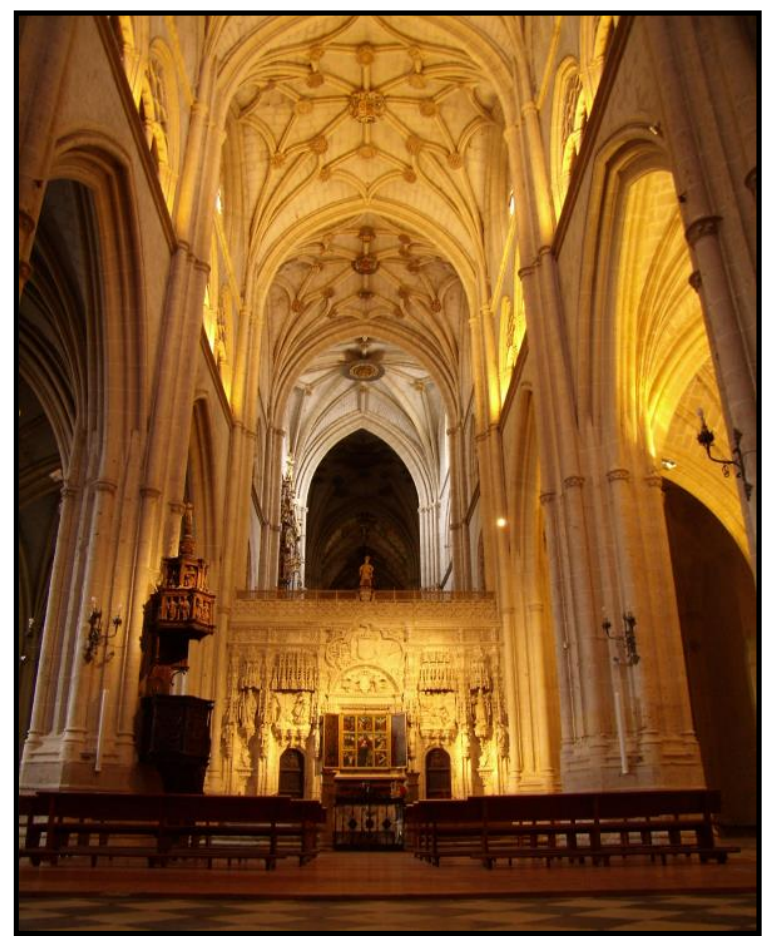

Il. 5- Catedral. Palencia.

Mateo Sedano fallece el domingo día 22 de septiembre de 1686 "a hora de las nueve de la noche poco más o menos requiescat in pace amen", siendo sepultado según fue su deseo en "la santa iglesia catedral de esta ciudad, frontero de la capilla de Señora Santa Ana, y en la sepultura donde lo están Juan Sedano y Catalina Enríquez, mis padres y señores, que santa gloria hayan". Un día antes había dictado testamento, gracias al cual podemos obtener algunos datos más acerca del escultor $^{41}$. En él ordenaba que su cuerpo fuera sepultado "con el hábito de San Francisco". A su entierro deberían de asistir "doce capellanes del número de dicha iglesia catedral con sus capas y cetros como acostumbran" y "las cofradías del Santísimo Sacramento de la iglesia parroquial de Santa María, Jesús Nazareno, San Pedro mártir, San Andrés, Santa Ana, San José, y los Santos Mártires de

Ídem, p. 183.

A.H.P.P., Leg. 6.670, ff. 1.010-1.011 (1684).

GARCÍA CUESTA, Timoteo: "El retablo...”, op. cit., pp. 183-184. Tras el cambio de signaturas de los legajos efectuado en el Archivo Histórico Provincial de Palencia, la referencia actual es: A.H.P.P., Leg. 7.232. 
las cuales soy indigno cofrade las cuales asistan con la cera e insignias que acostumbran para con los demás hermanos". Ordenaba se dijesen por su alma 100 misas rezadas "la cuarta funeral para la parroquia y las demás se dirán donde quisieren mis testamentarios". Además, al igual que su esposa, deseaba que todos los domingos y "fiestas del primer año de mi fallecimiento se lleve añal sobre mi sepultura poniendo por ofrenda un cuartal de pan dos velas y un librillo de cera tirado". En cuanto a temas relacionados con su oficio, señala que el deán y el cabildo catedralicio le estaban debiendo 1.500 reales "con poca diferencia los cuales son y proceden de resto del retablo que hizo para la capilla de la Cruz de dicha iglesia". Finalmente, mandaba entregar a su cuñado el licenciado Bernardo de Osorno "capellán de coro de la iglesia catedral de la ciudad de Valladolid un luto a su disposición"; además, nombraba como testamentarios a su propio cuñado y a don Andrés de Santiago, canónigo de la catedral palentino; y como herederos universales a "a Isabel mi hija legítima y de Isabel Caballero mi primera mujer, y a María asimismo mi hija legítima y de Inés de Osorno mi segunda mujer ya difunta para que lo hereden por iguales partes con la bendición de Dios y la mía".

Un día después, el 23 de septiembre, el teniente de corregidor palentino, don Domingo Joseph de Valcárcel, ante la circunstancia de que uno de sus testamentarios, don Andrés de Santiago, no aceptara el cargo, y que el otro, su cuñado Bernardo de Osorno se hallara ausente; y que sus dos hijas también "se halla ausentes de esta ciudad"; se decide dar comisión al escribano que redactó su testamento para proceder a inventariar los bienes del difunto escultor ${ }^{42}$. Así se hizo, y el escribano se presentó en las casas en que había morado Mateo Sedano, sitas "en la calle que llaman de Mazorqueros que hacen esquina frontero de la portería del Convento de Nuestra Señora del Carmen y lindan por una parte con casas que fueron de Baltasar de Aguilar y por otra casa de la capellanía que fundó Isabel Fernández de Manzanares", y con asistencia de "Carlos Sedano hermano de dicho difunto y de Luis de Madrid barbero" se comenzó a hacer inventario de los bienes que poseyó el artista. A la vista de la cantidad de bienes que se inventarían podemos hablar de un escultor con bastantes posibles, en los que destacaba la cantidad de pinturas repartidas por los diferentes ambientes del domicilio.

En la sala principal tenía "una hechura de San Miguel de bulto con el pecado a los pies y su peana de tres cuartas de alto", y "dos cabezas de ángeles de pasta con sus alas pequeñitos"; en el cuarto junto al portal "una cabeza de un Niño Jesús pequeña dada de encarnación"; y en la cocina una "hechura de una imagen de piedra de media vara de alta". No sabemos si todas, o alguna de estas imágenes, fueron obra del propio escultor; parece claro que al menos la cabeza de Niño Jesús dada de encarnación sí, la cual se encontraría en proceso de finalización, quizás secándose.

En un "aposento junto a la escalera" se guardaba un "escaparatico pequeño de pico con su cerradura y llave", dentro del cual se hallaba gran parte de su material de trabajo, como eran libros, estampas, modelos, etc...: "Primeramente nueve libros

$42 \quad$ A.H.P.P., Leg. 7.232. 
medianos y pequeños empergaminados y el uno de ellos encuadernado en tablas y todos de arte de arquitectura, otros dos libros empergaminados el uno de estampas y el otro dibujado de mano para el dicho arte, una docena de trazas en papel de marca pequeñas y medianas, dos ramilleticos hechuras de ciprés de seda deshilada verde, item dos libros descuadernados muy viejos de estampa dibujadas, y un relicario mediano con dos veriles y dos anus y su marco redondo dorado". Y además "docena y media de modelos de diferentes hechuras de santos, cabezas de ángeles, brazos y otros géneros del dicho arte de arquitectura, unos de cera y otros de barro, viejos".

Finalmente, en su taller se encontraban las esculturas en las que se encontraba enfrascado el artista en el momento de su fallecimiento. Lamentablemente desconocemos para qué lugar o personas estaban destinadas, lo que parece previsible es que se encargaría de rematarlas su hermano Carlos Sedano. Así, por ejemplo, en cuanto a esculturas tenía: "Cuatro hechuras de santos Cristos de madera medianos los tres sin brazos y otro con ellos que no están acabados de hacer", "una hechura de un San Juan de bulto de tres cuartas de alto de pino y no está acabado de hacer", "otra hechura de San Antonio de bulto de media vara de alto que tan poco está acabado de hacer", "medio cuerpo para un santo con su cabeza y brazos de bulto y no está acabado de hacer", "otra hechura de San Sebastián de bulto mediana que no está más que desbastada", y "dos cabezas de madera de tornear con sus bigornias". Que también fue ensamblador nos lo indica, además de la noticia de que talló de manera conjunta con su hermano Juan el retablo de la capilla de la Cruz de la catedral de Palencia, los siguientes elementos que se encontraba acabando en su taller: "una burna para una custodia mediana tallada no está acabada de hacer y es de pino", "cuatro columnas salomónicas de peral mediana revestidas de racimos y hojas de parra", "un pedestal, cuatro columnas salomónicas revestidas de hojas de parra y racimos con su caja en medio, capiteles, florones sueltos todo de pino y de talla para un retablo y no está acabado de hacer", y "un frontispicio de retablo mediano dorado".

Una vez inventariados todos los bienes, el escribano recibió juramento de "Bernarda García criada del difunto, y de Carlos Sedano y Antonia de Aguilar su mujer por Dios nuestro señor y a una señal de cruz para que si tuviesen más bienes que inventariar los declarasen y los susodichos juraron en forma de cómo no hay más bienes ni saben ni entienden haya otros algunos dé por inventariar". Posteriormente, el referido teniente de corregidor de Palencia ordenó "que todos ellos se depositaren y pongan en poder del licenciado don Bernardo de Osorno presbítero y capellán del número de la santa iglesia catedral de la ciudad de Valladolid (...) con tal que el dicho don Bernardo de Osorno dé por su fiador a Luis de Madrid barbero vecino de ella al cual se recibe por tal para que dará cuenta de todos los dichos bienes, y en caso de hacerse almoneda de ellos de su producto y donde no el dicho Luis de Madrid como su fiador lo ha de pagar de sus bienes y hacienda". Así se hizo, el 25 de septiembre de ese mismo año, Luis de Madrid "salió por fiador del dicho licenciado don Bernardo de Osorno y se obligaba y obligó en forma de que cada y cuando que por dicho señor teniente u otro juez. competente se han mandado entregar dichos bienes, expresados en dicho inventario o 
la cantidad que de ellas hubiere procedido el dicho don Bernardo de Osorno lo volverá luego que le sea pedido y donde no el otorgante como tal fiador lo pagará"43.

Un día después, el 26 de septiembre, el licenciado Osorno pide al teniente de corregidor palentino que le diera la licencia para sacar en almoneda "los dichos bienes muebles al pregón y rematen en el mayor postor" ${ }^{4}$, licencia que le fue otorgada esa misma jornada. Y Carlos Sedano, hermano del difunto adquirió "un cobertor berrendo negrillo en cinco reales" y "unas tijeras de partir chapas viejas, y una bigornia con su cepo de olmo, y un tornillo de cerrajero todo en diez y seis reales".

Su hermano Juan Sedano Enríquez (tío abuelo de nuestro Ávila) nació en Palencia en $1612^{45}$. Desde muy pequeño siguió el oficio familiar, al igual que sus otros dos hermanos Carlos y Mateo, aunque a la vista de sus obras más bien parece que fue ensamblador. Su catálogo es aún muy escaso, aunque bastante más amplio que el de Mateo: en 1625 realiza el retablo mayor y relicario de la iglesia parroquial de Fombellida (Valladolid) ${ }^{46}$; el encargado de dotar de esculturas a dicho retablo fue el también palentino Antonio de Amusco en 163047; en 1627 contrata junto al también ensamblador Pedro Rodríguez la hechura del retablo de la capilla de Nuestra Señora de la Presentación de la iglesia de San Miguel de Palencia ${ }^{48}$; en 1636 se obliga, de manera conjunta con el referido Antonio de Amusco de finalizar la custodia que había comenzado a tallar su padre en el retablo mayor de la iglesia de San Miguel de Villalón de Campos ${ }^{49}$; en 1646 los cofrades de la Cofradía de San Cosme y San Damián le encarga la realización del retablo de la capilla que poseían en el Convento de San Francisco de Palencia, "con figura e historia, como está en la capilla de los racioneros de la S. I. C. de esta ciudad"50; en 1664 ajusta la construcción del "retablo mayor con dos colaterales a los lados de la iglesia parroquial" de Santervás de la Vega (Palencia) $^{51}$; en 1665 se obliga a realizar el túmulo para las honras fúnebres del rey Felipe IV en la catedral palentina ${ }^{52}$; en 1667 se ocupa de fabricar, junto a su hermano Carlos, un retablo para una capilla de la iglesia de la Piedad de la iglesia de Herrera del Río Pisuerga (Palencia) ${ }^{53}$; en 1674 se concierta con Mariana de la Encarnación, novicia en el Convento de Recoletas Agustinas de Palencia, para realizar el retablo mayor de dicha iglesia ${ }^{54}$; y, finalmente, en 1679 , se ajusta junto con su hermano con el cabildo catedralicio de la seo palentina para fabricar el retablo de la capilla de la Cruz, el cual recibiría en su hornacina central la Inmaculada que años antes había tallado el

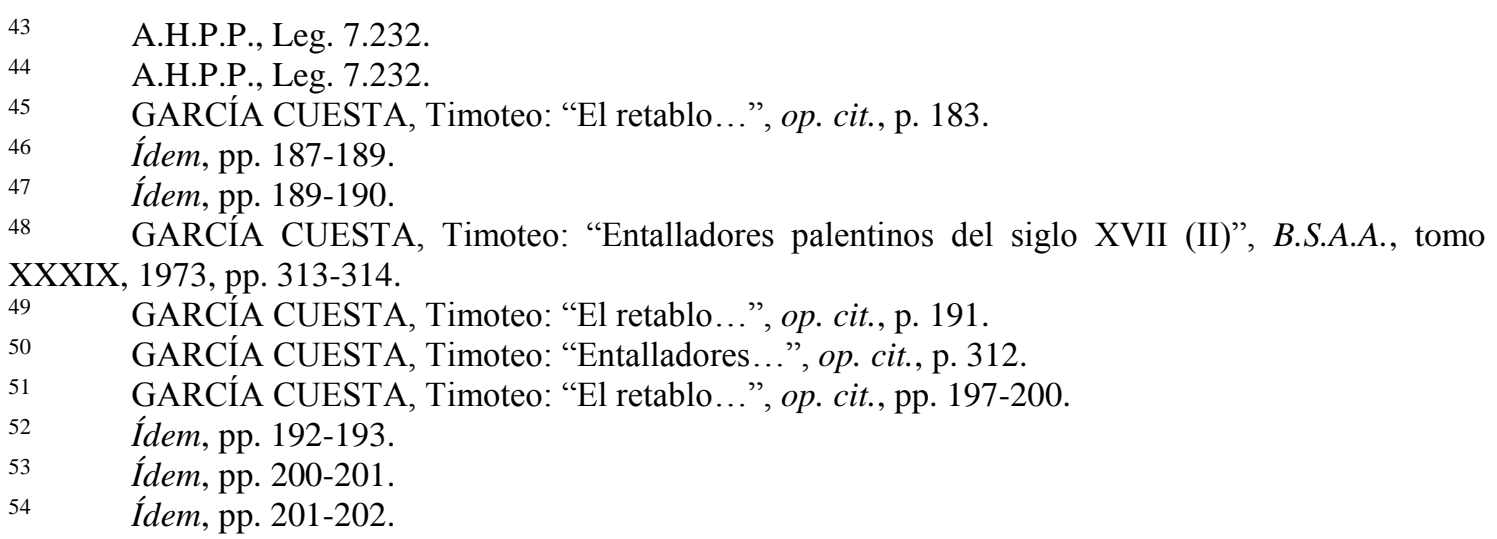


propio Mateo Sedano ${ }^{55}$. Hubo una obra que no llegó a realizar: se trataba de los retablos colaterales de la iglesia de Nuestra Señora de Pozobueno de la localidad palentina de Fuentes de Nava; efectivamente, el 17 de julio de 1676 ambas partes anularon el contrato $^{56}$.

Del que apenas tenemos datos es de su otro hermano, llamado Carlos. Sabemos que estuvo casado con una tal Antonia de Aguilar. En 1667 ayuda a su hermano Juan a fabricar un retablo para una capilla de la iglesia de la Piedad de la iglesia de Herrera del Río Pisuerga (Palencia) ${ }^{57}$. El 26 de septiembre de 1686 adquiere en la almoneda de los bienes de su hermano Mateo "un cobertor berrendo negrillo en cinco reales" y "unas tijeras de partir chapa viejas, y una bigornia con su cepo de olmo, y un tornillo de cerrajero todo en diez y seis reales" $"$.

\section{B- TÍA MATERNA: MARÍA SEDANO OSORNO}

Ya dijimos que fue fruto del segundo matrimonio de su padre, el contraído con Inés de Osorno. Debió nacer en Palencia hacia el año 1665 puesto que cuando su padre dicta testamento (1686) se dice de ella que era menor de edad, teniendo menos de 25 años, pero más de 19 años. Tuvo un hermano llamado Francisco. Extraña el hecho de que se los documentos se refieran a ella como María Sedano Enríquez y no como María Sedano Osorno, puesto que la primera fórmula hace referencia a los dos apellidos paternos.

Cuando fallece su padre, el 22 de septiembre de 1686, tanto ella como su hermana se encontraban ausentes; ya comentamos la posibilidad de que se encontraran en Valladolid al cuidado de su tío Bernardo de Osorno, capellán de coro de la catedral vallisoletana. El 30 de octubre de ese mismo año, María expuso que al ser menor de edad y dado que sus padres habían fallecido necesitaría se le nombrara "curador para regir y administrar sus bienes y hacienda usando de la facultad que el derecho la da por la presente en aquella vía y forma que mejor haya lugar de derecho nombraba y nombró por su curador de su persona y bienes al licenciado don Bernardo Osorno su tío presbítero vecino de esta dicha ciudad y pide y suplica al señor corregidor o su lugarteniente de dicha ciudad de Palencia y demás justicias donde convenga le haya por nombrado y le disciernan dicha curaduría en toda forma que el nombramiento que es necesario" $"$.

El 26 de junio de 1690 contrae matrimonio con Santiago Izquierdo en la Santa Iglesia Catedral de Valladolid ${ }^{60}$; si bien, previamente, el día 16 de junio, había firmado las

\footnotetext{
$55 \quad$ Ídem, pp. 203-208.

$56 \quad$ Ídem, p. 202.

57 GARCÍA CUESTA, Timoteo: “El retablo...”, op. cit., pp. 200-201.

58 A.H.P.P., Leg. 7.232.

$59 \quad$ A.H.P.V., Leg. 2.381, f. 362.

60 "En veinte y seis de junio de este presente año de mil seiscientos y noventa yo el licenciado don Ignacio de Villagarcía presbítero capellán de la iglesia mayor de esta ciudad de Valladolid habiendo
} 
capitulaciones matrimoniales. De la una parte compareció el tío de María, don Bernardo Osorno y Torralba "clérigo presbítero vecino de esta ciudad de Valladolid", y de la otra Santiago Izquierdo "mercader de libros vecino de esta dicha ciudad hijo legítimo de Miguel Izquierdo difunto y de Águeda Marcos vecinos de Villalumbroso obispado de León y natural que fue el dicho su padre del lugar de Guardo montañas de León"61. El clérigo Osorno "para ayuda de sustentar las cargas del matrimonio se obliga de que dará a la dicha su sobrina para que lleve por sus bienes dotales propios a poder del dicho Santiago Izquierdo que mediante Dios ha de ser su marido" 5.000 reales de vellón, los 2.880 reales "de ellos en una casa que la dicha doña María Sedano tiene en dicha ciudad de Palencia a la esquina del Convento del Carmen", y lo restante en efectivo cuando tenga efecto el matrimonio. Por su parte, el futuro marido, en virtud de que su futura esposa era "doncella honesta recogida y virtuosa y de tan gran calidad" la ofrecía de arras proternúpcias 200 ducados "que confiesa caben en la décima parte de sus bienes y en caso que no quepa se la sitúa y señala en lo mejor y más bien parado de los que adquiriere adelante". Si por cualquier caso el matrimonio se disolvía, Santiago Izquierdo "volverá y restituirá a la dicha señora doña María Sedano Enríquez o a quien en su nombre lo hubiere de haber la dote que hubiere recibido con más los doscientos ducados de las arras". Además de todo ello, Izquierdo "llevará a dicho matrimonio por su capital cien ducados que le mandó Francisco Esteban su tío y más los demás bienes que tiene de que hará inventario con citación de la dicha señora doña María Sedano para que siempre conste los bienes que cada parte lleva al dicho matrimonio". Dado que ambas partes cumplieron con lo prometido, el 16 de octubre de 1691 María Sedano le otorgaba la carta de pago de dote a su marido ${ }^{62}$.

El 15 de abril de 1717 es nombrada heredera por su tío Bernardo Osorno Torralba, presbítero capellán del número de la catedral vallisoletana; lugar, asimismo, en el que fue enterrado tras su fallecimiento, acaecido el 2 de agosto de ese mismo año ${ }^{63}$. Pocos

precedido las tres canónicas municiones que el Santo Concilio de Trento manda y asimismo licencia del licenciado Alonso Garrote y Prado cura propio de la parroquial de ella y juntamente la del señor don Francisco Zavala y Zulueta provisor general de esta dicha ciudad y todo su obispado que pasó ante Nicolás Burgueño notario de asiento de la Audiencia Episcopal su fecha dicho día de veinte y seis desposé por palabra de presente que hicieron verdadero matrimonio a Santiago Izquierdo natural de la villa de Villalumbroso en el obispado de León hijo legítimo de Miguel Izquierdo y Águeda Marcos con doña María Sedano Enríquez y Osorno, natural de la ciudad de Palencia hija legítima de Mateo Sedano Enríquez y de Inés Osorno; testigos Francisco Barcenilla, Feliciano Muñoz y Bartolomé Santos. Y asimismo dicho día de licencia del dicho cura velé a los susodichos según y cómo dispone el ritual romano y lo manda la santa madre iglesia, fueron padrinos Sebastián Estébanez y doña Luisa Seco Redondo, fueron testigos don Antonio Arguelles, Santiago López y Luis de Mojados vecinos y estantes en esta dicha ciudad, y por verdad lo firmé con dicho cura”. A.G.D.V., 1673M, ff. 152-153.

$61 \quad$ A.H.P.V., Leg. 2.382/4, ff. 58-59.

62 A.H.P.V., Leg. 2.382/4, ff. 56-57.

63 "En dos de agosto de mil setecientos y diez y siete años en la parroquial del señor San Juan Evangelista inclusa en la santa iglesia catedral de esta ciudad de Valladolid a la Librería (...) habiendo recibido sacramentos con el de la extremaunción don Bernardo Osorno Torralba presbítero capellán que fue del número de dicha santa iglesia otorgó poder para testar en quince de abril de dicho año ante Manuel Díez escribano de su majestad por el cual se mandó enterrar en San Felipe Neri de donde era congregante la demás disposición de su testamento dejó a la voluntad de Santiago Izquierdo a quien asimismo dejó por testamentario con don Juan de Toro sacristán mayor de esta santa iglesia y por 
años después, el 6 de agosto de 1721, fallece su marido, Santiago Izquierdo; el cual ordenó ser sepultado en el Convento de la Merced Calzada ${ }^{64}$.

María Sedano, que por entonces se encontraba viuda, falleció el 2 de diciembre de 1738 en la parroquia de San Juan Evangelista, inclusa en la santa iglesia catedral de Valladolid $^{65}$. Había dictado testamento el 21 de abril de 1731 ante el escribano Joseph Sanz del Río; en él ordenaba enterrarse en sepultura propia del Convento de la Merced Calzada. Nombró por testamentarios a Manuel Ceano y a Santiago Barba, y como heredero universal a Juan Ceano.

\section{C- SUEGRO: JOSEPH MARTÍNEZ}

El padre de su esposa fue el platero Joseph Martínez, uno más de los muchos que por entonces trabajaban en la ciudad, aunque a diferencia de éstos, sobre él poseemos muy pocos datos biográficos y ninguno artístico. Joseph Martínez Rodríguez nació en Valladolid el 11 de noviembre de 1663. Sus padres, Juan Martínez y Francisca Rodríguez, que por entonces vivían en la feligresía de la iglesia de San Lorenzo, le llevaron a bautizar a dicha parroquia el día 25 de ese mismo mes ${ }^{66}$.

El 8 de julio de 1685 firma, junto con sus futuras suegra y mujer, Catalina Mato y Andrea Cortés, las capitulaciones matrimoniales ${ }^{67}$. Ambas partes se comprometían a que contraerían matrimonio "según lo mandando y orden de la santa madre iglesia romana dentro de tres semanas contadas desde el día de la fecha”. Y así ocurrió, el 26 de julio la pareja contrajo matrimonio en la iglesia de El Salvador, pasando de esta

heredera a doña María Sedano mujer del dicho Santiago Izquierdo y sobrina del difunto y lo firmé". A.G.D.V., Catedral, 1684D, f. 208.

$64 \quad$ "En seis de agosto de mil setecientos y veinte y uno en la calle de la Librería habiendo recibido los santos sacramentos con el de la extremaunción murió Santiago Izquierdo bedel de la Universidad de esta ciudad y feligrés de la parroquial de San Juan Evangelista inclusa en la santa iglesia catedral de esta dicha ciudad que al presente testaba casado con doña María Sedano otorgó testamento, digo poder para testar en cuatro del dicho ante Manuel Díez escribano de su majestad y de la Real Universidad de esta ciudad a favor de doña María Sedano su mujer por el cual se mandó enterrar en el Convento de la Merced Calzada de esta ciudad, nombró por testamentarios a la dicha doña María Sedano su mujer a quien asimismo dejó por heredera a don Joseph Antón Magaz y a doña Luisa Seco vecinos de esta dicha ciudad y la sepultura en que se enterró es suya propia y lo firmé, dejó misas doscientas". A.G.D.V., Catedral, 1684D, f. 194.

65 "En dos de diciembre de mil setecientos y treinta y ocho habiendo recibido los santos sacramentos con el de la extremaunción murió en esta parroquia doña María Sedano, viuda de Santiago Izquierdo, la cual hizo testamento cerrado en veinte y uno de abril de mil setecientos y treinta y uno, el que pasó por testimonio de Joseph Sanz del Río escribano de esta Real Universidad, el cual fue abierto el día de su muerte con la solemnidad de derecho por el señor doctor don Juan Francisco de Lemos rector de dicha Real Universidad ante dicho escribano por el cual manda enterrarse en la Merced Calzada, en sepultura propia, fundó un memoria de cuatro misas cada año y para su cumplimiento dio doscientos ducados en dicho convento. Mandó se dijesen por su alma trescientas misas dejó por su único heredero a Juan Ceano, y por testamentarios al susodicho y a don Manuel Ceano y Santiago Barba, todos vecinos de esa ciudad y lo firmé como cura que soy de est aparroquia de San Juan Evangelista inclusa en dicha santa iglesia". A.G.D.V., Catedral, 1684D, f. 258.

66 A.G.D.V., San Lorenzo, 1601B, f. 396.

67 A.H.P.V., Leg. 2.381, ff. 286-287. 
manera Joseph a convertirse en cuñado del platero Damián Cortés ${ }^{68}$. La pareja tuvo numerosa descendencia: Luisa ${ }^{69}$, Joseph Facundo $(1687)^{70}$, Diego ${ }^{71}$, María Manuela $\left(1692^{72}\right.$, Santiago $(1694)^{73}$ y Catalina Felipa $(1701)^{74}$. Tenemos constancia de que el matrimonio moró en diversas casas, estando ubicadas éstas en el Corral de la Copera, en la calle de Guarnicioneros ${ }^{75}$, y en la de la Platería. En el arrendamiento de esta última morada, efectuado el 18 de octubre de 1720, fue fiado por su yerno Manuel de Ávila ${ }^{76}$. A pesar de los pocos datos que hemos conseguido encontrar sobre su persona, sabemos que durante cierto tiempo ejerció el cargo de depositario de la Cofradía de Nuestra Señora del Val y San Eloy de maestros plateros ${ }^{77}$.

El 12 de marzo de 1722 es nombrado testamentario por su cuñado, el platero Damián Cortes, cargo que desarrollaría in solidum con el cura de la iglesia de San Miguel, la mujer del finado, Lorenza Rosa de Castro, y don Pedro Martínez de la Puebla. Fallecería al día siguiente, siento enterrado en una sepultura que poseía en la iglesia conventual de San Francisco ${ }^{78}$. Así consta también en su testamento, otorgado ese mismo día ${ }^{79}$.

El 6 de diciembre de 1741 "estando enfermo en cama de la que Dios ha querido darme pero en mi sano juicio y entendimiento natural creyendo como firmemente creo en el misterio de la Santísima Trinidad y en todo lo demás" decide dictar testamento ${ }^{80}$. Entre otros datos, nos interesa saber que deseaba ser sepultado en la iglesia de San Miguel "en una de las sepulturas que tiene propias la Cofradía Sacramental”. El platero reconocía que además de ser cofrade de la de Nuestra Señora del Val y San Eloy, también lo era de la Penitencial de la Santa Vera Cruz y de la Sacramental de la iglesia de San Miguel. Instituía como herederos a sus hijos Luisa, Catalina, Joseph y María, esta última era la

68 "En veinte y seis días del mes de julio de mil y seiscientos y ochenta y cinco años habiendo precedido las tres canónicas municiones que el Santo Concilio de Trento manda y no resultado impedimento alguno y licencia del Ilmo. Señor don Diego de la Cueva y Aldana obispo de esta ciudad de Valladolid y su obispado refrendada de Marcos de Porras notario de asiento de la Audiencia Episcopal de ella su fecha de dicho día yo don Rafael García Quijano teniente de cura de esta iglesia parroquial del Salvador de esta dicha ciudad de Valladolid desposé por palabras de presente que hicieron verdadero matrimonio a Joseph Martínez natural de esta ciudad hijo legítimo de Juan Martínez y Francisca Rodríguez con Andrea Cortés natura de ella hija legítima de Pedro de Cortés y Catalina Mazo, mis parroquianos que viven a la Platería, fueron testigos Marcos Ibáñez, Juan de Paredes y Lucas Herrero y otros muchos vecinos y estantes en esta dicha ciudad de que doy fe". A.G.D.V., El Salvador, 1685M, f. 5.

69 A.G.D.V., El Salvador, 1668B, f. 389

70 A.G.D.V., El Salvador, 1666B, f. 411.

71 A.G.D.V., El Salvador, 1666B, f. 444.

72 A.G.D.V., El Salvador, 1666B, f. 489.

73 A.G.D.V., El Salvador, 1666B, f. 541.

74 A.G.D.V., El Salvador, 1697B, f. 76.

75 En la lista de vecinos que se realizó en la ciudad el 24 de julio de 1691 figura asentado en la calle Guarnicioneros, arteria perteneciente a la jurisdicción de la parroquia del Santísimo Salvador. "Joseph Martínez, platero, treinta años, casado, dos hijos”. A.H.P.V., Leg. 2.638, ff. 263-273.

76 A.H.P.V., Leg. 3.023/2, f. 673.

77 A.H.P.V., Leg. 2.822 f. 554.

78 A.G.D.V., San Miguel, 1711D, f. 46.

79 A.H.P.V., Leg. 2.963, ff. 31-34.

80 A.H.P.V., Leg. 3.282, ff. 1.165-1.166. 
esposa de Manuel de Ávila. Entre los testigos de la escritura figuran dos plateros: Sebastián de la Fuente y Juan Fernández Yáñez de la Vega.

Hemos logrado hallar dos tipos de noticias relacionadas con su oficio: unas hacen referencia a tasaciones y las otras a asientos de aprendiz. En cuanto a las tasaciones, sabemos que el 14 de abril de 1722 valúa los bienes de platería que dejó al fallecer Joseph Martín ${ }^{81}$. Por otro lado, podemos pensar que, a pesar de que su figura se nos presenta rodeada de neblina, su taller fue uno de los más activos de la época. Así parecen apuntarlo dos asientos de aprendiz muy cercanos en el tiempo. El 8 de noviembre de 1696 recibe en su obrador, por un periodo de dos años, a Juan Serafín de Losua, natural de Briviesca ${ }^{82}$; mientras que dos años después, el 27 de febrero de 1698, había hecho lo propio con Joseph Ferrel, el cual permaneció bajo la tutela artística de Martínez durante siete años ${ }^{83}$.

\section{D- TÍO POLÍTICO: DAMIÁN CORTÉS}

Damián Cortés Mato nació en Valladolid a comienzos de octubre de 1668. Sus padres, Pedro Cortés y Catalina Mato ${ }^{84}$, le bautizaron en la iglesia de El Salvador el día 7 de ese mismo mes ${ }^{85}$. El 29 de junio de 1692 contrae matrimonio con María de Escobar en la

$81 \quad$ A.H.P.V., Leg. 2.963, f. 296.

82 A.H.P.V., Leg. 2.387, f. 1.491.

83 A.H.P.V., Leg. 2.388, ff. 896-897.

84 De su padre tan solo hemos podido localizar un poder para testar, fechado el 4 de julio de 1685 , que entrega a su mujer Catalina Mato, dado que "la gravedad de mi enfermedad no me da lugar para hacer y disponer mi testamento el cual le tengo comunicado con Catalina Mato mi querida mujer en aquella vía y forma que mejor haya lugar". Ente los pocos datos que nos da a conocer se encuentra su deseo de que su cuerpo fuera "sepultado en la iglesia del Convento de San Francisco de esta ciudad en la sepultura que la Cofradía de Nuestra Señora del Val y San Eloy tiene de donde soy cofrade o en la sepultura que la pareciera a la dicha mi mujer". Dejaba nombrada por testamentaria también a su esposa, mientras que como herederos instituía a Damián y Andrea Cortés "hijos legítimos y de la dicha mi mujer" y también al padre fray Francisco Cortés "asimismo mi hijo religioso de la Orden de Nuestra Señora de la Merced Calzada o a quien en su nombre lo hubiere". A.H.P.V., Leg. 2.381, f. 281.

También debió de ser pariente suyo un tal Juan Cortés, quizás su tío, hermano de su padre. Sabemos que el 1 de septiembre de 1654 se concierta con Sebastián Alonso, mayordomo de la iglesia parroquial de Santiago de la localidad vallisoletana de Villagarcía de Campos para realizar "pie de una cruz correspondiente al árbol que está hecho". El referido pie de cruz "ha de pesar veinte y cuatro a veinte y seis marcos y ha de tener sus cartelas y esmaltes y la ha de dar acabada en toda perfección para el día de San Miguel de septiembre que vendrá de este presente mes y año". Por cada marco "de hechura" se le pagaría "treinta y tres reales y no cumpliendo con darla acabada para dicho día solo se le ha de pagar a veinte reales por cada marco de hechura". A.H.P.V., Leg. 2.352, f. 364.

85 "En siete días del mes de octubre de mil y seiscientos y sesenta y ocho años yo el bachiller Alonso Ruiz Cachupín teniente de cura de esta iglesia parroquial del Salvador de esta ciudad de Valladolid, bauticé e impuse los santos óleo y crisma según forma de la santa madre iglesia a Damián hijo de Pedro Cortés y de Catalina Mato su legítima mujer mis parroquianos, viven a la Platería, fueron testigos Felipe Gutiérrez y Andrea de la Penna dieronle por abogados a Nuestra Señora de la Guía y San Cosme fueron testigos Juan Cortés, Gaspar Antonio de Victoria y Francisco de Encabado sacristán de que doy fe y lo firmé fecho ut supra”. A.G.D.V., Salvador, 166B, f. 33. 
iglesia del Salvador, templo en el cual se velará al matrimonio el 5 de agosto de $1693^{86}$. La pareja tuvo dos hijos: Manuel (1694) y Bernardino $(1696)^{87}$.

Vuelve a contraer el 7 de julio de 1698 con Francisca de Pórtoles, también en la iglesia de El Salvador ${ }^{88}$. Este matrimonio tuvo una extensa descendencia: Jerónimo Bernardo (1699), Ángela (1701), Pedro (1702), Eugenio Lorenzo (1703), Pedro (1705), Damián Alejo (1706), Francisca (1707), María Brígida (1708), Jerónima (1709), Josepha María (1711), Manuela Isidora (1712), Teresa (1713), Luisa Bernarda (1715), Bernarda Nicanor $(1717)^{89}$. Aún se desposa en terceras nupcias el 6 de noviembre de 1718 con Lorenza Rosa de Castro en la iglesia de El Salvador ${ }^{90}$. En este tercer matrimonio tuvo otros tres hijos: Joseph Julián (1720) ${ }^{91}$, María Petronila $(1721)^{92}$, María $(1722)^{93}$.

El 22 de julio de 1704 firma junto a Pedro de Pradena y Lara y el hijo de éste, Pedro de Pradena, ambos vecinos de Aranda de Duero (Burgos), una escritura de asiento de aprendiz por la cual el joven había "de estar y asistir en casa del dicho Damián Cortés como aprendiz del dicho oficio de platero por tiempo y espacio de cuatro años que han de empezar a correr y contarse desde el día de San Juan de junio de este año"94. El menor de los Pradena debía hacer "todo lo que el dicho Damián Cortés le mandare en lo tocante y perteneciente a dicho oficio y servidumbre de su casa según y cómo lo han hecho y hacen los demás aprendices". Durante los cuatro años su padre le daría los vestidos y calzados necesarios, mientras que por cuenta de Cortés correría el sustento alimenticio y la ropa limpia. Damián se obligaba a darle enseñado el "oficio y arte de platero y todo lo a él tocante y no le dando le ha de dar y pagar lo que se acostumbra y paga a un oficial hasta que esté el susodicho hábil y capaz para ejercer dicho oficio y poner su tienda como maestro de él". Por cuenta del aprendizaje, el Cortés recibiría 300 reales de vellón "en buena moneda usual y corriente en estos reinos de Castilla". Un año después, el 22 de mayo de 1705, recibe en su taller a un tal Leonardo Vázquez ${ }^{95}$.

El 19 de agosto de 1715 figura como testigo, junto con Joseph Castilla, en el bautizo de Clara de Ávila, hija de nuestro escultor Manuel de Ávila ${ }^{96}$. Falleció el 13 de marzo de 1722, siendo enterrado en la iglesia conventual de San Francisco "en sepultura propia" 97 . Vivía en la calle Platerías. El día anterior había otorgado testamento ante

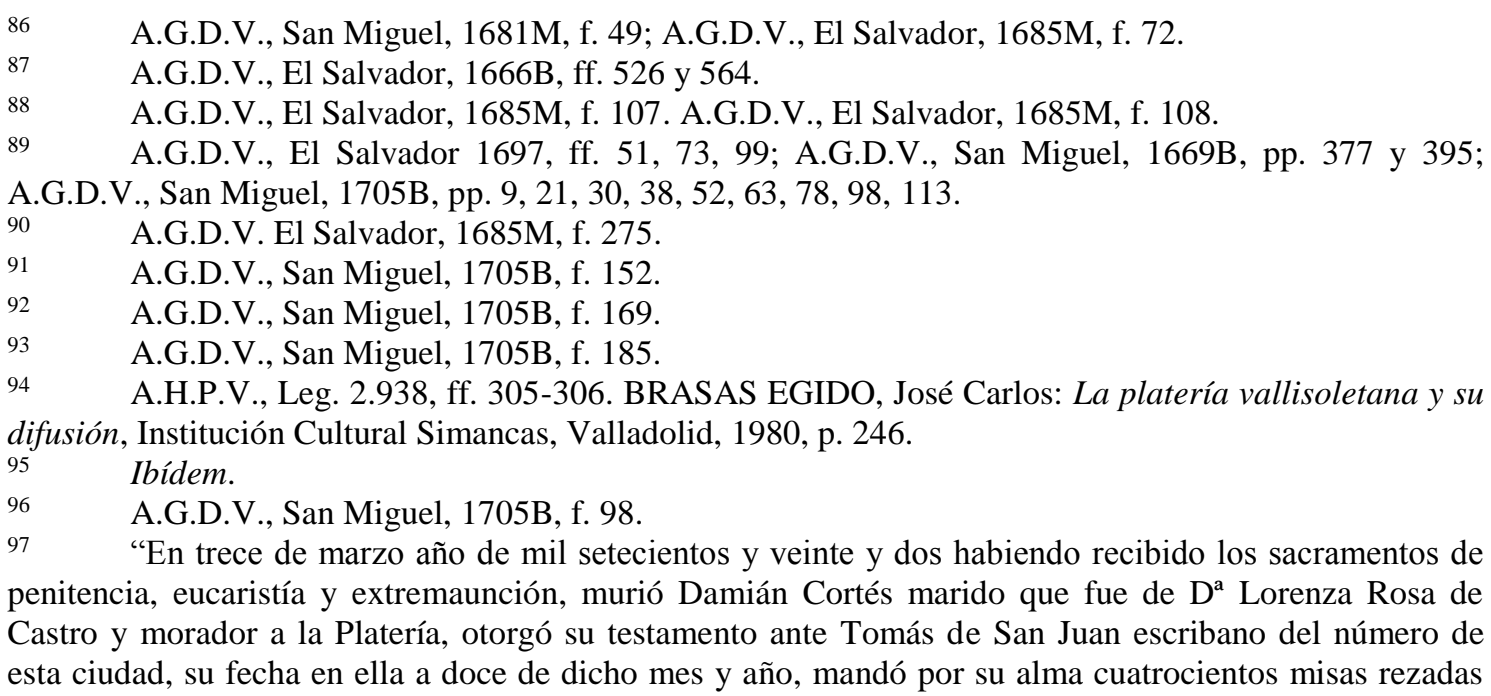


Tomás de San Juan el 12 de marzo de $1722^{98}$. En él ordenaba ser sepultado con el hábito de San Francisco en "el Convento de Nuestro Padre San Francisco de esta ciudad en la sepultura que allí tengo mía propia junto al púlpito", como así se hizo. A pesar de esto su deseo era otro, tal y como lo expresa a continuación: "mando que mi cuerpo siendo del agrado de la comunidad de San Francisco le metan en la capilla mayor y que vaya toda la comunidad a recibirle diciéndome un responso solamente y dando las velas acostumbradas". Deseaba que asistieran a su entierro "la cruz de la parroquia [de San Miguel] con doce señores sacerdotes en que entren cura y beneficiados, los niños de la doctrina y del amor de Dios y las cofradías de Nuestra Señora del Val y San Eloy y del Cristo de la Cruz donde soy cofrade". Mandaba se dijeran por su alma, las de sus padres, mujeres " $y$ demás parientes y personas por quien tuviere algún cargo y obligación" 400 misas, la cuarta parte en la iglesia de San Miguel; además de la "misa del alma en el altar privilegiado del Convento de Nuestra Señora de la Victoria de esta ciudad y las de San Vicente Ferrer". Su relación con los franciscanos debía de ser muy cercana puesto que envía 50 reales por vía de limosna al Convento de San Diego. Dejaba nombrados como testamentarios a su mujer Lorenza Rosa; a don Manuel Marqués, cura propio de la parroquial de San Miguel; a Pedro Martínez de la Puebla, contador de ella; al mercader de cerería Joseph Rodríguez González; y a su cuñado Joseph Martínez.

Cortés nos relata las tres veces en que contrajo matrimonio y los hijos que aún le quedaban: de su primer matrimonio habían fallecido todos; del segundo vivían Eugenio, Damián, María, Manuela, Teresa, Luisa y Bernardo; y del tercero tan solo un hijo que esperaban, puesto que por entonces Lorenza Rosa se encontraba embarazada. A todos ellos les dejó nombrados por herederos. Por entonces se hallaba a su cargo "el hacer un frontal de plata para el Convento de la Espina Orden de San Bernardo por cuenta del cual tengo recibido ciento y noventa doblones sencillos y en esto tiene razón y noticia el dicho Eugenio mi hijo quien dirá en ello con claridad el estado". En cuanto a deudas, don Francisco Carlos de Ulloa le debía "diez y ocho reales de a ocho de a quince del valor de una sortija"; asimismo tenía en su poder "unos pendientes de oro y diamantes de don Alonso de Ulloa señor de la Ventosa" que mandaba se le entregasen; además, tenía "otras cuentas sueltas con algunas personas que constarán de papeles y asientos del libro mando se ajusten y se cobre lo que se me debiere y pague lo que yo estuviere debiendo".

además de la de alma y de cuerpo presente, las de San Vicente y cincuenta y dos más, una cada semana en el discurso de un año después del día de su fallecimiento. Nombró por sus testamentarios a mí el cura, a $\mathrm{D}^{\mathrm{a}}$ Lorenza Rosa de Castro su mujer, a D. Pedro Martínez de la Puebla, a Joseph González y a Joseph Martínez dejó por sus herederos a sus hijos. Mandose enterrar y enterrose en la iglesia de San Francisco en sepultura propia, y por verdad lo firmé en Valladolid como cura propio de esta parroquial de San Miguel fecho ut supra". A.G.D.V., San Miguel, 1711D, f. 46.

$98 \quad$ A.H.P.V., Leg. 2.963, ff. 31-34. Tres años antes, el 7 de enero de 1719 había otorgado otro testamento. BRASAS EGIDO, José Carlos: La platería..., op. cit., p. 246. 
Brasas Egido en su fundamental libro La platería vallisoletana y su difusión aporta algún dato más sobre este artífice; si bien confunde y entremezcla constantemente datos de Damián Cortés con los de su hijo Manuel Eugenio Cortés, de tal manera que los funde en una misma persona. El investigador comenta que Damián Cortés ocupó los cargos de marcador y contraste de pesos de la ciudad de Valladolid hasta su fallecimiento en $1735^{99}$. Teniendo en cuenta que Damián Cortés fallece en 1722, parece claro que estos cargos los heredó su hijo Manuel Eugenio tras su fallecimiento. De su importancia como platero nos habla bien a las claras el hecho de que el 21 de noviembre de 1720 fuera elegido para tasar la platería que había dejado tras su fallecimiento el Vizconde de Valoria ${ }^{100}$

Parece ser que tan solo conservamos una de sus obras, se trata de una lámpara de plata realizada en 1718 y conservada en el Museo de San Joaquín y Santa Ana. Según relata Brasas

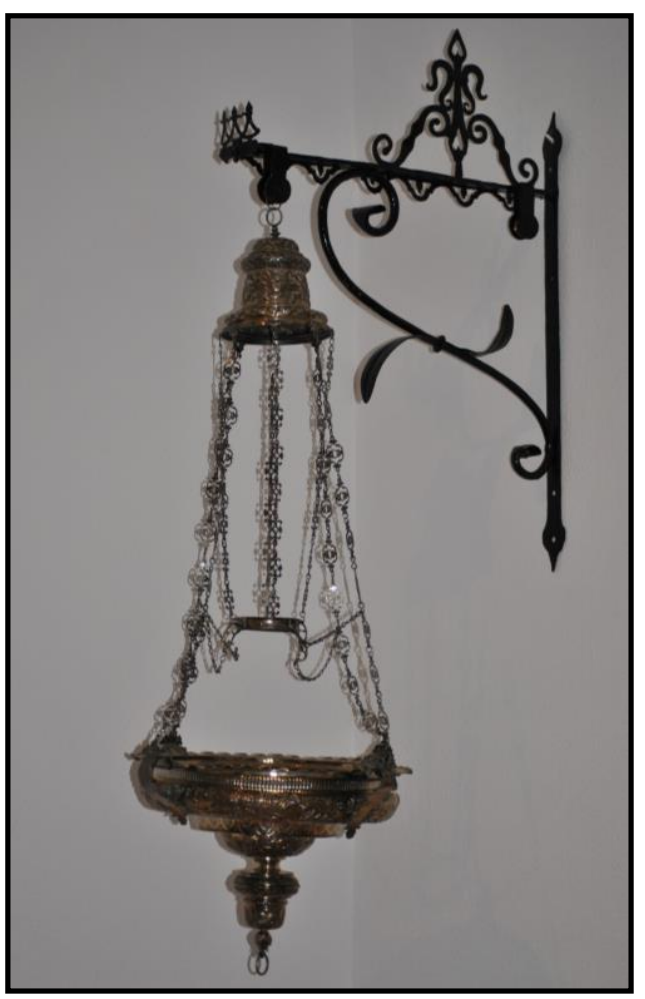

Il. 6- Damián Cortés. Lámpara de la Virgen de la Soledad. Monasterio de San Joaquín y Santa Ana. Valladolid. Egido, "ostenta punzón COR / TES que corresponderá al platero vallisoletano Damián Cortés. El plato lleva decoración repujada de ramajes, rematándose en una piña muy moldurada. Del copete penden cuatro cadenas formadas por eslabones de chapa calada. Lleva la inscripción: "Que es para $N^{a} S^{a}$ de la Soledad de Capítulo. Año de 1718"101.

\section{E- MUJER: MARÍA MARTÍNEZ}

Poquísimos datos poseemos sobre la mujer de nuestro escultor, apenas los relativos a los sacramentos de bautismo, matrimonio y defunción. Como acabamos de referir, era hija del platero Joseph Martínez y de Andrés Cortes, siendo por lo tanto también sobrina de otro platero: Damián Cortés. Había nacido en Valladolid a finales del mes de febrero del año 1692, siendo bautizada en la iglesia del Salvador el día 28 del referido mes ${ }^{102}$.

\footnotetext{
$99 \quad$ Ídem, p. 45.

$100 \quad$ Ídem, p. 37.

$101 \quad$ Ídem, p. 290

102 "En veinte y ocho días del mes de febrero de mil seiscientos y noventa y dos yo Antonio Rodríguez de Valcázar teniente de cura de la parroquial del Salvador de esta ciudad de Valladolid bauticé e impuse los santos oleos y crisma según forma de la santa madre iglesia a María Manuela hija legítima de Joseph Martínez y doña Andrea Cortés mis parroquianos que viven a la Platería fueron padrinos el licenciado don Manuel de Reinoso presbítero y doña María de Escobar dieronla por abogados a Nuestra
} 
El 22 de mayo de 1712 contrae matrimonio con Manuel de Ávila en la iglesia del Santísimo Salvador ${ }^{103}$. La ceremonia fue oficiada por el conocido presbítero don Pedro de Rábago, a quien la iglesia del Salvador debe alguna de sus obras escultóricas más importantes. Hasta unos meses después el matrimonio no fue velado, teniendo lugar el acto el 15 de febrero de 1713 , y siendo también oficiado por Pedro de Rábago ${ }^{104}$. El matrimonio, como a continuación veremos, se vería bendecido con la llegada de cinco vástagos, tres de los cuales llegarían a la edad adulta: María Teresa (1714), Clara (1715), Alfonsa María (1719), Feliciana (1725) y Pedro Manuel (1728).

Tras enterrar a su marido el 27 de septiembre de $1733^{105}$, hubo de vivir más de 20 años de viuda hasta que finalmente falleció el 14 de abril de 1756, siendo sepultada junto a Manuel en la primitiva iglesia de San Miguel ${ }^{106}$. Por entonces vivía en Cantarranas. No formó testamento. Por su sepultura se abonó 33 reales y por el hachero y paño otros 8 reales.

\section{F- HIJOS DE MANUEL DE ÁVILA Y MARÍA MARTÍNEZ}

\section{MARÍA TERESA DE ÁVILA}

María Teresa de Ávila Martínez fue la primogénita del escultor y su esposa. Nacida el 3 de abril de 1714, recibió las aguas del bautismo diez días después de manos de don Manuel Carrillo, cura ecónomo de la desaparecida iglesia parroquial de San Miguel ${ }^{107}$. Los padrinos fueron el matrimonio formado por Santiago Izquierdo "de esta Real Universidad" y María Sedano, tíos maternos de Manuel de Ávila ${ }^{108}$. Como testigos acudieron los plateros Damián Cortés (tío abuelo de María Teresa) y Joseph Martínez (abuelo de María Teresa) y Pedro de Ávila (tío de la recién nacida). Por abogados se la impusieron a San Miguel, patrón del templo en que se la bautizó, y a San Isidro Labrador.

Señora de la Guía y al Ángel de la Guarda fueron testigos Marcos Ibáñez, el licenciado Andrés de Sandoval y Damián Cortés de que doy fe y lo firmé”. A.G.D.V., El Salvador, 1666B, f. 489.

103 A.G.D.V., El Salvador, 1685M, f. 229.

104 A.G.D.V., El Salvador, 1685M, f. 233.

105 A.G D V., Valladolid, San Miguel, 1711D, f. 105.

106 A.G.D.V., Valladolid, San Miguel, 1711D, f. 205.

107 "En trece de abril de mil setecientos y catorce años yo don Manuel Carrillo cura ecónomo de la parroquial de Señor San Miguel de esta ciudad de Valladolid bauticé y puse los santos óleos según orden y forma de la Santa Iglesia Romana a María Teresa hija legítima de Manuel de Ávila y María Martínez mis parroquianos moradores del Corral de la Copera que dicen nació el día tres de este presente mes fueron sus padrinos don Santiago Izquierdo Vidal de esta Real Universidad y don María Sedano su mujer dieronle por abogados a San Miguel y San Isidro, fueron testigos Damián Cortés, Pedro de Ávila y Joseph Martínez y en fe de ello lo firmé”. A.G.D.V., Valladolid, San Miguel, 1705B, f. 82.

108 De Santiago Izquierdo sabemos al tiempo de contraer matrimonio con María Sedano (1690) era “mercader de libros". A.H.P.V, Leg. 2.382/4, ff. 56-59. Asimismo, en esta partida de bautismo de su sobrina se le califica como "de esta Real Universidad". Este último dato me lleva a pensar que pudiera tratarse del Santiago Izquierdo, bedel de la Universidad, al que alude García Chico al tratar sobre las esculturas de la fachada de la Universidad, realizadas por los Tomé en 1720. GARCÍA CHICO, Esteban: Valladolid..., op. cit., 1958, pp. 95-96. 
Como nos ocurre con el resto de hijos e hijas de Manuel de Ávila desconocemos la totalidad de su biografía, aunque al no dedicarse ninguno de ellos a un oficio dedicado con el arte tampoco nos interesa demasiado. Los únicos datos que podemos presentar sobre María Teresa son los referentes a su matrimonio: contrajo matrimonio con Francisco de las Pedrajas el 17 de enero de 1740 en la iglesia de San Miguel, ejerciendo el cargo de testigos su abuelo Joseph Martínez y el también platero Joseph Escobedo ${ }^{109}$. Su marido falleció al poco tiempo, dejándola viuda el 25 de mayo de $1743^{110}$.

\section{$\underline{\text { CLARA DE ÁVILA }}$}

Clara de Ávila nació el 12 de agosto de 1715. Una semana después don Domingo de Libarona, cura propio de la iglesia de San Miguel, exorcizó e impuso "los santos óleos y bauticé sub conditione por tener agua de socorro" "111. Se le dieron por abogados a Nuestra Señora de la Esperanza, San Miguel y San Bernardo ${ }^{112}$. Como padrinos de la recién nacida actuaron el presbítero Francisco Muñoz y Catalina Muñiz, mientras que como testigos figuraron su tío Damián Cortes, y Joseph Castilla.

\section{$\underline{\text { ALFONSA MARÍA DE LA PAZ DE ÁVILA }}$}

Alfonsa María de la Paz nació en Valladolid el 23 de enero de 1719, siendo bautizada el 1 de febrero en la iglesia de San Miguel ${ }^{113}$.

109 "En diez y siete de enero año de mil setecientos y cuarenta yo don Diego (...) teniente de cura de la parroquial de San Miguel de esta ciudad, habiendo precedido dos municiones, de las tres que el Concilio manda por haber dispensado en la tercera y sus veinte y cuatro horas el señor obispo y licencia del provisor de este obispado refrendada de Joseph de Nis notario de asiento despose por palabras de presente que hicieron verdadero matrimonio, para no haber resultado impedimento alguno a Francisco de las Pedrajas vecino de esta ciudad viudo de Josepha de Linozo y Atota con doña María Teresa de Ávila natural de ella hija legítima de Manuel de Ávila difunto y doña María Manuela Martínez fueron testigos el Señor don Joseph Escobedo y Joseph Martínez y lo firmé en Valladolid (...)” A.G.D.V., Valladolid, San Miguel, 1681M, f. 327.

$110 \quad$ A.G.D.V., Santiago, 1728D, f. 136.

111 "En diez y nueve de agosto de mil setecientos y quince yo don Domingo de Libarona cura propio de la Iglesia parroquial del Señor San Miguel de la ciudad de Valladolid exorcice, impuse los santos óleos y bauticé sub conditione por tener agua de socorro a Clara (que dijeron nació en doce de este mes y año) hija legítima de Manuel de Ávila y de María Martínez, fueron sus padrinos don Francisco Muñoz presbítero y Catalina Muñiz testigos Damián Cortés y Joseph Castilla; y la dieron por abogados a Nuestra Señora de la Esperanza, San Miguel y a San Bernardo y lo firmé’. A.G.D.V., Valladolid. San Miguel, 1705B, f. 98.

112 La Virgen de la Esperanza era una devoción mariana radicada en la iglesia de San Miguel; San Miguel era el santo titular de la iglesia parroquial en que se la bautizó; y la imposición de abogado de San Bernardo tendrá relación con que al día siguiente del bautizo de la pequeña (20 de agosto) se celebra la festividad de este santo.

113 "En primero de febrero de mil setecientos y diez y nueve yo don Simón Álvarez teniente de cura de la iglesia parroquial del señor San Miguel de esta ciudad de Valladolid exorcicé impuse los santos óleos y crisma y bauticé a Alfonsa María de la Paz (que dijeron nació el día veinte y tres del mes próximo pasado) hija legítima de Manuel de Ávila y de María Martínez Moradores al Corral de la Copera fueron sus padrinos Damián Cortés y doña Lorenza Rosa de Castro, testigos Joseph Martínez su abuelo, Joseph 


\section{FELICIANA DE ÁVILA}

Feliciana de Ávila nació en Valladolid el 20 de noviembre de 1725, siendo bautizada el 2 de diciembre por Gabriel Domínguez del Cid, "cura propio vicario perpetuo de la parroquial del señor San Juan Evangelista inclusa en la santa iglesia catedral”, el cual le impuso "los santos óleos y crisma e hice las demás ceremonias que ordena el manual romano a Feliciana, que nació el día veinte del mes próximo pasado la cual urgente necesítate bautizó don Juan Nieto cura propio de San Nicolás de esta dicha ciudad"114. Se le impusieron por abogados a Nuestra Señora de la Presentación y a San José ${ }^{115}$. Fueron sus padrinos Juan Sangáriz y María Lorenza de la Peña (esposa de Pedro de Ávila), mientras que como testigos actuaron Francisco Prieto y Pedro Pérez. La recién nacida falleció al día siguiente de ser bautizada.

\section{MANUEL PEDRO DE ÁVILA}

Manuel Pedro de Ávila, el último vástago del matrimonio, nació en Valladolid el 6 de mayo de 1728. El día 20 de ese mismo mes fue bautizado "sub conditione (...) en casa por la matrona antes de salir del vientre de su madre, en uno de los brazos" por don Gabriel Domínguez del Cid "cura propio vicario perpetuo de la santa iglesia catedral de esta ciudad de Valladolid"116. Se le dieron por abogados a Nuestra Señora del Sagrario y San Juan Evangelista ${ }^{117}$. Fueron sus padrinos el presbítero Francisco Muñoz

de Onís y otras personas, y la dieron por abogados a Nuestra Señora de la Esperanza, San Miguel y a San Cayetano. A.G.D.V., San Miguel, 1705B, p. 142.

114 "En la ciudad de Valladolid a dos días del mes de diciembre año de 1725 yo don Gabriel Domínguez del Cid cura propio vicario perpetuo de la parroquial del señor San Juan Evangelista inclusa en la santa iglesia catedral de dicha ciudad puse los santos óleos y crisma e hice las demás ceremonias que ordena el manual romano a Feliciana, que nació el día veinte del mes próximo pasado la cual urgente necesítate bautizó don Juan Nieto cura propio de San Nicolás de esta dicha ciudad hija legítima de Manuel de Ávila y de María Martínez, viven junto a las Angustias, fueron padrinos don Juan Sangáriz, doña María de la Peña, abogados Nuestra Señora de la Presentación y San José, testigos don Francisco Prieto y Pedro Pérez. Murió al día siguiente de la fecha de esta partida dicha bautizada y lo firmé fecho ut supra”. A.G.D.V., Catedral, 1681B, f. 372.

$115 \quad$ Nuestra Señora de la Presentación era una devoción radicada en el Oratorio de San Felipe Neri, lugar en el que se encontraba establecida la Congregación de San Felipe Neri y Nuestra Señora de la Presentación, institución para la que había trabajado años antes Manuel de Ávila. Allí pudo hacerse devoto de esta Virgen, y ser éste el motivo por el que le dio por abogada a esta Virgen a su hija.

116 "En veinte días del mes de mayo de mil setecientos y veinte y ocho yo don Gabriel Domínguez del Cid cura propio vicario perpetuo de la santa iglesia catedral de esta ciudad de Valladolid puse los santos óleos y crisma y bauticé sub conditione en ella a Manuel Pedro que lo estaba en casa por la matrona antes de salir del vientre de su madre, en uno de los brazos, quien nació el día de la Ascensión que se contaron seis del dicho mes, hijo legítimo de Manuel de Ávila natural de esta ciudad y de María Martínez natural asimismo de ella y su legítima mujer y mis feligreses que viven a la Plazuela del Almirante de Castilla abuelos paternos Juan de Ávila natural de esta ciudad y Bentura Sedano natural de Palencia, difuntos, fueron padrinos D. Francisco Muñoz presbítero y Teresa Illana abogados Nuestra Señora del Sagrario y San Juan Evangelista, testigos Juan de Laforga Pedro Pérez y Andrés de Vega vecinos de esta dicha ciudad y en fe de ello lo firmé Valladolid ut supra”. A.G.D.V., Catedral, 1681B, f. 388.

117 El motivo por el que se le impusieron por abogados a Nuestra Señora del Sagrario y a San Juan Evangelista está claro: eran dos de las devociones más importantes radicadas en la catedral, lugar en el que fue bautizado el recién nacido. Por un lado, Nuestra Señora del Sagrario, es la patrona del cabildo 
y Teresa Illana, mientras que asistieron como testigos Juan de Laforga, Pedro Pérez y Andrés de Vega.

\section{1-3 RELIGIOSIDAD}

Como venía siendo costumbre en su familia, y era muy normal en la época, Manuel de Ávila fue miembro de varias cofradías. A su ya consabida pertenencia a la de Jesús Nazareno, en la que ingresó con tan solo doce años, en $1704^{118}$, hemos de añadir su militancia en otras dos radicadas en la Santa Iglesia Catedral: la Cofradía Sacramental de San Juan Evangelista y la Santa Espina de Cristo ${ }^{119}$. Además, a diferencia de su padre y de su hermano, sabemos que perteneció a la de San Lucas Evangelista. Nacida como la cofradía gremial de los pintores, a lo largo de los siglos XVII y XVIII se abrió a otras disciplinas relacionadas con las Bellas Artes. Efectivamente, en los documentos de esta cofradía en los que aparece Manuel Ávila también vemos nombres como los del escultor Antonio Gautúa, el ensamblador Juan Correas o los miembros de la familia de doradores Martínez de Estrada.

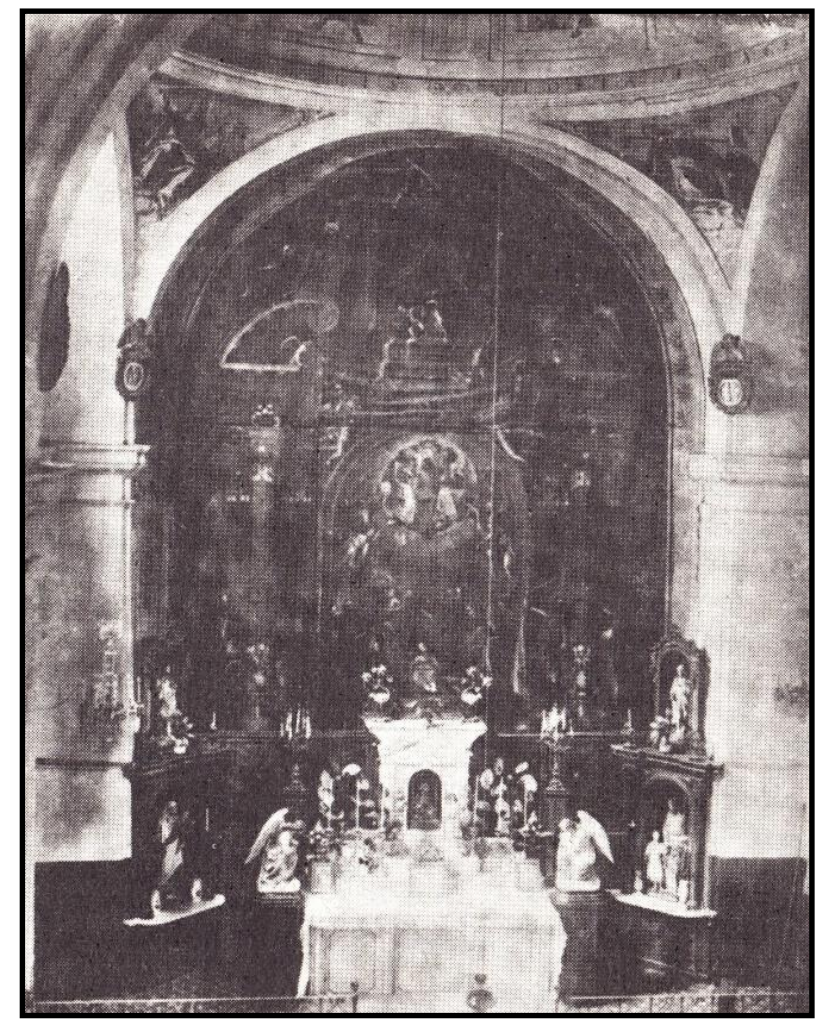

Il. 7- Colegio de Niñas Huérfanas, sede de la Cofradía de San Lucas. Valladolid.

catedralicio; mientras que por otro, San Juan Evangelista era el titular de la capilla catedralicia que ejercía las funciones de parroquia dentro de ella.

118 ARRIBAS ARRANZ, Filemón: La Cofradía..., op. cit., p. 94.

119 A.H.P.V., Leg. 3.127, f. 40 . 
$\sum 1260<$ 


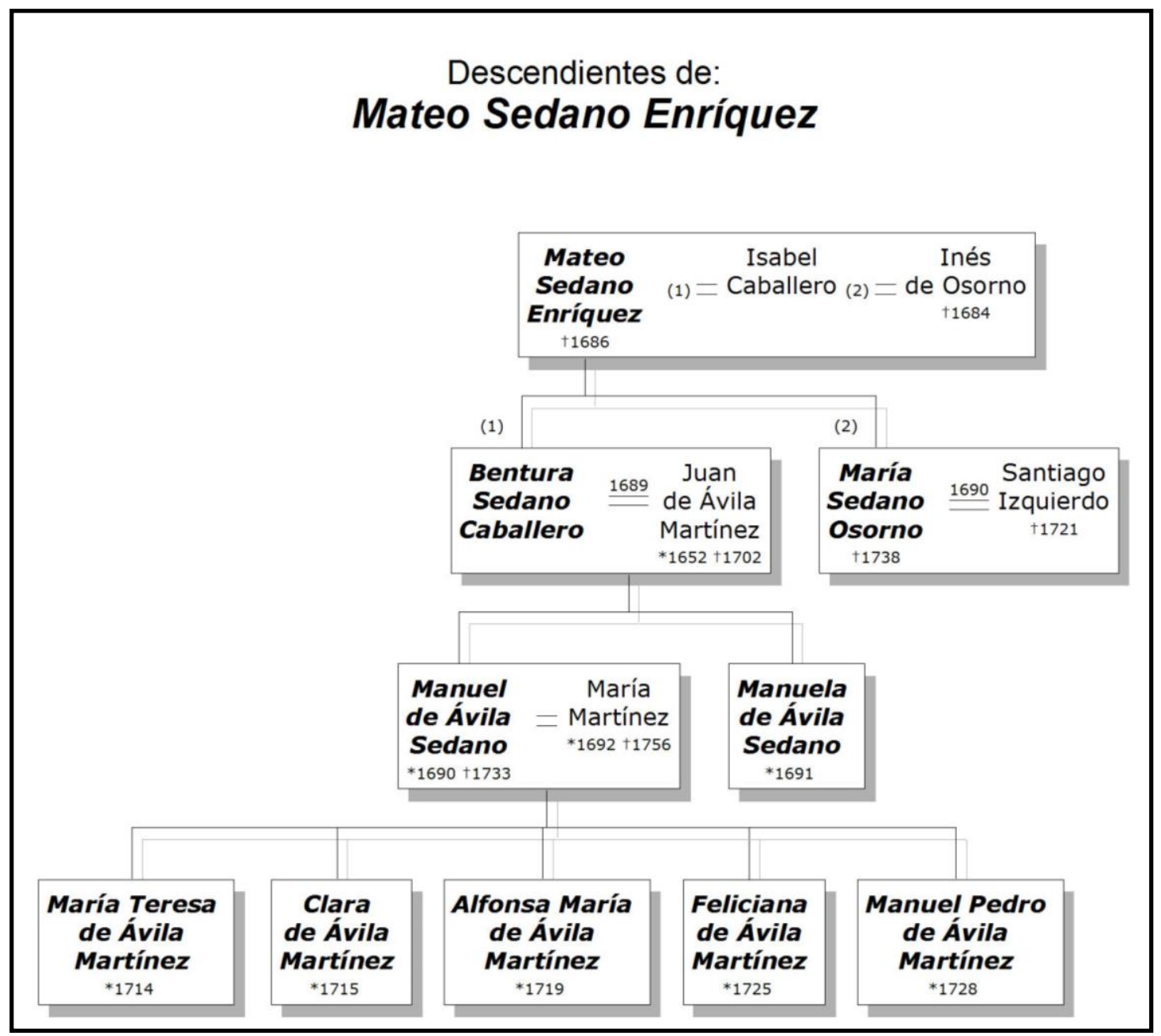

Fig. 1- Árbol genealógico general de Manuel de Ávila. 
$\sum \sqrt{1262}<$ 


\section{IZ- EL ARTE DE}

MANUEL, DE ÁVILA 
$\sum \sqrt{1264} \leq$ 


\section{2-1 MARCO DE TRABAJO}

No sabemos a ciencia cierta donde mantuvo abierto taller una vez que abandonó el de su hermano Pedro, lugar en el que se formó y trabajaría durante cierto tiempo hasta que pudo independizarse. Parece lógico pensar que esa independencia tuvo lugar en 1712, tras contraer matrimonio con Maria Martínez, hija del platero Joseph Martínez.

Lo que sí que conocemos es la localización de las diferentes casas en que residió Manuel de Ávila a lo largo de su vida. Todas ellas estaban situadas en un apretado espacio de terreno delimitado por cuatro monumentos importantes: al oeste la ermita de Nuestra Señora del Val y San Eloy de los plateros, al norte la iglesia de San Miguel, al sur la calle Platerías, y al este la iglesia penitencial de Nuestra Señora de las Angustias.

A pesar de que sus padres, Juan de Ávila y Bentura Sedano, vivían en la calle del Campo, en el tramo de la iglesia de Santiago comprendido entre la propia parroquia y la Plaza Mayor, una vez abandonó el hogar paterno no volvería a vivir en los límites de esa feligresía. Tras el fallecimiento de su padre se quedaría viviendo en esa misma casa de la calle del Campo con su madre (en caso de que no hubiera fallecido por entonces), o con sus hermanos Teresa y Joseph; no parece lógico pensar que se fuera a vivir con su hermano Pedro ya que este vivía en casa de sus suegros.

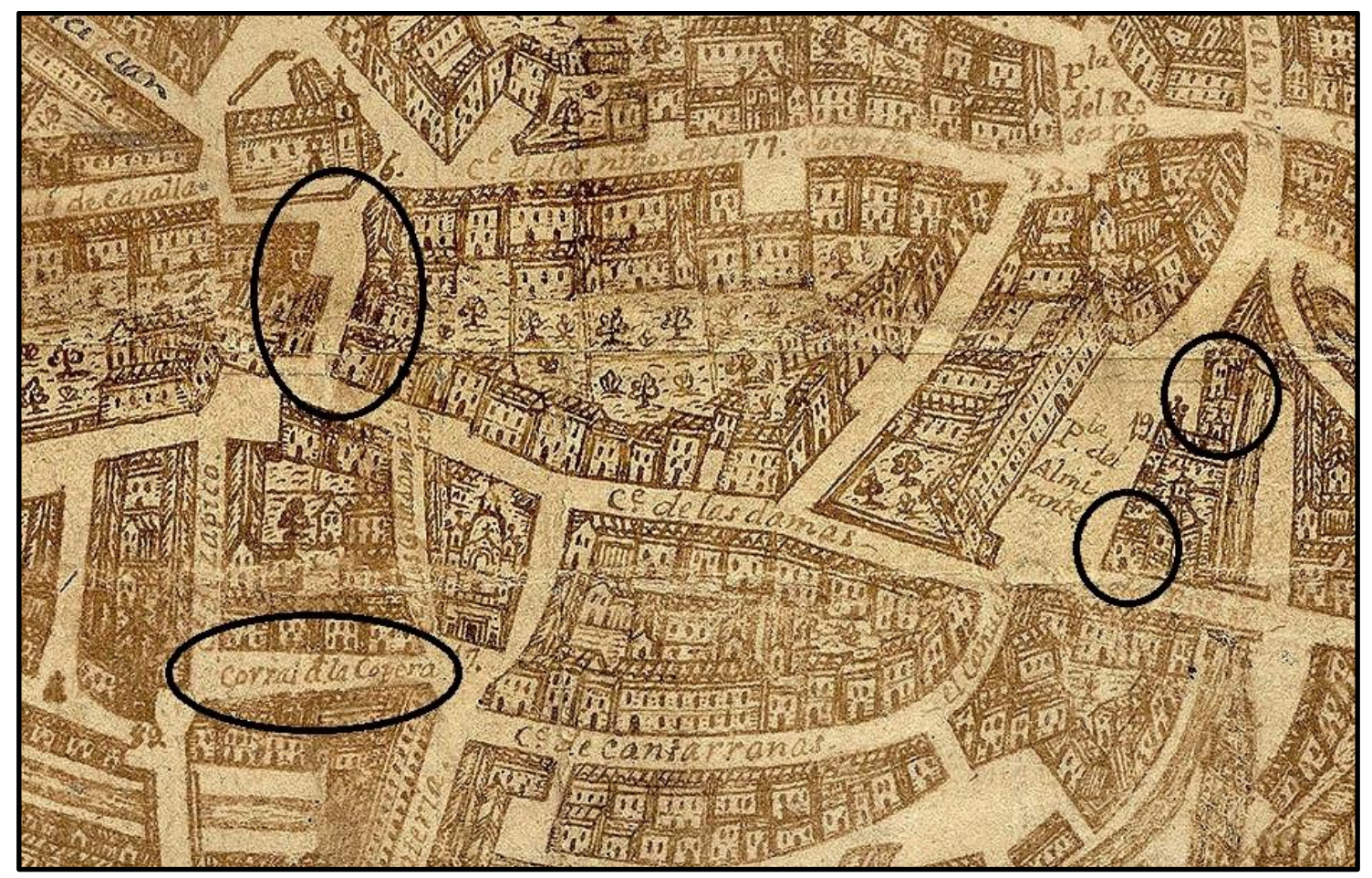

Il. 1- Localización de las casas que habitó Manuel de Ávila en el mapa de Bentura Seco de 1738.

Ya casado, la pareja se trasladaría a vivir a la casa de su suegro por un periodo de cuatro años, tal y como habían concertado en las capitulaciones matrimoniales. Esta casa debía estar localizada en el Corral de la Copera, calle en la que nace la primera hija de la pareja, María Teresa, en 1714; es decir, todavía dentro de los cuatro años durante los cuales viviría bajo el techo del viejo platero. Otra consideración a tener en cuenta es la

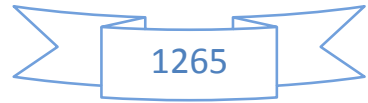


de que probablemente por entonces Manuel de Ávila trabajaría en el taller de su hermano Pedro; aunque también podría ser que tuviera su propio obrador abierto en casa de su suegro, suposición poco probable dado que este último tendría allí instalado el suyo.

Pasados los referidos cuatro años, hacia 1716-1717, el matrimonio y sus dos hijas (María Teresa y Clara) se trasladarían a un nuevo inmueble. Desconocemos donde se localizaría, quizás fuera el mismo en el que vivían en noviembre de 1725 cuando nació su hija Feliciana: "junto a las Angustias". Esta misma casa será la que aparece citada en 1728 en la partida de bautismo de su hijo Pedro Manuel, en la cual se refiere a "que viven a la Plazuela del Almirante de Castilla". Ese "junto a las Angustias" no puede significar otra cosa que su casa estaba pegando a la referida iglesia, por lo tanto, dos serían las opciones: el portal que hacía esquina entre la Plaza del Almirante y la calle de los Baños; o bien la casa situada justo a la derecha de la iglesia, es decir, enfrente de la portada de la denominada "Sala de Pasos" de la cofradía.

Después de esta fecha hubo un último traslado de la familia, de la cual ignoramos la fecha. El destino sería la calle de San Miguel, la misma en la que vivía su hermano Pedro. Cuando falleció el 27 de septiembre de 1733 se hablaba de él como "morador a la calle de San Miguel". A la vista de estos cambios de hogar y la ausencia de contratos de casas que pudieran ser utilizadas como taller, no podemos establecer una hipótesis acerca de donde se encontraba situado el obrador. Pudiera ser que este fuera itinerante o bien que hubiera uno fijo. Dada la proximidad de las casas de Manuel de Ávila con los de su hermano Pedro de Ávila, y por excusar repeticiones, remitimos a consultar el marco de trabajo de este último para conocer el barrio en que tenían abierto el taller, así como sus enclaves más destacados.

\section{2-2 EL OFICIO DE ESCULTOR}

Dada la escasez de obras documentadas no nos podemos hacer mucha idea de la dimensión como escultor que alcanzó Manuel de Ávila; en cambio, en su tiempo sí que era muy estimado. Es decir, al igual que su hermano, para sus conciudadanos su prestigio estaba fuera de toda duda.

Al contrario de lo que nos sucede con su hermano Pedro y su padre, no contamos con ninguna tasación realizada por Manuel de Ávila, aunque parece fuera de toda duda que las hizo; no solo porque de casi todos los escultores vallisoletanos del barroco tenemos documentada alguna de estas actuaciones sino porque si su prestigio era tal entre sus conciudadanos más razón para que estos solicitaran sus servicios. Lo que si tenemos acreditado es que se requirieron sus servicios para reparar esculturas. Efectivamente, 
entre los años 1726 y 1733 efectúa diversos arreglos en las esculturas del paso de Cristo Crucificado (actual Sed Tengo) de la Cofradía de N. P. Jesús Nazareno ${ }^{1}$.

En lo referente al material y tipología de sus esculturas poco podemos decir también, puesto que su escaso catálogo nos lo muestra únicamente aplicado a la imaginería en madera, de tema religioso, y con destino a retablos; si bien, el San José de los Nazarenos también entraría en el campo de la escultura devocional dado el especial cariño que profesaba la cofradía hacia su santo.

\section{2-3 FORMACIÓN}

Como ya hemos incidido en diversas ocasiones, la formación de Manuel de Ávila corrió exclusivamente a cargo de su hermano Pedro. Pudiera ser, aunque es poco probable, que su padre pudiera haberle dado alguna lección, pero estas habrán sido escasas dado que falleció cuando Manuel contaba con tan solo 12 años; es decir, justo cuando se suele comenzar el aprendizaje.

Dado que no poseemos ninguna escultura de Manuel hasta el año 1714, desconocemos los parámetros en que discurrió la escultura de sus primeros años. Pero, si tenemos en cuenta que tan solo recibió las enseñanzas de su hermano, parece claro que el estilo inicial de Manuel transcurriría paralelo al primero de Pedro de Ávila; y que tras la llegada de éste de Madrid y su concepción de su segundo estilo, mucho más personal, Manuel se amoldaría a estas nuevas características. Así parece indicárnoslo el hecho de que las pocas obras que conocemos de Manuel de Ávila siguen fielmente el estilo y los modelos implantados por su hermano Pedro.

\section{$\underline{\text { 12-4 ESTILO }}$}

Como ya comentamos al hablar de Juan y Pedro de Ávila, y en este caso es aún peor, la paupérrima cantidad de obra documentada nos dificulta en demasía poder discernir sus obras; y más si tenemos en cuenta que su estilo es gemelo al de su hermano Pedro. Además, dado que las tres obras documentadas están tan espaciadas no podemos trazar una posible evolución, si bien parece que no la hubo y que quedó acomodado al estilo de su hermano introduciendo algunas pequeñas variantes propias. Este "hermanamiento" de método entre ambos escultores ha llevado en alguna ocasión a la confusión; puesto que algunas obras de Manuel, como las esculturas del retablo mayor de Fuentes de Valdepero (Palencia), han estado atribuidas durante mucho tiempo a Pedro de Ávila.

1 ARRIBAS ARRANZ, Filemón: La Cofradía..., op. cit., p. 89. 


\section{$\underline{\text { Anatomías }}$}

Los tipos humanos están concebidos con movimientos tranquilos, tanto del cuerpo como de los ropajes. La serenidad reina en sus composiciones. Pareciera como si el hermano menor de los Ávila se contrapusiera a su hermano en cuanto a la concepción de sus esculturas: si en Pedro imperaban las poses declamatorias y la acentuada religiosidad, no exenta de belleza formal; en Manuel veremos un marcado gusto por la delicadeza y la estética. El canon es alargado, aunque más cercano a la proporción natural que los de su hermoso, que son algo más estilizados con el fin de resaltar la elegancia de sus formas. Para conocer sus cualidades como anatomista hemos de conformarnos tan solo con los Ángeles que talló para los retablos del Oratorio de San Felipe Neri; tampoco nos sirven de mucho puesto que nada tiene que ver la concepción de un cuerpo infantil con el de un hombre o mujer en edad madura. Sea como fuere, resulta especialmente destacable su capacidad para la captación de la morbidez de las carnes.

Relacionado con su concepción anatómica encontramos ciertos "préstamos" tomados de su hermano Pedro, y que ya dijimos que pudieran tener un origen napolitano. Se trata del ligero contraposto a través del adelantamiento de una de las piernas, con lo cual se dobla la rodilla; y, también, la colocación de los pies formando un ángulo de $90^{\circ}$.

En lo referente a manos y cabezas sigue la tradición de su padre y de su hermano: unas esculturas van talladas en un mismo bloque (San José de la Cofradía de N. P. Jesús Nazareno y Ángeles del Oratorio de San Felipe Neri), mientras que otras las esculpe con las manos por separado, y posteriormente las une al cuerpo mediante embones (esculturas del retablo mayor de la iglesia parroquial de Fuentes de Valdepero). Como vemos, en Manuel de Ávila no tenemos ningún caso en el que la cabeza esté tallada por separado; si bien tampoco podemos asegurarlo en el caso de las esculturas del citado retablo dada la escasa visión de la que gozamos.

A excepción de las manos del San José, en que observamos fuerza, potencia y vida, el resto de esculturas parecen tener unas manos correctas, anatómicamente hablando, pero que pecan de frialdad. Un detalle importante a destacar de estas manos, que son las únicas que podemos ver con cierta facilidad, es que siguen fielmente el modelo estereotipado creado por su hermano: el pulgar y el meñique no los mueve, siguen un movimiento natural; en cambio, con el índice y el medio realiza una "V", teniendo el primero de ellos algo doblado y el segundo estirado; por su parte, el anular lo dobla hacia abajo. También es similar a su hermano la manera de tallar y disponer las venas y los tendones de las manos, como así podemos comprobarlo en el referido San José. Además, en esta última imagen, para la cual puso Ávila todo su empeño ya que además de gozar de la cercana visión de los fieles, lo había hecho para su propia cofradía, observamos sus buenas dotes como escultor: cada falange, uña y vena se halla perfectamente tallada, el naturalismo y el detallismo se dan la mano.

Los rostros siguen puntualmente las pautas marcadas por su hermano. Nos encontramos con el mismo aspecto geometrizado, tendente al rectángulo, aunque Manuel suele 
concebir unos rostros ligeramente más estrechos y alargados, lo que conlleva que los ojos se encuentren más juntos. Para descubrir las semejanzas y diferencias en cuanto a la concepción del rostro de las esculturas por ambos hermanos, nada mejor que comparar su San José con los documentados y atribuidos a su hermano Pedro. Observamos que el San José de Manuel de Ávila bebe directamente de la fuente de su hermano, pero el acabado no es exactamente igual. Las faces de las esculturas de Manuel son algo más secas e indolentes, y no parecen demostrar sentimiento alguno.

Aunque no podemos asegurarlo con total rotundidad dada la altura a la que se encuentran, si observamos los rostros del San Pedro y San Pablo del retablo de Fuentes de Valdepero, parece que Manuel de Ávila también supo captar a la perfección las carnes fláccidas y las arrugas propias de la vejez. Efectivamente, así lo confirmamos al analizar la cara de la Santa Ana del relieve de la Visitación del referido retablo.

Los ojos adoptan una forma mucho más almendrada, estrecha y rehundida que los de su hermano; aunque sí que poseen el característico abultamiento que aquél coloca debajo

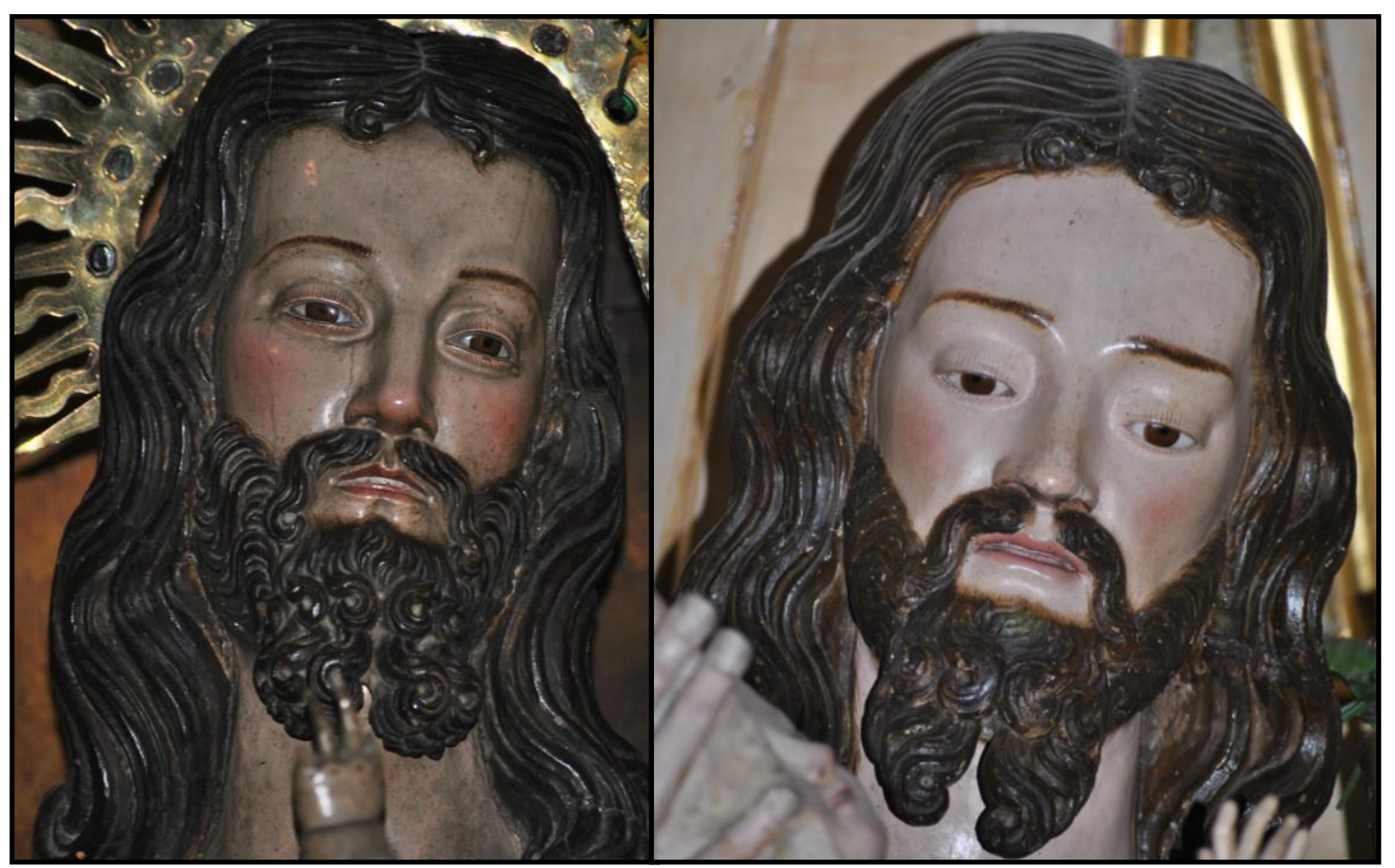

Il. 2- Comparación de los rostros de los San José de Manuel de Ávila y de Pedro de Ávila

de los globos oculares. Las cejas, por su parte, forman un ángulo recto, y el ceño lo normal es que aparezca liso. La forma de tallar la nariz es también plenamente deudora de las que hizo su hermano Pedro durante su segunda etapa; similitud que, por otra parte, nos complica el poder discernir con seguridad la paternidad de ciertas esculturas que creemos de Pedro pero que pudieran ser de Manuel. Son narices rectas, potentes, geometrizadas, con un tabique nasal todavía más ancho y aplastado. Asimismo, el transcurso de la nariz desde su parte superior hasta las fosas nasales no va "in crescendo" en anchura como en las de su hermano, sino que todo el trayecto posee la misma anchura. No son unas narices tan elegantes como las de Pedro de Ávila, pareciera como si Manuel las concibiera como narices de "boxeador". Las aletas nasales

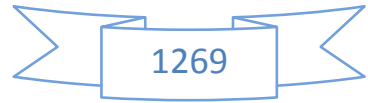


están levemente pronunciadas, mientras que las fosas nasales van perforadas, detalle que aporta un mayor grado de realismo.

Las bocas, que son muy estrechas tanto en longitud como en anchura, las concibe entreabiertas; lo que nos permite verle la fila superior de los dientes, tallados de una manera muy sucinta, e incluso parece apreciarse en algunos casos la punta de la lengua. Los labios son muy finos y las comisuras pronunciadas. Los pómulos son lisos, aunque como viene siendo normal en todos los "Ávila" van policromados con tonos rosáceos para resaltarlos.

El cabello y las barbas también son plenamente deudoras de las esculturas de su hermano; sin embargo, observamos que su tratamiento es algo más seco, lacio y sin volumen; tan solo podríamos excluir de este comentario el bigote y la barba del San José de la Cofradía de Jesús Nazareno, los cuales talla con verdadera maestría y exuberancia. Como dijimos con Pedro de Ávila, también en este caso todos los capilares del rostro tienden a la simetría, aunque a diferencia de aquél, Manuel la sigue todavía más a rajatabla.

La opción predominante para tallar las cabelleras es también una de las más usuales en Pedro de Ávila. Se trata de amplias y sinuosas madejas de cabellos situadas a ambos lados del rostro que caen formando numerosas y amplias ondas que se prolongan hasta la base del cuello; llegando en ocasiones hasta el pecho. La longitud y amplitud de estas madejas trae como consecuencia la total ocultación de las orejas. Este tipo de peinado lo vemos en el San José de la Cofradía de Jesús Nazareno y en las esculturas de la Asunción, el Salvador y San Isidro del retablo de Fuentes de Valdepero. En estas dos últimas imágenes, el tratamiento de los cabellos es ciertamente superficial y poco individualizado, motivo que, quizás, se encuentre en relación a la altura y la escasa visibilidad que de ellas tenían los fieles; es decir, se incidía en la escultura en sí, no en los detalles.

También encontraremos en Manuel otras "soluciones capilares" ya utilizadas tanto por su padre como por su hermano, como son las cabelleras con numerosos y amplios bucles compactos, que nos habla de una cierta maestría en el manejo del trépano. Esta tipología la observamos en dos esculturas del retablo de Fuentes de Valdepero: el San Gabriel del relieve de la Anunciación y el San Juan Evangelista. Este último, además, sería una copia puntual del que su hermano talló para la catedral de Valladolid (como veremos más adelante, parece que tan solo quedó de la escultura original la cabeza, por lo que tanto esta escultura de Manuel de Ávila como otra que le atribuimos en Castromocho pudieran indicarnos como fue en origen el prototipo creado por Pedro de Ávila). Otras tipologías de peinado las observamos en el resto de Evangelistas de este retablo, pero sin embargo la altura a la que se encuentran nos impide precisarlas con exactitud.

Las diferentes formas de resolución de los peinados sobre la frente de los personajes son también herederas de su hermano. Así, veremos todos y cada uno de los mencionados en Pedro de Ávila, sin novedad alguna: calvicie total; calvicie con un pequeño mechón 
circular sobre la frente; dos pequeños mechones rectos simétricos con los extremos apuntando hacia el exterior; dos mechones que apenas se separan de la cabellera pero que en su extremo se retuercen formando dos caracolillos simétricos, etc... Tampoco faltan las frentes despejadas, utilizadas exclusivamente para las figuras femeninas.

Finalmente, en lo referente a barbas, tampoco Manuel de Ávila protagoniza ninguna novedad; sino que se limita a seguir fielmente los modelos de su hermano. Vemos presente, por ejemplo, en su San José una barba bífida modelada a través de cuatro grandes caracolillos en cada una de las dos madejas, con un espacio en medio de ambos; esta solución no hace sino prolongar la tipología utilizada por Pedro para sus imágenes de San José. A Manuel también se lo veremos usar en el Salvador y el San Isidro del retablo de Fuentes de Valdepero.

Por su parte, tipos de barbas heredadas de Juan de Ávila figuran en el San Pedro del retablo de Fuentes de Valdepero, realizada a base una gran cantidad de pequeños bucles compactos, y directamente inspirado en el San Pedro en Cátedra de la Colegiata de Lerma (Burgos); y en el San Pablo del mismo retablo, cuya barba de largos y sinuosos mechones compactos simétricos procede sin lugar a dudas del San Francisco de Sales que su padre ejecuta para el Oratorio de San Felipe Neri.

\section{$\underline{\text { Indumentaria y pliegues }}$}

La escasa cantidad de obras documentadas implica que el número de vestimentas, lógicamente, sea muy reducida. Todas ellas visten túnicas intemporales a excepción del San Isidro del retablo de Fuentes de Valdepero, que porta el vestido de labriego castellano de la época.

En cuanto a los pliegues que surcan las vestimentas, sigue puntualmente el "pliegue a cuchillo" o "pliegue berninesco" introducido por su hermano en la escuela castellana. En la mayor parte de las ocasiones no serán unos paños tan pequeños, agudos y cortantes, sino que los suyos se caracterizan por ser algo más amplios y menos afacetados. No encontraremos en ellos la finura y delicadeza que imprime Pedro de Ávila a algunas de sus creaciones. Con esto no queremos decir que no fuera capaz de realizarlos, sino que, aunque siguió las "directrices" de su hermano, decidió adoptar un estilo diferente y propio. Además, como ya dijimos anteriormente, el hecho de que sus figuras sean menos movidas y tiendan a ser más elegantes propicia que los vestidos estén más quietos y por lo tanto los pliegues ni se agiten ni se multipliquen. En cambio, también se sitúa cerca de su hermano al querer arremolinar grandes porciones del manto alrededor del brazo o por debajo de él, con lo cual consigue una mayor complejidad formal y un ensanchamiento de la escultura.

En otras ocasiones pareciera como si simultaneara el "pliegue a cuchillo" con el pliegue redondeado propio de los escultores vallisoletanos del último cuarto del siglo XVII, 
entre ellos su padre. Así lo percibimos en el San Isidro del retablo de Fuentes de Valdepero.

\section{$\underline{\text { Iconografías }}$}

No podemos hablar en demasía sobre su capacidad creativa a la hora de concebir nuevas iconografías puesto que la escasa obra documentada nos muestra a un escultor que sigue "a su manera" algunas creaciones de su padre, de su hermano y del propio Gregorio Fernández. Tan solo cabe incluir en su haber la escultura del Salvador del retablo de Fuentes de Valdepero, la cual seguramente esté inspirada en alguna estampa o grabado; misma fuente utilizaría a la hora de esculpir el relieve de la Coronación de la Virgen de ese mismo retablo.

De Gregorio Fernández proceden los modelos del San Pedro y San Pablo del retablo de Fuentes de Valdepero; si bien cabría pensar que en realidad Manuel se basó más en las copias que de estos hizo su hermano Pedro para el Oratorio de San Felipe Neri. Aunque sigue los patrones de ambos escultores, Manuel parece realizar una versión propia que se aleja en demasía al fernandesco. Además, si comparamos los ejemplares de Pedro con los de Manuel, comprobamos que aquéllos son esculturas mucho más monumentales; y, sin embargo, en estas parece preponderar un cierto gusto por las formas y no por el fondo, algo que, por otra parte, es muy típico del siglo XVIII. También de Gregorio Fernández, pero de manera conjunta con su padre Juan de Ávila, copia el modelo de San Isidro del retablo de Fuentes de Valdepero.

Por su parte, de Pedro de Ávila copia la tipología de San Juan Evangelista del mismo retablo, cuyo prototipo será el que el hermano mayor de Manuel talló para la santa iglesia catedral de Valladolid; y del que, al parecer, tan solo conservamos la cabeza. Ya dijimos, y explicamos en profundidad, que, de confirmarse esta teoría, tanto esta escultura de Valdepero, como otra conservada en el retablo mayor de la iglesia de Santa María de Colaña de Castromocho (Palencia) nos ayudarían a reconstruir el cuerpo original del santo "catedralicio".

\section{$\underline{\text { Postizos }}$}

No tenemos constancia de que utilizara ningún postizo, amén de las referidas tapillas de vidrio para simular los ojos; pero no en todos, puesto que algunos van directamente pintados sobre la madera.

\section{$\underline{\text { Relieves }}$}

Los relieves son algo muy residual dentro de su escaso catálogo, puesto que se reducen a los dos que talló para el banco del retablo mayor de la iglesia parroquial de Santa 
María de Fuentes de Valdepero (Palencia). Se trata de dos temas marianos: la Anunciación y la Visitación. A pesar de todo el tiempo transcurrido desde que su padre tallara sus relieves, estos de Manuel no dejan de ser deudores de ciertas maneras paternas, si bien hemos de recalcar que son de mucha mayor calidad tanto en la consecución de los tipos humanos como en el movimiento de los mismos.

La semejanza con los de Juan de Ávila se basa en que también se trata de lo que Martín González llamaba "falso relieve", propia madera sino que son esculturas de altorrelieve adheridas al tablero del fondo. Además de ello, el fondo se encuentra pintado para dar mayor sensación de profundidad, dinamismo y realismo. Ello se debe fundamentalmente a la total y absoluta falta de perspectiva. Ávila practica en ellos lo que Martín González definía como "falso relieve". Hay que señalar que, aunque las esculturas son más que correctas, el pintor de estos dos relieves ni logra dar la ilusión de realismo a la escena ni siquiera consigue alcanzar una mínima perspectiva. Como podemos observar en el relieve de la Anunciación, el pintor no logra organizar una serie de arcadas tras la figura de la Virgen.

2 MARTÍN GONZÁLEZ, Juan José: Escultura barroca castellana..., op. cit., p. 24. 


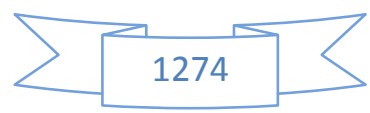




\section{3-MANUEL DE \\ AIILA. CATÁLOGO}




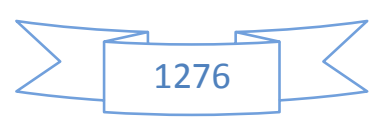


La estructura de este capítulo difiere a la forma en que lo tratamos tanto con Juan como con Pedro de Ávila puesto que la escasez de obra documentada unida al parecido que posee el estilo de Manuel de Ávila con el de su hermano Pedro hace que no podamos atribuirle mucha obra, y que tengamos que suprimir las secciones de "Obras relacionadas" y "Obras descatalogadas":

Obras documentadas. Son aquellas de las que tenemos constancia de su autoría ya sea porque conservamos los contratos de ejecución, por reseñas en libros de cuentas o de fábrica, etc...

Obras atribuidas. Son aquellas que sin tener constancia documental podemos adscribir al escultor mediante la mera comparación estilística con sus obras indudables. Muchas de las atribuciones que realizo son inéditas, no sé si con mayor o menor fortuna. El resto están recogidas de diferentes libros, si bien las dos fuentes principales han sido el Inventario artístico de Valladolid y su provincia $(1970)^{1}$, dirigido por don Juan José Martín González, y los veintiún tomos del Catálogo Monumental de Valladolid.

No todas las obras serán tratadas con la misma extensión ya que hay algunas de las que carecemos por completo de dato alguno. Además, una vez que se explique la iconografía de un santo no se volverá a hacer para así evitar repeticiones reiteradas.

La ordenación de las obras sigue un criterio cronológico en el caso de las "documentadas" y "atribuidas", mientras que las "relacionadas" y "descatalogadas" he preferido colocarlas en el orden alfabético de las localidades en que están situadas.

1 MARTÍN GONZÁLEZ, Juan José (dir.): Inventario artístico de Valladolid..., op. cit. 
$\sum \sqrt{1278}<$ 


\section{3-1 OBRAS}

DOCUMENTADAS 
$\sum 1280 \leq$ 


\section{FUENTES DE VALDEPERO. IGLESIA DE NUESTRA SEÑORA DE LA ANTIGUA}

\section{ESCULTURAS DEL RETABLO MAYOR (h. 1715)}

El grueso de la escasa obra documentada de Manuel de Ávila lo conforma las esculturas del retablo mayor de la iglesia parroquial de Fuentes de Valdepero (Palencia): trece esculturas de bulto redondo (cuatro de ellos pequeños angelotes) y cuatro relieves. Pues bien, estas esculturas que pregonan el estilo de Pedro de Ávila fueron relacionadas por Martín González con "estilo de Pedro de Ávila", del que Manuel es un completo deudor. Sería el padre Albano García Abad el que tras numerosas investigaciones logró documentar estas esculturas como obras de Manuel de Ávila en su Inventario documentado de la iglesia de Nuestra Señora de la Antigua de Fuentes de Valdepero ${ }^{3}$. Poco después el religioso publicó, por su trascendencia e interés, este mismo dato en un artículo en el Diario Palentino ${ }^{4}$.

El padre García Abad localizó el dato en un pleito suscitado entre Manuel de Ávila y la parroquial de Fuentes de Valdepero, la cual no había terminado de pagar todos sus emolumentos al escultor. Que la iglesia tuvo problemas económicos nos lo indica bien a las claras el hecho de que el retablo quedara sin policromar, con lo cual perdió parte de su encanto; aunque por otra parte un retablo "en blanco" sirve para valorizar los méritos puramente arquitectónicos.

La historia de estas esculturas es tortuosa puesto que no solo hubo pleito una vez acabadas, sino que también hubo problemas legales antes de comenzarlas. Efectivamente, al parecer Alonso Manzano subarrendó la ejecución de las esculturas a Tomás de Sierra; sin embargo, poco después, antes de que comenzara a tallarlas, se le apartó de la obra. No sabemos qué ocurrió y tampoco si la idea de que no esculpiera las imágenes partió de la iglesia o bien de Alonso Manzano. Ya decimos que se trata de una situación extraña puesto que las relaciones entre ambos artistas debían de ser buenas dado que colaboraron en diversas ocasiones. El caso es que finalmente fue Manuel de Ávila el que las talló, y eso trajo consecuencias: el 1 de julio de 1715 Tomás de Sierra daba poder a su hijo Francisco, escultor y religioso, para que en su nombre y de manera judicial o extrajudicial reconviniera a "Alonso Manzano y al cura mayordomo de dicha iglesia fiadores y a otras cualesquiera personas de cuya incumbencia ha sido y fuere a que en un todo se me cumpla dicho contrato y ajuste que por lo que me toca estoy pronto a observar y guardar y lo pactado y si sobre lo referido fuere necesario parecer en juicio lo haga" (DOCUMENTO 92). El escultor riosecano refería que el retablo "ha corrido y corre su ejecución a cargo de Alonso Manzano arquitecto y por lo que mira a la escultura para el mismo retablo ésta el susodicho la ajustó con mi el otorgante

\footnotetext{
2 MARTÍN GONZÁLEZ, Juan José: Escultura barroca en España..., op. cit., p. 448.

3 Debo toda la información acerca de este trabajo y la posibilidad de realizar las fotografías del retablo al concejal del Ayuntamiento de Fuentes de Valdepero don Fernando Martín.

4 GARCÍA ABAD, Albano: "Fuentes de Valdepero: Sobre el retablo mayor de la iglesia parroquial", El Diario Palentino (28 de septiembre de 1997).
} 
quedando a mi cuidado el hacerla". La cantidad que percibiría por esculpir todas las tallas, las cuales serían las mismas que ejecutó Ávila, ascendía a 6.700 reales.

Por otra parte, ya referimos que hubo también problemas una vez que Manuel de Ávila acabó de esculpir las tallas: la iglesia no pagó toda la cantidad estipulada al escultor, seguramente debido a que las arcas parroquiales no se encontraban en su mejor momento. La importancia de este pleito es fundamental por cuanto nos aporta el nombre del escultor, ya que antes de que se descubriera no teníamos constancia del autor de las imágenes, y se suponía que las había realizado Pedro de Ávila. Efectivamente, en el Archivo Provincial de Palencia, entre los protocolos del escribano Francisco Antonio Montero del año 1724, figura la autoría de las hechuras del retablo: "se ajustó la escultura para el retablo de la capilla mayor con Manuel de Ávila, vecino de Valladolid, en 6.600 reales" (DOCUMENTO 93).

Esta prolija escritura nos hace saber que todavía se le adeudaban al escultor vallisoletano 2.600 reales; o lo que es lo mismo, tan solo se le habían abonado 4.000 reales de los 6.600 reales en que se ajustó la obra. Como quiera que la iglesia no tenía "con que dar satisfacción" al escultor, el párroco y el mayordomo acudieron al provisor y vicario general de la diócesis, don Manuel González Benito, para proponerle como solución el que se redimiera un censo que tenían con la Cofradía de Los Veinte de la localidad de Carrión de los Condes. Tras una serie de informaciones y de autos, el día 24 de abril de ese mismo año el citado licenciado, "abogado de los Reales Consejos canónigo en la Santa Iglesia Catedral de la ciudad de Palencia provisor y vicario general en él dicho y su obispado por el Ilustrísimo Señor Don Francisco Ochoa Mendarozqueta obispo de dicho obispado Conde de Pernía del Consejo de su Majestad", daba el visto bueno a la fábrica de la parroquial de Valdepero para que pudiera "tomar y tomen a censo mil ducados de vellón a razón de a dos y medio por ciento y con ellos quitar el censo de ochocientos ducados que contra si tiene la fábrica a favor de la obra pía y cofradía de los veinte de la ciudad de Carrión y pagar los dos mil y seiscientos reales que se restan deber a Manuel de Ávila escultor vecino de Valladolid por el retablo que hizo para la capilla mayor que para ello". Probablemente, pocas fechas después Manuel de Ávila percibiría los 2.600 reales adeudados.

Una vez vistas ambas escrituras podríamos establecer una hipótesis de por qué apartaron de la ejecución de las esculturas a Tomás de Sierra. Como vemos, el artífice riosecano se había concertado en 6.700 reales mientras que Manuel de Ávila parece que lo hizo en 6.600 reales. Pudiera ser que el escultor vallisoletano llegara tarde a la subasta, una vez acabada, pero al ya conocerle los delegados parroquiales de otras ocasiones, y visto que hacía una rebaja de 100 reales, decidieron que fuera él quien se ocupara de tallar las imágenes. La suposición de una anterior relación de Ávila con la parroquia proviene del hecho de que hay en el templo una escultura de Santa Bárbara que le es plenamente atribuible, a pesar de que también posee estilemas propios de su hermano Pedro de Ávila, con quien se formó y del que su estilo es plenamente deudor. Sin embargo, la escasa calidad de la obra parece apuntar a un escultor novel, en este caso, el pequeño de los Ávila. Finalmente, y con respecto a esta última escultura, hay que incidir en que 
habría sido realizada antes que las esculturas del retablo, y que por eso le conocerían, dado que es altamente improbable que aceptara realizarla con posterioridad dada la tremenda dilatación sufrida para el cobro de las imágenes del retablo.

En cuanto a la cronología, parece claro que las esculturas fueron contratadas por Ávila a mediados del año 1715 (si tenemos en cuenta que Tomás de Sierra inicia las acciones legales el 1 de julio de 1715, cabe pensar que Manuel de Ávila comenzaría por estas mismas fechas a esculpir las imágenes) y acabadas un tiempo prudencial después dado el volumen de la obra, quizás a lo largo de 1716. Cabe pensar que la parte escultórica salió a subasta una vez finalizada la arquitectónica, este hecho incidiría de nuevo en los problemas económicos que sufría la iglesia, los cuales debieron de impedirle contratar a la vez arquitectura y escultura.

El retablo (Fig. 1) fue realizado en el año 1711 por el antedicho Alonso Manzano ${ }^{5}$ según las trazas de Lucas Ortiz de Boar, uno de los artífices más prolíficos en estos momentos por tierras palentinas y burgalesas. El ensamblador vallisoletano percibió por su ejecución la nada desdeñable cantidad de 28.000 reales, si bien hemos de tener en cuenta que se trata de un mueble inmenso que forra por completo el ábside mayor de la iglesia. Se compone de un pedestal de cantería, banco, un único cuerpo con tres calles de idénticas dimensiones articulado a través de cuatro estípites de orden gigante y un ático en forma de cascarón rematado en su clave por un relieve de Dios Padre. La planta del retablo no es recta, sino que las calles laterales y sus prolongaciones en ático y banco se arquean levemente de tal manera que tienden a la forma de un tríptico con las alas a medio abrir. En el banco encuentran asiento las ménsulas de los estípites gigantes mientras que entre ellas, en los netos, están los relieves de la Visitación y de la Anunciación, y en el neto central una gran custodia barroca de estos mismos momentos (a diferencia del retablo, la custodia sí que fue dorada). Por su parte, en el cuerpo, las calles laterales se subdividen en dos pisos, cada uno de ellos integrado por una hornacina de escaso resalte flanqueado por dos columnas salomónicas; dentro de ellas se halla un santo (San Pedro, San Pablo, el Salvador y San Isidro) sobre una peana con profusa decoración vegetal; la cual, por otra parte, recubre la totalidad del retablo, pues hay un claro horror vacui. La calle central tan solo exhibe una gran hornacina horadada que hace funciones de transparente, que también está flanqueada por un par de columnas salomónicas. En su interior aparece mágicamente flotando la Inmaculada rodeada de cuatro angelitos, dos a cada lado. Sobre ella un potente tarjetón con decoración vegetal que sirve para separar este cuerpo del ático. Finalmente, y separado por un entablamento partido, se encuentra el ático: en el aparecen los cuatro Evangelistas apeados sobre trozos de entablamento que se sitúan en la vertical de los estípites del cuerpo del retablo; en la parte central del cascarón exhibe un gran medallón poligonal en el que se desarrolla el relieve de la Coronación de la Virgen. El retablo alberga una clara iconografía mariana que repasa los grandes momentos de la vida de la Virgen, obviando los dolorosos de la Pasión de su Hijo.

5 MARTÍN GONZÁLEZ, Juan José: Escultura barroca en España..., op. cit., p. 448. 
Como podemos observar, el retablo fue realizado en una época en la que el estípite relega a la columna salomónica a un plano secundario, cuando no meramente ornamental. Toda la talla del retablo presenta un carnoso abultamiento, muy propio del estilo de Manzano. Los motivos, aunque sujetos a la traza general de Lucas Ortiz de Boar, pertenecen al estilo decorativo de Manzano. Las ménsulas de las estatuas son grandes mascarones, de enorme boca, que ya utilizó en el retablo de las Claras de Peñafiel y en el retablo mayor de la iglesia de Santiago Apóstol de Valladolid. También es característico de Manzano la adopción del ático de la forma de cascarón.

El total de esculturas realizadas por Manuel de Ávila fue de diecisiete: trece de bulto redondo (los cuatro Evangelistas, San Pedro, San Pablo, San Isidro, el Salvador, la Inmaculada y los cuatro ángeles que la rodean) y cuatro relieves (la Visitación, la Anunciación, la Coronación de la Virgen y el Padre Eterno). Pienso que el programa iconográfico, y por ende las condiciones para ejecutar las esculturas, pudo haber sido realizado por Tomás de Sierra dado que en alguno de los retablos para los que trabajó gustó de situar sobre pedestales en el ático a los Evangelistas o a los Padres de la Iglesia en posiciones teatrales; como ejemplos tenemos el retablo mayor de la iglesia del Salvador de Herrín de Campos (Valladolid) (Fig. 2) o el retablo mayor de la iglesia de Santiago de los Caballeros de Medina de Rioseco (Valladolid) (Fig. 3). Sin embargo, hemos de volver a recordar que en el área vallisoletana esta composición ya se venía usando desde Gregorio Fernández (el cual situaba en el ático figuras angelicales) e incluso desde Esteban Jordán, como así podemos comprobarlo en el retablo del Cristo de Burgos que talló para la desaparecida iglesia de San Antón de Valladolid y que actualmente se encuentra en el Santuario Nacional de la Gran Promesa.

En la visita del año 1757, el obispo de Palencia, don Andrés Bustamante, ordenaba "que se doren los santos que se hallan en el altar mayor" y en la visita de 1761 "que se dore el retablo mayor"6. Como vemos, el retablo al final no pudo dorarse; en cuanto al dorado de las esculturas puede ser que se quisieran repolicromar. Algunas de las esculturas parecen estar policromadas por las mismas fechas en que se ejecutaron, sin embargo, los relieves inferiores, San Pedro, San Pablo, el Salvador y la Inmaculada Concepción sí parecen poseer una policromía rococó acorde a esta citada fecha de 1757.

\section{RELIEVES}

Los relieves que contiene el retablo son cuatro: en el banco los paneles de la Anunciación y la Visitación; en el ático la Coronación de la Virgen por parte de la Santísima Trinidad; y en la clave del ático el Padre Eterno. Estos relieves no hacen sino venir a perpetuar el modo de proceder de su padre y de otros escultores vallisoletanos del momento: no son relieves tallados, sino que se trata de figuras de casi bulto redondo pegadas sobre el panel, el cual se encuentra pintado representando una escena que ayuda

6 GARCÍA ABAD, ALBANO: Fuentes de Valdepero: Inventario documentado de la Iglesia de Nuestra Señora de la Antigua, León, 1998, f. 5. 
a enmarcar la acción y a darla mayor realismo; es decir, tal cual hizo Juan de Ávila con los del Oratorio de San Felipe Neri y los del Monasterio de San Quirce. Me gustaría puntualizar que no trataremos sobre el relieve del Padre Eterno por cuanto a la duda de si fue hecho por el ensamblador o por el escultor se añade el hecho de que apenas es visible, problema que se incrementa al no estar policromado.

Hemos de desmentir la afirmación del padre Albano de que los relieves no pertenecen al retablo, sino que procederían del primitivo retablo del siglo XVI: "son de buen arte y es de ver claramente que están superpuestas. No es fácil poder probar su procedencia exacta, pero creo que no es nada aventurado que procedan del anterior retablo del s. XVI. Las características de su arte los denuncia como de Escuela Castellana del siglo $X V I$, en que además sabemos que hubo retablo en la iglesia"7. Para nada, los rostros de las figuras de estos relieves son característicos de Manuel de Ávila.

\section{$\underline{\text { La Anunciación }}$}

La composición de este relieve (Fig. 4) viene a ser en esencia la misma que desarrollaron su hermano en el grupo escultórico que se encuentra en Renedo, su padre en el relieve de Ataquines y Juan Antonio de la Peña en el retablo de las Claras de Peñafiel; sin embargo, con los que guarda mayores semejanzas es con los dos últimos ya que sitúa al Ángel al lado izquierdo, a la Virgen en el derecho y entre ellos un jarrón con azucenas que alude a la virginidad de María. Efectivamente, el Arcángel (Fig. 5) se aproxima de pie montado sobre una nube, con una posición muy hierática a la que no otorgan movimiento ni siquiera los pliegues. Viste túnica larga roja con motivos dorados y sobretúnica azul con dibujos vegetales ajustada a la cintura por un cíngulo y abierta al medio. En la espalda dos grandes alas policromadas en blanco, azul y rojo. Las manos han sido amputadas. En este caso no estaban talladas de manera exenta por lo que hemos de pensar que fueron serradas o se partieron debido a algún accidente fortuito. En la cabeza no reconocemos el estilo de Manuel, a excepción de la mueca de la boca, por lo que quizás esta pieza sea obra de taller; lo que a su vez explicaría el carácter seco y reposado de toda la figura, en clara contraposición al barroquismo con el que ha sido concebida la Virgen. Interesante cabellera realizada a base de amplios bucles que denota la utilización del trépano y parece recordarnos las masas capilares de algunas esculturas de su hermano (los dos San Miguel o el San Juan Evangelista de la catedral vallisoletana). En cuanto a los pliegues, no encontramos por ningún lado el característico plegado aristado a cuchillo: son dulces, combados, redondeados, si bien algo secos y duros.

Enfrente se encuentra la Virgen (Fig. 6), que ha sido concebida en una posición muy teatral, movida y barroca, contraponiéndose de esta manera al Arcángel. Esta pieza sí que denota la mano de Manuel de Ávila tanto en este detalle como en la utilización de un incipiente pliegue a cuchillo y también por los rasgos faciales, los cuales entroncan

$7 \quad$ Ibídem. 
con los de su hermano Pedro. La Virgen, que adopta una clara serpentinata, se encuentra arrodillada sobre un amplio cojín rojo con borlas en las esquinas. No está directamente de rodillas, sino que mantiene la derecha semiflexionada, de tal manera que crea un gran volumen con esa rodilla además de un elegante contrapposto. Se encontraba, antes de la irrupción de San Gabriel, leyendo una biblia apoyada sobre el atril; de tal manera que la llegada repentina del Arcángel le ha provocado el gesto automático de girar el rostro, detalle que ha captado el escultor a la perfección, no en el caso de la citada rodilla. Con una mano sujeta el lomo izquierdo del libro mientras que la derecha se la lleva al pecho en signo de devoción y sorpresa. Esta mano también ha desaparecido, si bien en este caso se encontraba tallada de manera exenta. Viste una ampulosa túnica blanca con decoraciones vegetales y geométricas doradas, y un manto azul echado sobre la cabeza y el hombro derecho, de tal manera que le cubre gran parte del brazo derecho y su extremo aparece como volado por el viento, con unas puntas bastante aristadas. En esta pieza sí que encontramos pliegues a cuchillo en el manto, pero los de la túnica son algo menos aristados. Como acabamos de comentar, el rostro presenta los típicos rasgos faciales de los Ávila como podemos comprobar en ojos, nariz y boca. A pesar de que el manto le cubre la cabeza, un pequeño mechón de pelo se desliza por el cuello.

Completa la escena la paloma del Espíritu Santo, cuya silueta se recorta sobre una gran nube similar a la de San Gabriel. En cuanto al fondo pictórico, este parece representar la entrada de una casa dado que en el suelo podemos ver pavimento, en la parte izquierda una zona arbolada con montañas al fondo y a la derecha una serie de arquitecturas clásicas cuya perspectiva deja mucho que desear. Parte de esta arquitectura está tapada por el tan manido recurso barroco del telón rojo.

\section{$\underline{\text { La Visitación }}$}

La Visitación (Fig. 7) transcurrió cronológicamente después de la Anunciación, debido a ello se ha colocado el relieve en la parte derecha del retablo. Este relieve alude al momento en el que tras haber recibido la Virgen María la Buena Nueva, y de que el Arcángel San Gabriel le contara que "Isabel, su pariente, hallábase preñada desde hacía seis meses", marcha apresurada "movida por la piedad y caridad de su corazón (...) hacia Jerusalén para felicitar a su prima y para prestarle su ayuda y servicio" ${ }^{\text {. El }}$ encuentro entre ambas en el patio de la casa de Santa Isabel se saldó con un abrazo, justamente el motivo que capta este relieve. Ya el pintor Francisco Pacheco había dictado las normas con que debía de concebirse esta escena: "se debe pintar esta visita en el patio de la casa y la santa anciana que sale a la puerta de la sala a recibir a la Santísima Virgen (...) y abrazándose las dos primas con grande alegría (...) No hubo testigos delante porque las palabras y misterios que allí pasaron ni aún San José estuvo presente a ellas que, a la sazón, o cuidaba de alguna cosa de importancia, o como es lo más cierto, saludaba al santo Zacarías como al señor de la casa, y así, estarán bien los dos apartados alabando a Dios, en distancia que no pudiesen atender a la conversación

$8 \quad$ VORÁGINE, Santiago de la: La leyenda dorada, Tomo II..., op. cit., p. 875. 
primera de las dos primas"9. Efectivamente, así ha concebido su escena Manuel de Ávila, que hubiera leído a Pacheco; si bien seguramente esta composición no derive de su ingenio sino de alguna estampa o grabado; de donde procederá también la disposición del relieve de la Coronación de la Virgen. Según comenta Díaz Vaquero, esta escena encierra otra lectura: "en este momento Juan el Bautista es liberado del pecado original en virtud de los méritos de Cristo Salvador. A partir del Concilio de Trento (...) Isabel fue representada como mujer de edad madura mientas que María aparece figurada como una joven"10.

El relieve lo copan las monumentales figuras de la Virgen y Santa Isabel, las cuales aparecen en el centro. El fondo lo constituye una pintura con dos espacios claramente delimitados: la parte izquierda, la de Santa Isabel, representa una arquitectura con una puerta que aludirá a la entrada de la casa de la santa; mientras que a la derecha, donde se encuentra la Virgen, el fondo presenta un bello jardín con árboles, flores y un amplio cielo azul surcado por pájaros. Podríamos darle la lectura de que la Virgen es un frondoso vergel y fuente de vida. Hemos de volver a reseñar lo mal que capta el pintor las perspectivas.

Ambas santas figuran abrazadas de pie. Podemos ver un detalle curioso: Manuel de Ávila ha concebido los pies de Santa Isabel de la misma manera que su hermano Pedro (en un ángulo de $90^{\circ}$ ), pero con la singularidad de que es la primera vez que lo vemos plasmado en un relieve. La anciana viste una túnica verde con esgrafiados dorados y un manto naranja con decoraciones vegetales también doradas, además de un velo que le cubre la cabeza. Por su parte, la Virgen viste sus ropajes tradicionales: una amplia túnica blanca con decoraciones botánicas en diversos colores y un manto azul con motivos dorados echado sobre la cabeza y que llega hasta el suelo, de tal manera que convierte la figura de María en una especie de triángulo; composición a la que también parece tender la fusión de las figuras de ambas mujeres.

Santa Isabel abraza a su prima por los codos, mientras que María hace lo propio pero por los hombros, de tal manera que parece indicarnos la supremacía de esta última. Además, mientras que Santa Isabel mira de frente, sin apenas movimiento, la Virgen gira la cabeza hacia la derecha como saludándola afectuosamente. Los rostros de ambas santas vuelven a presentar los rasgos típicos de Manuel de Ávila, de tal manera que el rostro de la Virgen viene a ser un calco del de la misma figura de la Anunciación.

\section{$\underline{\text { La Coronación de la Virgen }}$}

La Coronación de la Virgen (Fig. 8) sucede una vez que María fallece y es elevada a los altares, momento en el que le recibe la Santísima Trinidad y la corona. No cabe duda de que la composición fue extraída de una estampa o grabado. Hay muchos ejemplos que efigian esta escena de una manera parecida, por lo que tan solo destacaremos uno: la

9 DÍAZ VAQUERO, María Dolores: op. cit., p. 63.

10 Ibídem. 
Coronación de la Virgen diseñada en 1619 por Hieronymus Wierix (Fig. 9). Dejando de lado la indumentaria de Dios Padre, el resto, incluidas las actitudes, es completamente exacto.

La escena presenta una composición triangular si tenemos solo en cuenta a Jesucristo, Dios Padre y la Virgen; o romboidal si sumamos a la paloma del Espíritu Santo que contempla la escena desde la parte superior de la escena, cuyas formas se recortan sobre una nube (exactamente igual que en el relieve de la Anunciación). Los tres grandes protagonistas del relieve figuran sobre otras tantas nubes, Jesús y Dios Padre sentados y la Virgen arrodillada. Estas nubes son típicamente "avilesinas" puesto que se componen de numerosas líneas curvas.

La Virgen, situada en un plano inferior, figura arrodillada, con la pierna derecha semiflexionada de tal manera que volvemos a ver que emerge la rodilla sobre la túnica. La mano izquierda se la lleva al pecho mientras que la izquierda, que parecía estar extendida, la ha perdido; las manos se hallan talladas de manera exenta, por lo que se habrán caído. Viste de la manera usual, no hay novedades, tan solo destacar la caída del manto por el brazo izquierdo y la fuerte utilización en los paños del pliegue a cuchillo, con mucho mayor resalte que en los relieves inferiores. La cabeza, que posee los típicos rasgos del escultor y que nos recuerda a algunos rostros de su hermano Pedro, la levanta para mirar atentamente a la corona que le van a poner. También, como es típico de su hermano, deja caer una guedeja de pelo por el lado derecho de la cabeza hasta el pecho.

A la izquierda se sitúa Jesucristo, cuya nube se adapta perfectamente para que parezca estar sentado. Su cuerpo lo cubre casi en su totalidad una túnica roja con el borde dorado, sin embargo la parte derecha de su torso y el brazo queda al descubierto, mostrándonos el correcto estudio anatómico realizado por el escultor, teniendo bien definidos los músculos y las costillas. Mira al frente, no a la corona ni a la Virgen. En su mano izquierda porta una especie de centro mientras que con la otra sujeta delicadamente la corona. A la derecha está Dios Padre sentado en la nube en una posición muy arriesgada y elegante puesto que eleva la pierna izquierda de tal modo que le ayuda a sujetar la gran bola del mundo que tiene en la mano de ese lado. Mientras tanto con la derecha hace lo propio con la corona que junto a su Hijo está a punto de situar sobre la testa de la Virgen. Viste túnica blanca y capa roja con el borde dorado abrochada al cuello y sujeta también por sendas cintas que se entrecruzan a la altura del pecho. En ambas figuras también está presente el pliegue a cuchillo; los paños, que son muy movidos, crean profundas aristas y oquedades. En los mantos acertamos a ver, a pesar de la altitud, que Manuel de Ávila también sabe adelgazar bastante las maderas.

\section{ESCULTURAS DE BULTO REDONDO}

Las esculturas de bulto redondo las podemos dividir en tres grupos: los cuatro santos que ocupan las calles laterales (San Pedro, San Pablo, el Salvador y San Isidro), la Inmaculada con los cuatro angelitos que la rodean, y los cuatro Evangelistas del ático. 
Como veremos, algunas de estas esculturas copian modelos creados o difundidos por su padre, Juan de Ávila, y por su hermano, Pedro de Ávila; e incluso son una última vuelta de tuerca de algunas tipologías de Gregorio Fernández. Las esculturas, por lo general, se encuentran en buen estado de conservación, sin embargo el abundante polvo y la pérdida de algunas manos o dedos las hace perder parte de su encanto.

\section{$\underline{\text { San Pedro y San Pablo }}$}

Se sitúan en los pisos superiores de las calles laterales. Ambos santos vienen a ser una versión de los creados un siglo atrás por Gregorio Fernández y que fueron ampliamente copiados por la mayoría de los escultores vallisoletanos y castellanos a lo largo de todo el siglo XVII y gran parte del siglo XVIII, incluidos Juan y Pedro de Ávila. Son particularmente similares a los que hizo su hermano para el Oratorio de San Felipe Neri, en especial el San Pedro.

San Pedro (Fig. 10) viste túnica azul con motivos blanquecinos y manto naranja con decoraciones doradas. Dispone el manto de tal manera que le cubre el hombro izquierdo y gran parte de la cintura y las piernas. Los pliegues a cuchillo adquieren unas formas muy geometrizadas y cuadráticas, formando grandes concavidades pero no redondeadas sino rectangulares. Como es usual, adelanta la pierna derecha para formar contrapposto. La cabeza viene a ser una versión de las que su hermano hizo para todas sus representaciones de San Pedro, con barba y pelo concebido a través de pequeños caracolillos; aunque en realidad el modelo fue el San Pedro en cátedra de Juan de Ávila para la Colegiata de Lerma. En su mano derecha porta un libro cerrado que apoya sobre la cadera, de tal manera que se crean unas arrugas en el manto. En la izquierda exhibe orgulloso su atributo más conocido: las dos llaves.

Por su parte, San Pablo (Fig. 11) viene a ser una copia literal del San Pedro con la única excepción de que su composición se halla invertida, de tal manera que adelanta la pierna izquierda en lugar de la derecha; extiende el brazo derecho en vez del izquierdo y mantiene retraído el izquierdo en lugar del derecho. Asimismo, mientras que San Pedro mira hacia la derecha para observar a la Inmaculada, San Pablo dirige su mirada hacia ella pero girando la cabeza hacia la izquierda. El apóstol de Tarso ha perdido sus dos atributos. Cabe pensar que en la mano derecha portaría la espada y en la izquierda un libro, o viceversa. También los ropajes y la forma de disponerlos tanto ellos como sus pliegues son completamente exactos a los de San Pedro pero a la inversa. Tan solo se diferencian en la cabeza, pues ésta tiene unos cabellos mojados sobre la frente y una barba larga compuesta por sinuosos mechones.

Cabe destacar en ambas esculturas la delicadeza y las posturas tan elegantes con que han sido concebidas. El hecho de que Manuel de Ávila sea una década más joven que su hermano Pedro, y el que se haya formado con éste y no con su padre u otros escultores de la anterior generación, ha influido para que su escultura esté despojada de todas las ataduras de la escultura del siglo XVII y lo que ello conllevaba: el "fernandismo". Sin 
lugar a dudas Manuel de Ávila practica desde sus comienzos una escultura dieciochesca.

\section{$\underline{\text { Salvador }}$}

El Salvador (Fig. 12) se sitúa en el piso bajo de la calle de la izquierda. Es quizás la escultura más movida y de mayor calidad de las cuatro de este grupo. Se trata de una figura bastante inusual en la plástica barroca y más en esta situación, en la que el resto de imágenes representan a santos populares. Aparece efigiado de pie en una composición abierta con los brazos extendidos hacia los lados, con cuyas manos ejecuta sendos gestos declamatorios, la izquierda completamente extendida mientras que la derecha ha perdido todos sus dedos y se halla muy maltratada. Adelanta la pierna derecha según el modo usual y echa el cuerpo ligeramente hacia atrás. Viste una amplia túnica ceñida a la cintura y un manto que le cubre el hombro y brazo derechos, y además uno de sus pliegues adopta un detalle muy utilizado por su hermano: sale proyectado en diagonal desde la cadera izquierda del santo. Ambos ropajes poseen la misma policromía dual que hemos visto en San Pedro y San Pablo, tan solo escapa a esta bicromía la figura de San Isidro que viste su traje tradicional y con sus colores característicos. Los paños, de corte agudo, forman amplias concavidades, especialmente profundas en la túnica y aristadas en el manto.

\section{$\underline{\text { San Isidro }}$}

Completa el conjunto la efigie de San Isidro (Fig. 13), la cual no podía faltar dada la gran devoción que se le profesa en el ámbito rural. Una vez más, y como ocurría con su hermano, viene a copiar fielmente el modelo creado por Gregorio Fernández, popularizado por su padre Juan de Ávila y difundido por su hermano Pedro. Por evitar repeticiones tan solo diremos que adopta el mismo esquema y movimientos que el prototipo y sus copias, si bien su factura, especialmente visible en el rostro, es bastante más seca y torpe. Tanto los rasgos faciales, muy estereotipados, como el pelo, muy lacio, parecen indicarnos cierta labor de taller puesto que se contraponen con el vigor, movimiento y elegancia de San Pedro, San Pablo y el Salvador. También pudo influir en ello el que se trate de una copia literal. En la mano izquierda porta un arado y en la derecha el cayado. Viste a la usanza de la época, con indumentaria de labriego: chaqueta corta con cuello de encaje pequeño; calzas ajustadas al muslo con botas altas hasta la entrepierna. Vestido marrón rojizo, con dibujos dorados a pincel, ceñido con un cíngulo. Botones desde el cuello a la cintura. Llama la atención el hecho de que posea un tamaño ligeramente inferior a las otras tres. 


\section{Inmaculada Concepción}

La quinta talla del cuerpo del retablo es la Inmaculada Concepción (Fig. 14) que preside la hornacina central, la cual posee a sus espaldas un transparente, pero no solo eso, ya que el espacio que separa éste de la escultura se encuentra policromado con una pintura mural que representa un rompimiento de gloria en el que se ven nubes, cabezas aladas de serafines, la paloma del Espíritu Santo e incluso parece apreciarse un Cristo similar al del relieve de la Coronación, si bien la pintura se encuentra muy perdida.

Lo primero que hay que hacer es desmentir lo aseverado por el padre Albano: "no es del mismo autor y tampoco se conoce el escultor que la hizo, es barroca y de buena talla, y anterior al retablo" "11. Todo lo contrario, la escultura presenta todos y cada uno de los estilemas de Manuel de Ávila y fue realizada al mismo tiempo que el resto de esculturas del retablo; es más, la policromía es similar a la de todas ellas.

La escultura sigue lejanamente el modelo de su hermano, pareciéndose mucho más a la que Pedro Bahamonde talló para el retablo mayor de Autillo de Campos (Fig. 15), detalle que ya fue observado por Martín González ${ }^{12}$. Efectivamente, de Pedro de Ávila toma el detalle de la peana formada por una nube en cuyo frente se exhiben tres cabezas aladas de angelitos dispuestas con diversos gestos para crear variedad; mientras que de Pedro Bahamonde toma el resto; o más bien al contrario, Bahamonde copia la disposición de la Inmaculada de Manuel de Ávila. ¿Podría ser este detalle un indicio de una posible formación de Bahamonde con Manuel de Ávila? No lo sabemos, quizás tan solo sea una mera copia, pero el hecho de que por estos años Bahamonde pudiera estarse formando al lado del escultor vallisoletano y tuviera la posibilidad de ver de cerca esta pieza en el taller de su maestro es una hipótesis arriesgada a la vez que seductora.

La Inmaculada posee un canon muy alargado y estilizado lo que la otorga un plus de elegancia y sensualidad; además, sus contornos adoptan una serpentinata, a lo que hay que añadir el típico contrapposto creado mediante el adelantamiento de la pierna derecha. Dispone las manos de una manera muy delicada, con la derecha realiza un gesto declamatorio mientras que la izquierda se la lleva al pecho, de la misma manera que vemos en los relieves de la Anunciación y de la Coronación. La cabeza la ladea levemente hacia la izquierda mientras dirige su mirada hacia arriba, como queriendo que dirijamos nuestra mirada hacia el relieve de la Coronación. Viste túnica blanca con diversos elementos vegetales y un amplio manto azul oscuro con motivos dorados. El polvo apenas permite observar los matices y los colores en todo su esplendor. En esta pieza sí que observamos unos pliegues a cuchillo mucho más pronunciados, especialmente presentes en las pequeñas y múltiples concavidades del manto. Rodean a la Virgen cuatro angelotes que revolotean a su alrededor, dos a cada lado. Están concebidos realizando diferentes movimientos, de tal manera que la escena gana en

11 GARCÍA ABAD, ALBANO: Fuentes de Valdepero..., op. cit.

12 MARTÍN GONZÁLEZ, Juan José: Escultura barroca castellana..., op. cit., p. 449. 
naturalidad y en diversidad. Estos angelotes vienen a ser un precedente de los que años después esculpirá para dos de los retablos del Oratorio de San Felipe Neri de Valladolid.

\section{$\underline{\text { Los cuatro Evangelistas }}$}

Finalmente tenemos las hechuras de los cuatro evangelistas (Fig. 16), que apean en el ático sobre otros tantos entablamentos situados en la vertical de los cuatro grandes estípites del cuerpo del retablo. Los cuatro han sido concebidos de manera similar en la disposición del cuerpo, de la vestimenta y de los pliegues. Pero no solo eso sino que además todos ellos portan en su mano izquierda un libro cerrado y en la derecha una pluma, lo que les acredita como Evangelistas. Asimismo, cada uno lleva a sus pies su correspondiente viviente del Tetramorfos.

El Tetramorfos alude a la visión que tuvo el profeta Ezequiel: " $Y$ sucedió que en el año treinta, en el mes cuarto, a cinco del mes, estando yo en medio de los cautivos, junto al río Kebar, se abrieron los cielos, y contemplé visiones de parte de Dios. En el cinco del mes, en el año quinto de la deportación del rey Joaquín, fue palabra de Yahvé a Ezequiel, hijo de Buzí, sacerdote, en tierra de los caldeos, junto al río Kebar, y fue allí sobre él la mano de Yahvé. Miré, y he aquí que venía del septentrión un viento impetuoso, una nube densa, y en torno a la cual resplandecía un remolino de fugo, que en medio brillaba como bronce en ignición. En el centro de ella había semejanza de cuatro seres vivientes, cuyo aspecto era éste: tenían semejanza de hombre, pero cada uno tenía cuatro aspectos, y cada uno cuatro alas. Sus pies eran rectos, y la planta de sus pies era como la planta del toro. Brillaban como bronce en ignición. Por debajo de las alas, a los cuatro lados, salían brazos de hombre, todos cuatro tenían el mismo semblante y las mismas alas, que se tocaban las del uno con las del otro. Al moverse no se volvían para atrás, sino que cada uno iba cara adelante. Su semblante era éste: de hombre y de león a la derecha los cuatro, de toro a la izquierda los cuatro y de águila los cuatro. Sus alas desplegadas estaban desplegadas hacia lo alto; dos se tocaban las del uno con las del otro, y dos de cada uno cubrían su cuerpo"13.

A San Mateo le tira de la túnica un pequeño angelote; San Juan tiene a sus pies un águila que ha perdido las alas; detrás de la túnica de San Lucas asoma un toro, y a los pies de San Marcos se postra un león. Honorio de Autun, en su Elucidarium asigna a cada viviente el siguiente significado: "San Juan es el águila porque ésta "vuela más que todas las otras aves, ya que San Juan habló mejor y más elevadamente que el resto de los evangelistas". El ángel es Mateo porque éste trato "más señaladamente que los otros evangelistas la generación del linaje de María”, es decir, trató de la concepción terrenal de Cristo. Marcos es el león porque éste trató en extenso la resurrección de Cristo, simbolizada por el león, y también porque trató de los ayunos y del desierto donde mora este animal ("Voz de quien grita en el desierto: Preparad el camino del

13 NACAR FUSTER, Eloíno y COLUNGA CUETO, Alberto (O.P.): Sagrada Biblia. Versión directa de las lenguas originales, Biblioteca de Autores Cristianos, Madrid, 1993, pp. 1.086-1.087. 
Señor, enderezad sus senderos", Mat, 1, 3). Lucas es el buey o toro porque éste evangelista "habló más que los otros de la humildad de la virginidad de Santa María"14.

Se mueven graciosamente, los dos evangelistas de la izquierda (San Mateo y San Juan), adelantan la pierna derecha mientras que los situados a la derecha hacen lo propio con la izquierda, de tal manera que aparecen opuestos dos a dos. Los mantos, aunque los concibe de diferentes tamaños siguen una misma pauta, así como los pliegues que lo recorren en líneas diagonales fuertemente aristados. Debido a la altura a la que se encuentran poco más se puede analizar, tan solo señalar que el San Juan vendría a ser una copia literal del que realizó en 1714 su hermano Pedro para la catedral vallisoletana y del que por desgracia tan solo se conserva la cabeza; debido a ello es tan importante esta escultura puesto que nos ayuda a reconstruir la vallisoletana que sería el prototipo. Además, en el retablo mayor de la iglesia de Santa María de Colaña de Castromocho (Palencia) se conserva un tercero completamente idéntico y cuya factura se la hemos atribuido también a Manuel de Ávila, aunque no se puede descartar en ningún momento la autoría de Pedro de Ávila.

14 RODRÍGUEZ MONTAÑÉS, José Manuel: "Las visiones celestiales en la iconografía románica". En GÓMEZ GÓMEZ, Agustín [et. al.]: Poder y seducción de la imagen románica, Fundación de Santa María la Real, Aguilar de Campoo, 2005, p. 48. 


\section{VALLADOLID. ORATORIO DE SAN FELIPE NERI}

\section{HECHURAS DE NIÑOS PARA DOS RETABLOS (1720)}

El 1 de febrero de 1720 la Congregación de San Felipe Neri abona a Manuel de Ávila 100 reales "por las hechuras de los niños de los dos retablos que está ejecutando para dicha Congregación que con éste y su recibo" ${ }^{15}$. Estos dos retablos no pueden ser otros que los fronteros de la Magdalena y San Antonio (Fig. 17-18). Desconocemos la cantidad total en que se convinieron la Congregación y el escultor, y también el número de ángeles que debía de tallar; sin embargo, parece claro que estos serían ocho: en cada retablo se situarían dos en el ático, flanqueando a la escultura principal (San Rafael y San Miguel); y otros dos localizados a ambos lados de la hornacina central retirando las telas del pabellón que se situaría sobre la escultura que preside cada retablo. Todos ellos han sido concebidos de manera diferente para evitar repetición.

Cabe dentro de la curiosidad que en estos dos retablos trabajen tres escultores diferentes y que se encuentran interrelacionados entre sí: Pedro de Ávila efectúo las imágenes que presiden los retablos (Santa María Magdalena y San Antonio); Antonio de Gautúa, probable discípulo de Juan de Ávila en cuyo taller se formaría al lado de Pedro de Ávila, se ocupó de las hechuras de los áticos (San Miguel y San Rafael); y, finalmente, Manuel de Ávila talló los ángeles que adornan ambos retablos.

Estos niños, que Martín González define como "infantes muy del estilo de Juan de Ávila"16, poseen unos caracteres similares: son muy rollizos. Ávila remarca los diferentes pliegues que hacen en su piel sus rechonchas anatomías. Algunos aparecen alados y otros no. Destaca en ellos sus voluminosas cabezas que exhiben claramente los rasgos físicos que suelen explayar Manuel de Ávila y su hermano Pedro. A la mayoría les cae por la frente un mechoncito de pelo mojado. Algunos de estos ángeles adoptan unas posiciones muy elegantes e incluso inestables, como pueden verse en tres de los situados en el ático: tan solo apoyan en tierra firme uno de los pies, teniendo levantado el otro.

\footnotetext{
15 "Sírvase vuestra merced señor don Manuel de Oldi como depositario de nuestra Venerable Congregación de San Felipe de Neri manda entregar al señor Manuel de Ávila cien reales de vellón en cuenta de lo que ha de haber por las hechuras de los niños de los dos retablos que está ejecutado para dicha Congregación que con éste y su recibo se le pasaron en cuenta de la que diere dicha depositaria Valladolid y enero 30 de 1720". "Recibí lo contenido en el libramiento de arriba y por verdad lo firme en Valladolid a primero de febrero de 1720 años. Son 100 Reales Vellón. Manuel de Ávila". GARCÍA CHICO, Esteban: Documentos para el estudio del arte en Castilla. 2..., op. cit., p. 375.

16 MARTÍN GONZÁLEZ, Juan José: Escultura barroca castellana..., op. cit., p. 325.
} 


\section{VALLADOLID. IGLESIA PENITENCIAL DE NUESTRO PADRE JESÚS NAZARENO}

\section{SAN JOSÉ CON EL NIÑO (1730-1731)}

El 16 de febrero de 1730 el cofrade Pedro González expuso la conveniencia de que se hiciese "un San Joseph de bulto, del tamaño natural, con el Niño Dios en los brazos"17 para colocarle en el colateral del Evangelio, en correspondencia a Nuestra Señora de la Natividad que se encontraba en el de la Epístola. Seguidamente, González dio la noticia de que un cofrade escultor, Manuel de Ávila, se había ofrecido a realizarla gratuitamente "con todo primor por ser su habilidad bien conocida en esta ciudad" 18 , si a cambio se le concedían honores de diputado; es decir, si se le eximía de servir el cargo de alcalde, así como otros cargos importantes dentro de la cofradía que le restarían mucho tiempo a la práctica de su oficio.

El cabildo consideró y discutió el ofrecimiento, valoró la efigie entre 800 y 1.000 reales y acordó que la realizase sin cobrar maravedí alguno, y cuando estuviera acabada se le otorgarían los honores solicitados. La propuesta llevaba aneja un traslado del Cristo del Despojo, que había de quitarse del colateral del Evangelio y situarse en un "retablico del cuerpo de la iglesia", enfrente del de Nuestra Señora de la Soledad. La distribución de los altares quedó según muestra este grafico que publicó Arribas Arranz:

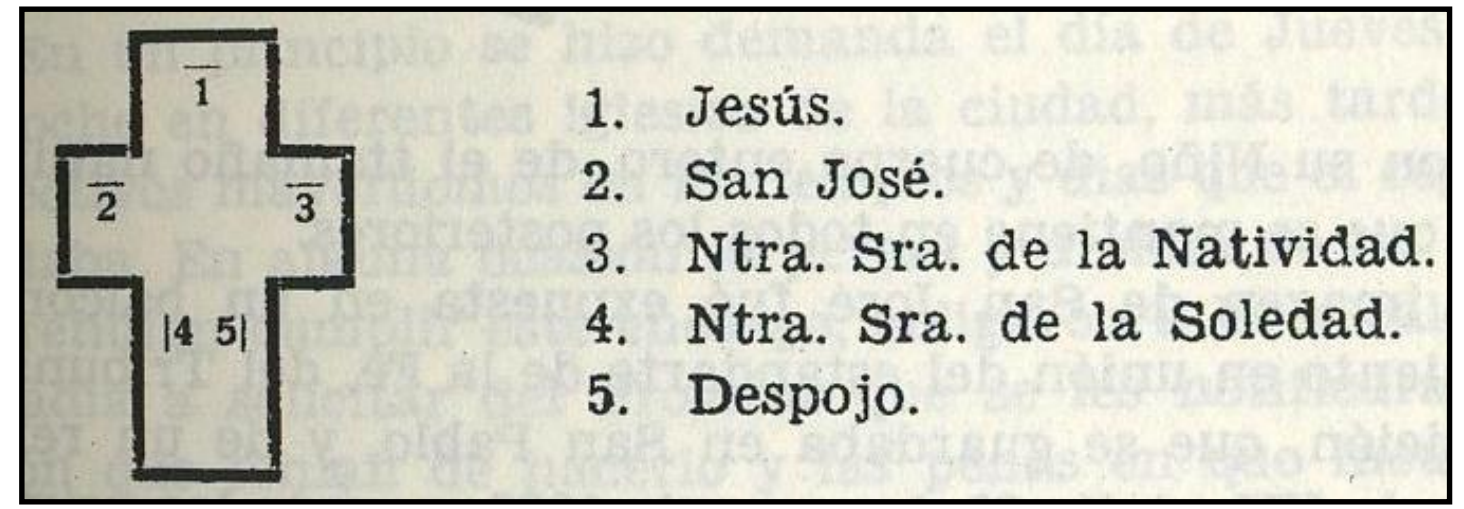

Il. 1- Localización primitiva de los retablos y altares en la iglesia penitencial de N. P. Jesús Nazareno. Valladolid.

Casi un mes después, el día 5 de marzo, otro escultor, también cofrade (posiblemente se trate de Antonio de Gautúa, que desempeñó varios cargos dentro de la cofradía, incluso el de alcalde), quiso competir con Ávila y ofreció hacer el San José con la misma condición de que le dieran los honores de diputado; sin embargo, esta propuesta no prosperó y Ávila se hizo con el encargo.

El 22 de diciembre de 1730 se firmaba uno de los libramientos a favor del escultor, el cual tenía un valor de "veinte y cinco reales de vellón, resto de lo que se le tiene señalado por la Cofradía de Jesús para la fábrica del San Joseph que está haciendo

17 ARRIBAS ARRANZ, Filemón: La Cofradía..., op. cit., p. 92.

18 Ídem, p. 93. 
para la iglesia"19. Aún se dilató la ejecución de la escultura unos meses puesto que hasta agosto de 1731 no procedió a policromarla el maestro dorador y estofador Bonifacio Núñez, el cual percibió por esta tarea 150 reales y otros 10 reales "por lo dorado de la diadema"20. En el inventario de 1752 ya figura descrito: "Un colateral tiene a San Joseph con su Niño, de cuerpo entero, del tamaño natural"21.

Años después del gravísimo incendio que sufrió la iglesia en 1799 la cofradía tuvo que sustituir el retablo mayor y los colaterales, de tal manera que los viejos retablos barrocos dieron paso a unos nuevos neoclásicos ${ }^{22}$. La imagen de San José pasó a presidir el retablo colateral de la Epístola, que fue realizado en 1802 por Eustaquio Bahamonde; este retablo sirvió de modelo para que años después, en 1811, José Bahamonde (hijo de Eustaquio y último eslabón de la gran estirpe de ensambladores comenzada por Pedro Bahamonde) realizara el colateral del Evangelio (Cristo del Despojo $)^{23}$.

El retablo-hornacina (Fig. 19) es muy sencillo dado que se estructura en un banco con dos gradas sobre la que asienta un único cuerpo compuesto por una hornacina rematada por un cuarto de esfera y flanqueada por dos columnas corintias. Ya en el ático, en el centro exhibe un medallón recubierto de laureles que contiene una grisalla que representa San Joaquín, Santa Ana y la Virgen Niña. A los lados del medallón, y justo en la vertical de las columnas del cuerpo del retablo aparecen dos angelotes situados sobre trozos de entablamento para darles mayor altura. A pesar de su aspecto marmóreo, seguramente se trate de dos esculturas en madera policromada pintadas de blanco. Algo similar ocurre con el retablo, que aunque es de madera se encuentra enmascarado por la policromía que finge ser de materiales nobles: mármol y bronce dorado. El lienzo de la Sagrada Familia de la Virgen tal vez procediera atribuírselo al pintor vallisoletano Leonardo Araujo (1762-1814), artífice que había trabajado unos años antes para la cofradía, de la cual era miembro ${ }^{24}$.

Muy tempranamente adquirió la escultura de San José gran popularidad y veneración. Esta importancia devocional fue dual: pública y privada. La devoción pública la

19 "Señor Juan de Santiago. Sírvase su majestad dar por éste a el señor Manuel de Ávila veinte y cinco reales de vellón, resto de lo que se le tiene señalado por la Cofradía de Jesús para la fábrica del San Joseph que está haciendo para la iglesia, que con éste y su recibo se lo pasaremos a su majestad en las cuentas que diere a dicha Cofradía. Valladolid y diciembre 22 de 1730 años”. Ídem, p. 133.

20 "Señor Juan de Santiago. Sírvase su majestad mandar se le dé a el señor Bonifacio Núñez cien reales de vellón con los cuales se le acaba de pagar lo pintado y dorado del San Joseph que se puso en el colateral de lado de la sacristía y es así los noventa reales por la resta de los ciento y cincuenta en que se ajustó y los diez reales por lo dorado de la diadema, la que no había entrado en el ajuste antecedente; que con éste y su recibo se los pasaremos a su majestad en cuenta que diere a la Cofradía. Valladolid y agosto 12 de 1731 años". Ibídem.

21 MARTÍN GONZÁLEZ, Juan José y URREA FERNÁNDEZ, Jesús: Catálogo Monumental de la provincia de Valladolid. Tomo XIV..., op. cit., p. 225.

22 Tan solo sobrevivió el retablo barroco de la Virgen del Sacro Monte Calvario, si bien se modificó su ubicación al pasar del fondo de la iglesia a la parte izquierda del crucero.

23 MARTÍN GONZÁLEZ, Juan José y URREA FERNÁNDEZ, Jesús: Catálogo Monumental de la provincia de Valladolid. Tomo XIV..., op. cit., p. 222.

$24 \quad$ En 1799 pintó los ángeles con las Arma Christi de las pechinas de la cúpula del crucero. ARRIBAS ARRANZ, Filemón: La Cofradía..., op. cit., p. 92. 
representaron las diversas ocasiones en que la escultura fue requerida para presidir desde el balcón del consistorio vallisoletano diferentes eventos populares. Así, por ejemplo, el 22 de mayo de 1808, fue situada en el balcón del Ayuntamiento junto con el estandarte de la Fe del Tribunal de la Inquisición, y un retrato de Fernando VII, cuando se produjeron las primeras protestas de la ciudad contra las maniobras napoleónicas en España $^{25}$. Poseemos dos descripciones de este momento gracias a las plumas de Domingo Alcalde Prieto ${ }^{26}$ y por Francisco Gallardo Merino ${ }^{27}$. San José volvió nuevamente al balcón consistorial el 2 de junio de ese mismo año con motivo de la proclamación como rey de Fernando VII. En esta ocasión San José estuvo acompañado de la Virgen del Pilar de la iglesia de Santiago Apóstol, del grupo de la Traslación de San Pedro Regalado (iglesia del Salvador) y el estandarte de la Fe de la Inquisición ${ }^{28}$.

25 Ídem, p. 94. corona de España en el hermano de Napoleón José Bonaparte. Con tan alarmantes noticias no era posible ya que el paisanaje se contuviera, y acudiendo a la plaza el día 21 de mayo, en ocasión que el ayuntamiento se hallaba reunido, pidieron con entusiastas voces que se procediera a un alistamiento general sin distinción de clases ni categorías para exterminar a los traidores. Ofreció hacerlo así el Ayuntamiento, y en seguida se dirigió el paisanaje al palacio del Capitán general D. Gregorio de la Cuesta, en el mismo edificio de la Chancillería, y le pidieron que les entregara armas y les nombrara un Jefe; a cuya demanda accedió, aunque a disgusto, S. E. dando la orden para que se les entregara las armas que hubiere disponibles, con lo cual lograron verse armadas como 250 paisanos. Recorrieron después las calles de la población, aprisionando a cuantos eran notados de sospechosos, y pusieron centinelas en las puertas de la Ciudad, sin permitir entrar ni salir a nadie, a no ser que acreditara su adhesión a la Religión, al Rey y a la patria. Al siguiente día insistieron en pedir el alistamiento forzoso, cuya demanda procuró eludir S. E., dándoles palabra de que se haría un alistamiento voluntario, pero que hasta tanto, se retirasen a sus casas. Poco satisfecho el paisanaje con esta respuesta, se dirigió en tumulto a la casa de la Inquisición y pidió el estandarte de la Fe, que entregado y conducido por algunos religiosos de San Pablo, fue llevado en triunfo a la plaza mayor, colocándole en las Casas Consistoriales con el retrato de Fernando VII y la efigie de San José, que sacaron de la Penitencial de Jesús. Hicieron en seguida que se tocaran en las parroquias las campanas ha vuelto, como día de gran fiesta; y por fin, al día siguiente 23 de Mayo lograron que se llevara a efecto el alistamiento forzoso". ALCALDE PRIETO, Domingo: op. cit., pp. 102-103.

$27 \quad$ Un jefe y alistamiento / Se saca de la Inquisición el estandarte de la fe. "Al día siguiente (22 de mayo de 1808) muchos hombres armados con una multitud de gentes de toda clase pidieron a su Excelencia mandase hacer el alistamiento, concediéndoles y nombrándoles cabeza o jefe; convino solo en que fuese voluntario, y que los que se alistasen, se retirasen a sus casas o cuarteles, ofreciendo señalar y darles jefes. No accedió el populacho a lo primero por creer se les engañaba y dilataban las providencias; se alteraban y pasaron al tribunal de la Santa Inquisición, pidieron y se les entregó el estandarte de la fe, le sacaron y llevaban por las calles tres sacerdotes, publicando el pueblo: ¡Viva la fe, la religión, el rey Fernando y la Patria! Hicieron tocar a rebato las campanas de la Catedral, San Pedro, la Magdalena, San Martín, Angustias y otras iglesias, y colocaron el estandarte con San José (que sacaron de la iglesia de Jesús) y el retrato de Fernando VII, en el balcón principal del Consistorio, adornándole con las colgaduras y velas; así estuvo todo el día y parte de noche, habiendo asistido a acompañar varios sacerdotes y religiosos, especialmente los de San Pablo, que desde su iglesia llevaron el estandarte hasta la Plaza". GALLARDO Y MERINO, Francisco: op. cit., p. 6.

$28 \quad$ "En el día 2 (Junio) se publicó un bando para la tranquilidad y que cada uno se retirase a su casa, lo cual fue causa de que creciese más el tumulto, y tocaron a rebato, saquearon todas las escopetas de las casas, poniéndose escaparelas, como también muchas mujeres; se levantó la horca para quitar la vida a los traidores. En los principales balcones del consistorio se pusieron: Nuestra Señora del Pilar de la iglesia de Santiago, San José de la de Jesús y San Pedro Regalado de la del Salvador, el retrato de Fernando VII, y se colocó también el estandarte de la Fe que sacaron de la Inquisición. (Esta casa de la Inquisición, sita al costado izquierdo de la iglesia de San Pedro, fue incendiada por los franceses, y no ha quedado más que las capas de los cimientos). Rápidamente en el mismo día 2 se dispuso la proclamación del rey D. Fernando VII y se pusieron colgaduras por toda la carrera. El regidor D. Pablo Salinas guiaba la 
En cuanto a la devoción privada, ésta es la que profesa cada persona de una manera más íntima, fundamentalmente en su casa. En siglos pasados no existía hogar en el que no hubiera pinturas o esculturas que sirvieran a su poseedor para realizar sus rezos y meditaciones. Con el tiempo fueron adquiriendo mucha importancia las estampas puesto que además de tener un menor coste podían propagar una devoción local o regional a territorios muy lejanos. Si hasta entonces poseer un lienzo representando a la Virgen de las Angustias o a la de la Pasión era algo bastante habitual, a partir de ahora lo sería el tener un grabado del San José de la Cofradía Penitencial de Nuestro Padre Jesús Nazareno. Efectivamente, el éxito de la imagen se vio reflejado en la apertura de un grabado, que según se lee en el mismo, fue realizado "A expensas de la Devoción" por Joaquín Canedo, y retocado por Solares ${ }^{29}$ (Fig. 20).

El grabado representa fielmente la escultura de San José con el Niño, si bien la calidad del mismo no es demasiado elevada. El santo aparece sobre su peana y al fondo unas nubes enmarcan su figura. En la parte baja figura un paisaje montañoso y a la derecha unas casas. Justo a los pies del santo hay un azadón. Enmarca el grabado una cenefa que abarca los lados laterales y el superior puesto que en la zona baja se desarrolla un escrito. Esta cenefa se encuentra recorrida por dibujos de diferentes herramientas propias de un carpintero, con lo cual se alude a la profesión del santo. La parte inferior de la estampa la completa, como ya dijimos, un texto en el que se puede leer: " $\mathrm{V}^{\mathrm{o}} \mathrm{R}^{\circ}$ DEL PATRIARCA $S^{N}$. JOSEF COMO SE VENERA EN LA YGLESA PENITENCIAL DE N.P.J.N.". "El Yll ${ }^{\text {mo }}$. $S^{\text {or }}$. Obispo de esta Ciudad de Valladolid $D^{n}$. Vicente Soto y Valcarce concede 40 días de indulgencia a todos los fieles christi ${ }^{\text {os }} q^{\text {e }}$ devotam $^{\text {te }}$. Rezaren la ora ${ }^{\text {on }}$. Del Paternoster y Ave María dela ${ }^{\text {te }}$. De la Efigie o estampa del $S^{\text {to }}$. rogando a Dios por la paz y concordia entre los Príncipes Cristi ${ }^{\circ}$. Victoria contra infieles extirpación de las eregias y necesidades del Reino". Ya fuera del recuadro, en el exterior inferior izquierdo se lee: "Canedo $\mathrm{D}^{\mathrm{o}}$ Solares la reto ${ }^{\text {co }}$. A expensas de la Devoción".

Al ver que su autor fue alguien apellidado Canedo, existen dos posibilidades: Ramón Canedo (1734-1801) o su hijo Joaquín (1757-d.1805). Dado que en la estampa se alude a que el obispo de Valladolid era don Vicente José Soto y Valcárce, que ejerció su ministerio entre los años 1803-1818, no cabe duda que el autor del grabado fue Joaquín.

El presente San José, que llegó a ser definido por Martín González como una "escultura de gran porte, entre las mejores del siglo XVIII vallisoletano" ${ }^{30}$, es una versión de la tipología creada por su hermano; hecho que, aunque visible, ya fue destacado por Martín González: "una escultura de San José, donde le vemos continuar el estilo de Pedro de Ávila" ${ }^{31}$. Hay que matizar que se trata de una versión y no de una copia puesto

procesión, e iba a pie, aunque su caballo era conducido del diestro por un criado. Seguían los guardias de corps a caballo, que se hallaban en Valladolid (...)". SANCHO, Hilarión, GALLARDO, Francisco y MARTÍNEZ, Demetrio: Valladolid: diarios curiosos (1807-1841), Grupo Pinciano, Valladolid, 1989.

29 A.H.P.V., Mapas y Planos, Carpeta 10-12.

30 MARTÍN GONZÁLEZ, Juan José y URREA FERNÁNDEZ, Jesús: Catálogo Monumental de la provincia de Valladolid. Tomo XIV..., op. cit., p. 222.

31 MARTÍN GONZÁLEZ, Juan José: Escultura barroca castellana..., op. cit., p. 325. 
que introduce leves variantes compositivas, pero también estilísticas, ya que no utiliza los paños de su hermano: minuciosos, muy aristados facetados y movidos. Manuel por contra concibe los pliegues con unas concavidades amplias, aunque no tan profundas, con un movimiento menos vertiginoso e incluso pueden parecer algo acartonados. Además, y como ya observó Martín González, "propende a geometrizar los perfiles y las líneas ${ }^{32}$. Así es, los perfiles son más sinuosos, en este caso en el manto parecen unos dientes de sierra. Las otras dos diferencias son de tipo compositivo: la cabeza no la gira levemente hacia abajo para observar al Niño Jesús que porta entre las manos, sino que la mantiene erguida y tan solo mueve los ojos para ver a su hijo. La otra disparidad con respecto al modelo de San José creado por su hermano es la más evidente: Pedro de Ávila dispone a su santo con una de las piernas adelantada, la cual podemos ver en parte gracias a que la túnica se encuentra abierta a la altura de la rodilla. Manuel de Ávila por contra no tiene la túnica abierta, por lo que tampoco se le ve la pierna; con lo cual pierde la elegancia y refinamiento que posee aquella.

San José (Figs. 21-23) aparece de pie, estático, al no tener la pierna derecha adelantada; sin embargo, para crear contrapposto remarca la pierna y sobre todo la rodilla mediante la técnica de paños mojados, ciñéndose fuertemente la túnica al cuerpo. Viste una túnica negra que tan solo deja libres la cabeza, manos y puntas de los zapatos; por encima tiene echado un gran manto marrón con una diminuta franja decorativa dorada corriendo el borde. Este manto es tan amplio y ampuloso que apenas permite ver la túnica. Los pliegues como ya hemos dicho son a cuchillo pero geométricos, creando amplias concavidades donde la recta impera sobre la curva. El borde del manto también acusa esa habilidad que tiene su hermano Pedro para adelgazar las maderas hasta la extenuación y moverlas con gran naturalismo. Crea unos pliegues especialmente amplios bajo el brazo derecho, de tal manera que lateralmente forma una gran curva pero que visto por el frente sube hacia el otro brazo en una perfecta diagonal regada de pequeños perfiles cóncavos. Donde los pliegues adquieren una forma más geométrica es en la parte baja de las prendas, que es donde parece formar lo que en su hermano llamamos "roca geométrica". Además, en este lugar figura uno de los clásicos estilemas de Pedro de Ávila: la colocación de los pies en un ángulo de $90^{\circ} \mathrm{y}$ separados por un pliegue fuertemente aristado.

El santo dirige la mirada hacia su hijo, al cual tiene tumbado sobre un paño blanco que agarra con ambas manos. El Niño es muy similar al que vimos en el San José con el Niño que su hermano talló para el Santuario del Henar (Segovia). Completamente tumbado, mira a su padre mientras eleva la mano derecha, con la cual intenta acariciar la barba paterna. Los pliegues del manto acusan perfectamente el peso del Niño y el efecto que provoca las manos del santo al sujetarlo. Estas manos, que parecen estar talladas directamente en la escultura, son un prodigio técnico, su tratamiento minucioso le lleva a que acusen blandura y a definir delicadamente las venas, articulaciones y hasta

32 MARTÍN GONZÁLEZ, Juan José y URREA FERNÁNDEZ, Jesús: Catálogo Monumental de la provincia de Valladolid. Tomo XIV..., op. cit., p. 222. 
las uñas. La manera de disponer los dedos también procede de su hermano pues repite la seriación con la que éste las concebía.

En la cabeza también encontramos diversos detalles que ayudan a diferenciar a esta pieza de Manuel de los San José de su hermano Pedro. Así, el rostro es algo más estrecho, lo que hace que los ojos se encuentren muy juntos, a la vez que están más cerrados, el achinamiento es mayor. No vemos el característico bulto bajo los ojos sino que hunde los ojos directamente. Las cejas son rectas; la nariz posee un tabique ancho y aplastado pues Manuel no la va ensanchando levemente hacia su parte inferior sino que es recta y adquiere mayor volumen en la punta. Podríamos decir que el geometrismo también lo aplica a la nariz; boca pequeña y estrecha en la que apenas se aprecian los dientes superiores y la punta de la lengua. En cuanto a la barba y el pelo, tiene muchas coincidencias con el San José que su hermano Pedro talló para el referido Santuario del Henar (Valladolid). Efectivamente, la barba es bífida y muy potente, concebida a través de una sucesión de mechones sinuosos en los laterales del rostro y en la parte frontal remata bífidamente en dos amplios mechones realizados a base de caracolillos. El bigote también remata sus dos puntas en caracolillos. El vello de bigote y barba no forma una masa compacta sino que el escultor se empeña en definir cada onda y cada mechón. Finalmente, la cabellera es simétrica y su talla adolece de cierta sequedad. Sobre la frente dos pequeños caracolillos que apenas se apartan del cuero cabelludo; el cual cae a ambos lados del rostro cual grandes masas de guedejas curvas que van formando una sucesión de ondas cada vez más anchas y profundas, llegan hasta la base del cuello y caen por la espalda. 
13-2 OBRAS ATRIBUIDAS

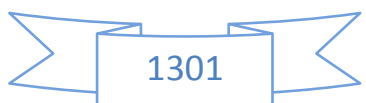


$\sum \sqrt{1302}<$ 


\section{TORDESILLAS. IGLESIA DE SAN PEDRO}

\section{ÁNGELES DEL ÓRGANO (1714-15)}

En el año 1714 Manuel de Ávila debió de contratar de manera conjunta con Antonio Gautúa (nuevamente vemos la estrecha unión que tenía con los Ávila, lo que refuerza la idea de que fuera discípulo de Juan de Ávila) la hechura de cuatro ángeles (Fig. 24) para decorar el órgano de la iglesia de San Pedro de Tordesillas (Valladolid) ${ }^{33}$. Como podemos observar al analizar los cuatro angelotes, vemos que hay dos manos: los dos inferiores tienen unos rostros que emparentan con Manuel de Ávila y con los ángeles que tallará algunos años después par el Oratorio de San Felipe Neri; mientras que los dos superiores, de constitución algo más regordeta e idéntico ademán pertenecerán a Gautúa.

Una vez expuestos estos datos fundamentales me gustaría exponer el porqué de esta atribución, aunque en realidad podríamos estar hablando de una obra documentada. En el libro de cuentas de la iglesia no figura Manuel de Ávila sino "Joseph de Ávila"; pues bien, no existe ningún escultor que se llamara así; cabría la posibilidad de que otro de los hermanos Ávila, Joseph, se hubiera dedicado a la escultura pero no tenemos noticia de ello; y, además, el hecho de que falleciera en 1708 nos descarta su autoría por completo.

Cabría la posibilidad de que hubieran sido tallados por Pedro de Ávila, pero hay dos hechos que me llevan a creer que son obra de Manuel de Ávila y que el escribano se confundió y puso "Joseph" en vez de "Manuel". Lo primero y más importante es que el análisis estilístico nos confirma una total similitud entre los dos ángeles que hemos referido y los ángeles que esculpió años después para el Oratorio de San Felipe Neri. Además hemos de tener en cuenta la noticia que nos aporta un documento relacionado con las cartas de pago que expidió Manuel de Ávila, en nombre de su hermano Pedro, al cura de la iglesia parroquial de Torrecilla de la Abadesa por el pago de unas cantidades que se le adeudaban a Pedro por la hechura de un Crucificado. En este documento, fechado el 6 de noviembre de 1714, se hace referencia a que Manuel se acercaría a cobrar las referidas cantidades en nombre de su hermano ya que se encontraba de paso por "Tordesillas a ajustar un poco de obra" 34 . No parece casualidad este hecho y la confusión del nombre en el libro de cuentas de la iglesia. Además, las fechas parecen confirmarlo dado que el pago a Gautúa y Ávila se produjo el 12 de abril de 1715.

Un error de escritura en los libros parroquiales no es nada inusual, puesto que, además, en muchas ocasiones se encuentran confundidos los nombres de los artistas o las profesiones que desempeñaban.

33 "195 reales que pagó a Antonio de Gaute, vecino de Valladolid, maestro escultor, por la hechura de cuatro niños que se pusieron en los arbotantes del órgano nuevo. Consta de recibos de dicho maestro y de Joseph de Ávila, también maestro de dicho arte". ARA GIL, Clementina Julia y PARRADO DEL OLMO, Jesús María: Catálogo Monumental de la provincia de Valladolid. Tomo XI..., op. cit., p. 234.

$34 \quad$ PARRADO DEL OLMO, Jesús María: Datos histórico artísticos..., op. cit., p. 106. 
Estos pequeños angelotes, apenas visibles dada la altura a la que se encuentra el órgano, asientan sobre peana. Están erguidos, y un pie lo apoyan mientras que el otro está levemente levantado de tal manera que parece que van a echar a andar. En la espalda llevan un par de alas mientras que sus cuerpecitos desnudos tan solo lo cubren sendas bandas rojas que cruzan el pecho diagonalmente. Los rostros, como ya hemos dicho, son en todo similares a los de los Ángeles del Oratorio de San Felipe Neri.

\section{SAN GABRIEL Y SAN RAFAEL}

En el ático de un gran retablo neoclásico situado en el lado del Evangelio de la iglesia de San Pedro se conservan dos esculturas de San Gabriel y San Rafael (Fig. 25) que deben ser inmediatamente incorporadas al catálogo de Manuel de Ávila; aunque, como en el caso de las esculturas del retablo de Castromocho, pero si cabe más en esta ocasión, no puede ser descartada en ningún caso la autoría de Pedro de Ávila dada la gran calidad que poseen ambas tallas. Este retablo debía de pertenecer a la Cofradía de la Vera Cruz por cuanto en ese lado de la iglesia se conservaba la capilla de la cofradía y además en las distintas hornacinas exhibe las figuras principales de sus pasos procesionales.

Estos dos ángeles, que flanquean una popular escultura de San Sebastián, se encuentran a tal altura y tan maltratados (uno de ellos incluso tiene notables pérdidas de policromía en el rostro) por el polvo y la suciedad que pasan completamente inadvertidos a pesar de la alta calidad que ya hemos dicho que poseen. Tal es así que Ara Gil y Parrado del Olmo en el respectivo tomo del Catálogo Monumental de Valladolid tan solo alcanzaron a reseñarlos como "dos ángeles del siglo XVIII"35.

Estos dos ángeles son sin ningún género de dudas los arcángeles San Gabriel y San Rafael; y, es más, serán los que flanqueaban a San Miguel (118 cms.) en el retablo mayor de la desaparecida iglesia de San Miguel de la propia villa de Tordesillas. En cuanto al San Miguel que presidía este desaparecido retablo será uno que tras estar una temporada en la iglesia de San Pedro desde la clausura de la iglesia de San Miguel pasó hace cierto tiempo al Museo de San Antolín. Esta escultura, que cabe relacionarla con las producciones de José de Rozas, o incluso con las de Juan de Ávila, fue descrita en el Catálogo Monumental de Valladolid de la siguiente manera: "Escultura de San Miguel venciendo al demonio, del siglo XVIII, resuelta con una apreciable calidad" ${ }^{36}$.

Desconocemos cómo era el retablo que compartían las tres esculturas puesto que ha desaparecido toda la documentación concerniente a estos años en las cuentas de la iglesia de San Miguel. Tan solo sabemos que en 1656 existía un retablo de "pintura antigua, con una escultura de San Miguel en el nicho principal"37. Esta escultura sería

35 ARA GIL, Clementina Julia y PARRADO DEL OLMO, Jesús María: Catálogo Monumental de la provincia de Valladolid. Tomo XI..., op. cit., p. 211.

$36 \quad$ Ídem, p. 216.

37 Ídem, p. 270 
otra anterior. Cabe pensar que el retablo se ejecutaría por la misma época en que se talló el San Miguel que aún se conserva; es decir, hacia el año 1700. También cabría pensar que se mantendría ese retablo y tan solo se renovó la escultura titular de San Miguel; y que ya una vez que se decidieron a completar el retablo con estas dos esculturas de San Gabriel y San Rafael, fue cuando construyeron el nuevo retablo, que por desgracia tampoco se conserva.

Tenemos muy pocos datos sobre estos dos arcángeles puesto que como ya hemos dicho la documentación desapareció. Sabemos que en 1793 el dorador Juan Mazón las retocó $^{38}$, y que en entre 1797-1799 Gregorio de la Cruz les construyo unos cascarones en los que irían metidos en el retablo ${ }^{39}$.

Es muy complicado establecer una cronología correcta para ambas esculturas puesto que a la falta de documentación hay que sumar la inaccesibilidad para estudiarlas y la malísima visión dada la gran altura a la que se encuentran. Quizás estas esculturas fueran las que se aprestaba a contratar Manuel el 6 de noviembre de 1714 cuando iba a acercarse a Torrecilla de la Abadesa para cobrar unas sumas que le debían a su hermano Pedro por un Crucificado ${ }^{40}$. Aunque este mismo hecho ya lo hemos esgrimido al hablar de los Ángeles del órgano de esta misma iglesia, parece probable que uno de los dos encargos habría desembocado en el otro. De lo que no cabe duda es que estos ángeles fueron tallados por los Ávila, y el nombre de Manuel lo barajo en función de ese hecho y de que los pliegues presentes en ambas tallas casan perfectamente con ese año de 1714. Sin embargo, no hemos de olvidar el nombre de Pedro de Ávila puesto que son imágenes de gran calidad y gozan de gran parecido con otras obras suyas de ese mismo año como ya expondremos más adelante.

San Gabriel y San Rafael, que son poseedores de unas anatomías algo achaparradas, aparecen con posturas contrapuestas de tal manera que se oponen y complementan al mismo tiempo; esto significa que flanquearían al San Miguel, pero no sabemos cuál ocuparía el lado izquierdo y cual el derecho, parece probable que en el izquierdo estuviera San Rafael y en el derecho San Gabriel. Mientras que San Rafael adelanta la pierna derecha, la cual queda visible; San Gabriel le responde adelantando la izquierda, la cual también queda al aire. Aunque ambas tallas responden a un mismo concepto y composición se hallan diferenciadas por la posición de las manos, por las vestimentas y por los atributos; por contra, los rostros y las alas de la espalda son completamente iguales. Estos rostros poseen los típicos estilemas faciales de Manuel y Pedro, a lo que hay que añadir una amplísima y espesísima melena a ambos lados del rostro concebida a través de grandes bucles rizados. Los rostros, pero especialmente las cabelleras, son casi exactos a los del San Miguel que Pedro de Ávila talló en 1714 para la parroquial de

$38 \quad$ 1793. "Ciento sesenta y cinco reales que tuvieron de coste los materiales, a saber, panes de oro, albayalde fino, azul de Prusia, espíritu de vino, grasilla, laca y otros para retocar a San Miguel, San Gabriel y San Rafael, con inclusión de las cintas para guarnecer a las de los dichos; los retocó don Juan Mazón". Ídem, p. 274.

39 1797-1799. "283 reales de vellón a Gregorio de la Cruz, por tres cascarones que hizo para los tres arcángeles de esta iglesia”. Ibídem.

$40 \quad$ PARRADO DEL OLMO, Jesús María: Datos histórico artísticos..., op. cit., p. 106. 
Castil de Vela; es decir, casi por las mismas fechas. Pero no quedan ahí las semejanzas puesto que la manera de disponer al San Gabriel con la mano elevada, el cuerpo formando una diagonal y el brazo izquierdo tensionado es muy parecida a la composición del citado San Miguel. Son esculturas bien plantadas, movidas y elegantes. Los pliegues presentes en ambos arcángeles son los mismos, los usuales paños berninescos a cuchillo, dulces y delicados que se curvan y recurvan con suma delicadeza, adquiriendo las telas gran finura.

San Rafael viste una amplia túnica ceñida a la cintura verde clara plagada de motivos florales dorados; se encuentra abierta a la altura de la rodilla derecha, recordándonos a otros ángeles como los de la Guarda conservados en las iglesias de San Martín y Santiago Apóstol de Valladolid o al del paso de la Oración del Huerto que talló Andrés de Solanes para la Cofradía Penitencial de la Santa Vera Cruz de Valladolid. Los pies van resguardados por unas sandalias azules y doradas que le cubren parte de la pierna. Complementa su vestimenta una esclavina verde oscura abierta al medio y con las solapas dobladas de modo muy naturalista. En cuanto a los atributos, en la mano izquierda porta el pez de la leyenda de Tobías y en la derecha el bastón/bordón de caminante.

Por su parte, San Gabriel viste sobretúnica y túnica, ambas ceñidas a la cintura por un cíngulo azul, y unas sandalias similares a las de su compañero. La túnica, blanca y con diversos motivos vegetales dorados, se abre en la pierna izquierda a la altura de la rodilla con lo cual nos permite verle algo de su anatomía. La sobretúnica es azul por el exterior y rosa por el interior, las mangas se encuentran recogidas, creando los pliegues amplios volúmenes. Esta escultura ha perdido los atributos pero cabe pensar que llevaría un bastón de mensajero (caduceo) y una filacteria, pero es posible que en la mano derecha no llevara nada y se limitara a señalar al cielo con el índice para indicar que portaba los designios divinos. 


\section{FUENTES DE VALDEPERO. IGLESIA DE NUESTRA SEÑORA DE LA ANTIGUA}

\section{SANTA BÁRBARA (antes de 1715)}

En un retablo clasicista (Fig. 26) situado cerca de la cabecera del lado de la Epístola se sitúa una escultura de Santa Bárbara (Fig. 27) que debe ser atribuida con toda certeza a los hermanos Ávila. Martín González se la atribuye a Pedro de Ávila ${ }^{41}$; sin embargo deja caer que sería de Pedro de Ávila por cuanto, según su parecer, él también habría tallado las esculturas del retablo mayor de la iglesia. Los motivos para decantarme por Manuel, en vez de por Pedro, son bastante débiles: por una parte, ya conocemos una escultura de esta santa realizada por Pedro de Ávila, y aunque se encuentra simplemente atribuida no tiene nada que ver con esta; y, por otra, el hecho de que no aparezcan los característicos abultamientos en las bolsas bajo los ojos esgrimido por Pedro de Ávila y si la misma solución de remarcar cierto hundimiento general que ya vimos en el San José que talló Manuel para la Cofradía Penitencial de N. P. Jesús Nazareno. A pesar de lo dicho, y como en todas las esculturas que le tenemos atribuidas, no podemos perder nunca de vista el nombre de Pedro de Ávila; el hecho de que posean un estilo tan similar y que tengamos tan poca obra documentada de Manuel de Ávila complica mucho la atribución más o menos segura de otras.

Como ya hemos dicho, Santa Bárbara preside un retablo clasicista, fechable en el primer cuarto del siglo XVII, que por supuesto no le pertenece. Este retablo (335 x $415 \mathrm{cms}$.), similar a uno frontero dedicado al Niño Jesús, se compone de un banco, dos cuerpos, cinco calles y un ático que parece un añadido posterior. Cada uno de ellos se haya articulado por un orden diferente: en el primer cuerpo el jónico, en el segundo el dórico y en el ático el corintio. Tan solo posee una escultura, la de Santa Bárbara, puesto que el resto de la decoración la conforman 37 pequeñas pinturas, algunas de las cuales tienen atisbos de cierta calidad. Las pinturas existentes son las siguientes: "en este retablo, la hornacina con la imagen de Santa Bárbara, ocupa toda la calle central. Las pinturas del retablo se distribuyen entre la predela, con tres medallones debajo de las tres calles centrales, dos similares, pero enmarcadas por un cuadrado, en los extremos y otras veinte con distintos motivos decorativos, todas ellas de muy pequeño formato; en el primer cuerpo, en el que se halla la talla de Santa Bárbara, hay cinco pinturas más; en el segundo cuerpo, otras cuatro pinturas; por último, en el ático, en el lugar destinado a otra pintura, se ha colocado un cuadro con su marco, no perteneciente, originalmente, al retablo. Hay que añadir otras dos pinturas de pequeño formato existentes debajo de las basas de las columnas corintias que enmarcan el ático"42.

\footnotetext{
41 MARTÍN GONZÁLEZ, Juan José: Escultura barroca en España..., op. cit., p. 579.

42 VILLA, Nicolás: "Informe histórico y artístico sobre los retablos del Niño Jesús y Santa Bárbara existentes en el presbiterio de la iglesia parroquial de Ntra. Sra. La Antigua en Fuentes de Valdepero", Horizontes, Asociación de amigos del castillo y monumentos de Fuentes de Valdepero, № 15, 2009, p. 14.
} 
Sin embargo, como ya hemos vistos éste no fue el lugar para el que fue ideada, y de hecho no fue realizada para la iglesia. La información sobre su procedencia nos la aporta el testamento del licenciado don Antonio Marcos, beneficiado mayor de esta iglesia parroquial de Fuentes de Valdepero, el cual falleció el 6 de marzo de 1724. En él se hace referencia a que donaba la imagen de Santa Bárbara y que deseaba que se colocase en el tabernáculo del altar mayor: "Ítem mando a la iglesia parroquial de esta villa una imagen de Santa Bárbara, de escultura de cuerpo redondo, colorida y doradas y estofadas los extremos, con el castillo plateado, como está, para que se pusiese y conservase sobre el tabernáculo del altar mayor" ${ }^{\prime 3}$.

Una vez que sabemos quién le encargó la escultura y que en el mes de marzo de 1724 ya se encontraba hecha, la duda sería cuándo fue hecha; si antes o después de las esculturas del retablo mayor de la iglesia. De lo que no cabe duda es que ambos encargos están relacionados, lo que no sabemos es cómo. Parece lógico pensar que si Manuel fue su autor, este no se aventuraría a realizar una nueva obra para alguien relacionado con la iglesia ante el impago al que le mantuvieron sometido hasta el año 1724, justo el año en que además fallece el comitente que le encargó la Santa Bárbara. Por lo tanto, creo que procede fecharla con anterioridad a 1715, que sería el año aproximado en que Manuel se concierta para realizar la parte escultórica del retablo mayor de la iglesia. Sería, por lo tanto, la "carta de presentación" del escultor en la localidad palentina, y no ante un cualquiera puesto que su comitente era ni más ni menos que el beneficiado mayor de la iglesia parroquial. Es probable que este hombre, además de otros motivos crematísticos, influyera en el parecer de los delegados parroquiales encargados de la obra del retablo para que sustituyeran a Tomás de Sierra por Manuel de Ávila.

Santa Bárbara figura de pie, en posición de avanzar. Aparece efigiada, como de costumbre, en el momento en que adelanta la pierna derecha, movimiento que se ve remarcado por el ceñimiento de las ropas a la pierna y sobre todo de la rodilla. No falta el característico distintivo de los hermanos Ávila: la colocación de ambos pies en un ángulo de $90^{\circ}$ y separados por un trozo de pliegue muy aristado. Mantiene los brazos semi estirados en ademán de sujetar algo; en su mano izquierda porta de una forma bastante artificiosa y poco natural una torre, el atributo más destacable de su iconografía. Pienso que esa no sería su colocación primigenia; sino que la torre se hallaría en posición oblicua, de tal manera que la asiera con ambas manos. La santa posee un cuello cilíndrico muy largo que recuerda lejanamente al de las esculturas manieristas de Gregorio Fernández (por ejemplo: el San Gabriel de Tudela de Duero actualmente conservado en el Museo Diocesano y Catedralicio de Valladolid). El rostro lo podríamos calificar "de receta" por cuanto figuran en él todas las características creadas por Pedro de Ávila en su segunda etapa y que Manuel copió con pocas innovaciones: ojos almendrados muy cercanos, con los párpados muy remarcados, nariz ancha con el tabique recto y aplastado, boca muy estrecha y poco definida, surco nasolabial muy pronunciado, etc... El cabello peca de ser bastante esquemático y sin

$43 \quad$ Ídem, pp. 14-15. 
apenas resalte, unas estrechas guedejas caen de manera simétrica a ambos lados del rostro, dejando la frente completamente despejada.

La santa de Nicomedia viste una gran túnica policromada en varios tonos de verde, exhibiendo en la parte inferior una estrecha orla dorada con motivos vegetales. Por encima tiene puesta una sobretúnica roja ceñida a la cintura. El borde inferior así como las mangas van decoradas con la misma franja anteriormente comentada. Por la parte interior, la sobretúnica es de unos tonos verdes similares a la túnica. Los pliegues que presentan estas prendas son aristados aunque su ejecución no es muy fina. Aparecen grandes concavidades con los bordes muy aristados que no acusan la finura que, por ejemplo, Pedro de Ávila no empieza a acusar hasta 1714. La parte baja de la escultura, como de costumbre, adquiere esa gran geometrización que parece convertir los pliegues de la ropa en verdaderas rocas; por su lado, la parte inferior de la sobretúnica se abre muy elegantemente de tal manera que esos bordes se curvan y recurvan a placer, estando realizados con unas finas láminas de madera. Me gustaría volver a repetir que no podemos descartar a Pedro de Ávila como autor de esta obra. 


\section{CASTROMOCHO. IGLESIA DE SANTA MARIA DE COLAÑA}

\section{ESCULTURAS DEL RETABLO MAYOR (h. 1716-1720)}

La construcción del presente retablo mayor fue impulsada por el cura de la parroquia, don Manuel Almarza, en el año 1716. Su financiación correría a cargo de la iglesia y de las limosnas que generosamente le aportarían los parroquianos. La obra, que al parecer corrió a cargo de los desconocidos ensambladores vallisoletanos Diego y Pedro Carrera, se dilató hasta el año $1720^{44}$. Anteriormente a este retablo hubo uno anterior gótico con pinturas que efigian escenas de las vidas de Jesús y María. Algunas de estas tablas aparecieron en el año 1979 dentro de la caja del órgano.

El retablo (Fig. 28) es el típico salomónico tetrástilo de los que tanto abundan por tierras vallisoletanas y palentinas Amplio banco que acogen las ménsulas de las columnas del cuerpo del retablo y en los netos, que se encuentran perforados, tienen su cabida unas puertas en los lados para el acceso al camarín de la Virgen y en el centro una gran custodia barroca también salomónica que sería hecha por las mismas fechas y por los mismos artífices que el retablo. El cuerpo, que lo articulan cuatro columnas salomónicas de orden gigante, lo componen tres calles: las calles laterales se dividen en dos pisos de hornacinas planas con el remate superior semicircular, en las cuales tienen cabida las esculturas de San Juan Evangelista, San Andrés, Santo Domingo y San Norberto (Figs. 29-32) ${ }^{45}$. Mientras tanto, la calle central la ocupa una gran hornacina forrada con un marco decorado con cabezas aladas de angelitos. En esta hornacina tiene cabida una Virgen con el Niño gótica que procede atribuir a Alonso de Portillo ${ }^{46}$. Remata el retablo un ático semicircular en cuya parte central hay una hornacina similar a las de las calles laterales y flanqueada por dos potentes estípites que sustentan sendos trozos de entablamento, los cuales se unen por medio de un gran tarjetón de hojas crespas. En esta hornacina figura San Antonio de Padua con el Niño.

Las esculturas que atribuyo a Manuel de Ávila son tan solo las que figuran en las calles laterales puesto que la de San Antonio de Padua parece algo anterior y la Virgen con el Niño es gótica. En el Inventario Artístico de Palencia, Urrea y Martín González fecharon todas las esculturas, a excepción de la imagen mariana, en el siglo XVII ${ }^{47}$. La base para su atribución, sin descartar en ningún caso que hayan sido hechas por Pedro de Ávila, es un simple detalle estilístico: se trata la forma de componer la nariz que se encuentra más cercana a la que Manuel diseñó en el San José de la cofradía de Jesús Nazareno que a las de Pedro de Ávila. A pesar de ser similares, la de Manuel posee un

\footnotetext{
44 http://www.castromocho.com/santa_maria.html

45 URREA FERNÁNDEZ, Jesús y MARTÍN GONZÁLEZ, Juan José: Inventario artístico de Palencia y su provincia I..., op. cit., p. 131.

$46 \quad$ El estudio más completo sobre este interesante escultor que trabajó en tierras palentinas fue acometido por la profesora Ara Gil. ARA GIL, Clementina Julia: "El taller palentino del entallador Alonso de Portillo (1460-1506), B.S.A.A., Tomo LIII, 1987, pp. 211-242.

47 URREA FERNÁNDEZ, Jesús y MARTÍN GONZÁLEZ, Juan José: Inventario artístico de Palencia y su provincia I..., op. cit., p. 131.
} 
tabique recto que en ningún caso se ensancha en su zona baja como ocurre con las de Pedro. Además de que adquiere mayor volumen en la punta. Además de esto se puede esgrimir el hecho de que el San Juan Evangelista sea completamente exacto al que Manuel talló para el ático del retablo mayor de Fuentes de Valdepero: coincide en todo, cabeza, movimiento del cuerpo, ropajes y hasta incluso la dirección de sus pliegues. Como ya hemos dicho en diversas ocasiones, el modelo para estos dos ejemplares de San Juan Evangelista es sin lugar a dudas el que su hermano Pedro esculpió en 1714 para la catedral vallisoletana, y del que tan solo se conserva la cabeza; por lo que estas dos esculturas son el único testimonio que nos queda de cómo sería aquella. Referente a este aspecto, hay que reseñar que por lo que se alcanza a ver en ambas imágenes, las cuales se hallan a gran altura y con mucha suciedad (a lo que hay que añadir el burdo repolicromado del rostro que tiene el San Juan de Castromocho), su talla es menos delicada y no alcanza la calidad del magnífico rostro concebido por Pedro de Ávila, por lo que esta merma de calidad se deberá sin duda a que fueron talladas por Manuel.

A Manuel de Ávila le corresponderán, además del San Juan Evangelista, las hechuras de San Andrés y San Norberto. La de Santo Domingo me crea profundas dudas, decantándome porque le sea ajena, al igual que el San Antonio del ático. Sin embargo, hemos de tener en cuenta que la suciedad y las amplias capas de polvo distorsionan bastante su apreciación; a todo ello hay que añadir el malísimo y grueso repolicromado al que se las ha sometido, especialmente los rostros y los cabellos, de tal manera que los rasgos faciales están falseados, con lo cual es muy complicado su estudio estilístico.

San Juan Evangelista (hornacina izquierda del piso inferior) es una copia exacta del ejemplar del retablo de Fuentes de Valdepero (Palencia). Aparece de pie, con la pierna izquierda adelantada. Ha perdido la mano izquierda, en la cual portaría el libro que le acreditaría como evangelista, mientras que en la derecha conserva su pluma, la cual sujeta de una manera muy elegante. A sus pies figura su "viviente" del Tetramorfos: el águila. El santo dirige su mirada hacia el cielo, como buscando la inspiración divina que le ayude a escribir el Evangelio. Tal y como el San Juan original de Pedro de Ávila, posee una gran melena a ambos lados del rostro realizada a través de amplísimos bucles en los que por desgracia no observamos la finura de la labra previsible, sin lugar a dudas debido al referido espeso y horroroso policromado. Los rasgos faciales están totalmente enmascarados por el mismo motivo, tan solo acertamos a ver la referida nariz que le acreditaría como obra de Manuel de Ávila. Viste una gran túnica verde que tan solo le deja libres la cabeza, las manos y la punta de los zapatos; por encima un manto rojo con ricas cenefas doradas en los bordes que se dispone verticalmente sobre el cuerpo del santo, cayendo uno de sus extremos por el hombro y el brazo izquierdo. Aunque también se encuentra enmascarado, los pliegues presentes en esta y en las otras esculturas es el usual pliegue berninesco a cuchillo. En algunos lados figura muy aristado creando unas concavidades bastante amplias, lo que sin duda concierta bastante con la fecha en que debieron ser hechas (h. 1716-1720). No falta la característica colocación de los pies. 
San Andrés (hornacina derecha del piso inferior) parece corresponder al movimiento de San Juan, contraponiéndose y complementándose al estar algo ladeado y mirando hacia la izquierda del espectador; es decir, hacia el Evangelista. También se halla de pie, con el clásico contrapposto realizado con el adelantamiento de la pierna derecha. En la actualidad la posición de sus manos no será la originaria puesto que la derecha parece medio despegada del cuerpo, realizando un gesto que no tiene sentido, y la izquierda también realiza otra acción que tampoco aporta nada como es el agarrar un paño blanco. Esta última acción cobraría todo su ser si entre mano y paño se le colocara la cruz aspada (su atributo universal) que tiene a las espaldas, de tal manera que el madero no lo asiera con ambas manos; de una forma similar a como compuso Juan de Ávila su San Andrés del retablo mayor de la colegiata de Lerma (Burgos). Como ya hemos señalado, tiene la cabeza completamente girada hacia su derecha. Su rostro y barba serán seguramente los más afectados por el burdísimo repinte realizado en fecha ignota, pues no hay nada más que ver los labios pintados gruesamente de un rojo chillón, o la manera de ejecutar el repolicromado de los ojos.... Sea como fuere y aunque los rasgos faciales están completamente enmascarados, podemos ver esa característica nariz de la que venimos hablando. Por lo demás, tiene una amplia y espesa barba concebida a través de sinuosas guedejas que van derivando en otras, de tal manera que la ensanchan y finaliza en numerosas puntas. Acusa calvicie puesto que la frente tan solo la tapan un par de mechones. A los lados de la cabeza una cabellera corta similar a la vista en la Santa Bárbara de Fuentes de Valdepero.

Santo Domingo (hornacina izquierda del piso superior) es quizá la pieza más floja de las cuatro. El hecho de que posea una talla muy dura y la ausencia de pliegues a cuchillo me hacen pensar que pudiera ser obra de taller o incluso que hubiera sido reutilizada; extremo que podría confirmarse dado el gran parecido que guarda con el San Francisco de Asís del ático. Posiblemente ambos santos, que suelen figurar asociados en muchas ocasiones, se incluyeron para completar las hornacinas. Como vemos, hay un gran parecido en sus rostros, narices, y aún en la forma de tallar el pelo e incluso los pliegues de los ropajes. No sería muy aventurado colocar al San Francisco, y por ende al Santo Domingo, en la órbita de los talleres vallisoletanos de finales del siglo XVII; quizás en los de José de Rozas o Juan de Ávila.

San Norberto (hornacina derecha del piso superior) adopta una posición similar a las otras tallas: de pie, con una pierna levemente adelantada con la rodilla remarcada bajo la ropa para crear un contrapposto. Eleva poderosamente su brazo derecho, cuya mano sujetaría, quizás, un báculo, que le acreditaría como abad; mientras que el brazo izquierdo se encuentra recogido para sujetar mejor un libro sobre el cual se alza la maqueta de una iglesia, atributos que le caracterizan como fundador de una orden, la de los Premostratenses, también conocidos como "Mostenses", "Canónigos blancos" o "Norbertinos". El hecho de que no lleve solamente el libro se deberá a que no redactó una Regla; pues la orden que fundó, de ahí el que aparezca la iglesia sobre el libro, seguía la confeccionada por San Agustín. Su cabeza presenta las mismas características de las de San Juan y San Andrés: grueso repolicromado que tan solo permite verle bien 
la forma de la nariz, que es la característica de los Ávila, especialmente de Manuel. A ambos lados del rostro, pelo blanco sobre las orejas, que van talladas en su totalidad. Viste una gran túnica grisácea ceñida a la cintura por un cíngulo dorado, el mismo color que adoptan las cenefas que recorren las empuñaduras de las mangas y la parte baja del hábito. En realidad, este hábito debería ser blanco, de ahí lo de "Canónigos blancos", pero posee ese color grisáceo que parece más bien un policromado jaspeado. Sobre los hombros tiene echada una capa corta roja, y cubre su cabeza con un bonete del mismo color.

En definitiva, habrá que esperar a una poco previsible restauración del retablo, y especialmente de las esculturas, para volver a hacer un análisis un poco más detallado y ver si seguimos atribuyéndole las obras a Manuel o las colocamos en el haber de su hermano Pedro. Probablemente la eliminación de los repintes nos muestre unas esculturas con una talla mucho más definida. Quizás ocurra como en el tantas veces aludido Cristo del Olvido, el cual tras ser restaurado hace un par de años y eliminada su gruesa capa de repinte se nos presentó como una de las mejores tallas que esculpiera Pedro de Ávila, el mejor escultor que vio Castilla durante la primera mitad del siglo XVIII. 
$\sum[1314 \leq$ 


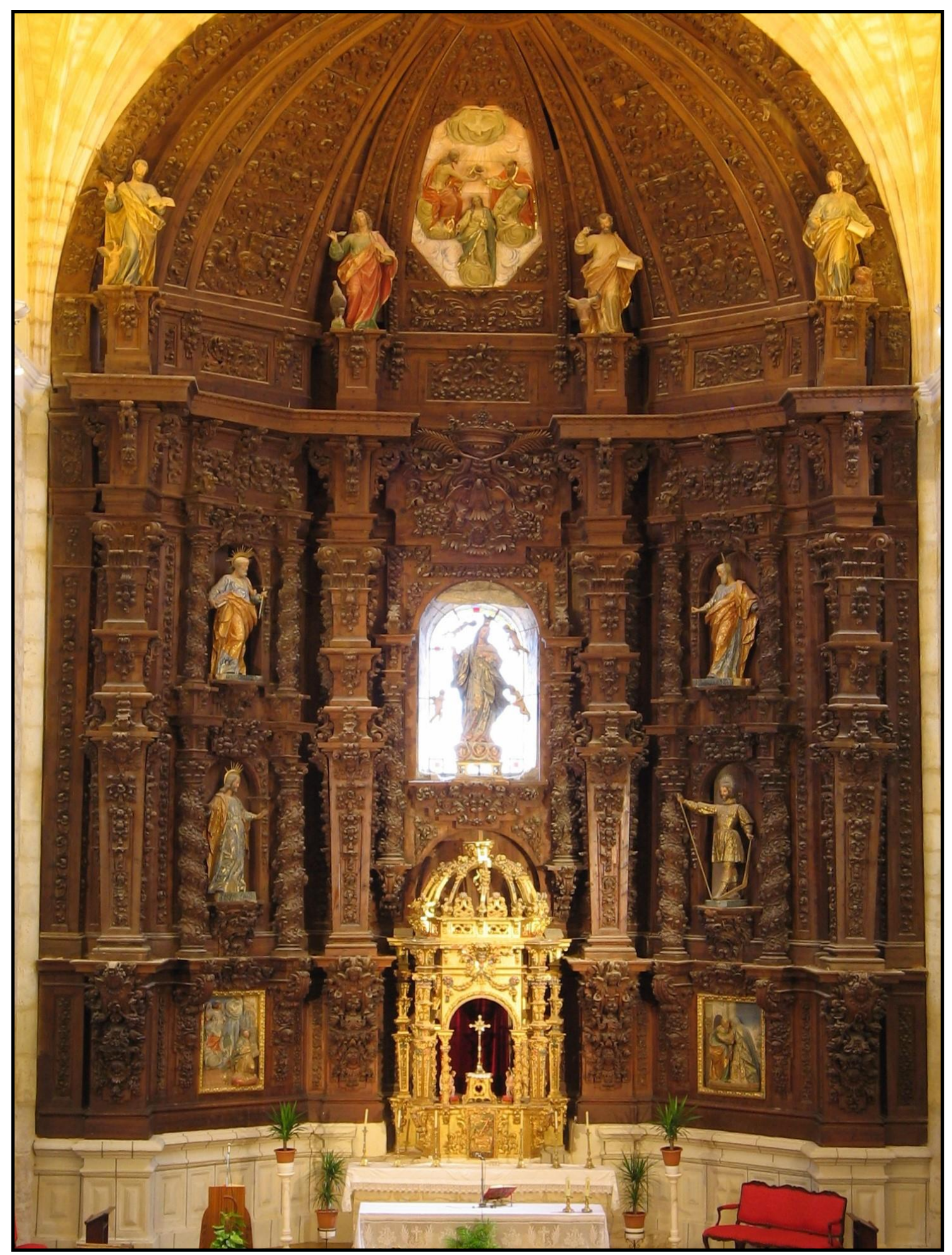

Fig. 1- Alonso Manzano. Retablo mayor. Iglesia parroquial de Santa María la Antigua. Fuente de Valdepero (Palencia).

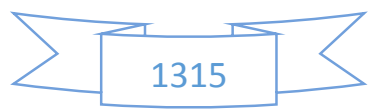




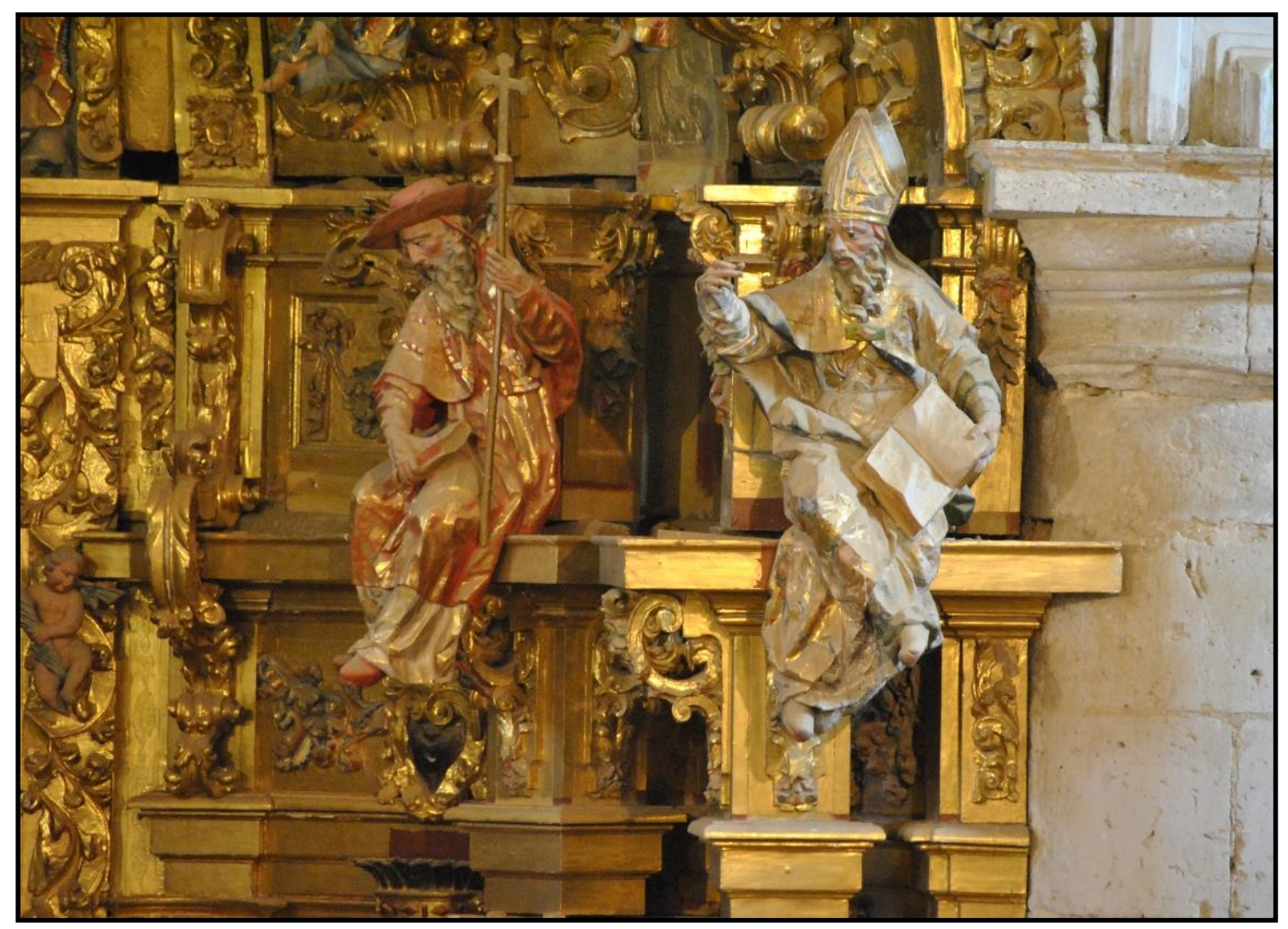

Fig. 2- Tomás de Sierra. Retablo mayor. Iglesia del Salvador. Herrín de Campos (Valladolid).

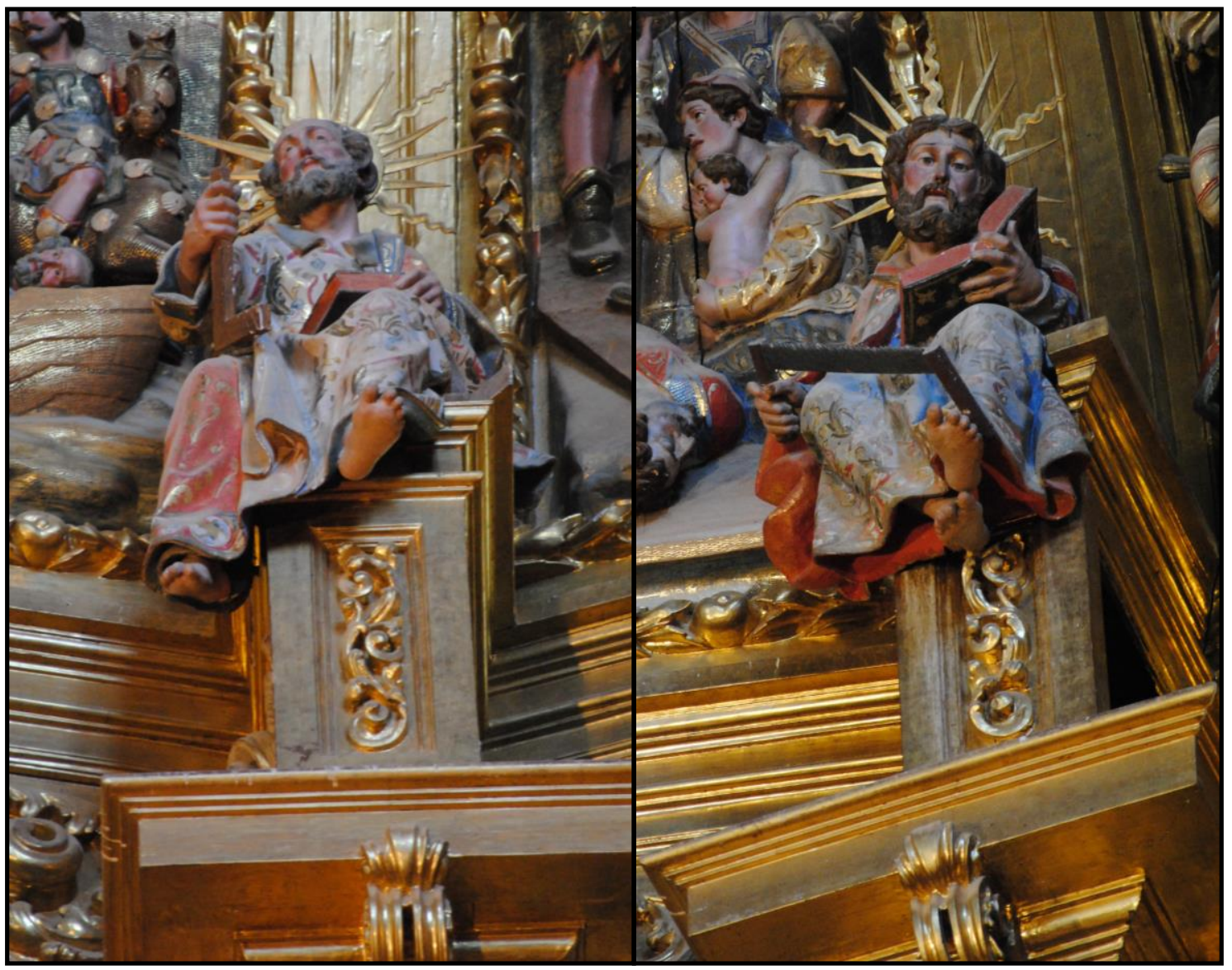

Fig. 3- Tomás de Sierra. Retablo mayor. Iglesia de Santiago de los Caballeros. Medina de Rioseco (Valladolid).

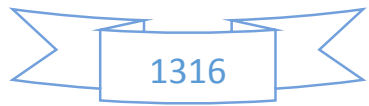




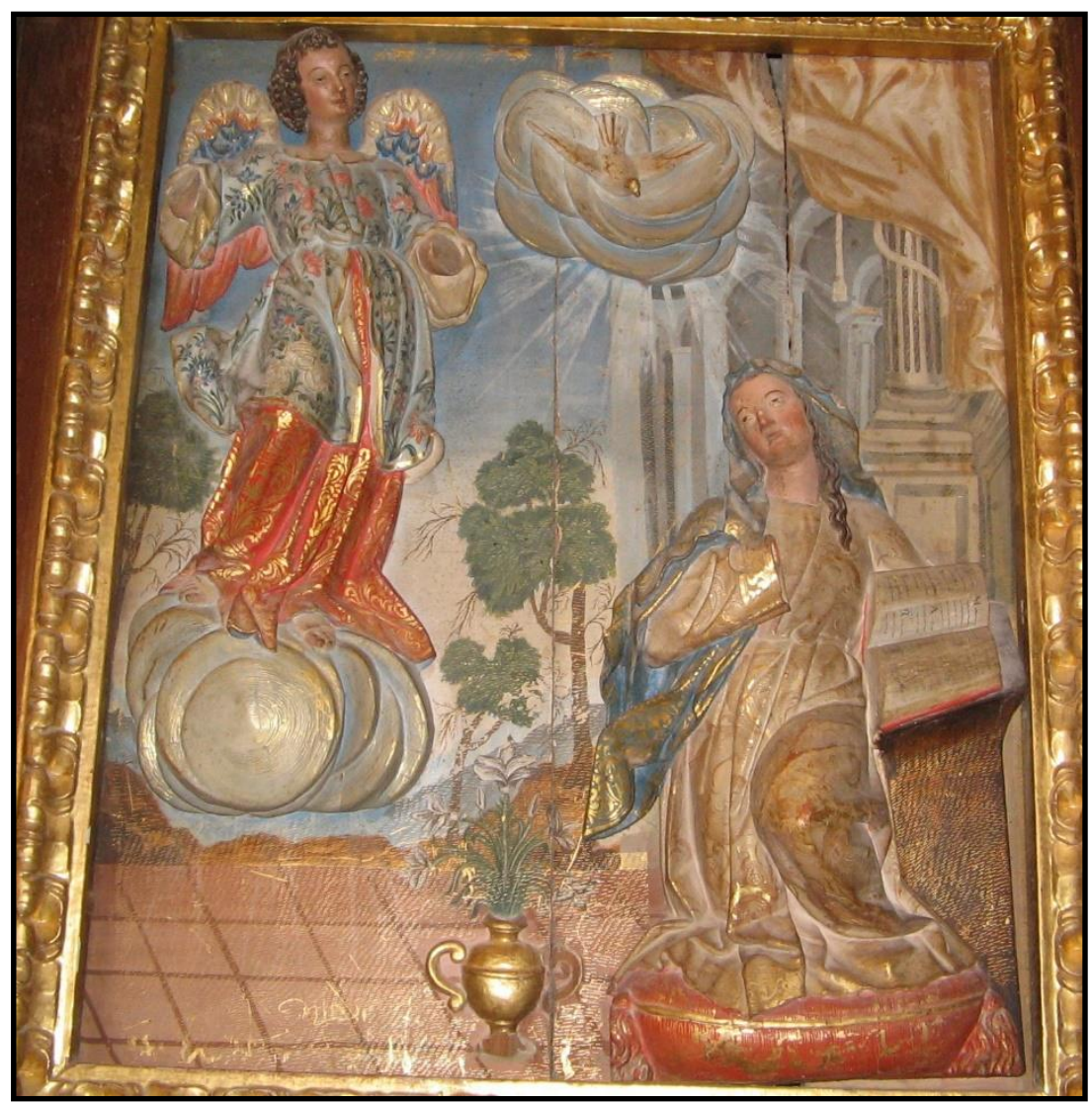

Fig. 4- Manuel de Ávila. Relieve de la Anunciación.

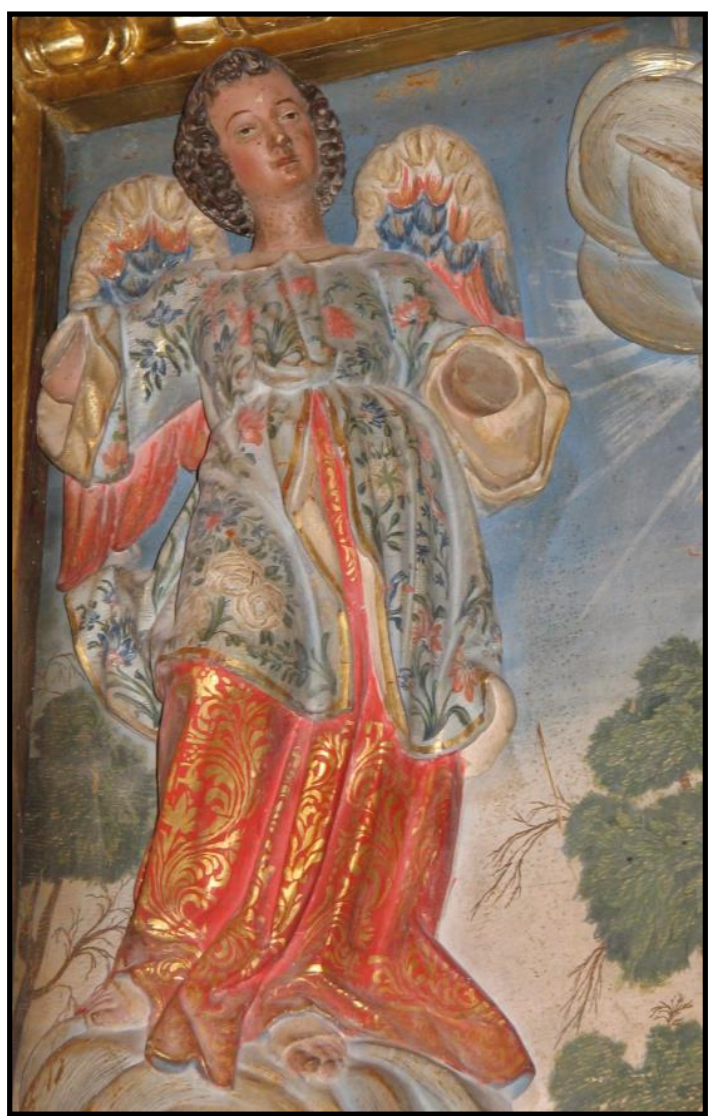

Fig. 5- Detalle de San Gabriel.

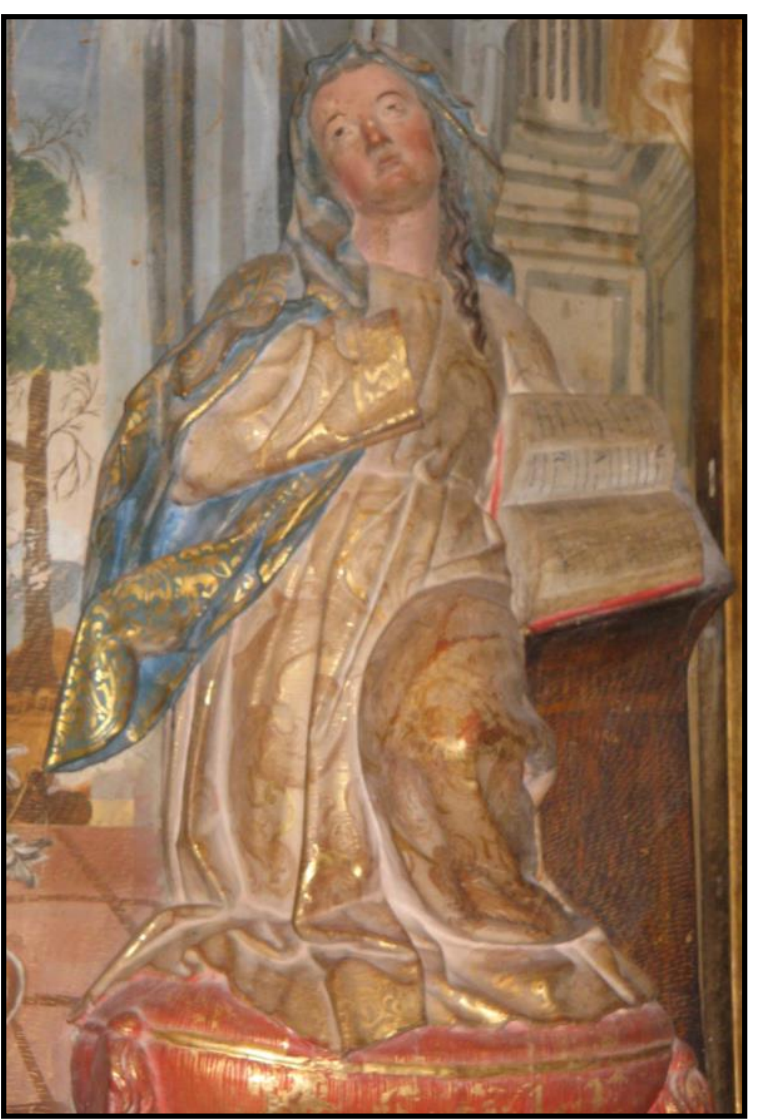

Fig. 6- Detalle de la Virgen María.

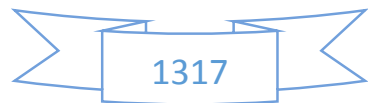




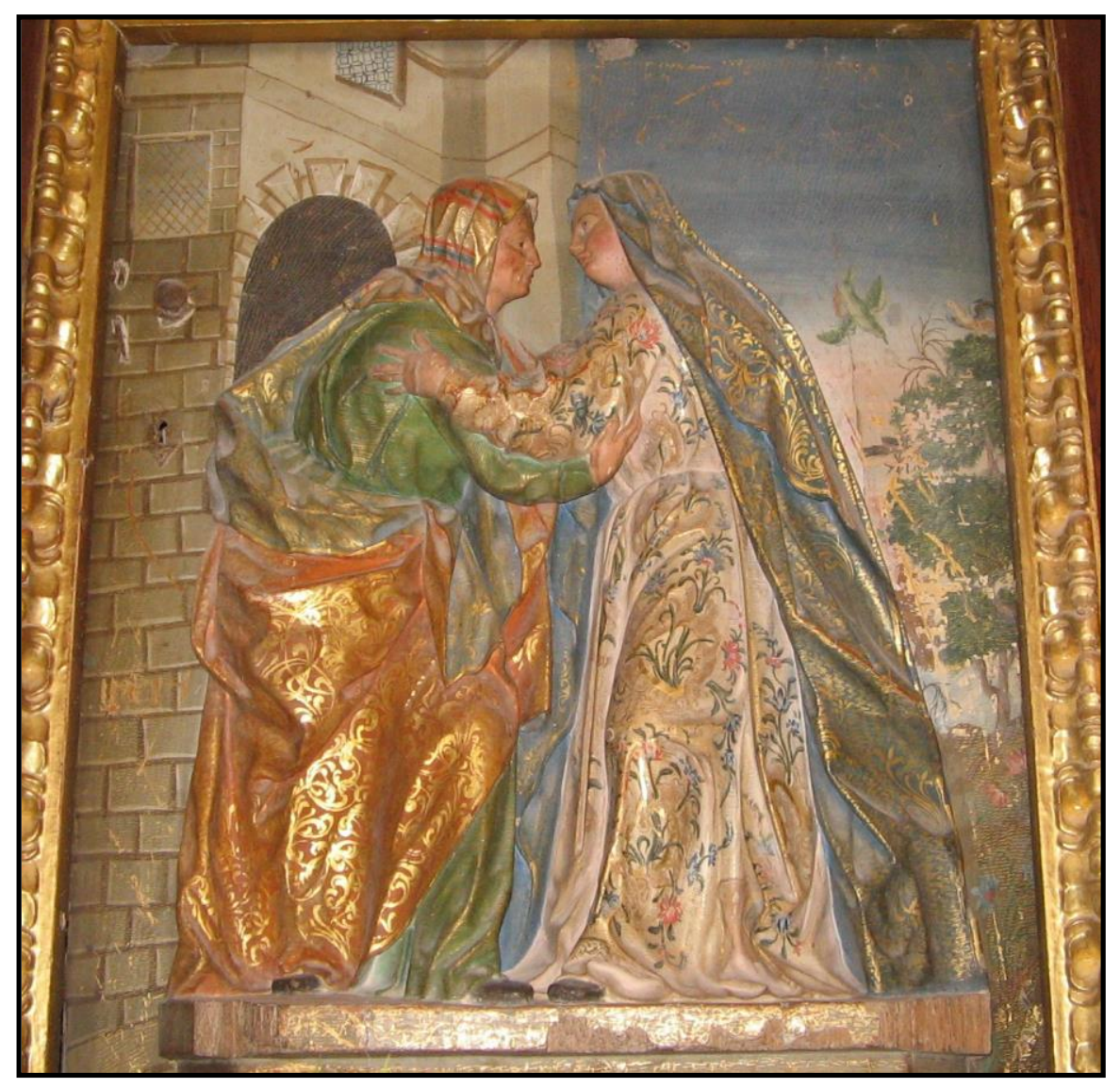

Fig. 7- Manuel de Ávila. Relieve de la Visitación.

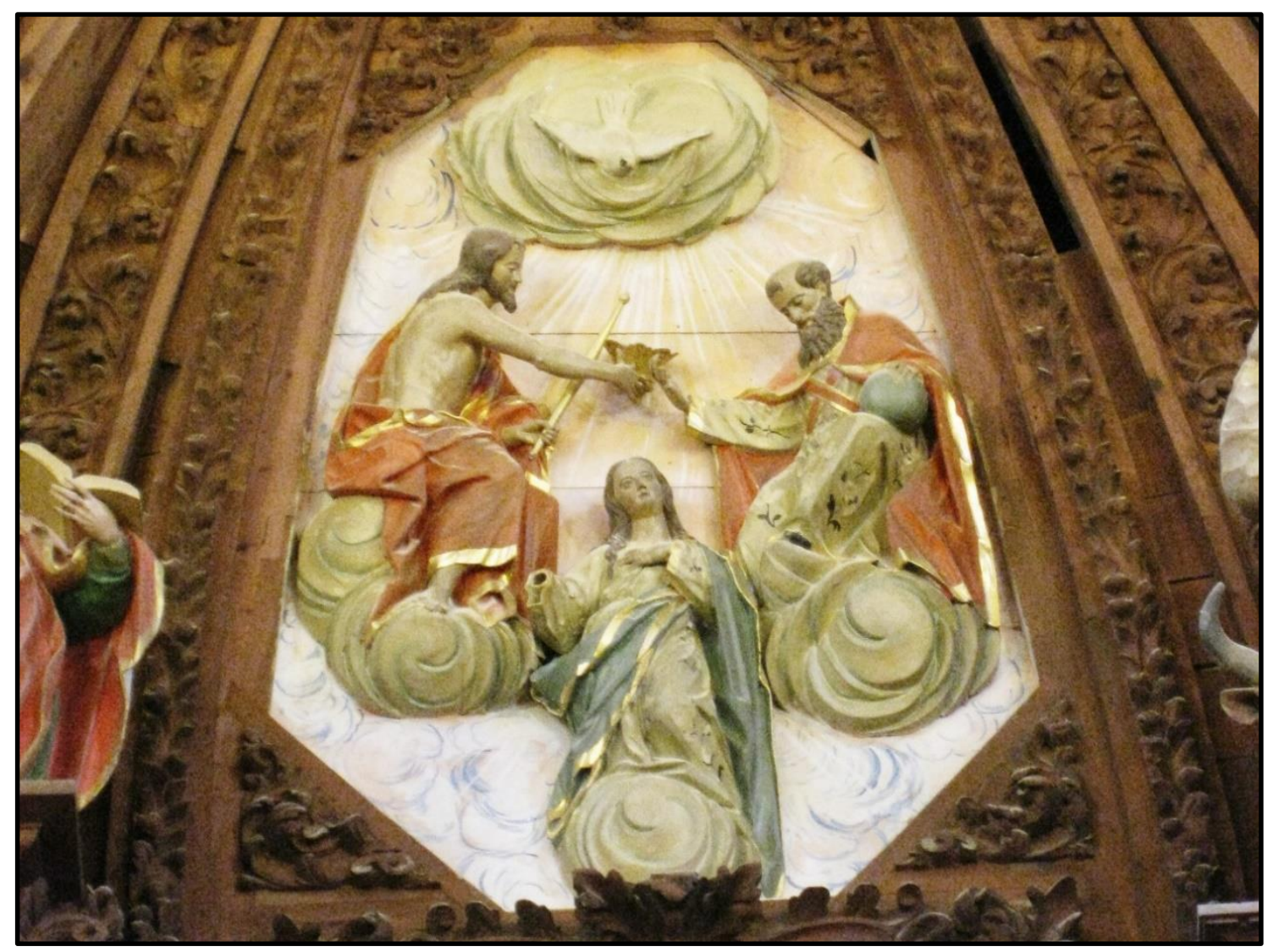

Fig. 8- Manuel de Ávila. Relieve de la Coronación de la Virgen.

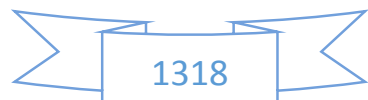




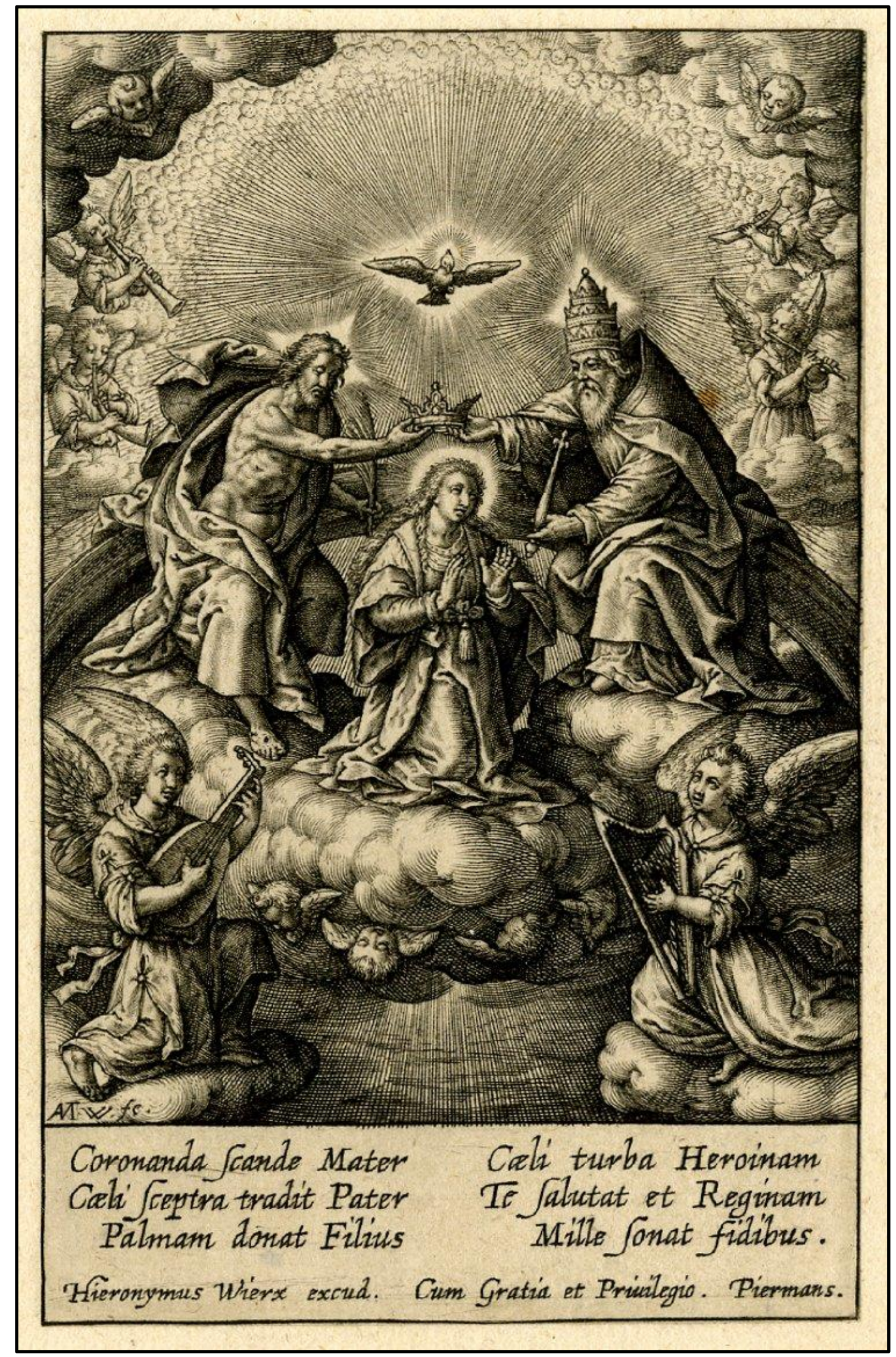

Fig. 9- Hieronymus Wierix. La Coronación de la Virgen.

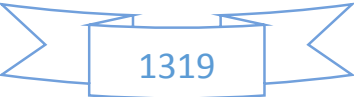




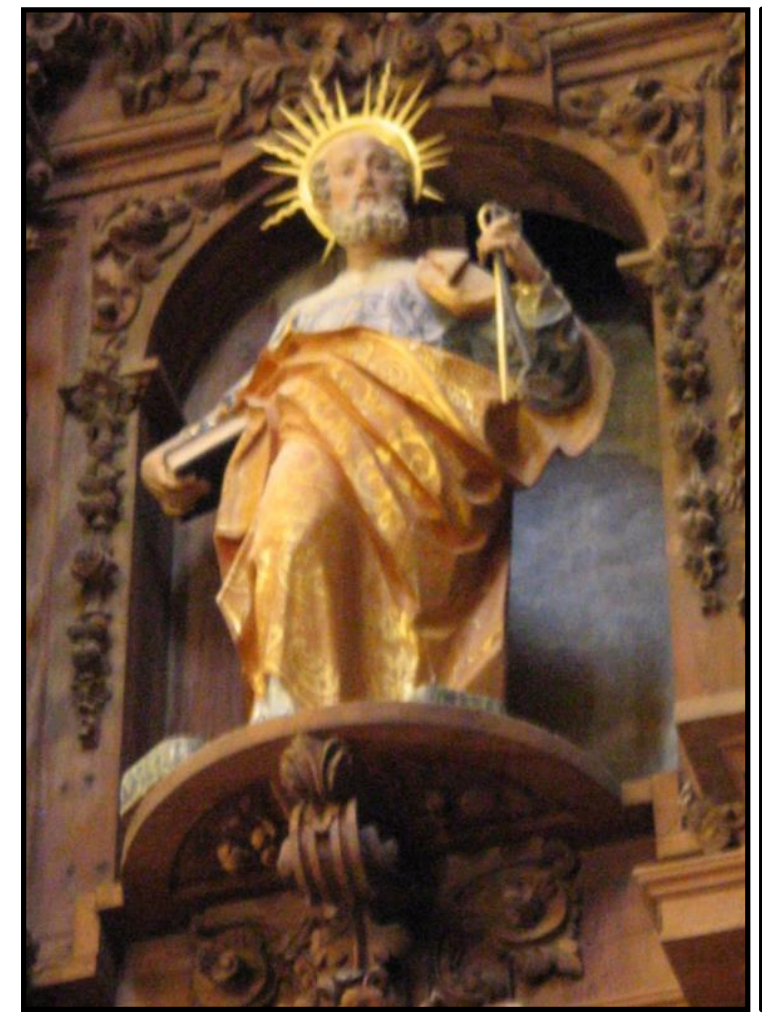

Fig. 10- Manuel de Ávila. San Pedro.

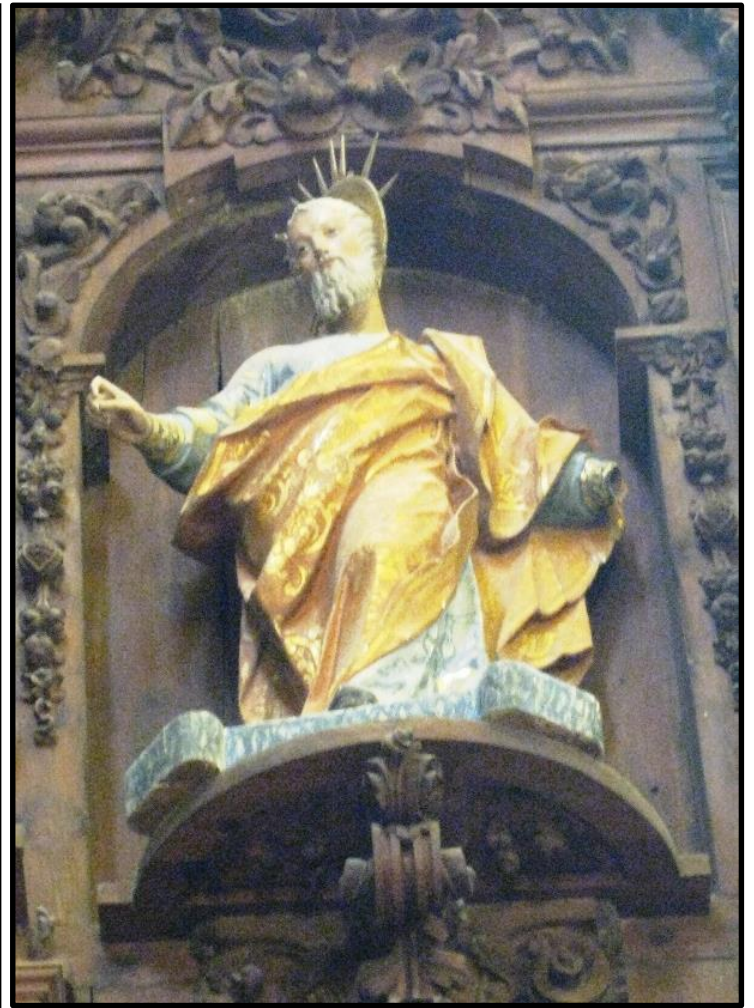

Fig. 11- Manuel de Ávila. San Pablo.

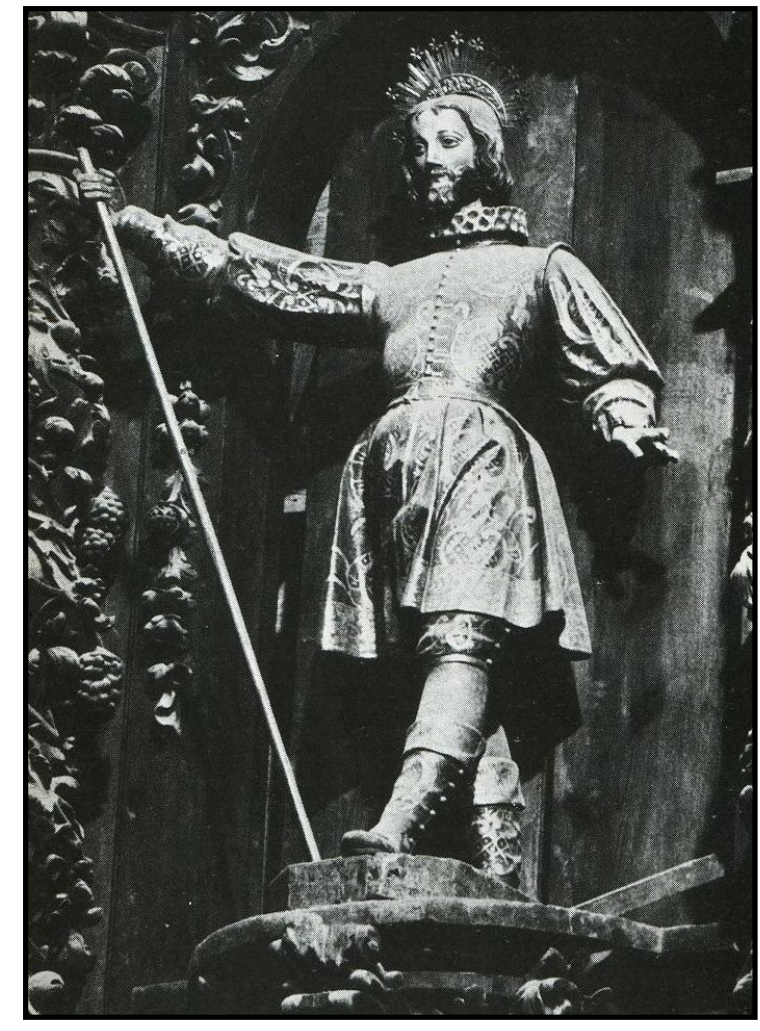

Fig. 12- Manuel de Ávila. San Isidro.

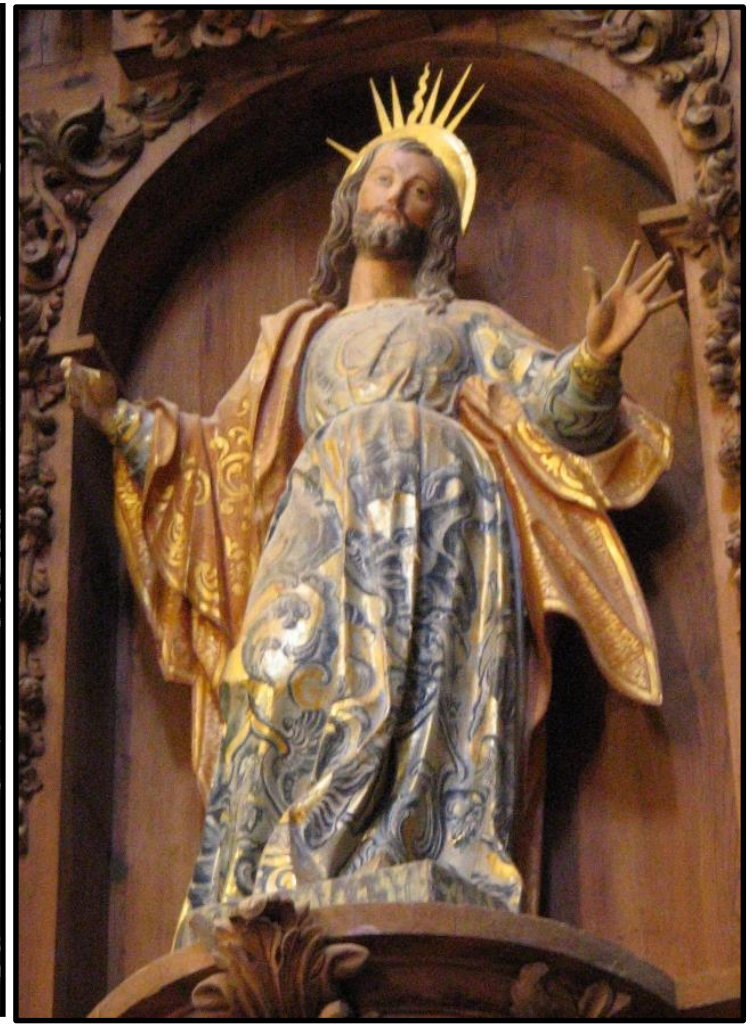

Fig. 13- Manuel de Ávila. El Salvador. 


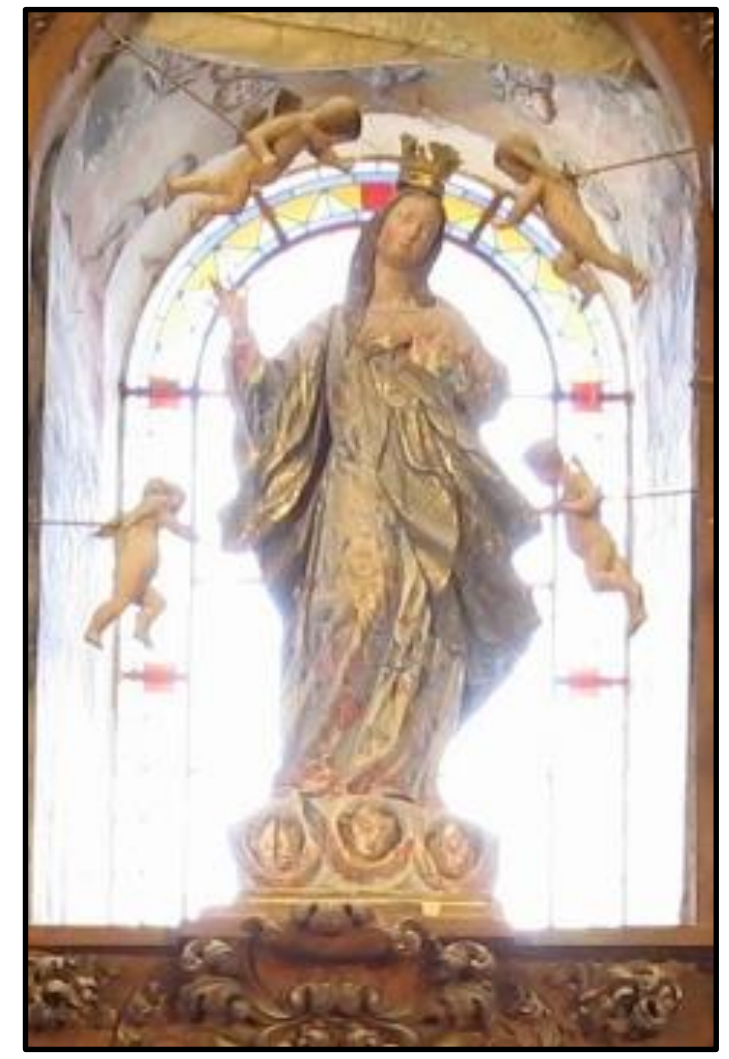

Fig. 14- Manuel de Ávila. Inmaculada Concepción

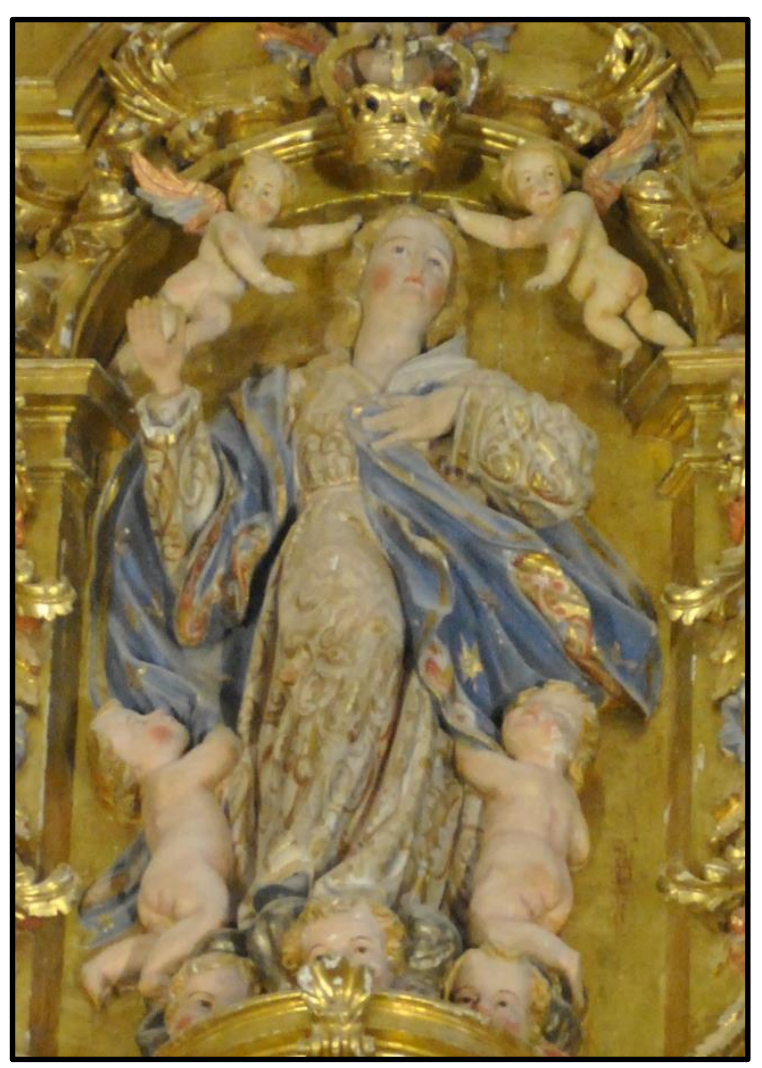

Fig. 15- Pedro Bahamonde. Inmaculada. Retablo mayor de la iglesia parroquial de Santa Eulalia. Autillo de Campos (Palencia).

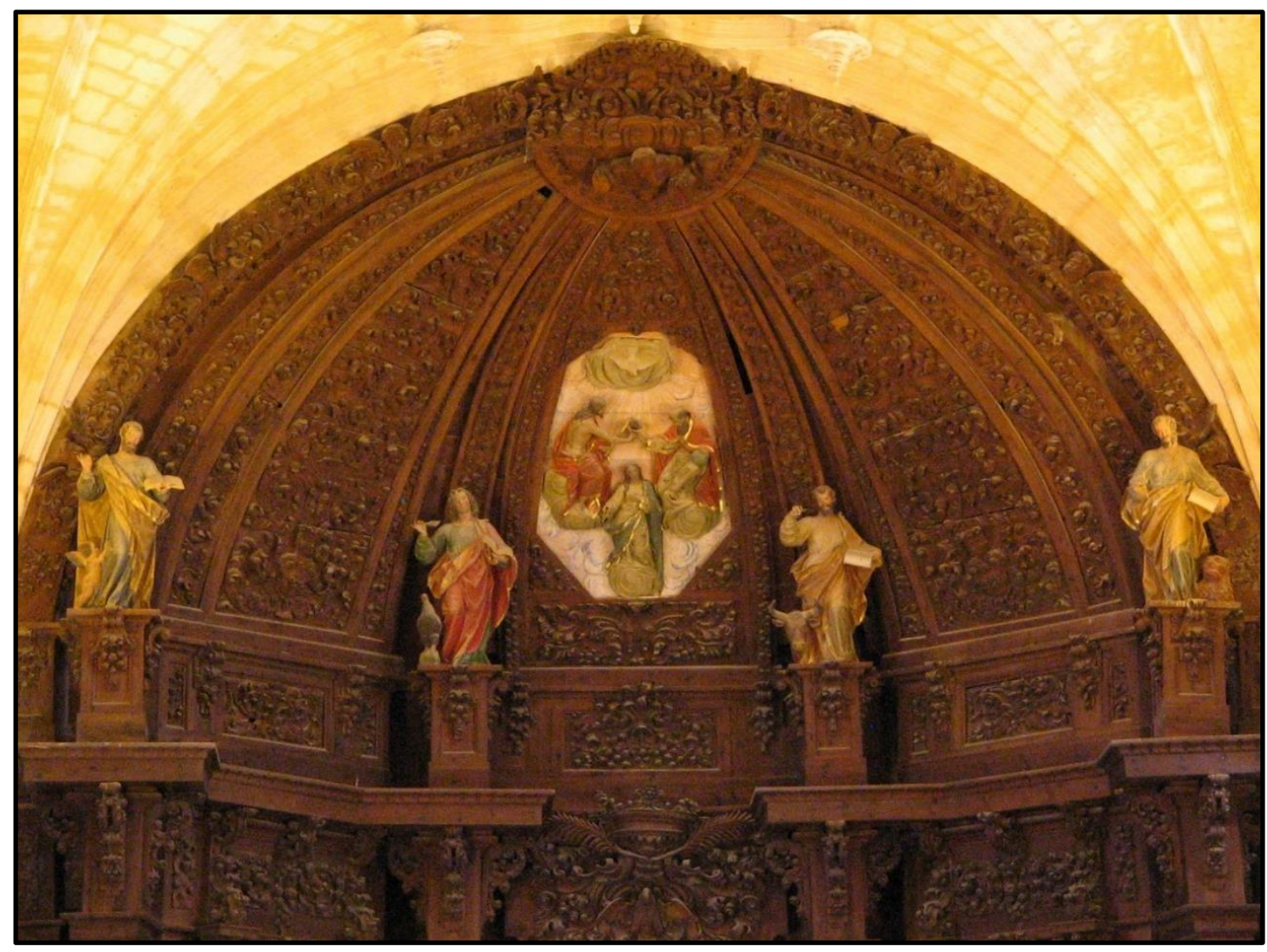

Fig. 16- Manuel de Ávila. Los cuatro Evangelistas.

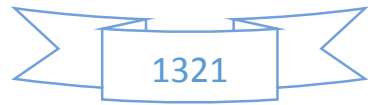




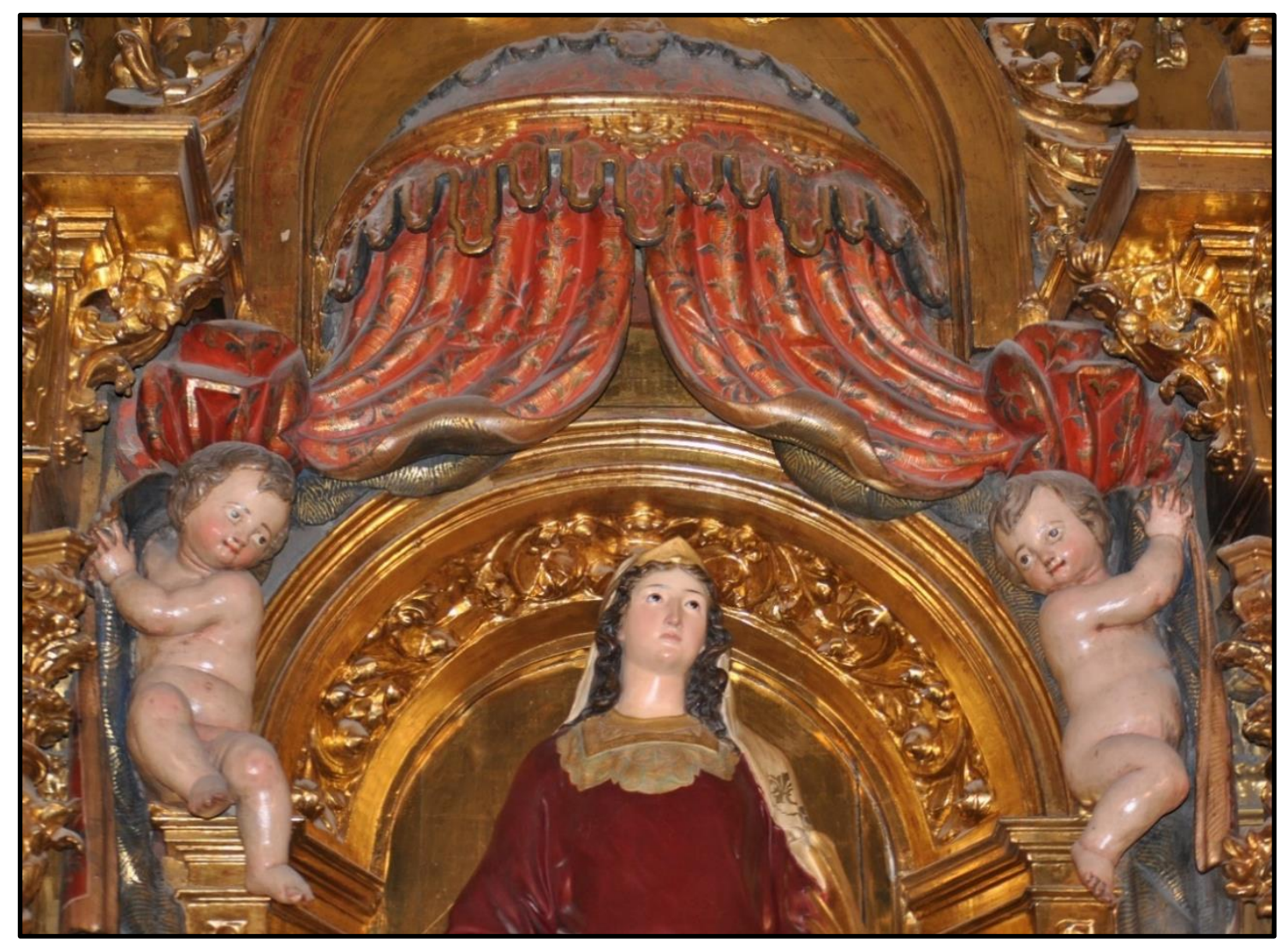

Fig. 17- Manuel de Ávila. Ángeles. Oratorio de San Felipe Neri. Valladolid.

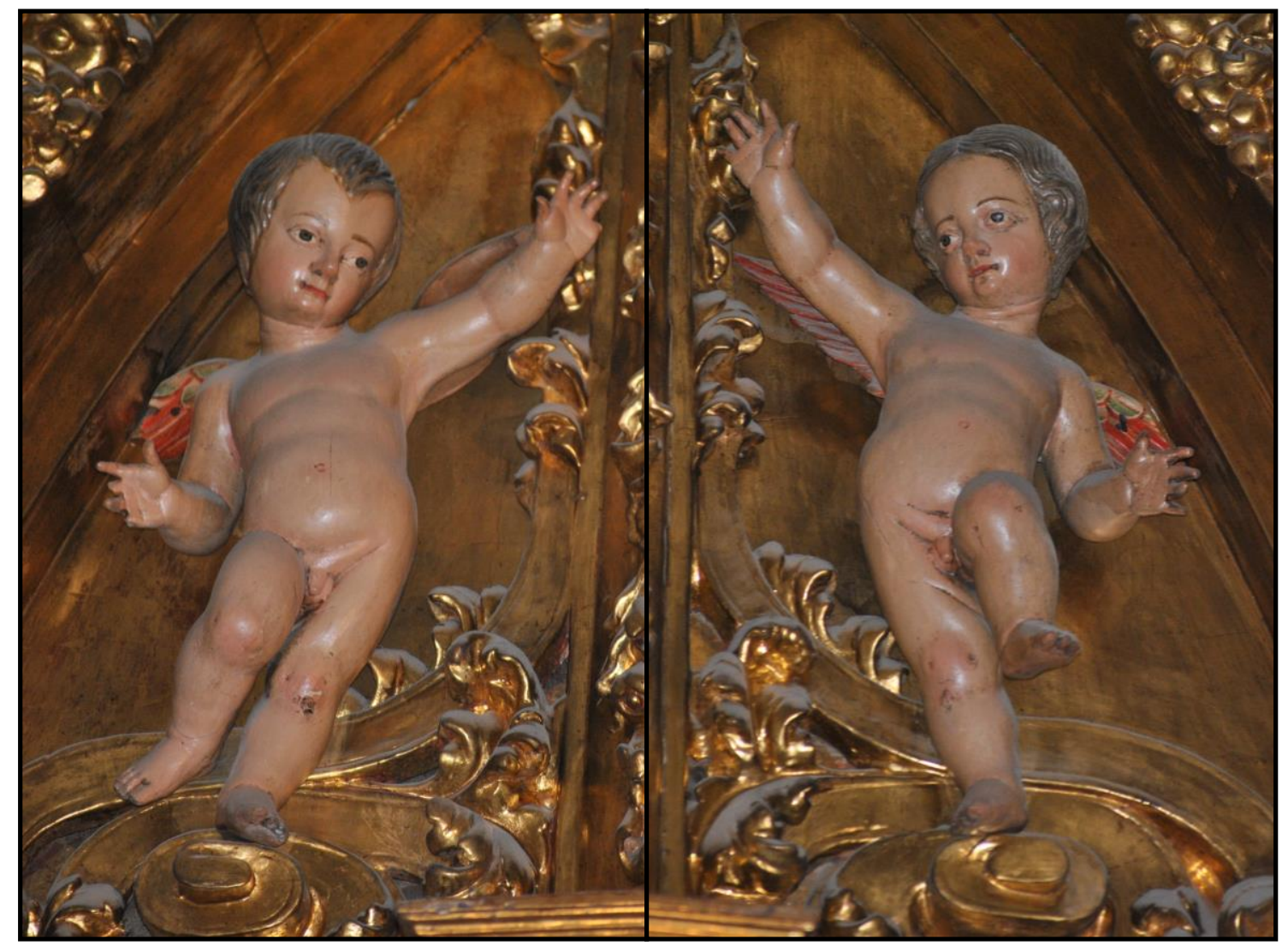

Fig. 18- Manuel de Ávila. Ángeles. Oratorio de San Felipe Neri. Valladolid.

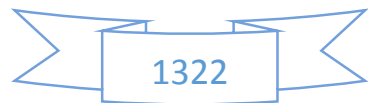




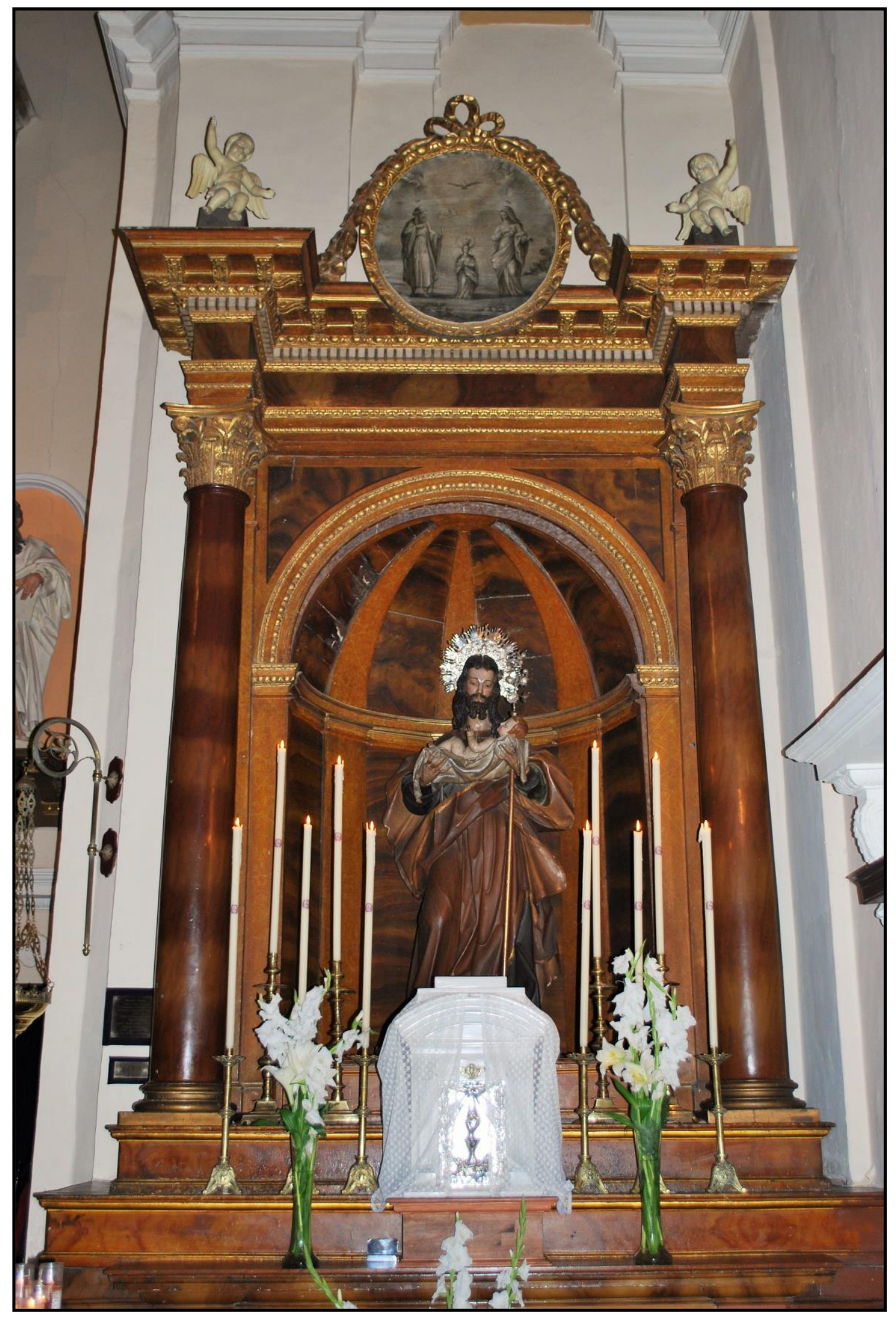

Fig. 19- Eustaquio Bahamonde. Retablo de San José. Iglesia penitencial de N. P. Jesús Nazareno. Valladolid.

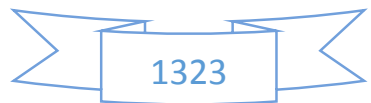




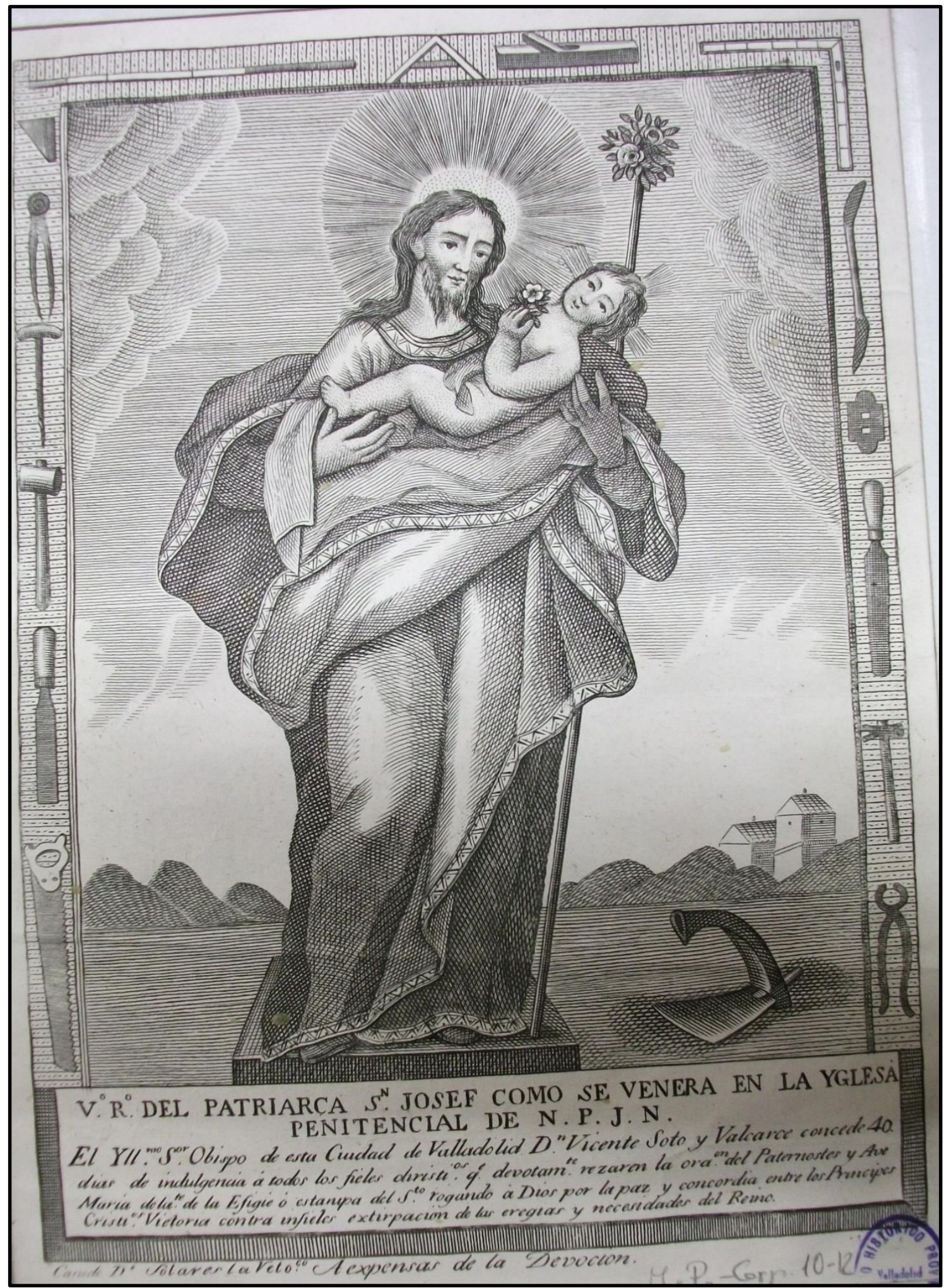

Fig. 20- Joaquín Canedo. Verdadero retrato del Patriarca San Josef como se venera en la iglesia penitencial de Nuestro Padre Jesús Nazareno. Archivo Histórico Provincial de Valladolid. Valladolid.

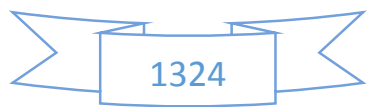




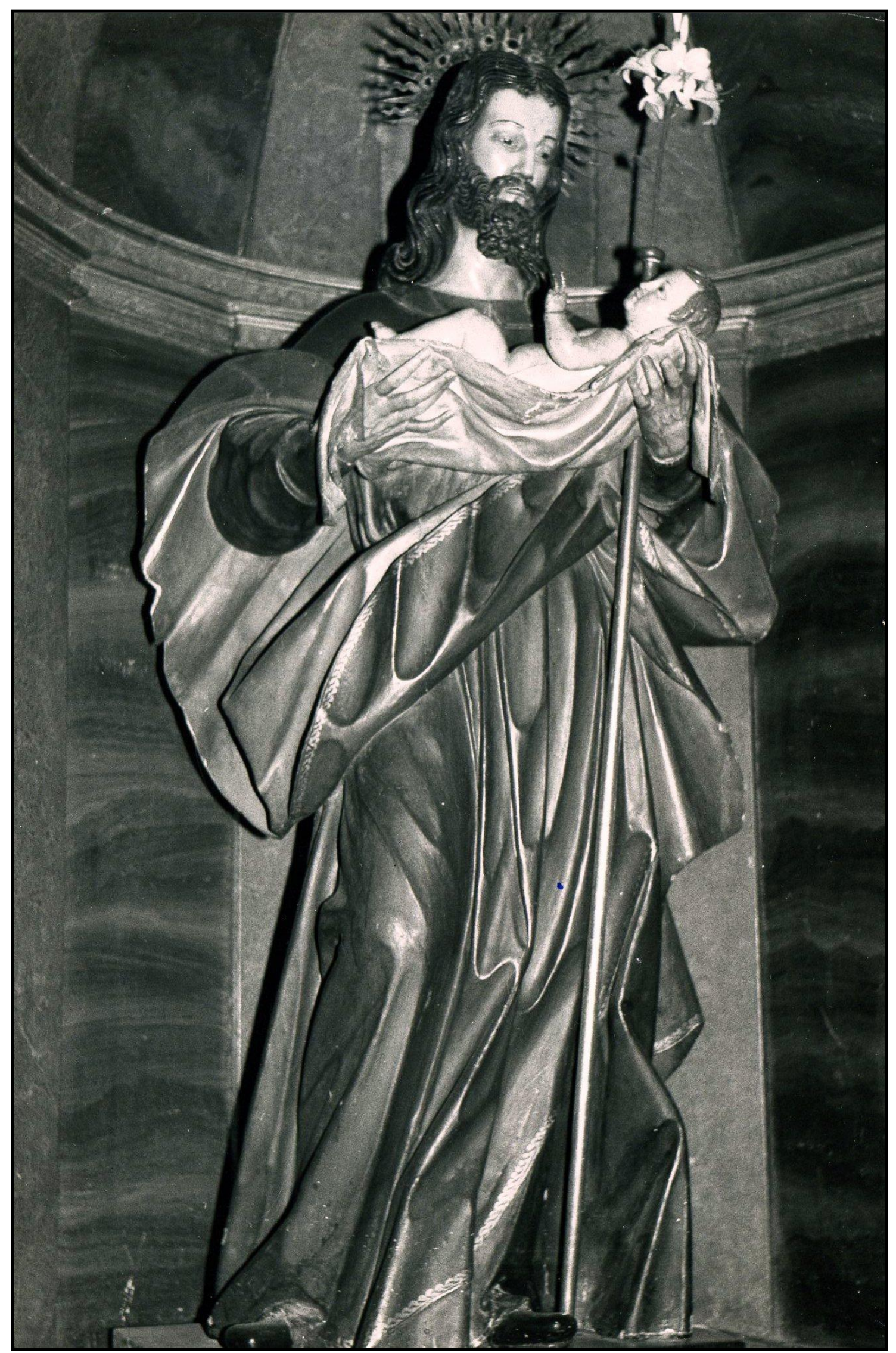

Fig. 21- Manuel de Ávila. San José con el Niño. Iglesia penitencial de N. P. Jesús Nazareno. Valladolid. () Departamento de Historia del Arte de la Universidad de Valladolid.

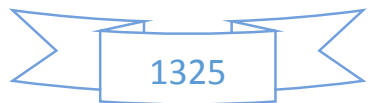




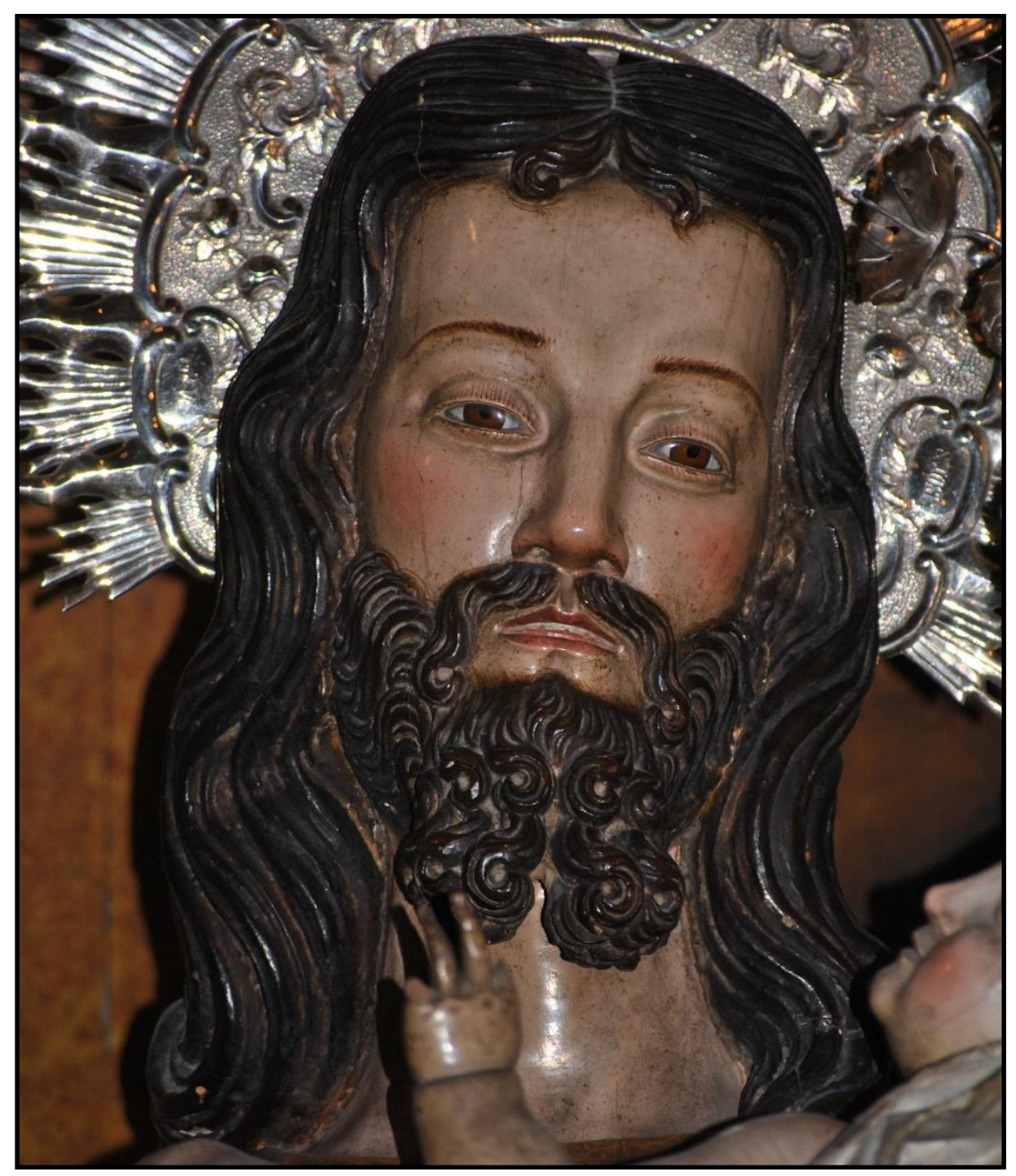

Fig. 22- Detalle de la cabeza de San José.

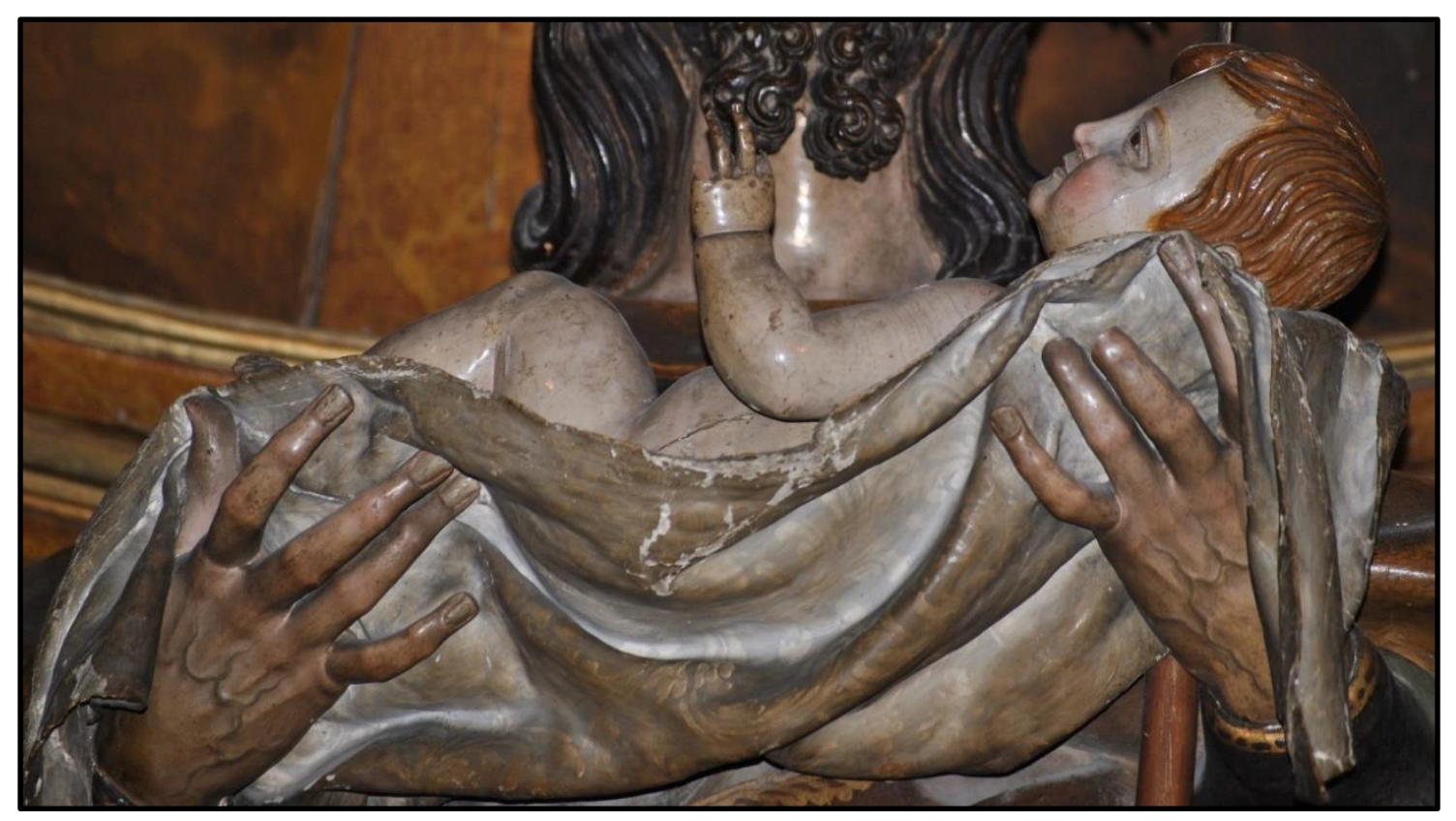

Fig. 23- Detalle del Niño.

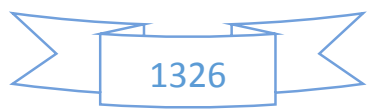




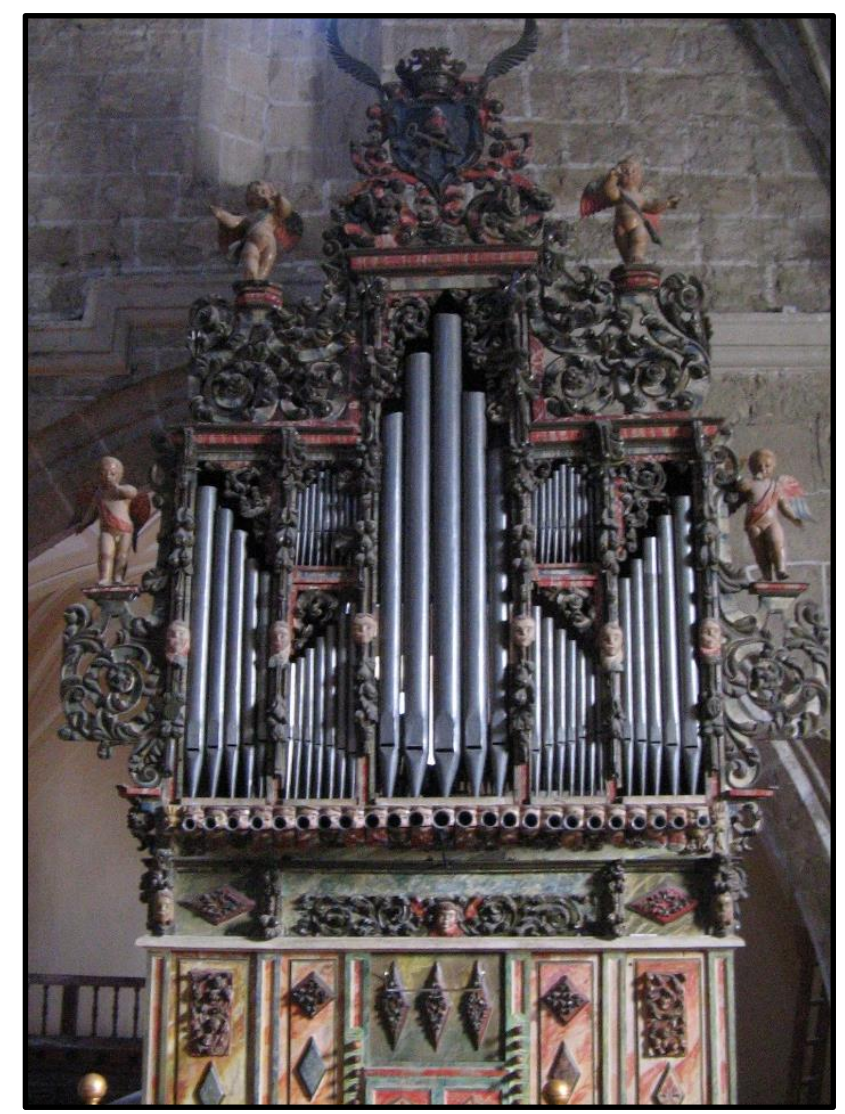

Fig. 24- Manuel de Ávila y Antonio de Gautúa. Ángeles del órgano. Iglesia de San Pedro. Tordesillas (Valladolid). (Valladolid)

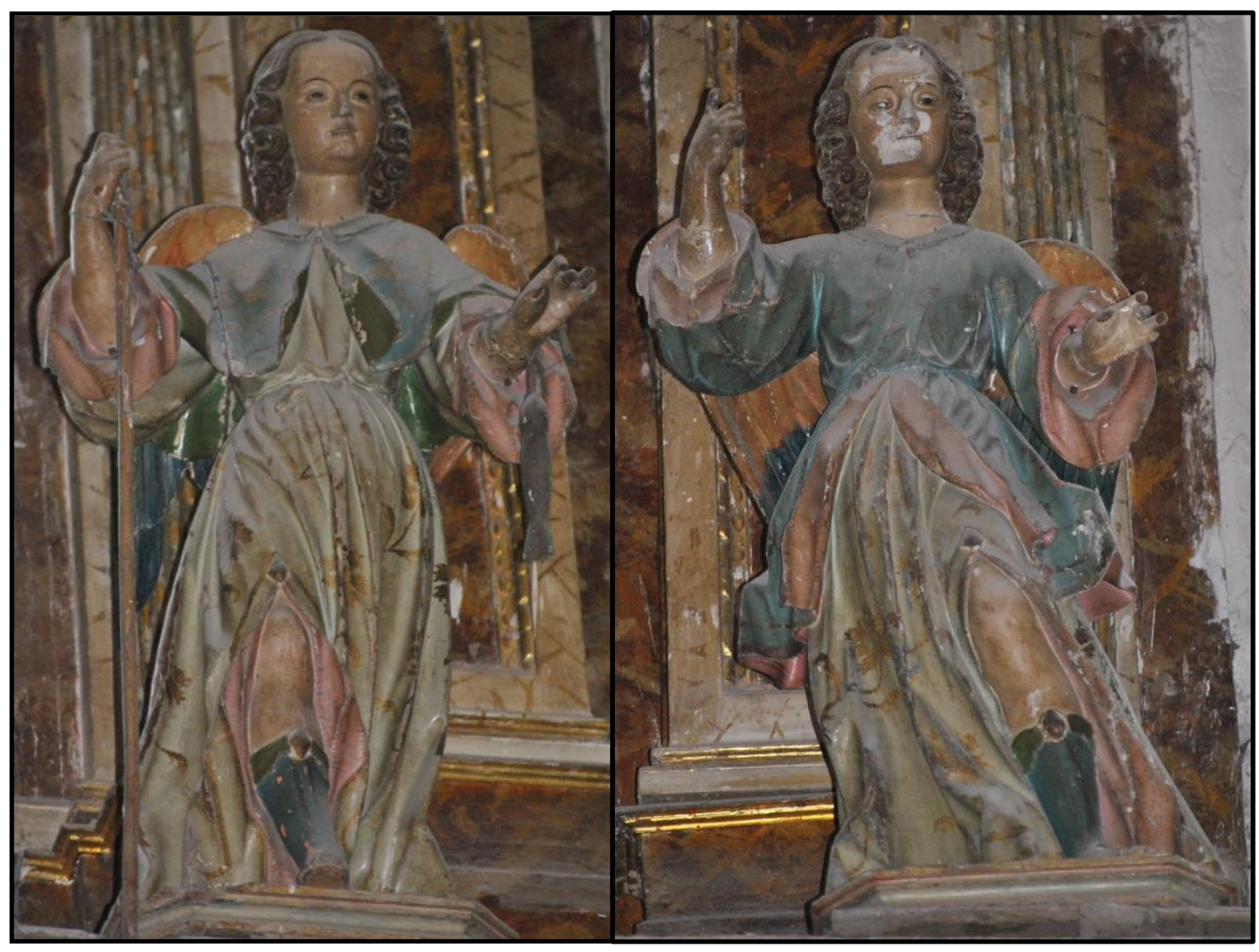

Fig. 25- Manuel de Ávila. San Gabriel y San Rafael. Iglesia de San Pedro. Tordesillas (Valladolid).

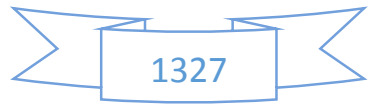




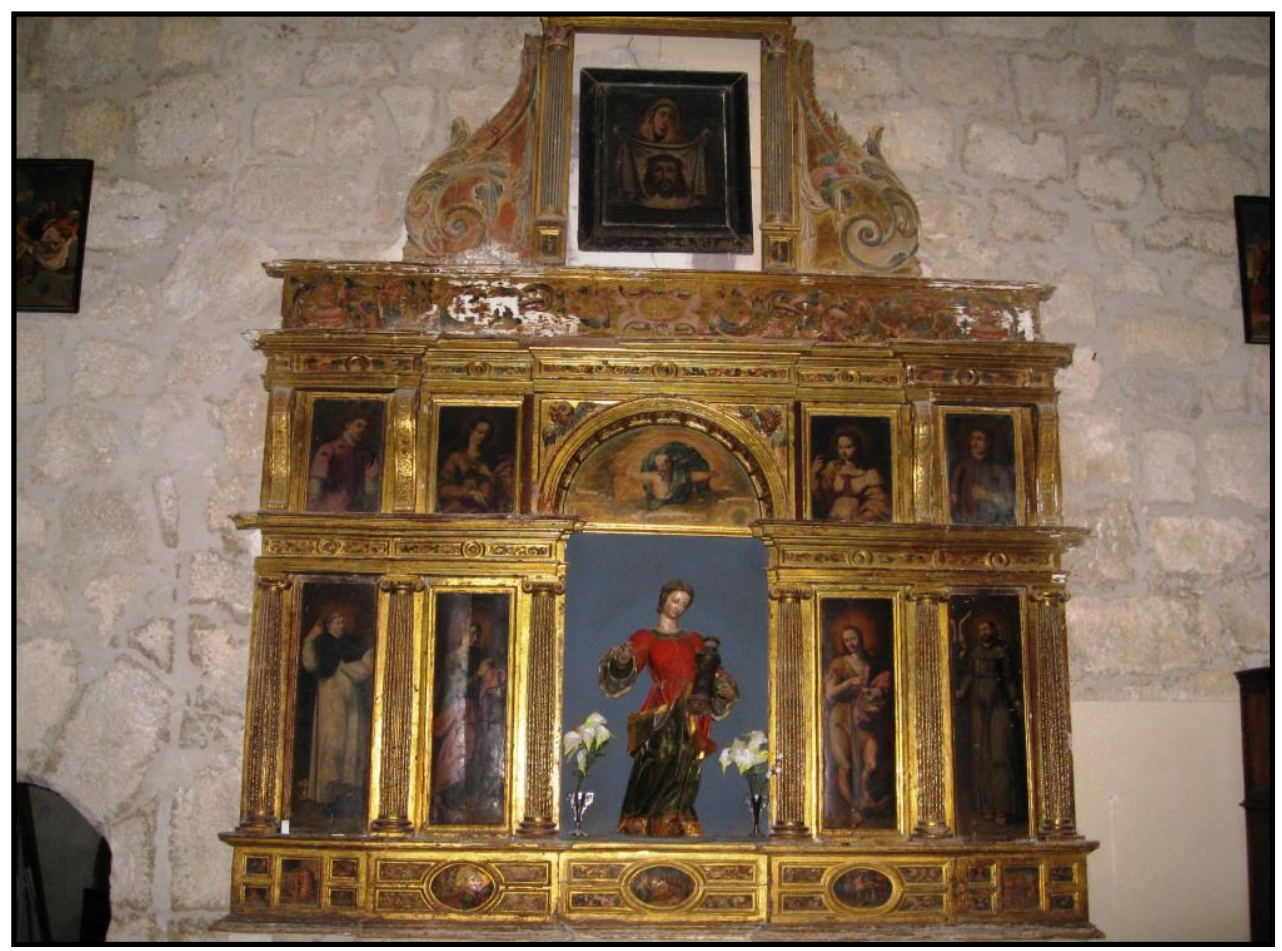

Fig. 26- Anónimo. Retablo de Santa Bárbara. Iglesia parroquial de Fuentes de Valdepero (Palencia).

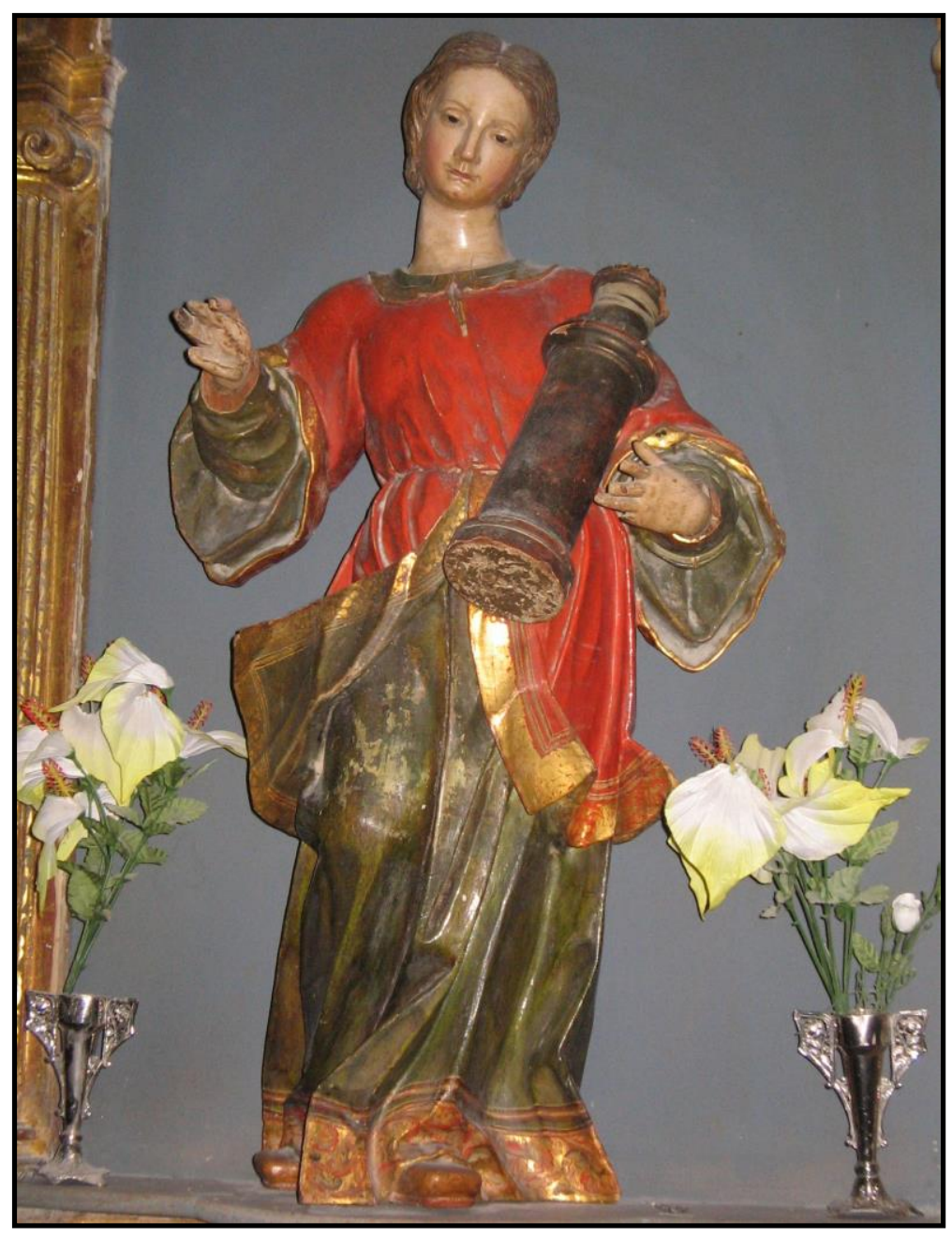

Fig. 27- Manuel de Ávila. Santa Bárbara.

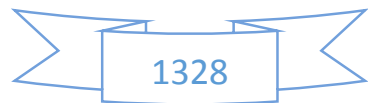




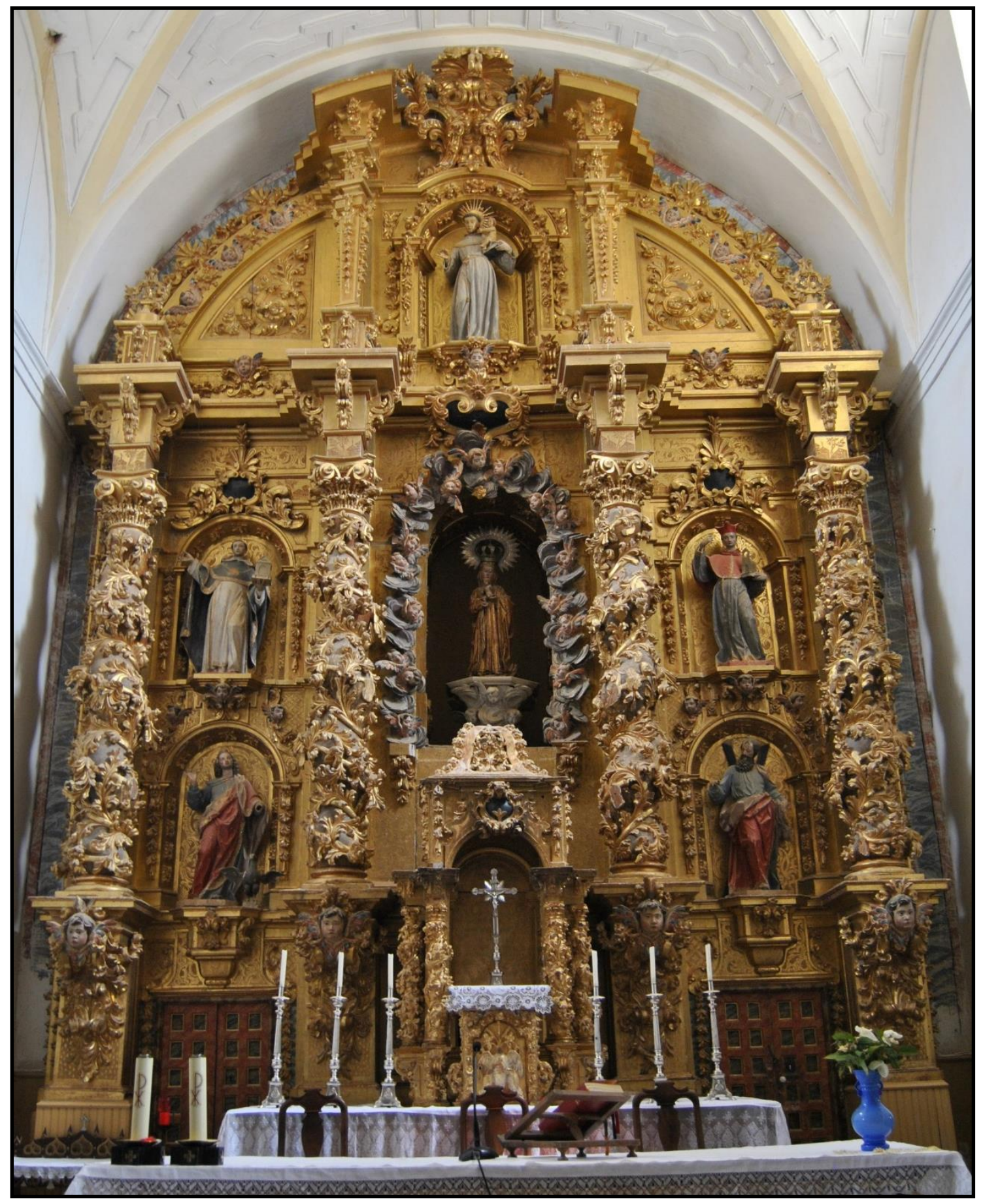

Fig. 28- Diego y Pedro Carrera. Retablo mayor. Iglesia de Santa María de Colaña. Castromocho (Palencia)

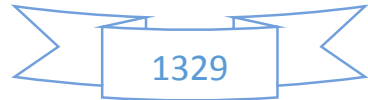




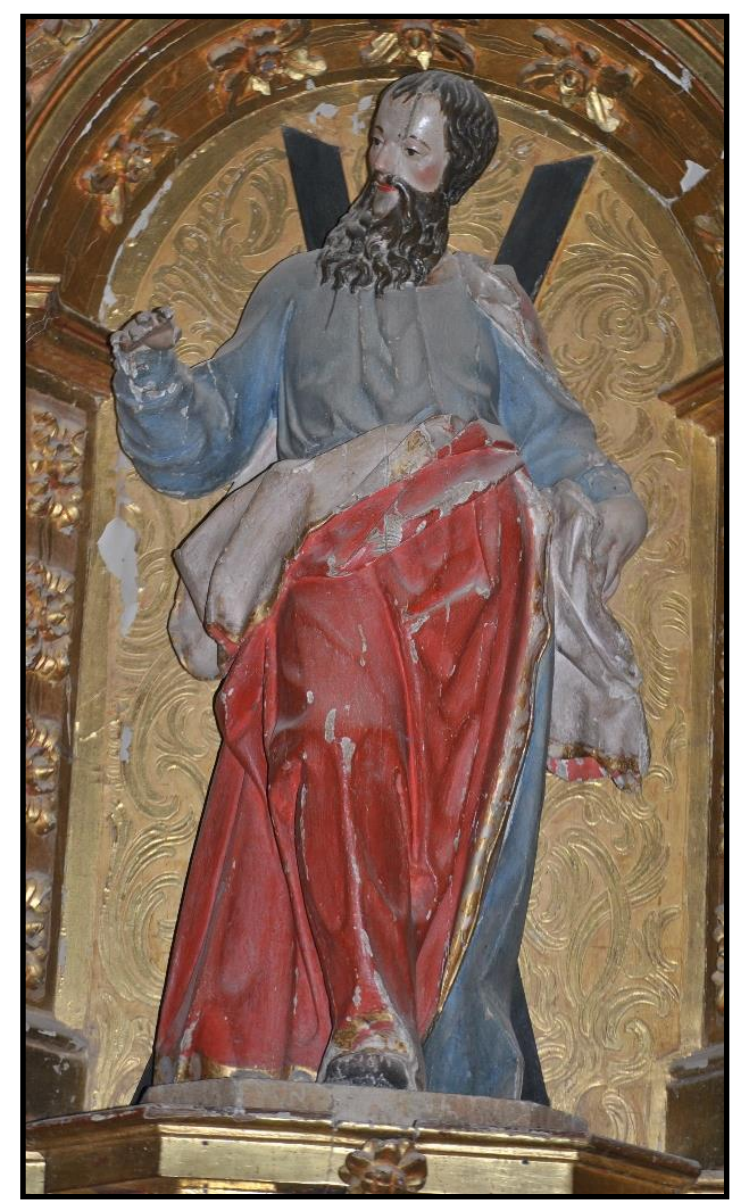

Fig. 29- Manuel de Ávila. San Andrés.

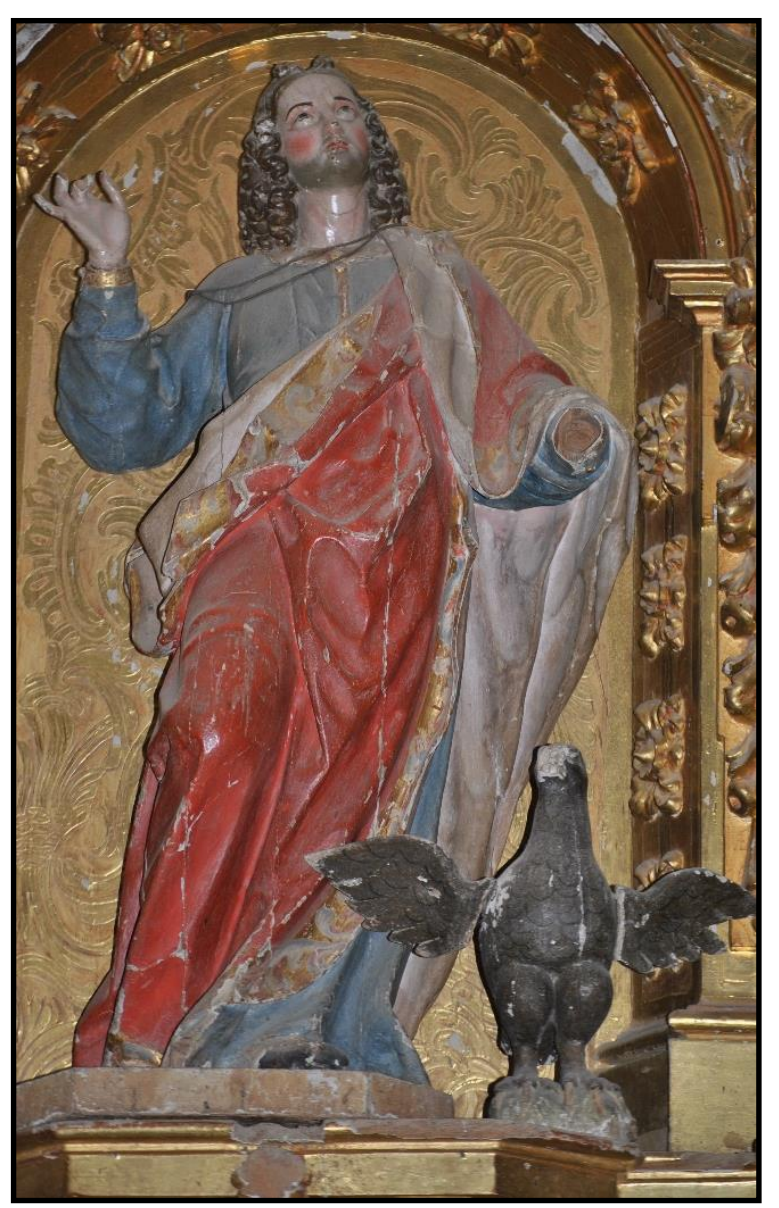

Fig. 30- Manuel de Ávila. San Juan Evangelista.

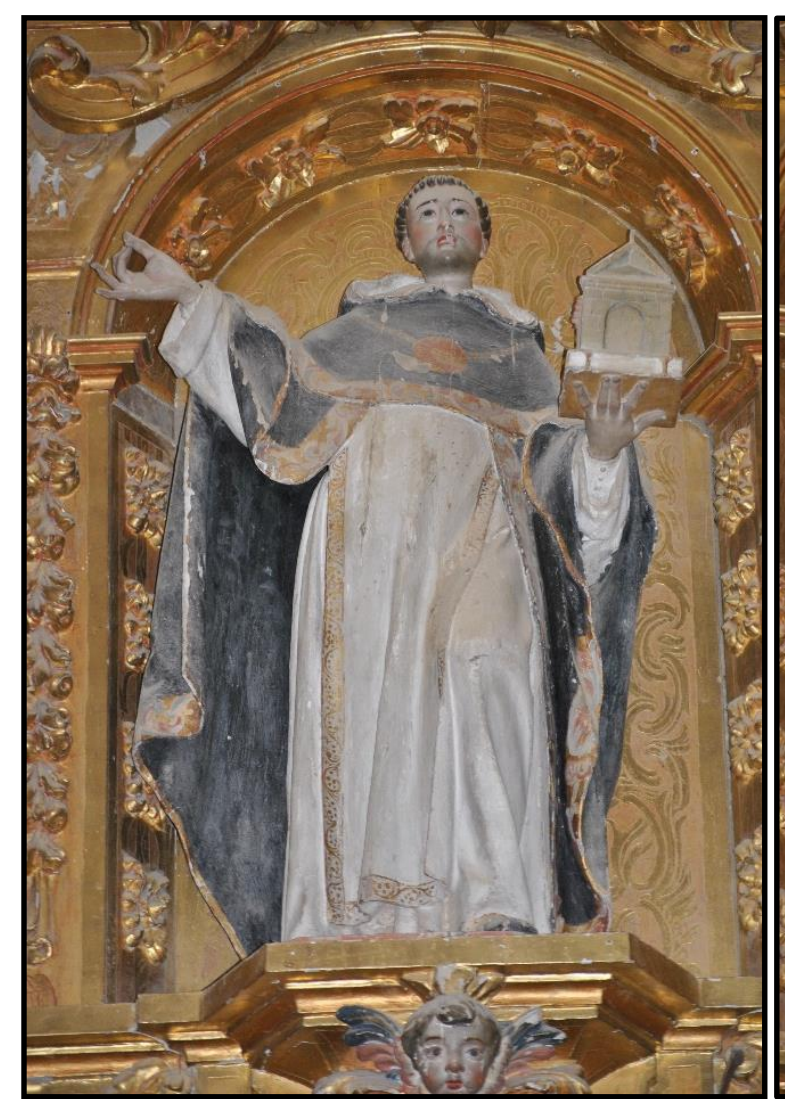

Fig. 31- ¿Manuel de Ávila? Santo Domingo.

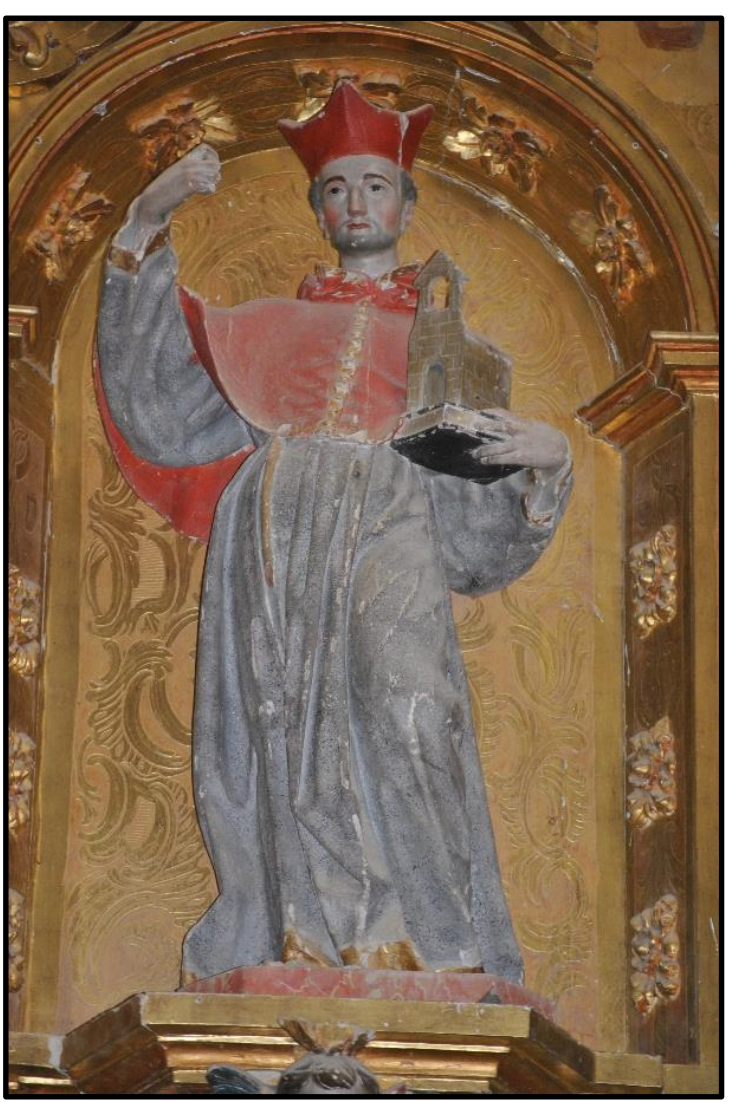

Fig. 32- Manuel de Ávila. San Norberto.

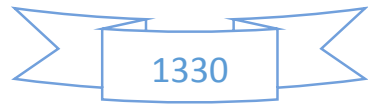


14-CONCLUSTÓN 


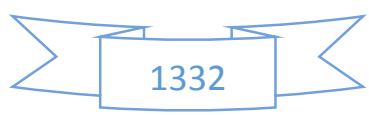


Los Ávila fueron una familia de escultores que nacieron, vivieron, trabajaron y murieron en Valladolid. Sus experiencias vitales y laborales comprenden un siglo de la historia de la ciudad, puesto que enlazan los años centrales del siglo XVII (1652) y los mismos del siglo XVIII (1755). Es decir, a través de ellos podemos seguir perfectamente la evolución que sufrió la escultura española, en general, y la vallisoletana, en particular, a lo largo de todo un siglo. En Valladolid esta evolución fue desde la plena influencia de Gregorio Fernández (aunque con la introducción de un movimiento ya plenamente barroco, así como otros estilemas propios) que tenemos presente en Juan de Ávila, a la ruptura con esta tradición, y a la adopción de modelos y maneras dieciochescos derivados de la influencia cortesana, pero también de la francesa e italiana, protagonizada por Pedro de Ávila. La importancia de esta familia dentro del barroco vallisoletano es esencial puesto que a ellos debemos dos de los grandes logros que tuvo este movimiento en la ciudad del Pisuerga: Juan de Ávila realizó el grupo escultórico más barroco que podemos ver en la urbe (el Santiago Matamoros venciendo a los moros del retablo mayor de la iglesia de Santiago Apóstol), mientras que Pedro de Ávila fue el primer escultor castellano en utilizar el plegado a cuchillo o plegado berninesco, el cual aportaba mayor dinamismo y vértigo a las composiciones.

Aunque Valladolid fue el foco desde el que irradiaron su arte, de éste se beneficiaron muchas localidades de buena parte del noroeste español: desde Orense hasta Pamplona, pasando por Santillana del Mar, Bernuy de Coca, Morales de Toro o La Aguilera. Dedicaron sus empeños casi exclusivamente a la escultura, si bien Juan de Ávila parece que diseñó arquitecturas efímeras e incluso pudo realizar labores puntuales de ensamblaje. Además, esta escultura es fundamentalmente religiosa. Tan solo Juan de Ávila rompe una vez esta norma cuando se ocupa de reparar los gigantes de la celebración del Corpus Christi, fiesta que por entonces era mitad religiosa mitad profana. No podemos descartar el hecho de que no solo reparara este tipo de piezas, sino que también pudiera haberlas realizado ex novo, así como tarascas y otras imágenes que desfilaban en estas celebraciones.

Por desgracia, los Ávila no han sido valorados por la historiografía, incluyéndoseles en muchas ocasiones en el grupo de los imitadores, seguidores o émulos de Gregorio Fernández. Ello hizo en que ni la bibliografía general ni la específica se ocupara de ellos, de tal manera que apenas encontraremos nada en enciclopedias, libros y artículos. Tan solo tenemos una excepción, el bello y poético artículo que le dedicó a comienzos del siglo XX Inés Durruty a una de las perlas de Pedro de Ávila: el Cristo del Olvido. Sin embargo, este "olvido" no debe resultarnos algo extraño ya que no ocurre solamente con los miembros de esta familia, sino con la práctica totalidad de los escultores del foco vallisoletano de los siglos XVII y XVIII: el interés por la gigantesca figura de Gregorio Fernández llevó al ostracismo tanto a los nombres como a los méritos de todos estos artífices. A esto hemos de añadir que, además, la escultura del siglo XVIII, no solo en Valladolid sino en gran parte de España, no ha suscitado el interés o no ha sido valorada como merece; esto se debe a que los eruditos y antiguos historiadores del arte menospreciaban la escultura dieciochesca por cuanto se había dejado influir por las corrientes europeas, especialmente por la francesa y la italiana; todo lo contrario a lo que 
sucedía con la escultura del siglo XVII que, según ellos, representaba a la perfección el sentimiento y devoción puramente españoles.

Hasta no hace demasiado tiempo se desconocía la práctica totalidad de las biografías de nuestros tres escultores; y, en cuanto al apartado laboral, tampoco eran demasiadas las obras que se les tenían documentadas y, como consecuencia, atribuidas. Apenas conocíamos unas fechas concretas: de Juan de Ávila las de su nacimiento, matrimonio y fallecimiento, además de las del nacimiento de alguno de sus hijos, entre ellos el de Pedro de Ávila, pero no el de Manuel. De Pedro de Ávila sabíamos, además del de su nacimiento, el de su matrimonio con María Lorenza de la Peña. Finalmente, de Manuel de Ávila no teníamos ningún dato; al revés, todo eran dudas, y se llegó incluso a la incertidumbre de si era hijo de Juan o de Pedro. Aparte de todo esto, a lo que habría que sumar algún dato suelto o noticia anecdótica, sus biografías nos eran completamente desconocidas, siendo especialmente sangrante el caso de Manuel, del cual no teníamos ni siquiera eso.

La presente tesis doctoral es la primera ocasión en que se emprende un intento de reconstrucción de sus biografías, así como de sistematización de las características que poseen sus estilos y de una catalogación de todas las obras que se les tienen documentadas y atribuidas, a las cuales sumamos una buena cantidad de esculturas inéditas. Este trabajo no pretende ser un punto y final sobre estos artífices sino el punto de partida para localizar nuevos datos que nos permitan profundizar en sus biografías, relaciones de amistad y laborales con otros artistas de la época; así como el comienzo para ir depurando y definiendo con mayor exactitud las características de sus estilos, de tal manera que podamos ir desgranando, en el caso de Juan de Ávila, los estilemas que ayuden a diferenciar su estilo del de otros escultores muy semejantes y con los cuales se le confunde en ocasiones como son José de Rozas y Juan Antonio de la Peña. Asimismo, los catálogos artísticos que presentamos no pretenden ser inamovibles, sino que a ellos seguramente se sumarán en el futuro bastantes nuevas obras que venga a dar sentido a esa importancia que tuvieron estos artífices en su época, y a lo ajetreados que estarían sus talleres, hecho que actualmente no podemos llegar a vislumbrar dada la escasez de obra que les tenemos documentada.

Por fortuna, el presente trabajo ha logrado desentrañar gran cantidad de dudas que giraban en torno a esta familia; así como reconstruir unas biografías coherentes (especialmente en los casos de Juan y Pedro puesto que de Manuel los datos hallados son mucho más parcos), sus catálogos de obras, así como las relaciones que mantuvieron con otros artífices que les trataron, especialmente ensambladores, pintores y doradores.

Este trabajo contribuye de una manera fundamental al conocimiento de la biografía de Juan de Ávila, de la que ya hemos dicho que tan solo teníamos constancia de unas cuantas fechas sueltas. Así, damos a conocer con pruebas que, efectivamente, Manuel de Ávila es hijo suyo, pero no del único matrimonio que hasta ahora se sabía que había contraído; sino de uno segundo que era ignorado por completo. Efectivamente, Juan de Ávila contrajo matrimonio en segundas nupcias con la enigmática Bentura Sedano, hija de Mateo Sedano, el escultor palentino del siglo XVII. Este descubrimiento nos abre una 
serie de nuevos planteamientos, entre ellos el de las posibles actuaciones del escultor vallisoletano en territorios palentinos. Además, aportamos la partida matrimonial de esta boda, así como las de los bautizos de los dos hijos habidos en este matrimonio: Manuel y Manuela. Pero no solamente damos a conocer a estos dos hijos, sino a otros dos habidos en su primer matrimonio con Francisca Ezquerra y que hasta ahora habían pasado desapercibidos, se trata de Francisco y Ana. También relacionado con su biografía, hemos logrado desentrañar las dudas acerca de sus antepasados y de sus orígenes, dado que en diversas publicaciones se habían ofrecido distintas hipótesis, ninguna de las cuales fue acertada. Ahora podemos asegurar que Juan de Ávila es hijo, nieto, y bisnieto, por línea paterna, de individuos de la localidad vallisoletana de Alaejos. Fue su padre el último miembro de la familia que vivió allí puesto que se trasladó muy joven a Valladolid para abrir junto a alguno de sus hermanos un taller de zapatería en la calle de Santiago. En cuanto a sus producciones hemos logrado avanzar en el conocimiento de sus obras documentadas, dado que hemos hallado sus intervenciones en la cruz del cementerio de la iglesia de Santiago y en los gigantes del Corpus. Aunque se trataría de modestos trabajos, estos son sumamente interesantes ya que nos aportan valiosa información sobre su magisterio ya que nos demuestran bien a las claras que trabajó la piedra (algo bastante inusual en Valladolid) y que no solamente se dedicó a la escultura religiosa, sino también a la civil o profana. También le hemos documentado la finalización del retablo mayor de la parroquial de Traspinedo, trabajo comenzado por su maestro, Francisco Díez de Tudanca, aunque acabado por él; esto nos demuestra que pudo realizar puntuales labores de ensamblaje, aunque, por desgracia, apenas se conserva nada de lo contratado. Asimismo, hemos intentado desgranar la totalidad de las obras que se le habían atribuido hasta el momento, manteniendo algunas atribuciones y desechando otras por no guardar ninguna relación con el estilo del escultor. Relacionado tanto con su biografía como con su obra estarían los comitentes. En este campo hemos establecido la hipótesis de una posible relación laboral continuada con los franciscanos, Orden que solicitaría sus servicios en diversas ocasiones. Es más, podríamos deber a esta relación el hecho de que fuera Juan de Ávila el que realizó la codificación escultórica de San Pedro Regalado, especialmente en lo que viene a ser la representación de uno de sus milagros más conocidos: la Traslación entre los monasterios del Abrojo y del Domus Dei.

Por su parte, la biografía y quehaceres artísticos de Pedro de Ávila eran también bastante desconocidos, si bien la documentación en los últimos años de cinco esculturas en la catedral ha ampliado sensiblemente su escaso catálogo. En cuanto a su biografía, como ya hemos dicho, apenas había nada escrito. Por fortuna, hemos conseguido trazar una biografía bastante aproximada y en la que se dan cita novedades capitales, a saber: hemos documentado un segundo matrimonio del que, como en el caso de su padre, no se tenía conocimiento. Se trata del contraído en segundas nupcias con Francisca López, con la cual tampoco logró tener descendencia. Asimismo, hemos clarificado bastante sus fatídicos años finales en los cuales quedó ciego y sufrió el robo y quizás el maltrato, por parte de su sobrina y el marido de ésta, los cuales se hicieron cargo de él al quedar viudo e invidente. También hemos desmentido que falleciera en 1742 como hasta ahora se decía en ocasiones, a raíz del descubrimiento de un testamento fechado en ese mismo año. El 
hallazgo de una serie de testamentos posteriores nos indica que aún viviría un buen puñado de años más, concretamente hasta 1755, año en que previsiblemente fallecería en el Hospital de San Juan de Dios. Aunque no hemos conseguido documentarle ninguna obra nueva, sí que hemos podido atribuirle sin ninguna duda otras muchas inéditas, lo que nos habla de la importancia capital que tuvo Pedro de Ávila no solo para la escultura vallisoletana sino para la castellana de los cuatro primeros decenios del siglo XVIII. El estilo de Pedro de Ávila es tan característico que ha bastado poco más de un golpe de vista para reconocerlas. Sin embargo, en esta tesis hemos conseguido establecer las dos grandes etapas que formaron su producción: la primera época, momento en el que se encontraba bajo el influjo de su padre y su suegro; y la segunda, la más conocida por ser de la que se conservan la mayoría de obras documentadas. Asimismo, referente a esta primera etapa, hemos averiguado que la inmensa mayoría de las obras de este momento se hallan casualmente en localidades cercanas a Olmedo (Valladolid). También hemos intentado buscar una explicación lógica al impresionante cambio de estilo que sufrió y que le llevó a practicar un estilo elegante, refinado y con influencias berninescas en el tipo de plegado de los paños; siendo, además, el introductor de este pliegue a cuchillo en el territorio castellano. Creemos que esto se debió a un posible viaje a Madrid, no demasiado prolongado en el tiempo, en el que tuvo la oportunidad de ver y estudiar la obra de los escultores cortesanos, de los escultores italianos (especialmente napolitanos), y de otros como Alonso Cano, Pedro de Mena y José de Mora, todos los cuales le influirían en su postrer estilo; ya fuera en cuanto al tipo de plegado, de composición o en cuanto a la finura a la hora de tallar la madera. Finalmente, en cuanto a su obra atribuida, hemos seguido manteniendo la atribución de un buen puñado de ellas, sin embargo, otras han sido derivadas a obras relacionadas con su estilo y las menos han sido descatalogadas.

Manuel de Ávila era, y es, el miembro más desconocido de la familia. Los datos tanto biográficos como artísticos siguen siendo muy escasos. Sin embargo, hemos logrado progresar en el territorio personal, aportando las partidas de bautismo, matrimonio y defunción. Queda por saber la posible relación artística que pudo mantener con los plateros, dado que su esposa era hija y sobrina de reputados artífices de esta disciplina (Joseph Martínez y Damián Cortés). En cuanto a su catálogo, no se ha logrado encontrar ninguna novedad, tan solo podemos atribuirle un par de obras y no con demasiada seguridad dado que su estilo, que deriva completamente del de su hermano, hace que confundamos los de ambos con bastante facilidad.

Además de todas estas novedades que hemos presentado muy someramente en lo referente a biografías y catálogos, esta tesis intenta sistematizar una serie de características de los estilos de los tres escultores, si bien hay diferencias en cuanto al conocimiento de ellos. Si ya hemos dicho que el segundo estilo de Pedro de Ávila es completamente personal y no encontraremos a otro escultor que se le parezca, no ocurre lo mismo con los estilos de Juan y Manuel. El de Juan es bastante similar al de otros artífices contemporáneos suyos, además de vecinos, como eran José de Rozas y Juan Antonio de la Peña. Por su parte, el de Manuel de Ávila ya hemos dicho que es del todo deudor del de su hermano Pedro, con quien aprendería el oficio; de tal manera que es muy 
difícil separar los estilos de ambos; a esta dificultad ayuda la escasez de obra que se le tiene documentada al benjamín de la familia.

A modo de resumen señalaríamos que los Ávila fueron unos escultores vallisoletanos, hijos de su tiempo, que gozaron del máximo crédito y respeto por parte de las instituciones y de sus conciudadanos, solo así podríamos explicar los epítetos que le dedica Canesi a Pedro de Ávila: "estatuario insigne vecino de esta ciudad"; y un anónimo cofrade nazareno a Manuel de Ávila: "por ser su habilidad bien conocida en esta ciudad"; asimismo, fueron los encargados de hacer evolucionar la escuela vallisoletana desde los modos y maneras de Gregorio Fernández en sus últimos momentos de influencia (a los cuales Juan de Ávila introdujo un buen puñado de novedades que sirvieron para barroquizarlos), hasta la escultura plenamente dieciochesca con influencias cortesanas y europeas. En definitiva, aunque algunos prototipos fernandescos se seguirían utilizando durante la mayor parte del siglo XVIII, Pedro de Ávila fue quien dio "portazo" a la influencia de Fernández en la escultura vallisoletana.

Esperemos que con la presente tesis los Ávila sean valorados como lo que fueron, algunos de los más brillantes artífices barrocos españoles, y no solamente como unos meros émulos de Gregorio Fernández (lo cual en cierta parte es mentira) o como esos nombres que figuran en los folletos de la Semana Santa de Valladolid como autores de algunos de los más destacables pasos procesionales que desfilan en la actualidad. Nuestro panorama escultórico durante los siglos XVII y XVIII es lo suficientemente rico y variado para que ésta sea una primera piedra para afrontar nuevas tesis que clarifiquen la vida y obra de los escultores que la protagonizaron. Finalmente, me gustaría señalar que cumplo así una deuda que tenía contraída con aquellos escultores con los que quedé fascinado al ver sus Santiago Matamoros (Juan de Ávila), Inmaculada (Pedro de Ávila) y San José (Manuel de Ávila). 


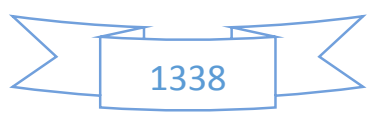




\section{5-APEINDICE \\ DOCUMENTAL}


$\sum[1340]<$ 


\section{DOCUMENTO 1}

\section{TESTAMENTO DE HERNANDO DE ÁVILA}

A.H.P.V., Leg. 2.276

In dei nomine amen sépase por esta carta de testamento vieren como yo Hernando de Ávila maestro de obra prima vecino de esta ciudad de Valladolid morador en la calle de Santiago de ella estando como estoy enfermo de la enfermedad que dios ha sido servido de me dar en mi juicio y entendimiento natural creyendo como creo firmemente en el misterio de la Santísima Trinidad y en todo lo que creí confiesa la santa madre iglesia de Roma debajo de cuya fe y creencia protesto viví y morir como católico cristiano y tomando como tomo por mi intercesora y abogada a la Virgen María para que interceda con su divina majestad ponga mi alma en carrera de salvación y perdone mi culpa y pecado cuando este mundo baja y temiendo me de la muerte pues es cosa cierta de toda criatura viviente hago mi testamento en la manera siguiente.

Primeramente encomiendo mi alma a Dios nuestro señor Jesucristo que la crió y redimió por su preciosa sangre el cuerpo mando a la tierra de que fue formado.

Mando mi cuerpo sea sepultado en la parroquia de Santiago de esta ciudad donde soy parroquiano en la sepultura que pareciere a mis testamentarios.

Mando me entierre la cofradía de Nuestra Señora de la Cabeza de donde soy cofrade y tengo pagada la entrada igual. Y también me acompañe la cofradía de la Cruz donde soy cofrade.

Ítem mando me acompañen los niños de la doctrina y quatro pobres. Ítem mando me acompañe la cruz de la parroquia con seis clérigos en que entre el cura beneficiados y se pague los derechos. Ítem mando me acompañe la cofradía de San Antonio de Padua de los mancebos sastres y se pague lo que se concertase.

Ítem mando se digan por mi alma cincuenta misas rezadas la cuarta en la parroquia y las demás a voluntad de mis testamentarios. Y se me diga la misa del alma en la Vitoria. Y la misa de cuerpo presente. Y me acompañen los niños de la doctrina. Y se paguen los derechos acostumbrados.

Ítem mando a las obras pías acostumbradas a cada una ocho maravedís con que las aparto de mis bienes.

Declaro que al tiempo yo case con Juana Martin mi mujer que lo fue de Pedro Rojo al tiempo y cuanto entró conmigo no se hizo inventario ninguno por lo que todos los bienes que están en ser son de dicha mi mujer y míos porque no trajo cosa ninguna a mi poder más de lo que se hallare declárolo así.

Declaro debo a Juan de arce mercader vecino de esta ciudad trescientos ducados de resto de una obligación que contra mi tiene Alonso González zapatero de La Bañeza mando se paguen.

Declaro debo a Simón Escudero escribano de esta ciudad ciento y diez reales de dinero que me dio mando se paguen.

Declaro debo a Manuel Domínguez cierta cantidad de maravedís de colambre que me ha entregado mando se ajuste cuenta con él y lo que yo debiere se le pague.

Mando se ajuste cuenta de la casa en que yo vivo y ajustada se pague lo que yo debiere. 
Declaro me debe Bartolomé González maestro de obra prima sesenta reales de resto de mercaderías que le entregue y mando se cobre.

Declaro que yo tengo una casa mía propia en la calle de Santiago que la compre durante el matrimonio con mi mujer $\mathrm{D}^{\mathrm{a}}$ Juana del Castillo en la cual vive al presente Joseph de León maestro de obra prima y de alquiler de ella debe setenta reales hasta San Juan pasado de este año mando se cobren.

Y declaro que el convento de San Benito de esta ciudad sea calzado en mi casa de que hay cédulas del padre abad del dicho convento mando se cobre lo que se me debiere conforme a las cédulas.

Declaro me debe Pedro de Ronda oficial del dicho oficio de zapatería noventa reales de dinero que le di prestado para salir de la cárcel mando se cobren.

Declaro me debe Joseph de Huertos oficial del dicho oficio de zapatería setenta reales mando se cobren del susodicho.

Yo declaro que yo tengo por mis hijos legítimos y de la dicha Juana Martín a Manuel y Juan de Ávila mis hijos legítimos de la dicha mi mujer a la cual conformándome con las leyes del reino lo que por ellas se dispone y manda nombro por tutora y curadora de dichos mis hijos a la dicha Juana Martin mi legítima mujer para que los críe administre y gobierne y pido y suplico a las justicias de estos reinos la disciernan la dicha tutela y curaduría sin fianzas ningunas pues yo la relevo de ellas.

Ítem mando a Francisco Rojo mi andado cuarenta ducados en pago y remuneración lo que yo podía haber recibido cuando case con su madre que sería poco yo le pido me encomiende a dios y me perdone.

Ítem declaro que al tiempo y cuando se casó Damiana Rojo con Gil de Ávila mi hermano yo la di en dote y casamiento cien ducados en una cama de ropa y vestir ambos a dos y paganle dos años de casa que fueron veinte y cuatro ducados a la iglesia mayor de esta ciudad y otros bienes que la di que montaron la dicha cantidad declaro lo así para que conste la verdad.

Ítem mando a Ana Monge mi madre cien reales por una vez y la pido me perdone que quisiera mandarla más y cuide de sus hijos y nietos.

Y para cumplirse y pagar este mi testamento y las mandas de él dejo y nombro por mis testamentarios a la dicha Juana Martin mi mujer y a Francisco Díez Moreno y a Francisco Flores maestros de obra prima a todos tres y a cada uno in solidum doy mi poder cumplido en forma y los vendan y rematen en publica almoneda o fuera de ella y de su valor cumplan y paguen este mi testamento y las mandas de él y les dure todo el tiempo que fuere necesario y el derecho les da. Ítem que en cuando a las misas lo dejo todo a voluntad de mi mujer.

Y cumplido y pagado este mi testamento y las mandas de él nombro por mis herederos en todos mis bienes a los dichos Manuel y Juan de Ávila mis hijos legítimos y de la dicha Juana Martin mi mujer para que lo hayan y hereden con la bendición de Dios y la mía.

Y por el presente revoco y anulo y doy por ninguno y de ninguna valor ni efecto otro cualquier testamento o testamentos codicilo o codicilos poderes para testar manda o mandas que haya dicho así por escrito o de palabra que quiero que no valgan salvo este que al presente hago que quiero que valga por mi codicilo y por mi última voluntad en la firma que haya lugar en testimonio de lo cual otorgo así ante escribano y testigos en la ciudad de Valladolid a seis días del mes de agosto de mil y seiscientos y cincuenta y siete años siendo testigos llamados y 
rogados Pedro Ruiz de Ceniceros oficial de la pluma y a Alonso de León y Antonio Hernández maestros de obra prima vecinos de esta ciudad y el otorgante dijo no saber firmar a su ruego lo firmó un testigo y el dicho otorgante y testigos yo mismo doy fe conozco. 


\section{DOCUMENTO 2}

\section{TESTAMENTO DE JUANA MARTÍNEZ (6 - MAYO - 1666)}

A.H.P.V., Leg. 1.974, ff. 1.570-1.572

In dey nomine amén sepan los que vieren la presente escritura de testamento, última y postrimera voluntad como yo Juana Martínez mujer de Gabriel del Pozo que primero lo fui de primero matrimonio con Pedro Rojo y de segundo con Hernando de Ávila y de tercero con el dicho Gabriel del Pozo estando enferma en cama de la enfermedad que Dios nuestro señor ha sido servido de me dar y en mi juicio y entendimiento natural creyendo firmemente en el misterio de la Santísima Trinidad y en todo lo que tiene, cree y confiesa la santa madre iglesia de Roma y tomando por mis intercesores y abogados a la Santísima reina de los Ángeles y a todos los santos de la corte del cielo a su honor y alabanza hago mi testamento en la forma siguiente:

Primeramente encomiendo mi ánima a Dios nuestro señor y el cuerpo a la tierra donde fue formado.

Mando que cuando la voluntad de nuestro Señor fuere servido de llevarme de esta presente vida mi cuerpo sea sepultado en la iglesia del señor Santiago donde se señalare.

Mando que venga la cruz y ocho sacerdotes y se la de sus velas y disposición acostumbrados y me entierre la cofradía que mis testamentarios señalaren y me acompañen los niños de la doctrina y pobres y lo demás que mis testamentarios dispusieren.

Mando venga a mi entierro los pobres como dicho es.

Mando que el día de mi entierro fuere hora de misa cantada y si no el día siguiente se me diga misa cantada de cuerpo presente y vigilia y se pague.

Mando se digan por mi alma cincuenta misas en la parroquia y donde mis testamentarios señalasen.

Declaro que al tiempo que me casé con el dicho Pedro Rojo mi primer marido ni él ni yo tuvimos bienes así declaro y de este matrimonio tuvimos por nuestros hijos a Francisco Rojo y Damiana Roja mujer de Gil de Ávila y al tiempo que murió el dicho Pedro Rojo dejaría algunos bienes que importaron a ejecución doscientos ducados los cuales se gastaron en su entierro y en los alimentos de sus hijos y míos y de segundo matrimonio me casé con el dicho Hernando de Ávila y no lleve a su poder la cantidad que podía importar hasta seiscientos reales además de otros cuatrocientos reales de algunos ajuares de por casa y no otra cosa y durante el matrimonio el dicho Hernando de Ávila compró la casa en que vivo que está en la calle de Santiago de esta ciudad que linda con casas del Colegio de San Gregorio y casa de María Rodríguez con cargo de dos ducados que se pagan de renta perpetua a la Cofradía de la Espina y (...) otra carga la cual es propia del dicho Hernando de Ávila y mía por haberse comprado durante nuestro matrimonio de Juan Canseco escribano ante Juan Bautista Belaya escribano del número la cual es mi voluntad que por lo que valiere del alquiler la habite y goce el dicho Gabriel del Pozo mi tercero marido y así es mi voluntad. Y cuando muró el dicho Hernando de Ávila no me quedó bienes ninguno porque lo que me quedó se vendió para paga deudas que dejó que vendí para 
pagarlas hasta la cama y solamente me quedó una pobre cama y unos cofres vacíos con que de tercero matrimonio me casé con el dicho Gabriel del Pozo la cual metió a mi poder tres pares de vestidos y otros dos ordinarios, cuatro sábanas y dos paños de manos, dos talas de manteles y doscientos reales en dinero lo cual se metió al matrimonio y lo debe cobrar en los bienes que dejó y me ha sustentado y a mis hijos por lo cual mando se le haga bueno en los bienes que dejo lo que así metió y le tocare como a mi marido.

Debense a Santiago Álvarez curtidor cuatrocientos y noventa y dos reales que nos ha dado de colambre.

A Diego Hernández coletero ciento y cincuenta reales de la compra de unas baquetas.

Ciento y setenta y cuatro reales a Pedro de Cabezón curtidor de cordobán que ha vendido.

Ciento y trece reales de dinero prestado a Jerónima de Morales mi amiga.

Ciento y treinta reales de la alcabala del año pasado.

A Simón Velázquez curtidor ciento y veinte reales.

Debo a Francisco Díez Moreno mercader treinta y un reales en prendas de los cuales tiene dos cucharas de plata.

Y para cumplir y pagar este mi testamento dejo y nombro por mis testamentarios, albaceas y cumplidores de él dejo y nombro al dicho Gabriel del Pozo y Simón Escudero y Francisco Díez Moreno vecinos de esta ciudad a los cuales y a cada uno de ellos in solidum y otorgo todo mi poder cumplido para que entren en mis bienes y los vendan y rematen y de su valor cumplan y paguen este mi testamento y cumplido y pagado este dicho mi testamento dejo y nombro e instituyo por mis universales herederos a Francisco Rojo y a Damiana Roja mis hijos y del dicho Pedro Rojo mi primero marido, y a Manuel de Ávila y Juan de Ávila mis hijos y del dicho Hernando de Ávila mi segundo marido para que lo hayan y hereden con la bendición de Dios y la mía, declarando como declaro que a la dicha Damiana Roja la di en dote y casamiento cuando se casó con Gil de Ávila su marido hasta dos mil reales en bienes y dinero en que entra lo que le dio el dicho Hernando de Ávila mi marido y su hermano y lo que Gabriel del Pozo mi marido ha pagado por el demás de lo cual se ha pagado por bienes y con dinero del dicho Gabriel del Pozo mi marido hasta novecientos reales a Pedro de la Rosa y Joseph de Altamira en virtud de escrituras y doce ducados del alquiler de la casa chiquita donde vivía y otros tres ducados a Miguel Bisojo del alquiler de un cuarto de casa.

Y en cuanto a los hijos del dicho Hernando de Ávila los ha alimentado y sustentado, vestido y calzado hasta hoy sin haber sido (...) y enseñándoles a leer y escribir y así lo declaro por descaro de mi conciencia.

Y revoco y anulo y doy por ninguno y de ningún valor y efecto otro cualquier testamento, codicilo y otras disposiciones que antes de esta haya hecho y otorgado que quiero no valgan ni hagan fe salvo este que al presente hago y otorgo que quiero valga por mi última y postrimera voluntad y lo otorgó en la ciudad de Valladolid a seis días del mes de mayo de mil y seiscientos y sesenta y seis años siendo testigos Francisco Flores y Manuel Garzón y Nicolás González y Francisco de Rivas y Gregorio Rojo vecinos y estantes en esta dicha ciudad y la otorgante que conozco dijo no saber firmar a su ruego lo firmó un testigo. 


\section{DOCUMENTO 3}

\section{TESTAMENTO DE MANUEL DE ÁVILA (5 - OCTUBRE - 1673)}

A.H.P.V., Leg. 2.605/2

In dei nomine amen sépase por esta escritura de testamento última y postrimera voluntad como yo Manuel de Ávila vecino de esta ciudad de Valladolid hijo legítimo de Hernando de Ávila y Juana Martínez mis padres ya difuntos vecinos que fueron de ella e y estando enfermo en la cama de la enfermedad que Dios Nuestro Señor ha sido servido de darme sano de mi juicio y entendimiento natural creyendo como firmemente creo en el misterio de la Santísima Trinidad Padre Hijo y Espíritu Santo tres personas distintas y un solo Dios verdadero en cuya santa fe he vivido y protesto vivir y morir temiéndome de la muerte que es cosa precisa a toda criatura deseando como deseo poner mi alma en carrera de salvación tomando por mi intercesora y abogada a la reina de los ángeles nuestra señora concebida sin manera de pecado original desde el primer instante de su ser natural y al bendito ángel de mi guarda apoyo ordeno mi testamento en la forma y manera siguiente.

Lo primero encomiendo mi ánima a Dios Nuestra Señora que la crió y redimió con su preciosa sangre y el cuerpo a la tierra de que fue fundado y cuando la voluntad de Dios fuere servido de llevarme de ésta presente vida mi cuerpo sea sepultado en la iglesia de Santiago de ésta ciudad en la sepultura que tiene Simón Escudero en dicha iglesia y sino viniere en ello a donde mis testamentarios eligieren.

Es mi voluntad se sepulte mi cuerpo con el hábito de Nuestro Seráfico Padre San Francisco.

Mando acompáñeme mi entierro seis sacerdotes de la parroquial del Señor Santiago y cura y beneficiado y se les pague sus derechos de mis bienes. Asimismo acompañen mi cuerpo cuatro niños del albergue y se les pague la limosna de mis bienes.

Mando asista a mi entierro la Cofradía de la Sagrada Pasión de Cristo y me entierre y diga las misas y sufragios que acostumbra con todos sus cofrades.

Mando que el día de mi entierro si fuere hora decente se me diga misa de cuerpo presente con la biblia y se paguen los débitos a la parroquia.

Mando se digan por mi alma sesenta misas rezadas la cuarta parte de ella en la dicha parroquia del Señor Santiago y las demás restantes a orden y disposición de mis testamentarios y encargo la brevedad.

Declaro que al tiempo y cuando me casé con Francisca de Argüello mi mujer trajo doscientos ducados en dinero y otras cosas a mi poder los cuales recibí y más cuarenta ducados de una prebenda que le toca pagar a la dicha mi mujer por ser para el dicho dote.

Y asimismo declaro que debo a Santiago González teniente de esta ciudad veinte y nueve reales de mercaduría que es... de su tienda mando se le paguen de mis bienes.

Declaro que debo a Lucía de la Lastra ocho reales veinte maravedíes mando se la paguen y se la pida lo que contase deberme.

Declaro que tengo empeñada en la dicha Lucía de la Lastra una cruz de plata de Caravaca en un real de a cuatro mando se saque de la susodicha pagándosele. 
Declaro deber a Lucas Martínez Mercader seis reales mando se le paguen.

Ítem debo a Simón Escudero de alquileres de un cuarto de casa que me arrendó veinte y siete reales mando se le paguen de mis bienes.

Declaro me debe Juan López oficial de... prior vecino de esta ciudad de dinero prestado diez y seis reales mando se cobren.

Mando que el día de mi fallecimiento se me diga la misa del alma en el Convento de Nuestra Señora de la Victoria y si no fuere a tiempo de misa se diga al día siguiente.

Mando se den seis reales que se repartan entre las manda pías y acostumbradas a ocho maravedíes cada una con que las aparto de mis bienes.

Y para cumplir y pagar este mi testamento mandas y legados en el contenidos dejo y nombro por mis albaceas y testamentarios a Francisco Rojo y Juan de Ávila vecinos de esta ciudad y a cada uno in solidum les doy poder cumplido para que entren en todos mis bienes y los vendan rematen en pública almoneda o fuera de ella y de su valor cumplan y paguen éste mi testamento como en él se contiene y les dure el dicho cargo en el tiempo que fuere necesario aunque exceda y pase del que se permite por derecho y en el remanente que quedare de todos mis bienes y de todos ellos y de los que me pudieren pertenecer se haga pago a la dicha mi mujer del dicho coste y se lo encargo a los dichos mis testamentarios.

Y por el presente instituyo y dejo por mi universal heredera a la dicha mi mujer para que haya y lleve mis bienes derechos y acciones con la bendición de Dios.

Declaro que me debe Juan de Ávila mi hermano cien reales pido se cobren del susodicho.

Y por éste mi testamento revoco y anulo y doy por ninguno y de ninguna valor ni efecto otro cualquier testamento o testamentos codicilo o codicilos o poderes para testar u otra cualquier disposición que antes de éste haya hecho y otorgado por escrito o de palabra que quiero no valga salvo éste que al presente hago y otorgo que quiero valga por mi testamento última y postrimera voluntad y en aquella vía y forma que mejora y a lugar de derecho y lo otorgo así ante el presente escribano y testigos que para ello fueron llamados y rogados en la ciudad de Valladolid a cinco de octubre de mil y seiscientos y setenta y tres años siendo testigos Antonio González, Hernando Bibas, Gaspar González, Gregorio Gallego y Manuel de los Reyes vecinos y estantes en esta dicha ciudad y el otorgante que yo el escribano doy fe conozco lo firmo. 


\section{DOCUMENTO 4}

\section{CONTRATO. FRANCISCO ROJO COMO TUTOR DE FRANCISCO Y JUANA GONZÁLEZ, HIJOS DE ANA VILCHES Y MANUEL GONZÁLEZ (12 - JUNIO - 1677)}

A.H.P.V., Leg. 2.629, f. 248

En la ciudad de Valladolid a doce días del mes de junio de mil y setecientos y setenta y siete años ante mí el escribano y testigo aparecieron Francisco Rojo maestro de obra prima vecino de esta ciudad y Antonia González su mujer y Juan de Ávila escultor asimismo vecino de esta ciudad como sus fiadores y principales pagadores y obligadores haciendo como para este caso hacen de deuda y fecho ajeno suyo propio y sin que sea necesario hacer excursión ni otra de licencia alguna aunque de derecho se requiera premisa la licencia y ejercitación de ella entre marido y mujer en tal caso necesaria todos tres juntos y de mancomún a voz de uno y cada uno de por sí in solidum y por el todo renunciando como renunciaron las leyes de duobus rex debendi y la auténtica presente hoc ita de fide iusoribus y la epístola del divo Adriano y el beneficio y remedio de la excursión y división de bienes de pósito de las expensas y las demás de la mancomunidad como en ellas y en cada una de ellas se contiene.

Dijeron que por cuanto en veinte y cinco de mayo pasado de este año se nombró a el dicho Francisco Rojo por tutor y curador de las personas y bienes de Francisco y Juana González hijos legítimos y de legítimo matrimonio que quedaron por fin y muerte de Manuel González y Ana de Viches su primera mujer y se dio auto para que lo aceptase y diese las fianzas en tal caso necesarias cuyo nombramiento el dicho Francisco Rojo tiene aceptado y siendo necesario de nuevo acepta y cumpliendo con lo que por el dicho auto se manda los dichos principal y fiadores debajo de la dicha licencia mancomunidad y renunciación de leyes.

Otorgan por esta escritura que se obligan con sus personas y bienes muebles y raíces derechos y acciones habidos y por haber y la dote y arras y bienes gananciales para parafernales y hereditarios de la dicha Antonia González, a que el dicho Francisco Rojo usara de la tutela y curaduría de los dichos Francisco y Juana González bien y fielmente en todo lo que a dichos menores tocare, educándolos rigiendo y administrando todos sus bienes y hacienda que les tocase y fuere adjudicado en las cuentas y particiones que se han de hacer de los bienes que quedaron de los dichos sus padres con Luisa Fernández su segunda mujer y Luisa González su hija y del dicho Manuel González que se le han de entregar y cobrará y percibirá todos los maravedíes que en cualquier manera tocaren a dichos menores y otras cualesquier cosas y efectos de las personas y comunidades que fueren deudores y lo debieren pagar y les defenderá en todos los pleitos y causas civiles y criminales que tuvieren durante el tiempo estuviesen bajo de la dicha tutela y curaduría en cualquier juicios instancias y tribunales demandando y defendiendo y asimismo para cuenta con pago a los dichos menores o a quien por la justicia ordinaria le fuere mandado de todos los bienes y rentas que entraren en poder del dicho Francisco Rojo como tal curador y tutor de dichos menores y tomara consejo para todo lo que hubiere de obrar de personas de ciencia y conciencia que se le puedan dar y en todo obrara lo que un buen tutor y curador tiene obligación hacer por sus menores y no lo cumpliendo todos los daños y costas intereses y menoscabos que sobre ello le siguieren y recrecieren lo pagaran y por ello y la satisfacción de los bienes y hacienda de dichos menores quieren y consienten se les 
pueda compeler y apremiar en virtud de esta escritura y de las cuentas particiones y demás instrumentos que hubiere como por garantía y llana obligación y si se fueren y ausentasen de esta ciudad quieren se despache persona a la parte donde estuvieren o tuvieran bienes y hacienda con quinientos maravedíes de salario que la pagaran en cada uno de los días que en ello se ocuparen y con más los de la ida y vuelta a razón de ocho leguas por día y por los dichos salarios y costas y traída del dinero a esta ciudad se puedan hacer las mismas de licencia que por el principal y en este caso renuncian las nuevas pragmáticas y cartas acordadas de consejo que hablan en razón de los excesos de salarios y para mayor seguridad de todo en que la hipoteca especial derogue ni perjudique a la general obligación ni por el contrario el dicho Juan de Ávila hipoteca por especial y expresa hipoteca una casa que tiene suya propia en la calle de Santiago de esta ciudad en que vive que linda por una parte con casa del Colegio de San Gregorio de esta ciudad y por la otra con casa de Isabel de Navias espartera vecina de esta dicha ciudad la cual dicha casa declara es suya propia libre de toda carga y tributo censo perpetuo ni al quitar memoria aniversario ni otra restitución que ninguna tiene excepto un censo perpetuo de veinte y dos reales de renta que se pagan a la Cofradía de la Espina sita en la Iglesia Catedral de esta ciudad y si pareciere lo contrario quiere y consiente le proceda contra el susodicho por delito de crimen este ... y desde luego prohíbe la enajenación de dichas casa en todas maneras y para el cumplimiento y paga de todo lo referido dan poder a las justicias y jueces de su majestad de esta ciudad y otras partes a quien se someten y en especial al fuero y jurisdicción del dicho señor teniente de corregidor de esta ciudad recibenlo por sentencia pasada en cosa juzgada renunciación su fuero jurisdicción y domicilio y la ley sit combenerit de jurisdictione omnium judicum y las demás leyes fueros y derechos de su favor con la general en forma y la dicha Antonia González renuncia las del emperador Justiniano senatus consultes Beleyano toro y partida nueva y antigua constitución y las demás del favor de las mujeres de que fue avisada por mí el escribano de que doy fe y por ser casada aunque mayor de veinte y cinco años jura a Dios y a una Cruz en forma que para otorgar esta escritura no ha sido inducida ni atemorizada por el dicho su marido antes confiese se convierte en su utilidad y provecho por ser sus sobrinos carnales y que le hace de su libre voluntad y que no ira contra esta escritura en manera alguna y si lo intenta requieren hacer oída en juicio o fuera de él y declara que del juramento no tiene pedida ni pedirá relajación y aunque de motu propio se la conceda de ella no usará y las dichas partes lo otorgaron así ante mí el escribano siendo testigos Domingo Arias Francisco Arias escribanos de su majestad y Alfonso de Santiesteban vecinos de esta ciudad y los otorgantes y yo el presente escribano doy fe conozco lo firmó el que supo y por el que no a su ruego lo firmó un testigo. 


\section{DOCUMENTO 5}

\section{PODER. GIL DE ÁVILA OFICIAL DE OBRA PRIMA A ISABEL DE ÁVILA SU HERMANA (30 - SEPTIEMBRE - 1667)}

A.H.P.V., Leg. 2.570, f. 569

Sépase como yo Gil de Ávila oficial de obra prima vecino de esta ciudad de Valladolid que asisto en la tienda de Pascual Martín maestro vecino de ella otorgo por esta carta que doy mi poder cumplido el que de derecho se requiere y es necesario por mi hecho propio y como curador que soy de las personas y bienes de Manuel y Juan de Ávila mis sobrinos hijos de Hernando de Ávila y Juana Martín su mujer difuntos vecinos que fueron de esta ciudad, a Isabel de Ávila mi hermana mujer de Francisco Blanco vecino de la villa de Alaejos con cláusula de que le pueda sustituir en todo o en parte especialmente para que en mi nombre y de los dichos mis sobrinos pueda recibir haber y cobrar toda la renta caída y que cayere de las dos tierra que tenemos en la dicha villa de Alaejos y sus términos la una a do llaman la sola y la otra do llaman el peñón que son notorias y las pueda quitar a las personas que las tienen y arrendarlas de nuevo a quien la pareciere por el tiempo y precio que se ajustare siendo de contado haciendo en razón de ello las escrituras que sean necesarias que desde luego las apruebo y ratifico. Y asimismo reciba y cobre la renta que adelante corre en virtud de los nuevos arrendamientos dando de lo que así recibiere y cobrar su carta o cartas de pago finiquitos y gastos concesión de acciones a los que pagaren como fiadores de otros o en otra manera y no pareciendo la entrega de presente la acepta con la renunciación del derecho en forma y siendo necesario parecer en juicio lo haga ante cualquier justicias eclesiásticas o seglares de estos reinos y señoríos donde convenga y sea necesario pidiendo ejecuciones prisiones ventas trances y remates de bienes tomando posesión de ellos presentando testigos escrituras y probanzas y otros papeles y género de prueba tachando y contradiciendo lo en contrario recusando jueces letrados y escribanos y otros ministros pidan costas y todo lo juren oigan autos y sentencias consientan lo a favor y de lo en contrario apelen y supliquen y lo siga ante todas instancias y tribunales hasta lo fenecer y acabar que el poder que de derecho se requiere y es necesario los doy con incidencias y dependencias libre y general administración y relevación de derecho en forma y me obligo de le haber por firme y lo que en su virtud hiciere. Y lo otorgué así ante el presente escribano y testigos en la ciudad de Valladolid a treinta de septiembre de mil y seiscientos y sesenta y siete siendo testigos Manuel Antecha Francisco Ruiz Canduela y Teodoro de Arce vecinos y estantes en esta dicha ciudad y el otorgante que yo el escribano doy fe conozco dijo no saber firmar y a su ruego lo firmó un testigo. 


\section{DOCUMENTO 6}

\section{CAPITULACIONES MATRIMONIALES. SANTIAGO BARBA Y D TERESA DE ÁVILA (22 - JULIO - 1714)}

A.H.P.V., Leg. 3.195, ff. 224-225

Lo que a honra y gloria de Dios nuestro señor y para su santo servicio se asienta capitula y concierta entre D ${ }^{a}$ Teresa de Ávila hija legítima de Juan de Ávila y de Da Francisca Ezquerra sus padres difuntos vecinos que fueron de esta ciudad de la una parte y de la otra Santiago Barba viudo de Juliana Meléndez hijo legítimo de Cristóbal Barba y de Isabel Carrasco sus padres difuntos vecinos que fueron de la ciudad de Toro y en razón del matrimonio que entre los dichos $\mathrm{D}^{\mathrm{a}}$ Teresa de Ávila y Santiago Barba se ha de celebrar Dios mediante, y una y otra parte se obligan a guardar y cumplir lo siguiente:

Lo primero que habiéndose publicando las tres canónicas municiones que el Santo Concilio dispone y manda o antes si de alguna se dispensare los dichos $D^{a}$ Teresa de Ávila y Santiago Barba se han de desposar y en tiempo debido velar como lo manda nuestra santa madre iglesia y a ello quieren ser compelidos y apremiados por todo rigor.

La dicha $\mathrm{D}^{\mathrm{a}}$ Teresa se obliga en forma a llevar a poder del dicho Santiago Barba su marido que ha de ser tres mil reales de vellón por bienes dotales suyos propios en alhajas y homenaje de casa que se han de tasar por dos personas nombradas por cada parte la suya y a su cumplimiento quiere ser compelida por todo rigor en virtud de esta escritura y certificación de estar desposados como por garantía y llana obligación que la ha de traer aparejada.

El dicho Santiago Barba atendiendo a las buenas prendas virtud y calidad de la dicha $\mathrm{D}^{\mathrm{a}}$ Teresa su futura mujer y hallarse doncella la ofrece y dota por razón de arras proternúpcias en quinientos ducados de vellón los cuales confiesa tienen cabimiento al presente en la décima parte de sus bienes y no le teniendo se los consigna, sitúa y señala en los mejores más prontos y efectivos de los que tuviere y adquiriere en delante de los cuales desde ahora para cuando llegue el caso hace a favor de la susodicha gracia, cesión y donación, buena, pura, mera, perfecta, y revocable que el derecho llama intervivos con la insinuación y requisitos en derecho necesarios para su mayor validación y a su cumplimiento obliga su persona y bienes muebles y raíces derechos y acciones habidos y por haber. Y asimismo se obliga a que siéndole entregados los referidos tres mil reales de dote ofrecidos de ellos y de los quinientos ducados de dotación que lleva hecha otorgará a favor de la dicha su mujer que ha de ser carta de pago en forma con obligación a su restitución en cualquiera de los casos que el derecho previene y para el cumplimiento de todo lo referido ambas partes cada uno por lo que le toca dan poder a las justicias y jueces de su majestad de esta ciudad y otra parte a quien se someten y en especial al fuero y jurisdicción de los señores alcaldes del crimen de esta corte corregidor y teniente que al presente son y fueren en adelante y a cada uno in solidum y lo reciben por sentencia definitiva y competente pasada en autoridad de cosa juzgada renuncian su propio fuero y privilegio jurisdicción y domicilio y a las leyes fueros y derechos de su favor y la general en forma, y asimismo la dicha $\mathrm{D}^{\mathrm{a}}$ Teresa renuncia las de los emperadores, Beleyano Justiniano y demás que hablan a favor de las mujeres y jura por Dios nuestro señor y una señal de la cruz en forma ser mayor de veinte y cinco años y ambas partes lo otorgaron ante mí el escribano en la ciudad de 
Valladolid a veinte y dos de julio año de mil setecientos y catorce siendo testigos Pedro de Ávila Juan de Aldaba y Lorenzo Negral vecinos y residentes en esta ciudad, y los otorgantes y yo escribano doy fe conozco lo firmaron. 


\section{DOCUMENTO 7}

\section{PODER PARA TESTAR. D ${ }^{\mathrm{a}}$ TERESA DE ÁVILA MUJER LEGÍTIMA DE SANTIAGO BARBA AL DICHO SANTIAGO BARBA (12 - AGOSTO - 1721)}

A.H.P.V., Leg. 2.962, f. 624

Sépase por esta escritura de poder para testar como yo $\mathrm{D}^{\mathrm{a}}$ Teresa de Ávila mujer legítima de Santiago Barba maestro cubero vecina de esta ciudad de Valladolid donde lo es el dicho mi marido estando enferma en cama de enfermedad corporal que mi Dios y Señor Jesucristo ha sido servido de darme porque le repito muchas gracias sana de mi juicio y entendimiento natural creyendo como firmemente creo en el misterio de la santísima trinidad Padre Hijo y Espíritu Santo tres personas distintas y un solo Dios verdadero y en todo lo demás que cree confiesa y enseña nuestra Santa Madre Iglesia Católica Apostólica y Romana debajo de cuya buena fe y creencia siempre he vivido y protesto vivir y morir tomando como tomo por mi intercesora y abogada a la Serenísima Reina de los ángeles María Santísima Señora Nuestra concebida sin pecado virginal en el primer instante de su ser natural y a todos los demás santos y santas de la corte celestial para que intercedan con mi Dios y Señor Cristo perdone mis culpas y enderece mi alma a su salvación.

Digo que por la gravedad de mi enfermedad no puedo formalmente hacer mi testamento el cual tengo comunicado muy pormenor con el dicho Santiago Barba mi marido mediante lo cual por la presente otorgo que doy todo mi poder cumplido el que de derecho se requiere y es necesario más puede valer al dicho Santiago Barba mi marido para que luego que yo fallezca en el término que el derecho permite pueda hacer y otorgar por mí y en mi nombre el dicho mi testamento última y postrimera voluntad haciendo en él las declaraciones mandas y legados que les pareciere y le tengo comunicado con tal que mi cuerpo sea sepultado en el Real Convento de San Francisco de esta ciudad en la sepultura propia que en él tenemos y mis testamentarios sean el dicho Santiago Barba mi marido y Pedro de Ávila mi hermano vecino de esta ciudad y a cada uno in solidum los cuales luego que yo falleciera entren en mis bienes así muebles como raíces y los vendan y rematen en pública almoneda o fuera de ella y de su valor cumplan y paguen toda mi disposición y la que en virtud de este poder le hiciere y les dure el cargo de tales testamentarios el tiempo necesario y además del que les da el derecho que yo les prorrogo y en el remanente que quedase de todos mis bienes así muebles como raíces dejo instituyo y nombro por mi heredera universal de todo ello a María Barba mi hija legítima y del dicho mi marido para que vaya y herede con la bendición de Dios y la mía.

Mando a María Martínez hija de Joseph Martínez dos casacas de paño una azul y otra negra y un guardapiés de droguete.

Asimismo mando a $\mathrm{D}^{\mathrm{a}}$ María de la Peña mi hermana mujer del dicho Pedro de Ávila tres casacas la una de nobleza otra de fondo y otra de lamparilla negra y un manto nuevo y un zagalejo blanco.

Asimismo mando a Ángela de Fuentes un delantal nuevo y un guardapiés blanco de bayeta bordado. 
Y a María de Teza mi criada los guardapiés ordinarios que yo dejase y a todas las pido me encomienden a Dios y reciban estas mandas en atención a lo mucho que las estimo.

Y revoco anulo y doy por ninguno y de ningún valor ni efecto otro cualquier testamento o testamentos poder o poderes para testar u otra cualquier disposición que antes de este poder y el testamento que en virtud se hiciese hubiere echo y otorgado que quiero que no valga ni tenga fuerza salvo el dicho poder y testamento que en su virtud se hizo que quiero tenga entero cumplimiento en juicio y fuera de él y así lo otorgo ante el presente escribano y testigos en la ciudad de Valladolid a doce días del mes de agosto de mil setecientos y veinte y un años siendo testigos D. Juan de Toro presbítero Julián Martín y Francisco Mozo Enríquez vecinos y estantes en esta ciudad y la otorgante a quien yo el escribano doy fe conozco aunque dijo saber firmar no pudo por la gravedad de su enfermedad a su ruego lo firmaron algunos de los testigos. 


\section{DOCUMENTO 8}

\section{PODER. BENTURA SEDANO A MARTÍN GARCÍA Y CATALINA CABALLERO MIS TÍOS (7 - NOVIEMBRE - 1687)}

A.H.P.V. Leg. 2.381, f. 453

Bentura Sedano soltera residente en esta ciudad de Valladolid hija legítima de Mateo Sedano y de Isabel Caballero mis padres difuntos vecinos que fueron de la ciudad de Palencia confesando como confieso ser mayor de veinte y cinco años y así lo juro doy mi poder cumplido el de derecho en tal caso necesario a Martín García y Catalina Caballero su mujer mis tíos vecinos de dicha ciudad de Palencia y a cada uno in solidum con cláusula de que le puedan sustituir en cuanto a pleitos y no en más especial para que en mi nombre pidan y tomen cuentas judicial o extrajudicialmente a todas y cualesquier personas así eclesiásticas como seglares de cualquier estado y calidad que sean o de quien as deban dar de todos los bienes y hacienda que me tocaron por las cuentas y particiones que se hicieron de los bienes que quedaron por fin y muerte de los dichos mis padres entre mí y demás herederos de los susodichos que constaran por mi abuela, y los dichos bienes y hacienda los perciban y cobren de las personas en cuyo poder pararen con todo lo que hubieren rentado desde el día que entraron en su poder hasta que se haga la entrega de los dichos bienes y de todo lo que recibieren y cobraren den y otorguen las cartas de pago, finiquitos, cesiones y lastos y los demás recados con renunciación de leyes de la entrega no pareciendo de presente o en otra manera y siendo necesario así en razón de la dicha cuenta recobre de los dichos bienes como en todos los demás pleitos en su razón se ofrezcan parezcan en juicio ante cualesquier tribunales, jueces y justicias donde convenga y hagan los pedimentos, autos y demás diligencias judiciales y extrajudiciales que se requieran y a mi derecho convengan hasta que se consiga lo aquí contenido (...) y lo otorgué así ante el presente escribano en la ciudad de Valladolid a siete de noviembre de mil seiscientos y ochenta y siete años siendo testigos don Francisco González de la Cruz, Julián García y Manuel de Medina vecinos y estantes en esta ciudad y la otorgante que yo el escribano doy fe conozco dijo no saber firmar a su ruego lo firmó un testigo. 


\section{DOCUMENTO 9}

\section{ESCRITURA DE ASIENTO DE APRENDIZ DE JUAN DE ÁVILA CON EL PINTOR GABRIEL DE PALACIOS (3 - NOVIEMBRE - 1666)}

A.H.P.V., Leg. 2.113, f. 216

Sépase por esta carta de asiento al arte de pintor vieren como yo Gabriel del Pozo maestro de obra prima padrastro de Juan de Ávila mi andado hijo de Hernando de Ávila y Juana Martínez sus padres difuntos otorgo por esta carta que asiento al dicho mi andado con Gabriel de Palacios pintor vecino de esta ciudad por tiempo y espacio de cuatro años que corren desde todos los santos de este año de sesenta y seis y en ellos le ha de tener en su casa darle de comer y cama y enseñarle el dicho arte de pintor de forma que esté hábil para trabajar como oficial del dicho arte y no lo estando le ha de tener en su casa hasta que lo este y darle cada mes tres ducados que es lo que se acostumbra a dar a los aprendices en dicho arte. Yo el dicho Gabriel del Pozo tengo de dar a dicho mi andado de vestir y calzar dichos cuatro años y asimismo le he de curar las enfermedades que tuviere durante ellos y por dicha enseñanza he de pagar al dicho Gabriel de Palacios ciento y cincuenta reales ciento de contado y cincuenta para la pascua de flores que viene del año de sesenta y siete con lo cual me obligo que el dicho mi andado no hará ausencia en el dicho tiempo y si lo hiciere le traeré donde estuviere siete leguas en contorno de esta ciudad para que cumpla lo aquí contenido y faltas que hiciere donde no lo pueda hacer el dicho Gabriel de Palacios y por lo que pueda ejecutarme juntamente por los cincuenta reales que refiere esta escritura y asimismo yo el dicho Gabriel del Pozo me obligo de dar al dicho Gabriel de Palacios una manta colorada para que utilice el dicho mi andado yo el dicho Gabriel de Palacios lo acepto y me obligo de haber por firme esta escritura a que quiero ser apremiado a su cumplimiento a quiero ser apremiado por todo rigor de derecho y ejecución y en todo cumpliré con lo aquí contenido y a ello como dicho es quiero ser apremiado y confieso recibir del dicho Gabriel del Pozo los dichos cien reales aquí referidos que me doy por entregado y renuncio las leyes de las entrega como en ella se contiene y le doy carta de pago en forma y el dicho Juan de Ávila lo aceptó como aquí va declarado (...) y el dicho Juan de Ávila por ser menor de veinte y cinco años juró a Dos y a una cruz en forma de derecho (...) firme esta escritura y no ir contra ella en manera alguna y lo otorgan así en la ciudad de Valladolid a tres de noviembre de mil y seiscientos y sesenta y seis años siendo testigos Juan López de Dios y Simón Escudero y Juan Asensio vecinos de esta ciudad de Valladolid y los otorgantes a quien yo el escribano doy fe conozco y lo firmo el que supo por el que no un testigo. 


\title{
DOCUMENTO 10
}

\section{ESCRITURA DE ASIENTO DE APRENDIZ DE JUAN DE ÁVILA CON EL ESCULTOR FRANCISCO DÍEZ DE TUDANCA $(8-\mathrm{MARZO} \mathrm{-} \mathrm{1667)}$}

\author{
A.H.P.V., Leg. 2.276, f. $669^{1}$
}

Yo Marco Antonio de Anaya procurador del número de esta ciudad curador ad litem de Manuel y Juan de Ávila mi menor hijo y heredero de Hernando de Ávila y Juana Martínez sus padres difuntos (...) curaduría y descernimiento de ella pasa ante la justicia ordinaria del presente escribano de que da fe. Y de ella usando pongo por aprendiz del arte de escultor al dicho Juan de Ávila mi menor con Francisco de Tudanca maestro del dicho arte vecino de esta ciudad por tiempo y espacio de cinco años que han de comenzar a correr y contarse desde hoy día de la fecha de esta escritura en adelante y se cumplirán a ocho días del mes de marzo del año que viene de mil seiscientos y setenta y dos años y en dichos cinco años al dicho mi menor le ha de dar enseñado del dicho oficio y arte a vista y satisfacción de maestros peritos en él y además puso a de dar dicho mi menor ropa limpia y le ha de curar sus enfermedades como no pase de quince días y si se fuere o a presentare a costa de mi menor se le a ir a buscar como no pase de quince días y no le dando enseñado hábil y suficiente del dicho arte y ha de tener en su casa hasta que lo esté. Dándole lo mismo que ganare un oficial en cada un día hasta que esté hábil y suficiente en el dicho arte y todo el tiempo que estuviere enfermo faltas que tuviere dicho mi menor. Y por enseñarle el dicho oficio y arte así concertado con el dicho Francisco de Tudanca de darle doscientos reales en dinero de contado ahora de presente y para que duerma el dicho mi menor un jergón y una sábana y una manta y el vestir y calzar ha de ser por cuenta del dicho mi menor. Presentes nosotros los dichos Francisco de Tudanca y Juan de Ávila mi menor que aceptamos todo lo contenido en esta escritura según y cómo en ella se contiene y cumpliremos con su tenor y forma yo el dicho Francisco de Tudanca recibo del dicho Juan de Ávila por aprendiz del dicho mi oficio arte y me obligo de darle enseñado de todo necesario en el en dichos cinco años de dar de comer cama y ropa limpia blanca tratándole bien de obra y palabra y si no le hubiera enseñado hábil y suficiente en los dichos cinco años a contento vista de maestros peritos en el dicho arte le he de tener en mi casa trabajando hasta que lo este y le ha de dar por cada día lo mismo que ganare un oficial hasta tanto que este capaz y suficiente. Y confirmo haber recibido de los dichos Marco Antonio de Anaya y Juan de Ávila su menor los dichos doscientos reales de moneda de vellón jergón sabana y manta para que duerma el dicho Juan de Ávila su menor y por haberlos recibido hoy dicho día me doy por pagado y en entregado de los dichos doscientos reales jergón sabana y manta por haberlos recibido con efecto y porque a entrega de presente no parece renuncio las leyes de ella con la excepción de la non numerata pecunia prueba paga mal engaño y las demás del caso como en ellas y en cada una se contiene de que otorgo carta de poder en forma (...) en testimonio de lo cual lo otorgamos así ante el presente escribano en la ciudad de Valladolid a ocho días del mes de marzo de mil y seiscientos y sesenta y siete años siendo testigos Joseph de Sotomayor Diego Hernández Melchor de Mendoza vecinos y estantes en esta dicha ciudad y los otorgantes antes a quien yo el dicho escribano doy fe conozco lo firmaron.

1 GARCÍA CHICO, Esteban: “Artistas montañeses. Francisco Díez de Tudanca, escultor”, Altamira: Revista del Centro de Estudios Montañeses, N 1-3, 1954, pp. 52-53. 


\section{DOCUMENTO 11}

\section{CAPITULACIONES MATRIMONIALES (6 - FEBRERO - 1672)}

A.H.P.V., Leg. 2.417, ff. 50-51

Lo que para servicio de Dios nuestro señor se capitula y concierta entre Juan de Ávila escultor vecino de esta ciudad hijo legítimo de Hernando de Ávila y Juana Martínez sus padres ya difuntos vecinos que fueron de dicha ciudad de la una parte, y de la otra Francisca Ezquerra hija legítima de Romualdo de Ezquerra y Ana González del portal sus padres también difuntos vecinos de esta ciudad sobre el casamiento que entre ellos está tratado es lo siguiente:

Lo primero que habiendo precedido las tres municiones que dispone el santo concilio a dispensación de ellas los dichos Juan de Ávila y Francisca Ezquerra se casarán y velarán según orden de la santa madre iglesia sin sustraerse por ninguna causa y a ello se les ha de apremiar.

Que la dicha Francisca Ezquerra luego que tenga efecto el matrimonio llevará a poder del dicho Juan de Ávila que mediante la voluntad de Dios ha de ser su marido por bienes dotales suyos trescientos ducados en esta manera: los cincuenta en una prebenda en que fue elegida por los testamentarios del licenciado Francisco García Álvarez cura que fue del lugar de Santovenia, y otros cincuenta en la prebenda de la cofradía de Nuestra Señora del Pilar sita en el Convento de Santa Ana, y otros cincuenta de la prebenda de la Cofradía de las Ánimas de la parroquial de Santiago de esta ciudad, y otros cincuenta por los mismos que por cláusula del testamento que otorgó Ana Gómez del Real vecina que fue de esta ciudad ante Gonzalo Maldonado escribano del número la mandó para ayuda de su remedio, y cien ducados por los mismos que entraron en poder de Francisco de Tudanca escultor vecino de esta ciudad que los cobró de Santiago Muñoz vecino de Villanubla los cuales se los mandó Francisco Ezquerra su abuelo por cláusula de su testamento para ayuda de su remedio que todas las dichas partidas hacen los dichos trecientos ducados.

Que además de lo referido llevará por bienes dotales la dicha Francisca Ezquerra un oficio de portero del número de esta ciudad que propio suyo durante su vida por gracia que hizo la Casa de Linajes al dicho Francisco Ezquerra su abuelo la cual al presente sirve Joseph Cencano y paga de renta por ella en cada un año diez ducados de que ha de comenzar a gozar desde el día de Navidad fin del año pasado de setenta y uno en adelante.

Que por cuanto Francisco Ezquerra y Juana Fernández de Geria su mujer abuelos de la dicha Francisca Ezquerra durante el matrimonio compraron una viña de diez y siete alanzadas camino de Fuensaldaña a huerta de Moro de la cual por muerte de la dicha Juana de Geria tocó la mitad al dicho Romualdo Ezquerra y la otra mitad a Francisca Ezquerra su hermana, y por haber muerto también el dicho Francisco Ezquerra se partió la otra mitad en la misma forma y ahora por haber muerto también el dicho Romualdo Ezquerra pertenecen ocho alcanzadas y media que es la mitad de dicha viña a la dicha Francisca Ezquerra y Juana y Jacinta Ezquerra sus hermanas entre quien se ha de partir y lo que tocare a la dicha Francisca Ezquerra ha de ser y quedar por bienes dotales suyos. 
Que para seguridad y paga de los dichos cien ducados que están en poder del dicho Francisco de Tudanca se ha de obligar el susodicho en esta escritura a entregarlos luego que tenga efecto el matrimonio al dicho Juan de Ávila en ropa blanca, vestidos y ajuares de por casa tasados y valuados por personas nombradas por ambas partes sin que se le pueda pedir lo entregue en otros efectos.

Que por cuanto luego que murió el dicho Francisco Ezquerra se hizo escritura entre Romualdo Ezquerra su hijo y padre de dicha Francisca Ezquerra con el dicho Francisco de Tudanca ante Francisco Rodríguez de los Ríos escribano real en primero de abril del año pasado de sesenta y cuatro por la cual quedó encargado el dicho Francisco de Tudanca de tener en su casa y compañía a la dicha Francisca Ezquerra y Juana Ezquerra su hermana y sustentarlas y alimentarlas hasta que tomasen estado y para ayuda de lo referido se le dio lo que podían redituar cada año así los dichos cien ducados como el dicho oficio de portero lo cual ha cobrado y percibido el dicho Francisco de Tudanca hasta el día de Navidad fin del dicho año de setenta y uno y ha cumplido con alimentar a las susodichas y aunque con dicha renta no era posible haber bastante para el dicho alimento y crianza se ha de apartar el dicho Francisco de Tudanca de cualquiera derecho que por dicha razón pudiera tener contra la dicha Francisca Ezquerra y en cuanto a lo que pudieran los otorgantes pedir al susodicho por todo lo que ha importado dichas rentas y también por doscientos reales que se le dieron al dicho Francisco de Tudanca en dinero también para el sustento de dicha Francisca Ezquerra ni por otra causa ni razón no le pedirán ni demandarán cosa alguna en ningún tiempo.

Que el dicho Juan de Ávila por la honra y linaje de la dicha Francisca Ezquerra la promete en arras y dotación proternúpcias para más aumento de su dote en doscientos ducados de vellón los cuales confiesa que caben en la décima parte de los bienes que al presente tiene y en caso que no quepan se los sitúa y señala en lo mejor y más bien parado de los bienes que tuviere y adquiriere de aquí adelante a donde la susodicha los quisiere escoger a su elección y voluntad.

Que el dicho Juan de Ávila se obliga de que habiendo recibido la dicha dote dará carta de pago de ella juntamente con los dichos doscientos ducados de arras en favor de la dicha Francisca Ezquerra para que todo ello lo tenga como bienes dotales sin que el dicho Juan de Ávila los pueda obligar ni enajenar en ningún tiempo y en caso que el dicho matrimonio fuere disuelto por muerte, divorcio u otra causa que el derecho permita lo ha de volver y restituir a la susodicha o a quien su derecho y causa hubiere y a ello se le ha de apremiar.

Presente a lo contenido en esta escritura el dicho Francisco de Tudanca que la aceptó por lo que la toca y se obligó de entregar al dicho Juan de Ávila luego que tenga efecto el matrimonio los dichos cien ducados en ropa, vestidos y ajuares como va declarado y no lo haciendo se le ha de poder ejecutar por ellos como por llana obligación de plazo pasado. Y asimismo se aparta de cualquier derecho y acción que pudiera tener por razón del alimento y crianza de dicha Francisca Ezquerra.

Y asimismo el dicho Francisco de Tudanca por el amor y voluntad que tiene a la dicha Francisca Ezquerra sobrina legítima de Francisca Ezquerra su mujer le dará y promete cincuenta ducados también en ropa y ajuares y herramientas del oficio de escultor para que la susodicha los tenga por más aumento de dote y los entregará al dicho Juan de Ávila luego que tenga efecto el matrimonio y no lo haciendo se le ha de ejecutar por ello. 
Y al cumplimiento de esta escritura y cada capítulo de ellos los otorgantes por lo que a cada uno toca se obligaron con sus personas y bienes muebles y raíces habidos y por haber dieron poder a las justicias de su majestad y renunciaron las leyes, fueros y derechos de su favor y la general y la dicha Francisca Ezquerra renunció las leyes de los emperadores, de Toro y partida y las demás del favor de las mujeres de que fue avisada por el presente escribano. Y los dichos Juan de Ávila y Francisca Ezquerra por ser menores de veinte y cinco años aunque mayores de veinte juraron a Dios y a una cruz en forma no ir contra esta escritura ni pedir restitución por la menor edad en ningún tiempo por hacerla de su voluntad y se le sigue provecho y todos lo otorgaron así en la ciudad de Valladolid a seis días del mes de febrero de mil y seiscientos y setenta y dos años siendo testigos Ignacio González del Portal portero y Joseph Ferrel torero y Diego de Fuertes pintor vecinos y estantes en esta ciudad, y los otorgantes que yo el escribano doy fe conozco lo firmaron. 


\section{DOCUMENTO 12}

\section{CARTA DE PAGO. JUAN DE ÁVILA Y FRANCISCA EZQUERRA A LAS MEMORIAS DE MARÍA DEL MILAGRO (15 - FEBRERO - 1672)}

A.H.P.V., Leg. 2.704, f. 292

En la ciudad de Valladolid a quince días del mes de febrero de mil y seiscientos y setenta y dos años ante mí el escribano y testigos parecieron Juan de Ávila y Francisca Ezquerra su mujer vecinos de esta dicha ciudad hija legítima de Romualdo Ezquerra su padre difunto vecino que fue de ella y confesaron haber recibido de las memorias que para casar huérfanas fundaron María del Milagro y Mateo Tristán de Abellaneda sitas en la Cofradía de la Virgen del Pilar que está en el Convento de Santa Ana de esta dicha ciudad por mano del Sr. D. Simón de Contreras y Rojas regidor de ella depositario de los bienes y rentas pertenecientes a las dichas memorias cuatrocientos y cuarenta reales de vellón por los mismos en que la dicha Francisca Ezquerra se la aplicaron el año pasado de mil y seiscientos y sesenta y ocho por la prebenda de las dichas memorias en que fue elegida y nombrada por la dicha cofradía como huérfana y bautizada en la pila de la iglesia de Santiago de esta dicha ciudad en conformidad de la fundación para que los cobrase en habiendo mudado estado y respecto de haberse casado con el dicho Juan de Ávila recibe los dichos cuatrocientos y cuarenta reales y de ellos los otorgantes se dieron por contentos a su voluntad y en razón de la entrega que de presente no parece renunciaron las leyes que sobre el caso hablan de que dieron carta de pago en forma y entregan (...) ella testimonio de Juan Rodríguez de Quiñones escribano real y de la dicha cofradía de la dicha elección y en fe de velaciones del licenciado Francisco García cura de la dicha iglesia y la otorgaron así y firmaron a quienes yo el escribano doy fe conozco siendo testigos Francisco de Tudanca, Francisco de Valdivieso y D. Gabriel de Sierra vecinos de esta dicha ciudad. 


\section{DOCUMENTO 13}

\section{CARTA DE PAGO A LA COFRADÍA DEL SANTÍSIMO SACRAMENTO DE LA IGLESIA DE SEÑOR SANTIAGO (16 - FEBRERO - 1672)}

A.H.P.V., Leg. 2.259, f. 145

En la ciudad de Valladolid a diez y seis de febrero de mil y seiscientos y setenta y dos años ante mí el escribano y testigos pareció presente Francisco de Ávila vecino de esta ciudad como marido y conjunta persona de Francisca Ezquerra y dijo y confesó haber recibido realmente y con efecto del señor don Simón de Contreras y Rojas regidor de esta ciudad como depositario de las Memorias del doctor Montemayor y doña Ana Núñez sita en la Cofradía del Santísimo Sacramento de señor Santiago cincuenta ducados de vellón los cuales son por razón de la prebenda que se adjudicó a la dicha Francisca Ezquerra por los electores de la dicha cofradía de que para su cobranza entrega fe de velaciones y nombramiento de la dicha prebenda de que de los dichos cincuenta ducados se dio por bien contenta, pagada y entrega a su voluntad y por no parecer de presente renunció las leyes de la non numerata pecunia, prueba de la paga y demás del caso en forma de que otorgó carta de pago como se requiere y firmó a quien doy fe conozco siendo testigos Manuel Fernández, Francisco Díez de la Guerra y Juan Alonso del Valle vecinos y estantes en esta dicha ciudad. 


\section{DOCUMENTO 14}

\section{VENTA DE UNA HEREDAD DE VIÑA DESCEPADA. FRANCISCO TUDANCA JUAN DE ÁVILA Y OTROS A MATÍAS MARTÍNEZ (21 - JULIO - 1673)}

A.H.P.V., Leg. 1.977, ff. 163-165

Sepan los que vieren la presente escritura de venta real y enajenación perpetua como nos Francisco Tudanca escultor vecino de esta ciudad de Valladolid y Francisca Ezquerra su mujer y Juan de Ávila escultor y Francisca Ezquerra su mujer vecinos de esta dicha ciudad y yo el dicho Francisco Tudanca como tutor de las personas y bienes de Juana y Jacinta Ezquerra hijas que fueron de Romualdo Ezquerra alguacil que fue de esta ciudad y de Ana González del portal su mujer difuntos vecinos que fueron de esta ciudad y los dichos Romualdo Ezquerra y Francisca Ezquerra hijos y herederos de Francisco Ezquerra difunto abuelo de las dichas Francisca Ezquerra, Juana y Jacinta y en virtud de la tutela de las dichas menores que me fue discernida por la justicia ordinaria de esta ciudad ante el presente escribano con licencia, autoridad y expreso consentimiento que nos las dichas Francisca Ezquerra mayor y Francisco Ezquerra menor pedimos a los dichos Francisco de Tudanca y Juan de Ávila nuestros maridos que nos den para otorgar y ajustar esta escritura y nos los susodichos se la damos y concedemos y nos las susodichas la aceptamos y de ella usando todos juntos y de mancomún a voz de uno y cada uno de nos por sí in solidum a voz de uno y cada uno de nos por sí in solidum y por el todo renunciando como renunciamos las leyes de duobus rex debendi y la auténtica presente hoc ita de fide iusoribus (...) decimos que el dicho Francisco Ezquerra nuestro padre y abuelo de las dichas menores quedó por suya propia una heredad de viña que está descepada y hecha erial al presente en término de esta ciudad al pago que llaman Huerta del Moro que hacía ocho alanzadas poco más o menos que linda con viña del Colegio de San Ambrosio y viña de Andrés Fernández escribano real por la parte de abajo y por la de arriba con viñas fueron del licenciado Antonio Ramírez clérigo y con la senda que baja al dicho pago de Huerta del Moro que hubo y compró de Gabriel de la Torre y doña María Rodríguez su mujer y la dicha heredad la tuvo y poseyó el dicho Francisco Ezquerra hasta que murió que dejó por sus hijos y herederos a mí la dicha Francisca Ezquerra y al dicho Romualdo Ezquerra y por no haberla dado las labores se ha hecho erial y no tiene cepas ni otros plantíos de manera que no ha sido ni es de ningún provecho y hemos tomado acuerdo de la vender y nos hemos convenido y concertado con Matías Martínez mercader vecino de esta ciudad de la vender la dicha heredad perdida y su precio está ajustado en cuatrocientos y cincuenta reales y para hacer esta venta yo el dicho Francisco Tudanca como tutor de las dichas menores y yo el dicho Juan de Ávila como marido y conjunta persona de la dicha Francisca Ezquerra hicimos pedimento ante el señor teniente de corregidor de esta ciudad y ante el presente escribano sufriendo las dichas causas pidiendo licencia para vender la dicha heredad y recibir la dicha cantidad y otorgar venta en forma en favor del dicho Matías Martínez y se admitió el dicho pedimento y al tenor de él se recibió información de la utilidad y provecho que se seguía a las dichas menores y con vista de la dicha información por el dicho señor teniente se dio licencia para hacer esta venta como todo consta de la dicha tutela y discernimiento, pedimento, información y licencia que su tenor es como se sigue:

Aquí entra 
Todo lo cual va cierto y verdadero y concuerda con sus originales de que el escribano doy fe y usando de la dicha licencia nos los dichos Francisco Tudanca y Francisca Ezquerra su mujer, hija y heredera del dicho Francisco Ezquerra y como tutor yo el susodicho de las dichas Juana y Jacinta Ezquerra sus nietas y nos los dichos Juan de Ávila y Francisca Ezquerra su mujer como tales herederos vendemos y damos en venta real por juro de heredad para ahora y para siempre jamás el dicho Matías Martínez y a Josepha Álvarez su mujer para ellos y para sus hijos, herederos y sucesores y para quien tuviere su derecho la dicha viña erial que fue del dicho Francisco Ezquerra que está en término de esta dicha ciudad al dicho pago de Huerta de Moro con los dichos linderos que van referidos y con todas sus entradas y salidas, usos y costumbres, derechos y servidumbres cuantas ha y tiene y la pertenece así de hecho como de derecho y por libre de todo censo perpetuo o al quitar, aniversario, vínculo, patronazgo, obligación, hipoteca que no la tiene y así lo declaramos y por precio y cuantía de los dichos cuatrocientos y cincuenta reales que nos paga de contado y los recibimos los dichos Francisco Tudanca y Juan de Ávila ahora de presente en moneda de vellón en presencia del presente escribano y testigos de esta carta de que le pedimos de fe y yo el escribano la doy que los susodichos recibieron la dicha cantidad en moneda de vellón en mi presencia y de los dichos testigos y de ello todos otorgamos carta de pago y finiquito en forma en favor de los dichos Matías Martínez y su mujer como a su derecho convenga y desde luego nos apartamos y a las dichas Juana y Jacinta Ezquerra y a nuestros herederos y sucesores de todo el derecho y acción, propiedad y señorío, título, razón y causa que tenemos a la dicha heredad (...) y todos lo otorgamos ante el presente escribano y testigos en la ciudad de Valladolid a veinte y un días del mes de julio de mil y seiscientos y setenta y tres años siendo testigos Juan Ruiz del Árbol y Diego Alonso de Quirós y Antonio González de Escobar vecinos y estantes en esta ciudad y los otorgantes que conozco lo firmaron los que supieron y por los que no un testigo. 


\section{DOCUMENTO 15}

\section{ESCRITURA DE APRENDIZ AL OFICIO Y ARTE DE ESCULTOR CON JUAN DE ÁVILA (4 - JULIO - 1674)}

A.H.P.V., Leg. 2.757/7, f. 15

En la ciudad de Valladolid a cuatro días del mes de julio de mil seiscientos y setenta y cuatro años ante mí el escribano y testigos parecieron de la una parte Juan de Ávila escultor vecino de esta ciudad y de la otra Pedro de la Vega vecino de ella. Y dijeron que los susodichos se convienen y conciertan en esta forma que el dicho Pedro de la Vega pone y asienta por aprendiz en el oficio y arte de escultura con el dicho Juan de Ávila a Francisco de la Vega su hijo para que por tiempo y espacio de cinco años que comienzan desde hoy día de la fecha de esta escritura le enseñe el dicho oficio de escultor de manera que en él quede hábil a vista y declaración de dos oficiales del dicho oficio nombrados por cada parte el suyo y durante el dicho tiempo el dicho Juan de Ávila le ha de tener en su casa y dar de comer y cama a su costa y si no le diere enseñado de allí en adelante le ha de pagar lo que más ganare otro oficial hasta que le acabe de enseñar y el dicho Francisco de la Vega aprendiz en el dicho tiempo de los cinco años referidos no se ausentará de la casa y servicio del dicho Juan de Ávila su maestro y si lo hiciere se le haya de volver el dicho Pedro de la Vega dentro de ocho días de cómo hiciere dicha ausencia y se le requiere para dicho efecto por parte del dicho Juan de Ávila y si dentro de ellos el dicho Pedro de la Vega no trajera al dicho su hijo a casa del dicho Juan de Ávila pueda buscar otro a costa del dicho Pedro de la Vega a quien le haya de dar su jornal y para la cobranza de lo que importaren los jornales que hubiere pagado al oficial que entrare con el dicho Juan de Ávila por ausencia del dicho Francisco de la Vega ha de ser creído el dicho Juan de Ávila solo por su declaración simple jurada hasta que le vuelva el dicho Pedro de la Vega al dicho Francisco su hijo y por ello le ejecute el dicho Juan de Ávila al dicho Francisco de la Vega en virtud de este contrato y de la tal declaración sin otro recaudo alguno. Y por el trabajo de la enseñanza el dicho Pedro de la Vega ha de dar al dicho Juan de Ávila doscientos reales de vellón los ciento de ellos hoy día de la fecha de esta escritura y los cien reales restantes a cumplimiento de dichos doscientos para el día del señor San Juan de junio del año que viene de mil seiscientos y setenta y cuatro y por lo dicho y para la paga siendo necesario se constituía y constituyó el dicho Pedro de la Vega por llano y verdadero deudor de la dicha cantidad e hizo de hecho ajeno suyo propio y para mayor firmeza se dio por entregado de la dicha suma y renunció las leyes de la non numerata pecunia prueba y paga y las demás del caso todo lo cual ambas partes guardarán y cumplirán cada uno lo que le tocan respectivamente según de suso se contiene pena de pagar la costas y daños que se recrecieren y por ello obligaron sus personas y bienes muebles y raíces habidos y por haber dieron su poder a las justicias de su majestad de cualquier parte que sean renunciaron su fuero y lo recibieron por sentencia pasada en cosa juzgada renunciaron las leyes de su favor con la general en forma así lo dijeron y otorgaron ante mí el escribano siendo testigos Juan de Silva y Gregorio de Rozas y Manuel Blanco vecinos y estantes en esta dicha ciudad y los otorgantes que conozco lo firmó el que supo y por el que no un testigo. 


\section{DOCUMENTO 16}

\section{ARRENDAMIENTO DE UNA VARA DE PORTERO DEL NÚMERO DE ESTA CIUDAD $(24$ - SEPTIEMBRE - 1674)}

A.H.P.V., Leg. 2.260/2, f. 46

Sépase como yo Juan de Ávila escultor vecino de esta ciudad de Valladolid como marido y conjunta persona de Francisca de Ezquerra su mujer hija y heredera que fue y quedó de Romualdo Ezquerra portero del número que fue de esta ciudad doy en venta y por arrendamiento a Manuel Fernández vecino de esta dicha ciudad la vara de portero del número de esta ciudad que es mía propia y de la dicha mi mujer con sus emolumentos y demás que le toca y pertenece según y de la forma que la uso y ejecutó Joseph de Cencano ya difunto que la tuvo en arrendamiento y se la doy por tiempo y espacio de dos años que corren y se cuentan desde el día que el susodicho fuere recibido al uso y ejercicio del ficho oficio de portero cada año diez ducados y un año de adelantando y el año adelantado que son diez ducados estoy satisfecho de ellos cuanto me los ha de pagar Andrés Carro que siendo necesario me doy por entregados de ellos y me lo ha de pagar para el día de Tolos los Santos que vendrá de este presente año de setenta y cuatro y por no parecer de presente renuncio su entrega en forma y consiento que le reciban al uso y ejercicio del dicho oficio y respecto de que le tenía ya arrendado antes de ahora al dicho Joseph de Cencano le doy por libre del dicho arrendamiento desde el día que (...) en adelante y a sus fiadores para no les pedir ni (...) cosa alguna y me obligo que por este tiempo le será cierta y segura la dicha vara no quitada por más ni por menos que otro dijere pena de le pagar costas y daños. Presente yo el dicho Manuel Fernández que habiendo oído y entendido esta escritura al acepto y pagaré la dicha renta referida de diez ducados de vellón desde el día que fuere recibido al uso y ejercicio (...) porque se me ejecute en virtud de esta escritura como por llana y guarenticia obligación y por más las costas que se causaren y a ellos nos obligamos cada uno por lo que nos toca con nuestras personas y bienes muebles y raíces habidos y por haber y para su ejecución y cumplimiento damos todo nuestro poder cumplido a las justicias de su majestad recibímoslo por sentencia pasada en cosa juzgada renunciamos todas las demás leyes fueros derechos y privilegios de nuestro favor con la general en forma y lo otorgamos así ante el presente escribano y testigos en la ciudad de Valladolid a veinte y cuatro de septiembre de mil y seiscientos y setenta y cuatro años siendo testigos Lázaro de Tirso Manuel Rodríguez e Isidro del Campo vecinos de esta ciudad y los otorgantes que yo el escribano doy fe conozco lo firmaron. 


\title{
DOCUMENTO 17
}

\author{
VENTA REAL DE UNA MITAD. FRANCISCO ENRÍQUEZ Y \\ FRANCISCA DE ARGÜELLO SU MUJER EN FAVOR DE JUAN DE \\ ÁVILA DE 1.250 REALES (26 - ABRIL - 1676)
}

A.H.P.V., Leg. 252, ff. 49-50 (1676)

Sépase por esta pública escritura de venta real y enajenación perpetua por juro de heredad por ahora y para siempre jamás vieren como nos Francisco Enríquez marido y conjunta persona de Francisca de Argüello como heredera que fue y quedó de Manuel de Ávila su primer marido difunto vecino de esta ciudad de Valladolid con licencia que para hacer y otorgar esta escritura yo la dicha Francisca de Argüello pido y demando al dicho mi marido y me la dio y concedió y de ella usando ambos a dos marido y mujer juntos juntamente y de mancomún a voz de uno y cada uno de nos por sí in solidum (...) decimos que por fin y muerte de Hernando de Ávila y Juana Martínez vecinos que fueron de esta ciudad ya difuntos entre los demás bienes que quedaron fue una casa en la calle de Santiago de ella que linda por una parte con casas del Colegio de San Gregorio de esta ciudad y por la otra casas de Isabel de Navas vecina de ella, que dicha casa y linderos son notorios en la cual sucedió como herederos que quedaron de los susodichos el dicho Manuel de Ávila difunto y Juan de Ávila su hermano, y por haber muerto el dicho Manuel de Ávila y haberme quedado a mí la dicha Francisca de Argüello por su heredera universal como consta de la cláusula del testamento que otorgó ante Cristóbal Redondo Arbulu escribano de su majestad vecino de esta dicha ciudad, su fecha en cinco del mes de octubre del año pasado de mil y seiscientos y setenta y tres a que nos remitimos tenemos tratado de vender la mitad de la dicha casa referida al dicho Juan de Ávila en precio de mil doscientos y cincuenta reales, encargándose de un censo perpetuo que sobre ella tiene la Cofradía de Nuestra Señora de la Espina de veinte y dos reales y dos maravedíes y poniéndolo en ejecución nos los dichos Francisco Enríquez y Francisca de Argüello su mujer otorgamos por la presente que vendemos y damos en venta real y enajenación perpetua ahora y para siempre jamás al dicho Juan de Ávila maestro de escultoría vecino de esta dicha ciudad para el susodicho, sus hijos, herederos y sucesores y quien de él y de ellos hubiere título o causa en cualquier manera la dicha mitad de la dicha casa referida que me toca por la dicha herencia y la otra mitad del dicho Juan de Ávila como hijos y herederos de los dichos Hernando de Ávila y Juana Martínez sus padres por precio y cuantía de los dichos mil doscientos y cincuenta reales en moneda de vellón en que nos hemos ajustado y por ella y en su compra nos ha dado y pagado y confesamos haber recibido de que nos damos por bien contentos, pagados y entregados a nuestra voluntad por haberlos recibido y pasado a nuestro poder con efecto y porque su entrega no parece de presente aunque es cierta renunciamos las leyes de este caso y otorgamos en su favor tan bastante carta de pago como a su derecho conviene y desde luego confesamos que los dichos mil doscientos y cincuenta reales es el precio justo que vale la dicha mitad de casa y aunque más valga o valen pueda ahora o en cualquier tiempo de la tal demasía y más valor en cualquier cantidad que sea le hacemos gracia, cesión y donación pura mera perfecta e irrevocable que el derecho llama intervivos con la insinuación y requisitos de derecho necesarios y en este caso renunciamos la ley ultradimidium justiprecio y las hechas en Cortes de Alcalá de Henares y los cuatro años en ellas declarados que se dan al comprador o vendedor para dentro de ellos pedir se rescinda el contrato al precio justo (...) lo otorgamos así ante el presente escribano público y testigos en la ciudad de Valladolid a 
veinte y seis días del mes de abril de mil y seiscientos y setenta y seis años siendo testigos Francisco Rojo maestro de obra prima, Francisco Martínez sastre y Manuel de Solera carpintero, y los otorgantes a quien yo el escribano doy fe conozco lo firmaron los que supieron y por el que no un testigo a su ruego. 


\section{DOCUMENTO 18}

\section{OBLIGACIÓN. JUAN DE ÁVILA ESCULTOR VECINO DE ÉSTA CIUDAD EN FAVOR DE FRANCISCO ENRÍQUEZ Y FRANCISCA DE ARGUELLO SU MUJER DE 832 REALES (26 - ABRIL - 1676)}

A.H.P.V., Leg. 252, f. 52 (1676)

Sépase por ésta pública escritura de obligación vieren como yo Juan de Ávila escultor vecino de ésta ciudad de Valladolid me obligo de pagar realmente y con efecto a Francisco Enríquez y Francisca de Arguello su mujer vecinos de ésta ciudad o quien su poder y derecho hubiere ochocientos y treinta y dos reales de vellón que les estoy debiendo y son por razón de resto de mil doscientos y cincuenta reales en que me vendió la mitad de una casa en que vivo a la calle de Santiago de ésta ciudad como heredera que quedó la dicha Francisca de Arguello de Manuel de Ávila mi hermano ya difunto primer marido que fue de la susodicha que por la otra cantidad a su cumplimiento con más diez ducados de la renta de ella se lo pague a los susodichos cuya venta se otorgó ante el presente escribano y día de la fecha de que de los dichos ochocientos treinta y dos reales me confieso por deudor de ellos y por justo y porque su entrega no parece de presente renuncio las leyes de la non numerata pecunia prueba de la paga y demás de éste caso en forma y pagaré la dicha cantidad en ésta forma la mitad de ella que son cuatrocientos y diez y dos reales para el día fin del mes de agosto que vendrá de éste presente año de setenta y seis y los otros cuatrocientos y diez y dos reales a cumplimiento de dicha cantidad para el día de Pascua de resurrección del año que viene de setenta y siete y si para dichos días y plazos no lo pagare se me pueda ejecutar y ejecute por cualquiera de ellos en virtud de ésta escritura como por llana y guarenticia obligación y por más las costas que se causaren y si me fuere o ausentare de ésta ciudad consiento vaya o envíe persona a su cobranza a la cual pagaré quinientos maravedíes de salario en cada un día de los que en ella se ocupare a razón de ocho leguas por día de ida, estada y vuelta y en éste caso renuncio las leyes que hablan en razón de los salarios porque asimismo se me ejecute como por el principal y para su ejecución y cumplimiento obligo mi persona y bienes muebles y raíces derechos y acciones habidos y por haber y doy poder a las justicias y jueces de su majestad de cualquier parte fuero y jurisdicción que sean a quien me someto perpetuamente al fuero y jurisdicción de los señores alcaldes del crimen de ésta corte y Chancillería de Valladolid corregidor y teniente de ella y a cada uno in solidum renuncio mi propio fuero jurisdicción y domicilio y la ley sit combenerit de jurisdictione omnium judicum recibiéndolo por sentencia pasada en cosa juzgada renuncio todas las demás leyes fueros derechos y privilegios de mi favor con la general del derecho en toda forma. En testimonio y firmeza de lo cual y lo otorgaron ante el presente escribano y testigos en la ciudad de Valladolid a veinte y seis días del mes de abril de mil y seiscientos y setenta y seis años siendo testigos Francisco Rojo maestro de obra prima Francisco Martínez sastre y Manuel de Solera carpintero vecino de ésta ciudad y el otorgante a quien yo el escribano doy fe conozco lo firmó. 


\section{DOCUMENTO 19}

\section{ASIENTO DE APRENDIZ DE MATÍAS ORTIZ MUCHACHO CON JUAN DE ÁVILA $(22$ - FEBRERO - 1677)}

A.H.P.V., Leg. 2.791, f. 58

Sépase por ésta escritura de asiento de aprendiz como yo don Gregorio Partearroyo vecino de ésta ciudad de Valladolid asiento con Juan de Ávila escultor vecino de ésta dicha ciudad de Matías Ortiz Muchacho de edad de doce años poco más o menos para que esté en casa y servicio del dicho Juan de Ávila por tiempo y espacio de siete años que han de comenzar a correr y contarse desde hoy día de la fecha y en el discurso del dicho tiempo ha de asistir en casa y servicio del dicho Juan de Ávila y le ha de dar de comer y ropa limpia y curarle las enfermedades que en el discurso del dicho tiempo tuviere como no pasen de quince días y darle hábil y suficiente de la parte de escultor y no lo estando le he de tener en mi casa hasta que lo esté dándole todos los días lo que ganare un oficial del dicho oficio; y si en el discurso del dicho tiempo hiciere algunas faltas o tuviere alguna enfermedad ha de cumplir al fin de dichos años; y yo el dicho don Gregorio Partearroyo en el discurso del dicho tiempo le he de dar al dicho Matías Ortiz de vestir y calzar y lo necesario para su persona y los tres años restantes se lo ha de dar el dicho Juan de Ávila su amo; y para que le pongan la cama le he de dar un colchón y una manta y cuatrocientos reales de vellón para el día de Nuestra Señora de marzo que vendrá de éste presente año y pasado el dicho día dicho Juan de Ávila me pueda ejecutar por dicha cantidad y si se fuere y ausentare de ésta ciudad le he de enviar y buscar ocho leguas en contorno de ésta dicha ciudad y cada una de las partes por lo que vamos obligamos así lo cumpliremos y pagaremos damos nuestro poder cumplido a las justicias y jueces de su majestad que de las causas de cada uno de nos puedan y deban conocer para que nos apremien a su cumplimiento recibímoslo por sentencia pasada en cosa juzgada renunciamos las leyes que a cada uno nos compete y la general en forma y lo otorgamos así ante el presente escribano y testigos en la ciudad de Valladolid a veinte y dos días del mes de febrero de mil seiscientos y setenta y siete años siendo testigos Alonso Martínez Manuel Díez y Juan de Partearroyo vecinos y estantes en ésta ciudad y los otorgantes que doy fe conozco lo firmaron.

Pago el Sr. D. Gregorio Partearroyo a Juan de Ávila los 400 reales de que dio recibo y lo firmé en 2 de mayo de 1677. 


\section{DOCUMENTO 20}

ARRENDAMIENTO DE LA CASA DONDE VIVE MANUEL DELFÍN POR 9 AÑOS DESDE JUNIO DE 1679 A 38 DUCADOS. LAS MEMORIAS DE ANDRÉS CARREÑO A JUAN DE ÁVILA ESCULTOR (7 - ENERO 1679)

A.H.P.V. Leg. 2.724/3, f. 120

[NO EXISTE NADA DENTRO] 


\section{DOCUMENTO 21}

\section{ARRENDAMIENTO. JUAN DE ÁVILA ARRIENDA A ISIDRO FRANCOS ESPARTERO LA CASA DE LA CALLE QUE TIENE PROPIA EN LA CALLE DE SANTIAGO (27 - ENERO - 1684)}

A.H.P.V., Leg. 2.792, f. 674

Yo Juan de Ávila escultor vecino de esta ciudad doy en renta y arrendamiento a Isidro Francos espartero vecino de ella una casa que tengo mía propia en la calle de Santiago linda casas del Colegio de San Gregorio y de Alonso Martínez por tiempo de seis años que han de correr y contarse desde el día de San Juan de junio que viene de este presente año de ochenta y cuatro en precio de veinte ducados pagados por mitad San Juan y Navidad y me obligo a que en ella se hagan los reparos de que necesita la dicha casa con tal que yo Isidro Francos anticipé para ellos el dinero que importaran el cual se lo hace bueno en cuanta de dicho arrendamiento y en dicha conformidad por dichos seis años no le será quitada dicha casa por más ni menos que otro me dé por ella pena de le dar otra tal casa y en tan buen sitio y lugar y de pagarle las costas y daños que sobre ello se causaren. Presente yo el dicho Isidro Francos espartero que habiendo oído y entendido esta escritura la acepto en todo como en ella se contiene y tomo en renta y arrendamiento de dicho Juan de Ávila dicha casa toda ella de alto abajo sin reservar cosa alguna por dichos seis años y en precio de los dichos veinte ducados los cuales pagaré por mitad San Juan y Navidad que la primera paga será para la Navidad que viene de éste año de ochenta y cuatro y la segunda para el San Juan de junio de ochenta y cinco y en cada una diez ducados y así sucesivamente en adelante hasta ser cumplidos los dichos seis años y haciendo en dicha casa los reparos precisos y necesarios dicho Juan de Ávila he de pagar yo el dinero que fuere necesario e importaren lo cual se me ha de hacer bueno en cuenta del primero año y de dicho arrendamiento y por cada paga que no cumpla se me ha de ejecutar en virtud de ésta escritura y si me ausentare de dicha ciudad pueda enviar persona a la cobranza con quinientos maravedíes de salario que pagaré a la persona que fuere a ella y quien viva o no en dicha casa ha de pagar enteramente dicha renta por cuenta asimismo se me ejecute y a ello ambas partes nos obligamos de cumplir lo que a cada uno toca con nuestras personas y bienes muebles y raíces, habidos y por haber y damos nuestro poder cumplido a las justicias de su majestad de nuestro fuero competente a quien nos sometemos, y a los señores alcaldes del crimen de esta Corte de quienes lo recibimos por sentencia pasada en cosa juzgada, renunciamos nuestro fuero y jurisdicción y demás leyes de nuestro favor, con la general en forma y lo otorgamos así ante el presente escribano y testigos en la ciudad de Valladolid a veinte y siete de enero de mil y seiscientos y ochenta y cuatro años siendo testigos Diego Fernández Pintado, Santiago Álvaro y el licenciado Juan Ruiz otorgantes que yo el escribano doy fe conozco lo firmo ut supra y por el que no un testigo. 


\section{DOCUMENTO 22}

\section{ARRENDAMIENTO PARA LAS MEMORIAS DE CARREÑO DE LA CASA DE LA CALLE DE SANTIAGO POR DOS AÑOS DESDE SAN JUAN DE 84 EN VEINTE Y OCHO DUCADOS CADA AÑO (20 - JULIO $-1684)$}

A.H.P.V., Leg. 2.427, f. 212

Sépase como yo Juan de Ávila escultor vecino de esta ciudad otorgo que tomo en renta y en arrendamiento de Juan de Tejares procurador del número de esta ciudad administrador de las Memorias que fundaron los testamentarios de Andrés Carreño pintor vecino que fue de esta ciudad de la Cofradía del Santísimo Sacramento del Hospital General de esta ciudad y por el poder que suyo tiene para dicha administración otorgado ante el presente escribano de que da fe y como tal arriendo una casa que las dichas memorias tienen en la calle de Santiago en la acera de los pintores toda ella de alto abajo por tiempo y espacio de dos años que comenzaron a contarse desde San Juan de junio pasado de este año de ochenta y cuatro y fenecerán el mismo día del año que viene de ochenta y seis [ILEGIBLE] y lo otorgaron así en la ciudad de Valladolid a veinte de julio de mil seiscientos y ochenta y cuatro años siendo testigos Juan Mir Martínez, Isidro Álvarez y Lorenzo de Aguirre vecinos de esta ciudad y los otorgantes que yo el escribano doy fe conozco lo firmaron. 


\section{DOCUMENTO 23}

\section{ARRENDAMIENTO. JUAN DE ÁVILA OTORGA ARRENDAMIENTO DE UNA CASA EN QUE VIVE EN LA CALLE DEL CAMPO A FAVOR DE JUAN DE TEJARES ADMINISTRADOR DE LAS MEMORIAS DE ANDRÉS CARREÑO (29 - JULIO - 1686)}

A.H.P.V., Leg. 2.827, f. 52 (1686)

Sépase como yo Juan de Ávila maestro de arquitectura vecino de esta ciudad otorgo que tomo en renta y arrendamiento de Juan de Tejares procurador del número de esta ciudad como administrador de las memorias que fundó Andrés Carreño en el Hospital General de esta ciudad con casa que está en la calle del Campo de ella en que al presente vivo que es propia de dichas memorias toda de alto abajo por tiempo y espacio de dos años que comienzan a correr y contarse desde el día de San Juan de junio pasado de este presente año de ochenta y seis en adelante en precio y cuantía de veinte y ocho ducados cada un año pagados por mitad Navidad y San Juan que la primera paga que tengo de hacer es de catorce ducados es para el día de Navidad que vendrá fin de este dicho año y la segunda de otra tanta cantidad para el día de San Juan de junio del año que viene de ochenta y siete y así sucesivamente hasta el dicho día de San Juan de ochenta y ocho que es cuando fenece éste arrendamiento puesto y pagado en esta ciudad en casa y poder del dicho Juan de Tejares a mi costa y riesgo pena de ejecución y costas de la cobranza y si no pagare las dichas cantidades a los dichos plazos se me pueda ejecutar en virtud de esta escritura como por llana y guarenticia obligación de plazo pasado las cuales he de pagar quien viva o no la dicha casa, y si me fuere o ausentare de esta ciudad pueda enviar una persona a la cobranza con salario de quinientos maravedíes que me obligo de pagar a que a ella fuere así en los de la ida, estada y vuelta a razón de ocho leguas por día y por lo que montaren dichos salarios y costas quiero ser ejecutado como por el principal. Presente el dicho Juan de Tejares como tal administrador y en virtud del poder general que tiene de los patronos de dichas memorias que es notorio acepto esta escritura según y cómo en ella se contiene y se obligó a que durante los dichos dos años le será al dicho Juan de Ávila cierta y segura la dicha casa no quitada por más ni por menos que otra persona de por ella pena de le dar otra tal y tan buena y en tan buena parte lugar y pagarle las costas y daños que se le siguieron y ambas partes cada uno por lo que les toca se obligaron a cumplir el dicho Juan de Ávila con su persona y bienes y el dicho Juan de Tejares obligó los bienes de dichas memorias dieron poder a las justicias de su majestad y en especial se sometieron a cualquiera de los señores alcaldes del crimen de esta parte y Chancillería recibieronlo por sentencia pasada en cosa juzgada renunciaron su propio fuero y privilegio jurisdicción y domicilio y todas las demás leyes, fueros y derechos de su favor y la general en forma y lo otorgamos así en la ciudad de Valladolid a veinte y nueve de julio de mil seiscientos y ochenta y seis años siendo testigos Joseph Morales Lorenzo de Aguite y Andrés Cuadrado vecinos de esta dicha ciudad y los otorgantes a quien yo el escribano doy fe conozco lo firmaron. 


\section{DOCUMENTO 24}

\section{ARRENDAMIENTO $(20$ - JUNIO - 1689)}

A.H.P.V., Leg. 2.430, f. 193

Sépase como yo Jacinto Mayo pintor vecino de esta ciudad tomo en renta y arrendamiento de la Cofradía del Santísimo Sacramento del Hospital General de esta ciudad patrona de las Memorias de Andrés Carreño y de Juan de Tejares procurador del número de esta ciudad administrador de dichas Memorias en virtud de poder que suyo tiene para dicha administración y cobranza de sus rentas otorgadas ante el presente escribano de que doy fe y en su virtud arriendo una casa que las dichas Memorias tienen en la calle de Santiago de esta ciudad frontero de las tapias del Convento de San Francisco en que al presente vive Juan de Ávila escultor vecino de esta ciudad toda la dicha casa de alto abajo por tiempo y espacio de dos años que han de comenzar a correr y contarse desde el día de San Juan de junio que vendrá de este año de ochenta y nueve y fenecerán el mismo día del señor San Juan de junio del año que viene de noventa y uno en precio cada año de veinte y cuatro ducados que me obligo de pagar a la dicha cofradía y al dicho Juan de Tejares su administrador y a quien adelante lo fuere y su poder hubiere por mitad Navidad y San Juan y la primera paga que tengo de hacer de doce ducados ha de ser para el día de Navidad que vendrá fin de este año de ochenta y nueve y la segunda de otros doce ducados para el día de San Juan del año que viene de seiscientos y noventa y así sucesivamente (...) y lo otorgamos así en la ciudad de Valladolid a veinte de junio de mil y seiscientos y ochenta y nueve años siendo testigos Juan de la Orta, Juan Mir Martínez y Lorenzo de Aguirre vecinos de esta ciudad y los otorgantes a quien yo el escribano doy fe conozco lo firmaron 


\section{DOCUMENTO 25}

\section{ARRENDAMIENTO. PARA LAS MEMORIAS DE ANDRÉS CARREÑO DE QUE ES PATRONA LA SACRAMENTAL DEL HOSPITAL GENERAL CONTRA ISIDRO FERNÁNDEZ DE LA CABEZA PINTOR PRINCIPAL Y FRANCISCO ESCOBEDO PINTOR SU FIADOR $(1-$ DICIEMBRE - 1702)}

A.H.P.V., Leg. 2.953, f. 848

Arrendamiento de una casa en la calle del Campo en que hasta que murió y vivió Juan de Ávila escultor que linda con casas del Convento de Prado y otra de dichas memorias por tiempo de dos años y medio que comienzan desde Navidad fin de 1702 y cumplen San Juan de 1705 a precio de 22 ducados y medio cada año y entra en este arrendamiento toda la dicha casa y un aposento que está en el portal que corresponde a la otra casa y también le tuvo Juan de Ávila.

Sépase por esta escritura de arrendamiento como nos Isidro Fernández de la Cabeza pintor vecino de esta ciudad de Valladolid como principal y Francisco Escobedo asimismo pintor vecino de dicha ciudad como su fiador y principal pagador haciendo como hago de deuda y hecho ajeno mía propia sin que sea necesario hacer excursión ni otra diligencia alguna en los bienes del principal y ambos a dos juntos juntamente y de mancomún a voz de uno y cada uno de nos por sí y por el todo in solidum renunciando como renunciamos las leyes de duobus rex debendi y la auténtica presente hoc quita de fide iusoribus dicha excursión y división de bienes depósito de las expensas y demás del mancomunidad como en ellas se contiene, otorgamos tomamos en renta y arrendamiento de las memorias de Andrés Carreño y de la Cofradía del Santísimo Sacramento y Ánimas del Hospital General de la Resurrección de esta ciudad como patrona de ellas y de Alonso Villares su administrador una casa que está en la calle del Campo de esta ciudad con un aposentillo que está en el portal de ella que corresponde a otra casa de dichas memorias aunque sirve a la declarada que linda con casas del Convento de Prado y otra de dichas memorias toda ella y dicho aposentillo de alto abajo con sus ventanas y salidas usos y costumbres derechos y servidumbres cuantas vienen y la pertenecen en la misma forma que la vivió Juan de Ávila maestro escultor hasta que murió por tiempo y espacio de dos años y medio que comenzarán a correr y contarse el día de Navidad que vendrá fin de este presente año de mil setecientos y dos y fenecerán el día de San Juan de junio de mil setecientos y cinco por precio y cuantía en cada uno de ellos de veinte y dos ducados y medio de vellón pagados por mitad San Juan y Navidad de cada un año puestos y pagados a cada plazo y paga en esta ciudad en casa y poder de la dicha Cofradía como tal patrona o de la persona que fuere y estuviese nombrado a la sazón por administrador de la hacienda y rentas de dichas memorias a nuestra costa con los de la cobranza pena que pasado que sea cualquiera plazo no habiendo cumplido se nos pueda ejecutar y apremiar sólo en virtud de esta escritura sin otro recado alguno como por obligación guarenticia de plazo pasado que la traiga aparejada y al fin de su arrendamiento dejaremos la dicha casa y aposentillo libre y desembarazada tal tan buena y bien reparada como las entrare a vivir yo el dicho principal pagaremos todos los daños y menoscabos con que estuviere a la sazón. (...) ambas partes lo otorgamos así ante el presente escribano y testigos en la ciudad de 
Valladolid a primero de diciembre de mil setecientos y dos años siendo testigos don Juan Antonio González Juan Prieto de Portia y Francisco Rodríguez de los Ríos vecinos y estantes en esta ciudad y lo firmaron los otorgantes a quien yo el escribano doy fe conozco. 


\section{DOCUMENTO 26}

\section{ARRENDAMIENTO QUE HIZO JUAN DE ÁVILA DE UNA VARA DE PORTERO POR TRES AÑOS EN PRECIO DE QUINCE DUCADOS A FAVOR DE SIMÓN CAMEA Y CASTELLANOS (2 - SEPTIEMBRE - 1682)}

A.H.P.V., Leg. 2.741, f. 101

Sépase como nos Simón Bautista Camer y Castellanos vecino de ésta ciudad como principal y Pedro de Villa como su fiador y principal pagador ambos juntos y de mancomún a voz de uno y cada uno de por sí in solidum por el todo renunciando como renunciamos las leyes de la mancomunidad en toda forma como en ellas se contiene otorgo yo el dicho Simón Bautista Camer y Castellanos que tomo de Juan de Ávila vecino de ésta ciudad en renta y arrendamiento por tiempo y espacio de tres años una vara de portero del número de ésta ciudad que vacó por fin y muerte de Manuel Fernández la cual tiene el dicho Juan de Ávila por los días de su vida y dicho tiempo ha de comenzar a correr y contarse desde el día que fuere recibido en ella en precio cada un año de quince ducados dando siempre un año adelantado en cuya conformidad el dicho Juan de Ávila se obliga que la dicha vara por el dicho tiempo y precio le será al dicho Simón Camer cierta y segura y no quitada más ni por el tanto que otra persona le dé pena de pagar las costas y daños que se le siguieren y darle o buscarle otra a su costa y misión

Y yo el dicho Simón Bautista Camer y Castellanos que presente estoy con dicho Pedro de Villa acepto ésta escritura en todo y por todo según y cómo en ella se contiene y me obligo de pagar los dichos quince ducados a los dichos tiempos y plazos contenidos en ésta escritura y donde no quiero y consiento seré ejecutado, y el dicho Pedro de Villa como su fiador y principal pagador dijo que no cumpliendo el dicho Simón Bautista Camer con lo aquí contenido él como su fiador dará y pagará los dichos quince ducados a los plazos contenidos en dicha escritura sin que sea necesario hacer excursión ni división en los bienes del dicho Simón Bautista Castellanos en cuyo testimonio todas las dichas partes por lo que a cada uno toca obligaron sus personas y bienes muebles y raíces habidos y por haber dieron poder a los jueces y justicias del rey nuestro señor de cualquier parte que sean a quienes se sometieron y en especial a los señores alcaldes del crimen de ésta corte, lo recibimos por sentencia pasada en cosa juzgada, renunciaron su propio fuero, jurisdicción y domicilio y las demás leyes fueros y derechos de su favor con la general en forma y lo otorgaron así ante el presente escribano en la ciudad de Valladolid a primero de septiembre de mil y seiscientos y ochenta y dos años siendo testigos Francisco Izquierdo escribano de su majestad Juan Topita Blas Delgado vecinos de ésta dicha ciudad y los otorgantes que yo el escribano doy fe que conozco lo firmaron que doy fe conozco lo firmaron. 


\section{DOCUMENTO 27}

\section{VENTA Y OBLIGACIÓN. MATEO DE CARBALLAS Y SU MUJER Y JUAN DE ÁVILA Y SU MUJER VECINOS DE ESTA CIUDAD (16- DICIEMBRE - 1683)}

A.H.P.V. Leg. 2.792, ff. 667-668

En la ciudad de Valladolid a diez y seis días del mes de diciembre de mil y seiscientos y ochenta y tres años ante mí el escribano y testigos parecieron presentes Mateo de las Carballas y María Rubio su mujer de la una parte y de la otra Juan de Ávila y Francisca de Ezquerra su mujer vecinos todos de esta ciudad, y dijeron que por cuanto los otorgantes tienen tratado entre sí que los dichos Mateo de las Carballas y su mujer han de vender a los dichos Juan de Ávila y Francisca Ezquerra la tienda que tienen hecha y fabricada en la casa que viven en la calle del Campo que son propias de las memorias que fundó Andrés Carreño y en que vive el presente escribano con todas las mercaderías de joyería y especería que en ella hay y en la trastienda de ella y con los pesos, ollas, mesas y demás que tienen sin reservar cosa ni género alguno salvo un peso grande de cobre que dijeron no ser suyo. La cual dicha tienda con todas las dichas mercaderías y géneros referidos por la presente se lo venden por precio y cuantía de mil y trescientos y cincuenta reales de vellón para que sea todo suyo y usen de ello como cosa suya propia por cuanto así estamos convenidos en dicha cantidad y por cuanto los han de pagar en cierta forma y como satisfechos Mateo Caballas y su mujer de la formalidad de la paga de dichos mil trescientos y cincuenta reales que ha de hacer dicho Juan de Ávila y su mujer se desisten y apartan del derecho y acción que tienen a dicha tienda y mercaderías y confesando como confesaron ser el justo precio y valor que en sí tienen la dicha cantidad y caso que más valgan les hacen gracia y donación en toda forma. Presentes los dichos Juan de Ávila y Francisca Ezquerra y su mujer que habiendo oído ducha escritura y mediante el trato que tienen hecho la acera como en ella se contiene y toma en venta dicha venta y mercaderías y demás cosas que en ella y su trastienda hay de los dichos Mateo Carballas y su mujer excepto un peso grande de cobre que va exceptuado en dicha cantidad de mil trescientos y cincuenta reales y habiendo precedido entre todos los otorgantes de marido a mujer la licencia y solemnidad en derecho necesaria y aceptación de ella en forma para lo que cada una de las partes van obligados los dichos Juan de Ávila y su mujer se obligan de pagar los dichos mil y trescientos y cincuenta reales a los dichos Mateo Carballas y su mujer y a quien su poder y derecho tenga en esta forma los ciento reales luego en contado y cuatrocientos reales para la Pascua de Flores que viene de seiscientos y ochenta y cuatro y otros cuatrocientos reales para el día de San Miguel de septiembre de dicho año y los cuatrocientos y cincuenta reales restantes para el día de Navidad que viene de dicho año de ochenta y cuatro y si en cada uno de dichos plazos y pagas referidas no lo cumplieren y pagaren se les ha de ejecutar en virtud de esta escritura (...) y lo otorgaron así ante mí dicho escribano siendo testigos Damián Díez, Manuel Díez y Antonio Ortiz vecinos y estantes en esta dicha ciudad y los otorgantes que yo el escribano doy fe conozco lo firmaron los que supieron y por los que no un testigo. 


\title{
DOCUMENTO 28
}

\section{ESCRITURA DE CONCIERTO PARA LA REALIZACIÓN DE UN RETABLO PARA LA IGLESIA PARROQUIAL DE CIGALES (30 - AGOSTO - 1685)}

\begin{abstract}
A.H.P.V., Leg. $15.030^{2}$
En la villa de Cigales a treinta días del mes de agosto de 1685 ante mí el escribano y testigos parecieron de una parte el licenciado D. Francisco Pinacho y Pareja canónigo de la santa iglesia de la ciudad de Palencia y vecino de dicha ciudad, y de la otra Blas Martínez de Obregón maestro de ensamblaje como principal y Juan de Ávila maestro escultor ambos vecinos de la ciudad de Valladolid como su fiador y principal pagador y juntos y de mano común a voz de uno y cada uno de por sí y sin que sea necesario hacer excursión en los bienes el principal ni otra diligencia $(\ldots)$

Primeramente con condición que el dicho retablo ha de llevar cuatro repisas principales de talla con basa y sotabasa tallados todos los miembros bajos.

Con condición que en el dicho retablo ha de ver su custodia con dos columnas salomónicas para poner el sagrario y encima de la puerta una tarjeta y dos arbotantes a los lados.

Es condición que el primer cuerpo a de llevar 4 columnas salomónicas con sus pilastras capiteles y basas enteras con sus entre columnas y su recuadro tallado y su repisa para el santo que eligiere el dicho señor Canónigo (...).

Ha de llevar sus pisos modillones (...) forma arte y todos los miembros (...) según se estila.

Es condición que el cuadro del segundo cuerpo ha de estar tallado con su tarjeta con remate y la clave de la cornisa en la forma conforme a arte.

Y por el dicho retablo que tengo que hacer según las dichas condiciones y siendo del gusto de del señor Obispo de la ciudad de Valladolid y del dicho Francisco Pinacho y de maestro o maestros si quisieren que le vea se me han de dar los dichos cuatro mil reales pagados a 500 reales el día del otorgamiento de esta escritura (...).

Luego se da por bueno, aunque las haya y no me lo pagando le pueda apremiar al dicho canónigo en virtud de esta escritura y asimismo es condición que el dicho retablo le tengo de fabricar en la dicha ciudad de Valladolid y acabado el dicho don Francisco Pinacho le ha de traer a la dicha iglesia por su cuenta.

Es condición que he de hacer el marco en blanco y tallado y un escañito con dos asientos todos los cuales dichas condiciones insertas e incorporadas nos los dichos Blas Martínez de Obregón y Juan de Ávila nos obligamos de las guardar y ejecutar según y cómo en ellas se menciona ya que pasado el dicho día de San Juan de Junio (...).
\end{abstract}

$2 \quad$ URREA FERNÁNDEZ, Jesús: Catálogo Monumental de la provincia de Valladolid. Tomo XX. Antiguo partido judicial de Valoria la Buena, Diputación de Valladolid, Valladolid, 2004, p. 50. 


\section{DOCUMENTO 29}

\section{ESCRITURA DE CONCIERTO. ALONSO MANZANO Y CONSORTES VECINOS DE ESTA CIUDAD Y MAESTROS ENSAMBLADORES Y ESCULTORES EN ELLA CON EL HOSPITAL DE SAN JUAN DE DIOS (7 - FEBRERO - 1687)}

A.H.P.V., Leg. 2.328, ff. 272-273

Lo que se concierta entre el Reverendísimo Padre prior de los hijos del convento y hospital de Nuestra Señora de los Desamparados orden de San Juan de Dios extramuros de esta ciudad de Valladolid juntos en su capítulo en la parte acostumbrada donde se suelen juntar a tratar y conferir las cosas tocantes al bien y utilidad del dicho convento y hospital llamados para este efecto por señal de Campana estando presentes el Reverendísimo Padre fray Gregorio del billar prior y provincial de este convento fray Francisco Álvarez Acebedo fray Andrés Lara fray Joseph Antonio Bernal fray Bartolomé Sobrino que confesaron ser la mayor parte de los religiosos que al presente tiene y por los ausentes enfermos e impedidos y que por tiempo fueren prestaron caución en forma de que estarán y pasaran por lo contenido en esta escritura y no lo contradirán debajo de expresa obligación que hacen de sus bienes y rentas de la una parte y de la otra Alonso Manzano Bernardo de Carvajal Juan Correas maestros ensambladores y Juan de Ávila escultor vecinos de esta ciudad juntos de mancomún a voz de uno u cada uno de por sí in solidum por el todo renunciando las leyes de duobus rex y la auténtica presente hoc ita de fide iusoribus beneficio y remedio de la excursión y división de bienes y las demás de la mancomunidad como en ellas se contiene, dijeron que el dicho convento y hospital, deseando el mayor realce y adorno del culto divino ha resuelto con el permiso y licencia del dicho Reverendísimo Padre Provincial y prior de este convento se haga un nuevo retablo para el sitio de la capilla mayor de dicho convento. Por estar el que al presente tiene muy antiguo y para que con más perfección se ejecute sea hecho traza con sus medidas que firmada del dicho Reverendísimo Padre provincial y de los dichos otorgantes que queda en su poder para que conforme a ella puedan hacer la fábrica en el precio y forma que aquí se dirá poniéndolo en efecto se obligan con sus personas y bienes muebles y raíces habidos y por haber debajo de la dicha mancomunidad y renunciación de leyes a que harán y fabricarán por su cuenta y riesgo a toda costa en blanco el dicho retablo tallado como lo demuestra la traza y las imágenes de bulto que en él se han disponer, todo ello en la forma y con las condiciones siguientes:

Que la madera de que le han de hacer y fabricar de ser de Soria y seca y limpia lo más que se pudiere y de satisfacción traerla a su costa a esta ciudad.

Que el pedestal que sube hasta la mesa de altar ha de ser de madera ensamblado metido sus collarinos en ranura conforme lo muestra la traza y las dos puertas en la misma forma que han de abrir a la parte de adentro llevando su cestón y tambanillo.

Que el pedestal principal ha de tener seis repisas las cuatro que reciban las columnas y las dichas dos el marco principal con su respaldo adornado lo que descubriese la custodia y los dos subientes a los lados conforme demuestra la dicha traza.

3 GARCÍA CHICO, Esteban: Documentos para el estudio del arte en Castilla. 2, Escultores, Universidad de Valladolid, Valladolid, 1941, pp. 352-354. 
Que todo el ornato de la caja principal ha de ser conforme demuestra dicha traza y la columna que recibe la imposta ha de ser en la forma que va puesta en dicha traza arrepisando en el piso de la caja principal. El fondo ha de coger todo el transparente dejando su forma para echar puesta o vidriera y el fondo de la caja alta coger el macizo de la pared ha de estar apeinazado y se ha de rozar en el arco de la parte de fuera un cuarto de pie. Por razón de que la cortina se embeba en el retablo con su trono que se ha de hacer de talla quedando dicha cortina embebida en la parte de arriba.

Que el cuerpo principal se ha de ejecutar que los dos muros que ciñen junto a él albañilería revestidos conforme se demuestra en la traza y las columnas en la misma conformidad con sus basas aticurvas y capiteles corintios compuestos las pilastras ensambladas con sus basas y capiteles y las entrecalles con sus subientes como lo demuestra la traza los intercolumnios conforme señala en dicha traza y en cada uno de ellos sus efigies que han de ser de escultura de todo relieve y a satisfacción y conforme a arte el uno de San Joseph con el niño Jesús en los brazos y en la derecha mano la vara que se ha de poner en el nicho de la mano derecha del alto correspondiente a él, el dicho de Santo Domingo de Guzmán con su insignia que se ha de poner al lado de la epístola correspondiente al nicho donde se ha de poner.

En la custodia se ha de poner una efigie de la fe con el Santísimo en la mano, vendados los ojos de alta tercia de alto más o menos lo que le correspondiere. Y en el último cuerpo en las dos cajas que están en él se han de poner en el lado del evangelio el arcángel San Raphael con el escapulario y capilla de dicha orden, y en la del lado de la epístola San Carlos Borromeo con las vestiduras de cardenal y en la mano una cruz con un santo bulto y ambas efigies cada uno correspondiente a las cajas donde han de estar.

En el cerramiento en la tarjeta dos niños de bulto de todo relieve desnudo con sus bandas conforme al cabimiento que hubiese en dicho sitio y en dicha tarjeta se ha de poner las armas de la religión como lo demuestra la traza y dichas imágenes de bulto ha de ser su fábrica por cuenta de dichos maestros juntamente con la demás obra del dicho retablo, y las dos imágenes que al presente están en el retablo de dicho convento la una de Nuestra Señora y la otra de Nuestro Padre San Juan de Dios son las que se han de ponerse. En los otros dos nichos de dicho retablo.

La cornisa principal y toda la demás obra ha de ser ensamblada a la obra guardando sus perfiles y medidas con forme está en la traza y diez y seis frisos con sus doce modillones y demás ornato que dicha traza demuestra.

Los intercolumnios así del primero como del segundo cuerpo han de ser en la forma que van dispuestos o como mejor convenga con sus repisas u tarjetas en la coronación y sus marcos de tarjetas enredadas como se dispone en la traza.

El pedestal del segundo cuerpo sea de escultura en la forma que va dispuesto en dicha traza guardando sus macizos y disminuciones con sus frisos lo que vuelve del fondo y la parte a que ciñe la albañilería en el macizo de la dicha columna un remate que sea como mejor convenga.

Las columnas pilastras y boquillas en la misma conformidad que va referido subiendo toda la obra como lo demuestra dicha traza.

La custodia ha de tener seis columnas en la misma conformidad rebutidas y guarnecidas como la demás obra con sus arbotantes que reciban los arcos y en los arcos en la clave tarjeta y arquillos tallados y en los arcos sus enjutas de talla y en la parte interior su anillo redondo de pechinas cuadradas y en ellas follaje de talla y para cerrarla han de subir seis cartelas adornadas de buena talla y esto ha de ser muy calado porque no encubra los pies de la imagen y ha de tener 
su hueco y forma para descubrir el Santísimo Sacramento en la custodia que tiene el convento de una vara de alto con su tramoya con forme mejor convenga y en el pedestal se ha de hacer un sagrario para que esté su divina majestad de continuo.

Toda la dicha obra así de ensamblaje escultura y talla han de hacerse ejecutar en la forma referida y conforme a arte y poner y asentar el retablo por su cuenta conforme a lo que les toca respectivo a su arte y habilidad de maestros que han de ver y reconocer las dichas condiciones traza y lo fabricado y dicha fábrica se ha de hacer y ejecutar dentro de este dicho convento donde ha de estar el obrador y taller y se ha de dar sitio para ello y para recoger lo que se obrase, y se ha de dar acabado en dicha perfección asentado y puestas las imágenes que van referidas para el día quince de agosto de este presente año y de mil seiscientos y ochenta y siete y a ello han de poder ser apremiados por todo rigor de derecho y no lo cumpliendo pueda dicho Convento buscar artífices que lo hagan y por lo que más costase así de ensamblaje como de escultura de la cantidad que se les ha de dar que irá declarada y por la demasía que tuvieren recibido en dinero de lo fabricado puedan ser ejecutado en virtud de esta escritura como por garantía y llana obligación y todos los daños que de no lo cumplir resultaren contra dicho convento ha de ser por su cuenta.

El dicho Reverendísimo Padre provincial y religiosos de dicho convento y hospital se obligan con los bienes y rentas del que tiene y tuviere a que por toda la dicha obra han de material como de manufactura pagaran a los dichos Alonso Manzano Bernardo de Carvajal Juan Correas y Juan de Ávila cuatro mil cuatrocientos reales de vellón alzadamente los un mil reales que recibieron de contado de que otorgan a favor de dicho convento y hospital carta de pago en forma con renunciación de las leyes de la entrega y prueba de ella por no parecer de presente aunque cierta y los tres mil cuatrocientos reales restantes de consentimiento de todos sean pagados y entregados a los dichos Alonso Manzano y Juan de Ávila a quienes dan poder para ello y con sus recibos ha de haber cumplido dicho convento con la entrega que ha de ser cien reales cada semana que ha de contar desde la en que empezaren a trabajar pagados en fin de cada una en monedas usual y corriente por cuenta y riesgo de este convento puesto en esta ciudad con toda puntualidad de forma que no se dé lugar a que cese la obra ni dejen de trabajar los oficiales y no lo cumpliendo pasado cada paga consiento sea dicho convento ejecutado en virtud de esta escritura como por garantía y llana obligación y no la tengan en continuar dicha obra y todos los daños y pérdidas que se les siguiere de la detención de las pagas ha de ser por cuenta de este convento y siempre poder se obligado al cumplimiento, y se declara que han de quedar reservados de los dichos tres mil y cuatrocientos reales que se restan quinientos reales que estos no se han de poder pagar hasta que dicho retablo e imágenes esté todo acabado y en perfección y asentado y vístose por maestros del arte y declarado haber cumplido y habiéndose cumplido con lo referido se han de dar y entregar a los dichos Alonso Manzano y Juan de Ávila. $\mathrm{Y}$ no se han de poder hacer ningunas mejoras en dicha obra por precisas que sean sin consentimiento y permiso de dicho Reverendísimo Padre provincial prior de este convento y si de dicha manera las hicieran las han de dejar estantes sin que por ello se les haya de dar maravedíes ninguno.

Lo aquí contenido ambas partes se obligan de guardar y cumplir inviolablemente con la forma y cómo va expresado en esta escritura (...) y lo otorgaron así ante mí él escribano en la ciudad de Valladolid a siete días del mes de febrero de mil y seiscientos y ochenta y siete años siendo testigos Manuel de la Torre y Ballesteros Pedro Cerezal y Francisco Ibarra vecinos de esta ciudad y los otorgantes que doy fe que conozco lo firmaron. 


\title{
DOCUMENTO 30
}

\author{
PODER. JUAN DE ÁVILA ESCULTOR Y BENTURA SEDANO \\ CABALLERO SU MUJER VECINOS DE ESTA CIUDAD A CATALINA \\ CABALLERO SU TÍA (30 - MAYO - 1690)
}

A.H.P.V., Leg. 2.855, ff. 179-180

Sépase por esta pública escritura de poder como nos Juan de Ávila escultor de esta ciudad de Valladolid y Bentura Sedano Caballero marido y mujer premisa la licencia y aceptada de ella entre nos en tal caso necesaria decimos que por cuanto Juana Caballero mujer que fue de Pedro de Soto vecino de la villa de Castrojeriz y tía carnal de mí la dicha Bentura Sedano Caballero pasó de esta presente vida abintestato por cuya causa sus bienes y hacienda me tocan y pertenecen como su heredera por no haber dejado otro más legítimo y para que se recobren estamos de acuerdo de dar poder para dicho efecto y ponerlo en ejecución en la vía y forma que podemos y mejor haya lugar de derecho otorgamos que damos todo nuestro poder cumplido el que de derecho se requiere y es necesario a Catalina Caballero mi tía vecina de la ciudad de Palencia con la vista expresa de que le pueda sustituir una y más veces revocarlos, sustituirlos y nombrar otros de nuevo especialmente para que por nos y en nuestro nombre y representando nuestras propias personas parezcan ante la justicia de la dicha villa y los demás tribunales que convenga y pida se me declare a mí la dicha Bentura Sedano Caballero por heredera única de la dicha Juana Caballero y declarada pida se la den y entreguen en mi nombre todos los bienes muebles y raíces que por muerte me hubieren quedado y tocaren a dicha herencia aceptándole con beneficio de inventario y no de otra forma y que de ellos se dé satisfacción de las deudas que hubiere dejado causadas y en mi nombre pueda tomar posesión en toda forma de los dichos bienes y arrendarlos a la persona o personas que le pareciere y por bien tuviere en la cantidad de maravedíes, plazos, consignaciones de pagas que ejecutare otorgando sobre ello las escrituras necesarias con todas las cláusulas, requisitos y circunstancias que para su validación fueren pedidas que en la forma que por la dicha Catalina Caballero tiene hecha y otorgadas las aprobamos y ratificamos y queremos tengan la misma fuerza y validación que si por nosotros fueren hechas y otorgadas y a su otorgamiento presentes fuésemos y de lo que recibiere y cobrare por teniente a la dicha herencia y frutos de ella de cartas de pago o finiquito, costos poderes en causa y las demás que sean necesarias confesando la entrega si no pareciere de presente renunciando las leyes de este caso y sobre la declaración de heredera entrego de los bienes de la dicha herencia y cobranza de sus frutos siendo necesario parezca en juicio ante cualesquiera tribunales y haga pedimentos, requerimiento, embargos, excursiones, protestas, recuso jueces, letrados, escribanos, jure las recusaciones, haga juramentos, apartamientos, informaciones, apelaciones, súplicas, contradicciones que convengan, transacciones, apartamientos y remisiones y todo lo demás que fuere necesario y lo mismo que nosotros pudiéramos hacer yendo presentes (...) y lo otorgamos así ante el presente escribano y testigos en la ciudad de Valladolid a treinta días del mes de mayo siendo testigos el licenciado D. Juan Delfín presbítero, Francisco Antonio de Colinas escribano real y Juan de Alba vecinos de esta ciudad y los otorgantes que yo el escribano doy fe conozco lo firmó el que supo y por el que no a su ruego un testigo. 


\section{DOCUMENTO 31}

\section{PODER. JUAN DE ÁVILA ESCULTOR Y SU MUJER A FRANCISCO $\underline{\text { ARTACHO }}(12$ - JULIO - 1690)}

A.H.P.V., Leg. 2.855, ff. 328-329

Sépase por esta pública escritura de poder como nos Juan de Ávila escultor vecino de esta ciudad de Valladolid y Bentura Sedano Caballero marido y mujer premisa la licencia y aceptación de ella entre nos en tal caso necesaria decimos que por cuanto Juana Caballero mujer que fue de Pedro de Soto vecino de la villa de Castrojeriz y tía carnal de mí la dicha Bentura Sedano Caballero pasó de esta presente vida abintestato por cuya causa sus bienes y hacienda me tocan y pertenecen como su heredera por no haber dejado otro más legítimo y para que se recobren estamos de acuerdo de dar poder para dicho efecto y poniéndolo en ejecución en la vía y forma que podemos y mejor haya lugar de derecho otorgamos que damos todo nuestro poder cumplido el que de derecho se requiere y es necesario a D. Francisco Artacho vecino de la villa de Castrojeriz con cláusula expresa de que le pueda sustituir una y más veces revocar los sustitutos y nombrar otros de nuevo especialmente para que por nos y en nuestro nombre y representando nuestras propias personas parezcan ante la justicia de la dicha villa y los demás tribunales que convenga y pida se me declare a mí la dicha Bentura Sedano Caballero por heredera única de la dicha Juana Caballero y declarada pida se la den y entreguen en mi nombre todos los bienes muebles y raíces que por su muerte hubieren quedado y tocaren a dicha herencia aceptándola con beneficio de inventario y no de otra forma y que de ellos se dé satisfacción de las deudas que hubiere dejado causadas y en mi nombre pueda tomar posesión en toda forma de los dichos bienes y arrendarlos a la persona o personas que le pareciere y por bien tuviere en la cantidad de maravedíes, plazos, consignaciones y pagas que ajustare otorgando sobre ello las escrituras necesarias con todas las cláusulas, requisitos y circunstancias que para su validación fuere pedidas que en la forma que por la dicha Catalina Caballero fueren hechas y otorgadas las aprobamos y ratificamos y queremos tengan la misma fuerza y validación que si por nosotros fueran hechas y otorgadas y a su otorgamiento presentes fuéremos y de lo que recibiere y cobrare perteneciente a la dicha herencia y frutos de ella dé cartas de pago, finiquitos, gastos, poderes en causa propia y las demás que sean necesarias confesando la entrega si no pareciere de presente renunciando las leyes de este caso y sobre la declaración de heredera reintegro de los bienes de la dicha herencia y cobranza de sus frutos siendo necesario parezca en juicio ante cualesquier tribunales y haga pedimentos, requerimientos, embargos, excursiones, protestas, recuse jueces, letrados, escribanos, jure las recusaciones, haga juramentos, apartamentos e informaciones, apelaciones, súplicas, contradicciones que convenga, transacciones, apartamientos y remisiones y todo lo demás que fuere necesario y lo mismo que nosotros pudiéramos hacer siendo presentes que para todo lo referido y lo demás en ella anejo y dependiente la damos éste poder con libre y amplia y general administración y relevación en forma y también se le damos para que si pareciere deberse partir los bienes de la dicha herencia entre otras personas que tengan el mismo derecho a ella que tengo yo la dicha Bentura Sedano Caballero estando declarado pido se haga cuenta y partición nombrando para dicho efecto contador y pidiendo que los demás interesados también y que no lo haciendo se nombre de oficio y hechas y aprobadas lo que nos tocare lo perciba y cobre como 
va dicho que cuantas circunstancias son necesarias las hemos aquí por expresas como si a la letra lo fueran y a su cumplimiento y lo que en su virtud se hiciere obligamos nuestras personas y bienes habidos y por haber y lo otorgamos así ante el presente escribano y testigos en la ciudad de Valladolid a doce días del mes de julio de mil y seiscientos y noventa años, siendo testigos licenciado D. Juan Delfín presbítero, Francisco Antonio de Colinas escribano real y Juan de Alba vecinos de esta ciudad y los otorgantes que yo el escribano doy fe conozco lo firmó el que supo y por el que no a su ruego un testigo. 


\section{DOCUMENTO 32}

\section{ESCRITURA DE OBLIGACIÓN (25 - OCTUBRE - 1694)}

A.H.P.V., Leg. 2.433, f. 415

En la ciudad de Valladolid a veinte y cinco de octubre de mil y seiscientos y noventa y cuatro años ante mí el escribano y testigos parecieron Sebastián de Olmedo y Manuel de Velicia vecinos de la villa de Traspinedo y regidores de ella y dijeron que por cuanto Francisco de Tudanca como principal y Juan de Ávila escultor vecino de esta ciudad como su fiador y de mancomún hicieron escritura en que se obligaron de hacer la talla y escultura del retablo de la iglesia de dicha villa y por no haber cumplido el dicho Francisco de Tudanca se convino y concertó el dicho Juan de Ávila con la dicha villa como tal fiador de que proseguiría en la dicha obra y con efecto prosiguió e hizo la mayor parte de talla y hechuras de escultura y por no poder acabarlo todo como estaba obligado y por excusar pleitos hubo nuevo concierto en que por razón de lo que faltaba cumpliese con hacer una hechura de un Santo Cristo y dos remates y dos festones que cuelgan a los lados de los arbotantes de dicho retablo y dos tarjetas que caen encima de las hechuras de Santa Teresa y Santa Catalina todo lo cual está hecho y se ha entregado hoy día de la fecha a los otorgantes en nombre de dicha villa de que se dieron por entregados a su voluntad y otorgaron carta de pago con renunciación de las leyes de la entrega en forma y con ello confiesan estar enteramente cumplido con todo lo que dicho Juan de Ávila como tal fiador estaba obligado para no le pedir otra cosa en ningún tiempo y para mayor seguridad de lo susodicho se obligaron de que dentro de ocho días primeros siguientes de la fecha de esta escritura en adelante traerán escritura de apartamiento de todo lo referido otorgada por dicha villa y la entregarán al dicho Juan de Ávila y no lo cumpliendo así pasado el dicho término se les pueda apremiar a ello a que obligaron sus personas y bienes muebles y raíces habidos y por haber dieron poder a las justicias de su majestad y en especial a los señores alcaldes del crimen de esta corte a quien se sometieron y lo recibieron por sentencia pasada en cosa juzgada (...) y todos tres lo otorgaron así siendo testigos Juan Ruiz de Quinta, Juan Mayo y Luis Jiménez vecinos de esta ciudad y los otorgantes a quien yo el escribano doy fe conozco lo firmó el que supo y por el dicho Sebastián de Olmedo que dijo no saber a su ruego lo firmó un testigo. 


\title{
DOCUMENTO 33
}

\section{ESCRITURA Y DEPÓSITO. ANTONIA GONZÁLEZ MUJER DE FRANCISCO ROJO A FAVOR DEL CONCURSO Y DE JUAN DE ÁVILA DEPOSITARIO (22 - DICIEMBRE - 1696)}

\author{
A.H.P.V., Leg. 2.641, ff. 1.060-1.061
}

En la ciudad de Valladolid a veinte y dos días del mes de diciembre de mil y seiscientos y noventa y seis años ante mí el escribano y testigos parecieron Francisco Rojo maestro de obra prima y Antonia González su mujer y permita la licencia y aceptación de ella entre los dos en tal caso necesaria dijeron que por cuanto el dicho Francisco Rojo hizo y formó pleito y concurso de acreedores a sus bienes ante la justicia ordinaria de esta ciudad y ante mí el escribano y en él dio memorial de bienes y de acreedores y se mandaron poner y depositar en Juan de Ávila escultor vecino de esta ciudad, el cual otorgó dicho depósito y estándose siguiendo el dicho concurso y habiendo salido a él como acreedora la dicha Antonia González por trescientos ducados de su dote y cien ducados de arras conforme a la carta de pago y recibo de dote que presentó se pidió que los bienes del dicho concurso como acreedora de mejor derecho se la entregasen por vía de depósito removiendo el hecho de ellos en el dicho Juan de Ávila y por auto de siete de febrero del año pasado de mil y seiscientos y noventa y uno se mandó que tasados los bienes del dicho concurso por las tasaciones se entregare a la dicha Antonia González por vía de depósito afianzándole con su crédito en cuyo cumplimiento se tasaron y valuaron por tasadores e importan su valor dos mil cuatrocientos y once reales como parece de las dichas tasaciones en cuya conformidad el dicho Juan de Ávila entregó a los otorgantes todos los dichos bienes de que así tenía otorgados dos depósitos el uno de cinco de abril del año pasado de mil y seiscientos y noventa y el otro en veinte y tres de octubre del dicho año ambos ante Antolín Álvarez de Salcedo escribano de su majestad y aunque había hecho la dicha entrega real y verdaderamente no se le había dado carta de pago ni la dicha Antonia González otorgado el dicho depósito y ahora cumpliendo con lo que les toca. Otorgan por esta escritura que confesase haber recibido del dicho Juan de Ávila todos los bienes que del dicho Francisco Rojo en el susodicho se depositaron y los mismos que en los dichos depósitos se expresan y se tasaron y valuaron por los dichos tasadores como consta de los autos del dicho concurso de que se dan por bien contentos, satisfechos y pagados a su voluntad por los haber recibido y pasado a su parte y poder con efecto y aunque su entrega no parece de presente renuncian las leyes de este caso y otorgar en favor del dicho Juan de Ávila tan bastante carta de pago como a su derecho conviene al que desde luego dan por libre de los dichos depósitos sin que por razón de ellos ni en otra forma se le pueda pedir ni pedirán por los acreedores ni por otra ninguna persona los dichos bienes al cual le sacarán en caso necesario a paz y a salvo indemne de todo y pagarán todas las costas y daños, intereses y menoscabos que sobre ello se le causaren porque quieren y consienten se les pueda compeler y apremiar por todo rigor de derecho en virtud de esta escritura como por guarenticia y llana obligación. Y desde luego la dicha Antonia González debajo de la dicha licencia se constituye por depositaria de los dichos bienes según y cómo se expresa en los depósitos otorgados por el dicho Juan de Ávila y en las tasaciones que de ellos están hechas que importan los dichos dos mil y cuatrocientos y once reales de que nuevamente otorga en favor del dicho concurso tan bastante carta de pago como a su derecho conviene con 
renunciación de las leyes de la entrega por no parecer de presente los cuales dichos bienes se obliga con su dote y arras y bienes gananciales y parafernales y hereditarios tenerlos en su poder a ley de depósito y no acudir con ellos a persona alguna sin licencia y mandado del señor teniente de corregidor de esta ciudad que del dicho pleito conoce y demás señores jueces que a él conocieren pena de los volver a pagar y de incurrir en las que incurren los depositarios que no acuden con los depósitos que en ellos se hacen porque que quiere y consiente se la pueda compeler y apremiar por todo rigor de derecho en virtud de esta escritura como por guarenticia y llana obligación. Y en cumplimiento del dicho auto a la seguridad de todo lo referido hipoteca por especial y expresa hipoteca los dichos cuatrocientos ducados de la dicha su dote y arras que por la dicha carta de pago y obligación a su restitución que tiene presentada en el dicho concurso la tocan y pertenecen de lo cual prohíbe la enajenación en todas maneras y para el cumplimiento de lo contenido en esta escritura dan poder a las justicias y jueces de su majestad de esta ciudad y otras partes a quien se someten y en especial al fuero y jurisdicción del dicho señor teniente de corregidor y de los demás señores jueces que conocieron del dicho pleito ha recibido por sentencia pasada en cosa juzgada renuncian su propio fuero, jurisdicción y domicilio y la ley sit combenerit de jurisdictione omnium judicum y las demás de su favor con la general en forma. Y la dicha Antonia González renuncia las del emperador Justiniano, senatus consultus, Beleyano, toro y partida, nueva y antigua constitución, y las demás del favor de las mujeres de que fue avisada por mí el escribano de que doy fe y como sabedora de ella las renuncio y aparto de su favor para no se aprovechar de ellas en tiempo alguno. Y por ser casada aunque mayor de veinte y cinco años juró por Dios y una cruz en forma haber por firme esta escritura y no ir contra ella alegando fuerza ni inducimiento, lesión ni engaño ni otra causa que impida su cumplimiento antes confiesa la otorga de su libre y espontánea voluntad, sin fuerza ni inducimiento alguno y declara que del juramento no tiene pedido ni pedirá absolución ni relajación a su santidad ni a su nuncio delegado ni otro juez ni prelado que poder tenga para se la conceder y aunque de propio motu la sea concedida de ella no usará y lo otorgaron así ante mí el escribano siendo testigos Juan de Tejares procurador del número, Jerónimo de Santillana y Alonso Álvarez vecinos de esta ciudad y los otorgantes que yo el escribano doy fe conozco lo firmó el que supo y por la que no un testigo. 


\section{DOCUMENTO 34}

\section{CAPITULACIONES MATRIMONIALES ENTRE JUAN ANTONIO DE LA PEÑA MAESTRO ESCULTOR VECINO DE ESTA CIUDAD Y PEDRO DE ÁVILA TAMBIÉN ESCULTOR VECINO DE ELLA SU YERNO (10 - AGOSTO - 1700)}

A.H.P.V., Leg. 2.692, ff. 316-3194

\section{Petición}

Pedro de Ávila maestro escultor vecino de esta ciudad marido y conjunta persona de Da María Lorenza de la Peña mi mujer. Digo que al tiempo y cuanto me hube de casar con la susodicha se otorgó escritura de capitulación matrimonial entre mí y Juan Antonio de la Peña asimismo escultor vecino de esta dicha ciudad mi suegro en razón de dicho matrimonio que pasó por testimonio de Domingo López ya difunto escribano que fue de su majestad y vecino de ella por el año pasado de mil y setecientos y es así que los registros y protocolos de escrituras públicas de dicho escribano paran y existen en poder de Lucrecia Ramos vecina de esta dicha ciudad testamentaria del susodicho y porque necesito un traslado de la dicha escritura. A vuestra majestad suplico mande que la dicha Lucrecia Ramos exhiba en el oficio del presente escribano el protocolo de dicha escritura de capitulaciones matrimoniales para que de ella me dé un traslado signado y en forma para los efectos que hubiere lugar y a que lo haga se apremie a la susodicha que es justicia que pido. Pedro de Ávila.

Auto

Notifíquese a Lucrecia Ramos a que exhiba en el oficio del presente escribano el protocolo de la escritura contenida en esta petición. Y de ella se le dé el traslado que pide signado y en forma para los efectos que haya lugar, el señor alcalde D. Francisco Antonio Francos lo mando en Valladolid a catorce de noviembre del año de mil setecientos y dos y lo señalo. Ante mí Isidro Calderón.

En cumplimiento del auto de suso con que fui requerido, y habiéndose exhibido en mi oficio la escritura de capitulación matrimonial contenida en el dicho auto y petición de esta otra parte, yo Isidro Calderón escribano del Rey nuestro señor y de provincia en la Real Audiencia y Chancillería de esta ciudad de Valladolid hice sacar y saqué un traslado de dicha escritura que su tenor es como le sigue.

\section{Capitulaciones}

Lo que honra y gloria de Dios nuestro señor y para su santo servicio se trata capitula y concierta entre Juan Antonio de la Peña maestro escultor y Francisca de Santiago su mujer vecinos de esta

4 GARCÍA CHICO, Esteban: Documentos para el estudio del arte en Castilla. 2, Escultores, Universidad de Valladolid, Valladolid, 1941, pp. 368-368. 
ciudad por lo que les toca y como padres y legítimos administradores de María Lorenza de la Peña su hija y asimismo la dicha María Lorenza de la Peña de la una parte. Y de la otra Juan de Ávila asimismo maestro escultor vecino de esta dicha ciudad como padre y legítimo administrador de Pedro de Ávila su hijo legítimo y de Francisca Ezquerra su mujer difunta, que está presente por su hecho propio y por lo que a cada uno toca y puede tocar para el matrimonio que con la voluntad de Dios nuestro señor y para su santo servicio tienen tratado y ajustado entre las dichas partes sea de contraer y celebrar entre los dichos Pedro de Ávila y María Lorenza de la Peña. Habiendo precedido la licencia pedida por la dicha Francisca de Santiago al dicho Juan Antonio de la Peña su marido para haber de hacer y otorgar esta escritura de capitulación y lo en ella contenido el cual se la dio y concedió y la susodicha la recibió y aceptó de que yo el escribano doy fe y de ella usando todas las dichas partes capitularon lo siguiente:

Que los dichos Pedro de Ávila y María Lorenza de la Peña se desposarán por palabras de presente que hagan legítimo y verdadero matrimonio y en tiempo debido se velarán según orden de la santa madre iglesia católica romana habiendo precedido las tres canónicas municiones que el santo concilio de Trento dispone y manda, o dispensándose en ello y con las demás solemnidades de derecho necesarias y con licencia del señor obispo o su provisor de esta ciudad y de que así lo cumplan los dichos contrayentes se dan su fe y palabra de uno a la otra y la otra al otro recíprocamente a que quieren ser compelidos y apremiados por todo rigor de derecho y vía ejecutiva y por más las costas y daños que sobre ello se causasen

Los dichos Juan Antonio de la Peña y Francisca de Santiago su mujer ofrecen y se obligan de dar y pagar en dote a la dicha María Lorenza de la Peña su hija para que lleve a dicho matrimonio con dicho Pedro de Ávila que siendo Dios nuestro señor servido ha de ser su marido para ayuda de sus alimentos cargas y obligaciones de dicho matrimonio y por capitales y caudales suyos propios y por cuenta de la herencia paterna y materna que ha de haber la dicha María Lorenza de la Peña y Francisca de Santiago sus padres quinientos ducados de vellón luego que tenga efecto el dicho matrimonio en dinero alhajas de por casa ropa blanca y alhajas de oro y plata que esto han de sumar y montar y no lo cumpliendo consienten se les ejecute y apremie a su paga entrega y cumplimiento por todo rigor de derecho y vía ejecutiva y por más las costas y dando que sobre ellos se causasen.

El dicho Pedro de Ávila desde luego por causa honrosa de dicho matrimonio y atendiendo a la calidad y prendas personales de la dicha María Lorenza de la Peña y por otras muchas causas justas y notorias que a ello les mueven ofrece y dota en arras y dotación proternúpcias a la dicha María Lorenza de la Peña en doscientos ducados de vellón que confiesa caben en la décima parte de sus bienes con que al presente se halla. Y en caso de que no quepan se los sitúa y señala en los que adelante tuviere y adquiriere para que lo haya y lleve en lo mejor y más bien parado de ellos además de su dote y a mayor abundancia desde luego la hace gracia y donación irrevocable de dichos doscientos ducados con todas las cláusulas y circunstancias que para su mayor validación sean necesarias y requieran de derecho.

Que habiendo tenido efecto dicho matrimonio y entregándose por los dichos Juan Antonio de la Peña y su mujer al dicho Pedro de Ávila dichos quinientos ducados en dinero alhajas de por casa y demás a que van obligados se darán cartas de pago y recibo de dicha dote tasadas y valuadas las que fueren en dichas alhajas y ropa blanca en toda forma con obligación de la restitución en cualquiera de los casos que el derecho previene 
Todas las dichas partes cada uno por lo que les toca y van obligados se obligan de lo cumplir con todos sus bienes muebles y raíces habidos y por haber y para que se lo hagan cumplir dan poder a la justicia y jueces que de cada una de sus causas puedan y deban conocer conforme a derecho de quienes lo recibieron por sentencia definitiva de juez competente pasada en autoridad de cosa juzgada renunciaron a todas las leyes fueros y derechos de su labor con la general del derecho que la prohíbe en forma y las dichas Francisca de Santiago y María Lorenza de la Peña su hija por ser mujeres renunciaron las leyes del Beleyano y jurisconsultus y emperadores Justiniano toro y partida y demás de favor de las mujeres de cuyas fuerzas y auxilios yo el presente escribano las avise de que doy fe y como sabedoras de ellas las renunciaron y apartaron de su favor y dicha Francisca de Santiago por ser mujer casada juró a Dios nuestro Señor y a una señal de cruz tal como esta de que para haber de hacer y otorgar esta escritura y lo en ello contenido no ha sido inducida ni atemorizada por el dicho su marido ni otra ninguna persona por hacerla y otorgarla de su libre y espontánea voluntad y que de éste juramento no tiene pedido ni pedirá absolución ni relajación a su santidad su nuncio delegado ni otro juez ni prelado que se lo pueda conceder y si se le concediere de él no usará pena de perjura y de caer en caso de menos valer y dicha María Lorenza de la Peña y el dicho Pedro de Ávila por ser menores de veinticinco años aunque mayores de veinte juraron a Dios nuestro señor y a una señal de la cruz en forma de derecho de haber yo firmé esta escritura en todo tiempo que no irán contra ella en manera alguna porque la otorgan de su libre y espontánea voluntad y confiesan se convierte en su utilidad y provecho pena de no ser oídos en juicio ni fuera de él y pagar las costas y daños que sobre ello se causasen. Y todas las dichas partes cada una por lo que les toca y van obligados lo otorgaron así ante mí el presente escribano en esta dicha ciudad de Valladolid a diez días del mes de agosto de mil y setecientos y siendo testigos Francisco de Santiago Joseph de Ávila y Joseph de Libarona vecinos y estantes en esta dicha ciudad y los otorgantes a quienes yo el escribano doy fe conozco lo firmaron los dichos Juan Antonio de la Peña Juan de Ávila y Pedro de Ávila y porque la dicha Francisca de Santiago y la dicha María Lorenza de la Peña dijeron no saber a su a su ruego lo firmó un testigo. Y es declaración que aunque en esta capitulación el dicho Juan Antonio de la Peña y Francisca de Santiago su mujer por ella se obligan a dar en dote a la dicha María Lorenza de la Peña su hija teniendo efecto dicho matrimonio con el dicho Pedro de Ávila quinientos ducados de vellón en dinero ropa blanca alhajas de oro y plata sea y se entiende les ha de dar los dichos quinientos ducados de vellón en especie de dinero y no en ropa blanca ni ajuares de por casa ni otras alhajas algunas y teniendo efecto dicho matrimonio ha de otorgar carta de pago el dicho Pedro de Ávila como va referido en esta capitulación fecho ut supra testigos los dichos.

Concuerda con el protocolo original de la dicha escritura de capitulación matrimonial que volví a entregar a la dicha Lucrecia Ramos de que doy fe y para que conste en cumplimiento de la dicha petición y auto que va por cabeza y de pedirme de dicho Pedro de Ávila lo signó y firmó en la ciudad de Valladolid a quince días del mes de noviembre del año de mil setecientos y dos. 


\section{DOCUMENTO 35}

\section{OBLIGACIÓN PARA LOS ALCALDES DE LA COFRADÍA DE LA PASIÓN DE ESTA CIUDAD CONTRA SANTIAGO GALINDO Y MANUEL DE ARAUJO VECINOS DE ELLA $(2$ - MARZO - 1702)}

A.H.P.V., Leg. 2.953, f. 334

Sépase por esta pública escritura de obligación como nos Santiago Galindo y Manuel de Araujo hermanos del trabajo vecinos de esta ciudad de Valladolid juntos juntamente y de mancomún a voz de uno y cada uno de nos por sí y por el todo in solidum renunciando como renunciamos las leyes de la mancomunidad, excursión y división de bienes, depósito de las expensas y demás de este caso como en ellas se contiene. Por la presente nos obligamos con nuestras personas y bienes a que por nuestra cuenta y riesgo sacaremos todos los pasos de que se compone el día Jueves Santo que vendrá de este presente año la procesión que celebra la Cofradía de la Sagrada Pasión de Cristo y los llevaremos en la forma ordinaria que se llevan en la dicha procesión por todas las calles que es uso y costumbre y con la regla que siempre van para lo cual tendremos prevenida toda la gente de que se necesitare y en caso que hasta volverlos a la iglesia de la dicha Cofradía de la Sagrada Pasión de Cristo se hubiese causado algún daño en los dichos pasos y sus hechuras ahora sea porque se quiebren o por otro accidente alguno hasta dejarlos en el sitio que se acostumbra lo que costare componer el dicho daño nos obligamos en toda forma a lo pagar de nuestros bienes esto por cuanto hemos ajustado lo referido con Juan de Ávila y Agustín González vecinos de esta ciudad los cuales de mancomún se obligan en la aceptación de esta escritura a que luego que hayamos cumplido como va dicho nos pagarán por el dicho trabajo y ocupación y de el de las demás personas que para ello hemos de buscar y tener prevenidas trescientos y quince reales de vellón en una vez y paga y sin ninguna dilación y con la calidad de que no nos puedan quitar aunque haya otras personas que hagan baja si no es que se nos ha de pagar enteramente la cantidad que va declarada y no cumpliendo por nuestra parte los dichos Juan de Ávila y Agustín González y demás cofrades de la dicha Cofradía puedan buscar personas las que basten y sean necesarias para la conducción y lleva de los dichos pasos en la dicha procesión concertando en las cantidades que les pareciere y si excediera a la referida nos obligamos a pagar dicho exceso por lo cual y para lo que importare cualquiera de los daños que causare en dichos pasos se nos pueda ejecutar sólo en virtud de esta escritura y de cualquier justificación que haya aunque sea corta como por obligación guarenticia de plazo pasado que la traiga aparejada sin otro recado alguno.

\section{Aceptación}

Presentes a lo que dicho es nos los dichos Juan de Ávila y Agustín González vecinos de esta dicha ciudad juntos juntamente y de mancomún voz de uno y cada uno de nos por sí y por el todo renunciando como renunciamos la excursión y división de bienes, depósito de las expensas y demás de la mancomunidad como en ellas se contiene. Aceptamos esta escritura en todo y por todo como en ella se expresa y declara y nos obligamos con nuestras personas y bienes muebles y raíces, derechos y acciones, habidos y por haber a que luego que se haya ejecutado la dicha procesión que celebra la dicha Cofradía de la Sagrada Pasión de Cristo de esta ciudad en esta 
cuaresma y presente año y habiéndose cumplido en el todo por los dichos Santiago Galindo y Manuel de Araujo con lo que van obligados les daremos y pagaremos realmente y con efecto los dichos trescientos y quince reales de vellón en que nos hemos ajustado y concertado con los susodichos por razón de la dicha saca y lleva de pasos todos juntos y en una sola vez y paga puestos en su poder a nuestra costa y riesgo con las de la cobranza y no lo cumpliendo pasada la dicha procesión se nos pueda ejecutar sólo en virtud de esta escritura sin otro recado alguno como por obligación guarenticia de plazo pasado y no hemos de poder admitir baja alguna en la lleva de dichos pasos por ninguna causa cumpliendo los susodichos. Y para el cumplimiento y paga de lo que dicho es todos cuatro damos todo nuestro poder cumplido a las justicias y jueces de su majestad de cualquier parte que sean para que nos lo hagan cumplir como por sentencia pasada en autoridad de cosa juzgada y obligamos las dichas nuestras personas y bienes renunciamos todas las leyes, fueros y derechos de nuestro favor con la general en forma en cuyo testimonio lo otorgamos así ante el presente escribano y testigos en la ciudad de Valladolid a dos de marzo de mil setecientos y dos años siendo testigos Manuel Álvarez, Joseph de Alba y Francisco Fernández vecinos y estantes en esta ciudad y de los otorgantes a quien yo el escribano doy fe conozco lo firmó el que supo y por los que dijeron no saber a su ruego un testigo. 


\section{DOCUMENTO 36}

\section{ESCRITURA DEL RETABLO DE SAN JUAN BAUTISTA DE PESQUERA DE DUERO $(1-$ JUNIO - 1671)}

A.H.P.V., Leg. 14.732

En la villa de Pesquera de Duero a primero día del mes de junio de mil y seiscientos y setenta y un años ante mí el escribano y testigos parecieron Juan Hernández y Pedro de Fuentes vecinos de la ciudad de Valladolid maestros de arquitectura como principales y Miguel de Illana padre del dicho Juan Hernández vecino de la dicha ciudad como su fiador todos tres juntos y de mancomún a voz de uno y cada uno de por sí y por el todo in solidum renunciando como renunciaron las leyes de duobus rex debendi y la auténtica presente hoc quita de iusoribus y las demás leyes de la mancomunidad como en ellas y en cada una de ellas se contiene debajo de las cuales dijeron que por cuanto en la iglesia parroquial del señor San Juan Bautista de esta dicha villa se ha tratado y trata de hacer un retablo en la capilla mayor de ella y altar mayor y para ello se ha pedido licencia al señor obispo de Palencia de esta diócesis y su señoría la ha dado y habiéndose hecho las trazas y condiciones de él y presentándolas ante su señoría por su señoría se cometió el concierto y ajuste de dicho retablo al cura y beneficiados y mayordomo de la fábrica de dicha iglesia y habiendo con los sobre dichos tratados del ajuste se han convenido y concertado en esta manera. Que los dichos maestros han de hacer dicho retablo conforme la traza y condiciones que dicho señor obispo remetió firmadas de su nombre y del dicho Pedro de Fuentes advirtiendo que en la condición de que las columnas estriadas se han de entender que han de ser salomónicas y vestidas de talla entera y en el último cuerpo a los lados las pinturas que tiene la traza han de ser enjutas de talla con que se entiende... doy condiciones se obligan excluyéndolas dos que a mí han de ocupar su lugar. El cual dicho retablo los dichos se obligan a dar acabado ajustado y puesto en el sitio dentro de veinte meses del día de la fecha a vista y satisfacción de maestros peritos en el arte, y la costa de ellos ha de ser por ambas partes, y para el cumplimiento de todo lo referido obligaron sus personas y bienes muebles y raíces habidos y por haber y presente acepta escritura los licenciaos Gaspar Bodigos cura de esta villa Tomás Cardenal vecino de la fábrica de dicha iglesia por sí y por las que adelante fueren obligaron en virtud de la dicha licencia los propios y rentas de la fábrica de la dicha iglesia que por el trabajo de hacer dicho retablo les darán a dichos maestros veintiséis mil reales de vellón que es en la cantidad en que se les ha rematado dicha obra los cuales les darán y pagarán a los plazos y conforme a las condiciones de dicho señor obispo y además de ellas se obligan a darles lo necesario para las pinturas y bulto de San Juan conforme se vayan haciendo de suerte que los que les hicieren tengan lo necesario y habiendo acabado dicho retablo y estando ajustado y asentado se ha de hacer cuentas y si los dichos maestros alcanzaren se les ha de pagar de contado porque dicho ha de ser visto haber caído el plazo y por ello se les pueda ejecutar y ejecute en virtud de esta escritura como por garantía y llana obligación y recíprocamente a dichos maestros si no cumplieren se les pueda obligar y obliguen y al dicho fiador (...) y así lo otorgaron ante mí el escribano siendo testigos Alonso Sarmiento Juan de Páramo Gutiérrez y Joseph Sanz Molo vecinos de esta villa y lo firmaron los otorgantes a quien doy fe conozco. 
Condiciones con que se ha de hacer el retablo de la villa de Pesquera de Duero, hechas por Pedro de Fuentes ensamblador vecino de la ciudad de Valladolid:

$1^{\mathrm{a}} \quad$ Primera condición es, que haya de ser de pino de Canicosa limpio y seco.

$2^{\mathrm{a}} \quad$ Segunda, que ha de ser ensamblador a la veta conforme al arte.

$3^{\mathrm{a}} \quad$ Tercera, que haya de ser moldado conforme a la traza.

$4^{\mathrm{a}} \quad$ Cuarta, que haya de ser tallado y ajustado conforme a dicha traza.

$5^{\text {a }}$ Quinta, que en el arco de la caja principal haya de llevar en la parte de antro seis florones.

$6^{\mathrm{a}} \quad$ Sexta, que los pedestales de las columnas hayan de ser repisas y que donde carga el primer pedestal, se haya de hacer un zócalo de piedra de grano con su moldura de un pie de alto.

$7^{\mathrm{a}} \quad$ Séptima, que en el San Juan que va en la caja del medio ha de ser de escultura de buena mano que corresponda decentemente a la obra del retablo.

$8^{\mathrm{a}}$ Octava, que los demás lienzos contenidos en la traza hayan de ser de pintura a arbitrio del cura, mayordomo y beneficiados de la iglesia en cuanto a las historias y en cuanto a su bondad de la pintura hayan de corresponder a la obra con la misma decencia y proporción.

$9^{a} \quad$ Nona, que la obra del retablo se ha de hacer y fabricar en la dicha villa de Pesquera.

$10^{\mathrm{a}}$ Décima, que al maestro que hiciere esta obra se le haya de dar casa y taller suficiente para fabricarlo.

$11^{\mathrm{a}} \quad$ Once, que se le han de dar al maestro en la primera paga 600 ducados de vellón para pagar la madera o la han de pagar el cura y mayordomo de la iglesia y demás obligados con asistencia del dicho maestro por cuenta de lo que hubiere de haber de la cantidad en que la obra se rematare.

$12^{\mathrm{a}}$ Doce, que si faltare algún dinero para más madera, le hayan de dar al maestro lo que fuere menester o lo han de pagar a los dueños que trajeron la madera.

$13^{\mathrm{a}} \quad$ Decima tercia que se le hayan de dar cada semana 200 reales para alimentar y satisfacer a los oficiales.

$14^{\mathrm{a}} \quad$ Y la décima cuarta que este retablo se haya de dar acabado y ajustado al sitio, en año y medio que empezará a correr desde el día en que se otorgare la escritura.

$15^{\mathrm{a}} \quad \mathrm{Y}$ conforme a la traza y condiciones referidas yo el dicho Pedro de Fuentes lo pongo en veinte y seis mil reales de vellón con que cualquiera otro maestro en quien se rematare esta obra me haya de pagar 600 reales de vellón por la traza y estas condiciones y así lo firmo de mi nombre en Palencia a veinte y cuatro de mayo de mil seiscientos y setenta y un años.

Fdo: Pedro de Fuentes

Fdo: Obispo de Palencia

Notario apostólico que se halla presente de más perfección y testimonio a mi Joseph Sanz Velázquez el... de la villa de Pesquera de Duero y mayordomo seglar que soy de la fábrica de la iglesia parroquial del señor San Juan Bautista de la dicha villa como requiero llamados tres veces y las demás que a la dicha iglesia... y a mí en... convenga a Bartolomé Martínez Montañés maestro de arquitectura estante en esta villa que por cuanto en el sobredicho le ha rematado la obra del retablo de la capilla mayor de dicha iglesia como mejor... dentro de seis 
días que corren y se cuentan desde hoy día de la fecha de éste requerimiento de... del cura y beneficiados de la dicha iglesia conforme a la orden el señor obispo y de no lo cumplir se pregonará en que echar y se dará a la persona que mejor postura haga y toda la que... costa... del lugar de Cogeces del Monte... es y cinco días del mes de octubre de mil y seiscientos y setenta y un años yo el notario notifiqué y ley el requerimiento de la otra parte a Bartolomé Martínez estante en ella en su persona el cual dijo que se le... para en verdad del alegar lo que le convenga y esto respondió y firmó de que doy fe... Francisco Martínez y Felipe Delgado...

Otro

Luego yo el notario di otro requerimiento como el de arriba al señor Bartolomé Martínez esta persona dijo lo que (...).

Otro

Luego yo el notario notifiqué y volví a requerir al señor Bartolomé Martínez en su persona (...) testigos (...) doy fe.

Apartamento de la obra del retablo de la iglesia de San Juan Bautista de esta villa en la capilla mayor de ella. En 29 de octubre.

En la villa de Pesquera de Duero a veintisiete días del mes de octubre de mil y seiscientos y setenta y un años ante mí el escribano y testigos parecieron de la una parte el licenciado Gaspar Bodigos cura de la iglesia parroquial del señor San Juan Bautista de esta dicha villa y Joseph Sanz Velázquez el mayor mayordomo seglar de dicha iglesia parroquial de la una parte y de la otra Bartolomé Martínez Montañés maestro de arquitectura vecino de la ciudad de (...) de Cogeces del Monte jurisdicción de la villa de Cuellar y el dicho maestro de arquitectura dijo que por cuanto en veinte y cinco de este mes se le requirió por (...) Joseph Sanz Velázquez como tal mayordomo viniese dentro de seis días a dar satisfacción del cura y beneficiados (...) tratado en él la obra del retablo de la capilla mayor de dicha iglesia en virtud de bajas de ocho mil reales que en él la hizo y se la admitió el señor obispo de Palencia y cumpliendo con dicho requerimiento viene a dar la fianza ofreciendo como dijo ofrecía a todo el lugar de Cogeces del Monte por sus (...). 


\title{
DOCUMENTO 37
}

\section{LICENCIA PARA EL DORADO DEL RETABLO DE SAN JUAN BAUTISTA DE PESQUERA DE DUERO $(20$ - SEPTIEMBRE - 1677)}

A.H.P.V., Leg. 14.734, ff. 99-104

\begin{abstract}
Al licenciado Gaspar Bodigos (...) cura de nuestra iglesia de la villa de Pesquera
Están las condiciones y escritura a continuación Ilustrísimo señor.

La edad me impide el ir en persona a besar los pies de su Ilustrísima que me holgare goce muy entera salud que sea por muchos años en servicio de Dios y para bien de este obispado, doy cuenta a su majestad Ilustrísima como la iglesia de esta villa necesita de dorar el retablo principal que está solo de madera como su majestad vio cuando vino a la visita, la iglesia se halla desempeñada y con más de veinte mil reales con lo que han ofrecido los vecinos con que se podrá hacer la obra sin empeñarse y quedar bastante caudal para los gastos ordinarios suplico a su majestad Ilustrísima sirva de dar su licencia que sin ella como dueño y señor de todo no podemos obrar que será para gran culto de Dios que... a su majestad Ilustrísima... años como está su más humilde capellán de... Pesquera y septiembre 20 de 1677. Muy humilde capellán de su majestad Ilustrísima el licenciado Gaspar Bodigos.
\end{abstract}

Visto este informe y que será del servicio de Dios la obra que se propone en esta carta concedemos nuestra licencia para que luego y cuanto antes se pueda ejecutar el dorar dicho retablo y encargamos se guarde la constitución en que dicha obra han de pregones y se remate en la persona que fuera de más conveniencia y utilidad de dicha iglesia que en esta conformidad la concedemos en Palencia a veinte y siete de septiembre de mil y seiscientos y setenta y siete años.

Condición para dorar estofar y colorir el retablo de la villa de Pesquera de la parroquia de San Juan:

$1^{\mathrm{a}} \quad$ Es condición que dicho retablo se haya de limpiar y lavar de aguacola con sus ajos.

$2^{\mathrm{a}} \quad$ Es condición que se hayan de dar seis manos de yeso grueso muy delgadas muy fijas y muy firmes para que ningún tiempo falte ni salte el oro.

$3^{\mathrm{a}} \quad$ Es condición que se haya de dar otras seis manos de yeso mate de lo más fresco.

$4^{\mathrm{a}} \quad$ Es condición que se haya de dar seis manos de bol de llanes muy molido.

$5^{\text {a }} \quad$ Es condición que el pedestal haya de ser dorado y la valla de laca de ser colorida sobre oro de diferentes colores y unas de grafios diferentes.

$6^{\text {a }} \quad$ Es condición que las cuatro columnas hayan de ser doradas enriendando y la talla de ellas haya de ser colorida sobre oro y hechas de grafios diferentes e imitar racimos hojas y vástagos y capiteles lo que requiere cada cosa.

$7^{\mathrm{a}} \quad$ Es condición que las entre columnas haya de ser dorado y los festones de arriba hayan de ser coloridos sobre oro de diferentes colores y hechos de grafios. 
$8^{\text {a }} \quad$ Es condición que la cornisa haya de ser dorada y la talla de ella haya de ser colorida sobre oro y hechas de grafios diferentes.

$9^{a} \quad$ Es condición que las pilastras hayan de ser doradas y los capiteles de ellas hayan de ser coloridos sobre oro de diferentes colores y los fondos de ellas se haya de hacer un subiente de cogollos pájaros y bichas a punta de pincel.

$10^{a} \quad$ Es condición que la caja de San Juan haya de ser dorada ante y respaldo y en el tablero se haya de hacer una roca de sobre oro de diferentes colores oscurecido y realzado.

$11^{\mathrm{a}} \quad$ Es condición que el pedestal del segundo cuerpo haya de ser dorado y la talla de ella haya de ser colocada sobre oro de diferentes colores y hecha de grafios y en los tímpanos de dicho pedestal se hayan de hacer unos estofados de cogollos vides y pájaros sobre oro.

$12^{\mathrm{a}} \quad$ Es condición que los dos machones del segundo cuerpo hayan de ser dorados y la talla de ellos haya de ser colorido sobre oro como requiere y hechas de grafios y en los fondos se haya de hacer unos subientes de cogollos a punta de pincel de diferentes colores.

$13^{\mathrm{a}} \quad$ Es condición que los dos arbotantes con su arco que guarnece y curta dicho retablo hayan de ser dorados y la talla de él haya de ser colorida sobre oro y hecha de grafios diferentes.

$14^{\mathrm{a}}$ Es condición que los remates de dicha obra hayan de ser dorados y la talla de... haya de ser colocada sobre oro.

$15^{\mathrm{a}} \quad$ Es condición que la custodia de dicho retablo haya de ser dorada por dentro y fuera y la talla de ella haya de ser colorida sobre oro de diferentes colores y hechas de grafios como requiere según arte.

$16^{\mathrm{a}} \quad$ Es condición que el pedestal sobre que carga dicho retablo haya de ser dorados los boceles y en los tímpanos de él se hayan de hacer unos jaspes de colores diferentes barnizados al óleo.

$17^{\mathrm{a}} \quad$ Es condición que la custodia pequeña haya de ser dorada por dentro y fuera y al Salvador que está hecho en la puerta se haya de estofar y hacer un grutesco en la tunicela y encarnar lo que requiere.

$18^{\mathrm{a}} \quad$ Es condición que los tableros de dicha custodia se haya de hacer pintados del óleo a la voluntad de los dueños de dicha obra.

19 $\quad$ Es condición que dicho retablo le tengo de desarmar y volver armar por mi cuenta.

Y con estas calidades y condiciones me obligo yo Bartolomé Duque Gómez dorador y estofador vecino de la ciudad de Valladolid hacer dicha obra en veinte y siete mil reales y daré fianzas de toda satisfacción en Palencia o en Valladolid a voluntad de los dueños de dicha obra.

Y el oro que se ha de gastar en dicha obra haya de ser de lo más... y color y caire y quilates que hubiere en Valladolid y no siendo eso a satisfacción se haya de traer de Madrid.

Fdo: Bartolomé Duque Gómez

Yo en abril y sigue mayo. En 21 de abril de 1678

Escritura del retablo que se otorgó para dorar el retablo de la capilla mayor de esta villa por Pedro Mondragón pintor y dorador de la ciudad de Valladolid concertado con el cura y beneficiado conforme al memorial que va con esta al presente. 
En la villa de Pesquera de Duero a veinte y un días del mes de abril de mil seiscientos y setenta y ocho años ante mí el escribano y testigos parecieron Pedro Mondragón vecino de la ciudad de Valladolid pintor y dorador como principal y Pedro Santos vecino de esta villa como su fiador y ambos a dos juntos juntamente de mancomún a voz de uno y cada uno de por sí y por el todo in solidum renunciando como renunciaron las leyes de duobus rex debendi y la auténtica presente códice hoc quita de fide iusoribus y las demás leyes de la mancomunidad como en ella y en cada una de ellas se contiene debajo de las cuales dijeron que por cuanto en la parroquial del señor San Juan de esta villa se ha tratado y trata de dorar el retablo de la capilla mayor de ella y altar mayor y para ello se ha pedido licencia al señor obispo de Palencia de esta diócesis y su señoría la ha dado y habiéndose hecho las condiciones por su señoría se acometió el concierto y ajuste de dicho retablo para dorarle y pintarle al cura y beneficiados y mayordomo de la fábrica de dicha iglesia y habiendo tratado con los susodichos el ajuste se han convenido y concertado en esta manera:

Que el dicho maestro ha de dorar dicho retablo conforme a las condiciones que van puestas antes de esta escritura en papel común firmadas de Bartolomé Duque Gómez maestro dorador sin faltar en dichas condiciones en cosa alguna el cual dicho retablo el dicho maestro principal y fiador se obligan a darle dorado puesto y asentado a su costa dentro del tiempo que el principal quisiere contado desde hoy día de la fecha a vista y satisfacción a vista y satisfacción de maestros peritos en el arte y la costa de ellos ha de ser por su parte, y asimismo se obligan a quitar el dicho retablo para dorarle y volver a asentar a su costa dándole la dicha iglesia la madera y clavo con que fuere necesaria para los andamios torno y maromas para bajar y subir las piezas de él, y para el cumplimiento de lo referido obligaron sus personas y bienes muebles y raíces habidos y por haber y presentes a esta escritura los licenciados Gaspar Bodigas cura de esta villa Tomás Cardenal beneficiado de ella y Manuel de Páramo mayordomo de la fábrica de la dicha iglesia por sí y por los que adelante fueren obligaron en virtud de la dicha licencia y asimismo va con ésta escritura los propios y rentas de la fábrica de la dicha iglesia (...) el trabajo de dorar el dicho retablo le darán a dicho maestro veinte y siete mil y quinientos reales de vellón, que es la cantidad en que se le ha rematado dicha obra los cuales darán y pagarán en esta manera nueve mil y ciento y sesenta y ocho reales para luego que comiencen la obra y a la mitad de la dicha obra nueve mil y ciento y sesenta y seis reales y acabada la dicha obra otros nueve mil ciento y sesenta y seis reales y todas tres partidas hacen los dichos veinte y siete mil y quinientos reales y acabada dicha obra ha de ser visto por maestros peritos (...) y así lo otorgaron ante mí el escribano siendo testigos Joseph Sanz Velázquez Pedro García alcalde ordinario Juan de Piedra y Tamayo y Lorenzo Aravingo vecinos todos de esta villa y los otorgantes que yo el escribano doy fe conozco lo firmaron los que supieron y por el que no un testigo. 


\section{DOCUMENTO 38}

\section{ESCRITURA DE CONCIERTO ENTRE LA COFRADÍA DE NUESTRA SEÑORA DE LA MISERICORDIA DE MEDINA DEL CAMPO Y EL ESCULTOR MELCHOR DE LA PEÑA PARA EL PASO DEL DESPOJO ( 8 - DICIEMBRE - 1629)}

A.H.P.V., Leg. 7.427, ff. 624-6275

Condiciones que los mayordomos diputados y cofrades de la Cofradía de Nuestra Señora de la Misericordia sita en el Monasterio de San Agustín de esta villa de Medina del Campo hacen para la pintura y disposición del paso y figuras que tiene hecho Melchor de la Peña escultor son las siguientes:

Lo primero es condición que los aparejos han de ser bien delgados lo que más se pudiese y las lienzas bien delilachadas y delgadas poniéndolas para todas las juntas y hendiduras, y los aparejos restantes como es costumbre y las colores más finas que se hallaren y todas asentadas lustrosas y limpias con toda publicidad y prolijidad.

El Cristo

Es condición que la figura del santísimo cristo ha de ser la encarnación mate y ha de estar maltratado en codos rodillas y espaldas, con sus desollones, puestos como en Valladolid, y la llaga de las espaldas a de ir con su corcho y sangre cuajada, el paño dorado y rajado, y sus cardenales con limpieza y los ojos de cristal. Y en el cuerpo derramada alguna sangre en parte que convenga y el cabello de color de avellana madura con su claro y oscuro.

El que tiene la lanza

Es condición que el de la lanza a de llevar el morrión planteado con la encarnación mate y hermoso cabello y bigote negro y la valona sus puntas naturales, el coleto imitando de ámbar, con la entretela encarnada y oro rajado; mangas y medias azules y las cuchilladas doradas; el calzón grande con las cuchillas azules y aorrajadas ligas y rosas encarnadas de tafetán; zapato blanco la botonadura dorada, petrina y espada; la lanza su color de yerro tahalí de color de baqueta de Moscovia; en las faldillas del coleto su ribete de oro y su cuadrado en las medias al natural y al oro darle su barniz al olio y en las mangas una trencillas.

El que barrena

Es condición que el que barrena ha de llevar la encarnación plomada, barba y cabello entrecano, valona algo azulada coleto imitando al natural de ante guarnecido con tres pasamanos contrahechos por el natural encarnado; los calzones de color violeta o morado las cuchilladas doradas y rajadas y en las puntas por el natural, su barrena del color del yerro.

El que quita la vestidura

Es condición que el que quita la vestidura ha de llevar la encarnación blanca, cabello y bigote bermejo, la gorra carmesí y las faldillas azules con ribetes de oro mate alrededor de la picadura,

5 GARCÍA CHICO, Esteban: Valladolid: Papeletas de Historia y Arte, Gráficas Andrés Martín, Valladolid, 1958, pp. 61-63. 
ropilla colorada encendida con las vueltas del forro pajizo o verde, los calzones verdes con entretela rosada, ribete de oro mate alrededor de las picaduras; medias encarnadas, ligas azules con ropacejos de oro naturales, borceguí blanco con zapato la carnaza fuera, el cinto de color de baqueta con yerros pavonados, y en la ropilla botones verdes.

El del azadón

Es condición que el del azadón ha de llevar la encarnación algo moreno encendido, bigotes castaños, y el cabello más negro, montera verde con forro amarillo, ropilla azul, forro dorado, calzones rosados, con los forros naranjados, medias caídas verdes, zapatos negros, medias amarillas, con su azadón de color de yerro, petrina con yerros pavonados, el puñal al natural (...) en Medina del Campo a 8 de diciembre de 1629. 


\section{DOCUMENTO 39}

\section{CONCIERTO. EL CONVENTO Y HOSPITAL DE SAN JUAN DE DIOS PARA EL DORADO DEL RETABLO $(11$ - ABRIL - 1688)}

A.H.P.V., Leg. 2.329, ff. 233-236

En la ciudad de Valladolid a once días del mes de abril de mil y seiscientos y ochenta y ocho años ante mí el escribano y testigos el Reverendísimo padre provincial y prior y religiosos del convento y hospital de Nuestra Señora de los Desamparados orden de San Juan de Dios de esta dicha ciudad juntos en su capítulo en la parte acostumbrada donde se suelen juntar a tratar y conferir las cosas tocantes al bien y utilidad de dicho hospital y convento y sus bienes y rentas llamados para este efecto por señal de campana estando presentes el Reverendísimo padre fray Gregorio del Villar prior, fray Francisco Álvaro Abedo, fray Joseph Antonio Bernal, fray Andrés Lara de la Hoz, fray Antonio, fray Francisco de Sotomayor y Estrada, fray Marcelino, fray Jerónimo Escudero que confesaron ser la mayor parte y por los ausentes enfermos e impedidos y que por tiempo fueren por quienes prestaron caución en forma que estarán y pasarán por lo contenido en esta escritura y no lo contradirán debajo de expresa obligación que hacen de los bienes y rentas de dicho convento de la una parte, y de la otra Antonio Barreda y Alonso Gutiérrez maestros dorados vecinos de esta dicha ciudad juntos de mancomún a voz de uno y cada uno por si in solidum por el todo renunciando las leyes de duobus rex y la auténtica presente hoc ita de fide iusoribus beneficio y remedio de la excursión y división de bienes y las demás de la mancomunidad como en ella se contiene. Dijeron que dicho convento y hospital ha hecho fabricar el retablo del altar mayor de su iglesia de madera tallada con las efigies de San Juan de Dios San Rafael San Carlos Borromeo San José y Santo Domingo y dos ángeles y para que esté con toda perfección se ha resuelto por dicho convento dorarle en la forma y con las condiciones que aquí irá declarado y poniéndolo en efecto por ambas partes se ha capitulado lo siguiente.

Lo primero los dichos Antonio Barreda y Alonso Gutiérrez debajo de la dicha comunidad y renunciación de leyes se obligan con sus personas y bienes muebles y raíces habidos y por haber aparejan toda la obra de dicho retablo y efigies de santos y ángeles con las manos de aparejo que dispone el arte como es una de agua cola y cuatro de yeso grueso y cuatro de mate y cuatro de bol y todas las rendijas que tuviere dicho retablo se han de enrejar y poner lienzos encima.

Lo segundo que desde el pedestal que carga sobre el altar mayor hasta la clave ha de ser de oro limpio cuanto registrare la vista desde la iglesia y coro y ha de quedar todo el retablo tan descubierto como al presente está y constar por declaración de las personas que fabricaron dicho retablo de madera.

Lo tercero que toda la custodia con todos los vaciados que tuviere han de ser picados de lustre y la custodia por dentro y se hará haciendo labor fingida como detalla con grandísimo a igual... y los tambanillos que tuviere y campos de talla en la misma forma referida diferenciando las labores y las cañas de las columnas de dicha custodia han de ser picadas en forma de grabados y las dichas veniadas de lustre se entiende desde el pedestal hasta la fe.

Lo cuarto las columnas principales y las del cuerpo segundo han de ser doradas de oro limpio y todos los recuadros que tuviere San José, el ángel San Rafael, Santo Domingo, San Carlos, 
Nuestro Padre San Juan de Dios y Nuestra Señora se han de dorar con dicho oro limpio y lo mismo las tarjetas principales que son cuatro.

Lo quinto que el pedestal que fija en el suelo se ha de aparejar en la misma conformidad que lo demás del retablo y todas las molduras y perfiles que tuviere han de ser de oro limpio bruñido y las restantes maderas jaspeado de diferentes jaspes y barnizado con barniz y las puertas en los claros se han de fingir unas perspectivas de tres términos y los perfiles que le cercan a la puerta y los festones han de ser de oro limpio. El San Juan de Dios ha de ser de oro limpio en redondo y en él se le ha de dar el color que pide el hábito y encima se ha de hacer un brocado metido de medias tintas del mismo color del hábito más claro y se han de sacar algunas alcachofitas y tallos de oro y se han de picar de lustre y la labor se ha de picar de grafio y el campo se ha de rajar y toda la labor de dicho brocado se ha de escurecer y realzar en la orilla de dicho hábito mangas escapulario y capilla y ruedo del hábito se ha de dejar como cosa de cuatro dedos de ancho de oro limpio y las restantes orillas de tres dedos y sobre dicho oro se ha de hacer de estofado fingiendo talla echando algunas cabecicas de serafines del campo de dicha orilla ha de ser picado de lustre, la caja de dicho santo sobre el oro limpio se ha de dar encarnado y se ha de sacar un brocado de oro guardado del mismo oro y se ha de picar algunas alcachofas de oro a trechos. El ángel San Rafael ha de ser de oro la frontera y los costados el escapulario y capucha ha de ser en la conformidad que el del santo la jaquetilla ha de ser encarnada y en ella echar una tela de diferentes colores que contrapongan con lo encarnado sacando alguna labor de oro y lo que está metido de color la labor picada de grafio y el campo rajado y el oro escarchado y todo oscurecido y realzado y en todas las orillas de jaquetilla y túnica se ha de hacer en la conformidad que la del santo en la tunicela se ha de hacer una tela de medias tintas y de diferentes grafios el forro verde y en él un chamelote de oro. El San Carlos dado los colores que le corresponde habiéndole dorado como el ángel la muceta hecho un chamelote de oro el roquete blanco y rajarlo el oro y abajo unas puntas y lo restante de la púrpura que corresponda a la muceta y las orillas que corresponda a las del santo y el ángel diferenciando en algunas labores. La imagen de Nuestra Señora se ha de dorar y lo mismo la caja que ha de ser de oro limpio. El San José ha de ser dorado por frontera y lados y la capa ha de ser encarnada y se ha de hacer en ella un brocado de diferentes colores sacando algunas labores y lazos de oro para picar de lustre y las labores que tuviere de colores picadas de diferentes grafios oscurecido y realizado y las orillas como las de los demás santos el forro morado claro y en él hecho una tela de diferentes colores oscurecido y realzado y de diferentes grafios y en las orillas de dicho forro una orilla de dos dedos de nacho y en él se ha de hacer un sacado picado de oro la túnica del santo ha de ser verde y en él se ha de hacer un grutesco oscurecido y realzado y el campo rajado y la orilla de la misma forma que la de los demás, el pañete del niño ha de ser acambrayado y picado de grafio y en la orilla un sacado de oro. Santo Domingo se ha de dorar como el San José y se ha de dar del color que requiere en la túnica blanca una tela de oro picado de lustre y en la capa un brocado de oro y guardado de dicho oro y las orillas como los demás. Que todas las carnes de santos y dos ángeles se han de aparejar muy delgados y bien ligados y en ellos se ha de encarnar a mate una mano y otra a pulimento y encima del pulimento a mate se han de dar dos manos con aceite de espliego. Que todos los ojos de dichas hechuras han de ser de vidrio cristalino y se han de pintar para dentro. Los pelos de todas las hechuras el color que corresponde a cada una y encima peleteado de oro molido y barnizado que la fe que está encima de la custodia se ha de dorar y después se ha de hacer un brocado sobre encarnado de oro picado de lustre y la túnica echar una tela de oro sobre blanco y la orilla que corresponda a las demás de los santos. Las dos tarjetas del ángel y San Carlos han de ser de la forma que las demás. El retablo que se ha de fingir por la parte de la sacristía con pedestal con sus repisas y dos hechas 
en forma de estípites han de subir desde el suelo a recibir el pedestal y encima dos columnas salomónicas con sus pilastras y recuadro el nicho de talla y cornisa con sus modillones y friso y tarjeta principal en que han de estar las armas de la orden encima del segundo cuerpo se ha de hacer un pedestal y encima las columnas que le corresponden en correspondencia de la orden de lo de abajo todo lo que fuere de arquitectura ha de ser de color de oro todo lo que tocare a medias tintas y oscuros y lo que toca a luces ha de ser todo de oro y toda la talla ha de ser de diferentes colores. Que el andamio que se ha de hacer para dorar dicho retablo ha de ser a costa de este convento y de los dichos Antonio Barreda y Alonso Gutiérrez por mitad.

Que todos los colores que se han de gastar como son carmines azules y demás colores han de ser muy finos y de no ser así y no haber dorado el dicho retablo y efigies de santos y ángeles conforme arte y vista de maestros se pueda por su cuenta volverlo a borrarlo y hacerlo nuevo y elegir dicho convento personas de su satisfacción que por cuenta de dichos maestros que lo hagan incurriendo en alguna cosa contra arte y lo que más costase de lo que aquí irá declarado y dinero que hubieren recibido de más de lo en que se estimare la obra hecha puedan ser ejecutados compelidos y apremiados con la décima costa y daños que se siguieren a dicho convento en virtud de esta escritura como por garantía y llana obligación y para ver y reconocer si van cumpliendo o no con estas condiciones no han de poder dichos maestros nombrar ni elegir tercero y lo ha de poder hacer dicho convento y han de ser hasta número de tres y hallando que han incurrido y faltado en alguna de las condiciones referidas se les ha de poder apremiar a que lo cumplan y han de pagar al maestro elegido por el convento la vista de dicha obra y si constare han cumplido con las dichas condiciones ha de pagar al maestro que hiciere la vista de ojos su ocupación dicho convento y no (...) maestros doradores advirtiendo que no han de poder pedir ni alegar en ningún tiempo mejoras que hayan hecho ni quedar el convento obligado a pagarlas que toda la dicha obra de dicho retablo dorado y el fingido pintado en la sacristía lo han de dar acabado en toda perfección para el día quince de agosto de este presente año debajo de pena de apremio y poder el convento elegir maestro que lo acaben con la dicha pena de pagar el más coste que tuviere de lo que en que se ha concertado y dinero recibido de más de lo hecho y obrado debajo de la dicha pena de ejecución.

Que por toda la dicha obra quedando dicho convento sin obligación de dar colores oro ni otra cosa porque esto queda por cuenta de dichos maestros se le ha de dar alzadamente por toda la obra cinco mil y quinientos reales los mil se han de pagar en habiendo dorado el primer cuerpo del retablo poniendo todo el oro necesario sin pedir maravedís ningunos hasta tener dorado el dicho primer cuerpo y hecho han de percibir dichos mil reales y la restante cantidad se ha de ir pagando como se vaya dorando el retablo quedando siempre mil reales en poder del dicho convento hasta tanto que esté acabada la dicha obra en toda perfección y declarada por tal y habiéndolo cumplido se les ha de entregar dichos mil reales retenido y a su paga dicho convento se obliga con sus bienes y rentas debajo de pena de ejecución recíprocamente.

Todo lo referido unas y otras partes se obligan de guardar y cumplir inviolablemente para su mejor guarda y cumplimiento dan poder a la justicia y jueces que de las causas puedan y deban conocer (...) y lo otorgaron así ante mí el presente escribano y lo firmaron a quienes doy fe que conozco siendo testigos Lorenzo Bahamonde natural de Mondoñedo Francisco de Medida y Nicolás Baticón vecinos y residentes en esta ciudad. 


\section{DOCUMENTO 40}

\section{OBRA DEL CEMENTERIO DE SEÑOR SANTIAGO DE ESTA CIUDAD DE VALLADOLID $(31$ - ENERO - 1688)}

A.H.P.V., Leg. 2.740, ff. 9-12

Memoria y condiciones con que mediante la voluntad de Dios he de ejecutar yo Tomás de la Riba maestro de cantería residente en esta ciudad de Valladolid en la obra que se ha de hacer en el cementerio de señor Santiago de ella que está cómo se va a la Puerta del Campo de esta dicha ciudad que son como se sigue:

\section{Condiciones}

$1^{\text {a }} \quad$ Primeramente es condición que se ha de abrir una zanja desde el pozo hasta la casa de la fábrica donde vive el pintor que es la que corresponde a la calle de Santiago y ha de tener dicha zanja dos pies y medio de ancho y de fondo tres.

$2^{\mathrm{a}} \quad$ Es condición que se han de abrir los cimientos de banda a banda y buscar sus escuadrías para la planta de dicha obra.

$3^{\mathrm{a}} \quad$ Es condición que los cimientos se han de profundar tres pies y sacarlos de buena mampostería de cal y cascajo y después de anivelada dicha obra hasta la superficie de la tierra se han de elegir tres puertas de a seis pies de hueco cada una donde mejor convinieren para dicha obra y en cada una de ellas se han de poner dos bolas y las demás repartidas conforme las tocare a cada una de dieciséis.

$4^{\mathrm{a}} \quad$ Es condición que se ha de hacer una cruz de siete pies de alto con sus brazos y cabeza conforme le tocare a la altitud y se entiende que ha de ser ochavada dicha cruz con su pedestal que lleve su basa y capitel de dos pies y medio de alto y dos de grueso y ha de llevar dicho pedestal en la cara que mira a la calle de Santiago su encomienda de la orden de Santiago.

$5^{\text {a }} \quad$ Y es condición que así bolas como cruz ha de ser de piedra de la cantería de Campaspero, y asimismo es condición que el antepecho ha de tener dos pies de grueso y dos de alto.

$6^{\mathrm{a}} \quad \mathrm{Y}$ es condición que las losas han de tener vara de largo y una cuarta de grueso y han de llevar por la parte de adentro su cuarto bocel y por la de afuera cuadradas y todas las losas y sillares han de venir de la cantera de Castronuevo.

$7^{\mathrm{a}} \quad \mathrm{Y}$ es condición que desde el pozo hasta la casa donde se recoge la madera se ha de abrir una zanja cerrándose toda ella de mampostería de cuatro pies de alto con su cal y cascajo revocada con su cal delgada y arrimada a la casa ha de quedar la bola conforme a las demás que van referidas y todo lo demás mampostería y se han de cubrir con sus losas y arambeles lo que más convenga y en la esquina que arrima a la casa del pintor ha de llevar una media bola.

$8^{\mathrm{a}} \quad \mathrm{Y}$ es condición que todas las bolas han de ser dieciséis las dos a las esquinas y las seis a las entradas y la otra arrimada a la casa de la madera y las otras siete restantes repartidas a tercios conforme les tocare para poder sentar la rejería por iguales partes.

Y con estas calidades y condiciones aprovechándome de todos los despojos que tiene dicha obra me obligo yo Tomás de la Riba maestro de cantería a hacerla y ejecutarla a toda costa en precio 
de cuatro mil y cuatrocientos reales de vellón y siéndome rematada otorgaré escritura de obligación obligándome al cumplimiento de todo lo aquí contenido y si fuere necesario daré satisfacción de fianzas a voluntad de la persona y a cuya cuenta y cargo corriere la administración y cuidado de ella y lo firmé en Valladolid a veinte y nueve días del mes de enero de mil y seiscientos y ochenta y ocho años. Y esta postura la hago con calidad de que si hubiere persona que me sacare de ella se me haya de dar satisfacción así de la traza como del trabajo y ocupación de estas condiciones hecho ut supra.

Y es condición que las bolas han de tener cuatro pies y medio de alto y dos en cuadro.

Y es condición que han de dejar sus conductos para que salgan las aguas a la calle.

Las bolas han de ser diez y seis.

Remátose esta obra con las condiciones expresadas y añadidas en Tomás de la Riba en precio y cuantía de tres mil y seiscientos reales con condición de darla fenecida y en toda perfección para 15 de julio de este año (...) declaración de maestro y dichos 3.600 y se le han de entregar conforme fuere trabajando y al principio para ir a la cantera se le han de dar 400 reales. 


\title{
DOCUMENTO 41
}

\section{CONCIERTO PARA EL RETABLO MAYOR DE LA COLEGIATA DE LERMA ENTRE EL DUQUE DE LERMA Y GREGORIO FERNÁNDEZ} $(15-J U L I O-1615)$

\author{
A.H.P.V., Leg. 1.445, ff. 966-968
}

En la ciudad de Valladolid a quince días del mes de julio de mil y seiscientos y quince años ante mí el escribano y testigos pareció presente Gregorio Fernández ensamblador y escultor vecino de esta dicha ciudad y dijo que se obligaba y obligó de hacer y que hará nueve figuras al natural para el retablo de la capilla mayor de la iglesia colegial de San Pedro de la villa de Lerma cuyo patrón es su Excelencia el señor Duque de Lerma que han de ser un Cristo Crucificado un San Juan y una María para el último cuerpo y dos figuras para los lados en el remate del retablo y cuatro para los cuatro nichos según y conforme a la traza del dicho retablo las cuales han de ser de la advocación que su Excelencia mandare y buen proporcionados que quedan en los nichos y remates donde se han de poner que han de ser de buena madera cortada y bien movidas las dichas figuras y con mucho aire que haga buen efecto para las partes donde se han de asentar y asimismo se obligó de hacer la escultura de la puerta de la custodia de un misterio del Santísimo Sacramento y tres figuras la una para el remate de la dicha custodia y las dos para dos nichos que hay en ella que han de ser de esta manera (...) todo lo cual se obliga dar hecho y acabado en toda perfección y dentro de un año (...) y le ha de dar y pagar sesenta ducados por cada una que con todas montan quinientos y cuarenta ducados los cuales se le ha de dar y pagar la mitad luego (...).

\section{Condiciones de las figuras}

Gregorio Fernández escultor vecino de esta ciudad se ha de obligar a hacer nueve figuras al natural para el retablo de la capilla mayor de la iglesia colegial de San Pedro de Lema cuyo patrón es el Duque de Lerma mi señor que serán Cristo San Juan y María para el último cuerpo y para los cuatro nichos que acompañan a los demás y para los remates hará seis de la advocación que su Excelencia mandare proporcionadas y como quepan en los nichos y remates donde se han de poner que sean de buena madera cortada en buena luna sin nudos y bien ensamblada y juntada y las figuras bien movidas y con mucho aire y que hagan buen efecto para las partes donde se han de sentar.

Y asimismo ha de hacer la escultura de la puerta de la custodia de un misterio del Sacramento y tres figuras la una para el remate de la dicha custodia y las dos para dos nichos que hay en ella que sean de tamaño de las partes donde se han de poner y de la significación de los santos que se le ordenare y en las unas y otras pondrá las insignias que se requieren para las figuras todo lo cual he de dar acabado a contento para el día que están obligados los ensambladores dándole el dinero luego porque las ha de entregar a los ensambladores del retablo porque las han de llevar y asentar por su cuenta en Lerma y se les haría agravio no se las dar para aquel día y el año ha

6 GARCÍA CHICO, Esteban: Documentos para el estudio del arte en Castilla. 2, Escultores, Universidad de Valladolid, Valladolid, 1941, pp. 171-172. 
de correr desde el día que se le dieren doscientos y setenta ducados que es la mitad de lo en que están concertadas las cuales dichas figuras se han de hacer con las condiciones arriba contenidas y para el tiempo que se declara por precio de sesenta ducados cada una de las nueve y no se le ha de pagar nada por las de la custodia y concertamos con orden de su Excelencia yo Tomás Guerra Ramírez veedor de las obras de su majestad y Juan Gámiz maestro de ellas en Valladolid a 11 de julio de 1615 .

\title{
ESCRITURA PARA LA CONSTRUCCIÓN DEL RETABLO MAYOR DE LA COLEGIATA DE SAN PEDRO DE LERMA (14 - JULIO - 1615)
}

\author{
A.H.P.V., Leg. 1.445, ff. 966-968
}

Sepan cuantos esta carta de obligación y fianza vieren como nos Francisco Velázquez y Melchor de Beya arquitectos vecinos de esta ciudad de Valladolid ambos juntamente (...) por esta carta que nos obligamos de hacer y que haremos el retablo y custodia para la capilla mayor de la iglesia colegial de la villa de Lerma conforme a la traza que de ello hizo Juan Gómez de Mora maestro mayor de las obras de su majestad que firmada de su nombre y de Pedro Gutiérrez (...) conforme a las dichas condiciones suso incorporadas los dichos Francisco Velázquez y Melchor de Beya nos obligaos hacer el dicho retablo y custodia guardando la dicha traza y cumpliendo todas las condiciones por el precio declarado (...) y para mejor lo cumpliremos damos por nuestros fiadores a Marcelo Martínez pintor y Pedro del Barco maestro de cerrajería vecinos de esta dicha ciudad (...) Valladolid 14 días del mes de julio de 1615 años.

Condiciones con las cuales se ha de hacer el retablo de la capilla mayor de la iglesia colegial de la villa de Lerma, y custodia del dicho retablo:

$1^{\text {a }} \quad$ Primeramente es condición que para este retablo y custodia se seguirá y guardará la traza, alzado y planta firmada de Juan Gómez de Mora maestro mayor de su majestad y estas condiciones firmadas también de su nombre y de Pedro Gutiérrez y Ramírez veedor de las obras de su majestad.

$2^{\mathrm{a}} \quad$ Es condición que toda esta obra ha de ser de madera de pino de Soria seca y limpia de nudos cortada en buena luna.

$3^{\mathrm{a}} \quad$ Es condición que ha de tener esta obra de alto cuarenta y cinco pies poco más o menos todo lo que fuere menester y de ancho por línea recta veinte y tres pies distribuyéndolo y repartiéndolo todo como muestra la traza por su pitipié. Y conforme a la planta y altura de la dicha iglesia cuyas medidas han de referir antes de empezar la dicha obra.

$4^{\mathrm{a}} \quad \mathrm{Y}$ es condición que si respecto de no estar acabada la dicha capilla de presente fuere menester ir una o dos más veces a tomar la medida de la dicha capilla quede obligado el dicho maestro hacerlo y acomodar el dicho retablo en la dicha capilla y si por no lo hacer así tuviese

7 GARCÍA CHICO, Esteban: Documentos para el estudio del arte en Castilla. 2, Escultores, Universidad de Valladolid, Valladolid, 1941, pp. 233-235. 
algún defecto la ejecución de la dicha traza tenga la obligación el dicho maestro hacerlo nuevo a su costa.

$5^{\mathrm{a}} \quad \mathrm{Y}$ es condición que el maestro que de esta obra se encargare no queda por su cuenta la escultura más tan solamente el ensamblaje y talla que muestra la traza.

$6^{\mathrm{a}} \quad \mathrm{Y}$ es condición que todos los tableros que muestra la traza para lienzos de pintura se han de hacer ensamblados entrepañados con sus tableros metidos en ranura.

$7^{\mathrm{a}} \quad \mathrm{Y}$ es condición que toda esta obra se ha de hacer como dicho es distribuida conforme a la dicha traza en los nichos, cajas y en todo lo demás guardando la orden de buena arquitectura.

$8^{\mathrm{a}} \quad$ Es condición que toda la obra ha de ir bien ensamblada y fortalecida con barrotes y colas donde hubiere menester. (...)

$12^{\mathrm{a}} \quad$ Más han de llevar por su cuenta y asentarlas figuras de escultura de dicho retablo y la asentaran en él dándoselas acabadas en Valladolid para cuando están obligados y se concierta con Melchor de la Beya y Francisco Velázquez maestro de ensamblaje en novecientos y cincuenta ducados los cuales han de pagar conforme a las condiciones que fue echar por Pedro Gutiérrez veedor de las obras de su majestad y Juan Gómez de Mora maestro de obras con orden de que para ello tuviere del señor Duque de Lerma en Valladolid a 11 de julio 1615. 


\section{DOCUMENTO 42}

\section{PODER. MANUEL HERNÁNDEZ Y CONSORTES A LEONARDO DE ESTRADA $(21$ - JUNIO - 1700)}

A.H.P.V., Leg. 3.012, ff. 316-317

Sépase por esta pública escritura de poder como nos Manuel Hernández, Joseph de Rozas, Joseph Garzón y Manuel de Estrada vecinos de esta ciudad de Valladolid, todos cuatro juntos y de mancomún a voz de uno y cada uno de nos por sí in solidum y por el todo renunciando como renunciamos las leyes y derechos de la mancomunidad y excursión y división de bienes depósito de las expensas y las demás de este caso como en ellas se contiene. Decimos que por cuanto Leonardo de Estrada dorador vecino de esta ciudad ha tomado a su cargo y por su cuenta el dorar un retablo que está en la santa iglesia colegial de señor San Pedro de la villa de Lerma en precio de veinte y ocho mil reales de vellón en que lo tiene concertado y ajustado con los señores abad y cabildo de dicha santa iglesia pagados en cierta forma y con ciertas calidades y condiciones, y para la seguridad de que el susodicho cumplirá con ellas le han pedido que de fianzas en las cuales los otorgantes le quieren fiar y poniéndolo en ejecución. Otorgamos por la presente y damos todo nuestro poder cumplido el que de derecho en tal caso se requiere y es necesario al dicho Bernardo de Estrada para en nuestro nombre y en virtud de este poder nos pueda obligar como nosotros desde luego nos obligamos a que el susodicho hará y ejecutará el dorado en dicho retablo con todo arte y perfección y cumplirá con todas las calidades y condiciones que para ello tuviere hechas y ajustadas sin faltar en cosa alguna a vista de maestros. Y a que en caso de no cumplir o en cualquier cosa o parte de ello se nos pueda obligar y a cada uno in solidum a su paga y cumplimiento para que él desde luego hacemos de deuda y caso ajeno nuestro propio sin que sea necesario hacer la excursión en los bienes del dicho Leonardo de Estrada ni otra diligencia alguna aunque estoy expuesto por derecho cuyo beneficio y remedio renunciamos, para no nos poder valer ni aprovechar y a él en ningún tiempo a todo lo cual nos pueda obligar como nosotros desde luego nos obligamos con nuestras personas y bienes muebles y raíces derechos y acciones habidos y por haber y para mayor seguridad y firmeza de lo aquí contenido y sin que la obligación general derogue ni perjudique a la hipoteca especial ni por el contrario, yo el dicho Manuel Hernández obligo e hipoteco por especial y expresa hipoteca, una casa que tengo mía propia en el Malcocinado de esta ciudad que linda por una parte con casa de Juan González y por otra con casa de Manuel Alonso con la carga de un censo perpetuo de veinte y nueve reales que sobre ella está fundado. Y yo el dicho Joseph de Rozas obligo e hipoteco un sitio de casa que tengo mía propia en esta ciudad a la plazuela del Conde de Nieva que linda por una parte con casas del señor Manuel de Arce y Astete y por las demás partes está exenta y es libre de todo censo y tributo y de otra carga. Y yo el dicho Joseph Garzón obligo e hipoteco una casa que tengo mía propia en la calle de Santiago de esta ciudad que linda por una parte con casa del Convento de Trinitarios Calzados, y por la otra con casa de Manuel Fernández calcetero que tiene veinte ducados de renta en cada un año de censo al quitar. Todos los cuales dichos bienes que aquí van obligados e hipotecados son nuestros propios y no tienen más cargas que las que aquí van declaradas y así lo juramos en forma de derecho y si lo contrario constare y pareciere en algún tiempo consentimos se pueda proceder y proceda contra nosotros y nuestros bienes por crimen estelionato. Y desde luego prohibimos la venta y enajenación de las dichas casas para no lo poder hacer hasta tanto que el 
dicho Leonardo de Estrada haya cumplido enteramente y nosotros cumplamos con esta obligación y fianza y si antes lo hiciéremos la tal venta y enajenación ha de ser y sea en tiempo ninguna y de ningún valor ni efecto y no pase ni se transfiera en el comprador ni compradores derecho de posición propiedad ni otra acción ni derecho alguno. Que para todo lo que dicho es y lo a ello anejo y dependiente le damos al dicho Leonardo de Estrada tan bastante poder como de derecho se requiere y es necesario sin ninguna limitación con libre y general administración y relevación en forma. Y para que en virtud de él pueda en nuestro nombre hacer y otorgar la escritura y escrituras de obligación y fianza que le pareciere así con las dichas calidades y condiciones con que se ha ajustado para hacer dicha obra como las demás que le pareciere y fuere necesario con todas las fuerzas y firmezas requisitos y circunstancias salarios poderíos (...) y lo otorgamos así ante el presente escribano y testigos en la ciudad de Valladolid a veinte y un días del mes de junio de mil y setecientos años siendo testigos Sebastián Prieto Negrete Joseph de Montenegro y Joseph Núñez de Peralta y los otorgantes que yo el escribano doy fe conozco lo firmaron los que supieron y por el que no un testigo. 


\section{DOCUMENTO 43}

\section{CONCIERTO PARA HACER LA ESCULTURA DEL RETABLO DE LA CAPILLA DEL OBISPO DE MÁLAGA EN LA IGLESIA PARROQUIAL DE ITERO DE LA VEGA (8 - JULIO - 1664)}

A.H.P.V., Leg. 2.361, ff. 417-418

En la ciudad de Valladolid a ocho de julio de mil y seiscientos y sesenta y cuatro años ante mí el escribano y testigos parecieron de la una parte Andrés de Oliveros Pesquera escultor vecino de esta ciudad y de la otra Manuel de Salceda vecino de la villa de Carrión ensamblador y dijeron están convenidos y concertados y por la presente se conciertan en esta manera:

Lo primero que por cuento el dicho Manuel de Salceda está a su cargo el hacer un retablo en el lugar de Itero de la Vega en la capilla del señor obispo de Málaga así de talla como de la escultura conforme a la traza y condiciones en que se hizo el concierto ahora el dicho Andrés de Oliveros se encarga de hacer la escultura de dicho retablo que es la siguiente: un San Pedro de seis pies de alto como el que está en el Convento del Abrojo y un San Antonio de Padua con su Niño de cinco pies y medio de alto y una Magdalena de cinco pies y medio de alto y un Santo Cristo Crucificado de cuatro pies de alto, San Juan y María de tres pies y medio de alto y un San Pedro y San Pablo de pie y medio de alto, una Resurrección de medio relieve para la puerta de la custodia con dos judíos y un sepulcro lo cual ha de ir a fabricarlo y ejecutarlo al dicho lugar de Itero de la Vega para los primeros de septiembre de este presente año de sesenta y cuatro y sin levantar la mano lo ha de acabar y el dicho Manuel de Salceda le ha de dar por toda la dicha escultura tres mil y ochocientos reales de vellón y más la madera para ello (...) y encolada a costa del dicho Manuel de Salceda y los dichos tres mil y ochocientos reales se los ha de dar y pagar quinientos reales el día que partiere y lo demás dándole todos los días lo que fuere necesario para su gasto y oficiales y en acabándose la restante cantidad y a su paga se le pueda apremiar por todo rigor de derecho y no lo cumpliendo el dicho Andrés de Oliveros además que se le pueda apremiar a ello pueda el dicho Manuel de Salceda o quien su derecho tenga buscar otro escultor que haga y acabe dicha obra y por lo que dijere le ha costado que ha de ser creído por su declaración se le pueda ejecutar y apremiar a su paga por todo rigor de derecho e ir y enviar una persona a todas las partes donde el dicho Andrés de Oliveros viviere o tuviere bienes y hacienda (...) y lo otorgaron así ante mí el escribano siendo testigos Cristóbal de la Guarda, Julián Gutiérrez y Manuel de Medina vecinos de esta ciudad y los otorgantes que doy fe conozco lo firmaron. 


\title{
DOCUMENTO 44
}

\section{CONSTRUCCIÓN DE LA ERMITA DE SAN ISIDRO (7 - ENERO - 1692)}

\author{
GARCÍA CHICO, Esteban: Valladolid. Papeletas de Historia y Arte, Gráficas Andrés \\ Martín, Valladolid, 1958, pp. 106-107.
}

En la ciudad de Valladolid a veinte de enero de mil seiscientos noventa y dos años, estando en la sala de la casa de los cabildos de la cofradía de Nuestra Señora de la O, y señor San Isidro labrador, los señores Ruiz Valdeón y Joseph Martin de la Villa alcaldes della, Joseph Gil y Pedro Concejo diputados, Francisco Barahona depositario y Sebastián de Pesquera mayordomo (...) llamados por Manuel Cuetos nuestro casero y llamador para tratar de las cosas del servicio de Dios Nuestro Señor y Nuestra Señora la siempre Virgen Santa María concebida sin pecado original en el primer instante de su ser natural y del bienaventurado y glorioso señor Sant Isidro labrador nuestro patrón y abogado a cuya honra y gloria y para su santo servicio el dicho Joseph Martin de la Villa, les dijo y propuso como en diferentes ocasiones sea discurrido entre algunos señores cofrades y devotos del santo, la incidencia con que está en la iglesia del señor San Andrés por no estar en capilla sino en un lado del altar mayor si el reverente culto y adorno que debe estar un tan excelso y gran santo patrón de la villa de Madrid y corte e en que asisten sus Majestades los Señores Reyes Católicos de España donde está colocado un santuario en una iglesia suntuosísima y grande su vocación Sant Andrés -y que a su imitación era cosa acertada se hiciese una capilla en la dicha iglesia o una ermita en el páramo sobre la fuente de la Salud a donde mejor se discurriese y que antiguamente se había intentado así por nuestros antecesores en el año seiscientos veinte y uno y habían puesto una cruz donde había de hacerse la obra y lo habían quedado en aquel estado-, y era así que los labradores de esta ciudad que asistieron con sus carros, cabalgaduras y criados a traer la piedra leña y carbón y a la limpieza de las calles de esta ciudad a la venida de sus Majestades los Señores Don Carlos Segundo y Da Mariana de Babiera de sus felices casamientos y bodas el año pasado de mil setecientos noventa que se celebraron sus bodas en el real convento de San Diego de esta ciudad el día tres de mayo de dicho año, otorgaron poder ante mí el dicho Joseph Martin de la Villa en que cedieron y donaron al santo todos los jornales y dineros que se les debía de dicha asistencia para que de ello se cobrase y se hiciese capilla y retablo en la dicha iglesia o se hiciese ermita al glorioso señor Sant Isidro encima del páramo de la fuente de la Salud de esta ciudad donde llevaban las mieses a trillar los labradores o en otra parte que les pareciese a la disposición del dicho Francisco Barahona y Martín de Rebolledo a quien se dieron bastante poder -y en su ejecución que había ido al sitio más conveniente para hacer la ermita por parecer tierra del santo en dicho paramo cómo se va de esta ciudad a La Cistérniga a mano derecha y estar en el distrito de la parroquia de San Andrés se había elegido aquel sitio para que en él se hiciese una ermita- y que dichos señores Joseph Martin de Villa, Francisco Barahona, Martin Rebolledo y Joseph Gil habían hablado y puesto en planta a la ciudad para el recobro de la limosna y que fueron a ver el sitio y reconocimiento del por parte de la ciudad el señor don Juan de Alarcón Marques de Palomares corregidor de esta ciudad y el señor don Antonio Rodríguez de la Vera... y los alarifes y maestros de obras y nos echaron cordeles por ser tierra del Santo les pareció muy bien se hiciese la obra y prometieron esforzar lo posible en el ayuntamiento (...) y ofrecieron trescientos ducados para ayuda de la obra con ciertas calidades. 


\title{
DOCUMENTO 45
}

\section{CUENTAS DEL RETABLO DE LA CAPILLA MAYOR DE LA IGLESIA DE SANTIAGO DE LA CIUDAD DE VALLADOLID}

\author{
A.G.D.V., Santiago, Libro de Cuentas (1673-1707), ff. 357 y ss. ${ }^{8}$
}

Cuenta que da el señor Don Juan Fernández de Salazar cura propio de la parroquial de Santiago de esta ciudad de retablo de la capellanía porque se hizo con acuerdo de la parroquia y siendo comisarios Juan Fernández de Salazar, Don Antonio de Vera, Don Juan de Venera y Andrés de la Cuesta; cuyas cuentas da dicho señor por haber sido caja del dinero que se sacó y se dio de limosna para dicho retablo la cual es en la forma siguiente:

Cargos al honor de Don Juan Fernández de Salazar

$\mathrm{N}^{\circ} 1$ : Limosna ofrecida Don Alonso de Aguayo patrón de la capilla mayor

Primeramente son cargo cuatro mil y cuatrocientos reales que valen ciento y cuarenta y nueve mil y seiscientos maravedíes lo mismo que ofreció dar de limosna Don Alonso de Aguayo yo patrón de la capilla mayor para ayuda del retablo de ella.

№2: Limosna ofrecida Don Antonio de Vera

Ítem se le hace cargo de un mil y cien reales de vellón que valen treinta y siete mil y cuatrocientos maravedíes los mismos que para el dicho efecto ofreció Don Antonio Rodríguez de Vera.

\section{No3: Limosna ofrecida Don Lope Quevedo}

Ítem, son cargo un mil reales de vellón que valen treinta y cuatro mil maravedíes los mismos que ofreció Don Lope Quevedo para el dicho retablo.

No4: Limosna ofrecida Don Sebastián Martínez

Ítem son cargo quinientos reales de vellón que valen diez y siete mil maravedíes lo mismo que para el dicho efecto ofreció dar de limosna Don Sebastián Martínez médico.

N5: Limosna que ofreció dar la Cofradía Sacramental sita en dicha iglesia

Ítem son cargo cuatro mil y cuatrocientos reales que valen ciento y cuarenta y nueve mil y seiscientos maravedíes los mismos que la Cofradía Sacramental sita en dicha iglesia de Santiago ofreció dar de limosna para ayuda de dicho retablo.

№6: Limosna ofrecida por la Cofradía de San Joseph

Ítem son data digo cargo un mil reales que valen treinta y cuatro mil maravedíes los mismos que para dicho efecto ofreció la Cofradía de San Joseph sita en dicha iglesia.

No7: Ítem por la del Ángel

Ítem son cargo seiscientos reales que valen veinte mil y cuatro maravedíes los mismos que ofreció asimismo dar de limosna para dicho efecto la Cofradía del Ángel.

8 GARCÍA CHICO, Esteban: Documentos para el estudio del arte en Castilla. 2, Escultores, Universidad de Valladolid, Valladolid, 1941, p. 373. 


\section{No8: Ítem por la del Santo Cristo}

Ítem son cargo doscientos y cincuenta reales que valen ocho mil y quinientos maravedíes ofreció de limosna la cofradía de Cristo sita en dicha iglesia.

Nº: Ítem por de la Concepción y Santos Mártires

Ítem son cargo doscientos reales que valen seis mil y ochenta maravedíes que ofreció y dio de limosna para dicho retablo la Cofradía de Nuestra Señora de la Concepción y Santos Mártires.

No10: Limosna ofrecida por ésta ciudad de Valladolid

Ítem son cargo cincuenta y un mil maravedíes los mismos que por esta ciudad de Valladolid se dio de la limosna para dicho efecto.

$\mathrm{N}^{\circ} 11$ : Limosna ofrecida por Cofradía de Ánimas

Ítem son cargo dos mil y doscientos reales que valen setenta y cuatro mil y ochocientos maravedíes que dio de limosna la Cofradía de las Ánimas de dicha Cofradía.

$\mathrm{N}^{\mathrm{0}}$ 12: Limosna que ofreció el gremio de herederos de viñas

Ítem son cargo otros dos mil y doscientos reales que valen setenta y cuatro mil y ochocientos maravedíes lo mismo que dio de limosna el gremio de herederos de viñas.

N¹3: Ítem por Juan de Aragón

Ítem son cargo un mil y quinientos reales que valen cincuenta y un mil maravedíes los mismos que dio de limosna Juan de Aragón siendo mayordomo de fábrica.

$\mathrm{N}^{\circ} 14$ : Ítem por Joseph Guerra

Ítem son cargo otros un mil y quinientos reales que valen cincuenta y un mil maravedíes los mismos que dio de limosna Joseph Guerra siendo mayordomo.

$\mathrm{N}^{\circ} 15$ : Limosna que ofrecida por la parroquia

Ítem son cargo un mil y ochocientos reales que valen sesenta y un mil y doscientos maravedíes los mismos que se sacaron de limosna por la parroquia como consta de asiento que para dicho efecto se hizo.

$\mathrm{N}^{\circ}$ 16: Legado de Manuel Recio

Ítem son cargo dos mil y doscientos reales que valen setenta y cuatro mil y ochocientos maravedíes los mismos que mando por su testamento a esta fábrica Manuel Recio con la carga de cuatro misas cantadas en cada un año.

Por manera que suma y monta el cargo de esta cuenta.

Ochocientos y noventa y cinco mil y novecientos maravedíes como parece de las partidas de ella para los cuales son data las siguientes:

Data a favor del Señor Don Juan Fernández de Salazar

№17: Pagado a Blas Martínez de Obregón por la traza del retablo

Primeramente son data seiscientos reales que valen veinte e mil y cuatrocientos maravedíes que en dicho Señor don Juan Fernández de Salazar pagó a Blas Martínez de Obregón maestro arquitecto por la traza que hizo de dicho retablo y no sirvió. 


\section{No18: Pagado a Alonso Manzano maestro que hizo el retablo}

Ítem son data veinte y cinco mil reales que valen ochocientos y cincuenta mil maravedíes los mismos que pagó a Alonso Manzano maestro que hizo el retablo de que entrega recibo.

$\mathrm{N}^{\circ}$ 19: Pagado a Juan de Ávila escultor por todas las esculturas que hizo

Ítem son data once mil reales de vellón que valen trescientos y setenta y cuatro mil maravedíes los mismos que pagó a Juan de Ávila escultor por toda la escultura que hizo para el retablo que se compone de la historia de Santiago Nuestra Señora del Pilar y seis ángeles de que entrega recibo.

\section{No20: Pagado a Manuel de Estrada dorador}

Ítem son data quinientos reales pagados a Manuel de Estrada maestro dorador y estofador por estofar el San Juan que se puso en correspondencia de San Joseph de que entrega recibo.

No21: Pagado a Pedro de Ribas cantero

Ítem son data trescientos y noventa reales que valen trece mil doscientos y sesenta mil los mismos que pagó a Pedro de Ribas cantero por quitar el retablo viejo las gradas de piedra y un pedazo de la pared y volver a poner el presbiterio de que entrega recibo.

$\mathrm{N}^{\circ} 22$ : Coste de una lámina que se puso en la puerta de la custodia

Ítem son data ciento y cincuenta reales que valen cinco mil y cien maravedíes los mismos que tuvo de costa una lámina y vidriera que se puso en la puerta de la custodia del retablo.

№23: Pagado por la casa en que se fabricó el retablo

Ítem son data cuatrocientos reales que valen trece mil y seiscientos maravedíes los mismos que pago por la casa en que se fabricó dicho retablo.

\section{No cobrado}

$\mathrm{N}^{\circ} 24$ : Limosna que ofreció la cofradía sacramental

Ítem son data por no cobrados cuatro mil y cuatrocientos reales que valen ciento y cuarenta y nueve mil y seiscientos maravedíes los mismos que quedan cargados a ijuicio y estas cuantas? por otros tantos que ofreció dar de limosna para ayuda de dicho retablo la cofradía sacramental de dicha iglesia de que no se ha podido cobrar.

Por manera que suma y monta la data que da el dicho Don Juan Fernández de Salazar... cuatrocientos y cuarenta y dos mil y novecientos y sesenta maravedíes que (...) contra dos de los ochocientos y noventa y cinco mil y novecientos maravedíes resulta de (...) a favor del susodicho quinientos y cuarenta y siete mil y sesenta maravedíes que hacen diez y seis mil y noventa reales y con lo susodicho le feneció y (...)”. 


\section{DOCUMENTO 46}

\section{$\underline{\text { ACUERDO PARA LAS FIESTAS DE SANTIAGO }}(2-$ JUNIO - 1730)}

A.M.V., Caja 51-1,f. 4

En Valladolid ayuntamiento ordinario viernes 19 de mayo de 1729 este día se dio una petición de los comisarios nombrados por la parroquia del señor Santiago de esta ciudad para la próxima fiesta que ha de celebrar a la colocación del Santísimo Sacramento han dorado el retablo y en nombre de dicha fábrica y demás parroquianos en que por ella expresan que por más aumento de dichas fiestas tenían tratado con los duelos de las casas de la plaza mayor les cedan balcones últimos y posteriores para que su producto sirva una corrida de toros después de la que la ciudad tiene acordada y que para acabarle de disponer era preciso el beneplácito y licencia de la ciudad lo ponían en una noticia para que como dueña de la primera y principal acción se sirviese resolver lo que fuese más de agrado facilitando a la parroquia aquella cesión o ayuda de costa que fuere servida como lo había hecho en igual circunstancia con otras iglesias y cofradías y en vista de dicha petición tratado y conferido por todos los caballeros capitulares que concurrieron a este ayuntamiento se votó y acordó se admite la oferta hecha por la parroquia y se reserva señalar día para dicho festejo de toros y para ayuda de él desde luego la ciudad hace largo de las portadas y balcones terceros que tiene propias y por derecho de prenda exceptuando las de San Francisco para que dicha parroquia se valga del producto de ello mediante la utilidad que se sigue en haber dicha corrida y alargo que se dice haber hecho los dueños de las casas de dicha plaza.

Concuerda con el que esté en los libros de ayuntamiento que para en mi poder y oficio quedada a que me remito y para que conste donde convenga de pedimento de D. Joseph de Santisteban Ahedo mayordomo de propios de esta ciudad doy el presente en Valladolid a 17 de abril de 1730. 


\section{DOCUMENTO 47}

\section{ESCRITURA. LA CONGREGACIÓN DE SAN FELIPE NERI CON MANUEL DE ESTRADA ESTOFADOR Y DORADOR ( 9 - OCTUBRE - 1690)}

A.H.P.V., Leg. 2.637, ff. 954-959

En la ciudad de Valladolid a nueve días del mes de octubre de mil y seiscientos y noventa años ante mí el escribano y testigos los señores D. Pedro de Rozas ministro de la Congregación de señores sacerdotes advocación de San Felipe Neri de esta ciudad, D. Alonso Romero, D. Felipe Sánchez Flores de Paz, el licenciado Juan Casado, licenciado D. Juan Fernández de Salazar y el licenciado D. Juan Redondo presbíteros y congregantes de dicha congregación, comisarios por ella nombrados en la junta y congregación que se hizo en diez y nueve de septiembre pasado de este dicho año y como tales y usando de la facultad y comisión que tienen de la una parte, y de la otra Manuel de Estrada dorador y estofador vecino de esta dicha ciudad, y dijeron que en la dicha iglesia de Nuestro Padre San Felipe tienen puesto un retablo de madera en blanco con sus columnas salomónicas el cual la dicha congregación quiere dorar y estofar para mayor adorno y culto de la dicha iglesia y de ello se quiere encargar el dicho Manuel de Estrada y otorgar escritura en forma sobre lo cual tienen tratado y conferido las calidades y condiciones con que se ha de ejecutar y precio que por ello se le ha de dar para cuyo cumplimiento capitulan se ha de guardar y cumplir lo siguiente:

$1^{\text {a }} \quad$ Primeramente que si hubiere en el retablo algunas rendijas o se hubiere venteado algo que se conozco al tiempo que se vaya aparejando se ha de enlenzar con lienzo crudo muy delgado, y su fueren las rendijas alto abiertas se han de enrajar y encima de las rajas se ha de echar lienzas para que por allí no vuelva nunca a abrir y después de hecha esta diligencia que es muy importante se ha de aparejar conforme lo pide el arte como es el yeso grueso y yeso mate con cuatro aseo fuere posible en cuanto a la talla, que sea juez el mismo que la ha hecho que es quien puede juzgar si se la han tapado o no. Encima de dichas manos de yeso que vendrán a ser en todas nueve se ha de dar encima cuatro de bolo.

$2^{\mathrm{a}} \quad$ Es condición que después de todo aparejado se ha de dorar de oro limpio desde la mesa de altar, muy bien dorado y bien recerado y bruñido y ha de quedar de oro limpio así ensamblaje como talla cuanto alcanzare la vista desde las tribunas y sitios de la iglesia y coro. El oro ha de ser de buen color y cuerpo cuanto pudiere adelantarse y para dar principio al dar oro se ha de hacer muestra y se ha de quedar en poder del ministro un libro y cuanto oro se gastare se ha de cotejar y esto conviene porque suele haber desigual dado y lo padece la obra.

$3^{\text {a }} \quad$ Es condición que la custodia de dicho retablo después de dorada con cuanto primor diere el arte en conformidad del retablo todos los vaciados que tuviere se han de laborear de picado de lustre y tambanillo de tarjetas y modillones y repisas se ha de guardar de picado y también la talla se ha de guardar de lustres y ventas. En cuanto al pedestal que es donde sienta el retablo se ha de hacer a disposición de los señores congregantes.

$4^{\mathrm{a}} \quad$ Es condición que todas las hechuras que tiene la obra como son siete hechuras redondas del natural y dos pequeñas y cuatro historias todas estas hechuras se han de aparejar a satisfacción de los escultoras que las hubieren hecho que reconozcan si en su aparejado se les ha 
tapado algo que sean en su perjuicio y después de aparejado con todo cuanto aseo fuere posible se ha de dorar así historias como hechuras y respaldos han de ser de oro limpio cuanto registrare la vista desde los sitios dichos.

$5^{\text {a }} \quad$ Es condición que encima del oro se ha de colorir conforme a lo que pida cada hechura. La hechura del Santo Cristo se ha de encarnar una mano a mate y después de muy bien seco se ha de imprimar a pulimento encima que vendrá a hacer imprimación y encima del pulimento se ha de encarnar a mate dos manos y coloriéndole en la conformidad que pida. Y después de echado les han precorrida le ha de echar sangre helada, al pañete se le ha de dorar y encima se ha de fingir un paño turquesco y en la orilla se ha de hacer un sacado de oro picado de lustre y lo restante del paño se ha de hacer de diferentes grafios. El pelo de la cabeza y barbas se ha de peletear de oro molido y muy bien barnizado en la cruz sobre el oro se ha de dar de color de palosanto y botear de oro sacándolo al grafio en el respaldo del Santo Cristo sobre el oro se ha de pintar un Jerusalén sobre su ciudad y sol y luna y todo éste respaldo se ha de picar del grafio y muy igual y granado para que haga salir el oro que está debajo. La hechura de Nuestra Señora en el manto se ha de dar de azul y en él se ha de hacer un brocado promediado de diferentes medias tintes y algunas alcachofas de oro y el campo de la labor ha de ser rajado y las labores de diferentes grafios y las alcachofas de oro picadas de lustre y después toda la labor se ha de descubrir y realzar en la orilla de dicho manto como cosa de cinco dedos de ancho se ha de quedar de oro limpio y encima se ha de estofar de variedad de cogollos entrometiendo algunos ricos muy bien realzados y con muy finos colores y el campo de la labor ha de ser grabado de lustre, el forro del manto ha de ser morado y encima se ha de hacer una tela de oro y en las orillas un sacado picado de lustre, en la túnica de dicha hechura se ha de dar de encarnado y encima hecho un grueso oscurecido y realzado el campo de los cogollos ha de ser rajado y la labor picada de un grafio muy igual y después de hecho de grafio se ha de fortalecer toda la labor de carmín fino, la toca se ha de dar un color acambrayado y en la orilla se ha de sacar un galoncico y lo demás bien picado de grafio. El San Juan se ha de hacer en la misma conformidad que la Virgen en cuanto a las labores que en los colores han de ser diferentes, que ha de ser la capa encarnada y el forro azulado y la túnica verde, los rostros y manos se han de encarnar en la conformidad del Santo Cristo sólo ha de tener de diferencia en los coloridos que han de ser diferentes, los pelos que hubiere y barba se ha de peletear de oro molido como el Santo Cristo. En la historia de la Oración del Huerto el Jesucristo ha de ser morada la túnica y en ella se ha de sacar una tela picado de lustre, las alcachones y otras labores perfilada y guardada de oro y picada de grafio y el campo rojado de oro y en la orilla se ha de hacer un sacado de oro y se ha de picar de lustre el rostro y el pelo en conformidad de lo referido sólo que entre la sangre se ha de echar unas gotas de vidrio como gotas de agua. El ángel que está en la misma historia ha de ser la jaquetilla rosada y encima se ha de hacer una tela de diferentes colores y sacar algunas laboricas de oro y hechos diferentes grafios y toda la labor oscurecida y realzada y en las orillas como cosa de tres dedos se ha de dar de un colorico muy honesto y encima se ha de hacer una orilla de estofador y variedad de colores oscurecido y realzado y el campo de la labor se ha de hacer un grafio letejeados muy igual el aforro ha de ser azul y encima se ha de hacer un chamelote de oro las faldas han de ser blancas y encima del blanco se ha de hacer una tela de colores muy honestas y la labor ha de ser picada de diferentes grafigos y el campo rajado y en las orillas se han de hacer unas horcas a trechos con algunas esmeraldas fingidas y rubíes y de joya a joya un sacado de oro y picado de lastre el aforro ha de ser encarnado y hecho un galoncico de oro en la orilla y lo demás picado de un grafio muy igual y en todas las orillas así en falda como en jaquetilla se han de poner unas pintas de hilo y se han de dorar a mate, el cáliz ha de quedar de oro limpio, las alas se han de estofar de colores muy 
finos y después se han de veniar las plumas y rajarlas y esto ha de ser sólo por la parte de delante, el tarrazo que es adonde asienta la rodilla del santo Cristo se ha de color del natural y con algunas florecillas y diferencia de grafio y en el segundo término se ha de pintar nos apóstoles durmiendo y más distante el prendimiento y lo demás pintado su cielo con sus lejos y horizontes y todo el tablero picado de grafio por igual menos las figurillas que se pintaren. La historia que está en correspondencia que es Jesús Nazareno en color y labor ha de corresponder al de la Oración y la mujer Verónica se la ha de dar de colores conforme pide y en ello se ha de hacer sus telas y grutescos en la misma conformidad que las demás hechuras y en el paño que tiene en la mano se ha de pintar el rostro de Nuestro Señor lo que coge el rostro no se ha de sacar oro más lo restante del paño se ha de hacer de grafio después de dado de blanco, la cruz en conformidad de la grande. En cuanto al respaldo se ha de pintar en el monte calvario y algunas ruinas por lejos y hecho el cielo y grafio en conformidad del correspondiente. Dos ángeles del natural que se han de poner encima de los pedestales del segundo cuerpo las túnicas sobre el color blanco y se ha de hacer una primavera de variedad de flores o de telas no mediada de tintas va brocatado a elección de los señores congregantes las orillas han de ser en la misma conformidad que están las del ángel de la oración y en las rodillas se les ha de echar puntas de hilo de tres dedos blanco doradas a mas el aforro de las faldas ha de ser verde y en ello hecho un chamelote la jaquetilla ha de ser encarnada y en ello hecha una tela promiedado de tintas oscurecidas y realzadas las insignias que tienen en las manos conforme el color que las pide se ha de hacer el pelo y encarnaciones en conformidad de lo referido.

$6^{\mathrm{a}} \quad \mathrm{Y}$ es condición que el San José de las entre columnas ha de ser la capa encarnada y en ella hecho un brocado de colores y a trechos sacando algunas joyas de oro picadas de lustre y las labores del brocado de diferentes grafios y en la orilla se han de estofar unos cogollos bien contrapuestos de colores, y el campo guardado y gravado de lustre en el forro sobre un color azulado se ha de hacer una telica como bordada de oro y matizada de colores y diferentes grafios y en la orilla un sacado de oro, picado de lustre, la túnica del San José ha de ser un grutesco, verde la albor picada del grafio y el campo rajado muy bien oscurecido y fortalecido y realzado después de hecho de grafio la orilla ha de corresponder a la de la capa del Niño Jesús que tiene al lado, ha de ser la túnica morada y la de la tela en la misma conformidad que el Nazareno. El San Joaquín ha de ser en la conformidad en cuanto a las labores como el San José la diferencia ha de ir en los colores como es la capa amarilla y el forro encarnado y la túnica azul claro y la imagen que tiene en la mano ha de ser el manto azul y bordado de oro picado de lustre y en la orilla se ha de hacer de joyas y de oro un adorno sobre un color oscurico muy bien oscurecido y realzado y vareado de colores y el campo leutejeadico de oro y el forro hecho una labor de oro con su guardilla alrededor de la orilla picado de lustre la túnica ha de ser blanca y en ella se ha de hacer una primavera de flores con sus soles sacados de oro y veucados de lustre y en el espacio algunas cabecica de serafines y en la orilla de las mangas como la túnica va sacado de lustre de dos dedos de ancho picado de lustre las encarnaciones y pelo como está dicho.

$7^{\mathrm{a}} \quad$ Es de condición que si los señores congregantes gastaren que los tres respaldos se estofen ha de ser a disposición de sus mercedes.

$8^{\mathrm{a}} \quad$ Es condición que dos historias que están entre las repisas del pedestal principal que en la una está San Pablo, el San Pablo se ha de estofar en la túnica sobre un color verde una tela sacada de oro y metida de diferentes colores y diferentes grafios y diferentes orillas que las del San José, muy bien oscurecido y realzado con cuanto primor y aseo le pidiere, la capa ha de ser acarminado y en ella hecho un brocado de diferentes grafios y colores sacando algunas alcachofas y grafios para picar de lustre y en la orilla se ha de hacer de diferentes adornos que la 
de San José entremetiendo algunos vivas en la labor a las dos figuras que está predicando se las ha de adornar de los dos colores que requiere echando en ellas unas telas de joyas lo más rico que se pudiere, el respaldo se ha de pintar un palacio en primer término en perspectiva y determinando en segundos términos otros trozos de fábrica y todo éste respaldo ha de ser picado de grafio muy menudo y muy igual. En la historia que le corresponde como es Cristo y San Juan, el Cristo ha de corresponder a las demás hechuras de los Cristos, en el de San Pedro ha de corresponder la labor a la de San Pablo sólo ha de diferenciar en los colores que ha de ser la capa amarilla y la túnica azul. En cuanto a las encarnaciones han de ser a pulimento todas las imprimaciones con cuanto así fuere imaginable porque conviene que se hagan para que nunca en jamás vacíe la encarnación, los pelos todo ha de ser peleteado de oro molido menos San Pablo y San Joaquín que ha de ser con plata y barnizado.

$9^{a} \quad$ Es de condición que todos los azules que llevaren las figuras así los de arriba como de abajo han de ser oscurecido, las orillas todos con ultramarino de primera suerte y todos los azules de tela grutescos y brocados ha de ser de azul cenizas muy finas las mejoras que se hallaren todos los carmines que se gastaren ha de ser muy finos los mejores que se hallaren con carmines de Indias. Y si el maestro que hiciere ésta obra incurriere o faltare en algunas de las condiciones referidas puedan los señores congregantes por cuenta del maestro traer la persona de la más adelantada utilidad por su cuenta de Castilla la vieja o nueva sin poder el maestro hacer ni elegir a nadie de su parte para ésta ni para hacerlo y no pueda el maestro quitar tabla ni andamio sin licencia de dichos señores hasta que esté registrada y dada por buena la dicha obra a vista de maestros peritos lo cual ha de guardar, cumplir y ejecutar el dicho Manuel de Estrada en la forma definida.

$10^{\mathrm{a}}$ Asimismo la Cofradía del Santísimo se ha de poner en la misma conformidad y ha de dorar y estofar el pastor bueno de fijo que se hiciere y pusiere en la puerta de la dicha custodia.

$11^{\mathrm{a}}$ Que aunque se pida por los dichos señores congregantes otras cosas que para pulimento de dicha obra se debieren ejecutar el dicho Manuel de Estrada las ha de hacer y no ha de poder pedir mejoras algunas porque todo hasta ponerlo en la única perfección queda ajustado en ésta escritura y precio que por la dicha obra se le ha de dar.

$12^{\mathrm{a}}$ Que por toda la dicha obra a toda costa la dicha congregación y en su nombre los señores D. Pedro de Rozas ministro D. Alonso Romero, D. Felipe Sánchez, D. Juan Casado, D. Juan Fernández Salazar y D. Juan Redondo en virtud de la dicha comisión la obligan con sus bienes y rentas de dar y entregar al dicho Manuel de Estrada diez y nueve mil reales de vellón con calidad y condición que la ha de tener acabada en toda perfección para el día veinte de mayo del año que viene de mil y seiscientos y noventa y uno y no lo estando haya de perder y se le haya de bajar de la dicha cantidad tres mil y trescientos reales de vellón en pena de no haber cumplido con dicha obligación y esta cantidad que nos ha de percibir del dicho precio principal el cual se le ha de pagar por la dicha congregación teniendo dorado el cuerpo de arriba hasta la cornisa a su costa y misión por razón de fianza y seguridad de que ejecutará la dicha obra y habiéndola puesto en el dicho estado se le han de ir dando cuatrocientos reales cada semana para pagar el oro que fuere gastando desde allí adelante y a los oficiales que tuviere y asistieren a la dicha obra sus jornales hasta el cumplimiento de la dicha obra y está en la dicha cantidad de los dichos diez y nueve mil reales y si acabada en toda perfección a vista, satisfacción y reconocimiento de maestros del dicho arte que se han de nombrar por la dicha congregación se les estuviere debiendo y restare alguna cantidad la que así se le debiere se la pagará luego de contado cómo se haya declarado haber cumplido y no lo haciendo los dichos señores congregantes quieren y consienten se pueda ejecutar y ejecute a la dicha congregación y a sus 
bienes y rentas en virtud de esta escritura y de la dicha declaración y ajustamiento de cuenta que se ha de hacer como por guarenticia y llana obligación juntamente con las costas y daños, intereses y menoscabos que por la dilación se les siguieren.

$13^{\text {a }}$ El dicho Manuel de Estrada se obliga con su persona y bienes muebles y raíces, derechos y acciones, habidos y por haber a ejecutar la dicha obra en la forma referida en los dichos diez y nueve mil reales a toda costa y darla acabada en toda perfección para el dicho día veinte de mayo del año que viene de mil y seiscientos y noventa y uno a vista y reconocimiento de maestros y si no estuviere acabado en toda perfección quiere y consiente se le quiten y bajen los dichos trescientos ducados del dicho principal en pena de su omisión y con la cantidad que quedare la ha de dar acabada y hará el dorado del primer cuerpo de arriba hasta la cornisa en lugar de fianza y de allí adelante recibirá las pagas en la forma referida a los dichos cuatrocientos reales cada semana y no pedirá mejoras algunas aunque se le mande añadir en la dicha obra algunas cosas para mayor hermosura.

$\mathrm{Y}$ en esta conformidad ambas partes cada una por lo que les toca se obligan y obligan a la dicha congregación a guardar y cumplir esta escritura y dan poder a las justicias y jueces que de las causas de cada uno puedan y deban conocer conforme a derecho a quien se someten y en especial el dicho Manuel de Estrada al fuero y jurisdicción del señor corregidor de esta ciudad y su teniente y a cada uno in solidum y todos lo reciben por sentencia pasada en cosa juzgada (...) y en nombre de la dicha congregación juraron en forma habrá por firme esta escritura y no ir contra ella y del juramento no pedirá relajación y si se la concediere no usará de ella en tiempo alguno y todas las dichas partes lo otorgaron así ante mí el presente escribano, siendo testigos Gregorio Díez de Mata, Juan Fernández y Manuel Basurto vecinos de esta ciudad y los otorgantes que yo el escribano doy fe conozco lo firmaron. 


\section{DOCUMENTO 48}

OBLIGACIÓN PARA LA OBRA DEL RETABLO DE SAN FELIPE NERI DE ESTA CIUDAD ENTRE EL LICENCIADO Y CURA DE SANTIAGO EN NOMBRE Y EN VIRTUD DEL PODER DE LA CONGREGACIÓN DE SAN FELIPE NERI DE ESTA CIUDAD Y DE LA OTRA ANTONIO Y FRANCISCO BILLOTA ENSAMBLADORES (10 - AGOSTO - 1685)

A.H.P.V., Leg. 2.774/1, ff. 203-2049

Condiciones para hacer y ejecutar el retablo para la iglesia del señor San Felipe Neri por la traza y planta hecha para ellos:

Es condición que ha de ser ejecutado en madera de Soria, seca y limpia de nudos y la mejor que se hallara.

Es condición que ha de ir todo ensamblado a la hebra sin que haya frente ninguna.

Es condición que el pedestal que asienta en el suelo ha de ser de piedra y ha de correr por cuenta del licenciado cura de Santiago, y el maestro que hiciere dicho retablo ha de hacer perfiles y planta para que se haga.

Es condición que el pedestal del retablo se ejecute conforme la traza, tallando todas las molduras como cada una lo requiere y haciendo toda la talla menos perfiles y bien rebajada y limpia y todos los vaciados que hubiere ha de llevar subientes de talla.

Es condición que las columnas grandes sean de seis vueltas de salomónico torcidas todo lo necesario y revestidas de vides y hojas con racimos bien adornadas y compuestas en toda perfección.

Es condición que los trasdoses de las columnas bajan vaciadas y en el vaciado la un subiente de talla y la moldura del vaciado vaya tallada de cascarilla y lleven basa sus capiteles conforme las columnas.

Es condición que todas las boquillas vayan vaciadas con un talón tallado y en el vaciado su subiente de talla.

Es condición que los intercolumnios han de ir ejecutados conforme el que está guarnecido con columnas dando al fondo del arco una cuarta y dicho fondo ha de ir adornado de subientes o talla. Haciendo las columnas del tamaño que demuestra la traza de cuatro vueltas y bien adornadas y a la repisa sobre que ha de estar Santo darlas el relieve todo lo necesario para la planta del Santo.

Es condición que la caja del San Felipe ha de ser conforme la traza echando las cuatro columnas conforme traza y planta y entre columna y columna en el fondo ha de ir un vaciado talladas las molduras y un subiente de talla así en las jambas como en él colocando el fondo que diere lugar

9 FERNÁNDEZ DEL HOYO, María Antonia: "El convento de San Francisco de Valladolid. Nuevos datos para su historia”. B.S.A.A., Tomo LI, 1985, p. 436. 
la pared y ha de hacer una peana para el Santo para sacarle en procesión y que levante todo lo necesario para estar en la caja del retablo toda dicha peana se adornará de talla.

Es condición que el marco principal ha de ser tallado con tarjetas bien rebajado a la tarjeta principal de une nos perfiles y bien rebajada.

Es condición que la cornisa ha de ir ensamblada conforme a dicho resaltándola con los resaltos de columnas y trasdoses tallando todas sus molduras como cada una lo requiere y adornándola con modillones y cogollos de talla.

Es condición que el pedestal del segundo cuerpo ha de ir conforme la traza echando talla en todos los vaciados y tallando todas sus molduras y ha de hacer dos repisas sobre que están el San Juan y María al ancho y alto que fueren necesarias y el fondo que tuviere la caja ha de ir de talla si fuere necesario y todo lo demás del dicho segundo cuerpo ha de ir conforme la traza tallado todas las molduras y echando tallas en todas las (...) necesarias sin que quede vallo ninguno.

Es condición que en el Santo del pedestal del segundo cuerpo donde está el remate se ha de echar dos ángeles desnudos con sus bandas y alas y con unos atributos de la Pasión en las manos y se les ha de levantar sobre unas peanas adornadas de talla para que estén más esbeltos.

Es condición que ha de hacer una custodia para dicho retablo conforme la planta hecha con doce columnas. Y el alzado ha de tener de alto hasta la cornisa de encima de los arcos lo que tiene el pedestal de la obra y de allí arriba el remate que ha de ser media naranja y arbotantes (...) de talla y en medio (...) y encima una hechura de escultura de la Fe. Y dicha custodia ha de ir adornada de talla conforme lo requiere cada miembro echándose en las cornisas por de dentro y de fuera y por de dentro sus enjutas y cornisa redonda que esté con la media naranja por de dentro y en el alto del pedestal ha de hacer caja para sagrario levantando la más que el pedestal lo necesario para que quepa el copón y adornándola con talla y marco y todo lo demás necesario todo a gusto y satisfacción del señor cura de Santiago.

Y además toda dicha obra la he de dar puesta y asentada (...) a satisfacción de maestros de dicho arte.

Y es condición que si alguna cosa fuere necesaria mudar o añadir de talla a lo que va puesto en la traza para que dé retablo quede con más perfección se ha de hacer disponiéndolo y ordenándolo el dicho señor cura sin que por ello ni toda la demás obra se puedan pedir ningunas mejoras.

Y con estas condiciones y calidades se ajustó el precio con Antonio Billota y Francisco Billota su hijo maestros ensambladores y vecinos de esta ciudad en quince mil reales de vellón a toda costa excepto la escultura que llevare dicho retablo y que ésta ha de correr por cuenta del dicho señor cura y de la congregación y sobre esto entre ambas partes se ha de hacer escritura obligándose dichos maestros a dar acabada dicha obra en todo el año de seiscientos y ochenta y ocho y que el dicho cura obligándose a la paga de dicha cantidad como su fuero trabajando y ambas partes que lo firmamos en Valladolid a 10 de agosto de 1685. 


\section{DOCUMENTO 49}

\section{CARTA DE PAGO. FRANCISCO BILLOTA VECINO DE ESTA CIUDAD A FAVOR DE LA CONGREGACIÓN DE SAN FELIPE NERI (25 - AGOSTO - 1694)}

A.H.P.V., Leg. 2.640, f. 244

En la ciudad de Valladolid a veinte y cinco días del mes de agosto de mil seiscientos y noventa y cuatro años ante mí el escribano y testigos pareció Francisco Billota ensamblador vecino de esta ciudad y dijo que por cuanto hizo y ejecutó el retablo que está puesto en la iglesia de la Congregación de Nuestro Padre San Felipe Neri de esta ciudad en el precio que se justó y de que se había hecho papel y de él fue recibiendo diferentes cantidades de maravedíes y habiendo ajustadose la cuenta con la dicha congregación así de lo referido como de armar y desarmar el monumento hasta el viernes santo próximo pasado de este año y de todas cuentas se le ha restado debiendo cuatrocientos y treinta y tres reales de los cuales se le ha despachado libramiento por el señor licenciado D. Joseph González ministros de la dicha congregación sobre el señor D. Pedro de Rozas el cual está llano a pagar la dicha cantidad otorgándose a favor de la dicha congregación carta de pago y finiquito en la forma y viendo ser justo el dicho Francisco Billota otorga por esta escritura que confiesa recibir de la dicha congregación por mano del dicho señor D. Pedro de Rozas y en virtud del dicho libramiento en diez y nueve de este presente mes y año que entrega original los dichos cuatrocientos y treinta y tres reales que así le restan debiendo de la fábrica de dicho retablo y de armar y desarmar el monumento de cuya cantidad se da por bien contengo y entregado a su voluntad por los haber recibido y pasado a su poder con efecto y porque su entrega no parece de presente renunció las leyes de este caso y otorga en favor de la dicha congregación tan bastante carta de pago y finiquito como a su derecho conviene a la cual da por libre de la obligación que tenía hecha a favor del otorgante sin que lo que de derecho alguno que poder repetir contra la dicha congregación hasta hoy presente día en que va comprendido el entierro de María de Iglesias mujer que fue del otorgante a que asistió a la dicha Congregación y se obliga a guardar y cumplir esta escritura y no ir contra ella en manera alguna y otorgó así ante mí el escribano y lo firmó a quien doy fe conozco siendo testigos Juan Barón de la Fuente, Joseph García y Joseph Freiría vecinos de esta ciudad. 


\section{DOCUMENTO 50}

\section{AJUSTE ENTRE D. FRANCISCO DE LA VEGA Y BLAS MARTÍNEZ DE OBREGÓN ENSAMBLADOR PARA LA REALIZACIÓN DEL RETABLO MAYOR DE LA IGLESIA DE NUESTRA SEÑORA DEL ROSARIO ( $9-$ JULIO - 1689)}

A.H.P.V., Leg. 2.984/1, ff. 31-35

En la ciudad de Valladolid a diez y nueve de julio de mil seiscientos y ochenta y nueve años ante mí el escribano y testigos parecieron presentes de la una parte D. Francisco de la Vega Sorriba vecino de esta ciudad en nombre y en virtud del poder que tiene de la cofradía y cofrades de Nuestra Señora del Rosario y Santos Mártires de esta dicha ciudad para el efecto que se dirá otorgaron en ella en dos de este presente mes y año ante Jerónimo de Vivero escribano de su majestad. Y de la otra Blas Martínez de Obregón maestro tallador vecino de esta ciudad como principal, y Juan de Bosques maestro cerrajero Antonio Álvarez tallador Antonio Barreda dorador y Antonio Vázquez escultor vecinos de ella como sus fiadores. Y dijeron que por cuanto el dicho D. Francisco de la Vega Sorriba en nombre de la dicha cofradía y en virtud del dicho su poder tiene ajustado con el dicho Blas Martínez de Obregón maestro tallador hacer y ejecutar un retablo que se ha de poner en la capilla mayor de la iglesia de Nuestra Señora del Rosario y Santos Mártires de esta dicha ciudad conforme a la traza que queda firmada de los otorgantes y de mí el presente escribano que es la misma que se ejecutó y está puesta en la iglesia del Convento de San Quirce de ellas y del dicho poder es como se sigue:

\section{Aquí el poder y condiciones}

El cual dicho poder y condiciones va cierto y verdadero y concuerda con su original de que yo el presente escribano doy fe y de él usando el dicho D. Francisco de la Vega dijo que cumpliéndose por parte del dicho Blas Martínez de Obregón con lo contenido en las condiciones aquí insertas obligaba y obligó a los cofrades de dicha Cofradía de Nuestra Señora del Rosario y Santos Mártires y a los bienes propios juros y rentas de ella a darle satisfacción de los siete mil y quinientos reales de vellón mencionados en una de dichas condiciones a los plazos y en la conformidad que en ellas se refiere. Y el dicho Blas Martínez de Obregón se obligó con su persona y bienes muebles y raíces habidos y por haber de guardar cumplir y ejecutar las dichas condiciones sin reservar cosa alguna según la dicha traza y arte a vista de maestros peritos en el arte y en defecto no lo cumplir, los dichos Juan de Bosques Antonio Álvarez Antonio Vázquez como sus fiadores llanos cumplidores y principales pagadores sin que sea necesario hacer excursión en el dicho principal ni sus bienes junto y de mancomún a voz de uno y cada uno de por sí y por el todo in solidum con renunciación de las leyes de la mancomunidad en forma se obligaron con sus personas y bienes muebles y raíces presentes y futuros harán el dicho retablo conforme a las condiciones aquí insertas a su costa y por su cuenta y riesgo y todos los susodichos para la guarda y cumplimiento de esta escritura y sus condiciones dieron todo su poder cumplido a las justicias y jueces que de cada una de las dichas

10 BALADRÓN ALONSO, Javier: "Nuevas obras de Francisco Díez de Tudanca y otros datos de escultores barrocos vallisoletanos", B.S.A.A., Tomo LXXVIII, 2012, p. 161. 
partes puedan y deban conocer a quienes se sometieron para que a ello les apremien por todo rigor de derecho y vía ejecutiva como si fuese sentencia definitiva de juez competente pasada en autoridad de cosa juzgada sobre que renunciaron todas las leyes fueros y derechos y demás que hablan en su favor con la general y derechos de ella en forma y así lo dijeron otorgaron y firmaron a quien yo el escribano doy fe conozco siendo testigos Juan de Santo Domingo escribano de su majestad Francisco de Salazar y Joseph de Sevilla vecinos y estantes en esta dicha ciudad.

Sépase por esta escritura de poder como nos la cofradía y cofrades de Nuestra Señora del Rosario y Santos Mártires San Cosme y San Damián de esta ciudad estando juntos en la sala de cabildos donde tenemos costumbre de nos juntar para tratar las cosas del bien y utilidad de la dicha cofradía y habiendo sido llamados por Simón de Villamor nuestro llamador estando presentes especial y señaladamente D. Antonio de Tapia y D. Pedro del Castillo alcaldes y los demás cofrades que al pie de este poder firmaremos nuestros nombres que confesamos ser la mayor parte de los que al presente hay en ella, y por los ausentes enfermos e impedidos por quienes prestamos caución en bastante forma, que pasan por lo que por nosotros fuere hecho y otorgado debajo de expresa obligación que para ello hacemos de los propios bienes y rentas de la dicha cofradía. Decimos que habiéndose reconocido que el retablo que estaba en dicha iglesia en el altar mayor por su mucha antigüedad estaba amenazando ruina, y que para que estuviese con la decencia que se requiere era necesario hacer otro nuevo para cuya costa por diferentes cofrades y bienhechores se habían ofrecido diferentes limosnas y asimismo de los efectos de la dicha cofradía aplicado algunos para dicho efecto y para que tenga ejecución el dicho retablo con la brevedad que se necesita por la presente otorgamos que damos todo nuestro poder cumplido el que de derecho se requiere y es necesario a D. Luis de la Vega y D. Francisco de la Vega Sorriba su hijo, y a cada uno y cualquier de ellos in solidum especial para que en nuestro nombre y de la dicha cofradía puedan ajustar con el maestro o maestros que les pareciere el que hagan el dicho retablo según la traza y condiciones que por el maestro con quien se ajustare les fueren entregadas valiéndose de la que les pareciere más decente y a su elección ajustando con el dicho maestro o maestros la cantidad que por él se hubiere de dar y tiempo en que le hubiere de hacer obligando desde luego y obligamos a la dicha cofradía a la paga de las cantidades en que se ajustare guarda y cumplimiento de las escrituras que en esta razón se otorgaren. Y asimismo les damos este dicho poder para que puedan ajustar que se abra y rompa el camarín de Nuestra Señora para que quede con la perfección que fuere necesario para el adorno de dicho retablo y sobre todo puedan otorgar la escritura o escrituras que se requieran con las cláusulas sumisiones poderíos de justicias y demás requisitos y circunstancias que convengan las cuales valgan como si por nos los otorgantes y la dicha cofradía fueren hechas y otorgadas como si presentes fuésemos que siéndolo por los dichos D. Luis y D. Francisco de la Vega o cualquiera de ellos desde luego para cuando llegue el caso las aprobamos y ratificamos y nos obligamos a su guarda y cumplimiento, y paga de las cantidades en que se ajustare el hacer el dicho retablo y el abrir el camarín de Nuestra Señora y todo lo demás que en esta razón se hiciere y ajustare por los susodichos que el poder que para todo se requiere les damos sin ninguna limitación con todas las cláusulas requisitos y circunstancias que menester sean, las cuales damos por expresadas en dicho poder como si a la letra lo fueren y con libre franca y general administración y relevación en forma y nos obligamos y a la dicha cofradía sus bienes y rentas de haber por firme todo lo que en virtud de este poder se hiciere y otorgare y lo otorgamos así ante el presente escribano y testigos en la ciudad de Valladolid a dos día del mes de julio de mil 
seiscientos y ochenta y nueve años siendo testigos Simón de Villamor Pedro del Valle y Jerónimo Ruiz vecinos de esta ciudad y los otorgantes a quienes yo el escribano doy fe conozco lo firmaron.

Memoria de las condiciones con que yo Blas Martínez de Obregón he de ejecutar el retablo que se ha de poner en la capilla mayor de la iglesia de Nuestra Señora del Rosario y Santos Mártires de esta ciudad conforme a la traza firmada de mi mano, que son las siguientes:

$1^{\mathrm{a}} \quad$ Lo primero que el pedestal principal ha de llevar cuatro repisas conforme está en la traza y entre repisa y repisa sus portadas que se han de ejecutar conforme están en Nuestra Señora de los Ingleses con la talla y molduras y codillos que tienen dichas portadas las cuales han de quedar con la altura que hoy tiene la yesería.

$2^{\mathrm{a}}$ Que la custodia se ha de ejecutar conforme está en el Convento de San Quirce de esta ciudad y dentro de ella ha de haber su tramoya para descubrir el Santísimo Sacramento la cual ha de llevar su trono en ochavo con sus molduras y una media caña grande con su plinto y media vasa y encima su tablero y media uña vuelta hacia arriba y en cada ochavo su cartela tallada a dos haces y entre cartelas y cartela un florón en la media caña. Y en los ocho ochavos ha de llevar ocho macollas de talla con sus mecheros para luces y encima del tablero ha de haber su arco con machoncicos con sus festones colgantes y encima de los machones su rosca de tarjetillas y esto ha de ser a dos haces y por remate una tarjeta que se baje ciñendo por encima del arco y ha de llegar a abrazar a la clave del arco y la tarjeta ha de ser a dos haces.

$3^{\text {a }} \quad$ Que la sotabasa se ha de ejecutar conforme el perfil de la traza y tallada todos sus miembros.

$4^{\mathrm{a}} \quad$ Que los muros del pedestal que arriman a la pared han de llevar sus tambanillos que aten con la sotabasa y encima de ellos sus festones colgantes así por perfil como por fachada, y esta condición se entiende para los muros del primer cuerpo.

$5^{\mathrm{a}}$ Que el primer cuerpo ha de llevar cuatro columnas salomónicas con basas aticurvas y capiteles corintios compuestos y las pilastras lo mismo y estas columnas han de ser de cuatro vueltas revestidas y bien pobladas de hojas y vástagos y racimos de parra y los intercolumnios se han de ejecutar como lo demuestra la traza y está ejecutado en San Quirce y también ha de llevar su marco tarjetas con sus codillos guarneciendo la caja de Nuestra Señora con sus enjutas de talla en el arco de Nuestra Señora y ha de llevar sus impostas con sus festones colgantes de perfil y fachada y su hachete tallado de tarjetillas y el fondo de la caja de Nuestra Señora ha de llevar sus florones de cogollos de buen relieve y esta caja ha de quedar hueco para correr velos y cortina y por la parte de dentro del camarín ha de llevar su arco de una cuarta de ancho para que tape la junta contra el yeso y este arco ha de ser tallado de tarjetas.

$6^{\mathrm{a}}$ Que la cornisa principal se ha de ejecutar conforme está en la traza con frisos y modillones a donde le tocare y conforme arte y todas las molduras talladas como está dibujado y en la clave de la cornisa ha de llevar su tambanillo que ate con los miembros bajos de la cornisa y baje ciñendo los codillos del cuadro principal y encima del tambanillo su tarjeta que se ciña y 
suba por encima de la corona de la cornisa y encima de ella su corona y de ella han de salir dos palmas y en medio de la tarjeta su peto.

$7^{\mathrm{a}}$ Que el nicho de Nuestra Señora se ha de levantar dos pies de albañilería y su coste ha de ser por cuenta de la cofradía.

$8^{\mathrm{a}} \quad$ Que el pedestal segundo ha de llevar sus tarjetas así por perfil como fachadas y se ha de ejecutar conforme está en la traza y en el macizo de las columnas del rincón sus escudos para poner en el uno el sol y en el otro la luna.

$9^{\mathrm{a}} \quad$ Que el segundo cuerpo ha de llevar dos columnas salomónicas ejecutadas con la misma condición de las del primer cuerpo así en pilastras como en todo lo demás y la caja se ha de ejecutar como está en la traza con su cuadro de tarjetas como el de abajo, pero a donde hay machones han de ser columnas salomónicas de la labor que la demás respective. Y en el fondo de la caja ha de llevar sus frisos de talla para poner a San Juan y María sus arbotantes de talla ejecutados conforme en la traza y ha de llevar sus enjutas de talla y en los cerchones sus festones colgantes y en la cornisa segunda sus modillones conforme arte y ha de llevar su frontispicio guardando sus resaltos y macizos y en la clave su tambanillo que ate con sus miembros y se baje ciñendo por los codillos del cuadro y encima su tarjeta de armas reales que suba a ceñirse hasta la bóveda.

$10^{\mathrm{a}}$ Que esta obra se ha de ejecutar conforme traza y condiciones según arte y a vista de maestros en término de ocho meses desde el día que se rematare y se otorgare escritura, en cantidad de siete mil y quinientos reales de vellón los mil y quinientos de ellos luego que se otorgue dicha escritura para dar principio a dicha obra y comprar la madera para ella, y ciento y cincuenta reales en cada semana contándose desde el día en que se otorgare dicha escritura hasta cumplirse el término de los dichos ocho meses de los cuales he de dar acabada dicha obra en la conformidad referida fenecida según dicho es y se me ha de entregar toda la cantidad que faltare al cumplimiento de los dichos siete mil y quinientos reales.

$11^{\mathrm{a}}$ Que el dicho retablo le tengo de dar puesto y asentado sin tener que pedir mejoras ni cosa alguna y dar llave en mano y bajar el retablo que hoy está puesto en la dicha iglesia y capilla mayor de Nuestra Señora del Rosario dejándola con la decencia que se requiere mientras se ejecuta esta obra y cualquier maestro o maestros que con ella quedare ha de dar trescientos reales por el trabajo y ocupación de traza y condiciones y según va referido en estas yo el dicho Blas Martínez de Obregón me obligo a ejecutar dicha obra, dando fianzas a satisfacción de la Cofradía de Nuestra Señora del Rosario y Santos Mártires o de la persona que su poder tuviere para el ajuste de ella con la advertencia que toda la escultura ha de ser por cuenta de dicha cofradía y lo firmé en Valladolid a diez de junio de mil seiscientos y ochenta y nueve años. 


\title{
DOCUMENTO 51
}

\author{
OBLIGACIÓN QUE OTORGA BLAS MARTÍNEZ DE OBREGÓN. \\ AJUSTA DE LOS DOS COLATERALES DEL CONVENTO DE SAN \\ QUIRCE DE ÉSTA CIUDAD LOS QUE SE HAN DE HACER A TODA \\ COSTA POR SU CUENTA EL UNO EL DÍA PRIMERO DE ENERO Y EL \\ OTRO PARA MAYO DEL AÑO 1694 (30 - SEPTIEMBRE - 1693)
}

A.H.P.V., Leg. 2.898, ff. 173-174

En la ciudad de Valladolid a treinta días del mes de septiembre de mil y seiscientos y noventa y tres años ante mí el escribano y testigos estando en el Monasterio Real de San Quirce de ella y en una de las gradas y locutorio de dicho Monasterio parecieron de la una parte la señora $\mathrm{D}^{\mathrm{a}}$ Francisca María de Hinojosa abadesa de dicho Monasterio y de la otra Blas Martínez de Obregón maestro tallista y ensamblador vecino de ésta dicha ciudad, y dijeron tenían tratado y concertado de que el dicho Blas Martínez de Obregón ha de hacer y fabricar en la iglesia de dicho Monasterio dos colaterales de talla según la traza que el susodicho tiene entregada a dicha señora abadesa de quien está firmada al pie de ella y con las demás calidades y condiciones que el dicho Blas Martínez de Obregón se ha de obligar en ésta escritura que son las de tenor siguiente:

$1^{\text {a }} \quad$ Es condición que el pedestal principal ha de llevar cuatro repisas de talla en los netos del pedestal sus variados y en el de en medio lo mismo con su tarjeta para poner las palabras de la consagración.

$2^{\mathrm{a}} \quad$ Más es condición que éste pedestal se ha de ejecutar con perfiles y molduras que tiene la traza.

$3^{\mathrm{a}} \quad$ Más es condición que el cuerpo principal ha de llevar cuatro columnas salomónicas revestidas de vástagos con sus hojas y racimos y los capiteles corintios compuestos y con basas articuladas.

$4^{\mathrm{a}} \quad$ Más es condición que el marco principal de Nuestra Señora se ha de ejecutar con los mismos codillos y resaltes que tiene la traza y se ha de tallar tarjetillas y la rosca del arco se ha de tallar de (...).

$5^{\text {a }} \quad$ Mas es condición que el fondo de la caja de Nuestra Señora ha de ser ensamblada susbarjados a trechos y en ellos sus florones.

$6^{\mathrm{a}} \quad$ Mas es condición que la cornisa principal ha de llevar sus (...) y frisos en donde le tocare a cada uno de dichos colaterales conforme arte y en la clave de la cornisa su tarjeta de buen rumbo y talla que ha de ceñir toda la cornisa y bajar hasta el tambanillo del marco principal y ésta cornisa ha de llevar sus perfiles según demuestra dicha traza.

$7^{\mathrm{a}} \quad$ Es condición que el segundo cuerpo de cada uno de dichos colaterales ha de llevar dos columnas salomónicas con las mismas condiciones que las del primer cuerpo y detrás de ellas sus (...) jugando con molduras y collarinos como lo demuestra la traza y de ellos han de salir sus arbotantes de talla cargando en los macizos de los intercolumnios y en los macizos de las columnas (...) han de llevar sus escudos para poner en cada una de ellas... de los cuatro hábitos de las cuatro órdenes militares que son Alcántara Calatrava Avis y Montesa. 
$8^{\mathrm{a}} \quad$ Es condición que el cuadro segundo que ha de ocupar la imagen que ha de ir tallado de hojas arpadas y uniéndose con las molduras de la cornisa postrera y encima su tarjeta con el adorno que está dibujado en la traza.

$9^{a} \quad$ Más es condición que las cornisas del segundo cuerpo de cada uno de dichos colaterales se han de ejecutar con los perfiles y molduras que está en dicha traza y en los macizos sus nudillos y encima de las columnas otros dos remates tallados.

$10^{\mathrm{a}} \quad$ Mas es condición que los intercolumnios del primer cuerpo han de llevar sus festones colgantes de talla y sus variados moldeados.

$11^{\mathrm{a}} \quad$ Mas es condición que cada uno de dichos dos colaterales han de llevar dos muros que arman a la pared para que hagan fondo a la caja y éstos han de ser vaciados y moldeados y dichos dos colaterales han de tener la altitud que les tocare conforme al ancho del sitio donde se han de poner.

$12^{\mathrm{a}} \quad$ Más condición que los santos que intitulan San Quirce y Santa Julita que están puestos en el retablo del altar mayor se han de bajar y poner en el segundo cuerpo de cada uno de dichos dos colaterales y si faltare algo de talla donde se han de quitar lo ha de hacer a su costa el dicho Blas Martínez de Obregón y según las calidades y condiciones aquí referidas y traza que tiene entregada se obliga el dicho Blas Martínez de Obregón acabar de manos y dar sentados en la iglesia de dicho Monasterio los dichos dos colaterales en toda perfección poniendo por su cuenta toda la madera y demás materia y manufactura para ellos necesario a vista de maestros peritos en el arte el uno acabado y sentado en el sitio donde se han de poner en blanco para el día primero de enero del año que viene de mil y seiscientos y noventa y cuatro y el otro para el día de fin de mayo de dicho año y no cumplimiento con cada uno de dichos plazos se le pueda obligar para que otro maestro lo haga por su cuenta y riesgo y que por razón del trabajo y ocupación que ha de tener el dicho Blas Martínez de Obregón en la fábrica de dichos dos colaterales manufactura y materiales se le han de dar tres mil y quinientos reales de vellón pagados en ésta forma, los quinientos reales ahora de contado los mil y quinientos acabado que sea uno de dichos colaterales y los mil y quinientos restantes al cumplimiento del dicho principal se le han de dar y entregar estando acabados y sentados ambos colaterales en toda forma (...) y lo otorgaron así ante el presente escribano siendo testigos (...) Díez vecino de la ciudad de Toro y estante al presente en ésta dicha ciudad el licenciado don Gabriel de Terán Mantilla y Alonso del Río vecinos y estantes en ésta ciudad y los otorgantes a quien yo el escribano doy fe conozco y lo firmaron. 


\section{DOCUMENTO 52}

\section{ESCRITURA DE LA OBRA QUE SE HA DE HACER EN LA FÁBRICA DE LA CAPILLA DE LA CONGREGACIÓN DE LA PURÍSIMA CONCEPCIÓN DE NUESTRA SEÑORA DEL COLEGIO DE SAN AMBROSIO DE LA COMPAÑÍA DE JESÚS DE ESTA CIUDAD DE VALLADOLID $(4-$ NOVIEMBRE - 1680)}

A.H.P.V., Leg. $2.399 / 1^{11}$

En la ciudad de Valladolid a cuatro días del mes de noviembre de mil y seiscientos y ochenta ante mí el escribano y testigos parecieron de la una parte don Francisco de Torres y Olvera abogado de esta Real Chancillería y (...) Maldonado, y Alonso Nieto Cervera relator de (...) y el capitán don Juan de Hoz criado de la calle (...) de esta dicha ciudad y congregantes de la Congregación de la Purísima Concepción de Nuestra Señora sita en el Colegio de San Ambrosio de la Compañía de Jesús de esta dicha ciudad por su hecho propio y en nombre de los demás congregantes que hay y por tiempo fueren por quienes prestan caución en bastante forma de la una parte, y de la otra Juan Tejedor maestro de obras y Francisco García su sobrino asimismo maestro de obras de esta dicha ciudad y dijeron que dicha Congregación tiene (...) la fábrica de la capilla de la dicha congregación y (...) el acabarla y para dicho efecto están convenidos y ajustados (...) congregantes con los dichos Juan Tejedor y su sobrino el acabarla según y de la manera y con las calidades que en esta escritura se dirán para lo cual todas las dichas partes capitularon lo siguiente:

Primeramente se obligan los dichos Juan Tejedor y Francisco García su sobrino de hacer en dicha capilla mayor (la arena del tejado) con su planta de tirantes y cuadrales con (...) y seis pastorales y las péndolas que le tocaren haciendo (...) de vigas labradas el uno a donde embarbillan las vigas y el otro al alto de la linterna con sus pies derechos de la linterna con ocho ventanas las cuatro (...) teniendo dicha linterna la proporción (...) corresponde a la media naranja (...) de yeso dentro y fuera con las molduras que se juzgaren (...) y abajo (...) y arriba su cornisa y la linterna ha de ser de pizarra y en la garganta y abajo ha de ir guarnecida de (...) su árbol de una viga labrada en donde se han de fijar la dorada y su cruz del modo y tamaño que está en la iglesia de San Ambrosio.

Ítem se ha de ensobradilar toda la armadura de tejado y trastejarlo de buena teja y repasar las tejas que se hubieren (...) del cuerpo de la capilla y la cornisa de la parte de afuera ha de ser de yeso y ladrillo de madera labrada si se juzgare ser mejor para la proporción de la obra y en dicha armadura se ha de hacer una contraarmadura a la parte del altar.

Ítem se han de cercar las cuatro pechinas y la media naranja de yeso y ladrillo y correr el anillo del tragadero de la linterna y el movimiento de la media naranja y en esta ha de llevar sus medallones y se le ha de guarnecer de yeso los cuatro arcos torales y los machones hasta abajo y las tres paredes de la capilla mayor amaestrándolas y se han de abrir dos ventanas en la capilla

11 FERNÁNDEZ DEL HOYO, María Antonia: "Notas sobre el Colegio de San Ambrosio de Valladolid", B.R.A.C., Tomo XXXVII, 2002, p. 82. 
mayor a cada lado la suya y hacer la cornisa dos pies de ancho o diez y medio si se juzgare bastante.

Ítem en el cuerpo de la iglesia se han de cerrar cuatro bóvedas de ladrillo sobrepuesto con sus arcos dobles y lunetos y se han de cerrar dichas bóvedas con yeso y dar de llana y hacer sus aristas y en los planos de en medio se han de hacer seis recuadros corridos hasta abajo entretejiendo Jesuses y Marías en las bóvedas coronadas con sus rayos de relieves si (...) poner cuadros haciéndoles sus boceles y guarnición y en los lunetos se ha de echar su guarnición y lo mismo en la media naranja y se han de abrir cuatro ventanas y si bastaren dos (...) a cada lado y se ha de hacer la cornisa con sus medallones.

Ítem se ha de hacer un coro con su cielo raso y una escalera con su puerta para salir al coro y un cimiento y división para el coro y se ha de abrir una puerta en el corredor de arriba por donde se entre y guarnezca las de yeso y así (...) y conveniencia de la capilla y abrir una puerta grande por la iglesia.

Ítem se han de guarnecer de yeso y arena las paredes hasta abajo y en el (...) donde se ha de hacer la escalera se ha de cerrar una bóveda.

Ítem se ha de blanquear toda la obra con yeso de Corcos y solarla toda de baldosas de pie en cuadro raspadas y cortadas y en el altar mayor se han de poner dos gradas de piedra y hacerse el altar de yeso y madera y su peana de madera con sus molduras y hacer el pedestal para el retablo de yeso y la (...) en la parte que se juzgaren conveniente puerta para la sacristía y asimismo para los dos altares de los lados se han de hacer dos arcos de yeso y ladrillo y hacer dichos dos altares de yeso y madera con sus peanas guarnecidas de madera con sus molduras.

Ítem se advierte que si en dichas condiciones faltare de expresar alguna cosa que a juicio de los peritos en el arte de dicha obra con diezma para la seguridad y utilidad, proporción y hermosura de toda la obra dicha (...) por expresada y contenida sin que en ningún tiempo haya recurso a mi (...). Y asimismo se obligan el dicho Juan Tejedor y el dicho Francisco García su sobrino a dar acabada dicha obra a satisfacción de dichos señores congregantes y maestros peritos en dicho arte para el día que vendrá de mil y seiscientos y ochenta y uno y no lo cumpliendo se les pueda apremiar en virtud de esta escritura como por (...) y obligación guarenticia de plazo pasado que la traiga aparejada.

Obligándose los dichos señores y Francisco de Torres y Olvera y don (...) Maldonado y Alonso Nieto Cervera y don Juan Díez criado de (...) u en nombre de los demás congregantes de dar al dicho Juan Tejedor y Francisco García su sobrino por razón de dicha obra trece mil y (...) reales de vellón acabada que sea a toda costa de manos y materiales (...) de aprovechar dichos maestros y valer para dicha (...) el material de madera, teja, ladrillo y cualquier otro género y corral de dicho colegio (...) ser de la dicha congregación (...) por su cuenta cómo va dicho los materiales que faltaren la madera que trajeren puedan hacer recompensa de la (...) sobrare de dicha congregación y dichos trece mil y cien reales (...) de dar en esta manera siendo necesario dichos maestros (...) material para proseguir dicha obra ha de estar de pronto (...) para pagarles, y doscientos reales para pagar (...) cada semana entera de las que trabajaren y la (...) referida a cumplimiento de los dichos trece mil y cien reales ha de ir dando según los materiales que fueren (...) obra y solo se ha de reservar cien ducados para cuando hubieren acabado en toda perfección. Y se advierte que las puertas, ventanas y antepecho del coro que tocare (...) junto con las vidrieras no ha de correr por cuenta de los maestros sino es de la dicha congregación que en (...) tener obligación a asentar las puertas, ventanas y antepecho. 
Y todas las dichas partes por lo que a cada una toca (...) y paga de todo lo que dicho es dieron todo su poder a las justicias y jueces del Rey nuestro señor que de sus causas puedan y deban conocer y por especial sumisión se someten al fuero y jurisdicción de los señores alcaldes del crimen, Corte y Chancillería, corregidor y teniente de esta ciudad (...) y así lo otorgaron así ante mí el dicho escribano siendo testigos Manuel Rodríguez y el licenciado Juan Antonio de (...) y Santiago Fernández labrador del campo vecinos y estantes en esta dicha ciudad y los señores congregantes y maestros quien yo el dicho doy fe conozco lo firmaron. 


\section{DOCUMENTO 53}

\section{ESCRITURA DEL DORADO DEL RETABLO DE NUESTRA SEÑORA DE LA LAURA ENTRE EL CONVENTO Y ALONSO GUTIÉRREZ (3 - ABRIL - 1693)}

A.H.P.V., Leg. 2.596, ff. 136-138

En la ciudad de Valladolid a tres días del mes de abril de mil y seiscientos y noventa y tres años, ante mí el escribano y testigos estando en el Convento de Nuestra Señora de la Laura extramuros de esta dicha ciudad parecieron presentes la Madre Priora y demás religiosas de dicho convento juntas y congregadas en el locutorio de él donde se suelen juntar para tratar de las cosas del servicio de Dios nuestro señor, bien y utilidad de este dicho convento llamadas por campana tañida como es costumbre estando presentes la madre Sor Ángela de Cristo priora, Sor Tomasa de la Encarnación su priora, Sor Luisa Antonia de la Ascensión y las demás que al pie de esta escritura firmarán sus nombres todas monjas profesas en este dicho convento que confesaron ser la mayor parte de las que hay en él por sí y nombre de las demás enfermas e impedidas y que adelante las sucederán por quienes prestaron voz y caución en forma de que estarán y pasarán por lo que aquí se dirá so expresa obligación que hicieron de los bienes y rentas de dicho convento habidos y por haber, y el dicho convento de la una parte, y de la otra Alonso Gutiérrez maestro dorador y estofador vecino de esta ciudad como principal y Francisco de la Peña vecino de ella como su fiador y principal pagador haciendo como para en este caso dijo hacía de deuda y hecho ajeno suyo propio sin que sea necesario hacer excursión en el dicho principal ni otro auto ni diligencia alguna y juntos y de mancomún a voz de uno y cada uno de por sí por el todo in solidum renunciando como renunciaron todas las leyes, fueros y derechos de la mancomunidad como en ellas se contiene, y dijeron que por cuanto entre las dichas partes están convenidas y ajustadas en que el dicho Alonso Gutiérrez haya de dorar y estofar el retablo, custodia y otras cosas de la iglesia del dicho Convento de Nuestra Señora de la Laura y el monumento de ella y para ello se han hecho condiciones de cómo se ha de ejecutar y en la forma que se han de pagar los nueve mil y quinientos reales en que está ajustado dicho dorado y estofado a toda costa de manos y materiales (...) las cuales dichas condiciones entregaron originales a mí el presente escribano para que las inserte en esta escritura que su tenor de ellas es como se sigue:

\section{Aquí las condiciones}

Las cuales dichas condiciones van ciertas y verdaderas y concuerdan con sus originales aquí se remiten y en conformidad de ellas los dichos Alonso Gutiérrez como principal y Francisco de la Peña como su fiador debajo de la dicha mancomunidad renunciación de leyes que llevan hecha se obligan aquí el dicho Alonso Gutiérrez dorará y estofará el dicho retablo, efigies y monumento y demás cosas del altar mayor e iglesia del dicho Convento de Nuestra Señora de la Laura que está recién hecho y en blanco según y en la forma y con las calidades y condiciones y demás (...) bondad y perfección que se expresan y declaran en las condiciones insertas y en cada una de ellas quedan por repetidas poniendo el oro y demás adherentes y andamios sin que corra nada por cuenta del convento todo ello sin reservar cosa alguna en precio de los dichos nueve mil y quinientos reales pagados en la forma que aquí se dirá sin que tengan derecho ni razón a pedir otra cosa alguna por razón de mejoras ni con otro pretexto alguno, el cual dicho 
dorado y estofado se obligan a comenzar desde hoy día de la fecha y darlo fenecido y acabado para fin de julio próximo que viene de este presente año de mil y seiscientos y noventa y tres a vista de maestros del arte que declaren si se ha cumplido o no y faltando algo lo fenecerán y acabarán en perfección y pasado dicho plazo quieren ser compelidos y apremiados a ellos por todo rigor de derecho y vía ejecutiva además de que si algo faltare de cumplir pueda dicho convento llamar otros maestros y hacer lo que faltare y por lo que se montare ejecutar a los otorgantes conforme a la relación jurada de la señora priora en que lo difieren como por guarenticia y llana obligación y por más las costas y daños que sobre ello se causaren.

La dicha señora priora y religiosas del dicho Convento de Nuestra Señora de la Laura cumpliéndose con lo referido se obligan de pagar al dicho Alonso Gutiérrez o a quien su poder hubiere los dichos nueve mil y quinientos reales en que está ajustado y contratado el dicho dorado y estofado en esta forma en dorando el primer cuerpo del dicho retablo tres mil y quinientos reales y en acabando el monumento y todas las demás cosas expresadas en dichas condiciones pagarán los tres mil y quinientos reales restantes todo ello habiendo cumplido conforme a dichas condiciones puesto y pagado en esta ciudad en poder del susodicho o de quien el suyo hubiere y no lo cumpliendo pasado cada plazo y paga se ejecute dicho convento en virtud de esta escritura como por llana y guarenticia obligación y por más las costas y daños que sobre ello se causaren.

Y todas las dichas partes cada una por lo que le toca se obligan de los cumplir el dicho Alonso Gutiérrez y Francisco de la Peña con sus personas y bienes y el dicho convento con sus bienes y rentas muebles y raíces habidos y por haber y para que se lo hagan cumplir dan poder a las justicias y jueces de su majestad que de cada una de sus causas puedan y deban conocer conforme a derecho de quienes lo recibieron por sentencia definitiva de juez competente pasada en autoridad de cosa juzgada renunciaron todas las leyes, fueros y derechos de su favor con la general del derecho que las prohíbe en forma y lo otorgaron así ante mí el dicho escribano de su majestad y de provincia en esta Corte y Chancillería siendo testigos D. Joseph Calderón mayordomo de dicho convento, Luis de Cañedo y Juan de Fuente (...) vecinos y estantes en esta ciudad y los otorgantes a quienes yo el escribano doy fe conozco lo firmaron.

Condiciones para dorar el retablo de la Laura de esta ciudad de Valladolid son las siguientes:

$1^{\mathrm{a}} \quad$ Primeramente es condición que dicho retablo y monumento se ha de picar los nudos y darlos de ajo para seguridad de dicha obra.

$2^{\mathrm{a}} \quad$ Es condición que se haya de dar dos manos de aguacola, cinco de yeso grueso, cinco de yeso mate, cinco de vil, todas en sus temples necesarias según y conforme arte.

$3^{\text {a }} \quad$ Es condición que se hayan de dar de tal suerte que no ofusque o tape la talla de dicho retablo.

$4^{\mathrm{a}} \quad$ Es condición que se haya de dorar todo dicho retablo y monumento de oro limpio sin que haya otra cosa así en fondos como en hojas y otra cosa que sea.

$5^{\mathrm{a}} \quad$ Es condición que se haya de dorar con el oro de más color y más cuerpo que haya en Valladolid.

$6^{\mathrm{a}} \quad$ Es condición que las dos efigies como son Santa María Magdalena y Santa Rosa se hayan de dorar las tres partes con el propio oro y después se han de estofar según y conforme a arte. 
$7^{a} \quad$ Asimismo los dos ángeles del último cuerpo se han de dorar y estofar en la misma conformidad que las santas referidas.

$8^{\text {a }} \quad$ Es condición que también se hayan de dorar tres marcos de frontales como es el del altar mayor y dos colaterales.

$9^{\text {a }} \quad$ Es condición que el andamio y lo necesario que mire a dicha obra lo haya de poner todo el maestro sin que haya obligación alguna por parte del convento.

$10^{\mathrm{a}} \quad$ Es condición que desde el día en que se empezare dicha obra en cuatro meses la haya de dar acabada.

$11^{\mathrm{a}} \quad \mathrm{Y}$ asimismo es condición que el convento haya de dar para empezar dicha obra cinco mil reales y lo restante hasta los nueve mil y quinientos reales en que está ajustada dicha obra se ha de ir dando durando dicha obra y guardando dichas condiciones por una y otra parte y dando la cantidad de los dichos nueve mil y quinientos reales.

$12^{\mathrm{a}} \quad$ Es condición que he de hacer y dorar la custodia todo lo que fuere necesario de oro limpio y la arca del Santísimo toda por dentro.

$13^{\mathrm{a}} \quad$ Es condición que he de dorar el asiento que hiciere Francisco Billota para Nuestra Señora y también los rayos que se han de hacer nuevos.

14 $4^{\mathrm{a}} \quad$ Es condición que he de dorar las dos cartelas de las lámparas que están en la iglesia.

$15^{\mathrm{a}}$ Es condición que he de dorar el remate del Santo Sudario y la tabla a donde se asientan los candeleros.

$16^{\mathrm{a}} \quad$ Es condición que he de dorar el primer cuerpo del dicho retablo sin ningún dinero y en acabándole se me ha de dar tres mil y quinientos reales y en acabando el monumento y todo lo demás lo restante hasta los nueve mil y quinientos reales que es el concierto.

$17^{\mathrm{a}} \quad$ Es condición que al poner el andamio no se ha de quitar baldosa alguna ni llegar a las cornisas a rozarlas y si hiciere algún daño me obligo a componerlos.

$18^{\mathrm{a}}$ Es condición que tengo de componer el pedestal de la manera que dijere Francisco Billota con florones de oro.

19 Es condición que pagándome dicho Convento de Nuestra Señora de la Laura los dichos mil y quinientos reales vellón dando la obra susodicha a satisfacción no pueda pedir a dicho convento otra cosa alguna en ningún tiempo por razón de mejoras ni otra alguna.

La cual dicha obra de dorado y estofado que va referida en estas condiciones y en precio de nueve mil y quinientos reales a toca costa de manos, oro y demás material me obligo hacerlo yo Alonso Gutiérrez maestro dorador y estofador vecino de esta ciudad y doy por mi fiador a Francisco de la Peña vecino de esta ciudad y haremos escritura luego in continente Valladolid a tres de abril de mil y seiscientos y noventa y tres años. 


\title{
DOCUMENTO 54
}

\section{POSTURAS, REMATE, OBLIGACIÓN Y FINAZA PARA DORAR EL RETABLO DEL ALTAR MAYOR DE LA IGLESIA PARROQUIAL DE SAN ESTEBAN DE LA VILLA DE TORRECILLA DE LA ABADESA $(9-$ MARZO - 1712)}

\author{
A.H.P.V., Torrecilla de la Abadesa. Iglesia de San Esteban. Papeles sueltos ${ }^{12}$
}

En la villa de Tordesillas a nueve días del mes de marzo de mil setecientos y doce ante mí el escribano y testigos parecieron de una parte el licenciado don Francisco Reinaltos vicario en ella y su arciprestazgo preste de la parroquial de San Pedro de esta villa, el licenciado Santiago Crespo cura de la parroquial de señor San Esteban de la villa de Torrecilla de la Abadesa y Juan Crespo Ramos vecino de ella mayordomo de fábrica de dicha iglesia en nombre de ella, y de la otra Manuel Barreda Lombera como principal Antonio Barreda su padre y Cristóbal Martínez de Estrada todos vecinos de la ciudad de Valladolid maestros doradores y estofadores como sus fiadores estantes en esta dicha villa y a todas las dichas partes dijeron que por la de dicho cura y mayordomo de fábrica se presentó petición ante el señor licenciado don Andrés de Orbe y Larreategui provisor de la dicha ciudad de Valladolid y su obispado haciendo relación que en el altar mayor de dicha iglesia había un retablo de madera por dorar y para más decencia del culto divino necesitaba dorarme pues la fábrica tenía caudal para ello y se pidió se diere comisión al dicho vicario para que junto con dicho cura y mayordomo se sacase al pregón la obra de dorar dicho retablo y se rematase en el mejor postor y por auto de diez y seis de febrero de este año se les dio comisión para que por término de nueve días y tres días se pregonase dicha obra y pusiesen cédulas para ella en esta villa y en la referida de Torrecilla y en el último día se rematase y que hecho y otorgando escritura de obligación y fianza a favor de dicha iglesia y a satisfacción de dichos vicario y cura y mayordomo de fábrica los autos originales se rematasen con un traslado auténtico de la escritura de obligación y fianza ante dicho señor provisor y al oficio de Antonio López Ramírez notario de asiento para su aprobación y proceder a lo demás que hubiese lugar en derecho y se hizo notorio al dicho don Francisco Reinaltos como tal vicario que la aceptó y mandó pregonar en la plaza de esta villa y poner cédulas en ella y en la de Torrecilla y se pregonó y en dos de este presente mes de marzo dicho Manuel Barreda Lombera hizo postura y condiciones en dicha obra en precio de diez y ocho mil reales que se habían de pagar en cierta forma y se admitió y pregonó y estando asignado el remate para el día de la fecha el dicho Manuel Barreda hizo mejora en razón de la paga de dicha cantidad para mayor seguridad de la obra y estándose pregonando para el remate que hicieron diferentes bajas y se remató dicha obra en el dicho Manuel Barreda Lombera en precio de diez y seis mil reales de vellón como parece del dicho pedimento condición postura pregón y demás diligencias y remate de que pidieron al presente escribano incorpore un traslado en esta escritura y yo el escribano le incorporé que su tenor dice así:

12 ARA GIL, Clementina Julia y PARRADO DEL OLMO, Jesús María: Catálogo Monumental de la provincia de Valladolid. Tomo XI. Antiguo partido judicial de Tordesillas, Diputación de Valladolid, Valladolid, 1980, pp. 343-346. 


\section{Pedimento}

Francisco Cenzano en nombre del cura de la iglesia parroquial de la villa de Torrecilla de la Abadesa de este obispado y mayordomo de fábrica de ella digo que estando su señoría Ilustrísima el señor don Diego de la Cueva y Aldana obispo que fue de esta ciudad y obispado haciendo visita en dicho lugar en el año pasado de mil seiscientos y noventa y ocho dejó dispuesto y mandado por su auto que del alcance que se le había hecho a Andrés García mayordomo que fue de dicha fábrica los años pasados de noventa y seis y noventa y siete se convirtiese en hacer un retablo para el altar mayor de dicha iglesia ajustándole en el precio o precios que pareciere ser de conveniencia para dicha fábrica según remates del dicho auto de que hago demostración como con efecto se puso en ejecución la factura de dicho retablo el cual está por dorar cosa indecente y contra el culto divino a que no es razón que dicho retablo esté así y respecto que la fábrica se halla con sobradísimo caudal así de más como granos de trigo cebada centeno y mosto como resulta del alcance de cuenta que se le tomó a Martín Rodríguez mayordomo que fue de dicha fábrica en el año pasado de setecientos y diez y setecientos y once que dicho alcance de maravedíes es de quinientos y ochenta y un mil seiscientos y sesenta y dos maravedíes: el de trigo cincuenta fanegas, el de cebada veinte y dos fanegas y veinte y cuatro cuartillos, el de centeno veinte y cinco fanegas, el de mosto novena y siete cántaras como resulta de dichas cuentas de que hago asimismo demostración y atento que la iglesia y su fábrica no necesitan de cosa alguna de dicho caudal y no tener obra que más se necesita que es el dorar dicho retablo: suplico a su majestad se sirva de dar su comisión al vicario de la villa de Tordesillas para que juntamente con el cura y mayordomo de fábrica de la parroquial de la dicha villa de Torrecilla de la Abadesa pongan cédula y saque al pregón por el término que quisieren la obra de dorar dicho retablo y la rematen en el mejor postor que hiciere postura más baja y hecho la remitan ante su majestad para en su visita proveer lo que convenga justicia.

Fdo: Cenzano

Auto

En la ciudad de Valladolid a diez y seis días del mes de febrero de mil setecientos y doce años ante mí el señor licenciado don Andrés de Orbe y Larreátegui colegial en el mayor de Santa Cruz provisor y vicario general de esta dicha ciudad y obispado se presentó esta petición y se pidió lo en ella contenido y justicia y por su visita junto con el libro de cuentas y auto de visita que en ella se expresa por ante mí el notario dijo daba y dio comisión y facultad en forma al vicario de la villa de Tordesillas y su arciprestazgo para que junto con el cura y mayordomo de fábrica de la parroquial de la villa de Torrecilla de la Abadesa por término de nueve días hagan poner y pongan cédulas en las partes acostumbradas así de dicha villa de Tordesillas como de Torrecilla para el que quisiere hacer postura y baja en dorar el retablo del altar mayor de dicha iglesia acuda ante los dichos cura y mayordomo de fábrica quienes por testimonio de notario o escribano admitan todas y cualesquiera posturas y bajas que se hicieren en cuanto al dorar el referido retablo y pasado el término de dichos nueve días con las posturas y bajas que se hubiere hecho se saque y traiga al pregón en la dicha villa de Tordesillas por término de tres días y en el último de ellos se remate en el mejor postor y así hecho y otorgado la persona en quien fuere rematada dicha obra de hacerla y acabarla en toda perfección con las condiciones que para ello se portaren con obligación y fianza a satisfacción de dichos vicario cura y mayordomo de fábrica y los autos que sobre todo ello pasaren y se hicieren originalmente en manera que hagan 
fe junto con un traslado auténtico de la dicha obligación y fianza se remitan y traigan ante su majestad y al oficio del presente notario para su aprobación y proceder a lo demás que haya lugar de derecho y este auto sirva de despacho por el cual que su majestad firmó así lo proveyó y mandó.

Fdo: Don Andrés de Orbe y Larreátegui

\section{Requerimiento}

En la villa de Tordesillas a veinte y seis días del mes de febrero de mil setecientos y doce años yo Francisco Redondo del Castillo notario apostólico vecino de ella de pedimento del licenciado Santiago Crespo cura de la parroquial de señor San Esteban de la villa de Torrecilla de la Abadesa leí y notifiqué el auto y comisión de esta otra parte al señor licenciado don Francisco Reinaltos abogado de los Reales Consejos vicario en esta villa y su arciprestazgo preste más antiguo de la parroquial de San Pedro de ella en persona que dijo acepta el poder y comisión que se le da y está presto a cumplir con su tenor y en su cumplimiento mandó se fijen cédulas en esta villa y en la referida de Torrecilla en partes públicas acostumbradas para si alguna o algunas personas quisieren hacer postura y condiciones en la obra de dorar el retablo del altar mayor de dicha iglesia de San Esteban acuda ante su majestad y dicho cura y ante el mayordomo de fábrica de dicha iglesia y asimismo se pregone en la plaza pública de esta villa por el término de los nueve días que por el despacho se manda lo cual respondió y firmó de que yo el notario doy fe. Licenciado don Francisco Reinaltos. Ante mí Francisco Redondo del Castillo notario apostólico. En la villa de Tordesillas a veinte y siete días del mes de febrero de mil setecientos y doce años en cumplimiento del auto de aceptación de veinte y seis del corriente se fijó en un poste de la plaza pública de esta villa una cédula escrita en ella lo siguiente:

\section{Cédula}

Quien quisiere hacer postura y condiciones en la obra de dorar y estofar el retablo del altar mayor de la iglesia parroquial de señor San Esteban de la villa de Torrecilla de la Abadesa acuda al señor licenciado don Francisco de Reinaltos vicario en esta villa y su arciprestazgo y al licenciado Santiago Crespo cura y Juan Crespo Ramos mayordomo de fábrica de dicha iglesia en virtud de despacho del señor provisor de la ciudad y obispado de Valladolid. Concuerda con el original que quedó en dicho poste donde su suelen poner y fijar semejantes cédulas a que me remito y para que conste lo pongo por diligencia de que doy fe. Francisco Redondo del Castillo notario apostólico.

Pregón

En la villa de Tordesillas a los dichos veinte y siete días del mes de febrero de mil setecientos y doce en la plaza pública de ella por voz de Pedro Fernández pregonero público se dio un pregón diciendo quien quisiere hacer postura en la obra de dorar el retablo del altar mayor de la iglesia parroquial de señor San Esteban de la villa de Torrecilla de la Abadesa acuda al señor licenciado don Francisco Reinaltos vicario en esta villa y su arciprestazgo y al cura mayordomo de fábrica 
de dicha iglesia que se admitirá la que hicieren de que yo el notario doy fe. Francisco Redondo del Castillo notario.

Otro

En Tordesillas a veinte y ocho días del mes de febrero de mil setecientos y doce años por el dicho pregonero en la dicha plaza se dio otro pregón a la dicha obra como el antecedente de que doy fe. Redondo.

Otro

En Tordesillas a veinte y nueve de dicho mes y año en dicho pregonero en la dicha plaza dio otro pregón como los antecedentes a la dicha obra de que doy fe. Redondo.

Otro

En Tordesillas a primero de marzo de dicho año el dicho pregonero en la dicha plaza dio otro pregón como los antecedentes a la dicha obra de que doy fe. Redondo.

Otro

En Tordesillas a dos de marzo de dicho año el dicho pregonero en la dicha plaza dio otro pregón como los antecedentes a la dicha obra de que doy fe. Redondo.

Postura

En la villa de Tordesillas a dos días del mes de marzo de mil setecientos y doce años ante el señor licenciado don Francisco Reinaltos vicario en ella su arciprestazgo y ante mí el notario y testigos parecieron de una parte el licenciado Santiago Crespo cura de la parroquial de señor San Esteban de la villa de Torrecilla de la Abadesa y Juan Crespo Ramos vecino de ella mayordomo de su fábrica en nombre de ella, y de otra Manuel Barreda Lombera vecino de la ciudad de Valladolid maestro dorador y estofador y dijeron que en virtud de comisión y licencia del señor provisor de la dicha ciudad se ha sacado al pregón la obra de dorar el retablo del altar y capilla mayor de la dicha iglesia de señor San Esteban de la dicha villa de Torrecilla en el cual el dicho Manuel Barreda hacia e hizo postura con las condiciones siguientes:

$1^{\text {a }} \quad$ Que se ha de limpiar el polvo y después se han de picar los nudos y partes y cosas que tuviere dicho retablo dándolas de ajo, y después se ha de dar su mano de agua cola y sobre ella sus manos de yeso grueso con mucha curiosidad dando tiempo de una a otra para que se seque lijándolo y escofinándolo para que quede con el aseo que está en madera en blanco y... cubierto solo plasteciendo lo que fuere necesario en dicha obra como son rendijas y hendiduras guardando la talla y en esta conformidad se han de dar sus manos de yeso mate con toda curiosidad sin que se tape la talla ni moldura ni a otro miembro de la arquitectura dando tan 
descubierto como esta en madera en blanco, y después se han de dar de bol las manos necesarias hasta que quede bien aparejado.

$2^{\mathrm{a}} \quad$ Que dicha obra se ha de dorar de oro limpio lo mismo por arriba que por abajo siendo el oro del mejor color que hubiese sin que se pueda gastar oro bajo ni oro partido ni otro color que lo imite.

$3^{\text {a }} \quad$ Que las hechuras que tiene dicha obra de la historia de San Esteban San Pedro San Pablo los dos ángeles la fe San Juan y María y San Antonio de Padua y Santa Águeda y serafines todo se ha de dorar de oro limpio y las ropas y después se han de matizar de colores muy finos echando a cada hechura el color que corresponde y se han de echar orillas de oro de diferentes colores con sus niños y pájaros y adornos diferentes ejecutando en cada santo diferente orilla que no se parezca una a otra y para más lucimiento de dichas hechuras.

$4^{\mathrm{a}} \quad$ Que en dichas hechuras se han de echar sus telas de oro como lo pide cada santo y en ellas se han de repartir sus colores con diferentes adornos de bichas niños y pájaros y dichas telas no se han de parecer unas a otras y en la misma conformidad se han de ejecutar en las tunicelas sus grutescos de cogollos diferentes y sus grabados y enveses sin que se parezcan unos a otros para más primor de dichas hechuras las cuales se han de encarnar y la hechura del Santo Cristo dando a cada una su colorido como corresponde y ha de ser con aceite de nueces para más permanencia y en el Crucifijo se han de poner las llagas donde corresponde para más devoción, y a dichas hechuras se les ha de echar ojos de cristal que han de ser a San Pedro San Pablo San Antonio y Santa Águeda, y los pelos de todas las hechuras se han de meter de color que a cada una toca y se han de peletear de oro molido, y las cabezas de San Pedro y San Pablo de plata molida como corresponde por su ancianidad.

$5^{\text {a }} \quad$ Que la hechura de San Esteban que está dentro de la custodia se ha de renovar la encarnación y el alba echándola su encaje de la parte de abajo, y la dalmática se ha de barnizar con espíritu de agua ardiente que es lo que necesita.

$6^{\mathrm{a}} \quad$ Que los ángeles han de llevar sus telas de oro y colores en las jaquetillas y en las tunicelas hechas sus primaveras de flores de colores y oro con el color que a cada una corresponde.

$7^{\mathrm{a}}$ Que dicha historia de San Esteban se ha de dorar de oro limpio de hechuras y campo dando sus matices de colores como pide cada hechura con sus telas orillas y grutescos sacándolo de grafio como también se han de sacar todas las demás hechuras de la obra, y se han de sacar echando sus cabezas de serafines en la gloria de dicha historia y las encarnaciones a cada hechura como le toca.

$8^{\mathrm{a}} \quad$ Que el pedestal de piedra se ha de fingir de mármoles de diferentes colores imitándolos al natural dorando todos los filetes y molduras que tiene a mate y en los tímpanos se han de ejecutar sus cogollos de oro con diferentes adornos para más lucimiento y la pintura ha de ser al óleo y se ha de barnizar con la quinta esencia del agua ardiente.

$9^{a} \quad$ Que si en el tiempo que fuere ejecutando dicha obra fuere voluntad de dicho cura y mayordomo de fábrica traer maestro que la vea y reconozca y si se ejecuta conforme a estas condiciones ya en los yesos y aparejos y ... la escultura y talla y si el oro es de calidad color y cuerpo y las hechuras si van estofados de la calidad expresada lo han de poder hacer sin que el 
maestro en quien se rematare pueda embarazarlo y sino fuere bien hecho le puedan compeler a que lo ejecute o expelerle y quitársela y buscar quien lo ejecute.

$10^{\mathrm{a}}$ Que no se han de pagar ningunas mejoras aunque se hagan en dicha obra porque el maestro que la hiciere la ha de dejar acabada en toda perfección como es de la obligación de su arte porque dichos cura y mayordomo por no ser de su profesión no pueden prevenir lo necesario para su adorno y perpetuidad, y acabada que sea se ha de ver y reconocer por dos maestros de inteligencia nombrados por cada parte el suyo y un tercero en discordia los cuales o uno de ellos con el tercero han de declarar si está acabada conforme arte y a estas condiciones y estándolo ha de haber cumplido dicho maestro con lo que fuere de su cargo, y no lo estando ha de ser obligado a cumplirlo a su costa y de no lo hacer puedan dicho cura y mayordomo buscar maestros y oficiales que lo ejecuten en toda perfección a costa del maestro en quien se rematare y ejecutar por ello y en virtud de la declaración del maestro que la acabare que pasados quince días después de hecho el remate el maestro en quien hiciese ha de ser obligado a otorgar escritura de obligación con fianzas a satisfacción de dicho señor vicario y de dicho cura y mayordomo de fábrica con salario y sumisión y no lo haciendo se pueda sacar al pregón por quiebra y la que hubiere cobrar la de dicho maestro por ejecución y todo rigor de derecho.

$11^{\mathrm{a}}$ Que luego que se otorgue dicha escritura se ha de comenzar dicha obra y sin alzar mano se ha de proseguir hasta su fenecimiento.

12 $2^{\mathrm{a}}$ Que se ha de dar casa para hospedarme el maestro y oficiales y cinco carros de leña de pino y treinta arrobas de carbón para aparejar los materiales.

$13^{\mathrm{a}}$ Que si el dicho Manuel Barreda no quedare con dicha obra le ha de pagar dicha iglesia ciento y ochenta reales por el trabajo de hacer estas condiciones y si quedase con dicha obra no se le ha de dar cosa alguna por ellas.

14 Que la iglesia ha de dar la madera necesaria para hacer los andamios puesta al pie de la obra y acabada ha de quedar para dicha iglesia la madera.

$15^{\mathrm{a}}$ Que el maestro en quien se rematare dicha obra ha de poner para ella todos los materiales oro y manos necesarios de cualquier género calidad condición o nombre que sean sin que la iglesia tenga obligación a dar más que el dinero en que se rematare y lo que va expresado.

$16^{\mathrm{a}}$ Que el dicho Manuel Barreda ponía la dicha obra en precio de diez y ocho mil reales de vellón que se han de pagar en esta forma la cuarta parte para comenzar a trabajar hasta acabar el primer cuerpo de arriba, cuatro mil reales para la obra del cuerpo de en medio, y quedando dos mil reales para cuando este fenecida y dada por buena lo demás se ha de pagar para obra del último cuerpo que es el de abajo y dichos dos mil reales se han de pagar un año después de acabada la obra y por ello se ha de ejecutar a los bienes de dicha fábrica.

Con las cuales dichas condiciones el dicho Manuel Barreda y Lombera dijo hacia e hizo postura y siéndole rematada se obligó de cumplir con ellas sin que falte cosa alguna y a su cumplimiento obligó su persona y bienes muebles y raíces habidos y por haber y para la ejecución dio su poder cumplido a las justicias y jueces de su majestad que conforme a derecho de la causa deba conocer y para que le apremien al cumplimiento como por sentencia pasada en autoridad de cosa juzgada y renuncio todas las leyes fueros y derechos de su favor con la que prohíbe la general renunciación de ellas: y visto por los dichos señor vicario cura y mayordomo de fábrica en virtud de la dicha comisión la admitieron en cuanto a lugar de derecho y mandaron 
se saque al pregón y se pongan cédulas en esta villa y en la de Torrecilla y ambas partes lo otorgaron y firmaron a quien yo el notario doy fe conozco siendo testigos don Manuel Maestro Basilio Caballero y Fernando Martín estantes en esta ciudad.

Pregón

En la villa de Tordesillas a tres días del mes de marzo de mil setecientos y doce años en la plaza pública de ella por voz de Pedro Fernández pregonero público se dio un pregón diciendo en diez y ocho mil reales con las condiciones de la postura esta puesta la obra de dorar el retablo del altar mayor de la iglesia parroquial de San Esteban de la villa de Torrecilla de la Abadesa quien quisiere hacer baja acuda ante el señor licenciado don Francisco Reinaltos vicario en esta villa y su arciprestazgo y al cura y mayordomo de fábrica de dicha iglesia que se le admitirá de que yo el notario doy fe. Francisco Redondo del Castillo notario.

Otro

En la villa de Tordesillas a cuatro días del mes de marzo de mil setecientos y doce en la dicha plaza por voz de dicho pregonero se dio otro pregón como el antecedente a la dicha obra de que doy fe. Redondo.

Otro

En la villa de Tordesillas a cinco días del dicho mes y año en la dicha plaza por dicho pregonero se dio otro pregón como los antecedentes a la dicha obra de que doy fe. Redondo.

Otro

En la villa de Tordesillas a seis días de dicho mes y año en la dicha plaza por voz de dicho pregonero se dio otro pregón como los antecedentes a la dicha obra de que doy fe. Redondo.

Otro

En la villa de Tordesillas a siete días del mes de marzo de mil setecientos y doce el señor licenciado don Francisco Reinaltos vicario en ella y su arciprestazgo dijo que por haberse pregonado por nueve días la obra de dorar dicho retablo y puesto cédulas en la plaza de esta villa y también en la de Torrecilla de la Abadesa y no hay más postura que la hecha por Manuel Barreda y Lombera vecino de Valladolid mando su majestad que en cumplimiento del auto de su comisión se pregone por tres días más como por él se previene y así lo proveyó y firmó de que yo el notario doy fe. Licenciado don Francisco Reinaltos. Ante mí Francisco Redondo del Castillo notario. 
Pregón

En la villa de Tordesillas a siete días del mes de marzo de mil setecientos y doce años en la plaza pública de ella por voz del dicho pregonero se dio otro pregón como los antecedentes a la postura de la dicha obra de que doy fe. Redondo.

Otro

En Tordesillas a ocho días de marzo de dicho año por el dicho pregonero en la dicha plaza se dio otro pregón como los antecedentes a la postura de la dicha obra doy fe. Redondo.

Otro

En Tordesillas a nueve de dicho mes y año el dicho pregonero en dicha plaza se dio otro pregón a la dicha postura como los antecedentes doy fe. Redondo.

\section{Certificación}

Torrecilla de la Abadesa a falta de notario aplico certifico y doy fe en la manera que puedo a los señores que la presente vieren como en el día veinte y siete de febrero pasado de este año de mil setecientos y doce fijé y puse un edicto en las puertas principales de la iglesia del señor San Esteban de esta dicha villa que decía quien quisiere hacer postura y condiciones en la obrar de dorar el retablo de la iglesia parroquial de San Esteban de esta dicha villa de Torrecilla de la Abadesa acuda ante el señor licenciado don Francisco Reinaltos vicario de la villa de Tordesillas, licenciado Santiago Crespo cura y Juan Crespo Ramos mayordomo de fábrica de dicha iglesia que se admitirá en virtud de comisión del señor provisor de la ciudad y obispado de Valladolid, y asimismo certifico como en el día tres del mes de marzo de este dicho año fijé y puse segundo edicto en dichas puertas que contenía en diez y ocho mil erales esta puesta la obra de dorar y estofar el retablo de la capilla mayor de la parroquial del señor San Esteban con las condiciones como consta de la postura que hizo ante el señor vicario cura y mayordomo de la fábrica (...) en nueve de marzo de mil setecientos y doce y lo firmé.

\section{Mejora}

En la villa de Tordesillas a nueve días del mes de marzo de mil setecientos y donde ante el señor licenciado don Francisco Reinaltos vicario en esta villa y su arciprestazgo estando presentes el licenciado Santiago Crespo cura de la parroquial de San Esteban de la villa de Torrecilla de la Abadesa y Juan Crespo Ramos mayordomo de fábrica de ella y ante mí el notario y testigos pareció Manuel Barreda y Lombera vecino de la ciudad de Valladolid maestro dorador y estofador y dijo que por cuanto en dos de este mes y año hizo postura en la obra de dorar el retablo del altar y capilla mayor de la dicha iglesia de San Esteban con ciertas condiciones en precio de diez y ocho mil reales vellón que habían de pagar a cierto plazo como de ella parece a que se remate, ahora por vía de mejora pone por condición que para más abono y seguridad de dicha obra el maestro en quien se rematare ha de hacer el primero cuerpo que es el de arriba de 
dicho retablo hasta dejarle acabado conforme a las dichas condiciones sin que la dicha iglesia y su mayordomo de fábrica paguen maravedíes algunos a dicho maestro porque lo ha de poner a su costa y el dinero que se le había de dar para dorar este cuerpo ha de quedar para que se le pague estando acabada toda la obra de dicho retablo y dada por buena y a ello se obligó con su persona y bienes muebles y raíces habidos y por haber con poderío a las justicias competentes y renunciación de leyes de su favor con la general en forma, y visto por dicho señor vicario cura y mayordomo de fábrica la admitieron en cuanto va lugar de derecho y acordaron se pregone y remate el día de la fecha por cumplirse los tres últimos días asignados para él y así lo otorgaron siendo testigos don Joseph Alaejos Fernando Martín y Basilio Caballero Girón estantes en esta dicha villa. Licenciado don Francisco Reinaltos. Santiago Crespo. Juan Crespo Ramos. Manuel Barreda y Lombera. Ante mí Francisco Redondo del Castillo notario.

\section{Remate}

En la villa de Tordesillas a nueve días del mes de marzo de mil setecientos y doce años en la plaza pública de ella estando presentes el señor licenciado don Francisco Reinaltos vicario en ella y su arciprestazgo, el licenciado Santiago Crespo cura de la iglesia parroquial de San Esteban de la villa de Torrecilla de la Abadesa y Juan Crespo Ramos mayordomo de fábrica de ella por ante mí el notario por voz de Pedro Fernández pregonero público dadas las doce horas del mediodía se dio un pregón diciendo en diez y ocho mil reales con las condiciones de la postura esta puesta la obra de dorar el retablo del altar mayor de la dicha iglesia de San Esteban de dicha villa de Torrecilla quien quisiere hacer baja acuda aquí luego que se aperciba el remate y en esta forma se dieron respectivos pregones y a la voz de ellos pareció Cristóbal Martínez de Estrada maestro dorador y estofador vecino de la ciudad de Valladolid y bajó un mil reales y la dejó puesta en diez y siete mil reales y se admitió por dicho señor vicario cura y mayordomo de fábrica y se pregonó en los dichos diez y siete mil reales con diferentes pregones apercibiendo el remate y a la voz de ellos pareció Joseph de Prado maestro dorador y estofador vecino de la dicha ciudad e hizo baja de trescientos reales y se admitió y se pregonó en diez y seis mil y setecientos reales y se dieron diferentes pregones y a la voz de ellos pareció Manuel Barreda Lombera maestro dorador y estofador vecino de la dicha ciudad de Valladolid e hizo baja de setecientos reales que se admitió por dicho señor vicario cura y mayordomo de fábrica y queda puesta dicha obra en diez y seis mil reales y a ella se dieron diferentes pregones y por no haber quien hiciese más baja aunque dichos maestros y otros del arte estaban presentes se mandó por dicho señor vicario y de consentimiento de dicho cura y mayordomo de fábrica se hiciese el remate, con lo cual prosiguió el pregón diciendo pues quien no haga baja de los dichos diez y seis mil reales en que esta puesta dicha obra a la una a las dos y a la tercera que buena pro y buen provecho le haga a quien la tiene puesta con lo cual se hizo el remate en el dicho Manuel Barreda Lombera el cual le aceptó y firmó y dicho señor vicario cura y mayordomo de fábrica siendo testigos don Joseph Alaejos Juan Díez y Jerónimo Calderón vecinos de esta villa de que yo el notario doy fe. Licenciado don Francisco Reinaltos. Santiago Crespo. Juan Crespo Ramos. Manuel Barreda Lombera. Ante mí Francisco Redondo del Castillo notario.

Auto

En la villa de Tordesillas a nueve días del mes de marzo de mil setecientos y doce años el señor licenciado don Francisco Reinaltos vicario en ella y su arciprestazgo dijo mandaba y mandó se 
entreguen estos autos originales al cura y mayordomo de fábrica de la iglesia parroquial de señor San Esteban de la villa de Torrecilla de la Abadesa para presentarlos ante el señor provisor de la ciudad de Valladolid como se manda por el auto de comisión quedando un tanto de todos ellos signado y en pública forma para poner con la escritura de obligación y fianza que se ha de otorgar el día de la fecha en conformidad de la postura y remate y que a ello interponía e interpuso su autoridad y decreto judicial para que valga y haga fe en juicio y fuera de él y así lo proveyó y firmó de que yo el notario doy fe.

Concuerda con el original a que me remito y en virtud del dicho auto lo firmé y signé en Tordesillas a nueve del mes de marzo de mil setecientos y doce.

\section{Prosigue}

Concuerda con su original de que yo el escribano doy fe y las dichas partes dijeron que aprobaban y ratificaban el dicho remate y cumpliendo el dicho Manuel Barreda con lo capitulado y como principal y los dichos Antonio Barreda y Cristóbal Martínez de Estrada como sus fiadores haciendo como hicieron de deuda ajena suya propia y sin que sea necesario hacer excursión división ni otra diligencia alguna aunque de derecho se requiere contra la persona y bienes del dicho Manuel Barreda Lombera cuyo beneficio y remedio y la auténtica presente hoc quita de fide iusoribus y demás auténticas y leyes que en este caso hablan renunciaron y apartaron de su favor se obligaron y el dicho Manuel Barreda Lombera se obligó de dorar el dicho retablo del altar mayor de la dicha iglesia de señor San Esteban de la villa de Torrecilla de la Abadesa y las hechuras de santos y crucificado en la forma que por el susodicho está ya condicionado en la postura que hizo en dicha obra en dos de este presente mes y año la cual comenzará luego y sin altar mano proseguirá en ella y hasta la acabar y fenecer en toda perfección conforme arte a vista y declaración de maestros de inteligencia en dicho arte según se contiene y declara en una de dichas condiciones y no lo haciendo y cumpliendo así los dichos Antonio Barreda y Cristóbal Martínez de Estrada como tales fiadores lo harán y cumplirán por el dicho Manuel Barreda luego que para ello se han requerido y no lo haciendo consintieron que la parte de dicha iglesia pueda buscar maestros y oficiales de toda inteligencia en dicho arte que ejecuten la dicha obra en toda perfección y por el coste y costas daños y menoscabos que se siguieren a dicha iglesia se ejecute compela y apremie a los otorgantes en virtud de esta escritura y de la declaración simple del maestro que hiciere dicha obra en que difieren la prueba y relevaron a la parte de dicha iglesia de otra justificación, y en hacer dicha obra no pedirán mejoras algunas antes si harán en ella todo lo posible para su hermosura seguridad y permanencia según las dichas condiciones que confesaron les son notorias así por haberlas hecho el dicho Manuel Barreda como por haberse leído por mí el escribano en presencia de los otorgantes de que doy fe los cuales consintieron que a las diligencias y cobranzas los dichos cura y mayordomo de fábrica y otra cualquier persona en nombre de dicha iglesia puedan ir o enviar persona contra las de los otorgantes así a la dicha ciudad de Valladolid como a otras cualesquiera partes donde vivieren o tuvieren bienes y hacienda con quinientos maravedíes de salario que pagarán por cada un día que se ocuparen con más los de ida y vuelta contándolos del viaje a razón de ocho leguas por día y por lo que montaren los salarios se hagan las mismas diligencias que por el principal de que no pedirán moderación y renunciaron la pragmática del año de mil seiscientos y veinte y tres y demás leyes y estilos y autos acordados que prohíben la paga de salarios, y se obligaron a que harán la dicha obra por los dichos diez y seis mil reales poniendo dichos maestros por su cuenta todos los materiales y manos necesarios y hacer y 
fabricar los andamios dando madera para ellos la dicha iglesia los cuales no se han de poder de hacer ni quitar hasta que dicha obra esté acabada y dada por buena para que se pueda ver y reconocer cada y cuando que por parte de dicha iglesia se quisiere hacer y también se les ha de dar cinco carros de leña de pino y treinta arrobas de carbón y casa desocupada en que puedan vivir en el tiempo que se tardare en hacer dicha obra sin que dicha iglesia tenga obligación a dar otra cosa, y al cumplimiento obligaron sus personas y bienes muebles y raíces habidos y por haber, y los dichos licenciado don Francisco Reinaltos licenciado Santiago Crespo cura y Juan Crespo Ramos mayordomo de fábrica de dicha iglesia mediante la dicha comisión admitieron esta obligación y fianza y obligaron los bienes y rentas de la dicha iglesia de dar y pagar al dicho Manuel Barreda o a quien su derecho tenga los dichos diez y seis mil reales de vellón en que le fue rematada dicha obra en esta manera cuatro mil reales luego que esté acabado de dorar el primer cuerpo de arriba de dicho retablo para fabricar el segundo cuerpo ocho mil reales luego que esté acabado de dorar todo el dicho retablo dos mil reales luego que se haya dado por buena la dicha obra a vista declaración y contento de maestros según está condicionado y los dos mil reales restantes se han de pagar dentro de un año después de declarada por buena la dicha obra y asimismo le darán los dichos cinco carros de leña de pino y treinta arrobas de carbón y casa desocupada para vivir el maestro y sus oficiales durante el tiempo que se tardare en hacer dicha obra y por todo ello y cada parte de ello pasado cada plazo y paga consintieron sean ejecutados los bienes y rentas de la dicha iglesia y su fábrica con costas porque desde luego para cuando llegue el caso los constituyen por legítimos y verdaderos deudores, y ambas partes para la ejecución dieron poder cumplido a las justicias y jueces de su santidad y de su majestad del fuero de cada una competentes y en especial los dichos Manuel Barreda Antonio Barreda y Cristóbal Martínez de Estrada se sometieron al fuero y jurisdicción de los señores alcaldes del crimen de la Real Audiencia y Chancillería de la dicha ciudad de Valladolid corregidor o su lugar teniente de esta villa de Tordesillas y cada uno in solidum para que las dichas justicias les compelan y apremien y las eclesiásticas a la parte de dicha iglesia y al cumplimiento y paga de lo que cada uno toca como por sentencia pasada en autoridad de cosa juzgada y renunciaron todas las leyes fueros y derechos de su favor y el de dicha iglesia y con la general en forma y los dichos principal y fiadores renunciaron su propio fuero jurisdicción y domicilio y la ley sit combenerit de jurisdictione omnium judicum, y dichos curas y mayordomo de fábrica renunciaron el capítulo suan de penis obduardus de solutionibus y demás leyes y cánones del favor de los bienes eclesiásticos y todas las dichas partes lo otorgaron y firmaron a quienes yo el escribano doy fe conozco siendo testigos don Pedro Malinas presbítero Fernando Martín y Basilio Caballero Girón vecinos y estantes en esta dicha villa. Licenciado don Francisco Reinaltos. Santiago Crespo. Juan Crespo Ramos. Manuel Barreda y Lombera. Antonio Barreda y Lombera. Cristóbal Martínez de Estrada. Ante mí Francisco Redondo del Castillo.

Yo Francisco Redondo del Castillo escribano del rey nuestro señor perpetuo del número y ayuntamiento de esta villa de Tordesillas por su majestad presente... a lo que de mí se hace mención y en fe de ello lo signe para la iglesia de San Esteban de Torrecilla de la Abadesa escrito en catorce hojas con esta la primera, sello primero y lo demás papel común en treinta de marzo de mil setecientos y doce años.

Fdo: Francisco Redondo del Castillo 
Yo Antonio López Ramírez notario de asiento de la audiencia eclesiástica de esta ciudad de Valladolid y vecino de ella doy fe que por el señor provisor de este obispado en vista de la escritura de obligación y fianza de esta escritura y de arriba y de los autos en ella insertos cuyos originales en mi poder y oficio paran se dio el siguiente:

En la ciudad de Valladolid a siete días del mes de abril de mil setecientos y doce años el señor licenciado don Andrés de Orbe y Larreategui colegial huésped en el mayor de Santa Cruz provisor y vicario general de esta dicha ciudad y su obispado habiendo visto estos autos que son sobre la obra de dorar y estofar el retablo del altar mayor de la iglesia parroquial de San Esteban de la villa de Torrecilla de la Abadesa de este obispado y el remate hecho de las dichas obras en Manuel Barreda Lombera maestro dorador y estofador vecino de esta dicha ciudad en diez y seis mil reales de vellón y la escritura de obligación y fianza sobre ello hecha y otorgada en la villa de Tordesillas a nueve de marzo pasado de este presente año ante Francisco Redondo del Castillo escribano del número y ayuntamiento de ella en que asimismo están insertos las posturas pregones y diligencias hechas en razón del dicho remate y su aceptación y asimismo el libro de cuentas y caudal de la fábrica de dicha iglesia que está (...) ante su majestad, dijo que autoritate ordinaria y en aquella vía y forma que más a lugar de derecho daba y dio por bueno aprobada y aprobó el dicho remate y escritura de obligación y fianza sobre ello otorgada según y cómo y con todas las condiciones en ella puestas y expresadas y condenó a las partes a que estén y pasen por dicha escritura y subsiguientemente daba y dio licencia al cura y mayordomo de fábrica de dicha iglesia para que del caudal y hacienda con que resulta de dicho libro hallarse la dicha fábrica se den y paguen al dicho Manuel Barreda Lombera los referidos diez y seis mil reales según y a los plazos y como se contiene en la dicha escritura y no en otra forma a cuya continuación y para que en todo tiempo conste el presente notario saque y ponga un traslado auténtico de este auto de aprobación y licencia por el cual que su majestad firmó así la proveyó y mandó y que se vuelva la dicha escritura y libro de cuentas a la parte de dichos cura y mayordomo de fábrica. Don Andrés de Orbe y Larreategui. Ante mí Antonio López Ramírez.

Así consta y parece de dicho auto que originalmente en mi poder queda y con que concuerda a que me remito y en fe de ello lo signo y firmo en Valladolid a nueve de abril de mil setecientos y doce años.

Fdo: Antonio López Ramírez 


\section{DOCUMENTO 55}

\section{CONCIERTO DEL RETABLO DE LA COMPAÑÍA DE JESÚS DE LEÓN $(26-$ MAYO - 1690)}

A.H.P.V., Leg. 2.384, ff. 345-348

En la ciudad de Valladolid a veinte y seis de mayo de mil seiscientos y noventa años ante mí el escribano y testigos parecieron el Reverendo Padre Provincial Pablo Abarca Rector del Colegio de la Compañía de Jesús de la ciudad de León a quien por el dicho oficio le toca la administración y gobierno del dicho colegio en virtud de bulas apostólicas y constituciones de la dicha compañía que son notorias de la una parte, y de la otra Alonso Manzano maestro arquitecto de talla y ensamblaje como principal y Juan Juárez Marroquín ambos vecinos de esta dicha ciudad como su fiador y principal cumplidor haciendo como en este caso hizo de deuda ajena suya propia y sin que sea necesario hacer excursión en el principal ni sus bienes (...) debajo de lo cual ambas partes dijeron que el dicho Alonso Manzano como principal y el dicho Juan Juárez como su fiador se obligan con sus personas y bienes muebles y raíces habidos y por haber de que el dicho Alonso Manzano como tal maestro arquitecto de talla y ensamblaje de ejecutar y hacer en lo que toca a dicha talla y ensamblaje del retablo de la capilla mayor de la iglesia de dicho colegio de León conforme a la traza que queda en poder del dicho Alonso Manzano firmada suya y del dicho Padre Rector y de mí el escribano y condiciones que asimismo están firmadas de los susodichos que me entregaron a mí el escribano para que aquí las inserte que su tenor son las siguientes:

\section{Aquí las condiciones}

Y conforme a las dichas condiciones y dicha traza el dicho Alonso Manzano ha de ejecutar dicho retablo y cumplir con su tenor y por el precio de maravedíes y acabarle en el tiempo que en dichas condiciones se declara y no lo cumpliendo el dicho Juan Juárez Marroquín como su fiador y principal cumplidor sin que sea necesario hacer excursión en el principal ni sus bienes ni otra diligencia alguna aunque de derecho se requiera cuyo beneficio renuncia como va referido buscará otros maestros peritos en dicho arte que le acaben y fenezcan conforme a dicha traza y condiciones además que dicho Padre Rector y quien su derecho tenga los pueda buscar y hacer lo ejecuten y por lo que dijere le ha costado y el dinero que tuviere recibido el dicho Alonso Manzano que ha de ser creído por su juramento en que lo difiere sin ser necesario testimonio ni otra averiguación que de ello releva por la cantidad que costare más de lo que refieren dichas condiciones se le pueda ejecutar a dicho fiador como por llana y guarenticia obligación de plazo pasado que consigo trajera aparejada ejecución (...).

Que el dinero que recibiere el dicho Alonso Manzano ha de bastar con sus recibos simples como si fueran cartas de pago auténticas y por ellos se le ha de haber el cargo de lo que tuviere recibido.

Que el dicho Padre Rector se obliga en nombre de dicho colegio de cumplir con lo que le toca y va expresado en dichas condiciones. 
Y para el cumplimiento y guarda de lo que dicho es cada parte por lo que les toca el dicho Padre Rector obligó los bienes y rentas del dicho colegio y los dichos Alonso Manzano principal y Juan Juárez Marroquín su fiador sus personas y bienes muebles y raíces habidos y por haber y ambas partes dieron poder a las justicias competentes a quien se sometieron (...) y lo otorgaron todos ante mí el escribano siendo testigos Juan de Illana, don Juan de Colombe y Manuel de Medina vecinos y estantes en esta ciudad y los otorgantes que doy fe conozco lo firmaron.

Condiciones para una obra de talla y ensamblaje agregadas a esta traza que se han de ejecutar en la ciudad de León en el Colegio de San Miguel de los Ángeles que es asistido por los padres de la Compañía de Jesús y es como se sigue:

$1^{\text {a }} \quad$ Es condición que el pedestal principal ha de ser de madera y hasta la grada de humillación ha de ser de piedra y en los intercolumnios se han de hacer sus alacenas y esto ha de correr por cuenta del maestro.

$2^{\mathrm{a}} \quad$ Es condición que el pedestal segundo se ha de ejecutar en la forma que demuestra la traza guardando sus macizos y perfiles todas las molduras metidas en ranura y todos los miembros tallados y esta regla se ha de guardar en todo el resto de la obra la sotabasa ensamblada toda a la hebra y las cuatro repisas que reciben las cuatro columnas principales ejecutadas en la misma forma que demuestra la traza caladas y sus cogollos en los costados y en el tímpano que cae en el intercolumnio ha de llevar un lienzo de pintura ochavado adornado de talla.

$3^{\mathrm{a}} \quad$ Es condición que el alzado principal que ciñe de la cornisa de albañilería con la de madera y en esta altura han de estar repartidos todos estos cuerpos a su proporción las cuatro columnas que lleva este alzado han de ser revestidos de vástagos, hojas y racimos sus basas aticurvas y sus capiteles corintios con sus dos pencas y todo en adorno de dicha columna del relieve que requiere tener para que los vástagos se puedan levantar y calar y se descubra la caña de la columna y en los intercolumnios el uno que corresponda con el del pedestal segundo y el otro repartido que levante dos pies de la sotabasa arriba y se han de ejecutar con sus recuadros y tarjetas y en todos los lienzos de pintura sus tableros embarrotados para mayor duración de las pinturas que así lo pide y requiere las pilastras con sus basas y capiteles que corresponda a las columnas y su vaciado con su talón tallado y los muros que ciñen a la albañilería revestidos como demuestra la traza.

$4^{\mathrm{a}} \quad$ Es condición que la caja principal ha de mover en arco y el marco que va jugando con sus codillos ha de ser de tarjetas enredadas y el fondo de la caja con sus florones y recuadros de talla menuda y su tablero que sirva de respaldo.

$5^{\mathrm{a}} \quad$ Es condición que el arquitrabe, friso y cornisa han de ser ensamblados todos a la hebra guardando sus perfiles y subiendo sus disminuciones y todas las molduras talladas los modillones en los macizos de las columnas de dos en dos y sus frisos con sus cogollos calados y de buen relieve que así le pide su altura y en el plafón de la cornisa se han de echar sus frisos en escuadra y en los demás repartimientos guardando sus fajas de uno y otro lado y en el medio de dicha cornisa se forma aquel tambanillo para recibir la tarjeta principal que ha de ceñir contra él y la cornisa. 
$6^{\mathrm{a}} \quad$ Es condición que el pedestal tercero que sirve de banco al cerramiento subiendo sus disminuciones y guardando sus perfiles sus cartelas y frisos como demuestra la traza y si se escogiere y cualquier lado de los dos tendrá obligación el maestro de ejecutarlo así.

$7^{\text {a }} \quad$ Es condición que el cerramiento cualquiera de los dos lados que se escoja que se escogió los estípites se ha de adornar como demuestra la traza y los cerchones y los cerchones que ciñen a la albañilería de tarjetas hasta topar con el frontis la caja principal donde ha de estar la efigie de Nuestro Padre San Ignacio al fondo ha de hacer su corte en perspectiva por que con eso no queda tan esbelto al tablero y sí ha de ser de arco o no queda a elección del Padre Rector y en la tarjeta que cierra la clave ha de ir el Jesús que harán la forma de tenerle con su corona encima y los dos Ángeles con sus alas y bandas que han de tener cuatro pies de alto y estos han de correr por cuenta del maestro que se encargare de su manufactura y en los macizos de las columnas que ciñen a la albañilería ha de lleva dos jarrones de azucenas.

$8^{\mathrm{a}} \quad$ Es condición que la custodia se la ha de dar el altura que el ancho pide a su proporción advirtiendo que el San Miguel ha de estar debajo de la cornisa principal y ha de ser ejecutada en la forma que demuestra la traza y planta y alzado y la cornisa ha de ir jugando con la sotabasa del retablo y todas las caras adornadas menos la que arrima al retablo y las columnas adornadas en la misma disposición que las grandes y la cornisa que su adorno corresponda con la principal con sus modillones, frisos y molduras talladas y en la parte interior en la misma conformidad en el segundo cuerpo en cada macizo que cogen las columnas de ochavo su estípite adornado que así corresponde con la obra del retablo y en la fachada ha de quedar un marco fingido con su adorno de talla para que en este se ponga un lienzo que ha de ser de pintura para que el santo asiste allí y el Santísimo en el centro de la custodia y los otros ochavos calados y las cartelas que suben hacen media naranja y cierran la custodia han de ir a topar contra un florón que sirve de peana para una jarra de azucenas que remata dicha custodia.

$9^{a} \quad$ Es condición que toda esta obra se haya de ejecutar en madera de Soria que para dicho efecto tiene concertada y ajustada el colegio y se le ha de entregar al maestro cada pieza por el coste que ha tenido y en dicha obra se ha de gastar lo mejor que para ese efecto es comprada.

$10^{\mathrm{a}} \quad$ Es condición que haya de hacer el marco de frontal y los dos de los colaterales.

$11^{\mathrm{a}}$ Es condición que el dicho colegio ha de dar taller suficiente y saludable para dicha ejecución y si se hiciere en otra casa particular lo haya de llevar el colegio a su cuenta y ha de poner allí ocho pedazos de álamo que cada uno tenga de largo ocho pies y estos son para fijar el retablo contra la pared maestra y diez y seis fanegas de yeso grueso para recibirlos.

$12^{\mathrm{a}} \quad$ Es condición que para el maestro se le ha de dar un aposento con su cama de ropa para él solo y las pagas dando la cantidad que fuere necesario para pagar los oficiales cada semana y al maestro lo que fuere menester y tiempo suficiente que fuere necesario para acabar dicha obra y yo Alonso Manzano vecino de la ciudad de Valladolid y maestro en la facultad me obligo hacerla en término de diez y ocho meses contando de San Juan de junio de mil seiscientos y noventa en adelante no faltando dinero a tiempo.

$13^{\mathrm{a}} \quad$ Y el maestro no puede pedir mejoras sin dar cuenta al Padre Rector de lo que convenga para haberla. 
Y por toda la dicha obra el dicho Padre Rector le ha de dar el dicho maestro veinte y un mil reales de vellón que es la cantidad en que se ajustó y acabada y vista por una y otra parte y con vista de maestros de inteligencia que para ello se me ha de dar satisfacción de los maravedíes que alcanzare a dicho colegio y convenidos en esto el Padre Rector de la Compañía de Jesús de San Miguel de los Ángeles de León y Alonso Manzano lo firmaron en Valladolid a 26 de mayo de 1690 . 


\section{DOCUMENTO 56}

\section{AJUSTE ENTRE PARTE DE D. JUAN BLANCO VECINO DE ESTA CIUDAD DE LA UNA PARTE Y DE LA OTRA ANTONIO VÁZQUEZ Y JOSEPH DE ROZAS VECINOS DE ELLA MAESTROS ESCULTORES (13$$
\text { - JULIO - 1689) }
$$

A.H.P.V., Leg. 2.984/1, ff. $28-29^{13}$

En la ciudad de Valladolid a trece de julio de mil seiscientos y ochenta y nueve años ante mí el escribano y testigos parecieron de la una parte Antonio Vázquez y Joseph de Rozas vecinos de esta dicha ciudad maestro escultores y de la otra D. Juan Blanco vecino de ella y dijeron que entre los susodichos tienen ajustado el hacer dos hechuras de bulto la una del glorioso Padre San Francisco y la otra de Santo Domingo para poner en el retablo que se está haciendo para la iglesia de Nuestra Señora del Rosario y Santos Mártires de esta dicha ciudad con las calidades y condiciones siguientes:

Lo primero es condición que la hechura de Nuestro Padre Santo Domingo ha de ser a semejanza de la que está en la capilla del Convento de San Pablo de esta ciudad en todos los movimientos excepto que no ha de tener al pie globo de nubes como le tiene el de dicha capilla sino es que ha de estar de planta firme pero ha de tener un Santo Cristo en la mano que le corresponde y en la otra su ramo de azucenas y en lo demás como va dicho cuya hechura ha de ser de dos varas de alto.

Es condición que la hechura de Nuestro Padre San Francisco ha de tener el mismo alto que la de Santo Domingo con la misma elevación y su Santo Cristo en la mano y así esta hechura como la de la condición antecedente ha de ser a contento y satisfacción de dicho D. Juan Blanco, y a vista de maestros escultores y no lo siendo nos los dichos Antonio Vázquez y Joseph de Rozas se han de quedar con dichas hechuras y volver la cantidad de maravedíes que hubieren recibido.

Es condición que las dichas dos hechuras de San Francisco y Santo Domingo las han de dar fenecidas y acabadas en toda forma para el día de Nuestra Señora de septiembre que vendrá de este presente año y si antes las acabaren y contentaren las han de entregar al dicho D. Juan Blanco, para poner en dicho retablo.

Presente a lo referido Blas Martínez de Obregón maestro tallador que junto con los dichos Joseph de Rozas y Antonio Vázquez y cada uno de por sí y por el todo in solidum salía y salió por fiador de los susodichos y como tal sin que sea necesario hacer excursión en los bienes de los principales ni otra diligencia alguna se obligaba y obligó con su persona y bienes en forma de que cumplirán con las condiciones y calidades de esta escritura.

Que el dicho D. Juan Blanco se obliga de dar a los dichos Joseph de Rozas y Antonio Vázquez por las dichas dos hechuras de San Francisco y Santo Domingo ochocientos reales de vellón, los cuatrocientos de ellos para el día veinte de este presente mes y año y los cuatrocientos reales restantes para el referido día de Nuestra Señora de septiembre que vendrá de este presente año de ochenta y nueve y si antes de dicho día estuviere acabadas dichas dos hechuras y fueren a

13 BALADRÓN ALONSO, Javier: "Nuevas obras de Francisco Díez de Tudanca y otros datos de escultores barrocos vallisoletanos", B.S.A.A., Tomo LXXVIII, 2012, p. 160. 
gusto del susodicho y vista de maestros escultores entregará los dichos cuatrocientos reales de vellón.

$\mathrm{Y}$ todas las dichas partes cada uno por lo que les toca se obligaron con sus personas y bienes muebles y raíces habidos y por haber a su guarda y cumplimiento de esta escritura y de sus calidades y condiciones y para su ejecución y cumplimiento dieron todo su poder cumplido a las justicias y jueces de su majestad de esta ciudad y otras partes a quien se sometieron recibieronlo por sentencia definitiva de juez competente pasada en cosa juzgada renunciaron las leyes de su favor y la ley sit combenerit de jurisdictione omnium judicum y la general y derechos de ella en forma y por firme lo otorgaron así ante mí el escribano y testigos y lo firmaron a quien doy fe conozco siendo testigos Francisco de Salazar Joseph de Sevilla y Andrés de Santarén vecinos y estantes en esta dicha ciudad. Y se declara que los cuatrocientos reales que por el dicho D. Juan Blanco se han de dar el día veinte del presente como va referido han de ser los doscientos de contado y los otros doscientos en todo el mes de agosto próximo que viene hecho ut supra. 


\section{DOCUMENTO 57}

\section{PODER. JUAN ANTONIO DE LA PEÑA A PROCURADORES PARA EL JUICIO CONTRA PEDRO DE ÁVILA (17 - NOVIEMBRE - 1702)}

A.H.P.V., Leg. 3.026, f. 152

En la ciudad de Valladolid a diez y siete de noviembre de mil setecientos y dos años ante mí el escribano y testigos parecieron Juan Antonio de la Peña maestro escultor y Francisca de Santiago su mujer vecinos de ella habiendo precedido la licencia en derecho necesaria para otorgar esta escritura de que yo el escribano doy fe y de ella viendo otorgan que dan su poder cumplido el que de derecho se requiere y es necesario a Manuel de Peña María y a Luis Antonio Canedo procuradores del número de esta ciudad y a Pedro Álvaros de Velasco y Pedro de Velasco Barreda Lucas de Cantabrana y a Pedro Domínguez de Vargas procuradores del número de esta Real Chancillería y a cada uno in solidum con cláusula de sustituir para que en su nombre parezcan en juicio ante los señores presidente y oidores y alcaldes del crimen de dicha Real Chancillería y les defiendan en un pleito ejecutivo que contra ellos ha pedido Pedro de Ávila marido y conjunta persona de María Lorenza de la Peña su mujer vecinos de esta dicha ciudad sobre la paga de quinientos ducados y otras cosas en el dicho pleito contenidas en el cual les defiendan en dicho pleito y hagan demandas (...) y lo otorgan así siendo testigos Juan Pérez, Francisco de Santiago y Joseph Ballesteros vecinos y estantes en esta dicha ciudad y los otorgantes a quienes yo el escribano doy fe conozco lo firmó el dicho Juan Antonio de la Peña por sí y por la dicha Francisca de Santiago que dijo no saber a su ruego lo firmó un testigo. 


\section{DOCUMENTO 58}

\section{PODER. PEDRO DE ÁVILA A LUIS ANTONIO CANEDO Y OTROS (22 - NOVIEMBRE - 1702)}

A.H.P.V., Leg. 2.692, f. 303

Sépase como yo Pedro de Ávila maestro escultor vecino de esta ciudad de Valladolid marido y conjunta persona de $\mathrm{D}^{\mathrm{a}}$ María Lorenza de la Peña mi mujer hija legítima de Juan Antonio de la Peña asimismo escultor y de $D^{a}$ Francisca de Santiago su mujer y mis suegros vecinos de esta dicha ciudad. Otorgo que doy mi poder cumplido el que se requiere y es necesario a Luis Antonio Canedo y Joseph de Medrano procurador del número de ella y a Juan Pérez de Medina y Antonio Rodríguez Román que lo son de esta Real Audiencia y a cada uno in solidum con facultad de sustituir especial para que me defiendan en un pleito ejecutivo que ante uno de los señores alcaldes del crimen de esta corte y el presente escribano tengo pendiente contra los dichos Juan Antonio de la Peña y su mujer sobre la paga de los quinientos ducados de vellón que me ofrecieron en dote los susodichos al tiempo y cuando casé con la dicha mi mujer y sobre otras cosas en el dicho pleito contenidos como de él parece en cuya razón parezcan ante cualesquiera señores jueces y justicia de su Majestad donde convenga y hagan y pongan cualesquier demandas respuestas negativas pedimentos (...) y así lo otorgo ante el presente escribano y testigos en la ciudad de Valladolid a veinte y dos días del mes de noviembre del año de mil setecientos y dos siendo testigos Juan Canedo Juan de Segovia y Alonso Ladrón de Guevara residentes en esta dicha ciudad y el otorgante que yo el escribano doy fe conozco lo firmo. 


\section{DOCUMENTO 59}

\section{CARTA DE PAGO DE DOTE DE PEDRO DE ÁVILA A JUAN ANTONIO DE LA PEÑA (9 - DICIEMBRE - 1702)}

A.H.P.V., Leg. 2.692, ff. 313-315 14

En la ciudad de Valladolid a nueve días del mes de diciembre del año de mil setecientos y dos ante mí el escribano y testigos compareció Pedro de Ávila maestro escultor vecino de esta dicha ciudad, marido y conjunta persona de $\mathrm{D}^{\mathrm{a}}$ María Lorenza de la Peña su mujer hija legítima de Juan Antonio de la Peña asimismo maestro escultor y de $D^{a}$ Francisca de Santiago su mujer y sus padres vecinos de ella, y digo que al tiempo y cuando se hubo de casar con la dicha su mujer por la escritura de capitulación que en la dicha razón se otorgó entre los susodichos y el otorgante ante Domingo López ya difunto escribano que fue de susodicha ciudad y de cámara en la Real Audiencia y Chancillería de esta dicha ciudad en ella a diez de agosto del año pasado de mil y setecientos los dichos Juan Antonio de la Peña y Francisca de Santiago su mujer le ofrecieron en dote con la dicha $\mathrm{D}^{\mathrm{a}}$ María Lorenza de la Peña y por cuenta de sus legítimos quinientos ducados de vellón en dinero de contado luego que tuviese efecto el dicho matrimonio, y el otorgante por vía de arras y dotación proternúpcias por justas causas que para ello tuvo ofreció a la dicha su mujer en doscientos ducados de vellón como todo consta y parece de la dicha escritura de capitulación que su tenor es como se sigue:

\section{Aquí la capitulación}

Concuerda con la dicha escritura que original queda con el registro de esta de que el presente escribano da fe. Y de ella usando el dicho Pedro de Ávila dijo que mediante la dicha capitulación tuvo efecto el dicho matrimonio y por causa de no haberle pagado la dicha dote en su virtud ante uno de los señores alcaldes del crimen de esta corte y el presente escribano en diez y seis de noviembre pasado de este dicho año pidió ejecución por los dichos quinientos ducados contra la persona y bienes del dicho Juan Antonio de la Peña y los de la dicha Francisca de Santiago su mujer por más su legítima y costas con protesta de recibir en cuenta lo legítimamente pagado la cual se mandó hacer y con efecto se hizo y trabó en bienes de los susodichos a cuya ejecución salió y se opuso el dicho Juan Antonio de la Peña y presentó cierto memorial de distintas partidas de dinero que por cuenta de los quinientos ducados dijo tenía recibidas el otorgante y pidió que a su tenor jurase y declarase y se mandó así y conforme a la declaración que el otorgante hizo en veinte del mismo mes ante el presente escribano estuvo confieso en haber recibido por cuenta de los dichos quinientos ducados, tres mil trescientos y treinta y cuatro reales porque aunque había percibido mayor suma no había sido por cuenta de la dicha dote sino es de diferentes obras de escultura que el otorgante hizo de orden del dicho su suegro como fueron trescientos y cincuenta reales por la hechura de una imagen de Nuestra Señora de la Pasión para el Colegio de San Albano de la Compañía de Jesús de esta dicha ciudad, cien reales por un niño Jesús, cuarenta reales por acabar una imagen de Nuestra Señora de la Concepción, y cien reales por dos niños para la parroquia de San Martín de ella con que quedó deudor al otorgante de resto de la dicha dote de dos mil ciento y sesenta y seis reales con

14 GARCÍA CHICO, Esteban: Documentos para el estudio del arte en Castilla. 2, Escultores, Universidad de Valladolid, Valladolid, 1941, pp. 369-371. 
treinta reales más de cierta labor de que se confesó deudor en su declaración el dicho Juan Antonio de la Peña que ambas partidas montan dos mil ciento y noventa y seis reales de los cuales hizo dos pagas reales en el oficio del presente escribano la una de mil setecientos y noventa y seis reales en diez y ocho del dicho mes de noviembre de este dicho año, y la otra de cuatrocientos reales en veinte y ocho del mismo mes.

Y asimismo en el dicho pleito tuvo pretensión el dicho Juan Antonio de la Peña que el otorgante le hubiese de volver y restituir unos perendengues de oro y aljófar, una sortija de oro, una pintura de Nuestra Señora de la Soledad con manto a la florentina, y unos morrillos medianos de hierro por decir le había entregado los dichos bienes con calidad de garantía el otorgante no saliese de las órdenes del dicho su suegro siendo licitas y decentes, y para ello pidió que el otorgante hiciese cierta declaración y con efecto la hizo y conforme a ella resulta que las dichas alhajas las dio y entregó al otorgante y a la dicha su mujer voluntariamente sin la dicha calidad. Y por parte del dicho Juan Antonio de la Peña se hizo consentimiento para que se entregase al otorgante el dicho dinero depositado en el oficio del presente escribano y para que además de la dicha dote y por más aumento de él se quedase con las dichas alhajas tasándose primero y que de uno y otro otorgase carta de pago de dicha dote y aumento y finiquito de todas las dependencias que entre los dos habían tenido y por auto del dicho señor alcalde de dos de este dicho mes y año se mandó tasara los dichos perendengues, sortija, pintura, y morrillos de hierro y que para ello las partes nombrasen tasadores y hecho se entregase al otorgante el dicho dinero depositado otorgando carta de pago de los dichos quinientos ducados contenidos en la dicha escritura de capitulación aquí inserta y también de lo que importasen las dichas alhajas las cuales fueron tasadas en la forma que adelante se dirá y para efecto de otorgar la dicha carta de pago se le mando entregar y entregó la dicha escritura de capitulación, y cumpliendo con lo mandado por el dicho señor alcalde el otorgante confesó haber recibido por bienes dotales de la dicha $\mathrm{D}^{\mathrm{a}}$ María Lorenza de la Peña su mujer por mano del dicho Juan Antonio de la Peña su padre y suegro respectivo cinco mil novecientos y seis reales de vellón en esta manera los tres mil trescientos y treinta y cuatro reales de ellos que en diferentes partidas tenía recibidos el otorgante antes de ahora del dicho su suegro en distintas partidas como resulta de la dicha su declaración hecha en el dicho pleito.

Dos mil ciento y sesenta y seis reales de las dichas dos pagas reales de que el susodicho hizo consignación en el oficio del presente escribano en los dichos días, porque aunque importaron dos mil ciento y noventa y seis reales los renta restantes (aunque también los ha recibido) no son por cuenta de la dicha dote sino es de resto de obra particular que hizo para el dicho su suegro.

\section{Aumento}

Cuatrocientos y seis reales que por más aumento de la dicha dote tiene recibidos del dicho Juan Antonio de la Peña en las dichas alhajas conforme a la tasación que de ellas se hizo en el dicho pleito por los tasadores nombrados por ambas parte cuya tasación el otorgante consiente aprueba y ratifica y conforme a ella se componen los dichos cuatrocientos y seis reales en esta manda trescientos y quince reales en que fueron tasados los dichos perendengues de oro y aljófar menuda de a tres trozos cada uno.

Quince reales en que fue tasada la dicha sortija de oro con tres piedrecitas blancas ordinarias. 
Sesenta y seis reales en que también fue tasada la dicha pintura de Nuestra Señora de la Soledad de cuerpo entero con su marco negro a la florentina.

Diez reales en que fueron tasados los dichos morillos de hierro medianos.

Que las dichas partidas montan los dichos cinco mil novecientos y seis reales y de ellos se dio por contento y pagado y entregado a su voluntad por haber recibido los dichos dos mil ciento y noventa y seis reales de las dichas dos pagas reales en dinero de contado y en moneda de oro y plata que lo sumo y monto por mano del presente escribano en quien estaban depositados en su presencia y de los testigos de esta escritura de cuya paga numeración y entrega y de que el otorgante lo conto recibió y paso a su poder yo el dicho escribano doy fe. Y en cuanto a ellos y a los tres mil setecientos y cuarenta reales restantes el dicho otorgante también se dio por contento pagado y entregado a su voluntad por haberlos recibido antes de ahora en las partidas y bienes de suso referidas sobre que renuncia las leyes de la entrega y su prueba excepción de la non numerata pecunia y demás del caso de que otorga tan bastante carta de pago como al derecho de la dicha su mujer convenga. Y también cumpliendo con el tenor de la dicha capitulación aquí inserta nuevamente ofrece a la susodicha por vía de arras y dotación los dichos doscientos ducados en la dicha escritura contenidos de los cuales la hace gracia y donación pura mera perfecta irrevocable que el derecho llama intervivos con renunciación de las leyes de su favor y del derecho de insinuación confesando como confiesa que la dicha cantidad cabe en la décima parte de los bienes que al presente tiene el otorgante y en caso que en ellos no quepa se los manda señala y consigna en los que adelante tuviere y adquiriere, uno y otro a elección de las susodicha que juntos los dichos doscientos ducados con los dichos cinco mil novecientos y seis reales que importa la dicha dote y aumento del suma todo ello ocho mil ciento y seis reales los cuales se obliga de tener de pronto y manifiesto y de no los vender enajenar ni obligar a ninguna deuda suya ni a otra cosa alguna. $\mathrm{Y}$ a que cada y cuando que el dicho matrimonio fuere disuelto o separado por muerte nulidad divorcio o por otro cualquier caso de los que el derecho permite pagar y volver a la dicha $\mathrm{D}^{\mathrm{a}}$ María Lorenza de la Peña su mujer, o a quien por la susodicha fuere parte legítima los dichos ocho mil ciento y seis reales de la dicha dote y arras y aumento de él a cuya paga quiere se compelido y apremiado y por más las costas de su confianza luego que llegue el caso sin otro plazo ni dilación alguna aunque de derecho se requiera el cual desde luego renuncia como si no le hubiera concedido. Y asimismo confesó estar enteramente pagado y satisfecho de todas las otras de escultura que hizo de orden del dicho Juan Antonio de la Peña su suegro y de todas las cuentas y dependencias que hasta hoy día de la fecha han tenido entre los dos sin que de partes aparte quede deuda alguna. Y de todo ello también le da y otorga carta de pago y finiquito con renunciación de las leyes y derechos de este caso en forma. Y a su firmeza obliga su persona y bienes muebles y raíces habidos y por haber y para su ejecución dio poder a las justicias de su Majestad y en especial a los señores Alcaldes del crimen de esta corte y a cada uno in solidum a cuyo fuero y jurisdicción se somete con renunciación del suyo propio para que a su cumplimiento le apremien como por sentencia pasada en cosa juzgada renunció las leyes de su favor con la general y derechos de ella y así lo otorgo y firmo ante mí el dicho escribano a quien doy fe conozco siendo testigos Luis Antonio Canedo, Alonso Ladrón de Guevara y Juan de Segovia residentes en esta dicha ciudad. 


\title{
DOCUMENTO 60
}

\section{NOMBRAMIENTO DE CURADOR DE PERSONA Y BIENES DE JUANA DE LA PEÑA (29 - FEBRERO - 1708)}

A.H.P.V., Leg. 2.956, ff. 780-782

\begin{abstract}
Andrés de Arce en nombre de Juana de la Peña una de las hijas y herederos que quedaron por fin y muerte de Juan Antonio de la Peña su padre y como su curador ad litem digo que ante su Majestad y el presente escribano se ha hecho inventario tasación cuenta y partición de sus bienes y hacienda entre la dicha mi menor y demás sus hermanos y a cada uno se le adjudicado la parte y porción que le ha tocado que están consentidas para las partes ya probadas por su Majestad y mediante hallarse la dicha mi menor, menor de veinte y dos y para la conservación y aumento de los bienes y hacienda que le tocan por su hijuela y para servirlos y administrarlos usando de la facultad q la da y concede el derecho desde luego nombra y yo en su nombre por su tutor y curador de su persona y bienes a Pedro de Ávila escultor su cuñado marido y conjunta persona de $\mathrm{D}^{\mathrm{a}}$ María de la Peña su mujer y hermana de mi menor. A su Majestad pido y suplico le haya por nombrado y mande se le notifique lo acepte y haga el juramento y obligación y de fianzas legas lanas y abonadas para la seguridad de dicha curaduría y haga la demás solemnidad necesaria y hecho le mande discernir y discierna el cargo y oficio de tal curador interponiendo a todo su Majestad su autoridad y decreto judicial que va lugar de derecho pido justicia y juro en anima de dicha mi menor lo necesario.
\end{abstract}

Fdo: Andrés de Arce

Por mi hecho propio y usando de la facultad que puedo por hallarme en edad competente nombro del mismo que tiene nombrado mi curador ad litem.

Fdo: Juana Rosa de la Peña

Auto

Hace por nombrado procurador de persona y bienes de Juana Rosa de la Peña a Pedro de Ávila su cuñado maestro escultor vecino de esta ciudad el cual se le notifique lo acepte jure y de la fianza y hecho se traiga para proveer justicia hace lo mando el señor Don Bartolomé Antonio de Badarán y Osinalde caballero del Orden de Calatrava corregidor de esta ciudad de Valladolid y su tierra por su Majestad en ella a veinte y siete de febrero de mil setecientos y ocho años.

\section{Notificación aceptación obligación y fianza}

En la ciudad de Valladolid a veinte y nueve días del mes de febrero de mil setecientos y ocho años yo el escribano notifiqué e hice saber el nombramiento de curador de persona y bienes de Juana Rosa de la Peña y auto antecedente a Pedro de Ávila vecino de esta ciudad en su persona 
el cual habiéndolo oído y entendido. Dijo aceptaba y aceptó el dicho nombramiento de curador de persona y bienes de la dicha Juana Rosa de la Peña su cuñado hija legítima de Juan Alonso de la Peña y Francisca de Santiago sus padres y suegros del otorgante y como tal se obliga y obligó a educarla enseñarla y adoctrinarla y a regir y administrar beneficiar arrendar y cobrar todos los bienes así muebles como raíces que a la dicha su menor tocaron y pertenecieron por fin y muerte de sus padres como otros cualquier bienes y efectos que en cualquier manera la puedan tocar y pertenecer todo ello con buena cuenta y razón inteligencia y cuidado dando cuenta con pago al fin de dicha curaduría sin ninguna mora ni negligencia de suerte que vayan en aumento y no en disminución los bienes de dicha menor y donde su parecer y confesó no bastare le pedirá y tomará de abogados y de otras personas de ciencia y conciencia que se le puedan y deban dar y en todo cumplirá y lo hará como debe hacerlo y cumplirlo el que fuere buen curador y tutor de su menor y de su persona y bienes y así lo promete y jura de guardar y cumplir a Dios y a una cruz en forma de derecho. Y para que así lo cumplirá da por s fiadora a María de la Peña su mujer legítima que está presente lo cual habiendo precedido primero entre los dos como marido y mujer la licencia que en tal caso se requiere y es necesaria que fue pedida concedida y aceptada en toda forma para hacer otorgar y jurar esta escritura de que yo el escribano doy fe y usando de ella ambos a dos juntos juntamente y de mancomún el uno como principal y la otra como su fiador a voz de uno y cada uno de ellos de por sí y por el todo in solidum renunciando como renuncian las leyes de duobus rex debendi y la auténtica presente de quita de fide y iusoribus excursión y división de bienes depósito de las expensas y demás de la mancomunidad como en ella se contiene. La dicha María de la Peña también dijo salía y salió por fiadora debajo de la dicha mancomunidad del dicho Pedro de Ávila su marido en esta curaduría de persona y bienes de la dicha Juana Rosa de la Peña su hermana y como tal también se obliga a todo aquello que va obligado el dicho Pedro de Ávila su marido como si aquí fuese vuelto a repetir y en caso que por no lo hacer y cumplir así algún daño y menoscabo viniere a la dicha menor y a sus bienes diferido que sea en juramento, y de quien en su nombre lo deba pedir sin que sea necesario otra justificación alguna porque de ella les relevan lo darán y pagarán así el principal como fiador a quien y como fuere mandado por juez competente sin pleito alguno, y para que así lo cumplieran se obligan con sus personas y bienes muebles y raíces habidos por y por haber generalmente y por especial y expresa obligación e hipoteca sin que la obligación real derogue ni perjudique a la especial ni por el contrario si no es que de ambas a un tiempo y de cada una de por sí se pueda usar y use obligan e hipotecan especialmente a la seguridad de esta juraduría, la mitad de una casa que tienen y poseen suya propia que está en la calle que sube a San Miguel y hace esquina a la calle que va a las espaldas de la ermita del Cristo de la Cruz de esta ciudad que es la misma en la que murió el dicho Juan Antonio de la Peña su padre y suegro que es se les adjudicó en las cuentas y particiones que se hicieron por su fin y muerte entre los otorgantes y demás hijos del susodicho ante mí el escribano en este presente año sobre las cuales tiene el Convento de San Pablo de esta ciudad un censo perpetuo de cien reales de renta cada año con derecho de veintena y tanto y son libres de otra carga perpetua ni al quitar y así lo juran a Dios y a una Cruz en forma de derecho prohibiendo como prohíben su venta y enajenación hasta que esté fuera de esta obligación y fianza absoluta y realmente sola clausula general, del derecho de no enajenar. Y para que así se lo hagan cumplir dan todo su poder el necesario en derecho a las justicias y jueves de su Majestad de cualquier parte que sean para que se lo hagan cumplir como por sentencia pasada en autoridad de cosa juzgada renuncian todas las leyes fueros y derechos de su favor con la que prohíbe la real renunciación de ellas. Y la dicha María de la Peña también renuncia las leyes del senatus consultus Beleyano y emperador Justiniano toro y partida nueva y antigua constitución y demás del favor de las mujeres de cuyas fueras y auxilios confiesa haber sido avisada por mí 
el escribano de que doy fe y como sabedora y enterada de ellas y de sus fuerzas y efectos hizo esta renunciación para que no la valgan en ningún tipo y si lo inventare quiere no ser oída ni admitida en juicio ni fuera de él. Y por ser casada aunque mayor de veinte y cinco años jura a Dios nuestro señor y una señal de la cruz en forma de derecho de guardar y cumplir esta escritura en todo tipo y no ir contra ella por ninguna causa ni razón por cuanto se convierte en su utilidad y provecho el ser fiadora del dicho su marido en esta curaduría ni de este juramento tiene pedida ni pedirá absolución a su santidad ni a su nuncio delegado ni a otro juez ni prelado que para se la conceder poder y facultad tenga y sí de su propio motivo se la concediere no usara de ella y si lo hiciere quiere no ser odia en juicio ni fuera de él antes repetida y en costas condenada y tantas cuantas veces se la concediere tantos juramentos halle y uno más y a la fuerza y conclusión de éste y de ellos dijo si juraba y amén en cuyo testimonio ambos principal y fiador lo otorgaron así ante mí el escribano y testigos siéndolo Francisco Prieto oficial de escultor Alonso del Río y Gregorio de Velasco Campo vecinos y estantes en esta ciudad y de los otorgantes a quienes yo el escribano doy fe conozco lo firmó el que supo y por la que dijo no saber a su ruego lo firmó un testigo.

Fdo: Pedro de Ávila

Fdo: Gregorio de Velasco Campo

Auto y descernimiento de persona y bienes

Vista la aceptación obligación y fianza antecedente por el señor Don Bartolomé Antonio Badarán y Osinalde caballero del Orden de Calatrava corregidor de esta ciudad de Valladolid y su tierra por su Majestad en ella a veinte y nueve días del mes de febrero de mil setecientos y ocho años por ante mí el escribano discierna y discerní el cargo y oficio de curador de personas y bienes de Juana Rosa de la Peña menor hija legítima que quedo de Juan Antonio de la Peña y Francisca de Santiago su mujer difuntos vecinos que fueron de esta ciudad, en Pedro de Ávila su cuñado vecino de ella al cual su Majestad daba y dio poder y facultad cumplida bastante y sin ninguna limitación para que eduque y gobierne la persona de la dicha Juana Rosa de la Peña su menor y para que administre arriende beneficie y cobre todos sus bienes y rentas así muebles como raíces y otros cualquier derechos y efectos que al presente tiene y adelante tuviere en cualquier manera y para todo ello y lo anejo y de pendiente pueda dar poderes a quien y como la pareciere por su cuenta y riesgo a todo lo cual su Majestad interponía e interpuso su autoridad y decreto judicial para que valga y haga fe en juicio y fuera de él. Y el depositario en cuyo poder para la presente y porción que tocó a la dicha Juana Rosa de la Peña de sus legítimas en especie de dinero y plata labrada se lo entregue luego al dicho Pedro de Ávila dejando recibo de ello a continuación de estos autos para que siempre conste con lo cual se le da por libre del depósito que tiene hecha en cuanto a lo que mira a la dicha menor y se declara haber cumplido con ello y por este su auto así lo mando y firmo y en fe de ello lo firmé.

Carta de pago

En la ciudad de Valladolid a primero día del mes de marzo de mil setecientos y ocho años ante mí el escribano testigos pareció Pedro de Ávila maestro escultor vecino de esta ciudad como curador de la persona y bienes de Juana Rosa de la Peña su cuñada. Y dijo que en cumplimiento del auto antecedente dado por el señor corregidor de esta ciudad que es el en que se le discierne la dicha curaduría recibía y recibió realmente y con efecto de Juan Antonio González 
Bahamonde presbítero vecino de esta ciudad como persona en quien está depositado el dinero y alhajas de plata que quedaron por muerte de Juan Antonio de la peña suegro del otorgante las cantidades de dinero y alhajas de plata y tocaron y se adjudicaron a la dicha Juana Rosa de la Peña su menor en las cuentas y particiones que lo que es alhajas y valor en que están tasadas es como se sigue:

DINERO. Lo primero recibe diez mil y cuarenta y siete reales de vellón en especie de dinero; con declaración que la dicha Juana Rosa de la Peña tiene percibidos antes de ahora para alimentarse de mano del dicho D. Juan Antonio cuatrocientos reales de que entrega al otorgante recibo firmado de la dicha Juan Rosa de la Peña para que se le hagan buenos en su curaduría al tiempo que de la cuenta de ella; y los nueve mil seiscientos y cuarenta y siete reales restantes los mismos se le entregan ahora en dinero por el dicho D. Juan Antonio González Bahamonde y es lo paraba en su poder que ambas partidas hacen los dichos diez mil y cuarenta y siete reales.

SALVILLA Y VASOS. Asimismo recibe una salvilla de plata con siete vasos ochavados que pesa todo treinta y seis onzas y media que a razón de a quince reales importan quinientos y cuarenta y siete reales y medio.

SALERO PIMENTERO Y AZUCARERO. Asimismo recibe un salero azucarero y pimentero de plata hechura ordinaria que pesa todo quince onzas y cinco ochavados que a precio de quince reales cada onza consta está tasado importado ciento y treinta y cuatro reales y medio vellón.

CUCHARAS. Asimismo recibe seis cucharas de plata ordinarias que pesan seis onzas y siete ochavas que a quince reales cada onza como está tasado importan ciento y tres reales de vellón.

Que todas las dichas partidas juntas importan diez mil novecientos y treinta y dos reales vellón los cuales como lleva dicho confiesa haber recibido como bienes de la dicha su menor de mano del dicho Juan Antonio González de Bahamonde en cuyo poder estaba depositado ahora de presente en presente de mí el escribano y testigos de esta escritura de que me pide de fe; y yo el escribano la doy que el dicho Pedro de Ávila como curador de la persona y bienes de la dicha Juana Rosa de la Peña su cuñada en mi presencia y a los testigos de esta escritura recibió del dicho Don Juan Antonio González Bahamonde los dichos diez mil novecientos y treinta y dos reales de vellón en la forma y manera que va expresado y declarado en esta carta de pago como contento y satisfecho otorga a favor del susodicho tan bastante carta de pago como a su derecho convenga. Y asimismo declaro pasan en su poder todas las demás alhajas y bienes que se adjudicaron en su hijuela a la dicha Juana de la Peña su menor por ser depositario de todos ellos, y de uno y otro dará cuenta cada y cuando que le sea pedido y lo firmo de su nombre a quien yo el escribano doy fe conozco siendo testigos Alonso del Río Gregorio de Velasco Campo y Joseph González de Segovia vecinos y estantes en esta ciudad.

Fdo: Pedro de Ávila

Fdo: Tomás de San Juan 


\section{DOCUMENTO 61}

\section{PEDRO DE ÁVILA PIDE SE SEÑALE ALIMENTOS A UNA MENOR (5 - MARZO - 1708)}

783

A.H.P.V., Leg. 2.956, f.

Pedro de Ávila vecino de esta ciudad tutor y curador de la persona y bienes de Juana de la Peña una de los hijos y herederos que quedaron por muerte de Juan Antonio de la Peña escultor vecino que fue de ella cuya curaduría me está discernida por mandado de su Majestad ante el presente escribano. Digo que la dicha mi menor se halla en el Convento de San Nicolás de esta ciudad y por ser preciso alimentarla y sustentarla y para que todo se haga con la cuenta y razón que se requiere. A su Majestad pido y suplico se sirva de señalar a la susodicha la cantidad que fuere servido en cada un día para sus alimentos que es justicia que pido.

\section{Pedro de Ávila}

\section{Auto}

Señalase a Juana Rosa de la Peña real y medio de vellón cada día para sus alimentos con el que le acuda Pedro de Ávila su curador de persona y bienes desde el día de la muerte de su padre y se le haga bueno en la forma que diere de dicha curaduría así lo mandó el señor D. Bartolomé Antonio Badarán y Osinalde Caballero del Orden de Calatrava corregidor por su Majestad en Valladolid a cinco de marzo de mil setecientos y ocho. 


\section{DOCUMENTO 62}

\section{CAPITULACIÓN PARA RELIGIOSA. CONVENTO DEL SANTÍSIMO SACRAMENTO Y SAN NICOLÁS DE ESTA CIUDAD CON LOS CURADORES AD LITEM Y DE PERSONA Y BIENES DE D ${ }^{\mathrm{a}}$ JUANA ROSA DE LA PEÑA (10 - MAYO - 1708)}

A.H.P.V., Leg. 2.956, ff. 935-93815

Lo que a gloria de Dios nuestro señor y para su santo servicio se capitulo trata y concierta entre partes de la una el Convento del Santísimo Sacramento y San Nicolás las religiosas del Orden de Nuestro Padre San Agustín calzados de esta ciudad de Valladolid señoras priora y monjas de él de la una parte. Y de la otra Andrés de Arce procurador del número de esta ciudad en nombre y como curador ad litem de $\mathrm{D}^{\mathrm{a}}$ Juana Rosa de la Peña. Y Pedro de Ávila vecino de esta dicha ciudad por su hecho propio y como curador que es de la persona y bienes de la dicha $\mathrm{D}^{\mathrm{a}}$ Juana Rosa de la Peña su cuñada, y ambos usando de la licencia que para lo que aquí se dirá tienen y se les ha concedido por lo que toca a la dicha su menor. Por el señor Don Bartolomé Antonio de Badarán y Osinalde Caballero del Orden de Calatrava corregidor de esta ciudad por testimonio de mí el escribano de día de la fecha que aquí irá inserta. En razón del hábito de velo y coro que en dicho convento de San Nicolás se ha de dar a la dicha $D^{a}$ Juana Rosa de la Peña hija legítima de Juan Antonio de la Peña y de Francisca de Santiago difuntos vecinos que fueron de esta ciudad. Estando junta la comunidad en una grada baja de dicho convento donde tiene costumbre juntarse para tratar y conferir las cosas tocantes al bien y utilidad del dicho Convento habiendo sido llamadas a son de campana tañida como tienen de costumbre de que yo el escribano doy fe, presentes es por tal y señaladamente $\mathrm{D}^{\mathrm{a}}$ Manuela Teresa de Fuentes priora y todas las demás religiosas que al fin de esta escritura firmarán sus nombres y firmas que confesaron ser la mayor parte de las que en él hay al presente por sí mismas en voz y en nombre de las demás enfermas e impedidas y que serán adelante por quienes prestaron voz y caución en bastante forma que estarán y pasarán por lo que por ellas fuere efecto y otorgado se expresa obligación que para ello hicieron de los bienes propio y rentas del dicho convento. Y dijeron que por cuanto para efecto de poder recibir en el dicho convento por religiosa de velo y coro a la dicha $\mathrm{D}^{\mathrm{a}}$ Juana Rosa de la Peña han obtenido y ganado licencia y patente del señor Don Francisco Martínez de la Fuente canónigo de la santa iglesia catedral vicario episcopal en sede vacante en esta ciudad y su obispado y conventos de esta filiación y obediencia que está refrendada de Juan García escribano del número y secretario de la dicha santa iglesia catedral la cual junto con la dada por el dicho señor corregidor a los curadores ad litem y de persona y bienes de la dicha $\mathrm{D}^{\mathrm{a}}$ Juana Rosa de la Peña que ya va citadas ambas aquí se incorporan y son del tenor siguiente:

\section{Aquí las licencias}

Y usando de las dichas licencias que aquí van insertas y concuerdan con sus originales cada parte por lo que toca. Y esta comunidad por la suya ha tomado los votos a las religiosas de este

15 URREA FERNÁNDEZ, Jesús: "La biografía al servicio del conocimiento artístico. El escultor Juan Antonio de la Peña”. B.R.A.C., Tomo XLII, Valladolid, 2007, p. 56. 
convento quienes han venido en que se reciba en él a la dicha $\mathrm{D}^{\mathrm{a}}$ Juan Rosa de la Peña por religiosa de velo y coro mediante lo cual se capitula trata y concierta lo siguiente:

Lo primero las dichas señoras priora y religiosas del dicho Convento del Santísimo Sacramento y San Nicolás de esta ciudad se obligan de recibir y desde luego reciben en él por monja de velo y coro a la dicha $\mathrm{D}^{\mathrm{a}}$ Juana Rosa de la Peña hija legítima de los dichos Juan Antonio de la Peña y Francisca de Santiago sus padres a la cual se obligan de dar y que darán el hábito de religiosa de velo y coro en el dicho Convento de San Nicolás de la dicha sagrada religión y pasado que sea el año de su aprobación y noviciado la darán solemne profesión con todas las ceremonias requisitos circunstancias y actos que se acostumbran en el dicho convento con las demás religiosas que en él profesan de velo y coro guardando en todo lo que se Ordena y manda por el Santo Concilio.

Los dichos Andrés de Arce como curador ad litem de la dicha su menor y en su nombre y Pedro de Ávila por su hecho propio y como curador de persona y bienes de la dicha $\mathrm{D}^{\mathrm{a}}$ Juana Rosa de la Peña también su menor se obligan el uno y el otro en la forma que va expresado que por razón del recibimiento y profesión solemne de la dicha $\mathrm{D}^{\mathrm{a}}$ Juana Rosa de la Peña su menor a que cuatro días antes de la dicha su profesión darán y pagarán por razón de su dote al dicho Convento de San Nicolás de esta ciudad sus religiosas o a quien su poder y derecho tuviere en cualquier manera ocho mil y ochocientos reales de vellón; y asimismo darán y pagarán otros doscientos ducados de vellón por las propinas, los cien ducados de ellos ahora de contado, y los otros ciento restantes quedarán y pagarán al tiempo y cuando se entregue la dote principal, y asimismo darán y pagarán cuarenta ducados de vellón por razón de alimentos de la dicha $\mathrm{D}^{\mathrm{a}}$ Juana Rosa de la Peña, los veinte de ellos también ahora de contado junto con la mitad de las propinas, y los otros veinte ducados restantes a los dichos alimentos se han de pagar al tiempo y cuando se entregue la dicha dote principal y cuatro días antes de la profesión solemne. De manera que la cantidad que ahora percibe y cobra de contado por razón de propinas y alimentos son mil trescientos y veinte reales de vellón los ciento ducados de ellos por la mitad de dichas propinas y los veinte ducados restantes por la mitad de los dichos alimentos de cuya paga y entrega se da toda la comunidad por contenta a toda su voluntad por los haber recibido y pasado a su poder realmente y con efecto ahora de presente de mano del dicho Pedro de Ávila como tal curador de la persona y bienes de la dicha $\mathrm{D}^{\mathrm{a}}$ Juana de la Peña en presencia de mí el escribano y testigos de esta escritura de que me piden de fe y yo el escribano la doy que en mi presencia y de los dichos testigos la madre priora y religiosas de dicho Convento del Santísimo Sacramento y San Nicolás, por la mano referida recibieron y pasaron a su parte y poder los dichos mil trescientos y veinte reales que importan las dos mitades de propias y alimentos y como contentas pagadas y satisfechas de la dicha cantidad otorgaron a favor de los dichos dos curadores y de la dicha $\mathrm{D}^{\mathrm{a}}$ Juana Rosa de la Peña tan bastante carta de pago como a su derecho convenga.

Los dichos Andrés de Arce como tal curador ad litem y Pedro de Ávila como curador de la persona y bienes de la dicha su menor y este último por su hecho propio mediante estar y parar en su poder el caudal de la dicha $\mathrm{D}^{\mathrm{a}}$ Juana Rosa de la Peña se obligan el dicho Andrés de Arce con los bienes y los de la dicha su menor y el dicho Pedro de Ávila con su persona y bienes y los de la dicha menor a que darán y pagarán al dicho Convento del Santísimo Sacramento y San Nicolás de esta ciudad su priora y religiosas a quien su poder y derecho tenga en cualquier manera los dichos ocho mil y ochocientos reales de la dote de la dicha $\mathrm{D}^{\mathrm{a}}$ Juana de la Peña, y asimismo dieron y pagaron en la misma forma los cien ducados que quedan por pagar de las propinas y más los veinte ducados que también quedan por pagar de los alimentos que todas tres 
partidas juntas importan novecientos y veinte ducados todos juntos y en una paga para el dicho día cuatro antes de la dicha profesión puestos en el dicho Convento en poder de las dichas señoras priora y religiosa de él o quien el suyo tuviere a costa y riesgo del dicho Pedro de Ávila y de los bienes de la dicha $\mathrm{D}^{\mathrm{a}}$ Juana Rosa de la Peña su menor pena que pasado que sea el dicho plazo no cumpliendo con puntualidad se les ha de poder y pueda ejecutar sólo en virtud de esta escritura sin otro recado alguno como por obligación garantiza de plazo pasado que la traiga aparejada.

Que la dicha $\mathrm{D}^{\mathrm{a}}$ Juana Rosa de la Peña antes de la profesión si quisiere habiendo pagado antes lo que va obligada ha de poder y puede usar y así libremente de todo el demás caudal que la queda suya y de los derechos transversales renunciándolos cediéndolos o traspasándolos en quien y como la pareciere sin que en esto se la pueda poner ni ponga estorbo ni impedimento alguno por el dicho Convento ni religiosas de él.

Todo lo cual las dichas partes cada una por lo que la toca y va declarado se obligan de guardar y cumplir en toda forma con sus personas y bienes y de la dicha menor y del referido Convento muebles y raíces derecho y acciones habidos y por haber y dan todo su poder cumplido y el de la dicha su parte a las justicias y jueces de su santidad y su Majestad cada uno a las de su fuero competentes para que les compelan a lo cumplir como por sentencia pasada en autoridad de cosa juzgada renuncian todas las leyes fueros y derechos de su favor con la general en forma. $\mathrm{Y}$ por lo que mira a comunidad y corresponde a menor y competer beneficio de restitución in integrum a ambas partes juran por Dios nuestro señor y una señal de la cruz en forma de derecho de guardar y cumplir en todo tiempo esta escritura y no ir contra ella por ninguna causa ni razón y si lo hicieron o intentaren quieren no ser oídos ni admitidos en juicio ni fuera de él antes repelidas y en costas condenadas y de este juramento no tienen perdida ni pedirán absolución ni relajación a su santidad ni a su nuncio delegado ni a otro juez ni prelado que para se la conceden tenga facultad y si de propio motu se les concediere o relajare no usarán de ella y tantas cuantas veces se les concediere tantos juramentos hacen y a no más y a la fuerza y conclusión de éste y de ellos dijeron si juran y amen en cuyo testimonio todas las dichas partes lo otorgan así ante mí el escribano y testigos en la ciudad de Valladolid a diez días del mes de mayo de mil setecientos y ocho años siendo testigos Agustín de Quiñones Manuel del Álamo y Gregorio de Velasco Campo vecinos y estantes en esta ciudad y lo firmaron los otorgantes a quienes yo el escribano doy fe conozco.

\section{PIDE LICENCIA PARA CAPITULAR PARA ENTRAR UNA RELIGOSA EN SAN NICOLÁS.}

Andrés de Arce procurador del número de esta ciudad curador ad litem de $\mathrm{D}^{\mathrm{a}}$ Juana Rosa de la Peña una de los hijos y herederos que quedaron por muerte de Juan Antonio de la Peña. Digo que ante su Majestad y el presente escribano se hizo inventario tasación cuenta y partición de los bienes que quedaron del dicho padre de mi menor entre ella y los demás herederos que están consentidas y aprobadas y a la dicha mi menor la tocaron y ha de haber diez y siete mil novecientos y veinte dos reales y medio de vellón que para su paga se la adjudicaron la mayor parte en dinero y lo demás en diferentes piezas de plata labrada y diferentes alhajas y ajuares de por casa como consta de la dicha cuenta que para en poder del presente escribano y todo lo adjudicado en dicha hijuela se entregó a Pedro de Ávila su cuñado como su tutor y curador de persona y bienes con cuyo poder para excepto lo que constare y posesiones haber gastado con la 
susodicha y sus alimentos y vestuario desde la muerte de dicho su padre. Y es así que Dios nuestro señor ha sido servido de llamarla para ser religiosa y se halla con deliberada y entera voluntad de tomar el hábito de tal religiosa en el Convento del Santísimo Sacramento y San Nicolás obispo Orden de Nuestro Padre San Agustín de esta ciudad, y para ponerlo en ejecución así yo como el dicho Pedro de Ávila su cuñado y hermano y otras personas de su cariño tenemos tratado y ajustado con la Madre priora y religiosas de dicho Convento la forma y disposición de recibirla en él por tal religiosa en la forma y manera siguiente. Que por razón de la dote se ha de dar a dicho Convento ochocientos ducados de vellón con más doscientos ducados de las propinas de entrada y profesión cuarenta ducados de vellón por razón de los alimentos del año del noviciado. De las dichas partidas importan once mil cuatrocientos y cuarenta reales que habiéndonos informado y lo menos que andado y pagado las demás religiosas de velo y coro que han entrado y profesado en dicho Convento. Y además de ello se la han de sacar tres hábitos los dos blancos y el otro negro con sus velos y los demás adherentes que les corresponden como también hacer todos los demás gustos que son preciosos e inexcusables en semejantes funciones, y para que tenga efecto. A su Majestad pido y suplico se sirva de darme licencia en forma para que como tal curador ad litem de la dicha $\mathrm{D}^{\mathrm{a}}$ Juana de la Peña pueda otorgar escritura de capitulación con el dicho Convento según y en la forma que está tratado y se contiene en esta petición con todas las calidades fuerzas y firmezas y juramento que para su validación se requiere y sea necesario interponiendo a todo su Majestad su autoridad y decreto judicial cuanto a lugar de derecho. Y hecho y otorgado más de que el dicho Pedro de Ávila entregue las porciones referidas y haga los demás gastos precisos que se ofrecieren y que se le abonen en cuenta del caudal que en su poder para propio de dicha mi menor por su justicia que pido.

\section{Auto y licencia}

En la ciudad de Valladolid a diez días del mes de mayo de mil setecientos y ocho años el señor D. Bartolomé Antonio de Badarán y Osinalde Caballero del Orden de Calatrava corregidor de esta ciudad y su tierra por su Majestad por ante mí el escribano habiendo visto la petición antecedente. Dijo daba y dio licencia y facultad cumplida en derecho necesaria a Andrés de Arce procurador del número de esta ciudad como curador ad litem de $\mathrm{D}^{\mathrm{a}}$ Juana Rosa de la Peña, y a Pedro de Ávila su cuñado y curador de su persona y bienes para que los susodichos puedan capitular y capitulen en la forma y manera que contiene la petición, con el Convento priora y religiosas del Santísimo Sacramento y San Nicolás del Orden de Nuestro Padre San Agustín de esta ciudad, entraron de darla en él el hábito de religiosa de velo y coro como por ella se expresa en las cantidades de maravedíes que se refieren por su dote propinas y alimento sobre lo cual hagan y otorguen el dicho Andrés de Arce en nombre de la dicha su menor y sus bienes y el dicho Pedro de Ávila en el mismo nombre y por su hecho propio mediante para el caudal de dicha menor en su poder, la escritura o escrituras de capitulación que convengan y sean necesarias para mayor seguridad y paga de lo que se concertare, dándolo y pagándolo en los días y plazos que se tratare y ajustare, y asimismo puedan hacer y hagan todos los demás gastos que se suelen y acostumbran hacer en semejantes actos y todo lo que así importaren unos y otros lo de y pague el dicho Pedro de Ávila por cuenta de la legítima de dicha menor en la cual se le hagan buenos, y otorgan sobre todo las escrituras necesarias a las cuales su Majestad para su validación firmara interpusiera e interpuso su autoridad y decreto judicial cuando a lugar en derecho y lo firmó y en fe de ello lo firmé. 


\section{Otra licencia}

D. Francisco Martínez de la Fuente canónigo de la Santa Iglesia Catedral vicario episcopal sede vacante de esta ciudad y obispado y conventos de esta filiación y obediencia. Damos licencia a la madre priora y demás religiosas del Convento de San Nicolás de esta ciudad religiosas agustinas que es de esta filiación y obediencia para que con nuestra asistencia puedan votar en razón de dar el hábito de voto y velo negro en dicho Convento a $\mathrm{D}^{\mathrm{a}}$ Juana de la Peña hija legítima de Juan Antonio de la Peña y de Francisca de Santiago sus padres difuntos vecinos que fueron de esta ciudad y habiéndose votado por la mayor parte de él que sea recibida por tal religiosa de voto y velo negro; también damos licencia para que con el curador de persona y bienes de dicha $\mathrm{D}^{\mathrm{a}}$ Juana de la Peña se pueda otorgar y otorgue escritura para que se la reciba por tal obligándose a pagar ochocientos ducados por la dote; doscientos de propias de entrada y profesión; cuarenta ducados de alimentos y los demás agasajos acostumbrados cuya escritura se pueda otorgar y otorgue con todas las calidades y condiciones que convengan y sean necesarias las cuales aprobamos y ratificamos e interponemos nuestra autoridad en testimonio de lo cual dimos la presente firmada de nuestra mano y refrendada del infrascrito nuestro escribano de cámara en Valladolid a diez de mayo de mil setecientos y ocho años. 


\title{
DOCUMENTO 63
}

\author{
OBLIGACIÓN PARA EL CONVENTO DEL SANTÍSIMO SACRAMENTO \\ Y SAN NICOLÁS DE ESTA CIUDAD DE VALLADOLID CONTRA \\ PEDRO DE ÁVILA Y SU MUJER VECINOS DE ELLA (14 - MAYO - \\ 1709)
}

\author{
A.H.P.V., Leg. 2.957, ff. 163-164
}

Sépase por esta escritura de obligación como nosotros Pedro de Ávila vecino de esta ciudad de Valladolid y $\mathrm{D}^{\mathrm{a}}$ María de la Peña su mujer habiendo precedido entre los dos primero y ante todas cosas la licencia que de marido a mujer en tal caso se requiere y es necesario que fue pedida concedida y aceptada para hacer otorgar y jurar esta escritura de que yo el escribano doy fe y de la dicha licencia usando ambos a dos juntos juntamente y de mancomún a voz de uno y cada uno de nosotros de por sí y por el todo in solidum. Renunciando como renunciamos las leyes de duobus rex debendi y la auténtica presente hoc quita de fide y iusoribus ejecución y división de bienes depósito de las expensas y demás de la mancomunidad como en ellas se contiene. Decimos que por cuento al tiempo y cuando entró por monja de velo y coro en el Convento del Santísimo Sacramento y San Nicolás religiosas agustinas calzadas de esta ciudad $\mathrm{D}^{\mathrm{a}}$ Juana Rosa de la Peña nuestra hermana y cuñada respectiva se capituló la dote, propinas, alimentos y otras cosas que se habían de dar al dicho Convento al tiempo que estuviese para profesar como de la escritura de capitulación consta que paso ante el presente escribano en diez de mayo del año pasado de setecientos y ocho, y porque siendo Dios servido ha de hacer su profesión solemne esta semana y no está en dinero pronto toda la dicha dote y demás que ha de haber la dicha comunidad por esta razón hemos tratado con la madre priora y religiosas de dicho Convento el que de mancomún haremos obligación a su favor obligándonos por ella a pagarlas dos mil reales de vellón que fueron los que faltan para el cumplimiento de todo lo referido de la fecha en un año y en ello han venido y en que otorgaran la carta de pago de dote enteramente para que no se retarde la dicha profesión y cumpliendo con lo tratado por la presente y en aquella vía y forma que podemos y a lugar en derecho debajo de la dicha mancomunidad. Otorgamos que nosotros obligamos de dar y pagar y quedaremos y pagaremos realmente y con efecto a la dicha madre priora religiosas y Convento del Santísimo Sacramento y San Nicolás de esta ciudad de la Orden de San Agustín calzadas o a quien su poder y derecho hubiere en cualquier manera dos mil reales de moneda de vellón que son los mismos que no tenemos depósito para acabar de pagar la dote, propinas, y alimentos de la dicha $\mathrm{D}^{\mathrm{a}}$ Juana Rosa de la Peña y de que se nos ha de dar enteramente hoy día de la fecha carta de pago y finiquito por haberlo tratado así con la dicha comunidad en cuya forma nos confesamos por verdaderos y llanos deudores porque la entrega no parece de presente renunciamos a las leyes de este caso como en ellas se contiene y otorgamos a favor del dicho Convento tan bastante carta de pago como a su derecho convenga. Y nos obligamos a dar y pagar los dichos dos mil reales juntos y en una sola vez y paga para el día catorce de mayo del año que viene de mil setecientos y diez puestos en esta ciudad a nuestra costa y riesgo con las de la cobranza y casa y poder del dicho Convento o quien suyo tenga pena que pasado que sea el dicho plazo no cumpliendo con puntualidad se nos de poder y pueda efectuar solo en virtud de esta escritura sin otro recado 
alguno como por obligación garantiza de plazo pasado que la traiga aparejada y para el incumplimiento y paga de lo que dicho es nos obligamos con nuestras personas y bienes muebles y raíces derechos y acciones habidos y por haber y damos todo nuestro poder cumplido a las justicias y jueces de su Majestad de cualquier parte que sean para que nos compelan a lo cumplir como por sentencia pasada en autoridad de cosa juzgada renunciamos todas las leyes fueros y derechos de su favor con la que se prohíbe la general renunciación de ellas. Yo la dicha $\mathrm{D}^{\mathrm{a}}$ María de la Peña también renuncio a las leyes del senatus consultus Beleyano y emperador Justiniano toro y partida nueva y antigua constitución y demás del favor de las mujeres de cuyas fuerzas y auxilios confesó haber sido avisada por el presente escribano de cuyo aviso y renunciación yo el escribano doy fe y que enterada de su efecto las renuncia para no se aprovechar de ellas en ningún tiempo y si lo hiciere o intentare dijo quería no ser oída y también declara no tener hecha protesta contra esta obligación y si pareciere quiere que no valga y juro a Dios y a una cruz en forma de derecho esta escritura porque se conviene y en mi utilidad y de este juramento yo la otorgante no tengo pedida ni pediré absolución ni relajación a su santidad ni a su nuncio delegado ni a otro juez un prelado que para me la conceder tenga facultad y si de propio motu se me concediese o relajare no usare de ello y tantas cuantas veces me fuere concedida o relajado tantos juramentos hago y uno más y a la fuerza y conclusión de este y de ellos digo si juro y amén de forma que el postrer acto sea juramento en cuyo testimonio ambos lo otorgamos así ante el presente escribano y testigos en la ciudad de Valladolid a catorce días del mes de mayo de mil setecientos y nueve años siendo testigos Andrés de Arce procurador del número de esta ciudad D. Pedro Martínez de la Puebla contador de rentas reales y de propios de esta ciudad y Gregorio de Velasco Campo vecinos y estantes en esta ciudad y de los otorgantes a quienes yo el escribano doy fe conozco lo firmó el que supo y por la que dijo no saber a su ruego lo firmó un testigo. 


\title{
DOCUMENTO 64
}

\author{
CARTA DE PAGO DE DOTE. EL CONVENTO DEL SANTÍSIMO \\ SACRAMENTO Y SAN NICOLÁS DE ESTA CIUDAD A FAVOR DE D \\ JUANA ROSA DE LA PEÑA Y SUS CURADORES (14 - MAYO - 1709)
}

A.H.P.V., Leg. 2.956, ff. 165-167

En la ciudad de Valladolid a catorce días del mes de mayo de mil setecientos y nueva años ante mí el escribano y testigos estando en el Convento del Santísimo Sacramento y San Nicolás de religiosas del Orden de nuestro padre San Agustín calzadas de esta ciudad, en una de sus gradas bajas que es el sitio y lugar donde la comunidad se acostumbra juntar para tratar y conferir las cosas tocantes al bien y utilidad del dicho Convento habiendo sido llamadas a son de campana tañida como tienen de costumbre de que yo el escribano doy fe, comparecieron presentes especial y señaladamente $\mathrm{D}^{\mathrm{a}}$ María Teresa de Fuentes priora y todas las demás religiosas que al fin de esta escritura firmaran sus nombres y firmas que confesaron ser la mayor parte de las que en dicho Convento hay profesas al presente por sí mismas en voz y en nombre de las demás enfermas e impedidas y que serán adelante por quienes prestaron voz y caución en bastante forma que estarán y pasarán por lo que por ellas fuese hecho y otorgado so expresa obligación que para ello hicieron de los bienes propios y rentas del dicho Convento. Y dijeron que por cuanto en diez de mayo del año pasado de mil setecientos y ocho otorgó este dicho Convento escritura de capitulación en razón de recibir en él por monja de velo y coro a $\mathrm{D}^{\mathrm{a}}$ Juana Rosa de la Peña hija legítima de Juan Antonio de la Peña y de Francisca de Santiago sus padres difuntos vecinos que fueron de esta ciudad, obligándose a que la darían el hábito de religiosa en dicho Convento pasado el año de su aprobación y noviciado solemnemente con profesión, y todas las ceremonias y actos que se acostumbran en el dicho Convento con las demás religiosas de velo y coro que en él profesan dando y pagando cuatro días antes de su profesión al dicho Convento o a quien su poder tuviese ocho mil y ochocientos reales por su dote y más dos mil y doscientos reales para propinas, la mitad de ellos al tiempo que se la recibió en el dicho Convento por tal monja de velo y coro; y la otra mitad que son mil y cien reales al tiempo que se diese y entregase la dicha dote; y cuatrocientos y cuarenta reales por razón de alimentos de la dicha $\mathrm{D}^{\mathrm{a}}$ Juana de la Peña la mitad de ellos que son doscientos y veinte reales al mismo tiempo que se la dio el hábito; y otra tanta cantidad al tiempo de la entrega de la dicha dote, a cuya paga se obligaron Andrés de Arce procurador del número de esta ciudad como curador ad litem de la dicha $\mathrm{D}^{\mathrm{a}}$ Juana Rosa de la Peña su menor en su nombre y Pedro de Ávila vecino de esta ciudad, hermano de la susodicha por su hecho propio y como su curador de persona y bienes en la dicha escritura de capitulación como de ella consta que aquí se incorpora y es del tenor siguiente.

Aquí la capitulación que está en 10 de mayo de 1708

Concierta con la dicha escritura de capitulación a que me remito, y porque ha llegado el caso de la paga de la dicha dote mitad de propinas alimentos y de los extraordinarios que en semejantes funciones se dan a la comunidad para que tenga efecto la profesión de la dicha $\mathrm{D}^{\mathrm{a}}$ Juana Rosa de la Peña de tal monja de velo y coro en el dicho Convento del Santísimo Sacramento y San Nicolás por el dicho Pedro de Ávila su hermano y curador de su persona y bienes en presencia y 
con asistencia del dicho Andrés de Arce curador ad litem de la susodicha se quieren dar y pagar al dicho Convento los dichos ocho mil y ochocientos reales de la dote, mil cien reales que se restan debiendo de la mitad de las propinas, doscientos y veinte reales que se restan debiendo de la mitad de los alimentos, y trescientos reales en que se han ajustado los extraordinarios que se han de dar a la comunidad que todas estas cuatro posturas juntas importan diez mil cuatrocientos y veinte reales de vellón y pide se le dé carta de pago para que siempre conste en toda forma y viendo que es justo lo quieren hacer y poniendo en ejecución por la presente y en aquella vía y forma que puede y a lugar en derecho. Otorgan y confiesan haber recibido realmente y con efecto de mano del dicho Pedro de Ávila como tal curador de persona y bienes de la dicha $\mathrm{D}^{\mathrm{a}}$ Juana Rosa de la Peña su hermana hallándose presente el dicho Andrés de Arce su curador ad litem los dichos diez mil cuatrocientos y veinte reales de vellón que importa la dote de la dicha $\mathrm{D}^{\mathrm{a}}$ Juana Rosa de la Peña mitad de propinas, mitad de alimentos y extraordinarios en esta forma y los ocho mil reales de ellos en especie de dinero, y los dos mil reales restantes cumplimiento a toda la dicha cantidad en una escritura de obligación que a favor del dicho Convento del Santísimo Sacramento y San Nicolás de esta ciudad han hecho y otorgado hoy día de la fecha ante mí el escribano el dicho Pedro de Ávila y Da María de la Peña su mujer de mancomún a pagar a cierto plazo como de ella consta que hace la porción en dinero como la de la dicha escritura entregan a la dicha comunidad ahora de presente en presencia de mí el escribano y testigos de esta carta de pago de que me piden dé fe y yo el escribano la doy que las dichas madre priora y demás religiosas del dicho Convento de San Nicolás recibieron de mano del dicho Pedro de Ávila en presencia del dicho Andrés de Arce y de la mía y testigos de esta carta de pago los dichos diez mil cuatrocientos y veinte reales los ocho mil cuatrocientos y veinte reales de ellos en especie de dinero y los dos mil reales restantes en la dicha escritura de obligación y en esta forma lo pasaron a su parte y poder realmente y con efecto y como contentas y satisfechas de la dicha cantidad otorgaron a favor de la dicha $\mathrm{D}^{\mathrm{a}}$ Juana Rosa de la Peña y del dicho Pedro de Ávila como tal su curador de persona y bienes tan bastante carta de pago y finiquito como a su derecho convenga, y dan por ninguna y de ningún valor ni efecto y por rota y cancelada la dicha escritura de capitulación en cuanto a la obligación que el dicho Pedro de Ávila hizo a favor del dicho Convento por cuanto confiesan haber cumplido con ella y que no se volverá a pedir en ningún tiempo otra cosa alguna por la dicha escritura de capitulación y para el cumplimiento de lo que dicho es se obligan con los bienes y rentas del dicho Convento habidos y por haber y dan su poder cumplido el necesario en derecho de las justicias y jueces de su santidad de cualquier parte que sean para que se lo hagan cumplir como por sentencia pasada en autoridad de cosa juzgada renuncian todas las leyes fueros y derechos de su favor con la que se prohíbe la general renunciación de ellas en cuyo testimonio lo otorgan así ante mí el escribano siendo testigos Don Luis de Mojados presbítero Don Joseph Calderón y Gregorio de Velasco Campo vecinos y estantes en esta ciudad y lo firmaron las señoras otorgantes a quienes yo el escribano doy fe conozco. 


\title{
DOCUMENTO 65
}

\author{
RECONOCIMIENTO. PEDRO DE ÁVILA Y MARÍA DE LA PEÑA SU \\ MUJER A FAVOR DEL CONVENTO DE SAN PABLO (29 - FEBRERO -
} 1708)

\author{
A.H.P.V., Leg. 2.956, f. $828^{16}$
}

Sépase por ésta pública escritura de renovación y reconocimiento de censo perpetuo enfitéutico como nosotros Pedro de Ávila escultor vecino de esta ciudad de Valladolid y María de la Peña su mujer legítima, hija y una de los herederos que quedaron por fin y muerte de Juan Antonio de la Peña asimismo escultor y de Francisca de Santiago su mujer difuntos vecinos que fueron de esta dicha ciudad, habiendo precedido primero y ante todas cosas entre los dos otorgantes la licencia que entre marido y mujer se requiere y es necesaria (...) decimos que por cuanto Toribio González de Linares carpintero Inés Gutiérrez su mujer vecinos que fueron de esta ciudad por escritura que otorgaron ante Manuel Álvarez escribano real su fecha en ella a doce de enero del año pasado de mil seiscientos y treinta y tres fundaron censo perpetuo de cien reales de vellón en retan en cada un año pagados por mitad San Juan y Navidad a favor del prior religiosos y Convento de San Pablo Orden de Santo Domingo de esta dicha ciudad el cual procedió de la venta y compra de una casa que les vendieron que antiguamente fue de Sebastián de Arellano vecino de esta ciudad y está sita en la calle de San Miguel que hace esquina a la que sube por detrás de la ermita del santo Cristo de la Cruz a la calle de las Damas, y linda al presente con las dichas dos calles y con casas hacia la parroquia de San Miguel del dicho Convento de San Pablo y casas del mayorazgo que posee D. Pedro de Velasco y por la parte que va a la calle de las Damas linda con casas de Francisco Freixo de Guitián su oficio frenero que también pagan censo perpetuo del dicho Convento de San Pablo y antiguamente eran la una de los dichos linderos de Diego García cirujano y la otra de Sebastián de la Torre. Y es así que después de algunos poseedores que tuvo la casa referida de que procede el dicho censo perpetuo recayó en ella Lucas de Cantabrana procurador del número de esta real chancillería con la carga y gravamen del dicho censo perpetúo el cual vendió y enajenó la propiedad de ella a los dichos Juan Antonio de la Peña y Francisca de Santiago su mujer padres y suegros de nos los otorgantes con la misma carga del dicho censo perpetuo y hallándose dueños de ella renovaron y reconocieron de mancomún a favor del dicho Convento de San Pablo el dicho censo perpetuo obligándose a guardar sus condiciones penas y comisos por escritura que otorgaron ante Manuel Francisco de Villa escribano del rey nuestro señor perpetuo del número de esta ciudad en ella a primero de junio de mil seiscientos y ochenta y cinco. Y por fin y muerte de los dichos Juan Antonio de la Peña y Francisca de Santiago su mujer nuestros padres y suegros respectivamente se hizo inventario cuenta y partición de sus bienes entre nosotros y los demás sus hijos y herederos nuestros hermanos ante la justicia ordinaria de esta ciudad por testimonio del presente escribano en este presente año de mil setecientos y ocho en las cuales dichas cuentas y particiones entre otros bienes que se me adjudicaron a mí la dicha María de la Peña como uno de sus hijos y hermanos fue la mitad de la dicha casa de que procede el dicho censo perpetuo y la otra mitad se adjudicó a Joseph de la Peña nuestro hermano con la carga del censo perpetuo

16 URREA FERNÁNDEZ, Jesús: "La biografía al servicio del conocimiento artístico. El escultor Juan Antonio de la Peña”. B.R.A.C., Tomo XLII, Valladolid, 2007, p. 56. 
referido, con cuyo motivo y causa nos hallamos dueños de la propiedad de la casa referida mediante la cual por parte del dicho Convento de San Pablo de esta ciudad prior y religiosos de él como señores del directo dominio de la dicha casa se nos ha pedido y pido renovemos y reconozcamos a su favor el dicho censo perpetuo y en todo cumplamos con sus condiciones y viendo que es justo lo que nos piden y que a ello estamos obligados lo queremos hacer sin excusa alguna, y poniéndolo en ejecución por la presente y en aquella vía y forma que podemos y a lugar en derecho debajo de la dicha mancomunidad y sin que se entienda que por esta escritura se innoven ni alteren en cosa alguna la del dicho censo perpetuo principal renovaciones y reconocimientos de ella hechos antes dejándolos como han de quedar y quedan en su fuerza y vigor prelación y antigüedad añadiendo fuerza a fuerza y contrato a contrato. Otorgamos que reconocemos por dueño y señor del directo dominio de la dicha casa aquí declarada y deslindada y hace esquina a las dichas dos calles de San Miguel y la otra que sube por detrás de la dicha iglesia del Cristo de la Cruz a la calle de las Damas de ésta ciudad; al dicho Convento de San Pablo de ella su prior y religiosos de él y a quien su poder y derecho tuviere en cualquier manera y como tal nos obligamos y obligamos a nuestros hijos hermanos y sucesores aquí desde el día de Navidad fin del año pasado de mil setecientos y siete en adelante que es hasta cuando están pagados y satisfechos los réditos del dicho censo perpetuo les daremos y pagaremos darán y pagarán en cada un año por mitad San Juan y Navidad los dichos cien reales de moneda de vellón puestos y pagados en su casa y poder a nuestra costa y riesgo pena de ejecución y costas de manera que la primera paga que hemos de hacer de los réditos del dicho censo perpetuo y en ella cincuenta reales de vellón ha de ser el día de San Juan de junio que viene de este presente año de mil setecientos y ocho y otra paga de otra tanta cantidad el día de Navidad fin de él y así en adelante o perpetuamente y para siempre jamás. Y otrosí nos obligamos de guardar y cumplir todas las condiciones veintenas comisos sumisiones salarios y demás contenidas y declaradas en la dicha escritura de censo principal que se nos ha sido leído a la letra por el presente escribano y aquí le damos por inserto e incorporado como si lo fuese, y para el cumplimiento y paga de lo que dicho es nos obligamos con nuestras personas y bienes muebles y raíces derechos y acciones habidos y por haber y damos nuestro poder el necesario en derecho a las justicias y jueces de su Majestad de cualquier parte fuero y ejecución que sean para que nos compelan a lo cumplir como por sentencia pasada en autoridad de cosa juzgada renunciamos todas las leyes y fueros y derechos de nuestro favor con la que prohíbe la real renunciación de ellos. Y yo la dicha María de la Peña renuncio las leyes del senatus consultus (...) y demás de favor de las mujeres para no me aprovechar de ellas en ningún tiempo y si lo hiciere no me valgan de las cuales confieso haber sido avisada por el presente escribano de cuyo aviso y renunciación yo el escribano doy fe y por ser casada aunque mayor de veinticinco años juró por Dios nuestro Señor y una señal de la cruz en forma de derecho de guardar y cumplir esta escritura en todo tiempo y no ir contra ella por ninguna causa ni razón (...) en cuyo testimonio ambos lo otorgamos así ante el presente escribano y testigos en la ciudad de Valladolid a veinte y nueve días del mes de febrero de mil setecientos y ocho años siendo testigos D. Joseph Calderón Alonso del Río y Joseph González de Segovia vecinos y estantes en esta ciudad y de los otorgantes a quienes yo el escribano doy fe conozco lo firmó el que supo y por la que dijo no saber a su ruego lo firmó un testigo. 


\section{DOCUMENTO 66}

\section{PODER PARA TESTAR. PEDRO DE ÁVILA Y MARÍA DE LA PEÑA SU MUJER. EL UNO AL OTRO Y EL OTRO AL OTRO RECÍPROCAMENTE $(7-\mathrm{MARZO}-1708)$}

A.H.P.V., Leg. 2.956, f. $842^{17}$

Sépase por esta pública escritura de poder para testar como nosotros Pedro de Ávila maestro escultor vecino de esta ciudad de Valladolid y María de la Peña su mujer estando sanos de enfermedad corporal por la misericordia de Nuestro señor Jesucristo, y en nuestros juicios y entendimientos naturales creyendo como firmemente creemos en el misterio de la Santísima Trinidad padre hijo y espíritu santo tres personas distintas y un solo Dios verdadero y en todo lo demás que cree enseña y confiesa nuestra santa madre iglesia apostólica católica y romana debajo de cuya buena fe y creencia siempre hemos vivido y protestamos vivir y morir, tomando como tomamos por nuestra intercesora y abogada a la serenísima madre de dios María Santísima concebida sin pecado original desde el primer instante de su ser natural y a todos los demás santos de la corte celestial para que intercedan por nosotros con la divina Majestad. Decimos que sin embargo de que nos hallamos santos y en pie por causas motivos y razones que tenemos justos no podemos al presente hacer nuestros testamentos para estar prevenidos del tiempo que Dios nos llame a juicio, y porque el uno al otro y el otro al otro y cual y recíprocamente tenemos comunicadas muy por menor nuestras voluntades, por la presente y en aquella vía y forma que podemos y a lugar en derecho. Otorgamos que nos damos todo nuestro poder cumplido el que de derecho se requiere y es necesario yo el dicho Pedro de Ávila a la dicha María de la Peña mi mujer, y yo la dicha María de la Peña al dicho Pedro de Ávila mi marido para que llegando el caso de que uno de los dos otorgantes muere el que de los dos sobreviviere al otro; pueda por el que falleciere y en su nombre hacer y otorgar su testamento última y postrimera voluntad en el término que le da el derecho y en el hacer las mandas legados y disposiciones que quisiere y que tenemos comunicadas entre los dos, con tal que nuestros cuerpos sean sepultados en la parroquial de San Miguel de esta ciudad donde somos parroquianos en la sepultura donde está enterrado Juan Antonio de la Peña nuestro padre y suegro como se entra en la sacristía en la capilla mayor no habiendo embarazo justo y habiéndole en la parte que eligieren nuestros testamentarios. Y para cumplir y pagar esta disposición y el testamento que en virtud de este poder se hiciere y otorgare también nos nombramos por nuestros testamentarios yo el dicho Pedro de Ávila a la dicha María de la Peña mi mujer y yo la dicha María de la Peña al dicho Pedro de Ávila mi marido para que luego que el uno de nosotros muera el que sobreviviere entre en todos los bienes del que faltare y los venda y remate en pública almoneda o fuera de ella y de su valor cumpla y pague su testamento que en virtud de este poder hiciere en el término que le da el derecho y en todo el demás que fuere necesario que nos le prorrogamos, y cumplido y pagado en toda forma en el remanente que quedare de los bienes así muebles como raíces del que primero muriere nos dejamos e instituimos por nuestros herederos legítimos y universales también el uno al otro y del otro al otro igualmente mediante que al presente no tenemos ningún hijo ni heredero legítimo y si en

17 URREA FERNÁNDEZ, Jesús: "La biografía al servicio del conocimiento artístico. El escultor Juan Antonio de la Peña”. B.R.A.C., Tomo XLII, Valladolid, 2007, p. 56. 
adelante tuviésemos alguno o algunos hijos legítimos llegando este caso les dejamos por nuestros herederos universales y unos y otros en los caso referido lo hayan y lleven con la bendición de Dios, revocamos y anulamos otro cualquier testamento o testamentos codicilo o codicilos poder o poderes para testar y otro cualquier género de disposición que antes de esta hayamos hecho por escrito o de palabra o en otra forma que queremos ninguna valga ni haga fe y que sólo se esté en juicio y fuera de él por lo contenido en este poder y en el testamento que en su virtud se hiciere sin cosa en contra en cuyo testimonio lo otorgamos así ante el presente escribano y testamentarios en la ciudad de Valladolid a siete de marzo de mil setecientos y ocho años siendo testigos Domingo Estévez Mateo Durante y Rodrigo Ibáñez vecinos y estantes en esta ciudad y de los otorgantes a quienes yo el escribano doy fe conozco lo firmó el que supo y por la que dijo no saber a su ruego un testigo. 


\title{
DOCUMENTO 67
}

\section{PIEZA POR LA CUAL CONSTA EL ENTREGO DE LA LEGÍTIMA QUE TOCÓ A JOSEPH DE LA PEÑA POR FIN Y MUERTE DE JUAN ANTONIO DE LA PEÑA SU PADRE. ESTÁ AQUÍ LA CARTA DE PAGO A FAVOR DE D. JUAN ANTONIO GONZÁLEZ BAHAMONDE (5 - DICIEMBRE - 1709)}

A.H.P.V., Leg. 2.957, ff. 352-358

\begin{abstract}
Manuel de Peñamaría en nombre y como defensor de Joseph de la Peña hijo y heredero que es y quedó de Juan Antonio de la Peña vecino que fue de esta ciudad. Digo que por cláusula de testamento debajo de cuya disposición murió el padre de mí parte mandó que respecto de hallarse ausente la cantidad que le tocase de su legítima y herencias se entregase a los demás sus hijos y herederos dando fianzas para que luego que viniese se le entregase y por muerte del susodicho se hicieron cuentas y particiones por testimonio del presente escribano y se nombró por depositario a Juan Antonio de Bahamonde vecino de esta dicha ciudad en cuyo poder quedó y está depositada la cantidad que tocó y se adjudicó a mi parte y mediante que $\mathrm{D}^{\mathrm{a}}$ Juana de la Peña hermana de mi parte entró y está religiosa profesa en el Convento de San Bartolomé extramuros de esta ciudad con que sólo han quedado en el siglo mi parte y Pedro de Ávila como marido y conjunta persona de $\mathrm{D}^{\mathrm{a}}$ María de la Peña hermana asimismo de mi parte, quien se halla en esta ciudad a prevenir casa para traer y conducir a ella a su mujer hijos y familia para que cuando vengan tenga de pronto el caudal que le ha tocado a su Majestad pido y suplico mande que dando el dicho Pedro de Ávila fianza de tener de pronto el caudal que a mi parte se le adjudicó y tocó se le entregue el dicho Juan Antonio de Bahamonde despachándole para ello su libramiento en forma pues así es de justicia que pido y costas y autos.
\end{abstract}

Fdo: Josephe de la Peña

Fdo: Manuel de Peñamaría

Auto

Esta parte por ahora justifique la entidad de su persona y hecho se traiga para proveer justicia así lo mando el señor Don Bartolomé Antonio de Badarán y Osinalde Caballero del Orden de Calatrava corregidor y superintendente general de rentas reales y servicios de millones de esta ciudad de Valladolid y su provincia en ella a veinte y nueve de octubre de mil setecientos y nueve.

Fdo: Badarán $\quad$ Fdo: Tomás de San Juan

Información

En la ciudad de Valladolid a dos días del mes de noviembre de mil setecientos y nueve años Joseph de la Peña contenido en la petición antecedente para justificación de lo mandado por el auto dado por el señor corregidor de esta ciudad, en cuando a la entidad y calificación de su 
persona presentó por testigo a Joseph de Rozas maestro escultor vecino de esta ciudad del cual yo el escribano tomé y recibí juramento por dios nuestro señor y una señal de cruz en forma de derecho prometió decir verdad y siendo preguntado al tenor del dicho pedimento y auto. Dijo que lo que sabe y puede decir es que conoce muy bien y ha conocido de más de veinticuatro años a esta parte a Joseph de la Peña hijo legítimo de Juan Antonio de la Peña maestro escultor y de Francisca de Santiago sus padres difuntos vecinos que fueron de esta ciudad el cual se acuerda nació en la calle de Cantarranas pegado a la casa de D. Juan de la Rumbe en una que llaman la del pozo y el dicho Joseph de la Peña que presenta la dicha petición es el mismo hijo de Juan Antonio de la Peña y Francisca de Santiago sus padres por haberle visto al tiempo de juramentarle el testigo además de que en la cara ojos, altura, y demás facciones es muy parecido a sus padres y a Juana Rosa de la Peña su hermana religiosa en el Convento de San Nicolás de esta ciudad por cuyas razones reconoce ser el mismo y por haberle tratado como vecinos y de una edad con corta diferencia todo el tiempo que estuvo en esta ciudad hasta que hizo ausencia de ella y habrá que falta de esta ciudad trece años, y ha sido decir se casó en Miranda do Douro reino de Portugal y que tiene un hijo o dos y que lo que lleva dicho es lo que sabe y la verdad para el juramento que lleva hecho en que se afirmó y ratificó y lo firmó que es de edad de cuarenta y cinco años poco más o menos y en fe de ello lo firmé.

Fdo: Joseph de Rozas

Fdo: Tomás de San Juan

En la ciudad de Valladolid dicho día mes y año dichos de la dicha presentación y para la dicha justificación de entidad de la persona del dicho Joseph de la Peña presentó por testigo a Manuel Hernández vecino de esta ciudad morador en la parroquia de San Miguel del cual yo el escribano tomé y recibí juramento por Dios nuestro señor y una señal de la cruz en forma de derecho prometió decir la verdad y siendo preguntado al tenor de dicho pedimento y auto. Dijo que lo que sabe y que puede es que conoce muy bien y ha conocido de más de veinticuatro años a esta parte a Joseph de la Peña hijo legítimo de Juan Antonio de la Peña maestro escultor y de Francisca de Santiago sus padres difuntos vecinos que fueron de esta ciudad el cual se acuerda nació en la calle de Cantarranas pegado a la casa de D. Juan de la Rumbe en una que la llaman la del pozo y el dicho Joseph de la Peña que presenta la dicha petición en el mismo hijo de Juan Antonio de la Peña y Francisca de Santiago sus padres por haberle visto al tiempo de juramentarle el testigo además de que en la cara, ojos, altura y demás facciones es muy parecido a sus padres y a $\mathrm{D}^{\mathrm{a}}$ Juana Rosa de la Peña su hermana religiosa en el Convento de San Nicolás de esta ciudad por cuyas razones reconoce ser el mismo y por haberle tratado como vecinos y de una edad con corta diferencia todo el tiempo que estuvo en esta ciudad hasta que hizo ausencia de ella y habrá que falta de esta ciudad de trece a catorce años, y ha sido decir se casó en Miranda de Douro reino de Portugal y que tiene un hijo o dos y que lo que lleva dicho es lo que sabe y la verdad para el juramento que lleva hecho en que se afirmó y ratificó y lo firmó y que es de edad de cuarenta y seis años poco más o menos y en fe de ello lo firmé.

Fdo: Manuel Hernández

Fdo: Tomás de San Juan

En la ciudad de Valladolid dicho día mes y año dichos de la dicha presentación y para la dicha justificación de entidad de la persona del dicho Joseph de la Peña presento por testigo a Juan González vecino de Valladolid del cual yo el escribano tomé y recibí juramento por Dios nuestro señor y una señal de cruz en forma de derecho prometió decir verdad y siendo 
preguntado al tenor de dicho pedimento y auto. Dijo que lo que sabe y puede decir es que conoce muy bien y ha conocido de más de veintidós años a esta parte a Joseph de la Peña hijo legítimo de Juan Antonio de la Peña maestro escultor y de Francisca de Santiago sus padres difuntos vecinos que fueron de esta ciudad el cual se acuerda nació en la calle de cantarranas pegado a la casa de D. Juan de la Rumbe en una que llaman la del pozo y el dicho Joseph de la Peña que presenta la dicha petición es el mismo hijo de Juan Antonio de la Peña y Francisca de Santiago sus padres por haberle visto al tiempo de juramentarle el testigo además de que en la cara, ojos, altura y demás facciones es muy parecido a sus padres y a $\mathrm{D}^{\mathrm{a}}$ Juana Rosa de la Peña su hermana religiosa en el Convento de San Nicolás de esta ciudad por cuyas razones reconoce ser el mismo por haberle tratado como vecinos y de una edad con corta diferencia todo el tiempo que estuvo en esta ciudad hasta que hizo ausencia de ella y habrá que falta de esta ciudad de trece a catorce años y ha oído decir se casó en Miranda do Douro reino de Portugal y que tiene un hijo o dos que lo lleva dicho es lo que sabe y la verdad para el juramento que lleva hecho en que se afirmó y ratificó y lo firmó que es de edad de cuarenta y tres años poco más o menos y en fe de ello lo firmé.

Fdo: Juan González $\quad$ Fdo: Tomás de San Juan

Testimonio

En la ciudad de Valladolid a tres días del mes de noviembre de mil setecientos y nueve años, para más justificación de la información que está mandada dar a Joseph de la Peña presentó por testigo a $D^{a}$ Juana Rosa de la Peña su hermana religiosa en el Convento de San Nicolás Orden de Nuestro padre San Agustín la cual antes y primero pidió licencia a la señora $\mathrm{D}^{\mathrm{a}}$ Manuela de Fuentes priora en el dicho Convento para hacer esta deposición y la dicha señora priora la dio y concedió dicha licencia en toda forma yo el escribano tomé y recibí juramento por Dios nuestro señor y una señal de cruz en forma de derecho y habiendo jurado prometió decir verdad. Y dijo que Joseph de la Peña por quien está presentada la petición antecedente que da principio a estos autos que es la persona que se halla presente al tiempo de decir este su dicho, es hermano legítimo de la testigo y declarante e hijo legítimo de Juan Antonio de la Peña y de Francisca de Santiago sus padres difuntos vecinos que fueron de esta ciudad de Valladolid y como tal su hermano carnal le reconoce por cuya razón le tocan y pertenecen todos los bienes dinero y alhajas que se le adjudicaron en la cuenta y partición que entre la testigo $\mathrm{D}^{\mathrm{a}}$ María de la Peña su hermana y el dicho Joseph de la Peña está hecha y aprobada ante el señor corregidor de esta ciudad por testimonio del presente escribano y que lo que lleva dicho es lo que sabe y la verdad para el juramento hecho en que se afirmó y ratificó y lo firmó junto con la dicha señora priora y que es de edad de veinte y tres años poco más o menos y en fe de ello lo firmé.

Manuela Teresa de Fuentes priora $\quad D^{\mathrm{a}}$ Juana de la Peña Tomás de San Juan

En la ciudad de Valladolid a tres días del mes de noviembre de mil setecientos y nueve de la dicha presentación y para la justificación de entidad de la persona de Joseph de la Peña yo el escribano tomé y recibí juramento por Dios nuestro señor y una señal de cruz en forma de derecho de $\mathrm{D}^{\mathrm{a}}$ María de la Peña mujer legítima de Pedro de Ávila vecino de esta ciudad estando presente el dicho su marido lo cual le hizo en forma de derecho prometió decir verdad y siendo preguntada al tenor del pedimento y auto quedan principio a estos. Dijo que Joseph de la Peña 
por quien está presentada la petición antecedente que es la persona que se halla presente al tiempo de decir este su dicho es hermano legítimo de la testigo y declarante y de $\mathrm{D}^{\mathrm{a}}$ Juana Rosa de la Peña religiosa en el Convento de San Nicolás de esta ciudad e hija legítima de Juan Antonio de la Peña y de Francisca de Santiago sus padres difuntos vecinos que fueron de esta ciudad de Valladolid y como tal su hermano carnal le reconoce por cuya razón le tocan y pertenecen todos los bienes dinero y alhajas que se le adjudicaron en la cuenta y partición que entre la testigo D ${ }^{a}$ Juana Rosa de la Peña su hermana y el dicho Joseph de la Peña está hecha y aprobada ante el señor corregidor de esta ciudad por testimonio del presente escribano y que lo que lleva dicho es lo que sabe y la verdad para el juramento hecho en que se afirmó y ratificó y no lo firmó porque dijo no saber y que es de edad de treinta años poco más o menos y en fe de ello lo firmé.

Fdo: Tomás de San Juan

Manuel Peña María en nombre y como defensor de Joseph de la Peña hijo y heredero de Juan Antonio de la Peña vecino que fue de esta ciudad. Digo que por mi parte se pidió que el depósito de la cantidad que le tocó de su legítima se removiese en Pedro de Ávila su cuñado en el ínterin que mi parte trae y conduce a esta ciudad dicha su mujer hijos y familia que se hallan cuarenta leguas de esta ciudad y por verdad se mandó que mi parte justificase la identidad de su persona la que tengo justificada plenamente como consta de la información que presentó y juró y mediante haber mudado de dictamen y no querer por ahora se haga la dicha remoción ni sisa que dicho caudal del depósito donde se halla hasta tanto que mi parte haya traído a esta ciudad su mujer hijos y familia y se halla sentado en ella con su casa y pasado pueda traer dicha su familia a esta dicha ciudad necesita caudal pronto mediante hallarse en la dicha distancia de cuarenta leguas y para poderlo hacer. A su Majestad suplico se sirva mandar se le den y entreguen por cuenta de dichas sus legítimas seiscientos reales que es lo que necesita para dicho efecto y para ello su libramiento sobre dicho depósito pido justicia

Fdo: Joseph de la Peña $\quad$ Fdo: Peñamaría

Auto

Despáchese libramiento a Joseph de la Peña contenida en la petición de esta otra parte sobre D. Juan Antonio González Bahamonde como persona en quien paran el dinero que le tocó por fin y muerte de Juan Antonio de la Peña su padre como uno de sus hijos y herederos de quinientos reales de vellón para el efecto de mover su familia y casa a esta ciudad como lo dice en dicha petición cuya cantidad se le haga buena al dicho D. Juan Antonio González Bahamonde en cuenta de lo que para en su poder perteneciente a la hijuela del dicho Joseph de la Peña sólo con el libramiento y recibo de lo recibido a su continuación así lo mandó el señor D. Bartolomé de Badarán y Osinalde Caballero del Orden de Calatrava corregidor de esta ciudad de Valladolid en ella a cinco de noviembre de mil setecientos y nueve.

$$
\text { Badarán Tomás de San Juan }
$$


Manuel de Peñamaría en nombre de Joseph de la Peña vecino de esta ciudad hijo y heredero de Juan Antonio de la Peña vecino que fue de ella ya difunto. Digo que por muerte del padre de mi parte (...) de bienes ante el presente escribano se hizo inventario cuenta y partición de los bienes que dejó y la porción que toco a mi parte se depositó por hallarse ausente de esta ciudad y habiendo venido por mandado de bienes se le libraron y pagaron quinientos reales para con ellos poder traer y conducir a ella su mujer hijos (...) como con efecto la ha traído y se halla con ella avecindado en las casas que dejó dicho su padre a la plazuela del conde de Nieva a la esquina a mano derecha de la calle que desde la plazuela va a la parroquial de San Miguel mediante lo cual, a su Majestad suplico de lo que a (...) que la persona en cuyo poder está viere depositado el dicho caudal y herencia que a mi parte tocó (...) entregué enteramente bajando los dichos quinientos reales que tiene recibidos que está pronto el otorgar carta de pago y asimismo se le dé la posesión (...) derecho mejor lugar haya de la parte y porción que le tocó y se le adjudicó de dicha casa para que la goce con sus frutos y rentas como suya propia (...).

$$
\text { Josephe de la Peña Joseph de Peñamaría }
$$

Auto

(...) Joseph de la Peña y obligándose el susodicho y María Pereda su mujer a que no se ausentaran con su casa y familia de esta ciudad, a otra parte de reino enemigo, se le despache libramientos para que se le den y entreguen los bienes y dinero que le toco por su hijuela y ha de haber como a uno de los herederos e hijos de Juan Antonio de la Peña su padre difunto vecino que fue de esta ciudad y las personas en quien están depositados los dichos bienes y dinero cumplan con entregárselo con dichos libramientos y carta de pago para que siempre conste, con cuyos instrumentos se declara por buena la dicha paga y entrega y se le da por libres de los depósitos que tienen otorgados así lo mandó el señor D. Bartolomé Antonio de Badarán y Osinalde Caballero del Orden de Calatrava corregidor de esta ciudad de Valladolid en ella a dos de diciembre de mil setecientos y nueve años.

Badarán Tomás de San Juan

Obligación y fianza

En la ciudad de Valladolid a dos días del mes de diciembre de mil setecientos y nueve años ante mí el escribano y testigos comparecieron Joseph de la Peña pintor natural y vecino al presente de esta ciudad y María de Pereda su mujer de nación portuguesa como principales, y Pedro de Ávila maestro escultor su cuñado vecino asimismo de esta dicha ciudad como su fiador y principal pagador haciendo como hace de deuda y hecho ajeno suyo propio y habiendo precedido primero y ante todas cosas entre lo dicho Joseph de la Peña y María de Pereda su mujer la licencia que en tal caso se requiere y es necesario para hacer y otorgar esta escritura que fue pedida concedida y aceptada de que yo el escribano doy fe, y de ella usando todos tres principales y fiador juntos juntamente y de mancomún a voz de uno y cada uno de por sí y por el todo in solidum renunciando como renunciaron las leyes de duobus rex debendi y la auténtica presente hoc ita de fide y iusoribus excursión y división de bienes depósito de las expensas y demás de la mancomunidad como en ellas y en cada una de ellas se contiene. Y dijeron que 
cumpliendo con lo mandado por el auto antecedente dado por el señor D. Bartolomé Antonio de Badarán y Osinalde Caballero del Orden de Calatrava corregidor de esta ciudad se obligaban y obligaron como principales y fiador debajo de la dicha mancomunidad a que los dichos Joseph de la Peña y María de Pereda su mujer estarán en esta ciudad y no harán ausencia de ella ninguno de los referidos al dicho reino de Portugal de donde la susodicha es natural ni a otro reino ni parte que sea contrario y enemiga de esta corona de España pena de que se les pueda castigar y castigue en todo aquello que deben ser castigados los que hacen semejantes fugas a reino enemigo; y el dicho Pedro de Ávila como tal su fiador de mancomún también se obliga a que en los dichos sus cuñados se asentaren e hicieren fuga a tierra o reino contrario a esta dicha corona luego que tal lo conste dará y pagará a la elección y voluntad del señor corregidor de esta ciudad o de otro cualquier señor juez que lo sea competente cada y cuando que le sea mandado y pedido los diez y seis mil ochocientos y veintidós reales y medio de vellón la misma cantidad que al dicho Joseph de la Peña le tocó en su hijuela y hubo de haber en los bienes que quedaron por fin y muerte del dicho Juan Antonio de la Peña su padre y suegro respectivamente por cuya cantidad se le haya de poder y pueda apremiar y ejecutar sólo en virtud de ésta escritura de fianza y obligación como por deuda líquida y obligación guarenticia de plazo pasado que le traiga aparejada sin otro recado alguno y para que así unos y otros lo cumplirán y pagarán se obligan con sus personas y bienes muebles y raíces derechos y acciones habidos y por haber y dan todo su poder cumplido el necesario en derecho a las justicias y jueces de su Majestad de cualquier parte que sean en especial al dicho señor corregidor como capitán a guerra que es o a quien lo fuere en adelante para que les compelan a lo cumplir como por sentencia pasada en autoridad de cosa juzgada renuncian su propio fuero jurisdicción domicilio y privilegio y la ley sit combenerit de jurisdictione omnium judicum con todas las demás leyes fueros y derechos de su favor con la que prohíbe la general renunciación de ellas, y la dicha María de Pereda también renuncia las leyes del senatus consultus Beleyano y emperador Justiniano toro y partida nueva y antigua constitución y demás del favor de las mujeres de cuyas fuerzas y auxilios fue avisada por mí el escribano y enterada de su efecto hizo la ducha renunciación de que yo el escribano doy fe. Y por ser casada aunque mayor de veinticinco años también jura por Dios nuestro señor y una señal de la cruz en forma de derecho de guardar y cumplir esta escritura en todo tiempo y no ir contra ella por ninguna causa ni razón y si lo hiciere no quiere ser oída en juicio y fuera de él y a este juramento no tiene pedida ni pedirá absolución ni relajación a su santidad ni a su nuncio delegado maestro juez ni prelado que para se la conceder tenga facultad y si de propio motu se la concediere o relajare del dicho juramento no usará de ello y tantas cuantas veces la fuese concedida o relajado tantos juramentos hace y uno más y a la fuerza y conclusión de esta y de ellos dijo si jura y amén en cuyo testimonio todos tres principales y fiador lo otorgan así ante mí el escribano y testigos siéndolo Gregorio de Velasco Campo Francisco Mozo y Joseph de Álvarez vecinos y estantes en esta ciudad y de los otorgantes a quienes yo el escribano doy fe conozco lo firmaron los que supieron y por la que dijo no saber a su ruego lo firmó un testigo. Y a la dicha María de Pereda doy fe conocerla sólo de dos días a esta parte fecha ut supra.

Josephe de la Peña Gregorio de Velasco Campo Pedro de Ávila

Nota

De esta fianza está dado por libre Pedro de Ávila en virtud de auto del corregidor D. Francisco Joseph Montalbo y Huerta corregidor de esta ciudad su fecha de veintidós de marzo de mil setecientos y catorce que queda en mi regidor de escritura del dicho año. 
Tomás de San Juan

\section{Auto}

Vista la obligación y fianza antecedente por el señor Don Bartolomé Antonio de Badarán y Osinalde Caballero del Orden de Calatrava corregidor y capitán a guerra de esta ciudad y su provincia en ella a cuatro de diciembre de mil setecientos y nueve años. Dijo declaraba y declaró la dicha obligación y fianza por bastante mediante la cual mandaba y mandó se despachen a Joseph de la Peña los libramientos de dinero y bienes que le faltan de percibir de su hijuela en la forma y manera que está mandado por auto de su Majestad de dos de este presente mes y año y lo firmó y en fe de ello lo firmé.

Badarán Tomás de San Juan 


\section{DOCUMENTO 68}

\section{CARTA DE PAGO. JOSEPH DE LA PEÑA VECINO DE ESTA CIUDAD A FAVOR DE D. JUAN ANTONIO GONZÁLEZ BAHAMONDE (4 - DICIEMBRE - 1709)}

A.H.P.V., Leg. 2.957, f. 359

En la ciudad de Valladolid a cuatro días del mes de diciembre de mil setecientos y nueve años ante mí el escribano y testigos compareció Joseph de la Peña vecino de esta ciudad, uno de los hijos y herederos que quedaron por muerte de Juan Antonio de la Peña su padre ya difunto vecino que fue de ella. Y dijo que por fin y muerte del dicho su padre se hicieron cuentas y particiones entre los interesados por testimonio de mí el escribano en el mes de febrero del año pasado de mil setecientos y ocho; en las cuales le tocaron al otorgante por su legítima diez y seis mil ochocientos y veinte y dos reales y medio de vellón que se le pagaron en la mitad de una casa que está a la parroquia de San Miguel; bienes muebles de por casa como son ropa blanca pintura y madera y otros de distintos géneros; y ocho mil y cuarenta y siete reales en especie de dinero que se halló en ser; y en una tembladera de plata lisa con asas labradas que pesa diez y siete onzas y media cuya cantidad de dinero y tembladera de plata se puso y depositó en el licenciado D. Juan Antonio González Bahamonde vecino de esta ciudad; y hoy día de la fecha por el señor Don Bartolomé Antonio de Badarán y Osinalde corregidor de esta ciudad y ante quien paso el inventario cuenta y partición de dicho su padre se le ha despachado libramiento al otorgante para que el dicho D. Juan Antonio González Bahamonde le dé y pague siete mil quinientos y cuarenta y siete reales que resta a los dichos ocho mil y cuarenta y siete reales que en su poder tenía tocantes al otorgante; porque los quinientos restantes cumplimiento a los dichos ocho mil y cuarenta y siete reales se los tiene dados y pagados antes de ahora en virtud de otro libramiento de dicho señor corregidor. Y asimismo se manda por el dicho libramiento también le dé y entregue la dicha tembladera de plata con que para su resguardo le entregue el dicho libramiento con carta de pago ante mí el escribano; y cumpliendo de su parte con lo mandado por el dicho señor corregidor por la presente. Otorga y confiesa recibir ahora de presente en presencia de mí el escribano y testigos de esta escritura de mano del dicho D. Juan Antonio González Bahamonde los dichos siete mil quinientos y cuarenta y siete reales de vellón que pasan y están en su poder del dicho resto junto con la dicha tembladera de plata lisa con asas labradas que pesa diez y siete onzas y media de cuya entrega y recibo de dinero y alhaja me pide a mí el escribano de fe; y yo el escribano la doy y que el dicho Joseph de la Peña en mi presencia y de los dichos testigos recibió de mano del dicho D. Juan Antonio González Bahamonde los dichos siete mil quinientos y cuarenta y siete reales en su poder paraban; y asimismo recibió la dicha tembladera de plata lisa con asas labradas que pesa las dichas diez y siete onzas y media y uno y otro lo pasó a su poder realmente y con efecto y como contento y satisfecho de la dicha cantidad y de la dicha tembladera de plata otorga a favor del dicho D. Juan Antonio González Bahamonde tan bastante carta de pago y finiquito como a su derecho convenga. Y con la cantidad de esta carta de pago y los quinientos reales que antes de ahora tiene pagados y entregados al otorgante en virtud del otro libramiento que va citado acaba de pagar y cubrir todos los dichos ocho mil y cuarenta y siete reales que paraban en su poder del otorgante y la dicha tembladera de plata y entrega con esta carta de pago al dicho Juan Antonio González Bahamonde el libramiento que va citado para su resguardo y lo otorga así y firmó de su nombre a quien yo el escribano doy fe conozco siendo testigos Joseph Delua Gregorio de Velasco Campo y Francisco Mozo vecinos y estantes en esta ciudad. 


\section{DOCUMENTO 69}

\section{ESCRITURA ENTRE PEDRO DE ÁVILA Y CONSORTES (30 - NOVIEMBRE - 1710)}

A.H.P.V., Leg. 3.124, ff. 377-378 18

En la ciudad de Valladolid a treinta días del mes de noviembre ante mí el escribano y testigos comparecieron Pedro de Ávila escultor y $\mathrm{D}^{\mathrm{a}}$ María de la Peña su mujer vecinos de ella habiendo precedido entre los dos la licencia que de marido a mujer el derecho dispone que fue pedida concedida y aceptada de que doy fe ambos juntos y de mancomún y con renunciación de todas las leyes que sobre este caso hablan en forma de la una parte y de la otra Joseph de la Peña pintor asimismo vecino de esta ciudad y hermano de la dicha $\mathrm{D}^{\mathrm{a}}$ María y ambos dos de tres hijos y herederos que quedaron por muerte de Juan Antonio de la Peña su padre difunto. Dijeron que por cuanto por su muerte ante la justicia ordinaria de esta ciudad y por testimonio de Tomás de San Juan escribano del número de ella se hizo inventario tasación cuenta y partición de todos los bienes así muebles como raíces dinero y efectos que quedaron y dejó el dicho Juan Antonio de la Peña y entre los demás que se adjudicaron a los otorgantes como tales herederos fueron la casa en que el susodicho vivió y murió que están en esta ciudad y hacen esquina a mano derecha a la calle que sube a la iglesia parroquial de San Miguel de ella y dan vuelta a la que van a la de las Damas tasadas en doce mil reales de vellón con la carga de cien reales a censo perpetuo que sobre ellas tiene de renta en cada un año el Convento de San Pablo Orden de Santo Domingo de esta dicha ciudad por mitad entre ambos para que la gozasen en posesión y propiedad para siempre jamás como de dicho inventario tasación y adjudicaciones más largamente resulta a que los otorgantes se remiten y es así que de conformidad de año y medio de esta parte han vivido y ocupado dichas casas deseando vivir con paz y quietud y excusar algunos inconvenientes que de lo referido se podían seguir en la misma trataron extrajudicialmente separar y dividir las viviendas para cada uno a fin de que estuviesen con libertad y sin embarazo para lo cual y que fuese con todo acierto y seguridad nombraron un maestro de obras que viese reconociese y midiese dicha casa y separase dichas viviendas dando y aplicando a cada uno su mitad y la vivienda correspondiente conforme a sus medidas sin perjuicio y con efecto se midió y conforme a la declaración vista y reconocimiento de dicho maestro resultó dicha casa las medidas siguientes. Desde la pared de la escalera interior de adentro hasta la puerta del patio veinte y ocho pies por cincuenta y cinco de ancho que multiplicado el uno por el otro importan mil quinientos y cuarenta con que toca cada parte a setecientos y setenta pies por su mitad. Asimismo tiene otra medida desde la puerta del patio hasta la superficie de la calle Real veinte y seis pies y tiene (...) cada uno por su mitad trescientos y sesenta y cuatro. Mas tiene otra medida desde la puerta junto al pasamano de la escalera hasta el bodegoncillo donde echa el carbón y hasta la pared del patio de doce pies a doce pies que importan ciento y cuarenta y cuatro y su mitad son setenta y dos con lo cual viene a tocar de sitio y pavimento y haría a cada parte mil doscientos y seis pies y... a la disposición de su alzado y división y partición tocan al dicho Joseph de la Peña la cocina baja con su despensa y el dormitorio de encima juntamente con la mitad de la antesala y todo el cuarto que tiene hoy en día y si en el algún tiempo quisiese levantar y hacer más obra había de ser a su costa en cuanto a lo que tocan a la otra mitad tocaba

18 URREA FERNÁNDEZ, Jesús: "La biografía al servicio del conocimiento artístico. El escultor Juan Antonio de la Peña”. B.R.A.C., Tomo XLII, Valladolid, 2007, p. 56. 
el portal de dicho Pedro de Ávila juntamente con la sala y el aposento del carbón y el otro hasta la mitad de los veinte y ocho pies donde va referido y el aposento de los moldes y el otro antecedente y juntamente todos los despachos y el dicho Joseph de la Peña hubiese de abrir puerta para la calle de San Miguel y su coste por su cuenta y cargo y en vista de dicha declaración y reconociendo lo justo y acertado de ella la consintieron y si necesario es de nuevo la consienten, aprueban y ratifican en forma y para su mejor cumplimiento y que en todo tiempo estén seguros se obligan a guardar y cumplir lo siguiente.

Los dichos Pedro de Ávila y $\mathrm{D}^{\mathrm{a}}$ María de la Peña su mujer debajo de la dicha licencia mancomunidad y renunciación de leyes otorgan que se contentan y satisfacen con la dicha separación y aplicación hecha por mitad de la dicha casa pieza y sitios que por dicha declaración aquí expresada se hizo de la sala aposento del carbón y el otro hasta la mitad de los veinte y ocho pies y el aposento de los moldes y el otro antecedente y todos los desvanes con la calidad de poder fabricar en dichos sitios y piezas a su costa por todo lo que les pareciere sin que en ello se les ponga embarazo por el dicho Joseph de la Peña sus herederos y sucesores y quien en su derecho sucediere para siempre jamás y respecto no haber más que un pozo ha de quedar y queda el uso libre de él para los susodichos y el dicho su hermano sin que ningún tiempo aunque se venda y enajene se pueda pretender cosa en contrario.

Que dentro de tres meses de la fecha de esta escritura se han de hacer los dichos reparos abrir puertas y lo demás necesario cada uno a su costa y en el ínterin la entrada principal y desde dicha casa le han de tener igualmente como hasta aquí y pasados al que no lo hubiere cumplido se le ha de poder compeler y apremiar a ello por la paga de las costas y daños que a ello se siguieren y causaren.

Que todo lo aplicado (...) Pedro de Ávila y su mujer corresponde a la entrada de dicha casa y la vuelta a la calle que baja a la de las Damas.

El dicho Joseph de la Peña habiendo visto las calidades y condiciones antecedentes las acepta y consiente por lo que le toca y se contenta y satisface con los dichos sitios que se le han aplicado y repartido por su parte que son la cocina baja con su despensa y el dormitorio de encima juntamente con la mitad de la antesala y todo el cuarto en que habita al presente según las medidas hechas y corresponden por la parte de arriba a mano izquierda y derecha como se entra en el patio que suben a la calle Real de San Miguel arriba y por la parte del patio confina con el corral y casas de D. Alonso Aguayo regidor de esta ciudad y recíprocamente se obliga a hacer a su costa la obra y reparos que necesitare en dichos sitios para su mejor habitación y conveniencia y abrir dicha puerta y ejecutar lo demás conveniente sin que en ningún tiempo a él ni a sus herederos y sucesores les quede derecho acción ni recurso alguno para siempre jamás a intentar ni pretender cosa en contrario, y si lo hiciere o hicieren no han de ser ni sean oídos y admitidos en juicio ni fiera de él, y condenados en todas las costas y asimismo se obliga a que si vendiere dicha mitad de casa será en esta forma y con estas calidades y no en otra y si hiciere lo contrario no valga.

Que el patio donde está dicho pozo toca y se aplica entre ambas partes para su uso y aprovechamiento conforme a sus medidas por mitad sin agravio ni perjuicio alguno.

Y para el cumplimiento guarda y ejecución de todo lo aquí referido ambas partes cada una por lo que les toca dan todo su poder cumplido y bastante a las justicias y jueces de su Majestad de esta ciudad y otras partes a quien se someten y en especial al fuero y jurisdicción de los señores alcaldes del crimen de esta corte corregidor y teniente que son y fueren de esa dicha ciudad y a 
cada una y cualquiera in solidum para que a ello se compelan como si fuese en virtud de sentencia definitiva de juez competente pasada en autoridad de cosa juzgada renuncian su propio fuero y privilegio jurisdicción y domicilio y la ley sit combenerit de jurisdictione omnium judicum y todas las demás leyes fueros y derechos de su favor y la que dice que general renunciación de leyes fecha no valga.

Y asimismo la dicha $\mathrm{D}^{\mathrm{a}}$ María de la Peña renunciando de los emperadores Beleyano y Justiniano senatus consultus toro y partida y demás que son y hablan a favor de las mujeres de cuyas fuerzas y auxilios confiesa haber sido avisada por mí el escribano y como sabedora de sus efectos y queriendo no la valgan las renuncia y por ser casada y mayor de veinte años jura por Dios nuestro señor y una señal de cruz en forma que para otorgar esta escritura no ha sido inducida ni atemorizada por el dicho Pedro de Ávila su marido ni otra persona en si nombre y confiesa la otorga de su libre voluntad y que se convierte en su utilidad y que se convierte en su utilidad y provecho y contra ella no tiene hecha protesta y si pareciere la revoca y quiere no valga y del juramento declara no tiene pedida ni pedirá absolución ni relajación a su santidad, su nuncio delegado ni otro juez que facultad tenga para se la conceder y aunque se la conceda de ella no usará tantos juramentos hace como relajaciones y uno más y lo otorgaron así ante mí el escribano siendo testigos Don Manuel Carrillo presbítero teniente de cura de dicha iglesia de San Miguel Joseph Gómez maestro de obras y Juan de Loyola vecinos y residente en esta ciudad y los otorgantes que doy fe conozco y lo firmaron los que supieron y por la que no a su ruego un testigo. 


\title{
DOCUMENTO 70
}

\section{VENTA REAL. JOSEPH DE LA PEÑA ( 8 - ENERO - 1714)}

\author{
A.H.P.V., Leg. 3.125, ff. 5-6
}

Sépase como yo Joseph de la Peña vecino de esta ciudad digo que por mí y en nombre de mis hijos herederos y sucesores vendo y doy venta real y enajenación perpetua por juro de heredad para ahora y para siempre jamás a Pedro de Ávila mi hermano asimismo vecino de esta para él y sus hijos y quien en su derecho sucediere y su poder hubiere (...) de una casa que tengo y me pertenece en la calle de San Miguel que hace esquina como se va a mano derecha y da vuelta a la calle que está a la calle de la Cruz linderos por una parte y otra casa (...) que tienen censos perpetuos del Convento de San Pablo Orden de Santo Domingo de esta dicha ciudad y por parte detrás casas de Joseph Ruiz mercader también vecino de esta ciudad y por delante dicha calle de San Miguel que es la misma mitad que se me adjudicó como uno de los hijos y herederos de Juan Antonio de la Peña mi padre difunto en las cuentas y particiones que hicieron de sus bienes ante la justicia ordinaria de esta dicha ciudad y Tomás de San Juan escribano del número de la cual dicha mitad se la vendo con todo lo que la toca y pertenece sin reservar cosa alguna por precio de dos mil y doscientos reales que me ha de dar y pagar de la fecha de esta escritura en (...) que se ha de obligar en la aceptación de ella con la cual me doy por bien contento, satisfecho y entregado a mi voluntad y a mayor abundamiento otorgo en su favor carta de pago en forma de derecho de los dos mil y doscientos reales (...) que me ha de dar y pagar de precio de esta venta es el justo que vale la dicha mitad de casa y no vale más y en caso que más valga o valer pueda ahora o en cualquier tiempo de la demasía y más valor en cualquier cantidad que sea hago en favor del dicho Pedro de Ávila mi hermano y quien en su derecho sucediere gracia, cesión y donación buena pura mera perfecta irrevocable que el derecho llama intervivos con la insinuación y requisitos en él prevenidos para su mayor validación (...) y declaro que dicha mitad de casa es mía propia por dicha adjudicación como va referido y libre de toda carga, censo perpetuo, capellanía ni otra alguna excepto cincuenta reales mitad de ciento que sobre toda la dicha casa tiene de renta y censo perpetuo en cada un año el dicho Convento de San Pablo que tiene reconocido y paga enteramente dicho Pedro de Ávila y lo mismo ha de hacer en adelante él y sus sucesores y si constare tener otra carga se ha de proceder contra mí y mis bienes como por delito de crimen estelionato (...) y lo otorgamos así ante el presente escribano en la ciudad de Valladolid a ocho días del mes de enero año de mil setecientos y catorce siendo testigos D. Juan Sánchez presbítero D. Miguel García Bara y Juan de Aldave vecinos y residente en esta ciudad y los otorgantes que yo el escribano doy fe conozco lo firmaron. 


\section{DOCUMENTO 71}

\section{CARTA DE PAGO. JOSEPH DE LA PEÑA A PEDRO DE ÁVILA (24 - MARZO - 1714)}

A.H.P.V., Leg. 3.125, ff. 10-11

En la ciudad de Valladolid a veinte y cuatro días del mes de marzo año de mil setecientos y catorce ante mí el escribano y testigos compareció Joseph de la Peña vecino de ella uno de los hijos y herederos que quedaron por muerte de Juan Antonio de la Peña su padre. Y dijo que por cuanto ante mí el escribano en ocho de enero pasado de este presente año otorgó escritura de venta a favor de Pedro de Ávila su hermano asimismo vecino de esta dicha ciudad y de quien en su derecho sucediese de la mitad de una casa en la calle de San Miguel que hace esquina y da vuelta a la de la Cruz de ella la misma que su padre en precio de dos mil y doscientos reales de vellón pagados de la fecha de dicha escritura en tres meses que aceptó el dicho Pedro de Ávila y se obligó a su cumplimiento como más largamente de ella resulta a que se remite y sin embargo de no ser cumplido el dicho Pedro de Ávila está llano a entregarla de contado otorgándose a su favor carta de pago dándole por libre de la referida obligación y reconociendo ser justo otorga que confiesa recibí realmente y con efecto del dicho Pedro de Ávila los dichos dos mil y doscientos reales de que le era legítimo deudor por la causa y razón aquí expresada ahora de presente en presencia de mí el presente escribano y testigos de que me piden de fe y la doy de que en la suya y mía el dicho Joseph de la Peña recibió de mano del dicho Pedro de Ávila los dichos dos mil y doscientos reales en doblones de a ocho de cuarto y sencillos reales de plata calderilla y ochavos reducidos a vellón a como hoy corren y valen que los sumaron y montaron y como contento satisfecho y entregado de ellos el otorgante otorga a favor del dicho Pedro de Ávila tan bastante carta de pago como a su derecho conviene y le da por libre de la obligación hecha en la referida escritura donde se note y otorga su persona y bienes que esta cantidad ha sido bien pagada y no ser vuelta a pedir en tiempo alguno y lo otorgó así ante mí el escribano y lo firmé a quien doy fe conozco siendo testigo Joseph Martínez Don Pedro Álvarez y Juan de Aldave vecinos y residente en esta dicha ciudad. 


\title{
DOCUMENTO 72A
}

\author{
ESCRITURA PARA LA FÁBRICA DEL RETABLO DE NUESTRA \\ SEÑORA DE LAS NIEVES DE LA IGLESIA DE LOS SANTOS JUANES \\ DE NAVA DEL REY $(10$ - AGOSTO - 1712) \\ A.H.P.V., Leg. 13.564, ff. 187-190 (1712) ${ }^{19}$
}

En la villa de la Nava del Rey a diez días del mes de agosto de mil setecientos y doce años ante mí Cruzado Luengo escribano de su Majestad del ayuntamiento y número de ella, y testigos parecieron de la una parte Pedro Castreño mayordomo de la Cofradía de Nuestra Señora de las Nieves, el licenciado Gregorio Pérez presbítero capellán de dicha cofradía, y Juan Villoria, diputado de ella y comisarios para la fábrica de un retablo, que se ha de fabricar y asentar en la parroquial del señor San Juan de esta dicha villa en la parte que se determinare para poner la imagen de Nuestra Señora. Y de la otra Felipe Sánchez vecino de la villa de Medina del Campo maestro arquitecto, y dijeron habían determinado fabricar un retablo en dicha iglesia, y están convenidos con el dicho Felipe Sánchez que le ha de ejecutar arreglándose en todo a la traza que se ha exhibido; y guardarán en la dicha fábrica las condiciones que quedarán a continuación de esta escritura firmadas por el dicho Felipe Sánchez y Francisco Martínez de Arce maestro de dicho arte y vecino de la dicha villa de Medina del Campo, sus fechas de doce y veinte y cinco de julio y ocho del corriente mes de agosto y año de setecientos y doce y además en el precio, pagas y fenecimiento de dicha obra se guardará lo siguiente:

Primeramente es condición que se ha de ejecutar dicho retablo arreglado a la traza dada y de las maderas que convengan más suficientes, según lo demuestra dicha traza.

Es condición que se le ha de dar y dio luego de contado seiscientos reales de vellón, que se acondicionó por primera paga, por cuenta de mil y seiscientos reales en cuenta ajustado de toda costa dicho retablo y los mil reales que se le deben restantes, se le han de dar y pagar, la tercera parte de ellos para el tiempo y cuando lleve de mediada la fábrica de dicha obra, y las otras dos terceras partes al cumplimiento de dichos mil reales poner luego que se fenezca y asiente, y se declare por maestros estar conforme arte y arreglado a la traza y condiciones referidas, y por los dichos mayordomos, capellán y diputado se convinieron en las pagas arriba declaradas y al fin de esta escritura harán obligación de ello.

Y el dicho Felipe Sánchez para que cumplirá en todo la dicha fábrica se obligó a darla sentada, fenecida y acabada según dicho es a vista de maestros, para el día último de noviembre que vendrá de este año de la fecha ocho días más o menos y pasados y no cumpliendo se le ha de apremiar a ello por todo rigor de derecho y vía más breve que haya lugar y perderá del precio de los dichos mil y seiscientos reales que ha de llevar por dicha fábrica, doscientos reales de vellón que queda asentado por pena con convencional sobre que no pedirá otra declaración y además para el cumplimiento de todo lo que toca al dicho Felipe Sánchez dio por su fiador y llano cumplidor sin que la obligación general perjudique a la especial a Gabriel de Velasco vecino de

19 GARCÍA CHICO, Esteban y BUSTAMANTE GARCÍA, Agustín: Catálogo Monumental de la provincia de Valladolid. Tomo V. Partido judicial de Nava del Rey, Diputación de Valladolid, Valladolid, 1972, pp. 84-86. 
esta dicha villa el cual que estaba presente se obligó en toda forma que el dicho Felipe Sánchez cumplirá en todo con lo que contienen las condiciones de la fábrica de dicho retablo y están puestas, firmadas y declaradas a continuación de esta escritura las cuales vio y reconoció, y cuando no lo haga el susodicho como su fiador y llano pagador lo cumplirá de sus bienes que obligó en toda forma sin ser necesario que el dicho principal haga excursión de los suyos y cada una de las dichas partes por lo que la toca los dichos Pedro Castreño, el licenciado Gregorio Pérez y Juan Villoria por sí y en nombre de la dicha cofradía y los dichos Felipe Sánchez y Gabriel de Velasco como principal y fiador se obligaron a cumplir y que cumplirán todo lo tratado y capitulado en esta escritura y se guardará en la fábrica de dicho retablo todas las condiciones que van citadas y en las pagas de la dicha cantidad, sin faltar en cosa alguna, ni alegar sobre ello cosa que se pueda desvanecer lo tratado aunque parezca haber razón para ello que por cuanto la hubiera la revocan y dan por ninguna para cuyo cumplimiento obligaron sus personas y bienes muebles, raíces presentes y futuros y para su ejecución dieron poder a las justicias de su Majestad y santidad que les sean competentes recibieronlo por sentencia definitiva de juez competente pasada en cosa juzgada, renunciaron las leyes, fueros y derechos de su favor, su propio fuero, jurisdicción y domicilio y la ley sit combenerit y el dicho licenciado Gregorio Pérez el capítulo suan de penis obduardus de solutionibus, y todas las demás que hablan en favor de los eclesiásticos con la general en forma y por firme lo otorgamos así ante el dicho escribano dicho día, mes y año dichos siendo presentes por testigos Cristóbal Pelaz regidor perpetuo de esta dicha villa de la Nava, Juan López vecino de ella y Sebastián Rico vecino de la villa referida de Medina del Campo y a los otorgantes que yo el dicho escribano doy fe conozco firmaronlo los que dijeron saber y por el que dijo no saber de dichos otorgantes un testigo a su ruego.

Condiciones declaratorias y ejecución del colateral de Nuestra Señora de las Nieves sita en la parroquial del señor San Juan Bautista en la villa de la Nava del Rey:

$1^{\text {a }} \quad$ Primera condición que se ha de ejecutar su pedestal conforme la muestra y su alzado con cuatro columnas sus intercolumnios y su caja con su cornisa como lo demuestra la traza.

$2^{\mathrm{a}} \quad$ Condición que ha de llevar segundo cuerpo para el Cristo de Burgos con su pedestal sus machones y frontal con su largete y lo demás que demuestra la traza y esto se ha de ejecutar conforme arte el ensamblaje y talla de relieve competente y todo por precio de doscientos ducados de vellón y se ha de dar acabado para fin de noviembre rematándose en todo el mes de agosto del año de 1712 dándome para empezar seiscientos reales y lo demás en dos pagas y me obligo a ejecutar todo lo que demuestra la traza que queda en poder del señor don Cristóbal Pelaz.

$3^{\text {a }} \quad$ Y ejecutada aunque ponga más obra que la que demuestra la dicha traza no tengo de pedir mejora ninguna porque si la hiciere desde luego la perdono a la Cofradía de Nuestra Señora de las Nueves y en esta conformidad me obligo [Felipe Sánchez] hacer dicha obra y por ser verdad lo firmé (...) 12 de julio de 1712.

$4^{\mathrm{a}} \quad$ Digo yo Francisco Martínez de Arce vecino de la villa de Medina del Campo y maestro de arquitectura que hago mejora en la obra del retablo que hace la Cofradía de las Nueves para poner en la iglesia del señor San Juan para poner a Nuestra Señora de las Nieves y es condición 
que el recuadrado de la caja de Nuestra Señora ha de buscar su machón con el del Cristo de Burgos y de la parte de adentro del bastidor de afuera se ha de guarnecer con su moldura y dentro en el liso que quedare su friso de talla en el fondo de la caja de Nuestra Señora ha de ir apeinazada y ensamblada con sus frisos de talla acogollados y la mejoría que hago en dicha obra son quinientos reales vellón conviene a quedar dicha obra en mil y setecientos reales vellón con las condiciones y calidades de la postura arriba hecha por Felipe Sánchez vecino dicha villa de Medina del Campo.

$5^{\text {a }} \quad$ Con condición y calidad que siéndome arrematada haré escritura a favor dicha cofradía con la seguridad necesaria.

$6^{\mathrm{a}} \quad \mathrm{Y}$ es condición que se me ha de dar seiscientos reales para empezar dicha obra y demás en tres pagas la una ha de mediar dicha obra y las otras dándola acabada y fijada con la seguridad necesaria en el puesto que señalaren los comisarios de la fábrica de dicha villa y en esta conformidad me obligo hacer y ejecutar la traza que queda en poder de Cristóbal Pelaz vecino de esta villa y dicha obra la tengo de dar acabada y asentada para el día y fin de noviembre de este año y dicha cofradía hará obligación a pagar en lo que fuere rematada dicha obra a los plazos que señalaren y en esta conformidad me obligo hacer dicha obra y lo firmé en la villa de la Nava del Rey a veinticinco de julio de mil y setecientos y doce años.

Con las condiciones hechas por Francisco Martínez habiéndolas visto y reconocido hago baja de cien reales con que viene a quedar dicha obra en mil seiscientos reales y me obligo [Felipe Sánchez] a hacer dicha obra siéndoseme rematada y lo firmé en la Nava en 8 de agosto de 1712. 


\section{DOCUMENTO 72B}

\section{ESCRITURA PARA DORAR EL RETABLO DE NUESTRA SEÑORA DE LAS NIEVES DE LA IGLESIA DE LOS SANTOS JUANES DE NAVA DEL REY $(24$ - ENERO - 1717)}

A.H.P.V., Leg. 13.591, ff. 28-2920

En la villa de la Nava del Rey a veinte y cuatro días del mes de enero de mil setecientos y diez y siete años por ante mí Diego Rodríguez escribano del número de ella y testigos parecieron de la una parte el licenciado D. Juan Pérez Moreda, Pedro Pérez, Antonio García mayor en días y Manuel Martín Sardina mayor en días, capellán, mayordomo y cofrades de la Cofradía de Nuestra Señora de las Nieves de esta dicha villa de donde son vecinos, juntos y juntamente de mancomún a voz de uno y cada uno de por sí y por el todo in solidum renunciando como renunciaron las leyes de la mancomunidad como en ellas y en cada una se contiene. Y de la otra Alonso de Neira maestro dorador y estofador vecino de dicha villa y dijeron que dicha cofradía tiene en la iglesia de señor San Juan de ella a Nuestra Señora de las Nieves con su altar y retablo y por estar por dorar ha dado su comisión a los dichos licenciado D. Juan Pérez Moreda y consortes para que traten con maestros de dicho arte el dorar dicho retablo ajusten su precio y traten sus condiciones atendiendo a mirar por la mayor utilidad de dicha cofradía en cuya virtud después de haber tratado con suyos han tratado con el dicho Alonso de Neira quien se ha ofrecido por menor cantidad dorar dicho retablo lo cual tienen tratado y ajustado el que lo ha de ejecutar en la cantidad que irá declarada y con las calidades y condiciones siguientes:

Que el oro que el dicho Alonso de Neira ha de gastar en dicho retablo ha de ser limpio y que los ángeles se han de encarnar y las alas se han de dorar y estofar, que el respaldo de la caja donde está colocada Nuestra Señora se ha de dorar y se ha de fingir una tela de lana encarnada o de cogollos en campo de oro, y el marco de frontal se ha de dorar, y que el pedestal del retablo se ha de pintar y todo se ha de dar fenecido y acabado a satisfacción de maestro que ha de ser nombrado para este efecto de ciencia y conciencia para el día de Santiago y Santa Ana que vendrá de este presente año y si así no lo cumpliese se le ha de poder obligar a ello como también buscar maestro que lo ejecute por su cuenta y riesgo a que se ha de obligar en esta escritura.

Que por dicha obra se le han de dar dos mil y quinientos reales de vellón en que la tienen ajustada a toda costa y se le han de pagar en esta forma setecientos y veinte reales para dar principio a dorar dicho retablo, ochocientos y noventa para el día fin de mayo que vendrá de este presente año, y los ochocientos y noventa reales restantes para el dicho día de Santiago y Santa Ana que es para cuando ha de dar fenecida dicha obra y si para dicho tiempo dicha cofradía no se hallare con los dichos ochocientos y noventa reales en este caso ha de suspender la cobranza de ellos hasta el día de San Miguel de septiembre que asimismo vendrá de este

20 GARCÍA CHICO, Esteban y BUSTAMANTE GARCÍA, Agustín: Catálogo Monumental de la provincia de Valladolid. Tomo V. Partido judicial de Nava del Rey, Diputación de Valladolid, Valladolid, 1972, p. 86. 
presente año y si pasado dicho día no se cumpliere con pagarle la dicha cantidad a los susodichos y cualquiera de ellos ha de poder ejecutarles en virtud de esta escritura sin otro instrumento alguno como también por las demás cantidades que van declaradas en caso de no cumplir con pagarlas a los tiempos y plazos que van referidos sin que tenga necesidad de entenderse para cosa alguna con la dicha cofradía ni demás cofrades.

Y el dicho Alonso de Neira habiendo visto las condiciones puestas por los susodichos licenciado D. Juan Pérez Moreda Pedro Pérez Antonio García y Manuel Martín que están presentes con el susodicho y estando como está entendido y cierto de todas ellas y de su contenido se obliga a dorar dicho retablo y darle fenecido y acabado para el dicho día de Santiago y Santa Ana que vendrá de este dicho año y a satisfacción de maestro de dicho arte que será nombrado de ciencia y conciencia para que se esté y pase por su declaración por los dichos dos mil y quinientos reales que van declarados que se le han de pagar en la forma que se ha determinado por los dichos licenciado D. Juan Pérez Moreda y demás consortes ejecutando todo lo que va dispuesto y declarado por las dichas condiciones sin faltar a cosa alguna de ellas porque en dicha conformidad ha sido tratado conferido y ajustado.

Y ambas partes por lo que a cada una toca se obligan a lo cumplir con sus personas y bienes muebles y raíces habidos y por haber y para su ejecución dieron poder a las justicias y jueces de su Majestad que de las causas de cada uno de ellos puedan y deban conocer a quien se sometieron y renunciaron su propio fuero jurisdicción y domicilio y la ley sit combenerit de jurisdictione omnium judicum y las demás leyes fueros y derechos de su favor con la general en forma y el dicho licenciado D. Juan Pérez Morena renunció el capítulo suan de penis obduardus de absolucionibus y demás que hablan a favor de los eclesiásticos para que no le valgan. Y por firme lo otorgaron así ante mí dicho escribano en dicho año dicho día mes y año dichos siendo testigos Juan López Diego Rodríguez Muñoz y Francisco Zarzuelo vecinos y estantes en ella y de los otorgantes que yo el escribano doy fe conozco firmaron los que supieron y por los que dijeron no saber un testigo a su ruego. 


\title{
DOCUMENTO 73
}

\section{VENTA REAL. PEDRO DE ÁVILA ESCULTOR VECINO DE ESTA CIUDAD A FAVOR DE MANUEL RODRÍGUEZ Y MARTINA CHAPÓN $(6$ - NOVIEMBRE - 1717)}

\author{
A.H.P.V., Leg. 3.126, ff. 934-935 21
}

Sépase como yo Pedro de Ávila maestro escultor vecino de esta dicha ciudad. Digo que por cuanto por muerte de Juan de Ávila mi padre del mismo oficio y como uno de sus cuatro hijos y herederos en las cuentas y particiones que de sus bienes se hicieron se me adjudicó una casa que está en la calle de Santiago de esta dicha ciudad que al presente linda por una parte con casas del Colegio de San Gregorio y por otra casas de Francisco Sáenz boticario vecino de ella sobre que la Cofradía de la Santa Espina sita en la Santa Iglesia Catedral de esta dicha ciudad tiene un censo perpetuo de dos ducados cada un año con derecho de veintena y tanto por tanto la cual trate vender a Manuel Rodríguez y Martina Chapón su mujer vecinos de ella en precio de doscientos ducados de vellón de vellón pagados en la forma que se expresara y por más precio con la carga de dicho censo quedando al mío la paga de dicha veintena y renta debida hasta hoy, quienes me ofrecieron comprarla y para poderlo hacer con toda seguridad pedí a dicha Cofradía su licencia y me la concedió el día cuatro de éste mes como de ella resulta que entrego original al presente escribano para que aquí la inserte su tenor el siguiente:

\section{Aquí}

El memorial y dicha licencia aquí inserta concuerda con su original de que el presente escribano da fe y de ella usando yo el dicho Pedro de Ávila vendo y doy en venta real y enajenación perpetua por juro de heredad desde ahora para siempre jamás a los dichos Manuel Rodríguez y Martina Chapón su mujer para ellos, sus hijos herederos y sucesores y quien su derecho tuviere la dicha cada aquí declarada y deslindada con todo cuanto la toca y pertenece sin reservar cosa alguna por precio de los referidos doscientos ducados de vellón que por ella y en su compra me dan y pagan y han de dar y pagar en esta forma mil reales ahora de contado en presencia del presente escribano y testigos de esta escritura de que me piden de fe y la doy de que en la suya y mía dicho Pedro de Ávila los recibió de mano de los referidos Manuel Rodríguez y su mujer en doblones de a cuatro y de a dos reales de a ocho y de plata de a dos y sencillos reducidos a vellón que lo sumaron y montaron; y los mil y doscientos reales restantes que los susodichos me han de dar y pagar en cinco plazos, los cuatro en cuatro años Navidad del año que viene de setecientos y diez y ocho y los siguientes hasta el de setecientos y veinte. Igualmente a razón de doscientos y cincuenta reales en cada uno que importan mil reales y los doscientos restantes otro tal día de Navidad del siguiente del setecientos y veinte y dos a que se han de obligar de mancomún en la aceptación de esta escritura en cuya forma me doy por contento y satisfecho a mi voluntad y a mayor abundamiento de lo recibido y demás que he de recibir desde ahora y cuando llegue el caso otorgo en su favor carta de pago en forma. Y los dichos doscientos ducados es el justo precio y valor de dicha casa y no más y en caso que le tenga ahora o en cualquier tiempo del exceso que fuere hago a los susodichos y quien es su derecho sucediere

21 GARCÍA CHICO, Esteban: Documentos para el estudio del arte en Castilla. 2, Escultores, Universidad de Valladolid, Valladolid, 1941, pp. 373-374. 
gracia cesión y donación pura mera perfecta irrevocable que el derecho llama intervivos con la insinuación y requisitos en el prevenido para su mayor validación y además renuncio la ley ultradimidium justiprecio y las del ordenamiento real hechas en Cortes de Alcalá de Henares y los cuatro años en ella declarados que se conceden al comprador o vendedor para dentro de ellos pedir recisión de los contratos al precio justo, los cuales doy por pasados y declaro que la dicha casa es mía propia libre de toda carta temporal y espiritual excepto el dicho censo perpetuo de dos ducados aquí expresado y así la hube y heredé del dicho mi padre y lo juro por Dios nuestro señor y una señal de la cruz en forma y sí lo contrario constare consiento se pueda contra mí y mis bienes por delito de crimen este les nato y me desisto aparto y desapodero y a mis herederos y sucesores del derecho acción propiedad dominio útil que a dicha casa tengo y me pertenece y todo lo dejo cedo renuncio y traspaso para siempre jamás en los susodichos y los suyos y les doy poder cumplido para que de su autoridad o de la justicia se entren y tomen posesión de dicha casa la real actual civil y natural y la que de derecho les compete y en señal de posesión y por posesión real les entregó testimonio de la adjudicación de ella y pido al presente escribano les dé un traslado de esta escritura para que todo lo tengan por título legítimo y bastante y en el ínterin me constituyo por inquilino tenedor y precario proveedor y me obligo con mi persona bienes muebles y raíces derechos y acciones habidos y por haber a la evicción saneamiento y entera seguridad de la dicha casa que ahora y en todo tiempo del mundo será cierta y segura a los susodichos y quien en su derecho sucediere y sobre ella ni parte no les será puesto pleito embargo ni mala voz por ninguna comunidad ni persona particular diciendo pertenecerles por causa justa o injusta y si se les pusiere saldré y dichos mis herederos cada uno en su tiempo a su defensa y los seguiré y seguirán en todas instancias hasta su fenecimiento a mi costa y suya y dejarles en quieta y pacífica posesión sin daño costa ni contradicción alguna y no pudiendo o no queriendo hacer y cumplirlo así les volviere y volverán dichos mil reales recibidos y las demás cantidades que constare haberme pagado en toro y en parte en los plazos explicados y más todas las mejoras precisas o voluntarias que en dicha casa hubieren hecho costas y daños que sobre ello se les causaren porque se me ha de compeler y a dichos mis herederos y cada uno en su tiempo por todo rigor de derecho y vía ejecutiva en virtud de esta escritura y testimonio por donde conste lo susodicho como por garantía y llana obligación que las ha de traer aparejada. Presentes nosotros los dichos Manuel Rodríguez y Martina Chapón marido y mujer habiendo procedido entre los dos la licencia dispuesta por derecho que fue pedida y concedida y aceptada de que el presente escribano da fe juntos y de mancomún a voz de uno y cada uno de nosotros por sí in solidum y por él todo con renunciación de las leyes de duobus rex debendi y la auténtica presente debita de fide y iusoribus y la epístola del divo Adriano y el beneficio y remedio de la excursión y división de bienes depósito de las expensas y las demás de la mancomunidad como en ellas y, en cada una se contiene bajo de lo cual aceptamos esta escritura y recibimos en nos y para nuestros hijos y herederos el derecho que por ella se nos concede da y transfiero y cumpliendo de nuestra parte con lo que nos toca nos obligamos con nuestra persona y bienes dote arras y demás derechos de mi la dicha Martina Chapón de pagar al dicho Pedro de Ávila o a quien su poder hubiere los referidos mil y doscientos reales de resto del precio de esta venta y de que nos confesamos legítimos y verdaderos deudores según y a los plazos y forma que van expresados y no lo cumpliendo pasado cualquiera de ellos consentimos ser ejecutados y cada uno in solidum en virtud de esta escritura como por garantía y llana obligación que la ha de traer aparejada esto sin perjuicio del derecho que contra dicha casa tiene el dicho Pedro de Ávila por proceder de su venta éste débito y con el privilegio en su propiedad $\mathrm{y}$ valor que le corresponder. Y para su cumplimiento ambas partes cada una por lo que nos toca damos poder a las justicias y jueces de su Majestad de ésta ciudad y otras partes a quien nos sometemos y en especial al fuero y jurisdicción de los señores alcaldes del crimen de esta corte 
corregidor y teniente que son y fueren y a cada uno in solidum para que a su guarda respectivamente nos compelan como si fuese en virtud de sentencia de juez competente pasada en autoridad de cosa juzgada renunciamos nuestro propio fuero y privilegio jurisdicción y domicilio y la ley si combenerit de jurisdictione omnium judicum y todas las demás y derechos de nuestro favor y la que dice que general renunciación de leyes fecha no valga. Y asimismo yo la dicha Marina Chapón renuncio las de los emperadores Adriano y Justiniano senatus consultus toro partida y demás que son y hablan a favor de las mujeres que aparto del mío para que no se mee valgan ahora ni en tiempo alguno y por ser casa y mayor de veinte y cinco años juró por Dios nuestro señor y una señal de la Cruz en forma que para otorgar esta escritura no he sido inducida ni atemorizada por el dicho Manuel Rodríguez mi marido ni otra persona en su nombre y confieso la otorgo de mi libre y espontánea voluntad por convertirse en mi utilidad y en contrario no tengo protesta si pareciere la revoco y del juramento declaro tengo pedida ni pediré absolución ni reclamación a su santidad nuncio delegado ni otro juez que tenga facultad para me conceder y aunque de propio motu o en otra forma se me concediere de ella no usare y tantas cuantas veces lo consiguiere tantos juramentos hago como relajaciones uno más de manera que lo sea el último acto y a la conclusión de ellos y este dijo si juro y amén: en firmeza de lo cual todos tres lo otorgamos así ante el presente escribano en la ciudad de Valladolid a seis días del mes de noviembre año de mil setecientos y diez y siete siendo testigos, Juan de Salazar y Miranda, Juan Santos de Obano y don Simón de Mazuelas vecinos de ella y los otorgantes que yo el escribano doy fe conozco lo firmaron los que dijeron saber y por la que no a su ruego un testigo.

Pedro de Ávila vecino de esta ciudad y residente en ella da cuenta que la Cofradía de la Espina sita en la Santa Iglesia Catedral de la ciudad de Valladolid. Como vendo una casa mía propia que está en la calle de Santiago como consta por un censo que pago de dos ducados cada un año y dicha casa se vende en dos mil y doscientos reales y así suplica si por el tanto gustan de quedarse con ella. Y si no me permitieran dándome licencia para que la venda por dicha cantidad que de ello recibiere merced Valladolid y noviembre a 4 de 1717 años.

Dase licencia al contenido en ésta de parte para que pueda venderla de cuyo efecto tiene censo perpetuo la Cofradía de la Santa Espina pagarlo que correspondiere a la venta. Noviembre 9 de 1717. 


\section{DOCUMENTO 74}

\section{CAPITULACIONES MATRIMONIALES ENTRE JUAN CEANO LIBRERO VECINO DE ESTA CIUDAD CON MARÍA BARBA HIJA DE SANTIAGO BARBA MAESTRO CUBERO VECINO DE ELLA (1 - MAYO - 1731)}

A.H.P.V., Leg. 2.968, ff. 112-113

Lo que a gloria de Dios nuestro señor y para su santo servicio se capitula trata y concierta entre partes de la una Santiago Barba maestro cubero vecino de esta ciudad como padre legítimo que es de María Barba su hija y de $D^{a}$ Teresa de Ávila su madre ya difunta en razón del matrimonio que siendo Dios servido se ha de celebrar entre Juan Ceano maestro librero vecino de esta ciudad con $\mathrm{D}^{\mathrm{a}}$ María Barba se capitula trata y concierta lo siguiente:

Lo primero que precediendo las tres canónicas municiones que el santo concilio de Trento dispone los dichos Juan Ceano y $\mathrm{D}^{\mathrm{a}}$ María Barba se han de casar y velar según Orden de la santa madre iglesia católica apostólica y romana habiendo precedido la licencia que en tal caso se requiere y es necesaria del Ilustrísimo señor obispo de esta dicha ciudad o su discreto provisor y para que así lo cumplieran el uno al otro y el otro al otro recíproco e igualmente se dan palabra fe y mano para lo cumplir así y para ello consienten se les pueda compeler y apremiar por todo rigor de derecho.

El dicho Santiago Barba se obliga y ofrece que para ayuda de mantener las cargas del matrimonio llevara la dicha $\mathrm{D}^{\mathrm{a}}$ María Barba su hija y se darán y entregarán por su mano al dicho Juan Ceano nueve mil y setenta y cuatro reales moneda de vellón que es la misma cantidad que de dicha su hija la tocan y corresponden por la mitad de los bienes gananciales que hubo durante el matrimonio con la dicha $\mathrm{D}^{\mathrm{a}}$ Teresa de Ávila su mujer en que van comprendidos dos mil ciento y un reales que la dicha $\mathrm{D}^{\mathrm{a}}$ Teresa trajo del matrimonio al tiempo y cuando se casaron cuya paga ha de ser parte en dinero y lo demás restante en bienes raíces y de por casa valuados y tasados al tiempo de la entrega. Además de lo cual también se obliga a darla y pagarla por más parte de su dote otros dos mil y doscientos reales de vellón por la legítima paterna y de ambas las dichas porciones y cantidades al tiempo de la entrega el dicho Juan Ceano ha de dar y otorgar carta de pago y recibo de dote a favor de la dicha $\mathrm{D}^{\mathrm{a}}$ María Barba y su padre para que siempre conste con claridad.

El dicho Juan Ceano en atención a que la dicha $\mathrm{D}^{\mathrm{a}}$ María Barba es doncella virgen y en cabello e hija de padres conocidos y cristianos viejos la dota en tres mil y trescientos reales de vellón los cuales confiesa caben en la décima parte de sus bienes que tiene al presente y en caso que no quepan se los sitúa y señala en los demás que tuviere en adelante y a ello quiere ser compelido y apremiado.

Todo lo cual las dichas partes cada uno por lo que le toca y corresponde se obligan de guardar y cumplir en todo tiempo y para que a ello se les compela y apremie dan todo su poder el necesario en derecho a las justicias y fuerzas de su Majestad de cualquier parte fuero y jurisdicción que sean con sus personas y bienes muebles y raíces derechos y acciones habidos y por haber renuncian todas las leyes fueros y derechos de su favor con la que prohíbe la general 
renunciación de ellas y la dicha $\mathrm{D}^{\mathrm{a}}$ María Barba también renuncia las leyes del senatus consultus (...) y demás del favor de las mujeres para no se poder aprovechar de ellas en ningún tiempo y por ser menor de veinte y cinco años jura por Dios nuestro señor y una señal de cruz en forma de derecho de guardar y cumplir en todo tiempo esta escritura y no ir contra ella por ninguna causa ni razón por convertirse como se convierte en su utilidad y provecho (...) en cuyo testimonio lo otorgaron así ante mí el escribano y testigos en la ciudad de Valladolid a primero día del mes de mayo de mil setecientos y treinta y un años a que fueron testigos Francisco Javier Fernández oficial de mí el escribano Tomás de la Cruz y Juan de la Pedraja oficiales del dicho Santiago Barba vecinos de esta ciudad y de los otorgantes a quienes yo el escribano doy fe conozco lo firmó el que supo y por la que dijo no saber a su ruego le firmaron algunos de los testigos. 


\section{DOCUMENTO 75}

\section{TESTAMENTO EN VIRTUD DE PODER. DON PEDRO DE ÁVILA POR Da MARÍA DE LA PEÑA SU LEGÍTIMA MUJER (24 - OCTUBRE - 1741)}

A.H.P.V., Leg, 3.330, ff. 32-33

En el nombre de Dios todopoderoso, y para su santo servicio sea notorio, por esta escritura de testamento y última voluntad que yo Don Pedro de Ávila maestro escultor vecino de esta ciudad en virtud del poder especial otorgado a mi favor para este efecto por $\mathrm{D}^{\mathrm{a}}$ María de la Peña mi legítima mujer ya difunta por testimonio de Tomás San Juan y Gamboa escribano que fue de su Majestad y número de esta dicha ciudad en siete de marzo del año pasado de setecientos y ocho que aquí se inserta su tenor a la letra es el siguiente:

\section{Aquí el poder}

El poder aquí inserto concuerda con su original de que el presente escribano da fe. Yo el otorgante en forma de derecho no habérseme recovado ni limitado en todo ni parte y de él usando en nombre de la referida $\mathrm{D}^{\mathrm{a}}$ María de la Peña mi mujer legítima otorgó su testamento y última disposición en la forma siguiente.

Lo primero fue expresa voluntad suya que cuando la de Dios la llevase de esta vida se la sepultase como se la sepultó su cuerpo en la sepultura donde se enterró Juan Antonio de la Peña su padre sita en la Parroquial de San Miguel de esta ciudad.

Ítem fue su voluntad mandar se la dijere y la hice decir la misa del alma el día que falleció por la suya en el altar privilegiado de Nuestra Señora de la Victoria extramuros de esta ciudad u que su coste se pagase y se pagó de sus bienes.

Ítem fue su voluntad asistiesen a su entierro la cruz de la parroquia con doce señores sacerdotes inclusos señor cura y beneficiados Niños de Doctrina y Amor de Dios y que siendo hora se la dijese como se la dijo misa de cuerpo presente con diácono y subdiácono. Vigilia y responso y el coste de todo se pagase y se pagó de sus bienes.

Ítem fue su voluntad se la dijesen por su ánima la de sus padres y difuntos de su obligación cien misas rezadas la cuarta en dicha parroquia, y las demás a elección de sus testamentarios, y por cada una se pagasen de limosna dos reales de vellón lo que se ejecutan.

Ítem fue su voluntad mandar a las mandas pías forzosas y casa de los santos lugares de Jerusalén diez y ocho maravedíes a cada uno con que las aparto de sus bienes.

Y para cumplir y pagar éste su testamento y última voluntad, fue expresa suya Nombrarme, y me nombró, por sus testamentarios, y único albacea para que después de su fallecimiento entrase en sus bienes y los vendiere y rematase en pública almoneda o fuera de ella y de su valor cumpliere y pagase dichas mandas y legados, y me durase el término prevenido por derecho y pasado me lo prorrogó.

Y cumplido éste testamento sus legados y mandas en el remanente de todos los bienes, y raíces derechos y acciones que por cualquier título la tocaban y pertenecían puedan tocar y pertenecer 
a la dicha $\mathrm{D}^{\mathrm{a}}$ María de la Peña me instituyó yo en su nombre me instituyo por su único y universal heredero, para poder haberlo disfrutado y gozarlo con la bendición de Dios y la suya.

Y por el poder aquí inserto, y éste su testamento fue su voluntad revocar yo en su nombre revoco anulo doy por ningunos y sin efecto otro cualquier testamento o testamentos poderes para testar mandas legados, y demás disposiciones hechas y otorgadas anteriormente por escrito y de palabra por la referida que quiso y quiero no valgan ni hagan fe en juicio ni fuera de él excepto dicho poder y éste que quiso, y quiero se tenga por su testamento y disposición última, y en la vía y forma que de hecho, y conforme a derecho mejor lugar haya el cual por firme otorgante el presente escribano en la ciudad de Valladolid a veinte y cuatro de octubre de mi setecientos y cuarenta y uno siendo testigos llamados y rogados Manuel de Barcenilla Manuel Atache Juan Atanasio Peñas y Alfonso Pardiñas vecinos y residentes en ella, y el otorgante a quien yo el escribano doy fe conozco no lo firmó, por hallarse privado de la vista a su ruego lo firmaron dos de dichos testigos.

\section{Petición}

Francisco de Ibarra en nombre de Pedro de Ávila vecino de esta ciudad digo que al derecho y para de mi parte y para los efectos que haya lugar conviene que el presente escribano como sucesor en el oficio y papeles de Tomás de San Juan escribano que fue de este número le dé un traslado del poder que para testar otorgo mi parte junto con $\mathrm{D}^{\mathrm{a}}$ María de la Peña su mujer en el día siete de marzo de setecientos, y ocho. A su Majestad suplico se sirva mandarse de a mi parte dicho traslado en fe de la información que se hizo de la muerte, y legalidad de dicho escribano, pido justicia.

Auto

Para los efectos que haya lugar el presente escribano como sucesor en el oficio, y papeles de Tomás de San Juan escribano que fue de su Majestad, y de éste número de a esta parte el traslado que pide, poniendo, por fe la información de la muerte y legalidad de el dicho Tomás de San Juan el señor licenciado D. Agustín Tramón Galán teniente de corregidor de esta ciudad de Valladolid que hace oficio de corregidor por enfermedad del señor D. Miguel Francisco de Medina y Contreras Conde de su apellidos corregidor y superintendente general de rentas reales y servicios de millones lo mandó en ella a trece de septiembre de mil setecientos y cuarenta y uno.

\section{Cumplimiento}

En cumplimento de lo mandado en el auto anterior con que me doy por requerido, yo Joseph de Hernando Díez escribano del rey nuestro señor, y número perpetuo de ésta ciudad de Valladolid sucesor en el oficio, y papeles de Tomás de San Juan hice buscar y busqué el poder, para testar que refiere la petición que con fe de la información de muerte y legalidad de dicho Tomás de San Juan es como sigue. 
Sépase, por esta pública escritura de poder para testar como nosotros, Pedro de Ávila maestro escultor vecino de esta ciudad de Valladolid y María de la Peña su mujer estando sanos de enfermedad corporal, por la misericordia de Nuestro Señor Jesucristo y en nombre, juicios, y entendimientos naturales creyendo como firmemente creemos en el misterio de la Santísima Trinidad, Padre hijo y Espíritu Santo tres personas distintas, y un solo dios verdadero, y en todo lo demás que cree enseña y confiesa Nuestra Santa Madre Iglesia Apostólica Católica y Romana debajo de cuya buena fe, y creencia siempre hemos vivido, y protestamos vivir, y morir tomando como tomamos por nuestra intercesora y abogada a la serenísima madre de Dios María Santísima concebida sin pecado original desde el primer instante de su ser natural y a todos los demás santos de la Corte Celestial para que intervengan por nosotros con la divina Majestad. Decimos que sin embargo de que nos hallamos sanos y en pie por causas motivos y razones que tenemos justos no podemos al presente hacer nuestros testamentos para estar prevenidos al tiempo que Dios nos llame a juicio, y porque el uno al otro, y el otro a el otro, igual y recíprocamente tenemos comunicadas muy por menor nuestras voluntad, por la presente y en aquella vía y forma que podemos y a lugar en derecho otorgamos que nosotros damos todo nuestro poder cumplido el que de derecho se requiere y es necesario yo el dicho Pedro de Ávila a la dicha María de la Peña mi mujer, y yo la dicha María de la Peña al dicho Pedro de Ávila mi marido, para que llegando el caso el que uno de los dos otorgantes muera el que de los dos sobreviviese a el otro pueda por el que falleciese y en su nombre hacer y otorgar en el término que le da el derecho y en el hacer las mandas legados y disposiciones que quisiere y que tenemos comunicadas entre dos con tal que nuestros cuerpos sean sepultados en la parroquial de San Miguel de esta ciudad donde somos parroquianos en la sepultura donde está enterrado Juan Antonio de la Peña nuestro padre y suegro como se entra en la sacristía en la capilla mayor no habiendo embarazo justo y habiéndole en la parte que eligieren nuestros testamentarios. Y para cumplir, y pagar esta disposición y este testamento que en virtud de este poder se hiciese y otorgare también nos nombrados por nuestros testamentarios, yo el dicho Pedro de Ávila a la dicha María de la Peña mi mujer y yo la dicha María de la Peña a el dicho Pedro de Ávila mi marido para que luego que el uno de nosotros muerta el que sobreviviere entre en todos los bienes del que faltare y los venda y remate en pública almoneda o fuera de ella, y de su valor cumpla y pague su testamento que en virtud de este poder hiciese en el término que le da el derecho, y en todo el demás que fuere necesario que nos le prorrogamos, y cumplido y pagado en toda forma el remanente que quedare de los bienes así muebles como raíces del que primero muriere nos dejamos e instituimos por nuestros herederos legítimos y universales también el uno al otro, y el otro a el otro, igualmente mediante que a el presente no tenemos ningún hijo ni heredero legítimo y si en adelante tuviéramos alguno o algunos hijos legítimos llegando este caso les dejamos por nuestros herederos universales, y unos y otros en los casos referidos lo hayan y lleven con la bendición de Dios, revocamos y anulamos otro cualquier testamento o testamentos codicilo o codicilos poder o poderes para testar y otro cualquier género de disposición que antes de éste hayamos hecho por escrito o de palabra o en otra forma que queremos ninguna valga ni haga fe, y que solo se esté en juicio y fuera de él por lo contenido en éste poder y en el testamento en su virtud se hiciese sin cosa en contrario en cuyo testimonio lo otorgamos así ante el presente escribano y testigos en la ciudad de Valladolid a siete de marzo de mil setecientos y ocho años, siendo testigos Domingo Estévez, Mateo Durante y Rodrigo Ibáñez vecinos y estantes en esta ciudad y de los otorgantes a quienes yo el escribano doy fe conozco lo firmó el que supo y por la que dijo no saber a su ruego un testigo. Pedro de Ávila. 
La petición auto cumplimiento y poder para testar que aquí va compulsado concuerda con su original el que queda en mi oficio el que doy fe y también la doy de que por la justicia ordinaria de esta ciudad y testimonio de Gregorio de Velasco Campo escribanos de éste número en ocho de enero de mil setecientos y treinta y dos a mi instancia como tal sucesor se recibió y aprobó la información de muerte y legalidad de dicho Tomás de San Juan que también queda en mi poder y oficio a que me remito y en virtud de dicho mandato yo el referido Joseph de Hernando Díez escribano del rey nuestro señor y número perpetuo de esta ciudad de Valladolid lo signo y firmo en ella a catorce de septiembre de mil setecientos y cuarenta y un años. 


\title{
DOCUMENTO 76
}

\section{TESTAMENTO DE PEDRO DE ÁVILA (11 - ENERO - 1742)}

\author{
A.H.P.V., Leg. 3.330, ff. 52-5322
}

En el nombre de Dios todopoderoso y yo en su santo servicio sea notorio por ésta escritura de testamento y última voluntad que yo Pedro de Ávila maestro escultor vecino de esta ciudad, hijo legítimo de Juan de Ávila y Francisca Ezquerra difuntos vecinos que fueron de ella, estando en sana salud aunque privado de la vista y con algunos achaques habituales y en mi juicio y entendimiento natural pues conozco a los que me tratan y me comunican, y creyendo firmemente el misterio de la Santísima Trinidad Padre Hijo y Espíritu Santo y todos los demás que cree confiesa Nuestra Santa Madre Iglesia Católica, Apostólica romana bajo de cuya fe y creencia he vivido protesto vivir y morir tomando como tomo por mi abogada intercesora a María Santísima Nuestra Señora de los Ángeles y a todos los santos y santos de la corte del cielo para quienes se dan con Jesucristo nuestro señor por mi anima en perfecto estado de salvación, cuando salga de esta ciudad temiendo la muerte natural a toda criatura deseando estar dispuesto para cuando llegue el día Ordeno mi testamento en la forma siguiente.

Lo primero encomiendo mi alma a Dios nuestro señor que la crio y redimió con su preciosísima sangre y el cuerpo a la tierra de que fue formado y que cuando fuere su divina voluntad llevarme de esta vida a la eterna es la mía que mi cuerpo sea sepultado en esta Iglesia parroquial de San Miguel de esta ciudad en la sepultura que me pertenece en ella o en la Santa Iglesia Catedral de esta dicha ciudad en la que eligieren y como les pareciese a mis testamentarios y siendo hora el día de mi entierro se me diga misa de cuerpo presente con diácono y subdiácono vigilia y responso y no lo siendo el siguiente día y que asistan a enterrarme la cruz de la parroquia donde soy o fuere feligrés con dos señores sacerdotes incluso el señor cura y beneficiados y las cofradías Sacramental del Hospital General extramuros de esta ciudad y la Penitencial de Nuestra Señora de la Pasión donde soy diputado y cofrade y los niños de la doctrina y amor de Dios y de mis bienes se pague por cada cosa lo acostumbrado.

Mando que el día de mi fallecimiento se me diga la misa del Alma y la mía en el altar por privilegiado de Nuestra Señora de la Vitoria extramuros de esta ciudad y de mis bienes se pague lo acostumbrado.

Mando a las mandas pías forzosas y santos lugares de Jerusalén siete ducados derechos con que las aparto de mis bienes.

Declaro fui casado según Orden de la Santa María Iglesia con Da María Lorenza de la Peña difunta y que de dicho matrimonio no tuvimos ni tengo sucesión legítima así lo declaro para descargo de mi conciencia y para que siempre conste.

Declaro estoy debiendo a diversas personas cantidades de maravedís los cuales su importe y de que proceden tengo declarado a Juan Ceano marido y conjunta persona $\mathrm{D}^{\mathrm{a}}$ María Barba mi

22 BRASAS EGIDO, José Carlos: "Noticias documentales de artistas vallisoletanos de los siglos XVII y XVIII”; B.S.A.A., Tomo L, 1984, p. 471. 
sobrina es mi voluntad se paguen dichas deudas del valor de los bienes que quedaran por mi fallecimiento y así lo declaro para descargo de mi conciencia y para que siempre conste.

Y para cumplir y satisfacer éste testamento mandas y legado que contiene nombro por mis testamentarios y albaceas a D. Juan Calvo presbiterio vecino de ésta ciudad y a D. Alonso de la Rumbe y Elizalde regidor perpetuo de ella y al dicho Juan Ceano mi sobrino a quienes y cada uno in solidum doy cumplido poder yo que luego que fallezca entreguen mis bienes y en pública almoneda o sin ella los vendan y rematen y de su precio y valor efectúen el cumplimiento de dichos legados demandas y les dure el tiempo preciso y pasado el asignado por derecho se le prorrogo.

Y cumplido y pagado en el remanente de mis bienes derechos acciones y por cualquier título o causa legítima y me tocan y pertenecen puedan tocar y pertenecen instituyo y nombro por mi única y universal heredera a la expresada ya María Barba mi sobrina para que lo herede con la bendición de Dios y la mía y por el presente revoco anulo doy por ningunos y sin efecto otro cualquier testamento o testamentos codicilo o codicilos, poderes para testar mandas legados y demás disposiciones por mi hechas y otorgadas anteriormente por escrito o de palabra que quiero no valgan ni hagan fe en juicio ni fuera de él y que solamente se tenga por mi testamento y disposición última ésta que otorgo ante el presente escribano en la ciudad de Valladolid a once de enero de mil setecientos y cuarenta y dos siendo testigos llamados y rogados D. Manuel de la Peña Matías Cortés Manuel Barcenilla y Mateo Negral vecinos de ella y el otorgante a quien yo el escribano doy fe conozco no lo firmó por la privación de la vista a su ruego dos de dichos testigos. 


\section{DOCUMENTO 77}

\section{PODER PARA TESTAR. D ${ }^{a}$ MARÍA BARBA Y ÁVILA VECINA DE ESTA CIUDAD A JUAN CEANO SU MARIDO VECINO DE ELLA (31 - ENERO - 1744)}

A.H.P.V., Leg. 3.542, ff. 48-49

In dey nomine amen sépase por ésta pública escritura de poder para testar como yo $\mathrm{D}^{\mathrm{a}}$ María Barba y Ávila hija legítima de Santiago Barba y D ${ }^{a}$ Teresa de Ávila y mujer legítima de Juan Ceano estando enferma en cama de enfermedad corporal que a su divina Majestad ha sido servido darme aunque en mi sano juicio y entendimiento natural creyendo como firmemente creo en el misterio de la Santísima Trinidad Padre Hijo y Espíritu Santo tres personas distintas y un solo Dios verdadero y en todo lo demás que tiene cree confiesa y enseña Nuestra Santa Madre la Iglesia Católica Apostólica Romana bajo de cuya buena fe y creencias protesto he vivido y protesto vivir y morir como fiel y católica cristiana tomando como tomo por mi intercesora y abogada a la Santísima Reina de los Ángeles María Santísima Señora María concebida sin mancha de pecado original en el primer instante de su ser natural y a todos los demás santos y santas de la corte celestial para que intercedan con su divina Majestad perdone mis culpas y enderece ésta mi disposición pública para su mejor servicio y mediante a que la gravedad de mi enfermedad no me da lugar a que traga y otorgue mi testamento o última disposición con los requisitos y con circunstancias necesarias y respecto a que en muchas y repetidas ocasiones la tengo comunicada con dicho mi marido quien se halla bien entendido de ella por la presente y en aquella vía y forma que de derecho mejor lugar haya. Otorgo que doy todo mi poder cumplido el que de derecho se requiere y es necesario más puede y debe valer al precitado Juan Ceano mi marido para que pueda hacer y haga mi testamento y última disposición según y en la conformidad que como dicho se lo tengo comunicado disponiendo la forma y modo de entierro misas que se han de decir con tal de que mi cuerpo sea sepultado en el Convento de Nuestra Señora de la Merced Calzada de esta ciudad en la sepultura que allí tengo y declare como yo desde luego declaro haber estado casado con el susodicho y que del referido matrimonio hemos tenido y tenemos por mis hijos legítimos y por tales les procreamos a Vicente y María Manuela Ceano a los cuales nombré como yo desde luego nombro por mis herederos de todos mis bienes y que les puedan corresponder y tocar por su legítima y asimismo se nombre (...) como yo le nombro y les nombro por mis testamentarios y albaceas a $\mathrm{D}$. Francisco Barreda canónigo lectoral de la Santa Iglesia Catedral de ésta dicha ciudad D. Manuel Ceano y dicho Juan Ceano mi marido para que luego que yo fallezca y hecho que sea el referido testamento le hagan guardar y cumplir y para ello entren en todos mis bienes y los vendan y rematen en pública almoneda o fuera de ella y de su valor cumplan y pague toda mi disposición y la que se hiciere por dicho testamento enterrándome con el hábito de Nuestra Señora del Carmen y les dure el cargo de tales testamentarios el tiempo necesario además del que les es permitido por derecho y nombre según que da propuesto en el remanente que hubiese de todos mis bienes por mí únicos y universales herederos a los expresados Vicente y María Manuela Ceano mis hijos legítimos, para que lo hayan y hereden por iguales partes con la bendición de Dios y la mía y les pido me encomienden a Dios y revoquen como yo por el presente revoco y doy por ninguno y de ningún valor ni efecto otro cualquier testamento o testamentos codicilo o codicilos poder o poderes para testar que antes de éste haya hecho y otorgado por escrito de 
palabra o en otra forma que quiero no valgan ni hagan fe en juicio ni fuera de él salvo éste poder y el testamento que en su vida se hiciere que quiero valga por mi último y postrimera voluntad y en la mejor vía y forma que hubiere lugar en derecho en cuyo testimonio lo otorgo así ante el presente escribano y testigos en la ciudad de Valladolid a treinta y uno de enero de mil setecientos y cuarenta y cuatro siéndolo Joseph Santos Martín Isidoro Rodríguez Castilla y Manuel Lozano vecinos y residentes en esta dicha ciudad y la otorgue ante a quien yo el escribano doy fe conozco no lo firmó no obstante saber por la (...) suya que de su enfermedad a su ruego firmó uno de dichos testigos. 


\section{DOCUMENTO 78}

\section{TESTAMENTO DE DON PEDRO DE ÁVILA (26 - JULIO - 1745)}

A.H.P.V., Leg. 3.538

In dey nomine amen. Sépase por esta pública escritura de testamento, última y postrimera voluntad como yo don Pedro de Ávila maestro escultor vecino de esta ciudad, hijo legítimo de don Juan de Ávila y de doña Francisca Ezquerra difuntos vecinos que fueron de ella, estando como estoy en sana salud aunque privado de la vista, y en mi juicio y entendimiento natural pues conozco a los que me tratan y comunican, y creyendo como firmemente creo en el misterio de la Santísima Trinidad, Padre, Hijo y Espíritu Santo tres personas distintas y un solo Dios verdadero, y en todo lo demás que cree y confiesa nuestra santa madre iglesia católica apostólica romana, bajo de cuya fe y creencia he vivido, protesto vivir y morir, y tomando como tomo por mi intercesora y abogada a María Santísima nuestra señora reina de los ángeles, y a todos los santos y santas de la corte celestial para que intercedan con su divina Majestad, ponga mi alma en perfecto estado de salvación cuando salga de esta vida, y temiéndome de la muerte que es cosa natural a toda criatura viviente, deseando como deseo estar dispuesto para cuando llegue el día, hago y ordeno este mi testamento en la forma siguiente:

Lo primero encomiendo mi alma a Dios nuestro señor que la crió y redimió con su preciosa sangre, y el cuerpo a la tierra de que fue formado.

Ítem mando que cuando Dios nuestro señor fuere servido de llevarme de esta presente vida a la eterna es mi voluntad que mi cuerpo sea sepultado en la iglesia parroquial de San Miguel de esta dicha ciudad en la sepultura que me pertenece en ella o en la Santa Iglesia Catedral de esta dicha ciudad donde al presente soy parroquiano, en la que eligieren y como les pareciere a mis testamentarios; y con el hábito de Nuestro Padre San Francisco.

Ítem mando que siendo hora el día de mi entierro se me diga misa de cuerpo presente con diácono y subdiácono, vigilia y responso, y no lo siendo, el siguiente día, y que asistan a mi entierro la cruz de la parroquia donde al presente soy o e adelante fuere feligrés con doce señores sacerdotes, incluso el señor cura y beneficiados; y las cofradías sacramental del Hospital General extramuros de esta ciudad y la Cofradía Penitencial de Nuestra Señora de la Pasión donde soy diputado y cofrade, y los niños de la Doctrina y Amor de Dios y de mis bienes se pague a cada uno lo acostumbrado.

Mando que el día de mi fallecimiento se me diga la misa del alma por la mía en el altar privilegiado de Nuestra Señora de la Victoria, y otra en el altar de San Basilio extramuros de esta dicha ciudad y por una vez, cuya limosna se pague de mis bienes.

Mando a las mandas pías, forzosas y acostumbradas un real de vellón a todas ellas con que las aparto de mis bienes.

Declaro fui casado según orden de la santa madre iglesia con doña María Lorenza de la Peña difunta, y que de dicho matrimonio no he tenido ni tengo sucesión alguna, y así lo declaro para que siempre conste. 
Declaro estoy debiendo a diversas personas algunas cantidades de maravedíes las cuales, su importe y de qué proceden tengo declarado a Juan Ceano vecino de esta ciudad viudo que es y quedó de doña María Barba mi sobrina, es mi voluntad se paguen dichas deudas del valor de los bienes que quedaren por mi fallecimiento y así lo declaro para descargo de mi conciencia y para que en todo tiempo conste.

Y para cumplir y pagar este mi testamento, mandas y legados en él contenidos nombro por mis testamentarios y albaceas a don Juan Calvo presbítero en esta ciudad, don Alonso de la Rumbe y Elizalde regidor perpetuo de ella y al dicho Juan Ceano mi sobrino a quienes y cada uno in solidum doy mi poder cumplido para que luego que yo fallezca entren en mis bienes y los vendan en pública almoneda o fuera de ella y de su precio y valor efectúen el cumplimiento de dichos legados y mandas y les dure el tiempo preciso, y pasado el asignado por derecho se le prorrogo.

Y cumplido y pagado dicho mi testamento en el remanente que quedare de dichos mis bienes, derechos y acciones que por cualquier título o causa me tocan y pertenecen, puedan tocar y pertenecer, instituyo y nombro por mi único y universal heredero de todos ellos al referido Juan Ceano mi sobrino en atención a que éste ha estado y está manteniendo, vistiendo y calzando de todo lo necesario y asistidome en mis enfermedades supliendo y pagando el susodicho el importe de cuantos gastos se han ocasionado por una y otra razón y con su propio caudal de más de cuatro años a esta parte sin que yo le haya podido satisfacer cosa alguna por mi imposibilidad que es notoria ni lo poder ganar por hallarme sin la vista natural; y que espero del bueno celo y cristiandad del referido Juan Ceano continuará en mantenerme, vestirme, calzarme y asistirme como hasta aquí lo ha hecho sin que yo tenga otro medio, modo ni arbitrio de poderlo remunerar lo mucho que le debo y gastos que conmigo ha hecho y espero haga en los restantes días de mi vida, más el instituirle como le instituyo por tal único y universal heredero de todos mis bienes, derechos y acciones, entre los cuales lo es una casa que tengo a la calle de San Miguel de esta dicha ciudad que hace esquina y vuelve a la calle de las Damas bajando de la iglesia de San Miguel con toda su vivienda, oficinas altas y bajas y servidumbre que la corresponde sin reservar cosa alguna, la cual es mía propia y libre de toda carga excepto el censo perpetuo que sobre el suelo de ella tiene el Convento de San Pablo de esta dicha ciudad, la cual a mayor abundamiento mando a dicho Juan Ceano y de ella le hago gracia y donación pura mera perfecta e irrevocable que el derecho llama intervivos con las insinuaciones y requisitos necesarios para su mayor firmeza y validación.

Y por el presente revoco, anulo y doy por ninguno y de ningún valor ni efecto el testamento que tengo otorgado en once de enero del año pasado de mil setecientos y cuarenta y dos por testimonio de Joseph Rodríguez de Salces escribano del número de esta dicha ciudad para que no se esté ni pase por él; y la misma revocación hago de cualquier otro testamento o testamentos, codicilo o codicilos, poder o poderes para testar u otra cualquiera disposición que antes de ahora tenga hecha por escrito, de palabra o en otra cualquier manera que quiero no valgan ni hagan fe en juicio ni fuera de él salvo este que al presente hago que quiero valga por mi testamento, última y postrimera voluntad o en aquella vía y forma que más haya lugar en derecho y por firme así lo otorgo ante el presente escribano en esta dicha ciudad de Valladolid, a veinte y seis días del mes de julio de mil setecientos cuarenta y cinco siendo testigos Roque Escobar, Antonio Jiménez y Manuel Salceda vecinos y estante en esta dicha ciudad y el otorgante a quien yo el escribano doy fe conozco no lo firmó por la privación de la vista, a su ruego lo firmaron dos de dichos testigos y firmé. 


\title{
DOCUMENTO 79
}

\section{TESTAMENTO. D. PEDRO DE ÁVILA VECINO DE ESTA CIUDAD (23 - ABRIL - 1747)}

\author{
A.H.P.V., Leg. 3.409/2, ff. 489-490
}

In dei nomine amén, sépase por esta pública escritura de testamento, última y postrimera voluntad como yo D. Pedro de Ávila vecino de esta ciudad de Valladolid estando al presente levantado y bueno por la misericordia de Dios y en mi sano juicio y entendimiento natural creyendo como firmemente creo en el misterio de la Santísima Trinidad Padre, Hijo y Espíritu Santo que son tres personas distintas y un solo Dios verdadero, y en todo lo demás que cree y confiesa nuestra santa madre iglesia católica, apostólica romana en cuya fe y creencia he vivido y protesto vivir y morir como católico cristiano temiéndome de la muerte que es cosa natural a toda criatura viviente, deseando estar prevenido para cuando llegue mi última hora y tomando como tomo por mi intercesora y abogada a la siempre Virgen María madre de nuestro redentor Jesucristo, al Santo Ángel de mi guarda el de mi nombre y los de mi devoción y todos los de la corte celestial para que intercedan con su divina Majestad perdone mis pecados y ponga mi alma en carrera de salvación cuando de este mundo vaya a honra y gloria suya hago y ordeno mi testamento, última y postrimera voluntad en la forma y manera siguiente:

Lo primero encomiendo mi alma a Dios nuestro señor que la crió y redimió con su preciosa sangre, y el cuerpo mando a la tierra de que fue formado el cual cuando la voluntad de Dios nuestro señor fuese servido llevarme de esta presente vida la mía lo es sea sepultado mi cuerpo en la iglesia parroquial de San Miguel de esta ciudad, donde al presente soy parroquiano en la sepultura donde está enterrada $\mathrm{D}^{\mathrm{a}}$ María de la Peña mi mujer por ser suya propia y haberme quedado a mí por su heredero, con el hábito de Nuestro Padre San Francisco y se pague de mis bienes.

El día de mi entierro si fuere hora y sino el siguiente se me diga misa de cuerpo presente con diácono y subdiácono, vigilia y responso sobre mi sepultura y se paguen los derechos acostumbrados.

Venga a dicho mi entierro la cruz de dicha parroquia y hasta diez señores sacerdotes en que entren cura y beneficiado y se les pague los derechos acostumbrados.

Asistan a dicho mi entierro los niños de la Doctrina y los del Amor de Dios y se les pague lo que es estilo.

Dígaseme la misa del alma en el altar privilegiado de San Francisco de Paula extramuros de esta ciudad y se pague su limosna.

Vengan a dicho mi entierro las cofradías de la Sagrada Pasión de Cristo donde soy diputado y la de la Sacramental del Hospital General de esta dicha ciudad por ser cofrade de ella. 
Díganseme por mi alma y de la dicha $\mathrm{D}^{\mathrm{a}}$ María de la Peña mi mujer cien misas rezadas la cuarta en dicha parroquia de San Miguel y las demás se digan y se celebren a elección de mis testamentarios y se pague por su limosna a dos reales vellón por cada una.

Declaro que después que falleció dicha mi mujer, por Juan Ceano librero vecino de esta ciudad marido de $\mathrm{D}^{\mathrm{a}}$ María Barba mi sobrina ya difunta y por hallarme privado de vista me convidó me fuese a su casa y compañía, y con efecto lo ejecuté, y me mantuvo cinco años poco más o menos, de cuyo mantenimiento no le debo maravedíes algunos mediante haberlo hecho en caridad, y ofreció me lo haría así y sin embargo de lo referido, todos los bienes muebles con que entonces me hallaba los llevó dicho Juan Ceano a su casa y los vendió sin haber percibido yo maravedíes, como también mil y ochocientos reales que el Ilustrísimo señor D. Julián Domínguez Toledo, obispo que fue de esta dicha ciudad y su obispado me había dado consignado por vía de limosna a razón de tres reales cada día y eran de veinte meses devengados hasta la muerte del dicho Ilustrísimo señor los que percibió y cobró dicho Juan Ceano. Y asimismo en la misma conformidad mil y quinientos reales poco más o menos que percibió y cobró el susodicho de los alquileres de la casa que tengo sita en esta dicha ciudad en dicha parroquia de San Miguel frontero a la que tienen los señores Arces por habérmela mandado la referida $\mathrm{D}^{\mathrm{a}}$ María de la Peña mi mujer y nombrado por su único y universal heredero de ella y de todos los demás sus bienes por el testamento que otorgó ante Tomás de San Juan escribano que fue del número de esta dicha ciudad bajo de cuya disposición falleció la susodicha, como también trescientos y setenta y cinco reales que también percibió y cobró dicho Juan Ceano del valor de una cruz de diamantes propia de dicha $\mathrm{D}^{\mathrm{a}}$ María de la Peña mi mujer, sin que de esto ni de lo demás que va referido haya recibido ni entregándoseme maravedíes algunos por el susodicho ni dicha su mujer mi sobrina, quienes al tiempo y cuando falleció la referida mi mujer por haberme reinado irme a su casa y compañía solicitaron marido y mujer con dicho Ilustrísimo señor no me contribuyese con la limosna de los referidos tres reales diariamente que me tenía señalados y por no perderlos me reduje, como va declarado a estarme con los susodichos bajo de las promesas que me hicieron de mantenerme en caridad sin que por esta razón les diese cosa alguna lo que es público y notorio y lo declaro así para el paso en que estoy, y que siempre conste.

Declaro fui casado in facie ecclesiae con la referida $\mathrm{D}^{\mathrm{a}}$ María de la Peña mi mujer y durante el matrimonio no tuvimos hijos algunos declárolo así para que en todo tiempo conste.

Mando a las mandas pías forzosas y acostumbradas los derechos que es estilo por una vez con que las aparto de mis bienes.

Y para cumplir y pagar este mi testamento mandas y legados en él contenidos dejo y nombro por mis testamentarios y albaceas al señor D. Alonso de la Rumbe y Elizalde vecino y regidor perpetuo de esta ciudad y a D. Manuel Canesi y Acebedo vecino de ella a los cuales y a cada uno de por sí doy mi poder cumplido para que luego que yo fallezca entren en mis bienes y les vendan y rematen en pública almoneda o fuera de ella y de su valor cumplan y paguen este mi testamento y todo lo en él contenido, y les dure el tiempo necesario aunque sea pasado el año que el derecho permite que yo se les prorrogo.

$\mathrm{Y}$ en el remanente que quedare de todos mis bienes muebles y raíces derechos y acciones habidos y por haber dejo instituyo y nombro por únicos y universales herederos de todos ellos a $\mathrm{D}^{\mathrm{a}}$ María $\mathrm{D}^{\mathrm{a}}$ Clara y D. Manuel de Ávila mis sobrinos carnales hijos legítimos y de legítimo 
matrimonio de D. Manuel de Ávila mi hermano ya difunto y de Da María Martínez su mujer vecina de esta dicha ciudad, para que los referidos mis sobrinos lo hayan y hereden y partan por iguales partes con la bendición de Dios y la mía y les pido me encomienden a Dios.

Y por el presente revoco anulo y doy por ninguno y de ningún valor ni efecto otro cualquier testamento o testamentos codicilo o codicilos poder o poderes para testar u otra cualquier disposición que antes de este haya hecho por escrito o de palabra que quiero ninguno valga ni hagan fe en juicio ni fuera de él salvo este que al presente hago y otorgo que quiero valga por mi testamento y última voluntad en aquella vía y forma que de derecho mejor lugar haya en cuyo testimonio lo otorgo así ante el presente escribano y testigos en la ciudad de Valladolid a veinte y tres de abril de mil setecientos cuarenta y siete años siendo testigos Francisco Xavier Pérez su arte tallista, Fernando Gómez llamador de la Cofradía de la Pasión y Cristóbal Hidalgo vecino de esta ciudad y el otorgante a quien doy fe conozco no lo firmó a causa de hallarse privado de la vista, firmaronlo dos de dichos testigos y en fe de ello yo el escribano. 


\section{DOCUMENTO 80}

\section{TESTAMENTO. D. PEDRO DE ÁVILA VECINO DE ESTA CIUDAD (12 - JULIO - 1747)}

A.H.P.V., Leg. 4.270, ff. 541-542

In dey nomine amén. Sépase por esta pública escritura de testamento, última y postrimera voluntad como yo D. Pedro de Ávila vecino de esta ciudad de Valladolid estando al presente levantado y bueno por la misericordia de Dios y en mi sano juicio y entendimiento natural creyendo como firmemente creo en el misterio de la Santísima Trinidad, Padre, Hijo y Espíritu Santo que son tres personas distintas y un solo Dios verdadero y en todo lo demás que cree y confiesa nuestra santa madre iglesia católica apostólica romana en cuya fe y creencia he vivido y protesto vivir y morir como católico cristiano, temiéndome de la muerte que es cosa natural a toda criatura viviente, deseando estar prevenido para cuando llegue mi última hora y tomando como tomo por mi intercesora y abogada a la siempre Virgen María, madre de nuestro redentor Jesucristo, al Santo Ángel de mi guarda, el de mi nombre y los de mi devoción, y todos los de la corte celestial para que intercedan con su divina Majestad, perdone mis pecados y ponga mi alma en carrera de salvación cuando de este mundo vaya, a honra y gloria hago y ordeno mi testamento, última y postrimera voluntad en la forma y manera siguiente:

Lo primero encomiendo mi alma a Dios nuestro señor que la crió y redimió con su preciosa sangre y el cuerpo mando a la tierra de que fue formado el cual cuando la voluntad de Dios nuestro señor fuese servido llevarme de esta presente vida la mía lo es sea sepultado mi cuerpo en la iglesia parroquial de San Miguel de esta ciudad donde al presente soy parroquiano en la sepultura donde está enterrada $\mathrm{D}^{\mathrm{a}}$ María de la Peña, mi mujer, por ser mía propia y haberme quedado a mí por heredero, con el hábito de Nuestro Padre San Francisco y se pague éste de mis bienes.

El día de mi entierro si fuera hora y sino el siguiente se me diga misa de cuerpo presente con diácono y subdiácono, con vigilia y responso sobre mi sepultura y se paguen los derechos acostumbrados.

Venga a dicho mi entierro la cruz de dicha parroquia y hasta diez señores sacerdotes en que entren cura y beneficiados y se les pague los derechos acostumbrados.

Asistan a dicho mi entierro los niños de la Doctrina y los del Amor de Dios y se les pague lo que es estilo.

Dígaseme la misa del alma en el altar privilegiado de San Francisco de Paula extramuros de esta ciudad y se pague su limosna.

Vengan a dicho mi entierro las cofradías de la Sagrada Pasión de Cristo donde soy diputado, y la de la Sacramental del Hospital General de esta dicha ciudad por ser cofrade de ella.

Díganseme por mi alma y la de dicha $\mathrm{D}^{\mathrm{a}}$ María de la Peña mi mujer cien misas rezadas la cuarta en dicha parroquia de San Miguel y las demás se digan y celebren a elección de mis testamentarios y se pague [...] a dos reales vellón por cada una. 
Declaro que después que falleció dicha mi mujer por Juan Ceano librero de esta ciudad, marido de $\mathrm{D}^{\mathrm{a}}$ María Barba mi sobrina ya difunta, y por hallarme privado de vista me convidó me fuese a su casa y compañía y con efecto lo ejecuté y me mantuvo cinco años poco más o menos de cuyo mantenimiento no le debo maravedíes algunos mediante haberlo hecho en claridad y ofrecidome lo haría así y sin embargo de lo referido todos los bienes muebles con que entonces me hallaba los llevó dicho Juan Ceano a su casa, como fueron: taburetes de vaqueta encarnada, sillas de lo mismo, dos escritores con sus mesas, sábanas apuntadas que fueron seis, y otra ropa blanca, unos pendientes de perlas netas tasados en diez o doce pesos, unas sortijas de oro con piedras ordinarias que tenía en sus manos dicha $\mathrm{D}^{\mathrm{a}}$ María mi mujer cuando murió, dos casacas de terciopelo, la una y la otra de damasco, un guardapiés de persiana nuevo, un dengue de grana nuevo con guarnición de seda, un manguito y dos mantos de diferentes piezas de espetera, cofres, arcas y otras cosas hasta que me quedaron sin camisa, vendieron dicho Ceano y su mujer sin haber percibido yo maravedíes algunos de las referidas alhajas vendidas como también como también cobró y percibió mil y ochocientos reales vellón que el Ilmo. Sr. D. Julián Domínguez, obispo que fue de esta dicha ciudad y su obispado, me había consignado por vía de limosna a razón de tres reales cada día y eran de veinte meses devengados hasta la muerte de dicho Ilmo. Sr., y en la misma conformidad mil y quinientos reales vellón poco más o menos que también percibió y cobró el susodicho de los alquileres de la casa que tengo, sita en esta dicha ciudad en dicha parroquia de San Miguel frontero a la que tienen los señores Arces, la que me mandó la referida $\mathrm{D}^{\mathrm{a}}$ María de la Peña mi mujer y nombrándome por su único y universal heredero de ella y de todos los demás sus bienes por el testamento que otorgó ante Tomás de San Juan escribano que fue del número de esta dicha ciudad, bajo de cuya disposición falleció la susodicha cuya casa al presente la tengo vendida. Como también trescientos y setenta y cinco reales que también percibió y cobró dicho Juan Ceano del valor de una cruz de diamantes propia de dicha $\mathrm{D}^{\mathrm{a}}$ María de la Peña mi mujer sin que de esto ni de lo demás que va referido haya recibido ni entregádoseme maravedíes algunos por el susodicho ni dicha su mujer mi sobrina quienes al tiempo y cuando falleció la referida mi mujer por haberme reusado irme a su casa y compañía solicitaron marido y mujer con dicho Ilmo. Sr. no me contribuyese con la limosna de los referidos tres reales diariamente que me tenía señalados y por no perderlos me reduje como va declarado a estarme con los susodichos bajo de las promesas que me hicieron de mantenerme en caridad sin que por esta razón la diese cosa alguna lo que es público y notorio y lo declaro así para el paso en que estoy y que siempre conste.

Declaro fui casado in facie ecclesiae con la referida $\mathrm{D}^{\mathrm{a}}$ María de la Peña mi mujer y durante el matrimonio no tuvimos hijos algunos declárolo así para que en todo tiempo conste.

Mando a las mandas pías forzosas y acostumbradas los derechos que es estilo por una vez con que las aparto de mis bienes.

Y para cumplir y pagar este mi testamento, mandas y legados en él contenidos dejo y nombro por mis testamentarios y albaceas al Sr. D. Alonso de Larrumbe y Elizalde vecino y regidor perpetuo de esta ciudad, y a D. Manuel Canesi y Acebedo vecinos de ella a los cuales y cada uno in solidum doy mi poder cumplido para que luego que yo fallezca entren en mis bienes y los vendan y rematen en pública almoneda o fuera de ella y de su valor cumplan y paguen este mi testamento y todo lo en él contenido y les dure el tiempo necesario aunque sea pasado el año que el derecho permite que yo se la prorrogo.

$\mathrm{Y}$ en el remanente que quedare de todos mis bienes muebles y raíces, derechos y acciones habidos y por haber dejo, instituyo y nombro por mi única y universal heredera de todos ellos a 
Francisca López, viuda vecina de esta ciudad para que los haya y herede con la bendición de Dios y la mía y la pido me encomiende a Dios.

Y por el presente revoco, anulo y doy por ninguno y de ningún valor otro cualquier testamento o testamentos, codicilo o codicilos, poder o poderes para testar u otra cualquier disposición que antes de este haya hecho (...) en cuyo testimonio lo otorgo así ante el presente escribano y testigos en la ciudad de Valladolid a doce de julio de mil setecientos cuarenta y siete siendo testigos Isidro Reguero, Manuel Pérez y Cristóbal Hidalgo vecinos de esta ciudad y el otorgante a quien yo el escribano doy fe conozco no lo firmó, sin embargo de saber escribir, a causa de hallarse privado de la vista a su ruego lo firmaron dos de dichos testigos. Y mediante hallarme al presente parroquiano de la santa iglesia Catedral de esta dicha ciudad si muriere en ella es mi voluntad se me entierre en dicha santa iglesia o en la parroquia donde me hallase al tiempo de mi fallecimiento. 


\section{DOCUMENTO 81}

\section{TESTAMENTO. FRANCISCA LÓPEZ VECINA DE ESTA CIUDAD (28 - MAYO - 1742)}

A.H.P.V., Leg. 3.528, f. 81

En el nombre de Dios todopoderoso a honra y gloria suya y de su santísima madre amén. Sépase por esta pública escritura de testamento como yo Francisca López vecina de esta ciudad mujer legítima de Gregorio González, estando enferma en cama en este Real Hospital de Santa María de Esgueva, y en mi sano juicio y entendimiento natural creyendo como firmemente creo en el misterio de la Santísima Trinidad, Padre, Hijo y Espíritu Santo tres personas distintas y un solo Dios verdadero y en todo lo demás que tiene, cree y confiesa la santa madre iglesia católica y apostólica romana bajo de que he vivido y protesto continuar hasta morir y suplico a Nuestra Señora la Virgen María se digne interceder con su precioso hijo, perdone mis culpas y encamine mi alma a la salvación fin principal para que la crió y temiéndome de la muerte que es natural a todo viviente, incierto de la hora deseoso hallarme prevenido para este lance, hago y ordeno este mi testamento y última voluntad en la forma siguiente:

Y lo primero encomiendo mi alma a Dios nuestro señor como suya propia que la crió y redimió con su preciosa sangre y el cuerpo a la tierra de que fue formado y cuando la divina voluntad fuere servido llevarme, mi cuerpo sea sepultado en el cementerio de la Antigua de esta dicha ciudad y con el hábito de Nuestra Señora del Carmen, asistiendo la Cofradía de las Ánimas Pobres de la parroquial, y con la demás disposición que es costumbre a los demás pobres que mueren en este dicho Real Hospital.

Es mi voluntad dejar como lo hago toda la demás forma de mi entierro y señalamiento de misas que se han de decir por mi alma a elección y arbitrio de los testamentarios que nombrare, para que no se ejecute más que lo que dispongan.

Declaro estoy casada legítimamente con dicho Gregorio González y actualmente no nos hallamos con hijo alguno.

Declaro asimismo que Agustín Alonso vecino de esta ciudad tiene en su poder como bienes míos propios diez y ocho varas de cotopra tejida, seis libras y diez onzas de seda por tejer, una basquiña de estameña, un guardapiés de sempiterna, una mantilla blanca con ribete azul, una olla de manteca y también de cuentas ajustadas me está debiendo el susodicho seis reales, es mi voluntad que uno y otro se recoja y cobre.

Declaro me está debiendo doña Manuela, que no me acuerdo su apellido y es costurera, tres reales y medio, o cuatro, y la guitarrera que tampoco hago memoria de su nombre tres reales y medio quiero que uno y otro se recobre de dichos deudores.

Es mi voluntad que todos los trastos que hay en la casa en que he vivido lo haya y goce para sí y como propio el dicho Gregorio González mi marido, excepto un brasero, un velón y una palmatoria y le pido me encomiende a Dios. 
Y para cumplir y pagar este mi testamento, mandas y legados en él contenido, dejo y nombro por mis testamentarios y albaceas a don Manuel Saavedra presbítero capellán de este dicho Real Hospital y a don Joseph Villar su mayordomo y a cada uno in solidum y les doy poder y facultad para que entren en mis bienes, los vendan y rematen en pública almoneda o fuera de ella y de su valor cumplan y paguen lo aquí dispuesto y les dure el tiempo necesario aunque pase el año prevenido por derecho que yo se les prorrogo.

Y cumplido y pagado en el remanente que quedare de todos mis bienes muebles y raíces habidos y por haber nombro por única y universal heredera de todos ellos a mi alma para que se distribuyan en sufragios para ella que así es mi expresa voluntad.

$\mathrm{Y}$ por el presente revoco, anulo doy por ninguno y sin efecto otro cualquier testamento o testamento, codicilos, poderes para testar, mandas y legados que antes de este haya hecho (...) y lo otorgo así ante el presente escribano en este dicho Real Hospital a veinte y uno de mayo año de mil setecientos cuarenta y dos siendo testigos don Manuel Saavedra, Andrés de la Torre y Raimundo Cerezo vecinos de esta ciudad y la otorgante a quien doy fe conozco no lo firmó porque dijo no saber, a su ruego uno de dichos testigos. 


\title{
DOCUMENTO 82
}

\section{VENTA REAL. DON PEDRO DE ÁVILA VECINO DE ESTA CIUDAD A DON JOSEPH PLAZA JAÉN VECINO DE ELLA (21 - AGOSTO - 1747)}

\author{
A.H.P.V., Leg. 3.288, ff. 300-302
}

Sépase por esta pública escritura de venta real y perpetua enajenación por juro de heredad para ahora y siempre jamás como yo don Pedro de Ávila vecino de esta ciudad de Valladolid heredero que soy y quedé de doña María de la Peña mi legítima mujer difunta instituido en el poder que recíprocamente de conformidad otorgamos en ella y testimonio de Tomás de San Juan escribano que fue de su número a siete de marzo del año pasado de mil setecientos y ocho y repetí yo el otorgante en el testamento que en virtud de él y después de su muerte hice y otorgué por el de Joseph Rodríguez de Salces escribano del mismo número a veinte y cuatro de octubre del de mil setecientos cuarenta y uno que uno y otro exhibo ante el presente y de su certeza doy fe, digo que a la referida doña María de la Peña como a hija única y heredera de Juan Antonio de la Peña su padre también difunto vecino que fue de esta misma ciudad la perteneció en ella una casa que hace esquina a las calles de San Miguel y las Damas linda al presente por esta con casa de Benito Oriz, y por la de San Miguel con otra del Convento de San Pablo Orden de Santo Domingo el cual tiene sobre la citada que va deslindada y me pertenece como heredero de la referida mi mujer cien reales vellón de censo perpetuo en cada un año con derecho de veintena y tanteo, con cuya carga y gravamen tengo tratado y ajustado venderla a don Joseph Plaza Jaén en precio de tres mil y quinientos reales vellón que me ha ofrecido pagar en la forma que adelante se explicará con que a su favor otorgue la escritura de venta en forma a lo que por ser justo he condescendido y para ello y más bien formalizar este contrato de mi parte se acudió al Reverendo Padre fray Manuel de Rozas depositario del enunciado convento que se halla con poder bastante de su comunidad para tomar por el tanto las heredades sobre que tiene censo perpetuo o dar licencias para su venta la tomase por dicha cantidad o me concediese la explicada licencia para su venta según me la dio y concedió y original entrego a dicho presente escribano para que aquí la inserte e incorpore como lo hace su tenor el siguiente:

Aquí

La preinserta licencia concuerda con su original que queda con el registro de esta escritura de que dicho presente escribano da fe de la cual y de mi derecho usando, otorgo por la presente que en la mejor forma que puedo y conforme de él haya lugar que vendo y doy en venta real y enajenación perpetua por juro de heredad para ahora y siempre jamás según dicho es, al expresado don Joseph Plaza Jaén, sus hijos y a quien en su derecho suceda la referida casa antes de ahora deslindada en el principio de esta escritura toda ella con sus entradas, salidas, usos, costumbres, derechos y servidumbres cuantas tiene y la pertenecen sin exceptuar cosa alguna por precio y cuantía en cuanto a su dominio útil de los mencionados tres mil y quinientos reales vellón que por ella y en su compra me da y paga en esta manera; los mil y quinientos reales de ellos ahora a presencia de la de dicho escribano y testigos de esta escritura de que le pio de fe, y yo el dicho escribano la doy de que en la suya y mía se contaron en especie de oro y plata que reducida a vellón al precio que hoy corre y vale lo sumaron y montaron y pusieron en mano del nominado don Pedro de Ávila quien los guardó y pasó a su parte y poder realmente y con efecto; y no contó por hallarse ciego; y como contento, satisfecho y entregado de ellos a mi 
voluntad yo el referido don Pedro de Ávila doy y otorgo en favor del nominado don Joseph Plaza Jaén tan bastante carta de pago, recibo y resguardo como a su derecho convenga; y los dos mil reales restantes cumplimiento a los tres mil y quinientos precio del dominio útil de la enunciada casa y esta venta en la aceptación de ella se ha de obligar pagarme en fin de mayo del año que viene de mil setecientos cuarenta y ocho; cuyo precio de dichos tres mil y quinientos reales juntamente con el de los ciento que anualmente tiene de censo perpetuo la explicada casa en cada un año que también se ha de obligar a pagar y reconocer es el justo que vale y no más y para en el caso que más valga o valer pueda de cualquier demasía y más valor en poca o mucha cantidad, hago en favor del mencionado don Joseph Plaza Jaén gracia, cesión y donación buena, pura mera, perfecta e irrevocable que el derecho llama intervivos (...) y se la vendo por libre de toda carga, tributo, censo perpetuo al quitar, memoria, capellanía que no la tiene a excepción del citado censo perpetuo de cien reales vellón que en cada un año se paga de censo perpetuo al dicho Convento de San Pablo (...) y en señal de posesión y para posesión real le entrego un traslado de la escritura de venta que en veinte y cuatro de febrero del año pasado de mil seiscientos y ochenta y cuatro otorgó por testimonio de Santiago Gil de Palacio escribano de su Majestad Lucas de Cantabrana procurador del número de la Real Chancillería de esta dicha ciudad a favor del mencionado Juan Antonio de la Peña mi suegro, de la enunciada casa con los demás instrumentos que en ella se citan y pido al expresado le dé y entregue un traslado de esta para que todo lo tenga por título legítimo y bastante de la dicha posesión; me obligo a los dichos mis herederos a la entera evicción y saneamiento de la referida casa y que sobre ella ni parte no será puesto pleito, embargo ni mala voz por comunidad ni persona particular diciendo pertenecerle por causa justa o injusta y si se le pusiere o moviere saldré y mis herederos y sucesores cada uno en su tiempo saldrá a la voz y defensa y lo seguiré y seguirán a mi costa y suya en todas instancias y tribunales hasta dejarle en quieta y pacífica posesión de la expresada casa, y no lo pudiendo o no lo queriendo hacer y sanear le volveré y volverán la cantidad que haya pagado por el precio de esta venta, costas, daños y menoscabos que sobre ello se le ocasionaren con más el importe y reparos útiles o inútiles que en ella haya hecho por solo su suple declaración en que lo difiero sin otra prueba de que le relevo (...) en cuyo testimonio por firme lo otorgamos así ante el presente escribano en la ciudad de Valladolid a veinte y cuatro de agosto de mil setecientos cuarenta y siete siendo testigos don Simón Gallegos, Juan Recio y Pedro de Mesa vecinos de ella y de los otorgantes que yo dicho escribano doy fe conozco lo firmó dicho don Joseph Plaza y no el referido don Pedro de Ávila por hallarse ciego como queda dicho a su ruego lo firmaron todos los dichos testigos.

Yo Pedro Ávila vecino de esta ciudad digo me pertenece por justos y derechos títulos una casa que existe en esta ciudad que hace esquina como se va de la parroquial de San Miguel a la calle de las Damas y sobre la cual tiene este Convento de San Pablo un censo perpetuo de cien reales vellón en cada un año con derecho de veintena y tanteo la cual tengo tratado vender en posesión y propiedad a don Joseph Jaén de la Plaza vecinos de esta dicha ciudad en precio de tres mil y quinientos reales vellón cargándose además con la del mencionado censo perpetuo en consecuencia de lo cual y de una de sus condiciones pido y suplico a V. P. Maestro R. que siendo del agrado de su comunidad y suya la tome por el tanteo y o en su defecto me de licencia para celebrar y otorgar la escritura de venta necesaria con la seguridad correspondiente a justicia y merced que pido y por estar ciego ruego a un testigo lo firme por mí.

Fdo: Pedro de Mesa 
Vista la petición y súplica antecedente por el M. R. P. fray Manuel Rozes depositario de este Convento de San Pablo Orden de Predicadores de esta ciudad de Valladolid como apoderado de él en virtud del que a su favor para este y otros efectos le tienen otorgado los RR.PP. Prior y sus religiosos y en él y testimonio de Manuel Padillo y García escribano de su Majestad y de la conservaduría y estudio de la Real Universidad a esta dicha ciudad en ella a vente y cuatro de julio del año pasado de mil setecientos cuarenta y cinco por ante mí el notario dijo que usando de las facultades de dicho poder concedía y concedió su licencia en forma a Pedro de Ávila para que sin incurrir en pena alguna pueda pasar y pase a celebrar el contrato y venta de la casa que menciona su pedimento en la cantidad de tres mil y quinientos reales en que la tiene ajustada por no necesitar de ella este dicho convento con que pague los réditos a traslados y del censo perpetuo que contra ella le pertenece la de la veintena y con que el comprado le reconozca y se obligue a la guarda y cumplimiento de sus condiciones, así lo proveyó y mandó en Valladolid a treinta de mayo de mil setecientos y cuarenta y siete.

Fdo: Fr. Manuel Rozes

Recibí de don Pedro de Ávila vecino de esta ciudad ciento y setenta y cinco reales vellón, derechos de la veintena parte en que vendió la casa que poseía en representación de su mujer doña María de la Peña de que fue y es único heredero a don Joseph Plaza Jaén vecino de esta misma ciudad en precio de tres mil y quinientos reales vellón San Pablo de Valladolid y agosto veinte y nueve de mil setecientos cuarenta y siete.

\#Son 175 reales\# 


\section{DOCUMENTO 83}

\section{TESTAMENTO DE PEDRO DE ÁVILA, VECINO DE ESTA CIUDAD (10 - JUNIO - 1755)}

A.H.P.V. Leg. 3.372, f. 508

En el nombre de Dios todopoderoso amen, sépase por esta pública escritura de testamento, última y postrimera voluntad como yo Pedro de Ávila vecino de esta ciudad de Valladolid, marido y conjunta persona de Francisca López mi mujer estando enfermo en cama de la enfermedad que Dios nuestro señor ha sido servido darme y en mi juicio y entendimiento natural creyendo como firmemente creo en el misterio de la Santísima Trinidad, Padre, Hijo y Espíritu Santo, tres personas distintas y un solo Dios verdadero y en todo lo demás que cree y confiesa nuestra santa madre iglesia católica, apostólica, romana, y tomando como tomo por mi intercesora y abogada a la serenísima Emperatriz de los Ángeles María Santísima madre de nuestro redentor Jesucristo y a los santos y santas de la corte celestial para que intercedan con su divina Majestad, ponga mi alma en carrera de salvación y temiéndome de la muerte que es cosa natural a toda criatura viviente y deseando estar prevenido para tan fuerte lance a honra y gloria de Dios nuestro señor hago y ordeno mi testamento en la forma siguiente:

Primeramente encomiendo mi alma a Dios nuestro señor, que la crió y redimió con su preciosísima sangre, y el cuerpo a la tierra, de que fue formado.

Que cuando la voluntad de su divina Majestad sea servido llevarme de esta presente vida la mía es que mi cuerpo sea sepultado en el Santo Convento Hospital de Nuestra Señora de los Desamparados, Orden de Nuestro Padre San Juan de Dios en donde al presente me hallo enfermo.

Declaro tengo por mío propio empeñado un San Antonio en ocho ducados vellón, es mi voluntad se traiga a dicho convento hospital pagando la referida cantidad y vendido que sea les mando cien reales vellón para mi entierro, los que se entreguen al Reverendo Padre Prior que al presente es o fuese en adelante, y lo restante de su valor lo dejo a la disposición de la referida Francisca López mi mujer.

Y para cumplir y pagar este mi testamento, mandas y legado, dejo y nombro por mis testamentarios y albaceas a la referida Francisca López mi mujer a la cual doy todo mi poder cumplido el necesario en derecho para que luego que yo fallezca entre en mis bienes y los venda y remate y de su valor cumpla y pague este mi testamento, mandas y legado el cual la dure el tiempo necesario, aunque pase y exceda del permitido en derecho para cuyo efecto se le prorrogo.

Y cumplido y pagado este mi testamento dejo, instituyo y nombro por mi única y universal heredera del remanente de todos mis bienes, derechos y acciones que en cualquier manera me correspondan a la nominada Francisca López mi mujer y la pido me perdone y encomiende a Dios.

Y por el presente revoco, anulo y doy por ninguno y de ningún valor ni efecto otros cualesquier testamentos, codicilos, poderes para testar, mandas y legados y demás disposiciones que antes 
de este haya hecho y otorgado que quiero no valgan ni hagan fe en juicio ni fuera de él, salvo éste que al presente hago y otorgo que quiero valga por mi testamento, última y postrimera voluntad, en aquella vía y forma que más haya lugar en derecho, y por firme lo otorgo así ante el presente escribano en la ciudad de Valladolid a diez de junio de mil setecientos cincuenta y cinco, siendo testigos llamados y rogados Manuel de Paul, Elías Paredes y Manuel Fernández de Bustamante vecinos de ella, y el otorgante a quien doy fe conozco no lo firmó por hallarse ciego, a su ruego lo firmó uno de dichos testigos.

Fdo: Manuel de Paul

Distribuido a dicho convento hospital en papel de oficio por pobre y sin derechos los que tampoco se pagaron de este original por la notoria pobreza del otorgante, de que doy fe. 


\section{DOCUMENTO 84}

\section{OBLIGACIÓN SOBRE LA FÁBRICA DE UN RETABLO PARA EL ARCÁNGEL SAN MIGUEL A CASTIL DE VELA (10 - NOVIEMBRE - 1749)}

A.H.P.V., Leg. 9.294, ff. 348-34923

En la ciudad de Medina de Rioseco a diez días del mes de noviembre de mil setecientos cuarenta y nueve, ante mí el escribano público y testigos, parecieron presentes Gabriel Pérez, Josepha de Loyo su legítima mujer y Manuel Benavente y Manuela Mazariegos su consorte vecinos de esta dicha ciudad, y maestros los sobredichos de arquitectura, y precedida la venia y licencia que se requiere que fue pedida concedida y aceptada de que hago fe y de ella usando todos cuatro juntos de mancomún, a voz de uno, y cada uno de los sobredichos de por sí, y por todo in solidum, renunciando como expresamente renuncian las leyes de duobus rex debendi (...) con toda las demás leyes privilegios e instituciones de la mancomunidad, según que en ella y en cada una se contiene, bajo de cuyo rigor conformes dijeron: que por el señor cura mayordomo y oficiales de la iglesia parroquial del arcángel San Miguel de la villa de Castil de Vela, se acordó hacer el retablo de su capilla mayor, con cuya noticia pasaron los referidos maestros a su reconocimiento, y con expreso consentimiento de su feligresía hicieron traza, que firmó dicho señor cura y a que se siguió en fuerza de haberles agradado la traza, hacer condicione sobre su fábrica y postura en la cantidad de cuatro mil reales de vellón, alzadamente, y a toda costa, inclusa la colocación de la efigie del arcángel San Miguel, santos y niños que incluyen las precitadas condiciones, y demuestra la relacionada traza, en razón de lo cual ofrecieron cumplir con lo allí pactado y de que hicieron obligación a continuación de dichas condiciones y posturas que firmaron en la villa en los diez y nueve de octubre pasado de este presente año que fue admitida por dicha feligresía, e hizo presente a varias personas de la misma profesión y fijaron edictos en la forma ordinaria, y por no haber habido quien hubiese hecho baja y mejora, se celebró el remate de dicha obra en los diez como es notorio y resulta lo dicho de condiciones y postura que hicieron en su razón que original se pone con este instrumento y son del tenor siguiente:

\section{Aquí las condiciones}

Las condiciones y postura aquí preinserto concuerda con su original de que yo el escribano doy fe, y los dichos Gabriel Pérez, Josepha de Loyo, su consorte, Manuel Benavente y Manuela Mazariegos su legítima mujer mediante la celebridad de dicho remate, se le ha pedido por parte de dicha fábrica se celebren a su favor la escritura de obligación correspondiente por todos los sobredichos a que van llanos, por ser justos y poniéndolo en práctica y para la debida seguridad de dicha iglesia en el mejor modo, vía y forma, que de derecho lugar haya y bajo de dicha mancomunidad y renunciación de leyes que llevan hecha y que en caso necesario de nuevo hacen, otorgan que se obligan con sus personas y bienes muebles y raíces derechos y acciones presentes y futuras a hacer y fabricar de maderaje y talla en dicho retablo para la capilla mayor

23 URREA, Jesús: “Arte y Sociedad en Medina de Rioseco durante el siglo XVIII”. En PÉREZ DE CASTRO, Ramón y GARCÍA MARBÁN, Miguel (coord.): Cultura y arte en Tierra de Campos. I Jornadas Medina de Rioseco en su historia, Diputación Provincial de Valladolid, Valladolid, 2001, p. 99. 
de la precitada iglesia del arcángel San Miguel de la precitada villa de Castil de Vela, arreglándose en un todo los sobredichos maestros a la traza y condiciones, que en el mismo asunto hicieron con las efigies del mismo arcángel San Miguel, santos niños y más comprensivo en uno y otro, dejándolo todo perfecto y concluido según reglas de este arte y a vista de maestros que se han de elegir por una y otra parte, para que declaren lo que tuviesen por convenientes, y hallando haberse cumplido en dicha fábrica de retablo y efigies con la perfección y hermosura que demuestra dicha traza y preinsertas condiciones, con arreglo a uno y otro y sin exceso aseverado por dichos maestros han de quedar los otorgantes libre de esta obligación, la que se entiende es a toda costa de materiales y manos, sin que dicha iglesia tenga que satisfacer por este respecto maravedíes algunos, y dicho retablo y efigies han de dar como ofrecen finalizado y sentado para el día veinte y nueve de septiembre del año próximo venidero de mil setecientos y cincuenta, siendo también el costo de dicho asiento del cargo de los otorgantes y la conducción de dichas efigies y piezas de dicho retablo, estos a cuenta y cargo de dicha fábrica, quien ha de pagar el porte de lo referido, y lo mismo de la del dicho arcángel San Miguel que ésta han de dar colocada y hecha según arte para el día veinte y cinco de diciembre de este presente año de cuarenta y nueve, en el sitio que le corresponde de dicha capilla mayor sin faltar en cosa ni en parte de lo que van obligados, y en el caso de que dicha obra y más conducente a ella se declare no estar ejecutada según arte y con arreglo a dicha traza y condiciones se ha de desmontar cuantas veces suceda, y volver a hacerlo nuevamente o las efigies y piezas que contenga la declaración de maestros que entienden en su reconocimiento hasta tanto que hayan cumplido con el tenor de esta su obligación, pagando el coste de dicha fábrica por su defecto se ejecute sin que quede responsable a cosa alguna dicha fábrica más de en cuanto a lo dicho de portes y costa principal que irá expresada y cuando no den fenecido y sentado dicho retablo y efigie de San Miguel para los días que van señaladas o se excusen a entender en esta obra, o en la que se diese, por defectuosa, en cualquier acontecimiento de lo dicho, consienten que dicha feligresía de cuenta y riesgo de los otorgantes por medio de maestros de esta profesión lo practiquen hasta dejarlas perfecta y sentada como corresponde, y que por su importe se les apremie por todo rigor de derecho en virtud de esta escritura y relación que diese la parte de dicha iglesia a que lo dejan diferido, esto con tal de que dicha iglesia ha de quedar como queda de su cargo el pagamiento de los dichos cuatro mil en que se remató dicha obra y en cuenta de ella entrega su parte a los otorgantes ahora de presente a presencia de mí el escribano y testigos un mil reales en especie de oro plata y vellón real, y físicamente de que hago fe, y otros mil reales ha de satisfacer para principio de mayo del dicho año de cincuenta y los dos mil reales restantes para luego que se declare haber cumplido con el tenor de dicha traza y condiciones, que es lo mismo que tienen pactados, y bajo de lo dicho todos los otorgantes reiteran la obligación que llevan hecha, y a que nuevamente sujetan dichas sus personas y bienes (...) así lo dijeron y otorgaron ante mí el escribano siendo testigos Miguel Aranaz, Juan Briz y Manuel Canseco vecinos de esta ciudad y los otorgantes a quienes doy fe conozco, firman los que saben y por la que dijo no saber a su ruego un testigo.

\section{Condiciones para hacer el retablo del arcángel San Miguel para su capilla mayor}

$1^{\mathrm{a}} \quad$ Primeramente es condición que se ha de hacer dicho retablo de madera de Soria limpia y seca y dicho retablo ha de tener diez y nueve pies de ancho y una pestaña que sobreponga a la pilastra de piedra y esto ha de tener además un cuarto de pie y su altura veinte y ocho pies pie más o menos. 
$2^{\mathrm{a}} \quad$ Es condición que se ha de hacer la mesa de altar a la medida del frontal que tenía y ha de tener sólo de salida una vara y a ella tengo de arrimar de madera una frontalera cerrada por todos cuatro partes bien ajustada y doble para defensa de los ratones, y sobre dicha mesa de altar ha de cargar el pedestal principal del retablo guardando su planta vivos y macizos según la traza demuestra con los adornos de talla, y en el medio de dicho pedestal se ha de hacer un arco con tres porciones de círculo a donde se ha poner la custodia que tiene la iglesia y servía en su retablo antiguo.

$3^{\text {a }} \quad$ Es condición que encima de dicha custodia antigua se ha de hacer una media naranja guardando los movimientos de ella con su remate y encima su caja principal para el arcángel adornándola de serafines y nubes según demuestra la traza añadiendo tres niños a cada lado y uno en medio en lo alto, del tamaño de tercia y entre niño y niño su cabeza de serafín con sus alas y ráfagas.

$4^{\mathrm{a}} \quad$ Es condición que se han de hacer sus cajas de intercolumnios con sus peanas y demás adornos según está en la traza dejando el hueco para poner un San José en un lado con su niño y también un San Isidro labrador al otro de estatura natural, y sobre dicho alzado ha de cargar la cornisa adornándola de miembros de arquitectura modillones y dentellones todo según demuestra la traza.

$5^{\mathrm{a}} \quad$ Es condición que sobre dicha cornisa ha de cargar segundo pedestal adornado de festones, frisos y bambolinas como está en dicha traza.

$6^{\mathrm{a}} \quad$ Es condición que sobre dicho pedestal cargue el segundo cuerpo adornando de arquitectura y talla todo según consta de dicha traza sin añadir ni quitar, pues aunque se hagan luces en ella parte se acomodará la obra en el mejor modo que haya lugar.

Y con estas condiciones y traza que presento firmada del señor Alonso Fernández Antolín cura de dicha iglesia me obligo yo Gabriel Pérez y Manuel Benavente vecinos de Rioseco y maestros de arquitectura con los dos santos que van expresados de San José y San Isidro hechos a su costa y los siete niños que en la caja principal, y de lo demás en estas condiciones expreso en cantidad de cuatro mil reales vellón en esta forma mil reales al principio y mil reales para principio de mayo y los dos mil reales restantes fenecido y acabado que sea dicho retablo y dado por cumplido por maestros peritos en el arte dando fianzas a satisfacción de dicho señor cura y mayordomo de fábrica y por verdad lo firmamos Castil de Vela octubre 19 de 1749. 


\title{
DOCUMENTO 85
}

\section{ESCRITURA. FRANCISCO BILLOTA Y JOAQUÍN SU HIJO PARA LA FÁBRICA DE RETABLOS EN SAN FELIPE NERI (27 - JUNIO - 1719)}

\author{
A.H.P.V., Leg. 3.127, ff. 578-57924
}

En la ciudad de Valladolid a veinte y siete días del mes de junio año de mil setecientos y diez y nueve ante mí el escribano y testigos pareció Francisco Billota maestro ensamblador vecino de ella y dijo que el (...) celo y devoción que siempre tuvo y tiene al señor San Felipe Neri sito en su iglesia y venerable congregación de señores sacerdotes de esta dicha ciudad y deseoso de manifestarle en cuanto pudiese ve alentó a dar y dio para siempre jamás para la sacristía una fuente grande de plata dorada por dentro de peso de setenta onzas poco más o menos con petición que presentó ayer veinte y seis de éste presente mes y ofreció hacer y ejecutar los seis retablos que necesitan las seis capillas de dicha iglesia los dos primeros según la planta y taza electa y los otros cuatro del mismo corte diferenciando la labor para más hermosura de dicha iglesia los dichos dos primeros ha de tener puestos y asentados para mediado de mayo del año que viene de setecientos y veinte y los cuatro restantes así sucesivamente hasta cumplimento de tres años corriendo el primero desde ayer dicho día en precio todos de siete mil y quinientos reales de vellón que le habían de dar y pagar dichos señores en el expresado tiempo, y asimismo ofreció dar dos mil reales de vellón a fin de que los sesenta que corresponden a su renta impuestos a censo se sirviese mandar decir las misas que les pareciere y no los entregando me obligué a dar y pagar dichos réditos con hipoteca de mi hacienda y por más seguridad entraría en la escritura que se hubiese de hacer Joaquín Billota su hijo para que si Dios nuestro señor fuere servido llevarme antes que se feneciese dicha obra se hiciese a costa de su hacienda y ambos la firmaron y oído por dichos señores y en consideración de ser todo en obsequio del mayor culto y lucimiento del santo y (...) iglesia aceptaron todo lo contenido y recibieron dicha fuente de plata y determinaron otorgase la escritura según y en la forma expresada con las demás ampliaciones que conviniesen al cumplimiento de lo cual otorgo que me obligo con mi persona y bienes muebles y raíces derechos y acciones habidos y por haber a guardar y cumplir lo siguiente:

$1^{\mathrm{a}} \quad$ Lo primero que para dicho día mediado del mes de mayo que viene de setecientos y veinte ha de tener puestos y asentados en sus sitios los referidos dos primeros retablos ejecutados y arreglados según la planta traza y condiciones hechas que para que las tenga presente se le han de dar originales o un tratado firmado y se ha de declarar por maestros del arte haber cumplido y por lo que faltare se le ha de apremiar.

$2^{\mathrm{a}} \quad$ Que después de ejecutado lo referido he de pasar a hacer los otros dos retablos segundos ponerlos y asentarlos en las siguientes capillas del mismo coste y sólo con diferencia de labores para más hermosura y lucimiento y en la misma forma los otros dos terceros y últimos y todos ellos dentro del término de los expresados tres años que corren desde hoy sin más dilación ni prorrogación.

24 GARCÍA CHICO, Esteban: Documentos para el estudio del arte en Castilla. 2, Escultores, Universidad de Valladolid, Valladolid, 1941, pp. 381-382. 
$3^{\text {a }} \quad$ Que al principio de fabricar dichos retablos primeros segundos y terceros se me han de dar y entregar por dichos señores dos mil y quinientos reales de vellón que importan todos seis dichos siete mil y quinientos hasta estar puestos y asentados los primeros no he de pedir los dos mil y quinientos reales para dar principio a los segundos y lo mismo para los terceros y últimos.

$4^{\mathrm{a}} \quad$ Que no ha de ser de mi cuenta y cargo las efigies de santos y ángeles que necesitaren dichos retablos ni las piedras para sentarlos por no corresponder a su arte y deben ser a la de dichos señores.

$5^{\mathrm{a}} \quad$ Que después de haber cumplido con haber puesto y asentado todos dichos seis retablos ha de pagar en contado los dos mil reales para la fundación de misas por mi alma que apareciere a dichos señores y en caso de que no los tenga fundará censo de ellos con hipotecas de sus bienes raíces para la mayor seguridad que han de aceptar dichos señores y obligarse a su cumplimiento corriente el efecto en que se impusieren y otros cualesquiera que nuevamente se hicieren y no en otra forma.

Y para que mejor guardará y cumplirá todo lo aquí contenido ofrece y da por su fiador al referido Joaquín Billota su hijo el cual que estaba presente dijo se constituía y constituyó por tal y se obligaba y obligo con su persona y bienes muebles y raíces derechos y acciones habidos y por haber a que el dicho Francisco Billota su padre guardará cumplirá y pagará en todo y por todo con lo que está obligado en esta escritura sin faltar a cosa alguna y dentro del término señalado y no lo haciendo y cumpliendo así, el otorgante como su fiador y principal pagador y obligado haciendo como para éste caso hace de deuda y hecho ajeno suyo propio y sin que sea necesario hacer excursión en la persona y bienes del dicho su padre ni otra diligencia alguna aunque de hecho o de derecho se requiera cuyo beneficio y las leyes que sobre éste caso hablan expresamente renunciando cumplirá y pagará y hará cumplir a su... en todo o parte sin falta ni dilación en virtud de esta escritura y del auto o sentencia que en esta razón se diere porque se le ha de poder compeler y apremiar por todo rigor de derecho y vía ejecutiva con testimonio o certificación por donde conste su contravención o falta y por más las costas y daños que sobre ello se siguieren y causaren.

Y para su cumplimiento dan poder a las justicias y jueces de su Majestad a su fuero competente a quien se someten y en especial al fuero y jurisdicción de los señores alcaldes del crimen de la corte corregidor y teniente que son y fueren de esta dicha ciudad y a cada uno in solidum para que a su guarda les compelan como si fuese en virtud de sentencia de juez competente pasada en autoridad de cosa juzgada (...) y lo otorgaron así ante mí el escribano y lo firmaron a quienes doy fe conozco siendo testigos Antonio García Joseph González Ochoa D. Antonio Herrera vecinos y naturales de esta dicha ciudad. 


\title{
DOCUMENTO 86
}

\section{OBLIGACIÓN DE DORAR Y ESTOFAR Y ENCARNAR EL RETABLO MAYOR DEL CONVENTO DE LA VICTORIA (25 - ENERO - 1747)}

\author{
A.H.P.V., Leg. 3.353, ff. 13-17 (1747)
}

En la ciudad de Valladolid a veinte y cinco días del mes de enero de mil setecientos y cuarenta y siete años ante mí el escribano y testigos parecieron D. Tomás de Sierra maestro dorador y estofador vecino de la ciudad de Medina de Rioseco y estante al presente en ésta como principal deudor pagador y obligado y don Pedro de Sierra y don Andrés de Montes maestros escultor y batidor de oro vecinos también de esta misma ciudad como sus fiadores y principales cumplidores haciendo como para en éste caso hacen de deuda y hecho ajeno suyo propio (...) dijeron que por cuanto el Reverendísimo padre corrector y religiosos del Convento de Nuestra Señora de la Victoria orden de los mínimos de San Francisco de Paula extramuros de ésta nominada ciudad han resuelto el dorar el retablo mayor que está puesto en su capilla mayor y estofar la escultura que en él hay, después de las efigies que hoy lo están para lo cual de su orden y mandato para el citado efecto se hicieron condiciones según y de la forma y modo como se ha de hacer y ejecutar dicho dorado y estofado las cuales para que siempre conste se pondrán a continuación de ésta escritura, y en la propuesta obra, por el dicho don Tomás de Sierra se hizo postura con arreglo a dichas condiciones y otras que incluye dicha postura en precio de treinta mil reales de vellón y habiendo exceptuado los vaciados de realce o rebajados del retablo del Carmen Descalzo la hizo también por último precio en la cantidad de veinte y ocho mil reales habiéndose hecho otra por Francisco Rodríguez maestro dorador vecino de Palencia en la misma cantidad sin poner la mencionada Concepción en dichos vaciados de realce si no es con arreglo total a las condiciones puestas de orden de dicha comunidad, por el nominado otorgante se hizo últimamente allanamiento a ejecutar la referida obra en la misma conformidad que se obligaba el enunciado Francisco Rodríguez y en el mismo precio de los dichos veinte y ocho mil reales de vellón y habiéndose remitido dichas condiciones y posturas al Reverendo Padre Fray Jerónimo Estensoro provincial de la expresada orden fueron aprobadas por su Reverendísima eligiendo y confirmando las firmadas últimamente por mí el referido don Tomás de Sierra en cuanto a la labor, maniobra y precio con carga que haya de ser también de mi cargo y cuenta el dorar todo el respaldo de los cajones de la sacristía y estofar el San Miguel del atril del coro, mandando que bajo de los propuestos aditamentos y condiciones y afianzando para el seguro quedase la expresada obra en el otorgante según que más por extenso consta de la aprobación de dicho Reverendo Padre con fecha en Madrid a diez y ocho del presente mes y año firmada de su Reverendísima en vista de la cual por el otorgante se hizo allanamiento a cumplimiento de lo que en dicha aprobación se menciona en el día veinte y cinco de éste mismo mes aceptándola en todo y por todo por el propuesto precio de los dichos veinte y ocho mil reales según también consta de dicho allanamiento que asimismo con la citada aprobación acompaña ésta escritura y para que lo referido tenga efecto cumpliendo con lo mandado por dicho Reverendo padre provincial para el afianzo y seguro de la ejecución de la referida obra de dorado y estofado de dicho retablo mayor y el del propuesto respaldo de los cajones de sacristía y estofado del San Miguel los dichos principal y fiadores bajo de la mancomunidad y renunciación de las leyes que llevan hecha y de nuevo hacen, otorgan que se obligan con sus personas y bienes muebles y raíces derechos y acciones habidos y por haber a que dorarán de 
oro limpio el dicho retablo mayor de la referida iglesia de Nuestra Señora de la Victoria extramuros de ésta dicha ciudad y el nominado respaldo según va referido y estofarán toda la escultura y tarjetas que haya que estofar y también el San Miguel según y cómo se expresa en las citadas condiciones sin faltar en cosa alguna en precio de los dichos veinte y ocho mil reales de vellón que se les han de dar y pagar por dicho Reverendo padre corrector y religiosos en esta forma, los diez mil reales de vellos de contado para principiarla, otros diez mil reales durante el todo de dicha obra, y los ocho mil reales restantes fenecida entregada y aprobada que sea por maestros peritos en la profesión de dorar y estofar que para ello se han de nombrar por ambas partes cuya obra se obligan a dar fenecida y acabada en toda perfección según antes va dicho para el día último de agosto que vendrá de éste presente año quince días más o menos en el cual dicho dorado y estofado no pedirán mejoras algunas aunque las hagan si no es en el caso que dicha comunidad las pida y mande ejecutar y añadir en el dicho retablo o en otra cosa que en éste lo que así les pidieren hagan de nuevo se ha de ejecutar y pasado que sea el término designado no habiendo cumplido con el fenecimiento de dicha obra se les ha de poder compeler y apremiar a ello por todo rigor de derecho en virtud de ésta escritura.

Y estando presentes a su otorgamiento los reverendos pares fray Monroy y fray Manuel de Almeida prior general en el propuesto convento en virtud de comisión y facultad que expresaron tener del nominado Reverendo padre corrector y demás religiosos a voz de comunidad para la aceptación de ésta escritura y obligación a la paga de los expresados veinte y ocho mil reales la forma que han capitulado y en ella se expresa habiéndola vista leído y entendido dijeron obligan los bienes y rentas del expresado convento a que darán y pagarán al dicho don Tomás de Sierra y a sus fiadores por razón del dorar el dicho retablo y respaldo de sacristía y estofar toda la escultura que antes va mencionado según y cómo se expresa en las condiciones allanamientos y su aprobación los referidos veinte y ocho mil reales de vellón en los tercios y forma de pagar que en dicha escritura se refiere de manera que la primera que se les ha de hacer y en ella los enunciados diez mil reales de vellón ha de ser luego de contado que esté puesto y armado el andamio para que puedan costear lo necesario, segunda paga de otra tanta cantidad en el tiempo que dicha obra se vaya ejecutando y hasta que se fenezca, y los ocho mil reales restantes cumplimiento a los nominados veinte y ocho mil acabada que sea toda la dicha obra y declarado por los maestros peritos que se nombraren por unas y otras partes haber cumplido en un todo con dichas condiciones y allanamientos, y a la paga de dichas cantidades en la forma que va expresada se ha de poder compeler y apremiar al dicho convento y a su comunidad sus bienes y rentas por todo rigor en virtud de ésta escritura sin otro recaudo alguno y como por obligación guarenticia de plazo pasado que ha de traer aparejada ejecución.

Todo lo cual las dichas partes se obligan a guardar y cumplir los dichos don Tomas don Pedro de Sierra y don Andrés de Montes con las dichas sus personas y bienes muebles y raíces derechos y acciones habidos y por haber y los dichos padre comisarios en nombre de su comunidad de quien como va referido dicen tener comisión obligan los bienes de dicho convento y dan poder cumplido a las justicias de su santidad y S.M. que de sus causas deban conocer para que a ello les compelan como por sentencia pasada en cosa juzgada renuncian las leyes fueros y derechos de su favor con la general en forma y los padres comisarios en nombre de su convento juran en toda forma ésta escritura y todos y cada uno por lo que les toca y lo otorgamos así ante el presente escribano en la ciudad de Valladolid a veinte y cinco días del mes de enero de mil setecientos cuarenta y siete siendo testigos Manuel Gómez, Pedro Bachiller e Hipólito Chamochín vecinos de ésta dicha ciudad y los otorgantes a quien yo dicho escribano doy fe conozco lo firmaron. 
Condiciones para pintar dorar y estofar el retablo de Nuestra Señora de la Victoria en la iglesia de ésta ciudad de Valladolid extramuros de ella

$1^{\circ} \quad$ Es condición que se ha de aparejar dando sus manos de cola y yeso en la forma siguiente: la primera mano de yeso se ha de plastecer las yendas y sitios repelosos que tiene sin llegar a la talla que no se ha de dar plaste alguno quedándolo tan descubierto como está en madera en blanco, lijándolo y escofinándolo para quedarlo con la tersura que pide el arte, después se ha de pasar a dar sus manos de yeso mate con la curiosidad que pide quedando tan terso y limpio como pide la condición y ejecuto esto se han de dar sus manos de bol las que pide para dorarlo.

$2^{\circ} \quad$ Es condición que se haya de dorar dicha obra de oro limpio lo que alcanzase la vista del coro tribunal y capilla mayor sin que se pueda reservar nada más que los dichos y ha de bajar igualmente dorado desde el cuerpo de arriba hasta el fin del pedestal reservándolo y dorándolo como así corresponde.

$3^{\text {o }}$ Es condición que el oro ha de ser de color subido igual sin que se gaste oro bajo ni oro partido, ni otro color que lo imite con la igualdad que las partidas de oro se registran y se vean por maestro del arte y si pudiese ser se hagan dos partidas la cantidad que llevase dicha obra a gusto de la comunidad o quien dispusiese ese registro.

$4^{\circ} \quad$ Es condición que todos los niños y cabezas de serafines se han de encarnar a pulimento con aceite de nueces y los pelos peleteados y los más de los sentidos que pertenece a dicha encarnación y toda esta a los que tuvieren y atributos se han de dorar y estofar de diferentes colores finos sacándolas de grafio de diversos géneros para más lucimiento y varios extremos de la talla de toda la obra, se han de estofar, dorándolo en la dicha conformidad y dando sus coloridos en la forma que va expresado, como son los capiteles, festones y peras sin que se comunique uno con otro y dicha talla quede tan dorada con si fuera de oro limpio abriéndolo de grafio como va referido.

$5^{\circ} \quad$ Es condición que toda la talla después de dorado sobre bruñido se ha de broncear de corleadura todos los fondos y venas que tiene para más realce y hermosura y algunos vaciados en el pedestal y otras partes que pidiesen dicha comunidad o particular que la gobernase lo haya de ejecutar el maestro como está ejecutado en el Carmen Descalzo extramuros de ésta ciudad.

$6^{\circ} \quad$ Es condición que todo lo que se ha de ejecutar nuevo de vuelos de cornisa morteretes gradas y tramoya para su majestad se ha de dorar en la misma conformidad como va referido sin que se pida mejora alguna con la obligación de ejecutar todo lo que pidiesen dichas partes.

$7^{\circ} \quad$ Es condición que si la comunidad viese alguna falta en tiempo se den los aparejos a dicha obra o en todo lo demás que va referido haya de llamar maestro que lo registre y vea si va según arte y condiciones sin que lo pueda estorbar el maestro para que lo enmiende y cumpla y en particular en la preparación de los aparejos que es a donde está el peligro de la obra.

$8^{\circ} \quad$ Es condición que el pedestal de piedra se ha de jaspear al óleo con diferentes mármoles de colores muy finos barnizados con el espíritu del agua ardiente y todas las molduras se han de dorar al óleo y en los tímpanos de él se han de ejecutar diferentes adornos de oro para más lucimiento y duración. 
Y dicha obra se ha de ejecutar en la conformidad que va expresada a vista de maestro peritos en el arte a costa de dicho maestro y por dichos maestros que valúen el cote de las condiciones para que se satisfaga a quien las hizo su trabajo, esta mande hacer a un maestro de ésta ciudad, de toda conciencia y experiencia para regularme a lo mejor y mayor lucimiento de la obra y habiéndolas visto Tomás de Sierra vecino de Rioseco dijo que arreglado a estas condiciones tomará la obra de su cuenta en tres mil ducados allanándose al modo y como está ejecutado el dorado del retablo del Carmen de descalzos de ésta ciudad y el andamio, y no haciendo los vaciados de realce o rebajados que adornan el retablo de dicha comunidad del Carmen la ejecutará en treinta mil reales de vellón y para obviar de todos rebajos que se puedan hacer por maestros que intenta tomar ésta obra, dice que sin los vaciados de realce o rebajados del retablo del Carmen lo ejecutaría y tomará a su cuenta y a toda costa y afianzando a satisfacción de la comunidad en último precio de veinte y ocho mil reales de vellón y que lo ejecutará en la misma conformidad que está el retablo de San Felipe el Real de la villa de Madrid, y lo firmó en veinte y seis de diciembre de mil setecientos y cuarenta y seis años, queda de su cuenta asimismo buscar batidor de su satisfacción.

Fdo: Tomás de Sierra

Vistas éstas condiciones digo que hace la obra arreglado a ellas lo que es el pedestal y cuerpo de columnas primero en la conformidad que está lo del Carmen Descalzo sin más añadición que lo en ellas estipulado en la cantidad de veinte y ocho mil reales y lo firmé Palencia y enero primero de mil setecientos y cuarenta y siete.

Fdo: Francisco Rodríguez

En la misma conformidad tomo y ejecutaré el dorado del retablo contenido en éstas condiciones que la firma el de Palencia Francisco Rodríguez en primero de enero de este año de setecientos cuarenta y siete años, y para que conste lo firmo Rioseco enero de 1747.

Fdo: Tomás de Sierra

Entre las condiciones y precios que se me han remitido del Convento de Valladolid para el dorado del retablo apruebo, elijo y confirmo las firmadas últimamente por Tomás de Sierra en labor, maniobra y precio, con carga que ha de ser también de su cargo y cuenta el dorar todo el respaldo de los cajones de la sacristía y la efigie de San Miguel del atril del coro, y bajo de éstas condiciones afianzando para el seguro quede con la obra el ya nominado Sierra, y la comunidad se la dé Madrid y enero 18 de 1747. Señálese asimismo tiempo fijo en que lo ha de dar dorado.

Fdo: Fray Jerónimo Estensoro

Digo yo Tomás de Sierra vecino de la ciudad de Medina de Rioseco y estante al presente en ésta ciudad de Valladolid que habiendo visto la anotación dada de las condiciones antecedentes para dorar el retablo del Convento de Nuestra Señora de la Victoria, orden de los mínimos de San Francisco de Paula extramuros de ella, dada por el Reverendo padre fray Jerónimo Estensoro 
provincial de dicha orden y aditamento que en ellas se expresa de haber de dorar todo el respaldo de los cajones de la sacristía de dicho convento a imitación de cómo están la tarjeta que calla hoy en medio del dicho respaldo y estofar el San Miguel del atril del coro, la fecha de dicha aprobación en Madrid a diez y ocho del presente mes y año firmado de su Reverendísima la aceptó y me allano a cumplir y ejecutar lo que previene el propuesto aditamento y dorar el dicho retablo mayor en el precio de los veinte y ocho mil reales que previene la referida aprobación y condiciones puestas y lo firmó en Valladolid a veinte y cinco días del mes de enero de mil setecientos y cuarenta y siete años.

Fdo: Tomás de Sierra 


\title{
DOCUMENTO 86
}

\section{PODER PARA LA COLOCACIÓN DE SAN PEDRO REGALADO EN EL $\underline{\text { SALVADOR }}(24-$ MAYO - 1709)}

\author{
A.H.P.V., Leg. $2.393 / 1$, ff. $504-507^{25}$
}

El cura y parroquianos de la iglesia parroquial del Salvador de esta ciudad de Valladolid, estando juntos en dicha iglesia habiendo sido llamados por campana tañida según lo tenemos de costumbre de nos juntar a tratar y conferir las cosas tocantes al servicio de Dios nuestro Señor, bien y utilidad de dicha parroquia estando especialmente nos el licenciado don Pedro de Rábago, cura propio de dicha iglesia, don Félix de Estefanía Ureta regidor, don Fernando Robredo, don Domingo Fernández del Val, don Francisco de Villegas, Jerónimo de Estrada, Juan Manuel Navarro Moreno, Juan de Mollinedo, Frutos Martínez, Julián García, y los demás cuyos nombres aquí firmaremos todos parroquianos de dicha parroquia, y los que nos hemos podido juntar habiendo tocado la campana más de cinco horas, y por los demás ausentes, enfermos e impedidos que no se pudieron juntar, y de los que adelante fueren prestamos voz y caución en bastante forma que estarán y pasarán por lo aquí contenido y lo que en su virtud fuese hecho debajo de expresa obligación que para ello hacemos de los bienes y rentas de dicha cofradía, y en voz de ella y estando así juntos por mí el dicho don Pedro de Rábago presenté una petición que se me había entregado por uno de los hijos y parroquianos de dicha parroquia la cual se leía que es la del tenor siguiente:

Aquí la petición

Concuerda con su original de que el presente escribano da fe y habiéndola oído y entendido tratado y conferido entre todos nosotros, todos unánimes y conformes y de un acuerdo y conformidad por la presente y en aquella vía y forma que mejor haya lugar en derecho damos licencia a dicho devoto para que coloque y ponga la efigie del señor San Pedro Regalado en dicha parroquia iglesia del Salvador donde está bautizado y se le da las dádivas, gracias y mediante debía ser propia causa de toda la parroquia por ser hijo de ella, y que lo razón se coloque en sitio el más decente que hubiere en ella acordamos se haga una capilla donde se coloque en el sitio de otra que está totalmente arruinada que se decía ser del Ilmo. Señor Obispo Soto de que sobre ella tenía dicha fábrica tres mil y tantos maravedíes de renta perpetua en cada un año de que se debían más de cien años como constaba de las cuentas, y asimismo se hiciese para su mayor decencia y culto un nuevo camarín que saliese al cementerio de dicha iglesia que cae a la plazuela con su transparente, y para que todo tenga efecto y que se consigan las licencias que fueren necesarias nombramos por comisarios a los señores don Manuel Vallejo Calderón caballero del Orden de Calatrava, don Félix de Estefanía Ureta ambos regidores de esta ciudad, don Fernando Robredo, don Domingo Fernández del Val, don Francisco de Villegas y a don Jerónimo de Estrada todos parroquianos a los cuales y a cada uno in solidum y con cláusula de que puedan sustituir les damos todo nuestro poder cumplido y comisión en toda forma para que parezcan ante el Ilmo. Señor Obispo de esta ciudad, y su discreto provisor y

25 MARTÍN GONZÁLEZ, Juan José y URREA FERNÁNDEZ, Jesús: Catálogo Monumental de la provincia de Valladolid. Tomo XIV. Monumentos religiosos de la ciudad de Valladolid (1 ${ }^{a}$ parte), Institución Cultural Simancas, Valladolid, 1985, p. 45. 
donde convenga, y podan se nos conceda y dé las licencias que fueren necesarias para hacer todo lo referido. Y mediante por todos nosotros unánimes y conformes y con gran regocijo y gusto por la mucha devoción que tenemos al dicho santo San Pedro Regalado y ser tal hijo de dicha parroquia le hemos votado por día festivo y de guarda en el día que le celebra la iglesia, perpetuamente y por la presente a mayor abundamiento lo votamos así y pidan al dicho Ilmo. Señor Obispo confirmación y aprobación de dicho voto y que declare por día festivo y de guarda en dicha parroquia el dicho día en que le rezare la iglesia de lo cual ahora ni en tiempo alguno por nos y los que nos sucedieren perpetuamente no pediremos ni pedirán absolución ni revocación del dicho voto y si fuere necesario más confirmación y declaración la pidan donde convenga. Y asimismo damos poder y comisión en forma a dichos señores comisarios y a cada uno in solidum para que puedan transigir y ajustar así con el patrono que hubiere de dicho sitio de capilla que se decía ser del dicho Ilmo. Señor Obispo Soto como con las demás personas que convenga haciendo las remisiones de los débitos que se debieren a la fábrica y dándoles por libres de lo que tuvieren que pagar en adelante otorgando en su razón todas las escrituras de transacción y concierto con las calidades y condiciones que trataren y ajustaren y con todas las fueras, requisitos y circunstancias que para su validación, firmeza y perpetuidad se requieran y quisieren poner a su elección y voluntad que todo lo que hicieren, ajustaren y otorgaren lo aprobamos y ratificamos (...). Y asimismo acordamos se saque en procesión a dicho santo San Pedro Regalado por toda la dicha parroquia colgando las calles por donde pasare con la mayor decencia que se pudiere y tener a trechos sus altares y todo lo ofrecemos así; y que dichos señores comisarios soliciten para ello a la Venerable Congregación de Nuestro Padre San Felipe Neri y cofradías Sacramental, Ánimas, Nuestra Señora de la Guía, Buen Suceso, San Bartolomé, Santo Toribio y la Piedad, todas de dicha parroquia y a las demás personas que les pareciere y convenga para su mayor culto; y asimismo acordamos se tengan tres días de fiesta de iglesia haciendo su altar y en él poner dicho santo y tener el Santísimo Sacramento patente, misas y sermones para cuyo efecto también damos a dichos señores comisarios y el mismo poder y para que se pueda pedir por dicha parroquia su limosna para dichos gastos y nombren depositario en cuyo poder entren las que se recogieren. Y para que de hoy en adelante se continúe la dicha devoción y que todos los años perpetuamente, a lo menos en el día que se rezare y celebrare la fiesta del Santo se diga en su altar y capilla una misa cantada con toda solemnidad yo el dicho don Pedro de Rábago por mí como tal cura y en nombre de los señores beneficiados me obligo y les obligo a que mientras fuéremos tales curas y beneficiados diremos dicha misa con toda solemnidad de cuya oferta por nos todos los dichos parroquianos damos las debidas gracias y en firmeza de todo lo cual todos lo otorgamos y acordamos así ante el presente escribano en la ciudad de Valladolid a veinte y seis de mayo de mil y setecientos y nueve años siendo testigos Tomás Álvarez, Lorenzo Rojo y Joseph de Medina vecinos de esta ciudad y los otorgantes que yo el escribano doy fe conozco lo firmaron los que supieron y por todos los que estamos presentes que no sabemos firmar pedimos al presente escribano nos ponga los nombres y al pie firme un testigo y de ello dé fe.

\section{Señor}

Un humilde hijo y parroquiano de esta iglesia del Salvador de esta ciudad de Valladolid con el rendimiento que debe a todos los individuos de dicha insigne parroquia y como amante y celoso de ella, dice: ser de su particularísima devoción hacer a su costa un San Pedro Regalado (como está en el Convento del Aguilera) altar donde se coloque; y retablo para su mayor decencia, en dicha iglesia; y por ser tan conforme a dicha parroquia esta súplica (por ser su hijo de pila dicho 
San Pedro Regalado) suplica encarecidamente a dicha parroquia se sirva de concederlo, y para ello conceder y permitir se haga dicho altar a la entrada de la capilla mayor, al lado del Evangelio en correspondencia del altar del Santísimo Cristo, lo cual concedido hará con otros devotos una fiesta muy solemne teniendo patente el Santísimo Sacramento y para que se haga la función con toda solemnidad pide a dicha parroquia nombre los comisarios que gustare para que haya procesión, altares y en las calles colgaduras para su logro y efecto.

Ítem pide el acompañamiento de las cofradías sita en dicha parroquia y la solicitud de obtener las licencias que para todo lo dicho fueren necesarias que pues todo cede en mayor honra y gloria de Dios, afianza el dicho suplicante el consentimiento gustoso de la devoción ardiente de dicha parroquia, y de paisano y parroquiano, a quien ha favorecido el Salvador con tanto esmero para que sus intercesiones logren (como logran cada día) tan singulares y repetidos beneficios (sobre sus patrienses y parroquianos) todos los que a su intercesión se encomiendan esperando juntamente de tan devoto y obligados a que se vote su fiesta en dicha parroquia, para que a su imitación lo hagan las demás de esta ciudad, estando seguros de que por demostración tan piadosa, y debida a tan gran santo impetrará para todos sus parroquianos especiales auxilios para que le vean con mayor culto en la gloria.

Fdo: El más humilde y rendido devoto de San Pedro Regalado 


\section{DOCUMENTO 87}

\section{PODER. ALONSO MANZANO VECINO DE ESTA CIUDAD A PROCURADORES (16 - SEPTIEMBRE - 1709)}

A.H.P.V., Leg. 2.923, f. 460

Sépase por esta carta de poder como yo Alonso Manzano maestro arquitecto vecino de esta ciudad, otorgo que doy mi poder cumplido, el necesario y que de derecho se requiere a Juan García Gago y a Manuel de Peñamaría procuradores del número de esta Real Chancillería de esta ciudad y a cada uno in solidum, especialmente para que por mí y en mi nombre parezcan ante el señor teniente de corregidor de esta ciudad y en otros tribunales donde sea necesario y me defiendan en una demanda que me tienen puesta los comisarios nombrados por la parroquial del Salvador de esta ciudad para la traslación de San Pedro Regalado en su capilla de la iglesia de ella sobre suponer que el adorno que hecho y ejecutado según mi arte no está arreglado a la traza ni vale el precio en que lo ajusté y otras cosas contenidas en su pedimento, siendo así que es incierto porque yo he cumplido con lo que ha sido de mi obligación como lo protesto justificar y sobre ello presenten pedimentos requerimientos (...) y así lo otorgo ante el presente escribano y testigos en la ciudad de Valladolid a diez y seis días del mes de septiembre de mil setecientos y nueve años siendo testigos Francisco Colinas, Martín de Aguirre y Francisco Arias vecinos de esta ciudad y el otorgante que doy fe conozco lo firmo. 


\section{DOCUMENTO 88}

\section{TESTAMENTO DE DON PEDRO DE RÁBAGO CURA DEL SALVADOR}

$$
(19-\text { JULIO - 1720) }
$$

A.H.P.V., Leg. 2.395, ff. 444-44726

En el nombre de Dios amén sépase por esta publica escritura de testamento última y postrimera voluntad vieren como yo don Pedro de Rábago cura propio de la Iglesia parroquial de el Salvador de esta dicha ciudad de Valladolid estando en pie aunque con algunos achaques que Dios nuestro señor ha sido servido de darme y sano de mi juicio y entendimiento natural creyendo como firmemente creo en el Misterio de la Santísima Trinidad y en todo aquello que cree y confiesa la Santa Madre Iglesia Católica Romana debajo de cuya fe reverencia protesto vivir y morir en su santo servicio y tomo por mi intercesora y abogada a la serenísima reina de los ángeles y hombres María Señora nuestra y al apóstol San Pedro mi padre al glorioso patriarca San Francisco de Padua San Pedro Regalado y al glorioso San Julián obispo de Cuenca y a la benditas ánimas del purgatorio con quienes tengo especial devoción y a todos los santos de la corte celestial a quienes pido y suplico humildemente pidan a Nuestro Señor Jesucristo me perdone mis grandes culpas y pecados y ponga mi alma en carrera de salvación y me de gracia y auxilio para hacer y disponer este mi testamento el cual hago como se sigue:

Lo primero encomiendo mi alma a Dios nuestro señor que la crió y redimió con su preciosísima sangre y el cuerpo mando a la tierra de donde fue formado y cuando su divina Majestad fuere servido se me lleve de esta presente vida mi cuerpo sea sepultado en dicha iglesia parroquial del Salvador en la sepultura que tengo mía propia que está en medio del arco toral de la capilla mayor que tiene su piedra y letrero de mi nombre la cual compré para dicho efecto y que se enterrasen después del mí todos los señores curas que me sucedieren en dicho curato perpetuamente sin carga ni gravamen alguno y por no haber tenido ni tener sitio en otra iglesia donde enterrarse como consta de la escritura de venta que lo otorgo ante el presente escribano en ocho de enero de mil setecientos diez y seis y la donación hecha a dichos señores curas mis sucesores también ante el presente escribano en diez de enero pasado del presente año de setecientos y veinte cuyos traslados tengo en mi poder y pido ruego suplico muy rendidamente a cada uno de los dichos mis sucesores siendo de más grado y voluntad me encomienden a Dios y me tengan presente en sus oraciones y sacrificios de quienes espero lo harán además que de Nuestro Señor tendrán el premio.

Y es mi voluntad se me entierre en la forma y según se han enterrado los demás señores curas mis antecesores y asistan en mi entierro el cabildo menor de señores curas y beneficiados de donde soy capitular, la Venerable Congregación de mi padre San Felipe Neri de donde soy congregante, la Cofradía de San Ildefonso y Ánimas de dicha iglesia, la de San Pedro Regalado y la de Nuestra Señora del Refugio y ambas están unidas y la de Nuestra Señora del Suceso de donde de todas soy cofrade. Y pido ruego y encargo a los señores alcaldes y cofrades de las demás cofradías de dicha iglesia se dignen de concurrir y asistir con su cera a dicho entierro en atención a lo mucho que como tal cura les he deseado servir en el mayor aumento de dichas

26 MARTÍN GONZÁLEZ, Juan José y URREA FERNÁNDEZ, Jesús: Catálogo Monumental de la provincia de Valladolid. Tomo XIV. Monumentos religiosos de la ciudad de Valladolid (1 ${ }^{a}$ parte), Institución Cultural Simancas, Valladolid, 1985, p. 46. 
cofradías y que todos me encomienden a Dios de quien espero de su buena atención y correspondencia lo harán que de Nuestro Señor tendrán el premio. Y en cuanto a lo demás de mi entierro lo dejo a elección de mis testamentarios para que le dispongan como les pareciere.

Y siendo hora de misa se me diga el cuerpo presente cantada con diácono y subdiácono y no lo siendo se me diga el día siguiente y todo el coste se pague de mis bienes ruego que yo fallezca se me diga una misa de alma en el Convento de Nuestra Señora de la Vitoria de esta ciudad y se pague su limosna lo acostumbrado.

Ítem es mi voluntad que su en el día en que Nuestro Señor fuere servido de me llevar de esta presente vida si fuere hora de misa y no se me enterrase hasta por la tarde se digan en dicho día todas las misas rezadas que se pudieren decir en dicha iglesia pro mi alma pagando por la limosna de cada una a tres reales y asimismo sino se me enterrase en dicho día de mi fallecimiento, también se digan el día de dicho entierro todas las misas rezadas que se pudieren decir en dicha Iglesia pagando tan bien por la limosna de cada una a los dichos tres reales.

Mando a las mandas pías acostumbradas y redención de cautivos sus derechos debidos con que las aparto de mis bienes.

Declaro que por la misericordia de Dios Nuestro Señor tengo cumplidas y pagadas todas las misas, así de las que me han tocado como tal cura como de las capellanías que tengo y gozo así en esta ciudad como fuera de ella y para que siempre conste así lo declaro.

Ítem declaro debo a $\mathrm{D}^{\mathrm{a}}$ María Prieto mercadera vecina de esta ciudad doscientos reales poco más o menos mando que la cantidad que fuera y la susodicha diferencia se la pague.

Ítem declaro asimismo que la demás que yo debiere a otra cualquier persona y todo lo que a mí me debieren contara por asientos de mi libro y papeles es mi voluntad se pague lo que yo debiere y se cobre todo lo que me debieren.

Ítem declaro que desde cuando entré a usar y ejercer el dicho curato únicamente y sólo con el fin de la mayor honra y gloria de Dios Nuestro Señor y de los Santos de quien he tenido y tengo particular devoción aseo y adorno de dicha iglesia parroquial y en cumplimiento de este mi buen deseo y sin otro fin ni pretexto alguno a mi costa y de mi propio caudal hice y adorné los tres altares hechuras y retablos, como al presente están por no haberlos en dicha iglesia con la ruina de la torre vieja como es público y notorio el uno de ellos debajo del arco toral de la capilla mayor al lado del evangelio en correspondencia del altar del Santísimo Cristo que está al lado de la epístola de Nuestra Señora del Consuelo. Y el otro de mi padre San Pedro apóstol en el sitio y capilla de Nuestra Señora del Descendimiento de la Cruz que dicha torre arruinó que es de los Señores Condes de Alba Real. Y el otro altar y retablo de Nuestro Padre San Francisco de Paula en el sitio y arco como se entraba a la capilla que era del señor obispo Soto que también arruinó dicha torre cuyo sitio pertenece a la Cofradía de las Ánimas de dicha parroquia como patrona de las memorias que en ella fundó el Señor Hernán Rodríguez del consejo que fue de su Majestad y juez mayor de licencia en esta Real Chancillería con dos sepulturas que están al pie de dicho altar por cuya razón y en atención (...) uno de los cofrades de dicha cofradía tengo hecha donación de dicho altar hechura de San Francisco de Paula con su retablo plateado y dorado su pabellón de talla estofado y cortina de tafetán azul según y en la forma que al presente está con calidad de que dicha cofradía ha de tener obligación de mandar decir por mi alma una misa cantada en cada un año perpetuamente en el día del Nuestro Padre San Francisco de Paula y en el que de su octava señalare los señores curas mis sucesores con dos responsos y de poner sobre 
mi sepultura dicha tamba con dos velas mientras se celebrase dicha misa y responsos asistiendo dicha cofradía a dicha misa y responsos son su cera como todo más largamente consta de dicha donación que se otorgó en esta ciudad en dos de junio pasado de este presente año de mil setecientos y veinte ante Joseph González Ochoa escribano del número de ella la cual tengo en mi poder y se entregará luego que yo fallezca a los señores curas y beneficiados de dicha iglesia a quien pido riego y encargo que envirare de ella hagan que se cumpla con dicha condición sobre que en esto les encargo las conciencias.

Ítem declaro y es mi voluntad que para que siempre irá permanente dicho altar de Nuestra Señora del Consuelo en dicho sitio y que la devoción cristiana vaya siempre en mayor aumento aseo y adorno de dicho colateral que es el fin que siempre he tenido y no otro alguno es mi voluntad de que si algún bienhechor hiciere alguna dotación memoria o fundare capellanía en dicho altar de Nuestra Señora del Consuelo desde luego le mando dicho altar hechura de Nuestra Señora retablo que esta dorado y pintado con el niño Jesús de Pasión recostado en una cama todo hecho con gran primor y vidrieras cristalinas que Nuestra Señora tiene y el niño según y cómo al presente todo ello está para él sus herederos y pueda poner en él sus armas y letrero que le pareciere de poner como de cosa suya propia y mediante haber hecho todo ello a mi costa pido y suplico al Ilustrísimo obispo su discreto provisor o visitador y fábrica de dicha iglesia le de licencia para todo ello sin poner estorbo alguno y yo se lo mando a dicho bienhechor sin ninguna costa ni gravamen alguno si no es solo de que los poseedores me tengan en su memoria para encomendarme darme a Dios y prohíbo a dicho bienhechor y a sus sucesores que no puedan quitarle ni promoverle a otra ninguna parte ni sacar cosa alguna de él fuera de dicha iglesia con ningún pretexto porque si lo hiciere o intentare en este caso quede todo ello propio de dicha fábrica.

Ítem declaro que por causa de la caída de dicha torre vino ruina a la capilla y hechura de Nuestra Señora del Descendimiento de la cruz retablo y altar que es propio del mayorazgo que goza el Señor Conde de Alba Real en la cual a mi costa hice y coloqué la efigie de San Pedro apóstol mi padre y puse el retablo que al presente tiene y el lienzo de Nuestra Señora del Descendimiento de la Cruz que está encima de dicho San Pedro todo lo cual por ser adorno para dicha Iglesia hice de mi voluntad y devoción y lo mando a dicho señor Conde y a sus sucesores perpetuamente con calidad y condición de que no lo puedan sacar ni quitar de dicho sitio con ningún pretexto antes bien les pido y suplico le adornen de todo lo demás que puedan y fuere su voluntad y si lo intentaren y quisieren sacar de dicho sitio en este caso lo mando todo ello a dicha fábrica para que le pongan y coloquen en otra cualquier parte de dicha iglesia y pido y suplico a dichos señores me encomienden a Dios.

Ítem declaro que como uno de los devotos de Nuestro Señor San Pedro Regalado asistí a la fábrica de su capilla y camarín retablo y colocación que está en dicha iglesia y solicité se formase como con efecto se formó congregación de diferentes parroquianos y devotos de donde soy congregante y por ser corto el número para que se aumentase la devoción solicité se uniese dicha congregación con la de Nuestra Señora del Refugio que estaba sita en el Convento de la Santísima Trinidad Calzada de esta ciudad como con efecto al presente está unida e incorporada y por no haber en dicha capilla ni tener la efigie de dicha advocación del Refugio hice a mi costa y expensa una de talla al pie de la Cruz y la puse y coloqué encima de el sagrario del altar de dicha capilla de San Pedro Regalado donde al presente esta cuya hechura e imagen mando a dicha cofradía de San Pedro Regalado y Nuestra Señora del Refugio sin que la puedan quitar ni promover de dicho sitio y capilla u otra ninguna parte con ningún pretexto y si lo que Dios no quiera ni permita dicha cofradía de Nuestra Señora desuniere y separase de la de San Pedro 
Regalado en este caso quede dicha imagen en dicha capilla y la mando a dicha cofradía de San Pedro Regalado y pido y suplico a todos sus congregantes y cofrades me encomienden a Dios.

Ítem declaro que a mi solicitud y cuidado y deseando el mayor culto de Dios nuestro señor aseo y adorno de su iglesia y que los pobres se enterrasen en parte decente se hizo el cementerio se embaldoso y entarimo la iglesia y capilla mayor se hicieron los dos canceles y las paneras que están encima del coro para encerrar los granos de la fábrica quedando con gran dolor y sentimiento de no haberse conseguido la fábrica de la sacristía y vivienda para los señores curas tan necesario como es en dicha iglesia aunque se han hecho muchas diligencias como todo se está reconociendo y en remuneración a este corto trabajo y haber asistido con toda vigilancia y actividad a los parroquianos a quienes pido y suplico muy rendidamente me perdonen mis muchos defectos estando ciertos que los que han sido no ha sido por falta de voluntad que esta ha sido muy grande y que me tengan presente en sus oraciones para encomendarme a Dios de quien espero lo harán que de Nuestro Señor tendrán el premio.

Ítem mando a María Álvarez mi criada si estuviere en mi casa al tiempo de mi fallecimiento cien reales de vellón por una vez y una cama de ropa doble como es un jergón, dos colchones, dos sabanas, dos almohadas con su lana una manta y un cobertor azul todo de lo que yo dejare y que eligieren mis testamentarios se la pague el salario que la debiere que constara para asientos de mi libro la pido me encomiende a Dios.

Y para cumplir y pagarme éste mi testamento mandas y legados en el contenido dejo y nombro por mis testamentarios y albaceas a don Francisco Muñoz capellán de la Congregación de Nuestro Padre San Felipe de esta ciudad don Juan de los Ríos Enríquez don Manuel de Estada beneficiados que al presente son de dicha iglesia y a los demás que en adelante lo fueren y al cura ecónomo den propiedad que por mi fallecimiento me sucedieren y don Francisco Joseph de la Vega Colmenares vecino y regidor perpetuo de esta dicha ciudad a los cuales y a cada uno in solidum les doy poder cumplido para que entren en mis bienes y los vendan y rematen en pública almoneda o fuera de ella y con su valor cumplan y paguen este mi testamento y cumplido y pagado el remanente que quedase de todos mis bienes muebles y raíces derechos y acciones que en cualquier manera me pertenezcan es mi voluntad que el dicho don Francisco Muñoz por si solo lo gaste y distribuya en lo que con el susodicho tengo comunicado y si muriere antes que yo lo gaste y distribuya la persona que al pie del traslado de este mi testamento señalare con quien lo dejare comunicado sin que a uno ni a otro por ningún fuese ni justicia eclesiástica ni seglar se entrometa con ningún pretexto a pedirles cuentas por que en este caso se lo manda a los susodichos a quienes nombre por mis herederos.

Y por la presente revoco y anulo todos y cualesquiera testamentos codicilos poderes para testar y otras disposiciones que haya hecho por escritos y de palabras o en otra forma que quiere no valga en juicio ni fuera de él salvo este mi testamento que al presente hago y otorgo que quiero valga por mi última y postrimera voluntad por aquella vía y forma que mejor haya lugar en derecho en firmeza de lo cual lo otorgue así ante el presente escribano de la ciudad de Valladolid a diez y nueve de julio de mil setecientos y diecisiete años siendo testigos Simón Halaguero, Jerónimo González, don Gabriel Pérez, Antonio Díez y Luis de Medina vecinos de esta ciudad y el otorgante que yo el escribano doy fe conozco lo firmo. 


\section{DOCUMENTO 89}

\section{OBLIGACIÓN. LA FÁBRICA DE LA PARROQUIAL DEL SALVADOR Y COFRADÍA DE SAN PEDRO REGALADO (30 - JUNIO - 1726)}

A.H.P.V., Leg. 3.335, ff. 337-341

En la ciudad Valladolid a treinta de junio de mil setecientos y veinte y seis años estando en la sala de cabildo de la Cofradía de Ánimas de la iglesia parroquial del Salvador de ella ante mí el escribano y testigos parecieron don Sebastián González Ochoa cura propio de dicha iglesia parroquial, Miguel Martínez mayordomo de fábrica, Joseph González Ochoa escribano de este número, Manuel Asensio Manso y Juan Hernández parroquianos de dicha parroquia por sí mismos y en nombre de dicha fábrica y en virtud de la comisión que para lo que aquí se dirá se les dio en la junta que celebró el día veinte y seis de diciembre del año próximo pasado de veinte y cinco que irá aquí inserta; de la una parte, y de la otra los alcaldes y cofrades de la de Nuestra Señora del Refugio y San Pedro Regalado sita en dicha iglesia parroquial estando juntos habiendo sido llamados por su llamador según lo tienen de costumbre de juntarse a conferir las cosas tocantes a su mayor utilidad estando especialmente Manuel de la Bastida, Manuel Crespo alcaldes, Pedro de Ribas depositario, Santiago Mancio escribano de los hechos, Manuel Villegas diputado (...) todos cofrades de dicha cofradía que confesaron ser la mayor parte de los que en ella hay y por los demás (...) ambas partes dijeron que por memorial presentado por dicha cofradía a la referida parroquia en la Junta General que celebró el día veinte y seis de diciembre del año próximo pasado haciendo insinuación del gran deseo que tiene, mayor culto y veneración de San Pedro Regalado y decencia de su capilla y por no tener en ella comodidad bastante para la asistencia de dicha cofradía a las funciones que en ella celebra por lo cual pidió a dicha parroquia licencia para hacer un nuevo camarín en el sitio que con la nueva obra de la sacristía ha quedado junto al camarín que al presente tiene dicha capilla quedado este unido a ella para que todo sea capilla alargando para este fin dicho sitio; y por acuerdo de dicho día se cometió la determinación de dicha petición a dichos comisarios para que no resultando ningún perjuicio ni inconveniente así a la capilla y camarín de dicho santo como a la nueva sacristía ni a sus luces; hiciesen dicho alargo y concediesen a dicha cofradía la licencia que pedían para la fábrica del nuevo camarín; y deseando dichos comisarios que por dicha obra no se siguiese ningún perjuicio a dicha capilla y sacristía acordaron que Matías Machuca maestro de obras vecino de esta ciudad declararse el que se podía seguir; y habiéndolo reconocido por la que hizo en veinte y seis de abril de este año resulta no seguirse ningún perjuicio antes bien de grande utilidad y conveniencia por las razones que en dicha declaración expresa y con vista de ella por dichos comisarios en nombre de dicha parroquia y en virtud de dicha comisión hicieron dicho alargo del expresado sitio y concedieron a dicha cofradía licencia para la fábrica de dicho camarín cumpliendo con lo que previene dicho Matías Machuca por su declaración y habiéndose presentado uno y otro ante el señor provisor de este obispado pidiendo la aprobación de dichos acuerdos y licencia para otorgar escritura sobre lo referido y por auto de veinte y cinco de este mes se mandó así como consta de dicho memorial acuerdos y declaración que su tenor es como se sigue:

Aquí entra 
Concuerda con su original de que yo el escribano doy fe y de ello usando de dichos comisarios en nombre de dicha parroquia y fábrica y en virtud de su acuerdo aquí inserto por la presente y en aquella vía y forma que mejor haya lugar en derecho dan y conceden licencia en forma a dicha cofradía para que en dicho sitio fabriquen dicho camarín a sus expensas para lo cual alargan el referido sitio y de él hacen a su favor en dicho nombre gracia y donación con el juramento y demás requisitos prevenidos por derecho para su validación y desisten y apartan a dicha fábrica del derecho que a él tienen.

Que dicha cofradía se obliga con sus bienes y rentas y limosnas que para este fin han ofrecido diferentes personas de la devoción de dicho santo hacer en dicho sitio el referido camarín con el mayor lucimiento que pueda dar de sí arreglándose en dicha nueva fábrica a lo prevenido en la declaración hecha por dicho Matías Machuca; y asimismo se obligan de que por dicha obra no se originara ningún perjuicio y daño así a dicha sacristía, capilla y camarín que al presente tiene dicho santo y caso que por algún accidente sucediese algún riesgo y daño acudirán a él con toda puntualidad hasta que quede con toda seguridad y sin esperanzas de ningún daño en adelante; y de tener perpetuamente bien reparada dicha capilla y camarín que al presente tiene y el que nuevamente han de hacer así de los retejos como de los demás reparos que para su conservación se necesitaren hacer a todo lo cual se pueda apremiar a dicha cofradía por todo rigor de derecho.

Todo lo cual ambas partes respective obligan los bienes y rentas de dicha fábrica y cofradía de guardar y cumplir lo contenido en esta escritura inviolablemente y de no reclamar ni ir contra ella por ninguna razón; y para su ejecución dan poder a las justicias que de sus causas deban conocer conforme a derecho y a cada uno in solidum recibieronlo por sentencia pasada en cosa juzgada (...) en firmeza de lo cual lo otorgaron así ante mí el escribano siendo testigos Jerónimo González sacristán de dicha iglesia, Pedro Ballesteros llamador de dicha cofradía y Ramón de Matesanz vecinos de esta ciudad y los otorgantes que yo el escribano doy fe conozco lo firmaron los que supieron y por los que no un testigo.

\section{Señor}

La cofradía de Nuestra Señora del Refugio y San Pedro Regalado sita en esta iglesia, dice que deseando la mayor decencia, culto y veneración del santo y de la dicha iglesia reconociendo lo estrecho que se halla; su capilla y no tener en ella comodidad para con toda solemnidad celebrar sus funciones; tiene acordado hacer un nuevo camarín en el sitio y rincón que ha quedado con la nueva fábrica de la sacristía quedando el camarín presente en la conformidad que se halla unido con la capilla y en una pieza colocando el altar del santo en medio del arco toral que se ha de hacer con dicha fábrica en el sitio en que al presente se halla el del Santo Ecce Homo, y porque en esta obra no se puede seguir ningún perjuicio a dicha iglesia capilla y sacristía ni a las luces antes bien de mucho adorno y seguridad de dicha sacristía, y hallándose esta parroquia interesada igualmente con dicha cofradía al mayor culto y veneración del santo como su hijo:

Suplican a esta Junta de parroquia se sirva dignarse de conceder su beneplácito y licencia para hacer dicho camarín alargando para este fin dicho sitio espera de su protección el bien éxito y despacho de esta súplica de quien recibirá merced.

Acuerdo 
El expediente de este memorial se comete a los señores don Sebastián Ochoa cura de esta iglesia, don Joseph González Ochoa, Miguel Martínez mayordomo electo, Manuel Asensio Manso mayordomo actual, Juan Hernández, y al presente secretario para que no resultando ningún inconveniente ni perjuicio así a la sacristía nueva, capilla del santo y sus luces hagan el alargo del sitio que contiene este memorial y se conceda la licencia que piden para la nueva fábrica que intentan hacer del camarín; y siendo necesario sobre ello hagan con dicha cofradía las escrituras necesarias que para todo se les da comisión en forma; así lo acordaron la Junta de parroquia del Salvador de esta ciudad en la general que celebraron hoy 26 de diciembre de 1725.

En la ciudad de Valladolid a diez y ocho de marzo de setecientos y veinte y seis años los señores Sebastián Ochoa cura, Miguel Martínez mayordomo de fábrica, Joseph González Ochoa, Juan Hernández y Manuel Asensio Manso diputados nombrados por dicha fábrica para la determinación del memorial de esta otra parte estando juntos en la sacristía de esta iglesia del Salvador para conferir sobre lo contenido en dicho memorial dijeron que para mejor determinar sobre él Matías Machuca maestro de obras y alarife de esta ciudad reconozca si de hacerse la obra que se expresa podrá resultar algún perjuicio así a la nueva sacristía, iglesia, capilla del santo Regalado, luces y cimientos y sobre haga declaración la que sea a expensas de dicha cofradía y hecha se traiga para determinar sobre ello así lo acordaron y lo firmé como secretario de la parroquia.

\section{Fdo: Luis de Medina Mieses}

Acuerdo y licencia

Mediante constar por la declaración de Matías Machuca no seguirse ningún perjuicio en el camarín que se intenta hacer y arreglándose la cofradía a las circunstancias prevenidas en dicha declaración y quedando a cargo y obligación de dicha cofradía cualquier daño y perjuicio que se pueda seguir por dicha obra; se concede a dicha cofradía la licencia que pide y como tales comisarios de dicha parroquia en su nombre hacen alargo del sitio que en dicho memorial se expresa para dicho fin; y su súplica al señor provisor apruebe este acuerdo y de su licencia así lo acordaron dichos señores comisaros en la Junta celebrada hoy diez y seis de junio de mil setecientos y veinte y seis años.

Fdo: Luis de Medina Mieses

En la ciudad de Valladolid a veinte y cinco días del mes de junio de mil setecientos veinte y seis el señor doctor don Cayetano Gaspar de Landa del gremio y claustro de la Real Universidad provisor y vicario general en ella y su obispado habiendo visto el memorial antecedente y declaración antecedente hecha por Matías Machuca y acuerdo de los comisarios nombrados por la fábrica de la iglesia del Salvador de esta dicha ciudad, y por ante mí el notario de asiento dijo aprobada y aprobó dicho acuerdo y daba y dio licencia a la cofradía y cofrades de Nuestra Señora del Refugio y San Pedro Regalado sita en dicha iglesia del Salvador para que en la conformidad que expresan en su memorial que dieron a la fábrica de dicha iglesia y por esta se les permitió puedan ejecutar la obra de la capilla que en dicho memorial y demás acuerdos 
hechos en dicha razón se contiene obligándose en conformidad que en él se expresan y sobre ello puedan otorgar las escrituras necesarias que haciéndolo entre la dicha cofradía y los comisarios nombrados por dicha fábrica desde ahora para entonces y desde entonces por ahora siendo por ante escribano público que de fe su merced interponía e interpuso a ellas su autoridad y decreto judicial y ordinario para que valgan y hagan fe en juicio y fuera de él donde fueren presentadas y por este auto de licencia que su merced firmó así lo proveyó y mandó.

Dr. D. Cayetano Gaspar de Landa

Ante mí: Antonio López Ramírez

Declaración de Matías Machuca maestro de obras y alarife de esta ciudad de Valladolid, quien habiendo sido nombrado por los señores de la fábrica de la iglesia parroquial del Salvador de esta dicha ciudad, para el efecto de ver y reconocer el sitio que pretende la cofradía de los que mueren sin confesión para alargar la capilla de San Pedro Regalado y por dichos señores de la fábrica se me encargó viese y reconociese si por dicha fábrica de capilla se podía seguir intervención a las luces y aguas de la sacristía de dicha iglesia y habiéndolo visto y reconocido todo ello muy por menor declaro no se sigue perjuicio alguno por la fábrica de dicha capilla, antes bien mucha utilidad por hallarse dicho sitio en un rincón solobrigo a donde cae la mayor parte de las aguas de sacristía e iglesia cuyo motivo es de repasarse todas las paredes de ella como se reconoce a donde está la lacena y por lo que mira a la luz de la ventana que mira a dicho rincón antes bien con dicha fábrica de capilla se la puede dar más luz de lo que tiene ejecutando una ventana mayor que ella enfrente y el motivo que doy para que pueda tener más luz es por hallarse dicha ventana por rincón en paraje triste a donde no la alcanza el sol, y la ventana que se ha de hacer enfrente la baña el sol la mayor parte del día y con los reflejos de él y la blancura de dicha capilla puede tener más luz que la que hoy tiene dicha sacristía y por lo que toca a la conducción de aguas de los tejados no hay embarazo alguno con una lima tesa y otra lima hoya, antes bien con esta obra se puede quitar parte de aguas que caen al corralillo las que sirven de gran perjuicio a los cajones de dicha sacristía y todo lo referido declaro según Dios nuestro señor me ha dado a entender en el arte que profeso y lo firmé en Valladolid a veinte y seis de abril de mil setecientos y veinte y seis años

Fdo: Matías Machuca 


\title{
DOCUMENTO 90
}

\section{CARTA DE PAGO DE LA DOTE DE MARÍA MARTÍNEZ AL TIEMPO QUE SE CASÓ CON MANUEL DE ÁVILA (3 - OCTUBRE - 1721)}

\author{
A.H.P.V., Leg. 2.395, f. 795
}

En la ciudad de Valladolid a tres de octubre de mil setecientos y veinte y un años ante mí el escribano y testigos pareció Manuel de Ávila vecino de ella y dijo que al tiempo y cuando se hubo de casar con María Martínez hija legítima de Joseph Martínez platero y doña Andrea Cortés su mujer capitularon verbalmente de que la dicha María Martínez llevaría a poder del otorgante por bienes dotales suyos propios y por cuenta en lo que hubiere de haber de las legítimas de los dichos sus padres tres mil cuatrocientos y cincuenta reales en bienes y alhajas de por casa tasados por personas nombradas cada parte la suya y más los tendría en su casa y compañía cuatro años dándoles lo necesario para sus alimentos reputado cada año a trescientos y cincuenta reales empezando desde el día que tuviere efecto el matrimonio y el otorgante por ser la dicha María Martínez su mujer doncella honesta y recogida y de buena vida y costumbres y caso honroso del matrimonio la ofreció en arras proternúpcias cien ducados de vellón de cuya cantidad a mayor abundamiento por dichas razones la haré gracia y donación irrevocable con los requisitos necesarios y mediante ha tenido efecto el matrimonio y el dicho Joseph Martínez cumplió con dar dichos alimentos de dichos cuatro años y le dio y entregó los dichos tres mil cuatrocientos reales y cincuenta reales que le ofreció de dicha dote en diferentes bienes pide le otorgue carta de pago de todo ello y viendo es justo lo quieren hacer y poniéndolo en ejecución confiesa haber recibido de dicho Joseph Martínez su suegro los dichos cuatro mil ochocientos y cincuenta reales de vellón los un mil y cuatrocientos reales en dichos bienes y alhajas los cuales se han tasado por personas nombradas por cada parte la suya que son los siguientes:

Ropa blanca

- Primeramente seis sábanas de lienzo de Santiago las tres a cuarenta reales cada una y las otras tres a tres ducados cada una que importan doscientos y diez y nueve reales.

- Más dos colchas la una con encajes y la otra labrada sin ellos en cien reales.

- Más dos tablas de manteles de gusanillo a veinte y cuatro reales cada una.

- Más otra tabla de manteles de topa en diez reales.

- Dos paños de manos deshilados a doce reales cada uno.

- Diez y seis servilletas de gusanillo delgadas nuevas a cuatro reales y medio cada una importan setenta y dos reales.

- Cuatro almohadas de morles a siete reales y medio cada una hacen treinta reales.

- Cuatro almohadas de lienzo de Santiago a cinco reales y medio cada una.

- Otras cuatro almohadas de lienzo casero a cinco reales cada una.

- Dos colchones a cinco ducados cada uno hacen diez ducados.

- Un jergón de estopa en doce reales.

- Una manta en veinte y cuatro reales.

- Media roba de lana para las almohadas en trece reales.

Cobre 
- Un caldero grande de cobre en cuarenta reales.

- Un perol de cobre diez y ocho reales.

- Un cazo de azófar grande en seis reales.

- Otro cazo de cobre en cuatro reales.

- Dos sartenes la una grande y la otra pequeña ambas en cuatro reales.

- Dos cazos de azófar medianas en siete reales.

- Una chocolatera en seis reales.

- Un frasco de cobre en ocho reales.

- Una cazuela de cobre con mango en seis reales.

- Una parrilla de hierro seis reales.

- Dos asadores en tres reales.

- Una cobertera de hierro grande en tres reales.

- Un velón de latón en diez y ocho reales.

- Cuatro bujías ochavadas a seis reales cada una veinte y cuatro reales.

- Una calderilla de hierro dos reales.

- Un almirez treinta y tres reales.

- Un brasero de cobre de tres pies pequeño ocho reales.

- Una tabla de espetera en tres reales.

- Unos trébedes y vinos garabatos en seis reales.

Vestidos

- Una basquiña de lamparilla doble en cincuenta y cinco reales.

- Otra vieja en quince reales.

- Un guardapiés de sempiterna encarnado bordado en sesenta reales.

- Una anguarina de paño en noventa reales.

- Una anguarina de tafetán en cuarenta reales.

- Un delantal de tafetán con encajes en ocho reales.

- Una mantilla blanca con encajes en treinta y cuatro reales.

- Dos mantos uno nuevo y otro con dos camas nuevas en ciento y sesenta reales.

- Nueve varas de raso para el guardapiés a veinte y tres reales veinte y tres reales vellón importa.

- Cuatro varas y media de nobleza para anguarina en ciento y ocho reales.

- Seis varas de mitán encarnado a cinco reales vara treinta reales.

- Tres varas de mitán negro a cinco reales quince reales.

- Una vara de tafetán negro en seis reales.

- Nueve varas de pelo de camelo para una basquiña a doce reales y medio.

- De mitán jerguilla se da y de él contra ruedo para la basquiña.

- De la trencilla de plata para la anguarina treinta y cuatro reales.

- Dos varas de raso azul para una almilla en cuarenta y cuatro reales.

- Vara y media de mitán para forrar la almilla ocho reales.

Madera

- Seis taburetes de baqueta de Moscovia a doce reales cada uno.

- Un bufete de nogal en cincuenta reales.

- Un escritorio de nogal con su mesa y cajón en setenta reales. 
- Un Niño Jesús con escaparate y bufete de nogal en 300 reales.

- Los países con sus marcos negros en 48 reales.

- Una pintura de Nuestra Señora de Belén con su marco negro en 45 reales.

- Otra de San Pablo con marco negro en 36 reales.

- Seis cuadros con sus vidrieras y marcos en 36 reales.

- Otros cuatro cuadros más pequeños del mismo género en 20 reales.

- Dos relicarios con marcos dorados con vidrieras en 30 reales.

- Dos marcos embutidos en concha pequeños con sus estampas y vidrieras 15 reales.

- Un espejo con su marco negro en cincuenta reales.

- Dos cuadros del Nacimiento y de la Adoración en cuarenta reales ambos.

- Un dosel para la cama ocho reales y un cofre claveteado diez y ocho hacen (...)

- Un arca de pino con llaves en (...)

- Una pila de cobre para agua bendita (...)

- Una cama de haya y una bonquilla en (...)

Plata

- Cuatro cucharas de plata en sesenta reales y una caja en quince hacen (...)

- Una gargantilla de aljófar con su cruz noventa y una hebillas ocho hacen (...)

- Diez y ocho botones de plata treinta; y unos pendientes de aljófar sesenta.

- Cinco sortijas de oro ordinarias en ciento y veinte reales vellón.

- Más de botones y hechura de vestidos...

Que todo importa tres mil quinientos y veinte y doscientos y noventa y ocho reales de vellón de los cuales en dichas alhajas se da por entregado a su voluntad y porque su entrega no parece de presencia renunció las leyes de ello y demás de este caso da y otorga carta de pago en forma y se obliga de usar de dichos bienes como de dotales y de no obligarlos a sus deudas y causas y cada y cuando que el matrimonio fuere disuelto por cualquier accidente que el derecho permite volverá dicha dote con dicha dotación luego que lo otro suceda y lo otorgó así ante mí el escribano siendo testigos don Alonso de la Torre, don Manuel de Medina y Ramón de Matesanz vecinos de esta ciudad y el otorgante que doy fe conozco lo firmó. 


\title{
DOCUMENTO 91
}

\section{PODER PARA TESTAR. MANUEL DE ÁVILA ESCULTOR A D ${ }^{\mathrm{a}}$ MARÍA MARTÍNEZ SU MUJER (4 - SEPTIEMBRE - 1733)}

\author{
A.H.P.V., Leg. 3.432, f. $130(1733)^{27}$
}

En el nombre de Dios todopoderoso amen sépase por esta pública escritura de poder para testar como yo Manuel de Ávila maestro escultor vecino de esta ciudad de Valladolid estando enfermo en la cama de enfermedad corporal y Dios nuestro señor sea servido darme aunque en mi sano juicio y entendimiento natural creyendo como bien y fielmente creo en el misterio de la santísima trinidad padre hijo y espíritu santo tres personas distintas y un solo Dios verdadero y en todo lo demás que tiene cree y confiesa la santa madre iglesia católica romana debajo de cuya fe y creencia protesto vivir y morir. Digo que por cuanto la gravedad de mi enfermedad no me da lugar para hacer mi testamento con las declaraciones y disposiciones necesarias, y que estas las tengo comunicadas con $\mathrm{D}^{\mathrm{a}}$ María Martínez mi mujer; otorgo que la doy todo mi poder cumplido el necesario y que de derecho se requiere para que habiendo yo fallecido haga mi testamento y última voluntad en mi nombre con la disposición de entierro misas y demás que la tengo comunicado y tratado con que no se entienda a señalar sepultura y testamentarios y herederos que esto lo reservo en mí y mando que cuando la divina voluntad fuere servido llevarme de esta presente vida mi cuerpo sea sepultado en la parroquia de San Miguel donde soy parroquiano en la sepultura que pareciere a dicha mi mujer a quien nombro y a D. Pedro de Ávila mi hermano por mis testamentarios debajo de la cláusula de in solidum y poder cumplido para que mis bienes vendiéndolos y rematándolos en pública almoneda o fuera de ella de su valor cumplan y paguen lo contenido en este poder y el testamento que en su virtud se hiciese y les dure el tiempo necesario aunque sea pasado el año de mi fallecimiento que yo se les prorrogo. Y cumplido y pagado lo uno y lo otro en el remanente que quedare de todos mis bienes muebles y raíces derechos y acciones habidos y por haber dejo nombro e instituyo por mis únicos y universales herederos de todo ello a Clara, María y Manuel de Ávila mis hijos legítimos y de legítimo matrimonio habidos con la dicha María Martínez mi mujer para que lo harán y hereden con la bendición Dios y la mía en iguales partes y por hallarse menores desde luego valiéndome del derecho y por leyes de estos reinos me es concedido nombro por curadora de sus personas y bienes a la dicha $\mathrm{D}^{\mathrm{a}}$ María Martínez su madre a quien la relevo de toda fianza por la mucha satisfacción que de ella y su cristiandad tengo y pido y suplico a todos los señores jueces y justicias donde ocurriere a pedir el discernimiento se le conceda sin ella. Y por el presente revoco anulo y doy por ninguno cualquier testamento o testamentos, poderes para testar codicilos y demás disposiciones que antes de ahora haya hecho por ser de palabra o en otra cualquier forma que quiero no valgan ni hagan fe en juicio ni fuera de él salvo lo aquí contenido y contuviere el testamento (...) y así lo otorgo ante el presente escribano en la ciudad de Valladolid a cuatro días del mes de septiembre de mil setecientos y treinta y tres años siendo testigos llamados y rogados Manuel Rodríguez Alonso Carnicero y Gregorio Lino estantes y vecinos de ella y el otorgante a quien yo el escribano doy fe conozco lo firmo.

27 ALBARRÁN MARTÍN, Virginia: El escultor Alejandro Carnicero entre Valladolid y la Corte (1693-1756), Diputación de Valladolid, Valladolid, 2012, p. 56. 


\section{DOCUMENTO 92}

\section{PODER A TOMÁS DE SIERRA A SU HIJO FRANCISCO DE SIERRA (1 - JULIO - 1715)}

A.H.P.V., Leg. 9.459, ff. 299-30028

Sépase como yo Tomás de Sierra vecino de esta ciudad de Medina de Rioseco digo que habiéndose resuelto la obra y fábrica de un retablo para la iglesia parroquial de la villa de Fuentes de Valdepero ha corrido y corre su ejecución a cargo de Alonso Manzano arquitecto y por lo que mira a la escultura para el mismo retablo está el susodicho la ajusto con mi el otorgante quedando a mi cuidado el hacerla y en la cantidad de seis mil y setecientos reales en la conformidad y como quedo pactado y siendo esto así y estando de mi parte llano a su cumplimiento mediante dicho ajuste y a que recíprocamente es obligado dicho Alonso Manzano parece que sin motivo justo se retira del debido cumplimiento del referido ajuste en que se haya constituido respecto de lo cual otorgo que doy todo mi poder cumplido el necesario y que de derecho se requiere a don Francisco de Sierra mi hijo presbítero vecino de esta ciudad con cláusula de que le pueda sustituir en todo o en parte especialmente para que en mi nombre judicial o extrajudicialmente reconvenga al dicho Alonso Manzano y al cura mayordomo de dicha iglesia fiadores y a otras cualesquiera personas de cuya incumbencia ha sido y fuere a que en un todo se me cumpla dicho contrato y ajuste que por lo que me toca estoy pronto a observar y guardar y lo pactado y si sobre lo referido fuere necesario parecer en juicio lo haga ante cualesquier justicias eclesiásticas o seculares donde convenga y presente peticiones y ejecute todos los demás autos y diligencias judiciales y extrajudiciales y lo mismo que yo el otorgante pudiera hacer alegue responda tache y contradiga pida termino haga probanzas presente las cartas misivas que califican mi arreglada pretensión y otros cualesquier recaudos concluya y pida sentencias y autos consiéntalo en mi favor y de lo en contrario apele o suplique y siga las apelaciones hasta que o que intentare tenga cumplido efecto y asimismo doy este poder a dicho mi hijo para que en dicho mi nombre conseguida mi justa pretensión pueda otorgar y otorgue a favor del dicho Alonso Manzano y de la parte de dicha iglesia y de otros cualesquier interesados escritura en toda forma obligándome con mi persona y bienes muebles y raíces habidos y por haber a la obra y fábrica de la escultura de dicho retablo por la cantidad de maravedís en que como va expresado sea justo y a que prontamente cumplirá lo que es y fuere de mi cargo según y cómo está pactado cuya escritura en dicho mi nombre haga y otorgue con todas las clausulas fuerzas y firmezas que le fueren pedidas o que convengan para la mayor validación y consistencia que siendo hecha por el dicho mi hijo o sus sustitutos desde luego para cuando llegue el caso la apruebo y ratifico y todo lo que hiciere o nuevamente asentase y condicionare y para haya reciba y cobre cualesquier cantidades de maravedís que debo haber y percibir por dicha obra (...) y así lo otorgo ante el presente escribano y testigos en la ciudad de Medina de Rioseco a primero día del mes de julio de mil setecientos y quince años siendo testigos Juan Antonio Blanco, Antonio Gutiérrez y Juan Vázquez vecinos de esta ciudad y lo firmó el otorgante a quien yo el escribano doy fe conozco.

28 GARCÍA ABAD, ALBANO: Fuentes de Valdepero: Inventario documentado de la Iglesia de Nuestra Señora de la Antigua, León, 1998. 


\title{
DOCUMENTO 93
}

\section{PLEITO ENTRE MANUEL DE ÁVILA Y EL CURA DE VALDEPERO POR IMPAGO DE 2.600 REALES (15 - MARZO - 1724)}

\begin{abstract}
A.H.P.P., Leg. 7.431, ff. 629- $643^{29}$
Pablo Abad en nombre de los mayordomos eclesiástico y seglar de la iglesia parroquial de la villa de Fuentes de Valdepero como haya lugar ante su majestad pareció y digo que habiéndose ajustado la escultura para el retablo de la capilla mayor de dicha iglesia con Manuel de Ávila vecino y escultor de la ciudad de Valladolid en seiscientos ducados de vellón debiendo de resto dos mil y seiscientos reales e intenta ejecutar a la fábrica por ellos sin tener con que dar satisfacción y para excusar las costas y salarios que se la pueden causare respecto dicha fábrica tiene contra sus bienes y rentas un censo de ochocientos ducados a favor de la obra pía y cofradía de los veinte de la villa de Carrión cuya redención y rédito anuales es de ésta obligación de conducirlos a costa de la fábrica a dicha villa, y por ser a razón de a tres por ciento y la injuria de los tiempos, de haber venido a disminución las rentas, no obran maravedíes en los mayordomos atendiendo a la utilidad de dicha fábrica han hecho diligencias y con efecto han logrado quien de mil ducados a censo a dos maravedíes por ciento su redención y réditos anuales en esta ciudad con que el tomarle y redimir el de dicha cofradía de los veinte y con el residuo pagar al escultor exigirse utilidad y no se malvendan los granos y vino con que se haya dicha fábrica de que ofrezco información. A su majestad suplico la mande recibir y para ella dé su comisión a cualquiera de los eclesiásticos de dicha villa pido justicia.
\end{abstract}

15 de marzo de 1724

Fdo: Abad

Nos el licenciado Don Manuel González Benito canónigo en la Santa Iglesia Catedral de esta ciudad provisor y vicario general en ella y su obispado por el Ilustrísimo Señor Don Francisco Ochoa Mendarozqueta obispo de dicho obispado conde de Pernía del Consejo de su Majestad. Por la presente damos comisión con facultad de citar excomulgar y absolver a cualquiera de los eclesiásticos de esta ciudad de Fuentes de Valdepero que requerido con ella por parte de los mayordomos eclesiástico y seglar de la parroquia de dicha villa la acepte y aceptada por ante notario o quien que presente sea: reciban información de los testigos porque los susodichos presentaron y les examinen a tenor de lo contenido en la petición de esta otra parte habiéndoles precedido juramento las preguntas y repreguntas que contengan para que den razón de la utilidad que la sigue en tomar el censo que menciona y hecha se la entreguen Palencia y Marzo quince de setecientos y veinte y cuatro años.

Fdo: Licenciado Benito

29 GARCÍA ABAD, ALBANO: Fuentes de Valdepero: Inventario documentado de la Iglesia de Nuestra Señora de la Antigua, León, 1998. 
Requerimiento

En la villa de Fuentes de Valdepero a dos días del mes de abril de mil setecientos y veinte y cuatro yo el infrascrito escribano requerí con el despacho y comisión despachado por su majestad el señor provisor y vicario general de este obispado a Don Lázaro García cura y beneficiado de preste en la iglesia parroquial de esta dicha villa por quien visto y entendido le obedeció con el respeto debido y que esta puesto cumplir con lo que en él se expresa y lo firmó y firmé yo el escribano de lo cual doy fe.

Auto

En la villa de Fuentes de Valdepero a dos días del mes de abril año de mil setecientos y veinte y cuatro el señor Don Lázaro García cura y beneficiado en la parroquial de esta dicha villa quien esta requerido con el despacho y comisión que está por cabeza y dado a él su aceptación por ante mí el escribano dijo que requiera a Don Joseph de Gatón cura y beneficiado en la iglesia de esta dicha villa mayordomo eclesiástico y a Ignacio de la Torre mayordomo secular presenten los testigos para hacerle información que tienen ofrecida en su pedimento que está presto dicho señor juez recíbela y en su visita proveer lo que convenga y por este auto que firmo lo mando y firmé yo el escribano doy fe.

Fdo: D. Lázaro García

Fdo: Francisco de la Torre

Requerimiento

En la dicha villa a los dichos dos días del mes de abril año de mil setecientos y veinte y cuatro yo el escribano cumpliendo con lo mandado por el auto antes pase a las cosas de Don Joseph de Gatón mayordomo eclesiástico y a la de Ignacio de la Torre mayordomo seglar de la fábrica de la iglesia parroquial de esta dicha villa y les requerí presenten los testigos para la información que ofrecen que esta dicho señor juez presto a recibirla y tomarles el juramento que se requiere y lo firmé para que conste.

Fdo: Francisco de la Torre

Información

En la villa de Fuentes de Valdepero a tres días del mes de abril año de mil setecientos y veinte y cuatro Don Joseph de Gatón e Ignacio de la Torre mayordomos eclesiástico y seglar de la Iglesia Parroquial de Santa María de la Antigua de esta dicha villa para la información que ofrecida tienen en el pedimento que esta por cabeza presentara por testigo ante el señor D. Lázaro García cura y beneficiado de preste en dicha iglesia juez de comisión. Por ante mí el escribano Joseph Gatón vecino de esta dicha villa de quien dicho Sr. juez recibió juramento y le hizo por Dios y a una cruz bien y cumplidamente prometiendo debajo de él decir verdad que supiere sobre lo que se le preguntare y siéndole ley del pedimento y demás escrito que va por cabeza entendido dijo que lo que sabe y puede decir que se ajustó la escultura para el retablo de la capilla mayor de la Iglesia de esta villa con Manuel de Ávila vecino de la ciudad de Valladolid en seis mil y seiscientos reales de vellón y que sabe el testigo se le deben de resta al 
susodicho dos mil reales y seiscientos más y ha oído decir intenta ejecutar a la fábrica por dicha cantidad y sabe este testigo no tiene dicha fábrica por ahora con que dar satisfacción y que para excusar los salarios y costas que se pueden causar y para evitar respecto la dicha fábrica tiene contra sus propios y rentas un censo del principal de ochocientos ducados a favor de la obra pía y cofradía de los veinte de la villa de Carrión este testigo sabe que la redención y réditos anuales es de la obligación de conducirlos a costa de la fábrica a la dicha villa y sabe asimismo está a razón de tres reales por ciento y que por la injuria de los tiempos y haber habido disminución en las ventas no obran maravedíes en los mayordomos y que sabe este testigo que mirando a la utilidad de la dicha fábrica se han hecho diversas diligencias y se ha logrado quien dará mil ducados a censo a razón de dos reales y medio por ciento y su redención y réditos anuales en la ciudad de Palencia con que tomándole y redimir el que tiene dicha fábrica de la dicha cofradía de los veinte y con el sobrante dar satisfacción al escultor exigirse utilidad a la dicha fábrica y de esta suerte no se malvenderán los granos y vino con que se halla esto que a dicho es la verdad y que es notorio en lo cual se afirma y afirmo y ratificó y lo firmo dijo ser de edad de sesenta y dos años poco más o menos fírmolo dicho señor juez de lo cual yo el escribano doy fe y firmé.

Fdo: Joseph de Gatón $\quad$ Fdo: D. Lázaro García $\quad$ Fdo: Francisco de la Torre

En la dicha villa el dicho día mes y año dichos los dichos D. Joseph de Gatón cura y beneficiado en la iglesia de esta dicha villa y mayordomo eclesiástico e Ignacio de la Torre asimismo mayordomo secular para la información que tienen ofrecida en su pedimento presentaron ante el señor D. Lázaro García juez de comisión por quien está aceptada por ante mí el escribano por testigo a Matías Pérez mayor en días vecino de esta dicha villa de quien recibió juramento como se requiere y hechole por Dios nuestro señor y a dicha cruz bien y cumplidamente prometiendo so cargo del decir la verdad de lo que le fuere preguntado y supiere y habiéndole hecho notorio y leído la petición y despecho que va por cabeza de esta información habiéndola entendido dijo que lo que puede decir es que se ajustó la escultura de los santos que se han de poner en el altar mayor de la iglesia de esta villa con un vecino de Valladolid que ha oído se llama Manuel de Ávila en seiscientos ducados de vellón y sabe se le están debiendo dos mil y seiscientos reales y un testigo ha oído intenta ejecutar a la fábrica por ellos y saben o puede dar satisfacción y que para excusar crecidos salarios y costas que pueden seguir respecto sabe el testigo que dicha fábrica tiene contra sus bienes y rentas dicha escritura y en mil de ochocientos ducados a favor de la cofradía y obra pía de los veinte de la villa de Carrión cuya redención y réditos anuales sabe el testigo es de la obligación de la dicha fábrica conducirlos a su costa y riesgo a dicha villa el cual dicho censo esta a razón de tres reales por ciento y sabe asimismo que por los tiempos haber venido a mucha disminución las rentas de la dicha fábrica tiene por ciento no habrán maravedís en los mayordomos que al presente son y asimismo sabe este testigo que atendiendo a la utilidad de dicha fábrica dichos mayordomos han hecho exactas y diversas diligencias y logrado quien de mil ducados a censo a razón de dos reales y medio por ciento y que su redención y réditos anuales se ha de ejecutar en la ciudad de Palencia con que sabe el testigo será útil tomar y redimir el censo de la dicha cofradía de los veinte de la dicha villa de Carrión y con lo sobrante dar satisfacción al escultor los maravedíes dichos que se le deben y que no se malvendan los granos y vino que al presente tiene dicha fábrica de que conoce este testigo será de útil y provecho como dicho lleva esto dijo ser la verdad en lo que se le ha preguntado y para el juramento que se le recibió en lo cual se ha firmado y ratificó y no lo firmó por no saber dijo ser de edad de cincuenta y tres años poco más o menos fírmolo dicho señor juez de lo cual yo el escribano doy fe. 
En la dicha villa el dicho día tres de abril año dicho de mil y setecientos y veinte y cuatro los dichos mayordomos eclesiástico y seglar presentaron por testigos para su información ante el dicho señor juez por ante mí el escribano Miguel de la Torre vecino de esta dicha villa de quien habiendo dicho señor juez recibido juramento y hecho por él sobre dicho Dios y a una cruz en toda forma prometiendo so cargo del decir la verdad de lo que le fuere preguntado y siéndole por el tenor y forma de la petición y despacho que se le leyó a la lectura habiéndole entendido dijo este testigo que sabe muy bien se ajustó la escultura para poner en el retablo que se hizo en la capilla mayor de la iglesia de esta villa con un escultor que es Manuel de Ávila vecino de la ciudad de Valladolid en el precio de seiscientos ducados de vellón a quien sabe este testigo se le deben de resto dos mil y seiscientos reales y sabe por ciento quiere pasar a ejecutar por ellos a la fábrica y no tiene ni se halla con que dar satisfacción y que se la causaran muchas costas y salarios y para evitarlos sabe este testigo como la dicha fábrica tiene contra sus bienes raíces y propios una escritura censual de ochocientos ducados de principal a favor de la Cofradía y Obra Pía de los Veinte de la Villa de Carrión cuya redención y réditos anuales está obligada dicha fábrica ponerles y redimir en la dicha villa, y sabe está fundado a razón de tres reales por ciento y por haber venido a disminución las rentas sabe este testigo no obran maravedíes en dichos mayordomos y habiendo atendido a la utilidad de dicha fábrica sabe este testigo han hecho diversas diligencias como un efecto hacer logrado personas que de mil ducados a censo a dicha fábrica a razón de dos reales y medio por ciento y la redención y paga de los réditos en cada una no sea de redimir y pagar en la ciudad de Palencia con que retomarle y redimir el de la dicha cofradía de los veinte será utilidad para dicha fábrica y de esta suerte los granos y vino con que se halla no les mal vendiera y redimido con el residuo pagar y dar satisfacción al escultor y en todo sabe es útil y conocido esto dijo ser la verdad para el juramento hecho en lo cual se firmó y ratificó y lo firmó dijo ser de edad de cuarenta y cuatro años poco más o menos firmo dicho señor juez de lo cual doy fe.

Fdo: D. Lázaro García $\quad$ Fdo: Miguel de la Torre $\quad$ Fdo: Francisco de la Torre

\section{Auto}

En la villa de Fuentes de Valdepero a tres días del mes de abril año de mil setecientos y veinte y cuatro el señor don Lázaro García cura y beneficiado de preste en la iglesia parroquial de esta dicha villa juez de comisión para los efectos que hace mención el pedimiento y despacho que está por cabeza por ante mí el escribano dijo que los testigos que llevan dispuesto en la información presentados por los mayordomos así eclesiástico como seglar son personas de todo buen celo y quienes han ¿regentado? En esta villa diversas veces los oficios honoríficos a quienes en sus dichos y deposiciones siempre se les ha dado y da en entera fe veredicto en juicio y fuera de él. Y asimismo mandaba y mando que el presente escribano entregue dicha información y demás escrito original a los dichos mayordomos para que la presenten ante su majestad el señor provisor para que con su visita provea lo que convenga y preste auto que provee y yo lo firmo y firmé doy fe.

Fdo: D. Lázaro García

Fdo: Francisco de la Torre 
Yo Francisco de la Torre escribano del número y ayuntamiento de esta ciudad de Fuentes de Valdepero presente fui a lo que de mi va hecha mención con el señor Juez de comisión y testigos y para que conste lo signo y firmo en dicha villa a tres días del mes de abril año de mil setecientos y veinte y cuatro en seis fechas con esta.

Fdo: Francisco de la Torre

Presento información de utilidad y licencia

Pablo Abad en nombre de los mayordomos eclesiástico y seglar de la villa de Fuentes de Valdepero. Presento en debida forma la información de utilidad e iba por mis partes en virtud de comunicación de este tribunal. A su majestad suplico en su vista servirá conceder la licencia que tengo pedida recibirán merced.

Traslado al fiscal abril 6 de 1724

Fdo: Abad

\section{Consiento}

El fiscal general eclesiástico de esta ciudad y obispado respondiendo al traslado que me ha dado de la pretensión introducida por los mayordomos eclesiástico y seglar de la iglesia parroquial de la villa de Fuentes de Valdepero sobre que se les conceda licencias para tomar a censo mil ducados de vellón a razón de dos reales y medio por ciento los réditos de dicho capital para con él redimir y quitar otro de ochocientos ducados que contra sus bienes y rentas tiene a tres por ciento conforme a la real pragmática a favor de la obra pía y cofradía de los veinte y con el resto satisfacer y pagar dos mil y seiscientos reales que estan debiendo por las esculturas para el retablo de la dicha iglesia al maestro Manuel de Ávila vecino y escultor de la ciudad de Valladolid por los motivos y razones que el pedimiento expresa de que se me ha dado traslado y en fuerza de lo que resulta de esta información de utilidad que se ha hecho consiento se conceda por su majestad la licencia pedida salvo justicia.

Abril 24 de 1724

En nombre del licenciado Don Manuel González Benito abogado de los Reales Consejos canónigo en la Santa Iglesia Catedral de la ciudad de Palencia provisor y vicario general en él dicho y su obispado por el Ilustrísimo Señor Don Francisco Ochoa Mendarozqueta obispo de dicho obispado Conde de Pernía del Consejo de su Majestad. Vista una petición ante nosotros presentada con una información de utilidad hecha en virtud de nuestra comisión a pedimento de los Mayordomos eclesiástico y seglar de la Parroquial de la Villa de Fuentes de Valdepero y consentimiento del fiscal a quien dimos traslado de ella. Por la presente y en fuerza de dicho consentimiento y utilidad justificada por dicha información concedemos licencia a los expresados mayordomos para que puedan tomar y tomen a censo mil ducados de vellón a razón de a dos y medio por ciento y con ellos quitar el censo de ochocientos ducados que contra si tiene la fábrica a favor de la obra pía y cofradía de los veinte de la ciudad de Carrión y pagar los dos mil y seiscientos reales que se restan deber a Manuel de Ávila escultor vecino de Valladolid 
por el retablo que hizo para la capilla mayor que para ello y que puedan hipotecar los bienes y rentas de dicha iglesia le hicimos la licencia necesaria como también para que puedan otorgar y otorguen las escrituras y tratados que convengan que a su validación interponemos nuestra autoridad y judicial decreto en forma para que hagan fe en juicio y fuera de él Palencia y abril veinte y cuatro de mil y seiscientos y veinte y cuatro. 


\section{6-BIBLIOGRAFÍA}


$\sum[1560$ 
AGAPITO Y REVILLA, Juan: Arte barroco en Valladolid, Imprenta provincial, Valladolid, 1931.

AGAPITO Y REVILLA, Juan: Catálogos del Museo de Bellas Artes de Valladolid. I, Escultura, Casa Santarén, Valladolid, 1930.

AGAPITO Y REVILLA, Juan: La obra de los maestros de la escultura vallisoletana: papeletas razonadas para un catálogo. II, Fernández - adiciones y correcciones, Casa Santarén, Valladolid, 1929.

AGAPITO Y REVILLA, Juan: Las calles de Valladolid: Nomenclátor histórico, Tipografías Casa Martín, Valladolid, 1937.

AGAPITO Y REVILLA, Juan: Las cofradías, las procesiones y los pasos de Semana Santa en Valladolid. Editorial Maxtor, Valladolid, 2007.

AGULlÓ Y COBO, Mercedes: "El escultor Pedro Alonso de los Ríos (1641-1702)", Boletín del Museo Nacional de Escultura, no 5, 2001, pp. 15-22.

AGULLÓ Y COBO, Mercedes: Documentos sobre escultores, entalladores y ensambladores de los siglos XVI al XVIII, Universidad de Valladolid, Valladolid, 1978.

ALARCOS LLORACH, Emilio: "Obras y artistas que se citan en los libros de la Cofradía de Nuestra Señora de la Piedad, de Valladolid”, B.S.A.A., Tomo VII, 1940-1941, pp. 197-204.

ALBARRÁN MARTÍN, Virginia: "Un San Francisco del escultor Felipe de Espinabete (17191799)”, B.R.A.C., No 45, 2010, pp. 65-68.

ALBARRÁN MARTÍN, Virginia: El escultor Alejandro Carnicero entre Valladolid y la Corte (1693-1756), Diputación de Valladolid, Valladolid, 2012.

ALCALDE PRIETO, Domingo: Manual histórico de Valladolid, Grupo Pinciano, Valladolid, 1992.

ALCÁNTARA BASANTA, Pedro: Libro de curiosidades relativas a Valladolid (1807-1831), Tipografía del Colegio Santiago, Valladolid, 1914.

ALONSO GARCÍA, David: Breve historia de los Austrias, Nowtilus, Navarra, 2010.

ALONSO PONGA, José Luis (coord.): La semana santa en la tierra de campos vallisoletana, Grupo Página, Valladolid, 2003.

ALONSO PONGA, José Luis y PANERO GARCÍA, Pilar: Gregorio Fernández: Antropología, historia y estética del Barroco, Ayuntamiento de Valladolid, Valladolid, 2008.

ÁLVAREZ VICENTE, Andrés (et. al.): Resurrexit, Ayuntamiento de Valladolid, Valladolid, 2010.

ÁLVAREZ VICENTE, Andrés y GARCÍA RODRÍGUEZ, Julio César: Damnatus, Ayuntamiento de Valladolid, Valladolid, 2009.

ÁLVAREZ VICENTE, Andrés y GARCÍA RODRÍGUEZ, Julio César: Dolor y Gloria, Ayuntamiento de Valladolid, Valladolid, 2006. 
ÁLVAREZ VICENTE, Andrés y GARCÍA RODRÍGUEZ, Julio César: Tradebatur, Ayuntamiento de Valladolid, Valladolid, 2007.

ÁLVAREZ VICENTE, Andrés: Imaginería ligera en Valladolid, Ayuntamiento de Valladolid, Valladolid, 2011.

AMIGO VÁZQUEZ, Lourdes: "El espectáculo de las postrimerías. Exequias reales en Valladolid durante los siglos XVII y XVIII”, B.R.A.C., Tomo XLV, 2010, pp. 43-60.

ANDRÉS ORDAX, Salvador: "El pintor Ramón Canedo: algunos retratos y lienzos religiosos", B.S.A.A., Tomo LX, 1994, pp. 515-520.

ANDRÉS ORDAX, Salvador: Carrión de los Condes: Iglesia de Santa María del Camino, Diputación Provincial de Palencia, Palencia, 1994.

ANDRÉS ORDAX, Salvador: Iconografía de San Pedro Regalado, Junta de Castilla y León. Consejería de Cultura y Bienestar Social, Valladolid, 1991.

ANDRÉS ORDAX, Salvador: Iconografía jacobea en Castilla y León, Real Academia de Bellas Artes de la Purísima Concepción, Valladolid, 1993.

ANDRÉS PÉREZ, Evasio: Santoyo: apuntes de historia y arte de la villa: (provincia de Palencia), 1983.

ANTOLÍNEZ DE BURGOS, Juan: Historia de Valladolid (1887), Grupo Pinciano, Valladolid, 1987.

ARA GIL, Clementina Julia: "El taller palentino del entallador Alonso de Portillo (1460-1506), B.S.A.A., Tomo LIII, 1987, pp. 211-242.

ARÉVALO ARÉVALO, José María: Matapozuelos: su historia y arte, Universidad de Valladolid, Valladolid, 1987.

ARIAS MARTÍNEZ, Manuel (coord.): Museo Nacional Colegio de San Gregorio: Colección / Collection, Ministerio de Cultura, Madrid, 2009.

ARIAS MARTÍNEZ, Manuel, HERNÁNDEZ REDONDO, José Ignacio y SÁNCHEZ DEL BARRIO, Antonio: Semana Santa en Medina del Campo: historia y obras artísticas, Junta de Semana Santa de Medina del Campo, Medina del Campo, 1996.

ARIAS MARTÍNEZ, Manuel: "La copia más sagrada. La escultura vestidera de la Virgen de la Soledad de Gaspar Becerra y la presencia del artista en el convento de Mínimos de la Victoria de Madrid", B.R.A.C., Tomo XLVI, 2011, pp. 33-56.

ARMENDÁRIZ UBIOLA, Fermín: "El retablo de la iglesia de San Andrés, de Valladolid", B.S.A.A., Tomo VII, 1940-1941, pp. 187-195.

ARRIBA CANTERO, Sandra de: "San José", Revista digital de iconografía medieval, Vol. 5, $\mathrm{N}^{\mathrm{o}} 10,2013$, pp. 57-76.

ARRIBAS ARRANZ, Filemón: "Dos censos vallisoletanos de artistas", B.S.A.A., Tomo XIV, 1948, p. 234. 
ARRIBAS ARRANZ, Filemón: La Cofradía Penitencial de N.P. Jesús Nazareno de Valladolid, Imprenta y librería Casa Martín, Valladolid, 1946.

ARRIBAS, Miguel María: "Retablo de Juan Correas y Blas Martínez de Obregón en Cuéllar", Estudios Segovianos, Tomo XXV, nº 74-75, 1973, pp. 556-560

ARRIBAS, Miguel María: Santuario de El Henar. Cuellar (Segovia), PP. Carmelitas, 1971.

ARTE, CONSERVACIÓN Y RESTAURACIÓN S.L.: Memoria final de restauración. Retablo de la Dolorosa. Iglesia Penitencial de Jesús Nazareno Valladolid, Junta de Castilla y León, Valladolid, 2002.

ASTIAZARIN ACHABLA, María Isabel: "La construcción del retablo de la parroquia de San Sebastián de Soreasu en Azpeitia: una obra de Juan de Apaeztegui, Martín de Olaizola y José de Echeverría", Boletín de la Real Sociedad Bascongada de Amigos del País, 46, 1-2, 1990, pp. $11-40$

AUCLAIR, Marcelle: La vida de Santa Teresa de Jesús, Palabra, Madrid, 1982.

BALADRÓN ALONSO, Javier: "Nuevas obras de Francisco Díez de Tudanca y otros datos de escultores barrocos vallisoletanos", B.S.A.A., Tomo LXXVIII, 2012, pp. 153-170.

BARBERÁN, Cecilio: Museo Nacional de Escultura, Valladolid, Afrodísio Aguado, Madrid, 1948.

BENITO ARRANZ, Juan: "Un retablo desaparecido: el de la capilla del Santo Sepulcro del Hospital de la Resurrección de Valladolid”, B.S.A.A., Tomo IX, 1942-1943, pp. 173-178

BOSARTE, Isidoro: Viage artístico a varios pueblos a España. 1, Viage a Segovia, Valladolid y Burgos, Imprenta Real, Madrid, 1804.

BOUCHER, Bruce: La escultura barroca en Italia, Destino, Barcelona, 1999.

BRASAS EGIDO, José Carlos y NIETO GONZÁLEZ, José Ramón: "Felipe de Espinabete: nuevas obras", B.S.A.A., Tomo XLIII, 1977, pp. 479-484.

BRASAS EGIDO, José Carlos: "Notas sobre la iglesia del monasterio de Nuestra Señora de Prado de Valladolid”, B.S.A.A., Tomo XLIV, 1978, pp. 462-467.

BRASAS EGIDO, José Carlos: "Noticias documentales de artistas vallisoletanos de los siglos XVII y XVIII”, B.S.A.A., Tomo L, 1984, pp. 464-476.

BRASAS EGIDO, José Carlos: "Noticias sobre Espinabete", B.S.A.A., Tomo XLV, 1979, pp. 495-498.

BRASAS EGIDO, José Carlos: Guía artística de Valladolid, Ediciones Lancia, León, 2005

BRASAS EGIDO, José Carlos: Guía de Valladolid, Ediciones Lancia, León, 1984.

BRASAS EGIDO, José Carlos: La platería vallisoletana y su difusión, Institución Cultural Simancas, Valladolid, 1980. 
BRAY, Xavier: Lo sagrado hecho real. Pintura y escultura española 1600-1700, Ministerio de Cultura, Madrid, 2010.

BURRIEZA SÁNCHEZ, Javier (coord.): La Ciudad del Regalado, Ayuntamiento de Valladolid, Valladolid, 2004.

BURRIEZA SÁNCHEZ, Javier (coord.): Una historia de Valladolid, Ayuntamiento de Valladolid, Valladolid, 2004.

BURRIEZA SÁNCHEZ, Javier: Cinco siglos de cofradías y procesiones: Historia de la Semana Santa en Valladolid, Ayuntamiento de Valladolid, Valladolid, 2004.

BURRIEZA SÁNCHEZ, Javier: Civitatis Domina. La Virgen de las Angustias y las gentes de Castilla, Ayuntamiento, Valladolid, 2009.

BURRIEZA SÁNCHEZ, Javier: Gólgota, Ayuntamiento de Valladolid, Valladolid, 2004.

BURRIEZA SÁNCHEZ, Javier: La Procesión permanente de Pasión: Espiritualidad de la Pasión en las clausuras vallisoletanas, El Día de Valladolid, Valladolid, 2005.

BURRIEZA SÁNCHEZ, Javier: Las letras de pasión: Antología histórico-literaria de la Semana Santa de Valladolid, Sever-Cuesta, Valladolid, 2008.

BURRIEZA SÁNCHEZ, Javier: Todos los pasos, todas las pasiones. El Mundo, Valladolid, 2007.

BURRIEZA SÁNCHEZ, Javier: Una isla de Inglaterra en Castilla, Iglesia del Real Colegio de San Albano, Valladolid, 2000.

BURRIEZA SÁNCHEZ, Javier: Varón de Dolores. Ayuntamiento de Valladolid, Valladolid, 2005 .

BURRIEZA SÁNCHEZ, Javier: Virgen de los Ingleses, entre Cádiz y Valladolid. Una devoción desde las guerras de religión, Real Colegio de Ingleses, Valladolid, 2008.

BUSTAMANTE GARCÍA, Agustín: La arquitectura clasicista del foco vallisoletano (15611640), Institución Cultural Simancas, Valladolid, 1983.

CAAMAÑO MARTÍNEZ, Jesús María: "Datos para la historia de la Real Academia de la Purísima Concepción, de Valladolid (1786-1797)”, B.S.A.A., Tomo XXIX, 1963, pp. 89-151.

CAAMAÑO MARTÍNEZ, Jesús María: "Sobre la influencia de Juan de Borgoña", B.S.A.A., Tomo XXX, 1964, pp. 292-305.

CABAllero, Arturo: San Cebrián de Campos: iglesia de los Santos Cornelio y Cipriano, Diputación Provincial de Palencia, Palencia, 1994.

CADENAS Y VICENT, Vicente de: Pleitos de Hidalguía que se conservan en el Archivo de la Real Chancillería de Valladolid. Extracto de sus expedientes. Siglo XIX, Tomo IX - Letras T-Z, Instituto Salazar y Castro, Madrid, 1980.

CAL PARDO, Enrique: Episcopologio Mindoniense, Cuadernos de Estudios Gallegos Anexo XXVIII, Santiago de Compostela, 2003. 
CALLEJA GAGO, Rosa María: Gobierno municipal, siglo XVIII, Ayuntamiento de Valladolid, Valladolid, 1993.

CALVO CABALLERO, Pilar: Fiesta y devoción popular: la Cofradía de San Pedro Regalado y Nuestra Señora del Refugio de Valladolid, Ayuntamiento de Valladolid, Valladolid, 2014.

CAMÓN AZNAR, José: Summa Artis. Tomo XXVII. Arte español del siglo XVIII, EspasaCalpe, Madrid, 1984.

CAMPUZANO RUIZ, Enrique: Catálogo Monumental de Cantabria Tomo II, Valles del Saja y del Besaya, Diputación Regional de Cantabria, Santander, 1991.

CANDEIRA PÉREZ, Constantino: "Los retablos de Gaspar de Tordesillas", B.S.A.A., Tomo VIII, 1941-1942, pp. 111-137.

CANDEIRA PÉREZ, Constantino: Guía del Museo Nacional de Escultura, Imprenta Gráficas Perdiguero Valladolid, 1945.

CANESI ACEVEDO, Manuel: Historia de Valladolid (1750), 3 Tomos, Grupo Pinciano, Valladolid, 1996.

CARAMES GONZÁLEZ, Concepción: "El escultor y entallador Francisco de Castro Canseco (1693-1724), Boletín auriense, $\mathrm{N}^{\circ} 2$ 2, 1972, pp. 167-192.

CARLOS VARONA, María Cruz, CIVIL, Pierre, PEREDA ESPESO, Felipe y VICENTCASSY, Cécile (coord.): La imagen religiosa en la Monarquía hispánica, Casa de Velázquez, Madrid, 2008.

CARRIÓN GONZÁLEZ, P. Fr. Luis (O.F.M.): Vida de San Pedro Regalado patrono de la M.N.M.L. y H. ciudad de Valladolid, Librería Editorial Imprenta Pontificia, Barcelona, 1924.

CASAS HERNANDEZ, Mariano: Escultura barroca en Salamanca: Imagen, discurso y culto en la catedral [Tesis doctoral], Universidad de Salamanca, Salamanca, 2013.

CASASECA CASASECA, Antonio (et. al.): Historia del arte de Castilla y León. 6: Arte barroco, Editorial Ámbito, Valladolid, 1997.

CASCIARO, Raffaele y CASSIANO, Antonio: Scultura di età barocca tra Terra d'Otranto, Napoli e Spagna, De Luca Editori d’Arte, Lecce, 2007.

CASTELLANOS CUESTA, Margarita: Ermita de Nuestra Señora del Villar. Laguna de Duero, Colección Tierras de Valladolid, Valladolid, 2012.

CASTRO BRUNETTO, Carlos Javier: "Iconografía de Santa Clara de Asís y Santa Rosa de Viterbo en Canarias", Revista de Historia Canaria, № 179, 1997, pp. 73-100.

CEÁN BERMÚDEZ, Juan Agustín: Diccionario histórico de los más ilustres profesores de las Bellas Artes en España, Istmo, Madrid, 2001.

CENDOYA ECHÁNIZ, Ignacio: "La aportación del taller de los Sierra a la escultura barroca en Gipuzkoa", Ondare: cuadernos de artes plásticas y monumentales, $\mathrm{N}^{\circ}$ 19, 2000, pp. 521-531. 
CENDOYA ECHÁNIZ, Ignacio: La Semana Santa en Guipúzcoa. Estudio histórico-artístico, Sociedad de Estudios Vascos, San Sebastián, 1995.

CERVERA VERA, Luis: La iglesia colegial de San Pedro de Lerma, Caja de Ahorros Municipal de Burgos, Burgos, 1981.

COLMENARES Y ORGAZ, Aurelio: "La Plaza mayor y la Real Casa Panadería", Boletín de la Sociedad Española de Excursiones, Vol. 21, nº 1, 1913, Madrid, pp. 37-62.

COSSÍO, Francisco de: Guía de Valladolid y su provincia (1922), Grupo Pinciano, Valladolid, 1922.

CRUZ YABAR, Juan María: "El escultor Pedro Alonso de los Ríos. I. Biografía y obra", Anales del Instituto de Estudios Madrileños, Tomo 47, 2007, pp. 133-154.

CRUZ YABAR, Juan María: "El escultor Pedro Alonso de los Ríos. II. Inventario de sus bienes y otros aspectos", Anales del Instituto de Estudios Madrileños, Tomo 49, 2009 pp. 97-116.

CHAMOSO LAMAS, Manuel: La Catedral de Orense, Everest, Madrid, 1980.

CHUECA GOITIA, Fernando: Breve historia del urbanismo, Alianza, Madrid, 1995.

CHUECA GOITIA, Fernando: La catedral de Valladolid: una página del Siglo de Oro de la arquitectura española, Instituto Diego Velázquez, Madrid, 1947.

DAZA, Antonio: Excelencias de la ciudad de Valladolid, con la vida y milagros del Santo Fr. Pedro Regalado, natural de la misma ciudad, uno de los tres fundadores de la Santa Provincia de la Concepción, de la Regular Observancia de la Orden de Nuestro Seráfico Padre San Francisco, Casa de Juan Lasso de las Peñas, Valladolid, 1627.

DE CASTRO ALONSO, Manuel de: Episcopologio vallisoletano, Tipografía y casa editorial Cuesta, Valladolid, 1904.

DELFÍN VAL, José y CANTALAPIEDRA, Francisco: Semana Santa en Valladolid: Pasos Cofradías - Imagineros. Lex Nova, Valladolid, 1990.

DÍAZ VAQUERO, María Dolores: La Virgen en la escultura cordobesa del barroco, Monte de Piedad y Caja de Ahorros, Córdoba, 1987.

DOMÍNGUEZ CASAS, Rafael: "Imago Pintiana": heráldica, emblemas y fastos de la Universidad de Valladolid (siglos XV-XXI), Universidad de Valladolid, Valladolid, 2012.

DOMÍNGUEZ ORTIZ, Antonio: Crisis y decadencia de la España de los Austrias, Ariel, Esplugues de Llobregat, 1984.

DOMÍNGUEZ ORTIZ, Antonio: El Antiguo Régimen: los Reyes Católicos y los Austrias, Alianza, Madrid, 1983.

DUQUE HERRERO, Carlos: Mucientes: historia y arte, Grupo Página, Valladolid, 1997.

DUQUE HERRERO, Carlos: Villalón de Campos: historia y patrimonio artístico: del siglo XVII hasta nuestros días, Valladolid, 2005. 
DURRUTY ROMAY, Inés: "El Cristo del Olvido. Escultura de Pedro de Ávila", B.S.A.A., Tomo VII, 1940-1941, pp. 205-209.

ECHEVARRÍA GOÑI, Pedro Luis: Policromía renacentista y barroca, Historia 16, Madrid, 1992.

EGIDO, Teófanes: San Pedro Regalado. Patrón de Valladolid, Obra Cultural de la Caja de Ahorros Popular, Valladolid, 1983.

ENCISO RECIO, Luis M. (et. al.): Valladolid en el siglo XVIII, Ateneo de Valladolid, Valladolid, 1984.

FERNÁNDEZ DEL HOYO, Ma Antonia: "Notas sobre el Colegio de San Ambrosio", B.R.A.C., tomo XXXVII, 2002, pp. 77-96.

FERNÁNDEZ DEL HOYO, María Antonia: "El Convento de Comendadoras de Santa Cruz de Valladolid: Nuevos datos para su historia". En Valladolid: historia de una ciudad. Congreso internacional. 1, La ciudad y el arte Valladolid villa (época medieval), Ayuntamiento de Valladolid, Valladolid, 1999, pp. 105-114.

FERNÁNDEZ DEL HOYO, María Antonia: "El convento de San Francisco de Valladolid. Nuevos datos para su historia". B.S.A.A., Tomo LI, 1985, pp. 411-439.

FERNÁNDEZ DEL HOYO, María Antonia: "El Cristo del Perdón, obra de Bernardo del Rincón”, B.S.A.A., Tomo IL, 1983, pp. 476-480.

FERNÁNDEZ DEL HOYO, María Antonia: "El escultor vallisoletano Francisco Díez de Tudanca (1616 - ?)”, B.S.A.A., Tomo. L, 1984, pp. 371-388.

FERNÁNDEZ DEL HOYO, María Antonia: "Ensambladores del círculo de Gregorio Fernández: los Velázquez y Beya", B.R.A.C., Tomo XLIV, 2009, pp. 47-60

FERNÁNDEZ DEL HOYO, María Antonia: "Fiestas en Valladolid a la venida de Felipe IV en 1660”, B.S.A.A., Tomo LIX, 1993, pp. 379-392.

FERNÁNDEZ DEL HOYO, María Antonia: "La compañía, Gregorio Fernández y los Condes de Fuensaldaña”, B.S.A.A., Tomo XLVIII, 1982, pp. 420-429.

FERNÁNDEZ DEL HOYO, María Antonia: "Oficiales del taller de Gregorio Fernández y ensambladores que trabajaron con él”, B.S.A.A., Tomo IL, 1983, pp. 347-374.

FERNÁNDEZ DEL HOYO, María Antonia: "Valladolid en el siglo XIX según el manuscrito de Telesforo Medrano. Noticia de Urbanismo, arquitectura y arte", B.R.A.C., Tomo XLII, 2007, pp. 67-85.

FERNÁNDEZ DEL HOYO, María Antonia: Cisneros. Iglesia de San Facundo y San Primitivo, Diputación de Palencia, Palencia, 1993.

FERNÁNDEZ DEL HOYO, María Antonia: Desarrollo urbano y proceso histórico del Campo Grande de Valladolid, Ayuntamiento de Valladolid, Valladolid, 1981.

FERNÁNDEZ DEL HOYO, María Antonia: Patrimonio perdido: Conventos desaparecidos de Valladolid, Ayuntamiento de Valladolid, Valladolid, 1998. 
FERNÁNDEZ DEL HOYO, María Antonia: Pintura y sociedad en Valladolid durante los siglos XVI y XVII, Real Academia de Bellas Artes de la Purísima Concepción de Valladolid, Valladolid, 2000.

FERNÁNDEZ GRACIA, Ricardo: La Inmaculada Concepción en Navarra: arte y devoción durante los siglos del Barroco. Mentores, artistas e iconografía, EUNSA, Pamplona, 2004.

FERNÁNDEZ JUÁREZ, Gerardo y MARTÍNEZ GIL, Fernando (coord.): La fiesta del Corpus Christi, Ediciones de la Universidad de Castilla-La Mancha, Cuenca, 2002.

FERRANDO ROIG, Juan: Iconografía de los santos, Omega, Barcelona, 1950.

FERRERO MAESO, Concepción: "El mecenazgo de la familia Berrio en la iglesia de San Julián (Carrión de los Condes). En CALLEJA GONZÁLEZ, María Valentina: Actas del III Congreso de Historia de Palencia, Vol. IV, Diputación Provincial de Palencia, Palencia, 1995, pp. 585-600.

FLÓREZ, Enrique: España Sagrada. Tomo XVIII. De las Iglesias Britoniense y Dumiense, incluidas en la actual de Mondoñedo, Oficina de Antonio Marín, Madrid, 1764.

FRANCO MATA, María Ángela: "El Devot Crucifix de Perpignan y sus derivaciones en España e Italia”, Melanges de la Casa de Velázquez, № 20, 1984, pp. 189-215.

FRUTOS SASTRE, Leticia María: "Dos nuevos pasos procesionales de Felipe de Espinabete en la provincia de Segovia", B.R.A.C., tomo XXXVII, 2002, pp. 107-112.

GALÍ BOADELLA, Montserrat y TORRES AGUILAR, Morelos: III Colegio Musicat. Lo sagrado y lo profano en la festividad de Corpus Christi, Universidad Nacional Autónoma de México, México, 2008.

GALLARDO Y MERINO, Francisco: Noticia de casos particulares ocurridos en la ciudad de Valladolid Año 1808 y siguientes. Obra publicada, corregida, anotada y adicionada con un prólogo por D. Juan Ortega y Rubio Catedrático de esta Universidad, Imprenta y Librería Nacional y Extranjera de los Hijos de Rodríguez, Valladolid, 1886.

GAMARRA CABALLERO, José María: Historia Moderna (Biblioteca básica de Valladolid), Diputación de Valladolid, Valladolid, 2008.

GARCÍA ABAD, Albano: "Fuentes de Valdepero: Detalles artísticos de la iglesia parroquial de Nuestra Señora de la Antigua", El Diario Palentino (10 de marzo de 1998).

GARCÍA ABAD, Albano: "Fuentes de Valdepero: Sobre el retablo mayor de la iglesia parroquial", El Diario Palentino (28 de septiembre de 1997).

GARCÍA ABAD, Albano: Fuentes de Valdepero: Inventario documentado de la Iglesia de Nuestra Señora de la Antigua, León, 1998.

GARCÍA CARRAFFA, Alberto: Diccionario heráldico y genealógico de los apellidos españoles y americanos, Imprenta Antonio Marzo, Madrid, 1920.

GARCÍA CUESTA, Timoteo: "El retablo de la Inmaculada, de la Catedral de Palencia y noticia de los Sedano", B.S.A.A., Tomo XXVIII, 1962, pp. 181-208. 
GARCÍA CUESTA, Timoteo: "Entalladores palentinos del siglo XVII (II)", B.S.A.A., tomo XXXIX, 1973, pp. 291-316.

GARCÍA CUESTA, Timoteo: "La Cofradía de Jesús Nazareno en Palencia", B.S.A.A., Tomo XXXVI, 1970, pp. 69-146.

GARCÍA CHICO, Esteban: “Artistas Montañeses. Francisco Díez de Tudanca, escultor", Altamira. Revista del Centro de Estudios Montañeses, tomo XII, 1954, pp. 38-56

GARCÍA CHICO, Esteban: "Valladolid. Iglesia conventual de Santa Clara. Retablo mayor". B.S.A.A., Tomo XXI-XXII, 1954-1956, pp. 159-162.

GARCÍA CHICO, Esteban: Documentos para el estudio del arte en Castilla: plateros de los siglos XVI, XVII y XVIII, Universidad de Valladolid, Valladolid, 1963.

GARCÍA CHICO, Esteban: Documentos para el estudio del arte en Castilla. 1, Arquitectos, Universidad de Valladolid, Valladolid, 1940.

GARCÍA CHICO, Esteban: Documentos para el estudio del arte en Castilla. 2, Escultores, Universidad de Valladolid, Valladolid, 1941.

GARCÍA CHICO, Esteban: Documentos para el estudio del arte en Castilla. 3, Pintores II, Universidad de Valladolid, Valladolid, 1946.

GARCÍA CHICO, Esteban: El arte en Castilla. Los templos riosecanos: el arte en Castilla, Diputación Provincial de Valladolid, Valladolid, 1955.

GARCÍA CHICO, Esteban: La ciudad de los Almirantes: su historia y tesoro artístico, Diputación Provincial de Valladolid, Valladolid, 1945.

GARCÍA CHICO, Esteban: La Cofradía Penitencial de la Santa Vera Cruz, Gráficas Andrés Martín, Valladolid, 1962, pp. 66-67.

GARCÍA CHICO, Esteban: Valladolid: Papeletas de Historia y Arte, Gráficas Andrés Martín, Valladolid, 1958.

GARCÍA DE CORTÁZAR, Fernando y GONZÁLEZ VESGA, José Manuel: Breve historia de España, Alianza, Madrid, 1999.

GARCÍA FERNÁNDEZ, Máximo: Los viejos oficios castellanos, Neumáticos Michelin, Valladolid, 1996

GARCÍA GARCÍA, Lorena: Evolución del patrimonio religioso en Carrión de los Condes, Palencia, desde la Baja Edad Media hasta nuestros días (tesis doctoral inédita), Universidad de Valladolid, Valladolid, 2012.

GARCÍA GUTIÉRREZ, Pedro F. y LANDA BRAVO, José: La escultura. Del renacimiento a la actualidad, Ediciones Antiqvaria S.A., Madrid, 1994.

GARCÍA IGLESIAS, José Manuel: "Francisco de Castro Canseco (Ca. 1655-1714), en la actividad artística de Galicia”, Laboratorio de Arte, N 5, Fascículo 1, 1992, pp. 241-263. 
GARCÍA MARTÍN, Enrique: Cristo yacentes de Valladolid, Ayuntamiento de Valladolid, Valladolid, 2000.

GARCÍA MARTíN, Enrique: El Seminario Diocesano de Valladolid. Notas de Historia y Catálogo Artístico, Diputación de Valladolid, Valladolid, 1998.

GARCÍA MARTÍN, Enrique: Imágenes de Ecce-Homo en Valladolid, Ayuntamiento de Valladolid, 2001.

GARCÍA MARTÍN, Enrique: Las cofradías y arte de Valladolid (siglos XVI-XVIII) (Tesis Doctoral inédita), Universidad de Valladolid, Valladolid.

GARCÍA MARTÍN, Enrique: Virgen de Pasión, Ayuntamiento de Valladolid, Valladolid, 2002.

GARCÍA VEGA, Blanca: "Estampas de imágenes vallisoletanas", B.S.A.A., Tomo LI, 1987, pp. 393-410.

GARCÍA-FRIAS CHECA, Carmen: Real Monasterio de Santa Clara de Tordesillas, Editorial Patrimonio Nacional, Madrid, 1992.

GILA MEDINA, Lázaro: Pedro de Mena escultor: 1628-1688, Arco Libros, Madrid, 2007.

GÓMEZ GÓMEZ, Agustín [et. al.]: Poder y seducción de la imagen románica, Fundación de Santa María la Real, Aguilar de Campoo, 2005.

GÓMEZ MORENO, Manuel: Catálogo Monumental de España. Provincia de León (19061908), Ministerio de Instrucción Pública y Bellas Artes, Madrid, 1925.

GÓMEZ MORENO, Manuel: La Inmaculada en la escultura española, Universidad Pontificia de Comillas, Santander, 1955.

GOMEZ RASCÓN, Máximo: Museo Catedralicio-Diocesano León, Editorial Everest, León, 1983.

GÓMEZ, Enrique y MARTíNEZ, Rafael: Semana Santa en Palencia. Historia, arte y tradiciones, Palencia, 1999.

GONZÁLEZ DORIA, Fernando: Diccionario heráldico y nobiliario, Trigo ediciones, Madrid, 2000.

GONZÁLEZ ECHEGARAY, María del Carmen: Artistas cántabros de la edad moderna: su aportación al arte hispánico: diccionario biográfico-artístico, Institución Mazarrasa, Santander, 1991.

GONZÁLEZ ECHEGARAY, María del Carmen: Documentos para la historia del arte en Cantabria (Escultores, entalladores y pintores de los siglos XVI al XVIII). Tomo II, Diputación Provincial de Santander, Santander, 1973.

GONZÁLEZ GARCÍA-VALLADOLID, Casimiro: Datos para la historia biográfica de la M. L. M. N. H. y Excma. Ciudad de Valladolid (2 Tomos). Imprenta y Librería Nacional y extranjera de Hijos de Rodríguez, Valladolid, 1893-1894. 
GONZÁLEZ GARCÍA-VALLADOLID, Casimiro: Valladolid, sus recuerdos y sus grandezas: religión, historia, ciencias, literatura, industria, comercio y política (3 Tomos), Imprenta de Juan Rodríguez Hernando, Valladolid, 1900-1902.

GONZÁLEZ MARTÍNEZ, Pedro: Compendio histórico y descriptivo de Valladolid: seguido del catálogo de pinturas y esculturas que ecsisten [sic] en el museo de esta ciudad, Imprenta de don Julián Pastor, Valladolid, 1843

GONZÁLEZ, Julio (coord.): Historia de Palencia II. Edades Moderna y Contemporánea, Excma. Diputación Provincial de Palencia, Palencia, 1984.

GONZÁLEZ-MARTÍNEZ ALONSO, Enriqueta: Patrimonio y Restauración: Tecnología Tradicional y Tecnología Actual, Universidad Politécnica de Valencia, Valencia, 2006.

GUTIÉRREZ ALONSO, Adriano (et. al.): Valladolid en el siglo XVII, Ateneo de Valladolid, Valladolid, 1982.

GUTIÉRREZ ALONSO, Adriano: Estudio sobre la decadencia de Castilla. La ciudad de Valladolid en el siglo XVII, Universidad de Valladolid, Valladolid, 1989.

HERAS GARCÍA, Felipe: "Marcos de Garay, Juan Imberto y el retablo de Matilla", B.S.A.A., Tomo XXXIX, 1973, pp. 261-268.

HERAS GARCÍA, Felipe: Arquitectura religiosa del siglo XVI en la primitiva Diócesis de Valladolid, Diputación de Valladolid, 1975.

HERNÁNDEZ DÍAZ, José, MARTÍN GONZÁLEZ, Juan José y PITA ANDRADE, Manuel: Summa Artis. Tomo XXVI. La escultura y la arquitectura españolas del siglo XVII, EspasaCalpe, Madrid, 1991.

IBAÑEZ, Manuel (O. Carmelita): Historia de la Virgen del Henar y su Santuario: estudio histórico crítico de la devoción a la Virgen del Henar en la villa y tierra de Cuéllar, Diputación Provincial de Segovia, Segovia, 1955.

IÑIGO FERNÁNDEZ, Luis: Breve historia de España. 2, el camino hacia la modernidad, Nowtilus, Madrid, 2010.

JORDAN, William B.: Juan Van Der Hamen y León y la Corte de Madrid, Patrimonio Nacional, Madrid, 2005.

KUBLER, George: Ars Hispaniae. Arquitectura de los siglos XVII y XVIII, Tomo XIV, Madrid, 1957.

LABRADOR GONZÁLEZ, Isabel María y MEDIANERO HERNÁNDEZ, José María: "Iconología del sol y la luna en las representaciones de Cristo en la cruz", Laboratorio de Arte, $\mathrm{N}^{\mathrm{o}} 17,2004$, pp. 73-92.

LAFUENTE FERRARI, Enrique. El libro de Santillana, Diputación Provincial de Santander, Santander, 1955. 
LEÓN, Alfonso: "Tesoros para una Colegiata: restauración del retablo mayor y tabernáculo de San Pedro de Lerma", Patrimonio. Fundación del patrimonio histórico de Castilla y León, $\mathrm{n}^{\circ}$ 36,2012 , pp. 28-35.

LEONARDI, C., RICCARDI, A. y ZARRI, G.: Diccionario de los santos (2 vols.), San Pablo, Madrid, 2000.

LÓPEZ SEVILLA, Luis Alberto: La Cofradía de Jesús Nazareno de Palencia, Cofradía de Ntro. Padre Jesús Nazareno de Palencia, Palencia, 1997.

LÓPEZ-GUADALUPE MUÑOZ, Juan Jesús: José de Mora, Editorial Comares, Granada, 2000.

LUNA MORENO, Luis: “Acerca de nuestra historia: Nuestro Padre Jesús con la Cruza cuestas y su grupo procesional”, Pasión Cofrade, nº 10 (segunda época), 2014, pp. 33-36.

LLAMAZARES RODRÍGUEZ, Fernando: "Alonso de Manzano y Tomás de Sierra en tierras sorianas”, Liño: Revista anual de historia del arte, $\mathrm{n}^{\circ} 15,2009$, pp. 39-55.

LLAMAZARES RODRÍGUEZ, Fernando: "El "Nazareno" en la escultura barroca castellana". En IBÁÑEZ MARTÍNEZ, Pedro Miguel y MARTÍNEZ SORIA, Carlos Julián: La imagen devocional barroca, Ediciones de la Universidad de Castilla-La Mancha, Cuenca, 2010, pp. 63109.

LLAMAZARES RODRÍGUEZ, Fernando: "El escultor Francisco Díez de Tudanca en la ciudad de León”, Tierras de León, 1979, Tomo XXXIV-XXV, pp. 55-57.

LLAMAZARES RODRÍGUEZ, Fernando: "Iconografías de los siglos XVI, XVII y XVIII en las capillas de la Catedral de León" en Entorno a la catedral de León (estudios), Universidad de León, León, 2004, pp. 363-398.

LLAMAZARES RODRÍGUEZ, Fernando: "José Mayo. Las esculturas del Monasterio de Santa María de Carrizo", Tierras de León, 1975, Tomo XXI, pp. 17-22.

LLAMAZARES RODRÍGUEZ, Fernando: "Un espacio barroco para la formación inicial de Lorenzana: la iglesia del Colegio de la Compañía de Jesús en León". En PANIAGUA PÉREZ, Jesús (coord.): España y América entre el Barroco y la Ilustración (1722-1804), II Centenario de la Muerte del Cardenal Lorenzana (1804-2004), León, 2005, pp. 55-92.

LLAMAZARES RODRÍGUEZ, Fernando: Fuentes documentales para el arte barroco en la provincia de León: ensambladores, escultores y pintores, Universidad de León, León, 2008.

LLAMAZARES RODRÍGUEZ, Fernando: Guía de León. Lancia, León, 2001.

MADOZ, Pascual: Diccionario geográfico-estadístico-histórico de Castilla y León. Valladolid, Valladolid, Ámbito Ediciones, 1984.

MARCOS RÍOS, José Antonio: La escultura policromada y su técnica en Castilla: siglos XVI y XVII [Tesis Doctoral], Universidad Complutense, Madrid, 2004.

MARTÍ Y MONSÓ, José: Estudios histórico-artísticos relativos principalmente a Valladolid: basados en la investigación de diversos archivos, Imprenta de Leonardo Miñón, Valladolid, 1898-1901. 
MARTÍN GONZÁLEZ, Juan José (dir.): Inventario artístico de Valladolid y su provincia, Ministerio de Educación, Valladolid, 1970.

MARTÍN GONZÁLEZ, Juan José y PLAZA SANTIAGO, Francisco Javier de la: El arte en las clausuras de los conventos de monjas de Valladolid, Museo Nacional de Escultura, Valladolid, 1983.

MARTÍN GONZÁLEZ, Juan José: "Cabezas de santos degollados en la escultura barroca española", Goya: revista de arte, $\mathrm{N}^{\circ} 16,1957$, pp. 210-213.

MARTÍN GONZÁLEZ, Juan José: "Documentación de las obras de escultura de la capilla del Relicario de la Colegiata de Villagarcía de Campos", B.S.A.A., Tomo XX, 1953-1954, pp. 206209.

MARTÍN GONZÁLEZ, Juan José: "El apóstol Santiago a través del arte vallisoletano", Compostellanum, vol. X, $\mathrm{n}^{\circ} 4,1965$.

MARTÍN GONZÁLEZ, Juan José: "El arte de los jesuitas en Palencia", Jornadas sobre el Arte de las Órdenes Religiosas en Palencia, Universidad de Verano "Casado del Alisal", Palencia, 1990, pp. 183-191.

MARTÍN GONZÁLEZ, Juan José: "Esculturas vallisoletanas en la Catedral de Orense", Cuadernos de Estudios Gallegos, Tomo XVI, Santiago de Compostela, 1961, pp. 253-254

MARTÍN GONZÁLEZ, Juan José: "Imágenes de escultura de la Concepción en Castilla y León de los siglos XVI al XVIII". En VV.AA.: La Orden Concepcionista: Actas del I Congreso Internacional, Tomo II, Universidad de León, León, 1990, pp. 15-24.

MARTÍN GONZÁLEZ, Juan José: "La policromía en la escultura castellana", Archivo Español de Arte, Madrid, 1953, pp. 295-312.

MARTÍN GONZÁLEZ, Juan José: "Lazos de arte entre Valladolid y Orense”, En torno al arte auriense: homenaje a D. José González Paz, Universidad de Santiago de Compostela, Santiago de Compostela, 1990, pp. 67-75.

MARTÍN GONZÁLEZ, Juan José: "Los "pasos” procesionales de varias figuras en Castilla y León", Primer congreso nacional de cofradías de Semana Santa, Diputación Provincial de Zamora, Zamora, 1987, pp. 123-133.

MARTÍN GONZÁLEZ, Juan José: "Noticias documentales sobre la Catedral de Valladolid", B.S.A.A., Tomo XXVI, 1960, pp. 188-196.

MARTíN GONZÁLEZ, Juan José: "Una atribución a Pedro de Bahamonde”, B.S.A.A., Tomo XXIX, 1963, p. 263.

MARTÍN GONZÁLEZ, Juan José: Arquitectura barroca vallisoletana, Diputación de Valladolid, Valladolid, 1967.

MARTÍN GONZÁLEZ, Juan José: Catálogo del Museo Diocesano y Catedralicio de Valladolid, Dirección General de Bellas Artes, Madrid, 1965.

MARTÍN GONZÁLEZ, Juan José: El arte procesional del barroco. Historia 16, Madrid, 1993. 
MARTÍN GONZÁLEZ, Juan José: El escultor Gregorio Fernández, Ministerio de Cultura, Madrid, 1980.

MARTÍN GONZÁLEZ, Juan José: El retablo barroco en España, Alpuerto, Madrid, 1993.

MARTÍN GONZÁLEZ, Juan José: Escultura barroca castellana, Fundación Lázaro Galdiano, Madrid, 1959.

MARTÍN GONZÁLEZ, Juan José: Escultura barroca castellana. Segunda parte, Fundación Lázaro Galdiano, Madrid, 1971.

MARTÍN GONZÁLEZ, Juan José: Escultura barroca en España, 1600-1770, Cátedra, Madrid, 1991.

MARTÍN GONZÁLEZ, Juan José: Guía histórico-artística de Valladolid, Imprenta Castellana, Valladolid, 1949.

MARTÍN GONZÁLEZ, Juan José: Guía histórico-artística de Valladolid, Miñón, Valladolid, 1972.

MARTÍN GONZÁLEZ, Juan José: La huella española en la escultura portuguesa, Universidad de Santiago de Compostela, Valladolid, 1961.

MARTÍN GONZÁLEZ, Juan José: Luis Salvador Carmona: escultor y académico, Alpuerto, Madrid, 1990.

MARTÍN GONZÁLEZ, Juan José: Valladolid artístico. 3, Monumentos religiosos: iglesias y monasterios, Miñón, Valladolid, 1950.

MARTÍN GONZÁLEZ, Juan José: Valladolid, Ediciones Everest, León, 1991.

MARTÍNEZ RUIZ, Enrique, GIMÉNEZ, Enrique, ANTONIO ARMILLAS, José Antonio y MAQUEDA, Consuelo: La España Moderna, Istmo, Madrid, 1995

MATAMALA, Pilar y URREA, Jesús: La nobleza y su patronato artístico en Olmedo, Diputación de Valladolid, Valladolid, 1998.

MATEOS RODRÍGUEZ, Miguel A. (coord.): La Semana Santa en Castilla y León, Junta de Castilla y León, Valladolid, 1993.

MATILLA TASCÓN, Antonio: "Estampas religiosas del siglo XVIII. Colección del Archivo Histórico de Protocolos de Madrid", Goya: Revista de Arte, No 166, 1982, pp. 184-197.

MERINO BEATO, María Dolores: Urbanismo y arquitectura de Valladolid en los siglos XVII y XVIII (2 Tomos), Ayuntamiento de Valladolid, Valladolid, 1990.

MONTANER LÓPEZ, Emilia: La pintura barroca en Salamanca, Universidad de Salamanca, Salamanca, 1987.

MONZAVAL, P. Fr. Manuel de: Historia de las heroicas virtudes. Aclamación de los estupendos milagros. Vida, muerte y culto de San Pedro Regalado. Fundador de los Conventos de Domus Dei de Aguilera, y Scala Coeli del Abrojo primeros Santuarios de la Observancia en España, Impresor Felipe Francisco Márquez, Valladolid, 1684. 
MORENO ALCALDE, Mercedes: "Noticias sobre el escultor Juan Imberto", B.S.A.A., Tomo XLVII, 1981, pp. 456-463.

MUÑOZ JIMENEZ, José Miguel: "Barroco y Peregrinación: El Santuario de San Pedro Regalado en La Aguilera (Burgos), Goya: Revista de Arte, nº 228, Madrid, 1992, pp. 332-333.

MUÑOZ, Juan A.: "Caja Cantabria. Santillana del Mar. Compromiso con el Patrimonio Cultura de Cantabria”, La revista de Cantabria, Caja Cantabria, No 135, 2009, pp. 26-37

NACAR FUSTER, Eloíno y COLUNGA CUETO, Alberto (O.P.): Sagrada Biblia. Versión directa de las lenguas originales, Biblioteca de Autores Cristianos, Madrid, 2003.

NAVARRO GARCÍA, Rafael: Catálogo monumental de la provincia de Palencia. 2, Carrión de los Condes y Frechilla, Diputación Provincial de Palencia, Palencia, 1948.

NAVARRO GARCÍA, Rafael: Catálogo monumental de la provincia de Palencia. 3, Partidos de Cervera de Río Pisuerga y Saldaña, Diputación Provincial de Palencia, Palencia, 1939.

NAVARRO GARCÍA, Rafael: Catálogo monumental de la provincia de Valladolid. Fascículo cuarto, Partido judicial de Palencia, Diputación Provincial de Palencia, Palencia 1946.

NAVARRO TALEGÓN, José: Catálogo monumental de Toro y su Alfoz, Caja de Ahorros Provincial de Zamora, Zamora, 1980.

NAVARRO TALEGÓN, José: Inventario y catálogo de bienes muebles de interés cultural propios del Excmo. Ayuntamiento de Toro.

NAVARRO TALEGÓN, José: La Colegiata de Toro, Junta de Castilla y León, Valladolid, 2005

NICOLAU CASTRO, Juan: "Nuevos datos documentales sobre Pedro de Sierra", B.S.A.A., Tomo IL, 1983, pp. 509-512.

NIETO GALLO, Gratiniano: Guía artística de Valladolid, Aries, Barcelona, 1954.

ONTORIA OQUILLAS, Pedro: "La iglesia de Santa María de Gumiel de Izán", Boletín de la Institución Fernán González, no 205, 1985, pp. 67-128.

ORBE SIVATTE, Mercedes [et. al.]: Catálogo monumental de Navarra. 5. III, Merindad de Pamplona. Índices generales de la obra, Institución Príncipe de Viana, Pamplona, 1997.

OROZCO DÍAZ, Emilio: Introducción al Barroco: ensayos inéditos, Universidad de Granada, Granada, 2009.

ORTEGA DEL RÍO, José Miguel: El siglo en que cambió la ciudad. Noticias artísticas de la prensa vallisoletana del XIX, Ayuntamiento de Valladolid, Valladolid, 2000.

ORTEGA Y RUBIO, Juan: Historia de Valladolid (2 tomos), Imprenta y Librería Nacional y Extranjera de Hijos de Rodríguez, Valladolid, 1881.

ORTEGA Y RUBIO, Juan: Los pueblos de la Provincia de Valladolid (2 tomos), Imprenta y Encuadernación del Hospicio Provincial Valladolid, 1895. 
ORTÍZ DE AZUELA, Julián: Monografía de la antigua Colegiata (hoy iglesia parroquial) de Santillana del Mar, Santander, 1919.

ORUETA, Ricardo de: Gregorio Fernández / La expresión de dolor en la escultura castellana, Museo Nacional de Escultura, Valladolid, 2013.

ORUETA, Ricardo de: Pedro de Mena, escultor: homenaje en su tercer centenario, 1628-1928, Sociedad Económica de Amigos del País de Málaga, Málaga, 1928.

OTERO TÚÑEZ, Ramón: "Las primeras columnas salomónicas de España" Boletín de la Universidad Compostelana, nº 63, 1955, pp. 335-344.

PALACIOS PALOMAR, César Javier: Patrimonio artístico y actividad arquitectónica del Monasterio de Santo Domingo de Silos (1512-1835), Universidad de La Laguna, La Laguna, 2000 .

PALOMINO DE CASTRO Y VELASCO, Antonio: Museo pictórico y escala óptica. II, Práctica de la pintura, Aguilar, Madrid, 1988.

PARRADO DEL OLMO, Jesús María: "El retablo mayor de El Salvador en Boadilla de Rioseco (Palencia)”, B.S.A.A., Tomo XLII, 1976, pp. 472-476.

PARRADO DEL OLMO, Jesús María: "La colaboración entre ensambladores en los proyectos de retablos de finales del siglo XVII y unas obras inéditas de Tomás de Sierra”. B.S.A.A., Tomo LXII, 1996, pp. 401-420.

PARRADO DEL OLMO, Jesús María: "La obra de Francisco Giralte en Valladolid", A.E.A., Tomo 82, No 326, 2009, pp. 195-202.

PARRADO DEL OLMO, Jesús María: "Nuevos datos sobre el retablo mayor de Santa María de Tordesillas", B.S.A.A., Tomo XLVIII, 1982, pp. 435-437.

PARRADO DEL OLMO, Jesús María: "Patronos y obras de arte en Santa María de Tordesillas", B.S.A.A., Tomo LVI, 1990, pp. 518-541.

PARRADO DEL OLMO, Jesús María: "Precisiones sobre el ensamblador José de Arroyo", B.S.A.A., Tomo LIV, 1988, pp. 430-436.

PARRADO DEL OLMO, Jesús María: "Precisiones sobre los Bahamonde", B.S.A.A., Tomo LV, 1989, pp. 343-361.

PARRADO DEL OLMO, Jesús María: Ampudia: Iglesia de San Miguel, Diputación Provincial de Palencia, Palencia, 1991.

PARRADO DEL OLMO, Jesús María: Datos histórico artísticos inéditos de la provincia de Valladolid, Diputación de Valladolid, Valladolid, 1991.

PAYO HERNANZ, René Jesús: "De los esplendores barrocos a las luces de la razón: retablos y esculturas del siglo XVIII en la Ribera del Duero", Biblioteca: estudio e investigación, $\mathrm{N}^{\mathrm{o}} 20$, 2005 (ejemplar dedicado a: Ensenadas del Duero ilustrado), pp. 293-342

PAYO HERNANZ, René Jesús: El retablo en Burgos y su comarca durante los siglos XVII y XVIII (2 Tomos), Diputación Provincial de Burgos, Burgos, 1997. 
PÉREZ CONSTANTI, Pablo: Diccionario de artistas que florecieron en Galicia durante los siglos XVI y XVII, Imprenta del Seminario C. Central, Santiago, 1930.

PÉREZ DE CASTRO, Ramón y GARCÍA MARBÁN, Miguel (coord.): Cultura y arte en Tierra de Campos. I Jornadas Medina de Rioseco en su historia, Diputación de Valladolid, Valladolid, 2001.

PÉREZ DE CASTRO, Ramón y RUBIO DE CASTRO, Alfonso (coord.): Hermandad de Nuestro Señor de la Desnudez. Medina de Rioseco. Valladolid, Gráficas Iglesias, Palencia, 2010.

PÉREZ DE REGULES, Agustín: Santillana del Mar, Bedia, Santander, 19??

PÉREZ PICÓN, Conrado (S. J.): Villagarcía de Campos: estudio histórico-artístico, Institución Cultural Simancas, Valladolid, 1982.

PÉREZ SÁNCHEZ, Alfonso Emilio: Pintura barroca en España (1600-1750), Cátedra, Madrid, 2010.

PÉREZ, Ventura: Diario de Valladolid (1885), Grupo Pinciano, Valladolid, 1983.

POLO SÁNCHEZ, Julio Juan: Arte barroco en Cantabria: retablos e imaginería (1660-1790), Servicio de Publicaciones de la Universidad de Cantabria, Santander, 1991.

PONZ, Antonio: Valladolid en el "Viaje a España" (1783), Grupo Pinciano, Valladolid, 1993.

PORTELA SANDOVAL, Francisco José: "Panorama actual de la escultura religiosa en Madrid (1500-1750), Cuadernos de Historia y Arte IV, Tomo IV, 1986, pp. 49-96.

PRIETO CANTERO, Amalia: Historia de la Real Academia de Nobles y Bellas Artes de la Purísima Concepción de Valladolid, Institución Cultural Simancas, Valladolid, 1983.

RAMALLO ASENSIO, Germán: Documentos para el estudio de la escultura barroca en Asturias, Instituto de Estudios Asturianos, Oviedo, 1991.

RAMALLO ASENSIO, Germán: Escultura barroca en Asturias, Instituto de Estudios Asturianos, Oviedo, 1985.

RÉAU, Louis: Iconografía de la Biblia. Antiguo testamento, Ed. del Serbal, Barcelona, 1999.

RÉAU, Louis: Iconografía de la Biblia. Nuevo testamento, Ed. del Serbal, Barcelona, 2000.

RÉAU, Louis: Iconografía de los santos. A-F, Ed. del Serbal, Barcelona, 1997.

RÉAU, Louis: Iconografía de los santos. G-O, Ed. del Serbal, Barcelona, 1997.

RÉAU, Louis: Iconografía de los santos. P-Z, Ed. del Serbal, Barcelona, 1998.

RÉAU, Louis: Iconografía del arte cristiano, Ed. del Serbal, Barcelona, 200.

REBOLLO MATÍAS, Alejandro y MINGO MACÍAS, Luis: "Acerca de nuestra historia: Real Monasterio de San Quirce y Santa Julita: arquitectura y patrimonio", Pasión Cofrade, no 11 (segunda época), 2015, pp. 16-31. 
REBOLLO MATÍAS, Alejandro: “Acerca de nuestra historia: la iglesia de la Pasión y su patrimonio (3 $3^{\mathrm{a}}$ parte), Pasión Cofrade, no 8 (segunda época), 2012, pp. 36-46.

REBOLLO MATÍAS, Alejandro: La Iglesia-Oratorio de San Felipe Neri de Valladolid: breve guía de su historia y patrimonio, Congregación de San Felipe Neri y de Nuestra Señora de la Presentación, Valladolid, 2008.

REBOLLO MATÍAS, Alejandro: Signa Christi. Símbolos y emblemas de la Pasión, Ayuntamiento de Valladolid, Valladolid, 2015

REDONDO CANTERA, María José: "Los inventarios de obras de arte de los conventos vallisoletanos durante la Guerra de la Independencia", B.S.A.A., Tomo LVIII, 1992, pp. 497510.

REDONDO CANTERA, María José: Los Bahamonde, una familia de artistas dedicados al retablo en Valladolid y Palencia: desde el Barroco Tardío hasta su disolución, Xunta de Galicia, 2002, pp. 287-316.

REVILLA VIELVA, Ramón: Catálogo monumental de la provincia de Palencia. 1, partidos de Astudillo y Baltanás, Diputación Provincial de Palencia, Palencia, 1951.

RICO DE LA FUENTE, Araceli: Monasterio de Nuestra Señora de Aniago: el sueño de una reina, Diputación de Valladolid, Valladolid, 2007.

RIPA, Cesare: Iconología (2 tomos), Akal, Madrid, 2007.

RIVERA DE LAS HERAS, José Ángel: La catedral de Zamora, Durius Cultural, Salamanca, 2001.

RIVERA DE LAS HERAS, José Ángel: Por la catedral, iglesias y ermitas de la ciudad de Zamora, Edilesa, León, 2001.

RODA PEÑA, José: Pedro Roldán escultor: 1624-1699, Arco Libros, Madrid, 2012.

RODRÍGUEZ MARTÍNEZ, Luis: Historia del Monasterio de San Benito el Real de Valladolid, Caja de Ahorros popular de Valladolid y Ateneo de Valladolid, Valladolid, 1971.

RODRÍGUEZ, Juan Luis y URREA FERNÁNDEZ, Jesús: Santa Teresa en Valladolid: historia de sus fundaciones hasta nuestros días. El arte en San José de Medina y en la Concepción de Valladolid, Caja de Ahorros Popular de Valladolid, Valladolid, 1982.

RODRÍGUEZ-MONSALVE PASTOR, Ernesto y MUÑOZ GONZÁLEZ, Alberto: "La imagen de San Pedro Regalado que se venera en nuestra Penitencial: Historia", Boletín informativo de la Insigne Cofradía Penitencial de Nuestro Padre Jesús Nazareno, Valladolid, № 31, 2014.

ROJO VEGA, Anastasio: Fiesta y Comedias en Valladolid: siglos XVI-XVII, Ayuntamiento de Valladolid, Valladolid, 1999.

RUBIO Y BORRÁS, Manuel: Nueva guía de Valladolid, Establecimiento tipográfico de Julián Torres, Valladolid, 1895.

SALCEDO TAPIA, Modesto: "Vida de don Tello Téllez de Meneses, Obispo de Palencia", Publicaciones de la Institución Tello Téllez de Meneses, Tomo LIII, 1985, pp. 79-266. 
SAN JOSÉ DÍEZ, Mariano: Barrio y parroquia de San Nicolás, Parroquia de San Nicolás de Bari, Valladolid, 2008.

SAN JOSÉ DÍEZ, Mariano: La parroquia de Cigales, Ayuntamiento de Cigales, Cigales (Valladolid), 1992.

SÁNCHEZ CANTÓN, Francisco Javier: "San Francisco de Asís en la escultura española", Academia: Boletín de la Real Academia de Bellas Artes de San Fernando, no 34, 1972, pp. 1936.

SÁNCHEZ DEL BARRIO, Antonio: Santa Teresa de Jesús y San Juan de la Cruz. El encuentro, Fundación Museo de las Ferias, Medina del Campo, 2014.

SÁNCHEZ HERRERO, José: "Pasión y Sangre: en torno al origen de las cofradías de Semana Santa hispana". En BALOUP, Daniel: L'enseignement religieux dans la Couronne de Castille: incidences spirituelles et sociales (XIIIe-XVe siècle), Casa de Velázquez, Madrid, 2003, pp. 125-142.

SÁNCHEZ MARCOS, Marta: "La Virgen de las Nieves. Transformaciones de una imagen vestidera". En Codex aquilrensis: Cuadernos de investigación del Monasterio de Santa María la Real, nº 9, 1993, pp. 97-111.

SANCHO CAMPO, Ángel (dir.): El arte sacro en Palencia. 3, La Pasión y Resurrección del Señor en el arte palentino. [s.n.] Palencia, 1972.

SANCHO CAMPO, Ángel (dir.): El arte sacro en Palencia. IV, Santa María y Santiago en el arte palentino. Palencia, 1975.

SANCHO, Hilarión, GALLARDO, Francisco y MARTÍNEZ, Demetrio: Valladolid: diarios curiosos (1807-1841), Grupo Pinciano, Valladolid, 1989.

SANGRADOR MINGUELA, Federico: La iglesia de San Benito el Real de Valladolid: Restaurada y dedicada, actualmente, al culto y veneración de la Santísima Virgen del Carmen, Imprenta de Juan Rodríguez Hernando, Valladolid, 1904.

SANGRADOR Y VÍTORES, Matías: Historia de la Muy Noble y Leal Ciudad de Valladolid, desde su más remota antigüedad hasta la muerte de Fernando VII (2 Tomos), Imprenta de D. M. Aparicio, Valladolid, 1854.

SANTAMARÍA, Alfonso R.: "Iglesia del convento de la Concepción”, B.S.A.A., Tomo XXVI, 1960, pp. 180-187.

SANTOS, Juan (O. H.): Lauros panegíricos en la solemne canonización del gran patriarca San Juan de Dios, Impenda de Bernardo de Villadiego, Madrid, 1693.

SEBASTIÁN, Santiago: Contrarreforma y barroco. Lecturas iconográficas e iconológicas, Alianza Editorial, Madrid, 1984.

SEOANE PRIETO, José Raúl: La Catedral de Ourense. I, Patrimonio Histórico Gallego. 1, Catedrales, Xuntanza, Laracha (A Coruña), 1997. 
SERRANO FATIGATI, Enrique: "Escultura en Madrid, desde mediados del siglo XVI hasta nuestros días", Boletín de la Sociedad Española de Excursiones, Vol. 17, № 3, 1909, pp. 201233.

SGARBOSSA, Mario y GIOVANNI, Luis: Un santo para cada día, Editorial San Pablo, 1987.

STRATTON, Suzanne: La Inmaculada Concepción en el arte español, Fundación Universitaria Española, Alcalá 93, Madrid, 1989.

TAPIÉ, Víctor: Barroco y clasicismo, Cátedra, Madrid, 1986.

TIEDRA, José de: El Hospital de Santa María de Esgueva de Valladolid. Fundación gloriosa y secular del conde don Pedro Ansúrez y doña Eylo su mujer, Imprenta-Librería Casa Martín, Valladolid, 1937.

TORMO Y MONZÓ, Elías: "Las Comendadoras. En el colegio de mis nietas en Valladolid", B.S.A.A., Tomo VII, 1940-1941, pp. 143-165.

TRAVIESO, José Miguel: “Ángeles y Demonios. Repertorio iconográfico en Valladolid”, Revista Atticus, nº 23, 2013, pp. 31-69.

TRENS, Manuel: María: iconografía de la virgen en el arte español, Plus Ultra, Madrid, 1946.

URREA FERNÁNDEZ, Jesús (coord.): Patrimonio restaurado de la provincia de Valladolid 1997-2003. Del olvido a la memoria (vol. 1). Pintura y Escultura, Diputación de Valladolid, Valladolid, 2008.

URREA FERNÁNDEZ, Jesús (dir.): La navidad en el arte vallisoletano, Caja de Ahorros Popular, Valladolid, 1985

URREA FERNÁNDEZ, Jesús (dir.): La pequeña escultura en Valladolid: siglos XVI-XVIII: (exposición) del 9 al 26 de marzo de 1983, Caja de Ahorros Popular de Valladolid, Valladolid, 1983.

URREA FERNÁNDEZ, Jesús y MARTÍN GONZÁLEZ, Juan José: Inventario artístico de Palencia y su provincia I, Ciudad de Palencia, antiguos partidos judiciales de Palencia, Astudillo, Baltanás y Frechilla, Ministerio de Educación y Ciencia, Madrid, 1977.

URREA FERNÁNDEZ, Jesús y MARTÍN GONZÁLEZ, Juan José: Inventario artístico de Palencia y su provincia II, Antiguos partidos judiciales de Carrión de los Condes, Saldaña y Aguilar de Campoó, Ministerio de Cultura, Madrid, 1980.

URREA FERNÁNDEZ, Jesús: "Acotaciones a Gregorio Fernández y su entorno artístico", B.S.A.A., Tomo XLVI, 1980, pp. 375-396.

URREA FERNÁNDEZ, Jesús: “Ángeles napolitanos”, B.S.A.A., Tomo L, 1984, pp. 442-445.

URREA FERNÁNDEZ, Jesús: “Apuntes para el estudio de la escultura en cera en España”, B.S.A.A., Tomo XLV, 1979, pp. 488-495.

URREA FERNÁNDEZ, Jesús: “Archivos parroquiales”, B.S.A.A., Tomo XXXVII, 1971, pp. 513-520. 
URREA FERNÁNDEZ, Jesús: "Capillas y patronos de la catedral de Valladolid", B.R.A.C., Tomo XL, 2005, pp. 107-124.

URREA FERNÁNDEZ, Jesús: "Don Pedro de Arce y su capilla en la Catedral de Valladolid", B.R.A.C., Tomo XXXIX, 2004, pp. 85-92.

URREA FERNÁNDEZ, Jesús: "El escultor Felipe Espinabete (1719-1799)”. En REDONDO, José, BAZÁN, Pedro y GARCÍA, Antonio María: Tordesillas a través de su Semana Santa, Diputación Provincial de Valladolid, Valladolid, 2000, pp. 119-122.

URREA FERNÁNDEZ, Jesús: "El escultor Francisco Alonso de los Ríos (¿-1660), B.S.A.A., Tomo XXXVIII, 1972, pp. 355-369.

URREA FERNÁNDEZ, Jesús: "El oratorio de San Felipe Neri de Valladolid", Boletín de la Real Academia de Bellas Artes de la Purísima Concepción, Tomo XXXIII, 1998, pp. 9-23.

URREA FERNÁNDEZ, Jesús: "Escultores coetáneos y discípulos de Gregorio Fernández en Valladolid I", B.S.A.A., Tomo L, 1984, pp. 349-370.

URREA FERNÁNDEZ, Jesús: "Escultores coetáneos y discípulos de Gregorio Fernández en Valladolid II”, Tomo LVIII, 1992, pp. 393-402

URREA FERNÁNDEZ, Jesús: “Gregorio Fernández en el Convento de Scala Coeli del Abrojo", Boletín del Museo Nacional de Escultura, n³ 3, Valladolid, 1998-1999, pp. 23-32.

URREA FERNÁNDEZ, Jesús: "La biografía al servicio del conocimiento artístico. El escultor Juan Antonio de la Peña”. B.R.A.C., Tomo XLII, Valladolid, 2007, pp. 43-56.

URREA FERNÁNDEZ, Jesús: "La capilla de D. Gabriel López de León en la iglesia de San Pedro de Zamora”, B.S.A.A., Tomo LI, 1985, pp. 500-507.

URREA FERNÁNDEZ, Jesús: "La capilla de Nuestra Señora del Sagrario en la Catedral de Valladolid”, B.R.A.C., Tomo XLI, 2006, pp. 67-78.

URREA FERNÁNDEZ, Jesús: "La escultura barroca en la comarca de Aranda de Duero", Biblioteca Estudio e Investigación, Tomo XIX, Ayuntamiento de Aranda de Duero, 2004, pp. 249-264.

URREA FERNÁNDEZ, Jesús: "Las esculturas de Villabrille y Ron del monasterio de San Quirce", Boletín de la Real Academia de Bellas Artes de la Purísima Concepción, Tomo XXXVI, 2001, pp. 137-138.

URREA FERNÁNDEZ, Jesús: "Los autores del retablo de Santa María de Tordesillas: nuevos datos", B.S.A.A., Tomo LIV, 1988, pp. 436-439.

URREA FERNÁNDEZ, Jesús: "Noticia Histórica Artística de Villanueva de Duero (Valladolid)", Boletín de la Real Academia de Bellas Artes de la Purísima Concepción, Tomo XXXV, 2000, pp. 95-126.

URREA FERNÁNDEZ, Jesús: "Noticias documentales sobre la Catedral de Valladolid", B.S.A.A., Tomo XXXVI, 1970, pp. 529-537. 
URREA FERNÁNDEZ, Jesús: "Nuevos datos y obras del escultor Andrés Solanes (+ 1635)", B.S.A.A., Tomo LV, 1989, pp. 481-488.

URREA FERNÁNDEZ, Jesús: "Nuevos datos y obras del escultor Felipe de Espinabete", B.S.A.A., Tomo LI, 1985, pp. 507-510.

URREA FERNÁNDEZ, Jesús: "Reflexiones sobre la Catedral de Valladolid y noticia de algunas de sus pinturas", II Curso de patrimonio cultural (2008-2009), Ayuntamiento de Valladolid, Valladolid, 2009.

URREA FERNÁNDEZ, Jesús: "San Fernando en Castilla y León”, B.S.A.A., Tomo LII, 1986, pp. 484-487.

URREA FERNÁNDEZ, Jesús: "Semana Santa", Cuadernos Vallisoletanos, no 24, Caja de Ahorros Popular de Valladolid, Valladolid, 1987.

URREA FERNÁNDEZ, Jesús: "Un Ecce Homo de Gregorio Fernández", B.S.A.A., Tomo XXXVIII, 1972, pp. 554-556.

URREA FERNÁNDEZ, Jesús: "Villabrille y Ron y la capilla de la Buena Muerte, de San Ignacio de Valladolid", Boletín del Museo Nacional de Escultura, № 11, 2007, pp. 22-29.

URREA FERNÁNDEZ, Jesús: Arquitectura y nobleza: casas y palacios de Valladolid, IV Centenario Ciudad de Valladolid, Valladolid, 1996.

URREA FERNÁNDEZ, Jesús: El retrato en la pintura vallisoletana del siglo XVII, Caja de Ahorros Popular de Valladolid, Valladolid, 1983.

URREA FERNÁNDEZ, Jesús: Guía histórico-artística de la ciudad de Valladolid, Caja de Ahorros Popular de Valladolid, Valladolid, 1982.

URREA FERNÁNDEZ, Jesús: La Catedral de Valladolid y Museo Diocesano, Everest, Madrid, 1978.

URREA FERNÁNDEZ, Jesús: La iglesia de Santiago de Valladolid, Parroquia de Santiago, Valladolid, 1977.

URREA FERNÁNDEZ, Jesús: La iglesia parroquial de San Andrés de Valladolid, Valladolid, 1974.

URREA FERNÁNDEZ, Jesús: Teresa de Jesús y Valladolid. La Santa, la Orden y el Convento, Ayuntamiento de Valladolid, Valladolid, 2015.

URREA FERNÁNDEZ, Jesús:” El retablo mayor y los colaterales de la Catedral de Valladolid", B.R.A.C., Tomo XXXVI, 2001, pp. 121-132.

VALDEÓN BARUQUE, Julio (dir.): Historia de Valladolid, Ámbito, Valladolid, 1997.

VALDIVIESO GONZÁLEZ, Enrique: La pintura en Valladolid en el siglo XVII, Diputación de Valladolid, Valladolid, 1971. 
VASALlO TORANZO, Luis, ALMARAZ VÁZQUEZ, María de las Mercedes y BLANCO SÁNCHEZ, José: "Antonio Tomé en el retablo de los Trinitarios de Zamora", B.S.A.A., Tomo LXXI 2, 2005, pp. 215-240.

VASALLO TORANZO, Luis: "El paso Camino del Calvario de Gregorio Fernández”, Boletín del Museo Nacional de Escultura, № 11, 2007, pp. 16-21.

VÁZQUEZ GARCÍA, Francisco: "Varias esculturas de Felipe de Espinabete en iglesias abulenses”, B.S.A.A., Tomo LVII, 1991, pp. 445-452.

VÁZQUEZ GARCÍA, Francisco: El retablo barroco en las iglesias parroquiales de la zona norte de la provincia de Ávila (2 vols.), Universidad Complutense de Madrid, Madrid, 1991.

VEIGA, Tomé Pinheiro da: Fastiginia: vida cotidiana en la corte de Valladolid, Ediciones Ámbito, Valladolid, 1989.

VELASCO BAYÓN, Balbino (O. Carmelita): Historia de Cuellar, Diputación Provincial de Segovia, Segovia, 1988.

VILA JATO, Dolores. Cuadernos no restauro, a capela do Santo Cristo de Ourense: Catedral de Ourense, Xunta de Galicia, Santiago de Compostela, 1996.

VILLA, Nicolás: "Informa histórico y artístico sobre los retablos del Niño Jesús y Santa Bárbara existentes en el presbiterio de la iglesia parroquial de Ntra. Sra. La Antigua en Fuentes de Valdepero", Horizontes, Asociación de amigos del castillo y monumentos de Fuentes de Valdepero, $\mathrm{N}^{\mathrm{o}}$ 15, 2009, pp. 13-15.

VORÁGINE, Santiago de la: La leyenda dorada (2 tomos), Alianza Forma, Madrid, 1982.

VV.AA.: Arte Americanista en Castilla y León [exposición], Junta de Castilla y León, Valladolid, 1992.

VV.AA.: Boletín de la Sociedad Castellana de Excursiones (1907-1908). Castilla artística e histórica. III, Grupo Pinciano, Valladolid, 1984.

VV.AA.: Boletín de la Sociedad Castellana de Excursiones (1913-1914): Castilla artística e histórica. VI, Grupo Pinciano, Valladolid, 1986.

VV.AA.: Clausuras: el patrimonio de los conventos de la provincia de Valladolid. 1, Medina del Campo, Diputación de Valladolid, Valladolid, 1999.

VV.AA.: Clausuras: el patrimonio de los conventos de la provincia de Valladolid. 2, OlmedoNava del Rey, Diputación de Valladolid, Valladolid, 2001.

VV.AA.: Clausuras: el patrimonio de los conventos de la provincia de Valladolid. 3, Medina de Rioseco - Mayorga de Campos - Tordesillas - Fuensaldaña y Villafrechós, Diputación de Valladolid, Valladolid, 2004.

VV.AA.: Conocer Valladolid. II Curso de patrimonio cultural 2008-2009, Ayuntamiento de Valladolid, Valladolid, 2009.

VV.AA.: En torno al arte auriense: homenaje a D. José González Paz, Universidad de Santiago de Compostela, Santiago de Compostela, 1990. 
VV.AA.: Gregorio Fernández y la Semana Santa, Ministerio de Cultura, Madrid, 1986.

VV.AA.: Gregorio Fernández: La gubia del barroco, Ayuntamiento, Valladolid, 2008.

VV.AA.: Guía oficial del Santuario Nacional de la Gran Promesa, Imprenta Avilista, Madrid, 1953.

VV.AA.: Iconografía de Santiago y de los santos burgaleses vinculados a la peregrinación, Fundación para el Desarrollo Provincial de Burgos, Burgos, 1993.

VV.AA.: La Orden Concepcionista: Actas del I Congreso Internacional: León, 8 al 12 de mayo de 1989, Monasterio de la Purísima Concepción (2 Tomos), Universidad de León, León, 1990.

VV.AA.: Las Edades del Hombre. El árbol de la vida, Fundación las Edades del Hombre, Salamanca, 2003.

VV.AA.: Las Edades del Hombre. El contrapunto y su morada [Exposición. Salamanca, 19931994], Las Edades del Hombre, Valladolid, 1993.

VV.AA.: Las Edades del Hombre. Eucharistia, Fundación Las Edades del Hombre, Valladolid, 2014.

VV.AA.: Las Edades del Hombre. Monacatus [Exposición. Oña, 2012], Fundación Las Edades del Hombre, San Bernardo (Valladolid), 2012.

VV.AA.: Las Edades del Hombre. Paisaje interior, Fundación Las Edades del Hombre, Valladolid, 2009.

VV.AA.: Las Edades del Hombre. Passio, Fundación Las Edades del Hombre, Valladolid, 2011.

VV.AA.: Las Edades del Hombre. Remembranza, Edades del Hombre, Zamora, 2001.

VV.AA.: Pasos restaurados, Museo Nacional de Escultura, Valladolid, 2000.

VV.AA.: Pedro de Mena y Castilla (Catálogo de exposición), Ministerio de Cultura, Valladolid, 1989.

VV.AA.: Pequeñas imágenes de la Pasión en Valladolid [exposición abril-mayo 1987 Palacio de Villena], Ministerio de Cultura, Madrid, 1987.

VV.AA.: Valladolid: historia de una ciudad. Congreso internacional 1. La ciudad Moderna, Ayuntamiento de Valladolid, Valladolid, 1999.

WATTENBERG, Eloísa y GARCÍA SIMÓN, Agustín: El Monasterio de Nuestra Señora de Prado, Junta de Castilla y León: Consejería de Cultura y Turismo, Valladolid, 1997.

WATTENBERG, Federico: Museo Nacional de Escultura, Aguilar S.A. Ediciones, Madrid, 1972.

WATTENBERG, Federico: Museo Nacional de Escultura, Madrid, 1966.

WEISE, Georg: Spanische plastik aus sieben jahrhunderten. I, Gryphius, Reutlingen, 1925. 
YARZA LUACES, Joaquín: "Un San Juan Bautista degollado de Felipe de Espinabete en Santibáñez del Val (Burgos)”, B.S.A.A., Tomo XXXVIII, 1972, pp. 560-562.

ZALAMA, Miguel Ángel: Ermitas y santuarios de la provincia de Valladolid, Diputación de Valladolid, Valladolid, 1987.

ZAPARAÍN YÁÑEZ, María José: "Dos obras vallisoletanas en la Ribera arandina: Los retablos principales del convento de San Francisco en Aranda de Duero y de la ermita de la Santísima Trinidad de Fuentespina", Homenaje al profesor Martín González, Valladolid, 1995, pp. 463468

ZAPARAÍN YÁÑEZ, María José: Desarrollo artístico de la comarca arandina: siglos XVII y XVIII, Excma. Diputación de Burgos e Ilustre Ayuntamiento de Aranda de Duero, Burgos, 2002.

ZAPARAÍN YÁÑEZ, María José: Fuentelcésped: la villa y su patrimonio, siglos XVII y XVIII, EMAN, San Sebastián, 1998.

ZAPARAÍN YÁÑEZ, María José: Fuentespina: la villa y su arte, siglos XVII y XVIII, EMAN, San Sebastián, 1995.

ZAPATA, Teresa: La entrada en la Corte de María Luisa de Orleans: arte y fiesta en el Madrid de Carlos II, Madrid Fusión, Madrid, 2000.

ZURIAGA SENENT, Vicent Francesc: "Entre la tierra y el cielo: el tipo iconográfico del Ángel Custodio". En VV.AA.: Entre cielos e infiernos. Memoria del V Encuentro Internacional sobre Barroco, Fundación Visión Cultura, La Paz, 2010, pp. 279-288.

\section{CATÁLOGO MONUMENTAL DE VALLADOLID}

GARCÍA CHICO, Esteban: Catálogo Monumental de la provincia de Valladolid. Tomo I. Medina de Rioseco, Diputación de Valladolid, Valladolid, 1956.

GARCÍA CHICO, Esteban: Catálogo Monumental de la provincia de Valladolid. Tomo II. Partido judicial de Medina de Rioseco, Diputación de Valladolid, Valladolid, 1959.

GARCÍA CHICO, Esteban: Catálogo Monumental de la provincia de Valladolid. Tomo III. Medina del Campo, Diputación de Valladolid, Valladolid, 1961.

GARCÍA CHICO, Esteban: Catálogo Monumental de la provincia de Valladolid. Tomo IV. Partido judicial de Medina del Campo, Diputación de Valladolid, Valladolid, 1964.

GARCÍA CHICO, Esteban y BUSTAMANTE GARCÍA, Agustín: Catálogo Monumental de la provincia de Valladolid. Tomo V. Partido judicial de Nava del Rey, Diputación de Valladolid, Valladolid, 1972.

MARTÍN GONZÁLEZ, Juan José: Catálogo Monumental de la provincia de Valladolid. Tomo VI. Antiguo partido judicial de Valladolid, Diputación de Valladolid, Valladolid, 1973.

URREA FERNÁNDEZ, Jesús: Catálogo Monumental de la provincia de Valladolid. Tomo VII. Antiguo partido judicial de Valoria la Buena, Diputación de Valladolid, Valladolid, 1974. 
VALDIVIESO, Enrique: Catálogo Monumental de la provincia de Valladolid. Tomo VIII. Antiguo partido judicial de Peñafiel, Diputación de Valladolid, Valladolid, 1975.

PARRADO DEL OLMO, Jesús María: Catálogo Monumental de la provincia de Valladolid. Tomo IX. Antiguo partido judicial de Mota del Marqués, Diputación de Valladolid, Valladolid, 1976.

BRASAS EGIDO, José Carlos: Catálogo Monumental de la provincia de Valladolid. Tomo X. Antiguo partido judicial de Olmedo, Diputación de Valladolid, Valladolid, 1977.

ARA GIL, Clementina Julia y PARRADO DEL OLMO, Jesús María: Catálogo Monumental de la provincia de Valladolid. Tomo XI. Antiguo partido judicial de Tordesillas, Diputación de Valladolid, Valladolid, 1980.

URREA FERNÁNDEZ, Jesús y BRASAS EGIDO, José Carlos: Catálogo Monumental de la provincia de Valladolid. Tomo XII. Antiguo partido judicial de Villalón, Diputación de Valladolid, Valladolid, 1981.

MARTÍN GONZÁLEZ, Juan José: Catálogo Monumental de la provincia de Valladolid. Tomo XIII. Monumentos civiles de la ciudad de Valladolid, Diputación de Valladolid, Valladolid, 1983.

MARTÍN GONZÁLEZ, Juan José y URREA FERNÁNDEZ, Jesús: Catálogo Monumental de la provincia de Valladolid. Tomo XIV. Monumentos religiosos de la ciudad de Valladolid (1 ${ }^{a}$ parte), Institución Cultural Simancas, Valladolid, 1985.

MARTÍN GONZÁLEZ, Juan José y DE LA PLAZA SANTIAGO, Francisco Javier: Catálogo Monumental de la provincia de Valladolid. Tomo XV. Monumentos religiosos de la ciudad de Valladolid (2 ${ }^{a}$ parte), Institución Cultural Simancas, Valladolid, 2001.

PARRADO DEL OLMO, Jesús María: Catálogo Monumental de la provincia de Valladolid. Tomo XVI. Antiguo partido judicial de Medina de Rioseco, Diputación de Valladolid, Valladolid, 2002.

WATTENBERG GARCÍA, Eloísa: Catálogo Monumental de la provincia de Valladolid. Tomo XVII. Medina de Rioseco, ciudad, Diputación de Valladolid, Valladolid, 2003.

MARCOS VILLÁN. Miguel Ángel y FRAILE GÓMEZ, Ana María: Catálogo Monumental de la provincia de Valladolid. Tomo XVIII. Antiguo partido judicial de Medina del Campo, Diputación de Valladolid, Valladolid, 2003.

ARIAS MARTÍNEZ, Manuel, HERNÁNDEZ REDONDO, José Ignacio y SÁNCHEZ DEL BARRIO, Antonio: Catálogo Monumental de la provincia de Valladolid. Tomo XIX. Medina del Campo, Diputación de Valladolid, Valladolid, 2004.

URREA FERNÁNDEZ, Jesús: Catálogo Monumental de la provincia de Valladolid. Tomo XX. Antiguo partido judicial de Valoria la Buena, Diputación de Valladolid, Valladolid, 2004.

CASTÁN LANASPA, Javier: Catálogo Monumental de la provincia de Valladolid. Tomo XXI. Antiguo partido judicial de Nava del Rey, Diputación de Valladolid, Valladolid, 2006. 